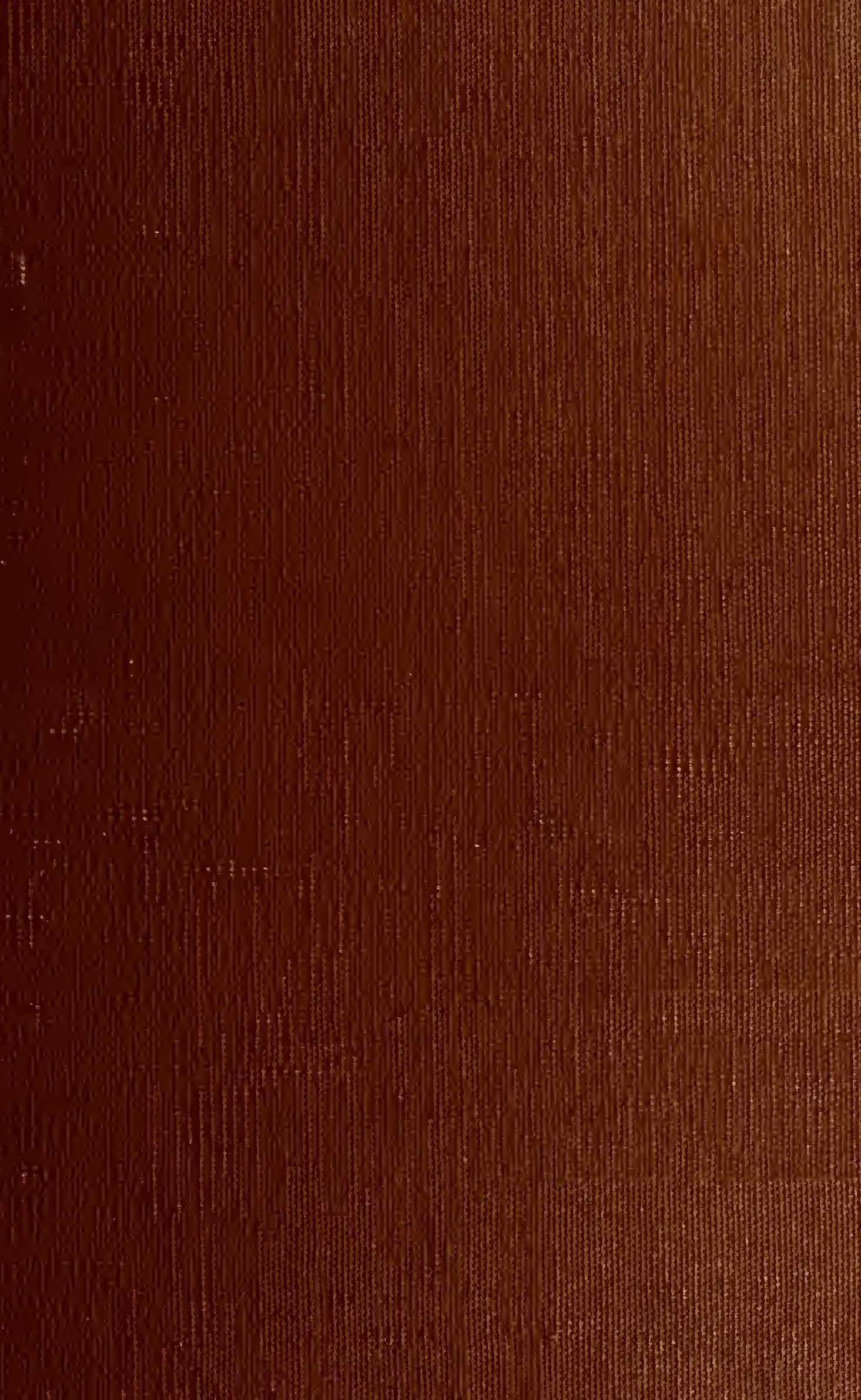


CRUSTACEA IIBRARY SMITHSOHIAN INST. RETURN TO W-119 





\section{ENCYCLOPÉDIE METHODIQUE, OU}

PAR ORDRE.DE MATIERES;

PAR UNE SOCIETE DE GENS DE LETTRES, DE SAVANS ET D'ARTISTES;

Précédée d'un Vocabulaire univerfel, fervant de Table pour tout l'Ouvrage, ornée des Portraits de MM. DIDEROT \& D'ALEMBERT, premiers Editeurs de l'Encyclopédie.

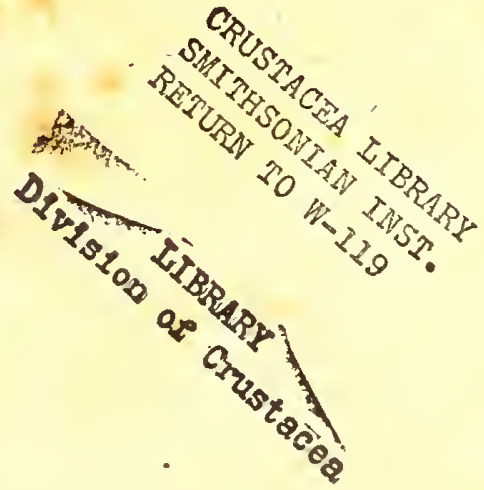





\section{ENCYCLOPEDIE METHODIQUE.}

\section{HISTOIRE NATURELLE.}

ENTOMOLOGIE, OU HISTOIRE NATURELLE DES CRUSTACES, DES ARACHNIDES ET DES INSECTES,

$$
\text { PAR M. LATREILLE, }
$$

MEMBRE DE L'INSTITUT, ACADÉMIE ROYAL DES SCIENCES, eR:

\section{TOME DIXTEME.}

Par MM. Latreilie, Le PeLETIER DE SAINT-FARgeaU, . SERVILLE et GUÉRTIN

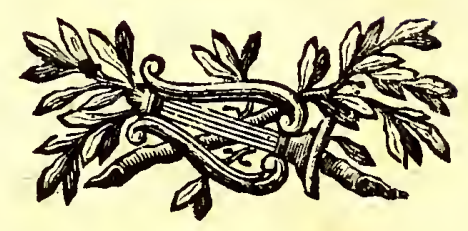

\section{A PARIS,}

Chez $M^{\text {me }}$ veuve AGASSE, Imprimeur-Libraire, rue des Poitevins, $n^{\circ} 6$.

M. DCCCXXV. 


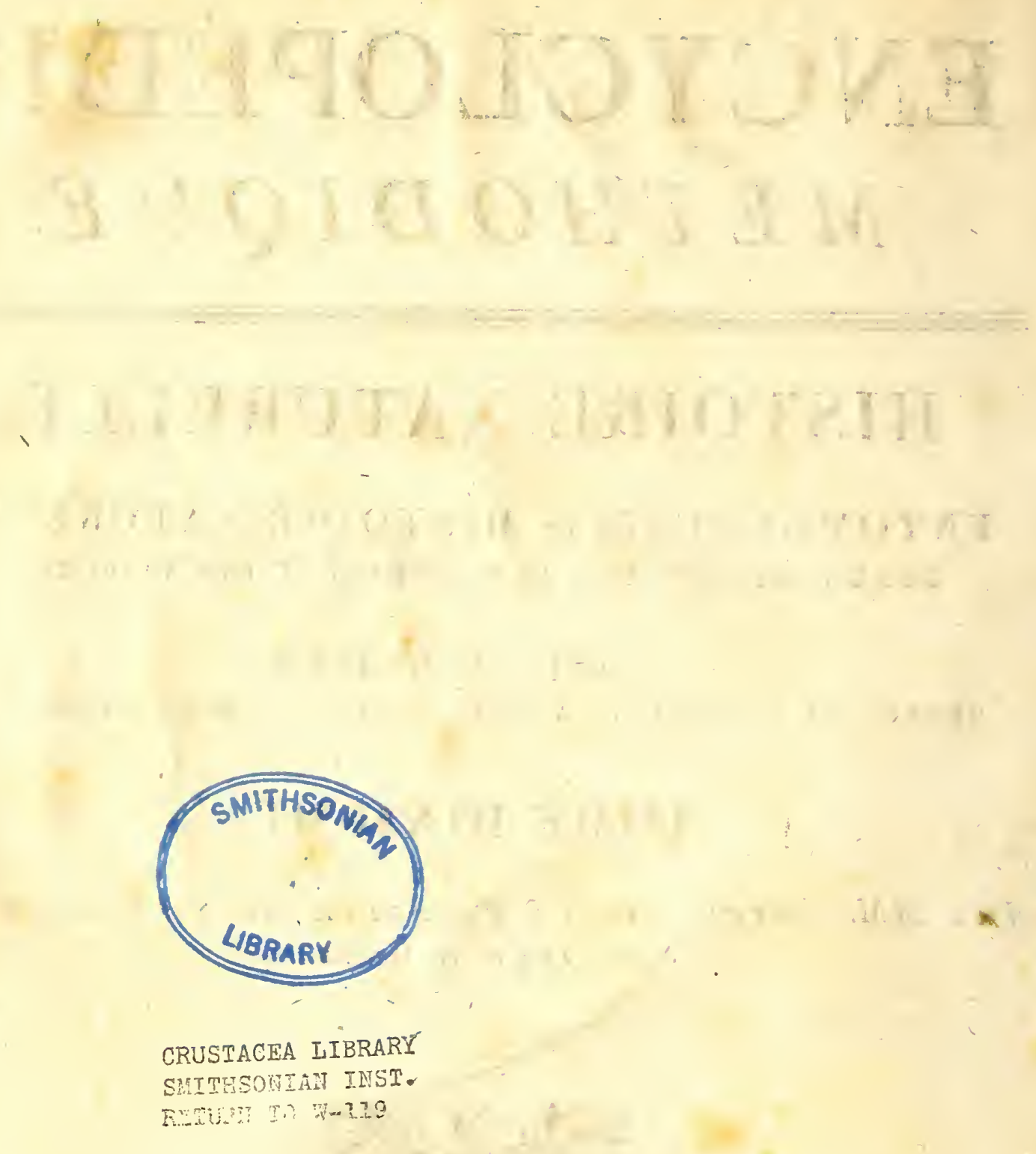




\section{AVERTISSEMENT DE L'ÉDITEUR. \\ t. 10 \\ INVZRB}

L'IMPATIENCE des Souscripteurs nous engageant à terminer promptement l'Encyclopédie méthodiquo, nous en avons pris les moyens qui nous ont paru pouvoir leur être le plus agréables. Nous avons dû en conséquence changer différentes choses dans l'ordre typographique, et engager les Auteurs de cette partie entomologique à supprimer les tableaux de caractères et d'espèces qui employoient beaucoup de place, sans être d'une nécessité absolue. Nous devons prévenir que la santé de M. Latreile ne lui ayant pas permis de rédiger en entier ce qui restoit à faire, il a prié MM. Le Peletier de Saint-Fargeau et Serville de se charger de ce travail, en se réservant à lui-mềme les insectes aptères de Linné : dans ces derniers temps, sa santé étant devenue plus foible, il a été forcé de renoncer même à ce travail et il en a chargé M. Guérin. M. de Saint-Fargead a donné au Public les Monographies des Chrysides ou Porte-tuyaux et des Tenthrédines ainsi que plusieurs Mémoires particuliers de Botanique et d'Entomologie. M, Senvilce est un des collaborateurs de la Faune française; enfin M. Guśrrs est auteur de plusieurs Mémoires sur les Insectes, dessinateur des Annales des Sciences naturelles et rédacteur de la partie entomologique du Dictionnaire classique d'Histoire naturelle. 


\section{AVERTISSEMENT DES AUTEURS.}

L'INTENTION de l'Éditeur étant de se renfermer strictement dans le cadre de cet Ouvrage pour le terminer promptement, on sentira parfaitement que dans le seul volume qui nous étoit laissé pour les articles dont nous étions chargés dans ce Dictionnaire, depuis les lettrés PAP jusqu'à $Z$ inclusivement, il ne nous étoit pas possiblè de donner le même développement à la description des espèces connues; mais un grand nombre de genres ayant été établis depuis la publication des volumes qui précèdent celui-ci, nous avons pensé que les naturalistes verroient avec plaisir donner les caractères de ces genres et y rapporter les espèces qui figurent sous leurs anciennes dénominations dans les volumes précédens de l'Encyclopédie. Nous aurions bien desiré pouvoir traiter ainsi tous les genres, mais on sent facilement que la chose étoit impossible, et que le seul moyen d'en publier au moins la majeure partie, étoit de les rattacher à des articles appelés par l'ordre alphabétique à faire partie de notre travail, comme nos prédécesseurs nous en avoient déjà donné l'exemple. Ces articles intercalés n'étant pas à leur lettre, nous nous proposons de donner une table particulière à la fin de ce volume, au moyen de laquelle on saura de suite si tel article qu'on n'aura point trouvé à sa lettre est traité ici, et à quelle page on en trouvera le développement. 


\section{$\mathrm{PAR}$}

PAPILLON-BOURDON. Nom donné par De Gécr aux insectes lépidop!ères des genres Sphinx, Smérintle et Sésie. Voyez ces inots. (S. F. et A. SERV.)

PAPIr.LONIDES, Papilionides. Première tribu de la famille des Diurnes, ordire des Lupidoptères. Vo, ez tome IX, page 9. (S. i'. el A. SERv.)

PAPILLON-PIIALÈNE. De Gée" nomme ainsi les insectes lépidoptères des genres Zygąine et Procris. Voyezces mots. (S. F. et A. SErv.)

PAPILLON-TIPULE. Dénomination donnée par De Géer aux iusectes lépidoptères du gente Ptérophore. Voyez ce mot. (S. H. et A. Senv.)

PARADCXITE. Nom donné par M. Bronguiart à un genre de Trilobites. I'oyez ce mot. (LATR.)

PARAGUE, Paragus. Latr. Meig. Malio. Ha B: Syrphus. Panz. Muscu. Gejf F.

Genre d'insectes de l'ordre des Diptères, section des Proboscidés, famille des Athéricères, tribu des Syrphies.

Un groupe de la tribu des Syrphies (voyez ce mot) a pour caractères : antennes plus courtes que la lềie, leurs deux pıemiers articles égaux entr'eux, point de tubercule froutal pour porter les antennes, ni cle cellule pédiforne aux ailes; cuisses simples, saus renflement ni ćpines; soie des antemes sans artieulations sensibles. Les Volucclles et les Séricomyies sont les seules duns ce groupe qui aient la suie des antennes plumeuse. Les geures Baccha, Chrysogastre, Psilote et Syrphe ont leur hypostome creusé on tuierculé. Les Pipizes et les Paragues ont la soie des antennes simple et l'hypostome uni; mais daus les premières, le truisième ou deruier article dey antennes est simplement ovale et non pas alongé, ce qui les distingue des Parigues.

Antennes atvancées, droites, presque de la longueur de la tête, composées de trois articles; les deux premiers courts, égaux; le troilième ou palette plus long que les deux précétens réunis, comprimé, portant une soie simple insérée un peu avant son milieu. - Yeux rapprochés et se réunissant 11n peu au-dessons du vertex dans les mâles, espacés dans les femelles. - Trois petits yeux lisses disposćs en triangle et placés sur le vertex. - Hypostome peu convexe, lisse. - Ailes parallèles, couchées sur le corps daus le repos, n'ayant point de cellule Hist. Nat. Ins. Tome $\boldsymbol{X}$. pédiforme. - Abdonen linéaire, convexe elı dessus, concave en dessous. - Pattes de longueur moyenne, cuisses simples, premier article des tarses postérieurs alongé et renflé.

On tronve ces diptìres sur les fleurs. M. Meigen décrit quatorze especes de ce genre établi par M. Latreille.

\section{PARAGue à zone, $P$. zonatus.}

Paragus niger, scutello immaculato, abdomine segmento secundo rufo (nuas) aut rufo basi apiceque nigris. (Fot'm.)

Paragus zonatus. Meig. Dipt. d'Europ.tom. 3. pag. $177 \cdot n^{\circ} \cdot 1$.

Longueur 2 lig. $\frac{x}{3}$. Antennes brunes. 'Tête noire, luisante, avec deux lignes blanches à l'orbite antérieur des yeux. Corselet entièrement noir luisant; cuillerous et bulanciers jaunâlıes. Abdomen noir luisant, le second segraent et uue grande partie du premier ferrugineux. Pattes noires, avec liextrémité des cuisses et les jambes blanches; le milieu de celles-ci brun. Ailes transparentes. Femelle.

Suivant M. Meigen, le mâle a l'hypostome entièrement hlanc et le deuxième seyiuent de l'abdomen, seulement, ferrugineux.

On le trouve au mois de mai dans les forêts, sur les fleurs; notamment sur celles du pissenlit. (Leontodon turaxacum.)

\section{Parague bicolor, $P$. bicolor.}

Paragus abdomine ferrugineo, basi apiceque nigris, scutello apice albo.

Paragus bicolor. Latr. Gener. Crust. et Ins. tom. 4. pag. 326. - Meig. Dipt. d'Europ. tom. 3. pag. 173. $n^{\circ}$. 2. - Mulio bicolor. Е'ав. Syjl. astlicat. pag. $186 . n^{\circ}$, jo. - La Mouche noire ì bande rouge trausverse sur le ventre. Georf. Ins. paris. tom. 2. pag. 520. $n^{\circ} .51$. - Coqueв. Illust. Icon. tab. 26. fig. 9. (Fabricins indique par erren la finure 9 de la plancle $2 \overrightarrow{5}$, qai est celle du Psure abuonitial.) - Encycl. pl. 39r.fig. 9-11.

Trongneur 3 lig. Anteunes brunes. Tête noire, lisse, avec deux lignes blanches à l'orbite antérteur des yeux. L'orbite postérieur couvert d'un duvet atgenté. Corselet noir luisant, ses côtés couverts d'un duvet argen!é; on lui voit deux petites lignes dorsales formées d'un semblable duvet. Bord postérieur de l'écusson blancbâtre. Cuillerons et balauciers jaunâtres. Abdomen noir; extrémité du preunier segment, le second tout enlier et la base du truisième, ferrugineux. Paltes 
noires, extrémité des cuisses, toules les jambes et les tarses intermédiures, d’un ferrugineux pûle. Ailes transparentes. Femplle.

Le màle a lihypostome entièrement blanc; ses quatre tarses antérieurs sont pâles et la partie ferrugineuse de l'abdomen est neçiće d'un peu de binn.

Des environs de laris uinsi gue le précédent.

\section{Pamagur arqué, $P$. arcuatus.}

paragus niger, scutello apice albo, abdomine físciầ testaceâ et arcubus tribus intetruptis abibis.

Paragus arcuatts. Meig. Dipt. d’Eutop. tom. 3. pag. 179. $n^{\circ}$. 3. tub. 27. fig. 20 et 21 .

Longneur 5 ligr. Noir. Extrémilé de l'écusson bianche. Partie poslérieure du prenier segment de l'abdomen et base du second, testacées. Le sccond, le troisième et le quatrième ayant clazcun une bande blanclse interrompue dans son milieu. Pattes pâles arec la base des cuisses, noire. Hypostome lolanc. Ailes transparentes. Mâle.

De Provenee. Nous n’avons pas va celle espèce.

\section{Parague rayé, $P$. strigutus.}

Paragus abdomine nufo, fasciis internplis nigris.

Paragus strigatus. Mrig. Dipt. d'Eur. tom. 3. pag. $180 . n^{\circ} .5$.

Longrueur 2 'igg. Antennes brunes. Tête noire. Hypostome blanc. Corselel noir, ses eôtés garnis d'un duvet argenté; il a une large ligne dorsale, formée d'un semblable duvet. Bord postéricur de l'éeusson blanchittre. Cuillerous et balanciers blancs. Abdomen ferrugıneux; base dı premier segment noire; une barde transverse, interrompue de même couleur sur tous les segmens. Paltes pâles; base des cuisses brune. Ailes transparentes. Mî̀le.

Il a été rapporté des envirnns de Montpellier far M. de Saint-Faryeau, oflcier de la Garde.

\section{Parague front blanc, $P$. albifrons.}

Paragus niger, abdounine arcubus quatuor interruptis scutelloque apice albis.

Paingus albifrons. MEig. Dipt. d'Europ. tom. 5. pag. 181. $2^{\circ}$. 8. - Parrgus thymiastri. I.Aт. Gen. Crust. et Ins. toru. 4. pag. 326. Syrphus thymustri. Panz. Fuun. Germ. fass. 6o. fig. I2.

Longuen 3 lig. Noir. Hypostome blanc. Bord postériear de l'écusson blanc; une baude arquée, blanche, interrompue dans son milieu sur chatcun des sermens de l'abdomen. Pattes blanchîtres, base de toutes les cuisses et extrémité des jambes postéricuses, noires. Ailes transparentes. Miale.

D'Autriche. Nous ne conuoissons point eelle espece, non plus que la suivante.

\section{Parague hénorrhoidal, $P$. hocniorrhous.}

Paragus niger, abdomine apice sanguineo, pedibus flavis, femortbus nigris apice fluvis.

Paragus hoxmothous. MeIG. Dipt. d'Europ. tom. 3. pag. 182. $n^{\circ}$. 10.

Longueur 2 lig. Noir. Deux lignes blanches ì l'orbile antérienr des yeux. Extrótnilé de l'abdomeas d'un ronge sanguin. Palles jaunes avec la buse des cuisses, noile.

D'Autriche et de France. (S. F. et A. Serv.)

PARANDRE, Parandra. Tast. Attelabus. DE GÉn. Isocerus. ilnig. Scurites, Tenebrio. Fab. Geure d'insectces de l'ordie des Colćonteres, section des Tétranceres, fumille des Platysomes.

Celle fanille ne comprenant que guatre genres, n’a pasété divisce in tribus. Les Ulíioles ct les Passulutres ont les antennes composées d'articles longs, cylindriques ou obconiques et conprimés. Lés Cucujes oat un labre avancé très-apparent, les tarses tres-courts, le corps fortement dépriné; par l'énoncé de ces caraclères on disliriguera fucilemeut ces trois genres de celui de Parundae.

Antennes filiformes, instries au-devant des yeux, courtes, comprimées, coinposćes lie onze articles presque moniliformes, le dernier oblong, termuré en pointe. - Labre point apparent. Mandibuies fortes, avancées, smrtout dans les mâles, tantơt lunulées, tantôt triangulaires, ayant quelques dents au côté interne. - Mâchoires nofirant à leur extrémilé qu'un seul lobe crustacé, presque cylindrique, un peu plus large et arroudi a son extrémité supérienre. - Palpes courts, litiformes, terminćs par un article ovale. - Lère entièrement crustacée, courte, large; langtietle entière. - Téle déprimée, horizontale, prescqu'aussi large que le corselel. - Yeux alongés, un peu écliancrés. - Corps alongé, peu déprimé. - Corselet de la largeur des élytres, presque carré, rebordé toll alalour. - Ecusson petit, lrianguluire. - Elytres longues, linćaires, rebordíes, couvrant les ailes et l'aldodomen. Pattes rohustes, un peu comprimées; cuisses ovales-oblongues; janbes en forme de triaugle alungé et renversé, terminées extéricurement par un angle aigu, avancé en manicre de deut et par deux épines situées à l'ingle iuterne; larses longs; leur cernier article très-alongé, globuleux à sa base, réréci ensuite, terminé par deux crocheis simplez, fort pointis, présentant daus leur intervalle un petil appendice muni de deux soies diverigentes. Les trois premiers arlieles garmis on 
dessnus d'une petite brosse qui parnit divisée longitudinalemeut en deux. Avant-durnier article un pen lificle; le premier un peu plus long que les denx suivans.

Ce genre, que l'on doit à M. Latreille, we contient yu'un petit nombre d'espèces, lir plupart américaines; leurs conleurs ordinaires sont le brun ou le marron. Nous ne connoissons point leurs noeurs, mais bous présumons avec M. Latreille qu'ils vivent daus le bois ou sous l'écurce des arbres al la manière des Cacnjes. Ces Coléoptères ont quelques rapports avec les lacanes, ainsi qu'on peut le voir par leurs caractères génériques.

\section{Parandre glabre, $P$. glabra.}

Parandra magna, casiunea, subtiliterpunctala; capite anticè fúsco.

Parandra glabra. Seно. Smon. Ins. - Attelabus glaber. De Géen, lns. tom. 4. pl. 13. Jis. 14. - Scarites testaceus. Fa B. Sy'st. Eleut. tom. I. pag. 123. $n^{\prime \prime}$. วँ.

Longuenr 15 à 14 ligg. Entière asent testacéechîtain, luisan!e, fimement pointillée; purtie antérieure de la tête de couleur brune.

Dn Brésil.

Nota. Notre individu femelle a les bords extérieurs du corselei ua peu arrondis, les mandibules courtes, triangulates, fortement irhancrées à leur partie interne avant le milieu. Datus celui que nous regirdons conne le mâle, la tête rest plus brune, les bords du corselet sont prescye droits, son rebord latéral est en partie caché en dessous; les maralibules sont presque de la longueur de la tête, arquées : elles n'ont qu'une très-petite dent intérienre vers le milieu.

\section{Parandre lisse, P. lovis.} fusco.

Parandia castanea, profundè punctata, ore

Parindra lavis. Lat. Gener. Crust. et Ins. tom. 3. pag. 23 pl. g. fig. 7. Le male. - Schos. Synon. Ins. - Encycl. pl. 30 ir.fig. 9. Le mâle.

Longuenr 6 à 7 lig. Entièrement lestacée châtain clair, assez fortement ponctuée, un peu luisante. Bonche biune. Mandibules très-ponctuées, bideulées au côté interne, presquatanssi longues que la tèie et terminées eu une pointe simple dans le mile, plus courtes et fourchues a leur extrémitédins la fémelle.

Des Antilles.

Nola. La Parandra brunnea. Seno. (Tenebrio branneus. Fas.) de l'Antérique septentionale paroît n'être qu'une variété de cette espèce. La Parandra purpurea. Scro. (Tenebrio purpurascents d'Herbs', Col. tab. 119. fig. 2.) appar- ticnt aussi à ee gente. Colle ei est din Duésil. (S. I. et A. Serv.)

PARASITES. Divisions daus les tribus des Andrenètes et des Aniaires.

'Tontes les larve's des insectes hymónoptères de la fumille des Nelliferes ont pour uourriture obligée une espèce de pâte fuite d’un mélange de pollen des fleurs et de miel. Mais dans perque le tier's des yenres de celle nombreuse fumille, les femelles sout privées de pillettes et de brosse: pour la rícolte du pollen, el par conséquent forcées de póndre dans le nid des espéces qui sarent et peuveut récolter (1). Nous rezardons ce curactère, fundé sur les moeurs et l'organisaion, comme devant délerminer les enlonologistes a admentre denx divisions dans la ribu des Andrenètes, aninsi que dans celle des Apiaires, sous les noms de purusites et de récolluntes.

Les organes des Melliferes pour la récole du pollen, sont de deux sortes, et lenr appareace extérieure les distingne les uns des autres au premier coup d'ail. Les uns sont nus; ce soni des parlies du corps dénuées de poils on un pen eufoncées et rebordées, ou onbragées de grands cils qui les entonrent, dont los extrénités tendent à se rapproclier, et forment par leur courbure une espece de berceau au-dessus de la partie une. Avec divers anteuls, nous appelons cet organe, palette.

La palcte, nue, un peu enfoncée et rebordée, sert au dépòt et au transport d'un pullen qui a déjà subi une préparation (cire brute, Récumr.), doot les grains ne soitt plus distiucts, et qui est uĉlé d'un pen de miel, ainsi que l'indique le goât, lorsqu'on pose sur sa langue la pelotte dont on vient de dépouiller une ouvrière abeille (apis) ou bourdon (bombus), qui revient chargée à sa ruche. Cette espèce de palette u'apparlient qu'alux Apiaires sociales de M. Liltreille. Ce sont les seuls insectes qui aient besoiu de prépurer de la cire brute. Cetorgane est placé sur le disque extérieur de chaque jambe postérieuré, el trujours en mêrne temos sur celni du prenier article du tarse de la unênc paire de pattes.

La palette, toujours nue, mais entourće et ombragée de cils en berceau, se trouve dans plusieurs gences d'Andrenètes et d'Apiaires. Le pollen qu'elles y amassent, n'a subi aucune préparation que lia compression; tous ses grains sont cucore reconuoissibles, el il n'est pas mêlé de miel. Cet organe est siluć sul les deux côtés du nélathorax, et alors il s'en trouve toujours un semólable placé sur la partie correspondante dus deux euisses postéricures.

(1) La larve du Parasite éciôt plus tôt que celle de l'ha. bitanre lérgitime, ę dévore la pâte mielleuse déposée par la mère qui a fait le nid, et dont la postérité se trouve par ce tais, lors de sa naissaice, réduire à une diserte absolus. 
L'autre organe accordé aux Mcllifères pour la récoltc du pollcn est ce qu'on a appelé la brosse. Il est garni de poils ćtagés, disposés par rangs distincts. La situation ct l'nsage de la brosse sont beaucoup plus variables que ceux de la palelte. Tous les Mellifères ont en effet des brosses, et la femelle féconde (reine, Réaum.) des ruches d'Abeilles ( Apis), est pcul-être la seule exception connue; mais ces brosses communes à tous, ne servent dans un grand nombre d'espèces et dans tous les mâles, qu'à la senle propreté. Cet organe est placé sur la partie intérieure des tarses de toutes les pattcs. En eflet, tons les Mellifères dans leur état parfait sont obligés d'aller chercher dans les fleurs le miel qui est nuc partic uotable de leur nourriture. 'Tous par conséquent en sortent ordinaircment suupoudiés de pullen. Ils peuvent, dans d'autres circonstances, sc salir de poussière qui, par sa ténuité, boucheroit leurs stigmates, si la nature ne leur avoil donné l'amour de la propreté et les instrumens ruécessiares pour se nettoyer. Les brosses dont nous venons de parler sont en géuéral cet organe de propreté, et sont accordées même aux Parasites, et nous les distinguons sous le nom de brossettes.

Dans tous les Mellifères récoltans, l'usagc des brossettes, outre cclui que nous venons de spécifier, est d'enlever le pollen aux étamines et de le transmettre aux palettes et aux brosses. Celui des organes auquel est confiée la fonctiou de rctenir en provision le pollen comprimé et de le transporter sans antre préparation au nid où il doit être employé, lorsque la placc quil occupe est couverte de poils, aura seul pour uous lc norm de brosse.

Dans les Apiaires sociales, les brosses sont situées à la partie intérieure des jambes et des tarses des deux pattes postérieures. Ditns d'autrcs genres de mellifères récoltans, elles sont placées sur la face extcrne des mêmes membres. Enfin, dans quelques autres genres d'Apiaires seulement, la brosse absolument conformée comme nous l'avons décrite, est unique, se trouve placée à la face inférieure de l'abdomen et couvre ainsi tout lc ventre.

Lorsque la brosse est située sur les jambes et les tarses postérieurs, conjointement avec la palette, cellc-ci sur la face, cxtérieure, l'antre sur lintérieure, ou seulement lorsque la brosse occupc la face extérieure dc ces membres, la jambe s'élargit insensiblement de sa base à sou articulation avec le tarse; elle devient un triangle plus ou moin' alongé, plus ou moins régulier. Dans ces mêmes circonstances, le premier articlc du tarse s'élargit et prend unc forme carrée; ce qui lui a fait donner par les auteurs le nom de pièce carrée.

La plupart des idécs que nous venons d'émettre sont dues à M1. Latreille, quc nous avonons facilcment poúr notre mâitre, et auquel nous devons en particulierla distinction méthrudiqne des Apiai r'es en solitaires ct sociales. Nous allons préseater ici, d'après les principes que nous venons de développer, le tablean des tribus des Andrenères et des Apiaires, dont nous adoptons tous les caractères posés par ce célèbre entomologiste.

$$
\text { Meziritéres (famille). }
$$

ro. Tribn des Andrenètes. (Lèvre repliée en dessus dans les uns, presque droite ou simplenent inclinée et courbe dans les autrcs.-Quatre palpes articulés, et ayant la forme ordinilire.) Latr.

I. Récoltantes (Fcmelles toujours pourvues de palettes ou de brosses pour la récolte du pollen des fleurs ), c'est-a-dire préparant ellesmêmes la nourriture de leur postérité.

A. Division intermédiaire de la lèvre lancéolée. - Femelles ayant unc palette de chaque côté du niélathorax, et une autre sur les cuisses postćrieures : leurs brosses placées sur le côtć extćrieur des jambes et du premier article des tarses des pattes postćrieures.

a. Trois cubitales. (Voyez Radiale.) Dasypode.

Scrapter.

b. Quatre cubitales. Andricne.

B. Division intcrmédiairc de la lèvre évasée et presqu'en coeur. - Femelles ayant une palelte de chaque côtć du métathoráx et une autre sur les cnisses postéricures. Point de brosses sur le côté extérieur des jambes ni sur celui dn premier article des tarses postérieurs. - Quatre cubitales. Collète.

C. Division intermédiaire de la lèvre courbée inférierrement, ou presque droite. - Feuielles comme dans le genre précédent. - Quatre cubitales.

$$
\begin{aligned}
& \text { Halicte. } \\
& \text { Nomie. }
\end{aligned}
$$

II. Parasites (Fernelles privées de palettes et de brosses pour la récolte du pollen des fleurs), c'cst-à-dire pondant dansle nid des récoltantes.

A. Division intermédiaire de la lèvre évasée et presqu'en cœur. - Trois cubilales. Prosope.

B. Division intermédiaire de la lèvre pea courbée inférieurement, presque droite. Quatre cubitales.

Sphécode.

Colux.

20. Tribu des Apiaires. (Lèvre fléchie en 


\section{P A R}

dessous et appliquée dans le repos contre sa gaîne. - Palpes labiaux ressemblant le plus souvent à des soies écailleuses, comprimées et terminées par deux aiticles très-petits.) Latr.

I. Parasites (Femelles privées de palettes et de brosses pour la récolte du pollen des fleurs), c'est-à-dire pondant dans les nids des récoltantes.

A. Ecusson sans épines, bituberculé an milieu; ces tubercules arrondis.

a. Quatre cubitales.

Nomade.

b. Trois cubitales.

Philérème.

B. Ecusson ayant une épine de chaque côté et deux tubercules au milieu. Epéole.

C. Ecusson bidenté.

a. Quatre cubitales.

Aglaé.

Mésochère.

Mélecte.

Mésonychie.

b. Trois cubitales.

Coelioxyde.

Dioxyde.

D. Ecusson mutiques

a. Quatre cubitales.

Cératine.

b. Trois cubitales.

Allodapé.

Pasite.

Ammobate.

Stélide.

II. Récoltantes (Femelles pourvues de brosses et quelquefois en outre de palettes pour la rècolte du pollen des fleurs), c'est-ì-dire préparant elles-mêmes la nourriture de leur. postérité.

A. Apiaires solitaires (Femelles à jambes privées de paleltes), c'est-à-dire ne vivant pas en société.

a. Point de palettes au métuthorax ni aux cuisses postérieures.

† Une brosse unique pour la récolte du pollen des fleurs, couvrant le dessous du ventre (dans les fernelles). - Trois cubitales.

* Abdomen ovalaire.

Anthidie.

Osmie.

Anthocope.

Mégachile.
* Abdomen alongé, presque cylindrique.

Hériade.

f $f$ Une brosse pour la récolte du pollen des fleurs, placée sur le côté extérieur des jambes et dı premier ariicle des tar'ses des deux pattes postérieures (dans les femelles).

* Trois cubilales.

Rophite.

Eucère.

** Quatre cubitales.

q Yeux lisses disposés en ligne tranaversale.

Macrocère.

Systrophe.

Monæque.

Mélitome.

Epicharis.

9 Yeux lisses disposés en triangle.

Centris.

Lagripode.

Anthophore.

Méliturge.

Acanllope.

Xylocope.

Lestis.

b. Une palette de claque côté du métathorax et une autre sur les cuisses postéricures.

Oxée.

Panurge.

B. Apiairessociales (Femelles pourvues d'une palette à la dernière paire de jambes), c'est-à-dire virant en société composíe de femelles fécondes, de femelles stíriles et de mâtles.

a. Jambes postérieures terminées par deux épines. - Radiule fermée; troisième cubitale n'étant pas placée obliquement. (Société d'une anuée, se dispersunt a la fin de la belle saison, renfer-m mant plusieurs fenelles fécondes. )

Euglosse.

Bourdon.

b. Jambes postérieures sans épines à l'extrémitć. (Société durant plusieurs années, n'ayant quu'une seule femelle féconde.)

f Radiale fermée : troisième cubitale oblique.

\section{Abeille.}

if Radiale ouverte : cubitales mal tracées.

Trigone.

$$
\text { (S. F. et.A. Serv.) }
$$


PARASITES ou RHINAPTERES. Dans sa $Z$ Oologie analytique, M. Dunéril a donné ce noı a une famblle d'Aptires ayant pour caractères: point de mâchoires ni d'arles; elle est composée des geures Puce, Pou et Tique. Dans un olivrage postérienr il l'a augmentée de trois antres geures. Yoyezl'article sutivint. (S. F. el A.Senv.)

PARASITES, Farufula. Troisiène ordie de ma classe des insectes, ainsi désigné, parce que tous ceux lont il se compose et compris pur Linné daus son gente Pediculus, vivent atux déficus de l'homue, de certains mamniferes et de divers nisein:, sur lesquels is se tienneat constaninent fixés : j’avois élabli celle coupe dars mon Précis des carictères génériques des insectes, imprimé en $179^{6}$, el il formoit alors le dixième ordre de celle chasse d'animaux. lacs l'arasites ne se partureoient d'abrorl qu'en deux gentes, dout l'un, celui de Ricm (De Géer), n'étoit qu'un démembrement de colni de Pou, pediculus. Le doctenr Léach a substitué la dénomination d'Anoplures, anoplura, à celle de Parasiles. Il divise cet ordre en deux timilles, les Péticulidés, pedicutuder (le genre Pou proprement dit) et les Nirmidós, nirmidea (le genre Ricin, De Géer). La premicre se compose des genres Phthire, phthirics, Irematopine, hermathopizus, et Pou, pediculus; et la seconde de cêlui de Nirue, mirnus, dénomination eupruntće d'Herruann. Le prolesseur Nit\%cli, dans sis Distribution générale des insectes épizoüques, faisant pattie du $\boldsymbol{M} \alpha_{\varepsilon}$ crasin entomologrque dr \$1. Germar, n'adinet point cet ordre. Lai jlemière de ces deus firuilles ou le genre primitif de licin est rapporté aux ortaopteres, et la secuade alux hémiptires. Les orthoptères épizn1ques on mallophages comprennent les genres suivans: $1^{\circ}$. Plisiloptèe, phalopterts, formé des soirsGeares Docophorus, Nimus, Lipcurus, Goniodes; $2^{\circ}$. 'Trichodecte, trichodectes; 30 . Linthé, liotheum, divisé en six sous-grenres, Colpocephalum, Menopon, Trinoton, Eureum, Lamobothrion, Physostomum; 40. Gyrope, gyropus.

Les hémipières épizoiques ne sonl composćs que dn gente Pou, pediculas. L'exposition des caractè es génúriques donnćs par ce naturaliste est fondće sur un grand notsore d'observations d'anatomie, tanl interne qu’extérieure. Il introdait quelgues nonveanx termes, et il est le premier qui ait employé les dénoninations de prothorax, de mésothoriax et de méthathorax, pour distinguer les trois segmens du thorax. Ea rendant justice an mérite de ce travail, nous croyons cependant qu'òn ne pent, diuns une arćthode natorelle, réunir ces auimaur soit avec les orthoptères, soit avec les hémiptères. Une telle confusion wous paroit même singulièrement bizarre.

Fabricius, d'après les bases sur lesquelles il avoit établi son système entomologique, a placé le grence Pediculas dans son ordre des Antliates ou celui des Diptères. Mais comme ces insectes sont sujels ì des métanor phoses conplètes, tandis que les hémiplères n'en éprouvent que d'incomplètes, c'est pour ce motif, je présume, que M. Nilzelh a triasporté dans cet ordre le gente précédent. Mais je tse vois pas quels rapports peurent avoir les Ricins avec les Orthoptères. Des insectes de cet nidre et du précédent sont, il est vrai, apteres; mais ce sont des anomalies. Les parasites, de même que les Accurus de Linné, autre limille de parasites, mais dans une classe différente, appartiennent à une division d'animanx naturellement et coustamment privés d'ailes. Telle a ćté leur destination primitive; car aucune espèce ne inous a offert jusqu'ici ni de rudimens d'ailes, ni d"indices d'avortemens de ces organes.

Dans la méthode de Bl. Duméril (Considé. rations générales sur les insectes), le nom de parasites ou de rhinapteres est doncé à sa première famille de son ordre d'A plères, la cinquantecinquième de la classe : elle comprend les genres Puce, Pon, Smaridie, Tique, Lepte et Sarcopte. Les quatre derniers appartiennent à notre ordre des Aracbnides trachéennes.

L'enscuble des caraclàres snivans ne permetlra point de conlondre les parasites uvec des insccles aptères des antres ordres. Ailes nulles. - Preds alu noubre de six. - Métamorphoses nulles. -Quatre ou denx ocelles ou yeux lisses. - Bouche des uns constilmée par un museau, arec un petil tube ou siphon inaticule, rétractile; celle des autres inférienre, composće de nándibules plus ou innins extérieures el en forme de crochets, de deux levves, cé michones cachées et quelquelois de palpes, mais tres-peti apparens; œsophage occopant nne grande partie de la lêtc. - Abdomen sans appeudices mohiles sur les côtés, et print ierminé par des sries articulćes ni de queue fonrchine. - Insectes vivant sur lhomme, sur dés fuanmifères et des viseaux, dont ils sucent le sang ou dont ils rongent des parties.

Je parlage les parasiles en deux familles, celle des Mandibules, misndibulata, et celle des Rusrasis, rostratre.

Les prenters onl des mandibules, des mâcloo:res et deux levres. Tes gemres de celte faniille seront exposés à l'article Ricin.

Dans la seconde, que j’avois désignée dans le Noupeau Dictionnaire d"histoire naturelle sous la dénomination d'Eadentulés (edentula), la bouclse ne consiste qu'en yo museau, d'vì sort à volonté un petit siphon. Voyez l'article Pou. (Litr.)

\section{PARNASSIEN, Parnassius.}

Genre de Lépidoptères diurnes. Voy. tor. IX, pag. 78 de ce Dictionnaire. (S. F. el A. SErv.)

PARNE, Parnus. Fabricius a filit sous ce nom, un genre de Coléoptères, daus lequel il mel le Dryops auriculé d'Olivier, l'Hydère acuminée de 
MI. Latreille (genre Potamophile de M. Germar), et une autre espèce, sous le nom spécifique d'Obscurus, qui a servi de type à M. Muller pour l'établissement du gente Macronyque. Voyez Ротаmophise et Macronyque à la iable de ce voluase. (S. F. et A. Serv.)

PARNopìs, Parnopes. LAt. Fab. Le P. SpIxol. Chrysis. Ourv. (Eneyel.) Jur. Ross.

Genre d'insectes de l'ordce des Hyménoptères, section des 'Térébrans, famille des Pupivores, tribu des Chrysides.

Dins la tribu des Chrysides, le genre Clepte se distingue de tous les autres par son corselet rétréci en devant, et par son abdomen qui n'est point voûté en dessous; les Euehrées, les Chrysis et les IIédychres n'ont poin! le milien de lenr métathorax prolongé en noe pointe scutelliforme. Daris les Elan pes et les Stilbes, le second seyment de l'abdomen est plus grand que le premier, et même que l'anus. Tous ces genres sont distingués, en outre, the celui de Parnopès, par la brièveté de lenrs mîtchires et de leur lèvre, qui ne formeut point de fausse trompe alongée.

Antennes tiliformes, coudées, vibratiles, inséries pres de la bouclie, de treize articles dins les deux sexes. - Mîchoires el lèvre très-longues, linéares, formant, réunies, une sorte de trompe fléchie en dessous. - Lèpre bitidc. - Palpes trèscourts, peu distincts, de deux articles. - Této transversale, ì peu près de la largeur du corselet. - Trois petits yeux lisses, pusés en trinugle sur le vertex. - Partic moyenue du métathorax s'avançant en une pointe seutellifurme; ćcalle des ailes grande, arrondie, convere. - tiles supéricures ayant nne cellule radiale el me cellnle cubitale, toutes deux ineomplètes; deux cellules discordales distinctes, savoir : la première el la seconde supérieures ( 1 ); la discoilale inférieure point tracée. - Abdomen convexe en dessus, concave en dessous, composé de deux segrnens, outre l'auns daus les femelles, en ayant un de plus dans les màles; anns très-grand, forianat à lui senl près de la moitié de l'abdomen, fincment dentelé sur ses bords, ayant nn enfoncernent transversal à sa parlie postérienre, sans línes de puinis cufoncés. Une tarière réltacile dans les femelli's, mais dont l'extrémité reste toujours un pen saillante, mềme dans le repos; nn aiguillon rétrac:tile, ayaut sa sortie un peu avant l'extrémité de la turièie. - Tarses fortement ciliés, et propres à fonir, dans les femclles.

C'est à M. Latreilie que l'on doit ee gente, colstposé d'une seule especce. Lit femelle dépnse ses oufs dans les nids du Beubex à bee ( $B$. rostrata); et soil que la larve qui en éclòt, doive se nourru de eelle dn Bembex, re que nous croyons, soit que la proie destinée à celle-ci soil dévorée

(1) Voyez la note di l'article Puprgonss. par elle, elle subit touies ses métamorphoses dans les trous creusés dans le sable par la femelle Bembex. C'est en l'absence de celle dernière que le Parnopès femelle s'y introduit; el comare le Bembex en partant recouvre de sable l'entrée de son nid, la nature paroit avoir donnć des paltes fouisseuses aux Parnopès, afn de pouroir déblayer l'ouverture de ce nid el y pénétrer. L'insecte parf.it paroit dans les moisde juillet et d'août, et n'est eommun que dans les endroils sablomeax, où les Bembex établissent leu's nids.

\section{Parnopìs incarmat, $P$. camea.}

Parnopes carnea. Sat. Gener Crust. et Ins. tom. 4. pag. 47. - FA B. Syst. Piez. pag. $177^{\circ}$ no. 1. - Ross. Fisun. Etris. tom. 2. tab. 8. fig. 5. - Chrysis carnéa. Coqueb. Illnst. Icon. tab. Ja. fig. 11. - Incycl. pl. 383. fig. 14-18.

Se trouve en France, aux environs de Paris.

Voyez pour la description et les autres synomes, Chrysis iuearnal, no. 3. pl. 583. fig. 14-18.

ĹLAMPE, Elumpus. Spinos. Lat. Chrysis. FAb. Jur. Oliv. (Eneycl.) Hedychrum, Le P. Paxz. révis.

Geare d'iuseetes de loordre des IIyménoplères, seetion des 'Téréprars, furbille des inpivores, tribu des Chrysides.

Le cenre Stibe, très-roisin de elui d'Elampe, s'cn distingae par ses riandibules dentées el par son anus portant un bourrelet transversal, audessous duguel est une cangée die prinis enfonećs. Les Parnopès qui, senls parmi les Chrysides, ont comme les Stibes el les Elames, le milicu da métathorax prolongé en une pointe sculelliforme, se reeounoissent facileneut al la longueur de lenrs urichoires et de leur levre, r̨ui soni linéaires et se réunissent eu une sorte de trompe longue, fléchie en dessous.

Antennes filifurmes, coudées, vibratiles, rapprochérs, insérces près de la bouche, de treize arbicles dans les deux sexes; les denx premiers obcorignes; le second court; le troisième cylirdrique, un pen aminci à sa buse jles autres courts, cylindriques; le dernier presque coniqne. - Nandibules munies de dens cients inguës at côté intéricur. - Máchoires ayant lem lube interne plas large que l'exí́rieur, presyu'aronia. - Palpes metxilhires phus longs que les labiaux, de cing articles, les tabianx dte tron. - Lère en cuiller ; languclle atrondie, entiere. - Téte anssi large que le rorm selet. - Trois pelits yeux lisses, placés en riangle sur le vertex. - Mćtathor ux ay aus sa parie moyesne avancée en une poinle sciatcliforme. - Ailes supérieures ayant une celiule radiale très-ineomplète et nne cellnle cubitale à peine tracće; la nervure qui les sépare, épaisse; denx cellules discoldales mal tracécs, il peinc visibles, savoir: la première et la seconde supérıeures. Cellule dis- 
coïdale nullement tracée. - Abdomen convexe en dessus, concave en dessous, ses côtés arrondis; il est composé de deux segmens outre l'anus; le second beaucoup plus grand que le premier. - Anus lisse, bi lenté postérientrement, sans bourrelet transversal ni rangće de points enfoncés; une tarière rétractile dans les fenelles, mais dont l'extréuité reste toujours un peu saillante, même dans le repos, et un aiguillon rélractile ayant sa sortie un pen avant l'extrémité de la tarièe. Paties de longueur moyenue.

Elanpe est tıré d'un mot gree, qui sionifie brillanl. (Loyez pour les mours le genre Enchrée à la colonne ci-contre.) On rapportera aux Elampes, le Chrysis doré, $11^{\circ}, 18$ de ce Diclionuaire; P'Elampus Panzeri de MII. Spinola et Latreille, Gener. Crust. et Ins. tom. 4, parr. 46 , et les esperces de na uremière division du genre Hédychre, dius aron Mémoire sur quelques espèces d'insectes hyminoplères porte-luyaux. Annal. alu Mus. d'List. nat. , ca':ier $58^{\circ}$

HÉDYCHRE, Hedychrum. LAt. Le P. Panz. Sprn.Chrysis. Linn. Laz. Onu v. (Encycl.)Ross. Jur.

Genre d'insectes de t'ordre des Hyanćnoptères, section des Térébrans, famille des Pupivores, tribu des Chrysides.

Daus le groupe des Chrysides, dont les Hédy chres font parile, les Euchrées el les Cinrysis se distinguent facilement par leur abdomen demicylindrique, dont les bords latéraux sont parallétes entreax, et par leur auas muni d'une rangée tratusversale de points enfonés.

Antennes contles, brisées, filiformes, s'amincissant petit à petit de la base à l'extrérnité, rapprochécs, viinratiles, iusérées près de la bouche, coinposées de treize articles duns les deux sezes; les deux premiers obconiques; le second court; le troisième cyliudrique, un peu aninci is sa base; les autres courts, cylindritgues; le dernier presque conique. - Mandibules au moins bidentées ilu côlé internc. - Mâchoires courtes. Palpes maxillaires Leaucoup plus longr que les labiaux, de cinq articles, les autres de trois. Lère profindénent échancrée, presque cordiforrae. - Tếe transversale, de la largeur du corselet. - Trois petits yeux lisses, piacés en triangle sur le vertex. - Cótés du métuthorax se prolongeant ea une épine lorte, sa partie noyenne arrondie. - siles supérieures ayant uise cellule radiale et are cellule cubitale, toutes denx fort ancomplètes; la nervare qui les sépare, épaisse - artont vers sa base, et denr cellules discoidales ual tracées, savoir: la prénic̀re et la seconde supérienres. Cellule discostale inférieure, nullement tracée. - Abdomen eonvexe en dessis, concave cu dessous, demi-tirculaire, ses côtés et son extrémité arrordis; il est composé do deux segmens, outre l'anus, celui-ci lisse, enier, n'ayaut ai Dourrelet transversal, ni rangée de points ; une tarière rélractile dans les femelles, mais dont l'extrémilé reste toujours saillante (plus que dans la plupart des autres Chrysides), même dans le repos, et un aiguillon rétractile, ayant sa sortie un peu avant l'extrémité de la tarière. - Pattes de longueur moyenne.

Les mœurs des Hédychres sont à peu près les mêmes que celles mentionnées au genre suivant. Les femelles pondent quelquefois dans les galles. L'Hédychre royal (Hed. regium) place ordinairement ses œut́s dans le nid de l'Osarie maçonne (Negachile muraria, Lat.). J'ai observé une feneile de cet Hédychre, qui, après être entrée la lête la première dans une cellule presqu'achevée de cette Osmie, en étoit ressortie, et comnençoit à y introduire la partie postérieure de son corps, en marchant en arrière, dans l'intention d'y déposer un œuf, lorsque l'Osmie arriva, porlant une provision de pollen et de miel; elle se jela aussitôt sur l'Hédychre, et il me parnt en ce moment que ses ailes produisoient un bruissement qui n'est point ordinaire. Elle saisit son ennemie avec ses mandibules; celle-ci, selon l'habitude des Chrysides, se contracta aussitôt en bonle, et si parfuilement, que les ailes seules dépassoient, L'Osmie ne pouvant la biesser, ses mandibules n'ayant ancune prise sur un corps aussi lisse, lui coupa les quatre ailes à ras du corselet et la laissit tomber à terre. Elle visita ensuite sa cellule avee une sorte d'inquiétude; puis, après avoiy déposé sa charge, elle retourna atix champs. Alors l'Hútlyclire, qui étoit resté quelque temps contracté, remonta le long du mur direciement an nid d’où il avoit été précipité, et reviat tranguillement pondre son cuf dans la cellule de l'Osmie. Il piace cet aull au-dessous du niveau de la pâtée, contre les parois de la cellule, ce qui empêche l'Osmie de l'apercevoir.

- Le genre Hédychre, fundé par M. Latreille, renferme plas d'espèces que le précédent.

On y rapportera le Chrysis lucidule, no. I 5 , et le Chrysis ardent, $1^{\circ}$. 16 , du présent Diciunnaire; le Chrysis rosea, Ross. Faun. Etrus. tab. 8. fig. 7; le Chrysis regia, HАв. Syst. Piez. pag. $175, n^{\circ} .26$, et d'aulres espèces qui forment la seconde divisiou du genre Hélycluce, dans le Méwoire cité à l'article précédent.

EUCHREE, Euchrous. Lat. Chrysis. FAB. Le P. Jur. Panz. Ontv. (Eacycl.)

Genre d'insectes de l'ordre des Hyménoptères, section des 'Térébrans, famille des Pupivores, tribu des Chrysides.

Les Eucbrées, les Chrysis et les Hédychres forment dans cette triba un petit gronpe distinct, parce que le milieu de !eur métathorax u'est point prolongé en une pointe scuielliforme et qu'ils n'ont point, comıne les Cleptes, le corselet retréci en devant. Les Hédychres ont leurs mandibnles au moins bidentées au côté interac, avec l'abdomea 
court, presque demi-circulaire. Dans les Chrysis, l'anus n'a point de bonrrelet transversal, la lèvre est entière, arrondie à son exıŕmité, et les palpes maxillaires sont plus longs que les mâchoires.

Antennes courtes, brisées, filiformes, s'amincissant petil à pelit de la base à l'extrémité, rapprochées, insérées près de la bouche, vibratiles; composées de treize articles dans les deux sexes, les denx premiers obconiques, le second court, le troisic̀me cylindrique, un peu aminci à sa base; les autres courts, cylindriques, le dernier presque conique. - Mandibules courtes, unidentées intérieurement vers leur bout. - Hâchoires ovales à leur sxtrémité, leur lobe intene plus courl que l'externe, et ne se prolongeant point en dent. Palpes égaux en longueur, les maxilaires plus courts que les mâchoires; leurs articles presque égalemenı gros, le dernier presqu'aussi long que le précédent; pilpes labiaux courts. - Lèure bifide, presqu'eu cœur. - Tête Iransversale, presqu'aussi large que le corselet, ayanı une dépression frontale. - Trois petits yeu.x lisses placés en triangle; l'antéricur sur le bord de la dépression fronlale, les autres sur le vertex. - Metathorax muni sur ses côtés d'une épiue forte; sa pariie moyenne arrondie. - Ailes superieures ayanı une cellule radiale et une cellule cubitule, toutes deux incomplètes. On voit dans celle-ci deux pelites nervures longitudinales coutes qui ne se rattaclient à aucune autre, et deux ccllules discoidales distinctes; savoir : la première el la seconde supérieures. Cellule discoïdale inférieure point tracée. - Abdollen convexe en dessus, concave en dessous, derni-cylindrique, composé de deux segmens, outre l'anus; le premier court, le second fort grand; l'anus traversé par un fort bourrelet, au-dessous duquel on voit une rangée transverse de points enfoncés; tarière (des femelles) rétractile, mais dont l'extrémité reste loujour's un peu saillanle même dans le repos; outre celte larière il $\mathrm{y}$ a dans les femelles un aiguillon rétractile qui a sa sortie un peu avant l'extrémité de la tarière. Pattes de longueur moyeune.

Les mœurs des Euchrées sont les mêmes que celles de la plupart des autres Chrysides; leurs larves vivent aux dépens de celles de divers hyménoptères. La femelle au moyen de sa tarière dépose un œuf dans la cellule commencée, à laquelle la propriétaire doit aussi confier le sien. Celui du Chryside n'éclôt que lorsque la larve, habitante légitime de la cellule où elles sont toutes deux renfermées, a déjà pris la plus grande partie de son accroissement; elle se pose sur le dos de celle-ci, l'altaque et la suce, mais d'une manière qui ne lui fait pas perdre promptement la vie; ce n'est que lorsqu'elle-même a pris dans un court espace de temps presque toute sa croissance, qu'elle achève de dél:uire sa viclime. Les larves des Chrysides ne se forment point de coque Hist. Nat. Ins. Tome $X$. pour subir leur mélamorphose. Elles restent longtemps à l'ćtat de nymphe'. L'insecte parfait ne parcît ordinairement que launée suivante.

Ce genre que l'on doit à M. Latreille, conlient peu d'espèces. On doit y rapporter, ${ }^{\circ}$. le Chrysis pourpré no. 10 de ce Diclionnaire (Euchrceus purpuratus, LAT.); $2^{\circ}$. l'Euchrous sexdentatus, Lat. Gener. Crust. et Ins. toun. 4. pag. 49. Ces delıx espèces sollt des environs de Paris. Leur anus est mulıidenlé.

ClePte, Cleptes. Int. Fab. Ie P. Panz., révis. Sphex. Linn. Vcspa. Geoff. Chrysis. Oliv. (Encycl.)

Genre d'insectes de l'urdre des Hy ménoptères, section des Térébrans, famille des Pupivores, tribu des Chrysides.

Tous les genres de cette tribu, excepté celni de Clepte, onl l'abdomen concave en dessous et le corselet point rétréci en devant.

Antennes filiformes, coudées, vibratiles, rapprochées, insérées prìs de la bouche, de treize articles dans les deux sexes, le dernier presque conique. - Mandibules courtes, larges, triangulaires, creuses en dessous, comprimées et bidentées à l'extrémité. - Mâchoires ayant leur lobe terminal membrancux, presque triangulaire, le lobe extérieur en forme de petile den1. - Palpes maxillaires plus longs que les labiaux, de cinq arlicles inégaux, les deux premiers plus courts, le troisième plus épais, les deux derniers beaucoup plus longs que les autres; palpes labiaux de trois articles. - Lèvere arrondie à son extrémité, entière. - Tête à peu près aussi large que la partie moyenne du corselet. - Trois petits yeux lisses placés en triangle sur le vertex, l'autérieur au bord d'une petite fossette. - Premier segment du corselet beaucoup plus étroit que les suivans; côlés du mélalborax se prolongeant en une épine forte, sa parlie moyenne arrondie. - Ailcs supérieures ayant une cellule radiule presque fermée et une cellule cubitale à pcine tracée, très-incomplète; trois cellules discoïdales, l'inférieure s'étendanl jusquau bord postérieur de l'aile. Abdomen presqu'ovoïde, un peu convexe en dessus, l'étanl également en dessous, coroposé de trois ou quatre segmens outre l'anus, selon les espèces; une tarière rétractile dans les femelles, mais dont l'extrémilé reste toujours fort saillanle, mème dans le repos, et un aiguillon rétractile ayant sa sortie un peu avant l'extrémité de la tarière. - Pattes de longueur moyenne.

Les femelles de ce genre, établi par M. Lai treille, et dont le nom vienl d'un mot gres qusignifie voleur, placent leurs $\propto u f s$ auprès des larves ou sur les larves mêmes qui doivent servir de pâture à leur postérité. J'ai vu une femelle du Cleptesemi-doré, entrer successivement à reculons dans les trous qu'avoient formés, en s'enfonçant en terre, un grand nombre de larves d'une Ten- 
thrédine, qui avoient véeu sur un mếre groseiller. L'année suivante, je jouis i celle mène place d'un spectacle fort biil!ant; une centainede inâles, et quelques femelles de eette espice, couroient dans tous les sens sur le petil espace de ter. rain où les larves de Tenthrédine s'étoient caehées, et reflétuient tontes lés contenrs des pierres précieuses; bientôt les máles s'amoncelèrent par peits groupes, dot1 nne fenclie, acconplée avec un d'enf:'eux, étoit le centre. Ce spectacle se renouvela pour moi plusieurs jours de suite, de dix à onze heures du matio; ces individus se dispersoient aprìs celle leure, et je pense que ceux que je voyois chaque jour éloient nouvellement éelos dans cet endrcit.

On doit rapporter au gente Clepte, le Chrysis semi-doré, nº. 2 I de ce Dictionnaile (Cleptes simi-aurata, HA в. Syst. Piez.). Nious ferons obstrver que dans celte espèce, le premier article des antennes est mélallique, le second jaune, taché de lırun, le troisiène et quelquefois les deux suivans entièrement jaunes. Le dernier segment de l'abdomen et l'anus sout noirs en dessus; fe milieu du troisième segment parlicipe de celte cunleur dans sa partie inférieure. Le mâle est le Cleptes splendens, FAB. Syst. Piez.; mais cet anteur dit à tort que les pattes sont noires. Voyez pour les antres espèces, non Mémoire cité à l'article Elampe, parr. 8 de ee volume. (S. F. et A. Serv.)

PAROPSIDE, Paropsis. OLrv. (Entom.) Lat. Chrysomela. Fab. Notoclea. MARsa.

Genre d'insectes de l'ordre des Coléoptères, section des 'Tétramères, famille des Cycliques, tribu des Chrysomélines.

Dans cette tribu, les genres Eumolpe, Gribouri, Clythre et Chlamyde se distinguent par Jear tête verticale; les Colaspes par des mandibules terminées en une pointe très-forte et par.le dernier article des antennes long, presqu'elliptique, portant all bout une pointe palticuliere; les Prasocures ont le-corps alongé, presque liñaire; dans les Clirysouèles le dernier article des palpes est oroïde-tronqué ou presque cylindrique; enfin les Doryphores les ont terminés par un article beaucon' ph phis court que le précédent, et leur sternum est avancé en pointe. On ne tronve aucuus de ces caractères dans le genre Paropside.

Antennes minces, filiformes, presque de la longrueur du corps, insérées au-devant des yeux, près de la bouclie, composées de onze articles, le premier plus loig, un peu rentié, le second court, les autres un peu lưbinés, à peu près égaux entr'eux. - Labre coriace, presque membraneux, conrt, légèrement échaucré. - Mandibules courtes, cornées, creusées intérieurement, terninées par denx dents égales, obtuses. - Mâchoires nembrimeuses, conrtes, bifides. - Palpes maxillaires un peu plus longs que les labiaux, composés le quatre articles, le premier très.court, le second alongé, u!: peu renllé ì l'extrémité, le troisième conique, le dernier large, triangulare, sécuriforme ; les labiaux de trois ar!icles le premier courl, le second alongé, conique, le troisième ovale oblongr. - Lèvre niembraneuse, courte, trilobée. - Tête penclíe en avant, formant un angle obtus avec le corselet. - Corps arrondi, plat en dessous, Lombé en dessus. - Corselet large, convexe, irs-échancré en devant, arrondi postérieurement. - Ecusson petil, triangulaire. - Elytres très-convexes, plus grandes que l'abdonien, qu'el!es cubrassent un peu par les cốlés. - Pattes de longueur moyenne; tarses courts, asse\% largeses, pénuliène arlicle bilobé.

Ce gince, dont le nom vient d'un not gree qui sıgnifie écuelle, a élé fondé par M. Olivier, dans sou Entomologie; il contient des espèces propres aux îles de: la mer du Sud et ì la NouvelleHollande, dont N. Latreille avoit préc:ćdenıment, dans son Generr, fait la première division du genre Clrysomèle, sous le nom de Coccinelloides. C'est à tort que M. Olivier, en convertissant en genre la eoupe faile par M. Latreille, y a joint une espèce européeune (Chrysomela flavicans), qui m'a proint les caractères des Paropsides, et que ce dernier auteur en exclut avec raison. On ne connoît point les larves des insectes de ce genre. On les tronve dans l'élat parfait, sur les feuilles et les fleurs des végétaux. Ce sonı les seuls détails qu'aient communiqu's les voyagrems. Le nombre des espèces de Paropsides connues s'élève aujourd'bui à près de trente.

\section{Paropside varioliee, $\boldsymbol{P}$. variolosa.}

Puropsis piceo-testacea, elytris punctato-rugosis, tuberculis flavis sparsis.

Notoclea variolosa. Mansu. Trans. Soc. Linn. Londr. vol. 9. pag. 285. tab. 24. fig. 1.

Longueur 7 lig. Corps d'un testacé brun. Antenues brunes, leurs premiers articles testacés. 'Téte poncluée, ayant in sillon transversal du ınilieu duquel nâ̂l une ligrne longitudinale enfoncée, rraversant la partje postérieure de la lête. Corselet irrégulièrement pouctué, ses côlés déprimés el un peu plissés; ses angles antérieurs ayant cliacun une pointe mousse. Elytres fortenuent ponctuées, ridées transversalenient, avec des élévations irrégulières jaunattres. Paltes et dessous du corp̣s un peu plus foncés que le dessus.

Nouvelle-Hollande.

\section{Paropside atomaire, $P$. atomaria.}

Paropsis pallide testacea, elytris scabris punctisque impressis, transversè rugosis.

Paropsis atomaria. Ouı. Entom: tom. 5. pag. 5g8. no. 1. Parops. pl. 1.fig. I.-Notoclea 
stomaria. MArsi. Trans. Soc. Linn. Londr. yol. 9. pag. 236.tab. 24. fig. 3.-Encycl. pl.37ı. I. fig. r. a-d.

Longueur 5 lig. Corps d'un testacé pâle. Antennes de même couleur, leur base plus pâle. labire jaune. Tè̀te finement pointillée, ayant un sillon transversal arqué, du milieu duguel nuît unc ligne longitudinale enfoncée, traversant la partie postérieure de la têtc. Corsclet peu pointillé sur son disque, ses rôlés nu pen déprimés, profondément ponctués. Elytres chatgrinées, chargées d'un grand nombre de points bruns enfuncés, e? de rides transversales, irrégulières. Dessous du corps et paltes d'une nuance plus foucée.

Nouvelle-Hollande.

\section{Paropside immaculáe, $P$. immaculuta.}

Paropsisfusca, thorace elytrorumque marginibus fusco-rubris.

Notoclea inmaculata. Marsh. Trans. Soc. Linn. Londr. vol. g. pag. 291. tab. 25. fig. 4.

Iongueur 5 lig. $\frac{1}{2}$. Antennes, labre et paltes reslacés. Têle d'un brun ferruginenx, pointillée, àvec un sillon transversal arqué. Corselel de même coulewr, presque lisse sur son disque, ses côtés fortement pointillés. Elytres fortemerıl punchuées, brunes, aver, tous leurs borts, la suture el l'écusson, de couleur ferminineuse. Dessous du corps et patles de cette inêrae couleur.

Nouvelle-Hollande.

4. Paropsine brune, $P$. picea.

Paropsis fusco-ferniginea, elytris subpunctatis.

Paropsis picea. Orrv. Entom. tom. 5. pag. $59 g$. n。. 3. Parops. pl. 1. fig. 3. - Encycl. pl. 37ı. I. fig. 4 .

Longueur 5 lig. Corps d'un brun ferrugineux, un pen moins arrondi que dans les précédentes. Aulenues brunes, leur base d'un lestacé pâle. Labre de cetle dernière couleur. 'Tête un peu pointillće, avec un sillun transversal arqué et une foible iapression de chaque côté postérienrement. Corselet finement pointillé, presque lisse sur le disque, ses côlés sensiblement déprimés, ayant des points enfoncés plus marqués. Elytres très-finement pointillées, ces points furmant presque des stries régulic̀res. Palles de la couleur du corps. Poilrine d'une auance plus funcée.

Nonvelle-Hollunde.

5. Panopside marbrée, P. marmorea.

paropsis luteo-rufa, elytrorum punctatorum disco ferrugineo flavo maculato.

Paropsis marmonea. Ourv. Entom. tom. 5. pag. 599. no. 4. Parops. pl. 1. fig. 4. - Encycl. pl. 37 i. R. fig. 7 .

Longneur $4 \mathrm{lig}$. Corps d'un jaune mêlé de ferrugineux. Anlennes noires avec la base jaunc. bre d'un blanc jaunàtrc. Têle pointillée avec un sillon transversal arqué. Corselet pointillé principalement sur ses bords qui sout sersiblement déprimés. Elytres irréguliçrement ponctuées, leur disque ferrugineix, portant des plaques irrégulières jaunes, un peu élevées. Pattes de la couleur da corps.

Nouvelle-Hollande.

6. Paropstde effacée, P. obsoleta.

Paropsis testacea, elytris punctatis, maculis duodecim obsoletis fuscis.

Paropsis obsoleta. Oniv. Entom, tom. 5. pag. 6oo. $n^{\circ}$. 5. Parops. pl. 1. fig. 5. - Notoclea obsoleta. Marsh. Trans. Soc. Linn. Londr. vol. 9. pag. 288. tab. 24. fig. 6. - Encycl. pl. 37 1. I. fig. 8.

Longueur 3 lig. $\frac{1}{2}$. Corps d'un testacé jannâuc. Antennes noires, lestacées à leur base. Corselet lisse au milieu, ponclué vers ses bords. Elytres ponctuées, ces poists ferrugineux; duuze petiles taches obscures sur chacune, peu marquées, disposées sur trois rangées.

Nota. Le nombre des taclies varie de dix à treize sur chirque élytre.

Nouvelle-Hollande.

7. Paropside leslacée, $\boldsymbol{P}$. testacea.

Paropsis testacea, elytris subtilissime punctato-striatis.

Paropsis testacea. Ouıv. Entom. tom. 5. pag. 602. $n^{\circ}$. 1о. Parops. pl. I. fig. 10. - Notoclea testacea. M Arsh. Trans. Soc. Linn. Londr. vol. 9 . pag. 289. tab. 24. fig. 10. - Lncycl. pl. 37ı. I. fig. 6.

Longuenr 3 ligr. Entièrement testacée. Elytres avec des strics de points peu marqués.

Nouvelle-Hollande.

8. Paropside australe, P. Australasia.

Paropsis testacea, elytrorum disco obscuriore lituris fluvescentibus.

Paropsis Australasiar. OLIv. Entom. tom. 5. pag. 603. no. 11. Parops. pl. 1. fig. 11. - Chrysomela Australasioe. H' $\mathrm{AB}_{\mathrm{A}}$ Syst. Eleut. tom. I. pag. 426. $n^{\circ}$. 23. - Encycl.pl. 37ı. I.fig. 9.

Longueur 2 ligr. $\frac{7}{3}$. Corps lestacé. Antennes testacées, obscures à leur extrćmité. 'Tête et corselet finement pointillés. Elytres chargées de points enfoncés, rapproclıćs, presque disposés en stries, leur disque plas obscur, avec quelques 
lignes jaunâtres courtes et irréculières. Pattes de la couleur dir corps.

Iles de la mer dn Sud.

Nota. Nous n'avons pas décrit ces trois dernières espèces d'après nature.

\section{Paropside six pustules, $P$. sexpustulata.}

Paropsis nigra, thoracis utrinquè intpressi margine externo et coleopterorum maculis sex rubris.

Notoclea sexpustulata. Marsh. Trans. Linn. Soc. Londr. vol. 9. pug. 293. pl. 25. fig. 8.

Longucur 6 lig. An:cnnes bruncs, leurs second et troisième articles un peu ferrugineisx. Tête noire, pointillée; bord antérieur du labre rougeitrc. Corselet uoir, poiutillé, ses bords latéraux rongeâlrcs avec une inupression très-marquée, un peu arquée. Elytres noires, légèrement pointillćes, ayant des stries pouctuies peu sensibles ct portant chacune tros taches rondes rougeiines, les dcux pnstérieures sur une unéme ligac transversale. Paltes et dessous du corps nuirs.

\section{Nouvello-Hollande.}

DORYPHORE, Doryphora. Iluig. Oliv. (Entom.) Lat. Chrysomela. Fad. De GÉer. Oliv. (Eacycl.)

Genre d'insectes de l'ordre des Coléoptères, section des 'Tétramères, firmille des Cycliques, tribu des Chrysomélines.

Tous les genres de cette tribu, sauf celui de Doryphore, oni leur sternum conrt et simple.

Antennes filiformes, guère plus longues que le corsclet, iusérées an-devant des yeux, conposées de onze articles, le premier peu alongé, le second court, arrondi, le troisièmc alongé, presque conique, les autres presqu'धgaux entr'eux. - Labre corné, un pen avancé, arrondi antérieurement. - Mandibules cornées, un peu arquées, creusées en cuiller intérieurement, dentelées au bord supérieur, terminćcs par deux on trois dents obtuses. - Mrâchoires cornées, divisées en deux loles, l'extérieur arroudi, cilié à son extrémité, l'inlérieur comprimé, pointu, cilié au bord interue. - Palpes maxillaires de quatre articles, le prenier petit, le second conrt, un peu conique, le troisième grand, presqu'cn entonnoir, le dernier très-court, eachâssé dans le précédent et trouqué; palpes latjiaux courts, de trois articles, le premier pelit, le second trèsgros, le dernier plus petit, ovale. - Lère cornée, étroite, avancée, un jpeu échancrée à l'extrémité. - Tête penchce en avant, formant un angle oblus avec le corselet. - Corps ovale ou arrondi, très-convexe en dessus, aplati en dessous, presqu'hémisphérique. - Corselet large ,
Échancré en devant. - Sternum portant une sorte d'épine grosse, forte, dirigée en avant, plns ou moius recoudjece. - Ecusson triangulatirc. Elytres convexes, couvrant les ailes et l'abdomen. - Pattes de longueur moyenue.

I.e nom de ce geure vient de deux mots grecs, et signifie porte-lance. Il est assez nombrenx en espèces et propre a l'Auérique méridionale; ses mœurs doiven ếre les mêmes que celles des Clirysomcles, aree lesquelkes on l'avoit ancicanenuent confondu.

Les Chrysomèles pustulée, $\mathrm{n}^{\circ} \cdot 12$, pointillée, no. 13, miliaire, $11^{\circ} .14$, aiguë, no. 15 , arquée, $n^{\circ} .16$, maculée, $n^{\circ} .17$, de ce Dictionnaire, sont de ce geure, ainsi que la Chrysontela suturalis, no. $n^{5}$. Fа а. Sjst. Eleut.

COLASPE, Colaspis. FAв. Oriv. (Entom.) Lat. Eumolpus. FAB. Cryptocephalus, Chrysomela. Otuv. (Encycl.)

Genre dinsectes de l'ordre des Coléoplèrcs, section des T'élramèrcs, famille des Cycliques, tribu des Chrysomélines.

Les genres tumolpe, Gribouri, Clythre it Chlamyde se distinguent dans cettc tribu par lear tête verticale, les Prasocures par leur corps linéaire, les Paropsides, les Doryphores et 1:. Chrysomèles par leur's mandibules courtes et obtuses, ainsi que par le dernier article de leurs aulcunes simple et sans pointe particulière.

Antennes longncs, filiformes, composées de onze articles, les quatre avant-derniers en cône renvcrsé ct alongé, comprimés ou obtrigones, le dernierdong, presqu'elliptique, terminé par une pointe qui semble former un donziène arliclc. Labre coriace, un peu échancré. - Mandibules cornées, arquées, peu avancćes, bidentées à leur extrémité, terminées par une forte pointe. Mâchoires coriaces, bifiłes, leur lobe exlérieur alongé, cylindrique, un peu arqué, l'intérien. comprimé, arrondi, presque membraneux. Palpes filiformes; les maxillaires un peu plus longs, dc quatre articles, le premier court, le second alongé, presque cylindrique, le troisième de même forme, mais plus court que le précédent, le dernier alongé, ovoide; palpes labiaux de trois articles, le premier court, les deux autres alongés, presque cylindriques. - Lèure cornée, peu avancée. - Tête un peu avancée, penchée en avant, formant un angle obtus avec le corselet. - Yeux saillans, un peu arrondis. - Corps ovale, plus étroit en devant. - Corselet rebordé. - Ecusson petit. - Elytres embrassant l'abdomen et recouvrant les ailes. - Pattes assez longues.

On connoît une soixantaine d'espèces de ce genre, la plupart exotiques. Leurs mœurs doivent peu différer de celles des Eumolpes et des Gribouris, Les larves sont inconnues.

Rapportez à ce genre le Gribouri cuivreux, 
$n^{\circ} .33$, et la Chrysomèle ûtre, $n^{\circ}$. 133, de ce Dictionnaire; les Colaspis crenata, $\mathrm{n}^{\circ} .2$, glabrata, $n^{\circ} .3$, favicornis, $\mathrm{n}^{\circ} .4$, 2iridis, no. 8, barbara, $1^{0} .15$, de Fав. Syst. Eleut., ainsi que son Eumolpus cerugineus, no. 25. Id.

Nota. N. Latreille réunit aux Altises, les Colaspes de la seconde division de Fabricius, dont les pattes postérieures sont propres à sauter.

EUMOLPE, Eumolpus. KogeI. WÉB. FaB. Ouiv. (Eutom.) Lat. Chrysomela. Linn. De Gér. Oliv. (Encycl.) Cryptocephalus. Geoff. Fai. Oliv. (Encycl.)

Genre d'insectes de l'ordre des Coléoptères, section des Tétramères, famille des Cycliques, tribu des Chrysomélines.

Les Colisspes, les Paropsides, les Doryphores, les Chrysomilss et les Prasocures se distinguent des autres Chrysomélines par leur tête penchée en avant, formant un angle obtus avec le corselet. Les Griburis, les Clythres et les Chlamydes ont leurs palpes plus épais a milieu, et leur corps est en forme de cylindre court, caractères qui les séparent du genre Eumolpe.

Antennes prescute filiformes, au moins de la longueur du corseiet, grossissant et s'élargissant insensiblement ver's l'extrémité, composées de ouze articles, les cinc derniers un peu plus grands et conprimés. - Labre coiné, trongué, un peu échancré. - Mandibules avancées, contúes, arquées, échancrécs à leur extrémité, ayant deux dents dans celle partie, don: l'apicale très-forte. - Mâchoires bitides, leur lobe extéricur longr, cylivdrique, l'intérieur comprimé, nembranenx. - Palpes terminés par un article plas gros, ovoide; les maxillaires de quatte articles, le prenier court, le second un peu alongé, presque conique, le troisième conique; palpes labiaux de trois articles, le premier petit. - Lèvre courte, cornée, échancrée. - Tète verticale, presqu'entièrement enfoncée dans le corselet. - Corps presqu'ovoide. - Corselet sensiblement plus étroit que l’ałdomen, se rétrécissant à sai partie antérieure. - Ecusson petit, triangulaire. - Elytres couvrant les ailes et l'abdomer. - Pattes assez longues.

Les Enmolpes, remarquables en général par leurs couleurs brillantes et métalliques, renterment près de quarante espèces dont la plupart sont exotiques. Ils fréquentent les planles. L'Lumolpe de la vigne est le seul dont on connoisse la larve. (Voy. pour les détails qui la concernent, les généralités du genre Gribouri, tome VI, page 600 de ce Dictionnaire.)

On doit rapporter à ce geare les Chrysomèles surinamoise, $n^{\circ} .27$, enflimmée, $n^{\circ} .28$, asiatique, $\mathrm{n}^{\circ} .29$; les Gribouris bleuet, $\mathrm{n}^{0} .1$, cyanicole, $\mathbf{n}^{\circ} .2$, globnleux, $\mathrm{n}^{\circ} .6$, bordé, $\mathbf{n}^{\circ} .8$, lar, $\mathrm{n}^{\circ}$. 1.4, de la vigne, $\mathrm{n}^{\circ} .22$, obscur, $\mathrm{n}^{\circ} \cdot \mathbf{2 5}$, ondé, $\mathrm{n}^{\circ} .31$, éperonné, $\mathrm{n}^{\circ} .34$, de ce Diction- nuire. Ajontez les Eumolpus cyaneus, $\mathrm{n}^{\circ} .4$, auratus, $\mathrm{n}^{\circ} .6$, splenaidus, $\mathrm{n}^{\circ} \cdot 9$, arenarius, $\mathrm{n}^{\circ} .26$, de Habricius, Syst. Eleut., et l'Eumolpus ruber de M. Latieille, Gen. Crust. et Ins. tom. 3, pag. 56, $n^{\circ} .1$, figuré sous le nom de C'ryptocephalus sub. serricornis, tom. 1. pl.11. fig. 6 .

CHLAMYDE, Chlamys. Kroca. Lat. Otip. (Ent.) Clyitira. Faв. Bruchus. OLiv. (Eacycl.)

Geure d'insectes de l'ordre des Coléoptères, section des T'étramères, fanille des Cycliciues, tribu des Chrysomélines.

Les gemres de cettc tribu, qni ont la tête verticale, sont, ontre celıi de Chlamyde, les Eumolpes, dont le dernier article des palpes est plus gros que les autres avec les antennes de la longrueur du corselet, celci-ci plus éiroit que l'abdomen; les Gribouris, gui ont les antennes sinples, tiliformes, et les Clythres, dont les palpes labiaux sont simples et qui n'ont point de rainure pectorale pour receroir les antcnnes.

Antennes couries, en scie, se logeant dans des rainures placées le long de la poitrine, composées de onze articles, le premicr alongé, renflé, un peu arqué, le second globuleux, les deux suivans amincis, les autres latéralenent clilatés et cn scie. - Labre coriace, un peu avancé, trongué à sa partie antérieure, légèreaıent écliancré. - Mandibules cont'tes, cornées, voûtćes, terminées par trois dents aigriës, inégales, l'internédiaire plus longue. - Hâchoires presque cornées, bifides, leur lobe extérieur cylindrugue, plus lon que l'intérieur, celui-ci comprimé. - Palpes filiformes, les maxillaires a peine plus longs que les labiaux, de quatre articles, le premier court, le suivant alongé, presque conique, le troisic̀me plus court que le second, le dernier ovale-oblong; palpes labiaux fourchus, de trois articles. - Lèure conrte, cornée, dentclée au bord antérieur. - Téte verticale, enfoncéc dans le corselet.-Ycux réniformes, ayantantérieurement une entaille assez profonde. - Corps court, très-inégal en dessus. - Corselct aussi long et presque aussi large que les élylics, un peu rebordé latéralement. - Ecusson petit, presque carré. - Elytres embrassant l'alidomen, le recouvrant ainsi que les ailes, fortement échancrées sur les côtés , le plus souvent munies de fines dentelures dans toute l'étendue de leur suture, coupées carréanent ¿́ lear pirtie posićrieure. - Patles courtes, se repliant dans des enfoncemeus de la poitrine et du corselel.

On connoît aujourd'hui une vingtaine d'espèces de ce genre qui paroît propre à l'Àmérique. M. V. Kollar en a donné réceminent une Monographie à laquelle nous renvoyons. L'auteur dir vise ce genre d'après la suture des élytres, denticulée ou simple. La seconde division ne renferme que quatre espèces.

Notu. Dans les Chlamydes, ainsi que dana les 
Clythres et les Gribouris , les femelles" ont un enfonceuseut circulaire très-pronoucé, au milieu de lat partie inférieure du dernier segment de l'abdoruen; cet enfoncenent est nul ou très-pen appareut daus les unâles. Nous ajouterons que les Clythres mâles ont nabilnellenent la tête beancoup plus forie que les femelies.

On doit rupporter ì ce gemre la Bruche bossue, 31". 8, du présent ouvrige (Chlamys plicata. OLiv. Entom.), aiusi (fueles Clythra monstrosa, $1^{\circ} .19$, gibuer, $\mathrm{n}^{\circ} .2 \mathrm{j}$, el cristata, $\mathrm{n}^{\circ} .23 . \mathrm{H}_{\mathrm{AB}}$. sjil. Eleut. (S. R. H A. Serv.)

PARTHENOLE, Parthenope. Fab. Genre de crustacés de l'ordse des Décapodes, famille des Braehyures, tribu des 'l'riangulaires, ayant pour curactères : serres ou les deux pieds auléricurs trís-grandes dans les deux sexes, s'étendant latéralement, horizouralement et it angle droit avec lu lvargueur da corps, jusqu'i !'origine du carpe, foruant ensuitc un coude ei se repliant sur ellesmêues; bras et piuces trièdres, avec les doigts comprimés, poiulus, théehis brusquenent; les autres pieds petits. - Test rhombordal ou triangulaire, rétréci en pointe en devant. - Anlentes latérales très-conrtes, de la longueur an plus dis pédicules des jenx; leur premier article totaleluent silué au-ciessons de leurs cavités. - Yeux toujonrs entièrement retiri's dans ces cavilés, et porlés sur un pédienle court el gros.

Quelcues autres genres de la mêue fimille, tels que ceux d'Etthra, d'Eurynome et de Muthrux ont, par la sranden de lears serres et la forme du test, des rapports avee les Parthenopes; mais duss le premier, les angles postérieur's du tesi recouvrent les autres pieds, caructère qui doil faire placer ece genre dans la lribu des Cryptopodes. Dans le second, le premier article des antenues latérules est ties-grand, et se prolonge jusqu'à l'extrómité supérieure interue des fosset tes veulaires; ces antennes sout d'ailleurs proportionnellement plus alongées et plus grêles supérieurement. Les serres des femeilles sont petites. Celles ctes Mithrax se portent en avant, et quoique trèsgrosses, ne sont point aussi longues, et les doigts ge terminent en inauière $d:$ cuiller. Leurs antennes latérales sont, en outre, insćrées eutre les yeux.

Des luuit espèees dont Fubricins compose le genre larthenope, il faut en ôter trois; celle qu'il nonme fomicata, appartieut an genre Athra; son $P$. Maju est une Lithode, et son $P$. dubia parcit devirir se rapporter aux Porcellanes.

La plurart des Purthenopes habitent les mers des Intes arientiles, et s'y tiennent probablement sur les rochers. Les autres se trouvent dans la Médileirranée, et il ne paroît pas que M. Risso en ait eu connoissance; quoiqu'Aldrovande, Olivi et quelques autres naturalistes italiens en aient parlé.

Dans les unes, le premier article des anteunes latérules est plus grand que les deux autres. Le post-abdomen ou la queve offre distincternent, $\in t$ dans les deux sexes, sept segmeus. Les serres ne sont poiut prismatiques, et n'ont point d'arêtes bien prououcées.

Ces espèees composent le genre Parthenope proprenient dil. La plus connue est la Parthexope hormble, $P$. horrida de Fibricius, ou le Cancer horridus de Linnée, et qui il été décrite daus cel ouvrage, sous le nom de Crabe hideux, $n^{n}$. 106. C"est la plus grande de toutes. Son test a près de neul centimètres de longueur, sur onze environ de lurgeur. Il est presque triangulaire, tuberculé, ponctué, caverneux, oblus en devant, avec des poinies spiniforues sur les cotés; la poitrine et le dessous de la queue sont comme vermoulus. Les serres sont verruquenses, avec des élévations coniques, iućgales et dentées; la droite esı plus épaisse que la gauclie. Les autres pattes sont épineuses en dossiss. Voyez la figure d'Herbst, Krabb. tab. 14. fig. 88. On la trouve aux Indes orientales. Je considere coume une espèce propre la variété mentionnée par Linuće duns le MIuseum Ludovica Ulrica regina.

Une secoude division des Parthenopes comprendra les espèees dont le premier article des antemnes latérales est plus court que le suivant, ou à peine anssi long; dont l. queue noffire dans les mâlès que ciny segmens, et dont les serres sont prismatiques, avé de vives arêtes. Ces espèces furment le genre Lambrus de M. Léach. Ici viennent les Parthenopes Giraffa, longimana, regina, Lar de F'abricius, et le C'tncer contrarius d'llerbst, Krabb. tab. 6o, fig. 3 , ou notre $\boldsymbol{P}$. ronce, rubus. Lal seeonde espèce a ślé décrite dans ce Dictionuaire, à l'article Crebe longimane, $\mathrm{n}^{\circ}$. 110 . Mais l'undiviáu que l'on a pris pour la femelle nous paroit devour cu être dıstingué spécifiquement : c'est le C'ancer macrocheles d'Herbst, thid.tab. 19. $/ 1 g .10 \%$, cr not e P. longues-pinces, P. macrocheles. Suu corps est Blanchître, avec quelques espaces d'un ronssitre clair. Le test est un peu rhomboidal, avec de petits tubercules rougeâtres; le miuseau esi un peu dentelélatéralement. Les serres, et surtout leurs arêtes, les doigts mêmes, sont verruqueux et ćpineux; les épines extérieures des pinces son plus forles; mais le dessons de ces serres est en grinde partie uni. Les autres paltes ont des bandes transverses rougeâtres. Les second et troisième segmens et la queue sont traversés, duus leur midieu, par une arête dentelée.

Elle vient des mers de la Chine.

La $\boldsymbol{P}$. Giraffe, $\boldsymbol{P}$. giraffa de Fabricius, a été figurće par Herbst, ibid., tab. 19, fig. $108 \mathrm{et}$ 109.

Aldrovande, de Mollibus et Crustat., lib. 2 , pag. 203 et 205 (édit. de Bologne), a représenté diverses Parthenopes; quelques-unes de ces fignres peuvent cependant convenir anx Eurynomes. L'espèce suivante, et qui m'a etté envoyée par 


\section{P A S}

M. Bonelli, paroît être eelle que le naturaliste précédent nomme Cancer macrochelos alius, pag. 205.

P. Front-Anguleux, $P$. angulifrons. Le premier artiele des antennes latérales est plus petit quele suivant. Ce test est presque rhomboïdal, plus large et arroindi latéralement, vers le milieu de sa longueur, avec le museau presqu'horizontal, foiblement unidenté de ehaque côié, près de sa poinle, et une double carène, convergente postérieurement, près de son origine. Le bord supérieur interne des eavités oculaires est entier. Les serres sont lisses en dessous, aver: des épines en dessus; celles des unains sont entières et très-yeu dentées; les euisses n'ont point de dentelures. Le bord postérieur du test est créuelé, avec deux deitelnres écartées; l'arête da second segment de la queue est partagée en trois lobes arrondis et erénelés. Cette espèce a aussi de grands rapports avee le Cancer macrochelos de Roudelel. C'est probableasent le Cancer longinanus d'Olivi et de Petagna. On la tronve dans la Médicerranée.

(LATr.)

PasimaQUe, Pasimachus. Bonell. Lat. Scarites. FAs. OLIV. PAI.-BAuv.

Genre d'insectes de l'ordre des Coléoptères, section des Pentamères, famille des Camassiers, tribu des Calrabiques.

Les Pasimaques font partie de la seconde divisin de la tribu des Carabiques, désignée sous le nom de Bipartis par M. Latreille (1), et caractérisée ainsi : palpes extérieurs point leruinés en munière d’alêne; rôté intérieur des deux janbes antérieures ordinairement fort échancré; élytres entières ou légèrement sinuées à leur extrémité postéricure. Tarses (le plus souvent courts) sembiables on sans différences sensibles dans les deux sexes, leur dessous dépourvu de brosses el simplement garui de poils ou de cils ordinaires. Anteunes souvent condées. Abdomen pédiculé. Corselet grand, lunulé dans plusieurs, carré on presque globuleux dans les autres. Jambes antérieures de p'usieurs, palmées ou digitées. Insertes fouisscurs, ierricoles, et peu ou point ealmassier, à ee qu'il paroît. Les Bipartis renferment, outre le genre Pasinaque, ceux de Siagone, Carène, Scarite, Cliviue, Ozc̀ne, Morion, Ariste et Apotome. Le prentier se distingue par son inenton : qui recouvie presque tout le dessous de la têle jusqu'au labre. Lues Carènes ont leurs palpes extérieurs dilatés à l'extr'mité; dans les Searites, le corps est alongé, le corselet eu croissant, les màchoires arquées à l'extrémité ; les mandibules des Clivines sont beaneonp plus courtes que la tête, et leur languette est saillante. Eutin les Ozc̀-

(1) Histoire naturelle et Iconographie des insectes colioptéres, par MM. Latreille et Dejean, a Paris, chez Crévor. nes, les Morions, les Aristes et les Apotones ont leurs jambes antérieures simples, sans dentelures ni digitations.

Antennes filiformes, insérces dans le ecin interne de l'œil, et composées de conze articles monilitormes; le second an peu plus court que le suivant. - Mandibules entierement saillantes, dentérs au côlé juterne, de la longueur de la tète. - Mâchoires obtuses, sans onglet mobile à l'extrémité, point arquées dans cette partic. - Palpes filiforunes, les maxillaires extérieurs de quatre articles, le dernier de la grosseur du préeédent, les labiaux de trois. - Lèvre arliculée à sa base, coriaee, courte, large, eoncave, velue postérieurement, dépassant à peine le menton; languetle arrondie à son sommet, terminée par deux soies. - Téte grande, presqu'anssi lingre que le corselet. - Yeux petits, arrondis, peu saillaus. - Corps assez court, large, de forme ovale.-.. Corselet en forme de cœur tronqué, très-éclsancré à ses denx extrémités. - Point d'écusson appareut. - Elytres déprimées, bordées, réunies, sans ailes dessouk. - Pattes de longneur moyenne; janbes autérieures éehancrées, dentées el comme digitées à leur côté extérieur.

On ne connoît qu'u perit nombre d'espèces de ce genre, établi par M. Bonelli, et adopté réeemment par M. Latreille. Ces espèces sout originarires de l'Amérique septentrionale. Le nom générique vient de denx mots grecs, dont le sens est : combattant contre tous. Les mexu's des Pasimaques doivent peu dillisicr de celles des Scarites, dont ils sont très-voisins.

\section{Pasimaque déprimé, P. depresstis.}

pasimachus ater, thorace subcordato, elytris laxvissinils, anteunis basi nugris apiceque piceis.

Pasimachas depressis. Bonell. Obs. entom. 2. part. pag. 45. $n^{\circ}$. 1.-Scantes depressus. FА в. Syst. lilcut. tom. 1. pag. 1 23. $n^{\circ}$. 1. - Otiv. Entom. tom. 3. Scart. $\mu$. 5. no. 1. pl. 2. fig. 15. -- LatT. Hist. nat. des C'rnst. et des 1ns. tom. 8. pag. $576 . u{ }^{\circ}$. 2. - P'ALs.-Bavv. Ins. d'Afr. et d’Anér. pag. 106. Coliopt. pl. 15. fig. 3.

Ionguenr 12 à 15 lig. Entièrement noir et luisant. Antennes nuires, obscures à leur extrénilé. Mandibules fortement deutées intérieurement, la dent de lit madionle gauche echancré à son exrémilé. Tête plane, large, avec deux impresstons longltudinales, et deux autres presque traugversales. Conselet rebordé, plus large antérieurenent, un peu rugueux sur ses bords, ayant un sillon longitudinal sur son milieu, et une impression de chaque côté vers sa base. Elylies fortement rebordées, lisses, un peu claagrioćes an bord extérieur.

Des Elats-Unis d'Amérique. 
2. Pasimaque bordé, P. marginatus.

$\boldsymbol{P}$ asimachus ater, thorace subcordato, elytris sulcatis margine cyaneo, antennis basi nigris apiceque piceis.

Pasimachus inarginatus. Bonelu. Obs. entom. $2^{2}$. part. pag. 45. $n^{\circ} .2 .-$ Scarites marginatus. F A . Syst. Eleut. tom. 1. pag. 1 23. $n^{\circ}$. 2. -OLrv. Entom. tont. 3. Scarit.pag. 5. no. 2. pl. 2. fig. 20. - Lat. Hist. nat. des Crust. et des Ins. tom 8. pag. 576. $n^{\circ}$.3. - Palis.-Bavv. Ins. d'Afiriq. et d'Amériq:" pag. 106. Coléopt. pl. 15. fig. 1 et 2. - Encycl. pl. 181.fig. 8.

Jougueur i 2 à 15 ligr. Entièrement noir et lujsant. Antenues noires, obscures à l'extrémilé. Maudibules fortement dentées intérieurement, la dent de la mandibule gauche échancrée à l'extrémité. Tête plane, large, ayant deux impressions longitudinales, et deux autres presque trans. versales. Corselet rebordé, warqué d'un sillon longitudinal sur le milieu, et d'un autre très-profond le long de ses bords lutéraux ; ceux-ci bleuâtres. On voil encore deux impression; de chaque côté vèrs sa base. Elytres fortement rebordćes, sillonnées; ces sillons formaut des côtes lisses et aplaties, dont plusieurs se réunissent avant d'atriver à l'extrémité; bords extćrieurs des élytres bleuâtres, accompagnés d'une ligne formée par de petits points enfoucés. Dessous du corps d'un noir bleuâtre.

De l'Amérique septentrionale. (S. F. et A. Serv.)

PASIPHÉE, Pasiphara. Telle est la dénomination donnée par M. Savigny (Mein. surles Aninz. sans vertèb., part. I, fasc. 1, parg. 5o), à un genre de Cluslacés décapodes, famille des Macroures, tribu des Salicoques, formé a vec l'Alphée sivado de M. Risso, et fuisant le passage de cetie tribu à celle de Schizopodes. Jl est distingué des autres Salicoques par les caractères suivans. Corps fort alongé, mon, sans saillie antérieure rostriforme. - Antennes longues, sétacées; les intermédiaires divisées en deux longs filets. - Les quatre pieds antérieurs beaucoup plus grands que les autres, presqu'égaux, avaucés, mais un peu courbés, terminés par nne main didactyle et alongée; carpe inarticulé; un appendice sétiforme et très-distinct à la base de ces pieds et des suivans; ceux-ci très-mous. - Pieds-mấchoires exlérieurs longs, très-menus, et paroissant servir à la locomotion.

Le Pasiraé sipado, Pasiphrea sivado, a le corps long d'environ deux pouces et denii, d'un blanc nacré, transparent et bordé de rouge. Les quatre serres sont rougeâtres, a vec l'article précédant le carpe garni inférieurement d'une série de dents très-fines, et les doigts alongés.

Le feuillet intermédiaire de la nageoire posté- rieure, on le dernier seyment abdominal, offre un sillon longitudinal, et se termine en me pointe tronquée et bordée d'une rangée de spinules. La nageoire est pointillée de rouge. Suivant M. Risso, la femelle fait sa ponte en juin et juillel. Ses œufs sout nacrés.

Cette espèce est commune sur la côte maritime de Nice. ( (Latr.)

PASlTE, Pasites. Jur. Lat. Spinol. Biastes, Tiphia. Panz. Nomada. Fab.

Geare d'insectes de l'ordre des Hyménoptères, section des Porte-aiguillon, famille des Melifèrcs, tribu des Apiaires.

Ce genre, élabli par M. Jurine, est de la division des Parasites. L'écusson bituberculé distingue les genres Nourade et Philérème. Les Epéoles ont l'ćcusson muni de deux épines et de deux tubercules; l'écusson bidenté est un caractère propre aux genres Mélecte, Mésochère, Mésonychie, Aglać, Colioxyde et Dioxyde. Dans les autres Apiaires parasiles, l'écusson est mulique; mais les Cératines ont quatre cellules cubitales aux ailes supérieures; dans les Stélides, la seconde cellule cubitale ne reçoil qu'une nervure récurrente, la deuxiène aboutissunt dans la cubitale suivante. Les Allodapés ont la troisième cellule cubitale qui atteint presque le bout de l'aile, enfin dans les Ammobates, la cellule radiale des ailes supérieures est appendiculée, et le labre incliné sous les mandibules, les dépasse notublement.

Antennes filiformes, peu brisées, grossissunt un peu vers l'extrénité, composées de douze articles dans les femelles, de treize dans les mâles; le premier long, le second court, les autres presqu'égaux entr'eux. - Labre n'étant point notablement plis long que large, demi-circulaire. - Mandibules étroites, pointues, unidentées et tuberculées au côté inlerne. - Palpes maxillaires très-courts, de quatre articles, les deux premiers plus grands, le dernier très-court; les labiaux sétiformes, de quatre articles. - Trois petits yeux lisses disposés en triangle et posés sur le vertex. - Corps court. - Corselet court, couvexe. - Ecusson mutique. - Ailes supérieures ayant une cellule radiale rétrécie depuis son milieu'jusqu'í son extrérnité, celle-ci un peu arrondie et écartée du bord extérienr, et trois cellules cubitales, la première plus petite que la suivante, la seconde recevant les deux nervures récurrentes, la troisième à peine commencée. - Abdomen court, conique presque cordiforme, composé de cinq segmens outre l'anus dans les femelles, en ayant un de plus dans les mâles. $P$ attes courtes; les quatre jambes antérieures munies à leur extrémité d'une épine simple, aiguë; les postérieures en ayant deux, l'intérieure plus longue. Premier article des tarses très-grand, presqu'aussi long que les quatre autres réunis; crochets simples. 
On ne connoit que deux ou trois espèces de ce genre. Elles sont d'Europe; les femelles déposent feurs œufs dans le nid des Mégachiles, des Osmies, des Anthophores, et probablenent aussi dans celui des Andrènes et des Halictes. Le reste de leur bistoire nous est inconnu.

\section{Pasite de Scliolt, P. Schottii.}

\section{Pasites nigra, abdomine ferrugineo.}

Pasites Schottii. Lat. Gener. Crnst. et Ins. tom. 4. pag. 171. - Pasites unicolor. Jun. Hyménopt. pag. 234. - Biastes Schottii. Panz. Entom. Vers. die. jurr. pag. 241. - Nomada Schottii. FAв. Syst. Piez. pag. 594. no. 15.-Tiphia brevicornis. Panz. Faun. Genn. fasc. 53. fig. 6 .

Longueur 5 lig. $\frac{2}{2}$. Antennes noires. Tête et corselel de même couleur, fortenient ponctués ainsi que l'abdomen, celui-ci ferrugineux. Cuisses noires; les quatre ja mbes antérieures ferrugineuses, noires à leur partie antérieure, les postérieures entièrement ferrugineuses; tous les tarses de celte deruière couleur. Ailes enfumćes avec quelques parties Iransparentes. Femelle.

Se trouve en Allemagne.

2. Pasite noire, P. atra.

Pasites nigra, tarsis piceis.

Pasites atra. Lat. Gener. Crust. et Ins. tom. 4. pag. 17I. - Spinol. Ills. Ligur. tom. 2. pl. 2. fig. 7 .

Longueur 3 lig. Corps fortement ponełué, entièrement noir. 'l'arses brons. Ailes enfuucées avec quelques parties transparen! es. Mále.

Elle se trouve en Allemagrne. Nons l'avons reçu de M. Ziégler, comme étant le wầle de l'espèce précédente.

\section{AMMOBATE, Anmobates. I.Aт. Antho- phora. Ilelig.?}

Genre d'insectes de l'ordre des Hyménoptères, section des Porte-aiguillon, fauille des Mellifères, tribu des Apiaires.

Ce genre fait partie de la division des Parasites et du groupe dont le caractère est : écusson mutique. Trois cubitales. (Voyez Parasites.) Dans ce groupe les Stélides se distingruent des Ammobates en ce que la seconde collule des aiIes supérieures ne reçoit qu'une nervare récurrente, les Allodapés par leur troisième cellule cubitale qui atteint presque le bout de l'aile, et les Pasites par leur cellule radiale sans appendiee, ainsi que par leur labre qui ne dépasse point les mandibules.

Antennes filiformes, peu brisées, grossissant un peu vers l'extrémité, composées de clouze articles dans les femelles, de treize dans les mâles, le I Hist. Nat. Ins. Tome $X$. premier long, le second court, les autres presque égaux entr'eux. - Labre notablement plus long que large, dépassant les mandibules. - Mandibules étroites, pointues, unidentées, tuberculées au côté interne. - Palpes maxilıaires de six articles, le troisic̀me iuséré sur le côté extérieur du précédent vers son extrémité. Palpes labiaux sétiformes, de quatre arlicles. - Trois petits yeux lisses disposćs en triangle sur le vertex. - Corps court. - Corselet court, convexe. - Ecusson mulique. - Ailes supérieures ayant une cellule radiale presqu'ovale, dont l'extrémité inférieure arrondie est écartée de la eốte et porte un appendice : trois cellules cubitales, les deux premicres presqu'égales, la seconde rétrécie vers la radiale recevant les deux nervures récurrentes, la troisième à peine complencée. - Abdomen court, conique, presque cordiforme, composé de cinc segmens outre l'anus dans les femelles, en ayaut un de plus dans les mâles. - Pattes courtes, les quatre jumbes antérieures munies à leur extrémilé d'uue épine sinuple, aiguë; les postćrieures en ayant deux, l'intérieure plus longue. Prenier article des tarses très-graud, presqu'aussi long que les quatre antres rou.s. Crochets simples.

M. Latreille, en créant ce genre, lui a douné le nom d'Anımobate liré de deux mols grees qui signifient marchant dans le sable. Ses inours sont celles des Pasites dont il es! très-voisin. Nous en mentionnerons deux espèces, les scules que nous connoissons.

\section{Amac B.te ventre-roux, $A$. rufiventris.}

Ammobates niger, abdomine tibius tarsisque ferrugineis.

Ammobates rufiventris. Lat. Gener. Crust. et Ins. tom. 4. pag. 169 .

Longneur $4 \mathrm{lig}$. Noir. Tête et corselet fortement pouctués, alyant un peu de duvet argenté. Abdomen, janlies et tarses d'un fiuve furrugineux. Fesiclle.

De Portugal.

\section{Ammozate bicolor, $A$. bicolor.}

Ammobates niger, abdomine ferrigineo, segmeentis quarto quintoque ct ano, nigrts.

Longueur $3 \mathrm{lig.} \frac{x}{2}$. Antennes noires. Têle et corselet de mêae couleur, fortement ponctués, avec un duvet argenté clair-semé. Abchomen pointillé, ayant ses trois premiers segmens ferrugineux. Les deux dernicrs et l'anus noirs. On voit une tache latérale sur le premier el le second segmens, une petite ligne de chaque côié du troisième, une bande interrompne sur le quatrième et une bande complète sur le cinquième, formćes par des poils couchés d'un blanc argenté. Paltes noires. 'Tarses hruns. Ailes enfumées. Femelle.

\section{Eavirons de Soissons.}

\section{C}


CERATINE, Ceratina. Latr, Jör. Sprosos. Diegilla, Prosopis. $\mathrm{F}_{\text {Ав. }}$

Genre d'iusectes de l'ordre des Hyménoptères, section des Porte-aiguillon, fanille des Mellifères, triba des Apiaires.

Ce ganre établi par" M. Latreille est de la division des Pirasites (voyez ce mol). L'écusson sans épines, portant deux tubercules daus son miJieu, caractérise les Nomades el Jes Pliilérèmes; ontre ces deux tubercules, les Epéoles ont une épine de chaque côté de l'écusson; cette même partie est bideutée dans les geures Mélecte, Mésochère, Mésonychie, Agtaé, Coelioxyde et Dioxyde. Les Pasites, les Ammobates, les Stélides el les Allodapés qui, comme les Cératines, ont l'écusson mutique, s'eir distunguent en ce que leurs ailes supérieures n'ont que trois cellules cubitales.

Antennes un peu brisées implantées chacune dans une fossette, grossissant un peu vers l'extrúmité, composées de douze articles dans les femelles, de treize dạns les mâtes, le premier long, le seeond court, les autres presqu'égaux 'entr'eux. - Labre presque carré, perpendiculaire, lisse, entier. - Mandibules tridentées à leur ext rémité. - Mâchoires el lèvre en forme de trompe et coudées. - Languette filiforme. - Palpes maxillaires de six articles; les labiaux de trois, les deux iuférieurs presqu'égaux, le troisième inséré un peu au-dessous de l'extrémité du second. Irois petits yeux lisses disposés en triangle sur le vertex. - Corps oblong, presque ras. - Ecusson mutique. - Ailes supérieures ayant une cèllulle radiale à peu près ovale, son extrérnité arroudie, s'écartant de la côte, et quatre cellules cubitales, la première un peu plus grande que la seconde, la deuxième fort rétrécie vers la radiale, recevant la première nervure récurrente; la troisième plus grande que la première, rélrécie vers la radiale, recevant la seconde nervure récurrente; la quatric̀nı incomplète, n'atteignant pas l'extrémité de l'aile. - Abdomen ovale, composé de cinq segmens outre l'anus dans les femelles, en ayant un de plus daus les mâles. - Pattes de longueur moyenue, les quatrc jambes antérieures manies à leur extrćmité d'une épine sirople, aiguë; les postéricures en ayant deux, l'intérieure plus longue; premier article des tarses très-grand, presqu'aussi long que les quatre autres réunis; crochets simpies.

Les Cératines sont dépourvues de tout organe de récolte. M. Maximilien Spinola a cru que les fošsettes cqu'elles ont à la tête remplaçoient les palettes destinées à cet office dans les Mellifères récoltans. Il a été trompé par l'apparence; il vit, en effet, une agglomération de miel et de pollen altachée à celte partie de la tête d'une ou de plusieurs Cératines; mais ce même accident arrive à des Leptures, des Eristales, des Sésies, qui certes n'ont point de récolte à faire pour la nourriture de lears larves. Les Cératines déposent leurs œufs dans les nids des plus petites espèces d'Osmies on d'Hériades, et si M. Spinolia a vu la Cératine entrer dins la tige creuse d'une plante, c'est parce que les espèces d'Apiaires récoliantes dont nous venons de parler, choisissent habituellement cette localité pour y construire leurs cellules. (Voyez pour le surplus l'article Parisitrs.)

On connoît six à sept cspèces de Cératines dont lannilié se trouve en Europe ; les autres habient l'Amérique méridionale.

\section{Cératine calleuse, C. caliosa.}

Ceratina nigra, caruleo-nitens, clypen fomince immaculato, maris albo lineato, alis subhyalinis.

Ceratina callosa. LAт. Gener. Crust. et Ins: tom. 4. pag. 160. tom. 1. pl. 14. fig. 11. Le unâle. - Megilla callosa. Fab. Sy'st. P'iez. pug. 334. $n^{n}$. 3r. Le mâle.

Longueur 3 ligo. Antennes d'un brun noirâtre. 'Tête, corselet et abdomen d'un noir bleuâtre à rélet métallique, ayanl quelques poils cendrés. On voit un point blanc un peu élevé au-dessous de l'écaille des ailes. Pattes noires avec des poils cendrés. Ailes presque trausparentes à reflel métallique. Femelle.

Le mâle diffère par son chaperon marqué d'une ligne perpendiculaire blanche. Son anus v'est ni tronquäe, ni bidenté.

Des environs de Paris.

Ncus rapportons en outre à ce genre l'Apis cyanea. Kinв. Mlonogr. Apum Angl. $n^{\circ}$. $7 \mathrm{I}$. ("Ceratina cyanea. Lep.), et le Prosopis albilabris, $n^{\circ} .2, \mathrm{H}_{\mathrm{AB}}$. Syst. Piez. Ces espèces se trouvent aux environs de Paris.

\section{ALLODAPE', Allodape.}

Genre d'insectes de l'ordre des Hyménoptères, section des Porte-aiguillon, famille des Mellifères, tribu des Apiaires.

Ce noureau genre fait partie dans celte tribu de la division des Parasites (yoyez ce mol) et du groupe qni a pour caractère : écusson matique.'Trois cubitales. I.es Stélides se distinguent fit cilenent dans ce groupe par leurs ailes supérienres dont la secunde celluie cubitale ne reçoit qu'une nervure récurrente, el les Pasiles, aiusi que les Ammobates, parce que leur troisième cellule cubitale est à peine commencće, et qu'ils n'ont qu'une seule épine à l'extrémité des jambes intermédiaires. Lear abdoinen ell outre est de forme conique.

Antennes filiformes, peu brisées, grossissant un peu vers l'extrémité, composées de douze articles dans les femelles, de treize dans les wâles; le premier long, le second court, les autres. presqu'égaux entr'eux. - Labre n'étant pas notablement plus long que large. - Mandibules étroites, 


\section{P 15}

pointues. - Palpes maxilkires très-courts, de quatre artivles, les labiaux de qunitc. - Trois pe. tits yenx lisses disposés en triangle sur le vertex.Corps de longueur moyenne. - Corselet convexe. - Ecusson muticue. - Ailes supérieures ayäut une cellule radiale ovalaire, rétrécie depuis son inilieu jusqu'à son extrénité, un peu appeudiculée, et trois cellules cubitales, la premicre plus grande que la seconde, celle-ci rétrécie vers la radiale, rocevant les deux rervules récurrentes; la troisième alleignant presuae le bout de l'aile. - $A b-$ domen uroyen, un peu cylincírique, composé de cing segmens outre l'anus dias les femelles, en ayaut un de plus dans les màles. - Paltes courtes, jambes antéricures nunies d'une seule ćpine à leur exırémité, les quatrc postérifures en ayaunt deux, les épiues grandes; crochets des lärses bifides.

Nous proposons ce genre pour quelques espèces du Cap de Bonne-Espćrance. qui dosvent avoir les mémes mueurs que les Pusites, et par couséquent leurs lärves vivent sans donte dans des nids qui n'ont poiut été construits par leurs mères; c'est de-là qu'est tiré le nom d'Allodapé, qui en grec signitie étranger. Ces Apiaires parasites ont plusieurs caractères, surtout ceux des ailes qui leur sont communs avec les Ammobates, mais plusicurs autres que nous a yons cités les él éloignent nolablenent. La forıne de leur corps est à peu près celle des Stćlides.

\section{Allodapé abdominale, A. ruförastra.}

Allodape nigra, abdomine ferrugineo, capite scutelloque albido maculatis.

Longueur 5 liğ. Antennes noires. Tète de même couleur avee l'orbite des yenx, une tache irrégnlière derrière ceux-ci el ure ligne perpendicularre sur le chaperon qui descend sur le labre et s'élargit à son extrémité supérieure, d'un blanc jauntilte. Corselet noir. Exsrémité inférieure de l'ćrusson blanchatre. Abdowsen d'un roux ferrugineux, portaut quclifues pelis poils blanchâtres. Paltes noires, usscz velues. Ailes transparentes. Fenelle.

Rapportée de la Cafierie par feu Dolalande, ainsi que deux aulres espèces qui sont égulement au (aubinet du Roi. (S. F. et A. SErv.)

PASSALE, Passalus. Faв. LAt. Lucinus. Lixn. DE GÉr. OLIV.

Geure d'insectes de l'ordre des Coléoptères, seclion des Pentamères, fámille des Lamellicornes, tribu des lucanides.

Celle ti ibu reuferme cing genres : Sinodendre, Esale, Lamprime, Lacane et Passäle. Les quatre premiers se distiugnent par leurs antennes coudées et leur labre nul ou point apparent.

Antennes point coudćes simplement arquées, relues, cowposćes de dix articles, le premies alongé, les derniers en massue feuillètée, plicatile; eelle massue formée de trois, quatre, einq ou six articles. - Labre grand, crustacé, en earté transversal, très-saillant, velu. - Mandibules fortes, dentées intérieurcment. - Inấchoires cornées, très-dentées à leur partic inicrne. Palpes presqu'égaux, leur dernicr article presque cy lindrique; les maxillaires de quatre arlicles, les labiaux iusérés à la base antérieure de la lèvre, de trois articles, le second plus long gue le troisième. - Lèvre crustacée, carrée, recue dans une profonde échancrure du menton; celui-ci ayant de cliaqne côté nue lưge dent relevée. T'éte aplatie, moins large que le corselet, trèsinćgale en dessus. - Corps alongé, déprimć, parallélipipède. - Corselct presque carré, déprimé. - Ecusson point apparent. - Elytres grandes, dépriaćes, brusquement rabaltues sur les côtés, recouvrant les ailes el l'abdomen. Abdomen grand, séparé du corselel par un élranglement; ses côtés umbrassés par les lytres. Pattes courtes; jambes ántérieures denlées latéralement, arnıécs d'uue forte épine près de leur insertion arec la cuisse; jambes intermédiaires et postćrieures ayant quelques épines, crocheis des tarses grands, forls, simples, ofliunt daus leur entre-dcux un pelit appendice anui de denx soits divergentes.

Ces coléuplères sont propres aux pays chands de l'Amérique et des ludes oriemales. Ils sont gćmérälement de graude taille et do coulenr noire ou brune. La larve d'unc c'spèce liguréc par naatemoiselle de Mírian daus ses Insectes de Surinam, vit dans les racines de la patate (Convolvalus Batatas). Elle paroit avoir heaucoup de resscmblance avec celles dics Lurantes. Sa lête est pelite, son corps tres-gros avec l'extrétkiić postéricure mince; elle est munie de six pattes écuilleuses. On croil gue ces larves sont plusieurs années avant de parvenir a l'étal partiait. On rapporte que les Pasales šntroduisent souvent à Saint-Domingrue dausles sucreries. M. DalisotBauvois dil qu'ou les trouve aussi dins les vicilles souches des arbies. Les especes de ce geure ont ćtć fort unal conmues autrefois, ou pour inicux dite on les a contonducs sous le nom de Lacane, ou Passale incrompu. Il est donc presqu'inapossible de rapporter la synonymie des auteurs auciens avec quelque cerlitude.

Ire. Division. Massne des antenues composíe de trois ou quatre articles.

\section{Passale iuterrompu, $P$. interruptus.}

Passalus antennarum clavâ trilannellatâ, capite subpunctato submermique, thoracss sulco huic aequali angulisque anticis rectis, elytrora.n striis dorsalibus basi non punctatis.

Passulus interruptus. Schon. Synon. Ins. - 
Jassalus grandis. Des. (Caial.) - Lucanus in"2 rruptus. Linv. Syst. Nat. 2. 560. 4.

Longueır 2 pouces. D'un brun noir, luisant. Antennes, bouche, dessous du corselet, ses cóićs, bords des élytres aux environs de leur angle Jıu iéral et jambes, couverts de poils roux. Tềie très-inégale, présentant en avant quelques pointes dont aucune n'est rclevée en manière de corne; les intervalles qui se trourent entre les deux pointes latérales sapérieures et l'intermédiaire, fortetement ponctués. Corselet ayaut un sillon longitudinal dans son milieu qui atteint les deux bords. $S_{1}$ dépression latérale, ainsi que ses rebords latíraux, fortement ponctućs. Ses angles antérieurs bien prononsés, presque pointus. Stries du disque des élytres peu profondes, sans aucuns points denuis la base jusqu'an unlieu, finement pointillées ensuite dans le reste de leur étendue; les latérales l'étant plus fortement.

De Cayenne.

\section{Passale céphalote, $\boldsymbol{P}$. cephalotes.}

Passalus antennarum clavâ trilaniellatâ, capite impunctato subinernique, thoracis sulco antice abbreviato angulisqne anticis rotundatis, rytroram striis dorsalibus basi non punctatis.

Passalus cephalotes. DeJ. (Catal.)

Longueur 20 lig. Cette espèce ressemble beancoup ì la précédente. Elle eu diffère en ce que les pointes de sa tète sont tnoins prononcées, que l'intervalle entre celles de la partie supérienre n'est pas ponctuće; les angles antérieurs du corselet sont manifestement arrondis; la dépression lat érale est à peine sensible, et les rebords latćraux ue sont ponctués que dans leirr milieu. Les siries latérales des ćlytres sont moins fortement ponctuées, et celles du disque un peu plus profondes.

De Cayeune.

Nota. On ne connoít pas encore les différences scxuelles des Passales; il serrit possible que cette espèce fût la fentelle du précédent.

\section{P.assate licorne, P. unicornis.}

Passalus antennarun clasá trilamellatâ, capite impunctato, cornuque recto horizontali armuato, thoracis sulco huic aquali angulisque anticis rectis, elytrorum striis punctatis, intervallis transversè rugosis.

Longueur r 8 lig. D'un brun noir, luisant. Antennes, bonche, dessous du corcelet, ses côtés, angles huméraux des élytres et leur partie latérale toute entièrc, couverts de poils roux, ainsi gue les jambes. 'Têto comme dans le Passale cépiralote, mais sa pointe supérieure internédiaire est prolongéc en une corne liorizontale, droite. Sillon longitudinal du corselet atteignant les deux bords. Dépression latérale forlement ponctuée; on voit quelques gers points enfoncés an-dessus de cetre dérression. Rebords latéraux du corselet ponctués ; ses angles antérieurs bien pronuncés, presque pointus. Stries din disque des élytres peu protondes, légèrement pointillées; leurs interva!les ridés transversalement. Les stries latérales foriement poncluées.

De Cayenne.

\section{Passale cornu, $P$. cormutus.}

Passalus antennarun clas'â trilamellatâ, capite impunctato cornu incurvo armato: thoracis sulco anticè multiun abbreviato angulisque anticis subrotundatis, eljtiorum striis dorsalibus vix punctatis.

Passalus cormutils. Fa . Syst. Eleut. tom. 2. peg. 256. $u^{\circ}$. 5. - P'AL.-B A v v. Ins. d'Afing. et d'Amériq. pag. I. Coléopt. pl. 1. fig. 1.

Longueur 16 à i 8 lig. D'un brun noir, luisant. Antennes, bouche, déssous du corcelet, ses côtés et les jambes intermédiaires seulement, garnis de poils roux. Tête inégale, ponctuée, ne présentant que trois pointes remarquables, les inférieures manquant presque totalement. L'iutermédiaire relevée en corne, d'abord droile, ensuite fortencnt fléchie en avant, dilatée avant sa pointe, presqu'en forme de hameçon. Sillon longitudinal du corselet n'atteignant point le bord antérieur. Dépression latérale uon ponctuée ; rebords latéraux peil ponctués. Angles antérieur's du corselet presquarrondis. Stries du disque des élytres a peine ponctuées, les latérales ne l'étant pas trèsforteuncnt.

Conmm aux Etats-Unis d'Amérique.

\section{Passale ponctué, $P$. punctiger.}

Passalus antennarum clà'â trilamellatô, capite punctato subinermi, thoracis sulco huic a quali angulisque antic:s rectis submucronatis, elytrorum.striis punctatis, intervallis transverse subrugosis.

Passalus punctiger. DaLm. Schos. Synon Ins. - Passalus interruptus. DEJ. (Catal.)

Longnemr 15 lig. D'un brun noir, luisant. Antennes, bouche, dessous du corselet, ses côlés, angles huméraux des élytres et janbes, garnis de poils roux. Tète forterrent ponctuée, ayant en avant plusieurs pointes dont aucune n'est relevée en manière de corne. Sillon longiludinal du corselet atteignant les deux bords. Dépression latérale fortement ponctuée; il y a quelques gros points enfoncés atu-dessus de la dépression; rebords latéraux du corselet fortement ponctués, ses angles an!érieurs très-prononcés, un peu mucronés. Stries du disque des élytrcs finement ponctuées, peu profondes, leurs iutervalles légè- 
rement ridís transversalement; stries tatérales fortement ponctuées.

De Cayenne.

\section{Passale barluu, p. barbatus.}

Passalus anten nanım clavâ trilımellatâ, corpoie nultim depresso, capite impunctato subinermi, thoracis sulco huic cecyuali, angulis anticis rectis submucronatis, elytronum striis punctatis.

Passalus barbatus. FAв, Syst. Eleut. tom. 2. pag. $256 . n^{\circ} \cdot 4$.

Longuenr 14 lig. Corps très-déprimé, d'un brun noir, Puisant. Antennes, bouche, dessous du corselel, ses córés, bords des élytres, leurs angles huméraux et les jambes, couvcrts de poils roux. 'Tête fort intigale, présentant quatre carènes dont les deux iutermédiaires se róunissent vers le milieu, les pointes supérieures manquant presque totalement. Sillon longitudinal du corselet atteignant les deux bords. Dépression latérale bien prononcée, mais per ou point ponctuće. Bords latćraux du cotselet et ses rebords ponclués; ses angles antcirieurs très-prononcés, presque mucronés. Stries du disque des élytres entièrement et distinetement ponctuées, les latérales l'étant plins fortement encore.

De Cajerne.

Nota. Ces six premières espèees n'ont que trois arlicles à la massue des antenues. Nous avons vu dins le cabinet de M. le comte Dejean un Passale dans lequel celte mas:ue est composće de quatre aricles, c'est le Tetraphyllus de son calalugue. Quelgues espèees à massue de trois articles ont un petit prolongement an septième article de l'antenne; cela force à confondre daus une mêne division le, Passales à massue des antennes de trois et de quatre articles.

$2^{\circ}$. Division. Massue des antennes de cinq articles.

\section{Passale brésilien, $P$. brasiliensis.}

Passalus antennarum clââ quinquelamellatâ, capite puncituto, inemi, thoracrs sulco antice subabbreviato, disco lavi angulisque anticis rects submucronatis, elytrorum strils punctatis.

Longueur 8 lig. D’un brun noir, luisant. Antennes, bouche et dessous du corselet légèrerieut garnis de poils rosx. 'Tète inégale, ponctuée, présentant quatre carènes dont ícs denx intermédiaires se réunissent vers le milieu, les pointes supérieures et inférieures manquant presque totalement. Sillon longitudinal du corselet n'at teignaut pas tou:- à-fait le bord äntérieur. Dépression iatérale du corselet, les côtés de celui-ci et ses re- bords latéraux forlement ponctués, ainsi que le bord untérieur; ses angles de devant très-prononcés, presque mucronés. 'Toutes les stries des êlytres forlement ponctuées.

\section{Du Brésil.}

\section{Passale poncticolle, $\boldsymbol{P}$. puncticollis.}

passalus antennarum clavấquinquelamellutî. catite punctato inermi, thoracis sulco antice subatbreviato, disco punctato angulisque anticis rectis submucronatis, elytrorum striis punctutis.

Longueur ro lig. D'un brun noir, luisant. Antennes, bouche, dessous du corselet et jambes internétiaires, légèrenıent garnis de poils ronx. Tête comme daus la précédente espèce; sillon longitudinal du, corselet n'alteignant pas tont-jfait le bord antérieur. Dépression latérale ponctuée fortcment, ainsi que les côtés et les rebords latéraux du corselet. Le disque du corsclet est parsencé irrégulièrement de gros points enfoncés ; angles intérieurs très-prononcés, presque nucronés. Toules las stries des élytres profondes et fortement ponctućes.

D’Américque.

Nota. Le Passale pentaphylle de M. PalisotBauvois appatient à cette division.

3e. Division. Massue des antennes de six articles.

\section{Passale échancré, $P$. emarginatus.}

Passalus antennarum clavâ sexlamellatâ, capite impunctuto, inermi, thorace non sulcato, etj trorum stris sublcevibus.

Passalus emarginatus. F.а. Syst. Eleut. tom.: pag. $255 . n^{\circ} \cdot 2$.

Longuenr n. Antcanes, lonche, dessous du corselet ct angles hunérạux des élytres, garnis de poils roux. 'Tète inégale, n’ayant presqu'aucunes pointes. Corselet entièrenient lisse, san; sillon Lnngitudiual. Elytres strićes.

De lile de Simalra.

Nota. Nous n'avons pnint ru cette espèce, cque nous décrivons d'après libricius. (S. F. et A. SERV.)

\section{PASSANDRE, Passandra. Datar. Scto.}

Genre d'imsectes de l'urdre des Colcoptères, section des Tétramères, farbille des Platysomés.

Les parandres et les Cucujes, par les articles moniliformes de lents antennes, les Uléjotes pal leurs palpes à dernier article presgre cunique, allant en pointe, se distingoruent facilemeut du genre Passandre.

$\mathrm{Ne}$ connoissaut point linsecte pour lequel $\mathrm{re}$ genre a tité établi, nous ne donnons ici les caractères el la description de l'espèce unique qui le compose, que d'après M. Schonnherr. 
Antennes filiformes, un peu plus longues que la unoitié du corps, insérées près cie la base des inandibules, de onze articles, le premier grand, épais, presqu'ovale; le second très-eourt, slobuleux, les suivans presqu'égaux, obconiques, un peu comprimés, presqu'en scie, uu peu ciliés intérienrement; le dernier ovale-globuleux, tronqué ohliquement. - Mandibules grandes, fortes, cornées, presque triangulaires, arrondies extérieuremeal, presque tridentées à leur partie interne (ces dents obtuses), entières à leur extrémité. Mâchoires linéaires, entières. - Palpes inégaux, filifornes, les maxillaires beaneoup plus longigue les màchoires, de quatre articles, le premier cobrt, le sečond et le troisieme alonǵs, presque cylindriques; le dernier encore plus long, plus épais, argué, arrondi à son extréonité; les luhiaux plus courts, de trois articles. - Lèvre coruée, bifide ; languctle membraneuse, cilı́e, bifide; divisions latésales de la lèvre et de la lauguette linéaires, éiroites, écartécs.

\section{Passandre six-stries, $P$. sexstriata.}

Passandra lorvis, nitida, depressa, subtùs rufofisca, thoric: obscure sunguinea. Elytris nigris, tristrialis.

Passandra sexstriata. Scuon. Synon. Ins. tab. 6. fig. 3 .

Longneur 14 lig. Corps lisse, luisant, déprimé, d'un roux brun en dessons. Antennes uoires. Coraelet d'un ferruginenx obseur. Elytres noires, ayant eliaeune trois stries; les latérales rapprochées l'une de l'autre.

De Sierra-Léon. (S. F. et A. SERV.)

\section{PATTE. Voyez Pied. (Latr.)}

PATTE ÉTHNDUE. Geoffroy désigne sous ce noos le Bombix pudibund. des auteurs. Voyez Bombrx, no. I3o de ce Diclionuaite. (S. F. et 1 . SERv. )

PAUSSILES, Paussili. Troisième tribu de la familla des Xyluphinges, section des Tétramères, orire des Coléoptc̀res, ayant pour calraetères :

Anterines conposées de deux articles dans les tas, dont le dernier tris-rrand; de dix articles dans les aulues, formant une massue cylindrique, presqu'entièreinent perfoliće. - Palpes coniques. - Corps oblong díprimé. - Etytres tronquies au bout. - Abdomen earré. - Turses à artieles entiers.

Cetle tiibu ne renferme que deux genres, Paussus ( yoyez ce mot) et Céraptère. Ce dernier paroâl he contenir go une espèce. Elle est entierewent lirune; on l'a tigirrée dans ce Dictionmaire, pl, 572 bis, nos. 26 et 27 , sous le now de Céraptère de Macleay. (C. Macleaii.)

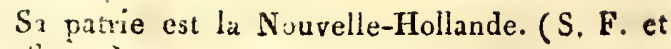
A. SERv.)

PAUSSUS, Paussus. Jing. Fab. lat. Herbst. Donov.

Genre d'insectes de l'ordre des Coléoptères, section des 'Tétrauceres, famille des Xylophages, tribu des Patissiles.

Celte tribu n'est composée que des genres Panssus et Céraplére; eelui-ci est suffisamenent dislingué par ses astennes perfuliées, composées de dix articles.

Antennes rapproehćes, insérées au-dessus de la bouche, composées seulement de deux articles; le premier très-petit, presque globuleux; le seeond trés-grand, tautút irrégulier, denté ou crochu, tantôt régulier, presquovale, orbieulaire.-Labre presque coriaee, perit, transverse, earré. - Mandibules petites, cornées, alongées, eomprimées, leur exirérrité pointue, un peil lanulée. - Mấchoires terminées en manière de dent arquée, pointue, ayant une dentelure sous l'extrénité. - Palpes conicques ou en alêne, courts et ćpais, les maxillaires un peu plus longs, se prolongeant jusqu'á l'origine des antenues, composés de qualre articles; le premier petit, en forme de tubercule; le second fort grand, en earré long; le troisièue beaucoup plus étruit, des deux tiers plins eourt que le précédent et presque cylindrique, le dernier très-petit, cylindro-couiçue; palpes labianx recouvrant la langnette, de trois articles; les denx preniers trés-petits, le dernier grand, ovoïle ou presque cylindrique, tinissant en pointe. - Téte presque de la largeui du corselet, à peu près carrée, déprimée, Jétrécie postérieurement ell une espèce de cou distinct. Corps oblong, apliti. - Corselet plus étroit que le corps, presque carré, brusque cuent plus élevé à sa partie aniérieure et dilaté sur les cótés. Ecusson petit, triangulaire, pen apparent. - Elytres formant un carré lony, laissant a découvert l'extrémité de l'abdomen, unies, planes, sans rebords, recouvrant deux ailes meıbraneuses. Abdomen earré. - Pattes eourtes, comprinces. Jaubes untérieures sans épines sensibles à leur extrémité; les postérieures assez larges. 'Tarses à articles entiers.

Les a œurs des Paussus doivent se rapprocher beaucoup de celies des autres genres de leur famille, teis que les Scolytes et les Bostriches. II est probable qu'ils vivent dans le vieux bois ou sous les écorees d'arbres. On soupeonne que les especes pourvues de dents ou de crocbets au dernier article des antennes, s'en servent pour se suspendre. Ce genre singulier est très-peu nombreux en espèces; elles sont de petite taille et ont pour patrie les Indes orientales et l'Afrique. L'insecte déerit par Fabricius sous le nom de Paussus flapicornis, qui a plus de deux articles aux antenaes d'après la description, est regardé par 


\section{P $A V$}

M. Latreille comme le type d'un genre propre.

I. Pavssus microcéphale, $P$. microcephalus.

Paussus fuscus, antennazzm articulo secundo incequaliter elevato, ad basim pedunculato, externè quadridentato, infià in uncun oblusuıu unicientatum producto.

Faussus znicrocephalus. LinNa. (DanL. Diss. Big. Insect. tab. 1. fig. 6-10.)-Afzer. Act. Soc. Linu. tom. 4. pag. 18. tab. 22. - Herbst, Coléopt. 4. tab. 39. Jig. 6. a. b. - Faв. Syst. Eleut. tom. 2. pagr. $75 . n^{\circ}$. 1. - LaT. Gener. Cillst. et Ins. tom. 3. pag. 2. $u^{\circ}$. 1 .

Longrieur 2 à 3 lig. Corps d'un brun noivâtre; dernier article des antennes irrégulier, rétréci à sa base en manière de pédoncule, son côté extérieur quadridenté et prolongé en dessous en un crochet unidenté; milieu du corselet ayant un enfoncement profond; janbes postéricures plus larges que les autres, un peurétrécies vers leur extrémité.

Afrique.

2. Paussus trigonicorne, $\boldsymbol{P}$. trigonicornis.

Paussus rubro-ferrugineus, elytris in unedio nigris, antennarum articulo secundo compresso, trigono, lateve interno acuto, externo in naviculunn excavato anguloque postico acuto.

Paussus trigonicomis. LAт. Gener. Crust. et Ins. tom. 5. pag. 3. $n^{\circ}$. 2. pl. 11. fig. 8.- Paussus thoracicus: Dovov. Natur. hist. of Ins. fasc. I4. tub. 4. fig. 2. - Encycl. pl. 361. fig. 18.

Longueur 3 lig. Corps d'un rouge ferrugireux; dernicr article des antennes comprimé, triangnlante; son bord interne argu, l'extérieur creusé longiludinalement en nacelle, ayant une suite de points enliuncés sur l'un et l'autre bord et son angle postérieur aigu. Bord antérieur de la tête aigu, éclıaneré ; vertex avec des impressions profondes, irrégulières. Corselet sillonné is sa partie postérieure, irrégulièrement creusé; ses angles latéraux aigus. Elytres noires dans leur milieu, ayant quelyues poils roides sur leur bord extéricur; leur angle nostérieur renflé. Jambes antérieures gr ڤ̂les, les deux pustérieures assez larges, compriusées, un peu rétrécies vers l'extrémité.

Des Indes orientales.

Nota. Nous n'avons point vo ces deux espèces.

$$
\text { (S. F. et A. Serv.) }
$$

PAVONIE, Pavonia. Nouveau genre de Lépidoptères diurnes, proposé par Mi. Gudart dans l'Encyclopédie, et qui répond exactement à la seconde division du genre Miorpho. Voyez pour les caractères, PapilLon, pag. 807 , et pour les espèces, pag. 446-455, du $\pi^{\circ}$. 2i à celui de 42 .

(S. F. et A. Serv.)
PAXYLOMME, Paxylomma. M. de Brébisson entomologiste distingné propose ce nouvean genre d'Hyménoptères, voisin des Fazes, suivant lui, et composé d'une seule espèce, dont il ne connoît que la femelle. Voici les caracières quil lui assigne : Antennes filiformes, inśré entre les yenx et de lreize articles. Túte tres-brosse aîsi gne les yeux qui sont saillans. Palpes très-petils, pe.? visibles. Corselet globuleux, ur jor bossu. Aljuemen on fauld, inséré ertue les hanches postérien-

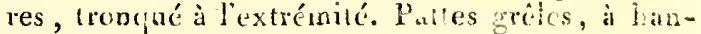
ches el cuisses posírieures alon ́c es Trenier atrticle des tarses postériens trés-long. Ailes supérieures ayant une cellu!e radiale alongś ; premiere cellule culitiale complète, recevant une nervure réc urrente; deuxième cellule cubrale incomple:e et terminale.

L'espèce citée par Mr. de Bróbisson a reçu de lui le rom de Paxylomne a bouche blunche (P. buccata); il la décrit ainsi : Longueur 2 lig. Brune. Ailes hyalines. Bouche et base des anienmes blanches. Dessus du corselet noir. Abơowen restacé, son extrómité brtinâtre. Puttes rousses. Très-comurun en julllet dans les terrains sablonueux et arides des envirous de Falaise.

M. Latreille, dans le Dictionnaire d'Histoire naturelle, $2^{\mathrm{e}}$. ídition, a:ticle Paxy que cet insecte appartient platôt à la tribu des Ichnenmonides qu'a celle des Lvanules; telle est aussi notre opinion. Il ajonte que ses antennes out treize ou quatorze articles. Nous devons à M. de B:ébisson l'espèce dont il est ici question, ainsi que la communication des caractères que nous venons d'énoncer. (S. F. et A. SEkv.)

PÉDICIE, pedicia. Lat. Tipula. Linv. Fab. De Géer. Lillnobia. Mrag.

Genre d'insccles de l'ordre des Diptères, seclion des Proboscidés, famille cies Néwocères, triba des Tipulaires.

Ce genre fait partie du groupe établi nar M. Tatreille dans cente tribu, sons le nom de Terricoles: Duns les Híxatomes de.cet auteur ( Nematocera, MElg. el peut-être aussi son genre Anisonzera) ainsi que daus les Ptychop!ère, le troisième articlé des autenues est fort long. Le gure Clénophore a les antennes pectinces dans les ináles, enscie dass les fernelles. Dans les limnobres, le demier aricle des palpes u'esá zuère plus longr que le précédent et ne paroil point divisé; de plus. les aíes diuns ce genre se recuuvrent l'une l'alulre en élat de repos. Le second article des antonnes est globuleux, et p!us petit que lo premier dins les 'lipules; ici d'ailtenrs les antennes re soni composíes que de treize articles. Dans les Néf!rotomes, is plupart des articles des atrtennes, mêtne vers base, sont cylindriques, ceux dn milien un pe! arqués. Les Erioptères ont tous- les articles de; anlennes, à partir du troisière, ovales, et is 
pattes iatermédiaires notablement plus courtes que les autres. Les 'Trichocères ont cing articles aux palpes. Dans ces denx derniers genres, les siles sorit en reconvrement l'une sur l'aulre dans le repos. Au moyen de cette comparaison, on reconnuit!al les Pédicies sans difficulté.

Antennes très-courles, à peine plus longues que la tête, un peu velues, conposées de seize articles, les deux premiers beancoup plus longs que les autres, relui de la base aylindrique et le plus grand de lous, le second en forne de cour renversé, les sept suivans beaucoup plus petits, presque grenus; les sept derniers plus grêles que les précédens et presque cylindriques. -- Palpes courbés, composés de quatre articles, le dernier beaucoup plus long, plus menu, noucux et comme articulé. - Trompe courte, terminée par deux grosses lèvres. - Tète ovale, prolongée antírieurement en forme de museau cylindigue, armé d'une pointe. - Point de petits yeux lisses. Corps alongé. - Ailes ćcartées l'une de l'autre, même dans le repos. - Pattes longrues; les quatré prenières à peu près égales entr'elles.

On ne connoit encore (qu'une seule espèce de Pédicie; clle paroit répandue dáns toule l'Eurepe. Ses moul's sont inconnues, mais ne doivent pas, d'après l'analogie, beauconp différer de celles des Tipules et des limnobies.

\section{Pédrcie il triangle, $P$. rivosa.}

Pedicia alis hyalinis, margine antico fasciâque angulutâs fiescis.

Pedicia rivosa. Lat. Gener. Crust. et Ins. tom. 4. pag. 255. - Limnobia rivosa. BJelg. Dipt. a Ézrop. tom. I. pag. I $16 . \mathrm{n}^{\circ}$. 1. - Tipula rivosa. Lisn. Syst. Nat. 2. 971. 2. - Tipula trianguharis. Fав. Syst.'antl. pag. 27. $1^{\circ} \cdot 14 .-$ Tipula rivosa. DEGEer. Ins, tom. 6. pag. 341 . n?. 3. pl. 19. fig. 1. - Encycl. pl. 384. fig. 11 et 12. La femelle.

Longueur 12 à $13 \mathrm{lig}$. Tèle brune. Anteunes, palpes et bouche roussâtres. Corselet brun, avec denx ligrneś dorsales d'un blinn roussâtre, ses côtés de ceste couleur mélée d'un peu de blanchàire. Abdoneu brun (rousaitre ver's l'anus dans le irâle), ses côtés bluncs. Pattes hrunes, leurs articalalions un peu plus foncées. Balanciers pâtes. Ailes transparentes, leur bord supérieur brunroussâtre, émettaut deus ligñes de nềne couleur qui forment une sorie de lriangle, et dont celle cui part de la base altein le bord interne de l'aile. Thâle et femelle.

Se tronve en France. Elle cst rare aux environs de Paris.

Nota. Celte espèce est bien la Tipula rivosa de Linné et de De Géer, mais non celle de riabricius. M. Meigen donue sous le nom de Tipuía varipennis, Horru., l'espèce qui portoil le now de Rivosa dans la collection da professeur de Kiel. (S. F. el A. Senv.)

PÉDICULE ou PÉTIOLE. (Voyez Abdomer, tom. 4, pagr. 45.) Les cellules cubitales des ailes supérieures daus les irsectes de l'ordre des Hyménoptères, sont appelées pétiolées lorsqu'elles ne touchent point a lit cellule radiale \& qu'elles font placées à l'extrémité d'une nervure qui part de cetse radiale, et porte dans ce cas le nom de pétiole. (S. F. et A. Serv.)

PÉDILE, Pedilus. Genre de Coléoptères héréromères, foudé par M. Fischer (Genres d'insectes publiés au nom de la Société impériale des naturalistes de Moscou, 182I ). Il a (quelque ressembance arec les Pyrochres, dont il dilfère, suivant cet auteur, par son corselel ulobuleux, non déprimé, et ses élytres paralièles. Ses caractères son! : Antennes de onze articles, le premier obconique, le second presque globuleux, le troisième long, presque cylindrique, les autres un peu dentés eu scie, le dernier court, filiforme; chaperon carré; labre conique, grand, un peu sillonué dans sa partie antérieuré; mandibules obtuses; mîchoires subulćes, acérées; palpes maxillaires de trois articles, celui du milieu trèsalongé, le dernier ovale; les labiüux phns courts, minces; lèvre triangulaire, large à sa base, peú pointue et ciliće.

Il en décrit une seule espèce qui est figurée dans l'Entomographie de Russie, Col. pl. 5, fig. 23 , scus le nom de Pédile brun. ( $P$ : fuscus.) ('et insecte a trois lignes de longu eur. Tôlte noire, raboteuse, très-rétrécie vers la houche. Yeux échancrés, recevant les autennes, celles-ci entièrement velues. Corselet noir, pointillé, très-étroit en devant, globuleux au milieu, très-rclevé au bord postérieur. Ecusson alongé, presque conique. Elytres pointillées, hrunes, velues, ciliées de blanc. Ailes brunes. Dessous du corps brun. Anus wuge. Pullesbrunes, jambes et tarses un pru plus clairs. Trcisième article des larses postérieurs orbiculaire, entier, sillonné en haul pour recevoir l'article suivint.

Il se trouve sur les monts Altaiqques en Sibérie. (S. F. et A. SEnv.)

PÉDINE, Pedinus. Lat. Tenebrio. IIINy. Geoff. Blaps, Platynotus, Opatrum. FАв. Helops, Tenebrio, Opatrum. Ulv.

Genre dinsectes de l'ordre des Coléoptères, section des Hictéromères, famille des Mélasomes, tribu des Blapsides.

La tribu des Blipsides a pour caraclères de manquer d'ailes et d'avoir les qualre palpes terminés par un article beaucoup plus grand, triangalaire el en forme de lrache. Parmi les genres qu'elle coutient, les Scotines de M. Kirby et les Asides 
Asides ont le onzième ou dernier article des anteunes très-court et engagé, au moins en partie, dans le dixièıne. Les Blaps ont le troisième article des antennes au moins deux fois plus loug que le quatrième. Les Misolampes ont les troisiène et quatrième articles des antennes longs et ́́gaux entr'eux. Les Platyscèles n'out point d'ćchancrure au chaperon et leur écusson est moins distinct que celui des Pédines; de plus.les mâles dans le preunier de ces genres, ont les denxième, troisièrne et quatrième articles des quatre tarses antérieur's dilatés latéralement et presque cordiformes.

Antennes filiformes, de onze articles, le troisième seulement moitié plus long que le second, et a'ayant pas deux fois la longueur du quatrième; les quatrième, cinquièure, sixième et septième, obconiqques, les huitième, neuvième et dixième, tantôt turbinés, taulôt prescque globu'eux, le dernier ayant au moins la grandeur du précédent et arrondi à son extrémité. - Labre coriace, ièscourt, transverse, entier ou un peu échancré. Mandibules bifides. - Mâchoires munies d'une dent cornée à leur côté interne. - Palpes terminés par un article beaucoup plus graud, conprimé, triangulaire ou sécuriforae, surtout dans les waxillaires; ceux-ci composés de quatre articles, les labiàux de trois. - Lèore légèrement Échaucrée. - Tête ovale, à moitié enfoncée dans le corselet et plus étroite que lui; chaperon distinctement échancié au milieu, de inanière à laisser apercevoir une grande partie du labre. - Yeux peu saillans, paroissant en dessus et en dessous de la tête, presque coupés pal son rebord latéral. - Corps en ovale court, un peu déprimé. - Corselet de la largeur ou à peine plus large que les élytres, traisverse, échancré en devant. - Ecusson distiuct. - Elytres réunies, enubrassant peu ou point les côtés de l'abdomen. - Point d'uiles. - Pattes fortes, jambes ouvent dilatées vers leur extrémité, surtout les ntérieures; tarses des deux pattes antéricures sculeneut, ayant plusieurs de leurs articles dilatés dans les wâles.

On doit l'établissement de ce genre à M. Latreille. Les Pédines habitent les sables arides et chauds. On en connoit trente ou quarante espèces qui se trouvent principalement daus les parties les plus méridiouales des deux Mondes.

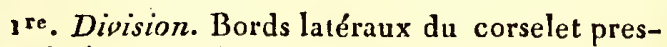
que droits postérieurement, sans rétrécissement brusque, furmant de chaque côté, avec le bord pustérieur, un angle presque droit.

\section{Pédine fémoral, P.femoralis.}

Pedinus niger, elytrorum striis octo punctatis per paria dispositis; tarsorum anticorum articulis Hist. Nat. Ins. Ins. Tome $X$. tribus primis in mare dilatatis; femoribus onnubus in utroque sexu canaliculatis.

Pedinusfemoralis. LAt. Gener. Crust. et Ins. tom. 2. pag. 165. $n^{\text {} . ~ 2 . ~-~ B l a p s ~ f e m o r a l i s . ~ F ~} \mathrm{AB}$. Syst. Eleut. tom. I. pag. I 43. $n^{\circ}$. I2. Lce wẩle. $\mathrm{P}_{\mathrm{Aaz}}$. Faun. Germ. fasc. 39. fig. 5. Le mále. Blaps, dermestoides. FАв. Syst. Eleut. tom. $\mathbf{~}$ pag. 142. $n^{\circ}$. 9. La fene!le. - Tenebrio femoralis. Lisn. Syst. Nat. 2. 679. 32. La femelle. Or.1v. Entom. tom. 3. Tenebr. pag. 17. $n^{\circ} \cdot 23$. pl. 2. fig. 22. La femelle. - YANz. Faun. Germ. fasc. 3g.fig. 6. La feurelle. - Le 'Ténébrion à stries jumelles. Georf. Ins. Paris. tom. L. pág. 348. $n^{\circ} .3$.

Longueur 4 à 5 lig. Entièrement noir. 'Têto ayant une légère impression transversale; elle est finement pointillée, ainsi que le corselet. Elytres portant chacune huit stries ordinairement disposées deux à deux, formées par des points peu enfoncés. Jambes antérieures et intermédiaires, dilatées vers l'extrémité. Cuisses canaliculées en dessous. Tarses antérieurs ayant leurs tross premiers articles dilatés dans les mâles, le sillon des deux cuisses postérieures garni d'un duvet serré de couleur rousse dans ce mềme sexe. Mâle el femelle.

Commun aux eavirons de Paris.

$2^{\circ}$. Division. Bords latéraux du corselet arqués, ayant un rétrécissement brusque très-marqué avant l'angle postérieur.

\section{PÉdine crénelé, $\boldsymbol{P}$. crenatus.}

Pedinus niger, elytrorun striis octo crenatis, intervallis subconvexis minutissime punctulatis, tarsonum anticorum arliculis tribus primis in mars dilatutis, femoribus in utroque sexu canaliculatis.

Pedinus crenatus. Lat. Dict. d'Hist. nat. édit. 2. - Platynotus crenatus. Faв. Syst. Eleut. tom. 1. pag. 139. $n^{\circ} .3$.

Longueur un pouce. Entièrement noir. Tête et corselet très-firement pointillés d'un noir un peu mat, le reste du corps luisaut. Elytres embrassant les côtés de l'abdouren; el'es ont chacune huit stries ponctuées el crénelées dont les iniervalles sont un peu convexes et très-finement poiutillés. Cuisses canaliculées en dessous. 'Tarses antérieur's ayaut leurs trois premiers articles dilatés dans le mâle.

Des Indes orientales.

\section{Pédine hybride, $P$. hybridus.}

Pedinus niger, elytrortun striis octo per parit desinentibus, punctatis, intervallis planis subpunctatis; tarsorum anticorum articulis secundo tertioque in mare dilatatis, femoribus omnibus in utroque sexu canaliculatis. 
Pedinus hybridus. Lar. Dict. d'Hist. nat. éd. 2. - Heliophitus hybridus. Des. Catal.

Longrzeur 6 lign. Entièrement noir. Tête el corselet pointillés. Elytres ayant chacune huit stries pointillées dont les iutervalles sont plans et finement ponctués. Cuisses canaliculées en dessons. Jambes antérieures dilatíes à l'extrémité ; second et troisiène articles des tarses de ces jambes dilatés dans le unâle. Sillon des cuisses postérieures, leurs jambosainsi que lesintermédiaires garnis de dựet intérieurement dans ce même sexe. Màle et fernelle.

Du midi de la Franee.

Nota. Dans celle espèce ainsi que dans la suivante, les stries des élylres se rejoignent par paires à leur extréreité, savoir : la première avec la huitième, la seconde avec la septième et ainsi de suite, de manière que la quatrième et la cinquième ne parvienoent qu'aux trois quarts de la longueur de l'élytre.

\section{Pédrne arqué, $P$. arcuatus.}

Pedinus niger, elytrorum striis octo profundè punctatis, crenatis, per paria desinentibus, intervallis subconvexis lovibus; tarsorum anticorum articulis quatuor prinis in mare dilatatis, femoribus omnibus in utroque sexu vix canaliculatis.

Longueur 6 lig. Corps assez étroit, entièrement noil. 'Tềte tínement ponctuée, marquée d'une foible impression transversale. Antenues d'uu brun noirître. Corselet presque lisse. Elytres ayant chacune huit stries ponctuées et crénelées, les points écartés les uns des autres; intervalles des stries lisses, un peu convexes. Jarnbes anł̧érieures arquées, forieunent écluncrées et mumies d'une coufle de poils recourbés placée au-dessous de l'échancrure, dans le màle. ll a en outre les quatre premiers articles des liarses antécieurs dilatés. Les quatre jambes postérieures, ainsi que les deux cuisses de devant, sont garines eu dedans d'un duvet grisitte. Cuisses un peu canaliculées en dessons. Mâle et femelle.

Des Indes orientales.

5. Pédrine gibboux, $P$. gibbus.

pedinus nigro picens, elytronum striis octo riuctatis, intervallis subconvexis, punctatis; tarsorum antacoruris artaculls secundo tertioque ill mare dilatutis, femorbus ornnibus canaliculatis, tibus suprà convexis.

Pedinus gibbus. L.A r. Dict. d'Hist. nat. édit. 2. - Opatrum gibbum. Fав. Sjst. Eleut. tom. 1. parg. $116 . n^{n} .6 .-$ Osw. Entom. tom. 3. Opatr. pag. $7 . n^{\circ} \cdot 7 \cdot p l$. 1.fig. 6. - Pasz. Faun. Gemm. fisc: $3.9 . f i g .4$.

- Iongneur $3 \mathrm{lig}$. Brun noirâtre. Tête et corselet fiicasent pointillús. Elyttes ayant chaciune huit stries ponctuées, dont les intervalles sont un peu convexes et pointillés. Jambes autérieures dilatées à l'extrémité. Second el troisième ar'icles des tarses de ces jambes"dilatés. Cuisses canaliculées en dessous. Sillon des postérieures, leurs jambes ainsi que les intermédiaires, garmis de duvet en dedans. Toutes les jambes eonvexes en dessus. Mâle.

1)u midi de la Franee, sur les bords de la Méditerranée.

\section{Pèdine grille, $P$. clathratus.}

Pedinus niger, elytronum striis octo profundius punctatis, subcrenatis, quatuor primis ad suturan in utroque elytro per paria dispositis, intervallis lavibus; femoribus omnibus canaliculatis.

Opatrum clatliratum. FAB. Syst. Eleut. tom. $\tau$. pag. $118 . n^{\circ}$ 14. - Opatrinus clathrutus. DEJ. Catal.

Longneur 5 lig. Entièrement noir. Tête et corselet ponclués. Elytres ayant chacune huit stries profondément ponctuées, crénelées, dont les quatre premic̀res à partir de la suture sont rapprochées par paires, leur's intervalles lisses. Cuisses canaliculées en dessous. Femelle.

De Cayenne.

\section{Pédine ponelué, $P$. punctatus.}

Pedinus niger, corpore subconvexo, elytronm seriebus punctorum octo, intervallis punctatis, femoribus subcanaliculatis.

\section{Heliophilus punctatus. DEJ. Catal.}

Inngueur 5 lig. $\frac{2}{2}$. Corps un peu eonrexe, entic̀rement noir et pointillé. Elytres ayant chacune huit lignes régulières de points enfoncés. Curisses un peu canaliculées en dessous. Jambes an téricures dilatées à l'extrémité. Femtlle.

De la Russie méridiouale.

\section{Pidre portugais, $P$. ulyssiponensis.}

Pedinus nigcr, corpone subconvexo, elytronim striis octo punctatis, interiallis subconiexis, punctatis, femoribus subcanaliculats; tibiis quatuor posticas suprà canaliculatis.

\section{Phylax ulyssiponensis. DEJ. Catal.}

Longueur 5 lig. Corps un peu convexe, entièrement noir et pointillé. Elytres ayaut chacune huit stries ponctuées, leus iniervalles un per. convexes; cuisses légèrement canaliculées on dessous, jambes antéricures dilatćes à l'extrémilé, les quatre postérieures ua peu candieulées en dessus. Femelle.

D'Esparne et ủe Portugal. 
3". Division. Bords latéraux du eorselet arrondis postérieurement, sans saillie en forme d'angle ou de dent.

\section{Pédra en deuil, $\boldsymbol{P}$. luctuosus.}

Pedinus niger, confertissimè punctato-rugosus, elytrorum striis octo punctatis, intervallis vix convexis; tarsorum anticorum articu! is secundo tertioque in mare dilatatis; femoribus omnibus canaliculatis.

Longueur 4 lig. Entièrement noir, très-pointillé, un peu rugueux. Elytres ayant chacune suit stries ponctuées, leurs intervalles peu convexes. Jambes antérieures dilatées à l'extrémitć, les quatre postérieur es garnies de poils en dedans. Cuisses canaliculées en dessous; sillon des deux postérieures ayant un duvet roux. Second et troisième articles des tarsés antérieurs dilatés. Mâle.

Du midi de l'Europe.

MISOLAMPE, Mtsolampus. Lat. Pimelia. Herbst.

Geure d'inseetes de l'ordre des Colćoptères, seetion dès Hétéromères, lainille des Mélasomes, tribu des Blapsides.

Tous les genres de cette tribu se distinguent de celui de Misolampe par le quatrième article de lenrs antennes sensiblement plus court que le troisième.

Antennes groossissant vers leur extrémité, eomposées de ouze articles, le troisième et lc quatrième lonsrs, cylindriques, égaux entr'eux; les cinquiène, sixième el septième eourts, obconiques, les trois suivans sensiblersent plns épais, turbinés; le deruier plus grand, ovale. - Labre coriace, avancé, transversal, entier. - Palpes terminés par un article grand, sécuriforme, les maxillaires avancés. - Tète pencliée. - Clua-peron terminépar une ligne droite. - Corps convexe, ovale-alongé. -- Corselet presque globulenx, un pen plus ćtroit que les élytres, échinncré ca devant pour reccvoirla partie postérieure de la tête.-Ecusson très-petit. - Elytres réunies, leurs côtćs arrondis, embrassant l'abdomen en dessous. - Point d'ailes. - Abdomen ovalaire, trongué traiasversalemeut à sa base, atrondi postérieucement. - Pattes grêles, jamhes alongées, ćtruites, sans épines distinctes à lenr extrémité.

Ce geure est dú à M. Latreille. Son nom vient de denx mots grecs et signifie : fuyant la lumièrc. On en connoit nne ou deux espèces. On les trouve en Europe.

\section{Misolampe d'Hoffinansegg, M. Hoffman- seggii.}

Misolampus ater, nitidus, punctatus, elytris punctato striatis, punctis numerosissinis, antennis, palpis iarsisque rifesicutibus.
Misolampus Ioffmansseggi. Lat. Gen. Crust. et Ins. tom. 2. pag. I6i.tom. I. tab. X., fig, 8. pimelia gibbuk. Herast, Col. VIII. CXX.7.

Longueur 5 lig. $\frac{1}{2}$. Noir foncé luisant, trèsponctué. Les points des élytres formant des lignes. Antennes, palpes et tarses roussútres.

De Portugal.

Nota. L'Helops pimelia $n^{\circ}$. 3q. FА в, syft. Eleut. (Scaurus viemensis. Sти м. Faun. Germ. II. $X L I)$ rapporté au gemre Misolampe par M. Latreille (Règn. aninz. tom. 3.p. 297 ) est aujourd'hui le type d'un nouveau genrc nommé Lana par M. Mégerle.

ASIDE, Asida. IAat. Machla. Herbst. Tenebrio. Georf. Opatrum. Oliv. Fab. Platynotus. FAB.

Genre d'inseetes de l'ordre des Colćoptères, seetion des Hétérơmères, faunillé des Mélasomes, tribu des Blapsides.

Aucun genre de cette tribu, sauf cenx de Seotine et d'Áside, u'a lc dernier article des antennes engagré en grande partie daus le disième ou avant-dernier; mais les Scolines ont ce dernier article à peine visible et leur labre est bifide. On ne peut done pás les eonfondre avec les Asides.

Antennes presque filiformes, plus épaisses vers leur extrémité, composées de onze articles, le troisième un peu alongré, les suivans jusqu’au huilième inclusivement presqu'obconiques, courts; les nellvic̀me et dixième plus épais, le prennicr obconiciue, le second presque semi-globuleux, plns large, échancré à sa partie supéricure pour recevoir la base du onzième, celui-ci peril, Irausverse, ovale. - Labre coriace, ivancé, transversal, arrondi en devant, à péine écliancré an nilien. - Palpes ayant leur dernier article plus grand, obtrigonc, les maxillaires de quatre anticles, les labiaux de trois. - Menton cordiforme, tionqué transversalement à sa partie inféricure, son bord supérieur arroudi, écl:ancré. - Corps ovale, un peu aplati en dessus. - Corselet presque carre, nu pien plus large à sa partic postérieure, échancré en devant pour recevoir me portion de'la tête, sescôtés rebordés, son bord postérieur de la laryeur de la base des ćlytres, un pèu sinué vers ses deux extrémités. - Ecusson pelit, distinct. - Elytres riunies, embrassant l'abdomen. - point d'ailes. - Abdomen ovale, tronqué transversaleratent à sa base. - Jambes alongées, obconiques, comprimées, plus larges à leur extrémité, terminées par deux épines trèspetites.

Ce genre eréé par M. Taltreille est composé d'une quinzaine d'espèces. Lenrs mours sont les mômes que eelles des Opûttres. On les trouve dang les endroits clauds et sablonneux. 


\section{Aside grise, A. grisea.}

Asida nigra, elytris rugosis, punctis elevatis longis in seriebus quatuor dispositis.

Asida grisea. L.1 T. Gen. Crust. et Ins. tom. 2. pag. 154. $n^{\circ}$. I - Opatrun griseum. FAв. Syst. Eleut. pag. $115 . n^{n}$. 1. - OLiv. Entom. tom. 3. Opati. pag. 4. pl. 1. fig. 1. - Le Ténébrion ridé. Geof F. Ins. Paris. tom. 1. pag. 347. $n^{\circ}, 2$. pl. 6. fig. 6. - Encycl. pl. 194.fig. 3.

Longueur 6 à 8 licr. Corps entièrement noir, couvert de petits poils roides. 'T'ête et corselet fortement ponctués, celui-ci très-reloordé sur les côlés. Elytres raboteuses, ayant de nonıbreux tubercules alongés, rangés pour la plupart sur quatre lignes, formant pres que quatre carènes longitudinales.

Nota. Celle espèce se tenant continuellement dans la poussière, contracle une couleur grise qui est due à la terre qui s'engage entre ses poils.

Très-commune aux environs de Paris.

Voyez pour les autres espèces, la remarque qui suit le genre Opâıre de ce Dictionnaire. Rapportez encore aux Asides, le Platynotus vairolosus no. 5. Fab. Syst. Eleut. (S. F. et A. SERv.)

PÉDIPALPE ou PIED-PALPE, Pedipalpus. Le docteur Léach désigne ainsi ces parties de la bouche des Crustacés maxillaires, que j’avois nommćes dans mon Genera Crustaceorum et Ins., palpes doubles exrérieurs (palpi gemini externi), ou les pieds-mâchoires extérieurs des Crustacés décapodes, c'est-à-dire ceux de la troisième paire, en allant de haut en bas, el qui recouvient ordinairement les autres orgaues de la manducation.

J'avois aussi appliqué cette dénomination de pied-palpe à ces appendices de la bouche des Arrchnides, qu'on a coutume d'appeler palpes ou antennules. D'après les idées de M. Savigny sur la correspondance de ces parties avec celles de la bouche des Crustacés (voyez son Mrém. sur les Aninz. sans vert., part. 1 , fasc. 1, pl. 3-6), ces palpcs représenteroient ces mêmes pieds-mâchoires dont je viens de parler, et dont la base formeroit de fausses máchoires, ou celles que j’avois nommées mâchoires sciatiques. Les mandibules des mêmes Arachnides répondroient à la seconde paire des pieds-nâachoircs, pièces que j'avois d'abord distinguées par la dénomination de pieds-mandibules. Mais d'après de nouvelles Eludes comparatives de toutes ces parties, j'ai reconnu que les mandibules des Araneides représentoient les antennes intermédiaireś des Crustacés, et que les palpes avec leurs mâchoires étoieut les analogues des premières måchoires des derniers, ou de celles de la partie supérieure, ainsi que des pièces des insectcs héxapodes, appelées uussi máchoires et palpes maxillaires.

Les Arachnides ne dilféreroient de ces animaux que par $\therefore$ 'Lsence des mandibules et de levre inféricure proprement dites. Les pièces composant, dans les insectes, cet!e lèvre inférieure, et qui dalıs les Crust:icés forment la seconde paire de mâchoires, répondroient aux deux premières pattes des Arachuides. La pièce buccale de ces derniers animaux, qui a reçu le nom de lèvre ou de languette, seroit la langue ou la languette proprement dile des précédens. La partie enfin que M. Savigny, relativerwent aux Arachnides, appelle pièce sternale, seroit le labre. (Latr.)

PÉDIPALPES, Pedipalpi. Famille d'Arachnides pulmonaires, ayant pour caraclères : quatre spiracules ou bouclies aériennes dans tous. Palpes en forme de bras ou de serres, sans aucun appendice relalif à la généralion, dans aucun sexe. Doigt mobile des Cliélicères sans ouverture propre au passage d'une liqueur vénéneuse. Abdomen toujours annelé, revêtu d'un derme coriace ou assez fertne, annelé, sans filières au bout.

Celte famille se partage en deux tribus, les Scorpionides et les Tarentules. Voyez ces muts. ( LATR.)

PÉLĖCIE, Pelecium. Kirb. Lat.

Genre d'insectes de l'ordre des Coléoplères, section des Pentamères, famille des Carnassiers, tribu des Carabiques.

Ce genre nouveilement créé par M. Kirby dans les Transactions de la Société linnéenne de Londres, est placé par M. Lalreille dans la troisième division de la tribu des Carabiques, nommée les Thoraciques. Parmi les genres qui composent cette division, les Harpale's et les 'J'échus se distiuguent par leurs quatre tarsès autérieurs dilalés dans les mâles; le dernier article de leurs palpes extérieurs est ovoïde ou acuminé; dans les Féronies, les Licines, les Badisters et les Remlses, l'extrémité supérieure de la languelte dépasse ou atteint au unoms celle de l'arlicle radical des palpes labiaux, et la partie supérieure de leur tête n'a point d'étranglemeut ni de dépression brusque immédiateneut derrière les yeux. Dans les Punagées, le corselet est visiblement plus large antérieurement qua ia sa partie postérieure, ceile-ci se rétrécit subitement avant sa jonction avec les élytres, et les mâles n'ont que deux articles dilatós aux deux tarses antérieurs. Les antennes des Loricères sont chargées de faisteaux de poils. Ces caraclères nous paroissent séparer suffisamment ces genres de celui de Pélécie.

Antennes filiformes, insérées vers la base des mandibules sous un petit rebord de la lêle, composées de once articles, le premier et le dernier plus grands que les antres. - Labre court, creusé au milieu. - Mandibules g:audes, sans dentelures, se croisunt dans leur nilieu. - Palpes extérieurs ayant leur dernier arlicle graad, sécuriforme, presque triangulaire; les auaxillaires ex- 


\section{P.E L}

térieurs de quatre articles, les labiaux de trois; palpes maxillaires intérieurs de deux articles, le dernier fort grand, courbe, grossissant insensiblement de la base à l'extrémité. - Lèvre échancrée à son extrénitić, portant deux petites pointes. - Téte déprimée ayant un eou distinet.-Corselet presque carré, ses bords latéranx arrondis; sa partie postérieure presqu'aussi large que l'antérieure êt ne se rétrécissant pas subitement avant sa jonction avee les élytres. - Elytres eonveses, entières, réunies, embrassant un peu l'abdomen. - Point d'ailes. - Pattes fortes, de longuenr moyenne. Jambes autérieures échanerées an côté interne; les deux tarses antéricurs ayant leurs quatre preniers articles dilatés et v'elus en dessous duns les mâles.

L'espèce qui a servi de type à ce genre, est du Brésil. Nous ne connoissons point ses mœurs. Le nom de Pélécie vient d'un mot grec qui sigaifie hachs, et a été donné à ce genre en raison de la forme du deruier artiele de ses palpes extériears.

\section{Pélécie cyanipède, $P$. cyanipes.}

Pelecium nigrum, capite, thorace pedibusque cyaneis, elyins profunde sulcatis.

Pelecium cyanipes. Kir в. Trans. Linn. vol. 12. tab. 21. fig. I.

Longuenr 7 à 8 lig. Antennes noires, leurs quatre premiers articles ayant un reflet bleuâtre, les autres chargés d'un duvet roussâtre. Deruier article des palpes extérierrs garni de poils roux. T'ête lisse, d'un noir blenâtre, ayant deux enfoncemens sur le front, et un petit rebord qui s'étend des yeux à la base des mandibules. Corselet lisse, d'un noir bleuâtre, fortement rebordé, muni d'no sillon longitudinal au milieu, d'une inpression de:ni-eirculaire à sa parie antérieure et de deux autres beancoup plus prononcées de chaque eôré postérieurement. Abdomen noir ainsi que les élytres. Celles-ei profondément sillonnées, leur bord cxtérieur ayant une ligne de points enfoucés. Les autres stries lisses Paltés bleuâtres; tarses noirs garmis de poils roux. Mâle.

Du Brésil. (S. F. et A. Serv.)

PÉLÉCINE, Pelecinus. LAT. FAв. Ichneumon. Oriv. (Eneyel.)

Genre d'inseetes de l'ordre des Hyménoptères, section des 'Térébrans, famille des Pupivores, tribu des Evaniales.

Ce genre fondé par M. Iatreille se distingue des Evanies parce que dans eelles-ei l'abdomen est très-petit et très-comprimé, des F'enes parce que dans ee genre le eou est très-distinct, des Aulaques en ce que l'abdomen de ces dernier's est inséré sur une élévation particulière du métathorax, et que leurs ailes supérieures ont des cellules très-différentes.
Antennes très-grêles, de quatorze articles; le prenier gros, renflé à sa partie interne, le seeond très-eourt, globuleax, les antres cylindriques, diminuant un peu de longuenr à mesure qu'ils s'óloignent de lia base. - Labre grand, menbrane!x, demi-circulaire, entier. - Mandibules fortes, trigones, dentées, la dent de l'extrémi é plns forte, la précédente obluse, l'inférieure plus grande que la seconde et échancrée. - Palpes maxillaires beaucoup plus longs que les labriaus, presque sétucés, de six articles inégaux, le premier très-cont, les second et troisième presqu'égaux, plus épais, obconiques, les trois dernicrs plas minces, le gualième et le ciruquierre de la longuenr des précédens, à per prés cylindriques, plus lurges et arrondis à leur extrécrité, !e dernier fort aminci, plus court que les précéciens, ayant une pointe particulière à son extréuité; päpres labiaux renllés graduellement à leur partic extérieure, de quatre articles à peu près égaux, le premier un peu plus petit, le dernier un peu plus grand que les autres, cylindrico-ovale. - Languette trifide; $s a$ division médiale plus étroite. - T'éte plus large que longue, sans eon apparent. - Trois petits yeux lisses disposés en triaugle et placés sur le vertex. - Corselet assez long, le métathorax formant à peo près la muitié de sa longueur. - Ailes inférieures sans nervurcs distinetes, exeepté celle du bord antérieur; les supérieures ayant ontre ba nervare da bord antérieur, une autse nervure qui part du point épais et se bifurque en se dirigeant vers l'extrémité de l'aile; de la partic de eetle nervare qui préeède la bifurcation, part nue autre nervure qui remonte d'abord vers la base de l'aile et redescend ensiite pour en atteindre ic bord postéricur; de la base de l'aile part une atútre nervare qui émet denx principaux rameaux, dont l'un rejoint la côte et l'antre le boid postérieur; dans l'angle lormé par le rameau qui rejuint la cóle et la nervure dont nous parlons, se tronve une petite cellule mal terminée qui est la prenière eellale discoidale supérienre, la seconde cellule discordale supéricure existant aussi. La cellule discoidale inérieure áciant nulleraent tracée. - Abajomen iuséré sur le bout inférienr. du métathorax près de l'origine des pattes postérieures et composé de cinq segmens outre l'anus. - Jumbes postéricures yuelquetors en massiae; premier article de lenrs larses, beaucouj plus court cque les suirans.

Ce genre propre à l'duxérique, n'est composé que de deux espèces. On n'a point encore distingué les sexes, nidécouvertla tarière cies ficaseites. Leurs mours sont incounues.

\section{Pélécine polycérateur,$P$. polycerator.}

Pelecinus polycerator. LAT. Gener. Crust. et Ins. tom. 5. pag. 255. - FAB. Syst. Piez. pag. 
111. n\%.1.-DrunY, Ins. tom. 3. pl. .1L. fig. 4.

Voyez pour les autres synonymes et la descripion, Jchneumon polycère, ॥ $^{\circ}$. I13.

Nota. Nous voyous à notre individu, ainsi que dans la figure et la description de Drury, le disic̀me article des antennes el la base du précédent blanchàlres. C'est donc à tort que cet insecte a ćić mis anciennement par Fabricius et par Olivier, dans la division des Iclnecanons à antennes tou'es noires, at moins qu'il ne varie sous ce rapport. Il y a aussi erreur sur la patric indignée par ces deux auteurs, celte espèce étant unéricaine ot non des Indes orienlales.

\section{Pélécine eu massue, $P$. clavator.}

Pelecinus niger, antennarum articulo decimo tarsorumque duorum posticorum articulis mtermediis albidis, abdomine clavato.

Pelecinus cluvator. Lat. Dict. d'Hist. nat. edit.2.

Longueur $8 \mathrm{lig}$. Noir mat. Antennes noires arec lear dixième article Jlanchâtro. Abdomen en massue alongće; l'extrémilé de cetic massue conique, pointae. 'Tète ayant une gibbosité placée au-dessous des antemes. Troisiène et quatrième arlicles des larses postérieurs, ainsi que l'extrémité du second, de couleur blauche. Jambes postérieures peu rentlées. Ailes légèrement enfumées,

Da Brésil.

FeENe, Fœnus. Fab. Lat. Jur. Paxz. Ich-

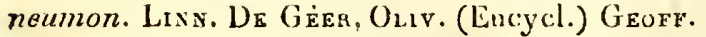
Gasteruption. Lat. (Précis de's caruct. genér. des lns.)

Genre dinsectes de l'ordre des IIyménopières, section des'Térébrans, fanuille des l'upivores, tribu des Evaniales.

D)ans cette tribu les Evanies et les Aulaques se distinguent aisément par lears jambes simples. Les premicres ont en outre l'a baomen très-court et la seconde cellu'e cubitule des ailes supérieures incomplète. Les Aulaques ont trois cellutes cubithes ì ces mêaras ailes. Les l'élécines n'ont point de cou apparent el leurs ailes supérienres u'offient ni collule radiale, ni cabilale distincles. Ces caractères séparent ces genres de celai de licose.

Antennes plus courles que le corps filiformes, droiles, cirrigées en avalni, composées de quiltorze ariclesdins les femetles, de treize dians les mảles, suirant Al. Lat:eille. - Labre longiludinal, Iiućairc. - Mandibules tridentées, la dent inféracure reeourisée én dedirs un crochue, - Palpes filifernes, olears aricles courts, presqu'égaux, abconiques, les maxillaines un peu plus longs que les labiaux, inais pius courls que les mâchoires, de six arlicles dont les trois derniers à peime plus longs que les antres, les labiaux de qualre. Lèvre ayant sou extrémité un peu alongée, cordiforme, replojée dans le repos; menton obeonique. - Téte ronde, portće sur un eou très-distiuct. - Trois petits yeux lisses disposés en triangite sur le vertex. - Corselet comprimé, arrondi en devant, son premier segment peu apparent. - Ailes supérieures ayani une cellule radiale grande, la nervare qui la ferme un peu ondulée, deux cellules cubilales très-griandes, aussi longues l'une que l'autre. la première reeevant la première nervare récurrente, la seconde cubitale atteignant le bout de l'aile, la deuxième nervure récurrente manque. Trois cellules diseoidales; les deux supérieures très-petites, l'inférieure se prolongreani jusqu'au bord postérieur de l'aile. - $A B-$ domen long, en massue un peu comprimée, relevé, iuséré près de l'ćcusson, composé de sept segmens outre l'uus. Turière (des femelles) toujours saillanle, jlus ou moins longue. - Pattes antérieures assez courtes, les postérieures lougues, leurs jambes en massue très-prononcée.

Les Fornes déposent leurs aufs dans le corps des larves qui doivenl servir de pâlure à leur postérité. Plusienrs parviennent au moyen de leur turicre à les placer dans les larves des $\mathrm{Hy}_{\mathbf{y}}$ ménoptères qui vivent en terre daus des cellules fermées. Les Fones ì l'élat parfait vienneut sur les flears el se nourrissent de miel. Ils balancent souvenl leur abdomen de bas ell haut, senvolent avec peine et leur vol' n'est pas vif. Ils se tiennent souvent accrochés par leurs mandibules aux plantes sur lesquelles ils se reposent; leurs maxurs sont à peu prìs celles des Icluneumonides. Ce genre est peu nombreux en espèces.

Rapportez-y l'Ichneumon jarulateur, $\mathrm{n}^{\circ} .149$ (Encycl. pl. vor. fig. 4. et pl. 37.3. fig. I2), et l'Ichneumon cambré, $1^{\circ}$. 15̃ I, de ce Dictionnaire. l.es mâles, qni ue sont poiul décrits dans ces articles, ne different de leur femelle que par le manque de taricre.

AUlaque, Aulacis. Jur. Spiyor. Lat.

Genre d'insecles de l'ordre des Hyménoptères, section des I'érébrans, famille des Pupivores, tribu des Evaniales.

Les livanies etoles Aulaques sont les seuls parmi les Evaniales qui aient les jambes simples el grêles, mais les premières se reconnoissent facilement à leur abdoınen $t$ ès-petit, très-compriné et dont le premier segment se rétrécit brusquement en pédicule.

Antennes sétacées, plus longues que là têle et le curselet, atvancées, grêles, insérées entre les yeux et la base du clayperon, de quatorze articles dans les femelles, de ireize dans les mâles, suivant M. Lutreille; le premier court, plus épais, ovale, obconique, les autres cylindriques, le second très-court, le troisième et les suivans s'alongeant graduellement, les derniers diminuant de 
longncur. - Mandibuics petites, échancries dans les femelies (suivant Juine), cortuées, eourtes, épaisses, tridentées à leur côté interne dans les mâles (selon M. Latreille). - Palpes maxillaires beaucoup plus longs que les labiaux, sétacés, minees, de six artieles, le premier trìspetil, les second et troisième plus épais que les autres, presqu'égaux, celui-lia obconique, l'aulre cyliudrique, les truis derniers plus longs, plus grêles, presqu'técuux entr'eux, eylindriques; palpes labiaux filiformes, de quatre articles, les deux inférieurs plus grands, obconiques, le pre. mier un peu plus long, le second ayant un perit appendice à l’augle extérieur de son extrénicé, le troisième petit, turhiné, le quatrième un pen plis grand que le précédent, presque trianguLaire. - Lèvre petite, membraneuse, presqu'en eapuchon, son extréuité arrondie, entic̀re; menton petit, coriaee, obirigone. - Téte presque globuleuse, plus large que longue, porlće sur un eou conique, alongé. - Trors petits yeux lisses gros, sailians, posés en ligne courbe sur le front. - Corselet coinpiimé; nıétathorax terminé en dessus à sa partie supérieure par une élévation pyramidale sur laquelle l'abdomen est inséré. - Ailes supérieures ayant une cellule radiale grande, rérrécie vers son extrémicé depuis la seconde cellule cubitale; trois cellules eubitales à pen près égales en longueur, la première recevant la premicre eervure récurrenle; seeonde cubilale plus étroite que les deux autres, recevant Ia deuxiène nervure récurrente, la troisième complète; trois cellules discoidales, l'inférieure fermíe pat la seconde nervure récurreule avant le bord fostérieur de l'aile. - Abdomen composé de six segrucus outre l'anus, le premier forilong, faisuat it loi seul presque la moitié de la longucur totale du l'abromen, sa partic antóreure se rérrécissant peu à peu en pédicule pour s’insérer suc le métahorax. Tarière (des femelies) toujimers suilante. - Fattes assez longuc's, aninces; hunches postérieures lougrues; jumbes simples.

On ne conncit point his nours des Aulacines, mais elles doivent se rapjrocher de celles des Ichueunonides. Les espices connues sont en trèspetit nombre.

\section{Auraque stri:?, A. striatus.}

Aulactis niger, abdominis segmentis duobus anticis, primu basi e.xceptà, genuculss tarsisque onnibus, tibits quatuor anticis et posticarmm apice rufis.

Aulacus striatus. Jur. Hyménopt. pl. $7 \cdot$ fig. 5 . La fit elle. - LAт. Gen. C'ust. et Ins. tom. 4. perg. 386. - Encycl. pl. 57-6. fig. 1. La fiemelle.

Longueur 4 lig. Nuir, brillant. Dos du eorselet stré iransver'salement, secunt segnent de l'abdomen et partic postérieure du prennier, les guatre jambes antricures et l'extrémité des posté- rieures, aiusi que tous les tarses, de cou'cue testacéc. Ailes ayant quelquefois un peu de brin. Se troure daus los $A l_{p}$ es et dans lés Pyrénées. (S. F. et A, Seliv.)

PÉLECOCÉRE, Pelecocera. Hoffm. Mrig.

Genre d'insecies de l'ordre des Diptères, section des Prolosicidés, famille des Alhúricères, tritn des Syrphies.

Ce geure créé par M. Holfranseggr a élé publié par M. Reigen dans son dernier ourge sur les Diplères d'burope ; il lui donue pour caractères: Anteunes dirigtes en avanl, de rois aribles, le dernier patelliforine, portant à son extréinicé une scic orosse, courte, disinctement triarticulẹ́e. - Hypostone voûté dans sa partie infúrieure.

Les Pélécocères se distinguent aisément de tons les autres Syrfhies par la soie de lenrs antenncis composce de trois arlicles distincts; caractìe propre à ce seul genre. M. Meigen décrit les donx especes suivaules d'après M. Hoflinansegg.

\section{I'écécocére à trois bandes, $\boldsymbol{P}$. tricincta.}

Pelecocera nigra; abdouniue fusciis tribus flavis subulerruptis; pedibus flavis. (NeIo.)

Felecocera tricincta. Hierg. Dipt. d'Eur. ton. 3. pag. 540. tab. 31. fog. 3 .

Longuenr $3 \mathrm{lig}$. Noire. Abdomen ayant trois bandes jaunes, un peu interrompucs. Pattes jaunes.

2. PéLÉeocére flavicorne, P. favicornis.

Pelecoceru abdonino fasciis tribus internuptis flavts, pedibus fuscauis. (Nivig.)

Pelecocera Ravicornis. Nero. Dipt. d'Eur. tolis. 3. pag. 341 .

Longueur ". Abdomen ayant trois baudes jaunes interrompues; paties brunes.

Nota. Nous ne conavissons point ces dipleres. (S. L. et A. Sent.)

PÉléCOPHORE, Pelecophora. Geure de C)líopleres faroissam appureuir a ha secilon des Tétrameres, fausile des Eupotes, tribu des Criocérides.

Ce genre fondé [ar M. le comte Dejear se conpose ve pelites erp.ces des flies de France el de bonrbon, qui unt les bahimes et le port des Dasytes et dont le dernier artucle des palpes est fortement sicur forme. Ausi son nom générigne estil tiré de deux mots grees qui signitient: portehache.

Une des espèces est la P'lecophore d'Liliger, (P. Illigeri). Notoxus Iligeri. Scn. Synonyn: insect. tom. 1. purt.2. pag.53.n . 6. pl. 4. fig.7.

Longuenr 2 hig. $\frac{5}{2}$. Corps ovale-oblong, din noir broná brillant, profondéwent ponciusé. An- 
tennes plus longues que le corselet, fermginenses à leur base, grossissảnt vers leur extrémité, noires et un peu pubesceutes dans cette partie. Côtés du corselet blanchâtres. On voit deux bandes sinueuses de cette couleur sur les ćlytres. Dessous du corps et cuisses d'un brun noiràtre, un peu pubescens. Jambes et tarses pâles. Palpes d'un ferrugineux pâle.

Ile de Frauce. (S. F. et A. Serv.)

PÉLÉCOTOME, Pelecotoma. Fisch. L.AT. Rhipiphorus. PAYK. GYLL.

Genre d'insectes de l'ordre des Coléoptères, section des IIétéromères, farnille des Trazchéides, tribu des Mordellones.

Ce genre est dî à M. Fischer qui l'a publié dans. les Mémoires des naturalistes de Moscou, tom. 2, pag. 293, et M. Latreille l'a adopté. Ces coleoptères sont voisins des Rhipiphores et des Myodes. Distingués des Mordelles et des Anaspes par leurs antennes en éventail ou même pectinćes dans les máles, et par leurs palpes presque filiformes, les Pélécotomes ont l'écusson apparent, tandis qu'il est caché sous un prolongement du corselet dans les Myodes et les Rhipiphores; les antennes (même daus les máles) ont leur panache simple, c'est-àdire que chágue article dont il est composé ne jette qu'un seul rameau, tandis qu'il en jelle deux dans les deux dernier's genres que nous lui comparons; ils se rapproclient des Myodes par les crochets des tarses dentelés en peigne, tandis que ces crochets sont simplement bifides dans les Rhipiphores.

Antennes insérées au-devant des yeux, près de la bouclie, composćes de onze articles; premier et troisième longs, second et quatriène courts; les sept derniers formant un éventail ou panache simple, chaque article n'érnetlant qu'ır seul raneau; ce rameau heaucoup plus court dans les fentelles, figuraut seulement une large dent de scie. - Labre carré. - Palpes presque filiformes. - Téte fortement inclinée sous le corselet. Yeż $x$ tri-s-grands, rapprochés en devaut, un peu écinanorés pour l'insertion des antennes. - Corselet rétréci en devant, ayant trois prolongemens, deux latéraux et un au twilieu, ce dernier court, ne cachant pas l'écusson. - Ecusson petit, lrianguiaice, apparent. - Elj tres longues, allant un pen en se rétrécissant vers l'extrémité. - Corps étroit, alougé, comprimé latéralement. - Pattes longues; jaubes antérieures munies d'une épine à leur extrémité, les intermédiaires en ayant deux, dont l'intérieure plus grande, les postérieures aves deux épines égales; tarses filiformes, le premier et le dernier articles alongés; crochets denrelés en peigne intérieurement.

On ne connoît qu'un petil nombre d'espèces de Pélícotomes; nous ignorons leurs mœurs. M. le comte Dejean pease que les espèces du Brésil doivent probablement former une nouvelle coupe gẻnériqne. Le véritable type du genre est le Pélés cotome moscovite.

1. Pézécotome de Léach, $\boldsymbol{P}$. Leachii.

Pelecotoma fuscè castaneuin, elytris apice cors. niventiöus.

Pelecotoma Leachii. I.AT. Dict. d'Hist. nat. $2 \mathrm{e}$. édit.

Jongueur 8 lig. Corps et pattes entièrement d'un brun châtain couverts d'un duvet soyeux gris jaunatre. Antennes de la couleur du corps. Elytres rebordées à la suture et au bord extérieur. Mâle.

Du Brésil.

\section{Pélécotome de Latreille, P. Latreillii.}

Pelccotoina tomentosum, nufo-griseum, fusco lineolatum, elytris albido sublineolatis, conniveritibus.

Longueur 5 lig. Antennes d'nn brun ferruginenx, dentées en scie. Corps et pattes de conlenr brune recouverts d'un duvet conché roussâtre, mêlé de petites lignes brunes; élytres ayant quelques lignes blanchattres avec une tache de même couleur vers leur milieú assez grande et assez visible. Femclle.

Du Brésil.

\section{PéĹ́cotome moscovite, P. mosquense.}

Pelecotoma nigıum, elytris fuscè rufis, apice dehiscentıbus.

Pelecotoma nıosquense. Fiscu. Mém. des natur. de Mosc. - Lat. Dict. d'Hist. nat. $2^{\mathrm{e}}$ édit. - Rhipiphorus fennicus. PAYX. Faun. Suec. tom. 2. pag. ${ }^{7} 78 . n^{\circ} .2$.

Longueur 3 lig. Tête et corselet noirs couverts d'un duvet soyeux gris jaunàtre. Antenues noires. Elytres d'un brun roussäire, un peu écartées l'une de l'autre à l'extrémité. Poitrine et abdomen noirs. Pattes d'un brun roussâtre.

Du no:d de l'Europe.

4. PÉcécotome de Dufour, P. Dufourii.

Pelecotoma nigrum, elytiris fuscè rufis, apico conniventibus.

Pelecotoma Dufourii. Lat. Dict. d'Hist. nat. $2^{\mathrm{e}}$. édit.

Longueur 3 lig. Corps noir, avec un duvet soyeux d'un gris cendré. Elytres d'un brun roussátre, présentint quelques inégalités. Pattes noires.

Elle se trouve en Espague et dans la France méridionale.

Nota. Nous n'avons point vu ces deux dernières espèces. (S. F. et A.SERv.) 


\section{P E L}

PÉlogONe, Pelogonus. Lat. Ochterus. Lat. Gener. Crust. et Ins.

Genre d'insecles de l'ordre des Hémiptères, section des Hétéroptères, famille des Hydrocorises, tribu des Ravisseurs.

Ce genre élabli par M. Latreille se distingue de tous les autres de sa tribn, en ce que ses pattes anlérieures sont semblables aux quatre suivantes et point ravisseuses.

Antennes insćrées dans le coin interne el inf:rieur des yeux, sans cavilé au-dessous destinće à les recevoir; elles sonl filiformes, de la lougueur de la tête, composćes de quatre articles, les deux premiers plus courts , celui de la base cylindrique, le second un peu plus gros, conico-cylindrique, le troisieme menu, alongé, cylindriçne, le dernier ovale, un peu plas court que le second. Labre petit, trigone, nu peu plus large que long. - Bec flérhi en dessous, droit, attcignant les cuisses postérieures, plus épais à sa base, cylindroconique à son extrémitć qui est urréle el très-pointue ; il est forné de qualre articles, les deux premiers plus épais, courts, ressemblant à des anneaux; celui de la base plus grand que le second, le troisième très-long, peu distinctement canaliculé, le dernier court, conique, très-pointu; soies du suçoir très-longues. - Corps ovale-arrondi, déprimé. - Tête plus étroile que le corselet. - Yeux grands, saillans, subtrigones, échancrés postérieuremen1. - Deux petits yeux lisses. Corselet plus large que long, demi-circulaire, son hord postérieur plus large, un peu sinué. Ecusson grand, Irignne. - Cuisses alongées, ovales; jambes grêles, cylindriques, un pen épineuses; tarses courts, filiformes, les antérieur's ayant leor premier article très-court; les quatre postérieurs n’ayant que denx articles distincts, de longueur égale, celui de la base paroissant articulé.

Ce genre ne coutient qu'une seule espèce. Elle se plait sur le bord des ruisseaux.

\section{P'́logone bordé, $P$. marginatus.}

Pelogonus suprà niger, abdominis elyirorumque margine cinereo maculato.

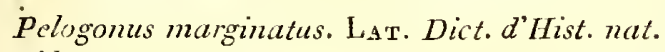
$2^{\mathrm{e}}$. $e^{\prime} d z t$.

Longueur 2 lig. Corps noirâtre, un peu cendré en dessous. Côtés du corsclel, quelques parties de son bord postétieur et des taches snr les bords extérieurs des śly tres et de l'abdomen, d'un bruu roussâtre; élytiés ayant quelques points cendrés. Pattes pâles.

Des environs de Bordeaux et de Brives. On le trouve aussi en Provence et es Espagne. (S. F. et A. S SRV.)

PÉLOPUILE, Pelophila. Ce genre de CoiéopHist. Nat. Ins. Tome $X$. tères pentamères camasciers fait partic de la quatrième division de la triba des Carrabigus, nommée par M. Latreille les Abdominaux. Dans eetle division il se range daus un petit groupe dont voici les caractères : waudibules sans dents notahles ou dentées seulement vers leur base; dernier article des palpes extérieurs presque cylindrique ou ovalaire. Antennes assez épaisses et courles. Dans les autres genies du nênue groupe les articles des tarses antérieurs ne sont que légèrement ou point du tout dilatés dins les mâles, tandis que dansles Pélophiles de ce sexe, les trois premier's articles des tarses antérieurs sont asoez fortement dilatés.

Mi. le comte Dejean a fondé ce genre sur le Cambus borealis de Fabricius el dOlivier, et M. le barron de Mannerheim en a donné une monographie (1). Cet auteur en décrit cinq espèces, dont trois sont regardées par M. Dejean comme des variétés de sa Pélophile boréale. (S. F. et A. Serv.)

PÉLOOPEE, Pelopceus. IAT. Fab. Spriou. Spher. Lunn. De Geer. Jur. Pepsis. F́a. Illig. Sceliphron. Küug.

Genre d'insectes de l'ordre des Hyménoptères, section des Polte-ai,uillon, fauille des F'ouisseurs, tribu des Sphégimes.

M. Jatreille a fondé ce genre aux dépens des Sphex des auteurs qui l'ont précédé. Fabricius l'a adopté, mais il y fait entrer des espèces qui lui sout étrangères, et rejelle dans son genre $P e p$ sis quelques vrais Pélopées. Ces hyménoplères ne péuvent êlre confondus avec les Dolichures, les Ampulex, les Chlorions et les Sphex; dans ces genres la seconde cellule eubilale des ailes snpécieures ne reçoil point les deux nervures récurrentes. Les Ámmophiles ont leur troisième cellule cubitale très-ćloignće du bord postérieur de l'aile e! la quatrième ì peine commen. cée. Les Podies se distingruer l par leurs antennes insérées au-dessons du inilicu de lia face de la tête, le chaperon pius linge que long, les mâchoiles entierement membraneuses et en outre par leurs qualre palpés presçu'ćgalement longs.

Antennes assez courtes, filiformes, un peu roulées en spirale à leur extrémité, de douze articles dans les temelles, de treize dins les mâles, insérées au milieu de la face de la lête. - Labre en carré transversal, placé verticalement sous le chaperon. - Rifundibules sans dents ou midentées au côté interue et strićes sur le dos. - Itâchoires assez conrles, presque droiles on peu courbées, ne formant poial par leur rćunion do fansse tronpe sensiblc; lenr extrémité en partie membraneuse. - Quatre palpes ; les muxillaires

(r) Observ. sur les Ins., par Arviel David Hummel. Sainc-Pitersbourg, 1823. (Essais entomologiques, $n^{\circ} .111$. ) E 
sílacés, beaucoup plus longs (pue les labiaux, de six articles; le troisiène plus grand que le second et le quauriène, dilaté au côté intcrne; les labiaux filiformes, de quatre articles. - Languette à clivisions courtes. - Tête comprimée, son devant plan, uni, soyeux. - Chaperon à dianc̀tres prescu'égaux. - Trois petits yeux lisses disposćs en Iriangle et placés sur le vertex. - Corsebet légèrement rétréci en devant, son prenier segment court et transversal, le second obtus postérieurement. - Ailes courtes, n'alteignant pas l'extrémité de l'abdumen, les supérieures ayant une cellule radiale longue, son extrémité arrondie ne s'écartatut pas dc lat côte; celte cellule s'avançant fort près du bord postérieur de l'aile, ainsí que la troisième cubitale et toulcs deux presquéralement, et quatrc cellules cubitales; la première presqu'aus;i longue que les deux suivantes réunies, la seconde presque carrée, lecevant les deux nervures récurrentes; la troisic̀me se rélrécissant un peu vers la radiale; la quatrième commencée, tracée jusqu'au milien de l'espace qui est entre lit lroisième et le bord postérieur. - Abdonen ovalaire-ylobuleax, composé de cinq segnens onite l'aus dans les femelles, en ayanı un de plus dans les máles, tenant au corselet par un long pédicule formé par lat partie antéricure du premier sejuent qui s'évase ensuite brusquemeul. -- Paties longues, les postérieures surtout; jambes n'étant point ou prescjue point épineuses au cốcé extérieur, les postérieures munies à leur extrémité de deux épines inógales, l'intérieure plus longue; les intermédiaires de deux épines égales et les antérienres d'une seule épiue courie et simpie. - Tarses à articles alongés, le dernier terminć par deux crochets unidentés dans les femelles, simples dins les mâles, avec une peloltc assez grosse dans l'entre-deux.

Les Pelopées habitent les pays chands et sont d'une tiille moyenue dans leur fanille. Ils sont remarquables par leurs habituiles. Dans les espèces d'Europe et d'Amérique dont lcs moeurs sont connues, les femelles conslurisent des nids de terre gâchée, ct c'est de cette occupation que le genre a pris son nom qui eu grec équivant au moí potier. Ce nid est composé d'un assez grand nombre de luyaux tons paralldes les tuls aux autres, formant une masse ordiuairement altaslsée à une corniche ou à uu plancher par le fond des cellules dont l'ouverture est cn bas et sur un mème plan. Il y a quelquefois deux ou trois rangs de ces cellules appliqués l'un contrc l'antre; l'ouverture de charque trou est l'entrée d'une cellule que linsecte ne constrnit que l'uue après l'antre; il la forme d'une spirale du mortier dont nous venons de parler. Ce nid doit ensuite être approvisionné d'insectes vivans pour la nourriture de la larve qui éclôra de l'œưf confié à chaque cellule par la femelle Pelopée, mais nous re savons pas d'une manière bien précise si le clioix de celte mère lombe toujours sur des araignées, comme le dit M. Palisot de Banvois du Pélopée tourneur; cet atuleur ajoute posilivement que cetle espècc ferme après sa ponte l'ouverture de cliaque cellule approvisionnée.

Ce genre peut renfermer une vinglaiue d'esp̀̀ces.

\section{P'́LOPÉE tourueur, P. spirifex.}

Pelopaus niger, antennanum nigranum articulo prino anticè luteo, thorace omnino nigro; abdoninis petiolo iuteo.

Pelopaus spirifex. Lat. Gener. Crust. et Ins. tom. 4. pag. 60. - Sphex spirfex. lirwn. Syst. Nat. 2. 942. 9. - Sphe.x rogyptia. Liva. Syst. Nat. 2. 942. 10. - Pepsis sprrifex. Iltig. Faun. Etıusc. tom. 2. 94.

Longneur 12 à 15 ligg. Corps noir. Antennes noires; premier arlicle arec une lache janne antérieuremen\}. Dessus du mélathorax très-strié, ces stries presque tralusversales. Ailes transparentes it ucrvares bruues avec une très-petite titche obscure at l'extrémité des supérieures. Létiole de l'ahdormen entièrement jamie. Les quatre pattes antérieures jaunes; leurs hanclies et la base des cuisses noires, tarses un peu bruns. Pattes postéricures noires, ayanl le second arlicle des hambles, la base des cuisses, des jambes et des larses, jaunes. Feruclle.

Le mâle est un peu plus petil.

Cette espéce communc dans le midi de la France paroit s'etende sur lous les bords de la Méditerianée.

\section{PÉLOPÉ sirpenseur, P.pensilis:}

Pelopceus niger, antennorum nigranim articulo prruno omminò luteo : thorace nigro, alarum squama lute $\hat{a}$; abdominis petiolo luteo, subties nigro lineato.

Pelopoeus pensilis. Lat. Gener. Cnist. et Ins. tour. 4. pag. 6o. -- Pepsis pensilis. Illug. Faun. Etrúsc. toill. 2. pag. 94.

Longuenr un pouce. Corps noir. Antennes noiles; premicr allicle entièrement jaune; face antérieure de la tête couverte d'un duvel grisatryenté. Lecailles des ailes jaunes. Dessus du métahorax it stries peu sensibles et couvert d'un duvet gris : ailes trausparentes, $1 n$ peu jaunâtres, nervures fauves. Pétiole de l'abdomen jaune, marqué en dessous d'une ligne noire, dins toute sa longueur. Les quatre pattes antérieures jaunes à banches et base des cuisses noires. Les postérieures jaunes avec le premier arlicle des banches, l'extrémiié des cuisscs, celle des jambes et le dernier arlicle des tarses noirs. Mâle et femelle.

Du midi de la France. 
3. Pédopsé distillateur, $P$. destillatorius.

pèlopaus niger, antennarim nigrarum articulo primo onmmo luteo; thoracrs mgri line $\hat{a}$ antıc $\hat{a}$, aliâ siztelluri et alurum squamâ luteis; abdominis petiolo lateo, basi et apice panum nigro : alis pellucritis.

Pel poeus destillatorius. Lat. Gener. Crust. et Ths. tom. 4. pug. 6o. -- Pepsis destillatorius. Ileig Flaun. Elrusc. tom. 2. pag. 94. - Sphex spiryex. P.Nz. Fuun. Germ. Jasc. ib. fig. 15 :

Longuen: i2 it 1 ju lig. Corps noir. An!eunes noires; premier article enlicrement jame. Tête garnie de poils woirs, son deran! et l'orbite des yenx ayaut un pen de duvet argenté. Corselet pubescent. Ecailles des ailes, ligne erminale de l'écusson et péliole de l'abiloncon jaunes; ce dernier ayant un peu de noir à sa base et í sun extrémité, surtout cn dessons. Ailes transpurentes, un peu jaunatres, nervurcs fauves. Les quatre pattes antérieures jaunes ì hanches et basc des cuisses noircs; leurs tarses d'un fauve brunitre. Paltes postérieurcs jannes avec le preater article des hanches, l'extrémité des cuisses el des jambes et lc dernier arlicle des lar'ses noirs. liemelle.

Du midi de la Frince.

\section{Pélopée de Madras, P. Miadraspaíanus.}

Pelopoeus niger, antennarum nigrarum articulo primo anticè luteo : thoracis migri linea anticâ, aliâ scutellari et alarum squamâ luteis; "bdominis petiolo omninó luteo: alis pellucidts apice fuscis.

Pelopons Mradraspatanus. Fав. Syst. Piez. pag. 203. $n^{\circ} .3$.

Longuem 10 à 12 lig. Corps ncir. An ennes noires; premier article jaune en devalut. Face antéricurc de la tête garnic d'un duvet argenté. Lignc antérieure dn corselet, ćcailles des ailes, ligne postérieure de l'écusson el pétiole de l'abdowen jauses. Ailes travspareutes, jannâtress, nervures fanves; leur extrémilé brune. Les quatre patles antérienres jauncs avec lish linnclecs ct lat base des cuisses noires; larses bruns, le premier article des intermédiaires ay ant un pen de jaune. Pattes postérienres noires, second article des hanches, base des cuisses, celle des jambes et la partie inféricure du premicr article des tajses jaunes. Featcle.

Des Indes orientales.

5. Pézopée lunulé, P. lunatus.

Pelopaus niger, antennanum nigrarum articulo primo ommino luteo: thorace luteo vario; abdoninis petiolo nigro, segmento primo ad marginem posticun luteo marginato.
Peloparus lunatus. FAв. Syst. Piez. pag. 203. $n^{\circ}$. 4. - Splhex coementaria. DRUR Y, Ins. tom. 1 . pag. 105. pl. XLIV. fig. 6. 7 et 8. - Sphex flavomaculatu. De GÉer, Ins. 3. 588 . 4. pl. 50. fig. 4 .

Longueur ro à-12 lig. Corps noir. Antennes noires, premier article toialement janne. Face antérienre de la lête garnie d'un duvct argenté. Ligne antérieure dir corselet, écailles des ailes, un trait descendant de la base des ailes sur les côtés, base de l'écusson, une ligne à sa partie inférieure et une tache snr le métathorax an-dessus de l'allaclic de l'abdomen jaunes. Ailcs supérien res un peu olsscures, fauves à nervures teslacées; l'extrétnité plus brune. Partie évasée dn premier seginest de l'abdomen marqué d'une lunule jaunc qui le borde postérieurement. Les quatre paltes antérieures jaunes, à hanches et base des cuisses noires; lcurs tarses bruns à l'extrémité. Paltcs postérieures noires avec la base des jambes et les premiers articles des tarses jaunes. Femellc.

Iles de l'Amérique méridionale.

Nota. Drury a donné des observations sur les mcurs de celle espece dont il a aussi figuré le nid. La femelle lapprovisionne avec des araignées. D'apiès la figure il paroîtroit n'avoir point les spires que l'on remarque dans les uids connus des autres Pálopées.

\section{Péropée violet, $\boldsymbol{P}$. violaceus.}

Pelopcers cyaneoviolaceus, antennis nigris, alis pellucidis aprce fuscis.

Pelopous wiolaceus. LAt. Gener. Crust. et Ins. tom. 4. pag. 61. - Pcpsis violacea. FAs. Sjst. Piez. pag. $211 \cdot n^{\circ} \cdot 16$.

Longueur 8 à so lig. Entièrement bleu changeant en violet. Antenues noire:. Ficc antérieure dc la lêtc garnie d'un duvet argenté. Ailes transparcentes à nerrules testacées-brines, lcur extrémité el la partie caractéristique obscures. Fenielle.

Iudes orieniales.

\section{Pélopé blcuâtre, P. cyaneus.}

Pelopars nigro violaceus, antennis nigris, alis opacis nig, -moluceis.

Pepsis cyane.. Fав. Syst. Piez. pag. 211. $n^{\circ}$ 1.7. - Sphex carulea. Linn. Syst. Nat. 2. 941. 2. - D) E GER, ins. 3. 589. 6. pl. 3o. fig. 6. - DE 'NIGN , Hist. .utur. des Ins. tom. 3. pag. 27-4. fig. 2.

Lcngneur 10 à 11 lig. Entièrement noir changeanter bleu ct en violet. Antennes uoires. Face antérie de la têle couverte d'us duvet argenté. Ailes op vues noires chungeant en violet, mais E 2 
un peu moins sur le bord intérieur; leurs ner-ares noires. Mâle et femelle.

De l'Amérique septentrionale.

$$
\text { (S. F. et A. SERV.) }
$$

PÉLOR, Pelor. Ce genre de Coléoptères, tribu des Carabiques, a été établi par M. Bonelli dans ses observations en tomologiques (Mém. de l'Acad. de Turin). Il a pour caraclères : langrnelle échancrée, courfe. Dern'er article des palpes maxillaices extériemrs ovale, plus court que le précédent. Mandibules eourtes, sans dentelures. Anteunes minces, plus courres que le corseler, leurs articles moniliformes. Cor'selet très-lisse, ses angles postélieurs arrondis. Ecusson à peine apparent. Dernière paire des jambes épirense posiérieurement. Elytres sans poiuls discrildaux. Anus très-lisse daus les deux sexes. (S. F. et A. Serv.)

PELOT'TE. Voyez Insecte, tom. 7. pag. 239 . (S. F. et A. Serv. )

PELTASTE, Peltastes. Illig. Mletopius. Panz. révis. Ichneumon. Fab. Lat. Olit. (Encyclop.) Panz. Fuun. Germ.

Genre d'insectes de l'ordre des Hyménoptères, section des 'Térébrans, famille des Pupivores, tribu des Iclineumonides.

Dans la tribu des Iehneumonides, les genres Bracon, Microgastre, Vipion et Helcon out les palpes maxillaires de cinq articles et les labiaux de trois. Les Chélones, les Sigalphes et les Alysies ont leurs palpes mixillaires de six articles. Les genres Stéphane, Xoride, Icbueumon, Pimple, Acconite et Agathis, quoiquayant comme les Peltastes, les palpes maxilhaires de cing articles et les labiaux de quatre, u'ont point le second article des maxillaires très-gros, leur écusson n'est point earré ni armé de deux petites épines à ses angles postérieurs; enfin la face antérieure de la lête ne porte pas une espèce de plarque rebordée.

Antennes longues, sélacées, mulliarliculées, vibratiles; leurs articles courls et peu distincts. - Boache pen avancée. - Nandibules fories, arquées, aiguës. - Aiâchoires courtes, cornées, obtuses à leur extrérnité. - l'a'pes maxillaires plus lougs que les labiaux, de cinq articles, le premier droit, cylindrique, le second très-grand, fort gros, les trois deruieis petils, grêles, filifurmes; les labiaux courts, de quatre articles presqu'égaux, le troisième un peu plus gros. -Lèsre cornce à sa base, membrineuse et îronquée à son extrémilé, entière. - Tête triangulaire, sa face anlérieure porlant une sonte de plaque rebordée.-Trois yeux lisses gros, saillans, disposés en triangle el placés sur le vertex. - Corps fortemeut chagriné. - Corselet ovale, couvexe; son segrnent antédien rétréci en devant, s'avançant láléralement jusqu'à la naissance des ailes superieures. - Ecusson carré; sa partie posté- rieure s'élevant brusquement au-dessus du métathorax, armé de cluaque côté, d'une petile pointe. - Ailes supérieures ayant me collule radiale fort grande et trois cellutes cubitales, la première grande, presque triangulaire, réunie ì la première celluse uliscordale supćrience; la seconde très-petite, ne s'apurochant de la radiale qu'con un seul point, de même forro que la première, recevant dans son milien la uervare récurrule qui est tròs-droile; la truisiène complète alleiguant l'extrómité de l'aile. Deux cellules discoidales, savoir : la seconde supériesure et l'inférieure; celle - ci (1) fermće arant le bout postéricur de l'aile par la nervure récurreate. - Abdomen composé de sept segmens outre l'anus; il est long et attaché au corselet par une base large et plitte, conve'xe en dessus, creusé en dessous, deveuant plus épais vers son extrémité; bord postérieur de ses segnens épais. Anus des femelles fendu en dessous en une conlisse dans laquelle la tarière rentre presqu'entièrement dans le repos; celle-ci courte, cylindripue. Anus des mîles entier en dessous; recouvert én dessus. Pattes de longueur woyenne, hanclies grandes, cuisses postéricures un peu rentlées; les qualte jambes antérieures muties d'une seule épine à leur extrérnité, les postérieures de deux. Crochets des tarses ayant une pelotte assez lorte dans leur entre-deux.

Ce geure fondé par M. Illiger, et dont le nom vient d'un mot grec qui signifie trmé d'un bouclier, reçut ensuite de Panzer, dins sa révision, celui de Melopizs. On n'en eomoit qu'un peist nombre d'espéces, toutes d'assez grande taille. Leurs n:ơur's sonl les nêmes que ceiles do's lchneunous. Leurs larves vivent dans le corps de différentes larves, et parliculièrement dans colui des chenilles. Le noil est la couleur dominanie des Peltastes; les segmens de leur abdomen ont ordiuairement des buadés marginales jaunes.

\section{Pectaste de Fabricius, P. micralorius.}

Pelíastes niger, luteo varius, alis falvo hyalimis, antenms subtius luteis ; palpis moris apuce juscis.

Ichneumon micratorins. FAB. Syst. Piez. pag. 62. $x^{\circ} \cdot 41$. Matle.

Longueur ro a 12 lig. Anlemes jannes, noires en dessus. Premier arille enlierement noir. Palpesmaxillates bruns, leur's deus premiers articles noirs. 'Têle noire marquée d'une ligne janne de chaque côté de la plafue ancórieure, près des yenx. Corsele! noir avec denx pelits points james près de lat base dẹs ailes et nia point de même couleur placé de chaque côlé dn mélathorax. Ecusson noir; ses qualre angles jaunes. Abdomen

(1) Voyez la note de l'article Pupivores. 
noir; bord postérieur des second, troisic̀me, quatrième, einquième ét sixième segrmens, jaune; le premier ayant de chaque côté nue tache de cette couleur. Pattes jannes; cuisses en partie noires. Ailes fiauves, transparentes. Fenelle.

Le mâle diffère en ce que lia presque lotalité de la partic antérienre de sa tête est janne au-dessous des antennes; son corselel a de chapue côlé une lig!ze bunérale et une tache arcurée an-dessons de l'écaille des ailes, jumnes. Le bord postéricar de l'écusson, le métathorax et une ligne sous l'ćcusson, sont encore de celle derniêre con!cur. Le septième segment de l'àbdomen a son hord postérieur jaune comme les précédens. Les patres sont entièrement de celte coukur, seulcuent les cuisses postérienres ont une taclie noire.

Environs de Paris.

\section{Peltaste de Panzer, P. necalorius.}

Peltastes niger, luteo varius, alis hyalinzis, antennis subtus luteis; palpis nigris apice luteis.

Ichneumon necatorius. Faв. Syst. Piez. pag. 62. $n^{\circ}$. 42. - Ichueumon vesjoides. Paxz. Faun. Gem. fusc. $47 \cdot f_{g} \cdot 19$.

Longueur 8 à 9 lig. Antennes noires en dessus, jannes en dessous. Palpes noirs, leurs derniers articles jaunes. Tète noire, sa plicque antérieure bordíe de jaune, surmontéce de trois pointes de cette conleur. Corselet noir avec une ligne humćrale et un print sous t'altache des ailes, jaunes; les deux pointes postérieures de l'écasson de mème coulcur. Abdomen noir. Les premicr, troisiène, quutriène el cinquième segmens hordés de jaune postóricurment; le second n'aysut que deux paints latéraux de eetle couleur. lies quatre paltes antérieures junnes, avec les cuisaes en partie noires. Pattes postérienres noires, ayant la bise des cuirees, des jambes et des tirrses jaures. Ailes transparientes. Femelle.

Nons avons une âutre femelle qui a le second et le sixième segmens de l'abdonè aịsi que l': cusson entibement hordís de jume protéricutement, et dont les jambes postéricures sont presqu'en totalité de cencenieur: dureste semblabie à la précédente. En est-clle une simple variété?

\section{Environs de Paris.}

Nota. Panzer ramporle à celte espóse liajg. 5 de la $p !$. 128. Scane. Fon. Ins. Raliso., et le Sphex zespoides. Scop. Carn. $n^{\circ} \cdot 789$.

\section{Peltaste d'rlliger, $P$. nigrator.}

Pellastes niger, huteo varius, alis hyalinis, cellu'ấ radiatr fuscâ, antenazis palpisque nigris.

Longneur 6 à 7 lig. Antennes et palpes noirs. Tête noire avec une tache jaune triangulaire au- dessus le sa plaque antérienre. Corselet entièrment nuir. Abdomen noir, ses rrisieme, quatrième et cinguicme segmens bordés de jume i lear partie postóriente, le previer ayant de chaque côté une laclie de celte coulenr. Les quatre paitles anféricures junaes, leurs cuisses en partie noires, lenrs jumbes tachées de cette coulen en detans. Patles postéreares noires avec la base des jurnhes, eclle des cuisses et leur exirénité jounes. Ales masparentes avec lin cellule radiale brune; cesle couleur s'étendant vors l’angle extérien. Fenelle.

Envirous de Paris.

\section{PELTASE de Gravenhorst, P. discectorizs.}

Peltastes niger, luteo varius, alis hyalinis, cellatia matali fitscâ, antemnis subties testace is; palpis nugras apice fiscis; abdomine comulescente.

Tihneumon dissectorius. PAnz. Faun. Germ. fusc. fig. 14.

Longneur 6 à 8 lig. Antennes noires, un per testickes ea dessous. Palpes noirs, leurs derniers arlicies bruns. Tête noire ayunt $n$ netit point jaune près des yeux, enlre ceux-ci et la base des antennes. Corselet noir. Abdonen d'un noir bleuàtre ehungeaut en violet, ses prenier, second et troisicue segmens aynn! une tache jaune de chatque côté au bord postérieur, et le quitrième entièrement borcié de cette eonleur. Pattes noires, genoux jauncs. Ailes transparentes avec la cellule radiale brune; celte con!eur s'étendant vers l'angle extérieur. Femelle.

Var. Quatrième segment de l'ablomen n'ayant de jomne que dcux points latéraux.

les environs de Paris.

ACCNNTE, Accenites. LAtr. Cryptus. Fab. Panz. révis. TChneumon. Onve (Encycl.) Ross. Anomalon. Jun.

Genre d'insectes de l'ordre des Hyménoptères, section des 'Térélrans, fanilie des P’upivores, tribu acs lchneumonides.

Les Accuiles font partie d'un groupe stabli par M. istreille disns eetc tribu; il a vour caracteres: palpes maxillates de cinq atricles, les labianx de cantle. Dans ce groupe, les Stéphanes et les $\mathrm{X} 0-$ ridus se distingneal par leurs mandibules femihées par me pointe entitre, les Agulhis, par lavancenent senablible a un ber que forment ics

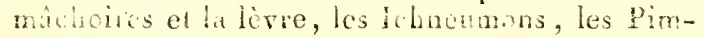
phes et les l'ctarses ont las articles des palyes

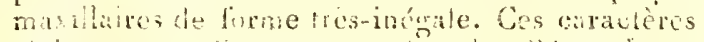
Cloighent ces divers gereres de celu d'Accrite.

ánténes flifomes ou sétaces, "muraticnlies, rismites; lenr prentur aricie gros, furJinó, érbucré extéreurement, le second cout, prestgue cyaltriforme, la ronsic̀ne petil, plas coust que le précédent; le quatriome presque 
cylindrique, le plus long de tous, les autres allant en décroissant insensiblemeut de longuerur jusquài l'exirúmité. - Mandihules bidentées, diroiles, alongrées et croisées. - Mâchoires el lève courtes, ne s'avauesant point en manière de bec ni de unsean. - Palpes maxallaircs beancoup plus longs que les labianx, de ciug articles, pea différens les uns des autres pou: la forme; palpes labiaux de quatre arides. - Tête triangalaire, presque de la larreur du corselet, léprimée en devarnt.Trois petits yeux lisses disposés en triangle sur le bord antéricar du vertex. - Corselet asicelong; mélathorax arrondi postćricurement, n'iyant pals de poilles lat'rales sensibles. - Ailes supérneures ayant une cellule radiale; la prenière ecllule enbitale eonfonctue avee la première cellule discoidale supé iemre; seconde cellule culitile recevant toujours la deusicine nervure récumente la premicue nervure manegue; denx collules discordales, salvoir : la seconte supérieure el l’infórirure; cellec Cermée par la nervare récurreb!e avant le bord postéricur de l'aile. - Abdonen se rélrécissunt à sa base el s"insérant an bas du métahorax, coinposé de sept segrmens outre l'anus; larière (des femelles) dépassint notablement l'abdumen, soutenue en dessous par une grande éeaille fille en soc de clartue, dont liusertion suit immédiatemeat le cinquième segment. -... Pattes de longueur noyenur; jambes antáricures termincés part une seule épire, les quilre postérieures en ayant denx; premier article des tarses fort long; crochets manis d'une pelote dius lenr eniredeux.

Consuliez pour les mours les généralićs de l'article leaxionos de ce Dictionnitire. Nuns ne comoissons pats encore les mâles de ce genre fondé par M. Lil!reille. Les fiemelles ont tonjours cinelques-uns des avant-derniers segneas de l'ahdonien échancrés inférieurenaent en dessiss; la partie coriace de ces segmcns est alors renplacée par une menbsiume lléxible, ce qui donne plus de facilité à ces insectes pour ployer l'abdomen en dessous et rameucr leur tarière en devant, afin d'en fare usage. Le petil nombre d'espèces d'Accenites eounues, est d'Emrope.

re. Division. Cellule radiale moyenne, pointue à ses deux extrémilés, allant en se rétrécissant depuis l'extrémité de la première cellùie cubitale; deux cellules cubitales tort graudes, la seconde presque eomplète; nervure récurrente un peu ondulce. - Anteunes lilifurmes, droiles, guère plus longues que lı tête et le corselet pris ensemble. - Cinquième article des tarses aussi long. que les trois précédens réunis : crochets unidentés vers leur extrémité; pelolie des deux tarses postéricuis plus forte.

\section{Accenite porte-soe, A. dubitator.}

Accenites niger, abdominis segmentis secundo, tertio, quartoque aliquando et pedibus omnibus, coxis tarsisque dnobus posticis exceptis, testaceoferrugineis, coeteris segrnentis inferioribns infià excisis, incisurâ albidâ.

Aconites dubitator. Lat. Gener. Crust. et Ins. toln. 4. pag. 9.-Coyptus dubitator. F A B. Syst. Piez. pag. $85 . n^{\circ}$. 64. - Ichneumon dubitator. Pavz. Fican. Germ. físc. 78. fig. 14. - Anomzalon dubitator. Jur. Hyménopt. pag. 116 . Lat fenelle.

Longuenr 5 à 8 ligr. Noir. Sceond, troisième et quelquefois le quatrième segmens de l'abdomen d'un testueé ferruginux. Patlles de même coulenr, it l'exceprion de toutes les hanclues el des deux talrses posiérieurs. Derniers segmens de l'abciomeu, a pautir da quatric̀ne, laissant clégonverte à leur partie inférieure une portion de membrane blanchâtre. 'Tauièe ferrugineuse, à peu près de la longueur de l'abdonen, ses fourreaux noirs, un peu relus. Feinelle.

Nota. M. Iatreille rappor!e à relle division l'Tchneumon arator. Ross. Faun. Etrus. tom. 2. pag. $49 \cdot n^{\circ} \cdot 77^{3}$.

$2^{c}$. Division. Cellule radiale plus longue que dans la première division, mais de la mêue forme; trois cellules cubitales, la prenière phus grande que la troisième; la seconde extrêmement petite, pétiolće, la troisiène complète; nervare récurrente un peu arçuée, mais point ondulée.Auleunes sélacées, sé recouribant un peu à leur extrómilś, beancoup plus longues que la tête et le corselet pris ense:uble. - Cimuuème arlicle des tarses giere plus long que le précédent. Ciochets simples; pilotles égitles.

\section{Aecenste ćcliancré, $A$. incisurator.}

Accenites niger, pedibus, alarmu squam $\hat{a} a b-$ doninisque inicisurs luteo fulvis.

Longueur 14 lig. Noir. Anteunes de eetie couienr en dessis, hrunes en dessous, surtout vers la base. Devant de la lête arirqué de denx taehes jaunes sous les anteques. Pralpes, écailles des ailes et pattes d'un jaune fauve, ainsi que les échancrures des derniers segmens de lablomen. Hanches noirâtres. 'Tarière de la longuenr de l'abdonen. Ailes transparentes, d'un jaune fauve; les supérieures ayant leur point marginal et la nervure du bord extéricur de cette dernière couleur. Femelle.

Des environs de Paris.

AGATHIS, Agathis. Lat. Bracon. Fab. SPINox'. Ichneunion. JuR.

Genre d'insectes de l'ordre des Hyménoptères, seetion des'Térébrans, famille des Pupivores, tribu des Iehneumonides.

Dans le groupe des Ichneumonides qui a pour caractères: palpes maxillaires de cinq aricles, 


\section{P E L}

les labiaux de quatre, aucun autre genre que celui d'Agathis n'a les mâchoires et la levre avancées en uue sorle de bec; ou de nuseau.

Antennes sélacées, multiarliculées, vibratiles, se iecourbant un peu à leur extrémité; leur pranice article gros, reconrbe; les second et troisième fort perils, le quatrière guère pius long que Les suivans, ceux-ci allant en dinumunt de Iongueur iuscrabiblement jus ju'à l'exlrémité. - Handibules étriles, alongées, croisées, bideutées ì l'extrénité. - Mâchoires el lève avancétes en me sorte de musean. - Palpes maxillates plus longs que les habiaux, composés de cinq articles, les labiaux de qualre; daus tous, ces articles pen difiétens les wis des des autres pon: la forme. - Tête triangulaire, plus ćtroite que le corselet; boubćc en devant. - Trois petits yeux lisses placés en triangle sur le vertex. - Corselet assez long; nétaThorax muni d'une petite poinle de chaque côté. - Ailes supérieures ayant une cellule radiale rèspetite, terminée en poinle le long du bord extérieur, hien arant l'extrénilé de l'aile; point unarginal fort grand, épais; trois cellules cubitales, la premicse lo:t grande, contonitue avec la première cellule discondale suprírieuse; seconcle cubilale tris-pelite, presque carrée, la troisic̀ne très-longue, point de nervares récurrentes; deux cellules discoidales; savoir : Ia seconde supérieure et l'inférieure; relle-ci s'étendant jusqu'au bord postérieir de l'aile. - Abdomen guvere plus long que le corselet, se rélrécissiut a sa base el siusérant an bas du niétallorax, composé de sepl segmens ontre l'anus; larière (des lemelles) dépassint l'abclomen, soutenue en dessous par une écaille presque laingulatire dont l'insertion suit immédiatement le cincjuiène segment. - Les quatie pattes antérieures de longueni moyenne, les postérieures plus longues et plus furtes. Jambes de devant terninées par une seule épine, les quarre autres en ayant deux. Premier article des tarses aussi long que les quatre autres pris ensenble; ceux-ci, allant en diminnant de longneur. Crochets et pelottes trèspetits.

Voyez poui les uncur les généralités du gence Ichnemmon. Celai d'Agathis dù à M. Satrublic contient un certain nombre d'espeees européenues.

\section{Agatrins rougeâtre, $A$. purğgutor:}

Asathis luteo-ferrugineus, ant:nnis, itb:arum duarum posticarum apice tarsorumque ejusdem puris suprà articulis, nigrris.

Agathis purgator. I.Aт. Gener. Crust. et Ins. tom. 4. pag. 9. - Bracon purgator. FAB. Syst. Piez. pag. 104. no. 10. - Ichneumon purgator. Jor. Hyménopt. pag. 1 13. La femelle. - CoQоев. Illustr. Icon. tab. 4. fig. 5. I.a feurelle. (Cette ligure est incorrecle.)
Longuear 4 à 5 liz. P’un jaune ferryineax. Antennes, extrénité des deus janbes postérieures et fonrrazur de la tai ière noirs. On remaruue nue lirrne de celfe coulcur sur la partie extéricure des deux clemicrs tarses. Ailes supéricures d'ua blanc jaunatre avec une bande transversale noire; leur parlie postérienre noile avec une grande t:1ehe ramspareate. Femelle.

Dans le mâte les aibes supérienres sont assaz souvent jilus foncées et la lache mauparente da hout est plus pelite.

Commun aux environs de Paris.

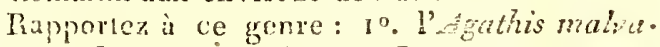
cerrum. La'r. Goner. Crust. et Iris, Zum. 4. pag. 9. tom. 1. aab. 12. fig. 2. lai lisuthe. Ichrean mon Panzeri. Sur. Hyménopt. gil. 3. I.al ficm melle. (Éncycl. pl. 376. fig. 6.) Cella espore iutroduit ses wefis dans le corps dume larve de 1:a nous ignorons le genre; relte larve vit aux di. pens des garaimes de maivacées et parliculièrement de la rose trímière (alcéa rosea et ficyfolic); $2^{\circ}$. le Bracon rostrator. Spixoz. Ins. Ligur. fasc. 3. pag. 113. no. 9 .

BRACON, Bracon. Jun. FAB. IAt. P'ANz. Sinoz. Ichneumon. Lixn. Groff. Oliv. ( Hucycl.)

Genre d'inseetes de l'ordre des Hyménoplices, seciion des 'Tórélsums, famille des l'upivores, uribu des Ichneumonides.

Quatre genres de celte tribu y forment un groupe disinct par lems palpes maxillaires de cinc articles en inême tenps que les labiaux n'en ont que trois. Dans ce greupe dont le grenre bracon fait patie, les Microosustres nont point leurs mundibules avancées de unzuière à laisser wa intervalle entrolies ei le labre. Les Vipions oul me espece de bec lormé par l'avanccuent des máchoires ef de la lèvre, el dins les Ileleons la partie antérienre dn second lobe du corselel s'avance en bosse d'une manière renarguable.

fintennes sétarées, muliarticulées, rilnailes, insérées sur le firont, point roulées à leur eriréinité; leur premier arlicle gros, turbiné, soupé droit à l'extrémité, plus lougr que les anlres; io second court, globulenx, un peu plus gros quo les suivans; le troisicne cylindrignc, un pera pius long que le quatricne; ceux qui vientet ensuite égurux.entr'eux, les demiers plus couris que les premiers, mais tous ne diminuml de longueu: gr:"insersiblement. - Mandalubes Jidentécs, avancéts, laissant entrelles el le laber un vide notible, lors même qu'elles sont ficimées et dans le repos. - Mâchoircs et lére ne s'avangant poiut en maniére de bec ni de museau. - Palpes maxallaires tres-alongés, deux fois plus longs que les labiaux, composés de einq articles, le second un peu plus gros que les autres, cylindrique comne eux; les labisux de trois aricles à peu pres fógaux en longueur. - 
Tête glo:uleuse, mnins large que le milieu du corselel. - Trois petits yeux lisses disposés en triangle sur un tubercule frontal entouré d'un sillon. - Corselet rélréci en devant; partie antérieure de son lobe moyen s'abaissaut graducllement; métathorax lisse, assez conrt. - Ailes orduairement colorces; les supécieures ayant unc cellule radiale yrunde, eommencint à se réltécir après la seconde cellule cubitale; trois ccllules cublitules, la première distincie de la premìre cellule discoidale supécieure; sceoude cellule cubiale grande, tcrimine carriment ì sa parlie postéricure et trois collụles disccidales, linféricure s'étcudant jusqu'au bord postéticur de l'alle. - Premier segnuent de l'abdonten ayant ordinairement son disque ćlévé, entouré en devant et sur les côlés par un sillon profond ; larière (des femelles) dépassant l'abdomen. Pattes de longueur moyenne, jambes postérieures cylundriques.

On trouve orlinatrement les Bracons dans les bois, voligeant ou comrast sur les arbres qui renfrment des larves; ce qui donue lien de croire que les femellcs déconvrent la siluitlion de ces larves cl quallcs parviennent au moyen de leur tarière à iutroduire leur's oufs dans le corps de ces dernières. Ce genre conlient un assez grand nombre d'espèces des deux eontinens, fort différentes cutr'elles, ce qui indique:cit encore le besoin d'élablir de nouvclles coupes génériques, e! pourtaut nous restrcignons davaulage ce gcare que les auteurs qui nous ont précédés.

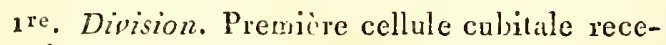
vant la tervure récurrente.

jre. Suldivision. Cellule radiale atteignant presque le bout de l'aile. - Seconde cellule cubiale plus longue que large.

Rapportez à celte suldivisinn, $1^{\circ}$. l'Tchneumon dénigrant, no. 105 de ce Dictionnaire. L'abdonut de la fernelle est ovule-ohlong, celni dn mâle est cylindrique, presque linúarre; dans les deux sexes, ces cinq preniers seymens sont plus grands que les suivans; $2^{\circ}$. le Bracon initiator, ${ }^{\circ} .37$. lials. Sysi. Piez.

$2^{e}$. Subdwision. Cellulé radiale se terminant lien avant le bout de l'aile, - Scconde cellu!e rubitule plus targe que longoe.

\section{Bracon maculé, B. maculator.}

Rracon huteo-albidus, metathorace abdomineque suprà nigro :maculutis.

Longueur 2 lig. $\frac{1}{2}$. Corps d'un Hinc jamâtre. Tubercule portant les yeux lisses, deswus des antennes et du mélathorax d'un brun noirâtre. Moitié inférieure du premier segment de l'ablomen, cốtés du second, et troisieme segment noirs en déssus. Taričre noire, moins longue que l'abdomen.
Jamhes postérieurs ayant une taehe brune en dessns. Les trois premicrs spymens de l'abdomen sont plus grands que les suivans; on voit sur le second une petite tache trinsparente placée sur lis partie noire latérale. Ailes irausparentes, iriséc. Vemelle.

Environs de Paris.

$2^{\mathrm{e}}$. Division. Seconde cellule cubitale recevant la nervure récurrenie.

\section{Bracon bifascié, B. bifasciator.}

Bracon fuserus, alus superioribus hyalinis fusco bifusciatis; fuscio posterioris maculâ in medio hyalinâ.

Longueur a lig. Brun. Tête, dessous des antennes cl du corsclet blanchatres. Pattes de eette couleur, varićes de brun. Ailes transparentes, les supérienres ayant deux larges bandes transverses brunes; la seconde portunt dans son milieu sur la nervure qui sépare les secoude et troisieme cellules cubitalcs, une petite taehe transparante. 'Tarière un peu plus longue que l'abdomen. Femille.

Des environs de Paris.

IJElCON, Helcon. Ness roN Esenbeck.

Genre d'insecles de l'ordre des Hyménoptères, section des'l'érébrans, famille des Pupivores, Iribu des Iclineumonides.

Ce nouvatu geure fait partie des Ichneumonides qui ont les palpes maxillaires de cing artieles et les labiaux de trois; ee petit groupe renferme en outre les Vipions, les Bracons el les Microgastres. Les preniers ont un caractère particulier, celui que présentent leurs mâchoires et leur lèvre, qui se prolongent en dehors el forment une sorte de bec. Les îlicrogastre's sont les sculs dont la bouche n'offre de partie suillante que les pa!pes. Dans les Bracons qui, comme les Helcons, ont des mandi ailes avancéres, le second article des palpes inaxillaires est cylindrique, sins aplatisseneut, ni dilatation scusibla; le dernier article des palpes labiand n'est pas beancoup plus long que le puécédent; la tête est globuleuse; le corsclet est proportionnellement beancoup plus court que celui des Helcons; il se rétréeit nolab!ernent en cievant et s'abaisse d'une manière inseusible; le métuthorax es! lisse et court; les petits yours lisses sont posćs sur une élévation entour'će d'un sillon, et la seconde cellule cubitale des ailes supérieures ne se rétrécil point vers la radiale. Celle masse de dilférences, anxquelles la conuparaison des caractères génériques ajoutera ellcore, justifie suffisanmenl l'adoption de ce genre.

Antennes longues, sétacées, multiarticulées, vibratiles, insérćes sur le rebord inférieur d'une cavité frontale, d'abord droiles jusqu'aux denx tiers 
tiers de leur longueur, se ronlant ensuite str elles-mêunes, priueipalement dans les feurelles; leur prenier artiele gros, très-cronflé à sa partie supérieure, coupé obliquennent ì son extrémité, un peu unoins long que le troisième; le second très-court, un peu plus gros que les suivans, renferrué en partie daus le premicr; le troisième le plus long de tous; eeux qui viennent ensuite allant ell diminuant de longrueur jusqu'ì l'extrémité. Mandibules bidentées, avaucées, laissant entr'elles et le labre un vide notable, lors même qu'elles sout fermées et dans le repos. - Mâchoires et livre ne s'avaiçint point en manière de bec ni de museau. - Palpes maxillaires très-alongés, denx fois plus longrs que les labiaux, composés de cinq articles, le second un peu aplati, diaté à sia partie intérienre; les labiaux de trois articles, le dernier cylindrique, anssi long que les doux antres pris ensemble. - Tète presque cubique, à peu près aussi large que le corselet, ayant une cavité frontale remarquable; celle-ci rebordée sur les eôtés, très-inégale daus sun iutérienr. Trois petits yeux lisses posés en triangle sur le bord supérieur de la earité frontale, l'antérieur placé même dans eette cavité. - Corselet long, point aminci en devant; partie antérieure de son lobe woyen s'élevant en bosse et s'avançant audessus du lobe autérieur; métathorax long, trèsrugueux, portant plusienrs lignes longitudinales ur peu élevées. - Ailes supérieures ayant une cellule riadiale qui n'atteint pas le bout de l'aile, se rétrćcissant apres la secoude cellule cubitale, pointne is son extrémité; trois ectlules cubitiles, la prenière plus grande que la seconde, distincte de la première eellule discoidale supérietre, recevant la nervure récurrente; seconde cellule cuJitale grande, se rétrécissut vers la radiale; la troisiène atteignant presque le bout de l'aile, aussi lonwue que les cieux précédentes réunies, et trois collules discoidales; l'inférieure s'étendant jusqu'au hord postérieur de l'arle. - Abdomen presque linéaire, composé de sept segrmens outre l'anus, le premier étant le plus souvent forlement canaliculé on dessus; auric̀re (des femelles) dépassant l'abdomen; sal base soutenue par une vonde écaille qui s'insère après le sixiène segnuent. - Paites de longutur moyenne, les postérieures m peu plus fortes. Jambes de celles-ci ca. maliculées extéricurement, au moins dans les femolles. Jambes anlérieures terminées par une seule épine, les fuatre autres en ayant deux pelites.

M. Nées d'Esenbeck a domé les cạactères de ce genre dans l'Appendix qu'il a joint à l'ouvrage de M. Gravenhorst, intilulé : Conspectus generum et fimnliamun Ichneumonidum. Les espèces que nous y rapportous líćquentent les ehantiers de bois eoupé et rangé eu piles, surtout eeux des lorêts. Il est probable que lears næurs ne different point de eelles du genre précédent. Nous n'en connoissons que peu d'espèces : elles sont europécnnes. Hist: Nat. Ins. Tone $X$.

\section{Hexcon bueberon, H. lisnator.}

Helcon niger, palpis pedibusque ferrigineis, posterioribus apice fuscis.

Longueur 7 ì $8 \mathrm{lig}$. Noir. Tête et eorselet fortement ponetués; les deux premiers segmens de l'abdomen ridés irrégulièrement. Palpes et paties de eoulen fauve; parie inférieure des derbieres janbes et leurs tarses noirûtres. Ailes transparentes, à nervures brunes, le point épais des supérieures noirûtre. Tarière plus longue que l'abdomen, ses fourreanx un peu velus. Femelle.

Le mâle a les jambes postérieures entièremen noires.

Commun aux envirous de Paris.

\section{Helcon ì épine, H. spinator.}

Helcon ater, pedibus rufis, femoribus posticis dentatis, ejusdem paits tibiis et tarsis nigras, horm articulis internediis albis.

Longneur 4 à 5 lig. Noir. Tête, eorselet et premier seginent de l'abdomen fortement ponctués. Anteunes noires, leurs douzième, treizieme, quatorzième et quinzieme articles blanes. Hanches des quatre premières pattes et janbes postérieur es noires. Palpes bruns. Pattes antérieures, dernières banclies et leurs cuisses fauves; ectles-ci ayant une forte dent inférieurement. 'Tarses postéreurs blancs, avec la hase da premier artiele et l'extrómité du dernier noires. 'Turière testacée, plus longue que l'abdouten, ses fourreaux noirs et velus. Ailes transparentes, nervures brunes. Fenielle.

Le mâle n'a point de blunc aux antennes. Il est un peu plus petit.

Des environs de Paris.

Nota. Nons ne doutons pas que la Pimpla dentaior de Fabricius ne soit de re genre, au nuvius la description du mále nous le persuade; mais il y a beaucoup de différences entre cette espece et celle que nous venons de décrire. D’ailteurs cet autem dit positiventent gue son mâle u'a point d'épince aux cuisses postérieures, ce qui est contraire au caraciòre qui exisie dans le nôtre. Une espèce de ce genre est ligurée dans l'ouvrage intitulé: Bert. Mag. tom. 0. part. 2. pag. 36. tab. 4. fig. 6, sous le wom d'Fécon tardator. Nous n'arons pas pu rencontrer cet onvrage daus les bibliothèques. H. d'Esenbeck, gui cite eetlo espece conme type de sua gence, annonce qu'd en eonnoît cing auties.

MICROGASTRE, Microgaster. Latr. Sproz. Ichneumon. Pab. Paxz. Jun. Bussus. Pavz. ı́́vis. Ceropales, Cryptus. Fab.

Genre d'insectes de l'ordre des Hyméuoptères, section des'Térébrans, famille ties Pupivorces, tribú des Icluetmonides.

Les genres Vipion, Braeon et Heleon qui, avec les Miriegastres, composent le groupe des Ichs 
neumonides dont les palpes maxillaires ont cinq articles et les labiaux trois, ont lous trois le second arlicle des antennes visible, et ontre les palpes, ils ont d'autres parties de lit houshe toujours saillantes.

Antennes longrues, sétaccées, multiarticulées, vibratiles, insérées au-dessous du frout, ne se roulant point à leur extrémité; leur prenier article assez gros, turbiné, un peu plus long que le troisième, le second entièrement caché dans le premier, le troisième et tous les suivans, de longueur à peu près égale jusçuau deraicr, mais dinuinuant un peu de grosseur passé le milieu de l'antenne. - Mandibüles point saillantes. - Mâtchoires et leore droites, courtes, ne s'avançant point en manière de bec ni de nuseart. - Pálpes maxillaires deux luis plus longs que les labiuux, composés de cinq ar!icles, le second long, un peu en massue; les labiaux de trois arlicles. Jéte petite, plus átroite que le corselet. - Trois petits yeux lisses disposés en ligne courbe sur le verlex. - Corselet courl. - Ailes supérienres ayant une cellule radiale grande, se rétrécissitut après la première cellnle cubitale ; preınière cellule cubita!e grande, distincte de la première cellule discoidale supérienre, recevant la nervure récurrente; dernic̀re cellule cubitale très-rrrande et très-longue; trois cellules discoïdales, l'ınfírieure se prolongeant jusqu'au bord postérieur de l'aile. - Abdonten petit, court, inséré à la partie postérieure du métathorax, paroissant presque sessile, peu convexe en dessus, caréué longiudinalement en dessous; tarière (des femelles) plus courte que l'abdomen, dépassant tonjours l'anus, ses fonrreanx un peu comprintés. - Les quatre pattes antérieures de longueur moyenne, les deux postérieures plus furtes, leu's hanches très-grosses et longues; les deux jambes antérieures terminées par une seule épine, les quatre autres en ayant deux; ces épines fortes et longues.

Oo doit à M. Latreille l'élablissement de ce geare dont le nom est tiré de deux mots urecs qui signifient : petit ventre. Les especes qu'il contieut sont fort petites. Leurs larves vivent isolées dans le corps de petites chenilies telles que celles des Pyrales, on en société dans des chenilles de moyenne taille.

1re. Division. Trois cellules culdilales; la seconde extrêuctuent potite, presque triangulaire, ne touchant que parr un de ses angles à la cellale radiale. - Deux impressions sur le front derrière linsertion des antenues.

1. Mrcrogastre déprimé, M. deprimator.

Microgaster nigur, femoribus tibïsque testaceis, alis hyalinis, fasciis duabus transversis fuscis in medio subconfluentibns.

Microgaster deprintator. LAт. Gener. Crust. et
Ins. tom. 4. pag. 11 . - Spinot. Ins. Ligzur. fasc. 3. pag. I43. no. 5. - Ichneunon deprinnator. Fав. Syst. Piez. pag. 69. $u^{\circ} .83 .-\mathrm{l}_{\text {anz. }}$ Faun. Germ. fiss. 79. fig. 11. Le male. - Bassus deprimatori. PAnz. révis. - Ichneumon deprimator. Juk. H ménopt. pag. I 12.

Longueur 2 lig. Noir. Cuisces, jambes el base des tarses, testacces. Base des cuisses antérienres et extrémité des postérieures noires. P'remiers segmens de l'abdomen páles en dessons. Ailes transparentes, les supérieures avec denx handes transversales brunes qui se réunissent un peu daus leur milieu.

Des environs de Paris. Sa larve vit solitairement daus des chenilles de Pyrales.

$2^{\mathrm{e}}$. Division. Deux cellules cubitales, la seconde u'existant plus, se confondant avec la troisième. - Antennes insérées au-dessus d'un petit rebord. - Frout régulièrement concave.

\section{Micnogastre américain, Mi. anericanus.}

Microgaster niger, antennis, palpis, abdomine pedibasque pallide tistaceis, alis hyalinis.

Longneur une ligue.- Noir. Antennes, palpes, pattes et a'̉ỏonen d'un teslacé pâle, celui-ci ayant quelques muances branes en dessus. Antenues brunes en dessus duns les femelles. Ailes trisparentes, nervures noires. Lae point épilis des supéricures püle. Mâle et lenelle.

De la Marlinique. 'Trouvé télos el mort dans le corps d’une clienille desséchéc venue de certe colonie.

Rapportez à celle division l'Ichneunon grlubu-

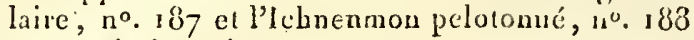
de ce lictionnaire.

Nota. On doit certainement rapporter plusieurs autres espèces, soil d'Enrope soit exoliques à chacuuc de nos divisions. Nous en zonnoissous même un certain unmbre, mais il est trés-difficile de les reconnoitre dans les anteurs. M. Spinola a décrit huit espèces comose appartenant it ce genre.

CHelone, Chelonus. Jưr. Sigalphus. Lar. SPINoL. Cynips. Linn. IChneumon. FAB. De GÉER. Ourv. (Encyl.)

Genre d'insectes de l'ordre des Hyménnplères, section des 'Térébrans, famille dés Pupivores, uribu des Ichneumonides.

Considérce sous un certain point de vue, ix tribu des Ichneumonides, telle ou à peu près que l'a élablie M. Lallreille, semble assez facile à diviser en sections d'aprìs des considérations qui n'ont pas encore été employées. Les genres qui la composent sont nombreux et leur nombre duil encore augmenter par la suite; les caraclères livés de la bouclie que l'on pent employer à celte division, sont : la longueur respective des palpes et le 


\section{P E L}

nombre d'articles dont ils sont composés (M. Tatreille ne s'est servi que du nombre de ces articles). Les ailes supérieures préseutent aussi un carractère facile à saisir, il nous es! fourni par la réunion de la première cellule discoïdale supérieure ì la première cellule enbitale ou par leur séparation. Il sembleroit peut-être utile de revoir ausit les tribus voisines et dans le cals par exemple où le earaetère de l'insertion de l'abdonten qui varie beaucono dans les Iehneunonides, ainsi que cclui tiré du nombre des articles des untennes, paroitroient d'un oribre inférieur a ceus tirés de la bonclie jrints anx caractìres d'aile, les genres de la tribu des Evaniales rentreroient pour la plupart dans eelle des Iclunenmonides dout ils différent si peu du reste. Alors eette deruic̀re trihu auroit deux divisions dun caractère facile ì saisir. Ire. Division. Palpes maxillaires n'étan! pas deux fois plus longs que les labiaux. Première cellule discoidale supérieure confondue avec l: premiere eulsitale (Iclineumonides vrais). $2^{\circ}, D i$ s'ision. Palpes maxillaires an moins trois fois anssi longs que les labiaux. Première cellule discoidale supérieure distinete de la premic̀re cubitale (Braconides). Nous pensons avec M. Latreille que le genre Pólécine doit être ríuni aux Oxyures. (Foyez l'article Purivonis.)

\section{Tribu des Iehaumonides.}

Caractères: Autennes filiformes on sétacćes, vibratiles, multiarieulées (de treize arlicles on plus). - Palpes maxillaires apparens, filiformes ou sétacés, composés de ciuq à six articles. Ailes intérieures ayant des uervurês distiuctes. Abdomen des femelles muni ì sou extrémité postéricure d'une tarière le plus souvent saillaute, "yant toujours deux fourreunx latćraux.

Ire. Division. Palpes maxillaires n'étant pas denx fivis plus longs que les labiaux. - Prcuière cellnie discoidale supérieure confondue avee lat prenière cubitale. - Palpes labianx eomposés de quatre articles. (Ichnemmonides vruis.)

Ire. Subdivision. Palpes masillaires guère plus longs que les labiaux.

\section{A. Palpes maxillaires de einq articles.}

Xoride, Pimple, Ichneumon (1), Pellaste, Oplion, Aconite, Stéphatace.

B. Palpes mixillaires de six artieles.

Evanie.

(1) Nous comprenons jusqu'ici dans ce genre la plupart des Anomalons ee des Ichueumons Jur., ei c'est pruacipalement de lui que nous avons entendu parler en donnant comme probable la création future de nouvilles coufes génériques.

\section{P L L}

$2^{\mathrm{c}}$. Sulidivisicn. Pulpes maxillaires pre que deux fois aussi longs que les labiaux.

A. Palpes maxillaires de cin વ articies. Arrathis.

B. l'alpes maxillaires de six artieles، Clıćlone.

2e. Dipision. Palpes maxillaires an moins trois fois plus longs que les labianx. - l'remière cellule discoidale supérieure distincte de la première cubitale. (Braconides.)

${ }_{1}$ re. Subdipision. Palpes maxillaires de six artieles, les labiaux de quatre.

$$
\text { Sigalple, Alysie, Fone, Aulaque. }
$$

$2^{\circ}$ Subdivision. Palpes maxillaires de cinq articles, les labiaux de trois.

$$
\begin{aligned}
& \text { Vijion, Bracon, Helcon, Miero- } \\
& \text { gastre. }
\end{aligned}
$$

Dans la mélhode de N. Latreille aueun genre d'Ichuenmonides antre que ceux de Sigalphe, de Chólone et d'Alysie, n'a les palpes natillaires composés de six arlicles, mais les premiers ont l'abdonten composé de trois segmens et les Alysies ı!e cinc.

Anlennes sétacées, multiarticulées, couposées de plus de treize articles, le prenier épais, le second pelil, globuleux; les fuivans atssez longs, cylindriques, les derniers tuès-courts. Mandabules !identées. - Palpes maxillaires filiforaes, fresque deux fois anssi longs que les liabiaux, composés de six arlicles. Palpes labiaux de quatre articles. - T'éte transversile. - Trois petits yeux lisses disposés en ligne courbe sur le vertex. - Corselet aussi large que la tête, son premier segment gand, arrondi antérienrement. - Ecusson assez grand, méralhorax sélcvaut moins haut que le reste du corselet, coupé droit postérieurenent, ses còlés munis d'une épine fort courte. - Ailes supéricures ayant une cellule radiale presque triangulaire et trois cellules cubitales, la première confondae avee la première cellule discordale supérieure; seconde eubitale petite, prescue triangutaire, la troisième eomplète; detix ceilules discoïdales, savoir : la seconde supérieure et l'iuférieure, celle-ci eompléc se tcrminant an bord postćrieur de l'aile. Abdomen ne paroissant eomposé que d'un seul segweut; ce segment très-grand, concave en dessous; taricre (des femelles) peu sailtante. - Les quatre pattes antéricures de longneni moyenne, les postérieures grandes, à hanches grosses et fortes; jambes antérieures munies d'une seule épine à leur extrémité, les quatre autres janbes en ayant deux. Premier article des tarses 
le plus grand de tous, les autres allant en décrois- Cant. Crochets et pelottes très-petils.

Les Chélones forment la seconde division du genre Sigalphe de M. Latreille (Diction. d'Hist. nat., 2e. édıt.), inais ces deux genres different par des caraclères si aisés à satisir gue notis croyous devorr les maintenir tous deux. Les Clólones duprosent lems oufs dans le corps des chenilies des Pyrite, du reste les habitules de ces peisls hymonapteres sont en gunóral celles des andres lohneumouides. Les espèces conumes son en petit noutre.

Ranpor:ez à ce genre l'fclineumnn oculé, 230. 154 de ve Dichinnanse. (S. F. el A. Servo)

PEL'TIS, Peltis. Genre d'insectcs de l'ordie des Colopreces, élähli par Fabricius, et qui répond exachement à cchui de 'Thymate de H. hatreille. Voyez ce mot.

(S. F. et A. SERv.)

PELTöides, Peltoidea. Quatrième arbu de la famble des Clavicornes, section des Peutamires, ordre des Colćoplères. Ses caractères soms:

Antennes plus lingues qus la tête, droiles on un pen coulfées, de dix à once arlin'les distincts, tantól au ensinlenent plus grosses vers leur extrémilé, lanôt en masine suil perlioliée ou cu scie, soit sulide. - Palpes maxallaires phus grands que les labanx, couris on de longuenr myeme. - Mandibules plis couries que lia lée, comprimées, coblungues el arqunés à lent extrémilé. Corselet de lu largenr de l'aldomen, du moins a sa base. - Pattés séparríes à leur naissunce par des intervalles égaux el u'étaut point contructiles.

Celle tribuse duvise ainsi qu'il sult.

I. Pointe des mandihules entière ou sins Echancrure ni dent particulicre.

Nécrophore, Buuclier, Agryrte.

II. Extrémité des maudiuules échancrée ou bidentée.

A. Massue des autennes ylus ou moins ronde ou ovale.

a. Les trois premiers articles de tous les tarses ou ceux des antérieurs au moins, counts, larges ou dilatés.

Nitiduie, Byture, Cerque.

b. 'Tarses poun dilatés; leurs quatre premiers articles presque cyliusrigutes et pea dillérens en lorue el propurtion.

Thymale, Colobique, Micropèple, Dacué, Ips, Sphérite.

B. Mussue des antenues oblougne, composée de ciny ì six ariscles ou formée insensiblement.

Scapbidie, Cholève, Mylæque.
La plupart des genres de celle tribu vivent à l'éat parfait et en larves dans les charognes, les clampignous ou sous l'écorce des arbres. Un peit nombre se nourrit de chenilles et de limaçons.

AGYRTE, Agyrtes. Froеs. Lat. Mycetophagus. FAB. PAYK.

Genre d'insecier de l'ordre des Colíoptères, secian des Protamères, farale des Cluvicornes, nibu des Pelionder.

Tuas les greures compris dans celle tribu ont l'extrémité des mandibules éclnancríe ou bidentie a l'exception des $N$ armphores, des Buncliers

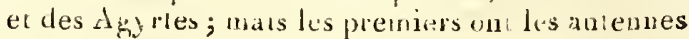
gucre qulus hongues que la têle, ter.tinces brus-

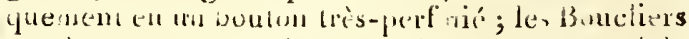
ont leurs quatre pilpos terruinćs prar un article plus menu yue les précédens el leus jumes ne

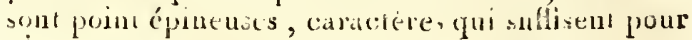
séparer ces deux geures de colu d'Agjrie.

Antennes i peupres de la longueur du corselel, insérćes devinll les yeux, comporées de onze articles courts, les truis preiniers arrondis, presque coniques, les suivans prerque ghobuleux, les seplième, huitieme, neuvième el dixiéme nu peu plus épais que les antres, iransverses, presque lentculares, égrux, perfoliés, le dermicr uvale-globuleux. - Labre membineux, Iranversal, linéaire, larbencurt échancré. - Mandabales cornées, lortes, avaluccées, très-cruchues a l'extrómité, fort pointues, sans dentclates. - Mâchotres portant deus lobes ćtroils a leur extrímini. Palpes maxillaires plus grandi que les tribiaux, avancés, plus ćpatis reas leur exliémitó, contiposés de quatre articles, le premier trè-petit, les second ct troisicme presqu'çanx, obcontigues, le second un peu plus lons; ie derinier plus stand, ovale: palpes labiaux prescque fithoruces, dépassant a peine le labre, de rrois anticles, les deux premiers égaux, cyludritues, le derner environ deux lois plus long que les autres, a poine plus gros qu'eux, ovale-cy hindrague. - Leore tronquée, cordifone, membraneuse, profondément ćchancré menton coriace, transversal, cout, presque 'carté, un pesu rétrícs vers l'extrémić. Corpsuvale, arqué eu dessus. - Corselet presqu'en lrapeze, se rélrécisant irscusiblement de la base à l'extrémité, it peu pies moitić plus large que long, assez aplati, se combant insensiblement surr les côlés, entièrement rebordá. - Ecusson dislinct, trigone. - Eלjtres rebordécs, arrukfies a l'exiremié, recouvrunt les anles et liaidenen. - Pattes fories, cuisses comprimćes, jambes épineuses, triangulaires, alongées ; larses courts, filformes; leurs qualle premers arlacles comrs, presque coniques, entiers, le premier un peu plus long que les suivans, te dernier plas long que le prenier, muni de deux forts crochets.

On ue connổl qu'uu pelil nombie d'espèces de 


\section{P E L}

ce genre. La plus eomuma se tencontre sous les feorces d'arbres. Elle est décrile daus ce Diclion-

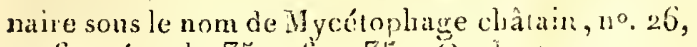
ct figurée pl. 359 , fig. 35 . Un la trouve atux cuvirous de Paris.

BY'TURE, Byturis. Latr. Dermestes. Fab. Oliv. De Géer. Geoft.

Geure d'insecies de l'ordre des Coléoptères, section des Pentamèıes, famille des Clavicornes, tribu des Peltoides.

Parni les genres de cetle tribu qui ont l'extrémité des mandibnles échancrée et la massue des antennes flus on moins ronde ou uvale, les Nitidules, les Bylures et les Cerques som les seuls dont les trus premiers articles des arrses, du moins cenx des antérieurs, suient cumrs, latges, dilutés; mais les Nitidules on le lonisiome arti.le des an!cunes une fois au moins plas long que te suivan:; le corselet des Cerques c'st arronti el surs angles it son exirúnité postéricure. Ces cal racteres séparent ces deux genres de colui de Byltire.

Antennes de onze articles, les deux premiers ì peu près égaux en grossenr, le troisieme pen différenten longucur du quatriene; lestroiscterniers furmant une massue alongée, perlolice, comprimée; les netuieme el dixirme transvcranx, trangulaties. - Mandibules bidenaćs à lextrémitó. - Mấchoires ayant deux lobes courts. - Palpes fillories, les maxillaires de guatre arlictes, le dernicr alongs, presque cylintrigue, nu peu

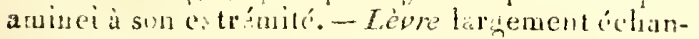
crée. - Corps oblon. - Corselot presigue trapsizonda!, pias lange a sa parlie postćrieure dont les angles som disincement atgh. - Ecussen arr ndi posteriencment. Litrires alongéé, convrant compé émom bes ailes "l labdnonen. Palies de longut ar an yenne; tarses ayant lears trois premint's articles courts, larges, dilatés, velus cu dessurs.

lespèce qui a servi de type a M. Latreille pont fonder ce gente, se remcontre fréquemutent all printcmps ditus les frês sur les fleurs et nofarmeni sur relles der ruoncules.

Doyez ponr sit description, Bermeste velu, no. 15 de de Dictionnatre.

Nola. M. Lalrentle croit que le synonyme de Fabricius ue doit pris être rapporté a cente espéce, a cause de dir points butus élevés que cet anreur allribue an front de son insecte. in. le comte Dejeun paroì être dinne opinon contruire.

Cerque, Cencus. Iat. Cateretes. Herbst. Indag. Dermestes I.rxx. Faв. Spherrdum. Hs B. Nitudah, Anthrbus. Univ. Scaphidium, Strongylus. Herss't.

Genre d'insectes de l'ordre des Coléoplères, secion des Pentameres, farmille des Clavicormes, tribu des Peltudes.

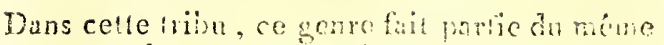
groupe que les Bytures ol les Bilidules ( Pratones); nais'les premiers ont les an les prostérienrs da eorselet disincts et aigns, lours alytres couvrent entièrement l'abdomen, et ditus les Nitidules, le trojsiome article des anlennes est whe fois plus long gue le quatriome.

Antenues de onze articles, les deux premiors du grasscur à peu près érale (quelcuelis tréogrands el dilatés daus les nitles), le troisième pou

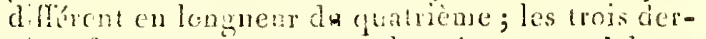
niers formant une mals ue alongre, prescu'obennique, comprimćc et perfolice. - Munaitules très-atguës à lequ estronité, échancrées, ayant un tubercule ass z gros a l'angle cxtéricur de len baine. - Díachoires à doux lobes, l'enlérieur capilliare. - I'alpes maxilaires filitumes, comiposés de quatre artacies, les latiaux de treis, domt le damer ćpais. - Constet grand, presgue sans rebords, rélrécion anrendi, mais sams anghtes a son extrian postérictare. - Ecrisson très-dislinct. - Eloticos cenerant les ailes, mais plus courles que labdomen. - Inall's de longucur m.yenue; tarses ayant leurs trois premicts aticies courts, larges, velus en dessous.

On ignote les mélamo!phuses des iu.eetes de ce cenre chable par al. Latreille. On les trouve sur

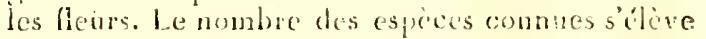
a une douzane, toulcs curopóemes el de peite laille.

Rapportez ì ee genre l'Anihribe puce, $n^{\circ} .4$ de

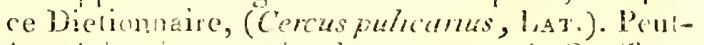
idre dobl-on retrancher le synonyme de Geothog. l.es Demestes urlico, $\mathrm{n}^{n}$. 44 , et pedicuhuring, $11^{\circ}$. 4.7. Ra s. Syst. Eleut. (Eurycl. pl. 553 , fig. 5z) apparlicunent a ce genre.

\section{COLObique, Colobicus. Lat.}

Genre d'insectes de l'ordre dics Coléoplères, secijon des l'oulanerés, funille des Clavicomes, uriou des laturites.

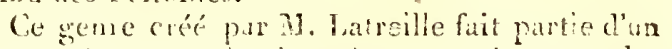

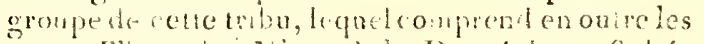

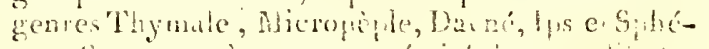

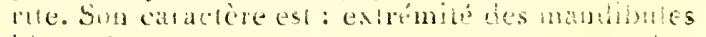

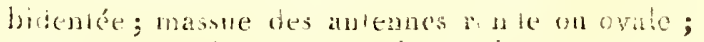

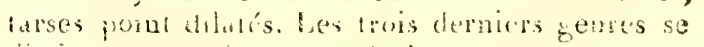

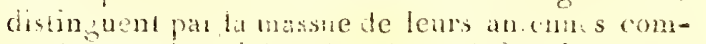

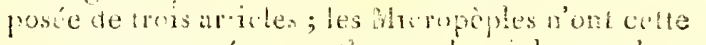
nabse compose que dinn seul article, el dans

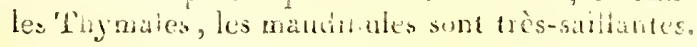

Antennes ayant lour morsicme article alongé, trois thi p tus long yue le suivant les deas corniers formant romis mue mosue solide, orliculuire. - Bouche at mandahles rewwe ertes pas wa avaseracest arrond et en firme de chaperon de l'extrénató antericure de la tóe. - Palues maxillares phins grands que es labias. - Corks

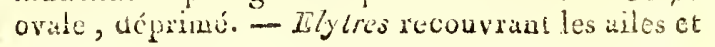


la colalité de l'ubdomen. - Pattes de longueur moyenne.

Les insectes de ce genre, dont le nom vient d'un mot grec qui signilie: mutiler, habitent sous les écorces des arbies. L'auteur n’en mentionne qu'une seule espèce.

\section{Coloneue hordé, C. marginatus.}

Colobicus migricans, antennis, capitis thosacisque marginibus exterioribus testaceo-fuscis.

Colobicus marginatus. I, т. Gener. Crust. et Ins. toun. 2. parr. 10. tom. 1. tab. 16. Jig. I.

Longueur 2 lig. Ovale-oblong noirâtre, avec les autennes. les bords cxlćrieurs de la têre et du corselet d'uu brun fauve. Dessus du corps parsemé de petites ácailles grises. Elyties ayant cles strices pointillées.

Des cunvirous de Paris.

Nota. Cet insec:e est peut-être la Nitidula hirta Ross. Fitun Etrus. tom, 1. pag. 59. tab. 5. fig. 9 .

MrCROPEPIE, Micrupeplus. Lat. Staphylinuls. Fas. P'ayx. Ondr. Nitidula. Herbst. Omalium, Gruenais.

Genre dinsectes de l'ord:e des Colfoptères, section de, Pentamères, fanille des Clavicornes, tribu de's Peliondes.

"ious les genres de cette tribu, excepté celui de Micropeple, ont leurs cuatre palpes très-apparens, lens antcunes ne se logent point dans une cavité particulière du corselet, et la massue qui les termine est de deux on trois articles.

Anterncs phus courles que le corsclet, se logeant daus dés cavités latćrales du corselet; leurs deux premiers arlicles plus grunds que les suivans, grobuleux, le dernier tris-rrand, formaut à lui sél une nüssue solide, globuleuse. - Manaibules arquées vers leur extrémilé, pointues, hidentées, sans dentelures. - Palpes maxillaires trés-petits, beaucup plus épais daus leur milien, leur sceond article étant trés-rentlé, aniacis à leur extrémité et terminćs en une pointe particulière, les labiaux point visibles. - Mlachoires bifides, lenr lube intéricur ayant la forme d'une dent. - Lève presgue carrie, dilatće et atrondic sur les côtés, son cxtrémité un peu plus étroite, lronguée, entière; menton transwersal, petit, entier. - Elytres beaucoup plus courtes que l'abdonen. -- Tarses ayant leur's prouier's articles trés-conrts.

On doit ce grenre il M. Latreille. Son $n n m$ vient de deux mots g̈recs qui signifienl: petit vétement, et a rapport it la brièveté de ses élytres. L'enpèce qui a servi de type est d'Europe.

\section{M̈̈rchopèpe sillonné, M. porcatus.}

Micropeplus niger, thoracis lateribus rugosis, elytris brevioribus tricarinatis, antennaram basi pedibusque fuscis. firicropeplus porcatus. I.AT. Gener. Const. et Ins. tom. 4. p. 377. - Nitıdula sulcata. Herвsт. Col.V. LIV. 6. - Staphylinus porcatus. OLIv. Entom. tom. 3. Staphyl. par. 35. no. 5o. pl. 4 . fig. 33. - Fa . Syst. Elcut. tom. 2. p.602. $n^{\circ} .68$. - Рахк. Faun. Suec.toin. 3. pag. 413. 7․ 59.

Irongueur une ligne. Corps ovale, noir. Tête petite. Corselet reburdé sur les côtés, très-raboteux. Elytres n'atteignant qu'environ la moitié de la longueur de l'abdoneu, marquées chacune de rrois lignes longitudinales ćlevécs. Dessus de l'abdomen ayani quelques inpressions. Base des anrennes et paltes bruues.

Il se tronve aux environs de Paris, parmi les matières animales et végćtales corrompues.

DACNÉ, Dacne. Lat. Engis. Paxx. Fab. Ips. Herbst. Erotylas. Oriv.

Genre d'insectes de l'orỏre des Coléoptères, section des Pentamères, famille des Clavicornes, ribu des pelwides.

Dans le groupe de cette tribu qui a prur caractère parliculier : extrénité des mandibules ćclancrée ou bidentée; massuce des antennes runde ou ovale; tarses point dilab́s; se rangent avec les Dacnés, les Micropéples qui en different par leurs palpes labiaux point distincts et leurs antennes se logeant dins une cavité particulière, les 'Thymales qui ont leurs mandibules très-saillantes, les Colubiques dout la massue des antennes est de deux arlicles et qui ont un avancernent en forme de chiperon recouvrant la bouche, les Sphérites ayant leurs b́lytres plus courles que l'abdome:n, et les Ips dont les articles des tarses sonl grếles et alongés.

Ainternes courtes, ayant lear massue crrande, presqu'ovate, compritice, colaposée de trois arlicles, les deux preniers laries. - MIandibules bifides à l'extrémité. - Mâchoires ayant deux lobes, l'extérieur presque trigone. - P'alpes maxillaires tiliformes, les libiaux terminés en massue, leur dernier articie étant plus épais. - Corps ovale. - Elytres couvrant les ailes et la tolalité de l'abdonea. - Pattes de longneur moyenne; tarses ayant leurs trois premiers arlicles courts et larges.

Ce genre est dâ a M. Latreille; son nom est tiré d'un verbe gree qui signifie : mordre. Il renferme une donzaine d'esperes, doni plus de la novití esl exolique. Plusicurs d'entr'elles vivent dans les champignous et sous les écorees des arbres.

Ripportez à ce genre l'Erotyle bifuscié, $n^{\circ} .11$ de ce Jictionnaice, les Engis humeralss, $\mathrm{n}^{n} .2$, et saluguinicollis, $11^{\circ}$. 5. HAB. Syst. Fileut. Ce's deux derniers sont d'Europe.

Cholève, Choleva. Latr. Peltis. Geofr. 


\section{P E L}

Dermestes. DE GÉer. Catops. PAYK. FAB. Hiclops. Panz. Ptomataphagles. Ileig.

Ginre d'susectes de l'ordre des Coléoptères, section des Pentamères, fuuille des Clavieornes, tribu des Peltoides.

Les genres de cette tribu qui ont l'extrémité des inandibules bidentée et la massue des antennes oblongue, composée de cing à six arlicles, sont ceux de Scaplidie, Clooleve et Mylæque. Mais les preniers ont des élytres tronquées, et dans le genre Mylaque, les deux premier's articles des antennes sont notablement plus gros que les suivans, el diffèrent d'eux par lü forine.

Antennes filiformes, grossissant vers leur extrémité, distantes à lenr base, insérćes au-dessous des yeux, composées de onze articles, les deux preuners peu différens des suivans en grosseur et quant à la furme; les cinq derniers pius gros que les autres. - Mandibules courtes, cornées, aiguès, éclbancrées à leur pointe.-Mâchoires ayaut deux lobes nembraneux. - Palpes subulés; les maxillaires composés de quatre articles, les second et troisiome à peu près d'égate longnenr, obconiciues; le dertrier coniyue, terminé en pointe; les libiaux petits, cylindro-eoniques, de trois artieles, dont le dermer pointu. - Lève inembraneuse, piesque earrée, lirgement échancrée ilu bord supérieur; menton corrace, presque trapézoidal. - Téte inclinée, presque de la larueur du corselet. - Ieux petits, peu stillans. - Corps pubescent, irqué en dessus. - Corselé convexe, sans rebords, de la largeué des élýres. - Ecusson triangrulaire. - Elytres convexes, de la lonmueur de l'abdomen, couvrant des ciles. $-A b$ domen terminé en pointe. - Palles longrnes, les postérienres sartoul; jambes un peu épineuses; turses filifurmes, à ariicles atongés, entiers; les trois preniers des tarses antérieurs plus gros que les autres et velins en dessons daus les mâles.

Ce genie foncié par M. Latreille est le même que celui auquel Paykull a imposé le nom de C'atops, et Illiger Ptomaphagus. Fabricins adopta la dénominaltion du naluratiste suédois, te préśćrence is celle de M. Latreille, qui avoit l'antériorilć. Le now de Cholève, lité du yree, exprime la démarche un peuboiteuse des espèces gui le composent; leurs couleurs sont grénéralencat sonbres : elles vivent dans les champignons et dans le bois pourri tombé en ponssière. On e'n connoit une quinzatine, toutes d'Europe et d'itssc'z petice taille.

\section{Cholève morio, C. morio.}

Choleva nigra, suhtomentoso-sericea, elyitris non síriatis, pedibus antennarunque basifuscotestaceis.

Cholewa villosa. Lat. Gener. Crust. et Ins. tom. 2. pag. 29. nn. 5. - Catops morto. FAn. Syst. Eleut. tom. 2. pag. 564. n०. 4. - РАYK. Eaun.

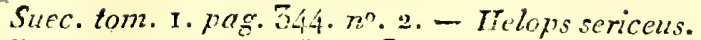
PAx\%. Faun. Germ. fasc. 73. fig. 10.-Dermestes fornicatus. DE Gerr, Ins. tom. 4. pag. 216. $n^{n} \cdot 9$.

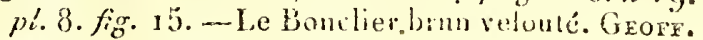
Ins. Paris. tom. 1. pag, $123 . n^{\circ}, 10$.

Longueur 2 lig. Noire, converte d'un dnvet rour cendré arès-colit. Antemues plas courtes que le corselet, un peu en massue; les seprième, huitième, neuvièrse et dixiène articles Iransversaux. Cursclet presque earré. Base des antenues et palteg d'un teslacé brun.

Commune alux environs de Paris.

Nola. Les Catops rufescens, $n^{\circ}$. I, et arilis, $n^{\circ} .6, \mathrm{~F}_{\mathrm{A}}$. Syst. Eleut., appariennent au genre Choléve. Ce dernier est représenté Encycl., pl. 559. fig. 10. (S. F. et A. SERT.)

PEMPJREDON, Pempliredon. LAT. Fab. Cemonus. Jun. P'anz. Inirg. Pelopa'us. Fab. Crabro. Ourv. (Encycil.) Paxz. Sphex. l'anz.

Genre d'msectes de l'ordre des Hyménoplìres, section des Porte-aignillon, furille des liouisscurs, tribu des Crabronites.

On doit ee gente à M. Lalreille, rui l'it ćtabli le premier dans son Précis des caracteres génériques des insectes. N. Jurine changea depuis sa dénomination sans en alléguer la raison. Fabricius en l'adoptant y introdnisitbeaucoup d'especes qui n'en dovent pas faire partie. Les Pemphrédons, les Mellines el les Alysons formen! un petit groupe daus la tribu des Crabronites; re groupe a pour caractère: $1^{\circ}$. antenues insérces près de la bonche ou au-dessous du milien de la ficede la tête, re qui le distingue des psen, des Cercéris et des Plilanthes. 29. Yeux entiers, ce rui le sipare des'Trypoxylons. $3^{n}$. Matndibules forles, dentées au côté merne, ce qui l'éloigne des Goryles, des Crabrons (Frelon, Oliv. Encjel.) et des Stigues. Les Punplurédons sont distingués des Melines et des Alysons, en ce qu'il's nont que trois ceilules cubitales anx ailes sulviricures, tairdis que ces denx demicrs genres cu ont quatre.

fintennes fitiformes, rapprochées, un petl plus longres gue lat têle, de douze itrich s dans ks fenolles, de treize daus las malles. le premier pen alongé, conique; le second eourt, le roisième le plius long de lous; les snivans allant en dimianant a mesuce quils approcisent da bout. - Labre entièrement caché. - Manábules presçu'eu forme de cuille:, mulidentées. - Ifiachorices coriaces, ovaluires; leurs bords membraneù. - Puatre palpes; les maxillaires beacoup plas longs que les labiaux, de six articles; les cinc preniers obconiques, les trois dermiers un pen pus longs le premier le plus connt, le second alssez gros, lo demier presque cylindrique; les labiaux de guattre articles; le premier obconigue, le dermes ovalaire; ces deux articles pius longs grae les intermédiatres. - Langruette trifide. - T'́le forte, 
presque carcée, sa face antérienre gamie d'un duret argenté (dius les mities serilement). Yeux petits, ovalaires. -- Trois petits yeux lisses disposés en triangle el placés all-devant du vortex. - I'remier segment du corcelet linéaice et transversil, dislaut en dessus de l'origine des ailes. - Ailes supéricures ilyant nne cellule radiale phns ou moins rétrécic après lia seconde cuJicule, son estrémité un peu aiguë ne s’écartant pais te la cóle, et trois cellules cubitales; la premicere ayant glus de denx fuis la longueur de la seconde; la treisième tracéc jusquau bord postériem de luile. - Abromen ovalaite, distinctement pétiv!é, composé de cinq segmens ontre l'aus dims les femelles, en ayant un de plus dans les wâles. - Paites de longrıeur mogene, les gualre jambes postérieures dentelées il leur partic extricure dans les fermelles; les antérieures el les iuternédiafres munies à leur extrémité d'une cine droile, argue; les postérieures de deux; premiel article des burses long, les autres conals, fo dernier terminé par deu: crochets simples, ćartés, munis d'une petite pelolle dans l'eutredeux.

Les cing ou six especes de ce geure qui nons sont conumes, hribitent l'uurope ; leur latle est jetite. Elles out le woir po: coulent dominante. 1.es femelles creusent des lrous, soit dans le bois, soit dars le cinient des unr's pour y déposer leurs arif. Elies y anportent des insecics pour servir de rourriture à leur postérité; uous croyons que cesont toujours des pucerons. Les trous sont partagés en plusieurs cellules, séparées par des cloisins. On trouve souvent les Peurjhredons str les Hhurs. D'après les aúteurs, nous partureons ce genre cu deux divisions, basées sur l'inserlion des netvurcs rócurrentes te l'aile.

15e. Disision, Preniòre cellule cubitale recevant la première nervuie récurrente; seconde cubitale recevant la deuxièue nervure sécurrente.

Ire. Subdipision. Deuxiène cellule cubitale de forwe currée.

1. Pegronadon lugubre, $P$. lugubris.

Panhredon totus ater, cellulâ cubitali primâ funicuin nervim recurrentem excipiente.

Poimphredon lugibris. Lat. Gener. Crust. et Ins.

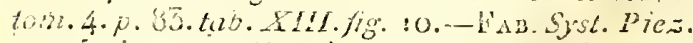

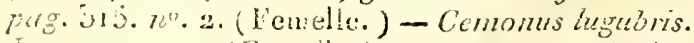
Juk. pug.2ia. (Femalle.) - Cemonis unientor.

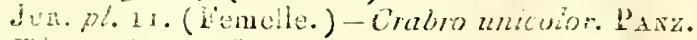

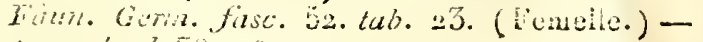
Lncyct.pos so. fig. 7 .

Lungucur 5 a 4 lig. Entièrement noir. Ailes tranparrates. Mále cl fentile.

Lie premier est un peu plus pelit.

liu founde construit son nid dans les cavités qu'el!e creuse dans le bois pourri des vienx arbres.

Commun aux environs de Paris.

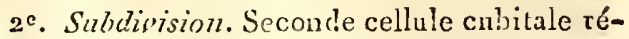
trécie vers lat radiale, presque triangulaire.

2. Pemirnédon nain, P. minutus.

Pempliredon niger, palpis taisisque luteis.

Pempliredon minutus. Lat. Crust. et Ins. tom. 4. pag. 84. - IA B, Syst. Pies. pag. 3ı6. $7^{\circ} \cdot 9$. (E'emelle.) - Cemonus minutus. Jur. pag. 214. (Wemelle.)-Sphex pallipes. PAxz. Fuun. Gemm. fiesc. 5z. tab. 22. (Milk.)

Longueur nue ligne $\frac{x}{2}$ à 2 lig. Corps glabre, brillan:. Arteanes et abdomen entièrement noirs. Tête noire; mindibules el palpes jamnes. Corselet noir, avec los écailles des ailes el un point callenx cn avant, de conleur jaune. Miles transpareutes. Palles jumes; hanches noires; cuisses jaunes à l'extrémité, noires à la base. Femelte.

Le mâle préseute les différences suivantes. Maudibules noires; jambes ayant du noir dans leur nilieu, surtout postélieurement. Exaréunité de l'abdomen d'un brun testacé.

La fernelle firit son wid dans les murailles. Cominar aux environs de l'aris.

$2^{c}$. Division. Premicre cellule cubitale recevant les deux nervures récurrentes.

\section{Pemparédon unicolor, $\boldsymbol{P}$. unicolor.}

Pemphredon totns ater, cellulầ cubitali primâa nervos duos recurrentes excipiente.

Pethphredon unicolor. LAT. Gener. Crust. et Ins. tom. 4. pag. 34. - Pelopeus mnicolor. lia B. Syot. Piez. pag. 204. $77^{\circ}$. 10. (Male.) - Cemonus. JuR. proro. 214 . - Sphex unticôlor. Panz. Fiaun. Gerin. fillsc. 5e. no, 24.

Longuen 5 lir. Entièrement noir. Ailes transparentes. Mhitle et fenelle.

Le nate est un peu plus petit. Commun dans nos environs.

Nokte. L'insecte décrit dans cet onvrage, tom. 6 , jay. 5i $7, n^{\circ} .28$, suns le mou de lireton attre, est probablement le mâle de cette espéce-ci, ou celui du l'emplirédon ligubre, no. J. Nous ne pouvous savoir à laquelio des deux espèces il ap-

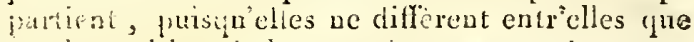
par la position de la seconde nervure récurreule cles ailes, caracière omis dans l'article précité.

Meldine, Rzellinus. Fab. Latr. Panz. Jur. Sphex. De Gerer. Vespa. Linn. Ross.

Gente d'insecies de l'ordre des Hyménoptères, sectiondes Porte-aiguillon, fanille des Fouisseurs, tribu des Crabronites. 
Les Pemphrédons, les Mellines et les Alysons forment dans eette trita un pelit groupe (1). Les Pemphrédons se distinguent par leurs ailes supérieures, n'offirant que trois eellules cubitales, et les Alysons, parce que ees mêmes ailes ont leur seconde eellule eubitale péliolée.

Antennes filiformes, pen ou point eoudées, insérécs près de la bonche, eomposées de douze articles dans les femelles, de treize dans les mîles. - Mandibules au moins tridentées daus les femelles, deux de ces dentelurcs placées au côté interne, l'autre longue et forte est à l'extrémité. - Puatre palpes, les maxillaires beancoup plus longs que les litbiaux, composés de six articles, les labiaux de qualte. - Languette distinctement divisée en trois parlies. - Téte grossc. - Trois petits yeux lisses disposés en triangle sur la partie antérieure du vertex. - Premier segment du corselet linéaire, transvèrsil, distant eu dessus de l'crimine des ailes. - Ailes supérieures ayant une cellule radiale qui va en se rélrécissant aprc̀s la seconde cellule eubitale, son extrénité aiguë, ne s'ćcartant pas de la côte, et quatre cellules eubitales; la première aussi longue que les deux suivantes réunies, recevant la première uervire récurrente près de la seconde eellule cubilate; cclle-ci réltécie auprès de la radiale; la troisième recevant la seconde nervure récnrrente, la quatrième prescine eomplète. - Abdomen eomposé de cinq séguens outre l'anns datns les femelles, en ayant un de plus dans les mâles; son premier segment ayant sa base rétrécie en pédicule. - Pattes de longuenr moyenne; les quatrc jambes postérieures munies à leur extrémité de dcux épines, les antérienres d'une seule. Premier article des tarses long, les autres eourts, le dernier terauné par deax crochets simples, écartés, mmis d'une torie pelotle dans leur entre-deux.

Los Mellines sont en géuéral d'une taille plus. forte que les Peuphrédons ; lcurs couleurs sont le jaune et le noi:"; les ficmelles ereusent des trous dans les terrains secs et sablonneux pour y déposer leurs œuls ; elles approvisionnent ces uids de Muscides dont leurs larves se nourrisseal.

On ne connoit qu'un petit nombre d'espèces. Nous indiquerons : ${ }^{\circ}$. Mellinus arvensis. FAB. Syst. Piez. pag. 299. $n^{\circ}$. 10. Guépe rurale, $n^{\circ} \cdot 95$ de ce Diclinmaire. Panzer a finuré la femelle Faun. Gerin. fius. 17. fig. 20. Le même auteur a représenté le mâle fiss. 46. fig. 31. sous le nom de $C r a-$ bro frontalis. $2^{\circ}$. Mellinus ruficornis. FAB. Syst. Piez. pag. 298. no.5. Panz. Faun. Gem fus. 77 . fig. 17. La femelle. Mellinus sabulosus. FA . Syst. P'iez.pag. 297. $n^{\circ}$. 2. Le mîle. $3^{\circ}$. Crabro petiotatus. PANz. Faun. Germ. fies. 46. fig. I $2.4^{\circ}$. Mellinus pratensis. Jur. Hyménopt. pl. 10. fig. 19.

(1) Toyç Pemphrédon. Hist. Nat. Ins. Tome $X$.
(Encycl.pl.580. fig. 11.) Ces espèces sont d'Europe.

\section{A}

ALYSON, Alyson. Jur. Panz. Lat. Pompilas.

Genre d'insectes de l'ordre des Ityménoptc̀res, section des Porte-diguillon, famile des frouisseur's, tribu des Crabronites.

Les Pemphrédons et les Mellines se distinguent des Alysons par leur abdomen nianifestemeut pédiculé, et par la seconde cellule cubitale de leurs ailes supérieures qui n’est point péliolée et qui atteint la eellule radiale.

Antennes filiformes, insérées près de la bouclıe, composées de douze articles dans les femelles, de Ireize dans les inâles. - Manáibules hidentées. On voit une on deux deuts au côté intérienr, dans les femelles: - Puatre palpes; les maxillaires plus longs que les labiatux, composés de six artieles, les labiaux de cuatre. - Languette distinctement divisée en trois parlies. - Tète assez grosse, carrée. - Trois petits yeux lisses disposés en triangle sur la partie antérieure da vertex. Segmont antéricur du eorselet transversal, assez larye, distant en dessus de l'origine des ailes supérieures; mélathorax muni d'une très-petite épine de chaque côté. - Ailes supérienres ayant une cellule radiale eourle, se rélréciss?nt après la premic̀re cellule eubitale, son extrémité assez ai ruë, ne s'ćcartaut pas de la côte, et quatre cellulcs cubitales, la première prescqu'aussi longue que lcs trois suivantes prises cusemble, la seconde petite, triangulaire, péliolíe, recevant près de son origine la premiérenervure récurrente; la troisième fort rétrécie vers la radiale, recevant la seconde nervure récurrente très-près de la deuxième enbitale; la quatrième n'étant ni tracée, ni fermće. - Abdomen composé de cing segmens outre l'anus dans les femclles, en ayant un de plos dans les máles, son premier segment ne se rétrécissant pas subirement en pédicule. Anus des femelles terminé en pointc, celui des mâles coupé earrément à l'extrémité et portant à ses deux angles postérieurs une soie courte, roide, spiniforme.Pattes de longucur moyenne, cuisses postérieures ayant une dent vers lenr extrémité; les quatre jambes postérieurcs dentelées ì leur partie extérieure dans les femelles, munies dans les deax sexes de deux épines à lcur extrénité dont l'untétérieurc plas petite; jambes antérieures n'ayant qu'nne très-petite épine. Tarses antérieurs ayant leur prenier article grand, les quatre autres eourts, éfrax entreux, le dernier terminé par deux forts crochets simples, écarlés, nunsis d'une grosse pelotte dans leur entre-cheux. Tirses iniermédiares el postérieurs ayant leur premier article long, les atutres allint en décroissant : croebets et pelottes assez petits.

Ainsi que les autres fouissenrs, les Alysons 1 creusent leur nid dans les sabtes et l'appropisiona 


\section{P E M}

nent d'insectes. Ils commencent à paroître dans nos climals vers la fin d'aoút. Le nombre des espèces counues est petit.

\section{Alysov lunicorne, A. lunicornis.}

Alyson niger, abdoininis segmentis duobus primis rufis, tibiis tarsisque quatuor posticis fuscè rufis, alarum superiorum fasciá transversalif úscâ.

Alyson lunicornis. LAт. Gener. Crust et Ins. tom. 4. pag. 86."- Pompilus lunicornis. FAB. Syst. Piez.pag. 194. no. 32 ? Le mâle.

Longueur 5 lig. Femelle. 3 lig. Mâle. Noir. Labre, bord antérieur du chaperon et base des mandibules d'un fauve pále. Premier artiele des antennes fauve en dessous. Epines latérales du métathorax assez fortes. Abdomen ayant ses deux premiers segmens et la base du troisième, testacés. Toutes les jambes et les quatre tarses antérieurs testacés. Ailes transparentes, les supérieures arec une bande brune qui part de la cellule radiale et rejoint presque le bord intérieur. Femelle.

Dans le mâle la couleur noire s'étend davantage et le dernier article des antennes est crochu et luntilé.

Il a été pris dans des terrains sablonneux entre Luc et Faluise par M. de Bazoche. On le trouve aussi aux environs de Paris.

Nota. Fabricius donne à cette espèce le premier segment de l'abdomen noir; cela jette du doute sur sa synonymie.

\section{Arrsov à épine, A. spinosus.}

Alyson niger, abdominis segmento primo basi latè testaceo, secundo utrinquè albo uniguttato, femoribus quatuor anticis apice albids, tibiis quatuor earumdem parium tarsisque omnibus antice albidis, tibiis posticis basi albo annulutis; alarum superiorum fasciâ transversalifuscâ.

Alyson spinosns. Jur. Hyménopt. pl. 10. fig. 21. La feaulle. - Encycl. pl. 380. fig. 12..

Longueur 4 lig. Noir. Parties de la bouche, bord antérieur du chaperon, orbite des yeux et dessous du premier article des antennes jaunes. On voit une ligne de cette couleur sur l'écusson. Abdomen ayant son premier segment d'un testacé-ferrugincux avec le bord postérieur noir, le second portant de chaque eôté une tache ronde, Jlanche. Extrémité des (quatre cuisses antérieures, devant de leurs jambes et base des jambes postérieures, bianchâtres. Tarses pâles. Ailes transparentes, les supérienres avec une bande brune qui part de la cellule radiale et rejoint presque le bord intérieur. Femelle.

D'Allemagne.

\section{Aryson bimaculé, A. bimaculatus.}

Alyson niger, abdominis segmento primo secundique basi latè testaceis, hâc utrinquè alho uniguttatô, pedibus duobus anticis nigris, tibiis tarsisque antice albidis, internediis testaceis, $f_{i}$ moribus subtis nigris; posticis testuceis, genubus tibiarumlute apice nigris, tarsisfiuscis; alarum superiorum fasciâ transversali fuscâ.

Alysson binnaculatus. PANz. révis. - Sphex bimaculata. PANz. Faun. Germ. fasc. 51. fig. 4. La femelle. - Alysson svinosus. PAnz. révis.? - Pompilus spinosins. Panz. Faun. Germ. fasc. 8o. fig. 17. Le nầle?

Longueur 5 lig. Noir. Parties de la bouche, dessous du premier article cles antennes, orbite des yeux et chaperon juunes. Celni-ci ayant une pelile taclie brune. Extrémité des mandibules de cette dernière couleur. Ecusson marqué de deux taches jaunes. Premier seguent de l'abdomen et base du second testacés; celle-ci portant de chaque côté une tache ronde, blanche. Paltes antérieures noires, leurs jambes et leurs tarses blanchatres en devant; pattes intermédiaires testacées, leurs cuisses noires en dessous. Jambes postérieures teslacées avec l'extrémité des cuisses et des jambes noire; leurs tarses bruns. Ailes. transparentes, les supérieures avec une bande brune qui part de la cellule radiale et rejont presque le bord intérieur. Femelle.

Des environs de Paris èt de Soissons.

Nota. Nous n'avons point vu le mâle; c'est peut-être lui que Panzer a représenté sous le nom de Pompilus spinosus.

\section{Anzsov tricolor, A. tricolor.}

Alyson niger, thorace suprà lateribusque fernugineo, abdominis segnento secundo albo utrinquè uniguttato, alarumı fasciis duabus trunsversalıbus fuscis.

Longueur 6 lig. Noir. Parties de la bouche, chaperon, orbite des yeux, dessous du preınier article des antennes et nue petite tache entre leur base, blanchâtres. Dessus du corselet ferrugineux ainsi que ses côtés et l'anus en dessus. Second segment de l'abdomen ayant de cliaque tôté une tache blanche presqu'ovale. Ses quatre paltes aniérieures blanchátres, rayćes de noir en dessus; patles postérieures noires avec un anneau blanc à la base des jambes, leurs tarses d'un brun testacé. Ailes transparentes, les supérieurcs avec deux bandes brunes qui partent du bord extérieur et rejoignent le bord interne; celle de la base n'étant pas toujours bien distincte. Femel!e.

M. de Bazoche qui a trouvé cet insecte à Lue en Normandie lui a donné le nom que nous lui conservons. Nous l'avons pris aussi aux environs de Pulis. (S. F. et A. Serv.) 
PÉNĖE, Penceus. Fab. Genre de Crustacés de l'ordre des Décapodes; famille des Bracliyures, tribu'des Salicoques, dontlescaractères sont : antennes extérieures ou latérales silućes au-dessous des mitoyennes, et recouvertes inf'riemrement par une grande écaille, annexée ì la base de leur pédonenle; les intermédiaires plas courtes, divisécs en deux filets, au-delì dc leur pédonculc; premier arlicle de ce pédoncule fort grand, creusé en dessus pour recevoir les yeux. - Palpes des mandibules saillans, couvrant le front, velus et terminés par un article foliacé, très-grand: Pieds-mâchoires extérieurs s'avançant jusque sous les écailles des antennes latéralcs, pédiformes, velus et pointus an bout; les appendices flarelliformes ou llagres de ces pieds-mâchoires el ceux des intermédiaires ou des deux suivans grands et pennacés. - Pieds des trois premièrcs paires terminés en pince didactyle, coudés, à carpe inarticnlé; cenx de la troisième paire les plus longs de tous. - Yeux gros, presque globuleux. - Test prolongé antérieurement en manière de bec, conıprimé, dentelé et cilié en dessous. Post-abdomen fortement caréné postérieurement le long du unilieu du dos; le dernier segment terminé en une pointe très-iliguë.

M. Risso a rapporté l'espèce de ce genre, la plus commune dans la Méditerranée, la Caramote de Rondelet, et qui pourroit ćtre la Caride bossue d'Aristole, aux Alphées. Olivier confond ces Cruslacés avec les Palémons, dont, en effet, ils se rapprochent beaucoup, quant ${ }^{\circ}$ au ficies, nais dont ils diffèrent évidemment par lè nounbre de lenrs serres ou des pieds terminés en pince. Le Péníe caramote est l'objet d'un commerce considérable. On le sale pour le conserver, et ainsi préparé, on en fait des envois en Grèce, daus l'Asie mineare et dansla Perse. Les Grees el les Arméniens en font une assez grande consommation, Les oufs sont ordinairement rouges ou anrorcs.

On peut diviser le genre Pénée en dellx scctious; ceux dont les antennes supéricures ont leurs divisions terminales très-petites, dc grosseur inégale, et beancoup plus conries quc leur pédoncule; et ceux où les divisions sont plus longucs, presqu'ćgales, en forme de filets grḉles et sćıcés. A li premic̀re apparliennent les I'atémon sillonné ( $P$ alamon sulcatus) et les $P$. cannelé ( $r$. canaliculatus) de ce Dictionnaire. La premiere espèce est commune dans la Méditerranéc, el identique, je présume, a vec lis C'aramote de Rondelet, ou l'Slphée caramote de M. Risso, quoique la descriplion donuće par celui-ci diffère par quelques points de celle d'Olivicr. (Voyez l'article Penrer du Nonveau Dict. d'ritist. nat. $2^{\mathrm{e}}$. édit.) On rangera ausci dins la mêne division le $P$. d'Orbigny (P. Orbigryyanus). Sun bec s'avance un peu au-delit du pécurcule des anlennes miloyennes et a huit dients en dessus el deux en dessous. Il n'y a point de sillon prononcé, de chaque côté, dẹ la carène antérieure du test. La ligne enfoncée qui dans l'espèce précédente traverse antérieureinent toute la largeur de ce test est ici très-courte. Le sixième segment de la quene n'il point suc les côlés de petites lignes enfoncées; lcs bords latéraux des suivans ne sont point épineux; le bord supérienr de la carène dersale et des derniers anneaux sont verdûtrcs; les dentclures ou ćpines des quatre scrres antérieures sont plus petites, et les pieds sont proportionuellcuent plus longs et pltts grêles quie ceux da $P$. Caramote.

Le Pénce monodon de Fabricius entre dans la seconde division. Peut-être aussi faut-il y placel les Péncis à longres untennes ct Mars de M. Risso. Ils me sont inconnus, ainsi que celui qu'il nomme membraneux, et de mèine que le $P$. très-ponctué de M. Bosc. (Latr.)

PENTANĖRES, Pentamera. Première section de l'ordre des Coléoptères; son caractèrecst:

Cinq arlicles à tous les tarses.

$$
\text { (S. F. et A. Serv.) }
$$

PENT ATONE, Pentatoma. Genrc d'insectes de l'ordre des Ilémiptc̀res, section des Météroptères, fanille des Gcócorises, tribu des Longilabres.

Nota. Te nombre des espices qui doivent être rapportées à cette tribu s'élant considérablement augmenté dans ces derniers temps, nous nous sommes crus obligés de proposer quelques nonveaux genres et de nouvelles divisions dans cette tribu, dont nous adoptons les caractères Iels que M. Latreille les a posés.

Lovginabres, Longilabres, Première fribu de la famille des Géocortses, scction des llélćrop. tìres, ordre des Hémiprères.

Ses caracticres sont: Bec découvert, de quatre articles distincls. - Labre très-prolongé au-delà de la lête, strié transrersalenent en dessus dans la plupart. - Tarses de trois arlicles distincts, le premicr de la longueur du second ou plus long.

I. Antennes de ciriq articles. - Deux yeux lisses apparens.

Scutellire.

lentitiome.

II. Antennes de quatre arlicles.

A. Deux pelits gerux lisses plus ou moins ape parco:s.

a. Antentes insártées sous un rebord latéral de la tère.

Tessaratome.

b. Autennes insćrćes à nu sur la partio supérienre des rôlés de la têle; leur premier arlicle dépassant notablement l'extrémité de la tête. 
Níide.

Coré.

Alyde.

Holbyménie.

Pachylide.

c. Antences insérćes à nu à la parlie inférieure des côlés de la tête; isu: premicr article court, dépassant a peise l'extrémité de la téte.

$$
\begin{aligned}
& \text { Myodoque. } \\
& \text { Lygée. } \\
& \text { Pachynère. } \\
& \text { Salde. }
\end{aligned}
$$

B. Point de petits yeux lisses.

$$
\begin{aligned}
& \text { Astemme. } \\
& \text { Miliris. } \\
& \text { Capse. }
\end{aligned}
$$

III. Antennes de trois articles. - Deux yeux lisses apparens.

\section{Plilæa.}

PENTATOME, Pentatoma. Orrv. (Encycl.) Lam. Lat. Pax.-Baut. Cimex. Linn. Geofi. De Géen. Fab. Edessa, Ellia, Halys, Cydnus. Fab.

Le noin de Pentatome venunt de deux mo:s grecs qui signitient cinq pièces, a été donné à ces unsectes cur raison de lutrs antennes composées se cing articles. Feu Olivier a établi ce genre en y réunissaut les Scutellères, dont il faisoit cejendant une division particulière. M. Launarck fa restrcint dans ses vérilables limites et M. Latreille l'a adopté ainsi. On voit par notre synoryymie que Fabricius en a dispersé les espèces dans divers genres. Le: Pentalomes sont avec les Scutellères les seuls longilabres qui aient cing arlicles aux anteones, mais ces deruieres se distingnent au premier aspect par la grandemr de lécusson qui leur recouve cntièrement l'abdomen el cache les ćlyircs presqu'en totalité, tanois qu'elles sout tout-à-fait à découvert dans les I'entatomes.

Anicnnes filiformes, plus courtes que le corps, insérées de chaque côté au devant des yeux, composées de cincr articles dont la longueur rcspeciive yarie selon les cspèccs. - Labre long, très-éiroit, prestju'aciculaire, finement strié transversalement, presant raissance à l'extrémité antéricure du chaperon et recouvrant la base du sucoir. - Saçoir formé de qunatre soies; les deux inférieures se réunissant cn une seule un peu au-deli de leur origine, rcnfermé dans une gaine nommée bec, divisé cn quatre articles distincts, le premier logé en grande partie dans une coulisse longitadinale du dessous de lit lête. Téte petite reçue postérieurencat dans une échancrure placée au bord antérieur di corselet. Ieux saillans, globuleux. - Deux petits yeux lisses placés sur lat parlie postérieure de la téte, un cle chaque côté, à peu de distance du bord interne des yeux. - Corselet beancoup plus large que long, rétréci en devant, dialé en arriere. - Ecusson tres-grand, triangulaire. - Ábdomen composé de six segmens oulre l'anus; ces segmens aỹant de chaque côlé un stiguale un peu rebordé, célui de l'anus plus pe:it. - Anus des ferselles sillonué longritudinalenent daus son milien: relui des mâles entier, sans sillon longiludirúl.-.. Jambes dépourvies d'úpines terainales; tarses courls, presque cylindriques, de trois articles, le second plus conit que les autres, le dernier terminć par deux crochets recourbés ayant une pelotte bilobće dans lear entre-deux.

Les Peniatomes dans l'élat de larve ne diffèrent de l'insecte parfait qu'en ce qu'ils sont tolalement dépaurvus d'ailes et d'élytres; sous la forme de nyinphe als ont de plus les foureaux dans lesquels sont renferuées ces parties; ceux des ailes sont plus petits et placés sous cenx des élytres. Ces change. mens sont accormpagnés d'une inue générale; nous croyons mî̀me que la larve en éprouve plusicurs. Dans tous ces étúts leurs inceurs sont parcilles et ils jouissent des mêmes facultés, à l'exception de celles du vol el de la reproduction. Dans l'état parfait, le mále monte sur lc dos de la femelle pour la provoquer í l'accouplement, mais quaud cet actes'accomplit, les deux sexes sont placés sur le même plan ct réunis bout à bout; la copulation dure assez long-temps, et pendant sa durée le málc se laïsse entrainer par sa femelle dans tous les mouvemens que celle-ci veut faire. Cos insectes se nourrissent par succion de la séve des plantes succulentes ou du jus des fruits; quelques-uns allaçuent aussi les insectes, nême ceux de leur propre genre, pour en tirer les parties molles intérieures. Le plus grand nombre des cspèces exhale une odeur insupportable ct la communique mêmc aux firuis pour peu qu'elles les aient entamés.

On trouve les œufs des Peutatomes déposés sux les feuilles ou sur les tiges des végétuux, réunis ensemble au moyen d'une matière visqueuse trèstenace. Ils sont placés par plaques très-régalières et ont scuvent des conleurs fort agréables. Les Pentatomes sont générailement connus sons te nom de Punaises de bois.

Le nombrc des espc̀ces de ce genre est considérable; elles paroisscnt répandues daus les quatre parties du monde et dars les températures les plus opposées. Dans la première division les couleurs varient beaucoup, mais dans la seconde, qui ne contient que peu d'espèces, le corps a constamment le noir ou le brun pour couleur dominante.

Ire. Division. Jambes simples.

$1^{\mathrm{re}}$ Subdivision. Une lame abdominale relevée et lancéolée. 
A. Sternum arancé, eomprimé. - Corse-

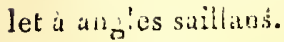

I. Pextatone hémorrhoidal, $P$. homorhoidalis.

Pentatoma griseo-viria'is, antennis fufcis, basi pallidis, yentre in medio carinato, ebtrorum nuentbranâ unicolori.

Pentatoma hamorrhoidalis. Lat. Gen. Crzist. et Ins. tom. 3. pag. I16. - Cimex homorrhoidalis. Faв. Syst. Rhyngot.pag. 160. $n^{\circ} \cdot 27 \cdot$ - La Punaice verte à pointes du corselet rouges Grofr. Ins. Puris. tom. 1. pag. 465. $n^{\circ}$. 63. - Wolr. Icon. cimic. fasc. 1. pag. 10. tab. 1.j7g. 10. Faun. franc. Hémipt. pl. 2. fig. 5.

Longueur 6 lig. Corps d'un vert pâle nuancé d'un peu de rouge, fortement ponctué en dessus. Autennes brunes; premier article de la couleur du corps; troisième et cinquième plas couris que les autres. Bec atteignant la base des cuisses postérieures. Corselet ayant ses angles latéraux mousses, rouges, tachés de noir a l'extrémité. Dessus du ventre et dessous de l'auus presciu'entièremeut rouges. Paltes d'unvert jaunâtre. Menbiane des élytres transparente et sins taches. Ventre caréné dans toute sa longteur. Femelle.

Commua aux environs de Paris.

2. Pentatone de Stoll, P. Stollii.

pentatoma luteo-viridis, antennis lute is, ventre in medio carinato, elytrosum nembrana fusco maculatâ.

La Punaise eusanglantée. STold, punais. pag. 120. pl. XXXIII. $n^{\circ}$. '229. - Faun. frunc. Hémipt. pl. 3. fig. 3.

Longueur 3 à 4 lig. Corps jaunâıre eu dessons, très-ponctuć en dessus. Autennes jaunâtres , troisic̀ue article plus court que les antres: Tête et cor selet de couleur verte lavée d'un peu de rouge. Bec dépassant à peine la base des cuisses iutermédiaires. Angles du corselet monsses, rembrunis. Elytres vertes, largement bordées de rouge sauguin intérieurement. Lenr membrane transparente marquće d'une tache brune sur lear bord, avant l'extrémité. Ventre d'un rouge sauguin en dessus, caréné en dessous au niilieu dans toute sa longueur. Dessous de l'anus d'un ronge de sang. Pattes verdâtres nu:tneées de rouge. Mî̀le et fémelle.

Commun en Europe.

B. Sternum simple.

a. Corselet à angles saillans.

3. Pentatome dix-sept taches, $\boldsymbol{P}$. I 7 -maculata.

Pentaína obscurè fusca, thoracis acutè spi- nosi maculis duodecin, scutelii trilus, elytronum unicâ luters.

Pentatoma i7-maculata. PALis.-BAuv. Ins. 'd'Afriq. et d'Anériq. pag. 112. Hémipt. pl. 8. fig. 4 .

Longueur 4 lig. Corps d'un brun obseur. Bord antéricur de la tếte droit, ì peine échancré. Bec a!teignant la basedes cuisses intermédiaires. Donze taches jaunes sur le corselet, trois sur l'écusson et une sar les flylres.

Nota. Les anteunes, les pattes et l'anus manquent dans notre individu.

De Buonopozo, royaume d"Oware.

$$
\text { Ђ. Corselet simple. }
$$

4. Pentatone nigripède, P. nigripes.

Pentatonna suprà rubra thoracis obtuse angrelatimarsine antico, sculelli maculis duabus, elytromm maculìu unicâ nigrts; subtùs lutea, lineâa transpersali maculisque marginalibus nigro-ceruleis, tibiis suprà canaliculatis.

Pentatoma nigripes. LAT. Gener. Critst. et Tns, tom. 5. pag. 117.-Edessa nigripes. FAE. Syst. Rhyngot. pag. $149 \cdot n^{\circ} .17 .-$ Cimex incarnatus. DrURY, Ins. tom. 2. pl. 36. fig. 5. - W Icon. cimic. fas. 1. pag. I1. tab. 2. fig. I1. Stold, Punais. pl. Ir. Jig. ro et $A$.

Longuenr un pouce. Antennes noires; premier article le plus court de tous, les autres égaux entr'eux. 'Tête d'un noir bleuitre en dessus. Bec atteignant la base des cuisses postérieures. Corselet, écusson et élytres rouges; bords autérieur et latéraux du corselet, deux taches latérales à la base de l'écusson, une autre sur chacine élytre, d'un noir bicnâtre. Membrane des élytres brune, opaque, bleuâtre. Ailes de même couleur. Dessous du corps jaune, marqué d'une ligne transversalo au bord du corselet et de guatre taches rondes latérales sur le bord de l'abdomen, d'un noir bleuâtre. Pattes de cette coulenr; jambes fortement canaliculées en dessus ct ciliées latéralement. Femelle.

Des Indes orientales.

5. Pentatome quadrimaculé, $P$. quadrinacue lata.

Fentatoma suprè rubra, thoracis obtusè angim lati disco nigro line $\hat{\boldsymbol{a}}$ albida secto, scutelli albidi maculis duabus nigris, elytris immaculatis, tibiarum parie inferiori suprì canaliculatâ.

Cimex calena. Drury, Ins. tom. 3.pl. ALIY. fig. I.

Longueur 6 lig. Aatennes noires; premier article très-court, le second le plus loug de tons, les trois deruiers ì peu près égaux. Tềe très- 


\section{P E N}

échancrée en devant, noire en dessus, avẻc une ligne jaune de chaque côté. Bec atteignant la base des cuisses postérieures. Corselet rouge, ayant dans son milieu une gande tache noire ar-rontie cu devant, séparée en deux longitudinalement par une ligue blauchâtre et bordée d'une semblible ligne inférieurement. Ecusson arrondi au bout, blanchàtre, presqu'entièrement couvert par une tache noire divisce en denx dans son milieu par nne ligne transversale blanchàlre. Elytres rouges; leur membrane opaque, noirc. Dessous du corps blanchâtre chargé de taches noires, excepté au milieu du veutre. Pattes noires en dessus, cuisses rayées de blanchâtre en dessous, partie inférieure des jambes canaliculée en dessus. Femelle.

Du Brésil,

\section{Pentatoue gris, P. grisea.}

Pentatoma griseo-fusca, thorace obtuse angulato, abdominis margine supero albido nigro maculato, tibiis supriz canaliculatis.

Pentatoma grisea. LAт. Gener. Crust. et Ins. tom. 3. pag. 116. - Cimex griseus. Linv. Syst. Nat. 2. 721.43. - FАв. Syst. Rhyngot. pag.

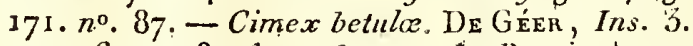
pag. 26r. $n^{\circ}$. 8. pl. 14. fig. 9. - La Punaise brune à antennes et bords panacliés. Grofr. Ins. Paris. tom. i. pag. 466. no. 64. - Wor. F. Icon. cimic. fits. 2. pag. 59. tab. 6. fig. 56. - Faun. fianc. Ifémipt. pl. 2.,fgr. 7 .

Lonqueur $\hat{a}$ lig. Corps d'un gris cendré mêlé de bran, fortement ponctué. Aniennes notres; premier article court; troisiène et cinquiène plus courts que le second et le quatric̀me; les denx derniers blancs à leur base. Bec alteignant la base des cuisses postérieures. Extrémilé de l'écusson jaunâtre, surmantće de deux petits points noirs. Bord de l'abdomer en dessus alternativement noir e! blane. Nembrane des ély tres transparente ponctuée de brtta. Dessons du corps blanchattre parsemé de points noirs. Cuisses et jambes d'uu vort jaunâtre, noires à l'extréwité ; larses bruns, jarbes fortement canaliculées dans toute leus longueui: Mâle et femelle.

Lo male a te troisième article des antennes blanchutre à sat base.

Nota. Geoffroy mentionne une variété femelle que nous conuoi-sons. Eile a la nembrane des élytres suns taches et le troisiène article des antenues blanc it sa bise.

Trc̀s-commun atix environs de Paris.

$2^{\mathrm{e}}$ Subdirision. Une lame abdominale courte, aplatie et couchée. - Siernim fourchu a ses deux extrénilés.

a. Corselet à angles saillans.

\section{Pexatoze Bison, P. Bison.}

Pentatoma testacea, thoracis angulo longiori obtuso, tibiis suprà canaliculatis.

Longneur un pouce. Corps d'un jaune testacé en dessus, son dessous plus clair, avec quelques ligues brunes trausverses. Antennes jaunâtres; les deux premiers articles à peu près égaux, le suivant plus long que le deuxième, le quatrième le plus long de cans, le dervier plus grand que le troisième. Bec n'alteignant pas la base des cuisses intermódiaires. Angles du corselet très-saillaus, presqu'en forme de cornes, leur extrémité noire et obtuse. Elytres ayant chacune cinq raies blanches, celle du milieu plus courte, n'alleignant pas la base, imitant grossièrement la leltre Y. Leur membrane opaque, brune à reflet brouzé. Pattes jaunâtres. Jambes canaliculées en dessus dans toute leur longueur.

De Cayenne.

Nota. Celte espèce est peut-être l'Edessa $A n$ tilope de Fabricius. Syst. Rhyng. pag. 147. $n^{\circ} .8$. Coquer. Illus, Icon. tab. 9. fir. 8. Mais elle en dilfere par les conleurs.

\section{Pretatome Bubale, P. Bubalus.}

Pentatoma thoracis acutè longissimèque spinosi parte anticâ testacêa , mediâ luteâ, postıcâque ziridi, tibiis suprà canaliculatis.

Longucur 8 à 9 lig. Dessous dı corps juune nuancé de rougreâtre et marqué de lignés transversales brunes. 'Tète fauve, inégale. Anteunes jaunes. Bec atteignant la base cies cuisses intermédiaires. Corselet ponctué, fauve à sa partie autérieure, d'un vert brun postérieurement ; une bande jaunc ansez large occupe presque le milieu et atteint des deux cotés la base des angles; ceux-ci pointus, très-longs, imitant des cornes, bruns à reflet violet. Ecusson ponctué, d'un fauve brun, bordé de vert extérieurenent et surtout ì l'extréuité. Lilytres d'un fauve brun, finement pouctućes, ayant quatre lignes longitudinales blarchâtres; leur tuembrane demi-transparente, brune, Patles d'un jaune rougeâlı e. Jambes canaliculćes en dessus dans toute leur longueur. Segmeus de l'abdomen ayant chacun une pointe latérale dépassaut les ćlytres, celle du sirième simple, très-longue, excédunt l'anus. Ventre caréné qu milieu dans tonte sa longreur,

De Cayeane.

b. Corselet siuple.

\section{Pentatome poli, $\boldsymbol{P}$. polita.}

pentutona viridis, thoracis angulis breviter subspinosis, elytris fuscis albido lineatis, tibiis suprà canaliculatis. 


\section{P E N}

La Punaise polie. Stonc, Punais. pag. 98.pl. XXV. $n^{\circ} .174$.

Longueur 12 à 14 lig. Corps vert en déssus, d'un vert jaunâtre en dessous. 'Têle sillonnée, un peu inégale en dessus. Bec dépassant la base des cuisses antérieures. Corselet très-ponetué, avee quel ques nuanees jaunes. Ecusson pointillé, ntiancé de jaune vers sa pointe. Elytres d'un brun fauve, avec des ligues blanchâtres. Leur membrane demitransparente, à reflet métallique. Pattes d'un vert jaunầtre. Jambes canalieulées en dessus dans toute leur longueur. Dernier segment de l'abdonen armé litéralcment d'une forte pointe dépassant de beall. coup l'anus, et munie intérieurement d'une petite dent. Mâle et femelle.

Le mâle a le corselet et l'éeusson d'un ver't sans mélange.

Du Brésil.

10. Pentatone lutéicorne, $\boldsymbol{P}$. luteicornis.

Pentatoma lutea, thoracis viridis anticèque lutei angulis subspinosis, elytris nigro maculatis, tibiis supid̀ canaliculatis.

La Punaise à antennes jaunes. Stond, Punais. pag. 81.pl. XX.fig. 137.

Longueur 8 lig. Corps jannátre en dessous, trèspunctué en dessus. Antennes jaunâtres; premier et troisième articles fort eourts, le second moyen, les deux derniers plus longs que les précédens. Bec natteignant pas la base des cuisses intermédiaires. 'Tềle jaunâtre, sillonnée en dessus. Corselet ver:, bordé de jauue en devant et sur les côtós, ses apglcs peu poinus. Ecusson jaune, sa pointe lavée d'un pcu de vert. Elytres jaunes, avec une tache brune irrégulière sur leur milieu; la membrane demi-transpurente à reflet métallique. Paltes jaunâtres; jambes canalieulées en dessus diuns toule leur longueur.

De Cayenue.

11. Pentatome ensanglanté, $P$. cmenta.

Pentatona suprè vilidis, subtùs lutea, lineis transversis fuscis, alte $n$ is brevioribns, tibuis suprè canaliculatis.

Edessa cruenta. Fа в. Syst. Rhyngot.pag. I 53. $n^{\circ} .51$. - Stole, Punais. pl. XVI. fig. 11 J.

Longueur to lig, Corps vert et très-ponctué en dessus. Son dessous jaune, avec des lignes brunes transverses alternalivement plus longues et plus comrtes. Antenncs ferrugineuses; prenier article court, second et troisiène égaux, le quatrième le plus long, le cinquicme moyen. Boc atieignant à peine la base des cuisses iutermédiaires. Bords extćrieurs du corselet et de l'abdomen ferrugineux. Paties de mème couleur. On voit quelquefois des nuances irrégulic̀res de jaune sur l'écusson. Mâle.

Comwun à Cayenne.

\section{Subdioision. Point de lame abdominalé}

A. Sternum saillant, comprimé, arrondi en devant. - Corselet simple.

- 32. Prntatone mucronć, P. mucronata.

Pentatoma scutello longiori, apice acute spinoso thoraceque in medio longrtadincsintè carinatis, tibiis suprà canaliculatis.

Pentatoma mucronata. PaLis.-BAuv. Insect. d'Afinq. et a's'nerig. pag. 46. Fimipt.pl. IF. fig. 5 e! 6.

Longueur $8 \mathrm{lig}$. Dessous du eorps, têle, partic aniérieure du corselet et paltes fauves. Antennes brumes, Jes deux premiers articles fiuves; le premier eotrt, le second et le cinquième un peu plus longs, le troisième très-court, le quatric̀me le plıs grand dé tous. Bec dépassant un peu la base des euisses antćrieures. Corselet et élytres d'un fauve verdǘre; une carc̀ne longindinale traversant dans leur milien le corselet et l'écusson, ce dernicr terminé en pointe aiguë s'avançant sur la membrane des Elytres; celle membrare opaque, brune à reflet un peu bronzé. Dessons du ventre fortement caréné au milier. Segmens de l'abiomen ayant une pointe latérale dépassant les élytres; cclles du sixième n'avançant point audaut que l'anus. Jambes canaliculées en dessus duns toate leur longueur. Irbâle.

Afrique, royaume d'Oware.

\section{B. Sternum simple.}

a. Corselet à angles saillars.

13. Pentatone rufipède, $P$. rufipes.

Pentatoma fusca; thoracis angulis obtusis lan teralitér acunninato-spinosis, tibuss suprà canairculatis.

Pentatoma iufipes. Lat. Diction. d'Hist. nat. 2. édit. - Cimex rufipes. Linn. Syst. Nat. 2. 7 I9. 24. - FА . Syst. Rhyyngot.pag. 156. no. 5. De Gier, Ins. 3. pag. 25J.no. 2. - Faun. franc. Hénipt.pl. 2. fig. 6.

Longueur 7 lig. Tête et corps d’̉u brun obscur en dessus et très-ponctuć. Antennes rousses; los deux derniers articles noirâtres; le premier petit, les second et troisieme éganx, plus lourgs gue les suivans. Bec dépassant la base des cuisses postérienrcs. Angles du corselet arrondis, munis d'une petile épine. Extrémité de l'écusson d'un janue orangé. Bords de l'abdomen marqués do laches noires, eoupées en denx par une ligne roussitte. Mlembrane des élytres demi-transpar entc. Dessous du corps d'un jaune roux, ainsi que les paites. Jambes canaliculées en dessus dans toute jeur longueur. Mâle ct femelle. 
Des plus communs en France, dans les jardins, les bois, etc.

14. Pentatone gardien, $P$. custos.

Pentatoma griseo fusca, thoracis angulis obtusis, antennarum annulis duobus nigris, tibins suprà canaliculatis.

Pentatoma custos. L.st. Hist. nat. des Crzist. et des Ins. tom. 12. pao. 188. no. 12.-Cimex custos. FАB. Syst. Rhyngot. pag. $157 \cdot n^{\circ} \cdot 7$.

Longueur 5 lig. Corps d'un gris brun en dessus et fortement ponctué. 'Tète échancrée en devant. Antennes rousses, leurs troisième et quatrième arlicles ayant chacun un anneau noir. Premier article petit, le second deux fois plus long que le suivant. Bec atteignant presque la base des cuisses postérieures. Angles du corselet obtus; bords de l'abdomen marqués de taches noires coupées en denx par ane ligne jaunâtre. Elytres ayant quelquefois une tache brune ì lenr angle postérieur interne. Membrane demi-transparente. Dessous du corps d'un jaune sale, très-ponctué, avec une ligne de points noirs de claque côté, élcignée du bord extćrieur. Pattes d'un gris roussâtre. Cuisses ponctuées de noir. Jambes canaliculées en dessus dans toute leur longueur. Fenelle.

Compan aux environs de Paris.

\section{Perratome gladiateur, $P$. gladiator.}

Pentatoma testacea, thoracis angulis acutis, tibiis suprì canaliculatis.

Peniatoma gladiator. Palss.-Bauv. Insect. d'Afriq. et d'Ainériq. pag. is7. Héinut. pl. IX. fig. 1. - Cimex gladiator. HAв. Syst. Rhyngot. pag. 162. $n^{2}$. 55. - Cimex albo punctatus. DE Gier, Ins. 3. prig. 33ı. nn. 5. pl. 54. fig. 6. Stole, Punais. pl. IT.fig: 12.

Longueur 6 lig. Corps d'un jaune fauve, poncthé en dessus. 'Tếle très-échancrée, sillonuée, nu per poncluée de noir, munie de deux poinles aiguës en devanl. Antenues d'un jaune fauve, les cernicrs articles brusâtres à l'extrémité; le prewier article comt, les ankes it fou pres éganx. Bec dípassant la base des caisses postérieures. Corsclet ct écusson atyant des points noirs entoncés, te rrearier atvec ses ingles très-aigus. Elytres rhargúes de poinis ćlevés, iméguliers, assez zros, blancintres. Leur membrane blanche, ransparenie. Dessous du corps phis clair que le desstas. l’attes jaunes; jumbes canaliculées en dessus dans toute leur longuenr. Niale et femelle.

Amérique méridionale; Suini-Domingue.

16. Pextatone ypsilon, P. ypsilon.

Pentatoma suprà fusca, thoracis angulis acutis, a'neo nitens, scutello litterâ y psilon notato, tibiis teretibus.
Cimex ypsil, n. Lrve. Syst. Nat. 2. 720. 32. FAв. Syst. Rhyngot. pag. 159. $n^{\circ}$. $21 .-$ Cimex ypsilon-ceneus. DE GÉER, Ins. 3. pag. 332. $n^{\circ} .6$. pl. 34. fig. 7 et 8 .

Longueur $4 \mathrm{lig}$. Corps ponctué en dessus. Antennes brunes ; base du quatrième et du cinquième, blancbe; prenier article très-court, le troisiène plus longr, les deux derniers égaux, les plus prands de tous. 'jèie d'uu jaune obscur ponctué de noir. Bec atteignant la base des cuisses postérieures. Corselet ponctué de noir, jaune et portant deux taches blanches irrégulières en devant, brun à rellet cuivreux postérieurement, ses angles autérieur's aigus. Elytres brunes à reflèt cuivreux, avec une tacke blanche un peu saillante vers leur milieu. Ecusson brun cuivreux, portant la figure d'un $Y$, de coulenr blanche. Membrane des élytres transparente. Dessous du corps vert jaunâtre. Pattes jaunâtres, fortement ponctuées de noir. Femelle.

Amérique méridionale.

Nota. De Géer a probablement été abusé par la pelitesse du premier artiele des antennes, lorsqu'il a placé cette espèce parmi ses Pumaises à autennes de quatre articles.

\section{b. Corselet simple.}

\section{I7. Pentatome Janus, $P$. Janus.}

Pentatoma suprì rubra, capite, thoracis linê anticâ scutellique basi et elytrorum membran $\hat{a}$ nigris, antennarum articuls quatuor primis tibizsque suprà canaliculatis.

Edessa Janus. FAB. Syst. Rhyngot. pag. $15 \mathrm{I}$. no. $25 .-$ Cimex afer. Druny, ins. 5. pl. XIVI. fig. 7. - La.Punase Janus. Stold, Punais. pag. 30. pl. VI. fig. 4 r.

-Longuenr a ligg. Corps lisse, finement pointillé en dessus. Antenncs noires, leurs quatre premiers articles canaliculés en dessus; le premier fort court, le troisième plus long, le quatrième un peu élargi, les dcux derniers plus grands que les autres. Téte noire, échancrée antérieurement. Bec dépassant à peine la base des cuisses antérieures. Corselet rouge; une bande noire à sa partie autéricure n'atteignant aucun des hords. Ecusson noir, son extrémité ronge, arrondie. Elytres rouges, leur rembrane opaque et brune. Dessous du corps noir luisint, avec la bordure du corselet et elle de l'alsciomen, àl'exception de l'anus, rouges. Pattes noires, jambes fortement canaliculćes en dessus dans toute leur longueur: Mille et femelle.

Indes orientales. Cồe de Coromandel.

18. Pentatome des potagers, $P$. oleracea.

Pentatoma nigro-carulea, lineis punctisque rubris albidisve, tibiis suprà y ix canaliculatis. Pentatoma 
Pentatoma oleracea. LAт. Dict. d'Hist. nat. Ire.édit. - Cimex oleraceus. Linn. Sy'st. Nat. 2. 722. 53.-F a b. Syst. Rhyngot. pag. 177. $n^{\circ}$. 112. - DE GEER, Ins. 5. pag. $266 . \mathrm{m}^{\mathrm{n}}$. 10. pl. I5. fig. 22 et 23. - Stole, punais. pl. V. fig. 32 et 33. - La Punaise verte a raics et laches rouges ou blunches. Geors. Ins. Paris. tom. 1. pag. $47 x$. $73^{\circ} \cdot 74$. - Fraun. frunc. Irémint. pl. 3. fig. 7 .

Longueur 3 lig. Corps noir-blenâtre très-ponctué en dessus. Aulcnnes noires. Premier article le plus court, second et quatrième prescru'égaux et les plus longs de tous. Bec atteignuml ì peine la base des cuisses postérieures. Têtc, corsclet et élytres bordés de rouge ou de blanc lant cn dessus qu'en dessous, une raie longiludinale de même couleur sur Je milieu du corselet. Ecusson ayant deur points el l'extrémitć rougcs ou blancs. On voit une tache de même couleur sur chaquc élyire. Leur membrane blanche, transparente a reflet un peu métallique. Dossous du corps noir luisant, ponctué. Palles pointiilées. Jaubes marqućes d'un annean rouge ou blanc dans leur milieu, foiblement canaliculćcs en dessus. Miâle et fernelic.

Commun dans les jardins potager's sur les plantes léguminenses qu'il détruit.

Notu. Une variélé femclle plas rare a le dessous du corps blanchâtre, avec un double rang de points noirs sur les côtés et une ligue de semblaJles points sur le milicu du vcutrc. La tache des jambes a plus d'étcric e et les cuisses sont prescqu'cntièrement blanclies.

19. Pentatome du Génévier, $P$. juniperina.

Pentatoma suprà viridis, thoracis elytrorumque margine exteriori tenui lateo, sublies luteo viriatis nigroque punctata, tibiis suprà canaticulatis.

Pentatoma juniperina. Lat. Gener. Crust. et Ins. tom. 3. pag. $117 .-C i m e x$ juniperinus. LunN. Syst. Nat. 2.722. 48.- Fав. Syst. Rhyngot. pagr. $167 . n^{\circ} .60 .-1 \mathrm{E}$ GEer, Ins. 3. pag. 231 et 253. $n^{\circ}$. i. pl. 13. fig. I et 2, - 1 a Puncise verte. Geore. Ins. Paris. tom. I. pag. $464 \cdot n^{\circ}$. $6 \mathrm{I}$.

Longucur 5 lig. $\frac{x}{2}$. Corps d'un beau vert en dessụs, très-cliargé de points bruns. Antennes faurcs; leurs trois premicrs articles verdâtres, à peu près égaux evtr'eux, premier très-court, deuxième le plus long de tous. Bcc atteignant la base des cuisses postérieurcs. 'Lète arrondie en devant, peu échancrée. Corsclet et base des élytres légèrétent bordés de jaune extérieurement. Niembrane des élytres demi-transparente. Ecusson quelquefois bordé de jaunc à l'extrémité. Pattes et dessous du corps d'un jaune verdâtre; jambes canaliculées en dessus dans toute leur longuear. Mâle.

La femelle a le bord dit corselet et de la base des élytres jaune rougeâtre; le dessous du corps Hist. Nat. Trs. Ins. Tome X. est de cctie conleur, lont an voit aussi quclguefois des nuances daus le mâle.

Très-eommun en Europe.

\section{Pentatome des baies, $P$. baccarum.}

Pentatoma cinereo fusca, pubescens, antennarum tuberculo radicali extemè spinoso, ahdominis margine stipero albido nigro maculalo, tibiis suprè canaliculatis.

Pentatoma baccarim. LAt. Gener. Crust. et Ins. tom. 3. pag. I16. - Cimex baccarum. Linn. Syst. Nat. 2. 72 1. 45.- FaE. Syst. Rhyngot. pag. 172. no. 92. -Cimex verbusci. DE Grin, Ins. 3. pag. $257 \cdot n^{\circ}$. 4. pl. 14.fig. 5. - Ia Punaise brune it antennes et bords panachés. Grofr.

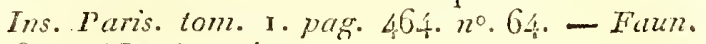
franc. Hémipt. pl. 2. fig. 1 .

Longreur 4 ì $5 \mathrm{lig}$. Corps légèrement pubescent, gris-brun ct finement ponctué en ciessus. Tubcrcule radical des antennes muni d'une épinc latćrale. Antennes brunes, premier article très-ccurt, presciuentièrement blanchâtre; les autres blancs il la base ct un peu ì l'extrémité, le second le plus long de tous. Mec altcignant $l_{1}$ base des cuisses postéricures. Têle arrondie et à peine échancrée en devant. Pointe de l'écusson blanchâtre. Niembrane des élytres transparente. Bords latćraux de ol'abdomen blancs tachetés de noir. Pattles ct dessous du corps rerdâtres, ponctués de neir. Jambes canaliculées cu dessus dans toute leur longueur. Mâle et fenelle.

Extrểmement comnum dans nos anvirons.

21. Pentatome mélanocéphale, P. melanocephaía.

Pentatoma grisea, capite, thoracis angulis anticis scutellique basi et femonum maculà nigroarcis, tibiis teretibus.

Cyanus melanoceplatus. Fıв. Syst. Rlyng. pag. $187 \cdot n^{\circ} \cdot 14$. - Cimex melanocepliaius. PAnz. Faum. Germ, fasc. 26. fig. 24. - Falno franc. Hémipt. pl. 3. fig. 4.

Longueur 3 lig. $\frac{t}{2}$. Corps d'un gris verdâtre en dessus, très-ponctué de brua. Antennes brunes. P'remier et second articles blanchiatres, le premier petit, les quatre autres érraux entr'eux. Bec dépassant la base des cuisses postérieures. Têtre, angrles antérieurs du corselet et basc de l'écr'ssoa d'un noir bronzé. Dessous du corps de même couleur. Bords de labdomen tachés de blanc. Patles blanchâtrcs, cuisses avce me tache d'un nois brouzé, jambes cylindriques. Femelle.

Des environs de Paris.

22. Pentatome acuminé, $P$. acuminata.

Pentatoma capite longo acuminato, alíidas H 
fusco longitudinalitèr lineatu, libiis terclibus.

Pentutona acuminata. Ls. Gener. Crust. et Ins. torn. 3. pag. 115 . Cintex acuminatus. Lins. Syst. Nat. 2. 725. 59. - Rlia acuminata. I. A . Syst. Rhyngot. pag. $18 \mathrm{~g} \cdot n^{\circ}$. 6. - Cinne.x rostratus. DE GEER, Ins. 3. pug. 271. $n^{\circ} .16 . p l$. 14. fig. 12 et 13. - La L'unaise à tête alongće. Groff. Ins. I'aris. tom. 1. pag. 472. $n^{\circ} \cdot 77$. Foun. fianc. Hénipt. pl. 4. fig. 6.

Longueur 3 à $4 \mathrm{lig}$. Corps jaunâtre ponctué tant en dessus qu'en dessous. Le dessus ayant des lignes longitudinales brunes. Antennes jaunâlres, leurs deux derniers ariicles fauves. Articles croissant en longueur du premier au quatrièrue. Le cinquième presqu'ćgal ì celui-ci. Bec atteignant la base des cuisses postérieures. Tếte longue, avancée, un peu échancrée en devant. Palles jaunâtres. Stigmates du cessous du corps noir's. Cuisses marquées de quelques points noirs. Men1brane des élytres blanche, transparente. Jambes cylindriques. Nile et fenelle.

Très-commun aux environs de Paris.

\section{2e. Division. Jambes épincuses.}

\section{Pentatome morio, P. morio.}

Pentatoma fusco-nigra nitens, scutello longo apice subrotundo, elytrorum membzanâ alisque albis, pedibus nigris, tarsis testaceis.

Pentatoma morio. LAr. Gener. Crust. et Ins. tom. 3. pag. 117. - Cimex morio. Linn. Syst. Nat. 2. 722. 51. - Cydnus morio. FAs. Syst. Rhyngot. pag. i84. $n^{\circ}$. 3. - Stols, Punuis. pl. XXXII. fig. 223. - Wonf. Icon. cintic. fasc. 2. pag. 67. tab. 7.fig. 64. - Faun.fianc. Hémipt. pl. 4.fig. 5.

Longuen: 3 i 4 lig. Corps ponctué, brun-noirâire luisant en dessus, noil luisant en dessous. Antennes brunes, leurs deux premiers articles et l'extrémité du dernier fauves. Le premier court, les autres presqu'égaux. Bec atteignant la base des cuisses intermédiaires. 'Tète arrondie, à peine écliancrée en devant. Corselet ayant sur son disque denx élévalions presque lisses. Elytres d'un brun assez clair; leur bord postérieur presque droit ne renfermant pas l'extrémilé de l'écusson. Celui-ci arrondi au bout. Membrane des élytres blanche ainsi que les ailes. Pattes noires, tarses fauves. Mâle et femelle.

Environs de Paris.

24. Pentatome triste, $P$. tristis.

Pentatoma nigra, opaca, scutello apice subacuto, elytroruin inembranâ snlffuscâ, pedlbus nigris, tarsis fuscè testaceis.

Pentctoma tristis. Lat. Hist. nat. des Crust. et des Ins. tom. I 2. pag. 198. $n^{\circ} .46 . .-C_{y} d-$ nus tristis. ل'а . Syst. Rhyngot. pag. 185. $n^{\circ} \cdot 7$. - Cinnex niger-spinipes. DE GÉER, Ins. 3. pag. 269. $n^{\circ}$. 15. - La Punitise noire. Georr. Ins. Paris. tom. 1. pag. 470. $n^{\circ}$. 70. - Faun. franc. Hémipt. p'. 4. fig. 4.-1'axz. Faun. Gelm. fasc. 32. fig. 16.

Longueur 5 lig. Corps entièrement noir, trèsfinement pointillé en dessus et en dessons. Antennes noires ayant un peu de fauve à l'exirémité des ruatre derniers articles. Premier et troisième plus courts. 'Téte arrondie en devant, pen ou peint échancrée, rebordée sur les cólès. Bec dépassant à peine la base des cuisses antérieures. Corselet ayant dans son nilieu une ligne trassversale enfoncće et liue dépression apparente antérieurement. Bords postérienrs des élyltes fortement sinućs renfermant l'extrémité de l'écusson, ce dernier pointu au bout. Membrane des élytres d'un blanc sale un peu obscur. Palles noires. 'Tatses bruns. Nitle.

Commun dans nos environs.

\section{Pextatome bicolor, $\boldsymbol{P}$. bicolor.}

Pentutouna nigra, nitens, albo maculata, pedibus nigris, tibus albo maculatis.

Pentatoma bicolor. LAT. Dict. d'Hist. nat. - Cimex bicolor. Lrva. Syst. Nat. 2. 722.55. - De GĖer, Ins. 3. pag. 263. $\pi^{\circ}$. I 2. - Li l'unaisc noire a qualrc taches blanches. Geofr. Ins. Faris. tom. 1. pag. 470. $n^{\circ} \cdot 73$. - S rold, Punais. pl. XXXII. Jig. 224. -- Faun. Jianç. Hémipt. pl. 3. fig. 8.

Longueur 3 lig. Corps finement poinlillé, noir luisant. Antennes noires, les deux premiers articles très-courts ; les autres égaux entr'eux. 'Tête arrondie, peu écliancrée en devant. Bec alleignant à peine la base des cuisses iuterınédiaires. Corselet un peu déprinć dans son milien avecune tache blanche assez grande, irrégulière aux angles de devint, et un point de même couleur à ses angles postérieurs. Elytres ayant à leur base une tache blanche irrégulière, échancrće en dedans et une autre de mếme couleur, irrégulic̀re aussi, a leur angle postérieur. Ecusson dépassant un pea les élyties, son extrémité arrondie. Membrane des élylres et ailes blanclies, transparentes. Pattes noires, jambes marquées d'une tache blanche en dessus. Femelle.

Coumun en France.

CORÉ, Coreus. Far. Lat. Cimex. Lirr. Geoff. De GÉr. Lygous. Fab.

Genre d'insectes de l'ordie des Hémiptères, section des Hétéroptères, famille des Géucorises, tribu des Longilabres.

Dans celte tribu les genres Néide, Coré, Alyde, Holbyménie et Pachylide forment un 
groupe distinct (2oy. Pevtatone), les Néides se distinguent facilement par leurs antennes coudées et leur corps linéaire; les Alydes ont leurs deux yeux lisses rapprochés l'un de l'autre sur le vertex , les Hollyyménies ont les trois premiers articles des antennes comprimés et les élytres entic̀rement membrancuses, enfin daus les Pachylides le troisiène article des antennes est diluté el comprimé surtout à son extréndité; ces caractères ne se retrouvent point dans le genre Coré.

Antennes point coudées, insérées à nu sur la partie supérieure des côtés de la tête, composées de quatre articles, le premier assez long, dépassant notablement l'extrémité de la tête, le second et le troisième toujours filiformes. - Labre long, strié transversilement, recouvrant la base du suçoir. - Bec de longueur valiable, conposé de quatre articles, renlermint un suçoir de quatre soies. - Tête petite, ordinairenient rétrécie à sa partic postérieure. - Yeux petits, saillans. -Deux petits yeu.x lisses saillans, assez éloignés l'un de l'autre, placés sur la partie postéricure de la tête près des yeux à réseau. - Corselet eu forme de triangle tronqué , élevć postérieutement, s'abaissant petit à petit vers le devant, rétréci dans celte partie. - Ecusson triangulaire, de longueur moyenue. - Elytres en partie coriaces. - Abdomen composé de segmens transversaux dans les deux sexes; anus des femelles sillonnć longitudinalement dans son milieu, celui des nuâtes entier, sans sillon longitudinal. - Jumbes dépourvues d'épines terminales. Tarses courts, presque cylindriques, de trois articles, le second plus court que les autres, le dernier terminé par deux erochets recourbés ayant une pelotle bilobée dans leur entre-deux.

Les inœurs des Corés et lenrs mélamorplioses sont les mêmes que celles des Pentatomes ( עoy. cet article), dont ils ont aussi la manière de vivre et la mauvaise odeur. Ils habitent les mêmes endroits. Ce genre élant très-nombreux surtout en espèces exoliqnes, nous $y$ arons introduit plusieurs divisions.

${ }^{\mathrm{re}}$. Division. Jambes postérieures simples, sans dilatation membraneuse.

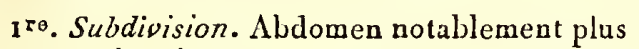
larg̈e que les élytres.

A. Cuisses postérieures dentées en dessous,
souvent rentlées.

\section{Coné hirticorne, C. hirticornis.}

Coreus tibiis posticis simplicibus, abdomine elytris latiore, femoribus posticis spinosis, clavatis, rufus, corpore, antennis pedibusque hirtis.

Coreus hirticornis. FAB. Syst. Rhyng. pag. 198. $n^{\circ}$. 3ı. - Lat. Gener. Crust. et Ins, tom. 3. pag. i.g. - Cceueb. Illus. Icon. tab. 10. fig. 3.-Co-l reus denticulatus. Wole. Cimic. fis. 2. pag. $7 x$. tab. 7.fig. 68.

Longueur $4 \mathrm{lig} \cdot \frac{x}{2}$. Corps velu, d'un roux ferrugineux. An! ennes très-velnes. 'Tête nuuie sur ses côtés d'une pelite dent près de l'insertion des antennes. Bec atteignant presque la base des cuisses iutermédiaires, ayant une ligne brune longitudinale. Bords latéranx du corselet denticulés; les épines qui les garnissent de coulenr pâle. Cuisses lachetées de brun, les postérieures éfineuses en dessous; ces épines inégales. Lessous du corps plus pâle. Dernier segment de l'abdonen (celui qui précède l'anus) prolongé de chaque côlé en une pointe distincte. Mâle el fernelle.

Commun aux environs de Paris sur difiérentes plantes.

Le Coreus marginatus $n^{\circ} .6$, FAB. Syst. Rhyng. appartient à cette section, ainsi que plusicurs espèces exotiques.

B. Cuisses postérieures simples.

2. ConÉ rhomboïdal, C. quadratus.

Coreus femoribus tibiisque posticis simplicibus, abdomine ely tris latiore i homboideo, suprà rafus, subtùs luteus, thoracis angulis posticis subspnnosis.

Coreus rhombeus. FAв. Syst. Rhyng. pag. 199. $n^{\circ} .35$. La femelle.-Coreus quadratus. Id. $n^{\circ} .56$. Le mâle.-LAt. Gener. Crust. et Ins. tom. 3. pagr. rig.-Wor. Cinic. fas. 2. pas. $70 . n^{\circ} .67$. tab. 7. fg. 67. Le mâle. - Stoll, Punais. pl. V. fig. 36. La femelle.

Longueur 5 lig. $\frac{1}{2}$. Antennes d'un fauve jaunátre. Dessus de leur premier article et le dernier, bruns. Bec jaune, brun au boul, dépassant un peu la base des cuisses internédiaires, ses derx derniers articles recus dans un canal de la poitriue. Corps fauve mêlé de brun en dessus. Angles postérieurs du corselet terminés en pointe. Dessous du corps et pattes jaunes. Abdomen rhomboüdal. Anus quadridenté, dernier segineut de l'abdomen prolongé de chaque côtié en une pointe distincte, Femelle.

lue mâle u'a pas de pointes au dernier segment de l'abdounen ni à l'anus.

'Très-commun aux environs de Paris.

Rapportez à cetle seconde section le $L_{1}$ graus pustulatus, $\mathrm{n}^{\circ} .8$, les Coreus insidiator, $\mathrm{n}^{\circ} .23$, Scapha, $\mathrm{n}^{\circ} \cdot 9$, Spiniger, ${ }^{\circ}{ }^{\circ}$. 10 el Paradoxus, no, 14. FAв. Syst. Rhyng. Ce dernier est le Coreus hystrix de M. Latreille.

$2^{e}$. Subdivision. Abdomen ne surpassant presque pas les élytres en largenr.

A. Cuisses postérieures dentées en dessous, souvent renflées.

H 2 
5. Costi hénorrhoïdul, C. hamorhoidulis.

Coreus tibiis posticis simplicibis, elytris fere lutitudinem abaminis aquantibus, fumoribus posticis subspinosis, niger, abdomine rubro, elvtronum parle coriaceẩ lestaceâa disci maculis nigris.

Iygeetes hamorhoidalis. Fab. Syst, Rhyng. pag. $212 . n^{\circ} \cdot 57 .-C i m e x$ hemorrhous. Linn. Syst. Nat. 2.719.27. - Cimex bipustulatus. Id. -9. - Srost, Punais. pl. Al.fig. 33.

Longueur 9 ligg. Noir. Second et troisième arlieles des antenncs ayont un auneau blanc vers leur base, le dernicr largement marqué de blane dans son miliea. Bee dépassant de beancoup la base des dernières cuisses; angles postérieurs dn corselet terminés en épine. Abdomen rouge. Partie coriace des élytres testacée, arec des points noirs. Cuisses postérieures très-grêles, leus dentelures fort petites. Niâle et femelle.

De Cayenne.

Nous ne eonuoissons dans eetle section que des espèces exotiques; rapportez-y le Lygous cruciger, $\mathrm{n}^{\circ} .32, \mathrm{FAz}$. Syst. Rhyng., ainsi que les espèces de Stoll, pl. $X$. fig. 7. et pl. XXXVI. fig. 2,55 . Cet autcur ne figure que des mâles, mais nous en eomnoissons les femelles.

\section{B. Cuisses postérieures simples.}

4. Conż à ceinture, $C$. cinctus.

Coreus femoribus tibiisque posticis simplicibus, elytris fere latitudinem abdominis cequantibus, siprì conaleo-niger, sublìs conulceus viridi nitens, capite, coxis, femoribus et corporis cingulo flavis.

La Punaise à bande orange. Stols, Punais. pag. 15. pl. II. fig. 13.

Longueur 10 à $12 \mathrm{lig}$. Corps noir bleuâture en dessus; son dessous d'ui bleu ehangeant en vert. "Yéte, base du premier article des antennes, hanclies et cuisses d'un beau jaune. On voit une large ceinture de cette couleur gui s'étend en dessons sur les trois premiers segrmens de l'abdomen et un peu sur le curselet. En dessus cette ceinture occupe le milieu des élytres. Bec jaune, brun à l'extrémité, alteignant $l_{\mathfrak{l}}$ base des cuisses intermédiaires. Antennes, jambes et tarses noirs. Mále et femclle.

De Cayenne.

Cetle section contient des espèces indigìnes et exotiques.

$2^{\mathrm{e}}$ : Division. Jambes postérieures dilatées, munies de membranes.

$1^{\mathrm{T} \theta}$ Subdivision. Cuisses postérieures longues et grêles.

\section{Coné foliscé, C. foliaceus.}

Coreus tibiis posticis foliaceo dilutatis, femoribus posticis elongatis, griacilbbus, supria nigrivindis rubro longitudinaliter viltatus, subtius lividus, tibiarum posticarum nombranầ extiks enarginatâ.

Lygeus, foliaceus. FAв. Syst. Rhyng. pag. 210. no. 28. - Stols, Punats. pl. XXYIII. fig. 201.

Longueur 6 lig. Antennes noires, leur premier article blane, marqué d'une ligne noire en dessous, en ayint aussi une en dessus, mais moins prononcée. Base et extrémité des second et troisième articles blanches. Têle blanchâtre, avec une bande longitudinale d'un brun rougreattre en dessus. Corselet d'un rouge brun entoure de noirverdâtre, ses bords latéranx blanchùtres. Ecusson d'un noir-verdâtre. Partie coriace des élytres rougeâtre, ses bords extérieurs noirs avec un liséré blanchâtre. Nembrane d'un brun-verdatre. Bec blanchâtre, brun à l'extrémité, dépassant la base des cuisses posiérieures. Dessous du eorps d'un blanc jaunâtre. Paltes blancliâtres, un peu nuancées de brun. Cuisses postérieures munies en dessons vers l'extrémité, de deux petites dents noirîttres. Membrane des jambes postérieures d'un jaune rougeâtre mêlé de brun, garnissant extćricurement toute la jambe, mais échancrée dans cette partie vers le milier, et allane en diminuant de largeur jusqu'à l'extrémité inféricure. Femel!e.

Nous avons une variété de "ce sexe dont le premier article des antennes est beaucoup plus brun, la tête d'un brun rougeâtre, sans ligne brune; !e corselet n'a rien de rougeâtre, et les élytres n'ont que quelques nervures de cetle couleur, qui se irouve remplacée par le noir-verdâtre.

Da Brésil.

$2^{\mathrm{e}}$ Subdivision. Cuisses postérieures renflées ou dilatées.

Rapporlezà cette subdivision les Lygceus membranaceus, no. 23 (Encycl. pl. 374. fig. 2.),

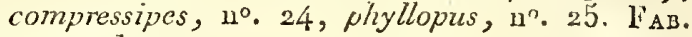
Syst. Rhyng.

Nota. Nous rapporterons eneore à la seconde division des Corés qui est nombreuse en espèces, et ne contient à notre conzoissance que des exotiques, les Lygceus auctus, $\mathrm{n}^{\circ} .26$, gonagra, $\mathrm{n}^{\mathrm{0}} .27$, et dilatutus, $\mathrm{n}^{\mathrm{0}} \cdot 29$, FАв. Syst. Rhyng., saus pouroir indiquer la subdivision à laquelle ils appartiennent.

ALYDE, Alydus. Fab. Cotcus. LAt. Cimex. LinN. De Grér.

Genre d'insectes de l'ordre des Hémiptères, section des Hétéroplères, famille des Géocorises, tribu des Longilabres.

Cinq gen res forment une subdivision dans cette tribu (voy. PeNtatome); les Alydes en font partie. 
Dans ce groupe lcs Néides se distinguca i par leurs antennes coudées et leur corps linéince ; les Hollyynúnies par les trois premiers articles des antennes comprinés et les élytres cutic̀rement meunbraneuses; les Pachylides par le troisième article des antennes dilaté et comprimé surtont à son extrémité, el les Corés par leurs petits ycux lisses assez ćloignés l'un de l'autre et placés strr la partie postérieure de la tête, près des yenx à réseau.

Antennes point coudécs, insćrées à nu à la partie latérale de la tête, composécs de quatre articles; le premier assez lono, dépassant notaJlement l'extrémité de la têtc, les second et troisic̀me toujours filiformes. - Bec de longueur variable, formé de quatre arlicles, renfermant un suçoir de quatre soies. - Tête triangulaire, de grandeur moyenne. - Y eux gros, sallaus, fornanat les angles postérieurs de la tètc. -- Deux petits yeux lisses saillans, rapprochés l'un de i'autre, placés sur le vertex. - Corps ordinairement alougé. - Corselet élevé postérieuremeat, s'abaissant petit à petit vers le devant. - Ecusson ordinairement triangulaire. - Elytron en partic coriaces. - Abdomen composé de segrmens transversaux dans les deux sexes; anus des femclles sillonné longitudinalement dans son milicu, celui des mâles entier, sans sillon longitudinal.

Cuisses postérieures dentées en dessous, ordinairement renflées; leurs jambes souvent arquées. 'I'arses de trois articlos, le second plus court, le 'demicr terminé par deux crochets recourbés ayant une pelotte bilobéc daus leur cn!re-dcux.

Nous connoissons une dizainc d'espèces d'AJydes, plusieurs sont exotiques. Leurs uncurs doivent se rapprocher de celles des Peatatomes et des Corés.

\section{Anvoe éperonné, A. calcaratus.}

Alyelus thorace mutico, fuscus, abdomine suprà sanguineo, sublic: fusco ceneo nitente, punctis marginalibus rubescentibus.

Alydus calcaratus. FA . Syst. Rhyng. pag. $25 \mathrm{I}$. $n^{\circ}$. 15. - Coreus calcaratus. Lit. Gener. Crust. et Ins. tom. 3. pag. 120. - Cimex culcaratus.

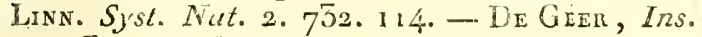
tom. 3. pag. $280, p l$. 14. fig. 23 et 24 .

Longueur 5 lig. Brun, pubescent, avec un rcllet métallique. Angles postérieurs du corselct sans épines. Pirtie moyenne du dessus de l'abdomen d'un ronge sanguin. On voit un point de cette couleur paroissant aussi en dessous, à l'argle supérieur des second, troisic̀me, quatrième et cinquième segrmens. Dessus du corselet et partie coriace des élytres moins foncés. Hanches ayant une tacherongeûtrc; milieu des jambes et base du premier article des tarses blanchâtres. Bec atteignant la base des cuisses internédiaires. Les trois premiers articles des antennes' sont blanchâtres avec l’extrémité brune. Cuisses postérieures ayant ea dessous quatre épines et quelques petits tubera cules. Mâle el fémelle.

Commun aux cnvirons de Paris.

Rapportez i cc genre les Alya'us arcuatus, no. I, et serripes, $\mathrm{n}^{\circ}$. 5. Fiв. Syst. Rizyng.

HOLEYMENIE, Hobnymana. Alydus. FAB。 Lygoeus. LAT.

Gerre d'insectes de lordre des Héruiptères, seciion des Héléroptères, fumille des Géocorises, tritu des Longilabres.

Dars le groupe partiel de cette tribu dont les Uoliyménies font pariie (voy. Pentatoñe), les grenrés Néide, Coré et Alyde ont les trois premilers articles des antennes simples, sans dilatation. Les Pachylides ont le corps large, les cuisses postérieures renílées et le premier article des antennes cylindrique. Tous ces genres ont d'ailleur's une purtie de leurs élytres cortace. Aucun de ces caractères n'apparlient aux Ifolhytaénies.

Antennos point condées, insúṕces it nu aux côlés de la tête, composécs de cruatre articles, le premicr long, arqué, comprimé, dépassant de beaucoup l'extrémité de la tête; le sccond et le troisième comprimés, fort dilatés surtout à leur partie supérieure; le quatrièurc cylindrique. ... BeC de quatre articles, renfermant un suçoir da quatre soies. - Téte rélrécie et élranglée postúrieurement. - Ieux de grandeur moyenue, peu saillans. - Deux petits yeux lissos sailluns, assez éloignés l'un de l'autre, hlacés sur le vertex. Corps ćtroit pour sa longueur. - Corsclet élcvé posićrieurement, s'abaissant petit à petit vers le devant, ayant une impression transversale. Ecusson triangulaire. - Elytres entièrement monbraneuses, dépassant l'extrémité de l'abdomell. - Abdomen composé de segmens transversaux. Anus des femclies sillonné longitudinalement dans son milieu. - Pattes longues, les postérieures surtout; cuisses postérieures simples, point renflćes. Tarses de trois articlcs, le second plus conrt, le dernicr terminé par deux crochets recourbés atyant unc pelotte bilobée dans leas entre-deux.

Cc nouveau genre tire son nom de deux mots grecs dont la signification est : entièrement membraneux. Il le doit à la uature de ses élytres qui a'ont rien de coriace. Ce caractère ne lui est cependaul pas exclusivement propre; nous counoissons des Corés qui onl des portions truisparentes et mombraneuses dans le disque de la partie des élytres qui est ordinairenent coriace dáns les Hémiptères-hétéroptères, et daus les Tingis ces denx parties ue peuvent se distinguer l'one de l'autre, leur consistance n'élaut point différente, et en totalité demi-coriace. Du reste les Hollyy ménies offrent d'autres caractères très-patticuliers daus la forme de leurs antenncs qui nous päm roissent jastifer l'établissezoent de ce geare. 
1. Hocarnésie de Latreille, $H$. Latreillii.

Holhymenia capite thoraceque nigris, luteo s'ariis, abdomine femoribusque rubris, tibiis luteis, posticis extius dilatatis, appendice ad medium nigro.

La Punaise à an!ennes feuilletées. Srolr, $P u$ nuis. pag. 88. pl. XXII. fig. : 52 .

Lonģueur a lig. Antenneg noires. Extrémité du troisième article et le quatrième blancs; celuici brun à son extrémité. Têle nóre; sa partie antérieure et son dessons jaunâtres. Elle a un collier de cette couleur postérieurement. Bec jaunâtre, bruu ì l'extrémité, dépassant notablement la base des cuisses postérieures. Corselet noir, son dessus fortement ponctué, ayant quatre taches, les angles postérieurs et une ligne lougitudinale qui part de la base de l'écusson et n'atleint point la tête, jaunâtres: son dessous portant plusieurs taches de cette couleur. Ecusson juunâtre avec un feu de noir à sa base et sur ses côtés. Nervures des élytres noires, l'extérieure rougeâtre. On voit une petite tache jaunâtre à la base des élytres. Abdomen et cuisses rougeâtres. Jambes et tarses d'un blanc jaunattre; jambes postérieures dilatées extérieurenent; celte dilatation éclancrée un peu après le milieu de la jambe, sa partie extézieure noire au dessus de l'échancrure. Femelle.

De Cayenne.

Nota. M. Latreille dans son Gener. Crust. et Ins. tom. 3. pag. 121 , place cet insecte dans une division de ses Lygées, mais sạns lui donner de nom spécifiqne. Nous avons protité de cette circonstance pour lui offrir ici un hommage mérité en lui déliant ceite jolie espèce.

Rapportez à ce gemre l'Alydus histrio, no. 2. (Holh. histrio) Fa B. Syst. Rhyng. Stold, Punais. pl. $X L I$. fig. 294́. Elle eșt de l'Amérique méridionale.

PACHYLIDE, Pachylis. Lygaus. FA . LAт.

Genre d'insectes de l'ordre des Hémiptères, section des Hétéroptères, famille des Géocorises, tribu des Longilabres.

Ce genie fait partie d'un groupe dans celle filbu (woy. Pantatome. Trois de ceux qu'il conlient, savoir : Néide, Coré et Alyde ont les trois prenuiers articles des antennes simples, sans dilatation. Dans les Folhyménies le preuier article est du uombre de celix qui sont comprimés, le corps est étroit, les élytres entièrement uembraneuses et les cuisses postérieures simples, șans renfleruent. Les Pachylides n'offrent aucuns de ces caracières.

Antennes point condées, insérées à au sur la partie supérieure de la tếe, composées de quatre articles.; le premier long, cyliudricque, le second long, toujours cylindrique, du moins à sa base; le trợicième plus court que les antres, comprimé, di- laté, surtout à l'extréraité, le quatriòne longy, $\mathrm{cy}$ lindrique, arqué. $-B c c$ court, atteignant il peine l'origine des cuisses intermédiaires, renfermant un suçoir de quatre soies. - Tête petite. - Y eux très-saillans. - Deux petits yeux lisses saillans, assez éloignés l'un de l'autre, placés sur la partie supérieure de la tête, près des yeux à réseau. Corps épais. - Corselet éievé postérieurement, s'abaissant petit à petit vers!e devant.--Ectsson triangulaire. - Abdomen composé de segnı̣ens transversaux dans les denx sexes; anus des femelles sillonné longitudinalement dans son milieu, celui des mâles entier, sans sillon longitudinal. - Pattes fortes; cuisses postérieures toujours renflées, celles des femelles l'étant moins; jambes postérieures armées d'une épine, au moins dans les mâles. Tarses de trois articles, le second plus court, le dernier terminé par deux crochets recourbés ayant une pelotte bilobee dans leur entre-deax.

Les Pacluylides sont d'une très-grande taille, elles tiennent le premier rang sous ce rapport parmi les Hémiptères de la famille des Géocorises, et si l'on e'. excepte quelques Bélostomes, ce sont les plus grands Hétéroptères connus. Elles ont le corps plus épais et les inembres plus forts qu'ancun insecte de cette section. C'est de cette conformation qu'est dérivé leur nom tiré d'un mo grec qui siguifie : épais. Les espèces que nous connoissons sont toutes de l'Amérique péridionale. Leur's mœurs sout ighorées. Nouss n'hésitous pas ì proposer ce nouveau genre qui n'a d'analogie qu'avec les Hollyyménies, mais dont il dilfère par tant de caractères quil nous a paru impossible de l'y réunị.

${ }^{\mathrm{r} e}$. Division. Abdomen beaucoup plas large que les ély'res. - Corselet un peu plus étroit que l'abdomen, angnleux postérieurement, mais sans épines; ayant toujours une impression transversale plus ou moins prononcée.

Rapporlez à celte division les Iygarus Pharao*

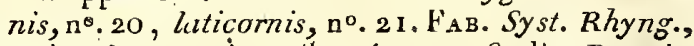
et les deux espèces tigurées par Sioll, Punais. pl. $X X V I$. fig. 181 et 182 .

$2^{\theta}$. Division. Abdomen ne surpassant guère les élytres en largeur. - Corselet plus large que l’abdomen, ses angles postérienrs prolongés en épines; point d'impression transversale.

Nous plaçons ici les Lyogocus compressicornis, no. 19, et biclavatus, no. 22. Faв. Syst. Rhyng: Ce deruier est figuré dans Stoll, punais. $p l . \Lambda_{\text {: }}$ : fig. 67 .

Nota. Fabricins et M. Coquebert, Illust. Tcon. tab. 10, fig. ro, n'ont point vu le dernier article des antemes de la Pachylide compressicorne; ils ont pris le tubercule radical pour un arlicle.

(S. F. et A. Serv.) 
PENTHCTRIE, penthetráa. Neto. Lat.

Genre d'insectes de l'ordre des Diptères, scction des Probosciclés, famille des Nénocères, tribu des Tipulaires.

M. Meigen a fondé ce genre adopté depuis par M. Latreille; il fait parlie du groupe nommé par ce dernier auteur Tipulaires floricoles. Les autres groupes de cette tribu ont les antennes filiformes ou sétacées. Les floricoles les ont épaisses. Parmi celles-ci, les Penthétries et les Scatopses ont seuls des anlenues de onze articles et trois petits yeux lisses distincts, tandis que les Bibions et les Dilophes n'ont que neuf articles aux antennes, et que lcs Cordyles et les Simulies n'ont point d'yeux lisses apparens. Entin le genre Pculhétrie dilfère de celui de Scathopse par ses yeux entiers et non lunulis comme duns ce dernier.

Antennes avancées, cylindriques, perfoliées, de onze articles, guère plus longues que la tête. - Yeux ovales, entiers, plus griunds et plus rapprochés à leur partie supérieure dans les inâles. -Trois petits yeux lisses distincts, disposés en triangle sur le vertex. - Falpes saillans, recourbés, de quatre articles. - Pattes sinples.

M. Meigen ne décrit qu'une seule espèce. Nous ac la connoissons pas.

\section{Penthétrie soyeuse, $\boldsymbol{P}$. holosericea.}

Penthetria atra holosericea; alis fuscis. (Mr1G.)

Penthetria holosericea. Meig. Dipt.d'Eur. tom. I. pag. 303. no . 1. tab. 10. fig. 17-22. - Penthetra funebris. LAт. Gener. Cirust. et Ins. tom. 4. paǵ. 267. - Encjcl. pl. 386. fig. 50-35.

Longueur. Nâle 2 lig. $\frac{r}{2}$ Femelle 5 ligg $\frac{r}{2}$. Noire, entièrement soycuse. Ailes olsscures.

\section{D'Europe. (S. F. et A. Serv.)}

PEPSIS, Pepsis. Fab. Latr. Palis.-Bauv. Sphlex. Linn. De Géer. Pompllus. Jur. Ilisig.

Genre d'insectes de l'ordre des Hyménoptères, section des Porte-aiguillon, tamille cles Fouisseurs, trilu des Pompiliens.

Fondateur de ce genre, Fabricins y a compris un grand nombre d'espècés qu'on ne peut y admettre. Hledivise d'a près l'abdomen, quiest pétiolé dans les uns et sessile dans les autres. 'Touse sa première division cst élrangère au genre et doit rentrer dans la tribu des Spliégines; beauconp d'espèces de la seconde nc lui appartienment pas non plis. C'est en y faisant ces retranchemens nécessaires que M. Latreille a publié le genre Pepsis, et nous le donnons ici tel que ce dernier auteur l'a conçu.

Les Pepsis sont voisins des Pompiles et des Céropales; ces trois genres se distinguent de celui d'Apore, en ce que leurs ailes supérieures offrent gnatre cellules cubitales, tandis que ce dernier n'en a que trois. Les Pompiles et les Céropales on! leurs palpes maxillaires pendans el heancoup plus longs que les labiaux; l'article terminal de ceux-ci et les deux derniers des maxillarires diffèrent peu en longueur des articles précédens. Dans les Pepsis au contraire, les quatre palpes sont presgu'égralement longs, les deux demiers arlicles des maxillaires et le terminal des labiaux sont plus courts que ceux qui les précèdent. Les ailes des Pepsis, comparées à celles des Pompiles et des Céropales, offient aussi des différeuces sensibles, quoiqu'iyant le méme nombre de cellules. Antennes longrues, presque sétactes, rupprochées à la base; leurs articles cylindrigues; lo prenier un pen plus gros, le second petit; au uombie de douze dans les femelles et se roulant en spirale, chaque article à partir du troisième faisant un conde avec le suivant; de treize articles, plus serrés les uns contrc les autres, et ne formant point de coude, dans les mâles. - Labre semi-circulaire, saillant, adbérent au bord antérieur da chaperon. - Mandibules unidentées intérieuremenl. - Mâchoires coriaces, terminécs par un petil appendice arrondi, sans division. Palpes filitormes, presqu'égalennent longs; les maxillaires de six articles, dont les deux derniers plus courts; les labiaux de quatre; le terminal plus court que les précélens.-Languette alongée, irc̀s-bifide. - Téte comprimée, de la larreur da corselet. - Trois petits yeu.x lisses disposés en triangle et placés sur le vertex. - Premier segment du corselet de méme largeur que le second, en carré transrersal, prolongé latéralement jusqu'aux ailes. - Acles supérieures ayant une cellule radiale oblonguc, s'avançant moins près du bord postérieur que la troisième cubitale; son extrénité arrondie, s'écartunt de la côté et quatre cellules cubitales; la première presqu'aussi longue que les deux suivantes réunies; la seconde recevant vers sa base la premiére nervure récurrenle; la troisième plus petite que toutes les autres, se. réllécissant vers la radiale et recevant près de son milien la deuxième nervure récurrente; la quatrième à peine commencée. - Abdonzen brièvement pétiolé, ovalaire, composé de cinq segmens outre f'anus dans les femelles, en ayant un de plus dans les mâles. - Pattes longues, les postéricures surtout; jambes finemeut dentées ì leur partie extérieure, ces dentelures moins prononćes dans les milles; les intermédiaires et les postérieures munies a leur extrémité de deux épines longues et aiguës; les antérieures d'une épine simple. "Tarses à articles alongés, le dernier terminé par deux crochels, simples dans les mâles, bifides dans les fervelles, et muni d'une pelotte dans l'entredeux.

Les Pepsis paroissent être propres à l'Amérique équinoxiale, et renferment des espèces de la plus grande dimension parmi tous les Hyménoptères connus. Ces insectes sont remarquables par de belles couleurs veloutées et changeantes, et pas 
des ailes presque toujours colorées en noir-bleuatre ou en roux tirant sur l'aurore. On ne sera point élonné, d’après la loealité assignnée, que nous ne soyons poiut suffisamment instruits de leurs monrs; cependant, par analogie, nous croyons qu'elles doivent peu différer de celles des Pompiles; comme dans ceux-ci, les femelles piquent fortement, et leur pifiûre est long-temps douloureuse par l'effet du venin, qui cependant a'ofire rien de dangereux à l'économie animale. Fepsis.

On counoît plus de vingt-cinq espèces de

\section{PEFsis marginée, $P$. marginata.}

Pepsis magna, subcceruleo-nigra, antennis ommino fuscis, alis opacis rufis apice et marrine interno fuscis.

pepsis marginata. PALIs.-BAUv. Ins. d'Afriq. et d'Amériq. pag. 94. Hyménopt. pl. 2. figr. 2. (Femelle.) fig. 3. (Mâle.) - REavr. Irzs. tom. 6. pl. 28. fig. I.

Longueur 2 pouces. Corps d'un noir velouté. Antennes brunes; premier article noir, un peu caréné en dessous. Antis revêtu, surtout dans son railieu, de grands poils d'un brun ronssâtre. Ailes opaques, d'un zoux ferrugineux avec un pen de noir à leur base et une baude de même couleur, crui s'étend sur tout le bord interne et va en s'élargissant vers l'extrémité. Femelle.

Le mâle ne dillère que par sa taille un peu plus petite. Feu M. Palisot de Bauvois qui a vu celle espèce rivante, remarque qualors ses parties noires out un reflet blen violet.

Wille se trouve à Saint-Douningue et role souvent autour des fleuls da palmier.

2. Persis bleuâtre, $p$. carulea.

Pepsis coruleo-nigra, antennis nigris, alis opacis mufis fusco submarginatis, superionum apjice allo pellucido.

Persis corrulea. Fав. Syst. Piez.pag. $214 . n^{\circ}$. 3.. ( Excluez les synon; ines de Linné et de De Géer.) - Druny, Ins. tom. 2. pl. 3g. fig. 6.

Longneur un pouce. Corps d’un bleu velouté. Premicr se grment de l'abilomen glabre. Antennes ngices. Ailes opacques, ferrugineuses; les supérịcures ayant leur extrénilé blanche et transparente; le contour des inférieures et celui des supérieures avant la partie blanche, avec une nuanee die brun. Fenelle.

Amérique mériàionale.

\section{Persis mi-partie, $P$. dimidiata.}

pepsis caruleo aut viridi nicens, antennis nigris apice rufis, alis opacis caruico fuscis, ad basin rufo miaculatis.

pepsis dimidiata. FAB. Syst. Picz. pag. 216. $n^{2} \cdot 47$.
Longaeur 14 à I 5 lig. Antennes noires; leurs six derniers arlicles funves. Têle, crrselet et-pattes d'un bleu velouté ì rellet violet. Abdomen de même eouleur, mais gtabre, ayant senlement quelques longs poils sur les côlés et vers l'extrémité. Ailes opaques, d'uu noir bleuâtre, ayant au tiers de leur longuen une tacke d'un funve aurore, qui s'avance davantage vers la base dans les inférieures. Femelle.

Le mále differe $1^{\circ}$. en ce que ses antennes n'ont de fauve que leurs deux derniers artieles et une partie du précédent. $2^{\circ}$. Par l'abdomen moins glabre, dépourvu de longs poils. $5^{\circ}$. Par le reflet verdître de son eorps.

le Cayenne.

\section{Pepsrs étoilée, $P$. stellata.}

Pepsis canuleo-nigra, antennis nigris, alis opacis, nigro-violaceo fuscis, superionum maculâ substeliatâ late rufâ, apiceque albo pellucido.

Pepsis stellata. FAB. Syst. Piez. pag. 2 I4. $n^{\circ} .34$.

Longunevir so lig. Corps d'un noir velonté à reflet bleuâtre. Antennes noires. Ailes opaques, noires-bleuâur es changeant en violet; les supéricures ayant dans leur milien une tache lobée et comme éioilée, d'un roux vif, et l'extrémitélulancibe, transparente. Les inférieures avec une trèspetile tache rousse an milieu du bord supérieur. Nisle.

Amérique méridionale.

5. Pepsis agréaljle, P. festiva.

Pensis viriai-aurea, antennis nigris, capite thoraceque subtis et lateribus aureo-raffo willosis: alis fulvis pellucidis, margine exteriori apiceque opacis fiuscis.

Pepsis festiva. Fai. Syst. Piez. pag. 214. $\pi \circ .31$.

Yongueur 14 ligr. Cor'ps d'un heau vert velouié; à reflet doré. Antennes noires; leurs trois derniers arlicles fauves. 'Tête, cêtés et dessous du corselet ayant des poils courts d'un roux doré. Pattes noires avec nu reflet bleu-verdâtre sur les cuisses. Ailes d'un fauve doré quoique transparentes; le bord extérieur des supérieures et la partie postém rieute des quatre, d'un brun foncé, clsangeant $\leq n$ viulet. Mâle.

De Cayenre.

\section{Pepsis ruficorne, P. ruficornis.}

Pepsis caruleo nigra, antennis rufis basi nigris, alis opacis violaceo cueoque nitentibus.

Pepsis ruficornis. Faв. Syst. Piez. pag. 215. $n^{0}$. 36.-PAL1s.-Pauv. Ins. d'Afiz. et d'Anériq. pag. 34. Hyménopi. pl. 2. fig. I. 
I.ongueur 18 à so lige. Corps d'un noir velouté, changeant en bleu violet. Antennes fauves; les deux preniers articles noirs. Ailes opaques à reflet bleu violet brillant. Femclle.

De Saint-Domingue et de Cayenne.

\section{Pepsis lutéicorne, P. luteicornis.}

Pepsis nigra subviolacea, antennis luteo iufis basi nigris; alis opacis, subviolaceis, non nitentibus.

Pepsis luteiconis. Fав.? Syst. Piez. pag. 214. $n^{\circ}$. 35. - Pepsis luteicornis. l'ans.-Bavv. Ins. d'Afi. et d'Amér. pag. 3g. Hynánopt. pl. Ire. fig. 5.

Longueur r 2 à $14 \mathrm{lig}$. Corps d'un noir velonté à rellet violet. Antennes d'un fauve vif; les deux preuniers articles noirs. Ailes opaques, d'un noir mat avec un léger reflet violet. Femelle.

De la Caroline méridionale.

$$
\text { (S. F. et A. SERv.) }
$$

PERCE-BOIS ou 'TÉRÉDILES. Neuvième famille des Coléoptères pentamérés selon M. Duméril. (Zoolog. analytiq.) Ses cal'aclèıes sant: Elytics dures, couprant tout le ventre: antennes fill forues, corps arrondi, alongé, convexe. Elle renferme les grenres: Vrillette, Panacle, l'tine, Mélasis, Tille, Limexylon.

(S. F. et A. Serv.)

PERCE-OREILLE. Nom vulgaire donné aux insectes Orthoptères du genre Furficule. Voyez cer mol. (S. F. et A. Serv.)

PERCUS, Percus. M. Bonelli dans ses observations entomologiques (llémoires de l'Acad. de Turin), a établi ce genre de Coléoplères dans la tribu des Carâtiques. Il le caractérise ainsi : languette échancrée, tronquée. Palpes asse\% épais, les maxillaires extérieurs ayant lenr quatrième article plus courl que le précédent, cylindrique, aminci a sa base. Anus souvent tris-lisse dans les deux sexes. Elyires entières, ayınt deux points placés sur une seule ligne, souvent oblitérés. Mandibule droite plus courte que l'aulre. Dernière paire de ja:nbes lisse postérneurement. Autennes plus longues que le corselet.

(S. H. et A. SEnv.)

pergue, Perga. Íach. Lat. Le P.

Genre d'insectes de l'ordre des Hyménoptères, section des 'Térébrans, faruille des P'orte-scie, tribu des Tenthrédines.

Ce genre élabli par le doctenr Léach, et adopté depuis jar. A. Latreille et les auteurs qui l'ont suivi, se distingue des autres Tenthrédines par l'extrémité de ses aniennes brusquement formée en niassue, caractère que l'on ne retrouve que dans les Cimbex; mais it est facile de le séparer de ces derniers dont les cellules radiales Hist. Nat. Tris, Tome $\boldsymbol{X}$. sont au nombre de denx presqu'çales, landis gue daus les pergues il n'y en it qu'une simplement appendiculée.

Antennes paroissant composées de six articles seulement, le dernicr beaucoup plus gros, formant une nassue globnleuse. - Labre apparent. - Mcundibules alonirées, comprixées, unidentíes. - Languette trifide el comme divitíc. - Ecusson carré, ayant une petite dent de chaque côté postérieurement. - Ailes supérieures ay ant une ccllule radiale appendiculéc el quatre cellnles cubitalis, la deuxième recevant la première nervure récurrente el la troisièrae la seconde nervure, la quatrième n'atteignant pas le bout de l'aile. tanles postérieures munies d'une épine dans lenr milien et de deux autres aignës, ì lenr extrémitú.

Ces Hyménoptères sout peu nombreux en espèces et rares dans les collections. Ils paroissent renfermés dans la nouvelle Hollande. Rien ne nous est parvenı sur leur manière de vivre; nous n'en avons vu aucune espèce.

I. Pergue polie, P. polita.

Perga cellulâ radiali elongatâ, utıinquè acutâ, capite flavo.

Petga polita. Léach. Zool. Miscell. ñ. 1. tah. 148. fig. 3. - Le P. Monogr. Tenthied. pag. 40. $n^{\circ}$. 110.

Lon rueur jà 6 lig. Antennes jaunes; troisième article plus long que les deux suivans. 'Tête jaune. Mandibules ferruyineuses a vec la base et l'extrémiténoires. Corselet ferrugineux, ayant uue tache dorsale, les écailles des ailes, une tache sous les ailes et la partie postérieure de l'écusson, d'un janne obscur. Abdomen d'uu violet brun en dessus, ferrucrinenx en dessous à reflet violet. P'altes jaunes, cursses ferrugineuses avec un reflel violet. Ailes funves, transparentes; Ies supérieures ayant lenr nervure extérieure ainsi que le point marginal, ferrugineux. Cellule radiale alongée, pointue aux denx exirémilés. Hilâle et lemelle.

Nouvelle Hollande.

\section{Pergue de Latreille, $P$. Latreillii.}

Perga cellulâ radiali ovatâ, capite nigro albo inaculato.

Perga Latreillii. LÉAcH. Zool. Miscell. $n^{\circ} .5$. tab. 148. fig. 2. - Le P. Monogrr. Tenthred. pag. $41 . n^{\circ}$. I I 2 .

Longueur 5 lig. Antennes d'un jaune ferrugineux; les denx premiers arlicles noirs, le troisième plus long que les deux suivans. Tête noire, chaperon et taches sur le vertex, de couleur blanche. Corselet noir en dessus, jaune en dessous, ses côtés et un point à la base des ailes supérieures, blanchâtres ainsi que l'écusson. Abdomen jaune en dessous, d'un jaune ferrugimeux en desI 
sus; premier et sccond segnews ayant m pen de noir sur lcs cócés, à ta buse. Palles lerrugineuses, tarses prócicurs noirs il leur basc. Ailestransparentes; les suṕrierres ayant leur nervuse extéricure juune. Cellule radiale ovale.

Nouvelle Hollamde. (S. H. et A. Senv.)

PERITA MPE, Perilampms. Lat. Diplolepis. Iab. Jlurg. Chalcis. Jur. Paxz.

Geme d'insectes de l'urdre des IIyménoptères, seciion des Térébrans, fawille des Pupivores, tribu des Chalcidites.

D:as la libu des Chalcidites, les genres Leucospis et Chalcis sout séparés des autres par leurs jaubes postérieures très-arquées. Le segnent antérieur du eorselet spacieux, en carré transversal ou eu triangle tronqué à sa pointe, distingue les genres Eurytome, Misocanpe, Eulophe, Cléonyme et Spalaingie; ee même segment est trèsétroit et ne forme qu'un pelit rebord transversolinéaire dans les Périlampes, les Ptéromales et les Encyrtes, mais ce deruier genre a les mandibules terminées en pointe et au plus bidentées, tandis que les Périlampes et les Ptéromales les ont presque carrées à trois ou quatre dents distinctes. Ces dentelures sont très-fortes dans les Périlampes, et la massue de leurs antennes est courle et $\in \mathbf{a}$ fuseau, earactères qui n'apparlieunent pas aux Ptéromales.

Antennes trìs-courtes, leur massue en fuseau. - Mandibnles fortes, presque carrées, ayant des deuts très - apparenles, au nombre de trois sur l'une et de deux sur l'autre. - Palpes fort courts. - Téte grosse, ayant une profonde carité fiontale qui s'étend jusqu'aux yeux lisses et reçoit les antennes dans le repos. Chaperon distinct. Trois yeux lisses gros, saillans, placés en ligne droile sur le bord antérieur du vertex. - Corps court, gros. - Segnent antérieur du corselet Irèsétroit, ne formant qu'un rebord transverso - linéaire. - Ecusson tì̀s-grand. - Ailes supérieures n'ayant qu'une seule nervure sensible, laquelle partant de la base de l'aile sans toucher au bord extérieur, se recourbe ensuile pour rejoindre ee bord qu'elle suit jusque passé le milieu, et émet intérieurement, avant de disparoître, un pelit rameau élargi à son extrénsité, qui commence la cellule radiale sans l'achever. Point d'autres cellnles dans l'aile. Ailes inférieures ayant une nervure semblable à celle des supérieures, mais qui n'émet point de rameau.- $A b d o m e n$ court, rhomboidal. - rattes assez fortes, de longueur moyenne, toutes les cuisses simples.

On doit ce genre à M. Latreille. I.e nom de Périlanpe est formé de deux mols grees dont le sens est : brillant à l'extérieur. Les espèces sont peu nombreases. Elles viveut dans leur premier élat aux dépens de dilférentes larves, particulièment de celles qui sont la cause de la production des galles.
I. Périlampi violet, P. violaceus.

Perilampus antennis luteis, capite thoraccive nigris, abdomine cceruleo nitente (Fxm.), antemins fiscis, coppte thonaceque coneo-nigris, abdomine violaceo. (Mas.)

Periampus riolaceus. L.4 Gener. Crust. et Ins. tom. 4. pag. 3o. - Diplolepis rilicornis. Fав. Syst. Piez. pag. 149. $\iota^{\circ}$. 1. - C (u) Illus. Icon. 1. tab. 1. fig. 8. liemelle.-Diplolepis violacer. Ha в. Syst. Prez. pag. 149. no. 4. Nale. - Chalczs violacea. 1'Anz. Famn. Germ. fasc. 88.fig. 15. Mâle.

Longueur a ligr. Tête et corselet noirs. Antennes entièrement rousses. Abdomen d'un bleu brillant. Ailes transparentes. Pattes d'un noir bleuâtre, avec une partie des jambes et les tarses jaumes. Femelle.

Le nâle a un rellet métallique sur la tête et le corselet, les antenues brunes et l'abdomen violet. Ses pattes ont un peu plus de jaune que dans la femelle.

Conunun aux environs de Paris.

ENCYR'TE, Encyrtus. LAT. Ichnemnon. Ross.

Geore d'inseetes de l'ordre des Hyménoptìres, section des 'Térébrans, famille des l'upivores, tribu des Chalcidites.

Dans cette tribu les Périlampes, les Ptéromales et les Encyrtes forment un petit groupe. ( Vojez (halcidites, article Poproones.) Les deux premiers de ces genres ont des mandibules dentées et presque carrées; ce qui empêcbe de les confondre avec les Encyrtes.

Antennes coudées, insérćes à une distance notable de la bouche, vers l'entre-denx des yeux, composées de neut à dix articles serrés; dans les femelles le premier est très-long , Tes autres sont comprités et vont en s'élargissant, le dernier est très-obtus. Celles des mâles ont leur premier article gonflé é dilaté inférieurement vers son extrémité, les autres formant une massue. Mlandibules élroites, sans dentelures an côlé interne. - Palpes très-courts. - Téte très-coucave à son point d'inserlion sur le cerselet; son bord supérienr aigu. -- Segment antérient du corselet très-étroit, ne formant qu'un pelit rebord trausverso-linéaire. - Eccisson graud. - Lliles supérienres ayant une nervare gui parlant de la base de l'aile sans toucher au hurd exlérieur, se recourbe ensuite pour rejoindre ce bord qu'elle suit jusque passé le milieu de l'aile el éast intérieurement avant de disparoittre un rimeau court, un peu élarogi à son extréuilé, qui commence la eellule radiale sans l'acherer. Une cellule cubitale u'élaut point séparée cin disque et se confiondant avee toutes les autres. - Abdomen trèscourt, triangulaire. - Cuisses posurieures simples, lems jumbes droites.

Les mœurs des insectes de ce genre dû à M. La* 
treille ne doivent pas beaueoup différer de eclles des Misocanpes. Les espèces connues sont peu nombreuses et de très-petite taille.

\section{Encrrte de Rossi, E. infialus.}

Encyrtus niger, antennarum basi, fronte pedibusque rufis; scutello flavo, metathorace utrinque unispinoso.

Encyrtus infidus. LAt. Gener. Crust. et Ins. tom. 4. pag. 3t. - Ichnennon infidus. Ross. App. Mantiss. tom. 2. pag. $11, n^{\circ} \cdot 9 \mathrm{I}$.

Longueur une ligne et demic. Antennes noires, le premier article d'un jaune roussâtre. 'Tête rousse, fronctuée, sa farlic postéricuse noire. Corselet noir, métathorax ayant dcux épines et une grande tache lunulée, de eouleur jaune. Ecusson jaune. Abdomen court, arrondi, noir, porlé sur un pédicule lrès-court. Palles roussâtres, jambes postérieures noires. Ailes transparentes, enfumées à l'extrénité. Le point marginal des supérieures est noil.

Rossi d'après lequel nous déerivons eet Encyrte l'a trouré sur le Citronnier anx environs de Pise.

EURYTOME, Eurytoma. Ilsig. Lat. Ichneumon. De Géer. Cynips, Diplolepis, Eucharis. IAa. Eucharis. Panz. révis. Chalcis. Jur. Panz. Fuun. Figites. Spixol.

Genre d'insectes de l'ordré des Iyménoptères, section des Tćrébrans, famille des Pupivores, tribu des Chalcidites.

Dans celte tribu les Eulophes se dislinguent par leurs antennes nayant au plus que sept articles; les Spulangits par l'insertion des antennes placée près de la bouche. Les Leucospis et les Chalcis ont les cuisses postérieures très-grandes à jambes arquées. I.es Périlampes, les Ptéromales et les Eucyrtes sont reconnoissables par le segment antérieur de leur corselet ne formant qu'un petit rebord transverso-linéaire. Dans les Cléonymes ce mêtme segment est aminci vers la tête et les mandibules ne présentent que deux dents. Enffin les Misocampes ont les arlicles des antennes cylindriques el nus dans les deux sexes.

Antennes insérćes à une distance nolable de la bouche, vers l'entre-deux des yeux; ayant au moins huit artieles; ces arlicles grenus, distincts les uns des autres, garnis de poils verticillés dans les mâles. - Mandibules munies de trois ou quatre dents. - Segrnent antérieur du corselet peu ou point rétréci vers la tête. - Palpes très-courts. - Ailes supérieures ayant une uervure qui partant de la base de l'aile sans toncher au bord extérieur, se recourbe eusuite pour rejoindre ce bord qu'elle suit jusque passé le milieu el ćmet intérieurenent arant de disparoitre un raneau un peu ćlargi à son extrémité qui se recourbe et comence la cellule radiale sans l'achever; sur cette nervure, tans la partie droite de sa base, on aperçoit une petiie cellule triangulaire, foiblement traeée. Une cellule cubitale n'étant point séparéc du distue et se confondan! avec toutes les autres de la partie caractéristique. - Abdomen très-comprimé. Taric̀ (des femelles) pen sili!lante. - Cuisses postéricures simples, leurs juzbes droiles.

Le nom de ce genre vient de deux mols grees dont la significalion est : bien coupé; il lui al sans doute étéimposé en riison dela séparation des arlicles qui eomposent les antenncs. Les mœurs des Eurytomes sont ì peu près les mênes que celles des Misocampes. (Cynips. Ourv. Encycl. Voyez ce mot.) Toutes les espéces d'Eurytomes sont fort petiles, l'une d'elles pond ses cuufs dans le corps de la Coclienille des serres.

\section{Eunyome de l'Auronne, E. Abrotani.}

Eurytoma nigra, tibiis anticis geniculisque posticis et tarsis ontnibias palliaè ferrugineis; antennarum articulis in mare intis appendiculatcserratis.

Eurytoma Abrotani. T,Aт. Gener. Crust. et Ins. tom. 4. pag. 27. - Chulcis Abrotani. PANz. Faun. Germ. fusc, n. fig. J 4. Le mâle. - Jun. Hyménopt. pag. 3.5.

Longueur I lig. $\frac{x}{2}$. Noire. Antennes tiès-velues, leurs articles à l'exception des deux premiers, portant chacun un large appendice au cóté iasterne; ees appendices élojgraés les uns des autres. 'Tête et corselet trc̀s-ponctućs. Premicr segment de l'abdomen globuleux, moins gros que les suivans et formant un pédicule. Palles anlérieures d'un jaune faure, leurs cuisses noires en grande parlie; les qualle palles poslérieures noires avec les genoux el les tarses d'un jaune fauve. Niles transparentes. Mâle.

Elle se trouve en France.

\section{CLÉNYNE, Cleonymus. I.AT. Diplolepis,} Fab. Spixol. Ichneumon. De Géer. Ross.

Genre d'inscctes de l'ordre des Itymónoptères, secion des 'Térébrans, famille des Pupivores, tribu des Chalcidites.

Dans le groupe gue forment dans celle iribn les Eurytomes, les Misocampes et les Cléonynes (yoyez Chalcidies, arlicle Puproses), les deux promiers se distingnenl par le segmont antérieur de leur corselel qui est en forme de carré transversal.

Antennes condées, insérćcs à une distarce uotable de la bouche, près da miliea de la face anlérieure de la tête, composíes de plus de sept arlicles. - Mandibules bidentées à leur extrémité. - palpes rì̀s-conts, les maxillaires de quatre articles, les labiatux de trois. - Corclet aminci en devant, son segment antérieur en f rwo 
de triangle tronqué à sa poinle, vers li lête. Ailes supérienres ayant une ncrvure qui parlant de la base de l'aile sans toucher au bord extérieur, se recourbe ensuite ponr rejoindre cebord qu'elle suit jusqu'an bout de l'aile et émet intérieurenent un peu après son nulieu un rameau assez long un pen élargi à son extrémité qui se recourlse et commence la cellule radiale sius l'achever; deux petites nervures pen apparentes, l'une vers le bord interne qu'elle suit à peu de distance, l'autre plıs courte, plaeée vers le milieu; toulcs les deux parcourant l'aile longitudinilement; une cellule cubitale u'étant poiut séparée du disquc et se confondint avec la plupart des autres. Quelquelois la nervure dir bord extéricur porte vers sil base et sur sa parlie droire, une pctite cellule triangulaire, fublement tracée. - Abdomen déprimé, en forme de triangle alongé, canaliculé en dessous dans les femelles. (La coulisse servant à loger li taric̀e s'étend dans toute li longueur du ventre.) Pédicule de l'abdomen très-court. - Cnisses postérienres simples, leurs jambes droiles.

11 est probable que les mours de ces Hyménoptères sont les mênes que celles de la plupart des autres Chalcidilcs. L'espèce suivante at servi de type à M. Latreille pour établir ce gento.

\section{Cléonyan déprimé, $C$. depressus.}

Cleonymus obscurè aureus, abdonnine depresso cyaneo, alis apice fiscis maculâfasciâque posticâalbis.

Cleonymus depressus. I.at. Gener. Crust. et Ins. tom. 4. pas. 29. - Diplolepis depressa. FAв. Syst. Piez. pag. 151. I $^{\circ}$. 13. - Ichneumon depressiss. Coqueb. Illust. Icou. tab. 5. fig. 5.

Longucul 2 liğ. $\frac{5}{2}$. Antennes roussâties avec l'extrémité noire. 'Téte et corselet fiuement cliagrinés, d'un rouge cuivreux foncé. Abdomen long, d'un vert mêlé de bleu d'acier très-luisant. Pattes roussâtres. Ailes supérieures ayant urie grande tache noirâlre, arquée du côté du bord postérienr.

On le troure aux environs de Paris, sur le tronc des ormes. (S. F. et A. SERv.)

PÉRITELE, Peritelns. Nonveau genre de Coléoptères fondé par M. Germar (Ins. Spec. Nov. vol. 1. Coleopt. 1824). Il apparlient à la tribu des Charansonites, famille des Rhyncophores; l'auteur l'avoil d'abord désigné sous le nom d'Onias, il a pour caractères : rostre court, épais, cylindiique, se rétrécissant vers l'extrémité, plus court que le corselet; ses fossettes placées sur la partie supérieurc, ver's son extrćmité; elles sont courtes, en entonnoir. Aniennes placées à l'extrémité du rostre, un peu plus longues que le corselet, leur premier article courbe, un pea en unassue, alleignant au-delì du bord antérieur du corstel; lear fouet de sept arlicles dont les deux premiers plus grands, en massue, les autres lenticulaires; massue ovale, annelće. T'ête cour!e, se rétrécissaut en rostre insensiblement. Ycux un peu saillans. Corselet court, n'ayant point de silIon en dessous. Ecusson nul. Elytres ovales; poiut d'ailes. Paltes courtes, éyales entr'elles. Cuisses mutigues, un peu en massue, jambes cyliudriques, rétrécies intérienrement vers lemr extrémité qui porte un angle saillaut. 'Tarses larges, assez courts.

l'auleur rapporle ì ce gen re entr'autres espèces le Curculio seminnlum de Fabricius.

(S. l. et A. SERr.)

PERLE, Perla. Geofr. Lat. Phy'ganea. Lin N. Genre d'insectes de l'ordre des Névroplères, famille des Planipennes, tribu cócs Perlides.

Les Perles confondues, avant M. Lalreille, avec les Némoures, s'en distingnent aisénent pá le labre peu apparent, les mandibules nembraneuses, la forme des articles de leurs tarses, inégaux cntr'eux, \& enfin par les deux lougs filels multiarticulés qui terminent leur abdomen.

On doit rapporter les fausses Friganes (Perla) de De Géer an gente Némoure. (Poyez ce mot.) La Perle $n^{\circ} 5$ de Geoffroy appartient aussi a cee gente.

Antennes longues, súlacées, composées d'un grand nombre diarticles conrts et cyliudriques; le premier gros; le second plus grand que les snivans, mais moins que le premier; elles sont trè:distantes entr'elles et insérćes à la partie latérate de la tête, un peu en devant des yeux. - Labre peu apparent, transverso-linéaire. - Mandibules presque membrancuses. - Mâchoires nues, nenbrancuses. - Lèvre à deux divisions. - Quatre palpes presque sétacés, les maxillaires saillans, de quatre articles; les labiaux de trois. - Téte jenchće, aplatie, de la largeur du corps. $Y$ eu $x$ à réseau un peu ovalaires. - Trois petits yeux lisses écartés, disposés en Iriangle et placés sur le front. - Corps alongé, étroit, aplati. Corselet carré, aplati. - Ailes longues, coucliées et croisées horizontalement sur le corps. Abdomen déprimé; son dernier segment teruiné dans les deux seres-par denx filets longs, mul. tiarticulés, antenuiformes et distans. - Pattes de longueur moyenne; tarses composés de trois articles; les deux premiers fort courts; le dernies très-alongé, muni de deux crochets ct d'une pelote dans l'entre-deux.

Les larres des Perles ressemblent un peu à celles des Friganes, et comme elles, vivent dans l'eau; elles habitent une espèce de tuyau de soie filée par elles, recouvert d'une autre matière. La lentille d'eau paroît êtı'e employée de préférence à cet usarge, par plusienrs espèces. Pour cela, l'insecte taille carrément les feuilles de cette plante et les ajuste les nnes auprès des autres 


\section{P E R}

comme des pièces de marqueterie, en sorte que leur liyau seoble recourett lout du longy et en spiralk, par un rusan vert assez étroit, mais qui augnente de ingeur a mesure qu'il approche de la partie anlóricure.

Quelques aulevis jensent que ces larves vivent de pelits insectes ainaliques; elles onl le corps alongé, divisé en plus eurs segmens, six paltes et la tếle écaillense. C'est dans le luyau dont nous veuons de parler, et qu'elles trunsportent avec clles à volunté, qu'elles snbissent leurs métamorphoses; avant de se changer en uymphes, elles en ferment les deux extrémilés avec une sorte de grille couposée de quelques fils de soie qui suffsent pour les gatantir de la voracité des insectes destructeris.

La uyıphe est de forme alongrée. On distingue facilement à son extérieur les différentes parties delinsecte parfait. Les Perles restent pen de temps sous cel e dernière forme; parrenucs a lear état de perfection, elles ne s'éloignent guère des eaux oì les feuselles, après l'accouplement, vont déposer leurs oufs : aussi est-ce principalement dans les lieux aquatiques gu'on trouve les iusectes de cc genre.

Nous ne connoissons que cing ou six espèces de Perles, qui toutes sont d'Europe.

\section{Perle brune, $P$. bicaudata.}

Perla fusca, capitis thoracisque linể longitudinali lutea; alis hyalınis, superiorum ad murgunem exterioren maculà parvâ subjuscâ.

Phryganea bicaudata. Lrns. Syst. Natur. 2. 908. I. - Semblis bicaudata. Fав. Entont. Syst. tom. 2. pag. 73. no. 8. - La Perle brune a raies jaunes. Geor f. Ins. Paris, tom. 2, pag. 231. $n^{\circ}$. 1. pl. 13. fig. 2. - RE्土м. Ins. tom. 4. pl. 1 1. fig. 9 et 10 .

Longueur 7 à $8 \mathrm{lig}$. Antennes entièrement brunes. 'Tête et corselel d'un brun noirâtre, avec une ligne dorsale jaune s'arrêtant an front; côtés du corselet ayant un pen de jaune. Alrdomen d'un brun noirâtre en dessus et sur les côtés, d'un gris jaunâtre en dessous. Palles d'un brun noirâlre; cuisses et jambes marquées d'une ligne jaune en dessous. Filets de l'abdomen bruns. Ailes transparentes; nervures brunes : les supérieures ayant une petite tache obscure vers les deux tier's de leur bord extérieur.

Tı̀̀s-commune en Europe dès le commeneement du printemps, au bord des eaux.

\section{Perra flavipède, $P$. flavipes.}

Perla suprà fusca, subtùs antennaruwi basi abdomineque luteis, alis hyalinis subglaucis, immaculatis.

Perla flavipes, LAт. Hist. nat. des Crust. et des
Ins. - La Perle brune à patles jaunes. Ge rr. Ins. Paris. tont. 2. pag. 25̃ . $n^{\prime} \cdot 2$. - Réaud. Ins. tom. 3. pl. 13. fig. 12.

I.ongneur 6 à $7 \mathrm{lig}$. Antennes hrunes, jannes en dessous de la base jusque vers le milien. Téte noire, arec ses parties latérales et antélieures jannes. Corselet noir en dessus, jaune mêlé de brun en dessous. Abdomen Lrun sur le dos, jaune en dessous et sur les côtés, avec quelques nuances de brun. Filets de l'abdomen jaunes à la base, bruns vers l'extrémité. Pulles jaunes, avec une ligne brune en clessus. Ailes transparentes, un péu verdìlres, sans taches; nervures brunes.

On la trouve avec la précédente.

\section{Perte jaune, P. lutea.}

Perla lutea, oculis stemmatiousque et antennarum apice nigris; alis hyalmis, glaucis, inmaculatıs.

Perla lutea. LAt. Hist. nat. des Crust, et des Ins. - Semblis viridis. Fав. Ent. Syst. tom. 2. pag. $74 \cdot n^{\circ}$. I I. - La Perle jaune. Gevfe. Ins. Paris. tom. 2. pag. 232. $n^{\circ} \cdot 4$.

Longueur 2 à 3 lig. Antennes jaunes jusque vers le milieu, noires dans le resie de leur étendue. Tête jamne, arec les ycux à résean et les petits yeux lisses, d'un beau noir. Corselei, abdomen, ses filets et les pattes cutièrementjaunes. Ailes transparentes, un peu verdâtres, sans taches; nervures jaunes.

Eile se trouve en Europe pendant l'été; on la voit souvent voler le soil dans les appartemeus, altirée par la lumière. ( $S . F$. et A. SEnv.)

PERLIDES ou PERLAIRES, Perlides. Huitième tribu de la famille des Planipenaes, ordie des Névroptères, caractérisée ainsi:

Piemier segment du tronc grand, sous la forme de corselet, les autres recouverts. - Ailes conchées horizontalement sur le corps; les inlérieures ¿eplićes ou courbées au côté interne; leur résean, aiasi que celui des supérieures, formé de mailles grindes et peu serrées. - Palpes maxillaires plus ou moins avancés, terminés par un ou deux articles plus grêles que les précédens, et dont le dernier est souvent plus grand. - Mandibules distinates. - Deux flets à l'extrémité de l'abdomen daus le plus grand nonbre. - Tarses à trois articles.... Larves aquatiques.

Cutte uribu se compose des genres Perle et Némoure. Voy. ces mots. (S. [. et A.SERv.)

PÉTALOCERES ou LAMLLLICORNES. Nom douné par M. Duméril ( $Z$ oolog. analyt.) à sa quatrième famille de Coléoptères pentamérés. Elle a pour caractères : Elytres dures, couvrant tout le ventre; antenres en masse feuilletée à l'extrémité. Ceite famille se compose des genres Géo- 
trupe, Bonsier, Apbodie, Scarabée, Hanneton, Cétoine, Triehie et 'Trox. (S. F. et A. Serv.)

PETALOCHERE, Petalocheinus. M. PalisotBauvois, dans son ouvrage intilulé : Insectes recueillis en Afrique et en Amérique, a donné ce nom à un genre d'Héraiptères-hétéroptères de la faunille des Ǵ́ocorises, tribu des Nadicolles, qui rentre comme division dans le genre Rćduve. Voyez ce mut. (S. F. et A. Serv.)

PÉTROBIE, Petrobins. Nom donné par TI. Léaclı à un genre d'insectes que j’avois étubli sous le nom de Machile (Machilis), et qui est un démembrement de celui de Lepisma de Linnée, ou de Forbicine de Geoflioy, Il diffère de celui - ci par les caractères suivans : Yeux très-composés, yresque contipus, occupant la majeure partie de la lête. - Palpes maxilliares rrèz-grands. -Corps convexe et arqué en dessus. - Thorax élranglé; son premier segment leauconp plus petit que le suivant. - Abáomen terminé par des filets propres pour le saut, et dont eelui du milieu beaucoup plus long.

L'espèce servant de type à ee genre est le Icépisme polypode de Linnée ( voyez Lépıste), que Jon trouve dans les bois, les lieux converts, et gui sante très-bien. Ellc à beancoup de rapports avee le pétrobie décrit par M. Léach soas le nom de Maritime, e! dont il a donné une figure trèsgrossie dans ses Mélanges de zoologie. A la même coupe appartient le Lepisina thezeana de Fabricias. (LATR.)

PETIT DIABLE. Nom vulgaire donné par Geofiroy à la Membracis cornue, $n^{\circ} .22$ de ce Dictionsaire. Celai de Grand Diable a été appliqué par le même auteur à la Membracis oreillarde, $71^{\circ} .26$, type du genre $L e d r$ de Fabricius.

(S. F. et A. SERv.)

PHALACRE, Phalacris. Payz. Latr. Sphceridium, Anisotoma. FAв. Anthrious. Geraf. Oliv.

Genre d'insectes de l'ordre des Coléoptères, seelion des Tétramères, famille des Clavipalpes, tribu des Globulites.

Dias celte tribu composée de quatre genres, celui cle Clypéastie a l.ı tête cachée sous le eorselet; les Agathidies crit le pénultième article des tarses entier; et dans les Languries, la massue ries antennes est formée de quatie ou cinq artides, et le corps est linéaire.

Antennes terminées en roassue alongće, perfoliée, triarticulée; leur dernier arlicle conique plus long que les prócédens. - Mandibules rétrécies, arcuces, ayant deux fortes deuts a leur extrémité. - Palpes filiformes, leur dernier article plus long, cylindrico-ovale. - Corp's hénisphórigue, ne se contractint pas en houle. - Paties comprintes, pénultièue ariicle des tarses bilobé.

Paykull a établi ce genre adopté depuis par
M. Latieille. Il est composé de six à sept espèces très-petites, dont le eorps est bombé, lisse, laisant, de couleur brtme on noire. Dans l'état parfait les Phalacres fréquentent les fleurs, surtout les semi-flosculenses. On les rencontre sonvent aurssi sous les écorces d'arlures, et il est probable que leurs larves y trourent leur nourritare. Ces insectes courent fort vile et échappent facilement des doigts en raison de leur petitesse et du poli de leur corps.

\section{Phalacre bieolor, P. bicolor.}

phalacrus bicolor. РАх к. Faun. Suec. tom, 3. pag. $43 \mathrm{~g} \cdot n^{\circ} .2$. - Latr. Gener. Crust. et Ins. tom. 3. pag. 66. -Gy LLENH. Ins. Suec. tom. 1. part. 3. pag. 43 r. $\pi^{\circ}$. 6. - Anisotoma bicolor. I'A B. Syst. Eleut. tom. I pag. soo. $n^{\circ} .3$.

Voyez pour les aulres synonymes et pour la description, Antribe bimaculé, no. 5 .

\section{Phalaere brillant, $p$. cortuscus.}

Phalucrus niger, nitidus, elytris ad suturam unistriatis.

Phalacrus corrusculs, РА х . Faun. Suec, tom. 3. pag. 438. $n^{\circ}$. 3..-Grletra. Ins. Suec. tom. 1. part. 3. pag. 427. n०. 1. - Sphoeridiun fimetarium. LА В. Syst. Elent. tom, 1. pag. 97. $n^{\circ}, 27 \cdot$

Longneur y ligne. Corps ovale, convexe, d'un noir brillant. Elytres lisses, ayant une seule strie placée vers la suture. Patles de la eouleur du corps. 'Tarses cendrés, un peu velus.

Environs de Paris.

\section{Pradaere testacé, $P$. testaceus.}

phalacrus nigro-testaceus, nitidns; antennis, pedibus elytroruinque apice testaceis; 7 horum striä unicầ suturali.

phalacrus testaceus. GyLr. Ins. Suec. tom. I. part. '5. pag. 432.n०. 7. - Anisotoma testaceum. PANz. Faun. Gem. fasc. 37. fig. 12.

Jougueur y ligne, Corps ovale, convexe, d'un testacé-brunấlre luisant. Antennes, paltes et extrémité des élytres plus pâles; celles-ci lisses, ayant une seule strie très-rapproehće de la suture. Environs de Parise

LANGURIE, Languria. LAt. Oliv. (Ent.) Trogosita. FAB.

Genre d'insectes de l'ordre des Coléop!ères, section des Tétramères, fanille des Clavipulpes, triba des Globulites.

Daus cette tribu on reconnoît aisément les Clypéastres à leurs antennes, composées seulenent de neuf articles, et les Agathidies ainsi que les Phalacies, par la massue des antennes de rrois articles, et par leur eorps hémisplérique, 
Antennes plus courtes que le corps, insérées devant les yenx, composées de onze articles: le premier court, arrondi, assez gros; le second arrondi, plus petit, les suivans presque coniques; les quatre ou cinq derniers formant une massue oblongue, comprimée, perfoliće. - Labre corné, peu avancé, presqu'ćchancré. - Mandibules alvancées, cornées, terminées par deux dents aiguës. - Mlâchoires cornées, bifides; leur lobe extérieur coriacé, un peu velu à sa partie supćrienre, le lohe intérieur plus court et bifide. palpes maxillaires presque filiformes, composés de quatre articles; le prenier trìs-petit, les deux suivans égaux, presque coniques, le deraier un peu plus long, plus épais, de forme ovale; palpes labiaux de trois articles; le premier petit, le suivant presque couique, le dernier un peu en massue, obtrigone. - Livre presque cordiforme, entière; nenton en carré trunsversal, beaucoup plus large que lis lève, un peu rétréci et arrondi supérieurement. - Corps linéaire. - Corselet arqué, convese. - Ecusson arrondi postérieurement. - Elytres longues, reconvrant les ailes et l'abdomen. - Pattes grêles, assez longues. 'I'arses ayant leurs deux premiers articles alongés, triangulaires, le troisième plus large, bifide, le dernier alongé, un peu arqué, terminé par deux crochels.

On counoît cinq ou six espèces de ce genre exolique, créé par M. Latreille. Ses mours sont ignoríes.

\section{Langurie iudienne, L. indica.}

Languria nigro-carulea, capite thoraceque ferrigneis.

Longueur 10 à 12 lig. Antennes noires, leur massue de quatre articles. Tête et corselet ferrugineux, tinement pointillés. Elytres et isbdomen d'un noir-bleuâtre, les premières ayant des stries pointıllées, peu enfoncées; on voit eatre ces strics quelques petits points placés sans ordre. Patles d'un brun noirâtre. Femelle.

Duns le mâle les antennes sont beaucoup plus longnes proportionnellement, leur's articles intermédiaires étant fort alongés. Sa taille est un peu plus forte.

Des Indes orientales.

On rapportera a ce genre les Languries bicolor, $\mathrm{n}^{\circ}$. 1 , thoracique, $\mathrm{n}^{\circ} .2$, et de Mozard, $\mathrm{n}^{\circ} .5$. d'Olivier (Entom. tont. 5. genre 88.) Les Trogosita elongata. $n^{\circ}$. 10. el filformss. $n^{\circ}$. 12. kis. Syst. Eleut. apparticment ausi aux Langurics.

CIYPÉEASTRE, Cypeaster. And. Lat. Cossyphus. GYL.L.

Genre d'insecles de l'ordre des Coléoptìres, section des Térrasaères, famille des Clavipalpes, tribu des Globulites.

Les genres gue contient cette tribu ont tous onze articles aux antennes, à l'exception des $\mathrm{Cly}_{y}$ péastres; leur corps est globuleux ou bien linéaite, et leur tête est avancée et découverte.

Nous ne connoissons pas ce genre cré par M. Andersh, rii les cepéces que l'on y rapposte. Son nom exprine la ressemblance de forme de ces inscctes avec un bourlier.

Antennes composécs de neuf articles. - Tére cachíe sous le corselet. - Corselet en deai-cerche - Corpo clypéifurme.

Nota. H. le conte Dejean mentionne quatre espéces de Clypéastres dans son Calalogue, toutes d'wurope deux d'eatrolles habitent aux environs de Paris.

AGATHIDIE, Agathidium. Iluig. Lat. Ani-

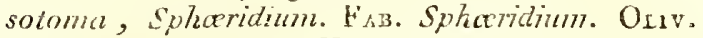
(Eimom.) Folvoxzs. KugenL.

Geure dinsecies de l'ordre des Colcoptìres, secrion des 'létramères, famille des Clavipalpes, tribu des Glofulites.

Les Languries et les Phalacres ont dans cette tribu, le pénulième article des tarses bilobé; dans le genre Clypéastre, les antennes n'offient que neuf articles, ce qui distingue ces geures de celui d'Agathidie.

Antennes conrles, de onze articles, terminces en missne, celle-ci presqu'ovorde, perfoliée, de trois atticles. - Mandibules triugulaires, leur extrémitté aiguë, peu ou point dentée. - $M \hat{x}$ choires ayant leur lobe extéricur étroit, presque linéaire, l'in térieur plus court, trigone. - Palpes filiformes, leur dernier article conique; les labiaux petits. - Corps ğlobuleux, hémisphérique, pouvant se contracter cn boule. - Corselet à angles arrondis, ses côtés ainsi que ceux des élytres très-inclinés; ces derniêres couvrant les ailes et l'abdomen. - Pattes courtes. 'larses ayant leurs quatre articles entiers.

Ces coléoptères sont de pelite taille; leur forme hémisplićrique leur a ralu le nou d'Agathidice, tiré d'un mot grec qui signifie peloton. On les trouve dans les bois; leurs uneurs sont innorées. Le nombre des espèces comnues s'élève à une quinzaine. Elles scut toutes d'Europe.

\section{Ag atnidie nigripenne, A. nigripenne.}

Agathidium ferrugineum, elytris nigris.

Aguthidium nignipenne. Lat. Gener. Cntst. ex Ins. tom. 3 pers. $67 . n^{\circ}$. 1. - Anisotoma litgit-.

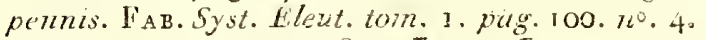
-PANz. Fuun. Gemin. filsc. 59. fig. 3.

Longueur ». Ferrugineuse. Antemes brunes. Elytres et abdonien noirs.

Wu ha trouve en firance el en Allemagne.

Rapportez a ce genre le Sphceridium globus, $n^{\circ} .11$, el l'Anisotoma semmulum, $n^{\circ} .5$. FAB Syst. Eileut. (S. E. et A. SERT.) 
PII ALAGE, Phalungiun, Phalanx. Les Aaciens ont ainsi désigné certain groupe d'Arat ncides dont ils distingubient plusieurs sortes. Mais comme ils ne nous ont laissé, ì cet égard, qu'une simple nomenclature et qui doit ĉtre très-enbrowillée, à raison de la divcrsité des idiômes, il est impossible d'cin laire une application eiême probable aux espèces qui nous sont connnes. Sealement il y a lon: lieu de présumer que les Arinéides vitgatondes et particulièremeut les Lyeoses et aures grenzes voisins étuient pour cux des Phalanges. Pline dit cependant que ces animanx, ct quili regarde comme ćtant lous mältasans, sont inconnus en lialie. Il sembleroit dess-lors que la 'Tarentule, espèce de lycuse, n'en feroit print farlie. Mais cela s'expliquera facilenent si l'on admet que la dénonination de Plalange étoit f́langère a la langue romaine; car la phupart des Aramérdes, que les Grees nommoient Phalanges, doirent se trouver dans l'Italie méridionale.

Ce nom a été ensuite donné par divers naturalistes modernes aux Araignées 'lu'on a cru venimeuses, e! des voy agears y ont compris !es grandes Mygales d'Amérique, appelées aussi AringnéesCrahes. (LАTн.)

Voyez le mếue arlicle dans le Nouv. Diction. d'Hist. nat. 2e. édit. torn. 25. pagr. 469 .

PHALANGIENS, phaiungita. 'Tribu äArachnides trachéennes, de la fauille des Holètres, ayant pour caractères: huit pieds dans tous. Chelicères ou mandibules très-apparentes, soit découvertes et avancécs, soil reconvertes par un musean en to:me de chaperon voûté (trogrule), de deux on trois articles, terminées par deux doigrts. - $\boldsymbol{1}^{\prime}$ alpes grêles, filiformes, terninés par un petit crocliet. - 1bdomen généralement plissé ou annelé, du moins en dessous.

Celle tribu comprend les genres Gonylepte, Funcheur, Trogule et Simn. (LATr.)

PIJLANGISTE. Geoffroy désigne sous ce nom le Geotrupes Typhoous de M. Latreille.

(S. F. et A. Serv.)

\section{PHaldagites. Voyez Phalatgiens.}

(LATR.)

\section{phalangium. Voy. Faucheur. (Latr.)}

PIIALÉte, Phuloma. Iinn. De Géer. Geoff. Fab. Latr. Geometra. Hub. Bombyx. Oliv. (Encycl.)

Gente d'insectes de l'ordre des Lépidoptères, farnille des Nocturnes, tribu des Phalénites.

Linnæus en établissant ce genre y conıprenoit tous les Lépidoptères désignés depuis sous le nom de Nocturnes. La réunion de tant d'espèces si différentes entr'elles, l'obligea lui-mêne à faire des divisions dans son genre. Nous croyons devoirles passer ici toutes en revue pour lien spécifier ce qui appartient an genre l'halène tel que nous l'entendons aujourd'hui avec M. Latreille.

Limné parlage sa première division en deax subdivisions: Attacus et Bomlyx. Les premiers caractérisés par leurs ailes étalét, sont divisés en trois sections, dont la prearitre à antennes pectinées et dépourvue de langue appartient au grenre Bombyx de M. Latreille: la seconde et la troisième ayant une langue en spirale et les antennes pectinées ou sétacées ne nous paroissent comprendre que des espèces du genre Erèbe. Lat.

La denxième subdivision comprend cinq sections. $\mathrm{I}^{\circ}$. Les Bombyx sans langue à ailes inclinées en toit, renfermant les genies Gastropacha et Odonestis de MI. Germar, et quelques vrais Bombyx. 20. Les Bombyx sans langue a ailes dépriuré et le dos lisse; ici sont placées quelques Arclies Lat. et quelques Bomby $x$. $3^{\circ}$. Les Bombyx sans langue à ailes déprinćes dont le dos est relevé eu crête, comprennent le genre Cossus, plus des Bomby $x$ et des Arclies. $4^{\circ}$. Les Boinby $x$ à langue en spirale ayant le dus lisse et les atles rabaltues, comprennent des Arclies et des Lithosies Lat. 50. Les Bombyx a langue en spirale, à dos relevé en irête é à ailes rabatlues sont des Noctuelles.

La seconde division porte le nom de Noctua et a deux subdivisions: ${ }^{\circ}$. les Noctuelles sans langue. Eiles renferment une espèce d'Érèbe (Érebus strix Lıт., qui malgré l'autorité de Linné est certainement pourva d'une langue en spirale), les genres Hépiale el Zeuzère et quelques Noctuelles. $2^{\circ}$. Les Noctuelles à langue en spirale contenant des Noctuelles, des Lithosies, des Arties el le genre Callmorpha Lat.

La troisième division ust celle des Geometra et it quatre subdivisions: $1^{\circ}$. les Géomètres à antennes pecliuées et ailes postérieures un peu anguleuses, renferunent le genre l'latyplère Lasp. et quelques Phalènes. $2^{\circ}$. Les Géomètres à antennes pectinées et à ailes artondies, ne conliennent que des Phalènes. $5^{\circ}$. Les Géornètres it antennes sétacées et à ailes anguleuses sont dans le même cas. $4^{\circ}$. Les Géomètres à antennes sétacées et ailes arrondies, contieunent des Botys Lat., des $\mathrm{Phalènes} \mathrm{et} \mathrm{quelques} \mathrm{(} \mathrm{G}$ alléries $\mathrm{L}_{\mathrm{AT}}$.

La qualrième division sous le nom de Tortrices, renferine le genre Pyralis EAs.

Ja cinquieme division sous le now de Pyrales, renferme les genres Aglosse, Cranbe el Herminie Lat. el des biotys.

La sixième division sous le nom de Tinece renferme les genres Teigue, Ecophore, Alucile, Yponomeute, Adèle Lat., avec des Lithosies, des Pyrales et des Galléries.

Eutin la septièmè division sous le nom d'Alucita comprend les genres Ptérophore et Ornéode I.AT.

Fabricius resserra beaucoup le genre Phalona 
de Linné en adoptant les genres Trigne et Ptérorophore de Geolfiroy et en créant les suivans: Bombyx, Cossus, Hipialus , Noctua, Lithosia et Alucita outre le genre Phalcena qu'il parlage en trois ainsi qu'il suit: $\mathbf{1}^{\circ}$. Phalènes à anteunes pecli. nées. Cette division comprend le genre Platyptère et des Phalènes de M. Latreille. $2^{\circ}$. Plialènes àntennes sétacées reufermant des Bolys et des Phialènes. Quant à sa troisième division dont le caractère est : ailes en queue d'hirondelle, il l'a lui-même modifiée dans le Supplément de son $E_{n}$. tomologie systématique en admettant le genre Crambus; telle qu'elle est après ce retranchement, celte division renferme encore des Bolys, les genres Aglosse et Herminie Lat., plus quelques espèces que nous ne pouvons rapporter avec certitude à ancun renre connu.

M. Latreille du genre Phalona de Linné a composé sa troisième famille des Lépidoptères qu'il appelle les Nocturnes. Il lui donne pour caraetères: ailes bridées dans le repos au moyen d'une soie en forme de criu partant du bord extérieur des inférieures près de leur base; ces mêmes ailes horizontales ou penchées. Antennes dimimuant de grosseur de la base a la pointe ou sétacées. Il divise cetle famille en huit.tribus : $1^{\circ}$. Bombyeites, coutenant les genres Hépiale, Cossus, Zeuzère, Bombyx. 20. Faux Bounbyx, se composant des genres Arctie et Callimorphe. $3^{\circ}$. Plialéniles, qui renferment deux genres, Platyptère et Plialène. $4^{\circ}$. Deltoïdes, contenant les genres Aglossé, Botys et Ilerminie. $5^{\circ}$. Noctuélites, qui coulieuuent les genres Erèbe et Noctuelle. $6^{\circ}$. Tordeuses, n'ayant que le genre $\mathrm{Py}$ rale. $7^{\circ}$. Tinćites, renfermunt les genres Lithosie, Yponomeute, Ecophn:e, Adèle, 'Teigne, Gallérie, Euplocampe, Alueite et Crambe. 8o. Fissipenues, eomposés des geures Piérophore et Ornéode.

Les Platyptères, seul genre de la tribu des $\mathrm{Pl}$ alénites avec celui de Phalène, se distinguent de ces dernières par leurs ailes supérieures ayaut l'augle du sommet prolongé et recourbé en forme de faucille et par lenrs Chenilles qui ont toujours quatorze pattes et dont le corps est terminé postérieurenient en me poiule simple, les patles postérieures lenr manquant.

Antennes assez eourtes, sétacées, multiarticulces, tantôt simples, tantôt pectinées ou plumeuses, soit daus les deux sexes, soit seulemeut dans les mâles. - Langue souvent petite, peu comée. - Palpes inférzeurs cacbant totalement les supérieurs, presqne cylindriques au coniques, courts et couverts uniformément de petites écailles. - Tête petile. - Corps ordinairement grêle. - Ailes grandes, étendues horizontalement dans le repos, toutes les quatre ayant daus ce cas, des teinles et des dessins qui leur sont communs, ou disposées (dans le repos) en toit très-écrasé, $n^{\prime}$ ayant plus ordiuairement sur les inférieures Hist. Nat. Ins. Tome $X$. que des teintes moins foncées que eelles des supérieures. - Chenilles arpenteuses ayant dix pattes (douze dans une seule espèee conuue).

Matlgré leur ressemblanee avec les Bombyx, les Phalèues en diffèrent notablement en ce que leur laugue est toujours plus apparente et plus longue, leur corps moius garni de poils, leurs ailes moins solides et ordinairemeut d'une étendue plus considérable comparées au volame du corps. La plupart des espèecs ne volent graprès le eoucher du soleil, cependant e'est le plus souvent pendant le jour que les mâles recherchent leurs femelles; mais on s'aperçoit aisément que ee n'est point la vue qui les dirige dans cette recherehe et que même la lumière leur ôte l'usage de leurs yeux, parce qu'ils heurtent indistinctement tous les obstacles qu'ils reneontrent; cependant ils arrivent assez directement au but qu'ils se proposent, guidés vraisemblablement par des émanations qui sortent à cette époque du corps de la femelle et qui eessent dès que l'accouplement a été consommé; cette particularité s'étend à un certain nombre de Lépidoptères nocturnes et notamment aux Bombyx, wais l'heure varie suivant les espèces (1).

Les Chenilles des Plialènes ont dix patles, l'espèce nommée Margaritaria $n^{\circ} .79$, en a seule douze, mais les deux pattes membraneuses qu'elle a en plus sont plus eourles que les autres. Les six antérieures, ou patles écailleuses qui revferment eelles que doit avoir l'insecte parfait, se remalquent d'abord, ensuite viennent les pattes wembraneuses placées vers l'extréunité du corps et ne rnanquaut jamais au dernier segrnent. Beaucoup de parlicularités relatives à ces Cheuilles, sont intéressantes, on les tronvera dans ce Dictionnaire à l'article $\mathrm{CE}_{\mathrm{a} \perp \mathrm{NILE}}$ et notamment aux pages 577 et 607 du tume V.

Ces Chenilles, pour se changer en chrysalides, enirent pour la plupart en terre ou resient à la superficie; plusieurs s'y construisent des espèces de coques ì mailles lấches. Celle de la Phalène du sureau $n^{\circ} .84$, altache la sienne ì un rameau et la suspend par un faisceau de fils assez longs, elle la recourre de morceaux de feuilles et les attache àla superficie. La Chenille de la Phalène du lilas no. 86 , construit la sienne immédiatement contre une branche. Celles des espèees nommées Airgus, no. 67 , et ponctuée, $11^{\circ}$. 80, fixent leur's chrysalicles à une petite branche absolument de la

(1) Nous avons remarqué que c'cst sur les dix heures du matin que les mâles des thalènes à femelles aptères recherchent l'accouplement. Les Bombyx Tau et Carpini (perit paon) se mettent en mouvement pour le mêne sujer da dix heurcs du matin à trois de l'après midi ; de cetre heure à cing le Bonbyx Quercus est à la poursuite de sa femulie et nous en avons eu la preuve jusque dans un des quarriers les plus peuplés de Paris. Le Bombyx Pavonia (grand paon) artend le déclin du soleil et ne se met en mouvemen. a u ua heure arant son coucher. 
mème manière que les Chenilles des Papillons et des Piériries.

La forme des ailes dans les Phalènes a'est pas toujours la même; on remiluquera que plusieurs les ont beancoup plus longues que larges, tandis que dans d'autres, ces dimensions se rapprochent beancoup. Quelques femelles sont privées d'ailes, ou ne les ont que comme des moirnons très-courts; certains máles an contraire scmblent en avsir six, parce que leurs ailcs inféricures ont à la base de lour bord intérieur un petit appendice qui se recourbe en dessus et paroit une seeonde aile inférieure surnuméraire.

M. Hiäbner a donné ct figuré pllus de quatre cents espèees de Phalèues curopéennes. On connoit en outre bcaucoup de Lépidoplèrcs nocturnes exotiques que l'on rapporte ì ce genre. Forcés de uous restreindre, nous nous contenterons de décrire les suivanles, en nons conformant it l'usage recu de prendre la terminaison aria pour lcs Phalènes dont les máles ont les antenues pectinées, et celle en ata pour les espèces à antenncs sélacées et simples dans les deux sexes.

ire. Division. Bords des ailes entiers, sans dentelures ni queve.

Ire. Subdivision. Ailes supérieures recouvrant les inféricurcs dans le repos, et formant avec elles un triangle.

A. Ailes étroites relativement ì leur longuenr.-Antennes pectinées dans les míles.

a. Corps gros (palpes très-velus).

1. Prariène à plumet, P. plumistaria.

Phalcena alis integris, incumbentihus, superioribus albidis, inferioribus julvis; ommibus nigro punctatis lineatisque.

Phalcena plumistaria. Esper, tom. V. Phal. Geom. tab. XXII. fig. 6-8. Mâle. - Hur. Geom. tab. 24. fig. 127. Mâle.

Euvergure 12 à 15 lig. Antennes ct eorps noirs. Abdomen portaut une lignc dorsale et deux latérales de poin!s d'un fiuve vif. Bords extérieur's et postérieurs des quatre ailes noirs. Les supérieures à fond blane marqqué de teintes d'un fiuve pâle, tacheté de points noirs; qualre lignes noires partant du bord antérieur, la premiére el la seconde irrégulières dans leur forme, rejoignant le bord postérienr; la troisième en crochet dont le bont rejoint le milien dc la scconde; la quatrième à peine commencée, continuéc par des points noir's irrégulièrement posés; entin, vers le bord extérieur de l'aile unc ligne de points d'un fauve vif. Siles inférieures ì fond d'un fauve vif tacheté de petits points noirs, avec un gros point de même couleur vers leur milieu; un pcu au-dessous est une ligne noire ondéc. Dessous des ailes supésieures d'un lauve vif; leur bord antérieur blan- chàtre, les lignes qu'elles portent en dessus trèscourtes; dessous des inférieures à fond blanchat tre, confomes au dessus pour les autres déiails. Male et fernclle.

Autenues de la femelle dentées en scie; celles du mâle exlrềmoment pecliuées.

Se troure en Europe, surtout dans la partie inéridionale.

Nota. Dans tous les mâles de celte section et dans cclui de la Phalètue zóne, qui commence la suivante, les antennes sont doublement pectinées, les rameaux latéraux émeltint sur toute leur étendue des filamens également latéraux.

2. Phalìne précoce,"P. prodromaria.

Phalcena alis integris, incumbentibus, albis nigro punctatis, superionum fasciis duabus, inferiorum unicâ fuscis.

Phalona prodromaria. FAв. Ent. Syst. tom. 5 . part.2. pag. 15 g. $n^{\circ}$. 105. - Ни в. Geom. tab. 33. fig. 172. Mille. Larv. Geom. arquiv. A. il. $n^{\circ}, 1$. - La Printannière. Georf. Ins. Paris. tom. 2. pag. 118. $n^{\circ}$. 22. Femelle.

Envergure 16 à $18 \mathrm{lig}$. Anlennes noires mêlécs d'un pea de blanc. Corps brun wêlé de blanc, surtout sur le devant de la tète et du corselet, ainsi que sur les côlés de ee dernier. Fond des quatre ailes blanc, chargé de points uoirs; deux bandes irrégulic̀res brunes, bordćes de noir sur les supérienres, une seule sur les iuférieures. Dcssous semblable au dessus. Antennes sétacées, un peu dentées en scie vues à la loupe dans la fcmelle; celles du mâle rousses, très-pectinées : colui-ci du resic semblable à sa femelle, si ce n'est que les parties brunes du corps et des ailes tirent sur le roux.

Chenille d'un brun roussûtre, avec des tubercules rougeâtres et quclques points blancs. Vit sur le chêue. Subit sa métanorphose en terre. La Phalc̀ne paroit ordinairement au mois de mars.

Des cuvirons de Paris.

\section{Pharìne hérissée, $\boldsymbol{P}$. lirtaria.}

Phalcena aiis integris, incumbentibus, rriseis, strigis tribus obscuris fuscis, antennis nigris.

Phalana firtaria. Linn. Faun. Suec. edit. 2. no. 1236. - Fав. Entem. Syst. tom. 3. part. 2. pag. 149. no. 72. - DE GÉER, Ins. tom. 1. pag. 354. pl. 22. fig. 6-9. et tom. 2. pag. 506. no. 5. - Hu в. Geom. tab. 33. fig. 175. Mâle.

Envergure 12 à $14 \mathrm{lig}$. Antennes noires. Corps brun. Ailes grises portant trois bandes brunes peu distinctes, la plus extérieure bordée d'une ligne blanchâtre. La femelle a les antennes sétacées, un peu dentées en scie vues à la loupe; elles sont trèspeetinées dans le mâle. Les eoulenrs dans ce dernier sexe sont mieux prononcécs, et il nous paroît $y$ avoir un point noir sur le disque des ailes inférieures. 
Chenille d'un gris brun avec plusieurs lignes longitudinales de eonleur de chair tant en dessus qu'en dessous. Bord antérieur du premier segment jaune; deux petits traits transversaux et un lubercule latéral de mêne couleur sur les quatrième, einquième, sixième, seplic̀me et huitième segrmens du corps. Téte et palles roses poncluées de noir. Vit sur l'osier et le saule. Subit sa mélamorpliose en terre.

Des environs de Paris. On la trouve désle commencement de mars.

\section{Pandexe velue, P. pilosaria.}

Plualcena alis integris, incumbentihus, rufescenti-griseis, superiorum strigis quatuor undutis, inferionum dualus, unâa abbreviatâ, fuscis.

Geometia pilosaria. IIu в. Geom. tab. 34. fig. 76. Mâle. Lary. Geont. cequip. A. d. $n^{\circ} .2$.

Envergure I 5 à s 6 ligo. Autennes très-pectinées, d'un gris brun ainsi que le corps. Ailes supérieures d'un gris roussâtre arec quatre lignes brunes un pen ondées; entre la seconde et la trojsième est un petit trait de même couleur. Ailes inférieures n'ay.ant que deux lignes brunes, dont celle qui avoisine le bord extérieur part de l'angle anal et alteint au plus le milieu de l'aile. Mâle.

Chenille un peu velue à poils roides, brune, rariće de peites lignes jaunes, noires et fauves. Vit sur le chêne suivant M. Hübner.

Des environs de Paris.

\section{Phalèxe du Bouleau, $P$. betularia.}

phalcena alis integris, incumbentibus albis, atomis punctisque multis inspersis nigris.

Phalona betularia. Lins. Syfl. Nat. 2. 862. 217. - Fа в. Ent. Syst. tom. 5. part. 2. pag. 153. $n^{\circ} .103$. - DE GÉER, Ins. tom. 2. pag. $534 . n^{\circ} .1$.

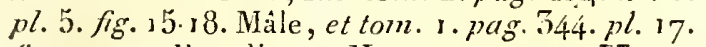
fig. 19-22. Femelle. - Huв. Geom. tab. 33. fig. 173. Femelle. Laro. Geom. aquip. $\Lambda$. b. $n^{\circ}$. 1. - La Grisuille. Georf. Ins. Paris. tom. 2. pag. 334. $n^{\circ} .51$.

Envergure 15 is $20 \mathrm{lig}$. Antennes noires annelées de blanc. Corps grisâtre unêlé de noir. Ailes à fond blanc chargé d'atônes, de points et de petiles lignes de couleur noire, les plus distinctes des lignes se trouvant près des bords extérieurs. An'ennes entièrement sétacées et simples dansla femelle; brunes, pectinées avec leur extrémité simple et rousse dans le mâle. Celuj-ci a les ailes moins chargées de noir.

Chenille d'un brun grisâtre ou quelquefois verdâtre. Têle aplatie en devant et comme refeudue dans sa partie supérieure en deux pointes coniques. Corps cliargé de quelques éminences rabo- teuses. Vit sur le bouleau et le sanle. Se métanorphose en terre d'où la chrysalide sort à moitié à l'époque où l'insecte parfait doit paroître.

Des environs de Paris.

\section{Phamine picotéc, $P$. atonuatia.}

Phalcena alis integris, incunbentihus, fomine albidis, maris lutescentibus, strigis atomisque multis sparsis fly fcis.

phalona atomaria. Linn. Syst. Nat. 2. 862. 2.14. - NAB. Ent. Syst. tom. 3. part. 2. pag. 144. $n^{\circ}$. 56. - DE GEER, Ins. tom. 2. pag. $344.7 z^{\circ} .2$. pl. 5. fig. 14. - Espen, tom. V. Phal. Genn. tab. X XIhl. fig. 4-8. - Hub. Geom. tab. 25. fig. 136. Henclle. Law. Geom. ampliss. V. b. $72^{\circ}$. 1. - La Rayure jaune picotéo. Georf. Ins. paris. tum. 2. pag. 153. $2^{\circ}$. 5o. Míle.

Envergure 3 ì 10 lig. Antennes noires annelées de blanc. Corps ljur. Fond des ailes blanchâlre, chargé d'itlômes bruns. I les supérieures portant quatre lignes irrégulières noires dont les deux intermédiatres se rapprocheat avant d'arriver au bord intérieur. Les inféricures n'ay ant que deux lignes brunes bien visibles. Bord extérieur des quatre ailes brun. Frange entrecoupée de blanc et de lrun. Antennes sélacées et simples dans la femelle, très-pectinées à barbes noires dans le mâle. Les ailes dans se dernier sexe ont leur fond jaunâtre et les bords d'ın brun plus foncé.

La Chenille varie tellement pour les couleurs qu'il est impossible d'en faire une description applicable a tousles individus : elle n'a aucun rubercule sur le corps. Les figures que nons citons, surtout celles de M. Hibuer, sont en assez grand nombre pour la faire recounôtre.

Très-commune aux environs de Paris dans les prairies.

\section{Pmaliene voisine, $\boldsymbol{p}$. concordaria.}

Phalana alis integris, incumbentibus, superioribus fuscis, fusciâ punctiaque albis; inferioribus testaceis strigis tribus trunsversis fuscis; omnium nuargine fusco albo fuscoque finbriato.

Geonetra concoráaria. Ilus. Geom. tab. 24. fig. I 26 . Mlâle.

Eavergure $8 \mathrm{lig}$. Antennes noites. Corps noiratre. Ailes supérieures brunes avec nne bande blanche dans leur milieu et quelques taches de nếene couleur sur le reste de l'aile; les inférieures filuves avec trois lignes brunes, transverses. Bord des quatre ailes bruu. Frange entreconpée de llanc et de brun. Dessous des supérieures fauve : leur disque portant une lache brune, une ligne de taches noires accompagne à quelcue distance le bord postérieur. Dessous des iuférienres portant los neêmes ligues qu'en dessus et de plus

Ii 2 
des taches blanches dont quelques-unes forment deux lignes longitudiuales interrompues. Antennes sétacées, un peu dentées en scie vues à la loupe dans la fernelle. Celles du mảle pectinées suivaut M. Hülner.

Des environs de Paris.

\section{Phaténe purpurine, $\boldsymbol{P}$. purpuraria.}

Phalona alis integris, incumbentibus, roseo fimbriatis superioribus finscis aut lutescentibus, fasciis duabus roseis; inferioribus flavis.

Phalona purpuraria. Linv. Syst. Nat. 2. 864. 221. - FAB. Ent. Syst. tom. 3. partie 2. pag. 161. $n^{\circ}$. 113. Mầle. - phalona purpurata. FAs. Ent. Syst. tom. 3. partie 2. pag. 201. $n^{\circ} .263$. Femelle. - Geometra purpuraria. Huв. Geom. tab. 38. fig. I 98 et 199. Larv. Geom. oequiv. C. b. $n^{\circ}$. 1. - I'Ensanglantét. GenfF. Ins. Paris. tom. 2. pag. 126. $n^{\circ} .34$. Màle.

Envergure 6 à 7 lig. Antennes brunes. Ailes frangées de rose. Les supérieures brunes ou jaunâtres avec deux bandes roses; les inférieures d'un fauve vif ayant le bord inférieur plus ou moins brun, leur dessous marg̣né d'une bande rose transversale. Celui des supérieures n'ayant qu'un petit trait de celte couleur placé près du bouı. La largeur des bandes roses varie extrêmement. Antennes sétacées et simples dans la femelle, trèspectinées dans le mâle.

Chenille rerte avec une ligne dorsale d'un jaune pâle et quelques traits de même couleur sur les côtés.

Très-commune aux environs de $P_{a r i s}$ sur les luzernes et dans les prairies artificielles.

\section{b. Corps grêle (I) (Femelles aptères.)}

\section{Pualène zône, $\boldsymbol{P}$. zonaria.}

Geometra zonaria. Нбв. Geom. tab. 3. fig.17.9. Mâle. Larv. Geon. oqquiv. A. c. $n^{\circ}$. s. a. b. c. Bombyx zona. FAB. Ent. Syst. tom. 5. $1^{\text {re }}$ partie. pag. $47^{8}$. $n^{\circ}$. 219 .

Voye $z$ pour la description et les autres synonymes Bounbyx zône, $\mathbf{n}^{\circ}$. 252.

Chenille verte ou bleuâtre ayant de chaque côté du corps une bande jaune régulière, assez large.

Cette espèce se trouve dans les prairies. Elle n'est pas très-commune aux environs de Paris.

(1) On comprendra parfaitement que les caractères dont nous nous servons pour ces deux premières pecitessections, n’empêchent pour qu'il ne soit de règle générąle que les femelles dans tous les Lépidoptères noccurnes aient l'ab. donen très-gíos, lorsqu'elles sont sur le point de déposer leurs oufs.
10. Pastène effeuillante, $P$. defoliaria.

Phalona alis integris, incumbentibus; superioribus griseo-albidis, fasciis fusco-rufis; inferioribus albidis, atomis griseis punctoque discoidali fufco: foemmầ apterâ lutêa nigio nuaculatâ.

Phaloena defoliaria. Linn. Faun. Suec. no. 1238. - FАв. Ent. Syst. tom. 3. partie ${ }^{\mathrm{e}}$. pag. 148. $n^{0} .68$. - EsPEn, tom. V. Phal. Geom. tab. XXXVII. fig. 1-7. - Huв. Geom. tab. 35. fig. 18. Mäle. Larn. Geom. aequiv. B. a. no. 1. a. b. - PĖaur. Ins.tom. 2. pag. 369 èt suivantes. pl. 3o. fig. 1-16.

Envergure in à 12 lig. Antennes brunes. Corp d'un brun roussâtre. Aites supérieures d'un blans sale avec quelques bandes roussâtres bordćes de brun. Les inférieures blanchátres clıargces d’atômes gris et d'un petit point brun sur leur disque; une ligne de mérne couleur borde ces ailes et précède là frange. Toutes les nuances moins distinctes en dessous. Anıennes peclinées. Mâle.

Femelle aptère. Antennes sétacies et sinuples. Corps janne taché de noir.

Chenille de couleur marron avec une ligne latérale de traits jaunes irrégulicrs. Elle est nuisible dans certaines années en dépouillant les arbres de leur verdure, principalement les chênes. Elle subit sa métamorphose en terre.

Comnune en France.

Notà. Dans le mâle de cette espèce, ainsi que dans ceux des quatre suivanles, les antennes ne sont pas à proprement parler doublement pectiućes, les filamens qu'émettent leurs rameaux listéraux étant presque tous réunis en faisceau terminal.

\section{Phaline noirâtre, $P$. nigritaria.}

Phalona alis integris, incumbentibus; superioribus griseo albidis fasciis finsco-rufis, inferioribus albidis aiomis sparsis strigisque duabns abbreviatis fuscis: forminâ apterâ.....

Geometra nigritaria. Нив. Geom. tab. 35. fig. 18r. Mále.

Envergure I pouce. Anlennes brunes, pectinées. Corps d'un blanc sale. Ailes supérieures brumes avec une large bande dans leur unilieu; cette bande blanchâtre, irrégul ère, semée d'atômes bruns; et une ligne de points blanchatres avoisinant le bord extérieur. Ailes inférieures blańchâtres, parsemées d'atômes bruns a vec deux petites lignes brunes transversales qui partent du bord intérieur et n'atlejgneul pas le milieu de l'aile; le bord qui précède la frange esı brun. Dessous des quatre ailes presqu'uniformément gris. Nâle.

Environs de Paris; 
32. Praxine de l'Erable, $P$. accruria.

phalona alis integris, incumbentibus ; superioribus fusco-rufis strigis duabus undato dentatis maculâque apicalifuscis; inferioribus griseo. albidis : omnium puncto discoidali lineâque subnuarginali punctariâ. fuscis: fơminâ apterâ.....

Geometra aceraria. Hus. Geont. tab. 35. fig. 85. Mâle. Laro. Geom, aquiv. B. a. b. $n^{\circ} \cdot 2$.

Envergure I pouce. Antennes grises, pectinées. Corps brun-roussâtre. Ailes supérieures d'un brum-ronssûtre, portant deux lignes ondées, dentelées, brunes; une tache de même corileur ì la partie supérieure du bout de l'aile. Les inférieures d'un gris blanchâtre. Un point brun sur le disque et une ligne de points de mêroe couleur accompagnant le bord extérieur, dans les quatre ailes. Dessous moins coloré, surtout cclui des ailes supérieutes. Mâle.

Chenille verte avec deux petites lignes latérales blauchâtres et une autre lignc jaune au-dessous de celles-ci. Vit sur l'érable; subit sa métaworphose en terre.

Des envirols de Paris.

\section{Phalène soyeuse, $\boldsymbol{P}$. sericearia.}

Phalona alis integris, incumbentibus, griseofuscis, apice fuscioribus fasciâ nigricante : foemincî̀ apter $\hat{a}$, griseo-fuscâ.

Phalcena sericearia. Esper, tom. V. Phal. Gconn. tab. XXXVII. fig. 3-6.

Envergure 8 à rolig. Ailes d'un gris brunâtre; leur partie inférieure avoisinant le bord posté rienr plus foncée et sćparée du reste par une li$z^{\text {ne }}$ d'un brun décidé. Dans la partie supérieure des premières ailes sculement, sont deux petites lignes brunâtres pell distivates. Dessous des quatre ailes moins coloré et mêlé d’atômes blanchiatres. Antennes pectinées. Mìle.

Femelle aptère. Antennes sétacées et simples. Corps d'un gris brun.

Chenille de couleur marron, un peu luberculée avec quelques lignes interrompues, blanchâtres , latórales. Subil sa métamorphose en terre.

Enviruns de Paris.

\section{Phalìne orangée, $\boldsymbol{P}$. aurantiaria.}

phalonn alis integris, incumbentibus; superioribus luteo-flavis punctis fasciisque duabus, unicâ undat $\hat{a}$, fuscis; inferıoribus pallidè fulvis puncto discoidal nigro : foeminâ apterâ.....

Geometra aurantiaria. Hu в. Geom. tab. 35. fo. 184. Mâle. Lanv. Geom. cequiv. B. a. $n^{\circ}$. 1 . c. $d$.

Euvergure 10 à $12 \mathrm{lig}$. Antennes pectinées d'un fauve jaunâtre. Corps de même couleur. Ai- les supérieures d'un fauve jaunátre arec deas bandes un peu brunes; celle qui avoisine la base de l'aile presque droite, l'aulre ondulée, non dentée; quelques points bruns entre cette ligne et le bord extérienr. Ailes inférieures el dessous des cqualre d'un fanve banchâtre. Un point noir sur le disque de tontes, plus sensible en dessous qu'en dessus. Mấle.

Chenille verte aveo grelgnes lignes plus claircs el d'aulres nlus foncées sur les côtís. 'Tête et dernier segment du corps ayant des mances conleur de clarir. Vit sur le bouleau. Subit sá métamorphose cu ierre.

Environs de Paris.

13. Ailes larges relativement à leur longueur. a. Antennes pectinées daus les mấles.

15. Puarise de la Hancienne, $P$. elinguaria.

Phalcena alis integris, incunbentibus, luteoalbidis; superioribu's fasctâ fuscâ a d marginerra internum coarctatâ; ommum puncto discozdali nigricante.

Phalana elinguaria. Lins. Syst. Nat.2. 862. 2 1 . - Fа в. Ent. Sysi. tom. 3. part. 2. pag. 159. $n^{\gamma}$. 107. - Esper, tom. V. phal. Geonl. tab. XXII. fig. 1-5. - Hषв. Geom. tab. 4. fig. 20. F'emelle. Larv. Geom. ampliss. C. c.fig. I. a. b.

Euvergure 12 à 14 lig. Antennes et corps d'un blanc jaunâtre ou couleur de café au lait. Ailes de mêne couleur ; les supérieures ayant une bande plus foncée se rétrécissant beaucoup vers le bord interne; un point brun sur le disque des quatre ailes, tant en dessus qu'en dessous. Dessous moins coloré, ayant sur toutes les ailes une petite ligue brune pen marquée. Mìale.

La fernelle a les couleurs plus pâles.

Chenille grise, un peu saboteuse, ayant que?ques pelits iubercules bruus qui portent des poils cocits, hérissés. Vit sar diférens arbres, nolamment sur ia mancienne (Vibumuin lantana). Subit sa mélamor phose en terre.

Environs de Paris.

16. Pralise plombée, $P$. plumbaria.

Phalona alis integris, incumbenibus; superiorlus plumbeis, strigus duabus rufescentilins "cries marginem internum approxumats, alicrâque aliquando ad basin concolori, puncto discoudah migro; "rifiroribus palludis, strigì ob: curâ griseâ.

Phaloena plumbarin. Fав. Ent. Syst. tom. 3. part. 2. pag. 16o. n". 110. - Geometra petraria. Hu Geom. lab. 21. fig. 113. l'eueile.

Envergure Io a 12 lig. Antennes dun gris roussâtre. Ailes suṕérieares grises, ayaut deux lignes roussâtres gui se rapproclieni l'ane de l'autre vers le bord interne; un point aoir dans l'es- 
pace contenu entre ces lignes; il y a quelquefois une ligne courbe roussittre pen apparente ver's la base de l'aile, et constamment un petit trait de cette conlenr à l'angle supérieur. Ailes inférieures plus pâles arvec une ligne transversule à peine distincte, d'un gris plus foncé. Jessons des quatrc ailes uniforménent plus pâle, sitns lignes ni poiuts. Feraelle. Paris.

Très-commune dans les bois des environs de

17. Praliene de l'Ansérine, F. chenopodiaria.

phalcona alis integris, incumbentibus, rufogriseis fusco lineolatis; superioribus fusciis dur bus nifescentibus undulatis, versus marginem internum approximatis, puncto discoidal nigro.

Phalena chenopodiata. Livn. Syst. Nat. 2. 868. 246. - FAB. Entom. Syst. tom. 3. part. 2. pag. I91. $n^{\circ} \cdot 227$. - Geometra mensurata. IIU в. Geom. tab. 37. fig. 195ु. Mâle.

Envergure 12 à J $_{4}$ lig. Ailes d’un gris-roussâtre, les supéricures ayant leur bord extéricur plus foncé; ce bord ainsi que sa base portant de petites lignes transverses peu distinctes; denx bandes assez larges, ronsstitres, ondulées, dont l'interralle est plus foncé et porte un point noir; ces bandes se rapprochant vers le bord interne et occupant la partic moyenne de l'aile. Ailes inférieuresavec deux ou trois petites bandes transversales per distinctes plus foncécs que le reste, ainsi que le bord extérieur. Dessous des quatre ailes plus clair avec deux lignes transverses à peine distunctes et un petit pout noir sur chacunc. Nâle.

Selon Fabricius la Cheuille est glabre, portant des ligues bruues on vertes; les scrmens dia corps sont itnguleux. Vil sur l'unsérine (C'henopodium).

Se trouve aux environs de Paris dans les bois.

\section{Phalìne tachée, $P$. contaminaria.}

phalona alis integris, incumbentious, grisescenti-luteis, atomis fuscis sparsis, strigis tribus fuscis; superionan strigis duabus exterioribus versis marginem internum approximatis; inferiorum strigầ baseos abbreviatâ.

Geometra contaminaria. Hun. Geom. tab. 68. fig. 556. Miale.

Envercrure 1 pouce. Antennes et corps d'an gris jonnàtre. Ailes de mêtue conlcur chargées d'itionwes bruns et ayant deux ligues branes qui les traversent du hord extérieur alu bord interne; ligres des supericures se rapprochant vers ic bord intéries:; lenr intervalle renfermant une grande tache brune ì l'eudroit où elles se rétrécissent; on voit une autre petite ligne transversale vers lit base des ailessunérieures, dont le commencenent seul cst indiçué sur les inférieures. Dessous des giratre ailes un peu plos pâle; une ligue brune transversale et un point noir sur le disque de chacune; ce point plus gros sur les supérieures. Mâle et femelle.

Environs de Paris.

19. Phalène embịouillée, $P$. gilvaria.

Phalcrna alis integris, incumbentibus, albidolutescentibus, atomis griseis sparsis, puncto discoiduli lnneâque ab angulo extemo descendente griseis.

Phalcena gilvaria. Fав. Entom. Syst. tom. 3. part. 2. pag. 162. no. 117. - EsPER, tom. $V$. Phal. Geom. tab. XXV. fig. 6-8. Mû̀le.-Hvn. Geom. tab. 33. fig. 201. Lemelle. Lard. Geom. aquiv. C. b. n'. 2. a.

Envergure I pouce. Antennes et corps d'un blanc jaunâtre. Ailes snpéricures de même conleur, chargées d'alòmes gris, les iuférievires plus blanches; tontes gaatre portant sur lenr disque un point gris ct une ligue de même couleur, qui part presque de l'angle extérieur et s'avance plus sur les supérieures que sur les inférieures, sans cependatil alteiudre dans aucunes le bord interne, vers le milicu duguel elle se dirige. Dessous semblable au dessus, lignes et poinis plus marqués; deux traits moirs longitudinanx allant de la base jusqria point discoidal dans les supérieures. Mâle ct femelle.

Chenille grise avec une ligne latéralc ferrngineuse et une dorsale blanchâtre. Vil sur la millefeuille (Achillea millefolium).

Environs de Paris.

20. Phaleine sacrée, $P$. sacraria.

phalcena alis integris, incumbentibus; superioribus pallide luteis, strigâ rectâ roseâ ab angulo superiori ad marginis infermi mediam partem decurrente; inferioribus pallidis.

Plualcena sacriria. I.nx. Syst. Nat. 3. 863. 220. - - $\mathrm{F}_{\mathrm{AB}}$. Fnt. Syst. tom. 3. part. 2. pag..15g. $n^{\circ}$. 106. - Hun. Gcom. tab. '38. fig. 200. Mâle. - Encycl. $p l$. go.jig. 16.

Envergure 3 lig. Anlcnnes et corps d'un blanc januâtre; ailes supéricures de même couleur avec une ligne rose partant de l'angle cxlérieur et venaut aboutir an milien du bord interne. Bord antérieu: ayant des nuances roses, surtout ver's sa base. Les intéricures et le dessous des quatre pluz pâles; le trait rose des supérueures à peine dislinct: Nikile.

Euvirons de Paris.

b. Antennes simples dans les denx sexes,

21. Phatine triple raie, P.plagiata.

phalona alis integris, incumbentibus, griseis; 


\section{P H A}

superiorum fasciis tribus tristrigatis fiscis lineolâque ad angulum exteriorem fusco-ferngined.

Phalana plagiata. LrNv. Syst. Nat. 2. 869 . 248. - Huв. Geont. tab. 4:. fig. 220.-Fhalwna duplicata. $\mathrm{F}_{\mathrm{AB}}$. Iint. Syst. tom. 3. part. 2. pag. J g3. $\pi^{\circ} \cdot 254$ - La Rayure à trois lignes. Geofr. Ins. Paris. tom. 2. pag. 148. no. 78 .

Fnvergure $5 \mathrm{lig}$. Antennes brunes, corps gris. Ailes supérieures d'un gris de sounis avec un petit trait brun râlé de ferrugineux s'avançant de l'angle extérieur, et trois bandes plus on moins ondées, composées chaeune de trois ligraes brunes; la bande la plús voisine de la base ayant ses lignes ordinairement moins distinetes. Alles inférieures d'un gris blanchâtre ainsi que le dessous des quatre ailes; un petit point noir peu apparent sur le disque de cliacune. Irange brune enlrecoupée de blanc. Femelle.

Selon Fabricius la Chenille vit sur le millepertuis (Eypericum perforatum). Elle est variée de brun et de ferrugimeux, avec une ligne latérale jaune.

Fort eommune daus les bois des environs de Paris.

\section{Phalène roussâtre, $\boldsymbol{P}$. centumnotata.}

Phalwna alis integris, incumbentibus, superiorum basi fuscâ rufo-unistrigat $\hat{x}$, medio albido nigro punctato, dehinc firsciù à murgine superiori poncedentifuscâ abbreviat $\hat{a}$ strigis duahus undatis ab ipsâ procedentibus ad unarginem internum perveniente, fasciâ tunc rufescente albido marginatâ ; margine extemo griseo-fusco.

Phalana centumnotata. ГАв. Ent. Syst.tom. 3 . part. 2. pag. 191.no.228. - Geonetru russata. Hus. Geom. tab. 59. fig. 305.

Envergure 12 à 14 lig. Antenues et corps diun brun-roussâlre. Ailes supérieures brunes à la base, presqque jusqu'au tiers de l'aile; sur celle partie est unc bande roussâtre, ensuile la partie noyenne cle liaile est blanche avec un point noir, puis vient une bande brune assez large, descendant du bord antérieur et n'alteignant gruere que la moitié de l'aile, cetie bande se continuant par deux lignes ondées brunes qui parriennent au bord iuternc. On voit ensuile une bande ronsse bordée de blane; le bord de l'atile est d'un gris-brun. Ailes inférieures gris-blanchâtre avec une ligne transverse blanchâtre peu apparente; plus près du bord extéricur est une autre ligne de points ßblancs. Frange des ailes roussâtre, piécédée d’une ligne brune. Dessous des quatre ailes plus pâlı; on remarque sur cluacune quelque ligues brunes et un point noir. Mále et fenclle.

Environs de Puris.

23. Phaliene Pie, $\boldsymbol{P}$. procellata.

Phalana alis integris, incumbentibus, supe- rörum basi fuscâ, medio abbo, dehinc foscita lutầ à margine superiori procedenti nigro-fuscẩ abbreviatấ strigis duabus vel tribus undatis'ab ipsâ procecientıóus ad nuargincm internum perveniente, nuarginis externifusci strigâa undatâ et maculâa mognầ aibis.

Phalana proceliala. FAB. Ent. Syst. tom. 3. part. 2. pag. 185. no. 20 I. - Hu B. Geom. tab. 48 . fig. $2 \check{5} \mathrm{I}$.

Envergure 44 à 5 ligg. Antennes, tête et dessus da corselet brums; on dessous blatac ainsi que l'abdomen. Ailes supétieures blanches à base noire, ayant apres un iniesvalle, une bande noirâtre assez la:ge qui n'atteist que la moilié de l'aile, mais qui se continue jusquiau bord interxe par deux ou trois ligenes ondées de même conlenr; bord extéricur assez large, brun, ayant une ligne ondée el dansson nilie: une grande tacbe de conlenr blanehe. Ailes inferieures blanches, porlant vers leur milieu une pelile lizne trapsversale brune, ondée; lcur bord extérieu: de mèrne couleur. Lu dessous le bord des quatre ailes est comme en dessus; base des supérieures d'un gris-brun s'étendant plus loin que In moilié de l'aile, portant à son bord aniérieur une tache blanche entourée d'un brun plus intense; les inféricures comme en dessus avec un point noir et lat ligne noire ondée mieux marquée. Femelle.

\section{Environs de Paris.}

\section{Phalìne oeellée, $P$. ocellata.}

Phalana alis integris, incumbentibus, superionum albarum basi fusco strigatâ, mediâ parte nigro fusciatầ, fasciá undatâ lat $\hat{\imath}$ ad marginem internum angustati, ocello albo nigro pupillaio notata, maroine externo sapilis fusco.

phalana ocellata. Linn. Sjst. Nat. 2. 870. 258? - HА в. Ent. Syst. tom. 3. part. 2. pag. 188. $n^{\circ} .216$. - Hub. Geom. tab. 48. fro. 252 .

Envergure 10 lig. Antenues et corps diun blancgrisâtre, tachelés de noir. Ailes supérieures J lanches, leur base portant quelques lignes brunes, et lenr milien uve largo bande noire ondée, non dentée, se rélrécissint avant d'arriver an hord interne, plus claire dans son miliev oi elle porie un point noir colouré de blanc; bord extrieur quelquefois brun. Ailes inférienres blanchatres, avec de petites lignes brunes plus op moins nombreuses partant du bord iutcrue et n'alteignant pas le supérieur. Dessous des quatre ailes blanchâtre avec un point noir sur le disque de chacune. Mâle et femelle.

Fabricius dit que la Chenille est brune avec des lignes latérales blanclies.

Environs de Paris. 
25. Parzine de l'Epine noire, $P$. pnenata.

Phalcena alis integris, incumbentibus, subfusco-rufis, superionum basi, dein fasciô undatâ latâ ad marginem internum angustatâ, maculầque semicirculari antè angulum externum fuscis.

Phaloena prunata.Linn. Syst. Nat. 2. $66 \mathrm{~g} .250$. - FAB. Ent. Syst. tom. 3. part. 2. pag. 178. $n^{\circ}$. 175. - Hlub. Geom. tab. 59. fig. 304.

Envergure 15 à 18 lign. Antennes et corps d'un gris-roussattre. Ailes de nême couleur niélće de brun; les supćrieures brunes à leur base, ayant après un intervalle une laroge bande brune ondée diminuaul de largeur en s'approshant du bord interne; sur le bord extérieur vers l'angle supérieur est une taehe demi-circulaire brune mal terininée; les iuférieures portant vers leur bord interne quelques lignes ondćes brunes, qui partent des environs de l'angle anal et n'atteignent pas ordinairement le bord supérieur. Dessous des quatre ailes plus pâle avec quelques lignes et des points de couleur brune. Mầle et femelle.

Suivaut Fabrieins la Chenille est cendrée avec un collier noir, des taches dorsales et les pattes rousses.

Trìs-commune aux environs de Paris dans les bois et les jardins.

\section{Phalèxe Geai, $P$, coraciata.}

Phalona alis integris, incumbentibus, superioribus griseis atomis virescentibus sparsis, basi fasciâque griseo-viridi ad marginem internum angllstatâ , marginis virescentis striga $\hat{a}$ undatâ punctorumque nigrorum ad finbritum serie. 278 .

Geometra coraciata. Нив, Geom. tab. 54. fig.

Envergure 12 à $14 \mathrm{lig}$. Antennes grises tachetcées de noir. Tête et eorps d'un gris-verditre. Ailes supérieures grises par'semrées d'atộmes verdâtres, leur base d'un gris-verdátre; elies ont après un intervalle une binde d'un gris-verdâtre qui se rétrécit en allant atteindre le bort inqerne. Bord extćrieur verdatre avec une ligne ondéc blanche, transverşale, et uue rangée'de points noirs précédant la fraugre. Ailesinférieures grises, leur borl extérieur plus ioncé. Dessous des quatre ailes d'un gris-blanchâtre avec un petit point noir discoidal; la hase des supérieures brune; celte couleur s'étendant an-delà du point. Ninle.

Euvirons de Paris.

37. Penzève Perroquet, $\boldsymbol{P}$. miata.

phalcena alis iniegris, incumbentibus, supevioribus griseo-fuscis, fasciầ viriall-fuscâ o tribus approxintatis noiutâ.

Phalana miata. Liss, Syst. Nat, 2, 869. 249.
- Faв. Ent. Syst. tom. 3. part. 2. pag. 180: $n^{\circ}$. 183. - Phalo'na psittacata. HАв. Ent. Syst. tom. 3. part. 2. pag. 195. $\pi^{\circ}$. 238. - Geometra psittacata. Hus. Geom. tab. 43. /g. 227.

Envergure 10 à 12 lig. Antennes grises. Tête et corps d'un gris-verdâtre. Ailes supérieures d'un gris-brun mêlé de verdâtre, leur base plus iuncée. Elles ont après un intervalle, uue bande brune-verdâtre diminuant de largeur avant d'atteindre le bord interne et marquée dans cette partic de trois petits o qui se touchent; en dehors de cette bande et contre son bord, est une taelie blanchâtre contiguë au bord extérieur de l'aile, et une autre semblable au bas de la bande près da bord interne; bord extérieur de l'aile d'un brunverdître portant mue ligne de points blauchâtres. Ailes inférieures d'un gris-brun, leur bord postérieur plus foncé; fringe de toutes les ailes brune entreeoupée de blanchâtre. Dessous dẹs quatre ailes ayant des baudes moins foneées qu'en dessus, tirant sur le jaune et un point noir sur leur disque; ee point peu visible dans les supérieures. Mâle.

Des environs de Paris.

28. Pratène du Caillelait, $P$. galiata.

Phalcena alis integris, incumbentibus, puncto nigro in disco notatis, albidis, superiorum basi fusco-strigat $\hat{a}$, dein fitsciâ ad marginem internum subangustatâfuscâ, marginis externifusci strig $\hat{a}$ undatâ albidâ.

Geometra galiata. Iú. Geom.tab.53. fig. 272.

Envergure 8 lig. Antennes et eorps d'un brunronssâtre. Ailes d'un blanc sale ayant un point noir sur leur disque. Base des supérieures chargée de petites lignes brunes. Eilles ont après un petit intervalle, une bande brune diminuant un peu de largeur avant d'atteindre le bord iuterne. Bord extérieur de l'aile brun avec une ligne ondulée blanchittre. Ailes inférieures clargées de petites lignes bruues, transverses. Dessous des quatre ailes, noir foncć avec le neême point diseoidal qu'en dessus et quelques ligues roussâtres.

Environs de Paris.

\section{PaAlk̀ne ondée, $\boldsymbol{P}$. fluctuata.}

phalona alis integris, incumbentibus, albidogrisescentibus, superionum basi, dein fascid abbreviatâ maculầque antè angulum externum fuscis.

Phalcina fluctuata. Linn. Syst. Nat. 2. 871, 26o. - FA . Ent. Syst. tom. 3. part. 2. p. 135. $n^{\circ}$. 203. - Нив. Geom. tab. 48 . fig. 249 .

Envergure $8 \mathrm{lig}$. Antennes grisûtres. Corps gris taebé de brun. Ailes d'un gris-blanchâtre chargées de petiles lignes brines ondulées. Base des supéricures bru.se. Elles ont après un intervalle, une bande brune qui finit en se rétrécissint, au miliea 


\section{P I A}

de l'aile; ensuile d'un autre intervalle vers l'ingle supériem est un eommencement de bande ou plutôt nue taehe brune conigguë au bord antérieur. Dessous des quatre ailes gris avec nne binde transversale dans leu milieu, d'un grisplus elair. Frange de toutes les ailes blancluâlre, narquéc de poin's bruns tant en dessus qu'en dessons. Wiâle.

Commune aux environs de Paris clans les jardins.

\section{Phatène double ligne, $P$. bilineata.}

- Phaikena alis integris, incumbentibus, flavis, superiorum singis undutisfuscis multrs, albrdis, tribus.

Phalona bilineata. Linv. Syst. Nat. 2. 868. 245. - $\mathrm{H}_{\mathrm{AB}}$. Ent. Syst. tom. 3. part. 2 . pag. 186. no. 206. - Huв. Geom. tab. 5 j.jg. 264 . - 1, al Brocalelle d'or. Geoff. Ins. Paris. tom. 2. p. 145 . $n^{\circ} .68$.

Envergure ro lig. Antennes grises. Têle et corps jaunes. Ailes supérieur's jaunes, leur base cliargée de lignes ondées brunes; rel espace le:miné par une peiile ligne blanche ondulée. Elles ont aprè. un iulervalle, une bande pius foneće, șe rétrécissant en s'approchant du bord interne et terrninée des deux côlés par une ligne blanche ondulée; le nilieu de eetre bande plus cluir clargé de petites lignes irrógulières brunes. Franğe brane mêlée de gris. Ailes inférieures jaunes chargées de petites lignes brunes transverses; une médiale plus apparente accompagrace d'une ligne blanche qui eu suit tous les eontours. Hessous des quatre ailes juunatre avee un petit point noir discoidal et quelques lignes brunes ondées dont la plus snarquée est vers le nilieu, Le mâle a une ligne de poinis blancs près du bord extérieur des quatre ailes et le dessous paroît avoir deux lignes brunes plus marquées. Màie et femelle.

Cluenille verte, presque saus taches, portant quelquefois des lignes blanches. Vit sur la lyclinide compaguon (Lychnis dioica) suivant labricius.

Très-commune anx eavirons de Palis dans les prairies el jardins, ete.

\section{3i. Phalène fúve, P. fulvata.}

Phalona alis integris, incumbentibus, superiorum lote flavarum strigis duabus ad basim aurantiacis, dem fasciâ subirregulari ad marginem internum angustatâ. fuschi.

Geonetrafulvata. Hu в. Geom.tab. 57.fig. 297 . - Phalana socrata. FАв. Ent. Syst. tom. 3. pait. 2. pag. 198. $n^{\circ} \cdot 253$.

Envergure 6 à $8 \mathrm{lig}$. Anténnes et corps jaunâtres. Ailes supérieures d'un beau jaune; près de leur base sont deux petiles lignes orangées; on voit, après un iutervalle, une bande irrégulièrs brune se rétrécissant en s'approchant Hist. Nat. Ins. Tome $X$.
Ju bord interne; le milieu de cetle bande plus clair; vers le bord extéricur une lache flus clatic bortée de binn occupe la inoilié de l'angle supérieur. Ailes inférieures d'un llanc-jaunàtre à frange jaune. Dessous assez senblable au dessus, mais plus páfe, ayant la bande moins distincte. Mîle.

Trís-commnne anx environs de Paris dians les jardins, sur les rosiers, dout se vourit probablement la chenille.

\section{Pracine de la Ronce, $P$. abicillata.}

Phalana alis integris, incumbentibus, albis,

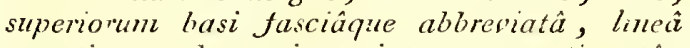
punctisque ad marginem internum continuatâ, et margine exterionifusco-nigris.

Phalana albicillata. Lixv. Syst. Nat. 2. 870. 255. - FАB. Eut. Syst. tom. 3. part. 2. pag. 182. $n^{\circ}$. 19o. - Hus. Geom. tab. 15. fig. 76. Lam. Geom. aquiv. L. a. $n^{\circ} \cdot 2$.

Envergure ro à 12 lig. Anlenneshrunes. Conps brun en dessus, blanc en dessous. Ailes blanches, les supérieures brunes ì leur base; ayant après un grand inlervalle une bande brune quifinit vers le liers de l'aile et se eontinue jusqu'au bord interne par une ligne ondée brune el des points de nćme eouleur. Bord extérieur brun séparé de la bande par une ligne blanche iræégulière. Bord des ailes inféricures brun. Dessous des qualre ailes blanclrátre, leur bord brun, celai des supérienres surtout. Un point noir sua le disque de chaeuse. peu visible en dessus. Mâle et femille.

Elle varie beaueoup par l'iutensité et l'éfendne des taches.

Chenille verte à bande labrírale blanehe, avce des raehes dorsales luuulíes ferrugineuses sur les segmens intermédiaires du corps. Vit sur la ronee et le framboisier.

Des environs de Paris.

\section{Prariexc du Fusain, $P$. adustata.}

Pllalcinci alis integris, incumbertibns, albis, supeiriorum basi fasciâyue sinuatâ et marginis extemi maculis fuscis.

Phalina adustata. FАв. Ent. Syst.tom. 3. part. 2. pag. $187.72^{\circ}$ 10. - IIus. Gcom. tab. I5. fig. $7^{5}$. Larv. Geom. aequiv. L. a. no. I.

Envergure $3 \mathrm{lig}$. Antennes, tête et corselet bruas. Abdomen blanchâtre. Ailes blanches, les stapérieures bruues à lenr base ayan: après un grrand intervalle, use bande brune sinucuse. Bord extérieur apròs cette ligne, plus ou moins marcjué cie brun. Ailes in lé:ieures marquées de quelqueslignes brunes per visibles. Dessons des quatre ailes blanelâtre avec des lignes brunes. Mále et femclle:

Chenaile verte a ligrne latérale blanche ot points 
rouges sur le dos. Vit sur le fusain. (Evonymus eturopacus.)

Eevirons de Paris.

\section{Phalìne de la Fougère, $\boldsymbol{P}$. flicata.}

Phalona alis integris, incunbentibus, à basi ad dinnidium nigris, posted albis strigis transversis griseis, puncto in singulâ dzscoidali nigro. 238.

Geonetra filicata. Нив. Geom. tub. 46. fig.

Envergure 4 it 5 lig. Antenves et corps roussârres. Ailes noires de la base presque jusqu'à la moitié, le reste blanc avec de petites lignes transverses, grises. Elles ont un point noir discoïdal tant en dessus qu'en dessous. Dans les inférieures la eonleur noire est plus claire. Dessous des quatre ailes grisâtre.

Environs de Paris.

\section{Phalène troublée, $\boldsymbol{P}$. turbata.}

Phalona alis integris, incuinbentibus, superiorum nigrarum ad basin strigis tribus gziseis, fasciâ posteà albâ undatî nigro unistrigatâ. 255 .

Geonnetra turbata. Huв. Geonl. tab. 49. fig.

Envergure to lig. Antennes noires. Tête et corps d'un bruı-noirâtre. Ailes supérieures noires chargées de lignes grises à leur base; vers le bord extérieur an-delà du milieu est une bande blanche ondulée portant une ligne noire et allant sans se rétrécir du bord antérieur au bordinterne. Ailes inférieures blanchâtres, leur bord postérieur plus ou moins brun. Frange de toutes les ailes noire entreeoupée de brun. Dessous des quatre ailes blanc portant plusieurs taclies noires, smitout vers les bords extérieurs. Un point noir discordal sur les inférieures tant en dessus qu'eo dessous. Femelle.

De France.

36. Phalìve oebracée, P. siluceata.

Phalana alis integris, incumbentilisus, superioribus fuscis, fasciis duabus albidis, externâ strigis duabus, unâ nuculari fuscis, margine exteriori albido fusco binuaculato.

Geonetra silaceata. Нов. Geont. tab. 5g. fig. 3o3.

Envergure 1o lig. Antennes noires. Tête et corps grisâtres. Ailes supérieures d'un bıun vineux, a vee une bande blanchâtre placée environ au tiers de l'aile, chargée de traits et de points bruns. Au-delà du milieu est une autre bande de même couleur portant une ligne brune. On voit après, une suite de taches de la couleur du fond; bord extérieur blaneliâtre, a vec deux taehes d'un brun vineux. Ailes inférieures grises ayant de petiles lignes brunes, transverses, vers leur bord extérieur. Dessous des quatie ailes gris avec de petites ligues et des points peu distincts, de couleur brune; nn point discoïdal sur chaque aile, tant en dessus qu'en dessous. Frange grise entrecoupée de brun. fiemelle.

De Franee.

\section{Phalène rougeâtre, $\boldsymbol{P}$. rubidata.}

Phaloena alis integris, incumbentibus, superioribus griseo-rubidis basi grised̀, fusciá ad nuedium alteruque post medium abbréviatâ nigris.

Phalcena mbidata. FAn. Entom. Syst. tom. 3. part. 2.pag. $180 . n^{\circ}$. 184.-Huв. Geom. tab. 56. fig. 290.

Envergare $10 \mathrm{lig}$. Antennes noires; tête et eorps rougeâttres. Ailes supérieures rougeâtres, lenr base brune mêlée de gris, bordée d'une petite ligne blinclie; vers leur milieu esi une bande voire terminée en dedans par une ligne blanclie; après un intervalle on voit une autre bande nuire n'atteignant que le inilieu de l'aile et se continuant jusqu'au bord interne par des lignes ondnlées. Borà extérienr de l'aile grisâtre, bordé de noir avant la frange. Ailes inférieures et dessous des quatre gris avee des lignes brunes peu distinctes. Un point noir discordal sur toutes, tant eu dessus qu'en dessous. Femelle.

De France.

\section{PaAline de la Linaire, $\boldsymbol{P}$. linariata.}

Phaloena alis integris, incumbentibus, superioribus griseo-rufis, fascià fiuscâ à margine superiori procedente, ad marginem internum angustata, marginis exterioris fusci striğ â albidi.

Phalona linariata. FAB. Ent. Syst. tom. 3. part. 2. pag. 190. $n^{\circ}$. 224. - Huв. Geon. tab. 46. fig. 242.

Envergure 4 ì 5 lig. Antennes brunes; tête et eorps d'un gris-roussâttre. Ailes supérieures d'un gris-roussâtre, avec une bande brune vers le milieu qui se rétrécit un peu en s'approchant da bord interne. Bord extérieur roussâtre portant une petite ligne blanchâtre. Ailes inférieures grises ayant une ligne transversale et leur bord extérieur bruns. Dessous des quatre ailes yris, avec une bande blanchâtre bordée de brnn; un poin diseoïdal sur toutes, visible seulement en dessous. Femelle.

Selon Fabrieius la Chenille est jaune, à taches dorsales et pattes rougeâtres. Vit sur la linaire. ( Anthirrhinum linaria.)

Environs de Paris.

39. Phaline de l'Alisier, P. cratogata.

phalcena alis integris, incumbentibus, luteis 
strigis punctorum punctisque griseis et maculis ad basim unarginemque superiorem ferrugineis.

Phalcena cratorgata. Linn. Sy'st. Nat, 2. 868. 243. - Fab. Ent. Syst. เont. 3. part. 2. pag. 178. $n^{\circ}$. 776 . - La Citronelle rouillée. G sofr. Ins. Paris. tont. 2. pag. I39. no. 59.-Geometra cratogaria. Hus. Geont. tab. 6. fig. 32. Larv. Geom. ampliss. F. a. $n^{\circ}$. 1. et F. a. b. $n^{\circ} .2$.

Envergure 15 is 16 lig. Antennes ferrugineuses, brunes en dessus. Têle ei corps jaunes. Ailcs jaunes lant en dessus qu'en dessous, portant des points grisâtres plus ou moins disposés en ligne; les supérieures ayant une tache ferrugineuse qui occupe la moitié de leur angle supérieur et touche au bord autérieui, lequel porte encore qnelques taches de même couleur, dout une plụs renarquable à la base de l'aile; on voit une tache blanche entourée de brun piès de ce mème bord; celte tache reparoît en dessons, mais presqu'entièrement brune. Ailes inférieures ayant un point noir discoïdal tant en dessus qư'en clessous. Mâle et femelle.

Le mâle a les antennes un peu élargies, mais non pectinées : donc $M$. Huibner a eu tort de terminer le nom spécifique en aria. Il a encore cornmis cette fante pour quelques autres espèces.

Chenille souvent brune ou verte, mais très-vaviable pour les coulenrs, portant sur le dos des inbercules, dont denx placés à côté l'un de l'autre. Vit sur l’aubépine (Mespillss oxyacantha) et sur l'alisier. (Cratogus aria.)

Commune aux environs de Paris.

40. PhaLène du Cerfeuil, P. charophyllata.

Phaloena alis integris, incumbentibus, fusconigris, superiorum ad angulum superiorem fintbriâ albâ.

Phalona choerophyllata. Linn. Syst. Nat. 2. 866. 237. - FАв. Entom. Syst. tom. 3. part. 2. prag. 184. $n^{\circ} .200$. - Hü. Geom. tab. 38. fig. 196.

Envergure io lig. Antennes noires, annelées de blanc. Corps et ailes d'un brnn noir couleur de suie. Frange de l'angle supérieur des premières ailes, blanche. Mâte et feinelle.

Nota. linné dit que cette Phalène porte ses ailes relevées dans l'état de repos. Suivant le même auteur la Chenille est verte, glabre, et vit sur le cerfeuil sauvage. (Charophyllum syluestre.)

De France. Je l'ai prise à Spa dans les montagnes.

41. Phalìne à six ailes, P. scixaluta.

Phalona alis integris, incunubentibus, griseofuscis, superionum fasciis tribus albidis olivaceo strigatis, nargine strigâ undatâ albi đâ griseo; inferiorunt margine interno ad basim duplicato.

phalarna sexalata. RETz. DE GËER, Gen. ot

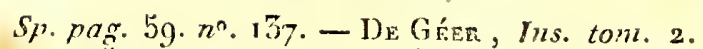
pag. 459. no. 9. pl. 9. fig. 6-9. - Hu B. Geom. tab. 44. fig. 228. Mẩle. Laro. Geon. oquiv. (i. a. b. no. r. al b. - La't. Dict. d'Hist. nat. y ${ }^{\mathrm{re}}$ éd. tom. 17. p. 3 go.

Envergure 8 lign. Antennes bruues. Tête et corps gris tachetés de brun et de noir. Ailes d'un gris. brun; les supérieures ayant trois bandes blanchatres portant chacune une ligne d'un jause foncó tirant sur l'olive. Bord extérieur d'un gris plus clair, a vec une petite ligne ondée blanchàtre peu distincte. Ailes inférieures moins foncées que les autres, surtout vers leur base. Dessous des quatre ailes gris avec des lignes ondées brunes et ua point noir discoïdal.

Le mâle porte un appendice en forme de petite aile ovale, garni tout antour d'une frange de poils, inséré vers la base du bord intérieur des secoudes ailes, plié en double, conché dans le repos entre celles-ci et les ailes supćrieures, et se développant dans le vol.

Chenille d'un vert pấle rayée de blanc, à tête refendue. Elle porte deux pointes horizontales sur le dernier segment du corps. Vit sur le saule et subit sa métausorplıose en terre.

Se trouve en Europe.

\section{Phalène hexaptérale, $P$. hexapterata.}

Phalena alis integris, incumbentibus, superioribus griseo fuscoque alternè fasciatis, sírigisque undatis albidis et puncto discoidali nigro; inferiontm margine interno ad basim duplicato.

Phalona hexapterata. FAB. Ent. Syst. tom. 3. part. 2. pag. 193. $n^{\circ}$. 233. Mâle. - Huв. Geom. tab. 44. fg. 232. Mâle.

Envergure 1o lig. Antennes et corrs bruns. Ailes supérieures ayant des bandes alternativement grises et brunes, ordinairenıent traversées par des lignes ondées, blanchâtres et marquées d'un point noir discoidal. Ailes inférieures blanchâtrrs, leur bord extérieur tirant sur le gris. Dessous des quatre ailes a vec un point noir sur leur disque. Mâle.

Le màle a aux ailes inférieures un appendice conformé et placé comze celui de l'espèce précédente.

Se trouve en Europe.

Nota. Nous n'avous point vu ces deux dernières Pbalènes.

$2^{*}$. Subdivision. Ailes étendues horizontalement dans le repos.

A. Antennes simples dans les deux sexes.

Nota. Antennes des mâles un pen velues sur l'un de leurs côtés ou même snr tous les deux. 
43. Pafalèn du Groseillier, P. grossu'ariata.

Phalona alis integris, patulis, albis nigroque maculatis, superiorum fasciis duabus luteo-ferrugineis, prinâa baseos breviort, secundâ sinuGłâ marginem anteriorem non attingente.

Phaloena grossulariata: Linv. Syst. Nit. 2. 867. 243. - FAB. Entom. Syst. tom. 3. part. 2. pag. $174 . n^{\circ} .162 .-$ Geonictra grossulariaria. IIun. Geoun. aub. 16. fig. 81 et 82. Lan. Geom. ampl. O. a. b. $n^{\circ}$. 2.-La Moluchetée. Grorf. Ins. Paris. tom. 2. pag. $136 . n^{\circ}$. 56. - Encycl. pl. 89. fig. $4-8$.

Envergure 16 ì 18 lig. Antennes et têle noires. Corselet et abdomen c'un jaunc-ferruginęux taché de noir. Ailes blanches, les supérieures ayant deux bandes d'un janne-ferruginenx, entources de taches noires plus ou moins réunies; la première bande très-courte, posée près de lia base, lu seconde sinueuse, placée au-delà du milieu de l'aile, n'atteignant pas tout-à-filit le bord antérieus. Entre ces deux bandes on voit quelques taches noires; une ligne de semblibles taches borde le contour de toutes les ailes; les inféricures ont anssi qnelques-unes de ces taches sur lenr disque. Dessous des quatre ailes semblable au dessus, it l'exception des bandes ferrugineuses. Mâle et femelle.

Clienille d'un gris un peu nacré ayant des taches noires sur le dos de forne irrégulière, nélúes de pelites lignes ferrugineuses, avec une ligne liztérale de celle dernière conleur bordée de points noirs. Elle vit sur les gुroseilliers (Ribes grossularia, alpinum et uva crispa), et lie ensemble à la surface de la terre quelques débris de feuilles sèches dans lesque!s elle se change en chrysalide. Celle-ci est noire avec les inlervalles des sermens de l'abdomen, d'un jaune-ferrugineux.

Commune aux environs de Paris.

\section{Phalène méridionale, P. pantata.}

Phalcena alis integris, patulis, albis, superiorurn basi feruuginea et fuscia punctorum fuscoferrugineorum, lineolis discoidalibus binis; abdominis luteo-ferruginei maculis nigris, lateralibus pupilli ferruguneâ ącellatis.

Phalcena pantaria. Linn. Syst. Nat. 2. E63. 218. - Huв. Geom. tab. 16. fig. 84.

Envergure s 5 à 18 lig. Antennes, tête et corselet d'un jaune-ferrugineux: Abdomen de même couleur cbargé de taches noires, les unes dorsales pleines, les autres ocellćes à prunelle ferrugineuse. Ailes blanches, la base des supérieures ferruginense, bordée d'un neu de brun; on voit une baude placée au-delà du milieu, composée de deux linnes de points d'un brun-ferrugineux, dont plusieurs se réunissent en une assez grande tache veis. le bord interne; le disque de l'aile porte denx petils traits bruns. Ailes inféricures blanches avec une bande semblable à relle des supérieures. Dessous des quatre ailes pareil au dessus, mais les taches y sont d'un brun pur. Vâle et femelle.

Du midi de l'Europe.

\section{Phaténe de l'Orme, $P$. ulinata.}

Phalona alis integris, patulis, cilins, superiorum basi fuscè fèmginea sericque post medium punctorunn fuscorun genninorum et narginis inteini unaculâ fuscè feruginéa, alterâque externi fuscâ.

Phaluena ulmata. Fab. Ent. Syst. toun. 3. part. 2. pag. 1.76. no. 171. - Geometra ulmaria. Hos. Geom. tab. 16. fig. 85. et tab. 76 . fig. 39 1 et 392 . Laro. Geonu. ampliss. O. a. b. no. 1 .

Envergure r 2 ì 14 lig. Antennes fanves. 'Tếte et corselet d'un janne-ferrugineux. Abdomen de même couleur avec des taches noires sans prunelle. Ailes hlanches, la base des supérieures ferrugrineuse mêlée de brun; on voit une bande placée au-delà du milieu conposée de points bruns, posés comme denx à deux et dont la plupart se confondent; "relte bande se termine vers le bord interne par une grande tache brune mélée de ferrugineux. Entse la base de l'aile et la bande, prés du bord antérieur est une assez grande taclie brune et d'antres petites placécs plus bas. Bord extćrieur de l'aile brun, cet!e couleur s'élargissant dans le milieu. Ailes inférienres blanches avec une ban?e scmblable à celle des supérieures et deux taches brunes sar lenr disque. Dessuns des quatre ailes pareil an dessus, nais sans nuances ferrugrinouses. Màle et lemelle.

(chenille cendréebleuâtre chargée de petits Inbercules noirs ayec une ligne dorsale jarne bordće de blanc et une autre latérale de même couleur bord'́e de points noirs. Vit sur l'orme.

l'eu commune aux environs de Paris.

\section{Pualière liastée, P. liastata.}

Phalona alis integris, patulis, nigris, fasciût labyrinthifonni albà apucibus pluribus hastatis.

Plialoena hastata. Livv. Syst. Nat. 2. 87o. 254. - FAB. Ent. Syst. ton. 5. purtie 2. p. I82. $n^{\circ} .192 .-\mathrm{DE} \mathrm{GÉ}_{\mathrm{ER}}$, Ins. tom. 2. pag. 455. $n^{\circ} .8$ : pl. 8. fig. 19 et 20. - Нив. Geom. tab. 49. Jig. 256. - Encycl. pl. go.fig. I.

Envergure 10 à $12 \mathrm{lig}$. Antennes noires fine= ment annelécs de bianc. 'Tête et corps noirs parsemés de taches blanches. Ailes noires traversées par une bande irrégulière blanche, quí clans les quatre ailes pénètre le bord noir sous la forme d'un fer de hallebarde à trois pointes et qui se joint plus ou moins à dilïrentes lignes blanches très-irrégulières qui pénètrent la base noire des 


\section{P II A}

ailes. Cette bande blanche porte assez souvent quelques points noirs; au-dessus de la tache en hallebarde il y a une perie ligne blanche ondulée qui va rejoindre le bord antérieur de l'aile dans les supériemres seulement, et dans toutes les quatre on roil des points blincs au-dessons de la mîne lache. Frange des ailes noire, entrecoupéc de blanc. Dessous entièrcment semblable au riessus. Hâle et femelle.

Cette Phalène varie beancoup.

De Géer a tronvé la Chenille sur le boulean. Elle est d'un bruı-noir et porle sur chaque segment excepté les trois preıiers et le dernier une ligne latéıale de taches circulaires nn peu saillantes de coulcur feuille morte, ainsi que ses pattes membranenses qui ont en oulre une raie longitudinale brune. Les segmens du corps ont des rides transversales et lears incisions sont profondes. Celte Chenille plie une feuille exactement en deux en allachant ses bords avec de la soie. Elles'y enferme et n'en mange que le pitrenchyme supérieur. C'est entre des feuilles réunies par des fils de soie qu'elle subit sa métanıophose. On la trouve quelquetois sur l'arbre ì la cire. (Myrica cerifera.)

D'Europe. Assez rare aux environs de Paris.

\section{Pinalène triste, P. tristata.}

Phalona ais integris, patulis, nigris albo strigatis, superiomm fasciis duabus, inferionm unuc $\hat{a}$ nigro punctatzs.

phalcena tristata. Live. Syst. Nat. 2. 869 . 252. - Fа . Ent. Syst. toin. 5. purt. 2. pag. 133. $n^{\circ}$ 193. - Huв. Geom. tab. 49. fig. 254. Encycl. pl. go.fig. 2.

Envergure 8 à 9 lign. Antennes n. ires. 'Tète et corps d'un noir mélangé de gris. Ailes noires; les supérieures ayant deux bandes blanches et les inférieures nue seule que parcourt une ligne de points noirs; les parlies noires des ailes supćrienres porlent des lignes blanches ondées et quelques points de celte coulent. Dessous assez semblable an dessus, mais aynt plus de blanc. I.es quatre ailes ont un poin! noir discoidal isoins distinct en dessus qu'en dessous. Frange des ailes noire entrecoupée de blanc. Mâle e t fernelle..

Linné dit que la Chenil!e vit sur le houlean à peu près de la même manière que la précédente.

De France.

48. Pealine margince, $P$. marginate.

phalona alis integris, patulis, albis margine onuni nigro interius lobos emitiente.

Phalana marginata. Liñ. Syst. Nat. 2.870. 257. - FAв. Ent. Syst. tom. 5. pag. 180. no. 182. -La Bordure entrecolpće. Grofs. Ins. Paris.

tom. 2. pag. 1.ing. no. 6.- Geometrat pollutoria, navaria, marginario. Muв. Geam. Lab. $15 . j \mathrm{jg} \cdot 77$. 79 et 3o. - Encycl. pl. 89. fig. 17.

Envergnue 8 à 10 lig. Antewnes, tèle et corps brums. Ailes blanclies ayant leur bord extéricur - noir. Dans les supérienres le bor? antérieur est toujours deux fois interrompu, la conleur noire sétend plus ou moins et en différentes formes dans l'intérienr des qualre aliles. Frange noire. Dessous semblable au dessus. Mille et femelle.

Les individns que nous avons sous les yeux étan internédiaires entre les trois espèces figurées pau M. Iiabner, nous nous croyons autorisés à réuniä celles-ci cr une seule.

Chenille verle ayant tantôt les segrmens séparéa par de peliles lignes blanches, tantôt une ligne Lilanche latérale. Vit sur le noiselice ou sur la \{remble.

Environs de Paris.

49. Phalexe ornce, $P$. ornata.

phalcna alis integris, palulis, albis, puncts discoidali nigro, marginns externi serie duplici punctormm fusconm, internầ lobos duos enitiente.

Phalcena ormata. FА . Ent. Syst. tom. 5. part. 2. pag. $20 \mathrm{I}$. $n^{\circ} \cdot 262$. - Geometra ormatoria. Huв. Geom. $t a b \cdot 14 \cdot f g \cdot 70$.

Envergure 8 ligr. Antennes rrises. 'Têle et corps blanchâtres. Abdomen mêlé de gris; les quatre ailes blinches avee nn point noil discoidal; leur bord extérieur portaut deur lignes ondées dé laches grises qui se contondent sonvent ensemble, l'intérienres'avançant deux fojs sn chaque aile et bordéc dans cet endroit par nue petile ligne noire, ondée. Dessous des supérienres lrun vers la bise; le resle secililable au dessus. Frange blanche ondée de gris. Nác et fenclle.

Environs de Paris.

5o. Р'galìne salinée, $P$. temerata.

Plalana alis interris, patulis, albo-sericeis, puncto discoidali nigro, superiorum maculà submarrinali físcâ albo strigatâ.

Phalona punctata. lis. Ent. Syst. tom. 3. part. 2. pag. I 97. $n^{\circ} \cdot 248$ ?" - Geomelia tementria. Hu b. Geom. tab. $17 \cdot f_{g} \cdot 9^{1}$ ct tab. $73 \cdot f i g \cdot 370$. et 377 .

Envergure 8 a so lig. An!emes grises. Túte et corselet blanes. Abdomen d’un biane-grisâtre. Ailes d'un lilane saline, ayant cn dessis et ea desscus un point noł discoñal. Les sapérieures marquées vers leur hord extérienr d'une tache grise on noilâke alongée, irrégulière, plus an moins étendue, traversée par une peliteligne on dée, blanche. Les inférieures avec quelques ! igves Iransverses grises, peu distinetes; le bord qui précède la lirayge est chargé de netices ligues 
noires. Frange blanche. Dessons des quatre ailes entic̀rement d'uu blanc sutiué. F'emelle.

Luvirons de Paris.

5.. Phanèxe ì deux taches, $P$. taminata.

phalcena alis integris, patulis, albis, superionim margine externo fusco bimaculato, omniunu serie duplici atomorum fiscorum transversâ.

Geometra taminaria. Hus. Geom. tab. 17. fig. 90 .

Envergure 8 à ro lig. Antennes grises. Tête et corselet blanes. Abdomen d'un gris roussatre. Ailes blanches; bord antérieur des supérieures portant deux taches brunes plus ou moins grandes de chacune desquelles descend une petite ligne de points de nềrne couleur presqu'imperceptibles, qui parcourt les guatre ailes. Un point noir discoidal sur toules les ailes, mais peu sensible. Dessous des quatre ailes semblable au dessus. Femelle.

Eavirons de Paris.

52. Phalène maculée, $P$. maculata.

Phalona alis integris, patulis, fulvis, nıaculis atomisque numerosis nigris.

Phalona maculata. Faв. Ent. Syst. tom. 3. part. 2. pag. 196. $n^{\circ}$. 244. - Plualana machluria. Livn. Syst. Nat. 2. 862. 213. - EsPER, tom. V. Hhal. Geom. tab. XXIII.fig. 2 et 3. - Hun. Geom. tab. 25. fig. 135. Larv. Geom. ampliss. V. b. c. $n^{\circ}$. 1. - La Phalène panthère. Geoff. Ins. Paris. tonl. 2. pag. 140. $n^{\circ} .6 \mathrm{I}$.

Envergure 10 à $12 \mathrm{lig}$. Antennes noires. Tête et corps d'un jaune-grisâtre. Ailes d'un beau jauue, chargées tant en dessus qu'en dessous d'atônes et de taches brunes dont plusieurs se réunissent quelquefois. Frange noire mêlée d'un peu de jaune. Màle et femelle.

Nota. Esper s'est trompé en altribuant dans sa figure 2 des antennes fortement pectinées au mâle de cette espèce.

Chenille d'un vert d'eau marquée de petiles lignes blanches, longitudinales. Vit sur le Lamium purpureunz suivant Hübner.

'Très-commune en France dans les prairies.

\section{Phalène à harreaux, P. clathrata.}

Phalcena alis integris, patulis, fonvino albidis, maris lutescentrbus, lineis clathratis atomisque nigris.

Phalana clathrata. Linn. Syst. Nat. 2. 867 . 238. - Fas. Ent. Syst. tom. 3. part. 2. p. 183. no. 194. - Geometra clathraria. Нив. Geom. tab. 25. fig. 132. - Les Barreaux, Georr. Ins. Paris. tom. 2. p. $135 . n^{\circ} .53$.
Envergure jo à $12 \mathrm{lig}$. Antennes brunes tachetées de blanc. Tête et corps bruns. Abdomen annelé de blanc. Ailes à fond b!anc chargré d'atômes bruns et de lignes irrégulières gui se croisent presque toutes à angles droits. Dessons parcil au dessus. Frange entrecoupée de brus et de blanc. Dans le mâle le fond des ailes est jauuâtre. Mâle et femelle.

Extrếmement commune aux environs de Paris, notaminent daus les prairies.

54. Phalène maillée, P. undulata.

Phalona alis integris, patulis, griseis, strigis undatis rufo-fuscis, octuvá à basi catenulaiâ.

Phaloena undulata. Livv. Syst. Nat. 2, 867. 239. - FАB. Ent. Syst, tom, 3. part. 2. pag. 175. no. 165. - Нив. Geom. tab. 51. fig. 262.

Envergure I 2 à i 5 lig. Antennes brunes. Tête et corps d'un gris-loussầlre. Ailes grises convertes en dessus de lignes très-iapprochées, très-ondulées, d'un brun-roussâtre dont la buitième à partir de la base (dans les supérieures) est composée d'anneaux oblongs comme une chatinelte; on remarque un point discoidal sur chaque aile, oculé en dessus, plein en dessous. Dessous des quatre ailes blanchâtre avec des lignés moins distinctes. Femelle.

Assez rare aux environs de Paris.

55. Phalène pâle, $P$. pallidata.

Phaloena alis integris; patulis, lutescentibus, fusco multistrigatis.

Geonetra pallidaria.Нuв.Geonı.tab. 18.fig. 96 .

Envergure 5 à 6 lig. Antennes, tête et corps fauves. Ailes d'un fauve-jaunâtre, chargées surtout dans leur mo:tié postérieure, de lignes plus foncées, transversales, peu ondées. Dessous semblable au dessus ayant les lignes transversales pius distinctes. Mâle.

Environs de Paris.

56. Phalìne côte-rousse, $\boldsymbol{P}$, osseata.

Phalcena alis integris, patulis, albidis, puncto discoidali nigro strigisque fusco-rufis, unicâ ante punctum et margine exterioriferrigineo.

Phaloena osseata. Fав. Ent. Syst. toni. 3. part, 2. pag. 204. $n^{\circ}$. 276. - Geometra ossearia. Нов. Geom. tab. 19. fig. 102.

Envergure $6 \mathrm{lig}$. Antennes, tête et corps grisâtres. Corselet ferrugineux en devant. Ailes blanchâtres avec un point noir discoidal et quelques lignes roussâtres peu distinctes dont une seule précède le point, les autres avoisinant le bord pustérieur. Bord anterieur entic̀rement ferrngineux. Dessous des quatre ailes gris. Mâle,

Des environs de Paris, 


\section{P II A}

57. Phalène blauche, $P$. dealbata.

Plialona alis integris, patulis, albis, nerpuris fiuscis.

phalana dealbaia. Linn. Syst. Nat. 2. 87o. 256. - FА в. Ent. Syst. tom. 3. part. 2.pag. 177. $n^{\circ} .173$. - Нив. Geom. tab. 41 . fig. 214.

Envergnre 15 ligg. Antennes noires. Tête. et corps blanes. Devant du corselet jaunâtre. Dessous de l'abdomen ayant trois lignes moires. Dessus des ailes blanc à nervires d un gris-brun, peu marquées; leur dessous de mêue couleur avec: les nervures noires, toutes très - distinctes dans les ailes supérieures. La nervure qui sé ${ }_{i}$ rare la cellule discoidale de celles qui vont au bord postérieur est entourée d'une tache noire; elles ont en outre une ligue noirâtre descendant transversalement du bord antérieur au bord interue. Ailes inférieures ayant un sinus rentrant à leur bord extérieur. Frange blanche précédée d'une ligne noire. Fernelle.

En Allemagne, daus les forêts. Je la dois à M. le comte Dejean qui l'a prise dans les Pyr'éaées.

B. Antennes pectinées dans les mâles.

58. Panlène du Prunier, $P$. prunaria.

Phalcena alis integris, patulis, luteis, fusco bineolatis, disci lunulâ nigrâ.

Phaloena prinaria. Linn. Syst. Nat. 2. 86r. 208. - FAв. Ent. Syst. tom. 3. part. 2. pag. 141. $n^{\circ} .43$. - Esper, tom. V. Phal. Geom. tab. XVII. fig. I-7. - Нив. Geom. tab. 23. fig. I23. Mâle. Larv. Geom. ampliss. H. a. - Encycl. pl. 89 . fig. 2.

Envergure 2 pouces. Anlennes, tête et corps jauues. Ailes jaunes, semées de petils traits bruns, ayant chacune sur leur disque une ligne courbe ou lunule noire. Dessous semblable au dessus. Frange jaune entrecoupée de noir. ha couleur du foud des ailes en dessus, dans le mâle, tire un peu sur l'aurore. Mâle et femelle.

Chenille de couleur très-variable, brune, grise ou ferrugineuse portant à la partie antérieure de son cinquième secrment, une petite épine dorsale; a la partie postérieure du neuvième est une autre épine un peu plus forte, et sur l'avant-dernier, un tubercule. Subit sa métaınorphose en terre.

Des environs de Paris.

59. Phalène du Noiseäer, $\boldsymbol{P}$. corylaria.

Phalona alis integris, patulis, lutescentibus, fasciâ discoidali latâ albido-lutêa, disci lunulâa fuscâ.

Phalcena corylaria. Esper, tom. V. Phal.
Gcom. tab. XVIII. fig. 1-3. - Geometra prunaria. Huв. Geom. tab. 23. fig. 122. Heinelle.

Envergure 2 pouces. Antennes brunes. Tếte et corps jauuâtres. Ailes d'un gris-jaunâtre avec une large bande discoïdale d'un blanc-jaunatre portanl une lunule brune. Les supérieures ayant une tache d'un brun-jaunâtre à leur angle supérieur. Frange des ailes bruse, entrecoupce de jaune. Dessous semblable au dessus. Ailcs du mâle d'une couleur plus fon cée en dessus. Mále et fenielle.

M. Hübner s'est trompé en prenant la femelle de celle espèce pour celle de la Phitiene Prancaric; nous avons sous les yeux mâle et fenelle des deux espèces.

De France.

6o. Phalène du Chêne, $P$. roboraria.

Phalona alis integris, patulis, griseis, suprà atomis strigisque undatis fuscis sparsis, subiils serie punctorum fiscorum marginali.

Phalona roboraria. Fав. Ent. Syst. tom. 5. part. 2.pag. $137 \cdot n^{\circ}$. 28. - Espen, tom. V. Phal. Geom. tab: $X^{\prime} X X I I I$. fig. 1-3. - Нов. Geom. tab. 32. Jig. 169 . Larv. Geom. ampliss. Y. a. $n^{\circ}$. 1 .

Envergure 2 pouces et demi. Antennes et corps bruns. Ailes grises semées d'atomes bruns et roussâtles avec quelques lignes brunes oudées; bord iuférieur des secondes ailes terminé par une ligne de points noirs. Frange grise entremelée de noir. Dessous des quatre aries gris, portant une ligne ondulée formée par des points bruns. Une tache noire à l'angle supérieur des premières ailes. On voit uue lnnule brune discoïdale sur chacuue tant en dessus qu'en dessous. Mâle.

Nota. Dans cette espèce ainsi que dans la suivante, le mâle a les anteuues simples ver's leur extrémité.

Chenille brune mélangée de roussâtre avec quelques tubercules sur le dos. Vit sur le chêne.

Eile a été prise dans les montagnes à Bagnères de Bigorre.

\section{Phalène semblable, $P$. consobrinaria.}

Phalana alis integris, patulis, griseis, supn atomis strigisque undatis fuscis sparsis, puncto discoidali fusco, subtùs strzgâ marginalifusconigrâ.

Geometra consobrinaria. HuB. Geom. tab. 29. fig. 152 .

Envergure 18 à 24 lig. Antennes noires variées de blanc. Tête et corps d'un brun-roussâtre. Ailes grises chargées d'atômes bruns et roux et de cuelques lignes ondées de même couleur; deux de ces lignes dans les ailes supérieures s'écartent l'une de l'autre en s'éloignant du bord antérieur et se rap- 
prochent vers le bora iuterne. Les guatre ailes marquécs clacuue d'un point discoidal. Lenc des-

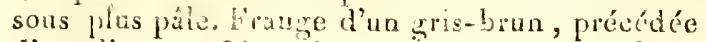
l'une ligue ondéc noite mêlíe de brun. Mále el feniclle.

Euvirons de Paris.

\section{Phalèye obscure, P. olfuscaria.}

Phalona alis integris, patulis, griseis, superiorum lineis duabus lumulîque internediâ fuscis.

Geometra obfascaria. Hue. Geom. tab. 27.

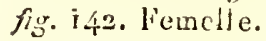

Eaverăure 16 lig. Antennes, tête el corps gris. Ailes grises. Les supéricures uvec deux lignnes brunces ondécs transverses, ayant dans lear entredeux une lunule brume. Ailes inférieures portant deux lignes bruneș peu.onchées avant lesquelles est une lunule de uếne couleur; sur les quarre ailes, une ligne blancbe accompagne à quelque distance le bord exiéricur. Frange blauchâtre. Dessous de toutes les ailes gris alvec une senle ligne brune peu ou point ondie at la lunale comne en dessus. l'cmclie.

Il n'esi pas bien certain que celte espèce appartienne à cette divi-ion.

Elle w’a éić donnée par M. le comte Dejeanqui l'a trouvée dans les l'yléuécs.

\section{Pramène Wau, P. ITavaria.}

Phalena alis integris, patulis, griseis, superiorum luneis nigricantibus, secunda inflexâ litieram $V$. efformunte.

Phalona TVavaria. Luxv Syst. Nat. 2. 865. 2 9. - FА . Ent. Syst. tom. 3. part. 2. pag. 150. $x^{\circ} \cdot 75 .-$ Hu в. Geom. $t a b .1$ I. fig. 55. Femclle. Laro. Geom. ampliss. K. a. $n^{n}, \mathrm{I}$.

Euvergure rolig. Antennes lrunes. 'Tète et eorps gris. Ailes de uêe coulcur, leur bord extérieur jrun. Du bord antéricur des supérieures parteut quelques bandes courtes d'un Jrun-noirâtre, dont la seconde a partir de la base est fléchic a angle droit de mavière à lorıner une espèce de V. Dessous ce $\mathrm{V}$, on voit an hord interue une petite tache brune presque carrée. Ailes inférneures avec mo point noir discoïdal. Dessous des quatre ailes gris parsencé d'atômes d'un brun-roussàtre. Mále.

Chenille verte ou bruse ajánt des tubercules noirs portant chacun un poil de mêtne coulcur, avec une ligne dorsale et une autre latérale, de couleur jaune. Vit sur les groseilliers.

De France.

\section{Pealène plumeuse, P. plumaria.}

phalcena alis integris, patulis, suprà subtùsque atomis fuscis rufisque sparsis, puncto discoidali nigro.
Geometra plumiaria. Ilvв. Geom. tab. 23. fig. 124. Nâle. Lurv. Geom ampliss. U. b. fig. 2. - phaiane ruraria. FA. Ent. Syst. tom. 3. part. 2. pag. $143 . n^{2}$. šo.

Envergure 12 à $15 \mathrm{lig}$. Antennes brunes. Corps d'un brun-roussútre. Ailes grises chargées d'atômes hruns et roussâtres, leur bord extéricur plus fon cé , terminé en dedans par une ligne sinuée de conleur plus intense; un point noir discoidal sue chaque aile tant en dessus (ju'en dessuns. Dessous des quatre atiles entièrenzent gris, charrón d'atômes bruns et roussattes. Mâle.

Il paroit dipres la figure de M. Miibuer que les ailes supérieures ont quelquefuis en dessus des lignes brunes transversales plus ou muins longues.

Chenilie !rune acêlée de rougeâtre, ayant deux lignenes plus foucćes et la séparialion des stgmens Janchấtre. 'Tête pâle. Vit sur le Dorycriamn.

Se trouve cn Allemagne et en Frante.

\section{Phatène à tache earrée, $P$. vincularia.}

phalana alis integris, patulis, griseis, atomis nigris sparsts, margme exterion fusiorl, disci superiorum maculá subquadratâ fuscâ.

Geometra vinculuria. Huв. Geom. tab, 78 . fig. 402 .

Envergure 10 à 22 lig. Antennes lurnoes. Tête et corps gris. Ailes de uême couleur sentées d'altônes nurs; leur bord extírieur un peu plus loncé. Bord antérieur des supćrieures portant vers sou milieu une petite ligne brune vis-á-ris de laquelle esi sur le disque une tache en carré alongé; plus loin, en suivant ce bord, on voit une baude d'abord brane easuite rousse et moins aistincte çui se prolonge jusqu'au bord interne. Dessous des quatre ailes conforme au dessi!s, ulilis sans aiche ni bande. Mâle.

De France.

\section{Phatène omicron, $P$. omicronaria.}

phalana alis integris, patulis, albidis, litterâ $O$ in medio notults, supertorum strtgâ nigrâ caracterem 3 delineante.

Geometra omicronaria. Hus. Geom. tab. 13. fig. 65. Wâle. - Phalcena annulara. FAB. Ent. Syst. tom. 3. part. 2. putg. $1470^{\circ} 22^{\circ} .64$. - Les quatre omicrons. Gefor. Ins. Paris. tom. 2. pag. $144 \cdot n^{0} \cdot 7^{1}$. Femelle. - Réaum. érs. tom. 2. pag. 376. pl. 31. flg. 16. - Encyct. pl. 89. fig. 3.

Euvergure $8 \mathrm{lig}$. Antennes, tête et corps jürnâtres. Àiles d'un blanc-jăunâtre, leur bord extérieur d'un jaune plus intense; vers la base on voit une petile ligne noire représentant le chiffre 3. Passé le milieu est une bande brune ondée, dentée extérieurement, qui s'ćlargit vers le bord interne; une ligne úe inếune cuuletur accompagne 
à quelque distance, le bord extérieur. Frange jaunâtre précćdée d'une ligne noire souvent interrompue. Toutes les ailes portent sur leur disque une pctite tache brune oculée à prunelle blanche qui imite un petit o. Dessous des quatre ailes ¿'un blanc satiné traversé par une ligne brune ondée et dentée. Mâle et femelle.

Les antennes du mâle sont simpleş à leur extrémité.

La Chenille vit surl'érable; elle est entièrement d'un beau vert et reste peu de temps en chrysalide, suivant Réaumur.

Des environs de Paris.

\section{Phanène Argus, P. poraria.}

Phalana alis integris, patulis, luteo favis, atomis fuscis sparsis, litterâa o in medio notatis.

Phalcena porata. Livn. Syst. Nat. 2. 866. 233. Femelle. - F ${ }^{173}$. $n^{\circ}$. 15g. Femelle. - DE GÉER, Ins. tom. 2. pag. 36o. $n^{\circ}$. 2. pl. 6. fig. 7. - Geometra punctaria. Hчв. Geom. tab. ı5. fig. 67. Mâle. Larv. Geom. ampliss. L. a. b. $n^{\circ}$. 1. fig. f. (Chrysalide. )

Euvergure so ligr. Antennes, tête et corps fuuves. Ailes d'un fauve-jaunâtre, chargées d'atômes la plupart : runs. Tous ceux du disque des ailes supérieures rouges et plus rapprochés. Bord extérieur des ailes un peı brun. Toutes quatre portent sur leur disque une petite tache blanche imitant un petit o, entourée dc rouge sur les supérięures, et de brun sur les inférieures. Frange d'un funvc-jaunâtre précédée d'une ligne de traits bruns. Dessous des ailes plus clair, moins chargé d'atômes avec un petit point noir discoïdal sur les supérieures. Mâle.

Chenille verte suivant Fabricius, ayant une ligne latérale rousse et des points de mềme couleur : elle se suspend à la manic̀re des Chenilles des Papillons et des Piérides. Sa chrysalide est verte.

Des environs de Paris.

Nota. De Géer cite ì torit Réaumur, dont les figures se rapportent à la Phalène ponctuée, n'. 80 ,

\section{PhaLène tigrće, $P$. melcinaria.}

phalana alis integris, patulis, superioribus suprà albis, iisdem subtùs inferioribusque suprà subtùsque luteis, omnium maculis seriatis nigris.

Phalona melanaria. Linn. Syst. Nat. 2. 862. 212. - F А . Ent. Syst. tom. 3. part. 2. pag. 143. $n^{\circ} .51 .-E s p e r$, toln. V. Placl. Geonz. tab. XXIIII. fg. 1. Mûle. - Нив. Geon. tab. 16. fig. 86. Mâle.

Envergure $18 \mathrm{lig}$. Antennes noires. Tête jaune. Corselet brun. Abdomen jaune avec une ligne Hist. Nat. Ins. Tome $\boldsymbol{X}$. dorsale de points noirs. Dessus des ailes supérieures blanc; lcur dessous, ainsi que les deux surfaces des inférieures, jaunes. Toutes les ailes portant des lignes de gros points noirs, assez régrulières: Mâle.

Se trouve en Europe.

69. Phalène du Pin, P. pimiaria.

phalona alis integris, patulis, fuscis, disco fulvo maculis atomisque fuscis sparso, inferiorum subtùs linêâ longitudinali interruptâ albâ.

Phalcena pisiaria. LinN. Syst. Nat. 2. 86r. 2 I0. - F $\mathrm{AB}$. Ent. Syst. tom. 3. part. 2. pag. 241. $n^{\circ}$. 45. -Esper, toin. V. Phal. Geom. tab. XXI. fig. I-8. - DE GEER, Ins. tom. 2. pag. $35 \mathrm{I} . n^{\circ} .5$. pl. 5. fig. 20. - Нив. Geom. tab. 22. fig. 119 et 120. Mâle.

Envergure 15 lig. Artennes et corps bruns. Ailes brunes, leur disque fauve avee des laches et des atômes bruns. Dessous des supéricures ayant des atômes blancs vers l'angle supéricur. Dessous des inférieures portant de sconblables atôtues et une ligne longitudinale blanche, interrompue. Frange brune entrecoupée de blanc. Femelle.

Le mâle diffère en ce que ses ailes supérieures ont sur un fond presque noir deux ou trois taches jaunes se terminant eu pointe du côté de la base, et que les inférieures u'ont, sur un mênıe fond presque noir, que quelques taclies jaunes. Dessons des supérieures à peu près semblable au dessus.

Cette Phalène porte ses ailes relevées dans l'état de repos ainsi que la suivante.

Chenille verte ayant des lignes blanclses et jaunâtres. Vit sur le pin, le bouleau et le tilleul.

Se trouve eu France.

\section{Phalène bordée, $\boldsymbol{P}$. linubaria.}

phalcena alis integris, patulis, luteis, atomis fuscis sparsis, margineque exteriori nigro.

Phalona limbaria. НАв. Entom. Syst. tom. 3. part.2. pag. $141 . n^{\circ} \cdot 46 .-$ Plalana conspicuaria. Esper, tom. ' $V_{0}$. Plaal. Geom. tab. XXIV. fig. 5-8. - 11ив. Geom. tab. 22. fig. 117 et 1 I 8.

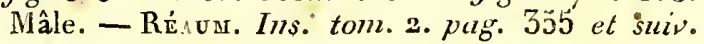
pl. 28. fig. 7-10.

Envergure $8 \mathrm{lig}$. Antennes noires. Tête et corps bruns. Ailes jaunes chargées d'atômes bruns; leur bord extérieur noir , t'autćrieur l'étant également dans les supérieures. Dessous de celles-ci assez semilablc au dcssus; celui des inférieures brua avec deux lignes blauches qui partent de la base et atteignent le bord extćrieur, et quelques autres plus pclites. Mâle et femelle.

Chenille d'un vert brun avec une ligne latérale étroite, jaune. Vit sur le gcnêt.

Commune dans les forêts. 
71. Praléne ealabroise, P. calabraiza.

Phalona alis integris, patnlis, luteo-olivaceis, fasciâ transversâ margineque exiterno roseis.

Phalcena calabraria. Esper, tom. V. Phal. Geom. tah. IV. fig. I et 2.- Нuв. Geom. tab. 10. fig. 49. Femelle, et tab. 7o. fig. 365. Nầle. - La Bande rouge. Grofr. Ins. Paris. tom. 2. pag. $\mathbf{3 2}$. $n^{\circ} \cdot 48$.

Envergure io liog. Antennes brunes. Téte cl corps verdútres mêlés de rose. Dessons de l'abdomen entièrement rose. Ailes d'un jannc-olivâtre, ayanl une bande rose assez large qui les traverse, et leur bord extérienc de même coulenr. Les sıpérieures out èn ontre une petite bande rose plus près de la base. Desions serablable an. dessins, mais la pctite bande rose manque dans les supérieures. Mâle et femelle.

Des environs de Paris.

\section{Phaline flagellée, P. vibicaria.}

Phalana alis integris, patulis, griseo-lutescentibus, vittî vel fasciis duabas, puncto discoiduli margineque externo roseis.

Phalona vibicaria. Linn. Syst. Nat. 2. 859. 198. - FАв. Ent. Syst. tom. 3. part. 2. pag. 139. $n^{\circ} .37$. - EsPEn, tom. V. Phal. Geom. tab. III. fig. 5-7. - IIU B. Geonz. tab. 10.fig. 50. Mâle.

Envergure ro lig. Antenncs, tête el corps gris. Ailes d'un janne-grisâtre traversées par une bande et par une ligne couleur de rose, qui quelquefuis se confoudent cn une scule bande laroe, conme on le voit dans la figure cilée de M. Huibner; un point discoïdal sur chacue aile et leur frange, roses. Les supérientes ayant en ontrc une petite ligne rose arquéc, plus près de la base que le point discoidal, laquellc manque eu dessous; cc deruier teinté de rose. Mầle et femelle.

Dans le inâle la couleur rose domine divantage.

Suivant Esper, la Chenilhe est rosc avec une ligue latérale jaune, et vit sur le genêt.

\section{Phalise jaune, P. alureolaria.}

phalona alis integris, painlis, luteis, superiorum lineis trious, inforiorum duabus fuscis.

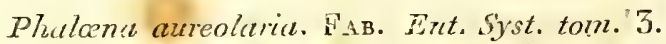
part. 2. pag. $161 . n^{\circ}$. 115.-Hu. Geoin. taj. 12. fig. 62 .

Envergnre 4 a 5 lig. Antennes el abdomeu jaunes. Têie el corsclet noirâtrcs. Ailes d'un bean jaune draversces par denx ligos Lrunes. Frange brunce. Les supéricures ont nue troisieure ligne brune plus près de la base que les autres. Dessous assez semblable au dessus.

Selon Fubricius la Chenille est lisse, blanehâtre,

\section{P H A}

avee le dos plus obscur portant use ligne brune. Vit sur la vesce. (Vicia dumetorum.)

Des environs de Paris; à Fontainebleau prineipalement.

74. Phalène erépusculaire, P. vespertaria.

Phalcena alis integris, patulis, luteis, atomis lineolisque sparsie fuscis, murgine intùs siruato fuscescente: superiorum ad basim strigà subundulatî̀ arcuatâ punctoque discoidalifuscis.

Phalena vespertaria. Linv. Syst. Nat. 2. 864. 224. - FАв. Ent. Syst. tom. 3. part. 2. pag. 149. $n^{\circ} \cdot 74 .-$ Phalana parallelaria. Espre, tom. $V$. Phal. Geom. tab. XV. fig. 4-6. - Huв. Geom. tab. 9. fig. 43 et 44 .

Envergure so lig: Antennes, tête et corps jaunûtres. Ailcs jitunes chargécs d'alômes et de petiles lignes fauves, ayan! une large bordure d'un brun un peu vincux, sinuée en dedans. Le supérienres avec un point discoidal et unc ligne plus près de la base, arquéc, un peu ondulće, de conleur brune. Dessous scmblable au dessus, avee un point discoïdal sur chaque aile. Màle et femelle.

D'après la figurc de $M$. Hübner et d'après la variété d'Esper, la femeile auroit quelquefois un point discridal sur le dessus des ailes inférieures.

Se trouve en Europe.

\section{Phalène délicate, P. pusaria.}

phalona alis integris, patulis, albis, superiorum strigis tribus, inferionum duabus, griseis.

Plalcena pusaria. Linn. Syst. Nat. 2. 364.223. - Fав. Entom. Syst. tonı. 3. part. 2. pag. 146. $n^{\circ}$. 61. - DE GÉR, Ins. tom. 2. pas. 448. $n^{\circ} .4$ : pl. 8. fig. 10-1 2. - Ни в. Geoin. tab. I7. fig. 87. Feuelle. Larv. ampliss. P. b. for. I. d. e. f.

Envergure o olig. Antennes griscs. Tête et corps blanchât!res. Dessus des ailes blanc traversé par deux petites lignes grises peu apparcntes. Les supérienres en ont une trosisiène plus près de la base. Dessous entièrcment blanc. Máte el femelle.

Chenille d'un vert-jaunâtre avec des taches et des marques de coulêur rose le long du dos. Vit sur l'aulne et le bouleau.

Environs de Paris.

Nota. Nous regurdons comme une variété la Geometra striarı de M. Hübner, tab. 17, fig. 88, dans iaquelle les bandes des ailessont mieux natqućes, ct qui ofire en dessous, sur ehaque aile, uis petit point noir discoidal.

\section{Pandive du Cytise, $\boldsymbol{P}$. cytisaria.}

Phalcona alis integris, patulis, griseo-vuresceníibus, omnium lineâ virrdi-fusc:i alterâque ad marginem exteriorem albidâ, superionm ad basim strigâa viridi-fascâ. 


\section{P II}

Geometra cytisaria. Hus. Geom, tab. 1,fig, 2. Fenelle. Larv. Geom. ampliss. B. a. $n^{\circ}$. 1. et B. a. b. $n^{\circ}$. I. - Phalana prasinaria. FAв. Ent. Syst. tom. 3. part. 2. pags. 151. no. 80.

Euvergure 1 pouce. Antennes gurises. Tête el corps d'un gris-verdâtre, ailes de même coulcur traversées pai une ligne ondée d'un brun-verdătre, et jar une autre de eouleur blanche placée plus près du bord extérieur. Ailes supérieures ayant en outre une petite ligne transverse d'un brun-verditre plus voisine de la base. Dessous de loutes les ailes d'un vert clair, a'ayant que la ligne brune commume aux quatre. Mâle.

Cheuille verte à tête refendue. Corps arec une ligne latérale blanchàtre. Vit sur le genêt et le eylise.

\section{Phalèxe papililon, $P$. papilionaria.}

Phalona alis integris, patulis, viridibus, strigis undulatis albis vix distinctis.

Plualana papilionaria. I.uxv. Syst. Nat. 2. 864. 225. - FА . Entom. Syst. tom. 3. part. 2. pag. $139 . n^{\circ} .39 .-$ Esper, tom. V. Phal. Geom. tab. VI. fig. 1-4. - Huв. Geom. tab. 2. fig. 6. Mâle. - Encycl. pl. 88. fig. 20.

Envergure 2 pouees $\frac{1}{2}$. Antennes faures. Tête et corselet verts. $\Lambda$ bdoinen grisâtre. Ailes d'un vert-bleuâtre avec 'quelques lignes ondées blanchâtres, peu distincies. Dessous pareil au dessus, les lignes à peine appareutes. Mâle et temelle.

Le mâle est d'un vert plıs pur, et ses lignes blanehâties sont un peu mienx prononcées.

Chenille verte portant sur le dos des tubereules pointus. Vit sur le bouleau. La ehrysalide est yerte et jaune.

- Des euvirons de Paris. On Ia trouve dans les bois.

\section{Phalene chrysoprase, $P$. chrysoprasaria.}

Phalana alis integris, patulis, viridi-griseis, inferioribus subangulatis, superiorum lineis duubus, inferiormm unicầ albidis.

Phalana chrysoprasaria. Espen, tom. V. Phal. Geom. tab. V. fior. I-4. - Geometru vernaria. - Huв. Geom. tab. 2.fig.7. Femelle. Larv. Geom. ampliss. B. a. $\pi^{\circ} .2$.

Envergure 2 ponces. Antennes blanchátres. Tête et eorps d'un gris-verdâtre. Ailes d'un vertblenâtre traversćes par une ligrne blanche peu ondée; les supérieures en ayınt nne seconde plus près de la base. Dessous des quatre ailes plus pầle; Ia ligne transversabo à peine indiquée; les ailes inférieures ont uń petit angle saillant vers le milieu du bord extérieur. Mâle et femelle.

Les antennes de la femelle sont un peu pectinćes.
Chenille verte ayaut sur le dos de très-pelites lignes hinchẩires. 'I'úte refendue. Vit sur la clémutite (Clematis sepinm ).

79. Рнадіге gris de perle, P. margarilaria.

Phalana alis integris, patulis, gluuco-viridilius, inferionbus sabangliktis, fusciâ onmium mescente, superiorum puncto apicalifisco.

Phalena margaritaria. Linv. Sy st. "Nat. 2.

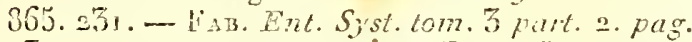
151.no. 10...Hun. Geomitab. 3.fig. 15. Pemelle. Iarv. Geom. ampliss. A. b. - Bombyx. sesquistriataria. Espen, torr. III. tab. LEIII. fig. I et 2.

Eurergure z pouces. Antennes roussâtres. Corps d'un blanc-verdâtre. Ailes d'un blare vert d'ean satiné imitant l'oricnt des perles avec nue large bande transverse un pen rousse, bordée de cliaque eôté sur les ailes supérieures par une ligne blanche, ne l'ćtant qu'en dehors daus les inférieures. On voit $\operatorname{lin} \mid \mathbf{r} \leq \mathbf{s}$-petit point brun à l'augle supérieur des premières ailes. Dessous d'un blanc sutiné pur. Ailes inférieures ayant un patit angle saillant vers le milieu du bord extérieur. Mâtle et femelle.

Chenille à douze patles, six éeailleuses et six membraneuses. La preinière paire de eelles-ci plus eourtes. Corps gris ou brun avee quelques points et de petites lignes sur les côtés, de couleur blanehe. Vit sur le charıne et le bouleau.

Environs de Paris.

80. Phalìne ponetuée, $P$. punctaria.

Phalana alis integris, patulis, luteis, inferioribus vix angulatis, atomis spursis fuscis, omnium line $\hat{a}$ rectâ fusco-ferrugineâ et punctorum nigronun serie.

Phalana punctaria. Linn. Syst. Nat. 2. 859. 200. - Кав. Ent. Syst. tom. 5. part. 2. pag. 15z. m. I I. - Espen, tom. V. Thal. Geom. tab. VI. fig. 5-9. et tab. VII. fig. I et 2. - RÉau. Ins. tom. 2. pag. 364 et saiv. pl. 29. fig. 1-5.-Encycl. pl. 88. fig. $2 \mathrm{I}$.

Envergure ro lig. Autenues, tête et corps jaunâtres. Ailes de mếme coụleur chargées d'atômes bruns et l'aversées par une ligne d'un rouge-bru qui part du milieu du br r l antérieur des snpérieures et se mantien! dans le milieu des quatre ailes; dans l'espace qui est entre cente licrue el le bord extérieur est me ligne ondée de petiss points noirs. Dessous des quatre ailes plus blanchatre, saus liğue nédiale. Un petit angle saillaut au milieu du bord extérieur des secondes ailes. Mâle et femelle.

Chenille d'un beau vert ayant uxe ligne latérale -étroite de couleur citron. Eille se transforre en se M 2 
suspendant à la manière des ehenilles des Papillons et hes Piérides. Vit sur le chêne. La chrysalide est très-obtuse antérieurement.

Environs de Paris.

Nota. Linné a eu tort de rapporter à la Phalène amataria les figures de Réanmur que nous avons cilées ici. Fabricius a fait une fuute plus grande encore de les conserver ì la Phalène amataria, après les avoir at:ribuées avec raison à la Phàlène punctaria.

\section{Phalène anguleuse, $P$. amataria.}

Phalcena alis integris, patnlis, lutescentigrisess, inferioribus angulatis, omnium line $\hat{a}$ rectâ roseâ, alterâque urıdulatî fuscâ, superorum puncto marginali fusco.

Phalcena amataria. Linn. Syst. Nat.2. 859. 201. - FAB. Ent. Syst. tom. 3. part. 2. pag. 132. $n^{\circ}$. 13. - EsPER, tom. V. Phal. Geom. lab. VII. fig. 3-6. - Нив. Geom. tab. г . fg. 52. Femelle. Larv. Geom. ampliss. I. b. $n^{0}$. 1.-L'Anguleuse. Geofr. Ins. Paris. tom. 2. pag. $128 . n^{\circ} .37$.

Envergure 6 à $7 \mathrm{lig}$. Antennes, tête et corps d'un gris-jaunâtre. Ailes de même couleur traversées pardeux lignes, l'une rose, droile, partant de l'angle supérieur des premières ailes, parcourant le milieu de loutes les quatre, la seconde brune, trèsondulée partant du même endroit que la première et s'en écartant; un point discoidal sur les ailes supérieures. Frange rose. Dessous des ailes assez semblable aa dessus. Angle supérieur des première ailes un peu en crochet. Ailes inféricures ayant un angile très-saillunt dans le milieu de leur bord extérieur. Mâle et femelle.

Chenille b:une avec des traits jaunes ou rougeâtres. Vit sur le chêne et sur l'oseille. Chrysalide un peu crochue antérieurement.

Commune aux environs de Paris.

\section{Phaldne imitatrice, $P$. imitaria.}

Phalcena alis integris, patulis, lutescentigriseis, superiorum angulo sub̆adunco, inferiorihus angulatis, omninm fasciâ punctoque marginali fuscis lineâque undatâ roseá, margine roseo.

Geometra imitaria. Hub. Geom.tab. 10. fig. 51. Mâle.

Envergure 8. lig. Antennes et corps d'un grisjaunâtre. Ailes de même couleur ayant une bande brune qui part plus loin que le milieu du bord antérieur des premières ailes et traverse presçu'en ligue droite le centre de toutes les quatre; plus près du bord extérieur est un petite ligne ondée qui parcourt anssi toutes les ailes; leur bord extérieur est rose. Frange jaunâtre. Les supérieures ont près de leur base une petite ligne brune ondée. Chaque aile est marquée d'un point discoidal.Dessous assez semblable au dessus, mais n'ayant ni le point discoidal, ni la ligne de la base des premières ailes. Angle supérieur de celles-ci un peu en crochet. Ailes inférieures ayant un angle très-saillant au milieu de leur bord extérieur. Mâle et femelle.

Environs de Paris.

\section{Pralène linéolée, $\boldsymbol{P}$. dolabraria.}

Phalorta alis integris, patulis, subangulatis, albidis, strigulis inoequalibus rufis, sparsis, superiorum angulo superiori violaceo.

Phaloena dolabraria. Linn. Syst. Nat. 2. 86 . 207. - FAB. Ent. Syst. tom. 3. purt. 2. pag. 138. $77^{\circ} .32 .-$ Esper, tom. V. Phal. Geom. tab. $X V$. fig. 1 et 2. - Нив. Geom. tab. 8. fig. 42. Law. Geom. ampliss. G. b. (bis.) $n^{\circ} .1$.

Envergure I pouce. Antennes, tête et corps roux. Corselet violet antérieurement. Ailes d'un blanc-jaunâtre, cliargées de petites lignes rousses, inégales, mieux prononcées dans les supérieures. Bord antérieur de celles-ci brull vers la base, ayant une petile tache de même couleur avant l'angle supćrieur. Angle inférieur des quatre ailes violet entouré de brun et de fuuve. Dessous assez. semblable au ciessus si ce n'est que les lignes sont d'un jaune-ferrugineux. Bord des ailes supérieures ayant deux petiles échancrures; celui des inférieures une seule, placće près de l'angle anal. Erange des ailes roussâtre. Mâle.

Chenille brune ayant un tubercule sur le dos et quelques traits blanchâtres. Vit sur le chêne.

Des environs de Paris. Elle n'est pas fort commune.

$2^{\mathrm{e}}$. Division. Bord postérieur des ailes supérieures sans dentelures; ailes inférieures prolongées en queue. - Antennes simples dans les deux sexes. (Genre Ourapteryx Lуасн.)

\section{Pralène du Sureau, $P$. sambucata.}

Phaloena alis integris, patulis, sulphureis; inferioribus caudatis, superiorum lineis duabus, inferiorum unica ; punctisque ad caudam, fuscis.

.Phaloena sambucaria. Linn. Syst. Nat. 2.86o. 203. - F $n^{\circ}$. 19. - DE GÉER, Ins. tom. 2. pag. 447. n०.3. Esper, tom. V. Phal. Geom. tab. VIII. fig. 1-8. - Hов. Geom. Lab. 6. fig. 28. Lary. Geom. ampliss. L. a. $n^{\circ}$. 1. - La Souffiée à queue. Grorf. Ins. Paris. tom. 2. pag. 138. no. 58. - Encycl. pl. 9o. fig. 22-26.

Envergure 24 à 28 lig. Antennes et tête fauves. Corps couleur de soufre. Ailes de même couleur; les supérieures avec denx lignes transversales d'un fauve obscur, qui se rapprochent un peu pour arriver au bord interne, et un petit trait arqué de même couleur entre les lignes. Ailes in- 


\section{P H A}

férieures ayant une ligne transversale d'un fauve obscur se dirigeant vers l'angle anal sans l'atteindre, avec deux taches à la base de leur queue; la supérieure oeulée à prunelle ferrugineuse; la tache inlérieure manque quelquefois. Frange des quatre ailes ferrugineuse. Dessous semblable au dessus, les lignes à peine apparentes; taches nulles. Mâle et femelle.

Chenille d'un roux-brun avee uu tubercule latéral vers le milieu du corps et d'autres dorsaux vers son extrémité. Vit sur le groseillier, le sureau et le rosier. Chrysalide ayant sa partie antérieure obluse. La coque a une forme particulière. (Voy. les généralités.)

Des environs de Paris. Assez commune dans les jardius au mois de juillet. Le mâle entre souvent la nuit daus les appartemens, attiré par la lumière.

\section{Phalène polie, $P$. politata.}

Phalcena alis integris, patulis, luteis, inferiorbus caudatis ; superiorum serie duplici punctorum ferrugineorum inonlinat $\hat{a}$, inferiorum fasciấfuscâ.

Phalcena politata. FAB. Ent. Syst. tom. 3. part. 2. pag. 163. $n^{\circ}$. 123. - Cram. Ins. I2. tab. 159.fig. E. - Encycl. pl. 88. fig. 10.

Envergure 16 lignes. Antennes, tête et corps jaunes. Ailes de unême couleur; les supérieures ayant deux bandes transversales de points d'un roux-ferrugineux placés sans ordre, dont une parcourt le milieu de l'aile; l'autre accompagne à peu de distance le bord extérieur. Au bord antérieur, près de l'angle supérieur est une tache formée de points ferrugineux entourée de bruv. On y voit aussi quelques points de eette dernière eouleur. Ailes inférieures ayant une bande transversale brune qui s'élargit pour arriver a l'angle anal.

De Surinam.

3e. Division. Bord postérieur des quatre ailes dentelé. - Antenues peetinées dans les mâles.

86. Phalène du Lilas, $P$. syringaria.

Phalcena alis dentatis, luteo, firsco lilaceoque variis, lineis duabus divaricatis.

phaloena syringaria. Linn. Syst. Nat. 2. 860. 206. - Fa . Ent. Syst. tom. 3. part. 2. pag. 136. $n^{\circ}$. 25. - Esper, tom. V. Phal. Geom. tab. XI. fig. 3-7. - Нuв. Geom. tab. 6. fig. 29. Mầle. Larv. Geom. ampliss. G. a. $n^{\circ}$. 1. - La Phalène jaspée. Geofr. Ins. Paris. tom. 2. pag. 125. no. 3z.

Envergure 15 à $18 \mathrm{lig}$. Antennes, tête et corps d'un fauve-brun. Ailes marbrées de jaune, de brun et de violet tendre. Au bord autérieur des premières ailes vers l'angle supérieur est une tache d'un brun-roussátre, entourće de violet tendre, d'où partent ensemble deux lignes transversales qui s'éloignent l'une de l'autre en se prolongeant, et pareourent le milieu des quatre ailes. Celle qui est la plus voisine de la base, brune. L'autre brune à sa base, d'un violet tendre ensuite avec des points bruns. Dessous assez semblable aul dessus, mais chargé de petits traits bruns, et portant un point discoidal de cette euuleur sur chaque aile. Mấle et femelle.

La femelle a les antennes pectinćes; ses couleurs sont plus pâles.

Chenille fauve ou jaunâtre mêlé de brun portant deux paires de tubercules assez gros sur le dos et quelques autres plus petits. Sur le huilième segment du corps est une longue corne un perz recourbée. Vit sur le lilas et les chèvréfeuilles. Chrysalide fort courte enveloppée de soie en mailie à jour et fixée anx branches des arbres.

Se trouve dans les jardins aux euvirons de Paris.

\section{Phalène à lunules, $P$. lunaria.}

phalona alis dentatis, fulvis, atomis lineisque fuscis sparsis, maculâque lunulatâ albidâ.

phalana lunaria. FAв. Ent. Syst. tom. 3. part. 2. pag. 136. $n^{\circ}$. 26. - EsPEH, tom. $V$. Phal. Geom. tab. XII. fig. 1-4.-Huв. Geom. tab. 7.fig. 33. Mále.

Envergure 14 à $15 \mathrm{lig}$. Antennes, tête et corps fauves. Ailes de même couleur chargées de quelques atômes bruns. Les premières anles ayant une tache roussâtre à leur angle suṕriem, une ligne brune, arquée, vers leur base et deux iutres de même eouleur renfermaut une bande roussâtle qui porte une pelite lunule blanche, transpareute. Ailes inférieures ayant trois lignes brunes dont l'intermédiaire part d'une tache brunce oeulée à prunelle blanche transparente. Dessous assez semblable au dessus, ses couleurs plus prononéées. Mâle.

Chenille grise ayant deux paires de tubereules sur le dos et un autre tubercule simple plus antérieur. Dessous du corps avee des lignes blanches et des points noirs. Vit sur le saule et le bouleau.

Environs de Puris.

\section{Phalène dentelée, $\boldsymbol{P}$. dentaria.}

Phalona alis dentatis, griseis, atomis fuscis sparsis, maculâ discondali fuscâ albo pupillatâ, superiorum lineis duabus obsoletis, inferiorum unicâ subduplici fuscis.

Phalcena dentaria. EsPER, toni. V. Phal. Geom.tab. XX. fig. 1-3. - Нuв. Geom, tab. 3. fig. 12.

Envergne 16 à 18 lig. Antennes, tête et corps d'un fauve-grisâtre. Ailes grisâtres chargées d'atômes bruns; les supérieures portant deux lignes 
brunes pen dis incies, l'cxtérienre accompayne. de points blanchâtres. Ailes inférieures ayant une ligne brane, double dans quelques endroits. Une tarche discoidale lrune a prunelle blanche sur chaque aile. Dessons assez semblable an dessus. Inâle et fenclle.

La Phalène dentaria de Talricius nous paroît differer de celle ci.

Chenille un peu velue, grise, ayant quelques ligues dorsales brunes en zigzatg. Vit sur le truëne.

Des environs de Paris.

89. Paslìve de l'Aulne, P. alniaria.

Phalona alis dentalis, fulpis, maculis atomisque fiescis spursis; stipieriorum Linets duabus scepè interruptis, inferiorum urricâ obsoletia, fuscls; omuium pancto discoidali fiusco, $m$ mare albido pupillato.

Phaloria alniurit. Lins. Syst. Nitt. 2. 860. 200̈. - FAв. Ent. Syst. tom. 5. part. 2. pag. 136. $n^{\prime \prime}$. 24. -Esper, tom. $V$. Phal. Geom. tab. $I X$. fig. 1-6.-DE GERR, Ins. tom. 1.pag. 340. pl. : o. fig. 9 d 14, tit tom. 2. pag. 5о5. $\iota^{\circ} \cdot 4$. - Нив. Geom. tab. 5. fig. 26. Femelle. Lary. Geom. amipliss. D. b. $n^{\circ}$. 1. - Encycl. pl. 89. fig. io.

Euvergure 15 à $18 \mathrm{lig}$. Antcnnes, tête et corps d'un jaune-fauve. Ailes de même couleur chargrées de taches et d'atômes bruns; les supérieures portant deux lignes transversales brunes souvent interrompues; les inférieures n'en ilyant qu'une de wemse couleur, mais peu distincte. Un point discoidal sur les quatre ailes, peu distinet dans la femelle, un pera oculé dans le wâle. Dessous seablable au dessus. Natle et femelle.

Celte derniere a les antennes dentées en scie.

Chenille d'un gris-birm avec des points blancliâtres et trois tubercules dorsax distans les nus des autres; on voit en outre quatre tubercules plus petils, presque réunis, sur le dernier segment da corps. 'Tềie petitc, presque carrée, marquée d'une ligne transversale ilancbâtre. Vit sur l'aulne et le bouleau. Chrysalide ayant quelques pelites épines dirigées en arrière à la jonction de ses segmens postérieurs.

Des environs de Paris.

\section{Phalène rongée, $P$. erosaria.}

Phalcence alis dentatis albido-luteis, superiorum lineis duabus, inferiorum unicâ fuscis.

Phalcena erosaria. Esper, tom. V. Phal. Geom. tab. II. fg. 1 et 2. -Н в. Gcom. tab. 5. fig. 25. Lars. Geonn. ampliss. D. a. $n^{\circ}$. 2. - Phalona crussaric. НАв. Ent. Syst. tom. 3. part. 2. pag. 135. $n^{\circ} .21$.

Envergure 15 lig. Antennes, tête et corps d'un blanc-jaunâtre. Ailes de même conleur. Les supérieures portant deux ligues brunes transverses, un peu courbes, les inférieures n'en ayant qu'une peu distinctc. Dessous des quatre ailes assez semblable au dessus, les ligncs moins prononctes. Un point discoïdal pea distiuct sur chacune. Nâle et femelle.

Dans ce dernier sexe les antennes sont dentées en srie.

Nota. Cette espècc a les principaux angles saillans qu'on remarque anx ailes des précédentes, mais moins de petites denteluies. Les Phalènes qu'Esper donne sous le noun de Tiliaria, tab. X, lig. 3 à 7 , et d'Unicoloric, tah. XIX, tig. 4, n'cu paroissent être que des variétés.

Chenille d'un gris-barnn ayant sni le dos des tubercules ferrutineux. Vit sur le chêne.

Environs de Paris.

\section{9i.Phalèné emplumée, $P$. pennaria.}

Phalcena alis dentatis, fuscis; superiorum atomis, lineis duatus, puncto discoidali nuculâque albido prepillatấ, fuscis.

Phalcena pennaria. Livn. Syst. Nat. 2.86r. 209. - FAB. Ent. Syst. toml. 3. purt. 2. pag. 152. no. 14.- Esper, tom. V. Pllal. Geonu. tab. $X I X$. fig. I. Màle. - Hus. Geom. tab. 3. fig. 14. Mầc. Laiv. Geom. anıpliss. C. L. no. 1.

Envergure 16 à $18 \mathrm{lig}$. Antennes, tête et corps fanves. Ailes d'un brun vineux; les supérieures clıargées d'atômes bruns, portant deux lignes brunes transyersales et nue tache de même couleur ì prunelle blanche transparente près de l'angle supćrieur. Un point discoidal brun sur les quatre ailes. Dessous à peu près semblable au dessus. İes ailes du mâle se rapprochent de la couleur fauve. Mäle et femelle.

Dans ce deruier sexe les antennes sont dentécs en srie.

Chenille grisc avec quelques taches rousses et une paire de tubercules sur le dernier segunent di corps. Vit sur le chêne.

Des environs de Paris. (S. F. et A. Serv.)

PIIALĖNE CULICIFORME DE L'ÉCLATRE. Geoflroy nowme ainsi un très-petit insecte de la tribu des Aphidiens, fumille des Hyménélytres, section des Homoptères, ordre des Hémiptèr es, qui a servi de type au genre Aleyrode fondé pa: M. Latreille; et que cet autear désigne sous le nom d'Aleyrode de l'écluire (Aleyrodes chelidoriii). Voyez la table du tome X.

(S. F. et A. SERV.)

PHALÉNITES, Phalanites. Troisième tifbu de la famille des Nociurnes, ordre des Lépidoptères. Ses curactères sont :

Ailes entières ou sans fissures, grandes relativement au corps, étendues horizontalement ou en toit écrasé; les supérieures point arquées à leur 


\section{$\mathrm{P}$ II A}

base extcrieure ou point en forne de chappe. Corps grêle. - Palpes infórieurs couvrant entièrement les supérieurs, presque cylindriques ou coniques, et clont l'épaisseur diminue gruduellement. - Chenilles le plus souveut arpenteuses, la plupart nues, n'ayant que dix paltes dans les unes, douze à quatorze dans les autres, les deux premières des membraneuses intermédiaires dans celles qui n'en ont que douze plus petites que les deux suivantes. Dans celles qui ont quatorze pattes les deux auales manquent et ne sont pas remplacées par deux appendices en forme de queue.

Cette ribu renferne les genres Phalène et Platyptère. (S.F. et A. Serv.)

PILALÉRIE, Phaleria. LAt. Tenebrio. Linn. Fав. Oriv. (Entom.) Ir.ig. Trogosita. Fab.

Genre d'insectes de l'ordre des Coléoptères, section des Hétéronères, famille des 'Taxicornes, tribı des Diapériales.

Dans la tribu des Diapériales les genreśLéiode, T'étratome, Eustrophe et Orchésie se distinguent des $\mathrm{Pbal}$ ries et des autres genres qui la composent, par leurs antennes dont l'insertion est découverte. Les Hy pophlées s'isolent par leur cörps linéuire ou cylindrique; les'Traehyscèles par leurs antennes à peine plus longues que la tête; les Epitrages, les Cnodalons et les Elédones par les deruiers articles des autennes initant par leur forme et leur avançement des dents de srie. Les Diapères, très-voisiues des Phaléries, en sont distinguées par leurs palpes n'allant pas en grossissant à leur extrémité, et par les jaubes antérieures n'étant point triangulaires ni plus larges que les autres.

Antennes insérées sous un rebord latéral de la tête, de onze articles, grossissant insensiblement ou un peu en massue; leurs articles de cinq à dix, semi-globuleux on leuticulaires, transverses, comprimés, très-souvent perfoliés; le nuzième ou dernier, globuleux. - Mandibules n'avançant point au-delí du labre. - Mâchoires ay ant leur division externe plus grande, obtrigone. - - Palpes ayant leur dernier article plus grand, celui des rnaxillaires trigone et compriné. - Lèvre nue, coriace, échancrée, menton presque cordiforme, plus large à l'extrémité. - T'éte sonvent tuberculée ou coruue en dessus dans les máles. - Corselet transverse, carré. - Ecusson distinct. - Pattes fortes; janbes antérieures alongées, trigones, plas largés vers lear extrémité, souvent dentées; leurs tarses courts.

Le genre Phalérie contient plus de vingt espèces. On en rouve dans les différentes parties du monde. Celles de la première division, dont M. Mégerle a composé son geure Ulonna, adopté par M. le conte bejean dans le catalogue de sa collection, se tienuent sous l'écorce des arbres; celles de la seconde habitent le sable des bordés de la mer. On ne connoit point cneore leurs larves. 1re. Division. Conps ovale-oblong.

1. Phalérie culinaire; $P$. culinaris.

Phaleria tota castanea, elytrorum striis profundis, thorace maris anticè subdepresso.

phaleria culmaris. L.Aт. Gener. Crust. et Ins. tom. 2. pag. 175. no. 2. - GYLLENH. Ins. Suec. tom. 1. partie 2. pag. 587. $n^{\circ} \cdot 1$. - Tenebrio culinaris. Lın. Syst. Nat. 2. 675. 5. - HAв. Syst. Eleut. tom. 1. pag. 148. no. 21 . On1v. Ent. tom. 3. Tenéb. pag. 12. $2^{\circ}$. 14. pl. 1. jo. 15. Panz. Faun. Germ. fas. 9. fig. 1. Hemelle. Encycl. pl. 372 lis. fig. 1-4.

Longueur 4 à 5 lig. Antennes et corps d'un fauve-marron luisant. Tète el corselet pointillés ; ce dernier rebordé latéralement. Elytres rebordées, ayaut chacune neuf stries asse $z$ profondes et pointillées. Jambes antérieures et intermédiaires dentelées. Jue utâte a une légète dépression à la partie anlérieure da corselet.

Commune dåns l'Europe septentrionale; elle liabite aussi le nord de la France. Rare a ux environs de Puris.

\section{Phalérie rétuse, P. retusa.}

Phaleria ferruginea, elytris nigris profunde striatis, thorace maris untice multiun depiesso.

Tenebrio retusus. Fав. Syst. Eleut. tom. 1. pag. $149 \cdot n^{\circ} \cdot 26$.

Longueur 5 lig. Corselet, écusson, dessous du corps et pattes d'wn ferrugineux luisint. $\Lambda$ : tenues d'uu bruu-ferrugineux. Tête de mềne couleur, sensiblement ponctuée áusi que le desuns du corselet. Elytres noires, Inisatutes, ayant chacune neuf stries profondes et ponctuées. Jambes antéricures et intermédiaires dentelées. Femclle.

Le mâle a une profonde dépression a la partie antérieure du corselet; ses quatre pre:ıières jambes sout difformes, arquées et moins dentelćes que dans l'autre sexe.

De Cayeune.

\section{Phalérie cornue, P. comuta.}

phaleria fervginea tota, capitis latteribus dilutals, maris verticis comibus duabus parvis, mandibulis longts, acutis, comyomibus.

Phaleria corinuta. IsdT. Gener. Crust. et Ins. tom. 2. pag. $175 . n^{\mathrm{o}}$. 1. tab. X. fig. 4 et 5. Le mâle. - Trogositu comuta. FaB. Syst. Eleut. tom. 1. pag. 155. no 14. - Encycl. pl. 56 r fig. 14. Le mâle, et fig. 15. Tête de la fentelle.

Longraeur 2 ì 3 lig. Antennes et paltes ferrugineuses. Corps alougé, presque carré, d'un re?uxferrugineux, finement pointillé; côtés de la tête díates; corselet à angles postéricurs un pen saillans avec une légère impression de chaque cốé I de son bord postérieur. Elytres ayact neuf stries 
nonctućes, peu profondes, à l'exception de celle qui avoisine la suture. Femelle.

Dans le mâle les mandibules sont très-avancées, grandes, recourbées à l'extrémité et ressemblant ì deux cornes. Les côlés de la tête sout plus dilatés et en manière d'oreillettes. Le vertex porte deux petites cornes.

Du midi de l'Earope.

$2^{\mathrm{e}}$. Division. Corps en ovale court, presque bémisphérique.

4. Phalérie bimaculée, P. bimaculata.

Phaleria palíde testacea, elytrorum maculâ medicú fuscî̀.

placleria bimaculata. LAт. Dict. d'Hist nat. $2^{e}$. édit. - Tenebrio himaculatus. Herbst.

Longueur $2 \mathrm{lig} \cdot \frac{1}{2}$. Dessous du corps et pattes fauves, le dessus plus clair. Anteanes d'un fauve clair. Elytres ayaut neuf stries peu marquées, finement pointillées, leurs intervalles peu sensiblement ponclués. Une tache brune plus ou moins apparente sur le milieu de chaque élytre.

Des côtes muritimes de la France. On la trouve dans le sable.

HYPOPHLÉE, Hypophloells. FAB. LAT. Ips. Ouv. (Entom.)

Geure d'insectes de l'ordre des Colćoplères, section des llétéromères, famille des Taxicornes, tribu des Diapéiales.

(Voyez twme VII, page 588 de ce Dictionnairé. Les espèces désignées par f'abricius sous les nonıs de Castaneus et de Bicolor, sont représentées pl. 372 bis nos. 13 et 15 du présent ouvrage. )

\section{ÉLĖDONE, Eledona. LATr. Boletoplaaglis.} Fa B. Illig. Diaperis; Opatrum. Olly. (Entom.)

Genre d'insectes de l'ordre des Coléoptères, section des Hétéromères, famille des 'Taxicornes, tribu des Diapériales.

Dans cette tribu les genres Léiode, Tétratome, Eustrophe et Orchésie se distinguent de tous les autres par leurs antennes dont linsertion est à nu on découverte. Les Hypophlées ont le corps libéaire ou cylindrique. Dans les Tracluyscèles les anteunes sont très-courtes, à peine plus longues quine la tête. Les Platéries et les Diapères n'ont point les derniers articles des antennes imitant des dents de scie. Les Epitrages ont la base des mâchoires recouverte par' le neuton et le dernier article des palpes maxillaires obtrigone; ce même aricicle est en forme de hache dans les Cinodalons.

sintennes arquées, notablement plus longues que la tête, insérées sous ses bords latéraux, compusées de onze arlicles, terminées en une masse furraée des sept derniers; ceux-ci compriunés,
P $\mathrm{H}$ A

saillans en dent de scie, le dernier assez grand. - Labre petit. - Palpes ayant leur dernier article cylindrique, alongé; les maxillaires de quatre articles, les labiaux de trois. - Lè̀re nue, coriace, transverse, plus large vers son extrémité, presqu'entière; menton se rétrécissant petit à petit, de son extrémité à sa base, presqu'obtrigone, ne recouvrant point la base des mâchoires. Téte inclinée. - Corps ovalaire, convexe. -Corselet grand, gibbeux. $-E_{\text {cusson }}$ petit. - Elytres dures, voûtées, couvrant eutièrement les ailes et l'abdomen. - Jambes antérieures menues, cylindriques.

Ces insectes sont de conleur obscure. On les trouve sous les écorces des arbres et idans les champignons dont ils paroissent se nonrrir. Leur's larves sont inconnues. Les espèces sont en petit nombre.

Nota. La Diapère hideuse $n^{\circ} .3$ de ce Dictionnaire appartient à ce genre. Les fig. 14 et 15 ( $\mathrm{pl} .3_{72}$ de cet ouvrage) représentent deux a u tres espèces d'Elédones.

\section{CNODALON, Chodalon. Lat.}

Genre d'iusectes de l'ordre des Coléoptères, section des Hétéromères, famille des Taxicornes, tribu des Diapériales.

Parmi les genres de cette tribu dont les antennes sont iusérées sous les bords latéranx de la tête, on reconnoît les Hypophlées à leur corps linéaire ou cylindriçue, les Trachyscèles à leur's antennes I rès-courtes, les Epitrages par la grandeur de lenr menton recouvrant la base des mâchoires. Dans les suivans, où l'insertion des antennes est à nu, les Phaléries et les Diapères n'ont point les åntẹnnes terminées par des articles en dents de scie, et dans les Elédones le dernier article des palpes maxillaires n'cst point sécuriforme, mais presque cylindrique.

Antennes notablement plus longues que la tête, insérées sous ses bords latéraux, -composées de onze articles et terminées en une massue formée des six derniers; ceux-ci très-comprimés, allant en grossissant, saillans en dent de scie. - Labre a vancé, transverse, en lier, de grandeur moyenne. - Palpes nuaxillaires grands, de quatre arlicles, le dernier plus gros, en forme de hache; les labiaux de trois articles. - Lèvre nue, crustacée, entière; menton presque carré, ne recouvrant point lat base des mâchoires; son bord supérien. plus large. - Tête presque carrée, beaucoup plus étroite que le corselet. - Corps ovale, gibbeux. - Corselet court, gibbeux, presque carré; avantsternum prolongé en poiule mousse; cette pointe pouvant se loger dans une cavité de la poitrine. - Ecusson petit, arrondi. -- Elytres voûtées, couvrant les ailes et l'abdomen. - Jambes alongées, menues, n'ayant point d'épines apparentes à leur extrémité. 'Tarses courts.

MI. Latreille a fondé ce genre, qui ne contient 


\section{P H A}

que cinq ou six espèces propres à l'Amérique méridionale. Ses mœurs sont inconuues ainsi que ses métamorphoses.

\section{Crodalor âtre, $C$. atrum.}

Cnodalon atrum, labri basi livido-luten, thorace lateribus subspinoso, elytris striatis, striis punctatis, punctis clongatis haud profundis.

Cnodalum atrum. Des. Catä.?

Longueur 8 lig. Noir. Base du l..bre d'un jaune livide. Tête finement ponctuée. Corselei ioriement rebordé, ses bord's latćraux nunis vers leur milieu d'une épine mousse assez saillante. Elytres ayant des stries formécs par des points alongés, péu enfoncés. Jambes garnies en dedans à leur parlie inférieure de posls roux, ainsi que le dessons des larses.

De Cayenne.

Nota. Peut-êlie la villosité des jambes n'appartient-elle qu'i l'uu des sexes. Ia tig. 13, pl. 36 I du présent onvrage, représente nue autre espèce de ce gente. (Cnod. vinde. LAT.)

\section{EPITRAGE, Epitragus. LAT.}

Genre d'insectes de l'ordie des Coléoptères, section des Hétéromères, furnille des raxicornes, tribu des Diapériales.

Les genres Hypophlée, Diapère, Phalérie, Trachyscèle, Elédone el Cnodalon forment dans cette tribu avec celui d'Epilrage un groupe caractérisé parl'insertion des anlennes sous les bords latéraux de la têle; mais les six promiers genres onl la base des mâchoires nue en dessous, nullemeni recouverte par le menton.

Antennes notablement plus longues que la tête, insérées sous ses bords latéraux, composées de onze articles, allant en grossissan! insensiblement de la base à l'extrenité. - Labre avancé, transverse, entier. - Talpes maxillaires long, de quare aricles, le dernier plus grand, obtrigone; les labiaux très-courts, de trois äticles. - Lèvre peu avancée, très-courte, bordaut transversalement l'extrémité du menton; celui.ci grand, presqu'hexagone, recouvrant par sa largenr la base des mâchoires. - Corps ovale, aminci à ses deux extrémités en forme de nacelle, son dos convexe. - Corselet trapézoidal, point rebordé latéralement; avant-sternum prolongé eu pointe mousse; celte pointe ponvant se loger dans une cavité de la poitrine. - Ecusson petit, arrondi postériearement. - Elytres voûtées, rétrécies postérieurement, convrant les ailes et l'abdoucen. - Jambes s'élargissant un per vers leur extrémité, terminées par denx courles épines.

On ne conncit pas les mours des insectes de ce geure étranger à l'Europe. Son nom est tilé d'un nol grec qui signifie: ronger. L'espèce qui a servi de type à M. Laltreille est d'Amérique.

Hist. Nat. Ins. Tome $X$.
$\mathrm{P} \mathrm{IA}$

I. Epitrage brun, E. fuscus.

Epitragus fuscus, flavescente-subtomentosus, elytris punctato-striatis.

Epitragus fuscus. Lat. Gener. Crust. et Ins. tom. 2. pag. 183. no. 1. tom. 1. pl. 10. frg. 1.

Longueur 6 lig. Corps entièrement d'un roux= brun foncé, ponctué, chargé de poils d'un rouxferrngineux. Elytres finement pointillées, ayant des stries formées par des poiuts assez enfollcés; tous les points portant cliacun un petit poil court, couclić, de même couleur que les autres.

Ve Cayenue. (S. F. et A. Serv.)

PHASIE, Phasia..Lat. Conops. Linn. Syrphus. Ross. Thereva. FAB. PAxz. Musca, Syrphus. PANZ.

Genre d'insectes de l'ordre des Diptères, section des Proboscidés, famille des Athéricères, tribu des Muscides.

Ce gemre est dù à M. Latreille. Fabricins en l'adoptaut en a cliangé le nom. Il se distingue de la plus grande partie de ceux de sa tribu, par les cuillerons grauds, recouvraut entièrement les balanciers. Les Lispes ayant lenrs palpes dilatés en cuiller, ne peuvent se confondre avecles lhasies; les antennes des Echinomyies, des Ocyptères, des Moucles et des Achias sont anssi longues que la face anlérieure de la tête, tandis que dans les Métopies, les Mélauophores et les Phasies, elles n'égalent que la moitié au plus cle la longueur de la face antérieure de la tête, mais les deux premiers de ces genres ont des antennes contiguës à leur naissance et allant en divergeant.

Antennes écartées entr'elles à leur base, parallèles, égalant en longuenr environ la moitié de la face antćrieure de la tête, composécs de trois articles, le premier court, le second un peu plus long, le troisicme on paletle plus grand, presque carré ou ovoide, porlant à sa hase une soie simple distinctement hiarticulće. - Yeux des mâles filus grands et plus rapprochés que dans ies fenclles. - Ailes grandes, écartées, un peu élevées. - Cuillerons grands, recouvraut les balanciers. - Trompe distincte. - Abdomen composé de cinq segmens outre l'anus çui paroit placé sous le cinquièue.

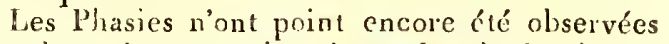
dans leurs deux premiers élats; dans le demier on les Irouve sur les lleurs, les Ombellifêres particulièrement, où elles se nourrissent de miel. Elles s'envolent arec quelque difículté, et cepcudaut leur vol est rapide. Ce genre se divise naturellement par la furme de l'abdonen. Les espéces de la première division appartiennent à notre climat et n'ofient ordinarenent que dcux conleurs, le roux et le noir , cont tantôt l'une, tantôt l'autre, est dominante. Les l'basies de la seconde division paroissent propres à l'Amérique septentrionale, N 
leurs jambes postérieures sont ordinitirement garrites d'ane fringe de cils imitant les barbes d'une plutuc; une espèce de cetle division habite la Fance méridionale, mais elle n'a point ce dervier caractère.

Ire. Division. Abdomen presque demi-circulaire ou en demi-ovale, fort déprimé.--Ailes ordinairement ćlargies à leur base extérieure.

1. Prasre ailes épaisses, $P$. subcoleoptrata.

Phasia capitis pallidi vertice lateribusque aureo villosis, pedibus fuscis, tihiis nudis.

Phasia subcoleoptrata. LAT. Gener. Crust. et Ins. tom. 4. pag. 345. - Thereva subcoleopfrata. FAB. Syst. Antliat. pag. 217. $n^{\circ}$. 1. PAvz. Faun. Goum. fas. 74. fg. 13. Femelle. fig. 14. Mâle. - Encycl. pl. 394. fig. 14. la feruclle, et fig. r5 le mâle.

Longueur 3 lig. $\frac{x}{2}$. Antennes d'un roux-brun, pâlette et soie noires. 'Tête pâle couverte d'un duvet argenlé et chatoyant, vertex noir. Corselet noir, ses côtés et sa partie antérieure couverts de poils roux et dorés. Ecusson pâle. Abdomen roux, cilié de noir à sa base, de roux vers l'anus et marqué d'une ligne noire dorsale assez large. Ailes rousses à leur base, avec la partie extérieure et l'extrénité brunes, cette couleur s'avançant dans le milieu presque jusqu'au bord interne. Pattes brunes, pelottes blanches. Femelle.

Le mâle n'a qu'un peu de bruu au bord extérieur des ailes et la ligne dorsale de son abdomen est plutôt brune que noire.

Nota. Panzer s'est trompé sur les sexes. Lni el Fabricius rapportent à cette espèce !e Conops subcoleoptrata de Linné. Nous pensons a vec M. Latreille que c'est une erreur. Le diptère décrit par Yinné appartient sans aucun doute au genre Phacie, mais il a l'abdomen roux avec l'exirémité soire, ce qui ne convient nullement à la $\mathrm{Phasie}$ ailes épaisses.

On la trouve en France.

\section{Prasir crassipenne, $\boldsymbol{p}$. crassipennis.}

Phasia capitis pallidi vertice aureo, pedum yestaceorum tarsis fuscis tibiisque nudis.

Phasia crassipennis. LAт. Gener. Crust. et Ins. tom. 4. pag. 345. - Thereva crassipennis. $\mathrm{F}_{\mathrm{AB}}$. Syst. Antliat. pag. $218 . n^{\circ} .3$. Femelle. - $\mathbf{P}_{A N z}$. Faun. Germ. fas. 74. fig. 17. Mâle. - Coques. Illust. Icon. 3. tab. XXIII. fig. 10. Mâle.

Longueur $3 \mathrm{lig} \cdot \frac{1}{2}$. Duvet de la partie supérieure de la tête d'un roux doré. Ecusson noir, couvert ainsi que le corselet d'un duvet roux doré. Pattes fauves, tarses bruns. Ailes noires avec le disque transparent, portant uue tache noire.

\section{J' II}

Semblable à la précédente p:ur le reste. Femelle.

Le mâle a le premier segment de l'abchomen roux à base et dos noirs; le second noir ì base rousse des deux côtés; on voit aussi du roux à la méme place sur le troisième segrment, mais en plus petite quantité; quatrième segment'noir couvert d'un duvet roux doré et clargé de lon rs poils noir's implantés sur de petits tubercules de même couleur. Jambes plus foncées cue dans la femelle. Ailes transparentes; nne tache brone chargée d'un point noir, sur le milieu de leur bord extérieur.

On la trouve en France sur les fleurs.

2e. Division. Abdomen presque cylindrique. - Bord extérueur des ailes ordinairement droit de la base jusque passé le milieu.

\section{Phasie hirtipède, $P$. hirtipes.}

Phasia capitis pallidi argenteo-tonzentosi vertice nigro, pedibus nigris, tibiis posticis pennatis.

Phasia hirtipes. Lat. Dict. d'Hist. Nat. $2^{\mathrm{e}}$ édit. -Thereva hirtipes. FA B, Syst. Antliat. pag. $2: 9$. $n^{\circ} \cdot 9$.

Longuemr 2 lig. : Tête pâle à duvet argenté; vertex et une ligue descendant jusqu'à la base dcs antennes, noirs. Antennes noires, leur second article roux. Corselet noir, couvert d'un duvet doré antérieurement. Ecusson noir. Abdomen roùx, avec le quairième segrnent et l'anus noirs. Pattes noires; hanches et base des cuisses rousses; jambes postérieures extérieurement garnies de longs cils imitant les barbes d'une pluane. Ailes noires, ayant leur bord intérieur transparent. Femelle.

De la Caroline.

ÉCHINOMYIE, Eclinomyia. DUMÉR. LATR. Musca. Linn. De Géen. Oliv. (Encycl.) Panz. Tachina. FAв. Me1g. Class.

Genre d'insectes de l'ordre des Diptères, section des Proboscidés, famille des Alhéricères, tribu des Muscides.

Ce genre fondé par M. Duméril, a été adopté par M. Latreille. Il fait partie d'un groupe de cette tribu, lequel a pour caractères : cuillerons grands; palpes filiformes ou grossissant un peu vers le buat : longueur des anteunes égalant presque celle de la face antérieure de la tête. Ce groupe renferme encore les Ocyptères, les Mouches et les Acbias; mais dans ces genres le troisième article des antenues est plus long que le second, ce qui empêche de les confondre avec les Echinomyies.

Antennes à peu près de la longueur de la face antérieure de la tête, composées de trois articles, le second alongé, presque cylindrique, comprimé; le troisième ou palette, plus court que lo 
précédent, large à son extrémilé, presçu’en hache, portant une soie simple, de deux arliculations distinctes, la seconde alongée. - Palpes presque filiformes, un peu plus gros à l'extrémité. - Ailes écartées. - Cuillerons srands, couvrant la majeure partie des balanciers. - Trompe distincle. - Abdomen composé de quatre sệnens outre l'anus, celni-ci paroissant plaeć sous le quatrième segment.

I.es espèces qui composent ee genre sont ordinairement chargées de grands poils roides, d'où vient leur nom générique tiré de deax mols grees qui signifient: Monche hérisson. Daus plusieurs ouvrages on a donné des délails de mæurs extraits de Réaunur comme appar!euant à l'Eehinomyie grosse ; mais eet autenr n'a point connu ce dipière. Il décrit une larve qui vit dans les bonzes de vache, el l'espèce dont il parle et qui provient de celle larve, n'appartient pas au genre Echiromyie, c'est la Mouc.he méridienne $\mathfrak{a}^{\circ} .4$ du présent Dictionnaire.

Ces diptères fréquentent les fleurs.

Rapportez à ce gemre la Mouche grosse no. 58, pl. $249, f_{g} .1$, en retranchant les synonymes de Réaumur et de Geoffroy, qui appartiennent à la Mouche méridienne $n^{\circ} .4$, et la Mouche farouche no. 54. pl.394. fg. 10-12 bis.

ACHIAS, Achias. Fab. LAt.

Genre d'inseetes de l'ordre des Diptères, section des Proboscidés, famille des Alhéricères, tribu des Muscides.

Ce geure est placé aujourd'hui par M. Latreille dans un groupe de eelle tribu qui renferme en outre les Eehinomyies, les Ocyptères el les Mouches ( עoyez Еснгломуге, pag. 98); mais daus ces trois genres, les yeux ne sont pas pédiculés.

Antennes écartées l'une de l'antre à leur base, couehées sur la tête, insérées sur le front, à peu près de la lingueur de la face antérieure de la tête, composées de trois articles, le dernier ou palelle alougé, plns grand que le second, portant à sa bise une soie très courte. - Bouche peu avaneée, son ouverture oblongue. - Trompe grande, a vané́e. - Deux palpes avancés, de la longuenr de la trompe, iusérés à sa base, nus, filiformes. - Yeux portés en avant chaeun par un pédienle cylindrique, épais, plus long que la tête. - Corselet aplati. - Ecusson arrondi, un pei échancré. - Ailes plus longues que l’abdomen. - Cuillerons grands, couvrant la majeure partie des balanciers.

\section{Acuras oculé, A. oculatus.}

Achicas thorace obscuro, abdomine cupreo, alis albis, pedibus nigris, femoribus testaceis.

Achias oculatus. FA B. Syst. Antl. pag. 247. no. 1. - Lat. Getor. Crust. et Ins. tom. 4. pas. 352.
Longuerr n. Corseles obscur. Aldomen d'un cuivreux brillant, un peu pâle à sa base. Ailes trausparentes, leur eôte obscure vers sa base. Paltes noires. Cuisses testacées.

De l'ille de Juva.

Nota. Nous n'avons pas va ce diptère; nous le décrivons iei d'après Fabrieius. Ce genre ne contient que celte seule espèce.

\section{MÉTOPIE, Metopia. MeIG. Class. L:T.}

Genre d'insecles de L'ordre des Liptères, section des Proboscidés, famille des Alluéricères, tribu des Museides.

Les Mélopies forment avec les Phasies ( z'oyez ce mol) et les Mélanophores un groupe dont les caractères sont : cuillerons grands; palpes filiformes; longueur des antennes n'égalant guc̀re que la moitié de celle de la face antérieure de la tête; mais les Plasies ont les antennes écartées à leur naissanee, presque parallèles, et daus les Mélanophores la paletle ou deraier arlicle des anlennes est presque lenticulaire.

Antennes contiguës à leur naissanee, divergentes, guère plus longues que la moitié de la face anlérieure de la têle, composées de trois artieles, le dernier ou palelle très-grand, oblong, porlant à sa base une soie simple, longue, subulée. - Palpes filiformes. -- Ailes écartées: Cuillerons grands, collviant la majeure partie des balanciers. - Trois yeu.x lisses très-petits, trèsrapprochés, placés en triaugle sur le vertex.

Ou tronve ces insectes dans les bois, voltigeant sur les feuilles. Ils se font remarquer par la couleur argentée, très-brillante, de la parlie antérieure de leur tête. Nous ne connoissons pas leurs métamorphoses.

La Mouche labice, no. 74 de ce Dictionnaire, est de ce genre. Sa tếte est entièrement argentée, à l'exception da verlex; ses balanciers sont blanchâtres. Le corps est chargé de grands poils assez roides, au travers desquels on aperçoil, surtout sur l'abdomen, un duvet trés-court, fori brillant, qui a dans quelques endroits et sous certain aspect un reflet argentiu.

Elle est comoune aux euvirons de Paris.

MÉLANOPHORE, Melanophora. Merg. Class. Lat. Musca. Linn. Groff. F.ad, Panz. Tephritis. FAB.

Genre d'insectes de l'ordre des Diptères, secion des Proboscidés, fumille des Athéricères, tribu des Nusciaes.

Dans le groupe partiel de cette tribu, dont les Mélanophories font parie (voyez Phaste), les Pliasies ont les antennes écartées à lcur naissance et presque parallèles; et dans les Mélopies le dernier article des antennes ou paletie est trèsgrand, oblong, muni d'une soie longue et subulée.

Antennes contiguës à leur naissance, diver- 
gentes, fuère plus longues que la moilić de la fuce antérieure de la têle, composées de lrois artirles, le dernier ou palette presque lerticulaire, portant une soie convle vers sa basc. - Ailes écartćes. Cuillerons grands, convrant li majeure partie des balanciers. - Trois yeux lisseslòs-pelits, peu appareus, rapprocbés en trangle sur le vertex.

Milanovlore vient de deux mols grecs qui expriment que ces Miscides po:tent une livréenoire. On les trouve volligeau sur les murs el les pierres exposés à l'ardeur áu soleil; leur vol s'exécute par sauts; on les rencontre aussi quelquefois sur les fleurs. Les espèces connues sunt en pelit nombre.

jre. Division. Suie des antennes nue.

La Monche grossificatienne, $n^{\circ} .124$ de ce Dictionnaire, est de celle division. Nous en counoissons une autre espèce des envirous de Paris,

$2^{\mathrm{e}}$. Division. Soie des antennes plumetise.

Nous rapportons icila Musca carbonaria. PAsz. Faun. Germ. fasc. 54.fig. 15. Les nervures des ailes ne sont pas tout-à-fait les mêmes que dans les espèces précédentes.

Nota. Au genre Mélanophore appartient encore la Mouche rorale $n^{\circ} .7^{5}$ du présent ouvrage.

LISPE, Lispa. IAat. Mulsca. DE GÉer.

Genre d'insectes de l'ordre des Diptères, section des Proboscidés, famille des Athéritères, tribu des Muscides.

Parmi les Muscides, les cuillerons grands caractérisent les genres Echinomyie, Ocyplère, Mouche, Achias, Phasie, Métopie, Mélanophore el Lispe, mais aucun des sepl preuniers n'a les palpes subitement dilalés en spatule ou plutôt en cuiller.

Antennes insérées près du front, plus courtes que la tête, composées de trois articles, le premier très-court, le second un peu plus long, le rroisième en palette alongée, presque cylindrique, portant vers son milieu une soie plumeuse dislinclenent arliculée à sa base. - Palpes toujours saillaus, mêıne dans le repos, subitenıent dilatés en cuiller à leur extrémité, un peu ciliés sur leurs bords. - Cuillerons grauds, couvrant la majeure partie des balanciers. - Ailes couchées sur le corps (suivant M. Lalreille). - Trois petits yeux lisses, disposés en triangle sur le vertex. - Jambes grêles, assez alongées.

On ne connoît qu'une seứe espèce de ce genre dú à M. Latreille. Elle ressemble un peu à la Mouche domestique et fiéquente les sables humides du bord des eaux.

\section{Lispe tentaculée, $L$. tentaculata.}

Lispa nigra, griseo subtomentosa, capite anticè sericeo, palpis testaceis.
Lispa tentaculilu. [, Ат. Gener. Crust. ę́ Ins. tom. 4. pag. 347. tom. 1. tab. I5. fig. 9. Mlusca tentaculata. Li G Gen, Ins. tom.6. pug. 86 . $30^{\circ} .15$.

Longuenr 3 lig. $\frac{1}{4}$. Noire, converte d'un duvet cendré soyeux. On voit quelques poils roides asscz grauds sur la lête, le corselel et l'écusson. Partie antélienre de la lête chargée d'un duvet roux ạ r'cilet argenté; quelques plaques semblables soui placées sur l'abaumen. Palpes jannes couverts extérieurement d'un duvet argenté. Ailes transparentes, nervures noires. 'Tarses antérieurs plus ou moins jaunâlres.

Nota. De Géer considere comme fenselles les individus qui onl. la plus grande partie des palles antéricures jaunâlre.

Des environs de Paris. (S. F. et A. Serv.)

PHASME, Phasma. FAB. LAT. Mantis. LINN. De Géer. Oliv. (Encycl.) Spectrim. Stolx. LAM.

Genre d'insectes de l'ordre des Orthoptères, famille des Coureurs, tribu des Spectres.

Celle tribu est composée des genres Phasme et Phyllie. Ce dernier se distingue des Phasmes par le corselet très-court dont les segmens sont presque triangulaires, par les tyyes imitanl des fenilles et par l'abdomen large, membraneux, ovale, très-plat.

Antennes insétces devant les yeux, plus pres de la bouche que du milieu de la lête. - Labre échancré, son bord antérieur droit. - Lèvre a quatre divisions inégales. - Palpes inćgaux, tiliformes, cylindriques. - Tête a vancée, alongée, arrondie pusićrieurement. - Yeux pelils. $Y$ enx lisses souvent peu distiucls. - Corselet formé de trois segmens, le premier ordinairement plus court que le second. - Pattes antérieures point ravisseuses; tarses de cinq arlicles, leurs crochets munis d'une pelolte dans l't:itre-deux. Corps très-étruit, imitant un rameau ou une tige de plante dépourvue de feuilles, à élytres trèscourtes ou souvent aplère.

Les insectes de ce grente habitent l'Amérique et les Indes orientales, sauf deux ou trois espèces propres au midi de l'Europe. Ils aiment à ce qu'il paroit à se tenir sur les branches d'arbres auxquelles ils ressemblent par leur forme et leur extérieur souvent raboteux, quelquefois même par les couleurs. Les femelles on la partie inférieure de l'anus creusée en grouttière de telle façon qu'elle pourroit leur servir à faire une excavation pour déposer leurs œufs; les mâles ont l'anus accompagné de deux petils appendices extérieurs. II paroît cerlain que les Pbasmes se nourrissent de végétaux. Dans ce genre nombreux on trouve des espèces ailées et d'autres aptères. M. Lansdoun Guilding, auteur d'un mémoire inséré dans la première partie du $14^{\mathrm{e}}$. volume des Transactions de la Société Linnéene de Londres, assure 


\section{P II}

positivement l'une espèce qu'il nomme Cornutum, que cet inseete reste tranquille pendant le jour, que la nuit il dévore une quantité notable de feuilles de véútaux, que sa démarche est vacillanle et que dans l'état de larve et dans celui de nymphe, lorsin'il perd une de ses pattes, celle-ci repousse et reparoît après le premier changement de peau qui suit l'accitent, mais plus petite que celle de la même paire qui lui est opposée.

jre. Division. Cuisses et jambes point dilatées et dépourvues de membranes.

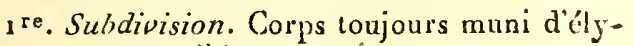
tres et souvent ailé.

\section{Passue nécydaloïle, $P$. necydaloides.}

Phasma necydaloides. L.Aт. Gener. Crust. et Ins. tom. 3. pag. 87. - FAB. Ent. Syst. Suppl. pag. 188. no. 7. - S'rold, Spect. pl. III. fig. 8. et pl. IV. fig. 11. - Encycl. pl. 13z. fig. 1.

$V o y$. Mlante nécydaloide $n^{\circ} .3$ el Hante tachelée $n^{\circ} .56$, qui est probablement la même espèce.

2. Paasme de la Jamäque, P. Jamaicensis.

Phasma Jamaicensis. LAT. Gener. Crust. et Ins. tom. 3. pag. 87. - Fа в. Ent. Syst. Suppl. pag. I88. $n^{\circ}$. 11. - StoLl, Spect. pl.VI. fig. 20 et 21 .

Voy. Mante jamaïcienne no. 42 et Mante verdoyante $n^{\circ} .60$ qui ne font peut-ètre qu'une seule espèce.

\section{Phasme latéral, $P$. lateralis.}

Phasma lateralis. L.4т. Gener. Crust. et Ins. tom. 3. pag. 87. - F'A . Ent. Syst. Suppl. pag. 188. $n^{\circ}$. 12. - S rold, Spect.pl. X. fig. 56. et 37 .

Voy. Mante latérale no. 43. La Mante Xanthomélas $\mathrm{n}^{\circ} .67$ n'en est peut-être qu'une variété.

\section{Phasme rose, $P$. rosea.}

phasma rosea. LAт. Gener. Crust. et Ins. tom. 3. pag. 87. - HAB. Ent. Syst. Suppl. pag. 19o. $n^{\circ} .17 \cdot-$ S TоLL, Spect. pl. V. fig. 17.

Voy. Mante érythroptèce $n^{\circ} .58$.

On doit encole rapporter à cette division les Mantes nos. 2, 5, 39, 40, 4r, 44, 63, 64, et celles numérotées 14 et 15 , dans les espèces moins connues.

2e. Subdivision. Corps sans ailes ni élytres.

A. Antennes longues, sétacées; leurs articles peu distincts.

Rapportez à cette coupe les Mantes nos. I, $7^{1}$, 72,74 et 75 .

B. Antenues très-courtes, conico-subulées à articles distincts et grenus.

\section{Paasme de Rossi, P. Rossia.}

plasma apitera, viriais aut cinereo-fusca, antennarum breviorum articulis distinctis.

Phasma Rossia. IA T. Gener. Crust. et Ins. tom. 3. pag. 80. - I'A . Ent. Syst. Suppl. pag. 187. no. 4. - Mantis Rossia. Ross. Faun. Etrus. $n^{\circ}$. 636. tab. VIII. figo I. - Eucyct pl. 134 . fig. 4 .

Longueur 4 prouces. Corps vert, jaunâtre o:ı d'un brun-cendré suivant l'íge. Cor'selet uu pere caréné dans son milieu. Palles strées. Cuisses munies d'un dent vers leur extrémitr.

Il se tronve aux environs d'Orléans, dans la France méridionale et en Italie.

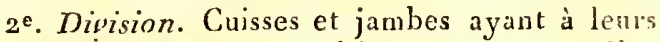
parties incórieure et extérieure, un appendice nembraneux.

A celte division apparticnnent les Mantes nos. 59 et 76 . (S. F. et A. Serv.)

PHÉRUSE, Pherusa. Nom donné par M. Léacb à un genre de Crusiacós de l'ordre des Amphipodes, très-voisin des Crevetles, mais à antennes supérieures simples ou point accompannés. comme les leurs, d'une soie. Les Amphithoës du même ressemblent sous ce rapport aux Phéruses; mais ici les mains ou pinces sont filitermes, et lit elle's sont ovordes.

Il ne cite qu'une espèce qu'il nomme Fucicole (Fucicola). Son corps est d'un cendré rouisâtre on d'un cendré gris et mélangé de rouge. On la trouve, mais rarement, parui les Fucus dela mer qui baigne quelques côtes méridionalcs de l'Angleterre. (Latr.)

PHILANTHE, Philanthus. M. Jurine a donné ce nom à un genre d'iisectes lyménoptères qui répond exaclement à celui de Cercéris de M. Latreille. Les Philanthes de ce dervier auteur ont reçu du premier la dénomination de Simbléphie. (S. H.. et A. Serv.)

PHILANTHE, Philınthus. FAB. IAAT. PANZ. Illig. Vespa. Geofr. Oliv. ( Lncycl.) Crabro. Ross. Simblephilus. Jur.

Genre d'insectes de l'ordre des Ifyrnénoptères, section des Porte-aiguillon, fauille des Fouisseurs, tribu des Crabronites.

Ce genre est dû à Fabricius, mais il y confond les Cercéris de M. Latreille; c'est eu élaguant ces derniers, que nous présentons ici le gevre Philantbe.

L'insertion des antennes près de la bouche distingue tous les autres Crabronites des Psens, des Cercéris et des Pbilanthes. Les Psens ont l'abdomen pédicudé; dans les Cercéris toụs les 
segruens de l'alddomen sont rútrécis à lear base, tandis que les Philanches ont l'abdomen sans pédicule appareut et point d'étranglement à la base des segraens. Les cellules cubiluites de leurs ailes sont sessiles, tandis que la seconde cubitale des Cercéris est pétiolée.

Antennesécartées à lcur base, grossissant brus. quement, guère plus longues que la têle, composíes d'ariticles serrés, au nowbre de douze dans les femelles, de treize dans les mâles; le troisième presque conique. - Labre coriace, carré, plus large que long, son bord antérieur quadúdenté; dents iutermódiaires plus pelites et aiguës; une lame membraneuse formant au-dessous comme un second labre. - Mandibules étroites, arquées, sans saillie au côté interne. - Palpes courts, filiformes, les maxillaires un peu plus longs, de six articles presqu'égaux, obconiques; les labiaux de quatre, le premier et le quatrième plus longs. - Yeux un peu échancrés intérieurement. - Serment antéricur du corselet très-court; wétatharax obius. - T'éte grande, chaperon trilobé, le lobe du wilieu remontant beaucoup vers l'origine des antennes. -Trois petits yeux lisses disposés triangulairement sur le vertex. - Ailes snpérieures ayant une cellule radiale pointue aux deux extrénités et quatre cellules cubitales, la première presqu'aussi longue que les deux suivautes réunies, la seconde et la troisieme rétrécies vers liaradiale, recevant chacune une nervare récurrente, la quatrième atleignant presque le bord postérieur de l'aile. - Abdomen ovale, composé de cinq segmens outre l'anus dans les femelles, en ayaut un de plus dans les mâles, ces segnens sans étrangrlement et le precuier n'étant point nodiforme; plaque supérieure de l'auss obluse à l'extrémicé, vin peu échancrée dans les fenelles et fourchue dans les mâles. - Pattes fories, jaubez et tar'ses ciliés et comme épineux, crochets grands, simples, munis d'une petite pelotte daus leur eutredeux.

Ires Philantles femelles font leur nid dans les sables en talus où ils creusent un trou assez profond et l'approvisionnent avec différentes espèces d'iasectes qu'ils picquent de leur aiguillon iu moment où jls s'en emparent, pour en disposer ensuite plus facileusent, Cette piquâre ne donue point une mort promple et l'oṇ peut encore reIn arquer des mouvemess dans la victime qu'on leur à eulevée, plusieurs jours après sa blessure. Lorsque le nid est surfisamment garni de proie, les femelles y poodent un cuf et ferment le trou. Elles vout en recomatencer un autre pour y déposer un nouvel œuf. La larve éclôt très-peu de temps après et consomme en quelques jours la proie qui a été mise à sa portée. Ces larves sont blanchâtres, molles, rases, convexes cn dessus, un peu aplaties en dessous, amincies vers l'ancis. Leur corps est cornprisé de douze segmens espacés par des érranglemens sensibleo avec des bourrelets latéraur. Les sligmates posés de chaque côté des segwens sont riès-itpparens sur le premier et l'divaul-dernier. Lia touche forme une espèce de bec aroné de deux petits crochets. Avant trois semaines la larve est arrivée à toule sa grandeur. Elle se forme alors une coque qui ne parồt point filée, mais plutôt composée d'une ưlatière visqueuse, laquelle en se desséchant, devient uve membrane flexible imitant une bouteille ì goulot fort court, l'extrémité opposée à celui-ci étant arrondie. La larve reste sous sa forme peudant plusieurs mois et ne se change en nymphe que vers la tin de l'hiver, et par conséquent il n'y a point deux générations dans l'année. La proie de ces insectes varie suivant les espèces, mais cliacuue se borne ì un petit nombre d'espèces fort voisiues les unes des autres. Les mâles sont trèsardens, on les voil se précipiter sur leurs femelles au moment où celles-ci rentrent chargées dans leurs nids en volant péniblement; ils se joignent à elles avec tant de violence qu'ils roulent souvent ensemble sur le sable dans un espace de plusieurs pieds. C'est en l'air que l'accouplement a lieu.

Dans l'état parfait ces hyménoptères se nourrissent de miel et vont le chercher sur les fleurs; c'est sûrement en raisoin de cette liabitude qu'on leur a donné le nom de Philauthe, composé de deux mots grecs qui siguifient: ani des fleurs, Ce grenre n'est pas nombreux en espèces. Leur couleur dominante est le noir varié de jaune.

\section{Phulanthe apivore, $\boldsymbol{P}$. apivorus.}

Philanthus apivorus. Lst. Hist. nat. des Fourmis, pag. 307 et suiv. pl. i2. fig. 2. Fenelle. Panz. iévis. Mâle. - Philanthus pictus. Fan. Svst. Piez. pag. 3oz. no. 5. Malle, - Pavz. Faun. Germ. fas. 47. fig. 23. Mâle. - Simblephilus pictus. Jưr. Hym. pag. 188. Mâle. - Simblephilus diadema. Juk. Hym. pag. 188. pl. 10. Mále varićté.

Voyez pour les autres synonymes et la description de la feunelle, la Guêpe lisérée no. 118.

Le mâle dillère par la lache jaune tricuspidée qu'il porte au-dessus du chaperon entre la base des autennes el par son écusson ayant deux ligne jaunes.

La femelle approvisionne son nid d'Abeilles domestiques et de diver'ses espèces d'Andrènes.

\section{Phipantere couronné, $P$. coronatus.}

Philanthus antennarum basi subtìs luteạ., abdominis segmentis luteo marginatis, duobus pronis interruptis, tertio subinterrupto.

Philanthus coronatus. Lat. Gener. Crust. et Ins. tom. 4. pag. 95. - H.1в. Syst. Piez pag. 3о1. $n^{\circ}$. 1. Femelle. PAxz. Faun. Gern. fas. 84, fig. 23. Femelle. - Simblephilus coronatus. Jus. Hym. 
pag. 188. Femellc. - Encycl. pl. 380. jog. 10.

Longueur 7 à $8 \mathrm{lig}$. Antennes roires; leurs trois rremiers articles jaunes, tacbés de noir postérieurement. 'Tćie noire avec sa parlie infériente audessous des yeux, la bouche et une tache sur le front jaunes. Corselet noir ayant sa lignc antérieure, l'éeuille des ailes, un point placé sous celle-ci et une ligne au bord postérieur do l'écusson, jaunes. Aisdomen noir. Chaque segment ayant une bande jaunc; les deux promières trèsinterrompues, la troisième l'étant à pcine. Anus aaché de jaune au milieu. Palles jantnes, hanches noires. Ailes fauves, deni-transparen!es, nervures de même coulecr. Fenelle.

Dins le mâle la tache frontale porte plusieurs pointes dont trois droites à la parlie supérieure. Le jaune de la base des antenines s'ćtend sur un plus grand nombre d'articles. L'écusson est enfic̀rement noir. Le sixième segment de l'ubdomen n'a que deux points jaunes et l'anns une trèspetile tache janne vers son extrémité. Les cuisses ont un peu de noir en dessons.

Des environs de Paris.

CERCÉRIS, Cerceris. Latr. Sprvor, Philanthus. Fab. Jur. Panz. Crabro. Oliv. (Encycl.)

Genre d'insectes de l'ordre des Ify urénoptères, section des Porte - aiguillon, famille des Fouisseurs, tribn des Crabronites.

Dans eette tribu les genres 'Trypoxylon, Goryte, Crabron (Frélon Encycl.), Sugme, Pemphrćdon, Melline et Alyson ont les autennes insérées près te la bouche ou au-dessous du milien de la face de la tête. Dans les Psens et dans les Pliilanthes l'abđơmon est uni, ses segmens n'étanl point séparés les uns des autres par un étranglement. 'Toutes les collules cubitules des ailes supérieures sont sessiles dans ces deux genres.

Antennes très-rapprochées, grossissant insersiblement, beaucoup plus longues que la tête, insćrées au milieu de la face anlérieure de la tête, composées de douze artieles dans les femelles, de treize dans les mâles. - Labre curiaee, en carré transversal, fléchi, son bord antérieur quadidenté. - Mandibules ayant leur cộté interne dilaté vers le milien en un appendice à deux dents obtuses. - Mâchoires ayant leur lobe terminal ovale et voûté, l'intérieur coriace, demi-trans parent. - Palpes courts, filiformes, les maxillaires plus longs que les labiaux, plus courts que les mâchoires, composés de six artieles presque égaux, obeoniques; les labiaux de quatre, le premier et le dernier plus longs que les autres. - Lèvre reployée en double dans le repos; menton alongć, cylirdriqué, coriace, presque trifide à l'extrémité. - I'éte épaisse, paroissant earrée vue en dessus; chaperon trilobé, le lobe da milieu remontant vers l'origine des antennes. - Yeux ovales, entiers. - Trois petits yeux lisses rap- prochés, presqu'éguux, disposés en triangle slir le vertex. - Corps alongé. - Corselet ovale, ol:tns postérieurement, son segment antérienr plus court que le second. - Ailes supérieures ayant une ccllule radiale longue, se rétrécissant aprìs la troisième cellule enbitale, sun extrémité arrondie, s'écartant un peu de la, côte; et quatre cellules cubitales, la promière plis tongue quaucnue des autres, la seconde petite, presuguen tritnqle curvitigne, distinctement pétiolée, recevan la première nervure récurrente, la troisième cubilale recevant la deuxième nervure récurrente, la quatrième atteignaut presque le bout de l'aile. - Abdomen composć de cinq scymens ontre l'anns dans les femelles, en ayant un de plus dàs les'uâles, Ic premier beaucoup plus petit qne les suivans, nodiforme; tous les segmens séparés les uus des autres par un étranglement notable; plaque supéricure de l'anus yresque triangulaire dans les femelles, presque carrée dans les mâles, l'intérienre un pen fourchue dans les femelles. Pattes forles dans ee sexe; jambes et tarses ciliés et comme épiueax : crochets grauds, simples, mnnis d'une pelorte dans lcur eutre-deux.

Les mours des Cercéris sont à peu près les mêmes que celles des Philanthes (voyez cet artiele). Leur proie ordinaire consiste en Charansonites. Nous sommes certains qu'ils savent trouver ees coléoptères, lorsque leurs blytres n'ont point encore pris de consistance; car nous avons épronvé que ces parties ployoient sous l'épingle; pour les transporter, la femelle Cercéris les renverse sur le dos, et passant son corps entre les jambes de l'insecie, elle lui laisse poser ses pattes sur elle, le retient de son côté avec les siennes et le porte ainsı très-facilement jusqu'à son nid. Lcs wâles sont très-ardens à l'épocque de l'accouplement. Ils ont un large faisceau de poils de chaque côté de la tête au-dessus de la base des randibules. Dans quelques femelles la partie moyenne du chaperou est relevée, formant audessous des antennes unc espćce de nez ou de palette ćchancrée. La covieur des Cercéris est le noir et le janne. Les femelles se servent difficilement de leur aiguillon. Les espèces connues ne sont pas nombreuses.

Rapportez à ce genre les Frélons cinq bandes no. 13 (wâle dı Cerceris quadricincta. LAT.), et arénaire $n^{\circ} .22$ du présent ouvrage.

$$
\text { (S. F. et A. Srav.) }
$$

PHILÉREML, Phileremus. LAT. Epeolus. FAs. Genre d'inseeles de l'ordre des Hyménoptères section des Porte - aiguillon, famille des Meli:fères, tribu des Apiaires.

Ce genre cuéé par $M$. Laireille est de la division des Parasites; il s'́loigne des Ćratines, des Pasites, des Ammobates, des Stélides et des Allodapés, parce que tous ceux-ci ont l'écusson autique; des genres Mélecte, Mésonychie, Aglá, 
Coelioxyde, Dioxyde, Mésnchère et Epíole, ence que ces huit derniers genres on l'écusson bidenté; des Nomades par la forme alongée et triangulaire de son labre et par ses ailes supérieures gui n'ont que trois cellnles cubitales. Voyez PARASITES MELLAEERES.

Antennes courles, filiformes, un peu brisces, s'écartant l'une de l'autre de la base à l'extrémité, composées de donze arlicles dans les femelus, de freize dans les míles. - Labre plus long que large, incliné perpendiculairement sous les mandibules, rétréci vers la pointe, en triangle trou"pé. - Mandibules étroites, pointues, unidenrées au côté interne. - Palpes maxillaires de deux articles d'irgale grosseur; le prenier du double plus long gue le second et cylindique; les lubiaux de ginatre articles, le troisiène inséré sous la poince exlérieure du précédent. - Trois tecits ycux lisses disposés en triangle et placés sur le vertex. - Corselet court. - Ecusson muni de denx tubercules, mais sans épines latérales. Ailes sapéricurcs ayaut nue cellule radiale courte, appendiculíe, aiguë à sa base ainsi qu'ì son extrémité, celle-ciécarlée dis bord extérielr., et trois cellules cubitales, la première un peu plus grance que la seconde, celle-ci rétrécie ver's la radiale recevant les deux nervures récurrentes, la troisième n’alteignant pas le bord postérieur de liaile. - Ab̉omen court, conique, composé de cinq segmens outrel'anus dans les feunlles, en ay ant va de jlus dans les malles. - Pattes courtes; les quatre prenières jambes muriés d'une épine simple à lear ratrénité; celle des intermédiaires courte, aigne; jarnbes postérieures ell ayant deux; premier irticie des tarses plus grand gue les auires; crochets sinples.

Oa connoit très-peu d'espèces de Philérèmes. On en trouve une aux environs de Paris; la femelle dépose ses a sf dans lc nid des Andrènes, des Halicles, et probablemers aussi dians celui de quelques $A$ piaires récoltantes solitaires.

\section{Purcénème ponciné, $P$. punctatus.}

Phileremus abdominis fuscè ferruginei lateribus albido micantzbus, alis fuscis maculâ in parte caracteristicâ pellucidâ.

phileremus punctatus. Lat. Dict. d'Hist. nat. 2". édit. - Epeolus punctatus. Hав. Sysi. Piez. pag. $38 \mathrm{~g} \cdot n^{\mathrm{n}} \cdot 2$.

Lonqueur 2 liè. Antenues noires. Tête et corselet fortement ponctućs, noirs avec un duvet couché de couleur argentée. Abdomen brun-fera agineux, ses cốés plus obscurs portant des taches formées par des poils couchés blanchâtres. Cuisses noires avec leur extrémité et les jambes ferrugineuses, ces dernières ayaut un anneau noir dans leur milieu : larses ferrugineux. Ailes brunes arec unc tache transparenie dans la partie caractéristigue. Feuclle.

\section{P III}

On le trouve à la fin de l'écé ct en automne aux environs de Paris.

EPÉOLE, Epeolus. Lat. Fab. Jur. Spin. Panz. révis. Apis. Linn. Kin B. Melecta. Fав. Nomada. PANz. Futun.

Geure d'insectes de l'crdre des Hymćnoptères, section des Poote-aiguillon, famille des Mellifères, triluu de's Apiaires.

Purmi les A piuires parasites, l'écusson sans épines, biluberculé au milieu, distingue les Nomades et les Philérèmes. L'écussen bidenté, mais sans tubercules arrondis, est le caractère distinctif des genres Mísochère, Málecte, Mésunychie, Aglać, Cœlioxyde et Dioxyde. L'écasson est entièrenent mulique dans ceux de Córaline, Allodapé, Pasile; Ammobale el Stélide, ce qui dislingue tous ces parasites du genre Epéole.

Antennes court's, filiformes, un peu brisćes, s'écartant l'une de l'autre a l'extrémité, composées de douze articles dans les fernelles, de treize dans les mâles. - Labre plus longr que large, incliné perpendiculairement sons les mandibules, rélréci vers la pointe, en triangle tronqué. Mandibules ćltroites, pointues, unidentées au côté interne.-Palpes maxillaires peu apparens, d'un. seul article; les labiaux de quatre, le troisième inséré à la partie externe du second, au-dessous de sou extrémité.-Lèvre ayant ses divisious latérales beaucoup plus courtes que les palpes. Trois petits yeux lisses disposés en ligne courbe sur la parlie antérieure du vertex. - Corps court. - Corselet cuupé brusquentent à sa parlie posté:icure. - Ecusson muni d'une épine de chaque cóté et de deux tubercules dans son vilieu. Ailes supérieures ayant une cellule radiale peu rétrécie postérieureinent, son extrémité arrondie, un peu écartée de la côte, et quatre cellules cubilales, la première grande, la secoude plus petite que les autres, très-rétrécie vers la radiale, recevant la premićre nervure récurrente, la troisième resevant la deuxième nervure récurrente, la quatrième à peine counmencéc. - Abdomen presque conique, composé de cinq segmens outre l'anus dans les femelles, en ayant un de plus dans les unâles. - Pattes courtes, fortes; les quatre premières jambes nunies d'une éjine simple à leur. extrémité, celle des intermédiaires forle, courte, aiguë; les postérieures en ayant deux sernblables a celes dés inlermédiaires : premier article des larses plus long que les quatrc autres pris ensemble; crochets simples.

Ce genre dû à M. Latreille contient peu d'espèces. Elles sont d'Europe ou de l'Amérique septentrionale. On rencontre les Epéoles dans les lieux. sablonneux et exposćs au soleil. (Your les mours, voy. Parasites. )

\section{Epźole de Bosc, E. remigatus.}

Epeolus niger; thoracis suprà nufo-cinerei 


\section{P H I}

maculà trilobâ nigrâ abdominis segmentis rufo fasciatis primi fasciâ in medio interruptâ, pedibus nigris tibiis tarsisque quatuor anticis piceis.

Melecta remigata. FАв. Syst. Piez. pag. 387. $n^{\circ} .5$.

Longueur 7 lig. Corps d'un noir reloulé. Antennes noires. Labre brun. Epauletles et dos du corselet d'un roux-cendré; on voit sur son disque une grande tache noire trilobée antérieurement. Partie postérienre du corselet et base de l'écusson d'un roux-cendré; entre les deux est une bande noire. Premier segment de l'abdonen ayant une large bande d'un roux-cendré interrompue dans sou milieu, écliancrée de claqque côtć dans cette partie, le second avec une baude d'un roux-cendré, Iarge sur les côtés, diminuant de largour en s'avançant verșle milieu où elle est quelquefuis un peu interrompue; les troisième, quatrième, cinquième et sixic̀me segmens largement bordés de roux-cendré à leur parlie inférieure. Patles uoires, les quatre janbes antérieures et les tarses bruns. Ailes un peu enfuntés. Mâle.

La couleur des bandes de l'abdomen ainsi que les taches du corselet sont dues à un duvet court et couclié.

Rapporté de la Caroline par M. Bosc.

Les Epeolus variegatus, $n^{\circ}$. 1. Encycl. pl. 38r. fig. 8, et mercatus, $n^{\circ} .3$. FАв. Syst. Piez., ainsi que la Nomada crucigera. PAxz. Faun. Germ. fas. 6 i.fig. 20, sont de cegenre. Cette dernière est peut-être le mâle de l'Epeolus variegatus de $\mathrm{F}_{\mathrm{AB}}$.

Nous ne croyons pas que l'Abeille bariolée, $n^{\circ} \cdot 7^{2}$ de ce Dictionnaire, appartienne au genre Epéole.

\section{AGLAÉ; Aglae.}

Genre d'insectes de l'ordre des Hyménoptères, section des Porte-aiguillon, famille des Mellifères, tribn des Apiaires.

Les genres Mésochère, Mélecte et Mésonychie forment avec celui d'Arlaé un groupe daus les Apiaires parasites (voy.l'arlicle Parasites), mais dans les trois premiers les mâchoires et la lève sont courtes et ne surpassent pas en longueur, la tête et le corselet réunis.

Antennes longues, filiformes, un peu brisées, insérées chacune dans une cavilé frontale, composćes de douze arlicles dans les femelles, de treize dans les mâles. - Mandibules assez larges, striées en dessus. - Mâchoires et lèvie trés-longnes, prolongcies en une trompe atteignant dans le repos au-delà du milieu de l'abdomen. - Palpes labiaux de quatre articles. - Trois petits yeux lisses dispozés en triangle sur le vertex. - C'orps alongé. - Corselet convexe en dessus; écailles des ailes assez grandes. - Ecusson déprimé, prolongé postérieurement, ses côtés formant deux pointes pius mousses que dans les autres Parasites de liz miême division. - Ailes supérieures ayant Hist. Nat. Ins. Tome $\boldsymbol{X}$. une cellule radiale ovale-alongée, son extrémité arrondie, écartée de la côte et quatre celtules cubitales, la première pelite, en lozangre, presque coupée en deux par une netite nervure qui desceud de la côte; la seconde un pell ićtrécie vers la radiale, recevant la preınière nervure récurrente, la troisième rétrécie vers la radiale, à peu près de la grandeur de la seconde, la deuxième nervure récurrente abontissant à la nervure qui sépare les troisième el quatrième cubitales, cette dernière celiule fort lougue, n'atteignant pas le bout de l'aile. - Abdomen long, un peu déprimé en dessus, caréné longitudinalement en dessous dans sou nilieu, composé de cinq segmens outre l'anus dans les femelles, en ayant un de plus dans les máles. - Pattes longues, surtout les postérieures; jambes antérieures courtes, terminées par une seule épine branchue qui porte à sa partio inférieure une membrane transparente, jambes intermédiaires ayant une épine simple à leur extrémité; les postérieures longues, terminées par deux épines dont l'intérieure plus grande, dans les deux sexes; sillonnées en dessus dans les mâles : premier arlicle des tarses plus long que les quatre autres pris ensemble : crochets unidentés.

Ce nouveau genre a beancoup d'affinité avec celui d'Euglosse dont nous le croyons parasite, car il nous paroît dépourvu des organes nécessaires à la récolte. Dans' les Euglosses femelles les jambes postérienres sont triangulaires, c'est-àdirc beaucoup plus larges inférieurement qu’a la partie supérieure, creuses en dedans; le prenier article des tarses de ces jumbes est fortement élargi et très-creusé en dessus. Les Aglaés femelies au contraire ont les jambes postérieures peu élargies vers le bas et presque convexes en dedans. Le premier article des tarses postćrieurs n'est pas fort large, il est à peine creusé en dessus. Nons possédons deux mâles et deux feurelles 'e l'espèce qui conslilue ce genre. Si malgré ce que nous venons de dire et les caractères qui nous la font considérer conme parasite, on venoil à découvrir qu'elle fút récollante, il faudroit reporter ce genre auprès de celui d'Euglosse. Son nom vient d'un mot grec qui signifie : brillant.

\section{Agraḱ bleue, A. corulea.}

Aglae violaceo-carulea nitidissima; antenniṣ moris, alis aureo-fisscis.

Longueur 14 lig. Corpss d'un beau bleu-violet des plus éclataus. Antennes noires. On voil quelque poils rares de celle couleur sur la tête, le dessous et les côtés de l'abdomen, ainsi qu'aux pattes. Ailes brunes avec un reflet doré trèssensible. Labre et écusson très-lisses. Trompe teslacée. Mâle et femeile.

Le mâle a les jaubes antérieures et leurs tar'ses, fortement ci.iés.

De Cayenue. 
MÉSOCHËRE, Mesocheira, Metecta. FаБ. Crocisa. Jun.

Genre d'insectes de l'ordie des Hyménoptères, seetion des Porte-aiguillon, famille des Mellifères, tribu des Apiaires.

Parmi les Apiaires parasites dont l'écusson est bidenté sans avoir de tubercules arrondis dins son milicu, les Cœlioxydes et les Dioxydes n'ont que trois ccllules cubuales aux ailes supérieures. les Mésonychies se distingrient par l'épine des jambes inlermédiaires dont l'extrêmité n'est $\mu \mathrm{i}$ dilatée ni échancrée. Les Mélectes outre ce caractère, ont la prenière cellule cnbitale notablement plus grande que la secoude. Dans les Aglaés les mấchoires et la lèrre sont prolongées en une 1rompe presqu'aussi lougue que le corps; on ne retrouve point ees caractères dans les Mésuchères.

Antennes filiformes, un peu brisćes, s'écartant l'une de l'autre de la base à l'extrémité, composées de douze articles dansles femelles, de treize dans les mâles. - Mâchoires et lèvie assez courtes, n'étant pas plus longues que la tête et le corselet pris ensemble. - Mandıbules pointues, étroites, upidentées au eôté interne. - Palpes maxillaires de six arlicles; les labiaux de quatre. - Trois petits yeux lisses disposés en ligne transversale sur le vertex.-Corselet court, eourexe en dessus.Ecusson bidenté. - Ailés supérieures ayant une cellule radiale qui va en se rétrécissaut apiès la troisième cubitale, son extrémilé arronàie, s'écartant de la côte el quatre cellules cubitales, les trois premières piesqu'égales entr'elles, lit première nervure récurrente aboutissant à la norvure commune alux seconde el troisièrae cubitales; troisième eubitale rétrécie vers la radiale, recevant la denxième nervure récurente; la guintrième à peine commencée, foiblement tracće. - Abdomen court, conique, composé de cinq segmens outre l'anus dans les femelles, en ayani un de plus daus les mûles. - Pattes de longueur moyenne; les quatre premières jumbes nunies d'une seule épine à leur extrémitć, celle des antésieures simple, celle des intermédiaires élargie ‘̀ son extrémité, échancrée, bilobée, l'un des lobes en forme d'épine aiguë, l'autre dentelé ; jamLes postérieures ayant deux épines dont l'intévieure plus grande: premier article des tarses plus grand que les quatre autres pris ensemble.

Un des caractères saillaus de ce nouveau genre cst la conformation de l'épine des jambes intermédiaires représentant une sorte de main; c'est de-là qu'est pris le nom du genre qui vient de deux mots grecs et signifie: main placée au milieu. Nous ve counoissons pas les mœurs des Mésochères, mais elles ne doivent pas différer essentiellement de celles des Mélecles parmi lesquelles Fabricius a placé notre première espèce.

$$
\text { 1re. Division. Ecusson aplati, prolongé pos- }
$$

térieureinent en deux pointes planes, longues et mousses. - Seconde cubitale presque parallélipipède. - Rasliale simple. - Crochets des tarses antérieurs bifides.

\section{MÉsochène bicolore, $M I$. bicolor.}

Resocheira nigra, subvillosa, abdomine suprà crneo subtus ferrugineo, antennis sublits pedibnsque ferrugine is, alis hyalinis nigro bimaculatis.

Melecta bicolor. Fав. Syst. Piez. pag. $586 . n^{\circ}$. 3. - Crocisa bicolor. Jun. Hýmériopt.pag. $24 \mathrm{~s}$.

Longueur 6 lig. Antennes noirüiles, d'un brun. ferrugineux en dessous. 'Tête et corselet noirs avee un duvet roussâtre. Ecailles des ailes supérieures ferrugineuses. Ecusson noirâtre, prolongé postérieurement en deux lougues dents plates, inousses, conleur de poix areci un reflet niétalliiue. Dessus de l'abdomen d'un verl-mélallique changeant en violel, ses cólés et son dessous de couleur ferrugineuse. Paltes de celle couleur avec la base des cuisses bruue. Ailes transparentes, les supérieures ay ant la moitié inférieure de leur cellule radiale noirâtre et une tache plus grande de mêne couleur vers le bout de l'aile. Femelle.

De Cayenne.

Nota. Suivaut Jurine, le mâle ne diffère point.

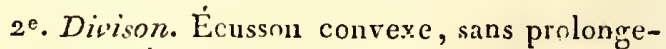
ment posiérieur, portant deux pointes assez aiguës,

re. Suhdivison. Poinles de l'écusson placées vers son milieu. - Seconde cellule cubitale tris-pétrécie vers la radiale, celle-ci simple. - Crochets des tarses antéricurs bifỉes.

\section{Mísochère azurée, Mr. azlurea.}

Mesocheira nigra, coruleo nitida, nigro et atbido subtomentosa, alss hyalinis apice fuscescentibus.

Longueur 6 à 7 lig. Noire, avec un reflet d'un bleu-azuré plus sensible sur l'abdomen. 'Têle, colsulet e: bords de l'abdomen ayant des poils blancs mêlés de poils noirs. Lobe extérieur de l'ópine des jambes intermédiaires porıant quatre peitiss dents. Ailes transparentes, les supérieures bruves à l'extrémité. Femelle.

Le inâle diffè̀re eu ce que les poils de la partie antérieure de la tête sont d'un beau jaune-citron; que les écailles des ailes supérieures sont a'mu testacé-brun et que les paltes et surtout les tarses ont un peu de cette couleur. Ses cuisses postérieures sont fortement tuberculées en dessous vers leur base.

De la Guadeloupe.

$2^{e}$. Subdivision. Pointes de l'écusson plaeées sur les côtés. - Seconde eellule cubitale pets 
Séuécie vers la radiale, celle-ci appeudiculée. Tous les crochets des tarses simples.

\section{MÉsocnìre veloutée, $M$. velutina.}

Mesocheira nigra, nigro tomentosa, abdonllnis segmentis, prino excepto, corruleo micantibus, alis violaceo-fuscioribus.

Longuenr 8 lig. Noire, assez fortement velue, ses poils noirs; ceux de l'abdomen fort courts. Artennes noires. Extrémité des mandibules d'un testacé-l/rus. Second, troisième, quatriène, cillquième segmens de l'abdomen el dessus de l'anus ayant un reflet vio!et très-sensible. Ailes violeltes, forlement enfumées. Pattes noir es et velues. Lobe extérieur de l'épine des jambes intermédiaires portant trois petites dents. Femelle.

Rapportée du Brésil pat notre savant compatriote M. Auguste de Sami-Hilaire.

MÉLECTE, Melecta. Lat. Fab. Spivol. Crocisa. Jur. Lat. Apis. Linn. Kirb. Oniv. (Encycl.) Centris. FA B. Andrena, Apis, Nomada. Panz. Faun. Mlelecta, Thyreus. P'sz. :évis.

Genre d'inseetes de l'ordre des Hyménoptères, section des Porte-aiguillon, famille des Mellifères, tribu des Apiaires.

Ce genre fait partie d'un groupe d'Apiaires parasifes dont le caractère est : écusson bidenté, saustubercules arrondis au milieu, quatre cellnles cubitales aux ailes supérieures. La cellule radiale est appendiculée daus les Mésonychies; les Mésochères ont l'épine des janıbes intermédiaires élargie au bout et comme digitée, lis première nervure récurrente de leurs ailes supérieures aboutit ¿ la nervure de séparation des deuxiène et troi- sième cubitales, et les Agliás sont reconnoissables par la grandeur des mâclioires et de la lèvre qui se prolongent dans ce genre en une trompe presça'iussi longue que le corps.

Antennes filiformes, un peu brisíes, s'écartant l'une de l'autre de la lase à l'extrómité, composées de douze articles dans les fenelles, de treize dans les mâles. - Mâchoires ct levere assez courles, n'étant pas plus longrues que la tête et le corselet pris ensenble. - Micandibutes pointues, étroites, unidentées an côté interne.-Palpes labiaux de quatre arlicles. - Tris petits yen.x lisses disposćs presan'en lirne transversale sur le vertex. - Corps court, ayant souvent des poils disposís par plaques. - Corselet court, convexe c'n dessus. - Ecusson bidenté, sans tabercules au milieu. - Ailes supérienres ayant une cellule radiale ovale, son extrémité anrondie, écaitée de la cóte et quatre eellules cubitales, lá première graude, la seeonde petite, très-rétrécie vers la radiale, recevant la première nervure récurrente, la troisième rétrécie des deux côtés, recevant la deuxième nervure récurrente, la quatrième point commencée, foiblement tracée. -
Abdomen court, conique, composé de cinq segmelus outre l'anus dans les femelles, en ayant un de plus dans les mâles. - Pattes de longueur moyenne, les quatre premières jambes terminées par une seule épine, celle des intermédiaires forte, pointue; jambes postérieures en ayant deux dont l'intérieure beaucoup plus longue; premier article destarses aussi grand que les quatre autres réunis : crochets bifides, renflés à leur base, parallèles entr'eux.

Les Mólecles sont les ennemies particulières des Anthophores et des plus grosses espèces du genre Mégachiie. Les femelles déposent leurs oufs dans les cellules que ces récoltanies construisent pour leur poslélité. (Voy. Parasites.) Ce genre est propre à l'ancien continent, il renferme à notre connoissance une dizaine d'espèces la plupart européennes.

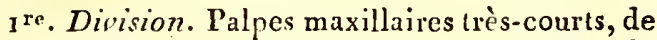
trois articles, les deux premiers plus épais, le troisième un peu plus long, grêle, cylindrique. - Eensson déprimé, prolongé postęrieurement. (Genre Crocisa. Lat.)

\section{MÉLecte brillante, $M$. nitidula.}

Melecta nigra, capite, thorace abdomineque et tibiis caruleo maculatis.

Melecta nitidula. Fав. Syst. Piez. pag. 386. $n^{\circ}$. 2. -Crocisa. nitidula. Jur. Hyménopt. pag. 241. La feraelle.

-Longueur 7 lig. Noire. Anlennes de cette couleur. Chaperon et partie antérieure de lá tête de couleur bleue. Dèsus du corselet, ses côlés, des lignes et des taches sous les ailes, de même conleur. 'Tous les sermens de l'abdonen ayant de chaque côté une tache blene plus on moins linéaire. Anus sans taches. Pattes noires. Jambes ayant une tache blcuc . leur partie extérieure. Ailes d'un brun-violet. ita ale.

La couleur bleue esi due à de petits poils coucliés.

D'Afrique.

A cette division appartiennent les Melecta histrio no. I, el Scutellaris n $^{\circ}$. 4. FAB. Syst. Piez.

$2^{\mathrm{e}}$. Division. Palpes maxillaires de six arlicles. - Eeusson à peine prolongé. (Genre Melecta. LAT. )

Rapportez ici l'Abeille ponetuéc no. 86 de ce Dictionnaire (Centris punctata. $\mathrm{F}_{\mathrm{AB}}{ }^{\circ}{ }^{\circ}$. 3o. Syst. Piez.) et la Melecta punctata no.7. F. B. idem. (Melecta anluata. P P $\mathrm{NZ}$. révis.)

\section{MÉSONYCHIE, Mesonychium.}

Genre d'insectes de l'ordre des Hyménoptères, section des Porte-aiguillon, famille des Mellifères, tribu des Apiaires. 
Dans le groupe d'Apiaires parasites dont le caractère est :écusson bidenté, sans lubercules arrondis au milieu : quatre cellules cubitales aux ailes supérieures; les Mélectes et les Aglaés ont leur cellule radiale simple, sans appeudice et toutes lẹs cubitu'es sessiles; dans les Mésochères l'épine des jambes intermédiaires est grande, ćlargie et échuncrée à son extrérnité.

Antennes filıformes, un peu brisées, s'écartant l'une de l'autre de la base à l'extrénité, composées de donze articles duns les fennelles, de treize dans les mâles. - Mấchoires et lèvie assez courtes, n'étant pas plus lougues que la tête et le corselet pris ensenible. - Mandibules pointues, étroites, unidentées au côté interne. - Palpes maxillaires de sir articles, les labiaux de quatre. - Trois petits yeux lisses disposés en ligne transversale sur le devaut du vertex. - Corps court. - Corselet court, convexe en dessus. - Ecusson point prolongé postérieurement, ayant deux deuts courtes posées sur son milieu. - Ailes supérieures ayant une cellule radiale pointue à sa base, allant en se rétrécissant du milieu vers l'extrémité, celle-ci arrondie, écartée de la côte, appendiculée, et quatre cellules cubitales, la première un peu plus pelite que la seconde, cette dernière presqu'en carré long; la première nervure récurrente aboutissant à la nervure qui sépare les seconde et troisième cubitales; troisième cubitale pétiolée, prescu'en demi-lune, recevaht la deuxième nervure récurrente; la qualiième poiut coumencée, mais tracée. - Abdomen court, conique, composé de cinq segmens outre l'anus dans les femelles, en ayant un de plus dans les mâles. Pattes de longueur moyenne, les quatre premières jambes terminées par une seule épine, celle des intermédiaires point dilatéc à son extrérnité qui porte une deat particulière; jambes postérieures ayant deux épines terminales : crochets des tarses bifides.

On ne connoît qu'une espèce de ce nouveau genre dont le nom vient de cleux mols grecs et signifie : onglet placé au milieu. Ce nom a rapport à la petite pointe particulière que porte l'épine des jambes intermédiaires. Les mœurs des Mésonychies ue doivent pas différer de celles des Mélectes.

\section{Mésonychre bleuâtre, $\boldsymbol{M}$. carnulescens.}

Mesonychium nigrum, abdomine carruleo viridique nitente, alis fusco-violaceis.

Longueur 6 lig. Noire, garnie d'un duvet de même couleur. Abdomen ayant un reflet bleu et vert métallique. Ailes brunes à reflet violet. Femelle.

Du Brésil.

CELIOXYDE, Calioxys. LAT. Apis. Liñ. Grosr. OLIv. (Encycl.) KunB. Anthophora.
FAB. Trachusa. Jun. Anthidium. $\mathbf{P}_{\mathrm{A} \text { Az. Heriades, }}$ SPinoz.

Genre d'insectes de l'ordre des Hyménoptères, sectiou des Porte-aiguillun, famille des Mellilères, tribu des Apiaires.

Les genres d'A piaires parasites dont l'écusson est bidenté, et qui n'ont que trois cellules cubitales aux ailes supérienres sont ceux de $\mathrm{C}$ lioxyde et de Dioxyde, mais ce dernier se distingue parce que l'extrémité de sa collule radiale est presqu'aiczuë, et que la première culitale est plus grande que la seconde; en ontre l'abdomen des Dioxydes n'est conique dans aucun des sexes.

Antennes filiformes, brisćes, composécs de douze articles daus les femelles, de treize dans les wâles. - Mandzbules étroites, peu fortes dans les deux sexes. - Palpes maxillaires très-courts, de deux articles, le prenier cylindrique, nne fois at moins plus long que le second, celui-ci conique; les labiaux de quatre articles, les deux premiers droits, veuant bout à bout dans une direction longitudiuale, le troisième inséré obliquement sur le cóté extérieur dı deuxième, près de son sommet. - Trois petits yeux lisses disposés en triangle sur la partie antérieure du vertex.-Corselet de forme presque globuleuse.Ecusson portant une dent de chaque côté. Ailes supérieures ayant une cellule radiale qui va en se rétrécissant du milieu jusqu'à l'extrémité, celle-ci arrondie, écartée de la côte, et trois cellules cubitales, la première et la seconde presqu'égales, cette dernière rétrécie vers la radiale recevant les deux nervures récurrentes, la troisième à peine commeucée.-Abdomen conique, surtout dans les femelles, composé de cinc segmens outre l'anus dans ce sexe, en ayant un de plus dans les naales : anus terminé par une seule. poiule dans les femelles, par plusieurs dans les mâles. - Pattes de longueur moyenne, mincés, les quatre premières jambes ayant une seule épine à leur extrémité, celle des antérieures échlincrée au bout el munie d'une petite mernbrane inlérieure, transparente, celle des intermédiaires simple, aiguë; jambes postérienres terminées par deux épines simples, presqu'égales : crochets des tarses bifides dans les nâles, siuples daus les femelles:

Les Cœlioxydes femelles piquent avec beaucoup de force; elles redressent souvent et fortement l'abdomen surtont lorsqu'elles veulent se servir de leur aiguillon, celui-ci ne sort pas dans une direction droite, il ne s'incline puint en dessous, mais il se redresse. Cest principalement dans les nids d'Anthidies, de Mégachiles, d'Osmies et. d'Authophores qu'elles déposent leurs œufs. (Voy. Parasitres.) Leur nom est tiré de deux mots grecs dont la signification est : ventre aigu. Ce genre est répandu dans toutes les parties du monde, et contient une douzaine d'espèces. Elles fréquentent les fleurs. On les rencontre souvent aussi 


\section{P H I}

ontonr des nids des A piaires solitiires récoltantes que nous venons de nornmer.

Ou doit rapporter à ce genre l'Abeille conique ${ }^{\circ} \cdot 9^{8}$ de ce Dictionnaire. ( $C$. Conica.) Femelle. Le mâle est l'Abeille quadridentée no ${ }^{\circ}$. Les deux pointes intermédiaires de l'unus sont doubles dans ce mâle, ce qui en fait réeliement six en tout.

Cette Coelioxyde est commune aux environs de Paris ainsi qu'une autre espèce ( $C$. méfescens Nов.) qui se distingue de la première par sa taille presque du double, ses poils roux, par lit partie inférieure de l'anus élargie avant sa pointe et presque tricuspidée dans les feme!les.

DIOXYDE, Dioxys, Trachusa. Jon. Heriades. Spinol.

Genre d'insectes de l'ordre des Hyménoptères, section des Porte-aiguillon, famille des Niellifères, tribu des Apiaires.

Dans le groupe d'Apiaires parasiles qu a l'écusson bidenté et trois cellules cubitales seulement aux ailes supérieures, les Colinxydes se distinguent des Dioxydes par l'extrémité de leur cellule radiale arrondie, par leurs deux premières cubitales presque d'égrale grandeur, et par la forme de l'abdomen qui est conique et terminé en pointe dans les femelles.

Antennes filiformes, brisćes, composées de douze articles dans les femelles, de treize daus les unâles. -Manảibules étroites, peu fortes dans les deux sexes. - Palpes maxillaires très-courts, de deux articles; les labiaux de quatre, les deux premiers venant bout a bout daus nne dircction longitudinale, le troisième insérć obliquement sur le côié extéricur du second, près de son sommel. - Trois petits yeu.x lisses disposés en triangle très-obtus sur le vertcx. - Corps alongé. Corselet court. - Ecusson portant une dent de chaque côté. - Ailes supérieures ayant une cellule radiale qui se rétrécil depuis son nilieu jusqu’à son extrémité, celle-ci presqu'aiguë, ćcartée de la côte et trois cellules cubilales, la première pius grande que la seconde, celle-ci rétrécie vers la radiale, recevant les deus nervures récurrentes, la troisième imparfaite, n'atteignant pas le bout de l'aile. - Abdonzen issez alongć, convexe en dessus et en dessous, composé de cinq segrmens cutre l'anus dans les femelles, en ayant un de plus dans les mâles : anus grand, larrọe, trouqué et légèrement écbancré à son extrémité dans les femelles; petit, entier et portant quelques petites dents dans les mâles. - Pattes de lougueur moyenne, les çuatre premières jambes terıninées par une seule épine, celle des antérieures obtuse, celle des intermédiaires pointue; jambes postérieures en ayanı deux à peu près égales : premier article des tarses aussi long que les quatre autres pris ensemble : crochets bitides dans les deux sexes.
Le nom de ce nouveau genre a pour étymologie deux mots grecs qui signifient : doublement aigu; il le doit aux denx pointes que présente l'écusson. L'espèce pour laquelle il a été formé habite les parties méridionules de l'Europe. Ses mours, que nous ne comnoissons pas, doivent se rapproches de celles des Śtélides. Voye $z$ Parasites.

\section{Droxrde csinte, D. cincta.}

Dioxys nigra, cincreo subtomentosa, abdominis segmento primo ferugineo.

Trachusa cincta. Jur. Hyznénopt. pag. 253. pl. 12. Lia femellc. - Heriades cincta. Spis. Ins. Ligur. fasc. 3. pag. 198. $n^{\circ} \cdot 2$.

Longueur 5 à 6 lig. Noire avec quelques poils blanchâtres. Preunier segment de l'abdomen ferrugineux, bordé inférieurement de poils couchés, blancs ainsi que les trois suivans, les côtés de ce bord dans le cinguième en ayant également. Ailes enfumées, surlout vers la côte et l'extrémité. Femolle.

Le mâle diffère en ce que le cinquième segment de l'abdomen est bordé entièrement comme les quatre précédens. L'anus a deux petites dents, une de chaque côté.

De la France méridionale. (S. F. et A. Serv.)

PHILEURE, Phileurus. LAT. Scarabarus. Linn. Oniv. Palis.-Bauv. Geotrupes. Fab.

Genre dinsectes de l'ordre des Coléopières, section des Pentameres, famille des Lanullicornes, tuibu des Scarabéides.

Ce genre, dû à M. Latreille, fait partie d'une section établie par lui dans la tribu des Scarabérdes sous le nom de Xylophiles (voyez ce mot). Les Eigialies et les Trox ont le labre saillant audelà du chaperon; daus les Héxodons et les Rutèles le chaperon est apparent et carré ; les Scarabés ont le corps convexe el le côté extérieur. des mandibules crénelé ou denté; enfin les Oryetès ont le corps conrexe et les côtés du corselet peu dilatés. Aucuu de ces caractères ne se trouve dans les Phileures.

Antennes de dix articles, le premier gros, plus long que les suivans, le second obconique, les. autres moniliformes, les trois derniers en feuillets alongés formant une massue plicatile. - Labre entiêrement caché. - Mandibules étroites, sans créuelures ni dents à leur côtć extérieur. - Inấchoires cornces, forteneut trideutées. - Palpes maxillaires uu peu plus longs que les labiaux, de quatre articles, le dernier cylindrique, alongé; les labiaux de trois articles, le dernier an moins aussi graud que le précédent. - Lèvre presque nulle ou cachée par le meuton; menton un peu échancré à l'extrémité. - T'ête petite, cliaperoi trigone ayant trois pointes sur ses bords. - Corps déprimé, ovoïde. - Corselet coupé à peụ ñè̀s 
droit en devant et postérieurement, dilaté et arrondi sur les cồiés. - Ecusson triangulaire. Pattes fortes; jambes dentées extéricurement; une seule épine ì l'extrémitć des antérieures; les quatre postéricnres munies de deux épines inćgales, l'intérienre plus grande ; tarses intermédiaires et postéricurs ayant leur premier article teraniné en dessus par un prolongemeat spiniforme.

Les Phileures habitent les contrées chaudes de l'Amérique; il est probable que leurs liurves vivent daus le bois. Le petit nombre d'espèces connues a le corps noir-luisant et les élytres chargćes de stries fortement ponctuées.

\section{Paileure didyme, P. didymus.}

Phileurus clytris striatis, striis punctatis, punctis irreguliaribus inter primam à suturì secundanque striam.

phileurus didynnus. I.at. Gener. Crust. et Ins: ton. 2. pag. 103. - Geotrupes didymus. FAB. Syst. Eleut. tom. .I. pag. 17. $n^{\circ} .59 .-1$ Drun, Ins. tom. I. pl. AXXII. fig. 3. - Scarabous didynius. Oriv. Entom. tom. 1. Scarab. pag. 42. $n^{\circ} \cdot 46 . p l$. 2. fig. 9. -Pisrs.-Bavv. Ins. d'Afriq. et d'Ainériq. Coléopt. pl. I. b. Jis. J, - Encycl. pl. 143.fig. 2.

Longueur 18 i 20 lig. Corps entièrement noir, luisint, ayaut un duvet ferrugineux sur certaines partics du dessous, et de pctits poils roides de mćme coulenr bordaut le devant du corselet. 'Téte striće irrégulièrement, les trois pointes du chapezon assez élevées. Partie antérieure du corselet irrégnlic̀rement striée, le reste un pen ponctué; un tubercule relevé placé sur le miliea de la partie antérieure; un sillon profund, ponetué, longitudinal, fimissant par une dépression plus forte et plus large, alteignanta base du tubercule. Elytres ayant des stries profondes, très-ponctuées; entre celle qui accompagne la snture et la seconde, se trouvent des poinls enfoncés qui ne forment pus une strie régntière.

Amérique méridionale.

Nota. Dans ce geure doivent entrer les Geotrupes valgus et depressus de liabricius, aini que les Scarabés tronqué, quadrituberculé et aplati de M. Palisot-lbauvois; espèces qulil seroit bon de compaier cntr'elles. (S. F. et A. Sert.)

PIILOSCIE, philoscia. J'at désigné ainsi un genrc dc Cruslacés, formé aux dépens de celni d'Oniscus, ou Cloporte de ́rimnú. De rồme que clans nos Cloportes proprement dits, les anternes extéricutes sont composces de liuit articles, mais leü insertion est découverte ou à su, et leur corps se terminc brasguement en pointe vors son exirémité postéricure.

La phroscie pes nousses, Fibiloscia minuscorum
(Oniscus syluestris. $\mathrm{F}_{\mathrm{AB}}$ ), a été décrite dans cet ouvrage sous le nom de Cloporte des mousses. Elle est bliuchâtre en dessous, et d'un cendré-brun, avec de petites linnes et des poinls gris ou jaun $\hat{a}-$ tres en dessus. Les pieds ont quelques traits foncés. Les cruatres appendices ou stylets qui terminent postérieurement le corps sont presque de longueur égale. Cette espèce est très-commune en France dans les lieux humides, sons les mousses, les feuilles tombées à terre, etc. M. Antoine Coquebert l'a figurće daus ses Illustrations iconographiques des insectes, première décade, $p l .6$. fig. 12. Elle l'avoit ćté aussi par M. Cuvier, daus le Journal d'histoire noturelle, rédigé par M. de Lanarck, Bruguière el Häiy. (LAтr.)

PHL. AA, Phloca, Cimex. Drur.

Genre d'insectes de l'ordre des Hémiptères, section des Hétéroplères, famille des Géocorises, tribu des Longrilabres.

A l'exception de ce genre tous ceux qui composent cette tribu ont at moins quatre articles aux antennes; leur corps est épais et n'est pas bordé d'appendices membraneux. Voyez Lo::GrLabres, tom, 10. pag. $5 \mathrm{I}$.

Antennes filiformes, assez longues, très-écartées à leur base, insúpíes de chaque côté de la têtc, composées de trois articles, coudées après le premier; celui-ci le plus grand de tous, $\mathrm{cy}^{-}$ lindrique, s'amincissant vers sa base; le second grossissuat un peu vers l'extrćnité ; le troisiène plus gros que le précédent, à peu près de la même grindcur, presrne cylindricue. - Labre long, irès-étroit, presqu’aciculiire, prenint naissance it l'exlrémité autéricure du chaperon, recouvrant lit base du suçoir et dépassant le premier article du ber. - Bec de quatre articles distincts, renfermant un suçoir de quatre soies; le prenier de ces articles logé en grande parlie dans une couliše longitudinale du dessous de la tête. - Tête assez grande, déprimcé, triangnlaire. - Yeux globuleux, saillans en des‘us el en dessons de la tête. - Deux petits yeux lisses placés un de chaque côté cutre les y eux a réseau el fort près d'eur. - Corps très-dépriné, garui tout iutrour d'appendic nembraneux. - Corselet beaucoup plus large que longr, se rétrécissant en devant à partir de sou milieu. - Ecusson grand, thiangulaire.Abdomen composé de quatre segmeus outre l'anus; ces seymens et l'anus ayant de chaque côté un sliymate très-apparent; anus des mâles enticr, sans silion longitndinal, parvissant en dessus et en dessous. - Pattes de longueur moyenne; tarses courts, presque cylindiques, composés de trois articles, le second plis court que les autres, te dernier terminé par deux crochels recourbús, sans pelotles apparentes au milieu.

Nous placous ce nouveau gence dans la tribu des Jongilabres, malgré sa ressemblance extérieure avec plusieurs genres de celle des Mem- 


\section{P H L}

braneuses, et notamment avec les Arades. Aı premier coup d'œil on raugeroit l'espèce cui nous a servi de type dans cetle dernière tribu, elle paroît même en mériter éminemment le noon à cause des appenoices nembraneux qui bordeut sa tête, son corselet et son abdonen, ainsi que par l'aplatissement de sou corps; mais il n'en est plus de même lorsqu'on examine les parties de sa bouche, et nous avons trouvé dans ces organes tous les caractères assignés aux Longrilabrès, à l'exception des stries transversales dulabre dont nons la croyons eniièrement privée. Nous ferons renarquer que les Phlæas sont les seules Géocorises dont los antennes n'wlicnt que trois atlicles distincts. Sunmes-nous ici trompés par l'apparence? Nous reconmaudons l'examen de ces orgranes à ceux qui observeront aptès nous. Liznpossibilité de ranger clans aucun gerre connu jusqu'ici une espéce aussi remalquable, figurée depuis long-lemps par Drury, et que nous possédons, nous a engagés à publier cette nouvelle coupe générique, dout le nom vient d'un mot srec qui signitie : 6́corce. Elle le doit à son aprence extérieure.

\section{Purfa cassidoide, $P$. cassidoides.}

Phlaca suprà grisea tuberculis multis rufofuscis subnitidis adspersa, subtùs nigra appendiculis marginalibus griseis.

Cinzex corticatus. Drur. Ins. tom. 2. pl. XL. fir. 2.

Longueur so lis. Téte Riungulaire, indépendamment des deux appendices cui la bordent en avant des yeux, et qui sont échanciés sur les côtés, coupés presque carrément en deviani. Yeux paroissanl eu dessus et en dessnus de la tête. Antennes fauves, lear premier arlicle brun, le dernier velu. Bec fanve, très-longr, dépassant le milieu de l'aludomen, se logeant de toute sa lon gueur dans uue eoulisse assez profonde. Premier serment du corselet portant un appendice latéral, rriand, taillé presque carrément à sa patric extérieure; second segment n'ayant qu'un appendice fort étroit. On voil une petite énine au-dessons de cel appendice. Troisième segruent du corselet et le prenier de l'abdowen bordés par un appendice qui dépend des élytres, mais n'en ayant pas qui lenr soient propres; les second, troisième, çuatrième segmens de l'abdomen et l'auus en ayant un de chaque côté. Ecusson grand, s’étendant jusque sur la base de la inembrane des élytres, un peu caréné dans son milien, s'élargissant un peu vers son extrémité qui est arrondie et calleuse. Membrane des élytres demi-transparente, laissant à découvert une partie de l'anus et tous les appendices membraneux de l'abdomen. Dessus du corps, a l'exception de la membrane des élytres, d'un blane-sale, ponctué et chargé de tubercules assez lisses, roux, ordinairement entourés de brua. Dessous du corps (les appendices exceplés) noir. Palles d'm blanc-sale arec quelques tubercules et les cuisses de couleur noire. Mâle.

Du Brésil. ( S. F. et A. SERv.)

PILOTOTHPIBE, Phloiöhrizus. LAт. Flyle. sinus. FAB. Scolytus. Oliv. (Entoin.)

Genre d'insecles de l'ordre des Coléoplères, section des 'T́tuaneres, fanille des Xylophinges, tribu des Senlytailes.

Tous les Scolytaires ont les antennes composées de six a dix arlicles distincts et lerrainées en mas. sue. Le genre l'bloioiluribe que l'on doit a M. Latreille se disingue seul dans sa ribu parce que celle massue n'est point solide, nais composée de trois longs fenilteis distincts.

Antennes plias longut's que la tête et le corselet, teruinées par une niassue formée de trois feuillels très-longs, linéaires, formant l'éventail. Labre étroir, jeu avancé, corné, cilié, légèrem neut échancré. - Manảibules couttes, épaisses, pointues, presque dentées.- Muchoires coriaces, eomprimées, très-velizes extérueutement. - $P$ a $\dot{z}$ pes très-courls, presqu'çgaux, distiucls, plus gros à lenr base; les marillaires de quatre aritcles, les labiaux de trois. - Lère petite ne paroissant que comme nu tubercule placé sur la base du menton. - T'éte peu rétrécie en devant. 1 eux ulongés, élruils. - Corps ovale-cylindrique, convexe. - Corselet convexe. - Janbes comprimées, tarses ayant leur pénuliieme articlo bilide.

On ne connoît que fort peud'espèces de Phloiothribes; elles patoissent nuisibles aux jeunes brauches des arbres. Liune d'elles a été l'objet spécial d'un mémoire de M. Bernard, par le tort notable qu'elle tait aux oliviers.

\section{Pilloiotharbe de l'Olivier, $\boldsymbol{P}$. olece.}

Phloiothribus cinereo subtomentosus, elytrorum apice subnudo.

Phloiothribus olea. Lat. Gener. Crust. et Ins. tom. 2. pag. 280. - Hylesinus olea. FAB. Syst. Eleut. tom. 2. pag. 3g5. $n^{\circ}$. 24. - Scolytus olece. Otrv. Enton. tom. 4. Scolyt. pag. $13 . n^{\circ}$. 21. pl.2. fig. 21. a. b. - Scolytus scaribceoides. Bera. Mém. d'Hist. nat. tom. 2. pag. 27 I.

Longueur 1 lig. $\frac{1}{2}$. Antennes fauves. Corps noir couvert d'un duvet cendré, plus clair-semé à l'extrémité des élytres, celles-ci avec des stries peu marquées. Patles brumes.

Du midi de la liance. Il fait beaucoup de tort aux oliviers dont il ronge les branches.

(S. F. et A. SERr.)

PHOLCUS, Pholcus. Walex. Genre d'Aracl. nides pulmonaires, famille des Aranéides oเ des Fidequses, tribu des Inéquilèles ou des Arazo 
gnées flanaières, ayant pour caractères essentiels : pattes très-longes et très-déliées, la prepuiẻre paire et cnsuite la seeonde et la quatrième plus longues, - Mâchoires alongées, rétrécies et inclinées vers leur extrémité. - Languette (ou levre) grande, triangulaire, dilatée dans son nilieu. - Yeux au nombre deluuit, presqu'éganx, placés sur un tubercule : trois de chaque côlé, disposés triangulairement, et les deux autres intermédiaires, plus écartés, plus antérieurs et sur une ligne transversale.

Le Prolcus phatangiste, Pholcus phalangioides, et la seule espèce connue, est très-commun dans nos maisons; c'est l'Araignée domestigue à longues pattes de Geoffiroy, et dont il forme, à raisou de ses yeux en bouquets, une dirision particulière. Elle a été décrite dans cet ouvrage sous le nom d'Araignée phalangiste, $n^{\circ}$. 40. Nous ajouterons simplement que la fewolle agghluliue ses œufs en une masse globuleuse, qu'elle porte entre ses mandibules ou plutôt ses chélicères. Nous a vons observé que celte Aranéide agite quelquefois son corps d'une manière trèsritpide, à l'instar de quelques 'Tipulaipes. (Latr.)

PHORE, Phora. LAt. Trineura. Mełg. Class. Tephritis. FАB.

Genre d'inseetes de l'ordre des Diptères, section des Proboscidés, famille des Atbéricères, tribu des Muscides.

Parmi les Muscides le genre Phore est le seul ckont les antennes scient insérées près de la bouche et les palpes tonjours extérieurs. La réunion de ces earactères fait aisément reconnoître ces diptères.

Antennes insérées près de la bouche, de trois articles, les deax prchiers très-petits, pen distincts, le troisième ou palette, épais, globuleax, porlant une soie simple; très-longue. - Trompe nembraueuse, bilob́e, coudée, entic̀rement retirće dans la caviléde la bouche (dans le repos) ct renfermant dans une groutrière de sa partie supérieure un suçoir composé de deux soies. palpes cylindriques, hérissés de poils, obtis à l'extrérnité, toujours extérieurs, point rétraciiles, n'ayanl d'articulation que celle de la bise. - Téte pelite, hasse, hémisphérique, hérissée de poils. - Trois petits yeux lisses disposés cn triangle et piacŕs sur le vertex. - Corps un peu alongé, arqué en dessus, hérissé de poils roides. - Corseiet grand. - Ailes grandes, lcur bord extérieur forlement cilié de la base au milieu où la nervare coni tarmine ce bord, se joint à une autre nervure descendant de la base de l'aile; poriut de nervures transversales, toutes les cellules atteignaut le bord postérieur. - Cuillerons pelits ne couvrant pas enièrement les balanciers. - Abdomen conigue crim posé de sia segmens outre ianus. - Pattes longues; cuisses postérieares comprimées; jambes hérissées de piquans.
On connoit très - peu d'espèces de Phores; elles sont fort petites et se trouvent aux environs de Paris. Leur manière de vivre n'est pas counue.

\section{Phone tres-noire, $\boldsymbol{P}$, aterrima.}

Phora tota atra, tibiis et posterioris paris femoribus compressis.

Phora aterrima. LAT. Hist. Nat. des Crust. et des Ins. tom. 14. pag. 394. $n^{\circ}$. 1. - Tephritis aterrima. Fав. Syst. Antliat. pag. 323, no. 35. - Trineura atra. MeIg. Class. und bésch. tom. 1. pag. 315. tab. 15. fig, 22. - Coquer. Illust, lcon. 3. tab. 24. fig. 3. - Encycl. pl. 390. fig. 58.

Longueur I lig. - à 2 lig. Corps entièrement d'un noir mat. Antennes de même eouleur. Ailes transparentes, leur côte et la nervure qui $s^{\prime} y$ réunit, noires. Toutes les jambes comprimées.

On la trouve dans les bois, sur les plantes; elle est vive et s'arrête peu.

2. Pноne pallipède, $\boldsymbol{P}$. pallipies.

Phora fisca, peditus pallidis, femoribus tibiisque omnibus compressis.

Phora pallipes. Lat. Hist. Nat. des Crust. et des Ins. tom. 14. pag. 595. $n^{\circ}$. 2. - Trineura rufipes. Merg. Class. und besch. tom. i. pag. 313. tab. 15. f2g. 23. - Scuell. tab. i2. - Encycl. pl. 39 o.fig. $5 g-63$.

Longueur 1 lic. $\frac{2}{2}$. Gorps brun. Antennes brunes. Pilpes, cuillerons, balanciers et pattes livides. 'Toutes les cuisses et loutes les jambes comprinées. Aịles trausparentes avec la cọte et la ṇervuie qui s'y réunit, brures.

On la voit souvent dins les maisons, sur les vitres des croisées. ( $S$. F. et A, SERv.)

PIIOTOPHY GES ou LUCIFUGES. Qninzième famille des Colcoptères, section des Hétéromérés dans la Zoologic analytique de Bl. Duméril; il lui donne les caractères suivans : Elytres dures, soudées, sans ailes. Elle se compose des yenres Blips, Pimélic, Eurychore, Akide, Scaure, Sépidie, Erodie, Zophose et 'Tagénie.

$$
\text { (S. I. ed A. SrRv.) }
$$

PHOXIGHLE, Phoxichi'us. Genre d'Arachnides tracisćeunes, de la famille des Pycnogonides, tris-analogue à celui de Nymphon, mais en étant distinct : $2^{\circ}$. par l'absence de palpes. $2^{\circ}$ : En ce que le premier segmeni du corps n'est point rétréci postérieurement en manière de col; qu'il est eourt, Iransversal, de sorie que les deux paltes antérieures et celles qui dans la femelle pcrient les guts, sont insérées prés de la base da siphọ, ei que les yeux sont dès-lors plus antérieurs: 
rieurs. $3^{\circ}$. Les organes du mouvement sont proportionnellement moins alongés et paroissent avoir un article de moins, ou huit au lieu de neuf. J'a vois d'aboid cru que les mandibules, ou plutôt les chélicères, étoient monodactyles on terninées par un seul doigt. Mais j'il recounu depuis qu'il y en avoit un autre, unais plus petit.

J'avois ćtabli ce geure sur la description du Pycnogonum spinipes d'O hon Fabricius. (Fauna groenlandica, pag. 5\%.) J'ai vu depuis une seconde espice, recueillie par feu Peron et M. Lesueur, dans leur voyage unx Terres australcs, et dont $j$ 'ai donné la description dans la seconde édition dı nouveau Dictionnaire d'Histoire nuturelle, sons le nom de Phalangioüdes (Phalangioides). Son corps est long de cinq ligues, d'un brua olsscur, avec les pattes environ trois fois plus longues, un peu velues et tuberculées. Feu Lalande a rapporté du Cap de Bonne-Espérance une variété de cette espèce.

Le Nymphon femoratum des nouveaux Actes de la Société d'histoire naturelle de Copenhaugue (1799, tom. 5. part. I. tab. 5. fig. I-3.) et le phalangium spinosum de Montagu (Act. Societ. Linn. tom. 9. tab. 5. fig. 7), paroissent être des l'hoxichiles. (Latr.)

PiHRonime, Phronima. Latr. Genle de Cruslacés de l'ordre des Aıphipodes, ayant pour caractères : tête fort grosse, presqu'en forme de cœur. - Deux antennes très-courtes et biarticnlées. - Quatorze pieás, y compris les quatre derniers pieds - inâchoires, et dont la cinquième paire, ou la troisième des pieds proprement dits, terminée en une piuce didactyle et précédée de deux articles arrondis, les autres simples; six sacs vésiculeux disposés sur deux rangées longitudinales cntre les derniers. - Corps alongé, mou, de douze articles, non compris la tête, terminé postérieurement par six appendices en forme de stylets, fourchus au bout; six autres appendices, mais natatoires, sur le dessons du post-abdomen, et dispesés sur deux liernes longitudirıales. "C'est à Forskhal que nous devons la connoissance du singulier Ciustacé qui a servi à l'établissement de ce genre, et qu'il a nommé Cancer sedentarius. (Faun. Arab. pag. 95.) Herbst a ensuite reprodiat cette description ct la tirure qui l'accompagne dans son ouvrage génćral sur les animaux de cette classe ( $t a$ h. 36 . fig. 8 ). Le mềne Crustacé, ou du moins une espèce très-analogne, a été décrit et représenté dans le quatrième volume des nouveaux Actes de la Sociésé d'histoire naturelle de Copénhague, publiśs en 1802 . J'en ai donné une nouvelle figure dans le premier volume de mou Generu Crustaceorum et Insectorum, et jy ai désigné cette espèce sous lc non de Phroninie sédentaire (Phronima sedentaria). Dans son Histoire des Crustacés de la rivière de Nice, M. Risso en a publió et figuré une autre, et qưil Hist. Nat. Ins. Torne X. a nommée Phronime sentinelle (Phronima custos). Elle habite, suivant lui, l'intérieur des Equorées et des Géronies, genres qui dérivent de celui de Méduse de Linnée. "Semblables, dit-il; aux Argonautes et aux Cirinaires, ces Crustacés vieunent pendant le calme des eaux; dans la belle saison, voyager dans les nacelles vivantes, sans se donner le soin de nager. Néaumoins, lorsqu'ilśs veulent se plonger, ils rentrent au gite et se laissent tomber par le seul effet de leur pesanteur. Ces animaux, qui se nourrissent d'animalcules; ne se montrent $\grave{a}$ la surface des eaux qu'à la fin du printemps, et restent dans les profondeurs un peu vaseuses pendant tout le reste de l'année. Lear manière de se propager nous est encore inconnue; mais il est certain que les fcmelles ne portent pas leurs aufs sur un de leurs côlés conume les Pagures, quoiqu'ellcs aient comme ceux-ci l'habitude de se loger dans les dépouilles des corps vivans. "Le corps inarin dans lequel étoit renfermé l'individu de la première espèce que nous a vons vu et sur lequel uous avons établi ce genre, étoit le cadavre d'une espèce de Béroë. Suivant M. Risso, elle différeroit de la seconde en ce que son corps est plus grand, nacré et ponctué de ronge, tandis que celıi de la seconde est trèsblanc; mais c'ćtoit d'après la comparaison réciproque des appeadices et des proportions relatives du corps, plutôt que d’après les couleurs, qu'il anroit dú distinguer ces deux espèces. Jiune et l'autre liabitent la Méditerranée; la première cependant se trouveroit aussi, au témoignage du docteur Léach, sar les côtes de la Zélinnde.

(LATK.)

PHRYNE, Phrynus. Orrv. Ces Araclinides avoient ćté placées par Linné et Pallas dans le genre Phalangium. Brown en avoit fait des Tarentules, dénomination que Fabricius a adoptée, mais qui, ayanı été donnée à une espèce d'Arachnide n'ayant que des rapports trc̀s-éloignés avec les précédentes, ne peut, afin d'éviter une confusion, être admise. Olivier ayant depuis longtemps distingné ce geure sous le nom de Phrjne; nous avons dî préférer cette désignation.

Les Phrynes font partie de la famille des Pédipalpes, ordre des Arachnides pulmonaires. Ifs ont, aiusi que les Mygales et les Thélyphones, quatre cavites branchiales on pulmonaires, ilez organes sexuels doubles, silués à li base infériere de l'abdowen, huit yeux lisses, des chél:cères (mandibules) monodactyles, et l'abłomen pédiculé; mais ils n'ont point de filières à l'anus, leur corps est très - aplati, entièrement revêtu d'une pealu assez ferme, avec le corselet presque lunulé ou réniforme; les palpess en forme de bras ou de serres, très - śpineux, sans aucun appendice au bout relatif aux diffences sexuelles; les deux pieds antérieur's très-longs, antenniformes êt terminés par un tarse presque sćtiforıe, fort 
alongé, et composé d'un grand uonbre d'articles, sans crochets au bout; la langue cornće s'avancant entre les wâahoires en manière de dard, fourchu au bout, et l'abdomen asuebé. Leurs petits yeux lisses sont d'ailleurs disposés en trois gronpes; savoir, deux au nilieu, porlćs sur un tubercule, et trois de chaque côté formant un triangle. Les Plirynes font le passage des 'Thélyphones aux Mygales, mais en se rapprochant davanlage de ces premières Arachnides que des secondes : ils en diffèrent néanmoius par l'aplatissement de leur corps, la forne dis corselet et par leur abdomen, dépourru à son extrémité postériemre de ce filet arliculé et en forme de queue qui caractérise les Thélyphones. Ces Arachnides sont pareillenient propres aux contrées équaloriales ou iutra-tropicales; il parritroil qu'on les y redoute, mais saus motif récl, à ce que je pense. J'ai ouï dire qu'elles se temoient dans les fentes des rochers, les cavernes, etc. Nous n'avons aucun autre document sur leurs habiludes. Pallas (Spicil. Zool. fasc. 9.) et Herbst dans sa monographie qu'il a publiće de ce geure, en ont firit comontre atvec délails diverses espèces. Les derux plus grandes sont celles que Fabricius nomme Tarentula lunata et T. reniformis. Ja première est le Phalangium reniforme de Linné (Pallas, ibid. tab. 3, fig. 5-6; Herbst, Naturg. Phalang. tab. 3.), ou notre Paryne ruNox', Phrynus lunatus. Ses palpes sont presque trois fois plus longs que le corps, et n'offrent d'épines remarquables qu'à l'extrémité de leur troisième article; il y en a quatre, dont les cleux supérieures plus fortes. Celle espèce se trouve aux Indes orienlales. Iä seconde, ou le Phryxe reNiғовме, Phrynus renifornis, habite la Guiane et quelques-unes des Autilles. Ses palpes sout de la longueur du corps, avec le's second et troisième articles coinprimés, armés au côté interve d'épines; il y en a cinq à six à l'extrémité, uu peu dilatće, du troisième.

Les individus que j'ai eus de Saint - Donningue et de quelques autres îles de l'Archipel américain, sont génćralement plas petits que ceux que l'on reçoit de Cayenue; mais peut-être appartiennent-ils à l'espièce nommée par Herbst Phrynus medius. (tab.4.fig. 1.) C'est par la comparaison d'un grand nombre d'individus doat la patrie sera bien connue, que l'on pourra éclaircir ces difficullés spécifiques. (LAtr.) FAB.

PHTHIRIN, Phthiria. Meig. Lat. Voluccella.

Genre d'iusectes de Fordre des Diptères, section des Proboscidés, famille des Tanyslomes, tribu des Bombyliers.

Le premier article des antennes plus long que le second distingue suffisamment du genre Ptithirie, les Cyllénies, les Bombyles et les Ploas des auteurs, ainsi que les Gérons et les 'Toxophores de M. Neigen. On ne voit point de palpes distincts daus les Usies, taudis qu'ils sont apprarens dius les Phthiries. Ce genre est donc bien distinct de lous ceux de sa tribu.

Antennes avancées, rapprochćes, composles de trois articles, les deux premers courts et égaux entr'eux; le troisiène alongé, comprimé, fusifurme. - Trompe très-lonģne, avanće, horizontale, cylindrique.-Palpes distincts, en massue. - Tete arrondie. - Y eut.x grands, rapprochés et se rénnissant all-dessus du front dans les mâles, espaećs daus les femelles. - Trois petits yeux lisses disposés en iriangle et placés stir le vertex. - Corps presque glabre. - Liles grandes. - Point de culllerons. - Balunciers grands , très - apparens. Abdomen composé de six segrnens outre l'anus. - Pattes longues, minces; jambes enlièreanent dépourvues dépines.

Les espèces connues de ee genre sont toutes d'Europe et ne s'élèvent guère qu'à cinq ou six. Leur taille est períe. Elles se plaisent daus les lieux secs, s'urrêtant sur les tleurs, principalement sur celles du liseron des champs.

\section{Peturie fauve, $P$. filioa.}

phthiria fulvo-pubescens, alis fuscescentibus.

Phthiria fulsa. Meig. Dipt. d'Eur. ton. 2. pag. $218 . n^{\circ}$. 1. tab. 18. fig. 15. Femele. Lat. Gener. Crist. et Ins. tom. 4. pag. 314.

Longueur \& lig. Fauve, pubescente. Ecusson blinchâtre, balanciers blincs. Ailes obscure? Elle a ćté tronvée an mois de juin à Fonlainebleau sur la marguerite commune. (Chrysantheinum leucautheinum.)

Nous n'avons point wn celte espèce.

2. Petunne pulicaire, $P$. pulicaria.

phthiria nigra, alis subhyalinis.

Phthiria pulicaria. Me1c. Dipt. d'Eur. tom. 2. pag. $219 \cdot n^{\circ}$. 5. - Phthiria nigra. Meig. Class. tom. 1. pag. 193. tab. 10. fig. 11. - Voluccellu pyginea. Fав. Systo Antliat. pag. 115. $n^{\circ} .5$. - Bombylins pulicarius. Mrkan. Monog. 58. tab. 4. fig. 14. - Encycl. pl. 388. fig. 38-41.

Longueur 2 lig. Noire. Extrémité de l'écusson et balanciers de couleur blanche. Ailes transparentes. Femelle.

- Le mâle ( suivant M. Meigen) est entièrement noir avec les ailes transparentes.

Des environs de Paris. (S. F. et A. Sęrv.)

PHTHYRIDIE, Phthyridiuni. Voyez NrcisRIBIE. (LATr.)

PHTHYROMYIES, Phthyromyia. Seconde tribu de la famille des Pupipares, section des Epro- 


\section{P H Y}

boscidés, ordre des Diptères. Elle a pour caractères :

Téte confondue avec le corselet. - Sucoir. renfermé dans un petit tube. - Point d'ailes ni de balanciers.

Elle ne contient que le seul genre Nyctéribie. (S. F. et A. SERv.)

PhiYCIDE, Phycis. Fas. Lat. Tinea. Hubs. Genre d'insectes de l'osdre des Lépidoptères, famille des Nocturnes, tribu des Tinéites.

Daus ce:te tribu, les palpes inférieurs rccourbés dì̀s Jeur origine, distingueint les genres Lithosie, Yponomeute, Ecophore, Adèle et Teigne; les Cirambes ont celit de particulier que leurs quatre palpes sont découverts et avancés cn forme de bec. Les Galléries ont les palpes inférieurs couverts d'écailles avec le dernier article un peu courbé. Dans les Eaplocampes les antennes des mâles sont distincteuent pectinécs. Les Alucites ont les antennes presque simples et leur langue cst assez longue et apparente. Les Phycides ne présentent aucun de ces caractères.

Antennes sétacées, celles des mâles ciliées ou baribues. - Langue très-courte, peu distincte.Palpes supérieurs entièrement cachés, les inférieur's senls apparens, avancés, de trois articles, Le second portant un fiusceau d'écailles, le troisième relevé perpendiculairement et presque nu. --Corps enveloppé par les ailes, ceiles-ci entières; les supérieures longues ct étroites, les inférieures larges et plissées dans le repos. - Chenilles vivant à couvert dans un fourreau.

1. Paycrde du Bolet, P. boleti.

phycis alis superioribus nigris, dorso marginegue postico albidis.

Phycis boleti. FAв. Entom. Syst. Suppl. pag. 463. $n^{\circ}$. 1. - Tinea boletella. Huв. Tin. tab. 3. fir. 18. Larv. Tin. 1. Bombycif. C. a. $n^{\circ}$. 2. a.

Envergure 16 lig. Tête et corselet cendrés. Ailes supérieures noires, leur dos et lem bord postérieur blanchâtres; celte couleur se répandaut irrégnlièrement et ponctuée de noir.

Chenille blanchâtre ponctuée de noir, à tête brune. Vit dans les bolets du hêtre.

Du nord de l'Europe.

Nota. Nous décrivons celte espèce que nous n'avons point vue, d'après Fabricius.

(S. F. et $\Lambda$. SERv.)

PHYLLIE, Phyllium. Illig. Lat. Mantis. LinN.

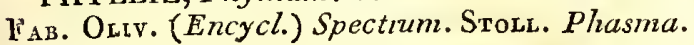

LAM.

Genre d'insectes de l'ordre des Ortboptères, famille des Coureurs, tribu des Spectres.

Cette tribu n'est composée que des genres Phasme et Phyllie. On distingue aisément le der-

nier par son abdomen ovale, large, déprimé, membraneux, ses élytres imilant des feuiles et le premier segrnent du corselet cordiforme.

Antennes insérées devant les yeux, plus près de la bouclıe que du milieu de la tête. 2 Labre écliancré; son bord antérieur droit. - Lèure à quattre divisions inégales. - Palpes comprimés. - T'éte avancée, alongée, arrondie postérievrement. - Yeux pelits. - Yeux lisses souvent peu distincts. - Corselet formé de trois segmens; le premier déprimé, en forme de cœur; le second et le troisième formant ensemble un triangle tronqué antérieurement. - Pattes antérieures unn ravisseuses; toutes les cuisses comprimées, ayant un appendice membraneux à leur partie intérieure et extérieure ; jambes s'appliquant dans le repos au côté interne de la cuisse et sous son appendice; tarses à cing articles, leurs crochets munis dans leur entre-deux d'une pelotte trèsapparente.

Les Phyllies habitent les parties orientales des Grandes-Indes. Ce sout des insectes d'une forme très-singulière, mais qui est utile à leur sûrelé ; leurs élytres imilant une feuille peut les faire coufondre avec celles des arbres où elles prennent leur repos, tant par leur couleur et leur figure que par la disposition des nervures. Il est probable que leur nourriture est végétale. Nous ignorons au reste ce qui appartient à leurs mœurs. On n'en connoît encore que fort peu d'espèces.

I. Phyldie feuille sèche, $P$. siccifolium.

Phyllium siccifolinun. Lat. Règn. anim. tom.3. pag. 375. - Stold, Spect.pl. VIII. fig. 24-26. (Les figures 25 et 26 représentant la femelle lui donnent par erreur des antennes très-longues, tandis qu'elles sont fort courtes dans ce sexe.)

$V o y$. pour les autres syncnymes et la description de la femelle, la Mante siccifcuille $n^{\circ} .6$.

Le mâle a les élytres courtes, les ailes grandes, transparentes, vertes au bord antérieur; son corps est plus étroil que celıi de la femelle, et ses antennes sont longues, sétucées, composées d’articles nombreux et cylind:iques.

M. Latreille dit que les habitans des îles Séchelles élèveut cette espèce cornme objet de conmerce d'histoire natuielle.

\section{Payllie de Stoll, P. Stollii.}

\section{Phyllium lutescente-decolor.}

La Patte fuillette. Sroul, Spect. pag. $6 g$. pl. XXIII. fig. 89.

Longueur 3 pouces. Cette espèce entièrement modelée sur le mâle de la précédente est partout de sette conleur jaune tannée quant certaines fenilles qui dépérissent.

Sa patrie est inconnue. (S. F. et A. SERv.) 


\section{6}

PIIYLlOBE, Phyllobius. Ce genre de Coléop!ères créé parr MI. Sebonnherr a été adopté par M. Germar dius son ouvrage ayant pone tilre : Ins. Spec. Nov. vol. r. Coléopt. I 324. Il appartient à la tribú des Cbarausonites, famille des Rhynchophores. Les P'hyllobies ont pour caractères : rostre court, cylindrique, guère plus étroit que La tîte: celle-ci sitllante, oblongue, cylindrique; fosseltes courtes, profondes, plicées à l'extrénité du rostre. Yenx petits, globuleux. Antennes insérées an bout du rostre, plus longues que le corselet; leur premier article courbe, en massue, le second courbe ; le touct de sept atticles dont les deux premiers plus longs que les autres, ceux-ci presqu'éganx entr'eux, en massue, obconiques ou lenticulaires; massue ovale-oblongue. Corselet court, presque globuleux ou presque cylindriqne, tronqué à sa base et à son extrémité; point de sillon en dessous propre à recevoir le rostre. Ely tres pluslarges que le corselet, oblongues, couvrant des ailes, ordinairement assez molles. Ecusson petit, triangulaire. Paltes longues, presqn'égales entr'elles. Cuisses en massue, sonvent dentées; jambes cylindriques, leur extrémité mntique, les mutérieures souvent sinnées. 'Tarses courls, larges; lenrs premiers articles égaux. Corps oblong, assez mou, écaillenx.

Ce genre voisin te celni de Péritèle du même auteur, s'en distingue par une forme plus oblongue et par la présence des ailes et d'un écusson. Les neuf espèces rapportées à ce genre par M. Germar, sont européennes. L'une d'elles est le Charanson Pomone. Otrv. Entom. $n^{\circ}$. 455. Curculio Pomonce. (S.F.et A. Serv.)

PHYLLOCÈRE, Phyllocerus. Genre de Coléoptères Pentamères Serricornes, de la tribu des Elatérides, très-voisin des Taupins, et qui a pour caractères : premier article des autennes grand, renllé en devant, coupé obliqueunent à son extrémité, le second petit, un peu gonllé à sa partie antérienre, le troisième grand, égalant le prémier en longueur, le quatrième plus grand que lés suivans, mais plus pelit que le troisième. Les six suivans pelits, portänt chacun sur leur parlie supérieure un appendice latéral aplati, dentés en scie de l'autre côté ; le onzième on dernier alongé, cylindrique, portant un appendice comme les précédens. Corselet absolument conformé comme celui des Taupins.

M. le comte Dejean qui a bien voulu nous communiquer les caractères ci-dessus et nous permettre de décrire l'espèce, a fondé ce genre dont le nom a pour étymologie deux mots grecs qui signifient : antennes en feuille, sur un individu unique trouvé par lui dans l'île de Curzola ẹn Dalmatie. Il la nomme : Phyllocère flavipenne. ( $P$. flavipennis.) Longueur 7 lig. $\frac{x}{2} \cdot$ Noir, convert d'nn léger duvet roussâtre. Elytres d'nn châtain clair, très-finement pointillées, striées; ces stries ponctuées depuis leur milien jusqu'à l'extréınité. Tarses garnis en dessous de poits ferrugineux.

$$
\text { (S. F. et A. Serv.) }
$$

PHYLLOPES, Phyllopa. J'ai désigné ainsi, dans le troisième volume de l'ouvrage sur le règne animal de M. Cuvier, une fanille de Crustacés de l'ordre des Branchiopodes, distinguee de tous les autres animatix de celle classe par le moinbre des pieds, qui, en y comprenant les pieds-mâchoires, semblables ici, à l'égard de leurs functions, aux pieds thoraciques, est de vingt-denx, et qui sont tous natatoires, branchiauix el foliacés, ou composés d'articles comprimés en forme de lames : de-la l'origine du mot Phyllopes, pieds en feuilles. C'est à la dernière paire on un peu au-delà que sont situćs les sacs renfermant les ceslls. Ces Crustacés ont tous deux ou trois yeux. Dans qnelyues-uns, et tous binocles, ces organes sont insérés à l'extrémité de deux prolongemens latéraux el en forme de cornes de lit tête, mais non articulés, à la manic̀re des pédicules portant les yeux des Crustacés décapodes.

Dans la seconde édition du nouvean Dictionnaire d'Histoire naturelle, j'ai divisé cetle famille en deux tribus, les Aspidiphores ef les $C \dot{E}-$ pHALÉs. Les premiers ont un test clypéiforme, trois yeux placés sur ce test et sessiles. Le nombre de leurs pieds est de cinquante à soixante paires. I.es seconds sont dépourvus de test, n'ont que derx yeux, et ces organes sont pédiculés. Le nombre de leurs pieds ne surpasse pas vingt-deux. La première tribu se composoit du genre Apus; ceux de Branclıipe, d'Eulimène et d'Artémie formoient la seconde. Le doctenr Léach réunit le second au dernier, et rectifie l'erreur' que j'avois commise à l'égard de la déuomination (Artémisie) de celui-ci. Depnis î. Adolphe Brongniart nous a fait connoître un nouveau genre appartenant $\dot{a}$ la mêrne famille, et auquel il a donné le nom de Limniadie (Linınadia). Ici le test est bivalve; les yeux, au nombre de delix et sessiles, ne font point partie de la tête; l'animal a onze paires de pattes.

D'après cet exposé, la famille des Phyllopes pourroit être partagée ed trois sections :

10. Un test clypéiforme, poriant trois yeux sessiles; cinquinte à soixante paires de pieds (dont les deux antérients fort grands, antennifornues).

Le genre $t$.pus.

$2^{\circ}$. In tesi bivalse, renfermant le corps; deux yeux sessiles; onze paires de oiecis.

Le genre Lruvadie, ayani pour typela Daphnie géanie, décrite et tigurée $\mathrm{p}$ : Metrana fls (Ménuires aptérolog gues, pis. I34. lab. V.) on la Lintnadie d'Lentann. (Voyez le tome 


\section{P $\mathrm{H} \mathrm{Y}$}

sixic̀me des Mémoines du Muséum d'Histoire naturelle, pagc 83 et suivantes.)

$3^{\circ}$. Point de test; deux yenx pédiculés; onze paires de pieds.

Les genres Branchippe, Artémie.

Supposé que ces animaux fossiles et anomaux, que l'on connoît sous le nom de Trilobites, et sur lesquels H. Alexandre Brongniart nous a domné un si beau travail, soient des Crustacés, ils formeront une quatrième division (voyez TrinoBITES).

Mais pour ne pas trop multiplier les tribus, les deux premières divisions séront réunies en une, qui conservera la dénomination d'Aspidiphores et ayant pour caracières : un test clypéiforme un conchiforme; yeux sessiles. La troisı eme division composera une antre tribu el que nous nommerons Cératophthalmes au lieu de Céphalés, expres. sion moins caractéristique. Nous pensons aussi que pour facilíter l'étude des Crustacés, il est nécessaire d'élablir de nouveanx ordres aux dépens de celui de Branchiopodes. Il faut d'abord en détacher ceux qui ont un siphon on un rostre et qui sont tous parasites; ensuite ceux qui, comme les Limules, n'ont point de mandibules ni de mâchoires propres. Ces Branchiopodes formeront, parni les Crustacés, une section particulière, celle des Edentés. Une autre section, et la première, comprendra les Crustacés pourvas, à la manière ordinaire, de mandibules et de mûchoires. Cette section ou celle des Maxillaires se partagera en deux, d'après le nombre des pieds; savoir : $1^{\circ}$. seize au plus, y compris les six pied.smâchoires; $2^{\circ}$. vingt-deux et plus. Tel sera le caractère de l'ordre des Phyllopodes on des Ci usiacés qui sont l'objet de cet article. Les Crustacés branchiopodes de la famille des Lophyropes composeront aussi un nouvel ordre bien distinct, celisi de Lophyropodes, et que l'on"signalera ainsi : un seul cil et sessile; un test corné clypéifurme ou conchiforme. Branchies faisant partue soil des pieds on de quelques-uns d'entr'eux, soit des organes de la manducation; ces pieds tous ou prescre tous uniquement natatoires. Les décapodes et les stomapodes s'éloignent de tous les Crusıacés maxillaires, à raison de leurs yeux pédiculés et de leur test. Dans les antres Crustacés de la même section, le corps ust entièrement segmentaire ou articulé, et les yeux, au nombre de denx, sont sessiles.

(LATR.)

PHYLLOPHAGES, Phyllophaga. Quatrième division de la tribu des Scarabéides, famile des Lamellicornes, section des Pentamères, ordre des Coléoptères, dont le caractère cst :

Mandibules recouvertes par les mâchoires et par la partie antérieure de la tête, point saillantes, leưr côté extérieur seul apparent. - Mâchoires arquées à leur extrémité.

\section{P H Y}

Les genres qui appartiennent à cefte dirision sont : Hannetch et Hoplie.

Les Phyllophages (nom venant de denx mots grecs cui signifient : mangeurs de feuilles) causen $t$ fréquemment un grand dommage en déponillant les arbres de leur verdare. Leurs larves, ou du moins celles de plusieurs espèces, atlaquent les racines et font souvent périr un grand nombre de végétaux.

HOPliE, Hoplia. Ildig. Lat. Scarabaus. Lint. Geofe. De Géer. Melolortha. Has. Oliv.

Genre d'insectes de l'ordre des Coléoptères, section des Pentamères, familie des tameliicornes, tribu des Scarabéíles.

La quatrieme division de la tribu des Scarabéides, nommée les Pliyllophages par M. Latreille ( $20 \%$ ce mot), contient les grenres Hoplie et Hanneton. Plais ces demiers ont tontes leurs jambes munies d'épines it leur extrénité, et les tarses postérieur's offient deux croclets ainsi que les quatre uutres tarses.

Antennes de neuf à dix arlicies, les trois derniers formaut une massue fenilletée, plicalile. Mandibules membraneuses au côlć interne et terminées par une pointe simple on entière. Mâchoires comprimées, denticulées. - paljes maxillaires une fois plus longs que les labiaux, de quatre articles, le dernier atongé, épais, ovoide et pointu; les labiaux de trois arlicles. Corps déprimé, ovale, couvert ou parsemé de petites écailles brillantes. - Corseletpointrebordé. - Ecusson petit, arrondi postérieurement. Elytres unies, plus larges on conme dilatées a leu. base extérienre, couvrant les ailes et la plus grande partie de l'abdomen. - Abdomen presque carré. - Pattes postérieures grandes; jambes dépourvues d'épines terminales; tarses antérieurs et intermédiaires terminés par deux crochets, l'uu petit sans division, l'autre pius grand et hifide; tarses postérieurs n'aỷant qu'un senl crochet très-grand, très-fort et saus division à sa pointe.

Le nom de ce genre, tiré du grec, signifie: armé d'ongles. Les Hoplies se tiennent sur les teuilles de différeus végétaux qu'olles rongent; elles semblent préférer ceux qui croissent au bord des eanx. Le nombre des espèces comues est de quinze et propres à l'Europe ou à l'Afrique.

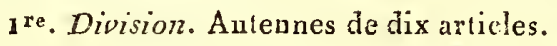

On rapportera à cette division le Hanneton argenté, $\mathrm{t}^{\circ}$. 115 de ce Dictionnaire.

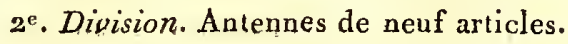

Cette division renferme le Hanneton écailleux, no. 114 . (Hop. squamosa.) 
Nous indiquerons en outre comme étaut de ce genre le Hanneton farinezx, $n^{\circ}$. 113. (Hop. furinosa, Scarabceus furinosus. Iisn.), et le Hunnelon royal, no. 112. (Hop. aulica, Scarabous (uulicus. Linn.)

\section{(S. F. et A. Serv.)}

PHYLlOSOlle, Phyllosoma. Genre de Crustacés, de l'ordrc des Slomapodes, établi par M. Léach, dans une Notice sur les animaux recueiliis par Joseph Cranck, naturatiste de l'expédition anglaise, qui avoit pour but la déconverte de la source de la rivière de Zarre en Afrique. Une espèce de ce gentre avoit élé décritc et figurée, depuis long-temps, sous le nom de Cancer cassideus, dans un journal allemand (der Naturforscher) sur l'historre naturelle; c'esi ce qu'jgnoroit le docteur Léach, lorsquil we communiqua, avec sa grénérosité accoutumće, plusieurs de ces Crustacés, si remarquables par leur corps tellemeut aplati, que son épaisseur ne surpasse point celle d'une feuille ce papier à écrire, presque diaphane, ei, comne l'indique l'étymologie du wot Phyllosome, seublable à une feuillc. Ces animaux composent daus l'ordre des Siomapodes une famille particulière, que je nomme Bipeltés. La partie antérieure du corps, répondint au thorax des Dica podes, ou celle que $j$ 'appelle thoracia'e, est enelfet divisée cn deux boucliers, dont l'antérieur plus grand et plus ou moins ovale, forme la tête; et dont le second ou l'alvithorax, porte les piedswächoires et les cinq paires de pieds ordinaires, a la fortue d'un ovale transiversal, coupé en lignc droite au bord postérieur, et anguleux dans sou pourtour. Le post-abdomen est très-petil. Sur le devant du premier bouclier sont situés lcs yeux et les antennes. Los yeux sout poriés sur un pédicule long, menu, divisé en deux articles, dont le radical beaucoup plus alongé et cylindrirque, et dont le dernicr un peu plus yros, forme un bouton, en cône renversć, terminé par l'œil proprement dit. Les antennes sont sur une ligne transvcrse, fliformes, et composées, à ce qu'il sna paru, de quatre articles, dont le quatrième ic plus long. Les latérales n'ont point d'écaille à leur base, et leur longueur varie selon les espèces. Les mitoyenues, toujours plus courtes que les pédicules oculaires, sont partagées depuis l'extrémité supérieure dn troisièrne article, en deux filets, doni l'interne un peu plis court, et paroissaut biarticulé. La bouche est placée vers les deux tiers de la longueur médiane de ce bouclicr, à partir de son sommet, et ne présente, au premier coup d'œil, qu'un groupe de mamel.ms disposés en rosette, et qui soul probablewent les analogues des organes composant la bouche des Squilles. La Iransparesce du corps permet de distinguer le canal alimentairc, qui à la suile d'un osophage dilaté, de figure carrée et un peu plus large que long, s'étend eu ligne droite dans la longueur du tronc et présente vers son milieu un rétrécissement. Les deux deruiers piedsmâchoires et les quatre premières paires de pieds sont grêles, filiformes, et généralement fort longs; tantôt cette longueur, en allant de devant en arrière, dimiıue progressivement ; tantôt la première et la troisième paires de pieds, ou même les deux derniers pieds-mâchoires et qui sont toujours pédiformes, sout les plus longues. Si l'on exceple lés deux palles postérieures, de l'extrémité du troisième article des autres on. de la plupart d'entr'elles naît, soit en devant, soit postérieurcment, un appendice sélicé, cilié, articulé, el qui paroît être l'analogue de celui que l'on observe anx jieds nageur's et simples des Squilles. Dans le Phyllosome clavicorne, le luitième et dcrnier article des deux pieds antérieurs, ou plutôt des deux dernicrs pieds-mâchoires, et qui sont les plus longs de tous, m'a paru se terminer par deux pctits onglets alongés et articulés, tandis que les autres sont presqne sétacés et simples a leur extrémité. Les deux pieds postérieurs sont toujours plus petits et simples. Tous ces appendices sont insérés sur le contour du second bouclier. Les qualre premiers pieds-mâchoires occupent le milicu du bord antérieur du tronc et sont fort petits. Les deux antérieurs ou les plus rapprochés de la bouche se distirguant à peiue, sont, autant que j'ai pu en juger, d'une forne conique, el composés de trois articles, dont lcs deux premiers accompagnés chacun d'nn trc̀spetit appendice; le prenier article des quatre autrcs picds-mâchoires est aussi appendicé, et l'extrémité du second article des seconds se divise eu deux lanières sélacées. L'extrémité postérieure du premier bouclier ou de la tête s'avance en arrière sur le second; cependant, vue en dessous, la tête paroît être continue avec le tronc ou le secoud bouclier. Le post-abdomen, ou communement la queue, est $11 n$ peu plus court que la partie précédente, en forme de triangle étroit, alongé et très-obtus au bout, de cinq segmens, avec une nageoire terminale composée de cinq feuillets, dont deux de chaque cóté, ovales et portés sur un article radical commun, et dont le cinquième au nulieu, triangulaire et arrondi an bout; chaque segment a en dessous une paire d'appendices natatoires, composés de la même manière que les pièces latérales de la nageoire précédente. De cinq espèces décrites, qualie sont africaines, et l'autre se trouve aux Indes orientales. Elles sont loutes marines. M. Gaymard, naturaliste de l'expédition du capitaiue Freycinet, nous donnera probablement quelques détails sur les habitudes de ces animaux, dont il a apporté plusieurs individus.

Nous avons donné, Planche 354 de l'Ailas dhistoire naturelle de cet ouvrage, des figures complètes ou partielles de quatre de ces espèces, copiées du Mémoire précilé de M. Léach. 


\section{P H Y}

\section{Bouclier antérieur ovale et entier.}

A. Antennes latérales plus longues que les pédicules oculaires.

I. Payclosome elavicorne, Phyllosoma clavicorne. Ĺ́ $A$ ch. Antennes latéráles ou extérieures trois fois plus longues que les pédicules oculaires; les deux derniers pieds-mâchoires plus longs' que les aulres pieds.

2. Phyirosome common, Phyllosoma commune, ejusd. Longueur des antennes latérales double de celle des pédienles oculaires; les première et troisième paires de pieds plus longrues que les antres et que les pieds-mâchoires.

\section{B. Les quatre antennes plus courtes que les pédicules oculaires.}

3. Peyllosoue uaticonne, Phyllosoma laticome, ejusd. Antennes laiérales longues et un peu plus larges que les deux autres, avec le premier artiele dilaté extérieurement et le dornier plus grand, elliptique; celles-ci sétacées. Voyez le Cancer cassideus de l'ouvrage allemand précité, cah. $17, p l .5$.

4. Phyllosome brévicorne, Phyllosoma brevicorne, ejusd. Antennes latérales un peu plus courtes que les interı́diaires, ni plus rrosses, ni dilatéés extérieurement à leur base; Jes unes et les autres sétaeées.

Voyez pour les quatre espèces, toutes africaines, la planche de l'Atlas d'histoire naturelle meutionnée ci-dessus, et le Mémoire du doeteur Léaeh, intitulé : $A$ Gener. Notic. of the anim. Tak. by John Cranck, Append. $n^{\circ} \cdot 4$.

II. Bouclier antérieur ayant la forme d'un carré, arrondi à ses angles, avec une échancrure au inilieu du bord antérieur.

5. Phyllosone front-échencré, Phyllosoma lunifrons. [ıат. Nouv. Dict. d'Btist. nat. $2^{\mathrm{e}}$. élit. tom. 26. pag. 36. Rapporté de la eôte de Coromandel par M. Lesehenault. (LATr.)

PHY HA'IE, Phymata. LAtr. Syrtis. FAв. Cimex. Linn. Geoff. De Géer.

Genle d'insectes de l'ordre des Hémiptères, section des Hétéroptères, famille des Géocorises, tribu des Membraneuses.

Les Macroeéfhales et les Phymates sont les seuls genres de leur tribu qui aient les pattes antérieures ravisseuses; mais les premiers n'ont point de cavilé sons les bords du corselet pour recevoir les antennes; leur éeusson est très-grand, arrondi au bout, couvrant la plus grande partie de l'abdomen.

Antennes courtes, rapprochées à leur base, reçues dans des cavités latérales du corselet, in- sérées sous un cluaneron fourehu, an dessous de l'origine du bec et composées de quatre arficles, le dernier plus grand en forme de bouton alongé. - Bec court, triartierlé, engitiné à sa base avec: le labre. - Labre court, sins slries. - Ketsx petils, globultus. - Beux petits yeux lisses plitcés plus lanut que les yeux it rístan, assez pré. l'uu de l'autre. - Corps aplati, membrancux; ses hords latéraux élevés, dencelés et comme rongl's. - Ecusson nefit, friangulaire, printa, caréń dans toute sa longueur. - Elyties beuncoup plis étroites que l'abdomen, recues daus un enfoni ement dorsal de ce dernier. - Abdomen en formo de nacelle, rlomboidal; ses bords latératiz televé: angulainement. - Pates antérienres ravisseuses; Jurs euisses grandes, comprimées, presque trimgrulaires, ayant en dessous un sillon tcrminé par une forie dent; leurs jambes en forme de crochet arqué, se logeant daus le eanal irérieur des cuisses et privées de tarses; les quatre pattes postérieures moyennes; tarses composés de trois ariicles, les deux premiers furt courts : crochets simples sans pelotles apparentes.

Ces hémiptères remarquables par leur forme singulière, se trouveut dians les bois sur les fleurs, où ils s'emparent de divers insectes plus foibles qu'eux pour les sucer. Leurs pattes antérieures sont faites de mänière à cajotiver leur proie. Nous n'ern conuoissons que sept ou hrit especes, foutes de même taille et moyenne, wue de France qui es: de la prenière division, les autres d’Amérigne apparteuant à la seconde.

1re. Division. Dernier articlo des antennes presque cylindrique, plus long que les trois au-. tres réunis.

\section{I. Рнчмate crassipède, ?. crasioues.}

Phymata antennarum luteanum articu'o ritimo cotcris simul sumptis longiori.

Prymata crassipes. LAт. Gencr. Cinst. et Y7t. tom. 3. pag. 138. no. 1. - Syris crussipes. FAB. Syst. Rhyng. pag. 121. $n^{\circ}$. 1. - La l'unaise à pattes de crabe. Georr. Ins. Paris. tom. 1. pag. 447. $\pi 2^{\circ} \cdot 24 .-$ W OLF. Icon. Cinic fors. 3. pag. 83.tab. 9.fig. 82. - PAFz. Faten. Germ. fas. 20. fig. 24. - Coquer. Illus. Icon. tab. Yri: jiu. 6. - Encycl. pl. 37j. fig. $2 \dot{i}-25$.

Longueur 3 lig. $\frac{x}{4}$. Téte et corselet d'un rouxbrun. Abdomen un peu plus foncé jusquau milieu; ses côtés vers la base plus pâles. Antennes, dessons du corps et paltes d'un jaune-roussâtre.

Environs de paris.

$2^{e}$. Division. Dernier article des antennes oralealougé, moins long que les trois autres réunis.

2. Phymate rongée, $\boldsymbol{P}$. erosa.

Phymata antennarum fusce fernginearmor 
articulo ultimo cateris simul sumptis breviori, thorace eroso-dentato.

Plymata erosa. LATr. Gener. Crust. et Ins. tom. 3. pag. $139 . n^{\circ}$. 2. - Syrtis erosa. FAB. Syst. Rllyng. pag. 12 I. $n^{\circ}$. 2 - - Punaise-seolpion. DE GFER, Ins. tom. 3. pag. 350. pl. 35. fg. 13 et 14 . - Wolf. Icon. Cinic. fasc. 3. pag. 8g. tab. 9. fig. 83. - Encycl. pl. 374. fig. 6.

Longueur 4 li.r. Anteunes d'un brun-roussâtre. Tête et corselet de mème coulenr, portant en dessus plusieurs pointes; les bords latéraux du dernier découpés. Abdomen d'un blanci-jannâtre, avec une bande transversule brune au milieg. Elytres Jrunes ayrant une tache latérale pẩle. Pattes et dessous du corps blanchâtres; angles latéraux du ventre bruns.

De Surinam et de Caroline.

MACROCÉPHALE, Macrocephalus. SwED. LAT. Sy.rtis. Fав.

Genre d'insectes de l'crdre des Hímiptères, section des Hétéroptères, famille des Géocorise's, tribu des Memibraneuses.

Dans celte tribu les genres Tingis, Arade et Puaaise ont les pattes antórieures simples, pro-pres senlement à la inarche et non pas à saisir une proie. Leurs jambes de devant ont des tarses et ne sont pas conformées de minière à pouvoir se rapprocher de la cuisse et à arrêter l'objet que l'insecte a besoin de fixer près de lui. Les deux autres renres qui complètent cette tribu sont ceux de Phyinate et de Macrocéphale, mais les antenues du premier se cachent à l'état de repos dans une rainure latérale de la têle et du eorselet; les bords latćrath du corps sont dentelés, et l'écusson est petit et pointu.

Antennes en massue, rapprochées à leur base, insérées à l'extrémité d'un ciraperon pen fourchu, composées de quatre articles, le premier plus long que le suivant, conique, coupé obliquement à l'extrémité; le second presque carré, de la longueur du troisième, celui-ci plus mince que les autres; le quatrième ovale-oblong, plus gros et plus grand que les préeédens et formant la massue.-Bec court, engaîné à sa base avec le labre, de trois articles apparens. - Labre court, sans 8 llies. - Tête lungue, cylindrique. - Yeub $x$ petits, aryondis, globuleux. - Deux petits yeux lisses placés plus haut que les yeux à réseau, assez près l'un de l'autre. - Corps assez épais, se retrécissant en devant. - Corselet rugueux, fort rétréci antérieurement, guère plus liuge que la têle dans cette partie, de la largeur de l'abdomen postérieurement. - Ecusson grand, couvrant lia partie moyenne de l'abdomen presque jusqu'à l'anus, arrondi à son extrémité. - Elytres eachées en grande partie sous l'éeusson.-Abdomen ovale, tronqué à sa base, d'́passant un peu les élytres par sẹs eôtés, sẹs bords latéraux unis, point re- levés. - Pattes antérieures ravisseuses; leurs euisses grosses, leurs jambes en forme de crochet, privées de tarses, s'appliquant exaetement et se repliaut sous la cuisse. Les quatre pattes postérieures petites, leurs tarses ne paroissant composés que d'un seul arlicle; crochets bitides sans pelottes apparentes dans leur entre-deux.

Ies Macroeépliales, dont le nom vient de deux mots grecs et signifie: grosse tête, ont probablement les mours des Phiymates; leurs métaunorphoses ne doivent pas différer de celles des antres Hémiptères hétéroptères. Les espèees eonnues habitent les deux Amériques. Fabrieius en déerit trois espèces dans le Syst. Rhyng. pag. I 23, sous le noun de Syrtis; savoir : Manicata, $\mathbf{n}^{\circ} \cdot 7$, Prehensilis, $n^{\circ} .8$, et Crassimana, $n^{\circ} .9$.

(S. F. et A. SERv.)

\section{PHYSAPODES. Voyez V'́sltarses.}

(S. F. et A. SERv.)

PHYSODE, Physodes. Nom donné par M. Daméril à un genre de sa classe des instctes, ordre des Aplères, famille des Quadricornes on Pulyguathes. L'espèce dont il a donné la figure, sous le nom de Marin, dans son ouvrage intitulé : Considérations générales sur la classe des insectes, se rapporte à notre Idotée poirtue (noup. Dict. 'a'Hist. nat. seconde édit. tom. 16. pag. to5.) Ce savant naturaliste ne comprenant dans cette famille, la soixantième et la dernière de sa classe des insectes, ue les genres Armadille, Cloporte et Pliysode, celui-ci doit être le mêtue que le geare Aselle d'Olivier, et embrasser dèslors notre ordre des Crustaeés isopodes. (Latr.)

\section{Pify'Tadelges. Voy. Plantisuges.}

\section{(S. F. el A. Sirv.)}

PHYTIBRANCHES, Phytihranchia, Dansl'on vrage sur le régne anima! de M. Cuvier, jai désigné ainsi une famille de Crustacés, de l'ordre des Isupodes, dont les appendices brauchiferes situés sous la queue ressemblent à de petits piedts artieulés ou à des tige's ramifiees, landis que ceurx des autres Isopodes sont en forne de lames ou d'écailles. Ayant, defuis l'impression de cet ouvrage, observé des palpes aux mandibules de divers Phytiphiıges, curactère qui distingue les Amphipodes des Isopodes, jai transporté cette tribu dans le premier de ces deux ordres. Les autres Ainphipodes ayant d'ailleurs sous le postabdomen des appendices d'une forme analogue, ee grompe ordinal n'en est que mieux assorti. Je le divise en quatre familles.

$1^{\circ}$. Les Chevertines, Grammarince, dont tous les pieds sont onguiculés, an noanbre de quatorze, et dont l'extrémité postérieure du corps est munie de pièces cylindriqués ó sans appendices.

Iei viemnent lés genres Crepetle, Talitre; 
Corophie, Phronime et plusieurs autres établis par M. Léach.

$\varepsilon^{\circ}$. Les URoptères, Uroptera. Semblables aux précédens par la manière dont se terminent leurs pieds et par leur nombre, mais don! le corps offre à son extrémité postćrieure et latérale des appendices en nageoires.

Le genre Phrosine de M. Risso et quelques autres inédits appartiennent à cette famille.

Les suivans comprennent mon ancienne tribu des Phytibranches.

$3^{\circ}$. Les Décempèdes, Decempedes. Les pieds sont onguiculés, mais réduits à dix.

Elle se compose des genres Typhis, Ancée, Pranize.

$4^{\circ}$. Les IÉTÉRopes, Heteropa. Les nieds sont au nombre de quatorze, comme dans les delix premières fumilles, mais tous, on les quatre derniers au moins, sunt mutiqueset simplement natatoires.

Là se placent les genres Apseude, Ione, Ptérygocère.

Le genre Ascés, Anceus, de M. Risso, ou Gnathia de M. Léach, est distingué de tous les autres de la même famille par les caractères suivans. 'Tous les pieds simples. Deux fortes saillies, inilant des mandibules, au devant de lit tête, dans les nâles. Queue terminée par des feuillets en nageoile. Lal fig. 24 de la planche 336 de l'Allas d'histoire naturelle de cet ouvrage, représente l'Ancée forficulaire mâle de ce naturaliste. La figure suivante est celle du Cancer maxillaris mâle de Montagı, ou du Gnathic termitoides de H. L'́ach. D'après des reuseigriemens communiqués par le dernier, l'Oniscus corruleatus du précédent, d'atprès lequel nous avons formé le genre Pranize, Praniza, et dont on trouvera aussi la figure, même planclse, $n^{\circ} .28$ (1), et pl. 229 , fig. 24 et 25 , seroit la femelle. Je soupconne quil y a ici quelque erreur.

La fignre 26 de la même planche $n^{\circ} .36$, est celle de l'A pseude taupe, Apseudes talpa, genie du même naturaliste, et auquel paroít devoir se rapporter celui d'Eupheus de II. Risso ( Même plauche, fig. 27 ). Les quatre terniers pieds sont seuls nutiques et propres it la natation. I.es deux premiers se terminent el piuce, et les deux suivans s'ćlargissent au bout, en mauière de main dentelée. L'extrémité postérieure dı corps olfie deux longues soies articulées et velues.

Dans le genre lone, Ione, probablement celui de Cólino de M. Léach, tous les pieds sont muliques. C'est l'Oniscus thoracicus de Montagu, dont la fyure est reproduite même planche 336 de cet Allas, no. 46 .

Le genre Prénygoère a été établi sur une figure de Slabber, copiće ici, pl. 33o, nos. 3 et 4 . Voyez cet ariticle et celui de Tiphis. (Latr.)

(I) Il s'est glissé une faure dạrs l'expliçarịon de cẹtre Ggure. Lisez creruleatus, au lieu de thoracicus. Hist. Nat. Ins. Tome $X$.
PHYTOPHAGES CU HERBIVORES. Nom donné par M. Duméril ( $Z$ ool. anal.) à sa vingtunième famille de Coléoptères, section des Tétramérés, offrant lés caractères suivans : antennes filiformes, rondes, non portées sur un bec; corps armondi. Elle se compose des genres Donacié, Criocère, Hispe, Halode, Lupère, Galéruque, Altise, Gribouri, Clytre, Chysomèle, Alurne, Erotyle et Casside. (S. E. et A. Serv. )

PIED ou PAT'TE, Pes. Appendice ou membre inférieur du corps, propre à la marche ou à la natation, et composé d'une suite d'articles tubulaires, renfermant chaeun des muscles propres (denx rians la plupart, dont l'un extenseur at l'autre fléchisseur ).

"La forme générale des pattes, dit M. Clzvier, Lecons d'Anatomie compurée, tom. I, pag. 452 , dépend de la manière de vivre des insectes. Sont-ils destinés à demeurer dans l'eau, à nager? alors les pattes sont aplaties, longues, ciliées. Doivent-elles servir à fouir la terre? elles sont élargies, crénelées, tranchantes. Serveut-elles seulenient à la marclue? elles sont longues, cylindriques. Sont-elles propres au sant? la cuisse est plus grosse, la jambe plus alongée, souvent arquée. Entin, d'après ces eonformations diverses, on peut très-bien reconnoître, même dans l'insecle mort, ses habitudes, sa manière de vivre.

"Les pattes des insectes sont composées de quatre parties principales, qu'on nonme la hanche, la crisse ou fémur, la jambe on tibia, le tarse (I) ou doigt.

" Chacune de ces parlies est enveloppée dans un étui de substancecornće : elles jouent l'une sur l'autre par gynglime, parce que lit substance dure étant en debor's, l'articulation n'a pu se faire par moins de deux tubercules. Le motivement de chaque article ne se fait donc que dans un seul plan, à l'exception de celui de la hanche, comme nous allons le voir.

"La hanche (2) joint la palle au corps et joue dans une ouverture correspondante du corselet ou de la poitrine, siaus y être articulée d'une manière posilive, mais comme emboîlée. La figure de la hanche varie. Chez l's insectes auxquels les pattes ne servent qu'à la mäche, comme les $C a$ pricomes, les Chrysomèles, le plus grand nombre des Hyménoptères, des Diptères, etc., les hanches sont globuleuses et forment un vérilable genou des mécaniciens. Mais chez cenx dont les paltes devoient avoir ce mouvement latéral nécessaire à l'action de nager, de fouir la terre, etc., la banche est large, aplatic, et a ordinairemont son plus grand diamètre daus la direction trausversale du corps. Dans quelques-uns même, comme

(1) Ou plutôt le pied proprement dit.

(2) La pluparc des entomologístes la considèrent comme formée de deux articles, la rorule ( pattlla) er le trocha..us ro 


\section{$\$ 22$}

les Dytisques, la hanche postéricure est soudéc et immobile. Elle est compriméc et en forme de lames dins les Blattes, les Forbicines, et quelques genres d'insectes qui marchent très-vîte.

"Le fémuer suit immédiatement la lianche, à la partie internc de laquelle il s'articule, de maniçre à être parallèle à la face inférieure du corps, dans l'état de rcpos; les mouvcmens, sur cette prenière pic̀ce, se bornent à celui de devant cn arrièrc. la nature et l'étendue du nouveuent de la cuisse paroissent avoir déterminé ses formes. Dans les insectes qui marchent beaucoup et qui volent peu, comme les Carabes, les Cicindeles, etc., il y a à la base du fémur, unc on deux émiuences qu'on nomme trochanters. Elles paroissent destinécs à éloigner les muscles de l'axe de l'articulittion. Chez ceux qui avoicnt besoin de musclcs forts pour sauter, la cuisse est épaisse et souvcnt alongéc, comme dans les Sauterelles, les Altises, quelques Charançons, les Puces, etc. Dans ceux qui fouisscnt la terre, et chez lesquels la cuisse doit općrer un fort mouvement, elle porte une facette articulaire, qui correspond au plat de la hauche sur laquelle elle s'appuie. C'est ce qu'on obscrve dans les pattes antérieures, des Scarabéés, des Scarites, des Taupes-grillons, etc. Enlin la forme de la cuisse est toujours subprdonnée au genre du mouvement.

"La jambc est la troisième articulation de la pattc; elle se meut en angle sur la cuisse, et n'est point susceptible d'autre mouvemeut. La tigure du tibia dépend essentiellement des usages auxquels il est destiné. C'est ce qu'on voit dans les insectes nageurs, où il est aplati et cilié; dans les fouisseurs, où il est crënclé et tranchant sur les bords. Dans les Nèpes, les Mantes et plusieurs autres, la patte antérieure est tcrminée par un onglet, et forme avec la cuisse une espèce de pince on de tenaille, dont les iusectes se servent pour reteuir leur proie, qu'ils dévorent toute vivante.

"Le doigt ou tarse des insectes forme la dernic̀re pièce de la patte. Il est ordinairement $\mathrm{c} \cdot \mathrm{m}$ posé de plusieurs articles, dont le deruier est terminé par un ou deux ongles crochus. Ces articles jouent les uns sur les autres, et quelquefois mème ils sont opposables au tibia, et forment ainsi une espèce de pince. La configuration du tarse est toujours en rapport avec la mauière de vivre de l'insecte. Les artictes sont grêles, à peine distincts, sans pelottes ni boupes, dans le plus graud nombre de ceux qui creusent la terre et qui marchent peu à sa surtace, comıne les Scarabéés, les Escarbots, les Sphéridies, les $S c a r t e s$, les $S$ phex, etc. Ils sont aplatis en nageoires, ciliés sur leurs bords, et souvent privés d'ongles dans les insectcs qui nagent, comme lcs Hydrophiles, Tourniquets, Naucores, Corises, etc. Ils sont garnis de pelottes visqueuses, de houpes soyeuscs ou de tubercules charnus, vésiculeux, chez ceux qui marchent sur des corps lisses et glistans, comme les Mouches, les Chrysomèles, lcs Capricornes, lcs Thrips, etc. Ils sont torués de deax ongles mobilcs et oppoșables dans ceux qui doivent marcher et s'accrocher sur les poils, comme les Poux, les Ricins, les Cirons. L'un des articles est extrêmement dilaté, et couvert de poils disposés sur des lignes parallèles, dians les mâles de quelques especess du genre Crabro et de quelques Dytisques. *

Le mouvement de chaque arícle des pattes ne se fait, selon M. Cuvicr, que dans an seut plan. II n'est opéré que par deax muscles qui sont enveloppés dans l'article précédcut, un extenseur et un tléchisseur.

“Dans les Coléoptères, les lianches sc meuvent par une espèce de rotatiou sur leur axe longitudinal, lequel, comme nous l'avons dit, est placé en traver's, et fait avec l'axe ou la lignc moyenne du corps, un angle plas on moins approchant de $90^{\circ}$. La cuisse étant attachée à l'extrémité interne de la bauclie, est d'autant plus ćcartíc de la cuisse opposée, qu'elle est plıs fléchie sur sa propre lianche. Oı sent que la position du plan dans lequel cette. Hexion se fait, dépend de la situation de la hanche. Lorsque cclle-ci est tournće en avant, le plau est vertical. Lorsqu'elle est tournće en arrière, il devient tonjours plus obliquc, et même horizontal dans les espèc:es qui nagenl. C'est donc du nonvement sensible de la hanclue que dépendent les mouveuens les plus remarquables de la pattc:

"Les muscles de cbaque paire de lianches et des cuisses sont placés dans la partie du corselet ou de la poitrine qui est au-dessus; et, pour les bien voir, il faut couper le corps de l'insecte par tranches verticales.

"Au-dessus de la dernière paire, dans la poitrine, csl une pièce écailleuse en forme d'Y. Sa tige donne attache an muscle qui fait tourner la banche en arrière, en s'insérant à son bord postérieur. Ceui qui le fait tourner en avant est âttaché au dos, et s'insère par un tendon mince ì son bord antérieur.

"Le muscle qui ćiend la cuisse, eu le rapprochant de l'autre, est très-considérable, et s'attache à toute la branclie de la pièce en forme d'Y, pour s'insérer au bord interne de la tête de la cuisse. Son antagoniste est logé dans l'épaissear même de la hancilic.

"Quant aux deux paires de cuisses antérieures, les muscles qui les étenaent sont attachés aux parties dorsales qui lenr répondent, et non à des pièces intéricures particulières; mais ceux quile fléchissent sont toujours situćs dans l'épaissear mème des hanches.

"Les muscles qui font tourner celles-ci sont aussi attacléés aux parois du corselet; savoir : cclui qui les porte en arrièrc, à la partie dorsale; et celui qui les porte en avant, à la partie latérale. Dans les Dytisques, dont la hanche de 
derrière est, comme nous l'avons vu, soudée et immobile, les muscles semblent se porter au féunur, qai en a ainsi quatre, deux extenseurs et deux fléchisseurs.

"Les autres ordres d'insectes sont, à peu près, conformés de la mềme manière que les Coléoptères. Les muscles de la jambe sont situés dans l'intérieur de la cuisse. L'extenseur est court et grêle, attaché à son bord externe (le fémur supposé éleadu dans la longrueur da corps). Le fléchisseur est beaucoup plus fort et plus lougr; il est silué du côté iuterne, et dans toute la partie supérieure. Il y a de nême deux muscles pour chacun des arlicles du tarse : l'un sur la face supérieure ou dorsale : c'est un extenseur; il est pelit: lautre, sur la face inférieure, plus marqué, et agissant comme fléchisseur."

Le niême anatomiste nous a donné, pag. 436 du premier tome du même ouvrage, un extrait des observations de Lyonet sur la myologie des pattes de la Chenille qui ronge le bois du saule (Cossus ligniperda. $\mathrm{F}_{\mathrm{AB}}$ ). Les muscles sont pareillement intérieurs. On peut distinguer ceux des pattes écailleuses en ceux qui meuvent leurs trois articulations of en ceux qui agissent sur l'ongle ou crochet terminal. Les muscles du premier article sont au nombre de cinq ou six faisceaux altachés an rebord supérieur, et s'iusèrent aussi àu rebord supéricur de l'article suivant. Ceux du second article sunt, à peu près, en nombre égal, et s'iusèrent au rebord du troisième. Les muscles de l'ongle sont terminés par deux tendons; mais ils sunt formés de plusieurs taisceaux qui s'attachent, les uns sur le second et le troisieme arlicles, par deax plans bien distincts; les aulres, sur une ligne qui correspond à la convexité dé l'ougle; et enfun les derniers, sur une ligne répondant à sa concavité. Les deux tendons s'insèrent à deux tudercules de l'extrémité supérieure de l'ongle, du côté de sa concavité et de sa pointe, et servent à la fléchir. M. Cuvier conjecture que cet ongle se redresse par l'ćlasícité de son aticulation.

Chacgue patte membraneuse ou fausse a deux muscles, dont la direction est, à peu près, trausversale au corps. Ils s'élendent da centre de la patte où ils s'insérent., jusqu'au-delà du stigmale du côté du dos, où ils śattachent par des bandeleties latérales et plus ou noins obliques. L'un de ces musctes est situé au-devalll de l'autre, qu'il recouvre en partie. Ils servent ì faire rentrer le centre de la patte et les crochets du liube de san extrémité.

Chaque articulation des paltes des Crustacés, Cuver, ibid., pag. 408 , a deux muscles, l'uu exterseur et l'aulie fléchissenr. Ceux de la hanche sont atlachés sur la pièce coruće qui soutient le: brauchies. lies autres sont renferviés dans l'intérieur des articles suivans. Je fléchisseur du ponce on du doigt molile des serres a un fort tendon osseux intermédiaire, plat, oblong, ou en forme de lame et d'une grandeur remarquable. Nous renverrons pour d'autres détails au même ouviage.

Telle est , en général, la composition des pattes des animaux articulés, appelés Insectes par Linnée. Nous avous présenté, tom. JI , pag. 184 et suiv. de notre Histoire générale des Insectes, faisant suite au Búfton de Sonnini, d'autres détails, que les bornes trop resserrées de ce Dictionnaire ne nous pernetteut pas de reproduire. Quclques-uns d'ailleurs (cuisse, jambes) rentrent dans des articles qu'on a déjà traités avec assez d'étendue. L'une des pièces de ces organes qui mérite une attention plus particulière, à raison des caractères qu'elle fournit, et dont nous avons parlé sous le nom de tarse, sera l'objet d'un article spécial. (LATr.)

PIEDS-MACHOIRES, Maxillipedes.Je désigne ainsi les trois paires de pièces articulées en forme de palpes ou de petits pieds ; qui, dans les Clustacés décapodes, recouvrent inférieurement les parties de la bonche, ou sont les plus extérieures, et que M. Savigny nomme môchoires auxiliaires. Voyez le premier fascicule de la première partie de ses Mémoires sur les animaux sans vertébres, et l'article Bouche de ce Dictionnaire. (LAtr,)

PIÉRTDE, Pieris. Genre de Lépidoptères diurnes. Voy. tom. IX, pag. 105 du présent Dictionnaire. (S. F. et A. Skrv.)

PIESTE, Piestus. M. Gravenlıorst a fondé ce genre de Coléoptères penlaınères dans sa NIonographia Coleopterorum micropterorum; il esi de la famille des Brachélytres. Ses caractères son!: corps déprimé, linéaire. 'Tèie triangulaire, trois fois plus petite que le corselet, ponctuće. Yeux un peu rlobuleux. Chaperon obtus. Mandibules en faucille. Antemnes filiformes, plus longues que la moitid du corps, un peu velues; son premier article en nassue plus gros que les autres, le second et le troisième en massue, tous les suivans cylindriques. Palpes filiformes. Corselet un peu plus large que long, à peine plus étroit et un peu plus court que les alytres, ponctué; angles de sa hase tronqués; il a un sillon longitudinal conplet dans son milien, et un autre court à chaque angle de la base. Elytres un plus larges que longues, ay ant douze sillons longitudinanx droits, prufouds et entiers. Abdomen uu peu obtus, très-finement pointillé. Pattes courtes, fortes. Janbes cilićes, paroissant connme dentées en scie.

M. Gravenhorst u'en décrit gu'une seule espèce. Pieste sillonné ( $P$. sulcatus). Longueur 2 lige. Brun brillant; antennes, palpes et pattes pâtes. 'Tète très-finement ponchuée avec un petit sillon 
longitudinal entre les antennes. Chaperon pále. Prenier arlicle des antennes portant une toufle de poils roides à sa partie intérieure.

Il est du Brésil et a été pris sur une espèce de bananier. Musa. (S. F. et A. Sert.)

PIEZZATES, Piezata. Nom donné par Fabricins à un ordre d'insectes désignć antérieurement par Iinné sous celui d'Hyménoptères. L'aulcur lui donne pour principaux caractères : six pattes; deux anlennes; corps ayant quatre ailes membraneuses, nues, quelquefois ployées longitudinalement; ces ailes wanquant entièrement dans quelques-uns; quatre palpes égaux ou de grandeur inégale, ordinairement filiformes; mundibules cornées, droiles nu courbées et arquées, suit aiguës soit tronquées, avancées, simples ou dentées; mâchoires courtes, cornées ou me mbraneuses, obtuses, entières, quelquefois alongées, fléchies, formaut les divisions extéricures de la langue; lèvre courte, cornée ou membranense, tronquée ou arrondie, formant les divisions intérieures de la langue. (S. F. et A. Serr.)

PILULAIRES. Geoffroy donne ce nom à deux espèces de Coléoptères du geure Géotrupe de M. Latreille, le Stercorarius et le Vernalis.

\section{(S. F. et A. Serr. )}

PIT.UMNE, Piluminus. Genre de Crustacés décapodes, famille des Brachyures, établi par M. Léacli, très-voisin de celui de Clabe, dont il faisoit partie et dont il diffère par les caractères suivans : Pieds de la qualrième et de la troisième paires les plus longs. - 'Tige des antennes latérales beaucoup plus longue que leur pédoncule (1), sétacée et composée d'un grand nonbre de petits articles. - Corps proportionnellement inoins large que celai des espèces du genre Cancer, et plus rapproshé, pour la forme, de celui des Crustacés de la tribu des Quadrilatères.

Espèces généralement petites, longues an plus de vingt millimètres sur vingt-six de large, projres aux mers de l'ancien continent. Ce geule ne diffère de celui d'Eriphie qu'en ce que le pédoncule des antennes latérales occupe uue échantrure du bord intérieur des cavités oculaires; que le test est plus arqué en devant, et que les yeux sout moins écartís.

(1) Les trois articles dont ii se compose sont, ainsi que daus les Crabes, presque cylindriques. Le premier est plus grand, particulıèrement daus ceux-ci. Souvent, ici, il se présente sous ĺa figure d'unc lame étroite, paroissanc tixe ou peu mobile, dyec la partic cxtérieure du sommer flus ou moins dilarée. Ces antennes latérales des especes cxotiques que j'ai étudiées érant souveit mutilées, il m'a exé impossible de faire usaje de ces differences de formes. Cot cimploi minutieux m'eût d'alleurs entrainé trop loill.

\section{Corps presqu'en forme de losange, dilaté ét amondi vers le milieu de ses cótés.}

Nota. Les deux espèces de cette division forment peut-être un genre propre. La seconde ne m'est connue que par la description de Fabricius et la figure qu'Herbst en a donnée; peut-être se rappor:e-t-clle au genre Mursia de M. Léach. Je u'ai vu gu'un seul inaliviciu de la seconde, et à antennes latérales iaparfaites. Les yeux sont situés à l'extrémité d'un pédicule courbe, et plus épais ou plus large à sa base. Le sommet du troisième article des pieds - mâchoires extérieurs est tronqué obliquement en dehors, de sorte qu'il paroít se terniner en pointe.

\section{Pir.umne? porte-cupules, $\boldsymbol{P}$. cupulifer.}

Front droit, rebordé, presqu'entier, un peu enfoncé et refeadu au milieu; côtés du lest saus dcnts; quatre petites éminences en forme de disque plat, ovale, un peu rebordé, plus solide sur ses bords, semblable à une cupule de lichen, de chaque côté de la partie anlérieure et inférieure du test, depuis la bouche jusqu'au canthus postérieur des yeux.

Corps blane. 'Test long d'environ seize millimétres sur vingt-deux de large, mesuré au milieu, nince, foible, assez convexe, ayant dins son milieu quelques lignes enfoncécs, tout eucroûié, ainsi que les pieds, d'une matic̀re paroissant formée par un duvet. Cupules noirâtres avec le rebord roussâtre; les supérieures plus oblongrues. Serres petites, courtes; doigts lonys, grêles, arqués, crochus, armés de petites deuts aivuës; une substance peut-ĉtre gonımense et glulinaute, fornan un empâtcinent ì l'extrémité; les autres pieds grands, comprimés et empâtés. Individu femelle.

Ile de Frauce. M. Mailitu.

\section{Pilunare? à deux épines, P. bispinosus.}

Cancer bispinosus. FAв. - Henвs, Krabben, tab. 6. fig. 45; tab. 54. fig. I.

Quatre dents au front, les oculaires internes comprises; deux à chaque burd latéral du test.

Test long de quatre centimètres sur près de six de large. Sures luberculées.

Indes orientales.

11. Corps trapézoïde, avec la partie antérieure plus large et arquée; bords latéraux antérieurs déprimás et aigzus.

1. Dessus du corps et des pieds entièrement couvert de poits, cachant presque le fond.

Front incliné; son bord antérieur divisé au milieu par une échancrure en deux lobes courts, larges, arrondis, continus latéralement avec la portion interne du bord supérieur des cavités oculitires, qui forme de chaque côté une dent 
entière ou échancrée. 'Test inégal, plus convexe-an milieu.

\section{Pilume chauve-souris, $\boldsymbol{P}$. vespertilio.}

Cancer vespertilio. FАB.

Test et pieds laineux (poils longs); trois dents simples, presque coniques et de uuếue consistanee, à chaque bord latéral du test, la post-oeulaire non eomprise; échanerure du milieu du front presque carrée; ses deux lobes adjaeens presque droits au bord interne, sans dentelures ni granulations sensibles en devant; serres de grandeur moyenne, presqu'égales, à doigts lisses et ordinairement blanchâtres.

Corps blanchâtre, mais tout hériffé de poils noiràtres; les deux saillies du canthus interne des cavités oculaires continues avec les lobes frontaux, échancrées et bidentées. Quelques tubereules sur les côtés diı test.

Iatles orien:ales.

\section{Pinuma laineux, P. lanatus.}

Test et pieds laineux; trois dents simples, presque eoniques, terminées en une pointe plus dure ou éeailleuse à chaque bord latéral du test, la post-oeulaire non comprise; éehanerure du milieu du front en forme d'angle; les deux lobes adjacens parfaitement arrondis, avec le bord antérieur granuleux; l'une des serres (la droite) plus graude; doigts noiratres; ceux de la serre la moins grosse, striés.

Un peu plus grand que le précédent, avee les serres épaisses et graveleuses; d'ailleurs presque semblabl.. Variélé peut-être du wâle de cette espicie.

Indes orientales et nouvelle Hollande.

\section{Pilvane duveté, $P$. tomentosus.}

'Test et pieds couverts d'un duvet très-eourl; trois dents à ehaque bord laréral, formées par de petits tubereules coniques, éeailleux et spiviformes.

Corps d'un brun - noirâtre, très - pointillé en dessus; quelques petits tubercules sur les côtés du test analogues à ceux des bords. Front divisé en deux lobes arrondis et crénelés; suillies oculaires adjacentes, entic̀res, avec trois girains b́lcvés en dessus. Serre droite grosie, fortement graveleuse ou chagrrince en dehors; doigis noirâies, striés, avee le bout blanebâtre.

Nouvelle Hollande.

2. Dessus du corps et des pieds simplement pubescent (poils clair-semés et laissant à découvert ces parties) ou presque glabre.

6. Pruunase hérissé, P. hitellus.

Pilumnus Tirtcllus. LEACB, Malacost. Podopht.
Brit. tab. 12. - Cancer hirtellus. Lrs. FAB. Bosc, Risso. - C. vespertilio. Bosc, Hist. nat. des Crust. tom. 1. pag. 177. pl. 2. fig. 1. -Hensst, Krabben. tab. 7. fig. 5ı. - Ljusd. C. ferrugineus. tab. 21.fig. 127?. - Cancre velu, $n^{\circ}$.2. RONDELET?

Dessus du corps d'un rouge de sang foncé, avec la partie supérieure des paties plas pâle; dessons jaunâtre, mêlé d'un yeu de rouge; paltes de quelques individus ayaut des baudes ou taches transverses de celte dernière couleur; milieu du dos plus elair, un peu jaunâlre ; le eorps, daus d'autres, presqu'entièremeut juunâtre-pâle, plus on moins taehelé de brun on de roussâlre. T'est pointillé, hérissć çà et là de poils peu éfais, jaunâtres, avec une ligne enfoncíe, longitudinule, bifide postérieurement, partant da front, finissant près du milieu du dos. Front droit, échaneré au ınilieu et de chaque côré, près des yeux; bord antérieur des deux lobes et contour des orbiles oculaires garnis de petites épines; ehaque bord latéral du test ayant près de l'extrémilé antérieure trois à quatre épines isolées ou un plus grand nombre, mais plus petites et très-rapproehées; puis au-dela, et constaminent dans lous, trois dents terminées en une épine très-aiguë et dirigées en avant. Les deux paltes antérieures de yrandeur un peu inégale, ehargées extérieurcment de tubercules épineux et de poils, mais n'en ayant dans queliques individus que sur la trauche supérieure, l'une des deux en étaut mêrne dépourvue. Doigts noirâtres, striés, pointus au bout; eóté interne fortement denté; dents des doigts de la main le plus souvent obtuses; les autres pattes hérissées de longs poils, à tarses saume stries et terminés par un croehet aigu.

Daus l'Oeéan européen et dans la Méditerranée; ceux qui habitent les mers du nord de l'Europe sont plus petits, jituautres, un peu moires ćpineux, avec le bord antérieur du front. 'Telle est la variésé déerite par linnæus. Les individus de la Méditerranće sunt d'un ronge de sang obscur, a vec les serres et les pieds d'une teinte plus elaire. Le bord antérieur du front est eutièrement hérissé de pelits graius qui le font paroître cannelé. Comme l'on trouve des variétés in itermédiaires, on ne peut distinguer spécufiquement ces individus des premiers.

Lia fenelle, suivant M. Risso, fait sa ponte en juillel. Les veul's sosl d'un brun-giruile. (Lata.)

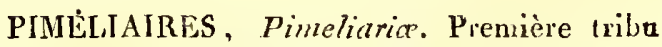
de la famille des Nélasomes, section des Hétćromères, ordre des Culćupieres. Elle offre pour caractères :

Point d'ailes. - Palpes maxillaines filiformes ou terminés pur un article guère plus ćpais que les précédens, et plutôt cyliudrique ou olsconique 
que triangulaire ou en hache. - Elytres soudées ensemble.

I. Menton recourrant la base des mâchoires. Erodıe, Zophose, Pinélie, 'Tentyrie, IIégètre, Eurychore, Akis.

II. Basse des mâchoircs dícouverte. 'Taýnie, Moluris, Scaure, Sépidie.

La plupart des Pimćliaires vivent dans les terres salines des pays casauds et sablonneux de la partie occidentatc de l'ancien eoutinent; elles sont abondxates sur les bords de la mer, pirmi les soudes (sidsolat), et se couvrent souvent d'une poussière bianchi re, de mêue que cerlaines espéces du gerare Aplodie.

HÉGETRE, Hogeter. LAt. Blaps. OLıv. (Ent.)

Genre d'insectes de l'ordre des Coléoptères, section des Ilétérounères, famille des Mélasomes, tribe des Pinı́liaires.

Dans le groupe de Piméliuires dont les Hégètres font partie ( voyez Piálisiags), les grevres ḱrodie, Zophose, Pimélie et'Tentyrie se distinguent par leur corselet trés-convexe, et les Lurychores ainsi que les Akis ont cette nuême parlie du corps presque concave, ses bords latéraux élant trèsrclevés.

Antennes filiformes, composées de onze ar!icles, la plupart cylindriques, le troisièune alongéé, les trois avant-derniers diminuant graduellenent de longueur, un peu obconiques; le onzième petit, court, ovale. - Labre coriace, avaucé, en calré transversal. - Mandibules écliancrées au bout. - Mâchoires rétrécies antérieurenent vers la base, reçues dans une fente linéaire et recouvertes à leur base par le menton. - Palpes maxillaires composés de qualre arlicles, le dernier un pelı plus grand, presqu'obconique, comprimé; palpes labiaux triarticulés. - Menton grand, transversal, semi-orbiculaire, sc-n bord supéricur coupé droit thausversalement. - Téte courte, en. foncée jusqu'aux yeux dans le corselet. - Corps ovale, peu convexe en dessus. - Corselet un peu plus étroit que les élytrés, carré, très-rapproché de la base des élytres, presque plau et sans bords relevés. - Ecusson très-petıt. - Elytres soudíes ensemble, se rétréeissant et se courbant sensiblement à leur patrlie postérieure, leur bord latéral embrassant l'abdomen; ailes nulles. - Abdomen alongé, trigone. - Pattes grêles; jambes ayant deux courtes épines ì leur exirémité.

On connoîl environ six espèces de ce genre fondé par MI. Latrcille : elles habileut les clinats les plus chands de l'ancien et du nouveau continent. Leurs tnours sont inconnues.

\section{Hégètra strié, $H$. striatus.}

Hegeter niger, cupite thoraceque lievibus, elj tris subsulcalis basi et externè marginatis.
Hegeter striatus. Latr. Gener. Cnust. et Ins. toml.2. pag. $157 \cdot n^{\circ}$. 1. tab. $I X$. fig. 11. - Blaps elongata. Oniv. Entoin. tom. 3. Blaps. pag. 9. $n^{\circ} \cdot 7 \cdot p l$. 1. fig. 7 .

Longueur 8 lig. Noir. Antennes brunes, extrémité des palpes maxillaires de même coulear. Tête et corselet lisses, ce dernier rebordé sur les côlés et à sa partie postérieure dont les angles sont aigus. Ecusson linéaire, transversal. Elytres légèrement sillonnées, un peu rugueuses, rebordées à leur hase et latéralement.

Des îles de Ténériffe et de Madère.

EURYChORE, Eurychora. Thunb. Latr. Fas. Herbstr. Pilnelia. Uliv. (Entom.)

Genre d'insectes de l'ordre des Coléoptères, section des Hétírunères, famille des Mélusomes, tribu des Piméliaires.

Dans le groupe de cette tribu dont le menton recolvre la base des mâchoires, les genres Erodie, Zophose, Prmélic at Tentyrie ont le corselet très-convexe. Dan; les Hfégétres il est carré et presque plan en dessus. Les Akis ont leurs antenues composées de onze articles distincts, ét leur corselet n'est point transversal, naais presque aus i long que large.

Antennes filiformes, comprimées, composées de dix articles presque cylindriques, le troisième très-alongé, les autres courts, le dixième plus gros, coupé eń coin à sou extrémité. - Labre pen ou point visible. - Mandibules cornées, dentées dans lèur milieu intérieni, bilides à l'ex.lréniié. - Máchoires étroites äleur basc. - Palpes maxillaires filitormes, de quatre articles presque égaux, presque coniques et oblus; les lubiaux plus conrts, triarticulés. - Menton crustacé , count, tres-large, transversal, recouvrant la base des wâtchoires. - Corps en ovale courı, déprinsé et comme concave en dessus. - Corselet grand, large, transversal, semi-circulaire; ses bords lis télaux comprimés, trancbans, relevés, velus; son bord postérieur coupé droit, éloigné de la base des élytres, l'antórieur très-échancré carrément pour recevoir la tête. - Ecusson très-petit, triangulaire. - Elytres soudées ensemble, concaves en dessus, leurs bords extérieurs comprimés, relevés, tranchans, velus, embrassant la plus grande partie de l'abdomen; ailes nulles. $-A b$ doinen ovale, tronqué en devant. - Pattes mintes, assez longues; janbes ayaut deux épines courles à lent extréaité, celles des postérieures surtoat. Tarses conrls; premier aricle des postérieurs de li longueur des deux suivans.

Eurychore vient de deux mots qui expriment la séparution bien marquée qui se voit entre le corselet et l'abdomen de ces coléoptères. On ignore leurs nocurs. Les deux espèces connues sont d'Afrique. 


\section{P I M}

1. Eurychnre ciliée, E. ciliata.

Eurychora nigra, thorace elytrisque rufo maximè ciliatis.

Eurychora ciliata. FAB. Syst. Eleut. tom. I. pag. 133. $n^{\circ}$. 1. - Latr. Gener. Crust. et Ins. tom. 1. pag. 151 . $n^{\circ}$. 1. - Pimelia ciliata. OLiv. Entom. tom. 3. Pimél. pag. 26. $n^{\circ}$. 5j. pl. 2. fig. 19. - Encycl. pl. 195. fig. 8. a. b.

Isongueur 6 lig. Noire, lisse. Bords du corselet et des élytres furtement ciliés de poils roax.

Du Cap de Bonne-Espérance.

AKIS, Akis. Herbst. Fab. Lat. Tenebrio. Linn. Pimelia. Oliv. (Entom.)

Genre d'insectes de l'ordre des Coléoptc̀res, section des Hétéromères, famille des Mélasomes, tribu des Piméliaires.

Le seul genre de celte tribu qui comme celni d'Akis, a là base des mâchoires recouverte par le inenton et les bords latéraux du corps relevés, est crlui d'Eurychore, mais clans ce dernier les antennes u'ont que dix articles et le corselet est transversal.

Antennes fliformes, comprimées, composées de onze articles distincts, le second très-petit, le troisième trc̀s-long, cylindrique, le quatrième et les suivans jusqu'au huitième inclusivement, obconiques ou cylindriques; les trois deruiers plus petits, le dixième turbiné, le dernier court, ovale, obcouique, sa base étant souvent enchâssée dans le précédent. - Labre coriacc, transverse, entier. - Mandibules cornćes, dentées dans lenr milieu intérieur, bifides à l'extrémité. - Mâchoires élroiles à leur base. — Palpes maxillaires filiformes, de quatre articles, le dernier obconique, comprimé; les labiaux plus courts, triarticulés. - Lèvre peu ou point appaparente; menton presquc carré, recouvrant la base des mandibules, sou bord supérieur un peu arrondi, échancré dans son milieu, l'inférieur tronqué transversalement. - Tête large, échancrée en devant pour recevoir le labre. - Corps ovale, quelquefois un peu alongé. - Corselet plus étroit que les élytres, presqu'aussi long que large, presqu'en cœur tronqué postérieurement, ses bords laléraux très-relevés. - Ecusson trèspetit, distinct._Elytres soudées ensemble, assez aplaties en dessus, leurs bords extérieur's tranchans, embrassant une grande partie de l'abdomen; ailes nulles. - Abdonen ovale, rétréci et arrondi aux angles extérieurs de la base. - Pattes minces, alongécs; jaobes ayant deux épines courtes à leur extrémité, celles des postérieures sur:out : premier article dcs tarses postérieurs de ia longuen des deux suivans.

Les Akis habitent les pays qui bordent la Méditerranée et la mer Noire. Leurs mours paroissent tenir de celles des Pimélies et des Blaps. On fen eonnoít nne dizaine d'espèees, toutes d'ilssez grande taille.

\section{Axıs réflérhie, A. reflexa.}

Akis atra nitida, elytris dorso lavi lateribus transversè carinatis tuberculatisque.

Akis reflexa. Гав. Syst. Eleut. tom. 1. pag. 135. $n^{\circ}$. 4. - LAт. Gener. Crust. et Ins. tom. z.

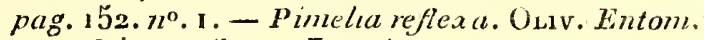
pimél. pag. 25. no. 34. pl. 1. fig. 9. - Encycl. pl. 194. Pimél. fig. 17.

Longueur 11 lig. Noire, luisante. Tĉte finenient pointillée. Corselet ayant une forte ćpinc is chaque angle postćricur, ses bords latéraux un pcu plissés, ceux des élytres portant aussi quelques plis et quelques tubercules ainsi que leur partie inférieure qui embrasse l'abdomen. Elytres prolongécs en pointe mousse postérieurement; leur carène latérale tuberculée el comme dentée en scie.

Fille se trouve dans l'Orient, en Afrique et dans la France méridionale. Les Akis spinosa no. 2 , et acuminata no. 5, de FAB. Syst. Eleut. (Encycl. pl. 196. fig. 2 et 5) sont de ce genre, mais beaucoup d'autres espèces que cet auteur y comprend sell éloignent et appartiennent à ceux de Pimélie, Tenlyrie et Tagénie.

Nota. L'Akis collaris des auteurs (Encycl. $p l$. 194. Pimél. fig. 16.) est le type d'un nouveau genre auquel M. Mégerle a donué le nom d'Elenophorus, mais dont nous croyons que les caraclères n'out pas encore été publiés.

MOLURIS, Molutis. Lat. Tenebrio. De Géer. Pimelia. Fab. Oniv. (Entom.)

Genre d'insecles de l'ord'e des Coléoplères, section des Hétéromères, famille d’cs Mélasomes, tribu des Piméliaires.

Les Piméliaires qui ant la basc des mâclioires déconverte forment un groupe daus cette tribu. Ce sont les genres Tagénie, Moluris, Scaure et Sépidie. Les 'Tagénies ont le corps étroil et alongé, le dessins de celui des Scaures est déprinné, et dans les Sépidies le corselet est rétréci à ses extrćmilés et dilaté au milieu de ses côtés.

Antennes filitornes, insérées sous un rcbord de la lcte, composées de onze articles, le premier assez long, gros; Ic secoud très-court, conique : le troisième le plus long de tous, cylindrique; les suivaus obconiques : les quatre derniers un peı plus gros que les autrcs, les dixième et onzième turbinés, ce deruier ovale-globuleux. - Labre coriace, avancé, entier, en carré trausversal. Mandibules échancrées vers leur extrémité. Mấchoires ayant leur base décourerte; leur lobe intérieur muni d'un onglet carré.-Palpes maxiblaires filiformes, de quatre articles, le dernier un peu plus court que le précédent, presque trian- 
gulaire, comprimé; palpes labiaux de trois a!ticles. - Lère crustacée, avancée, fortement échancrúe; menton court, large, en carré iransversal, son bord sunérieur presque droil. - Téte plus étroite que le corselet, inclinée perpendiculairement, $\cdot$ enfoncée jusqu'aux yeux dans le corsclet. - Corps alongé, ovale, très-convexe. Corselet plus étroit que l'abdomen, convexe, presque globuleux, tronqué antérieurement et à sa partie postérieure. - Ecusson nul. - Elytres soudées enseable, très-convexes, couvrant tout l'abdomen et embrassant ses côtés; ailes nulles. - Abdomer grand, ovale, tronqué antérieurement. - Pattes assez fortes; jambes étroites, les postérieures longues, un peu cambrées; tontes les jambes ayant deux courtes épiues à leur extrémité.

Les auteurs mentionnent un petit nombre d'espèce de ce gense fondé par $\mathrm{M}$. Latreille, elles sont d'Afrique ou des contrées de l'Asie qui en sont voisines; leurs mœurs parvissent être les mêues que celles des Pịnélies.Leur taille est généralement grande.

\section{Moluzis striée, $M$. striata.}

Moluris atra, glabra, lineis tribus in singulo elytro suturáque obscurè sunguineis.

AIoluris striata. Ist . Gener. Crust. et Ins. tom. 2. pag. 149. $n^{\circ}$. 1. - Pinelia striata. FAB. Syst. Eleut. tom. I. pag. 128. $n^{\circ}$. 1. - Oniv. Entont. tom. 3. Pimél. pag. 4. $n^{\circ} .2$. pl. I. fgo. I1. - Encjcl. pl. 194. Pimél.fig. 19.

Longueur i 5 à 16 lier. Noire. Antennes un peu velues, tête et corselet finement pointillés. Les bords latéraux de celui-ci raboteux, plissés. Corselet et élytres un peu rebordés, ces demières finement ridées, ayant chacuire trois lignes longritudinales et la suture d'un roug - janguin obscur.

D'Afrique. (S. F. et A. SEkv.)

PIMÉLIE, Pimelia. Fab. Lat. Otiv. (Ent.) Tenebrio. Liñ Ge Goff.

Genre d'insectes de l'ordre des Coléoptères, section des Hétéromères, famille des Mélasomes, tribu des Piméliaires.

Fabricius fonda le genre Pimélie aux dépens de celui de Tenebrio de Linnacus, mais il y renfermoit encore un grand nombre d'espèces que des caractères saillans distinguoient les unes des autres; il le sentit lıi-même lösqu'il adopta daus son Systema Eleutheratorum le genre Eurychora de 'Thunberg et celui d'Akis d'Herbst, compris précédemment dans ses Piuiélies. M. Latreille, à plusjeurs reprises, compléla la réforme par la création de quelques nouveaux genres et restreignit celui-ci de la manière que nous allons le présenter.

Les Pimélies font partie d'un groupe dont le caractère est : menton recouvrant la base des

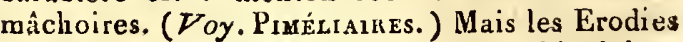
et les Zopboses ont le corps presqu'orbiculaire; le corselet des Hégètres est plan ea dessus; celui des 'Tentyries est presqu'orbiculaire, guère plus étroit que l'abdomen, presqu'aussi long que large. L'abdomen est en ovale tronqué dans les Eurychores, et le corselet est aussi long ou plus long que large dans les Akis : ces deux dernicrs genres ont en outre les bords latéraux du corselet très-relevés.

Aniennes filiformes, insérées sous les bords latéraux de la lête, de onze articles, le troisième fort àlongé, cylindrique, le dixiène semi-globuleux, le deruier petit, très-court, à moitié enchàssé daus le précédent. - Labre coriace, avancé , carré, plus large que long, entier.-- Mandibules conées, dentées dans leur milieu intérieur, bifides à l'extrémité. - Mâchoires étroites à leur base qui est recouverte par le menton, et reçues de chaque côté dans une fente linéaire. - Palpes maxillures filiformes, de quatre articles presqu'égaux, presque coniques et obtus; les labiaux plus courts, triarliculés. - Menton transversal, ses côlis arrondis, son bord supérieur échancré. - Carps ovale, sit partie antérieure se rétrécissant sulritemeni. - Corselet beaucoup plus étroit que l'abdomen, un peu plus large que la tête, court, seani-orbiculaire; ses bords latéraux arrondis. - Ecusson très-petit ou nul, - Elytres soudées ensemble, leur bord extérieur embrassant les côtés da ventre; leur bord latéral ou celui qui borde les côtés apparens da corps, ordinairement élevé; ailes nulles. - Abdomen grand, ovale-orbiculaire. - Jambes ayant deux épines à leur extrémitć, tarses courts; premier article plus long que les autres.

Ces coléoptères n'habitent que les pays chauds de l'Asie et de l'Afrique; ils se tiennent dans les terrains arides et siblonneux, particulièrement ceux des bords de la mer. On en connuit cependant une espèce en France qui se rencontre sur les côtes de la Méditerranée. Le nom de Pínélie est liré d'un moi grec qui signilie: gras. La coulcur de ces insectes est ordinanement noire ou brune.

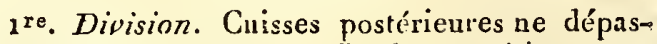
sant pas l'abdomen. - Jambes antérieures ea triaugle alongré.

\section{Priśtir anguleuse, $\boldsymbol{P}$. angulata.}

Fimelia femoribus posticis abdomine brevioribus, elytris tuberculatis, tuberculis posticè inclinatis.

Pimelia angulata. LAт. Gener. Crust. et Ins. tom. 2. pag. 148. - HAB. Syst. El kut. tom. 1. pag. 131. no. 17. - Pimelia angulosa. OLIv; Entom. tom. 3. Pimćl. $u^{\circ}$. 13. pl.2. fig. 23 . - 


\section{P I M}

Tenebrio asperrimus. PaLL. Icon. 1. 55. $n^{\circ}$. 22.Encycl. pl. 195. fig. 12.

I.onoueur 1 I à I 2 lig. Corps entièrement noir. Neuvic̀me article des antennes turbiné. 'Tête peu rugueuse. Dessus du corselel peu rugueux, ses côtśs l'éiant beaucoup plus. Suture des élytres sans élévation; bord extérieur des élytres peu élevé vers la base, l'élant beaucoup, el de plus très-denté en scie vers l'anus; ligne latérale fort élevee, dentée en scie. Eutre celle-ci et la suture sont trois lignes plus élcvées de tubercules épineux entrc lesquelles sont quatre autres lignes de tubercules plus petits; les pointes de tous ces tubercules se dirigeant un peu en arrière. Dessous dı ventre et bord extérieur des élytres couverts d'un duvet blanchàtre. Palles hispides.

D'Asie et d'Afrique.

\section{Prácle biponctuée, $\boldsymbol{P}$. bipunctata.}

Pimelia femoribus posticis abdomine brevioribus, elytrorum striâ post suturam secundâ breviori, tertıâ longiori.

Pimelia bipunctata. LAт. Gener. Crust. et Ins. tom. 2. pag. 147. $n^{\circ}$. 1. - FAB. Syst. Eleut. tom. 1. pag 150. $n^{\circ}$. 14. - Pimelia muricata. OLI v. Entom. tom. 3. Pumél. no. 10. pll. 1.jg. I. a. H. et fig. 4. - Le Ténébrion cannelé. Gkoff. Ins. Paris. tom. 1. pag. 352. - Encycl. pl. 194. fig. 9 et 12.

Longueur 7 lig. Corps entièrement noir. Neuvième article des antennes turbiné. Têie et corselet chargés de petils tubercules, de chacun desquels part un poil rris-court. Corselet bordé postćrieurement et à sa parlie antérieure de cils roux; on voit sur son disque deux petites impressions. Ecusson exlrêmement pelit. Elytres ayant la suture et leur hord extérieur embrassant les côtés du ventre, élevés; elles ont en outre quatrelignes élevées, lisses, dont la seconde après la sulure est plus courte que les autres, la troisième la plus longue, la quatriene formant le boid latérial, aucune de ces qua:ré lignes n'atteignant le bout postérieur. Intervalles des lignes et pattes chargés de tubercules seublables à ceux de la tête et du corselet.

Des bords de la Méditerranée.

3. Pimélie lachetée, P. maculata.

Pinneliafemoribus posticis abdomine breviorihus, corpore griseo-tomentoso, capitis punctis thoracisque lineis irregularibus nigrs.

Pinelia naculata. LAт. Gener. Crust. et Ins. tom. 2. pag. 148. - $\mathrm{FAB}$. Syst. Elent. tom. I. pag. 13r. un. 23.-Óliv. Eutont. tom. 3. Pinzél. no. 38. pl. 5.fig. 3r. - Encycl. pl. 195. fig. 21 .

Longueur 4 lig. Corps convert d'un duvet gris très-court. Nenrième arlicle des antennes globuHist. Nat. Ins. Tome $X$. leux. Tête chargée de petits points noirs. Corselet strié irrégulièrement de petites lignes noires; il a de plus quelques taches blanchầtres duveteuses. Suture et bord extérieur des élytres peu élevés; leur hord latéral composé de deux lignes élevées dont l'intérieure plus courte, clargée de taches brunes cotonneuses; entre la suture et ce bord sont deux autres lignes élevées, la plus rapprochée de la suture chargée de taches brunes cotonneuses plus grandes que les autres; de semblables taches, muis fort petites, sont disperséez sur toute la surface des élytres. Ventre et pattes couverts d'un duvet blanchâtre et chargés do petits tubercules noirs.

Du Cap de Bonne-Espérance.

$2^{\mathrm{e}}$. Division. Cuisses postérieures dépassant l'abdomen.- Jambes antérieures ne s'élargissant pas dans leur partie inférieure.

\section{Prmélie longipède, $P$. longipes.}

Pimelia fennoribus posticis abdomine longioribus, elytrorun striis sex muricato-dentatis, $t i$ biis hispidis.

Pimelia longipes. Lat. Gener. Crust. et Ins. tom. 2. pag. 148. - FAв. Syst. Eleut tom. I. pag. 129. no. 9. - Ourv. Entom. tom. 3. Pimél. $n^{\circ}$. 20. pl. 1. fig. 3. - Encycl. pl. 194. Pinnél. fo. II.

Longueur 6 lig. Corps noir. Corselet glabre, canaliculé dans son milieu. Elytres ayant chacune six lignes élevées, dentées, muriquées; leurs intervalles rugneux et muriqués en même temps. Palles poncluées, jambes bispides.

Afrique.

Nous n'avons point vu cette espèce.

5. PI:UÉne aranipède, $P$. aranipes.

Pinelia femoribus posticis abdonine longioribus, elytronum striis tribus, pedibus scabris.

pimelia aranipes. Otrv. Entom. tom. 3. Pimél. $n^{\circ}$. 22. pl. 4. fig. 6 .

Longueur 5 lignes. Corps entièrement noir. Tête trè̀sefinemeut pointillée, assez aplatie, ayant un peu de duvet conrt, fauve. Neuvième article des antemnes turbiné. Corselet lisse, glabre. Suture des élytres assez élevée, chargée la téralement de tubcrcules. Bord extérieur peu élevé, le latéral et trois lignes élevées entre ce bord et la suture composés de gros tubercuies obtus entre lesquels on en voit d'autres moins élevés. Pattes finement tuberculées, cuisses légèrewent ponctrées.

Patrie inconnue. (S. F. et A. Serv.)

pJMple, Pinlpla. Fab. Ichnelmon. Lat. OLiv. (Encycl.) P Panz. Cryptus. FAB.

Genre d'insectes de l'ordre des Hyaúnoptères ? $\mathrm{n}$ 
section des Térébrans, famille des Pupivores, tribu des Ichneumonides.

Danscelte tribu nombreuse les Sigalplies et les Alysies ont les palpes muxillaires de six articles; les Bracons, les Microgastres, les Vipions et les Helcons ont ces mêmes palpes de cinq articles et les labiaux de trois. Tousles autres Ichneumonides ont cinq articles anx palpes maxillaires et quatre aux labiaux. Les Stéphanes n'ont que denx cellules cubitales anx ailes supérieures. L'abdomen des Xorides est distinctement pédiculé et leur tête est globuleuse. Dans le genre Ichncumon la nervure récurrente des ailes ne se courbe pas d'une manière remarquable en s'écartant de la cellule cubitale. Les Peltastes ont le second article des palpes maxillaires grand et renflé. Les Accenites ont les articles de ces wêmes palpes peu dilférens entr'eux pour la forme. Dans les Aorathis les mâchoires et la lèvre s'ivaucent en une sorte dè museau. Ces caractères séparent suffisamment tous ces genres de celui qui est l'objel de cet article.

Antennes filifornes, multiarticulées, vibratiles, leurs articles courts et peu distincts. Bouche peu avancée. - Mundibules distinctement bidentées à l'exılrétnité.-Palpes filiformes, les maxillaires plus longs que les labiaux, de cinq articles de forme très-inćgale; le second n'étant point de grosseur reurarquable : les labiaux comjosés de quatre articles. - Lèvre inembraneuse, presqu'en ccur, dilatée à l'extrémité. - T'ête triangulaire. -- Trois petits yeux lisses gros, saillans, disposés eu triangle sur le vertex. - Corps alongé, presque linéaire.-Corselet lonon, son segment antérieur rétréci e devant, s'avançant latéralement jusqu'à la naissance des ailes; métathorax fort grund, presiqu'aussi long que le resic du corselet el à peu près de sa grosseur. - Ecusson petit, convexe. - Ailes supérieures ayant une cellule radiale grande, se rétrécissant sensiblement jusquu’à son extrémité apiès son point de contact avec la seconde cellule cubitale; et trois cellules cubitales; la première grande, bilobée, réunie à la discoidale supérieure, sou angle postérieur terminé en pointe : la seconcle fort jetite, presque triangulaire, alteignant la radiale par la pointe seule d'un de ses angles, recevant la seconde nervure récurrente auprès de la troisième cubitale. Nervure récurrente arquée, se courbant d'une manière sensible auprès de son insertion sur la secondc cubitale. Troisième cellule cubitale grande, complète. Deux cellules discoidales, savoir : la seconde supérieure et l'iıférieure; celle-ci fermée avant le bout postérieur de l’äle parla uervure récurreute. - Abdomen composéde sept segmens ontre l'anus, attaché an corselet par une base assez large et plate, plus long que la tête et le corselet pris ensemble, convexe en dessus, devenant plus ćpais vers son extrémitć. Anus et derniers segrnens dı ventre entiers dans los mâles; fendus-en dessous dans les femelles en une coulisse où la base de la tarière reste logée dans le repos. 'Tarière (des femelles) toujours saillante, d'une longueur remarquable; ses fourreaux velus. - Pattes moyennes, hanches grandes; jambes antérieures munies d'une seule épine à leur extrénité, les quatre postérieures de deux : crochels des tarses ay ant une forte pelotte dans leur entredeux.

Les mœurs des Pimples n'ont rien de particulier pour ceux qui connoissent celles des Ichneumons (voyez ce mot). Nous croyons seulement devoir ajouter qu'il nous a paru que les femelles de ce genre déposent leurs œufs dans le corps des larves qui vivent dans le bois.

1'e. Division. Tarière (des femelles) plus longue que l'abdomen.

\section{Pimple altrayant, $P$. persuasoria.}

Pinupla persuasoria. Faв. Syst. Piez. pag. 112. $n^{\circ}$. 1. - Ichneumon persuasorius. P'Anz. Faun. Germ. fas. 19. fig. 18. La femelle. - Ichneumon camelus. Scop. Carnio. $n^{\circ}$. 742. La femelle. - Encycl. $p t$. 100. fig. 26. La femelle.

Il a été pris en 1817 en Auvergne, sur le mont d:Or. Toyez pour-la description et les autres synonymes Ichueumon attrayant, $\mathrm{n}^{\circ} .42$.

\section{Pimpie manifestateur, $P$. manifestator.}

Pimpla manifestator. FAB. Syst. Piez. pag. 113. $n^{\circ}$. 5. - Ichneumon manifestator. PANz. Fuun. Gernı. fus. 19. fog. 21. La femelle.

Il varie'beancoup pour la grandenl. On irouve sonveut des femelles qui ont jusqu'à vingt lignes de longueur. Dans ce sexe les seymens de l'abdomen sont comme renflés sur les cólés et tuberculés. Il paroît que M. Gravenhorst ayant remaroué ces anbercules plus saillans sur de petits individus, en a fait une espèce que l'on voil dans quelques collections sous le nom de Pimpla tuberculator. Le mâle est plus petit et plus grêle que la femellę, à laquelle du resie it est parfaitement semblable. Voyez pour la description et les autres synonymes Icheumon manifestateur, "n. $^{\circ} 112$.

\section{Praple médiateur, $P$. mediatoria.}

Pimpla nigra, thorace anticè pedibusque rufis, metathorace abdominisque segmentorume margine inferiori albido fasciatis.

Pimpla mediator. РАв. Syst. Piez. pag. 117. $n^{\circ}$. 25. La femelle. - Ichneumon Scurra. PANz. Faun. Germ. fas. 92. fig. 6. La femelle. (J'aile supérieure est déféctueuse en ce (qu'clle indique mal la forme des cellules cubitales.)

Longueur 6 lig. Antennes brunes, d'un blancjảnnâtre en dcssous. Tête noire, orbite des yeux eptièrement blanc en devant. Corselet d'un testa- 
cé-ferrngineux, sa partie antérieure bordée de blanc. On voit une tache de cette couleur sous l'insertion de chaque aile. Pointe de l'écusson Wanchâtre. Métathorax noir , bordé postériemrement par une ligne arquée d'un blanc-roussâtre. Abdomen noir ayant le hord postérieur des segmens blanchâtre. Pattes testacées, les quatre antérieures et les jambes postérieures plus pâles. Tarière de la longueur lu corps ou seulement de celle de l'abdomen dans quelques individus. Ailes trånsparentes, nervures bruuses, leur point marginal blanchâtre. Femelle.

Le mâle est plus petit, plus grêle ; il a le devant de la tête blanchâtre ainsi que la totalité de l'orbite des yeux; ses pattes sunt plus pâles.

Des environs de Paris.

$2^{\circ}$. Division. Tarière (des femelles) plus courte que l'abdoinen.

\section{Prmple insligateur, $P$. instigator.} atris.

Pimpla atra, pedibus rufis, femoribus basi

Cryptas instigator. FAB. Syst. Piez. pag. 85. $n^{\circ} .6 \mathrm{r}$. La feacelle.

Longueur 6 à 8 lig. Antennes noires. Tête, corselet et abdomen noirs, chaygrinés. Pattes testacées, lianches noires. Tarses postérieurs bruns. Ailes transparentes; nervures et point marginal de couleur brune; ce dernier précédé d'une petile tache blanchâtre. Tarière dépassant l'abdomen environ du tiers de la longueur de celui-ci. Femelle.

Le mâle est semblable; il a quelquefois un peu de blanc sur les écailles des ailes supéricures.

Comunu aux environs de Paris, près des bois abaltus et dans les chantiers.

\section{Pimple turionelle, P. turionello.}

Ichneunion turionellce. Lrvv. Syst. Nat. 2. 955. 40. - Cryptus turionello. Fав. Syst. Piez. paó. $87 \cdot n^{0} \cdot 7^{2}$.

Tarses postérieurs blancs avec l'extrémilé de chaque arlicle noire. 'Tarière dépassant l'abdomen de près de moitié de la longueur de celui-ci.

Des envirous de Paris.

Voyez pour la description el les autres synonymes Ichnesinon turionelle, $n^{\circ}$. 15்o.

\section{Pimple piqueur, $P$. compunctor.}

Cryptus conipunctor. FA B. Syst. Piez. pag. 84 . $n^{\mathrm{n}} .58$.

Toutes les parties de la bouche sont d'un jaunetestacé. Le mâle a les écailles des ailes supérieures bianchâtres.

Des environs de Paris.
Voyez pour la description de la femelle et les autres synonymes, Ichneumon piqueur, $n^{\circ}$. I 5 . pl. 101. fig. I.

\section{Prmple jaunâtre, P. flavicans.}

Pimpla flava, thoracis fasciâ longitudinali fuscâ, fenoribus posticis crassis, subtis canaliculatis, denticulatis.

Pimpla favicans. FAв. Syst. Piez. pag. IIg. $n^{\circ} .33$.

Longueur 6 à 7 lig. D'un jaune-ferrugineux luisant. Corselet ayant une bande longitudinale brune et un peu de jaune sous l'atlaclie des ailes. Ecusson jaune avec deux petites laches lrunes latérales. Segmens de l'abromen ay ant quelquefois un peu de bran à leur basc. Cuisses postérieures grosses, canaliculíes en dessous, souvent noires dans celle partie; les deux bords de ce canal denticulés. Ailes jaunâtres, transparentes, nervures ferrugineuses. 'larière dépassant l'abdomen à peu près de la moitié de la longueur de celui-ci. Mâle et femelle.

Commun aux environs de Paris.

$$
\text { (S. F. et A. SERv.) }
$$

PINCE, Chelffer. Geort. De Gér. Orv. Latr. Lam. Líach. Acarus, phalanginm. Linn. Scorpio. FAB. Obisium. Irlig. W A LCK.

Genre d'Arachnides de l'ordre des Trachéennes, famille des Fanx-Scorpions, ćlabli par Geoffroy anx dépens du genre Faucheur de Linné et dont les caractères sont : Palpes alongés en forme de bras, avec une pince au bout. - Pieds égaux, terminés par deux crochets. - Yeux, dont le nombre varie de deux à qualre, placés sur les côtés dı corselet; point de queue ni de lame pectinée à lit base du ventre.

Limné avoit d'abord placé l'espèce la plus connue de ce genre, la Pince cancrö̈de, on Scorpion-Araignée de Geoffroy, le même unser:te que de Géer appelle le Faux-Scorpion d’Europe, dans son genre Acarus; plus tard, ce grand naturaliste réunit cette espèce à ses Faucheurs (Phalangium), avec lesquels e!le n'a que trés-peu de reflemblance. Gcolfiroy en a formé un geure sons le noun de Pince (Chelyfer), dans lequel il a transporté l'Acorzs langicornis de Linné, Arachnide d'une autre famille et qui appartient a genre Bdelle de M. fatreille. Fabricius a placé la Pince cancrö̈de parmi les Scorpions. Dans un travail sur les insectes aplères de Linné, Hermann fils al fait connoitre plusicurs espèces du genre Chelifer, qu'il a réparties duns deux divisions; il a fait de l'Acarus longicornis el de quelques autres Araclinides, le genre Scirus, qui n'a pas élé adopté, pare que Mî. Latreille aroit déjà séparé ces insecles des l'inces avant la publication de l'ouvrage de Hernanu. R 2 
Enfin Illiger, dans un tableau nominal des genres de la classe des insectes qu'il a placé à la fin de son ouvrage sur les Coléoptères de la Prusse, sépare des Scorpions, les espèces que Habricius nonıme Cancroïdes et Cimicoïdes, pour en faire un genre particulier qu'il appelle Obisium. Ce genre a été conservé par le docteur Léach (Zool. Miscell., vol. 3. pag. 48) aux espèces de Pinces qui ont quatre yeux lisses, le corps presque cylindrique et les huit pattes postérieures composées de six articles; celles qui n'ont que cinq articles aux pattes, dont le corps est déprimé et qui n'ont que deex yeux lisses, forment seules le genre Chelifer.

Les Pinces ont le corps ovoide et déprimé, ou oblong et presque cylindrique; il est revêtu d'un derme un peu coriace, presque glabre ou peu velu, et se compose, $\mathrm{I}^{\circ}$. d'un segment antérieur beaucoup plus grand, presque carré ou triangulaire, tenant lieu de tête ou de corselet, portant denx ou quatre yenx lisses, situés latéralement, les organes de la manducation, deux piedspalpes en forme de serres, terminés par une pince didactyle, et les six premières pattes; $\mathbf{2}^{\circ}$. de onze autres segmens transversaux et annuliformes, et sur les premiers desquels la quatrième et dernière paire de pattes paroît insérée; les annealux suivans composest l'abdomen. Leur bouche se compose de deux mandibules cornées, situées à l'extrémité antérieure et supérieure du corselet; elles sont en forme de pince didactyle, dont le doigt extérieur est mobile, dentelé ou cilié; dans les Obisies, elles sont entièrement découvertes. Ceite bouche se compose en outre de deux mâchoires formées par le prolongement interne de l'article radical des serres, valvulaires, un peu bombées ou convexes au milieu, déprimées et rebordées près des bords internes, terminées en pointe, se joignant le long des bords et fermant aiusi la bouche inféricuremeut : de deux grands pieds-palpes, composés de six articles et terminés en pince didactyle : enfin d'une laugue sternale située dans l'intérieur de la bouche, cuspidée à son extrćmité supérieure, et oflrant, suivant Savigny, un petit appendice de chaque côté de celle pointe. C'est celte pièce que Hermann fils avoit appelée une papille conique embrassée par deux espèces de valvules (les mâchoires), et qu'il avoit considérée conıme la trorape de ces animaux. Les pieds sont divisís en cinci articles dans les Pinces proprement dites et en six dans les Obisies, selon que le tarse est composé d'une ou de deux pièces; l'extrémité du dernier article est toujours arınée de dents crochues sous lesquelles est une pelotte. L'article qui répond aux cuisses est plus large et alongé; la longueur des pattes va en croissant à partir de la seconde paire, et elies sont plus courtes et plus grosses dans les Pinces proprement dites que dans les Obisies.

Les Pinces vivent en général dans les lieux écartés et humides, dans les endroits peu fréquentés des maisons, sous les pierres et les pots à fleurs des jardins, dans les vieux livres et ies herbiers; elles se nourrissent de petits insectes, tels que les $P_{\text {oux }}$ de bois (Psocuspulsutorius. FAB.), les Mittes et même les Mouches: Goetze en a nourri avec de petits Pucerons. Linné dit que ces Aracbnides s'introduisent quelquefois dans la peau et qu'elles y produisent une enllure douloureuse; il rapporte, sur la foi du docteur Bergius, qu'un paysan ayant eu la cuisse percée pehdant la nuit par un de ces insectes, il s'y forma une pustule de la grosseur d'une noisetto qui lui causa des douleurs très-vives. Ces insectes marchent assez vîte en avant, de côté et à reculons, comme les Scorpions et les Crabes. Suivant Roesel, la femelle pond des oufs petits, d'un blanc-verdâtre, qu'elle rassemble les uns après les autres. Hermann père dit qu'elle les porte sous son ventre ramassés en une pelotte, comme le font plusieur's autres Arachnides.

On peut diviser' ce genre, d'après Hermann fils, en deux sections : dans la première se trouvent les espèces qui ont le premier segment du tronc, ou le corselet, parlagé en deux par une ligne imprimée et transver'sale; les tarses d'un seul article, nne espèce de stylet au bout du doigt mobile des mandibules et les poils du corps en forme de spatule. Cette setion renferme le genre Chelifer proprement dit.

\section{Pince cancroïde, $C$. cancrü̈des.}

C. thorace lineâ transversâ, impressâ, bipartito; bruchiis corpore duplò longioribus, articulis secundo tertioque conicis elongatis; corpore rubro-brunneo; abdomine ovali.

Chelifer cancroïdes. Lat. Gen. Crust. et Ins. tom. 1. pag. 1.32. - Pince cancruide. Lat. Hist. nat. des Crust. et des Ins. tom. 7:pag. 141. pl. 61. fig. 2. - Le Scorpion-Araignée. Grofr. Hist. des Ins. tom. 2. pag. 6 1 8. - Faux-Scorpion d'Europe. DE GEER, Mém. sur. les Ins. tom. 7 . pag. 355. pl. 19. fig. 14. - Phalungium cancrö̈les. Linn. Syst. Nat. edit. 13, tom. 1. pars 2. pag. 1028. - Faun. Sluec. edit. 2. $n^{\circ}$.

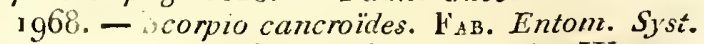
tom. 2. fag. 436. - Obise cancroide. Walck. Fann. Faris. tom. 2. pag. 263. - Fúrsch. Ins. tom. 8. tab. 1. - Roes. Ins. t. 3. Suppl. tab. 64.

Cette espèce a environ une ligne et demie de longueur; tout le corps et les pattes sont d'un brun-rongeâtre; les palpes sont le double plus longs que le corps, avec les articulations alongées.

Elle se trouve en Europe dans les vieux livres, les herbiers, etc., où elle se nourrit des petits insectes qui les rongent. 


\section{P I N}

2. Pince cimicoide, C. cimicoïdes.

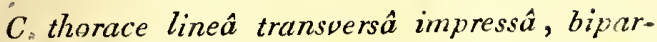
tito, brachiis mediocribus, articulis bresibus, subovalibus, pilosis; abdonine orbiculato-ovato.

Chelifer ciniccïles. I.aт. Gen. Crust. et Ins. tom. 1. pag. 133. - Pince cimicoide. Hist. nat. des Crust. et des Ins. tom. 7. pas. $142 .--$ Pince parasite.-Herm. Mém. aptérol. pag. 117.pl. 7. fig. 6. - Scorplo cumicö̈des. Fа в. Ent. Syst. tom. 2. pag. 436. - Obise cimicoide. Walck. Fauz. Paris. tom. 2. pag 253.

Cette espèce a le corps plus arrondi que la précédente, ses bras sont tout au plus une fois et demie aussi longs que le corps, et à articles arrondis.

Elle se trouve fréquemment sous les écorces des arbres dans le midi de la France.

La seconde section renferme les espèces qui ont le corselet sans division, les mandibules sans stylet, les poils du corps en forme de soies : elle correspond au gence Obisizun.

\section{Prnce trombidioide, C. trombidiö̈des.}

C: oculis quatuor, mandibulis maxinis, exsertis; brachiornm articnlo secundo elongato; digitis longis, rectis.

Pince trombidioïde. Lat. Hist. nat. des Crust. et des Ins. tom. 7. pag. 142. - Gen. Crust. et Ins. toni. 1. pag. 133. - Pince ischnochèle. Невм. Mém. apterol. pag. II8, pl. 6. fig. 14.

Cette espèce se trouve en France, aux environs de Paris, sous les pierres et sous les mousses.

(E.G.)

PINICOLE, Pinicola. Bréb. Genre d'Hyménoptères térébrans. Voyez Xxìne.

\section{(S. F. et A. S SRV.)}

PINNOTHÈR, pinnotheres. Genre de Crustacés de l'ordre des Décapodes, famille des Bracliyures.

J'ai le premier séparé ce genre de ceux de Crabe et de Porcellane, avec lesquels il avoit été confondu, et daus l'ouvrage sur le règne aoimal de M. Cuvier, je l'ai associé à quelques autres groupes génériques, formant aver lui lis tribu des Orbiculaires; mais je pense anjourd'hui qu'il appartient plus naturellement à celle des Quadrilatères. Les antennes mitoyennes, de nuême que celles des Gécarcins, des Plagusies, des Grapses, elc., sont très-distincternent bifides à leur extrémité, et leur premier article esı plus transversal quelongitudiual. Les pieds-lnâchoires extérieurs n'offient distinctement que trois articles, dont le premier grand, disposé transversalement, concave ou arqué en dessous, et formant une sorte de cintre à l'extrémité supérieure de la poitriue; la base interne du cernier olfie un appencice $\widehat{L}_{\bar{\alpha}}$ néaire, en forme de rameau.

Parmi les Crustacés décapodes, nous n'en connoissons point de plus petits. Leur corrs, généralement orbiculaire et lisse, ciffire un peu seton los sexes. Ciclui des mâles est proportionnelleureut plus petit, plus bombé, de consistunce ferme, et un peu plus rélréci à sa partie antérieure, ‘jui forme une sorte de nuseau lrès-court, armindi on tronqué. Le corps des femelles est presque carré, avec les angles atrondis; son test est mou ou presque inewbrateux, et sonvent aatrement coloré que celui de l'autre sexe. Les jeux sont silués de chaqune côté du cliaperon, un peu écatés et ferminant chatun un pédicule conrt, assez gros, presque globulenx. Lcs qualre antennes sont placćes sir une lirne transverse et contiguë : les latérales ont leur nuserion à l'angle interne des fossettes recevant les yeux; elles sont fort petites, menues, en côue along̣é, et conıposées d'uo pelit nombre d'ariicles; les inlermédiaires, plus grandes que les précédentcs, sont logées dans deux cavités, au-dessous du chaperon ou dumuseau; leur premier article paroît comane unidenté à son extrémité interne el supérieure, près de l'insertion du second, qui, de même que les suivans, est repíié en dehors et couché sur la face supérieure du premier. Les deux serres iont égaies, plus grosses que les aulres pieds, mais plus courtes que ceux de la troisième et qualriène paire, les plus longs de tous; les mains sont ovoides, plus cunrtes et plus renilćes dans les màles, et terminées dans les deux sexes par des doigts coniques et pointus; ceux des inâies sont un peu arqués ou moins droits, et uront paru avoir des dentelures plus appareutes. Les larses sont courts, coniques, comprinés, et finissent brusquenent en une poinle fine et très-ricérćc. Le post-abdomen est conposé de segmens tränsversaux; celui da måle esı en forme de iriangie, élroit et aloniré, el ses appendices sexuels sont [resque foliacés. J]est très-grand et presqu'orbiculaire clans les fumelle's adultes.

Les premiers vaturalistes grecs designèrent sous les noms de Pinnother et de Pinnophilax, de petits Crustacés qu'ils regardoient comme les gardiens e! les sentinelles des Mollusque: du genre des Piunes ou Jambomueaux, et comune étant eucore leur commensaux, leurs vivandiers même. On croyoit qu'ils naissoient avec eux et pour leur conservation; on supposuit que ces Mollusques. privés d'yeux et dont le sentiuent a peut d'énergie, ouvroient leurs coquilles, afin que les petils poissons dont ils étoient censés se nommir, pussent $\mathrm{y}$ entrer, et que lorsqu'il s'y en éroil zutroduit une quantité suffisante, le Pinnotbère cu avertissoit le propriétaire naturel, par une morsure, ce qui le déterminoit à fermer sa coquille. Le butis étoit ensuite partagé entr'eux. Qucique Rondelet eût remarqué depuis long-temps que l'eau de is 
mer suffit à la nourriture de ces Mollusques, et qu'on en trouve souvent de solitaires dans leurs coquilles, plusieurs naturalistes du dernier siècle out para néanmoins adopter cette opinion fabuleuse des Anciens. La figure symbolique de la Pinne et du Cancre représent oit, chez les premiers Egyptiens, un homme ou un père de fannille qui ne devoit son existence qu'aux secours de ses proches on de ses enfans (1). Telle est probablement, par rapport au Pinnotlière, la source primitive de ces uraditions erronces; mais quel qu'en soit le fondement, la connoissance des animax qui en ont été l'objet, mérite notre atteution.

Camus, dans son Commentaire sur l'Histoire des animaux d'sirstote, articles Cancre pett, Pinne, Pinne et P'innothère, fait, ia cet égard, des réflexions très judicieuses. Le même sujet a intéressé M. Cuvier, et dans une Dissertation critique sur les Ecrevisses mentionnées par les Ancieus, il a discuté avec son habileté et sa sagacité ordinaires, les divers passages relatifs au Piunothère. Non-sealement il considère l'histoire qu'on en a donnée conme le produit de l'imaginatiou, mais il semble croire encore que les Anciens, on du moins Aristote, n'avoient point d'idée positive sur cet animal. Sa détermiuation lui piroit d'autaut plus difficile, que l'habitude de se loger dans chivers coquillages bivalves est connuue à pluoieur's autres Crustacés. C'est ainsi juc l'on trouve quelqnefois le Cribe coumun et l'Etrille dan's les Moules, et le Cancer strigrosus de Liunæus (voyez GalathéE), dans les Cardium ou ceurs; muls uous observerons que ces circonstances sont rares et simplement furtuites. Il n'en est pas de mêue des Pinnothères et des Pagures ou dies Ileruites. Lat nature n'ayant point protégé ces Crustacés par des tégumens solides, comme elle l'a fait pour les autres, on conçoit qu'elle a dî̀ garaniir ces animaux d'une autre manière, et c'esidaus ce but qu'elle leur a donné l'instinct de se thosir des doniciles particuliers, tels que des Eugtiallugres. Illilis les Piuuothères dillerent, a cet byard, des Pagres, en ce qu'ils n'babitent que tes souguilles bralves, et toujours de compaguie \&Vec leurs vérituhles possesseurs. Plusieur's iudividus de ces Crustacés parasites peuvent, en outre, vivre sous le nême toit. Les Pagures, au contraire, se logent uniquement et toujours solitariernent dans des coquillages univalves et vides.

* Iss Pinaes, dit Aristote (Hisloire des Anm., aranction de (anus, tome I, page 273 ), ont, dun: leu: curaille, l'aninal appeí le gurdien de la Fisne. Cest une petite Syuille on un petit Crabe, yúelles ne peuvent perdre sans périr bieutòt âlies-ẩ anes. 11 nait dans quelques testacés, ajoutetwit jus bus, des Cincres blancs, fort petits : le

(I) 1 l paroît que sur le zodiaque circulaire de Dendérah, C: 3 ti un zoldiayue indien, le Pinnorbère ou un Crusracé zátulugue (Leucosic.') a été pris pour cype du signedu Cancer. plùs grand nombre se trouve dans les espèces de moules dont la coquille est renflée (Modioles); après vient la Pinne; son Crabe se nomme le Pinnothère. Il s'en trouve aussi dans les Petoncles et les Huîlres. Les petits Cancres ne prennent aucun accroissement sensible, et les pêcheurs piétendent qu'ils se forment en même temps que l'animal avec lequel ils habitent. "Plus loin, il dit encore qu'il nait dans les cavités des éponges de petits Cancres semblables au gardien de la Pinue; qu'ils y sont comme l'Araignée dans sa retraite, et qu'en ouvrant ou fermant à propos ces cavités, ils prennent de petits poissous; ils les tiemnent ouvertes pour y laisser entrer leur proie, et ils les ferment aussitôt qu'elle s'y trouve. Il est maintenaint certain que les Moules, les Huîtres et les Petoncles de nos côtes maritimes, coquillages mentionnés précisément par ce père de la Zoologie, renferment, du moins à une époque de l'année, des Crustacés très-petits, blancs ou blanchâtres, tels qu'illes désigne, ou ceux quej'appelle Piunothères. Il est encore certain que ces coquilles n'offient point habituellement d'autres animaux parasiles, et que l'on trouve souvent dans quelques espèces de Pinnes, soit d'autres Pinnothères (veterum, Léach) un peu moins petits que les précédens, soit de petites Salicoques (Caridion, Aristote), telles que le Cancer custos de Forskaël, l'Alphacels thyrrlienus de Risso, ainsi qu'un autre Crustacé de là même famille, dont le corps est très-mou, et que feu Olivier a observé diıns des Pinnes de la Médilerranée. Nous savons aussi que des Pagures et des Porcellaues s'ćtablissent daus les éponges, et ce sont probablement ces Crustacés qu'Aristote a eu en vue -dans le dernier passage que j'ai cité. Il a donc été fondé à dire que le gardien de la Pinne étoit un petit Crabe ou une petite Squille, ẻt je ne puis admettre l'opinion de M. Cuvier, qui voit dans cette expression disjonctive une preave qu'Aristote ne parle ici que d'après les autres, ou que son témoignage est incertain. Peut-on d'ailleurs imaginer que ce naturaliste n'auroit point eu occasion de voir des animanx aussi commurs que nos Pinnollères et si connus du vulgaire?

Pline a confondu sous le now de Pinnothères les espèces de ce genre proprement dit, et celles de celui de Pagnre. Plusienr's auteur's rapporteut un passage des Halieutiques a'Oppien, où il racomle que le Cancre, lor'sque l'Huitre vient ouvrir sa coquille, met une pierre entre ses deux valves, afin qu'elle ne puisse se fermer, et qu'il ait aiusi le moyen de s'y introduire et de dévorer son habitant. Niais rien n'indique que ce passage s'applique aux Pinnothères. Oppien fait menlion de ces derniers animaux dans un autre endroit, et en dépeint les habitudes absolument de la miême manière que ses devanciers. Hasselquist, Voyage au Levant, traduction française, pag. 64 , avance, à l'occasion de la l'inne muricata, que la Sèche 


\section{$P \perp \mathbb{N}$}

est l'ennemi le plus irréconciliable de l'animal de cette coquille; mais qu'heureusement pour lui, il y a toujours dedans une ou plusieurs écrevisses qui se tiennent à l'entrée de sa demeuré, lorsqu'il l'ouvre, et qui l'avertissent du danger à l'approche de son adversaire. Aussi, ajoute l'auteur, l'animal de lit coguille permel-il, en revanche, à ces Cruslacés de se loger avec lui. On pensebien que cette autorisation ıe leur est pas nécessaire, et qu'effrayćs les premiers de la vue de la Sèche, ils doivent, pour ćchapper au péril qui les menace, faire en arric̀re quelques mouvernens brusques, et déterminer ainsi l'animal de la Pinne à se tenir clos. Cette Ecrevisse d'Hasselquist est probablement une espèce de Salicoque ou de Pinophyläce, selon la nomenclature des Anciens. Linuæus, d'après le témoignage de son disciple, avoit d'abord rangé ce Crustacé dans sa division des Macrontes du genre Cancer; mais il paroît qu'il l'a ensuite réuni avec une espèce de la division des Brachyures, le Cancer pinnotheres, et dont la description lui avoit été envoyće par Forskbal.

Cornme c'est plus particulièrement en hiver que lintérieur des Moules nons offre des Pinnothères, il y a lieu de présumer que ces aninaux s'y retirent, afin de s'abriter contre les riguears de cette saison. Il est encore possible cque de jeunes individus choisissent de préférence un tel séjour, atiu de se puéscrver des dangers qui les menacent. Les femelles que l'on y trouve sont toujours dins un état de mollesse analogne à celui d'une Ecrevisse qui vient de changer de peau. Il paroîtroil que dans cette circonstance les Moules peuvent être pour guelques personnes un aliment nuisible; mais les Pinnolbères ne leur ont pas, ainsi qu'on le pense, communiqué cette qualité malfaisante. Les autres hahitudes de ces Crustacés me sont inconnues.

Nous devons au docteur Léach des délails nouveaux et très-exacts sur les caractères de ce genre et la description des espèces en faisant partie, qui ont été olsservées sur les côtes de ja GrandeBretagne. Le sigualement de ces espèces est d'autant plus difficile qu'elles subissent avant l'ìge des unudifications, et que le corps des femelles est sujet, par la dessiccation, à se déformer.

Le lest des plus grands individus est long de huit nillimètres. Le même diamètre n'en a que deux dans les plus petits.

\section{Pinnotaine des Moules, P. Mytilornun.}

Abdominis inaris ultino segunento precedenti angustrove, írigono; clypeo integro aut vix emar ginato.

P. Mytilorunu, Pisunu. LAtr. - P. variuns. Léser, Malac. Podopht. Brit. iab. 14.fig. 9-11. Le mâle. Ejusd. P. Pisum, ibid. tab. ead. fig. 1-3. La femelle. - Cancer Pisunu. Lasn. Hersst, Krabben. tab. 2. fig. 27. Le múle; ibid. fig. 24. 25. Le même jeune; ibid. fig. 21. La femelle.

Très-commun dans les Monles et le Modioles.

Test du mâle blanchâtre, un peu marbré de ronssâtre, lisse et luisant; dessous des mains marqué de denx lignes de poils noirâtres; le pouce arqué, avec une dent assez forte, près de la base de son bord interne; ce bord et l'opposé de l'index un peu ciliés; cuisses des autres pieds ayant sur leurs tranches une ligne de poils ou de cils noirûtres. Fennelle plus grande, presqu'orbiculaire, roussâtre ; mains des serres n'ayant, à ce qu'il m'a paru, qu'une seule ligne de poils et qui s'efface même dans quelquesunes.

Ie P.innothère de Cranch (Cranchii), représenté par M. Léach, ibid. tab. ead. fig. 4, 5, ct dont il n'a commn que la fenselle, ne differe de celle de l'espèce précédente qu'en ce que son chaperon est un peu arqué, au lieu d'être droil, et que le milieu du bord postéricur des segnens de l'abdumen, à partir da second, est un peu échancré. Même liabitation, nais rare.

\section{Pinnothìre des Anciens, P. Veterum.}

Abdominis nuaris ultino segnento ad basirb pracedente latiore; clypeo enarginato.

P. Veterum. Bosc, Léac日, ibid. tab. 15. fig. 1-5. - Cancer Pinnotheres. LuNn.?'

Un peu plus grand que le P. des Moules; dans les l'innes el quelquefois dans les Muitres.

Le milieu de l'abdomen des femelles est un peu caréné et comme noueux. 'Test pointillé.

La figure 3 de la planche 20 dc Jouston, citée par Linnæus à l'article Concer Pinnotheres, représente un Pagure qui vit dans un Alcyon; il fuut lire, tab. 7. fig. 5. Gesuer avoit, depuis long-temps, distingué cette espèce de la premiere.

Le $P$. de Rontagu (Montugui) de M. Léach, ibid. tab. cad. fig. $6-8$, dilfès e pen du $P$. des Anciens. liabdonien du mấle cst plus brusquiscment rétréci vèrs son extrémité, avec le dernier segrment proportionnellemeut plus large e! plitôt carré que demi-circulaire.

Son $P$. de Latreille, ibid. tab. 14. Jig. 6-8, formeroit une division particulière, s'il ćtoit vrai que les femelles adultes ensseni l'abdomen ovale ou plus long que large. Mais cette fome pourroit bien n'êtıe propre qu'aux jeuses individus, et Montagn même ne considéroil ce l'innothère guac comme une variélé d'âge du Cancer Pisum. Je soupçonne, en outre, que I1. Léach s'esi mópris a l'égard du sexe. La solidité du test, sa forme et celle des serres paroissent l'indiguer. Le test offriroit cependant, de chaque côté de sa partie postérieure, deux lignes enfoncées et con- 
fluentes, ce que l'on n'observe point dans le $\boldsymbol{P}$. des Anciers.

Le $P$. de Latreille se trouve, mais très-rarement, dans les Modioles.

M. Thomas Say a décrit dans le Journal de l'Académie des sciences naturelles de Philadelphie, no. 6, octobre 1817 , deux espèces de Pinnothères de l'Amérique septentrionale; l'une sous le nom de $P$. ostrenm, pl. 4 , fig. 5 , et l'autre sous celui de $\boldsymbol{P}$. depressum. Je n'ai point va ces Cirustacés. (Latr.)

PINOPHILE, Pinophilus. Genre de Colćoptères de la famille des Brachély tres, établi par M. Gravenhorst dans l'ouvrage intitulé : Coleoptera microptera, et qu'il a réuni ensuite au genre Lathrobium dans sa Monographia Coleopterorum micropterum. (S. F. et A. Serv.)

PIPIZE, Pipiza. Falén. Meig. Mrilesia. Lat. Eristalis, Mulio. FAв. Musca. Linn. Syrphus. Panz.

Genre d'insectes de l'ordre des Diptères, section des Proboscidés, famille des Athérières, tribu des Syrphies.

Les Piprizes font partie d'un groupe dans la tribu des Syrphies (voy. ce mol), dont le caractère est d'avoir les antennes plus courtes que la têle, leur's deux premiers articles égaux entr'eux; point de tubercule frontal pour porter les antennes ni de cellule pédiforme aux ailes, les cuisses simples, sans rentlement ni épines et la soie des antennes sans articulations sensibles. Les zulres genres du mếrue groupe sont Baccha, Chrysogastre, Psilote et Syrphe, distingués des Pipizes par leur hypostome ou dessus de la bouche creusé ou luberculé; les Paragues, qui s’en éloignent par la palette de leurs antemes fort alongée, enfin les Volucelles et les Séricomyies, qui seules dans ce groupe ont la soie des antennes plumense.

Antennes avancées, courbées, composées de trois articles, le dernier ou palette ovale, comprimé, portant à sa base une soie dorsale rue. - Yeux rapprocbés et se réuvissant un peu audessous da vertex, dans les mâles, espacés dans les femelles. - Trois petits yeux lisses disposés en triangle, très-rapprochés et placés sur le vertex, dans les mâles, distans el posés uı peu au dessous du vertex dans les femelles. - $H_{y}$. postome lisse, plane. - Ailes parallèles, couchées sur le corps dans le repos, n'ayant point de cellule pídiforme. - Abdomen oblong, presqu'elliprique. - Pattes moyennes, cuisses postérieures peu renflées, simples; tarses (les postérieurs surtout) ayant leur premier article long et le quatrième fort court.

On trouve ces diptères sur les fleurs. M. Meigeu, dans son ouvrage intitulé Diptères d'Eurape, en décţit vinğt-neuf espèces.
Ire. Division. Abdomen unicolor.

1. Piprze lugubre, $\boldsymbol{P}$. lugubris.

Pipiza abdonine unicolori, geniculis tarsisque ferrugineis, alarum pellucıdarum maculâ fúscâ.

Pipiza lngubris. Merg. Dipt. d'Europ. tom. 3. pag. $250 . n^{\circ}$. $18 .-$ Errstalis lugubris. FAB. Syst. Antliat. pag. $246 . n^{\circ} .64$.

Longueur 4. lig. Noire, avec un peu de duvet ferrugineux; genoux et tarses ferrugineux. Ailes transparentes ayant une tache brune.

\section{Pipize verdâtre, $P$. virens.}

Pipiza abdomine unicolori, pedibus nigris, alis totis pellucidis.

Pipiza virens, ME1G. Dipt. d'Ezirop. tom. 3. pag. 253. $7^{\bullet}$. 26. - Pipiza campestris. FALLÉN. Syrph. 59.4. - Mulıo virens. Fав. Syst. Anțlat. pag. $186 . n^{\circ}$. 22.

Longueur 2. Jig. $\frac{x}{2}$. Corps d'un bronzé obscur. Antennes noires, de la longueur de la lête. Corselet d'un brun-verdâtre, couvert d'un léger duvet cendré. Abdomen noir, pätles de mêuse couleur, genoux ferrugineux. Ailes transparentes.

D'Autriche.

Nota. Nous n'avons point vu celte espèce rón plus que la précédente.

2e. Division. Abdomen ayant â sa base des taches jaunes ou rougcâtres, ordinairement transparentes.

\section{PIPIze fasciée, $P$. fasciata.}

Pipiza abdominis lineis duabus pellucidis, in secundo tertioque segmenlo positis, posticâ interruptâ.

Pipiza fasciata. Meig. Dipt. d'Europ. tom.3. pag. 242. $n^{\circ} \cdot 1$. tab. 29. fig. 17. Fenelle.

Longueur 4 à 5 . lign. Noire. 'Tète et corselet ayant un duvet gris. Second segment de l'abdomen avec une large ban de transparente d'un blancroussûtre; troisième segment ayant uue petile ligne interrompue de même couleur. Pattes jaunes; cuisses et un anneau aux jambes de conleur noire. Ailes Iransparentes avec une large tache brune. Femelle.

Des environs de Paris.

4. Pipize à taches transparentes, $P$. noctiluca.

Pipiza abdominis lineâ arcuctâ pellucidâ, in primo segmento positâ.

Pipiza noctiluca. FarLín. Syrph. 59. 2. - 
Nis. Dipt. d'Europ. tom. 3. pag. 244. n०. 6. - Eristalis noctilucus. FAl3. Syst. Antliat. pag. 247. $n^{\circ} \cdot 69$. - Milesia noctrluca. LAт. Geper. Crust. et Ins. tom. 4. pag. 332. - Hilusca noctiluca. Linn. Syst. Nat. 2.986. 48. - Syrphus rosarum. PANz. Fuun. Germ. fis, $9^{5}$. Jig. 2.I. Feinelle.

Longrueur 3 a 4 lig. Tête et corselet noirs avec un léger duvet cendré. Abdomen noir, son premier segment ay ant une bande un peu arquée, interrompue, jaune, transparente. Pattes noires, jambes antérieures jaunes à la base. Ailes transparentes avec une tache brune. Mâle.

Des euvirons de Paris.

5. PIPsze quadrimaculce, P. quadrimaculata.

Pipiza abdominis maculis quatuor pelluciais in secundo tertioque segmento per paria dispositis.

Pipiza quadrimaculata. FA titén. Syrph. 59. 3. - Merg. Dipt. d’Europ. tom. 3. pag. 249. no. 16. - Syrphus quadimaculatus. Paxz. Faun. Germ. fis. 86. fig. 9 .

Longueur $4 \mathrm{lig}$. Corps noir à reflet un pea bleuâtre, ayant un lóger duvet gris. Second et troisième segmens de l'abdomen portaut chacun deux taches transparentes jaunâtres; celles du second beaucoup plus grandes. Pattes jaunâtres, cuisses et un anneau aux jumbes de coulear noire. Ailes transparentes ayant une large tache brune. Femelle.

Eavirons de Paris.

\section{Pipize vitrée, $\boldsymbol{P}$. yitrea.}

pipiza abdominis inaculis duabus pellucidis in secundo segmento positis.

Pipiza vitrea. MeIg. Dipt. d'Europ. tom 3. pag. $249 \cdot n^{\circ} \cdot 15$.

Longueur 2 lig., à 2 lirr. :- Corps noir à reflet nn peu bleuâtrc. Second segment de l'abdomen ayant deux points transparens dun jaune soufić. Les quatre jambes antérieures et leurs tarses jaunâtres à la base. Ailes transparentes.

Elle a été prise aux envirous de Paris dans les bois au mois de mai sur une espèce de polentille (Potentilla verna). (S. k. et A.SrRv.)

PIPUNCULE, Pipunculus. I.A T. Musca. Bosc. Genre d'insectes de l'ordre des Diptères, section des Proboscidés, famille des Athéricères, tribu des Muscides.

Parai les Muscides qui ont les cuillerons petits, les yeux sessiles, les antennes plus courtes que la tête, le corps simplement ublung et l'extrémité postérieure de l'abclomen sans prolongement particulier, les Pipuncules sont les seuls dont la tête soit presqu'ealièremeut occupée par les yeux à réseau.

Antennes insérées sur le front, de deux articles apparens, le second terminé cn une pointe fine, portanl à sa base une soic longue qui paroit composée de deux articles, le premier court, assez zros. - Trompe nembraueuse, bilabiée, rétraclile, entic̀rement retirée dans la cavité de la bouche ì l'état de repos, renfermant un suçoir composé de deux soies. - Téte rrosse, ronde, tronquée postérieurement. - Ý eux très-grands, occupant la presque totalítéc la tête. - Thais petits yenx lisses très-rapprochés, disposés en triingle sur le vertex. - Corps alongé. - Corselct un peu plus étroit que la tête. - Ecusson gुrand, un peu gibbeux. - Ailes grandes, beaucoup plus longues que l'abdomen, couchées l'nne snr l'autre dans Je repos. - Cuillerons petits, balanciers grands, tout-à-fait à découvert. - Abdomen cylindrique, recourbé à son extrémité, composé de six segrmensoutrel'anus.-Paties grandes, hanches fortes; crochets des tarses grands, écartés, muuis dans leur eutre-denx d'une très-graude pelotte bificie à divisions fortes.

On connoît deux ou trois espèces de ce genve Établi par M. Latreille. On les rencontre sur les fleurs. Leurs métamorplıoses sont iguorées, mais elles doivent se rapprocher de celles du genre Moucle.

\section{J. Pipuncule cliampêtre, $P$. campestris.}

pipunculus niger, alis pellucidis, genubus pallidis.

Pipunculns campestris. LAT. Gener. Crust. et Ins. tom. 4. pag. 353. - niTusca cephalotes. Bosc, Journ. d'Hist. nat et de Phys. toin. 1. pas. 55 . pl. $20 . n^{\circ} .5$.

Longueur n. Tries-petit, d'un noir terne, genoux ct peloties destarses d'nn filuve-jituâke. Jambes el tarses en grande partie quelquefois de cette conleur. Ailes irausparentes.

Des environs de Paris.

ANTHOHYIE, Anthomyia. Merg. Class. Inlig. Lat. Mizsca. Linn. Geort. Was. De Gér.

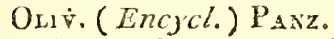

Gemre d'insectes de l'ordre des Diptères, section des Proboscidés, fuwille des Athéricères, iribu des Muscides.

Dans le groupe de Muscides qui a pour caractères: cuillerons petits; ycux sesciles; antemes plis courtes que la têic; corps court; extrénité postérieure de l’abdomen sans prolongement; les Phores se distinguent par leurs antennes insécics prés de la bouclic; les Pipnucules par leurs yeux qui occupent presque toute la superficie de la lête; les Oscines par leur tête qui vuc en dessus parroit pyramidale; les Mosilles par le troisième article $\mathbf{S}$ 
des antenres presque triangnlaire; les Ochtères par lenrs pallés antérieures ravisseuses; les Scatopharges et les 'Thyréophures par leur tête presque globuleuse, eiles $S_{\text {fihzrocè }}$ par le dernier article de lenrs auteanes plis large que long. Le genre Anthongie u'a aucun des caractères que Ions venons dénoncer.

Antennes plins courtes gue la tête, insérćes au milieu de la pariie antéricure de la tête, composćes de trois articles, le dernicr plus long que large, plus alongré que le second, porlant vers sa base une assez longue soie un peu velue. - Trompe anembraneuse, bilabiće, coudce, son extréuilé restant loujours extéricure, renfermant un sucoir conposé de deux soies. - Palpes presque tiliformes, un peu plus épais vers leur extrémité. - Téte hémisphérique, transverse, son verlex un peu incliné en devant. - Yeux rapprochés dans les mâles, très-espacés dans les femelles. Trois petits ycux lisses disposés en triangle sur. le vertex. - Corps peu alongé relalivement ì son ćpainseur. - Corselet presque de la larreur de la tête. - Ecusson grand, distinctement séparé du corselet. - Ailes assez grandes, plus longues que l'ublomen, conchées l'une sur l'autre dans le repos. - Cuillerons fort petits, balanciers découverts. - Aldomen con posú de six segmens outre l'anus. - Paties de longuenr moyenue; crochets des tarses tourts.

Les Anthonyies dont le nom vient de denx roots grees qui ignilient: mouche desfleurs, conposent in genre cintenaut peu d'especes. L'une d'elles est fort incominode dans les temps de pluie et paroit alor clierclecr à se jeter dans les yenx des hommes et des animaux. Les métamorphoses de ces diplères ne doireut pas différer de celles du genec Houche.

Rapportez à ce genre les Mouches médilulnende (lisez néditibunde), $\boldsymbol{u}^{\circ} .53$ et plaviale, $n^{n} \cdot 70$ de ce Diclionnaire.

MOSILLE, Mosillus. Iast.Musca. Linn. Geoff. IAs. Pasz. OLIV. (Encycl.)

Gene d'insectes de l'ortre des Diptères, section des Proboscidés, famille des Alléricéres, tribu des Muscides.

Neuf geares de celte tribu ont pour caractères commus : cuillerons pelirs; yeux sessiles; autenues plus courtes que liz tête ; corprs conrt; $a b-$ domen salıs prolongeraent à sou extrémité. Dans regrouje les i'hores ont seules les antennes inséréespres de la bouche, les lipuncules sont remarciables par la grandeur de lenr's yeux qui occupent presque toute la tête; celle des Oscines vue en dessus paroît pyramidale. Dans les Anllomyies le trosieme articie des antennes est beaucoup plus long que lapre; les Ochlires ont les palles anlírienres ravisseuses; les Scalophages et les Thyréophones sont distingúes par leur tête globuleuse, enfin les Splixucères ont leurs paltes pos- térieures grandes et arcuées en dehors. On ne retrouve point ces caractères dans le genre Mosille. Antennes insérćes près du milieu de la face antéricure de la tête, plas courles qu'clle, coinposées de trois arlicles, le dernier en fortue de palelle presque triangulaire, guère plus long que le second, porlanl une soie latérale. Trompe épaisse, reçue à sa base sous une espèce de voûte saillante. - I’ète liémisphérique, comprimée transversalement. - Corps courl. - Ailes couchées l'une sur l'autre dans le repos. - Cuillerons petits, balanciers découverts. - Pattes propres pour sanitller.

l'lusieur's espèces de ce grenre fondé par MI. Latreille sont attirées par les substances acides; d'aulres sont soupçonnées de nuire aux plantes céréales; en général elles paroissent différer entr'elles par lés nours, ce qui seinbleroit annoncer que ce genre auroit besoin d'une révision que la nature de cet ouvrage ne nous permet pas d'entreprendre. Les auteur's rapportent aux Mlosilles, les Mouches sautillante $\mathbf{1}^{\circ} \cdot 7^{\mathrm{I}}$, putréfiante $n^{\circ} .80$, frit $1^{\circ} .82$, et peut-être la Houche du seigle ${ }^{\circ}{ }^{\circ} .85$ du présent ouvrage. Celte deraière pourroit cependant ère une Oscine. Il faut encore y adoct. tre le hosillus arcuatus. Lat. Gener. Crust. et Ins. tom. 4. pag. 357, et la MLusca erythrophthalma. Helww. Paxz. Faun. Germ. fils. 17. fig. 24.

\section{(S. H. et A. Serv.)}

PIRINLLE, pirimela. Genre de Crustacés, de l'ordire des Décapodes, famille des Brachyures, établi par M. Léach, et ne différant guère de celui de Crabe, Cancer, que par les calractères suivans. Les antennes inlermédiatres sont replices longitudinalement, et les fosselles qui les reçoivent ont la même direclion. : c'est ce ciu a encore lieu dans les Atélécycles et la Crabe Tourleau (C. Pagurts); leur premier article est aussi plutôt longitudinal que trausversal; le inème des lalérales, proportionnellement plus épaisses que celles des Crabes, est dégagé ou libre el guère plus grand que le suivani. Le troisiène article des pieds-mâtuhoires extérieurs est presque carré, avec le bord suprérien presigue droit et un peu avancé à son angle interne, au-dessus du sinus d'où nait l'article suivant. Les yeux sont petis et porlés sur des péthcules un peu plus longs que ceux des Criabes, et sensiblement courbés ou arcqués. Les serres sont pelites. Le corps est légèrement plus large que long et bumbé au milieu du dos. Les seconds pieds sont aussi longs ou plus longs que tes suivans. Lee post-ibdomen ou lia queue est alongé dans les deux sexes; colui des mâles ne paroit composé que de cinq segmens ou tablelles.

On n'en connoil qu'une seule espèce.

Pirimèle dentelée, $P$. denticulata.

Pirimela denticulata. Léacr, sualac. Podopht. 
Brit. tab, 5. - Cancer derítculatus. Mostac. I'rans. Linn. Soc. tom. 9. tab. 2. fig. 2.

Test long de dix-luuit millinèlres, sur vingt-r?cux de large, très-inégal sur sa moitié postéricure; trois dents an front, dont l'interrédiaire plus tongue; cinq plus fortes à chaque bord latéral, l'antéricure un peu plus pelite; une autre plus foible, près d'elle, formée par un avancement du milieu du bord supérienr de la cavilé oculaire; portion interne du bord intérienr de celle cavilé alvancée aussi en manière de denl. Le carpe et le poing ayant plusieurs arêles ou anguleux; une dent au còté interne du premier ae ces articles; doigts striés, pointus, avec de petiles dentelures presqu'égales; les autres pieds ayant sur leurs bords des franges de puils; quelques cannelures sur les jambes. Dessus du corps d’une jaunâıre pû̉e, mais fortement mélangé de rougeâlıe, dominant même dans quelques individus; $l i c$ dessous d'un blanc luisant, avec des points et des taches rougeâlies.

Côtes d'Espagne siluées sur la Méditerranée, et celles d'Angleterre. (LATr.)

PISE, Pisa. Genre de Crustacés, de l'ordre des Décapodes, fumille des Brachyures, tribu des Tringulaires (voyez cet arlicle), formé, aux dépens du genre Inachus de Fabricius, par M. Léach, et ayant pour caractères : corps en forıne de triangle alongé. - Troisième article des pieds-mâchoires extérienrs ou de la paile inférieure presque carré, échancré ou tronqué obliquement au côté intérne : le suivant inséré dans cette écliancrure ou troncalure. - Les qualre pieds antérieur's et pédicules oculaires de longueur ordinaire ou moyenne. -- Serres des mâles plus grandes que celles des femelles : celles-ci plus courles que les deux pieds suivans ou à peine aussi longues. - Le second article des antennes latérales (sonvent beaucoup plus long que le suivant) s'avançant au-dela de l'origine du museau. - Tarses deatelés ou épineux en dessous.

Ires anlennes latérales sont souvent garnies de poils, terminés en massne. Quelquefois aussi des corpsélrangers s'altachent au nuseau, et c'est sur un individu de la Pise armée ćlant dans cet ćtal, que M. de Lamarck avoit élabli le genre Arctopsis.

Je réunirai aux Pises quelques autres coupes génériques du docteur Léach.

I. Les troisièmes pieds et les suivans beaucoup plus courts dans les mâles que les seconds; cent $x$-ci, et surtout les serres, contrastant singulièrement par leurs longueurs avec les autres. (Le g. Chorinus. LÉaCa.)

1. Prse héros, $\boldsymbol{P}$. heros.

Thorace subovato, tomentoso, spinis quatuor anticis, medis majoribus bubatis; mas chelis pedibusque duobus sequcnibus elongatis.

Cincer heros. Hensst, Frabben, $t a b .42$. fro. I; le lest, tub. 13, entre les fig. 102 ct 103.

'Test petit, presqu'ovö̈le, blanc, mais convert d'nn duret d'un brun-obscur; qualre poinces coniques ct avancées an front; les deax incomédiaires beancoup plus grandes, trés-bartues, thberculfes et pointues; les latcrales petites, formées par le prolongemeni des hords dés cavicís oculaires, un peu arquées el oblases; prortion da test siluée par-derricre, graveleuse. Yeux trìspetils; un tubercule bilide au bord supérieur de leur cavité ; deux dents obtuses et doni la poskírieure plus pelite a chaque bord latéral, derricre ces cavités; le reste de ce bord finement dentelé; impression dorsale ordinaire grande. Piecls sans épines, couverts de duvet; les serres beutcoup plus grandes, avec les mains longues, ej lindriques; les doigts courts, courbés, dentelés, écarlés à leur base; les seconds pieds longs, avancés; les autres brusquement plus petits; longuenr des troisièmes n'ćgalaut guère que lia moilié de celle des deux prócódens; serres des femelles beaucoup plus courtes. 'Troisière articlo des pieds-mâchoires extérieurs marquéàun sillon lougitudinal, ses deatelures trés-petites.

Indes orientales.

II. Longueurs des seconds prieds et des suivans diminuant progressivement dans les deux sexics, ou sans contraste bien maryzié.

1. Bord supériezrdescavités oculaires entier, nu divisé au plus, près de l'angle en forme de dent terminant postérieuremonl ces carlités, par une fissure ou une forle échancruere, sans dent particuliere entre la précédente et l'autre platios (temince par une dent plus ou noins forte) du bord supérieur.

Espèces des mer's orientales:

A. Borla supérienr des cavités oculaires (1) parfaitement entier ou légèrement échuncré, sans fissure. (Tarses ayanit dans la plipart deux rangs de dentclures.)

\section{Pise licorne, $P$. monoceros.}

Fronte unicomi; thorace trigono, tuberculis acutis; tribus utringuce marginalibus.

Test long d'environ dix-sept milliuc̀tres. Corps d'un roussâttre jále, légèrement pubescent, en forme de triangle alongé, déprimé, inégal, aves quelques tubercules, dont quictques-uns velus ou

(1) J'y comprends non-seulement le tronl d'où jaillit le pédicule oculaire, mais encore la fossette postéricure où is se loge dans le repos. 
terminés en manière d'épine; bords laléraux un peu siuués, avec cing ubercules, dont trojs plus Coris, le deruier surtont; unseau avancé en ume pointe conique, longne, horizontale, velue; une dent do chaque côlé, au-devant des yeux, produi e par la saillie de l'angle autérieur du bord supéricur des cavilés ocularles; l'extrémité opposće du même bord point prolongée. Serres grandes avec quelques tubercules sur les bras; carpe presque globuleux; mains alongóes, en carré long ou presque cylindriques et comprimíes, unies; doigls tort courts, blinucs, arqués, finement dentelés et presqu'en cuiller à leur extrémité : une dent solilaire, forte et tronquée, au bord intérieur de l'index, près de sa base; un vide remarquable entre les doights (1). Pieds presque nus, avec quelcues tubercules et quelques poils; les roisiènes et les suivans sensiblement plus conrts que les seconds; rarses à deux rangées de dentelures. La femelle a les serres petites et l'abdomen large, presqu'orbiculare.

lle-de-France, M. Mathiea.

\section{Pise espadon, P. xyphias.}

Fronte unicorni; thorace, trigono, depresso, sublcevi, dentibus utrinquè duobus, alio proeoculari, altero postico.

Test long, depuis l'extrémité du musean jusgu'au bord postćrieur, de onze millimètres. Corps ğlabre, blanclıâtre, très-cléprimé, légèrement iućgal à son extrémité postérienre, en forme de triaugle alongé, se terminant en devant par une pointe on forle dent, barbne ou ciliće sur ses bords; l'extréusite vue de prolil, comprimée et paroissant arrondie au bout. Antennes latérales avancées, fortement encroúlées et divisées en deux branches à leur extrémilé, dans l'individu que je décris. Une petite dent avancée et poiutue de chaque cóté, wn-devant des yeux : ces organes très-petils, presque grlobulenx, un peu saillans; contours 'de" leur's cavite's point saillans. Bords latéraux du lest assez airus, dilatés et aronàis vers leur extrémité poitérieure et letminés par uoe dent. Serres petiles, mentes; mains alongées, cylindriques, avec lez doigts courts, rapprochés, crochus, et dentelés intérieurement daus prosque toute leur longueur; les aulres pieds longs, grêles, unis; un petii avanceucent, tel'miné par un faiscein de poils, an-dessous de l'avantderned arlucle, à pen de distance de son extrémić; tarses compr rués, nolfiant qu'une rangée de denielares. Abramen de la fenelle triangulinite.

Nouvelle-Hollande.

L'Inachus angustatus de Fabricins avoi ine

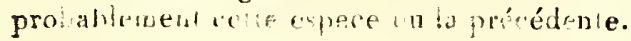

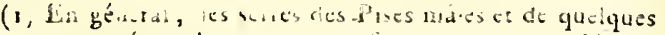
autres crustacés analogues ont une tor ane presque semblable.
4. Prse à oreilles, $\boldsymbol{P}$. aurita.

Fronte spinis duabus longis, porrectis, dissitis, villosis; thorace subovato.

I'est long de quatre centimètres. Corps ovoöđe, convexe, inćgal, de couleul d'os, paroissaul aroí été garni de poils. Deux frounies an front, comiques, longues, droiles, avancées, sćparées par un angle très-ouvert, et velues.Y Yax peu sailluns; bord su. péricur des cavités oculaires nn peu prolongé en manière d'oreillette, trontyuée, largenentent écharrcrée et terminće par deux dents comles, presque égales, uue à chaque extrémité; une dent transverse et pointue par-enrière. Chaque bord latéral du test ayant ensuite quatse dents fortes, tròspointues, spiniformes, dout l'antérieure avancíe obliquement et dont la postérieure plus petite: un tubercule pointu, en deça de la dernière, et en remontant vers le dos; quelques petits ubercules, doat trois disposés eu triangle, vers l'extrémilé antérieure. Serres épaisses, mais un peu plus courtes que les deux pieds suivaus; trois petits tubercules, en une rangée lougitudinilc, et dont l'intermédiairc plus foible, sur le dessus des bras; une dent forte et aiguë a son extrémité; le reste des serres uni; carpes ayant une dépression longitudinale et comme oblusément cureués en dehol's; mains en carré long, comprimćes, avec les doigts coniques, très-pointus, presque droits, sans dentelures. Les autres pied's proportionnellement plus longs que ceux des congéneres, très-bérissés de poils on de soies, sillonués; jambes alongées, aussi longues au moins que les cuisses, s'élargissant un peu vers lemr extrémité; tarses courts, arqués, très-pointus, avec deux rangées de dentelures.

Caual d'Entrecasteaux, nouvelle Hollande; Péron et M. Lesmeur.

Cette espèce est le type du genre $N a x i a$ de M. Léach.

B. Bord supérieur des cavités oculaines divisé, soit par une fissure dont les hords sont contigus, soit par une profonde entunlle. ( $U_{n}$ seul rang de dentelures sous les tarses.)

\section{Prse bélier, $\boldsymbol{P}$. aries.}

Fovearum ocultrium margine supero profunds fisso; fronte spinis duabus subparallelis; thorace subovato, pubescente, fusco, rubro punctalo, utinquè retiorsùn unispinoso.

Longneur du test, depuis l'extrémité des pointes frontales, d'environ six centimètres et dermi. Corps et les pieds, à l'exceptinu des mains, couverts d'un duret noirâtre; teus pointes fories, comicues, un peu parallèles et velues au front; portion ancérieure du bord postérienr des cavilés oculaires, velle qui précéde la fen e, obluse ì son angle pustérieur, prolongé en unanière de dent 


\section{PIS}

courte à l'angle oppostí deax tubercules sur le cos; l'antéricü plus élevé et plns grèie que le suivant, conique; surface du test presqu'naie ailJeurs. Serres de la longueur environ des deux pieds suivatus, mais fortes, onies; le poing en forme de carré long; doigts plus longs, ćloigrnés entr'eux à leur base, avec l'extrémité plas foncée, brune, poinlue, finement et également dentelée; dentclures des tarses peu nombreuses, sinuées près du crochet qu les termine. Màle.

Pondichéry. M. Leschenault de Latour.

\section{Prse barbicorne, $\boldsymbol{P}$. barbicornis.}

Fovearum ocularium margine supero profundè enuarginato; thorace subovato, fiusco-rufescente, pilis elongatis, spinulis marginalibus; fronte cornibus duobus duvaricatis.

Bord snpérieur des carités oculaires profondément écbancré vers sou extrémilé postérieure; parlie quila précède arrondie en devant, teruinée à l'antre bord pal une petite dent; deux autres dents après l'écliancrnee, plus fortes, l'antérieure surtout : celle-ci formant l'extrémité postérieure de cette partie du bord. Corps long d'un pouce, presqu'ovoïde, convexe, peu inégal, d'un brunroussâtre et livide, tout hérissé de poils concolors ou d'un brun tirant sur le blond; deux dents fortes, triangulaires, pointues et divergen'es, au front; côtés du test dilatés et renflés immédiatement après les deuts postoculaires; quatre petites épines en deçà, dont les deus antérieures rapprochées, petites, obtuses, situées derrière les renflemens; les deux postérieures aiguës, écartées. Serres un pcu rougeâtres, pelites, unies; carpes aussi longs que les poings; doigts menus, coniques, Llasis, pointus, sans dentelures. Les autres pieds as:ez grands relativement au corps, Lérissćs de longs poils jaunâtres. Eemelle.

Nouvelle Hollande.

\section{Pise cornigèère, $\Gamma$. comigera.}

Fovearum ocularium margine supero fisso; thorace subovato, retrorsim díatato, valde tuberculato, spunis duabus anticis, porrectis, parailelis; manubus nudis; digitorum apuce coshleari.

Bord supérieur des cavités oculirires sans échancruie profoude, ue présentant qu'une simple îssure, lerminée par deux dents, me à chaque extréaité, et dont l'antérieurc plus forte, en forane dépine et arquée. Corps lougr d'un peu plus de trois centinctres, d'un gris-rou duvet court et terreux, preşru ovoide, dilaté el arrondi postérieurement, tout chargé de iubercules inćgaux; ceux des bords forment des apparences dc deutelares; deux pointes on cornes longnes, grêles, druites, avancées, contiguës et parallèles dans toute leur longueur, terminant le front. Pieds tuberculeux, velus; mains nues, unies, blanches, en carré long; doigts cours, écartés entr'eux à leur base, presqu'cn cuiller on taillés en biseau et dentelés au bout; dentelures des tarses petitcs, peu nombreuses et obtuses. Mâle. Lïndividu femelle de la collection du Jardin du Rni est d'un bon tiers plus petit.

Nouvelle Hollande. Péron et M. Lesuenr.

Nota. Cette espece a de glauds rapporis avec le Cancer plejone diliont; mais ici les deux poinles fiontales sont divergentes el les pieds sonk unis.

\section{Pise styx, P. styx.}

Foveárum oculurium margine supero fisso; thorice subovato, tubercubis sparsis, spinis duabus frontalibus alvusicatıs; pedious spinosis.

Carcer sty $x$. Merest, Krabben, taó. $5 \& . f_{g} .6$. Femelle.

Bord supérieur des cavités oculaires sans échan. crure profionde, nofirant qu'une sinple tissure, avec unc deut spiniforme, droite et avancée à son extrémité antérieure. Corps d'un roussâtre-pâle, un peu plus étroit ou plus ollong, el presque de moitié plus court que celui de l'cspèce précédente, beaucoup morus tuberculé; cornes fiontales plas comrtes. Pieds garnis de poils tuberculés, avec des petites dents aiguës, ou des épiues, à leu tranche supérieure, plus nombreuses et plus apparentes sur les seconds; sertes petites, presque nues, géneralement unies; deux petites épines sur le dessus da bras, l'uue prés di: milieu, l'autrc a l'extrémité; manns presque cylındriques; doigls très-fincment et égulement deutelés et appliqués l'uu contre l'autre, daus presque toute leur longueur. Femelle. Abulomen aruple, presqu'orticulaire.

Ile-de-France. MI. Malhieu.

Je présune que l'Lnachus Uisus de Fabricias, Herbst, tab. 14, fig. $86^{\circ}$, doit être placé dans le voisinage de cette espuce ou des suivantes.

\section{Prse à deux cornes, $P$. bicomuta.}

Fovearum ocularim margine supero fisso; thorice subtrigono, incequal, grinulato, spinulatutrinqué postica, fronte spinas duabus longr, gradu im divaricatss; dente utruque pra'ocuturi.

Espèce lungue de vingl-sept millınèties, voí

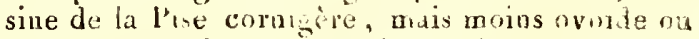
plus triangulaire; taberroles moios nombrenx, cn forme ae grains inégux; deux vers le nuilien de charge bord laléral, surs l'apparence de dencelures. Dessus du test et piteds converts d'an duvet tereux; extrémités du bord supérieur des cavilés oculares ne formant point ac dents saillantes. Pieds velus; Itu tessus, ainsi que celui des bras tuberculé; carpes courts, arronds, unis; 
mains pareillement unies, nues, de conleur cendrée, veinée de blanc, en carré longe; doiģts courts, écartés entr'eux à leur base, deulelés au bout. Extrémité supérieure et latérale des anteones latérales prolongée en manière de dent, a-devant des yeux.

Nouvelle Hollande. Péron et M. Lesueur.

\section{Prse à trois épines, P. trispinosa.}

Fovearum ocularium margine supero fisso; thorace trigono, elongato, spunis tribus posticis; kateralubus validionibus.

Longueur du test depuis l'extrćmité des cornes frontales d'environ vingt-huit millinèties. Corps couvert d'un duvet fin, d'un brun-roussâtre foncé; denx pointes longues, avancées, divergentes, en avant du front; une deist de cliaque côté, au-devant des yeux, formée pir un prolongement du bord supérieur du premier article ledes antennes latérales; contour extérieur des cavilés oculaices un peu avancé, avec uue dent à chaque extrémité, dont l'antérieure uu peu plus forte ; trois élévatious en forme de petites bosses, termin ́es eu poiate, le longr du milieu du dos; l'exp̣rémité supérieure de la dernière prolongée en pointe; deux aulres protubérances arrondies, nue de cluaque côté; angles postérieurs prolongés en une épine trè-forte. Pieds et serres galrnis d'un duvet semblable à celui du corps; doigts courts, dentelés; deux stries sur le dessus du pouce. Abdomen étroit comme dans les mâles des autres espèce :i. Serres pelites.

Nourelle Hollande ? Péron et Lesueur.

2. Bord supérieur des cavités oculaires offrant, près de leur extrémité postérielure, une échancoure oufissure, avec une petite dent au inilieu (distincte de celle qui termine postérieurement ce bord).

A. Front teminé par aeux pointes. (Un seul rang de dentelures aux tarses. Corps inégal, tubercalé et garni de duvet, ainsi que les pieds.)

\section{PISE armée, P. armata.}

Thorace triangulari, oblongo, spinis tribus posticis, validis duabusque anticis; manibus elongatis; pollice triquetro, marginibus acutis.

Pisa nodipes. Lticn, Zool. Miscell. tab. 78. Ejusd. Pise Gibsii. Maluc. Podopht. Brit. tab. I7. - Maja arnata. Lıт. Risṣ. - Cancer muscosus. Rinn. ?-Hersit, Rrabben, tab. 16. fig. 92. - Plaxc. Conc. Append. tab.4. B. - Cancerhirsutus minor. Ádaov. De Crist. lib. 2. pag. 93. - Ejusd. Ibicl. C. hirsutus minimus.?

Iongreux du test des yrands individus, depnis l'eatyémité des pointes frontales, d'environ cinq centimilres. Corps proportounellement phas éroit que celui de l'expéce suivante, avec les protubérances dorsales plas prononcíes, à raison des enfoncemens qui les séparent, et dont deux plus fortes et se terninant en pointe, le long dn milieu du dos; poiutes frontales fort longues?, paralièles ou simplement divergentes à leur extréunité; milieu de l'extrémité postérieure du test prolongé en forme de pointe on d'épinc un peu recourbée; deux autres pointes, mais un peu plis longues vers l'extrérnité postérieure de chaque bord lutéral; trois à qualre petites dents, ou tubercules coniques, enir'clles et les cavilés ocnlaires; un seul tubercule de chaque côté, entre les épines latérales et la base postérieure dn milieu dn tos; plusicurs aulres tubercules aigus près de l'extrémité antérieure du test, derrière le front. Mains plus alongées que dans l'espèce suivante, deux fois an moins plus longres que hautes; doigts presqu'entièrement dentelés dans leur longueur et peu écartés entr'eux, même dans les mấies.

Sur les côres océaniques de France, d'Augleterre et dans lis Mediterranée.

Lil Mä̈a corallina de M. Risso, Hist. nat. des Crust. de Nice, pag. 45, pl. 1, fig. 6, n'est, à ce que je présume, qu'une variélé du jeune âge de la précédente. Elle est peu garuie de dnvet, d'un rouge de corail; les trois épines postérienres sont moins fortes que les mêmes de la précédente, tandis que les antérieures des côtés sont plus aiguës et plus saillantes; mais la première de celles-ci, ou eelle qui vient après les orbites oculaires, n'est jamais plus forte que les autres; c'est le contraire dans l'espèce suivante. Le ponce est arrondi en dessus.

Ce Custacé d'aillcur's ressemble, pour le reste, ì lit Pise armée, et s'il forme one espèce propre, elle est intermédiaire entre la prócédente et la sui. vante, mais plus rapprocluće de la précédente.

Comıune à Marseille, M. Roux.

\section{Prse tétraodon, $P$. tetraodon.}

Thorace subovato, dentibus utrinquè quatuor spiniformibus, aduncis, anticovalidiore; maris digitis ad basin hiantibus, inaice arcnato.

Pisa tetraodon. Líacn, Malac. Podopht. Brit. tab. 20. - Cancer tetraodon. Os.rv. - Cancer praedo. Henust, Krabben, tab. 42. figr. 2. Maja praedo. Bosc. Lat. - Maja tetriodon. Bosc. - Mraja hirticornis. Risso. - Cancer heracleoticus. Rondel.? Aldouvande?

Corps long de près de six centimètres, rongeâtre, presqu'ovoide, parsemé de tubercules hispides; quatre dents spiniformes et crochues, à chaque bord latéral ; la première, ou la plus voisine des cavités oculaires, plus forte; l'antérieure de ces cavités de moitié au moins aussi longre que les 
deux pointes frontales; ces pointes très-barbues, diveryentes; uue élévation, plus ou moins poinlue, près clu anilieu du bord postérieur. Doigts des serres des mâles très-écartés entr'eux à leur origine; l'index arqué à sa base; les poings moins alonarés que eeux de l'espèce précédente, environ une demi-fois plus longs que hauts.

Côtes océaniques de France, d'Angleterre, et celles de la Méditerranće.

B. Front prolungé en une espèce de museau plat, carré, Jèndu a'ans le milieı de sa longueur, avec l'extrénité dilatée et courbée latéralement, en nuanière de crochet arqué et obtus. (Le gr. Lissa. Líach.)

13. Pise goutteuse, $P$. chiragra.

Thorace pedibusque nodulosis; rostro plano, fisso, obtuso, utrinquè ad apicem exteriüs dilistato, uncinetto.

Inachus chiragra. Fa B.-MIaja chiragra. Bosc. L.1т. Rrss. - Lissa chiragru. LËaga. Zool. Miscell. tab. 83. - Henbsr, Krabben, tab. 17. fig. 96 .

Longueur du test, depuis l'extrémité du museau jusqu'an hord postérieur, d'euviron quatre coulianctres et demi. Corps presque triangulaire, dun rouge de corail sur le rivant, glabre; exvímilé antérietare des bords des cavilés oculaircs prolongé eu arant en marière d'oreillette ou de dent forte et obtuse; quatre grosses éminences, cn forme de bosses, au milieu du dus, disposécs cu croix; quatre autres plus petites et en forme degros tubercules par-derière; les deux ciernières réunies et placées au milieu du bord postérieur ; deux autres, placées dans l'aliguement de cclles clu milieu du dos, mais plus petites, l'antérieure surtout, à chaque bord latéral; une éminence plus fuible an mêrne bord, derrịère les cavités oculaires; de petits tubercules granuliformes, épars sur toute la surface da test. Dessous di corps très-inesal. Pieds, it l'exception des serres, cbargés de pelites nodositís; mains unies; le poing en forng de carré, un pen plus long que laige, arrondi sur les tranches; doirgts un peu plus courts, arqués, séparés l'uu de l'atutre par un vide presque circulaire, terminćs en pince conpante et dentelée. Tarses arqués, avec une rangée de très-petites dentelures en dessous.

Dans la Méditerranéc. (LATr.)

PISITOE , Pisitoe. M. Rafinesque donne ee nom à un genre de Crustacés voisin des Phronimes, ot auquel il donne pour caractères d'avoir les ycux mrégaliess, point d'antennes; la bouche sous la tête, recourbée postérieurement et uunie de crochets; six articles an corps et autant de paires de janbes inégales; la quatrième plus grande; queue à quatre articles, les trois an!érieurs à appendices.

Ce genre, qui se trouve dans la mer quibaigne les côtes de lit Sicile, renferme denx espèces: ce sont la P'isitoé à deux épines et la Plsitoé sans épines. La première a deux épines au front et un - 1) ougle aux trois premières paires de pattes; la seconde a le front lisse et deux ongles aux trois premicres puires de pattes. (E. G.)

PISON, Pison. Jur. Ins. Ligut. Sas. 4. Spix. LAT.

Gcare d'insectes de l'ordre des Myménoptères, section des Porte-aiguillon, fitmille des Fouisseurs, tribu des $N_{\text {yssoniens. }}$

Ce genre fondé par M. Jurine dans une lettre eitée par M. Spinola (quatrième fascicule des insectes de Lignurie) avort d'abord reçu de H. Latreille le nom de Tachybule, qu'il a ensuite abandonó pour adopter le premier.

Dans rette tribu les Niceles et les Oxybc̀lez sont fáciles à séparer des Pisons, leurs ailes supérieures n'ayunt que deux cellules cubitales; les Astates en ont quatre, mais la seconde n'cst pas pétiolée; les Myssons qui en ont anssi quatre dont la seconde pétiolée comme dans les Pisons, se distinguent de cenx-ci par leurs yeux entiers.

Anternes de donze arlicles duns les femelles et un peu roulées en spivale; de treize dans les mâles. - Labre petit. - Mandıbules arciućes, unidentées', silonnées longitudiuatcoent. - Palpes maxillazes de six articles presqu'égaux, les labiaux de quatie. - Ieux échancrés. - Premier segment du corselet très-court, ne formant qu'un simple rebord. - Ailes supérieures ayant une cellule radiale grande, oblongue, un peu oudulćc inférieurement, et quatre eellules cubitales, lat première presque earrée, la seconde trèspetite, longuement pétılée, recevaut la première nervure récurrente, la troisième graude, pentagone, recevant la seconde nervure (1). - Ababmen conique.

Les auteurs ne mentionnent qu'une seule espèce; nous iguorons ses muxurs, mais il est ì présuwer qu'elles diffèrent pou de celles des Nyssons.

1. Pison de Jurine, P. Junini.

Pison ater, subpubescens, clypeo argenteo micunte.

Pison Jurini. Sprvot. Ins. Ligur. Sas. 4. pag. 256. - Alyson ater. Ideur. fus. 4. pag. 25. tab. TII. fig. 12. Mîle. - Tachzbulas niger. Lat. Gener. Crust. et lus. tom. 4. pag. 75 . liemelle.

Longueur 4 lig. Corps entièrement noir, lain

(1) Suivane M. Larreille, les dewx nervures récurontos aboutissent dass lia deuxième cellule cubiale. 
sant, irrégulièrement ponctué, un peu pubescent. Chaperon couvert d'un duvet soyeux argenté, métathorax ayant en dessus dans son milieu rue petite fossette striée transversilement el une ligne longitudinale élevéc. Segmens de l'abdomen on peu étringlés ì leur base. Ailes trausparentes. Fesnelle.

Il paroît que le mâle ne diffère pas.

Du midi de la France et des environs de Gênes.

ASTATE, Astata. Lat. Spinou. Sphex. Poss. Dimorpha. Jur.Panz. révis. Tiphia. Panz. Faun.

Genre dinsectes de l'ordre des Hyménoptères, section des Porte-aiguilon, famille des Fouisseurs, tribu des Nyssoniens.

Dans cette tribu les genres Astate, Nysson et Pison ont quatre cellules cubitales aux aites supérieures, mais la suconde de ces cellules est pétiolée dans les deux derniers genres. (Voy.
Prson.)

Antennes filiformes, rapproehées, insérées à la base du chaperon, composées de douze arlicles dans les femelles, de treize dans les mâles, le premier gros, le second très-petit, les autres presqu'égaux et cylindriques. - Labre petit, caché. - Mandibules arquées, sillonnćes en dessus, unidentées sous la pointe. - Mâchoires ayant leur base coriace el comprimée. - Palpes filiformes; les maxillaires deux fois plus longs que les labiaux, de six articles inégaux, le premier petit, le second obconique, le troisième plus épais, convexe en dedans, arqué, le quatrième le plus long de tous, presque cylindrique, aminci à sa bise, le dernier plus mince que les précédens, cylindrique. Palpes labiaux de quatre articles, le premier plus long que les autres, obconique, le second plus large, presque trigone, dilaté à l'angle cxlérieur de son cxtrémité. le troisième obconique, le dernier presqu'orale, rejeté en deliors. - Lève membraneuse, composéc de trois divisions également longres, les Laterales ćtroites; menton coriace, court, presque cylindrique, unidenté de chaque côlé à son Estrénite. - Téte grosse, transverse; chuperon court, petit, hunsversal, tronqué en deviat, conveze dars son milieu, ayaut une impression de chrque cúré. - Feux gुtrinds, réunis postéricurement dans les mâtes. - Trois petits yeux tisses disposés cn triangle sur lefiont. - Segment antéricurda corselect tres-cour, droit, en lorase de rebord; métatiorax tronqué postérieurement. - Ailies supérieures ayant une cellule radiale courte, appendiculée er quatre cellules cubitales, la premicte assez grande, coupée en deux pár une perite nervare peu prononcée, gui descend de la côte; la secondé très-rótrécie ver's la radiale, recevant les deux nerrutes récurrentes, la troisiènie presqu'en losanģe, la qualrictue à peine commencée. - Ausionen court, conique, comgosé de cing segmens ouiro l'inus dans les fe- melles, en ayant un de plus dans les mâles. Pattes de longueur moyeune; jambes épineuses extérieurement surtout les quatre postérieures, l'étant moins dans les máles; tarses antérieur's des femelles très-ciliés. Jaubes de devant munies d'une seule épine à leur extrémité, cette épine ayant une petite membrane interne à sa base, les quatre antres jambes ayant deux ćpines inégales, l'intérieure plus courte que l'extérieure danc les intermédiaires, l'intérieure plus longue que l'autre dans les postéricures.

Ces liyménoptères sont très-vifs et toujours en mouvernent; aussi leur nom vient-il de deux mots grecs dont la signification est : qui ne s'arrête point. On ne counoît qu'un pelit nombre d’espèees de ce grenre fondé par M. Latreille. Elles labitent les lieux sal)lonneux; c'est là que les femelles déposent leurs oufs ainsi que la proie qui doit servir de nourriture à leur postérité.

\section{Astate abdominale, A. abdoninalis.}

Astata nigra, abdomine nitido ferrugineo, apice nigro, alis subfuscis.

Astata abdominalis. LAт. Gener. Crust. et Ins. tom. 4. pag. 6g. - Astaia boops. Sprnol. Ins. Ligur. fas. 1. pag. 72.-Dimorpha abdoninalis. Jur. Hyménopt. pag. 147 . la femelle. Dimorpha oculata. Id. pl.9. Le wâle. - Sphex boops. Ross. Mant. Faun. Etrus. tom. 1. pag. 128. - Tiphia abdominalis. Panz. Faun. Germ. fas. 53. fig. 5. Le wúle. - Encycl. pl. 380. fig. 3. Le wâle.

Longueur 5 à 6 lig. Noire, devant de la tête surtont près des yeux garni d'un duvet blanc argenté. Abdomen ayant ses deux premiers segmens ferrugineux. Les autres et l'anus plus ou moins noirấtres, ainsi que la base du premier. Ailes légèrement enfumées. Mále et femelle.

Des environs de Paris.

Nota. M. Spinola s'est trompé en rapportant à celle espèce comme feunelle la Larra pompiliformis de Panzer, mais contre le sentiment de Jurme il a raison en dósiguant comme inâle la Tiphia abdominalis de l'auteur allcmand.

(S. F.el A. SERT.)

PISSODE, Pissodes. 11. Germar, dans son onvrage intitulé Insectorum species nova aut minùs cognitce, vol. 1. Coléopt. I \&̊n, désigne sous ce nom un genre de Coléoptères de la trịbu des Charansonites, famille des Rhynchophores. Il lui donne pour caractères : rostre presqu'aussi long ou flus long que le corselet, cylindrique, arqué, mince, un peu aplativers le bout, ses fossettes se rejoignant a la base du rostre " fléclies insensiblement pour passer en dessous. Antennes insérées presqu'un milieu du rostre, courtes, coudées, leur preanier article droit, un peu 
en massue, lenr fouet composé de sept articles, ccs articles presqu'ćgaux, lenticulaires, les deux premiers un peu plus longs, obconiques. Massue ovale. Yeux écartés, enfoncés, ronds. Tête petite, arrondie. Corselet convexe, transversal, subitement rétréci vers son extrémité , légèrement échancré au-dessous de. la base de la tête, sans sillon pour recevoir le rostre. Ecusson distinet. Elytres oblongues, couvrant l'abdomen et les ailes, un peu plus larges à leur base que le corselet. Paltes forles, presqu'égales entrelles, les antérieures rapprochées l'uue de l'autre. Cuisses en massue, ordinairement dentées. Jambes armées d'un crochct courbé à leur partie extérieure. 'Tarses courts, largcs, leur avant-dernier article bilobé. Corps oblong, souvent obscur et tacheté.

Les Rlıynchènes dı Pin no. 10, picoté no. 42 , et Panthère $n^{\circ} .43$ de ce Dictionnaire, appartienuent à ce genre. (S. F. et $\Lambda$. Serv.)

PIVE. Sur quelques cótes on donne ce nom à des Crustacés du genre. Crmotroé ( $C$. Asilus, C. (Estrunı), qui vivent sur diverses espèces de poissous, leur font dc larges blessures et donnent ư mauvais goût à leur chair. Voy. Cryotroé.

(E. G.)

PLAGUSIE, Plagusia. Genre de Crustacés, de l'ordre des Décapodes, famille des Brachyures.

Les Plagusies et les Grapses, d'abord réunis dans lc mêmc genre, forment daus la tribu des Crustacés décapodes brachyures ou ì qucue courle, désignée par nous sous la dénomination de Quadrilatères, une petite division très-remarqrable. Le corps est déprimé, presque carré ou trapézoïde, avec les extrémités antérieures des côtés dı test terminées en pointe ou par un angle aigu. Le chaperon s'étend dans presque toutc la Jarryeur autérieure du corps. Les yeux, portés sur de courts pédoncules, sont situés près des angtes latéráux antéricurs et très-écartés l’un de l'an1re. Lc premier article des antennes latérales est courl, large et preş̧u'en forme de cœur. Les pieds-mâchoires extćrieurs sont généralement écartés entr'eux, avec le troisième article plus long ou presquáaussi long que large, et le quatrième inséré près du milieu du sommet du précédent. Lues serres sont généralement conrtes et épaisses. Ial quatrième paire de pieds et ensnite lit troisième sont les plus longues de toutes. Ces Crustacés sc tiennent, sqit à l'embouthure. cles fleuves, soit dans les fentes des rocher's, près des bords de la mer. Ils se retirent aussi quelqnefois sous les racines et les écorces des arbres riveritins.

Nous allons faire connoître les deux genres de celle division.

Les Plargusies diflèrent des Grapses par leurs Hist. Not. Ins. Tome $X$. antennes intermédiaires. Elles sont logées dans deux fissures longitudinales et obliques de la partic supérieure et miloyenne du chaperon. Le troisième article des picds-mâclıoires extérieurs est presque carré, avec le côté extérienr arqué, et lopposé tronqué obliquement ì son extrémité. Le test cst sensiblement plus étroit en devant. La queue ou lc post-abdomen des mâles ne paroit composé que de quatre à cinq segmeus, quelques-unes des sutures interućdiaires étant en tout ou en partie oblitérées. Le test des plus grands individus a environ quatre centimètres de loug. Le même diamètre dans les plus petits est de quinze centimètres.

I. Portion da chaperon comprise entre les antennes intermédiaires inclinée ou point sail. lante en manière de bec; point de dents au bond supérieur des cavités oculaires; une seule aux tranches supérieures des cuisses des deux pieds antérieurs ou des serreset située près de leur base. Dessus du test graveleux ou tuberculé. Mains cannelées, surtout dans les mâles.

Espèces de l'Océan atlantique et des mers des Indes orientales.

\section{Pragusie écailleuse, $P$. squamosa.}

Thorace suprà dilutè rubro, punctis sanguineis, tuberculis ciliatis.

Plagusia squamosa. LAт. Lan. - Grapsus squamosus, Bosc. - Herdst, Krabben, tab. 20. fig. 113. Le mâle.

Dessus du test d'un rougeâtre-clair, ponctué de rouge-sanguin, parsemé de inbercules bortés de cils noirâtres, avec l'extrémité grise. Arête transverse et arquée, formée parla saillie du bord supérieur de la cavité buccale, bidentée de chaque rôlé, an-dessous des yeux, aver trois lobes intermédiaires, tronqués, et donl les latéraux plus lirges et tridentés. Des laches sanguines sur les paites. Dessous du corps jaunître.

Des plus grandes.

Envoyée de 'Ténériffe par M. le marquis do Poudens. M. Lichtenstein, directeur du cabinet d'histoire naturelle de Berlin, l'at reçue du Brésil.

2. Plagusie aplatie, $P$. depressa.

Thorace suprà favo sanouineogue vario, tuberculis glabris.

Plagusia depressa. Lıт. Le mâle. ... Plagusi. immaculata. lam. Le même individa décoloré. - $\mathrm{S}_{\mathrm{AY}}$, Journ. of Acad. scienc. nat. tom. 1. pag. Joo. - Cancer depressus. F'aB. Oliv. Grapsus depressus. Bosc. - Ilerbst, Krabben, fig. 55 . La temelle.

Dessus du corps jaunâtre, mélangé de rouge$\mathrm{T}$ 
sanguia, ponctué de jaunâtre. Tubercules du test généralement moins élevés que ceux de l'espèce précédente, point ciliés; arêle transverse et arquée, formée par la saillie du bord supérieur de la cavité buccalc, unidentée de clraque côté, avec trois lobes intermédiaires; celui du milieu entier, les deux autres tridentés.

Grande ou moyenne.

Pondichéry. Mi. Leschenault de Latour.

\section{Plagusie tuberculée, $P$. tuberculula.}

Plagusia tuberculata. LAm. - LAт. Encycl. méthod. Hi.t. nat. pl. 3o5. fig. 1.

Deșsous du corps d'un rouge de sangr foncé, mélangé de gris luisant ou comme vernissé, particulièrement sur les côtés; quatre impressions d'un blanc-rougeâtre, disposées en croix au nilieu du test; ses tubercules nus ou sans cils, mais très-saillans et rapprochés; arête fornce par le bord supérieur de la cavité buccale très-denteléc; trois dents plus fortes, obluses, dont l'une au milieu et les autres sur les côtés.

Des p!us grandes.

Recueillie par M. Mathiea à l'Jle-de-France. Je n'ai vu que la femelle.

II. Portion du chaperon comprise entre les antennes internuédıaires ayancée en manière de bec, armé de quatre dents, dont deux terminales et les autres latérales; bord supérieur des cavités oculares dentelé; une série de dents aux tranches supérieures des cuisses, à commencer par celles de la seconde paire de pieds; dessus du test sans tubercules; mains sans sillons.

Espèces petites et propre à l'Australasie.

4. Peagusie clavimanc, P. clavimana.

Thorace suprà flapescente, lineis impressis, pubescentibus, fuscis vario.

Pligusia clavimaina. Lat. Lam. - Herbst, Krabben, tab. 5y. fig. 3.

Dessus du test ayant divers enfoncemens garnis d'un duvet obscur ; espaces intermédiaires lisses, d'un jaunc pâle ainsi que le corps, en forme de traits ou de petites lignes inégales. Mains ovoïles, reuflées, sensiblement plus grandes dans le mâle.

Des côtes de la nouvelle Hollande. Péron et M. Lesueur.

5. Placuste serripède, $P$. scrripes.

Thorace suprì sublcevi, pubescente, allucante, punctis rubescentibus; predibus fasciatis.

plagusia serripes. Limars.
Un peu plus grande que la précédente. Dessus du test presqu'uni et prescju'également garni de duvet; corps blanchâtre, avec des points rougeâtres; des bandes de cette couleur sur les pieds.

Les serres manquent aux individus du Muséum d'histoire naturelle.

Côtes de la nouvelle Hollande. Péron et M. Lesueur.

Genre Grapse, Grapsus. LaM.

Les antennes intermédiaires sont logées dans deux fossettes au-dessous du chaperon. Le troisième article des pieds-mâchoires exlérienrs est en forme de triangle renversé et alongé on en denı-ovale, plus étroit à sa base et formant, au côté interne, avec l'extrémité correspondanle du. second article, un angle rentrant. Le test s'élargit vers son extrémité antéricure et n'est guère plus étroit qu'aillcur's. La queue des deux sexes est composée de sept serrmens distincts.

$M$. le chevalier de Lamarck a le premier disingué ces Crustacís des Crabes, avec lesquels Daldorff et Fabricius les réunissoicnt, et a donné à ce genre le nom de Grapse, que l'espèce servant de type avoit reçu de Linnæus. Ces animaux sont répandus sur toutes les plages maritimes des deux Mondes, et la nouvelle Hollande fournit nême une espèce très-reunarquable, tant par sa taille que par ses couleurs (G. masqué). Alais ils aiment la clateur, et !cur habitation a pour limites celle des zônes tempérées. Je n'indiquerai point les diiverses dénominations que l'on dome vulgairement, dans nos colonies du nouveau Monde, aux Grapses. Je me bornerai à dire que ces Crustacés sont les Cériques de vivière des colous de la Martinique (Voyage à la Martinique de Chauvalon); ils sont confondus par d'autres avec les Crabes des Palćtupiers. Leur forme aplatie el piesque carrée, la situation de leurs yeux, la teinle d'un ronge vil et coupée ou ponctuće de jaune qui orne le dessus de leur corps et leurs allurcs, les font aisément reconnoître. “ J'ai vu, dit M. Bosc (noup. Dict. d'Hist. nat. ${ }^{r}$ re ćdit. article GrAPSE), beaucoup de Grapses peinis en Aunérigue, et j'ai observé qu'lls se tenoient tonjonrs, pendant le jour, sous les pjerres el antres corps qui se trouvent dans la iner. J'ai de plus remarqué que, quoiqu'ils ne nageni point, ils ont la faculté de se soulenir momenlanément sur l'eatu, à raison de la liurgeur de levir corps et de ars patles, et cela par le moyen de sauts répetés; ils font ce mouvement toujours de côté, tasiốt í droite, tantôt à gauche, selon les circonstances. Ils vivcar, comme les autres Crustacés, de la chair des antres animaux qu'ils trouvent worts, ou qu'ils peuvent suisir en vie et tirer avec leurs pinces.

* Le Grapse cendré que jai ćual roent observć, I vil daus les rivières ou remonte le flux de la mer, 
oi mieux sur leurs bords : car il est plus souvent hors que dans l'eau. Lorsqu'il paroît quelqu'un dans les lieux où its se trouvent rassemblés, et c'est ioujours ell numbre très-considéruble, ils se sauven dans l'eau, en faisunt un très-griand bruit aves leurs paties, qu'ils trappent l'une contre l'autre.

"Les femelles de ces dèx espèces de Grapses ont des oufs au prizlemps, époque oì elles connnencent à reparoitre; cirr, pendaut l'biver, la preznière reste au fond de la mer, et la seconde, sans doute, enlermée dans les boues."

Cet observateur m'a riconté qu'il avoit trouvé ces Crusincés sous des écorces de vieux arbres, et wême jus:qu’ì une assez grande hauteur. Suivant Rondelet, son Cancre madré ou notre Grapse mélangé vient souvent sur le rivage ou sur les rochers, pour jover ou se soleiller, ainsi que s'exprime cet auteur.

Le test des plus grands individus est long de cinq centimètres, sur six et derui de largeur; cclui des plus petits n'a suère au-dela de huil millimètres de longueur sur onze à douze, dans un sens opposć.

\section{Tarses épineux.}

3. Bords latéraux du test tridentés en devant, l'angle extcrne des cavités oculaires compris.

Quatre érninences presque carrées à la base dis chaperon.

1. Grapse masqué, G. personatus.

Thorace latiore quàmı longiore, lateribus arcuatis, nubro, marginibus maculisque septem favescentibus.

Grapsus personatus. Laмıйcк, Hist. nat. des anim. sans zerteb. tom. 5. pag. 249.

Corps sensiblenient plus large que long, arqué latéralement, d'un rouge pâle, a vec les bords et sept taches, dont trois en avant, trois an milieu, et la septième postérieure et en forme de bande, jaunâtres; mains gravelenses, de cetlc conleur ainsi que les bords des cuisses.

Des plus grands. Nouvelle Hollande. Péron et N. Lesueur:

2. Grapse mélangé, G. varius.

Thorace subquadrato, lincolis, punctis maculisque rubescenti-fuscis vario; mambus lavibus.

Grapsus varius. Lat. Risso. - Cancer marmoratuls. F $\mathrm{F}_{\mathrm{B}}$. Ljusd. C. variegatus, var.? C. marmoreus. OLiv. Ejusd. C'. femoralis. Herbst, Krabben, tab. 20. fig. 114. - Cuncre mudré. Rondelet.

Corps de moyenne taille, presque carré, lérgèrement plus large que long, jaunâtre ou livide, très-mélangé en dessus de brun-rongeâtre foncé, formant de petites lignes, des points et de petites taches; la majeurc partie des pieds de cette couleur; mains lisses.

De moyenue taille. Côtes de la Méditerrance, MM. Dulour, de Serres, Risso et Roux; celles des départenens de la Vondéc ci de la Iroire-iuférieure, M. le docteur d'Orbigny.

Selon M. Risso, cetfe espere quilte plusieurs fois le jour sa demenre pour se prounener an soleil (voyez Roxizete). Il rode, jendant la nuit, afin de rechercher les cadtures rejetés par les tlots. Les femelles pondent chayue fuis de 400 it 500 œuts; elles se tiennent alors, jussu'ia ce qu'ils sojent éclos, sous les pierres. Ce Grapse varie pour la grandeur et la teinte supérieure du corps.

Le Cancer tridens de liobricius est peut-êlre un Grapse de celle division.

\section{Bords latéraux du test ayant en devant doux: dents.}

\section{A. Doigts des mains arrondis et creusés en ma- nière de cuiller à leur éxtrémuté.}

Corps très-aplati.

3. Grapse ficint, $\dot{G}$. pictus.

Corpore pedibusque suprà sanguineis, maculls lineolssque flavidis albidas'e; carpis intùs valide unidentatis.

Grapsus pictur. Lat. LAM. - CатеsB. Carol. tom. 2. tab. 56. - Herbst, Krabben, tab. 3. fig. 33.-Grovov. Mus. $n^{\circ} \cdot 966 .-$ Grapsus albolineatus. Lat. Encycl. méthod. Hist. nat. pl.505. $n^{\circ}$. 3. Variétć. - Cancer strgosus. Hen Bsт, Krabben, tab. 47. fig. 7. La même.

Dessus du corps et des pieds d'un rouge de sang, avec un grand nombre de petites titches et de points jaunatres on blanchâtres, formant souvent des lignes transverses sur les côlés lu test; ćlévations interoculaires gravelcuses, obtusément deutées; les latéralés plus étroites; une saillie grandé et comprimée, en forme de dent au côté interue du carpe. 'Test d'un quart cnviron plus larye que long, arqué et plissé latéralement. Tranches internes des bras peu dilatées, avee quelques dents aignës; mains renllées, luberculées et ridées, a vec une dent pròs l'origine du pouce et le bout des doights blanc.

Aux Aurilles et à la Caruliue.

On a confondu arec cette espèce une autre des mêmes contrées, et que j'ai disliuguce, le premier, sous le nom d'Ensauglanté, Cruentatus. Quoique la description que linarus a donnée du C'ancer grapsas dans le tome quatrième de ses Ancénites académiques soit incouplèle, il paruit néanmoius, d’après la figure dont elle est accompaguće, qu'il a ea en vue la seconde. 
Vans quelques individus du Grapse peint, le rouge dowine moins et le blanc ressort davantage.

Les pinces sont mélangées des deux couleurs. II. Robin a observé cette variété à l'ile de la Trinité, et en a fail hommage à MM. les professenrs et administrateurs du Musénon d'histoire naturelle. Roemer en a représenté une presque semblable.

Ise Grapse raies-blanches, Grapsus albolineatus de M. de Lamarck, et dont j'ai donné une figure dans l'Atlas d'histoire naturelle de l'Encyclopédie méthodique, we paroît former une autre variété. Les caractères essentiels sont les mêmes; mais les aspérités des éminences frontales sont un peu plus saillantes; les impressions dorsales et les plis latéraux du rest sont plus profond's; ces plis sont tistingués par des raies blanches qui, avec d'autres de cette couleur, coupent agréablement le rouge vif du test. Les pinces sont rouges; et cette couleur est plos uniforme ou moins tachetée sur les pieds que dans les individus ordinaires.

Linnæus dit que le Cancer grapsus se trouve en Amérique et à l'île de l'Ascension. Il seroit possible que les individus propres à cette dernière localité se rapprochassent de la variété précédente, recueillie par M. Mathieu à l'Iie-deFrance.

\section{B. Doigts des mains terninés en pointe.}

\section{Grapse ensanglanté, $G$. cruentatus.}

Fronte plicis quatuor edentulis; digitis conicis; carpis spinoso tuberculatis.

Grapsus cruentatus. Lat. LaM. - Cancer grapsus. Lin. FAb. - Cancer ruricola. DE GÉER, Insect. tom. 7. pag. 417. pl. 25. Le mâle. Aratu, Aratu pinima. MancG. Bras. pag. 185.

Grand, d'environ un tiers plus large que long. Corps trapézoïde; son dessus d'un rougeâtre clair ou jaunâtre, avec un grand nombre de p ints et de traits d'un rouge de sang foncé; des taches jaunàtres et arrondies surles cốtés et sur les cuisses. Chaperon tombant brusquement; de petites lignes transverses sur les éminences interoculaires. Còté interne des bras dilaté, arqué, avec un grand nombre de dents aiguës; l'extrémité supérieure de celui du carpe dentelé; mains tris-comprimées, avec les tranches dentelées; jambes garnies de longs poils.

A la 'Tirinitè, Mĩangé. Au Brésil, MM. de SaintMilaire et de Lalande fils.

\section{Tarses non épineux.}

5. Grapse porte-pinceau, G. penicilliger.

Cinereo-albidus, immaculatus; chelis crassis, digitis penicillatis.
Grapsus penicilliger. LAT. LAM.-CUVTER, Rd gne anim. tom. 4. pl. 12. fig. 1. - Ruмrн. Mills. tab. 10. $n^{\circ} .2$.

Corps épais, blanchâtre. Chaperon fort court. Serres graudes; mains lu:ges, presqu'en forme de cour; doig!s garnis en dessus, juscrue près du bout, de poils nombreux, longs, noirútres et divergens; une dent forle et tronquée près de l'extrémité di bord interne (ou supérieur) de l'index; une frange de poils à la tranclie supérieure des cuisses et au côté interne des bras.

Indes orieutales. (LATr.)

PLANIPENNES, Planipennes. Seconde famille de l'ordre des Névroptères. Ses caractères sont :

Antennes multiarticulées, tantót filiformes ou sétacées, lantôt plus grosses à leur extrémité. IIandibules très-distinctes. - Ailes inférieures étendues ou simplement un peu repliées au bord interne, de la grandeur des supérieures ou plus petites (les quatre ordinairement réticulées et toujours nues).

Cette famille se compose de huit tribus et se divise ainsi :

J. 'Tête prolongée antérieurement en manière. de bec ou de trompe.

Ire. Tribu. Panorpates, Panorpatce.

Tarses à cinq articles.

Némoptère, Panorpe, Bittaque et Borée.

II. Tête point prolongée antérieurensent en manière de bec ou de trompe.

A. Premier segment du tronc trc̀s-court, le second -rand, découvert. - Ailes toujours en toit.

a. Cinq articles à tous les tarses.

$2^{\mathrm{e}}$. Tribu. Fourmilions, Myrmeleonides.

Antennes allant en grossissant ou terminées brusquement par un bouton. - Six palpes; les labianx plus longs que les autres et renflés. Tête transverse, verticale. - Ailes graudes. Mandibules cornées.

Myrméléon, Ascalaphe, Nymphès.

3e. Tribu. Hémérobins, Hemerobini.

Antennes filiformes ou sétacées. - Puatre palpes; leur dernier article plus épais, ovoïde et pointu. - Yeux globuleux.

Hémerobe, Osmyle.

b. Trois ou deux articles aux tarses.

4e Tribu. Psoquilles, Psoquilloe. (Voyez ce mot.)

B. Premier segment du tronc le plus grand 


\section{P L A}

de tons, formaut le corselet; les autres couverts par les ailes ouvertes.

a. Ailes inférieures entièrement étendues, finernent réticulées ainsi que les supérieures. - Palpes eourts, filiformes ou un peu plus gros à leur extrćmité.

5e. Tribu, Termitines, Termitina. (Toyez ce mot.)

6e. Tribu. Raphidines, Raphidince. (Joy. ce mot.)

b. Ailes inférieures pliées on courbées an bord interne; leur réseatu ainsi giee celui dẹs supérieures, formé de grranıdes mailles.-Palpes maxilluires, au moins, avancés, presque sétacés, te:minés par un ou denx articles plus grèles, dont le dernier souvent plus court.

$7^{\mathrm{e}}$. Tribu. Mégaloptères, Megaloptera:

Mandibules distineles. - Ailes presqu'égales. - Antennes filiformes ou sélacées. - Turses à cinq articles.

Corydale, Chauliode, Sialis.

8e. Tribu. Perlides, Perlides. Voyez ce mot. (S. F. et A. SERv.)

PLANIFORMES ou OMALOÏDES. M. Dumér.1. a nommé ainsi dans sa Zoologie analytique sa dix-neuvième famille de Coléoptères tétramères. Elle a pour caractères : antennes en masse, non portées sur un bec; corps déprimé. Elle comprend les genres Lycte, Colydie, Trogosite, Cucuje, Hétérocère, Ips et Mycétophage.

(S. F. et $\Lambda$. SERv.)

PLANTISUGES on PHYTADELGES. Nom d'une famille d'Hémiptères dans la méthóde de M. Duméril ( $Z$ ool. analyt.), ayant pour caraetères : ailes semblables, non croisées, souvent ctendues, transparentes; bec naissant du cou; tarses à deux articles. Elle comprend les genres Aleyrode, Cochenille, Puceron, Chermès et Psylle. (S. F. et A. Serv.)

PLAQUE DOREE. Nom vulgaire donné par Geoffroy au Botys palustrata de M. Latreille. ( phaliena palustrata. $\mathrm{F}_{\mathrm{AB}}$ )

$$
\text { (S. F. et A. Senv.) }
$$

PLATYCÈRE, Platycerus. M. Latreille avoit séparé des.Lucanes sous le nom générique de Platyeère les espèces appclées Caraljoïde, Rufipède et Ténébrioidde. Il paroit maintenant abandonner ce gcnre et proposer de rétablir l'intégrité de celui de Lucane en y formant deux sections, la première ayant pour caractère : yeux
DI, 1

coupís par le bord latéral de la tête. raa scconde qui comprend les l'latycères, ayant les yeux entièreinent découverts. (S. F. et A. Serzv.)

PLATYDACTYLES, Plalydactyla. Seconde trihn de la famille des Hyarocorises, section des Elétéroptères, ordre des llémiptères, ayant pour curactèles :

Pałtes antérieures simplement conbées en dessous; leurs cuisses de grandear ordinaire, leurs :arscs allant en pointe et très-cilićs on ressemblant an: tarses des autres paties. - Pattes postérietires tres-cilićes en forme de rames, terminées par deux crochets très-petiis et peu saillans.

lics genies de cette tribu sont: Nolonecte et Curise.

IJota. Les anlenncs sont insérćes et cachécs sous les yeux et tout au plus de la longreur de la tête, comme dans touies les Hydrocorises.

$$
\text { (S. F.et A. SERV.) }
$$
JUR.

PLATYGASTRE, Platjgaster. LAt. Psilus.

Genre d'inseetes de l'ordre des Hyménoptères, section des Térébraus, famille des Pupivores, tribu des Oxyures.

Daus cetle tribules genres Platygastre, 'Télóade, Seélion et Sparasion forment un groupe d:nt je caractère est: antennes toujours condées et insérćes près de la bouche; celles des fenelles plus grrosses à lcur exlrémité. Segrnent antérieur du corselet eourt et transversal. Les Téléades et les Sparasions ont leursantennes de donze articles : les Scćlions comme les Platygüstres n'en ont que dix, mais ceux-là se distinguent de ceux-ci par le peu de longueur du premicr et du troisième articles.

Antennes eoudées, insérées près de la bonche, plus grosses à leur extrémité dans les feurelles, composées de dix articlei, le premier et le troisiène beancoup pius longs que les autres. - Mandibulas terminées par deux dents. - Palpes maxullaires eomposés de dicux articles, ainsi que les labiaux. - Téte grosse. - Trors petits yeuix lisses disposés en triangle sur le vertex, écartés entr'eux.- Corps alongé.-Seghzeni antérieur an corselet court, transversal. - dilles supérieures n'ayant qu'une nervure qui part de la base en sćcarlant peu dubord extéricur et qui est ter- munée par un point plus gros. - Abdomen déprixú, alongé, en spatulc. - Pattes de longue moyenuc.

M. Latreille a donné à ee genre le nom de Pla1) gyastre tiré de deux mots grecs qui significnt: ventre large. Les espèccs qui le composent sont très petiles et rares dans les collections. Leurs larves comme tontcs cclles des hyménoptères de ceite tribu vivent sans doute aux dépens d'autres larves. 
850

1. Platygastre de Bose, P. Eoscii.

Platysaster niger, abdominis feminei basi suprà comulâ, cormu in thoracis dorso reflexo, alis hyalinis.

Plilygasire de Bosc. Lat. Règn. anim. tont. 4. pag. 179. - Psilus Boscii. Јия. Hyménopt. pag. 3 iós.

Longuen 1 lig. $\frac{7}{2}$. Noir. Ailes transparentes. P'remier segnent de l'aljodomen émettant en dessus ma corue qui se recourbe sur le dos du corselet al dont l'extrémité iouche la tête. Feraelle.

On trouve cetle femelle alu mois de juin sur les fleurs en onbelle. Nu sommes de l'avis de N. Jurine et nous ne pensons puilat que la corne que nous venons de décrire sonl le tourrea cle la lalière, son insertion rendant tout-ia-fait invrailserabliable l'opinion contraire.

\section{AN'FEN, Anteon. Jur. Lat.}

Genre d'inectes de l'ordre des llymúnoptères, scction des 'l'érébrans, fanille des Pupivores, tribu des.Oxyures.

Les Antíuns el les Céraphrons forment danscetle. tribu un petil groupe (2oy. Oxyuaes, articie PuPIV.ORES), dont le caraciere est : antennes tún jours condiées, insérées près de la bouche, filifin ures dans les deux sexes. Segment autérieur du corselet conit el transversal; mais les Céraphrons ont leurs anteunes composées de onze articles dont le preinier est très-long, ce qui les distingue des Antéons.

Antemes coudćes, filiformes dansles deux sexes, inséríes pres de lia bouche, composées de dix articles cylindriçues, alongés; le premier arqué, guère pius long que les autres. - Mandıbules iyant trois ou quatre dents. - Palpes maxallaires de six atricles, les labiaux de trois ou de quatre. - T'ele grosse et ronde. - Corselet efti.é postérieurement, son prenier segment court et tíunsversu!. - Alles supérieures ayant une cellule radiale très-incomplète et uue cellule culibale $\mathrm{n}$ étant point séparée du disque et se confondant arec toutes le's autres de la partie calactéristique. - Abdomen plus large que le corselet wesuré entre les ailes, dépriné, rétréci a sa base en forme de pédicule. - Tuutes les pattes semblables.

Nons ignorons la manière de vivre des insectes de ce gense.

\section{Axrios de Juriue, A. Jurineanum.}

\section{Anteon nigrum, pedibus luteis.}

Anteon Jurineanum. LAT. Dict. d'Hist. nat. $2 *$ édit.

Longucur ^. Petit, noir-luisant. Patles jaunes. Mâle.

Des environs de Paris.
Nota. Nous natrons pas vi - et insecte.

CÉRAPHRON, Ceraphron. Jur. LAt SPinol.

Genre d'insectes de l'ordre des Hyméinoptères, section des Térébrans, famille des Pupuvores, tribu des Oxyures.

Les Autéons se distinguent des Céraphrons par leurs antennes de dix articles dont le premier ne surpasse guère les autres en longueur. (Voyez Oxyures, article Popivores.)

Antennes coudćes, insérées près de la bouche, filifurmes dans les deux sexes, composées de ouze arlicles, le premier très-long. - Mand bules dentées, courtes, larges. - Premier segment du corselet court, transversal. - Alles supérieures ayant nne cellule radiale ovale, incomplete; point d'autres cellules distinctes, la partie caractéristique se trouvant contondue avec la presque totalicé du haut de l'aile ou partie brachiale. - Abdomen presqn'ovorde, comprimé, à pédicule très-court. - 'T'outes les pattes semLlables.

On ne connoît point les mœurs des Céraphrons. El'es doivent se rapprocher de celles des autres Oxyures.

\section{Céraphron sillonué, C. sulcatus.}

Ceraphron niger, pedibus rufis; alis subfuscis.

Ceraphron sulcatus. Jun. Hyménopt. pl. 14.L.AT. Gener. Crust. et Ins. tomil. 4. pag. 36. Spinol. Ins. Ligur. fas. 3. pag. 168. - Encycl. pl. 577 . fig. 2.

Longueur 1 lig. Nuir. Palles d'un brun-ferrugineux. Ailes un peu enfumées.

D'Europe.

Nota. Nuus "n'avons point vu cet insecte. 11. Spinola nous paroît avoir tort de rapporter à cette espèce le Scelio rugosulus de M. Latireille.

(S. H. et A. SERV.)

PLATYNE, Platynus. M. Bonelli dans son ouvrage intitulé : Observ. entom., inséré dans les IMém. de l'Acad. de Turn, a douné ce nom à un genre de coléoptères appartenant à la tribu des Carabiques. Ses caractères sout : labre trausverse, entier. 'Tous les palpes ayant leur dernier article cylindrique, ovale, à peine tronqué. Corps trèsdépriné. Corselet sessile. Abdomen très-large. Menton ayant nne dent simple, obiuse, à l'extrémitć de la saillie du milieu. Elytres échancrées obiquement, sans points discoidaux remarquables. Point d'ailes.

L'auteur fail enirer dans ce genre.les Carabus ungusticollis et scrobiculatus de Fibricius. (S. F. et A. SERv.)

PLA'TYNO'TE, Platynotus. Genre de Coléoptères bétéromères établi par k'abricius (Syst. 


\section{P L A}

Eleut.), sur quelinues espèces exotignes du genre l'édine de M. Latreille, auxqueiles il associe des Asidesdu même auteur. Ce genre n'cst point adopté par les entomologistes fiançais.

\section{(S. F. et A. Senv.)}

PLATYONIQUE, Platyonichus. Genre de Crustacés de l'ordre des Décapodes, famille des Brachyures, tribu des Nageurs, ayant pour caractères: tous les tarses (les serres exceptées), les postérieurs surtout, aplatis el en nageoires. - Test presqu'isométrique, d'une forme se rapprochaut de celle d'un cour tronqué postérieurement, ou suborbieulaire; espace pectoral compris entre les pieds, ovale. - Pédicules oculaires courts. - Seconde vaire de pieds aussi longine au moins que la suivanit. - Antennes latérales beaucoup plus couries quele corps, presque glabres. -Troisième article des pïcds-mấchoires extérieurs tronqué ou arrondi obliquement au sommet, avec un sinus interne sons le sommet, servant d'insertion à l'article suivant. - Post-abdomen ou queue des nâles de cinq segmens distincts; celui des femelles de sept.

Chaque côté du test, dans toutes les espèces connues, offire constanment cinq dents.

La dénomination de Portumnus, sous laquelle M le doeteur Léach a désigné ce geure, sitaul presqu'identique avec celle da genre Porlunc, j'ai proposé, dans la seconde édition du nouveau Dictionnaire d'Histoire naturelle, de lıi substituer celle de Platyonique. La manière dont je signale ce gente me permet de lui réunir celui que le même naturaliste a publié sous la dénomination de Polybius. Dans l'espèce (Variegatus, Léach) qui sert de type an genre Platyonique, ainsi que dans un grand nombre de Portunes, les tarses, à partir de la scconde paire de pieds jusqu'à la quatrième inclusivement, out une forme comprimée et se rapprochaut de celle des nagevires postérieures. Ces tarses sont plus élargis et plus menıbraneux dans les Polybies; mais leuis rapports areciles nageoires sont essentiellement les mênes que reux que l'on observc entre ces parlies dans les Crustacés précédiens. L'abdonıen est eepiendant presque semblable à celui de plusievrs Ṕortunes. Il est en forme de triangle alongé, et son troisième article est dilaté de chaque côté à sa naissance. Les yeux sont plus gros que dans les autres Platyoniques. Les autennes intermédiaires se replient Iransversalement, et le preaier article se prolonge dans la même directiou.

Les habindes particulières des Plaíyoniques me sont d'ailieurs incounucs. Elles doivent se rapprocher beaucoup de celles des Porlunes, avec lesquels ces animaux ont ane grande athini. Le test des plus grandes espèces est long de cing centimètres, et celuides yius petils de deux.
1. Front asancé en manière de museau trianculaire et simplement ondulé sur ses bord's. Test bombé.

\section{x. Peatyonique musclier, $P$. nasuíus.}

Thorace convexo, antrorsim in rostrim trigonum, subintegrum producto.

Portunus biguttatus. Risso, Hist. nat. des Crust. de Nice, pl. 1. fig. 1.

Très-petit, glabre. Dessus du corps d’un jaunître-roussâtre pấle ou couleur de noix et sans laches, dans l'individu nnique que je possèce el qui est une femelle. Dessus du test inégal, mais sans aspérités, bombé au milieu, déprimé au devant, avee cinq dents eourtes, larges, dont la poin:e est tonrnée en avant de chaque côté; la première un peu plus large et un pen échincréc ; la dernière plus étroite; le musean en forine de triangle presyn'isocèle, avec une pointe obtuse à son extrémité et denx fojbles sinus à chaque bord latéral. Une seule fissure au bord supérieur des cavités oculaires. Serres petiles; carpe ayant des arêtcs en dessus et dilaté au côté interne en uranière de dent déprimée; le pring plus court que le doigt, sillonné longiludinatenent en delors; arêtes assez vives aiusi que la tranche supéricure; une frange de poils sur la paume; doigts comprimés, strićs, pointus, avec de pelites dents aux bords iuternes; les autres pieds comprinsés, avec des stries sur les jambes et sur les tarses; les nayeoires des deux deruiers presqu'elliptiques, acui: iués, avec la pointe assez prolongće el wis-aiguc; wo ligne rilevée et lissc parcourant le milieu de len longueur; lenr bord in!erne el celui des janibes des mêmes pieds garnis d'une frange de poils; bout de tous les tarses noir. Dessous diu corps et mêrne la majeure partio des pieds blanchâace.

Si ce Crustacé est, comme je le présume, le Portune à deux taches de Mi. Risso, son teot oflie, dansles individus vivans, deux prandes taches d'un rouge de corail, el qui sont plus griandes dans les fenelles. Leur ponte a lieu en mai ct en août. Les wufs son! d'un jaune-doré. Celle espèce se Irouve dans la Médienranée cl labite la rígion des Coraux. Je stis redevalle a l'amitic de M. Je docteul dorbigny de l'individn que je posside. Il l'aroil pris sur les côles maritimes du départeneat de la Vendée; uaris il paroîi que ce Crustacé.y est très-rare.

II. Front peu avancé, trilenté (les dents latérales formées parla division interne des oculaires); dessus du test plun ou peru convexe.

1. Test un peu plus large que long, très-arqué latéralement; longueur de son bord antérieut, juqu'aux angles extérieurs dess cavités oculawes, faisant la moitié du plus grand diumetre transversal de ce test; nageoires itrsales ou celles des deux picds postéricurs, grandes, oviles. 
Dents frontales et serres proportionnellement pius graudes que dans la dernière division.

\section{Platyonique ocellé, P. ocellatis.}

Pinnis posticis magnis, ovatis; thorace latiori quàm longiore, scabriusculo, flavescente, punctis fulvis; dentibus lateralubus validis, spinifornubus; vediculis ocularibus subcylindricis.

Cancer ocellatus. Herist, Krabben, tab. 49. fig. 4.-Portunus pictus. SAY, Journ. of the Acad. of nat. Scienc. tom. 1, pag. 6\%. pl. 4. fig. 4.

Grand. Dents fronlales pointues, presqu'ćgales; celle du milieu un peu plus grande; lcs latérales grenues sur leurs bords. Cóté interne des bras dentelé et vclu; deux dents sur le carpc, l'une extérieure, l'autre iuterne et plas forte; lc poing et le pouce trièdres ou ì trois pans, avec l'arcte antérieure très-forte, rongcâtre, ainsi que les doigts; une frange de poils sous lia tranche supévieure et une antre plus petite derrière l'index; ces doigts inégalement et forlement dentés. Les second, troisième ct qualrièmc tarses étroits, avec plusieurs stries; les nageoires formées par les derniers unies. Une seule fissure au bord suppérieur des cavités oculaires.

États-Unis. Apporté de la Caroline par M. Bosc.

\section{Pratronique de Henslow, $p$. Henslowii.}

Pinnis posticis nuagnis, ovatis; thorace lationt quàm longiore, sublovi, lineolis albidis; dentibus lateralibus brevibus, latis; oculis claratis.

Polybius Henslowii. LEAca, Malac, Podoplbt. Brit. tab. 9. B.

Très-grand. Dents fiontales dentelkes; la mitoyenne plus étroite, aiguë; les latéralcs obtuses; dcux lissures au bord supérieur des cavités oculaires. Les pieds d'un bimn-foncé. Les second, troisic̀ne el quatrième tarses très-comprimés, en forme de nageoires triangulaires, alongrées, presqa'nuis, avec une ligne de points enfoncés plus ou moins réunis, au milieu, el frangées de poils, ainsi que l'article précédent qui est lui-même comprimé; quelẹues dentelures au côté interne du Lyas; ane émitenec angulaire sur le dessus du carpe; une dent acééée à son côté internẹ. Mains robustes, un pen et finement clanrinées, avce quelciues arétes; la supćriesre terminée en pointe; doiggts, surtout liudex, forts et très-deintés.

Côtes d'Augleterè, M. Lćach; cclles du départemeat de la Vendée, MI. d’Orbignğ.

3. Test aussi long que large; la longueur de son bond antériezrjusqu'uux argles extérieurs des cavités ocularies sterpassant la moitié du plus grandidianietwe transwersal; nageoires tarsaies ou celles des deux pieds postćrieurs presque elliptiques.

Dents du chaperon petites, obtuses; la mitoyenne un pen plus longue; celles des bords latéraux courtes; l'antérieure plus grande ct la postórieure plus petite; le poing comprimé, surtout au bord supérieur, sans arêles, s'unissant inférieurement avec le carpe dans presque toute la longueur dc cet article; tranclue supérieure de cet article terminée par une dent; une petite frange de poils. at-dcssons de ce bord et sous le même du poing; le dernier article de la jambe et le tatse des second, troisième ct quatrième pieds, striés; les nagoires des deruiers unies.

\section{Platyonreve dépurateur, $\boldsymbol{P}$. depurator.}

Pinnis posticis oblongis; thorace subcordato, diametris suboqualibus.

Cancer depurator. Lins. - Portumnns vanegatus. LÉacu, Malac. Podopht. Brit. tab. 4. Pianc. de Conc. min. not. tab. 3. fig. 7. B. C. Mâle. - Herast, Krabben, tab. 54. fig. 6, et tab, 21 .fig. 126?'- Cancer latipes. RondeIET.

Petit. Blanchâtre, mais avec une teinte d'un brun cendré ou rougeâtre sur le dessus du test ct $\mathrm{y}$ formant soit des points très-nombreux, soit une marbrure très-fine. (Voyez l'arlicle Crabe de cc Dictionnaire, espèce $11^{\circ} 46$, Cribe rauneur.) Sur les côtes océaniques de la France, de l'Angleterre, et sur celles de la Médilerranée.

A ce genre, et particulièremcnt à l'espèce avec laquelle le doctenr Léach a formé celui de Polybie, se rattachent les Matutes et les Orythies, et dont nous traiterons supplémenlairement. Ce sont des Crustacés décapodes, brachyures et nageurs, $\mathfrak{a}$ forme orbiculaire, et qui nous présentent lẹs caractères communs suivans.

Antennes miloyenues beaucoup plus longues quc latérales, se repliant tranversalement sous le bord anlérieur du fiont, mais souvent saillantes; Ia fossctic où est logée lcur premier article, pres'quaussi longue que large. - Corps prcsqu'isomélique, d'une forme se rapprochant de l'orbiculaire, déprimé, presque glabre; son dessus ayant quelques petits tubercules et l'impression dorsale ordinaire, d'ailleurs assez uni et finement chagriné. - Youx situés à l'extrémité de pédoncules assez longs, presque cylindriques, un peu plús gros à leur bise et un peu courbes; leur's cavitćs occupant une grande partie de la largeur antérieure du test. - 'Troisième arlicle des pieds-nıâchorres extérieurs en forme de triangle étroit et alongé. Division extérieure de ces pirties oul le flagre sans ligre articulće à sou cxtrémilé. - Tranclie supérieure des mains plus ou moins dentelée, un peu en crête; doigts comprimés, pointus, dentelés; les seconds pieds plus longs que les suivans, 
suivans.Poitriue ovale.-Abdomen des máles composé de sept segmens, de même que colui des fémelles, ou n'en ayant que cinq, mais offrant les vesliges des sutures des denx autres.

Espèces propres aux mers orientales, depuis I'Tle-de-France jusqu'ì la Chine et à la nouvelle Hollande inclusivement.

Genre Matute, Mituta. Fab.

'Tous los pieds, à l'exception des serres, en nageoire. Antennes latéráles très-petiles. Troisième article des pięds-mîchoires terminé en pointe: tels sont les caractères essentiels de ce genre. Exposons maintenant eu détail ses caractères naturels.

'Tous le: pieds succédant aux serres terminés en nageoires. Corps arqué et arrondi antérieurement, rétréci triaugulairement à sa partie postérieure, déprimé en dessus près du'front, avec une pointe très-forte, conique, s'étcndant latéralement de chaque côté, près du milieu; portion antérieure des bords dentelée (1), l'autte portion de ces bords ou celle qui vient après les pointes, rebordée; inilieı du bard autérienı avancé en mauière de lobe presque carré, uu peu échancré on presque bidenté à son extrémité; le reste de ce bord droit et fermant de chaque côté l'angle interne el supérieur des cavités oculaires. Antennes latérales tiès-petites. Le premier article de leur pédoncule aussi long au moins que le reste de l'antenne, cylindrique, insćré avec le tubercule auriculaire au-dessous de l'arlicle radical des antennes intermédiaires, transversal; les deux autres articles de ce pédicule avec les trois à quatre dont se compose la tige, formant une petite pièce conique, et qui se termine au-dessous de l'extrémité de l'hiatus inférieur des cavités oculaires. Les secoud et troisième articles des pieds-mâchoires éxtérieurs formant avecle pédonsule conique et alongé dn flugre un grand triangle très-pointu; sommet fermant exactement la bouche; bords internes de ces deux articles droits; les trois derniers intérieurs et cachés. Serres fortés; tranches des poiugs aiguës, dentées; la supérienre frangée; trois impression transverses au-dessous, forinanı des plis, avec deux rangées de tubercules; d'autres éminences, et dont une à trois plus grandes, coniques, spiniformes, plus bas; quelques dents très-petites sur les cuisses; avaut-dermier article des autres pieds très-aplati; sa tranche iuterne anx seconds pieds et aux qualre suivans, son côté postérieur aux deux derniers, dilatés triangulairement; celte saillie recouvrant une partie du tarse ou de la nageoire lorsqu'il se

(1) Les trois dencelures postéricures sont ordinäirement plus fortes. Le dos oifre six perits tubercules disposés sur truis lignes transverses, de ta manière suivante: $2,3,1$; on en voit que'quefois un ausre sur chaque rebord latéral et postérieur du rest.

Hist. Nat. Ins. Tome $\boldsymbol{X}$. replie ; plus grande, arrondie aux deux derniers, termince en pointe aiguë aux alutres; les tarses des niêmes pieds très-ilplatis, en forme de nageoire, avec une arête écrasée et arrondie dans le milieu de leur longueur; les six premières nageoires, ou celles des second, troisième et quatrième pieds, presqu'elliptiques, poiutues, d'une étendue diminuaut graduellement; colles des quatrième picds petites et élroites; les deux dernières presqu'orbiculaires, obtuses, presqu'aussi grandes que les deux premières; celles-ci un peu crochues au bont, leur bord interne ćtant presque droit et un peu concave, et le bord opposé étaut argué; extrémité de l'article qui les précède, bord interne de saillie du même article, aux deux pieds postérieurs, le niêue bord de leur nageoire et quelques autres parties, grarnis de franges de poils. Le premier segment du post-abdomen très-court, linéaire, resserré au milieu; le troisième et le second ayant une carène transverse et dentelée. Dessus du corps januâtie ou roussître, ponctué d'un rouge de sang; une taclie de cette couleur, mais plus vive, sur les deux derniers articles des denx ou quatce pieds antérieurs et des deux dernicrs, dans plusieurs individus; dessus do ces pieds et des antres ponctué aussi de rouge; le dessous du corps d'un blanc luisant. Partie ctu flagre et l'adjacente de lis poitrine graveleuses ou chargées de petits graius élevés et alongés.

Lorgueur du test des plus grands individns, o mèt. 044; largeur, o mèt. 047. Ces proportions réduites de moitić dans les plis petits.

Le docteur léach est le premier qui ait employé des caraclères rigourensenient propres à distinguer les espèces. Il en a décrit et figuré deux dans le troisième volume de ses Mélanges de Zoologie, l'nue sous le nom de Lutraris, que je lni avcis tonné d'après Herbst, et l'autre sons celui de Peronii. La première est probablement celle que Fabricius appelle Planipes. Herdst l'a confondue avec celle gu'il avoit représentée antérieurement sous la même dénounination, et qu'il a empruntée de Rumphe. La seconde espéce avoit été décrite par Fabricius : c'est son Portune lancifer. Les pinces des serres nous fuurnissent les différences les plus importantes.

I. Milieu de la fuce extérieure du poing ayant à la sunte de deux ou trois dents plus fortes et latérales une carène pre'squ'entiére, ou ayant simplentent deux incisions prolongées sür tindex ( tout l'espace adjacent jusqu'au bord inférieur, ou la mijeure partic de cette face très-lisse et luisunt); une ligne élevée, forte, strice transversulement, le long du milieu dus pouce.

Dessus de ce doigt ayant un sillon piofond servant d'insertion aü poils de la fiange; pointes latérales du test tant soit peu portées en avant; 
l'espace compris entre la carène du poing el l'origine du pouce proportionnellement plus étenda que dans les espèces suivantes; carène du second segment abdominal moins saillante.

I. Matute lunaire, M. lunaris.

Pugillis tuberculis validis, subarqualibus; testâ punctis rubıis, reticulatis.

Matuta lunaris. LÉACH, Zool. Misccll. tom. 3. pag. 13. tab. 127. fig. 3-5. - Matuta planipes. FAB. - Cancer lunaris. Her Bst, Krabben, tab. 48. fir. 6.

Premier ayticle des jambes des troisièmes et quatrièmes pieds alyanı en dessus deux petites carènes longiludirales; 1 ubercules (3 et 4) supérieurs du poing forls, presqn'égaux, arrondis, unis et continus; trois dents triangulaires, petiles (la seconde surtout), presque tuberculiformes, et dont l'antérieure un peu plus grande seulement que la postérieure, précédant la carène de son nilieu; points rougeâures du test formant des lignes réticulées.

Des plus grands. Les six tubercules dorsaux du test dislincls; les deux pointes latérales un peu plus courtes que celles de l'espèce suivanie. Tranche inférieure de l'index un peu rebordée; stries de la ligne élevée du pouce oblitérées dans notre individu.

Sur les côtes de l'Ile-de-France. M. Mathieu.

\section{Matete doryphore, $M$. doryphora.}

Pugillis tuberculis incrqualibus; testâ vagè rubro punctatâ.

\section{Cancer lunaris. Fonskanz.}

Une seule carène sur le dessus du premier article des quatre dernières jambes; deux sur le dessus du même article des troisièmes jambes; tubercules supérieurs du poing inégaux; quelo ques-uns un peu pointus, $d^{\prime}$ autres graveleux; leur rangée inférieure interrompue; deux dents (outre un pelit tubercule intermédiaire) coniques, et dont l'antérieure fort grande, spiniforme, avant la carène du milieu de cet ar!icle; tout le dessus du test vaguement et finement pointillé de rouge.

De la laille du précédent. Pointes latérales du test très-fortes, de la longueur du bord supérieur du carpe; tubercules dorsaux moins saillans que dans l'espèce précédente.

Ile-de-France, golfe Arabique, Indes orientales; Pondichéry, M. Leschenault de Latour.

II. Milieu de la face exiérieure du poing sans carène, ou n'ayant qu'une foible élévation et point prolongée sur l'index; des petites éminences tuberculiformes ou des dents (1) à la

(1) J'ai observé sur un grand nombre d'individus de l'espèce suivante, envoyés de Poadichéry par M. Leschenault place (espace adjacent et lisse très-peucétendu); le côté extérieur du pouce uni ou légèrement élevé et très-foiblement strié dans son milieu.

Sillon supérieur du pouce foible; sa frange plus petile ; l'index ayanl inférieurement un rebord, paroissant, dans quelques individus, naîlse du poing, et quelquefois même divisé eu tubercules; dents internes de la base de ces doigts plus divisées, ou ayant moins la forme de dents molaires que les mếmes des deux premières espèces. Premier article des jambes conformé de même quie dans la seconde.

\section{Mature victorieuse, M. victor.}

Matata victor. Fab. - Herbst, Krabben, tab. 6. fig. 44. - Rumpe. is. tab. 7. S. - Ma-

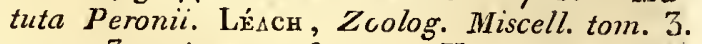
pag. 13. tah. 127. fig. 1-2. Var. - Porturus lancifer. FAB. Même variété.

Individus de Pondichéry de moyenne grandeur, avec les deux pointes latérales forles et un peu rejetéęs en arrière, à leur extrénité. Individus de la nouvelle Hollande plus petits, avec les éminences remplaçant la carène du poing, propre aux deux prenières espèces, plus fortes, presqu'en forme de denıs, et dont celle du milieu plus grande; rebord inférieur du poing divisé en tubercules dans les jeunes individus; pointes latérales du lest un peu plus courtes; ses bords la!éraux et antérieur's offrant chacun, dans presque tous les individus de celte espèce, immédiaiement avant la pointe du milieu des côtr's, trous dentelures pius grandes que les autérieures ou celles qui viennent à la suite de la dent formće par l'angle antérieur; ces trois dentelures moins distinctes, à raison de leurs crénelures, dans la plupart des autres espèces.

\section{Le Crabe ă pattes plates (latipes) de De Gćer,}

de Latour, que les mâles n'ont sur le rudiment de la carène de cet article, à la suite des dcux pointes latérales et semblables pour les tormes et les proportions relatives à celles de l'espèce $n^{\circ} .2$, qu'une a trois putites ćminences; que dans les femelles, ou le nombre de ces élévations est ordinairement de trois, celle du nilizu est plus grande, de la forme des pointes latéraĩes, mais plus perites. Les deux autres saillies sont plus prononcécs dans les Matutes de la nouvele Hollande, celles done M. Léach fait uie espèce (de ['éron), mais qu's! s'est burné à comparer avce la première. Je n'ai vu que des individus mâle's de celle-ci et de celle $\pi^{\circ}$. 2. Les ditférences sexuelles indiquées ci-dessus leur sont peut-être communes. Mlais dans l'une et l'autre espèce, la carène du troisième segment déborde forrement la première ou celle du second segment, tandis que les deux carc̀ues sont à peu près de niveau ou presqu'égales et dentelécs dans la troisième espèce. D'après ces transitions graduelles, je suis tenté de croire que les trois espèces n’en torment naturellement qu'rne, mais composée de flusieuis variétés produites par l'influence du climat. Il $\mathrm{m}^{\prime}$ a paru encore que certaines éminences s’affoiblissoient avec l'âge. 


\section{P L A}

IJém. Ins. tom. 7. pl. 26. fig. 4 et 5, est évidemment du genre Matute. Si la figure quil en a donnée est exacte, cette espèce est distinguée de toutes les autres par la forme de la saillie frontale; son bord antérieur est tout-à-fait droit ou sans avancement au milieu. Cette Matule seroitelle particulière aux Autilles? C'est ce que jignore, mais qui seroit possible.

Genre Orithy Ie, Orithyia. Fab.

Les deux tarses postérieurs en forme de nageoires. Corps rélrécí et tronqué antérieurement, presqu'orbiculaire ensuite. Voyez, pour les autres détails, l'article Orituye. (Latr.)

PLATYOPE, Platyope. Genre de Coléoptères héléromères voisin de celui de Pimélie, établi par M. Fischer dans l'ouvrage ayant pour titre : Genre d'Ins. publiés au nom de la Soc. imp. des nat. de-Moscou, 182 r. L'auteur lui donne pour caractères : antennes insérées loin des yeux sous un appendice réfléchi du chaperon, leurs articles allant en grossissant et plus séparés les uus des autres vers l'extrémité, le dernier globuleux et tronqué. Labre presque carré, distinctement écliancré. Palpes inógaux, les maxillaires gros et courts, le dernier arlicle obconique, tronqué; eslabiaux extrêmement foibles, filiformes; meuton très-échancré, ses côtés triangulaires et pointus. Corps triangulaire. Elytres un peu plus larges que le corselet, slongées, rriangulaires, trèspointues. Corselet chargé de tubérosités. Jambes courtes, dentées en scie extèrieurement. Tarses postérieurs longs, comprimés. M. Fischer en décrit trois espèces; l'une d'elles est l'Akis leucographa de Fabricius; l'auteur la figure Entom. Russ. Col. pl. 15. fig. 2. Les deux autres paroissent nouvelles, et sont de la 'Tartarie déserte. La première nommée Platyope granuleuse ( $P$.grunulata) Col. pl. 15, fig. 1, est longue d'un pouce, noire, courerte d'un duvet blauc. Corselet et élytres granuleux, avec trois raies élevées, crénelćes. L’autre, la latyope proctoleuque ( $P$. proctoleuca ), Col. pl. i5, fig. 3, a 7 lignes. Elle est noire, à corselet raboleux; ses élytres sont lisses avec des raies apicales courtes, bianches. (S. F.et A. SErv.)

PLATYPE, Platypus. Herbst. Lat. Bostrichus. Fa b. Scolytus. OLIv. (Entom.) Panz.

Genre d'insectes de l'ordre des Coléoptères, section des Tétranères, fanille des Xylophages, tribu des Scolytaires.

Ce genre établi par Herbst et adopté par M. Latreille se distingne des Phloiothribes parce que ceux-ci ont la massıe des autennes composée de trois longs feuillets distincts; des Hylurges, des Scolytes et des Hylésines par le pénultiène article des tarses qui est bifide dans ces trois genres, et des 'Tomiques parce que la massue des an- tennes de ces demiers est distinctement anuelée et ne commence qu'an septième article.

Antennes à peine de la longueur de la tête, n'offrant distinctemeni que six articles, le premier et le dernier grands, les intermédiaires trèspetits, le sixième ou la ma isne solide, presqu'ovoïde. - Labre étroit, peu a vancé, corué, légèrement échancré. - Mandrbules courtes, épaisses, cornées, pointues, presque dentées.-Palpes petits, coniques. - Tête un peu prolongée antérieurement. - Corps cylindrique, linéaire. - Corselet alongé, cylindrique. - Ecusson nul. - Elytres tronquées postérieurement, tuberculées ou épineuses dans cette partie. - Pattes comprimées, les deux dernières éloignées des qualte autres; toules les cuisses comprimées, auguleuses, les quatre postérieures canaliculées en dessous; jambes courtes, strićes transversalement dans leur partie postérieure, celles de la première paire terminées par une épine aiguë; leurs tarses trèsgrêles, plus longrs que les cuisses et les jambes prises ensemble, leur premier article très-long; tous les tarses ayant leurs articles entiers.

On trouve ces insectes sur les arbres en partie cariés dont il paroît qu'ils se nourrissent dans leur premier état. Les auteurs font nuention de lutit ou dix espèces de Platypes; leur couleur dominante paroit 'être le brun-noirâtre. Ils n'affectent point de patrie particuliere.

\section{i. Platype cylindre, P. cylindrus.}

Platypus elytris posticè truncatis, post truncaturam villosiorbus.

Platypus cylindrus. Hersst, Col. 5. tab. 49. fig. 3. - LAт. Gen. Crust. et Ins. tom. 2. pag. 277. - Bostrichus cylindrus. FАв. Syst. Elent. tom. 2. pag. 384. $n^{\circ}$. 2. - Panz. Faun. Germe. fas. 15. no. 2. - Scolytus cylindrus. Osiv. Eint. tom. 4. Scolyt. no. 2. pl. 1.fig. 2. a. b. - Encycl. pl. $367 \cdot$ fig. 2 .

Longueur $2 \operatorname{lig} . \frac{8}{3}$. Corps brun, un peu velu. Têle aplatie, un peu ruguense en devant; tête et corselet légè̀nement poinvillés, celui-ci ayant un petit sillon à sa partıe postérieure. Elytres chargées de stries profondes, trouquées et dentées avant leur extrémité, fort velues an-delà des dentelures. Antennes, paltes et dessous du corps d'un brull-marron.

D'Europe. Assez rare aux environs de Paris.

(S. F. et A. SErv. )

PLATYPEZE, platypeza. M. Meigen dans son ouvrage intitulé Classification des Diptères, a fait un gemre sous ce nom, qui équivaut à l'une des divisions de celni de Dolichope de M. Latreille, et dont le caractère est : autennes avancées, de trois articles, les deux inférieurs courts, presque cylindriques, le troisième conique ter$\mathrm{V} 3$ 
miné par nne soie. Tarses postériedis comprimés, dilatés, leur troisième artiçle pluns grand. Aidomen aplati. Ailes couchées sur lc corps, se recouviant l'une l'antre dans lc repos. Yeux rapprocbés et convergens dans les mấles, espacés dans les femelles.

L'anteur décrit trois espèces de ce gente. Elles Jabitcnt l'Europe. Liune d'elles est le Dolichopus fusciatus no ${ }^{\circ}$ 22. Fав. Syst. Antliat. ( Plat. fasciata. Encycl.pl.3go. fig. 47-5 I.)

(S. H. et A. Serv.)

PLATYPTÉRE, Platypteryx. - LASP. LAT. Drepana. Semanck. Phalcena. Linn. De Géer. Geopf. Fab. Bombyx. Esp. Engram. Huba.

Genre d'insectes de l'ordre des Lépidoptères, famille des Nosturnes, 'Tribu des Phalénites.

Ce genre a été fondé par M. Laspeyres et adopté par M. Latreille; il compose avec celui de Phalène la tribn des Phalénites; mais ce dernier genre n'a point l'angle du soumet des ailes supérieures recourbé en forme de faucille; les chenilles ćes Phalènes sont arpenteuses et n'ont que dix à douze pattcs, du nombre desquelles sont les postérieures; leur corps n'est janais terminé par une pointe simple; ces caractères sont propres au genre l-halène et empêchent de le confondre avec les Platyptères.

Antennes courtes, sétacées, toujours peclinées dans les mâles, pectinćes on simpiles dans les femelles. - Langue très-courte; presque nulle. Palpes inférieurs très-petits, presque coniques. - Tête petite. - Corps ordinaireınent grêle. Ailcs graudes, en toit aigu dans le repos, les supérieures recouvrant les inférieures; les premières ayant leur angle supérieur alongé, reconrbé en faucille. - Chrenilles non arpenteuses, munies de quatorze pattes, six écaillenses et huit membraneuses, les derniers segmens du corps en étant privés, le segment anal terminé en uné pointe simple.

Le nom de Platyptère vient de deux mols grecs qui signifient: grandes ailes. Les espèces qui composent ce genre sont en petit nombre; elles volent et vivent à la manière des Phalènes. Ceurs chenilles se tieunent dans des feuilles qu'elles plien t en rouleau en les assujettissant avec quelques brins de soie. Elles y font aussi leurs coques en fortifiant l'intérieur du rouleau au moyen d'une plus grande quantité de soie. C'est là qu'elles subissent leurs métamorphoses.

\section{Platyptìne lézard, $P$. lacertula.}

Platypteryx alis superioribus eroso-dentatis, luteis, superionum strigis undatis atomisque, puncto discoiduli et lineis duabus rectis fuscis.

Platypteryx lacertinaria. LAr. Dict. d'Hist. nat. $2^{\mathrm{E}}$. édit. - Bombyx lacertula. Esper, tom. III. tab. LXXII. fig. 3-6. - Hun. Boinb. tab.
12. fig. 49. Fenelle. - Engram. Pap. d'Eur. pl. CCIXY. $n^{\circ}$. 27.9. - Phalcena lacertinaria Lin. Syst. Nat. 2.860. 204. - Fав. Ent. Syst. tom. 3. partie 2. pag. 135. no. 20. - Encyet. pl. 9o. fig. $18-20$.

Envergure 8 à ro lig. Antennes, tête et corps d'un fauve-jaunátre. Ailes de mĉme coulenr, le's supérieures plus fonctés, chargées de petites lignes oudulées et d'atômes bruns ou fiuves, en ayant deux transverses, droites et plus distinctes, entre lesquelles est un poir: hrun discoidal; leur bord extérieur denté et sinné. Frange blanche nuêlée de brun. Dessous assez semblable audessus. Màle et femelle.

Antennes pectinées dans les deux sexes.

Chenille d'un brun-clair el jaunâtre inêlé de taches et de nuances d'un brun plus obscur., ayant plusieurs rides et quelques tubercules, ccux du second et du troisième segmens très-f́levés, composés de dcux mameluns de chacun desquels part un petit poil. Vit sur le cliêne et le bouleau. Chrysalide brune, mais recouverte d'une watière blanche, farineuse, qui la déguise.

Des environs de Paris.

\section{Platyptìre harpon, P. harpagnila.}

Platypteryx alisfalcatis fulvis, lineis undatis fuscis; in superionbus ad angulum superiorem conniventibus.

Boinlyx harpagula. Huвn. Lomb. pl. I r. fig. 42 et 43. - Engram. Pap. d'Entop. pl. CCVIII. $n^{\circ} .276 . \mathrm{f} . \mathrm{g}$.

Envergure 10 lig. Antenncs, tête ct corps d'un fauve tcslacé. Ailes de même couleur, chargées de lignes transv'erses ondées, brunes. Toutes celles des supérieures à l'exceplion de la plus extérieure, se prolongeant en angle vers le crochet de l'aile. Dessous d'un beau jaune ayant sur le disque de chacune uu point et une pelile ligrie de couleur noire. Irrange brunàtre. Mâle et fericlle.

Antennes pectinées dans les deux sexes.

Des environs de Paris.

\section{Pratyptène faucille, P. falcula.}

Platypteryx alis falcatis albidis, lineis undatis fuscis, snperiorum inaculâ discoidali punctisque duobrus, unico pupillato, fuscis.

Platypteryx falcataria. Lat. Dict. d'Hist. nat. $2^{\mathrm{e}}$. édit. - Bombyx falcula. Esper, tom. III. tab. LXXIIT. fig. 3-6. - Huв. Bomb. tab. 11.fog. 44. Mále. - Evara M. Pap. d'Eur. pl. CCVII. $n^{\circ}$. 276. a. b. c. d. e. - Phalcena falcataria. Linn. Syst. Nat. 2. 85g. 202. - FAB. Ent. Syst. tom. 3. partie 2. pag. 133. $n^{\circ}$. 16. DE GEer, Ins. tom. I. pag. 333. pl. 24. fig. I-7, et tom. 2. pas. 353. n०.7. pl.6. fig. 1. - E7tcycl. pl. 90. fig. 17 . 


\section{P L A}

Envergure 10 ì 12 lign. Antennes, têle et abdo. men jauuâtres, corselet blauchâlre. Ailes de unêne couleur avec des lignes brunes, transverses et ondées; les supérieures ayant deux points et une tache discoidale de coulem brune; l'un de ces poinls oculé à prunelle grise, la tache renferuaut quatre ou cinq petits points gris. Les deux ayantdernières lignes se prolongeant en angle vers le crochet de l'aile, la demière composée de points sur les quatre ailes. Dessous d'un blauc-jaunatre, presque dépourvu de lignes, du reș assez semblable au dessus. Feınelie.

Dans le mâle les lignes et les points sont plus foncés et plus distincts, taut en dessus gin'en dessous.

Antennes peetinées dans les deax sexes, jusqu'aux deux tiers de leur longueur seulernent.

Clenille verte ayant le dos d'un brun-pourpré, portant six tubercules charnus, placés pàl pailes sur les second, troisième et cinquième segmens du eorps. Vit sur l'aulne et le bouleau. Cirysalide brume avee les fourreaux des ai's et la pièce de la poitrine de couleur verte; elle a deux pointes pyramidales au-devant de la tête.

Des environs de Paris.

Nota. Engramelle a en tort de prendre l'espèce précédente pour une variélé de celle-ci.

\section{Platyptène hameçon, $P$. hamula.}

Platyptery:x alis falcatis luteo fulvis, superiorum lineis duabus luteis incurvis, inferiorum lineis duabus obsoletis omnimmque punctis geminis discoidalibus fuscis.

Bombyx hamula. Esp. tom. III. tab. LXXIV. fig. 1-3. - Huвn. Bonıb. tab. 12. fig. 46 et $47 .-$ Engram. Pap.d'Eurisp. pl. CC'VIII. $7^{\circ} \cdot 27^{8}$. Platyptery $x$ falcata. LAT. Dict. d'Hist. nut. $2^{\mathrm{E}}$. édit. - Phaloena falcata. FАв. Ent. Syst. tom 3. partie 2. pag. 165. no. 131. - Encycl. pl. 90. fig. $2 \mathrm{I}$.

Envergure 8 à 10 lign. Antennes, tête et corps fauves. Ailes d'un jaune-fauve. Les supérieures un peu plus foncées, porlant deux lignes jaunes courbes; entre ces lignes sout deux points tiscuidaux bruns. La ruoitié inférieurc de l'angle supérieur est aussi de celle couleur. Ailes inférieures ayint deux petites lignes peu appareutes et deux poinls de couleur brune. Dessous cies quatre ailes d'un jaune plus clair, sans lignes ni points. Mâle et femelle.

La femelle a les antennes simples et sétaéécs.

Chenille jaunâtre aves quelques lignes ferrugineuses et les côtés du eorps bruns; elle a deux tubercules sur la têle et deux autres sur le troisième segment du corps. Vit sur le prunier.

Se trouve en France.

Nota. A ce genre appartiennent encore les Phalcena culturia et flexula de Fabricius et peut-être aussi la Fhalcera compsessa du máae auteur. (S. K. et A. Seruv.)

PLA'lYRHINE, Platyrhinus. M. Clairvilie dans son Entomologie helvétique, divise les Amhinhus de Falricius en denx genres; it donne à l'uu d'eux le nou de Platyrhine, ce sont les $\Lambda$ uthribes de M. Latreille, et conservi it'autre le nom d'Antlribe; ce deruier correspond exacteneat à celui do lihinosine de l'auicur français.

(S. . et A. Sarv.)

PLATYSCELE, Platyscelis. Lat. Blaps. Srund. Tenebrio. Pall.?

Genre d'insectes de l'ordre des Coléoptères, seclion des Hétéromères, famille des Mélasomes, tribu des Blapsides.

'Tous les genres de cette tribu manquent d'ailes et leurs quatre palpes sont terminés par un article beacoup plus grand que les autres, triangulaire et en forme de hache. Les Seotines et les Asides se distinguent par le dernier article des autennes très-court et engagré, au moins en partie, dans le disième on avant-dernier; le troisième artielo des antennes est a moins deux fois plus long que le quatrième dans le genre Blaps, ce dernier article et le troisiène sont lougs el égaux entr"eux daus les Misolampes. Ias Pédines oni un éeusson ordinairenent distinct, leur clıaperon est échaneré antérieurement et les mâles n'ont de dilatation aux tarses que dans les deux patles antérieures.

Antennes filifurmes, de onze articles, le troisième moilié plus long seulement que le précédent et n'ayant pas deux fois la lougueur du quatrième; les quatrième, cinquiène, sixième et septiène obconiques, les huitième, neuvième ef dixième turbinés ou globuleux, le dernier de la grandeur du préeédent a moins et arrondi l'extrénnité. - Iabre coriace, très-contt, transverse, entier ou ún peu échaneré. - Irandibules bifides. - Mâchoires ayant uu dent cornće, au côté interne. - Palpes terminés par un artiele beaucoup plus grand, comprimé, iriangulaile ou sécuriforne, dans les maxillailes surtout, ceuxci composés de guatre articles, les labiaux de trois. - Lèvre légèrement échaucrée. - Tête ovale, à moitié enfoneée dans le corsclet et pluz étoite que lui, chaperon sans échancrure à sa. partie antérieure. - Yeux peu saillaus patroissant en dessus et en dessous de la'tête, presque coupés par son rebord latéral. - Corps en ovale court ux peu déprimé. - Corselet de la largeur ou à peino plus large que les élytres, trausverse, échancré en devant. - Ecusson peu ou point distiact. - Elytres réunies, embrassant peu ou point l'abdomen; point d'ailes. - Pattes fortes; tal'ses des quatre pattes antérieures ayant leurs douxième, troisieme et quatrième articles dilatés et presque cordiformes dans les mâles.

On présume que les mours ded Platyscèles, soret 
les mêmes que celles des Pédines. L'élymologie de ce unom est tirée de deux mots grecs dont le sens est: cuisses grandes. On n'en conmoit que fort peu d'espèces.

\section{Prat yscène bypolithe, P. hypolithos.}

Platyscelis nigra, punctata, clypeo labroque nefo ciliato, tarsis subtùs rufo tomentosis.

Longuenr 6 lig. Corps finement pointillé, entièrement noir avec un reflet bleuâtre-obscur. Chaperon et labre ciliés de roux autérienremeut. Corselet et élytres, légrèrement rebordés. Dessous du corps, jambes et cuisses plus fortement ponctués, ces dernières un pen canaliculées en dessous, les antérienres ayant une petile dent en devant, les postérieures plus profondément canaliculées, leu: sillon couvert d'un duvet roux. Tarses garnis de poils roux en dessous. Mâle.

De la Russie atéridionale.

Nota. Cet insecte est peut-être 's Tenebrio Jypolithos de Pallas. M. Sturm dans sa Faune d'Allemagne, tom. 2, pl. 45, fig. c. C. D., a représenté la f'emelle d'une espèce de Platyscèle; c'est son,Blaps politu. (S. F. et A. SERv.)

PLATYSME, Platysma. Genre de Coléoptères élabli par M. Bonelli (Obs. entom. Mém. de l'Acad. de.Turin) dans la tribu des Carabiques et dont il pose ainsi les caractères : languelle tronquée, coriace. Palpes maxillaires extérieurs ayanl leur quatrième article cylindrique, anninci is sa base, plus court que le précédent. M!enton ayant - une dent bifide a l'extrémité de la saillie du unilieu. Aulentes compiarées, plus grêles à leur extrémilé. Corselel presqu'eu cœur, ayant deux stries de chaque côté à sa base, l'extérieure plus pelite; angles du corselet droits. Corps déprimé.

Une des espèces rapportées à ce genre par l'auteur est le Caratus niger de Fabricius.

On la trouve aux environs de Paris.

$$
\text { (S. F. et A. SERr.) }
$$

PIATYYSOME, Platysoma. İ́Ac日. Nom donñé par cet autcur à un yenre de Coléoplères pentausères, famille des Clavicornes, tribu des Hisléjoirtes de M. Latreille : il le compose des Hister de Fabricius qui ont le corps dépriné, l'avantsternum dilaté pour recevoir la bouche à l'exception des mandioules, les quatre jumbes antéricures ¿voc un senl rang d'épines, le dessous dı corps presune plane, le corselet carré, soit transversal, soit équilatéral. Il y rapporte les Hister oblongus et picipes de Fabricins, le flawicornis d'Herbst, le depressus de M. Marsham et deux autres espèces inédites. ( $S$. F. et A. SERV.)

PI.ATYSOMES, Platysoma. Troisième fawille de la section des 'Tétranères, ordre des
Coléoplères. M. Latreille lui assigne pour caractères :

Antennes sétacées ou filiformes. - Tarses ayant tons les articles entiers. - Tête forte, triangulaire. - Corselet presque carré. - Corps alongé, déprimé.

Le nom de Platysome vient de deux mots grecs et a rapport à la grandeur des parties de la bouche de ces coléoptères. Ils vivent dansle bois on sous les écorces d'arbres. Cette famillen'est poinl divisée en tribus; clle comprend les genres Cucuje, Uléiote, Parandre et Passandre. (S. F. et A. Senv.)

PLATYSTOME, Platystoma. Meig. Class. LAT. Dictya. FAB.

'Genre d'insectes de l'ordre des Diptères, section des Prosboscidés, liamille des Áchéricères, tribu des Muscides.

Parmi les Muscides, les genres Plalystome et Téphrite forment un groupe dont le caractère est : cuillerons pelits; balanciers nus; yeax sessiles; antenses sensiblement plus courtes que la lête; corps simplement oblong; abdomen prolòngé en une queue écailleuse dans les femelles; ailes écarlées l'une de l'autre dans le repos. Mais les 'Téphrites sont bien distinctes des Platystomes par leur trompe entièrement rélraclile.

Antennes insérées au milieu de la face autérieure de la têle, composées de trois árticles, le deruier ovale, portant a sa base une soie siuple.Trompe très-grosse, ses lèvres épaisses, son extrémité faisanl saillic au-delà de la cavité orale. - Vertex s'abaissant en pente sur lc devant. - Yeux assez grands, espacés dans les deux sexes. - Trois petits yeux lisses rapprochés, disposés en triangle sur la partie la plus élevée di vertex. - Corps court, un peu oblong. - Ecusson un peu relevé, distinctement séparé dn corselet.- Ailes vibratiles, écartées l'une de l'autre dans le repos, un peu pendantes sur les côtés, ordinairement cclorées en noir et comme piquelées dé blanc. - Cuillerons pctils, balancier décoliverts. - Abdomen terminé dans les femelles par un oviducte toujours sai!lanl. - Pattes de longueur moycnne; prenier article des tarses presqu'aussi long que les quatre aulres pris ensemble; crochels très-petits, munis d'une forte pelotte dans lenr entre-deux.

Platystome vient de denx wots grecs qui signifient : grosse bouche. Les espèces connues de ce genre se tiennent volontiers au soleil sur les feuilles des arbustes ou sur les fleurs; elles agitent assez souvent leur's ailes et soulèvent leurs patles les unes après les autres, mais assez lentement; elles restent à la mênie place des beures entières; lorsqu'un nuage empêche le soleil de donner sur elles, les Platystomes passent sur le dessous des feuilles sans chercher à s'envoler, et se laissent quelquefois prendre à la main en rejetant alors par la trompe une liqueur brine d'une odeur assez désagréable. 


\section{P L A}

Rapportez à ce geure les Monches seminatienue $\mathrm{n}^{\circ} .142$ (Dictya senimationis. FAB.) et fulviventre $n^{\circ}$. 200 de ce Dictionnaire. Les auteurs regardent ces deux espèces comme n'en formant qu'une seule, ce qui ne noùs paroît pas certaiu.

CALOBATE, Calobata. Meig. Class. Irtig. Lat. FAB. Ceyx. Dunér. IMuscu. Panz.

Genre d'insectes de l'ordre des Diptères, section des Proboscidés, famille des Âthéricères, tribu des Muscides.

Les Calobates et les Micropèzes se distinguent des autres Huscides par les caractères suivans : cuillerons petits; balanciers nus; ycux sessiles; antennes sensiblement plus comrtes que la tête; corps longr et étroit. Mitis dans les Micropèzes les ailes et les pattes sont proportionnellement plus courtes que dans les Calobates et leur abdomen est plus sensiblement rétrćci à sa base.

Antennes beaucoup plus courles que la tĉte, insérées au milieu de sa face antérieure, composée de trois articles, le dernier plus long que le précédent, portant une soie latérale. T'rompe en partie rétractile, son extrémité faisant saillie au-delà de la cavité oralc. - Tête un peu pyramidale. - Yeux grands, espacés dans les deux sexes. - Trois petits yeux lisses rapprochés, disposés en triangle sur le vertex. - Corps grêle, élroit, alongé. - Corselet en ovale alongé. Ecusson petit, distinctement séparé du corsclet. - Ailes longues, étroiles, vibratiles, écartécs dans le repos. - Cuillerons tris-petits; balancier's grands, découverts. - Abdomen point rétréci sensiblement à sa base. - Pattes très-longrues, cuisses postérieures filiformes. Prenier article des tarses presqu'aussi grand que les quatres autres pris ensemble. Crochets des tarses fort petits. Pelotles bifides.

Le nom de Calobate vient de deux mols grecs qui signitient : beau marcheur. On trouve les espèces de ce genre sur les fleur's ct les feuilles des arbustes, dans les jardins et dans les bois; elles warchent plus volontiers qu'elles ne volent. Les espèces connues sont en petit nombre.

jre. Division. Soie des antennes plumcuse.

1. Casobate à cothurne, C. cothumata.

Calobata antennis plumatis, abdonine clavato suprà nigro, pedibus flavis, femoribusquatuor posticis ad gènicnla fusco annulatis.

Musca cothurnata. PA vz. Faun. Germ. fas. 54 . fig. 20. La femelle.

Longueur 4 lig. Têle noire, d'un jaunè-ferrugineux antérieurement. La trompe et les antennes (excepté lu soie) de cette même couleur. Environs de la bouche d'un blanc argenté ainsi que l'orbite des yeux; corselet noirâtre en dessus, ses côtés et sou clessous couverts d'un duvet court, couché, argenté. Cuillcrons et balanciers jaunátres. Abdomen noir en dessus, jaunâlre en dessous, de même que l'extrémité entière du dernier se onent qui précède le pondoir, celui-ci noir, corisposé de deux articles appareus, globuleux dans le repos; le dernicr plus gros que le précédent. Pattes d'un testacé pàle, les quatre cuisses postéricures ayant un anneau brun à leur extrémité. Ailcs transparentes, nervurcs testacées. Femelle.

I.e mâle a l'abdomen en massue, le dernier seginent très-gros, testacé. On voit sous l'un des segrmens intermédiaires uu appendice en forme de bourse, ouvert posléricurcuent.

Des environs de Paris.

$2^{\mathrm{e}}$ Division. Soie des antennes nue.

2. Calobate porte-selle, $C$. ephippium.

Calobata antennis setariis, nigra, thorace rufo, pedibus testaceis, femoribus posticis fusco blan nulatis.

Calobata ephippium. FАв. Syst. Antl. pag. 263. no. 13. - Musca ephopium. PsNz. Faun. Germ. fas. ". fig. 2 I. La finelle.--Coqueb. Illus. Icon. tab. 24. fig. 8. Le mâle.

Longueur 2 liğ. Tête brune. Antenncs et trompediun jaune-pâle. Environs de la bouche et orbiles des yeux un peu argentés. Corselet ferrugineux, sa partie inférieure nn peu plus foncée. Cuillerons et balanciers blauchátres. Abdounen d'un noir luisant, en wassue, le demier scument très-gros. On voit sous l'un de ses segruens intermédiaires un appendice blanc moins gros que celui du wâle de l'espèce précédente. Pattes d'un blanc sale, cuisses postérieures ayant chacune deux anneaux bruns, l'un daus leut milieu, l'autre vors leur extrémilé. Ailes wansparentes, vervures brunes. Mâle.

Des euviruns de Paris.

Nota. Les femelles de celle division qui nous sont connues ont leur pondoir filifurme. Une espèce de ce genre est représeutée pl. 595 , fi. 13-16 de cetouvage.

MICROPËZE, Micropeza. Metg. Class. LAT. Muscu. Linn. Panz. DE GEER. Tephritis, Calobata. FAB.

Geure d'insectes de l'ordre des Diplères, section des Proboscidés, famille des Athéricères, tribu des Muscides.

Deux genres de cette tribu sont très-veisins l'un de l'auire, ce sont ceux de Calobate et de Micropèze. (Voy. l'article prócédent.) Daus les Calobates les ailes et les pattes sout plus longues proportionnelloment que dans les Micropc̀zes et l'abdomen n'est pas rétréci à sa base dune manière sensible, 
Antennes beaucoup plus courtes que la lête, insérées près dı milieu de sa face antérieure, composées de trois articles, les deux premier's trèscourts, le dernier formant une palette en carré long munie d'une soie dorsale, simple, ay aut son insertion près de la base. - Trompe en partie rétractile, son extrémité faisant saillie aı-delà de la carité orale. - Téte globuleuse. - Уeux assez grands, espacés dans les denx sexes. - Yeux Cisses peu distincts. - Corps alongé. - Corselet ovalaire. - Ecusson petit, relevé, distincternent séparé du corseler. - Ailes de grandeur médiocre, assez étroites, vibratiles, écartées l'une de l'autre dans le repos. - Cuillerons très-petits, balanciers découvcr's. - Abdomen sensiblement rétréci à sa base. - Pattes de longueur moyenne, les antérieures (cians les ruâles) propres ì saisir, leurs cnisses dentées on fortenent cilices en dessous, leurs jambes ayant souvent un appendice remarquable à leur partie intéricure et s'appliquant exactement contre les cuisses; ces mêmes parties simples dans les femelles. Premier article des tarses presqu'aussi long que les quatre autres pris ensenuble. Crochets et pelottes fort pelits. Oviducte des femelles point apparent dans le repos.

Les Micropèzes paroissent aimer à marcher; elles se posent ordinairement assez loin de l'ubjet qui les attire; leur démarche est vive. Quelques espèces se tiennent volontiers sur les éviers des cuisines el sur les bords des tuyaux pratigués pour l'écoulemert des eaux grasses; elles y cléposent leurs cenfs. D'atutre; fréquentent les feuilles de diverses plantes. Tuntes les Micropèzes balancent leurs ailes de haut en bas lorsquelles marchent et quelquefois aussidans le repos. Leur nom vient do deux mots yrecs qui signifient : petit pied. Il leur: a suns cioute été donué par comparaison de leurs pattes avec celles des Calobates.

Rapportez à ce genre la Mouche cynips no 128 de ce Distionuaire (la description ne convient qu'au mâle, la femelle ayant les cuisses antéjieures sinples) et la Micropèze ponctnée. ( M. punctum LAT. Dict. d'Hist. nat. $2^{\mathrm{e}}$. édit.) Tephritis punctum no. 40. Fав. Syst. Antl. Encycl. pl. 395. fig. 27-29. Peut-être la Musca stigma. P P Fa. Faun. Germ. fas. ". fig. 21 , l'eprésentée pl. 394, fig. 26 de l'Encyclopédie, es:elle la méme espèce. (S. F. et A. Serv.)

PIATYURE, Platyura. M. Meigen dans ses Diptères d'Europe, a réuni sous ce nom les genres Céroplate et Asindnle de M. Iatreille qui tous deux doivent être conservés; il lui donne pour caractères : antennes avancées, comprimées, de seize articles, les cleux inférieurs distincts. Yeux ronds. 'Trois petits yeux lisses placés sur le froụt, rapprochés en triangle. Jambes sans épines sur les côtés. Abdomen déprimé postérieurement.

$$
\text { (S. F, et A, Senr.) }
$$

PLECTE, Plectes. M. Fischer a créé sous ce nom dans l'ouvrage intitulé Genres d'insectes publiés au nom de la Soc. imp. 'des nat. de Nloscou I 321 , un nouveau gente de Coléopières pentamères carnassiers qu'il dislingue des Carabes et des Harpales par les parties de la bouche et par le corps très-dépriné. Il en mentionne une espèce qui est figurée sous le nom de Carabe de Drescher, Entom. Russ. Col. pl. 3. fg. 4. a. b. et qui se tronve dans les monts Altaiques.

(S.F. et A. SERv.)

PLEIN-CHANT. Nom trivial donné par Geoffroy à l'Hespérie plaiu-chlant no. 145 de ce Dictionnaire. (S. F. et A. SERV.)

PLÉSIE, Plesia. Jur. Genre d'Hyménoptères qui répond à celui de Myzine de cet ouvrage. Voy. ce mot. (S.F.et A. Serv.)

PLICIPENNES, Plicipennes. Troisième famille de l'ordre des Névroptères. Elle a pour caractères :

Antennes filiformes ou sétacées, beaucoup plus longues que la lête, composćes d'un grand nonibre d'articles. - Ailes infërieures plissées, beauconp plus larges que les suptrieures. - Mandibules nulles ou très-petites.

Cetle famille ne contient que le genre Frigane, phryganea. (S. F. et A. SERv.)

PLINTIIUS, Plinthus. Nouveau genre de Coléoptères créé jar M. Germar (Ins. Spec. nov. vol. 1. Coléop. 1824), appartenant à la tribu des Chatansonites, famille des Rhynchophores, et caractérisé ainsi par l'auteur. Rostre presqua aussi long ou plus court que le corselet, cylindrique, ses fossettes le parcourant dans toute sa longueur et se recourbant insensiblement en dessous vers la base du rostre. Antennes insérées entre le milien et l'extrémité du rostre, courtes, leur fouet de sept articles, les deux preniers en massue, les autres lenticuläires; massue presque solide, en ovale court. Yeux enfuncés. Curselet tronqué postérieurement, fortement écliaucré en dessous à la base de la iêle, sans sillon pour revevoir le rostre. Point d'écusson. Elytres un peu plus larges que le corselet, réunies, de la longueur de l'abdomen, oblongnes, tronquées à leur base, leurs côtés droits jusqu'au delà du milieu, leurs angles postérieurs oblus, arrondis. Point d'ailes. Patles fortes, égales entr'elles, les antérieures rapprochées l'une de l'autre. Cuisses en massue, ordinairement dentées; jambes comprinées, leur extrémité armée intérieurement d'une dent hovizontale. Tarses courts, larges.

L'une des espèces de ce genre est le Lixus. caliginosus de Fabricius, Charanson caligineux $\mathrm{n}^{0}: \mathbf{1 5 6}$ de ce Dictionnaire. 
ProAS, Ploas. Lat. Fab. Meig. Bombylius. Oriv.

Genre d'insectes de l'ordre des Diptères, section des Proboscidés, famille des Tanystomes, tribu des Bombyliers.

Les Cyllénies et les Ploas se distinguent aisément des autres genres de leur tribu, ceux-ci ayant la trompe plus longue que la tête, cylindrique ou terminée en pointe et le troisième article des antennes plus grand que le premier. Lans les Cyllénies les deux premiers articles des antennes ne sont pas fort gros, mais égaux entr'eux sous ce rapport; le second est en forme de coupe. Dans les Ploas au contraire le premier article est irès-gros et le deuxième menu.

Antennes plus longues que la tête, avancées, rapprochées, de trois articles, le premier trèsgros, conique, le second menu, presqu'en forme de coupe, le troisième fusiforme, aminci vers le Lout et terminé par une pointe articuléc. - Palpes ne paroissant pas an dehors de la bonche.Trompe dirigée eu avant, horizontale, un peu plus longue que la tête. - Tóte basse. - Yeux contiguis duns les mâles, espacés dans les femelles.Trois petits yeux lisses disposés en triangle et placés sur le vertex. - Corselet bombé. - Ailes écartées ayant une cellule presqu'arrondie, placée ver's l'angle supérieur; balanciers plus longs que les cuillerons. - Abdomen ovale, plus large que le corselet, composé de six segmens outre l'anus. - Pattes grêles, longrues, les postérieures surtout.

Ce genre paroit appartenir au midi de l'Europe. On suppose à ces diptères les habitudes des Bombyles auxquels ils ressemblent beancoup. Les especes connues sont en très-petit nombre.

\section{Ploas lierticorue, P. hirticornis.}

ploas hirt:cornis. LAT. Gener. Crust. et Ins. ton. 4. pag. 312. "tab. XV. fig. 7. - Ploas vtrescèns. $\mathrm{A \textrm {B }}$. Syst. Antliat. pag. 136. $n^{\circ} .1 .-$ Merg. Dipt. d'Europ. tom. 2. pag. 231. $n^{\circ}$. 1. tab. 19.fig. 6.

Voyez pour la description et les autres synonymes Bombille verdâtre $\Perp^{\circ}, 18$.

\section{Ploas gris, P. griseus.}

Ploas grisea. Merc. Dipt. d'Europ. tom. 2.

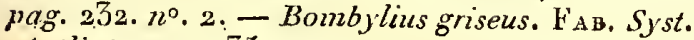
Antliat. pag. 135. $\pi^{\circ} .29$.

Voyez pour la description et les autres synonymes Bombille gris $n^{\circ} .17$.

3. Ploas átre, $P$. ater.

Ploas ater. LAt. Gener. Crist. et Ins. tom. 4. pag. 313.

Voyez pour la description Bombille maure no. 15. pl. 388. fig. $42-46$.

Hist. Nat. Ins. Tome $X$.
CYLLÉNIE, Cyllenia. Lat.

Genre d'insectes de l'ordre des Diptères, section des Proboscidés, fumille des 'Tanystomes, tribu des Bombyliers.

Deux genres de cette tribu n'ont jamais la trompe plus longue que la tête, ni terminée en pointe; le troisieme article de leurs antennes n'est pas plus long que le premier; ce sont cenx de Cyllénie et de Ploas, mais dans ce dernier genı e le premier article des antenues est très-gros et le second menu, ce qui l'éloigne des Cyllénies.

Antennes rapprochées, plus conrtes que la tête, composées de trois articles, le premier presque cylindrique, un peu obconique, plus gros et plus long que le troisième, le second de la grosseur du précédent, transversal, presque cyathiforme, le dernier ovale, coniqne, presque tarbiné. - Trompe presque membraneuse, lléchie un peu après sà base, portée eusuite en avant, guère plus longue que la tête, épaissie vers son extrémité et renfermant un suçoir de quatre soies aiguës. - Palpes cachés. - Tête plùs basse que le corselet. - Yeux gros. - Petits yeux lisses point apparens. - Ailes étroites. - Abdomen alongé, presque cylindrique. - Pattes longues; cuisses assez fortes, les postérieures surtout; tarses un peu alongés, leur's crochets munis d'une pelotte bilobée dans leur entrè-deux.

M. Latreille qui a fondé ce genre n'en mentionne qu'une seule espèce. Elle habile les parties méridionales de la Frạnce et fréquente les fleurs.

\section{Cructrie tachetée, C. maculata.}

Cyllenia nigra, cinereo villosa, alis hyalinis nigro naaculatis.

Cyllenia maculata. Lat. Gener. Crust. et Ins. tom. 4. pag. 312. tom. I. tab. XV. fig. 3.

Longueur $3 \mathrm{lig}$. Ncire, converte d'un duret gris-cendré et parsemće de poils inoirs. Ailes transparentes avec denx petites taclies près de la côte, un point et un pelit trait au-dessous, denx autreg points et à leur extréunité un antre trait, de couleur nuire. Cuisses chargées d'un davet cendré foncé. Jambes el tarses d'un brun-foncé.

NI. Latreille l'a trouvée anx environs de Bordeaux sur les fleurs de la millefenille. Achillaca millefolium. (S.F. et A. SERv.)

PloChrone, Ploclionus. Ce genre de Coléoptères pentamères de la famille des Carnassiers, tribu des Carabiques, apparlient a la premicre division de cette tribu, nommée les étuis tronqués par M. Latreille, et fait partie d'un groupe qui a pour caracteres: crochets des tarses dentelés en dessous.

M. le comte Dejean a eu la bonté de nous communiquer le caractère de ce genre créé par lui : antenues courtes, moniliformes. Dernier atticle 
des palpes très-légèrement sćcuriforme. Pénultième arlicle des larses point bilobé. Cọselet coupé carrément à sa partie poṣtérieure.

L'espèce qui a servi de type est le Plochione de Bontils ( $P$. Bonfilaii). ionguear 4 lig. Eutièremeut d'un jaune testacé. 'Tểe triangulaire, avancée, lisse avec deux enfoncemens lougiludinaux entre les yeux. Antemes plus courtes que la tête et le corselet pris ensemble, leu: premier articie assez gros, le second plus petit et court, le troisième de la même grosseur que le précédenl, mais un peu plus long;, le qualrième allant en. grossissant vers le bout, les aulres assez gros, égaux, presque carrés, le dernier un peu plus alongé. Corselet guère plus large que la tête, presque carré; ses angles antérieur's arrondis, ses bords latéraux dépriatés vers les angles postérieurs; on voit une ligne longitudinale enfoncée sur le milien et quelques rides transversales pen inarquées sur son disque. Ecusson petit, triangulaire. Elytres plus larges que le corselet, un peu alongées, tronquées, légèrement sinuées à l'extrénité, fortement striées; les stries paroissant lisses. Dessous du corps et pattes plus pâles que le dessus.

Trouvé aux environs de Bordeaux sous des écoices de pin.

M.'le comte Dejcan, de qui nons empruntons celte description, pense que cette espèce pourroit être originairement exolique. Il a dans sa collection un individu absolument semblable rapporté de l'Amérique septentrionale par feu M. Ya: lisol-Bauvòis. Ni. Latreille en posside un autre de couleur un pca plus foncée venant de l'lle-deFrance. (S. F. et A. Serv.)

PLOIERE, Ploiaria. Scop. Lat. Cinlex. Livin. Geoff. De GEen. Gerris. Fab.

Genre d'inșectes de l'ordre des Hémiptères, section des Hétéroptères, famille des Géocorises, tribu des Nudicolles.

Ce genre a été créé par Scopoli, et adopté par M. Latreille. Les Holoptiles se distingueut par leurs antennes qui n'on que trois articles apparens; les Nabis et les Rédaves par leur corps ovale et les Zélus par les pattes antélieures seniblables anx quatre autres. Ces cinq gemres ont en outre les hanclies antérieures courtes.

Antennes coudées après le prcmier article, longues, grêles, presque sétacées, cornposées de qualre articles, les deux premiers très-longrs, le troisième court, le dernier encore plus court, un peu en massue. - Bec arqué, court, ne dépassant pas la naissance des cuisses antérieures, de trois articles, le premier court, le second long, cylindrique, le dernier en forme de boule alongée à sou origine, diminuant ensuite et se terminant en poinle conique. - Téte alongée, pelite, portée sur un cou distinct, ayant un sillon transversal quila fait paroitre bilobée, son lobe postérienr large, arrondi. - Yeux placés sur le lobe antérieur de la tête, prìs dı sillon transversal. Corps linéaire. - Corselet alongé, rétréci antérieurement, un peu aplati en dessus., comme composé de deux lobes, l'antérieur plas court. Elytres plus longues que l'abdomen. - Abdomen convexe en dessous, ses bords un peu relevés, composé de six segmens dont le deruner ne recouvre point l'anus; ces segmens ayanlebacun dechaque côté, un stigmate un peu élcvé. Anus des mâles entier. - Pattes anterieures ravisseuses, courtes, grosses, avancées, avec les lianches el les cuisses alongées; celles-ci garnies de poils roides en dedans, lenrs jambes et leurs tarses courts, s'appliquant sous les cuisses pour relenir la proie qui sert à la nourrilure de l'insecte; les auties paltes très-longues, fort menues.

Le Cimex vagabundus de Linné qui a servi de type à ce genre vit en élat de larve et de nymphe dans !es ordures. On trouve celle espèce jusque dans les appartemens. Dans l'élat partail on la renconire aussi sur les arbres. Sa démarclie est vacillante et elle se balince comme les Tipules, même sans :llanger de place. Ses patles antérieures, dit De Geer, ne sont point ordinailement emplcyées pour la inarche, elles restent relevées et reployées en trois, la cuisse reposant sur la lianche, et la jambe et le tarse sur le dessous de la cuisse ; mais les antennes appuyant leur extrémité sur le sol, maintienneut l'équilihre de la partie antérieare da corps. Les Ploicres saisissent leur proie avec les pattes antérieures; lear bec étant fort court paroît devoir diflicilement atteindre à leur nourrilure, parce que le corps se trouve très-élevé au-dessus da sol. Celle proie ne doit consister qu'en insectes fort prits. La nymphe de cette espèce que De Géer a observíe ressemble presqu'entièrement à l'insecte pa:fait, cornme cela est constant dans l'ordre des-Hémiptères, les antennes et les pattes ainși que le corps sont couverts de poils longs et firisés; sa coulcur est d'un gris-clair avec des points noirs sur le corps, la tếle, les fourreaux des élytres et des ailes. Ses pattes sont taclietées de bruı.

\section{Ploiére vagabonde, P. vagabunda.}

Ploiaria albida fusco varia, scutello spinoso.

Ploiaria vagabunda. Lat. Gen. Crust. et Ins. tom. 5. pag. 130. - Gerris vagabundus. FAB。 Syst. Rhyng. pag. 262. no. 9. - Cimex vagabundus. Linn. Syst. Nat. 2. 73̈. 119. - Cimex culicifonnis. DE GÉER, Ins. tom. 3. pag. 383. pl. 17. $/ g$. 1-8. - La Puarise cultciforine. Geoff.Ins, Paris. tom. 1, pag. $462 . n^{\circ} .58$.

Longueur 2 lig. $\frac{x}{2}$. Grise. Corps et élytres tachetés de biun. Antennes et palles aninelées de cette même couleur. Partie coriace des élytres courle, leur membrane brune, irisée, réticulée de 
blanc. Ecusson portant sur le disque une épine mince fort pointue, relevée à demi. Mâle.

Des environs de Paris.

Nota. Les auteurs ne font aucune mention de l'épine de l'écusson.

M. Latreille rapporte à ce genre la Punaise à très-longues pattes de De Géer, Ins. tom. 5 . pag. 352. pl. 35. fig. 16 et 17 , qui .est de Pensylvanie. Cette espèce diflère génériquement de la Ploière vagabonde, $1^{\circ}$. par la position des yeux, reculés sur le second lobe de la tête $; 2^{\circ}$. par la forme du corselet dont la partie antérieure est déliée, presque cylindrique, plus longue que la postérieure, celle-ci courte, grosse, convexe; $3^{\circ}$. par lez élytres beancoup plus eourles que l'abdomen; $4^{\circ}$. par les cuisses antérieures fortement épineuses en dedans. Nous possédons une espèce du Brésil en état de larve, où nous retrouvons les mêmes caractères, sauf celui des élytres.

(S. F. et A. Serv.)

PLUTUS. Nom trivial donné par Geoffioy à l'Altise plutus, $\mathrm{n}^{\circ} .26$ de ce Dictionnaire. Chrysomela. fulvicornis. F $\mathrm{AB}$. Syst. Eleut. tom. I. pag. 447. $n^{\circ}$. 143. (S. F. et A. SERv.)

PNEUMONURES, Pnezmonura. C'est ainsi que, daus mon.Gener. Crust. et Ins., javois nomıné une division des Crustacés branchiopodes, ou des Entomostracés de Müller, composée des geures Calige et Binocle. Les observations de feu Jurine fils nous ayant fait connoître que le dernier répondoit à celui d'Argule de Mïiller, j’ai rétabli ensuite eette dénomination. Les Pnentnonures forment, dans l'ouvrage sur le Règne animal de M. Cuvier, une division des Poecilopes. Voyez ce mot. (Latri.)

PNEUMORE, Pneumota. Thuns. Lat. Gryllus (Bulla). Linn. Gryllins. Faв. Acrydinm. DE Gérr. Oliv. (Encycl.)

Genre d'insectes de l'ordre des Orthoptères, famille des Sauteurs, tribu des Aerydiens.

Dans la tribu des Acrydiens quatre genres, Truxale, Proscopie, Criquet et 'Tétrix, se distinguent des Puecmores par leurs pattes postéricures plus longues que le corps et éminemment propres ì sauter. lies Pneumores senles ont ces mêmes paltes plus courtes que le corps et moins propres pour le sant.

Antennes filiformes, de seize à vingt articles cylindriques, écartées, insérées près da bord interne des yeux. - Palpes ayant lear dernier article un peu obconique. - Lèvie bifide. - Trois petits yeux lisses rapprochés, placés en triangle sur le front, à écrale distance les uns des autres. - Corselet grand, comme partagé eu denx segmens en dessus; sternum point creusé en menołnnière. - Elytres jetites, en toit écrasé, ou oulles, - Abdomen très-grand, ienflé , parois- sant vide. - Pattes menues, les postérieures plus courles que le corps; tarses de trois articles, le dernier portant un appendice membratieux, arrondi, placé cotre les croelets.

I.e nom de Pueumore tiré d'un mol grec qui signifie : air, a été donné à ces insectes en raicon de leur abdomen qui paroît vide et boursoufflé. Les espèces ccnuxes soul eu petil nombre et puropres à l'Africque australe. On les lrouve sur dilférentes plantes dans les mois de septernbre et d'octobre.

\section{Pneumore tachetée, $P$. variolosa.}

Pnezmora maculata. LAT. Dict. d'Hist. nat. - Gryllus variolosus. Faв. Entom. Syst. tom. 2. pag. 5o. $n^{\circ}$. 14 .

Voyez pour la description et les autres synonymes Criquet variolé $n^{\circ}$. 14 .

\section{Pneumore sans taelres, $\boldsymbol{P}$. immaculata.}

Pneumora immaculata. LAT. Dict. d'Hist. nat. - Gryllis papillosus. Fав. Entom. Syst. tom. 2. pas. 49. $n^{\circ} \cdot 13$.

Voyez pour la description et les autres synonymes Criquet papillaire $n^{\circ}$. 13.

\section{Pneumore mouehetée, $P$. sexguttata.}

Pneumora sexgutiata. LAT. Dict. d'Hist. nat, - Gryllus inanis. FAB. Entom. Syst. tom. 2. pag. $49 \cdot \mathrm{n}^{\circ} \cdot 12$.

Voyez pour la description et les autres synonymes Criquet boursoufflé $n^{\circ}$. I 2 .

$$
\text { (S. F. et A. SERv.) }
$$

POḌIE, Podium. Fab. Lat. Pepsis. Fab.

Genre d'insectes de l'ordre des Hy ménoptères, section des Porte-aiguillon, famille des Fouissenrs, tribu des $S_{\text {phégines. }}$

Fabricius a foudé ce genre dans son Systema Piezatorian et M. Latreille l'a adopté. Dans la tribu des Sptrégimes, les Dolichures se distinguent par leur abdomen ne tenant au corselet que par un pédicule très-courł. Les Anpulex, les Chlorions et les Sphex ont le pédicule de l'abdomen trés-distinct comme celui des Podies, mais les nervures récurrentes des ailés supérieures sont recues par la première el la troisieme cellules cubifales daus les Anipulex, el par la seconde et la troisième dans les Chlorions el les $S_{p} h e x$. La cellnle radiale est un peu pointue à l'extrénité dins les Anmopliiles et leurs antennes sont insérées audessus du milieu de la face antérieure de la têle; ils ont en outre les mandihules dentées. Dans les Pélopées la première cellule cubitale est aussi longue que les deux suivantes prises ensembie et leurs palpes maxillaires sont beacoup plus longs 
que les labianx. Tous ces genres sont donc bien séparés de celui de Podie.

Antennes assez longues, filiformes, un peu roulées en spirale à leur extrémité et de douze articles dans les femelies, de treize lans les mâles, insérées un peu au-dessous du milieu de la face antérieure de la tête. - Labre placé sous le chaperon, point apparent. - Mandibules sans dentelures, peu strićes. - Mâchoires entièrement corjaces. - Palpes filiformes, presqu'égaux, les maxillaires de six articlès, le troisième peu différent du second et du quatrième, les labiaux de qaaltre articles. - Lèvre ayant sa division interm diaire alongée, striée, profondément richancrée, les latérales plus courles, presque linéaires. - Téte comprimée, chaperon plus large que long. - Trois petits yeux lisses disposés en trian. gle et placés sur le vertex. - Corselet peu rétiéci en devant. - Ailes courtes, n'alleignant pas l'extrénité de l'abdomen, les supérienrés ayant une cellule radiale courte, son extrétnité arrondie, ne s'écartant pas de la cóte et quatre cellules culbilales, la première aussi longue que la troisième, la seconde presque carrée, recevant les deux nervures récurrentes, la troisième rétrécie vers la radiale, s'ávançant plus près du bord postérieur de l'aile que la radiale, la quatrième commencée. - Abdomen ovalaire, alongé, composé de cinq segmens outre l'anus dans les. femelles, en ayant nu de plus dans les máles, teнint au corselet par un assez long pédicule formé par lia partie antérieure du premier segment qui s’évase ensuite hrusquement. - Pattes assez longues, les postérieures surtout; jambes épincuses iu côté interne, les postérieures ununies à leur extrémité de deux épines inégales, lintérieure plus longue, les intermédiaires de deux épines égales et les antérieures d'une seule épine courte et simple; tarses à articles alongés, le dernier terminé par deux crochets unidentés dans les femells $s$, avec une pelotle dans leur entre-deux.

Les Podies habitent les pays chands de l'Amérique méridionale et sont de taille moyenne dans leur famille. Les mœurs de ces insectes sont ignorées, naais elles ne peuvent être fort diffërentes de celles des Anmophiles. Les espèces connues sont en très-petit nombre.

\section{Podre flavipenue, P. flavipenne.}

Podium atrum, nitidum, metathorace aureo tomenloso, alis luteo. subfuscis, abdoninis segmentorum margine postico obsoletè rufo.

Podium fluvipenne. LAт. Gener, Crust. et Ins. tom. 4. pog. 59. - Pepsis luteipennis. FAB. Syst. Piez. pag. $210 . n^{\circ} .10$.

Lorgueur 15 lig. Noire, un pen Inisante. Antennes de même coulear. Face de la tête ayani ane cxcavation de chaçie côté eutre l'ceil et l'in- sertion de l'antenne. Métahorax convert d'un duvet jaune-doré. Ecailles des ailes d'un jaunefauve, ainsi que le bord postérieur des segmens de l'abdomen. Jambes antérieures d'un janneroussâtre en devant ainsi que les tarses. Ailes jaunes avec nn reflet un peu doré, leur extrémité presque brune; nervures testacées. Femelle.

De Cayenue.

Nota. M. Latreille rapporte à ce genre les deux espèces de Podies décrites par Fubricius. Nous ne les connoissons point.

$$
\text { (S. F. et A. Serv.) }
$$

PODOCÈRE, Podocenis. M. Léach désigne ainsi un genre de Crustacés dè l'ordre des Amphipodes, ayant ainsi que les Coropbies, le corps cylindrique, les antennes composées de quatre pièces et dont les inférienres grandes, pédiformes; mais ayant la seconde paire de pieds termivée par une pince en grifle d'une grandeur très-remarquable. La seule espèce connue, le $\mathbf{P}$. mélangé , $P$. variegatus, a le corps varié de blanc et de fauve. Elle se trouve, parmi les Conferves, dans les mers de la Grande-Bretagne.

Ce genre pourroit être réuni à celui de Corophie dont nous ne connoissons aussi qu'nne seule espèce, la $C$. à longues cornes, $C$. longicorne, qui est le Cancer grossipes de Linnée, l'Oniscus volutator de Pallas et le Gammarus longicornis de Fabricius. On en a donné plusieurs ligures, mais suns délails particuliers. Ses habitudes ont été observées avec beaucoup de soin par un naluraliste des plus zélés et des plus instruits, M. d'Orbigni père, docteur en médecine, correspondant du Muséum d'histoire naturelle de $\mathrm{P}_{a-}$ in et conservateur de celui de La Rochelle. On lira sans donte avec plaisir l'histoire de ce petit Crustacé telle qu'il ne l'a communicquée dans une de ses leitres.

"Avant d'entrer dans le détail des habitudes et de la manière de vivre de ce petit animal, il me prait convenable de vuis donner succinctement une idée da lieu de son habitation et des. circonstances qui le déterminent a le choisir de prélérence à un autre.

.) La baie de l'Aiguillon, située à deux lienes au nord de La Rochelle, est très-étendue, et quoiqu'elle ail été considérablemenı ressemée par des desséchemens et pár les délaissemens et atlérisscmens annuels, elle oflire encore, à marce basse, plusieurs lieues carrées de surface; les comnune's d'Esnandes el de Charon la terminent anjourd'hui; la première à l'est-sud-est, la seconde à l'estnord-est : l'espace compris entre ces deux communes qui est de plins d'une lieue, est rempli par des terrains desséchés. Le sul de celle baie n'est qu'une vaste vasière qui n'est interrompue que par le courant de la Sevre, laquelle, après avoi. passé à Marans et au Brand, vient s'y jeter vis-àvis Cliaron : la surface de cette vasière, surtout 


\section{P O D}

vis-à-vis et cutre les deux communes, est en grande partie couverte de parcs en bois que les babilans nomment bouchots, et daus lesquels ils élèvent des m:sules, que des voiluriers viennent journellemient chercher pour les transporter à plus de liente lieues à la ronde; de grandes barques s'en chargent aussi tous les ans pour les porter à Bordeaux, etc.

"Les bouchots sont formés par deux rangées de pieux à incitié enfoncés. dans la vase, et espacés l'un de l'autre de trois à quatre pieds. L'espace compris entre chaque pieu est rempli par un clayunnage de branches d'arbres entrelacées; ces deux rangées de palisses, qui s'élendent souvent à plusieul's centaines de toises, sont disposées de ınanière a former un angle plús on moins ouvert, đont le sommet est du cốté de la nıer, et l'ouverture du côlé de la terre; ce sommet n'est pas entièrement fermé. On y laisse un espace de qualre à cing pieds pour plaçer un engin d'osier en entonnorr carré, nomı́é bourne, an bout duquel on met un autre panier nommé bourole, destiné à recevoir le poisson qui s'est laissé reuleriner à marée descendante dans l'intérieur du bonchot.

"Pour peupler ces parcs, les boucholeurs, en saison convenable, el aux époques des grairdes malines, vont, à marée basse, rcuplir des barques de pelites moules qu'ils ramassent sur les rochers de la côte au dehors de la baie. Ils en metlent quelques poignées duss un suc fait d'uu morceau de vieux filet; ils garnissent de ces sacs l'intérieur des clayonnages. Ces petites moules, apris quelques jours, filent leur byssus ponr s'attacher soit au bois, soit entr'elles; le filet est bientôt détruit et les moules alors s'étendent sur tout l'intérieur de la palisse, y premnent un accroissement rapide, et sont marchandes la secontle année; il s'en tronve qui acquièrent jusqu'à qualre pouces de longueur.

" La manière donı les boucholeurs se rendent à marée basse a leur bouchat, sur la vase, pour chercher les moules, est assez singulière; ils ont de pelites nacelles plates en carré-long, quils nomment acons ou pousse-pied, dont le devant est relevé, de huil à nouf pieds de longr sur un pied et demi a deux pieds de large; le fond est fait d’une scule planche de noyer très-mince, bien unie en rlessous; les bords n'ont guère plus d'un pied de hauteur et sont en sapin. L'lomme s'appuie sar un genou dans le fond et au milieu de la vacelle, saisit des deux mains ses deux bords, et ayunt aiusi pris son íquilibre, il se sert de la jambe libre qui es! en deliors, il plonge le pied (nu eu été, botté en hiver) au fond de la vase (quoique molle à la surface, elle offre assez de résistance duns le fond pour former un point d'appui) et il pousse; par célie manouvre répétée, la nacelle avauce aves assaz de promplitude : rendu an bouchol, il clioisit et détache des clayons, avec un crocbet de fer, les groupes de moules les plus

beaux, et en cliarge son acon. Si dias ce travail, ou en revenant, il est surpris par la marée montante, alors il s'assied daus le fond da baleau anquel il ne reste pas alors deux pouces de bord au. dessus de l'eau, et se sert de la pelle de bois (dont ils sont tous pourvus pour décharger les moules au port) comme d'une rame, mais à la manière des payayes cles nègres des colonies.

"Pendant l'hiver, le vent qui règne le plus babilueliement du sud au nord-oncsl, rend la wez très-grosse dans la baie; la lawe délaie la vase et la porte à marée baule daus les tronchots; les clayonnages rompant l'eflorl de la houle, la uner y est toujours moins agitée, aussi la vase s'y dépose-t-elle plas que pattuut ailleurs et s'y amoncèle; l'eau, co se retirant entre les pieux, creuse ces monticules d'espace en espace; alors le sol des bouchots a l'aspect d'un champ préparé ex sillons élevés quelquelois de plas de deux pieds. Les habitans appellent la vase dans cet état guérel. Lorsque la saison devient chaude, le somulet do ces sillons, restant à ratrée basse exposé à l'ardeur du suleil, s'égoutteroit, se duriroil el rendroil lit manœurre des pousøc-pieds liés-pénible, si do petits animaux ne venoient au secours des boucholeurs, en délruisünt toutes ces érninerces, en dólayaut a leur tour la vase qui est remportéc, à chayue marée, par la mer, de sorte que, dans l'espace de quelques semaines, le sol cies boumchots se retrouve aussi uni et presqu'au mếnt niveau qu'à la liu de l'iulomne précédent. Ces petils aniuaux sont les Cirustacés dont nous voulons nous occuper : on les nomme ici Perny.

En" Soit qu'ils s'enfoncent profondément dans la vase pour y passer l'hiver, soit que, comme Ji plupart des C'rustacés, ils se retirent pendant la saison froide daus des mers plus prolondes, ce qui me paroît plus probable, ils ne commeucent à paroilre qu'au commencement de mai; c'est aussi dans celte saison que les sillons de vase dont j’ai parlé sont habités par une multitude de petits vers marins des genres Nérćite, Amphinome, Arénicole, Nayade, elc. Tuus ces petits vers que l'on voyout dans le mois d'avril, dès que: là mer conmencoil à les couvrir, se montrer à l'orifice de leurs relraites, pour saisir les animalcules marins qui prassoient a leur portée, se cachent el s'enfoucent dans la iase; dés que leurs ennemis sout antives, on ue les revoit plus: les Pernys, qui qaroisseni cuếire lres-firands, leut font ane guerre cruclie, lis les poursurvent sans cesse; ll n'esi rien de phus curieux que de voir, à la maréc moname, des millinns de ces Crustacés sagller cu toul selss, baltre la vase de lemrs grands bras; la délayer pour tâcher d'y découvrir ienr prole. Out-lls lrouvé un ver sollvent dix, vingt fors plus gros qu'eux, ils șe réunissent pour l'arlaguer ei le dóvorer; î́s ne cessent leus carnage que lursqu'yant aplani et foullé foutea les vasis, ils u $^{3}$ y trouvent plus de quoi assourir 
leur voracité; alors ils se jettent sur les poissons et les mollusques et même les cadavres qui sont restés à sec pendint la basse mer, surles moules qui sont tombées des palices; les boucholeurs prétendent méme que lorsqu'ils éprouvent de la disette, ils grimpent aux clayons, et coupent les soies qui y retiennent les moules, pour les fuire tomber daus la vasc et s'en repaitre. Je u'ai pas encore trouvé l'occasion de massurer de ce fait. Je les ai souvent vus monter aux clayons, et même sur les moules, mạis șans pouvoị les surprendre dans ce travail. Dans toas les cas, il ne paroit pas que le dommage qu'ils y feroient puisse entrer en compensation avec les services qu'ils rendent.

„Ils paroissent se multiplier pendant toute la belle saison; car en automne on en observe de toutes les grandeurs, et j'ai souvent rencontré des fcmelles portant des outs à différ entes époques.

"Si ces petits animaux sont de cruels ennemis pour les vers marins, ils ont à leur tour des ennemis qui en font une grande destruction, ce sont les oiseaux de rivage et un grand nombre d'espèces de poissons. Ils quittent ordinairement notre bạie vers la fin de septembre, et presque tous à la fois; car souvent, dans celte salson, on n'en rencontre pas un dans les lieux où ils fourmilloient quelques jours avant.

"Je n'avois pas rencontré ce Custacé avant de venir à Esnandeș (1). ” (Latr.)

PODOPHTHALNE, Podophthalmus. LAмаяск. Genre de Crustacés, de l'ordre des Décapodes, famille des Brachyures, tribu des $\mathrm{Na}$ genrs, ayant pour caractères: les dcux pieds postérieurs terminés en nageoires. - Yeux portés sur des pédicules longs, linćaires, grêles, très-rapprochés à leur base.

Le corps est en forme de triangle renversé, ccurt, mais très-large en devant, et tronqué postérieurement ou à sa pointe, avec le chaperon étroit, incliné, sur les ·côtés desquels s'insèreut les pédicules oculaires. Lc premier article de ces - édicules est beaucoup plus long que le second et uernier, ainsi que dans les Homoles; e'est l'inverse dans les Qụadrilatères ayant des yeux portés sur de longs pédicules. Le troisième article des pieds-michorres extérieurs est presqu'en formc de hache alongée, oblus ou arrondi à son extrémité, avec le côlé ioterne cu peu échancré. La tige des abtennes latérales est assez longue, sétilcće, pluriarticuléc. Lal troisième paire de pieds est plus longue que la seconde.

1. Podcphthalme épineux, $P$. spinosus.

Podophthalmus spinosus. Lam. - Lat. Gener.

(1) Ce naruraliste habizoir auparavant près de Noirpoutiers.
Crust. et Insect. tom. 1. tab. 1 et 2. fig. 1. LéAcr, Zool Miscell. tab. 118. - Portunus vigil. $\mathrm{F}_{\mathrm{AB}}$.

Corps long de dix-sept millimètres sur cinquaute-lıuit de largeur à son extrémité antérieure. Deux dents en forme d'épines, et dont l'autérieure beaucoup plus forte et arquée, à chaque côté antérieur du test; cinq sur les bras, dont trois au côlé interne, et les deux autres au côté opposé; deux au corps et pareil nombre aux mains, une à leur naissance et l'autre près de leur extrémité.

Ile-de-France. M. Mathieu.

Nous devons ì M. Desmarest la connoissance d'un Podophthalme fossile, distingué du précédent par l'absence des épines latérales du test; c'est le $\boldsymbol{P}$. de Defrance. (Nouv. Dict. d'Hist. nat. 2e. édit. tom. 8. pag. 496.) (Latr.)

PODOPHTHALMES, Podophtalma. Le docteur Léach comprend sous ce nom général tous les Crustacés dont les yeux sont porlés sur des pédicules articulés et mobiles, ou les Crustacés pédiocles de M. de Isamarck. Cette. division se compose de nos Crustacés décapodes et stomapodes, ou des genres Crabe, Ecrevisse et Squille d'Olivier. A l'époque où ce naturaliste se chargea de la partie entomologique de l'Encyclopédie rnéthodique, on avoit peu étudié ces animaiux, et on les rangeoit , avec Linnće, parmi les insectes. Un grand nombre de genres ayant été établis depuis, et la méthode naturelle ayant fait de grands progrès, les derniers volumes de cet ouvrage doiven t singulièrement contraster avec les premiers. Un tableau général, avec uue concordance synonymique, peut seul rétablir l'harmonie. Nous renverrons pour cet objet à notre ouvrage ayant pour titre : Familles nuturelles du règne animal.

(LATR, )

PÓDOSOMATES, Podosomata. Léach donne ce nom au premier ordre de sa sous-classe des Céphalostomes, classe des Araclinides. Cet ordre répond à la famille des Pycnogonides de M. Latreille, qui, dans la méthode de Léacl, en forme deux, celle des Pycnogonides et celle des Nympho: nides. Voy. Pycnogonides. ( $\mathrm{E}_{i} \mathrm{G}$. )

PODURe, Podura. Linn. Geoff. Dr Géer. Lat. Fab. Oliv. Lam. Hermann.

Genre d'insectes de l'ordre des Thysanoures, famille des Podurelles, dont les caractères sont? corps aptère; têle distincte, portant deux antenues droites de quatre articles; des mâchoires, des lèvres et des palpes, mais peu distincts; corselet à șix paltes; abdornen alongé, linéaire; queue fourchue, repliée sous le ventre, propre pour sallter.

Ces insectes sont très-petits, fort mous, et 
leur forme semble approcler un peu de celle du pou de l'homme; leur corps est alongé, annelé , paisemé de petites écailles qui s'enlèvent par le frottement, et quelquefois velu. Leur tête est séparée du corselet par un étranglement profond ; elle est ovale et porte deux yeux formés chacun de huit petits grains rassemblés; leurs antennes sont filiformes, de quatre pièces, dont la dernière cst simple. Leur's pieds n'ont que quatre articles distinets et leurs tarses sont terminés par deux petits crochets.

Ce genre se distingue des Smynthures par la forme de l'abdomen qui est globuleux dans ces derniers; ceux-ci ont de plus la dernière pièce des anteunes formée de petits articles.

L'abdomen des Podures porle une queue molle et flexible, qui est extrêmement remarquable par l'usage qu'en font ces inseetes; ils peuvent, à l'aide de cette queue, s'élever en l'air et exécuter des sauts analogues à ceux que font les puees. Cet organe est composé d'une pièce inféricure, mobile à sa base, à lextréinité de laquelle s'articulent deux tiges susccptibles de se rapprocher, de s'écarter ou de se croiser, et qui soal les dents de la fourche. Cette queue est reçue dans une rainure du ventre quand'insecte est en repos; mais lorsqu'on le trouble et qu'on l'oblige à sauter, il exécute ce mouvement en redressant sa queue, qui s'étend en arrière, frappe et pousse fortement contre le sol et produit l'effet d'un ressort qui se débande : ce saut éloigne l'insecte de deux ou truis ponces de l'endroil-oì il étoit, et le dérobe aiusi subitement au danger. Il le répète un grand nombre de fois si on l'inquiète. Quand le saut est achevé, la Podure remet doucement sa queue dans sa premic̀re posilion.

Les Podures sont oripares et ne subissent aucuue métumorphose. En sortant de l'œul elles ont les formes qu'elles auront toute leur vie; elles croissent journellement et changent de peau. De Géer, dont le nom se rattache aux observations les plus curieuses sur les mours des inseetes, a trouvé en Hollande des Podures vivantes et trèsalertes pendaut les plus grands fioids; leurs œufs étoient auprès d'elles; ils étöient d'une eouleu: jaune qui chängea en ronge-foncé quand ils furent près d'éclore : ayant ouvert-de ces ceufs, il ne trouva rien dedans qui eût la figure d'un insecte, mais il vit seulement quelques points noirs. Peu de jours après, il en étoit sorli de petites l'odıres qui a voient leur queue fourchue dirigée en arrière. II a remarqué que les Podnres aquatiques ne peuvent vivie long-temps hors de l'eau; elles se dessèchent et meurent bientôt, ce qui fait voir que ces Podures different des Podules terrestres, gui supportent la chaleur du soleil sans en souffrii.

Ces insectes se tiennent sur les arbres, les plantes, sous les écorces ou sous les pierres, quelquefois dans l es maisons. D’autres vivent à lá surface des eaux dormantes, où ils exćeutent leurs sauts; on en trouve quelquefois sur la neige, mênie au temps du dégel. Plusieurs se réunissent en soeićlés nombreuses sur la terre, les chemins sablonneux, et ressemblent de loin à dc petits las de poudre à canon. Vient-on à toucher ce petit amas de Podures, chaque iudivinu fait un ou plusieurs sauts et tout disparoît bientôt. Il est probable que les Podures vivent de matieres végétales altérées qu'clles rongent.

Les auleurs ont décrit dix-buit espèces de Podures. M. Latreille a restreint ce gcnre et a placé dans celui des Smynrmunes (vojez ce mot), celles dont De Géer a fait sa seconde támille des $\mathrm{Po}$ dures.

\section{Podure plombée, P. plumbea.}

Fodura fusco-corulea, nitida, capite pedibustue griseis.

Podira plumbea. Lisn. Syst. Ivat. ed. 15. tom. I. pars 2. pag. 1013. - Fauna Suec. eal. 2. no. 1930 . - la Podure grise commune. Geore. Hist. des Ins. tom. 2. paor. 610. - Podure plombée. De Géer, Mém. surles Ins. tom. 2. purg. 31. pl.3. fig. 1. - Podura plumbea. HАв. Lintom. Syst. tom. 2. pag. 66. - REM. Gen. Ins. tab. 29. fig. 2. - Podure plombée. Lit . Hist. nut. des Crust. et des Ins. toni. 8. pag. 76. - Gen. Crust. et Ins. tom. $1, p a_{g}^{g}, 166$.

Cetle espèce est oblongue, velue, variée de brin-obseur et de noir.

On la trouve aux environs de Paris, sous les pierres. Ellen'est jamais en société.

Ja Podure aquatique, $P$. aquatica, Lins. Georf. Fab., se trouve en quantité sur les eaux dormantes; elle se tient près des bords. et couvre quelquefois toutes les feuilles des plantes aquatiques.

La Podura nivalis, Linn. Geoff. FaB., vit dans les bois. On la trouve en hiver sur la neige et dans les traces qu'y ont empreinles les hommes et les animaux en marchaut. (E. G.)

PODURELTES, Podurellce. Famille d'insectes de l'ordre des 'l'hysanoures, établie par M. Latreille et comprenant le grand geire Podure de Linué é des autres entomologisles. Ses caractères sont : corps aptère; tête distinguée dan corselet, portant deux antenies filiformes de quatre articles simples, ou dout le dernier est composé; mâchoires, lèves et pralpes pell distincts ; corselet portant six palles; abdomen terminé par nne queve fourchne, appirquée dans l'inaetion sous le ventre et servan à sauter. Cette famile renferme lejgenres Podvke et Sarntuune. Doyez ces mots: (L.G.)

P(ECILE, Pacilus. Genre de Coléoptères éta-

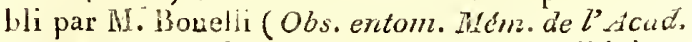
de Turin) dans la tribu des Carabiques; il lui ato 


\section{8}

tribue les caractèrcs suivans : palpes maxillaires extéricurs ayant leur quatrième artrcle de la lona gueur du précédent. Languette courte, un peu tronquée, ayant des soies terminales écartées. Labre tronqué, entier ou à peine échancré. Mandibules munies de petites deuts a leur basc. Corselet plus étroit à sa bise, ayant deux stries de chaque côté, l’extérieure très-petite ou oblitétiée par des points enfoncés. Ailes quelquetois courtes. Antennes comprimées, plus ćpaisses à leur extrémité.

Les Carabus punctulatus, cupreus (voy. $\mathrm{C}_{\mathrm{A}-}$ пАвЕ cuivreux $n^{\circ}: 9^{8}$, Encycl.), dimidialus et lepidus (voy. Carabe agréable no. 93, Encycl.) de Fabricius, appartiennent à ce genre.

(S. F. et A. Serv.)

PCECILloptére, Pceilloptera. Nom donné par M. Germar ( $M$ ag. entom. Halle, 1818) à un genre d'insectes hémiptères démembré de celui de Flata de Fabricius, pour y placer l'espèce nomınée par ce dernier Phalcnoides. Ses caractères., suivant M. Germar, sunt : tête obtuse à sa partie antérieure, front presqu'ovale, rebordé sur les côtés; sa base occupant le vertex, son extrémité ayant une impressioa transversale. Chaperon altaché à l'extrémité du front, conique, subulé à son extrémité. Labre reconvert. Rostre à peu près de la longueur de la moitié du corns. Yeux globuleux, pédiculés en dessus. Point d'yeux lisses. Antennes ćloignées des yeux, courtes; leur premier article menu, cylindrique: le second obconique, concave à son extrémité, portant ure soie qui est ćpaisse à sa base.

Dans le volume du mêne ouvrage de l'année I821, l'auteur décrit trois nouvelles espèces de ce genre, $1^{\circ}$. P. tortricina du Brésil et du Mexique; $2^{\circ}$. P. py ralina de Curaçao; $3^{\circ} . P$. roscida du Biésil. (S. F. et A. Srnv.)

PCEILRE, Pacilma. Nouveau geure de Colíopieres fondé par M. Germar. (Mag. entom. Halle, 1821.) Il appartient à la tribu des Charansonites, famille des Rliynchophores el a pour caractères : rostre plus long que le corselet, filiforme, arqué; ses fossettes commençanl vers l'extrémité avant son milieu, se recourbant ensuite en dessous sur la iartie intérieure de la base du rostre. Antennes insérćes vers le milien du rostre, phus courtes que la - noitié du corps, n'altciornaut point la base du corselet, lursqu'elles sont rabattues; leur premier article atteignant au plus I angle incérieur de l'oil ; le fouet ou partie intermédiaire entre le premier article et la massue, composé de sept articles, dont le premier et le second presque cylindrigues ou presqu'en massue, un pè plus grands que les cing suipans, ceux-ci jlus courts, rétrécıs, presque globuleux. Massue courle, ovale, ses articles point distincts. Tôte petite, presque ronde. Yeux grands, globuleux, proémi- nens, occapant presque loute la partie supérieure de la tête, rapprocliés et se touchant presque sur le front. Corselet oblong; très-rétréci antérieurement, ayant à sa partie postérieure deux sinuosités protondes, prolengé dans son milieu et s'avancant sur l'écusson, ses angles latéraux arrondis. Licusson distinct, ponctiforme. Elytres à peine plus larges que la partie postćrieure du corselet, presquovale, un peu aplaties, ayant leurs angles huméraux proéminen;, un peu plus larges que longues, arrondies et obluses à leur extrémité, couvraut des ailes et laissant dépasser l'anus.

Liauteur fait deux divisions dans ce genre. La première a pour caractères : pattes alongées et grêles; cuisses linéaires, denticulées; jàmbes cylindriques nunies de deux épines à leur extrémité : premier article des tarses très-long. Il met dans cette division le Rhynchanus bispinosus Fab. à qui il donne pour patrie l'Amérique méridionale, quoique $F$ aloricius indique Sumatra.

Sa seconde division est caractérisée ainsi : pattes courtes; caisses épaisses, en massue, dentées : jambes presque cylindriques, obliquement tron fucées à lenr extrémité, anguleuses à leur partie intérieure; tarses courts, larges, leurs articles presqn'éganx. Il décirit deux espèces de celte division sous les noms de Capucinum et d'Ardea; elles lui paroissent nouvelles et sont d'Allemagne; la dernière n'est peut-être qu'une variété de l'autre.

M. Germar observe que les Rhynchanus taums, cornutus et guttatus, $\mathrm{F}_{\mathrm{AB}}$, forment peutêtre dans ce genre une division particulière.

\section{(S. F. et A. Seriv. )}

POECII,OPES, Pocilopa. Dans louvrage sue lc Règue aninual de M. Cuvier, j’ai désigné ainsi une section (la première) de l'ordre des Branchiopodes, classe des Crustacćs, et à laquelle.jai assigné les caracteres suivans : quelques pieds ou pieds-mâchoires terminés par ún ou deux crochets, prop̣es à la course et à la prébension, suivis de pieds en nageoires, soit composés ou accompagnés de lames, soil membraneux et en digitaion. - Téte coulondue avec le tronc, avec des yeux distincts, dans la plupart. - Partie antérieure du corps au moins recouverte d'un test clipéacé ou se présentant sous cètte forme. Antennes toujours courtes et simples. - Branchies postérieures. - Animaux pouvant courir et nager, et en partie parasites.

Les uns errans on vayabonds, n'ont ni bec ni suçoir, et leurs organes masticateurs sont formés pa: les hanches des pieds, hérissćes de pointes ou depetites épịnes, et converties ainsi èn espèces de mâchoires, qui entoureat le pharynx. C'est ce qui est propire aux Limules de Fubricius. ou Yyphosures de Groncvius. Les autres preque toujours tixés an corps de divers reptiles batracions ou sur des poissuns, ont soit un rostre ou bec, 
oit quelque mamelon caché, mais exsertile, ténant lieu de suçoir. Celte division comprend les gences Argule et Calige de Muller, ou les Caligidés du docteur Léach.

Dans la seconde édition da nonveau Dictionnaire d'histoire naturelle, article Pacilopes, ces Crustacés composent une famille que je partage, d'après.les mêmés principes et d'après la présence ou l'absence d'un test, de la manière suivante :

I. Des mâchoires sciatiques ou formées parles hanches. Un test de deux pièces. Crustacés vagabonds.

Première tribu. XYphosuras.

Le genre Limule.

II. Un bec pour la succion. Test nub au d'une pièce. Crustacés parasites.

Seconde tribu. Ichтromrzes.

\section{J. Un test. (Les Paeumonures.)}

Les geures Argule et Calige de Muller.

\section{Point de test. (Les Helminthoides.)}

Ie geure Dichelestion.

On pourroit encore diviser les Pæcilopes, d'après la présence ou !'absence du test, en trois tribus : les Xyphosures, les Pneumonures et les Helminthoides. Celte autre distribution est présentée au mêroe article.

Il est évident que les l'ocilopes s'éloignent sous la cousidération des organes propres à la manducation de tous les autres Crustacés, et c'est ce quàait déja observé feu Jurine fils relativemeut aux Argules. 1/s fornent nbe section particulière et que l'on pourra désigner sous le nom d'Edentés, par opposition á celle qui cornprendra les autres Crustacés, et dont la bouche est constituée comme à l'ordinaire, par un labre, deux nanulibules, des michoires, souvent aussi par un nombre plus ou moins graud de pieds-máchoires, organes tous placés en avaat des pieds proprement dils. Ces Cruslacés serout diskingućs des prẹcédens par l'épithète de maxillarres ou broyeurs. Tclle est la marche que je suis daus mon ouvrage ayant pour titre : Famulles naturelles du rigne arimal. J'y divise les Crustacés édentés en denx ordres, les Xyphosures et les Siphonostomes (voyez ces arlucles). Les autres Brinchiopodes y sont distribnés en diver's ordres, de maniere que ctelui que j'unois d'abord nommé ainsi, el qui eunbrassoit les Entomostracés de Muller, est détruit. Sans cette dilacération, al seroit très-dilficile de signaler ce grunpe d'une waviêre simple et rigoureuse. ( Lata.)

POGONOCÉRE, Pogonocerus. Genre de Coléoptères bétéromères établi par M. Fischer dans leš Mémoires des naturalıstes de Moscou, année Hist. Nat. Lns. Tome $X$.
1321. It en Ggare une espèce sur le frontispice de son ouvrage. Ce genre est le même que celui de Dendroide de M. Latreille, qui donne à l'espèce gui lui a servi de type le nom de Dendrö̈le du Canada ( $D$. Canadensis). Peut-être est-ce la mêrne que celle figurée par M. Fischer. Voy. Detdnoïe, article Prroctroides.

(S. F. et A. Serv.)

POGONOPHORE, Pogonóphorus. IAat. Leistus. Frasuz. Clatrv. Carabuls. Linn. Fab. Oliv. Genre d'insectes de l'ordre des Coléoptères, section dés Pentamères, famille des Carnassièr, tribu des Carabiques.

Ce genre fait partie de la quatrième division de la tribu des Curabiques, nominée par M. Latreille les Abdominaux. Cette section présente ponr caractères: palpes extérieurs point subulés ni en alêne; point d'échancrure aı côté interne des jambes antérieures on cetle échancrure ne formant, quand elle existe, qu'un canal oblique linéaire n'avançant point sur la face antérieure de la jambe. Elytres entières on simplement sinuées à leur extrémité postérieure. Deroier article des palpes extérieurs ordinairement dilaté soit en forme de triangle ou de bache, soit en forme do cône renversé plus ou moins oblong. Yeux saillans. Alidomen souvent très-yrand relativement au corselet.

Les gemres qui en dépendent sont: Cychre, Pambore, Calcsome, Carabe, Nébrie, Omom phiron, Pogonophore el Elaphre. Ancus de ces genres si ce n'est celni de Pogonophore n'a la base extérieure des nuâchoires munie d'un rangr d'épines parallèles, très-apparenles, et nous croyons ce caractère sulfisant pour faire distinguer ce genre de tous les autres que nous venons de citer. Antennes sétacées, grêles, écartées à leur base, de onze articles, le premier alongé. Labre coriace, transversal. - IMandibules conrtes, larges, très-dilatées à lenr hasc, pointuès à l'extréunté. - Machoires très-ocluez, terminées en poiute äiguë et arquée, leur base extérienre ununie d'un rang d'épines parallc̀les très-apparenies. - Palpes cxtéricurs avancés, alongés; leur dernier article long et conique. - Lève étroile, très-alungéé, a vatrcée, trićpincuse à son extrémilé supríricure. - Tếte ayant un cou distinct. - Teux saillans. - Corps aplati, aile. Conselet court, cordiforme. -- Elytres entières. - Patics longues, peu fortes; jamlies antérieures sans échavcrure; tarses rnenus, filiformes, les quatre premiers articles des antérieurs larges et aplatis dams les máles. Le uon de Pugronophore vieut de deux mots grees qui signifient: portebarbe; il a ćlé donné à ces insectes par Mi. Iar reille, à canse de leurs unâchoires très-remarquables par les longs poils roides dont elles sont garnies extérieurement. Ce genre se compose d'un pelit nombrę d'espèces qui babitent l'Europe tewyérée 
et se trouvent sous les pierres dans les cndroits Jumides ou sous les écorces des vieux arbres.

\section{Pogonopene bleu, $\boldsymbol{P}$. coruleus.}

Pogonophorus coruleus. Lat. Gener. Crust. et Ins. tom. 1. pag. 223. no. 1. tab. 7. fig. 4. Carabus spinibarbis. Fав. Syst. Eleut. tom. I. pag. 181. no.61. - PANz. Faun. Germ. fas. 3o. fig. 6. et Manticora pallipes, fas. 89. fig. 2. Faun. franc. Coléop. pl. 6. flo. 5. - Encycl. pl. 179. fg. 2. et pl. 357: fig. 12. bis.

Toyez pour la description et les autres synonymes Carabe spinibarbe $n^{\circ} .87$.

\section{Pogovophore luisant, $P$. nitidus.}

Pogonophorus niger, antennis, labro, palpis, mandibulis pedibusque ferrugineis.

\section{Leistus nitidus. Dufrs. Faun. Austr.}

Longueur 2 lig. $\frac{1}{2}$ à 3 lig. Noir en dessus, d'un brnn-rougeâtre en dessous. Antennes, labre, palpes, mandibules el pattes d'un fauve-ferrugineux. Corselet un peu pointillé surtout vers ses bords. Elytres marquées de stries pointillées. Mâle.

Des Alpes de Styrie. Donué par M. le comte Dejean.

\section{Pogonophore anal, $P$. analis.}

Pogonophorus niger, antennis, capitis anticâ parte, ore pedibus et ano, ferrugineis.

Carabus analis. FAв. Sy'st. Eleut. tom. I. pag. 197. $n^{\circ}$. 148. - Leistus piceus. Frовн. - Leistus Frochlichii. Durss. Faun. Austr.

Longueur 4 à 5 ligr. Corps plus étroit que dans ses eollgénères. Noir en dessus, d'un brun-roussâtre en dessous. Antennes, partie autérieure de la tête, bouche, pattes et auus d'un fanve-ferrugineux. Curselet lisse, un peu pointillé postérieurement. Abdomen ovale. Elytres fortement strićes; siries poiutillées, mais peu distinetes vers l'extrémité. Fenelle.

Nous en somues redevables à $M$. le comte Dejean qui l'a pris dans les Alpes de Siyrie.

CYCHRE, Cychrus. FАв. PAтк. Laт. Carabus. De Géer. Oslv. I'enebrio. Linn.

Genre d'insectes de l'ordre des Coléoptères, seetion des Pentamères, famille des Carnassie!s, ribu des Carabiques.

Daus les Abdominaux ou quatricme division de Carabiques (voy. Pogoropнore) les genres Carabe, Calosorie, Pogauophore, Nébrie, Ómophron et Elaphre ont les mandibules à dentelures nulles ou cantonnées ver's la base, et dans les Paınbores le côté extérieur des mandibules est très-arqué, le côté interne est dilaté et armé de trois dents, caractères qui distinguent ces divers genres de celui de Cyehre.

Antennes filiformes, insérées sous un rebord de la tête, leurs articles alongés, le second et le quatrième plus courts que les autres. - Labre profondément éehancré, bidenté. - Mandibules fortes, avaneées, élroites, droites au côté externe dans la plus grande partie de leur longueur, munies de deux fortes den's vers le milieu de leur côte intérieur dont la base est velue et comme frangée. - Mâchoires étroites, cylinåriques, crochues à l'exırémité, ayant intérieurement vers le milieu un avancemeut membraneux, linéaire, frangé.-Palpesextérieurs terminés par un article ırès-grand, dilaté en forme de cuiller, les maxillairés extérieurs composés de quatre articles, les labiaux de trois. Palpes maxillaires interves de deux articles, le dernier déprimé, demiovale. - Lève ayant deux lauières étroites, nembraueuses, entre lesquelles on aperȩoit un tubereule qui porte denx soies; menton carró, fourelıu, sa partie moyenne plate, ses côtés eouvexes. - Téte étroile, avancée. - Corps rétréci en devant. - Corselet presque cordiforme, tronqué transversalement à sa partie postérieure. Ecusson nul. - Elytres réunies, eouvrant l'abdomen et embrassant ses eôtés. - Point d'ailes. - Abdonien grand, ovale, plus large que le corselet. - Pattes de longueur moyenne; jambes et tarses grêles; jambes antérieures sans échanerure, leurs deux épinesterninales petites.

Les mœur's des Cychres doivent être les mêmes que eelles des Carabes (voy. ce mol). Leur livréc est la couleur noire ou bronzée. On en connoît cinq ou six espèees d'Europe ou de l'Amérique boréale.

Rapportez à ce genre le Carabe muselier $n^{\circ} \cdot 48$ (Cychrus elongatus. DEJ. Catal.), en retranchant les syunnymes de Linné, de Fabricius et probablement aussi eelui de De Géer. Le $C_{y}$ chrus rostratus (Tenebrio rostratus. LinN.) diffère du préeédent en ce qu'il est un peu plus brillant, que ses élytres paroissent avoir quelques stries très-irrégulières, les points élevés se réunissant souvent dans une direction longitudinale, que la ligne enfoneée du eorselet est beaueoup plus marquée, enfin que la têle et le corselét sont moins rugueux.

Les Carabes relevé no. 49 et unieolor n०. 5o, Encycl. (Cychri, nos. 4 et 5. FАв. Syst. Eleut.) constituent aujourd'hui un nouveau genre nommé Scaphinote.

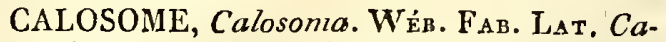
rabus. Luin. De Géñ. Cliv. Buprestis. Georz. Genre d'insectes de l'ordre des Coléoptères, section des Pentamères, famille des Carnassiers, tribu des Carabiques.

Les Carabes et les Calosomes forment un pelit 
groupe dans la division des Caraliques Abdominaux. (Voyez Pogonoprone.) Ce groupe est ainsi caractérisé : mandibules suns dents notables, ou v'en ayant que vers la base. Bord antérieur du labre bilobé ou trilobé. Les Carabes ont le dernier article de leurs palpes maxillaires extérieurs sensiblement plus large que le précédent, eu forme de hache, et l'abdomen ovale, ce qu'on ne voit pas dans les Calosomes.

Antennes sétacées, insérées sous un rebord de la tête, leur troisième article alongé. - Labre ayant son bord antérieur bilobé. - Mandibules fortes, arancées, sans dentelures. - Mâchoires courbées, assez grosses au bout, brusquement et extérieurement à angle aigu. - Palpes extérieurs terminés par un article assez gros en cône renversé; les maxillaires extérieurs de quatre arlicles, les internes de deux artieles, le dernier dépassant entièrement l'extrémité des mâchoires. Palpes labians de trois artieles. - Lèvre courte, large, coruée; menlon terminé par une pointe siuple. - Yeux globuleux, proéminens. - Corps un peu déprimé. -- Corselet assez court, corcliforme, plus étroit que l'abdomen. - Ecusson trèspetit, triangulaire. - Elytres grandes, recouvrant l'abdomen et les ailes. - Abdomen grand, carré, déprimé. - Pattes longues, fortes; jambes antérienres sans échancrure. Les quatre premiers articles des tarses antérieurs dilatés en forme de palette carrée dans les mâles.

Des couleurs brillantes et métalliques ont fait donner à ce genre le now de Calosome qui vient de denx mots grecs dont la signifieation est : bel extérieur. Lues espèces de ce genre sont toutes d'assez graude taille et s'élèvent à pen près au nombre de douze. Les indigènes habitent les forêts. Voyez pour les détails de mœurs le not Carabe.

On doit rapporter aux Calosomes les Carabes calide $n^{\circ} .26$, inquisiteur $n^{\circ} .43$, scrutateur $\mathrm{n}^{\circ} .44, \mathrm{pl} .178$, fig. I, réticulé no. 45 , sycoplianle, no. $46, p l .17^{8}, f_{g} .2$, et rechereheur no. $47, p l .178, f g .3$ de ce Dietionnaire.

$$
\text { (S. F. et A. Serv. ) }
$$

POITRINE, Pectus. Voyez Thorax.

$$
\text { (S. F. et A. SERv.) }
$$

POLISTE, Polistes. Lat. Fab. Vespa. Linn. Geoff. De Gierr. Oriv. (Encycl.) Jur.

Genre d'insectes de l'ordre des Hyménoptères, seetion des Porte-aiguillon, famille des Diploptères, tribu des Guêpiaires.

M. Latreille divise en deux cette tribu, les Solitaires et les Sociales. Les Guêpiaires solitaires qui renferment les genres Syuagre, Odynère, Eumène, Zèthe, Discolie et Céramie ont pour caractères: mandibules très-étroites, rapprochées en devant en forme de bee. Division intermédiaire de la languette étroite, alongée. Chaperon presqu'en forme de coeur dont la pointe est en devant et tronquée; tandis que les Guèpiaires sociales contenant les genres Poliste et Guêpe ont les mandibules guère plus longues que larges, la division intermédiaire de la languette en coeur et le chaperon presque carré. Le genre Guêpe se rapproche des Polistes par ses mours et par la conformation de plusieurs de ses parties; il s'en distingue eependant facilement en ce que le premier segment de son abdomen est aussi large on même plus large que le second, ce qui ne se voit point dans les Polistes, lesquelles ont d'aillenrs le corps plus étroit et moins gros.

Antennes grossissant insensiblement vers l'extrémité, terninées en pointe, insérées vers le milieu du front, brisées, de douze articles dans les femelles, de treize dans les mâles. Le premier long et cylindrique, le second très-petit, le truisième alongé et conique. - Mandibules fortes, dentées, guère plus longues que larges, en carré long, obliquement et largentent trouquées. - Mâchoires ayant un appendice teruninal peu alongé, marqué dinne suture transversale vers sa pointe. - Palpes courts. - Lievre portant quatre poinis glanduleux à son extrémité, sa division intermédiaire peu alongée, presqu'en eœur. - Chaperon presque carré, milieu de son bord antérieur avancé en une petite dent aiguë et envière. - Yeux échancrés intérieurement. - Trois petits yeux lisses disposés en triangle et placés sur le vertex. - Corps étroit et alougé. - Premier segment du corselet formant nn arc, prolongé en dessus jusqu'à la naissance des ailes supérieures. - Ailes ployées longitudiualement et doublées dans le repos; les supérieures ayant une cellule radiale pointue à ses deux extréunités, se rétrécissant après la deuxième cellule cubiale; et quatre celtules eubitales, la première aussi longue que les deux suivintes prises ensemble, la seconde sexangulaire, se rétrécissant vers la radiale, recevant les deux nervures récurrentes, la troisième en lozange, placée un peu obliquement, la quatrième presque complète et fort graude. Abdomen composé de ciuq segmens oulre l'anus dans les femelles, en ayant un de plus dans les môles; le premier sensiblemeut plus petit et plus étroit que le second. - Pattes de longueur rnoyenne; jumbes antérieures munies d'une épine à leur extrémité ; les quatre autres de deux : crochets des tarses simples avec nue pelotte dan. leur entre-deux. - Trois sortes d'individus vivant en société, mâles, femelles fécoudes et oвvrières ou femeiles stériles.

Nous ne nous appesantirons pas sur les mœurs des insectes de ee genre dù à M. Latreille, quoique très-intéressantes; la plupart des faits que nouః aurions à rapprrter se trouvant déjà consigués dans l'article Guêpe de cet ouvrage. Quelqué Polistes exotiques construisent leurs nids d'uae $\times 2$ 
matière assęz solide que l'on a comparce au carton, et les gâteaux qu'ils renferment sont recouverts par une enveloppe commune (voyez l'article G पEP,E, page 659 et suivantes). D'autres es: pèces et celles que nous avons pu observer aux environs de Paris sont de ce nombre, composent leurs gâteaux avec une matière analogue au papier et particulièrement à celui dont est fait le nid de la Guêpe vulgaire, le laissent à découvert el se contentent de le poser ou contre un mur à l'abri d'une pierre en saillie ou d'une lranche de quelque arbre en espalier, où même elles l'attathent à une brauche dans un buisson touflu. Ce uid n'a qu'un rang de cellules s'il n'est composé que d'un seul gâteau, je veux dire qu'une seule des faces de celui-ci qui est posé verticalement, porte des cellules; lorsque ce gâtean a déjì quelques pouces de diamètre, la femelle en construit un second par-dessus. Ces gâteaux sont pédiculés; on en voit jusqu’à trois aiasi superposés, dont le premier est toujours le plus grand. Ce nid est fondé au printemps par une seule femelle qui a été fécondće avant l'inver ; elle pond d'abord des œufs destinés à produire les ouvrières qui doivent l'aider dans ses Iravaux; ce n'est que dans l'été qu'elle commence à déposer des œuf́s d'où naîtront d'abord des nuales et ensuite des femelles fícondes. A cette époque on trouve dans les nids quelques cellules pleines d'un excellent miel. Voyez pour les autres détails relatifs aux mours, larticle Gú̃e.

On coanoîl aujourd'lui un grand nombre d'es pèces de Polistes, qui appartiennent toutes aux climats chauds ou tempérés des deux Mondes. Elles n'affectent point de couleur particulière.

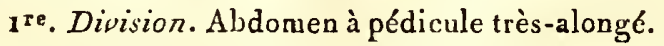

I $^{\mathrm{re}}$. Subdivision. Pédicule for'mé du premier segment de l'abdomen et de la base du second.

1. Poliste cyanipenne, P. cyanipennis.

Polistes atra, metathorace rufo tomentoso, abdomine longè pedunculato.

Polistes cyanipennis. FAB. Syst. Piez. pag. 275. $n^{\circ}$. 30. - Coqveв. Illust. Icon. tab. 6. fig. 4 .

Longueur I 2 à 15 lig. Antennes et tête noires. Corselet de même coulenr avec le métathorax testacé el convert d'un duvet roussâtre. Abdonien noir, premier seginent testacé en dessous à sa base, le second rebordé postérieurement, les derniers garnis de poils blanchâtres en dessous. Ailes d'un bleu-violet. Pattes noires. Femelle.

Le mâle a le bord antérieur du chaperon testacé, et porte sous le ventre deux appendices latéranx qui paroissent sortir de la buse du cinquième segmeut de l'aidomea.

De Cilyenne.

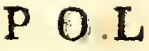

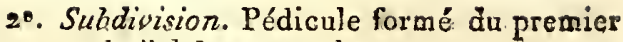
segment de l'abdoren seulement.

2. Poriste tatua, $P$. morio.

Polistes nigra nitens, punctulata, abdonino pedunculato.

Polistes morio. FAB. Syst. Piez. pag. 279. $n^{\circ} .45$. - Lat. Gener. Crust. et Ins. tom. 4. pas. 142.

Longuenr 6 lig. Corps entièrement d'un noirluisant et finement pointillé. Autennes noires. Ailes en partie transparentes, brumes vers le bord antérieur, surtout du côté de leur base. Mâle et femelle. Voyez pour la duscription de son nid, l'article Gû́PE, à la page 659 et suivantes.

De Cayenne.

\section{Poniste bleue, P. cyanea.}

Polistes cyanea. FАв. Syst. Piez. pag. 279. $n^{\circ}$. 47. - Lat. Gen. Crust. et. Ins. tom. 4. pag. 142.

Voyez pour la description et les autres, synonymes Guêpe bleue $n^{\circ} .22$.

\section{Poliste fasciée, P. fisciata.}

Polistes fulvo-fasciata. Lat. Gen. Crust. et Ins. tom. 4. pag. 142.

Voyez pour la descripion et les autres synonymes Guêpe fasciée no. 35 .

2e. Division. Abdomen pen sensiblement pédiculé.

re. Subdivision. Parlie postérieure du corselet compée droil et comme tranchée subileinent.

\section{Ponsste cartonnière, $P$. nidulans.}

Polistes nidulans. Lat. Gener. Crust. et Ins. tom. 4. pag. 141.- Vespa nidulans. Fa . Syst. Piez. kag. 266. no. 68. - Сoqu вв. Illust. Icon. tab. 6. fig. 3.

Voyez pour la description et les autres synonymes. Guêpe carlonnière no. 88 .

$2^{\circ}$. Subdivision. Parlie postén Eeure dn corselet allant en peote, s'abaissant progressivemeut.

6. Polistz française, $P$. gallica.

Polistes gallica. Fав. Syst. Piez. pag: 27 r. no. 8. - Lat. Gen. Crust. et lns. toml. 4. pag. 142. - Panz. Faun. Germ. fas. 49. fig. 22.

Nota. M. Latreille, dans le Dictionnaire d'histoire naturelle, et Olivier, Guêpe $n^{\circ}$. 5o da préseat ouvrage, donnent pour synonyme 
de cette espèce la Guêpe no. 5 de Geofroy, qui nons paroit différer essentiellement. C'est notre Poliste de Geoffroy. $n^{\circ} .8$.

Voyez pour la description de la femelle et les autres syononymes Guêpe gauloise $\mathrm{n}^{\circ}$. 50 .

Le wâle dilfère en ce que ses mandibules sont jaunes ainsi que le front et que les cuisses ont plus de jaune surtout dans leur partie antérieure.

Très-commune aux environs de Paris.

\section{Poliste diadême, $\boldsymbol{P}$. diadema.}

polistes clypeo nigro luteo bilineato, antennis suprà nigris.

\section{Polistes diadema. Lat. Dict. d'Hist. nat.}

Longueur 7 lig. Antennes fauves, noires en dessus. Leur premier arlicle jauue en dessous. Tête noire, chaperon ayant denx lignes jaunes, la.supérieure crénelée en dessous; une autre ligne jaune sur le front, trois taches de même couleur, l'une avant la base des mandibules, une autre au bord iuterne des yeux et la troisième derrière eux. Corselet noir, son bord antérieur, le bord supérieur des épiulettes, celui de l'écaille des ailes, une tache sous cette écaille, deux autres sur l'écusson, deux au-dessous, deux lignes longitudinales ainsi que deux points latéraux sur le métallorax, de couleur jaune. Abdomen noir; tous ses segmens bordés d'une ligue jaune transverse, ondée autérieurcisent; les deux premiers portant en outre un point juune latéral. Paltes jaunes, hanches noires, cuisses noires, jaunes à l'extrémité. Ailes un peu fauves. Femelle.

Moins cammune que la précćdente aux environs de $\mathbf{P}$ aris.

\section{Poisste de Geoffroy, P. Geoffroyi.}

Polistes clypeo nigro maculato firnteque linteis (fæm.) clypeofionteque luters (mas); antennis suprà uigris in utroque sexu.

La Guêpe à anneaux bơrdés de jaune et deux iacbes jaunes. Grofr. Ins. Paris. tom. 2. pag. 574. $n^{\circ}$. 5. Fenelle.

longucur 5 lig. $\frac{1}{2}$. Antennes fauves, noires en dessus, lcur premier arlicle jaune en dessolis. Tête noire, chaperon jun avec une tache noire; unc ligne froutale, base des mandibules, une tache avant celle base, une attre au bord iuterne des yeux et une troisième derrière eux, jaunes. Corselet ncir, son bord antériear, le bord supćrieur des épaulettes, écailles des ailes, une tache sous claque écaille, delux autres sur l'écusson, deux au-dessous, deux lignes longitudinales ainsi que deux points latéraux sur le mélalhorax, de couleur jaune. Abdomen noir, tous ses segmens bordés d'une ligue jaune transverse oudée antérieuremeat, lesecond seulement portaut on outre un point janne latéral. Pattes jaunes; hanches noires: cuisses noires, ayant l'extrémilé jaune surtout.à sa partie antérieure. Ailes un peu fauves. Feurelle.

Le mâle a tout le front et les mandibules à l'exception de leur extrémité jaunes. Son corselct a plusieurs taches latérales et la poittiue de cette couleur. Le premier seguent de l'abdomen a un poiut jaune latéral. Les paties sont jaunes avec les hauches el les cuisses rayées de noir en dessns.

De France. Plus comnune daus les environs de Soissons que la Poliste française.

Nous citerons encore comne appartenant au genre Poliste les Guêpes $11^{\circ 3} .16,59$, 61 et 105 de ce Dictionnaire. ( $S . H$. et A. SERv.)

POLISTIQUE, Polistichus. M. Bonelli donne ce nom dans ses Observ. entom. (Mézn. de l'Acad. de Turin.) à un scenre de Coléopleres de la trisu des Carabiques. il le cairactérise ainsi : antenues filiformes, leur premier article plus court que les trois suivans pris ensemble. Palpes médiocrement alongés, le quatrième article des maxillaires extérieurs dilaté à l'extrémilé. P'ièce nitoyenue du menton se terminant en une pointe simple. Labre tronqué. Mandibules courtes, dentées. Mâchoires pointues, sans divitelures. Quatrième article des tarses simple. Un cou distinct. Corps pointillé.

Ce genre a pour ispe la Gulerita fisciolato de Fabricius. Voyez Zupha lassiolée.

(S. F. et A. Serv.)

POLLYX̃ÈE, Pollyxenes. Iat. La ir. LÉacir. Scolopendra. Linn. Geors. Far. Iulus. DE GeEk. ULiv.

Genre d'insectes de l'ordre des Myriapodes, fauille des Chilogrables, dont les caractires sont d'avoir le corps membraneux, très-mou, lermiué par des piuceaux de petites ćcailles; des autennes de la mêne grosseur duns toute leur longueur, et composées cie sept articles.

Ce genre a élé élabli par M. Latceille sur la Seolopeudre à pinceau ( $S c . l_{0}$ gorus ) de lianué, de Geolfroy et de Fubsicius, que De Geer a placé dans les Iules, el dout il a donné vae discriptiou très-détaillée.

Cet insecte est très-pelit, plat, ovale alongé, et, vu eu dessus, il paroit compos de huit anneaux. Sa tête est grande, arrondie, elle a, de chaque côlé, une petite émrinence en forme de poinle dirigće en avant, les yeux soul situés áaprès de ces pountes; ils sont nuirs, gravds et ronds, et l'ou voil entr'eux et en avaut une frange d'un double rang d'écailles; celles du ring antérieur sont dirigées en araut et celles de luare sont portćes en arrière; les antennes, que linasecte t'einue sans cessequand il marche, sunt composées de sept ariiclss presque cylindriques. Chacua des huit derni-anticaux superriens da corps a, de I chaque côté, une toulte de poils ou de longues 
écailles dirigćes en arrière, et deux touffes sur le dos, composées d'écailles plus petites, ce qui fait en tout trente-deux bouquets; en outre cliaque anneau du corps a deux rangées transversales de courtes écailles, l'une située près du bord antérieur, et l'autre vers le bord postérieur. Le corps est terminé par une espèce de queue qui paroît composée de deux parties alongées, arrondies au bout, séparées ì leur naissance, appliquuées eusuite l'une sur l'autre et consistant en deux paquets de poils d'un bean blanc de satin luisant; le boul du corps cst terminé par une pièce circulaire sous laquelle est l'anus. Le dessous du corps al, suivant De Géer, douze demi-anueanx portant chacun une paire de paltes très-petites, coniques et semblables aux paltes écaillenses des chenilles.

L'organisation de cet insecte n'est pas si compliquée lorsqu'il est jeune. Le nombre de ses anneaux, de ses honquets de poils et de ces pattes est moindre, et il accroit avec l'âge. Les anneaux des jeunes individus, dont De Géer a vin plusieurs n'en ayant que trois et par conséquent trois paires de pattes, ont la mêerne quantité de bouquets d'écailles que les adultes; les pattes des jeunes individus sont plus grosses proportiounellement, que celles des individus plus âgés.

1. Poldyxìne à pinceau, $P$. lagurus. Lat. Gen. Crust. et Ins. tom. 1. pag. 76. - Hist. nat. des Crust. et des Ins. tom. 7. pag. 82. pl. 59.

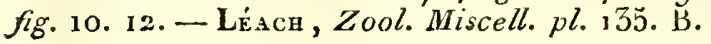

Voy. la description et la synonynue̊ au no. 2I, article Iule de ce Dictionuaire. (E. G.)

POLOChRE, Polochrum. Sin. Lat.

Gemre d'insectes de l'ordre des Hyménoptères, section des Porte-aiguillon, famille des Fouisseurs, tribu des Sapygites.

Les Sapyges et les Thynnes composent avec le genre Polochre, la tribu des Sapygites. Les premiers diffèrent des Polochres en ce que leurs autennes vont en grossissant vers le bout; les seconds s'en disinguent par leurs yeux entiers.

Antennes filiformes, insérées duans une échancrure des yeux, cornposées de douze articles dans les fe melles, de treize dans les nuâles. - Labre presque cacbé, membraueux, triangulaire, cilié en devant. - Mandibules arquées, fortes, tridentées à l'extrémité. - Mấchoires plus courtes que le mentou, cornées et un pen rentlées à leur base, terminées par un appendice merabraneux, cilié au bout. - Palpes maxillaires filitormes, de six articles, le premier plus gros, les autres presqu'ćranx entr'eux, inśrés à l'extrémité des mâchoires an-dessous de l'appendice ; les labiaux plus conrts gue les maxillaires, filiformes, de quatre articles presqu'égaux. - Rève dirigée en avant, membraneuse, trifide; languctte grande, célargissant et très-échancrée antêrieurement. -
Tête grande, aussi large que le corselet; chaperon élevé. - Yeux échancrés, réniformes. Trois petits yeux lisses. - Corselet convexe. Ecusson marqué de deux lignes enfoncées, transversales. - Ailes supérieures ayant une cellule radiale et quatre cellules cubitales, la seconde et la troisième recevant chacune une nervure récurrente, la quatrième atteignant le bout de l'aile. - Pattes fortes, courtes; premier article des tarses plus grand que les autres qui vont en décroissant de longueur.

Ce genre n'est coraposé qne d'une seule espèce dont nous ignorons les mœurs.

\section{Pozochre ondulé, P. repandum.}

Polochrum nigrum, luteo maculatum, abdominis segmentorum secundi, tertii quartique fas ciis undulatis luteis.

Polochrum repandum. Sprvox. Ins. Ligur. fas. 1. pag. 20 et suiv. tab. 2. fg. VIII et fas. 2. pag. I. - Lat. Gen. Crust. et Ins. tom. 4. pag. 109 .

Longueur 9 ì ro lig. Antennes jaunes, rayées de noir en dessus à l'exception du premier et des deux derniers articles. 'Tête noire, mandibules de même couleur avec une tache latérale jaune. Chaperon, uue ligne brisée entre les antennes et orbile des yeux jauues. Corselet noir avec sa ligne antérieure, l'écaille des ailes et sept taches dorsales jaunes; celles-ci placees par paires, excepté l'antérieure qui est seule; on voit une ligne arquée jaune eutre les ailes et quelques taches de même conleur sur les cốiés du corselet. Abdomen noir, son premier segment portant deux taches jannes; les second, troisième et quatrième ayant en dessus une baude ondulée et en dessous deux points, de couleur jaune. Anus de mêue couleur. Palles jaunes; cuisses et banches noires tachées de jaune. Ailes jaunâires. Femelle.

Le mâle est un peu plus petit ; le sixième segment de son abdomen est jaune, bordé de noir inférieurement; il n'a point de li gne arquée eutre. les ailes ni de taches jaunes latéräles a corselet.

Il se trouve aux euvirons de Gênes et dans le Piémont. Nous n'avous point va cet insecte.

(S. F. et A. Skrv. )

POLYBIE, Polybius. Genre de Ciustacés. Voyez Platronique. (Latr.)

POLYDÈME, Polydesmus. LAt, LÉAch. Iulus. Linn. Fab. Oliv. Lam. De Géer. Scolopendra. Geoff. Scopor.

Genre d'insectes de l'ordre des Myriapodes, famille des Chilognathes, établi par M. Latreille, qui l'a démembré du grand gence lule de Linné, et auquel il a assigné les caractcores suivans: corps linéaire, composé d'uu grand nombre d'anneaux qui portent chacun, pour la-plnpart, deux 
paires de pattes. Segmens comprimés sur les côlés inférieurs, avec une sailie en forme de rebord ou d'arête au-dessus. Antennes presque filiformes, courtês, de sept articles, dont le troisième est alongé.

Les Polydèmes diffèrent des genres Glomeris et Tule par la forme du corps; ils se distinguent des Pollyxènes parce que ceux-ci ont le corps membraneux, très-mou et terminé par des pinceaux de petites écailles.

Les Polydèmes ont les antennes, les organes de la manducation et ceux du mouvement cunformés à peu près de même que dans les lules. Le nombre des pattes et des anneaux u'est pas aussi considérable que dans ces derniers insectes. M. Latreille a vu sur ces anneaux des apparences prononcées de stigmates, ce qui rapproche encore davautage les Polydèmes des Scolopendres. Le plan supérieur de ces segmens ressemble à uve écaille presque carrée; il offre quelques inégalités.

M. Latreille a observé les organes sexuels de l'espèce la plus conmone de ce pays, le Polydesmus complanatus, Iulus complanatus de Linné. Il a reconuu que ces organes occupent la place d'une paire de pattes dans les mâles, et que c'est à cette parlicularité que l'on doit altribuer la différence qui existe entre les descriptions que Geoffroy et De Géer font de cet insecte. Le premier lui donne soixante palles et n'a par conséquent observé que des mâles; le second, qui n'a òservé que des femelles, lai donne une paine de pattes de plus. Les orgaues de lis générition de cet insecte sont situées à l'extrémité postéricure et infèrieure du septième anneau; ils sont trèsappareus, composés de deux tiges ruembraneuses qui s'élèveut d'une base érgalement membraneuse et un peu velue. Ces deux tiges sout presque démi-cylindriques, convexes et lisses à leur face antérieure, concaves sur la face opposée; du sommet de chacune part un crochel écailleux, d'un j:une-clair, long, arqué du côté de la tête, avec un avancement oblus, dilaté à sa base, et une dent vers le unlieu interne du même côté. M. Latreille a également cherclié les partics de la femelle; il croit les avoir aperçues sous le troisième anucan et répondant à là seconde paire de patles; eiles ne s'auuoncent par ancun signe extéricur.

L'Iule aplati s'accouple en automine; on rencontre souvent alors les sexes réunis. Leur's corps sont de la mêmegrandeur, appliqués l'uu contre l'autre par leur face inférieure, couchés surle côté el l"extrémité antérieure du corps du mâle dépassant celui de la femelle. L'ovaire remplit une bonne portion de la cavitó intérieure din corps de la femelle; il forme une espèce de boyau aboutissant à une fente placée au bout postérieur du corps.

Les Polydèmes se roulent en cercle comme les Iules; ils vivent sous les débris de végétaux, sous les pierres, dans les lieux frais et près des étangs. Ils se nourrissent, comme lcs Iules, de substances animales et végétales, wais morles ou décomposées.

1. Polydène aplati, $P$. complanatus. LAT. Gen. Crust. et Ins. tom. r. pag. 76. - Lغ.AcH, Zool. Miscell. tom. 3. pl. 135.

Poyez pour la suile de la synonymie et la description le $n^{0} \cdot 19$, article Iune de ce Dictionnaire. Les Iules décrits sous les nos. 15 et 14 appartiemuent alussi ì ce genre.

GLOMERIS, Glomeris. Lat. Iulus. Linn. Fab. Ouiv. Lam. Oniscus. Gronov. Fab. Armadillo. Curier.

Ce genre, établi par M. Latreilie aux dépens des Iules de Liuné, a pour caractères : córps convexe en dessus, concave en dessous, composé de onze à douze segmens ou tablettes, doni le dernier beaucoup plus grand et en demi-cercle, ayant le long de chacun de ses côtés inlérieurs, nnc rangée de petites écailles analogues aux divisions latérales des trilobiles, antennes renflées vers leur sommet.

Ces insectes ressemblent assez à des Cloportes; ils ont le corps crustacé, ovale, sílns appendice au bout et ils se roulent en boule. Le nombre de leurs pattes varie de seize à viligt paires suivant les espèces. Les uns font leur séjour sous des pierres, dans des terrains montueux; les autres vivent dans la mer.

1. Gloménis ovale, G. ovalis. Lat. Ger. Crust. et Ins. tom. I. pag. 74. - Hist. nat. des Crust. et des Ins. tom. 7. pag. 64. pl. 5g. Jig. 5. 6. Iulus ovalis. Linv. Syst. Nat. edit. 13. tom. 1. pars 2. pag. 1064. - Aman. Acad. tom. 4. pag. 253. $n^{n}$. 36. tab. 3. fig. 4. - Hesor. Hist. nat. lib. 2. pag. 51 .

Voyez pour la suite de la synonymie et la des. cription le $n^{0}$. I , article Iure de ce Dictionnairc. On doit rapporter à ce genre les nos. 4 et 6 du nuême article. (E. G.)

POLYDRUSE, Polydrusus. M. Germar a fondé ce gremre de Coléoplères (Ins. Spec. noo. vol. ", Coleopt. 1824), de la tribu des Charansonites, famllc des Rhynchophores. Ses caractères sout: rostre court, cylindrique, ses fossettes cornmençăl en dessus vers son extrémité, se conillant subiteınent pour se réunir en dessous au miliea du rostre. Antennes grêles, plus longues que le corselet, le premier articlc atteignaint plus loin que les yeux, très-peu en usassue, le fouct de sept articles, ceux-ci en massue, les p:emiers plus longs; massue ovale-oblongue. 'Tête ublongue, uu peu cylindrique. Yeux globuleux, saillans. Corselet tíonqué a sa base et à son extrémilé, 
transterse, presque cylindrique, point échancré ni creusé en sillon ea dessous a la base de la tête. Ecusson distinct. Hiytres oblongues, tronquées à leur base, plus larres que te corselet, convexes apròs leur pratie moyenue et couvraut des ailes. Pattes assez longues, presqu'égates entr'elles, les antérieures queiquefóis plus longnes que les autres. Cuisses en massue, lurement dentées. Jambes comprimées, à penue courtúes, leur extréunité inutique. Tarses assez courts, leurs trois :)emiers articles trigones, presqu'égaux. Corps oblonge, mou, écailleux.

Les Polydruses aroisinent les Phyllohies, mais ils en different par les antennes plus grêles et par 1es fossettes du rosire qui se courbent subitement en dessous. Les espèces de ce genre vivent sur les feuilles des arbres. Le Charanson ondé $11^{\circ} .300$ de ce Dictionoaire, le Charaason brillant $n^{\circ} .431$, Oliv. Entom. et le Curculio picus de Fubricins, apparticunent ì ce genre. (S. F. et A. SERv.)

pOLYergue, Polyergus. Lat. Spixol. For mica. Jur.

Genre d'insectes úe l'ordre des IIyménoptères, section des Purte-aiguillou, farnille des lfétérogynes, tribu des lormicuires.

La tivisu des fiormicaices se compose des genres Fournil, Polyergue, Ponère, Myrmice, Eco. dome et Cryptucere. Ces trois derniers se distinguent facilement par le pédicule de leur abdomen composé de deux segmens en forme de nouds, tun lis que daus les premiers ce pédicule est formé d’unc seule écuille. La présence d'un aiguillon dans les fermelles, trois cellules cubitales et une nervure récurrente aux ailes supérieures, sont des cilractères propres àx Ponères. Les antemues insérćts près du front ainsi que les anandibules épaisses et dentelées intérieurearent éloignent les Fourwis des lolyergues.

Antennes tiliformes, condces, iusérées près de 1a bouche, de douze articles daus les feurelles, de treize dans les mâles, le prenier tres-grând, faisaut au woins le liers de la longucur toliale de l'untenne. - Labre grand, cornć, perpendiculaire. - Míandibules itroiles, alongées, arruées, pointues, sans dentelures. - Falpes maxillaires plus courts que les wâchoiras, presqque sétacés, de guatre ou de ciuq articles, les labiaux $n^{2} \mathrm{cu}$ ofliaut distiuctement que trois. - Lèore trèspetitr. - Téte currée, presque verticale. - Yeux petits, presque ronds. - Trois petits yeux lisses (dans lo:1s les individus) disposés en triangle et flacés sur le haut du front. - Corselet comprimé vers l'alsdomen, hossu en devant, plus étroit que la têle - Likhs graades, les supérieures ayaut, srivant M. filtsellle, deux cellules cubitales compietes, la scconde alteimant le bard postćrieur; point de ne:vulcs récurientes. - Abdomen ovoide, composé de cinq segmens oulre l'anus dans les femelles, en ayuat ua de plas dans les mâtes, le

\section{PO L}

premier forrant un pédicule surmonté dane écaille épaisse et lenticalaire; point d'aiguillon. $P$ attes de longueur moyenne; jambes munies de deux épines à leur extrémité, l'autérienre trésgrunde an moins dans les ouvrières. - Trois sortes $d^{\prime}$ indwidus vivant en société. Mâles, femelles ficondes (cenx-ci ailés) et ouvrières ou femelles stếriles (privées d'ailes).

On trouve dans certains temps de l'année trois sortés d'individus de uiêne espèce dans les habitations des Polycrgues; des mâles et des femelles féconiles et d'uuldes femelles stériles que les anciens auteurs ont désignées mal-à-proposs sors le nom de neutres, et qui le sont aujourd'bui avec plus de raison sous celui d'ouvrières. Mais il paroit extraordinaire à l'observateur d'y trouver des ouvrières d'une espèce différente et qui appartiennent même à un autre genre, celni de Fonrmi; ces Fourmis onvrières s'occupent de l'intérêt commun, travaillent le plus souvent seules à apporter les provisions, à les distribuer et à transporter au besuin les larves et les nymphes dins les différen étages de la fourmilière. Ce fait singulier que M. Huber fils habitant de Genève a remarqué le premier, l'engararea $\dot{a}$ observer de plus près les Polyergues, genre fạsant partie de ses Fourmis amazolles. Il vit avec un grand étonnensent, mais sans ancun doule, que les Polyergues se procurent des auxiliaires en s'assujettissant un asséz grand nombre d'individus des espèces de Fourmis que M. Latreille a dócrites sous les noms de Noir-cendrée et de Mineuse. Les Polyergués vont atlag er leurs fourmilières et choisissent pout cela le inoment où la chaleur du jour commence à décliner; ils y pénètrent unalygré l'opposition des Fouraris, saisissent a ver: leurs mandibules les larves et les nymphes des seules ouvrières appartenant à ces sociétés el les transportent daus leur liatilation, manơuvre qu'ils répètent plusieurs jours de suile jusqu'à ce qu'ils se soieut procuré le nombre nécessaire d'auxiliaires. Ils u’en ont jumais à la fois des deux espèces cilées; loon n'y rencontre pas d'ouvrieres de la Fourmi mineuse lor'squ'il s'y trouve des Funmis noir-cendrée et réciproquement. Nous devons faire renatquer que ce sont les Polyergues onvrières seulenent qui exécutent ces exp. ¿́ditions et qu'ils les font en rwarchant par colonnes serrées. Ces larres et ces nyaphes de Fourmis ga'on croirvit d'abord d'après l'instinct connu dés Foraticaires, devoir servir à la nourriture des Polyergues, sont ail contraire soiraces par eux et lorsya'elles sont devenues insectes parfirits, ces Fouras exécutent tons les travaux uéciessares ì la suciété où elles ont été f́levées, sans retonrner it celle où elles ont pris naissance. Quoiqu'il soit certain que les Polyergues ouvrières s'exemptent anuji du travail, ils n'en sont pas moins capables d'expéditions fatigantes conue on vient de le voir et com:ue il est encore prouvé par les déatéa greanens qu'ili font 
quelquefois; dans ce cas ce sont eux seuls qui trausportent lenr postérité et même leur's Fonrmis a uxiliaires dans un nonveau domicile qui est ordinairentent une fourmilière abandonnée par les Fourmis noir-cendrée. Ces fails extraordinaires onlété revus depuis aux environs de Paris par plusieurs observateurs el particulièrenent par notre célèbre compatriote, M. Latreille. La soeiété des Polyergues dure piusieurs années. Voyez l'ouviage de. M. Huber intitulé : Recherches sur les maurs des Fourmis indigènes, chap. 7 et 8 , et l'artiele Fourmi de ee Dietionnaire.

$\therefore$ On ne connoît encore qu'une seule espèce de Polyergue.

\section{Ponyergue ronssâtre, $P$. rufescens.}

Polyergus castaneo-rnfus (frmina); niger, femorum, tibiarum tarsonemque apicibus pallidis (mas).

Folyergus rufescens. La'T. Gen. Crust. et Ins. tom. 4. pağ. 1 27. pl. 13. flg. 5. Ouvrière. - Id. Hist. nat. des Foumis, pag. 186. pl. 7. fig. 38. Oıvrière. - Fourmi roussâtre. Нuв. Recherch. Fourm. indig. pag. $210-260$. pl. 2. fig. 1-4..

Longueur 3 ì 4 lig. Femelle entièrement d'un fauve-marron pâle." Corps glabre, luisant. Yeux noirs. Mandibules brunes. Dos du corselet continu, sans enfoncement. Ailes blanehes, leur point marginal et les nervures d'un roussâtre-clair.

Ouvrière. Second segment du corselet petit, rabaissé, ee qui forme un enfoncement sur le dos. Plus petite que la femelle.

Mâle. Noir , organes sexuels roussâtres. Ecaille de l'abdomen échancrée. Extrémité des euisses, jambes et tarses pâles. Du reste semblable à la femelle. Taille de l'ou vrière.

Se trouve dans toute l'Europe.

OECODOME, OEcodoma. LAt. Atta. Fab. Lat. Jun. Formica. Linn. Fab. De Géer. Oliv. (Encycl.) Ross.

Geure d'inseetes de l'ordre des IIyménoptères, seetion des Porte-aiguillon, famille des Hétérogynes, tribu des Formicaires.

Parmi les genres qui composent celte tribu, les Fouruis, les Polyergues et les Ponères ont le preinier segment de l'abdomen en forme d'ćeaille et formant à lui seul le pédieule. Dans les Myrmices, les CEcodomes et les Cryptocères, ce pédicule est composé de deux nœuds; mais ce dernier geure a le premier article des antennes logé dans une *ainure latérale de la tête, et les palpes maxillaires des Myrmiees sont longs, composés de six articles distinets. (Voyez Mirrmice et rapportez-y les Fourmis des gażons no. 3o, tubéreuse $n^{\circ} .5 \mathrm{I}$, et ronge no. 14 de ce Dictiounaire.)

Antennes filiformes, eondées, entièrement découvertes, insérées près de la bouche, compoHist. Nat. Ins. Tonze $X$. sées de donze articles dans les fernelles, de treize dans les mâles; le fremier très-grand, faisant ì lui seul au moins le tiers de la longueur totale de l'antenne. - Labre grand, eorné, perpendiculaire.-Mrandibules aplaties, alongées, tricrones, dentelées tont le long de leur eốté interne. Palpes très-courts, les maxillaires n'ayant que quitire ou einci artieles distinets, les labiaux eomposés de deux ou trois artieles. - Tête grosse, presqu'en cœur, échancrée postérieurement (au moins dans les femelies et les ouvrières). - I eux petits, presque ronds. - Trois petits yeux lisses disposés en triangle dans tous les individus, les deux supérieurs rapproehés, l'inférieur éloigné et plaeé beaucoüp plus bas dans les femelles et les ouvrières, très-rapproehés et en triangle régulier dans les rầles. - Corselet gros, convexe, terminć brusquement; eelui des ouvrières ayant son premier segment plus élevé, plus large que le seeond et salartie postérieure comprimée latéralement. - Ailes grandes, les supérieures ayant une cellule radiale très-étroite, le point marginal nul, et deux eellules cubitales; la première étroite, la seconde très-longue, presque eomplète, ne touchant à la première que par son angle supérieur : disque de l'aile ne forumt pas de eellules ou plutôt n'en ayant qu'une qui s'avance jusqu'au bord postérieur. Point de nervures réeurrentes. Abdomen globuleux, composé de cinq segmens outre l'ạnus dans les femelles, en ayant un de plus dans les mâles, les deux premiers formant un pédicule, le premier globnleux, le second surmonté d'une écaille lentieuliaire dans les femelles; ee même segment globuleux dans les mâles, ses angles irréguliers. Un aiguillon dans les femelles et les ouvrières. - Pattes longues. Jumbes antérieures munies d'une épine à leur extrémité. 'Trois sortes d'individus vivant en soeiété; mâles, femelles féeondes (ceux-ei ailés) et ouvrières ou femelles stériles (privées d'ailes).

M. Latreille a donné à ee genre exotique le nom d'Geodome, tiré de deux mols grecs qui signifient : construisant des maisons. L'espèee appePée Céphalote porte en Amérique le nom de Fotirmi de visite. (Voyez pour ses mours l'arlicle Fourm, tom. 6 , pages 484 et 485 .)

Rapportez à ce genre les Fourmis eéplalote no. 47, et six dents nº. 48 (Encycl.).

Nota. M. Lalreille rétablit actuellement son genre Eciton publié dans l'Histoire naturelle des Crustacẽs et des Insectes. Il a le pédieule de l'abdomen composé de deux segmens. Les Fouruis crochne $\mathrm{n}^{\circ} .57$ Encycl. (MIymecia lamata. FAB.) binode $\mathrm{n}^{\circ} .27$. Encycl. (Formica linodis. $\mathrm{FAB}$.) et la Formica jupenilis de ee dernier auteur, sont de ee genre.

CRYPTOCERF, Crypocertes. TAT. FAB. ILLIG. Formica. Linn. De Geer. Oriv. (Encycl.)

Genre d'insectes de l'ordre des Hyménoplères, Z 
section des Porte-aiguillon, famille des Hétérogynes, tribu des Formicaires.

Trois genres de cette tribu ont le pédicule de l'abdomen formé de deux nouds, ce sont les Myrmires, les (Ecodomes et les Cryptocères. Les deux premiers se distinguent facilement par leurs ant’unes insérées entre les yeux au milieu de la face antérieure de la tête.

Antennes courles, coudées, grossissant vers l'extrémité, inséréés sur les côtés de la tête dans une rainure fort grande qui cacle la base du premier article, composées de douze articles dans les fenelles, de treize dans les mâles, le premier trèsgrand, faisant au moins le tiers de la longneur totile de l'anteune. - Labre grand, corné, perpendiculaire. - Mandibules triangulaires, denticulées au côté interne. - Pulpes naxilluires plus courts que les mâchoires, filiformcs, composés de cinq aricles distincts, rylindriques, d'égale grosseur, le second plus long que les autres; palpes labiaux de quatre articles. - Tete grande, dépritiée, presque carrée. - Yellx placćs latéralement sous l'extrémité de la raiuure de la lête.Foux lisses peu distincts. - Corselé comprimé à sa partie postérieure, élevéen devan t dansles ouvrières, ovoïde, plau en dessus dans les fetnelles. Ailes supérieures ayant une cellule radiale longue, étroite, appendiculée; l'appendice long, trèsétroit et deux cellules cubitales, la première de longueur moyenne, anguleuse, recevant la première nervure récurrente, la seconde presque complète, n'atteignant la précédente que par son angle supérieur. Trois cellules discoidales ; l'inférieure grande, s'étendant jusqu'au bord postérieur de l'aile. - Abdomen ovordo-globuleux, composé da cinq segmens outre l'anus dans les femelles, en ayant un de plus dans les mâles; les deux premiersglobuleux, anguleux, formant le pédicule; le troìsième très-grand, laissant peu paroître les suivans. Un aiguillon dans les femelles et les ouvrières. - Pattes assez longues; jambes antérieures munies d'une épine à leur extrémilé. Trois sortes d'individus vivant en socićté; mâles, femelles fécondes (ceux-ci ailés) et ouvrières ou femelles stériles (privées d'ailes).

Les mœurs des Cryptocères ne nous sonf point connues, mais elles doivent se rapprocber de celles des Fourmis. Ce genre remarquable par la rainure latérale de sa tête, qui contient les antennes reployées dans le repos, a pris son nom de deux mots grecs qui expriment cette attitude et signifient: cornes cachées. Le pètit nombre d'espèces connues est de l'Amérique méridionale.

Rapportẹz aux Cryptocères la Fourmi âtre $n^{\circ} .49, p l .99, f g .15$ du présent ouvrage, et le Cryptocerus Pavonii. Lat. Gen. Crust. et Ins. tom. 4. pag. 132. (S. F. et A. SERv.)

\section{POLYGNATES. Voyez QUAdRICORNES.}

(S. F. et A. SERr.)

\section{P O M}

POLYOMMATE, Polyonmatus. Genre de Lépidoptères Diurnes. Voyez tom. 9 , page 595 .

(S. F. et A. Serv.)

POLYPHËME, Polyphemus. MoLL. T.Aт. MOnoculus. De GÉER. Fab. Cephaloculus. LAM.

Genre de Crustacés de l'ordre des Branchiopodes, section des Lophyropes, extrait par Muller du grand genre Monocle de Linné, et ayant pour caractères : pieds uniquement propres à la natation, simpleinent garuis de poils, tantôt simples, taniôt branchus ou en forme de rames. T'ête confondue avec l'extrémité antérieure du tronc; denx yeux réunis en un seul fort gros, situé à l'extrémité antérieure du corps et figurant une espèce de tête. Pieds au nombre de dix, dont les deux premiers plus grands et ressemblant à deux rames fourchues.

Le corps de ces aniananx est transparent, presque crustacé, comprimé et teruiné par une queue en forme de dard, a vec deux soies au bout; ils nageut sur le dos et poussent ícau avec promptitude à l'aide de leurs pieds en forme de rames. De Géer a vu une femelle accoucher de tous sea petis à la fois; ils étoient au nombre de sept.

1. Poutraeme oculé, $\boldsymbol{P}$. oculus. Lat. Gen. Crust. et Ins. tom. 1. pag. 20. - Hist. nat. des Crust. et des Ins. tom. 4. pag. 287. pl. 3o. fig. 3. 4. 5. - Monoculus pediculus. Fав. - Cephialoculus stagnamem. Lem. Syst. des Anim. suns vert. pag. 170.

Yoyez pour la suite de la synonymie et la description le $n^{\circ}$. I de l'a ticle Monocre de ce Dietionnaire. (E. G.)

POLYTOME, Polytomus. Nom donné par M. Dalman (Analecta entomologica, Holmix, 1823 ) à un genre d'insectes coléoptères qui répond exactement à celui de Rhipicère. Voyez ce mot. (S. F. et A. SERV.)

POMPILE, Pompilus. Fab. Lat. Jur. Paxz. Sphex. Linn. De Gérr. Ross. Pepsis, Cryptus. FAB. Cryptocheilis. P Panz. révis.

Genre d'insectes de l'ordre des Hyménoptères, section des Porte-aignillon, famille des Fouisseurs, tribu des Pompiliens.

La tribu des Pompiliensest composée des genres Pepsis, Pompile, Céropale et Apore; ce dernier seul n'a que trois cellules cubitales aux ailes supérieures. Les Pepsis ont leurs quatre palpes presqu'également lonzss, tandis que dans les Céropales et les Pompiles les palpes maxillaires sont beaucoup plus longs que les labiaux; mais les Céropales ont leur labre eutièrement découvert, ce qui les distiugue aisémènt des Pompiles.

D'autres genres voisins, non adoptés yar M. Latreille, pourroient encore se confondre avec celui qui nous occupe : ce sont les Misques de M. Ju- 


\section{$\mathrm{PO} \mathrm{M}$}

rine et les Salius de Fabricius, mais dans les Misques la troisième cellule cubitale est pétiolée, et les Salius ont les mandibules sans dentelures avec le premier segment du corselet beaucoup plus long que ne l'est celui des l'oupiles.

Alntennes.longues, presque sétacées, insérées au milieu de la fuce antérieure de la tête, composées d'articles cylindriques, le premier plus gros, le seeond petit, an nombre de douze dans les l'emelies, de treize dans les mâles. - Labre enlièrẹment caché ou peu découvert. - Mandibules dentelécs au côté interne. - Hâchoires coriaees, terminées par un petit appendice arrondi. - Palpes maxillaires notablement plus longs que les labiaux, pendans, de six arlicles, le troisième plus gros, conico-ovale; les trois derniers presqu'égaux en longueur; les labiaux de quatre articles à peu près égaux. - Lèvre trifide, sa division interméliaire plus large et échancrée à son extrémité. - T'ête comprimée, de la largeur du corselet. - Trois petits yeux lisses disposés en triangle sur le verlex. - Premier segment du corselet plus large que long, transversal, échancré postérieurement; ses eôtćs prolongés jusqu'à la uaissance des ailes. - Ailes supérieures ayant une cellule radiule petile, eourte; son extrémilć ne s'écartant pas de la eôte et quatre cellules cubitales, la première.aussi longue ou plus longue que les deux suivanles réunies, la seconde recevant au-delà de son milieu la première nervure récurrente, la troisième reeevant la deuxième nervure récurrente, la quatrième commencée. Abdonen brièvement pédieulé, ovalaire, eomposé de cinq segmens outre l'anus dans les femelles, en ayauı un de plus daus les mâles. Pattes longues, les postérieures surtout; jambes finement deulelées à leur partie extérienre, les intermédiaires et les postćrieures munies à l’extrémité de deux épines lougues et aiguës, les autérieures d'une seule; tarses ciliés de poils roides, spiniformes, surtout les anlérieurs; leurs crochels unidentés à la base et munis d'une pelite pelotle daus leur entre-deux.

M. Latreille a fondé ce genre dans son Précis des caractères génériques des Insectes, sous le now de Psammochare. Il a adoplé ensuile la dénomination de Pompile que Fabricius lui avoit substituće. Les Pompiles varient beatcoup pour la taille et les couleurs Ils u'affectent point de clicrits particuliers, naais ils préterent Jes localités chaudes et sablonneuscs; les f'urelles y construisent leurs nids, ordinairement dans un trou qu'elles creusent clles-mêmes dans le sáble; elles y apportent des insectes et uolamuent des Arachnides qu'elles ont piqués de leur aiguillon et qui servirout de nourilure à la larve qui éclóra de l'veuf toujouts unique qu'elles déposent dans chaque trou. Quelques espices font aussi leurs nids dins des trous gu'elles trouvent tont litils daus le buis. Ces lyyménountères sont très-rilís dars leurs mouvemens: Iorsque les femelles cherchent lenr proie, on les voit perpétucllement eourir en voletant, ce que font aussi les mâles lorsqu'ils recherelsenl l'accouplemera, ceux-ei ordinairement plus pelils s'accrochent sur le dos de la femelle qui les porte ainsi longr-temps avant de céder à leurs desirs. Les femelles piquent d'une manière fort prompte et leur blessure est très-douloureuse.

Les Pompiles dans l'état parfait se nourrissent du miel des fleurs, sur lesquelles on les piend quelquefois. On en eonnoít au moins soixante espèees.

re. Division. Troisième cellule cubitale trèsrétrécie vers la radiale, presqu'en triangle carviligne.

\section{Pomple voyageur, $P$. viaticus.}

Pompilus niger, abdominis segmentis tribus primis rubro-ferrugineis, posticè nigro marginatis.

Pompilus viaticus. $\mathbf{P}_{\mathrm{AB}}$. Syst. Fiez. pag. 190. no. 12. - l. A T. Règn. anim. tom. 3. pag. 476. Pinz. Faun. Germ. fas. 67. fig. 16. - Sphex viatica. Linv. Syst. Nat. 2. 943. 15. - DE GÉER, Ins. tom. 2. pag. 822. no. 4.pl. 28 fgo. 6.

Longueur 8 à 9 lig. Femelle. 4 à 5 lig. Mâle. Noir. Les trois preniers segmens de l'abdomen portant cluacun à leur base une large bande d'un rouge-ferrugineux, échancrée postérieurement. Ailes brunes, plus foncées vers l'extrémité. Femelle.

Le måle est beaucoup plus petit, les bandes ferrugineuses de son abdomen ne sont pas aussi visiblement échancrées que dans la femelle, et la partie autérieure de sa tête est garnie d'un duvet argenté.

'T'rès-eommun aux environs de Paris.

Nota. Geoflioy a décrit cette espèce sous le nom d'Ichneumon noir avec les trois anneaux antérieurs du ventre rougeitres et les ailes noires, $\mathbf{1}^{\circ}$. 74. Mais il nous paroit qu'il y eontond deux especes, car il dit que les trois premiers articles de l'abdomen sonl rougetitres et souvent bordés d'us peu de noir. Les individus qui ont ces segmens bordés de non apparticnnent certainement au Pompile voyagenr; les antres nons paroissent devoir être rapporiés au Pompile brun no. 16 .

2. Pompiez renflé, P. gibbus.

Pompilus niger, abdominis segmentis duobus primis tertinque basi ferrugineis, alis liyalins upice fuscis.

Pompilus gibbus. FAB. Syst. Piez. pag. 195. $n^{\circ} .27$ - Panz. Faun. Girm. fas. 77. jlg. 15. - Sphex glbba. Linn. Syst. Nat. 2. 946.33.

Longueur 5 à 6 lig. Femelle. 3 à 4 lig. Mále. $\mathrm{Z}_{2}$ 
Noir. Devant de la tête un peu argenté. Premier et second segmens de l'abdomen ainsi que la base dir troisième ferrugineux. Ailes transparentes, leur bord posiérieur brun. Mâle et femelle.

Euvirons de Paris.

3. Pompile rufipède, P. rufipes.

Ponupilas niger, abdonuinis segmentis secuncio, tertio quintoque albido utrinque unaculatis.

Pompilus rufipes. FaB. Syst. Piez. pag. 195. no. 37. - I.A T. Gener. Ciust. et Ins. touz. 4. pag. 64. - P Asz. Faun. Genu. fas. 65. fg. 17. - Spliex rufipes. Irive. Syst. Nat. 2. 945. 29.

Longreur 6 à 7 lig. Noir. Second, troisième et cióquiène segmens de l'abdomen ayaut une taclue latérale blanchâtre. Pattes noires, les quatre jambes postérieures et l'extrémité de leurs cuisses rougeâtres. Ailes transparentes, is supérieures ayant leur bord postérieur brun.

Midide la France. Montpellier.

\section{Ponpile noil', P. niger.}

Poulpilus totus niger, alis hyalinis posticè Suscis.

Pompilus niger. Fав. Syst. Piez. pag. igr. $n^{\circ}$. 15. - PANz. Faun. Germ. fas. 7I. fig. 19.

Longueur 4. lig. Noir. Devant de la tête garni d'un duvet argenté. Ailes transparentes avec leur bord postérieur brun. Mále.

Des environs de Paris.

$2^{\text {e }}$. Division. Troisième cellule cubitale peu on point rétrécie vers la radiale. leur.

${ }_{1}$ re. Subdivision. Abdomen d'une seule cou-

5. Pompine noble, $P$. nobilis.

pompilus niger, argenteo tomentosus, alis nigro bifasciatzs.

Pompilus nobilis. FAB. Syst. Piez. pag. 199. $n^{\circ} .58$.

Longueur I ponce. Antennes et pattes noires. 'I'ête, corselet et abdomen de celte couleur, mais chargés de plaques d'un duvet argenté. Ailes trausparentes, noires à l'extrérnité, les supérieures ayant en outre deux bandes transverses, les inférieures une seule, de couleur noire. Femelle.

De Cayenne.

\section{Pompile sanguinolent, $\boldsymbol{P}$. sanguinolentus.}

Pomplus niger, thoracis anticâ parte et metathorace utrinque spinoso uubris, abdominis segmeniorum margine argenteo subnitenti.

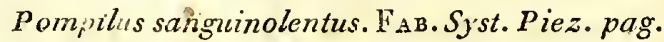
192. $n^{\circ} \cdot 19$.

Longueur 4 à 5 lig. Antennes, lête et palles noires. Corselet noir, son premier segment et le métachorax rouges; celui-ci ayanl un prolongement spiniforme de chaque côté postérieurement: Abdomen noir avec le bord des segmens garni d'un peu de duvet argenté. Ailes brunàires. Femelle,

Des environs de Paris. Il n'est pas commun.

7. Pompile fenestré, $\boldsymbol{P}$. hircanus.

Pompilus totus niger; alis superioribus nigro fasciatis, apicis nigri maculâ fenestratâ rotundấ lacteâ.

Pompilus hircanus. Fав. Syst. Piez. pag. rg5: $n^{\circ}$. 40. - Panpilus hircana. PAnz. Faun. Germ. fas. 87. fig. 21.

Longueur 4 à 5 lig. Entièrement noir et luisant. Devant de la tête garni d'un peu de duvet argenté. Ailes transparentes, les supérieures ayant dans le anilieu une bande transversale noire et l'extrémité de même couleur; celle-ci portant une taclie ronde d'un blanc-laiteux. Femelle.

Commun aux environs de Paris. La femelle établit ordinairement son nid dans le bois.

$2^{e}$. Subdivision. Abdomen de deux conleurs:

\section{A. Abdomen taché.}

\section{Poupile varié, $P$. variegatus.}

Pounpilus niger, inetathorace rubro, abdouninis segmentorum secundi tertiique maculâ utriñ que laterali, quinti lineâ dorsali albis.

Pompilus variegatus. F $\mathrm{BB}$. Syst. Piez. pag. r 9 r. $n^{\circ}$. 17. - PANz. Faun. Germ. fas. 77. fig. I 2.

. Longuenr 7 à 8 lig. Femelle. 5 à 6 lig. Mâle. Antennes et pattes noires. 'Tête noire garuie en devant d'un duvet argenté. Corselet noir, métathorax rouge. Abdomen noir ayec deux taches latérales blanches sur les second et troisième segmens, et une ligne de même couleur sur le cinquième. Ailes transparentes, leur extrémilé noire. Femelle.

Dans le mâle la couleur rouge du métathorax s'étend moins et la bande blanche du cinquième segment de l'abdomen manque totalement.

Du midi de la France et des environs de Paris.

9. Pompile biponctué, $P$. bipunctatus.

Pompilus niger, abdominis segnientouzun secundi muculâ utrinque laterali, quintı lineâ dorsali albis.

Pompilas bipunctatus. FAB. Syst. Piez. pag. 195. $n^{\circ}$. 38.-Lat. Gener. Ciust. et Ins. tont. 4. pag. 64. - PAnz. Faun. Gerun. fus. 72. fig. 8. Cryptus tripunctator. FA в. Syst. Piez. pag. 86. n०. 67. - Ichneuulon tripunctator. CoqueB. Illust. Icon. tab. III. fig. 10. Mâle et fenelle.

Longueur 3 à 7 lig. Antennes, tête et corselet s 
noirs. Abdomen noir avec deux póints latéraux blancs sur le second segment et une ligne de même conleur sur le quatrième. Ailes brunes, leur extrémité plus foncće. Pattes noires, euisses de la dernière paire rougeâtres, avec leurs deux extrémités noires. Base des jambes de la mème paire et enisses intermédiaites ayant quelquefois un peu de rouge. Femelle.

Commun aux eavirons de Paris.

Nota. Nous avons sous les yeux un assez grand nombre d'individus des deux sexes voisins de eette espèce; ils en diffèrent, aiusi qu'ils le font entr'eux, par lè nombre ei la position des taches de l'abdomen et par les portions des pattes intermédiaires et postérieures plus ou moins-ronges. Quelques-uns ont du blanc à l'orbite des yeux et des lignes de même couleur au bord des épaulettes. Nous ignorons si ce sont des espèces ou seulement des variétés.

10. Poimpre quadriponctué, $P$. quadripunctatus.

Pompilus niger luteo varius, abdoninis segmentorum secundi, tertii, quarti quintique basi in medio interruptâ albidâ.

Pompilus quadripunctatus. LA T. Dict. d'Hist. nat. $2^{\mathrm{e}}$. édit. - Pompilus octopunctatus. Panz. Faun. Germ. fas. 76. fig. 17. - Pepsis quadripunctata. FAB. Syst. Piez. pag. 215. no. 39.

Longneur 10 à 12 lig. Antennes jaunes, brunes à l'extrémité. Tête norre. Mandibules d'un jaunefuuve au milieu, deux taches sur le chaperon et orbite des yeux d'un janne-fauve. Corselet noir avee le bord postérieur du premier segment, l'écaille des ailes, une tarhe dorsale et une autre sur l'éeusson, jannes. Abdomen noir ; ses second, troisième, qualriène et cinquic̀ne segmens ayant à leur base une bande blanchâtre, interrompue dans son milicu. Ailes jaunes, leur extrémité hrune. Palles jaunes, hanches noires, cuisses de 'même couleur avec l'extrémité jaune. Femelle.

Variété femelle. Une bande jaune à-la base de l'anus.

Midi de la France, Italie, Espagne.

B. Abdomen fascié.

11. Pomprle des tropiques, $\boldsymbol{P}$. tropicus.

Pompilus niger, abdominis segmenti secundi basi latâ posticè emarginatâ, testaceo-Jerrugineâ.

Pompilus tropicus. Fав. Syst. Piez. pag. 194. $n^{\circ}$. 33. - Sphex tropica. Lins. Syst. Nat. 2. 945. 27 .

Longaear 1 pouce. Antennes, corps et patles d'un noil-mat. Base du second segment de l'abdomen formant une large bande d'un lestacé-fer- rugineux, échancrée postériearement. Ailes tota= lement brunes.

Amérique méridionale.

\section{Ponpile annulé, $P$. annulatus.}

Ponnilus capite luteo, (maris vertice nigro), thorace fusco, testaceo vario, aldominis lutei segmento primo nigro, cateris margine postico fusco-nigris.

Pompilus annulatus. FAB. Syst. Piez. pag. ' 97 . $n^{3} .55 . \cdot-$ Iat. Gener. Crust. el Ins. tom. 4. pag. 64. - PANz. Faun. Germ. fas. 76. fig. 16. - Cryptocheilus anmulatus. P Pavz. révis. Cogn в. Illust. Icon: tab. XII. fig. 4: Femelle.

Jongueur 15 à 16 lig. Antennes et têle d'un jaune-fauve. Corselet Jrun, sa partie antérieure et quelques traits sur le dos, de couleur faure. Ecusson taché de celle même couleur. Premier segment de l'abdomen noir, les autres jaunes avec leur bord postéricur d'un brun-noirâtre. Ailes fauves, les supérieures ayant l'extrémité brune. Pattes testacées. Hanches, base des euisses et extrémiré des’tarses, d'ử brun-noirâtre. Femelle.

Dans le mâle la partie supérieure de la tête est noire et les tarses postérieur's sont presqu'entièrement de eette couleur.

D'Espagne et d'Italie. On le trouve aussi dans nos départemens méridionaux.

13. Poxpile jaune, $\boldsymbol{P}$. flavus.

Pompilus capite testaceo-nigro, thoracis testaceo-nigri lateribus fuscis, abdominis nigricantis segmenti prinni punctis duobus, secundique basi luteo-testaceis.

Pompilus flavus. FAB. Syst. Piez. pag. 197. $n^{\circ} .52$.

Longueur 14 à $15 \mathrm{lig}$. Antennes, tête et corselet d'un jaune-testacé, les côtés et le dessous de eelui-ci plus bruns. Aldomen d'un brun-noirâtre, ayant deux points sur son prenier segment, la base du secoud et l'anus d'un jauue-testacé. Ailes fauves, brunes à l'extrémité. Paltes d'un jitunetestacé avec les hanches, la base des euisses et l'exirémité des tarses brunes. Femelle.

Des lndes orientales.

\section{Pompile rouge, $P$. coccineus.}

Pompilus niger, metathorace utrinque trispinoso abdominisque segmenti prini fasciâ et secunai basi postice enuarginatis late ferrugineis.

Pompiluscoccineus. Fan. Syst. Piez. pag. 19ז. $n^{\circ} .18$.

Longueur $8 \mathrm{lig}$. Antennes, tête et pattes noires. Corselet noir, métathorax d'u rouge-ferrugi- 
neux, portant de cháque côté trois petites épiues. Abdomen noir, son premier segment ayant une bande d'un rouge-ferrugineux, échancrée en dessus et en dessous. Bitsc du sccond segment portant une bande de même conleur échancrée pos'éricurement dans son milieu. Ailes brunes. Femelle.

Environs de Puris. Rare.

\section{Pompine vitré, P. exaltatuls.}

Pompilus niger, abdominis segmentis duobus primisferrugiueis, alis hyalinis, apicis fusci maculâ suhrotiundâ albâ.

Pompilus exaltatus. FAB. Syst. Piez. pag. 195. 及 ${ }^{\circ}$ 41. - Panz. Faun. Germ. fus. 86. fig. 10.

Longueur 4 ì $6 \mathrm{lig}$. Antennes, tếte, corselet et pattes de couleur noire. Abdomen de mếme coufeur avec ses deux preniers segrmens ferrugineux, le troisième participant quelquefois plus ou moins de celte couleur, Ailes transparentes, leur extrémité brune, renfcrmant dans les supérieures uce tache arrondie d'un blanc-laiteux. Femelle.

Environs de Paris.

\section{Pompile brun, $P$. filscus.}

Pompi.us niger, abdominis segnentis duobus primis ferrugineis, alis hyalinis uniformitèr subfuscescentibus.

Pompilus fuscus. FaB. Syst Fiez. pag. 189. $n^{\circ}$. 11.-Lar. Dict. d'Hist. nat. $2^{\mathrm{e}}$. édit.-Panz. Faun. Germ. fas. 65. fig. 15. - Sphex fusca. LINN. Syst." Nat. 2. 944. 16. - DE G'̈Eн, Itus. tom. 2. pag. 83o. $n^{\circ}$. 6. pl. 28. fig. 16.

Longueur 4 à 6 lig. Antenres, tête, corselet et pattes de coulenr noire. Alucomenta de mêrue couleur, ses denx premicrs segrneus lerrucineux, lc troisicme participant tonjours, mais phos ou unoins, de cette couleur, strtout dans le pade. Ailes d'une couleur uniforme, transparentes, trèspé enfunécs. Hile et femelle.

'Irès-commun aux envicuns de Paris.

Nota. Cumue nous l'avons dit plus haut an 13 $^{\circ}$ 1, Geofiroy nous paroit avoir confondu cette espèce arec le Pompile royageur.

$$
\text { (3. I. ct A, SERt.) }
$$

POMPLLIENS Fompilii. Troisième tribu de 1. fumillc des Fouisseurs, sectiog des Porteignillon, crdre des Myminopieres. Elle présente les caractìres suivaus:

Patles postcricures longrnes. - Antennes filiformes on sítacécs, souvent roulécs ou très-allquées dans les femelles, composées d'articles alungés. - Abdomen ovorde cu ovalaire, tenant au corselet par un filct très-court. - Mâchoires ct lìvres droires, de longueur moyenne. - Seginznt antértcum du trone en carré trabsversal ou longitudinal; son bord postérieur presque droit, s'élendant jusqu' à l'origne des ailes.

Cetle tribu contient quatre genres : Pepsis, Pompile, Córop:ile et Apore.

CÉRoPAle, Ceropales. LAt. Fab. Jur. Panz. Spinol. Pomipilus. Panz. Evatila. Oriv. (Encycl.) lioss.

Genre d'insectes de l'ordre des Hyménoptères, section des Porte-aiguillon, famille des l'ouisseurs, tribu des Pompilieus.

Cette tribu renferme quatre genres: Apore, Céropale, Ponnile et Pepsis. Le premier n'a que trois cellules cubitalcs aux ailes supérieures, tes Pepsis ont leurs quatre palpes presqu'également longs et dans les Yompites le labre est iuséré sous le chaperon, de manière 'qu'il est presqu'entièrement cacbé. Voyez PEPsis.

Antennes filitormes, presque droites dins les deux sexes, assez épaisses, insérćes au milieu de la face antérieure de la lôte, composées de douzc articies dans les femelles, de treize daus les'mâles. - Labre presque trigone, un peu obtus à l'extrćmité, iuséré sur le bord antérieur du chaperon, entic̀rement découvert. - Mandzbules ayant une dent aigruë au-dessous de leur extrémité. - $M \hat{a}-$ choires terainées par un lobe ovale, un peu coriace. - Palpes maxillaires sensiblement plus longs que les lubiaux, pendaus, composés de six articies, le troisième plus gros, conico-ovale, les trois derniers presqu'également longs; palpes labiaux de quatre arlicles a peu près égaux entr'eux. - Lèvre à trois divisions courtes, presqu'égales en longueur, l'intermédiaire plus large. - Iéte comprinée, assez épaisse vue en dessus, de la largeur du corsclet. - Trois petits yeux lisses dispesés en triangle sur la partue antérieure du vertex. - Prenuzer segment ducorselet transversal, ses côlés prolongés jusqu'à la naissance des ailes. - Arles supericrires ayant une cellule radiale, son extrémité ne s'écartant pas de la côte et quatre cellules culsitales, la premiere un peu plus longue que la secondc, celle-ci presqu'en currélong, recevant la premicre nervure récurrente, la tronsieme très-rétrécie vers la radialc, recevant fa deuxièue uervurc récurrente, la quatriène atteignant presque le bout de l'aile. - Abdomen ovalc, rétréci seusibleucut à sa base. - Pattes de longueur moyenue, les postérieures plus longues; jumbes incerunédiaires et postérieurtes peu dentées extírieurement, ununies àaledri eatréruité de deux épines aiguẹs, l'intérieure plus longue; janbes autérieuresn'en ayant qu'une : larses peu ou proint ciliés; crochets petits, muais d'une lurte pelot!e dans leur en:re-dieux.

Les Céroprales feruelles ont la partie infórieure de l'anus prulongée au-dela de la partie supírieure, comprimée, ne se terminant pas en portite; creusćo en dessus eat gouttière citroite. On aperçoit souvent atu-dessus, sortant de l'anus, un tube dons 


\section{P O M}

l'extrémité est presque mousse, et que nous considérons comme un pondoir. Nous ne savons si l'aiguillon sort de ce tube ou bien de l'anus. Les Ceropales n'ont point les tarses antérieurs propres à fonir, leurs jambes postérieures ont trop peu de dentelures el d'épines pour qu'ils puissent transporter aucune proie; alussi la nalure ne leur a-telle point donné cette tâche. Ils sont parasites des Sphex, des Pompiles, des Mellines et autres vrais Fouisseurs; leurs larves vivent des provisions destinées par ceux-ci à leur postérité. Nous avons vu souvent les femelles de Céropales eut. -ar à reculons dans le nid des hyménoptères que nous venons de nonmer, ce qui selon nous est une marque certaine qu'elles y alloient déposer leurs aufs. Ce gcnre contient peu d'espèces. Leur taille est assez petite. On les prend quelquefois sur les fleurs.

Rapportez à ce genre l'Evanie maculée no. 3 de ce Dictionnaire. Panzer a représenté ce Céropale, fas. $7^{2}$ ? fig. 9 , sons le nom de pompilus frontulis. Il varie pour la grandeur. Le mâle est ordinairement plus petit que lat femelle et n'en dilfère point pour les couleurs. Cette espèee esI commune aux envirous de Paris.

APORE, Aporus. Spinoz. I.AT.

Genre d'insectes de l'ordre des Hyménoplères, section des Porte-aiguillon, fumille des Fouisseurs, tribu des Pompiliens.

Les trois genres qui composent cette tribu avec celui d'Apore sont distingués de ce dernier par leurs ailes supérieures, qui ont quatre cellules cubitales. Voyez Pompre.

Antennes filiformes, de douze articles dans les femellos, de treize dans les males, le premier assez gros, le second plus long proportionnellement que dans les Ponpiles, le troisième environ deux fois aussi long que le précédent, les autres cylindriques. - Mandibules fortes, arquées, bidentées au côté interne. - Mâchoires cornées. - Palpes maxillaires beaucoup plus longs que les labiaux, de six arlicles, les trois premiers assez gros, les autres minces, presque cylindriques. Palpes labịaux de quatre articles. - Lère membraneuse, à trois divisions, les latérales plus courtes, linéaires; menton corné, entier. - Tête comprinée, de la largeur du corselet. - Trois petits yeux lisses disposés en triangle sur lc verlex. - Preniersegnent du corselet transversal. - Ailes supérieures ayaut une cellule radiale extrêmemeut petite, son extrémité pointue ne s'écartant pas de la côte et trois cellules cubitales, la première plus grande que la seconde, pointue à ses deux extrémités, la seconde très-rétrécie vers la radiale, recevant les deux nervures récurrentes, la troisième très-graude, incomplète. - Abdomen biièvenient pédiculé, ovalaire, conıosé de cinq segmens outre l'anus dans les femelles, en ayant un de plus dans les mấles. - Pattes dissez longues, les dernières surtout; jambes dentelées à leur partie extéricure, les intermédiaires et les posterieures mmies à leur extrémité de deux épines dont l'intérieure plus longne; jambes antéricures I'en ayünl qu'une seule; tarses ciliés de poils roides, spiciformes, ceux de devant surtout. Crochels ne paroissan poinl denlés : anunis d'une très-petite pelotte dans leur entre-deux.

M. Spinola qui a fondé ce genre adoplé depuis par M. Tatreille, en dricrit cienx espèces d'Europe. leurs mœurs doivent ressembler i celles des Pompiles.

\section{Apone bicolor, $A$. bicolor.}

Aports ater, abdonizis segmentis arteriorio bus saturatè rubris.

Aporus bicolor. Srivol. Ins. Ligur. fas. 2. pagg 34. no. 31. - Lat. Gener. Crust. ct lns. toni. 4. pag. 64.

Longuenr 4 lig. Noir. Devãnt de la tẻte et côtés du corselet gallilis d'un duret trc̀s-court, argenti". Abdomen ayant ses truis premiers segmens d'un rouge-ferrngineux, leur bord postérieur quelqucfois plus brun. Femelle.

Il se trouve aux environs de Génes et dans le midi de lit France. (S.F. et A.SERv.)

PONĖRe, Ponera. Lat. Illug. Formica. Linx. De Gíer. Fab. Oliv. (Encycl.) Mymmecia. FAB.

Genre d'inseetes de l'ordre des Hyménoptères, section des Porte-aiguillon, famille des Hétérogynes, tribu des Formicaires.

Parmi les genres de la tribu des Formicaires qui sont : Fourni, Polyergue, Ponère, Myrmice, Ecodome et Cryptocère, on distingue facilement les trois derniers au pédicule de l'abdomenn composé de deux segmens en forme de nœuds; le défant d'aiguillon et deux cellules cubitales seulement aux ailes supérieures, caractérisent les Fonrmis et les Polyergues el les séparent des Ponères.

Antennes filiformes, coudées, insérces audessous du milieu de la face antérieure de la tête, conposées de douze articles dans les feralles, de treize dans les mồles, le premier très-long, faisant au moins le tiers de lit longruen de l'antenne. - Labre prescjue nal. - Miandibules (des ouvrières ) étroites, alongées en forme de pinces ou bien larges et trigones. - Dalpes maxillaites courts, presque sétacés, de qualre à cinq ariicles; les labiaux de qualre. - Chaperon triangulaire. - Corselet un peu comprimé latéralement. - Ailes grandes, les supérienres ayant, suivant M. Latreille, trois cellules cubitales complètes, les deux prepuières petites, presque carrées, lis troisième alongée, alteignant le bout de l'uile, la seconde recevant une nervure récurreale. 
Abdomen cornposé de cinq segmens oulle l'anus dans les femelles, en ayant un de plus dans les mâles, le premier formant un pédicule et ressemblant à une ćcaille ou à un noud. - Un aiguillon dans les femelles. - Pattes de longueur moyenne. Trois sorles d'individus vivant en sociélé, mâles et femelles férondes (ceax-ci ailés) et ouvrières ou femelles stériles (privées d'ailes). Ri. Latreille a créé re genre dont les mœurs ne diffèrent pas essentie!lement de celles des Fourmis. Il y réunit alujond'hui celui d'Odontomaque, et y forme deux divisions dont la première équivaut à se dernier gente. Le nom de Ponère vient d'un mot grec qui signifie : méchant ou travailleur. Les espèces sont peu nombreuses et habitent diverses parties du monde. On n'en à encore trouvé qu'une seule aux environs de Paris. Les couleurs ordinaires de ces lyyménoptères sont le brun et le ronx.

jre. Division. Mandibules des ouvrières étroites, alongées en foṛme de pinces. (Ecaille du pédicule de l'abdomen ordinairement pyranidale et portant unc pointe aiguë, spiniformc.)

1. Ponène chélifère, $P$. chielifera.

Ponera corpore clongato, angusto, fusco, capite maguo; mandibulis longis, linearibus, ad apicem dentatis, dentibus validis.

Ponera chelifera, LAT. Gen.' Crust. et Ins. tom. 4. pag. 128. - Fourmi chélifère. Lat. Hist. nat. des Fournuis, pag. 188. pl. 8.fig. $5 \mathrm{I}$. Ouvrière.

Longueur $8 \mathrm{lig}$. Corps très-étroit, alongé, d'un brun-marron foncé, finement strié. 'Tète grande", en carré long, plus large que le corselet, ayant à sa partie antérieure une proéminence qui porte en devant une petice cavité; deux petils sillons près du côté inlerne des yeux allant se réunir vers le milieu de la tête en un seul qui aboutit au bord postérieur. Yeux petits, ovales, noirs, avec un petil enfonceraent derrière chacun d'eux. Mandibules drès-denlées à l'extrémité. Corsselet et écaille de l'abdomen d'un brun plus clair, cclleci terminée an-dessus de sa partie antćrieure en une pointc très-aiguë, un peu recourbée. $A b$ domen légèrement pubescent vers l'anus. Ouvière.

Patrie incomate.

2. Povìre hématode, $P$. hamatoda.

Ponera hoematoda. Lat. Gener. Crust. et Ins. tom. 4. pag. 128. - Fourmi hématode. L_st. Hist. nat. des Foumis, pag. 192. - Mlyrmecia hoenatode. l's s. Syst. Piez. pag. 427. $n^{\circ} \cdot 7 \cdot$

froyez pour la description et les autres synonymes, Fourini hémalode $1^{\circ} .58$.

Nota. 11 fant ercore rapporter à celle division la Punère ì une épine (Mlyminecia unispinosa. lias. Syst. Piez.pag. 423. $n^{\circ}$. I.) $2^{e}$. Division. Mandibules des ouvières larges, trigones.

\section{Ponìn armée, P. aculeata.}

Ponera clavata. LAт. Gener. Crust. et Ins. tom. 4. pag. 128.- Fonnica clavala. Fав. Syst. Piez. pag. $410 . n^{\circ}$. 61. - Fornica spininoda. LAT. Hist. nat. des Fonmis, pag. 207. pl. 7.fig. 45.

Voyez pour la description Fourni armée $n^{\circ} \cdot 42$.

\section{Ponìre resserrée, $P$. contracta.}

Ponera corpore elongato, subcylindrico, fusco, oculis subnullis, antennis pedibusque luteo-fiscis.

Ponera contracta. Lat. Gener. Crust. et Ins. toin. 4. pag. 128. - Fourmi resserrée. Lat. Hist. nat. des Founznis, pag. 195.pl.7.fig. 40. Ouvrière.

Longucur 2 lig. Fermelle. Corps d'un brunfoncé. Antennes grossissant un peu vers l'extrćmité, d'un brun-jaunàlre ainşi que les pattes. Yeux pelits, mais distincts. Ailes transparenles, nervures jaunâtres, point marginal d'un brun clair.

Ouvrière. Plus petite que la femelle: Yeux it peine apparens.

Mâle. Antennes filiformes. 'Tête plus large que le corselet, mandibules sans dentelures distincics: Corselet presque cylindrique, un peu plus gros en devant; saus enfoncement. Ecaille de l'abdomen épaisse, compriurée transversalement. Second scgment de l'abdomen un peu alougé, séparé du troisième par un petit étranglement. Anus roussâtre.

Rare aux environs de Paris. Vit en société peu nombreuse sous les pierres on entre les racines des plantes. E!le paroît craindre le juur.

Nota. Rapportez a cetle division les Ponères crassinode et tarsière, Lat. Gener. Crust. et Ins. tom. 4. pag. I28. (Form. crassinoda el tarsata. FaB.) et encore la Ponère apicale. Lat. idem, (Fourmi apicale. Fist. nat. des Foumis, pag. 204. $p l .7 \cdot$ fig. 42. a. Ouvière. )

Les Lasius albipennis et pallipes de $\mathrm{F}_{\mathrm{AB}}$. sont des mâles de l'onères. (S. F. ct A. SERv.)

PONTIE, Pontia. Genie de Lépidoptères Diurnes établi par liabricius, et qui paroît êtree le mêrne que celui de Piéride de Schranck et de M. Latreille. Voyez PAPILIoN, pag. 10.

(S. F. et A. Senv.)

PONTOPHILE, Pontophilus. M. Léach donne ce nom (Malacost. Podophth. Brit. fas.) ì un genre de Crustacés de l'ordre des Déeapodes, fumille des Macrourcs, tribu des Salicoques. Ce genre we differe de celui des Crangons, que par 
les longueur's relatives des deux derniers articles des pieds-mâchoires extérienrs et dı premier article du pédoncule des autennes inférieures. Dans les Pontophiles, cet article se prolonge au-delà da milien de la longueur de l'écaille annexée au pédoncule; le dernier article des pieds-mâchoires extérieurs est presqu'une fois plus long que le prét:édent, et pointu. Dans les Crangons, il est de sa longueur et obtus. Le prenier article des antennes est plus court.

M. Risso avoit établi ce genre sous le nom d' $E$. geon, daus son Histoire nalurelle des Crustacés de Nice. On doit, a l'exemple de H. Latrenlle, réunir les Poutophiles aux Crangons, et nous atlons en traiter à ce mot, qui n'a pus été fait dans ce Dictionnaire.

CRANGON, Crangon. Fab. Lam. Lat. Ce genre a été étabjli par l'abricius, et conservé par M. Latreille avec ces caracteres : antennes latćrules situées au-dessous des mitoyennes et recouvertes à leur bare par une grande écaille aunexée à leur pédoncule; anteunes mitoyenues ou supérieures à denx filets; les deux pieds antérieurs terminés par une main renflée, à un sęul doigı; ; l’iıtérieur, ou celui qui est inmobile, simpleaseut avancé con manière de deut; la seconde paire de pieds filifurme, eoudée el repliće sur elle-même dans le repos, terminée par un article bifide, mais à divisions per distinctes; prolongement antérieur du test, ou le bec, tries-courr.

Les Crangons dilfèrent essentiellement des Alphées par le doigt inférieur ou inmohile des deux premiers pieds et par ceux de la seconde paire qui sont coudés et filiforues. Ils s'éloignent des Pialémons par les deux filels dès antennes miloyeunes, par la pelitesse du prolongement antérieur de leur earapace et par la maniere dont se terminent les deux premières paires de paltes. Ces Crustacés ont un test incolore ou tirant un peu sur le vert, marqué souvent d'une iufinilé de points et de ligues noires. Ces couleurs cluangent singulièrement lorsqu'on les cuit ou quand on les plonge dans l'esprit-de-vin. Alors ils se colorent en rouge. Les Crangons ont des mouvemens très-brusques. Ils nayent ordinairemeut sur le dos el frappent l'eau a vec leur abdomen, qu'ils replient contre leur thorax et qu'ils distendent ensuite avec beaucoup de force. On les trouve communémeut sur nos côtes dans les endroi!s sablonneux, où nos pêcheurs en prennent en grande quantilé daus leurs filets et s'en servent quelquefois come d'amorce pour allirer plusieurs poissous riverains qui s'en nourrissent. On les confond quelquefois avec les Chevrettes : on les nomme indistinctement Crevett.s de mer, Chevrettes, Cardons, et on les sert aussi sur nos tables, mais leur chair n'est pas aussi délicate que celle des Chevrettes proprement dites, qui a au genre Palénon. Voyez ce mot,

Hist. Nat. Ins. Tome $X$.
1. Crangon vulgaire, C. vulgaris.

Testâ lavi; rostro brevi, edentulo.

Crangon vulgaris. Faв. Suppl. Entom. Syst. pag. 410.-Crangon vulgaire. I.AT. Hist. nat. des Crust. et des Ins. tom. 6. pag. $267 \cdot p l .55$. fig. I. 2. - Gen. Crust. et Ins. tom. 1. pag. 55. - Cancer crangon. Linv. Syst. Nat. ed. 13. tom. 1. pars 2. pag. 1052. - Faun. Suec. ed.2. $n^{\circ} .2038$. - Roes. Ins. tom. 3. tab. 63. Jig. 1. 2. - Bast. Suls. tom. 2. pag. 27. tab. 5. fig. 1. 2. Herbst, Canc.tab. 29.Jig. 3. 4 .

Cette espèce est fort petite; la pointe antérieure de son test, qui est lisse, est très-courte et sans dents. Il est fort commun sur nos côtes.

Le Crangon boréal ( $C$. boreas), décrit et représenté par Phıpps, dans son Voyage au Nord, Hanche I I , fig. I, est le plus grand de ceux que l'on connô̂.. Herbst (Canc. tab. 39.fig. 2.) a copié cette figure. Le Crangon épineux ( $C$. spinosus de Léach) se truuve sur les côtes mérilionales d'Angleterre. Enfin, nons citerons les deux espèces que Rissn décrit dans son Histoire des Crustacés de Nice, pay. 81. - La première est son Cangon fascié ( $\dot{C}$. fasciatus), qu'il représente tab. 3 , fig. 5 . Il sembleroit appartenir, suivant M. Latreille, à un autre genre. La seconde espèee n'est pas figurée; 1) lui a donné le nom de Crangon ponctué de rouge ( $C$. rubro punctatus). L'une et l'autre de ces espèces se trouvent sur les bas-fonds, dans la wer de Nice. (E. G.)

\section{PORCELET. Troyez Cloporte.}

PORCELET DE SAINT-ANTOINE. Dénomination vulgaire du Cloporte. Voyez ce mol.

PORCEllane, Porcellana. Lat. Lam. Bosc. Itéach. Risso. Cancer. Livn. Fab. Oliv.

Genre de Cruslacés de l'ordre des Décapodes famile des Macroures, section des Anomaux, établi aux dépens du genre Cancer de Linué, et adopté par M. Latreilin, qui lui donne pour caraclèı́s (Règne animal de Cuvier, tom. 3): queue repliée en dessous, presque conme les Bracliyures; tronc presque carré; antennes mitoyennes retirées dans leurs fossettes; serres ovales on triangulaires.

Ces Crustacés qui, à la première inspection, paroissent appartenir à la famille des Brachyures et qui en effet ont été placés avec les Crabes par Fajriciuset d'autres naturalistes, sont très-voisins des Galathées, genre de Macroures; ils leur ressemblent par les antemies, Jes pattes, et surtout par la manière dont se termine la queue; mais ils s'en distinguent par la forme et les proportions du corps, par les antennes intermédiaires et par les piedsA a 
mâchoires extérieurs, qui ont plus de rapport avec ceux des Brachyures qu'avec ceux des Galathées. Le corps des Porcellawes est presqu'orbiculaire, un peu rétréci en pointe à son extrémité antérieure et aplati; la queue est plus courte que le test, entièrement repliće sous la poitrine, comme celle des Brachyures, et divisée à son extrémité postérieure, en manière de compartimens, par des lignes enfoncées; elle a denx petites lames foliacées, ou nageoires portées sur un arlicle. commun, situées de chaque côtć, près de l'extrémité postérieure de cetle queue, et cachées en partie sous son dernier segment qui est arrondi et échancré. Le dessous de la queue des mâles office des appendices qui dépendent des organes sexuels; celle des femelles porte en dessons quatre paires de filets ovigères. Les deux pattes antérieures sont en forne de serres terminúes par une pince didactyle, dont le pouce ou le doigt mobile est intérieur; les six suivantes sont onguiculées et les deux dernières sont petites, filiformes, inuliques, repliées de chacue côlé du test et cachćes ou peu apparentes. Les antennes latérales sont insérées au côté extéricur des yeux, elles sont sétacées et longues; les intermédiaires sont très-petites, semblables à celles des Crustacés brachyures, et logées entre les yeus dans deux cavités longitudinales et sous-frontales. Leurs yeux sont portés sur un pédicule fort court et logés dans des fossettes arrondies, de chaque côté du bord antérieur du test, dont l'espace qui est compris entr'eux s'avance un peu en pointe le plus souvent bifide ou tridentée.

On ne sait presque rien des habitudes des $\mathrm{Por}-$ cellanes; seulement Risso dit qu'elles sont foibles et timides, et qu'elles restent dans le jour cachées sous les pierres des bords de la mer; elles n'en sortent que pendant la nuit pour chercher leur nourriture. Suivant cet auteur, elles pondent leurs œufs dans le sable graveleux baigné par les flors. Ce naturaliste (Hist. des Crustacés de Nice) s'est trompé en prenant les deu^ Cancres velus, figurés par Rondelet, pour deux espèces de Porcellanes : l'un doit être rapporté au Cancer spinifrons de Fabricius, et l'autre peut-être à son Cancerhirtellus. Il mentionne dans cet ouvrage trois espèces de Porcellanes, dont deux lui ont paru nouvelles. Le Cancer sexpes de Fabricus appartient au genre Porcellane; on doit peut-être y rapporter aussi sa Leucosie planata.

Porcellane large pince, $\boldsymbol{P}$. platycheles. Lat. LAM. LÉack.

\section{Porceliane longicorne, $\boldsymbol{P}$. longicornis.}

Porcellane à six pattes, $\boldsymbol{P}$. hexapus. Lat. Gen.Crust. et Ins. toni. I. pag. 49. - Hist. nat.des Crust. et des Ins. tom. 6. pag. 75.-Voyez pour la suite de la synonymie et pour les descriptions de ces trois espèces, les nos. 19, 25, 27, à l'article Crabe de ce Dictiomnaire.

\section{Porcelnane galathine, $\boldsymbol{P}$. galathina.}

Testâ striatâ, brachïs basi dentatis, manibus villosis. Bosc, Hist. nat. des Crust. torn. 1. pag. 233. pl. VI. fig. 2. - LAT. Hist. nat. des Crust. et des Ins. tom. 6. pag. 76 .

Corselet aplati, ovale, tronqué en àrière, couvert de suies transversales irrégulières, $d$ '، it sortent des poils extrêmement courts, égaux to toujours dirigés en avant. firont un peu saillam, accompagné de deux épines de cliaque cóté, er:tre el au-dessus desquelles est la cavité des yeux; de la base de la dernicre et all-dessous sortent les grandes antennes, composéc's, autunt qu'on a pu en juger, de trois articles; les deux premiers très-gros el I rès-courts, et le dernier très-lonk, sétacé et subdivisé en une très-grande quantits d'articulalions. Yeux très-gros, portés sur de courls pédicules; pièces extérieures lermant la bouclse, très-longues et se repliant sur elles-mêwes; queue très-large, velue; pinces aplaties, larges, aveo le troisieme article fortement denté au côté intérieur. Main sans épines et doig!s sans dents. Les deux premières paires de palles plus cour!es que les pinces et onguiculćes; la dernière encore plus courte, extrêmencent relevée sur le dos, avec le dernier article sans ongle; tarses et pinces velis, et composés d'écailles disposées de la même manière que les stries du corselet.

Celte espèce vit aux Auliles; elle a été rapportée par Maugé.

La. Yorcellana anisocheles de Latreille vit dans les mers d'Europe. (E. G.)

PORCElilion, Porcellio. Lat. Oniscus. Linn. Geofr. Fab. Oliv. Cuv. ilam.

Genre de Crustacés de l'ordre des Isopodes, section des Plćrygibranches, établi par Mi. Latreille aux dépens du genre Cloporie (1), (voyez ce mot), et ne difiěrant de ce genre que par leurs antennes qui n'ont que sept articies, tandis que celles des Cloportes en ont huit. Ces insectes ont absolument les mêmes mœurs que les Cloportes, et nous renvoyons à cel article pour ce qui concerne cette partie de leur histoire : seulement on a observé depuis que les appenaices de la queue des Purcellions, ou du moins deux d'entr'eux, laissent échapper une liqueur visqueuse que l'on peut tirer à plusieurs lignes de distauce; ils paroissent être des sortes de filières. Dans les zuâles, les petites pièces ou valvules qui recouvrent, sur

(r) Le grand genre Cloporte (Oniscus) de Linné, forme, Règne animal de Cuvier, tome III, la troissème secrion des Isopodes, ceile des Ptérigibranches (yoyez ce mor), où nous donnons les caractères des gejres qu'elie comprend. 
deux rangs, le dessous de la quene, sont plus longues que dans les fémelles, el terminées en pointe alongée. Les appendices latéraux do bout de la queue sont aussi plus longs.

1. Porcellion rude, P. scaber. Iatt. Oniscus asellus. Cuv. Journal d'Hist. nat. XXVI. 9. Var. C. du Cloporte ordinaire. Geoff. Voyez pour la synonymie et la description le $n^{\circ}$. I, art. Croronte de ce Diclionnaire. (E. G.)

PORTE-AIGUILLON, Aculeata. Seconde section de l'urdre des Hywénoptères, dont le earacière est :

Point de tarière.-Abdomen ayant un aiguillon intérieur on des glandes renfermant un aeide partieulier dans les femelles, soit féeondes, soit stériles.

Cet aiguillon est eomposé de trois pièces; il est caché et rétraetile. Dans quelques Formicar'es il n'existe pas, mais alors les femelles éjaculent une liqueur a eide renfermée dans des grlandes spéciales placées vers l'anus.

Les Porte-aignillon ont tonjours les antennes composées de treize arlicles daus les mâles et de douze dans les femelles. Si l'apparence porte à croire dans quelques espèees quilil y a moins d'articles, on ne doit point regarder eette anomalie apparente comme une réalité, clle ne provient que de l'emboîtement des derniers articles dins l'un des intermédiaires. L'abdomen est eomposé de cinq segmens ontre l'anus daus les femelles; il en a un de plus dans les mâles. Les larves soni toujours apodes. (S. F. et A. SERV.)

PORTE-LANTERNE. Nom vulgaire donné à quelques espèces de Fulgores. Voyez ee mot.

$$
\text { (S. F. et A. SERV.) }
$$

PORTE-MIROIR. Nom vulgaire donné au Bumbix Allas et à quelques espèees voisines. Voyez Bonbix. (S. H'. et A. SERV.)

PORTE-QUEUE. Nom donné à beaucoup d'ezpèces de Lépidoptères, surtout des genres $\mathrm{Pa}$ pillon, Polyommate et Erycine. Voyez Papincos. (S. F. et A. Serv.)

POKTE-SCTE, Securifera. Première famille de la seetion des Térébrans, ordre des Hyménoptères. Ellè a pour earaetc̀res:

Abdomen sessile, sa base s'unissant au corselet dans toute sọ̣ ćpaisseur et paroissant en ètre une continuation, il $y$ a une articulation entre le premier et.le seeond segment. Celui-là ayant sa plaque supérieure échancrée pour la faeilité des monvemens du resle de l'abdomen. - Tarière (des femelles) eomprimée, dentée en seie, plaeée dans une coulisse longitudinale de l'extrémité inférieure de l'abdomen qui la cache en partie dans le repos; cetle tarière servant anx fumelles à déposer leurs œuts et à préparer l'incision qui doit les reeevoir, - Larves ayant toujour's six paties éeailleuses, et souvent d'autres qui sont membraneuses; leur nourriture étant toujours végétale.

Celte famille eontient denx tribus: Tentlirédines et Uroeérates. Voyez ees mols.

$$
\text { (S. F. el A. Serv.) . }
$$

PORTume, Portumnus. Voyez PratroNIQUE. (LATR.)

PORTUNe (Etrille, Cuv.), Portunus. Fas. Cancer. Linn. Genre de Crustacés de l'ordie des Décapodes, tribu des Nageurs, ayant pour caractères : test en segment de cercle, pluslarge que long, dilaié en devant, rétrćei et tronqué postérienrement. - Les deux pieds postérieurs terminés cn nageoires. - Cavité buccale carrée.-Troisième article des pieds-mâchoires extérieurs presque carré, avee un sinus ou éehanerure interne près du sonmet pour linsertion du suivant. Pédicules oculaires eourts. - Post-abdomen ou queue des mâles de einq anneaux distinets, de sept dans les femelles.

Ces Crustacés ne diffèrent presque des Crabes ordinaires que par la mauière dont se terminent leurs pieds postérienr's.

Mil. Bosc et Risso nous ont doñné quelques déluils intéressans sur les mœurs de quelques espèces. Celle que le premier nomme pélagique nage presque eontivuellement avec facilité et neême une sorte de grâce. Elle peut se soutenir sur l'ean assez loug-lemps, sans paroitre se mouvoir ; les varees et antres plantes de l'Océan atlantique lui servent de points de repos. Elle vit des auires animanx marins qui s'y trouvent. Un autre Portune (hastatus, $F_{A B}$.) observé par ce naturaliste sur les côtes de la Curoline, nage aussi très-bien; mais il marche antant qu'il nage. D'ordinaire il se promène lentement sur le bo:d de la mer ou à l'embonelıure des rivières el à la marée inontante pour ehersher, de côté et d'autre, sa nouriture. Lorsque la marée se retire, il s'en retourne avee elle en uageant, parce qu'il appréhende de rester alors sur le sable, el qu'il n'a plus à espérer de curée. Le plus souvent il nage et marche en avant; mais saisi par la frayeur, il se sanve en nageant de eôté et nıême en arrière. Pendant l'hiver, il disparoît de la côte et se retire dans les profondents de la mer. Il revient au printemps, et la femelle, à raison des cufs quielle porte, est alors très-estimée pour la table. A Charles-'Town, on en preud journellement ne grand nombre pendant l'été, à la marée montante, a vee un cercle de fer, garni d'un filet et suspenda par trois cordes à un long bâton, au milieu duquel est attaelué, pour appât, un morceau de chair. Cet instrument est semblable à celui emA a 3 


\section{8}

ployé en Europe pour la pêche des écrevisses.

"Tous les Poriunes, dit M. Risso, qui habitent nolre uner (côte de Nice), vivent réunis en société; et chaque espèce choisit une demeure conforme à ses besoins et à ses habitudes. Le $b i-$ maculé fait son séjour dans les régions des polypiers corlicifòres. Le pubère et le plissé préfèrent les rochers de quatre à cinq cents mètres de profondeur. Le dépurateur ne se plaît que dans les plaines des galets, se mêlant toujours avec les petites colonnes de Clupées, telles que les Auchois et les Sardines. Un antre imparfaitement décrit par Rondelet, dont il porte le nom, se cache sous la vase de nos bords. Le moncheté babite au milieu des algues qui croissent à quelques mètres de profondeur; et l'espèce a laquelle j’ai imposé le nom de longues-pattes fiéquente les trous du caicaire compacte qui borde nos rivières. Les Portumes se nourrissent de Moliusques et de petits Crustacés qu'ils brisent par morceaux et broieut au moyen des osselets de leur estomac. Leur chair n'a pas le même goût dans toutes les espèces, et ce n'est que celles qui vivent dans les rochers qui sont euployées comme coniestibles; les autres servent d'appât pour la pêche. Plusieurs de ces Crustacés sont tourmentés par des petites Asellotes parasites qui se glissent sous lenr corselet et s'atlachent sur leurs branchies. Les femelles des Portunes fout plusieurs pontes dans l'année, et déposent chaque fois de 400 à 600 mille petits œufs globuleux et transparens, qui éclosent en plus ou moins de temps, sûivant le degré plus ou moins considérable de la température."

J'ai observé à l'article Porrune de la seconde édition du Nouvean Dictionnaire d'Histoire naturelle, dont MI. Déterville est éditeur, que cette multiplicité annuelle de pontes me paroissoit doutense ou peu conforme à l'analogie.

Le Ciri-Apoa, dont Marcgrave fait mention dans son Histoire naturelle du Brésil (liv. 4, pagg. 183 ), espèce très-voisine' du $P$. hastatus de $F$ 'abricius, vit habituellement au fond de la mer et ne gagne le rivage que pour y chercher l'ambre gris, rejeté par les flots. 'in ne le prend qu'au moment des fortes marées. Sa cbair est d'un goît excellent. On le met dans du vinaigre, et quoiqu'on puisse en manger beaucoup, préparé de cette manière, il est rarement indigeste. Quelques autres espèces sont aussi un aliment pour les habitans des côtes maritimes de la Chine, des Indes orientales, etc. Ces Crustacés abondent dans les mers avoisinant les tropiques. L'Océan septentrional et la Méditerranée n'en fournissent que peu d'espèces, et généralement fort petites ou de taille moyeune.

Le docteur Léach a formé un genre, sous le nom de Lupa, avec les espèces dont le test, généralement plus large que celui des autres, a neuf dents de chaque côté, et dont la postérieure plus forle et en forme d'épine.

\section{$\mathrm{P} O \mathrm{R}$}

Lorsqu'Olivicr rédigea l'article Crabe de ce Dictionnaire, celte coupe générique avoit pou subi de modifications, et embrassoit notre famille des Décapodes brachyures. Les Portunes faisoient donc partie des Crabes, et les espèces connues alors y sont décrites sous ce titre générique. Voici la liste des espèces qui y sont mentionnées et qu’il faut dès-lors rapporter aux Portunes. Crabe pélagique, u० ${ }^{\circ}$ 55. - Crabe défenseur, no. 37.Crube porte-lance, $\mathrm{n}^{\circ}$. 39. - Crabe six-denté, $n^{\circ}$.47. - Crabe sauteur, $n^{\circ} .48$. - Crabe lancifere, $n^{\circ} .49 .-$ Crabe pubère; $n^{\circ} .9^{\circ}$ - Crabe velu, $\mathrm{n}^{\circ} \cdot 9^{1}$.

I. Serres fort alongées: longueur des mains (depuis leur naissance inférieure jisqu'au bout des doigts) surpassant notablement celle du test (neuf dents de chaque côté).

Serres généralement plus étroites ou plus cylindriques que dans les Portunes de la divisica opposée. Le second article des bras ou le plus long est piesqu'entièrement à découvert ou en dehors des bords lateraux du test, si les pieds se dirigent en avant. Ces nuances de proportion étant difficiles à saisir, on arrivera au suiplus à la déterminatiou des espèces avec le secours des autres caractères.

A. Pieds, et surtout les serres robustes, point filiformes; doigts fortement dentés et dont la longueur égale au plus celle du poing; second article des jambes et tarses très-comprimés; ce dernier article presque lancéolé au demi-elliptique aux pieds de la seconde paire et des deux suivantes.

a. Côtés les plus larges des derniers articles des pieds, à partir de la seconde paire, sans sillons ni impressions garmis de duvet, ayant au plus une ou deux lignes enfoncées, longitudinales, nues.

\section{Pontune pélagique, $\boldsymbol{P}$. pelagicus.}

Portunus pelagicus. $\mathrm{FAB}$. - Cancer pelagicus. Linn. - Cancer cedo-nulli. Herbst, Krabben, tab. 37. - Ejusd. C. reticulatus. Ibid. tab. 50. Var. - Rumpr. Mus. tab. 7.R.

Grand. Dessus du test finement chagriné, d'un gris-verdâtre ou d'un rougeâtre-violet et tacheté de jaunâtre. Pattes colorées de même en dessus, avec les doigts et les tarses rouges. Dents frontales et celles des bords latéraux, les deux dernières exceptées, courtes, en forme de triangle presqn'isosèle, acuminé au bout, séparées par des angles assez onverts; les deux du milieu plus petites; les oculaires internes entières, un peu plus longues que les voisines. Cloison des antennes intermédiaires avancée en pointe. Trois 


\section{$\mathrm{P} O \mathrm{R}$}

fortes dents spiniformes, au côté interne des bras; une autre près de l'extrémité du côté opposé; deux dents sur lo carpe, l'une interne el l'antre exterue; trois sur le poing, dont une à la base et les deux autres an bont des deux côles supérienres; une autre, mais peti'e, près de l'extrémité de la paume. Impression dursale ordinaire assez forte.

Indes orientales; Pondichéry, M. Leschenault de Latour; côtes de la nouvelle Hollande, Péron et M. Lesuenr, et non dans tout l'Océan, ainsi que le disent Linnæus et Fabricius. Il ne laut pas confondre celte espèce avec le $C$. pelıgicns de De Géer et le Portune pélagique de M. Bose. Voyez Portune diacanthe.

b. Côtés les plus larges des derniers articles des pieds, à commencer à la seconde paire, ayant des sillons ou des impressions garnis de duvet.

Dessus du test et des serres inéçal ou rugueux, chagriné, chargé de duvet. Côté interne des bras mrini de denls spiniformes (4-6) daus toute sa longueur; mains forlement sillonnées; la ligne lisse du milieu cles deux derniers articles des pieds postérieurs divisée longitudinalement.

* Les deux dents du milieu du front aussi grandes ou un peu plus longues que les deux latérales voisines; les deux oculaires internes fortenent échancrées; celles des bords latéraux du test déprnntées ou triangulaires; les deu.x postérieures à peine une denu-fois plus longues que les précédentes.

Rides ou inégalités du test et des pieds tranchatut par leur couleur rougeâtre ou jaunâtre avec celle (brune ou noirâtre) du duvet. Doigts rougeâtres, avec l'ex îrénité noire; l'index de la serre droite ayant à sa base interue une rangée de grosses dents molaires. Espèces de l'Amérique méridionale.

\section{Pontune spinimane, $P$. spimimanus.}

Portunus spinimanus. LAt. Nouv. Dict. d'Hist. nat. $2^{\mathrm{e}}$ édit. tom. 28. pag. 47.

Portunus hastatus. FАB. - Cancer ponticas. HER Bst, Krabben, tab. 55. fig. 5.?

Dents du front petites et pointues; celles des bords latéraux du test, la dernière exceptée, égales; une seule sur le dessus du carpe; une aulre, pareillement solitaire, vers l'extréunité supérieure du poing.

De taille moyenne. Cayenne; Brésil, M. de Lalande fils. Labricius a pris cette espéce pour le Cancer hastatus de Linnæus; mais celle-ci est de la mer Adriatique et appartient à la division suivante. J'ai cité Herbst avec doute, parce que les épines postérieures du test sont beanconp plus fortes dans la figure ciue col!e de notre espice; tout convieut d'aulleurs tres-bien pour le reste.

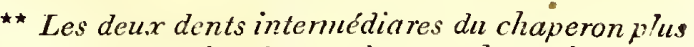
petites que les deux plus proches; les deux oculaires internes entieres; celles des bords latéraux du lest presque comiques, en forme d'aigulilons ou de piquuns, les deux postérieures beaucoup plus fortes que les précćdentes.

\section{Pontune gladiateur, $P$. gladiator.}

Corpore pedibusque penitus ferè sericeis; brachiis apice bidentatis, anguls granulatis, rubro maculatis, pugnorum apice unidentato.

Portunus gladiator. FАв. - Cancer menestho. Herbst, Krabben, tab. 55. fig. 3 ? Ejusd. ibid. figr. 1. Jeune individu?

De moyenne grrandenr, d'nn jaunâtre-pâle. La trancbe inférieure et antérienre des pieds, la poitrine même, garnies de duvet. Quatre épines au côté intérieur des bras. 'Trois lignes lisses sur le disque de la nageoire des pieds postérieurs. Cloison des antennes mitoyennes a vancíe en pointe. Extrénité des doigts blanchâtre. Les deux premiers segmens de la fausse queue fortenent prolongés en arrière, en manière de tranches, le second surtout, et séparés par un canal profond; l'avant-dernier un peu dilaté et arrondi latéralement à son extrérnité. Segmens antérieurs de la poitrine gravelenx.

Pondichéry, M. Leschenault de Latour.

Les jeunes individus sont entièrement jaunâtres, a vec des nageoires demi-transpareules el inarquées d'une tache noirâire à leur extrémité.

Nota. Le Portune gladiateur de Fubricius (Supplém. Entoni. Syst.) n'est pas le mêrne que le Cancer gladiator de ses autres ouvrages. Voy. Portune sanguinolent.

\section{Portune hasté, P. hastatus.}

Corpore pedibusque suprà glabriusculis; digitis rubis, albo intersectis; brachiis apice unidentatis, angulis acutis, lcevibus; pugnorum apice bidentato.

Cancer hastatus. Lins. - Cancer pelagicus. IEnвsт, Krabben, tab. 8. fig. 55?

Petit. Dessons du corps et des pieds presque sans duvet et d'un blanc-luisant; le dessus trèsinégal, d'un rongeâtre de brique pâle, avec les doigts d'une teinte un peu plus vive et entre-coupée de blanc; arêtes des serres unies, aiguës; une seule dent à l'extrémité antérieure du cơté postérieur des bras; côte supérieure du poing échancrée et bidentée à son extrémité antórieure.

Une tache rongeâtre à l'extrémite des nageoi- 
res. Segmens pectoraux ayant dans leur milieu une impression linéaire noirâtre. Cloison des antennes intermédiaires point saillante en pointe. L'avant-dernier ségment de la queue du mâle en forme de triangle alongé et tronqué, sans dilatation latérale. Les deix dents postérienres du test fort longues. Cette jolie espècc, et la seule du genre Lupa de M. de Léach que nous ayons en Europe, m’a été donnée par mon ami M. I.éon Dufour, qui l'avoil prise eu Espagne, sâr les côtes de la Méditerranée. Je ne doute pas qu'elle ne soit le vrai Cancerhastutus de Linnæus, habitant, selon lui, la mer Adriatique. La description, d'ailleurs, hai convient parfaitement.

Seloa Fubricius (Entomol. System. Supplém.) le Portune armiger a de l'aflinité avec celui de. Tranquebar ( Tranquebaricus). Il le place néanmoins arec ceux dont les dents postérieures du test soni plas grandes ou en forme d'épines, sans songer qu'il contredit, à cet égard, la description quil avoit donnće daus son Entonologie systématique. Thorax haud spinosus. - Des mers australes.

Son Portune hastatoïde ( hastatoides) m'es! inconnu. Il différeroit des autres espèces de cette division en ce que les deux épines du test auroient de chaque côté une dent petite ei arquée. Une observation analogue me donne lieu de soupçovier que ce Portune ponrroit bien n'ĉtre qu'un très-jeune individu du Pélagique. Il habite aussi l'Océan indien.

B. Pieds très-grêles; - mains plus menues que les hras; doigts beaucoup plus longs que le poing, filiformes, subulés à la pointe, à dents très: petites:

\section{Pontone tenaille, $\boldsymbol{P}$.forceps.}

Portunus forceps. FAB.- Herbst, Krabben, tab. 55. fig. 4 .

Petit, jaunâtre. Test un peu et finement chagriné; dents intermédiaires du front plus petites que les voisines; les oculaires internes entières; celles des bords latéraux du test, les deux dernières exceptées, courtes, triangulaires, pointues; six au côté interne des bras, une au côté opposé et située près du bout; deux sur le carpe, dont une intéricure; deux autres sur le poing, une à chaque bout. Pieds sans sillons ou impressions garnis de duvet. Troisième article des piedsmàchoires extérieurs large. La 'Trinité , Maugé.

II. Longueur des serres ordinaire; celle des mains à peu près égale d̀ celle du test, ou du moins ne la surpassant point d'une manière notable.

A. Neuf dents de chaque côté du test; quatre au front.

Eaces les plus larges des derniers articles des pieds, en commençant à la seconde paire, toujours sans sillons ou impressions garnis de duvet.

\section{a. Les deux dents postérieures beaucoup plus fortes que les autres.}

\section{Portune sanguinolent, $P$. sanguinolentus.}

Thorace sublocvi, maculis tribus sanguineis, rotundatis, per lineam transversam, ancuatam dispositis.

Portunus sangzinolentus $\approx \mathrm{FAB}$. Ejusd.Portunus defensor. Variété jenne, sans taches; ejusd. Cancer gladiator. Variété plus jeune. - Неввst, Krabben, tab. 8. fig. 56.57 .

De taille moyenne. Corps d'un jaunâtre-pâle; la tache ronge mitoyenne un peu plus grande et plus en arrière queles latérales; impression dorsale ordinaire très-foible, imparfaite; dents latérales du test, à l'exception des dernières, égales, triangulaires, courtes, terminées un pen brusquement en pointe, égales. Extrémité supérieure du côté postérieur des bras sans dent; le côté interne du carpe fortement unidenté; mains assez profondément sillonnées; une ligne élevée et Jongitudinale sur la paume, un peu au-dessous de son milieu. Australasie, Indes orientales; Pondichćry, M. Leschenaulı de Latour.

Les jeunes individus, souvent d'une jaune tirant sur le blond ou roussâtres, sanstảches; arêtes des mains plus prononcées. Fabricius a distingué sous le nom spécifique de Defensor, les individus de moyen âye. Il a encore fitt une espèce des plus jeunes : c'est le C'ancer gladiator de son Entomologie systématique. Dans le Supplément de cet ouvrage, il l'a confondu, sous la même dénomination, a vec un Portune de l'Inde, très-différent. Péron et M. Lesueur ont apporté de la nouvelle Hollande un grand nombre d'individus et de toute âge du Portune sanguinolent.

\section{Pontone diacanthe, P. diacantha.}

Thorace suprà granulato, flavescente, maculis rubris, elongatis ; medio incaquali, valdè iinpresso.

Portunus pelagicus. Bosc. -DE GEER, Insect. tom. 7. tab. 26. fig. 8. - Lupa pelıgica. SAY, Journ. of Acad. scien. rat. Philad: tom. 1. pag. 97.-Ciri-apoa. MArcG. Brasil. lib.4.pag. 183.

De taille moyenne et quelquefois très - grand. Le dessus du test plus foncé et d'un verdâtreobscur eu devant. Les deux petites lignes élevées, en forme de rides et granulées, qui traversent le test, et dont celles du milien plus longues, mieux exprimées et plns longues que dans $r$ espèce précédente. Dents internes des bras, et souvent 
celles des bords latéraux du test, plns fortes; cellesci un peu dentelées; une autre dent à l'extrémité de leur côté externe, le côté opposé dı carpe en étant dépourvu ou n'en ayant qu'une trèspetite; dessus des serres lavé de rougeâtre-clair; maius plus grosses que celles de l'espèce précédente, moins profondément sillonnées, du moins dims les plus gros individus. Amérique septentrionale, Antilles, Brésil, etc.

Quelquefois, comme dans deux individus envoyés de Philadelphie par M. Milbert, les quatre dents du front sont réunies et ne forment qu'un lobe largement échancré. Les arêtes extérieures du carpe ne sont point terminées par des dents. Les descriptions qu'ont données de cette espèce De Géer et M. Bosc ont été faites sur des individus dı même pays.

Marcgrave a représenté la variété à taches rouges. Les dents latérales du test paroissent être plus fortes ou séparées par des incisions plus profontles, sans dentelures sensibles sur leurs bords. Le côté interne du carpe oflire une petite saillie pointue. Cette variété surpasse les autres en grandeur.

\section{b. Dents latérales du test presque de la même grandeur.}

\section{Pontune de Tranquebar, P. Tranquebaricus.}

Portunus Tranquebaricus. FAB. - Hersst, Krabben, tab. 38. fig. 3.

Très-grand. 'Test d'un gris-verdâtre, assez lisse, avec neuf dents aiguës de chaque côtć, et six au front, les deux oculaires internes cornprises. 'Trois au côté interue des bras et deux au côté opposé; trois sur le carpe, dont deux extérieures et plus petites; mains fortes, épaisses, lisses, a vec trois dents, dont une a la base, et les deux autres près de l'origine du pouce; une très-grosse dent molaire à li base interne de ce doiğt. Pieds postérieurs veinés de brun, sans sillons latéraux, garnis de duvet. Indes orieutales; Hondichéry, M. Leschenault de Latour.

\section{B. Six dents à cluaque bord latéral du test, les ocularres externes comprises.}

Nota. Huit dents frontales. Pieds postćrieurs unis ou sans sillons garnis de duvet.

9. Pontune porte-croix, $P$. crucifer.

Portunus crucifer. Faв. - Herbst, Krabben, tab. 8. fig. 53, et tab. 38. fg. 1. - RомРн. Mus. tab. VI.P.

Epines des serres très-fortes; les dents marginales du test profondes, trianguldires; la plupart des latérales courtes, Jarges, comme tronquées obliquement en arrière; l'antérienre ou la postoculaire très-obtuse, échancrée dans plusieurs; celles du front obluses; dessus da test d'un ronge de sang, avec des bandes, dont nne au milicu, et en forme de croix, d'un rougeâtre-pâle. Mers des Indes orientales.

Le Portune lucifer de Fabricius n'en est pen:être qu'une variété, dans laquelle les bandes du test forment quatre grandes taches blanches phosphorescentes, lorsque l'animal est en vie, et daus laquelle les deux dents antérieures des bords latéraux du test n'ont point d'échancrures; mais ct: caractère varie dans l'espèce pécédente, ain si gu'on peut te voir par la seconde figure d'Hexbst gue nous avons citée.

\section{Cing à quatre dents à chaque bord latéral dus test, les arrière-oculaires comprises.}

\section{a. Huit dents ou dentelures au front.}

Corps garni de duvet; des sillons sur les pieds postérieurs, remplis aussi de petits poils. Le carpe et la main profondérnent sillonués et graveleux. Taille moyenue.

\section{Portone étrille, $P$. velutinus.}

Portunus puber. L'Acr, Malacost. Podopht. Brit. tab. 6. - Cancer velutinus. Pexs. OLiv. - Herbst, Krabben, tab. 7. fig. 9 .

Huit petites dents coniques, et dont les deux mitoyemes plus graudes, obtuses et divergentes, au milieu da front; dents oculares inerases finement crénelées; bras inermes; une dent forte et dentelée au côté interue du carpe; une seule sur le poing et terminant l'arète supérieure. Bout des doigts noirâtre.

Sur les côtes maritiones ocidentales de lis France et sur celles de l'Angleterre.

b. Front soit entier ou simplenent sinué, soit anné de dents, mais dont le nombre ne s'éleve pas au-dessus de cinq.

Bras inermes; une dent au côté interne du carpe, el une à deux autres sur la partie supérieure du poing, près de l'origine du pouce.

\section{* Front entier ou simplement festonné et à dents très-courtes et arrondies.}

Milieu de la face extérieure du poing n'ayant an plus qu'une arête longitudinale (les deux supérieures non comptées) bien prononcée. Lames natatoires outarsales des denx pieds postérienrs ellitiques, terminées par use petite pointe saillante ou cuspidćes, et traversćes presque toujours dans le nuilieu de leur lougueur par uce ligne lisse ou arête aplatie. 
I) 2

11. Portune front-entier, P. integrifrons.

\section{Thoracis lateribus dentibus quatuor.}

De taille moyenne. Dessus du test d'un rongeâtre-obscur; quatre dents, et dont la plunart, l'antélieure surt al, larges, à chaque bord latéral. Sillons et livers infoncemens des pieds, hachures nombreuses et finement dentelées du test, très-garnis de duvet. Serres fortes, tris-gravelenses; cốéiuierne du carpe avaucé en une forte dent. Estrémitś des duigts noire.

Nouvelle JL llance, caual d'Entrecasteaux. Espèce très-clistincte de quelques variétés du Portune de Rondelet, dont, selon M. Risso, il dillère très-peu.

12. Pontune ridé, $p$. comgatus.

Thoracis lateribus dentibus quinque, suboequè longis, tribus posticis spiniformubus, fionte brevi, trilobatâ.

Portunus corrugatus. LEA CE, Malac. Podoph. Bitt. tab. 7.fig. 1.2. - Portunus puber. L.Aт. Gener. Crust. et Ins. - Cancer puber. Linn.?

Sillons et divers enfoncemens des pieds, hachures nombreuses et très-finement dentelées du test, très-garnis de dirvet; cinq dents presque d'égales longueurs, et dont les trois postérieures, terainées en manière d'épine, à chaque bord latéral du test; front très-court, large, divisé en trois lobes courts et dentelés. Rouncàtrêuvec le duvet jaunâtre.

Europe tempérée et méridionale; l'Océan et la Méditerranée.

\section{Pontuxe de Rondelet, P. Rondeleti.}

Thoracis lateribus dentibus quinque, duobus posticis, penultinlo picesertinu brevioribus ; fronte subinlegrâ ant in medio entrinatâ.

Portunus Rondeleti. Riss. Hist. nat. des Crust.

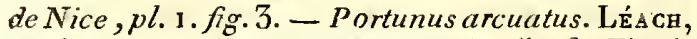
Malac. Podopht. Brit. tab. 7.Jig. 5. 6. Ejusd. ibid. P. ennarginatus. fig. 3. 4. - Aldrov. de Crust. lib 2. pag. 175 .

Faces latérales des pieds peu velues; cuisses presqu'unies; dessus dlu test pubescent, avec les hachures légères, très-lines et très-coupées; cinq dents à chacun de ses bords latéraux, dont les deux postérieures et surtout la pénultièn:e plus petites; front très-court, large, entier ou simplement un peu et largement échancré au milieu de son bord antériem. Dessus du corps d'un brunobscur: front cilié. Serres proportionnellement plus épaissis , du moins dans les mâles, que celles de l'espèce précćdente; l'une d'elles plus grosse, avec les doigts plas écarlés 'que ceax de l'autre; les uns et lé autres d'un rongeâtre-clàir, avec l'extrémité d'un brun-noirâtre.
Dans les couches vaseuses et peu profondes de la Méditerrancé, suivant M. Risso. Il se trouve aussi sur les côtes océaniques de la France et de l'Angleter'e.

\section{Portune longipède, $P$. longipes.}

Thoracis lateribus dentıbus quinque, posticis tribus spinifornibus, fionte brevissina $\hat{\text {, medio }}$ subsinuato; pedibus elongatis.

Portunus longipes. Riss. Hist. nat. des Crust. de Nice, pl. 1. fig. 5.

Fáces latérales des pieds peu velues; cuisses unies; dessus du test glabre, finement chagriné, élevétransversalement dans sun inilieu; cinq dents à chaque bord latéral; les trois dernières trèsacérées et spiniformes à leur exirénité ; la pénultième un pins courte; front très-court, larige, avec trois foibles sinus au milieu. Dessus du corps d'un brun-rongeàtre, avec les pieds plus pàles. Pieds proportionneilement plus longs que ceux des espèces de la inême division.

Dans les truus profonds des rochers de la Méditerranée.

\section{Pontune nain, P. pusillus.}

Thoracis lateribus dentibus quinque; tertio majori, postico spiniformi ; fronte in rostrusia breve, rotundatum, trilobun, productî.

Portunus pusillus. LÉACI, Malac. Podoph. Brit. tab. 9. fig. 5-7.

Faces latérales des pieds pen velues; cuisses unies; dessus du test glabre, très-inégul et graveleux; cinq dents, doni la postérieure spiniforme, et dont la troisiène un peu plus grande, à chacun de ses bords latéraux; firont avancé en nıanière de museau court, arrondi et trilobé à son extrémitć. Dessus du corps d'un roussâtre très-pâle. Côtes d'Angleterre, M. Léach; côtes du département de la Vendée, M. d'Orbigny. L'indıvidu que j’ai reçu de lui forme une variélé distincte par une bande blanchâtre el bordée de brun, parcourant la longuear du milieu de test.

* Front divisé profondément en trois dents triangulaires, allant en pointe (les oculaires internes non comprises $)$.

Milieu de la face extérieure du poing ayant deux arêtes longitudinales très-disinćtes. Launes'natatoires des deux pieds postérieurs ovales, entièrement unies et sans pointe bien saillante ou lurièvement cuspidées à leur extrémité.

16. Pontune plissé, P. plicatus.

Thoracis rugis denticulatis, villosis; pugnis lineis elevatis, angulatis; pedun posticorum articulo penultimo, villoso, utrınquè bistricito. 


\section{P O S}

Portunus plicatus. Riss.-P. depurator. LẺAct, Malac. Podoph. Brit. tab. 9.fig. 1 12.-Barres. Icon. tab. 1287 . fig. 2.

Deux lignes élevées sur cliaque face latérale de l'avant-dernier article des deux pieds postérieurs; les sillons nombreax et finement dentclés du dessus du test garnis de duvet; arêtes du poing dentelées, conleur de chair très-pâle; lest trèsrabotcux; cuisses cliagrinées.

Sur lcs côtes de la Méditerranée, de l'Océan, en l'rance, en Angleterre et cu Espagne. M. Risso dit que la femelle est moins colorée que le mâle; crue ses oufs sont d'un jaune pâle, et qu'il $y$ a deux pontes par annće, l'une en mars et l'autre en septembre.

\section{Portune holsalien, P. holsatus.}

Thorace suprd scabriusculo, subpubescente; pedum posticorum articulo penultimo nudo, lincâ impressâ, punctatầ ; pugnorum anouls ferè lavigatis.

Portunus holsatus. FAB. - P. depurator. TAт. Risso. - P. lividus. Léacn, Malac. Podoph. Brit. tab. 9. fig. 3. 4. - Cancer depurator. Ouiv. - Herbst, tab. 7. fig.4. 8. - C. ferialus. Linn.?

Une simple ligne cnfoucée et ponctuée sur chaçne face latéralc de l'avant-dernier article des deux pieds postéricurs; ces faces rues; dessus du test fin ement ch agriné, légc̀rement pebesccnt; a:ĉtes du poing unies ou foiblcment chagrinécs.

Sur nos côtes, tant de l'Océan que de la Médilerranće.

M. Risso nous apprend que la femelle fait sa ponte en mai et en juillet, et que ses œufș sont couleur d'aurore-pâle.

Le Portune marbré (marnoreus) de M. Léach, Malac. Podoph. Brit. tab. 8, n'est peul-être qu'une variété de cette espèce, avec les dents latérales du test presqu'égales, celles du front obtuses, lcs arêtes des mains moins saillantes, et la teinle supérieure du test souvent plus variée. J'avois annoncé à l'article Portune de la seconde édition du Nouveau Dicíonnaire d'Histoire naturełle, que j’avois recu cçtte êspèce des côtes du départcment de la Vendée; mais j’ai recounu depuis que cc Portune étoit utue variété de celui que M. Lćach nomtue pusillus, variété menlionnée plus liaut.

Le Poriuno moucheté de M. Risso appartient au genre Cancin. Celui qu'il nomme $P$. $a$ deux taches est une espèce de Platyonique.

$$
\text { (LATR.) }
$$

POSYDON, Posydon. FAe.

Genre de Crustacés de l'ordre des Décapodes famille des Macroures élabli par Fabricius qui lui dnoue pour caractères essentiels : palpes exHist. Nat. Ins. Tome $X$. térieurs foliacés, ou onguiculés an bout; quatre antennes séracées, avec leur pédoncrle simple; les intérieures courtes, bifides. Il ci!e deux espèces de ce genre; ce sont les Posydon depressus et Posydon cy-lindricus; ils se trouvent tous deux dans l'Océan indien.

M. Latreille, qui n'a pas vu ces Crustacés, n'a pu leur assigner un rang dans sa múthode sur la description incomplète qu'en a donuée Fabricius. (E.G.)

POTAMOPHILE, Potamophilus. Gen"e de Crustacés de l'ordre des Décapodes, faunille des Bracbyures, élabli par M. Latreille, qui ne savcit pas que M. Germar avoit déjà donné ce nom à un genre d'insecte coléoptc̀re. Fidèle aux principes de justice qu'il a toujours suivis à cet égard, M. Latreille a désignć autrement le geure de Cruslacé auquel il avoit imposé ce nom. Yoyez ThelPHUSE. (E. G.)

POTAMOPHILE, Potamophilus. Germ. Iydera. LAt. Parnus. Fab. Dryops. Oniv.

Gcure d'insectes de l'ortce des Coléoptères, section des Pentamères, famille des Claricornes, tribu des Macrudactyles.

Parmi les genres de cette tribu, ceux de $\mathrm{Ma}$ cronyque et de Géorisse se distinguent par lears antennes composées seulement de six à sept articles apparens. Les Hétérocères ont leurs tarses courts, ne paroissant formés que de qualre articles, le premier étant presque nul. Dans les Dryops les antennes se logent dans une cavité, leur second article est très-grand et recouvre tous lcs aulres; ces insectes on cn outre l'avant-sternum dilaté et recevant la bouclie.

Antennes presque filiformes, guère plus longues que la tête, insérées près du bord interne des yeux, toujours saillantes, composées de onze articles, le premier de la longueur des dix autres pris cnsemble, presquc cylindrique, aminci vers sa base, un peu courbc, le second plus grand que les suivans, prosqu'cn cône renversé, les autres très-courts, transvcrsaux, un peu en scic, formant rénnis une petite masse presque cylindrique, un peu plus mince à son origine, obtuse vers le bout. - Labre grand, en cône transversal, un peu échancré au milieu de son hord antérieur. - Mandibules arquées, ayant trois dents dont deux à la pointe el une plus petite au-dessous. Palpes courls, terminés par un arlicle plus gros, tronqné, presqu'obtrigone, les maxillaires plus grands. - Menton très-court, transversal. Corps elliplique, conrexe. - Corselet transrersal, cu trapèze, rebordć sur les côtés, plus large postérienrement; a vant-sternum pointavaneé surla bouche. - Ecusson petit. - Elytres alongées, recouvrant les ailes et l'abdomen. - Pattes ălongées; jambes longues, grêles, sans ép u:cs; tarses longs, ayant cinq articles distinct;, les B b 


\section{4}

quatre premiers courts, presqu'égaux, le dernier beaucoup plus long, grossissant vers le bout ct muni de deux crochets forts et mobilcs.

Quoique nous trations de cc grenre sous le nom de Potamophile, nous préférons celui d'Hydère qui lui avoit été donné par M. Latreillc bien avant Gue M. Geranar eût publié le sien, d'iutant plus qu'il existe un genre de Crustacés qui porte le nom de Potamophile. L'espc̀ce d'Europe se troure sur le hord des eaux. lics deux noms qu'on a donné à ce genre lui viennent de cette babitude.

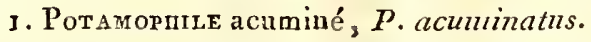

Potamophilus fuscus, thorace posticè utrinquè emarginato, elytris acuminatis, striatis; striis punctatis.

Hydera acuminata. LAT. Dict. dHist. nat. $2^{\mathrm{e}}$ édit. - Parinus achuninatus. $\mathrm{F}$ A B. Syst. Eleut. tom. 1. pag. 532. $n^{\circ}$. 2. - PANz. Faun. Gernt. fas. "fig. 8. - Potanophilus acuninatus. DEJ. Catal.

Longueur $3 \mathrm{lig}$. $\frac{x}{2}$. Corps woirâtre. Corselet ayant une échancrure à chacun dc ses angles postérieurs, ce qui les fait paroitre bidentés. Elytres terminées en pointe, à stries fortement ponctuées. Dessous du corps couvert d'un duvet court, blanchâtre. Antenues et pattes bruncs.

Rare aux environs de Paris.

Nota. Le Dryops picipède $\mathrm{n}^{\circ}$. 2 de ce Dictionnaire appartient peut-être à ce geure.

MACRONYQUE, Macronychus. MuLl. IAt. Parnus. FA B. ?'

Genre d'insectes de l'ordre des Coléoptères, section des Pentamères, famille des Clavicornes, tribu des Macrodactyles.

Les Géorisses et les Macronyques sont les seuls genres de leur tribu dont les antcnies n'offrent gue six à sept irticles distincts, mais les premiers g'ont que quatre aricles distincts aux tarses, ceux-ci n'ćtant point d'une longueur remarquable, leurs antennes sont composées cie sept articles et leur corps est court et renflé.

Antennes très courtes, trìs-minces, beancoup moins longues que la tête, n'ayant que six articles distincts; le premier très-court, menu, le second gruc̀re plus long, très-épais ver's son cxtrćmitć, le troisième un peu plus court que le précćdent, rossissant un peu vers le bout, les quatrième, cinquic̀me et sixième plus courts, arrondis, de là grosseur de l'extrćmité du troisième; le sixième égalant en longueur les trois qui le précédent, beaucoup plus gros qu'eux, formant une massue o'sluse, pouvant ĉtre regardé coume composé de trois aricles réunis en masse solide. - Labre yrand, corné, un peu arrondi à l'extrémité. Mandıbules cachées, cornćes, courtes, épaisses, très-jeu courbćes, bidentécs veis leur extrémité qui ejt obiuse. - Mlấchoires membraueuses, bifides; leur lobe extérieur oblong, rétréci, légèrement dilaté vers sol extrémité, refendu en plusieurs lanières, le lobe intérieur un peu courbé en dedans, son bord extérienr garni vers le bout de cils tres-rapprochés. - Palpes courts, les naxillaires à peine plus longs que les unâchoires, le dernier article plus long ciuc les autres et guère plus épais, de forme cylindrique. Palpes labiaux beaucoup plus courts, leur dernier article presqu'en lache. - Lèvre membraneuse, presque carrće, un peu dilatée vers son extsćmité, arrondie et un peu cilí́e. - Tête arrondie, plane, verticale, rétractile.-Corps oblong, presque cylindıique, obtus à sa partie antérieure, funissant en pointe, convexe, rebordé. - Corselet presque cylindrique, rebordć; parlie antćlieure du stcrnum presque rćunie à sa partie moyenne. - Ecusson pctit. - Elytres élroites, dures, voûtées, rebordées. - Pattes simples, alongées, de la longneur du corps; cuisses point canalicul'es, l'extrémité des antérieures grosse. 'Tarses alongés, de cing articles distincts, leurs crocliets forts.

Le now de ce genre vient de deux mots grecs qui signifient : grands ongles. L'espèce qui a servi de type se tient dans l'eau parmi les conferves; elle marche mal et ne sait point nager.

1. Macronyque quadrituberculé, $M$. quadrituberculatus.

Macronychus niger, subcneus, antennis flavis, thorace elytrisque margine laterali subauzeis basi bituberculatis; tuberculis elytrorum elevatis, compressis, cristato-pilosis.

Macronychus quadrituberculatus. MuLl. InLIG. Mag. V. pag.: 215. ann. 1806. - Lat. Gener. Crust. et Ins. tom, 2. pag. 58. no. 1. - Parnús obscurus. Fab. Syst. Eleut. tont. 1. pag. 332. $n^{\circ}$. 3. (M. le comte Dejean regarde ce dernier synonyme commc douteux.)

Longueur ". Noir, avec un reflet inétallique. Antennes jaunes. Corselet et élytres ayant lcurs bords latéraux comme dorés et deux tubercules vers leur base, ceux des ćlytres élevés, comprimés, garnis de poils disposés en crêie.

Ce très-petit coléoptcre a été trouvé en Alleinagne.

GÉORISSE, Georissus. Lat. Pimelia. Fab. PAYK.

Genre d'insecles de l'ordre des Coléoptères, section des Pentamères, famille des Clavicurncs: tribu des Macrodactyles.

Tous les genres dc cette tribu, excepté celui de Ǵorisse, ont plus ou moins de sept articles aux antenues.

Antenzles plus courtes que le corselet, n'ayant que sept articles distincts; lc premier le plus long de tous, presque cylindrique, le second épais et 


\section{$\mathrm{P} O \mathrm{~T}$}

slobuleux, le troisième très-eourt, le quatrième alongé, cylindrique, les cinquièmc et sixième très-eourts, le septième ou dernier formant une massue presque globuleuse (composée probablement de trois articles réunis en une masse presque solide.). - Mandibules cornées, assez fortes, plus larges à lenr base, arquées et rétrécies an-delà, obtuses ì l'extrénnité. - Mâchoires courtes, presque droites, lrigones à leur extrémité. - Palpes courts, presqu'égaux, terminés en massue, leur dernier article étant plus long et plus épais; les maxillaires un peu plus grands que les labiaux. Lère membraneuse, transverse; menton en triangle tronqué, plus large vers sa base, son extrémilé rétrécie des deux côlés. - Tête lrès-inclinée, pouvant se retirer eu entier sous le corselet. - Corps court, renflé, presque globuleux. - Jambes étroites, d'égale largnur dans toute leur ćtendue; lenr partie supérieure plus ou moins canaliculée; tarses n'ayant que quatre articles distincts, le prenier étant presque nul.

Ce genre fondé par. M. Latreille a pris son nom de deux mots grees qui signifient: creusant la terre. Il n'est composé que d'une seule espèce qui habite en Europe dans les endroits sablonneux du bord des eaux.

\section{Géonisse pygmée, G. pygmous.}

Georissus niger, antennis brevissimis clavatis, elytris globosis, crenato striatis.

Georissus pygmoeus. LAat. Gener. Crust. ot Ins. tom. 4 pag. 378. - Pimelia pygmaca. Faß. Syst. Eleut. tom. 1. pagr. 133. no. 31, - PaYk. Faun. Succ, toin. 3. pasg. 440. $n^{\circ}$. 1 .

Longueur 2 lig. Noir. Antennes brunes. Corselet convexe plus large dans sil partie moyeme, arrondi et rétréci postérieurement, mais plus encore à sa partie antérieure. Elytres nn peu pluslarges que le corselet, guère plus' longues que larges, convexes, profonclément striécs, ces stries crénelées; leurs angles liunéraux saillius. Ailes grandes.

Rare aux environs de Paris; il a été pris au bord d'une mare de la forêt de Bondi. LAT.

HÉTÉROCÉRE, Heterocerus. Bosc. Fab. ILLIG:

Genre d'insectes de l'ordre des Coléoptères, section des Pentamères, fanille des Clavicorues, tribu des Mirerodactyles.

Parai les genres de cette tribu qui ont les antenurs composées de plus de sept articles, les Lryous at les Hétérocères ont setils l'avant-sternum avancé, dildié et recevant la bouche; mais los Dryops ont des tarses longs, de cinc atrticles distincis et leurs aniennes peuvent se loger dans une cuvité qui est placće sous les yeux.

Antemes tris-courtes, at peine de la longucur de la tête, insérées en atvant des yeux, arguées, eomposées de onze articles; les deux premiers plus grands que les autres, le premier le plus long de tous, presque eonique, le second triangulaire, le troisième et le quatrième les plus petits de tous, les six suivans très-eourts, transverses, deniés eu scie intérieurement, formant avec le onzième qui est arrondi, une massue arquée dont la largeur est égale partout. - Labre grand, avaucé, coriace, demi-circulaire; la partie moyenne de son bord antérieur est un peu échancrée et porte deux petites dents pen distinetes. - Mandibules cornées, fortes, alon rées, un pen arquées, épaisses à leur base, dilatées de chaque côté, téirécies ensuite, aiguës vers leur exilrémité, Lidentées intérieurement. - Mî̀choires alıngées, étroites, composées de deux lobes membraneux, cilićs. - Palpes courts, filiformes, les inaxillaires un peu plus grands, insérés sur le dos des mâclioires ver's leur extrémité, leur dernier article plus long que les précédens, presqu'ovale, le second presque conique. Palpes labiaux insérés sur la partie moyenne du bord antérieur de lia lèvre, leur's deux derniers articles presqu'égaux, cylindriques. - Lève coriace, alongée inférienrement en carré, étroite, ensuite dilatée insensiblement en cœur vers l'extrémité; son bord supérieur très-écliancré; menton grand, coriace, plan, profondément échancré, ayant de chaque côté une dent droite, aiguë. - Tête déprimée, avancée, large et arrondie, enfoncée jusqu'aux yenx dans le corselet. - Corps elliptique, déprimé. - Corselet court, transversal, point rebordé, ses côtés arrondis. Partie antérieure du sternum très-dilatée en devant, concave, recevant la bouche. - Ecusson peu distinct. - Pattes courtes, comprimées, propres à fouir; jambes presque triangulaires, cilices, ayant de fortes épines à leur exirémité; les quatre jambes antérienres plus larges que les autres, leur côté extérieur et leur extrémité munis d'un rang d'épiues fortes, parallèles et droites. 'Tarses courts, se reployant le long de lit jambe, n'ayant que quatre articles distincts, le premier tant presque nul; le second et le dernier cylindriques, plus grands, les troisième et quatrième plus courts, presque coniques. Crochets minces, arqués.

La forme particulière des anteunes de ce genre a motivé son nom tiré de deux mots grecs. Les Inétérocères sont de retite taille. Les espèces connues ne sont pas en grand nombre; elles habitent le bord des eanx, se cachent dans le sable, s'y creusant elles-mêmes des trous. On peut se les procurer en pićtinant ce sable, ce qui les foree à sortir de leur retraite.

\section{Hе́т⿺́丶оеѐ̀ e marginé, H. marginatus,}

Heterocerus fuscus, villosus; thoracis, abdominis elytronimque marginibus, horum maculis pedibusque pallidé ferrng 
Hcierccerus marginatus. Bose, Act. Soc. Hiist. nat. Paris. tom. I. pl. 1. /g. 5. - Lat. Gen. Crust. et Ins. tom. 2. pag. 53. $n^{\circ}$. 1. - FAB. Syst. Eleut. tom. I. pong. 355. no. 1. - Paxz. Faun. Germ. fas. 23. fis. 1 I ct 12.

Longuenr 2 ligg. $\%$ Noirâtre, velu. Côtés du corselet et des ćlyries d'un fermgineux-pále ainsi que les bords de l'abdomen et les paltes. On voit sur les dytres des taches de celte couleur qui varient pour le nomb re et pour l'ćtendue.

Des enzirons de Paris. (S. li. et A. Senv.)

pOU, Pedicullus. Lixv. Geoff. De Géer. Oliv. Lav. lieruans. Iéach.

Genco diusectes de l'ordre des Parasites, famille des Rustrés, étab!i par Livné et adopté par tous les entomologistes. De Geer a le premier divisé ce grant gonre en-Pous proprement dits et Ricins. (Voy. ce mot.) M. Latreille conserve le nom de Poa aux insectés qui ont pour caractères essen'iels : bouche consistant en un museat, d'oì sont ì volonté un pelit snçoir.

Ces insectes, qui ve sont que trop connus des personnes malpropres, des entans et des individus athiquós de maladies particulières qui semblent les propager, méritent autant l'attention du naturaliste que les animanx ornés des pius belles couleurs: ils ont le corps aplati, demi-lransparent, mou au miliea, et revếu d'une peau coriace sur les bords; $l_{a}$ tète assez petite, ovale ou triangulaire, mulie, à sa partie antérieure, d'un petit mamelon charnu, renfermant un suçoir qui paroît simple, de deux antennes courtes, filiformes, de cinq articles et de deux yeux pelits et ronds. I e corselet est presque carré, un pen plus étroit en devant; il porte six pattes coultes, grosses, composées d'une hanche de deux pièces, d'une cuisse, d'une jambe et d'un fort crochet arqué et tenant lieu de tarse, dont l'insecte se sert pour se cramponner aux poils ou ì la pear des animaux sur lesquels il vit. L'abdomen est rond ou ovale, ou oblong, lobé ou incisé sur les côtés, de huit anneaux, pourxu de seize stigmates sensibles et d'une pointe écailleuse au bout dans les deux sexes.

Swammerdam a soupçonné quiele Pou de l'homme, dont il a donné une anatomie, étoit herma phro. dite : il a été portéà cette idée parce qu'il n’a pas découveıt de mâles parmi ceux qu'il a examinés et qu'illeur a trou vé un ovaire. Lecuwenhoek a fait sur: cette même espèce des observations qui diffèrent beaucoup de celles dont nous venons de parler : il a observé, parmi ces insectes, des individus pourvus d’organes générateurs mâles dont il a donné des figures ;.il a découvert dans ces mâles un aiguillon recourbé, situé dans l'abdomen, et avec lequel, selon lui, ils peuvent piquer ; il pense que e'est de la piqû́re de cet aiguillon que provient la plus grande démangeaison qu'ils causent, parce qu'il a remarcué gue lintroduetion de leur trompe dans les chairs, ne produit presqu'ancure scisation si elle né touche pas quelque nerf. De Gíer a va un aiguillon semblable placé aı bout de l'abdomen de plusicurs Pous de l'honme; ceux-ci qui, d’aprc̀s Leeuwenhoek, sont des uáles, ont, suivant De Géer, le bout de l'abdomen arrondi, au licu que les femelles, ou ceux à qui l'aiguil! ou manque, l'ont échnucré. M. Latreille a vu trèsdislinclement.dans un grand nombre de Pous, l'aiguillon ou la pointe dont parlent ces unteurs.

Les Pous vivent de sang; les uns se noumissent de celui des hommes, les autres de celui des quadrupèdes : c'est avec leur trompe qu'on n'apercoit prestrue jamais, quand flle n'est pas en action, qu'ils le sucent. Chaque quadrupède a son. Pou particulier, et quelques-nus même sont atlaqués par plusieurs. L'homme nourrit trois espicces de ce geure, le $P_{o u}$ conımún on des vêlemens, le Pou de la tête et le Pou du pubis ou morpion. Ces insectes sont ovipares; leurs aufs, qui scont connus sons le nom de lentes, sont déposés sur les cheveux ou sur les habits; les petits en sortent au bout de cinq à six jours; a près plusieurs mues et environ dix jours après, ils sont en. état de reproduire: ils multiplient beaucoup; et des expériences ont prouvé qu'en six jours un Pou peut pondre cinquante œuts, et il lui en reste encore dans le ventre. On a calculé que deux femelles peuvent avoir dix-huit mille petits dans. deux mois.

La malpropreté et l'risage de la poudre à cheveux mal préparée, et qu'on laisse trop longtemps sur la tête, surtout en été, attirent les loux et leur fourcissent un local favcrable pour la reproduction de lenr postérité. Les moyens que l'on emploie pour se débarrasser de ces insectes sont $x$ Io. l'emploi des substances huileuses ou graisseuses qui contiennent du gaz azote et qui bouchent les stigwates de ces insectes et les étouffent; $2^{\circ}$. les semences de staphis agria, du pied-d'alouette, les coques du Levant, le tabac séduit en poudre, et surtout les préparations mercurielles, font sur ces insectes l'effet d'un poison violent qui les fait périr promplement. On prétend que' ces insectes, en perçant la feau, font naître des pustules qui se convertissent en gale et quelcirielois en teigne : leur multiplication, dans certilins sujets, est si grande, qu'elle finit par produire une maladie morielle, connue sons le nom de phthiriase, et dont M. Alibert a parlé dans son bel ouvrage sur les maladies de la peau. M. Latreille lui. a fourni des observations d'où il résulte que l'espèce qui cause cette maladie est le Pou humain. Oviedo dit a voir observé que les Poux quittent les tnarins espagnols qui vont aux Indes, a une cerlaine latitude, et qu'ils les reprennent. au retour au neême degré : c'est ì peu près à la liauteur des tropiques que cela a lieu; mais cos observations ont besoin d'être coufirmées et ap- 
puǵes de émnionages plus cer'ains. Ou dit ca-

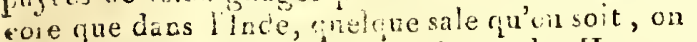
n'cu a jamais qu'a la iélo. les nagres, ?es IIotientols el dillerens singes mangert les Poux, et ont

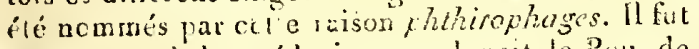
un lemps vù la médecine em loyoit le Pu de l'howme pour les suppressions turine, en l'introduisant dans le canal le l'nrèlre.

Dans la méthode de M. Dunćril, le genre Pou est placé dans son ordre des Aptères, famille des Rhinoptères. (Joyez ce mot.) Le profsseur Ni zcla le place dans son ordıe des Hémiptères Ćpizciques; entu le ducteur Léach place les Poux dans son ordre des Anoplures, famille des Pédiculidés; il les divise en trois genres, auxquels il donne des caractères qui vont nous scrvir à établir trois coupes daus ce genre.

A. Corselet très-court, point dislinct; les cieux palles antérieures monodactyles, les autres didactyles. Abdomen brusquement plus large que la tề!e. (Genre Pathire, Phthirus. Líaca.)

1. Pou da pubis, $P$. pubis.

$P$. thorace brevissimo, vix distincto; abdomime postice bicornuto, peditus validis.

P. pubis. Livs. Syst. Nat. ed. I3. tom. I. pars $2 . p a g .1017 \cdot-F a u n$. Suec. cd. 2. $n^{\circ}$. I940. - Le Murpion. Groff. Hist. des Ins. tom. 2. pag. 597. - P. pubis. Faвr. Entom. Syst. tom. 4. pag. 418.- Pou du pubis. I.AT. Hist. nat. des Crust. et des Ins. tom. 8. pass 94. - Gen. Crust. et Ins. tom. 3. pag. 168. - Kegne amim. de Cuvier, tom. 3. pag. 165. - RenI, Experim. tab. 9. fig. 1 .

Il cst à peu près de la faille dir. Pou de têle; sa couleur est plus brune ct sa peau est plus dure, l'abdomen a, postéricurement, deux crénelures longue's en forme de cornes. Celle espèce, que l'on désigne vulgairement par le nom de Morpion, sallacle aux poils des parties sexuelles, des aisselles et des sourcils; sà piqûure est trèsfortc.

B. Toules les patles didactyles; corselet distinct, brusquement plus étroit que l'abdomen. (Genre II matopixe, Hamatopinus. LEAcH.)

2. Pou du cochon, $\boldsymbol{P}$. suis de Linné, décrit par Mullcr, Lin. not. cl. V. pag. so3o, et figuré par M. Léach (Mélanges de zool. tom. 3.pl. 1 46); il forme le type de cetle division et vit sur le cochon commun.

C. Corselet n'étant pas plus étroit que l'abdomen, qui est linéaire.

3. Poy humain, $P$. humanus.

$\boldsymbol{P}$. thorace segmentis tribus, aqualibus, dis-

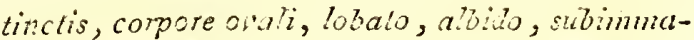
culilo.

P. Kumanus. Insis. Sjst. Nat. at. 13. icm.". pars 2.pag. 1016. - Fann. Stlec. ot. 2. $\left.2^{\circ} \cdot 19.9\right)$

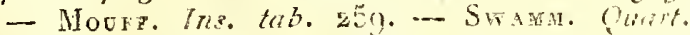

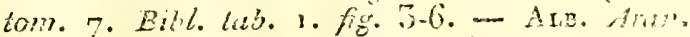
tab. 42. - Scsart. Elem. lab. 9j. - Souz. Ins.

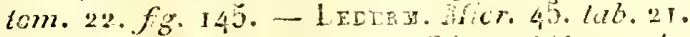
- Pou hunain da ccrps. ZE GeEr, Wóm. s. los Ins. tom. 7. pag. 67.pl. 1. fgg.7. - D. humanus,

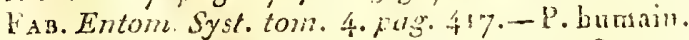
L. T. Hist. nat. des Crust. ct des ins. lom. 8. pas. 417. - Gon. Crust. et Ins. tom.1. pag. $168 .-$ Règne anim, de Cuvier, tom. 5. pag. ibł.

Cette espcce est d'un blanc sa?e, sans tack s. Les découpures de son abdomen sont mcins saillantes que dans l'espece que M. Latreille nozing

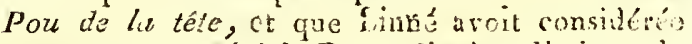
comme une vamété du Pou ortiratre. 11 vit sur ! corps de l'homme. Voyez, pour lcz autres cspeces, M. Eatreille dans son Hist. nat. des Crust. et das Ins. fom. 8; Linué, Eatricas, Rédi et Albin. Vojez aussi le mal Parasitas de ce Diclionnaire. (ii. G.)

POU AILE. Voyez Pou veLaxt.

POU DE Baleine. Vojez Crame, Pycro. GONON. (E. G.)

POU DE BOiS. Nom donné par plusieurs auteurs au Psoque pulsateur. Voyez Psoque no. 0.

(S. F. et A. Serv.)

POU DE BOIS ou FOURMII BLANCHE. Vojez Trines.

\section{POU DE MER. Loyez CYмотнов.}

POU DE MER D'AMBOINE. Espèce de Crustacé qui nous est inconnu et que l'on mange dans quelques parties de l'Inde, sous le nom de Fotoki.

POU DE MER DU CAP DE BONNE-ESPERANCE. Crustacé dont il est fait mention danz Kolbe et qui est probablement un Cymothoa.

POU DES OISEAUX. Vnyez RICrx.

POU DE PHARAON. C'est peut-êtrc une es* pèce d'Ixode ou de Chique.

POU DES POISSONS ou POU DE RIVIERE. Espèce d'Entomostracé qui s'altache aux ouies de plusieurs poissons. Voyez Carig a Angule.

POU DES POLYPES. Animal qui saitache aux polypes et qui est peut-être une $H y d r a c h-$ nelle. 
pou PUlsateur. Voyez Psogue pulsateur.

\section{POU DES QUADRUPEDES. Voyez Pou.}

POU DE RIVIÈRE. VOYez Pou DEs POIssoNs.

POU DE SARDE (Nicholson). C'est peut-être le Cymothoa guadelonpensis de Fubricius.

POU VOLANT ou POU AILE. Ce sont des insectes qui habitent les lieux bumides et se jettent, dit-on, sur les eochons qui vont se vautrer dans la fange. Il sont de la grossenr des Pous qui se trouvent sur ces animaux, mais ils sont noirs et ailés. Ce sont des Diptères peut-être des genres Simulie et Cousin.

(E. G.)

Pranize, Praniza. Léaeh. Jaat. Desmar. Genre de Crustacés, qui dans l'ouvrage sur le Règne animal de M. Le buron Cuvier, fail partie des Phytibranches, seconde section de l'ordre des Isopodes, et a pour caraetères : dix pieds ouguiculés, sans pinces, et dont la longueur augmente graduellenent, en allant de devint en arrière. - Quatre antennes sétacées, simples, courtes. - Tronc ou thorax divisć en trois segmens, dont le dernier très-grand, portant les trois dernières paires de pieds; une paire à chacun des autres. - Post-abdomen ou quene de six segmens, avec quatre limes on nirgeoires cilićes itu bout.

Ce genre a été établi sur un Crustacé, dont la longueur n'excèdé pas denx lirnes, de couleur bleuâire, que l'on trouve dans la Manche et la Dléditerranée, et que Monlagu a décril et figuré dans la premicre, partie (pi. 4. fig. I et 2) du tome onzic̀me des Transactions de la Société Linnéenne de Londies, sous le nom d'Oniscus carulatus. Ce sera pour nous le Pranize breuaтал, Pranizus carulatus. Slibber l'avoit déji تeprésenté dans son Recueil d'observations niicroscopiques, pl. 1.ffg. I. Cette figure et celle de Monlagu ont été reproduites dans l'Atlus d'listoire naturelle, accompagnant cette partie de l'Encyclopédie méthodiçue, pl. 329, fig. 24, et 336 , fig. 28; raais il s'est glissé, relativensent à lexplicalion de la dernière, une erreur; il faut lice : Oniscus corulatus, an lien d'Oniscus thorecicus. M. Desmarest avoit déja, en partant de ce genre, présumé qu’il yo avoiṭ ici quelque méprise. Je préviens aussi que le genre que j’ai noumé Lone dans l'ouvrage précité de M. Cuvier, cat celui que M. Léach appelle Calino. Ces deux coupes gentriques, ainsi que celles de Typhis, a'sincée et d'Apseude, composent dans mon onviage ayant pour titre : Familles naturelles ăl Règrne animal, celle des Décempèas, terminant l'orare des Amphipodes. (Latr.)

PRASOCURE, Prasocuris. LAT. Helodes.
Payk. Fab. Oliv. (Entom.) Chiysoniela. Livi. Geoff. De Gierr, Oluv. (Encycl.)

Genre d'insectes de l'ordie des Coléoptères, section des Tétramères, famille des Cycliques, tribu des Chrysomélines.

La tribu des Clirysomélines se compose des genres Paropside, Doryphore, Chrysomèle, Prasocure, Colaspe, Eumolpe, Gribonri, Clythre et Chlanyde. Les quatre derniers se distinguent de tous les autres par leur têle verticale et le genre Colaspe par ses mandibules terminées en une pointe très-forte et par le dernier article des antennes long, presqu'elliptique, portant is sou extrémité une pointe particulière. Enfin les Paropsides, les Doryphores et les Chrysomèles ont le corps ovale ou liémisphérique; tels sont les earactères qui séparent lous ces geures de eelui de Prasocure.

Antennes de onze articles, les einq derniers formant une espèce de massue alongée; les seplième, huitième, nenvième et dixième qui lont partie de celle massine, semi-globuleux, pas plus longs que larges. - Labre coriace, court, assez large, arrondi antérientement. - Mandibules contes, cbtuses. - Mâchoires membraneases, bifides. - Palpes cuurts, plus épais dans leur milieu; les masillaires de quatre articles, les labiaux de trois. - Lèvre plus étroitc à sa base, ayant son extrémité arrondie, dilatée, membraneuse. - Téte pres(qu'horizontale, un peu enchassće dans le corselet. - Corps alongé, presque linéaire, an moins trois fois plus lang que large, déprimé. - Corselet carré. - Ecusson triungulaire, assez grand. - Elytres débordant peu l'abdomen. - Pénultzène article des tarses bilohé.

l.es Prasocures vivent sur des plantes aquatiques; la larve de celle de la Phellandrie est blanche, hexapode, alongće; elle ronge la substance intérienre des liges et des racines de la plellandrie aqualique ( $\mathrm{Ph}$. aquaticum). La nymphe est blancire, presque cylindrique, un peu anguleuse. L'insecte parfait vit auss sur la mêne plante. Ce genre conlient fort peu d'espèces.

1. Prasocure de la Pliellandrie, P. Pheblandrii.

Prasocuris Phellandrii. Lat. Gener. Crust. et Ins. tom. 3. pag. 59. $n^{\circ}$. 1.-Helodes Phellindrii. P.YK. Fintil. Suec. tont. 2. pag. 84, $7^{\circ}$. 1. Fa . Syst. Eleut. tom. 1. pag. $469 \cdot n^{\circ} .1 .-$ Oriv. Entom. tom. 5. pag. 594. no. 1. Helod. pl. 1. fig. 1.a. b. - GrLéna. Ins. Suec. lom. I. part. 3. pag. 499. $n^{\circ}$. I. -- Crioceris Phellandrii. Paxz. Faun Gerri. fas. 85. fig. 9.

Toyez porr la deseription et les autres synonymes Chrysomèle de la Phellandrie no. ${ }^{130}$. 


\section{P R I}

3. Prasocure violette, $P$. violacea.

Prasocuris violacea, elytris punctato striatis.

Prasocuris violacea. Lar. Gener. Crust. et Ins. tom. 3. pag. 6o.-Helodes violacea. HAB. Syst. Eleut. tom. 1. pag. $470 . n^{\circ} .3 .-$ Oniv. Entom. tom. 5. pag. 594. $n^{\circ}$. 2. Hélod. pl. 1. fig. 2.-.-

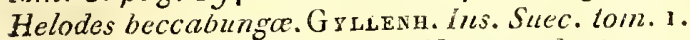

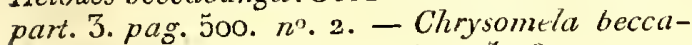
bunga. Panz. Faun. Genn. fas. 25. Jig. 11.

Longueur 2 lig. Violette, antennes noires. Corselet pointillé avec un petit sillon transversal dans son milieu. Elytres alyant des lignes de points izrilaut des stries.

Elle se trouve en France et vil sur le Beccabunga (V'eronica Beccabunga).

Nota. Le synonyme de Geoffroy, lom. I, pag. $254, \mathbf{n}^{\circ} .6$, donné à cette espèce jar Fabricius, doit être exclu. Il nous paroit appartenir, coume plasieurs auteurs l'ont cru, à lu Galeruque violette (Chiysomela alni. Linn. no. 13.) Voyez ce mot.

M. Carcel, entomologiste dislingué, a observé cette Prasocure en Anjou dans un moment où il ćclosoit un très-grand nonbre d'individus. It les a vus remonter du fond de l'eau le long de la lige des plantes. Il est donc probable que c'est dans cet eićment qu'elle subit sa métamorphose.

\section{(S. F. et $\Lambda$. Serv. )}

PRIN'TANNIÉRE. Geoffioy nomme ainsi la Phalène précoce $n^{\circ} .2$ de ce Dictiouuaire, $P h a-$ lana prodromaria. FAB. (S. F. et A. Serv.)

PRIOCERE, Priocera. Nouveau genre de Coléoptères pentamères établi par M. Kirby daus les Transactions Linnéennes, vol. 12, payg. 479 . 11 paroil voisin de ceux de Tille et de Tianasime; liauteur lui assigne pour caraclères : labre ćchancré; lèvre bifide; palpes maxillares filiformes, de quatre articles, le dernier coupritué, oblong; les labiuux de trois articles, ic deruier prand, pédonculé, sácurifortue; antennes deulćes ća scie; corselet presque cylindíique, très-resserrć ; corps convexe.

Il en décrit une espèce sous le nom de Priocère variće ( $P$. variegata). Longueur $6 \mathrm{lig}$. Corps linéaire, d'un brun-noirâtre luisant, velu. Corsclet brun, ponctué. Elytres ayant leu: partie antérieure fortement pouctuće et l'exirćnité lisse, sans taclej; clles sont de couleur rousse avec quatre grandes taches jaunes posćes carréuent. On voit sur chaque élytre une bande brune, large, placée près d’une autre bande de conleur jaune. Paltes d'un brun-noirâtire. 'Tarses et anus roux.

Cette espèce qui paroît nouvclle csı du Brésil, elle est représentée pl. $21, f_{0} .7$ de l'onviage précité. (S. H. ct A. SEnv.)

PRIOCÈRES. Foyez Serprcorines.

$$
\text { (S. Y. et A. SEnv.) }
$$

PRTONE, prionus. Groff. Fab. Lat. Oriv。 (Entom.) Cerambyx. InN. De GEer. Leptura. ĠefF.

Genre d'insectes de l'o:dre des Colćoplères, section des Tétramères, fanille des Longieornes, tribu des Prioniens.

La tribu des Prioniens se compose des genres Spondyle et Prione; le premier se distingue facilemeni du sccond par ses antennes courtes, moniliformes et son corps convèxe.

Antennes sćtacées ou filiformes, souveat plus longues que le corps on dépassant au moins sa moilié, insérées au-devant des yeux et composées de onze à vingt-un artıcles de forme très-variable. - Labre très-petit, presque nul, entier, corné, cilié antérieurement. - Mandlbules de forme variable, fortes, avancées, dentées intérieurement. - Hấchoires cornées, courtes, ćlroites, cylindriques, entières, obtuses et cilićes, quelquefois un peu aplaties. - Palpes presqu'égaux entr'eux , leur dernier article un peu plus grand; les maxil laires de quatre articles, les labiaux de trois. Lèvre cornée, très-courte, presque triangulaire; menton très-court, transverse. - Tête aplatie, placée dans la direction de l'axe du corps, ayant un prolongement sjiniforme sous la base des mandibules. - I'eux écliaucrés. - Corps déprimé. - Corselet de forme variable, épineux ou dentelé sur les côtés. - Ecusson petit. - Elytrés grandes, recouvant entièrement l'abdomen ou raccourcies, rétrécics vers l'extrémité et laissaut it découvert une parlie de l'abdomer a des ariles. - Pattes conprimćes jaubes terminćcs par dcux pelites ćpines. Pénuliciose article dés tarses bilobć.

Geolfiroy a fundé ce geure sur l'espèce la plus comnune ( I'. lanneur) et lui a domnéle non de Prione, tiré d'nu mot grec qui signitie: scie, suns doutc en raison de la forno des arlicles des antalenres. On troure ces insectes dans les grandes forêts peuplées de vieux arbres: c'esl dabs ceuxci quo leurs larves habitent. Blles y tronentear noniriture cin rongeant le hois. Ces latves dilicrent peu de celles des autres colópperes qui vivent de la mêne musiere quelles. Leur corps est divisé en douze segmens. La ićle csi un peu jolus large que le corps el d'une consistance assez solide; lit wonche es! petite, armée de deux mandibules courles, mais fortes; les trois segmens antéricurs du corps portent chactu une pare de patics écatileuses trís-pedites, a peine visibles et qui ne peurcat leur scrvir a marcher. los nouf dernicrs segmens sont gatnis de petis manelons au noyer des. 
quels seuls la larre peut ehanger de place. Lo:squille a pris tout son accroissement, elle se file une coque grossière eomposće de soie fortifiće de sciure de bois et elle y subit ses métanorphoses. lille a són de p!rcer cetie coque près de la surfirce de l'arbre, atin que l'insecte parfait puisse sortir plus facilement. Les femclles sont munies d'une espèce de tuyau corné, ordinzirement rétractile, à l'aide duquel elles déposent leur's cufs dans les fentes et les gerçures du bois.

Ces coléoptères son femelles surlout. Pendint le jour qui paroit les ollusquer, ils se tiennent cachés dans des trous d'arbres dont ils sorteut le soir pour voler et rechercher l'accouplement. Leur vol est lourd. Ce genre renferme plus de cinquante espèces, dont on ne iroure que quatre ou cinq en Europe.

$3^{\text {Te. }}$ Division. Elylres !raccoureies, rélrécies vers lcur extrémité, ne se rejoirnajt pas ì la suture et laissant à déconvert, mếme dans le repos, une parlie de l'abdomen et des ailes.

\section{Prrone sanguin, P. sanguinens.}

prionus sanguincus, antennis, mandibularum, elytronumque apice tibiis tarsisque nugris.

Longueur 1o lig. Corps d'un rouge sangnin, entièrenent pointillé. Antenues noires, de onze inticles, les cinq avant-dernier's dentés en scie, peu aplatis. Mandibules aiguës, plus conrles que La tête, armćes d'une forte dent iuterne, leur extrémité et leur partie intérieure noires. Yeux, extrếmilć des dytres, jambes et tarses noirs. Corsclet rebordé, ses bords latéraux portant chacun une épine peu saillante ver's leur milieu. Eeusson triaugnalaire. Elytres couvraut plus des deux ticrs de l'aljdomen et des ailes; elles sont chargées dé quatre lignes longitudinales peu élevées, n'allant pas jusqu'à l'extrémité. Les deux premiers articles des tarses sont peu dilatés. Femelle.

Du Brésil.

\section{Prore lugubre, $P$. lugubris.}

\section{l'rionus niger, fumeris pallide testaceis.}

Longueur 7 à 3 lir.r. Corps entièrement noir, pointilie. Autennes de onze articles, les huil avantCernicrs fortement dentés en scie , pou aplatis. Aitandibules aiguës, phus courtes que la tête; on voit une forte dent inferue a la mandibule gauche gui mañque dias la droite (il en est peut-être de mềne daus le précéden1); corselet peu reboráé, ses bords latéraux portant chacun une pelíte épine ve:s leur wilien. Ecusson presque triangulare; élytres ne convraut guère que la moilié de l'abdomen, ayant leurs angles humćraux d'un testaeé pầle et deux ligues lonyitudinales élevées, trèsLeu visibles, y’allant pas jusqu'à l'extrémité. Les deux premiers articles des quatre tarses antérieurs sont liès-dilatés. Mâle.

Du Brésil.

Nota. Nous avous une variélé ou peut-êlre une espèce très-voisine qui ne diffère qu'en ce qu'elle est eutièrement noire, sans tache licmérale aux élytres. M. le comie Dejean possède une autre espèce du b:ćsil égalemeul de celte division, qui approche beaucoup du Itione sanguin. Is Stenocorts hemipterus de Fabricius pourroit encore lui appartenir. Celui-ci est de Java.

$2^{\mathrm{e}}$. Division. Elytres grandes, de la longuen de l'abdomen, le couvrant en entier, ainsi que les ailes.

- jre. Subdivision. Côlés du corselel se rabattant insensiblement, leur rebord se voyant toujours en dessus (tarière des femelles rétractile).

\section{$\Lambda$. Troisième arlicle des antennes au moins deux fois plus long que le qualrième.}

\section{Prode serraticorne, $P$. serraticornis.}

Prionus fuscus, thorace marginato, utrinque tridentato, antennis serratis.

Prionus seriaticornis. Oulv.. Entom, tom. 4. parg. 14. no. 9. Prion. pl. 9. fig. 33. - Incyl. pl. 204. fig. 3 .

Longueur 3 pouces. Antennes noires, de douzo articles, les neuf avant-derniers ayant en dessous à leur exırémité, un appendice spiniforme, peu sensible dans les trois premiers. 'lête noire arec un peu de duvet roux sur sa parlie antérieure. Mandibules grandes, noires, de la longueur de la têle, arquées, fortement deulées intérieurement. Corselet noir; ses côtés un peu relevés en bosse, chargés d'un duvet ronx; ses bords latéraux portant chacun trois épines, l'intermédiaire plus longue. Elytres de couleur marron, brunes vers la base, pointillces. Ecusson arrondi postérieurement. Dessous de l'abdomen brun. Poitrine garnie d'un duvet roux. Palles brunes. Mále.

Des Indes orientales.

\section{Prione à collier, $P$ : armillatus.}

Prionus thorace marginato utrinquè quadridentato, elytrorum testaceorum, margine nigro.

Prionus armillatus. Fав. Syst. Eleut. tom. 2. pag. $261 \cdot n^{\circ}$ 19. - OL:v. Entom. tom. 4.pag. g. no. 4. Prion. pl. 5. fig. 17. - Lat. Gener. Crust. et Ins. tom. 3. pag. 53. - Ceramby $x$ amnillatus. Lin . Syst. Nat. 2.622.4.-Encycl.pi.200.Jig. 4.

Longueur 3 pouces $\frac{x}{a}, 4$ poụces. Antennes noires, de onze aricles, le premier ayant extéricurement une épine très-forle, les neuf derniers garnis d'un graud nombre de tubercules spiniformes. Tête moire. Mandibules courtes, grosses, 


\section{R I}

très-crocliues. Corselet noir, ses bords latéraux un peu lestaés, portant chacun quatre épines noires. Elytres testacées, bords extérieurs noirs; leur extrémité un peu écliancrée avec une épine qui temine la ligne sulurale. Ecusson arrondi justérieurement, testacé, bordé de noir. Dessous du corps noir, cliargé d'un duvet roussâtre. Pattes noires. Cuisses et jambes antérieures garnies de iubercules; eenx de dessous spiniliones.

Des Indes orientales.

Nota. Nous avons sons les yeux un autre Prione plus petit d'un tiers dont les antennes sont à proportion beaucoup plas esurtes, les neuf deruiers articles n'ont aueuns tubereules non plus que les paltes autćrieules. L'épine postérieure du corselet esi plus grande à proportion ainsi que eelle de la suture des élytres, l'extrémité de celles-ei n'est pas aussi ćvidemonent échancrée, mais dcutée en scie. Les pattes sont noins brunes et les autéricures sout beaucoup plus courtes. Seroit-ce l'autre sexe du Prione à collier ou une espèce différente?

\section{Prione noir, $\boldsymbol{P}$. ater.}

Prionus thoracis lateribus crenatis, elytiis mucronalis, margine exteriori arcualo.

Prionus ater. OLIv. Entom. tom. 4. pag. II. no. 6. Prion. pl. 7. fig. 24. - Encycl. pl. 202. fig. 3 .

L,ongueur 4 pouees. Entièrement noir. Tète et poitrine couvertes d'un duvet roux. Anteunes de onze articles gariis, surtout en dessous, de tubercules spiniformes. Palpes bruns. Mandibules courtes. Corselet ayant de chaque eôté une plaque triangulaire et une petite ligne furmées par des lubercules luisans; ses bords latéraux crénélés. Elytres pointillées, fortement cliagrinées à leur base, portant quelques petites lignes longitudinales peu élevées dont la plus visible est placée vers le bord extérieur. Ligne suturale termincée par une épine. Ecusson chagriné, arrondi postćlieurewent avee une impression vers l'extrémité. Bords postérieurs des segrnens de l'abdomen ferrugineux. Jambes épineuses; les quatre euisses antérieures garnies de tubereules spiniformes.

De Cayenne.

6. Prione dentelé, $P$. scriarius.

Prionus fuscus, thorace subcrenulato, punctis in inedio duobus iupressis.

Prionus serraitus. Pavz. Faun. Germ. fas. 9 . fig. 6. - Prioulus obscurus. Or.1v. Entom. tom. 4 . jug. 26. $n^{\circ}$. 27. Prion. pl. 1.fig: 7. - LAT. Gener. Cnust. et Ius. tom. 5. pag. 55. - Encjcl. pl. 196 . fig. 18 , et pl. 198. fig. 5.

Louguear 2 pouces. Noir, avec les elytres ponetuées.et d'un brun-testacé. Antenues aussi longues Hist. Nat. Ins. Tome $X$. que le corps, de onze articies. Misnäiunles con tes, très-arquées. 'Tête et corselet chağrinés, celui-ci ayant deux points enfoneés derric̀re chacun desquelsest un tubercule luisant, et sur les côtés une petite ligrne élevée, luisante; ses borcus latéraux légèrement crénelés. Ligne sumurate des élytres terninée par une petite épina. Cuisses c $t$ jumbes antérieures garnies de tubercules; les quatre pattes postérieures linement ponctuées. Ecusson arrondi postérieurement. Poitrine et abdomen bruns.

Il se trouve en Allemagne sur les pins et les sapins. Suivant Olivier if hubite aussi la l'rovenee.

\section{Prione arisan, $P$. fuber.}

Prionus thorace marginato, utringue unidentato, elytris pices.

Prionus faber. FAв. Syst. Elent. tom. 2. pag. 258. $n^{\circ} .5$. - Lat, Gener. Crust. et Ins. toll. pag. 33. - Oliv. Entom. tour. 4. pag. 18. $n^{\circ} .15$. Pron.pl. g.fig. 35.-1Anz. Faun. Genu. fas. 9 . fig. 5. - PAYK. Faun. Suec. tom. 3. pag. 50. $n^{\circ}$. I. - Cerambyx faber. Linn. Syst. Niat. 2: 622. 6. - Encycl. pl. 204. fig. 5.

Longueur 20 lig. Corps glabre, d'un brun.noirâtre ou tout-à-fail noir. Antennes beaucoup plus courtes que le corps, de onze aricles. Mandibules eourles, arquées. 'Tête et corselet cliagrinés. Celui-ci portant sur son disque deux petits tuberculcs un peu plus saillans que les autres; ses bords latéraux dentelés, ayaut en outre une épine un peu avant l'angle postérieur. Elytres pointillées irrégulièrement. Ligne suturale terminée par ane épine plus forte dans le mâle. Mâle et femelle.

Se trouve en Europe.

\section{Prtone écorce, $P$ : corticinus.}

Prionus rufescens, fronte villosâ, thorace margiuato crenulato, posticè unidentato.

Prionus corticiulus. Oriv. Entom. tom. 4. pag. $21 . n^{\circ}$. 20. Frion. pl. 9. fig. 34. - Encycl. pl. $204 \cdot f i g .4$.

Longueur 2 pouces à 2 pouces $\frac{x}{2}$. Corps de couleur marron, couvert d'un duvet roux, soyeux, un peu chatoyant. Antennes de onze articles, leur base plus brune. Tête brune, sa partie antérieure cliargée d'un duvet roux. Mandibules eourtes, très-arquées. Corselet a yant sur son disque quatre petits tubereules; ses bords latéraux porlant chacun trois épines, la postéricure plus grande. Paltes $\mathrm{un}_{\odot}$ ! u rembrunies. Femelle.

Le mâle a le premier arlicle des antennes duveté en dessous, et le troisic̀mc chargé, aussi en dessous, de petits tubercules spiniforme; et fortement canalieulé en dessus. L'épine postéricure du corselet est plus forte gue dans la femelle et C 
nn peu reeourbée en arrière; la ligne suturale des ćlytres est terminée par une épine.

De Cayenne.

\section{Prione boulanger, $\boldsymbol{P}$. depsàrius.}

Prionus ferrugineus, pubescens, subtics fuscus, thorace utrinque unidentato, antennis brevibus.

Prionus depsarius. $\mathrm{F}_{\mathrm{AB}}$. Syst. Elent. tom. 2. pag. 258. $n^{\circ}$. 7.-LA T. Gen. Crust. et Ins. tom. 3. pag. 32. - GuIv. Entom. toriz. 4. pag. 37. $n^{\circ} .44$. Prion. pl. II. fig. 41. Femelle. - Panz. Faun. Gem. fas. 9. fig. 7. Hemelle. - РАчк. Faun. Suec. tom. 3. pag. 52. no. 3. - Ceranthy depsarius. Linn. Sy'st. Nat. 2. 624. 12. - Encycl. pl. $205 . f_{0} .11$.

Longueur r $8 \mathrm{lig}$. Corps de couleur de poix, son dessous plus cluir. Antenues de onze artieles dans les denx sexes. Corselet finement chagriné, ayant sur son milieu une ligne longiludinale trèslisse, et quelques poils jaunâtres clair-semés; ses bords latćraux munis chacun d'une épine. Elytres finement chagrinées, portant des lignes longitndinales peu marquées, qui n'atleignent ni la base ni l'extrémité. Poitrine un peu duvetée. Mâle et femelle.

Celte espèce est proportionnellement plus étroite que le.Prione tanneur.

Du nord de l'Europe.

3. 'Troisième article des antennes n'étant pas nne fois et demie aussi long que le quatrième.

a. Antennes peetinées dans les mâles.Ecusson arrondi postérieurement.

ro. Prione tanneur, $P$. coriarius.

Prionus fuscus, thorace marginato utrinquè trispinoso, antennis brevibus.

Prionus coriarius. FAв. Syst. Eleut. tom. 2. pag. 260. $n^{\circ}$. $16 .-$ Lat. Gen. Crust. et Ins. tom. 3.pag. 32. -Otuv. Entom. tom. 4. pag. 29. $n^{\circ}$. 32. Prion. pl. 1. fig. 1. - PaNz. Faun. Germ, fas. 9.fig. 8. Femelle.-PАу . Faun. Suec. tom. 3. pag. 5I. no. 2. - Cerambyx coriarius. Linn. Syst. Nat. 2. 622. 7. - Le Prione. Geoff. Ins. Paris. tom. I. pag. 198. $n^{\circ}$. 1. pl. 3. fig. 5. Femelle. - Encycl. pl. s97. fig. 3-6.

Longueur i 5 à 18 ligr. Corps ehagriné, d’un brun couleur de poix. Antennes de donze articles dentés en seie, à l'exception des trois premier's et du dernier. Mandibules eourtes, arquées. Bords latéraux du corselet portant chacun trois épines, l'intermédiaire plus longue. Elytres ayant chảcone trois lignes longitudinales pen élevées, à peine visibles. Ligne suturale terminée par une épine très-courte. Corselet et poitrine un peu duvetés en dessous. Femelle.
Le måle diffère par ses antennes pectinées et de treize artieles; sa couleur est plus brune.

Il se trouve en Europe dans les forêts et n'est pas très-commun aux environs de Paris.

Nota. Geoflroy a décrit et figuré une femelle quoiqu'il dise positivement le contraire.

On trouve dans De Géer les détails suivans : la tarière de la femelle, longue de plus d'un demipouce, est composée de plusieurs pièces qui r'entrent les unes dans les autres comme les tuyaux d'une lunette d'approche; son extrémité est garnie de deux parties éeailleuses ressemblant un peuà des ciseaux; à l'endroit où elles se réunissent on voit de chaque côté un petit tubercule. La partie qui suit est longue, éeailleuse, concave en dessus. A sen origine on voit une ouverture qui probablement donne passage aux œufs; (cenx-ci sont alongés, d'un jaune-blancbâtre, ayant environ deux lignes de longueur), ensuite viennent deux espèces de tuyaux membraneux qui rentrent l'un dans l'antre et tous deux dans un troisième tuyau plu: gros d'une consistance assez dure, mais cependant flexible. Enfin toutes ces parties trouvent place dans l'abdomen lorsque l'insecte n'en. fait pas usage.

\section{Prione imbricorne, P. imbricornis.}

Prionus ferrugineus, the race marginato utrinquè tridentato, antennis utrinquè pectinatis brevious.

Prionus imbricornis. OnIv. Entom. tom: 4. pag. 28. $n^{\circ}$. 31. Prion. pl. 13. fig. 52. Mâle. LAT. Gen.Crust. et Ins. tom. 3. pag. 32. - PaLis.Bauv. Ins. d'Afriq. et d'Amér. pag. 242. Coléopt. pl. 36. fig. 2. Mâle. - C'eramby $x$ imbricornis". Lix̣. . Sy'st. Nat. 2, 622. 5. Mâle.

Longueur 11 à $1 \dot{2}$ lig. Corps chagriné, ponctné, de couleur marron. 'Tête, corselet et base des antennes plus foncés, presque bruns. Ces dernières composées de vingl-un articles pectinés des deux côtés, à l'exception des deux prcmiers et du dernier. Mandibules courtes, trèsarquées. Bords latéraux du corselet portant ehacun denx pelites épines vers leur partic antérieure. Elytres ayant chacune deux lignes élevóes peu visibles; lugne suturäle terminée par une petite épine. Corselel et poitrine un peu duvetés en dessous. Màle.

De la Calroline.

b.Antenues simples, composćes d'articles comprimés aı nombre de onze. Mandibules courtes, arquées.

$\dagger$ Eeusson pointu postérieurement.

1.2. Prione spécieux, P. speciosus.

Frionus viridi-ceneus, thoracis margine spinosó crenato. 
Prinnus speciosus. Olv. Entom. tom. 4. Prion. jag. 31. no.34. pl.12. fig. 48?-LAT. Gen. Crust. et Ins. tomr. 3. pag. 53. - Encycl. pl. 199. fg. 6?

Longneur: $18 \mathrm{lig}$. Dessus du corps chagriné et ponctué, d'un vert-brun à reflet cuirreux, son dessous plus lisse et brillant. Antennes et pattes d'un noir-bleuâtre à reflet cuivienx en dessous. Les cinq ou six premiers articles des antennes trèsmugneux en dessous, les quatre derniers portant chacun à leur base latérale inférieure, deux tubercules. Bords latéraux du corselet trè̀-dilatés, ayant chacun une épine, crénelés au-dessus et au-dessous de cette épine. Jambeses rugueuses, les antéricures ainsi que leurs cuisses, chargées en dessous de lubercules presqu'épiueux.

Du Brésil. .

Nota. Nous rapportons à cette espèce, quoiqua a vec doute, lis figure 48 , planche 12 de l'Entomologie d'Olivier, qu'il donne pour être celle de son Prione brillant $11^{\circ} .33$, mais qui ne lui ressemble en rien. Cette figure quoique mal faite convient mieux an Prione spécieux que ceile no. 13, planche 4 , indiquée par Olivier comme lui appartenant.

13. Prione brillant, $P$. nitidus.

Prionus coruleo-violacaus, thorace marginato, crenato, unidentato, elytris rugosis, cupreis.

Prionus nitidus. F. B. Syst. Eleut. tom. 2. pag. 258. $n^{\circ} .4$. Femelle. - Lia . Gener. Crust. et Ins. toim. 3. pag. 53. Femelle. -Oulv. Entom, tom. 4 . prion. pag. 3o. $\pi^{\circ}$. 33. Fenelle. (Supprimez la figure citée.) - Prionus angulatus. LA' Gener. Cirust. et Ins. tom. 3. pag. 33. Mile. - Oniv. Entom. tom.4.Prion. pas.31. $n^{\circ} .35$. pl. 1.fig. 2, et pl. 4. Jig. I3? Mâle.

Longuear 15 is 18 lig. Dessus du corps chagrine et ponctué. 'Tète, corselet et écusson d'un blenviolet ì rellet cuivrenx. Antemies et pattes bleues à :ellet verdatre. Bords latérant du corselet ayant chacun une épine; ils sont crénelés depuis leur base jusqu'à l'ćpine seulement. Elytres d'un beau rouge-cuivreux. Dessons du corps brillant, d'un bleu-violet avec des reflets verts et cuivreux. Femelle.

Le mâle diffère en ce que la partie postćrieure de la tête, l: corselet et l'écusson ont un reflet d'un ronge-cuivreux et que ses élytres sont vertes à retlet doré.

Du Brésil.

Nota. Olivier s'est trompé en rapportant au Prione spécieux la figure 15 de la planche 4. Elle nous paroit ètre celle du Prione brillant máte, quoique très-incorrecte.
14: Prone bifascié, P. bifasciatus.

Prionus niger, thorace marginato, denticulato, clytris rubris, fusciis duabis atris.

Prionus bifisciatus. Far. Syst. Elcut. tom. 2. pag. 262. no. 24.-Oliv. Entom. tom. 4. Prion. pag. 32. no. 37. pl. 1.fig. 4. a. b. - Cerambyx bifasciatus. Lrnn. Syst. Nat. 2.624. 16. - Encyel. p!. 198. fig. 2.

Longueur I pouce. Dessus du corps chagriné. Antennes, tête, corselet, écusson et palles d'un noir-violet. Bords latéraux du corselet entièrement crénelés et munis chacun d'une épine. Elytres d'un rouge-cuivreux avec deux bandes transverses d'un brun-cuivreux à reflet violet, la première irrégnlière dans sa forme, placée au-delà du milien et l'autre à l'extrémité. Dessous du corps d'un bleu-violet brillant.

De Cayenne.

t† Ecusson arrondi postérieurcment.

15. Prtone canaliculé, $P$. canaliculatus.

Prionus thorace marginato, crenulato, sulco longitudnali dorsali albo villoso, antennis brevibus.

Prionus canaliculatus. FAв. Syst. Eleut. tom. 2. pag. 264. $n^{\circ}$. 32. - Oliv. Entom. tom. 4. Prion. pag. 25. no. 26. pl. 9. fig. 52, a. b. - Encycl. pl. 204. fig. I et 2.

Longueur 20 lig. Corps chagriné en dessus. Antennes, tête, corselet, pattes et dessous du corps bruns. Corselet ayant au milien un sillon longitndinal garni d'un duvet blanc, ses bords latéraux fortement crénelés, leur pointe postérieure spiniforme. Elytres de couleur marron, chargées de lignes peu distinctes, formées par des points enfoncés dont chacun porte une pelite tonfíe de poils blancs; leurs bords exiérieurs jannes. Jambes antérieures garnies on dessous d'un duvet touffu, roussâtre.

Amérique méridionale.

16. Prione quadrilinéé, P. quadrilineatus.

Prionus thorace crenulato, testaceus, elytiorum lineis duabus impressis albo villosis.

Prionus quadrilineatus. Orrv. Entom. tom, 4. Prion. pag. 40. $2^{\circ}$. 48. pl. 3. fig. I I. - Encjcl. pl. $199 \cdot$ fig. 4 .

Longuear it lig. Corps testacé, chitgriné en dessus. Bords la téraux du corselet crénelés, échancrés à l'angle postérieur', ce qui y forme deux pointes. Elytres diune nuance plus claire, portant chacune dans leur milieu deux lignes longifudinales enfoncées, garnies d'uu duve blarachâtre très-serré, qui n’atleignent ni la base ni l'extrémité. Ligne suturale terminée par une très-pe.ile C c 2 
pointe. Pattes, dessous de la téle, du corselet et poitrive, de couleur brune. Les côlés de celle-ci et le ventre garnis d'un duvet roussâtre.

Patrie inconnue.

17. Prionz élégant, $P$. elegans.

Prionus thorace utrinque bispinoso, elytrorum lineis ducubus longitudinalibus nigris, exteriori carinatâ, alterầ suturali.

Prionus elegans. Palis.-Bauv. Ins. d'Afriq. et d'Amériq. pag. 217 . Coléopt. pl. 34. fig. 5.

Longueur $18 \mathrm{lig}$. Corps lisse, luisant. Antennes, 'lête, corselet, écusson el palltes de couleur ferrugineuse. Corselet portant deux lignes élevées, inégales, ses bords latéraux ayant cliacun denx épines un pen recourbées. Elytres fauves; on voil sur chacune deux larges linnes longitudinales noires dont une accompagne la sulure el l'autre très-relevée, partant de l'angle huméral; partie postérieure des élytres crénelce, précédée d’une épine latérale. Dessous du corps ferrugineux. Abdomen brun avec une ligne latérale ondíe, forusée de poils roussâtres. Jambes garnies eu dessous de poils roux.

Décrit d'après un seul individa trouvé à SaintDomingue par M. Palisot-Bauvois.

c. Antennes simples, composées d'articles cylindriques, au nombre de onze.

\section{Prione cervicorne, $P$. cervicomis.}

Priomus thorace marginato utrinquè tridentato, mandrbulis porrectis, maximis.

Prionns cervicornis. FАB. Syst. Elent. tom. 2. pag. 259. $\|^{\circ}$. 12. - I.Aт. Gener. Crust. et Ins. tom. 3. pag. 33. - Oliv. Entom.tom. 4. Prion. pag. 13. $n^{\circ}$. 8. pl. s.fig. 8. - PaL1s.-Bauv. Ins. d'Alfriq. et d'Aimériq. pag. 215. Coléopt. pl. 34. fig. 1.-Ceramby.x cervicornis. Lın. Syst. Nat. 2. 622. 5. - De GÉER, Ins. tom. 5. pag. 94. Bincycl. $\mu l .198$. fig. 7 .

Longueur 4 pouces $\frac{x}{2}$. Corps très-finement pointillć en dessus. Tête brune avec devix catrènes élevées, longitudinales, précédées d'une épine; vers la partie postérieure de ces carènes sont intérieurement deux pelits espaces chagriaés. Mandibulés plus longues que la lête et le corselet pris ensemble, crénelées en dedans avec une forte dent inteine placée aux deux ciers de leur longueur environ, et une autre à la partie extérieure plus près de l'exlrémilé. An!enues fauves, guc̀re pius longues que les mandibules. Corselet d'un bruu - mat, sa partie noyenne fortement chagrinée, assez luisante; ses bords latéraux porlant chacun trois épines, l'espace qui est entre les deux premières fortement crénelé; on voit une cobuncraré assez grande sans crénelures entre les

\section{P R I}

deux épincs postérieures. Ecusson brun. Elytre d'un jaune-ferrugineux, chargées de lignes et de taches brunes; ligne suturale terminée par une. épine fort courte. Dessous du corps et pattes de. couleur brune. Poitrine garnic d'uu du vet grisâtre.

De l'Amérique méridionale. Sa larve vit dans les fromager's (Bombax), et suivant M. PalisotBuuvois, dans les f:uits du cacaotier. On assure que les naturels du pays la mangent.

Nota. Nous connoissons un individu qui n'a guère que trois pouces. Ses mandibules sout plus courtes que la tête et le corselet pris ensemble, leur dent interne est peu sensible, l'extérieure l'est. davantage à proportion et siluée vers le milieu.. Toules les parties anlérieures du corps et les pattes. sont d'une nuance plus claire. De Géer après avoisdécrit l'espéce en lui donnant les mệes proportions de corps et de mandibules que nous, fait aussi mention d'individus conformés contume celuici, ce qui pourroit faire croire que c'est un sexe diflérent. (Encycl.pl. 197.ffg. 1.)

\section{Prone maxillaire, $P$. maxillosis.}

Prionus thorace marginato crenulato, mandibulis porrectis.

Prionus maxillosus. $\mathrm{F}_{\mathrm{AB}}$. Syst. Eleut. tom. 2. pag 264. n'.31. - Oliv. Entom, tom. 4. Prion. pag. 16. n⿳. 13. pl. 1. fig. 3.- - Dй Y, Ins. 1. pl. 38. fig. 3. - Encycl. p!. x 98. fig. 1.

Longueur 2 pouces. Entièrement bran. Téte ponctuée et clagrinée. Mandibulcs arquées, un peu plus longues que la tête, garnies intéiieurement de poils roux et cle trous dents, les inférieures un peu au-dessus du milieu, la dernière très-petile placée près de la pointe. Anlennes égalant en longueur la noitié du corps. Corselet portant sur sés côtés deux petiles lignes luis ntes, un peu élevées et sur son disque trois aréoles un peu élevées, luisantes, dont l'inférieure est posée vis-à-vis de l'écussun; bords latéraux crénelés, angles supélieurs très-avancés, arrondis. Ligne suturale des élytres terminée par une petite épine. Poitrine garnie d'un duvet grim. sảtre.

A mérique méridionale.

20. Prone géant, $P$. giganteus.

Prioms thorace utrinquè trispinoso, niger, elytris ferrugineis, mandibulis porrectis validis.

Priontes gigantells. FAB. Syst. Eieut. tom. 2. pag. $261 . n^{\circ}$. 17. - Lat. Gener. Crust. et Ins. tom. 3. pag. 33. - Oniv. Entom. tom. 4. Prion. pag. 12. $\pi^{\circ} \cdot 7 \cdot$ pl. 6. fig. $21 .-\mathrm{D}_{\mathrm{R}} \mathrm{nr}$, Ins. tom. 3. pl. 49 .fig. 1. - Encycl. pl. 201. fig. 4

Longueur 6 pouces $\frac{1}{2}$. Entièrement d'un brunncirâtre. Mandibules fortes, plus courtes que la tê!e, pointıllées, très-arquées, ajant une forle 
dent interne. Antennes alteignant à peine en longueur la moilié dn çorps, le troisième el le premier articies ere usés en dessus, celui-ci échaucré et crénelé en dessous. 'Fête finement pointillée. Corselet fortemeni chagriné sur les côtés, son disque un peu pointillé, luisant. Bords latéraux portant charun trois épines, l'interwédiaire plus Jongue. Elytres d'une nuance plus claire, chargées de petiles vides et de quatre lignes longitudinales peu marquées qui n'alleignent pas l'extrémité; ligne suturale terminée par une très-petile épine. Jambes fortenent épincuses en dessous ainsi que les cuisses anlérieures. Dessous da corselet el poitrine gainis d'un duvet roux, brillant. Wâle.

De Cayenne.

Nota. Ce Prione nous paroît surpasser par sa wille tous les autres colćoptères eonuus.

20. Subdivision. Côtés du corselet rabattus subitement; leur rebord ne se voyant qu'eu dessous. ('l'arière des femelles saillaute.)

\section{Prione scabricorne, P. scabricornis.}

Prionus thorace subcylindrico, eljtrorum lineis tribus elevatis abbreviatis.

Prionus scabricomis. Fав. Syst. Eleut. tom. 2. pag. 258. no. 6. - Lat. Gener. Crust. et Ins. tom. 3. pag. 33. - Ok1v. Entom. tom. 4. Prion. pag. 55. $n^{\circ} .41 . p l .11$. fig. 42. liemelle. - P Anz. Faun. Germ.fas. 2. fig. 7. Mâle. - La Lepture rouillée. (ieofr. Ins. P'aris. tom. 1. pag. 210. $n^{n}$. 6. - Encycl. $p l$. 2.15. fig. 12. Femelle.

Longueur 20 à 22 lignes. Corps brun. Mandibules veaucoup plus courtes que la tête, trèsarquées, sans denielures. Autennes plus courtes que le corps, de once articles, le troisième plus long que les deux suivans réunis; les cinq premịers chayrinés, raboteux. 'Tèle et corselet chagrinés, uvec un peu de duvel roussâlre; angles poslérieurs du corselet relevés, presque spiniformes. Elytres de couleur marron, un peu chagrinées et duveiées, porsunt cluacrine trois lignes longitudinales élevées, celle du milieu plus longue que les deux autres qui s'y réunissent, n'attciguant pas l'extrémitć; ligne suturale ter'minće par une très-petite épine à peine visible. Dessous du corps el palles d'un Lrun-marrou clair. Tarière ayant près de quatre ligues de longueur. Poitrine légeremeil garnie d'un duvel grisâtre. Femellc.

Le mâle a les antennes entièrement chagrinées et mème épineuses en dessus. Les lignes des élytres sont moins distiucles.

Se trouve en Europe sur le trone des vieux arbies. II habile aux envirous de Paris, suivant Geoffioy. ' (S. l'. et A. Serv.)

eRIONIENS, Prionii. Première tribu de la famille des Longicornes, scetion des 'l'ćtrauères, ordre des Coléoptères, iyant pour earactères :

Labre nul ou très-petit.

Celle tribu ne contient que les genres Spondyle et Prione. Voyez ees mols.

(S. F. el A. Serv.)

PRISTIPHORE, Pristiphora. Lat. Considér. généval. Téntliedo. Fab. l'arz. Pteronus. Jur.

Genre d'insectes de l'ordie des Hyménoptères, section des Térébrans, famille des Porle-scie, tribu des Tenthrédizes.

Parmi les yenres de cette tribu, les seuls qui aient les antennes compostes de neuf arlicles sont: Cladie, Pristiphole, Némate, 'Tenthrède et Dolère. Les denx derniers ont denx cellu'cs riadiales aux ailes supérieures; les Némates ont quatre cellu'es cubitales; les antennes des Cladi s sont velues el lenrs arlicles à partir du troisièmo sout insérés obliquement sur chacun de cenx qui les précèdent; ces divers caractères distinguent ces gemres de celui de Pristiphore.

Antennes filiformes, de neuf arlicles; ces àlicles nus el n'élant point lironqués obliquerment. - Labre apparent. - Mandibules échancrées ou légèrement bidentées. - Palpes filiformes, les maxillaires plus longs que les labiaux, de six arlicles, les labiaux de quatre. - Lèvere trifide. Trois petits yeux lisses disposés en triangle sur le vertex. - Corselet un peu eylindrique. - Ailes supérieures ayant une eellule radiale grande et trois cellules cubitaies, la dernière alleignant l'extrémité de l'aile.-Abdomen éomposé de lutit. segrmens oulıe l'anus; tégnment supérieur du premier incisé dans son nilieu; une tarière daus les feinelles ne dépassant pas l'extrémité de l'abdomeu, logée dans le repos dans une coulisse qui partage eu deux le tégument inférieur de l'anus, ce même tégument entier avec le supérieur presque nul dans les mâles. - Pattes de longucur moyenne, les quatre jaubes postérieures dépourvues d'épine médiale.

Le nom de Prisliphore vient de denx mots grees. qui signifient : Porte-scic. Ce genre a été créé par Ni. Lalreille anx dépens des Ptérones do M. Juriue el adopé par les auteurs subséquens. Il ne contient jusquà à présent que huit espèces qui toutes sont de Frinuce.

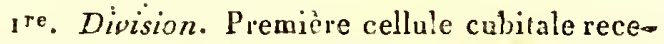
vant les deux nervures récurrentes. - Mandibules. un peu échaạcrées.

\section{Pnistiphore de la Myosotis, P. Myosotidis.}

Pristiphora nigra, abdominis lutei segmentis omnibus nigro transversè sțrigatis.

Pristiphora Myosotidis. Le P. Monogr. Tenthred.pag. 59 . no. $17.0 .-$ Faun. franc. Hy mézopt. 


\section{P R O}

pag. 74. 20.1. - Pieronns Myosotidis. Jur. pag. 64. - Tenthredo Myosotidis. FAB. Syst. Piez.pag. 41. $n^{\circ}$. 60.- Panz. Faun. Germ. fas. n. fig. 13 .

Longueur 2 lig. $\frac{1}{2}$. Antennes, tête et corselet noirs. Bouche, épaulentes, paltes antérienres et interınédiaires jaunes. Abdouen jaune; ses serrmens marqués en dessus d'une ligne dorsile, noirâtre, runsversalc. Paltes postćrieures noires arec les lianches et la plus grande paric des cuisses jaunes. Ailes supérieures ayant leurs principales nervurcs et le point marginal jaunes. Femelle.

Des euvirons de Paris.

2. Pristiphore testacće, $P$. testacea.

Pristiphora nigra, humeris punctisque duobus subscutello luteis, abdomine testaceo, pedibus testaceis tibiarum posticatum apuce fisco.

Pristiphora testacea. I.at. Consid. gen.-Le l'. Monogr. Tenthred. pag. 5. . n०. 171. - Pteronus testaceus. Jur. pag. $64 \cdot \% l .15$.

Longueur a lig. $\frac{1}{2}$. Anteunes, tête et corselet noirs. Epauletles et deux poinis sous l'écusson, jaunes. Abdomen teslacé pâle. Extrénité des jambs postéricures brune. Ailes transparentes, nervures noires. Femelle.

Des envirous de Genève.

3. Pristiphone rufipède, $\boldsymbol{P}$. rufipes.

Pitstiphora nigra, pedibus testaceo-flavis, femorum anticorum quatuor basi nigro maculatâ.

Pristiphora rufipes. Le P. Monogr. Tenthred. pag. 6o. $n^{\circ} \cdot 1.74$ - Faun franc. Hyménopt. pag. $75 \cdot \pi^{\circ} \cdot 4 \cdot p l \cdot 12 \cdot f i g .4$.

Longueur $2 \mathrm{lig} . \frac{z}{2}$. Noire. Labre testacé. Mandibules bruues. Patles fauves, les quatre cuisses antérieures tachées de noir à leur base. Ailes transparenles, nervures brunes. Femelle.

Du nord de la France.

$2^{e}$. Division. Seconde cellule cubitale recevant les deux nervures récurrentes. - Maudibules légèrement bidentées.

\section{Pristengore âtre, $P$. atra.}

Pristiphora nigra, peaun pallidorum femorious basi nigris.

Pristiphora atra. Le P. Bronogr. Tentlived. pag. 61. n०. 176. - Faun. franc. Hyménopt. pag. 76. n०.6. - Pteronus ater. Jur. $p l .6$. Pteronus niger: Jur. pag. 64 .

Longucur a lig: $\frac{1}{2}$. Noire. Paltes pâlles avec la Lase des cuisses noire. Male et feutle.

Des environs de Soissons. 3e. Division. Seconde cellule cubilale recevant la premic̀re nervure récurrente; troisième cellule culilale recevant la deuxième nervure récurrente.

\section{Pristiphore varipède, $\boldsymbol{P}$. varipes.}

Pristiphora nigra, ore pedibnsque albo variis.

Pristiphora varipes. Le P. Monogr. Tenthred. pag. 61. no. 178. - Faun. franç. Hynténopt. pag. $76 . n^{\circ} \cdot 8$.

Longueur 5. lig. Noire. Bouche et pattes variécs de blanc. Ailes transparentes. Mâle:

Du Solssomuis. (S. F. et A. Servi.)

PRO-ABEILLE. Réaumur et De Géer ont donné ce nown aux Hyménoptères mellifères de la tribu de Andrenètes. Toyez Andrène.

(S. F. et A. Serv.)

PROBOSCIDES, Proboscidea. Première section de l'ordre des Diplères; ses calractères sont : Gainze de la trompe toujouts univalve, renfermaul dans me gouttière supríreure et longiludinale le siacoir, coudée à sa base el termiuée par un empâtemient plus ou moins marqué, divisé $\mathbf{E n}$ deux lèvres. - Tête toujours très-distincte du tronc. - Crochets des tirses droits ou simplement arqués et unideulés au plus en dessous.

(S. F. el A. Serv.)

PROCESSE, Processa. Líach. Lat. Niká. Risso. Lam. Desn.

Geure de Crustacés de l'ordre des Décapodes, famille des Macroures, section des Salicoques, établi par M. Léach (Crust. Podoph. de la Gr: Bret. $4^{\mathrm{e}}$. cah. 18,5 ), et doul les caractères sont : anlennes inlernédiaires on supérieures terminćes par deux filets sétacés, đisposés presque sur une même ligne horizontale, et donl l'iulérieur est le plus longr., portécs sifr un pédoncule formé de trois articles, dont le premier plus grand et le second plus court. Anlennes inféricures ou extérieures sétucées, beaucoup plis longues que les premières, poutvnes, à leur base, d'une écaille alongée, unidentée à̀ l'exlrémité et en dehors, et ciliée sur le bord iuierne. Pieds-mâchoires extérieurs ne couvranl pas la bouche; formés de quatre articles visibles, dont le second est très-Jong el forlement échancré à sa base du côté inlerne: Pieds gínérulemeul grêles et longs; ceux de la premicre paire mouodactyles à gauche et didactyles à droite, n’ayaut pas de carpe multiariculé; fieds de la seconde paire plus grêles, très-longs, filiforues, de crandeur inégale et finissant cluacun par une petite main didaclyle; le carpe et l'article qui le précède étant nuliarticulés dans la plus longue, et le carpe seulement l'élant dans lit. plus courle : les trois dermières paires de pieds simplement termivées par un ongle aigu, légèrement 


\section{$\mathrm{P} R \mathrm{O}$}

arqué et non épineux; earapare un peu alongée, lisse, pourvue en avant d'un petit rostre enmprimé. Abdomen arqué vers le truisième segrnent, terminé par des lames foliacécs, alongées, dont l'extérieure, de chaque côté, est bipartie à l'extrémité.

Ce genre a de grands rapports avee celui des palémons, mais il s'en dislingue ainsi que des antres genres de la seetion des Salicoques par la singulière anomalie de ses pieds autérienrs. Ces Crustaeés sont très-communs sur nos eôtes, sur tout sur celles de la Méditerranée; c'est en été qu'on en tronve en plus grande abondanec. Ils n'abandonnent jamais le rivage, et les femelles déposent leurs cufs plusieurs fois dans l'année sur les plantes marines; ils sout géuéralement de petite taille, leur chair est très-estimée, et on s'en sert conme d'un exeellent appât pour prendre le poisson.

M. Risso, dans son ouvrage sur les Cruslacés de Nice, a voil donné le nom de Nika aux Crustaećs de ee genre, mais comme son onvrage n'a paru qu'un an après celui de M. Léach, M. Latreille a adopté la dénomination de ee dernier comme étant antórieure.

i. Processe eomestible, $P$. edulis. Léaeur. I.A.т. Crust. pag. 85. Nika edulis. Risso, pl. 3. fig. 5. Lam. Desm. Longrie d'environ un-pouce et demi, d'un rouge-inearnat, pointillée de jaunâtre, el ayant une rangée de taches jannes an milieu de la earapace qui est très-lisse, termiuée par trois pointes aiguës, dont celle du milieu, o. le rostre, est la plus longue; yenx verts; pattes de la première paire égrales en yrosseur. Cette espèce qui a élé connue de Rondclet (Hist des Poiss. éd. francaise). el qu'il a nommée la Civade ou petite Squille, a la chair tellement douee, snivant cet auteur, qu'elle répugne ì certaines persorues. Elle fait son nid dans la région des algues et on la vend pendani toute l'aunće dans les inarchés de Nice : la femelle pond en tout temps; ses œufs sont d'un janne-verdâtre. MM. Risso el Léach dêcrivent plusieurs autres espèees de ce genre. (E. G.)

PROCESSIONNAIRES. Nom donné par Réaumur aux ehenilles de dcux espèees de Bombix. Voy. Bombix proeessionuarre $\mathrm{n}^{\circ} .9^{6}$ et Bornbix pithyocampa no. 97. (S. F. el A. Senv.)

PRO-CIGALE. Nom donné par Réaumur et Geoffroy (Ins. Paris. tom. I. pag. 429) aux Hémiptères qui composent les genres Telligone et Membraeis. Voy, ces mots.

$$
\text { (S. F.et A. Senv.) }
$$

PROCRIS. Nom donné pa: Geoffroy an Satyre Pamphile. Toy. Iom. 9, pag. 549 de ee Dictiomnaire. (S. F. et A. SERv.)
PROCRIS, procris. FaB. Sirt. Gibsat, Lat, Sphinx. (Adscita.) Lrvx. Sphin.x. Ess. Hun.' Zyganar. FAB. Ent. Syst. PANz. Ross. Phalcule. Georr. Papillon-phalène. DE Gier.

Genre d'insectes de l'ordre des Lépidoptères, famille des Crépusenlaires, rrín des Zygénides.

Les Sésies, les Egoctres, les Thyrides, les Zygènes et les Syntomides, genres de eelle tribu ont dans les deux sexes les antennes simples ou à peine peelinées. Les Griucopides, les Aglaopes et les Stygies les ont bipectinces dans les dear sexes; dans les Atychies ainsi que dans les Proeris elles sont bjpectinées dans les mìles, simples daus les femelles, mais on reconnoittra les premières à leurs palpes trc̀s-velus, s'élevant notiblement au-dessus du chaperon, à lenrs ailes eourtes et aux fortes épines qui terminent leurs jambes postéricures.

Antennes sans looppe à leur extrémilé, simples ou garnies d'écailles peu alongées dans les femelles, bipectinces dans les mâlcs. - Langue disţincle. -Palpes point velus, s'élevant à peine au-dela du ehaperon. - Ailes oblongues, ciliées. - Jambes pastéricures términées par deux épiues très-peites. - Chenilles eonrles, ramassées, peu garnies de poils, se rapproebant beaueoup f:ar la forme des Chenilles-cloportes. - Chrysalide renfermée dans une eoque.

Les espèces de ce genre sor en peit nombre et se ressemblent toutes; leur taille est moyenne, leur conleur uniforme, les ailes n'ont ni taches ni bandes, un vert mélatlique quelquefois mêlé d'un peu de brun est lenr livrée ordinaire. Les Proepis se trouvent dans les prés secs, dans les clairières des bois et le long des lraies.

\section{Proeris de lit Statice, P. Statices.}

Procris alis superioribus suprà viridibus aurer subnitentibus, subtic inferioribusque cmereo fuscis, antennis maris apice vix.pectinatis.

Procris statices. Lat. Gen. Crust. et Ins. fomr. 4. pag. $214 .-$ God. Hist. nat. des Lépid. de Fr. tom. 3. pag.158. p. 22. fig. 15. - Zygona statices. FAB. Ent. Syst. tom. 5. part. 1. pag. 406. n⿳. 63. - Splinix statices. Linv. Systo. Nat. 2. 808. 47. - Hur. Sphing. tab. 1. fig. 1. - PANz. Faun. Germ. fus. "ffor. 24. - Esp. Sphinx. tab. XVIIK. fig. «. - Le Sphinx inrquoise. Fxoro Pap.d'iur. pl. 10J. fig. 150. - DE GEER, Ins. tom. 2. pag. $=55$. $i^{\circ}$. 2. pl. 5. fig. 8-10. - La Turquoise. Groms. Ins. Paris, tom. 2. pag. 120. $n 2^{\circ} .40$.

Envergure 9 lig. Iangue noire. Anteunes ct corps d'un veri-doré. Dessus des ailes sujérieures de uême conlen:, leur dessons el les inférientes, d'un brun-ecidré. Dans le mâle les sept on huit derniers arlieles des antenaes sont peu pectinés, lèurs dents étant très-eourtes et en forme de stries. 
Chenille verdátre arec deux rangées longitudinales de chevrons noirs sur le dos, et le long du corps une sérielongitudinale de points ronges bordée d'une linne noire flexueuse. T'ète et pattes ćcailleuses noires; pattes merobraneuses blanchâtres. Vit sur la l'atience (Rumex patientia) et la Globulaire (Globularia vulgaris).

Commnne aux enrirons de Paris.

\section{Procris de la Globulaire, P. Globulario.}

Procris alis superioribus suprà coenuleo viridibus nitentibus, subtis inferioribusque cinereo fuscis, antennis maris omninò pectinatis.

1'rocris Globularice. La'r. Nouv. Dict. d'Hist. nat. $2^{\mathrm{c}}$. édit. - God. Hist. nat. des Lépid. de Fr. tom . 3. pag. I6o. pl. 22.fig. 16. - Sphinx Globularia. Huв. Sphing. tab. I. fig. 2 et 3.

Envergure 9 lig. Anteunes et corps verdâtres. Dessus des ailes supérieures d'an vert-bleuảtre, leur dessous et les inférieures d'ın brun-cendré. Le mâle a les antennes entic̀renent et régulièrement pectinées.

Chenille verdâtre ayant le long du dos des losanges noirs et de chaçue cốté du corps une bancle amarante bordée de deux liynes noires flexueuses. "Tète entic̀rement noire. Chrysalide d'un brunpâle avec l'enveloppe des ạiles terminée par un prolongenent.

Des environs de Chartres.

\section{Procris du Prunier, P. Pruni.}

Procris alis superioribus supcà viridi-fuscis, basi aurio nitentibus, subtìs inferioribusque nigrofuscis, antennis maris omninò pectinatis.

Procris Pruni. Lat. Gen. Crust. et Ins. tom. 4. pag. 214 - - God. Hist. nat. des Lépid. de Fr. tom. 3. pag. 162. pl. 22. fig. 17. - Zygona Piuni. FAB. Ent. Syst. tom. 3. part. I. pag. 406. $n^{\circ}$. 6. - Sphinx Pruni. Нив. Sphing. tab. I. fig. 4. - Esp. Sphinx. tab. 35. fig. 2 et 3. - Le Sphinx du Prunellier. Engr. Pap. d'Eur. pl. io3. fir. 151 .

Envercure 6 lig. Langue d'un janne-paille. Antennes d'uu beau bleu-verdàtre. Corps d'un vertobscur. Dessus des áiles supérieures de mêne coulenr, leur base ayant un refiet doré ; leur dessous et les inférieures d'un brunnoirâtre. Antennes dì mâle entièrement et régulièrement pectinées.

Chenille de couleur rosée; stigmates noirs. Dos divisé par une double série de losanges noirs disposés transfersalement. Vit sur le Prunellier et le Chêne. Chrysalide un peu verdấlre, son dos et l'enveloppe des ailes noirütres. Coque d'un tissu läche, alongée, suspendue par l'une de ses extrémités.

Des environs de Paris. (S.F. et A. Serp.)
PROCRUSTE, Procrusies. M. Bonelli, dans ses observations enlomologiques consiguées dans les Mémoires de l'Académie de 'Turin, a forué scus ce nom $n 11$ genre de Coléoptères dans la tribu des Carabiquss; il lui donne pour caractères : labre trilobé : palpes extérieurs ayant leur dernier article sécuriforme, le premier article des maxillaires intérieurs très-petit : menton ayant deux dents à l'extrérnité de la sailtie du milieu. Antennes sétacćes, leur premier et leur quatrième articles plus courts que les aútres, ćgaux entr'eux, les autres d'égale lougueur : abdomen ovale on ovalaire : point d'ailes.

Le type de ce genre est le Currabe chagriné no. 8 de ce Diclionnaire. C. coriaceus. HaB.

(S. F. et A. Serv.)

PROCTOTRUPE, Proctotrupes. Lat. Spin. Banchus, Bassus?' Fae. Codrus. Jur. Panz. Erodorzs. WALK.

Genre d'insectes de l'ordre des Hymónoptères, section des Térébrans, famille des Pupivores, tribu des Oxyures.

Datis cette tribı les genres Hélore, Proctotrupe, Cinc̀te, Bélyte et Diaprie forment un groupe distingué par les antenues qui prennent naissance an uilieu de la face antécieure de la lête, tandis que tous les autres Oxyures ont ces organes insérés près de la bouche. Les Hélores ont l'abdonen louguement nédiculé ; les ailes supérieures des Cinètes offrent deux cellules cubilales; les Bélytes ont des antemnes perfoliées et les Diapries n'ont aucunes cellules aux iiles supérieures. Dans ces trois derniers grenres les an! ennes sont condées. Les Proctotrupes ont des caractèresoparticuliers qui les séparent des genres que nous venons de citer.

Antennes filiformes, point coudées, presque de la longreur du corps, un peu velues dans les mâles, insérćes au milieu de la face antérieure de la tête, composées de clonze articles dans les deux sexes (1). - Mandibules arquées, aiguës, sans dentclures. - Palpes maxillaîres beancoup plus longs que les latiaux et pendass, composés de quatre articles inéganx, les labiaux de trois. - Lèvre entière. - Tête verticale, comprimée, presque carrée, ses angles arrondis et lisses. - Yeux ovales, entiers. - Trois petits yeu.x lisses disposés triangnlairement sur le haut du front. - Corps étroit, alongé. - Corselet long, son premier segment court; métathorax alongé, obius, clıagrinó. - Ailes supérieures ayant nne cellnle radiale extrćmement petite, qui, avec le poinl marginal, forme un triangle

(r) MII. Latreille et Jurine donnent treize articles aux antennes. Nous croyons qu'i!s supposent la présence d'un petit article après celui de la hase; nous avons fair de vains efforts pour l'apercevoir et nous restons convaincus qu'il n'existe pas. M. Jurine lui-même n'en figure que douze. 


\section{P R O}

et émet une nervure se dirigeant vers le disque; point d'autres cellules distinctes. - Abdomen ovale, eonique, lisse, eompriné, très-brièvement pédiculé, son premier segment fort grand, en forme de eloç̉e. Anus des inâles terminé par deux valvules latéra!es, pointues; une tarière simple, curnće, toujours saillante, servant de conduit aux oufs, terminant le eorps dans les femelles. - Pattes assez gritudes, jaubes antćrieures sans échancrure.

Les Proetotrupes sont de petite taille, peu nombreuses en espèees. On en trouve einq ou six aux environs de Paris. Elles fréquentent les plantes ou même eourent sur la terre. Leurs mours sont probablement semblables à eelles des autres Oxyures, c'est-ì-dire que les femelles déposent lenrs ceufs dans le eorps de eertaincs larves d'insectes, aux dépens desquelles leur postérité doit se nourrir. OII doit l'établissement de ce geare à M. Latreille.

\section{Proctotrupe féeonde, P. gravidator.}

Banclus gravidator. FAB. Sjst. Piez. pag. 128 . $n^{\circ}$. 10 .

Nota. M. Latreille pense que cette espèce appartient au genre Proctol'upe. Voyez pour la description et les autres synonymes Ichnemuon fécond, $n^{\circ} .143$.

2. Proctotrupe bimaculée, $P$. binaculata.

proctotmpes nigra, abdonine testaceo, pedibus pallidis.

Erodorus binaculatus. WaLkn. Faun. Paris. tont. 2. pag. $47 \cdot n^{\circ} \cdot 1$.

Longueur 2 lig. $\frac{1}{4} 3$ lig. Antennes, tête et corselet noirs. Abdomen d'un testaeć-ferrugineux; le dessus et la tarière plus foncés; eelle-ci presqu'aussi longue que l'abdomen. Paltes pâles, cuisses ayant un peu de brun; nervares des ailes noires: poiut marginal brun. Femelle.

Le mâle ne diflère poiut.

Des envirous de Paris.

\section{3. Гroctotrupe pallipède, $F$. pallipes.}

Proctotrupes autennis pedibusque testaceis, capite thoraceque nigris, abdomine puceo.

proctatrupes pallipes. Lat. Gener. Crust. et Ins. tom. 4. pag. 38. - Codrus pallipes. Jur. Hymézzopt. pag. 3og. pl. 13. Mäle. - Encycl. pl. 377. fig. 5.

Longuear $2 \mathrm{lig} . \frac{x}{2}$. Antennes et paltes testacées. Tête et corselet noirs. Ahdonen eouleur de poix. Tacière à peu près de la longueur de la movité de l'abdouen. Ailes trassparcntes, nervares de eouleur brune ainsi que le point margiusl. Femelle.

Wist. Nat. Ins. Tonne $X$.
Des environs de Paris.

Nota. Quoique M. Jurine ait cru fignrer me femelle, les deux petites laines qni termiuen! l'a! domen de sun individu nous démontreut qu'il avoit un mâle sous les yeux.

\section{Proctotrúpe noire, $\boldsymbol{P}$. nigra.}

Proctotrupes nigra, antennarum nigrarum articulo primo baseos luteo, palpis pedibusque pallidis.

Proctotrupes nigra. LAT. Gener. Crust. et Ins. toin. 4. pag. 38. - Spinol. Ins. Ligur. fis. 5. pag. 168. $2 z^{\circ}$. 2. - Codrus niger. Jur. Hyménopl. pag. 39. - Panz. Faun. Gern. fis. 85. fig. 9 .

Longneur 2 lig. Antennes noires, lenr premier artiele jannâtre. Palpes et pattes de conleur pâle. Tếe, corselet et abdomen d'un noir-luisant. Ailes transparentes, point marginal et nervares de couleur brune. Male.

Connune aux environs de Paris.

Nota. Ce genre renterme encore la Proetotrupe brévipenne de H. Lalreille; il efl probable aussi qu'on doit y rapporter le Basszes campanulator de Fabricius.

HELORE, Helorus. LAT. Jur, Sphex. Panz. (Faun.) Psen. Panz. révis.

Genre d'inseetes de l'orủe des Hyménoptères, seetion des 'Térébrans, fumille des Pupivores, tribu des Oxyures.

Cing geures de eette tribu, Hélore, Proetotrupe : Cinète, Bélyte et Diaprie ont pont earaetère commun d'avoir les antennes insérées an milien de la face antérieure de la têle; mais les ailes supérieures dans les quatre derniers de ces genres n'ont aucunes eellules discoidales disliuctes.

Antennes fliformes, point coudćes, insérées au milieu de la faee antérieure de la tếie, composées de quinze arlicles, le troisic̀me presque eonique, less autres ejlindriques. - Mandibules alongces, pointues, ayant nn avancement interne bidenté. - Palpes maxillaires filifornıes, longs, eomposés de einf articles, les labiaux de trois, dont le dernier plus gros, ovale - Lèvre évasće, arrondie, presqu'entière au bord supériẹnr. Tête comprinée, de la grandeur ảu corselet. Yenx $x$ ovales, entiers. - Corselet globuleux. Alles supérieures ayant une cellule radiale triangulaire, angulense à sa partie intérieure, denx cellules eubitales, la preuière grande, quelquefois coupée eu deux jusqu'à la moitié par une petite nérure qui part du point épais, lia seconde alteignant le bord postérieur de l'alite; et trois cellules discoruales, la preaière supé rieuse triangulaire, en sorte qu'il n'y a point de nervure récurrente; la discoidale inféricuse atteignant le bord postérieur de l'aile. - Abdomen ovale-globuleux, son prenier segusint id 
s'amincissant brusquement en un pédicule alongé et cylindrique, le suivant en forme de cloche et le plus grand de tous. - Pattes de longueur moyeune.

iil. Latreille a établi ce genre et M. Jurine l'a adopté. On n'en mentionne gu'une seule espèce dont les nocurs nous sont inconnues.

\section{Hélone noir, H. ater.}

Helorus ater, subpuhescens, rugosulus, abdomine nitido, petiolo rugoso, pedum geniculis tarsisyue testaceo fuscis.

Helorns ater. LAT. Gener. Crust. et Ins. tom. 4. pag. 3g. - Jur. Hyménopt. pag. 215 pl. $14 .-$ Sphex anomalipes. Psvz. Faun. Gernn. fas. 52. fig. 23 , et fas. 100. fig. 18. - Psen anomalipes. Panz. révis.

Longueur 3 lig. Très-noir, un peu pubescent. Tète, corselet et pédicule de l'abdomen fiuement chagrinés, celui-ci ayant en outre quelques petiles carcines longitudinales, les autres segmens de l'abdonen lisses, anus en pointe un peu conrbée. Pattes noires, leurs articulations ct les tarses d'un tesiacé-brun. Ailes transparentes, nervures noires.

On le trouve en France. Il n'est pas commur.

ClNEte , Cinetus. Jur. LAT.

Genre d'insectes de l'ordre des Hyménoptères, section des Térébrans, famille des Pupivores, tribu des Oxyures.

Dans le groupe de celte tribn qui a les antennes insérées au milieu de la face antérieure de la tête (voyez Proctotrupe), le genre Diaprie n'a aucane cellule aux ailes supérieures, les Hélores ont deux cellules cubitales et trois discoïdales. Dans les Bélytes les antennes sont perfoliées et les Proctotrupes les ont droites, leur premier article n'étunt pas très-long.

Antennes filiformes, coudées, insérées sur un tubercule placé au milieu de la face antérieure đe la tête; leur premier article de grandeur notable. Elles sont composées de quinze articles dans les femclles, le premier très-long, et de quatorze dans les mâles, le troisième arqué. Mandibules légèrement bidentées. - Tête un peu pyramidale. - Trois petits yeux lisses assez gros, disposés en triangle our le devant du vertex. - Corselet muni postérieurement d'une petite épine latérale; métathorax mince. - Ecusson arrondi. - Ailes supérieures ayant une cellule radiale très-petite, pointue à son extrémité inférieure, triangulaire, angnleuse intérienrement, cet angle émeltant une nervure qui se perd dans le disque sans atteind:e aucune cellule; de ce disque part une autre nervure, crochae à son commencement et qui descend jusqu'au bord postérieur ; une cellule cubilale con- fondue arec les discoïdales. - Abdomen un peu aplati. Son premier segment formant un pédicule long, sillonné en dessus, velu et un pen arqué. Second segixent très-grand, les autres fort étroits. - Pattes longues.

Le nom de Cinète paroît venir d'un mot grec qui signilie : remucant. Nous ne somınes pas certains que l'espèce que nous alfons décrire soit celle que M. Jurine a connue.

\section{Cinète iridipenne, $C$. iridipennis.}

Cinetus niger, alarum squamâ antennarum basi pedibusque fusco testaceis.

Longueur 2 lig. Noir. Antennes brunes, leurs denx premiers articles testacćs. Ecaille des ailes de cette dernière conleur. Pattes testacées mêlées d'un peu de brun. Ailes velues, irisées, à nervures brunes. Tarière blanchâtre. Cuisses renllées en massue à leur extrémité. Femelle.

L'individu que nous considérons comme le mâle diffère par ses antennes dont le premie. article et le devant des trois suivans sont testacés, par la base du second segment de l'abdomen qui est testacée-brune el par les pattes d'un testacé beauconp plus clair et sans málange de brun.

Environs de Paris.

\section{BÉLYTE, Belyta. Jur. Lat.}

Genre d'insectes de l'ordre des Hyménoptères, section des 'Térébrans, famille des Pupivores, tribu des Oxyures.

Les Hélores, les Cinètes et les Bélytes appartiennent au gronpe d'Oxyures, dont le caractère est d'avoir les antennes insérées au milieu de la face antérieure de la tête, mais ils se distinguent des autres genres dn inême groupe par leurs anterines composées de quatorze is quinze articles (1). Dans les Hélores ces articles sont cylindriques. Les Cinètes ont la cellule radiale de leurs ailes supérieures triangulaire, et lemrs antennes ne sont point perfuliées, nou plus que celles des Hélores.

Antennes longues, presque filiformes, perfolićes, insérées sur un tubercule placé au nirlieu de la face antérieure de la tête, plus grosses ver's le bout, au moins dans l'un des sexes, composées de quinze articles, le fremier long, le second fort petit, le troisieme conique, les suivans grenus, perfoliés, le dernier ovorde, conique. - Mandibules rès-petites légèrement bidentées. - Trois petits yeux lisses disposés en triangle sur le haut du front. - Corselet aplati, guilloché en dessus, ayant une épine de cliaque côté postérieurement. - Ailes supérieures ayant

(1) Les mâtes des Diapries ont aussi les antennes de quatorze articles, mais dans ce genre les ailes supérieures sons toralement privées de cellules. 
une cellule radiale petite, ovale, peu distincte et une seule cellule cubitale confonduc avec les cellules discoidiales. - Abdomen pédiculé, son second seyment très-grand, quelquefois sillonné lon riludiualcment daus son milieu, les autres très-étroits. 'Tarière (des femelles) un peu saillante. - Pattes de longueur moycnne.

M. Jurine en créant ce gcnre qui depuis a été adopté par M. Latreillc, le compose de deux cspèces. Ses habitudes ne nous sont point connucs.

\section{Béctre bicolore, B. bicolor.}

Belyta nigra, antennis, pedibus, abdominoque primo segmento excepto, testaceis.

Belyta bicolor. Jur. Hyménopt. pag. 311. pl. 14. - Lat. Gener. Crust. et Ins. tom. 4. pag. 37 .

Longneur 2 lig. Noire. Antennes et paltes testuccés. Abdomen de même couleurr, à l'exccption du premier segment formant le pédiculc et qui est noir.

Se trouve en Europe.

DIAPRIE, Diapria. Lat. Chalcis. Fab.Ichneumon. Ross. Oliv. (Encycl.) Psilus. Jur. Panz. SPIN.

Gcnre d'insecles de l'ordre dcs Hyménoptères, seciion des Térébrans, fumille des Pupivores, tribu des Oxjures.

Dans le groupe de cette tribu dont les Diapries font partie (vogez Oxyures, article $\mathrm{Pu}-$ PIVOREs ) tous les autres genres ont des cellules aux ailes supérieures.

Antennes longues, filiformes, grossissant insensiblement vers le bout ou presqu'en massue, insérécs sur un tuberculc placé au milieu de la face antérienre de la tête, composées de douze articles dans lcs femelles, de quatorze dans les máles. - Mandibules fortes, alongrées, ayant trois ou quatre deutelures. - Palpes maxillatres longs, filifurnes, composés de cinq articles, le quatrieme un peu plus gros que lcs autres, le dernier le plus long de tous. Pulpes labiaux plus gros vers leur extrémité, de trois articles. - Tête un peu pyramidale. - Corps alongé, étroit. - Corselet rétréci cn devant. - Ailes longues, les supéricures vclues, dépourvnes de cellules, n'ilyant qu'une nervure courte qui part de la base, suit le bord extéricur et se termine bienlôt par un point assez épais. - Abdomen terniné eu pointe, son pretsier scgnent rétréci en pédicule, lc second trc̀s-yrand, les derniers fort étroits. 'Tarière (des fcmelles) un peu saillante, susceptible d'alongement, composée de tuyaux qui renurcint les uus dans les autres. - Pattes grêles, cuisses renflécs vcrs l'ex!rómité.

le rom de ce genre est un mol grec qui signifie: tarière. Les Diapries sont peties, lcar dómarclie est lenic et elles s'ruvolent difficilement. On les trouve sur les planics, lo long des nurs et jusque dans les maisons, marchant quelquefeis sur les virres des croisées. Le nombre d'espèces comnu?s est peu cousidérable.

Rapportez à ce genre l'Ichneumon conique, no. 186 de cet ouvrage, Diapria rufipes. LAT. Chalcis conica. FАB. Syst. Piez.

(S. F. et A. SERV.)

PRO-GALLINSECTES. Nom donné par Réaumur anx inscctes hémiptères du genrc Cochenille. Voyez ce mot. (S. F. et $\Lambda$. SERV.)

PRONÉE, Pronaus. Genre d'HyménoplèresPorte-aiguillon, famille des Fonisseurs, tribn des Spleégimes, Établi par M. Latreille. Le $p_{e p-}$ sis maxillaris de Palisol-Bauvois, Ins. d'Af: et d'Amériq. Hyménopt. pl. 1. fig. 1. et le Dyinus aneus de Fabricius composcnt seuls ie geure, qui differe très-pen de celui de Chlorion, ct qui peut y être réuui en y formant une division. Voyez Clilorion à la suite du mot Spé́gimes.

(S. F. et A. SERv.)

PROSCARABE. Nom donné par Geoffroy à une espèce de Méloé. Voyez Nléloé proscarabú no. I. (S. F. et A. SErv.)

\section{PROSCOPIE, Proscopia. Klog.}

Gcnre d'insectes de l'ordre des Orthoptères, famille des Sauteurs, tribu des Acrydiens.

Cettc tribn est componsée des genres 'Truxale; Proscopie, Pneunore, Criquet et Tétrix. Les trois derniers n'ont point d'érninence rostriforme sur le soumet de la tête et leurs trois paires de pattes sont à peu pròs également espaḉes. Les Truxales ont des antennes lengues, ordiuatrement ensiformes, composées d'un grand nombre d'articles. Ainsi ces quatre genres se distinguent parfaitement de's Prusconies.

Antennes filiformes, plus courtes que la tête, composées de sepr auticlês dans les fcunclles, de six dans les màles, lc dernier plus long, acumiué. - Labre grand, mennbraneux, voûlé, échancré à l'extrémité. - Mandibules cornées, épaisses, crénelées, tronquées à l'extrémité, ayant quatre dents obtuses et des tubercules vers le bout. Mâchoines conrles, cornées, bifides on plulôt bidentées; ces dents aiguës, linterne simple, l'externe pelite, portant el'e-même une pctite dent avant son extrémité. - Lève graude, mernbruneuse, échancrée. - Quatre palpes mcmbraneux à articles cyliudriyues; les maxillabics plus longs, de cinq a:ticles, les labiaux de tocis don' le dernier plus long. - Téle ay ant sa partie supérieure sinuće, souvent très-longue, s'élcvant co une appiarence de rostre conique, lissé ou anguleux. - Yeux saillaus, hémisph $\therefore$ cues, D d 2 
simés à la base du prolongement assez près du sonmet de la tête et placés latéralement. - P'oint de pelits yeux lisses. - Corps cylindrique, trèslong, aplère. - Corselet long, cylindrigue; métaiholax eourt. - Point d'ailes ni d'élytres. Abdomen cylindrique, faisant à lui seul la moitié de la longreur du corps, composé de luit segrnens, les preaiers plus grands, le dernier très-conrt. 'Tégumen: supérieur de l'anus plan, alongé. Oviructe nul. Parties sexuelles saillantes, déprassint l'anus, eonsistant en quatre dents courtes, cornées, fortes, recourbées au bout et poinlues, jointes cnsemble par leur base. - Cuisses et jambes presque d'égale lougueur; les quatre pattes antéricures presque de lil longueur du cou, presqu'égales entr'elles. Les deirx premières insérées vers le milieu du corselet, très-éloignćes des autres; les quatre suivantes très-rapprochíes; les deux postérieures plus longues que l'abdomen, leurs euisses alongées, renflées, propres à sauter; leurs jambes un peu courbes, carénées en dessus, munies de deux rangs d'épines ou de dents; ces pattes ont leur attache ì la partie postérieure du corselet. - Tarses de trois articles, le second plus eourt : erochets aigns, un peu dentés, numis dans leur entre-deux d'une pelotte grande, membraneuse, dilatée.

Ce genre est dî à M. Klïg qui en a donné une monographie. C'est de eet anteur que nous avons emprunté les caraetères génériques. Il én décrit quinze espèces, toutes de l'Amérique méridionale, mais il ne nous apprend rien des mouls ni des trausformations. Le nom de Proscopie vient de deux mots grees qui signifient: voyant d'en haut. Ces inseetes le doivent sans doule à l'élévation où leurs yeux sont placés ver's l'extrémité supérieure du prolongement de la tête. Ces Orthoptères sont de très-grande taille. Nous devons observer que leurs parties sexuelles telles que nous les déerivons, d'après M. Kliig, ne nous paroissent appartenir quaux femelles; celles des mầles dans un individu malheureusement incomplet que nons avons sous les yeux, sont fort différentes; la partie inférieure de l'ams est grande et en cuilleron, tandis que dans la femelle elle a absolument la forme d'un soe; -nous ne voyons que denx dents non recourbées aux organes de la génération de ce mâle. Sur le euilleron repose une partie assez grosse, mais dont la forme nous paroît altérée duns notre individu.

\section{Proscopie géante, $P$. gigantea.}

Proscopia collari utrinquè elevato, punctato, rostro elongato, telragono, obtuso; antennis rostro brevioribus. (KLUG.).

Proscopia gigantea. Ku.ug. Prosc. Nov. Gen.. pag. 18. no. 1. tub. 3. fig. 1.

Longueur 6 pouces. Antennes à peine plus longues que le prolongement rostriforme, brunes. Corps d'un testacé -grisâtre. Tête entièrement lisse, peu rétrécic au-dessus des yenx, son prolongement rostriforme quadrangulaire, caualiculé à sa partie antérieure. Corselet testacé, granulé, ayant sur les côtés une ligne de points plus élevés. Métathorax court, granulé. Entre la basse des paltes antérieures on voit un petit tubercule. La poitrine oflie trois enfoncemens, le postérieur placé entre la lase des pattes intermédiaires, un autre plus grand entre la base des pattes postérieures. Abdomen lisse, d'un testacéclair, légèrenent earćué en dessus et en dessous, ses eôtés ayant qu:elques petiles lignes élevées qui ne sont bien distinetes que sur les premiers segmens. Les derniers un pen canaliculís entre ces lignes. Pattes plus foncées que le reste du eorps.. Epines des ja mbes postérieures fortes. Femelle.

Dn Brésil et de Cayenne.

Nota. Stoll a figure celte espèce Spect. $p l$. $X X I V, f_{g} g 9^{\circ}$, mais il lui attribue dans son texte ainsi que daus sa figure des antennes très-longues et sétacées, avec des pattes antérieures contorinćes comme celles des Phasmes; cela prouve que son iudividu avoit été mntilé et ensuite maládroilement raecommodé. M. Kliig n'a point eité eette ligure.

\section{Proscopie granulíe, $\boldsymbol{P}$. granulata.}

Proscopiacollari punctis elevatis scabro, rostro telragono apice dilatato, antennis rostro: brevioribus. (KLug.)

Proscopia granulata. Kivg. Prosc. Nov. Speca. pag. 22. $n^{\circ} \cdot 7 \cdot \operatorname{tab} \cdot 4 \cdot$ fig. 7 .

Longueur 5 pouces. Corps testacé-obscur, lête lisse, rétrécie au-dessus des yenx, son prolongement rostriforme étroit à la base, Irès-dilaté et obtus à l'extréuité; ses cồtés membranenx, s'avanģant an-dela de l'extrénité. Yenx grands. Antennes plus eourtes que le prolongement, brunes, subuices. Corselet ayant sa partie antérieure chargće de points élevés, bordée ì ses dcux extrémi és, marquée en dessons d'une carc̀ue longitudinale. Abdomen presque lisse, un peu.pọnclué à sa base, avec une ligne longitudinale peu: marquée sur le dos. Jambes postérieures con rbées, sillonnées latéralement, ayant quelques épinces sur lenrs bords; leur dessons épineux avec quarse. baudes noites. Tarses bruns.

Du Brésil.

Nota. Nous n'avons point vu cette Proscopio non plus que la suivante.

3. Proscopie oeulée, $P$. oculuta.

Proscopia collari punctis elevatis scabro, rostro brevissimo, anteninis restro duplo longioribus,. abdomne reliquo corpore breviore. ( $\mathrm{K}_{\mathrm{LUG}}$.)

Proscopia oculata. Klug. Prosc. Nov. Spec.. pag. $26 . n^{\circ}$. 15. tab. 4. fig. 15 . 
Inngueur 3 ponees $\frac{1}{2}$. Corps linéaire, enlièrement testacé. 'Tête courte, rétrécie avant lcs yeux, un peu brune postérieurement; son prolongement rostriforme très-court, anguleux, un peu (-snique, incliné, obtus à l'extrémité. Yeux grands, très-saillaus avec leur orbite pâle. Antennes irès-couries, testacées à la base. Partie antérueure du corselet étroite, chargée de points élevés; ceux du dos se réunissant, ceux des côtés plus élevés; partie moycrne presque bossue, un peu raboteuse, élevée en arrière. Métathorax lisse. Poitrine plane, lisse, ayant quelques enfoncemens. Abdomen lisse, linéaire, un peu plus gros au bout. Cuisses postérieures dentées en scie à leur partie inférieure seulement. Jambes de la longueur des cuisses; les postérieures rousses, arncées d'épincs noires. 'Tarses roux.

Du Brésil. (S. H. et A. Serv.)

PROSOPE, Prosopis. Jur. Lat. Fab. Panz. Spin. Apis. Linn. Geoff. Andrena. Oliv. (Encyc.) Melitta. KIr.

Genre d'inseetes de l'ordre des Hyménoptères, section dos Porte-aiguillon, familic des Mellifères, trihn des Andrénètes.

Un uenre avoil été étalbli sous le nom d'Hylceus par Fabricius dans son Entomologia systematica, mais sur des caractères teliement trompeurs que les insectes qu'il renfermoit ne pouvoient rester ensemble, et que même plusieurs n'étoient que des mâles d'espèces placées par l'auteur lui-même dans les Andrènes. M. Latreille en réformant les caractères de ee genre et supprimant les espèces qui ne lni appartenoient point conserva d'abord le nom d'Hylocus. Fabricius adopta ce nonveau genre et changea son nom en celui de Prosopis emprunté de M. Jurine, mais il joignat encore aux vétitables Prosopes des espéces qui leur étoient étrangères, telles fue des náles de son genre $\mathrm{An}$ drène, dont il parut tirer les caractères génériques, et une Cératine de M. Latreille. Cependan! Fabricius conserva toujonrs mu gene sous le nom d'Hjlons qui ne renterme aucune espèce qui lui suit propre : ce nom palnt done it tous les eniczaologistes devoir être rejeté ils adoptèrent celui de Prosope conformément aux idées de M. Jusine; et M. Latreille s'est joint it eux, en admettant cette dénomination pour sou genre Hylceus qui est exactement le mêrne.

Dans la tribu des Andrénètes trois genres seulement sont parüsili: , les Prosopes, les Sphécodes et les Colax (le P. inćdit); mais ees deux derniers ont la division inlecuédiaire de la lèvre peu courbće inférieurement, presque droite, et leurs aides supérieures ont quatre cellules cubitales, caracieres qui les séparent des Prosopes.

Antennes filiformes, point coudées, insérées au malicu du front, compośes de douze articles, grossissant un peu vers le bont dans les femelles, de treize articles dans les mâles dont le premier assez lone, sonvent renflé et patelliforme; second et troisième articles égaux en longuemr dans les deax sexes. - Mandibules sans dents dans quelques-uns, dans les autres obtuses ì leur bout, échiıncrées et ayant deux dentségales. - Mâchoires conttes, leur bord interne membraneux en forme de dent. - Languette membraneuse, cordiforme, divisće en trois lobes égaux en longueur. - Palpes ayant leurs dernicis articles plus petits, les maxillaires longs, de six articles, les labiäux de quatre. - Téte verticale, apptiquée contre le corselet; face plane. - Trois petits yeux lisses disposés en triangle et posés sur le vertex. - Corps glabre, presque cylindrique. - Segment antérieur du corselet très court, ne formant qu'un rebord transversal, ses côtés se prolongeant jusqu'à la naissance des ailes en manière l'épatulettes arrondie: et ciliées; métathorax coupé presque droit postérieurement. - Ectrsson mutique. - Ailes su. périeures ayant une cellule radiale se rétrécissan: du milieu à l'extrémilé, celle-ci presqu'aiguë, un peu appendiculée et trois cellules cubilales, in première plus grande que la seconde, recevant la première nervure récnrrente près' de sa jonction avec la seconde; la denxième un peu rétrécie vers la radiale, recevant li seconde nervure récurvente près de sajonction avec la trósième; celle ci atteignant presque le bout de l'aile. _ P'attes de longueur moyenne, jambes intermédiaires n'ayant qu'une seule épine courte et aiguë à leur extréniité : crochets des tarses petits, unidentés.-Point d'organes pour la récolte du pollen, de simples. brosses de propreté à la face interne du premier article des tarses.

Les couleurs ordina'jes des Prosopes sont le jaune et le noir et quelquefois un peu de ferruginenx. Les mâles se distingtenı facilement des. temelles, la face antérieure de leur tête étant presqu'entièrcment colorée cn jaune. Ces petits hynénopières ont une odeur agréable qui approche de celle de l'eau de rose. On n'en connoit qu'un petit nombre d'espèces, nuais qui paroissent susceptibles de beancoup de variétés. L'insecte parfit fréquente les fleurs, particulièrement celles de l'oignon et du résédá. Les fernelles déposent leurs ouf́s dans le nid des Andrénètes et des Apriaires réçollantes. (Foyez l'article Parasites.)

\section{Prosope variće, $P$. variegata.}

Prosopis nigra, albido varia, abdominis se mento primo secundique basi Jerruginers.

Prosopis wniegala. FАв. Syst. Piez. pag. 295 , $t^{\circ}$. 9.-..Jur. Hyménopt. pag. 220. - Prosopis coloraia. $\mathrm{P}_{\mathrm{ANZ}}$. Faln. Germ. fas. 89. fig. 14.

Longueur $3 \mathrm{lig}$. Antennes noires, un peu testacées en dessons (a l'extréuité. Orbite des yeux d'un blanc-jaunâtre en devant. Corselet noir bord da premier segment, épaulettes, écuilla 
des ailes et deux taches sur l'écusson, d'un blanc-jannâlre. Abdomen ayaut son premier segnenel ferrugineux, le second noir, ferrugineux à sa buse, son bord inférieur conteur de poix; les troisiène, quatrième et cinquieme noirs avec leur bord inférieur couleur de prix. Anus noic. Paiciviore's, base de toules les jämbes d'un blancisunarue. Partie anterieure des jambes et des larses de la première paire de palles de coulear ferrugineuse. Ailes transpartentes à nerrurcs noires. Femelle.

Environs de Paris.

Nota. La Prosope bifascice de M. Jurine, pag. 220 , pl. 11 , fig. 3o (Encycl. pl. 38I. fig. 5), paroît être une simple variété de cette espèce. Elle n'en diffère que par le bord inférieur du premicr segment de l'abdomen qui est couleur de poix. La Prosopis albipes de Fabricius, Syst. Piez. pag. 294, $n^{\circ} .4$, est une autre variété. C'est ì celle-ci que nous rapportons l'Hylows albipes. LAT, Dict. d'Hist. nat. $2^{\mathrm{C}}$. édit.

\section{Prosope de Rhodes, P. Rhodia.}

Prosopis nigra, albido varia, segmentorum abdominis margine infero ferrugineo.

Longucur 3 lig. Antennes noires, leur partie entérieure d'un testacépấle. Le premier article blanc en devant. Tête noire, blanche au-dessous des antennes. Mandibules noires à leur extrémité. Corselet noir, bord du premier segment, épaulettes, écaille des ailes et angles latéraux de l'écusson blanchâtres. Abdorien brun, le bord postérienr des segmens ferrugineux. Patles antérieures noires, jambes ei tarses blanchàres en devant. Les quatre postérieures noires, base de leurs jambes et de leurs tarses blancliatres. Ailes transparentes. Mâle.

On pourroit prendre sette espèce pour le mâle de la précédente si elle n'étoit de l'ile de Rlıodes, d'où elle a été apportée par feu M. Olivier.

\section{Prosope tachée, $\boldsymbol{P}$. signata.}

Prosopis nigra, luteo varia, abdomine nigro.

Hyloeus signatus. LA . Dict. d'Hist. nat. $2^{\mathrm{e}}$ édit. - Melitta signata. Кгвв. Mlonogr. Apum. Anglioe. $n^{\circ}$.6.- Hyloeus annulatus. var. D. LAT. Hist. nat. des Crust. et des ins.

Longueur 2 lig. $\frac{1}{2}$ à 3 lig. Antennes noires, testacées antérieurenent, sultout vers leur extrémilé. 'Tête noire avec une tache triangulaire blanchâtre de chaque côié au-devant des yeux. Corselet noir, bord du prenier segment, épaulettes et un point sur l'écailile des ailes, d'un blanc-jaunàtre. Abdomen noir, bérds latéraux du premier segment portant un lóger duvet d'un blanc-argenté. Paltes noires, les deux jawbes nntérieures un peu ferrugineuses en devant.
Toutes les jambes ayant un point blanc à leat base. Ailes transparentes. Femelle.

Elle varie beaucoup. $1^{\circ}$. Tache placée près des yenx fort petne, ligne marginale du premier segment du corselet interrompue, pattes enlièrement noires. $2^{\circ}$. Ligne marginale du premier segment du corselet entièrement noire, base des deux jambes postćrieures blanche. Nous rapportons à celle variéré l'Hylaus annulatus. Lat. Dict. d'Hist. nat. $2^{\mathrm{e}}$. édit. et sa variété $a$, mentionnée par cet autenr dans son. Histoire naturelle des Crustacés et des Insectes, ainsi que la Melitla annulata de M. Kirby, $n^{\circ} .3$, pl. 15, fig. 3. 3o. Trois fois plus petite, ayant tantôt une petite ligne blanche, tantôt un point rond de cette conleur auprès des yeux, en remplacement de la tache iriangulaire; ligne miryinale du premier segment du corselet noire. 'loutes les jambes à base blanche. Nous rapportons à cetle troisième variété l'Hylous annularis. LAT. Dict. d'Hist. nat. $2^{\mathrm{e}}$. edzt. et la Melitta annularis. Kıвв. $n^{\circ} .4$, ainsi que le Sphex annulata de Panzer, Faun. Germ. fas. 53. fig. I.

Le inâle a la partie de la tête au-dessous des antennes blanche, à l'exception du labre et des mandibules.

11 varie. $1^{\circ}$. Premier article des antennes un peu dilaté, tantôt tout noir, tautôt obscurément rayé de ferrugineux. $2^{\circ}$. Il prend les mêmes couteurs que les variétés femelles précédemment décrites.

Nota. Souvent le frottement enlève les poils argentés de l'abdomen, comme dans le Sphex signata de Panzer, Faun. Germ. fas. 53. fig. 2. Riupportez aussi à cette espèce l'Audréne porteanuéau du présent ouvrage, $\mathrm{n}^{\circ}$. 28 .

'Très-commin en France. Feu M. Olivier a apporté de l'île de Rhodes un individu absolument semblable. (S. F. et A. SErv.)

PROSTOMIS, Prostomis. Lat. Trogosita. Fab. Panz. Sturam.

Genre d'insectes de l'ordre des Coléoptères, section des Tétıancies, fanille des Xylophages, tribu des Trogossitaires.

La massue des antennes est distincte et de deux articles dans les genies Lycte et Ditome, qui par cette raison forment un petit groupe dians cette tribu. Les nandibules peu ou point saillantes distingment les Colydies, les Latridies, les Silvans, les Mérix et les Mycétophages; enfin les 'Trogossites n'ont que deux dents au cóté iuterne de leurs mandibules. Ces caractères éloignent ces divers genres des Prostomis.

Antennes plus courtes que le corselet, plus épaisses vers leur extrémité, comprimíes, de onze articles, les cinç internédianres moniliformes, les trois deruiers arrondis, formant une 
massuc. - Labre avancé, coriace, petil, plıs large que long, presque carré, velu en devant. -Mândibules avancées, forles, très-grandes, trigones, leur côté nuterne finenent multidenté. -Mâchoires bilobées, s'avançant sous les mandibules. - Palpes courts, les maxillaires in peu plas longs que les autres, presque filiformes, de quatre articies, le derner plus long ovalecylindrique : les labiaux de trois, le dernier plos épais presqu'ovalc-oblus. - Lèvre coriace, presque carrée; languetle étroite, fort alongée, s'avauçant sous les mádibules. - Corps étroit, alongé. - Corselet en carré-loner, séparé de l'abdomen par un étranglement très-visible.

Le nom de ce genre vient de deux mols grecs et signifie : bouche avancée. Il est probable que ses mours se rapprochent de celles des Trogossites, avec lesciuels il a de nombreux rapports.

\section{Prostomis mandilualaire, P. mandibularis.}

Prostonis castanea, antenuis villosis, capite posticè transversìm sulcato, elytris striatis, striis numerosis, punctatis.

Prostomis mandibularis. Lat. Nouv. Dict. d'hist. nat. 2e édit. - Trogosita mandibularis. F.4. Syst. Eleut. tom. I. pag. 155. $n^{\circ} \cdot 26 .-$ Strum. Faun. d'Allem. tom. 2. pl. 49. - Panz. Faun. Germ. fas, 105. fig. 3. - Encycl, pl. 372. fig. $1-\bar{j}$.

Longueur 4 ligg. Entièrement d'un châtainbrun. Autenues assez velues. 'Tèle pointillóe, ayant un sillon transversal très-prononcé à sa partie postérieure. Corselet finement pointillé, avcc un léger sillon Inngitudina! daus son milieu. Elytres un piè rebordíes, forlenent striées; ces stries rapproclices, nombrcuses, distinctement ponctuées.

Du nord de l'Allemagne.

Nota. M. Latreille a vu dans la collection de N. de la Billardière une espèce voisine de la précérleste, d'une taille un peu plus petite et de couleur fauve-marron vif. Elle est des Indes orientales. (S. F. et A. SERv.)

\section{PROTEINE, Proteinus. Lat.}

Genre d'insecres de l'ordre des Coléoplères, section des Pentamères, fanille des Brachélytres, tribu des Aplatis.

Cinq genres composent relte tribu. Les Oxytèles et les Omalies ont le dernier article des tarses presqu'aussi long à lui senl que tous les précédens réunis. Dans les Lesic̀ves les antennes sont presque filiformes. Les Alíochares ont ce's organes insérés enlre les yeux ou près de leur bord extérieur, mais cette insertion n'est point recouverte par un rebord latéral de la tête, ce qui distingue ces genres de celui de Proteine.

Antennes insérécs devant les yeux sous un reford de la têle, allant en grossissant, conrposées de onze articles presquentièicnent urenus, les dernicrs notablement plus gron cia les précúdens. - Labre enties. - Paljes maxills. res beauconp plus couris que la lête, de quatre articles, le pénultième épais, le dernier distinct, grêle, acictilaire, presciu'iussi longr grie le précédent; les labiaux de trois articies. - Téle libre, entièrement décourerte. - Corsclct coun, transversal. - Elytres couvran! la plas grunde partie de labdomen et les ailes. - Tarses à articles alongés, le derrier beaucoup plus court que les quatre autres réunis.

On ne comnoit qu'une scule espèce de ea genre. Elle est très-petite et vit à terre parwi les plantes.

\section{Proteine brachyptòre, P. brachyptezus.}

proteinus niger, nitidus, mandibulis antennarum basi pedıbusque ruféscentzbus.

Proteinus brachypterus. Lat. Gener. Crust。 et Ins. tom. I. pag. $298, n^{\circ}$. 1 .

Longneur une lig. Corps déprimé, noir-lnisant, irès-finement pointillé. Nandibules, base des anlennes et paltes d'un bron-roussâtre. Elytres rebordées extérieurement, le dessus des quatre derniers segmens de l'abdomen paroissant à nu; anns qưclquefois roussâtre.

Des environs de Paris.

Nota. Cetle espc̀ce pourroit être l'Omalie mar croptère, $n^{\circ}$. 21 de ce Dictionuaire.

LESTĖVE, Leste:a. LAт. Staphylinus. FAв。 Paхк. Onlv. (Lutomll.) Anthophagus. Grav. Carabus. Paxz.

Genre d'insectes de l'ordre des Coléoptères, section des Pentamères, fauille des Brachélytres, tribu des Aplalis.

Parmi les cinq genres qui composent cette tribu les Aléocbares se risinguent par l'insertion de leurs intennes qui nest point recouverte par un rebord latéral de la tête. Dans les Proteines les antennes vont en grossissant vers l'extrémité ainsi que dans les Omalies et les Oxytèles; le dernier arlicle des tarses de cea deux derniers genres est prestin'aussi long que les quille précútens pris cosemble.

Antenines presque filiformes, insérécs devant les yeux sous un rebura de la tête, composées do onze artiles, le second et los suivaus jusqu'an disiènc inclusivcuent, obcuniques, le dernier presque cylindrique; tous ces articles presque. de la même grosseur. - Palpes filiformes, les unaxillaires de quatre articles, le troisième un peu plus gros que les autres, le dernier beaucoup plus grêle, alongé, plus long que les trois auties réunis; palpes labiaux de trois articles. Têie libre, entièrement dégagée du corselet.- 
Corps déprimé. - Corselet alongé, presqu'en cueur, tronqué et rétréci postérieurement. Elytres recouvrant ordinairement la plus graude partie de l'abdomen et les ailes. - Tarses ayant Leurs articles alongés, le dernier beaucoup plus court que les précédens réunis.

Les Lestèves se trouvent sur les arbres et sur les lleurs, quelques-unes fréquentent particulièrement celles de l'épine blanclie (Cratogus oxyacantha). On en connoît une douzaine d'espèces, toutes européennes et de petite taille. Leurs métamorphoses ne sont pas connues.

\section{Lestève alpine, L. alpina.}

Lesteva fusca nitida, antennarum apice tho. raceque fuscis, antennarum basi elytris pedibusque testaccis.

Lesteva alpina. LAт. Gener. Crust. et Ins. tom. 1. pag. 297. $n^{\circ} \cdot 2$. - Staphylinus alpinus. HAB. Syst. Eleut. tom. 2. pag. 598. $\pi^{\circ}$. 53. $\mathbf{P}_{\mathrm{AY}}$ K. Faun. Suec. tom. 3. pag. $387 \cdot n^{\circ}$. 27. Ouiv. Entom. tom. 3. Staphyl. pag. 32. no. 4.5 . pl. 6. fig. 55. - Anthophagus alpinus. Grav. Col. Micropt. pag: 188. $n^{\circ} .2$.

Longueur 2 lig. $\frac{1}{2}$. Tête noire. Antennes brunes, rousses à leur basc. Bouclie un peu testacée, front très-enfoncé. Corselet bruı, ponclué, un peu bordé. Elytres d'un testacé-pâle luisiut. Dessous du corps noil. Pattes d'un testacé-pâle.

Se trouve en Laponie sur les saules, et daus le nord de l'Europe.

ALÉOCHARE, Aleochara. K Noch. GRAV. IAT. Staphylihus. Linn. Geoff. De Géer. Fab. Oli. (Entom.)

Genre d'insectes del'ordre des Coléoptères, section des Pentamères, fanille des Brachélytres, tribu des Aplatis.

Tous les genres de cette tribu à l'exception de celui d'Aléochare ont leur's antennes insérées sous un rebord qui en cache l'origine.

Antennes filiformes, grossissant ordinairement ver's le bout, insérées à nu entre les yeux ou près de leur bord intérieur, composées de onze arlicles, le premier long, les second et troisième conrts, plas gros a leur extrémité, les suivans couris, le dernier ovale. - Palpes terminés en alène, les maxillaires avaucés, de quatre articles, l'avant-dernier grusd, lo quatrième trèspetit: palpes labiaux cie trois acticles. - Corps alongé, un peu épais. - Corselet suavent convexe, quelquefois dépriaé. - Elytres courrant les ailes et une partie de l'abdomen. - Abámen aplati en dessus, rebordé surles côtés, convese en dessous. - Paites grêles, sans épines, banches antérieures rupprochées, plus grosses que les cuisses et aussi longues. Hunches inlermédiaires yn peu écartćes, gucie plus grosses que les cuis- ses, mais de même grandeur. Hanches postérieures courtes et rapprochées. Cuisses postérieures ayant un fort appendice à leur base.

Les Aléochares sont petites. On les trouve danş les cadarres d'animaux, les excrémens, les fumier's, les chanıpignons, sous les écorces et sous les pierres. Elles y sont quelquefois rassemblées en asse $z$ grand noinbre, elles courent fort vîte et se dispersent aussitôt qu'on a découvert leur retraite. M. Gravenhorst dans sa Monogr. Coleopt. micropt. eu meutionne soixaute-seize espèces dont trois sont de l'Amérique septentrionale. Ces espèces par leurs mœurs, la forme du corselet, des antennes et de la tête diffèrent tollement que suivant l'auteur même que nous veuons de cilcr et dont nous partageons la manière de voir, on pourroit en constituer plusieurs genres. Lears mćtamorplioses ne nous sont point connues.

yre: Division. 'Tête avancée, enlièrement dégagée da corselet.

rre. Subdivision. Corselet canaliculé au milieu.

I. Anéochare canaliculée, A. canaliculata.

Aleochara rufa, antennarum basi pedibusque dilutioribus.

Aleochara canaliculata. Grat. Col. Micr. pag. 68. $n^{\circ}$. 1. - Lat. Gener. Crust. et Ins. tom. 1. pag. 3o1. $n^{\circ}$. 2. - Staphylinus canaliculatus. Fas. Syst. Eleut. tom. 2. pag. 599. $n^{\circ}$. 52. -OLIv. Entom. tom. 3. Staphyl. pag. $21 \cdot n^{\circ} \cdot 25$. pl. 3. fg. 31. - P А x. Faun. Suec. lom. 3. pag. 385. $n^{\circ}$. 23. - Panz. Faun. Gerin. fás. 27. fir. 13. - Encjel. pl. 189. fig. 1.

Longueur 2 lig. Corps d'un roux-brun. La couleur de la tête, de l'avant-dernier ou des deux avant-derniers sermens de l'abdomen est souvent presque nuire. Base des autennes et pattes d'un jaune-roussâtre. Tête, corselet el élytres finenentent pointillés.

On la trouve très-coınınunément aux environs de Paris sous les pierres, dans les ordures, etc.

$2^{\mathrm{e}}$. Subdivision. Curselet sans sillon longitudinal.

2. Ad.̇och Ane terminale, $A$. terninalis.

Aleochara fusca nitida, palpis, pedibus anoque rufis, elytris ficscioribus.

Aleochara terminalis. Grav. Monog. Col. micropt. pag. $160 . n z^{\circ} \cdot 29$.

Longueur I lis.r. $\frac{x}{2}$. Tète, corselet et abdomen d'un brun-noirâtre. Antenues un pea en fitsean, roussaitres ainsi que les palpes, $l$ aus et les pattes. 
Elytres d'un testacé-brun, finement pointillées ànsi que la tête et le corselet.

Des euvirons de laris.

¿ə. Division. Téte enfoncée en partie dans le corselet.

\section{Aléochare fuseipède, A. fuscipes.}

Alaochara nigra, elytrorum disco ferrugineo, pedibus fuscis.

Aleocharce fuscipes. Grav. Col. micropt. pag. 92. $n^{\circ} .36$. - Staphylinus fuscipes. F. Syst. Elent. tom. 2. pag. $59^{8}$. $n^{\circ} .47$. - РАхк. Fuun. Suec. tom. 3. pag. $397 \cdot n^{\circ}$. 3g.

Longueur 2 lig. $\frac{7}{3}$. Noirâtre. Tête, corselet et élytres finement pointillés. Disque de celles-ci ferrugineux; leurs bords antérieur et extérieur noifaities. Pailtes brunes.

Environs de Paris. (S. F. et A. Sert.)

PRo'THOLAX, Prothorax. Voy. Thorax.

(S. F. et $\Lambda$. Senv, )

PRÓTỎN, proto. LEACH. LAt. Squilla. MuleER. Leptomeral. lamk.

Genre de Crustacé de l'ordre des Isopodes, section des Cistibranches (Régne animal de Cuvier), élabli par M. Léach et. ayant ponr caractères : dix pieds disposés en une série continue depuis la tête jusqu'au dernier annean inclusivement; corps terminé par deux ou trois articles qui forment une espèce de queue; un appendice ì la base des pieds de la seconde 'paire et de ceux des paires suivantes. Femelles portant leur's cufs dans une poche formée d'écailles rapprochées et placée sous les second et troisième segmens du corps.

M. Léach avoit placé avec doute, dans son genre Proton, la Squilla zentricosa de Muller, mais M. Latreille en a formé le genre Leptonière. ( $V o y$. ce mot plus has.) L'espèce qui sert de type au genre Proton est :

Le Proton pédraire, $P$. pedatum. Desm. Lat. Squilla pedata. Mulc. Zool.Dan. tab. 10 r. fig. I et 2 , que M. Desmarest a trouvé en ạbondance au IIavre sur des éponges ramenées du fund de la mer par la diague, et il eș probable que ce Crustacé se nourrit des animaux qui les forment. M. Latreille pense que l'on doit réunir à ce geure le Cancer linearis de Linné.

\section{LÉACL.}

LEPTOMÉRE, Leptomera. Lat. Lamk. Proto?

Ce genre diffère du précédent par les pieds qui sort au nombre de quatorze, disposés dans une cérie continue depuis la têle jusqua'à l'extrémité postérieure du corps, y compris les deux premiers qui sont annexés à la tête. Ces pieds sont trèsHist. Nat. Ins. Tome $X$. grêles. Le Crustacé qui en forme le type est la Squilla ventricosa de Muller. Zoll. Dan. tab. 56. fig. 1-3. -. Herbst, Cancr. tom. 36. fg. I I. M. Latreille rapporte aussi à ce genre l'espèce représentée par Slabber, Meira. tab. 10, fig. 2, qui a un appendice en forme de lobe à tous les pieds, les deux premiers exceptés, et le Cancer pedatus, Montagu, Trans. Linn. tom. XI. pl. 2. fio. 6, qui en a tous les pieds pourvus moins ceux de lit première et des trois dernières paires.

CIIEVROLLE; Caprella. Lamk. Lat. Léacr. Cancer. Linn. Gammarus. FAB.

Les Chevrolles ont beaucoup d'analogie avec les deux genres précédens; elles ne s'en distinguent que par leurs pieds, qui sont au nombre de dix, wais placés daus une série interrompue; le second et le troisième anneaux du corps n'en offrent d'ilucune sorte. Ces Crustacés vivent clans les profondeurs de la mer ou près des côtes parmi les varecs et les fucus; ils courbent, en nageant, les extrémilés deleurs pattes; ils marchent presque àla façon des Chenilles arpenteuses, en s'accrochant aux diflérens corps par les pattes de devan!, et ramenant ensuite près de celles-ci les postérieures; c'est ainsi qu'ils courent assez vîte et qu'ils vont même également bien ì reculons. Quelquefois aussi ils touinent lenr corps de côté et d'autre, se tiennent droits sur leirrs pattes postérieures et agitent leurs antennes. La principale espèce est la Chevrolle hinéaire, Caprella linearis. Lat. Hist. nat. des Crust. et des Ins. tom. 6. pag. 324. pl. 37. fig. 2. 3.4. 5. - Caprella scolopendroides. Lañ. - Cancer linearis. Linn. - Oniscus scolopendroides. Pallas, Spicil. Zool. fas. 9. tab. 10. Jir. 15. - Squilla lobata. Отн. ЕАв. Groenl. $n^{\circ} \cdot 225$.

CYAME, Cyomuls. Lat. Lam. Onischs. Pallas. Squilla. DE GEer. Pycnogonum. FaB. Larunda, Panope. LÉaca.

Ce genre se distingne des précédens par son corps ovale, formé de segmens transversaux et larges; par ses pieds qui sont de longueur moyenne et robustes, par la quátriène et dernière pièce des antennes silpérieures qui est simple on sans articles, et far deux yenx lisses placés sur le sommet de la têle entre les yeux composés.

Ces Crusiacés nont que dix pieds parfails; le second ef le troisième anneaux du corps en sont dépourvus et offrent à lcur place des appendices grêles, articulés, ou des fansses pattes qui portent les organes vésiculenx présuwés respiratoires; ces corps sent alongús et non globuleux on ovales comme dans les genres précédens.

Les Cyames vivent en parasites sur les baleines et sur les branchies de quelques poissons. Ils sont connus des pécheurs sous le nom de Poux de baleines; ils se crampunnent forlement, et se pla. E e 
cent surtout aux lèvres, aux nageoires ou anx partics génitales, comme étant lés licux où ils peuvent trouver une nourriturc plus abondante et où ils sont plus en sûretć. M. Latreille connoît deux espèces de ce genre, dont l'une est inédite et provient des mers des Indes orientales; l'autre est couzue sous le nom de Crame de la bateine, C. ceti. Latr. I lam. Oniscus ceti. Linn. Pall. Spic. Zool.fisc. 9. tab. 4. fig. 14. Munc. Squille de la buleine. DE GEer, Mém. surles Ins. tom. 7 . pl. 42. Fig. 6-7. Pycnogonum ceti. FAs. Panope ceti. Leace, Edimb. Encycl.'tom. 7. pag. 404. Larundra ceti. LEAce, Trans. Soc. Limn. tom. XI. pag. 36千. Cyame. SAVIGN , inéni. sur les anim. sans vert.

Celte cspèce se trouve dans l'Océann d'Europe sur les lateines, et, selon M. Latreille, sur les scombres ou miquereaux.

PROTONIA. Genre de Crustacé établi par IM. Rafiuesque (Précis des découvertes somiologiques), ct dont M. Desnarest fut mention à l'article Malacostracé du Dictionnaire des sciences naturelles, pag. 421. Il l'a.placé parmi céux qui ont échappé à ses recherches. I,es caractères de ce genre nous sont inconnus. (E. G.)

PSALIDIE, Psalidium. Nom donné par M. Germar à un nouveau genre de Coléoptères tétramères, famille des Rhynchophores, tribu des Charansonites. Il a pour principal caractc̀re : rostre court; corps aptère; antennes plus courtes que la tĉte et lc corselet; mandibules extrêmemcnt avancées. L'auten' donne pour type la P. maxillaire ( $P$. maxillosum), espèce qui se trouve en Hongrie.

(S. F. et A SERV, )

PSAMNODE, $\boldsymbol{p}_{\text {sammodes. M. Kirby désigne }}$ sous ce nom dans les Transactions Linnéennes, vol. 12, un nouveau genre de Coléoptc̀res hétéromères, voisin des Pimélies, et lui assigne pour caractère : labre échancré ; lèvre bifide, ses lobcs divergens; mandibulcs se touehant l'une l'autre par lcurs extrémités, bidentées; mâchoires écartées à leur base; palpes filiformes, les maxillaires alongés. Menton en trapèze; antcnnes grêles, un peu en massue, cette masse de trois articles; corps ovale-oblong.

L'auteur citc une espèce de ce genre; il la nomme Psammode longicorne ( $P$. longicornis). Longueur to lig. Noire, avec des poils cendrés; anterues lonoves, élytics granulées et raboteuses. Sa patrie est le Cap de Bonne-Espérance. Elle esi représentée $p l .21, f i g .15$ de l'ouvrage précité.

$$
\text { (S. F. et A. Serv.) }
$$

PSAMMODIE, Psammodius. M. Gyllenhall dans son ouvrage intitulé : Insecta suecica, 1806 , désigne sous ce non un reire de Coléoptères pentaueres de la famille des Lamellicornes, tribu des
Scarabéides. Il le caractérise de la manière súi vantc : mandibules cornées, arquées, dentées. Mâclioires courtes, cylindriques, armées d'une dent intérieurement. Lèvre ovale, obtuse, à peine échancrée. Corps petit, ovale-oblong, entièrement convexe. Ecusson distinct. Chaperon court, large, transvcrse, convexe.

L'auteur fait entrer dans ce genre les Aphodius arenarius (AEgialia globosa.+ LAт.), elevatus, sabuleti, porcatus, asper. FAB. et autres espèces.

(S. F. et A. Serv.)

PSARE, Psarus. Latr. Fab. Meig. Musca. GEOFF.

Genre d'insectes de l'ordre des Diptères, section des Proboscidés, famille des Athéricères, tribu des Syrphies.

Dans la nombreuse tribu des Syrphies les genres Cérie, Callicère, Chrysotoxe et Aphrite se dislinguent par leurs antennes sensiblement plus longues que la tête. Tous les autres genres ont. ces organes seulement de la longueur de la tĉte, ou plus courts qu'elle; mais tous aussi, ì l'exception des Psares, ont les deux premiers articles des antennes égaux entr'cux.

Antennes presque de la longueur de la tête, insérées sur un pédicule commun et frontal, composées de trois articles, les deux derniers comprimés, le second plus long que le premier, le troisième guère plus long que le précédent, portant une soie dorsale simple, biarticulće. Trompe longue, bilabiée, canaliculée, se retirant dans la cavité de la bouclie, renfermant dans une gouttière supérieure un suçoir de quatre soies et deux palpes linéaircs, comprimés, adhéręns chacuu à une de ces soies. - Tête plus large que le corselet. -- Hypostonze tuberculé. - Yeux grands, rapprochés, mais sans se joindre, dans les mâles. - Trois petits yeux lisses disposés triangulairemcnt sur le haut du front. - Ecusson assez grand, arrondi pastérieurcment. - Ailes dépassant un peu l'abdomen, le recouvrant cn partie, parallèles entr'elles, sans céllulc pédiforme. - Abdomen convexe en dessus, déprimé sur le dos, composé de quatre segmens outre l'anus. - Pattes de longueur noyennc; crochets petits, leur pelotte assez grande.

Ou ne connoît encore qu'ıne seule espèce de Psare; elle fréquente les p̣luntes de la famille des Chicoracées, et notammeut les fleurs da pissenlit (Leontodon taraxacum).

I. Psare abdominal, P. abdominalis.

Psarus nigro-cceruleus, abdomine flavo, in mare ferrugineo, basi anoque nigris.

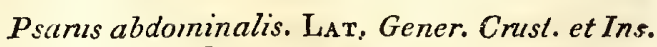
tont. 4. pag. 326. - Faв. Syst. Antl. pag. 211. $n^{\circ}$ 1. - Mers. Dipt. d'Europ. tom. 3. pag. 174. 
n". 1. tab. 27. fig. 8-12. - Ceria abdominalis. Coqu eв. Illust. Icon. tab. 23. fig. 9. - La Mouche à antennes réunies. Geofr. Ins. Paris. tom. 2. pag. 519. $n^{\circ}$. 5o? - Encycl. pl. 3g1. fig. 12-14.

Longueur 3 lig. Antennes, tête et corselet d'un noir-blenâtre. Soie des antennes d'un blanc-jaunâtre. Ailes transparentes avec quelques nuances obscures, particulièrement au bord extérieur et sur les nervures transversales. Abdomen fauve, con premier segment, le milieu du second, celui du quatrième et l'anus d'un noir-bleuâtre. Pattes d'un fauve-brun. Femelle.

Le mâle a les pattes noires, avec les genoux teslacés ct les parties de l'abdomen qui sont fauves daus la fermelle, ferrugineuses.

Des environs de Paris.

Nota. Il est difficile de concerroir pourquoi Geofiroy donne six segmens à l'abdomen de ce diptère, et comment il a pu voir la soie des antennes insérée à l'extrémité du dernier article; cela rend sa synonymie douteuse.

$$
\text { (S. F. et A. Serv.) }
$$

PSÉlapHe, Pselaphus. Herbst. Payk. Illig. Lat. Reich. Anithicus. Panz.

Genre d'insectes de l'ordre des Coléoptères, - ection des 'Trimères, famille des Psélaphiens.

Le genre Clavigère est le seul de cette tamille dont les antennes ne soient composées que de six articles. Les Chennies, les Cténistes et les Dionyx ont deux crochets au dernier article des tarses; les Bryaxis ont leurs palpes maxillaires droits, plus' courts que la 'tête et le corselet pris ensemble; on ne peut donc confondre ces genres avec celui de Psélaphe.

Antennes plus courtes que le corps, de onze articles moniliformes, les trois derniers plus gros; surtout le onzième, celui - ci de forme ovale. - Mandibules cornées, trigones, pointues, dentéeŝ au côté interne. - Mâchoires ayaut un double prolongement, l'extćrieur plus grand, presque triangulaire, l'intcrnc eu forme de dent. - Palpes maxillaires très-saillans, fort longs, coudés, plus grands que la têle et le corselet pris ensemble, composés de quatre articles, le dermier grand, ovale, ayant une petite pointe particulière à son extrénité ; les labiaux cou: filiformes. - Lèvre mesuluaneuse, menton en carré transversal. - Téte petite, dégagée. Corselet tronqué, - Ecusson très-petit, - Elytres courtes, assez convèes, tronquées postérit:uremeut, laissant à découvert une partie de l'abdomell. - Abdomen s'úlargissảnt postérieurement, arrondi à son extrémité. - Cuisses et jambes assez épaisses. - Táses ayant leur premier article court, Ics deux suivaus ectiors, alongés, le demier terminé par un seul crochet.
Ce genre fondé par Horbst renferzoit des insectes fort difféi ens les uns des autres, ainsi que l'avoit observé Paykull. M. Latreille en sépara la seconde division et lui donna le nom générique de Scydinène. Plusieurs auteurs l'out encore dininué depuis, de sorte qu'il est réduit à un très-petit nombre d'espèces. Elles se trouvent ea Europe; leur taille ne surpasse guère une ligne de longueur. Leurs métamorphoses n'ont pas encore été observées.

\section{Psélaphe de Heis, $\boldsymbol{P}$. Heisei.}

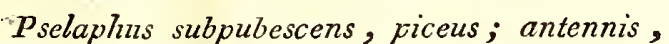
elytris pedibusque rufescentibus, elytrorum basi substriatâ.

Pselaphus Heisei. Lat. Gener. Crust. et Insa tom. '3. pag. 76. $n^{\circ}$. 1. - HERBst, Coleopt. 4 . tab. 39. fig. 10. - Reich. Monogr. Pselaph. pag. 28. $\dot{n}^{\circ}$. 2. tab. I. fig. 2.

Longueur une ligne. Corps d'un testacé-brun, un peu pubescent. Corselet muni d'une petite fossette transversale vers l'écusson. Elytres ayant chacune deux stries; l'une suturale, l'autrc plus courte, placée près de la base et u'atteignaut pas le milieu de l'élytre; poitrine et dessons de l'abdomen noirâtres.

D'Allemagne. On le trouve aussi aux environs de Paris.

Rapportez à ce genre le Pselaphus dresdensï. Herest. Coleopt. tab. 3g. fig. I I. ( Reich. Monogr. Pselaph.pag. 32. no. 4. tab. 1. fig. 4. Psela-

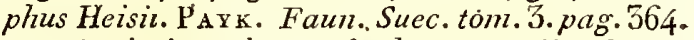
$n^{\circ}{ }^{2}$.), ainsi rue les Pselaphus Herbstii et longicollis. Reich, Mllonogr. Ce demier est l'Anthicus dresdensis. Panz. Faun. Gemn. fas. 98. no. 1 . - Encycl. pl. 372 bis. Jig. 28.

Ce genre tel que nous venons d'en donner les caractères, se rapporte exactement à la première famille des Psélaphes de M. Reichenbach.

$$
\text { (S. F. et A. SERv.) }
$$

PSÉLAPHIENS, $\boldsymbol{p}_{\text {selaplizi. Troisième familla }}$ de la section des Trimèrcs, ordre des Colépoptères; cile a pour caractères :

Elytres tronquécs, plus courtes que l'aldomen, laissant à découvert son extrémité postérieure. Tête dégagée du corselet. - Antenues en tout ou en partie grenues, grossissant ver's l'extrćmité. - Corselet tanlôt presque cylindrique, tanlôt presqu'ell forme de cour tronqué ou arrondi. Abdomen plus large que le reste du corps, presque carré, obtus postérieurement. - Tarses ayant léur premer article court; les deux autres alongés, le dernier termiué par un ou deux crochets. - Palpes maxillaires le plus souvent fort longs, rentlés à leur exirémité et termiués par une petile poiute spinuliforme.

Cette famille se divise ainsi : 


\section{Antenues de onze articles.}

A. Deux crochets au dernier article des tarses.

a. Palpes très-courts.

Chenuic, Cténiste (I).

b. Palpes maxillaires très-saillans. Dionyx.

B. Un seul crochet au dernier article des tarses. - Palpes maxillaires très-saillans.

a. Palpes très-longs, coudés. Psélaphe.

b. Palpes droits, plus courts que la têle et le corselet pris enseable.

Bryaxis.

II. Antennes de six ariicles.

Clavigère.

Les Psélapliens sont en général très-petits; on les rencontre dans les lieux frais et humides, parmi les plantes et quëlquefois sous les écorces, les pierres et les mousses; ils ne.sorteut volontiers de leur retraite que le soir. Les espèces du geure Clavigère ont particulièrement été trouvées dans les fourmilières.

CHENNIE, Chennium: LAT.

Genre d'insectes de l'ordre des .Coléoptères, section des'Trimères, famille des Psélaphiens.

Parmi tes genres de cetle famille les Chennies, les Cténistes et les Dionyx sont les seuls qui aient en même temps onze articles aux antennes et deux crochets au dernier article de lérrs tarses, mais les Cténistes qui comme les Chennies ont les palpes très-courts, en diflèrent parce que chacun des trois derniers articles de leurs palpes maxillaires est armé d'une épine latérale; les Dionyx se distinguent aisément par leurs palpes maxillaires très -saillaus ainsi que par les articles de leurs antenues fort différens les uns des autres tant en forme qu'en longueur.

Antennes presque perfoliées, moniliformes, plus grosses vers leur extrémilé, composées de ouze arlicles, les dix premiers à peu près égaux et lenticulaires, le dernier plus grand, presque globuleux. - Mandibules cornées. - Palpes très-courts, peu ou point apparcns, les dernier's articles des maxillaires simples, sans épines latérales. - Téte dégagée du corselet. - Corselet cylindrique. - Elytres tronquées; plus courtes

(1) II. Reichenbach, fondateur de ce dernier genre, ne lui tonne quiun seul crochet aux tarses dans son texte coname dans sa figurs. M. Larreille nous assure en avoir observé deux. que l'abdomen, laissant à découvert son extrémité postérieure, recouvrant les iles. - Abdomen plus large que le reste du corps, obtus postérieurement. - Pattes de longueur moyenne, hanclies alongées, pédiculées; tarses très-courts, le dernier article muni de deux crochets.

M. Latreille à qui l'on doit l'établissement de ce genre n'en mentionne qu'une seule espèce; nous ignorons sa manière de vivre.

\section{1.. Chennie bituberculée, ' $C$. bituberculatum.}

Chennium castaneo-rufum, capite sub antennis utrinquè uniluberculato; clytris loxvibus, lineis impressis ad marginem externum et suturam.

Chennium butuberculatuin. LAт. Gener. Crust. et Ins. tom. 3. $p a g .77 \cdot n^{\circ}$. 1 .

Longueur ". Corps d'un cliâtain-ronx; têle ayant de cliaque côté sous les aniennes un tubercule aigu; front suillanc, mésal; rertex un peu enfoncé. Corselet bordé antérieurement, un peu cilié avec une ligne enfoncée et arquéc sur chaque côté postérieur. Elytres lisses ayant chacune deux stries; l'une suturale, l'autre placée le longdu bord extćrieur.

On la trouve dans le midi de la France; a Brives.

CTÉNISTE, Ctenistes. ReIcr. Lat.

Genre d'insectes de l'ordre des Coléoptères, seclion des 'Trimères, famille des Psélaphiens.

Dans cette farnille les Chennies, les Cténistes et les Dionyx forment un groupe particulier ( Psélaphiens), mais le premier el le dernier de ces geures se distinguent du second par leurs palpes maxillaires simples, c'est-à-dire dépourvus d'ćpines latéiales.

Antennes plus grosses vers leur extrémité, composćes de onze articles, les deux premiers prescjue cylindriques, un peu plus longs que les autres; les suivans presque globuleux, les neuvième et dixic̀me semi-globuleux, le dernier plus grand que cenx-ci, oblong et obtus. - Palpes conrts, dirigés en avant, les maxillaires de la longuenr de la tête, composés de quatre articles, le premier petil, presque cyliudrupue, le second trés-long, arqué, renflé au bous, muni d'une petite pointe ou épine latérale; les deux demiers presqu'égaux entreux, globuleux, ayant chacun me petite poinie latćrale. Palpes labiaux de trois articles, le dernier muni d'une pointe apicale. - Téte dígagée du corselet, avancée, bilobée ; déprimée. -Corselet presque cylindrique, plus long que la tête, rétréci antérieuremenl.-E'/ytres tronquées, plus courtes que l'abdomen, laissant à découvert l'extrémité postérieure de ce dernicr. - Abdomers plus large que le reste du corp;, dilaté pospérienrement.-Pattes grêles, de iongueur moyenne; tarses ayant leur premier article fort long, le 


\section{P S E}

dernier muni de deux crochets, suivant M. Latreille.

M. Reichenbach dans sa Monographic des Psélaphiens, imprimée à Leipsick, a institué ce genre dont le nom vient d'un mot grec qui signifie: peigne, par allusion aux dents latérales que l'on voit âux palpes maxillaireş. Cet auteur. n'?ıl décrit qu'une espèce et ne dit rien de ses mœurs; nous allons rapporter sa description.

I. Créniste de Reichenbach, C. palpalis.

Ctenistes testaceo-rufus, pubescens.

Ctenistes perlpalis. Rercir. Monogr. Pselaph. pag. $76 . t a b .2$.

Longueur a lig. Corps pubescent, entièrement d'un roux-testiccé. Front convexe avec cieux foibles enfoncervens. Anteanes pubescentcs, un peu brunes vers lemr extrćmité. Corselet ayant au milieu de sa parlie postérieure un petit enfoncement garni de poils blanes ainsi que la partie antérieure de ses côtés. Elytres presque triatngulaires, réunies, de la laryemr da corselet ì leur base, dilitées et tronquées postérieurement, prespue glabres, fortenent girnies de poils à leur bord postérieur, ayant une strie qui accompagne la suture; augles huméraux élevés. Abdomen rebordé, pubesceut, son premier segment plus large que les élytres, la dernier obtus. Pattes rousses, pubescentes; tarses jaunâtres.

Il se trouve en Allemagne.

DIONYX ; Dinnyx. Des. inéd.

Geure d'insectes de l'ordrc des Coléoptères; section des Trimères, famille des Pólaphiens.

Les Chemnies, les Cténistes el les Dionyx sont les seuls Pólaphiens qui aient à la fois lés anteunes composées de onze articles ęt deux crochets au dernier article de laurs tarscs, mais les premières ont des palpes peu ou pötnt apparens et les dix preniers allicles des antennes a peu près égaux entr'eur; les second's ont les trois derniers arlicles de leurs palpes maxilluires muias chacun d'une épine latérale.

Antennes couposées dc onze arlicles, le premier gros, plus long que le second, celur-ri grlobaleux; les cing suivans tress-petits, transvetses, moniliforires, le haiseme cylmilrique, phus ys que les précédcns, aussi long que les sept premiers róunis; les nenviène âdiriene cy ndionconiqnes, égatux eutroux, alongés, muis moms lon rove le huirieme; le demier oroude-alungé, pointu at son extrémité, le plus gros de lous et formant a lui scul la massue. - Mandibales cornées, pou apparcntes. - Palpes maxillatires très-sillans, recourbés en arricre, phlus couts que la lête el le corselet p:is ensenble, composés de quatre articles cyindriques; pal ces labiaux conrts, dirigés en aratat, de trus wricles, bc

dernier muni d'une pointe apicale. - Tête retite, dégragée du corselet. - Corielet tronqué. - Ecusson très-petit. - Elytres courtes, tronquécs postérienrement, laissant ì découvert plis de la moitié de l'abdomen. - Abdomen s'éliagissant postérieurement, arrondi à son extrémité. - Pattes de longneur moyenne; tarses ayant lew dernier article terminé par donx crochets.

M.le comte Dejean qui a bien vouln nous commuluiquer ce nouveau genre et nous permettre de décrire dans sa collection l'espc̀ce qui a servi de type, lui a donué le nom de Dionyx, tire de deux mots grees qui signifient: ongle double; ce genre a des rapports avec les Clénistcs par la forme et la direction des palpes labiăux; il en difière principalcment par ces mèmes considér ttions appliquées aux palpes maxillaires.

\section{Dionyx de Dejean, D. Dejeanii.}

Dionyx testaceus, granulatus, subvillosus, elytrorum striis duabus longitudinalibus, uns suturali, alterầ mediuli sutir âque fuscâ.

Longueur I lig. Corps testacé, granulcux, couvert ainsi que les antennes ct les pattes de poils courts, usscz gros, distincts, un peu conchés et écartés les uns. des autres. 'Tète égalant en longueur celle du corselet; ce dernier ayant avant son milieu un sillon transversal peu apparent. Elytres avec deux stries longitudinales : l'une sulurale, l'autre placée vers le milieu; stoture un peu rembrunie.

Il a élé pris au rol le.soir, par M. Ie comte Dejean, dans le dípartement de l'Aude.

BRYAXIS, Bryaxis. Kхосn. LÉAct. LAT. Pselaphus. Rerç. Payk. P'anz. Arthicus, Fab. Stcphylinus. Lixx. Oun. (Entone) P'Axz.

Gonre d'insectes de l'oidre dis' Coléoptères, seciion des 'Trimcères, famille des 'sélaphicns.

M. Latreille dans un travail inćdit dont il a cou la bonté de nous fuire part, réurit aux Bryaxis les genres Euplectus, Bythinas, Aicopugus, 1'ychus et Bryaxis publiés par le doctenr Léach, dins ie Zool. misgctl. C'est de cétle manère que nous allows honner ce penve; il répond aux deux dernicres familles des Psćlaphes de M. Reichenbach.

- Les Psélaplicns ciui ont omze articles anx anlennes et un scul crochei an dernier arlicle des larses sont les genres Pséliphe et Bryaxis; lc premicre est bien reconinoisable par ses palpes maxil. lities coudés, plus longs que la lête el le conselet pris ensemble.

satenes plus commer rue le corps, composkes de wize aricles unoniliturmes, les derniers plus gros, is onzieme ovale. - Mrandibules corúes, pointues. - Palpes maxillares droils, avancín, Jlas courls que la léic en le corselet pris ensentire, composís de guatre artieles; le deruicr gros, 
rcallé, en massne, soit sécuriforme, soit conique; palpes labiaux courts, filiformes. - Lèure inembranense. - Tếte petite, dégagée du corsèlet. - Corselet tronqué. - Ecusson très-pelit. - Elyires courtes, tronquées postérieurement, laissant à déconvert une partie de l'abdomen. - Abdomen s'élargissant postérieurement, arrondi à son extrénité. - Pattes de longueur moyenne; tarses ayant leur dernier article ternuiné par un seul crochet.

Ce greure est le plas nombreux en espèces de toris ceux de sa famille. On trouve les Bryaxis cu Europe. Leurs métamorploses ne sont pas colmues.

${ }^{\mathrm{re}}$. Division. Dernier article des palpes maxillaires sćcuriforme.

1. Bnyaxis porte-hache, B. securiger.

Bryaxis piceo-rufescens, thorace latitudine capitis postioè yaldè coarrtuto, antemnarum articulo secundo in fominâ crassiore conico; in mane securiformi.

Pseliphus securiger. Rегсн. Monogr, Pselaph. pag. $45 . n^{\circ}$. 5. tab. 1. fig, 9 .

Lougueur $\frac{t}{2}$ lig. Corps d'un roux-brum. Corselet de la larkeur de la tête, fortement rétréci à sa partic postérieure; secondarticle des antennes plus épais que les autres et conique dius la feoelle, sécuriforane dans le nuâle.

D'Europe.

Ratpportez à cette division les Pselaphas niger.

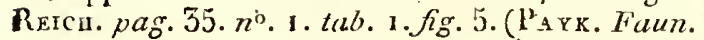
Suec. tom. 3. pag. 365. $n^{3}$. 4.) Bulbifer. R匹iсн. pag. 57. $n^{\circ}$. 2. tab. 1. Jig. 6. Clavicornis. ReICn. kag. 40. no. 3. tab. I. fig. 7. (P A xz. Faun. Gelm. fis. 89.fig. 3.) Glabricollis. Reicн. pag. 4.3. 7n. 4. tab. 1.fig. 8. Brevicornis. Re1сн. pag. 47 . $n^{n} \cdot 6 . t a b \cdot 1 \cdot$ fig. 10.

$2^{\mathrm{e}}$ Dicision. Dernier äticle des palpes maxillaires conique.

tre. Subdivision. Corselet arrondi.

\section{BRyayis sanguin, B. sanguineus.}

Brraxis niger, nitidus, elytris sangilineis, tho. ruce subgloboso fopeolis tribus sulco conjunctis.

Pselaphus sanguineus. РА Ү . Faun. Suec. tom. 5. parg. 365. n" . I. - Lat. Dict. d'Hist. nat: $2^{\mathrm{e}}$. édit. - Reica. Monogr. Pselaph. pag. 49. tab..2. fig. I1. - Fselaphus mucronatus: P.Anz. Faun. Germ. fers. 89. Jig. 10. - Anthicus sanguineus. Fa B. Syst. Eleut. tom. I. pag. 293. $n^{\text {a. }}$ 22. (Retranchez les syoonymes de Panzer et d'Hepbsí.) - Staphylinus sunguineus. LinN. Syst. Nat. 2. 685. 19. - Otiv. Entom. tom. 5. Staphyl. pas. $24 \cdot n^{0} \cdot 20 \cdot p l \cdot 6 \cdot f_{g}$. 54 .
Longueur 1 lig. $\frac{1}{4}$. Corps noir, luisant. Antennes de la longueur de la moilié du corps, noirâtres, velues. 'Tête ayant une impression de chaque côté, derrière les yeux ; corselet presque globuleux, a vec trois impressions réunies par un sillon transversal. Elytres d'un ronge - sanguin, marquées chacune de deux lignes longitudinales enfoncées. Patles roussâtres.

Des environs de Paris.

Rapportez à cette subdivision les Pselaphus homaticus. Rетсн. pag. 52. no. 2. tab. 2.fg. 12. Fossulatus. Re1ch. pag. 54. no. 3. tab. 2. fig. 15. Xanthopterus. Reich. pag. 56. $n^{\circ}$. 4. tab. 2. fig. 14. Impressus. Reich. pag. 58. $n^{\circ}$. 5. tab. 2. fig. 15. (Panz. Faun. Gemi. fas. 89. fig. 10. LAT. Gen. Crust. et Ins. tom. 3. pag. 77.) Insignis. ReICI. pag. 6o. no. 6. tab. 2. fig. 16.

\section{$2^{\mathrm{e}}$ Subdivision. Corselet anguleux.}

\section{Bryaxis nain, B. nanus.}

Bryaxis elongatus, badius, fronte inter fossas, duas anticè couvergente, elevatâ, lavi.

Pseliphus nanus. Reica. Monogr. Pselaph. pag. $69 \cdot \pi^{\circ} \cdot 4$. tab. 2. fig. 20.

Longueur $\frac{2}{3}$ lig. Alongé, châtain. Front élevé, lisse, placé enti'e deux fossettes qui se réunissen. en avalit.

D'Europe.

Rapportez à cette subdivision les Pselaphus sulcicollis. Retcin. pag. 62. $n^{\circ}$. 1. tab. 2. fig. 17 . (P seluphus dresdentis. PA Y K. Faun. Suec. tom. 3. pag. 365. no. 3. Anthicus dresdensis. Faв. Syst. Eleut.tom. 1. pag. 293. $n^{\circ}$. 23.) Venustus. Reic日. pag. 63. no. 2. tab. 2. fig. 18. Ambiguus. Reicr. pag. $67 \cdot n^{n}$. 3. tab. 2. fig. 19. Karstenii. RE1сn. pag. 71. $n^{\circ}$. 5. tab. 2. Jig. 21, (Staphylinus sanguuneus. Paxz. Faun. Germ. fas. I I. fig. 9?') Signatus. ReIch. pag. 73. no. b. tab. 2. fig. 22.

Clavigère, Clapiger. Preyst. Lat. Panz.

Genre d'insectes de l'ordre des Coléoptères, section des Trimères, fimillè des Pséliuphiens.

'Tous les genres de cetle famille, excepté celui qui est l'objet de cet article, sont pourvus de palpes labiaux et leurs antenies sont composées de plus de six articles.

Antennes terainées ẹ massue, composées de six articles. - Point de mundibules. - Mâchoires très-petites, consistanl en un appendice membraneux. - Palpes maxillaires tiès-courts, presque filiformes, très-petits, de deux ou trois articles; point de palpes labiaux. - Lèvie núlle. Tête dégagcé du corselet. - Yeux peu apparens. - Corselet guere plus largare que lia lêle, audinci à ses deux extrémités: - Elytres tres-contes, laissant à déconvert plas de la mortié de l'abdo1 men. - Abdomen plus large que le corselet, s'é- 
largissant à son extrémité ; celle-ci arrondie. $\boldsymbol{P}$ attes fortes; cuisses antérieures amincies à leur base; tarses ayant leur dernier article muni d'un seul crochet.

Ce gemre a été fondé par M. Preysler, auteur d'un ouvrage sur les insectes de Bohêtue. 'Son nom vient de deux mots latins qui signifient : porte-massue; it est analogue à lá furme die ses antennes. Les deux espèces que nous décrıvons ont été trouvées daus le nid de la l'ourmi jaune (F. flava). Nous allons entrer dans quelques détails sur les mours de ces insectes; ils sont extraits d'une lettre adressée à M. le comle Dejeiu en 1823 , par M. C. Wesmaël, habitant de la ville de Liége. Cet observateur a souvent trouvé le Clavigère testacé aux environs de cette ville, daus l'habitation de la Fourmi déjà mentionnéc. - Lorqu'on a soulevé la pierre qui recouvre la n fourmilière, dit $\mathrm{N}$. Wesmaël, les Fourmis, au " milieu de l'agitation générale, veillent néan" moins sur les Clavigères : ceux-ci prenuent sou- vent d'eux-mêmes le chemin des galeries, mais $n$ s'ils' ont l'air de s'enfuir, les Fourmis les entou" rent, les poússent jusqu'à l'entrée de ces mêmes "galeries, et les forcent d'y entrer; quelquefois " l'une d'elles saisit un Clavigère au.travers du " corps avec ses mandibules et va le déposer dans "les conduits souterrains. On aperçoit ò̀ l'extré" nité des élytres du Clavigère testacé, des poils " longs, suritout au côté extérieur, où ils parois» sent oriinairement agglutinés parl'effet de quel" que:liqueur. Ne seroit-il pas possible quil y " eût de chaque côté du corps, à cet endroit, » une ouverture d'un ou de plusieurs conduits qui "sécrétassent un liquide mielleux analogue à » celui des Pucerons? Ainsi s'expliqueroit l'affec"tion des Fournis pour ces petits coléoptères."

Jre. Division. Antennes grossissant insensiblement vers l'exirémité; leurs deux prewiers articles très-petits, presque globuleux, les trois suivans pertoliés, lenticulaires, semi-globuleux, le dernier cylindrique, plus gránd que $\cdot$ les autres.

\section{Ciavigìre lestacé, $\boldsymbol{P}$. testaceus.}

Claviger antennis apice sensim crassioribüs.

Claviger testaceus. IAAT. Gen. Crast. et Ins. tom. 3. pag. 7S. $\iota^{\circ}$. I. - Preysi. Ins. Boh. pag. 68. tab. 3. fig. 5. a. b. - PANz. Falln. Gem. fas. 59. fig. 3. - Encycl. pl. 372 bis. Jig. 53.

Longneur $\frac{3}{4}$ lig. Entièrement d'un roux-châtaiu. Corse!et ayant une petite fossette au milieu de sa parlie postérieure. Elytres finement striées.

D'Europe.

$2^{\mathrm{e}}$. Division. Antennes brasquement en $\mathrm{m}$ assue, leur premier article un peu plus long el un peu plus gros que le sccond, celui-ci très-petit, globuleux; les troisième et quatrième cylindriques, alongés; le troisième plus long que le quatrième; le cinquiène court, presque globuleux, le sixième beatrcoup plus. gros que les autres, formant à lui seul une inassue ovoido-globuleuse.

\section{Craprgitre longicorne, C. longicomis.}

Clovizer antennarum articulo extremo abruptè cateris crassioni.

Caviger ?.jigicomis. Germ, Mag. Ent. 1818. pag. $35 . t_{2} z .2 . h_{5} \cdot 16$. a. L. et fio. Io.

longneur I lig. ì I lig. - Corps testacé ; tête, corselet al abdonon n! peu granuleux, lógèremeut.velas; leurs pors rous. Elytres munies de Loms poils à leur bord posterien:, snitout vers I'angle externe de ce hord. Abdumen ovale-ajrondi, marqué de deux petits silloxs conts, longitudinaux a la partie qui vient inmédiatement après les élytres; celles - ci ne recouvrant qu'un tiers de sa longuear totale.

Il a été truuvé à Gảeubach dans le nid de la Fourmi jaune, et envoyé à IM. le coute Dejean par M. Germar. C'est d'après cel individu unique qu'a été faite la description ci-ćessus.

$$
\text { ( S. F. et A. Sirv.) }
$$

PSI. Geoffroy a donné ce nom à une espèce de Noctuelle. Voyez Noctuelle Psi, no. 388 de ce Dictionnaire. (S.F. et A. SERv.)

PSILE, Psilus. Le genenre d'Hyménoptères que M. Jurine nomme ainsi, répond en partie à celui fondé auparavant sous le nom de Diapria pur M. Latreille. Voyez Diaprie, article Proctotrupe. (S. F. et A. Serv.)

PSILO'TE, Psilota. Nom donné par M. Meigen dans son ouvrage sur les Diptères d'Europe, a un geure voisin de celui de Pipize, et qui n'en dilfère que parce que le dernier article des antennes ou la palette est ovale-obloug et l'Lypostome renfoncé à sa base, tronqué à sà partie inférieure. H n'en - décrit qu'une seule espèce sous le nom de Psilota anthracina. Elle paroit nouvelle, l'autcur ne lui donaant aucuus synonymes. (S.F. et A.SERT.)

PSOA, Psoa. Herbst. Fab. Lat. Dermestes. Ross.

Genre d'insectes de lindre des Coĺoptercs, section des 'Tétramères, fumilie des Xylophages, tribu des 15ostrichins.

Cette libu est composće des gcares Bostriche, Psoa, Némozome, Cór l a et Cus. Ce dernier se distingue par la fortoervitu on arroudie de son corps; les Cérglous ont des atitennes ferzanées par une raassue solide, presçue glolulerse ; les Térrozomes ont la tête presajuaussi longue que le corselet, celui-ci et le corps linéaires. Les Bostriches onł 
le corps convexo, le corselet élevé, globnleux ou cubicine. 'T'els sont les caractères qui séparent ces quatle grenres des l'soas.

Antennes plus longucs ano la tête, de dix articles, les trois derniers plus gros, formant nne massue perfoliće. - Lábre suillaut, très-petit, transrersal, très-velu an !ord antérienr. - Manditules courles, épaisses, sans dentélures, point bifides à l'extrémilć. - Ihâchoircs à up seul lobe. - Palpes courts, mais apparens, presque filiformes; leurs articles à peu près égraux, le dernier tronqué ou oburs à son soumet; les maxillaires un peu plus longs, de quatre articles, les labiaux très-rapprochés à leur insertion, de trois articles. - Levre alongée, merbiancuse, dilate piesqu'en cour ì son extrémité; puenton tratusversolinéaire, - Téle plus courte gre le corselet. Yeux globulenx. - Corps linéaire, déprimé. Corselel presque carc. - Ecusson petit. - Elytres de la lougueur de l'abdomen, an moins truis fois phus longues que le corselel. - Tarses it articles enticrs.

Ce genre élabli par Ilerlust et adopté parles anteurs subsćquess ne paroit renfermor que denx ou trois especes; ses moxirsosont encure inconnues, tais ne doivent pas dillérer essenliellement de celles des Bostriches, avec lesquels il a de grands rapporis.

\section{Psoa vicnnoise, $\dot{P}$. vienzensis.}

Psoa corpore nign-2irescenti, elylris fuscorubris aut fuscis, prifunde punctatis.

psoa viennensis. Hab. Sjscl. Eleut. tom. r. pag. 20j. $n^{n}:$ 1. - Paxz. Faum. Gemm. fits. g6. fig. o. - incycl. pl. 392.jig. 42.

Longuenr 5 lig. $\frac{1}{2}$. Antennes, devant de la téle et tarses d'un testacé-brun. Pario postérieure de la lếle, corselet, dessous du corps, ecuisses et jambes d'uin noir-verdatre un peu bronac. Elytres légèrement velues, d'un brun-ronseâttre ou branes, forlenent poncluées. Bords latéraux du corselet finement denticulís postérieurement.

D'Aulriche et de Dalmatie.

2. Psos italienne, $P$. ilcalica.

Psoacorpore nigro-ccerulescenti, elytris rubris, funclites, thansverse rugosis.

Psoa ilalica. Des. Calal. - Demestes dubius Ross. Fann. Etrusc. BIantis. tom. I.

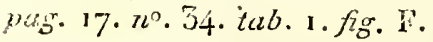

rongueur 4 lig. $\frac{1}{3}$. Aniennes et tårses noirs. Corps ponctué, velu, 'iète, corselet, écusson, abdomen, cuisses et jambes d'un noir-bleuâtre un pen bronzé. Elyıres presque glabres, rouges, poncluées, converies de petiles ridẹs transver*ales. Bords latéraux du corselet finement denTiculés postérieurement.

D'llitilie.
CERYION , Cerlon. IAst. Milyzoplaggus, Monotoma. Henвst. 'Temebro. linn. Iyclus. FAB. PaYk. Ips, Lyctus. OLIv. (Encycl.)

Genre d'insectes de l'ordre des Colćopteres, section des 'Tétramères, familie des Xylophages, tribu des Bostrichins.

Les cinq genres qui composent celte tribu, qualre : Bostriclie, l'soa, Némozome et Cis out lit massue de leurs antennes perfolice.

Azlennes presque deux fois àusi longues que la tête, plus courles que le corselet, composées de dix. articles presque monilifornes, terminées par une massue solide, presque globuleuse, formée d'un un de deux articles. - Laḅre avancé, t:ansverse, membraneux, entier. - Mandibules cacluces, déprimúes, trigones, bidentées au côté interne; l'angle extcrne de leur base portant un tubercule aigu ì l'extrémité. - Palpes tiliformes, leur dernier article le plus long de tous, eylindrigue, presqu'aign au bout; les maxillaires deux fois plus longs que les labiaux. - Mâchoires ayant deux lobes, t'exléricur presque triangulaire, plus giand gue l'interne qui a la forme d'une dent. - Lesore preque corrace, carríe; menton plus large que la levre, transversal, au moins trois fois plus long. - Corps alongé, carré, presque linéaire dans quelques-uns, aćpriné. Corselet sarré. - Elylres recouvränt labdotnen et les ailes. - Patles de longueur moyeune; jambos s'élargissinl un peu vers leur extrénité.

Ce.s coléoplères vivent dans le bois. On les trouve ordinitirement sous li's écorces des vieux arbres. Nous n'avons aucune nolion sur leurs larves.

lixpportez à ce genre l'Ips tarière $n^{\circ} .5$, les Lyctes bipustulé, coin. Vi!, pag. 589 et histéruide, parr. 5 go de ce Dictionnane.

CIS, Cis. Lat. Anohium. Fat. Ithig. Hersst. PaYk. Panz. Uliv. (Ëlom.) Hylesinus. Fas.

Genred'insectes de l'ordre des Coléoplères, section des 'T'étramères, fimmlle des Xylophages', tribu des Bostrichins.

Dans cette tribu Ies genres Bostriche, Psoa, Némozome el Cérylon on le corps étruit el alungré, ce quiles distingue des (is.

Anteinnes deux fois plus longues que la tête, composées de dix articles et teraninćes en massue perfulice, celle-ci de trois aricles. - Labre àvancé, apparcnt, transversal, entier, membraneux. - Miandibules.courles, coniques, triangullaires, leur extrémité munie de deux dents érgales.-Mâchoires à deux lobes, l'extérieur presque triangulaire, plus grand, l'intérieur petit, en forme de dent.-Palpes très-inégaux, les maxillaires beauconp plas grands que les labiaux, grossissant petit it petit ver's leur extrémité, leur dervier article plus grand que les autres, presqu'ovale; les labraux très-petits, subulés, obconiquẹs, le dernier article plus mince que le précédent. - 
Lèure et menton formant ensemble un earré long, étroit, demi-eoriace. - Téte transversale, un peu rebordée en devaut, souvent bituberculée dans les mâles, ćlevéc à sa partie postérieure. - Yeux proéminens. - Corps ovale-oblong, déprimé, un peu convexe en dessus. - Corseles transversal, con bord antérieur largement voúlé, un peu avancé pour recevoí la tète, ses côlés rebordẻs. - Elytres recouviani l'abciomen et les ailes. Pattes courles, les trois prewiers arlicles des tarses égaux et velus.

Ia dénomination de ce gente czéé par Mi.zatreille, vient d'un mot par lequel les Grecs désigooient une larve qui vivoit dans le bois. On trouve ces peti!s coléoplères dins les bolets coriaces qui viennent sur le tronc des chênes et des arules; ils se tiennent à la partie inférieure des chanpignons; plusierır's espèces y sout assez communes au printemps. Lorsqu'on approche des Cis, ils replient leurs pattes et leurs antennes et se laissent tomber. Le nombre des espèees connues s'élève à scize et habitent l'Europe.

\section{Crs da Bolet, $C$. boleti.}

Cis fusco-castaneus, subnitidus, temere punctulatus, elytris subrugrosulis, antennis pedibusque dalutè rufescentibus.

Cis boleti. Lat. Gener. Crust. et Ins, tom. 3. pag. 12. $n^{\circ}$. 1. - Anobium boleti. FA . Syst. Eleut. tom. 1. pag. 323. no. 7. - PAnz. Faun. Germ. fas. го. fig. 7. - P P Arr. Faun Suec. tom. I. pag. 308. $n^{\circ}$. 7. - Anobium bidentatum. OLiv. Entom, tom. 2. Vrill. pag. 11. $n^{\circ} \cdot 9$. pl. 2. fig. 5.

Longueur 2 ligg. Corps brun ou châtain, assez luisant, irrégulierement et finement pointillé. Elytres un peu rugneuses. Antenues el pattes d'une couleur moins foncée, presque testaeće.

Des environs de Paris.

Nota. M. Lalreille rapporte encore à ce genre les Anobium reticulatum no. 5 , micans $\mathrm{n}^{\circ} .14$ FАв. Syst. Eleut. et quelques itultes es pèces.

$$
\text { ( S. F. el A. SERv. ) }
$$

PSOQUE, Psocus. LAT. Fab. Coqueb. Termes. Linn. De Gér. Hemerobius. Lavy, Oliv. (Encycl.) Pediculus, Phryganea, Psylla. Grofr.

Gente d'insectes de l'ordre des Névropteres, famille des Illanipennes, tribu des Psoupuilles.

Ce genre compose à lui seul eette tribu.

Antennes sétacées, longues, avancées, insércées devant les yeux, de dix articles environ peu distiucts, la plupart cylindriques, les deux premiers plus courts, plus épais, les autres grêles, alongés. - Labre avancé, membranenx, transversal, arrondi en devant et sur les côtés, presqu'entier: - Mandibules fories, cornces, fortemeat échancrées dans leur partie moyenue, les Hist. Nut. Ins. Tome $X$. deux extrémités de cette échancrure formant des der:ts. - Mâchoires composées de denx parties, l'une intérieure cornée, alongée, linćaịce, crénelée à l'extrémité, souvent avancée, l'antre ex-. térieure membraneuse, formant une gatine cylindrique un peu eompriméc, obtuse, ouverte à son extrémité, enveloppant les parties cornées. - Palpes maxillaires alonésés, saillans, de gratre articles, le premier peu apparent, les second et roisième obconiques, le dernier ovale, rentlé; les labiaux point distincts. - Zève prescue earrée, nembianeuse, large, accompagnće de chaque sôté d’une sspìce d'écaille. - Téte grosse, très-eonvex z en devant et en dessus. - Yeux gros el ronds. - Trois petits yeux lisses groupés. - Corps court, ramassé et mou. - Premier segment du corselet très-petit, ne s'apercevant point en dessus, le secord grand, sillonné. - Ailes de grandeur inégale (les inférieures plus pelites), en toit, transp:trentes, ayami souvent un reflet briliant, irisé; lents nervures fortes. - Abaomen court, sessile, presque conique, pourvu dans les femelles d'une sorte de tarière logée entre deux coulisses. - Pattes assez longues, grêles; jambes alongées, cylindriques, saus épines; tarses conrts, de deux ou trois articles.

Le nom de Psoque vient d'un mot gree qui signifie : réduire en parcelles. Il a été donnè à ces tiès-petits névioptères en raison des labitudes de leurs larves. Ces insectes sont vifs, marchent vîte et sautent pour éviter le dinger. On les trouve sur les arbres, les pierres, dans les livres, les collections d'insectes et les hertiers, aux dépens desquels ils vivent, sans faire cependant beaucoup de tort vu leur pelitesse. Les larves qui ressemblent à l'insecte parficit, hảbitent les mêmes endroits el jouissent des mêmes fucultés, excepté celle de se reproduire; elles n'en différent que parl'absence totale des ailes; dans l'état de nymphe elles en portent les fourreaux.

On connoit une douzaine d'espèces de ee genre, touies européennes.

x. Psopue longicorne, $P$. longicornis.

Psocus longicomis. Fав. Ent. Syst. Suppl. pag. 203. $n^{\circ}$. 1. - L - Len. Cnust. et Inis. tom. 3. pag. 208. - Panz. Faun. Germ. fas. 94. Jig. ig.

Voyez pour la descriplion'et les autres syno. nymes llémerobe longicorue $\mathrm{n}^{\circ} .17$.

\section{Psoque six-points, P. sexpunctatus.}

Psocus sexpunctatus. I.ar. Gen. Crust. et Ins. tom. 3. pag. 208. - Cuques. Illust. f́con. pas. 13. tab. 2. fig. 10 et I I. - FA . Ent. Sy'st. Suppl. pag. 203. $n^{\circ}$. 5. -- La Frigane à ailes ponctuées. Geofr. Ins. Paris. tom. 2. pag. 250. $n^{\circ}$. 10. Encycl.pl. 397. I1I. Jig. 2-4.

Il se trouve aux environs de Paris. 
Voyez pour la description et les anires synosynes Hémcrobe six-points $n^{\circ} .23$.

3. Psopue quadriponclué, $P$. quadripunctatus.

Psocus quadripunctatus. LAT. Gener. Crust. et Ins. tom. 3. pas. 203. - Coqurs. Illust. Icon. pag. 12. tal. 12. frg. 9. - FAB. Ent. Syst. Suppl. pag. 204. n०. 8. - Paxz. Faun. Genn. fits. 94. fig. 22.

Des environs de Paris.

Foye $z$ pou $i$ la description et les autres synosymes Hémerobe quadriponctué $n^{\circ} .28$.

\section{Psoque biponctué, P. bipnnclatus.}

Psocus bipunctatus. Lax. Gener. Crust. et Ins. tom. 3. pas. 203. $n^{\circ}$. 1. - Coqueb. Illust. Icon. pag. 11 . tab. 2. fig. 3. - FAB. Ent. Syst. Suppl. pag. 204. $n^{\circ} \cdot 7^{\text {- }}$ - PANz. Faun. Germ. fas. 94 . fig. 21. - La Psylle des pierres. Geofr. Ins. Paris. tom. 1. pag. 488. $n^{0} \cdot 7$.

Des environs de Paris.

Voyez pour la description et les autres synonymes Hémerobe biponctué n ${ }^{\circ} .27$.

\section{PsoQue abdominal, $P$. abdominalis.}

Psocus abdominalis. Fad. Ent. Syst. Suppl. pag. 204. $n^{\mathrm{a}} \cdot 9$.

Voyez pour la descriplion et les autres synonymes Hémerobe abdominal no $\mathbf{n}^{\circ}$ o.

\section{Psopue jaunâlire, $P$. flavicans.}

Psocns flavicans. FAв. Ent. Syst. Suppl. pag. 203. $n^{\circ} .2$.

Voyez pour la description et les autres synonymes Ilémerobe jaunâtre $n^{\circ} .25$.

Nota. Ces deux dernières espèces ne sont pas bien distincles l'une de l'autre.

\section{Psoque fuscié, P. fasciatus.}

Psocus fasciatus. FAв. Ent. Syst. Suppl: pag. 205. $n^{\circ}$. 4. -PAvz. Faun. Gem. fas. 94. fig. 20. - LAt. Gener. Crust. et Ins. tom. 3. pag. 208.Psocus variegatus. Сoqueb. Illust. Icon. pag. 13. tab. 2. fis. 13? - Encycl. pl. 397. IIL. fig. 5 et 6 ?

Vnyez pour la description et les autres synonymes ilémerobe fascié $\mathbf{n}^{\mathrm{o}}$. 22 .

\section{Psoque pulsatenr, $P$. pulsatorius.}

Psocus pulsatorius. Lat. Gener, Crust. et Ins. tom. 3. pag. 208. - CoQueB. Illust. Icon. pag. 14. tab. 2. fig. 14 et 15. - FАB. Ent. Syst. Suppl. pag. 204. no. 10. - Encycl.pl. 397. III. s. 1 .
Nota. M. Latreille regarde le Psoque fatidique ( P. fatidicus. FA . Ent. Syst. Suppl. pag. 204. $n^{\circ}$. I I ) comme une simple variélé d'àge de celle. espèce.

Foyez pour la description et les autres synoyymes Hémerobe pulsaleur $^{\circ} .3$ i ct Hérnerobe prophète no 33.

On doit probablement rapporter encore an genre Psoque, l'Hémerobe strié n ${ }^{\circ} .18$ et l'ilémerobe pédiculaire $n^{\circ} .52$ de cet ouyrage.

(S. F. cl A. SERV.)

PSQQUILLES, Psoquilloe. Quatrième tribu de la famille des Planipennes, ordre des Névropières, ayant les caractères suivans:

Tête point prolongée antérieurement en manière dc bec ou de trompe. - Premier segment du tionc très-court, le second grand, découvert. - Ailes en toit, peu réticulées, les intérieures plus petiles. - Tarses composés de deux ou trois articles. - Antennes sélacées, d'une dizaine d'aricles. Deux palpes maxillaires saillans, les labiaux point distincts.

Celle tribu nc contient que le genre Psoque. (S. F. et A. SEllv:)

PSYCHE, P syche. Schranck. Lat. inéd. Bomhyx. Fab. Ilub. Oliv. (Encycl.) Tinea. Geory. Hus.

Genre d'insecles dc l'ordre des Lépidoptères, famille des Nocturnes, tribu des Bombycites.

Les caraclères de ce genre n'ayant point encore été posés d'une manière cerlaine, nous nous contenterons de dire qu'il répond à la seconde division du genre Bombyx. LA T. Gener. Crust et Ins. tom. 4. pag. 219. Les espèces cu'il contient ont les anteunes pectinées dans les deux sexes : leurs ailes sont en loit, presque transparentes, peu convertes d'écailles. Les femelles les ont forl courtes, aussi volent-elies peu ou point du tout. Les chenilies ont le corps alongé, seize pattes distinctes el se renferment dans des fourreaux de soie qn'elles traínent avec elles et qu'elles recouvrent de petits morceaux de feuilles, de fétus de paille ou de pelites baguelles de bois sec.

On rapporterit à ce genre le Bombyx de l'Hiéracium no. 114 de ce Diclionnaire ( $B$. hieraciz. FА .Ent.Syst. tom. 3. part. 1.porg. 434 . no. 86.); le Bombjx viciella. Faв. id. pag. $481 . n^{\circ} .231$. Нив. Tinea. tab. 1. fig. 2. Le Bombyx muscella. EAB. id. pag. 482 . $n$ o, 233. Huв. Tinea tab. 2. fig. 8. Le Bombyx vestita. Fab. $i d . p a g .481 . n^{\circ} ; 202$. Tinea plumella. Huв. tab. 1. fig. 7. Le Bombyx

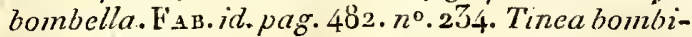
cella. Huв. tab. 1 fig. 4. Le Bombyx pectinella. FA B. id. pag. $482 . \pi 2^{\circ} .255$. Hu в. Tinea. tab. J. fig. 5 , ainsi que les Tinea d'Hubrer, Fuscella. tab. 44. fig. 5o5. Siciella. $a$ ab. 4I. Jig. 280. Plumistrella. tab. 31. fig. 2i3. Graminella. tab. 1. fig. I.. Hirsutelía. tab. 1. fig. 3. Nitidella. tab. 1. fig. 6. 
Penclla. tab. 67. fig. 447. Bombyco a'trita. tab. 16. fig. 58 et 59, et entin le Bombyx morio. $n^{\circ}$. 149 de ce Dictionnaire, pl. 79. fig. 7 et 8 . (B. morio. Faв. id. pag. 445 . no. I 16. Hus. Bomb. tab. 54.fig. 23 a et 232 , et tab. 16. fig. 57.)

Nota. Nous ne garantissons pas que toutes les espèces de M. Hubner soient distinctes les unes des autres. Cet autemr figure des Chenilles de ce genre. Laro. Tin. 1. Bombycif. A. 1. Hirsutella et Nitidella, et Laro. Tin. 1. Bombycif. A. a. Lathyrella et Graminella.

LIMACODE, Limacodes. LAt. inéd. Bonlbyx. Oliv. (Encyct.) Hepialus. FAB. Tortirix. Hus.

Genre d'insectes de l'ordre des Lépidoptères, famille des Noctumes, tribu des Borubycites.

Ce genre dont les caractères n'ont point encore été publiés, répond à une sous-division de la première division des Bombyx. LAT. Gener. Crust. et -Ins. tom. 4. pag. 219 . Ces lépidoptères out les antemues peu ou poini pectinées dans les deux sexes, ils portent leurs ailes en toil. Les cilenilles riont que des mamelons a lieu de paltes membraneuses; la partie inférieure de leur corps est garuie d'une membrane extrêmement souple, susceptible de se plisser et toujuurs enduite d'une liqueur un peu gluante, au moyen de laquelle elles glissent plutôt qu'elles ne marchent sur le plan de position. Letir forne est à peu près celle d'un Cloporte, lenr dos paroît conáposé de truis parties; l'intermédiaire séparée de chacune des autres par une eśpèce de carène, est ovale, un pen pointue aux deux bouts, les deux parties latćrales dépissent un pen les bords du corps proprement dit, et forment une espèce de rebord linsquon regarde ces chenilles en dessous; ces trois divisions sont d'une consistauce beaucoup plus ferme que la peau des chenilles ne l'est ordiuairement. La têle est entièrement rétractile et se cache sous un avancement circulaure de cette espèce de carapace solide dont nous venous de parler. Pour passer à l'état de chrysalide ces chenilles se font une coque qui paroit plutôr membraneuse que soyeuse.

Rapportez à ce genre, ro. le Bombix tortue no. 1 bu. pl. 79. fig. I 2 de cet ouvrage, Hepialus testudo. Haв. Ent. Syst. tom. 3. 2e.part. pag. 7 . $n^{\circ}$. 8. Tortrix testudinana. Huв. Tontric. tab. 26. fig. I64. Mâle et 165 femelie. Lar. tórtric. pseudobombyc. A. fig. 1. 2०. Le Bombix aselle, $n^{\circ} \cdot 361$. Hepialus asellus. HAB. id. $n^{\circ} \cdot 9$. Tortrix asellana. Нив. Tortric. tab. 26. fig. 166 et 167. Larv. tortric. pseudobombyc. $\Lambda$. fig. 2. $3^{\circ}$. Le Bombix cloporte, no. 162. pl. 79. fig. 13. Hepialus. bufo. FAB. $i d . n^{\circ}$. 10 . (S. F.et A. SERT.)

PSYCHODE, Psychoda. Lat. Fab. MeIG. Tipula. Linn. De Gerr. Bibio. Gera. Oliv. (Encycl.)
Genre d'insectes de l'ordre des Diptères, section des Proboseidés, famille des Némocéres, tribu des Tipulaires.

Ce genre fait partie d'un groupe établi dans cette tribn par N. Latreille et qu'il a nommé Culiciformes. Les 'Tanypes, les Corèthres et les Chironomes ont leurs denx pattes antéricures ćloignées des quatre autres et comme insérées sous la tête; leur poitrine est grande et renflée. Les Cératopogons et les Cécidomyies ont leurs ailes couchées sur le corps, les premiers ont en outre les articles dés palpes inégaux, et les secondes n'ont que trois nervures longitudinales aux ailes. (Voyez Tipulaires.)

Antennes filiformes, avancécs, velues, de quinze c i seize articles moniliformes, les deux premiers beaucoup plus gros, les autres globuleux, portés sur des pédicelles très-menus; les derniers un peu plus petits. - Trompe en forme de bec, plus courte que la tête. - Palpes avancés, de ciuatre articles ésaux entr'eux. - - Y eux lunulés. - Point de petits yeux lisses. - Corps très-court. — Ailes fort grandes, en toit, larges, lancéolées, trèsvelues et frangées, sans nervures transversales, en ayaint au moins huit longitudinales dont deux bifides. - Paties assez courtes, placées à une distance presqu'égale les unes des autres; les antérieures insérćes assez avant sous le corselet.

Les espèces qui composent ce genre sont trèspetites, mais remarquables par leurs ailes trèsgraudes en proportion de leur taille; les écailles et les poils qui recouvrent le corselet et les ailes donnent à ces diptères une grande ressemblance a vec de petites I'halènes. Ils fréquentent les lieux humides et sombres et paroissent craindre la lumière, ue marchant que dans l'obscurité, les uns se tiennent près des immondices et dans les lieux d'aisance, d'autres habitent dans les bois parmi les mousses et les plantes marécageuses. Lcurs métamorphoses sont inconnues; cependaut M. Macquart, habitant de Lille, naturaliste instruit et bon observateur, croit arec beaucoup de probabilité que plusieurs vivent en état de larve et de nymphe dans les ordares comme les Scathopses ou dans les mousses humides. On connoîl aujourd'hui une dizaine d'espèces de Psycliodes. toutes d'Europe.

\section{Psycrode phalénoide, P. phalcenoides.}

Psychoda plalcenoides. LAт. Gener. Crust. et Ins. tozi. 4. pag. 251. - MEIG. Dipt. d'Europ. tom. 1. pag. 104. $n^{\circ}$. 1. - FAB. Syst. Antl. pag. $49 \cdot n^{\circ}$. 1. - Encycl. $p l .385$. fig. 29.

Voyez pour la description et les autres syna nymes Bibion phalénoïde $n^{\circ} .12$.

2. Psychode hérissée, P. hirta.

Psychoda hirta. Lat. Gener. Cnust. et Ins, FI2 
tom. 4. pag. 251. - FАB. Syst. Antl. pag. 5o. $\pi^{\circ}$. 2. - Tipula hirla. DE GÉr, Ins. tom. 6. pl.27. fig. 10 et 11. - Encycl. pl.585. fig. Jo.

$V o y^{\prime}$ z pour la description et les autres synoFymes Bibion hérissé no. 15.

Nota. Cette espèce est peut-être la P.ychnoda ocellaris de M. Meigen, mais cet anteur en rapportant à son espece la P’sychode hérissée de M. Iatreille, ne rappelle aucuns des synonymes que l'auteur fraurais donne à la sienne.

$$
\text { (S. F.et A. Serv.) }
$$

PSYLLE, Psylla. Georf. Lat. Chemes. Linn. De Géer. Fab.

Genre d'insectes de l'ordie des Hémiptères, section des Homoptères, famille des Hyménélytres, tribu des Psyllides.

Les Livies qui forment avec ce genre la tribu des Psyllides, s'en distinguent facilement par la brièveté de leurs antenues dont la longueur ne surpasse pas celle du corselet, et qui étant fort grosses depuis leur base jusqu'au milieu, s'amincissent ensuite subitement.

Antennes filiformes, de la longueur du corps, insérées devant les yeux, près de leur bord interne, à articles cylindriques; les deux premiers plus courts et plus épais que les autres, ceux-ci irès-alongés et très-grêles, le dernier bifide à son cxtrémité. - Labre grand, trigone. - Bec trèscourt, presque perpendiculaire, naissant de la poitrine entre les pattes anterieures, cylindroconique, de trois articles, le dernier très-court, conique. - Chaperon court, presque demi-circulaire, convexe, arrondi à sa base, tracé par une ligne arquée. - Yeux souvent proéminens, semi-globuleux. - Troispetits yeux lisses distincls, disposés en triangle; les deux postérieurs placés de chaque côté derrière les yeux, le troisième sur le front, dans son échancrure. - Corselęt composé de deux segmens distincts, l'antérieur beaucoup plus court, transversal, linéaire, le second grand, comme partagé en deux par une ligne transverse, rebordé postérieurement. - Ecusson élevé, marqué de lignes imprimées. - Elytres et ailes grandes, presque de la même consistance et plitcées en toit. - Abdomen conique. Tarière (des femelles) alongée, terminée en pointe et formée par quatre lames qui se réunissent. - Pattes propres à sauter; tarses de deux articles, le dernier un peu plus long, muni de deux crochets, ayant dans leur entre-deux une petite vessie membraneuse.

M. Latreille a restreint ce genre en es ôtañt a vec raison la Paylle du Jonc type de son genre Livie (voyez Psyllides), et il nous semble que le caraclèrẹ d'antennes domé par cet auteur à ces deux genres èxclut également la Psylle du Figuier. Dans celle-ci les articles qui les composent sont grenus, in peu ovales, courts, velus. Dans d'auurcs, tellès que celles du pin et du unélèze les an- tennes nous paroissent avoir beaucoup moins d'arlicles; le corps de ses espèces se couvre d'une matière filamentense analogue à celle qu'on voit sur. les Dorthésies. En général les Psylles nons semblent wériter l'attention des naturalistes; ils reconnoitront infailliblement qu'elles exigent de nouvelles coupes génériques et s'y prêtent. Daus l'élat actuel de ce genre les espèces qui le composent ont une nanière de vivre très-variable, les unes se trouvent sur les végétaux, et y occasionnent quelquefois des galles ou difformités; d'antres habitent sur les écorces des arbres et sur les pierres. 'Toutes ont une nourriture végétale et vivent du suc des feuilles ou de celui des plantes lichenoïdes ou byssoides. Les larves ont ordinairement le corps plat, la tête large et l'abdomen peu pointu postérieurement; les nymplıes ont de plus que celles-ci quatre larges pièces plates qui sont les fourreaux des élytres et des ailes. les insectes parfaits sont munis d'ailes pour lit plupart, ils volent et marchent bien; muis uous pensons que certaines femelles restent presqu'immobiles lorsqu'elles sont fécondées et même que quelques-unes d'entr'ellesn'acquièrent point d'ailes, ou du moins que ce sexe eu est privé dans les prenières générations de l'anrée; il nous a paru qu'il en étoit ainsi de la Psylle du mélèze. Elles déposent leurs $œ u f s$ les unes dans des flocons de ces filets blancs dout nous avons parlé, les autres dans des entailles qu'elles font aux branches. Il est probable que celle des pierres a une autre manière d'en disposer que nous ne conuoissons pas. Les Psylles ont deux ou trois générations pal all. Le nou de ces hémiptères, que Réaumur el De Géer désignent sous celui de faux Pucerons, est un mot grec; c'étoit le nom propre de la Puce.

\section{J. Psycle du Frêue, P. fiaxini.}

Psylla lutea, dorso nigro hiteo vario, elytris pellucidis, marginibus supero ad basim posticoque nigris.

La Psylle du Frêne. Grofr. Ins. Paris. tom I. pag. 486. $n^{\circ}$. 4. - Chermesfiaxini. Lis s. Syst. Nat. 2. 7z9. 15. - FAB. Syst. Rhyngot. pag, 305. $n^{\circ} .15$.

Longueur a lig. $\frac{x}{2}$. Tête jaune, sa partie supérière noire, mêlée d’un peu de jaunc. Yeux lisses d'un ronge-brillant. Corselet jaune; dos du secoud segmeńl et celui da métalborax noirs avec une ligne longiludinale jaune, dorsale, un peu in terrompue et urrégulièrement dilatée dans quelques endroits. Abdnmen noir. Elyltes transparentes, leur bord supérieur uu peu brun vers la base, cette couleurse terminant versle milieu par une assez grande tache noire; botd postérieur noir, celle couleur entrant en crochet à sa parlie supérieure dans le milieu de l'ély!re. Patles jaunes. Cuisses posíérieures en partie noires.

Nota. Les élytres de cette espèce (fermées 
comme ellcs le sont dans le repos) et de la plupart de celles que nous avons sous les yeux, ont leurs deux nervures supérienres bifurquées vers leur extrémité, ces fourches étant courtes, leurs branches ne divergeant pas beancoup l'une de l'uutre, et b nervure quileur sert de pádicule, longue. Les deux premiers articles des antennes sont jaunes, les autres manquent dans notre individu. Geofiroy décrit ces autennes tomme étant fioes et sétacées.

Environs de Paris.

\section{Psylue de l'Aulne, $P$. alni,}

Psylu viridi-flavescens, scutello, clytromm squamâ basilari nervurisque viridlbus.

Psylla alni. Lat. Gen. Cinst. et Tns. tont. 5. pag. $169 . n^{\circ}$. 1. - La.Psylle de l'Aulne. Geofr. Ins. P'aris. tom. I. pag. 486, $\iota^{\circ}, 5 .-$ Chermes alni. Lisn. Syst. Nat. 2. 738 . 10. - DE GÉer, Ins. tont. 3. pag. 148. pl. 10. fig. 8-20.

Longueur 2 lig. D'un vert un peu jaunâtre. Anteunes verdâtres avec l'extrémité des ałticles intermédiaires, el les derniers noirâtres. Ecusson, érailles de la base des élytres et leurs nervurcs d'un vert plus pur. Iemelle.

Celte Psylle se reconvre de filets cotonneux en état de larrve, et vit alors eu société sur l'aulne. Ses élytres sont conformes, sous le rappoit de lat réticulation, à celles de l'espèce précédente.

\section{Psyle du Figuies, P. ficus.}

Psyllu lutea, elytris subpellucidis, nervoris fuscis.

La Psylle du Fignier. Grofr. Ins. Paris. tom. 1. pag. $484 . n^{\circ} \cdot 1 . p l .10$. Jig. 2. - Chemes ficus. LiNi. Syst. Nat. 2. $759.17 .-F_{\text {AB. Syst. Rhyg. }}$ pag. $506 . n^{\circ} .18 .-$ KEaum. Ins. tphl. 5. pl. 29. fig. $17-24$.

Longueur a lig. $\frac{r}{2}$. Janne, plus foncée cn dessus. Antemues tres-velues, paroissant composíes de nenf articles, le premier et le second courts, globuleux, le troisiene longr, cylindrique, les six derniers ovales-globuleux, le dernier brun, torminé par deux petiles suies divcrentes. Mélathorax (peut-être l'écusson) portant à son extrémité supérieure denx pointes en forme d'épines, un peu bruncs ì leur pointe. Elytres demi-transpitrentes, leurs nervures brunes, les deux supérienres bifurquées; ces fourches assez longues, Ji nervure qui sert de pédicule ì la fonrche supérienre fort courte, et les brunches de l'inférieure trèsdivergentes, formant un angle droit.

Nota. Nouts pensons que cette espèce cst la Psylle du Figuier des auicurs, millgré la différence des couleurs, qui peuvent varier da vivant at pzort. (S. E. et A. Senv.) .
PSYLLIDES, Psyllidar. Prenière tribu de la famille des Hyménélytres, section des Homoptères, ordre des Hémiptères. Elle a pour caractere : Antennes composces die dix à onze articles, he dernier terminé par deux soies.

Elle comprend les gucures Psylie et Livie.

\section{LIVIE, Livia. Lat. Dirapha. Illig.}

Genre d'inscctes de l'ordre des Fómiptères, section des Homopières, famille des Hyménélytres, tribu des Psyllides.

Les Psylles se distinguent des Livies par leurs antennes plus longues que le corselet et filiformas.

Antennes dirigćes cu avant, un peu plus courics que le corselet, fort grosses dans leur moitié intéricure, la supérieire cylindrique; composées de clix articles, les trois inférieurs plus grands; le premier conique, le second en forme de fuscalu et le plus grand de tous; le troisieme arrondi, un peu plus gros que les suivans; ceux-ci ģrenus, très-serrés, presqu'égaus; le dernier terminé par deux soies divergentes, dont l'inférieure pis courte. - Bec palroissunt mître de la poürrine. Téte carrée, alongée. - Icux oblongs. - Dezux petits yeux bisses placés clencre les yeux ì réseau, un de chaque côtć. - Corselet griand, peu convexe, ayant son premier seguent trés-petit, court, en carré transversal. - Ecusson triangnlaire et obtus. - Elytres un peu coriacées, denitransparentes, en toit assez aigu; ailes plus courtes que les élyties. - Abdomen conique, son extrémité munie dans les femclles d'une tariète logée culre deux pointes coniqucs. - Paties courtes, grosses, propres à sumber.

Les hivies femelles déposent leurs oufs duns les fleurs du Jouc articulé (Juncus urticulatus) longtemps avant la floraison; lisritation occasionnée par cos oufs et par les jeunes larves qui en éclosent, donne a ces parties un développement triple ou guadruple de cehi qui leur est uaturel. Cette. monstruosité a la lorme d'un épi de palinte gratminée, composé de bules imbriquées; les divisions du cälice se prolorgent eir une especte de barbe. Les ceufs sont peu nombreus, grands, ovales, luisans; ils adacircot aux feuilles an moyen d'un pricicale. hes larves et les nymphes ressemblent a celles des Psylles. Elles demeurent ronslamentrufermées dans les galles du Jonc, se nourissant du sue de la planle : elles rendent pae l'anas ane matiè farincuse tres-blanche. L'insecte parfait s'y tient aussi habituellement. Il sauce. phis voloniess quil ne marche.

On ne comnoîl qu'une espéce de ce gente dâ à M. Latreille.

\section{Livie des Joncs, L. juncorutn.}

Livia rubra, antemis à meaio albis apice nisro, el iris fasco-castanezs.

Liviajuncormul. Lat. Gen. Crhist.et Ins. Gom. J. 
pag. 1,0. no. 1. - Psilla juncorum. LAT. Hist. zut. des Fourmis, pag. 322. pl. 12. fig. 3.

Longueur I ligg. $\frac{1}{2}$. Antenues ayant leurs trois premiers articles d'un ronge vif, les cing intermédiaires blanc's, les ncuviene el dixième noirs, ainsi que los deux soies qui termiment celui-ci. Tête ef corselet ronges, la première ayant dans son inilieu un sillon longiludinal profond. Son bord antírieur pûle, étılıncré. On voil une tache d'un rouge plus prononcé derrière les yeux. Dessous de la tête noiràtre, poilline brune. Elytres d'un brun-châtlain, un peu lnisantes. Abdouen rougểire à sa base, d'uu jaune pâle dans le reste de son élendue. Pattes d'un blanc-jaunátre:

Des environs de Paris. (S. K. et A. SERv.)

PTEROCIILE, Pterochilus. Genre d'insectes Hyránoptères, de la tritun des Guêpiares, établi par M. Kligg et adopté par Putzer duns sat révision. ll répond i la seconde division de celui d'Odyà̀re de M. Latreille. (Vopez ce mot.) Le Genre l'érochile a pour type la tespa phalerata. Paxz. Fam. Gem. fás. 47. fig. 21. Plerochilus phaleratus. PAaz. révis.

$$
\text { (S. H. et } \dot{A} \text {. Serv.) }
$$

PTERODIPLES ou DUPLICIPENNES. Dans sa Zoologie analytique M. Duméril désigne sous ce nom une famille d'Hynénoptères a laquelle il donne pour caractèes : abdonlen pédiculé; lèsre inférieure plus longue que les mandabu!es; antennes, brisées. Cette finille renlerine les genres Guepe et Masare. (S. F. et A. Serv.)

ptéromale, Pteromalus. Swfo. Lat. Dalm. Diplolepis. Fas. Cynips. (Urv. (Enc;cl.)

Genre d'inseetes de l'ordre des Hy nénoptères, section des 'lérébrans, famille des P'upivores, tribu des Chalcidites.

Ce genre a été créé par M. Swedlerus et adopté par MW. Latreille et Da!man. Les Leucopsis et les Chalcis se distinguent des atutres Chalcidites par leur's janbes postérieures très-arquées. Les grenres Eurytorne, Bisocampe, Eulophe, Cićonywe et Spalangie ont le segment antérieur du corselet spacienx, formé en carré transversal on en triansle tronqué ì sa pointe. Les Encyrtes ont les mananbules terminées en pointe et au plus bidentées. Les Périlampes sont reconnoissables par la massue de lenrs antennes courte, en fuseau, et par lcurs mandibules forlement deutées.

Antennes filiformes, de longueur moyenne; leur premier atticle mince, cylindrique : les autres presqu'égaux entr'eux, ne formant point de znassue. - Mandibules fortes, presque carrées, leurs dentelures petites, peu appürentes. - Palpos fort courts. - Téte noyenue, min peu déprimée entre la base des anlennes et les yeux lissess - Trois yeux lisses pelils, plucés en ligne courbe snr le bord antéricur du verlcx. - Corps assez lony pour sa grosseur. - Segment antérient du corselet issez ćlroil, ne formant en devant qu'un rebord transverso-linćatire. - Ecrusson petit. - Ailes supérientes n'ayant qu'une seule nerrure sensible, lacquelle parlant de la base de l'aile sans toncher an bord exiérieur se recourbe ensuite pour rejoindre ce bord qu'elie suit presque passé le rnilieu, et émet intćrieurenent avant de disparvitre mu ratmeall assez long, recourbé en crochet; ailes inférienres ayant unc nerrure semblable à celle des supérieures, mais qui n'éwet point de rumeau. - Abdomen assez long , presque cordiforme, poinlo à son exlrénité quai est relevée dins les femelies; latière (de'colles(i) presqu'entièrement cachée dans la cavité abdoninale. - Pattes assez fortes; cuisses simples.

Ce yente dont le nom vient de denx mots grecs qui sigurnifient : ailes délicates, est composé d'espèces très-petilés, ayant ordinairement des couleurs méta liques. M. Dilman dans un ouvrage quí a pont' titre: Insectes de la famille des Ptéromaliens, dontie un catalogne de soixante-dixneuf espèces sans en décrire àcune. Il parcit que dias leur premier fiat ces petits Clalcidiles vivent anx dépens de diliérentes larres, surtoul de celles des habilans naturels des galles.

\section{Préromate quadrille, $P$. quadrum:}

Pteromalis quadrum. Ds L. Ins. de la famille des Ptéromal. - Diplolepis quadrum. Faв. Syst. Piez. pag. 152. $n^{\circ}$ : 16.

Voy.z pour les autres synonymes, en retrincliant celoi de Geoffioy, Cymips quadri!le, no. I I de ce Diclionnaire. Nous atjoulerous á la description que la base de l'abdomen est de couleur testacce-ferngineuse. ( S. F. et A. Serv.)

PTERONE, Pteronns. Dins son onvrage intilulé : Nouvelle Méthode de clusser les Hyménoptères, Ml. Jurine éluılit ce genre en le divisant en trois familles; la prenière est séparée par lui en quatre sections, dont la premicre ne contient que des femelles et ce sont celles des mâles qui composent seuls la troisieme section. Ces deux sections répondent au geure Lophyre de M. Latreile. Il faut répéter la même chose pour la seconde et.la quatrième section. C'est le genre Cladie tel que nous l'adoptous avec M. Lalreile. I.es deux autres fanilles des Ptérones correspondent an geure Prisliphore. Saroir la troisième à noire première division et la seconde à notre deuxième division. Voyez Pristiphore.

(S. F. el $\Lambda$. Senv.)

PTÉROPHORE, Pterophorns. Geoff. FaB. I.at. Phalana. (Alucita.) Lisn. Alucita. Hub. Papillon-i ipule. De GÉER.

Genre d'insectes de l'ordıe des Lépidoptères, 


\section{P $\mathrm{T} E$}

Pamille des Nocturnes, tribu des Ptérophorites ou Fissipennes.

Celte tribu ne eomprend que deus genres, Plérophore et Orréode; ce dernier se distingue facilement par ses palpes sensiblentent plus longs que la têtc, avancés et dont le second article est très-garui d'écailles tandis que le troisic̀me est presque nu.

Antennes simples, sétaećes. - Langue alongée, distiuete. - Palpes pas plus longs que la tête, rceourbés dès leur naissance, entièrement et uniforméunent garnis de petiles écailles. Ailes eomposées de divisions linéaires, muaics sur les côtés de longs poils ressemblant aux barbules des pennes des oiseaux; ailes supérieures ayant deux divisions plus on moins profondes, les inférieures ell ayant trois. - Pattes très-épincuses, longucs et. uninces. - Chenilles velues, à seize pattes. -Chrysalides nues, suspendues par un fil.

Les Ptérophores dont le nom vient de deux mots grecs qui signifient : porte-plime, volent pesamment, ne sélèrent guère au-dessis des plantes et font rarement usage de leurs ailes. On en connoit une quinzilue d'espèees presque loules européennes. Ces petits lépidoplères trèsremarciuables par leurs ailes digitées se tiennent de préférenee sur les berbes des prairies et sur l'ortie.

\section{r. Pténophone pentadaetyle, $P$. pentadac- tylus.}

Pterophorus albus, alis superioribus ultrà medium bifdis; divisionibus apice recurvis; inferiorum divisionibus prinuâ secundâque usquè ad tertiam. longiludinis parten coadunatis, tertiâ libcrâ.

Pterophorus pentadactylus. F. En. Syst. tom. 5. purt. 2. pug. 348. $n^{\circ}$. 13.-LAт. Gener. Crust. et Ins. tom. 4. pag. 234. - Le Plérophore blanc. Groff. Ins. Pans. tom. 2.pag. 91. $n^{\circ}$. I. w). $1 \mathrm{~J}$. fig. 6. - Plualana (Alucita) pentadactyla. Lixм. Syst. Nat. 2. 900. $45 \mathrm{~g}$. - Huв. Larv. alucit. communif. A. a. fig. I. La chenille. RÉsuM. Ins. tom. I. pt. 20.fig. I-6. - Encycl. pl.94. Ptéroph. fig. 5.

Envergure $8 \mathrm{lig}$. Entièrement d'un heau blanesoyenx. Divisions des ailes supérieures séparćes jusqu'au-delà du milieu, reeourbées à leur extrémitć. Les deux premières des inférieures réunies seulement jusqu'au tiers de la longueur de l'aile, la troisième entic̀rement libre.

Chenille rerte ayant une liggne latérale rosée, bordée de hlincliâtre et guelques poils noirs épars. Vil sur le liseron. Chrysalide verte, velue avec des lignes de points un peit rougeâlres; elle est fixée $\mathrm{f}^{\mathrm{a}}$ sa purtie postérienre sur nu petit mamelon de soie, elle a en outre une ceinture qृui.lui soutient le milieu du corps.

\section{$\mathrm{P} \mathrm{TE}$}

Commun aux environs de Paris sur lortie.

2. Ptérophore piliodaetyle, $P$. pílodartylas.

Pierophorus rufus, alis superioribus ferè ad medium usquè bifidis, dibisione extenuâ apice recuvva $\vec{a}$; injerioribers ;iscis, divisionibus prima secundique usrace ulichian longitidinis partem,

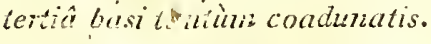

Alucita ptitodaciyla. Tive. Alucit. tom. 3. fig. 16 , et lub. 5.jg. 25 .

Envergure 8 lig. Ronssître. Divisions des ailes supćrieures ś́pacées presque jnsqu'au milieu, l'estúlieure "ecouthée à son cxlrémite; ailes inférienres bruves, leurs doux prentères divisions réunies senlement juscru'au tiers de l'aile, la troisiéme l'élant un pea à sa base.

Euvirus de Paris.

3. PтÉROPRORE rhododaetyle, $\boldsymbol{P}$. rhododactyhus.

Pteroptiorus testaceo-fernugineus, alis superioribus albo bistrigatis, apice bifidis, divisionibus planis tertiam aloe partem vix attingentilus, ad strigam secundan teminatis; inferio rum divisionzbus priniâ secundâque usquè ad medium, tertiâ basi tantìm coadunatis.

Pterophorus rhododactylus. FAB. Entom. Syst. tonl. 3. part. 2. pag: 347. $n^{\circ}$. 7. - Alucitu thododactyla. Нив. Alucit. tab. 2. fig. 8. Law. alucit. conumunif. B. a. $n^{\circ}$. 1. a. b.

Envergure 7 à $8 \mathrm{lig}$. Testaeé-ferrugineux. Ailes supérieures marquées de deux lignes lransverses, blanches, la première plaeće vers le tiers supérieur de liaile, la seeonde aux deux tiers. Divisions de ces ailes n'atleinnant pas le milieu de leur longueur et liuissant a la seconde ligne blanehe, ces deux divisions planes à leur extrénité, la supérieure ayanı une troisième pelite ligne Llan. ehe vers le bout. Première et seconte divisions des inférieures réunies jusqu'au milieu de l'aile, lis troisième l'élant un peu à sa base ; eelle-ci courte et portant avant son extrémité parmi sa frange, un faisceau de poils ferrugineux plus gros que les autres terminés en spatule. Janibes et tarses annelés de blane.

Chenille verte à sa partie postérieure; l'antérieure a une teintc rosée et poile une ligue brune. dorsale. Vit sur les rosiers. Chrysalide verte, ил peu velue sur le dos. L'élui gui contient-les patles défuasse les fourtcaux des ailes et n'est point appliqué exactemest contre le veutre.

Assez rare aux cnvirons de Paris.

4. Ptéroriore monodactyle, P. monodictylus.

Pterophorus testaceo-fuscus, alis superiorio 
bus apice bifidis, divisionibus planis tertiam alu partem vix atiingentibus, interiori apice subacuto; infiriorum dissionibus primâ secundique usqué ad tertiam alos pariem coadumals, teríầ liberâ.

Pteroplyoris monodactylus. FАв. Ent. Syst. tom. 5. pag. 345. $2^{\circ}$. 1. - Pho. race alucila

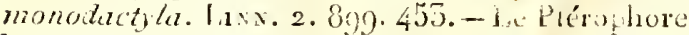
brut. Geufr. Ins. Paris. tom. 2. plag. 92, $7^{\circ} .5$. - RÉun. Ins. toill. 1. pl. 20. fig. 7-18. Encycl. pl. 94. Ptíroph. fior. 2.

Envergure 7 ligg. Enlic̀rement d'un testacébrun, Diviouns des ailés supérieutes n’alleigrant que le tiers de leu: longueur, leur extrómilé plane, lintérienre u'ayautqu'une seule pointe. P'remiére el seconde divisions les inférieures réunies presgue jusqu'à la moilić de l'aile, la troisième entièrement libre.

Suivanl Réaumur la elsenille vit sur le liseron. Elle est d'un rert blancháne aveedes poils médiocrement longs, placés au moins sur quatre rangs de lubereules. La chrysilide est presqu'anssi velue que la clenilie, l'inserle parficil en sort a bout de quinze jours it peu prè. Il se serl pou de ses janbes postérieures et les tient plus sonvent ćlendues le long des côtés de l'abdomen et quíl que$f$ is dessous; alors il les croise el elles semblent lii former une sorte de queue. Les tivisions de ses aliles tant inférieures que supérieures rentrent tonies à létal de repos daus la cavilé de lat division extériente des preanieres ailey, ce qui féroil croire dans ces mounens que l'insecien'a que deux ailes el qu'elles sunl sans divisions.

Des euvirons de Pairs.

\section{Pínophore didactyle, $P$, diduclylus.}

Plerophorus fuscus, alis supcroribus atho lineatis ad medium usquè bifilts, dowsomibus planis, interrori apice emargmatà; infirionm aivisionihus primâ secundaque hon usquì meJian, iertiâ ad quartum usquè alo longitudinis partem coudanatis.

Pierophorus didactylus. FA . Ent. Syst. tom. 3.

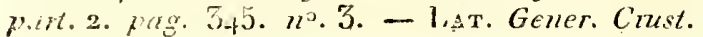
't hns. tom. 4.pag. 254. - Phalama (Alacila) didactyla. Lixs. Syst. Nat. 2. 89g. 454. - DE f́Eer, flis. tom. 2. pag. 260. fl. 4. fig. 1. Uinclci.pl. 94. Ptéroph. fig. 1.

Envergnre 6 lig. D'un brun-ferrugineux. Ailes supérieufes ayant des lignes et des points blanes; I crour, leu: extrénité plane; celle de la division micriente cohancré. l'remière el sfeonde divispons des ailes infrienres n'élabl pas ront-it-fait ronies jusqu'a nilieu; la trossiène l'étant jusgu'an quarl de la longucur de l'aile. Jambes et tarses annelés de blanc.
Chenille d'un vert-clair avee une ligne dorsals d'ure nuance plus obscire, a ecomparyce de chaque côté d’une bande blänchâtre. 'Tềte un peu jaunatre, les segmens du corps (eeux du milieú atu moins) portanl chacun dix tubercules noirâres garnis d'aigretles de prils blanes; pour se translormer en chrysalide, elle lapisse de soie l'eudroit ò clle veut s'arrêter et s'arcroche par les palles de derriçe. Clrysalide hérissée de pointes blanches, spiniformes; elle a deux lignes blanchâtres sul le dos un peu élevées en forme d'arêtes, portant une suile de tubercules irrégrliers, garnis ebacun de quatre épines. Son venire est armé de petits crocliets bruns, nombreux, au noyen descucls elle se úre sur la couche de soie dont nous venons de pit!!er. Celte chenille vit sur la benvite (Geam rivale). Elle en mange les lleurs et le calice.

Environs de Puris. (S. F. et A. Serv.)

P'TEROPIORI'TES ou FISSIPENNES, P'terophorites. Huiliene ribu de la fimille des Noeturues, orulre des lépidoplères. Ses caractéres solli:

Les quatre ailes on deux au moins, refendues dans leur longuenr en manière de branclues ou de doints, barbues sur leur bord et resseublant à des plumes.

Les chenilles de ces lépidoplères ont seize palles, vivent de feuilles el de fleurs, sans se construire de fourieaux.

Celle lribu conlient les gentes Ptérophore et Ornéode. Voyez ces mots.

(S. F. et A. Serv.)

PTÉROSTIQUE, Pterostichus. Genre de Coléopleres funé pal M. Bonelii (Obsew. entom. Mrín. de l'scad. de Turin), appartenant ì la rribu des Calrabigues, et ofluant pour earactères: langrnelle ariondie. Palpes issez épais, le quatrieine des maxilaires excérieurs plus long que le précédent, cylindrique, àminci a sa basse. Auns ayant un pli lompiludinal ílevé (dans les mâles) quelqueluis, mais rarement, transversal ou remplasé pü nue impressiou. Elytres souvent échancrées oblinuement, ayant trois points eufoneés ou plus, rangés au moins en deux séries. Les $\mathrm{Ca}$ ribus fasciato punctatus et oblongo-punctatus (voyez Fncycl. Carabe points oblougs no. I12) de Fubricius, ansi que le Curabus Jurine do Punzer, sont de ce šenre.

\section{(S. F. et A. SERv.)}

PTERYGIBRANCIIES, Pteryibranchia. LA

C'est, dans la mélhode de M. Laltreille (Règne animal de Cuvier, tom. 5), la troisième section de l'ordie des Crustacés isoprodes; ses caractères sont d'avoir des branelies sous la queue, soit libres et en fürme d'écailles vasculaires on de boutses meanbrancuses, tantôt nues, lantôt recou- 
vertes par dcs lames, soil renfermites dans des écailles en recouvrement. .

Ces Crustacés formoieut, dans les ouvrages antérieurs de M. Latreille, un ordre particulier, celui des Tétracères, placé d'abord ì la lête de la classe des insectes, ct ensuite dans celle des Arachnides, dont il étoit le premier : ils comprennerit la plus grande partie du genre Oniscus de Liliné.

Cetle section est divisée ainsi qu'il suit. Nous domnerons quelques détails sur chacun des genres qu'elle renferine, ct qui n'ont pas été traités à leur letire daus ce Dictionnaire. .

\section{Quatre antennes très-apparentes.}

A. Extrémité postéricure du corps offrant de cliag̣ne côté une nageoire formée de deux feuillets portés sur un pédicule commun; écailles sous-caudales se recouvrant graduellement. Les genres:

CYMOTIீOÉ, Ċynothoa. FA3. DALD. Bosc. Iat. Lam. Léaca. Oniscus. Linn. Pall. Asellus. Oirv. Lam.

Iis ont la queue composée de six segmens; les pieds insérés aux boods latéraux du trone, terminés par un crochet très-fort. Plusieurs segmeus du tronc ont, de chaque côté, uṇe division en forme d'articlc. M. Léach a formé aves le genre Cymothoa de Fabricius, et tous cellx qui en ont été extraits depuis, sa famille des Cyzuothoadées, qu'il a divisée en plusieurs stirpes, races ou soustamilles. Le peu d'ćtendue que nous sommes obligés de donner ì cet article ne nous permet pas de donner de délails sur tous les genres que Léach a formés dinns celte famille, et qui nont pas été conservés par M. Latreille. Nous présentons ici le genre Cymothoé tel qu'il est adopté par ce savant (Règ. aninz:), qui y réunit les genres Limnoria, Eurydice et Aga de Léach.

Les Cymothoés, vulgaircment nommés Poux de mer, QEstres, ou Asiles de poissons, sont des Crustucés voraces et parasiles; ils sc fixent sur divers poissons, et semblent affecter de próférence certaines cspèces. On les rcucontre près des ouies, aix lèvres, à l'anus, et dans l'intérienr même de la boucle: Aristoie (Hist. des anim.) a en connoissance des Cymothna. Les poissons, dil-il, sont atlagués de poux lans la mor; inais ceux - ci ne vienment pas da poisson même, c'cst la buurbe "qui les produit. Ils ressemblent pour la forme aux cloportes, à l'exception quils ont une queue large, ete.

Les priucipales cspèces sont :

ı. Cy мотнов asile, C. asilus.

Capite postice trilobo; segmentis posticis, ultimo excepto, retrorsum arcuatis, sublunatis; isto semielliptico.

Hist. Nat. Ins. Tome $\boldsymbol{X}$.
Cymothoa asilus. FAB. Suppl. Ent. Syst. pag. 305. - Cymothoi asile. M.atr. Hzst. natur. des Crust. et des Ins. tom. 7. pag. 25. pl. 58. fig. 9 et 10. - Gen. Crust. et Ins. tont. 1. pag. 66. Rondelet, Hist. des Poissons, liv. 18 , chap. 26. Voyez pour la suite de la synonymie et la description le ${ }^{\circ} .5$ de l'article Aselle de ce Dictionnaire, el pour les autres espc̀ces les $\mathbf{n}^{0 s} .2,3,4$, 6 et ir du même article.

\section{SPHÉROME, Spharoma. Voyez ce mot.}

B. Extrémité postérieure du corps sans nageoires latérales. Les genrẹ :

IDO'TÉE, Idoted. FA⿱ LAT. LAM. LÉACH. Rrss. Oniscus. Lrnn. Pald. Squilla. DE GÉer. Asellus. Oriv. Lam. Cymo:hoa. Fab. Dald. Physodes. DumÉr. Pallasius, Stenosome. Itíacr.

Ces Crustacés avoient été placés par Linuans el Pallas dans le gense des Cloportes. De Géer les rangeoit ivec les Squilles, et Olivier avec les Aselles. Fabricius, qui les avoit d'abord placés avec les Cymothoús, les en a séparés et en a fait le genre qui cst généralementa adopté aujourd'hui, et dont nous allons domer les caraclères : antennes intermédiaircs insérécs un peu plus hant que les latéralcs, beaucoup plus petites, filiformes, composées de quitre articles; antennes latérales sétacées, médiocrcment alongées, avec un pédonculc de quatre articles et lcur extrémité multiarticulée. Tête de la largeur du corps, ou un peu plus étroite, presque carrée. Deux yeux ronds, composés, peu saillans. Bonche petite, formíe d'un labre, de denx mandibules, de deux paires de mâchoircs ot de deux pieds-mâchoircs foliacés de cinq arlicles qui remplacent par leur basc la lèvre inférieure; les sept anneaux du corps transversaux, presqu'éganx et unis, ordinairement marqués de chaque côté d'une impression lougitudiuale qui, avec sa correspondante, divise le corps en trois parties comme dans le genre fossile des Trilobites. Queue très-grande, viarticuléc, sans appcndices terminanx, rccouvrant les branchics et les lames qui protègent celles-ci. Pieds moyens à peu près égaux entr'eux, dirigés les premicrs en avant, et les derniers en arrière.

De Géer, qui a donné unè description délaillée de l'Idotée entomon, a vu sous sa queue, et daus un système d'organes assez compliqué, deux filets dont il ne connuît pas les fonctions. M. Latreilie a reconno que ce sont des appendices des organcs générateurs uâles. De Gécr à vu aussi sous le preinier anneau de la queue d'un individu du même scxe, denx pièccs ovales, membrancuses, manquant dans les femelles, et d'où il a vu sorlir, apris la mort de l'animal, unc matière blancté en tortilée comme du fil o el qu'il sọpçonue être la liqueur séminale.

Les Idotées se trouvent en abondance dans la G.g 
mer, où elles nagent très-bien à l'aide de lears partes et de leurs branchies, qui sont mobiles d'avant en arricre lorsque les limes qui les recouvrent sont écartées. Ellles se nourrissent de corps morls, et on assure qu'clles rongent et détruisent à la longue les filets des pêcheurs.

M. Latreille divise ce genre ainsi qu'il suit:

1. Cótés du second segment et des suivuns toujours aivisés par une ligne imprimée, ou même fendue postériemrement, cette ligne s'étendunt dans tonte la longueur do ces segmens ou de leur plus grand nombre; antennes íatérales plus courles que lu tête et le tronc, les intermédiaires presqu'unssi longues au inoins que les deux premers articles des lutérales; corpssouvent ovale, oblong; griffes temmnant les pattes, de longueurmoyenne.

a. Antenues intermédiaires presqu'aussi longues que les latćrales; tronc en ovale tronqué; fausses articulations latélales de ses segmens trèssaillantes, trianguluires; têtlc incisée sụr les côtés.

1. Iроте́ entomon, I. entomon. Lit. Hist. natur. des Crust. et des Tns. tomi. 6. pag. $36 \mathrm{I}$. pl. 58. fig. 2. 3. Voyez pour la description et la synonymie l'urticle Aselle de ce Dictionnaire, $11^{\circ} \cdot 7 \cdot$

M. Latreille a observé que cetle espèce est bien diflérente dc celle que Léach a décrite sous le mêne now. Trans. Linn. tom. XI. pag. 364 .

b. Antennes intermédiaires guère plus longues gue les denx prenniers articles des latérules, ou yuc la mọtié environ de lcur pédoncule; rronc alongé relativement à sa largeur, en carré long ou elliptique, ct tronqué aux.denx bouts; fausses arliculations de ses segunens peu saillantes, en carré long ou linćaiıes.

* Longuear des antennes la térales ne surpassant guc̀re cêlle de la tête et des deux premiers seginens.

2. IDotéE pélagique, I. pelagica. LÉACH, Trans. Soc. Linn. toin. XI. pag. 365.

Corps linéaire ovale; queue arrondie avec une dent très-peu apparente dans son milieu; antennes ayant le tiers de la longueur du corps; tête échaucrée en devant.

De la mer d'Ecosse.

* Longueur des antennes surpassant cclle de la tête et des deux premiers seguens du corps.

3. IротÉe marine, I. marina. Voyez pour la description et la synonymie le ${ }^{\circ} .8$, ar. Asêtre de ce Dictionnaire.

2. Côtés du second ${ }^{0}$ egment dutrone et des sui"'snis, soit à ậlvisions latérales très-courtes, n'oc- cupant qu'une partie de leur longueur, soit entière; antennes latérales aussi longurues au moins que la tête et le tronic; les intermédicirés de la longueur du pédoncule des précédentes (corps toujours linéaire; griffes des deux pattes antérieures an moins, longues et fortes).

a. Secoud segment du corps fe les suivans offrant l'apparence d'une petite articulalion. Les especes de cette division forment le geare Sténosome de Léach.

4. IDOTÉE filiforme, I. filiformis. Gronov.Zooph. tab. 17. fig. 3. - Bas'rer. Opusc. sabs. tom. 2. tab. 13. fig. 2. Cymothoa chcípes? FAB. - Idotée armie. Latr. Hist. natur. des Crust. et des Ins. tom. 6. pag. 372. - Stenosoma lineare. Léacr. Voyez pour la description et la suite de la synonymie le no. 10, art. Aselle de ce Dictionnarre.

b. Segment du corps sans divisions latérales.

5. Idotŕ hectique, I. hectica. Idotée hétique: LAt. Hist. nat. des Crust. et des Ins, tom. 6. pag. 371. - Idotea viridisssima. Riss. Hist. nnt. des Crust. de Nice, pl. 3. fig. 8. Voyez pour la suite de la synonymie ét la descriptien le.no. 13, art. Aselle de ce Dictionnaire.

ASELIE; Asellus. Geoff. Oliv. Lam. Latr. Léach. Oniscus. Linn. Squilla. De Géer. Cymothoa. Daldorf. Idotea. '.а. Physodes. Cuvier. Duméril.

Ce genre, tel qu'il est adopté par M. Latreille (Règri. arim. de Cus. tom.5.pag. 56.), a pour cariclères essentiels : deux poinles fourcbues ou denx appendices en forme de tubercules au biont de la queue. Lcs deux écailles exiérieures recouvrant les branchies arrondies et fixées seulenent à leur base.

L'espèce la plus commune est l'Asset.le ORDTnaine, $A$. vulgaris. Tat. Hist. nat. des Crust.et des Ins. tom. 6. pag. 359. - Gener. Crust. et Ins. tom. 1. pag. 63. - Idotea aquatica. FAB. Suppl. Entom. Syst. pag. 3o3. - Entomon hieroglypihicum. Krein. Dob. fig. 5. Voyez pour les généralités l'art. Asecle de ce Dictionnaire, et pour la syuonymie et la description de l'espèce que nous citorons, le no. I du mćme article.

M. Latreillc réunit aux Asclles les genres que M. Léach a décrits sous les noms de Janira et Jara; le premier se distimgue des Aselles par les crochets bifides des tarses, par les antcnnes intermídiaires plus courtes que le dernier article des extérieures et par des ycux plus gros et moins distans. Le second genre en diffère par la présence de deux tubercutes qui remplacent les filets bifides de l'extrćnité du corps des Asell's, et par l'absence de rcuflement ou de mains aux pattes. antérieures. Les individus qui composent ces deux 


\section{P T E}

genres se rencontrent dans la mer, sur les fucus ou sous des pierres.

II. Antennes intermédiaires peu ou point apparentes.' Les genres :

LIGIE, Ligia. Fab. Lat. Lamk. Léach. Oniscus. Linn. Osiv. Asellus. Oliv.

Antennes extćrieures assez grandes, arguleuses, très-rapprochées à leur base, formées de six articles, dont les deux premiers fort courts el les trois derniers alongés; le terminal plus grand que les autres, et composé lui-même de petils articles nombreux. Antennes intermédiaires très-petites, for mées de deux arlicles comprimés, dont le dernier est obtus. Pieds-mâcboires membraneux, comprimés, concaves, divisés en six articles. Tête carrée, plus large que longue. Yeux composés, assez grands, ronds. Corps alongé, ovafaire, convexe en dessus, très -semblable à celui des Cloportes, composé de treize segmens transrersuux, pointus en arrière de chaque côlé, dont les sept premiers soul pédigères, et dont les six derniers constituent la quene; le treizième presque carré, avec le bord postérient arrondi au milieu el échancré latéralement, opour l'arliculation des appendices. Les quatorze pied's insérés sur les côtés du corps, ayant leur premier article dirigé de dehors en dedans, très-long, et folmant avec le second, qui se porte de dedans en delors, un angle aigu; tous étant terminés par un article écailleux, pointu au bout, et pourvu d'une pelite dent' en dessus. Brancluies en forme de lames triangrulaires, placées sous l'abdomen ou lí queue, au nombre de six paires.

Ce. Crustacés sont communs sur les bords de la mer; ils grimpent à la mavière des Cloportes sur Les rochers du rivage el sur d'autres endroits humides. Ils replient promptement leurs paltes et se laissent tombei si on clierche à les prendre.

On peut diviser ce genre ainsi qu'il suit :

* Antennes ot appendices caudales presque de la longueur du corps.

\section{Ligí italique, L. italica.}

L. antennis corporis ferè longitudine, articulo ultimo circiter è septeindecin aliis minimis conferto; stylis caudde exsertis aqualibus; pedunculis angustis, elongatis. LA T. Gen. Crust.et Ins. tom. 1. pag. 67. - Hist. nat. des Crust. et des Ins. tom. 7. pag. 3r. - Ligia italica. FAB. Suppl. Entom. Syst. pag. 302.

Cetle espèce se trouve sur les bords de la Méditerranée, en Iralie.

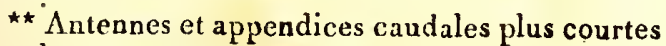
que le corps.

2. Ligre océanique, L. oceanica. Far. Suppl.
Entom. Syst. pag. Jó - T.Aт. Gen. Ciust. et" Ins. tom. 1. pag. Ј. - Hist. nat. des Crust. et des Ins. tom. 7. pag. 51. Voyez pour da suite de la synonymie le $n^{\circ} .15$, article Cloporte de ce Dictionnaire.

3. Ligre cloportide, L. oniscides. Lat. Gen. Crust. et Ins. tom. I. pag. 69. -Cymothoa assimilis. F $\mathrm{AB}$. Entom. Syst. tom. 2. pag. 510. Voyez pour la synonymie et la description lo ${ }^{\circ}{ }^{\circ} .15$, article AsEL de de Dictioinaire.

\section{PIIILOSCIE, Philoscia. Voyez ce mot.}

CLOPORTE, Oniscus. Ce genre, tel qu'il est. adopté (Règne anim. tom. 3. pag. 57.), a pour caractères essentiels: antennes latćrales de huit articles, ayant la base recouverte par les bords latéraux de la tête. Appendices de la queue d'inégale longueur, les deux latéraux étant beaucoup plus grands. Voy pour les détails historiques et les espèces le noot Cloporte de ce Dictionnaire.

\section{PORCELlion, Porcellio. Voyez ce mot.}

ARMADILLE, Armadillo. Ce genre a été établi par N. Latreille, qui lui a donné pour caractèrcs dislinctifs : quatre antennes, dont les intermédiaires très-petites, à peine distinctes, et dont les extérienres ou latérales sétacées de sept articles, insérées dans une fossette relevée sur les bords; appendices latéraux du bord de la queue ne faisant point de saillie, terminés par un arlicle triııngulaire; corps se roulant en boule.

M. Cuvier (Journal d'Hist. nat. tom. 2.) a désigné sous le même nom, un genre d'iusectes myriapodes, appelé depuis Glomeris par M. Latreille. (Voyez ce mot à la suite de l'article PoLxpìir de ce Dictionnaire. ) Les Armadilles de M. Latreille ont de grands rapports avec les Cloportes et les Porcellions. Leurs organes respi'ratoires sont renfermés dans la duplicature de petites écailles branchiales et supérieures du dessous de leur quene, présentant une rangée de trois à quatre petites ouvertures pour l'introduction de l'air. C'est aussi sous des valves de la partie inférieure du corps que ces animanx conservent leurs œufs qui y éclosent. Leuirs mœurs sont tì̀s-analogues à celles dés Cloportẹs. Ils habitent comme eux des lieux liumides, tels que les caves, les trous de murailles, etc. On les rencontre dans toutes les saisons; leur dćunarche est très-lente. Ils passent l'hiver engourdis.

J. Armádille commune; $A$. vulgaris. Lat. Gen. Crust. et Ins. tom. J. pag. 71. - Hist. nut. des Crust. et des Ins. tom. 7. pag. 48. - Oniscus armadillo. Cuv. Journ. d'Hist. nat. tom, 2. pag. 23. pl. 26. fig. 14. 15. - Sumz. Hist. des Ins. tab. 5o. fig. 15. Voyez pour la suite de la 
synonymie et la description le no. 2 , article CroPORTE de ce Dictionnarre. Les nos. 3-7 appartiennent aussi au prême genre.

\section{Antennes nulles. Le genre:}

BOPYRE, Bopyrus. Lat. MIonoculus. Fab. Les Bopyres s'éloignent de tous les genies des Isopodes par le dófaut d'antennes, d'organes de la vue et de mandibules; leur corps est en ovale conrt, réiréci et terminé en pointe à son extrémité postérieure, presque prembraneux, trèsplat, avec un rebord inferieur portant les pieds, et au-dessons d'eux de pelites lames nucmbraneuses, dont les deux dervieres alongées. Les piceds sont très-petils, contournés; le dessous de la quene esı garui de deux rangées de petits feuillets ciliı́s. Sun extrémité n'à point d'atppendices.

La femelle porte sous son ventre une prodigieuse quantité d'œufs qu'elle dúpose daus les lieux habités par les Palémons. L'antre sexe n'it pas été encore positivement recounu; on a cepeudant regardé comme le nâte un très-petit Bopyre qui se rencontre sonven! près de la queue cles individus chargés d'oufs. De même que les Cymothoés auxquels ils resseublent à quelques égards, les Bopyres sont parasiles : ils vivent cachés sous un des côtés antérieurs du test de quelques Constacés, el surtout de la Crevette commune ou Palémon-squnlle; où ils donnent lieu à uue tumeur très-remarçuable qui s'ćlève en forme de tubercule ou de petite loupe. Les pêcheurs de la Mauche sout imbus, ì l'égard de ces animanx, d'un préjugé absurde; ils cröient que les Soles et quelques espèees de Pleuronectes sont engendrées par les Palémons, et ils preunent les Bopyres ponr ces poissons encore tort jeunes. Deslandes avoit consacré ce préjugé dans un liémoire lu à l'Académie des seienees en 1722; mais Fougeroux de Bondaroy l'a complétement réfuté en $: 77^{2}$ dans un Mémoire lu à la même Académie.

\section{Bopyre des Chevreltes, B. squillanum.}

B. corpus depressum, planum, subinciurvoovatum, appendicibus utrinquè quatuor, foliaceis, marginalibus, inferis. Pedes minimi, spurii, marginales arcuati. Caudee segmento ultimo parvo.

Bopyre des Chevre!tes. LAт. Hist. nat. des Crust. et desIns. tom. 7. pag. 55. pl. 59 . fg. 2-4. - Gen. Crust. et Ins. tom. I. pag. 67. - Bopyre des Crustacós. Bosc, Hist. nat. des Crust. tom. 2. pag. 216 . - Monoculus crangorum. FaB. Suppl. Ent. Syst. pag. 3o6. - Fougeroux De Bondarox, Mém. de l'Acad. des Scien. 177\%. pag. 26. pl. I.

Cette espèce est longue de quatre lignes, sa. couleur est pâle-blanclıâtre, si ce n’est sur les écailles du dessous du corps où elle passe au noirâtre. - Commune sur nos côtes dans toutes les saisons de l'année.

M. Risso (Crust. pag. I 48) décrit une autre espèce sons le nou de Bopyrus pulaemonis. Elle se tronve sur plusieurs especes de Palénons. Enfin 11. Latreille en a décunvert une sons la caripáce d'un Crustacé du genre Alphée qu'il a reçu del'île Noirmoutier. (E. G.)

\section{ṔTERYGOCERE, Pterygocerus. Genre de Crus-} tacés que j'ai inciqué a l'urlicle Paytibranenes de cet ougrage, et qui est formé lìaprís la fignre de l'Oniscus arenanius de Slabjer. (Observ. microscop. tab. XI. fig. 3. 4. ) Quoique nous n'ayons point vu cet animal en nature, il nous paroit cependant qu'on ne peut le rapporter à aucun geure de Crustacé connu. Ses quatre antennes sont très-garines de poils barbus ou formant des pinuales aux premiers articles qui sont beancoup plus grands que les autres. Les quatre paltes postérieures présentent les mêmes caraclères; les quatre premières, ou du moins celles qui semblent l'être d'après la figure, sont velues, courbes, et se termiuent par une nageoire ou ur article arrondi et mutique. L'extrémité postérieure du corps est terminée par plnsieurs appendices ou styles velus. Ce Crusticcedoit appartenir à l'ordre des Amplipodes ou à celui des Isopodes.

(LATR.)

PTÉRYGOPHORE, Pterygophorus. KIUG. Lat. LÉach. Le P.

Genre d'insectes de l'ordre des Hyménoptères, section des 'Térébrans, lamille des Porte-scie, tribu des Tenthrédines.

Ce geure a élé établi par M. Klüg pour quelques espèces de 'Tenthrédines; il est aldopté par M. Latreille et les auteur's qua l'ont survi. Les genres de cette tribu qui ont plus de dix articles aux antennes et une seule cellule radiale appendiculée sont : Pergue, Hylotome, rilie et Ptérygophore. Les Pergues ei les Hylotomes ont quatre cellules cubitales et les Ptilies des antennes tilifurmes et velues, même dans les femelles, caractères qui distinguent nettement ces trois genres de celui de Ptérygophore.

Antennes nues, pecincies en dessous avec une seule raugée de deuts dans les màles; grossissant vers leur extrénité, presque moniliformos et un peu dentées en suie dans les temelles : leurs articles nounbreux (le nombre variant selon l'espèce où le sexe de dix-sept à vingl-trois, suivant M. Léach ) (1), insérés obliquement sur chacun

(1) Cetce observation a d'atuant plus besoin d'un examen ultérieur, que l'auteur.anglais donne tantôt plus, tanrôr moịns d'articles aux antennes des mâıs qu'à celles des femelles. De pareilles anomalies sont rares. 


\section{$\mathrm{PTE}$}

de ceux qui les précèdent, à l'exception des deux premiers. - Liabre apparent. - Mandibules alongées, comprimées. - Langzuette trifide et comme digitée. - Corps gros et court. - Ecusson presque cạrré avec une petite dent de chaque côté postérieurement. - Ailes supérieures ayant une cellule radiale appendiculée et trois cellules cubitales, la seconde recevant les deux nervures récurrentes, la troisième attcignant le bout de l'aile. - Les quatre jambes postérieures sans épine dans leur unilieu, en ayant deux à leur extrémité. - Tarière peu saillante.

Le nom de ce genre vient de deux mots grecs qri signifient : portant un plumet. Les espèces labitent da nouvelle Hollande. On n'en connoît encore que trois ou quatre; elles sont rares dans les collections. Leurs mour's doivent peu différer de celles des Lophyres.

\section{Ptérygophore à ceinture, $\boldsymbol{P}$. cinctus.}

Pterygophorus thorace nigro-violaceo luteo iario, abdonine nigro-violaceo, segmento secundo toto, sexti basi et lateribus, septimi maculâ laterali anoque suprà luteis, alis hyalinis marginibus subfiscis.

Pterygophorus cincius. KuUg. LÉAcIr. Zool. Miscell. $n^{\circ}$. 2. tab. 148. fig. 6.-Le. P. Monogr. 'Tenthred. pag. $5 \mathrm{I}$ : $n^{\circ} .147$.

Longueur 6 lig. Antennes dentées en scie, leur premier article biun, les stivans jaunes, les derniers d'un brun-noirâtre. 'Tête noire, palpcs d'un testacć-brunâtre. Corselet noir-violet, une tache de chaque côté à l'épaulette, une autre sous l'aile, écusson et ane ligne au-dessous de lui juunes. Abdomen d'un noir turant sur le violet, second segment, bord supérieu: ei côté da sixième, tache latérale sur le septième et partie supéricure de l'auus jaunes. Les quatre palies intérieures noires avec la base des jambes jaune, les postérieures jüues, á cuisses noircs. Ailes transparentes un peu brunes à leur bord cxtćrieur ansi gu'au bord interne. Femelle.

Le mâle a, selon M. Eéach, vingl-trois articles aux anteunes, et la femcllc vingi-un, ce rque nous n'avons pu vérifier sur ce dernier sexe, les antennes de notre individa ćtant incomplètes.

Nouvelle Hollande.

Nota. Il faut rapporter à ce genre, $1^{\circ}$. le Ptérygophore blen. LËAcr. Zool. Miscell. (Le P. Monogr. Tenthred: pag. 51. $n^{2} .148$. ) Cct auteur domne aux antennes du mâle dix-sept articles et dix-huit à celles de la femelle. $2^{\circ}$. Son Ptérygophore interrompu. (Le P. Monog. Tenthred. pag. 5o. $n^{\circ} .146$ ), au mâle duquel il donne cies antennes de vingt-deux articles, tandis que la ferolle n'en auroit que dix-huit.

$$
\text { (S. F. et A. SeRr.) }
$$

P'TILIE, Ptilia. Le P.

Genire d'insectes de l'ordre des Hyménoptères, section des Térébrans, familie des Porte-scie, tribu des Tenthrédines.

Dans notre Monographie des Tenthrédines, publiée en 1823, nous avons introduit ce genre pou: y placer des espèces qu'il nous paroissoit impossible de faire entrer dans les coupes génúriques adoptées jusque-là. Les Hylotomes, les Ptérygophores et les l'eigues ont bien comme nos Ptilies le antenues composées de plas de dix articles et une seule cellule radiale, laquelle est appendiculée, ce qui les distingue des autres 'Tenthrédines, mais les Pergues ont quatre cellules cubitales ainsi que les Hylotomes et les antennes des Ptérygophores sont nues, pectinées ou dentées en scie. Aucnng de ces caractères n'étant communs aux Ptilies, nous espérons que les entomologistes adopteront ce nouveau genre et regarderont son établissement comine néccssaire.

Antenues (dans les femelles) fliformes, velues, composćes d'un grand nombre d'articles, les deux premiers seuls distincts. - Labre apparent. - Mandibules alongées, comprimées. - Palpes maxillaires fort longs, les labiaux beaucoup plus couris. - Languetíe trifide et comme digitée.

- Téte transversale. - Trois petits yeux lisses disposés en ligne courbe, placés sur le vertex. - Corps couit. - Ailes supérieures ayant une cellule radiale appendiculée et trois cellules cubitalcs, la premiere grande, recevant la preunière nervure récurrente, lis seconde recevant la deusième nervure rćcurrente, la troisième atteiguant le bout de l'aile. - Abdomen caréné en dessus, cn dessous et des cótés, ce qui le rend presque quadrangulai: (dans les temelles); tilsère peu saillante. - Les quatre jambes postérieures sins épine dans leur milic'u, wais eu atyant deux à leur extrémité.

il est probable que les Ptilics sont originaires de l'Amérique ruér dionale; lenr nom vient d'un mot gree qui signilie: plume. Nous ignorons les mours de ces ịnsecies, mais il y a lieu de croise qu'elles doivenis se rapprocher de celles des $\mathbf{H}_{\mathbf{y}}$ lotomes.

\section{Prame lrésiienne, P. brasiliensis.}

Ptilia abdominis nigri segmento prino flavo; pa?pis fuscis.

Ptilia brasiliensis. Le P. Monogr. Tentlured. pag. 50. $n^{\circ} \cdot 143$.

Longueur 5 lig. Antennes el tête noires. Palpes bruns. Corselet fauve (1). Abdomen noir, sou premicr segment fituve. Alles fauves, l'extrémité des supérieures noire aissi que celie des inférieu-

(1) Par une erreur rypographique, le corselec est indiqué da couleur noire dans notre Monographie. 
res, celles-ci ayant de plus lenr bord interne de celle couleur. Pattes noires avec les jambes et Les tarses des deux antérieures fauves. Femelle.

Du Brésil.

\section{P ticie mélanure, $P$. melanura.}

Ptilia abdominis flavi seginentis quatuor ultimis anoque nigris; palpis flavis.

Longueur 6 lig. Antennes et lête noires. Palpes fauves. Corselct et paltes fiuves. Abdomen de mêne couleur; ses quatre derniers se gmens et l'anus noirs. Ailes fauves, l'extrémité des supérieures noire ainsi que celle des inférieures et une partie de lear bord interne. Femolle.

Anérique méridionale. (S.F. et A. Srrv.)

PTIIIN, Ptilinus. Georf. Orit. (Entom.) IAt. Ptinuls. lanN.

Gcnre d'insectes de l'ordre des Coléoplères, section des Pentamères, famille des Seríicornes, tribu des Ptiniores.

Lil tribu des Pliniores renfcrmc deux genres à satennes uniforuses et simples, Pine et Gibbie; deux autres, Dorcatome el Vrillefte les ont terminées brusquement par trois articles plus grands; les Xylétines les ont dentées en scie dans les deux scxes, leur corps est ovoide, court, tandis que dans les Plilins le corps est presque cylindrique, plus alongí, ẹt lés mâles ont leurs an' eunes en panache ou flabelliformes.

- Antennes plus longues que le corselet, distanics a leur base, insćrées pris et devaul les ycux, composícs de onze articles, le premier assez gros, plus long que le sccond, celui-ci trèscrurt, globuleux, le troisième portant une forte dent el les huit antres un long appeudice dans les máles, les neuf derniers fortement demtés en scie dans les femelles. - Labre arrondi, cilić. Mundibules courtes, un peu arquées, bidentées ì l'cx'rémitć. - Mấchoires merabraneuses, simples, presque rylindrigues. - Falpes fililormes, inégaux, les. maxillaires plús longs, de quatre articles, le premier petit, le second et le trossième coniques, le dernier alongé, pointu; les labiaux de trois apticles, le premier petit, le second conique, le dernier alongé.-Lè̀re membraneuse ả l'extrémité, échaucrée. - Tête verticale.-Yeux petits. - Corps presque cyliadrique. - Corselet bombé. - Puttes de longueur noyenne, tarses à ariicles entiers.

Ce genre créé par Geoflroy a été adopté depuis par la plupart des auteurs. 11 renferme un très-petit nombre d'espèces de couleur brune ou uoirấre et de petite taille, mais dont les máles sont remarquables par la forme de leurs antennes, ce qui a valu au genre le nom de Ptilinus tiré d'un mot grec qui signifie : panache. Leurs larves vivent dans le bois sec; les femelles le quittcnt peu, s'y accouplent même à l'entrée de leurs trous; le unâle durant cet acte reste suspendu en dehors.

1. Prinin pectinicorne, P. pectinicornis.

Ptilinus fuscus, antennis, pedibus elytrisque castaneis.

Ptilinus pectinicornis. Lat. Gener. Crust. et Ins. tom. I. pag. 277. -- OL1v. Entom. tom. 2. Ftilin. $n^{\circ}$ 1.pl. 1. Fis. 1.- Panz. Faun. Germe fas. 3. fig. 7 .

Longueur I lig $\frac{1}{*}$. Antennes, pattes el élytres d'un brun-urarron. 'Tête, corselct et dessous. du carps bruns. Elytres ayant des lignes longitudinales de points enfoncćs, peu distinctes. Mî̀ie tt femelle.

Des envicons de Paris. On le trouve dans les maisons.

Nota. Dans la figure citée de Panzer il n'y a point d'appondice au quatrième article des antemnes du wâle; elles n'unt en lout que sept ritmeaux ontre la dent du troisieme article. Datus les individus que nous avons exaninés les liuit demiers article's des antennes ont cliacun lour appendice presque d'égale longueur.

\section{Prinin flabellicorne, P. flabellicornis.}

Ptilinusfusco-niger, antennis, tibiis tarsisque castaneis.

Ptilinus pectinicomis. Fав. Syst. Eleut. tom. $\mathrm{t}$. pag. 32g.no. 2. - GYILEXB. Ins. Suec. tom. 1 . part... pag. 3o1. $n^{\circ}$. 1. - Ptimes pectinicomis. Linn. Syst. Nat. 2. 565. 1. - I'tilinus fabellicornis. Meg. (Dej. Catal.)-La Paracbe bruue. Geory. Ins. Paris. tont: 1. pagr. 65. $n^{\circ} .1$.

Longweur 2 lig. Antennes, jambés el tarses d'un brull-marron. 'Tête, corselel, élytres, cuisses et dessous du corps d'un brun-noiràtre. Elytres ay ant des lignes distinctes formécs par des points enfoncés. Corps plus gros en proportion de sálougueur que dansle précédent. Nâle et femelle.

Des environs de Paris. Il sc trouve dins les arLres creux, particulièrement dans les saules.

(S. F. et A. SERv.)

PTILODACTYLE Ptiodactyla. Genre d'insectes de l'ordre des Coléoptères, section des Ilétíromc̀ces, créé par M. llliger et qui a pour type la Caidinale pulie. (Pyrochroa nitida. DE GEER, Itus. tonl. 5. pcrg. 27. pl. 13. fig. 6.) Dans cette espece de l'Amérique méridionale, les articles des anteunes ont clacun un rameau élargi à son extrémité. Sous ce rapport elle paroît avoir quelqu'analogie avec la Cisiéle céramboïde no: 4 de ce Dictionnaire. (S. F. et A. SERv.)

PTILOTOPE, Ptilotopus. Genre d'insectes Hyménoptères-Porte-aiguillon, famille des MelI1 fères, tribu des Apiaires, proposé par M. Klüug. L'áuteur donne pour ıpe une espèce qui appai- 
tient évidemment au genre Centris. Cette Apiaire est fort bien déerite par Fabricius (Syst. Piez. pag. 346. $n^{\circ}$. 16.) sous le nom de Bombus americanorum, mais ce dernier auteur auroit dí placer cet insecte parai les Centris et ne point lui donner pour synonyme l'Apis americanorum de son Entomol. Syst. tom. 2. pag. 3ıg. $n^{0}$. 18, qui est un véritable Bombus dont les caractères sont bien détaillés dans la deseription; mais la phrase spéeifique du même article paroît se rapporter à une troisième èspèce toute différente. La Centris americanorum est représentée dans le présent Dictionnaire pl. 579 , fig. 19 .

$$
\text { (S. E. et A. SERv.) }
$$

Ptine, Ptinus. Linn. De Géer. Fab. Olit. (Entom.) Gydient. I_at. Bruchus. Geoff.

Genre d'insectes de l'ordre de Coleoptères, section des Pentamères, famille des Serricornes, tribu des Ptiniores.

Dans cette tribu les Ptines et les Gibbies ont seuls des antennes simples, mais dans les Gibbies ces organes sont insérés au-devant des yeux, le corselet n'est point en forme de eapuehon et le corps est gibbeux, caractères que l'on ne retrouve point dans les Ptines.

Antennes filiformes, longues, surtout dans les máles, insér ées entre les yeux, composées de onze arliclés presque cylindriques; le dernier oblong. - Labre arrondi, cilié. - Mandibules arquées, unidentées. - Mâchoires presque bitides. $-P_{\text {Palpes }}$ inégaux, presque filiformes, les maxillaires plus longs, de quatre articles, le premier plus petit, les deux suivans coniques, le dernier* plus long, un peu plus épais; les labiaux composés de trois articles, le premier pelit, le second conique, le troisiène ovale. - Yeux saillans. - Corps cylindrique. - Fartic antérieure du corselet savanraut en forme de capuchon comme pur abriter la tête. - Ecusson petit. - Elytres convexes, un peu cylindriques el ne paroissaul pas rétrécies at lcur base dans les mâles; convexes-ovales dans les femelles; celles-ci privées diailes (aru moius ảans la plupart des espèces). - Pattes assez longues, premier article des tarses aussilong que les deux suivans réunis.

Les larves de ces inseetes ont six pattes terminées.par un seul crochet, leir corps est mou, ridé, un peu velu, les segmens en sont pen distincts. Elles se nourrissent de bois et altaquent aussi les plantes, les auimaux desséchés ainsi que les pelleteries.

On counoît une dizaine d'espèces. de Plines, leur taille est petite et leurs couleurs sombres. On les trouve souvent daus les maisons. Lorsqu'on veut lés saisir ils retirent leur tête sous le corsclet, ramènent leurs antennes et leurs palles contre le corps et se laissent tonber, espérant saus doute par ce a yers éviler le danger guiles menace; cette babitude se retrouve dias beaucoup d'autres coléoptères.

Ire. Division. Antennes ì articles peu aplatis, presque dentés en scie.

\section{Prrse pubeseent, P. pabescens.}

Ptinus niger, rufo villosus, elytris testaceis. punctato striatis.

Ptinus pubescens. Faв. Syst. Eleut. tom. I. pag. 324. $n^{\circ}$. 1. - Oliv. Entom. tom. 2. Ptin. pag. 5. $n^{\circ}$. 1. pl. 1. fig. 7. a. b. - Hedobia pubescens. Dru. (Catalogue.)

Longueur 4 lig. Noir, dos du cor'selet gibbeux postérieurement. Elytres testacées ayant un grand nombré de stries fortement ponctuées. Tout le corps est chargé d'un duret gris-roussâtre. Mâle. Ailé.

Rare aux environs de Paris. Nous l'avons pris dons la forêt de Saint-Germain sur du boiz coupé.

Nota. Cet insecte est le type d'un nouveau genre proposé par M. Ziégler et qu'il nomne Hedobia. Nous pensons que ce genre peut être adopté.

$2^{e}$. Division. Antennes artieles presque eylindriques.

\section{Ptrne impérial, $P$. imperialis.}

Ptimus fuscus, thoracis loteribus, elytrorum maculâ lobatâ, lobis aliquando liberis, apice que griseo-tomentosis.

Ptinus imperialis. Liwa. Syst. Nat.2. $565.4 .-$ Fan. Syst. Eleut.tom. 1, p.326.n.7.一G

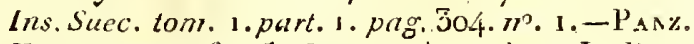
Faum. Germ. fas. 5. fig. 4. a. b. c. d. - La bruche ì croix de Saiut-André. Founc. Entom. Paris. tom. $1 . p a g .53 . n^{\circ} .3$.

Longueur a à 3 lig. Antennes et eorps entièrement d'uu brun-roussâtre. Corselet carćné an milieu, très-bombé postérieurement, ses côtós couverts de poils gris. Elytres portant une taclee divisée eu lobes irréguliers qui se séparent quelquefois les uss des aulres. Cetle tache est formée par un duvet gris à travers lequel on voit ressortir de petits tubercules bruns dont les élytres sont parsenées. Extrémité de celle-ci, tête, dessons du corps et paltés, couverts d'un duvet gris. Male. Ailé.

Des environs de Paris.

Rapportez à cetle division les Ptinus fur, clegans et rlifipes. Fав. Syst. Eleut.

Nota. M. le comle Dejean regarde cetle de:nière espècę comıe le mâle de la précédente.

(S. H. et A. SFr. 
PTINIORES, Ptiniores. Sixièn:e tribu de la famille des Serricornes, sestion des Pentamères, o:dre des Coléoptères. Eille a pour caractères:

Antennes de onze articies, rarement de neuf; tantôt pecinées ou en scie, tantôt filifurines ou sétacées, quelquefois teruinées brusquement par trois articles plus grands que les précédens, sans être réunis en unssue. - Mandibules courtes, triangulaires, échancrées ou bidentées à leur extrémilé.-Palpes très-courls, terminés par un article plus gros, élargi à son extrémité. - T'ête conve, arrondie ou presque giobuleuse, recue en grande partie dans le corselel, - Corselet trèsciniré en forme de capuchon.-. Tarses ordinairewent cousts. - Corps le plus sument ovoidiocylindricgue, arronci et convese en dessus, de consislance ferme.

1. Antennes uniformes, simples. Ptine, Gibbie.

II. Antennes unifornes, pectinées ou fortement ell scie. Ptilin, Xylétine.

III. Antennes terminées brusquement par trois articles plus grands.

Dorcatome, Vrillette.

Ies Pliniores habitent le vienx bois que lenrs larvès rongent en y pénétiant dins tous les sens; elies ont une grande ressemblance avec celles des Scarubé ides, lear corps souvent courbé en arc est ınou, blanchâtre, arec la lête et les pattes brunes el écailleuses; leurs mandibales soni fortes; clles se construisent nne coque avec les fratgmens des malières qu'elles ont rongées et $s^{\prime} y$ changent en nymphes. On voit sument courm les insectes parfiuls sur les mêtnes bois, dès qu'on les approche ils contretont le mort en haissant la lête, contractant lenrs pattes et inctinant leurs antennes et se laissent mênue quelquefois tomber par terre; ils demenrent quelcue temps dans celte lél hargie apparente, lenrs monvemens sont assez lents et les undividus ailés ont rareinent recours au vol pour s'éclupper.

G IBBIE, Gibbiuin. Scop. Litr, Scotias. Schrancx. P'tinus. Fab. Oliv. (Entont.) Bruchus. GEOFF.

Genre d'insectes de l'ordie des Colćoptères, - cection des Pentamères, famolie des Serricones, sriba des l'tiniores.

L.es an icunes uniformes, sinples, forment dans relie ribu ue gronpe conjposé des Ptines et des Gibbies, mais les premiers ont les antennes filiformes, inséríes entre les yeux; leur corps est oblong et la partic antérieure du corselet s'avance en manière de capuchon.

Autennes sétacées, insérées au-devint des yeux et rapprochices, composées de onzê articles, les second ei trojsieme p! gra grads que les suivans, ceux-ci diminuant insensiblement de grandeur jusqu'au dermier qui est conique. - Mandibules arquées, unidentúes. - Míachoires presque bifides. - Palpes inégaux, presque filiforunes, les maxillaires plus longs, de quatre articles, les labiaux de trois. - Yeuæ petits, point saillaus.-Corps court, globuleux, renllé. - Corselet plus étroit que l'abdomen, cylindrique, très-court, son bord postérieur avancé au milieu en angle. - Point d'écusson distinct. - Abdomen globuleux. Elytres soudées ensemble et ecoibrussant l'abdumen. Ailes nulles, - Pattes longues; jambes garnies extćricuresłaent d'une trange serrée, forměe de poils roides et égraux; premier article des tarses plus loug que les autres.

Les Gibniesse trouvent principalement parmi les plantes dessćcluées; elles sont nuisibles aux herbier's et l'on y rencontre souvent l'insecte parfait dout la larve a eoupć et rongé les tiges des plantes. Le nom de ce gyenre vient d'un mot latin qui exprime sa fortne renflée. Leur's mours sont los unêmes que celles des Ptines. On en connoît deux vu trons espèces dont une est auéricuine et les autres des environs de Paris.

\section{Gibmrescolias, G. scotias.}

Gibbium castaneum, nitidum, lave, antennis pedibusque pubescentibus.

Giblium scotias. LAT. Gener. Crust. et Ins. tom. 1. pag. 273. $n^{\circ}$. 1. tab. 8. fog. 4. - I'tonus scotias. FА . Syst. Eleut. tom. 1 . pag. $327 \cdot n^{\circ} .14$. - Oliv. Entom. tom. 2. Ptin. pag. 9. no. 9. pl. 1. fig. 2.a. b. - Pavz. Faun. Germ. fas. 5. fig. 8. - La Bruche sansailes. Grorf. Ins. Paris. tom. $1 . p a g .164, n^{\circ} .2$.

Longuetr I lig. $\frac{1}{2}$. D'un châtain-rougreâtre, luisalic, entièrecment lisse, à l'exception des pattes el des dix derniers articles des antennes quı sont clargés d'un ciavet court, jaunâtre.

Environs de Patris.

Nota. M. Latreille en mentionne une autre espèce sous le nom d'Hirticolle; elle est remarquabile farr le duvet épais et juinâtre de son corselet.

DORCATOME, Dorcatoma. HERRST. FAB. LAT. Dermuestes. Panz.

Genre d'insectes de l'ordie des Coléoptères, section des Pentamères, famille des Serricornes, tribu des Ptiniores.

Les Dorcalomes et les Vrilletles forment $\mathrm{nm}$ groupe düns celle tribu (voyez l'liniores), uais les derières ont onze aricles aux antenues et lear corps n'est point arroudi.

dincenaes composíes de neuf articles, les trois derniers beaucoup plus grinds, les septièrne et huitiène conformés en dents de scie. - Mandibulles épaisses, cornćes, aìgrües, bilides. - Mâa- 


\section{P T Y}

choins membraneuses, bilobées; ees lobes âtroadis, l'extérieur un peu plus grand. - Palpes incógaux, leur dernier article sćeuriforme; les maxillaires plus longs, de quatre articles presqu'égaux, insérés sur le dos des mảehoires; les lubiaux de trois articles égaux. - Corps presqu'arrondi. - Ecusson très-petil. - Elytres eouvrant les ailes et l'abdomen. - Pattes de longueur moyeune.

lie nou de ee genre est tiré de l'aplatissement et de la largeur de quelques-uus cles articles de ses untennes qu'on a comparés aux cornes du daim. Les espèces qu'il renterme; au nombre de cinq ou six, sont fort petites; leurs habitudes doivent ĉtre ì peu près les mêmes que eelles des Ptilins.

\section{J. Doreatome saxon, D. dresdense.}

Dorcatoma elytris lavibus, strïs tribus, unâ suturali subobsolet $\hat{x}$, duabus aliis ad marginem exteriorem, interiori abbreviatá.

Dorcatomia dresdensis. НЕRвsт, Col. IV. XXXIX. 8.-Dorcatoma dresdense. $\mathrm{F}_{\mathrm{AB}}$. Syst. Eleut. tom. 1. pag. 530. $n^{\circ}$. I. - Dermestes serra. Panz. Fran. Gern. fas. 26. tab. 10. Encycl. pl. 55g. fig. 44 et 45.

I.onguenr I ligr. $\frac{5}{2}, 2$ lig. Brune ou rougeâtre, un peu velue; antemnes d'un testacé-januâtre; pattes rougcâtres; ćlytres lisses, ayant trois stries, l'une peu apparente le long de lasuture, les deux autres sur le bord externe dont l'intérieure plus conrte.

De France et d'Allemague.

$$
\text { (S. F. et A. Serri:) }
$$

PTOMAPHAGE, Ptomaplaggiss. Nom donné par Illiger dans son Catulogue des Insectes de Prusse a un genre de Coléopteres que M. Latreille anoit précédemment fondé sous celui de Cholève. Voyez Clolève, article Peltoides.

$$
\text { (S. F. et A. Serv.) }
$$

PTYChOptére, Ptychoptera. Mrig. Lat. TaE. Tipula. Linn. Geoff.

Geure d'insectes de l'ordre des Diptères, seetion des Proboscidés, fawille des Némocères, tribu des Tipulaires.

Ce genre fuit partie d'un groupe établi dans celle tribu par M. Latreille sous le nom de Terricales; dans ce groupe les genres 'Tipule, Chénopho:e, Pédicie, Limonie (Limnobia. Meig.), Néphrolome, Trichocère et Erioptìre ont le troisième article des antences court. Dans les Hexatomes de M. Latreille (Nératocère Mérg. el peut-être aussi ses Anisomères), ainsi que thus les P'tychopières, è troistème alticic est fort longr; mais dans les deux premiers genres les antennes n'ont que six articles; le quatriêtre śgale presqu'en longueur le précédent dans les Jiexatomes; au Hist. Nat. Ins. Tome X.

\section{$\mathrm{P} \mathrm{T} Y$}

moyen de eette comparaisou on stiparcia aisément. tous ces geures de celui de Plychoptère.

Antennes avancées, presçue sétacées, de seize articles, le premier court, cylindrique, le seeond en forme de coupe, le troisième très-grand, ayant plus de trois fois la longueur du quatrième ; celuiei et tous les suivans petits, oblongs. - Trompo ayant ses ièvres inclinées et très-longues. - Palpes très-saillans, courbés, longs, de quatre artieles, le premier court, le seeoud et le troisième alongés, égaux entr'eux, le quutrième sétacé, plus longr que les antres. - Téte petite. - Yeux yrands, ovales, entiers. - Point de petits ycux lisses. - Corselet gros. - Ailes écartées, ayant denx cellules pédiculées ressemblant ehaeane à uu Y aboutissant vers l'angle extérieur de l'aile ; ón voit entr'elles une nervure peu distinete, dont les extrémités sont libres. Bord postérieur de l'aile se reployant en dessus dans le repos. - Abdomen rétréci à sa base, grossissant vers l'extrérnité dans les deux sexes. Auus des mâles ayant deux grands erochets un peu arqués, très-saillans, aecompagnés de fiès velus; eelui des femelles portunt deux lanes aplaties et pointues. - Pattes longues, grêles, simples; premier article des larses plus long que les quatre autres réunis.

Les lirrves de ees diptères viveut dans les eaux dormantes; c'est là que Réaumur a trouvé leurs nymphes; celles-ei sont de forme alougée el velues inférieurement. Leur partie supérieure est munie d'uu fil fort long, e'esı un tuyau extrêmement déliédont l'extréinité reste toujours à la surface de l'eau; il paroît certain que la nymple l'y tient pour recevoir l'air qu'elle a besoiu de respirer. Cette nymphe peut changer de place daus l'eau, Réaumur cröit même qu'elle peut y nager. C'est également dans eet élénuent que ces inseêtes subisseul leur dernière transformation pour elı sortir daus l'élat parfait. Cet auteur n'a point vu lia larve, mais seulement sa dépouille gui lui a paru un peu velue. Ces observations ont été failes sur la P'tyehoptère tacluée.

Ce genre dont le nom vient de deux mots grees qui signifient : ailes ployées, contient fort per d'espcees. On les trouve au bord des eaux.

\section{Pтrenoptìre taehce, $P$. contaninata.}

Ptychoptera atra, nitida, abdoninis fascirs duabus in mare, maculis duabus lateralibus in faminâ ferrugeneis; alarum maculis quinque fuscis, duabrus majoribres fuscias dimndiates mentientibus : ano pedibnsque ferrugineis.

Ptychoptera contuninata. Mers. Dipt. d'Eur. tom. 1. pag. Jo5. $n^{\circ}$. I. - Lat. Gener. Crust. et Ins. tom. 4. pag. 257. - FAB. Syst. Antliat. pag. $20 . n^{\circ}$. I.--Tipula contaminata. L.Ins. Syst. Nut. 2. 972 . 8. - RÉaum. Ins. tom. 5. pag. 29. pl. 6.fig. 1-3. - La 'T'prule noire à lacleses jaunes et ailes maculées. GzOrF. Ins. Paris. tom. 2. $\mathrm{HL}$ 
pag. 558. $n^{\circ}$. 3. - Encycl. pl. 384. fig. 27-29.

Longueur 4 lig. $\frac{1}{2}$. Noire, luisante. Trompe, palpes, ćcusson, anus et pattes jaunes. Antennes noires plus courtes que le eorselel, garnies de poils verticillés. Abdomen ayant au moins deux bandes d'un jaune-ferrugineux et quelquefois des points de même eouleur. Extrémité des cuisses noire. Ailes portaut cing taches brunes dont deux s'avancent du bord extérieur jusqu'au milieu de l'aile. Femelle.

Le mâle a les antennes deux fois plus longues, et moins de ferruginenx à l'alidomen.

Commune aux environs de l'aris.

\section{Pтүснорте́e albimane, $\boldsymbol{P}$. albimana.}

Ptychoptera nigra, abdomine (fomince) maculis duabus lateralibus, segmentis duobus anoque ferrugineis: tarsorum posticorum articulo primo albo.

Ptychoptera albinuana. MEIG. Dipt. d'Europ. tom. I. pag. 207. $n^{\circ}$. 4. tab. 6. fig. 17. Femelle. - FAB. Syst. Antliat. pag. 2 I. $n^{\circ} .3$.

Inngueur 5 lig. à 5 lig. $\frac{1}{2}$. Noire. Antenines noires, plus courtes que le corselet, garnies de poils verticillés. 'Trompe, palpes, éeusson, balunciers, base des ailes, taches latérales sur l'abdomen, bord postérieur de ses deux derniers segmens et anus, de eouleur jaune. Pattes jaunes mèlées d'un peu de brun; jambes postérieures hrunes, leurs tarses noirs avec le premier article presqu'entièrement blane. Ailes transparentes, leurs nervures transversales eutourées d'un peu de brun. Feuselle.

Environs de Paris. (S. F. èt A. Serv.)

PUCE, Pulex. Iinn. Geoff. Sehaff. Scop. Sehr. Fab. Ifatr. De Géer. Oliv. Vill. Ross. Cot. Lam. Walek. Illig.

Les Puces unt été eonnues de lont temps sous ee nom par les auteurs. Dans le derrier ouvrage de M. Latreille, intitulé : Fanilles naturelles du règne animal, et que ce célèbre naturaliste a bien roulu nous communiquer avant qu'il soit entièrement imprimé, elles forment un ordre dans la classe des Inseeles aptères, auquel il a donné le nom de Siphonaptères, Siphonapéera. (Voyez ee mol.) Les caraclères essentiels de ce grenre sont : six palles, poinl d'ailes, des métaziorphoses, un bec articulé, foracé de deux lames renfermant un sueroir.

Dans ses ouvrages antéricurs, M. Latreille avoit formé avec ces inseetes, ainsi que De G.'er, l'ordue des Suçeurs, qu'il avoit placé (Consid. génér. sur les,Crust. et les Ins., et Gener. Crust. et Ins.) $\checkmark$ at lin des Diptères, el qu'il a rangés depuis ( $R e_{0}$. anim. de Cuv. et fam. natur., ete.) à la fin des In.ectes aptères. Dans le système de Fabricius, ess iasertes apparienneut i son ordre des Rhin- gotes; ils appartienuent à l'ordre des Aptères dans la plupart des autres métlodes, et forment seuls l'ordre du mêıne nom dans eelle de $M$. de lamarck. Le corpss des Puees est ovale, comprimé, revêlu d'une peiru assez ferme, et divisé en douze segrmens, dout trois composent le tronc, qui est court, et les âuires l'abdomen; ces derniers sont composés de deux lames, l'une supérieure, l'autre iaférienre : la têle est très-comprinćc, petile, arrondie en dessus, tronquće et eiliće en devant; elle a de chaque eôté an oil petit et arrondi, derrière lequel est une fossetle où l'on décourrc un petit eorps mobile garni de petites épines. An bord antéricur, près de l'origine du bee, sont insérées les antennes, qui sunt presque filiformes, ou un peu plus grosses au bout, de qaatre arlicles presque cylindriques, dont le dernier est un peu plus alongé, eomprimé et arrondi à son extrérnité. La bouche consiste en un rostelle ou petit bec, composé d'un tube extérieur on gaine, eorrespondant à la lèvre inférieure des autres insecles; celle gaine est divisée en deux valves articulćes qui renferment un suçoir de trois soies, dont deux représentent les mâchoires, et la troisième la languelte; enfin, deux écailles recouvrant la base du lube représentent les palpes. Les pieds sont forts, plus ou moins épineux; les postérieurs leur servent pour exćcuter des sauts exc:essivement vifs, el les quatre antérieurs sont insérćs presque sous la lête, de sorle que le bec se trouve dans leur entre-deux. Les hanehes sont grandes; les tarses sont composés de cinq artieles; ils sont presque eylindriques, longs et terminés par deux crochets contournés. Tes organes sexuels du mile consistent en une pièce eylindrique, renllée, tronquée et charnue à son extrémilé, lngée entre deux pièces on valvules, sur la fuce interue et eoncave de chacune desquelles est un erocliet ćeailleux : ces organes sont placés eomme à l'ordinaire à l'extrémité de l'abdomen. Dans les femelies, on iperçoit ì la même place deıx valvules latérales, voûtées et arrondies, et dans l'entre-deux une pièce faite un pen en losange, dont la moilié supérieure est coriacée, ponetuće et a une arête, et dont l'autro ou l'inférieure est membraneuse et percée d'un trou au milien, qui est t'ouverture destince à recevoir l'organe du mâtle et à rejeter les excrémens.

Daus l'arceouplement, le uâle est placé sous la femelle, de nninière que leurs têtes sont en regard et que le ventre de l'une est appuyé contre eelui de l'autre par les mêmes faces.

M. Defrance a publié daus les Annales des sciences naturelles, tom. I, p. 440 , des observations fort intéressantes sur les œuf́s et la larve de lia Puce commnne. Nous allons laisser parler ee savant.

"Qnoique lés Puces soient des inseetes fort conzuns, il reste peut-être beaucoup de choses à conpoître à leur' ćgard. L'on sait que de leurs wufs il sort des larves qui filent des eoques soyeuses dans lesquelles elles se cliangent eu nywphes et 
Ensuite en insectes parfaits. Lorsque l'on ouvre des teniclles prêtes à pondre, on tronve dans leurs corps luit à douze cufis oblongs, blancs, arrondis et d'égale grosseur aux deax bouts. Quand ils viennent d'être pondus ils sont lísscs, secs, et coulent comme des globules de mercure, cherchant, an moindre mouvenent, les lieux plus bas et leg fentes où les larves ponrront se trouver protégées. Si l'on veut se convaincre de ces faits, il suffit de visiler, pendant l'été surtoul, un fauteuil sur lequel un clié ou un chat se sera reposé; on y trouvera beaucoup d'œufs que ces insectes ont pondus en se plaçant entre l'animal et le corps sur lequel il étoit couché.

" Si ces insectes n'éloient pas aussi nuisibles qu'ils le soat, l'on pourroit avoir' quclqu'inquiétude snr le sort de la larve sanguinipore qui-doit sortir d'un ouf ainsi abandonné au hasard; mais la nalure a ponrvu i la conservation de toules les espèces, mêtrne de celles qui peuvent nous nuire. Avec les cufs on trouve des grains noirs presque anssi roulans qu'enx qui proviennent de l'animal qui in servi de pâture à l'insecte, et qui doivent être dévorés par les larves.

"Jusqu'à présent lion a pris ces petits corps pour les excréatens des Puces; mais il y a bien des ruisons de douter qu'ils aient cette or yiue. Ils ne sont autre chose que du sang dessćché, qui reprend sur-le-champ sa licjuidité, si on lui restilue l'eau qu'il a perdue. Si c'étoit des excrémens et le résidu de matières digt́rées, ils auroient une forme régulière, et il semible qu'ils ne présenteroient pas une malière aussi disposée à se dissoudre et ì reprendrc lit conleur da sang. D'ailleurs, leur grossenr est telle qu'elle ne pourroit couvenir à l'organe par lequel ils seroient rejetés par un anssi pelit insecle. Ces grains affectent différcntes formes. Les uns sont irrégulièrcment arrondis, mais ordinairement ils sont cylindriques et luisins; quelques-uns qui sunt contournés sur euxmêucs ct discoides, seroient plus longs que l'iusecıe lui-même s'ils étoieat déroulés.

$\because$ Quand ils n'aluroient pas tous ces caractères, qui paroiss ent ne pouvoir convenir à des excrémens, ayan! pu vérilier que ces corps sont dévorćs avec avidité par les larves et cu'ils leur servent de zourriture, il semble que ce fail seul ponrroit suflire pour penser quils n'ont pas cette origine, car on ne voít pas que des animaux se nonrissent des excrémens de ccux qui les ont procréés.

"Il resie à découvrir et à expliquer commeut cec sang desséché peut se présenler pour la nonrrilure des larves sans provenir du corps des Puces; mais qquoique ce qui se passe à cet égard soit extyêtnenent fréguent, personnc, peut-être, n'a été it portée de l'observer. Je hilsarderai celtc conjecture : c'cst que diuns certains cas les Puccs, et peut-être les femelles exclusivcment, auroient la faculté d'ourrir la pean non-seulement piour se courrii du sang qu'illes peuvent pomper, mais encore d'y faire (comme les sangsues) une blessure qui le laisseroit couler pendant un certain temps; ce sang, fluide en sortant de la peau, se dessécheroit promplement par la chaleur de l'animal à mesure qu'il découleroit de la blessure, et ce seroit là la cause de la forme de ceux de ces grains qui sont contonrnés sur eux-mêmes. Ce qui viendroit a ppryer celle conjecture, c'est qu'on ne trouve ce sang desséclić et calibré que dans les poils des animaux qui l'ont fourni, et dans les endroits où ils ont reposé, quoique les insectes se rencontrent ailleurs. S'ils provenoient des excrémens des insectes, on en trouveroit partout où ces derniers auroient habité, et c'est ce que l'on ne voit pas. Quand ils attaquent la pea des hommes, on remarque quelquefois des taches du sang qui a dî découler d'une plaie, mais non des grains calibrés.

"Le 23 aon̂t j’ai ramassé des œufs pondus du même jour, et ils sont éclos cinq jours après. Ayant nourriles perites larves a vec le sang dessćchs que j'avois trouvé avec les œufs, j’ai remarqué qu'elles marchent fort vîte en élevant la tête, et aprìs l'avoir avancée, elles alliroicnt lenr corps; mais elles ne pouvoient s'élever contre les parois de la boite.

"Je n'ai jamais trouvé ces larves ni leur coque sur les animaux qui servent de pâture à l'insęcte parfait; et n'ayant pas, comme ce dernier, une forme et une peau ferme qui puissent les protégcr, il est cxtrêmement probable qu'elles doivent s'y trouver bien rarement. Je leur ai présenić dés mouches, quelques-unes ont paru vouloir se nourrir de la substance qui se présentoit aux endroits où les ailes avoient été arrachces ou aux fentes du corselet qui avoit élé un peu écrasé; mais clles ne les auroient pas allaquées sans ces sortes de blessures. Lenr corps transparent laisse voir la nourriture qu'elles ont avalée.

" Lé 9 septembre elles ont commencé à filer des cocjues; mais avant de le faire elles ont attendn, comme le font les chenilles, et probablement toutes les larves, que tout ce qu'elles avoient mangé fût sarti de leur corps; et, dans cet état, elies étoient blanches et tout-à-fait transparentes.

n Les nymples qui présentent les pattes collées contre le corps, ont beaucoup de rapports dans leur forme avec les insectes parfaits; et ceux-ci pcrcèrent leur coque seize jours après qu'elle eut . été formée. "

Les $P$ uces vivent en parasiles sur plusieurs mammifères et sur quelques oiseanx, tels que pigeons, poules, hiroudelles, etc. Elles préfèrent la pean delicate des femmes et des enfaus à celle d'uulres personnes, et elles nicbent dans la fourrure des chiens, chats, lievres, etc., qui en sont très-tourmentés en été et en automne. La prícaution que l'on prend de baigrner ces animaux pour les détalrasser de ces insectes est inutile, et M. Defrasce II. t 2 
prouvé par l'expérience, que des Puees qui avoient été :enues sous l'eau pendant vingt-deux lieures, avcient repris la vie après en avoir élé retirées. J) es fernelles pleines d'aufs ont péri à eet le épreuve, mitis el!es ont subi jusqu'it onze heures d'immersion sarts en souffrir. Pour chasser ces insectes incommodes, quel ques personues on recommandé de metlre dans les appartemens des nlantes d'uze odeur forle et pínétrante, comme la sarriette, le pouliot; d'autres ont recours à ure eau boai!lante dans laquelle on a mis du mercure et que l'on répand dans la chambre, ou à un onguent mercuriel. Jes habitans de la Datécarlie placenl daus leurs mais nus cles peaux de lièvres où les l'uces vont se réfirvier et dans lescuelles il es! facile de les faire púrir par le moyen de l'ean chiude ou par le fell. () n a proposé encore beaucoup de unoyens pour se defairede res insectes, mais ils sonl tous lrès-pen cificaces. Le meilleur, à notre avis, est d'entretenir une grande propreté dans uos appartemens, et d'exposer vers la fin de l'automne ou au commencement du printeraps, à une assez forte chaleur, les menbles qui pourroient recćler ces insectes in commodes.

Le genre des Puces est composé de peu d'espéces; peat-ôtre en déconvirira-t-on d'autres graud on examinera arec plus d'atlention les Pures de divers aniasaux.

I'espèce lit plus commune esl la Puce irrutante, Pulcxirritans, de Linné et de tous les auleurs; sa couleur esi brun-marron, ses pattes sont d'une cotilenr moirs foncée, et ses anneaux sont bordés de poils courts et roides, couchés sur la pean. II. Bosc (Bull. des scienc. par la Soc. phizom.) a fait connoître une autre espèce qu'il appelle Puce a dardes, Pulex fasciatus, el qui se trouve sur le renard, le lérot, la laupe et le rat d'A méjigue. La Puce pénétrante, P. penetrans, Linn., qui est connue dans les colonies francaises sous le nom de Chique, doit former un genre particulier. Son bec est de la longueur du corps; elle s'introdait ordinairement sous les ongles des pieds et sous la pean du talon, et y accquiert bieniôt le rolume d'un petit pois par le prompt accroissemenl des anfs qu'elle porte dans un sac memJraneux sous le ventre. La famille nombreuse à liquelle elle donne maissance ocrazionne, parson sífour dans la plaie, na nlcère malia diffeile à détruire, et quelquefois mortel. On est peu exposé ì eelle incommodilé fàchense, si on a soin de se lilver souvent, el surlout si on se frolte les pieds arec des feuilles de tabue broyrées, avoc le rocou on d’autres planles âcres et amères. Les nègres suvent extraire avec adresse l'animal de la partie cì il s'est ćtabli.

\section{PUCE AQUATIQUE. Voyez Dapanie.}

PUCE AQUATIQUE. Nom qui a été donné queligufuis aux Grmins ou Touriguets.
PUCE DES FLEURS DE SCABIEUSE. Nom donné par Nuralto (Collect. acad. part. étrang. tom. 3, pag. 476) à un insecte peu connu.

\section{PUCE DE NEIGE. Voyez Podone.}

\section{PUCE DE TERRE. On a donné ce nota aux} Mordelies.

PUCE DE TERRE. Inseele du Cap de BonneEspérance, que M. Latreille creit être une Altise, et qui fait un grand dógat dans les jardius en gat tant et broulant les jeunes et tendres jels, et en rongeant les semences de diverses plantes.

( E. G. )

PUCeron, Aphis. Linn. Geoff. De Géer. FAB. LAT.

Genre d'insectes de l'ordre des Hémiplères, section des Ifomoptères, famille des Hyménćlytres, triliu des Aplidiens.

lies Pucerons el les Aleyrodes composent seuls celte tribu, mais ces derniers ont des antennes comtes n'ayant que six arlicles; chacun de leurs yeux est partagé en deux, et ces insectes porteat dans le repos leurs álytres en toil écrasé, cellesci ne surpassant guère les ailes en longueur.

Antennes plus longues que le corps, souvcnt sélacées, quelquefois plus grosses à lemr extrémité, composées de sept articles, les deux premier's très-courls, grenus, le troisième fort long, cylindrique. - Bec presque perpendiculaire, prenant naissance à la partie la plus inférieure de la tête dans l'entre-deux des pattes antérieures, de trois arlicles. - Ycux serri-globuleux, entiers. -- Corps mou, ovale. - Corselet ayant sen segment antérieur petil, lransverse, le second beitucoup plus grand et élevé. - Elytres plns gsrandes gue les ailes, ayant ordinairenent sur leur bord extćrieur un poizt épais d'où part une nervare qui se comrbant en demi-cercle, va rejoindre la côte et forme une cellule assez somblalle à la radiale des Hyménoptères; au-dessous est une antre nerrure qui se dirige -vers le bord postérieur et se bifuroue nne on decix fois avant d'y arriver en manicire d'y agrec. - Elytres et ailes membinuenses, de mêne consisłance partoul, élevées en toit aigu dans le repos. - Abdo rem a yant de chaque côté postérieurement une pelite corne on un tabercule. - P'attes longues et grêles; dernier article des larses muni de deux crochels et point vésiculenx.

Les Púcerons vivent en société et n'éprouvent aucune métamorplose réelle. Ils șuhissent en élat de larves plusieurs changenens de peau; ils sortent du dernier puar paroìre en état de nymphe, et ont alors deux fourreaux de chacque cóté dia corps, dont le supérieur renferme l'élytre et l'autre l'aile. P'ar un nouveau changement de peau ils. deviennent insecles parfaits et développent leurs 
flytres et leurs ailes. Ils volent bien, mitis no !e fonl que rarement. I Leur dénarche est lente, et le plas souvcut ils restent dans an repos parfait. Ils se nonrrissent de la sève des plantes; leur bec est jresque toujours enfoncé dans le lissu des végétaux doutioutes les partics sont également propres à leur fouruir cc suc. On en trouve sur lès racines, les riges et les feuilles, ei mêrme en quielque sortc certaines especes vivent dans l'intérienr des plantes; lcur présence y occasionne lat formation de galles quelquefois furt grosses. ( I'oyez an mot GALLE, 10m. 6. pag. 1933.) Dans loutes les espèces on trouve desindividus qui ne deviennent point ailés, qui unême n'acquièrent jamais les fourreax des organes da vol. Ces individus sunt lous des femeiles; elles sont cependiunt fécondes et alors vivipares. 'Tous les mâles el lir plupart des femelles de la dernitre génération qui a lieu vers la fin de claque aunée prennent des ailes : ces dernières sont ovipares. (Voy. l'article INsecre, tom. 7. pag. 29 r.) Un fait qui paroit propre à ce gcnie est que les fiemelles ¿qui vicnnent de ces oul's nont pas bcsoin d'accouplement pou: produire des petits vivans, non plus que les jeunes lemelles qui maissent d'elles, et cela pendaul piusieurs générations, l'accoruplement de la femelle cripare de la dcrnic̀re génération de l'anncé précédenle suffisant à féconder un asscz grant noonbre des suirantes, c'est-à-dire toutes celles qui se suecèdent pendant la belle saison. (Foy. Rkaumni, tom. 3, 9*. Mémoire, et tom.6, 13. Mémoire.) Dis que les jeunes Pucerons sont nés ils lixcnt de suile leur hec dans le végétal sur lequel vi! leur mère, ils se placent ilussi près d'elle quils le puvent, ce que font émalement tous ceax gui naissent successivement. Jis multiplient considéribleusent, ce qui est prouré par les expériences de Bosuet, rapporićes pa: Réilumur qui a vu une seule nc̀re Puceron dunncr naissance à 95 petits en vingt-un jours. Il faut remarquer que ce Puceron conmença à produire dix jonrs après sa naissance. Réaumur, d'a près ees donnćes, a calculé rque cing générations provenu cs d'une seule mère produiroient $5,904,900,0$ Jo individus tous issus originairement de la nème mère, et que chaque année il doit y avoir au moins vingot générations. Les espèces munies de corncs à l'äbdomen rondent par l'extrénité de ces parlic's me liqueur. sucréc. On peut lui altribuer dans certains cas l'apparition du uiellat gui se répaud sur les feuilles. Les Fonranis sont très-friandes de cclte maijc̀rc, et on en voit presque continueliement la lécber au moment où clle sort du corps du P'uceron. Quelques espèces axême transportent des Pucerons sur les racines des plantes autoul desquelles elles ont construit leurs demenres souterraines, et l'on en conçoit facilement la raison; d'ailleurs on $u^{\prime} a j$ jamilis remarqué qu'aucune Formicaire enlevât un Puceron vivant pour en faire sa proie on celle des larves de son espèce ì la nourriture desquelles elle est obligée de fournir, quoiqu'on en rore sourent attaquer desirsccles et même des animaux d'anlres classes dont il leur est bien plus difficile de s'enparer.

Si la multiplicalion des Pucerons est extraordinaire, la valure a d'un autre còté multiplié le nombre de leurs ennemis; plusieurs genres d'oiseanx en font une partie de leur nonmilure. Les larves des nombreuses espèces de Coccinelles, cclles de quelques Crabronites, d'I chncumonides et de Chalcidites, des Hémérobes et de tout le genre Syrphe, qui conlient haucoup d'espèces doul les individus sont très-multiplićs, font des Pucerons leur unique subsistance. Ils ont encore pour crnemis, nous dit De Géer, de petites mitles rouges qui les succnt. (Leptus aphidis. I_AT.) Dans l'accouplement le mâle est monté sur la femelle; cet acle dure peu de iemps, le inĉme mâle se joint de suite à plusieurs femelles : celles-ci déposent lcurs œufs ordinairement par plaques, les serrant les uns contre les autres le plus possible, et les fixant par une natière gluante qui les accompagne à leur sortie du corps; ces cuts séparés du végétal sul lecquel ils ont été déposés, périssent en se desséchant. Dautres femelles qui paroissent pouvoi: filire sortir de leur abdomen une espèce de tarière, fixent leurs cufs entre les bourgeons des arbres el la tige; elles les déposent isolémeat ou pal petits paquets.

Ce genre tel qu'il est aujourd'hni renferme des espèces fort différenles les unes des aulres par des caractères qui appelleront un jour l'atlention des naturalisies et motiveront la fondation de nouvelles coupes géuériques.

\section{Poceron du Prunier, A. Pruni.}

\section{Aphis dilutè viridis, albo furinosa, abdomine} bicorniculato, corniculis brevioribus.

Aphis Pruni. FАв. Syst. Rhyngot. pag. 296.

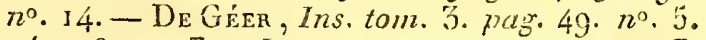
pl, 2.fig. 1-17. - - I.ат. Gen. Crust. et Ins. tom. 5. pag. 173. - Résun. Lns. tom. 3. pag. 296 et3ı7. pl.a3. fig. 9 et 10. - Le Pucerondul'runier. Grofr. Ins. Pars. tom. 1. pag. 497. $72^{\circ} \cdot 10$.

Longueur n. D'un vert-blanchâtre saupoudié d'une poussière blanche. Corp's alongé, conique postérieurezacut. Cornes de l'abdomen courtes. Lez individus ailés ne diffèrent poinl des aptc̀res par leurs conleurs. Leurs ćlytrcs.sont transparentes.

Sur le prunicr et l'abricotier (Prunus sativa et Prumus armeniaca).

Nota. De Géer a va l'accouplement de celte espèce. (Yoyez ccl auteur, tom. 3, pag. 51 et suivantes.) La nymphe a la tête, le corselet et les antennes noirîlyes. Réanmur a remarqué que lorsque ce l'uccron s'établit sur les feuilles encore jeuncs, il les courbe cu divers sen:; mais quand ces fevilles ont aequis leur grandcur et leur consistance il n'en altere point la forme. On voit sou- 
veut tous les Pucerons qui sont sur une de ces f'euilles élever presqu'en nême temps en l'air leur derrière et lenrs quatre jambes postérieures; ils ne sont alors portés que par les deux premières. Si quel qu'individu commence à fatire ce unouvement, ses voisins en font ensuite un pareil, et - uccessivement tous cenx de la fenille; c'est là t:mul lear exercice, car ils ue changent guère de place.

\section{Puceron du Pommier, A. Ponni.}

Aplis favo-viridis, abdomine bicomiculato, corniculis longioribus, pedibus antennisque, ni- escentibus.

Aphis Ponni. De Gerr, Ins. tom, 3. pag. 53. no. 6. pl. 3. fig. 18-23. - Lat. Gener. Crust. et Ins. tom. 3. pag. 173 .

Longneur ". D'un vert mat tirant sur le jaune. Antennes, pattes el cornes de l'abdomen noirî́tres; celui-ci terminé par nue partie cylindrique, arrondie, ressemblant i une petite queue, et garnie de poils courts, firisés. Antennes de la longueur de la moitić din corps. Corselet ayant une petite éwinence pointue, suivie de petits tubercules; on remarque vers le milieu du corps deux aulres petites pointes élevées. Cornes de l'abdomen assez lungues, un peu renllées dans leur milieu, trouquées trausversulement à leur extrémité. Yeux de figure irrégulière, munis d'un appendice conique. Le mâle a les incisiors des segmens de l'abdomen mieux marquées que celles de la femelle, et sou dos a de chaque côté une rangée de taches obscaves. Ce Puceron s'accouple saus que les mấles ni les femelles soient derenus ailés. Ses oufs sont d'un noir-luisant. Il oblige tes feuilles du poinmier à se courber eu dessous, et se retire dans cette cilvité; il se multiplie quelquefois si prodigieusement qu'il fait périr ces jennes arbres fruiliers.

Il se trouve en Europe sur le pommier ( Pyrus malus ).

Nota. Nous doulons que cette espèce soit celle que M. Blot, correspondant de la Société Linníenne de Caen, a proposée comme type d'une nouvelle coupe générique sons ie nom de $M Y z o-$ xyle. Il ne lui accorde point de cornes à l'abdowien, et il donne aux anlennes cinq articles, le sutsond le plus long de tous. Du reste, cet observaleur atribue à lespèce dont il parje les mémes glingâts que De Géer reproche à la sieune, et dit quil fait périr les jeunes pousses.

\section{Puceros de la Millefeuille, A. Millefolii.}

Aptis viridis, nigro maculata, pedibus antennisque nigris, abdomine bicomiculato, corniculis torigiorious.

Aphis Millefolii. $\mathrm{D}_{\mathrm{x}} \mathrm{GËER}$, Ins. tom. 3. pag. 60. n?. 9. pl. 4. fig. 1-6. - I. AB. Syst. Rliyngot. pag.
214. $n^{\circ}$. 17. - Lat. Gen. Crust. el Ins. tom. 5. pag. 173.

Longueur ». Vert avec des points et des taches écailleuses de couleur noire, garnis de poils. 'Tête, antennes, pattes, cornes de l'abdomen et une pelite queue cylindrique à l'anus noires. Antennes prescue de la longueur du corps. Le mâle est ailé, noir ou d'un brun-obscur; il a le ventre rougeătre ou d'un vert foncé, avec des taches noires en dessus.

Se tronve en Europe sur la millefeuille (Achillea millofolium ).

Nota. De Géer a vu le même mâle s'accoupler consécutivement avec cinq femelles. "Ayant eu» suite pressé le corps de ce mâle pour en fiare sor" tir l'organe qui lui cst propre, il le vit paroitre "d'ilbord; c'est une partie älongée, cylindriçue

- et transparente dont le bout est arrondi, et dont "la peau est membraneuse el llexible; proche de "son origine elle a une inflexion en forme de " genou, et ensuite elle se recourbe vers le dos "de l'insecte. Par la forte pression qu'il employa, - la partie se courba considérablement en forme "de spirale; vers la base on voit cenx petiles "éminences, une de chique côté, garnies de " poils, et qui semblent équivalentes anx crochets " du clerrière der mâles de pinsieurs autres insec"tes dont l'usage est de s'accrocher an ventre de "La feruelle; ces deux poinles forment une émi" nence au ventre du unte quand la partie de la "génération sa troure retiréc daus le curps. Celle "qui caractérise le sexe de la femelle, qu'uu ub" serve aussi eu lui pressant un pen le ventre, est " nn enfoncement ou une ouverture en forme de "fente, fermée par des espèces de lèvres en desn sous de la petite queue din derrière; c'est aussi "par-lir que les cuĺs sont pondus : ceux-ci sout n d'abord verts, ensuite ils deviennent d'un bear "uoir-luisant. La femelle les place sur les feuilles " de la plante. n

\section{Puceron du Rosier, A. Rosce.}

Aphis viridis, abdomine bicomiculato, comiculls longissimis.

Aphis Rosa. Linn. Syst. Nat. 2. 734. 9.-DE GÉER, Ins. tom. 3. pag. 65. no ${ }^{\circ}$ 10. pl. 3. fig. I-r4. - Fa B. Syst. Rhyng. pag. 298. no. 5o. LAT. Gener. Crust. et Ins. tom. 3. pag. 173. RÉauma , Ins. tom. 3. pl. 21. fig. 1-4.

Longuenc ». Vert. Extrémité des antennes, comes de l'abdomen et bout des pattes noirs. 'f'ête petite. Antennes très-longnes, égalant au moins hil longueur du corps. Palles longrues et yrếles. Cornes de l'aludomen très-longuzes, grosses, cy-. lindriques, se terwinant ta uue sorta de bouton. Femelle aptère.

la lémelle ailée evt d'un vert-olsscar mêlé dẹ. noir. Sa tẹte et son corselet sont presque toat uoirs; 
le ventre a de chaque cóté une suite de points noirs. Ses pattes et son bee sont noirs. Elle porte ses élytres et ses ailes en toit.

Le mâle est ailé, d'un bruu-obscur presque noir; son ventre est un peu roussâlre avec des taches noires vers les côtés; les pattes sont moitié noires, moilié d'un brun-pûle.

Commun en Europe sur le rosier.

Nota. Celle espèce vit en grande soeiété sur les jeunes pousses de diverses espèces de rosicrs où elle se tient ordinairenent le derric̀re élevé, oecupée dans cette attitude à pomper le suc de l'arbuste. Elle fait souveut périr les boutons de rose.

\section{Puceron furineux, A. farinosa.}

Aphis obscurè viridis, maculis lanuginosis albis, abdomine bicorniculato, conniculis longioribus.

Aphis salicis farinosa. DE GÉER, Ins. tont. 3. pag. $76 . n^{\circ}$.11. - LAт. Gener. Crust. et Ins. toni. 3. pag. 173.

Longueur ». D'un vert très-foncé tirant sur le noir, ayant sur le dos deux rangées de taches b)anches cotonneuses. Antennes de la longueur de la moilié du eorps. Cornes de l'abdomen assez longnes. Femelle aptère.

I.e mâle que De Géer a vu s'aceonpler avec cette femelle et même uvee deux de suite étoit d'un jaune-d'ocre tiraut un peu sur le rouge et aptère. Ses taehes colonneuses étoient peu ou point visibles. Cet auteur les a rencontrés dès le unilien de l'été en copulation, chose peu eommune parmi les Pueerons.

On le trouve eu Europe sur une espèce de saule à fiuilles cotonneuses donı De Géer ne donne pas le nom spécifique.

\section{Puceron di Tilleul, A. Tilice.}

Aphis flavo-viridis, line is punctorun nigrorunu, alis nigro nuaculatis, abdonine bicomiculato, coriniculis brevioribus.

Aplis Tilio. Linn. Syst. Nat. 2.734. I I. DE GEER, Ins. tom. 3. pag. 77. $n^{\circ}$. 12. pl. 5. fig. I -6. - FA в. Syst. Rlyzngot. pjag. 299. no. 39. - L.aт. Gen. Crust. et Ins. tom. 5. pag. 173. Réaumu, Ins. tom. 3. pl. 23. fior. 1-8. - Le Pueeron du 'Tilleul. Georf. Ins. Paris. tomı. 1. pag. $495.72^{\circ} \cdot 6$.

Longuenr ". D'un vert très-clair et jaunître avec plusieurs taches noires. Aniennes un peu plus longues que la moitié du eorps, d'un vertblanchâtre avec des tacbesalongées, noires au bout des troisième, quatrième, cinquième et sixième artieles. Cornes de l'abdowen fort eourles. Femelle aptère.

Lia feinelle ailée a les côtés de la têle, du corselet et de la poitrine marqués dans toute leur lon- gueur d'un raie noive, le dessus de l'abdomen a denx rangrs composés de six taches noires, lunulées. Les antennes sont plus courtes que le eorps, variées de noir et de blane-verdâtue. les pattes d'un vert-cluir avec les deux cuisses postérieures noires. Poitride jaune. Les élytres transparentes avec des nêrvures brunes, lenr eôlé exlérieur a une large bande noire qui porte une laehe jaunâtre à l'extrémitć. On voit une petile taehe noirâtre à l'endroit où aboutit cette nervure, au bord postérieur et intérieur de l'élytre. Lics œufs sont noirs, oblongs, couverts d'un duvet blanc.

Commun en Europe sur le tilleul (Tilia europea).

Nota. De Géer rapporte que ce Puceron ne produit aucune altération sensible sur la forme des feuilles qu'il babite. Réaumur au contraire a remarqué qu'il fait recoquiller les feuilles du tillenl et même qu'il force les jeunes branclies sur lesquelles ì s'étabit à se contourner fortement.

\section{Puceron du Pin, A. Pini.}

\section{Aptris fusca, abdomine bituberculato, pedibus} nudis.

Aphis Pini. Line. Syst. Nat. 2. 736. 25. FAB. Syst. Rhyngot. pag. 50o. $n^{\circ} .44 .-$ Aphis nuda Pini. DE GEER, Ins. tom. 3. pag. 27. $n^{\circ}$. 1 . pl. 6. fig. I-18. - Lat. Gener. Crust. et Ins. tom. 3. pag. 173. - Panz. Faun. Germ. fas." . fig. 17.

Longueur 2 lig. D'un gris-brun mêlé de roux. Cornes de l'abdomen presque nulles en forme de mamelons. Fenelle aptère. CEufs oblongs, d'un noir très-luisant. De Géer remarque que ces œufs apportés dans me chambre chande s'y desséchèrent quoigu'il les en̂t laissés sur les feuilles du pin sur lesquelles ils avoient été poudus, d’où il infére gu'il faut donc que ces oufs tirent quelque substance de la fenille propre is les conserver ou bien que l'humidité qui transpire de eelle-ci est nécessaire pour empêcher leur dessćchement.

La femelle ailée est d'un brun-noirâtre avec qualcques taches ceudrées, le dessous du eorps est d'un brun-januâtre; ses pattes longnes et délices: les élytres fort longues, transparentes, à nervures brunes; vers leur bord extérieur est une longlie raie brune.

Je mâle, suivant De Géer, est semblable à la femelle et aptère.

Cetie espece se ticnt sur les jeunes pousses da pin. "Lorsqu'un jeune individu sort de l'œuf, il " se fait d'abord une ouverture is l'un des bouts de "la coque et le petit Puceron avance la tête hors de cette ouverture, peu à peu il fait glisser le " corps eu avant parle gonflement et la eontrae"tion des segrmens el se met presque dins une position perpendicalaire à la branclie, de facoa 
; cuilil se trouve comme placé sur le bout de sa ¿queue. Les palles et les antennes restent exac¿ tement appliquées contre le dessons du corps 2) jusqu'i ce qu'il ne tienne plus is la coque que par " sa parlie postérieure; il seliasse et se baisse a 2) (iifírcutes reprises et commeuce entin à faire " usage de ses pattes qu'il écarte el remue chern chant à les fixer sur la branche; lorsquil y est "parenu il tre douetment sou corps cn avant poir en ás ager l'extrérailé hors de la coque et "va se placer sur la branche.

Se trouve en Europe sur le pin sylvestre (Pinus oylvestris).

\section{Puceron eotonneux, $A$. pineti.}

Aphis nigra, albo farinosa, abdomine bituberculuto, pedibus vallosis.

Aphus pineti. is. Syst. Rhyngot. pag. 500. $n^{2} .45 .-$ Aplis tomentosu P'In. DE GEER, Ins. tom. 3. pag. 39. no. 2. pl. 6. fig. 9-24. - LAT. Gener. Cinist. et Ins. tom. 5. pas. 173.

Ionguevr I lig. Noir, fortement saupoudré d'une matiòre blanche. Antennes de la longneur de la moitió du corps, tris-relnes, brunes avec lrur extréxuité très-noire. Bec alleiguant l'origine des pattes postéricures; celles-ci grosses, épaisses, phus longues que le corps, chargúes d'une grande quantité de poils longs, fins, laineus, couverts d'une matière cotonneuse blanche qui est altachée anx poils et entrelaccé avec eux. Antennes ayant aussi le celle wême matière dont on voit de petits flocons sous le vertre. Crochels des tarses grands. liemelle aptère.

Les jeunes individus scut plus noirs, les pattes suriout; les pestériemes ne sont pas ansii longues en proportion, mas renfles ainsi que les antennes, La femelle ailce est semblable it la femelle aptère; ses élytres sont transparentes avec une large bande d'un brun-nciratre le long du Lord extírieur.

Céte espèce se tient sur le côté eonvexe des fenilies du pia sylvestre (Pinus sylfestris); elle marche mal à cause de la longueur et de la confurmaion de ses paltes posiérientes, mais se erampone aisćment au moyen de la force des crochets de ses tares. Leo aufs sont noirs, semhlahles a ceux du Pucerou di Piu.

L'kirope.

9. Pucrnox de l'Anlne, A. Alni. bito.

Aphis favescente-alba, abdomine bitubercu-

Aphis Alni. De Gér, Ins. tom. 3. pag. 47. n॰. 4. pl. 3. fig. 15-17.- - FAB. Syst. Rhyngot. purg. $293 . n^{\curvearrowleft}$. 26. - Lis. Gener. Crust, et Ins. toin. 3. pag. 173.

loggueur . D'un blane-jaunâtre tirant un peu sur le vert. Tubercule's de l'abdomen bruns. Dest sous du ventre ayant deux plaques recouverles d'une matic̀re d'un bluncargentá. l'enclle aptc̀ı. Guts verts saluzoudrís d'une malic̀re farineuse qui les fait paroitre blanes. En sortant du corpss de la femelle ces cufs ne sont point euduits de cetle matic̀re blanclie.

De Gécr remarqua sur une branche une femelle qui y faisoil beaneoup de mouvemens avee sis paties postérieures : "elle éloit justement pla" cée au-dessus d'un œuf nouvellement pondu et * encore tout rert; j'élois altentif, dit-il, à ob» server à quoi alle s'occupoit, et je vis qu'elle " froltoit de tempsen temps et a vec vitesse les denx " palles postćrieures contre le dessous du ventre " et ru'eusuile elle les fuisoit passer sur l'œuf à "différentes reprises. A mesince qu'elle répéloit "cetle manæuve, je vis que l'ouf devin! poudré "de pius en plus jusquà ce calerenfin il fut tout " couvert d'une malicre blanche. Il paroit que "Le Puceron détache de son ventre la matière "dont il recouvre ses oufs."

Il se trouve en Europe sur l'aulne (Betula. Alnus )

\section{Puceron de l'Orme, A. Ulmi.}

\section{Aphis nigricans, abdonine bituberculato.}

Aphis Ulmi. Inss. Syst. Nat. 2. 733. 2. Aphis foliorum Ulmi. DE Gं்ूn, Ins. tom. 3. pag. 81. $n^{\circ}$. 13. pl. 5. fig. 7-21. - Lat. Gener. Cirust. et Ins. tom. 5. pag. 173.

Iongrueur ". 1)'un ardoisé-noirâtte sanpoudré d'un matière colonneuse blan he. Antennes courtes. Bec ne dípassant pas de beaucoup la base des pattes antérieures. Abdumen ayant en dessus quatie ragogs de taches circulair es d'oi sortent des toulles bion fournies de maliere colouneuse blanche. Ferselle aptère.

I,es jennes individus suivant leur âge sont bruns, verts ou coulear de chair; leur abdomen teruniné en cône porte de chaque côté un manelon arroudi. 'loul le long du dos il y a des suites de points ronds d'une coulent plus obseure gui procuisent une inatière cotonneuse blanehe. Jies intennes sont de la longnenr de la moitié du eorps. Dansl'état de nymplieils sont d'uu vert-livide grisâtre, tiraut snr la couleur de chair. Tout le ecrps est couvert d'un duvet blanc, épais. I.es antennes sont très-couries et uc sétendent que juscru'au bout de la poitrine; elles sont divisies en six articles garnis de beaucoup de poils court; lenr troisicme arliclesest beaucoup plus long que les autres.

Ta femelle ailće a le corps et toutes les parties d'un noir luisint, les élytres transparentes ì nervures noires et près du berd extérieur une nervure plus grosse que les atutres qui vers le bout de liuile 
l'aile se dilale en une plaque assez large d'un brun-obscur. Les antennes sont presqu'aussi conrtes que dans les nymplies, divisées, selon De Gćer, cn un très-grand nombre d'articulations. Je même auteur dit què ces femelles ailées sont vivipares. Nons nous croyons autorisés à penscr le contraire d'après ce qu'il ajoute, que ces petits insectes naisseut enveloppés d'une pellicule qui leur donne d'abord la figure d'une simple petite masse ovale, dont bientôt ils savent se tirer. Cette petite masse ovale ponrroit fort bien être un œuf, duquel le Puceron écloroit immédiatement après la ponte. De Géer u'a point connu le mâle de cette espèce. Elle vit dans les feuilles roulées de l'orme. On trouve dans ces feuilles des gonttes d'uue malière gommeuse qui ont cela de renarguable que jetées sur du papier, quoique liquides, elles roulent dessus sans s'y altacher pendani quelque temps, parce qu'elles sont comine poudrées de la malière blanche qui se détache des Pucerons. Cette liruemr' n'est aut:e close que les excrémens de ces hćmiptères.

Commun en Europe sur les feuilles de l'orme.

Nota. La troisième division du genie Puceron de M. Lilleille, Gen. Crust.et Ins., dont le caracière 'st : antennes conrtes, filiformes; point de corries ni de tubercnles à l'abdomen; insectes vivant ordinairement dans des sortes de galles ( 1 , nous paroit contèni des espèces très-dilférentes entrelles et fort distincles des vrais Pucerons; nous n'avons pas cru devoir les y réunir dans l'élat actuel de la science. Plusieurs semblent firire le passage du gucure Puceĩon à celui de Dorthésie.

ALEYRODE, Aleyrodes. Lat. Phalcena Tinea. Livx. Phalcena. Geoff.

Genre d'insectes de l'ordre des Hémiptères, section des Houoplères, famille des Hymérićlylres, tribu des Aphidiens.

Cette tribu ne contient que les genres Paceron et Aleyrode; le premier est bien séparé du second par ses antennes plus longnes que le corps, les élytres notablenent plus grandes que les ailes et par les yeux entiers.

Antennes courtes, de six articles, le premier fort gros, les autres filiformes. - Bec court, partantdu dessous de la tête, ses articulations peu distinutes. - Yeux partagés en deux par le rebord de la tête. - Corps très-mou, farineux, ailé dans les denx sexes. - Corselet "yan! son seyment antérieur petit, transverse, le second beaucoup plus grand et élevé. - Elytres et ailes de même consistance, à peu près de mêne longueur, cn toit écrasé dans le repos; on n'y aper-

(1) Aphides gallarum Vlmi, Tremule, Xylostei, gallanum Abieris. De G Ġ́. R.

Hist. Nat. Ins. Tome $X$. coit qu'une seule nervure iongitudinale gui, partant de la base s'avance dans le milieu et se courbe un pen en se dirigeant vers le bord postérieur qu'elle n'atleint pas. - Pattes de longueur moyenne; tarses d'un ou de deux articles.

Le nom d'Aleyrode donné à ce genre par M. Latreille, vient du grec; il exprimc que ces insectes sont couverts d'une poussic̀re farineuse. La seule espèce que l'on connoisse est très-petile, vit sur le chon (Brassica oleracea) et l'éclaire (Chelidonium majus). La larve s'écarle pen de l'endroit où elle est sortie de l'œuf. Elle se fixe sur le dessous de la feuille dans laquelle elle enfonce son bec. Sa forme est à peu piès celle d'une tortue, mais plus plate, le contour de son corps est ovale, le côté de la tête est moins large que l'autre; sa conleur est blanche avec denx petites taches jaunâtres. Son corps est presque transparent. Elle a six pattes écailleuses placées près de la tête. On ignore le nombre de ses changemens de peau. Réanmur qui a suivi ces larves de près, n'a pu s'assurer qu'il y en eut, mais il observe que des déponilles aussi minces que celles dont se seroient défaits d'aussi petits insectes auroient pu facilement lui échapper. Six ou sept jonrs après leur naissance il leur trouva une forme beaucoup plus alongée, qui approchoit de la triangnlaire, un de leurs bouts étoil arrondi, il avoit son premier diamètre; le corps diminuoit ensuile insensiblement et se terminoit à l'autre bout par une pointe fine. Après cinq jours ćconlés, elles reprirent une forme analogue à la première, mais plus renflée; ce cluangement ne se fit que pelit à pelit en trois ou quatre jours. Dans cet étal le corps s'étcit raccourci et sur sa partie supérieure, près dı bout le plıs étroit, il y avoit deux taches brunes; telle est la nymphe de l'Aleyrode, qui reste immobile pendant les quatre jours qu'elie passe dans cet état; alors elle se fend sur le dos et l'insecte parfait sort de son enveloppe absolument de la mềne manière que les Papilloñs. L'accorplement a lieu sur la plante où ces insectes sont nés, pendant cet acte les deux sexes sont posís à côté l'un de l'autre. La fcrnelle dépose ensuile de nenf à quatorze œufs sur un pelit espace circulaire aisé à distinguer, en ce qu'il est saupoudré de celte même poussière farineuse blanche qu'on remarque sur tontes les parties de l'insecte parfail et qui recouvre aussi les œut's; ceux-ci sont très-petits et placés a la circonférence de l'espace dont nous venons de parler, ils sout oblongs, en forme de petits cylindres à pointes arrondies. Ils éclosent à peu pres douze jours après la ponte. La multiplicalion de cette espèce est très-considćralle; rlle a quelques ememis. La larve d'un coléoplère, peut-être celle d’nne Coccinelle, dévore les larves et les nymphes. Réaumur la représente aiusi que l'insecte palfait, tom. 2, pl. 25, ffo. 18-2 I, mais d'une mauière si imparfaile que nous ne pourous être sû: du genre. 
3. Aleyrode de l'Eclaire, $A$. Chelidonii.

Aleyrodes corpore fajescente vel roseo, albido pulverulento, elytri singuli nebuli punctoque nigricuntibus.

Aleyrodes Chelidonii. Lat. Gener. Crust. et Ins. tom. 3. pag. ${ }^{7} 74 \cdot n^{\circ}$. 1. - Phalcena Tinea Proletella. Linx. Syst. Nat. 2. 889. 379. RÉ uss. Ins. tom. 2. $\mu l$. 25. fig. 1-17. - La Phalène culiciforme de lEclaie. Georr. Ins. Paris. tom. 2. pag. $17^{2} \cdot n^{\circ} \cdot 126$.

Longueur 1 lig. $\frac{5}{2}$. Corps jaune tirant quelquefois sur le rose, reconvert d'une pnussiere far:neuse blinche ainsi que les élytres et les ailes qui paroissent d'un blanc-mat et ont chacune sur leur disque un point el un espace irrégulier un peu noirit!res. Yeux noirs.

Très-cominune pendunt toute l'année aux environs de Paris sur le chou et l'éclaire.

(S. F. et A. Serp.)

PUlmonaIRes, Pulmonarice. Lat. Ugonata. FAB.

C'est, dans la méthode de M. Latreille (Fam. nat. du Règne anim.), le premier ordre de la clusse des Arachnides; il le caractérise ainsi: un organe de circulation; des branchies respirant directement l'air ou fuisant l'office de poumons, et toujours siluées sur chaque côté du dessous de l'abdomen; deux clélicères en forme de inandibules, terminées par un ou deux doigts et dont l'un toujours mobile; deux mâchoires poriant chacune, soit à leur extrémité, soit itl côté extérieur, un palpe de cinq articles; un labre, une langue, quitre paires de pieds.

Cet orảre est divisé en denx familles.

\section{Pédipalpes, Pedipalpi.}

Ils ont constamment huit on quatre spiracules ou bouches aériennes, les palpes en forme de serres ou de bras, sans aucun appendice relatif à La génération dans aucun sexe; le doigt mobile des chélicères sans ouverture propre au passage d'une liqueur venirseuse; l'abdomen lotijour's revêtu d'un derme coriace ou assaz ferme, annelé et sans filière fau bout. Cet ordre renferme les tribus des Scompionides et des Tarentules.

\section{Araxítdes, Araneides.}

Itlles n'ont, dans le plus grand nombre, que deux spiracules, un de chaque côté du dessous de l'abdomen, près de sa base, et jamais au delì de quatre. Palpes pédiformes simples, terminés au phns ptr un petit crochet; le dernier article diftère selon les sexes, et ofïre dans les mâles divers appendices écailleux plus ou moins compliq̣ués, Jelatifs à la génération. Les chélicères sont tonfours monodactyles ou en grilfies; le doigt mobile

\section{$\mathrm{P} \mathrm{UN}$}

on le crocliet terminal est loujours percé pour livrer passage à une liqueur venimeuse. L'abdomen est orlinarenemt mou, sans anneaus, avec yuatre ou cing papilles cyliudriques ou coniques, criblíes de pelits trous el servaut de lilières, à l'anus. Les pieds, de lougucur variable, sont de forme identique et loujuurs terninés par deux ou trois croclicts. La lungue est toujours d'une seule piece, plus ou moins avaucée entre les mîchoires, mais jamais linéaire et en forme de dard.

Lit plupart, pour saisir leur proie, construisent avec de la soie des pićnes, le plus souvent sous la furme de toiles, soil ćtendues, soit tubulaires. 'Tuutes emploient la shêue matiè ${ }^{\circ}$ e pour envelopper leurs cufs. Celle famille correspond aux Pulmonaires fileuses du Règne animal de Cuvier, tom. 3. Elle comprend deux sections; ce sont les Tétrapneumones et les Dipneumones: Ia seconde section est divisée en six llibus qui sont les Tubitébes, Inéquitèles, Orbiteles, Latérigrades, Citigrades et Sultigrades. (E. G.)

PUNAISE, Cimex. Linv. Latr. Geoff. Dr GÉER. Acanthia. FAB.

Genre d'insectes de l'orlre des Hémiptères, section des llétéroptères, fauille des Géocorises, tribu des Membraneuses.

Les genres Níacrocéphale, Pliymale, Tingis, Arade et Punaise forment cette tribu, mais les qualre premiers sont bien distincts du cinquiène parr leurs antennes ou régulièrement filiformes ou terminées en massue.

Antennes presque sétacées, insérćes devant les yeux, un peu plus longues que le corselet, cornposées de quatre arlicles cylindri jues, le premie plus court que les autres, le second épais, fur'r long, le troisième très-long, beaucoup plus mince que les précédens, le dernier grossișsant à pein vers sou exirénité. - Bec court, ne dépassatat pas la base des cuisses antérienres, courbé directernent sous la poitrine, composé de trois articles, le premier et le second cylindriques, un peu déprimés, presque d'égale tongneur; le second plus large, le dernier conique, un peu plus long que les autres. - Labre visible, assez petit, triangulaire, son extrémité presqu'obluse. - Téle s'avançant en carré et fordant it l'origiue du bec un chaperon en forme de capuchon qui ser't d'élui à la base du bec. - Point a'yeux lisses. - Corps ovale, déprimé, un peu plus étroil en devant, ses bords latéraux aigus. - Segment antérieur du corselet transversal, échancré antérieurement, tronqué à sa partie postérieure, ses côtés dilatés, membrabeux, arrondis. - Ecusson grund, trigone, formé par le dos du second segueal du corselel. - Elytres extrêmement petiles et ailes nulles (du moitus dans l'espèce conuae). - Abdomen grand, orljiculaire, très-déprimé. - Cuisses ovales, aluz- 
Ećes; jambes assez longues, cylindriques; tarses iourts, de trois arlicles distincts, le premier trèscourt, le seeond cylindro-conique, le dernier un peu plus eourt que le seeond, cylindrique et muni de deux forts crochers.

On donnoit aneiennement le nom de Punaises \& tous les bémiplères béléroplères, à cause de la manvise odeurqu'exhalen la plupart d'entreux, el le vulgaire se sert encore aujourd'hni de eerle dénominalion. M. Lalteille l'a justement restreinie à l'espèee incomnode yui habite nos maisons, et dont l'odeur est insupportable. Itat Punaise craint le jozr et se caehe dins les moindres fenles des cloisons, sous les piriers qui ne sont pas exactement collés, etc. C'est lì qu'elle s'accouple, fait sa ponte el subit ses métamorphoses : the en sort lorsque l'obscurilć règne, se répand daus nos li!s et nous suce le sang impunéuent pendant notre sonımeil. Ses pigúres occisionnent une fllflure et une démangenison assez lorles, mais peu durables. L.es précautions que l'on prend pour s'en garantir, mêare l'isolement du lit, sont toujours insullisantes; elle monle alor's le long du unur et se laisse tomber du plafond directenent sur le lit. La propreté, des recherches exactes et fréquentes peuvent scules, sinon délruire, au moins diminuer considérablement le nombre de ces enneruis de notre repos. La Punaise eommence sa ponte vers Je mois de mai, et l'on en voit de très-petites sortant de l'ouf dans les mois de juin, juillet et août. La larve ne diffère de l'insecte parfatit que par l'absence des élytres, encore-celles-ci sont-elles exeessivement conrtes. La Punaise des lits n'est point originaire d'Europe; on sail qu'elle fut apportée à Londies dans des bois d'Anériçue après lineersdie de 1666 . Cependant Dioscoride fait mention qu'elle existoit de son temps dans l'ancien coutinent.

\section{Punarse des lits, C. lectulurius.}

Cimex fusco-ferrugineus, abdomine suborbiculari.

Cimex lectularius. Linn. Syst. Nat. 2. 715.1. - LAx. Gen. Crust. et Ins. tom. 3. pag. $137 \cdot n^{\circ}$. I. -DE GEER, Ins. tom.3. pag. $296 \cdot p l .17 \cdot f_{0} \cdot 9-15$. - Storr, Punais. pl. AXX. fig. 13 r et B. - Acanthia lectularia. FAB. Syst. Khyngot. pag. 112. no. I. - La Punaise dés lils. (ieoff. Ins. Pars. tom. 1. pag. 454. no. 1. - Encycl. pl. 122. Punais. $\int 1 g .1-3$.

Longucur 2 à 3 lig. Entièrement d'un brun-ferrugineux. Abdomen orbiculaire, ses bords garuis de quelques poils courts assez roides. Hytres tricspeities, sans parlie mombraneuse, couvrant à peine le quart de l'abdomen, éeartées l'une de l'autre dass leur milieu.

Nota. Au sorti de l'œuf les jeunes Punaises ront blanchâtres. Ce que nous décrivons d'après les auteurs comme des élytres, n'a point d'artienlation à sa base ni de mouvement qui lui soit propre; tandis que les vraies élytres s'élèvent ou s'ahaissent dans tous les autres hélćroplères. Peulêtre devroit-on regarder ces organes eomme des fourreaux d'élytres, el l'insecte qui les porte eomme n'étant qu'en élat de nyauphe.

M. Latreille soupçonne qu'il y a me seconde espèce de ce genre, celle qui vit daus les nids d'hirondelle; son caractère particulier est d'être plas velue que la précédente sur les bords de l'abdonen : il se pourroit aussi que celle des uids de pigeon fùt une troisième espèce distincte pür sor abdomen beaueoup plus oblong que ne l'est eelun des espèees dont nous venons de parter.

$$
\text { (S. F.et A. Serv.) }
$$

PUNAISE A AVIRONS. Geoffroy donne celle dénomination aux insectes hémiptères du genre Notonecte. Voy. ce mol. (S. F. et A. Serv.)

PUNAISE DE BOIS. Nom trivial par lequel on désigne ordinárement les insectes luémipłères des genres Pentalome et Sentellère. Voyez ces mots.

$$
\text { (S. F. et A. SERt.) }
$$

PUPIPARES, Pupipara. Famille unique de $\mathbf{l}$ section des Eproboscidús, ordre des Diplères.

On eonçoit que celle famille étant unique ses caraetères sont les inêmes que ceux de la section à laquelle elle appartient. Comme le mot EproBoscriés n'a point été traité à sa leltre, nous donnerons ici les caractères des l'upipares.

Bouche en forme de bec, eonposée d'une à deux lames, reeouvrant une manière de tube ouvert en dessous, renfermant un suçoir (de deux soies rénnies en ane), partant d'un bulbe radical de la cavité buecale. ('I'ête souvent intimement unie ou comme soudée au eorselet, quelquefois ue se présentant que sous l'apparenee d'un tubercule inséré verticalement sur le corstlet; crochets des tarses très-contournés, paroissant doubles ou wême triples.) Cetie famille coutient deux tribus, Coriaees et Philiyromyies.

Ces diplères, nommés par d'anciens auteurs mouches-araignées, vivent exclusivement sur des mammiferes ou sur des viseaux. Leur eorps est eourl, assez large, a plati ei dífendu par un derme solide, presque de la consistance dir cuir.

$$
\text { (S. F. et A. Sent.) }
$$

PUPIVORES, Pupivora. Seeonde fauille de la section des 'Térćbraus, ordre des Hyméuopières. Elle oflire pour earactères :

Abdomen fixé au trone par un pédieule ou ura rétrérisseruent de la buse de son premier segrnent, de manière que son point d'insertion est très-distinet et qu'il se neut sur cette partie du corps. - Taridre (des femelles) eylindrique. 
Cetle famille renferme six tribussuivant M. Latreille.

Ire. Tribu. Evaniales, Evaniales.

Antennes de treize ì quatorze articles. - Ailes inférieures plus petites (proportions gardées) que dans les Ichneumonides, ne présentaul gu'une ou deux nervures lonizudinales. - Aldomen inséré à l'extrérnité supćrienre du mélathorax ou près de l'écusson.

\section{Pólícine. \\ Evanie. \\ Forne. \\ Aulaque.}

$2^{\circ}$. Tribu. Ichoeunonides, Ichneumonides.

Antennes filiformes au sétacées, viluratiles, multiar!im!'es. - Palpes maxillaires apparens, atungés, lilifurines nu sóltcés, composés de cinq on sivarlicles. - Alles inférieures ayant des nervul'es dictinctes, - Aldomen (des fenelles) muri a son extrémité postórieure d'une tarise le plus soavent saillante, enfermée dans deux fourreaux. - Femelles yueliguefivis àtes.

1. Palpes maxillaires de cing articles, les lubiuux de quatre.

Stéphane.
Xoride.
Ichueumon.
Pimple.
Pellaste.
Acænite.
Agatbis.

๑. Palpes maxillaires de cinq articles, les labiaux de trois.

Vipion.
Bricon.
Helcon.
Microgastre.

3. Palpes maxillaires de six arlicles, les labiatux de quatre.

$$
\begin{aligned}
& \text { Sigilplie. } \\
& \text { Cbéione. } \\
& \text { Alysie. }
\end{aligned}
$$

\section{3e. 'Tribu. Gallicoles, Gallicolce.}

Antennes troites, fliformes ou légèrement pins grosses vers le bout, ordinairement composées de ireize à quinze articles. - Palpes trés-courts, terminés par un article un peu plus gros et quelquefois nul. - Ailes inférieures sins nervures distinctes. - Tarière (des femelles) naissant de la partie inférieure de labdomen, ronlée cn spirale à sa base et logée dans une coulisse.
Segment antérieur du corselet très-arqué.-Femelles quelquefois aptères.

\section{Ibalie. \\ Cynips. \\ Figile. \\ Eucharis.}

\section{4e. Tribu. Chalcidiles, Chalcidioe.}

Antennes brisćes, de six à douze articles et formant a partir du conde une massue al nngée on en fuseau. - Pápes rès-coults. - Télc souvent malqu' d'une ou de doux imurensions pont recevoir le desseur du premier article desantennes. - Segment antéricur du corselct ayant son loord postćricur dmil. - Alles inférieures sans nervures distinctes. - Abdomen comprimé ou déprimé, r a réns et munien dessoni: (dans les fernclles) d'une tarière filiforme souvent saillante hors du corps. - Femelles quelquetois aptères.

I. Antennes composées de plus de sept articles.

A. Antennes insérées à une distance notable de la bouche, vers l'entre-deus des yeus.

a. Cuisses postéricures très-renflées; leurs jaubes arquées.

\section{Leucospis. \\ Chalcis.}

b. Cuisses postérieures simples, leurs jumbes droiles.

† Segment antérienr du corselet large, en carré transversal ou eu triangle troncqué à sa pusuie.

$$
\begin{aligned}
& \text { Eurytome. } \\
& \text { Miscampe. } \\
& \text { Ci onyne. }
\end{aligned}
$$

If Segment antólieur du corselet trèsétroit, ne firmant qu'un pelit rebord transierso-liućare.

$$
\begin{aligned}
& \text { Firilaupe. } \\
& \text { Encyre. } \\
& \text { Fićromale. }
\end{aligned}
$$

B. Antennes insérées tiès-près de la boache.

$$
\text { Spalangie. }
$$

II. Antennes composées de sept arlicles au plus.

\section{Ealople.}

5e. Tribu. Oxyures, Oxyurce.

Antennes presque tonjours filiformes dans les mâles, en massue ou plus grosses au bout disass 


\section{$P U P$}

plusieurs fenielles, composées de dix à quinze arficles, tantôt droites, tanlôt coudées. - Palpes maxillaires souvent longs et pendans. - Ailes inférieures sans neıviures distinctes. - Tarière (des femelles) scit intérienre et ne surtant que jar l’auns, soil estérieure et formée par le proJongenent du bout de l'abdomen. - Femelles quelquefois aptères.

I. Antennes insćrées au milieu de la face anlérieure de la têle.

\section{Hélore. \\ Proctotrupe. \\ Cinète. \\ Bílyte. \\ Diaprie.}

II. Antennes toujour's coudées et insérćcs près de la bouchc.

A. Segment antérieur du corselet court et transversal.

$t$ Antennes filiformes dans les deux sexes.

Antéon.

Céraphron.

t† Antennes des femellcs plus grosses à leur extrémité.

Platygastre.

Télédde.

Scélion.

Sparasion.

B. Seguent antérieur du corselet alongé.

Dryine.

Béthyle.

6e. Tribu. Chrysides, Chrysidides.

Antennes courtes, filiformes, brisćcs, vibratiles, dc treize articles dans les deux sexes. Mandibules étroiles, arqućes, pointues. - Palpes maxillaires ordinairement plus longs que les labiaux, de cinq articles; les labiaux de trois. Ailes inférieures sans nervures distinctes. - Tarière (dcs femelles) arliculée, rétractile, s'alongeant ou sc raccoutcissant à volonté et portant à son extréaité un petit aiguillon. - Corps se contractant en boule, l'abdomen formant un demiovale, concave ou plan cn dessous et s'ippliquant contre la poitrine.

I. Curselet point rétréci en devant. - Abdomen voûté en dessous.

A. Mâchoires et lèvre très-longues, linéaires, prolongúes en noe sorte de trompe fléchic en dessous.

Parnopès.

B. Mâchoircs el lèvre courtes, point prolongées en trompe. a. Milieu du métathorax prolongé en uno pointe scutelliformc.

Stilbe.

Calliste.

Elanipe.

b. Milieu du métathorax n'étan pas pro longé en pointc.

Hédychre.

Euchrée.

Chrysis.

II. Corselet rétréci en devant. - Abdomen point voûté eu dessous.

\section{Clepte.}

Nota. Dans les caractères des genres de cette famille nous avons néccssairement dû comprendre ceax que l'on peut tirer des ailes supírieures; nous avons adopté les dénominations inposées par Jurine anx cellules et aux nervures; nous croyons cependant devoir prévcnir que nous ajoutons ì la partie caractéristique enployée par cel autenr, trois autres cellules, ce sont celles qui occupent le disque de l'aile et que nous nommons par cette raison avec M. Latreille qui nous a précédé dans cette manière de vour : cellules discoidales. Nous disons qu'elles sont an nombre de trois, regardant comme type complet d'une aile parfaite dans celte famille celle du gerre Aulaque. (Voy. Jurine, Hyménop. pl. 2. ordre 2. genie. 3. ) La première celluie discoidale supérieure est celle qui, placée vers le milicu de 1 aile, touche par un de ses côtés à la première cubitale; la seconde cellule discoidale supérieure est placíe derrière la première vers le sinus rentrant du bord interne de l'aile : la cellule discoilate infírieure est celle qui est comprise entre les deux nervures récurrentes, la première de ces nervurea lui étant commune avec la première celiule discoidale el l'en séparant, ou entre la prenicre nervare récurrente et le bord postérieur de l'alie. Cela posé, on voit sur la fiunre indiquée gue la partie caractéristique de l'aile supérience daus le genre Aulaque se compose d'une ratiale, de trois cubitales et de trois discondales, dont l'unfírieure ne s'érend point juscin'au bord postríreur de l'ale. Dans lous les autres genre, de Pupivores que nous connoissons, il manque une ou piusieurs de ces cellules et quelqueturs la discondule infíreme s'étend jusquau bord postérieur de l'aile. Il en est ainsi dans les gem es Evarie, Siéphane el quelques auties.

Dans celui d'Ichnenmon prenice fanille et d'Anomalon, il n'y a que deus rellules òiscondites, ce sout la secunde simpériente et l’uffirme; dans ces deux deiuiers geures la preniche dis coidale supérienre est confondue avec la premic̀re cubitale : mais elle est assez souven: mdiquée par un pelit trail partant de l'angle seurant de la premò̀re cubitale. Lorsque lir preuicère dison 
coidale se confond avec la première cubitale, la prenièere nervure récurrente manque toujours. Lorsque la cellule discordale inféricure s'étend jusqu'au bord postérieur de l'aule, il n'y a jamais de seconde nervure récurrente. Pour nous faire ptas liacilement comprendre, nous nous sommes rervas des figares de Jarue qui avoisment celle da genre Aulaque cilće plus haut. Nous avous eraployé les ménes dénomuations que lui pour pariel des gentes quil y ligure, saus les approurer jusciuc-lí un les rejeler.

$$
\text { (S. F.et A. Serv.) }
$$

PYCNOGONIDES, Pycnogonides. $\mathrm{I}_{4 \mathrm{AT}}$. Podo-

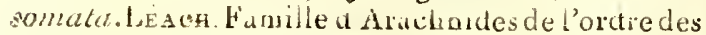
Trachicnnes, dont les cardeleres sont, suivant M. Lairenle (Fam. natur. du Reghe anm.) : siphos andivis, rubercutare, avancé, taniól accompaidué de deux chélicères et deux palpes, tantôt simplemeat de deax pälpes, même privé de ces deux sortcs d'orgunes. Qualre yeux sur un tubercule. Céplatuthorax occupant presque la longueur du curps. P'ieds souvent fort longs, terminés par des crochets inćgaux; deux pieds ovilères, situés a la base des premiers.

Les Abuchnides de cette tamile avoient été mis par Linné avec les laucheurs, Phalangiann. Branuich a formé le gense Pyczogonum, avec l'espece que le naturatiste sućlois uvoit nommée Fuacheurdes baleines. Fabricius a étahli à côté de celui-ci le genre Nymphon, et a pris pour type de ce genre le Pycrogonum grossipes d'Oihon Fabricius. Ces deux gentes font pärie de l'ordre des Ryngotes du Système de fubricios; selon M. Saviguy, les Pycnogonides font le passage des Aruchnides aux Crustacés; entin, dians lat Héthode de Líath, ils forment le prenier ordre de la sous-classe des Céphalosionates, celui des l'odosomates; il le partige en deux fitmilles, les Pycnogonides et les Nyinplsorides, dont les curac:teres sont fondés sur áabence ou la préscince des yatiolibules.

Le corps des Pycnogonides est ordinairement linéare, avec les pied's très-longs, de neuf a hait articles, et terminés par deax crochels inćgaux paroissant n'en former qu'un seul, et dont le petit est tendu. Le premier arlicle du corps tenant lieu de tête et de boache, forme un tube avancé, presque cylindrique ou en cône tronqué, simple, biats offrual quelquefois des apparences de suwares longitudinales (voyez Pнохсндие) avec une ouveriure triangulaire ou figurée en trèfle à son exiréranté. A sa base supérieure sont adossés, dans ylusieurs, deux madibules el deux palpes que les auteurs ont pris pour des antennes: on ne vioit daus d'autres que cette dermière paire d'orgaues; il en est entin qui en sonı privés, aissi gुue de randiludes. Les nandibules sout avancées, cylinciriques ou presque finfurues, simplement fresurates, plus on moins longues, composécs de deux articles, dont le dervier en forme de muir ou de pince, avce deux doigls; le supérieur est mobile et représente un troisième article; l'inférieur est quelquetois plus court; ces mandibules ont aussi la lorme de pelits pieds. Les deux palpes insérés sous l'origine des maudibules, sunt tiliformes, de cind ariacles, avec un crochet au bout du dernier. Cihaque seguent suvant, it l'exception du dermier, serl d'allache a une paire de preds; mais le premer, ou celui avec lequel s'articule la bouche, a sur le dos, un tubercule porlant de cliaque côté deux yeux lisses, el ea dessous, dans les temelles seulement, deux autres petits preds repliés sur cux-mêmé, et portant les ceufs qui sont rassemblés autour d'eus eà une ou deux pelotes, ou bien en maniere de verticilles; le dernier segment est petit et percé d'un petit trou ì son extréuité; on ne découvre aucun vestige de stigmates, et peul-être respirent-ils par cette ouverture.

Les Pycnogonides se tiennent sur les bords de la mer, parmi les varecs et les conferves, et s'y nourrissent de pelits animanx marins; quelquesuns vivent surles cétacés. 1ts marchent tres-léntement et s'actroctient par leurs ougles aux corps qu'ils rencoutrent.

Cette firmilie se compose des geńres :

\section{NYMPHON, Nymphon. Voyez ce mot.}

AMMOTHÉE, Ammothea. Léaer. Lat. Ce gente as été élabli par M. Liach ( The Zoological miscelicuny, etc. et Truns. Linu. Soc. tom. XI); il est tres-voisin du genre Nymphon, dont 1 differe surlout par tes anandibules beaucoup plus conrics que le siphon, par les palpes composés de neuf arlicles el par les crochets des turses qui sont doubles ct inéganax. On n'en connuit qu'une espèce, l'Amuotate de ra Carolise, Ammothea Carolnuonsis, décrile el figurée daus les ouvrages que uous arvons cités plus liaut. Elle habrte les côtes de la Caroline méridionale.

\section{PHOXICHILE, Phoxichilus. Voyez ce mot.}

PYCNOGONON, Pycnogonzm. Brunv. Mull. Oth. Hab. Joan. Haz. Oliv. List. Ladr.

Les caractères de ce genre sont: point de mandibules ni de palpes; suçoir en forme de cône alongé el tronqué; corps presqu'ovale, point linéarte; paltes de longueur moyenne, de huit articles; les lausses pattes oviferes de la feruelle très-courles.

Ces Arachuides diffèrent des autres genros de la même famille par l'absence des mandibules et des palpes, el par les proportions plus courtes da corps et des paltes qui paroisseut avoir an article de moins que dans les, autres Pycmogonides; l'avant-dernicr article ve paroit former, dans les Pycnogonons, qu'un pelil næuà infúrieus, et jol- 


\section{P Y P}

gnant le dernier article des tarses avee le précédent.

Isa seule espèce de ce genre est le Prcrogonon DES BALEINEs, Pycnogonum balcenanum, figuré par Brunnich, Nulle: (Zool. Dan. tab. 1ig. fig. 10-12) et quelques autres naturalistes. Il vit sur les cúlacés,

Le Pycnogonum ceti $\mathrm{FAB}_{\mathrm{B}}$. est le type du genre Cxame. Voj. ce mot à la suite de l'article Proton de ce Dictionnaire. (E. G.)

PYRALE, Pyralis. Fab. Lat. Phalona (Tortrix ). Linn. Plackena. Geoff. Tortrix. Hub. Tinea. FAB.

Genre d'insectes de l'ordre des Lépidoptères, famille des Nocturnes, tribu des Tordeuses. Celle tribu ne comprend que le seul genre Pyrale.

Antennes simples dans les deux sexes, presque sélacées. - Langue membraneuse, distincte. Deux palpes peu alongés et formant alors un petit museau ou longrs, avancés, recourbés sur la tête en furme de cormes. - Ailes supérieures élargies en chappe à leur base, formant avec le corps une espèce d'ellipse tronquée ou un triangle dont les cótés opposés sont arqués piès de leur réunion. - Chenilles à seize palles, rases ou peu velues, roulant les feuilles ou en pliant les bords; vivant quelquefois dausl'intérieur des fruits. Chrysalide reufermée dans une coque.

Les chenilles des espèces de ce genre se nourrissent du parenchyme des feuilles, de la pulpe des fruits et de leurs pepius. On connoit un grand nombre d'espèces de Pyrales, la plupart europiennes. On les a nommées Phalènes-ehappes on à larges épaules parce que le bord exteme de leurs ailes supérieures est arqué à sa base et se rétrécit ensuite; lcur forme est courte, large, en ovale tronqué. Ces lépidoptères sont vîfs, souvent agréablement colorés, mais leur taille est pctite. Ils portent leurs ailes en toit écrasé ou presqu'horizontales, mais toujours couchées sur le corps; les supéricures se croisent un peu le long de leur bord interne.

La forme des palpes dans les Pyrales varie beancoup ainsi que les incurs, et ce genre paroit demander un nouveau travail pour ctre restreint dans ses justes limites, ce qui ne peut entrer dais le cadre du présent ouvrage. Nous renvoyons donc aux espèces pour traiter des différences qu'elles préseutent entrelles sous ces deux points de vue.

\section{Pyralae verle ì bandes, $P$. quercana.}

Pyralis alis superioribus viridibus, strigis dua. bus obliquis murgineque postico albidis; inferioribus albis.

Pyialis prasinaria. Fав. Ent. Syst. tom. 3. part. 2, pag. 243. $n^{\circ}$. 4. - Tortrix quer:ana. Hov. Tortric. tab. 25. fig. 159 . Liarv. Tortric.
Psendotortr. A. «. ז๐. т. - Plalona tortrix prasinana. De ViLs. tom. 2. pag. 388. $\pi^{\circ}$. 649 . -RÉaum. Ins. tom. 1. pl. 59. fg. 10-14. - DE GŕER, Ins. tom. I. pıg. 58. pl. 3. fig. I-3, ct tom. 2. pag. 410. - La Chappe verte à bande. GeOTF. Ins. Paris. tom. 2. pag. 172. $n^{\circ}$. 124. - Encycl.pl. 91. Pyral. fig. 1. - Pyralis prasiniana. PAnz. Faun. Germ. fas. ". fig. 23.

Lavergure $15 \mathrm{lig}$. Antennes blanchâires ou rougeâtres. Palpes courts. 'lête et corselet verts. Ailes supérieures de même couleur avec deux lignes étroires obliques et les bords extérieur et postérieur blanchât!res. Dessus des inférieures d'un blancverdâtre. Abdomen, dessous du corps et des ailes blanchâtres. Pattes de mêue couleur avec quelques nuances rougeâtres sur les antérieures.

Chenille d'un beau vert-clair ayant une ligne jaune latérale qui commence après le troisième segment et va jusqu'à l'anus. On voit un petil lubercule sur le dos du second segment. La partie postérienre du corps est beaucoup plus mince que l'antérieure et la chenille retire souvent sa tête sous les premiers segmens du corps; elle vil sur le chêne et quelques autres arbres. Sa coque est entièrement composée de soie d'un jaune-serin, elle a la forme d'uu bateau reaversé; pour la construire la chenille file séparément l'une à côté de l'autre deux pièces semblables de la forme d'une coquille, elle en réunit ensuite les bords supérieurs avec de la soie. Renfermée dans la cavité qui se trouve entre ces deux pic̀ces, la che. nille donne de la solidité aux parois en filant de nouvelle soie. C'est vers le milieu du printemps - qu'elle la construit, et l'insecte parfait en sort environ un mois après. La clrýsalide est veriiâtre avec une ligne dorsale de points noirs.

Des environs de Paris.

Nota. Pour bien compre adre la synonymie de cette espèce et de la suivante, il est nécessaire de lire les Remarques de De Villers, tom. 2, pag. 387, no. 648, et la plurase de la Faunck Succica de Linné qu'il rapporte.

\section{Prrale du Hêtre, P. prasinana.}

Pyralis alis superioribus viriditus, strigis duabus aut tribus ob́liquis, albido-luteis, mar. gine postico loete rufo; inferioribus luteo-albiais.

Pyralis fagana. FАв. Ent. Syst. tom. 5. part. 2 。

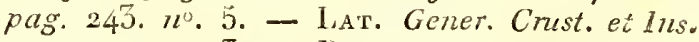
tom. 4. pag. 230. - Pasz. Faum. Germ. Jas. "。 fig. 22. - Phalana tortrix prasinana. LinN. Syst. Nat. 2. 875. 285. - Toririx prasinana. Huв. Tortric, tab. 25. fig. 153. Le mâle. Lar. Tortric. Pseudotortric. A. a. $2^{\circ}, 2 .-$ Phaloencs tortrix fagana. De Vild. Ins. tom. 2. pag. 58-, $7{ }^{\circ}$. 648. - La Phalène verte ondée. Geofr. Ins. Paris. tom, 2. pagr. 172. $70^{\circ}, 125 .-E n c y c h$ pl. 91. Pyral.fig. 4 . 
Envergure 1 lig. Antennes rongeâtres. Palpes courts. Tèle et corselet verts. Parties de la bouche rougeâtres. Ailes supérieures vertes avec trois lignes blanchâtres, obliqques, bordées d'un vert plis inlense et les bords extérienr et postérieur jaunes ou rongeâtres. Dessus des inférieures d'uu blanc-jaunâtre. Abdomen, dessous du corps et des ailes d'un vert-blanchâtre. Pattes d'un jaunerougeâtre. Femelle.

Dans le mâle lés nuances jaunes et rougeâtres sont plus prononcées. Chenille d'un beau vert, ayant une ligne latérale jaune qui commence au premier serment et va jusqu'à l'anus; elle a en outre une ligne dorsale jaune accompagnée de traitsobliques et de points de même couleur; patles rougeâlres. Sa confortnation est la mêıne que celle de la précédente. Elle vit sur le hêtre. Sa coque est semblable à celle de la Pyrale verte à bandes, mais de cou!eur feuille-morte.

Des environs de Paris.

\section{Pyrale clorane, P. clorana.}

Pyralis alis superioribus viridibus, margine externo latè posticoque albis; inferioribus albis, strigâa submarginal viridi.

Pyralisclorana. FA B. Ent. Syst. tom.3. part. 2. pag. 244. $n^{\circ}$. 8.-Lat. Gen. Crust. et Ins. tom. 4 . peg. 230. - Plialona tortrix clorama. LivN. Sy st. Nat. 2. 876. 287. -.. Tortrix clorana. Huв. Tortric. tab. 25. fig. 160. Law. Tortric. Psendotortric. A. $n^{\circ}$. 1. - RËAUm. Ins. tom. 2. pl. 18. fig. 1-7. - Encycl. pl. gi. Pyral.fig. 5-9.

Envergure 7 lig. Anteunes grises. Palpes courts. Tète et devant du corselel d'un blauc-argenté, parlie postérieure de céui-ci varle. Ailes supérieures de cente dernière conleur arec nue large bascle à leur bord externe et l'extrénité de la fran io postérieare blanches. Ailes iulénicurcs d'unbiauc-argenté avec nne pelite ligne revditire peu marquée qui accompagre le hond postérienr. Dessous des quatre ailes e! du corps diun blancargenté. Paltes de même conleur.

Chenille d'un blanc-verdâtre avec des nuances hrunes sur les côtés du corps qui formeut une linge bande irrégulièrer On voit sur chaque segment phsieurs tubercules portant chacun un poil noir; sa conformation est absolument celle des précédentes. Elle vit sur le saule et se lient ordiaurement dans un paquet qu'elle fitit arec les fenilles du bout des tiges réunies par des fils de soie. Arrivée à sa grossen vers le milicu de l'été, elle se construit une coqne de soie blauclue de la mêne forme que celle des Pyrales précédentes; elle y passe l'hiver en clurysalide et n'en sort qu'au colamencement de l'été suivant. La cbrysalide est d'un brun-januatre saupoudré d'une mafière tarineuse.

Environs de Paris.

\section{Pyrale veidâtre, $r$. viriduna.}

Pyralis alis superioribus viridibus; inferioribus griseis : omnium marginibus albidis:

Pymalis viridana. FA B. Ent. Syst. tom. 3. part. 2. pag. 244. no. 7. - P.Axz. Faun. Germ. fas.". fig. 24. - Phalcena tortrix vividana. Lin. Syst. Nat. 2. 875. 286. - Tortrix viridana. Нив. Tor tric. tab. 25. fg. 156 . - La Chappe verte. Geofr. Ins. Paris. tom. 2. pag. 17 . no. 123.

Envergure 6 lig. Antennes grises, palpes droits, de longueur moyenne. Tête jaunâtre. Corselét verl. Ailes supérieures de même couleur, les inférieures d'un gris-cendré. Bordure des quatre ailes blanchâtre. Dessous du corps et des ailcs aiusi que les palles, d'un blanc-argenté.

Chenille verte avec des tubercules noirs portant chacun un poil de cette couleur. Paties postíricures jaunes. Chrysalide brune, son extrérnité postérieure terminée par doux petiles pointes. Vit sur différens arbres tels que le chème, le lilas, etc.

Comume aux environs de Paris.

\section{Prrale de Godart, P. Godarti.}

Pyralis alis superioribus finsco-vinosis, maculầ disci fénestratá, angulo externo postico dilatato, subhamuto-producto; inferioribus abbidis, margine postico fusco-vinoso.

Envergure 15 lig. Femelle. 10 lig. Mâle. Antennes d'un gris-vincux. Palpes extrêmement courls, de wême couleur ainsi que la tête et le corselel. Ailes sup'rientes d'une nuituce plus claire avec quelques lignes trausverses, ondées, d'un bran-vineux fincé, dont une près du milien de l'aile plas large que les autres; celles-ci cantonnées vers le bord postéricur; sur le disque assez prés dir bord exlerne on voil ume plaque ovale, irróguliere, blanche, assez transparente; angle extérien de l'aile prolongé en une pointe tro:saillante, recourbée en crochet. Ailes inférieures d'uu blanc-sale un pen vinenx surtont vers le bord postérieur. Dessous des quatre ailes roussatite, les bords postérieurs plus foncés. Corps et pattes roussuties. Femelle.

Le mâle est d'une taille bien plus petite, sa couleur est beancoup plus vineuse et empêche presque de distinguer les lignes transverses.

Du Brésil,

Nota. Nous consacrons cette nouvelle espèce à l'estinable auteur de l'article Papilion de ce Dictionuaire.

6. Prrate du Rosier, P. rosana.

Pyralis alis superionibus luteis, flavo maculatis, strigls argenteis; inferioribus fuscis.

Tortrix rosana. Нив. Tortric. tab. 22. fig. 137. Equergure 


\section{P $\mathrm{I} R$}

Envergure 6 lig. Palpes droils, de longneur moyenne. Antennes grises. 'Télc et corselel jaunes. Ailes supéricures jaunes, bordées et un peu nuancées d'aurore, avec quatre bandes transverses, irrégulières, brunes, chargées d'écailles argentées. Ailes inférieures grises. Corps et dessous des ailes infćrieures jaunâtres; celui des supérieures de celle même conleur, avec une bande brune qui accompague le bord postérieur. Patles grises.

On la trouve dans les jardins sur les rosiers.

Nota. Celte espèce nous paroît diflérer essentiellement de cetle qui porte le même nom dans Linné et dans Fabricius.

\section{Prrale du Groseillier, P. ribeana.}

Pyralis alis superioribus fuscis lutescentibuspe, basi, fasciâ latầ mediâ alterâque posticâ sapiùis ablireviatâ, fuscioribus.

Tortrix ribeana. llub. Toríric. tab. 18. fig. 114. - La Chappe brune. Geoff. Ins. Paris. tom. 2. pag. $169 . n^{\circ}$. 118 , et la Chappe à bande et tache brune. Id. pag. $170 . n^{\circ} \cdot 119$.

Envergure 7 lig. Palpes droils, assez longs. Antennes brunes. Tête, corselel et fond des ailes supérieures d'uu jaune-roussître, ces dernières ayant trois baudes broues transversales, l'une vers la base, l'autre au milieu, la dernière près du bord postérieur; cellc-ci ainsi que la premic̀re souvent raccourcie et n'alteignant pas le bord intérieur. Ailes inféricures grrises, leur bord extérieur souvent blanchâtre, ce bord portant quelquefois des points brnns. Corps, paltes el dessous des quatre ailes d'un blanc-jaunâtre. Femelle.

La couleur jaunâtre passe scuvent dans le mâle au brun-roussâtre.

Chenille verle à tête et tubercules épars, noirs; elle est très-vive et habiie dans des teuilles roulées, particulièrement dans celles du lilas.

'Très-commune anx environs de Paris.

Nota. Nous croyons pouvoir rapporter à celle espice les figures 113 , 115 et 117 de la pl. 13 de NI. Hibner, ainsi que celles 118,159 et 120 de lia pl. 19. Peut-êlre aussi da Pyralis xylosteana de Fabricius n'est-elte que la mêtne espèce. La Phalcena tortrix xylosteana de Limnć parroit s'en ćloigner heaucoup plus.

\section{Pyrale de Lech, P. lecheana.}

$P_{y}$ ralis alis superioribus testaceo-fuscis, maculis argenteis litteras J. L. fingentious ; inferioribus fuscis.

Pyralis lecheana. HAB. Entom. Syst. tom. 3. part. 2. pag. 260. $n^{\circ} \cdot 73 .-$ phalcena tortrix lecheana. Linn. Syst. Nat.2.877.501. - Tortrix lecheana. Hus. Tortric. tab. 11. Jig. 67.

Envergure ro lig. Autennes brunâtres. Tête et corselet de même conleur avec quclques écailles argentées, brillantes. Dessus des ailes supérieures Hist. Nat. Ins. Tome X. d'un brun-testacé, ayant clacune deux ligues argentées qui paroissent représentcr les letlres J. L. et guelques points de urême couleur. Ailes inférieures brunes.

On la trouve en Europe sur le bois de SuinteLucie. (Prunus Padus.)

\section{Prrale de Zoega, P. zoegana.}

Pyralis alis superioribus favis, puncto medio ferrugineo, posticè ferrugineis maculâ flavâa; inferioribus griseis.

Pyralis zoegana. Faв. Fntom. Syst. tom. 3. part. 2. pag. 256. $n^{\circ}$.55. - phaloena tortix zoegana. Lin v. Syst. Nat. 2. 876. 289. - Tortrix zoegana. Huв. Tortric. tab. 22. fig. 138. - Entcycl. pl. g1. Pyràl. fig. 12.

Envergure 7 à 8 lig. Palpes droits, alongés. Antenues d'un jumne-grisâtre. 'Tête jaunâtre, corm setet de cette coulenr, a vec ses côtés terrugineux. Ailes supérieures jüunes, ayan! un peu de ferrugiucux à leur base et une pelite tache de même couleur sur leur disqne près du bord intérieur; l'extrémilé de ces ailes ferrugiuense renfermast une tache jaune. Ailes inférieures din gris-brunâtre. Dessous des quatre ailes, corps el paltes, jaunâtres.

Des envirous de Paris.

\section{ro. Prrale de Fraun, P. frauniana.}

Pyralis alis superioribus fuscis, maculâ communi dorsali mediâ punctisque ad marginem exteriorem albido-aureis.

Tortrix frauniana. Нив. Tortric. tab. 7. fg. 38.

Envergure $5 \mathrm{lig}$. Palpes courts. Antennes brunâtres; tête el corselet de celle couleug avec des points dorés, brillans. Ailes supérieures brunes a vec une taclie dorsale commune à loutes deux lorsqu'clles soutfermées, de forme arrondie, blanche, changeant en or rue is certain jonl' il y a quelques points de même couleur le long da Jord extérieur. Ailes inférieures brunes. Frange des quatre ailcs d'un vert-doré. Corps, patles et dessous des ciuitre ailes bruns, arec un reflet doré.

Environs de Paris.

11. Pyrale à crochel, P. hamana.

Pyralis alis superioribus fovis, puncto liturâque posticâ hamatâ ferngineis; mérionbus griseis.

Phaloena tortrix hamana. Lixv. Syst. Nat. 2. 876. 290. - DE Vilu. Ins. tom. 2. pag. 3go. $n^{\circ}$. 654. - Tortrix luamana. Huв. Tortric. áio. 22. fig. 140 .

Linvergure 7 lig. Tête et corsclet jaunes; dessus des uiles supérieures de mêne couleur, avec un point commu lorsqu’elles sont fermécs, de conleur ferruginense; elles portent chacune une baude de cetté couleur qui part de l'angle posté$\mathrm{J} \mathrm{K}$ 
rieur et se recourbe en erochet vers le milieu de l'aile. Ailes inférieures grises ainsi que le corps.

Se trouve en Franee.

12. Praale de Christiernin, P. christiemana.

Pyralis alis superionibus flavis, venis ferrugineis reticulatis; inferioribus griseis.

Pyralis christiemana. Fав. Ent. Syst. tom. 3. part. 2.pag. 260. no.74.-Pyalis christiemiana. Panz. Fann. Gernz. fas." fig. 23. - Plalcenatortrix christiernana. Lisw, Syfl. Nat. 2. 877. 303. - Tortrix christicmana. Hub. Tortric. tab. 24. $f g .152$.

Envergure 7 ligg. Antennes et tête d'un jaunepảle. Corselei ferrugineux. Ailes supérieures d'un bean jauue, portant des bandes ferrugineuses irrégulières, qui s'anastomosent entr'elles et forment une espèee de réseau. Ailcs iuférieures et abdomen de couleur grise. Dessous des quatre ailes pâle.

Du nord de l'Europe.

13. Prrale de Krekéritz, P. kokeritziana.

Pyralis alissuperioribus flavescentibus, puncto medio margineque postico ferrugineis; inferioribus fuscis.

Pyralis kaekritziana. FАв. Ent. Syst. tom. 3. part. 2. pag. $256 . n^{\circ} .57 .-$ Plialoena tortrix kekeritziana. Linn. Syst. Nat.2.876. 291. - Tcrtrix kakeritziana. Huв. Tortric. tab. 26. fig. 163.

Euvergure 1o ligs. Antennes brunes. Tête et corselet jaunâtres. Dessous des ailes supérieures jaune avec un point discoidal ferrugineux et une baude de même couleur qui aecompagne le bord extérieur. Ailes inférieures brunes.

D'Europe.

\section{Pyrale de Hast, P. hastiana.}

Pyralis alis superioribus fusco-castaneis, fuscuâ obliquâ margineque postico albidis; inférioribus fuscis.

Pyralishastiana. FАв. Ent. Syst. tom.3.part. 2. pag. $261 . n^{\circ} \cdot 79 \cdot$ - Phalona tortrix hastiana. Linx. Syst. Nat. 2. 878. 311.- Tortrix hastiuna. Ilub. Tortric. tab. 29. fig. 186. - Encycl. pl. 91. Pyral. fig. 15.

Envergure 7 lig. Antennes brunes. 'Tête, corselet et abdomen d'un brun-marron. Dessus des ailes supérieures de eette même couleur avec une bande oblique qui part du milieu du bord extérieur et se dirige vers l'angle postérieur, de coulenr blanchâtre ainsi qư'une ligne qui a eeompagne le bord postérieur. Ailes inférieures brunes.

D'Europe. La chènille viı sur le saule.

15. Pyrale faseiée, $P$. rivulana.

Pyralis alis superioribus griseo-fuscis, fasciis tribus albidis secundâ bis bifidâ ; inferioribus griseis.

Pyralis undana. FАв. Ent. Syst. tom. 3. part. 2. pag. 281. $n^{\circ}$. 160. - Phaloena tortrix rivulana. DE VILL. Ins. tom. 2. pag. 423. $n^{\circ}$. 754.-Tortrix rivulana. Нu в. Tortric. tab. 29. fig. 184.

Envergure 5 lig. Antennes, tête et corselet d'un gris-brun. Dessus des ailes supérieures de eelle inême couleur avec trois bandes blanehâtres dont la seconde se divise deux fois en avançant vers le bord extérieur; on voit aussi quelques points blanchâtres le leng de ee bord. Ailes inférieures d'un gris-elair, leur bord postérieur plus foncé.

D'Enrope.

Nota. Seopoli a déerit le premier eette espèce sous le nom que nous lui eonservons.

16. Pyralz roussâtre, P. rufana,

Pyralis alis superioribus luteis, maculâ marginali fuscâ punctoque medio albo; inferioribus griseis.

Pyralis rufana. FА . Ent. Syst. tom. 3. part. 2. pag. 263. $n^{\circ}$. 87. - Tortix mifana. Hu B. Tortric, tab. 28. fig. 178, et tab. 20. fig. 127 .

Envergure 6 lig. Antennes, tête et eorselet bruns. Dessus des ailes supérieures jaunâtre avec une tache presque triangulaire brune qui eommenee un peu avánt le milieu du bord extérienr et finit à l'angle supérieur dont elle oeeupe la moitié, le troisième angle de la tache se termine vers le milieu de l'aile près d'un gros point roud, de eouleur blanche qui manque quelquefois; ailes inférieures grises.

D'Europe.

\section{Pyrale moyenne, $P$. mediana.}

Pyralis alis superioribus fusco-fernogineis, macula duplici aurantiacâ; inferioribus tuigris.

Pyralis medicuna. FАв. Ent. Syst. tom. 3. part. 2. pag. 248. $n^{\circ} \cdot 17^{2}$. - Tortrix mediana. Нuв. Tortric. tab. 28. fig. 179 .

Envergure 5 lig. Antennes, tête, corselet et abdomeu noirâtres. Dessus des ailes supérieures d'un brun-ferrugineux avee deux grandes lacłes d'un beau jaune et une petite ligne de même eouleur qui aecompagne le bord postérieur. Ailes inférieures noires, bordées eomme les supérieures. D'Autriche.

18. Pynale lunulée, $P$. lunulana.

Pyralis alis fuscis, superioribus lineâ arcuatô dorsali conmuni albâ.

Pyralis dorsana. ГАв. Ent. Syst. tom. 3. part. 2. pag. 282. no. 164. -- Tortrix lumulana. Hов. Tortric. tab. $7 \cdot$ fig. 35 . 


\section{P Y R}

Envergare 7 lig. Ailes noirâtres, les supérieures ayant une ligne blanclie arquée, commnne, qui s'arrête vers le milieu de l'aile et forme un demicercle sur le dos, lorsqu'elles sont fermées; elles ont en outre quelques points de même couleur le lnng du bord externe et deux lignes un peu argentées accompagnant le bord postérieur.

D'Allemagne.

Nota. Fabricius nous paroît rapporter mal-àpropos à cette espèce la Teigne ${ }^{\circ}$. 16 de Geoffroy. La Pyralis conwayana de FAB. $\mathrm{n}^{\circ} . \quad 39$ (Tortrix montana. Huв. ${ }^{\circ} .37$. ) nous semble très-voisine de celle-ci et n'en être qu'une simple variété sexuelle.

19. Pyrale des pommes, P. pomana.

pyralis alis superioribus fuscis griseo strigulatis, plag:î apicis communi fuscâ , aureo unaculata ; inferioribus fuscis.

Pyralis ponnana. FAB. Ent. Syst. tom. 3. part. 2. pag. 279. $n^{\circ}$. 155. - Lat. Gener. Crust. et Ins. tom. 4. pag. 230. - Phaloena Tinea pomonella. Linv. Syst. Nat. 2. 892. 401. Tortrix pomonana. Hus. Tortric. tab. 6. fig. 3o. Lary. tortric. noctuoid. C. b. no. 2. - RÉaumor, Ilss. tollı. 2. pl. 40. fig. 1-10. - Encycl. pl. 92. Pyral. fig. 8-13.

Envergure 8 lig. Palpes assez longs, leur second article le plus grand de tous, recourbé; le deruier pelit, dirigé en avant. Antennes, tête et corselet d'un brun-chocolat, dessus des ailes supérieures de même couleur avec un grand nombre de lignes irrégulières d'un blanc-argenté, leur partie postéricure portant une tache dorsale commune, semi-lunaire, privée de lignes blanches et ayant des plaques dorées assez grandes. Ailes inférieures brunes surtout vers leur bord extérieur. Dessous des quatre ailes grisâtre avec beaucoup de lignes transversales de couleur brune. Abdomen, dessous du corps et pattes d'un grisbrun à reflet argenté.

Cheuille d'un blane-jaunâtre quelquefois un peu rougeâtre, tachetée de noir, avec quelques poils courts, épais. Tête d'un brun-rougeâtre. Elle vit dans l'intérieur des pommes dont elle mange principalement les pepins et les parties quiles avoisinent. L'œut paroî́t avoir été déposé dans le fruit quand il étoit encore très-petit. La chenille n'éclot que lorsque la pomme a dćjà alteint les deux tiers de sa grosseur; pour se transformer en chrysalide elle sort du fruit et se file une coque à la superficic de la terre parmi des cúbris de feuille ou sous les écorces; elle passe l'hiver sous cette forme et linsecte parfaitparoit de bonne heure au printemps. Les fruils ainsi rongés à l'intérieur atteignent leur maturité avant ceux qui sont restés inlacts, et n'en sont pas moins agréables au goût.

Des environs de Paris.
20. Pyrale rosée, P. fugana.

Pyralis alis superioribus flavis, ioseo irroratis, naculis duabus costalibus luteis; inferioribus luteo-albidis.

Pyralis quercana. FАв. Ent. Syst. tom. 3. part. 2. pag. 271. $n^{\circ} \cdot 126$.. - Tortrix fagana. Hoв. Tortric, tab. 24. fig. 153.

Envergure 7 lig. Palpes longs, recourbés, leur second artıcle très-long, un peu en massue, le terminal long, conique, pointu. Antennes fort longues, d'un rose pâle. Tềre et corselet jaunâtres. Dessus des ailes stupérieures d'un jaune un peu aurore nuancé de rose-vif surtout vers les bords extérieur et postérieur, avec deux taches jaunes placées le long du bord extérieur. Leur dessous presçu'entic̀rcment rose. Ailes inférieures d'un blanc-jaunâtre avec les bords rosês tant en dessus qu'en dessous. Pattes blanchâties, les qualic antéricures nuancées de rose.

Nota. On aperçoit quelquefois des petits points noirs sur les ailes supérieures.

On la trouve aux environs de Paris daes les hois et les jardins.

\section{Prrale de la Beree, P. heracleana.}

Pyralis alis superioribus griseis, strigis atomisque nigris, punctis duobus nigris albo pupillatis, strigôa subpositâ nigrấ; inferionbus griseo-albidis.

Pyralis heracleana. FАв. Ent. Syst. tom. 3. part. 2. pag. 286. $n^{\circ}$. 178. - Lat. Gener, Crust. et Ins. toun. 4. pag. 230. - Phalon to tortrix heracliana. Linn. Syst. Nat. 2. 88o. 326. - DE Gíer, Ins. tollt. 1. pag. 424. pl. 29. fig. 1-8.

Envergure ". Palpes absolument conformés comme ceux de l'espèce précédente. Ailes grises, les supérieures ayant de petites taches et des raies noirâtres, avec deux pelits points blaucs bordés de noir, au-dessus desquels est un petit trait de cette dernière couleur.

Chenille verte ayant trois lignes longitudinales d'un brun-verdâtre, une dorsale el une de chaque côtć du corps. Chacin de ses segmens porte deux petits points noirs. Elle est très-vive, habite sur les plantes ombellifères, notamment la Berce (Heracleum sphondylium). Elle en lie les fleurs avec de la soie et après les a voir rongées elle descend sur les tiges, pénètre dans leur intérieur par l'aisselle des feuilles, el en mange la moelle. Elle en sort au commencement de l'élé, s'enfouce en terre et $y$ fait une coque ovale de grains de terre liés avec un peu de soie. Elle y reste environ un mois sous la forme de chrysalicie; au bout de ce temps paroît l'insecte parfait.

De Géer a trouivé cette chenille sur le cerfeuil sauvage (Chorophyllnun syluestre); elle s'y tenoit dans des rouleaux de feuilles et se nourrissoit de 
ees mêmes feuilles. Cet autemr décrit fort au long la manière eurieuse dont celtechenille forme son rouleau.

Nota. Les auteurs rapportent mal-à-propos à eelle espèce des figures de Réaumur.

Des environs de Paris. (S. F. el A. SERV.)

PYROCHRE, Pyrochroa. Geoff. Fab. Lat. DE Géer. Oliv. (Entom.) Cantharis, Lampyris. LivN.

Genre d'insecles de l'ordre des Coléoptères, section des Htétéromères, farnille des Traehélides, ribu des Pyrochroildes.

Celle tribu ne renferme que deux genres, Dendroide et Pyroclire; le premier se distingue suflisamment par son corselet rétréci en devant.

Antennes filiformes, peetinées dans les deux sexes, mais plus fortement dans les mâles, insérées devant les yeux, eomposées de onze articles, le premier alongé, pyriforme, le seeond petit, globuleux, les autres obconiques. - Labre menıbraneux, transverse, presque tronqué, un peu eilié antérieurement. - Mandibules eornées, foibles, arquées, aiguës, sans dentelures. - Mlâchoires presque numbraneuses, entières. - Palpes maxillaires filifurmes, de quatre articles, le premier court, le second alongé, le troisième petit, le dernier longr; palpes labranx plus courts que les maxillaires triarticulés, articles cylindricques, alongés. -- Lèvre bifide. - Tête presque triangulaire, un pen penchée, dégagée du corselet. Y eux x alongés, échanerés intérieurement. - Corps déprimé. - Corselet arrondi. - Ecusson petił. Elytres planes, flexibles, allant un peu en s'élargrissant vers l'extrémilé. - Pattes longues, euisses et jambes grêles; tarses filiformes à pénultième artiele bilobé, le dernier long, arqué, terminé par deux crochets simples.

Ce genre no eontient ì notre connoissauee que quatre espèces, dont une d'A nuérique. Leurs couleur's dominantes sont le noir et le rouge ; c'est de celle derniere qu'est pris le nom générique qui vieut de deax mots grecs dont la signification est: couleur de feu. Leurs larves, du moins eelle de la Pyrochre rouge, vivent dans le bois : elles ressemblent à celles des Ténébrions et des Hélups; leur eorps est un peu déprimé, le dernier segment atjdominal porte deux grands croclets argués en dedans. On rencontre les inseetes parfuits a pied des haies, sur !es buissons, sur les arbres et sous les écorces.

1. Pyrochre écarlate, $P$. coccinea.

Pyrochroa nigra, thorace suprà elytrisque sericeo coccineis.

Pyrochroa coccinea. Гав. Syst. Eleut. tom. 2. pag. 108. no. 1. - I.Aт. Geñer. Crust. et Ins. tom. 2. pag. 205. - OLiv. Ent. tom. 5. Pyroch. $n^{\circ}$. 1. pl. 1.fig. 1. a. b. c. Femelle.-Paxz. Faun. Germ. fis. 13. fig. 11. Mâle. - Grulenir. Ins.
Suec. tom. 1. part. 2. pag. 505. no. 1.-Lampyris coccinea. Lrnn. Syst. Nat. 2. 646. 18.

Longueur 8 lig. Antennes, tête, éeusson, dessous du eorps et pattes de couleur noire. Dessus du corselet et élytrcs d'un beau rouge-soyeux. Mâle et femelle.

D'Allemagne et du midi de la Franee.

\section{Prrochan rouge, $\boldsymbol{P}$. rubens.}

Pyrochroa nigra, capite, thorace suprà, scutello elytrisque testaceo-rubris, his sericeis.

Pyrochroa rubens. FAB. Syst. Eleut. tom. 2. pag. Iog. $n^{\circ}$. 2. - Lat. Gener. Crust. et Ins. tom. 2. pag. 205. no. I. - Oliv. Ent. tom. 3. Pyroch. $n^{\circ}$. 2. pl. I. fig. 2. a. b. Femelle.-P Fann. Gem. fas. g5. fig. 5. Femelle. -Gxuleni. Ins. Suec tom. 1. part. 2. pag. 507. no. 2. - Ia Cardinale. Georf. Ins. Paris. tom. 1. pag. 338. $n^{\circ}$. 1. pl. 6. fig. 4 .

Longueur 5 à 6 lig. Antennes, dessous du corselet, palpes, abdomen et pattes de eouleur noire. Tête, dessus du corselet, écusson et élytres d'un fauve-rougeâtre, ees dernières soyeuses. Mâle et femelle.

Des environs de Paris.

Nota. Fabricius, Olivier et Panzer ont rapporté à tort le synonyme de Geollioy à la Pyrochre écarlals.

\section{Pyrochre pectinicorne, P. pectinicornis.}

Pyrochroa nigra, thorace suprà elytrisque testaceo-rufis, forminoe thoracis disco impresso fusco, maris anlennis subfabellatis.

Pyrochroa pectinicornis. FA в. Syst. Eleut.tom, 2. pag. $109 . n^{\circ}$. 4. - Oriv. Ent. tom. 3. Pyrochr. $n^{0}$. 4. pl. 1. fig. 4. a. b. Femelle. - Panz. Faur. Germ. fas. Iว̃. fig. 12. Mâle. - Grrennu. Ins. Suec. tom. 1. part. 2. pag. 507: no. 3. - Cautharis pectinicornis. LinN, Syst. Nat. 2. 650. 20.

Louguenr $5 \mathrm{lig} . \frac{1}{2}$. Antennes, tête, écusson, dessous du corselet, abdomen et pattes, de eouleur noire. Dessus du eorselet et élyties d'un testacé-roussâtre. Une impriession brunâtre sur le disque du corselet dans la femelle. Antennes du mâle presqu'en panache.

D'Allemagne et du nord de l'Europe.

(S. F. et A. SERV.)

\section{PYROCHROÏDES, Pyrochroides.}

Première tribu de la famille des Trachélides, section des Hétéromères, ordre des Coléoptères. Ses caractères sont :

Corselet rond un eonique. - Elytres de la longneur de l'abdomen, de largeur égale on plus dilatées ef arrondies au bout. - Crochets des tarses simples, sans divisions ni appendices. - Corps alongré, droit, déprimé.-Pénultième article de 
rous les tarses bilobé. - Antennes en peigne ou en panache dans les mâles.

Celle tribu renferme les genres Pyrochre et Dendroïle.

DENDRÖ̈DE, Dendroides. Lat. Pogonocerus. Fiscir.

Genre d'insectes de l'ordre des Colúoplères, section des Hétéromères, famille des Trachélides, tribu odes Pyrochroides.

Les Pyrochres qui avec les Dendroïdes composent celte tribu, se distinguent de celles-ci par leur corselet orbiculaire et par les articles de leurs antenues, seuleuent pectinés ou en scie.

Les caractères principaux assignés à ce genre sont: Antennes branchues, leurs articles se prolongeaut latéralemeut en de lougs filets. - Corselel conique, rélréci en devant.

M. Latreille donne pour type un insecte da Canada de la collection de M. Bosc; il le désigne sous le nom de Dendroides canadensis. Nous navons pas vu cette espèce. Voyez Poconocìr.

(S. F. et A. Serv.)

PYTHE, pytho. Lat. Fab. Tenebrio. Lisn. DE Géer. Oliv. (Entom.) Cucujus. Payk. Oriv.

Genre d'insectes de l'ordre des Coléoptères, section des Hétéromères, famille des Sténélytres, tribu des Hélopiens.

Cinq genres composent cette tribu : Hélops, Hallomine, Pythe, Cistèle et Nilion. Les Hélops, les Cistèles et les Nilions par leur corps bombé, et les Hallomènes par la forme cylindrique du dernier articlede leurs palpes naxillaires, se distinguent suffisamment des Pythes.

Antennes filiformes, insérées à ni cievant les yenx, composécs de onze articles, le premier obconique, les cinq suivans presque de cetle mêroe forme; les second, troisième et quatrième presqu'égaux entr'eux, les cinquième et sixième un peu plus courts que les précédens, les quatre suivans semi-globulenx, le onzième ou dernier ovale, diminuant de grosseur et finissant en pointe. Labre apparent, meubraneux, transverse, entier. - Mandibules avancées, fortes, déprimées, pointues. - Mâchoires à deux divisions presque triangulaires et velues, l'extérieure plus grande.-Palpes grossissant vers le bout, leur dernicr article plus large, comprimé, picsque triangulaire, tronqué; les maxillaires deux fuis plus longs que los labiaux, s'avancant un péu en devant, de quatre articles, les labiaux de trois. - Lère coriace, membraneuse, prolondément ćchancréc on bifide, presqu'en cœur. - Téte avaucée, un peu plus étroite que le corselet, presque iriangulaire. Yeux saillans, entiers. - Corps très-déprimé. Corselet presqu'orbiculaire, tronqué en devant et postérieurement, aplati, sans rebords. - Ecısson petit. - Elytres point rebordées. - Pattes de longueur moyenne; cuisses ovales, ćtroites, compri- mées : jambes longues, grêles, à peine flargics a l'extrémité; tarses courls, pelils, à articles entier's; crochets courts.

Ce genre a été fondé par M. Latreille el adopté par les auteurs subséquens. 11 parcît ne renferwer jusqu’à présent qu'une seule espèce qui varie beaucoup par les coulears. On la trouve sous les écorces d'arbres, où il est probable que la larve trouve sa nouriture.

I. Pyтre déprimé, $P$. depressus.

Pythodepressus. DEJ. Catalog. - Pytho corzeleus. Lat. Gener. Crust. et lns. tom. 2. pag. 196. $n^{\circ}$. 1. - F Ав. SJst. Elcut. tom. 2. pag. 95. $n^{\circ}$. 1. - Panz. Faun. Genn. fas. g5. fig. 2. - Gyil. Ins. Suec. tom. 1. part. 2. pag. 509. $n^{\circ}$. 1. -Tenebrio depressus. Linn. Syst. Nat. 2. 675. 1 1.Ourv. Ent. tom. 5. Teneb. no. 19. pl. 2. fig. 18. - Cucujus coruleus. OLIv. Entom. tom. 4. Cucuj. $n^{\circ}$. 11.pl. 1.fig. I 1. a. b. c.

$V$ oyez pour les autres synonymes et la description Cucuje bleu, no. $4, \mathrm{pl} .56 \mathrm{~g}$. I. fig. 10. I et 12 .

Variété A, élyires violeutes. (Pytho festivus, Fа в. Syst. Eleut. tom. 2. pug. gó. $n^{\circ}$. 2.)

Variété B. Côtés du corselet chàtains; d́lylres de mêrne coulenr, avec leur bor'd catérieur bleu. (Pytho castaneus. FAB. Syst. Eleut. tom. 2. pag. 96. $2^{\circ}$. 3. - PAnz. Fanm. Germ. fits. 95. fig. 5.)

Nota. Cet insecte varie beaucoup par l'éicndue Gu'occupe la couleur châtain-roussâtre, soit sur le dessous du corps, soit aux pattes, où elle passe souvent an noir : quelquefors elle sélend plus ou moins sur le dessus du corselet et sur les ćlytres. Nous suivons ici l'exemple cie MiI. Gyllenhal et Dejean qui réduisent à unc stule espéce ces diversos variélés.

HALLOMENE, Halloments. Hellw. PAYk. I.ATR. Dirccea. Fat. Serropalpus, Dinophorts. I LLIG.

Genre d'insectes de l'ordre des Coléoplères, section des Méléromères, famille des Sténélytres, ribu des Hélopieus.

Le corps bombé en dessus est un caraclère commun à trois geures de cetc lribu; savoir: Hólops, Cislèle et Nilion. Les deux autres qui la complitent sont : Pythe et Hallomène; mais dans les Pythes le dernier article des palpes maxillaires cst large, comprimé et presque triangulaire.

Antentes filiformes, insérées à nu presque dans l'échancrure des yeux, composćes de onze articles presque tous courts et obconiques. - Mandubules cornées, arquées, bifides a leur extrémilé. - Mâ. choires membrineuses, courtes, bifides, leur lobe extćrieur plus pelit, arrondi à son extréuile, l'inrérieur prescque filiforme. - Palpes presque filiformes, les maxillailes beancoup plus grands que les laliaux, wrancés, un peu plus gros vers leur 
- Irémité, leurs articles inégaur, le dernier court, eylindrique, tronqué. Päpes labiaux composés d'articles presqu'égaux entreux. - Lèvre menbraneuse, petite, tronquée, enlière. - T'ête inclinée, plus étroite que le corselet, rétrécie antérieurement. - Corps ovale, étroit, un peu déprimé en dessus. - Corselet presque demi-circulaire, tronqué à sa partie antérieure, point rebordé. Ecusson pelit, arrondi postérieuremeut. - Elytres un per rétrécies à lear partie postérieure, couvraut l'abdomen et les ailes. - Pattes de longneur noyenne, propres à sauter; tarses ayant tous leurs articles encitrs.

Les mœurs des IIallomènes sont peu connues; ces insectes se trouvent dans les champignons el sous l'écorce des arbres. M. Paykull rapporle à ce genre les Hallomenus micans et fasciatus, que les auteurs subséquens placent dans le genre Orcbésie. Le nom générique vient d'un mot grec qui signifie : sauter. Le petit nombre d'espèces connues appartient au nord de l'Europe.

\section{Hallomène huméral, $\boldsymbol{H}$. humeralis.}

Hallomenus mifescens, sericeus, thorace maculis duabus nigris, posticè utrinquè impresso; elytris obsolete striatis, humeris luteis.

Hallomenus humeralis. Lat. Gener. Crust. et Ins. tom. 2. pag. 194. $n^{\circ}$. I. tom. I. tab. 10. fig. I1. - PANz. Faun. Germ. fas. 16. fig. 17. Hallomenus bipunctatus. Park. Faun. Suec. tom. 2. pag. 179. no. 1. - Dircaea humeralis. FAB. Syst. Eleut. tom. 2. pag. 91. no. 10.

Longueur 3 lig. D'un roux-brun, un peu pubescent. Corselet ayant deux marques noires sur son disque, plus ou moins grandes, et deux im pressions à sa partie postérienre. Elytres légèrement striées, plus ou moins jaunes à leur base, surtont vers les angles huméraux. Abdomen et palles pâles.

D'Allemagne et de Suède.

2. Haimomine flexueux, H. flexuosus.

Hallomenus suprà testaceus, thorace fascia unicâ, elytris fasciis duabus flexuosis; transversis, nigris.

Hallominus flexuosus. PAYк. Fiunn. Suec. tom. 2. pag. 18\%. $n^{\circ}$. 5. - Hallomenus undatus. PANz. Faun. Germ. fas. 68. fig. 23.

Longueur 2 lig. Tête noire. Bouche testacéebrune. Antennes testacées, leurs ârticles intermédiaires noirs. Corselet testacé avec une ligne noire dorsale et transversale, un peu rétrécie dans son milieu. Ecussontes tacé. Elytres testacées, glabres, luisantes, finement pointillées, avec deux bandes très-irrégulières, transversales, noires, communes aux deux élytres, mais n'atteignant point leur bord extérieur. Poitrine et abdomen de couleur brune. Patles testacées.

Même patrie que le précédent.

(S. F. et A. SERV.)

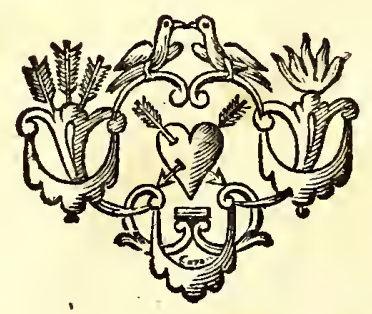




\section{Q U A}

Quadricornes ou Polygnates. M. Dumeril donne ce nora dans sa $Z$ oologie analytique à une famille d'Aptères dont les caractères sont: des mâchoires. Abdomen peu distinct, ayant des pattes sous quelques anneaux. Elle se compose des genres Physodes, Cloporte et Armadille.

(S. F. et A. Sert.)

QUADRILATĖRES, Quadrilatera. Troisième section de notre famille des Bracbyures, classe des Crustacés, ordre des Décapodes, ayant pour caractères : poiut de pieds nageurs; test presque carré ou en cœur; front prolongé, infléchi on très-incliné et formant une sorte de chaperon. Elle comprend les genres : Ocypode, Gécarcin, Mictyre, Pinnothère, Gélusime, Grapse,
Plagusie, Rhombille ou Gonoplace, Telphuse (ou Potamophile), Eriphie, P'ilumne. J'avois d'abord placé ceux de Mictyre et de Pinnothère dans la section des Orbiculaires. (Latr.)

QUEUE. Voyez Insecte, tom. 7 , pag. 238.

(S. F. et A. Serv.)

QUEUE FOURCHUE. Nom donné par Geoffroy au Bombix vinula des auteurs. Voyez Bombix , $\mathbf{n}^{\circ}$. go de ce Dictionnaire.

(S. F. et A. Serv.)

QUEUE JAUNE. Geoffroy nomme ainsi la Phalcena urticata. Lins. Botys urticata. Lat.

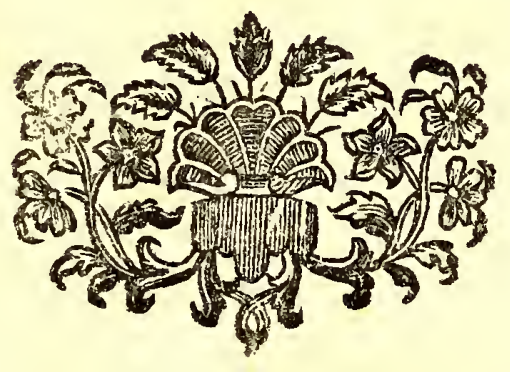




\section{R A D}

R DIALE. M. Jurine ayant adopté comme premier caractère générique dans les Hyméuoptères le nombre et la disposition des cellules des. ailes supérieures, n’a pas juyé c.ependant à propos d'eanloyer celle de toutes les parties de l'aile indistincteraent; il n'a considéré que les ce!lules qui sè trouvent bornées d'un côlé pār le point marginal ou épais et la partie du bord extérieur qui est inféricure á ce point et de l'autre côté par une rervure qu'il appelle cubitus, laquelle part de la partie supérieure du point milrginal ou d'un peu au-dessus en se dirigeant à peu près vers lc milieu du bord postérieur qu'elle atteint quelquefois. La cellule ridiale que nous appellerons quelquefois simplement radiale, est celle qui est placée le long du birrd extérieur de l'aile sous le point marginal; elle est bornée de l'autre côté par une nervure que M. Jurine appelle le radius, et qui, partant du point marginal, va rejoindre le bord de l'aile soit à sa partie exlérieurc, soit près de soṇ angle exterieur. La radiale est nulle, appendiculće, double ou triple. Elle est nullc lorsque la parrie inl'érieure du point marginal n'émet point de nervure qui combence au moins à séparer da reste de l'aile la partie inféricure et voisine du bord cxtérieur (Psile Jur.). Elle est incomplète lorsçue la nervarc dont nous venons de purles on le radius n'alteint par son extrćmité infériemreaucune partie du bord de l'aile (Omalc Jur.). Elie est complète lorsque la caécoc nervure atleint ce bord (la plus grande partie des yenres de l'ordre des Hyı́noptères). Wlle est simple lorsçu'elle n’est point divisée on qu'elle ne prorle point d'appendice à son extrémitć (la plupart des Hyraénoptères, tels que les Néarates ét les Ptérones Jur.). Elle est appendiculće lorsqu'elle porte à son extrérnité postérieure une très-petile cellule complète ou incomplète (Cryple, Dimorphe, Gonie, Dinète Jur.). Elle est double on il y a deux radiales lorsque l'espace qu'elle comprend est divisé par une nervare transversale en deux parties à peu pròs Euales ('Teuihrìde, Dolère Jur. elc.). Lnfin elle est triple ou il y a trois radiales lorsqu'elle se divise en lrois porions presqu'égales comane dans le genre Xyèle Dulın.

Copirale on Cellulacuditale. Lescellules cuLitales sout renferanées d'un côlé entre les riadiales on le rudius qui circonscrit celles-ci et le cubitus de l'autre; lorsque le cubitus n'existe point ou lorsque l'espuce qu'il circonscrit n'est point séparé par des nervures transversalcs, il n'y a qumne cellule cnbitale. Dans le premier cas la cubitale est dite se confondre avec les cellules discoidales (zoyez ce mot in la fis de cet article). Cela a lieu dans les Orales et les Bélytes Jur. Pour le secondcas, voyez les Chrysis Jur. Le nombre des cellules cubitales dépeud de celui des nervures transversales qui coupent l'espace circouscrit entre le radius et le cubitus. Leur nombre varie d'uue à quatre : l'inférieure on celle qui va jusqu'au bord postérieur est incomplète, lor'sque le cubilus n'atteint pas ce bord.

Drscoïnace. A la parlie caractéristique employée par Jurine, M. Latreille a ajouté les cellules qui occupent le disque de l'aile; elles sont situées entre le cubitus et le sinus restrant du bord intériérr, au-dessous des cellules brachiales et ae descendent pas ordinairement jusqu'au bord inférieur. Nous n'en avons jamais vu pius de trois, savoil : deux supérieures qui confinent immédiatement aux brachiales : celle que vous appelous la première est la plus voisine des cubitales, celle que nous appelons la seconde se rapproche du sinus rentrant du bord intérieur de l'ailc, la troisième ou l'inférieure est placée au-dessous des deux autres ditus le sens de la longueur de l'ailc dont la base est pour nous la parlie supérieure. Les cellules discoidales sont nulles lorsque le cabilus n'existe point, comme dans les Onales, les Clualcis, les Psiles et les Bélytes Jur. eıc. La première discoidale n'existe point lorsqu'elle est confondue avec la prenière cubitale comme dans les Anomalons, les Ichnenmons première famille et les Oxybèleśs Jur. La discoïdale intérieure descend jusqu'au bord poslérieur lorsqu'aucune nervure transversale ne lá feruse avant ce bord, commc dans les Bracons ct les Ichreumons deuxième fámille. Jur. Jua nervure qui sépare la discoidale inférieure de la première est appelée prenière nervure récurrule; lorsquelit discoidale inférieure u'atteint pas le bord postérieur, la nervure liransversalc qui la forme avint ce bord est nomrnée seconde nervare récurrente; on concoit done qu'ii n'y a qu'une nervure récurrente dans le cas où la premiere discoidale est confondue avec la première cubitale (voyez le genre Anomalon Jul.); dans ce ('as la seconde nervure récurrente existe seule; il n'y a encore qu'une ncrvure récurrente et c'est la première, lorsque la troisième discoidale atteint le bord inférieur (voyez Bracon Jur. etc.). Jurine ne nous parvit point avoir ea de raisons sulfisantes pour accolder deux nervures récurrentes anx genres qui sont daus les deux cas que nous venons de citer.

Bracarace. Cellules formées par les nervures longiludinales droites ou presque droites qui occupent la partie supéricure de l'aile et descendent de sa base jusqua disque. Queluntois ces cel- 
lules n'existent point (Psile Jur.) ou bien il n'y en a qu'une (Chalcis Jur.). On ne lcs a enployées jusqu'à présent qu'au défaut des autres parties caractérisliques de l'aile.

Bords des aILes. Le bord extérieur est celui qui lorsque l'insecte est dans lc repos, est placé au-dessus des côtés ou le longr des côtés de l'abdomen; ce bord est souvent muni d'une forte nervurc que l'on appelle côte et qui le bordc ordinairement presque dans toute sa longueur. Le bord intérieur est celui qui lui est opposé; les bords intérieur's des deux ailes de la même pairc se recouvrent souvent dans lc repos; lc bord intćrieur n'est pas ordinairement muni de nervure qui en snive le contour, il s'étend de ka base jusqu'au sinus rentrant. Le bord postérieur ou inférieur de l'ailc est celui qui vadepuis le sinvs rentrant jusqu'à l'extrémité de l’aile, c'cst-à-dire jusqu'à la pointe la plus éloignée de sa base. ( $\mathrm{S}$. F. ct A. Serv.

RAMEURS, Ploteres. Cinquième tribu dc la faraille des Géocorises, section des llétéroptères, ordre des Hémiptères. Elle a pour caractères:

Pattes intermédiaireset postérieures in sérées sur les côtés de la poitrine, écartées entr'elles à lenr naissance, longues, grêles, servant à marchier ou à ramer sur l'eau. - Tarses à crocbets très-petits et situćs dans une fissure latéralc.

Cette tribu se compose des genres Hydromc̀tre, Vélie et Gerris.

HYDROMETRE, Hy drometra. LAT. FAB. $C i$ mex. Linn. Geoff. De Géer. Aquarus. Schell.

Genre d'inscctes de l'ordre des Hémiptères, section des Hétéroptères, famille des Géocorises, tribu dcs Rameurs.

Les Vélics et les Gerris qui composent cette tribu avec les Hydromètres se distinguent de cellesci par le premier article de leurs antennes plus long que les autres et par leurs pattes antérieures ruvisscuses.

Antennes presque sétacées, insérées à l'extrémité d'un prolongement aztérieur de la tête, composées de quatre articles, le troisième beaucoup plus long que les autres. - Bec sans arliculations distinctes, reçu dans le rcpos dans un sillon situé à la partie inférieure de la tête. Tête alongée, avancée, cylindrique, plus longue et plus étroite que le corselet, plus épaissc vers son extrémité. - Yeux globuleux, proéminens, placés vers le milieu de la tête. - Corps linéaire. - Corselet ayant son segment antérieur de la forme d'une laime qui s'avance sur le dos jusqu'audelà des pattes intermédiaires. - Point d'écusson distinct. - Elytres courtes, de consisłance inégale. - Abdomen ayant scs bords latéraux un pcu élevés. - Pattes longues, grêles, filiformes, propres à marcher sur l'eau, les qualre antérieures ayant leurs tarses biarticulés, les intermédiaires insérées plus près des antérieures que des postéHist. Nat. Irus. Tome $X$. rieures. Tarses de trois articles, Ic premier pen distinct dans les quatre pattes antérieures; leurs crochels trc̀s-pétits situés dans une fissure latérale.

Ce genrc a pris son nom de dcux mots grecs qui significnt: mesureur d'eau. Ces insectes marchent sur lcs eaux, mais avec moins de vilessc que les Gerris et ne s'y plongent jamais. Il est probable qu'ils vivent de petits insectes; les $\mathrm{H}_{\mathrm{f}}$ dromètres paroissent préférer les eaux tranquilles à celles que le vent agite ou dont le courant est rapide. La larve ne différe de l'insecte parfait que par lo défaut d'ailes et d'élytres. On ne mentionne que deux espèces de ce genre, l'une d'Europe, Fydiometra stagnorum. $\mathrm{F}_{\mathrm{A}}$. Syst. Rhyngot. (Encycl. $p l .374$. fig. 21-23. La larve) et l'autre des Indes orientales.

GERRIS, Gerris. FAв. (Entom. Syst.) LAт. Hydrometra. FАв. (Syst. Rhyng.) Cimex. Lisin. Geoff. De Gére. Aquarius. Scheld.

Genre d'insectes de l'ordre des Hémiplères, section des Fétéroptères, famille des Géccorises, tribu des Ramenrs.

Les Hydromètres, les Vélies et les Gerris composent celtc tribu; les premières se dislinguent par le troisième article dés antennes qui est le plus long des qualre. Dansles Vélies le bec n'a que deux articles apparens et les pattes intermédiaircs sont presqu'également distantes des untévieurcs et des postérieurcs.

Antennes filiformes, insérées au-devant des yeux, sur les côtés du prolongement antérieur de la têtc, composćes de quatre articles, le prcmier lc pluslong de tous, le dernier cylindrique. - Bec court, arqué à sa base, de quatrc articles dont lcs deux premiers fort cour's (le second surtont), le troisic̀me long, le dernier très-pctit. - Tête triangulaire, prolongée antéricurement. - Yeux globuleux, trés-saillans. - Corps alongé, elliptique, très-étroit, presque linéaire, couvert en dessous et sur les cốtés d'un duvet argentin. - Corselet alongé, rétréci en devant, son extrémité postérieure prolongée en forme d'écusson. - Elytres étroites, croisées l'une sur l'autre dans le repos, demi-opaques; leurs nervurcs assez grosses; ailes membranerses, de la longueur des élytres et repliées sous celles-ci.-Abdomen conposé de six segmens transversaux dans les deux sexes, outre l'anus; le sixième ayant de chaque côté un prolongement spiniforme, très-long durs les mâles. Anus des femelles sillonné longiludinalement dins son milieu, celui des mâles entier, sans sillon longitudinal. Dessous de l'abdomen en carènc. Pattes antérieures courles, pliées, ravisseuses; les quatre autres fort éloignées des précédentes, rapprochćes à leur basc, très-longues, menues, filiformes, propres à marcher sur l'eau; tarses ne paroissant que de denx articles; point de crocl:ets distincts aux quatre larses postéricurs, ceux des anlérieurs très-courts. 
Les maurs des Gerris sont à peu près les mêmes que celles de Hydromètres, mais leurs monvemens sont beancoup plus vifs et elles ne fuient pas entièrement les eaux courantes; la partie inférieure de leur corps ainsi que les côtés sont garnis d'un duvet très-court, tr'cs-serré, fort propre à les garautir de l'humidité; ce duvet a un reflet argentin qui paroît particulier à ce genre. Ces hémiptères dont plusieurs espc̀ces sont furt communes ont le corps ordiuairement brun ou noirâtre en dessus; ils marchent sur l'eau et s'avanceut par saccudes en glissant; ils sont carnassiers. On les désigne vulgairement sous le nom très-impropre d'Araignées d'eaul. Les mâles faciles à reconnoître par les caractc̀res iudiqués plus haut ont l'abdomen proportionnellemeut plus lon r que celui des femelles et leur taille est en général plus grande d'un tiers. Le noubre d'espèces connues est pelit.

\section{Gerris des lacs, G. lacustris.}

\section{Gerris suprà omninò fusco-olivacea.}

Gerris lacustris. La'r. Gener. Crust. et Ins. tom. 5. pag. 134. $n^{\circ}$. 3. La femelle. - Hydiometra lacustris. FAB. Syst. Rhyngot. pag. 256. $77^{\circ}$. 1. La femelle. - Cimex lacustris. Linn. Syst. Nat. 2. 732. 117. La femelle. - DE GÉER, Ins. tom. 3. pl. 16. fg. 12. La femelle. - La Punaise nayade. Geoff. Ins. Paris. tom. I. pag. 463. $n^{\circ} .59$. - Gerris paludum. Lat. Gener. Crust. et Ins. tom. 3. pag. 133. $n^{\circ}$. 1. Le mâle. - Hydrometra paludum. FA B. Syst. Rhyngot.pag. 258. $n^{\circ}$. 3. Le mâle.-DE GÉER, Ins. tom. 3. pl. 16. fig. 7. Le mâle.-Stole, Punais. pl. IX. fig. 63. Le mâle. - Encycl. pl. 374.fig. 20. La larve.

Longueur 5 lig. $\frac{3}{2}$. Mâle. 3 lig. $\frac{3}{2}$. Femelle. Corps d'un brun-olivâtre en dessus, convert en dessons d'un duvet blanchâtre et argenté. Antennes et pattes brunes, les quatre postérienres pâles, surtont vers leur base; les antérieures pâles, tachées de noir. Corselet ayant une ligne longiiudinale élevée sur le dos. Côtés de l'abilomen portant une série de petites lignes enfoncées qui nous paroissent êrre les stigmates. Femelle.

Le mâle a les bords latéraux du corselet et l'extrémité de l'écusson roussàtres, aiusi que les bords de l'abdomen. Les pattes sont beaucoup plus brunes que dans la femelle.

'Très-commune anx environs de Paris.

Nota. Les signes caractéristiques des sexes dans l's Gerris n'ayant point été observés avant nous, il n'est pas étonnant que les auteurs aient fait deux espèces sous les noms de Lacustris et de Paludum. On remarqnera que le principal caractère qu'ils ont employé pour les séparer l'une de l'autre est la forme des derniers segmens de l'abdomen; différence qui est purement sexuelle.

\section{Gerris écusson roux, G. rufo-scutellata.}

- Gerris suprà fusco-olivacea, scutello nifo.

Gerris rufo-scutellata. La'T. Gener. Crust. et Ins. tom. 3. pag. $134 . n^{\circ} .2$.

Longueur 6 lig. Mâle. 4 lig. $\frac{1}{2}$. Femelle. Corps d'un brun-olivâtre en dessus, couvert en dessous d'un duvet blanc-jaunâtre argenté. Corselet ayant sir le dos une ligne longiludinale élevée qui est rousse sur le premier segment. Bords latéraux du corselet et de l'abdomen ainsi que l'écusson, roux. Antennes et pattes d'uu roux-brun. Pattes autérieures noires avec leur base d'un roux-pâle, surtout ell dessus. On voit une série de petites ligues entoncées sur les côtés de l'abdomen. Femelle.

Le mâle diffère en ce que le dessus du secend segment du corselet est eatièrement roux ef qué les ćlytres sont d'un brun-roussâtre. Les paties et les autennes sont d'une nuance plus claire que dans la femelle.

Des envirous de Puris.

Nota. Les synonymes rapportés jusqu'ici à cette espèce nous paroissent douteux, De Géer n'ayant pas parlé de la couleur rousse du corselet et Stoll ne l'ayant pas figuré tel.

(S. F. et A. Serv.)

RANATRE, Ranatra. Fab. Lat. Nepa. Lins. De Géer. Hepa. Geuff.

Geure d'insectes de l'ordre des Hémiptères, section des Hétéroptères, famille des Hydrocorises, tribu des Ravisseurs.

La tribu des Ravisseurs se compose de six genres. Pélogone, Galgule, Bćlostome, Naucore, Nèpe et Ranâtre. Les trois premicrs ont tous les tarses biarticulés. Les Naucores ont leurs quatre pattes postérieures ciliées et natatoires avec les tarses de ces patles de deux articles distincis. Dans les Nèpes et les Ranátres ces mêmes patıes sont peu ou point natatoires, leurs tarses n'ont qqu'un seul article, mais le bec des Nèpes est recourbé, leurs hanches sout courtes, le corps est ovale, fortement déprimé. On ne peut donc confondre ces genres avec les Ranâtres.

Antennes très-courtes, peu apparentes, cachées sous les yeux, de trois articles dont le second fourchu. - Bec avancé, pas plus long que la tête, conique, de trois articles, les deux premiers plus gros, celui de la base en forme d’anneau, le dernier conique. - Téte petite. - Yeux globuleux, très-saillans. - Point de petits yeúx lisses. - Corps linéaire. - Corselet très-alongé, presque cylindrique,"plusépais duns sa partie postérieure qui s'échancre pour recevoir une portion de l'écusson. - Ecusson pointu à l'extrémité. Elytres de la longueur de l'abdomen, leul partie membraneuse fort courte. - Abdomen alongé, terminé par deux longs filets sétacés. - Pattes 
très-longues, très-grêles, les antéricures ravis- 1 seuses à hanches et cuisses fort longues, de même grosseur, cylindriques. Ces cuisses unidentées, ayaut depuis leur extrémité jusqu'à cette deıt un sillon pour recevoir la jambe et le tarse, qui forment réunis, une sorte de crochet conique; les quatre pattes postérieures point ciliées, rapprochées, éloignées des antérieures, à hanches très-courtes, leurs tarses d'un seul article très-long, terminé par deux crochets menus, alongés, presque droits.

Les auteurs ne mentionnent dans ce genre que cinq espèces, auxquelles on a donné vulgairement le nom de Scorpions aquatiques. Deux habitent les grandes Indes, la troisième les environs de Paris. De Géer en décrit une quatrième de Surinam, et M. Palisot-Bauvois une des ElatsUnis d'Amérique. C'est dans l'eau que vivent ces hémiptères, ils marchent ral et nagent encore moins bien, la nature ayant refusé à leurs jambes ainsi qu'à leurs tarses ces cils qui aident si puissamment à la natation dans les genres voisins, habitant comme celui-ci les eaux stagnantes. C'est dans ces eaux que les femelles déposent leurs œufs. Ceux-ci ont une forme un peu alongée et portent à l'une de leur's extrémités deux fils ou poils. La mère fixe chaque œuf dans la tige de quelque plante aquatique, de manière qu'il y est caché et que ses poils sont seuls apparens. La larve et la nymphe ainsi que l'insecte parfait sont voraces et leurs pattes anterieures leur donnant la facilité d'arrêter la plupart des animaux aquatitiques, ils les sucent avec leur bec aigu. Ils ne sortent point de l'eau pour subir leurs métamorphoses. La larve ressemble à l'insecte parfait, si ce n'est qu'elle manque entièrement d'ailes et d'élytres. Dans la nymphe on commence à voir des étuis latéraux attachés au corselet, qui renferment ces parties. Celles-ci se développent lors de la dernière transformation. Alors l'insecte parfait vole très-bien, ce qu'il fait principalenent le soir et la nuit. pour se transporter d'une mare à une autre lorsque celle qu'il habitoit coumence à se dessécher ou à manquer de la proie dont il se nourrit.

\section{Ranatre linéaire, $R$. linearis.}

\section{Ranatra caudâ abdominis longitudine.}

Ranatra linearis. FaB. Syst. Rhyng. pag. Iog. no. 2. - LAT. Gener. Crust. et Ins. tom. 3. pay. 149. no. 1. - Panz. Faun. Gem. fas. ". fig. 15. - Nepa linearis. Livn. Syst. Nat. 2. 714.7. D) G ǴER, Ins. tom. 3. pag. 36g. $77^{\circ}$. 2. pl. Ig. fig. 1-7. - StoLL, Punais. pl. XII. fig. 7. - Le Scorpion aquatique à corps alongé. Georr. Ins. Paris. tom. 1. pag. 480. $n^{\circ}$. 1. pl. 10.fig. 1. Encycl. pl. 374. fig. 16-19, et pl. 22. Nèpe, fig. $1-10$.

Longueur 18 ligg. Corps d'un gris-roussâtre, jaune en dessous. Abdomen rougeattre en dessus. Ses filets de même longueur que lui.

Commune aux environs de Paris dans les eaux slagnañutes.

\section{Ranatre alongíe, $R$. elongata.}

Ranatra caudâ corporis longitudine.

Ranatra elongata. FAB. Syst. Rhyng.pag. rog. $n^{\circ} .3$.

Longueur 18 lig. Corps d'un gris-roussâtre, jaune en dessous. Corselat et pattes plus páles. Filets de l'abdomen de la longueur du corps.

Des Indes orientales. (S. F. et A. SERV.)

RANINE, Ranina. De LAm. Albunea. FAb. Genre de Crustacés de l'ordre des Décapodes. famille des Brachyures, teraninant la tribu des Nosopodes, la dernière de cette famille, et conduisant ainsi à celle des Macroures, qui commence par le genre Albunée, dont les Ranines font partie dans le Système entonologique de Fabricius.

Deux caractères très-remarquables distinguent ce genre de tous les autres Brachyures. La queue est étendue et leurs pieds, tous, à l'exception des serres, terminés en nageoires, sont disposés sur deux rangs, les quatre postérieurs étant placés au-dessus des précédens ou étant dorsaux. A ces caractères nous ajouterons les suivans. Test en forme de triangle renversé ou d'ovale tronqué; front, y compris les angles latéraux, divisé en se $t$ ou neuf parties, sous la figure de dents, de lobes ou d'épines, celle du milieu formaut un museau pointu. Yeux portés sur des pédicules longs, cylindriques, naissant près du milieu du front, divisés transversalement. Antennes latérales convergentes intérieurement, avancées ensuite, longues et sétacées; les intermédiaires repliées, mais saillantes (1). Pieds-mâchoires extérieurs écroits et alongés; leur troisième article long, pointu, avec une troncature oblique, précédée d'un angle, à l'extrémité de son côté extérieur. et uue échancrure au bord opposé, au-dessous de la pointe terminale; le quatrième article inséré dans cette échancrure, mais caché et reçu ainsi que les deux suivans et derniers dans une rainure longitudinale de ce bord. Cavité buccale creusée, à sa partie supérieure, de deux profonds sillons, recevant une portion des premiers piedsmâchoires. Mains très-comprimées, oblongues, avec les doingts, le pouce surtout, couchés. $N a$ geoires (le iarse) des pieds presqu'elliptiques, arquées au bord interue, allaut en pointe et un peu courbées à leur extrémité ou un peu luaulaires; l'article précédeut transversal. Queue alongée,

(1) La Ranine dentée ae m'a pas offirt de cavités proptes à les recevoir. 
garnie de poils, de sept segmens; le second et le troisième portant les appendices sexuels.

Crustacés habitant exclusivement les mers des Indes orientales.

Au rapport de Rumplie, l'espèce nommée Dorsipède grimpe jusque sur les toits; inais les pieds, a l'exception des serres, n'étant propres qu'à la nalation, cela me paroit impossible. Ce genre avoisine ceux de Platyonique et de Coriste, et semble couduire aux llacroures.

\section{Ranine dentée, $R$. dentata.}

Ranina dentata. $\mathrm{DE}$ LArr. - Albunea scabra. HAB. - HeRBST, Krabben, tab. 22. fig. 1. RuMPн. Mus. tab. 7. fig. 'T. 'T.

Test en forme de triangle reaversé, très-chagriné, avec une rangré de petits tubercules et dont les antérieurs en forme de petites dents, sur les rebords latéraux. Milieu du firont formant une saillie tridentée; une dent simple, trois lobes, dont le plus interne bifide ou bidenté, et les autres trifides, à chaque côté antérieur; tranclıes des poings et la supérieure du pouce fortement denlées.

Test loug de près de quatorze centimètres sur près de treize de large. Dernier article des pédicules oculaires relevé à angle presque droit.

\section{Ranine dorsipède, $R$. dorsipes.}

Ranina dorsipes. DE LAM. - Cancer dorsipes. Linn. - Albunea dorsipes. Fab. - Rumpu. Mus. tab. $10 . n^{\circ} .3$.

'Test en forme de triangle renversé, chagriné; sept dents presqu'égales, eutremêlées de petites dentelures, et précédées d'une ride transverse finement dentelée et ciliée au bord antérieur ; tranches des mains sans dent.

Tust long d'enviren un pouce. Appendices ovifè̀res pennacés. Vue dins la collection de la Société linuéenne. Les articles inférieurs des antennes intermédiaires m’ont paru comprimés et presque foliacés. 'Troisième paire de pieds et même la qualrième plus longues que la seconde.

\section{Ranine lisse, R. lovis.}

Test ovale, tronqué en devant, lisse.

Petite. Test macifestement plus long et plus étroit que celui des précédentes; une épine forte et avancée près de claque extrémitć latérale et antérieure; milieu du front formant un lobe presque carré, terniné par deux échancirures et trois dents, dont celle du milieu plus avancée; deux petits lobes étroits, échancrés à leur extrémitć et teiminés par une petite dent, de chaque côté, "entre le lobe frontal et l'épine latérale; le plus voisin d'elles terminé extérieurement par une petite épine. Seires moins robustes que celles des précédens; quatre dents à la tranche intérienre du poing; une autre au bord opposé; une aulre sur le pouce, en dessus de son origine; carpes unidentés extérieurement.

Muséum d'Histoire naturelle.

Le genre Symethis de Fabricius vient peut-être près de celui-ci. (LATr.)

R.APIIIDIE, Raphidia. Linn. Geoff. De GÉER. FAB. LAT.

Genre d'insectes de l'ordie des Névroptères, famille des Planipennes, tribu des Raphidiues.

Cetle tribu se compose des genres Raphidie et Muntispe. On dislingue ce dernier par ses pattes antérieures ravisseuses.

Antennes grêles, sétacées, insérćes entre les yeux, distanies à leur base, de la longueur du corselet, uulliarticulées, ces articles très-courts, cylindriques, les deux premiers plus épais que les autres, celui de la base le plus long de tous, le dernier un peu ovale. - Labre avancé, attaché au chaperon, un peu coriace, preśque carré, un peu plus large que long, arrondi et entier à sa partie antérieure. - Mandıbules forttes, cornées, ne s'avancant pas au-delà du labre, en forme de triangle alongé, ćtroites, munies d'un fort crocbet arqué et aigru à leur extrémité et de deux dents aiguës à leur bord interne. - Mâchoires courtes, crustacées, porlées sur une base distincte, divisées en deux lanières à leur extréuité, l'extérieure de deux articles presque cylindriques, l'intérieure petile, curiace, trigone, en forme de dent. Quatre palpes courts, filiformes, leurs articles cylindriques, le dernier un peu plus long et plus grêle, les maxillaires un peu plus longs que les labianx, composés de cinq arlicles, les labiaux de trois, non compris le tubercule radical. Lèvre courte, carrée, inembraneuse. - Téte grande, presque verlicale, déprimée, atténuée postérieurement, sa base se rétrécissant en une espèce de cou; chaperon membraneux, presque coriace, divisé en deux à sa partie supérieure, en carré tränsversal commençant à l'origine des antennes; la parlie antérieu e plus large que le labre, presque trapéziforme, se l'étrécissınt un peu de sa base à l'extrémité. - Yeux un peu saillans, en ovale court. - Trois petits yeux lisses disposés en triangle sur le front. - Corps alongé. - Corselet ayaut son segment antérieur très-alongé, étroit, presque cylindrique, le second transversal, beaucoup plus large et beaucoup plus court que le précédent. - Ailes de grandeur égale, élevées en toit dans le repos, un peu réticulées, la plupart des nervures qui se dirigent vers les bords postérieur et intérieur se bifurquant en manière d' $Y$ grec. -Abdomen morl, alongé, comprimé ; anus alongé, portant deux forts onglets dans les mâles, munidans les feınelles d'une tarière de la longueur de l'abdomen, á peu près courbe, un peu comprincée, sillonoée dans sa longueur sui chacua de 


\section{R A P}

ses côtés. - Pattes minces, jambes cylindriq . Tarses de cinq articles, le premier plus long que les autres, cylindrique, le troisième presque cordiforme, bilobé, le quatrième très-court, à peine visible, n'atteignant point l'extrémité des lobes du troisième, le cinquième alongé, obconique, muni de deux crochets simples et aigus à leur extrémité, point de pelottes distincles.

On connoît deux espèces de ce genre dont le now vient d'un mol grec qui signifie : alêne et a rapport à la tarière des femelles. La larve de ces insectes est d'une forme presque linéaire, un peu large cependant vers le milieu du corps; la tête est grande, carrée, déprimée; les antennes courtes, coniques, de trois articles, les yeux paroissent for'més d'un assemblage de petits grains; les six pattes sont courtes, arnées de deux crochetsà leur extrémité, elles sont insérées par paires sous les trois premiers segmens du corps. Cette larve est très-agile et se roule avec vivacité; sa nourriture ainsi que celle de l'insecte parfait, se compose de petits insectes. La nymphe marche et ne se distingue de la larve que par les fourreaux des ailes.

\section{RaphIdie serpentine, $R$. ophiopsis.}

Raphidia capite post oculos subtriangulari, alurum puncto marginali subpellucido.

Raphidia ophiopsis. Linv. Syst. Nat. 2. 9i6. 1. - HAB. Entom. Syst. tom. 2. pag. 99. $n^{\circ} .1$. - Panz. Faun. Germ. fas. 5o. fig. 31 . La femelle. - Lat. Gener. Crust. et Ins. tom. 3. pag. 203. - La Raphidie. Geoff. Ins. Paris. tom. 2. pag. 233. $n^{\circ}$. 1. $p l$. 13. fig. 3. Le mâle.

Longueur 6 lig. Corps noir. Anteunes testacées, plusbrunes vers leur extrémité. Mandibules, bords du chaperon, dessous du prenier lobe du corselet, son bord antérieur en dessus, partie antérieure du second, milieu de l'écusson, taches latérales sur l'abdomèn et pattes, d'un jaune-ferrugineux.Cuisses postérieures noires. Tête et corselet puinitllés; celie-là diminuant insensiblement de largeur inwédiatement après les yeux. Ailes transparenies à nervures brunes, le point marginal des quatre étant presqu'aussi diaphane que le reste de l'aile. Mâle et femelle.

Les antennes, dans le prewier, sont un peu plus brunes en deśsus.

Assez commune dans les bois des environs de Paris. La larve est biune avec des lignes courtes, arquées et des points d'un blanc sale; elle vit dans les fentes de l'écorce des arbres.

2. Raphidie notée, $R$. notata.

Raphidia capite subquadrato in parte posteriori subito coarctato, alarum puncto marginali fusciore.
Raphidia notata. FAв. Mrantiss. Ins, tom. 1. pag. 251. $n^{\circ}$. I. - Raphidia ophiopsis. DE GÉER, Ins. tom. 2. pag. 742. pl. 25. fig. 4-9. La femelle. - Schaeff. Elem. tab. 107.

Longueur 9 lig. Cette espèce ressemble beancoup à la précédente; elle en diffère outre sa taille par ses antennes noires dont quelques articles $e$ la base seulement sont testacés, par une ligne dorsale et longitudinale jaunâtre qui s'avance de la base jusqu'au milieu de la tête, celle-ci ay'ant sí partie antérieure presque carrée et ne commençant à se rétrécir que loin des yeux; par ses cuisses postérieures d'un brun-roussàtre et par le point marginal des quatre ailes, d'un brun-noirâtre. Femelle.

Des environs de Paris.

Nota. Fabricius a réuni à fort cette espèce à la Raphidia opluopsis daus les ouvrages qu'il a publiés après son Mantissa. Les fig. 1 et 2 de la tab. 95̃ de Scliaefler, Icon., sont douteuses. De Géer décrit le mâle et la femelle quoiqu'il n'ait figuré que celle-ci; il dit positivement que les ailes ont une tache noire et opaque vers le bout, au bord extérieur, cé qui ne peul s'appliquer qu’à la Raphidie notće. (S. F. et A. Sekr.)

RAPHIDINES, Raphidince. Sixième tribu de la fanille des Planipennes, ordie des Névroptères. Elle présente les caractères snivans :

Aniennes sétacées, multiarliculées. - Tète rétrécie en arrière. - Corselet long, étroil, presque cylindrique. - Ailes grandes, en toit dins le repos. - Tarses de cinq articles.

Cette tribu renferme les gemes Raphidie et Mantispe.

MANTISPE, Mantispa. IrIIg. I.AT. Raphidic. Linn. Scop. Mantis. FAB. Oriv. (Encycl.; P PAz. Genre d'insectes de l'ordre des Névroptères. famille des Planipennes, tribu des Raphidines.

Les Raphidies, seul genre qui compose. cette tribn avec celui de Mautispe, ont le troisième article des tarses fortement bilobé, le quatrième très-court, le dernier muni de crochets simples, aigus à leur extrémité, sans pelotles apparentes et leurs puttes antérieures ne sont point lavisseuses.

Antennes sétacćes, seulement un pen plus longues que la têle, composées d'articles nombreux, moniliformes, les deux de la base presqu'égaux entr'eux. - Lab̀re avancé, attaché au chaperon, presque carré, arrondi et entier à sa partie antérieure. - Mandıbules fortes, cornées. - Puatre palpes filiformes, presqu'égaux en longueur, le dernier article des maxillaires en ovile fort alongé. - Tête rriangnlaire, verticale. - Yeux zrands, sailluns. - Yeux lisses peu apparens. - Corps alongé. - Corselet long, ayant son segment antérien fort alongé, 
évasé à sa partie antérieure; le second conrt, en carré transversal. - Ailes de grandeur égale, un peu réticulées, élevées en toit dans le repos; la plupart des nervures gini se dirigent vers les bords postérieur et intérieur se bifurquant en manière d'Y grec. - Abdomen un peu en massue, rétréci vers sa base; anus simple dans les deux sexes. - Pattes antérieures longues, ravisseuses, leurs hanches très-longues; cuisses dilatées, carénées en dessons, cetle carène garnie de dents; une épine longue placée en dedans, près de la carène; jambes arquées, comprimées, tranchantes en dessous, sappliquant sur la cuisse entre la série de dentelures et l'épine, tarses de paroissant consistor qu'en un fort onglet; les quatre autres pattes petites, leurs tal'ses de cinq articles, le premier aussi long que les trois suivans réunis, ceux-ci courts, égaux entr'eux, le cinquième un peu plus grand, muni de deux crochets s'élargissant un peu vers leur extrémité qui est tridentée, et d'une pelotte grosse et bilobée.

Les iusectes de ce genre ont été long-temps placés parmi les Orthoptères et confondus avec les Mantes; la forme de leur's pattes antérieures pouvoit en effet autoriser cette réunion ainsi que les mceurs; il faut néanmoins remarquer que Poda, et après lui, Linné et Scopoli, n’avoient point commis cette faute : non-seulenent ils placoient la seule Manlispe alors connue ( $M . p a-$ gana) parmi les Névroptères, mais ils en faisoieut même une espèce du genre Raphidia. Les autres caractères fixent définitivement la place des Mantispes auprès des Raphidies ; nous ajouteterons que la disposition des nervures des ailes cont ici d'accord avec la méthode; cette observaion n'a élé faite, à ce qu'il nous paroit, par aucun auteur. On connoît aujourd'hui cinq ou six espèces de ce genre, dont une seule d'Europe. La forme des pattes antérieures prouve évidemment que ces insectes sont carnassiers. Leurslarves ne uous sont pas connues.

\section{Mantispe payenne, MI. pagana.}

Mantispa pagana. Lat. Gen. Crust. et Ins. tom. 3. pag. 93. no. I. - Mlantis pagana. $\mathrm{F}_{\mathrm{AB}}$. Entom. Syst. tom. 2. pag. 24. $n^{\circ} .49$. - Stole, Spect.pl. II.fig. 6.-PANZ. Faun. Gem. fas. 5o. fig. 9 .

Yoyez pour la description et les autres synonymes, la Manle payenue ${ }^{\circ} .28$. (Au synonyme de Scopoli, lisez 712 au lieu de 722.)

\section{Mantispe pusille, $M$. pusilla.}

Mantispa pusilla. Lat. Gen. Crust. et Ins. tom. 3. pag. 94. - Mantis pusilla. HAB. Eritom. Syst. tom. 2. pag. 25. no. 51. - Sтогк, Spect. pl. I. fig. 3.

Longueur so lig. D'un jaune-faure arec quel- ques teintes brunàtres sur le corselet et sur l'abdomen. Ailes d'un jaune-transparent avec leurs nervures de celle même couleur ainsi que le poiut marginal qui est fort alongé.

Du Cap de Bonne-Espérance.

Voyez pour les autres synonymes la Mante pusille $n^{\circ}$. 3o de ce Dictionnaire.

3. MANTISPE demi-transparente, $M$. semihyalina.

Mantispa nigra, coxis femonumque basiferrugineis, alarum nigrarum parte interiori hyalinâ.

L.ongueur 5 lig. Noire. Hanches antérieures, moitié de leurs cuisses et parties de la bouche d'un testacé-ferrugineux ainsi que la base des antennes (le reste manque). Abdomen fortement rétréci antérieurement. Ailes d'un noir-bleuâtre, leur partie intérieure transparente depuis le tiers de l'aile jusqu'à l'extrémité.

Du Brésil.

Rapportez en outre à ce genre, $1^{\circ}$. la Mantispa flavo-maculata. LAt. Gen. Crust. et Ins. tom. 3. pag. 94. Stoll, Spect. pl. II. fig. 7. De Surinam; $2^{\circ}$. la Mantispa rufescens. Lat. idem. StolL, Spect. pl. IV. fig. I 5 . Des Iudes orientales. (S. F. et A. SERv.)

RAVISSEURS, Raptores. Première tribu de la famille des Hydrocorises, section de Hétéroptères, ordre des Hémiptères. Ses caractères sont :

$P$ attes antérieures ordinairement propres à saisir uue proie, composées d'une cuisse soit très-grosse, soit très-longue, ayant en dessous une rainure pour recevoir le bord inférieur de la jambe, et d'un tarse très-court, se confondant mème dans plasieur's avec la jambe et formant avec elle un grand crochet. - Corps ovale, trèsdéprimé ou de forme linéaire.

Les antennes sont tout au plus de la longueur de la tête, insérées et cachées sous les yeux comme duns toutes les $\mathrm{Hydrocorises.}$

les genres qui appartiennent à celte tribu sont : Pélogone, Galgule, Bélostomè, Nèpe, Ranûtre et Naucore.

GALGULE, Galgzilus. LAt. Naucoris. Fad.

Genre d'insectes de l'ordie des Hémiptères, section des Hétéroptères, famille des Hydrocorises, tribu des Ravisseurs.

Le genre Pélogone se disingue de tons les autres de cette tribu en ce que ses pattes antérieures ne sont point ravisseuses; les Bélostomes ont les antennes demi-pectinées; le corps des Naucores, des Nèpes et des Ranâtres n'est point court et presque carré; ces trois genres ainsi que celui de Bélostome n'ont pas d'yeux lisses apparens.

Antennes insérées sous les yeux, plus courtes que la tête, composées de trois articles, dont le dernier plus grand, ovoïde-alongé, les deux pre- 


\section{R A V}

miers presqu'égaux. - Labre grand, avancé, presque demi-circulaite. - Bec conique, plus court que la tête, de trois articles; celui de la buse court, large, les deux autres presqu'égaux entr'eux. - Téte perpendiculaire, sa partie antérieure avancée. - Yeux suillians. - Deux petıts yeux lisses apparens, placés entre les yeux à réseau. - Corps court, presque carré.-C'orselet cuart, dilalé sur les côtés. - Ecusson grand, triangulaire. - Sternum ayant une poinie saillaute. - Elytres recouvrant les ailes et l'abdomen, leur membrane étroite, ne s'étendant guère qu'à la parlie inférieure da bord interne. - Abdomen court, large, ses côtés dépassant un peu lcs élytres; il est couposé de six segmens outre l'anus, les avant-derniers réirécis dans leur milieu par le sixiène qui s'élargit et s'étend dans cette partie ver's le milieu du ventre; anus enlier et plat dans les máles, ayaut, dans lcs femelles, une fente longitudinale dont les bords forment une carène et sont connivens. - Hanches munies à leur base d'un fort appendice ou trochanter. - Pattes antérieures ravisseuses, hanches courtes, cuisses grosses, jambes courtes, s'appliquant en dessous de la cuisse. Les quatre paltes postérieures propres à maicher, ne pouvant servir à la natation, leurs tarses de deux articles, le dernier muni de deux crochets.

Les espèces connues de ce genre fondé par M. Latreille, habitent l'Amérique. On trouve ces insectes dans les caux où ils marchent pluı ôt qu'ils ne nagcnt. Ils sont carnassiers et se nourrissent d'insectes plus foibles qu'eux. Une larve de Galgule que nous avons sous les yeux et que nons croyous ctre celle du Galgule ravisseur diffère de l'insecte parfait par le manqne d'ailes, d'élytres et d'yeux lisses, sa tête est horizontale a bord antérieur tranchant, renfermée ainsi que les yeux dans l'échancrure antérieure du corselet, formant avec lui une section de cercle; les yeax sont ovales, point saillans; les pattcs autérieures composées d'uu hanche fort courle, d'une cuisse grosse après laquelle vient un crochet inarticulé fort et aussi long que la cuisse; les quatre pattes postérieures sont composées d'une cnisse, d'une janbe, d'un tarse uniarticulé muni de deux crochets; les jambes de la dernière paire sont garnies de cils et paroissent propres à nager. Le second segment de l'abdomen porte dans son milieu une pointe dont l'extrćmité est recourbée en arrière et aiguë.

Ire. Division. Cuisses antérieures canaliculées en dessous, les deux bords de ce canal muni de nombreuses dentelures, leurs jambes garnies antérienrement de petites dents dont une plus forte vers la base. - Tarses antérieurs composés d'un seul article à ce qu'il nous paroît (de deux articles, suivant M. Latreille), terminé par deux crochets.

\section{GaLGdLe oculé, G. oculatus.}

Galgulus oculis pedunculatis, pedibus anticis biungiuiculatis, corpore suprì rugosiore.

Galgulus oculatus. Lat. Gen. Crust. et Ins. tom. 3. pag. 144. $n^{\circ}$. 1. - Naucoris oculata. F.1. Syst. Rhyngot.pag. $11, n^{\circ} .5$.

Longueur 5 lig. Antennes jaunâtres, corps brun en dessus, très-raboteux, sur!out sur la tête et le corselet, celui-ci ayant un sillon trinversal profond. Dessous du corps brun; bord extérieur du corselet et de l'abdomen d'un jauue-sale. Paltes de cette même coulcur, tachées et rayćes de brun. Yeux pédiculés. Jambes postélieurcs irrégulièrcmont épineuses sur toute leur superficie. Femelle.

De la Caroline.

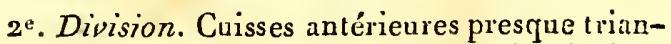
gulaires, ayant une impression longitndinale à côté de lcur bord antéricur; ce bord garni d'un seul rang de fines dentelures, leurs jambes sillounćes longitudinalement. - Point de tarses antétérieurs distincts; un seul crochet gros et fort, placé à l'extrémité des deux premières jumbes.

\section{GALGULE ravisseur, G. raptorius.}

Galgulus oculis sessilibus, pedibus anticis umiunguiculatis, corpore suprà vix rugoso.

Longueur 5. lig. Plus large quc le précédent. Antennes jaunes. Corps d'un jaune-sale mêlé de brun, tête et corselet un peu raboteux, celui-ci ayant un sillon transversal. Dessous du corps Lruı, bord extérienr du corselet et de l'abdomen d'un jaune-sale, ce dermier laché de brun en dessus et cn dessous. Yeux sessiles. Pattes jaunâtres annelées de brun. Jambes postérieures irrígulièrement épineuses sur toute leur superficie. Miale et femelle.

Du Brésil.

Nota. Cette espèce est'peut-être la Naucoris raptoria. FAв. Syst. Rhyngot. pag. $111, n^{\circ} .6$. Naucore ravisseur $n^{\circ} .5$ de ce Dictionnaire.

BÉLOSTOME, Belostoma. LAt. Nepa. Linn. De Géer. Fab.

Genre d'insectes de l'ordre des Hémiptères, section des Hétéroptères, famille des Hydrocorises, tribu des Ravisseurs.

Aucun genre d'Hémiptères ravisseurs sauf celui qui est l'objet de cet article n'a les antennes seraipectinées.

Antennes filiformes, plus courtes que la tête, cachées dans une cavité, insérées sous les yeux, composées de quatre articles, les trois derniers prolongés extérieurement en un rameau alongé, linéaire.- Labre alongé, aciculaire, renfermé dans la gaîne du suçoir. - Bec conique, s'avan- 
çant jusqu'à l'origine des paltes antérienres, composé de deux articles, le dernier plus long. Téte triangulaire. - Yeux grands, saillans, alongés, trigones. - Ponnt d'yeux lisses. - Corps ovale, très-déprimé, ses bords extérieurs aigus. - Corselet trapézoïdal, se t'étrécissant insensiblement depuis la base jusqu'à sa jonction avec la tête. - Ecusson grand, triangulaire. - Elytres au moins de la largeur de l'abdomen, recouvrant des ailes. - Abdomen déprimé, caréné longitudiualement en dessous daus son milieu, ordinairement terminé dans les fenelles par deux filets courts. - Hanches ayant à leur base un fort appendice ou trochanter. - Pattes antérieures ravisseuses, hanches courtes, cuisses grosses, jambes courtes s'appliquant en dessous de la cuisse; les quatre pattes postérieures propres à marcher et quelquelois aussi à nager; leur's tarses de deux artucles, le dernier muni de deux crochets.

Nous devous ce genre à M. Latreille; son nom vient de deux mots grecs et exprime que ces insectes ontla bouche pointue; ils sont aquatiques et carnassiers; si nous en croyons mademoiselle de Mérian, ils ne se bornen! point pour leur proie à de foibles insectes, mais attaquent anssi des reptiles de l'ordre des Batraciens, ce que la grande taille de quelques espèces autorise à croire. On voit à l'éxtrémité de l'abdomen de la Bélostome grande femelle, une espèce de queue semblable à celle des Nèpes, mais plus courte et dont les deux filets ne sont pas divergens. Il ne paroît point cerlain que ce soit un organe respiratoire. Nous ne connoissons que des mäles de ce genre. Dans ceux-ci la plaque anale est entière et complétement renfermée dans le dernier segment de l'abdomen qui l'entoure de tous côtés; cette plaque a la fignre d'un triangle alongé, son angle aigu se dirige vers l'extrémité de l'abdomen, dont le deraier segment est fendu vis-à-vis de celte pointe. La Bélostome rustique qui par ses caractères propresponroit former un autre genre, porte ses œul's sur le disque desély tres. Stoll la représente ainsi et croit mal-ì-propos que ce sont des œufs de certaines Arachnides trachéennes ou Mites aquatiques comme il les appelle; ces oufs sout rangés symétriquement et fixés au moyen d'une mattère gluante, ce que nous avons été à porlée de voir sur un individu de la collectiou de feu M. de Tigny. Nous ne connoissons pas l'iustrument a vec lequel cetle ferrelle place ses oufs sur son dos, wais lentr arrangement est absolument le même que celui des plaques d'œufs déposés sur les plantes par les Pentatomes de ce sexe.

Les larves vivent dans les wêmes endroits que les iusectes parfaits, se meuvent et se nourrissent de même qu'eux, ainsi que les nymphes. Le petit nomirre d'espèces connues est exotique.

1re. Division. Elytres de la largeur de l'abdomen, leur membrane occupant environ le tiers

\section{$\mathrm{R} A \cdot \mathrm{V}$}

de leur étendue. - Tarses antérieurs munis d'un seul crochet. - Corselet ayant un sillon transversal. - Jambes postérieures et leurs tarses fort élargis.

$I^{\mathrm{re}}$. Subdivision. Abdomen de même largeur que la partie postérienre du corselet.

\section{Bе́Lostome indienne, $B$. indica.}

Belostoma squalide lutea, maculis fuscis, femoribus anticts nigro lineatis, coxis quatuor posticis immaculatis.

Longueur 3 pouces. Corps d'un jaune-sale; sillon transversal du corselet le divisant en deux parlies dont l'antérieure a cinq taches irrégulières brunes, une médiale qui la parcont longitudinalement el s'élargit en descendant sur le sillon, une antre de chaque côté de celle-ci partant de la portion du corselet contiguë à la tête et n'atteignant pas le sillon, la dernière placée de chaque côté partant du sillon et n'atteignant pas la tête, les deux latérales un peu accolées l'une à l'autre. Ecusson paroissant séparé en deux par une carc̀ne trausrersale, peu élevée; sa partie antérieure brune. Pattes un peu brunesà leur partie supérieure, cuisses antérieures rayées de brin. Dessous du corps d'un roux brun, ses bords latéraux d'uu jaune-sale; hanches de cette couleur.Dessous des cuisses antérieures rayé longitudinalement de noir, les quatre postérieures ainsi qne leurs jambes rayées transversalement de cette couleur. Mâle.

\section{Des Indes orientales.}

Nota. Nous pensous que les parties du corps qui sont brunes dans les individus desséchés étoient vertes dans l'insecte vivant. Cette espèce a été confondue par quelques auteurs avec la suivanle. Nous sommes certains de la patrie que nous indiquons, ce qui, joint à sa taille et aux différences de coulcur, nous engage à la distinguer spécifiquement.

\section{BÉlostome grande, B. grandis.}

Belostoma fusca, flavo maculata, femoribus anticis subtius unicoloribus, coxis quatuor posticis nigro maculatis.

Belostoma grundis. Lat. Regn. anim. tom. 3. pag. 397. - Encycl. pl. 121. Nèpe, fig. 1. Femelle.

Longueur 2 pouces et demi. Brune en dessus avec des taches irrégulières d'un jaune - sale. Ecusson ayant une carène transversale peu élevée. Dessous du corps brun, ses bords latéraux d'un jaune-brun. Pattes d'uin jaune-sale en dessus; cuisses antéricures sans taches en dessous, celni des quatre cuisses postérieures et de leurs janbes, jaunâtre rayé transversalement et taché de 


\section{R A $V$}

roir; leurs hanches portant chacune une grande tache de cette dernière couleur, Mâle.

De Cayenne.

Nota. Rapportez à cettcespèce la Nèpe grande $n^{\mathrm{N}}$. I de ce Dictionnaire avec les synonymes de Fabricius, de Linné, de De Géer et de Mérian. Rejellez celui de Stoll qui se rapporte peut-êtrc à la Bélostome indienne $n^{\circ} .1$. Les autres sont douteux.

2e. Subdivision. Abdomen plus large dans son milieu que la partie postérieure da corselet.

\section{Bélostome de Bosc, B. Boscii.}

Belostoma suprà luteo-fusca, subtùs pallidior, femoribus tibisque quatuar posticis fusco annulatis.

Longueur $13 \mathrm{lig}$. Dessus du corps et pattes antérieures d'un jaune un peu brun. Dessous du corps d'un janne plus clair. Les quatre pattes postérieures annelées de brun. Mâle.

Rapportée de la Caroline par M. Bosc.

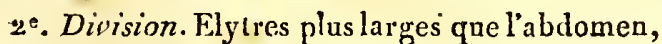
leur membrane n'occupant qu'une très-petite portion du bord postérieur. - 'Tarses antérienrs munis de deux crochets courts. - Corselet sans sillon transversal. - Abdomen beaucoup plus large dans son milieu que la partie postérieure du corselel. - Les deux jambes postérieures et leurs tarses point élargis.

\section{Bélostome rustique, $B$. rustica.}

Belostoma fusco-testacea, thoracis marginibus lateralibus posticoque et elytrorum parte coriaceâ pallidioribus.

Belostoma rustica. LAt. Règn. anim. tom. 3. pag. 397 .

Longueur in lig. Corps ovale, d'un brun-testacé, les bords latéraux et postérieur du corselet plus pâles ainsi que les élytres. Partie supérieure des bords latéraux des élytres dépassant le corps; leur membrane extrêmement étroite, bordant la partie extérieure vers le bout. Bords latéraux du corselet dilatés, commemembraneux et tranchans. Mầle.

La femelle a l'abdomen terminé par deux courts filets. (Consultez les généralités.) Voyez Stoll, Punais. tom. 2. pl. VII. fig. A, et pour les autres synonymes la Nèpe rustique $n^{\circ} .3$ de ce Dictionnuire.

Nota. Rapportez à ce genre, $\mathbf{I}^{0}$. la Nèpe an-

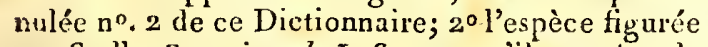
par Stoll, Punais. pl. I. fig. I, qu'il prend malì-propos pour la Bélostome iustiqque; $3^{\circ}$. cellc dc la pl. XXII. fig. $14 \mathrm{du}$ mếme auteur.

Hist. Nat. Ins. Tome $X$.

\section{$\mathrm{R} \mathrm{E}$}

RAYURE A TROIS LIGNES. Geofiroy donne ce nom à la Phalcana plagiata de Linné. (Phaloena duplicata, $\mathrm{F}_{\mathrm{AB}}$.) Voyez l'ualène triple raie $n^{0}$ 2I $_{\text {de }}$ ce Dictionnaire.

$$
\text { (S. F. et A. SERt.) }
$$

RAYURE JAUNE PICOTÉE. Nom donné par Geoffroy à la Phalvena atomaria. Irins. Voyez Phalène picolée no. 6 de ce Dictionnaire.

$$
\text { (S. F.et A. Serv.) }
$$

RÉCURRENTES (Nervures). Les nervures récurreutes sont celles qui bornent en haut et en bas la cellule discoidale inférieure des premières ailes dans les issectes hyménoptères. Voyez Discoïdale à l'article Radiate.

$$
\text { (S. F. et A. SERV.) }
$$

RÉdUye, Reduvius. Fab. Lat. Pat.-Bauv. Cimex. Linn. Geoff. De Géer. Petalocheirus. Pal.-Bauv.

Genre d'insectes de l'ordre des IIémiptères, section des Hétéroptères, fawille des Géocorises, tribu des Nudicolles.

Des cinq genres qui composcni celle tribu, deux, Zélus et Ploière, sont regardés par M. Latreille comme suffisamment distingués par lenr corps linéaire et leurs quatre pattes postérieures trèslongues et filiformes; les Nabis n'ont point comme les Réduves le corselet manifestement bilobé; les Holoptiles on leurs antennes composées seulement de trois articles.

Antennes longues, sétacées, très-grểles, ordinairement de quatre articles séparés par dcs articulations assez longues et visibles dans ceux dc la base principalement. - Bec court, arqué, découvert à sa naissance, de trois articles, le second pluslong que les autres: ex trémité de ce bec reçue dans une gouttière du dcssous du corselet dépassant peu ou point la naissance des cuisses antérieures; suçoir composé de quatre soies écailleuses, roides, très-fines et pointues, les deux inférieures se réunissant un peu au-dclà de leur point de départ. - Labre court, sans strics, recouvrant la base du suçoir. - Tête longue, petite, portée sur un cou ordinairement fort distinct, ayant souvent un sillon transversal qui la fait paroitre comme bilobée. - Yeux arrondis, saillans. - Deux petits yeux lisses apparens. Corps alongé. - Corselet triangulaire, très-distinctement bilobé; le lobe antérieur ordinairement plus petit et séparé du second par un sillon profond. - Ecusson triangulairc. - Elytres de la longueur de l'abdowen au moins. - Abdomen convexe en dessous, ses hords souvent relerés, composé de six segmens dont le dernier recouvre l'anus qu'on n'aperçoit qu'en dessous, ces segmens ayant de chaque côté un stigraate un pen rebordé, celui de l'anus plus petit. Anus des femelles sillonné longitudinalement dans son as tieu; MI In 
entier et sans sillon longitudinal dans les inäles. - Jambes dépourvues d'épines terminales; tarses fort courts, de trois articles.

Les Réduves dans les trois états par lesquels ils. passenl, vivent de rapiue et s'emparent de divers insectes quils sucent après avoir fait péuétrer l'extrémilé de lenr bec dans le corps de leturs victimes. On est souvent ì même de remarquer que la larve du Réduve rnasqué se déguise en quelque sorte en se couvrant d'ordures et de petits lambeaux de forme urégulièse. A la fuveur de ce masque clle s'approclie de sa proie doucement en murchant par saccades sans lui inspirer de crainte et s'élance sur elle. Cetle espèce labite nos maisons et exhale unc odeur fort désagréable. Nous pouvons assurer qu'elle fait particulièrement la guerre à la Punanse des lits; dans les jours les plus chauds de l'été elle vient souvent voler la nuit autour des lumières, attircé par la clarté. Lorsqu'on saisit les Réduves on doit éviter la piqûre de leur bec qui est fort douloureuse. Nous tenons de M. Latreille qu'ayant été piqué à l'épaule par une espèce de ce genre, il eut sur-lechamp le bras entier engourdi, et cet état dura pendant quelques heures. Ces liémiplères fout entendre un petit bruit souvcut répété, semblable à cclui que produiseut les Criocères; il est occasionné par le frottement de la-partie postérieure ce la tête contre le bord antérieur du corselet. Plusieurs' Réduves se tiennent dans les lieux sablonueux et chauds. Ce genre est nombreux en espèces, mais l'Europe en contient peu.

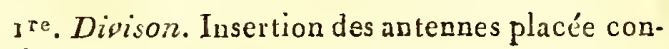
tre les yeux.

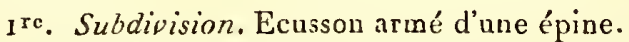

- Yeux lisses rapprochés l'un de l'autre sur un tubercule commun placé sur le dos de la partie posiérieure de la tête.

\section{A. Epine de l'écusson discoidale et re- levcée.}

a. Second lobe du corselet ayant en même temps des épines sur son disque et ì ses angles postérieurs.

1. RÉDu spinifère, $R$, spinifer.

Reduvius scutello erecto-spinoso, thoracis an*icâ parle bispinosâ, posticâ quadrispinosâ; clytris fuscis, maculâ mediầ rotundâ testaceâ.

Reduvius spinifor. PaLIs.-BAuv. Ins. d'Afr. et a"Amèr. pag. 15. Hémipt. pl. I. fig. 4 .

Longueur 5 lig. $\frac{1}{2}$. Corps d'un, brun-ferrugineux. Antennes el paltes de même couleur. Lobe antórieur du corselet pále, portant sur sun disque deux épines noirûres, un pen recourbées postérieurement. Secunt lobe presque noir, araé de quatre épines divites, deux sur le disque et une à chaque angle postérieur, entre chacune desquelles on voit une tache ronde de couleur fauve. Epine de l'écusson furte. Elytres ayant dans leur milieu une tache arrondie d'un testacé-fauve ( 1 ).

Des environs de la ville de Benin (Afrique).

b. Second lobe du corselet ayant seulement une épine à chaque angle posléricur.

† Jambes antérieures ayant une dilatation membraneuse. - Quatrième et dernier article des antennes velu. - Deux appendices saillans au-dessous du corselet, le terminaut antérieurement et recevant entr'eux dans le repos l'extrémité du bec. - Segment de l'ahdowen portant une épine à chaque angle postérieur. ( $G$. Pétalochère. PAL.-BAvv.)

\section{RÉDUve varié, $R$. variegatus.}

Redupins scutello erecto-spinoso, fuscus, albido varius, tibiis anticis in scutum dilatatrs.

Redusins variegatus. Jat. Gener. Crust. et Ins. tom. 3. pag. 128. - Petalocheirus variegatus. Palis.-13Auv. Ins. d Afr. et d'Amér. pag. 13. Hémipt. pl. 1 . fig. 1 .

Longuenr 6 lig. Antennes, têle, corps, álytres et pattes de couleur brune vitriée de blanchâtre. Epine de l'écussou forte, presque dioite.

De Buonopozo, royaume d'Óware.

Rapportez à celle section le Reduvins rubiginosus. I.ат. Ger. (Petalocheirus rublginosus. P'Alis.-Bavv. ut suprà, fig. 2.)

\section{†† Poinl de dilatalion membranerse aux jamılses antérieures. (Corps presque linéairé.)}

\section{RÉduye âtre, $R$. ater.}

Reduvius scutello erecto-spinoso, ater, abdo. mine femoribusque duobus posiaicis subtis oneo nitentibus, antennarum articulo secundo partin ferrugineo.

Longrzerr i3 à I4 lig. Corps d'un noir-mat. Dessous de l'abdomen et des cuisses postérieures luisant avec un reflet métallirgne. Antentres noires, lenr second aricle ferrugineux en grande partie. Loive antćrieur du corselet portant quatre épines; ceile de l'écusson forte, courte. Elytres beaucoup plus longues que l'abdomen. Femelie.

Du Brésil.

(1) La mauvaise habitude que quelques voyagcurs one d'enlever la plaque anale de ces moceres, four buarres l'abtomen, nous prive seule de désigner le sexe d'une partie des individus que nous décriyons. 


\section{RÉDove thoracique, $R$. thoracicus.}

Reduvius scutello erecto-spinoso, niger, thoruce fernigineo.

Longueur 7 lig. Noir: Antennes et pattes trèsvelues. Corselet ferrugineux, son lobc antérieur portant deux tubercules latéranx et deux épines noires, discoïdales; lobe postérieur ayant ses épines longues et noires. Ecusson un peu bordé de ferruginenx latéralement. Cuisses et jambes postérieures lonques et grêles. Elytres beaucoup plus longues que labdomea. Mẩle.

Du Brésil.

\section{RÉduve liséré, R. limbatus.}

Reduvius scutello erecto-spinoso, niger, capite rubro uigro vario, thorace rubro marginato, elytronm parte coniace $\hat{a}$ albo marginatâ.

Longneur 8 ì 9 iig. Noir. Antennes, et pattes de même conleur et velues. 'Tête rongeâtre avec denx petites liones allant des yeux à la base du lec, les deax derniers articles de celui-ci et une tache atutour des yeux lisses, de conlenr noire. Corselet entièrement bordé de rouge, son lobe anlérieur portant quatre épines, les deux discoïdales grandes et noires. Celle de l'écusson droite, forte, longue. Elytres plus longues que l'ạdomen; leur partie coriace bordée de blanchâtre extérieurement et vers la membrane; lianches, bords de l'abdomen et taches sur son milieu, rongeâtres. Mâle et femelle.

Du Brésil.

\section{RÉduve tricolor, $R$. tricolor.}

Reduvius scutello erecto-spinoso, niger, rubro varius, elytrorum parte conace $\hat{a}$, margine et inferion parte albudis.

Longueur 6 lig. Tête noire variée de rouge. Antennes et paties noires un peu velues. Lobe antérieur du corselet rouge, noir postérieurement, portant quatre épines, les deux discoilales noires à l'extrémité. Second lobe nuir, bordé de ronge latéralement el à sá partie postérieure. Ecusson rouge, son épinc droite, forle. Elytres noires, gruère plus longnes que l'abdounen, leur partie corliace blunchitre à son extrémité el sur ses bords. Abdomen rougentre, ses derniers segmens noirs an milicu. Habches et cuisses tachées de ronge en dessous. Mâle.

Du Brésil.

\section{RÉduve à laches d'ivoire", R. eburneus.}

Reduvius scutello crecto-spinoso, testaceo-fervugineus', clytrorunn partis coriaceo maculâ eburmeâ nigro marginat $\hat{u}$.

Longueur 7 lig. $\frac{x}{2}$. D'un faure-ferrugineux. Antennes un peu velues, fauves avec le premier ar- ticle et l'extrénité du second nosirs. Lobe antérieur du corselet ayant qualle épines, les latérales fort peliles, les deux discoidales noires et fortes. Second lobe marqué sur le dos d'une lignc longitudinale noire, ses épizes et une tache près de leur base, de celte coulenr. Epine de l'écusson forte, droite, nuire à son exirémilé. Parlie coriace des elytres portant une tache ovale d'un blanc d'ivoire entourée de noir. Bords latéraux de l'abdomen tachés de noir à l'angle antérieur des segmens. Pâtles un peu velues, les quatre cuisses antérieures munies en dessous de deux ou trois petiles épines. Mâle et femelle.

Du Brésil.

\section{Réduve rayé, $R$. lineatus.}

Reduvius scutello erecto-spinoso, testaceus, nigro varius, elytronum partis coriacect disco fusco.

Longueur 8 lig. Fauve. Antennes et paltes un peu velues. Partie inférieure du frenier lnbe de la lête hrnne. Yeux lisses entourés de uoir. Dessus du corselet rayé de noir, son lohe anté:ieur portant guatre épines, les deux latórales fort petites, les deux discoidales grandes, fortes, brunes à l'extrémité. Ecusson noil, fauve postérieurement, son ćpine presque droite, fauve. Membrane des élytres brune dans son milieu. Derniers segmens de l'abdomen noirs. Femelle.

De Cayenue.

\section{c. Corselet mutique.}

\section{RÉdove agréable, $R$. amcenus.}

Reduvius scutello obtusè erecto-spinoso, thorace posteriùs longitudinaliter sulcato, rubro nigroque varius; abdonine subtús livido, lineis duabus in singulo segmento plerisque interruptis, nigizs.

Longueur I5 lig. Antennes et paltes noires. Tête testacée avec une petite corne bifurquée derric̀re l'insertion de chaque antenne. Bec court, mince, testacé. Corselet rouge, plissć transversalement. Son lobe antérieur ayant une ligne noire postérieurement; second lobe marqué alı milieu d'un sillon longitudinal profond et d'un point latéral, de couleur noire. Ecusson testacéroussâtre, ses bords latéraux noirs; son épine courte, obtuse. Elytres noires ayant leur basc rouge, cctle couleur s'élendant sur le bord extéricur et formant vers la naissance de ls partie membraneuse, une plaque rouge renfermant une tache noire. Bords de l'abdomen rouges avec une tache noire à l'angle postérieur des segmens. Abdomen livide en dessous avec deux lignes noires transverses sur chaque segraent, la plupart iuterrompues au milieu. Feaılle.

Du Brésil. 
B. Extrímité de l'écusson prolungée en une épine horizontale plus ou moins aiguë.

ro. RĖDyve ailes tachées, $R$. maculipennis.

Reduvius scutello horizontalitèr spinoso, niger, -lytris albido substrigatis, ochraceo bimaculatis, abdomine carulescenti, maculis marginis luteis.

Longueur $6 \mathrm{lig}$. Noir. Elytres ayant quelques petiles lignes blancluatres près de la poinle de Yécusson, une tache carrée d'un jaune-d'ocre dans le milieu et une autre ovale de même couleur à l'extrémité. Abdomen d'un noir-bleuâtre, hordé de taches d'un jaune-pâle placées à l'angle antérieũ: de chaque segment. Cuisses ayant un peu de jaune à leur base. 'Tarses testacés. Femelle.

Du Brési!.

On rapportera à celle section, $1^{\circ}$. le Redupius personatus. FA B. Syst. Rhyng. (Encycl. pl. 373 . fig. 32-36); $2^{\text {o. }}$ le Reduvius stridalus. $\mathrm{FAB}_{\mathrm{AB}}$ id. (Encycl. pl. 373. fig. 37-40.)

2e. Subdivision. Ecusson mutique. - Yeux lisses fort éloignés l'un de l'autre, placés latéralement sur la partie postérieure de la tête, derrière les yeux à réseatu. - (Pattes antérieures longues, leurs jambes grosses et velues.).

A. Abdomen n'étant pas plus large que les élytres.

\section{I1. RÉDuvf rufipède, $R$. rufipes.}

Rednvius scutello mutico, niger, thoracis maculis tribus rufis.

Reduvius rufipes. FAB. Syst. Rhyng. pag. 270. $n^{\circ}$. 19 .

Longueur 16 lig. Noir. Antennes de même couleur, presque glabres. Lobe postérieur du corselet ayant trois taches roussâtres, celle du milieu trianguliuire, les deux autres placées aux angles postéricurs. Elytres beaucoup plus longues que l'abdomen, Jeur parlie coriace courte, bordće intérieurement et vers la membrane de grisroussâtre, membrane brune. Pattes antérieures noires, les quatre postérieures ferrugineuses. Bords latéraux de l'abdomen rouges. Naâle.

De Cayenne.

\section{RÉdeve de Stoll, R. Stolliii.}

Reduvius scutelli mutici basi albo interruptè tomentosâ, testaceo-ferruginens, nigro varius.

Stoll , Punais. pl. XXII.fig. 153.

Longuear $7 \mathrm{lig}$. Tête noire, ayant une ligne blanche longitudinale à sa partie supérieure. Antennes noires avec la base du troisième article blanchâtre. Corselet testacé-ferrugineux, son lobe antérieur un peu plus püle. Ecusson caréné ayant à sa hase ane bande transverse interrompue, formíe par un duvet blanc. Elytres un peu plus longues que l'abdomen, leur partie coriace d'un teslacé-ferrugineux, noire à l'extrémité. Menbrane noire. Dessous du corps teslacé-pâle. Seğmens de l'abdomen et lianches des qualse paltes postćrieures ayant une tache hlanchâtre fornice par un duvet. Pattes d'un testacé-pále. Extrémité des jambes et tarses de coulear brune, surtouk dans les deux antérieures. Mâle et femelle.

De Cayenne et de Surinam.

\section{B. Abdomen surpassant les elytres en lar- geur.}

13. RÉduve lanipède, $R$. lanipes.

Reduvius scutello mutico, niger, villosulus, elytrorum parte coriaceâ albidâ, nigro pilosâ.

Reduvius lanipes. FАв. Syst. Rhyng. pag. 274. $n^{\circ} .40$.

Longueur I pouce. Noir, pubescent. Duvet de la tête, du corselet et des pattes antérieures d'un. gris-roussâtre, celui de l'abdomen er des deux pattes postérieures noir. Partie coriace des élytres d'un blane sale portant des poils noirs. Menbrane à reflet métallique. Bords latéraux de l'abdomen comme découpés, les segmens laissant entr'eux un petit intervalle dans lequel on voit: une tache d'un blanc sale. Mâle.

De Cayenne.

\section{Rédote lunulé, $R$. lunatus.}

Reduvius scutello mutico, niger, nitidus, subtomentosus, femorum apice, tibiarum quatuor anticarum basi, posticis omnind, elytrorum maculâ, ano laterumque abdoninis maculis. rubris.

Reduvius lunatus. FAB. Syst. Rhyng. pag. 274. no. 39. - Stold, Punais. pl. X111. fig. 91.

Longueur 15 à 16 lig. Noir-luisant, pubescent. Antennes noires. Tête ayant un tubercule velu derrière l'iusertion de chaque antenne. Extrémité des cuisses, base des quatre jambes antérieures, les postérieures en lolalité, une lache avaus l'extrémité de la partie coriace des élytres, anus et taches sur les bords latéraux de l'abdomen rouges. Ely tres plus longues que l'abdomen. Patles antérieures très-longues, grosses et vielues. Mẩle et femelle.

De Cayenne.

Nota. L'iasertion des antennes visiblement éloignée des yeux sembleroit placer ce Réduve dans la seconde division, mais tous ses autres caractères lui étant communs avec les espèces de cette section-ci nous avons cru devoir l'y faire entrer.

A cette section appartiensent les Reduvius. 
Kirtipes, pilipes, lineola et crinipes. Ma. Syst. Rhyngot.

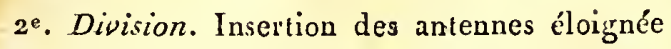
des yeux.

re. Subdivision. Corselet sans sillon longitudi nal. - Eensson entier, terminé par une seule pointe. - Yeux lisses érartés l'un de l'autre, plucés latéralement sur la partie postérieure dcla tête, mais non pas derrière les yeux à réseau.
A. Lobe postérieur du corselet portant une caréne longitudinale élevée et décou- pće en crête.

15. Réduve crêlé, $R$. serratus.

Reduvius scutello mutico, thorace cristato, niger, griseo subtomentosus.

Reduvius serratus. FAв. Syst. Rhyngot. pag. 266. $n^{\circ}$. 2. - Lat. Gen. Crust. et Ins. tom. 3. pag. 129. - Cintex cristatus. Linv. Syst. Nat. 2.723.62. - DrURY, Ins. tom. 2. pl. 36 . fo. 6. - Stold, Punais. pl. I. fig.6.-Encycl.pl. 124. Rćduv. fig. 31.

Longueur 15 à $16 \mathrm{lig}$. Noir, couvert d'un duvet court, grisâtre. 'l'ète ayaut une petile corne derrière l'insertion de chaque antenne. Cótés du corselet portant postérieurement quelques dents obtuses. Antenues, bec, extrémité des cuisses et jambes rougeâtres. Elytres beancoup plus étroites que l'abdomen, leur membrane bronzée. Feinelle.

Amérique méridionale.

B. Lobe postérieur du corselet portant en même temps des épines sur son disque et à ses bords latériaux, sans carène longitudinale.

a. Abdomen surpassant les élytres en largear.

16. RéDove anguleux, R. angulosus,

Reduvius scutello mutico, thorace spinoso, fuscus, abdominis segmentis margine angulosis.

Longueur 12 à 14 lig. Dessus du corps de couleur de feuille sèche; son dessous d'un gris-blanchàtre. Antennes velnes, de même couleur que le dessus du corps avec un anneau sur le premicr article et la base du second blanchâtres. Téte mu nie d'une petite corne derrière l'insertion de chaque anteune. Lobe antérieur du corselet portant deux épines sur son disque. Second lobe armé de einq épines dont trois petites discoïlales. Scymens de l'abdomen anguleux à leurs bords latéranx. Pattes de la cualeur cá corps. Femęlle.

Du Brésil..
17. Rédu Ve festonnó, R. sinuosus:

Reduvius scutello mutico, thorace spinoso, nigro-fuscus, abdominis segmentis margine iotundatis.

Longueur 12 à 14 lig. D'un noir-brun; les denx dernicis arlicles des anienncs testacés-rongeâtre.. 'Tête munie d'une très-petite corne derière linsertion de cluque antenue. Lobe antérieur da corselet portant dcux épines sir sou disque, second lobe en ayant quatre, dont deux discoidales. Bords latéraux des seguens de l'abdomen arrondis, formant comme un lieston. Pattes de la couleur du corps. Elgtres beaucoup plus longues qua l'abdomen.

Du Brésil.

b. Abdomen n'étant pas plus lavge gitos: les Elytres.

\section{RÉDove binoté, $R$. binotatus.}

Reduvius scutello mutico, thorace spinoso, testaceus, elytris scutellique apice albo punctatis.

Longueur ponce. Corps presque linéaire, testacé; les trois derniers articles des antennes bruns. 'Tête munie d'une corne droite derrière l'insertion de chaque antenne. Lobe antérienr du corselet portant deux épines sar son disque. Second lobe plus brua, en ayant quatre dont les deux latérales plus fortes. Extrémilé de l'écusson et partie coriace des élytres portant un pelit point blanc formé par un duvet. Côtés du corselet et dessous de l'abdomen marqués de semblables. points qui forment une ligne longitudinale do chaque côté. Pattes testaccées. Femelle.

\section{Du Brésil.}

\section{Ríduve géniculé, $R$. geniculaturs.}

Redupius scutello mutico, thorace spinoso, luteo-pallidus, geniculis fuscis.

Longueur 8 lig. Corps presque linéaire, d'un jaune-pâle. Yeux noirs. 'Tête munie d'un petit lubercule derrière l'insertion de chaque antenne. Lobe antérieur du corselet fort petit, portant deux épines sur son disque. Second lobe en ayant quatre, les deux latéralrs beaucoup plus fortes, brunes à l'extrémité. Elytres beaucoup plus longues que l'abdouen, leur membrane blanche, transparcnte. Paites d'un jaune-pâle avec les genoux bruns. Mâle.

Amérique méridionale.

C. Lobe postérieur du corselet porting seulement une épine à chaque angie postérieur, sans carène longitudinà. - Abdomen n'etant pas ylus lam que les élytres. 
2O. RĖduve alongé, $R$. elongatus.

Reduvius scutello inntico, thorace spinoso, testaceus, capite thoraceque finsco maculatis, fenoribus albicio anmulatis.

Longrieur $16 \mathrm{lig}$. Corps presque linéaire, testacé. 'Tète nunie d'un très-petit tubercule derrì̀re l'insertion de chaque antenne, et marquée de quelques taches d'un brun-noirâtre ainsi que le premier lobe du corselet. Second lobe Jrun bordé de fauve poslérienrement, ses épines de cette dernière couleur. Pattes testacées, cuisses avec un petit anneau blanchâtre dans leur milieu. Femelle.

Du Brésil.

21. RÉduve à bracelets, R. armillatus.

Reduvius scutello mutico, thorace spinoso, suprà fuscus, testaceo varius, subtùs lutescens, nigrn macuilutus, pedibus testaceis, fomoribus tibiisque nigro annulatis.

Longuevi to lig. Corps presque linéaire, brun en dessus. Antennes testacées anmelées de hoir. 'Îête munie d'un pelit tubercule derrière l'insertion de chaque antenne. Lobe antérieur du corselet noiràtre bo:dé de testaeé. Second lobe ayant un point rond, ses bords latéraux et la partie qui avoisine l'écusson, de couleur testacée.Ecusson de cette couleur, son disque noir. Elytres brunes, leur partie coriace bordée de testacé. Dessous du corps jaunâtre avec des lignes transverses et des points noirâtres. Les quaire pattes antérieures testacées avec un anneau noir aux cuisses et un autre aux jambes. Pattes postérieures testacíes avec deux anneaux noirs aux cuisses el un autre fort large à leurs jambes, Femelle.

Du Brésil.

\section{RẺDणve brésilien, $R$. brasiliensis.}

Redue'ins scutello mutico, thorace spinoso, niger elytronum parte coriaceâ thoracisque posticâ testaceis, hujus maculâ discoidali nigrâ bilobâ.

Longuewr 8 lig. Corps presqne linéaire, noir. Antenues de même couleur avec la base du second article et le troisième testacés (le dernier manque). Second lobe du corselet teslacé én dessus, portant sur son disque une taehe noire presque bilobée. Elytres guère plus longues que l'abhoncr, leur pariie coriace testucèe. Malle.

pu Brésil.

D. Second lobe du eorselet poriant seulement un tubercule à chaque angle postérienr, sans épines, ni carcue jongiudiuale. a. Abdomen n'étant pas plas large qre les élyues. - Corps presciue linciuire.

\section{RÉduve ronguâtre, R. rubidus.}

Reduvius scutello mutico, thorace tuberculaio, rubro-fuscus, antennis nigris albido anmulatis, elytrorum menthranâ et partis coriacece lineâ nuedia nigris, femorum annulis binis, tibiarulis quatnor posticarum ninico albis.

Longueur 6 lig. Rongeâtre. Disque du second lobe du corselet, extrémité de l'écusson, une baude sur le milieu de la partie coliaee des élytres ct leur membrane noirs. Antennes noires avec quelques anneanx blancs; palles noires, cuisses ayant claeune deux anneaux blancs; les qualre jambes postérieures en ayant un seul. Elytres un plus longues que l’abdomen. Mâle et feuelle.

De Suint-Domingue.

\section{Réduve carćné, R. carinatus.}

Reduvius scutelio mutico, thorace tubercilato antice striato, niger; antennis, rostro, pedious, elytroruin basi, abdominis medio laterrbusque rubris, his nigro maculatis.

Reduvius carinatus. Far. Syst. Rhyng. pag. 278. $n^{\circ}$. 57. - Coqueb. Illust. Icon. tab. 10. fig. 15.

Longueur to lig. Noir. Bec et pattes rouges. Partie coriaee des élytres, milieu de l'abdomen el ses bords de couleur ronge, ces derniers tachés de noir. Antennes d'un brun-rougeâlre. Cuisses el jambes antérieures grosses et courtes. Elytres un peu plus longues que l'abdomen. Mâle et femelle.

Des Etats-Unis d'A mérique.

Notu. Le lobe antérieur dı corselet est trèsremarquable par sa longueur qui surpasse eelle du lobe postérieur et par sa largeur à peu près égale; il est marqué de plusieurs stries longiludinales. Cette conformation se retrouve dans quelques autres espèces que nous n'avons pas eu oecasion de décrire.

Le Reduviusfasciatus. Palrs.-Bavv. Ins. d'Afr. et d'Amér. pag. 64. Hémipt. pl. 2. fig. 5, vient se placer ici.

\section{b. Abdomen surpassant les élytres en lar- geur.}

25. RíDणve longicolle, $R$. longicollis.

Reduvius scutello erecto-spinoso, thorace tuberculato, niger, glaber, elytris albidis basi nigris, abdomininis serie laterali punctonim albidorum, pedibns subvillosis.

Stosi, Puncis. pl. XLI. fig. 295. 


\section{$\Pi \pi \mathrm{D}$}

Longneur to lig. Noir, glahie. Parlie coriace des.élytres ayant sa moitié inférieure blanchatre. Membrane de cette couleur et transparente. Abdomen avec une ligne de points blanchattres de chaqque côté. Lobe postérieur de la tête très-long. Ecusson armé d'une épine forte et droite. Pattes un peu velues. Mîtle et femelle.

Des Indes orientales.

26. RE்Duve corail, $R$. corallimus.

Reduvius thorace mutico, corallinus, capitis parte posticâ suprà, thoracis lobo secundo antice et lateralitèr, scutelli disco, abdominis lineis maculisque, femoribus albido lineatis, tibiisque nigris.

Longueur $6 \mathrm{lig}$. D'un ronge de corail. Partic supérieure du second lobe de la tête, partie antérieure du second lobe du corsclet, côlés de celuici, disque de l'écusson, taches et lignes sur l'abdomen, cuisses et jamlies de couleur noire. On voit nue ligne blancbâtre sur la partie antérieure de chaque cuisse. Antenpes uoires, d'un brun-rongeâtre à l'extrémité. Elytres un peu plus. Iongues gue l'abdomen, leur membrane demi-transparente. Mâle.

Des Indes orientales.

\section{Réduve annelé, $R$. annulatus.}

Reduvius thorace mutico; niger, v'erticis puncto, fenuonum duonum anticonum annulis duobus, tibiis onnibus apice excepto et abdominis segmentorum angulis posticis, anoque sangruineis.

Reduvius annulatus. FAв. Syst. Rhyng. pag. $271.4 \iota^{\circ} \cdot 24 .-$ LAт. Gen. Crust. et Ins. toml. 3. pag. 129.-PANz. Faun. Germ. fas. ", fig. 23.-

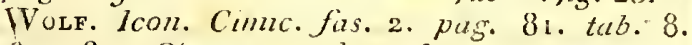
fig. 78. - Cimex annulatus. Lins. Syst. Nat. 2. 725. 7 I. - Cime.x niger rufipes. DE GEer, Ins. tom. 3. pag. 286. no. 26. - La l'unaise monche it pattes rouges. Grofr. Ins. I'aris.tom. 1. parr. $437 \cdot r^{\circ}: 5$.

Longueur 6 lig. Noir. Antennes de même couleur. 'Tête et corselet pubescens. La première ayant un point rouge entre les yeux lisses. Base des hanclies de devini, deux anneaux sur !es deux cuisses antérieures, autant sur les deux postérieures, toules les jambes, à l'exception de leurs exlrémilés et taches à l'angle postérieur de chayue segment de l'abdomen ainsi qu'àl'anus d'un rougesanguir. Mäle et femelle.

Nota. Le milieu de l'abdomen a plas ou moins de rouge.

Des environs de Paris.

On placera dans celle section les Reduvius hoomonthoidalis et agyptus de F. A . Syst. Rhyngot.

$2^{\mathrm{e}}$. Subdivision. Corselet ayant un sillon longitudinal sur ses deux lobes. - Écusson éclana- cré postérieurement, terminé par deux pointes. -Yeux lisses assez rapprochés l'un de l'autre sur un tubercule commun placé sur la partie postérieure de la tếte. - Antennes velues, de six articles, non compris les petites articulations.)

Nota. Le sillon transversal qui sépare les deux lobes du corselel, forme arec le sillon longiluliaal une croix dans toutes les espèces de celle sabidivision. S’il nous ệt été possible de vérifier les antenues de plusicurs especes, pops n'aurions pas hésité à proposer cette subdivision comme genre sous.le nom d'Ectrichodie (Ectrichodia), nais nous ne les avons completes que dans une seulo espèce.

\section{RÉdUve luisant, $R$. lacidus.}

Reduvius thorace cruciatinn sulcato, ruber, nitidus, glaber; antennis, thorace subtius, elytris basi exceptâ, ano et segmentonuni abdonninis posticorum lateribus nigris.

Longueur 15 lig. Rouge, glabre, luisant. Antennes, dessous du corselct, poitrine, élyties (leur base exceptée), anus el côtés des derniers segmens de l'abdonen de couleur noire. Les qualre cuisses antérieures ayant quelques petites deuts en dessous. Mâle.

Patrie inconnue.

29. RÉDUve croisé, R. cruciatus.

Reduivius thoruce criciatint sulçato, antennis sexarticulatis, niger, nitidus, slaber, thorace luteo sulcis nigris, elytrorim basi, tibitis quatuor anticis extirs, abdominis margine discoque luteis.

\section{Srocr, Punais. pl. I.Y.fig. 65?}

Longneur' pouce. Noir, glabre, luisant. Dessus du corseitet june, ses deux sillons formant une croix noire. Base dés élytres, bords de l'abdomen et son disque en dessous, partie exićrieure des quatre premières jambes de couleui jaune. Mâle.

Du Cap de Bonne-Espérance.

Nota. Notre individu a manifestement six articles aux antenues saus compter le tubercule radical ni les pelites articulalions qui sont entre le prenier, le second ct le troisième articles. Stoll ne donne que cinq arlicles aux antennes du sien et encore compte-t-il le lubercule de la basc. Il les figure glabres: duus le nôlue elles sont velues; enfin il in lique Surinam pour patrie. Ces différences nous font citer cel ataleur arec doute.

30. Réduve latéral, $R$. lateralis.

Red:uius thorace cruciatim sulcato, niger, glaber, capite suprà thoracisque lobo antico lateis nigro variis, tharacis posticâ parte s:utelloque nubris. 
Longueur 10 lig. Noir, glabre. Dessus de la Aète et du premier lobe du corselet, jaunâlres mêlés de noir. Dessus du second lobe rougeâtre ainsi que l'écusson. Bords latéraux de l'abuowen jaunâtres. Mâle et femelle.

Du Brésil.

\section{I. RÉDUVE rentral, $R$. ventralis.}

Reduvius thorace cruciatim sulcato, niger, nitidus, glaber, capite, rostro colloque exceptis, thorace subtùs; scutello abdominisque lateribus ot disco rubris, hoc nigro transperse striato.

Longueur 7 lig. Noir, glabre, luisant. 'Tête, ¿ l'exception du bec et de la base du con, dessus du corselet, écussou, bords latériux et disque de l'abdomen de couleur rouge. Dans cette dernière partië le rouge est entrecoupé de lignes trausverbales noires.

De Cayenne.

\section{RÉDUve frontal, R. frontalis.}

Reduoius thorace cruciatim sulcato, niger, glaler, capitis parte anticâ suprà, thoracis lobi pos. tici marginie laterili', abdominis margine ventreque luteis, hoc nigro utrinquè lineato.

Longueur 6 lig. Noir, glabre. Dessns de la par\{ie antérieure de la tête, bords latéraux du sccond lobe dn corselet, base des élytres et bords de l'abdomen jaunes. Ventre de cette couleur ayant de chaque cốté une ligue noire.

De Cayenne.

Nota. Les parties jaunes de ce Redure étoient peut-être rouges dans l'insecte vivant.

A cette seconde subdivision appartienuent lcs Reduvius trimaculatus. PAL1s.-Bauv. Ins. d'Afr. el d'Amér. pag. 64. Hémipt. pl. 2. fig. 3, et hirficornis. FaB. Syst. Rhyngot.

\section{HOLOPTILE, Holoptilus.}

Genve d'inscctes de l'ordre des Hémiptères, - cection des Hétéroptères, famille des Géocorises, ribu des Nudicolles.

Aucun antre genre de cetle tribu n'a moins de gaatre articles aux autennes.

Antennes sútacées, de longueur moyenne, coudées sprès le premier article, insérćes sur la unrtie antérietre de la tête, rapproshées à leur bise, composées de trois articles, le premier \&ros, court, glabre; le second fort long, arqué, jorlant deux rangs de longs poils roides, divergrens, qui le font paroitre comme pectiné et à sa partie supérieure un autre rang de poils longs, :errés et couchés; le troisième article un peu plus long que le promier, plus mince à sa base qu’à Cn extrémité, portant quclques poils disposés par verticilles. - Bec court, arqué, ne dépassant pas "origine des cuisses antérieures, découvert à sa paisiance, composé de trois articles; le premier court, le second lon court, conique. - Labre point apparen1. - Tête petite, rétrécie postéricurement, sans con distinct. - Yeux arrondis, saillans. - Point d'yeux lisses apparens. - Corps assez court, rétréci à sa partie antérienre. - Corselet rétréci en devant; bilobé; son lobe antérieur plus petit et séparé du second par un sillon transversal. - Ecusson petit, triangrulairc.-Elyties de la longucur de l'abdumen, de consisiancc demi-membraneuse dans toute leur étendue. - Point d'ailes. - Abdomen très-convexe en dessous, con posé de six segmens presque transversaux, le dernier plus large dans son milieu que sur les côtés, chacun d'eux portant un stignuate peu rebordé. - Cuisses, jambes et tarses garuis de trois rangs de poils roidcs et divergens; jambes dépourvnes d'épines terminales, les postérieu res assez longnes, un peu arquées; tarses de trois articles, le dernier muni de deux crochets saus pelotte apparente.

Nous ne counoissons pas les mours de l'espèce pour laquelle nous proposons ce nourcan genre dont le nom vient de deux unots grecs, et a rapport aux panaclies de poils dont elle est presqu'entièrement converte. Les Holoptiles par la wasse de leurs caractères, sc rapprochent des Rédnves, mais les autennes triarticulées, la nature homogèue de leur's ćlytres et l'abseace des ailes les en distingnent ássez pour nous faire espércr que les entomologistes accueilleront cette nouvelle coupe géućrique.

\section{Holoptile Ours, H. Ursus.}

Holoplilus fuscus, elytris squalide argenteis, maculâ magnâ sub basi punctısque tribus márginalibus fuscis.

Longueur 3 lig. Corps d'un brun-puce, entièrement couvert de poils roides, à l'exception de l'abdomen et de la plus grande partie des élytres; rillieu du venıre un peu jaunâtre; poils divergeus des antennes d'un brun-puce, ceux qui sont couchés blanchâtres. Dessus du corselet raboteux; tubcrculé; ces tubercules portant chacun une touffe de poils divergens de conleur puce mêlée de poils grisâtres. Elytres demi-transparenles, d'une couleur argentée sale, munies à leur base extćrieure d'une toulfe de poils hrunâtres. On voił vers leur base une grande tachè transversale puce qui n'atteint pas le loord intérienr, et des points de même couleur dont trois plus remarquables placés sur le bord extérieur. Ventre très-convexe en dessous depuis l'anus jusqu'au second segarent, se déprimant subitement à sa base, en sorte que le second segmcnt forme dans son wilien un tubercule garni de poils sur sa partie antérieure. Pattes d'unc nuance plus claire que le dessus du corps, leurs poils brius.

Du Cap de Boune-Espérance.

(S. F. et A, Serv.) REMISE, 


\section{$\mathrm{R}$ i $\mathrm{I}$}

REMBE, Rembzs. LAT. (Hist. nat. et Icon. des Coléopt. a’Europ.) Genre de Carabiques trèsroisin des Licines, mais en différant par ses mandibules qui sont terminées en pointe simple. Ise Car,bbusindicus I IERBst el le Carabus politus FA B. appartiennent à ce genre. Ces deux espèces sont de; Judes orientales. (S. F. et A. Serv.)

REMBE, Rembus. M. Germar (Ins. Spec. nov. yol. 1. (Coleopt. 1824) désigne sous ce nom un gence de la tribu des Charansonites, famille des Rhyn shophores de M. Latreille, avant pour carac ères : rostre court, épais, parallélipipède, à pei ie plus long que la tête, plus étroit qu'elle; ses fosseltes courbées subitement en dessous, se rejoignant dans cette partie. Yeux ronds, proćmine.1s. Antennes grêles, insérćes au bout du rostre, plus longues que le corselet, leur premier artic'e court, en massue, fouet grêle de sept article; dont le second alongé, les autres presqu'égaux. Massue oblongue. Corselet transversal, troncqué à sa base, arrondi sur les côtés, sans cillon en dessous pontr recevoir le rostre. Ecusson distinct, petit, presque carré. Elytres renflées, couvrant l'abdomen et les ailes, presque deux fois plus largres que le corselet, Ironquées à la base, leurs angles huméraux saillans. Pattes courtes, égales entr'elles. Cuisses muliques, en massue; jambes cylindriques; premier article des tarses an peu plus long que les autres, le second court, - Iri jone, l'avant-dernier très-large, bilobé.

Ce genre est composé d'une seule espèce; ellc est du Brésil: l'auteur la nowme $R$. auricinctus. C'est le Thylacites trifasciatus du Catalogue de M. le comte Dejean. (S. F. et A. SErv.)

RÉVIIPĖDE, Remipes. Lat. Lamarck. Genle de Crustacés de l'ordre des Décapodes, famille des Macroures, division des Macroures anomaux, tribu des Hippides, établi par M. Latreille, et dont les caractères sont : antennes latérales et intermédiaires courtes, presque d'égale longueur, avancćes, un peu recourbées. Pieds-mâchoires extérieurs semblables à de petits bras et ayant au bout un fort crochet. Pieds de la première paire adactyles, terminés par ales lames qui finissent en pointe; ceux des auires paires terminés par des laøes ciliées également poiutues, mais uu peu julus larges dans leur milieu.

Ce genre est très-voisin de celui des Hippes de Fahricius, mais il s'en dislingue par les pieds antérieurs, par lés antennes et par la position des yeux : il a été établi sur une seule espèce propre aux iners de la nouvelle Hollande et a été rapporté par Péron et Lesueur.

r. RÉmrpìde tortue, $\boldsymbol{R}$. testudinarius. T.A.T. Gen. Crust. et Ins. tom. 1. pag. 45.-Hippa adactrla. КАв. Supp. Entom. Syst. pag. 37o. -HEßूST, Ca7LC. tab. 22. $\mathrm{fg}_{\mathrm{g}} 4$ ? Hist. Nat. Ins. Tome $X$.
Long d'euviron un pouce; carapace ovale, longue d'environ un ponce, finement ridfé en dessus, avec cinq dents à son bord antriveur, dont les trois iniermédiaires ont moius de longueur que les deax latérales, au-dessons desquellet sont insérés les pédoncules grêles qui supportens les yeux; bords du dernier article de l'ablomen et pattes velus.

On tronve surles côtes de la Martinique une autre espèce qui paroît a voir été figurée dans un nuvrage anglais surl'histoire naturelle des liarhades.

(E. G.)

REMIPLDES ou NECTOPODES. N. Duméril nomme ainsi dans sa Zoologie analytique, la seconde famille des Coléoptères pentamérés, avant pour carartères : ćlytres dures conprant tout l'abdonlen ; antennes en soie ou en fil, non dentées; tarses natatoires. Celte famille comprend les genres Dytisque, Hyplydre, Haliple et Tourniquet. (S. F. et A. SERY.)

RÉMITARSES ou TIYDROCOREEES. C'Est sous ce nom que M. Duméril dans la Zoologie analytique, désigne une famille d'Hémiptires ayant pour caractères: élytres dures, coriaces. Bec paroissant naître du front. Antennes sétacées, trèscourtes. Pattes postérieures propres à nager. Elle renferme les genres Ranâtre, Nèpe, Naucore, Notonecte et Sigare. (S. F. et A. Senv.)

RÉTITÉLES. Nom donné par M. Walkenaer à la dix-neuvième division de la seconde tribu des Araućides. Elle comprend les espèces qui fabriquer: tes toiles à réseaux formés par des fils per serrés, tendus irrégulièrement en tout sens.

$$
\text { (E.G.) }
$$

RHAGTONIDES on LEPTIDES. Neuvième tribu de la famille des Tanystomes, secliou des Proboscidés, ordre des Diptères. Elle offie pou: caractères :

Trompe à tigge très-courte, retirée dans la cavité buccale, ou à peine extérieure, terminée par deux lèvres grandes, saillantes et relevées. - Antennes fort courles, grenues; leur demier article sans divisions, ayant une soie dorsale on !erminale.Palpes extérieurs presque coniques. (Ailes presque tonjours écartées.)

Elle comprend les genres Leptis ou Rhagion, Allérix et Clinocère.

LEPTIS on RHAGION. Leptis. FAB. MEIo. Rhagio. LAt. Panz. Musca. Linn. Geort. Nemotelus. DE GÉn. Atherix, Sciara. FAs.

Genre d'insectes de l'ordre dès Liptères, section des Proboscidés, famille des Tanystomes, tribu des Leptides.

Les genres Leptis, Athćrix et Clinocère composent celle trikn. Le second se distingue aisément par le troisième article de ses an:ennes qui 
est ovale et porte une soie dorsale vers son milien. Les Clinocères qui comme les Leptis ont cette soie terminale, ont les deux premiers articles des antennes de forme presque sphérique; leurs yeux lisses sont placés sur le front, et elles porrent (dans le repos) leurs ailes en recouvrement l'une sur l'autre.

Antennes moniliformes, presque cylindriques, beaucoup plus courtes que la tête, dirigées en avant, rapprochées à leur base, composées de trois articles, le premier cylindrique, le second en forme de coupe, le troisième conique, simple ou per distinctement annclí, portant une soie à son extrémilé.-Trompe saillante, presque membraneuse, bilabiée, recevant un suçoir de quatre sties. - Pálpes presque coniques, verticaux, velus; leur second article long. - Tête de la largreur du corselet, verticale, comprimée de devaut en arric̀re. - Yeux grands, espacés dans les fewelles, rapprochés dïns les mûles. - Trois petits yeùx lisses disposés en triangle sur un tubercule vertical. - Corselet un peu convexe. Ailes très-ćcartées. - Balanciers saillans. Abdomen alongé, cylindro-conique. - Pattes très-longues, premier article des turses aussi long ou plus loeg que les quatre autres réunis, le dernier muni de deux crochets ayant trois pelottes daus leur entre-deux.

Le nom de ce genre paroît venir d'un mot grec qui sirnifie : grêle. Ces diptères se tiennent roloutiers en une espèce de société sur les troncs des arbres où 'ils ścmblent se jouer entr'eux en courant et voltigeant les uns après les autres. On les trouve quel quefois, mais isolément sur les fleurs dout ils sucent le miel; ils attaquent aussi de petits diptères.

Il est probable que les larves de toutes les Leptis vivent en terre ou dans le sable, mais on n'a des notions certaines que sur celles de la première division. Ces larves sont apodes, alongées, annelées, avec une tête constante et écailleuse; pour passer à l'état de nymphes, elles quittent leur peau et ressemblent dans cet état aux nymphes des IIyménoptères : car on aperçoit alors la forme de toutes les parties de l'insecte parfait. La larve de la Leptis bécasse a la tête petite, brune, avec deux antennes courtes; quelques mamelons charnus qui garnissent le dessous du corps, lui servent de pattes et l'aident à changer de place. Elle subit toutes ses métamorphoses dans la terre où elle a vécu. La nymphe a plusieurs rangées d'épines courtes sur le corps. L'insecte parfait paroît vers la fin d'avril. Les œufs de cette Leptis sont minces, alongés, courbés en arc, d'un blanc-jaunâtre. La larve de la Leptis ver-lion (Leptis vermileo. Fab. Syst. Antl.) a le corps alongé, cylindrique, d'un gris-jaunâtre, composé de onze segmens. Sa tête est conique, munie antérieurement d'une espèce de dard écailleux; l'anus est terminé par quatre appendices charnus, ea forme de mame- lons munis de poils longs et roides; celte larve vit d'insectes; pour les prendre elle se forme dans le sable un entonnoir semblable à celui des $\mathrm{M}^{\prime} \mathrm{r}^{\mathrm{r}}-$ méléons. Elle se place au fond, dans le milieu et s'y tieut à l'affût pour saisir les petils insectes qui tombent dans ce trou; elle les entoure avec son corps, les perce de son dard et les entraîne sous le sable pour les sucer tranquillenent; elle rejette ensuite le corps hors de son entonnoir quand elle en a tiré toute la substance; clle se change en nymphe dans le sable sans se faire de coque, vers la fin de mai, et devient insecte parfait environ quinze jours après sa métamorphose.

M. Meigen décrit vingt-deux espèces de ce genre, toutes d'Europe. Fabricius en cile une de la. Caroline.

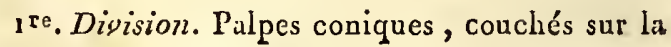
trompe.

\section{Leptis Bécasse, L. scolopacea.}

Leptis palpis conicis, in proboscide incumbentibus, thorace cinereo, suprà fusco trivitlato, abdomine rufo trifuriam nigro maculato, pedibus flavis, femoribus posticis annulo fusco, alis fusco maculatis.

Leptis scolopacea. FАв. Syst. Antl. pag. 69. no. 1. - Merg. Dipt. d'Europ. tom. 2. pag. 8g. $n^{\circ}$. 2. - Rhagio scolopaceus. LAt. Gen. Crust. et Ins. tom. 4. pag. 288. - P Anz. Faun. Germ. fus. 1 4. fig. 19. - Musca scolopacea. Linn. Syst. Nat. 2. 982. 16. - Nemotelus scolopaceus. DE G'́er, Ins. tom. 6. pag. s62. no. s. pl. 9. fig. 6-9. - RÉau. Ins. tom. 4. pl. 10. fg. 5 et 6.

Longueur 6 à 7 lig. Antennes, tête et corselet d'un cendré-roussâtre, celui-ci portant en dessus trois raies longitudinales d'un roux-brun. Abdomen d'un roux-clair, son dos ayant tune suite longitudinale de points noirs, et ses côtés une suite de lignes de cette même couleur. Ailes transparentes, leurs bords postérieur et interne un peu enfumés, l'extérieur ayant vers les deux tiers de sa longueur, une grande tache noire; toutes les nervures transversales bordées de cette couleur. Pattes d'un roux-clair; cuisses postérieures ayant un anneau plus ou moins brun vers leur extrćmité. 'Tout le corps a des poils noirs et assez roides. Femelle.

La larve vit dans la terre. (Voyez les Généralités. )

Environs de Paris.

Rapportez à celte division, $I^{\circ}$ la Leptis tringaria. Meig. (Leptis Iringaria et Leptis vanellus. FAB.); $2^{\circ}$. la Leptis lineola. MeIG. (Alherix ineola. $\mathrm{FAB}$.); $3^{\circ}$. la Leptis vermileo. Me1G. FAB.; $4^{\circ}$. la Leptzs conspicua. MeIs. - Encycl. pl.3go. fig. $41-46^{\circ}$. 
2. Division. Palpes cylindriques, relevés, aryués.

\section{Lepris diadême, $L$ diadema.}

Leptis palpis cylindricis, recurvis, erectis, cinerea, aureo tomentosa, proboscide pedibusque flavis; maris abdomine atro foscrato; alis hyalinis, irisantibus, puncto marginalifusco.

'Leptis diadema. MeIG. Dipt. d'Europ. tom. 2. pag. 10 I. no. 19. - Atherix diadema. FА в. Syst. Antl. pag. 75. n०. 2. - La Mouche à point marginal brun sur lcs ailes et pattes jaunes. Geofr. Ins. Faris. tom. 2. pag. 535. $71^{\circ}$. 8o.

Longuemr 2 lig. $\frac{1}{2}$. Corps cendić, couvert d'un duvet doré très-court et trc̀s-fúrace. Antennes brunes. Trompe et pattes d'uu jaune-pâle. Ailes trausparentes, irisées, avec un poiut marginal brun. Fernelle.

Le mâle a des bandes brunes sur l'abłomen, selon M. Meigen.

Des environs de Palis.

${ }^{\circ}$. La Leptis aurata. Merc. (Atherix atrata. FAB. Le mâle; Atherix anrata et Atherix tomentosa. FAB. La femelle); $2^{\circ}$. la Leptis splendida. Merg. (Atherix nigrita. FAB.); 3o. la Leptis bicolor. MeIG. (Leptis bicolor et Atherix oculata. $\mathrm{F}_{\mathrm{AB}}$ ) appartiennent à cette seconde division.

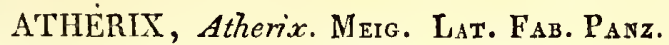
Leptis, Anthrax, Bibio. Fab.

Genre d'insectes de l'ordre des Diptères, section des Proboscidés, famille des Tuaystomes, tribu des Leptides.

'Trois genres composent cetle tribu; les Leplis et les Clinocères se distinguent des Athérix par la soie de lenrs antennes qui est terminale.

Antennes moniliformes, beilucoup plus courtes que la tête, avancées, rapprochées à leur base, composécs de trois articles, le troisième simple, ovale, demi-globuleux, prescue réniforme, portant en dessus une soie simple, insér'ée vers son bord postérieur. - Trompe à peu près de la longueur de la tête, presque membraneuse, ayant un canal court, un peu au-dessous duquel elle est coudée; ensuite dirigée en avant; ses lèvics grandes, alongées surtout postérieurement; suçoir de quatre soies. - Palpes apparens, velus, recourbés, presquaussi longs que la trompe. Tóte transversale, de la largenr du corselet. Yeux grands, espacés dans les femelles, rapprochés dans les mấles. - Trois petits yenx lisses disposés en triangle- sur un tubercule vertical. Corselet un peu convexe. - Ailes écarlées. Balanciers saillaus. - Abdomen large et presque carré dans les femelles, cylindro-conique daus les mâles. - Patles de longueur moyenue; prenier atticle des tarses aussi long ou plus long que les quatre autres réunis, le demier muni de denx crochets écartés ayant deux pelottes dans leur entre-deux.

On trouve ces insectes dans les bois sur les flcurs. Il y ea a douze cspèces déerites dans M. Meigen. (Dipt. d'Enrop.)

\section{Ataérix Ibis, A. Ibis.}

Atherix nigro-fuscus, alis fusco macnlalis, abdonine partim pedibusque rufis.

Atherix Ibis. Metg. Dipt. d'Europ. tom, 2. pag. ј05. $n^{\circ}$. 1. - Atherix macnlatus. LAT. Genei. Crust. et Ins. tomr. 4. pag. 289. La fcrelle. Leptis Ibis. Fa B. Syst. Antl. pag. go. no. 5. Le mäle.Anthrax Titanus. Id. pag. $126 . n^{\circ} .37$. La femelle.

Longuenr 4 à 5 lig. Antennes et têle brunes, couvertes d'un duvet conrt, couché, grisâtre ; celleci garnie à sa partie inférieure de poils d'un grisroussâtre. Corselct gris, portant trois raies longitudinales brunes sur le dos. Ecusson brun. Abdomen noirâtre, tous ses segmens ayant leurbort inférieur d'un roux-pâle. Pattes de cette decuièrc couleur. Ailes transparentes avec leur côte brune et trois bandes transversales noirâtres qui partet t de la côte et n'atteignent pas le bord inlerne de Y'aile. Femelle.

Le mâlc diffère par son àbdomen dout les sccond, troisième et quatrième segmens sont roux, ayant chacnn metache dorsale, noire et une autro litérale; les suivans sont noirs avec leur bord poslérieur plus on moins ronx. L'anus estroux, noir i l'extrémilé. Pattes, et surtout les tarses plus foncés que dans la femelle. Les ailes plus brunés que dans celle-ci, la couleur noire plus prononcée ct s'élendant davantage.

Environs de Paris.

CLINOCÉRE, Clinocera. M. Latreille paroit croire que ce genre de Diptères, créé par Ml. Neigen et placé pirr lui auprès des Atbérix, est de la tribu des Leptides, ce qui nous engage à donner ici le peu gुue nous en savons, ne l'ayaut point va. L'anteur allemand lui donne pour caractères : antennes avancées, écartées, composćc de trois arlicles, les deux de la base sphériques, le troisième conique, portant une soie terminale recourbée; trois yeux lisses placés sur le front. Ailes parallèles et se cruisant sur l'abàonendans le repos. Il en décrit en allemand nne senle espèce sous le nom de $C$. nigra. Elle est figurée dans ses Dipt. d'Enrop. pl. 16. fig. 1-4.

Le nom de Clinocc̀re vient de deux mots grecs et signifie : comres inclinées.

$$
\text { (S. F. et A. SERv.) }
$$

RHAGIE, Rhagrim. Genre de Coléoplìres tétramères, famille des Longicornes, tribu des Leptarètes de M. Latreille, créé par Fabr cius et $\sin 2$ 
caractérisé ainsi par snn au!eur : quaire palpes terminés en masse. Mâchoires unidentées; languletie membraneuse, bifide. Antennes sétacées, alongées, rapprochées, insćr'es entre les yenx: ceux-ci arrondis, saillans. Téte grande, ovale, avanć́e. Corselet étroit, cylindriçue, ses côtés épineux. Elytres dures, voútées, plus larges que le corselet ef de la longrueur de l'abdonen. Fabricius compose ce genre d'espèces que les entomologistes modernes placent dans plusieurs. Lues $R$ hagium mordax, inquisitor, indagator, salicis, bifusciatum et minutum sont des Stencores. Foyez ce mot. (S.F. et A. Senv.)

RHAMpIIE, Rhamphus. Clairt. Lat. Oriv. (Eutom.)

Genre d'insectes de l'ordre des Colćoptc̀res, section des 'Téranères, fanille des Rhynchophores, tribu des Charansonites.

Tous les genres de celle tribuse diswinguent de celai de Rharmphe par leurs antennes insérées sur un prolongement rostriforme de la lête. Parmi ces genres plusieurs ont comme lui les antennes droites, mais aucun ne les a placées sur la tête à la lra e de son prolungement et entie les yeux.

Antennes non coudces, insérées sur la tête, entre les yeux, composées de onze articles, le premier court, le secoud assez gros, obconique, el ?e plus grand de tous, les trois suivans obcoui1.iques, les sixiène et scptic̀me arrondis, le huilieme en forme de coupe, les trois dernicrs renflés, formant par leur rénnion une massue serrée, finissant en pointe. - Téte un peu globuleuse, ayant un prolongement cylindrique et rostriforme à l'extrémité duquel est silure la bouche; ce prolongement dépriué, appliqué contre la poitrine dans l'ćlat de repos. - Yeux rapprocisés. - Corps court, ovale.-Corselet court, ses côtés arrondis. - Pattes postćrienres propres pour santer, leurs cuisses rentlées, sans dentelures; jambes sans épines visibles à leur extrémité.

Ce genre est dû à M. Clairville. Son nom vient d'un mot grec qui signifie : bec d'oiseau. Les mœur's des denx espèces qu'il renferme ne paroissent point différer de celles de la plnpart des Charansonites. Ces très-petits coléoptères se tiennent d'babitude sur les feuilles des arbrisseaux.

\section{Rhamphe flavicorne, $\boldsymbol{R}$. flavicornis.. "}

Rhamphus glaber, antennis flavis, clavâ fuscâ.

Ramphus flavicornis. Cuarav. Entom. Helvét. pag. IO4. pl. 12. - Lat. Gen. Crust. et Ins. tom. 2. pag. 250. $n^{\circ}$. 1. - Oniv. Entom. tom. 5. Attelab. n'. 58. pl. 3. fig. 58. a. b. c. - Encycl. pl. 366. III. fig. 1 et a.

Eongueur $\div$ lig. ou une lig. Noir, glabre. An- tennes jamatres, leur massue brune. Corselec pointillé. Elytres ayant des strics pointillées.

Se trouve en France et en Allemagne sur le prunellier (Frunus spinosus).

\section{Rhamphe tomenteux, $R$. tomentosus.}

Rhamphus tomentosus, antennis fuscis.

Rhamphus tomentosus. Or.1v. Entom. tom. 5. Attelaj. no 5 g. pl. 3. fig. 5g. - Encycl. pl. 366 . III. fig. 2.

Longuenr $\frac{x}{3}$ lig. Noir, couvert d'un duvet gris. Anteanes brunes. Stries des élytres moins app:rentes que dans l'espèce prćcédente. Corselet un pen plus convexe, moins aminci antérieurement.

Des environs de Genève.

$$
\text { (S. F. et A. Serv.) }
$$

RTIMMPHOMYIE, Rhamphomyia. Nom donné par M. Meigen (Dipt. d'Europ.) à un genre de Diptères, section des Proboscidés, fauille des Tanystomes, tribu des Empides de M. Latreille, ayant pour caractères: antennes avancées, de trois articles, le premier cylindrique, le second cyathiforme, le troisième conique, comprimé, portant à son extrémilé un sıyle biarticulé; trompe avancée, perpendiculaire on penchée, mince; ailes couchées sur le corps dans le repos, parallèles, n'ayant point de nervure transversale qui forme une petite cellule vers l'extrémité de' l'aile.

Ce genre dont le nom vient de deux mots grees qui signifient: mouche à bec, ne diflère des Empis que par le dernier de ces caraclères. MI. Latreille, d'après cette considéralion, en fait la seconde division de son genre Empis. M. Meigen décrit trente-sept espèces de Rhamplamyies dont beancoup sont nouvelles.

Rapportez à ce genre les Empis bordée no. 3, et cendrée $n^{\circ}$. 10 de ce Dictionnaire.

$$
\text { (S.F. et A. Sent.) }
$$

RHETIA. Gente de Cruslacés établi par Léaclz: (art. Crustacés du Dict. des Scienc. natur:) et. dont il ne donne pas les caraclères. (E. G.)

\section{RHINAPTERES. Vojez Parasites.}

(S. F. et A. Serat.)

RHINARTE, Rhinaria. M. Kirby a fondé ce genre de Coléoptèı es daus les Transactions Linnéennes, vol. XII. Il est de la tribu des Charansonites, famille des Rhynchopbores et ofire pour caractères : labre à peine ciistinct. Lèvre.presque: trapézoidale. Mandibules sans dents. Mächoires. ouvertes. Palpes très-courts, coniques. Nenton. carré. Antennes point coudćes, en niassue à l'ex-trémité, celle-ci de trois articles très-étroiteroento 


\section{IR $\mathrm{T}$}

séunis. Corps ovale-oblong. Corselct presque gylobuleux.

L'auteur ne mentionne qr'une scule espèce. Rhinarie crêtré ( $R$. cristata.) Longueur 4 lig. $\frac{3}{4}$, non compris le rostre. Corps convert en dessous d'écailies blancliâtres, gris en dessis. Elytres un peu sillounées, écailleuses, les sillons ayant des points blancs oceliés; les inter valles portant une suite de suies roides, couchées, alternant avec de petits tubercules. De la nourelle Hollande. Elle est représentée pl. 22, figr. 9 du vol. XII*. des Transactions Linnéennes.

RHINE, Rhina. Lat. Oliv. (Entom.) Lixus. Fa B. Curculio. Or.1v. (Encycl.)

Genre d'insectes de l'ordre des Coléoptères, section des 'T'étranères, famille des Rhynchophores, tribu des Charansonites.

Dix genres de celte tribu y forment un groupe caractérisé par les antennes coudées, ayaut leur prenier article très-long; mais ces or gaanes ont flus de dix articles dans les Charansuns, les Lixes, les Lipares, les Rhynchiènes et les Cryptorhyngues; tand's que les Cines, les Orchestes, les ribines, les Calandres et les Cossons ont leur's antennes composées de dix articles au plus, mais la massue est de quatre articles dans le premier de ces senres, le second a les paties postérieures renflées et propres à sauter; dans les Calandres les autennes sont insćrées à la base du prolongement vostriforme de la tête; enfin le ncuvième article forrae seul la masse des aatennes dans le genre Cosson.

Antennes coudées, insérées vers le milieu ot sur les côtés du prolongement rostriforme de la lête, composćes dè lisit articles, le premier trèslong, les six suivans courts, le huitième formant the massue ovale cylindrique, très-alongée, de substance spongicuse, excepté dans une petite portion de sa base. - Prolongement rostriforme de la tête long, dirigé en avant, cylindrique, ayant de claque côté un sillon qui part de la base des antennes, se dirige vers l'œil et reçoit (dans le repos) une partie du premier article des antennss. - Mandibules munies de trois dents, les deux plus fortes placées vers l'extrémité, l’autre an côté interne. - Mấchoircs alongées, presque membraneuses, velues. - Palpes marcillaires n’ayant que trois articles distiacts, le dernier plus lung que le second, ovale-conique. - Yeux assez yrauds, se rejoignant presque sur le devant de la tête, à la base de son prolongement. - Corps cyliadrique. - Corselet convexe, ovale, tronqué à ses deux extrérailés. - Ectsson petit, triangulaire. - Elytres recouvräut les ailes et l'abdomen. - Abdomen de la largenr du corselet. Pattes longues, les antérieures surtout; jambes aninces, un peu croclunes à leur extrénité; tarses ayant leur troisième article bilobś.
Ce genre fondé par M. Latreille tire son nom d'un nol grec qui signifie : nez. Cet auteur aroit réuni sous ce nom des espèces des pays étrangers à d’autres d'Europe, aujourd hui il le restrint à deax espèces exolignes. Fa O:ivier dans son Entomologie décrit six esperes corma élant de ce genre, mais les quatre dervic̀res doivent en être exclues, la Rhina prani appartient au geore. Rhinodes. Scrons. et la Rhina plagiata à cetui de Cleopus. Míg.

\section{J. Raune barbirostre, R. barbirostris.}

Rhina barbirostris. LAs. Gen. Crust. et Ins. tom. 2. pag. $26 \mathrm{~g} \cdot n^{\circ}$. 1. Le mâle.-OLIIv. Entom, tom. 5. pag. $232.7 n^{\circ} .229$. Charans. pl. 4. fig. $37 \%$ a. b. Le wále. - Lixus barbirostris. $\mathrm{F}_{\triangle \mathrm{B}}$. Syst. Eleut. tonn. 2. pag. 5or. $n^{\circ}$. 18. Le mâle. Encycl.pl. 226. fig. 14. Le mâle.

$V o y e z$ pour la description et les autres syno. nymes Charanson barbirostre $n^{\circ} \cdot 9 \mathrm{I}$.

Nota. Inliger a décrit la femelle sous le rom de Verrirostris; le prolongement rostriforme de sa tête n'est point lisse, mais dépourvu, ainsi que le dessous du corselet, de l'épaisse barbe que l'on: voit dans l'antre sexe. Les individus que $M$. le comte Dejeau et nous possédons, sont de l'Amérique méridionale; les auteur's indiquent cependant pour patrie les Indes orientales et l'Afrique.

\section{RHine scrutaleur, $R$. scrutator.}

Rhina nigra, elytris albo maculatis.

Rhina scrutator. Otrv. Entom. tom. 5. pass 233. $n^{\circ} .230$. Charans. pl. 29. fig. 428.

Longneur $18 \mathrm{lig}$. Noire. Corselet pointille, Elytres ayant une tache irrégulière blanchâtre qui s'étend jusclu'au-delà du milieu; elles sont chargées de stries formées par des points enfoncès trìs-ripprochés.

De Sxint-Domingue. (S.F. et A. SERt.)

RHINGIE, Rhingic. Scop. Fab. Lat. Mrig, Panz. Conops. Linn. Musca. De Géer.

Genre d'insectes de l'ordre des Diptères, section des Proboscidés, famille des Athéricères, tribu des Syrphies.

Dans la tribu des Syrphies (voyezce mot), un petit groupe a pour caractères : antennes plus courtes qrie la tête, portées sur un tubercule fíontal; leurs deux premiers articles éganx entr'eux; cuisses postérieures simples, c'est-à-dire poiz renflées. Ce groupe renferme les genres Niilécie, Brachyope et Rlingie. Le premier se reconnoît par son bypostome yui n'est point alongé inférien-i rement; le second l'a un peu avancé daas celte partie, mais tronqué brusquement: de manièra que ces genres se distinguent aisćment des Rhialgies. 
Antennes très-courtes, rapprochées à leur basc, avancées et penchées, insérées sur un tubercule frontal, composécs de trois articlcs, le premier et le second très-courts, le troisic̀me con't, ovalaire, comprimé, portant à sa parlie supérieure une soie nue, longue, uuiarticulée à sa base. - Sucoir très-alongé. - Palpes plus courts que les soies inférieures du sucoir. - Hypostonte trèsprolougé en avant iufírieurement, formant une corte de bec conique dans lequel est renfermée la trompe. - Yeux grands, espacés daus les femelles, rapprochés et se touchaut dans les mâles. - Trois petits yeux lisses disposés en triaugle sur un tubercule du vertex. - Ecusson grand, denicirculaire. - Cuillerons assez grands, distincteunent ciliés. - Ailes longues, parallèlcs et se croisant sur l'abdomen dans le repos. - Abdomen un peu convexe en dessus, composé de qualre segmens outre l'auus. - Pattes de longueur moycunc, cuisses postérieures simples et mutiques; tarscs ayant leur dernier article muni de deux crochets sous chacun desquels est une pelotte assez forte; lc premier article des tarses postéricurs est alongé ut reuflé.

Le nom donné par Scopoli aux diptères do ce genre vient d'un mot grec qui signifie:nez. Réauraur dit qu'un individu de la Rhingie à bec cst éclos chez lui dans un poudrier où il avoit renfermé de la bouze de vache avec des larves qui s'en nourrissoient, d'où il pense que celle de cette 'spèce subit ses métamorploses dans cette matière. Fabricius dansle Systema Antliatoruna décrit trois espèces comme étant de ce genre; les cleux dernic̀res appartiennent à celui d'Helophilus de M. Meigen et ue constituent qu'une seule espèce que ce dernicr auteur désigue sous le nom de Lineatus, Les Rhingies fréquentent les fleurs et les plantes.

\section{Rurwgre à bec, $R$. rostrata.}

\section{Rhingia abdomine pedibusque ferrugineis.}

Rhingia rostrata. FAB. Syst. Antliat. pag. 222. no.1. - Las. Gen. Crust. et Ins. tonu. 4. pag. 52 г. - Panz. Faun. Germ. fas. 87. fig. 22. MEIg. Dipt. d'Europ. tom. 3. pag. 258. no. 1.Conops rostrata. Lixx. Syst. Nrt. 2. 1004. 1. Réaus. lns. tom. 4. pag. 233.pl. 16. fig. 10 et II.

Jonguenr 4 lig. 'Tète brune, sa partic antérienrc et inférieure testacéc. Antennes de cette couleur. Corselet bruu avec quatre lignes longitudinales grises sur le dos. Epanlettes, parties qui avoisineut la base des ailes, écusson, abdomen et pattes, dc couleur ferragineuse. Ailes un peu jaunâtrcs vers la côte, leurs nervures testacées. Fenuelle.

Le mấle a l'abdomen très-cilié vers ses bords avec une petite ligue courte, brune sur le milie du second segment.

Eavirons de Paris.

\section{Rhixgie champêtre, $R$. campestris.}

Rhingia abdomine ferrugineo, lineâ dorsali lateribusque et feruorum basi nigris.

Rhingia camestris. MeIg. Dipt. d'Eur. tom.3. pag. 259. no. 2. tab. 29. fig. 27. Le mâle.

Longueur $4 \mathrm{lig}$. Antennes, tête et corselet comme dans la précédente ainsi que les ailes. A ১domen ferrugineux, ses second, troisièbse et quatrième sernmens ayant unc ligne dorsale noire et leurs bords de cette mêmc conleur. Pattes ferrugineuses, base des cuisses noire ainsi que la partie extérieure des deux derniers tarscs; toutes les jambes ont un anneau brua plus ou moins funcé. Fenclle.

Le millc diffère en ce que le premier segment de son abdoneu est noir et que l'anueau de ses jambes est beaucoup plus marqué.

Envirous de Paris.

Nota. Dc Géer (Ins.tom. 6.pag. 129. no. 19.) décrit ce mâle el le représente pl. 7. fig. 21 et 2\%, mais il Jui donne pour femelle celle de la Rhingie ì bec et les regarde comme une seule espèce.

(S. F. et A. SERV.)

\section{RHINOCÉRES. Voyez Rostricornes.}

\section{(S.F. et A. SERv.)}

RHINOMACER, Rhinomacer. Fab. OLIV. (Entom.) Rhynchites. Gyld. Oliv. ?' (Entont.) Anthribus. LAT. PAY K.

Genre d'insectes de l'ordre des Coléoptères, section des 'Tétramères, famille' des Rhynchophores, tribu des Bruchèles.

Celte trihu se compose des genres Anthribc, Rbinomacer et Bruche. Le premier se distingue par le prolongement rostriforme de la lête qui est de la uncene longueur qu'elle ou à pcu près, et par le troisième article des tarses encbassé dans le second; et les Bruches par leurs yeux échancrés ainsi que par leurs antennes filitormes, souveat pectinées.

Antonnes un peu en massc, insérées sur le milieu du prolongennent rostriforme de la tête, à peu près de la longueur du corselet, composées de onze articles, le premier court, un peu renflé, le second arrondi, plus court que le premier; les six suivans courts, presque coniques, les trois deruiers un peu plus gros, formant une masse alongée. - Mandibules cornées, avancées, alquées, simples ou unuuies intérieurement d'une dent assez furte. - IIÂchoires cornćes, bifides, leur lobe intérieur coupé obliquement et cilié, l'extérieur mince, alongé, arrondi. - Palpes maxillaures courts, filiformes, composés de quatro 
articles, te premier tris-petit, les second et troisième presque coniques, le dernier oblong ; palpes labiaux courts, filiformes, presque sétacés, de trots articles presqu'égatux, insérćs sur le menton à la base latérale de la lèvie. - Lèvre membraneuse, avancée , bificle. - Tête ayant un prolongement rostriforme aplati, étroit à sa base, s'élargissant vers l'extrénité. - Corps alongé.Corselet convexe, à pea près de la largeur de la tète. - Ecusson petit, arrondi postérieurement. - Elytres assez molles, plus larges que le corselet, couvrant les iiles et l'abdomen. - Pattes de longueur moyenne; tarses de qualre articles bien distincts, le premier un peu alongé, triangulaire, le second de même for ne, mais moins long que le premier, le troisième bilobé, cordiforme.

Les Rlinomacers dont le nom est composé de deux mols grecs qui signifient: gros bec, fréquenteut les fleurs et se trouvent dans les forêts. On ac connoit ni leurs larves, ni la manière dont elles vivent. Les espèccs connues sont en petit nombre.

1. Rhivoracer lepturoïde, $R$. lepturoides.

Rhinomacer niger, suprà subtùsque cinereo villosus.

Rhinomacer lepturoides. FAB. Syst. Elent. tom. 2 . pag. $429 . n^{\circ}$. 4. - Oliv. Entont tain. 5. pag. $45 \mathrm{~g}$. no. 1. Rhimom. pl. I. fig. 1. - PANz. Faun. Gern. fus. ". fig. 8. - Encycl. pl. 362. III. fig. I et 2 .

Longueur 3 lig. Noir, couvert d'un duvet cendré. Buuche un peu roussittre. Corselet et élytres finement pointillús.

D'Aulliche. Il est rare aux environs de Paris.

2. Rumomacer attelaboïde, $R$. attelaboides.

$R /$ inomacer niger, griseo-villosus, antennis pedibusque dilutè testaceis.

Rhinumacer attelaboides. F.в. Syst. Eleut. tom. 2. pag. 428. no. 3.-OLiv. Entom. tom. 5. pag. 45g. Rhinom. pl. 1. fig. 2.-Anthribus rhinomacer. LAт. Gen. Crust. el Ins. tom. 2. pag. 237. $n^{\circ}$. 1.-P Р Y K. Faun. Suec. tom. 3.pag. 160. n". 8. - Encycl.pl. 562. III. Jig. 1 bis.

Longueur 2 lig. $\frac{x}{2}$. Noir, légèrement couvert d'un duvet cendré qui tire quelquefois sur le jaunàtre. Bouche, antennes et pattes d'un roux clair.

Du nord de l'Europe et des environs de Bordeaux. On le trouve dans les endroits plantés de pins.

Nota. Le synonyme de Paykull que nous donnons à cetle espèce et dans lequel nous comprenons aussi la varićté dont cet auteur fait mention doit être ôté au Myctère curculioïde du présent
Diclionnaire. Fabricius en regardant avec raison lis variété mentionnée par Paykull corme identique avec le Rhinomacer at teliboïde, réunit mal-itpropos l'espèce de l'auteur suéd ois au Rhinomacer curculioides; ce dernier insecte est le Myctère que nous venons de ciler. I es deux espèces dé-crites par Olivier dans son Entomologie, sous les noms de Rhynchite nigripenue et de Ryuchite à collier, appartiennent peut-êire au genre Rhinomaccr. (S. F. et A. Serv.)

RHINOSIME, Rhinosimus. LAT. OLIT. (Entorn.) Curculio. Linn. Ds GÉrr. Anthribus. ÉaB. Clair. Payx. Panz. Salpingul. Ilitg. Gyllanir. Curculio, Riacrocephalus. Ourv. (Encycl.)

Genre d'insectes de l'ordre des Coléoptères, sectiou des Hétéromères, famille des Sténćlytres, tribu des Qdémérites.

Dans celte tribu les geares Serropalpe, Mélandrye, Lagrie, Calope, Nothus et OEdénc̀re n'ont point la lête prolongée en une sorte de bec, ce qui les dislingue sulfisamment des genres Sténostome, Rhinomacer Lat. (Myctère Oliv.) et Rhinosime. Les élytres molles des Sténostomes et les antennes filiformes de celles-ci et des Rhinomacer's, ainsi que leur muscau peu élargi à l'extrémité, séparent ces deux genres de celui de Rhinosime.

Antennes inserées derant les yeux, sur le prolongement de la tête, à peu près de la longreus du corselet, composées de onze articles, le premier gros, arrondi, le second plus petit, de même forme; les troisième et quatrième obconiques, les suivans un peu globuleux, les cinq derniers un peu plus grands, formant par leur réunion une massue alongrée. - Labre avancé, carré, cntier. - Mandibules cornées, ayant une petite dent au côté interne, vers l'extrémité. - Palpes grossissant vers le bout; leur dernier article un peu plus grand, cylindrique - ovale dans les waxillaires, ovale-court dans les labiaux; les premiers composés de quatre articles, les seconds de trois. Lèvie rétrécie à sa base, dilatée vers son extrémité , arrondie et eutière. - Tête très-déprimée, prolongée en une sorte de bee large et aplati, plus ou moins avancé. - Corps ovale-oblong. Corselet un peu en cœur, rétréci postérieurement. - Elytres dures. - Abdomen ovoide, presque carré.-Tarses courts, velus en dessous, lous leurs articles entiers.

Ce genre a été crćé par M. Latreille; son nom vient de deux mots grees dont la signification est: nez camus. Cés insectes sont petits, mais de conleur assez brillante; on les rencontre sur les arbres et particulièrement sous les ćcorces; on croit que leurs larves vivent dans le bois mort; quoique pourvus d'ailes, ils paroissent en faire peu d'usage. Le nombre des espèces connues toutes eurapéennes ne s'ćlève qu' ì sept ou buit. 
y re. Division. Prolongement anterieur de la têı, peu remarquable. (Sil pingus. DEJ. Calal.:')

I. Rhisosime quadrimoucheté, $R$. quadriguttatus.

Rhinosimus elytris fuscis, livido quadriguttatis, punctato-striatis.

\section{Salpingus quadriguttotus. Des. Càtar.}

Iongrueur une lig. $\frac{1}{2}$. Entièrewent d'un testacébrun avec deux taches pailes sur chaque élytre, I'une vers l'anstc liuméral et l'autre un peu avani l'extrémité. Elytres ayaut des stries pointillées.

Environs de Paris.

$2^{\mathrm{e}}$. D'oision. Tête avancée en un prolongezacnt rostriforme élargi au bout.

\section{Rninosine du Chêne, R. Roboris.}

Rhinosinus Roboris. Laт. Gen. Crust. et Ins. tom. 2. pag. 232. $n^{\circ}$. 1. - OLlv. Entom. tom. 5. Rhinos. pag. $454 . n^{\circ}$. 1. pl. 1. fig. 1. - Anthribus roboris. FAs. Syst. Eleut. torr. 2. pag. 410. $n^{\circ}$. 23. - Anthribus ruficollis. CuAlp. v. Entom. IIcliét. pag. 123. $n^{\circ}$. 1. pl. 15. fig. 4 et 5. Curculio rostratus. DE GEer, Ins. tont. 5. pag. 252. pl. 7. fig. 27 et 28. - Salpinguls ruficollis. Grilexu. Ins. Sulec. tom. 1. part. 2. pag. 640. $n^{\circ} .1$.

Voyez pour les autres synonymes et la description Charanson ruticolle no. 105. pl. 362. II. tirr. 1 .

\section{Rurosiue, ruficolle, $R$. ruficollis.}

$R$ hinosimus niger, capite thorrceque ferrugineis, elytris viridi-aneis punctato striatis, pedibus pallidè flavis.

Rhinosimus ruficollis. Jast. Gen. Crust. ct Ins. tom. 2. pag. 233. - Otiv. Entom. tom. 5. Rhinos. pag. 455. no. 2. pl. 1. fig. 2. a. b. Anthribiss ruficollis. PAxz. Faun. Germ. fas. 24. fig. 19. - Encycl. pl. 362. 1I. fig. 4. a-g.

Longuêr. $1 \mathrm{lig} \cdot \frac{2}{2}$. Antennes noirûtres, tête et eorselet d'un fauve-rougeâlre. Eiylres d'un noirverdâtre à reflet métalligue avec des stries poiutillées. Aludunen noir. Paltes d'un fauve-pâle.

Euvirons de Paris.

\section{Renosine planirostre, $\boldsymbol{R}$. planirostris.}

Rhinosinus planirastris. Lat. Gen. Crust. et Ins. tom. 2. pag. 233. - Oliv. Enlom. tom. 5. Rhinos. pag. $456 . n^{\circ} \cdot 4$. pl. 1. fig. 4. - Anthribus planirostris. Ha13. Syst. Elout. tom. 2. pag. $410 \cdot n^{\circ} \cdot 24 .-$ Panz. Faun. Germ. fas. 15. tab. 14 . - Salpingus planirostris. Ǵs.texu. Ins. Suec. tom. 1. part. 2, pag. $641, n^{\circ} .2$.
Longueur 1 lig. Anleunes brunes; leur base, lit partie antérieure de la tête et les pattes fauves. Derrière de la tête, corselet et élytrés d'un noirbronzé; eelles-ci ayant des stries pointillées. Dessons du eorps noil.

Voyez pour les autres synonymes en retranchanl celui de De Géer, Macrocéphale planirostre $1^{\circ}$.5. pl. 562 . fig. 3 dis ee Dictionmaire.

$$
\text { (S.F. et A. Serv:) }
$$

RIINOSTONES on FRONTIROSTRES. M. Duméril dans sa Zoologic analytique nomme ainsi une famille d'flémiptères, présentant les caractères suivans : élytres demi-coriaces. Bec paroisant uấlie du fiont. Antenues longues, non cn soie. Tarses propres à marcher. Elle renferme les genres Pentatome, Scutelluire, Corée, Aeanthic', Lygée, Gerre et Podicère.

$$
\text { (S. F. et A. Serv.) }
$$

RHINOTIE, Rhinotia. M. Kirlyy a établi ce nouveau genre de Coléoptères dans les Transactions Linnécnnes, vol. 12. Il appurtient à la tribu des Charansonites, famille des Rhypachophores. Cet autenr le caraetérise ainsi : labre réuui postérieurement au rostre, très-petit, éehancré; lèvre très-petite, cunćiforne. Mandibules forles, tridentćes à l'extrćmilé. Màchoires ouvertes. Palpes très - courts, coniques. Menton presque transverse, convexe. Antennes poinl eoudcées, plus épaisses vers l'extrémité, leur dernic. article ovale, laucéolé. Corps rétréci, linéaire. Corselet globuleux, conique.

Ce genre n'est composé que d'une seule espèee, Rhinolie hémoptère ( $\boldsymbol{R}$. hamoptera). Longueur 7 lig. $\frac{t}{3}$ non compris le rostre. Corps noirâtrc ayant quelques poils blanchâatres en dessous, Corselet velouté avec une bande latérale formíc de peils d'un fauve-doré dont les bords intérieus sont mal terminés. On voit une ligne dorsaie et deux taches à la partie postérieure formécs de semablables poils. Elytres très-ponctuées, cinalgées de poils d'un futuve-doré; sulure noirâtre: De la nouvelle Hollaude. Elle est ligurée pl. $\Sigma 2$, fig. 7 de l'ouvrage précité.

$$
\text { (S. F. et A. SERv.) }
$$

RHINO'TRAGUE, Rhinotragues. Dans son oqvage intitulé : Ins. Spec, nov. vol. I. Coleopt, 1814 , M. Germar propose ce nouveau genre de la funille des Longicornes; il a pour earactères: bouche placée au bont d'un rostre cylindrique. Palpes courls, presqu'égraux, leur dernier article obconique. Labre saillant, sirué à son extrémité. Yeux échancrés. Antemes filiformes, dentées en scie vers l'extrémilé. Corselet un peu arrondi, point rebordé. Ecussou pelit, arrondi. Pattes do longuenr moyenne, premier article des tarses postérieurs un peu plus long que les autres.

L'auteur 


\section{R H I}

L'anteur n'en mentionne qu'un seule espèce sous le nom de $R$. dorsiger. Elle est du Brésil.

(S. F. et A. SERV.)

RHIPICÉRE, Rhipicera. LAT. Polytonuts. Dalm. Ptilinus. Fab. Ptyocerus Hofrm.

Genre d'insectes de l'ordre des Coléoptères, section des Puntamères, famille des Serricornes, tribu des Cébrionites.

Les genres Rhipicère, Cébrion, Dascille, Elode et Scirle composant dans les ouvrages de M. Latreille, la tribu des Cébrionites, nous y joignous celui d'Eubrie (Eubria), nouveilement fondé par M. Ziégleì. Ce genre ainsi que les trois précédens n'a que onze articles aux antennes, et ce nombre est le même dans les deux sexes. Les Cébrions qui se rapprochent des $R$ hipicères par le nonbre des antennes variables selon le sexe, se distinguent de ces dernières en ce qu'ils n'en ont pas plus de douze $\epsilon t$ que leurs tarses sont dépourvus en dessons de pelotes membraneuses.

Antennes en panache, de la longneur de la tête et du corselet, insérées devant les yeux, près de la bouche, composées de vingt à quarante articles (ces articles plus nombreux dans les mâles que dans les femelles). Le premier grand, obconique, le second et le troisième trèspetits, transversaux, les autres courts, s'alongeant en une lame très-courte dans les premiers, wais devenant (surtout dans les mâles) fort longue, principalement dans les intermédiaires; celle lame étroite, linéaire, unique sur cliaque article. - Labre petit, échancré. - Mandibules comprimées, très-arqućes, leur extrémité aiguë; clles laissent entr'elles et le labre un vide remarquable, même étant fermées. - Mâchoires linéaires, leur extrémité un peu frangée. - Palpes presqu'égaux, fliformes, de la longueur des mandibules, leur dernier article oblong, ou presqu'en massue, les maxillaires beaucoup plus longs que les mâchoires, velus, composés de quatre articles, le premier très-court, le second long, obconique, le troisième conrt; palpes labiaux un peu plus courts, de trois articies, le premier petit, le second alongé, obconique. - Lèvre très-petite, comprimée, velue à son extrémilé. - Tête de grandeur moyenne, avancée, rétrécie avant la bouche. - Yeux oblongs, entiers. - Corps alongé. - Corselet court, convexe, point reborde. - Ecusson petit. - Elytres longues, un peu rétrécies vers leur extrémité, recouvrant les ailes et l'abdomen. -. Pattes de longueur noyenne, jarnhes un peu comprimées, tarses ayant leurs quatre premiers articles très-courts, cordiformes, garnis chacun en dessous d'une pelote membraneuse, longue, bifide, lamelliforme; le dernier plus long que les quatre autres réunis, muni à son extrémité de deux forts crochets entre lesquels on remarque un petit pinceáu de soies divergentes porté sur un tubercule.

Hist. Nat. Ins. Tome $X$.
Le nom de ce genre fondé par M. Latreille est composé de deux mots grecs dont la signification est : cornes en éventail. Nous ne connoissons point ses mœurs. Le petit nombre d'espèces connues appartient à la nouvelle Hollande et au Brésil.

\section{Rhipicère marginée, $R$. marginata.}

Rhipicera antennanum articulis in mare triginta duobus, in forminá viginti duobus.

Polytonus narginatus. Dalm. Analect. Entom. pag. 22. $n^{\circ}$. 2. tab. 4. L.e mâle.

Isonguenr I pouce. Corps d'un noir-verdâtre bronzé, garni d'uu duvet roussâtre. Elytres d'un brun-cuivreux; leur base, leur suture et le bord extérieur d'un testacé pâle. Base des cuisses ferrngineuse ainsi que les hanches. Antennes, jambes et tarses noirs. Mâle et femelle.

Cette dernière a vingt-deux articles aux antennes, le mâle en a trente-deux : leurs rameaux sunt beaucoup plus longs dans ce dernier sexe.

Du Brésil.

Rapportez à ce genre le Ptilinus mystacinus. Fав. Syst. Eleut. tom. 1. pag. 328. $n^{\circ}$. I. Drur Y, Ins. tom. 3. pl. 48. fig. 7 , et le Polytomus fenoratus. Dalar. Ouvrage précité.

CÉBRION, Cebrio. OnIv. (Entom.) Fab. Lat. Ross. Tenebrio, Cistela. Ross. Hamnionia. La'r.

Genre d'insectes de l'ordre des Coléoptères, section des Pentamères, famille des Serricornes, tribu des Cébrionites.

Dans cette tribu les genres Dascille, Elode, Eubrie et Scirte sont reconnoissables par leurs antennes de onze articles dans les deux sexes; les Rhipicères ont les leurs composées de vingt à quarante articles, ce qui éloigne tous ces genres de celui de Cébrion.

Antennes insérées à l'angle autérieur des yeux; celles des femelles plus courtes que la tête, terminćes en massue et composées de dix articles (suivant MM. Latreille et Olivier); ces articles courts, serrés, moniliformes; celles des mầles longues, filiformes, un peu en scie, de douze articles, les second et troisième courts, les autrez alongés. - Labre très-court, transverso-linéairc. - Mandibules fortes, avancées, arruées, pointues, laissant un espace notable lor'squ'clles sont fermées, entr'elles et le labre. - M.choires courtes, presque membraneuses, simples, arrondies, ciliées. - Palpes alongés, les maxillaires plus longs que la tête, de quatre arlicles, le premier court, les autres égaux, le dermier cylindricjue, un peu a minci à sa base; palpés labiitux de trois articles, le premier court. - Lèvre courte, presque cornée, entière. - Tête courte, assez large, mais moins que le corselet, légèrement inslinće. _- Yeux arrondis, un peu saillans. - Corps oblong, suaclinant un peu en avant. -- Corsele: Oo 
presque trapézoïdal, son bord postérieur plis liurge que l'antérieur, s'avançaut eu angle ris-àvis de l'écusson et ayant une dent de claqque côlé. - Ecusson petit, peu apparent. - Elytres un pen flexibles, écarlées postérienrement et plus courtes que l'abdoinen dans les femelles; se rejoignant dans toule leur élendue el recouvrant entièrement l'abdomen dans les mâles : ceux-ci ailés, les femelles aptères. - Pattes assez longues; cuisses postérienres munies d'un appendice á leur base interne; larses filiformes, leurs articles égaux, entiers, simples en dessous, le dernier terminé par deux crochets sans peloles.

Les femelles de ce genre ont longr-temps abusé les entomologistes par leurs antennes conformées autrement que celles de leur's mâles; ainsi le type dn genre Hammonie de M. Latreille n'est que la femelle du Cébrion géant. Nous ue pouvons pas admettre non plus les sept genres créés par M. Iéach dans sa Monographie des Cébriouides publiée dins le Zool. journ. mars $1821, n^{\circ} .1$, prag 33, car plusieurs de ces genres ne sont ćgalement formés que sur des individus femelles et les autres nous sont inconnus.

On ne connoît point les larves des Cébrions; il cst cependant probable qu'elles vivent dans la terre. Les insectes parfitits s'y tiennent cachés daus des trous pendant le jour, ils u'en sortent gruère que la nui:; cependant les pluies d'orage les forcent quel ruefois de se mettre en campagne, alors a p:ès la pluie on les trouve conrant à la superficie du sol; les mâles volent peudant la nuit et leur vol est assez rapide. Nous avons posé les caractères de ce genre d’après le Cébrion géant, seule espèce que nons connoissions.

1. Cébrion géant, $C$. gigas.

Cebrio apterus, testaceus, mare alato anticè filsco.

Cebrio gigas. Fав. Syst. Eleut. tom. 2. pag. 14. $n^{\circ}$. I. Le mâle.-Lat. Gen. Crust. et Ins. tonu. 1. pig. $25 \mathrm{I} \cdot \pi^{\circ}$. I. Le mâle. - Cebrio brevicornis. Onv. Entom. tom. 2. Cébrion. pag. 5. no. 2. pl. 1. fig. 2. La temelle. - Cebrio longicomis. Osıv. Entom. tom. 2. Cébrion. pag. 5. no. 1. p’! 1. fig. 1, et Taupin. pl. I. fig. I. Le mâle. Tenebrio aubius. Ross. Faun. Etrusc. tom. I. fag. 254. $n^{\circ}$. 583. tab. 1. fig. 2. La femelle. - Cebrio brevicomis. Ross. Mantiss. tom. I. pag. $34 . n^{\circ}$. 84. La femelle. - Cistela gigas. Ross. Faun. Etrusc. tom. r. pag. 100. $n^{\circ}$. 256. tab. 7. fig. 9. Le màle. - Cebrio longicornis. Ross. Mantiss. tont. 1. pag. 34. $n^{\circ} .83$. Le mâle. - P'Anz. Faun. Germ. fas. 5. fig. 10. Le mâle.

Longueur \& pouce. 'Téte et corselet ferrugineux, finement pointillés. Antennes, abdomen et pattes testacés. Ełytres de mếme couleur, béautes postérieurement, plus courtes que l'abdomen, ne couviant point d'ailes. Femelle.

I.e mûle a la tête et le corselet plus bruns, les ćlytres recouvreut des ailes et l'abdonen en entier; elles se rejoignent tout le long de la suture.

Du midi de la France et d'Italie. Rossi a vu le mâle entrer la nuil dans son appartement après nne grande plaie et se jeter sur les lnmières; c'étoit vers le commencement de septembre.

$$
\text { (S. F. et A. SERv.) }
$$

RIHPIDIE, Rhipidia. M. Meigen dans son ouvrage sur les Diptères d'lurope donne ce nom à un genre de la famille des Némocères, tribu des Tipulaires; il appartient à la division des Tipulaires terricoles de M. Latreille et paroît voisin des Cténophores et des Lirnnobies; son caractère est : anteunes dirigées en avant, composées de quatorze articles, le premier cylindrique, le second et le troisième en forme de coupe, les suivans globuleux, écartés les uns des autres; celles des nałles bipectinćes. Pulpes avancés, courbes, cylindriques, de quatre articles presqu'égaux entrenx. Point d'yeux lisses. Ailes parallèles, se recouvrant l'une l'autre dans le repos. L'auteur n'en donne qu'uue espèce sous le nom de Rlzipidia maculata. Il en ligure le mále !ab. 5, nos. 9-11.

(S. F. et A. Skrv.)

RHIPIPHORE, Rhipiphorus. Bosc. LAt. FAB. Ouv. (Entom.) Paxz. Mordella. Linn. Ross. Osiv. (Encycl.)

Genre d'insectes de l'ordre des Coléoptères, section des Hétéromères, faunille des 'Trachélides, tribu des Mordellones.

Dans cette rriou les Mordelles, les Anaspes et les Scrapties se distinguent des Rhipiphores par leurs antennes simples ou seulement dentées en scie ainsi que parle dernier arlicle de leurs palpes maxillaires grand, sécurifornie; les Myodes ou inyodiles et les Pélécotones sont reconnoissables par les crochets de leurs társes dentés en peigne. Antennes composées de onze articles, pectinćes des deux cốlés dans les máles, d'un seul côté dans les femelles, à commencer du second ou du troisieme arlicle. - Labre avancé, coriace, demiovale. - Mandzbules arquées, creusées en dedans, dépourvues de dents, leur extrémité aiguë. -Mâchoires ayant leurs lobes sétacés, l'extérieur long, linéaire, saillant, l'intérienraigu. - Palpes presque filiformes, ayant lenr second article long, obconique; les maxillaires de quatre articles, le dernier semblable anx autres; les labiaux de trois, le dernier ovalaire. - Lèvre alongée, étroite et membraneuse à sa base, prenant ensuite la forme d'un cœur et devenant coriace; languette alongée, profondément bifide. - Corselet ayant le milieu el les deux angles latéraux de son extrémité postérieuı e prolongés en 


\section{R II I}

pointe. - Ecusson trìs-petit. - Elytres rétrécies en pointe et écartées l'une de l'aulre vers leur extrémité. Ailes étendues, plus longues que les élytres. - Pattes assez longues; tarses composés d'articles entiers, le dernier muni de deux crochets simplement bifides.

Ce genre fondé par M. Bosc et publié ensuite par Fabricius tire son nom de deux mols grecs qui signifient: porte-panache. On trouve ces insectes en Anŕrique, en Asie et en Europe, leur taille est petite ou moyenne; ils ne sont pas communs et fréquentent les fleurs ou les nlcères des arbres; on doil croire que leurs larves sont parasites d'après ce que l'on sait de celle du Rlipiphore paradoxal.

re. Division. Anteunes pectinées à partir du second article, la base de celui-ci presque cachée dans l'intérieur du prenier; le dernier long, linéaire comme les rameaux des articles précédens. -Têle ayant son sommet droil, déprimé, de niveạu avec l'extrémité antérieure du corselet; face de la tête formant un angle avec lecorselet. Corselet ayant un sillon dans son milieu et terminé postérieurement vis-à-vis de l'écusson par un lobe très-obtus et arrondi.-Abdomen presqu'aussi long que les ailes.

1. Rnipiphore paradoxal, $R$. paradoxus.

Rhipiphorus abdomine, thoracis lateribus elytrisque apice excepto, rufescenti-flavis.

Rhipiphorus paradoxus. FAB. Syst. Eleut. tonı. 2. pag. $119 . n^{\circ} .6$ - OLiv. Entom. tom. 3. Ripiph. pag. 7. $n^{\circ} \cdot 7 \cdot p l$. 1. fig. 7. La femelle. PAтк. Faun. Suec.tom. 2. pag. 177. $n^{\circ}$. 1. - LAт. Gen. Crust. et Ins. tom. 2. pag. 207. no. 1. Panz. Faun. Germ.fas. 26. fig. 14. Le mâle. - Mordella paradoxa. Ross. Faun. Etrusc. tom. 1. pag. 244. $n^{\circ} \cdot 603$.

I.ongueur 5 lig. Antennes, pattes et eorselet noirs, côtés de celui-ci d'un roux-jaunâtre. Elyties de celte couleur, à l'exceplion de leur ext:émilé postérieure qui est noire. Abdomen d'un roux-jaunâtre.

La femelle a souvent beaucoup plus de noir au corselet et aux élytres. $M$. Latreille pense que le $R$. angulatus de Panzer, Faun. Germ.fas. go. fig. 3, n'est qu'urie variété de ce sexe.

Des environs de Paris. Il est rare.

Nota. La larve de cetle espèce que l'on trouve à l'état parfait vers la fin de l'été, vit et snbit ses métamorphoses dans le nid de la Guêpe commune (Vespa vulgaris) et dans celui de la Guêpe frélon (Vespa crabro).

Voyez pour les autres synonymes la Mordelle paradoxale $n^{\circ} .4$ de ce Dictionnaire.

2०. Division. Antennes pectinées à partir du troisième article; le second ayant sa ljase libre, le dernier s'élargissant de la base à l'exı́rémité en forme de triangle renversé; lenrs rameaux plus courts que dans la précédente division. - Tète ayant son sommet comprimé, arrondi, élevé audessus de l'extrémité antérieure du corselet. Corselet saus sillon, teruniné vis-à-vis de l'écusson par un angle un peu pointu. - Abdomen plus court que les élytres.

Rapportez à celle division, ${ }^{\circ}$. Ia Mordelle flageliée no. 5 de ce Dictionnaire. (Rhip. flabellatus. FAB. Syst. Eleut. tom. 2. pag. $\left.119 . n^{\circ} \cdot 7.\right)$ $2^{\circ}$. La Mordelle bimaculée $n^{\circ}$. 8. $(R h i p$. bimuculatus. FА в. Syst. Eleut. tom. 2. pag. 120. $n^{\circ}, 15$. Panz. Faun. Germ. fas. 22. fig. 7. OLIV. Entom. tom. 3. Ripiph. pag. 5. $n^{\circ}$. 4. pl. 1.fig. 4. a.b.) 3०. Le Rhipiphorus spinosus. Fав. Syst. Eleut. tom. 2. pag. $119 \cdot n^{\circ}$. 4. $4^{\circ}$. La Mordelle partagée no. 9. (Rhip. dinidiatus. FAB. Syst. Eleut. tom. 2. pag. 120. n०. 16. Encycl. pl. 361 . fig. 27 et 28.) 5\%. La Mordelle bordée $n^{\circ}$. 10. (Rhip. limbatus. FА B. Syst. Eleut. tom. 2. pag. $121 . n^{\circ}$. I9. Oniv. Entom. tom. 3. Ripiph. pag. 6. $n^{\circ}$. 5. $p l$. 1. fig. 5.) 6०. La Mordelle six taches no. 7. Rhip. sexmaculatus. FAB. Syst. Eleut. tom. 2. pag. I 20. $n^{\circ}$. 12. Or.1v. Entom. tom. 3. Ripiph. pag. 7. $n^{\circ}$.6.pl. 1.fig. 6.)

MYODITE, Myodes. LAT. Rhipiphorus. FAB. Ouiv. (Entom.) P Parz.

Gente d'insectes de l'ordre des Coléoplères, section des Hétéronières; famille des 'Trachélides, tribu des Mordellones.

Dans le groupe de cette tribu qui a pour caractères : antennes en érentail; palpes presque filiformes, le genre Rhipipbore se distingue par l'extrémité des crochets de ses tarses qui est bifide et les Pélécotomes parce que chaque article des antennes dans les mâles ne jette qu'un seul ramesu et que leurs antennes sont insérées au-devant des yeux près de la bouche.

Antennes flabelliformes, insérées sur le front, eomposées de onze articlcs, les quatre premier's sans appendice laléral; les autres en ayant deurs, un de chaque côlé, ces appendices plus courrts dans les femelles. - Labre corné, ovale, alongé, terminé par deux soies. - Mandzbules cornćes, arquées, sans dents. - Mâchoires niembraneuses, très-courtes, obtuses. - Palpes inégaux, filiformes, les maxillaires plus longs, composés de quatre articles alongés, le premier très-pelit, le second le plus grand de tous; les labiaux de trois articles à peu près égaux. - Lève cornée postérieuremeni, membraneuse à sa partie antósieure. - Tête arrondie supérieurement, très-inclinée seus le corselet. - Corselet convexe, point hordé, rétréci antérieurement. - Elytres très-courtes, voûtées; ailes découvertes, étendues. - Abdomen grand, alongé. - Pattes de longrueur moyenne; crochets des tarses eutiers à leur ex. $\mathrm{O} 02$ 
trémité, dentelés en pcigne le long de leur côté inférieur.

On ne connoît pas les mours des Myodites; le noın de ce genre dû̀ à M. Latreille vient du grec et exprime qu'il a de la ressemblance avec une mouche. La seule espèce connue se trouve, mais très-rarement sur les fleurs.

\section{- Mrodite musciforue, $M$. subdipteris.}

Myodes niger, elytris pallidis, abdomine fomince pallide testaceo upice nigro, marisomnino nigro.

Rlipiphorus subdipterus. Fав.Syst.Eleut.tom.2. pag. 118. no. 1.- OLIv. Entom. toms. 5. Ripiph. pag. 4. $n^{\circ}$. I. pl. I. fig. I. Mâle et femelle. Panz. Faun. Germı. fus. 97. fig. 7. La femelle.

Longueur 3 à 4 lig. Antcnnes courtes, celles du mâle jaimes, leurs sept derniers articles jetant chacun des rimeaux de chaque côté ; celles dela femelle noires, leurs articles n'ayant des rameaux que d'un seul côté, ceux-ci plus courts que dans l'autre scxe. 'Tête et corselet noirs, élytres d'un janne-pâle. Abdomen de la femelle de cette couleur avec l'anus noir; l'abdomen du mâle entièrement noir. Pattes d'un brun-noirâtrc unçlé d'un pen de roux-jaunâtre.

Il sc trouve en Languerloc et dans tout le midi de l'Europe. Il est rare.

\section{(S. F. et A. SERv.)}

RHIPIP'TERES, Rhipiptera. LAt. Ord̆re onzième de la division métbodique des insectes, selon M. Latreille; scs caractères sont :

Six pattes. - Deux ailes membraneuses, plissées en éventail. - Deux corps crustacés mobiles en forme de pelites ćlytres, situés à l'extrémité antérieure du corselet. - Organes de la manducation consistant en deux simples mûchoires sétiformes avec dcux palpes.

Les insectes ds cet ordre désignés d'abord par M. Kirby sous le nom de Strepsiptèrcs ont deux or ce sont deux petits corps crustacés, mobiles, insérés aux deux extrémités antérieures du tronc, près du cou ct de la base extérieure des deux premic̀res pattcs, rejetés en arrièrc, étroits, alongés, dilatés en massue vers leur extrémité, courbes au bout et se terminant à l'origine dcs ailes; ces organes ont la forme de petites élytres et l'insecte s'en aide pour marcher ainsi que pour voler, en lenr donnant un mouvement ondulatoire. Les ailes sont grandes, membraneuses, divisées par des nervures longitudinales qui forment des rayons; elles se plient dans leur longueur en manière d'éventail, ce que le nom de Rhipiptère tiré de deux mots grecs, exprime parfaitement. Leur bouch e est composée de quatre pièces dont deux plus courtes sont des palpes composés de deux articles : les de ux au-
$\mathrm{R} \mathrm{HO}$

tres insćrés prc̀s de la base interne des précédentes ont la formc de petites lames linéaires, pointues et se croiscnt à leur extrúnité; ces parties sont des mâchoires, mais elles resseınblent beaucoup aux soies qui composcnt lc suçoir des Diptères. Les yeux sont gros, hémisphériques, un peu pédiculés et grenus, les antcnnes presque filiformes, courtes, composées de trois articles, les deux premiers trèscourts, le troisième long, divisé jusqu'à son origine en deux branches; les yeux lisses manquent. Le corselet est analogue à celui des Cicadaires et des Psylles. L'écusson est granå et recouvre eis partie l'abdomen; celui-ci est cylindrique el paroît formé de sept à huit segmens outre l'anus; it se tcrmine (au moins dans un scxe que nous croyons être le masculin ) par des pic̀ces fort analogues à celles des mâles dc la tribu des Cicadelles, ordre des Hémiptèrcs. Les pattes sont presquc membraneuses, comprimées, à peu près égales et terminées par des tarses filiformes, composés de quatre articles unembraneux, comme vésiculaircs à leur extrémitć, dont le dernier un pcu plus grand n'offre point de crochets. (La figure du Stylops melitto donné par M. Kirby, tab. 14, fig. 1 I, Monogr. Apum Anglice, tom. I, semble leur en accorder.) les quatre paltes antérieures sont très-rapprochées, lcs autres rejetées ell arric̀re; l'espacc de la poitrine compris entre celles - ci est très-ample et divisé en dcux par un sillon longitudinal; les côtés du métathorax sur lesquels s'insère cette dernière paire de pattes forment en arrière, par leur dilatation, l'écusson dont nous venons de parler.

Les Rlipiptèrcs ont lc vol prompt et fucile; ils vivent en état de larve entre les écailles des segmens de l'abdomen de quelques espèces d'Hyménoptères des genres Poliste et Halicte. La larve est ovale-oblongue,-sans pattes; sa bouche est formée de trois tubercules au moyen desquels on croit qu'elle suce sa nourriture aux dépens dcs insectes que nous venons de désigner. Ces larves se mćtamorphosent en nymphes dans la mêne place où elles out vécu; leur propre peau est leur senle enveloppe dans cet état.

Cet ordre nc contient que deux genres, Xénos et Stylops. Voyez ces mots.

$$
\text { (S. F. et A. Serv.) }
$$

RHOMbille (1), Gonoplax. LÉach. Cancer. Linn. Fab. Genrc de Crustacés décapodes, famille des Brachyures, tribu des Quadrilatères, ayant pour caractères : Corps en trapèze transversal, plus large au bord antérieur et commençant à se rétrécir à ses angles latéraux; chaperon en carré transversal, recou vrant les antenncs intermédiaires. Yeux insérés près du milieu du front,

(1) Certe dénomination, proposée par M. de Lamarck, me paroîr plus significative en notre langue, que celle de gonoplace. 


\section{$\mathrm{R} \mathrm{HO}$}

et portés sur des pédicules fort longs et grêles. Antennes latérales insérées au-dessous du canthus interne des cavités oculaires, composées d'un pédicule court, cylindrique, et d'une tige longue, menue, sétacée et multiarliculaire. Troisième article des pieds-mâchoires extéricurs presque carré; son côté inlerne tronqué obliquement à sa partie supérieure et formant un angle vers son milieu. Serres grandes, beaucoup plus longues et plus cylindriques dans les nâles; pinces des jeunes individus du unême sexe et des femelles proportionnellement plus courtes et plus larges; le carpe court et arrondi; les autres pattes Tongues, grêles, unies, terminées par un tarse conique, pointu, sans épines, paroissant, du moins quaıt aux derniers, comprimé dans un autre seus que les pattes, ou un peu plus large, vinen dessus, que hat, avec quelques stries garnies de poil; ; celles de la quatrième paire et de la troisième ensuite surpassant les autres en longueur; celles de la seconde el de la dernière pare presun'égales. $A b$ domen de sept segmens dans les deux sexes; celui des mâles en triaugle alongé, plus large et dilaté angulairement à l'origine du troisiène article; les deux premiers plas courts, très-étroits, linéaires, réunis l'un à l'autre au moyen d'une memJirane déconverte; le dernier triangulaire, de la largeur du précédent à sa base. Abdomen de la femelle en forme d'ovale tronqué, resserré à sạ naissance et cilié sur ses bords. Corps généralement uni et gíabre.

\section{Rrombille biépineuse, $G$. bispinosa.}

Gonoplax bispinosa. LÉACH. Malacost. Podoph. Brit. tab. 13. - Gonoplax longimanus. LAm. Ejusd. G. angulatus. - Cancer rhomboides. Linn. FAB. - Cuncer angulatus. FAB. - Ocypode rhomboides. Bosc. OLIv. - Ocypode angulata, eoruind. - Tongimana. Risso. - Her is'r , Krabben, tab. 1.jg. 12. 13.

Longueur du test des plus grands individus

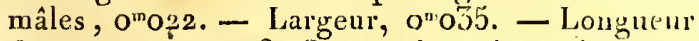
des serres, $\mathrm{o}^{\mathrm{m}} \mathbf{1} 16$. Corps d'un blanc-inciarnit pâle, dans les individus jeunes et ceux du moyeu âge, roussâtre ou rougeâtre dans les plus grauds. 'Test un peu plus élevé transversalement, un peu avant son milieu; nne dent plus ou moins distincte, lantôt aiguë, tantôt obtuse, aux extrénités antérieures de cetle élévation; angles antérieurs des côtés prolongés en une dei: forte et pointue; chaperon rebordé en devant. Serres égales, plus épaisses que les pattes suivantes, longues, surtout dans les mâles âgés, avec les bras et les mains fort alongés; une dent terwinée par un aiguillou sur le dessus du bras; uue autre et petite au côté interne du carpe; mains un peu plus hautes que larges, unies, arrondies sur leurs tranches, s'élargissant un peu et graduellement de la base à l'origine des doigts; ces doigts d'un tiers environ plus

courls que le poing, droils; coniques, comprimés, simplement ponctués, termisér en pointe aiguë et un peu crochue; bords inlernes de ceux de la serre gauche connirens ou rapprochés dans toute leur longuear, entièrement dentelés; dentelures nombreuses, petites, iúgales, li plupart pointues et s'enyiaiuant réciproquessen; doigls de la serre droite écartés eutr'eux à leur naissance, offrant, au aêtne bord, des dents plus fortes, mais variables, et dont quelques-unes en forme de grosses verrues; une die celle sorle, pius robuste à l'origine de ce bord dans plusieurs individus; la plus grande partie du pouce noixatre; ure dent près de l'extrénité supérieure cảes ruisses des autles paltes.

Serres des femelles et des jeunesindividns mâles plus courtes, ayec les mains en ovale-oblong avec les doights entièreuent contigus intéricurement.

Côles maritimes d'Angleterre; celles de nos départenens de l'Ouest, M. d'Orbigny; Méditerrannée, Barrelier, el MM. Risso et de Lalande fils. Daprès les observations de M. Risso, ce Crustacé se tient ordinairement dans les fentes des rochers submergés., à une profondeur de vingl à trente mètres. Il marche sur ce fond avec deatérité, et sapproclie de la surface de l'eau, mais sans jamais en sortir. Il se nourrit de petits poissons et de radiaires qu'il poursuit mêne dans les filets des pêcheurs. Il n'abandonne sa proie que lorsqu'il se sent entraîné lior's de l'eau. L'on n'en prend jamais qu'un ou deux dans le même lieu, ce qui ammonce qu'il vit solitaire. (Latr.)

RHYGUS, Rhygus. M. Dalman a fondé re genre adopté par M. Gernar (Ins. Spec. nov. vol. 1. Coleopt. 1824). Il est de la famille des Rhynchophores, tribu des Charansonites de M. Latrellle et offre pour caractècs : rostre court. épais, parallélipip̀ède, plus épais vers le bout; ses fossettes anguleuses, se courbant brusquement vers le dessous. Yeux globuleux, saillans. Autennes plus longues que le corselet, coudées; leur fouet de sept articles égaux eatr'eux, en massue. Corselet lobé auprès des yeux, échancré en dessous près de la base de la tête. Ecusson petit, distinct. Elytres grandes, bossues, recouvraut des ailes. Pattes assez longues, presqu'égales entr'elles. Jambes de devant armées intérieurement d'une dent aiguë.

M. Germar décrit comme érant de ce genre. trois espèces, dont l'une est le Curculio tribuloides de Pallas et d'Herbst. (S. F. et A. SERt.)

RHYNCHÈNE, Rhynchonus. RAB, OLr. (En* tom.) LAT. (Règ.anim.) Cunculio. LinN. Grorz. Clantr. Fab. Lixus, Calandra, Allelabus. Fab.

Genre d'insectes de l'ordre des Coléoptères. section des 'Tétramères, famille des Rhyacion phores, ribu des Charasonites. 
M. Clairville avoit créé le nom de nhyncì̀ne pour désigner des Charansonites sauleurs; les autenrs moderves ont préféré à ce nom celui d'Orclueste. Fabricius en s'emparant de la déuomination de Rhyuchène réunit sous ce nom aux Rhynchènes de M. Clairville ou Orchestes des auteur's, les especes dont on a fait depuis le grenre Cryptorhynque, quelques Lixes, les Lipares, les Ciones, peut-être quelques Rhinodes et en outre tout ce que l'on comprend aujourd'hui sous le nom de Rhynchènes. Olivier dans son Entomologie restreignit ee genre en adrettant ceux d'Orcheste et de Cione et en créant celui de lipare, mais il ne distingua point les Cryptorhynques des Rhynchènes. Mi. Latreille avoit d'abord appliqué le nom de Rhynchène aux Orchestes; depuis il adopta ce dernier noun et du genre auquel il donnoit celui de Claranson se formèrent cen : de Rlyynchène et de Cryptorhynque; d'après cela les Bracliyrrhines de cet auteur perditent Jeur dénomination et prirent celle de Cluaranson.

Les gen res Orcheste, Cione, Chasanson, Lixe, Lipare, Rhyncliène, Cryptorhynque, Rhine, Calandre et Cosson se distinguent des autres Charansonites par leurs antenues coudées dont le premier article est très-long. Ces parties n'out que dix arlicles ou moins dans les Ciones, les Orchestes, les Rhines, les Calandres et les Cossons. Dans les Charansons les antennes sont iusérées à l'extrérnilé du prolongemeut de la tête; dans les Lixes et les Lipares la massue des antennes est de quatre articles au moins. Les Cryptorhyngues ont en dessons du corselet un sillon longritudinal qui reçoit le prolongement de la tête dans l'élat de repos. Ces caracières distiuguent suffisamment ces genres de celui de Rhynchène tel que nous l'entendons avec $\mathrm{M}$. Latreille.

Antennes coudćes, insérćes vers le milien du prolongenent de la têle, composées de ouze articles, le premier très-long, les trois derniers formanl subitcment une massue ovale. - Mandizules larges, dilatćes sur le côté externe de leur base et arquées ensuite, biclentées vers l'extrémité. - Lève presque nulle. - Palpes peu appurens. - Tête ayant un prolongement rosiriforme très-long, man festement plus étroit qu'elle, sillonné laléralement pour recevoir le premier article des antennes dans le repos, un peu courbé en devant el portant à son extrémiléles parties de la bouche. - Corps ovale-arrondi. - Corselet sans sillon longitudinal en dessons, se rétrécissant vers la tête, a peu près de la largenr des élytres dans la partie qui les avoisine. - Pattes anbulatoires, lungues; jambes ayant sonve.nt un crochet à l'extrémité de leır partie interne; troisième ariicle des tarses bilobé.

Le nom de ce genre est dérivé d'un mot grec qui signifie : bec. Il contieat plus de cent cinquaute espèces, l'Europe en renferme un assez grand nombre. Voyez pour les généralitís le mot Charanson.

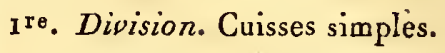

\section{Rhynchène picirostre, $R$. picirostris.}

Rhynchanus picirostris. FAB. Syst. Eleut. tom. 2. pag. 449. $n^{\circ} .55$. - Oliv. Entom. toin. 5. pag. 139. $7^{\circ}$. 97. Charans, pl. 33. fig. 507. GYLLENH. Ins. Suer. tom. I. part. 3. pag. 121. no. 48. - Curculio picirostris. PAYK. Faun. Suec. tom. 3. pag. 253. no. 73. - Sibinia picirostris. Germ. Ins. Spec. nov. Coleopt. I. pag. 291. $n^{\circ} \cdot 4$.

Voyez pour la description et les autres synonymes Charanson picirostre no. 58.

\section{Rhynchìne du Lychnis, R. Viscario.}

Rhynchonus Viscario. FAB. Syst. Eleut. tom. 2. pag. 449. $n^{\circ}$. 56. - G rulent. Ins. Suec. tom. 1. part. 3. pag. $132 . n^{\circ} .56$. - Curculio Viscaria. Park. Faun. Suec. tom. 3. pag. 261. no. 82. Stbinia Viscarice. Germ. Ins. Spec. nov. Coleopt. 1, pag. 291. no. 1 .

Voyez ponr la de cription et les antres synonymes Charanson du Lychnis no. 106.

\section{Rhynchine en croix, $R$. crux.}

Rhynchanus crux. FAB. Syst. Eleut. tom. 2. pag. 455. n०. 87. - OLiv. Entoni. tom. 5. pag. 154. no. 120. Charans. pl. 29. fig. 440. - Balaninus crux. Gera. Mlagaz. Entome. 1821. pag. $296 . n^{\circ} \cdot 7$.

Des environs de Paris.

Nota. 11 ne paroît pas probable qu'il faille avec M. Germar rapporter à celte espéce les Cunculio salicis el iota de Panzer.

Voyez pour la description et les autres synonymes Cliaranson en croix $n^{\circ} .73$.

\section{Rhy nchène de la Prêle, R. Equiseti.}

Rhynchoenus Equiseti. FA B. Syst. Eleut. tom. 2. pag. 443. $\pi^{\circ}$. 24. - Oliv. Entom. tom. 5. pag. 115. $n^{\circ}$.60. Charans. pl. 27. fig. 400. - Curculio Equiseti. PAx . Faun. Suec. tom. 3. pag. 226. 1 $^{\circ}$. 44. - Cunculio nigro-gıbbosus. DEGÉEK, Ins. 5. pag. 224. $n^{\circ}$. 17. - Curculio Equisetr. Panz. Faun. Germ. fas. 42. fis. 4 -

Iroyez pour la description el les autres synonymes Charanson de la Prêle $n^{\circ} .34$.

\section{Rhynchìne acridule, $R$. acridulus.}

Rhynchopnus acridulus. FА в. Syst. Eleut. tom. 2. pag. 454. $n^{\circ} \cdot 79 .-G_{\mathrm{LLENH}}$ Ins. Suec. tom. I. part. 3. pag. $75 . n^{\circ}$. 1о. - Ourv. Entom. tona. 5. pag. 147. no. I09. Charans. pl. 27.fig. 400. 


\section{R H Y}

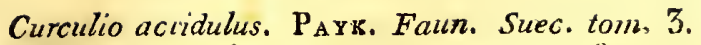
pag. 238. $n^{\circ}$. 56. - P ANz. Faun. Gern. fas. 42. fig. 10.

Voyez pour la description et les autres synonymes Charanson acridule $n^{\circ} .69$, en excluant la citation de Geoftioy.

\section{Rhynchine bicolor, $R$. bicolor.}

Rhynchonus feuroribus muticis, fuscus, thoracis lateribus elytrorumque busi et sutur's rufo-toinentosâ ; antennis, rostro, pedibusque testaceis.

\section{Ellescus bicolor. DEJ. (Catalog.)}

Longueur 3 lig. Bruaâtre, duveteux. Côtés du corselet, base des ćlytres et la suture ayant leur duvet roussâlie. Anteunes, lête tl palltes lestacées. Elytres strićes.

Environs de Paris.

7. Rhyncuène biponctué, $R$. bipunctatus.

Rhynchoenus hipunctutus. Faв. Syst. Eleut. tom. 2.pag. 452. $n^{\circ} .70$. OLiv. Entom. tom. 5. pag. 153. n'. 118. C'harans. pl. 29. fig. 439. Gy rlent. Ins. Suec. tom, 1. part. 5. pag. IIg. $n^{\circ}$. 46. - Curculio bipunetatus. РАхк. Faun. Suec. tom. 3. pag. 250. $2^{\circ}$.69. - Panz. Falln. Gurn. fas. 42. fig. 7. - Hypera bipunctata. Germ. Magaz. Enloul. 1821. pag. $338 . n^{\circ} .4$.

Voyez pour la description et les autres synonywes Charansom uniponctué ${ }^{\circ} .107$.

\section{Raynchène nigrirostie, $R$. nigrirostris.}

Khynchanus nigriostizs. FAu. Syst. Eleut. tom. 2. pag. $448 . n^{\circ}$. 53. - G Y Llexi H. Ins. Sluec. tom. 1. part. 5. pug. 114. $n^{\circ} .42 .-$ Oniv. Entour. tom. 5.pag. 140. no. 98. Charans. pl. 33. fg. 508. -c Curculio nigrirostrzs. PАY K. Faun. Suec.tom. 3. pag. 247. $n^{\circ} \cdot 67 \cdot-$ Panz. Faun. Germ. fils. 36. fig. 14. - Hypera nigruostris. Gекм. Magaz Entom. pag. 358. $n^{n} .5$.

Cumuun aux environs de Paris.

Voyez pour la deseription et les autres synonymes Charansou nigricostre $n^{\circ} .55$.

9. Ruyncežne du Polygronum, R. Polygoni.

Rhynchanus Polygoni. Ouiv. Entom, tom, 5. pag. 125. $n^{\circ} .75$. Charans. pl. 27. fig. 3go. GYLlent. Ins. Suec, toln. I. part. 3. pag. Iog. $n^{\circ}$. 39. - Curculio Polygont. Fав. Syst. Eleut. tom. 2. pag. 520. $n^{\circ}$. 77. - PAYK. Fiaun. Suec. toln. 3. pag. 228. $n^{\circ}$. 46 . - Panz. Faun. Gelm. fas. 19. fig. 10.- Hypera Polygoni.Germ. Nagaz. Entolu. 1821. pag. 342. $n^{\circ} .15$.

Voyez pour la description et les antres synonyunes Charasson du Polygonum a ${ }^{\circ}$. 2 go.
10. Raynchère du Pin, R. Pini.

Rhynchonus Pini. Fав. Syst. Eleut. tom. 2. pag. 440. $n^{\circ} \cdot 7 \cdot$ - Grilenh. Ins. Suec. tom. 1. part. 3. paø. 66. no. 3. - OLtv. Entont tom. 5. pag. 116. nn. 61. Charans. pl. 16. fig. 4\%. b. c. -Curculio Pini. Payx. Faun. Suec. tom. 5. Fas. 225. $n^{\circ}$. 43. - PANz. Faun. Gern. fas. 42. for. 1. - Encjel.pl. 225. fig. 13.

Nota. Les élytres ont un tubercule vers leur parie postérieure. Voyez pour la description et les antres synonymes Charanson du Pin $n^{\circ} .22$, els excluant la citation de l'Entonologie d'Olivier, qui doil être rapportée au Rbyarhene du Sapin 12". 164 .

11. Raxnchène du Rumex, R. Rumicis.

Rhynchanus Runicis. FAB. Syst. Elteut.tom. 2.

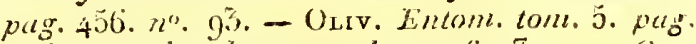
$126 . n^{\prime \prime}$. F0. Charans. pl. 27. fig. 391. - Cur culio Rumicis. Paxk. Fuzn. Succ. tom. 万o, pug. $229.7 \iota^{\circ} \cdot 47$.

Nota. M. le comte Dejean regarde le Cuculio murnus de Fabricius comose appartesant a cello espèce.

Voyez pour la description, les aures synonymes et les délails de moeur's, Claaranson de l'useille $\mathrm{n}^{\circ} .77$; ces détails sunt extraits des Ménoires de De Géer; ce que cel auteur dit sur ta conformation des larves du Rhynchene de l'oseilles (Charanson De G.) ne nous laisse aucun doule, les uyant véritićs nous-mèmes, que les larves dout les Odyuères approvisiounent leur's nids no soient celles de ciuelques Charansonites voisines de celles-ci. Nous semarquerons en outre gue ha position de ces larves daus le nid de l'Odynere esi absoluusent celle ou elles se tienneut naturelleinent dans leurs coques. Vozez De Géer aricite cilé et Réamaur tosn. 6. pag. 25 เ el suivantes.

12. Ray nchève du Plantuin, R. Plantaginis.

Rhynchanus Plantagini.j. FAн. Syst. Eleut.

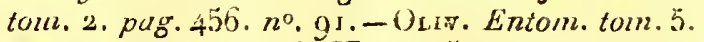
pag. 128. $n^{\circ} \cdot 79 \cdot p l$. 33. fig. 5ı. - GYLLENA. Ins. Suec. tom. 1. pait. 3. pag. : o3. no. 34. -... C'urculio Plantugizus. PA Y K. Faun. Suec, tom. 3. pag. $251 . n^{\circ} \cdot 480 .-$ Hypera Plantaginis. Gerir. Magaz. Entom. 1821. pag. 343. no. 16.

Voyez pour la description ei les autres syonnymes Chararsion du Pluatiza $n^{6} \cdot 7^{6}$.

13. Rexncaise limide, R. tursians.

Rhynchanus fenoribus muticis, ovato-ooblongus, uter, mithdus, et, tris puraclis uter stinas șem riatzs.

Rhynchareus timidus. Orry. E'niom. Cort.

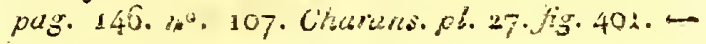




\section{6}

Cálundra nitens. FAB. Syst. Eleut. tom, 2, pag. 436. $n^{\circ} .35$. - Curculio timidus. Ross. Mantiss. pag. 37. no.92. - Baris nitens. G⿺廴м. Ins. Spec. nov. Coleopt. I. pag. 199.

Longneur 3 lig. Très-noir, luisant. Corselet finement pointillé. Elytres à slries ponctuées; on voit entre ces stries une suile die très-petits points enfoncés. Antennes et pattes no.res.

De Perse et des iles de l'Archipel; on le trouve aussi en flalie et daus le midi de la France.

14. Ruynchène anal, $R$. analis.

Rhynchoenus analis. OLIv. Entoni. tom. 5. pag. $151 . n^{\circ}$. 1 15. Charans. pl. 16. fig. 197. a. b. - Encycl. pl. 226. fig. 10.

Voyez pour la description Charanson anal n. 80 .

\section{Ruynchène de l'Absinthe, $R$. Absinthii.}

Rhynchonus femoritus mnticis, elongatus, ater, nitidus; thorace punctato, elytis striatis, inter strias punctatis.

Rhynchonus Artenisioe. Oriv. Entom. tom. 5. pag. $150 . n^{\circ}$. I13. Charans. pl. 29. fig. 430. (en excluant la syuonymie de Fabricius et peulêtre aussi celle de Paykull.) - Baris Absinthii. DEJ. (Catal.) - Curculio Artenuisice. PANZ. Funn. Germ. fas. 18. fig. 10.

Lougueur 2 lig. Alongé, noir, luisant. Corselet large postéricurement, ponctué en dessns et en dessous ainsi que l'abdomen et les cuisses. Elytres striées, ponctućes entre les stries.

Des environs de Paris.

Nota. Nous ne croyons pas que cette espèce soit le Baris Artemisioe de M. Germar. Cet auteur paroît s'être trompé en citant Olivier.

\section{Rhyncmine cuprirostre, $R$. cuprirostris.}

Rhynchanuscuprirostris. Ourv. Entom. tom 5. pag. 1 $49 \cdot n^{\circ}$. II I. Charans. pl. 27. fig. 408.Attelabus cuprirostris. Fав. Syst. Eleut. tom. 2. pag. 424. no. 4I. - Panz. Faun. Germ. fas. 94. fig. 7. - Baris cuprirostris. Germ. Ins. Spec. nov. Coleopt. 1. pag. 199.

Voyez pour la description et les autres synonymes Charanson cuprirostre $n^{\circ} .54$.

17. Rнхnchìne de l'Arroche, $R$. Atriplicis.

Rhynchonus femoribus muticis, elongatus, ater, subtùs albo squamosus, elytris striatis et inter strias pilis albis brevibus.

Rhynchanus Atriplicis. OLIv. Entom. ton. 5. pag. 148. $n^{\circ}$. 110. Charans. pl. 27. fg. 404. Rhynchcenus T. album. Gyul, Ins. Suec. tom. I. part. 3. pag. 79. $n^{\circ}$. 14. - Lixus Atriplicis. $\mathrm{F}_{\mathrm{AB}}$.

\section{R H Y}

Syst. Eleut. tom. 2. pag. 504. no. 3r. - Curculio Atriplicis. PAYK. Faun. Suec. tom. 3. pag. 243. no. 62. - Curculio T. album. IInN. Syst. Nat. 2. 6og. 23. - Baris T. album. Gram. Ins. Spec. nov. Coleopt. 1. pag. 199. - La Pleureuse. GeOF. Ins. Paris tonz. I. pag. 285. no. 7 .

Longueur 2 lig. Alongé, noir, corselet ponctué, large postérieurement. Elytres striées avec une ligne de points eufoncés entre chaque strie. Dessous da corps et surtout ses côtés chargés d'écailles blanches. Cuisses ponctuées. 'Tous les points énoncés portent chacun un petit poil blanc très-court.

Environs de Paris.

Nota. Cette espèce est la même que celles décrites imparfaitement dans ce Dictionnaire, sous les noms de Charanson de l'Atriplex no. $9^{8}$ et Charanson T. blanc u. $^{\circ}$ 104. M. Gyllenhal peuse avec Illiger que ce Rhynchène n'est pas le Lixus atriplecis de Fabricius.

Rapportez à cette première division les Rhynchoenus scirpi, oethiops, chloris et aneus. H'ав. Syst. Eleut. ainsi que les Rhynchonus suspiciosus et acetosa. Oriv. Entom.

\section{Division. Cuisses dentées.}

\section{Rhynchène valide, $R$. validus.}

Rhynchoirus validus. Otrv. Entom. tom. 5. pag. 157. $n^{\circ} \cdot 124$. Charans. pl. 15. fig. 186. FAB. Syst. Eleut. tom. 2. pag. 458. $\pi^{\circ}$. Io3, et Rhyncharnus calcaratus. pag. $457 \cdot n^{\circ} \cdot 9^{5}$. Encycl. pl. 227. fig. 8.

Voyez pour la description Charanson valide no. 131.

19. Rhynchise miliaire, $R$. miliaris.

Rhynchanus miliaris. FAB. Syst. Eleut. tom. 2. pag. $457 . n^{\circ} \cdot 99$. - Ouiv. Entom. tom. 5. pag. 159. $n^{\circ}$. 126 . Charans. pi. 3. fig. 33. - Encycl. pl. $227 \cdot$ fig. 6 .

Nota. L'extrémité des quatre jambes postérieures est ciliée de poils norrs extérieurement.

Voyez pour la description Charanson miliaire $\mathrm{n}^{\circ}$. 129 .

20. ReYvChìne six-taches, $R$. sexmaculatus.

Rhynchanus sexmaculatus. OLIv. Entom. tom. 5. pag. 166. $n^{\circ}$. 157. Charans. pl. 17. fig. 207 .

Voyez pont la description Charanson six-taches $n^{\circ}$. 145 .

21. Rhychìne hystrix, $R$. hystrix.

Rhynchonus hystrix. Fав. Syst. Eleut. tom. 2. pag. 462. no. 121. - Ousv. Entom. tom. 5. pag. 
167. no. 138. Charans.pl. 15. fg. 82. -Encycl. pl. 228. fig. 6 .

Voyez pour la description Charanson histrix no. 147 .

22. RuYnchène de Dufresne, $R$. Dufresnii.

Rhynchœenus femoribus dentatis, niger tomentosus, rostri elytrorumque basi, thoracis posticâ parte corporeqne subtus aureo tomentosis, elytrorum maculis sex aurantiacis.

Rhynchcenus Dufresnii. Krвв. Linn. Trans. 2'ol. 12. tab. 22. fig. 20. - Ameris Dufresnii. DEJ. (Catal.)

Longueur 8 lig. Noir, duveteux. Ce duvet dun jaune un peu doré sur la base du prolongement rostriforme de la tête, la partie postérieure du corselet, la base des élytres, le dessous du corps à l'exception des deux avant-derniers sègmens de l'abdomen et les jambes. Corselet fortement tuberculé. Elytres striées, tuberculées, portant chacune trois grandes taches d'un bel aurore sur leur partie noire. Extrémité des quatre jambes postérieures ciliée de poils noirs extérieurement. 'Toute la couleur de cet insecte est due au duvet qui le recouvie.

Du Brésil.

Nota. Le Rhynchanus pardalis. DAxMr. AnaEect. Entom. Holm. 1823. pag. 85. $n^{\circ} \cdot 9^{2}$, uous paroit être celte espèce décrite d'après un individu dont les couleurs éioient altérées.

23. Rиynchìve Ynca, R. Inca.

Rhynchanus femoribus dentatis, niger, luteo tomentosus, nigro tuberculatus.

\section{Ameris Ynca. Des. (Catal.)}

Longueur 9 lig. Noir, couvert d'un duvet grisjaunâtre semé de tubercules noirs, excepté sur la tête et sur les pattes. Extrémité des quatre jambes postérieures ciliée de poils noirs extérieurement.

Du Brésil.

\section{Rhynchìne Paon, R. Pavo.}

Rhynchanus fentoribus dentatis, niger luteo prosertion subtis squamosus, elytrorum striatopunctatorum maculis tribus squamoso-fernigine is luteo cinctis.

Ameris Pavo. Germ. Ins. Spec. nov. Coleopt. I. pag. 286. $n^{\circ} \cdot 425$.

Longueur 5 à 6 lig. Noir. Antennes brunes à massue noire. Tête chargée d'écailles jaunâtres à l'exception de l'extrémité de son prolongement. Corselet chagriné ayant de semblables écailles surtout sur les côtés et en dessous, avec une tache latérale près de la tête, ferrugineuse entourée de Hist. Nat. Ins. Tome $\boldsymbol{X}$. jaune. Elytres ayant des points enfuncés rangr's en stries, cbargées d'écailles jaunes et de trois taches ferrugineuses sur chacune, entourécs de jaune. La première placéc à la base près de l'ćcussou, la seconde plus loin que le milieu, s'étendant un peu vers le bord extérieur, la troisième vers l'extrémité. Dessous du corps couvert d'écailles jaunes ainsi que les paltes, celles-ci de couleur lestacée.

Du Brésil.

25. Rhynchène dentipède, $R$. dentipes.

Rhyruchaonus dentipes. Fав. Syst. Eleut. tom. 2. pag. 465. $n^{\circ}$. 135. - Oniv. Eatom. tom. 5. pas. 202. $n^{\circ}$. ! 88. Charans. pl. 8. fig. go. a. b. Encycl. pl. 228. fig. 10.

Voyez pour la description Claranson dentipède $n^{\circ} .153$.

26. Rhrochène cinq-poinls, $R$. quinquepunctatus.

Rhynchonus quinquepunctatus. FAs. SYst. Eleut. tom. 2. pag. 482. $n^{\circ}$. 204.-Os.iv. Entom". tom. 5. pag. 208. no. 197. Charans. pl. 2.\%. fig. 33o. -Gy LlenH. Ins. Suec. tom. 1. part. 3. pag. 197. $n^{\circ}$. 110. - Curculio quinquepunctatus. PAYE. Faun. Suec, tom. 3. pag. $20 \mathrm{I}$ no. 18: - Panz. Faun. Gemn.fas. 84. fig. 8.

Voyez pour la description et les autres synonymes Charanson cinq-points no. 188.

27. Reyvchène des hoiseltes, $R$. nucum.

Rhynchanus nucum. FAв. Syst. Elext. tom.2。 pag. 486. $n^{\circ} .228$. - OLIv. Entom. tom. 5.pag. 215. $n^{0}$. 207. Charans. pl. 5. fig. 47.-G y LL. Ins. Suec. tom. 1. part. 3. pag. 201. no. 113. - Curculio nucum. Ross. Faun. Etrus. tom. 1.pag. $123 . n^{\circ} .314$. - PAYK. Faun. Suec. tom. 3. pag. 204. $n^{\circ}$. 20. - Panz. Faun. Gem. fis. 42. fig. 21 . - Encycl. pl. 229. fig. 13. a. b. c. d. -Balaninus nucrum. Germ. MIagas. Entom. I821. pag. 284. $n^{\circ} .3$.

$V o y e z$ pour la description et les autres synonymes Charanson des noiselles no. 201.

Nota. M. Germar croit que le synonyme de Panzer appartient plulôt au $R$. "gulosins de Fab.

28. Rhynchène dés cerises, $R$. cerasotum.

Rhynchanus cerasorum. FAB. Syst. Eleut. tom. 2. pag. 488. no. 238.-OLrv. Entom. tom. 5. pag.224. $n^{\circ} .218$. Charuns.pl. 4. fig. 35. - Curculio cerasorum. PAYX. Faun. Suec. tom. 3. pag. 206. no. 22. - Panz. Faun. Genn. fas: 42. fig. 23.

Nota. On le trouve dans toute l'Europe.

Voyez pour la description et les autres synow nymes Charauson des cerises $\mu^{\circ}: 207$. 
2q. Ruyncà̇e velu, $R$. villosus.

Rhynchanus villosus. $\mathrm{F}_{\mathrm{AB}}$. Syst. Eleut. 1om.2. pag. $484 . n^{\circ} .218$. - Oriv. Entom. tom. 5. pag. 229. n०. 225. Charans, pl.5ं.fig.525:-Curculio villosus. P PY r. Faun. Suec. tom. 3. pag. 205. $n^{\circ}$. 21 .

Nota. On le trouve aux environs de Paris. Cotte espèce appartient au genre Balanimus de M. Germar.

Voyez pour la description et les autres synonymes Charanson velu no. 194.

30. Ruynchìne louleur, $R$. tortrix.

Rhynchanus tortrix. F. S. Syst. Eleut. tom. 2. pag. $491 . n^{\circ} \cdot 252$. - Oliv. Lntom. tom. 5. pag. 200. $n^{\circ} .213$. Charans. pl. 34. /ig. 521 . - Gy2L. Ins. Suec. tom. 1. part. 3. pag. 173. $n^{\circ} \cdot 9^{1}$. Curculio tortrix. РА у K. Fann. Suec. tom. 3. pug. 192. no. 9. - Cearnv. Entom. Helv. pag. 92. 7i. 8. pl. 9. fig. 3 et 4. - 1'ANZ. Faun. Genn. fis. 18. fig. 14 .

Voyez pour la description et les autres synonymes Charanson rouleur no. 214.

3ı. Rhynchìne du Tremble, $R$. Tremulae.

Rhynchanus Tremula. FAB. Syst. Eleut. tom. 2. pag. $49^{2} . n^{\circ}$. 253. - Oulv. Entom. tom. 5. pag. 221. $n^{\circ}$. 214. Chamns. pl. 34. fig. 520. a. b. Gyllen. Ins. Suec. tom. J. part. 3. pag. 171. no. 90. - Curculio Tremulae. PАYK. Faun. Suec. tom. 3. pag. $189 \cdot n^{\circ} \cdot 6$.

Des environs de Paris.

Voyez pour la description et les autres synonymes Charanson du Tremblen ${ }^{\circ}$. 2 I 5 .

32. Rynchìve rubané, $R$. toeniatus.

Rhynchanus torniatus. F А B. Syst. Eleut. tom.2. pag. 492. $n^{\circ} \cdot 255$. - Otıv. Entom, tomb. 5. pag. 223. $n^{\circ} .217$. Charans. pl. 22. fig. 307. - GYLl. Ins. Suec. tom. 1. part. 3. pag. I $75 . n^{\circ} \cdot 9^{3} \cdot-$ Curculio toniatus. PAYK. Fuun. Suec, tom. 3. pag. 191. no. 8 .

Voyez pour la descripion et les autres synonymes Charanson rubané no. 2 i 6 .

\section{Reynchìre des vergers, $R$, pomorum.}

Rhynchoemus ponzorum. FAB. Syst. Eleut. tonı. 2. pag. 491. $n^{\circ}$. 25o. - On1v. Entom. tom. 5. pag. 224. $n^{\circ} .219$. Charans. pl. 3. fig. 27. a. b. - Gy LL. Ins. Suec, tom. 1. part. 3. pag. 188. $n^{\circ}$. 103. - Curculio ponzorum. PAY K. Faun. Suec. tom. 3. pag. 199. $n^{\circ}$. $16 .-$ Anthonomus pomorum. Geru. Magaz. Entom. 1821. pag. 323. $n^{\circ} .3$.

Voyez pour la description et les autres synonymes Charanson des vergers $n^{\circ} .213$.
34. Ray cuèse parsemé, $R$. conspersus.

Rhynchanus conspersus. OuIv. Entom. tom. 5. pag. $170 . n^{0} \cdot 143$. Charans. pl. 14. fig. 179:Lixus roreus. Faв. Syst. Eleut. tom. 2. pag. 505. $n^{\circ} .35$ ? - Encjcl. pl. 228. fgr. 14.

$V o y e z$ pour la descriplion et les autres synonymes Cliarauson parsené no. $35 \mathrm{~g}$.

35. Rнyсcuèse anuulé, $R$. anñulatus.

Rhynharnus annulatus. FАв. S st. Elent. tom 2. pag. 463. $n^{\circ}$. 128. - Ouv. Entom. tom. 5. pug. $170 . n^{\circ}$. 148. Charans. pl. 6. Jig. 62. a. b. - Encycl. pl. 228. fis. 11.

Voyez pour la description et les autres synonymes Charanson ansulé $n^{\circ}$. $154 .-$

36. Rhyncaìne oculé, $R$. ocellatus.

Rhynchœenus ocellatus. F $\mathrm{F}_{\text {B }}$. Syst. Eleut. tom.2. pag. 472. $\|^{\circ}$. 168. - OIIv. Entom. tom. 5. pag. 183. $n^{\circ}$. 162. Charans. pl. 3. fig. 31. - Encjel. pl. 229. fig. 8.

Voyez pour la description et les autres synonymes Churanson oculé $n^{\circ}, 181$.

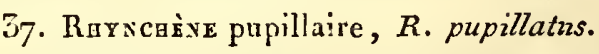

Rhynchonus pupillatus. Oliv. Entom.tom. 5. pag. 184. $n^{\circ}$. 163. Charans. pl. 15. fig. 183. Rhynchanus pupillator. Fав. Syst. Eleut. tom. 2. pag. $466 . n^{\circ}$. 37 .

Voyez pour la description Charanson pupillaire $n^{\circ} .{ }^{1}$ jo.

38. Rиулснѐne moucheté, $R$. multigutlatus.

Rhynchanus multiguttatus. FAB. Syst. Eleut. tom.'2. pag. 465. $n^{\circ}$. 136.-OL18. Entom. tom. 5. pag. 182. Charans. pl. 13. fig. 163. - Encycl. pl. 229. fig. 2.

De Cayenne.

Voyez pour la description Charanson mulimoucheté no. 369 .

39. Rhyncaìne couronné, $R$. coronatus.

Rhynchanus coronatus. FAB. Syst. Eleut. tom. 2. pag. 45g. $n^{\circ}$. 105 . - Osiv. Eutom. tom. 5. pag. 163. $n^{\circ}$. 132. Charans. pl. 6. fig. 70. - Encycl. pl. 227. fig. 9.

Voyez pour la descriplion Charanson couronné, $n^{0} .132$.

40. Rayscà̀se du Sapin, R. Abietis.

Rhynchanus Abietis. Fав. Syst. Eleut. tom. 2. pag. 464. $n^{\circ}$. 13o. - Otiv. Entom. tom. 5. pag. 185. no. 164. Charans. pl. 4. fo. 42, et pl. 7 , 


\section{R H Y}

\$g. 78. a.b.-GrLd. Ins. Suec. iom. 1. part. 3. pag. 166. no. 86. - Curculio Abietis. Pay . Faun. Suec, tom. 3. pag. 186. $n^{\circ}$. 3. - Panz. Faun. Germ. fos. 42 fig. 14 .

Voyez pour ia descriplion el les autres synogymes Charauson du Sapin $\mathbf{u}^{\circ}$. I64.

\section{Rhyxcrène caligineux, R. caliginosus.}

Rhynchcenus caliginosus. Ouv. Entom.tom. 5. pag. 191. $n^{\circ}$. 172. Charans. pl. 22. fig. 3oo. Lixus culiginosus. FAB. Syst. Eleut. tom. 2. pag. 504. $n^{\circ} .33$. - Plinthus caliginosus. Germ. Ins. Spec. nov. Coleopt. 1. pag. $330 . n^{\circ} .469$.

Vovez pour la description et les autres synonymes Charanson ealigiueux no. 156 .

42. Rhynemìne pieoté, $R$. apiatus.

Rhynchonus femoribus dentatis, niger, nitidus, maculis rufo tomentosis, in thorace sinuatis, in clytris subrotundis.

Rhynchœnus apiatus. Ourv. Entom. tom. 5. par. 171. $n^{\circ}$. 144. Charans. pl. 28 . fig. 424.

Longueur to lig. Alongé, noir, luisant. Têle, corselet, cuisses et dessous du corps ayant un peu de duvel roussâtre. Corselet earéné, chagriué, avec quelques laches sinueuses sur ses côtés. Elytres ayint des lignes lougitudinales de points enfoncés et chargćes de taches irrégulières presque tontes arrondies. Les taches sont formées par des plaques de poils ronx. Extrémité des quatre jambes postérieures ciliée de poils noirs extérieurement.

De Cayenne et re Surinam.

\section{RuYnchène Panthère, $R$. pantherinus.}

Rhynchanus pantherinus. OLIv. Entom. tom. 4 . pag. $177 \cdot n^{\circ} \cdot 154$. Charans. pl. 13. fg. 153. Rhynchoenusmarmoreus. Fа в. Syst. Eleut. tom.2. pag. 462. $n^{\circ} .122$. - Encycl. pl. 228. fg. 16.

Voyez pour la deseription Claranson Panthère $n^{\circ} .161$.

\section{Ruynehène charbonnier, $R$. carbonarius.}

Rhynchonus carbonarius. FaB. Syst. Eleut. tom. 2. pag. $485 . n^{\circ} .224$ - OLrv. Entom. tom. 5. pag. 228. no. 223. Churans. pl. 34. fig. 518. Curculio carbonarius. РАY к. Faun. Suec. tom. 3. pag. 194.no. 11. - Pavz. Faun. Germ. fits. 42. fig. 18.

Nota. Nous pensons que cet insecte est le Magdalis carbonaria de M. Germar. Ins. Spec. nov. Colcopt. 1. pag. 193.

Voyez pour la descriplion et les autres synonymes Charanson charbonuier $n^{\circ}$. 184 .
45. Reyncazve dorsul, R. dorsalis.

Rhynchanus dorsatis. FA B. Syst. Eleut.tom. 2. pag. 454. no. 83. - Osiv. Entom. tom. 5. pag. 155. no. 122. Charans. pl. 14. fir. 169. a. b. GyLl. Ins. Suec. tom. 1. part. 3. pag. 176. no. sog. - Curculio dorsalis. Pay z. Faun. Suec. tom. 3. pag. 200. no. 17. - Pavz. Faun. Gerin. fas. 17. fig. 9. - Encycl. pl. 226. fig. 6.

Nota. Fabrieins et Olivier placent à tort celte espèce parmi celles à cuisses simples.

Voyez pour la descriplion el les autres synonymes Charanson dorsal $u^{\circ} \cdot 70$.

On placera dans celle division les Rhynchornus avarus, pectoralis, vorax et rana. liab. Syst. Eleut. et les Rhynchanus leopardus el laticollis. Utrv. Entom.

CfOne, Cionlis. Clamrv. Lat. Orrv. (Entomi) Rhynchoonus. Fab. Curculio. Lixn. Geoff. De GEER. Oniv. (Encycl.)

Geure dinsectes de l'ordre des Coléoptères, section des'Tétramères, famille des Rhyuchophores, tribu des Charansonites.

Parmi les genres de cette tribu qui ont les anrenues eoudées avec leur premier article trislong, eeux de Charanson, Lixe, Lipare, Rlynchène et Cryptorhynque ont plus de dix articles aux antennes; les Rhines et les Calandres n'en ont que huit, les Cossons en on! neuf et les Orchestes qui cn -ont dix comme les Ciones se distinguent facilement de ees derniers par leurs paltes postérieures propres à sauter et par la massue de leur's antennes nayanl que trois articles.

Antennes eoudées, insérées un peu après le milieu du prolongement de la tête, composées de dix articles, le premier long, les quatre derniers réunis en une massue ovale.-Mandibules courtes. - Lèvre presque nulle. - Palpes peu apparens. - T'éte ayant un prolongement rostriforme fort long, manifestement plus étroit qu'elle, sillonué latéralement pour recevoir le preuier article des antennes dans le repos, peu courbé en devant et portanl à son extrémilé les parties da la bouehe. - Corps globuleux. - Corselet petit, ayant sa partie postérieure presque de moitié plus étroite que les élytres. - Elytres convexes, presqu'aussi larges que longues, se reeourbant postérieurement et couvrant des ailes. - Abdomen grand, presque earré. - Pattes de longueur moyenue, propres à la marehe; tarses ayant leur troisième ar. tiele élargi, cordiforme, profondément bilobé.

Le nom de ce genre est celui que les Grecs donnoient à des insectes qui attaquoient les grains. Plusieurs espèces vivent tant sous'la forme de larve qu'en état parfait surles Serophulaires et les Verbaseums.

Rapportez aux Ciones les Rhynchoenus scro. phularice, verbasci, thapsiss et blattarioe de Fав. Syst. Eleut. (auxquels il faut eomparer les Cha$1 p_{2}$ 
ransons de la Serophulaire ${ }^{\circ}$. 185 , et da Verbas(um n ${ }^{\circ}$. 86 deceDiclionnaire.) Le Rhynchanus olens de Fab. est encore de ce genre.

LIXE, Lixus. Fab. Oliv. (Entom.) Curculio. 1.uxv. Geoff. De Géer. Fab. Oriv. (Encycl.) Rhynchanus. FАв.

Genre d'insectes de l'ordre des Coléoptères, section des 'Tétramères, famille des Rhynchophores, tribu des Charansonites.

Dans le groupe de Charausonites fracticornes qui a les antenues counposées de onzearticles, les genles Charanson, Rhynchène el Cryptorhynque ont la massue des antenues forméc de trois articles seutement; les Lipares qui cornme les Lixes ont la massue de quatre articles, s'eu distiuguent en ce que celle massue est formée brusquement et de figure ovale.

Antennes condées, insérées près du milieu du prolongement de la tête, composées de onze articles, le premier plus court que le prolongement, u'alteignant pas au-delà des yeux, leur massue de quatre articles, en fuseau alongé et formée pre equ'inseusiblement. -- Mandibules larges, leur côlé extérieur arqué avec un sinus ì sa base. lè̀ve cornée, en carré transversal, petite, entière. - Palpes très-courts. - Téte ayant un prolongement rostriforme long, manifestement jlus élroit qu'elle, sillonné latéralement pour recevoir le premier article des antennes dans le rejos, un peu courbé en devant et portant à son extrémilé les parties de la bouche. - Corps ordinaireurent étroit, alongé, quelquefois filiforme. - Corselet se rétrécissant vers la tête, presque de la largeur des élytres à sa parlie postérieure. Elytres très-dures, recouvrant l'abdomen. Pirtes de longueur moyenne; jambes ayant une sent forte, cornée, à la partie antérieure de leur extrémité; tarses garnis en dessous de fortes pelotes spongieuses, leur pénultième article bilobé , he dernier nuuni de deux forts crochets.

Plusieurs espèces de Lixes fréquentent les fleurs synanthérées el particnlièrement les Chardons; itautres se trouvent par terre dans les páturages et au bord des chemins : celle nommée paraplecticus se tient sur la Phellandrie (Phellandrium aquaticum). V̌oyez pour ses maurs le Charanson paravlectique $n^{\circ} .82$ de cet onvrage. Les larves vivent en géuéral dans les tiges des plantes, elles s'y transforment et n'en sortent qu'à l'état partiil.

Rapportez à ce genre les Charansons rétréci $\mathrm{s}^{\circ} \cdot 9^{2}$. pl. 227 . fig. 1 , serpent $\mathrm{n}^{\circ} \cdot 85$. pl. 226 . tig. 12 , huit lignes no. 84. pl. 226. fig. 15, semiponctué no. 85 . pl. 226. fig. 16 , paraplectique $1^{\circ}$. 32. pl. 226. fig. I I d'Ascanius n ${ }^{\circ}$. 94. pl. 227 . fig. 2, filiforme $n^{\circ} .87$. pl. 226. fig. ${ }^{19}$, cylindrique $n^{\circ} .88$. pl. 226. fig. ı 8 , mucroné no. go. f.l. 226. fig. 17 de ce Diclionnaire.

Les especes suivantes doirent entrer dans le geure Cleonis. DEs. Catal. (démemhrement des. Lixus). Les Charansons livide no. 325. pl. 231. fig. 26 , sulcirostre ${ }^{\circ} .266$. pl. 23ı. fig. 1, nébuleux $n^{\circ}$. 265. pl. 23o. fig. i 8. (le synonyıne de Geoffroy nous semble douteux), tigré no.267. pl. 23r. fig. 2. (Curculio morbillosus. FaB. Syst. Eleut. tom. 2. pag. 514. no. 45), grammique $\mathrm{n}^{\circ}$. 282. pl. 23 $\mathrm{I}$. fig. 8, ophtalmique $\mathrm{n}^{\circ} .280$, (Curculio distinctus. FA B. Syst. Eleut. tom. 2.pag. $516 . n^{\circ} .56$ ), blanchâlre $n^{\circ} .27^{2}$, tabide $n^{\circ} .28 \%$, barbaresque $n^{\circ} .279$, plissé $n^{\circ} .258$ (le synonyme de Geoffioy ne paroit pas convenir) de ce Diclionnaire et les Lixes pacifique $n^{\circ} .282$, a rabe $n^{n} .265$, fauue $n^{\circ} .280$, allernant $n^{\circ} .257$, treillé $n^{\circ} .263$, madide $n^{\circ} .259$, déclive $n^{\circ} .288$, du Myagre $n^{\circ} .253$, palmé no. 246, de l'Entomologie d'Olivier.

On doit rapporler au genre Rhinobate DEJ. Catal. (démembrement des Lixus), les Charansons pulvérulent $\mathrm{n}^{\circ}$. 158. pl. 228, fig. 13, de l'Artichaut $n^{\circ} .27$ (le synonyme de Geofiroy est très-douleux), de la Jacée $n^{\circ} .25$ du présent Dictionnaire ainsi que les Lixes du Scolyne $n^{\circ} .292$, buccinateur $n^{\circ}$. 29 l et de la Carliue $n^{\circ}$. 3or de l'Entomologie d'Olivier.

Nota. Les caractères des genres Cléonis et Rbinobate ne nous sont pas connus.

I.IPARE, Liparus. Ontr.(Entont.)Lat.(Consid.) Rhynchanus, Curculio. FAB. Curculio. Linn. Geofr. Payk. Panz. Oliv. (Encycl.)

Geure d'insectes de l'ordre des Colóoptères, section des 'Tétramères, famille des Rhynchophores, tribu des Charansonites.

Parmi les Charansonites fracticornes à antennes de onze articles, les genres Charanson, Rhynchène et Cryptorhynque ont luit de ces articles distincts avant la massue, celle-ci n'étant composée que de trois; dans les Lipares et dans les Lixes on ne distingue que sept articles avant la massue, celle-ci étant formée de quatre (voyez RHYNCrophores), mais ce dernier genre est séparé des Lipares en ce que celte massue est en fuseau alongé et formée presqu'insensiblement.

Antennes coudées, insérées un peu au-delà du milieu dn prolongement de la tête, composíes de ouze articles, lÆ premier fort long, les sept suivans petits, mais distincts; les quatre derniers qui formeut brusquement la massue, peu distincts. - Mandibules courtes, arrondies et bidentées à leur extrémité. - Palpes très-courts. - Téte ayant un prolongement rostriforme long, manifestement plus étroit qu'elle, sillouné látéralement pour recevoir le premier article des antennes dans le repos, portant à son extrémité les parties de la bouche. - Corselet rétréci à sa partic antérieure. - Elytres très-dures, reconvrant l'abdomen. - Abdomen gros. - Pattes de longueur moyenne; jacobes terminées par un onglet solide; tarses garnis en dessous de fortes 


\section{R II Y}

peiotes spon rienses, leai pénulième arivle bilobé, le dcrnier muni de deux forts crochels.

Les insectes de ce gemre dont le nom vicnt d'un mol grec qui signifie : renflé, vivent ordinairement à terre et ne sont pas vifs dans leurs mouvemens; la plupart manquant d'ailes; les espèces sont en pelit nombre, elles habitent l'ancien contineat, l'Europe principalement. Leurs lidres ne nous sunt point connues.

Rapportez à ce genre le Charanson germain n? 183. pl. 229. fig. 10 de ce Dictionnaire (en selranchant le synonyıne de Linné; ceux de Scopoli, de Sulzer, de Sclıæffer, de Schranck, de luaicharting, de Deviller's sont douteax), et les Lipares, $1^{\circ}$. tacheté de brun $n^{\circ} .307$ (Curculio gemmanus. LivN.); $2^{\circ}$. siuistre $n^{\circ} .310$ (Cunculio glabratus. FA B. Syst. Eleut.); 50. porte-faix $n^{\circ} .512$ de l'Entomologie d'Olivier.

Les Cluaranson colon $n^{\circ} .28$, et bimaculé $n^{\circ} .29$ de ce Dictionnaire duivent se rapporter au genre Lepyrus. DEs. Catal. (dérnembrement de celui de Lipare ). Le Charanson caréné no. 277 (Curculio sariolosus. Fав. Syst. Eleut. Liparus carinatus. Orav. Entom. $\left.n^{\circ} .316\right)$ appartient au genre $M e-$ léus. 1)es. Catal. (démembrement du genre Lipare ).

Nola. Nous ignorons les caractères des genres Lepyrus et Meleus.

CRYPTORHYNQUE, Cryptorhynchus. Itrtg. L.at. (Consid.) Rhynchanus. VAB. Oruv. (Entom.) Curculio. Linn. De Géer. Payk. Geoff. Panz. () LIV. (Encycl.)

Genre d'insectes de l'ordre des Culéoptères, section des 'Fétranıères, firmille des Rlyynchoploores, tribu des Charansonites.

Les autennes ayant liuit articlesavant la massue, celle-ci composée de trois, tel est le caractère d'un groupe de Charansonites fracticornes (voyez Rнукснорновеs) dans lequel se rangent les genres Charanson, Rlynchène et Crypiorhynque. Le premier a ses antennes insérées vers l'extrémité du prolongement antérieur de la tête, cclui-ci toujours court et épais; ce genre ainsi que celui de Rhynchène n'a point de sillon à la poitrine pour recevoir dans le repos le prolongement de la tète.

Les caracières génériques des Cryplorbynques élant absolument les mêmes que ceux des Rhyncliènes, à l'exceprion de l'existence d'un sillon longitudiual sous le corselet, nous renvoyons à ce dernier genre pour éviter les répétitions. Pojez RaYNChine.

Le nom de ce genre est dérivé de deax mots grecs qui signifient : bec caché. Les Cryptorhynques contiennent plus de cent espèces dout la plupart habitent l'Europe. Quelques mâles exoliques ont deux corues placées latéralemeat sur le prolongement rostriforme de la tête. Voyez pourles généralités les articles Craransor et Rayzchopuoras.

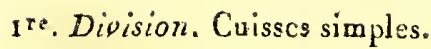

On rapportera à relte division les Charansons péricarpe $n^{\circ}$. 6o, jayet no 39 . pl. 226 . fig. 1 , e du Vélas 130. 64 de ee Dictionnaise.

\section{2e. Division. Cuisses dentées.}

A cette seconde division apparliennent les Chinransons'Iaureau no. 135. pl. 227 . fig. 10 et pl. 234. fog. 19, cornu n. 134. pl. 227. fig. 13, raboleux $\mathrm{n}^{\circ}$. 142 , bombine $\left.\mathrm{n}^{\circ} .138 . \mathrm{p}\right] 227$ fig. 14 , valiqueux pl. 228. fig. 3 , et Scorpion (ces deux del-

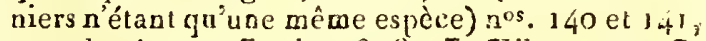
nouchetć no. 143. pl. 228 . fig. 3 , Hibou no. $163 y_{3}$ de la Patience $n^{\circ} .171$, stigmate ${ }^{\circ} .151$, trimitculé $n^{\circ} .192$, didyme n०. I go, goultelte $n^{\circ} .189$, troglodyte $n^{\circ}$. I 96 de ce Dictionnaire.

Nota. Nous ne doutons pas qu'il n'y ail d'autres cspèces de ce genre décrites parniles Cliaransons de cet ouvrage, mais l'auieur ne faisant point nien." tion de la prósence ou de l'absence du sillon pectoral qui distingue les Cryptorhynques, nous ne pouvons citer avec certitude que les précédentes.

Les autcurs moderncs ont dispersé ces Charansonites dans différens genres et particinlièremcnt dans ceux de Falciger, Campylirhynchus, Cryptorhynchus et Eccoptus. DEs. Catal.

CALANDRE, Calundra. Clatrv. Fab. IAt. Oliv. (Entom.) Curculio. Linv. Geoff. De GEer. Oliv. (Encycl.) Rhynchophorus. HERBst.

Genre d'insectes de l'ordre des Coléoptères, section des 'Tétramèrcs, famille des Rhynchophores, tribu des Charansonites.

'Tous les Charansonites ont plus de huit articles aux antennes, à l'exception des genres Rline et Calaudre ; les premières se distingruent de celles. ci par l'insertion de leurs autennes vers le usiliea du prolongement de la têlc ct par la forme cylindracée très-alongèe de la massue.

Antennes coudées, insérées prés des jenx it la base latérale et iuférieure dn prolongement de la tête, composées de huit articles, le premier fort tong, les six suivans courts, le seconci et le troisième presqu'égaux entr'eux, obconiques, un peu plus longs que les qualre d'après, les quatrième, ciuquième, sixieme et septièmc semi-globuleux, égaux entr'eux, le liuilième tantôt en massue presque triangulaire, revêtue d'une peau coriace, composée intéricurement d'une substance molle, comme spongieuse; son cxtrémité comprimée transversalement, son bord antérieur formant uns petite pointe aiguë : ‘antôt en une massue ovale globuleuse que la pcau coriace ne recourre pas en entier, en sorte qu'on apercoil la substance spongieuse qui en sortant semble former un neuvième article, son extrémité comprimée des deux côtés, son bord antérieur tronqué, aign ; quelquefois en une masse ovale, - Mandibules obiuses, 
ayant trois crénelures dont l'apicale on l'intermédiaire est plus grande et plus profonde, leur extrémité ayant deux deats inégales, obtuses. Mâchoires ayant un appendice demi-membraneux, velu. - Palpes maxillaires très-petits; palpes lalbiaux nuls ou peu distincts. - Lère et menton réunis en un corps de substauce cornẹe, étroit, presque linéaire, un peu échancré au milien de son exırémité. - Tête plus étroite que le corselet, ayant un prolongement rostriforme manifestenient plus étroit qu'e!le, alongé, recourbé, cylindrique, grtêle, n'ayant point de sillon latéral pour recevoir le premier article des antennes dans le repos et porlant à son exlrémité les parties de la bouche. - Corps ovale-clliptique, un peu déprimé en des:us. - Corselet grand, rétréci antériecurement. - Elytres un peu aplaties en dessus, ne recourrant point l'anus. - Patles fortes; jambes cilićes intérieurement, terninécs par nue pointe forte et crochue, les deux ou les guatre antćrieures muidentées à lcur partie intérieure vers l'extrénitć; tarses ayant leur આroisiène article plus large que les antres, cordiforme, mais point distinctement bilobé, spongieux en dessons.

On connoît plus de trente espèces de ce genre ènt le nom vient d'un mot vulgaire appliqué dans plusieurs de nos provinces aux insecles qui dévorent les semences. L'un des scxes dans quelques espèces exotiques a sur le prolongement de lì têle un sillon longitudinal duquel sortent des poils roides et serrés qui forment une espèce de crête. Voyez pour les généralités le mot ChaRAKSON.

Rapportez aux Calandres les Charansons colosse n०. 2. pl. 224. fig. 2, palmisle no. 3. pl. 233. fig. 17 et 18, longipède no. 5. pl. 225. fig. 2, fcrJugineux no. 6. pl. 225. fig. 3.pl. 233. fig. 19 et pl. 234. fig. 1, géant no. 1. pl. 224. fig. 1, bordé $10^{0} \cdot 7 \cdot \mathrm{pl}$. 225 . fíg. 4, ensanglanté $\mathrm{n}^{0}$. 4. pl. 225 . fig. I, sangninolent no. 8. pl. 225. fig. 5, fuscié 20. 9. pl. 225. fig. 6, cafte no. 17. pl.225. fig. 9, Jubérra no.21. pl. 225. fíg. I1. (le synonyme de Fabricius est douteux ), hémiptère no. 14.1 l.225. fig. 7 , bariolé no. 15. pl. 225. fig. 8 , quadripustulé $\mathrm{n}^{\circ} .100 . \mathrm{pl}$. 227. tig. 3 , bituberculé $11^{\circ} .8 \mathrm{r}$, cu blé no. 78. pl. 226. fig. 8 , du ris no. 79 . pl. 226 . fig. 9 , et raccourci no. 35 . pl. 225 . fig 75 de ce Dictionnaire.

Cosson, Cossonus. Clalnt. Fab. Lat. Ótetv. (Entom.) Curculio. Fав. Payk. Panz.

Genre d'insectes de l'ordre des Coléoptères, section des Térranc̀res, fanille des Rhynchophores, trihu des Charansonilcs.

Parmi les Charansoniles fraclicornes, les OrGhestes et les Ciones ont les antennes composées de dix articles; les Rhines et les Calandres de huit : dans les genres Charanson, Rhynchène, Cryptorbynque, Lipare et Lixe, ces articles sont au nombre de onze, ce qui sépare tous ces genres de celui de Cosson,

Antennes coudées, insérées vers l'extrémitélatérale du prolongement de la lête, composées de neuf articles distincts, le prennier alougé, le second et le troisième un peu plus longs que les suivans; les quatrième, cinquième, sixième, septième et hui. lième très-courts, le reuvième formant une massue ovale que la peau coriace ne recouvre pas en entier, de sorte qu'on aperçoit la substance spongieuse qui en remplit l'intérieur et qui semble former un article particulier. - Mandibules aiguës, unidentces au côté interne, au-dessous de Pextrémité. - Palpes distiucts. - Lèvre presque nulle. - Tête àyant un prolongement rostriforme manifestement plus étroit qu'clle, sillonué latéralement pour recevoir le premier article des antennes dans le repos, un peu courbé en devant et portant à son extrénité les parties de la bouclee. - Corps alongé, presque linéaire, un peu déprimć en dessus. - Corselet plus élroil antćrienrement. - Ecusson peu distinct. - Elytres dures, recouviaul les ailes et l'abdomen. - Pattes de longueur moyenne; jambes terminées à leur partie intérieure par une épine crocliue; tarses linéaires, lcur troisième article d peine diflérent des précédens.

Le greare Cosson renferme peu d'espèces, elles labileat sous les écorces d’arbres; c'est lia probablement que les larves trotiveat lear subsistance: cette liabitude paroît rapprocher les Cossons des Scolytaires, première tribu de la famille des Xylophages.

Rapporlez à ce genre le Charanson linéaire $\mathrm{n}^{\circ} \cdot 9^{6}$ de ce Dictiounaire. (Cossonus linearis, Clairv. Entom. Helvét. pag. 5g. $n^{\circ}$. 1. pl. I, fig. 1. 2. et a. b. - Ouv. Entom. tom. 5. pag. 425. $n^{\circ} .525$. Charans. pl. 35. fgo. 534. a. b. c. - Curculio linearis. Panz. Faun Germ. fas. 18. fig. 7 .

Nota. M. Olivier mentionne à cet article une variété entièrement ferrugineuse qu'il nous paroit avoir décrile depuis daus son Entomologie sous le nom de Cosson ferrugineux (Cossonus ferrugineus. Clatav. Entom. Helvét. pag, 6o. $n^{\circ} .2 . p l$. 1. fig. 3.4 et C.)

Le Cossonus lymexylon. OLIV. Entom. tom. 5. plag. 427. $n^{\circ}$. 529. Charans. pl. 35. fig. 538 est regardé par MN. Mćgerle et Dejean (Catal.) comme le type du genre Bulbifer.

II. Latreille dans son Gener. Crust. et Ins. tom. 2. pag. 273 fait une seconde division dans le genre Cossonus; cette division nous paroît différer des espèces dont nous venons de parler par les caractères suivans. Prolongement antérieur de la tête très-court; dernier article des antennes entièrenent recouvert d'une peau coriace, point de sillon apparent propre à recevoir le premicr article des anlennes; corps presque cylindrique, son dos convexe; troisième article des tarses large. 


\section{$\mathrm{R} H \mathrm{Y}$}

cordiforme, Éclancré en dessus pour recevoir le quatrième. Là vient se placer l'Hylesinus chloropus. Faв. Syst. Eleut. Curculio chloropus. Panz. Faun. Germ. fas. 19. fig. 14. MH. Germar et Dejean (Catal.) metlent cet insecte dans leur gence Rhyncolus. (S. H. et A. Senv.)

RHYNCHITE, Rhynchites. Herbst. LAT. OLIv. (Entom.) Rhinomacer. Georf. Cuarrv. Attelabus. FaB. Oliv. (Encycl.) PaYK:

Genre d'insectes de l'urdie des Coléoptères, section des 'Tílramères, famille des Rhynchophores, tribu des Charansonites.

Les Charansoniles recticornes, c'est-à-dire à antennes droites, sont les genres Brente, Cylas, Apodère, Attelabe, Rhynchite, Apion, Brachycère et Rhamplue. Le caractère distinctif de ce dernier est d'avoir les antennes placées entre les yelix, à la base du prolongement rostriforme de Lit tête. Les Brachycères n'ont que neuf arlicles aux antennes, et tous les articles des tarses entiers; le prolongerment de la têle, dans les A pious, est cylindique ou conique, et leur abdomen est renllé, globuleux. L.es Brenies ont les antenucs presque liliformes et le corps linéaire; la unassue des autennes dans les Cylas n'est fornéc que d'un seul article. Les Apodères ont la tête dégagyé du corselet et un cou distinct. Enfin, les Attelabes ont le prolongement de la tête conrt, et leurs mandibules sont sans dentelures saillantes à leur partie exlérieure.

Antennes non coudées, insérées vers le milieu du prolongenent de la tête, composées de onze articles, les inlírieurs un peu plus longs, presque cylindrigues, cenx du milieu presque globuleux ou obconiques, les trois derniers distincts, formant réunis, une missue ovale, un peu perfoliée. Mandibules nunies d'une dent interne avant leur pointe, creusées intérieurement, ayant des dents rrès-apparenies sur leur convexilé extérieure. Mâchoires étroiles. - Palpes très-courts, peu apparens, couiques, les maxillaires de quatie articles, les labiaux de trois. - Levre peti!e, entière, peu apparente. - Téte pelite, à moitié enfoncée dans le corselet, ayant un prolongement rostriforme très-long, dilaté à l'extréhité. Corps ovale, allant en se rétrécissant en devant. - Corselet cylindro-conique, plus large postérieurement, portant souvent dans les inâles une épine latérale.-Abdomen carré, un peu arrondi posiérieurement. - Jambes ayant à leur extrémité deux épines très-petites, presque nulles; pénultième arlicle des tarses bilobé.

Ce genre dont le nom vient d'un mot grec qui siguifie: bec, renferme plus de trente espèces presque toutes européennes. Leur taille n'est pas grande; la plupart brillent de belles couleurs métalliques. Leur manière de vivre ne dilfère point de celle des Attelabes, non plus que leurs laryes. Foyez AтtrLaвE.
1. Rнy schíe Bacchus, R. Bacchus.

Rynchites Bacchus. LAT. Gen. Crust. et Ins. tom. 2. pag. 248. no. 1. - OL1v. Entom. tom. 5. pag. 20. $n^{\circ} \cdot 27 \cdot$ Attelab. pl. 2. fig. 27. a. b. c. Gyllene. Ins. Suec. tom. I. part. 3. pag. 25. no. 3. - Attelabus Bacchus. НА . Syst. Eleut. tom. 2. pag. $42 \mathrm{I} \cdot n^{\circ}$. 27. - PAXX. Faun. SlLe', tom. 3. pag. $17 \% n^{\circ}$. 4. - HAsz. Faun. Germ, fas. 2o. fig. 5. Mâle.

Voyez pour la description et les aulres synonymes Attelube cuivreux, no. 16. pl. 366. I. fig. 1. $a-d$.

\section{Rayrcnite du Bouleau, R. Betuleti.}

Rynchites betulce. Oriv. Ent. tom. 5, pag. 21. no. 2g. Attelab. pl. 2. fg. 29. a. b. - GYLIY甘. Ins. Suec. tom. 1. part. 3. pag. 1 g. $n^{\circ}$. 1. - Attelabus Betuleti. 1. Ав. Syst. Eleut. tom. 2. pag. 421. no. 28. - Paxz. Faun. Germ. fas. 20. fg. 6. Femelle. - Attelubus Fopuli. Parx. Finul. Suec. tom. 3. pag. 170. $n^{\circ} .3$, en excluant sa variété $\gamma$, qui est le Rhynchite du Peuplier.

Nota. On en trouve une variété dont tout los corps est violet.

Toyez pour la description et les autres synonymes Attelabe vert, no. 14, pl. 366, I. fig. 3.

\section{Rernchrte du Peuplier, R. Populi.}

Rynchites Populi. Oniv. Ent. tom. 5. pag. 20. no. 28. Attelab. pl. 2. fig. 28. Mâle. - G тLleni. Ins. Suec. tom. 1. part. 3. pag. 21. $n^{\circ} \cdot 2$. $-A t$ telabus Populi. F а . Syst. Eleut. torn. 2. pag. 422. n०. 29. - РАхв. Faun. Suec. tom. 3. pag. 17 I. $n^{\circ}$. 3. Variété $\gamma$. Panz. Faun. Gemm. fas, zo. fig. 7. Mâle.-Rhinomacer Populi. Clatrv. Ent. Helvet. pag. I Io. no. 2. tab. 13. frg. 3 et 4. Femelle.

Voyez pour la description et les autres synonynues Attelabe duré, no. 15, pl. 366,1 . fig. 2.

\section{Rhrnchite cramoisi, R. aquatus.}

Rynchites aquatus. Oniv. Entom. tom. 5. pag. 24. n०. 33. Attelab. pl. 2. fig. 53. - GYLL. Ins. Suec. tom. I. part. 3. pag. 25. n०. 5. - Attelabus aquatus. Hав. Syst. Eleut. tom. 2. pag. 422. no. 32. - PAYK. Faun. Suec. tom. 3. pag. 173. no. 6. - Panz. Faun. Germ. fas. 20. fig. 8.

Fayez pour la description et les autres syno. nymes, en excluant la citation de Linné, Attalabe cramoisi, n०. $17, \mathrm{pl} .366$, I. fig. 7 .

5. Raynchite bicolor, $\boldsymbol{R}$. bicolor.

Rynchites niger, capite (mstro excepto), thoracis dorso, scutello elytrisque rubris.

Rynchitos bicolor. Oxr. Ent. tom. 5. pasi =5, 
n?. 31. Attelab. pl. 2. fig. 3 1. - Attelabus bicolor. NAB. Syst. Eleut. tom. 2. pag. 422. no. 3o. Encycl. pl. 366. I. fig. 5.

Longueur 4 lig. Noir; lête, dessus du corselet, écusson et élytres rouges. Prolongement rostriforme de la tête noir. "Tête et corselet finement pointillés. Elytres poncluées, une partie de ces points formant des stries très-distinctes.

Il se trouve en Amérique.

6. Rarnchite pubescent, R. pubescens.

Rynchites pubescens. Otrv. Entom. tom. 5. pag. 24. no. 34. Atteiab. pl. 2. fig. 34. - Attelabus pubescens. FA в. Syst. Eleut. tom. 2. pag. $42 \mathrm{I}$. $n^{\circ} .25$. Paris.

De France; il est commun aux environs de

Voyez pour la description et les aulres synonymes Altelabe pubescent, $n^{\circ} .12$, pl. 366,1 , jig. 8.

\section{Rerncurte violet, $R$. alliarioe.}

Rynchites alliarice. OnIv. Ent. tom. 5.pag. 25. no. 35. Altelab. pl. 2. fig. 35. - Gy Luenh. Irts. Suec. tom. 1. part.3. pag. 26. $n^{\circ}$. 6. - Attelabus alliario. FАв. Syst. Elcut. tom. 2. pag. 425. $n^{\circ}$. 47. - PAYK. Faun. Suec. tom. 3. pag. 175. $n^{\circ} .8$.

Voyez pour la description et les autres synoaymes, en excluant la citation du no. 6 de Geoffioy, Attelabe violet, $\mathrm{n}^{\circ} .18, \mathrm{pl} .366^{\circ}, \mathrm{I}, \mathrm{fig} \cdot 9$.

8. Rhynchite poli, $R$, politus.

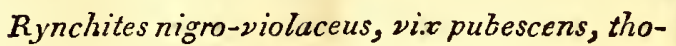
race elytrisque punctatis.

Rỹnchites politus. Stìv. (Dejean. Catalog.)

Longueur I lig. D'un noir-violet, un peu pubescent. Corselet et élytres ponctués irrégulièrenent.

De la Rnssie méridionale.

Rapportez à ce genre les Attelabus cupreus, hungaricus et corruleocephalus. FAв. Syst. Eleut.

Nota. Les Rhynchites nigripenne et à collier de l'Entomologie d'Olivier nous paroissent appartenir au genre Rhinomacer.

CYLAS, Cylas. Lat. Ourv. (Entom.) Brentus. FaB. Oliv. (Encycl.)

Genre d'insecres de l'ordre des Coléoptères, section des 'Tétramères, famille des Rhynchophores, tribu des Charansouites.

Les Charansonites recticornes qui ont les anrennes de onze articles sont les genres Brente, A podère, Attelabe, Rhynchite, Apion et Rhamphe; les Braclyycères n'ont leurs antennes que de neuf articles, ce qui distingue tous ces genres de celui de Cylas.

Antennes non coudées, moniliformes, plus courtes que le corselet, insérées vers' le miliea du prolongement de la tête, composées de dix arlicles distincls, les neuf premiers très-courts, le dernier grand, formant une massue ovale trèsalongée. - Mandibnles courles, bidentées à leuŕ exlrémité. - Mâchoires, palpes et lèure peu distincts; menton presqu'orbiculaire. - Tête ayant un prolongement rostriforme manifestement plus étroit qu'elle, plus épais à sa base qu’à son extrémilé, alongé, presque.cylindrique, point courbé, portant à son extrómité les parties de la bouche. - Yeux grands. - Corps alongé. - Corselet dila té antérieurement, ovale-globuleux, rétréci à sa partie postérieure et devenant brusquement cylindrique. - Ecusson nul. - Elytres dures, voûtées, embrassant les côtés de l'abdomen. Abdomen ovale, convexe, aigu postérieurement. - Pattes assez longues; jambes n'ayant qu'unc pointe très-courte ì leur extrćmité; pénultième article des tarses bifide, cordiforme.

M. Latreille est le fondaleur de ce genre. On n'en connoît que deux espèces, l'une du Sénégul ( $C$. brunneus), l'autre des Indes orientales ( $C$. fornicarius ).

Rapporlez ì ce genre le Brente brun, $n^{\circ} .4$ de ce Dictionnaire, pl. 236. fig. 2. (Cy.las uninneus. Lat. Gener. Crust. et Ins. tom. 2. pag. 244. $n^{\circ}$. 1 . Brentus brunneus. FAB. Syst. Eleut. tom. 2. pag. 548. $n^{\circ}$.11.)

APODERE, Apoderus. Oniv. (Entom.) I,AT. Attelubus. Linn. Fab. Panz. Clairv. Oniv. (Encycl.) Rhinomacer. Geoff.

Genre d'insectes de l'ordre des Coléoptères, section des Tétramères, famille des Rhyuchophores, lribu des Charansonites.

Dans les Charansonites recticornes, un petit groupe (voyez Rнтмснорнолеs) a les antennes terminées en massue, composées de onze articles, dont huit distincts avant cetle massue; les Attelabes, les Rhynchites et le Apions qui avec les Apodères forment ce groupe n'ont point comme ce dernier genre la tête portée sur un cou distinct; de plus les Apions et les Rhynchites ont les deux épines qui terminent leurs jambes fort petites et dans les Attelabes ces épines toujours au nombre de deux, sont très-fortes.

Antennes non coudées, insérées à la parlie supérieure du prolongement de la tête et vers son miliea, composées de onze articles, les trois deruiers formant une massue. - Mandibules entières, aiguës intérieurement, creusées, dentées vers le milieu. - Palpes maxillaires filiformes. - Tête dégagée du corselet, postérieurement alongée en un cou dislinct et nodiforme, ayanit un prolongement rostriforme court, large, dilaté à son extrémité, celle-ci terminée par les parties de la bouche. - Yeux ronds, un peu saillans. - Corps ovale. - Corselet arrondi, sans rebords, plus lirge que la tête, plus étroit que les élytres. 


\section{$\mathrm{R} \mathrm{HY}$}

Ficusson assez grand, arrondi postérieurement. - Elytres dures, convexes, couvrant les ailes et l'abdomen. - Abdomen earré. - Pattes de longueur moyenne; jambes terminées par une seule et forte épine; tarses ayant leur troisième article large et bilobé.

Apodère vient d'un mot gree qui siguifie : écorché. On eonnoît une douzaiue d'espèees de ee genıe, tontes de l'ancien continent; leur taille est petite. Leurs mœurs et lews larves ne diffèrent point de celles des Attelabes. Voyez ce mot.

\section{Apodkerre de l'Aveline, $A$. Avellano.}

Apoderus niger, femoribus rubris, thorace partim omnindve nigrolongitudinalitèr profiendè sulcato; elytrorum rubrorum striis crenato-punctatis.

Attelabus Avellanoe. Lin , Syst. Nat. 2.619.2. - Attelabus Coryli. var. b. EAB. Syst. Eleut. tom. 2. pag. 416. n०. 1. - РАҮK. Faun. Suec. tont. 3. pag. $168 . n^{\circ}$. 1. - Laт. Gen. Crust. et Ins. tom. 2. pag. 246. - Attelabus Coryli. Cra irv. Entom. Helvét. pag. 118. no. 1 . pl. 15. fig. 1.2.3. et a. b. -DE GEER, Ins. tom. 5.pag. $257 \cdot n^{\circ} .46$. pl. 8. fig. 3. - La 'Tète écorchée. Georr. Ins. Paris. tom. 1. pag. 273. $n^{\circ}$.11. - Encycl. pl. 365. Apod. fig. 1 .

Longueu: 3 lig. $\frac{1}{2}$. Noir, luisant. Elytres et cuisses à l'exception des genuux, d'un beau rouge. Corselet souvent eutièrecuent rouge avec un sillon longitudinal profond. Elytres striées; ees stries ponctuées et erénelées.

Commun aux euvirons de Paris.

2. Apudíne du Noisetier, A. Coryli.

Apoderus niger, thorace longitudinaliter profundè sulcato, elytrorum rubrorum striis crenutopunctatis.

Attelabus Coryli. Lrns. Syst. Nat.2.619. 1. Attelubus Coryli. F. B. Syst. Eleut. tom. 2. pag. 416. $n^{n}$. 1. - PA Ү . Faun. Suec. tom. 3. pag. 168. $n^{\circ}$. 1. - Attelubus Coryli. var. a. LAт. Gen. Crist. et Ins. tom. 2. pag. 246. no. 1. DE GÉER, Ins. tom. 5. pag. $257 \cdot n^{\circ} \cdot 46 . p l .8$. fig. 3. val.

Longueur $3 \mathrm{lig} \cdot \frac{1}{2}$. Entièrement noir-luisant à l'exeeption des élytres qui sont ronges, eelles-ei ayant des stries ponetuées et crénelées. Le corselet a un sillon longitudinal profond.

Du nord de l'Europe.

Nota. Ces deux premières espèees ne sont peutètre que des variétés l'une de l'autre; on les a confondues enseuble sous le nom d'Attelabe lête écoreluée $\mathrm{n}^{\circ} .2$ de ce Dietionnaire.

\section{Apodìne de Panzer, A. internledius.}

Apoderus niger, elytrorum rubrorum punctis seriatis, thorace vix longitudinalitèr sulcato. Hist. Nat. Ins. Tome $X$.
Attelabus intennedius. PaNz. Faun. Gern. fas. 25 . fig. 22.

Longueur 2 lig. $\frac{2}{2}$. Noir, luisant; corselet a yant un sillon longitudinal peu apparent. Elytres rouges avee des séries de points enfoneés. Conslammieut plus petit que les préeédens.

D'Autrielie. Il n'est pas eommun.

Rapportez encore à ce rrente les Attelabes perle no. 7. pl. 365. A pod. fig. 3, et corselet roux น०. I I. pl. 365. Apod. hig. 2 de eet ouvrage.

APiON, Apion. Hensst. Lat. Ortv. (Entom.) Kirb. Curculio Linn, De Géer. Rhinomacer. Geoff. Clairv. Attclabus. Fab. Oxiv. (Encycl.)

Genre d'iusectes de l'ordre des Coléoplères, section des Tétramères, famille des Rhyuchophores, tribu des Charansonites.

Un groupe de Charansovites reetieornes a pour caractères : aulennes eomposées de onze articles. terminées en massue, en ayant huit distinels avant celte massue. (Foyez Rey ncaophores.) Dalls ce groupe les Apodères sont reconnoissables par leut tête portée sur un eou distinet; les Altelabes ont le prolongement rostriforme de leur tête gros et court, leurs jazubes sont munies à leur extrémilé de deux fortes épines; les Rhynchiles ont le prolongement de la tête dilaté à son extrémilé et l'abdomen carré : ee dernier earaclère leur est eommun avec les Attelabes.

Antennes non coudées, insérées sur la parlie inférieure du prolongement de la tête, avant sou milieu, se caehant sous la tête (dans le repos), composées de onze artieles, les trois derniers fur. tement réunis en une massue ovale-aiguë.-Mandibules courtes, ayant uue dent à la partie extérieure de leur base et deux autres fortes vers l'extrémité. - Mâchoires et palpes peu distincts. Lèvre presque carrée, entière; menton en earré alongé. - Tête alongée postérieurement, reçue dans le eorselet, sans cou apparent, ayant un piclongement roftrifurme alongé, conique on cylindrique à l'extrémité; celle-cii portant les parties de la bouche. - Yeux proémiuens. - Corps ovale, arrondi à sa partie postérieure, diminuaut grraduellenient ver's l'antéricure, absolument pyriforme. - Corselet presque cylindrique, un peu plus mince antérieurement. - Elytres dures, cassantes el fragiles. - Abdomen ovalaire. - Pattes de longueur moyenne; épines de l'extrémilé des jambes à peine visibles; tarses ayant leur troisième article large et bilobé.

Le noin de ce genre vient d'un mot grec qui siguifie : poire; il a été appliqqué à ces tièspetits coléoptères par allusion à la forme de leur corps. L'abdomen pyriforme et le prolongement de la tête ordinairemeut subulé, jamais élargrini aplati vers son extrémité, donnent à ces insectes un port qui leur est particulier. Ils sont nombreux en espèces européenues; il paroit que 
leurs larves vivent aux dépens et en dedans des semences de plusieurs végélaux.

On doit rapporter à ce genre les Attelabes rouge $n^{\circ} .19$. pl. 366. Apion fig. 5 , bleuet $n^{\circ} .20$. pl. idcm. tig. 14 (en retranchant les synonymes de Geoflroy et de Fourcroy), flavipède $n^{\circ} .2$. pl. idem. fig. 7 , puce $n^{\circ} .22$, fascié no. 23 , et de la Vesce no. 25 de ce Dictionnaire.

Les Attelabas rufirostris $n^{\circ}$. 43. (Encycl. $p l$. 366. Apion.fig. 6), Powona $n^{\circ}$. 48. (Encycl.pl. idenr. fig. I), sorbi $n^{\circ} .52$, aneus $n^{\circ} .37$. (Encycl. pl. idem. fig. 3.) FАв. Syst. Eleut. sont dc ce genre, auquel on doit rapporter aussi les Apions longirostre $n^{\circ} .5 \mathrm{I}$, renflé $\mathrm{n}^{\circ} .44$ et rayé $\mathrm{n}^{\circ}$. 50 de P'Entomologie d'Olivier.

\section{(S. F. et A. Serv.)}

RHYNCHOPHORES, Rhynchophora. Premic̀re famille de la section des Téltamc̀res, ordre des Coléoptères ; ses caractères sont :

Tête prolongéc antérieurement cn forme $\mathrm{dc}$ museau ou de bcc avec la bouche terminale.

Cette famile se coinpose de deux tribus.

Iro. Tribu. Bruchèles, Bruchelce.

Tête avancće en un museau large et aplati et non en forme de bec ou de prolongement cylindrique. - Palpes fíliformes, très - distincts. Labre apparent.

Anthribe, Rhinomacer, Bruche.

se. Tribu. Charansonites, Curculionites.

Tête avancée en forme de bec ou de prolongement cylindrique portant les antennes. - Palpes coniques, pcu distincts. - Labre nul.

Cette tribu renfermant un grand nombre de genres, nous paroît devoir se diviser ainsi :

I. Recticornes. Antennes non coudées, leur premier article n'étant pas très-long:

A. Antennes de dix articles ou moins; massne d'un seul article.

a. Antenues de neuf articles dont luit dislincts avant la massue.

Brachycère.

b. Antennes de dix articles dont neuf distincts avant la massue.

Cylas.

B. Antennes de onze articles.

a. Antennes presque filiformes.

Brente.

b. Antennes terminées en massue. f Huit articles distincts avant la massue : celle-ci de trois articles.

Apodère.

Aitelabe.

Rliynchite.

Apion.

†† Sept articles distincts avant la massue : cclle-ci de quatre articles.

Rhamphe.

I1. Fracticornes. Antennes coudées, leur premier articlc très-long.

A. Antenncs de dix articles ou moins.

a. Antennes de dix articles.

† Sept articles distincts avant la massue : celle-ci de trois articles.

Orcheste.

†† Six articles distincts avant la massue : celle-ci de quatre articles.

Cione.

b. Antennes dic neuf articles, dont huit distincts avant la massue.

Cosson.

c. Antennes de huit articles, dont sept distincts avant la massue.

Rhinc.

Calandre.

B. Antennes de ouze articles.

a. Huit articles distincts avant la massue: celle-ci dc trois articles.

Charanson.

Rhynchène.

Cryptorhynque.

b. Sept articles distincts avant la massue: cellc-ci de quatre articics.

\section{Lipare. \\ Lixe.}

Les Rliynchophores vivent tous de végétaux à l'état de larve et d'insecie parfail. Les uns attaquent les feuilles, les autres l'intérieur des. tiges ou des fruits. Leurs larres ont le corps presque cy² lindrique, oblong, très-mou; leur tête est écaillcuse : elles sont dépourvucs de paltes et n'ont à la place que de petits mamelons; les larves des Brachèles se transforment sans faire de coque dans l'intérieur de la cavité qu'elles ont pratiquée en rongeant les végétanx : celles des Charansonites se forment une coque ordinairement fort claire et composée d'un réseau à mailles, au travers duquel on aperçoil facilement la nymphe.

(S. F. et A. Senv.)

RHYNGOTES, Rhyngota. Linné avoit formé 


\section{R II Y}

nne classe d'insectes sous le nom d'Hémiptères; Fabricius divisa depuis cette classeen deux ordres, les Ulonates ( voyez ce mot) et les Rhyngotes; il donne à celui-ci pour principaux caractères : six pattes; deux antennes; souvent des demi-élytres; quatre ailes ou deux ailes ou point d'ailes; bouche consistant en un bec alongé, fléchi ou arqué, composé d'une gaîne de trois à cinq articles, renfermant trois soies aiguës; une lèvre couvrant la base du bec, insérée à l'extrémité de la tête; un chaperon horizontal, corné.

Cet ordre répond exactement à celui des Hémiptères de MH. Latreille ei Olivier.

(S. F. et A. Serv.)

RHYPHE, Rhyphus. Lat. Metg. Tipula. Réadm. Scop. Sciara. Fab. Anisopus. Illlig. Meig. Class.

Genre d'insectes de l'ordre des Diptères, scclion des Proboscidés, famille des Némocères, tribu des Tipulaires.

Un groupe de cette tribu que M. Latreille nom me f'ungivores a pour caractères : trois petits yeux lisses; ailes couchées sur le corps dans le repos. Il conlient les genres Asindule, Rhyphe, Céroplate, Molobre, Mycétophile et Macrocière. Les Asindules out la trompe beaucoup plus longue que la têle et dirigée en arricre; les Céroplates, les Molobres et les Nycétophiles ont leur trompe terminée par deux grosses levres fornant un easpatement à son extrémité, et les Macrocères ont les antennes très-longües à artucles peu distincts, exceptés les deux premiers.

Antennes couries, avancées, subulées, composées de seize articles distincts; les deux preusiers séparés des autres. - Trompe avancée, un peu plus courte que la tête, cylindrique, en forme de bec. - Palpes avancés, recoürbés, composís de quatre articles inégaux, le second en urassue. - T'éte globuleuse. - Yeux entiers, espacés dans les femelles, se rejoignant et se réunissant au-dessous du vertex daus les mâles. - Trois petits yeux lisses égaux, placés en triangle sur le vertex. - Corps mince. - Corselet globuleux. - Ailes cilićes sur leurs bords et sur leur's nervures; couchées l'une sur l'autre dans le repos. - Balanciers grands. - Pattes inégales; deux postérieures grandes; crochets des tarses furt petits.

Réaumur a eu occasion d'observer les mœurs du Ribyphe des feuêtres, en ayant souvcnt trouvé La larve vers la fin de septembre, liabitant en grand nombre daus les bouzes de viaches; elle a six à sept lignes de longueur lorsquelle est parrenue à son entier accroisseasent; sun corps est cylindrique, composé de segmens qui ont le luisant de l'écaille quoiqu'ils ne soient que membraneux; leur moitié aulérieure forme une bande brune, le reste est d'un blanc sale; on ne voit sous aucun d'eux ni pattcs, ni maınelons. La tête est écailleuse et se rapproche par sa forme de celle des larves de Stratyones; on en voit sortir en dessous deux appendices frangés qui rentrent quelquefois daus la bouche; de clıaque côté l'on aperçoit une tache brune que notre aluleur prend pour un œil; le dernier segunent du corps ou anus porte quatre tuyaux cylindriques, dout deux plus courts auxquels se rendent deux tráchées que l'ou aperçoit au travers de la peau de la larve; les deux autres tuyaux sont plus longs et placés plus près de l'extrémité du corps : ces quatre tnyaux sont les organes de la respiration. Cefte larve se clıange en une nymphe semblable à celle des autres Tipulaires; les segrrens de son abdomen sont hérissés d'épines inclinées vers le derrière; lorsque le temps de la dernière métamorphose est arrivé, celle nymphe se sert de ces épines pour s'élever à la superficie de la bouze de vache; elle ne reste qu'à peu près une semaine sous celle forme de nymphe. M. Latreille dit que cette larve se trouve aussi dans les maisuns et qu'elle s'y nourrit de vieux linge pourri.

M. Meigen décrit trois espèces de ce genıe, toutes d'assez petite taille.

\section{Ruypee des fenêtres, $R$. fenestralis.}

Rhyphus alis punctis fuscis, apice maculâa concolori.

Rhyphus fenestralis. MEIG. Dipt. d' Eur. tom.1. pag. 323. $n^{\circ}$. 3. - Rhyphus fenestrarum. LAT. Gen. Crust. et Ins. tom. 4. pag. 262. - Sciara cincta. FAв. Syst. Antliat. pay. 6о. $n^{n}$. $15 .-$ RÉA uM. Ins. tom. 5. pag. 21 et 22. pl. 4. fig. 3-10. - Tipula fenestralls. Scopos. Carniol. pag. 322. $n^{\circ} .858$.

Longueur 5 lig. $\frac{1}{2}$. Corp̣s tesłacé. Tête d'un brun-grisåtre. Antennes noires; dessus du corselet ayant trois lignes hrunes, raccourties; segmens de l'abdomen ayant en dessusi leur hase brune. Ailes transparentes avec des taches noirâtres vers la côte el dans leur milieu; on en voit une plus grande placée au bonl de l'aile. Les quatre cursses postérieurcs sont noires à leur extrémité.

On rencontre souvent cette espèce sur lcq vitres des croisées; elle est conunune d̀ Paris tt dans les environs. (S.F. et A.Senr.)

\section{RHYSODE, Rhysodes. Illig. Daim. Lat.}

Genre d'insectes de l'ordre des Coléplère, section des Pentamères, fámille des Serricornes. tribu des Lime-bois.

Cette tribu se compose des genres Cupis, Rhysode, Hylécæle, Lymexylon et Alractocère; ces trois dermiers ont le corpos mou, la tête glabuleuse et inclinée; dans les Capis le péuultième article des tarses est bilobé et les articies des antennes sont de forme cylindrique, point séparés distiactemeut les uns des autres. 
Antennes droiles, avancées, composées de onze articles globuleux, transversaux, très-distinctemeut séparés les uns des autres, le premier le plus gros de tous, les autres presqu'égaux entr'eux. - Bouche rentrée, peu apparente. - Palpes ayant leur dernier article elliptique; menton grand, couvrant la bouche, simué antérieurement; son lube du milieu aigu. - Tête pelite, avancée, presqu'cn cour, pointue en devant, ayant un cou distinct. - Yeux saillans, grands, demi-circulaires. - Corps dur, linéaire. - Corselet un peu 1) lus large que la tête, plus long que large, rebordé latéralernent; partie postérieure du sternum descendaut très-bas sur l'abdonen. - Ecusson point apparent. - Elytres plus larges que le corselet, ayant deux fois sa longueur, couvrant les ailes et l'abdomen. - Pattes courtes; les postérieures extrêmement éloignées des autres; leurs cuisses ayant un appendice à leur base : tarses filiformes, presqu'aussi longs que les janı. bes: leurs quatre premiers articles égaux entr'eux, le quatrième entier, le cinquième un peu plus lous que les autres, muni de denx crochets.

Le nom de ce genre vient d'un mol grec qui exprime que le corps est rugueux. On n'en connoît encore que deux espèc's. Elles habitent dans le buis.

1. Raysode sillonné, $R$. exaratus.

Rhysodes fuscè castaneus, nitidus, thorace sulcis cequalibus, elytris profunde punctato-striatis.

Longueur 3-lig. $\frac{1}{2}$. Corps glabre, d'un châtainbrun luisant. Tête marquée en dessus d'un sillon qui a la forme d'un U. Corselet ayant trois profonds sillons longitudinaux, égaux entr'eux. Elytres chargées chacune de sept stries profondes, fortement ponctuées, la suturale s'avançant jusqu'à l'extrćmié de l'élylre, les cinq suivantes se raccourcissant de plus en plus; la plus extérieure bifurquée à son extrémité; l'espace qui est entre cette strie et le bord de l'élytre est un peu panctué irrégulièrement. Menton, sternum et abdomen fortement ponctués. Cuisses antérieures unidenlíes en dessous; les intermćdiaires munies d'un petit tubercule poriant un poil roide.

De l'Amérique septentrionale.

Nota. La seconde espèce est le Rhysodes europaus. Des. Catal. (Rhysodes exaratus. DaLm. Analect. Entom. Holni. 1823. pag. 93. n?. 3.), qui d’après la description a les deux sillons latéraux du corselet plus courts antérieurement que celni du milieu. Elle a été trouvée dans les Alpes de la Croatie par M. le comteDejean: eı Suède par Paykull et en 'Tauride par M. Ślèven. Le second l'a prise dans de vieux sapins pourris.

CUPÈS, Cupes. Fab. Ĺat.

Genre d'insectes de l'ordre des Coléoptères, section des Pentamc̀res, famille des Serricornes, tribu des Lime-buis.
Dans cette tribu les genres Hylécæete, Lymexylon et Atractocère se distinguent par leur tête grosse, globuleuse, inclinée, et encore par leur corps de consistance molle. Les Rhysodes ont leurs antennes composées d'articles moniliformes distinctement séparés les uns des autres, et le pénultième des tarses entier.

Antennes longues, filiformes, composées de onze articles, le premier plus gros que les autres, le second globuleux, les neuf autres cylindriques, égaux enir'eux, à l'exception du dernier qui est un peu plus long. - Mandibules courtes, épaisses, échancríes à l'extrénite. - Mâchoires ayant deux lobes, l'extérieur linéaire, l'intérieur plus petit. - Palpes égaux, presque filiformes, les maxillaires de quatre articles presqu'égaux entr'eux, le dernier tronqué; les labiaux de trois articles dunt le second plus long. - Lèvre bilide; menton corné, transversal, de forme demi-ovale. - Tête petile, avancéc, presque cordiforme. Yeux globuleux, saillans, de grandeur moyennc. - Corros dur, linéaire, déprimé en dessus. Corselet trés-court, guére plus large que la tête, transversal, un pen rétréci postérieurement. Ecusson petit, apparenl, globuleux. - Elytres linéaires, quatre fuis atussi longues que le corselet, plus larges que lui, couvrant les ailes et l'ubdomen. - Pattes courtes, presqu'également espacées; tarses à peu près de la longueur de la jambe, leurs quatre premiers articles ćgaux, le quatrième bilobé, le dernier un peu plus graud, muni de deux crochels.

Cc genre ne contient qu'une seule espèce dont nous ignorons les mours.

\section{Cup̀̀s tête raholeuse, $C$. capitata.} lato.

Cupes nigra, capitis rufi vertice sex tubercus-

Cupes capitata. FAв, Syst. Eleut. tom. 2. pag. 66. $n^{\circ}$. 1. - Lar. Gener. Crust. et Ins. tom. 1. pag. 255. no. 1. tab. VIII. fig. 2. - CоQUев. Illust. Icon. tab. 3o. fig. 1. - Encycl. pl. 3̈̈g. fig. 8 et 9 .

Longueur 5 ligr. $\frac{1}{2}$. Corps d'un noir-mat; antennes de même coulcur. Tête couverte de poils d'un jaune-roux, munie de six tubercules sur le vertex; savoir: deux a sa partie antérieure derrière les antennes, deux autres à la partie postérieure, de forme conique, entre lesquels on en voit deux plus petits. Côtés 'du corselet chargés de poils d'un jaune-roussâtre, cclui-ci ayant aux deux côlés de sa partie supérieure un large enfoncerrent et ses bords latéraux un peu relevés. Elytres portant chacune neuf stries longíludinales fortement ponctuées, les intermédiaires raccourcies postérieurenent, la troisiéme et la quatrième en parlant de la suture les plus courtes de toutes; les intervalles qui les séparent inćgatux, les. se- 


\section{$\mathrm{R}$ H Y}

cond," qnatrième et sixième plus élevés que les autres. Jambes et tarses a vec quelques poils roux.

Elle a été rapportée de la Caroline par M. Bosc.

HYLÉCATE, Hylecatus. Lat. Lymexylon. Fa B. Oriv. Paxí. Cantharis, Meloe. Linn.

Genre d'insecies de l'ordre des Coléoptères, section des Pentamères, famille des Serricornes, tribu des Lime-buis.

Dans cette tribu les Cupès et les Rliysodes se distinguent par leur corps dur et leur tête cordifurme; les Lymexylons par leurs antennes simples, presqu'en fuseau, plus larges vers leur milieu, et les Atractocères par leurs élytres trèscourtes, laissant les ailes découvertes presqu'en totalité.

Antennes insérées au-devant des yeux, trèsécartées entr'elles à leur naissance, assez courtes, n'étant pas notablement plus larges dans leur milieu, comprimées, composées de onze articles, ceux-ci, ì commencer du troisième, en dent de scie. - Mandibules courtes, épaisses, relendues à leur pointe. - Palpes maxillaires beaucoup plus grands que les labiaux, pendans, grossissant évidemment vers leur extrémité dans les femelles, de quatre articles, le premier fort fetit; le troisième (dans les mâles), le plus gros de tous, portant un appendice lacinié en forme de houpe: palpes labiaux de trois articles. - Têté globuleuse. - Yeux petils, globuleux, espacés, velus. Corps mou, cylindirique. - Elytres molles, flexibles, couvrant en entier les ailes et l'abdomen. - Pattes de longueur moyenne; arlicles des tarses entiers, le dernier terminé par deux crochets.

Hylécæete vient de deux mots grecs qui signifient : habitant dans le bois, ce qui exprime la unanière de vivre des insectes de ce genre daus leurs différens états.

\section{Hхце́c zete dermestoïde, H. dermestoides.}

Nota.MM. Latreille et Dejean rapportent cotnme femelle à cette espèce le Lyınexylon dermestoide, no. I du présent ouvrage (Lym. dermestoides. $\mathrm{F}_{\mathrm{AB}}$. Syst. Eleut.). Selon ces auteurs, le mâle est le Lymexylun muselier $n^{\circ} .5$ de ce Dictionnaire (Lym. proboscideum. FAB. id.). M. Latreille rupporte encore à ce mêtue mâle le LymexyIon printannier $n^{\circ} .2$ de l'Encyclopédie, ainsi que le Lymexylon barbu no. 3 (Encycl. pl. $55 \mathrm{~g}$. fig. 24-26.), el le Lymexylon morio. FAB. id. M. le comte Dejean considere ce dernier comme formant une espèce différenle.

Voyez pour les descriptions et les autres synonymes, les articles cilés du genre Lymexylon.

ATRAC'TOCERE', Atractocerus. PAL.-B Auv. L.A.r. Iymexylon. Fan. Necydalis. Linn.

Genre d'insectes de l'ordre des Coléoptères, section des Pentamères, fanille des Serricornes, tribu des lime-bois.

Dans tous les genres de cette tribu les élytres couvrent en entier ou presqu'en entier les ailes et l'abdomen, excepté dans les Atractocères. Les Lymexylons seuls se rapprochent un peu de ces derniers insectes sous cerapport; mis ontre que l'extrémité de leurs ailes et de leur abdomen dépasse de bien peu les élytres, on remarquera que leurs paires de paltes sont plus égalenent espacées entr'elles; et que leurs yeux sunt trèsdistans l'un de l'autre.

Antennes simples, assez courtes, insérées audevant des yeux, très-écartées entr'elles à leur naissance, composées de onze articles; le troisième et les suivans comprimés et allant en s'élargissant jusqu'au milieu de l'antenne. - Mandibules courtes, épaisses, refendues à leur pointe. - Mâchoires très-courtes, terminées par un lobe arrondi, velu. - Palpes maxillaires beaucoup plus grands que les labiaux, pendans, composés de quatre articles; le troisième (dans les mâles), le plus gros de tous, portant un appendice lacinié en forme de houpe, le quatrième mince, aciculaire, velu : palpes labiaux de trois articles, velus, couchés et dirigés en avant. - Tête ovale, inclinée.- - Yeux très-grands, occupant la plus grande partie de la têle, rapprochés et se touchant en devant. - Corps mou, très-alongé, linéaire. Corselet convexe, coupé carrément en devant et à sa partie postérieure, ayant un sillon longiiudinal dans son milieu. - Elytres extrêmement courtes, placées des deux côtés de l'écusson, ne pouvant se rapprocher; ailes découveríes, à peine plus longues que la muitié de l'abdomen. - $A b-$ domen long, rebordé latéralement, caréné en dessus dans son milieu. - Pattes de longueur moyenne; les deux premières paires très-rapprochées entr'elles, la dernière ayant son insertion fort loin de celles-ci : tarses simples, leur premier article le plus grand de tous, le dernier plus long que le quatrièue, muni de deux crochets à son extrémité.

Le nom de ce grenre est tiré de deux mots grecs qui signitient : cornes en fuseau. Les espèces conuues sont des parlies les plus chaudes de l'Afrique et de l'Amérique méridionale. Elles vivent dans le bois.

\section{Atractocén brésilien, A. brasiliensis.}

Atractocenus thorace transverso, piceus, capite, vertice thoraceque longitubinalitè sulcato, sulco lutescente.

\section{Atractocerts brasiliensis. DEJ. Catal.}

Longueur 15 à $20 \mathrm{lig}$. Antennes d'un testacéferrugineux, leurs deux premiers articles bruns. Palpes testacés, les deux derniets articles des maxillaires bruns. 'Tête et corselet d'un brun-fer. 
rugineux, ayant tous deux dans leur nilieu une ligne longiłudiuale enfoncée, d'un jaune-ferruginenx. Ecusson fortement sillonné dans son milieu, hrun à sa base, d'un jaune sale postérieurement. Elytres et abdomen noirâtres en dessus, les bords de celui-ci d'un testacć-ferrupineux mêlé d'un pèu de binn. Ailes transpareutes, irisées. Dessous du corps d'un testacé-felrugineux, mêlé d'un peu de brun; partie postérieure des seguens de l'abdomen de cette dernière couleur. Pattes d'un jaune-ferrugineux, cuisses brunes.

Du Brésil.

Rapportez à ce genre l'Alractocerus necydaloides. PAl.-BAuv. Mag. Encycl. (Lyunexylon abbreviatum. НАB. Necydalis brevicornis. LiNN.), qui paroît diflérer de l'espèce que nous venons de décrire par son corselet plus long que large.

Il est de Guinée.

(S. F. et A. SERv. )

RICANIE, Ricania. Genre d'insectes de l'ordre des Hémiptères, créé par M. Germar (Mag. Entom. Hallc, 1818), pour placer les Flata ocellata et hyalina de fiabricius. Les caracticres assigiés à ce nonveau genre sont : tête courte, transversale, front bas, presqu'ovale, rebordé sur ses côtés; chaperon rattaché à l'extrémité du front, conique, subulć à son extrémité. Liblure caché; rostre plus court que la moitié du corps. Yenx globuleux, pédonculés en dessus. Un petit cil lisse de chaque côté, inséré sur le bord inférieur de l'œil. Antennes courtes, éloignées des yeux, leur prenier article petit, cylindrique; le second court, plus épais à son extrémité, tronqué obliquement et portant nue soie.

(S. F. et A. Serv. )

RICHARD (Cucujus). Nom donnć par Geoffroy à un genre de Coléoptères qui répond à ceux de Buprestis at de Trachys de Fabricius. Voyez Bopreste. (S. F. et A. Serv.)

Ricin, Ricinus. De Géer. Oliv. Lam. Laat. Pediculus. Linn. Geoff. Fab. Nimnuls. Hermann.

Genre d'iusectes de l'ordre des Parasites, famille des Mundibulés (Mandibulala. Lat. Farn. nat. du Règne animal), ćlabli par De Géer, qui le premier a reconnin que les insectes qui le composent, et que limné et les autres ualutalistes rangeoient avec les Poux, ont une bouche munie de mandibulos. Le uom de Riein avoit été donné par les Anciens ì des Acarides du geure Ixode de N. Latreilte, et De Géer auroit nieux fait d'adopler nn autre nom pour désigner ces in sectes. Aussi M. Léach a-t-il enployé lé nom de Nirmus donné par Hermann fils. Quoi qu'il en soit, le genre Riciu, tel qu'il est adopté dans ces derniers temps, a pour caractc̀res: une bouche inférieure, composće à l'ex:érieur de deux lèvres el de deux maudibules en crochet; lar'ses très-distincts, articulés et terminés par deux crochets égaux.
Tous les Ricins, à l'exception de celui du chien, se trouvent exclusivement sur les oiseaux: Leur tête est ordinairement grande, tantôt triangulaire, tantôt en demi-cercle ou en croissant, et a souvent des saillies angulaires; elle diffère quelqucfois dans les deux sexes de même queles antennes. M. Iatreille a vu dans plusieurs espèces deux yeux lisses rapprochés de chaque côté de la tête. Suivant M. Savigny, ces insectes ont des mâchoires avec un palpe très-petit sur chacune d'elles, et cacbćes par la lèvre inférieure qui a aussi deux organes de la même sorte. Ils ont aussi une espèce de langue.

Les Ricins s'éloignent des Poux par la forme de leur bouche et par lenr manière de vivre. Ils ont ordinaireraeut beaucoup de vivacité et marchent bien plus vîte que ceux-ci. Jls se tiennent de préférence sous les ailes, aux aisselles et à la tête des oiseaux. Ils pullulen l prodigieusement, et souvent à un tel point que les oiseaux qui en sont attaqués maigrissent et tinissent mêtne par périr. De mểme que les Poux, les Ricins ne peuvent pals vivre long-teraps sur des animaux morts; ils les quittent bientôt, et c'est alor's qu'on les voit courir comme avec inquiétude sur les plumes et particulièrement sul celles de la tête et des environs du bcc.

D'après les observalions de M. Leclerc de Laval, la seule nourriture des Ricins seroit des parcelles de olumes, et il se base sur ce quill en a va, ainsi que M. Nitzch, dans l'estomac de quelquesuns : mais De Géer assure avoir trouvé l'estomac des Ricins du Pinçon rempli de sang dont il venoit de se gorger: Redi a figuré un très-grand nombre d'espèces de Ricins, mais très-grossièrement; De Géer et Panzer en ont figuré aussi quelques espèces. M. Latreille dans uu Mémoire imprimé à la suite de son Histoire des Fourmis, a remarqué sur le ficin du Paon quelques particularités quilui semblent devoir être cornmunes à toutcs les antres espèces du uiême geure. Ainsi il a vu que les anteuncs du mâle sout fourchues, et il a conjecturé, d'après l'examen attentif des organes de la généraliou daus les deax sexes, que le mode d'accouplement de ces insectes n'est pas tout-à-fuit le même que celui des autres, c'est-àdire, que le mâlc ne doit pas être placé sur le dos de la femelle, unais que leurs abdomens doivent être appliqués l'un contre l'autre.

Ce genre a été divisé par M. Latreille en deux coupes parfaiteweut nulurelles, bascées sur la position de la bouche.

I. Bonche située près de l'extrémitć antérieure dc la tête; antennes insérées à côté, loiu des yeux et très-petiles.

I. Ricin de la Corneille, R. Cornis. Lat. Gen. Crust. et Ins. tom. I. pag. 167.-Ricinus coni. Ibid. Hist. nat. des Crust. et des Ins. tont. 8. pag. so5. - Le Pou de Corbeau. Grozt. List. des his. 


\section{$\mathrm{R} \mathrm{O} \mathrm{P}$}

tom. 2.-Ricin de la Corneille. Dr Géen, Mém. sur les Ins. tom. 7. pag. 76 . pl. 4. fig. 11.

$R$. albidus, capite cordato; thoracis segmentis utrinquè in dentem prominulis; abdomine ovali, transversè fisco-fasciato.

Ovale, gris; tête noire, petite; anlennes recourbées en arrière. Patles courtes, tachetées de noir ainsi que les anteunes. Abdomen ovale, de couleur cendrée, orné de chaque côté de huit bandes noires à la jointure des ameaux. Lorsqu'il est jeune, il est blanc, avec une simple rangée de points de chaque côté de l'abdomen.

On le trouve sur les oiseaux du genre Corbeau.

II. Bouche presque centrale; antennes insérées très-près des yeux et dont la longrneur ćgíle presqua celle de la tête.

2. Ricin de la Ponle, R. Galtince.

R. albidus, abdomine svalo, capile semiorbiculato, posticè angrulatum, posticè setis quatuor longioribus.

Pediculas Gallince. Linv. De Géen, Ins. tom. VII. pl. 4. fig. I2. - F tête et corselet pointu des deux côtés. Geofr. Ins. tom. 2. - Sсна а ск. Beyt. 114-3. - Ricin de la Poule. Lat. Hist. nat. des Crust. et des Ins. tom. 8. pag. rog.

Tête arrondie en devant et représentant un croissant dont les angles ou pointes regardent le corseler qui est court, large, armé de chaque côté d'une pointe droile, aiguë et saillante. Le ventre est alungé; lout ie reste du corps est parseınć de poils gris.

Voyez pour !es autres espèces Redi, De Géer, Geofficy, Latreille, etc. (E. G.)

\section{RICINS. Voyez Orithom yzes.}

$$
\text { (S. F. et A. Serv.) }
$$

ROBERT-LE-DIABLE (Je Gama ou). Nom vulgaire donné par Geulfiroy à la Vanesse C. blanc n". 17. Lom. IX. par. 302 de ce Dichonnairc.

$$
\text { (S. F. et A. SERv.) }
$$

ROPAEOCÉRES On GLOBULACORNES.- M. Dunérii dans sa Zoologie analytique désigne suus ce nom une fimille de Lépidoplères à laquelle il assigne pour caractères: antennes terninées en massue; elle est composée des genres Papillon, Hétéroptère et Hespérie. (S. H'.et A. Sarv.)

ROPALOMERE, Ropalomera. M. Wiedmann (Analecta entomologica. Kilica, 1824) a établi sous ce nou un genre de Diptères aux dípens des Dictya de Fabricius. Il lui donne pour caractères: antennes rabaltues, composées de trois articles, le deruier comprimé, ovale, portant à sa bisse une soie un per plumense; palpes en massuc comprimée; hypostome tubercule; cuisses rentlćes; ailes couchées sur le corps dans le repos et parallèles.

Le nom de ce genre vient de denx mots grecs dont la signification est : cuisses en massue. Il a pour type le Dictya clavipes $\pi n^{n} .17$. HAB. Syst. Antliat. Ropalomera clavipes. WiedM. fig. 12.

$$
\text { (S. F. et } A . S \text { servo) }
$$

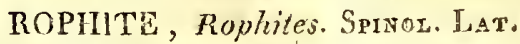

Genre d'insectes de l'ordre des Hyménoprères, section des Porte-aiguillon, fanille des Mellifères, tribu des Apiaires.

Parmi les Apianes récoliantes solitaíes qui n'ont pas de palelle au uétathorax ni aux cursses postérieures, un groupe a pour caractères : unc brosse pour la récolte du pollen des fleurs, placric sur le cóté exlćrien des jambes et dn prennier átlicle des tarses des denx pattes postérieures (danz les femelles). Voyez Parasizes. Dans les gcures faisant partie de ce groupe ceux de Macrocère, Systrophe, Monæque, Mélitonse, Epicharis, Centris, Lagripode, Anthophore, Méliturge, Acanthope, Xylocope et Lesis se reconnoissent facilement par lears ailes supérieures ayant quatre cellules cubitales; les Eucères qui comme les Ro phites u'en ont que trois, se distinguent de ce dernier genre en ce que la preuière cubitale est plus pelite que les antres et notamment que la seconde, que l'extrémité postérieure de la cellule: radiale n'est point appliquée contre la côte et qu'enlin les antennes des mâles sont d'une longuenr remarquable, úgalant celle du corps.

Antennes filiformes, brisées et de douze articles dans les femelles, simplemeat arquées, à peu près de la longueur de la moilié du corps ek de treize articles dans les mâles, le preunier grand, le second petit, les autres cylindrirues, presqu'égaux entr'eux. - Labre court. -- Mandibules étroites, pointues, bidentées. - Nấchoires recourbées conjointemeut avec la lèvre et formant une sorie de trompe. - Palpes de forme presqu'ideuliques, leurs articles grêles et linéarres; les maxillares desix articles presque cylindriques. le premier et le second un peu plus longs et un peu plus gros que les autres; le troisième et le guatrième plus petits, les cinquième et sixièue très-minces, celui-ci plus court ; pat̀pes labiuux de quatre articles, le premier et le second égaux entr'eux, un peu concaves à lenr partie antérieure et servant cue gaîne à la lèvre, le troisièrne de moitié plas court que le précédent, aplati, le quatrième très-court, obconique, inséré sur le côté extérieur du précédent. - Trois petits yerw lisses disposés presqu'en ligne transversale sur le verlex. - Corps assez alongé. - Corselet globuleux. - Ailes supéreures ayant une cellule radiale à peine rétrécie depuis son milieu jusgetà sou ex- 
trénité; celie-ci ne s'écartant pas de la côte et trois cellules cubitales, la première un peu plus lougue que la seconde quii est très-rétrécie vers la ridiale et reçoit les deux nervures récurrentes; la troisième commencée ; traccée presque jusqu'au milieu de l'espace qui est entre la seconde cellule cubitale et le bord postérieur de l'aile. Abdomen ussez long, ovale, composé de cinq segmens outre l'anus dans les femelles, en ayant un de plus daus les nâles.-Pattes assez grandes; les quatre jaunbes antérieures munies à leul extrémilé d'une seule épine simple et aignë ; les postérieures n'en ayant point de distinctes; dernier article cles tarses muni de deux crochets bifides.

L'espèce qui a servi de type ì ce genre se trouve sur les tleurs dans le midi de l'Europe.

\section{Ropalte à cinq épines, $R$. quinque-spinosa.}

Rophites nigra, abdominis segmentorum marginibus albo ciliatis.

Rophites quinque-spinosa. Srivon. Ins. Ligur. fis. 2. pag. $72.77^{\circ}$. 5o? - LAT. Gen. Crust. et Ins. tom. 4. pag. 161?

Longueur 4 lig. Antennes noires, avec la plus grande partie dé leur dessous d'un testacé pâle. Tête et corselet noirs, couverts de poils blanchâ tres. Abdomen noir; le bord inférieur de chaque seguent est chargé de poils cendrés presqu'entièrement coucliés. Anus ayant en dessous une pointe droite quí part de sa base, et de chaque côté une pelite dent courle et crochue. Palles noires avec des poils cendrés; tarses pâles. Ailes transparentes, un peu nébuleuses à leur extrémité. Mâle.

De la France méridionale; elle est rare aux en. virons de Paris.

Nota. Nous ne sommes pas certains que cette espèce soit celle des auteurs que nous avons cités, les individus que nous possédons ne nous paroissant aroir qu'une seule épine de clıaque côté de l'anus. Nous croyons que l'on ne connoît jusqu’à présent que des mâles de ce genre.

EUCÈRE, Eucera. Scop. Fad. Lat. Panz. Ross. Spinol. Apis. Linn. Geoff. Kirb. Panz. Trachusa. Jur. Andrena. PANz.?

Genre d'insectes de l'ordre des Hyménoplères, section des Porte-aiguillon, facmille des Meilliferes, tribu des Apiaires.

Ce genre est du même groupe d'Apiaires récoltantes solitaires que celui de Rophite qui précède; comrae lui il n'a que trois cellules cubitales aux ailes snpérieures, mais dans les Rophites la première de ces cellules est plus longue que la seconde et l'extrémité de la cellule radiale ne s'écarte point de la côte; de plus daus ce genre les antennes des mâles sout à peine plus longues que la moitié du corps.

Antennes filifurmes, bristes et composées de douze articles courts dans les femelles : très-longues, de treize articles, ces articles à partir du troisième, longs, cylindriques, un peu arqués dans les mâles. - Labre presque demi-circulaire. - Mandibules étroites, arquées, pointues, munies d'une seule dent au côté interne. - Palpes maxillaires de six articles; les labianx de quatre, le troisième insérć sur le côté extérieur du précédeut près de sa pointe et formant avecle quatrième une petite tige oblique. - Langueite ayant ses divisions latérales en forme de soies et aussi longues au moins que les palpes labiaux. - Tête assez torte, basse. - Yeux ovales, eutiers. - Trois petits yeux lisses disposés en ligne transversale sur le vertex. - Corps assez gros. - Corselet convexe, élevé. - Ailes supérieures ayant une cellule radiale qui se rétrécit un peu de sou nilieu à son extréunité, celle-ci s'écartaut de la côte et trois cellules cubitales, la première plus petite que les autres, la seconde rétrécie vers la radiale, recevant les deux nervures récurrentes, la troisième a peine conmencée, très-foiblement tracée. - $A b$ domen composé de cinq segmens outre l'anus dans les feraelles, en ayant un de plus dans les mâles. - Pattes de longueur moyenne; jambes antérieures munies à leur extrémité d'une seule épine garnie d'une combrane à sa base latérale; jambes intermédiaires ayant une seule épine lougue, simple, aiguë; jambes postérieures n'ayant point de palette, mais une brosse sur leur face extérieure ainsi que sur celle du premier article du tarse et munies à leur extrémité de deux longues épines aiguës. Dernier article des tarses muni de deux crochets bifides.

Les Eucères dont le nom est tiré de deux mots grecs et fait allusion ì la longneur des antenues des mâles, font leur nid dans le mortier qui joint les pierres des murailles ou dans les terrains sablonneux coupés presqu'à pic. Le nid est composé d'un tuyau cylindrique, recourbé inférieurement, qui après s'ètre enfoncé de quelques pouces se rapproche en section de cercle de la superficie du terrain; au bout de ce tuyau sont creusées différentes celinles en forme de dé à coudre, très-lisses intérieurement, dans cbacune desquelles la mère dépose une petite masse de pollen des fleurs délayé de miel et un ceuf: de cet œuf sort une larve semblable à cel'e des Abeilles, qui subit toutes ses métamorphoses dans la cellule où elle est née. L'entrée de chaque cellule est fermée par une cloison particulière faite de terre. C'est sur les plantes labiées que les feınelles récolıent particulièrement le pollen et le nicl qu'elles emploient. L'Eucère longicorne qui paroit de très-bonne beure au priniemps dans les environs de Paris, fréquente surtout l'Ajuga reptans el le Glechoma hederacea.

Les espèces conunes de ce genre au nombre de douze sont des parties de l'ancien continent voisines de la Mléditerrauée. Ces Apiaires ont pour 
ennemis les Mellifères Parasiles (Doy. Parasttes), cerlains Iclineumonides, entr'aulres le Pimple manifestaleur, quelque Chalcidiles, quelques Oxyures, et parni les Coléoptères les espèces du genre Clairon.

\section{Eucére longicorne, E. longicomis.}

Eucera abdominis fomince segmentis primo secundoque rufo-villosis, tertii quartique margine infero pilis stratis albids villoso, quirto et ani lateribus rufo-villosis; maris abdominis segmentis prino secundoque rufo-villosis, coteris anoque nigro-villosis.

Eucena longicomis. Faв. Syst. Piez. pag. 382. n'. 1.-Lat Gen. Crust. ei Ins. tom. 4. pag. 174. - Apis tuberculata. Panz. Faun. Germ. fas. 78. fig. 19. Apis strigosa. 1d. fas. 64. fig. 16. (Andrenc derasa. Id. fas. 64. fig. 17?). Ces trois ligures représentent la femelle. Euceralongicornis. Ị̇. fas. 64. Jig. 2 1. Le inâle. - Apis longicornis. Lixs. Sy'st. Nat. 2. 953 . I. Le mâle. líAbcille a longues antemnes. Geoff. Ins. Patis. tonn: 2. pag. 413. $7^{\circ}$. 10. Le mâle.

Jonguenr 5 ì 6 ligr. Antenues noires. Tète et corselet de celte coulear', couverts de poils rouxcendrés. Abdomen noir, ses deux premiers segmeus couverts de poils roux, le troisième ayant les côtés de son bord inférieur couverts de poils couchés, blanchâatres aiusi que le bord inférieur entiar du quatrième; le cinquième et les côtés de l'anus cluargés de poils roux, couchés. Dessous de l'abdomen ayant ses segmens ciliés de poils cendrés. Paltes couvcrtes de poils cendrés. Ailes transparentes. Quelquefois les mandibules sont testacées vers leur extrémité. Femelle.

Le mâle préscnte les différences suivantes. Chaperon et labre d'un blanc-jaunâtre ; troisième, quatriènı, cinquième et sixième segmens de l'abdomen chargés ainsi que l'anns, "de poils noirs dont au cuu n'est coucbé.

Commune aux envirous de Paris dès les premiers jours du printemps.

Rapporlez à ce genre les Eucera atricomis $n^{\circ} .2$, linguaria $n^{\circ} \cdot 6$, grisea $n^{\circ}$. 7. F $\mathrm{F}_{\mathrm{B}}$. Syst. p'iez. (Males) el l'Apis pollinaris $n^{\circ}$. 61. Krnb. Monogr. Apum. Angl. (Femelle.)

ANThIDIE, Anthidium. Fas. Panz. Iate. Apis. Linn. Geoff. Oliv. (Encycl.) Ross. Kirb. Anthophora. Inerg. Megachile. Sernoz. Trachusa. Jur.

Genre d'insectes de l'ordre des Hyınénoptères, section des Porte-aiguillon, fumille des Mellifieres, tribu des Apiaires.

Qualte genres d'Apiaires récoltantes solitaires privés de palelte au unétatliorax $\mathrm{cl}$ anx cuisses postériences turasent un groupe qui a pour caraclères : une brosse unique pour la récolte du pollen des tleurs, couvrant le dessous du veatre (ciaus les Hist. Nat. Ins. Tome $X$. femelles). Trois cellules cubitules aux ailes superieures. Abdomen ovaliaire. (Voy. Parasttes.) Ces genres sont: Antlidie, Ostnie, Anthocope et Mégachile; dans ce deruier l'abdomen est aplati en dessus et ainsi que dans les Osmics et dans les Anthocopes la secondc nervrire récurrente des ailes supérieures vient aboutir dans la deuxième cellule cubitale; ces trois genres ont en oulte leurs palpes maxillaires cornposés de plusieurs articles.

Antennes filiformes, brisées; dc douze arlicles dans les femelles, de treize dans lcs mâles. Labre en carré alongé, incliné verticalement sous les mandibules. - Mandibules forles, mulisdeslées au côté interne. - Palpes maxillaires trèspetits, oblus, velus, d'un senl article. - Máchoires et lèvre formant une trompe fléchie en dèssous. - Lèore longne, filiforme. - Téte transversale. - I eux grands, ovales. - Trois petits ycux lisses disposés en triangle sur la partie antéricure du vertex. - Corps gros et court. - Colselet globuleux, pas plus long que large. - Ailes supérieures ayant une cellule radiale aiguë à sit base, allant en se rétrécissant depuis son milien jus qưà son cxtrémilé, celle-ci un peu arrondie; et trois cellules cubitales, la première presscru'égale à la seconde, celle-ci un peu rétrécie vers la radiale, la troisième à peine commencée, point tracée au-deli de ce commencement, recevant la seconde nervire récurrente fort près de la seconde cubitale. - Abdomen court, convexe en dessus, composé de cinq segınens outre l'anıs, sa superficie inférieure entièrement couverle par une brosse dans les femclles, de six segmens outre l'anus dans les mâles, ce dcrnier portint à son e $\lambda$ trémité une ou plusieurs épines crochnes, ce qu'on remarque aussi quelquefois aux bords latéraux des segmens qui le précèdent. - P.attes assiz forles, toutes dépourvues de brosses et de paletles; jambes antérieures ayant à lear extrćmité une seule épine garnie d'une menibrane à sa base latérale; janbes internédiaires n'ayanı qu'une sevle épinc simple et aigrä̈; jambes postérieures en ayant deux presqu'égales entr'clles : dernier article des tarses muni de deux crochets simpies dans les fermelles, bifides dans les inấle's.

Le non d'Anthidie vient d'un mot grec gisi signifie : fleur. Le port de ces Apiaires est à peu près cclui des Osmies, mais leur corps est ua peu plus court, moius ve!n en dessus, légèrement cliagriné , ordinairement noir tachelé de jaune, quelquefois mélangé de ferrugineux. Les lemellestont leur nid dans les tertres un peu élevés ou dans les bords des fossés garnis de gazon; ellcs creusent elles. mêmes ce nid dans la terre, mais elles ne savent point maçonner; leurs cellules sont garnies tant au fond que sur leurs parois du duvet qu'elles recueillent sur certaines espèces de plantes: nous les a vons vues tondre et couper avec leurs man i jules celui des Stachys gemanica es lanate, du Ma$\mathrm{R}:$ 
rube commnn et de quelques Xeranthemum et: Filago; les cellules sont approvisionnées de miel et de pollen de fleurs mêlés ensemble, qui servent à li nourriture des larves. Leurs ennemis sont les mêmes que ceux dés Eucères. Les mâles sont en grénéral d'une taille plus forte que l'autre sexe; ils sont extrêmement ardens à l'époque del'accouplement, les crochets de l'extrémité de l'abdomen leur donnent le moyen d'assujétir leurs femelles jusqu'au monneui de la copulation. Ce genre renferme une vingtaine d'espèces toutes du midi de l'Europe et du nord de l'Áfrique.

$1^{\text {ro. }}$ Division. Première nervure récurrente abontissant à la nervure qui sépare la première et la seconde cellule cubitale.

A cette division appartient l'Abeille sept crochets, no. 67 de ce Dictionnaire ( Snth. florenzirum. Fав. Syst. Piez.) Mâle. La femelle nous est inconnue.

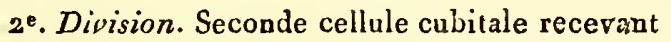
la première nervure récurrente.

Rapportez à celte division, $1^{\circ}$. l'Abeille tachetée no. 69 de ce Dictionnaire. L'individu décrit est une femelle. Le mâie diffère en ce que le sixième segunent de son abdomen est sans taches et que le bord postérieur de ce segment a dans son milieu un prolongement presque carré; en vutre, l'anus porte une épine de chaque côté. $2^{\circ}$. L'Abeille macnlée no. 70 . Femelle; le mâle est l'A beille cinq crochets no. 66. Les seuls synonymes certains de ce mâle sont ceux de Linné et de Geoffroy. Il faut retranclier de la description ce qui est dit des prétendus mulets; c'est une erreur qui a été copiée de Geofïroy.

Nota. Nous connoissons une Anthidie mâle des environs de Parris, à laquelle convient parfaitement la phrase spécifique de l'Anthidium manicatum. Fав. Syst. Piez. $n^{\circ}$. 1. (Apis manicata. FAB. Entom. Syst.)

L'Abeille interrompue $n^{\circ}$. $7^{1}$ de ce Dictionnaire est probablement du genre Anchidie.

A NTHOCOPE, Anthocopa. Osmia. Lst. Spinol. Megachile, Anthophora. Pavz. Andrena. OLlv. (Encycl.)

Genre d'unsectes de l'ordre des Hyménoptères, section des Porte-aiguillon, famille des Mellifères, tribu des Apiaires.

Dans le groupe de cette tribu qui se compose des genres Anthidic, Osuie, Anthocope et Mégachile (voyez Parasites), les Authidies se distinguent par lears palpes maxillaires d'un seul article et par la seconde nervure récurrente des ailes supérieures qui aboutit daus la troisième cellule cubitale; les Mégachiles ont leurs mandibules quadridentées, l'ubdomen aplati en dessus et les palpes maxillaires de deux articles; dans les Osmies, les mandibules ne sont que bidentées, caractères qui éloignent ces genres de celui d'Anthocope.

Antennes filiformes, brisées, composées de douze articles dans les femelles, de treize dans les mấles. - Labre en carré alongé, incliné verlicalenient sons les mandibules. - Mandibules fortes, tridentées. - Mâchoires et lèvre formant une trompe fléchie en dessous. - Lèure longue, filiforme. - Palpes maxillaires de quatre arlicles; palpes labiaux de qualre articles, le troisième inséré sur le côté extérieur du second. - Tête transversale. - Yeux grands, ovales. - Trois petits yeux lisses disposés en triangle sur la partie antérieure du vertex. - Corselet globnleux. - Ailes supérienres ayant une cellule radiale qui va en se rétrécissant depuis son milieu jusqu'à l'extrémité, celle-ci presquaiguë, et trois cellules cubitales, la premiere un peu plus petite que la seconde, cette seconde rétrécie vers la radiale recevant les deux nervures récurreutes, la troisième commencée, tracée dans le reste de sa longueur. $-A b d o$ men convexe, ovalaire, composé de cinq segmens outre l'anus, sa superficie inférieure entièrement courcrte par une brosse daus les femelles, ayant un segment de plus dans les mâles; le sixième segment, dans ce sexe, échancré et fortement unidenté de chaque côté; l'anus échancré dans son milieu, ce qui forme sur les côtés de ce dernier deux dents très-fortes, arrondies alı bout; en dessous le sixième segment, ainsi que l'anus, a son bord postérieur échancré, cette échancrure garnie dc poils. - Pattes de longuear moyenne, toutes dépourvues de brosses et de palelles : jambes antérieures ayant à leur extrénité une seule épine garnie d'une membrane à sa base latérale; jambes intermédiaires n'ayant qu'nne scule épine simple, aiguë; jambes postérieures en ayant deıx presqu'égales entr'elles : dernier article des tarses muni de deux crochets simples dans les fenelles ( bifides dans les mâles? )

Les Antlocopes, dont le nom vient de deux mots grecs qui signifient : coupeuses de fleurs, ne sont point maçonnes, aussi leurs mandibules diffèrent-eiles un peu de cclles des Osunies. Quant à leurs mours, poyez dans ce Dictionnaire Andrène tapissière, tom. 4. pag. 140 , et Osmie du Pavot, no. 21 . On ne connoit avec certitude que cetle espèce; nous la noinmons Aullocope du Pavot (Anthocopa Papaveris); cependant nous soupconnons qu'il en existe une seconde espèce dans le Midi, d'une taille plus petite, et qui emploie pour li construction de son nid les pétales des Crucifères.

HÉRIADE, Heriades. SpINoz. Lat. Chelostoma. LAT. Hyloeus, Anthopliona. $\mathrm{FAB}_{\mathrm{AB}}$ Anthidium. Panz. Trachusa. Jur. Apis. Linn. Krrb.

Geare d'insectes de l'ordre des Hyménoptères, 
section Aes Porte-aiguillon, famille des Melliferes, tribu des Apiaires.

Dans le groupe d'Apiaires rćcoltantes solitaires qui n'ont pas de palettes au métathorax non plus qu'aux cuisses postérieures, dont le caractc̀re est d'avoir une brosse unique pour la récolte du pollen des fleurs qui courre le dessous du ventre (dans les femelles), et trois cellales cubitales aux ailes supérieures; les geares Anthidie, Osmie, Anthocope et Mégachile se distinguent au premier coup d'eil par leur abdomen ovalaire.

Antennes presque filiformes, grossissant un peu vers l'extrémité, brisées, de douze articles ditus les femelles, de treize dans les mốles. - Labre eu carré alongé, incliné verlicalement sous les mandibules. - Palpes maxillaires très - courts ; les labiaux de quatre articles. - Mâchoires et lèore formant une trompe fléchie en dcssous. Tête transversale. - Trois petits yeux lisses disposés en triangle sur le vertex. - Corps alongé, étroit, cylindrique. - Corselet globuleux. - Ailes supérieures ayant une cellule radiale ovale-oblongue, et trois cellules cubitales, la première et la secónde prcsqu'érrales, celle-ci très-rétrécie ver's la ridiile, recerant les deux nervures récurrentes, la troisième natteignant pas le bord postéricur de l'aile. - Abdomen alongé, convexe en dessus, composé de cinq segmens outre l'anus ; sa superficie inférieure entièrement couverte par une brosse dans les femelles; celui des mâles ayant un segment de plus, le troisièıne a en dessoús dans son milicu un enfoncement garni de poils; anus souvent denté. - Pattes de longueur moyenne, toutes dépourvues de brosses et de palettes; jambes antérieures ayant à leur extrémité une seule épine obtuse garnie d'une membrane dans toute sa lougueur'; jambes intermédiaires n'ayant qü'une seule épine, simple, aiguë; jambes postérieures en ayant deux, aiguës : dernier article des tarses portant denx crochets simples dans les femelles, bifides dans les mâles.

Les Ilériades, dont le nom tiré d'un not grec qui signifie: laine, et a rapport au duvet épais que les femelles ont sous le veutre, ne sont pas nombreuses en espèces; les huit ou dix connues sont d'Earope et de petite taille. Les femelles font leur nid dans les tnyaux cylindriques qu'elles tronvent tout faits : ainsi un tuyau de paille, une tige creuse de plante, on le tron fait par un insecte qui a rongé le bois, sont pour elles une localité conveuable. Lcurs cellules sont posées bout à bout et sćparées par des cloisons de terre gâchée. Ces Apiaires ont les Prosopes pour ennezois particuliers (voyez Parasites). Les crochets qui accompagnent l'anus, et quelquefois aussi le sixième segment de l'abdomen des mâtes, leur servent à saisir les femelles lors de l'accoụplement, pour lequel ils sont très-arclens.

zro, Division. Cellule radiale des ailes supé- rieures point rétrécie. Labre trois ruis plus long que large et mandibules très-longues, en forne de pinces dans les fenelles. Un tubercule en forme de fer à cheval placé sous le second serment de l'abdomen; articles intermédiaires cies antenues un peu dentés en dessous dans les nuálcs. (Geure Chelostoma. LAT.)

Rapportez à cette division, $1^{\circ}$. l'Andrène maxilleuse $\mathbf{n}^{\circ} .26$ de ce Dictionnaire (Heriades naaxllosa ). L'individu décrit est la femelle. Le mâle a l'extrémité de son anus fortement échancrée, cette échancrure formant deux dents obtuses; le dessons de l'anus offie deux autres dents un veu arquées : les poils de l'abdomen sont moins conchés que daus la fernelle; la partie antćrieure des antennes est brune et non pas d'un noir prononcé. Cette espèce est commune aux environs de $\mathrm{P}$ aris. $2^{\circ}$. LiAndrèue somuiflore $\mathrm{n}^{\circ} .27$, Heriades flori. somnis, (Apis florisomnis, no. 49. Кгвв. Monogr. Apum. Angl. ). Mále. Nous ne connoissons pas la femellc.

Des eqvirons de Paris.

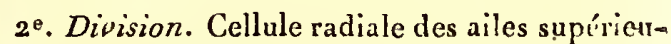
res rétrécie depuis son milieu jusqu'ì son extrémité. Labre et mandibules cour's, dans les lemelles. Dessous de l'abdomen n'ayant pas de tubercule en fer à cheval; antenues n'ayant ancun de leurs articles denté en scie dans les mâles. (Genre Heriades. LAT.)

Rapportez à cette seconde coupe, $1^{\circ}$. l'Alicille velure jaune, $\mathrm{n}^{\circ} .99$ de ce Dictionnaire (Herictes truncorum ). Fenelle. Le mâle a les poils des bords des segmens de l'abdomen moins courhés que dans la fermelle; son anus est entie:. $2^{\circ}$. L'Apis campanularum, no. 5o. Kirb. Monógr. Apum, Angl. (Heriades campanularun.)

(S. F. et A. SERv: )

ROSALIE. Geoffroy désigne ainsi le Ceramby. alpinus de Linné (Callichroma alpina. Lat.) Voyez Capricorne no. 41 de ce Dictionnaire.

(S. F. et A. Serv.)

ROSETTE. Geoffroy nomme ainsi le Bomby.x rosea de Fabricius. Voyez Bombyx n०. 268 du présent ouvrage. (S. F. et A. Serv.)

ROSTRICORNES ou RHINOCERES. C'est aiusi que M. Duıéril (Zoolog. analyt.) nomme la dix-septième famille de ses Coléoptcres, section des Tétranères. Ses caractc̀res sont : antennes portées sur un bec ou prolongement du front. Elle renferme les genres Bruche, Becmare, Anthribe, Brachycère, Attelabe, Oxystome, Chiranson, Rhynchène, Ramphe et Brente.

(S. F. et A. SERv.)

RTĖLE, Rutela. LAT. Cetonia, Melolontha. FAB. Ondv. Scarabaus. LinN. De GÉER. 
Gerre llinsestes de l'oidre des Coléuptères, section des I'entamères, famille des Lamellicornes, tribu des Scarabéides.

iv. Latreile a établi dans cette tribu une division sous !e hon de Xylophiles (voyez ce mot), qui contient sept genres. Dansles Aivialies et les 'Trox le lalre est saillant an-delì du chaperon; les élyitres sont lrès-bombées et enbrassent tous le: cốtés de l'abdomen; le labre est entierement caclié dans les Oryctès, les Philenres et les Searabés, en butre les iniles dans ces trois genres, ont le corsclet ou la tête, quelquefois méme tous les deux, coruus ou unberculés; le boid extćrient des élytres dilité et canaliculé, la massue des anteunes petite et ovale, les palles grêles aver: les crochets des tarses fort petits, distinguent érintmment les llexolons.

Antennes eomposées de dix articles, le premier velu, plus gros que les six snirans, les trois clerniers formant une massue lanellée, plicatile, plus on moins ovale. - Labre apparent, son bord antríleur séparant distinctement le rhaperon des mandibules. - Mandibules cornées, très-comprimées, avec leur partie extérienre saillante ou d'́converle, presque toujour's échancrée ou sinuée aı bout latéral; leur extrémitć obtuse ou tronquée. - Mâchoires coruées, dentées. - Palpes ayant leur dernier article nu peu plus gros; les in:uxillaires de quatre articles, un pen plus longs que les labianx, ceux-ci de trois. - Téte nutique dlans les deux sexes. - Corselet convexe, mutique dans les denx sexes, ses bords latéraux arrondis; sterun plus ou moins élevé et aivancé. - Ecusson apparent, de forme el de grindenr variable. - Elytres n'ayant ni dilatation, ni canal à leur bord extéxicur, couvrant des ailes et laissant l'itnus à déconvert. - Pattes robustes; jambes antrieures terminées par une ćpine simple, aiguë; les quatre postérieures en ayant deux d'égale lonyueur; crochets des tarses forts.

Le gevre Rutèle fondé par M. Latreille, a ćté restreint par les auteurs subséqueus; airsi M. Macleay en a séparé une parie des espi ces pour former deux genres qu'il appelle Pelidnota et $M I a-$ craspis. Nous ne connoissons pas les caractères de ces yeures et nous maintenous celui de Rutèle tel 'iu'il est défini dansle Gen. Crust, et Ins. Ce genre est propre aux parties chaudes de l'Amérique, et les espèces qu'il reuferme, d'après la consistance écailleuse de leurs mâchoires et les dents nombrenses dont elles sont munies, doivent avoir beanroup d'babiturles comnunes avec les Hannetous, onnme par exemple de se nourrir de feuilles des végétaux; leurs coulenrs brillantes semblent indiquer que res insectes ne craignent point la lamièrs. On connoît aujourd'lui plus de trente espèce de Rutèles.

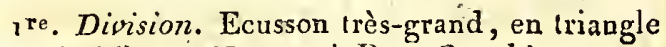
alongré. (Genre Macraspis DEJ. Catal.)

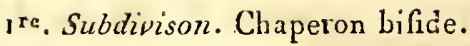

A. Une pièce triangulaire entre l'angle latéral postérieur di corselet et l'angle supérieur des élytres.

\section{Ru'tèle Cétoine, R. celonioides.}

Rutela elytris scapulatis, castanea, thoracis suprà angulis posticis, scapulis, sublius pectore, sterno, femoribus ventrique maculis luteis ; elytris. subtilissinè punctutis, punctonun seriebus paucis subobsoletis, capute, tubiis tarsisque nigricantibus.

Longueur ro lig. Corps de coulenr marron. Tête, jambes, tarses el dessous de l'abdomen d'une nuance plus foncée tiraut sur le noir. Corselet ayant quelques enfoncemens dont le plus grauch est vers le bord à l'endroit oì ce bord est le plus élargi ; ses angles postérieur's ayant une grande tache jaune; pièce triangulaire entre les ćlytres, dessous du corselet, celıi des cuisses et quelquest taches surle dessous de l'abdomen de cette dernière couleut. Elytres très-finement pointillées, les plus apparens de ces poinls rangés par séries longitudiuales, formant un petit nombre de stries peu distinctes. Partie postérieure du steruum prolongée en devant en un appendice aplati, recourbé et anninci en pointe vers son extréınité, atteignant la base des cuisses antérieures.

Du Brósil?

$N^{\top} \theta t a$. Cetle espèce est anomale; c'est la seulc que nons comnoissions qui porte une pièce triangulaire à la base des élytres, comme les Cćtoines.

B. Point da pièce triangrulaire entre le corselet et les ćlytres. - Les quatre larses postérieurs ayant un de leurs crochets bilide et l'autre entier.

\section{Rư⿱宀亡te brune, $R$. brunnea.}

Rutela castanea, nitida, elytrorum margine externo à medio ad suturam serrato, thoracis marginibus dilutioribus.

Macraspis brunnea. Des. Inéd. - Chasmodia bipanctata. MACL. Hor. Entom. tom. 1. part. 1. pagr. 156. $n^{\circ} .2$.

Longueur 8 à ro lig. Corps entièrement d'un chatain-brun, luisant; tous les bords di corselet plus clairs ainsi que le bord extérieur des élytres vers leur base. Ecusson bordé de brun, excepté it sa partie antérieure. Elytres lisses̀, avec une forte dćpression sur le cóté, au-dessous de l'angle huméral. Aruns ayant de chaque côté une tache jaune, arrondie. Partie postérieure du sternum prolongée en un appendice aplati, recourbé vers son extrémité, alteignant la biuse des euisses antérieures.

Du Brésil.

Rapportez à celte section la Maciaspis emar- 
ginata. Des. Catal. Celle csiecc a conme la procédente le bord extéricur des élytres denté en scie.

2e. Subdivison. Chaperon entier. - Poinl de fic̀ce triangulaire entre le corselet et les élytres.

A. 'lous les tarses ayant un de leurs crochets bifide, l'autre entier.

Rapportez à celle section les Céloines massne no. 108. pl. $6: .6 \mathrm{~g} .5$, convexe no. 109. pl. 162. fig. 6 , quadriayée pl. 162. fir. 8. (Cetonia fucata n ${ }^{\circ} .82$. Fa . Syst. Eleut.), splondide no. 114 . pl. 162. lig. 11 , chrysis $n^{\circ}$. 135 . pl. 155. fig. 34 de ce Diclionnaire, ainsi que la Celonia virens n॰. 29. Fan. Syst. Eleut.

B. 'Tarscs antérieurs seulement ayant un de lears crochets bilide, l'ante eutier.

3. Rutèle éclatanle, R. corrusca.

Rutela tota cenco-nitida, capite, thorace, scutello elytrisque testaceis.

Ionguenr I ponce. Antennes et partics de la bouche d'un lestacé-brun. Dessous du corps, palles et anus bruns, arec in bean reflet d'un verledor'́. Dessns de la tête, du corselet, ćcusson el élyires testacés avec un reflet vort-doré moins scnsible sur les ćlytres. 'Tèle, corselet et ćcusson finement pointillés, les élytres l'élant plus distinctement; quelques-uns des points se confondiant el formant de pelites slrics irrégnlières. Pirlie postérienre du sleıram prolongee en devant en un appendice fort relcvé, allant en grossissant vers l'extrémití; celle-ci est peu recourbee et dépasse les banches antérieures.

De Cayenne.

$2^{2}$. Division. Ecusson petit, tanłôt arrondi à son extrónité, tanlôt en triangle conrt. - Point de fièce triangutaire entre le corsclet et les ćlytıes.

re. Subdivision. Ecusson arrondi à son extrémité. - Chaperon enlicr. (Genrc Pelsdnota. DEJ. Catal.)

A. I.es denx tarses antérieurs ayant un de leurs crochets hifide dans l'un des sexcs, l'autre entier : ces deux crochets entiers dans l'aulre sexe. (Corps un peu déprimó en dessus, large pour sa longueur; forme des (éloines.)

\section{Rutris terninale, $R$. teminata.}

Rutelu fusca, ceneo-micans, subtìs hirsuta, elytris castaneis nitidis, post medium fuscis, ad apicen dilutioribus, opacis, scabris.

Pelidnota terminata. Des. Catal.
Longusur i lig. Antennes de couleur marron. Tète, écnsson et corselct bruns avec nn beau reflet vert-cuivroux; le dernier bordé cxtriters renent de testacé. Elytres brillantes, testacées à lcur base, ayant uve petite dépression vers le milieu de celle base et nne autre bcaucoup plus torte sur le côté, ausslessous de l'angle huméral: ces dépressions ayant des poinis enfoncés; ensuite et passé le unilien, la conleur devient plas foncée. Extrémité des Elytres raboteuse, fortement ponctnće, d'un jaune-mat; cette coulen: s'élevant un peu le loner du bord extérieur. Des sous du corps et anus hérissés de poils roussâtres, cle couleur cuivrcuse ainsi que les pattes; partie postćlicure du sterizum se prolongeant eu devant en nue petite pointe mousse qui ne dépasse pas les hanclies in!ermédiaires. Näle et femelle.

De Cayenis.

B. Tons les crochets des tarses entiers dans les deux scxes. (Corps convexe en desins, long pour sa largeur. Forme des Haunelons.)

Rapportez à celte section les Hannetons ponctué $\mathrm{n}^{n}$. 12. pl. 154. fig. 15 ; et glancuue $\mathrm{n}^{\circ}: 20$ de ce Dictionuaire.

2e. Subdivisior. Ecusson en triangle eourt. - Chaperon échancré en devant. - Tous les crochets des tarses entiers. (Genre Rutela. DE.s, Catal. )

Rapportez à celle subdivision les Cétoines linéole $n^{\circ} .117$. pl. 162. fig. 13 , surinamoice n⿳. 118. pl. 162. fig. 14 (celle-ci n'est qu'une variélé de la preniére), striće $n^{n}$. 119. pl. 162. fir. 15 , et le Hanneton d'Orey $n^{\circ} .55$, décrits davs ce Dictionouire. Ce dernier est la Cctonica gloriosa. no. 120. EA B. Syst. Eleut.

Nota. La Cétoine létradactyle n? 1 12. pl. 162. fig. 9 de ce Diclionnaire est du genre Rutcile ainsi que quelques Céloines de la troisième division, et plusieurs espèces de Hannelons.

$$
\text { (S. F. et A. Serv.) }
$$

RYGCHIE, Rygchium. M. Spinola dans le premier fascicule de ses Insectes de Ligrurie, pay. 84, a fondé sous ce non un genrc diusectes de l'ordre de Fyménoptéres, section des Porteaiguillon, famille des Diploptères, Iribu des Guèpiaires. Ce genre n’a pas été adopté par M. Latreille daus ses derniers ourrages, il en fait senlcment la première division da genre Odyuère dont il est très-voisin. Voyez l'article OdYiere de ce Dictionnatre el la Guêpe oculéc nn. 80 , seule espèce rappottée au genre Rygchic.

Nota. On a écrit par errcur à l'arlicle cisé, Rhynchic au lieu de Rygchie.

(S. F. et A. SErV.) 


\section{S A G}

Sagaris, Sagaris. Nom donné par Panzer (Faun. Germ. révis.) à un genre d'Hyménoptères Gallicoles qui correspond à celui d'Ibalie de N. Latreille. (S. F, et A. SERv.).

SAGRE, Sagra. Fab. Wér. Oliv. (Entom.) Alurrus. Ofiv. (Encycl.) Tenebrio. Sulz. Drur.

Genre d'insectes de l'ordre des Colóoptères, section des 'Tétramères, fanille des Eupodes, uribu des Siugrides.

'Irois genres composent cette tribu. Les Mégalopes sont reconnoissables par leurs antennes presqu'en scie et lenr corselet court, presque carré. Dans les Orsodacnes le corselet est alongé, rétréci postéricurenent; ces derniers ont en oulre les yeux entiers et le corps étroit.

Antennes simples, filiformes, insérées a devant des yeux, composées de onze articles, le premier reallí, les swivans courts, presqu'obconiques, les derniers cylindriques, - Mandibules yraudes, forles, un peu arquées, creusées intérieurement, pointues, entières. - Mâchoires bifides, leur lobe extérieur grand, arrondi, terminó par des poils serrés, lougs et roides, le lobe intérieur presqu'une lois plus court, comprimé, cilié, un peu pointu. - Palpes filiformes, leur dernier article piesqu'ovale, aigu à son extrémité, les maxillaires un pen plus loness, de quatre articles, le premier court, peu a pparent, les second et troisième égaus, coniques. - Lèvre bifide, es divisions égalęs, avancées, fortement ciliées ou velues. - T'ête avancée, inclinée, un peu plus étroite que le corselet, ayant à sa partie antérieure deux sillons croisés en forme de $X$, dont les branches supérieurés font le tour des yeux. Feux saillans, échancrés au térieurement,-Corps alongé, - Corselet cylindrique, beancoup plus étroit que les élytres, ses angles antérieur's suillans; parlie postérieure du sternum descendant très - bas sur l'abdowen. - Ecusson très-petit, ponctiforme. - Elytres convexes, leurs angles humeraux forts, relevés; elles recuuvrent les ailes et l'abdomen, - Pattes frrtes, les postéricures beaucoup plus graudes que les autres, ayant leurs caisses très-renilées et leurs jarnhes plus ou moins arquées; tarses aveo leurs trois premiers ariicles la1 ges, cordiformes, garnis en dessous de pelotes spongieuses, le troisieme profoudément bifide, le qualrième fort long, arqué, nuni de deux crochets conrts.

Ce genre est composé d'espèces assez grandes, ornées des plus belles couleurs et ordinairement méraliliques; il est étrangrer à l'Europe et a l'A mérique. Oa ignore ses mours. Le nombre d'espèces connules est petit.

\section{SAGRE triste, $S$. tristis.}

Sagra viridi-cyanea, fomince femoribus intermediis posticisque dente valudo armatis, tibiis posticis ad basim et apicem dentatis; maris femorum internediorum dente obtusiore, tibilisque posticis ad basin subtuberculatis.

Sagra trisis. Fав. Syst. Eleut. tom. 2. pag. 27. $n^{\circ}$. 5. Feınelle. - Univ. Entom. tom. 6. pag. 499. $n^{\circ}$. 4. Sagr. pl. 1. fig. 4. Femelle. incycl. pl. 370. fig. 7. Femelle. - Sugra marosa. OLIv. Id. no. 5. Sagr. pl. 1. fig. 5. Mâle. Encycl. pl. 37o. fig. 8.

Loungıenr ro lig. Fem. 8 lig. Mâle. Corps d'un blen-verdâtre foncé. Antenues et pattes d'un bleunoiràre. Elytres cluargées d'un grand nombre de petites lignes siunées, irrégulières, enlinncées. (iuisses interınédiaires et postérieures munies en dessous d'une forte dent aiguë; jumbes postérieures un peu arquées à leur base, y ayant un assez gros tubercule et un autre à leur extrémité. On voit des poils d'un roux-doré garnissunt un enfoncement de la base des cuisses postéitieures ainsi qu'une ligne médiale du sternum et de l'abdomen. Femelle.

le mâle diffère en ce que les dents des cuisses et les inbercules des jambes sont plus obtus, que les cuisses postérieures n'ont point d'enfoncement ni de poils dorés et que les dernières jambes sont beaucoup plus arquées dins toute leur étendue.

Elle se trouve sur la côte d'Angrole en Afrique.

\section{SAGRE pourpre, $S$, purpurea.}

Sagra purpurea, nitida, antennis, tibiis tarsisque nigro-viridibus; foemina femoribus posticis tridentatis, maris umidentatis.

Sagra splendida. Fав. Syst. Eleut. tom. 2, pag. 27. $n^{\circ}$. 2. Femelle. - Os.rv. Entom. tom. 6 , pag. 497. $n^{\circ}$.2. Sagr. pl. 1. fg. 2. a. b. Fetnelle. - Encycl. pl. 370. Jig. 3 et 4 . Femelle. - Sagro purpurea. НАв. Syst. Eleut. tom. 2. pag. 27. $n^{\circ}$. 3. Mâle. - Oliv. Entom. tom. 6. pag. 493. $n^{\circ}$. 3. Sagr. $p l$. 1. fio. 3. Mále.-Encycl. pl. 370, fig. g. Mầle.

Longueur ro lig. Fem. 8 lig. Màle. Corpgs d'un beau vert-doré très-Lrillaut à reflet pourpre. Antennes noires, pourpres a la base. Cuissés postérieures munies eu dessous ver's leur extrémitó de trois dents, l'intermédiaire forte, aiguë: les dernières jatmbes sont terminées par troois dents, l'une extérieure forte, aiguë; la seconde interne, petite, la troisième terminole et crochue. $\mathrm{Fe}$ melle. 


\section{S A G}

te mále diffère par sa coulear d'un pourpre plus décidé; ses antennes, ses jambes et ses tarses sont d'un noir-bleuâtre; les cuisses postérieures n'ont qu'une petite dent; les dernières jambes sont lrès-arquées et terminées par une seule dcnt inlérieure.

Des Indes orientales et de la Cline.

Nota. Nous exprimons ici notre opinion sur Jes sexes des Sigres en desirant que les entomologisles les vérifient sur les insectes vivaus, d'autaıt plus que notre manière de voir à cet égard est en opposition avec celle de M. Dalman, silvant très-distingué. Voyez Analect. entom. Holm. 1825. pag. 72 , observation après la description de la Sagra cyanea.

On rapportera à ce genre, $1^{\circ}$. l'Alurne grosse cuisse $n^{\circ} .2$ de re Dictionnaire (Sagra femorata. FAB. Syst. Eleut. tom. 2. pag. 26. $n^{\circ}$. 1. Encycl. pl. 370. fog. I et 2 ); $2^{\circ}$. l'Alurne denté no. 3 (Sagra dentipes. Fав. Syst. Eleut. tom 2. pag. 28. $7^{\circ}$. 6. ); 3०. la Sagra fulvida. Fa в. $n^{\circ} .4 ; 4^{\circ}$. les Sigres nègre (Encycl.pl.37o. fig.6) et bronzée (Encycl. pl. 37o. fig. 5.) de l'Entomologie d'Olivier ainsi que la Sagra cyanea Dacm., ouvrage précilé.

Nous pensons que l'Alurne violet no. 4 du présent ouvrage appartient aussi au genre Sugre.

( S. F. et A. Serv. )

SAGRIDES, Sagrides. Première tribu de la famille des Eupodes, section des 'Tétramc̀res, ordre des Colćoptères, offrant pour caractères :

-Mandibules ayant leur extrémité entière, sans échancrule. - Languette profondément écbancrée.

Cetle tribu se compose des genres Mégalope, Orsodacne et Sazre.

MÉGALOPE, Megalopus. Faв. Lat. OLiv. (Entum.)

Gen:e d'insectes de l'ordre des Coléoptères, section des Tétraunères, famille des Eupodes, tribu des Sigrides.

Des trois genles qui composent cette tribu ceux d'Or'sodacne et de Sagre se dislinguent par leurs antemres simples; de plus, les Orsodacnes ont les yeux entiers, et les $S_{a y}$ res le corselet cylindrique.

Antennes presqu'en scie, insérées vers le tord inlerne de la partie antérieure des yeux, composées de nnze articles, le premier assez long, en massue; le second plus court, presqu'en cône renversé, les autres s'élargissant de plas en plas à leur partie antérieure et formant cluacuu une espèce de dent de scie. - Bouche avancéc. - Mandibules proćminentes, élroites, alongées, aiğü̈s, leur extrémité entière ; se crorisant l’une sur l'autre. - Mâchoires cornées, bifid ss; lobe extérieur grand, très-velu à son extrémité, l'intérieur court, forteneut cilié au bord interne. Palpes égaux, filiformes, leur dernier arlicle alongé, conique, très-aigu; les maxillaires de quatre articles, le premier très-court, le second alongé, le troisièue court; les labiaux de trois articles, dont le premier court, le second tièslong. - Ldure bifide, ses divisions très-alongées, obtuses et cilićes. - Tête inclinće, dégagée di corselet et plus large que lui. - Yeux grands, fortemcnt échancrés en devant, ayaut aussi parderrière un siuus large, peu profond. - Corps peu alongé. - Corselet un peu plus étroit que la têtc, presque carré, moins lar que que les élytres, rebordé antérieuremenı el à sil parie postérieure. - Ecusson distinct, triangulaile. - Elytres rem couviant les ailes et l'abdornen. - l'attes fortes; cuisses postérieures souvent renflées; jambes iuterinédiaires et postérieures ordinairement a:quées : tarses assez courts, garnis de peloles en d́cssous, leur pénulième article plus ou moins bilobs, le dernier terminé par deux crocbets forts, simples, aigus.

Olivier a remarqué avec raison que le nom de ce genre, tiré de deux mots grecs qui signifient : grand pied, ne paroît pas fort justifié par l'orgatnisution. Ces insectes, dont on connoit aujourd'hri une quinzaine d'espèces, habitent l'Amérique, et particulièrement le Brésil. Leurs mours sont inconnues. On présume qu'ils fréquentent lee feuilles des plantes.

\section{MÉgalope bordé, $M$. cinctus.}

Megalopus pallide luteus, antennis et capitis vertice nigris, elytris vinidi-caruleis, malgirrs exteriori luteo.

\section{Megalopus cinsțus. Des. Cata?.}

Longueur 6 lig. Corps d'un jaune-pâle. Antennes noires, leur premier article jaune à sit partie supćrieure. Tèle ayant le vellex noir avec une tache entre les yeux et l'extrémité des mandibules de celte couleur; la partie intérieure dn front auprès des yeux est ponctuée. Corselet ayant quclquefois uue petite ligne dorsale et des points à sa partic antérienre, bruns. Elytres d'un bieu-foncé changeant eu vert, très-ponctuées; leur bord extérieur, depuis les angles hanéraux jusqu'a la sutrre, d'un jame-pâle; celle couleur s'élirgissant an-dessus de l'anns : tarșes postérieurs bruns, cuisses postérieures renflées; les quatre dernières jambes arquées.

Du Brésil.

$$
\text { 2. MT́gatope fémoral, M. femoratus. }
$$

Megalopus luteus castineo varius, femoribus posticis maximis midentatis, tibiis ejusdens paris maximè arcuatis.

Longueur 5 lig. $\frac{1}{2}$. Tète et corselct de coulen: marron mêlée de quelques vuances janues per distinctes. Parlic intérieure du front aupres des 
ycux, panctuée. Antennes brunes, leurs premiers articles jaunes à leur parlie extérieure. Ecusson mạron. Elytres ponctuées, jaunes, avec la suture et ane bande longitudialie dans lear milieu de conleur marron, cette bande n'atteignant pas l'extrémité postérieure. Déssous du corps et pattes jaunes, rayés de couleur marron. Cuisses postérieures tres-rentlées, ayant en clessous une dent forte, aigaë, un peu trochue; les quatre dernic̀res jumbes arquáes, les postérieutes l'étant excessivement.

Da Brésil.

\section{MEgalope fronbal, MT. frontalis.}

Megalopics fulvo-ferrugineus, anteninis, fronto, elytrorum parte dininidia posticâ tarsisque posticis nigris.

Longueur 5 lig. Corps d'un fanve-ferragivieux luisant. Anteunes noires, fort élargies el aplaties après le quatrìme article. Front noir entre les yeux, sa partic intérieure anprès de ceux-ci fortement ponctuée; mandibules noires í lonr extrémité. Elyures pointillées, lear moitié inférieure de couleur aorre, ainsi cque les deux tarses postérieurs. Ailes noires; cuisses postérieures renflées; les quiztre dernières jaubes peu arquées.

Du Brésil.

Nota. Celte espèce a quelque ressemblance avec le Megalopes dorsalis d'Oliv. Entom.

\section{MÉgalore point d'exclamation, M. excla- mationis.}

Megalopus Jerrugineus, antennarum basi, capitis parte superâ, thoracis maculâa dorsali quadratâ, pectore et alytrorum luteorum lineâs humerali, alià parvâ interiori punctoque subapicali nigris.

Longueur 5 lig. Aútennes ayant leurs qualre premiers articles noirs, les quatre suivans d'un testacé-lerrugineux avec leur dos ou partie supérieure de couleur noire, les trois deruiers entièrement ferrugincux. Tête noire, sa parlie antérieure an-dessous des yeux et des antennes, ferruginense. 13rase du labre et extrémité des mandibules noires. Parlie intérieure du front auprès des yeux forteinent ponctnéc. Corselet ferrugineux ayaut une tache dorsale noire, presque carrée. Ely tres ponctuées, jaunâtres, avec une ligne longitudinale fartunt des angles hunéraux, dépassant un peu le milicu del'élytre, une autre très-conte, plus voisine de la sulure, et une tache presque triangulaire vers l'extrémité, de couleur noire. Poitine el écrissou de cette couleur. Paltes el dessous du corps d'un jaune-ferruginenx; cuisses postépieures renllées, les quatre demières jumbes peu arquéés.

In linsil.
5. MÉgalore hutméral, MI. humeralis.

Megalopus ferrugineus, thoracis inaculà subovatâ, elytrorum humeris maculisque duabus nigris, pedibus nigro variis, femoribus posticis bidentatis, tibiis cjusdem paris maximè arcuatis.

Longuear 5 lig. $\frac{1}{-}$ Ferruginenx; antennes noires, leurs sept derniers articles ferrnginenx inferieurement. Partie intérienre du front auprès des yeux furement pointillée. Une tache sur le vertex, ijase du labre, extrémilé des mandibules de conleur toire. Le milien da corselet oflre une tache ovale de celte couleur. Elytres poncluées; leurs angles huméraux et deux taches assez rapprochices sul chacune, noirs. Poitrine ayant quelques taclies brunes. 'Tarses el dessus des jarubes nuirs; cuisses postérieures très-renllées, bidentées en dessous; ces dents forl courtes, larges. Les quatre dernières jambes arquées, les pustélicures l'élaut excessivenent.

\section{Du Brésil.}

Nota. Cetie espèce n'est peut-être qu'une variété de la précédente, d'un sexe différent. Nons engargeons les entomologistes à porlće d'exisuiner sur le vivant, de voir si ces individus à jambes postérieures très-arqućes ne servient pas les màles, ce que nous présurnons.

\section{MÉga Lope linéé, M. lineatus.}

Megalopus niger, thorace pullido marginato, elytrorum lineâ $a b$ humeris descendente aliâque internâ abbreviatấ nigris, scutello nigro pallido maculato.

Longueur 4 lig. $\frac{1}{2}$. Noir. Partie de la tête sous les yeux d'un juuue pâle. Bouche noire, bord inférieur du labre d’un jaune paile. Parlie intérieure du frout auprès des yeux fortement ponctuće. Corsclet bordé lout autour de jaune pâle, ce bord émeltant au-dessus de l'écnsson denx petites ligues de même conleur que lui qui s'avancent en divergeant jusque vers le milien du corselet. Eljutres ponctućes, un pou velues, páles, avec une ligne longritudinale quin descend de l'angle huméral sans coucher le bord postérienr ni l'extćrieur', justrue vers le bout de l'élytre, et une autre ligne courte plus près die la sulure, de conlear norre. Ventre, cuisses et hanches rayés de jaune paile; cuisses postéricures peu renflées, lis quare deruières jambes peu arquées.

Du Brésil.

7. Mricazope il épine, M. spinosus.

Mregalopus subinearis, ferrugineo-testaceus, antelmis, capiac, abdomine, pedibus posticis elytrur:unque apice nirris, coxarmu posticusum appendice magno compresso apice aculo.

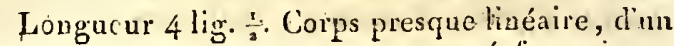
testacé-ferrugincux 
lestacé - ferrugineux luisant, ún peu velu. Tête noire excepté les palpes et le bord inférieur du labre. Partie intérieure du front auprès des yeux, ponctuée. Abdomen noir, ainsi que les pattes postérieures. Elytres pointillées ayaut quelques dépressions vers leur suture, leur extrémité noire. Ininches testacćes, les postérieures munies d'un appendice long, aplati, dilaté, pointu et noir ì sou extrémité; cuisses postérieures moyennernent renfles, ayant une ligne ferrugineuse ì leur partie postérieure : les quatre dernières jambes peu arquées, les postérieures aplaties, un peu deutées en scie intérieurement.

Du Brćsil.

Rapportez à ce genre, $1^{\circ}$. le Mogalopus nigricomis. FAB. Syst. Eleut. tom. 2. pag. 368. $n^{\mathrm{o}} \cdot 2$ (LA T. Gener. Crust. et Ins. tom.3. pag. $45 . \mathrm{n}^{\circ}$. I. tom. I. tab. XI. fig. 5. - OtIv. Entont. toin. 6. pag. 920. $n^{\circ} .2$. Megal. pl. 1.fig. 2$) ; 2^{\circ}$. le Megalopus dorsalis, $n^{\circ}$. 1. Otrv. id. fig. 1. a. b.; $3^{\cap}$. Ic Megalopus fasciatus. Da cm. Anal. Entom. Holm. 1823. pag. $7^{2} \cdot n^{\circ} .65 ; 4^{\circ}$. le MLgalopus sellatus. Germ. Ins. Spec. nov. yol. 1. Coléopt. 1824 .

Le Megalopus ruficornis. FAB. Syst. Eleut. tom. 2. pag. $367 . n^{n}$. 1, est probablement aussi de ce genie. (S. F. et A. SELv.)

SALDE, Salda. Fab. PAyz. Lygarus. Lat. Acanthics. Wolf. Cimex. Linv. Geocoris. Fali.

Geure d'inscctes de l'ordré des Fémiptères, section des Hétéroptères, famille des Géocorises, tribu des Longil:? res.

Un groupe de celte tribu est formé des genres Myodoque, Lygǵć, Pachymère et Salde (voyez par. 52 de ce volume); niais dans les trois premiers les yeux nc débordent pas la partie postérieure de la têle : en outie les Myodoques ont un cou très-distinct. Les ocellcs ( 1 ) sout sitillans dans les Lygées, et les Pachymères ont lears cuisses antćrieures canaliculées en dessous.

Antennes filiformes, grossissant un peu vers l'extrémité, à peine de là longueur de la tête et du corselet pris ensemble, composées de quatre articles, le premier court, dćpassant à peine l'extićmité de la tête; le second lc plus long de tous, les troisième et quatrième égaux entr'eux, à peu près de la longueur du premier; le dernier plus "gros que les autres, fusiforme. - Bec long, de quatre articles, renfermąut uı suçoi: de quatre

(1) Nous préférons, avec M. Latreille, le nom d'ocelo les à la périphrase peties yeux lisses. Ce savant auceur vient de publier un ouvrage intitulé : Familles naturelles du règne animal, dans lequel il donne lis caractères de plusieurs nouvelles famil'es, tribus et genres, dont nuus fụrons dorénavant usage : si douc, à conprer de cer arricle, ôn aperçoit quelques noms nouveaux dans des sujers déjà traités, on lie devra les atribuer qu'aux progrès imprimés à la sçience yar ce célèbre zoologiste.

Hist. Nat. Ins. Toine $\boldsymbol{I}$. soies. - Tête transversale, un peu triangulaire, plus large que le corselet. - Yeux grands, trèssaillaus, rejetés sur les bords latéraux du corselet et dépassant de beaucoup le bord postérieur de la tête. - Deux ocellés peu distincts, placés sur la partie postérieure du vertex à la jonction de la tćte avec le corselet. - Corps court, large pour sa longueur. - Corselet presque carré, point rebordé. - Ecusson assez grand, triangulaire. Elytres de la largeur de l'abdomen. - Abdomen composé de segmens transversaux dans les mâles, ses avant-derniers segmens rétrécis dans leur nuilieu, posés obliquement et en forme de clsevrons brisés, le dernier s'ćlargissant et s'étendant dans son milieu vers la partie moyenne du ventre dans les femelles; anus de celles-ci sillonné longiludinalement, ce sillon renfermant une tarière ployée en deux sur elle-même dans le repos, et pouvant en être retirée : anus des mâles entier, court, sans sillon longitudinal._Pattes asscz fortes; cuisscs simples : tarses de truis articles, le premier plus long que les deux autres pris ensemble; crocbels forts, recourbés, divergens.

En créant le genre Salda, Fubricius y comprit uu grand nombre d'espèces qui a voient peu d'analogie entr'elles, dont quelques-unes même apparlenoient à celui de Miris, qu'il avoit fondé. Depuis, M. Latreille en a ôté quelques espèces pour cn former son genre Acanthie. Quant à nous, le genre Salde tel que nous le présentons ici, équivaut absolument à la seconde section de la seconde division du genre Lygée. La T. Gener. Notre célc̀bre auteur français, dans une remarque, pilroissoit porté à regarder cetle seconde scction comme devant constituer un genre particulier : il vient de le caractériser dans ses Familles naturelles du règne animal. Nous ne connoissous qu'un petit nombre d'cspèces de Saldes; leuts mours ne sont pas counues, mais elles doivent se rapprocher beaucoup de celles des Miris et des Capses. Leurs métamorphoses n'offient rien de remarquable. Voyez Pentatome.

\section{SArDz érythrocéphale, S. erythrocephalc.}

Saldu atra, punctata, capite pedibusque nufis, elytronum membranâ hyalinâ.

Longueur 2 lig. Antennes d'un fauve-brun; tête et pattes d'un fauve-rougeâtre. Corselet, abdomen, élytres et écusson forlement ponctués et d'un noir-brillant. Membrane des elytres transparente. Mâle.

Du midi de la France.

\section{a. Salde de Stéven; $S$. Stevenii.}

Salde nigra, punctata, thoracis et elytricujusque lineâ longitudinali mediâ luteâ, pedibus oculisque rufis; elytromin nuembranâ subopacá.

Longueur I lig. $\frac{1}{2}$. Noire. Antennes bruses, S s 
Jonr dernier article plus cluir. Tête, corselet, ícusson et poitrine très-ponclués, le second ayant dans son milien une ligne longitudinale étroite, jaune. Elyires avec des sllics formées de points; on voit ver's leur milieu une ligne longitudinale assez large, de couleur janne; membrane un peu obscure. Abdomen lisse. Yeux et pattes roussâtres; cuisses ayant quelques nuances bruncs. Femelle.

D'Europe. Cette espèce nous a élé donnée par M. le conseiller Stéven, directeur des établissemens botaniques en Crimée, à qui nous la dédions.

Rapporlez à ce genre les Salda atri , $n^{\circ}$. 4 . ( l'sxz. Faun. Gemn. fas. 92. fig. 20.) Albipenuis, $u^{\circ} .5$, et Grylloides, $n^{\circ} .7 \cdot$ (Acanthia grylloiáes. Wouf. Icon. Cimic. lab. 5. fig. 41. Encycl. pl. 374.fig. 5.) Faв. Syst. Rhyngot.

IYGE', Ligons. Fab. Lat. Cimex. Linn. Groff. De Grer. Coreus. lab.

Gence d'insecles de l'urdre des Hémiptères, seclio.r des Hétéroptères, fanille des Géocorises, trilsu des Longilabres.

Ies Myodoques, les Lygées, les Pachymères et les Saldes forment un groupe dans cette tribu ( voy. par. 52 de ce volume); mais les Myodogues se reconnoissent à leur tête ovale-alongrée, portée sur un cou que forme le rétrécissement sabit de sa partic postérieure; les Pachymères unt leur's ocelles peu saillans, les avant-derniers seymens abdominaux des femelles sont rélrécis da us leur miliea et posés obliquement; les cuisses antérieures dans les deux sexes sont toujours camaliculíes en dessous, ordinairement renflées et épineuses inférieurement; exfin les Saldes ont la tête transversale, les yeux grands, rejetés sur les bords latéraux du eorselet. Au moyen de cette compitraison on reconnoitra aisézient le genre 1.ygće.

Antennes ordinairemeut filiformes, insércées à la partie inférieure des côtés de la tête, composées dc qualre arlicles eylindriçues; le premier beaucoup plus court que le second, dépassant à peine l'extrémitć de la tête, le dernier quelquefois un jer plus rios que les autres. - Bec assez long, de quatre articles, renfermant un suçoir de quatre soies. - Tête petite. - Yeux pétits. Deux ocelles saillans, écartés l'un de l'autre, placés eutre les yeux à réseau. - Corps ovalealongé. - Corselet un peu rebordé, trapézoidal, ses còtés extérieurs peu arrondis. - Ecusson triangulaire. - Elytres dépassant l'extrémité de l'abdomen et de même largeur que lui. - Abdomen composé de segmens transversaux dans les deux sexes; anus des femelles sillonné longiluclinalenent dans son milieu, eelui des mâles entier, sans sillon longitudinal. - Pattes simples, assez longues; tarses de trois articles, le second ulus court que les autres : erochets recourbés, munis d'une pelote bilobće dans leur entie-deux.

Les métamorphoses et la manière de vivire des insectes de ce genre dont le nom vient d'un mot grec qui sionnifie : obscur, sont les mêmes que celles des aulres Longilabres (voyez Pexтatoms.); ils n'exhalent point d'odeur désagráable; on les tronve souvent réunis en une espece die société. Nous avors beaucoup restrcint ce genre, nousen présentous les raisons en développant les earactères de ceux que nous en avons extrails; cepeudant malgré cetle réduction il est encore trèsnombreux en espèces tant européenues qu'exotiques.

On doit y rapporter les Lygoens familiaris $n^{\circ} .64$, militaris $n^{\circ} .56$, equestris $n^{\circ} .57$, saxatilis $n^{\circ} .62$, hyosciami $n^{\circ} .63$, et punctumn $n^{\circ} \cdot 94$. FAB. Syst. Rhyngot.

PACHYMÉRE, Pachymerus. Lygarus. FAB. Lat. Panz. Wolp. Cimex. Linn. Geoff. DE Géer. Miris. Fab.

Genre d'insectes de l'ordre des Juémiptères, section des Hétéroptères, famille des Géocorises, tribu des Longilabres.

Quatre genres de celte tribu y forment un petit groupe (voyez pag. 52 de ce volume). Les Myodoques onl un cou très-distinct; les Saldes ont des yeux très-grands, rejetés sur les côtés du eorselet, leur tête est large, transversale, et les Lyóes ont leurs ocelles siillans, les segunens de l'abdomen transversaux dans les deux sexes, les euisses autérieures jamais renflées ni épineuses en dessous, ordinairement sans canal dans celte partie.

Antennes ordinairement filiformes, insérćes à la partie inférieure des côtés de la tête, composées de quatre articles cylindriques, le premier berucoup plus court que le seeond, dépassant à peine l'extrémilé de la tête, le dernier quelquefois un peu plus gros que les autres. - Bec de longueur moyenne, eomposé de qualre articles, et renfermant un suesoir de quatre soies: - Téte petite.-Yeux petjts. -Deuxocelles peusaillans, éeartés l'un de l'autre, placés près des yeux à réseau sur la partic de la tête qui est derriere ceux-ei.-Corps ovale. - Corselet ordinairement plat et sans l'cbords, peu rétréci en devant. - Ecusson triangulaile, assez grand. - Elytres de même longueur que l'àdomen, le couvrant en enlier. - íbdomen composé de segmens transversaux dans les máles, les avant-derniers segmens rélrécis dans leur milieu, posés obliquement et en forme de chevrons brissés, le dernier s'élargissant et s'étendant souvent dans son milieu presque jusqu'à la moilié de la longueur du ventre dans les femelles; anus de celles-ci sillonné longitudiualement : ce sillon renferwant une tarière longue, comprimée, ployée en deux sar elle-méme dans le repos et pouvant en être retirće; anus des mâles eulier, eourt, sans sillon longitudinal. - Pattes de longueur moyenne; cuisses antérieures toujour's canalicn- 


\section{S A L}

l'es et souvent épinenses en dessons, ordinairement renflées; tarses de trois artieles, le seeond plus court que les autres; erochets recourbés, munis d'une pelole bilobće dans leur entredeux.

Ce nonveau genre est un démembrement de celui de Zyogreus des autears; son nom tiré de deux mots yrecs a rapport ì la grosseur des cuisses antérieures. Ce que l'on eounoit de ses mœurs est eonforme à eclles des Lygées, mais la longue tarière dont les femclles sont pourvues et qui néeessite chez elles une organisation des segmens de l'abdomen différente de eelle qui cxiste dans les genres voisins, fuit regretier qu'il n'y en ait point exeore eu d'observées au moment où elles déposent leurs cufs. Nous eonnoissons une vingtaine d'espèces de Pachymères toutes de l'ancien eontinent, la plupart européenues; elles ont des couleurs sombres el généralement une mauvaise odeur.

A ce genre appariennent les Lygans echii no.

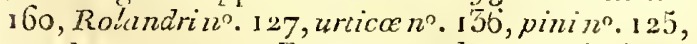
quadratus $n^{\circ}$. 14 L. FAr. Syst. Rhyngot. ainsi que son Miris alietis no. 16. On doil eneore y rapporter le Lygaus pedestris. PAxz. Faun. Gernu. fas." ". fig. 14, et la Punaise brune à pointe des ćluis blanche. Groff. Ins. Paris. tom. 1. pag. 450. $n^{\circ} \cdot 29$.

ASTEMME, Astcmma. Lygaus. FАв. LАт. Cimex. Linn. De Géer. Gloff.

Genre d'insectes de l'ordre des IIémiptères, farnille des Géocorises, iriba des longilabres.

Les Astemmes, les Miris et les Capses sont les seuls longilabres privés d’ocelles; mais diars ees denx derniers genres les antennes sout sétaećes et 1. corps mou.

Antennes ordiuarement filiformes, insérées ì la partie inférieure des côtés de la têle, composćes de quatre arlieles cylindriques; le premier aussi long que le second, dépassant de beacoup l'extrérmilé de la tête ; les troi:ième et quatriène plus courts que les précédens, ee dernier quelquefnis un peu plus gros que les autres. - Bec long, de quatre articles, renfermant un suçoir de quatre sıies. - Tête petite. - Yeu.x pétits. - Point $d^{\natural}$ occllcs. - Corps ovale-ilongé, de consistance assez ferme. - Corselet un peu rebordé, trapézoïdil, ses côtŕs extérieurs peu arrondis. Ecusson triangulaire. - Elytres de même largeur que l'abdomen. - Abdonzen eomposé de segmens transversaux dans les deux sexes; anus des femclles sillonné longitudinalement dans son milieu, celui des mâles enticr, sans sillon longitudinal. - Pattes simples, assez longues; tar'ses de trois artieles, le second plus court que les sutres; crochets reeourbés, munis d'une pelote bilobéc dans leur entre-deux.

Le nom de ce nonveau genre exprime qu'il est privé d'oeelles; les especces qui le composent ontété eonfondues juscqu'à présentaveeles Lygées : le earactère que nous venons d'énoncer et les dimensions des arlicles des antennes nous fout croire que les entomologisles verront avec plaisic eelle séparation. Les Astcmmes renferment un assez grand nombre d'espèces ornées de conlenrs agréables et variées, mais presque tontes exoliques. Celle dont nous connoissous les mœurs ( $A$. aptera) vit en société; elle esi remarquable en ee que ses élytres sont ordinairement, au moins dans notre climat, privées de parlie membraneuse. Elie n'a point de mauvaise odeur et est eonnue de tout le mondo, étant très-commune dans les jardins; on la désigne popnlairement aux environs de Paris sous les noms de Suisse et de Cherchemidi.

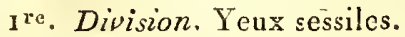

Rapportez à celte division les Lygacus apterus $n^{\circ} .116$, et suturalis $n^{\circ} .102 . F_{\mathrm{AB}}$. Syst. Rhyngot。

2. Division. Yeux pédieulśs.

\section{Astemine cornue, $A$. comuta.}

Astemma nigra, elytrorum parte coriaceâ rzbrâ, abdoninis segnnentis duobus intermedits subties albidis.

Longneur 6 lig. D'un noir mal; têle et eorselet un peu velus : dernier article des antennes blanc avec l'ex Irémité brune; base de l'éeussou et parlie eoriace des élytres rouges. Celle-ci ayant un perı de noir vers sa base; membrane d'un noir bat a rec une pelite tache blanchâtre à l'endroil oń elle se croise. Segmens intermédiaires de l'abdomen d'un blane-jaunâtre. Yeux portés sul dcux tubereules ayant à peu près une ligne de longueur, ce yui forme comme deux cornes. Femelle.

\section{De Cayenne.}

Nota. Nous pensons que le Cimex oculus cancri. De Géer, Ins. toml. 5. pl. 34. Jig. 24, dolt être rapportée à eelle division.

MiRIS, Miris. Fab. Lat. Painz. Cimex. Livi. Geoff. De Géer. Lygocus, Salda, Capsus. Fai. Ljgaus , Capsus. P'axz.

Genre d'insectes de l'ordre des Hémiptères; section des Héléroptères, famille des Gćocorises, tribu des Longilalbres.

Dans le groupe des Longilabres qui a les antennes de qualre articles el point d'oeelles (20y. pag. 52 de ee volume), les $\Lambda$ stemmes se distiuguent par lenrs antenoes filiformes el les Canses parce qu'ils ont ces orgunes bruscguemeut sítacés, dont le second article va en grossissant cu en se dilitant vers sou extrémité.

Antonnes longues, insensiblement sétaećes, infeirćes ì nu sur la gartie supérienre des côtés de la lête, 
composées de quatre articles cylindriques; le premier dépassant de beaucoup l'extrémité de la tête, le second le plus long de tous, ayant à peu près deux fois la longueur du premier, le troisième presqu'aussi long que le premier; le dernier le plus court de tous; ces articles conservant dans toute leur longueur leur grosseur parliculière; le premier le plus gros de tous, chacun des suivaris plus mince que celui qui le précède. - Bec long, atteignant au moins les hanches intermédiaires, composé de qualre articles et renfermant un sucoir de quatre soies. - Téte petite, triangulaire. - Yeux saillans, globuleux. - Point d'ocelles. - Corps mou, ordinairement étroit et atongé. - Corselet se rétrécissaut à partir des élytres jusqu'à la tête; tous ses bords droits. - Ecusson triangulaire. - Elytres un peu plus larges et un peu plus longues que l'abdomen, assez molles, souvent deai-transparentcs. - Abdomen composé de segmens transversaux dansles mâles; les avantderniers plus ou moins rétrécis dans leur milieu, posés obliquement et en forme de cluevrons brisés, e dernier s'élargissant à sa partie moyenne dans les femelles; anus de celles-ci sillonué longitudinalement, ce sillon renfermant une tarière longue, comprimée, ployée en deux sur elle-même dans le repos et pouvant en être retirée; anus des unâles entier, court, sans sillon longitudinal. Pattes longues, les postćrieures beaucoup plus que les autres; tarses de trois articles, le premier plus longr que les suivaus, le second et le troisième presqu'úgaux entr'eux, celui-ci terminé par deux petits crochets.

Les Miris n'oflent rien de particulier dansleurs mćtamorphoses; ils vivent sur les végćtaux dont ils nous paroissent sucer le suc; ils poinpent aussi le aiel des fleurs. Nous n'avons point de preuve qu'ils soient carnassiers; sans qu'ils vivent précisément en société, il est ordinaire de rencontrer un assez grand nombre d'individas d'une même espèce sur une seule plante. Ils marchent et volent avec une grande facilité et s'échappent beaucoup plus vîte par ce dernier moyen qua aucun des autres Longilabres. Il nous a paru qu'ils n'exhaluient pas d'odeur désagréable. Les espèces sont nombreuses, surtout en Europe.

I $^{\text {re }}$ Division. Pattes postérieures propres à sauter, leurs cuisses renflées. - Corps ovalaire, ses bords latéraux arrondis. (Corps court; antennes insérćes entre les yeux; tête distinctement séparée du corselet; corselet plus large que long, saus sillon trausversal ni bourrelet à sa partie antérieure.)

\section{Mrris cou janne, M. luteicollis.}

Miris petibus posticis saltatorïs, niger, nitidus, capite thoraceque fluvis; antennis pedibusque luteis, femoribus nigro maculatis.
Lygous luteicollis. Payz. Faun. Germ. fas. \#. fig. 18.

Longueur I lig. $\frac{x}{4}$. Tête et corselet d'un beau jaunc; on voit une petite ligne noire descendant des yeux à la base du bee. Antennes jaunes a vec l'extrémité du second et du troisième articles $n n$ peu brune. Poitrine, élytres et abdomen d'un noir brillanl. Paltes jaunes avec l'extrćmité des tarses et une tache vers la base des cuisses de couleur noire. Mâle.

De France et d'Allemagne.

Rapportez à celle division les Salda flavipes $n^{\circ} .3$ et pallicornis $n^{\circ}$. 6. FАB. Syst. Rhyngot. Cette dcrnière espèce est l'Acanthia pallicornis. Wolf. Icon. Cimic. tab. 15. fig. 122.

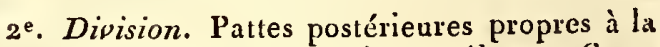
marche seulement ; leurs cuisses grêles. - Corps alongé, ses bords latéraux droits.

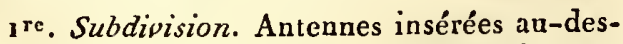
sous et assez loin des yeux; tête alongée, peu distinctement séparće du corselet; corselet plus long que large, sans sillon transversal ni bourrelet à sa partie antérieure.

\section{Miris vert, M. virens.}

Miris pedibus ambulatoriis, viridis, tarsis antennisque prosertim apice rubris.

Miris virens. FАв. Syst. Rhyngot. pag. 254. $n^{0} .7 .-$ Cinex virens. Linn. Syst. Nat. 2. 730.102. - Wolf. Icon. Cimic. tab. 8. fig. $7^{5}$.

Longueur 3. lig. Corps vert. Abdomen, pattes et antennes un peu velus; celles-ci de couleur rouge surtout vers leur extrémité, ainsi que les tarses. Femelle.

Commun aux environs de Paris.

Les Miris vagus $n^{\circ}$. 12. FAB. Syst. Rhyngot. (Wor. Icon. Cimic. tab. 16. fig. 153.) et Hortorum. Wolf. id.fig. 154 , appartiennent à cette subdivison.

$2^{e}$. Subdivison. Antennes insérées au-dessous et près des yeux; lête distinctement séparée du corselet; corselet pas plus long que large, ayant un sillon transversal et un bourrelet à sa partic antérieure.

\section{Mrns strié, M. striatus.}

Miris pedibus ambulatoriis, niger, elytris luteo ferrugineove striatis, partis coriacea apice pedibusque fermigineis, thoracis dorso maculâ ferrugineâ.

Miris striatus. FAB. Syst. Rhyngot. pag. 255. no. 15. - LAт. Gen. Crust. et Ins. tom. 3. pag. I 25. - Cimex striatus. De GÉER, Ins. torn. J́. pag. 2go. no. 29. pl. 15 . fig. 14 et 15.-Lrve. Syst. Nat. 2. 730.105. - Wolf. Icon. Cimic. fas. 1. 
pag. 37. tab. 4. fig. 37.- Lygaus striatus. Parz. Faun. Germ. fas. ". fig. 22. - Encycl.pl. 374 . fig. 10.

Longueur 6 lig. Antennes noires, leur premier article ferrogineux, le troisième blanc à sa buse. 'Tète noire avec une tache d'un blanc-jaunàtre à la partie supérieure de l'orbite des yeux. Corselet noir ayant une tacbe dorsale plus ou moins étendue de couleur jaune ou ferrugineuse, et quelquefois les bords latéraux de celte coulenr. Ecusson moir avec ses côtés plus on moins ferruginenx. Elytres rayées longitudinalement de noir et dc ferrugineux; l'extrćmité dc leur partie coriace de cette dernière couleur. Hessous du corps noir; bord postérieur de la poitrine et des cinq preniers segmens de l'abdomen blanc. Pattes ferrugineuses a vec l'extrémité des jumbes posiérienres pâle. Fcmelle.

Nota. C"est à tort que Fabricius et De Géer rapportent à ce Miris la Punaise no. 38 de Geoffroy. Ce synonyme appartient à l'espèce suivante.

\section{Mrrs écrit, M. scriptus.}

Miris pedibus ambulatoriis, niger, elytris luteo striatis, partis coriacece apice pedibusque ferrugineis, thorace posticè luteo trilineato.

Miris scriptus. Lat. Gen. Crust. et Ins. tom. 3. pag. 125.-Capsus scriptus. FAB. Syst. Rhyngot. pag. 247. $n^{\circ}$. 32. Mâle. - Coques. Illust. Icon. tab. 10. fig. 13. - La Punaise rayée de jaune et de noir. Georf. Ins. Paris, toml. 1. pag. 454. $n^{\circ}$. 38. Mâle.

Longueur 3 lig. $\frac{\pi}{2}$ a 4 lig. Antennes noires avec le nitieu de leur premier article et la base du second de couleur ferrugineuse; une très-petite portion de la base du troisièin carticle est blanche. Partie antérieure de l'orbite des yeux d'un blaucjannâtre. Corselet noir, son bord antérieur et trois lignes longitudinales de son lobe postérieur de couleur jaunâtre. Elytres noires, rayées de blancjandâtre; leur partie coriace terminée par une tache ferrugineuse. Ecusson noir. Paltes ferrugineuses; tarses et cxtrémité des jambes noirs. Milieu des quatre premières jambes blanchàtre. Dessous du corselet taché de blanchâtre. Abdomen fcrugineux, son unilieu ainsi que $i a$ coulisse qui renferme la tarière de couleur nuir. Femelle.

Le mâle diffère en ce que ses autennes et sou abdomen sont entièrement noirs : il a les pattes plus brunes que celles de la femelle.

\section{Mrnis de Carcel, M. Carcelii.}

Miris pedibus ambulatoriis, niger, thorace, scutello elytrisque rubris nigro maculatis, abdonine rubro marginato.

Longneur $4 \mathrm{lig}$. Antennes noires; base dn troisième article blanche, le dernier brun. Tête noire.
Corselet noir, ses bords latéraux et one petile ligne longitudinale sur son lobe antérieur de couleur rouge. Ecusson noir, rouge à son extrémité; élytres rouges ayant chacune deux laches noires, l'une vers la suture à côté de la pointe de l'écusson, l'autre vers l'ex!réınité : nembrane enfumée. Ventre noir burlé de roughc; celle bordure s'élargissant un peu auprès de l'anus. Pattes noires; milieu des jambes blanc ì sa partie extérieure. Femellc.

Le mâle diffìre en ce qu'il a le dessus dn corselet rouge avec deux taches noires; la couleur rouge descond davantage sur les côtés qui ont chacun une tacle noire et l'abdomen a beauconp plus de rouge que dans la femelle, cette couleur formant deux lignes de chaque côlé et bordant inférieurement les segmons du ventre entre ces deux lignes; les cuisses postérieures ont un peu de rouge en dessous vers leur base.

Nous devons cette espèce à $M$. Carcel qui l'a prise dans l'Anjou.

Nota. Le Lygaus sexpunctatus $n^{\circ}$. $100 . \mathrm{F}_{\mathrm{AB}}$ Syst. Rhyngot. n'est peut-être qu'une variété du mâle. Cet auteur donne des cuisses rousses, un écusson noir et la conleur dominante du dessus du corps rousse à l'individu qu'il décrit comme étant d'Espagne.

On doit rapporter à cette seconde subdivision les Ly'gaus campestris $n^{\circ} .15$, pratensis $n^{\circ} .155$ et striatellus $n^{\circ}$. I64. Les Capsus gothicus $n^{\circ} .20$. (Panz. Faun. Gem. fas. ". fig. 15. ), alhomarginatus $n^{\circ} .24$, flavomaculatus $n^{\circ} .30$. ( $\mathrm{P}_{\mathrm{ANz}}$. id. fis. "). fig. 16.), les Miris lavigatus $n^{\circ}$. 2. ( PaNz. id. fas. ". fig. 2I.) et laterulis $n^{0}: 3$. WA S $_{y}$ st. Rhyngot. ainsi que le Lygocus viulneratus. Pasz. id.fas. "fig. 22.

CAPSE, Capsus. Far. Lat. Cimex. Linn. Geoff. De Géer.

Genre d'insectes de l'ordre des Hémiptères, section des Hétéroplères, famille dés Géocorises, tribu des Longilabres.

Les Longilabres qui ont les antentes de quatre articles et qui manquent d'occlles forment un groupe (voyez pag. $52 \mathrm{dc}$ ce volume), dans lequel les Ástenumes sc distinguent par leurs antennes filiformes et les Miris parce que chez eux ces orgazes vont en diminuant iusensiblement de grosseur depuis la base jusqu'à l'extrémité.

Antennes longues, insérées ì nu sur les côtés de la tête en devant et tout près des yeux, composées de quatre articles; le premier dépassant de beaucoup l'extrémité de la tête, le second le plus longr de tous, terminé en massue; les deux derniers pris ensemble plus courts que le secosd, brusquement plus minces que les précédens. Bec long, atteignant au moins les hanches intermédiaires, composé de quatie articles et renfermant un suçoir de quatre soies. - Téte petite, triangulaire, rétrécio postérieurerato - Ieux 
saillans, clobuleux. - Poine d'ocelles. - Corps ovale. - Corsclet élevé postérieurement, se rétrécissant insensiblement vers lit tête, ayant un sillon transversal et un bourrelet ì sa partie antérieure. - Ecusson triangulaire. - Elyties un peu plus longues que l'abdomen. - Abdomen corn posé de segrnens transversanx dans les mâtes: les avant-derniers plus on moius rétrécis dans lcur milier, posés obliquement et en forme de chevions brisés, le clernier s'ćlarghissant à sal partie moyenne dans les femelles; anus de celles-ci sillonné longiludinalemeat, ce sillon renfermant nne tarière longac, eompriusée, ployée en denx sur elle-méne dans le repos el pouvant en ètre retirće : anus des mâles entier, large, sans sillon longiludinal. - Palies de loagueur moyenne; tarses de trois articles, le prenier plus long que les suivans, le troisicue terminé par deux petits crochets.

Les mœurs de ces hémiptères sont les mêmes que celles dn trenre précédent. On en conzoit une trentaine d'espices.

\section{Capse bicolor, C. bicolor.}

Citpsius subsericeus, ater, thorace, scutello, elytrorum basi, pectoro coxisque sunguineis.

Longuenr 5 lig. $\frac{1}{2}$. Noir, un peu soyenx. Corselet diun rouge-siltiguin, à l'exceplion du dessus de son bonrelet antérieur qui cst noir. Ecusson, base des élytres, poitrine et hanches d'un rougesanguin. Antennes et pattes noires. Mále.

Amćrique méridionale.

Rapportez ì ce genre les Capsus elatus $n^{\circ} .1$, ater $n^{\circ}, 2$, flavicolitis $n^{\circ} .13$, dunicus $n^{\circ}, 25$, olivacetts $70^{\circ} .17$, yui n'est pent-être qu'une variéré du précédent, cl capillaris $n^{\prime \prime}$ 19). (lemelle; nous regrardons le Capsus seticornis $n^{n}$. 18 conime élant le maile.) FAB. Syst. Rhyngot,

Nota. M. Yalreille pense gu'on doit former deux fouveanx genres voisins de celui.ci: $1^{\circ}$. Héléro-

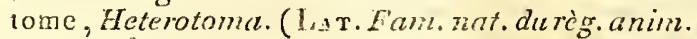
pag. 422.) Ses caractères n'étant point publiés, nous dirons sculement qu'il diflere du précédeni an ce que le second article des antennes est en forme de lame elliptigne, large et conprimée; le corps ćlroit, à peine ovale; le corselet sans élévation postéricure. L'anteur y rapporte le Capsus spissicornis no. 29. Fав. Syśt. Rhyng. Nous pensons que le Capsus crassicomis no. 29 de cet aulemren fuit ésaleacnt patrie. $2^{\circ}$. Globiceps, GloTrceps. Les caractères apparens de ce creare sont: ci'arvit la tête forte, globuleuse, plus farge que le corselel; celui-ci séparé en deux lobes par un sillon transversal profond et le corps linćaire. Nons en connoissons une espèce des environs de Paris; Glnbiceps groosse tête, G. capito. Nов. Longueur 2 lignes $\frac{x}{2}$. Noir; paltes d'un urun-rougeâtre ou livide; bec, hanches et base des cuisses blanchatres ainsi çue le premier article des aniennes. Segment inté- rient din corselct portant en dessus deux tribercules presqu'ćpineux. Les angles postérieurs du second presqu'aigus, ailes irisées. I'emelle.

(S. F. et A. Senv.)

\section{SALICOQUES, Carides. LAt.}

'Tribu de Crustaećs de l'ordre des Décapodes, famille des Macroures, ćtablie par M. Larreille, et ayaut pour caractères essentiels : pieds formés d"une série unique d'artienlations, et ayant, dans un petit nombre, un petit appendice sćliforne. Antennes'latérales on extéricures situées aurclessous des mitoyennes, et ayant leur pédonculo enlièrement reconvert par une grande éeaille.

Les Grees aroient disingué plusieurs de ces Crustacés sons les noms de $C$ aris et de Crungon; ce sont cenx quion appelle vulgairement Crevettes, Salicoques, etc. Ils ont le eorns d'une consistance moins solide que celui des autres Décapodes, quelquefois même ussez mon, arqqué, ou comrae bossi, ce qui leur a encore valu le nom de Squilles bossues. Les antennes, qui sont toujour's en forme de soies, sout avancées; les latérales. sont fort longıes, et les intermédiaires, ordinairement plus courles, ont leur pédoncule termicé par deux ou trois filets sétacés et articulés; lorsqu'il y en a trois, un de ces fitels est phis pelit cl souvent recouvert par l'uu des deux antres; les yellx sont très-rapprochés, presque globulews et' portés sur un pédicule très-court. La face supérienre du pédoucule des antennes mitoyenues olfie dans.la plupart une excavation qui reçoit la partie inférieure de cet organe de la vue ; l'exlrémité aniérieure du test s'arance presque toujours entr'eux et celle saillie, a la forme d'un bec ou d'un rostre poinlu, déprimé quelquefois, nais le plus généralement comprimé, avec une carcine de chargue côté, et les bords supérieur et inférieur aigus, plus ou moins dentés en scie. Les côtés antérieurs du test sont sonvent armés de quelques den:s acérées eu forme d'épines; les pieds - rnâchoires inféricurs ressemblent, daus le plus grand nombre, à des palpes longs et grếles, ou mếne, soit à des pieds, soit a des antenues; les quatre pattes antćrieures sont, dans beacoup d'especes, terninées par une pince double, ou unc sorte de main didactyle; deux de ces partes, ordinairement la seconde paire, sont doub!es ou pliées sur clles-mêmes; le carpe de celle secondo pince, ct quelquefois celui des deux dernic̀res, í l'article çui précède immédiatement la pince, offe dans plusieurs ceile parlicnlatité ģue l'on n'observe point dans les antres Crustacés; il parô̂t comme divisé transversalcment en un nonuse variable de petits articles, ou anrelé. La troisic̀me paire de pattes est elle-même quelquefois, eomme dans les Pénées, en forme de serres; dans plusieurs celte trisic̀me paire est plus courte que. les deux dernières. En général, on n’a pas fait assez d'attention à ces différences dans les lon- 
grueurs relatives des pattes. Les seguens dn milieu de la queve sonl dilatés sur les côtés; elle se termine par une nageoire en forme d'éventail, ainsi que dans les autres Maeroures, mais le feuillet du milieu est plus étroit, pointu ou épinenx at bout; son dos est armé dius pluzieurs de quelques petites épines. Les fausses pattes ou pátles eaudales sont alongcies et sourent en forme de feuillels.

Ces Crustacés sont assex. 1echercisés, et on en fuit une grande consommation dans toules les parties du Munde; on les sale même quelquefuis alin de les conserver et de les transporter dans l'intérieur des terres. 'Tous les Salicogues habilent les mers de nos côtes; la Méditerrancée en olfie beaucoup.

M. Latreille (Fann. natur. du règne anim.) divise la tribu des Salicoques ainsi quil suit. Nons serons obligés de donner ici l'histoire des genres qui n'out pas été truités dans ee Diclionnaire.

'I. Test généralement ferme quoique mince, une forme de corps analogue à celle des écrevisses, et la base des pieds dépourvue d'appendices ou "'en ayant que de très-petits.

I. Les six pieds antérieur's didaelyles.

Le genre Pénée, Pchocus. Voyez ee mot.

Le genre Sténope, Stenopus. Voyez ce mot.

3. Les quatre' pieds antérieurs au plus didactyles.

\section{A. Pieds antérieurs parfaitement didaetyles.}

a. P'inces point divisées jusqu'à leur base; earpe point enlaillé en manière de croissant.

* Antennes intermédiaires à deux filets.

† Pieds réguliers (les deux de chaque paire semblables).

- Pieds-mâchoires ex!érieurs point foliacés êt ne recuurrant point la bouche.

Ihe gente Alpiée, Alpheus. Fab.

Test prolongé en avant en forme de bec; antennes du milieu toujours plus peliles que les externes. Ces Cruslacés diffèrent des Ecrevisies et des Thalassines par l'insertion des deux paires d'antenues; ils se distirguent des Pénées par la forme du corselet et parles deux premières paires de paltes qui sont didactyles, et des Palamons ainsi que des Crangons par les antenues intérieures terminées par denx filets. Les mœúrs de ces crustacés sont tranquilles; ils ne quittent guère la région qu'ils ont choisie pour demenre que lorsgue plusieurs animaux marins, el surlout des troupes de poissons, vicnnent pour les dévorer. Ia fin du printemps et le milieu de l'été sont les époques de leurs amours. L’espèce qui peut ếre considérée comme type générique est:
Alphée de Maiabar, A. Mralabaricus. Fab. Supp. Syst. Ent. pag. 406 Mains de la première paire de pieds difiormes, l'nue très-grande, comprinće, avee le pouce très-arqué, aign, et l'autre plus peitie, a vec les dioigls filiformes, très-lonģs; rosire court, subulé.

Risso a décrit quatre espèces de ce gerire qu'il a trouvées dans la mer Mćditcrúnée aux environs de Nice. On doil en outre sapporter à ce genre, suivant M. Eatreille, le Cancercandidus d'Olivior, oul'stséacus tyrenus de P'elagna; le Crangon monopodium de Bose (Crust. tom. 2.pl. 15.jig. 2 ); les Pulomon diversimanus, villosus et favescens de ce Diclionnairc.

Le geme Hipportite, Hippolyie. Licicr. Alpheus. LAT. LEACH.

Antennes supérieures on intrimédiates les plus courtes, bifides, supportées par an pédoncule do trois arlieles dont le premier, et le plus grand, est ćchancré du côté des yeux et pouriı d'une lamelle qui se prolonge au-dessons de cenx-ci; antennes extérieures ou iuférieures plus longues que le corps, sétacées, pourvues ì leur base dune écaille alongée, unidentée en dehors vers son extrémité. Pieds des deux premières paires didactyles, les autres terminés par un ongle simple, trćs-épineux sur son bord inférieur; ceux de la paire antérieure les plus courls et les plus gros de tous; ceux de la seconde paire, les plus longs et les plus grêles, avec leur carpe et la pièce qui le précède multiarticulés; ceux des troisième, qualrième et einquième paires intermédiaires aux deux premiers pour la longrueur, et décroissant successivement d'avant en arrière. Avant-dernie: arliele des pieds-mâchoires extćrieurs beaucoup plus eourt que le dernier, qui est épineux. Caritpace courle et large, terminée en avant par un rostre assez eonrt, mais très-comprimé ct haul, non relevé en arc à sia pointe, el plus on moins découpé en dents de scie sur ses bords. Abromen arqué vers le troisième article, lames natatoires de la queue alongées, surtout l'iulormédiatre qui est pourvue de pelites épines it son extrémité.

On peü ranger les espèces de ce genre dians deux coupes. Dans la premiere se tronvent toules celles qui ont le dernier article des pieds - mâchoires extérieurs trouqué obliquement à l'extréunité; la base des aniennes intermédiaires pourvue d'une épiue, et la lane natatoire médiane de la nageoire caudale garnie de deur épines sur chacun de ses bords latéraux.

Hippotyte de Prideux, Hipp. Pridelxiana. LÉAch, Malac. Britann. tab. 38. fig. 1. 3. 4 et 5. Son rostre est droit, simple, arec ure scule dent en dessous prés de son extrúmić. It est lonģ de six lingrnes. On le trouvesur les côles de Devoushire en Angleterre.

Dans la secende coupe, cenx qui ont le dernicr article des pieds-máchoires extérieurs ter- 
minć par un faisceuu de poils, la base de leurs antennes intermédiaires pourvue d'une lame spiniforme, et la pièce istermédiaire de la nameooire de ka queue munie de chaque côté de quatre petiles épines également distantes entrelles, se place :

L'Jippolyte de Craxci, $H$. Cranchi\%. Líach, Malac. britann. tab. 38. fig. 17-21. Long d'environ dix lignes; rostre avancé, légèrement infléchi, pourva de trois dentelures à la base en dessus, et de deux pointes an bout, dont la supérieure est la plıs forte. 'Trouvé sur les cótes d'Angleterre.

Le genre Pontoxie (ćlabli par MI. Latreille dans sun nouvel onvrage intitulé : Familles naturelles du régne animal. Il ne donue pas les caractères de ce nouveau grenre.)

Le genre Avтonoméc, Autonomea. Risso.

La première paire de pattes terninée pal une main didactyle, les autres simples; antennes intermédiaires ou supéricures terıninées par deax filets, dont un est beaucoup plus long et plús épais que l'autre; les externes ou inférieures plus longures que le corps, sétacées. Pédoncules des premic̀res triarticulés, ayant leur pièce inféricure renllée et arınée d'un aiguillon, l'intermédiaire longue et cylindrique, et la dernière courte et arquée; ceux des secondes biarticulés, sans écailles, leur deuxième pièce élant velue à son extrémilé. Pieds-mâchoires extérieur's non foliacés. Curps alongé, gläbre. Carapace un peu renflée, terminée en avant par une pointe aiguë ou rostre qui dépasse à peine les yeux; ceux - ci globuleux, portés sur des pédoncules très-courts. Les truis lanies nalatoires intermédiaires de l'extrémité de l'abdomen tronquées au sommet, avec une petite pointe de chaque cóté; les deux latérales arrondies et ciliées.

La seule espèce de ce genre est:

L'Autonomér d'Orivi. A Olivii. Risso. Crust. pag. 166. Cancer glaber. Ourv, Zool. adriat. pag. 51. pl. 3. fig. 4. Quinze lignes de long, forme à peu près des Nikas et des Alphées. Carapace glabre, demi-transparente, jaunâtre, légèrement variéc de teintes rougeâtres; pattes de la premic̀re paire d'un assez beau rouge en dessus, et d'un jaune clair en dessous; autennes extérieures blanchâtres. Il vit isolé dạns les algues et les cndroits fangeux. Sa femelie porte des oufs rouḱteâtres vers le milieu de l'été. Il se trouve dans lit mer Adiatique, et rarement aux environs de Nice.

- Pieds-mâchoires extérieurs foliacés recouvrant la bouche.

Le gente Gnatophylue, Gnatophyllum. Lat. Ce nouveau genre a été établi par M. Latreille - ux dépens des Alphécs. Ses caractères distinc- tifs sont : carpes des denx premières paires de pieds non divisés eu pelites articulations; antennes extćrieures terminées par deux filets. Ce gémre s'éloigne des Alphées et des Hippolytes, auxqunels il ressemble par la forme générale du corps, pas des caracières lirćs des pieds-máchoires extérieurs; ils se distingueul des Pénées et des Sténopes par la forme de la première paire de pattes, et des Hyménocères par les antennes. L'espèce qui sert de type il ce genre est :

Gxatophylle élégant, G. elegans, Alpheus elegans. Rısso (Hist. des Crust. de Nice, pag. 92. pl. 2. fig. 4.) Long d'un pouce et demi. Corps obloug, renflé, arqué ver's le troisième article de l'abdomen; carapace lisse, terminće en avant par nu pelit rostre compriuć, sexdenté en dessus; les qualre antennes épineuses à leur base; pièces natatoires de la queue arrondies, ciliées et blanclies; couleur généräle variée de nuances carmélites el dé points d'un jiune doré. Pédoncules des yeux jaunes; rostre et pieds des deux premières paires blancs; dernier segment de l'abdomen violet. La femelle de cetie espèce pond des oufs dou brunviolittre en juillet et novembre.

Ce Cruftacé se trouve sur les rivages de Nice.

L'Alpheus tyrhenus de Risso apparlient aussi à ce genre.

Le genre Hymínocìne, Hymenocera. Latr.

Ce genre a été établi par M. Latreille; il a pour caractères : antennes mitoyennes ou supérieures bifides, ayant leur division supérieure foliacée. Pieds - mâchoires extérieurs foliacés, couvrant la bouche. Les quatre pattes antérieures terminées par une main didactyle foliacée. Carpe ou pince qui précède la main dans ces quatre pattes, non divisé en petites articulations; pieds des trois dernières paires terminés par des ałticles sinples, ceux de la troisième étant plus petits que ceux des deux qui précèdent.

L'espèce qui sert de type à ce genre hous est inconuue; elle vient des Indes orientales, ot Desmarest pense qu'elle a quelques rapports avec le genre Atye, à cause de la forme de ses deux premières paires de pieds plus courtes que les deux autres, didactyles et foliacées. Ce qui l'en distingue éminemment, est le filet supérienr des antennes intermédiaires et les pieds-mâchoires extérieurs.

$\dagger †$ Pieds antérieurs dissemblables; l'un de la même paire didacıyle, l'autre simple.

Le genre Nira, Nika. Risso. Lanarck. Processa. Ĺ́acr. Lata. Voyez le mot Processe de co Dictionuaire.

\section{* * Antennes intermédiaires à trois filets.}

Le genre PalÉzon, Palcemon. Voyez ce mot.

Je genre Lysmate, Lysmata. Risso. Latm. Melicerta: Rrsso. 
M. Risso a voit déj̧à donné le nom de Mélicertes à ces crustacés, mais ce nom ayant déjà été eunployé par P'éron pour désigner un groupe de Méduses, il l'i changé en celui de Lysmate; les caractères de ce genre sont: antennes extérieures longues et sétacées. Pieds des deux premières paires didactyles, ceux de la seconde étant les plus longs, et ayant leur corps divisé en plusieurs petits articles. Pieds des trois dernières paires très-minces, terminés par un ongle simple, les quatre derniers étant plus courts que les autres. Carapace carénée en dessus et terminée en avant par un rostre fort court. Le corps de ces crustacés est plus raccourci que celui des Palémons, el leurs pieds sont plus minces; ils ont comme eux les quatre premiers didactyles, mais ce qui les en distingue surtout, c'est que ceux de la seconde paire, qui sont aussi les plus grands, ont la pièce qui précède la main subdivisée en petits articles, ạu lieu d'être entière.

Liespèce qui sert de type à ce genre est la Lys. mate soyeuse, $L$. seticauda. Rrsso, Crust. $p$. I 1 o. $p l$. 2. fig. I. Longue d'un pouce et demi; rostre très-court, sexdenté en dessus et bidenté en dessous; pièces natatoires de la queue ciliées sur leurs.bords, celle du milieu étant terminée par dix longues soies très-déliées; corps d'un rougre de corail, marqué longitudinalement de lignes blanchâtres. La femelle de ce crustacé porte des œufs en juin et en juillet : ils sont d'un rougebrun.

On le trouve dans les eaux profondes, aux environs de Nice.

Risso a décrit une autre espèce de ce genre, mais elle doit être rapportée aux Palémons.

Le genre Atranas, Athanas. Léach. Latr. Cancer (Astacus). Montagu. Palcemon. Léach.

Antennes extérieures ou inférieures un peu plus courles que le corps, sétacées, ayant l'écaille de leur base grande et terminée par une seule pointe aiguë au côté exterue de son extrémité. Piedsmấchoires assez grêles, Je prenier article étant plus long que les detix auties ensewble, et le dernier de ceux-ci plus long que l'arant-dernier. Pieds des deux premières pailtes terminés par une main didactyle; celte prenière paire étant la plus grande de toutes, et la seconde, qui est la plus grêle, ayant son corps mulıarticulé; pieds des troisième, quattrième el cinquième paires, finissant par un ougle simple, un peu arqué; carapace cylindrique, un peu plus étroite en avant qu'en arrière, et prolongée en forme de rostre aigu, mais coult. Lames nataloires extérieures de la queue formées de deux pièces.

Ce genre, qui a les plus grands rupports avec le précédent, s'en distingue principalemeut par la proportion de ses paltes de la première paire, qui sout les plus grosses, taudis que dans les Lysmates, ce sont les pattes de la seconde paire qui ont le plus de volume.

Hist. Nat. Ins. Tome $X$.
La seule espèce de ce gen:e est :

l'Atranase luisante, $A$. mitescens. Léack, Malac. Brit. tab. 44. - Palcemon nitescens. Ejusd. Edimb. Encycl. Longueur huit à neuf lignes; rostre avancé, inerme.

Il se trouve en Angleterre sur les cótes du Devonshire et du comté de Cornouailles, et en France.

b. Pinces divisées jusqu'à la base, ou mains formées uniquement de deux doigts réunis à leur base.

Le geure Atre, Atya. Léach. LAtr.

Autennes sétacées, presque de la longueur du corps, pourvaes, à leur base et du côté extérieur, d'une grande écaille uvidentée; les intermédiaires formées de deux filets, placés sur une même ligne horizontale. Pieds de la preınière paire petits, ayant leur avant-dernier article ou le carpe très-court, et le dernier divisé en deux lanières d'égale longueur, dout l'extrémité est garnie de longs cils; ceux de la seconde paire conformés de la même manière, mais plus grands; ceux de la troisième beaucoup plus longs et plus gros que tous les autres, inégaux entr'eux, et pourvus d'un ongle très-court et crochu; ceux des deux dernières paires médiocres et finissant par un ongle peu robuste. Carapace lisse, deıni-cylindrique, terminée en avaut par un petit rostre, et tronquée en arrière. Abdomen alongé, formé de six articles, et pourvu d'une nageoire flabelliforme, dont les deux lames latérales sont composées de deux pièces, et dont l'intermédiaire est triangulaire et tronquée droit à son extrémité.

Atye raboteuse, $A$. scabra. Léach, Linn. Soc. Tranis. tom. XI. p. 345. - Ejusd. Zoolog. Misc. tom. 3. p. 29. tab. 131. Longue de deux pouces et demi ; corps et pieds des deux premières paires glibres; rostre caréné, trifide; pieds des trois dernières paries couverts de petites aspérités el de poils roides épars.

Patrie inconnue.

B. Pieds antérieurs monodactyles on imparfaitement didactyles (les deux doigts élant à peine visibles). Autennes intermédiaires à deux filets.

Le genre Egeov, Egeon. Risso. (Voyez le mot Pontophile de ce Diclionnaire.) L'espèce sur laquelle Risso a établi ce genre est : l'Eceon cuirassé, T. loricatubs. Risso. Cancer. Olivi, Zool. adriat. tab. 3. fig. I. Ce crustacé est remurquable par les partici-'uitćs suivantes. Son corps est alongé, un peu arqué, recouvert d'un test dur et solide, d'un biauc-rouge itre, finement pointillé de pourpre. Le corselet est traversé longitudiinalement par sept rangs de piquans, courbés en cievant, placés les uns au-dessus des autres, et formaut une espèce de cuirasse; les yeux sont petits, grisâtres, rapprochés, presque sessiles. Tt 
Les pieces latérales sont triangulixires et eiliées; les antennes intérieures sont courles et poilues, les extérieures très-longues; les palpes sont alongés, garuis de poils; la première puire de pattes est monodactyle, la seconde didactyle, la troisième longue et grêle, et les deux dernières sont épaisses, garnies de quelques poils et terminées par ıles crochets aigus. L'abdomen est composé de six seginens chargés de proéminences raboteuses, et de catvités flexueuses et irrégulières, qui semblent représenter diverses fignres sculptées en relief; le dernier segment est recouvert d'épines. Les écailles natatoires sont ovales, oblon. gues, ciliées, non adlıérentes à la plaque intermédiaire qui se termine eu pointe.

Cet Egeon habite la Méditerranée et l'Adriatique; il se tieut à une profondeur de deux à trois cents nètres, sur des fonds rocailleux, et ne s'approclıe ordinairement des côtes que pendant l'été. On le prend difficilement, et sa chair n'est pas aussi estimée que celle des Palémons. La femelle dépose ses œufs, qui sout rongeâtres, pendant le mois de jnin; elle choisit, pour s'en débarrusser, les endroits couverts de plantes marines.

Le gente Crangon, Crangon. Voyez l'artiele Pontophile de ce Dictionnaire.

Le gente Pandale, Pandalus. LÉach. Latr. Astacus. Fab. Palcemon. Risso.

Les earactères de ce grenre sont : antennes supérienres ou intermédiaires les plus courtes, bifides, supportées par un pédoncule de trois articles, dont le premier, et le plus grand, est éclıancré du côté des yeux et pourva d'une lamelle qui se prolonge al-dessous de ceux-ci. Autenues extérieures ou inférieures plus longues que le corps, sétacées, pourvues à leur base d'une écaille alongée, unideutée en dehors vers son extrémité. Pieds-mâcboires extérieurs fornés de trois articles visibles, dont le premier est aussi long que les autres ensemble, échancré en dedans depuis sa base jusqu'à sou milieu, et dont les deux derniers, égaux entr'eux, sont couverts de petites épines sur toutes leurs faces. Pieds de la première paire assez courts, sans pinces, avec lenr dernier article simple et pointu. Ceux de la seconde paire didactyles, très-longs et grêles, inégaux entr'eux, ayant les troisième, quatrième et cinquième articles marqués de beauconp de petits sillons transverses et comnıc multiartieulés; pieds des trois dernières paires, plus gros et moins long's yne ceux de la seeonde, et décroissant successivement de grandeur entr'eux, tous étant ta'minés par un ongle simple, pourvu de petites épines du eôté interne. Carapace alongée, cylindrique, carénéc et dentelće dans son milieu, terminée en avant par un long rostre comprimé, denté en dessous et relevé à sa pointe. Abdomen arqué vers le troisième article; écailles de la queue alongées, étroiles, surtout celle ciu milieu, qui est garnie de petites épines à sa pointe. Nous citerons le Pandale annulicorne, $P$. annulicomis. Léach, Malac. Britan. tab. 40. Longueur trois pouces. Rostre multidenté en dessous, relevé et échancré à sa pointe. Antennes latérales ou inférieures marqnées de huit ou dix anneaux rouges aussi larges que les intervalles qui les séparent, épineuises du eôté intérieur.

Des eôtes d'Angleterre.

II. Corps mou et très-alongé, la base des pieds pourvus d'appendices trés-distincts et filıformes.

Le genre Pastplié, Pasiphaca. Voyez ce mot. (E. G.)

SALIUS, Salius. Fan. IAtr. Fam. nat.

Genre d'insectes de l'ordre des Hy ménoptères, section des Porfe-aiguillon, famille des Fouisseurs, tribu des Pompiliuns.

Nous ne counoissons pas les espèces qui eomposent re genre. Fabricius l'a créé dans son Syst. Piez. Il lui donne pour earactères : quatre palpes ayant leurs second et troisième artic:les presque sécuriformes; lèvre avancée, arrondie, élargie, eutière; antennes sétacées.

M. Latreille qui fait de ee genre une division de ses Pompiles (Gen. Crust. et Ins. tonı. 4. pag. 65), dit que le segment antérieur du corselet ou prothorax est aussi long ou plus long que large; que le corselet pris eu entier est quatre ou cinq fois plus long que large, que la tête est arrondie postérieurement, munie de trois ocelles rapprochés, et qu'enfin les auteunes sont plus yrandes dans les mâles que daus les femelles. L'auteur francais cite comıne se rapportant à sa division les Salius bicolor $\mathrm{n}^{\circ} .1$ et unicolor $\mathrm{n}^{\circ} .2$.

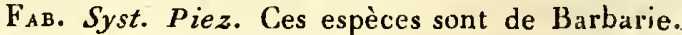
M. Tatreille en adoptant cetle division comme genre dans son nouvel ouvrage ayant pour titre Familles naturelles du Règne animal, lui doune pour caractère différentiel: proihorax presqu'aussi long que large; mandibules sans dent au côté interne; tète convexe, du moins postérieurement.

Il établit eu outre dans cette tribu nn nouveau genre sous le nom de Planiceps, Planiceps; celnici très-voisin des Salius a le prothorax conformé de la même manière; il en diffère par ses mandibules ayant au moins une dent au côté interne, la tête déprimée, les ocelles très-petits, écartés; les antennes insérúes très-près du bord antérieuc de la tête, les deux pattes antérieures eouries et repliées. L'espèce qui a servi de type est du midi de la France. (S. F. et A. SER .)

SALIUS, Salius. M. Germar a donné ce nom aux Orchestes d'llliger dans l'ouvrage intitulé : Magaz. Entom. Halle, 1818. Voyez Orcheste.

(S. F. et A. Serv.) 
SALPINGUE, Salpingus. M. Gyllenhall dans son ourrage intitulé : Insecta suecica, 1818. tom. 2. (Sispplém. du tom. I), fait un gelle de Coléoptères. Métérunières sousce nom; il lui donne pour caractères: quatre pälpes filiformes, ayant leur dernier article un neu plus épais que les autres et obtus; mâchoires lifices; languette membraneuse, arrondıe, très-entière; antennes plus grosses vers leur extrémilé; bouche avancée en un rostre aplati , presque toujours rélréci dans son milieu; corselet presqu'eu cour, plus étroil à sa partie postérieure.

Cet auteur cite quatre espèces do ce genre sous les noms de ruficollis, planirostitis, ater et birnaculatus. M. le comte Dejean admet dans son Catalogue deux genres (comprenant les trois premières espèces que nous venons de citer), ceux de Salpiugue et de Rhinosime. M. Latreille dans ses Fam. nat. admet également ces deux genres et les place parmi les Anthribides en convenant cepeadant que seuls de cette tribı, ils sont Hétéromèris. (Voyez Rhinosime.) Il nous sembleroit $p$ us naturel de suivre la classification indiquée dans la note de la page 384 de l'onvvrage précité et de ranger ces geures dans les Rhyuchostomes, nou elle tribu qui termineroit la section des Hétéromères; cette tribu seroit immédiatement précédée des CEdémérites.

$$
\text { ( S. F. et A. Serve) }
$$

SALTIGRADES, Saltigrado. Araignées phalanges de plusieurs naluralistes, tribu de la famille des Aranćides ou Fileuses, ayant pour caractères : pieds propres à sauter. Groupe oculaire formant un graud quadrilatère, soit simple, soit double, et dont un plus petit et inserit dans l'autre. Yeux latéraux de devant situés près des angles du bord anlérieur du céphalothorax; les deux postérieurs séparés par toute la largeur de cette partie du corps et opposés aux précédens.

Les araignées de cette tribu marchent comme par saccades, s'arrêtent tout court après avoir fitit quelques pas, et se banssent sur les pieds antérieurs. Découvrent - elles un insecte, une mouche, on un cousin surtout, elles s'en approchent doucement jusqu'à une distance qu'clles paissent franchir d'un seul saut, et s'élancent tout$\dot{a}$-coup sur la victime qu'elles épioient. Ces araignées ue craignent pas de sauter perpendiculairement sur un mur, parce qu'elles s'y trouvent toujours attachées par le moyen din fil de soie qu'elles dévident à inesure quelles avaucent : il leur sert encore à se suspendre en l'air, à renonter au point d'où elles étoient descendues, ou a se licisser trausporter par le vent d'uu lieu à un autre.

Plusieurs Saltigrades construisent entre les feuilles, sous les pierres, etc., des nids de soie en forme de sacs ovales et ouverts aux deux bonts; ces Aracbaides s'y retirent pour se reposer, faire leur mue et se garantir des intempćries des saisous. De Géer trouva à la fin de juillet, sur une branche de pin, une grande coque ovale de soie blanclie placée autour d'elle et cuirelaccée entre les feuilles : elle étoit la demeure d'une arairnce sauteuse ( $d u$ pin) et de ses petits qui vivoleut avec elle en bonne intelligence, et paroissoient se nourrir en cornmun du gibicr qu'elles prenoient. Sur le milieu d'uu des eôlés de la coque étoit une ouverture cylindrique, une espèce de porte où la mère se tenoit à l'affît. Ce célèbre observateur trouva sous des pierres, sur les bords de la mer Ballique, plusieurs individıs d'une autre espèce ressemblant à une fourni : ils étoient logés séparément dans de petites coques ovales de scrie blauche, ayant une ouverture à chaque bout, et qu'ils avoient filées contre le dessous des picrres. Pour peu qu'il touchất à leurs coques, ils sortoient par une de ses ouvertures et s'enfuyoient avee une grande vitesse. Lorsqu'il voulnit les preudre, ils s'échappoient aisément en se laissant descendre sur un fil de soie : ils quittoient leurs nids sans difficulté, et ne tardoient pas à en filer de nouveaux. De Géer les a vus changer de peau. Quand ils inarchent, ilss'arrétent par intervalles, élèvent les denx pattes antérieures eu l'air, les agitent de haut en bas, et tâtent avec elies lo terrain tout cornue ils le feroient avec de véritables antennes : on diroit alors qu'ils n'ont que six pieds. Des individus de cette espèce que ce naturaliste conservoit dans un pondrier, paroissoient se redouter exirêurement; quand ils se rencontroient ils se mettoient d'abord en défense et face à face, courbant le corps, baissaut l'abdomen, contractant les paltes, faisant quelques pas de côlé et puis en avant, se rapprochaut ensuite davantage; ils ouvroient leurs unandibules el sembloient voulvir se mordre; mais le combat finissoit soit par la fuite de l'un des deux, on quelquefois des deux ensemble. M. Latreille a vu une espece ne pas craindre l'approche de sa inain, et lui présenter aussi ses tenailles. Rossi avait fait la mêsue observalion par rapport ì l'Aranea pagana.

De Géer a vu les préludes amoureux des sexes d'une espèce (Salticus grossipes'). Le mâle et la feuelle s'approchoient l'un de l'autre, se tâtoient réciproquement avec leurs pattes antérieures et lemr's tenailles : quelquefois ils s'éloignoient un peu, mais pour se rapprocher de nouveau; souvent ils s'embrassoicut avee leurs paltes et formoient un peloton, puis se quittoient pour reeommencer le méme jeu, mais il ne put les voir s'accoupler. Il fut plus heureax à l'égard de l'Aranea scenica. Le mâle inonta sur le corps de sa femelle en passant sur sa tête et se rendaut à l'autre extrémité; il avauça un de ses palpes vers le dessous du corps de sa compagne, souleva doucement sou abdomen sans qu'elle fil de résistance, et alors il appliqua l'ex trémité du palpe sur l'endroit du yen- 
tre de la femelle destiné à la copulation. II vit ce snâle s'éloigner et revenir à plusieurs reprises et se réunir plusieurs fois à sa femelle : celle-ci, loin de s'y opposer, se prêtoit aisément à ce jell.

Celle tribu se compose de deux genres; ce sont les Erèses et les Salliques.

ÉRÈSES, Eresus. Walk. Lat. Aranea. Linn. Fab. Oliv. Rossi. Villers. Coqueb. Schaffer. Petagna. Salticus. Lat.

Ce genre, qui a élé élalli par M. Walkenaer, a pour caractères, suivant M. Latreille, quatre yeux rapprochés en un petil trapèze près du nilieu de l'extrémité antérieure du corselet, et quatre autres silnés sur ses côtés, formant aussi un quadrilatère, mais beitucoup plus graud. Les Erèses different essentiellement des autres Aranéides par la position des yeux; leur bouche présente une lèvre alongée, triaugulaire, termince en pointe arroudie, el des mâchoires droites plus hautes que larges, arrondies et dilatées à leur extrémité. Lenr tronc est plus élevé que dans les Saltiques. Son bord austérieur est siuué et plus ou moius avancé sur la ligne moyenne; il supporte des pattes grosses, courtes, propres au saut, presqu'égales en longuenr; la quatrième est la plus longue, la première ensuite, et la troisième est la plus courte. Ces Arachnides se reucontrent sur les troncs d'arbres et sur les plantes. M. Walkenaer dit qu'elles épieit leur proie et sautent dessus. Elles se reuferment dans un sac de suiefine et blanche entre les feuilles qu'elles rapprochent.

M. Walkenaer, dans son Tablean des Aranéides, $p l .21$, n'a décrit que deux espèces propres à ce genre. N. Laireille en admet deux autres: l'une d'elles lui a été envoyée par M. Léon Dufour, et il établit pour les classer les divisions suivantes :

A. Yeux latéraux de la première ligne portés sur un tubercule très-saillant; les deux intermédiaires de la mêıne ligne plus grands que les qua. tre latéraux; abdomen notablement plus volunineux que le tronc (ovalaire), el convexe.

3. Érk̀se rayée, Er. lineatus. Lar. Cette espèce a été trouvée en Espagne par li. Lé́on Dufour; elle se rapproche plus que lcs suivantes des Araiguées-loups.

B. Yeux latéraux de la première ligne sessiles, ou point portés sur un tubercule bien distinct; les deux interucédiaires de la première ligne plus petits, on de la grandeur au plus des latéraux; abdomen petit ou inoyen (se rapprochaul souvenl de la forme carrée ).

2. Énìse frontale, Er. frontalis. LAт. Elle est originaire d'Espagne, où l'aide-naturaliste Lalancie l'a recueillie : on la trouve aussi à Montpellier.

3. Énèse cinnabre, Er. cinnaberinus. WaLK.
Tabl. des Aranéides, pag. 21. - Araignée-cinnabre. Faun. Paris. tom.2. pag. 249. - Aranea moniligera. VıLL. Ent. tom. 4. pag. 128. tab. 1 I. fig. 8. - Aranea 4-guttats. Ross. Faun. Etrusc. tom. 2. pag. 135. pl. 1. fig. 8. 9. - Araignée ronge. Lat. Hist. nat. ${ }^{\prime}$ S Crust. et des Ins. tom. 7. pag. 297.- Saliique. Nouv. Dict. d'hist. nat. tom. 24. Tabl. pag. 136. - Screfr. Icon. Ins. pl. 32. fig. 20. - CoQUEв. Illustr. Icon. Ins. dec. 3. tab. 27. fig. 12. - Araignée rouge. Ourv. Voyez pour. Ia description le $\mathrm{n}^{\circ} .85$ du mot Araignée de ce Dictionnaire.

SALTIQUE, Salticus. Lat. Aranea. IInN. Geoff. De Géer. Fab. Oliv. Altus. Walk.

Ce genre a été élabli par M. Latreille, qui liñ donne pour caractères huit yeux formant, par leur réunion, un grand carré ouvert postérieurement, on une paribole, quatre situés en a vant du corselet sur une ligne transverse, et dont les deux iutermédianires plus gros, les autres placés sur les bords latéraux de la même partie; deux de chaque côlé, et clont le premier ou le plus antérienr très-petil; nàchoires droites, longitudinales, élargies et arrondies à leur extrénité; lèvre ovale, très-obtuse ou tronquée à son extrémité; pieds propres au saut on à la course, la plupart robusles, surtout les premiers; ceux des quatrième et première paires géućralement plus longs, presqu'égaux : les internédiaires presque de même grandeur relative.

Ce genre est si naturel qu'il a été établi dans presque tous les écrits des naturalistes qui ont irailé des Aranéides. Aristole (Hist. des anim. liv. 9 , chap. 39 , trad. de Camus) en distingue plusieur's espèces. Lister, daus son Trailé des araignées d'Angleterre, désigne les Saltiques sous le nom d'Araignées phalanges ou Araignées-puces. Clerck les appelle Araignées santeuses. Geoffioy forme une fanille particulière avec ces Araignées et les Lycoles de M. Latreille. De Géer et Olivier ont suivi l'exemple de Lister et Clerck, et ont formé avec ces araignées leur fauille des Phalanges. Falricius, à l'exemple de Geofroy, réunit dans la même section les Araignées citigrades et saltigrades. Linné comprend les Saltiques duns son grand genre Araignée. Scopolı en forme un groupe sous le noin d'Araignées vo ageuses, qu'il distingue en vibrantes el santeuses. Ev fin, M. Walkenaer a désigné celle coupe sous le nom d'Atie (Attus), que M. Latreille n'a pas conservé parce que ce nom ressernble trop à celui d'Atte (Atta), que Fabricius a dominé à un genre d'Hyménoptéres, et parce qu'il lui avoit déjà donné le nom de Saltique. M. Walkenaer partage ce genre en trois familles, les sauteuses, les voltigeuses et les paresseuses. Leurs caractèré sont foudés sur la grandeur des palpes, sur celle des pattes et leurs fonctions. La première famille est divisée en deux races, les courtes et les alongées; la troisième 


\section{S A L}

fumille ne renferme qu'une seule espèce indigène.

Les Saltiques sont des araignées de taille moyenne; leurs mâchoires sont toujours droites, resserrées ou marquées d'un sinus extérieur, audessus de l'insertion des palpes, dilatées et arrondies à leurs extrémités; Ja lèvre est alongée, presque triangulatire ou en ovale, tronquée ù son extrémité supérieure; les uandibules sont courtes, fortes, rylindriques, très-inclinées et armécs d'un crochet courbé, se repliant dans une cavité dentée des deux côtés, du moins dans les tenıellcs ; mais celles des mâlcs sont souvent grandes, avancćes, et armées d'un long crochet, droit et uu peu courbé seulement au bout; dans quelques autres, elles sont courbées et arqućes. Les pulpes sont ordinairement courts, velus ou plumeux, et courbés an-dessus des mandibules qu'ils cacheut presqu'entièrement. Le corps est pabescent et soycux, et souvent orné de couleurs très-brillantes on agrćablement mélangées. Les yeux ont aussi beaucoup d'éclat. L'abdomen cst ovalaire; les pattes sunt généralement courtes; leur longueur varie dans ce genre, et il est assez difficile de les mesurer exacternent.

Ce genre se compose d'un très-grand nombre d’espćces, et M. Lalreille y a formé trois coupes bien distinctes.

A. Corselet épais et terminé postérieurement en un talus brusque et très-incluné. (Corps tonjours garni d'un duvet caduc ou velil, proportionnellement plus court que dans $k$ s divisions suivantes. Paltes, surlout les antéricures, plas robustes; abdomen ovoïte, court, déprimé; plan dorsal du corselet horizoutai, formant avec le talus un carré long, tunt soit peu iucliné et arrondi postérieurcment à quelgue distince des derniers yeux; mandibules des. mâles, grandes.)

1. Saltique de Sroane, $S$. Slounii. Latr. Gener. Crust. et Ins. tom. 1. p. 12J̄. Araiguée sanguinolente. Hist. nat. des Crust. et des Ins. tom. 7. p. 3o2. - Aranea Sioanii. Scopont, Entom. C'arn. $n^{\circ}$. 1108. - Arunea sanguinolenta. linn. Syst. ed. 13. tom. 1. pars 2. p. $1032 . n^{\circ} .18$. - Arunea sanguinolenta. Fавв. Inzom Syst. tom. 2. p. 422. - Arunea Sloanii. Rossi, Faun. Etrusc. tom. 2. $p$. 134. - Atte sanguinolent. W Ank. Tabl. des Aran. p. 24. - Araıgnée sanguinolente. (var.) Univ. Voyez pour la descriplion le $n^{\circ} .84$, article Aralgnèe de ce Dicionnaire, et pour les autres espccces, les $n^{0^{5}} .83,9^{\circ}$, $9^{3}$ et 94 .

B. Corselet déprimé, incliné presqu'insensiblement à son extrémuté postérieure, corps oblong sans être cylinalrique ui linéatre, gami de poils ou d'un duvet épars; pattes courtes et robustes; (abdomen toujours ovalarre ou ovoide.)

2. Saltique chevhonnée, $S$, scenicus. Latr.

Gener. Crust. et Ins. tom. 1. p. 123. - Araignće chevionnée. Hist. nat. des Crust. et des Ins. tom. 7. p. 299. - Atte paré. Walk. Tabl. des Aran. p. 24. - Araignée parée. Faun. Paris. tom. 2. p. 245. - List. Arun. p. 87. tit. 131 . fig. 31. - Araignée chevronnée. Oulv. Voyez pour la description el la suite de lis synonymie le $\mathrm{n}^{\circ} .8 \mathrm{I}$, arlicle Aratcsée de ce Dictionuaire, ct pour une autre espèce, le $n^{\circ} .80$.

C. Corselet déprimé, incliné presqu’insensiblement à son extrémité postérieure; corps presque linéaire ou cylindracé, glabre ou peu velu; pattes longues et grêles. (Dessus du corselet conıme divisé en deux parties; l'une antérieure, plus ćlevée, carrée, aplatie, portant les yeux; l'autre, ou la postéricure, presque conique ; abdomen en forme de fuseau ou de cône; pattes antérienres antenuiformcs, à cuisses grandes.)

Ces espèces ressembient à des fourmis; elles se renferment dans des coques de soie qu'elles placent ordinairement sous des pierres, et y chan. gent de peau.

3. Saltique fourmi, $S$. formicarills. Latr. Gener. Crust. et Ins tom. 1.p. 124. - Araignée fourmi. Hist. nat. des Crust. et dis Ins. tom. 7 . p. 304. - Alle tourmi. Walk. Tiabl. des Aran. p. 26. - Araignée fourmi. Faun. Parrs. tom. 2. p. 24I. Voyez pour la description le no. 87, article Aratgné cle ce Dictiounaire.

M. Walkenuer a découver't a ux environsde Paris quelques autres espèces de cette division. Il fait montion d'une espèce du inême genre qu'il nomine Atte fossile, ct qu'il a observée dans un morceau d'aubre de la collection de M. Faujas.

$$
\text { (E. G.) }
$$

SANDALUS, Sandalus. Genre de Coléoptèrcs créé par M. Knoclı (Netce beytraege zur insectenkunde 1.V. 5. 1801) ; il appartient à la fanille des Serricornes, section des Malacodermes, tribu des Cébrionites. Scs caractères particuliers sont d'avoir lcs anteuncs en scie dans les deax sexes, plas courtes que le corsclet et les mandibules furtes, avancées et très-crochues.

L'auteur en mentionue une espèce sous le nom de $s$. petruphya. (S. F. et A. SERv.)

SA NGARIS, Sangaris. Nom appliqué par M. Dalinan dans ses Analec. entom. ì un genre de Coléoptèrcs 'Tétranères dont l'auteur ne mentionne point les caractères. Il en décrit une espèce sous le nom de $S$. concinna. Longueur 6 lig. 'Tête, corselet et dessous du corps d'un tcstacéblanchâtre. Elytres tronquées, épineuses, aplaties supérieurement, ayant leurs angles huméraux saillans, brunes, plus pâles vers leur extrémité, avec une tache dorsale, un point de chaque côté et une bande vers le bout de couleur blanchâtre. 
Corselet presque globuleux, mutique. Corps soyeux. Du Brésil.

L'auteur ajoute que cette espèce est distincte de tous les Cérambycins Lamioïdes par ses cuisses postérieures s'étendant au-delì du bout des élytres; cependant nous connoissons une autre espèce de Lamiaire du mềme pays à qui ce dernier caractère convient éminemrnent, mais dont le corselet est fortement déprimé et muni d'une épine latérale. M. Latreille place ce genre (Fam. nat.) dans les Nécydalides, troisième tribu de la famille des Lougicornes, sans en donuer les caractères. Nous croyons que l'espèce citée appartient plutôt à celle des Lamiaires.

$$
\text { (S. F. et A. Serv.) }
$$

SANG UISUGES ou ZOADEI,GES. Nom donné par M. Duméril (Zool. analyt.) à une famille d'Ilérniptères offiant pour caractères : Elytres demi-coriaces. Bec paroissant naître dufront. Antennes longues, terminées par un article plus grêle. Paittes propres à marcher. Elle comprend les genres Miride, Punaise, Réduve, Ploière et Hydromètre.

$$
\text { (S. F. et A. Serz.) }
$$

SAPERDE, Superda. Fab. Oliv. I Aat. Fam. nat. Lainia. Fab. Oliv. Lepturu. (ienff. Cerambyx. LinN.

Genre d'insectes de l'ordre des Coléoptères, section des 'l'étramères, fanille des Longicornes, tribu des Lamiaires.

Nota. Quelqnes genres des auteurs modernes entrant dans cette tribu, et la création d'un certain nombre de nouveaux nous parcissant nécessaire, nous allons donner ici les caractères des Lamiaires teis qu'ils sont indiqués par M. Latreille.

Lamiaires, Lamiarioe. Q inatrieme tribu de la famille des Longicornes, section des Tétramères, ordre des Coléoptères.

Téte verticale. - Palpes filiformes, terminćs par un article ovalaire et pointu.

I. Corselet épineux latćralement.

Nacrope.

Lanie.

Dorcadion.

II. Corselet mutique.

'Tupeine.

Colobotée.

Hippopsis.

Saperde.

Guome.

l'armi les Lamiaires à corselet mnique, les Tapeines l'ont transversal et le corps trés-déprimé; les genres Colobotée, Hippopsis et Gnome se distinguent suffisamment des Saperdes par leur corselet plus long que large. Quant aux autres genres de Lamiaires dont on trouve le nom dans les auteurs, et notamment dans le Catalogue de M. le comie Dejean, ils ne uous sont pas assez connus sous le rapport de leurs caractères pour pouvoir les adopter, quoique nous ne dontions pas que la plupart ne doivent l'être. Aïusi, pour le moinent, les Monochames, les Acanthocines, ainsi que les Pogonochères, rentrent dans le geure Lanic; celui d'Adesmus est réuni maintenant par son autcur lui-mème aveci les Saperdes, parmi lesquelles nous rangeons aussi le geure Tetraopes : ceux d'Apomecyna, de Parmena et de Tragocerus nous sont inconnus, leur's caractères ne sont pas publiés nou plus que ceux de la plupart des genres nourmés plus haut.

Antennes sétacćes, insérées sur le devant de la tête dans une échancrure deş yeux, un pen andessns de la face autérieure de la tête, cistantes eutr'e!les à leur base, composées de onze ou de douze articles; le premier plus gros, presque conique; le second très-petit, les suivans cylindriques, diminuant insensiblement de grandemr et de grosseur; le troisième le plus lang de tous, le dernier sensiblemeut plus long dans les mâles cque daus les lemelles, quelquefois (lorsqu'il n'y a que onze articles) divisé vers son milieu par un sillon et paroissaut tormer deux articles. - Labre petit, aplati, coriace, arrondi antérieurement, uu peir échancré daus son milieu. - Mandibules cornćes, aplaties, tranchantes au côté interue, sans dentelures, terminées en une pointe un peu arquée. - Mâchoires cormées, aydut deux lobes courts, coriaces, l'extćrieur ì peine plus grand, arrondi, l'intérieur presque triangulaire. - Palpes filiformes, leur dernter article ovalaire, assez pointu; les maxillaires uu peu plus grands que les labiaux, de qualte articles, les labiaux de trois. - Lèvie rétrécie dans son milieu, échancrée à son extréunité. - Téte verticale, courte, pas plus large que le corselet. - Ycux fortement éclianerés au côté interue. - Corps plus ọu moins alongé. Corselet mnlique, aussi large que long, cylindrique. - Ecusson petit, presque triangulaire. Ellytres alongées, reisordées, presque de mème largeur daus toute leur étendue, recouvrant les ailes et l'abdomen. - Pattes de longuenr moyenne, assez fort es : cuisses point en massue; tarses cou:ts, assez laryes, leur deanter article le plus long de tous, unui de deux forts crocliets.

On voit par ces caractères, et notamment par celui que nous donnons au corselet, qué ce genre, tel que uous le présentons ici, est renferiné dans les limites que M. Latreille a imposíes à sa seconde division des Lamies, Gen. Crust. et Ins. Par conséquent nous admeltons parmi les Saperdes les Lamies des auteurs à corselet mntique, et réciproquement nous reportous aux Lamies les Saperdes à corselet épineux. Les larves de ces insectes vivent dans le bois; elles sont apodes et munies de fortes mandibules: elles subissent leurs métamorplioses dans l'endroit où elles out vécu. Par- 
renues à l'état parfait, les Saperdes fréquentent les fleurs; on les rencontre aussi sur les arbres. Ce genre est nombreux en espèces; leur taille varie beaucoup.

Ire. Division. Corps court. mité.

$1^{\mathrm{re}}$. Subdivision. Elytres arrondies à l'extré-

A. Cbaque oil entièrement partagé en deux. (Genre Tetraopes. Scros.)

Rapportez à cette section la Lamie tornator, $n^{\circ} .64$ de cet ouvrage, et le Tetraopes cordifer. DEJ. Catal.

\section{B. Yeux simplement échancrés.}

Daus cetle section se placent les Lamies charauson $n^{\circ} .7^{2}$, nébuleuse $n^{\circ}$. 7o de ce Dictionnaire, ainsi que la Lamia vemicularis. Donov. Scuon. Append. ad synonym. tom. 1. part. 3. $n^{\circ}$. 233. Cette dernière espèce est de la nouvelle Hollande.

$2^{e}$. Subdivision. Elytres tronquées an bout.

J. SAPERDE rugicolle, $S$. rugicollis.

Sapenda picea, rufo-ferrugireo tomentosa, elytris tuberculatis albo adspersis, tuberculis nitidis.

Lamia rugicollis. Scron. Append. ad synonym. tom. 1. part. 3. $n^{\circ}$. 234. - Lamia porphyrea. Donov.

Longueur 13 lig. Corps d'un bran coulenr de poix, couvert d'un duvet court, serré, rotxferrugineux. Antennes noires, velues extérieurement; leur premier article ferrugineux. Corselet fortement ridé transversalemeut. Elytres ayant leurs angles huméraux très-prononcés; elles sont chargées de tubercules lisses, luisans, plus gros vers la base, et de petits points formés par 111 duvet blanc; cenx de l'extrémité plus grands que les autres. Dessous de l'abdomen couvert du même duvet que les élytres. Pattes ferrugineuses, duveteuses; extrémité des cuisses noire, ainsi que les trois premiers articles et les crochets des tarses.

Nouvelle Hollande.

Nota. Nous connoissons deux autres espèces du mêıe pays qui appartiennent à cette sectiou.

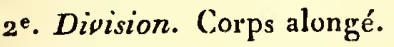

j re. Subdivision. Antennes de douze articles dans les deux sexes.

Rapportez à celte subdivision les Sapenda cardui $\mathrm{n}^{\circ} .45$, suturalis $\mathrm{n}^{\circ} .48$, irrorata $\mathrm{n}^{\circ} .8$. Syst. Eleut. $2^{e}$. Subdivision. Antennes de onze articles daus les deux sexes.

A. Elytres entières.

a. Elytres arrondies à leur extrémité.

† Tête simple.

Les Saperda scalaris $\mathrm{n}^{\circ} .2$, populnea $\mathrm{n}^{\circ} .55$, violacea $\mathrm{n}^{\circ} \cdot 7^{5}$, lateralis $\mathrm{n}^{\circ} .34$, enythrocephala $n^{\circ} .24$, punctata $n^{\circ} .57$, virescens $n^{\circ} .59$, et ferrea no. 52. FAB. Syst. Eleut. sont de celle section, ainsi que l'Adesmus luctuosus. DEJ. Catal. (Saperda hamispila. Ger..)

t T Tête portant en avant une lunule saillante dont les pointes s'élèvent plus ou moins en cornes.

2. Saperde Phobé, S. Phoebe.

Saperda framinea, capite, thoracis parte inferâ fusciisque duabus longitudinalibus superis et elytrorum maculis octo niveo tomentosis.

Longueur 7 lig. Corps linéaire, de conleur paille foncée, velu. 'Tète presqu'entièrement garnie d'un duvet serré d'un beau blanc; son croissant couvert de poils dorés-bruns. Dessous du corselet et deux bandes longitudinales sur ses côtés en dessius garnis d'un semblable duvet; ces bandes un peu ćchancrées intérieurement dans leur milieu. Elytres ayant chacune une forle carène qui descend de l'angle liuméral presque jusqu’à l'extrémité, et huit taches furmées par un duvet blanc, dont cinq entre la carène el la suture, el trois plus petites entre la carène et le bord extérieur. Cốés de l'abdomen couverts de duvet blanc. Pattes et antennes un peu plus pấles que le corps, celles-ci pubescentes, leur premier article noir chargé d'un duvet blauc.

Du Brésil.

Ici se placent les Saperdes cornue no. 3o et bicorne no. 3ı. Oliv. Ent., ainsi que la Saperdis albida. Des. Catal.

\section{b. Elytres acuminées postérieurement.}

\section{SAPERDE mulliponctuée, $S$. multipunctata.}

Sapenda fusca, viridi-luteo tomentosa, elytrorum fúsciâ longitudinali submiarginali albâ ; elytris nigro punctatis.

Longueur 9 lig. Brune, couverte d'un duvet jaune-verdâtre. Ëlytıes ayant chacune une bande longitudinale formée par un duvet blanc près dn bord extérieur, commençant un peu au-dessous de l'angle buméral, et n’atteignant pas tout-ì-fait l'extrémité de l'élytre; celles - ci terminées par i ane forte épine et parsemées de pclits points nois 
ainsi que le corselet. Antennes velues, surtout extérieurement.

Du Brósil.

Rapportez à celle section la Saperda carcharias $\mathbf{n}^{\circ}$. 1. FAB. Syst. Eleut.

B. Elyties échancrées ou tronquées an bour.

On doit mettre dans celte section les Saperda oculata $\mathrm{n}^{\circ} .1 \mathrm{1}$, linearis $\mathrm{n}^{\circ} .15$, ephippiun $\mathrm{n}^{\circ} .7^{8}$, lineola $\mathrm{n}^{\circ} .86^{\circ}$, cylindrica $\mathrm{n}^{\circ} .17$. F AB. Syst. Eleut. et les Saperda pupillata. Schon. et affinis. Panz. Faun. Germ.

HIPPOPSIS, Hippopsis. Saperda. Gвам.

Genre d'insectes de l'ordre des Coléopières, section des Tétramères, famille des Longicornes, tribu des Laniaires.

Dans le groupe de cette tribu qui a pour caractère d'a voir le corselet mutique (voyez S :PERDE), les 'Tapeines se distinguent par lcur corselet trausversal; les Saperdes par'ce qu'elles ont celte même partie du corps aussi large que longue; les Gnomes ont la base des élytres beaucoup plus latrge que la partie postérieure du corselet et les antennes écartées entr'elles à lenr insertion; ce dernier caractère leur est commun avec les deux premiers genres que nous venons de nommer. Dans les Colobotées la base des élytres est la partie la plus large du corps; celui-ci va en diminuant insensiblement d'un côté jusqu'à la tête et de l'antre jusqu'à l'extrémité des élytres qui est fortemeut tronquée; leur corselet est un peu comprimélatéralement et les autennes n'ont (daus les espèces qui nous sont connues) aucune villosité remarquable.

Antennes très-longues, sétacées, insérćes trèshaut, sur la ligne qui sépare le front du vertex, dans une échancrure des yeux, très-rapprochées l'une de l'autre à leur base, composées de onze articles; ces articles velus à leur partie extérieure, surtout les cinq premiers. - Palpes maxillaires de quatre articles, le second et le troisième presque coniques, le quatric̀ne assez long, ovalecylindrique, un peu pointu à son extrémité. Tête plus que verticale, fortenent rabattue en dessous, sa partie la plus antérieure étant lat ligne qui porteles antennes. - Corps très-alongé, presque linéaire. - Corselet plus long que large, cylindrique; sa partie antérieure n'étant pas plus étroite que la tête. - Pattes courtes, cuisses épaisses, point en nassue.

Ces principaux caractères nous semblent suffisans pour signaler ce genre nouveau (pour les autres voyez ceux des Saperdes). Son nom vient de deux uots grecs qui signifient : tête de cheval. Le caractère tiré des antennes demandera à être cbservé daus les femelles, nous croyons n'avoir sous les yeux que des mâles. Le petit nombre d'espèces connues habite le Brésil.

\section{Hippopsis linéolé, $H$. lineolatus.}

Hippopsis fuscus, capitis thoracisque lineis sex elytri cujusque lineis tribus, interioribus apice conniventzbus, luteolis.

Longueur 5 ligg. Corps d'un brun-noirâtre, ponctuć. Antennes ayant plus de deux fois la longueur du corps. Face antérieure de la tête d'un jaune-verdâtre; ses côtés, ceux du corselet et les élytres ayani ciacun trois lignes de cette dernière couleur : les intérieures se rénnissaut à leur extrémité vers le bout des élytres, qui se terminent en pointe. Côtés de l'abdomen ayant une ligne lnngiluclinale du même jaune que les précédentes. Palles d'un brun-noirâtre. La couleur jaune de cet insecte est due à des poils courts et couchés.

Du Brésil.

Nota. Peıt-être doit - on rapporier à cetle espèce la Saperda lenuniscata. FA B. Syst. Eleut. tom. 2. pag. 330. $n^{\circ} .69$. Mais cet anteur dit que son espèce est de la Caroline, et il ne parle pas de la poinie qui sermine chaque élytre.

A ce gemre appartient encore la Saperda pennicomis de M. Germar, Ins. Spec. Nov. 1824. Saperda pilosicornis. Des. Catal. (Hippopsis penniconnis. Nов.)

COLOBO'TÉE, Colobotea. Des. Catal. Ceranlbyx. Oliv. (Entoul.) Saperda. Latr. Fam. nat.

Genre d'insectes de l'ordre des Coléoptères;, section de Télramères, famille des Longicornes, tribu des Lamiaires.

Dans la division de cette tribu dont ils font partie (voyez SaPERDE), les Hippopsis et les Colobotées sont lcs seuls gentes qui aient les antennes fort rapprochées à leur insertion et placces sur la ligne qui sépare le front du vertex; mais dans les premiers le corps n'est pas comprimé sır les côtés, les aniennes sont velues extérieurement et les élyrres ne vout pas en diminuant selsiblement de largeur à leur exirénité.

Antennes sélacées, glabres, insérées très-haut dans une échancrure des yeux, sur. la ligne qui sépare le front du vertex, très-rapprochées l'uue de l'autre à leur base, composées de onze articles cylindriques, le premier un peu en massue. Corps comprimé latéralensent, allant en dininuant sensiblement d'un cóté jusqu'à la tête inclusivement el de l'autre jusqu'à l'allus, sa partie la plus large étant la base humétale des élytres. Elytres longues, fortement échancrées à leur extrémité, couvrant les ailes er l'abdomen. - Pattes de longueur moyenue; cuisses longues, en massue très-prononcéc; larses antérieurs très-élargis et très-velus dans l'un des sexes.

Tels sont les caractères distinclifs de ceux des Saperdes que présentent les Colobotées, et qui nous ont paru d'assez grande importance pour: adopter ce genre proposé par M. le cumte Dejean. 
dans le Calalogue desa collection. Colobotée vient d'un verbe grec qui a rapport à la forte troncasure qui termine les élytres de ces coléoptères. L'auteur en mentionne huit espèces, toutes de l'Amérique méridionale.

\section{CoLobotée tachée, C. contaminata.}

Colobotea nigra, thoracis lineis quatuor dorsalibus obsoletis alterî̀que laterali inferâ, elytronum maculis plurimis subconfluentibus albidis.

Longuenr 9 à 12 lig. Noire. Antennes ayant la partie inférieure de leur sixième article jusque passé son milieu, revêtue d'un duvet cou:t, ras, d'uu beau blanc. Face antérienre de la tête terminée sar ses côtés par deux lignes blanches duveleuses, son vertex ayant trois petites lignes de cetle couleur. Dos du corselet ayant quatre lignes longitudinales semblables, mais moins distinctes; ses côtés en portant une plus large et plus visible qui s'étend sur la tête jusqu'au-dessous des yeux. Elytres ponctuées, surtout à leur base; elles ont un grand nombre de taches duveteuses blanchâtres dont plusieurs sont confluentes et en outre une forte carène qui descend des angles luméraux vers l'extréninié de l'élytre sans atteiudre cette extrémité. Angle extérieur de la troncature épineux. Múle et femelle.

De Cayeune.

On rapportera à ce geure la Saperda cassandra. D.sur. Analect. Entom. pag. 70. $\pi^{\circ}$.61. (Colobotea albo-maculuta. DEJ. Catal.) et les Capricornes inaculaíre $n^{\circ}$. 129, Capr. pl. 20. fig. 154 , échanuré no. 63, Capr. pl. 12. fig. 82, anuulaire no. 55, Capr. pl. 16. fig. 117. On1v'. Entom. tom. 4. Capr.

GNOME, Gnoma. FAB. Cerambyx. Oliv. Lamia. I.Aт. Gen. Crust.

Genre d'iusectes de l'ordre des Coléoptères, section des Tétranères, famille des Longicornes, tribu des Lamiaires.

Dans la seconde division des Lamiaires, laquelle a pour caractère d'a voir le 'corselet mutique (עoyez S Aperde), les Colobotées et les Hippopsis se reconuoissent à leurs antennes rapprochées à lenr insertion; les Tapeines par leur coirselet transversal et les Saperdes en ce qu'elles ont cette même partie da corps aussi large que longue.

Les caractères des Gnomes sont en majeure partie ceux du genre Saperde, mais dans les premiers le corselet est beaucoup plus long que large, presque cylindrique, se rétrécissant un peu et insensiblement vers la tête; les élytres sont linéaires dans la plus grande partie de leur longueur et beaucoup plus larges à leur base que la partie postéricure du corselet; le dernier article des palpes est long et effilé vers la pointe,

Hist. Nat. Ins. Tome $X$.
Nous ne rapportons avec certitude à ce genre que le Capricorne lougicolle $n^{\circ} .75$ de ce Dictionnaire. Gnoma longicollis. FAB. Syst. Eleut. tom. 2. pag. 3r5. $\pi^{\circ}$. 1. Ceramby $x$ longicollss. Oniv. Entom. tom. 4. Capr. pag. 49. no. 64. pl. 11 . fig. 73.

Nota. La Gnoma rigicollis. FAB. eft pour nous un Obrion; il est probable que la Gnoma clavipes de cet auteur appartient aussi à ce même genre.

MACROPE, Macropus. Turnb. Ceramliy.x. Linn. Fab. Prionus. Oliv. (Entom.) Lamic. Lat. Acrocinus. Inerg. Des. Catal.

Genres dinsectes de l'ordre des Coléoptères: section des Tétramères, famille des Longicornes, tribu des Lamiaires.

Trois genres composent la première division de celte tribu caractérisée par le corselet ayant une épine de chaque côté ( voye z S SPRRDE). Dans les Lamies et les Dorcadions ces épines sont fixes, ce qui les sépare des Macropes.

la majeure partie des caractères génériques des Macropes sont ceux des Lamies (voyez ce mol), mais le corselet porte de chaque côté un fort tubercule armé d'une épine, lequel tourne conıme une poulie dans la cavité où sa base est engagée; le corps est toujours très - déprimé ; dans l'un des sexes les pattes antérieures sont très-longues; les tarses glabres dans tous les individus.

Rupportez à ce genre, Io. Ceramby $x$ longimanus. Linn. Syst. Nat. 2. 62 г. I, FAв. Syst. Eleut. tom. 2. pag. 266. no. 1. Prionus longimanus. Oliv. Entom: tom. 4. Prion. pag. 6. pl. 3. fig. 12. b. pl. 4. fig. 12. c. - Encycl. pl. 199. fig. 5. $2^{\circ}$. Cerambyx trochlearis. Livs. Syst. Nat. 2. 622. 2. Prionus trochlearis. OL1v. Entom. tom. 4. Prion. pag. 7. pl. 13. fig. 49. 30. Le Prione a ccentué. Otrv. Id. pag. 8. pl. 4 . fig. 16. - Encycl. pl. 200. fig. 5.

DORCADION, Dorcadion. Scron. Des. Catat. LAt. Fam. nat. Lamia. FAB. Oliv. Cerambyx. Linn. Groff.

Genre d'insectes de l'ordre des Coléoptères, section des Tétramères, famille des Longicornes, tribu des Lamiaires.

Dans le groupe formé par les Lamiaires à cor selet épineux (voyez SAPERdE) les Macropes se distinguent par les épines mobiles de leur corselet et les Lamies par la base de leurs élytres carrée, leurs angles huméraux étant fart saillans et par leurs antennes plus longues que le corps (au moins dans les mâles) dont les articles sopt plus longs et presque cylindriqnes.

Antennes sétacées, plus courtes que le corps dans les deux sexes, composées de onze articles courts, obconiques, le dernier un peu plus long dans les mâles que dans les femelles. - Corps I aptẹre, ovale. - Elytres ovales, rétrécies à leü $\mathrm{V}$ V 
base, leurs angles huméraux étant arrondis, point saillaus. Les autres caractères comme dans les Lamies. Voyez ce mot.

Nous ne connoissons pas les caractères assignés à ce genre par M. Schonner; son now vient d'un mot grec qui signifie : petite chève. Les Lamia lugubris $n^{\circ} \cdot 9^{2}$, tristis $n^{\circ} \cdot 9^{3}$, et funesta $n^{\circ} \cdot 94$. FAr. Syst. Eleut. ont quelques rapports par leur forme et par l'absence des ailes avec le genre Do:cadion, mais elles s'en éloignent par la forme carrée de la base des élytres dont les angles huméraux sont sailians; moins cependant que dans les autres Lamies.

Rapportez aux Dorcadions les Lamies morio et fauve (cette dernière décrite sous le $n^{\circ} .94$, est en outre confondue avec la première sous le nom de Lamie bouffone $n^{\circ}: 7^{8}$ de ce Dictionnaire), pédestre $n^{\circ} .79$, mennière $n^{\circ} .80$, carinée $n^{\circ} .81$, du réglisse $n^{\circ} .82$, fuligineuse $n^{\circ} .83$, cendrée no. 84 du présent ouvrage ainsi que la Lamia cruciata $n^{\circ} .100$, mufipes $n^{\circ}$. 116 , lineata $n^{\circ} .118$, vittigera $n^{\circ}$. 119. FАB. Syst. Eleut.

(S. F. et A. SEnv.)

SAPYGE, Sapyga. Lat. Jur. Krug. Illitg. Spin. Vespa. Groff. Oliv. (Encycl.) Hellus. Fab. Panz. Masaris. Panz.

Genre d'insectes de l'ordre des Hyménoplères, section des Porte-aiguillon, familie des Fouisseurs, tribu des Sapygites.

Quatre genres composent cette tribu ( voyez SAPYgites); les antennes sont filiformes ou presque sélacées dans les Scotænes, les Polochres et les 'Thynnes; de plus ces derniers ont les yeux entiers, ce qui sépare suffisamment ces genres de celui de Sapyge.

Antennes longues, brisées, insérées vers le milieu du front sous uuc ligne élevée en saillie, un peu ren. flées en massue vers l'extrémité dans les deux sexes, composées de douze articles dans les femelles, de treize dans les mâles. - Labre peu apparent. - Mandibules fortes, ayant plusieurs deutelures au côté interne. - Palpes courts, les maxillaires de six articles, les labiaux de quatre. - Lèvre à trois divisions étroites, alongées, les latérales plus pelites, pointues, celle du nilieu échancrée. - Tête un peu plus large que le corselet, arrondie postérieurement. - I'el $x$ fortement échancrés au côté interne. - Trois ocelles disposés en triangle sur la partie antérieure du verlex. - Corps étroit, alongé. - Corselet presque cylindrique, coupé droit en devant, oblus postérieurement. - Ailes supérieures ayant une celInle radiale longue, allant en se rétrécissant après la troisiène cubitale jusqu'à son extrémité qui finiten pointe, et quatre cellules cubitales presqu'égales entr'elles; la seconde et la troisième qui se rétrécit vers la radiale, recevant chacune une nervure récurrente, la quatrième atteignant le bout de l'aile. - Abdomen alongé, ellipsoïde, composé de cinq segmens outre l'anus dans les femelles, en ayant un de plus dans les mâles. - Pattes dé longueur moyenne; jambes antérieures munies vers leur extrémité d'une seule épine dont le bout est échancré : les qualre autres en ayant deux; tarses longs, le premier article le plus grand de tous.

Les femelles de ce genre crensent des trous dans le morlier des murs ou dans le bois pour $y$ déposer leurs œufs : elles appruvisionnent leurs nids de proie; nous en avons pris nous-mêmes une espèce (Sap. sexpunctata) chargée d'un insecle qu'elle laissa tomber au monent où nous la saisissions, mais que llous reconnûmes cepeudant pour une larve. On ne connoît qu'un petit nombre d'espèces de Sapyges; elles sont toutes d'Europe.

1re. Division. Antennes des mâles ayant leur massue oblongue, formée insensiblement; leur avant-dernier article le plus gros de tous, recevant en grande partie le dernier qui est globnleux et court.

\section{SAPYGE variée, S. varia.}

Sapyga nigra, abdominis segmentis secunda tertioque ferrugineis, margine infcro fusco; secundi, tertii, quarti quintique maculâ utrinquè laterali albidâa : antennis maris sensini clavatis.

Longueur 5 lig. Noire. Articles intermédiaire des antennes testacés en dessous. Front et orbile de la partie inférieure des yeux blanchấtres. Bord antérieur du corselet portant deux petits points de cette même couleur. Second et troisième segmens de l'abdomen ferrugineux en dessus; ces mêmes segmens, ainsi que le quatrième et le cinquième, ayant chacun une tache blanclie latérale, celui-ci en porlant deux très-petites en dessous, de chaque côlé. Jambes antérieures un peu tachées de blanc en devant. Ailes transparentes, nervures noires. Mâle.

Des environs de Paris.

Nota. Il nous sembleroit naturel de rapporter cetle espèce comme mâle à la Sapyge six points de M. Latreille; mais cet auteur et M. Jurine affirment que le mâle de celte dernière est l'Hellus quadriguttatus. FAB. N'ayant point d'expérience positive à opposer à l'opinion reçue, nous cédons à la manière de voir de ces savans auteurs.

\section{Saptge trompeuse, $S$. decipiens.}

Sapyga nigra, abdominis segmentis secundo, tertio, quarto (quintoque sappiùs) suprà albida utrinque maculatis, quarti quintique subtus maculâ utrinquè simili : antennis maris sensim clavatis.

Longueur $4 \mathrm{lig} \cdot \frac{7}{2}$. Noire. Articles intermédiaires 


\section{$S A P$}

des antennes testacés en dessous, front blanchátre, une petite ligne de même couleur dans l'échancrure des yeux. Bord autérieur du corselet portant de cliaque côté une très-petite tache blanche. Second, troisième, quatriène et cinquième segmens de l'abdomen ayaut en dessus de chaque côté une tache Jlauche, le quatrième et le cinquième en offiant une semblable en dessous. Jambès ayant un peu de blauc à leur base. Ailes transparentes, nervures noires. Mâle.

- Environs de Paris.

Nota. La taclie latérale du dessus du cinquième segment de l'abdomen manque quelquefois ; Jujiue a donné cetfe espèce à tort comme étant le mûle de la Sapyga prisma.

Rapportez à cette division la Sapyga sexpunctata. l.at. Dict. d'Hist. nat. $\mathbf{2}^{\mathrm{e}}$. édit. Gen. Crust. et Ins. tom. 1. tab. XIII. fig. 9. Femelle. (Hellus sexpunctatus. FА A S st. Piez. pag. 246. no. 1 . Femelle. Hellus quadriguttatus. Id, pag. 247. $n^{\circ}$. 3. Mâle. Suivant MM. Latreille et Jurine.) Ce mâle est la Guêpe noire à quatre points blancs sur le ventre. Geoff. Ius, Paris. tom.2, pag. 379. $n^{0}$. 13, et la Guêpe quadrille $n^{0} .2$ des espèces moins connues de ce Dictionnaire, tom. 6. p. 694 .

$2^{e}$. Division. Antennes des mâles fort longnes, ayant leur massue formée assez brusquement; leur dernier article entièrement libre, le plus gros de tous.

Rapportez à cette division la Sapyga prisma. Lat.Gen. Crust. et Ins. tom. 4. pag. 108. $n^{\circ} .1$. Hellus prisma. FАв. Syst. Piez. pag. 247. $n^{\circ} .5$. Femelle. Sapyga punctato. Panz, Faun. Germ. fas. 100. fờ. 17. Mâle. Masaı̀s Crabroniformis. Panz. Id. fits. 47, fig. 22. Femelle. Elle se trouve aux environs de paris. (5. F. et A. SEKV, )

SAPYGITES, Sapygites. Seconde tribu de la famille des Fouisseurs, section des Porte-aiguillon, ordre des Iyménoptères, ayant pour caractères :

Segment antérieur du tronc prolongé sur les côtés jusqu'à lạ naissance des ailes. - Pattes courtes, grêles, peu on point épineuses, - Corps étroit et alongé, presque glubre. - Antennes composées d'articles serrés, aussi longues au moius dans les deux sexes que la tête et le corselet. - Ailes supérieures ayant une cellule rạdiale et quatre cubitales, la quatrième atteignant le bont de l'aile, la seconde et la troisième recevant chacune une nervure récuriente.

I. Antennes filiformes ou presque sétạcées. Scotæne. Thynue, Polochre.

II. Antennes grossissant vers le bout ou mẹme en massue. Sapyge.
S A R

SARARE, Sarapus. Nom donné par M. Fischer à un genre de Coléoptères à qui M. Duftschmid avoil imposé celui de Sphérite. Voyez ce mot. (S. F. et A. SERv.)

SARCOPTE, Sarcoptus. Nom que M. Tatreille donne au genre Acarus de Fabricius. Doy. Mitte. (E. G.)

SARGUS, Sargus. FAв. Lat. Meig. Musca. Linn. Geoff. Panz. Nemotelus. De Gérr.

Geure d'insectes de l'ordire des Diptères, sectiou des Proboscidés, famille des Notacanthes, tribu des Stratyomides.

Des neuf genres contenus dans cette tribu, les Ptilocères out les antennes flabellées: les Stratyomes ainsi que les Odontomyies, les Oxycères et les Ephippies ont l'écusson épineux; les Vappons et les Némotèles qui, comme les Sargus, ont l'écusson mutique, s'en distinguent, les premiers par les deux premiers articles de leurs antenues transversaux, dont le second forme avecle troisième ou dernier une tête presque hémisphérique et les secondes par un avancement pointu de la partie antérieure de la tête, imitant un bec sous lequel la trompe se retire.

Antennes avancées, rapprochées à leur insertion, de trois articles; le premier presque cylindrique, le second cyathiforme, le troisiè une lenticulaire ou elliptique, annulé, plus long que les autres, portant une longue soie à son extrémité. - Suçoir composé de deux pièces, renfermé dans une trompe courte, munie de deux grandes lèvres saillantes. - Téte arrondie en devant, plus large que le corselet. - Segment antérieur du corselet égalant les deux autres en longueur. - Ecusson mutique. - Yeux très-grands. - Ocelles distincts. - Ailes longues, en recouvrement dans le repos, ayant une cellule discoïdale presque triangulaire et une cellule marginale au-dessous du point épais séparée en deux par une nervure transversale oblique; toutes les nervures qui sont au-dessous de la cellule discoïdale, atteignant le bord postérieur de l'aile. - Abdonnen elliptique, déprimé, composé de six segmens outre l'anas. -Pattes delongueur moyenne; tarses longs, leur premier article aussi grand ou plus grand que les autres.

La larve du Sargus auquel on a donné le nom de Réaumur a été observée par cet auteur; elle vit dans les bouzes de vache, sa forme est ovaleoblongue, rétrécie et pointue en devaut ; sa tête est écailleuse, munie de deux crochets : son corps parsemé de poils. Elle se métamorphose sous sa peau qui s'endurcit et de laquelle l'insecte parfait sort en faisant sauter la partie antérieure do cette espèce de coque.

Les Sargus dans leur dernier état vont peu sur les fleurs; mais ils aiment à se tenir au soleil sur les feuilles oùils se promèuent assez lentement les $\mathrm{V} \vee 2$ 
'ailes très-écartées : ils ne volent avec aclivité que lorsque la chaleur est forte. Quand il fait froid, ils paroissent engourdis et se laissent aisément saisir à Ja main. Le nombre d'espèces connues ne s'élève guère au-delà d'une douzaine; leur corps est ordinairement de couleur brillante et métăllique.

I $^{\mathrm{re}}$. Division. Troisième article des antennes obtus à son extrémité, marqué de trois anneaux.

I $^{\mathrm{re}}$ Subdivision. Troisième article des antennes presqu'arrondi, lenticulaire; yeux séparés dans les deux sexes : palpes nuls.

A. Ocelles placés sur le front, l'antérieur éloigné des autres.

\section{Sargus enfumé, $S$. infuscatus.}

Sargus thorace ocneo nitido; abdomine cupreo ( mas), aut violaceo (formina) : alis infuscatis; pedibus fuscis.

Sargus infuscatus. Merg. Dipt. d'Eur. tom. 3. pag. $107 \cdot n^{\circ} .3$.

Longuenr 5 lig. Tête d'un noir-cuivreux. Trompe blanchâtre. Deux points de même couleur audessus de la base des antennes. Corselet cuivreux. Abdomen violet, à reflet doré. Pattes noires, leurs genoux blanchâtres. Ailes un peu brunes avec leur bord postérieur irisé. Femelle.

Le mâle diffère en ce que con abdomen est d'un doré cuivreux.

Commun aux environs de Paris.

\section{Sargos cuivreux, S. cuprarius.}

Sargus cuprarius. Fab. Syst. Antl. pag. 256. no. 3. - Lat. Gen. Crust. et Ins. tom. 4. pag. 278. - MEig. Dipt. d'Eur. tom. 3. pag. 106. $\pi^{\circ}$. 1. - Encycl. pl. 249.fig. 7.

Voyez pour la description et les autres synonymes la Mouche bronzée no. 85 de ce Dictionnaire. (A la citation du Species de Fabricius, lisez $n^{\circ} .52$ au lieu de 50 , et retranchez les figures de Réaumur qui appartiennent au Sargus de Réaumur.)

On rapportera à cette section les Sargus coeruleicollis $n^{\circ} .2$, nitidus $n^{\circ} .4$, et flavipes $n^{\circ} .5$. Meig. Dipt. d'Eur.

\section{Ocelles placés sur le vertex, également es- pacés.}

A cette section appartiennent le Sargus Reaumurii. Faв. Syst. Antl. pag. 256. no. 2. Me1G. $n^{\circ}$. 6. Dipt. d'Eur, et le Sargus sulphureus. Meig. $7 t^{\circ} \cdot 7 \cdot i d$.

2e. Subdivision. Troisième article des antennes elliptique. Yeux convergens dans les máles. Ocelles placés sur le verlex. Palpes apparens.

\section{SARg os agréable, $S$. formosus.}

Sargus ahdomine violaceo (famina), aureo ( $m a s)$, alis ferrugineis, pedibus nigris favo geniculatis.

Sargus formosus. MEIG. Dipt. d'Eur. tom. 3. pag. 1 10. $n^{\circ}$. 8. - Sargus xanthopterus. FAв. Syst. Antl. pag. 255. no. 1. Femelle. - Lat. Gen. Crust. et Ins. tomi. 4. pag. 278 . Femelle. - Nemotelus flavogeniculatus. DE GERr, Ins. tom. 6 . pag. $201 . n^{\circ} .17$. Femelle.-Sargus auratus. FAB. Syst. Antl. pag. 257. $n^{\circ}$. 4. Mâle. - Lat. Gener. Crust. et Ins. tom. 4. pag. 278 . Mâle.

Longueur 4 lig. Tête noire. Corselet d'un vertbleuâtre cuivreux. Abdomen d'un violet-cuivreux. Ailes jaunâtres. Pattes noires, genoux d'un jaunetestacé. Femelle.

Voyez pour la description du mâle et ses antres synonymes, la Mouche dorée no. 86 de ce Dictionnaire.

Rapportez à cette seconde subdivision la Mouche polie $n^{\circ} .87$ de cet ouvrage (Sargus politus. FAB.Syst. Antl. pag. $257 \cdot n^{\circ} \cdot 7$. Le Sargus cyaneus id. pag. $258 . n^{\circ}$. 10 , en est une variété femelle suivant M. Meigen.), et le Sargus flavicomis. Meig. Dipt. d'Eur. pag. I12. $n^{\circ} .10$.

$2^{{ }^{\theta}}$. Division. Troisième article des antennes long, conique, terminé en pointe, marqué de six anneaux.

Cette division renferme $1^{\circ}$.le Sargus amethystirus. FAB. Syst. Antl. pag. 258. $n^{\circ}$. 13 , de l'île de France; $2^{\circ}$. le Sargus vespertilio du même, pag. 259. $n^{\circ}$. 14, du Brésil. (S. F. et A. Serv.)

SAROPODE, Saropoda. M. Latreille a proposé sous ce nom un genre d'Hyménoptères mellifères, démembré de celui d'Anthophore. Il lai donae pour caractères : mandibules unidentées intérieurement au-dessous de leur pointe (obtuses et presque fourchues, au moins dans les femelles). $\mathrm{Pa}$ raglosses beaucoup plus courles que la langue. Palpes maxillaires de cinq articles; les labiaux sétiformes, aigus; leurs articles au nombre de quatre, droits; les deux derniers peu distincts, réunis étroitement pour former une pointe.

La seule espèce que l'auteur rapportè à ce genre est l'Anthophore bimaculée. Voyez Anthophore, article XrLocope. (S.F. et A. Serv.)

SARROTRIE, Sarrotrium. Genre de Coléoptères fondé par Fabricius, qui répond à celui d'Orthocère de M. Latreille. Voyez ce mot.

(S. F. et A. Serv.)

SATURNIE, Saturnia. Genre de Lépidopières 
nocivines proposé par M. Schranck pour y placer une partie des Bombyx que Linué avoit auparavaut nommés Phaloena Bombyx Attacus. Nous pensons qu'il tépond au genre Altacus. Lat. Fam. natur. (S. F. et A. SERV.)

SATYRE, Sazyra. Genre de Diptères proposé par M. Meigen dans son premier ouvrage intitulé : Classification des Diptères d'Europe. Il équivaut à celui de Dolichope de M. latreille.

(S. F. et A. SEnv. )

SATYRE, Satyrus. Genle de Lépidoptères Diurnes. Voyez tom. IX, pag. 460 . Geoffroy a voit réuni sous ce nom comme spécifique deux espèces qui entrent dans ce geture; ce sont les Satyres Mœra no. 86, et Mégéra $1^{\circ} .87$ de ce Dictionnaire. (S. F. et A. SERV.)

SAUterelle, Locusta. Geoff. De Géer. Faв. Lat. Gryllus. (Tettigonia : Linn.

Genre d'insectes de l'ordre des Orthoptères, fumille des Locustaires. (Il appartient aux Ortlioptères sauteurs.)

Ce genre compose à lui seul cette famille, dont les caractères sont : élytres et ailes en toit. - $A n$ tennes très-longues, sétacées, multiarticulées; articles peu distincts. - Tarses composés de quatre articles.

Antennes très - longues, sétacées, à articles nombreux, courts, peu distincts, insérées entre les yeux vers leur extrémité supérieure. - Labre entier, grand, presque circulaire en devant. Mandibules fortes, peu dentées. - Mấchoires bidentées à leur extrémité, ayant une seule dent alongée au cỏté in terne. - Galète alongée, presque irigone. - Palpes inégaux, les maxillaires plus grands, de cing articles, les labiaux de trois; le dervier obconique dans tous les quatre. - Lèvne à quatre divisious, celle du milien fort petite, les exterieures arrondies à leur extrémité; menton presque carré. - Tête grande, verticale, de la largeur du corselet. - Y Y eux petits, saillans, arrondis. - Ocelles peu ou point apparens. - Corps alongé: - Corselet souvent tétragone, court, comprimé sur les côtés. - Point d'écusson. Elytres inclinées, réticulées, recouvrant ordinairement des ailes. - Abdomen terminé par deux appendices sétacés, écartés en tr'eux à leur insertion; ayant de plus, dans les femelles, un oviscapte ou pondoir ensiforme, très-saillant, comprimé, composé de deux lames accolées l'une à 1'antre. - Pattes fortes, les postérieures trèsgrandes, propres à sauter; leurs cuisses renflées dans leur première moitić; leurs jambes munies en dessus de deux rangs d'épines nombreuses, assez grandes; tarses composés de quatre articles distincts, le pénultième bilobé, le dernier terminé par deux crochets sans pelottes.

Les Sauterelles habitent les prairies et les champs herbeux; quelques espèces se tienneut dans les vignes et sur les arbres. La longueur de leurs ailes et des élytres qui les recouvrent opposeroient noe difficulté à ce qu'elles pussent s'envoler lorsqu'elles sont posées; mais au moyen d'an saut assez considérable elles s'élèvent de manière à les pouvoir déployer. Leur vol ne s'ćtend guère qu'à une vingtaiue de pas de distance de l'entroit d'où elles sont parties. Elles se nourrisent de végétaux; les mâles, ou au unoins une partie d'entre eux, font entendre un bruit plus ou moins fort, aign et long-temps continué, que l'on appolle communément le chant des sauterelles : il paroî produit par le frottement des élytres l'une contre l'aulte, et n'appartient qu'aux espèces dont les mâles font voir à la base supérieure de cette partie un espace scarieux, décoloré, transparent, et ressemblant en guelque sorte à un miroir. Ce que nous avons dit de la longueur des élytres et des ailes n'appartient pas à toutes les espèces de ce genre : il en est qui sont aptères dans l'élat parfait, telles que la Sauterelle porte-selle ( $L$. ephippiger), qui diffère égilement de beaucoup d'autres, en ce que sa nourriture habituelle sont les fruits, et particulièrement le raisin, dout elle entame les grains.

Les femelles de ce genre déposent leurs œufs dans la terre, où elles les enfoncent au moyen de leur oviscapte. Les larves qui en sortent ne diffèrent de l'insecte parfait que par la petitesse et le manque d'ailes et d'élytres : elles jouissent des mêmes facultés, excepté de celle de la reproduction. Les nyaphes ont des ailes et des élytres, mais enveloppées dans des four:eaux qui ressemblent en quelque sorle à des boutons, et ce n'est que lursque ces organes sont développés que l'insecte alors parfait est propre à se reproduire. Le vulgaire confond les Sauterelles avec les Criquets, et lenr attribue des ravages dont elles ne sont pas coupables. Voyez CrIquet.

Ce genre est nombreux eu espèces des différentes parties du monde. Leur taille est généralement fort grande.

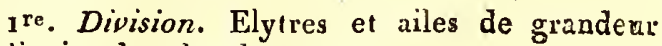
ordinaire daus les deux sexes.

$1^{\text {re }}$ Subdivision. Antennes garnies inférieurement de poils.

Ici se placent des espèces du Brésil qui composent le genre Pennicorne, mentionné par M. Latreille dans ses Fam. nat. pag. 413. Elles nous sont inconnues.

$$
\begin{aligned}
& 2^{e} \text {. Subdivision. Antennes entièrement gla- } \\
& \text { bres. }
\end{aligned}
$$

A. Front terminé en un cône obtus. (Genre Conocéphale. Latr. Farm, nat. pag. 41 ỉ.) 
1. Sauterelle longue épće, $L$. xiphias.

Locusta antennis nudis, fronte elongatê, conic $\hat{a}$, elytris lanceolatis alis oequalibus, viridigrisea, oviscapto longitudine corporis recto.

Longueur 3 pouces (i). D'un vert-grisâtre. Front très-élcvé, pyramidal, un peu plus foncé que le reste du corps. Elytrcs dépassant l'abdomeu de près de moilié. Oviscapte de la longueur du corps, troit, dépassant les élytres de près de moitié. Femelle.

De Cayenne.

\section{Sauterelle bouche rose, L. erythirosomia.}

Locusta anbennis nudis, fronte conicâ ; elytris lanceolatis alis aqualibus, vitidis, ore rubro wisantiaco.

Longueur 20 lig. Verte. Bouche d'un rougeorangé avec l'extrémilé des mandibules brune. Jambes postérieures, tarses et extrémité des antennes de couleur brune. Oviscapte de la longucur de l'abdomen, atteignant presciuc l'extrémité des élytres. Femelle.

Des environs de Grenoble.

Rapportez à celte section les Locusta maxillosa $n^{\circ}$. 13 et conocephála $n^{\circ}$. 23. F $\mathrm{F}_{\mathrm{AB}}$. Entonlı. Syst. tonı. 2.

B. Front portant une pointe particulière entre les antennes.

a. Elytres larges, imitaut des feuilles.

3. Sauterelle feuille varte, $\boldsymbol{L}$. viridifolia.

Locusta antennis nudis, fronte acuminatâ, elytris latis alis cequalibus, viridis, abdomine lutescente subtùs viridi, lateribus luteis serram fingentibus : femoribus quatuor posticis unâ serie spinosis; oviscapto abdomine breviore, recurvo, apice fusco.

Longueur 2 pouces. D'un bean vert. Pointe frontale très-courte. Bouche ct palpes jaunâtres. Ailes d'un vert-pâle. Abdomen d'un jaune-pâle en dessus, vert en dessous, sur les côtés duquel la couleur du dessus s'avance en une série de dents de scie. Anus et base de l'oviscapte verts; l'cxtrémité de celui - ci dépassant les élytres, brune depuis le milieu. Cuisses postérieures d'un jaunc-testacé à leur partie interne, garnies en dessous d'un rang de fortes épincs ainsi que lcs jntermédiaires : les antérieures en ayant aussi quelques-unes peu remarquables. Jambes et tarses un peu bruns. Femelle.

Du Brésil.

(1) Nous comprons la longueur dequis la partic antérieure de la tête jusqu'au bout des ailes, des élyrres ou de "oviscapre, suivant que les uns ou les autrẹs se prolongent layantage.

\section{S A U}

b. Elytres lancéolées.

† Dos du corselet aplati.

Rapportez à celte conpe la Sauterelle serretéc ( Locusta serrulata.) P.Lis.-B.suv. Ins. d'Afr. et d'Amér. pag. 218. Orthopt. pl. VIII. fig. 2. Ajoutez à la dicscription quc les élytres dépassent un peu l'abdomen, et que l'oviscapte beaucoup plus court que celui-ci dćpasse les élytres de plus de moilié de sa longueur. Femelle. De Saint-Domingue.

\section{tt Dos du corselet convexe.}

* Corselet marqué de sillons transversaux.

\section{Sauterelde bisillonnée, L. bisulca.}

Locusta antonnis nudis, fronte acuminatâ; elytris lanceulatis alis aequalibus, viridibus : fusca thoracis fasciâ luteolâ, oviscapto nigra suprì à basi ad medium rabro.

Longueur 2 pouces $\frac{3}{2}$. D'un vert-brunâtre, les trois segraens du corselet séparés par deux sillons transversaux, assez profonds, Parlie autérieure du troisième segment porlant une bande transverse jaunâtre. Elytres d'un vcrt plus yai , dépassant de beaucoup l'oviscapte. Celui-ci noirâtre, sa partie supérieure rouge depuis la base jusqu'un peu passé le milieu de la longueur de l'abdomen. Antennes une fois et demie aussi longues que le corps, annelées de blanc. Tarses bruus. Femelle.

De Cayenne.

On doit rapporter à cette section la Locusta specularis $n^{\circ} \cdot 7$. FAs. Entom. Syst. tom. 2.

\section{* Corselet sans sillons transversaux.}

\section{Sauteprlde poncluée, L. punctata.}

Locusto antennis nudis, fronte acuminata ; elytris lanceolatis alis cequalibus, viridi-fusca, capitis thoracisque dorso et elytronem punctis nigricantibus.

Longueur 2 pouces. D'un verlegrisâtre. Partie supérieure de la tête et du corselet d'un bruunoirâtre. Elytres marquées chacune dans toute leur longueur d'une quinzaine de points noirâtrcs, épars, dépassant l'oviscapte : celui - ci court, recourbé, large, de la longueur de l'abdomen? F'emelle.

\section{Du Brćsil.}

Rapportez à cette seclion, $1^{\circ}$. Locusta viridis sima $n^{\circ}$. 32. FА . Entoni. Syst. toin. 2. Encycl. pl. I3o. fig. 3. Femelle. Cette espèce est la plus commune de toutes celles des environs de Paris. Son tubercule frontal est presque carré à l'extrémité. $2^{\circ}$. Locusta varia n ${ }^{\circ} .35$. FAB, Id. Environs de Paris. 
C. Front mutique.

a. Elytres larges, imitant des feuilles.

† Ailes ne dépassant pas les élytres.

* Dos du corselet convexe.

A celle section appartient la Locusta ocellata $n^{\circ}$. 19. Fав. Entom. Syst. tom. 2.

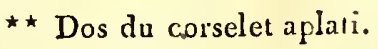

6. Sauterelle feuille de Cassiné, $L$. cassincefolia.

Locusta antennis nudis, fronte muticâ, albidâ, elytris latis, alis cequalibus; luteo-viridis: oviscapto brevissino, recurvo. Fedibus quatuor anterioribus brevissimis.

Longueur 20 lig. D'un vert-jaunâtre. Face antérieure de la tête d'un vert-blanchâtre. Bouche et palpes pâles. Anteunes et pattes antérieures d'un vert-brun, celles-ci et les intermédiaires courtes et foibles. Cuisses postérieures fort menues depuis leur milieu jusqu'à leur articulation avec la jambe, à peine dentées en dessous. Oviscapte recourbé, très-court, n’atteignant pas à beaucoup près le bout des elytres. Femelle.

Du Brésil.

\section{†† Ailes dépassant les élytres. \\ * Dos du corselet ayant ses côtés élevés en carène.}

Cn rapportera ici la Locusta citrifolia $n^{\circ}$. $\mathbf{r}$. FB. Entom. Syst. tom. 2. Encycl. pl. 129. Sauterel. fig. I. Femelle.

* Dos du corselet déprimé, sans carène latérale.

\section{Sauterelle double cœur, $\boldsymbol{L}$. bicordata.}

Locusta antennis nudis, fronte muticâ, rusosâ; elytris latis, alis brevioribus, viridi-fusca thoracis nugosi maculis duabus dorsalibus cordutis apice oppositis viridious : elytris viridibus plagâ duplici quasi exsiccâ erosâque, alterâ marsinali.

Longueur 15 lig. D'un brun-vercảtre. Antennes annelées et ponctuées de noir. Dos du corselet portant deux taches d'un beau vert imitant denx cœurs opposés par leur pointe. Elytres vertes, deux fois plus longues que liabdomen, portant chacune deux plaques ressemblant absolument à des portions de feuilles dont le parenchyme auroit été rongé ; l'une d'elles placée sur le bord de l'élytre avant le bout. Les qualre cuisses antérieures dentées, tachées de brun en dedans; leurs jambes dilatées a la base, annelées et tachées de brun. Cuisses pos- térieures muliques, ayant deux anneaux bruus. Oviscapte très-relevé, court. Femelle.

Du Brésil.

b. Elytres lancéolées.

† Ailes dépassant les élytres. Dos du corselet point caréné.

Ici se place la Locusta lilifolia $n^{\circ} \cdot 9$. FАв. Ent. Syst. tom. 2.

t† Ailes ne dépassant pas les élytres. Dos du corselet ayant dans son nilieu une carène longitudiuale.

Rapportez à cette section les Locusta verrucivora $n^{\circ}$. 33. (Encycl. pl. 15o. fig. 4. 6) et 7 . lemelle. fig. 5. Mále), et grisea $n^{\circ} \cdot 3 \mathrm{I} . \mathrm{F}_{\mathrm{AB}}$. Ent. Syst. tom. 2.

$2^{\circ}$. Division. Femelles aptères; leurs élytres très-courtes, en forme d'écailles arrondies et voùtées. (Les genres Anisoptère et Lphippigère. Lar. Fam. nat. pag. 413.)

On placera dans cette seconde division la Locusta ephippiger $n^{\circ} .42$. (Encycl.pl. 131 . fig. 3. Femelle. fig. 3. $n^{\circ}$. 2. Nâle), et pupa $n^{\circ} \cdot 3 g$. (Encycl. pl. 131. fig. 2. Femelle.) Fав. Entom. Syst. tom. 2. (S. F. et A. SERY.)

SAUTERELlES DE PASSAGE. Nom donué par Stoll et quelques autres autemrs aux insectes Orthoptères composant le genie Criquet. Voyece mot. (S. F. et A. Serv.)

SAUTEURS, Saltatoria. Deuxième division de lordre des Orthoptères, renfermant les scconde et troisième sections de cet ordre. Son caractère est: pattes postérieures toujours propres à sauter.

\section{2e. Section.}

Cuisses postérieures forl grandes. Mâles produi sant une sorte de cliant ou stridulation en frottant l'une conlie l'autre une portion iuterne, élastique, spéculiforme et à nervures irrégulières, de leurs élytres. Premier segnent abdominal dépourvu d'organe aérien particulier. Presque tontes les femelles ayant à l'anus un oviscapte ou tarière bivalve, saillante en forme de sabre, d'épéc ou de long stylet; elles enfouissent leurs oufs en terre, mais sans les envelopper.

Cette section renferme les cinquième et sisième familles de l'ordre des Orthoptères.

\section{5e. famille. Grilloniens, Gryllides.}

Elytres et ailes horizontales. Tarses de trois arlicies.

Courtillic̀re , Tridactyle, Grillon, Myrmúcophile. 
be. finille. Locustaires, Locustarice. Voyez Sajterelle.

\section{Section.}

Elytres et ailes toujours en toit. Tous les tarses de cing articles. Les deux sexes produisant une stridulation au moyen d'un frottement allematif et instantanément réitéré de letirs cuisses postériemres contre les élytres. Ces ély:res semblables dans les deux sexes. Premier seoment abdominal ayant de chaquie côté, dans le plus grand nombre, une sorte de tambour distingué extérieurement par un opercule membraneux, circulaire on lusulé. 'Tarière composée de qua tre pièces crochues, réunies, fúisant peu de saillie. Anteunes tantôt en forme de lame d'épée ou subulées, tantôt filiformes ou en massue dans les deux sexes, ou seulement dans les måles. Les femelles renfermant leurs œuffs dans une enveloppe comnune, ou les réunissant au moyen d'une matière écunieuse, visqueuse, et les enfouissant souvent dans le sable.

Cette troisième section ne contient qu'une seule famille, la septième de l'ordre; Acrydiens, Acrydites. Elle se divise ainsi :

I. Pattes postérieures plus courtes que le corps, foibles,

\section{Pnenmole.}

II. Paltes postérieures plus longues que le corps, robustes.

A. Extrémité antérienre du présternum ne recouvrant pas la bouche. Tne pelutte entre les cruchets des tarses.

a. Corps ordinairement long et étroit. Tête pyramidale. Antennes courtes et coniques, ou comprimées et lancéolées.

Proscopie, Truxale, Xiphicère.

b. Corps court ou obloug, épais. Tête point pyramidale. Antennes aussi longues que la tête et le corselet, filiformes ou en massue.

$\dagger$ Antennes filiformes dans les deux sexes.

* Présternum cornu. Criquet.

* * Présternum sans corne. Edipode, Podisme.

it Antennes, ou du moins celles des mâles, renilées à leur extrémité.

Gomphocère.

B. Estrémité antérieure da présternum concave, en forme de mentonnière, recevant une parlie de la bouche, Point de pelottes entre les crocheis des tarses. Tétrix.

Nota. Cet article est extrait de l'ourrage que
M. Iatreille vient de publier sous le titre de Familles nuturelles du règne animal.

(S. F. et A. SERV. )

SC瓜VE, Scceva. Fabricius désigne sous ce nom un genre de Diptères-Proboscidés de la famille des Alhéricères, tribu des Syrphies de M. Latreille; il répond en partie à celui de Syrphe de M. Meigen. Voyez ce mot.

SCAPHIDIE, Scaphidium. Oriv. Fáb. Iat. Payk. Silpha. Lixn.

Genre d'insectes de l'ordre des Coléoptères, section des Pentamères, famille des Clavicornes, tribu des Peltoides.

D'après les modifications introduites dans cette tribu par M. Latreille dans son ouvrage des $F a-$ milles naturelles, ce genre fait partie d'un groupe qui a pour caractères : palpes maxillaires filiformes ou plus gros à leur extrémité, point terminés en nanière d'alêne. Extrémité des mandibules fendue et lidentée. Ce groupe renferme outre les Scaphidies les genres Thymale, Colobique, Strongyle, Nitidule, Ips, Cerque, Dacné, Byture, Anthérophage, Cryptophage et Micropèple; mais aucun de ces onze derniers genres n'a le corps sizultanément d'une forme naviculaire ou elliplique, avec les deux extrémités rétrécies en pointe.

Antennes insérées au-devant des yeux, sur les côtés de la partie supérieure de la iête, presque de la longueur du corselet, compasées de onze articles, les six premiers minces, alongés, presque cylindriques, les cinq autres formant une massue, presqu'ovales, un peu comprimés. Labre entier. - Mandibules obtuses à leur extrémité et bifides. - Palpes maxillaires filiformes, de quatre articles, le dernier presque cylindrique, terminé en alêne; palpes labiaux très-courts, filiformes, ne s'avançant pas au-delà de la lèvre, de trois articles presqu'égaux. - Lève membra= neuse, sa partie saillante courte, twansversale, son bord supérieur un per plus large, presque concave; menton coriace, presque carré. - Yeux arrondis, à peịne saillans. - Corps épais, de firme naviculaire, rétréci et pointu aux dẹx bouts ${ }_{q}-$ Corselet convexe, presque trapéziforme, beaucoup plus étroit en devant, un peu plus large à sa partie postérieure qu'il n'est long, le bord de cette partie un peu sinué. - Elytres tronquées à leur extrémité, laissant l'anus à découvert, recouvrant des ailes, - Abdomen épais, terminé en pointe vers l'anus. - Pattes grêles; jambes longues, presque cylindriques.

Le nom de ce genre fondé par Olivier vient d'un mot grec qui signifie : petite barque, et a rapport à la forme naviculaire de ces insectes. Le petit nombre d'espèces connues vit sous les écorces et dans les champignons; leurs mœurs et leurs transformations sont ignorées. 
${ }^{\mathrm{re}}$. Dipision. Ecusson distinct.

A cette division apparliennent les Scaphidics quadrimaculé (Scaphudúun quadrinaculatum n ${ }^{\circ}$. 1. Fab. Syst. Eleut.), et immaeulé (Scaph. immaculatum $\mathrm{n}^{\circ}$. 3. FAB. id.).

$2^{e}$. Division. Ecusson nul.

Le type de cette seconde division est le Sciaphidie des Agaries (Scaphid. agaricinum no. 4 . FAв. Syst. Eleut.). (S. F. et A. Serv.)

SCAPHINOTE, Scaphinotus. LaAt. DeJ. (Spéc.) Cychrals. Fab. Carabus. Oliv.

Genre d'insectes de l'ordre des Coléoptères, section des Pentameres, famille des Carnassiers, tribu des Carabiques (division des Abdominaux).

Cettc division contient deux subdivisions; l'une a pour caractèrcs : mandibules sans dents notables ou n'en offiant qu'à leur base; elle contient les grenres 'iefllus, Procère, Procruste, Carabe, Carlosome, Pogonophore (Leistus, Lat. Fam, nat. Des. Spéc:), Néiscie, Omophron, Bléthise, Elaphre et Notiophile, auxquels M. ie comte Dejean joint le genre Pélophle; l'autre subdivision renfirme les Pambores, les Cychres, les Scaphinotes et les Sphérodères, qui oni les maudibules dentées dinus presque toute la longneur du côté interne. Mais les Pumbores u'ont point leur's élytres carénées latéralement et ces élytres n'embrassent pas l'abdomen, et dans les Cychres ainsi que dàns, es Sphérodères les bords latéraux du corselet ne sont point prolongés postérieur eurent et ils ne sont que peu ou point relevés; er outre les Cychres ont les tarses antérieurs point dilatćs et semblables dans les deux sexes, ce qui distingue ces trois genres de celui de Scaphinote. M. Latreille en créant ce dervici genre (Iconogr. des Colćopt. d'Europ.) et en le maintenant daus ses fiamilles naturelles, n'en a point posé les caractères. Nous les présentons donc ici tels quiils sont énonećs dans le Spéciès de Mi. le coute Dejean.

Antennes sét acées. - Labose bifide. - Mandibulles étroit's, avancées, dentées intérieurement: Dernier article des palpes nès-fortement sécuriforme, prescru en cullier et plus dilaté dans les mâlcs. - Menton très-lortement échancré. - Bords latéraux du corselet très-díprimés, relevés, prolongés postérieureureul. - Elytres soudées, trèsforlement carénées latéralement ct embrassint une partie de l'abdomen. - Tarses antérieurs ayant leurs trois preniers articles légèreuent dilatés lans les matilcs.

I،e nom de ce genre vient du grec, il a rapport à la forme du corselet de ces insectes, qui se rapproche de celle d'un bateau. Le Carrabe relevé $n^{\circ} .49$, Encycl., est de ce genre et peut-êtıe anssi le Carabe unicolor $\mathrm{n}^{\circ}$. "jo. Ce sont les Cychras nos. 4 et 5. FAB. Syst Eleut.

Hist. Nat. Ins. Tome $X$.
SCAPHURE, Scaphura. Genre d'insectes Orthoptc̀res-Sauteurs, de la famille des Locustaires, équivalant à celui de Pennicorne de M. Latreille (1) et à notre première subdivision de la preuière division du genre Sautcrelle. (Toyez ce mol.) IM. Kirby qui a créé ce genre, en développe les caractères dans le Zoological Joumal no. 5 , avril 1825 , de la manière suivarte : labre orbiculaire. Mandibules cornćes, forles, presque trigones, arrondies à leur partie dorsale, munies intérienremcrit de cinq deuls, lestrois de l'cxtrémité faites en lanières, l'intermédiaire jucisive, échancrée; celle qui est la plus près de la base, I essemblant assez it une dent nolare; lobe supérieur des mâchoires coriace, linéairc, courbe à son extrémité, l'inférieur ayant à sa pointe trois épines dont l'inférieure est la vlus longue. Lèvre coriace; sou extremité divisée en deux lobes oblongs. Palpes filiformes; les maxillai!'es de quatre articles; le second et le quatrième plus longs que les an!res, eelui-ci grossissint vers le boul. Palpes labiaux de trois arlicles, le premier le plus court de lous, l'intermédiaire moius long que le dernier. Anlemes muliarticulées, filiformes à leur base, sétacées à l'extrémité. Oviscapte en forme de nacelle, garni d'aspérités. Corps oblong, coinpriać. Le type de cc geare est la Scaphure de Vigors, S. Vigorsii (Locusta Vigorsii Nob.) Longueur 14 lig. Noire. Abdomen bleuâtre. Cuisses postćrieures ayant dans leur milieu une bande blanche. Extrémité des élytres pâle. Antenues velues dans leur partie iuférieure. Du Brésil. Cette espèce est figurée dans l'ouvrïge que nous venous de ciler, vol. 2. pl. 1. fig. 1-6.

(S. F. et A. Serv.)

\section{SCAPTÈRE, Scapterus. Des. (Spéc.)}

Gcnre d'insectes de l'ordre des Coléoptères, section des Pentancres, fämille des Carnassiers, tribu des Carabiques (division des Bipartis).

La divisiou de la tribu des Carabiques nommée par M. Latreille les Biparlis (Scartides DeJ.) nons paroît devoir êlre divisée d'apres les excellentes viles de cet autcur (Iconogr. des Coléopt. d'Europ.) el celles de M. le comte Dejean (Spéciès des Coléopt., etc.) qui dins cet ouvrage y a introduit quelques nouveaux genres.

I. Menton inarliculé, recouvrant presque tout le úesscus de la tête.

\section{Encelade, Siagone.}

II. Menton articulé, liissaut à découvert une grande purtie de la bouclse.

A. Jambes autérieures palmées.

(1) M. Latreille nous charge de déclarer en son nom qu'il abandonne la dénominarion de Pennicorne, et adopte cuile de Scaphure donnée par Mi. Kirby.

$\mathrm{Xx}$ 
a. Mandibules fortement dentées intériearezient.

Carène, Scarite, Acanthoscèle, Pasimaque, Scaptère.

b. Mandibules point ou très-légèrement dentées intérieuresncut.

Oxystome, Oxyornathe, Campiodonte, Clivine.

B. Jambes antérieurcs non palmées.

a. Antennes grenues ou presque grenues. Corselet presque carré.

\section{Ozène, Morion.}

b. Antennes à articles alongés, presque cylindriques. Corselet presque lunulé ou cordiforme.

Ariste, Apotome.

Daus le groupe dont fait partie le genre Scaptère, les Carènes se disinguent par leurs quatre palpes extérieurs dont le dernier article est dilaté. Les Scarites et les Acanthoscèles ont leurs mandibules grandes et avancées; de plus les Scarites ont leur corselet presqu'en croissant, arrondi postérieurement. Dans les Acantlioscèles le corps est court; enfin les $P$ asimaques ont le corselet large, plane, presque cordifornse, échancré postérieurement.

M. le comte Dejean a créé ce genre dont le nom est tiré d'un mot grec qui signifie : fouisseur. Il lui donne, dans son Spéciès, les caractères suivans : menton articulé, légèrement concave, fortement trilobé, ridé transversalement. Labre très-court, tridenté. Mandibules peu avancées, assez fortemeat dentées à leur base:Dernier article des palpes labiaux alongé, presque cyliidrique. Antennes courtes, moniliformes; le premier article assez gland, à peu près aussi long qne les trois suivans réunis; les autres beaucoup plus petits, très-courts, presque carrés et grossissant un peu vers l'extréuité. Corps alongé, cylindrique. Jambes antérieures fortement palmées. Corselet carré, convexe, presque cylindrique. Elytres cylindriques, presque tronquées à leur extrémité; leurs bords latéraux parallèles. Pattes très-courtes. Jambes intermédiaires ayant deux dents près de l'extrémité. Tête courte, presque carrée.

\section{ScAptère de Guérin, S. Guevini.}

Scapterus niger; capitis tuberculo elevato subcornuto; elytris profundè punctato-striatis.

Scapterus Guerini. DEJ. Spéc. tom. 2. p. 472. $n^{\circ}$. I.

Longueur 7 lig. $\frac{x}{4}$. Noil. Tête ayant un tuber- cule élevé, presqu'en forwe de crrne. Elytres striées; ces stries fortemeul ponctuées.

Des Iudes orientales. (S, F. et A. Serv.)

SCARABÉ, Scarabazts. FAB. Fabricius dans son Systema Eleutheratnum a compris dans cetto coupe générique les espèces des genres Géotrupe Lat. $€ \iota$ Bolbocière Kirb. Celles qui appartiennent aux Géotrupes son! ses Scarabceus suivans : dispar $\mathrm{n}^{\circ} .1$, typhoeus $\mathrm{n}^{\circ} .3$, momus $\mathrm{n}^{\circ} .4$, stercorarius $\mathrm{n}^{\circ}$. 10, sylvaticus $\mathrm{n}^{\circ} .1 \mathrm{1}$, vernalis $\mathrm{n}^{\circ} .12$, loveigatus $\mathrm{n}^{\circ} .13$, splendidus $\mathrm{n}^{\circ} .15$, Blackburnii $\mathrm{n}^{\circ} .16$, et peut-êtue aussi le cordatus no. 14 . Les espèces composant le gente Bolbocère sont : corjphacus $\mathrm{n}^{\circ} .2$, quadridens $\mathrm{n}^{\circ} .6$, lazarus $\mathrm{n}^{\circ} .5$, mobilicornis $\mathbf{n}^{\circ} .7$, cyclops $\mathrm{n}^{\circ} .8$, testaceus $\mathrm{n}^{\circ} .17$. Cet auteur place encore parmi les Scarabés l'espèce nomnée longimanus qu'il auroit dû, d'après ses principes, rapporter à son genre Géolrupe (Scarabé LAT.). (S. F. et A. Skrv.)

SCARABÉ, Scarabous. LiNN. De GÉÉr. Oniv. (Entom.) LAT. Geotimpes. F ${ }_{A B}$. Dynastes. MAcL.

Genre d'insectes de l'ordre des Coléoptères, section des Pentanières, famille des Lamellicornes, tribu des Scarabéides (division des Xylcphiles ).

Parmi les Xylophiles, les uns ont le bord antérieur du labre apparent, séparant distinctement le chaperon des mandibules; ce sont les genres Hexodon, Rutèle, Chasmodie, Macraspis, Pélidnote, Cbrysophore et Oplogna ihe; quatre autres : Scarabé, Uryctès, Phileure el Cyclocéphale, ont le labre caché; mais dans les trois derniers, le côté extérieur des mandibules cst sans dents ni crénelures. Par cette comparaison on distinguera tous ces genses de celui de Scarabé.

Antennes courtes, composées de dix articles, le premier long, conique, gros, renflé, velu; le second presque globuleux, les suivans très-courts, transversaux, grossissant un peu depuis le troisième jusqu'au sıxième inclusivement, le septième presque cyathiforme, les trois derniers formant une massue feuilletée, ovale, plicatile. - Labre membraneux, cacbé par le chaperon, adhérant à la surface intérieure de celui-ci, son bord antérieur cilié. - Mandibules presque trigones, cornécs, très-dures, épaisses á leur base, sinuées, crénelées on dentées sur leur côté extérieur. Mâchoires dures, arquées, terminées en pointe, souvent dentées, velues. - Palpes maxillaires presqu'une fois plus long's que les labiaux, conposés de quatre articles, le premier court, trèspetit, le second assez long, presque conique, le troisième conique, plus conrt que le puécédent, le quatrième au moins aussi long que le second, arrondi à son extrémité ; palpes labiaux courts, insérés ver's l'extrémité du menlon, de trois articles, les denx premiers gourts, presqu'ćgaux, le troisième long, un peu plus gros que les autres, 
arrondi à son extrémité : menton velu, convexe, alongé, cachant la lèvre, son extrémité obtuse ou tronquée. - Tête presque trigone; chaperon simple ou muni d'une corre. - I'eux globuleux. - Corps ovoïde, convexe. - Corselet légèrement bordé, armé d'une ou de plusieurs cornes, ou échancré antérieurement. - Sternum simple, uni. - Ecusson distinct, triangulaire. - Elytres grandes, recouvrant les ailes et l'abdomen. $P$ attes fortes; jambes s'élargissant vers le bas, les anterienres munies de trois ou quatre dents latérales à leur partie extérieure et d'une forte épine au-dessons de leur extrémité; les quatre postérieures en ayant deux, et munies en outre de rangées transversales d'épines roides; articles des tarses garnis de poils, principalement à leur partie inférieure; le dernier muni de deux crochets simples et d'un faisceau de poils dans leur entre-deux.

On donne vulgairement le nom de Scarabés à tous les insectes de l'ordre des Coléoptères; c'est dans ce sens que d'ancieus auleur's parlent de Scarabés aquatiques (les Dytiques et les Hydrophiles ); de Scarabé des Lys (le Criocère du Lys); de Scarabé pulsateur (une espèce de Vrillette); de Scarabés à ressort (les 'Tuupins); de Scarabés tortues ou hémisphériqnes (les Cuccinelles), et enfin de Scarabés à trompe (les Rhyncophores). Linnélui-même et les auteurs ses contemporains ont réuni dans le genre Scarabé tous les insectes qui composent aujourd'hui la tribu des Scarabéides. Voyez se mot.

Les larves et les mœurs des insectes de ce genre ne sont pas conuues, mais elles doivent peu différer de celles des Oryctès. Voyez ce mot à l'article Xymophiles.

Les Scarabés, presque toujours de grande taille, ne sout surpassés sous ce rapport, parmi les Coléoptères, que par quelques Priones; lenrs couleurs habituelles sont le noir et le brun. Its appartienueut anx climats chauds des deux contineus; ou en connoît à peu près soìante - dix espèces.

$1^{r} \cdot$. Division. Elytres sans stries longitudinales.

\section{Scarabé Entelle, S. Entellus.}

Scarabceus elytris hand striatis, capitis carinâ. mediâ transpersâ, subobsolet $\hat{\imath}$, thorace antice excasato, tricorni; cornu medio ad nuarginem anticuln brevissinno, lateralibus longis, rectis, apice emarginato biden'alis, suprà fusco-castaneus, corpore subtùs antennarumque clavâ et femoribus castuneis.

Longueur 16 lig. Corps lisse, luisant, d'un châtain foncé; son dessous, aiusi que les cuisses el les antenoes, d'une nuance plus claire, garnis de mème que les jointures, d'un duvet roussâtre. Tète fortement rugueuse, ayant dans son milieu une carène transversale élevée qui n’alleiut pas les deux côtés; celte carène un peu interrompue da:ns son milieu. Corselet très-échancré en devant, muni au milieu de son bord antérieur d'une petite corne conique et d'une autre de chaque côté, longue, droite, échancrée à son extrémité qui' forme deux dents, dont la supérieure plus courte. Jambes antérieures ayant deux fortes denț à leur partie extérieure, non compris la terminale. Mâle.

Du Brésil.

A cette division appartiennent : ${ }^{\circ}$. le Scarabé Hercule, Encycl. pl. 157. fig. 3. mâle. (Gentrupes Hercules no. 1. FАв. Syst. Eleut.) $2^{\circ}$. Scarubé Actéon, pl. 158. fig. ı. mâle. (Geotr. Acteon n. 20. FAв. id. Le Geotrupes Simson n ${ }^{\circ}$. 2 I. de cet auteur, Scarab. Simson de Linu. et d'Oliv., ne nous paroît être qu'mue variété de l'Actéon.) 30. Scarab. Tityus, pl. 137. fig. 7. mâle. (Geotr. Tityus no. 28. FАB. $1 d$.)

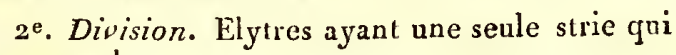
est suturale.

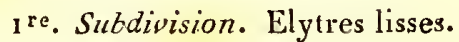

Rappoitez ici : $1^{\circ}$. Scarab. Aloéus, Encycl.pl. I40. fg. 8. (Geotrupes Aloeuis no. 32. FAB. Syst. Eleut. mâle.) $2^{\circ}$. Scarab. Sémiramis , PAL.-BAuv. Ins. d'Afriq. et d'Amér. pag. 73. Coléopt. pl. 2. fig. 1. 30. Scarab. Chorinée, $p l$. 139. fig. 5. mâle. (Geotrup. Chorinaus no 9. FА . idem. mâle.) $4^{\circ}$. Scarab. Philoctète, OLiv. Entonz. tom. 1. Scarab. pag. 16. $n^{\circ}$. 12. pl. 14. fig. 125. inâle. Celui-ci n'est peut-ĉtre quo vane variété du Scarab. Chorinée. 5\%. Scarab. Cadmus, pl. 143. fg. 4 . Oniv, id. pag. 43. $n^{\circ}$. 48. pl. I. fig. 4. b. Ce Scarabé est regardé par quelques entomologistes comme étaut la femelle du Chorinée, cependaut Olivier lui donve le Sénégal pour patrie; cet auteur mentionne comse variété, même planche, fig. $a$, un individu une fois plus petit, à dytres punctuées et ayant les tubercules diu corselei plus rapprochés.

$2^{c}$. Subdifision. Elytres poncluies sul les côtés.

A cette seconde subdivision appartienaent le Searábé Enewa, Encycl. pl. 140. fig. 6. (Geotrupes Eneman ${ }^{\circ}$. 13. WAB. Syst. Eleut.) et le Scarabé Pan. (Geotrup. Pan no. 14. FAB. id. mâle.)

Nota. Ces deux espèces sont remarquables par leurs élytres un peu élargies dans lear partie moyenne et fortement reburdées depuis cetie parlie jusqu'à l'extrémité.

3e. Division. Elytres ayant plusieurs stries longitudinales.

On rapportera à cette division le Scarabé bilobé, Encycl. pl. 142. fig. 10. mâle et feinelle. (Geotrupes bilobus no. 15. FAB. Syst. Eleut. mâle. 
De Cayenne. C'est ì lort que Fabricius lui assigne pour patrie l'Europe australe.) et le Scarabé Sylvain, pl. 141. fig. 6. (Geotrupes Sylvanus no. 42 . FAB. id. mâle.)

$4^{\mathrm{e}}$. Division. Elytres irrégulièrement ponctuées dans toute leur élendue.

I.es Scarabés Syphax, Encycl. pl. r4r. fig. r. (Geotrupes Syphax no. 37. Fав. Syst. Eleut.) et ponctué (Geotrup. fiunclatus nº. 63. FAв. idem.) sont de celte division. (S. F. et A. Serv.)

SCARABÉ, Scarabaus. Mact. M. Nacleay (Hor. entom.) comprend sons cette dénomination les Aleuchus Fa b. el les Gymnopleures Ilimig. Les premiers types renferment les espèces du genre Aleuchus; le dernier type seul se compose des Gymuopleures. (S. F. el A. SEHV.)

SCARABËİDES, Scaraboides. Première tribu de la famille des Lamellicornes, section des Pentamères, ordre des Coléoptères, ayant pour caractères :

Massue des antennes composće de feuillets, snit pouvant s'ouvrir el se fermer à la manière de cenx d'un livre, soit cupulitires; le premier de cette massue étant (dans ce dernier cas) plus grand, presqu'en forme de cornet et enveloppant les auires.

Celte tribu comprenant plus de soixunte genres, M. Latreille a senti la nécessité d’y établir plusienrs divisions, anxquelles il a donné des dénominations partieulières. Nous allons en présenter ici le tableau.

I. Antennes de huit à neuf articles. - Labre et mandibules cachés, de consistance nembraneuse. - Mâchoires terminées par un grand lobe membraneux arqué, large et tourné en dedans. - Dernier arlicle des palpes labiaux beaucoup plus grêle que les prérédens, quelquefois très-petit, presque nul.

\section{Coprophages, Coprophagi.}

A. Palles intermédiaires beancoup plus éeartées entr'elles ì lem insertion que les autres. - Palpes labiaux très-velus, leur dernier article beaucoup plus perit que le précédent, ou même peu distinct.Extrémité postérieure de l'abdomen découverte.

a. Ecusson nul (I).

† Les quarre jambes postérieures presque

(r) L'écusson est mul lorsque les élytres ne cessent point de s'e toucher à l'endroit de la suture qui joint le corselet, et qu'elles ne laissent pas entrelles de place pour un écusson ou pour un espace scutellaire.

\section{S C $\Lambda$}

cylindriques, n'offrant ni renflement ni dilatalion sensible à leur extrémité.

\section{Ateuchus, Gymnopleure, $\mathrm{Hy}$ - bôme, Sisyphe.}

$\dagger+$ Les quatre jambes postérieures courtes, sensiblement dilatées et plus épaisses à leur extrémité.

* Corps déprimé en dessus.

Onthophage, Pliance.

* * Corps convexe en dessus.

Bousier, Chœridie.

b. Ecusson petit, mais distinct ou au moins un espace seutellaire libre.

Onite, Oniticelle, Aeschrotès.

B. Toutes les pattes insćrées à égale distance les unes des antres. - Palpes labiaux velus, leurs aricles cylindriques, presque semblables. - Ecusson très - distinct. Elytres embrassant les côtés et l'extrémité postérieure de l'abciomen.

Euparie, Aphodie, Psammodie.

II. Antennes le plus souvent de dix à onze articles. - Mandibules du plus grand nombre cornées el décuuvertes. - Labre de la plupart coriace el plas ou moins à nu dans plusieurs. - Palpes labiaux filiformes on terminés par un article plus grand. - Mâchoires soit enlièrement cornées, soit terminées par nu lobe membraneux ou coriace, mais dioit et longitudinal.

A. Mandibules cornées, n'étant pas en forme de lames très-minces ou d'écailles.

a. Mandibules et labre coujours totalement ou en partie à nu, saillans au-delà du chaperon. - Elytres enveloppant le contour extérieur de l'abdomen et lui formant une voûte complète. - Antennes de plusieurs à onze articles. Paltes postérieures très-reeulées en arrière.

\section{Arénicoles, Arenicolae.}

† Languelle bifide, ses denx lobes saillans au-delà du menton. - Mandibules généralement saillantes, arquées.

* Antennes de neuf articles.

Chiron, Aegialie.

* * Antennes de onze articles. (Celte coupe formoit antrefois la division des Géolrupins Latr.) 
$5 \mathrm{C} 1$

I Articles de la massue des antennes prescqu'éqaux, pouvant se séparer les uns des autres dans l'action.

Ochodée, Bolbocère, Eléphastome, Athyrée, Géotrupe.

q $q$ Nenvième article des anlennes (le premier de la massue) infundibuliforme, plus grand que les deux autres, les renfermant entièrement.

\section{Ićthrus.}

$\dagger \dagger$ Languelte entièrement reconverte par le menton. - Mandibules et labre moins saillans que dans les précédens et ne paroissant point, la tête étant vue en dessus. - Hanclies antérieures souvent grandes et recouvrant le dessous de la têle. - Côté interne des mâclioires denté. - Insectes produisant une stridulation.

* Antennes de neuf articles.

Ciyplode, Méchidie.

* Antennes de dix articles.

Phobère, Trox, Hybosore, Orphné? Acantliocère?

b. Mandibules et labre rarement saillans audelà du chaperon. - Extrémité postérieure de l'abdomen découverte.

† Languette cntièrement cacliée par le menton el confonclue même avec lui. - Corps rarement alongé, avec le corselet oblong. - Elytres point béantes à la suture.

* Antennes loujours de dix articles, les trois derniers formant la massue. - Mandibules saillanies ou déconvcrtes, du moins à leur partie latérale cxternc (point entièrement recouvertes en dessons par les mâchoires ni en dessus par le chaperon). - Hâchoires da plus grand nombre entièrement cornées et dentées, terminées dans les autres par un lobe coriace et velin.

Xylophiles, Xylophili. Voyez ce mot.

* Antennes de hnit à dix articles, massuc de plusieurs mâles formée par les cinq à sept derniers, de trois dans les autres. - Mandibules recouvertes en dessus par le chaperon et cachées en dessons par les mâchoires, leur côté extérieur seul apparent.
Phyllophages, Phyllophagi. Voyez ce mot (I).

q Mandibules fortes, entièrement cornées. - Extrémité des mâchoires sans dents ou n'en ayant que deux. - Antennes de dix articles.

Anoplognathe, Leucothyrée, Apogonie, Amblytère.

๑ Mandibules fortes, entièrement connées. - Mâchoires pluridentées. - Tarses antérieurs des mâles dilatés et garnis eu dessous de brosses. - Antennes de neuf articles.

Géniate.

ऽ ๆ Mandibules fortes, entièrement cornées. - Mâchoires pluridentées. - Tarses semblables et sans brosses clans les deux sexes.

A. Massue des antennes de cincf feuillets (mâlcs), de quatre (femelles), ou de sept feuilIcts (mâles), de six (femelles).

o. Antennes de dix articles.

Hanneton.

o o. Antenxes de neuf articles. Pachype.

A $\Lambda$. Massue des antennes de trois fenillets dans les deux sexcs.

o. Anteones de dix articles.

Rhizotrogue, Aréode.

o o. Antennes de neuf articles.

Popillie, Amphimalle, Euchlore, Plectris, Dasyus.

Nota. Nous rapportons à cette coupe, mais avec donte, le genre Agacéphale Mannerh.

- 9 Portion interne des mandibules moins solide quc l'auire ou membraneise. - Antennes de neuf à dix articies, les trois derniers formant la massie.

(1) Lors de la tédaction de l'article auquel nous renvoyous, M. I arreille n'avoit pas encore publić ses Familles naturelles du Règne animal, ouvrage plein de riches aperçus et de vues nouvelles usiles à la science. 
A. Denx crochets aux tarses postérieurs.

o. Crochets antérieurs égaux, bifides; les postérieurs inégaux, le petit bifide.

Céraspis.

oo. Tous les crochets égaux, bifides.

Dicranie, Macrodactyle, Diphucéphale, Sérique, Dichèle.

o o o. Crochets inégaux, les postérieurs eutiers.

Anisoplie, Lépisie.

$\Lambda \Lambda$. Un seul crochet aux tarses postérieurs.

Ifoplie, Monochèle.

†† Languelle saillante au-delà du menton, bilobée. - Mandibules cornées. Mâchoires terminées par un lobe membraneux et soyeux. - Corps souvent alongé. - Chaperon a vancé. - Corselet oblong ou presqu'orbiculaire. - Elytres écartées ou béantes à leur exirémité postérienre. - Antennes de neuf à dix articles, les trois derniers formant la massue.

\section{Antholsies, Anthobii.}

* Un seul crochet aux tarses postérieurs. Pachycnème, Anisonyx.

* * Deux crochets aux tarses postérieurs. Amphicome, Glaphyre, Chasmatoptère, Chasmé.

B. Mandibules très-aplaties, en forme de laines minces ou d'écailles, ordinairement presque nembraneuses. - Labre presque membianeux, caché sous le chaperon.Mâchoires terminées par un lobe en forme de pinceau. - Languette point saillante. - Corps le plus souvent ovale, déprimé.

- Corselet en trapèze ou presqu'orbiculaire.

\section{Mólilophiles, Melitophizi.}

a. Pirce triangnlaire saillante en dessus, remplissant au moins une partie notable et souvent la totalité de l'intervalle compris entre les angles postérieurs du corşeiet et cenx de la base des élytres.

Platygénie, Crémastocheile, Macronoie, Gymnétis, Cétoine. b. Pièce triangulaire ne saillant pas en dessus, et ne s'avançant point dans l'intervalle compris entre les angles postérieurs du corselet et ceux de la base des élytres.

$$
\text { Trichie, lncą, Lépitrix. }
$$

A'TEUCHUS, Ateuchus. Wéb. FAb. Illig. Lat. Scaraboeus. Linn. De Géer. Oriv. (Entom.) Macr. Copris. Geoff. Oliv. (Encycl.)

Gente d'insectes de l'ordre des Coléoptères, section des Pentamères, famille des Lamellicornes, tribu des Scarabúides (division des Coprophages).

Huit genres de celte division se distinguent par l'absence de l'écusson. Quatre d'entr'eux ont les jambes intermédiaires et les postérieures presque cylindriques. (Voyez Scarabéïdes.) Les Gymnopleures et les Hybômes sont reconnoissables par Je sinus profond qu'offre l'angle extérieur de la base des élytres; les Sisyplues n'ont que huit articles aux antennes, leurs élytres forment un triangle par leur réunion et leur's pattes postérieures sont beaucoup plus longues que le corps.

Antennes de neuf articles, le premier cylindrique, un peu plus épais tant à sa base qu'à son extrémité, le deuxième petit, les troisième, quatrième et cinquième (le troisième surtont) plus longs que les autres, de forme obconique ainsi que le second; le sixième très-court, patériforme; les trois derniers formant une massue libre, lamellée, plicalile, irrégulière, un pen comprimée; le septième fort grand, le huitième plus mince que les deux qui l'avoisinent, le dernier presque trigone, un peu acuminé. - Labre caché , membraneux, presque carré, un peu aigu à son extrémité, arrondi aux angles antérieuıs. - Mandibules cachées, membraneuses, tricuspidées à leur base, s'avançant en une lame concave, trigóne, leur côté extérieur et leur extrémité frangés de poils courts. - Mâchoires se prolongeant à leur extrémité en un lobe fort grand, presque carré; leur bord extérieur un peu arqué, frangé; leur loise intérieur en forme de dent aiguë. - Palpes maxillaires de quatre articles, le premier très-petit, les second et troisième obconiques, le dernier cylindrique-ovale, très-long. - I'alpes labiaux insérés aux angles supérieur's du meuton, très-velus, de trois arlicles, le premier presqu'ovale, comme transverse, dilaté intéricurement, le dernier obconique, beancoup plus petit que le précédeut. - Lèvre membraneuse, cachée par le menton; celui-ci presque carré. - Tête presque demi circulạire, mulique dans les deux sexes. - Chaperon muni ì sou bord antérieur de deux, quatre ou six dents. - Yeux petits, peu saillans. - Corps court. - Corselet grand, mutique, sans petite cavité latérale. Ecusson nul. - Elytres presque carrées, n'ayant 
ni échancrure, ni sinuosité à lenr partie extérieure, laissant à découvert l'extrérnité de l'abdomeu el recouvrant ordinairement des ailes. - Abdomen large, court. - Pattes plus ou moins velues, jas plus longues que le corps; hanolyes intermédiaires très-écartées entr'elles, les autres rapprochéez : les quatre jaınles postérieures trc̀speu dilatées a leur extrétuité, presque eylindriques, peu ou point arquées; tarses eomposés d'articles eylindro-coniques : crochets apparens.

J.es $A$ teuchus doni le nom vient d'un mot gुrec qui siguilie : désammé, vivent dans les fientes d'animaux, dont ils forment des boules qu'ils roulent pendant quelque temp's et enfouissent ensuite après y avoir déposé leurs oufs; leurs larres et leurs métamorphoses dillerent peu de celles des Oryelès. (Vojez ce mot.) Ces Coléoptères sont propies aux climals chauds des deux Mondes; on en connoît une quarantaine d'espèces dont la talle et les couleurs varient beaucoup.

$1^{\mathrm{re}}$. Division. Chaperon presque trilobé, muni de six pointes, dont quatre sont portées par le lobe intermédiaire. - Abdumen carré. - Corps déprimé en dessus. - Corselet presqu'angulaire postérieurement, c'est-it-dire s'avançant un peu entre la base des élytres. (Insectes de l'ancien continent. Heliocantharns M $\mathrm{AcL}$.)

Ire. Subdivision. Les quatre jambes postérieures tronquées oblirquement à leur extrémité, prolongées en une forte pointe non articulée, atteignant au moins la longueur de la moitié du tarse.

A cette subdivision se rapportent: $r^{\circ}$. A leuchus saint, A. sanctus $n^{\circ}$. 6. $\mathrm{F}_{\triangle \mathrm{B}}$. Syst. Eleut. (M. Nacleay indique trois variétés, Horæe entomol. vol. 1. pay. 500. $\left.n^{\circ}, 9^{\circ}\right) 2^{\circ}$. Bunsier sacré $n^{\circ} .117$. pl. 15r. fig. 5. de ee Dictionnaire (Ateucluts sacer ${ }^{\circ}{ }^{\circ}$. 1. Faв. Syst. Eleut.)

$2^{\mathrm{e}}$. Subdivision. Les quatre jambes postéjieures tronquées presque carrément à leur extrémité : les dernières munies d'une seule épine qui est articulée.

$$
\begin{aligned}
& \text { A. Jambes intermédiaires terminées par } \\
& \text { une seule épine; celle-ci forte et } \\
& \text { articulée. }
\end{aligned}
$$

\section{Arevcrus cafre, A. cafer.}

Ateucluzs aier, clypei dentibus obtusis, capite confertissimè punctato, cruce subelevatâ loevi; thorace punctis sparsis non multis : elytrorum striis sex punctatis, punctis aliquot sparsis interjectis.

\section{Ateuchus cafer. DEJ. Colleetion.}

Longueur 8 lig. Noir. Dents du ehaperon obtuses. 'T'ếe forlement poncluée portant deux lignes peu élevées, l'une longitudinale, l'autre trans. versale, formant une sorte de croix. Corselet ajant des peiuls épars peu nombrcus, surtont sur le disque et la partie pustérienre : ses bords latéraux erénelés avec des poils roides eatre les crénelures. Elytres chargées chracurse de six stries pointillées ayaut dans leurs intervalles un petit nombre de points enfoncés. Jambes de deraut munies de gualre dents à leur partie extericure; les quatre jimbes postérieures n'en ayant point dans eetle prartie.

Du Cap de Bonue-Espérance.

Nota. Cette espèce nous parnit avoir de grands rapports avec le Scarabceus hottentotus. Macs. Horce entomol. vol. 1. pag. $498 . n^{\circ} .5$.

Dius ce groupe entrent les Bousiers variolé no. 1:3. pl. 151. fig. 6. (Atenchus semipunctatus $11^{\circ} .3$. Far. Syst. Eleut. ), large col no. I 19. pl. $15 \mathrm{r}$.tig. 7. (Atenchus laticollis $\mathrm{n}^{\circ} \cdot 2 . \mathrm{I}_{\mathrm{AB}}$ id.), Palómon $\mathrm{a}^{\circ} .135$ (Ateuchus intricatus $\mathrm{n}^{\circ}$. 8. IAB. id.), ainsi que l'Ateuchus variolosus $\mathrm{n}^{\circ} .4 . \mathrm{F}_{\mathrm{AB}}$. id. (Petranchez le synonyme d'Olivier qui appartienl au sentipunctatus.)

\section{Jambes intermédiaires terminées par deux épines furtes et artieulées.}

\section{Ateuenus Adamasior, A. Adamastor.}

Ateuchus ater, clypei dentibus obtusis, internediis duobus elevato-subincurvis; capite antice confertissimè punctato: thorace lavi; elytronm striis sex vix conspicuis impunctatis, tuberculis minutissinis multis sparsis.

Tongueur 9 lig. Noir, un pen luisant. Dents du chaperon obtuses, les deux intermédiaires un peu relevées en manière de cornes; tête fortement ponctuće surtout à sa partie antérieure, presque lisse postérieurement. Corselel lisse. Elytres ayant claeune six stries peu visibles, now ponctuées; leurs intervalles cliargés d'un grand nombre de tubercules extrêmement petits. Jambes de devant crénelées extérieurement et annies en outre de quatre dents. Jambes intermédiaires en ayant deux petites; les postérieures v'en ayant pas dans cette partie.

Du Cap de Bonne-Espérance.

Nota. On trouve dans les Iíore entomologicae de M. Macleay ainsi que dans l'Eritomographie de Russie, vol. 2 , de M. Fischer de Waldheim, plusieurs espèces nouvelles qui duivent faire partie de cetie preasière division dos Ateuchus.

$2^{\ominus}$. Division. Chaperon point trilobé. - Les quatre jaubes postérieures tronquées presque carrément à leur extrémité.

Ire. Subdivision. Les quatre jawbes posterieures munies à leur extrémité d'une seule épine forte, articulée. $-\Lambda$ bdomen arroodi. ... 
Corps un peu convexe. - Chaperon quadridenté. - Corselet ayant les angles de sa partie postérieure arrondis et une échancrure daus son milieu. (Insectes de l'ancien continent. Genre Pachysoma HAcL.)

On rapportera à cette subdivision $1^{\circ}$. le Bousier Esculape no. 121. pl. 151. fig. 9. de ce Dictionnaire (Scarabous Rsculapius Macr. Hínce entom. vol. 1. pag. 507. n० ${ }^{\circ}$. A. Asculapius); $2^{\circ}$. le Scarubceus Hippocrates MacL. id. io 22. ( A. Hippocrates.) Nous pensons que ces deux especcos sont aptères.

$2^{e}$. Subdivision. Jambes intermédiaires nunies à leur extrémité des deux épines ordinaires; jambes postérieures n'en ayant qu'ute.

A. Chaperon bidenté. - Corps convese en dessus. - Abdomon arroudi poslérieurement. - Corselet coupé droit ì sat partics postérieure.

A cette coupe appartieut le Bonsier Bacehus $n^{\circ} .120$ pl. 151 . Cir. 8 . de re Dictionative ( $A$. Bacchus no, 12, Hab. Sy, st. Eleut.). Cet Atenchus est aptère. Togez l'allas, Icon. Ins. Sibir. pag. 20. A. 23. tab. B. fig. 23. A.

B. Clsaperon ayast de deux à six dents; les latcérales dans ce demier cas plus on moins saillantes. - Corps déprimé en dessus. - Abdousen carré. - Corselel arrondi en arric̀re d'un angle postérieur à l'autre.

\section{Atevchus Histrion, A. Histrio.}

Ateuchus tsatacens; capite, thoracis margine tenui, firsciâ sinuatû discoidali punctoque laterali, rlyirorum marginibus, pectore, maculâ veutrali, femorini apice, tibits tarsisque nigris viridi nutentabus.

\section{Ateuchus Histrio. Des. Catal.}

Longueur 5 ligg. Testacé brillant. Téte noire à rellei verdâtre ainsi que los bordo du corselet; celui-ci ayant une bande sinueuse sur son disque, suivie de chaque côlé d'un pelit point, d'un noir verdâtre : bords des élytres de certe conleur, laquelle s'étend plus à la base et ì l'extrénité que sur les côlés. Dessous du corselet el base de l'abłonien entièrement noirs atrec le reflet; cette coulcur s'avance sur le discue de la fartie postérieure de ce dernier. Cuisses testacées avec leur calrémité noire, ainsi que les jamles et les tarses. Du Brésil.

Nota. Nous avons reçu sous le nom d'Ateuchus coronatus une varićté squi a un peu moins de noir ¿a la base el a l'extrénité des élýties ainsi que sur le dessous de l'abdomen.

Il faut rapponter ici : io. le Bousier lisse no. 132. pl. 152. 1. 3. (Ateuchus volvens no. 26. HAB.
Syst. Eleut.). Cetle espèce est partout granuleuse et chaque élytre a huit stries peu marquées; $2^{\circ}$. le Bonsier grenu $n^{\circ}$. 145. pl. 152. fig. 14. (Ateuchus Olivieri Des. Calal.) d'Afrique; $3^{\circ}$. le Bousier violel $n^{\circ}$. 15o. fir. 19. (A. violacells $n^{\circ}$. 48. FAB. D'après une note manuscrite de $\mathbf{M} . \mathbf{P a}_{\mathbf{a}}$ lisol-Beauvois, la tache anale de celte espèce ainsi que la massue des antenues sont d'un blanc de neige dans l'insecte vivant.); $4^{\circ}$. le Bousier éméraude $n^{\circ} .129 \cdot \mathrm{pl}$ 151. Gị. 16. ( $A$. smaragdulus $\mathrm{n}^{\circ}$. 17. Fab. La hinssue des antennes est blanche.); 50. le Bousier triangulaire ${ }^{\circ}$. 140 . pl. 152. fig. 10. (A. tricungularis u ${ }^{\circ}$ 42. FAB.); $6^{\circ}$. le Bousier six points $11^{\circ} .141$. pl. 152. fig. I1. (A. sexpunctulus $n^{\circ}$. 47. $\mathrm{HAB}_{\text {A }}$ ); $7^{\circ}$. le Bousier discoide $11^{\circ}$. 149. pl. 15\%. fig. 18. (A. discoideus no. 5o. Faz.), du préseut ouvrage ainsi que les Ateuchus affinis no. 43. FaB. el viridicollis DeJ. Catál.

Les Bousiers crénelé no ${ }^{\circ}$ 97. (Copris cristatus no. 110. H. AB. Syst. Eleut.), brillant no. 13o, bipustulé $n^{\circ}$. 1560 . (Aleuchus bipustulatus $n^{\circ} .37$. $\mathrm{F}_{\mathrm{AB}}$ ), appartiennent peut-être aussi au genre Ateuchus.

GYMNOPLEURE, Gymnopleumis. ILLIGER. Ateucluls. Fab. Lat. Scarabopus. Linn. Oritv. (Entom.) Macl. Copris. Georr. Oliv. (Encycl.)

Genre d'insectes de l'ordre des Coléoptères, section des Pentamères, famille des Lamellicornes, tribu des Scarabéndés (division des Coprophages ).

Les Gymnopleures, dont le nom tiré de denx mots grecs a rapport ì l'espace des côtés du corps que laisse ì nu le sinus des ćlytres, diffèrent des Aleuchus par une échancrure subite et profonde placée au-dessous de l’angrle extérieur de la base des élutres, et par la petitc cavité que porte chaque côté du corse!el. (Voyez pour les autres caractères génériques el pour les mueurs, ceux des Aleuchus, article précédent.) Toutes les espèces connues sont de l'ancien conitneut.

On rapportera à ce genre les Bonsiers suivans du présent ouvrage : $1^{0}$. sinué no. 131. pl. 152. fig. 2. Ateuchus sinuatus no. 28. FAB. Syst. Eleut. (Gymn. sinuatus.) $2^{\circ}$. piluaive no. $133 . \mathrm{A}$. pilularius $\mathrm{n}^{\circ} .27$. li $\mathrm{AB}$. (Cymn. pilularius.) $3^{\circ}$. flagellé $\mathrm{n}^{\circ}$. 154. pl. 152. tig. 5. A. flagellatus $\mathrm{n}^{\circ} .22$. FAB. (Gymn. flagellatus.) 40. de Koenig. $1^{\circ} .136$. 1.1. 152. fig. 8. A. Kcenigii no. 19. Hs B. (Gymm. Kanigii.) $5^{\circ}$. miliaire $n^{\circ}$. 143. A. miliaris no. 5. FAB. (Gymn. miliaris.) $6^{\circ}$. éclatant $1^{\circ}, 144$. (Gym. fulgidus.) $7^{\circ}$. bleû̀ıre no. 151. (G)m. carulescens.)

Nota. M. Macleay, dans ses Horce entomologicae, décrit plusieurs autres espèces de Gyumopleures.

HYDOME, Hyboma. Ce nouveu genre, dont 
le nom vient d'un mot grec qui signifie : bossu, est très-voisin des Ateuchus, des Gymnopleures et des Sisyphes; il a pour type le Brousier bossu

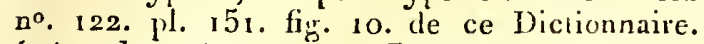
(Atcuchus gibbosus n॰. 13. FAB. Syst. Eleut.) Cette espèce a le port dcs Ateuchus à abdomen earré; une sinuosité aux élytres, mais qui ne laisse pas à nu les côtés du corps, la rapproche des Gymnopleures; enfin ses quatre jambes postórieures très-longues et arquées lui sont communes avec les Sisyphes. (Les autres caractères sont ceux des Ateuchus. Voyez ee mot par. 35o.)

La descriplion du Bousier hossu (Iybonra gibbosa) n'cst applicable ' qu'ì l'un des sexes; dans l'autre les élytres n'on pas de gibbosité et les jambes de devant manquent d'épine à leur cóté illterne. Sa patrie est l'Amérique septentrionale.

Nota. Nous pensons devoir en outre rapporter aux Hybômes, le Bousier leare no. 123. pl. $15 \mathrm{r}$. fig. $11 .($ Hyb. Icants.)

ONTHOPHAGE, Onthophagus. LAT. Scarabaus. Lixn. De Gérr. Oliv. (Entom.) Copris. Groff. Fab. Illig. Oliv. (Encycl.) Ateuchus. $F_{\text {AB }}$.

Geure d'insectes de l'ordie des Coléoptères, section des Pentamères, famille des Lamellicornes, tribu des Scarabéides (division des Coprophages).

Deux genres de la division des Coprophages ont l'écusson nul, les quatre jambes postérieures courtes, sensiblement dilatées, plus épaisses à leur extrérnité et le corps déprimé en dessus; ce sont les Phaućcs et les Onllophages : nuais les premiers se distinguent par la massue des antennes infundibuliforme, le premier article recevant le second et le troisième, et par leurs quatre tarses postérieurs composés d'articles aplatis, triangulaires, allant en décroissant de largenr jusqu’au dernier, qui est dépourvu de croeheis.

Antennes de neuf articles; le premier alongé, cylindrique, le second petit, globuleux, les trois suivans obconiques, guère plus longs que le second; le sixième pelit, court, trausversal; les trois derniers formant une massue lamellée, plicatile, presqu'aussi longue que large. - Labre et mandibules ınembraneux et cachés. - Mấchoires terminées par un grand lobe membraneux, arqué, large, tourné en dedans. - Palpes maxillaires de quatre articles, le dernier médioerement alongé, presqu'ovale. - Palpes labiaux urès-velus, de trois articles; le premier et le second ovalaires, le dernier presque nul. - Menton ayant une Échancrure aiguë vers l'insertion des palpes labiaux. - Tête et corselet ayant tous deux ensemble (ou au moins l'un d'eux) des cornes ou des éminences distinctes. - Chaperon ordinairement ent er. - Corps large, court, ovale-arrondi, déprimé en dessus, tout au plus mgitié plus long que

Hist. Nat. Ins. Tome $X$. large. - Corselet plus large que long. - Point d'écusson. - Elyties arrondies postériearement, läissant à déeouvert l'extrémité de l'abdomen, recouvrant des ailes. - Pattes courtes; hanches internıédiaires très-écartées entr'elles, les autres rapprochées; les cuatre jambes postéricures s'élargissant subitement et grossissant vers l'extrcimité ; larses intermédiaires et postćricurs composés d'articles presque cylindro-coniques, légèrement aplatis. Crochets apparens.

1I. Olivier a traité de ce genre tome VIII, pag. $4 y^{5}$, mais sans dóveloppement de earaetères géuériques; ceux même quil assinne aux palpes labiaux sonı erronés, et il n’a poin rappelé tontes les espèces d'Ontbophages confondues dans cet ouvrage arec les Bonsiers. Nous éssayons d’y suppléer ici. Ce geme élabli par M. Latreille, tire son nom de deux mots gress dont la signification est: "uivant d"ordures. Les espèces qui le composent sunt nombrenses, de taille pctite ou moyenne et se tronvent dans tous les climals. Lenrs nocurs et leurs métamorploses ne diffèrent pas de celles des Bousiers. Voyez ce mot, tom. V.

I $^{\mathrm{re}}$. Division. Tête bicorne dans les mîtles.

A cette première division appartiennent les Bousiers Séniculus no. 75. pl. 149. 6ig. 14. (Onthophagus Seniculus. LAT.), Bonasus no. $71 . \mathrm{pl}$. id. fig. 10. (O. Bonasus. LAt.), fourchu $\mu^{\circ} .116$. pl. 151. fig. 4. (O. furcatus. Lat.), Taurcau " ${ }^{\circ}$. 106. pl. 150. fig. 17. (O. Taumis. Latr.), Chèvre no. 107. pl. id. fig. 18 (O. Capra. I.aT.), Vean no. 78. pl. 149. tig. 17. (O. Cameelus. Des. Catal. Copris Camelus no. 43. Fав. Syst. Eleut.) de ce Dietionnaire, ainsi que l'Onthophagus lucidus. Des. Ciltal. (Copris lucida no. 4I. Hab.)

20. Division. Tête unieorne dans les mâles.

On placera ici $1^{\circ}$. les Bousiers nuchicorne no. 109. pl. 15o. fig. 20 , et Vache ${ }^{\circ} .80$. pl. 149 . fig. 19, le premier mâle, le second fenelle de l'Onthophagus medius. Des. Catal. (Copris media no.71. Ha . Syst. Eleut.) 20. cénobite no. 110. pl. 15o. fig. 2 I. (O. coenobita. LAT.) 30, sagittaire no. 77. pl. 149. fig. 16. (O. sagittarius. LAt.) $4^{\circ}$. 'Tagès no. 105. pl. 150. fig. 16, et Anyntas no $79 \cdot$ pl. 149. fig. 18 , le premier mâle, le second femclle dc l'Onthophagus Hybneri. DEJ. Cittal. (Copris Hybneri no. 107. FAB.) 50. porteépine no. 114. pl. 151 . fig. 2. (O. spinifex. Lat.) $6^{\circ}$. thoracique no. 115. pl. 151 . fig. 3. (O. thoracicus. Lat.) du présent cuvrage. Et en oulte les Onthophagus austriacus. DEJ. Calal. (Scarabaus austriacus. Panz. Faun. Germ.) et fructicornis. id. (Copris fracticornis $\mathbf{n}^{\circ}, 9^{1}$. FAB. SJ $\mathrm{F}_{\mathrm{A}}$. Eleut.)

3e. Division. Tête sans cornes dans les deux sexes.

Rapportez à cette division les Bousiers de ¿ y 
Schreiber no. I52. pl. 152. fig. 20. (O. Schreiberi. Lат.), Lémur no. 81. pl. 149. fig. 20. (O. Lemuir. LAT.), et ovale no. 150̈. (O. ovatus. LAT.)

On doit meltre encore parmi les Onthophages, mais sans que nous puissions indiquer dans quelle division, $1^{\circ}$. le Bousier Calta ${ }^{\circ} .76$. pl. 149. frg. 15. (Copris Catta no. 23. Fab. Syst. Eleut. femelle. (Onthophagus Gazclia femelle, Des. Catal. dont le unâle est le Copris Gazella n. 76 . $\left.F_{\mathrm{AB}}\right)$ ) $2^{\circ}$. bronzé $\mathrm{n}^{\circ}$. 34. pl. 149. fig. 23. ( $O$. cenens. Lat.) 5?. biluberculé no. 85. (O. bituberculatus. Lat.) $4{ }^{\circ}$. quatre points $n^{\circ}$. 104. pl. 150. fig. I5. (O. quadripunctalus. Lat. ). 5o. bifascié no. 82. pl. 149. fig. 21. (O. bifasciatus. LAт.) $6^{\circ}$. bident $1^{\circ}$. 83. pl. $i d$. fig. 2,2. (O. bidens. Liт.) $7^{\circ}$. penché no. 108. pl. 150. fig. 19. (O. mutans. LAT.) $3^{\circ}$. verlicicorne $n^{\circ} .111$. (O. verticicomis. I_AT.), et avec doute les Bousiers Dorcas n ${ }^{\circ} .70$. pl. 149. fig. 9, rebordé n$^{\circ}$. 112, ferrugiueux no. 115. pi. 151. figr. 1, el quadripustulé no ${ }^{\circ} 157$. pl. 152. fig. 25.

PHANÉE, Phanezs. Mact. LAT. Lonchophorus. Germ. Scurabocus. Linn. De Géer. Orav. (Entom.) Copris. Haв. Oli. (Encycl.) Onitis. FAB.

Genre d'insectes de l'ordie des Coléoptères, section des Pentamères; famille des Lamellicornes, tribu des Scarabéides (division des Coprophiiges).

L'écusson nul, les quatre jambes postérieures courtes, sensiblement dilatíes, plus épaisses à leur extrémité et le corps déprimé en dessus, sont les caracières qui font des Phanées el des Onthophages un groupe particulier. (Voyez ScarABÉIDEs.) Les seconds se distinguent des premiers par les articles de leur's quatre larses postérieurs presque cylindro-coniques, peu aplatis et par la massue des antennes dont le premier article n'est point infundibuliforme et laisse libres le second el le troisième.

Antennes de neuf articles; le premier alongé, cylindrique, grossissant un peu vers son extrémité, le seeond eourt, patérifurme ou seni-circulaire; les troisième, quatrième et cinquième plus longs que le second; le sixième plus court que ceux-ei; les trois autres formant une massue infundibuliforme : le premier de cetle massue presque trignne, renfermant et resserrant les deux suivans; le bord extérieur du second article figuré en fer à cheval; le dernier article ayant la forme d'un opercule, son bord exićrieur un peu échancré. - Bouche coinme dans le genre Aleuchus (voyez ce mot), à l'exceplion du dernier article des palpes labiaux qui est presque eylindrique. - Téte presque trigone, tonjours cornue ou portant des éminences. - Chaperon souvent bidenté ou échancré. - Corps ćpars, clépriuné ẻn dessus. - Corselet toujours excavé en devant daus les deux sexes et souvent eornu ou luberculé, muni d'une petite fossette de chaque eôté, ordinairement plus large à sa partie antćrieure que l'abdomen; ses côtós sinués, bordés; son bord postérieur portant habiluellement deux points enfoncés, rapprochés et une ligne élevée de cha. que côté. - Ecusson nul. - Abdomen aplati dans sou nilien; arrière-slernum aigu ou caréné. - Elytres sillonnées ou fortement striées, laissant à découvert l'ex!rémité de l'abdomen et recourrant des ailes. - Pattes fortes; hanches intermédiaires très-éeartées entr'elles, les autıes rapprochées; les quatre janbes postérienres courtes, s'élargissant brusquement et grossissant rers l'extrémité; tarses antérieurs caduques dans l'insecte vivant; les quatre postérieurs composés d'articles aplatis, triangulaires, allant en décroissant de largeur du premier au dernier; crochels nuls.

Ce genre démembré par M. Macleay (Hore entomol.) de eelui de Bousier, en a retiré presque toutes les espèces mćtalliques; aussi son nom vient-il d'un verbe grec qui signifie : briller. Depuis, M. Germar lui a imposé eelui de Lonchophorns (porte-lance en grec). Les Phances appartiemnent au Nouveat-Monde ; ils y rempli:sent, dit N. Macleay, les fonctions des Onites dans l'ancien continent; ces insectes habilent les fientes d'animaux et en approvisionnent leurs larves. Leur taille est généralement grande ou du moins moyenne, et leur corps le plus souvent brillant et métallique.

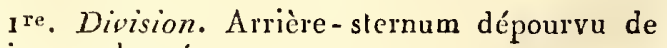
pointe prolongée en avant.

I $^{\mathrm{re}}$ Subdivision. Chaperon évidemment bidenté à sa partie antérieure. - Bord postérieur du corselet arrondi.

A cette subdivision appartiennnent $1^{\circ}$. le Bousier porte-lance $n^{\circ}$. 45. pl. 147. fig. 8. (Copris lancifer ${ }^{\circ}$. 58. $\mathrm{I}_{\mathrm{AB}}$. Syst. Eleut. Phaneus lancyfer Noв.); $2^{\circ}$. bellique ux no. 46. pl. 147. fig. 9 . (Phaneus bellicosus $\mathrm{M}_{\mathrm{Acc}}$. Horoe entom. vol. 1 . pag. 125. no. 1. ); 30. Jasius no. 54. pl. 148. fig. 8. feme le (Phaneus Jasius Macr. |ag. 126. $0^{\circ} .2$. ) (1) de ce Dictionnaire, ef encore le Phaneas Dardanus $\mathrm{H}_{\mathrm{ACL}} \mathrm{n}^{\circ} .5$. (Onitis Jasius n . 8. $\mathrm{F}_{\mathrm{AB}}$.)

$2^{\mathrm{e}}$. Subdivision. Cliaperon entier on ćchaneré antćrieurement. - Bord postírieur du corselet ayant une tendance à s'avancer en pointe vis-à vis de la sulure des ćlytres.

Rapportez ici les Bousiers suivans de ee Diclionaire: $1^{c}$. Mlinuas $n^{\circ}$. 53. pl. 148. lig. 7· (Copris

(1) A la fin de l'article Onite du présent ouvrage, l'aucenr se trompe en regardalit comme une seule cspèce l'Onizis Jasius de Fabricius et le Copris Jasius no. 54. de !'Ficyc opedic. La frumière de cos deux esfècos est le Phancus Dardanus MaCL. $\mathrm{H}^{\circ}, 3$. 


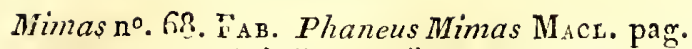
127. $n^{\circ} 4$. ) $2^{\circ}$. Belzébut no. 52 . (Sous ce numéro sont renfermées deux espèces suivant M. Macleay; savoir : le Phaneus Belzebul Macs. pag. 128. no. 5. Copris Belzebul no. 32. Faв. C'est l'individu décrit comme temelle et le phaneus Moloch. MacL. pag. 1 $\approx 9 . n^{\circ}$. 6. qui est le wâle Belzébut OLiv.) $3^{\circ}$. bourreau $n^{\circ}$. go. pl. r5o. fig. 4. (Copris carnifex $\mathrm{n}^{\mathrm{D}}$. 84. FAв. Phanells caralfex MACL pag. 132. $\left.1^{\circ} .11.\right) 4^{\circ}$. érlatant $\mathbf{u}^{\circ} .56 . \mathrm{pl}$ 1 148. figr. 10. (Copris splendidulus $n^{\circ}$. 8. FАв. Phaneus splendidulus Noв.) $5^{\circ}$. Faune n०. 47. pl. 148. fig. 1. (Copris Faunus no. 36 . FAb. Phaneus Faunus NoB.) et encore les trois espèces suivantes : $1^{\circ}$. Phaneus conspicillatus Nob. (Lonchophorus conspicillatus Germar. Copris conspicillatus $\mathrm{n}^{\circ} .9$. $\mathrm{HAB}_{\mathrm{AB}}$ ) $2^{\circ}$. hastifer Nов. $^{\circ}$ (Lonchophorus hastifer Germar.) 3o. Columbi MACL. pag. 3o. no. 7 .

$2^{\mathrm{e}}$. Division. Arrière-slernum armé antérieurement d'une pointe qui se prolonge entre les pattes de devant. - Bord postérieur du corselet nanifestenent avancé en pointe vis-à-vis de la sulure des élytres.

Cette division comprend : $r^{\circ}$. le Bousier élégant $n^{\circ}$. 55. pl. 148. fig. 9. de cet ouvrage. ( $\mathrm{Co}-$ puisfestivus no. 10. Fa . Plianeus festivus $M_{\mathrm{AcL}}$ par. $151 . \mathrm{n}^{\circ} .8$.) $2^{\circ}$. les Phaneus hularis $\mathrm{Ml}_{\mathrm{AcL}}$.

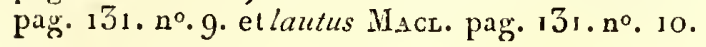

BOUSIER, Copris. Georf. Fab. I at. Oliv. (Encycl.) Scaraboeus. Jinn. De Géer. Oliv. (Entom.)

Genre d'insectes de l'ordre des Coléoplères, seclion des Pentamères, famille des Lamellicornes, tribu des Scarabéides (division des Coprophages).

Nota. Ce genre a díjà été traité dans ce Dictionnaire, tom. V; mais tel que l'auteur l'y caractérise, il renferme les suivans : Aphodie, Bousier, Planée, Oniticelle, Onthophage, Onite, Ateuchus, Gymnoplenre, Hybôme, Sisyphe et Clıeridie, formés depuis à ses dépens. Les espèces de ces différens genres se trouvent mêlées les unes avec les antres dans cet article; les caractc̀ıes génériques des Bousicrs propremont dits devant ếtre très-restreints, il est nécessaire de les donner ici, en renfermant ce genre dans ses justes limites.

Deux genres de Scarabrijdes forment un grompe parmi les Coprophages (vojez Scara b́́ides ), caractérisé ainsi : écusson nul. Les quatre jambes postérieures courtes, sensiblement dilatées et plus épaisses à leur extrémité. Corps convexe en dessus. Ce sont les Bousiers et les Choridies, mais les seconds ont tonjours la tête et le corselet dépourvus de cornes et de tubercules dans les deux sexes.

Antennes courtes, de neuf articles, les trois derniers en massue lamellée, plicatile; le premicr de ceux-ci point infundibuliforme, laissant litres les deux autres. - Labre et mandibules cachés, membraneux. - Náchoires membraneuses, leli extrémité se prolongeant en un lobe fort grand, presque carré. - Palpes maxillaires filiformes, presque de moirić pilus longs que les labiaux, de quatre articles; le premier très-petit, les second et troisième ofjconiques, le second alongé, le terminal au moins de la longuen da denxième, presque cylindrique. - Palpes labiaux trcsvelus, de trois arrites; le derbier petit, gi êle, mais distinct. - Téte presque demi-circuluire, toujours cornue ou portaat des érvinences dans les deux sexes. - Chaperon entior ou échancré. - Corps court, convexe en dcsaus el en desscus. - Corselet grand, plus court que les ćlytres, pas plus long cue large, quelquefois plus large que long, se rapprochant de la forme orbiculaire, ordinairement tulerculé dans les dcux sexes. Point d'écusson. - Elytres convexes, sans échancrure à leur partie cxtérieure; laissant à découvert l'extrémilć de l'abdomen et recouvrant des ailes. - Abdomen court. - Pattes fortes; hanches intermódiaires très-ćcartées entr'el!es, lcs autres rapprocliées; les quatre jambes postérieures courtes, très-dilatées et plus épaisses à leur extrémilé; tarses internédiaires et postérietrs composés d'articles aplatis, triangulaires; le prenier plus large que les suivans, ceux-ci allant en décroissant jusqu'an cinquicme. Crochets apparcis.

Le noir luisant est la couleur habituclle de ccs insectes. Leur taille est grande ou noyenne. Ils n'affectent point de climit particulier. Les mours et les métamorphoses étant les mêmes dans tous les Coprophages, nous renverrons pour cet objet a l'article Bousier, tom. V, pag. 133.

Les Bousiers proprement dits, désrits dans cet ouvrage, sont : 10. Anlínor no. 39. pl. 147. fig. 1. (Copris Antenor n . 48. FА в. Syst. Eleut.) $2^{\circ}$. Hamadryas no. 40. pl. 147. fig. 5 . (C. $11 a-$ madryas no. 28. $\mathrm{F}_{\mathrm{AB}}$ ) $3^{\circ}$. Bucéphale $\mathrm{n}^{\circ}$. 4r. pl. 147. fig. 4. (C. Bucephatus $\mathrm{n}^{\mathrm{n}}$. 54. $\mathrm{F}_{\mathrm{AB}}$ ) $4^{\circ}$. Molessus no. 43. pl. 147. fig. 6. (C. MO. Lossus $n^{\circ} .56 . \mathrm{F}_{\mathrm{AB}}$ ) 50. Janus $n^{\circ}$. $44 . \mathrm{pl}$. 147 . fir. 7. 6०. Némestrinus no. 48. pl. I 48. lig. 2 . (C. Neuestrinus no. 3. FAB.) $7^{\circ}$. Jacchus $n^{\circ}$. 49. pl. 148. fig. 3. (C. Jacclius no. 4. FаB.) $8^{\circ}$. Phidias $n^{\circ}$. 5o. pt. 148. fig. 4. $9^{\circ}$. Boréce no. 51. pl. 148. fig. 5. so ${ }^{\circ}$. Edipe no. 57.

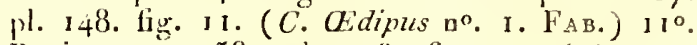
Paniscus no. 58. pl. I48. fig. 12. (C. Paniscus $n^{\circ} .59 . \mathrm{F}_{\mathrm{AB}}$ ) $12^{\circ}$. Espagnol no. 5g. pl. 148. fig. 13. (C. hispanus no. 86. 130. Lunaire $n^{\circ} .60$. pl. 149. tig. I. (C. lunaris no. 29. Fab.) 140. Echaucré no. 61. pl. 149 . fig. 2. (C. enarginata no. 3o. $\mathrm{F}_{\triangle B}$ ) $15^{\circ}$. Ancée $n^{\circ}$. 62. pl. 149. fig. 3. I6 $6^{\circ}$. Capurio $n^{\circ} .63$. (C. capucinus $11^{\circ} .39$. FAB.) $17^{\circ}$. Pithécins $n^{\circ}$. 64. pl. 149. fig. 4. (C. Pihecius no. 14. FAB.) 
180. Sabaus no. 65. pl. 149. fie. 5. (C. Sabaus $n^{\circ}$. 6. FAB.) $19^{n}$. T'ullius $n^{\circ}, 66$. pl. 149. fig. 6 . (C. Tulinis no. 65. Fав.) $20^{\circ}$. Pactole $n^{\circ} .67$. pl. 149. fig. 7. (C. Pactolus no. 12. Fas.) $21^{\circ}$. Frolleur no. 72. pl. 149. fig. 11. (C. flicator $\left.\mathrm{n}^{\circ} \cdot 67 . \mathrm{F}_{\mathrm{AB}}\right)$ ) $22^{\circ}$. Sinon $\mathrm{n}^{\circ} 73 . \mathrm{pl}$. 149. fig. 12. ( $C$. Sinon $11^{\circ}$. 35. FAB.) $2 \overline{3}^{\circ}$. Ammon no. 74. pl. 149. fig. 13. (C. Amuton no. 25. FAB. ) $=4^{\circ}$. Grani $11^{\circ}$. 86. pl. 119. fig. 25. (C. gigus no. 55. FAB.) $25^{\circ}$. Acluate 130. 87 . pl. 150 . fig. 1. $26^{\circ}$. Eridanus $n^{\circ}$. 88. pl. 139 . fig. 6. et 15o. fig. 2. $27^{\circ}$. Carolinois $\mathbf{n}^{n}$. $8 \mathrm{~g}$. pl. s5o. fign. 3. (C. Cacolina no. 60. FАВ.) 280. Nisus no. 96. pl. 15o. tig. 9. (C. Nisus $n^{\circ}$. 61. l'ав.) $29^{\circ}$. 'Trident $n^{\circ} .98$. pl. 150 . fig. 10. (C. Tridens $n^{\circ}$. 85. FAB. ) $30^{\circ}$. Marsyas $n^{\circ}$. 99. $51^{\circ}$. Ondé $11^{\circ}$. Ioo. pl. ı5o. fig. $1 \%$. 520. Sillonnew: 110. 103. pl. 15o. fig. 14. $(C$. sulcator $n^{\circ}$. 104. $\mathrm{F}_{\mathrm{AB}}$ ) $35^{\circ}$. Hespríris $\mathrm{n}^{\circ}$. 128 . pl. 151. fig. 15. Cetle espèce est du Brésil et uon des Indes orientales.

Nows rapportcrons encore à ce genre, mais avec doute, 10. Bonsier Midas 110. 42. pl. 147. fig. 5. (C. Midas $1^{\circ} \cdot 27, \mathrm{FAB}_{\mathrm{A}}$ ) $2^{\circ}$. Pélée $\mathrm{n}^{\circ} .102$. 3०. Oblique $n^{\circ}$. 159. pl. 152. ligo. 9. du présent ouvrage.

CHOERDIE, Chacridium. Ateuchus. FAB. Copris. Oliv. (Eucycl.)

Genre d'insectes de l'ordre des Colćoptères, section des Fenlamères, fumille des Lumellicornes, tribu des Scarabéides (division des Coprophages ).

Dans cetle division un groupe a pour caractères : point d'écusson; les quatre jambes postérieures conrtes, scnsiblement dilatées et plus épaisses à leü extrémité. (Voyez Scarabéides.) Ce groupe contient quatre genres, Onthophage, Phanće, Bousier el Chœridie; les trois prentiers se distinguent aisément du dernier par leur tête ou lcur corselel loujours cornus ou tuberculćs dans les deux sexes; en outre, les Phanées et les Onthophages ont le corps déprimé en dessus.

Les Choridies présentent les caractères suivans:

Antenzes de neuf articles, les trois derniers en massue lamellée, plicatile. - Labre et mandibulcs cachés et membraneux. - Téte presque demi-circulaire, muique dans les deux sexes. Chaperon visiblement échancré, toujours bidenté à son bord antérienr. - Corps court, convexe en dessus et en dessous. - Corselet mutique dans les deux sexes. - Ecusson nul. - Elytres convexes, sans ćchancrure à leur partie extćrieure, laissant à découvert l'extrémité de l'abdomen et recouvrant des ailes. - Aibdoncen court. - Hanches intermédiaires trc̀s-écartées entr'elles, les autres rapprochées. - Les quatic janibes postérieures courtes, très-dilatées et plus épaisses à leur extrémité. - Les quatre dermiers tarses composés d'articles aplatis, triangulaires, le premier plus large que les suivans; cenx-ci allant en àévicissnt jusqu'au cinquième. Crochets apparens.

Les insecles de ce nouveau genre, dont le nom vient d'un dininulif du substantif grec qui désigne un Porce, ont ćté confondus avec les Ateuclus par Fabricins, en raison sans doute de la conformicé de leur chaperon avec celui de plusicurs espèces de ce dernicr genre. Il nous paroît impossible de les y hisser, vu la structure de leurs quatre jambes postérieures qui sont courtes, dilatćes el beaucoup plus ćpaisses à leur extrémité, tinndis qu'elles n'offient ni renflement ni dilatation sensible dans les Atcuchus; ceux-ci ont les quatıe derniers tarses composés d'irticles évidenment cylindro-coniques, conformation très-différente de celle que prée entent les tarses des Cliceridies. Les espèces gue nous connoissons sont d'une taille au-dessous de la moyenne et propres aux climals chauds des deux $\Lambda$ mériques.

\section{Crequde simple, $C$. simplex.}

Choridiun fuscum, subnitidum, clypeo acutè enairginato et bidentato, capite thoraceque subtilitèr punctatio; elytris septem striatis, striis subcrenulatis : thoracis subtus et abdominis lateribus punctutis; pedibus fuscè testaceis.

Ateuchus simplex. DEJ. Catal.

Longueur 3 ligr. $\frac{x}{2}$. D'un brun-noirâtre; chaperon échancré, iarmé dè deux dents qui, aiusi que l'échancrure, sont aiguës. Têle et corselet tres-finement pointillés, un peu luisans; celui-r.j ayanl de chague côté une petite fossetle, et poscéricurement, vis-à-vis de la sulure, un sillon longitudinal qui ne dépasse pasle nilieı du disque. Elytres peu luisantes, chargćes chacune de sept stries, lesquelles ont guclques petils poinls peu enfoncés. l.es côtés du corselet et de l'abdomen sont en dessous ponclućs el comme chagrinés. Palles d'un testacé foneé. Jambes de devant nunics de quatre dents extćrieures.

De Cajenne.

On délachera des Bousiers du présent ouvrage, pour les rapporter aux Choridies, les espéces suivantes : $1^{\circ}$. squalide $n^{\circ} .142$ (Ateuchus squalidus nº. 3о. Fав. Syst. Eleut. Charidium squalidum. Noв.); $2^{\circ}$. quadrille ${ }^{\circ}$. 153. (Charidıum quadirguttatum Nов.); 3०. têle noire $\mathrm{n}^{\circ}$. 154. (Choriduun melanocephalum Nов.) et penl-être encore te Bonsier de la nouvelle Hollande ${ }^{\circ}{ }_{1} 55$. (Ateuchus Hollandice 110. 15. FAB., dont nous croyons la parrie mal indiquée par les auteurs), ainsi que l'Ateuchus capistratus no. 36. FAB. (Charidium capistratum Noв.) de la Caroline. les Ateuchus concolor el. carbonarius DEJ. Collect. appartiennent aussi à ce genre.

ONITICELLE, Oniticellus. ZuÉgr. Des. Catal. Onthophagus. LAт. Ateuchus. FАB. Scarabceus. 


\section{S C A}

Oriv. (Entom.) Copris. Geort. Oirv. (Encycl.)

Gente d'insectes de l'ordre des Coléopières, section des Pentamères, famille des Lamellicorres, tribu des Scarabéides (divisiou des Coprophiages ).

Les Onites, les Onilicelles et les Eischrotès forment un groupe dans cette division, dont le calractère consiste eu re que les élytres à la base de leur sutnre ne se rejorgnent pas parfaitement entr'elles ni avec le corselet, mais laissent an contraire dans celle partie un espace libre occupé par un ćcusson daus les deux dernicrs genres, et nềme assez souvent dans le premier. lies Onites se dislingruent des Oniticelles par la massue de lcurs antennes en forme de carré à angles adoucis, dont le diamètre longitudinal ue surpasse presque pas le transversal, et par la forme des articles cui composent celle massue, le premier étant infundibuliforme, le second plus court que les deux antres et presqu'entièrement renferné entr'eux; le dernier en forme de cupule renversće. Il parôí aussi que les Oniles ont le clernier arlicle des palpes libiaux clistinct. Jans les Isschrotès la mas. sue des antennes a aussi ses deux diamètres presqu'́́gaux; le coréet est torlement échancré sur ses Lords latéraux depuis le nilieu jusqu'à la partie postérieure; les ćlytres ont leurs côlés ruballus subitcment, avee leur dessus absolument plane. Les Oniticelles, antrefuis confondus avec les Onthophages, en different par la présence d'un écusson; par le corselct anssi lon ó que large, et par les élytres beacoup plus longues en proportiou. Les caraclères génńriques de ces Coprophitges n’ayant pas encore élé publićs, nous nolis en référons à la cormparaison que nous venons d'établir. Les espèces peu nombreuses dont ce genre est composé sont de petite taille et habilent l'ancien continent.

Les Onilicelles déjà décrits dans cet ouvlage sont : 10. Bousier ceint no. 146. pl. 152. fig. 15 . (Ateuchus cinctus $1{ }^{\circ}$. 41. F A B. Syst. Eleut. Oniticellus cinctus. DEJ. Catal.) $2^{\circ}$. Ha vipc̀de $\mathrm{n}^{\circ} .147$. pl. I52. fig. 16. ( $A$. flavipes $\mathbf{n}^{\circ} .39$. Fав. Onilicellus flavipes. DEJ. Calal. Le Copris verticicornis no. 103. FА . Syst. Eleut. n'en cst qu'une variété, selon Ni. Schœuherr.) $3^{\circ}$. pâle no ${ }^{\circ}$ 148. ( $A$. pallipes nо. 38. $\mathrm{F}_{\text {Ав. Oniticellus pallipes. Nов.) }}$ On observera que c'est par erreur que lauteur regarde ce dernier comme privé d'écusson. L'individu que nous croyous mâle, a sur le cliaperon une corne courte, un peu comprimée en travers, et une ligne transversale peu élevée à la parlie tout-à-fait postérieure de la têle ; dans l'autre sexe, le chaperon porte deux lignes transversales peu élevées: le derrière de la tếle en a également deux, dont la postérieure est la plus saillante de toutes. Celle espèce, que les auteurs eitent comme étant de Maroc, du Sénégal et d'Italie, a été rapportée des Indes orientales par feu Sonnerat.

Il seroit possible que le Bousier Rhadamiste no. 63. de ce Dietionnaire (Copris Rhadamistus ${ }_{12}^{\circ}$. 2. FAB. Syst. Eleut.) fût un Cniticelle.

RSCHROTES, Aschrotes. MAcs. inéd. Isonotus. Dasm. inéd.

Ce genre a pour caractères distinctifs de ceux des Onites ct des Oniticellcs (vojez Scarabúl一es): massue desanlcnnes ayant ses deux diamètres presqu'égaux; bords latéraux du corselet fortenent ćchancrés, depuis leur milieu jusqu'a la partic pos. térieure; élytres ayant leur dessus absolumént plime et leurs côlés raballus subitement.

Le mot grec dont est formé le now de ce genre signifie : saleté; il a rapport à la manière de vivre des insectes quile composent.

\section{Escrnotés plane, AR. planus.}

Esschrotes squalidè testaceus, fusco mixtus; elytris glubris; pedrbus nigris, Jemoribus quattuor posterionbus testacels, posticis duobus remoté buspinosis.

\section{Onitis planus. Des. Catal.}

Longueur I pouce. D'un testacé sale, tacheté de brun; élyl:es glabres: palles noires, cuisses intermédiairics et postérieures testacées; celles-ci ayant chacune deux fortes épines très-éloignécs l'une de l'aulre.

De Cayenue.

A ce genre appartient l'Onitis deplanatus de Ni. Germar. Du Brésil.

EUPARIE, Fuparia. Ce nouveau genre trìs. voisin de colui d'Aphodie s'en distungue par les curäcic̀res suivans: côtés de la tête dilatés et foraratnt un triaugle; angles postérieurs du corselet forleurent échancrés; angles huméruux des élythes pointus et très-prolungés én devant. (Voyez pour les autres caraclères ceux des Aphodies, irrisle suivant.)

Euparia vient de deux mols grecs qui ont rapport a la dilatation des parties latérales de la tête de ces iusecles.

\section{Euparie marron, E. castanea.}

Euparia fuscè castanea, punctata; capitis angulis lateralubus dilatato-subspinosis; thoracis

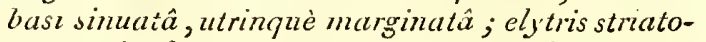
punctatis, humeris porrecto-subspinosis.

Longneur 3 lig. Corps d'un brun-marron, ponctué. Bord postérieur du corselet fortement sinué, comme échlancré vis-à-vis des angles huméraux des élytres; celles-ci ayant des stries poinlillées, et leurs angles huméraux épineux.

Patrie inconnue.

APHODJE, Aphodius. Inlig. FAb. Lat. Gule. Scaraboeus. LinN. De GEER. Geoff. OLiv. (Entom.) Copris. Oux. (Encycl.) 
Genre d'insectes de l'ordre des Coléoptc̀res, section des Pentamères, famille des !ranenilicornes, tribu des Scarabéides (division des Coprophages).

Dans cette division trois genres : Euparie, Psammodie et Aplodie, sont dislingués jar les caractères suivans: toutes les palles insérées à égale distance les unes des autres. Palpes labiaux velus, lenrs articles cylindriques, presque semblables. Ecusson très-distinct. Elytres embrassant lcos côtés et l'extrémité postérieure de l'abdomen. Mais les Psammodies ont les mâchoires armées intérieurement d'un appendice corné en forme de dent bifide, et se nourrissent probablement de substances plus solides que celles qu'attaquent les Aphodies; dans les Euparies les côtés de la lête sont dilatés et furment un triangle; les angles huméraux de leurs élytres sont pointus et trèsprolongés en devaınt.

Antennes un peu plus longnes que la tête, de neuf articles, le premier alongé, un peu plus épais vers l'extrémité, le second presque hémisphérique, le troisième petit, les quatrième, sinquiène et sixième très-courts, transversanx; les trois derniers formant une massue lameliée, plicatile, ovale. - Labre membraneux, caché pall le chaperon. - Mandibules membraneuses, cachées.-MIâchoires terminées par un grand lobe membraneux. - Palpes maxillaires filiformes, plus longs que les autres, de quatre articles, le second commençant à dépasser le chaperon, alongé; le dernier encore plus long. - Palpes labiaux pen velus, de rois articles cylindriques, presqu'égaux entreax, le dernier plus grêle. - Lèure fort veluc à sa partie suṕrieure; menton profundément échancré, ses anghles supérieurs aigus. - Chaperon demi-circulare, ordinairement tuberculé. Corps ovale ou ovale-linéaire, convexe eu dessus, arrondi aux extrémités. - Corselet mulique, cu carré transversal. - Ecusson très-distinct.-Elyties embrassant les côtés ainsi que l'extrénité postérieure de l'abdomen et recouvrant des anles; leur partie antérieure coupće droite. - Pattes fortes, insérées par paires à égrale distance les unes des autres; cuisses antéricures portant une ligne enfoncće grarnie d'une frange de poils, leurs junbes tridenlées extérieurement; les quatre autres presque coniques, ayant des incisions transversales un peu épncuses; tarses filiforme:, leurs articles cylindro-coniques, le premier beaucoup plus long que les autres: crochets apparens.

Ces insectes dont les goûts sont les mêmes què ceux des autres Coprophages, en ont tiré leur nom, dérivé du grec. Les espèces sont eu grand nombre et toujours petiles ou moyennes; leurs conleurs sont le noir-luisant ou bien un gris plus ou moins briqueté, sans aucun reflet métallique. Toutes ou presque toutes hubitent l'ancien contineat.

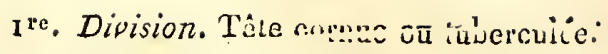

Les Aphodies décrits dans ce Dictionnaire sont les suivans : $1^{\circ}$. Bousier fossoyenr $\mathrm{n}^{\circ}$. 1. pl. 145 . fig. 5. (Aphodius fossor no. 2. Fав. Syst. Eleut.) $2^{\circ}$. Anill no. 2. (A. analis no. 9. HAB.) $3^{\circ}$. Souterrain $\mathrm{n}^{\circ}$. 3. pl. 145. fig. 6. (A. subterraneus no. 18. ГАв.) $4^{\circ}$. Terrestre no. 4. pl. 145. lig. 7 . (A. terrestris $\mathrm{n}^{\circ}$. 13. F今B.) $5^{\circ}$. Rougeâttre $\mathrm{n}^{0} .4$. pl. r45. fig. 8. (A. scrututor $n^{\circ} .5$. F $\mathrm{AB}_{\mathrm{B}}$ ) $6^{\circ}$. Fimétaire $11^{\circ}$. 6. pl. 145. fig. 9. (A.fimetarius 110. 19. Fав.) $7^{\circ}$. Errant $1^{\circ}$. 8. (A. erraticus $n^{\circ}$. 21. VAB.) $3^{\circ}$. Scybalaire $n^{\circ} \cdot 9 \cdot \mathrm{pl}$. 145. fig. 10. (A. scybularius no. 10. $\mathrm{F}_{A B}$.) $9^{\circ}$. Brûlé no. 10. pi. 140. fig. 11. (A. conflagratus $\mathrm{n}^{\circ}$. 20. FAB.) 10 . Sule $1^{\circ}$. 11. pl. 145. ligr. 13. (A. conspurcatus $\mathrm{1}^{\circ}$. 22. $\mathrm{FAB}$.) $11^{\circ}$. Surdide $\mathrm{n}^{\circ}$. 12 . pl. 145 . lig. I 4. (A. sortidus $1^{\circ} \cdot 26 . \mathrm{F}_{\mathrm{AB}}$ ) $12^{\circ}$. Grenaille n". 13. ( $A$. granarius no. 29. Has.) ) $3^{\circ}$. Hémorrhoidal no. 14. pl. 145. fig. 15. ( $A$. hasmorrhoidalis $\mathrm{n}^{\circ}$. 30. $\mathrm{FAB}$.) $14^{\circ}$. Taché $\mathrm{n}^{\circ}$. 15 . pl. 145. fig. I7. ( A. inquinatus $\mathrm{n}^{\circ} \cdot 23 . \mathrm{F}_{\mathrm{AB}}$ ) i50. Bimaculé no. 16. pi. 145. fig. 19. (A. bimaculatus $\mathrm{n}^{\circ}$. I7. $\left.\mathrm{F}_{\mathrm{AB}}\right)$ I $6^{\circ}$. Puant $\mathrm{n}^{\circ}$. $17 \cdot \mathrm{pl}$. 145. fig. 21. (A. foetens no. 8. FAB.) I $7^{\circ}$. Livide no. 18. pl. 145. fig. 25. (A. anachoreta $\mathrm{n}^{\circ} .28$. FAB.), ot peat-útre encore le Bousier bicolur $11^{\circ} \cdot 7$.

\section{2 ${ }^{\mathrm{e}}$ Division. Tête sans cornes ni tubercules.}

A cette division appittiennent les Bousiers suivans de ce Diclionnaire : $1^{\circ}$. Rufipide $n^{\circ} .19$. pl. 145. fig. 25. (A. rufipes $11^{\circ}$. 35. Fав.) $2^{\circ}$. Jayet $11^{\circ}$. 20. pl. 145. fig. 26. (A. nigripes no. 36. Faв. ) 3o. Sept taches no. 2i. pl. 145. fig. 27. (A. septemmaculatus $n^{\circ}$. 33. Fав.) $4^{\circ}$. Fascié $n^{\circ}$. 24. pl. 145. fig. 5. ( $A$. fitsciatus $n^{\circ} .49 . \mathrm{F}_{A \mathrm{~B}}$ ) $5^{\circ}$. Luride $\mathrm{n}^{\circ}$. $25 . \mathrm{pl}$. 145. fig. 6. (A. lurdus no. 37. FAB.) 6०. $\mathrm{Pu}_{\mathrm{u}}$ bescent $n^{\circ}$. 26 . pl. 145. figr. 7. ( $A$. Sus no. 44 . Fab. Le Bousier Pourcean no. 3o. est peut-être la même espèce.) $7^{\circ}$. Marginé $n^{\circ}$. 27. pl. 145 . fir. 9. (A. marginellus no. 48. Fab. Selon N. le comte Dejean, celle espèce est des îles de l'Amćrique.) 8०. Biponctué no 28. (A. blpunctatus no. 34. FAs.) 9?. Quadrimaculé no. 29. pl. 146. ti g. 11. (A. quadrinaculatus $n^{\circ}$. 42. FAB.) 10 ${ }^{\circ}$ A plaie no. 3̋. pl. 146. fig. 13. (A. plagiatus n ${ }^{\circ}$. 47. FAB.) 1 I $^{\circ}$. 'Torme n०. 32. pl. 146. fig. 15. ( $A$. testudinarius $n^{\circ}$. 5o. FAB.) $12^{\circ}$. Truie no. 33. ( $A$. Scropha $\mathrm{n}^{\circ}$. 51. FAв. ) 13 ${ }^{\circ}$. Fouille-merde. no. 35. pl. 146. fig. $\mathrm{s}$. ( $A$. merdaruus $\mathrm{n}^{\circ}$. 52. FAB. ) $14^{\circ}$ - Ordurier $\mathrm{n}^{\circ}$. 34 . pl. 146. fig. 17. ( $A$. merdarius $\mathbf{n}^{\circ} .52$. variét. FAB.)

Nous croyons aussi devoir rapporter à ce genre le Bousier arénaire n $^{\circ} .38$. pl. 146 . fig. 25 . de cet ouvrage ( $A$.arenarius), mais il faut retrancher le synouy ure de Fabricius qui appartient à l'AEgialia globosa Lat. 
Nota. Lues Bonsiers relevé no. 22. pl. 146. fig. I. ( $A$. elevatus no. $\left.46 . \mathrm{F}_{\text {Ав. }}\right)$, ridé $\mathrm{n}^{\circ} .34$. pl. 146. fig. 17. (A. asper $1^{\circ}$. 61. HAs.), merdeux n⿳. 23. pl. 146. n०. 3. (A. stercoratorn ${ }^{\circ} .58$. $\mathrm{FAB}_{\mathrm{AB}}$ ) et sillonné no. 37. pl. 146. fig. 25. ( 1 . porcatus no. 57. FАB.), qu'on a rapportés mal-àpropos au genre Psammodie, sont aussi de la seconde division des Aphodies.

PSAMMODIE, Psammodius. LAt. Nows avons traité ce grente à sa lettre d'après M. Gyllenhall. Dans la niéthode de M. Lalreille on deit le restreindre. Une partie des espèces cilées par l'auteur suédois, telles que celles nommées eleratus, sabuleti, porcatus et scaber sont de vrais Aphodies; une autre (globosus) est le type du genre Tigialie Latr. (Voyez ce mot, colonne suivante.) L'espèce appartenant vélitablement au genre Psamrodie, tel que nous l'entendons avec le naturaliste fiançais, qui nous a communiqué ses observations avec'sa hienveillance labituelle, est

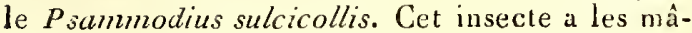
choires armées intérieurement d'un appendice corné en forme de dent bilide comme les Aigialies, au lieu que les Aphodies sont dépourvus de cette partie dure conformée en crochel : ceuxci ne se nourrissent que de malières molles, tandis que les l'sammollies et les Fialies attaquent probablement des substances solides, c'està-dire vivent à la manière des Trox; mais leurs mandibules et leur labre sont entièrement cachés, et les antennes n'ont que neuf arlicles de mème que dans les Aphodies.

\section{Psammodre sulcicolle, $P$. sulcicollis.}

Fusco-testaceus, capite scabemimo; thorace transversaliter ely tris longitudinalitèr porcatis.

Psammodius sulcicollis. GrLL. Ins. Suec. $t$. I. 1808. - Aphodius sulcicollis. Schen. Syn. Ins. tom. I. part. 1. pag. 88. $n^{\circ} .85$.

Longueur 2. lig. D'un brun-testacé; tête trèsraboteuse, son bord antérieur un peu plus clair ainsi que les pattes et le dessous du cöps. Corselet fortement sillonné transversalement, les člytres l'étant de ınême, mais longitudinalewent.

\section{D'Allenague.}

CHIRON, Chiron. Ce genre de ColéoptètesScarabérdes indiqué d'abolod par M. Latreille a été caraclérisé depuis par M. Macleay (Horce entomologica) de la manic̀re suivante : antennes de neut articles, le premier alongé, cylindrique, le second globueux, le troisieme cunique, les quatrième, cinquieme et sixième très-couris, les trois dernie s lormant une massue ovale. Labre en carré transversul, entièrement proéuinent. Handibules courtes, à peine sarllantes, lortes, arquées. Palpes maxillaties gréles, leur dernier article en alẹne. Menton prescue triangulaire. Corps cylindrique. Elylres ne recouvrant pas entièrement l'abdomen. 'Têtc transversale, sans cou dislinct, de même largeur que le corselet. Ecusson très-petit, à peine distinct, se prolongeant entre les élytres. Paltes assez courtes; cuisses épaisses; jambes antérieures dilatées el digitées. M. Macleay rapporle à ce genre le Sinodendron digitatum n ${ }^{\circ}$. 3. F А в. Syst. Eleut. (Chir. digitatus.) Des Indes orientale.

Agtalie, Agralia. Lat. Aphodius. Illig. Panz. Fab. Payk. Psammodius. G Yllen.

Genre d'insectes de l'urdre des Coléoptères, section des Pentamères, famille des Lanellicornes, tribu des Scarabéides (division des Ar'́nicoles ).

Ce genre avee celui de Chiron forme un groupe dans cette division, caractérisé ainsi : langruette bifite, ses deux lobes saillans au-delà du menton; mandibules généralement saillantes, irquées. Antennes de neuf articles. (Toyez Scarabéides.) $\mathrm{Mlais}$ les Chirons se distinguent du genre dont nous traitons ici par leur corps alongé, cylindrique, et par leurs élytres qui ne reccuvrent pas entièrement l'abdomen.

Antennes plus longues que la tête, de nenf articles; celui de la base cylindrique, presque glabre, les trois deruiers foruant une massue lamellée, plicatile. - Labre coriace, très-court, transverso-linéaire, ses angles latéraux arrondis, son bord antérienr largenent éclianeré , garni de cils courls. - Mlandrbules forles, épaisses à leur base, arquées, comprintées ensuile, se rétrócissant insensiblement, leur pointe bifide. - $\boldsymbol{M a}$ choires ayant en place de lobe intérieur, un fort crochet corné, dentifirme, bifide à l'extrémilé. - Palpes maxillaires grêles, de quatre articles, le dernier ovale, plus long et plus épais que les autres; les labiaux de trois articles. - Menton crustacé, en carré alongé, son extrémité échancrée au milieu. - Tète arrondie, penchée. Corps ovale, court, renflé et très-globuleux postóreurement. - Corselet arqué, arrondi, ses côlés rabaltus. - Ecusson petit. - Elytres recouvrant entièrement l'abdomen et cacliant des ailes. - Pattes assez courtes; jambes antérieures ayant trois furtes dents au côté externe; jambes intermédiaires et postérieures portant sur ce mêtne côté, des lignes transvirsales ćlevées; paltes postérieures épaisses, leurs jambes munies de deux épines lerminules, lanellées, presqu'en forme de spatule; tarses composís d'aricles courls, cylindro-coniques, le dernier terminé par deux crochets tris-counts.

On conmoit deux ou trois espèces de ce genre élabli par M. Latreille; elles se trourent éa Eurupe dans les lienx sablonneux; la plus commune est I'A.gialie glubuleuse AL. globosa l.at. Gener. Crust. et Ins. tom. 2. pas. 97. n०. 1. (Aphodius 
arenarius. FAB. Syst. Eleut. tom. 1. pag. 82. $n^{\circ} .63$, en retranchatit les synonymes de Geoffroy eł d'Olivierqui appartiennent à un vériłable Aphodie; le synouyme de Jablonski est fort doutcux. ) Scarabcus arenarius. РАук. Fuun. Suec.tom. 1 , pag. 27. $n^{\circ} . X X X I I I$. Psamnodius arenarius. GYLien. Ins. Succ. tom. 1.

OCHODÉE, Ochodous. Meg. Des. Catal. Melolontha. Far. Panz. Scarabaus. Sturar.

Genre d'iusectes de l'oritre des Coléoptires, section des Ṕentamères, famille des Lamcllicurnes, tribu des Scalabéides (division des Arénicoles).

Ies deux lobes de la languetle saillans an-delà du menton, les mandibules généralement saillantes et arqućes avec les antennes de onze articies, sont les caracteres qui distinguen! un groupe de Scarabćides-Arénicoles, composé des gentes Oclodée, Bolbocère, E'ćpltastome, Athyrée, Géotrupe et Jeéllrus. (Toyez Scarabéides.) Ce dernier est bien sépraré des autres en ce que le premier article de la massue de ses antennes est infundibuliforme et plus grasi que les deux deruiers qüil renferme eutiérement. Les Géotrupes ont le corps convexe, et leur écusson est plus lurige que long; dans les Bolbocères, les Elćphastomes el les Athyrées, le second article de la massne des antennes est presqu'enlièrement caché entre le précédent et le dernier; ceux-ci sont cupalaires et d'une climension plus grande que la sienne.

M. Mégerle en créant ce genre n'en a pas publié les caractères; nous nous contenterous par conséquent d'en donner les notes caractéristiques les plus apparentcs. Antennes nons paroissant être de onze articles; leur massue forte, ylobuleuse, conposce de trois feuillets éraux, le second Étant aussi visible que les deux autres, qui sont convexes extérieurement, mais point cupulaires à l'intérieur. Tête el corselet mutiques. Cha. jeron fortement échancré sur les côtés. Corps presque déprimć en dessus, peu épais. Ecusson plus long que large. Les quatre jambes postérieures aplatics, triangulaires; leurs tarses fititornes.

La seule espèce qui constitue ce genre est la Melolontha chrysonuelina F а B. Syst. Eleut. tom. 2. pag. 179. $n^{\circ}$ 103. PAnz. Faun. Germ. fusc. 34. fig. II. Scarabous chrysomeloides Sтик. I’erz. 1. pag. 62. $n^{\circ}$.56. Les mours de cel insecte ne sont pas connues et auroient besoin d'être étudiées avec attention.

BOLBOCĖRE, Bolboceras. Genre de Coléoplères-Scarabéides de la division des Arénicoles de M. Latreille, fondé par M. Kirby (Trans. Linn. Soc. vol. 12.) 11 répond exaclement à celui d'Odontarus Meg. DeJ. Catal. L'auteur anglais lui assigne entr'autres caractères : labre transverse. Miacuibules cornées, l'une concave, l'autre bidentée à l'extrémité. Palpes filiformes. Menton presque carré, entier. Anienues de onze articles, le premier très-mince à sa base, presqu'en massue, le second cylindrique; les six suivans courts, transversaux, les trois derniers formant une massuc très-grosse, peu comprimée, presqu'orbiculaire, velue, l'article intormédiaire presqu'entièrenent caclué entre les deux antres.

Le nom de Bollocère vient de deux mots grees qui expriment la forme splićrigue de la massue des anteunes. On doit rapporter à ce genre: $1^{\circ}$. Bolb. Australasio Kıв. ul suprit pag. 462. $n^{\circ}$. 11. p. 23. fig. 5. $2^{\circ}$. Scarabaus Lazarus no. 5. FA . Syst. Eleut. (Bolb. Lazanus.) 30. Scar. quadridens $1^{\circ}$. 6. id. (Bo/b. quadridens.) $4^{\circ}$. Scar. mobalicomis no. 7. idt. (Bolb. mobilicornis.) 50. Scar. testaceus no. 17. id. Celui-ci n'est qu'une variété de ta femelle du précédent. $6^{\circ}$. Scar. aneas PANz. (Bolh. oneas.) 70. Scar. tumefuctus Palis.-Bauv. Ins. d Afr. et d'Antér. pag. 91. Coléopt. pl. 2. b.fig. 6. (Bolb. tumefactus.) $8^{\circ}$. Geotrupes farctus $11^{\circ} .6_{4}$. FА в. Syst. Eleut. (Bolb. farctus.)

ELÉPHAS'TOME, Elephastonus. Ce yeure de Colćoptères-Scarabéictes c réé par M. Macleay (Horce entomologica, vol. 1. pag. 121.) tire son uom de deux mots grecs dont le sens est : bouche d'éléphant. L'auteur lui donne les caractères suivans: antennes de onzo articles, le premier peu alougé, garni de longs poils, le second court, épais, presque conique, les six suivans très-courts, cupulaires, les trois dernicrs formant une massue forte, presque spheringe, le neuvième et le onzième hémisphériques, renfermanl et cachant al)solument le dixiène. liabre transverse, linéaiıe. Mandibules triangulaires, en forme de faulx, lem. extrémité bidentće intérieurement. Mâchoires cornées, arquées. Pallyes maxiliaires très-longs, l'étant presque trois fois plus que les labirux, leur dernier article cylindruque, alongé, lancónlé; palpes labiaux ayant leur article termiaal presque cylindrique. Menton tiès-court. Lève presque nulle. Chạperon dilaté de chaque côté, se prolongeant en devant et dans son milieu en une laine presque carrée, échancrée à l'extré mité, solide, iunperfor'ée, extrémité de cette läme plus épaisse, fourchue; les cốés de la fuurche diiigés en bas. Bouche cacthée en entier sons le chaperon. Corps entièrement velu et très-cunvexe en dessous. Corselet obtus, mutique. Elytres recouvrant tout l'abdomen. Ecusson grau.t, tri”ngulaire, plane. Pattes ve!ues. Cuisses antćrieures et postérıeures fortes. Jumbes de devant ayant six dents extérienrement; jambes intermédiaires et postérieures triangulatres.

M. Macleay rapporte à cé genre une espèce de la nouvelie Hollande qu'il nomme Eleph. proboscideus (Scarah. proboscideus. Sспrвiв. Truns. Linn. Soc. vol. 6. pay. 185.) 
ATHYREEE, Athyreus. Genre de ColéoptèresScarabéides élabli par M. Macleay (Hore entom. vol. 1. pag. 123.) II a pour caractères : antennes conformées presque conme celles des Eléphastomes ( voye zl'article précédent), le bord de la massue un peu plus arrondi. Labre large, en carré transversal, à peine trilobé à sa parlie antérieure. Mandibules cornées, fortes, triangulaires, presqu'arquées, planes en dessus, bidentćes extérieurement. Dernier article des palpes labiaux éyalant presqu'en longueur celui des maxillaires. Menton presque carré. Lèvre bifide. Chaperon dilaté postérieurement de chaque côté, se prolongeant en devant en une lame presque carrée, portant dans son milieu une élévation muaie de trois pointes dont l'intermédiaire est plus longue. Col'ps très-convexe, velu en dessous. Corselet mucroné en devant, prolongé en dessus, à sa partie postérieure vis-à-vis de l'écusson. Ecusson linéaire, peu distinct, se prolongeant entre les élytres. Pattes intern:édiaires très-écartées l'une de l'autre. Jambes antérieures munies de qualre ou cinq dents extérieures.

L'auteur rapporte à ce genre dont le nom tiré dn grec signifie : sans écusson, trois cspèces du Brésil: $1^{\circ}$. Athyr. bifurcatus. Noir, chargé de points élevés; corselet muni d'une dent élcvée, large, Jifurquée. Elytres ayant de petites stries glabres, élevées; leur suture velue, ferrugineuse. $2^{\circ}$. Athyr. tridentatus. Ferrugineux, un pen ruguenx; corselet glabre, excavé dans son nuilieu, à trois dents, l'antérieure plus longue, les latrírales plus obtuses; élytres à peine striécs. $3^{\circ}$. Athyr. bidentatus. Nnir, un peu rugueux. Corselet excavé daus son milieu, glabre, à deux dents latérales assez obtuses. Elytres ayant des stries peu marquées.

GÉOTRUPE, Geotrupes. LAT. Scarabous. Linn. Geoff. De Géer. Panz. Fab. Oliv. (Entom.)

Genre d'insectes de l'ordre des Coléoptères, section des Pentamères, famille des Lamcllicornes, rribu des Scarabéides (division des Arénicoles).

Les genres de cette division qui ont les deux lobes de lat languette saillans au-delà du menton, les mandibules généralement saillantes, arquées, avecles antennes de onze articles, sonı les suivans: Géotrupe, Bolbocère, Eléphasıome, Ochodée, Athyrée et Léthrus. Ce demier est remarquable en ce que le neuvième arlicle de ses antennes, ou le premier de la massue, est absolument infundibuliforme et renferme tout-a-fail les deux autres dans son intérieur. Le genre Ochodée a le corps assez déprimé, arec l'écusson plus long que large. Dans celui d'Eléphastome, le devant du chaperon est prolougé en une lame fort longue. Les Bolbocères sont absolument convexes et presque glubuleux. Enfin les Athyrées, dont la forme est la mème, ont eu outre leur écusson Hist. Nat. Ins. Tome $X$. linéaire et peu visible. De plus, dans ces quatre grenres la nassue des antennes est forte et presque ronde.

Antennes de onze articles; le pronier grand, velu, cylindro-conique; le second globuleux, gros; les troisième, quatrième et cinquième cylindro-coniques; les trois suivans cupulaires; les neuvième, dixième et onzième formant une massue ovale, alongée, lamellée, plicatile, composée de trois feuillets presqu'égaux. - Labre découvert, ayant son bord antérieur droit, cilié. Mandibules cornées, triangulaires, déprimées, arquées à lear extrémité; leur bord extérieur aigu, l'intérieur mcmbraneux, velu. - Mâchoires composées de deux appendices mombraneux-coriaces, leur bord très-velu. - Palpes filifornes, courts, presqu'égaux; leur dernier article presque cylindrique, de la longueur ou plus long que de précédent; les inaxillaires de quatre articles; les labiaux de trois, ceux-ci ayant leur tubercule radical grand, imitant un article. - Languette composée de deux divisions presque coriaces, conniventes, frangées intérieurement, arrondies à leur extrémité, s'avancunt au-delà de l'extrémité du menton. - Menton crustacé, presque carré. - Tête cugagée daus le corselet jusqu'auprès des yeux; chaperon ordinairement rhomboidal, terminé en angle ou en arc à sa partie antérieare. - Corps oblong, convexe. - Corselet grand, rebordé de tous côtés, de moitié plus court que l'abdomen, se rétrécissant en dcvant. - Ecusson très-apparent, presque cordiforme, plus large que long. - Elytres convexes, recouvrant entièrement l'abdonen. - Pattes forles; jambes antérieures plus ou moins dentćes extélieurement, terminées par une forte épine; les intermédiaires et les postérieures profondément incisćes ì leur partie externe; jambes interınédiaircs munies à leur extrémilé de deux épines longues, aiguës; jambes postéricures en ayant deux obluses : tarses composés d'articles couiques, velus; le demier terminé par deux crochets longs et grêles.

Les Géotrupes, dont le nom vient de dcux mots grecs qui signilient : percerla terre, crcuscnt des trous cyliudriques au-dessous des excrémens qu'ils babitent et entrainent dans ces trous une portion de celle matière; c'est auprès de ce depôt qu’ils s'accouplent et qu'ils déposent leurs œufs : les larves qui eu sortent devant s'en nourrir. L'espèce nommée Sylpatique paroît rechercher pour sa nourriture les différentes espèces du genre de champignons que Linné a nommé bolet, et choisit de préférence les plus grosses et les plustendres; mais elle vit aussi dans les bouzes de vache et le crotin de cheval. Les Géotrupes privés d'uiles liabitent ordiuairement les terrains sablouneux; ce que M. le comte Dejean nous a attesté, ayant souvent été à même d'observer ces insectes dans le midi de la France. Le noir est la couleur domi$Z_{2}$ 
nazle des Géolrupes; ils ont souvent des reflets violets on d'un vert doré plus pronoucés en dessous 'Tu'en dessus. On en connoît une vingtaine d'espèces gónéralement d'assez grande taille, qui nous paroissent appartenir toules à l'hémisphère septentrional, tant dans l'ancien que dans le nouveau Monde.

\section{ire. Division. Corps oblong. Des ailes.}

1re. Subdivision. Corselet cornu ou tubereulé.

- lies trors articles de la massue des antemes roujours distiucts, laneéolés, libres, aucun d'eux n'étant cupulaire.

Mapporlez à celle subdivision : $1^{\circ}$. le Scarah.eus disparno. 1. Fав. Syst. Eleut. (G. dispar.); 2 ". le Scarabous Tjphceus no. 3. FAв. Id. (G. Typhas.) Encycl.pl. 144.fig.9. Wâle el fernelle. Doil-on regurder comme une variété de celui-ci, un individu du midi de la trance qui a les cornes du corselet leaucoup plus courtes; les latérales atteignant senlement le milien de la tête; les côtés du corsclet ponctués el ridés comme dans la fenielle Typhous; les stries des élytres comme dans le mâle, et la carène des jambes antérieures suns dentelures. Est-ce lit le Scarab. puniclus Mansa. Entom. britann. p. 8. n. 2?

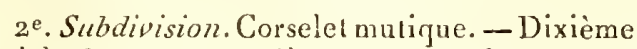
article des antennes (le second de la massue) peu distinct dans le repos, presqu'entièrement renfermé entre le neuvitme et le onzième; ceux-ci cupulaires, leurs concavités tournées en face l'une de l'autre.

\section{Géotrupe hypocrite, G. hypocrita.}

Geotrupes suprà niger, aut nigro-viridi-ceneus, infrà viridi-aureus; capite tuberculato; elytris ohsoletè striato-punctatis. Striis circitèriredecinn.

Geotrupes hypocrita. Schwns. Synonym. ins.

Longueur $8 \grave{a} 12$ lig. Noir en dessus, ayant souvent un rellel vert-cuivreux; dessons du corps et des cuisses d'un verl doré. T'ête munie dans son milieu d'un petit tubercule. Elytres ayant chacune environ treize stries à peine prononcées, légèrement pointillćes; celle qui accompagne la sulure au-dessous de l'éeusson parcourant plus distinetement un espace enfoncé à peu près de la longueur du quart des élylies.

Des environs de Paris. Il se trouve aussi en Espagne.

I.es indivilus que nons regardons comme femelles, out la carène interne des jambes antérieures garnie de dents, dont deux plus fortes; savoir, une très-sallante placée vers le milieu, l'autre moins élevée, situće près de l'extrémité; leurs cuisses postérieures ont un tubercule dentiforme court, avec le trochanter un peu saillant. Dans ceux que nous consiclérons comme mảles, la carène interne des jalubes de devani n'a que de petits dentieules '́gaux entr'enx; les cuisses postérieures sont muliques et leur trochanter n'est pas saillant. On observera des différences analogues ì celles-ci dans les deux sexes des autres espèces de ce genre.

On placera iei les Géotrupes suivans: $1^{\circ}$. Stercorarius (Scar. stercorarius no. 10. Fав. Syst. Eleut.) ; 20. Sylvaticus (Scar. sylvaticus no. 11. $\mathrm{F}_{4 \text { B. }}$ ); 3o. Blackburnii (Scar. Blackbumii no. 16. $\mathrm{F}_{\mathrm{AB}}$ ) ; $4^{\circ}$. vernalis. (Scar. vernalis $\mathrm{n}^{\circ} .12$. FAB.)

$2^{e}$. Division. Corps presqu'arrondi. - Point dailes. - Les trois articles de la massue des antennes torjour's distinc:s, lancéolés, libres, aucun d'eux n'étant cupulaire.

A cetle division-appartiennent les Géotrupes hemispharicus (Scar. hemisphcricus Oniv. Entom. tom. 1. Scarab. p.66. n.74. pl. 2. fig. 15) et loovgatus (Scar. lavigatus no. 13. Fa B. Syst. Eleut., en retranchant le synonyme d'Olivier, qui apparlient à l'espèce précédente). On rapporteria en outre à ce genre le Scarabcus Momus no. 4. Fas. Syst. Eleut. (G. Momus) Encycl. pl. 144. fig. 10.

CRYPTODE, Cryptodus. Gưre de ColéoptèresScarabéides, division des Arénicoles suivant $M$. Latreille, créé par M. Nacleay (Horce entoin. vol. 1. pag. 33.), ofliant pour caracteres : antennes deneuf articles, le premier dilaté, triangulaire, cachant les autres jusquà la massue, le sixième à peine distinct, les trois derniers dilatés, formaut une inassue, le prenier de ceux-ci presque conique. Labre corné, semi-circulaire, son bord seul visible. Mandibules n'élant ni fortes, ni épaisses, triangulaires, arquées, très-aiguës à leur extrémité, unidentées à leur base. Mấchoires glabres, fortes, cornées. Palpes maxillaires ayant leur dernier article presque cylindrique; les labiaux cachés par le menton; leur article terminal beaucoup plus long que les deux autres pris ensemble, cylindroconique, grêle, mn peu obtus. Minton grand, eachant la plus grande portion des parties de la bouche. Tête plane, scmi-circulaire. Corps ğlabre, déprimé, ovale-oblong. Corselet en carré transversal. Ecussun distincl, triangulaire. Elytres laissant à découvert l'extrémité de l'abdomen. JamLes antérieures trideutées extérieurement.

Cryprode vient de denx mots grecs el signifie : dents cachées. L'espèce citée pall'auteur (C'rypt. paradoxus) est entièrement noire, parsenuée de points enfuncés. Tête bitulerculée. Elytres à stries élevées; iutervalles de ces strices ponclués. Nouvelle Hullande.

MÉCHIDIE, Mechidius. Genre de ColéoptèresScarabéludes, division des Arénicoles de M. Latreille, fondé par M. Macleay (Hora entom. vol. 1. pag. 140.) Cet aulear lui assigne pour caractères: 
antennes de neuf articles, le preaier grand, alongé, conique, le second court, coniquae, le truisième plus grêle, de même forme; le quatrièıne très-court; les cinquième et sixième cupulaires, les trois autres lancéolés, aigus, formant une massue ovale. Labre crustacé, son bord échancré. Mandibules courtes, triangulaires, arquées extérieurement, aiguës à l'extrémité, sans ancunes dents intérieures. Mâchoires sinuées, multidentées à leur extrémité. Palpes maxillaires ayant leur dernier article cylindrique, tronqué an bout. Palpes labiaux très-courts. Meuton grand. Tèle demi-circulaire, sans suture trans. versale. Chaperon échancré en derant, son bord relevé. Cavité buccale fermée dans le repos par le labre et le menton. Curps oblong, ovale, rlabre, déprimé. Elytres laissant à découvert l'exirémilé de l'abdomen. Corselet transversal, presque convexe, échinacé en devant, ses côlés convexes, sou bord postérieur tronqué presqu'en angle obtus. Ecusson triangulatre. Palles forles, un peu comprintées. Jambes antérieures tridentées extérieuremens. Le type de ce genre est le Mech. spusrius. (Trox spurius Kıв. Truns Limn. vol. 12. pag. 462.) Nouvelle Hollaude.

phoßERe, Phoberus. Genre de CuléoplèresScarabéides, division des Arénicoles de M. Latreilie, établi par M. Macleay (Horce entom. vol. 1 . l)ag. 137.$)$ Il a pour caracticres : antenues de dix articles, le premier triangulaire, grand, épars, velu; le second oblong, globuleux; le troisieme conique, grèle; les qualicune, cinquième, sixie me et septiene cupalaires. Labre deni-cirulaire, cruslacé, à peine échancré en devaut, cilié. Mundibules forles, courtes, épaisses, triarsnnlaires, arquées, puint dentées, très-aiguës à lenr extrémité. Máchones velues. Demier article des palpes marillaires ovale, cylindique; les labiaux courts, leur arlicle terminal ovale, cylindrique, plus gros que les autres. Menton court, presque ciaré. Têle deni-circulaire. Corps convexe, un peu plane en dessous. Corselet un peu rugneux, recourran la base de la tête, ses bords latéraux dilatés. Ecussan pretit. Elytres recouvrant entièrement l'abdomen. Point d’ailes. Jambes antérieures à prone dentées. H. Macleay place dans ce gente le Tiox horridus no. 7. FAB. Syst. Eleut. Da Cap de Bonnc-Espérunce.

HYBOSORE, Hybosorus. Genre de Cul'oplèresScarabéiles appartenant a la division des Arénicoles de M. Latreille; M. Macleay a qui l'on doil ce senré, en développe les caractères dans ses Hore entom. (vol. r. pay. i2o.) de la manière suivante : antennes de dix articles, le prenier grand, épais, velu; le second presque globuleux ou conigne, les cinq suivans cupulaires, le huitiene infundibulitorme, iecevant les deux derniers et fícuasl a véc eux une massue atrondie, pres- que conique. Labre apparent, très-convexe en devant. Mandibules fortes, avancées, en faux, aignës à l'extrémité, point dentées. Quatrième article des palpes maxillaires allongé, cylindrique, un peu aign à l'extremité. Dernier article des labiaux à peu près de la longucur des cleux autres pris ensemble. Menton en carré-oblong. Corps ovale, convexe. Têle semi-circulaire. Ecussou distinct. Elytres recouvrant l'abdomen. Jambes antérieures tridentées extérieurement. Ce genre a pour lype l'Hyb. arator. (Geotrupes arator $1^{\circ} .75$. FAB. Syst. Eleut.) D'Espagne.

ORPHAÉ, Orphnus. Ce genre de ColéoptèresScarabéides rapporté avec diuce par M. Latreille à un groupe de la division des Arénicoles, a été fondé par M. Macleay ( Itorce entom. vol. 1. pag. 119.) Il a pour caractères: antennes de dix arlicles, le premier grand, peu alongé, conique, le secoud presque globuleux, les cinq suivars très-courts, transversaux, les autres s'élargissant un peu progressivenent el furmant une trassue lamellée, presque globuleuse. Labre presque caché par le chaperon, son hord autérieur seul apparent. Mandibules avancíes, arqućes, presfue triangulaires, épaisses ì leur base, arrondies extérieureneat, atguës à leur pointe, midentées intérieurement. Mấchoires non dentées. Deruier a:tiele des palpes labiaux plus grand que les autres, presqu'ovale. Menton presque carré, tronqué ì l'extrémité. Chaperon des máles unicorre. Elytucs ne iecourant pas l'abdomen postérienrement. Jaubes antérieures tridentées a leur côté externe. Lianteur cite comne type de ce gente le Geotrupes bicolor no. 27. Fa B. Syst. Eleut. (Orph. bicolor.) De l'Inde.

ACANTHOCERE, Acanthocerts. Ce genre de Coléoplères-Scarabéides créé par M. Macleay (Horce entom. vol. 1. pag. 136), tire son nom de deux nots gress cqui ont rapporl à l'épine dont les antenues sont nunies. Il eal placé par M. Latreille dans sa division des Arénic les, mais avec doute. L'auleur lui donne pour caractères: antennes de dix articles; le premier éuais, triangnlaire, son angle antérieur prolongé en une épine aigné, l'antre tronqué, reeevant le second article qui est peit el conique. Massne presqgue pectinée, compośe d’arlicles divergens. Labre incliné, a vancé, : n carré transversal. Mandibules saillantes, cornćes, fortes, oblongues, épaisses, presque pen'agones, concaves en dessus, leur extrémité prescynaignë. Mâchoires unidentées intírieurement. Palpes maxillaires ayant leur dernier article tres-long, cylindrique, obtus à l'extrénité; les labiaux courts, leur troisième article presque conique. Chaperon avancé, presque carré, son bord autérieur portant un lobe un pen aigu. Cavité buccale cachte sous la lêle. Parties de la bouche verticales. Corps ovale, tres-convexe. Abdomen 
globulenx, entièrement reconvert par les élytres. Corselet orbiculaire, son hord postérieur demi-circulaire; ses angles postéricurs éclıancrés. Ecusson grand. Pattes (surtout les postérieures) grandes, Jarges, comprimées, pouvant un peu se contrac1er. Jamhes extórieurement arquées, plus étroites et presqu'aigruës à leur base, les antérieures à peine dentelées au côté externe, les autres ne l'étant nullemeut: tarses grêles, les quatre postérieurs se recourbant le long des jambes et s'y cachant. M. Macleay mentionne deux espèces de ce gente; l'une d'elles est le Trox spinicornis $\mathrm{n}^{\circ} .10$. FAB. Syst. Eleut.

ANOPLOGNATHE, Anoplognathus. Léach. Mace. Lat. Rutela. Schenn.

Genre d'insectes de l'ordre des Coléoptères, section des Pentamères, famille des Lamellicornes, tribu des Scarabéides (division des Playllopliages ).

Celte division conlient plusieurs groupes dont le premier a pour caractères : mandibules forles, entièrement. cornées. Extrémité des mâchoires saus dents ou n'en ayant que deux. Antennes de dix articles. (Voye ScarabéiDes.) Quatie gentes en dépendent: Amoplognathe, Leucothyrée, Apogonie et Amblytère. lie second et le dernicr out leurs mâchoires un peu dentées. Les Amblytères ont en outre les troisième et quatricme articles des antennes globuleux; les Leucothyrées ont ces mêmes articles grêles, cylindriques, et l'un des crochets de leurs tarses est bifide : dans les Apogonies tous les crochets des tar'ses sont bilides. Du reste ces trois genres onl toujours l'arrière-sternum sans prolongeinent.

Antennes de dix articles; le premier conique, épais; le second presque globulenx; les quatre suivans presque coniques; le septième cupulaire, très-court; les trois derniers formant réunis une massue lamellée, plicatile, alongée, demi-ovale, velue. - Labre corné, transverse, acuminé au milieu de sa parlie antérieure. - Mandrbules courtes, un peu comprimées, fortes, entièrement cornées, presque urigunes, épaisses à leur base, obtuses à l'extrémité, sans dents, très-eutières, convexes extéricurement. - Mâchorres enlièrement dépoxrrues de dents, fortes, cornées, presque trignnes, voûtées, obtuses au bout, un peu ćchanciées. - Palpes maxillaires presqu'en massue, de quatre articles; les laliaux courts, de trois articles, le second très-court, le dernier ovale, s'avançant à peine au-de!à du menton. Menton presciue carré, échancré de chaque côté à sa base, sun milieu muni d'un prolongement un peu relevé. - Tête presque carrée, marquée d'une suture transversile. - Chaperon des femelles toujours arrondi, semi-circulaire, celui des miles quelquefois anguleux; son bord autéricur toujours relevé dans les deux sexes, quelquefois semi-cir- culaire eomme dans les femelles. - Corps un peu convexe, ovale. - Ecusson distinct, arrondi postérieuremen1. - Elytres recouvrant des ailes. Extrémité de l'abdonzen découverte, au moins dans l'un des sexes. - Amière-sternum souven: prolongé en pointe aiguë atteiguant presque la base des hanches antérieures. - Pattes trèsfurtes. Jambes antérieures (au moins daus les máles) foiblement bidentées au côté externe, les posiérieures ayant à leur extrémité une coúronne d'épines outre les deux ordinaires. Les quatre premiers articles de tous les tarses très-courts, un peu triangulaires, le cinquiène cylindro-conique, plus long que les quatre autres réunis, terminé par deux crochets forts, inćgaux, enliers.

Ce genre dont le nom vient de trojs mots grecs qui signifient : mâclıoires dépourvìes de dents, rerferine un petil nombre d'espèces propres à la nouvelle IJollande; leur taille est grande on moyenne; leurs couleurs sont brillantes, souvent mćtalliques. On ignore leurs moenrs et leurs babitudes, mais daprès la conformation de leur bouche, il est probable qu'ils se nourrissent de feuilles ainsi que les IIannetons.

Ripportez it ce genre les Anoplognathes $1^{\circ}$. viridi-ceneus. Léac日. Zool. miscell. vol. 2. pag. 44. ( Macs. Hor. entom. pag. 144. $\mathrm{n}^{\circ}$. 1. Melolontha viridi-aurea. Donov. Ins. New. Holl.); $2^{\circ}$. viridi-tarsis. Líach.; $3^{\circ}$. rugosus. Kıв .; $4^{\circ}$. inustus. Krnb. Ces trois derniers probablement décrits dans le Zool. miscell.; 50. Dytiscoides. Macr. Hora entom. page 144. no. 2. et 6०. Brownii. MAcL. id. $n^{\circ}$. 3 .

LEUCOTHYRÉE, Lencothyrens. Genre de Coléoptères-Scarabérdes de la division des Phyllophages de M. Latreille, fondé par M. Macleay (Horce entom. vol. I. pag, 145), et qui suivaut cet auteur a pour caractères : antenues de dix articles, le premier conique, velı, le second presque glo! uleux, les troisième $t t$ quitrième assez longs, cylindriques, très-grêles; le septième trèscourt, cipulaire, les auties formant une massue demi-ovale, velue. Labre grand. Mandibules eonrtes, presqne triangulaires, planes en dessus, plus épaisses à leur extrémité, entières, obtuses, arquées extérieurement, velues. Mâchoires fortes, courtes, leur pointe obtuse, inunie de deux petites dents. Palpes maxillaires presqu'en massue; les labianx très-courts, leur dernier arlicle dépassant à peirse le menton. Menton transversal, presque carró. 'Tète presque carrće, narquée d'une suture transversale. Chaperon demi-circulaire, son bord relevé. Corps ovale-ọblong, un peu convexe. Côtés du corselet sinués. Arrière-sternım sans prolongement. Cuisses point renflées. Jambes antérienres n'ayant que trois dents très-petites an côté externe. 'Tarses terminés par deux crochets dont l'un est bifide. Leueothyrée vient de deux 


\section{S C A}

mots grecs dont le sens est : écusson blanc. L'auteur n'en décrit qu'une seule espèce qui lıabite le Brésil. ( L. Kirbyanus.) Côlés du corselet et du dessous du corps couverts d'écailles blanchâtres ainsi que l'écusson. 'Tête et corselet cuivreux, ponclués. Elytres d'un vert brun, mattes, ayant quatre lignes peu élevées. Anus rugueux, ayant deux petiles liznes formées par des écailles blanches. Corps cuivreux en dessous.

APOGONIE, Apogonia. Kirв. Lat. Genre de Coléoplères-Scarabćides établi par M. Kirby (Traus. Linn. Soc. vol. I2. pag. 401 , mémoire intilulé : Cent. of. ins.) et placé par M. Latreille dans sa division des Phyllophages. L'autenr lui attribue les caractères suivans : labre arrondi postérieurement, muni dans son milieu antárieur d'une pointe parliculière. Lèvre Iransversale, presqu'acuminée dans son nulieu, portant les palpes labiaux à sa base. Mandibules un peu arquées, cornées, très-forles, voûlées et presqu'échancrées à l'extrémilć. Palpes un peu en massue. Anteunes de dix arlicles, les trois derniers formint une massue presque lancéolée, velue. Point de prolongement au steruum ni à l'arrière-slernum. Tous les crochets des tarses bifides. M. Kirly ne décrit qu'une seule espèce, Apog. gemellata, $p l .21$. fig. 9. de l'ouvrage précilé. Corps oblong, presque cyliudrique, glabre, brillant, fortement ponctué, d'un brun-noirâlie. Antennes et palpes de conleur rousse. Corselet transversal, convexe. Elytres d'un brun cuivreux, ayant quatre stries longitudiuales. Du Brésil?

AMBLYTìRE, Amblyterus. Genre de Colónptères-Scarabéites de la division des Pbyllophages de M. Latreille. M. Macleay (Horce entom. vol. I. pag. I 42.) l'a étalili et caractérisé ainsi : antennes de dix articles, le prenier soyeux, les second, troisième, quatriène et cinquième globuleux; les sixième et sepptième courts, cupulaires. Iabre velu, avancé, un peu lobé en devant et fléchi. Mandibules cornées, courles, forles, presque triangulaires. Mîthoires presque cylindriques, garnies de très-petites dents. Palpes maxillaires grêles, leur dernier article lancéolé, plus long que tous les autres pris ensemble. Palpes labiaux ayant leur article terminal nvale, épais. Menton presque carré, très-velu. 'Tête presque carrée, ayant une suture transversale. Chaperon arondi en devant, son bord un peu relevé. Corps ova!e, Ecusson grand, triangulaire. Elytres ne recouviant pas l'extrénilé de l'abdomen. Arrière-slernum sans prolongement. Palles assez fortes. Jambes antérieures tridentées exlérienrement. L'espèce rapportée par M. Macleay est l'Amb. geminatus. Brun, convert en dessous de poils testacés. Chaperon et corselet ponctués, d'une coulcur d'olive cuivreuse. Ecusson glabre, cuivreux. Elytres d'un brua cnivreux, ponctuées, ayant quatre séries de points disposées par paires. Anns velu. Pattes cuivreuses, velues.

Nouvelle Hollande.

\section{GÉNIATE, Geniates. KIRB. Lat.}

Genre d'insectes de l'ordre des Coléoptc̀res, section des Penlanères, famille des Lamellieornes, tribu des Scarabéides (division des Phyllopliages ).

Ce genre forme seul parmi les Phyllophages, une subdivision qui a pour caractères : mandibules lortes, enlic̀rement cornées. Màchoires pluridentées. 'Tarses antérieurs des máles dilatés et garnis de brosses en dessous. Antennes de neuf articles.

Antennes de neuf arlicles, le premier long, conicque, fort grêle à sa base, le second globuleux, les deux suivans presque cylindriques, courts, le cinquiène un peu plus long, en cornet; le sixième très-pctit, cupulare; les trois derniers formant une massue alongée, lancéolće, linéaire, velue. - Labre lrausversal à angles antérieurs oblus, ayan! un pelit prolongrement unclinédans son milieu en dessous. - Mandihules un peu arguées, cornces, fortes, tridentées à l'extrémilé. - Mâchoires pluridentées. - Palpes maxillaires de quatre arlicles; les second et troisième assez courts, coniques, le deruier fort long, presque cylindrique, linćaire, comprimé. Palpes labiaux de trois articles courts, le dernier plus long que les autres, linćaire, comprimé. - Lèvre transversale, très-large, courte; menton portant (dans les mâles) une plaque circulaire très-velue, imilant une brosse courle. - Téte forte; claperon arrondi antériemrement, rebordé, séparć de la tête par une strie ondulée, trausversale, un peu saitiınle. - Yeux lrès-gros, saillaus.-Corps presque liuéuire, arrondi à ses deux extrémilés, convexe. - Corselet transversal, ses angles antérieuts assez saillans, ses côtés arlondis, son bold postésieur un peu sinué. - Ecusson grand, presqu'arrondi postérieurement.--Elytres recouvrant des ailes, laissant l'exlrémilé de l'abdomen à découvert. - Abdonen épais. - Pattes fortes; tarses antérieurs des mâles ayant leurs qualre premiers articles très-dilalés, garmis en dessous de brosses fort éparsses; le cinquième terminé par deux crocluets, l'un entier, l'autre bifide; crochets ancérieurs inégaux, le plus gros bifide, l'une de ses divisions obıuse dans les uales.

On doit l'établissensent de ce genre à M. Kirby, qui l'a publié daus les Transactions de la Société Linnéene, yol. 12. pag. 40 I. Son nom vienl du grec et a rapport à la brosse de poils que l'on voit au menton des máles. l.es mœur's de ces Colćoptères nous sont inconuues. Ils nous paroissent propres à l'Amérique méridionale. Le type du genre est le Geniates barbatus. Kонв. Trans. Linn. Soc. vol. I2. pag. 405. pl. $21 . \mathrm{Jig} .8$.

Du Brésil. 
HANNETON, Melolontha. LAT. Voyez pou" les autres synonymes le mol HaNNETON, tom. VII. frag. 4 .

Genre d'insectes de l'ordre des Coléoplères, section des Pentanéres, famille des tamellicornes, tribu des Scarabéites (division des P'luyllophages ).

Nota. Ce genre tel qu'il a été publié tome VIT. de cet onvrage, renferme un très-grand nombre d'espèces que les naturalistes modernes ont depuis placées dans plusienrs aulres genres. L'auteur lui ussigne positicement pour premier caractère d'avoir dix arlicles aux antennes, tandis qu'il est certain que plusieurs des espèces qu'il y range r'en on que neul. Tel qu'il est adopté aujourd'liui par M. Latreille, il fuil partie d'un groupe de la division des Phyllophages ( yoyez Scarabéides), qui a nour caractères : ntandibules fortes, entièrement cornées. Mâchoires pluridentées. 'Tarses semblables el sans bosses dans les deux sexes. Massue des antennes de cinq fevillets dans les inâles et de qualıe dans les fermelles, ou de sept feutllets dans les mấes et de six dans l'autre sexe. Le genre Pachype qui seul fait parlie du même groupe, se listmgue des Hannetons pare que ses duteunes ont unarticle de moins, c'est-i-dire neuf, et que le corselet a un enfoncement ì sa partie antérieuse.

Les Ilannetons ont le corps revètu d'écailles, ou de poils courts, couchés et aplatis; leurs tarses sont conposés d'articles cylindro-coniques, le dernier leraniné par deux crochels entiers el fortenıent deutés ì leur base dans les deux sexes.

Ce grente ainsi restreint peut être divisé comme il suit :

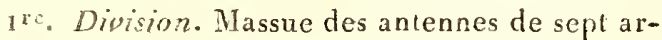
lives dans ter mâles, de six dans les fernelles.

re. Subdivision. Partie supérieure de l'anus ayaut un prolongement.

On rapportera à celle subdivision le Hanneton vaigaire $0^{0}$. 7. fl. 155. fig. A-H. el pl. 154. li.r. $1-5$. de ce Dictionnaire, ainsi que la MeloIontha Hippocastuni $n^{\circ}$. 7. FAB. Syst. Eleut.

$2^{\mathrm{e}}$ Subdivision. Anus san prolongement.

Dans cette subdirision viennent-se placer : les llannetons $11^{\circ}$. foulon $11^{\circ}$. 1, pl. 153 . fig. 10. $2^{\circ}$. blanclâare no. 2. $3^{\circ}$. semi-strié $1^{\circ} .6 .4^{\circ}$. cilié $\mathrm{n}^{\circ}, 25$. pl. 153. fig. 13. de ce Dictionnaire, et Les Melolontha Olivieri. Des. Catal., et Papposa. liLig. Mlagaz. tom. 2. pag. 215. no. 3 .

$z^{\mathrm{e}}$. Division. Massue des antennes de cinq artictes dans les mâles, de quarre dans les fenelles.

Là se rangent les Hannetons cotonneux no. 8. pl. 153. fig. 6 , et occidental no. 9. pl. 154. fig. 17 . (Meloiontha austratis. Scran N, Sym. Ins. 3,p. $16 \mathrm{~g}$. $\left.3 t^{\circ} .15.\right)$ dn present ouvrage.
PACHYPE, Pachy'pus. Dej. Lat, Melolontha. Orrv. Geotrupes. FAB.

Genre d'insectes de l'ordre des Coléoptères, section des Pentauères, firmille des Lamellicornes, tribu des Scarabćides (division des Pbyllophages).

Le genre Janneton et eelui de Pachype snnt les seuts de cette division qui aient pour caractères communs : mandibules fortes, entierement cornées. Mâchoires pluridentées. 'Tarses semblables et sans brosses dans les deux sexes; mais le premier a souveut plus de cinq feuillets à la massue des antennes; celles-ci ont constamment dix articles, et le corselet est eonvexe, sans aucumo excavation antérieure.

M. le comte Dejean n'a pas encore publié les caractères propres à ce genre. Fabricius trompé par l'habitus de cesinsectes, et surtout par l'excavalion de la parie antérieure de leur corselet, avoit placé l'espèce qui a servi de type parmi ses Géolrupes, sans aroir fait une attention suffisante à la structure de la bouclie et des antennes.

\section{Pachype excavé, $p$. excavatus.}

Pachypus excavatus. Des. Caltal. - Geotrupes excavatus. FAB. Syșt. Elcut. tom. 1. p. 19. $76^{\circ} .67$. -Encycl. pl. 156 . fig. 19 el 19 bis.

Longueur 6 à 7 lig. D'un châtain clair. Antennes de neuf articles; le premier alongé, très-velu d l'extrémité; le second court, grenu; le troisième presque cylindrique; le quatrième petit, crupulaire; les cinq derniers formant une massue lamellée, assez grosse. Tête pointillée, ayant au nilie a une ligne transversale saillante. Chaperon arrondi, rebordé. Corselel lisse, luisant, a vec une profonde excavation antérieure accompagnée d'une petite fossetle latérale et munie en avant d'une petilo corne pointue et relevée. Ecusson lisse, luisant, s.rrondi postérieurement. Elytres de conleur matte, allant ẹn diminuant de laryeur, à stries pointillées, peu prononcées; leur extrémité portant une grande tache noirâtre ayaut plus on moins d'éiendue. 1)es. sous du corps, de la bonche et eôlés du corselet garnis de longs poils roux ou cendrés. Pattes d'un fauve plus ou noins foncé. 'Tarses très-longs; chaque article garni à son extréunté d'une couroune de cils longs et roides : crochets simples, entiers, égaux. Màle.

Il vatrie: le corselel etl'écusson sont quelquefois noirâtres.

'Trouvé en Corse par M. Binot de Villiers, dans les sables eutre Cervione et Alléria, $\therefore$ sur les rochers bordant la route qui conduit a Bonilacio. Il habite aussi dans le midi de la France.

Voyez pour la phrase latine Hannelon corna no. 19. du présenı Dictionnaire. (Retranchez le synonyme de Petagna d'après les observations de M. Louis Petagna daiss les Atti del. reul. Acad. 
Napol. 1819. Mem. class. di fisic. di Stor. nat. pag. 24. Cet auleur assure qne le Scarab. Candidoe de Vineent Petayna a les élytres plns longues que le eorps, ee qui ne convient nullement au Paehype excavé; mais eomme il ne décrit pas le Scacub. Candidoe, nous ignorons à quel genre uppartient celle dernière espèce mentionnée dans le Spec. Ins. Calab. Fabricius a fait la même faute, trompé probablement par Cyrillo, Entom. Ncapol., qui le premier a confondu ces deux espèces.)

lRHIZOTROGUE, Rhizotrogus. LAT. Melolontha. OLuv.

Genre d'inseetes de l'ordre des Culéoptères, section des Pentamères, famille des Lanellicornes, triba des Scarabéides (division des Phyllophages).

l,e grompe de cette division qui contient les geñres Rhizolrogne et Aréode a pour earacières : mandibules forles, entièrement cornées. Mûchoires phuridentées. 'Tarses semblables el sans brosses dans les deux sexes. Antennes de dix articles, leur massue tonjonrs de trois feuillets. (Joy. Srarapćides.) Mais les Aréodes sont suffisamment disingnés des Rhizotrogues par la forme du eorps beacoup plus large, l'arrière-sternum pointu, arancé, el par les crochets des tarses non dentés à leur base.

M. Latreille n'ayant pas encore donné les earactères de ce geure, nous ne pouvons le désigner que pär la comparaison que nous venons d'établir entre lin et les autres Phyllophages, en ajoutant que les crochets de tous ses tarses sont entiers, '́gaux, fortement unidentés vers leur base. Les espèces peu nombrenses qu'il contient n'ont point d'autres wours que celles des Hannerons, ce qu'indique le nom de Rhizotrogne tiré de deux mots grees dont la signilicalion est : rongeurde racines. Le type est le Hanneton estival $n^{\circ} .13$. de ce Dictionnaire (Rhiz. astivus). Nons pensons que la Melolontha nuaritima. Bureheis. Des. Catal. est de ce genre. Dans le unâle de cette espèee lè septième article des antenues est prolongé en uue lame, mais beaueoup plus eourte que eelles de la massue.

ARÉODE, Areoda. Genre de Coléoptères-Scarabćides de la division des $\mathrm{Pl}$ hyllophages de $\mathrm{Ml}$. Latreille, élabli par M. Nacleay (Horee entom. vol. t. pag. 158.) Ses caraetères sont: antennes de dix articles, le preuier oblong, conique, velu; le second eourt, presque glohuleux, les cinq suivans courts, les trois derbiers formant une massue alougée, presque lancéolće. Labre corné, son bord antériear apparent, épais, profondément échancré à sa partie inférieure. Mandibules cornées, forles, presque trigones. Màchoires fortes, cornées, ayant six dents à leur exırémité. Palpes maxillaires ayant leur qualrième ou dernier arti- cle alongé, ovale ou eyliudrique, un peu aigu à son extrémité. Article terninal des palpes labiaux assez gros, ovale. Menton et tête presque earrés. Cliaperon ayant ses côtés arrondis et son bord relevć. Corps ovale, eonvexe. Elytres convrant des ailes et laissant à déeouvert l'exirémité de l'abdomen. Corselet presque trapézoidal, à peu près deux fois plus large à sa base que longr, son bord postérieur sinué, à peine lobé. Ecusson moyen, en eœu tronqué. Arrière-sternum prolongé en p inte, au moins jusqunà la base des hanelıes intermédiaires. Paltes assez fortes. Jambes bidentées. Croehets des tarses entiers, égaux el simples dans les individus que nons regardons comme femelles; ińgaux, les antérieurs ayant leur gros eroehel bifide, les intermédiaires et les postérieurs enties's et simples, dans ceux que nous soupconuons mâles.

Ce genre américain ne paroît eontenir qu'un petit nombre d'espèces. Elles sont remarfuables par le beau reflet brillant et métallique çu'offre leur eorps. M. Macleay en décrit me espéce da Brésil sous ie nom d'Ar. Leachii. Vert très-brillant. Dessus du eorps d'un testaeé livide à reflet verl-doré. Tête et corselet poncluŕs. Elytres ponctućes, à stries géminf́es. Eeusson glabre. Anus vert, ruguenx. Patles d'un vert-doré. Suivant nous le Hanneton laineux $n^{0} .2$ ! pl. 156. tig. 2. de ese Dierionnaire esl une Aréode.

POplulde, Popillia. Léach. Dej. Catal. Eat. Trichius. Fab. Melolontha. Oliv.

Genre d'insectes de l'ordie des Coléoplères, section des Pentamères, famille des Lamellieornes, tribu des Scarabéides (division des Playlluphages).

Les Phylloplages qui ont les mandibules fortes, entièrcment coruées, les mâchoires pluridentées, les larses semblables et saus brosses dans les deax sexes, les antennes de neuf artieles avee la massue cie trois artieles dans les mâles ainsi que dans les femelles, sont les genres Popillie, Amphimalle, Euchlore, Pleetris et Dasyus. Mais ces quatre dermiers ont l'arrière-sternum mulinue; de play les Amphimalles ont tous les crochets des tarses égaux, entiers, unidentés à leur base; dans les Euchlores tous les eroehels cies tarses sont manifester enı inégaux entr'fux; les Plecuris et les Dasyus ont tous leurs crochets antérieurs bifices.

Le doetenr léaeh n'ayant pas eneore publié les earaetìres de ce genre, nous allous présenter ici ceux qui nous ont paru les plus firappans.

Antennes de ncuf arlicles, le premier en massue, dilaté à sa partie supérieure, le second globuleux, le troisiène cylindro-eonique, m pen plus lung que le précédent, les trcis suivans cupulaires, diminuant de longueur en approchant de la massue. Massue ovale-oblongue, peu velue. --. Dernier article des palpes maxillaires presque cylindrique, beaucoup plus long que le précédent; 
palpes labiaux fort eourts. - Chaperon transversal, rebordé, séparé de la tête par une suture transverse, ses angles antérieurs arrondis.-Corps large, déprimé. - Corselet beaucoup plus étroit en devant qu'à sa partie postérieure, sa base rentrant beaucoup dans son milieu entre les angles huméraux des élytres, eette partie rentrante coupée et un peu échancrée vis-a-vis de l'écusson. Arrière-stermum élevé, avancé en pointe mousse jusqu'à la base des hanches antérieures. - Ecusson grand, triangulaire, - Elytres recouvrant des ailes, laissant à nu l'extrémité de l'abdomen. Pattes de longueur moyenne. Jambes antérieures ayant deux dents au côté externe, la supérieure peu prononcće ; les intermédiaires et les postérieures garnies de petites épines placées par lignes transversales. Dernier arlicle des tarses aussi long ou plus long que les quatre autres réunis. Crochets postéricur's presqu'égaux, entiers dins les deux sexes. Les antérieurs et les in termédiaires inégaux, le petit entier, le gros bilide, ses divisions pointues, presqu'égales dans les femelles; les aniérieurs et les intermédiaires f́gaux, le petit entier, le gros bifide, ses deux divisions, dans les antérieur's seulement, inégales; la plus grosse obtuse dans les máles.

Une espèce de Popillie ( $P_{o p}$. bipunctata) est décrite dans le présent ouvrage sous le nom de Hanneton biponctué $\mathrm{n}^{\circ} .62$. Les deux taches blan. ches dont il est parlé dauss la description sont situées près du bout des élytres en dessus de l'extrémité de l'abdomen. Sa patrie est l'Afrique australe. On doit aussi rapporler à ce genre la Cétoine quadriponctuée no. 120. pl. 16, fig. 162. de ce Dictionnaire. (Pop. quadripunctata.)

Des Indes orientales.

AMPHimalite, Amphimallon. Lat. Melolontha. FAb. Oliv. PAYK. Herbst. Scarabaus. Linn. De Géer. Geoff.

Genre d'insectes de-l'ordre des Coléoptères, section des Pentamères, famille des Lamellicornes, tribu des Scarabéides (division des Phyllopliages ).

Cinq genres forment un groupe parmi les $\mathrm{Plyy}$ lophages (voyez Scarabeides); ils ont pour caractères communs: mandibules fortes, entièrement cornées. Màchoires pluridentées. Tarses semblables et sans brosses dans les deux sexes. Antennes de neuf articles, leur massue de trois feuillets dans les mâles comme dans les femelles. Les Euchlores se distmguent des Amphimalles par les crochets de leurs tar'ses inégaux et non dentés à lenr base; les Popillies par leur arrière-sternum prolongé en devant; en outre, ainsi que les Plectris et les Dasyus, elles ont toujour's quelques-uns des crocliets de leur's tarses bifides.

$\mathrm{Ne}$ connoissaut point les caraetères propres à ee genre, l'auteur ne les ayant pas encore publiés, nous pensons que eeux indiqués ci-dessus et les croehets de tous les tarses égaux, unidentés à leur base, peuvent suffirc pour le faire reconnoitre. Son nom vient de deux mots grecs qui ont rapport à la villosité des espèees qu'il contient.

Les Hannetons erénelé no. 5. (Amph. serratum ), solstitial no. 12. pl. 154. fig. 7. (Amph. sol stiticle), du pin $n^{\circ}$. 14. (Amph, pini), villageois no. 15. (Alimph. paganum), noirâlte no. 16 . (Amph. atrum. Melolontha atra $\mathrm{n}^{\circ}$. 19. FAB. Syst. Eleut.) de ce Dictionnaire, doivent être rapportés à ce genre.

EUCHLORE, Euchlora. Maci. Lat. Anoinala. MÉg. Des. Catal. Melolontha. Fab. Olt. Payk. Herbst. Scarabceus. De Géer.

Genre d'insectes de l'ordre des Coléoptères, section des Pentamères, famille des Lamellicornes, tribu des Scarabéides (division des Phyllophages ).

Le second groupe de la troisième subdivision des Phyllophages (voyez Scarabeïnes) a pour caractères : mandibules fortes, entièrement cornées. Mâchoires pluridentées. Tarses semblables, sans brosses dans les deux sexes, qui ont également tous deux la massue des antennes de trois feuillets; il renferme sept genres, dont deux : Rhizotrogue et Aréode ont les anteunes de dix articles; les genres Euchlore, Amphimalle, Popillie, Plectris et Dasyus n'en onl que neuf, mais les Amphimalles different des Euchlores par les crochets de leurs tarses égaux, unidentés à la base; les Popillies par leur arrière-sternum prolongé en devant; les Plectris par les erochets des tarses bifides et les Dasyus parce que tous les erocliets de leurs tarses sont égaux.

Antennes de neuf articles, le premier eonique, alongé, le second court, globuleux, les trois suivans presque coniques, le sixième cupulaire, les septième, huitième et neuvième composant (dins les deux sexes) une massue ovale-alongée. Labre peu apparent, eaché en grande partie par le ehaperon; son bord antérieur cilié, échancié, ses cốiés arrondis. - Mandibules eachées, presque trigones, planes en dessus, leur côté extérieur arrondi, l'inlérieur cilié, tridenté à son extrémité. - Mâchoires flćclies ver's leur extrémité, celle-ci portant six dents. - Falpes maxillaires de quatre articles, le dernier cylindrique-ovale; les labiaux de trois articles, les deux preuier's égaux en longueur, le dernier en cône renversé, plus long que les précédens. - Menton presque carré, son bord antérieur échaneré. - Téte presque carrée; chaperon séparé de la tête par une suture transversale, ses côtés arrondis, son bord antérieur relevé. - Corps ovale, convexe. Corselet presque carré, à peu près deux fois plus large à sa base que long; son bord postérieur sinué, à peine lobć. - Arrière-sternum sans prolongement. - Ecusson petit, en cœuir tronqué. Elytres recouvraut des ail s et laissant l'anus à 
découvert. - Pattes assez forles. Jambes antérieures ayant deux dents au côté externe. Articles des tarses cylindriques, le dernier le plus long de tous : crochets inégaux, simples, c'est-à-dire non dentés à la base, dans les deux sexes; entiers dans les femelles : le plus gros des antérieurs et des intermédiaires, bitide dans les mâles.

Les Euchlores démembrées des Melolontha de Fabricius tirent leur nom du beau reflet vert dont brillent la plupa:t des espèces. Leurs mœurs sont celles des Hannetons. (Voyez ce mot.) Elles babitent les diflérentes parlies du monde et sont liabiluellement de moyenne taille.

On placera dans ce genre les Hannetons suivans de ce Dictionuaire : $1^{\circ}$. pâle, $n^{\circ} .34$. pl. 154 . fig. 8. (Euchl. pallida.) $2^{\circ}$. vert, $\mathrm{n}^{\circ} .47$. pl. 155. fig. 33. (Euchl. viridis.) 30. erranl, no. 76. de la Russie méridionale. (Elichl. errans.) $4^{\circ}$. de la vigne, no. 56. pl. 155. tig. 25. (Euchl. vitis.) 50. de Frisch, no. 57. pl. 155. fig. 23. (Euchl. Frischii.)

\section{PLECTRIS, Plectris.}

Genre d'insectes de l'ordre des Colćopières, section des Pentamères, famille des Lamellicornes, tribu des Scarabéides (division des Pliyilopliages).

Un groupe de cette division renfermant les genres Popillie, Amphimalle, Euchlore, Plectris et Dasyus, a pour caracteres : mandibules fortes, entièrement cornées; mâchoires pluridentées. 'larses semblables et sans biosses dans les deux sexes; antenoes de neuf arlicles; leur massue de trois feuillets dars les unâles et dans les femelles. De ces cinq genres, celui de Popillie a seu! l'arrière-sterouu élevé et avancé en pointe; les Anphimalles ont tous les crochets des tarses entiers; ces crochets, dans le genre Euchlore, sont manifestement inégaux; enfiu les Dasyus n'out aucun de leurs crochets iutermédiaires el postérieurs, bifide.

Anteunes de neuf articles, le premier alongé, en massue; le second globuleux, revilé ì sa partie extćnieure, le suivaut deux fois plus long que le deuxic̀me, un pen aplati et dilaté antérieurement vers son extrémiló; le quatrième alongé, cylindrique; le cinquième sourl, prolongé antériéurement cu une petule lame tort courte; le sixiène très-court, peu visible, copulaire; mässue trèslongue, velue, composée de trois feuillets égaux, étroits, presque linéaires. - Labre el mandıbuies cacliés. - Palpes maxillaires ayant lear dernier article long, presque cylindrique, beancoup plus grand que le précédent; palpes labiaux courls.Tête arrondie postérieureınent. - Chaperon rebrrdé, très-échancré en devant. - Yeux grands. -Corps assez ćpais, un peu convexe.-Corselet traasversal, ses côtés prolongés dans leur milien eu angle arrundi; son hord postérieur sinué. - Arrière-sternum sans prolongement. - Ecsisson. Hist. Nat́. Ins. Tome X. assez grand, arrondi postérieurement. - Elytres un peu convexes, recouvrant des ailes et l'abdomen. - Pattes de longueur moyenne; jambes antérieures un peu aplaties, n'ayant qu'une petite dent à leur côté extérieur; les cquatre postéicures cylindriques, assez courtes, un peu renllées; les denx dernieres munies d'un appendice fort lono, un peu aplati avant son extrémité qui est crochue et terminée en pointe. Tarses postérieurs ayant leur premier article très-long; leurs crochets, ainsi que les antérieurs, éyaux, bitides; ceux des tarses intermédiaires très-inégaux, l'un gros, bifide dès sa base, l'aulre très-mince, bifide.

Nous donnons à ce nouveau genre le nom de Plectris, liré d'un mot grec qui signilie: éperonné. L'insecte qui nous a servi de type présente des caractères si particuliers dans ses antennes et dans ses paltes, que l'on ne peut le joindre à ancun genre connu. Nous avons hési'é sur le groupe de Phyllophages auquel il appartient; lorsquion connoitra les deux sexes, si le mîle avoit les tarses antérieurs dilatés et garnis de brosses en dessons, il fatudroit le rapprocher des Géniates, mais nun pas le confondre avec eux.

\section{Plecrris velue, $\boldsymbol{P}$. tomentosa.}

Plectris testaceo-fusca, nufo tomentosa : pilorum ordine duplici, multis parvis substratis, paucis sparsis longionibus erectus : elytris costzs tribus obsoletis.

Longueur 7 lig. Corps d'un testacé-brun, chargê de poils roux, les uns très-nonbreux, courts et un peu couchés, les autres rares, longs et droits. Ecusson plus velu que le reste du corps et d'une nuance plus claire. Elytres ayant chacune trois peittes côtes, feu ćlevées, à peine apparentes.

Du Brési!.

\section{DASYUS, Dasyus.}

Genre dinsectes de l'ordre des Coléopières, section des Pentamères, famille des Lanellicornes, tribu des Scarabíides (division des Phyllophages ).

Cinq gentes composent le groune des Phyllophaces qui a pour caractères : nandibules fortes, entièrcuent cormées, mâclioires pluridentées. 'Tarses sans brosses el semblables dans les deux sexes. Antennes de neuf articles, leur massue do trois icuillets dans tous les individus. (Voy. Scar ABĖides.) Dans les Popillies l'arrière-sternum est élevé et avancé cn poiule; les Ampluinalles ont tous les crochets des tarses entiers; ceux des Euchlores sont tous inégaux, et les Plectris onı leus crocliets postérieurs bifides. On ne retrouve poins ces caracic̀res daus le geure Dasyus.

Anternes de neuf aricles, le premier conique, renflé antérieurement; le second trc̀s-court, glcbuleax, les trois suivans cylindriques, éganx, lo sixième petit, cupulaire; los truis denners form A a a 
$3-0$

mant une massue ovale-alongé, velue. - Labre et mandibules cachés. - Delnier article des palpes maxillaires assez grós, ovale, court (plas long cependant que le précédent); palpes labiaux peu apparens. - Tête presque carrće, ses angles un peu arrondis; chapcron trorqué antérieuremcut, réborcée. - Corps un peu déprimé en dessus. Corselet ayant ses bords latéraux et postérieur, arrondis. - Arrière-stemum sans prolongement. - Ecusson grand, plus large gue long. - Elytres reconviant des ailes, laissant à nu l'extrémicé de l'abdounen. - Pattes de longueur moyenne; jambes assez conrtes, les antérieures n'ayant qu'une petite dent an côté extérieur; les quatre postérienres cylindriques, renflées; crocliets des tarses égaux, les antérieurs bifides, les intermédiaires el les postéricurs entiers.

Le nom de ce genre a élé pris d'nn mot grec qui exprime la villosité de l'espèce qui nous sert de type. Nous regardons comme un fait certain que dans beaconp de geures Scarabéides-Phyllophages qui ont lears deux crochets antérieurs ou au moins l'un d'eux bifide, l'individu nâle a l'une des divisions du crochet bifide plus large, un peu aplatie et presqu'obınse à l'extrémité. N'ayant qu'un des sexes dalıs le genie qui nous occupe, nous engageons les entomologistes à examiner s'il n'en seroit pas ainsi des wăles que l'on duit y rapporter.

\section{D.ssrus à collier, D. collaris.}

Dasyus niger, punctatus, antennarum duobus articulis basilaribus, thorace suprà unguibusque ferrugineis.

Longuenr 4 lig. Noir-luisant, velu, ponctué. Les deux premiers articles des antennes ferrugineux ainsi que le dessus du corselet et les crochets des tarses.

Du Brésil.

AGACÉPJIALE, Agacephala. Ce nouveau genre a été envoyé par.M. le baron de Mannerheim à M. le comte Dejean qui a bien voulu nous permettre d'en prendre les caractères dans sa colleetion. Il appartient à la tribu des Scarabéides et, à ce que nous pensons, à la division des Phyllophages. Voici ce que nous avons aperçu de ses caractères.

Antennes de neuf artieles, le premier grand, en massue, gonflé à sa partie extérieure, portani dans cette partie des faisceaux de poils roides, le second conique, plns long que le suivant, gouflé extérieurement et hérissé de poils roides dans cette partie; le troisième conique, le quatrièmc moniliforme, les deux suivans cupulaires, les trois derniers formant une massue ovale-arrondie, velue. - Dernier article des palpes maxillaires très-long, en fuseau; palpes labiaux fort courts, dépassant à peine le chaperon ; leur dernier arti- cle court , ovale. - Mandibules et mâchoircs cachées par le chaferon et le menton: celui-ci presque triangnlaire, fortement cilié sur ses Dords, un pen échancré à sa partie antérieure. - Chaperon ćchancré en devant, ses denx angles antérieurs peu saillans, peu relevés. - Tête cornue. - Corselet très-bombé, son bord antérietr. śavançant sur la tête, un peu sinué sur les côtés derrière les yeax : bords latéraux arrondis; bord postérienr presque droit. - Ecusson transversal, presque triangulaire, un peu arrondi postérieurement. - Corps épais, un peu pubescent en dessous, à peu près conformé comne celui des Pélidnoles. - Elytres reeouvrant des ailes et laissant à nu l'extrémité de l'abdomen. - Pattes longues; jambes antérieures munies extérieurcment de denx fortes dents, outre la terminale : dernier article de leurs tarses anssi long que les qualre autres réunis. Jambes intermédiaircs et postérieuı es mnuies de deux dents (la supérieure seule bien visible ). Leurs tarses longs, à dernier arlicle plus long que les autres, t́galant à peu près en longueur les deux précédens réunis: crochels grands, simples, égaux, pointus, munis daus leur entredeux d'un appendice portant au bout deux ou trois soies roides.

Le nom d'Agacéphale vient de deux mots grees et signifie : tête remarquable. L'espèce servant de type a été nommée par M. de Mannerheim, Agacephala cornigera. Longueur 14 lig. Antennes, palpes et abdomen d'un testacé-brun; tête d'un noir-violet, portant de chaque côté au-dessus des yeux, une corne longue, triangulaire, un peu recourbće; ces cornes réunies à leur base postérieurement par une ligne élevée. Corselet, écusson, cuisses et jambes d'un vert-noirâtre un peu métallique. Le premier assez fortement ridé, un peu ponctué, ayant une pointe dorsale conique qui s'avance en devant. Elytres d'un testacé clair, fortement ponctuées, entièrcment bordées de brun; suture de celte dernière coulenr. Poils des antennes, de la bouche et du dessous du corps d'un roux ferruginenx ainsi que la base du dernier article des tarses.

Ce singulier Colćoptère cst de la province de Minas Geraes au Brésil.

\section{CÉRASPIS, Ceraspis.}

Genre d'insectes de l'ordre des Coléoptères, section des Pentamères, famille des Lamellicornes, tribu des Searabéides (division des Phyllophages;.

Dans le quatrième groupe des Pbyllophages, lequel a pour caractères : portion interne des mandibules woins solide que l'autre ou membrianeuse. Antennes de neuf à dix articles, les trais derniers formant la massue; deux crochets aux tarses postérieurs, les genres Dicranie, Macrodactyle, Diphucéphale, Sérique et Dielièle ont toús les crochets des tar'ses égaux et bilides. Dans 
les Anisoplies et les Lépisies tous les crochets sont inégaux et les postérieurs entier's; caractères qui éloignent tous ces genres de nos Céraspis.

Antennes de dix articles, le premier en massue, le second globuleux, les deux suivans ovales, plus longs que le second; le cinquic̀me plus long que le précédent, cylindrique, le sixième assez grand, cupulaire, le septième de même forme que le sixième, mais beaucoup plus petit; les trois derniers formant une massue ovale, très-alongée surtout dans les nâles, velue. - Labre et mandibules cachés. - Palpes cuurts; dernier article des maxillaires court, ovale, plus long cependant que le précédent. - Tête asscz petite, se rétrécissant en devant; cliaperon rebordé, tronqué en devant; ses angles antérieurs arrondis clans les feouelles, presque droits daiss les mâles. - I eux grands. - Corps assez épais, un peu convexe en dessus, garni de petites écailles. - Corselet convexe, ses bords laléranx assez arrondis, le postérieur ayant dans son milieu trois dentelures qui laissent entr'elles deux échancrures. - Ecusson cordiforme, un peu arrondi postérieurement, ses angles supérieur's presquaiarus, se logeant dans les deux échancrures que présente le bord postérieur du corselet. - Elyties un peu convexes, recouvrant des ailes et laissant à nu l'extrémité de l'abdomen. - Pattes assez longnes; jambes un peu aphaties; les antérieures munies d'une petite dent au côté externe; les deux crochets antérieurs égaux, bifides; les deux intermédiaires un peu inégaux; bifides dans les femelles; le plus fort des deux entier dans les mâles. Les dcux crochets postérieurs inégaux, le petit bifide, l'autre entier.

Ces jolis insectes dont le nom vient de deux muts grecs qui signifient: écusson en cour, ont quelques rapports avec les Géuiates; mais les signes caractéristiques des sexes les en distingue facilement. Les écailles qui garnissent le corps leur donne quelque ressemblance a vec les Hoplies, mais les Céraspis ont deux cruclets aux tarses pustérieurs; la forme particulière de leur écusson es de la partie postérieure du corselet les ćloigne de tous les autres Scarabéides. Ces diverses cunsidérations nous aulorisent à proposer ici celte nouvelle coupe générique.

\section{Céraspis écailleuse, $C$. pruinosa.}

Ceraspis ferrugineo - testacea, clypeo nigro marginato, undiquè squamosa, squamis dorsalibus et analibus albidis, catcris lutescentibus.

Longueur.7 lig. Futièrement d'un testacé-ferruginenx, garnie d'écailles; corselet et élytres ayant une ligne dorsale beaucoup plus large sur celles-ci, foruée d'écailles blanchàtres. I.e corselet a en outre des deux côtés de cette bancle blanche des écailles relevées, noires. Celles qui couvrent et avoisinent l'auus blanchâtres; les au- tres d'un jaune sale. Chaperon bordé de noir antérieurement. Mâle et femelle.

Du Brésil.

Nota. Cette espèce porte dans la collection de M. le comte Dejean le nom que nous lui avons conservé; elle y est placée parmi les Géniates.

\section{CÉraspis demi-deuil , C. melanoleuca.}

Ceraspis migra, suprà squamis fuscis ct nigris, sublis et ad latera postica thoracis squamis niveis obsita, unguibus testaceis.

Longueur 3 lig. $\frac{x}{2}$. D'un noir mat. Dessus de la tête, du corselet et des élytres couverı d'écailles noires; on en voit quelques-unes roussâtres sur les élytres. Côtés postérieur's du corselet et dessous du corps garnis d'écailles d'un blanc de neige, ainsi que le dessus de l'anus. On en remarque aussi quelques-unes de cette couleur au-dessus de l'écusson : celui-ci, le corselet et la base des élytres ont des poils noirs, roides, assez nombreux. Crochets des larses testacés. Mâle.

Du Brésil.

\section{CÉraspis farineuse, $C$. nivea.}

Ceraspis testacea, corpore toto squamis obsito albis aut albidis, illis fascias tres in thorace constituentibus; pedibus dilntè testaceis.

Longneur 4 lig. $\frac{1}{2}$. 'Westacée, entièrement recouverte d'écailles blanches ou blanchâtres; les premic̀res formant sur le corselet trois bandes longitudinales: l'une étroite placée sur le milieu, les deux autres largés, joignant les hords latéraux. Pattes d'un testacé plus clair, pea garnies d'ècailles. Nâle.

Même pa!rie que les précédentes.

Nota. Cette espèce est dans la collection de M. le comte Dejean sous le nom de Geriutes nivea.

\section{DICRANIE, Dicrania.}

Gcnre d'insectes de l'ordre des Colćoptères, section des Pcutamères, famille des Lamellicornes, tribu des Scarabéídes (division des Phyllophages ).

Cinq genres ayant pour caractères communs : deux crochets aux tarses postérieurs, tous les crochets des tarses égaux, bifides, forment un groupe dans la quatrieme șublivision des Phyllopliages. ( $V^{\prime}$ oyez Scarabéions.) Ces genres sont: Hifacrodactyle et Sérique, dont le chaperon est peu échancré antérieurement, ses angles point alongés, ne formant pas la fourche; Dichèle, qui a les cuisses posterieures renflées à jambes arquées; Diphucépbale, remarquable par sa tête en carré transversal, son corselet sillonné longitudinalement sur le dos, ayant ses côtés presque unidentés dans leur milieu, et encore par ses jum- 
bes antéricures bidentées an côté externe. Les Dicranies n'ont aucun des caractères que nous venons d'énoncer.

Antennes courtes, de neuf articles, le premier conique, hérissé de poils roides surtout à sa partie postérieure, le second globuleux, gros, un peu plus court que les suivans; les troisième, quatrième et cinquième cylindro-coniques, presque Egaux entr'eux, le sixième cupulaire; les trois autres formant une massue ovale, un pcu velue. -Labre e! mandıbules cachés. - Palpes maxillailes assez grands, leur dernier article de longueur moyenne, ovale, un peu arqué, plus grand que le précédent; palpes labiaux fort courts. Tête presqu'en triangle tronqué. - Chaperon séparé de la têle par une ligne transversale, profondément échancré en devant, ses angles anléricurs relevís et fortement prolongés en dent de fourche. - I eux grands. - Corps ovale, large, déprimé en dessus. - Corselet trìs-bornbé, beancoup plus élroil en devant, ses bords latéraux arrondis, le postélieur sinué, formant un arc. Ecusson grand, presqu'arrondi postérieurement. - Elytres déprinces, couvrant des ailes et laissant a nu la partie postérieure de l'abdomen. Pattes fortes; jamlies autćrieures n'ayant qu'une dent au côté extérieur; les intermédiaires trèsvelues inlérieurement; les postérieures dilatées en triangle alongé; cuisses poslérieares grosses et larges : crochels des larses tous égaux, forlement bifides, leur division inférieure plus courle que l'aulre.

Les espèccs qui conslituent ce genre s'éloignent par la forne de leur corps et par celle des janbes postéricures de tous les auıres genres de la même division. Le norn de Dicranie liré du grec a rapport à la fourche que présente la partie antériente du chaperon. Nous ignorons les mœurs de, ces insectes, mais par la conformalion de leur bouche ils sont évidemment Phyllophages.

\section{Dicranie rubricolle, $D$. rubricollis.}

Dicrania nigra, nitida, lowis, capite punctato; thorace suprà lateribusque et ano, prosertim infrà, sangumeis.

Longueur 7 lig. Noire-luisante, lisse. Tête fortemeni ponc luće. Dessus du corselet, ses bords latéraux en dessous, extrémité de l'anuset ses côtés d'un rouge sanguin : celte couleur s'élend un peu plus en dessous et alteint le segment qui précède l'anus.

Du Brésil.

Nota. Une autre espèce du même pays ne diffêre de la rubricolle que par sa taille un peu plus petite et sa couleur entièrement roire. ( $D$. nigra.) Ces especces que $M$. le comte Dejean possède ainsi que nous, et qu'il n'a ratlachées à aucun genre, portent dans sa collection les noms spécifiques gue nous avons aduptés.
MACRODACTYLE, Macrodactylus. LAT. Melolontha. FAB. Oniv. Herest.

Genre d'insecles de l'ordre des Coléoptères, seclion des Pentamères, famille des Lamellicornes, tribu des Scarabéides (division des Phyllophayes ).

Un groupe de la quatrième subdivision des Phyliophages contient cind genres (voyez ScaRABÉides) ayant pour caraclère commun : deux crochels à chaque tarse, ces crochets tous égaux eı bifides; ce sonı ceux de Dicranie, Séricjue, Dichçle, Diphucéphäle el Macrodaclyle. Mais les quatre premiers n'ont pas le corselet plus long que large, et la partie postérieure de celui-ci ne se réluécit pas; elle en est au contraire la portion la plus large; en outre leur corps est court en proportion de sa largeur.

Antennes de neuf articles, le premier conique, assez court, le secend globuleux ; les deux suivans coniques, un peu plus ton rs que le second, le cinquième en cornet; le sixième très-petit, cupulaire, les trois derniers formant une massue ovale, presque glabre. - Mandibules ayant leur portion interne moins solide que l'externe.-Palpes maxillaires de qu? re articles, le premier peu disinct, les deux suivans coniques, le quatrième ovale, un peu plus long, mais guère plus gros que los précćdens. Palpes labiaux très-courts, peu visibles. - Téle alongée, beaucoup plus longne que large; chaperon allant en se rétrécissant, très-pen écliancré antérieurement. - Corps fort lung en proportion de sa lisrgeur. - Corselet hexagone, beaucoup plus long que large, point rebordé, se rétrécissant trc̀s-notablement en arrière, ses cốlés anguleux vers leur milieu.-Ecusson assez grand, arrondi postérieurement. - Elytres recouvrant des ailes, laissant à nu l'extrémité de l'abdonen. - Pattes assez fortes; jambes antérieures munies de deux fortes dents au côlé externe, les autres épineuses dans toute leur longueur. Tarses iutermédiaires et postérieurs fort longs; leur premier article ainsi que celui des antérieurs presqu'aussi long que les Irois suivans pris ensemble; le dernier assez long, terminé par deux crochets égaux, bifide, les deux divisions égales en longueur, la supérieure plus grêle et plus aiguë.

L'espèce qui a servi de type à M. Latreille pour fonder ce genre, dont le nom formé de deux mots grecs signifie : grand doigt, est le Hanneton subépineux $n^{\circ}$. I 2.3. de ce Dictionnaire (Mlacr. sul:spinosus. Melolontha subspinosa ${ }^{\circ} .124$. FAB. Syst. Elcut. Oriv. Entonl. torn. 1. Hanneton, pag. 70. no. 97. pl. 7. fig. 73. a. b.) Une autse espèce de Macrodartyle est dérrite par M. Latreille dans la partie zoologique du Voyage de MM. de Humboldt et Bonpland.

DIPHUCÉPHALE, Diphucephala. Des. Catal. LAT.

Geare d'insectes de l'ordre des Coléoptères, 
section des Pentamères, famille des Lamellicornes, tribu des Scarabéides (division des Pliyllopliages).

Dans un groupe de la quatrième subdivision des Phyllophages ( voyez Scarabéides), cinq geares ont pour caractères particuliers : deux crocbets à tous les tarses, ces crochets éganx et bifides. Mais quatre d'entr'enx, Séríne, Macrodactyle, Dichèle et Dicranie, se distinguent des Diphucépliales par leur chaperon entier ou presquentier.

Antennes terminées par une massue lamellée, plicatile, composfe de trois feuiliets dans les deux sexes. - Mandibules ayant leur portion interne moins solide que l'externe. - Palpes maxillaires velus, de quatre articles, le second assez grand, conique, le troisième court, de même forme, le quatrième plus graud que les précédens, ovaleoblong. Palpes labiaux peu distincts. - Tête en carré transversal. Chaperon grand, carré, ssparé de la tête par une ligne transversale; sa partie antérieure très-échancrée, les angles latéraux arrondis, relevés, bordés de poils; celui des mâles ayant ses deux angles très-alongés. fort relevćs, formant deux espèces de cornes. - Yeux suilluns, - Corps asse z alongé. - Corselet transversal, ses côtés légèrement unidenlés dans leur milieu, ayant un sillon longiludinal sur le dos et un enfoncement de cliaque côté près de l'angle postérieur. - Ecusson presque cordiforme. - Elytres allant un peu en se rétrécissant vers leur extrémité, reconvrant des ailes et laissant à nu l'extrémité de l'abdomeu. - Pattes assez fortes. Jimbes de devant ayant deux dents au côlé extćrieur; les quatre preıniers articles des tarses antérieurs el intermédiaires dilatés et velus en dessous dans les mâles; le dernier article de tous les tarses muni de deux crochets égaux, bilides.

Ce genre a été fondé par M. le comte Dejean. Son noon vient de deux mots grees qui ont rapport à la singularité que présente la tếle; elle paroit refendue en deux, surtout dans les mâles. les caractères génériques des Diphucéphales n'ont pas encore été publićs. On en connô̂t quatre espèces de moyeune taille, de couleur métallique et propres a la nouvelle IIollande. Ml. le conte Dejean nous a permis d'exauiner ce genre daus sa collection et d'y décrire l'espèce suivante.

1. Diphocéphale soyense, $D$. sericea.

Diphucephala viridi-aurea, sericea, subtus villosior, thorace sulpunctato; elytrorum costis duabus longitudinalibus, discoideis, elevatis, striisque punctatis : pedibus testaceis, tarsis apice fuscis.

Diphucephala sericea. DeJ. Catal.

Longueur 7 lig. Corps d'un vert doré, un peu soyeux en dessus, très-velu en dessous. Tête et corselet pointillés. Elytres l'étant plus fortement, leurs points presque rangés en stries; elles ont quelques liguts longitudinales élevées, dont deux plus saillantes placées vers le milieu. Pattes testitcées, velues; tarses bruns à leur extrémité. Mâle et femelle.

Nouvelle ITollande.

DICHÉLE, Dichelus. Melolontha. Fas. Oniv. Scren.

Geure d'insectes de l'ordre des Coléoptères, section des Pentamères, famille des Lamellicornes, tribu des Scarabíides (division des Phyllophages ).

Dans la quatrième suldivision des $\mathrm{Phyll}_{\text {upha- }}$ ges un groupe offie pour caractères : deux crochets aux tarses postérieurs; crochets des six tarses égalix, bitides. (Voyez Scarabéides.) Des cinc genres qui composent ce groupe, trois : Macrodactyle, Sérique et Diphucéphale n'ont point les deux deruières cuisses reuflées ni les jambes postérieures arguées. Dans les Dicranies les angles antérieurs du chaperon sont aigus, relevés et prolongés $\mathrm{en}$ dent de fourche; caractères que l'on ne retrouve pas dans les Diclièles.

Antennes courles, de neuf arricles, le premier assez long, conique, hérissé de poils; le second globuleus, plus long que le troisième; les trois suivans courts, presqu'égaux, ovales-cylindriques, le sixième cupulaire, un peu prolongé en lane à sa partie intérieure; les trois derniers formant une massue ovale, un pea velue. - Labre et inandibules cachés. - l'alpes courts; dernier aricle des naxillaires plus long que le précédent, presqu'en alène. - Tête petite; chaperon beaucoup moins large que la lête, séparé d'elle par une ligne transversale, légèrement rebordé autérieurement, point ćchancré. - Corps court, assez épais, un peu garui d'écailles. - Corselé convexe, ses bords latéraux et postérieur arrondis. - Elytres déprimées en desus, ayant un tubercule lsuméral assez prononcé, recouvrant des ailes et laissant à nu la partie postérieure de l'abdomen. - Abdomen ayant son segment anal rentré en dessous. - Les quatre pattes antérieures assez fortes, leurs jaubes comprimées; celles de devant ayant deux dents au côtć extérieur; cuisses postérieures grosses, rentlćes en dessous, convexes du côté du corps, ayant (dans les máles seulement) deux dents fortes, l'une ver's leur milien, l'uatre près de l'arliculation de la jambe. Jaunbes postérieures larges, un peu aplaties, arquées, crochues, susceplibles de s'appliquer dans une coulisse de la paltie inféricure de la cuisse. Dernier article des tarses le plus long de tous, terminé par deux crochets longs, grêles, égaux, bilides.

Le nom que nous donnons à cette nouvelle coupe générique est opposé à celui de Monochc̀le. Les espèces dont nous la composons ont été jus- 
qu'à présent réunies à ce dernier genre dans la plupart des collections, nıais les Monochèles n'ont qu'un seul crochet aur tarses postérieurs. Le mot Dichscle signifie en grec : double pince. Ce geure nous paroit propre it l'Afrique. Il ne conlient que de petiles espèces dont les nuours sont ignorées.

A ce genre appartient le Hannelon dentipède $n^{0}$. 129. de ce Diclionnaire (Dich. dentipes). L'individı décrit esı un mâle; la femelle a les cuisses postérieures mutiçues. Les Hannetons spinipède $n^{\circ}$. 127. et podagre $n^{\circ} .128$, sont peulêtre aussi des Dichèles.

ANISOPliE, Anisoplia. MÉg. Dej. 'Catal. LAt. Melolontha. FAв. OLI. PAyк. Scaraboeus. Linn. De Gér. Georf.

Genre d'insectes de l'ordre des Coléoplères, section des Penlanères, famille des Lamellicornes, tribu des Scarabéides (division des Phyllophages).

La quatrième subdivision des Phyllophages qui offie pour caractères particuliers : portion interne des mandibules moins solide que l'externe. Antenues de neuf à dix articles; les troiz derniers formant la massue, se compose de dix genres. (Voy. Scarabéides. ) Ceux de Sérique, Mlacrodactyle, Dichèle, Dicranie et Diphucéphale diffèrent des Anisoplies par les crochets de leurs tarses tous égaux et bifides; dans les Céraspis les crochers des tarses antérieurs sont égaux et le plus petit des postérieur's est bitide. Les Lépisies sont reconnoissables par lears crochets àlérieurs et intermédiaires tous bifides. D'un autre côté les Hoplies et les Monochèles ne peuvent se confondre avec les Anisoplies puiscuu'ils n'ont qu'un crochet unique aux tarses poslérieurs.

Antennes de neuf arlicles, le premier conique, le sccond globuleux, les deux suivans ovales, alongés; les cinquième et sixième cupulaires; les trois derniers formant une massue assez grosse, ovale, presque glitre. - Mandibules ayant leur portion interne moins sulide que l'externe. - $M \hat{a}$ choires pluridentées; leurs dents très-fortes, surtout la terninale. - Palpes maxillaires de quatre articles, le premier très-pelit, le second conique, ussez long, le troisième court, conique, le dernier aussi long que les deux précćdens pris ensemble, ovale, alongén; palpes labịaux de trois articles, le premier peu distiuct, le second conique, le terminal ovale, aussi long que les deux autres réunis. - Chaperon souvent avancé et relevé dans ce cas, séparé de la lête par une ligne transverse peu prononcée. - Corps ovale, un peu déprimé en dessus, - Corselet ayant ses angles antérieurs saillans, échaucré en rondeur à sa partie. antérieure; ses côtés arroudis antćrieurement, son bord postérieur sinué, saillant vis-à-vis de l'écusson. - Eçusson large, arrondi postérieurement. - Elytres déprimées eu dessus, élargies gu: leur bord, au-dessous de angles huratraux, en une sorte de bourrelet; elles recouvrent des ailes et laissent à découvert l'extrémité de l'aldomen. - Pattes assez fortes; jambes courtes, les anlérieures bidentées à leur parlie externe; tarses longs; leur dernier article presquaussi long que lés qualre précédens réunis; les six tarses terminés par deux crochels; crochets antérieurs et intermédiaires très-inégaux, le plus menu entier, l'autre bifide; (l'une des divisions des crochels bilides, plus large et plus longue dans les máles que dans l'autre sexe). Crochets postérieus s un peu inégaux, enliers, l'intérieur guère plus petit que l'extérieur.

Le nom de ces Coléoptères, dont la taille est petile ou moyenne, vient du grec; il exprime l'inégalité des crochels de leurs tarses. Ces Pbyllophages habitent les diverses parties du Monde. Leurs larves doivent être confurmées comme celles des Hannetons, et vivre de la même manière. Les iusectes parfaits mangent avidement les feuilles des arbres et les pélales de certaines fleurs. L'Anisoplie horticole a un goût très-décidé pour celles des roses sauvages.

On placera dans ce genre : $1^{\circ}$. le Hanneton agricole $n^{\circ}$. 108. pl. 154. fig. 12. de ce Dictionnaire. (Anis. agricola. Dans le mâle le boód des élytres a tres-peu de noir et la lache carrée de cette couleur qui entoure l'ćcusson dans la femelle, manque enticrement.) $2^{\circ}$. horticole $n^{\circ}$. 109. pl. 155. tig. 16. (Anis. horticala.) 30. fiuticole no. 110. pl. 155. tig. 15. (Anis. fiuticola.) $4^{\circ}$. arvicole $11^{\circ}$. $11 \mathrm{x}$. pl. 155. tig. 17. (Anis. arvicola. ) 50. marginé no. 122. (Anis. cincta. Melolontha cincta 口$^{\mathrm{o}}$. $110 . \mathrm{F}_{\mathrm{AB}}$. Syst. Eleut.)

\section{LÉPISIE, Lepisia. Melolonthoe Hopliaformes.}

Scræ. Synon. Ins. tom. 3. pag. 206. Melolontha. $F_{A B}$. Oliv.

Genre d'insecles de l'ordie des Coléoptères, section des Pentameres, famille des Lamellicornes, tribu des Scarabé1des (division des Phy!llophages).

Daus la qualrième subdivision des Phyllophages, un groupe a pour caractere parliculier :crochets des larses inégaux, ceux des tarses postérieurs au nombre de deux el entiers. (Voy. ScarabéiDEs.) (e groupe ne renferme que deux genres : Anisoplie et Lépisie; les premières differrent des secondes par leurs quatre tarses antérieurs ay ant un de leurs crochels entier, et par leur corrs dépourvu d'écailles.

Antennes velues, surtout à leur base, composées de neuf articles, le premier assez long, en nuassue; le second gros, globuleux; les trois suivans courts, globuleux, le sixième très-petit, cupulaire; les trois derniers formant une massue grosse, ovale-globuleuse, un pen velue. - Labre et mandibules cachés. - Dernier article des palpes maxillaires assez long, presque cylindrique. - Tête en carré-long; chaperon séparé de la tête 


\section{S C A}

par une ligne transverse peu apparente, rebordé, ce bord arrondi porıant dans son milien antérieur une petite deut relevée (au moins dans les mâles). - Yeux assez grands. - Corps un peu déprimé en dessus, entièrement garni d'écailles. - Ecusson de grandeur moyenne, triangulaire. - Elytres déprimées en dessus, ayant un tubercule homéral asscz prononcé, recouviant des ailes èt laissant à nu la partie postérieure de l'abdomen. - Pattes assez longnes; janbes un peu comprimées, les antérieures munies d'une forte dent an côté externe; dernier article des tarses le plus lon de tous; deux crochers inégaux à tous les tarses. Crochels antérieurs et intermédiaires tous bifides; les deux de chaque tarse postérieur entiers.

Les Iépisies dont le nom vient d'nn mot grec qui signifie : écailleux, nous semblent appartenir à l'Atrique australe. Le corps couvert d'écailles en dessus comme en dessons, leur donne une grande ressemblance avec les Hoplies, mais elles en dilf"rent évidemment par les crochets des tarses postérieurs au nombre de deux. Nons avons été d'autant plins autorisés à présenter ici ce noureau genre, qu'il se rapporte parfaitement à une section des Melolontha de M. Schœnlerr, nommée par lui Hoplioformes.

On placera dans ce genre le Hanneton rupicole no. 116 . de ce Dictionnilie. (Lep. rupicola.) Dans les individus que nous possédons, le chaperon n'est pas échancré, il porte dans son milieu une petile dent relevé; nous ferons encore remarquer que l'une des divisions des crochets antérieurs des taıses est plus large que l'autre et un peu aplatie, ce qui nous paroît être un signe caractéristique du sexe masculin.

Rapportez en ontre aux Lépisies, les $\mathrm{N}^{\prime r}$ clolontha militaris Gyx. in Schoen. Append. pag. 116. no. 160. (Lep. mititaris) et ferrugata id. pagg. 117. $\mathbf{n}^{\circ} \cdot 161 .($ Lep.ferrugata.)

MONOCHÈLE, Monochelus. Iruig. Inéd. Metolontha. FАв. Oliv. Henвst.

Genre d'insectes de l'ordre des Coléoptères, section des Pentamères, famille des Lamellicornes, tribu des Scarabéides (division des Phyllophages).

Daus la division des Phyllophages un groupe se distingne de tous les autres par la présence d'un seul crochet aux tarses postérieurs. Il contient les genres IIoplie et Monochìle. (Voy'. ScaRABÉínes.) Le premier diffère essentiellemeut dn second par ses deux dernières cnisses peu ou point renflées, par ses jaınbes postérieures longues, droites, dépourvues de la dent terminale crochue, que l'on remarque dans les Monochèles, et encore par sa lête presque carrée.

Les caractères de ce genre n'ayant pas été publiés, nous nous bornerons à indiquer les ronsidérations suivantes. Second article des antenues fort gros, parfaitement gloJuleux, les suivans très-courls, peu distincts, la massue grosse, ovale-renflée. Tête presqu'en triingle tronqué, c'est-à-dire se rétrécissant visißlement de la partie postérieure à l'antérieure. Cuisses postérieares très-grosses, renflées; leurs jambes fort courtes, assez grosses, munies à leur extréuilé d'une furte dent crochue et recourbée.

Pour les antıes caractères voyez ceux des lỉoplies, page 117. de ce volume. C'est à tort que nons avons dit à cet arlicle que le petit crochet des tarses antérieurs et internédiaires est entier; mieux examiné avec une très-forte loupe, nous avons reconnu qu'il est réellement bifide.

Rapportez à ce genre, dont les espèces nous paroirsent toutes habiter l'Afrique méridionale, les IIannetons suivans de cc Dictionnaire : $7^{\circ}$, enflé $n^{\circ}$. 130. (Monoch. gonager.) $2^{\circ}$. goutteux no. 13r. (Monoch. arthriticus.)

PACHYCNĖUE, Pachycnema. Anisonyx. Lat. Anisony.x, Trichius. Scnen. Melolonthe, Trichius. FAв. Melolontha, Cetonia. Osiv. Hoplia. Des. Catal.

Genre d'insectes de l'ordre des Colénptères, section des Pentamères, famille des Lamellicornes, tribu des Scarabéides (division des Anthobies ).

Des six genres que contient la division des Anthobies, cenx de Glaphyre, Amphicome, Chasmatoptère et Chasmé ont lenrs tarses postérien's munis de deux crochets; dans les Pachycnèmes et les Anisonyx ces mêmes tarses n'ont qu'un seul crochet, ce qui rapproche ces deux genres de cenx d'floplie et de Monochèle qui terminent la division des $\mathrm{Pl}_{\text {ryllophages. On séparera aisément }}$ les Anisonyx du genre qui nous occupe, par l'inégalité de leurs palpes, ainsi que par leurs élytres presque de mêne largenr dans toute lenr élendue, et encore par les paltes (même les postérieures) qui sont longues, grêles et très-velues.

Antennes courtes, de neuf articles, le premier le plus long de tous, vclin; les quatre suivang globuleux, le premier de cenx-ci plus gros que les troisième, quatrième el cinquiène; le sixième très-petit, cupulaire; les trois derniers formant une massue courte, ovoïdo-globuleuse. - $M_{(a n-}$ dibules cornées. - Mâchoires terminées par un lobe membraneux et soyeux. - Palpes assez longrs, éganx, avancés, dépassant à peine le bord antérienr du chaperon; leur dernier article cylindrique, plus long que le précédent. - Languette saillante au-delà dn menton, bilobée. Tête et chaperon comme dans le genre suivant. - Ieux de grandeur moyenne. - Corps raecourci. - Corselet et écnisson des Anisonyx. Elytres un pen béantes à leur extréınité postírieure suturale, sensiblement plus larges que le corselet à leur base, se rétrécissant ensuile jusqu'à leur extrémité; elles recouvrent des ailess et 
laissent à nu les derniers segmens de l'abdomen. - Pattes postérieures renllées, leurs jambes courtes; les anlérieures ayant deux dents au côté externe; tarses postérieurs n'ayant qu'un scul crochet qui est grand, simplc, entier; crochets antérieur's el intermédiaires à peu près conformés comme dans le genre suivant.

Le nom que nous donnons à ce nouveau genre vient de deux mots grecs qui désigncnt la grosseur des jambes postérienres de ces Scarabérdes. Les espèces que nous y faisons entrer paroissent avoir embarrassé plusieurs auteurs, puisqu'ils les ont dispersées dans des genres fort différens les uns des autres; on ne peut en faire des Anisonyx, car la structure de leurs antennes, des palpes, des élytres et le reuflement des jambes postérieures s'opposent à celle réunion. La conformaliou de ces jambes scmble les rapprocher des Monochèles, mais les Pachycnc̀mes ont tous les carac. tères propres aux Anthobies et ne peuven! être placécs avec les Phyllophayes.

Les espèces qui nous sont connues, babitcnt lc Cap de Bonne-Espérance.

Ire. Division. Corps entièrement velu. - Crochets des tarses anléricurs et intermédicires tous profondćment bifides.

Rapportez à cclte division lc IIanneton ceudré no. 78. Onav. Entom. Hauneton, pl. 4. fig. 3o. Anisonyx cinereum. Lat. (Pachyc. cinerea. Nов.)

$2^{\theta}$. Disision. Corps peu velı, un peu écailleux en dessus. Abdomcn l'élant entièrenicnt. - Crochets des iarses antérieurs et intermédiaires légc̀rement bifides.

A cctte seconde division appartient la Cétoine crassipèdc no. 102. pl. 161. fig. 26. de ce Dictionnaire. Trichius maculatus nо. 18. Fав. Syst. Eleut. Hoplia crassipes. Des. Calal. ( Pachyc. crassipes. Nов.)

Nota. Ia Melolontha crassipes $\mathrm{n}^{\circ}$. 1 17. Fa . id. est regardée par les auteurs coun une variélé dc cetle espèce.

ANISONYX, Anisonyx. Lat. Melolontha. Fab. Oliv. Scaraboeus, hinn.

Genre d'insectes de l'ordre des Coléoptères, section des Pentamères, farnille des Lamellicornes, tribu des Scaraberides (division des Anthobics ).

Cette division comprend six gcnies. (Voyez Scarabéides.) Quatre d'entr'eux, Amphicome, Glaphyre, Chasuatoptère et Chasmé sont distingués par leurs tarses postérieurs munis de deux crochets, tandis que les Pacbycnèmes et lcs Anisonyx n'en ont qu'un seul; mais les Pachyenc̀mes difièrent des Anisonyz par l'égalité de leurs quatre palpes, lc rétrécissemeat postérieur des élytres et la grosseur des cuisses et des jambes postérieures. Antennes de neuf articles, le premier long, conique; le second petit, globuleux; les deux suivans cylindro-coniques; le cinquic̀me aussi long que les deux précédens pris enscmble; le sixiène cupulaire; les trois autres composant une massue lougue, linéaire, un peu velue. - Mandibules cornées. - Mâchoires terminées par uи lobe menbranenx et soyeux. - Palpes longs, avancés, inégaux; les maxillaires sensiblement plus grands que lcs autres, leur's trois derniers articles cylindriques, lc terninal dépassant do toutc sa longueur le bord antérieur du chaperon, cct article plus long que le précédent : palpes labiaux ayant leur dernier article aussi long que les dcux autres réunis, dépasiant peu ou point le bord du chaperon. - Languette saillante au-delà du menton, bilobée. - Tête pelite; chaperon avancé, en carré alongé, plus long que large, beaucoup plus étroit que la tête, échancré antérienrement et presque bilobé. - Yeux grands. Corps très-velu, alongé, un peu déprimé et souvent écailleux eu dessus. - Corselet ayant ses bords latéraux arroudis ainsi quc le postérienr. Ecusson triangulaire. - Ely،res un peu béantes à leur extrémité postérieure suturale, ne se rétrécissant pas visiblement, couvrant des ailes et laí-sant. à nu l'extrémité de l'abdomen. - Pattcs lougu@s, grêles, très-velues, les postérieures principalewent; jambes anlérieures n'ayant qu'uno dent au côté cxterne; crochets de's tarscs antérieurs et intermédiaires inćgaux, profondément bifices; tarses postéricurs n'ay ant quóun seul crochet, lequel est grand, simple, colier.

Ce genre établi par M. Litlrcille a été nommó Anisonyx de deux mots grecs dont la signification est: ongles inégaux. II ne reuferme gu'un perit nombre d'espèces qui, dit-on, irćquentent les tleurs; elles sont du Cap de Bonnc-Espérance.

P'lusieurs Hantietons de ce Dictionnaire apparliennent is ce genrc, tels que cenx-ci : $1^{\circ}$. chevelu no. 102. ph. 155. fig. 29. (Anis. crinitum); $2^{\circ}$. Ours no. 103. pl. I55. Gu. 14. (Anis. Ursus); 30. Lynx no. 104. (Anis. Lynx) ; $4^{\circ}$. à trompo no. ıо๖. (Anis. proboscadeum.)

AMPIICOME, Amphicoma. Lat. Melolontha. Fab. Oliv. Scarabaus. De Géer. Pale.

Genre d'insectes dc l'ordrc des Colćoplères, section des Peutamères, famille des luamellicorncs, tribu des Scarabéides (division des Anthobies).

La division des Scarabéides nornmée Anthobies, se compese des geures Pachycnème, Anisonyx, Glaphyre, Chasenatoptèrc, Chasmé ct Amphicome. (Voyez Scarabeides.) Les dcux pieniers ont les tarses postérieurs munis d'un seul crocliel; le quatriène a tous les crochets des tarses bifides. Dans les Chasmés l'un des crochets, au moins, est toujours bitide, et les antérieurs ainsi qque lus incermédiair th 
intermédiaires sont inégraux entr'eux; enfin les Glaphyres ont leurs mandibules dentelées intérieurement et portent en outre une dent au côté externe; leurs cuisses postérieures sont renllées dans les deux sexes.

Antennes de dix artieles, le premier conique, le second globuleux, tous deux très-velus, le troisième de forme variahle; ; les qualrième, einquièruse, sixième el septième eupulaires, allant en s'évasant de plus en plus jusqu'a la massue ; celle-ci de trois feuillels dins les deux sexes. - Labre saillant. Manaibules entièrement cornées, sins angle au côté exterue, ni dents, tant intérieures qu'entérieures.-Mâchoires terminées fiar un lobe membraneux et soyeux. - Palpes velus, leur dernier arlicle glabre, tronqué à l'extrémité.-Languette bilobée, saillante au-delit du menton.-Chaperon séparé de la têle par une ligne transversale. Yeux très-éclianerés intéricurenteut. - Corps alongé. - Corselet assez bombé, presqu'arondi. - Elytres recunvrant des ailes, béanles ì leur extrénilé, laissant à nu la partie postérieure de l'abdomen. - Tarses intermćdiaires el postérieurs alongés : crochets des tarscs lous éganux el entiers.

On doit ce genre à M. Latreille qui l'à nonumé Anuphicome, de deux mots grécs quidésignemt la quantité de poils don! le eorps est souveni recouvert. Les especes gui le composent sont de taille moyenve et labitent l'ancien continent, surtout les parties cbaudes.

I $^{\text {re }}$ Division. Massue des antennes ghbulcuse, presque solide, ses deux derniers articles rentrant dans le prenier. - Tère sans plaque rebardíe. Chaperon très-rebordé en devant et sur les côlés. - Janbes autérieures tridentres atu côté externe; les quatre preniers, articles de leurs tarses fortement eilićs intérieurement dans les mâles.

A celle division appartiemeut les H.mnetons suivans de ce Dictionluaise : $1^{\circ}$. rayè $11^{\circ} \cdot 95$. pl. 35.. tig. 30. (Amph. viltala); $2^{\circ}$. Renard $1^{\circ} \cdot 96$. pl. 155. tig. 28. (Amph. Vulpes) et velu no. 99. Celui-ci est ia lemelle du précédeut; 50 . Bombile no: 97. (Amph. Bomblylus); 40. bumbylitorme ${ }^{\circ}{ }^{\circ}$. y3. (Amph. bonblylyformis); $5^{\circ}$. archique no. 101. pl. 155. fog. 26 . (Amph. arcios.)

$2^{\mathrm{e}}$. Disision. Massue des antennes ovale, ses trois feuillets libres, prescqu'éganx. - Partie médiale de la lête formant avec le chaneron une plaque en carré long, rebordée sur les cốés el postérieurenent. Chaperon point rebordé en devant. - Jaribes antérieures tidentées an côlé externe; les quatre preniers articles de leurs tarses bolićs intérieurement et formant réunis une espere de peigne à guatre denls, dans los mâles.

Rapportez is eelte seconde division le Hanneton alpin $11^{\circ} .21$. de ee Dictionuaire (Amph. abdominalis las.) Le Hanne ton abdominal no. go. nous parnì êlre la même espéce que la précteleate, ou Lut an plus une légère variétéc.

Hist. Not. Ins. Tome X.
GLAPHYRE, Glaphyrus. LAT. Melolontha. Fab. Oliv. Scarabous. lisn.

Genre d'insectes de l'ordre cles Coléoptères, section des Pentamères, famille des Lamellicornes, triiu des Scarabéides (division des Anthobies ).

Cette division conlien+ les gentes suivans: $\mathbf{P a -}$ cliyenème, Anisonyx, Glaphigre, Amplisome, Chasmatoptère et Chasmé. Dars les deax premiers, les tarses postóricur's ne présentent qu'un crocliel unique. lacs Chilsinatop!ècs el les Chasmés ont loujours quelyuessins de leurs crochets (at moins) bilides. Les Auplieomes n'ont ni angre, ni dent à la partie extérieure de leurs mandibules, et lears enisses postćrieures ne sont pas renflies, ce qui sépare ces truis genres de celui de Glaphyre.

Antennes de dix articles, les rois derniers formant une massue fevillerce, presqu'ovoide. Labre saillant. - Mandibulcs corncies, saillantes, ayant une deat à leur partie extérieure, dentelćcs intérieurement un peu avant leur extrémilé. Mâchoires bilides, leur divioion externe presqu'urorde, linterne très-pelice, en forme de cient. - Palues lerminés par un aricie un pen plas gros que les autres, presqu'ovride. - Langueite bilobée, saillante au-dela da menton. - Chaperon aussi long ou prescyutaussi iong que lurge, à peu pres carré. - Conps de forme alongé - Corselet camé, aussi long ou julus long que large. - Zlytres arrondies, béules au bour, recouvrant des ailes et laissant à nu la partie postérieure de l'abdomen. -.. Paltes anléricures comres, leurs jambes très-den'́́es; les qualre demières patles fóles; cuisses postérienares reullécs dans les deux scxes. Dernier article de chaque larse terminé par deux crochets égaux, entiers, ayant une perite dent is. leur côté intene.

Ce genre dî à M. Latreille et donı le nom vient d'un mol grer quisignite: álégant, ne se compose eneore que de trós especes propres à l'Afrigue. Elles fréquentent, à ce quiil parî, les lleurs sy:génicses.

On rapportera aux Glaplyres: $]^{\circ}$. le Hanneton

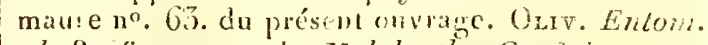
pl. 8. Jig. g'. a. b. Melolontha Cardui no. $7 \mathrm{I}$. $\mathrm{F} \pm \mathrm{B}$. Syst. Lileut. (G. nuturus); $2^{\circ}$. le Glaphyrus Semalulo. Lat. Gener. C'mest. el Ins. tom. 2. pag. 118. $n^{\circ}$. 2. tab. IX. fig. 6. Nelolontha Servalula

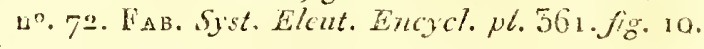

CHASWAJOPTERE, Chasmalopierus. DFu. Catal. Las. Mielolontha. Ituro.

Genre d'insectes de l'orthe des Coléoptères, seetion des Pentamères, lanille des Lamelticornes, tribu des Scurabéides (division des Anthobies ).

Dins eetle division qui eomprend six gepres (voyez Scarabíides), les Pacliycuènes et les Ansonyx se distonguent parse qu'ils a'val qu'um B b ! b 
seul crochet aux tarses postérieurs. Dans les Amp!ricomes el les Glaphyres tous les crochets sont entiers. Les Chasiás ont tous leurs crochets inceganx, et dans les postérieurs le plus gros des deux est ea!ier.

Antennes ayant leurs denx premiers articles très-bérissés de poils, celui de lit base en missue, le second globuleux, le troisièue un per alonspí, cyliudro-coniguc, les suivans cupulatipes, les tor is derniers formant une massue ovale cians les deux sexes. - Manabules cornées. - Máchoires turminérs par un lodse membraneux el soyeux. l'alpes maxillaires de cruatrc arlicles, le dernicr un peu plus long et un peu plus gros que les autres; les labiatix de trois articles, rallant pus en grossissant. - Languctte bilobee, saillante au-celit du menton. - Téte avaucée. Chaperon arroudi, rebordé, point sépraré de la têtc par une ligne transversale, quclpuefois un peu échancré et comme tronqué en devanst. - Corps velu, point écailleux. - Corselct oblong, phus large dars sa partie moyense, son bord postérieur arrondi. Ecusson presque rrimunlaice. - Elyires reconvrant de's rités, béanles vers l'extrinité de leur suture, laissant á déconvert la partie postériente de l'abdomen. - Pattes de longueur mojenne; jambes ancérieures bidentées extérieurencrit; lar. ses de devant courts, les interméctiures et les postérieurs alronés, leurs aricles presqu'égaux; Je deruier de tous les tarses terminé par deux crochets pe!tits, figalux, bifides.

Ce genre a été créé par II. le conte Lejean, mais il u'en a pas encore publié les caracières. lie nom tiré de dear noss grecs exprime que les élytres sunt béactes. Il ne contient que quelques petiles espices propres á líspague et au undi de la france; elles viven! probablement sur ies flcurs. Leur larve nest pas connue.

\section{Chasmatoptìre relu, $C$. villosulus.}

Chasuatopterus niger, cinereo-sillosus, capite suprà nigro vilioso: elytris pallidè testacess, nigro subnariginatis, punctulo-substrutis.

Chasmatopterus villosulus. Des. Catal.

Longucur 3 lìn. Novir. Têse el corselet fortement ponctués. Cors presquerticiencut couvert de poils grisiatres, ceux du dessus de la tếce, notirs. Elytres lestacées, lígèrement bordécs de unir, fortcment ponctuces, leurs prints presque rangés en slries. Rities d'un brun neivitre.

D'Lspazice.

CHASHÉ, Chasme.

Gonce d'inceses de l'ordre des Colćoptères, section des Pentanc̀res, fanille des Lamellicornes, tribu des Scarabérdes (division des Authobies).

Des six genres qui composent cette division, les Pachycnèmes et les Anisonyx n'ont qu'un senl crochet anx tarses postcrieurs. Dans les Amphicomes et les Glapligres tous les crochets des tarses sont ŕgaux et entiers; enfiules Chasmatoptères ont tous léurs crochets petils, égạux, bifides.

Antennes courtcs, ayant leurs deux premiers articles tiès-hórissés de puils, le prenier conique, le second globuleux, le troisic̀me conique, las suivans cupulaires; les trois desniers formant une massie ovale-arrondie. - Mandabulcs cormées. Rhâchoires terminćes par un lobe nembraneux et soytux. - P'alpes ćgaux, velus, leur dernier article assez long, presqu'cn alène. - Languette saillane au-delì du men!on, bilobée. - Téle atrancíe; chaperon transversal, presque carré, plus étroit que lis lête, rebordé, un peu tronqué en devant. - Yeux assez grands, suillans. Corps velu el écailleux. - Corselet ayant son bord postérieur el les latćraux, arrondis. - Ecusson moyen, presque triangulaire. - Elytres recouvrant des ailes, Léanles vess l'extrémité de leur stiture, laissaut à découvert l'extrémité de l'aljdomen. - Pattes assez grandes; janbes antérieures n'ayant qu'une dent à leur côlé extcrnc; larscs antérieurs pas plus courts proportionuelloment que les autres tarses; le dernicr article de lous un pou plus grand que les précédens; cror.jels antrírieurs et intermédiaires inégaux, hif:des; crocliets postérieurs inégaux, le gros entier, le petit bilite.

Les Chasmés tròs-voisines des Chasmatoptircs. prennent lem nom d'un mot grec qui sigunlie : licatus, à cause de leurs élytres béanles. Lacs caractères que nous i irons de la prósence des écailles dont le corps est en partie couvert, ceux que fuumissent les palpcs, le chaperin, le corsclet, et surtont l'évidente clifférence des crochers des tarses comparés à cewx du gente précédent, les ell sciparent sulisamment.

Nous ne comoissons que l'espèce suiyante.

\section{Chasmé décorée, $C$. decora.}

Chasme nigra, suprì fermigineo squamosa, nigro prlosa; siblis albido squamosa plosaque: pedilus moris, tarsis apice ferrugiues.

Longneur 3 iig. $\frac{s}{2}$. Noire, chargće en dessus, principalement sur les élytres, décailles ferrugineu es mêlúes de puls norrs, atyant tin dessous dies bait es hinchâtres el des prils de néme coulent. Palles noires; larses ferrngincux à leur exirénijis.

Du Cạj de Bonne-Espérance.

PLATYGENIE, Platygenia. MacL. Isat. Genie de Coliopteres Scarabisiles de la division des Mblitophiles de M. Laitreilfe, fondé pár M. Macleay (liora entomol. vol. 1. pag. 152.) Il a pour caracteres, suivant cet auteur : antenies de dix articles, le premier graud, épais, conique, peu 
alongć; le second presque globuleux, le sixième large, cupulaire, le septic̀me très-court, à peine disinct, les trois derniers formant une massue ua pen constimée, ovale-alongće. Labre preoru'entièrement caché sous le chaperon, litrgenent transversal, un peit en cour, presque membraveux, échancré en derant, très-velu. Mandibules courtes, éparisses à la base, cornées, aplaties, en forme de lames uninces, presque carrées, transparentes et frangées. Màchoires ayant leur lobe intérieur presque litirone, dilaté, échancré à l'extrérnité ; l'extérieur en forme de pinceau. Pulpes maxillailes ayaut leur second arlicle presque globuleux, le troisieme à pea près conique, le quatrième ovale-cy!indrique, obtus à l'extré:uité; les labiaux souvent caclés dans la cavité buccale. Menton graud, trìs-iarge, presque carré, concave dans son milieu, un peu ćchancré sur ses côtés, son bord antéricur échancré. 'Tète carrée; chaperon entier, un peu rebordé. Cor j's déprimé, ses derniers segrners n'étan i point recouverts par les élytres. Corselet large, déprimé, ses côtés convexes, son bord postérieur tronqué. Ecusson moyen, presque tringulaire; sternum sans prolongearent. Pattes forles; jambes antéricures bidentées extériebrement; les postérieures trèsvelues.

Le type de ce genre est la Platygénic du Zaire, Platyogenia,Zairica. Noire, brillante. 'T'ête ponetuée. Corselet ğłabre. Elytres striées. Anus et des. sous du corps d'un bruu-ferrugineux mat.

Trouvée sur les bords du Zaive par II. Cranch daus son expédition en Afrique, od il a péri par l'insalubrité du climat.

Le norn de Palygénie vient de denx mots greers qui expriment que le menton de ces insectes s'étend beaucoup en largeur.

\section{CRÉVASTOCHEIIE, Cremastocheilus. K vocn. LAT.}

Genre d'insectes de l'ordre des Coléoptères, section des Pentamères, famille des lamellicornes, trilı des Scarabérdes (division des Mélito. philes).

Des cinq genres qui composent une suldivision des Mélitophiles (voyez Scarabéides), ceux de Platyogénie, Macronole, Cétoine el Gymnétis ont le premier article de leurs antenues moins long que les six suivans pris ensenble, et cet article laisse le secoud à déconvert.

Antennes composées de dix arlicles, le premier très-grand, plus long que les six suivans réunis, triangulaire, arqué au côté interne, recouvrant en dessus le second article; les trois derniers f.rmant une missue courte. — Labre presque merubraneux, caché sous le chaperon. - Mandibules très-aplaties, en forme d'ćcailles. - Mâchoires terminées pir un lole corné, resonrbé, aigu à l'extrémilé, armé de petites épines intérieurement. - Palpes ayant leur dernier article très-long, obtus à l'extrúmilé; pulpes labiaux de tois aricles, les deux premiers irc̀s-petits, le troisième courbe. - Languelte point sallante. Menlon tres-grand, occupant presque torte la partic infóricure de la lête, concave en cievant en forme de hassin, ovale, transverse, ses bords álevés, aigus. - Chaperon transversal, son bord antérieur releré, entier, arqué. - Corpo alongé, ovale. - Corselel en carré transversat, éclanucré à ses angles antéricurs et postérieurs gui sont prolongís en tuhercules. - Pièce triangulaire saillante, remplissant une partie de lespace compris entre les angles postéciems dn eoretel el ceux de la base des élyures. - Slemum sans prolongement. - Palles coutles; croclieis des tarses courts.

Ne possédant pas ce genre, nons en donnons les caractères diaprès M. Latreille: le type douné par l'autenre est le Crémastocheile de la châtaigne, Cremaslocheilus castanea. Noiv, velu, cliargé de points enfoncés qui forment comme des cicatrices. Jaubes antérieures ayant denx dents au côté extórieu. De l'Aunérique seplentrionale. Cette espece a d’aboed élé décrite par M. Knorde (Neue beyt. zur insect. 1801. pag. I 15.taf: 3.)

Nota. Ja Céloine alongée n⿳. 30. pl. 159. lig. 13. du présent onvrage apparlient aussi à ce gente. (Cremast. elongalus.)

MACRONOTE, Racronota. Wieden. Analecl. Entom. Fillae. 1824. patg. 8.

Co genre de Coléopteres-Scarabéiles appartient il la division des Méliophiles. Son cánctère le plus apparent est d'avoir, comme les Gjonućtis, la partie médiale da corselet prolungée; ce qui sćpare ces lenx gevres ác celui de Céloine. Ici re prolongement couvre en partie l'écusson, mais il nous paroit qu'il en laisse loujours à découvert lat portion postélicure. L'anter. (M. Wiedemann) n'ćnunce point ses autres carncteres. Tel que nous entendons ce genre, il nest pas ridentique avec celui de Gyunélis de M. Muclcay; il en dillere

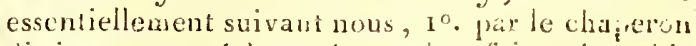
distinctement cehancré, quelquefuis asêno bidenlé; $2^{\circ}$. par la màssue des antenues notablement alongće, composée de trois leuillets presque linéaires ( 1$) ; \overline{3}^{\circ}$. par la forme du corps plus alongée, allant en se rétrécissant sensiblement it parur de la base des ćlytres jusqua sat parlie posićrienre. M. Wieden anu dunne pour type l'espèce suivante, que nous reryons nouvelle. Nacronote radiée, Macronota radiata. Longukur 8 lig. D'un noir-pourpre en dessus, avec le discgue des élytu's de couleur orangée, ainsi que des rayons qui s' cartent de ce disque; cuivreuse en dessous. Du nord de l'Inde.

(1) Ce caracic̀re se retrouve daas quelques vraics C'óroilies de la nouvelle Hollande. 
Toutes les espèces de Macronoles que nons con. noissons sout propres a l'Asie. On placera dans ce yenre le: Cétuines suivantes de ce Dicionnaire : $\mathbf{1}^{\circ}$. chinoise $\mathrm{n}^{\circ} .5$. 1.. 158 . lig. 1. (Macr. chinensis) ; $2^{\circ}$. nègre no. 6. pl. 158. li . 2. (Macr. nigrita ); $3^{\circ}$. l.leuâtre $n^{\circ} .7^{2}$. pl. 160. fig. 21. (Nucr. carulea), et ebiore les espèces inédites suivantes de la colliction de hl le comte Dejean, nommées par lui sulcicollis, antiqua, regia, (celle-ci est pent-être la Cetona regia de Fabricius) et bisignáta. Ces quatre dermères sont de Java.

GYMNÉTIS, Gymnetis. Genre de ColéoptèresScarabérdes, division des Mélitoplites, créé par M. Nlacleay (frorce encom. vol. 1. pay. 15\%.) aux dépens des Cetonia de liabricius et d'Ulivier.

Le seul caractère frappant qu'oflie ce genre est celni que préscute le corselet qui est lobé postérieurenent; ce Iolie recunvrant l'écusson. M. Macleay prétend que dans l'unique espèce qu'ıl ite, l'érnsson ro'est pas entic̀rement courert; le contraire nous parồt évicient dans les individus sounis à notre examen; il ajoute qu'il connoit d'autres esprices dans lesquelles l'écusson s'épanount tout-ci-fuit. Nous n'entendons pas eelle phràse, car l'écusson existe dans tous les Mélitophiles, et il est (ont anssi grand duns les Gymnétis que dans la Céroine dorée par exemple. Nous ne voyons done pas pourquari l'auleur anglais soupçonne que les espère; on il nie l'existence de l'écusson, par opposition à celle qu'il décril (Gymnetis nitidu), pourroient former un zenre dilférent de celui-ci. Au reste les caractires généricpues qu'il assigne aux Gymútis (horscelui du corselet) sont alssolument les inêtnes que cemx des vérihahles Cétoines. Nous remarquerons"stulentent; ce que ne dit pas M: Ma-, cleäy, que les espères que l'on doil y rapporter sont toures amciricaines; leur chaperon est entier, le corps cst toujours mat et velouté en dessus; la suture des élytres se termine de chaque côté par me perice épine. (Voyez Macrovore, pag. 379 de ce volune.) En admellant celle coupe gónérique, un y poarre élablır deux divisions. La premiere aura pour caractères : tête portant nne épine dirigée en ardul; hord antérieur do chaperon ayant un appendice dreil, en carré long (au moins dans les mâles). Insectes de l'Amćrique septentrimale. la se place la Cétnine brillante $0^{0}$. 14. pl. 159 . fig. 2. de ce Dictionnaire (Gymn. mitida. MAcL.). la seconde division sera anosi signalée : lêle et clłaperon simples, mutiques dansles steux sexes. Insectes de l'A mérique méridionale. On y rap orteri les Córoines suivantes de ce Dictionare: $1^{\circ}$. buuclier ${ }^{\circ}$. i7. pl. 159 . fig. 3 ; $2^{\circ}$. on dáe $n^{\circ}$. $19 ; 3^{\circ}$. soyense $n^{\circ} .26 ; 4^{\circ}$. trisle no. 27. pl. 155. lig. 8; 5". lobée $n^{\circ}$. 28. pl. 159 . fig. $9 ; 6^{\circ}$. sall jouldre no. 29. pl. 159. lig. 10; $7^{\circ}$. usarisrée $\mathrm{n}^{\circ} .13$. pl. 159 . tig. 1 , ainsi que les
Cétoines peinte, maculée, liturée, linéolée et porte-fuix de l'Entomologie d'Olivier.

JNCA, Inca. Goliathus. Inam. Lat. Des. Catal. Celonia. Wéd. Trichius. Schen.

Genre d'inset:tes de l'ordre des Coléoptères, scction des Pentamères, fantille des Lamellicornes, tribu des Scarabéades (division des Mélitophules ).

Le genre Goliath créé par le savant M. de Lamarck (Syst. des anim. sans vertèb.) contenoit prinitivement toutes les espèces de Císoines dont les mâles (au moins) portent un chaperon trèsavausé et très-visiblement fonr-hu. M. Latreille te restreignit depuis en en ôtanı la Cítoine éclatante d'Olivier (Encycl. pl. 157.Jig. 4. Cetonia micans Onrv. FAB.) et quelque's autres, qui ont comme les vraies Cétoines, la pièce triangulaire grande, saillante en dessus, remplissant elıtièrement l'intervalle compris entre les angles posterieurs da corselet et ceux de la base des élytres. Soil donc que res espèces rentrent comme division dians les Cétoines, scit qu'on en constilue un genre dislinct, on remarquera comme leur étant particulicrs, au moins dans l'un des sexes, les caractères suivans : chaperon en carré un peu rétréci postćrieurenient, son bord autćrieur sinué, ayant ses an les angles postérieurs formant aussi nne petite corne de cliaque côts au-clessus de la base des antennes. Disque du claperon portanl une corne longue, courbe, relevée, aplatie depuis son milien jusçu'à son extréniré, fort ćlargie, creusée et plus on moins ćchancrée dans cette dernière parite. IIenton grand, presque trilobé, ses lobes latéraux courts, l'intermédiaire f.r" grand, carré, ayant ì ses anyles littéraux une petile épine droite, liorizontale. Nuns avons oliservé ces caractères dans un individu non rommé de la collection de M. Bosc, qui a eu la cumplaisance de nous le communiquer et dont la patrie esı l'île de Java; nous pensons que res caractères lni sont conmuns avec la Cetonia micans citée plus haut, el qu’i's se relruveront dans toutes les espèces asiatignes qu'on a pu joindre jusqüici aux Goliallss; inais ce derrier genre tel qu'il reste après ce premicr retranchement comprend encore des especes très-s dilféren'es les mnes des autres. Aiusi les Goliarlis . Rrivain Lam. (Céluive Goliall no. 1. de ce Diclionnare) el Cacique Ian. (C'́loine Cacique no. 2. pl. 157. fig. 2. Encycl.) ont la pièce triangulaire assez sallante el reuplissani envirun la moitié de l'espace compris entre les augles postérieurs du corselet el ceux de la base des clytres; lenr tête et leur chiaperon sont à peu près contorniés comme dans la. Cetonia micans et l'espèce de Java, d́́jä mentionnées ici, leurs cnisses antérieures sont mutiqgues et leurs jambes de devant n'ont las d'échanciure.

N'ayant pu voir en nature qu'un seul individa. 
faisant partie de la collection publique du Roi, et encore à travers une glace, nous n'avouns pu décider si ces insectes duivent seulement fornicr ane division dans lés Cétoines ou un genre parliculier auquel il faudroit conserver le nom de Goliath. Dans l'un ou l'antre cas ils auront pour caractères disinctifs : pièce triangulaire astez saillante, mais n'occupant que la unotić de l'espace compris entue les anyles postérieurs du corselel el ceux de la base des ćlylres. Corstet arroncii sur ses côtés et presque jusque vis-it-vis de l'ćcusson, prolongé en face de celui-ci, mais ne le couvrant pas. D'après cela nous proposerons ici l'áablissement d'un genre nouveau sous le nom d'Inca, lequel renferinerai des espèces de Goliatlis de l'Amérique méridionale qui offreut des caracteres particuliers que nous allons signaler, el diffírens de tous ceux gitue nous venons de mentionner.

La subdivision des Málitophiles yui a pour caractère : pièce triangulaire re sallant pas en dessus et ne s'avançant point dans l'intervalle compris entre les angles postérieurs du corselet et reux de la lase dés ély tres, contient trois genies: Trichie, Inca el Jópitrix. (Voyez Scala gámess.) Ce dernier ve prósente qu'un seul crochet aus tarses postérieurs. Daus les 'Trichies le mentun est petit, à peine écliancré, le claperon n'est ni releve, ni fourchu; les cuisses de devant sont uutiques, et les jambes antérieures n'ont aucune échiancrure notable.

Antennes composées de dix artirles, le premier le plus long de tous, hérissé de poils roiles, les quatre suivans coniques, les sixième el scptieme courts, cupulaires, les trois derniers formant une massue ovalte-ilongíe, un peu velue, plus longue dans les unâles que daus les femelles. - Labre presque membraneux, caché sous le cláperon.-Mandebules très aplatic's, en furme de lanes minces. - Mâchoires terninćes par un lobe en forme de pinceau. - Palpes maxillaires ayant leur dernier article trét-ling, fresque cylindrique; las labiaux fort courts. - Languette point saillante. - Menton grand, large, trés-c'chancré en clevant. - Téte en carré jeu alongé; chaperon fortement

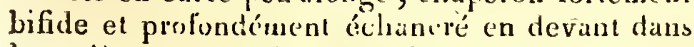
les inâles; ses anğles postérieurs ayant dons les deux sexes une peltte pointe élevée en devant des yeux; chaperon dés femelles nolablement releví $\grave{a}$ son bord antćritur; celui-ci portant souveut trois petites pointes spiniformes. - Ycu.x grus, saillans. - Corps assez épais. - Corselet paroissant arrondi vu en dessus, à peine éctiancré éa devant, ne l'étant pas en arrière, ni prolongé dans cette partie. - Piéce triangulaire nullenent suillante. - Ecusson assez grusd, en triangle curviligne. - Elytıes saus simus latéral, recouvrant des ailes ti lairsant à un l'extrémité de l a bdomen. - Abdomen assez épjais. - Pattes longues; cuisses antérieures armées dans les deux sexes d'une éprne assez forte; leurs jambes forte- ment écliancrées à leur base interne dans les deux sexes, ayant deux fortes dents, outre la termianale, au côté extérienr. Jambes interácítiaires et postórieures ununies extórieurement de deux épines, plus prononices dans les măles que dans les femelles: dernier article des tarses le plus grand de lous, terminé par deux crochets grands et simples.

Jes quatre espèces que nous plaçons dans ce genre vosisin des'lrichies, sont de grande taille el propres à l'Antérique méricionale. Leurs mœurs ne nous sout pas comnues.

Nous indiguerons 1 $^{\circ}$. Inca barbicorne (Incel batbicornis. Noв. La femelle a le chaperon selevé, saus pointes particulières, c'est la Cétoine pulvérulente n². 38. pl. 161. fir. 14. de ce Dictionnaire. Trichiuspulperulentus. Scnas. Syn. Ins. tom. 3. pag. roo. $n^{n}$. 6. Le mâle est le Goliati baldironlle. Lat. Regn. anim. tom. 4. pl. XIII. fig. 1.) Da Brisil. 2". In'a de Wéler. Inca Weberi. N⿴в. Cetonia Ynca. Wёв. Cbserv. entona. pag. $66 . n^{\circ}$. 1. Wille. la A. Syst. Eleut. tom. 2. pagr. 136. $n^{\circ} .5$. Mále. Du Pórun. 3". Inca bifron: (Incalifions. Nов. Cétonuabifions. Ouv. Entom. lom. 1. C'étoin. p.82.n". 114 1,1. 12. fig. 117. Mâle. FA B. Syst. Eleut. tom. 2. pug. 135. $n^{\circ}$. 3. Hate. ) De Cayenue. 4․ Ine'a serricolle. (Inca serricollis. Noв. Goliath serricollis Vej. Calal.) Du Brésil. Dansces denx dermères espéces le chaperon de la fenclle porte sur son bord antérieur trois petites pointes spiniformes.

I.ÉPITRIX, Lepitrix. Trichius, Melolontha. Fab. Cetonia, Melolontha. (Univ.

Genıe d'unsectes de l'urdre des Colfóptères, section des Pellamires, famille des lamellicornes, lribu des Scaral-ides (division des Méliluplisiles).

Dans les Mólitophiles dont la pièce triangulaire ne fait point de suillie en de-sus ( voyez Scaraiéides), les lneas el !es Trithics oul deux crochets eutiers el cugalux à chacun de leurs tarses, ce gui les distingue suffisimment des Lópitrix.

La's espèces qui composent ce gence nouveat dont le now viem de deas mots grecs qui indiquent que le corps est en mème temps écailleux et velu, avoient ćlć coulondues jusıu’à présent par tons les atuteurs avee les lricliges (1) et les Hannetons. Il est imposidible de les réunir à l'un nu i l'autre de ces genres, les crochets de leurs quatre tarses antélieurs élant négaux el inégalement bitites, et leurs tarses pustérieurs n'ayans qu'mu seul crochet, celui cu enties; au lieu que les Hannetons ont d'ux crocluets à chacuu de leurs tarses, ces crochets entiers, dentés à leur base et la massue des antennes composée de quatre à scpt

(1) Dans les ouvrages d'Olivier les T'richies re forment quiune division du geare Citoide. 
feuillets. Ajoutez à cela la forme de la bouche très-différcule daustes Phyllophages, de celle cies Dlélitophiles. Quant aux Trichiés, nous ajouterons ì la dillérence énoncée plus haut, que leurs antennes sont de dix arlicles, tandis cqu'elles n'en ont que neuf dont les trois dernier's forment la massue, daus nos Léfitrix; ces dernities ont quelques trais de resscmblance arec les Anisonyx, mais clles en dilliıent par leur têle moins alungée, les parties de la bonche plus couries et presquidendicues is celles des richies. Ces remitrques nous ont ćlé communiquées pal' notre excollew guide M. latreille, qua se résenve de donner plus en délai! les calractères propres à ce gente. Nous y rapportons avec lui les Céloines suivantes de ce birtionnaire: $1^{\circ}$. lilyée no. 100 . pl. 16 . fig. 24. Trichius lineatus $10^{\circ}$. 15. l'AB. Syst. Eleul. Lepitrix lineata. Noв. 20. nigripode n". 101. Trichus nioripes $\mathrm{n}^{\circ}, 17$. l' $\mathrm{AB}$. id. Lepatrix nigripes Nob., el encore le flumeton ritcuarci a $0^{\circ}$ 132. Mclolontha abbreviata n". 126. NAB. id. Lepitrix abórevata. hon. Tous du Cap de BuneEspérance. (S.H. ei A. Serq.)

SCARiTL, Scarites. Fab. Oenv. Lat. Dej. (Spéc.) T'enebrio. lirnv. Attelubus. Lle ('éer.

Genie d"insectes de l'ordre des Colćoplères, section des Pentancres, fumille des Carnassiers, tribu des Carabiques (division des Biparlis).

Les Surites funt partie d'un groupe de cetle division dont le caractère est: meaton arliculé lisissant à ḋcourcrt une grande partic de lit bouche; junbes antérieures palmées : matudibules forlenent dentces inlérieurement. (Voyez Scaprìre.) La les (Garnes se disinguent par la dilatation du dernier aricle de leurs quatre palpes exićieurs: les Acimlloscèlus par leurs jumbes postérieures larges, courles, arquées, ainsi que par les trochanl'rs de leurs deux dernicres cuisses presqu'aussi grands que ces cuisses mêmes. Les Pasiunaques onl le col'selel éctancré postérienrement ct les Scapteres l'ont presque carré; en oule lcs mandibules dans ce derzier genre sont peu avancécs.

Antennes presque moniliformes, composées de onze articles, le premier très-grand, les autres beaucoup plas petits, grossissant insensiblement vers l'extrénité. - Labre très-court, tridenté. Mandibules grandes, avancées, fortement dentées intérieurcuncot. - Mâchoires crochues à leur extrémité. - Palpes maxillares extéricurs de yuatre aricles; les labiaus de trois; ces qualre palpes ayant lenr dernier article pícsque cylindrique; les maxillaires internes de deux arlicles. - Menton articulé, concave, fortement trilobé.-Languette courte, lurge, évasée au bord supérieur. - Tête très-grancle, presque carrée. - Corps assez alongé, cylindrique ou peu aplati. - Corselet séparé des dytres par un ditanglement, convexe, presqu'en croissant, échäicré antéficurement, arrondi à sa partie postérieure et souvent un peu prolongé d.ns son milieu. - Ecusson nul. - Elytres assez alongres, souvent parallèles, s'élaryissunt quelquetois un peu postérieurement, recouvrant lout l'abclomen ol rarement des ailes. - Abdomen apliti, arrondi sur les côtés. - Pिattes assez fortes; jaubes antérienres larges, dentécs extérieurement el comme palmées, échancrées aú côté interne; jambes inlermédiaires simples, quelquefois un peu plas larges vers lcur extrénilité, ayant seulement sur le côté cxtćrieur, nne ou deux épines assez forles. Jambes postérieures quelquefois cilices: tarses simples dars les deux sexcs.

Les Scarites vivent dans les terrains siblonneax près de la mer et dans les coutrées imprégnées de substances salines. Ils se tiennent dans les zônes chandes des deux Mondes el creusent la terre où ils se forment des espèces de terriers ponr éviter lat lumic̀re du jour; ils en sortent la nuit et vont allaquer d'antres insectes. M. Le Fúbure de Cérisy nous a assuré s'être souvent servi du moyen suivint pour prendre le Scärite Pyracmon. Cet observaleur déposoil des Tannelons comıuns dans les endroils ou il croyoil que cette espèce faisoït son babitation, el venoil en uite saisir ces insectes à la lumic̀re; cependuut quelques auteurs ayant avancé que les Scarites n'ont point d'habiludes carnissières, il seroit utile que les entomologistes des pays qu'ils habitent pussent bien éludier les noul's des autres espèces de ce genre. Les larves somt inconnucs. Ces Coléoptçres d'assez grande taille sont de couleur usire, ordinairement luisante. On en conuoît au moius use quarantaine d'espèces. M. le comte Dejeau daus son Spéci:s en décrit un assez grand nombre de nouvelles; il divise ce gemre de la manière suivante.

${ }^{r e}$. Division. Jambes intermédiaires armées de deux épines.

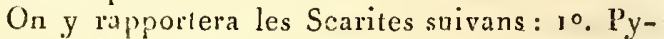
racmun. Encycl. pl. 181, fig. 2. (Scar. Pyracmon. Boneits. Scar. gigalls. Oliv. Entoml tom. 3. Scant. pag. 6. no.5. pl. 1. fig. 1. Fuun. fianc. C'oléopt. pl. 2. fig. 1.) 2o. siliunné. Encjel. pl. 181. fig. 12. (Scar. sulcalus. Oliv. id. pagr. 7. $n^{\circ} .5 . p l$. I. fig. 11.$) 3^{3}$. susuterrain. (Scar. sabterranélis no. 8. FAB. Syst. Eleut.)

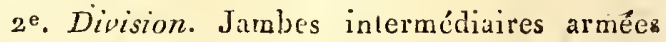
d'une seule épine.

Cetle division comprend les es]jèces suivantes : $1^{\circ}$. indien. (Scar. indus. Oriv. Entom. tom. 3. Scarit. pag. 9. $\pi^{\circ}$. 8. pl. 1. fig. 2.) $2^{\circ}$. terricole. (Scar. terricola. Boner. Lat, nouv. Dict. d'hist. nat. $2^{\mathrm{e}}$ édit.) $3^{\mathrm{o}}$. lisse. (Scar. lovigatus $\mathrm{n}^{\mathrm{n}} \cdot \mathrm{g}$. FaB. Syst. Eleut.)

ACANTHOSCELL, Acanthoscelis. LAT. (Fum. nat.) DEJ. ( $S_{\text {svéc. }}$ ) Scarites. FAB.

Gearc d'insectes de L'ordre des Coléoptères, 
section des Pentamères, famille des Carnassiers, tribu des Carabiques (division des Biparlis).

Parni les Carabiques-Bipartis à menton arliculé laissant à découvert une grande parlie de la bouelie, ayanı les jambes antéricures palmées et les mandibules fortement denlées intérienrement, les Carènes on les palpes extérieurs dilalćs; le corselet des Pasimaques est éehaueré postéricurement; les Scarites ont leurs jambes postéticures droites el presque simples; enfin les mandibules des Scaptères sont peu avancées. Cette eomparaison isole le genre Acanlhoscèle.

Thenton articulé, presque plane, forlement trilobé. - Téte courie, Iransversale. - Corps court, convexe. - Corselet très-convexe, court, presqu'en earré transversal. - Elytres courtes, trèsconvexes, recouvrant tout l'abdomen. - Pattes assez courtes; jamlies antérieures très-forlement palmées : euisses postérieures conrtes, un pea renflées; leurs trou hanters tris-gros, plus longs que la moitié des cuisses ; jambes postérieures eourlus, larges, arquées, couvertes d'épines.

Les aulres caraclères conune dans les Scariles (voyez ee mol). Le type de ce genre dont le nom tiréde deux mols grecs signifie : jambes épineuses, est le Scarites mificomis no. 11. FA в. Syst. Eleut. (Acanthoscells ruficomis. LÁt. DeJ.) Du Cìp de Bonne-Espérance.

OXYSTOME, O.xystomus. LAT. (Fam. nat.) DEJ. (Spéc.)

Genre dinsectes de "orlire des Colćoplères, seelion des Pentamères, limille des Carnassiers, tribu des Carabiques (division des Biparlis).

Parni les Carahiques de cetle division dont le menton articulé laisse à déconvert lone grande par. tie de la bouclie, qui ont les janbes antérjeures palmées el les inandilules point ou légèrement dentelćes intírien:ement (aroy. Seaptèm:), les Clivines ont le dernier ar:icle des quatre palpes extéricurs conformé unilormément, c'es!-a-dire en fuseau, leur's inaudibules sont coultes. Dans les Oxy. gnathes le men!on est presque plane et le dernier article de leurs palpres libiaux presque eylindrique: ce dernier carractère se reirouve dans les Camplodontes, qui ont en outre le corps dépriané el le corselet presque corliforune.

Antennes moniliformes, de onze arlicles, le preaier très-grand, les auıres beaucoup plus peits, presqu'égaux. -- Labre eourt, tridenté.Mandibules grandes, très-avancćes, aignës, non dentées intérieurement, tròs croisćes l'une sur l'autre dans le repos._- Mấchoires crochues à leuŕ extrémité. - Palpes extérieurs très-grands, les maxillaires exterses ayant lenr dernier article long, cylindrique, troupué à l'extrémité; les labiaux l'ayant plus long que le pareil des maxillaires, un pen courhe el pointu. - Menton arliculé, très-concave, trilubé. - Tête ayant ses bords latéraux munis de deux ou trois appcndices spiniforizes (au moins dans l'espèce serrant de type ). - Yeux petils, peu saillans. - Corps linéare, très-alongé, presque eylindrique, ipais proporlionnel!enent ì sa largeur. - Corselet presque earré, très-foiblenıenı, échancré cn devant, sćparé des élytres par un élranglement. - Ecusson nul. - Elytres recouvrant entièrement l'ahdomen. - Abdomen épais, cylindrique. - Pattes caurles; jambes antélieures palmées, les inlernćdiaires et les postérieures ayant quelques épines au côté extérieur.

Oxystome vient de deux mots grees doul le sens est : bouche pointue. On ne connoit pas les inours de ces insectes, mais il est présumable yu'elles dillèren! peu de celles des Scarites; cependant lc manque de dentelures anx mandibules pent apporter des dilférences que nous recommandouns à I'élude des naturalistes. Les deux espèces comnnes sont du Brésil.

\section{Oxystome cylindrique, O. cylindricus.}

Oxystomus niger, nitidus; tibits anticis tridentatis : clylris profundè sulcatis, pilis ruris longioribus.

Oxystomus cylindricus. DEJ. Spéc. tom.. pag. 410.

Longueur 14 lig. D'un noir luisant; jambes antriemres muies extérieuremont de trois dents ourre la terminale. Elyrres profondéanent sillonnées, ayant des poils lungs et rares.

Du İrésil.

\section{OXYGNATHE, Oxygnathus. DF.s. ( $s_{p e ́ c}$.)} Scarites. WIFDEM.

Gcure d'insectes de l'ordre des Coléoplines, secrion dos Pentamères, funille des Carnassiers, rribu des Carabiques (divisiou des Biparlis).

Le groupe dont les Oryginalles dépendent renferme qualre genres ( voyez Senptìr), savoir : Oxystorse, Oxygnalhe, Camptodonte el Clivine. Le premier est dislinet par sin menton très-concave el par le dernier arlicle des palpes labianx un peu courlue ét pointur. Les Caluptodontes ont le corsele! presque cordiforme, leurs antenues sont presque filitormes, un peu plus longues que la tête et les mandibules réunics; enfin dans ce genre les élytres sont un pea déprimces. Dans les Clivines le dernier arlicle des quatre palpes extérieurs est en fusea et les mandibules sont coniles.

M. le conte Dejean a fondé ce grenre dans son Spéciès. Le Iype est un Colíontìre que M. Wiedemann avoit placé parıni les Scarites. Le non générique vient de denx mots gress qui signifient: mâchoires aiguës. Ses caraulèrés son!: menton articulé, presque plane, légòrement urilobé. Labre très-court, pen dislince. Mandibules avancées, arquées, tranchantes intéricurement et non 
dentées dans cette partie, très-aiguës á leur extrémilé et se croisant l'une sur l'autre. Palpes assez alongés, les laliaux un pen plus courts que lcs maxillaires; dernier article des uns et des autres, alongé, très-légèrement ovalaire, presque cylindrique. Antenne's monilifornes, flus courtes que la tête et les mandibules réunies; lenr preınier article à pcu près anssi long que les tıois suivans pris enseable, allant un peu en grossissant vers le bout, les autres beaucoup plus courts, presqu'ćgaux cutr'eux, arronds, grossissint seusiblement à leur extrémité. l'ête assez grande, alongée, préque carréc. Corps alongé, cylindrique. Corselel presque carré. Elyzres alongées, parrallc̀les, cyliudriques et arrondies à l'extrónité. Jambes antérieures assez fortement palncées.

\section{Oxygnatere alongé, O. elongatus.}

Oxyguathus niger, cylindricus; mandibulis exsertis, tibiis aulicis tridentritis, posticè unidentatis; elytris elongatis, parallelis, sulcatis: sulcis punctatis; antennis pedibusque piceis.

Oxygnathus elongatus. DEJ. Spéc. tom, 2. pag. 47 . $n^{\prime}$. 1. - Scarites elongaíus. Wiedem. Zoolog. magaz. I1. 1 . pas. 33. $n^{\circ} \cdot 52$.

Longueur $5 \mathrm{lig}$. Noir, cylindrique; mandibules avancées. Jámbes autéliéures ayant au côté cxterne trois fortes dents et en outre une petite dentelure après la troisième dent; leur côté intérieur est muni de detix fortes éprines; on en remarque aussi une assez forle près de l'extrénité des janbes intermédiures. Eytres alongées, paralliéles, sillonnées; ces sillons poucitués. Antemes et partes brunes.

Los Iudes orientales.

CAMPTODONTE, Camptodonlus. Des. (Spéc.)

Genre d'insectes de l'urdre des Coléoplères, section des Penlancres, fumblle des Carnissiers, ribu des Carabiques (division des Biparlis).

Les genres Oxystome, Oxygnathe, Cimptodonle et Clivine forment un groupe dans cette division. (Toyez Scaprére.) Daus les Oxystomes le menton est tres-concave et le dernier arlicle des palpes labiäux nn peu courbe et poinla. hes Oxyguathes ont le corselct presque carré, les antennes moniliformes, plus couries que la tête et les mandibules rónuics; lenrs élytres sont cylindriques el arrondies à l'extrénité: enfin les Clivines soni recounoisnibles par leurs mandibules vourtes el par leurs quatre palpes extrrieurs doni ke deruier article est en fuseau.

Ce yrenre dont le nom est liré de deux mots prrecs dunt le sens est: dents courbées, a élé établi par M. Le comle Dejean dans son Spéciès. Ses caractères, suivant l'anleur, sont : menton arliculé, plane, trilobé antórieurement, la dent du milieu plus longue gue les latéxales, parcissant formée de deux côtes élevées qui se prolongent jusuqu'à la base et laissent entrelles un sillon asse 4 inarqué. Labre très-court, peu distinct. Mandibules grandes, avancées, conrbées, un peu concaves, tranchanles intérieurement, très-aiguës, sans deni sensible à leur base interne. Palpes alongés, les lithiaux pius courts que les maxillaires. Dernier article des uns el des autres alongé, lićs-lígèrement ovalaire et presque cylindrique. Antenues presque filitormes, un peu plus longues que la tête et les mandibules réunies; leur previer article un pen plus gros que les antres et presqu'aussi long que les deus suivans pris enscmble; tous les autres plus petits, assez alongés et grossissant un peu vers l'extrémicé. 'Tête assez grinde, ovale, plane, un pen rétrćcie postéricuremcnt. Corpss alongé, un pen dépriné. Corselet presque cordiforme, assez plane. Elytres un peu déprinées, alongées, presque parallèles. Paatles à peu près semblables à celles des Cliviues. Jannies antéricures palinées.

\section{Camprodon're cayennois, C. cayennensis.}

Camptodontus niger, maudibulis exsertis; capite punctato, thorace sublutiato, quinquessicato; elytris sulcatis: sulcis profunde punctatis.

Camptodontus cayennensis. De.J. Spéc. tonı. 2. pag. $477 \cdot n^{\circ} \cdot 1$.

Longueur 6 lig. Noir. Mandilules avancées. Têle poncluće. Corsclet semi-luoaire, margué to cinq sillons. Elytres sillonnées, ces sillons profondónen! pouctués.

De Cayenne.

Clivine, Clivina. Lat. Dej. Bonelz. Disc7irius, bonel. Scarites. Fab. Osiv. Tenebrio. LIN N.

Genre d'insectes de l'ordre des Coléoplères, section des Peotamères, famille des Carnassiers, tribu des Carabiqucs (division des Biparlis).

Dans les Bipartis à jarbes antérieures palroées, à menton articulé laissant à découvert la plus grande partie de la bouche et dont les mandibules sont saus dentelures sensibles à leur parlie interne (voyez Scaptìre), les genres Oxyslome, Oxygnathe et Camptodonte se distinguent par leurs arandibules avancées. En ouire dans les Oxyslomes le derrier article des quatre palpes extérieurs est conformé d'une maniçre différente, celui des masillaires étant cylindrique, ironqué au bout, tandis que dans les labiaux il est pointu it l'extrémité. Les Oxyguathes ainsi que les Camptodontes ont le dermer article des patpes labiaux cylindirique.

Antennes mouiliformes, de onze arlicies, ls preińie: presque cylindrique, aussi long que les deux suivans ríunis. - Labre peu arancé, coupé presque 
presquue carrément en devant. - Mandibules pen avaneées, sans aueunes dents à leur partie iulérieure.-Mrâchoires crochues à leur extrénité.Palpes extérieurs ayant leur dernier article en fuseau; les maxillaires de quatie artieles, les labiaux de trois. - Lère avancée en languette alongée dont les denx êtlés se prolongent en un pelit appendice membritneux. - Téte petite, alongée.-Yeux saillans. - Corps alongé. - Corselet plus on moins orbieulaire on plus ou moins tarré. - Ecusson nul. - Elytres plus ou moils elliptiques et convexes, reeouvrunt des ailes.-Jumbes antérieures presque toujours palmées.

Les insectes de ee genre sont de petite taille; on les trouve ordinairement cachés dans la terre ou eourant sur le sable dans les lieux liunides. On en connoit une vinglaine d'espèees. Lears larves et leurs métamo:phoses nous sont inconnues.

Aux Clivines appartiennent les Scaries suivans de Fabrieius. Syst. Eleut. $1^{\circ}$. bipustulatus no. 14. (Cliv. bipustulata.) $2^{\circ}$. arenarius $\mathrm{n}^{\circ}$. 15. $\mathrm{l}_{\mathrm{ANz}}$ Faun. Germ. fas. 43. fig. 11. (Cliv. aremaria. Faun. franc. Coléopt. pl. 2. fig. 2. Encycl. pl. 356. fig. 8.) 30. thoracicus no. i6. (Clwo. thora cica. Faun. franc. Coléopt. pl. 2. fg. J. ) $4^{\circ}$. gibbus nn. 17. Paxz. Faun. Gern. fies. 5. fig. 1. (Cliv. gibba.) Encycl, pl. 356. fig. 7. Ces deux dernières sont des Dischirius pour M. Bonelli.

\section{MORION, Morio. Lat. DeJ. (Spéc.) Scarites.} Pat.-BaUt.

Genre d'inseetes de l'ordre des Colénptères, seetion des Penlamères, famille des Carnassicrs, tribu des Carrabiques (division des Binalris).

Parmi les Carabiques-Biparlis dont le menton artieulé laisse à clécouvert une grande partie de la bouche et qui onf les jambes antérieures non pa!mées, les antennes moniliformes et le corsulet presque carré, le genre Uzène se dislingue de celui de Morion par le dernier article de ses antennes qui est plus gros que les autres et eomprimé à son exırémilé.

Antennes moniliformes, plus eourles que la moitié du eorps, ne grossissaul pas à leur extrénité, eomposíes de onze articles dislinets. -- Labre assez avaneé, fortenent íchancré. - Mandtbules assez fortes, peu avancées, arquées, assez aiguës. - Palpes peu saillans derier article des labiaux presigue cylindrique, un peu ovalaire, trouqué à l'extrémité. - Menton àiculé, eoneave, très-fortement échaniré et ayant dans son milieu une dent peu saillante, obluse, presque bilide. - Tâte un peu rétrésie derrière les yeux. - Yeux assez saillans. - Corps plui ou incius alongé. - Corseiet plane, presque curré, flus ou moins rétréci postérieurement, séparé des élytres par un érrauglement. - Elytres plus ou moins alongées, plus ou moins parrilieles, plus on moins planes. - Pattes assez fortes, mais point tresgrandes; jarbes antérienres s'álir gissant vers l'exHist. Nat. Ins. Tomb $X$. trémité, terminées par deux épines assez fortes, et très-échanrrées intérieurement, nais sans aueune dent au côté extérieur; jambes intermediaires et postérieures simples.

Nous navons vu aucune espèce de ce genre fondé par il. Latreille; nous eu dunnons les caraetìres d'apròs $M$. le eomle Dejean qui en décrit I rois espèces, denx d'Amérique et l'autre de Java. Son lype est le Morion monilicorne (Morio monilicornis. Harpalus monilicornis. I.A'T. Gert. C'rust. et Ins. tom. I. pag. 206. $n^{\circ}$ 12. Scarites Georgine. PA I.. BAuv. Ins. d' Afr. et d'Anér. Coléopt. pl. 15. fig. 5.) Des Etats. Unis, de Cayenne et du Brésil.

ARISTE, Aristus. Záge. Lat. Ditomms. Bonell. Zíége. Des. Siarites. Oliv. Carabus, Scallrus. Fab.

Genre d'insectes de l'ordre des Colínplères, section des Peutameres, famille des Cirruassiers, rribu des Carabiques (division des Bbipartis).

Les deux geures qui purmi les Carabiques-Bipartis ont pour caractè licolé, laissut à découvert une grande parlie de la bouche; jambes antírieures non piluies; antennes ì artieles presque cylindriques, sont ceux d'Arisie et d'Apolome; ethi-ci est bien chistint des Aristes par ses palpes labiaux très-alnngés et encore par son eorsilet orbiculate el glubuleux.

Antennes à peu près de la longneur cie la nocitie du corps, tiliformes, de onze aristes, le premier un peu plus gros et un pen plus long que les antres, le secoud plas court que le troisiène; tons les autres égux, alongés, presque cylindriques. - Labre arrondi, écbancré. - Mandebules courbes, assez fories, peu avanećes, unidentíes an milien de leur bord interne, sillonnces au cóté extórieur près de la base. - Pápes filiformes, les labianx plus eourts que les maxillaires axtérieurs, le dernier arlicle de tons, ovale.-Menion arieulé, concave, trilobé. - Corps déprimé.Corselet séparé de l'ahdonen par un érranglemen'. - Ecusson nul. - Elytres recouviant des ailes et l'abdomen. - Pattes de longueur mogenne; jam. les antérieures assez fortement échancrées au coblé interne.

Ces Coléontères carnassiers de moyenne gran. deur, ont le corps isoliâlre, ordinailement lrìs. ponctué; ils habitent les endroils chauds, seces et sablonneux, se lieanent dans des trous cylindriques asıez prolonds qu'ils creusent à eet ellet suit dans les crevalsses de ta terre, soit sous les pierres. Leurs larves ressemblent à celles des Ciciudètes et viveat de la mêane manière. M. le comle Dejean divise ce genve ainsi qu'il suit.

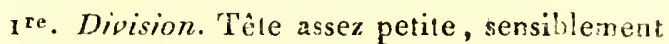
zétrécie à sa partie postérieure (celle de quelques males pottant une corne dans san milieu el me autre sur chaque nandibule). - Labre a sez avaneé, notabiement échanuré, - Yeux très-sal lu(ice 
lans. - Corselet plus an muins cordifurme. Corpns âszez alongré.

Cette division renferme ${ }^{\circ}$. Ariste calydonicn (A. culydonius.) Fuun. franc. Coléopt. pl. 2. fig. 4. Le mâle. Scarites calydonius. Oniv. Entom. tom. 3. Scarit. pag. 10. $n^{\circ}$. 10. pl. 2. fig. 12. Encycl. pl. 181. fig. 4. Le mûte. $2^{\circ}$. Ditomus fulvipes. Des. Spéc. tom. 1. pag. 444. (A. fulwipes.) $3^{\circ}$ comutus. id. pag. 440 . (A. comutus.) $4^{\circ}$. Dama. id. pag. 442. (A. Dama.) 5o. pilosus. id. pag. 445. (A. pilosus.) 6०. cordatus. id. pag. 441. (A. cordatus.)

$2^{e}$. Division. 'Tête très grosse, (mulique ainsi que les mandibules.) - Labre peu avancé, peu échancré. - Yeux peu saillaus. - Corselet presqqu’en eroissant, cuurt, très-ćchancté antérieurement pour recevoir la tête. - Corps ordinairement raccourci.

Ici se rangent 1․ Ariste bacépliale ( $A$. bucephalus.) Scarites bucephalus. Ourv. Entomol. lom. 3. Scririt. pagr. 12. no. 14. pl. 1. fig. 3 et 5. Scaurus sulcatus n ${ }^{\circ}$. 3. F. в. Syst. Eleut. 20. Ariste sphérocéphiate ( $A$. sphocrocephalus.) Scarites spharocephalus. OLiv. " $2 d$. pag. 13. $n^{n}$. 15. pl. 1. fig. 4. 3o. Dilomints capito. Des. Spéc. tomn. I. pag. 444. (A. capito.) $4^{\circ}$ obscurus. id. pag. 445. (A. obscurtes.) 5०. eremita. id. pag. 447. ( $A$. cremitu.) 6 ${ }^{\circ}$.nitidulus. id. pag. 447. (A. nitidulus.)

APOTOME, Apotomis. Hoffmans. Lat. Dej. (Spéc.) Scarites. Onı. Ross. Seвqx̃.

Genre d'iusectes de l'ordre des Coléopières, sećtion des Pentamères, famille des Carnassiers, tribu des (alabiques (division des Bipartis).

Dans les Carabiques de cette division un groupe a nour caractères: menton articulé, laissant à découvert une grande partie de la bouche; janbes antérieures non palniées; antennes composées d'articles presque cylindriques. Il ne renferine que denx genres: Ariste et Aprotome. Dans le premier les palpes labiaux sont conts et le corselet est cordifurme ou en croissant.

Antennes filiformes, à peu près do la longueur de la muilié du corps, coinposées de onze articles alongés, presque eylindriques, le prenier un peu plus grand que les suivans, le secoud un peu plus court. - Labre peu arancé. - Mandibules trèspeu suiltantes. - Palpes labiaux älongés, leu dennicr article cylindrique. - Nenton artieuḱ. - Téte peite. - Ieux saillans. - Corps alongé. - Corselet giobuleux, un peu prolongé postérieureinent, st'paré des éljtres par un étrauglement. - Ecussori nul. - Elytres plus larges que le corseler, assez alongres, convexes, arrundies postérieurement, recouvrant tout l'abdomen. - Pattes de longuenr unoyenae; cuisses un peu renliés, surtoul lcs antérieures. Jambes de devant échancrécs an!érieurement à leur côté interne.
Les Apotomes paroissent aimer à se réunir ; on les trouve sous les pieires. Ces insectes sont petits; les deux especces connues appartiennent à l'Europe méridionale.

$1^{\circ}$. A potome ronx (A. ruflus. Des. Spéc. tom. I. pag. 450. Scarites rifus. Ross. Faun. Etrusc. tom. 1. pag. 220. $n^{\circ}$. 572. pl. 4. fig. 3. Ourv. Entom. tom. 5. Scarit. pag. 15. $n^{\circ}$. 13. pl. 2. fig. 13. a. b.) D'Italie et d'Espagne. $2^{\circ}$. A potome leslacé (A. testaceus. Dev. Spéc. tom. 1. pag. 45r.) De la Russie méridionale. (S. li. et A. SERv.)

SCARITIDES, Scaritides. Nom donné par M. Bunellı à sa qualorziène famille des Carıbiques, dans laquelle il ne fait entrer que les genres Scarite, Clivine et Dischirie. M. le comte Dejean (Spéc.) reprenant ectte dénounination, l'applique aujourd'hui à la division des Carabiques de M. Latreille, yui avoit reçu de ce dernier le nom de Bipartis. M. Dejeun en forme une tritu qui renfume exactement les mêmes genres que la division des Bipartis Lat.

$$
\text { (S. F. et A. Striv.) }
$$

SCATHOPHAGE, Scathophaga. Meig. Lat. Musca. Linn. Geoff. De Géer. l'ab. Oliv. (Encycl.) Panz. P'yropa. Illug.

Genre d'insectes de l'ordre des Diptères, première section, famille des Athéricères, tribu des Huscides (division des Scalhophiles).

Cinq genres de cette division ont ponr caraclères communs : tontes les pattes simplement ambulatoires; antennes insćrées entre les yenx. 'Têle point prolongcée de chaque côté en manière de cornes. (Yoyez Scatropaices.) Les Anthomyies se distinguent facilement par leurs ailes asscz covrles, dépassant de peu l'abdomen, ainsi que par leurs yeux se touchant l'nn l'aulre dans les mâles. Les Mosilles par leur tête creusée postćrienrement et poinl du tolit convese dans celle parlie; les 'Thyréophores ont lenrs euisses postérieures grandes et ainsi que leurs jambes, arquées en dehor; enfin les Splúrocères ont le dernier article des antennes sphérique, leurs euisses de derrière larges et comprimées, les jambes posturieures n'ayunt qu'une scule épine terminale, laquelle est un peu crochue.

Antennes insérées entre les yeux, presque conliguës a leur base, plus courtes que la fiace antérieure de la têle, de trois articles; le dervier infiniment plus long que le second, en earrélong, muni près de sa base d'une soie longue, biarliculce, son premier article fort eourt, le second velu, s'amineissant notablement de son milieu à son extrúmité. - Hypostome erensé. Trompe très-distincte, de longueur moyenne, nembraneuse, rétractile, teruinée par deux grandes lèrres et eachée dans le repos. - Palpes grands, avancés, un peu en massuc aplatie, velus. 
- Tête transverse, presque conicque en devant, arrondie postérieurement. - Ieux grands, sai!lans, éeartés l'un de l'aulre dans les deux sexes. - Trois ocelles placés en triangie sur le vertex. -Corps assez alongé, ordinairement velu,-Cor. selet muni de lon l'écussoll et les pattes. - Ecusson grand, a vancé, conique. - Ailes grandes, longues, couchées l'une sur l'autre daus le repos. - Cuillerons petits. - Balanciers nus. - Abdomen alongé, presque conique. - Pattes grandes, euisses longues, assez grêles; jambes postérieures munies à leur extrémité de deux épines droiles : tarses ayant leur premier article presqu'aussi long que les quatre autres pris ensemble; eeux-ci éyaux enti'enx, le dernier terminé par deux crochets grêles, simples, et par deux pelottes grosses, assez longues, velines en dessous.

Le nom de Scallophage formé de deux mo!s -grees dont la signification est : mangeur d'ordares, a été donné à ces Diptères en raison de leurs halitudes. L'espèce la plus commune ( $S$. stercoraria) a élé observée prar Réaumur ; c’est de lui que nous transciirons lés détuils suivans. Ces insectes fréquentent habituellement lés excrémens hurnains et eeux des Purcs, c'cst là que les femelles déposent leurs œufs : eeux-ci sont oblongs; ils ont à l'un de leurs bouts deııx ailerons qui s'éeartent l'uu de l'autre eomme deux petites cornes. A mesure que la femelle pond un ceuf clle le pique dans la fiente et elle l'y fait entrer. Deux paires de Scathopliages ayaut été mises le soir dans un poudrier, étoient eneore aceouplées le lendernain vers dix lieures quö̈que la fiente partât piquée de beaucoup d'œuf; ; les femelles avoient donc pondu et s'étoient réaccouplées depuis; elles eontinuèrent ee manège pentant quatre à cinq jours qu'elles vécurent. Les aufs ont besoin pour éclore d'être environnés d'une matière molle et humide, ear ceux que Réaumur fit relirer et placer sur un papier se ridèrent et se dessécluèrent en moins de douze heures; eependanr l'œuf ne doit être plongé qu'en partie dans les exerémens, car si le bout par où la larve doit sortir en étoit eouvert, elle seroit suffoquée dans linstant où elle voudroit paroître au jour. Celles observées par notre auteur étoient provenues d'oufs pondus vers le 8 d'octobre; ces larves entrèrent en terre pour passer à l'état de nymphe sous leur propre peau qui se darcit et leur gert de coque. Linseete parfait parut à la fin du même mois.

Aux Scatlophayes appartiennent les Mouches suivantes de ce Dictionnaire : $1^{\circ}$. scybalaire $n^{\circ}$. 112. Mlusca scybalaria no. 119. F ${ }^{\circ}$. Syst. Antl. (Scathoph. scybalaria. IAT.) $2^{\circ}$. stercoraire $n^{\circ}$. 113. (S. Stercoraria). Musca stercomaria uo. 120. FA B. id. (Scathoph. vulgarts. LAT. Dict. d'hist. nat. $2^{\mathrm{e}}$. édit.) Ce dernier auieur a fort bien décrit les deux sexes : ils le sont d'une manière trèsinexacte dans Geoflioy et dans l'Eneyclopédie.
3०. Musca merdaria no. 114. F. . Syst. Antl. Scathoph. merdaria. LAT. (S. K. et A. Serv.)

SCATHOPHILES, Scathophila. Sixième division de la tribu des Muscides, famille des Athériè̀res, première section de l'ordre dies Diptères, établie par M. Latreille dans ses Familles naturelles; elle offre pour caractères : cuillerons petits, balanciers nus, ailes couchées sur le corps, antennes plus eourtes que la face de la tête, celle-cí presque globuleuse ou transverse. Celle division dont le nom tiré de denx mols grees signilie: aimant l'ordure, se partage ainsi :

I. Yeux et antennes silués à l'extrémité de deux prolongemens latéraux et en forme de cornes de la tête.

\section{Diopsis.}

IJ. Tête point njolongée de cliaque eôlé en manicre de cornes portant les yeux et les antenues.

A. Anteunes insérées entre les yeux.

a. Påles antérieures ravisseuses. Ochtère.

b. Toutes les paties simplement ambulatoires.

Anthomyie, Mosille, Scathophage, 'Thyréophore, Splıéroeère (1).

B. Autennes insérées près de la cavité buceale.

Phore. (S. F. et A. Serv.)

SCATHOPSE, Scathopse. Groff. Lat. MeIg. Fab. Mace. Tipula. Linn. De Géer. Cevia. Scopol. Bibio. Oniv. (Encycl.)

Genre d'inseeles de l'òdre des Diplères, première section, famille des Némocères, tribu des Tipulaires (division des Florales).

Ce genre a été fondé par Geoifloy et adopté par les auteurs subséquens. M. Lalreille le place dans la division des 'Tipulaires gu'il nomme les Florales (voyez Trpulares). Des sept genres quila eomposent, deux, savoir : Cordyle et Simulie n'ont point d'ocelles; parmi les genres qui en sont pourvus*les Bibionset les Aspistes ont au plus neuf arlicles aux antennes; dans les Penthétries ainsi que dans les Dilophes les yeux sont entiers, en outre ee dernier genre se distingue parfaitement de eelui de Scathopse par la partie antérieure de son eorselet garnie, ainsi que l'extrémité des jambes antérieures, d'une eouronne d'épines roides.

Nous avons dit au mot Penthétrie que les antennes des Dilophes n'avoient que neuf artieles d'après M. Latreille qui ne leur donne que ce

(1) M. Latreille pense que les genres Ropalomern er Timia de M. Wiederaann se classent dans cete subdivision. 
nombre dans son Genera ainsi que dans ses Considératzons; il est reconnu anjourd'hui qu'il y en a onze; au reste il est très-dificile de comprer. exactement le nombre des artucles des autennes dins des insectes aussi petils.

Antennes avancres, épaisses, cylindiques, insérées en avant des yeux, perfoliées, conposées de onze arlicles, le dernier slibuleux. - Trompe très-courle, hilabiée. - Páljes caclıés. - Téte petile, arrondic. - Yeux réniformes. - Trois ocelles distincts, disposés en livangle sur le vertex. - Corps obiong.-Corselet alungé, convexe. - Ailes grandes, coucliées sur le corps daus lo repres. - Abdomen large, très-obius au bont. Puttes courles, sins ópines; tarses grros, cylindriques, munis de denx petits crochets el d'ure pelotte.

Le nom donné aux iuscoses de ce genıe 'si tiré d'un mol greo qui signnifie : orlure. Ces Diptères de coulen ordinairement nuire sont de très-petite taille; leurs larves et leurs nyıphes nout aucun orune de loconnotion; celles-ci sont nues. Les Seallopses fiéfuentent les trones d'arhe et les murs humides; ils vonl ausi quelquefois sucer le miel des fleurs. L'espèce la plus conmmune vit dans les linlrines et dans les lieux sales; c'est lì aussi gue l'ou trouve sa larre. l’̈usecte parfiit quitte peu ces mêmes lienx et s'y accouple. M. Meigen décrit huit espèces de Scahopses; la suirante est nouvelle, et nous la donuons d'apiès M. Nacquart qui vienı de puhlier un ouvrage remarquable sur les Tipulaires du nord de la France.

\section{Scatнopsf majeur, $S$. major.}

\section{Scathopse thoracis lateribus argenteis.}

Scathopse major. MAcQ. Ins. Dipt. Tipul.pag. 33. $n^{\circ} \cdot 2$.

Longueur 2 lig. D’un noir velouté; côtés dı corselet argentés antérieureıneut; partie des janbes el des larses blanchitre.

Des environs de lillie. Il y est rare.

On rapportera à ce sence: ${ }^{\circ}$. Scathopse noté, S. notata. Meig. Dipt. d'Eur. tom. 1. pag. 30o. $n^{\circ}$. 1. - Mace. Ins. Dipt. Tipul. pag. 13. $n^{\circ}$. 1 . Cest le Bibion orduricr no. 10. de ce Dictionnaire.

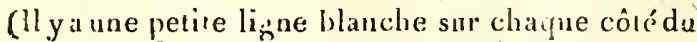
corselet et les antennes ont onze ariticles.) $2^{\circ}$. Sca. thonse flavicolle, $S$. flavicollis. ME M. id. p. Joz. $n^{\circ}$. 8. Il se trouve aux environs de Paris sur les Aleurs.

Nota. Fahricius, Syst. Antliat.; décrit rois espèces comme élanı de ce genre, mais celles quilil nomme reptans $\mathrm{n}^{\circ}$. 2. et maculata $\mathrm{n}^{\circ} .5$. appartieanent aux Sinulies. Le Scallopse du Buis de Geoffroy n'est pas de ce genre. M. Laideille présune qu'il fait partie des Cécidomyies.

DILOPHE, Dilophus. Merg. Lat. Mace. Mirtea. Fав. Bibio. OLIv. (Encycl.) Tipula. I.rnv.

Genre diosectes de lordre des Diptcies, pre- mière section, famille des Nómocères, tribu des 'Tipulaires (division des Florales).

Sept genres rontposent cette division. (Foyez Tipulares.) Ceux de Condyle et de Simulie sont séparés des antres par l'absence d'ocelles. Les Bibions, les Asprisies, lcs Penthélries et les Scathopises ont leur corselet inulique et leurs jambes autérieures déprou rues d'épines disprosées en conlonnée. Antennes avancées, cylindriques, perfiliées, composíes de onze articles, les qualre derniers peu distincts. - Trompe courte, bilabiée.- Palpes avancés, reconruŕs, de cing articles, les deux premiers cousls, eylindriques, le troisième plus long, ćlarui à son extrénité; les deux derniers plus longrs que les précédens, cylindirques. Téte peive el aplatie dans les femelles, grosse et arondie dans les mâles. - Y eur entiers, velus; très-petits, ovales et espacés dans les femelles, grands, arondis et réuris daus les mâles. - Trois ocelles distincı, disposćs en triangle sur une éminence du verlex. - Corys court, assez gros. Corselet couvexe, muni à sa plartie anlérieure de deux rangées de pelites épines dentiforares. Ailes de la longueur de l'abdomen. - Abdomen alongé, linćaire dans les mâles, un peu renflé dans les femelles. - Cuisses ayant un sillon longiludinal. - Jambes antérieures terninćes par une couronne d'ćpines; leur milieu offrant aussi quelques épines à sa partie extérienre; premier article des tarses long; les suivans allant en diminuant de longuenr, le dernier terwiné par deux crochets et une pelotte trifide.

Ce genre qui paroî a voir les mêmes mœurs que celui de Bibion, a élé démembré de ce dernier par M. Meigren; il l'a nommé Dilophus, de deux mols grecs qui signifient : double peigne en raison des denx raugées d'épines que l'un remarque sur le corselel. Cet auleur en décrit cinq espèces; la plus cominune esı le Dilophe de févicier, Dil. febrilis. Encycl. pl. 386. fig. 49. Feunelle. Dilophus wulgaris. Meig. Dipt. d'Eur. tom. 1. pag. 506. no. I. MacQ. Ins. Dipt. Tipul. pag. 19. no. 1. Tipiela febrilis. Lin n. Hirtea febrlis. $n^{\circ}$ : 13. Fав.Syst. Antl. (en retuanchant le synonyme de Geoffroy). C'est prohablement aussi le Bilsion nègre $n^{\circ} .9$. du présent Dictionauire. (S. F. et A. Serv.)

SCATOPHAGE, Scatophaga.FAв. (Syst. Antl.) Les Diplèies que Fabricius pluce dans ce genre doivent êlre rćpartis dans plusieuls autres; ainsi unus signalerous comme appartenant à celai de Téla nocè re Lst. les Scatophaga murginata $\mathrm{n}^{\circ}$. 1 . rufifrons $n^{\circ} \cdot 7 \cdot$ graminum $n^{\circ} .8$. obliterata $n^{\circ} . y$. reticulata $11^{\circ} .12$. el stictica $n^{\circ}$. 13. Le genre Oscine La t. réclaine les Scatophaga nigripennis no. 6 . et marmorea $\mathrm{n}^{\circ} .27$. La $S$ catophaga rufipes $\mathrm{n}^{\circ}$. 18. et la Baccha splegea n $^{\circ}$. I. de Fabricins, ne firment qu'une seule es:ièce; c'est lé Sepedon palustris Lat. Voyez SÉpédon.

(S. H. et A. SERv.) 
SCAURE, Scaurus. Fab. Oliv. (Entom.) Lat. Henest.

Genre d'insectes de l'ordre des Coĺoplères, section des Hútéromères (première dirision), famille des Mélasomes, tribu des Pinćliaires.

Parmi les genres de cette tribu daus lesquels le menton ne recouvie point la base des mâchoires (vovez Prmeliarase), ceux de Moluris, Psammode, Tagénie et Sépilie se distingnent par le dernier arlicle de lears antennes, legeel n'est pas sensinlement plus grand que le précédent; en outre, le second de ces genres a le labre échancré el la lèvre bifide.

Antennes filiformes, de onze articles, les deux premiers, mais surtout le second, petits; le troisième plus long que clıacun des sept suivans; les premiers de ceux-ci un peu coniques, les derniers ovales-globuleux; ie onzieme un peu obconique, pointu à l'extrémité, de la longuear du troisième, et par conséquent beaucoup plus long que le dixième.-Labre coriace, avancé, transversal; son bord antérieur entier, cilié.-Nandibules contles, cornées, à peine bifides à l'extrémilé. Mâchoires droitcs, cormées, bifites, dilatétes et comine tronquées à leur extrémité. - Palpes maxillaires presque filiformes, plus longs que les labiaux, de quatre arlicles; palpes labiaux de trois articles presqu'égaux. - Henton de grandeur moyenne, en carré transversal, entier, ne recouvrant pas l'origine des mâchoires. - Languette nue, encière. - Téte plus élroite que le corselet. - Corps ovale-oblong. - Corse?et point rebordé, tronqué à ses bords antérieur et postćrieur. les latéraux arrondis. - Ecusson petit. - Elytres soudées ensemble, embriassant les côtés de l'abdomen, s'alongeant en pointe mousse. Ailes nulles. - Abdomen ovilaire. - Pattes fortes; cnisses antérieures assez grosses, ordinairement nunies d'une ou de deux épines; jumbes rabotenses, les antérieures souvent un peu conrbes; tarses filiformes, leur premier article plas grand que les intermédiaircs, le dernier le plıs long de tous.

Ce genre a été eréé par Fabricius qui y introduisit mal-à-propos sous le nom de Sulcatus un Carabique du genı A Ariste. Ite petit nombre d'espèces quil contient habitent les contrées voisines des hords de la Míditerranée : elles se plaisent dans les sables ou parmi les décombres et hes nierres; leur démarche est pesante; les sexes différent l'un de l'antre par le plus ou moins de tubercules aux patles antérieures; les individus les mieux armés sont-ís du sexe féminin? M. Latreille est de celte opiniou (Dict. d'hist. nat. $\mathbf{2}^{\mathrm{e}}$, édition).

Ce genre renferme : ${ }^{\circ}$. Scaure tris!e. Encyl.pl. 195. fig. 7. S. tristis. OuIv. Entom. tom. 3. Scaur. pag. 4. $n^{\circ}$. 1. pl. 1. fig. 1. $2^{\circ}$. Scaure âtre, $S$. atrutus $\mathrm{n}^{\circ} .1$. FAB. Syst. Elcut. 30. Scaure strie,
S. striatus no. 2. Fав. id. (Encycl. pl. rg5. fig. 4.) 4. Scilure ponctué, S. punctalus rio. 4. Fab. id. (S. l. et $\Lambda$. Senv.)

SCELION, Scelio. I.atr. Ceraphron. Jur. SPIXOL.

Genre dinsectes de l'ordre des Ityménoptères, section des 'Térébrans, famille des Pupivores, nilu des Oxyures.

Parmiles Oxyures, les genres Bélhyle, Dryine, Antéon, Hélore, proctotrupe, Cinète el bélyte ont des cellules brachiales aux ailes supérieures; les Diapries ont leurs antennes insérées sur le front; dans les Céraphrons et les Sparasions les palpes maxilaires sont saillans; les Platygastres u'ont point de celfule radiale anx ailes supérieures et les 'Téléas ont leurs autenues de douse artic les, ce qui éloigne tous ces genres de cclui de Scélion (i).

dnennes instries prés de la bouche, filiformes dans les raâles; plus courtes et grossissant insensiblement vers l'extrémilé dans les femelles, composées de dix articles distincts. - Manciluales bidentées à leur extrémilé. - Patpes maxillarires point saillans, de trois arlicles au moins, les latbianx de denx. - Téte glolulense, un pen trianguluire. - Trois ocelles placés en devan: du froml, sur sa partie supérienre, disposés en triangle, tresécartís. - Corks alongé. - Prothorar court, transversat. - filcs supérieures n'ayant qu'une seule cellule (la radiale). - Abdomen aplati. - Paties de lnngueur moyenise.

Ces très-petits Hyménoplères vivent proballement dans des larves pendant leur preatier ttar. Le lype de ce genre dù à M. Latreille est le Scḱ lion rugosule, S. rugosulus. Lax. Gener: Crust. ef Ins. tom. 4. pag. $52 . n^{\circ} \cdot 1$.

$$
\text { (S. F. el A. Senvo) }
$$

SCÉNOPINE, Scenofinus. TAT. FAB. MEIG. Musca. Linn. Scop. Oti. (Encyl.) Nemotelus. DE. Gern. Panz. Cona. Schelhimb.

Genre d'insectes de l'ordre des Diptères, première section, fumille des Athéricères.

M. Laireille en créant ce gente le placa parmi les Muscides et l'y avoit maintenn jusqua a la publication de ses Familles naturelles; uous avons loujonrs pensé que par ses antennes priv'es die soie il ne devoit pas appartenir à cette tribu; notre manière de voir a été celle de M. Meigen, qui dans son quatrieme volume des Diptères d $d^{3} u-$ rope admet pour lui une famille partivulière quil nomme les Scénopiniens. Voyez ce mot.

Antennes rabat!ues, de trois articles, les denx premiers courts, le troisième alongé, comprimé,

(1) Certe compatzison est érablie d'après le nonveau travail do M. Latreilic dans ses Fanil'ís rararelles. 
en carré-long, comine tronqué à son extrémité, 1'ayant ni soie, ni style. -- Trompe rílractile, cachée dans le repos; ses levres un peu velues. ralpes extérieurs à la trompe, allant en grosissant vers leur extrénilé qui est arrondie. - Snsoir de deux pièces. - Téte hémisphírique, un peu crensće postérienrement. - Yelx grands, rapprochés dans les nûles, espacés dans les femelle:. - Trois ocelles rapprochés, placés en liangle sur nu pelit tuhercule de la partic la plus reculéc du verlex. - Corps alongrí, presque linéaile, un per eoriace.-Corselet oblong. ficusion assez grand, arrondi postéricurement. - Ailes assez pelites, parallicles et couchées l'une sur l'aulre dans le repos. - Balanciers nus, grands. - Cuillerons très-petits, peu visibles. Abdomen un peu déprimé, linćdire, en carrélons, composé de sejt segmens ontre l'anus; la plupart de ces segrnens marqués d'une ligne iransverse enfoncée. - Palles de longueur moyenne; premier article dos larses beacoup plus long que les antres, le dernier icrminé par deux erocliets et munis d'une pelotle bifide assez forle.

L.es Seénopines se pluisent à voltiger sur les murs exposés à un soleil ardent; ils cuitrent quelquefois dans les apparternens el s'y $\vec{l}$ r ent sur les vilres où ils restent, sans s'érarter dans les autres parties de la chambre. L'absence du so'eil seable leur ôler le desir de se mouvoir. Leurs larves nous sont inconnues. M. Meiggen en décrit onze espèces donl la plus grande n'excède fras trois ligues. Le noir est leur couleur dominante.

On rapportcra à ce genre: $1^{\circ}$. lia Nonche fenestrale 0".52. pl. 595. fig. I. de ce Dictionatire. scenopinus fenestralis. L'individu décrit esi un mâle ; la femelle n'a pas de stries blanches transrersales. 20. Scenopimus rugostus no. 2. FAB. Syst. Antl. 3o. Scenopinus senilis no. 5. FAB. id. $4^{\circ}$. Nemotelus niger. DE GEER. Ins. tom. 6. pl. 9. fgo. 5 . Scenopimus niger. MEIG.

\section{(S. F. et A. SErv.)}

SCENOPINIENS, Scenopinii. M. Meigen dans ses Diptères d'Emope nomme ainsi sa dix-neuvieme famille et lui donne ponr calractères: antemnes rabaltues, de trois articles, le deruier obturs, sans soie. Trompe caclıée. Abdomen composé de huit segmens. Elle ne corilient que le genre Scénopine. (S. F. et A. SERY.)

\section{SCHIZOPODES, Schizopoda. I.ATr.}

M. Latreille désigue sous ce.uom (Fam. nat. du Rógne anim.) la liuilième ribu de la firnille des Macroures, ordre des Décapodes. Les crustacés qui la composent tiennent sous quelques rapports des Stomapodes, des Amphipocies et même des Entomostracés. Les femelles portent leurs œufs at la base inférieure du pré-abdomen. Tous les pieds de ces inimaux sont foibles, tiliformes, simplenent propres ì la uataiion, et soit aecompagnés d'un long appendice latéral, soit profondément bifi les ou mulifides à leur extrémilé; aucun d'eux n'est terminé par ce renflement que l'on a désigné sous le noun de main; le crochet lerminal est très-petir. Dans cenx dont les pieds ont un long appendice, ces organes paroissent former quatre raugées lor:gitudinales, dont les deux latćlales se eomposent de ces appendices. M. Latreilie divise celte tribu ainsi qu'il suit :

I. Posl-abdomen terminé par une nageoire à cinq feuillets.

Les genres Molcion, Myzis, Crytops.

II. Appendices latéraux de l'extrémité postérieure du post-abdomen en forme de stylets.

Les genies Nébalie, Zó́, Condylure. Voyez tous ces mols. (E. G.)

SCIAPE, Sciara. FAB. Cet auteul dans son Systema Antliat. donne ce nom à un genre de Diptères qu'il compose d'espèces qui auparavant figuroient dans ses genres Hirtea el Rhagio. Les aulres sont nonvelles pour lui. Ces espèces appartiement à diver's genres, ainsi : $1^{\circ}$. les Sciara Thomo $\mathrm{n}^{0}$. 1, morio $\mathrm{n}^{\circ}$. 2. font partie des Molobres LAт. $2^{\circ}$. les Sciara lineata no. 3. nigricornis $n^{\circ} .4$, sont des Platyura MEIg. 3०. les Sciara striata $\mathrm{n}^{\circ} .5$, lunata $\mathrm{n}^{\circ}$. 6. appartiennent aux Mycelophila Merg. $4^{\circ}$. les Sciara fiscata no. 7 , punctata no. 13, cincta no. I5. sont des Rhyphus MErG. (S. F. et A. SERV.)

SCIARE, Sciara. Mejg. Ce genre de Diptères est le même que celıi de Molobre de M. Latreille. Voyez lia Tuble alphabétique.

$$
\text { (S. F. et A. Serv.) }
$$

SCIOPhile, Scioplila. Hoffit. Meig. Lat. Msce. Asindulum. Lat. (Gener.) Tipula. Fab.

Genre d'insectes de l'ordre des Diptères, premic̀re section, famille des Némocères, tribu des Tipulaires (division des Fungivores).

Dans celle division trois genres se distinguent par les caraetères suivans. ( ${ }^{\prime}$ oyez Tipulaires.) Yeux entiers : musea point rostriforme : antennes de la même grósseur ou plus menues vers le bour, grennes, noueuses ou perfolićes. Les Campylomyzes sont distinctes par leurs antennes composées seulement de quatorze articles, et les Platyures qui en ont seize comme les Sciophiles, n'ont point leur's jambes épineuses et leurs ailes uolfirent pas de pelite cellule carrée.

Les caractères de ce genre fondé par. M. Huffmansegg et dont le noin vient de deux mots giecs dont le sens est: qui aime l'ombie, sunt exposés par M. Meigen de la manière suivante. (M. La (reille ne les a pas encore développés.)

Antennes avancées, un peu comprimées, grenues, presque de même grosseur dans tonte leur étendue, composées de seize articles, les deax 
premiers courts, cupulaires, velus, les autres pubescens. - Bouche point alongéc. - Palpes avancés, recourbés cu dedans, articulés; ces articles paroissant être aı nomhre de quatrc. - Tête presque sphiérique. - Yeu.x ronds ou un peu alongés.-Trois ocelles placés en triangle sur le haut du front, rapprochés, inégaux entreux, celui du milieu très-petit, souvent à peine visible. - Corselet ovale. - Métathorax coupé presque droil. - Ailes offrant une cellule orcinairemeut trèspeite, carrée, placée à pcú de distance de leur bord extérieur. - Balanciers nus, - Abdomen composé de sept segmens, quelquelois un peu dilaté postérieurement dans les femelles, grêle ct cylindrique dans les mâles. - Hanches alongées. - Janubes garnies latéralement de petites épines, en ayant deux fortes ì leur extrémilé.

Les mœụrs de ces Diptères ne nous sont pas connues; snivant M. Meiren on les trouve ordinairement daus les bois; il est probable quc leurs larves vivent dans les champignons. Il y en a quatorze espèces de décrites; on peut les paıtager ainsi qu'il suit.

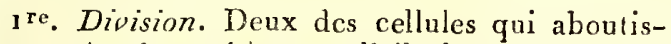
sent au bord postérieur de l'aile longuement pétiolées.

re. Subdivision. Cellule earrée de forme longue et étroite.

A cette subdivision appartiennent les Scioplita striata $\mathrm{n}^{\circ}$. 1. tab. 9. fig. 5. et lineola $\mathrm{n}^{\circ}$. 2. MErG. Dipt. d'Eur. tom. 1. pag. 246.

$\mathbf{2}^{\mathrm{e}}$ Subduvision. Cellule earrée assez large.

On placera ici les Scioptila fintbriata no. 5, annulata $\mathrm{n}^{\circ} .4$, cinguluta $\mathrm{n}^{\circ} .5$, punctata $\mathrm{n}^{\circ} .6$. (Asindulum punctatum. LAT. Gen.) maculata no. 7. (Tipula platyura n० ${ }^{\circ} 46$. Fав. Syst. Antl.) marginata $\mathrm{n}^{\circ} .8$, ferruginea $\mathrm{n}^{\circ} .9$, omata $\mathrm{n}^{\circ} .10$, et collaris no. 11 . Nieig.

3e. Subdivision. Cellule carrée très-petite.

Ia Sciophila hiria no. I 2. MEIG. est de cette subdivision.

$2^{e}$. Division. Une seule des cellules qui aboutissent au bord postárieur de l'aile lorguement pétiolée. Ceilule carrée très-petite.

Rapportez à cette seconde division la Sciophila vitripennis $\mathrm{n}^{\circ}, 13$. MEIG.

Nota. Nous ne pouvons déterminer à quelle division appartient la Sciophila fusca ${ }_{12}{ }^{\circ}$. 14 . du même auteur. (S. F. et A. SERv.)

SCIRE, Scirus. Herm.

Hermann fils donne ce nom à un genre d'Arael nide déjà établi par Latreille, sous le nom de Bdeles. Ce mot n'ayant pas été traité à sa lettre, nous allons donner uci les caractères de ce genre. Il appartient à l'ordre des Traehéennes, faraille des 'Tiques, et est ainsi caractérisé : luvit pieds uniquement propres à la marche; bouche consislant en un suçoir avancé, err forme de bec conique ou en alène; palpes alongés, coudés, avec des soies ou des poils au bout; quatre yeux; pattes postérieures plus longues. Les Bdelles se distingucat du genre Acarus par l'absence des mandiEnteś, et des Suaris qui en sont comme eux privós, par l'alongement de leurs patpes, le nombre de leurs yeux et la plus grande longueur des patles postérieures. Ils se disinguent des Ixudes et des Argas par l'existence des yeux.

Ces Ararhnides ont le corps très-mou, le plus sonvent de conleur rouge; ils sont vagabonds et se rencontrent dans les lieux humides, sous les pieries, les écorces des arbres ct dans les mousses. L'espèce qui sert de type au genre es! :

la B Derde rovge, $B$. rubra. - Bdelle rouge. Lat. Hist. nat. des Crust. et des ins. toin." 33. p. 57. pl.67. fig. 7. - Précis des car. ctc. p. 180. - Gen. Crust. et Ins. tom. 1.p. 154. - Cuvier, Règhe anim. tom. 3. p: 121. - Bdella mbria. 1.AM. Aninu. sans vert. p. 179. - Scins vulgaris. IERMAn , Mém. Apt. p.6il. pl. 3.fig. 9, et pl. g. S. Voyez pour la description el la suile de la synonymie, le no. 41 dn mol Mutte de ce Dictionnaire. Rapporlez encore à ce genre les espèces décrites par Hermann solis les noms de Scirns longirostris, latirostivis et setirostris. (E. G.)

SCIRTE, Scirtes. Illig. Lat. Cyphon. Payk. Fab. Chrysomela. Linn. Ailtica. Ollv. Panz.

Genre d'insectes de l'ordre des Coléoptètes, section des Pentanères, famille des Serricornc's (Nialacodermes), tribu des Cébrioniles.

La seconde division de celte uibu a pour caractères: mandibulcs peu ou point apparentes; palpes maxillaires terminés en pointe. Curps presyue hémiophériçue on en ovoide cont, bombr. Antennes simples, dc onze articles. (Vojez Cébrionites, article Sernicornes.) Quatre genres vicnment s'y placer, savoir: Nyctée et Eubrie "qui ont tous les articles des tarses enliers, Elode, dont les pattes postérieures sont simplenent ambulatoires, les cuisses minces et les jamles presque muliques; enfir les Scirtes dislingués par. les caractères suivans. Ces Coléoptères ont comme les Elodes le pénultième article des tarses bilobé; et en opposition atrec eux, les paltes pessírieures propres à sauter, les euisses de celles-ci renflées et leurs jambes terminćes par une forte épine. A cela près les autres caractères génćriques sont ceux des Elodes. Voyez ce mol, artucle suivant.

Les insectes de ce gूenre dont le non vient d'un verbe grec cill signific sauter, sont de cculeur sombre et se tiennent sur diverses plantes dans les endroits humides et aquatiques. Les espèces sont peu nombrenses. Nous eiterons les snivantes: $3^{\circ}$. Altise héunisphérique no. 44. de ce Dictiosnaire, 
Seirte hémisphérique, Scirtes hemispharicus. (Elodes hemisphaerica. LAt. Gener. Crust. et Ins. toul. 1. pag. 254. $n^{\circ}$. 3. Cyphon hemispharicus. Lncycl. pl. 359. fig. 18.) $2^{\circ}$. Scirte arbiculaice, Scirtes orbicularis. (Altica orbicularis. Pavz. Fuun. Germ. fus. 8. fig. 6. Sub nomine orbiculata. Cyphon orbiculuris. Scaen. Symon. Ins. toml. 2. pag. 323 . $n^{\circ}$. 9.) $3^{\circ}$. Scirte arrondi, Scirtes orbiculatus. (Cyphon arbiculatus no. 8 . FAB. Syst. Fileut.) De la Caroline.

ÉlOde, Elodes. Lat. Cyphon. Paтx. Fab. Cistela. Panz.

Genre d'insectes de l'ordre des Coléoptères, seçion des Pentanèıes, funille des Serrieornes (Malacodurmes), tribu des Cébrionites.

M. Latreille pariage cette tribu en deux divisions, la seconde a pour caractères: mandibnles peu ou point apparentes. P'ulpes minillaires terminés en pointe; corps presque hémis hérique ou en ovoide courl, bonibé; antennes simples, de onze arlicles; clle se compose des genres Nyctée, Eulıie, Elode el Scirle. Les deux premiers sent distincts des autres par les articles de lenrs tarses tous enticrs ; celur de Scirte a les pattes postćlieures propres à saluter, leurs cuisses étant rentlées: les deux dornières jambes sont armées d'une épine for:e et teruinale.

Antennes filiformes, simples, plus longues que le curselet, composées de unze arricles cylindroconiqnes, le second le plus court de tous. - Indendibules entières, couvertes par le labre.-Palpes filiformes, le dernier article des maxillitires presque cylindrique, terminé cu pointe: palpes labiaux paroissant comme fourchus a leur extrémilé. - Corps-ovale-arrondi, gévératement bombé el mon. - Corselet deni-circulaire, transversal, plus larve postéricurement. - Ecusson distinct, triangualire. - Elytres flexibles, recourrant des ailes et la totalité ve l'ubdomen. - Pattes de longueur moyenne, simplement ambulaivires; cuisses point renilées. Jambes terminées par deux épines à peine apparentes : tarses filifurmes, leur péculirorme article bilobé.

On tronve ces insecles sur les plaa!es qui se plaiselit au bord des eatux el dans les mácécages, c'est ce qu'indigue le nom d'Elode liró d’un mô grec qui signifie : marais. Les esjèces connes sont d'Enrope; lear caille est assez pelice. Nous indiguerois celles-ci : $1^{\circ}$. Elode pâle, Elodes pallidus. I.Aт. Gen. Crust. et Ins. tom. 1. pag. 253. no. I. p!.7.fig. 12. (Cyphon pallidus no. 1. et Cyphon melumirus no. 6. 'Аa Syst. Eleut. Celui-ci n'étant qu'une zariété de l’autre. Eacycl. pl.559. fig. 15.) $2^{\circ}$. Elute gris, Elodes griseus. ( Elodes fuscescens. Laт. Genel. Crust et ins. tom. 1. pag. $253 . n^{n} .2$. Cyphon giseus 1 $^{\circ}$. 5. FAB. Syst. Eleut. Schex. Synon. Ins. tom. 2. pag. $322 . m^{\circ}$. 5.) 50. Holue

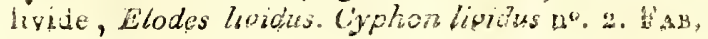

Syst. Elent. Scuđr, Synon. Ins, tom. 2. pag. $32 \mathrm{r}$. $n^{\circ}$.d. (S. F. el A. SERv.)

SCI.EROSTOMES ou HAUSTELLES. Nom d'une familie de Diptères dans la Zoologie analytique de M. Duméril, à laquelle il doune pour caracièr es : suçoir saillant, alongé, sortant de la tête, souvent coudé. Elle se cumpose des genres Cousin, Bombyle, Hippobosque, Conops, Myope, Stomoxe, Rlingie, Chrysopside, Taon, Assle et Empis. (S. F. et A. Serv.)

SCOBULIPEDES ou PIEDS - HOUSSOIRS, Scobulipedes. Division introdnite par M. Latreille ( Famr. nat.) dans la tribu des Apiaires; elle a pour caractères : premier article des tar'ses postérieurs dilaté à l'anyle extérieur de son extrémité inférieure; l'artiele suivant inséré plus près de l’angle de cetle extrémité que de l’anğle opposé.

I. Palpes maxillaires de cinq à six arlicles.

Eucère, Mélissode, Macrocère, Mélilurge, Télrapédie, Saropode, Anthophore.

II. Palpes maxillaires de qratre artieles au plus; quelquetois nuls ou d'un seul article.

Centris, Melitome, Evicliaris, Acanthope. (S. F. et A. SEav.)

SCOTte, Scolia. Far. Ross. Panz. Jur. Sptr. Lat. Sphex. Lran. Scop. Elis, Tiphia. FAв.

Genre d'iusecles de l'ordie des Hyınénoplères, section des Porte-aignillon, famille des Fouisscurs, tribu des Scoliètes.

Trois geares de cette tribu ont les palpes maxillaires courts, à articles presqu'égaux avec le premier article de leurs an'enues alongé, cylindracé. (Voyez Sconitetes.) Les Myzines el les iléries se distinguent des Scolies par le second article des antennes qui est reçu dans le premier.

Antennes épaisses, formées d'articles courts, serrés, le premier le plus grärd de tous, presgriobconique; elles sont insérées près du milieu a la face antérieure de la tête; droites, presque cylindriques, de la longueur de la têle et da eorseler, et de treize articles dur les wâles; plus courtes, arquées et de douze articles daus les femelles; le second découvert dans les denx sexes. - Mand bules fortes, arquées, étroites, pointues, creusées et sans dents notables au côté interne. - Palpes courls, filiformes, presqu'égaux. Languette divisée jusqu'à sa base en trois peits lilets presqu'égaux, divergens à la manière d'un trident. - Téte assez forle dans les femelles, petite dans les míles. - Yeux petits, échancrés. Trois oceiles grunds, risposés en triangle sur le laút du froml. - Corps alongé, velu. -- Corselet piesune cyliadrique, trongué vieare; 


\section{$S \mathrm{CO}$}

rieure; prothorax arqué postérieurement. - Ailes supérieures ayant une cellule radiale petive.Abdomen ovale, tronqué à sa base; plus étroit, presqu'en fuseau et terminé par trois épines dans les mâles. - Pattes courtcs; cuisses des femelles comprimées, arquées; jaubes trc̀s-ćpineuses dans ce sexe, les postérieures terminćes par deux longs, appendices souvcnt spiniformes, plus ou moins creusés en goutière.

Les Scolies sont généralement de grande taille et habitent les pays chauds ou du moins tempérés des deux Mondes; elles se plaisent dans les lienx secs et dans les forêts. Leur's métamorphoses sont iuconnues. Ce genre est nombreux en espèces.

Ire. Division. Quatre cellules cubitales aux ailes supérieures; la deuxième n'atteignant pas la radiale; la troisième petite, la quatrième à peine commencée.

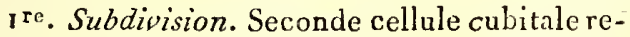
cevant les deux nervures récurrentes. (Jambes postćrieures des femelles qui nous sont connues terminées par deux appendices spaluliformes, presqu'en cuiller, remplaçant les deux épines ordinaires. )

Rapportez à cetie subdivision la Scolie interrompue (Scol. interrupta LAT. dont le mâle est l'Elis internupta n०. 2. FАв. Syst. Piez.) Du midi de l'Europe.

$2^{e}$. Subdivision. Une senle nervure récurrente; cette nervure recue par la seconde cellule cubitale.

On doit placer dans cette seconde subdivision: 10. Scolie procère, Scol. procer. no. I. FAB. Syst. Piez. De Java. $2^{\circ}$. Scolie frout-jaune. Encycl. pl. ro6. fig. 10. femelle, et fig. 14. mâle. Scol. flavifions $n^{\circ} .7$. Fав. Syst. Piez. dont le mâle est sa Scolia hortorum $10^{\circ}$. 24. Du midi de la France. $5^{\circ}$. Scolie flavicorne, Scol. flavicornis. Dufts. D'Espagne.

$2^{e}$. Division. Trois cellules cubitales aux ailes supérieures, toutes atteignant la radiale, la troisième à peine commencée.

Ire. Subdivision. Seconde cellule culitale recevant les deux nervures récurrentes.

I. Jambes postérieures des femelles terminées par deux appendices spatuliformes, presqu'en cuiller, renuplaçant les deux épines ordinaires.

Là se rangent les Scolies suivantes: $I^{\circ}$. âtre, S. atrata no. 2. FAв. Syst. Piez. $2^{\circ}$. ciliée, $S$. ciliata $11^{\circ}$. 14. $i d$. dont le mâle est la Scolia aurea no. I5. $3^{\circ}$. fouisseuse, S. fossulana no. נ8. id. dont le mâle est suivant nous la Scolia radula $\mathbf{n}^{\circ}$. 19. id. De la Caroliue.

Hist. Nat. Ins. Tome $\boldsymbol{X}$.
II. Appendices des jambes postérienres spiniformes, point dilatés à l'cxtrémilé.

On placera dans ce groupe la Scolie quadrinotée, Scol. quadrinotata no. 6. Far. Syst. Piez. Scolie à quatre taches. Dr. TIGNY, Hist. nat. des Ins. tom. 3. pag. 274. fig. 4. Femelle.

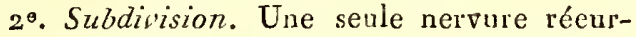
rente; celle nervure reçue par la seconde cellule cubitiale.

Cette subdivision contient: $1^{\circ}$. Scolie érythrocéphale, Scol. erythrocephala no. 23. Hai. Sysi. Piez. $2^{\circ}$. Scolie notée, Scol. notata no. 31. HАв. id. $3^{\circ}$. Scolie noble, Scol. nobilitata $\mathbf{n}^{\circ} .32$. FAB. id. $4^{\circ}$. Scolie quadriponctuće, Scol. quadripunctata no. 3g. FАв. id. (S. F. et A. SERv.)

SCOLIETES, Scolietoe. Première tribu de la famille des Fouissenrs, section des Porte-aiguillon, ordre des Hy ménoptères. Ses caractères sont: Prothorax arqué on carré, prolongé latéralcment jusqu'à la naissance des ailes supérieures.-Pattes couries, celles des femelles épaisses, très-épineuses ou fort ciliées, avec les cuisscs arquées près de leur origine. - Antennes épaisses, à arlicles seriés; celles des femelles arquées, plus courtes que la tête et le corselet.

$\mathrm{I}^{\mathrm{re}}$. Division. Palpes maxillaires longs, composés d'articles sensiblemeut inégaux.-Prenicr article des antennes obconique.

$$
\text { Tiphie, Tengyre. }
$$

$2^{e}$. Division. Palpes maxillaires courts, composés d'articles presque semblables. - Premier article des antenues alongé, cylindracé.

1r: Subdivision. Second article des antennes reçu dans le premier.

$$
\text { Myzine, Mérie. }
$$

$2^{e}$. Subdivision. Second article des antennes découvert.

\section{Scolie.}

MÉRIE, Meria. Ir.hG. LAT. Bethylus. FAB. Tiphia. Ross. Panz. Tachus, Jur. Spinoc.

Genre d'insectes de l'ordre des Hyménoplères, section des Porte-aiguillow, famille des Fouisseurs, tribu des Scolièles.

Dans les Scoliètes (voyez ce mot), deux genres: Myzine et Mérie sont distincts des autres par le second arlicle de leurs antennes qui est reçu dans le premier; leurs palpes maxillaires sont courts, composés d'articles presque scmblables, et le premier article de leurs antennes est alongé, cylindracé; dans les Myzines la seconde cellule cubirale des ailes supérieures atteint la radiale, celle-ci est fermée dans les deux sexes; ce caractère les sépare des Méries.

\section{$\mathrm{D} \mathrm{d} \mathrm{d}$}


Antennes filiformes, insérécs vers le milieu de la face antérieure de la tête, rapprochées à leur base, de douze articles dans les femelies, le premier fort loug; le seend reçu entièrement ou presqu'entièrenıent dans le premier; les trois suivans eoniques, tronqués obliquement, un peu gronflés supérieurement à leır partie extérieure, les autres cylindriques; le dernier plus long que les précédeus; de treize arlicles dans les nıâles. (Nous ne connoissons pas ee dernier sexe.) Labre caché, petit, enriace, eilié, en carré trausversal. - Mandibules fortes, a vanećes, étroites, arquées, strićes tongiindinalement en dessus, ordinârement saus dents à leur eôlé iusterne. - Mâchoires eoriaces, très-comprimées, eu carré alongé, terminées par un lobe presque membranoux. - Palpes maxillaiies reeourbés, deux fois jolus longs que les labiaux; ceux-ci de quatre articles presqu'égatux, les trois premiers obeoniques, le quatriène ovalaire. - Lèvre eourte, reit'vée, sans lobes latéraux ou les ayant très-petits; usenton eoriace, obconique. - Tête plus large que le corselet, déprimée au-dessous des antennes. - Yeux pelits, très-peu échancrés. - Trois ocelles placés en triangle daus des fosseltes dı vertex. - Corps oblong, un peu veln. - Prothorax presque carré; métathorax tronqué brusquement à sa partie postérieure. - Ailes supérieures des femelles ayant une cellule radiale eniièrement confondae avee la quatrième eubitale, et quatre cellules cubitales; la première pelite, la seconde très-petite, pétiolée, triangulaire, plaé́e vis-à-vis du point épais, et n'y aboutissant point; la troisième fort grande, la qualrième esquissée du côié du limbe postérieur; les deux nervures récurrentes aboutissent dans la troisième cellule cubitale, savoir : la première presque vis-à-vis de la nervure d'intersection de eetle eellule et de la seeonde, el la deuxièure un peu passé le milieu de la noême eubitale; trois eellules discoidales, les deux premières presqu'égales, l'iuférienre fort longue, presque linéaire, terminće à ses deux extrémités par deux nervures courbées en chevrons brisés. Ailes supérieures des mâles ayant, suivant $\mathbf{M}$. Latreille, leur cellule radicle ferbée. - Abdomen ovale, un peu déprimé, de cinq segmens outre l'anus dans les femelles, en ayant un de plus dans les mâles. - Pattes eourles, lortes; euisses larges, un peu comprimées; jambes et larses garnis dans les lemelles de cils roides et d'épines assez fortes: jambes eourtes, épaisses; les intermédiaires et les postérieures terminces par deux épines presqu'égáles; jambes antérieures n’en ayant qu'uue, laquelle est guruie en partie d'une membrane : crocbets des tarses bifides (au noins dans los femelles), zaunis d'une trés-getite pelo:le.

Ie nom de Mćrie vient d'un mol grec qui signifie : cuisse. Les espèces qui eomposent ce rem sout en petit nombre et propies atux parties acéri- dionales de l'Europe. On les rencontre sur les flenrs et dans les endroits sablonneux.

\section{MÉrı de la Millefeuille, M. Millefolii.}

Meria nigra, nitida; abdominis segmentis duobus primis tertiique basi suprà ferrugineis: secundo tertioque lateralitèr albo guttato.

Longueur 4 lig. $\frac{1}{2}$. Antennes, tête, eorselet et paltes d'un noir luisant. Abdomen de même eouleur, à l'exeeptiou de ses deux premiers segmens et de la base supćrieure du troisième qui sont ferrugineux; second et troisième segmens portant de chaque côté un point blane, preque rond. Tarses ayant des poils roussâtres. Ailes un peu enfumées ì leur buse. Femelle.

D'Allemagne. Nous l'avons recue de M. Ziégler sous le nom spéeifique que nous lui eonservons.

On rapportera eu oulre à ce genre: $\mathbf{I}^{\circ}$. la Mérie de Latreille (Meria Latreillii. Encycl. pl. 378. fig. 2. Femelle. Bethylus Latreillii n ${ }^{\circ} .4$. Fas. Syst. Piez. Sa description est peu exaete. Tiphia tripunctata. Panz. Faun. Germ. fas. 47. fig. 20. liemelle. Ross. Faun. Etrusc. tom. 2. $7^{\circ}$. 83ı. tab. 6. fig. 10. Fenelle. Tachus staphylinus. Jor. Hyménopt. pl. 14. Femelle.) 2 ${ }^{\circ}$. La Mérie mipartie (Meria dimidiata. Tachus dimidiatus. SPINoc. Ins. Ligur. fas. 2. pag. Jı. Mâle et femelle. tab. 1. fig. 1. La femelle.

\section{(S. F. et A. SERT.)}

\section{SCOLOpENDRE, Scolopendra. Linv. Istr.} LAM.

Genre de Myriapodes de l'ordre des Chilopodes, famille des Aiquipèdes de Latreilie ( $\mathrm{Fam}$. nat. dn Fì̀gn. aniin.), établi par Linné, qui comprenoil sous eette dénomination beaueoup d'insectes qui ont été rangés depuis par Latreille dans plusieurs genres distinets. Le genre Scolopendre, tel qu'il est adopté par ce savant, a pour caraetères : denx yeux distincts compesés ehaeun de quarre petits yers lisses; antennes de dix-sept artieles; vingt-denx paires de pieds; les denx derniers ser:siblement plus longs; corps étant éyalement divisé en dessas et en desscus, avee les plaques supérieures érales ou presqu'égâles et découvertes.

Ce genre se distingue de celui de Crytops par les yeux qui ne sont pas bien distinets dans ees derniers, et par les paltes postérieures qui sont presqu'ćculis anx préeédens; les Gćophiles s'en éloignent par les antenues qui ont qualorze articles, et par d'autres caractères tirés du nombre et de la lorne des pieds; enfin les Lithobiegs en sont bien distingués par le nombre de leurs pieds et pár la forme et l'arrangentent des segmens di eorps. lia bouche des Scolopendres est composée d'une lèrre çuadrifide, de deux mandibules, de deux palpes ou pelits pieds réunis à leur base, et d'une seconde tivre formée par une seeonde paire de pieds dilatés, joints à leur vaissance et 
terminés par un fort crochet pereé sur son extrémité d'un trou pour la sortie d'une liqueur vénéneuse. Les antennes des Scolopendres sont un peu plus longues que la têle, et vont en diminuant depuis la base jusqu'à l'extrémité. Leur corps est déprimé et membraneux, composé d'une vingtaine d'anneaux, reeouverts eliacun d'une plaque coriace et earlilagineuse, et ne portant qu une paire de pattes. Ces paltes sont eourtes, presqu'égales, excepté les deux dernières, et composées de sept articles décroissant presqu'insensiblement pour se terminer en pointe. Leurs organes sexuels sont intćrieurs et situés, à ce qu'il paroît, à l'extrémité postérieure du eorps. Les stigmates sont assez sensibles.

Ces animaux ont été réputés venimeux par tous les auteur's, et surtout par les voyageurs, parce qu'il survient une enflure assez sensiblc aux endroils qui ont eté mordus; mais quoique la morsure des grandes Scolopendres exoliques soit beaucoup plus viulente que celle du Scorpion, elle n'est cependant pas mor! elle. M. Worbe (Bull. de la Soc. philonı. janvier 1824. pag. 14.) rapporte quelques faits qui tendent à prouver que la morsure de la Scolopendia morsitans de Linné (que l'on nomme malfaisant aux Antilles et mille pattes sur la côte de Guinée) est malfaisante; mais il paroît qu'en trajtant la plaie avec l'ammoniaque, on guérit assez promplement le malade. Amoreux (Ins. venimeux, pag. 277.) dit qne les Scolopeudres de nos climats sont dépourvuesde venin. Leuwenlioek a exanuiné les crochets de ces insectes, et a trouvé près de leur pointe une ouverture eommuniquant à une cavité qui s'éiend jusqu'à l'cxtrémilé des crocbets; il pense que c'est par là que sort la liqucur âcre qui cause la douleur quon ressent après avoir élé mordu.

Ces animaux courent très-vîte, sont carnassiers, fuient la lumière et se cachent sous les pierres, les vieilles poutres, la terre, le fumier humide, les écorces d'arbres, etc. Ils se nourrissent de vers de terre et d'insectes vivans; quelques espèces répandent une lumière phosphorique. Les dimensions des Scolopendres varient beaucoup; les plus grandes d'Europe n'ont guc̀re que deux pnuces de long; celles de l'Inde atteignent jusçu'à huit à dix pouces.

Ce genre se compose de peu d'espèces; celle qui lui sert de type est :

\section{La Scolopendre mordante, $S$. morsitans.}

S. antennis setaceis; pedibus quadraginta duobus posticis spinosis.

Scolopendra morsitans. Linn. Syst. nat.édit. 13. tons. 1. part. 2. pag. 1063. - Amoen. Acad. tont. 1. pag. 325.506. Scolopendre mordante. DE GÉER, Mém. sur les Ins. tom. 7. pag. 563. pl. 43. fig. 1. Scolopendra morsitans. Fа в, Entom. Syst. toml. 2. pag. 3go. - Villehs, Entom. tom. 4. pag. $19 \mathrm{I}$. tab. I fig. I7. J8. Scolopendre mordante. I.AT. Hist nat. des Crust. et des Ins. tom. 7. pag. 93. Gen. Crust. et Ins. tom. 1. pag. 78. no. 2.-P匹u. Gen. Ins. tab. 30.fig. 14. - Scolopendra alternans. LÉACH, Zool. miscell. tom. 3. tab. 138.

Longue de quatre à six pouees. Corps brun, dix fois plus long que large, à segmens plus larges que longs, surtout en arrière, le premier très-court, transverso-linéaire; le troisième évidemment plus eourt que le second et le quatrième; pattes au nombrc de quarante-deux, ayant presque la longueur de trois segmens réunis. Cette espèce se trouve aux Antilles et dans l'Amérique méridionale.

CRY'TOPS, Crytops. LÉach. Lat.

Ce genre a été établi par Léach aux dépens du précédent; Latreille l'a adopté (Famı. nat. du Règru. anim.). On peut le caractériser ainsi : yeus oblitérés, tous les pieds égaux entr'eux, même les deux postérieurs. Ces Myriapodes ressemblent enlièrement aux Scolopendres, et il est probable qu'ils ont les mêmes mœurs et la même organisation. Léach en décrit deux espèces propres à l'Angleterre; colle qu'il nomme 7ortenisis est figurée Zool. miscell. tom. 3. pl. $15 \mathrm{~g}$.

\section{GÉOPHILE, Geophilus. J'́́, Lit.}

Ce genre, qui cst encor'e démembré du genre Scolopendre proprement dit, a pour caractères: yenx oblitérés; anlennes de quatorze articles; un :iombre variable et très-considérable de pieds, les deux derniers guère plus longs. L'espèce qui sert de type à ce genre est :

\section{Le Géophile ḱlectrique, $G$. electrica.}

G. antennis subflifonibus, corpore lineari, favescente; pedibus circiter centum quadragint, quatuor.

Scolopendra electrica. Livv. Syst, nat. édit. 13. tom. 1. part. 2. pag. 1063.-Faun. Suec. edit. 2. $n^{\circ}$. 2065. Scolopendre à cent quarante pattes. Georf. Hist. des Ins. tom. 2. pag. 676. - Scolopendra electrica. FА . Entom. Syst. tom. 2. pag. 391 . - Scolopendre électrique. Lat. Hist. nat. des Crust. et des Ins. tom. 7.pag.94.-Gen. Crust. et Ins. tom. I. pas. 79 .

Longueur huit à neuf lignes; corps de couleur fauve, avcc une ligne noire au milieu. Son corps paroit quelquefois lunineux pendant la nuit. Elle vit en Europe et s'enfonce souvent dans la terre.

\section{LITHOBIE, Lithobius. LÉACH. LAT.}

Les caraetères de ce genre sont : antemes sétacées, composées d'articles presque coniques, dont les deux premiers sont plus grands. Lèvre largement échancrée en devant, avec le bord supérieur dentelé et les yeux grenus : quinze paires de pieds, 
plnsieurs des demi-segmens supérieurs eaehés par les autres.

Ces animaux se distinguent des Seuígères par les pieds, qui dans ceux-ci sont inégaux; ils s'éloignent des Scolopendres et des Crytops par les anneaux du eorps, qui dans ceux-ei ont tous les demi-segmens dorsaux déeouveris. Léon-Dufour (Ann. des sc. nat. tom. 2. pag. 81.) a donné Janalomie de ce genre. D'après ce savant, les organes de la digestion se composent $1^{\circ}$. de deux glandes salivaires; $2^{\circ}$. d'un tube alimentaire droit de la longueur de l'animal, et $3^{\circ}$. d'une paire de vaisseaux hépatiques. Lcs organes générateurs mâles sont composés $I^{\circ}$. de deux testieules eomposés chacun d'une paire de glandes alongées, pointnes et pareourues par une rainure mćdiane: ils ont été pris par 'Tréviranus pour des masses graisseuses. $2^{\circ}$. De trois vésicules séminales, deux latćrales et une intermédiaire; cette particularité qu'offie seul le Lithobie d'avoir trois vésicules séminales, est fort remarquable, et Léon-Dufour dit qu'il n'en a jamais rencontré que dans ee genre en nombre impair. 3’. D'une verge qui est placće dans le dernier segment du corps du Lithobius. Les organes femelles se composent $1^{\circ}$. de l'ovaire, qui consiste en ur, seul sac alongé qui contient des œufs globuleux et lbancs; $2^{\circ}$. des glandes sébaées de l'oviduete, et $3^{\circ}$. de la vulve, qui est flanquée à droite et à gauehe par une pièce erochue, biartieulée, terminée par une pointe bifide, et armée à sa base de deux dents courtes.

Les Lithobies vivent à terre sous des pierres comme les Scolopendres; on en rencontre sonvent en été sous les tas de plantes, le bois pourri, etc. Léach en décrit trois espèees, dont deux se trouvent en Angleterre; celle que nous tronvons en Franee et qui sert de type au genre, est:

Le Litruobie fourcau, $\mathcal{L}$. forficata. LÉach. Lat. Scolopendra forficata. Linn. 'Treviranus (Venn. Schrift. anat. tab. 4. fig. 6. 7.) S. forficata et colcoptrata. PANz. (Falln. Ins. fasc. 5o.fig. I312.) La Seolopendre à trente pattes. Grofr.

Longueur un pouce at plus. Lisse, luisante, tantôt d'un brun de poix, tantôt d'un roux qui tire sur l'ambre. Elle se trouve fréquemment en été dans les jardins du midi de la France et de Paris.

(E. G.)

\section{SCOLOPENDRE A PINCEAU. Vojez Seoti- GERE. (E. G.)}

SCOLOPENDRIDES. Famille établie par Léach dans sa nouvelle distribution des insectes aptères de Linné, et renfermant les genres Lithobie, Sco. lopendre el Crytops. Voyez ces mols.

(E. G.)

SCOLYTAIRES, Scolytarii. Première tribu de la famille des Xylophages, section des 'Tétramè- res, ordre des Coléoptères; ses caraetères sont : Antennes composées de moins de onze artieles, en ayant toujours at moins einq avant la massue. - Corps subovoïde ou cylindrique. - Corselet de la largeur de l’abdomen, du moins à son bord postérieur. - Palpes trc̀s-pelits, coniques.

I. Pénultième artiele des tarses bifide. Seolyte, Hylésine, Camptocère, Phloiothribe.

\section{Tous les artieles des tarses entiers.}

$$
\text { Tomique, Platype. }
$$

De tous les Xylophages, les Scolytaires sont les plus destructeurs; leurs larves rongent et sillonneut en divers sens, sonvent en manière de rayons, les premières eouehes du bois; quelquefois même elles pénètrent plus avant. Les forêts de pins en souffrent partienlièrement; quand ees espèces s'y muliplient trop, elles font périr en peu d'années une grande quantité d'arbres. Elles nuisent aussi beaucoup à l'olivier, au ehêne et à l'orme.

HYLÉSINE, Hylesinus. FAB. LAT. Scolytus. Oliv. Bostrichus. Payk. Panz.

Genre d'insectes de l'ordre des Coléoptères, section des 'Tétramc̀res, famille des Xyloplages, tribu des Seolytaircs.

Dans cette tribu les genres Tomique et Platype ont pour earactères conınuns d'avoir tous les arlicles des tar'ses entiers. (Voyez Scolytaires.) Des quatre autres genres les l hloiothribes ont seuls la naassue des aniennes formée par trois feuillets alongés, et les Scolytes ainsi que les Camploeères ont cette massue fort eomprimée, arrondie et toul-à-fait obtuse à l'extrémité.

Antennes en massue solide, eelle-ci ovoïde, peu comprimée, pointue au bout, eomposée de trois ou quatre articles transverses, distincts. Les autres caractères sont ceux des Seolytes. Voyez ee mot.

Le nom de ce genre indique ses habitudes, et vient de deux mots grecs dont le sens est : nuisant at bois. Il se compose d'un petit nombre d'epèces. Nous allons en indiquer quelques-unes. $1^{\circ}$. Hylésiue du Frêne, Hyles. Fraxini no. 3. Faв. Syst. Eleut. Bostrichus Fraxini. Panz. Faun. Germ. fas. 66. fig. 13. Scolytus varizls. Orıv. Entom. tom. 4. Scolyt.pag. 1 1. no . 17. pl. 2. fig. 17. a.b. Encycl. pl. $567 \cdot$ fig. $17 \cdot 2^{\circ}$. Hylósine varié, Hyles. varius no. 4. FAB. Syst. Eleut. 3․ Hylésine crénelé, Hyles. crenatus n ${ }^{\circ}$ 2. FAB. Syst. Eleut. Scolytus crenatus. Oliv. id.pag. 12. pl.2. fig. 18. a. b. Bostrichus crenatus. Panz. Faun. Germ. fas. 15. fig. 7. Encycl. pl. 367 . fig. 18. 40. Hylésine velu, Hyles. villosus $\mathrm{1}^{\circ} .7$. F AB. id. Bostrichus villosus. PAnz. Faun. Germ. fas. 15 . fig. 8.

$$
\text { (S. F. et A. Serv.) }
$$

SCOLYTE, Scolytus. FAB. Ce genre de Coléop- 
tères est le mème que celui d'Omoplron de M. Latreille. Voyez ce mot. (S. F. et A. S₫Rv.)

SCOLYTE, Scolytus. Geoff. Olit. Lat. Hylesinus. FAв. Ekkoptogaster. HЕввsт. Bostrichus. PANZ.

Genre d'insectes de l'ordre des Coléoptères, section des Pentamères, famille des Xylophayes, tribu des Scolytaires.

La première division de cette tribu, ayant pour caractères : pénultiène article des tarses bifide, renferme quatre genres. (Voyez Scolytaires.) Celui de Phloiothribe est remarquable par ses antennes terminées par trois feuillets alongés; dans les Hylésines la massue des antennes est pen comprimée, pointué au bout et distiuctement composée de trois ou quatre articles. Les caractères génériques des Camptocères v’ayant pas été publiés, nous ne pouvons comparer ce genre à celui de Scolyte; nous nous réservons d'en traiter plus tard.

Antennes composées de dix articles, le premier alongé, en massue, égalant à peu près le tiers de la longueur totale de l'antenne; les sept suivans très-petits, les deux derniers formant une massue un peu ovale, très-comprimée, arrondie, obtuse et s'élargissaut vers son extrémité. - Mandibules fortes, trigones, se touchant l'une l'autre par lenr bord interve, sans dentelures distinctes.-Palpes très-petits, coniques, presqu'égaux. — Mâchoires coriaces, comprimées. - Lèvre très-petite. -Tète presque verticale. - Yeux alongés, étroits, distinctement échancrés. - Corps presque cylindrique. - Corselet convexe, un pen plus long que large, de la largeur de l'abdomen depuis son milieu jusqu'au bord postérienr, un pen rebordé latéralement. - Ecusson triangnlaire. - Elytres convexes, déprimées près de l'écusson, recouvrant des ailes et l'abdomen. - Abdomen court, diminuant d'épaisseur de la base à l'extrémité. Pattes fortes; cuisses échancrées en dessous, les antérieures surtout; jambes terminées par un crochet à leur angle externe. Pénultième article des tar'ses bifide.

Geoffroy a tiré le nom de ce genre d'un verbe grec qui signifie : déchirer. Les Scolytes subissent leurs métamorphoses dans le bois dont leurs larves se nourrissent. L'espèce qui a servi de type se trouve très-communément au printemps dans les bois et dans les maisons. Beaucoup d'individus ont le front garni de poils fort serrés qui forment comme une brosse; nous ignorons si ce caractère est spécifique ou simplement sexuel. Fabricius dans la description de son Hylesinus aneipennis $\mathbf{n}^{\circ} .10$ (genre Camptocerus DEJ. très-voisin de celui de Scolyte), prétend que l'un des sexes seulement a le firnat velu.

On rapportera à ce genre : $1^{\circ}$. le Scolyte destructeur. Encycl. pl. 367. fig. 4. Scolytus destructor. Lat. Oliv. Des. Hylesinus Scolytus no: 1 .
FAB. Syst. Elent. Bostrichus Scolytus. RAnz. Faun. Germ. fas. 15 . fig.6. LeScolyte. G Eofr. Hist. abrég. des Ins. tom. I. pag. 3ro. pl. 5. fig. 5. $2^{\circ}$. le Scoly te pygmée. Encycl. pl. 367.fig. 5. Scolytus pygmorus. Des. Catal. Hylesinus pygmaceus no. 25. Fав. Sy'st. Eleut。 (S. F. et A. Serv.)

SCORPION AQUATIQUE. Geoffroy a donné ce nom français (en latin hepa) ì un genre d'insectes hérmiptères, qu'il compose de deux espèces; la première est la Ranâtre linéaire no. I, Ranatra linearis, et l'autre la Nèpe cenòrée $n^{\circ}$. $8, N e p a$ cinerea. Voyez ces muts.

$$
\text { (S. F. et A. Sert.) }
$$

SCORPION, Scorpio. Linn. De Géer. Fab. Lam. Lat. Léach. Herest.

Genre d'Arachnides de l'ordre des Pulmonaires, famille des Pédipalpes, tribu des Scorpionides (voyez ce mot), élabli par Linné, adopté pal tons les entomologistes et restreint par Léach, et dans ces derniers temps par Latreille (Fam. nat. du Règn. ariin.), aux espèces (qui out pour caractères : six yeux; abdomen sessile et offrant eu dessous et de chaque côté quatre spiracules, avec: deux lames pectinées à sa base; les six derniers anneaux formant une queve noneuse dont le dernier finit en pointe servant d'aiguillon et percé pour donner passage au veniu. Palpes en forme de serres d'écrevisses; chélicères didactyles. Pieds égaux; langue divisée en deux jusqu'a la base; corps étroit et alongé. Nous avons parlé de l'o:- . ganisation et des mours de ees animanx à l'article Sconpronides; nous ae ferons que ciler ici les espèces qui sont les types de ce genre.

\section{Scorpion d'Europe, $S$. Europcus.}

S. pectinibus novem dentatis; manibus subcordatis, angulatis, carpis unidentatis; corpore obs. curè bruneo, caudce articulo ultimo pedibusque brinneo-flavescentibus.

Scorpion à queue jaune. De GÉr, Mém. surles Ins. tom. 7. pag. $33 \mathrm{~g} \cdot \mathrm{pl}$. 40. fig. 11. - Scorpio Europarus. VInLers, Entom. tom. 4. pag. 13 I. tab. 7. fig. I 1. - Herbst, Naturg. Scorp. tab. 3. fig. 2. - Scopol. , Entom. Carn. no. 1122. SÉBA, Mus. 1. tab. 70. $n^{\circ}, 9$. 10. - Res. Insect. tom. 3 . Suppl. tab. 66. fig. 1. 2. - Seorpion d'Europe. Lat. Hist. nat. des Crust. et des Ins. tom. 7 . pag. 116. - Gen. Crust. et Ins. tonı. 1. pag. 101.Cuvier, Règn. anim. tom. 3. pag. io6.

Long d'un pouce. Corps d'un biun très-foneé noirâtre; bras anguleux, avec la main presqu'en cœur et l'article qui la précède unidenté. Queve plus courte que le corps, menue, d'un brun-jaunàtre, avec le cinquième noud alongré et le dernier simple. Paltes jannâtres; peignes ayant cliacun neuf dents.

Ce Scorpion a été le sujet de bien des erreurs 
parmi les auteurs qui l'ont déeril. Limportance de cette esrèce, qui intéresse d'autant plus qu'elle est indigèe, et que Rédi et Maupertuis ont fait sur elles de précituses observations, nous oblige à entrer ici dans quel pues détails à son anjet. Linné et de Géer, l'un daus la $12^{2}$. édition de. son Systema naturce, et l'aulre dans ses Mlémoires, on! décrit sous le nom de $S$. Europaus, une espèce qui u'est pas ceriainement le Scorpion ordinaire du midi de l'Europe, celui d'Aldrovande, de Ray, le même que Scopoli (Entom. Carniol. 7\%. I 122 .) a vudans le midi de la Carniole, e1 que Roësel a bien figuré (tom. 3. tab. 66. fig. I et 2.); cal Linné donue dix-huit dents à ses peignes, et notre Scorpion n'en a que neuf. On pourroit croire qu'il énonce le nombre total des dents de ces appendices, et gu'alors il he s'est pats trompé; mais il dit que la queue de cet insecte at une poiute sous l'aiguillon, ce qui est réel pour ee!ni d'Amérique, mais ce qui n'existe pas dans le Scorpion d'Europe. Fabricius a copié Linné, et il rapporte au Sempion d'Europe l'espèce que de Géer a prise your telle, que Séba a représentée el que Lisué a citée (Mus. Ludovica Virica, pag. 429). Cette figure de Sét)a représente un Scorpion d'Amérique, et Linné dit que le Seorpion d'Europe se truuve aussi dans celte contrée. Roemer, dans l'édition qu'il a publiée de Sulzer, a figuré l'espèce d'Anérique mentionrée plus haut. Enfin Herbst, dans sa belle ieonographie des Scorpions, ne s'est pas donné la peine de débroniller celle synonyrnie, et a donné le Scorpion d'Europe sous le nora de Scorpio germanicus (tab. 3. fig. 2.). Son Scorpion italique ( $t a b .3$. fig. I. ) n'est gu'une variété de cetle espèce.

Cette espèce est comroune dans le midi de l'Lurope, à commencer vers le $44^{\mathrm{e}}$. degrré de laiitude.

Foyez pour les autres espèces la monographie de ce genre pär Herbst.

BUTHUS, Buthus. LÉaca. Scorpio. Linn. De Géer. Fab. Lam. Lat. Herbst.

Ce genre établi par Léach, ne diffère de celui de Scorpion proprement dit, que par le nombre des yeux qui est de huit, tandis qu'il n'est que de six daus les Scorpions. Nous citerons:

\section{Le Butrus roossatre; $B$. occitanus.}

S. pectinibus viginti octo dentibus; corpore flavescente; cuudâ corpore longiore, lineis elevatis, granulosis, mucrone nullo subaculeo.

Scorpio occitanus. Amorrox, Joum, de Phys. juillet $1789 .-$ Scorpio tunetanus. Her bst, Naturg. scomp; tab. 3. fig. 3. - Redi, De Gener. Insect. Maupertuis, Mém. de l'Acad. des sc. année $173 \mathrm{r}$. pl. 16.

Long de deux pouees. D'un blanc-jaunâtre; gorselet et queue ayant plusicars arêtes graveleu- ses. Bras terminés par une main petite, ovale, et dont les doigts sont longs; peignes de vingt-sept a vingt-huit denis; queue un peu plus longue que le corps, ayant le dernier article siople. Celte espèce se trouve dans le ci-devant Languedoc, en Espagne et en Bar'járie; c'est le Scorpion de Souvignargues, sur lequel Maupertuis a fait plusieurs expéricuces.

Le Buthus d'Afrueve, $B$. afer, Scorpio afer, décrit el figuré par Herbst (Monogr. Scorp. tab. 1.), figuré par Séba (tom. 1. pl. LXXX. fig. I à 4.) et par Roësel ( $t o m .3$ t tab. 65.), eș le plus grand de tous : il a de trois à quatre pouces de long. Sun eorps est noirâtre. Il se trouve en Afrique et aux grundes Indes. Voyez pour les autres caractères louviage d'Herbsi dójü cité. (E. G.)

\section{SCORPiON (movehe). Voyez Panorpe. \\ SCORPION ARAigné. Voyez Pinee.}

\section{SCORPIONS FAUX ou FAUX SCORPIONS,} Pseudo-scorpiones. Lalreille a donné ce nom à une famille d'Arachnides trachéennes qu'il earactérise ainsi: dessous du tronc partagé en trois segmens, dont l'intérieur beaucoup plus spaeienx, en forne de corselet; un abdonen très-distinct et annelé; des palpes grands, pédiformes, soit terminés par nne main didaclyle, soit par un bouton vésieuleux sans croeliets. Cette famille renferme les geures Obisie, Pince el Galéode. Voyez ees wots. (E. G.)

SCORPIONIDES, Scorpionides. LAT.

Tribu d'Arachnides de l'ordre des Pulmonaires, établie par Latreille et ay ant pour caraetères $\left(F_{a m}\right.$. nat. du.Règn. anim.) : abdomen sessile et offrant en dessous, de chaque côté, quatre spiracules, avec deux lames pectinées à sa base : les six derniers anneaux formant une quene noueuse et le dernier finissant en pointe, servant d'aiguillon et pereé pour donner passage au venin. Palpes en forme de serres d'écrevisses; ehélieères didactyles. Pieds égaux; langue courte, divisée en denx jusqu'à sa base. Corps étroit el alongé.

La tribu des Scorpionides a été divisée en deux genres par Léach. Ces deux genres ne diffèrent entreux que par le nombre des yeux. Ces Arachnides ont le corps alongé et terminé brusquement par une queue longue, composée de six nœuds dont le dernier, plus ou moins ovoide, finit en poinle arquée et très-aiguë; c'est une espèce de dard sur l'extrémité duquel sont denx petits trous servant d'issue à une liqueur vénéneuse contenue. dans un réservoir intérieur : les palpes sont trèsgrands, en forme de serres, avec une pinee au bout, imitant par sa figure une main didactyle, dont l'un des doigts est mobile. A l'origine de cbacun des quatre pieds antérieurs, est un appendiee triangulaire, et ees pièees présentent, étant rap- 
prochées, l'apparenee- d'uue lèvre à quatre divisions. Ea dessous de l'anirual et près de la naissance du ventre, sont situŕs deux organes extraordinaires dont l'usage n'est pas encore bien connu, nommés peignes, et composés chacun d'une pièee principale étroile, alongée, ariculće, mobile à sa base, et garnie le lonờ de sou côté inlérieur d'une suite de petites lames réunies avec elles par une articulation, étroites, alongées, creuses intérienrement, parallèles et imitant les dents d'un peigne. Le nombre de ces dents varie suivant les espèces et sert de cariacière pour les distinguer.

Plusieurs savans se sont occupés de l'anatomie des Scorpions. MH. Trévirantus, Cuvier, LéonDufour et Miareel de Serres ont donné des Mémoires très-intéressans sur cette matière. Nous allons donner ici le résultat des travaux de toas ces observateurs. Le sysı̀me respiratoire, daus ces Arachnides, est composé de poumons et de stigmales; les poumons, au nombre de huit, sont situés sur les côtés des quatre premières plaçues ventrales; elles en offrent chacune une paire qui est annoncée à l'extćrieur par autant de taches ovales, blanchâtres, de pres d'une ligne de diametre: ce sont les stigrnates. Ces orgänes sont situés audessous d'une toile musculeuse qui revêt la surfice interue du derme corné, on la peau de l'animal: mis à nu, le pounıon paroît ĉtre d'un blanc läitenx, mat, et d'me forme presque semblable à celle de la coquille d'une moule. Il est formé de la réunion d'environ quarante feuillets fort minces, étroilement imbriqués, taillés en demi-croissalus et qui confluent tous par lenr base en un sinus commun, membraneux, et où s'aboucbe le stigmate. Le bord libre est d'un blanc plus funcé que le reste, d'où II. Léon-Dufour présume quịl est lui-même composé de plusieurs lames superposécs, et que c'est là que s'opère essentiellement la fonction respiratoire. Cet auteur pense aussi que ehaque feuillet est couposé de deux lames. Cés bosses auxquelles M. Latreille donne le nom de pneumobranches, offient, selon Léon-Dufour, la mềne structure que celles des Arachnides, et particulièrement de la Tarentule.

L'organe de la circulation, que Léon-Dufour nomme vaissecu dorsal, mais que l'on doit considérer, d'après les observatious de $M$. Cuvier, comme un véritable cœur, est alongé, presque cylindrique, et s'étend d'une extrémité du corps à l'autre, en y comprenant la queue de l'animal. Il fournit de chaque côté du corps quatre paires de vaisseaux vasculaires principaux qui se rendent dans les poches pulnonaires el s'y ramifieat. Il existe encore quatre autres vaisseaux qui croisent les premiers, en formant avec enx un angle aigu, et qui, a vec quatre branches moins considérables, reprenuent le sang des polles pulmonaires el vont le répandre dans les différente̊s parties du curps: ce sont les artìres. Avant que de s'éleudre dans la queue, le eour jetie encore deux rameaux vasculaires, qui ne se rendent pas dans les poches pulmonaires, mais qui, distribuant le sang dans diverses parties, doiveni être considérés encore comme des arlères.

Le sysième nerveux est silué sous le tube alimentaire, le long du milieu du corps. Le cordon médullaire est formé de deux filamens contigus, mais distincts, et de huit ganglions lenticulaires. Le premier ou le céplialique est comme bilobé en devant, et senble être produit par deux ganglions réunis. Il est placé justement en dessus de la buse des mandibules, vers l'origine de l'œesophage. Chacun des lobes de ce ganulion lournit deux nerfs optiques, dont l'un, plus court, va s'épanouir sur te bulbe diu grand ceil eorrespondant, et dont l'autre, plus long et plus antérieur, va se distribuer anx trois autres yeux latéraus. Un autre neif part de ebaque côte du bord postérieur áu même ranglion, en se diligeant en arrière dans le voisinage da prenier poumon. Le cordon médullaire s'engage ensuite sous une espice de menbrane tendineuse qui se ceutinue jusqu'à l'extrémité de la queue. Dans ce trajet, il présente sep: autres ganglions, dont trois dans la cavité abulominale et quatre dans la queue; ceux de l'abdomen, plus distans entr'enx que les autres, émettent chacun trois nerfs, dont deux latéraux, pénélrant dins le panieule musculeux, envoieni des lilets aux pouraons correspondans, et dont le troisicre, qui est inférienr, rétrograde un peu à son origine et va se distribuer aux viseères. Les quatre derniers ganglions correspondent aux Ifutre premiers nouds de la queue, et ne fournissent chacun, de chaque côté, quu un senl nerf. Les deux filets des cordons s'écartent ensuite en divergeant, se bifurquent et se ramifient dans les muscies du dernier nocud, ou de l'arlicle à aiguillon. Les deux supérieurs se porten! sur les uruscles moteurs de la vésicule vénénifère, et les inférieurs pénètrent dans la vésicule mêrae en se distribuant probablemeat dans les gliudes de cet organe. Le corton verveux, it son trajet de l'ubdomen, est constamment accompagné de petits corprs alongés, cylindracés ou fusilormes, blanchâtres, d'apparence graisseuse, accolés à sa surface et liés less uns à la file des autres.

Les nuuscles des Scorpions sont assez robusfes, formés de fibres simples et droites d'un gris-blanchâtre. Une toile musculeuse assez forte revêt intérieurement les parois de l'abdomen, el enveloppe tous les viscèces, à l'exception des prumoes et peut-ĉtre du vaisseau dorsal; elle n'adhère pas duns la plus grande partie de son étendue à ces parois. La région dorsale de cette toile dome naissance à sept paires de muscles filiformes, qui traversent le foie par des trous nu conduits pratiqués dans la substance de cet organe, et vont se fixer à un ruban musculeux qui règne le longr des parois ventrales, en pissant au-dessu; des poa- 
mons. Ces muscles, mis à découvert, ressemblent à des cordes lendues. Le cinquième anneau de l'abdomeu, ou celni qui précéde immédiatement le premier nœud de la queue, ei gui u'a point de poches pulmonaires, est rempli par une masse musculare très-forte, qui sert à impriner à la queue les divers mouvenuens dont elle est susceptible. Les noends de celte queue ont un panicule charnu, dont les fibres disposées sur deux côtés opposés, se rendent obliquement à la ligne médiane, comme les barbes d'une plune sur leur axe comunn. On voit de chaque côté a la base du deruier noud, ou celui de l'aiguillon, un muscle robuste.

Le foie cst partagé superficiellement en deux lobes égaux par une rainure médiocre où se loge le cour'; il est d'ute consistance pulpeuse et d'uue coulcur brunâtre plus on moins toncee : il remplit presque toute la capacité de l'abdomen et du corselet, et sert de réceptacle an caual inlestinal. Sa partie antérieure se divise en plusieurs prolongemens irrégulicrs qui s'entoncent dans les anfractuosités du corselet; it se termine à l'autre extréwité par deux digitaltions aiguës qui pénètreut dans le premier ancean de la gueue. Sa face supérieure est lígèrement convexe, lisse, et présente une réticulation très-fine, semblable à celle de certains Madréporites polis et que l'on voit, au moyen de la loupe, être le résnltat du rapprochement de lobules polygones très-manifestes, surtont lorsque l'animal a jeûné, ou lor'squ'on déchire la cubsiance de l'organe. L'intérienr de cette substance est un tissu de glandes infiniment petiles, et présente à la surface externe une apparence réticulaire. La face inférieure oflie une slructure analogue, mais bien plus distincte; on y comple une quaranlaine environ de lobules pyranidaux détachés les uns des antres, et dont les sommels forment, par leur réunion, des grappes ayaut leurs canaux excréteurs. Les vaisseaux hépatıques sont au nombre de huit paires, trois dans le corselet, tiois autres dans l'abdomen, et deux plus longues près de l'organe de la queue.

Le tube alimentaire est grêle et se porte directemeut, sans aucune inflexion, de la bouche à l'origine du dernier noud de la quene, en traversant le foie, avec lequel il a de noubrenses conpexions au moyen des vaisseaux hépatiques. Son diamètre est à peu près égal dans toule son étendue; cependaut il présenie souvent une dilatation informe dans le corselet el mène avant l'anıs.

Les organes de la génération des Scorpionides sont doubles dans chacue sexe. Ceux du mâle sont de deux sortes; les uns préparent et recèlenı la semence et ont reçu le nom de préparateurs; les autres servent à l'acte de la copulation: ce sont les organes copulatenrs. Les organes préparatcurs se composent $1^{\circ}$. des testicules qui présentent une conformation singnilière, et qui àa avec celle qu'on observe dans les mêmes organes des insectes qu'une analogie très-indirecte. Chaque testicnle est un vaisseau spermalique forıné de trois grandes mailles à peu près semblables, anastomosées entr'elles et conchées le long du foie. Ces mailles sont conslitućes par un conduit filiforme, demitransparent, ue communiquant que rarement avec celle de l'aulre organe prépitraleur, et aboulissant, par son extrémilé postérieure, à un canal déférent long de quelques lignes, et qui s'abouche à la base c'nne vésicule spermatique insérée au côté externe de L'organe copulateur. $2^{\circ}$. De deux vésicules spermaliques d'une nalure idenlique et remplies d'un sperme plus on moins blanchâtre; l'une, plus petite, conico-cylindrique, longue de deux a trois lignes, est celle qui reçoit à sa base le canal déférent; l'autre, de forme cylindrique, droite, cst adhérente à l'organe copulilleur et couchée sur lui. Les vaisseaux spermatiques, formés par des cananx longs et cylindriques, naissen! d'une des branches des giandes, descendent sur les parties latérales de l'andumen, en passant sous le réseau des vaisseaux hépaliques, et communiquent ensemble par des branches latérales assez multipliées. Lorsque la técondation est sur le point d'avoir lieu, les vaisseaux sont remplis d'une humeur blanchâtre el épaisse, et leur diamètre paroît alors assez considérable.

Les organes copulateurs mâles sont composés de deux verges que Lcéon-Dufour nomme armures sexuelles; elles sont accolées à droite et à gauche le long du bord externe dn foie : chacune d'elles, essentiellement destinée à transmettre au dehors la liqueur fécondante, se présente sous la forme d'une tige etillée, on d'un étui mince presque droit, de consistance cornée, d'un brun pâle et enveloppée d'une snbstance comme gélatineuse. Leur exlrémité antéricure ou la plus interne est bifurquée; la branche extérieure est courle et conoide, pointne, d'un brun foncé, tandis que l'interne se prolonge en un cordon filiforme, blanchâlre, courbé sur lui-même de manière à former une anse, et revenant, en sens contraire de sa première direction, se coller cuntre le corps de l'organe. Son issue en dehors du corps a lieu par l'ouverture bilabiée située à la base de l'abdomen, entre les lames pectinées; la partie supérieure qui doit saillir hors du corps est très-mince.

Les organes prépiaraleurs des femelles sont aussi doubles, et placés à droite et à gauche dans l'intérieur du foie: ce sont les ovaires et les œufs. Chacun des ovaires est un conduit membraneux formé de qualre grandes mailles quadrilatères anastomosćes entr'elles, ainsi qu'avec celles de l'ovaire opposé. Lorsque les germes ne sont pas apparens, cet organe ressemble beaucoup à l'orgune préparateur mâle; mais outre qu'il offre une maille de plus, il en diffère encore par sa connexion intime et constante avec l'ovaire correspoudant. Les mailles aboutissent à un condnit 
simple, peu alongé, au véritable oviductus qui, avant sa réunion avec celui de l'ovaire opposé, offre constamment une légère dilatation. Un col extrêmement court et commun anx deuz matrices, débouche dans la vulve. Jues œufs sont ronds, blanchâtres; Rédi en a compté quarante, mais LéonDufour, d'accord avec Maupertuis, en a vu jusqu'à soixante. Leur disposition est très-différente suivant l'époque de la gestation. Dans les premiers temps, ils sont logés chacun dans une bourse sphérique, pédiculée, flottante hors du conduit. Vers la fin de la gestalion, et devenus plus gros, ils rentrent dans la matrice, se placent à la file les uns des autres, séparćs par des étranglemens bien marqués, et lcs bourses s'oblitèreut. L'organe copulateur se compose de la vulve, qui est unique, placée entre les deux peignes et formée de drux pièces ovales, plates, séparcées par une ligne médiocre enfoncée et susceptibles de s'écarter l'une de l'autre. M. Léon-Dufuar a observét dans cet organe nn corps oblong, corné, creusé en grouttière sur une face, caréné sur l'autre et long d'cuviron une ligne. Liune de ses extrémités esi libre, largement tronquée et comme finement dentelée; l'autre, fixće au moyen de deux muscles assez longs et qui paroissent insérés dans la purtie dilatée de cbaque oviductus, est terminec par trois lobes, dont les deux latéraux plus pelits, courbés en crochets, et dont l'intermédiaire plus grand, en pointe mousse, donvent attache aux muscles précédens.

On présume qụe lés amours, dans ces Arachnides, sont noclumes; ces animaux doivent aussi avoir un mode particulier d'accouplement nécessité par la forme et la situation des orgaues copulateurs. Leur gestation est bcancoup plus longue que celle des aures insectes. Dès le commencemeat de l'automne toutes les ferpelles sont fácoudes. Leurs œufs sont alors latéraux, petits et pédiculés. Ils augmentent de volume pendant l'biver, et au printemps leur volume est quatre fois plus grand. Leur gestation dure près d'un an, ce qui est fort extraordinaire, comparativement même à celle des animaux à sang rouge. Les œufs éclosent dans l'intérieur du corps de la mère et en sortent vivans.

L'organe destiné à sécréler l'humeur vénéneuse est revếtu extérienrement d'une membrane corruée et assez épaisse; il offie dans son intérieur deux glandes jaunàtres, très-àdhérenies à la substance cornée, et se prolongrant par un canal qui s'étend jusqu'à l'extrénité de l'aigruillon; ce canal est élargi vers sa hase et ollie une solle de réservoir pourr l'humeur sécrétée par les glandes jaunâtres, qui sont composées d'une infinité de glandules arrondies, très-serrées les unes contre les autres et communiquant ensemble. M. Marcel de Serres qui a fait ces observations, ne dit pas par quelle voie la liqueur vénéneuse arrive anx glandes qui en sont le réservoir, el comment elle y est eutreHist. Nat. Tns. Tome K. tenue; mais M. Latreille pense qu'elle dérive principalement de ces vaisseaux situés près de l'origine de la queue, que M. Marcel de Serres présume être chylifères, et que M. Léon-Dufour place au nombre des vaisseaux liépatiques. M. Marcel de Serres pense que les peigues des Scorpionide's leur servent pour la marche, qu'ils élèvent leur corps au-dessus du sol et facilitent leurs mouvemens, qui sans ce secours seroient rampans; notis ue partageons pas cette opinion, car ayant vu dans la Provence beaucoup de Scorpions, nours nous sommes assurés qu'ils ne rampent point, et que bien au contraire ils courent avec beaucoup d'agilité. Au reste on pourroil, comme le dit $\mathbf{M}$. Laireille, s'assurer aisément si les peignes les fatvorisent ponr la locomotion; on n'auroit qu'ì les attacher avec un fil contre le corps, on pourroit voir alors si les mouvemens de ces animaux seroient plus gênés. Ce savant pense que la composition et la consistance de cet or'ganc, la diversité qu'il présente dans lc nombre de ses lames ou dents et sa position, paroissent indicjuer d'autres fonctions qu'il est impossible de déterminer sans faire un grand nombre d'expéricnces à ce sujct. l'eut-être, dit-il, ces peignes sont-ils un instruinent hygrométrique qui leur fait connoitre l'état de l'atizosphère, et leur évite des courses dangercuses et inutiles qu'ils pourroient faire dans l'intention de satisfaire aux premiers besoins.

Les Scorpionides habitent les pays chauds des deux hémisphères, vivent à terre ou dans les lieux sablonneux, se cachent sous les pierres ou d'autres corps, le plus souvent dans des masures ou dans des lieux sombres et frais, on même dans l'intérieur des naaisous; ils comrent vîte en recourbant leur queue en forme d'arc sur le dos, et la dirigent en tous sens en s'en servant comme d'une arme offensive et défensive. Leurs serres lear servent à saisi: les insectes qui doivent faire leur nourriture; ce sont ordinairement des Carabes, des Charancons, des Cloportes, des Orthoptères et d'autres insectes vivant à terre qui deviennent leurs victimes : ils les piquent avec l'aiguillon de lear queue, et les font ensuite passer à leur bouche pour les dévorer. Ils aiment surtout beaucoup les aufs d'Arachnides et des aufres insectes. Ces Arachnides sont si mulipliés dans certains pays, qu'ils devicnuent pour les habitans un sujet continuel de crainte, et que même, suivant quelques témoignages, on s'est vu forcé de leur abandonner le terrain. Les Scorpionides ont été connus par les Anciens, et la constellation zodiacale du Scorpion nous annonce que la connoissance de cet animal remonte à la plus liaute antiquité. Dans la Mythologie égyptienne, son efligie est devenue le symbole typhon du génie malfaisant. Anubis est représenté eu face du Scorpion, comme s'il vouloit conjurer et anéantir l'influence de ce maurais principe. Pline expose dans son Histoire naturelle tuules leo fables que l'ignorance el la superstitiun E e e 
ont enfantées pendant un grand nombre de siècles sur le compte de ces animaux. Il dit que les Psylles avoient essayé de naturaliser les Scorpions d'Afrique en Italie, mais que ces tentatives avoient été infructueuses. Il en distingue, sur l'autorité d'Apollodore, neuf espèces; Nicander (Alexipharmaca) en comple une de moins, et présente à cet égard quelques détails particuliers sous des considérations médicales. Les Anciens avoient observé que les Scorpions s'accouploient, qu'ils étoient vivipares, et que leur aiguillon étoit percé et donnoit passage à un venin blanc. On avoit aussi remarqué que les fenelles portoient leurs pelits; mais on supposoil que le seul qui leur restoit avoit éclrappé par ruse à la destruction qu'elles avoient faite de leur postérité, et qu'il la vengeoit en dévorant l'auteur de ses jours. Selon d'autres, celte mère étoit la proie de sa famille. Il n'en est pas moins vrai que leur voracité étoit connue dans ces temps reculés. L'existence de Scorpions à deux queues n'est pas fabuleuse, et il existe au Muséum de Paris un individu qui présente cette singulière conformation. Les Scorpions ailés, que Mlégasthènes disoit se trouver dans l'Inde et chez les Prosiens, et qu'ils disuient être si grands, ne sont autre cliose que de grands Orthoplères du genre Phasme ou Spectre, ou quelques Nepa de Linnæus. Latreille a domé lui-même le nom de Scorpion aquatique à un insecte de ce dernier genre.

En France, le Scorpion d'Europe commence à se montrer vers le $44^{\mathrm{e}}$. degré de latitude, ou sous la zône propre à la culture de l'amandier, du grenadier, et se rapproche des limites septentrionales de celle de l'olivier. Celui que Maupertuis a distingué sous le nom de Souvignargucs, canton du Languedoc où il se trouve plus particulièrement, est mentionré dans Mathiole, Mouffet et Jonston; il est très-commun dans le royaume de Valence et la basse Catalogne, provinces où M. Léon-Dufour n'a pu découvrir aucun individu du Scorpiun d'Europe. Ces denx espèces paroissent s'exclure réciproquement des mênes localités; ainsi on chercheroit en vain le Scorpion d'Europe dans les montagnes arides des environs de Narbonne, sur celles de nature schisteuse qui forment du nord au sud une limite maritime de luit à dix lieues au plus de largeur entre Barcelonne et Saint-Philippe, ainsi que sur les confins de la basse Catalogne et de l'Aragon, pays où l'on trouve le Scorpion roussâtre souvent en grandes quantités. Sa patrie, en Espagne; est absolument celle du caroubier. (Ceratonica siliqua, Lins.) C'est ainsi, par exemple, qu'un peu au-delà de Barcelonne, oì l'on rencontre les premières plantations de cet arbre, l'on commence aussi à trouver les premiers individus de ce Scorpion. M. Léon-Dufour ne l'a plus rencontré à une hauteur de plus de 150 toises au-dessus du niveau de la mer.

Les Scorpionides varient beaucoup pour la grandear; ceux d'Europe n'ont guère plus d'un pouce de long, tandis que ceux d'Afrique et de L'Inde atteignent jusqu'à cinq à six pouces. On peusc qu'ils sont très-venimeux. Les Persans emploient contre la piqûre dn Scorpion, qu'ils nomment $A$ grab, et qu'en indoustan on nomme Gargouali (Sc. australis, Linn.), la scarification et l'application d'un peu de chaux vive; quelques personnes se servent de l'huile où l'on a rassemblé et laissé digérer plusieurs de ces Arachnides ; d'autres préfèrent d'écraser sur-le-champ l'animal même, et de l'assujettir sur la plaie : enfin d'autres font l'application d'une humeur sébacée qui suinte entre le prépuce et le gland de la verge.

Les auteurs modernes, tels que Maupertuis, Rédi, Maccari, Léon-Dufour et beaucoup d'autres ont fait des expériences pour savoiv jusqu'à quel point ces Arachnides sont venimerx. Il résulte de tout ce qui a été dit à ce sujet, que la piquâre des Scorpions d'Europe ne peut causer que des accidens légers et jamais la mort; cependant celle du Scolpion roussâtre ou de Souvignargues produit, d'après les expériences que Maccari a faites sur lui-même, des accidens plus graves et plus alarmans, et le venin paroît être d'autant plus aclif, que le Scorpion est plus âgé. Quant au Scorpion noir ( $S$. afer, Lins.) qui vit dans les fentes de roches ou les creux d'arbres, et qui est quatre ou cinq fois plus grand que les précédens, il peut causer la mort en moins de deux lieures, et les seuls remèdes sûrs contre sa blessure, sont ceux que l'on emploie contre les serpens les plus venimeux; c'est l'alcali volatil euployé soit extérieurement, soit à l'intérieur, des cataplasmes de buuillun-blanc et des sudorifiques.

Quant à l'opinion où l'on est qu'on force un Scorpion à se tuer lui-même quand on l'enferme dans un cercle de charbons ardens, elle a été combattue par Maupertuis, qui a fait des expéliences à ce sujet; nous avous eu occasion nousmêmes d'essayer sur des Scorpions de Provence, qui ne se sont pas plus piqués que ceux de Maupertuis; ils couroient seulement çà et là d'un air très-inquiet, et ils ont fini par être étouffés par la chaleur. Cependant les observations de M. le comte de Senneville, grand référendaire de la Chambre des Pairs, senibleroient confirmer l'opinion populaire à cet égard. M. Latreille dit, d'après M. Léman, que M. de Senneville a fait des expériences en présence d'un grand nombre de personnes, et que le résultat a toujours été la mort du Scorpion, qui se l'est dunuée lui-même.

Les Scorpionides portent leurs petits sur leur dos pendant un mois après qu'ils sont éclos. Dans quelques circonstances ils les tuent et les dévorent à mesure qu'ils uaissent. Si on en enferme plusieurs ensemble, ils ne tardent pas à se baltre à mort et à se dévorer jusqu’à ce çu'il n'en_reste plus qu'un.

Cette tribu est divisée, comme nous l'avons dit plus laut, en deux genres; ce sont les genres 
Scorpion proprement dit et Buthos. Voyez ces mots. (E. G.)

SCOTINE, Scotinus. KIrB. LAT. (Fam. nat.) Genre d'insectes de l'ordre des Coléoptères, section des Hétéromères (première division), famille des Mélasomes, tribu des Blapsides.

M. Latreille (Fam. nat.) inet dans celte tribu dix genres. Trois d'entr'eux, savoir : Oxure, Nyctélie et Eurynote nous sont entièrement inconnus. Du reste le genre Aside se distingue par son menton grand, recouvrant la base des mâchoires. Dans les Pédines et les Platyscèles les tarses antérieurs des mâles sont dilatés; ce caractère est aussi, d'après le savant auteur que nous venons de citer, l'nn de ceux des Eurynotes; les Misolampes ont les troisième et quatrième articles des antennes longs, égaux entr'eux. Les Blaps et les Scotobies sont séparés des Scotines par le onzième on dernier article de leurs antennes qui est libre et entièrement distiuct du précédent.

Voici les caractères assignés à ce genre par MI. Kirby. (Trans. de la Soc. Linn. de Lond.)

Labre bifide. - Lèvre bifile, ses lobes allant en divergeant. - Mandibules dentées, se touchant l'une l'aulre par leur extrćmité. - Mâchoires laissant un espace libre à leur base. - Palpes assez épais; leur dernier article plus grand que les autres, presque trianguläire. - Menton bifide, ses lobes allant en divergeant. - Antennes moniliformes, plus grosses vers leur extrémité; leur dernier article très-court, ’̀ peine distinct. Corps ovale, rebordé.

Nous observerons en outre que les antennes sont composées de onze articles, le troisième le plus long dc tous; le dernier ne paroit court que parce qu'il est entièrement plongé dans le dixième; celui-ci est infundibuliforme; le menton ne recouvre point la base des mâchoires et les tarses antérieurs ne sont pas dilatés dans les mâles.

Le nom de Scotine vient d'un mot grec qui signifie : ténébreux. L'auteur n'en décrit qu'une espèce. On ignore ses mœurs.

\section{Scotine crénicolle, $S$. crenicollis.}

Scotinus subcinereus, obscurus, thoracis margine crenato.

Scotinus crenicollis. Kirb. Trans. Soc. Lin. vol. v. pag. n. pl. 2 I. fig. 14.

Longueur 9 lig. Noir, couvert presqu'en totalité d'un duvet court, roussâtre, mêlé de gris. Corselet très-échancré au bord antérieur, dont les angles sont très-saillans et aigus. Bords latéraux crénelés. Elytres ayant latéralement uue carc̀ne tort élevée qui ne s'étend pas tout-à-fait jusqu'à leur extrémité et fait suite aux bords latéraux du corselet; après cette carène les élytres se recour- bent fortement en dessous et embrassent les côtés de l'abdomen. Antennes hérissées de poils.

Du Brésil. (S. F, et A. SER7.)

SCOTOBIE, Scotobius. Genre de ColéoptèrcsHétéromères proposé par M. Germar dans l'ouvrage intitulé : Insectorum species nova aut ininus cognitoe, vol. I. Coleopt. 1824 , et placé par M. Latreille dans la tribu des Blapsides. Il offre pour caractères, suivant M. Germar : antennes plus courtes que le corselet, insérées sous un rebord de la tête, leur troisième arlicle en massue, plus grand que les autres; les quatrième; cinquième et sixième globuleux; les septième, hui tième, neuvième el dixième transverses, le dernier transverse, tronqué obliquenent à son extrémité. Chaperon grand, un peu arrondi, inséré dans une échancrure de la tête. Palpes filiformes. Menton transverse, bisinué. Lèvre prescu'arrondie. Yeux transverses, point saillans. Corse!et transverse, rebordé. Elytres réunies, ovales. Extrémité des jambes ayant deux dents.

Ce genre est interunédiaire, suivant M. Germar, entre les Scaures et les Sépidies d'un côté et les Akis de l'autre. Il en décrit trois espèces de Buénos-Ayres, et figure l'une d'elles pl. 1. fig. 5. sous le nom de Scotobius crispatus.

$$
\text { (S. F. et A. Serv.) }
$$

SCOTODE, Scotodes. Escrischor.tz. Genre de Coléoptères.Hétéromères. M. Fischer dansle $2^{e}$. volume de l'Entomographie de Russie, Moscon 1823 , donne les caracteres de ce genre ainsi qu'il suit: antennes allant en s'épaississant vers l'extrémilé, leur troisième article très-long, le dernier ovale. Labre presque carré. Mandibules cornées, arquées, unidentées. Mâchoires membraneuses, bifides; leur lobe antérienr large, cilié; l'intérieur linéaire. Palpes naxillaires sécuriformes; les labiaux presque filiforıes. Menton entier, transversal.

Le nom de ce genre cst tiré d'un mot grec qui signifie : sombre. Les insectes qui le composent sont lents; ils ont la tête inclinée et le corps velu. M. Fischer rapporte les Scotodes aux Hélopiens. Il en décrit une espéce sous le nom de Scotode aunelé, Scotodes annulatus. Escuschoutz, Mém. de l'Acad. des scienc. de Saint-Pétersb. tom. 6. pag. 454 . no. 3. - Germ. Mag. vol. IV. p. 3g8. Longueur 4 lig. $\frac{1}{2}$ à 5 lig. Brun avec un duvet gris. Jambes grises annelées de brun. On le trouve en Livonie dans les licux ombragés; il est représenté sous le nom de Pelinatopus Hummelii, Eutom. de Russ. vol. 2. tab. 22. fig. 7. à 9 .

(S. H. et A. Serv.)

SCRAPTER, Scrapter. Andrena. LAt.

Genre d'insectes de l'ordre des Hyménoptères, section des Porte-aiguillon, famil!e des MelliEee 2 
fères, tribu des Andrénètes (division des Récoltantes).

Dans eette division des Andrénètes (voyez Mellifères famille, article Parasites) trois genres se distinguent par les caraetères suivans : division intermédiaire de la lèvre lancéolée; femelles ayant une palette de chaque côté du inétathorax et une autre sur les cuisses postérieures; leur brosse placée sur le eôté extérieur des jambes et du premier article des tarses des pattes postérieures. Ce sont les $A$ drènes, les Dasypodes et les Scraptèrs. Les premières sont faciles à recounoître par la présence de quatre eellules cubitales aux ailes supérieures; les Dasypodes n'en ont que trois ainsi que les Scraptèrs, mais elles s'éloigneut de ces derniers $1^{\circ}$. par la forme de leur cellule radiale qui u'a point de rétréeissement sensible; $2^{\circ}$. par les ocelles disposés en ligue droite; $3^{\circ}$. par l'épine terminale de leurs jambes antérieures ayant avaut son milieu une dent latérale jusqu'à laquelle seulement elle est garnie d'une membrave..

Les Scraptèrs ont beaucoup de caractères eommuns avee les Dasypodes (voyez ce mot à la suite de cet article), wais ils en diffèrent sensiblement par cenx que nous allons únoncer. Antennes des mâles allint un pen en grossissant vers le bout. Irâchoires fléchies près de leur extrémité. Lèvre peu alongée, plus courte que les palpes maxillaires, son appendice terminal guere plus long que large. Cellule radiale allant en se rétréeissant depuis le milieu jusçu'à son extrémité qui est presqu'aiguë; trois cellules eû́bitales, les deux premières presçu'égales, la seconde rétrécie vers la radiale, recevaut les deux nervures récurrentes. Troisième cellule atteignant presque le bout de l'aile. Ja arbes an térienres munies d'une seule épine terminale garnie dans tonte sa longueur d'nne membrane étroite; cette épine échancrée à l'exmité, terminée par deux pointes aiguës, divergentes. Premier article des tarses postérieurs plus court que la jambe. Trois ocelles disposés en triangle sur le vertex.

Ce genre dont le nom vient d'un mot grec qui signifie : fouissent, équivant à la première division des Andrènes de M. Latreille, Gener. Crust. et Ins. tom. IV. pag. 15 r. Ses mœurs doivent être les mêmes que celles des Dasypodes. Nous en connoissons quatre espèces que nous allons mentionner.

\section{Scraptèr bieolor, S. bicolor.}

Scrapter niger, griseo seu rufo tomentosus; abdomine nigro, segmentis secundo terlioque cun primi parte posticâ ferrugineis.

Longueur 6 lig. Noir, chargé de poils d'un grisroussâtre. Antennes allant en grossissunt vers le bout; ferrugineuses, à l'exception de leurs trois premiers articles qui sont noirs. Seeond et troisième segmens de l'abdoraen de couleur ferrugi- neuse ainsi que la moitié postérieure du premier segment. Ailes transparentes. Mâle.

D'Afrique. ( Cafierie.)

\section{Scraptèr ponctué, $S$. punctatus:}

Scrapter punctatissimus, nufo tomentosus; lineis tribus faciei, orbitâ oculorum posticâ line $\hat{a}-$ que scutelli pallidè luteis : pedibus posticis rufo hirsutissinnis.

Ionguenr 5 lig. Corps noir, très-ponetué, arec trois lignes longitudinales sur la face antérieure de lat tểe, l'orbite des yeux et mue ligne transverse sur l'écusson, d'un jaune sale. Pattes postérieures très-garnies de poils roux. Ailes transparentes. Femellé.

Mème patrie que le Scraptèr bieolor.

\section{Scraptìr noir, S. niger.}

Scrapter totus niger, capite, thorace pedibusque cinereo tomentosis; alis apice subfuscis.

Longueur 3 lig. $\frac{1}{2}$. Eutièrement noir, avec des poils nombrenx d'un gris-cendré principalement sur la tête, le eorselel et les pattes. Ailes transparentes, leur bord postérieur brun. Mâle.

Miême patrie que les précédens. Ces trois espèces ont été rapportées par feu Delalande et font partie de la collection du Musée royal d'histoire naturelle.

Nota. L'Andrena lagopus Lat. loc. citat. du midi de la Franee, appartient aussi à ce genre. (S. F. et A. SEnv.)

DASYPODE, Dasypodil. Lat. Fab. Panz. (Révis.) Krvg. Andrena. Ross. Panz. (Faun.) Apis. P. Pa. (Faun.) Melittc. Kir b. Trachusa. Jur.

Genre d'insectes de l'ordre des Hyménoptères, seetion des Porte-aiguillon, famille des Mellifères, tribu des Andrćnètes (division des Récoltantes).

La première subdivision des Andrénètes réeoltantes se distingue par les earactères suivans: division intermédiaire de la languette laneéolée; trois eellules cubitales aux ailes supérieures. (Voyez P Pasites.). Elle renferme les genres Dasypode et Seraptèr. Ce dernier est bien séparé des Dasypodes par ses mâchoires fléchies simpllement près de leur extrémité, par le premier article de ses tarses postérieurs plas court que la jambe, et par la eellule radiale des ailes supérieures qui se rétrécit à partir du milieu jusqu’à l'extrémité.

Antennes assez longues, filiformes, fléchies forternent au second article, ees artieles au nombre de douze clont le troisièrme plus long que les suivans et aninci à sa base daus les femelles; simplement arqućes et de treize articles daus les mâles, le premier beaucoup plus eourt que dans l'aulre sexe. - Labre semi-cireuluire. - Mandi- 
bules arquées, pointues, bidentées dans les deax sexes. - Mâchoires fléchies dans leur milieu ou au-dessous, leur lobe terminal lancéolé-trigone. - Palpes artieulés; leurs articles de forme ordinaire, insérés ehacun à l'extrémité du précédent; les maxillaires ayant à peine la longueur du lobe terminal des mấchoires, de six articles, les labiaux de quatre. - Lèvre alongée, presque linéaire, sà division intermédiaire lancéolée. Téte transversale, étroitc; toute sa partic antérieure très-velue. - Yeux ovales, alongés. Trois ocelles disposés sur une ligne transversale presque droite et placés sur la partic antérieure du vertex. - Corps velu, surtout dans les mâles. - Corselet globuleux. - Ailes supérieures ayant une cellule radiale d'une largeur à peu près égale dans toute son étendue, sa base et son extrémité finissant presqu'en pointe, et trois eellules eubitales, la première plus grande que la seconde; eelle-ei fort rétrécie vers la radiale, recevant les nervures récurrentes : la troisième la plus grande de toutes, n'atteignant pas le bout de l'aile. Abdomen ovale et peu convexe en dessus dans les femelles, de einq segmens outre l'anus; conique et de six segmens outre l'anus, dans les mâles. Pattes de longueur moyenue; jambes antérieures n'ayant qu'une seule épine terminale qui porte avant son milieu une dent latérale jusqu'à laquelle elle est munie d'une membrane. Jambes intermédiaires terminées par une seule épine longue et simple. Jambes postérieures en ayant deux fort longues, simples, presqu'égales; ees jambes extrêmement velues dans les femelles ainsi que le premier article de leurs tarses, ee premier article un peu plus loug que la jambe : crochets des tarses bifides, munis dans leur entre-deux d'une pelotte courte, assez grosse. - Organes de récolte des femelles consistant daas une palette placée de chaque eôté du inétathorax et dans nne autre sur la partie correspondante des cuisses postérieures; des brosses placées sur le eôté extéileur des jambes et du premier article des tarses des pattes postériegres; une brosse!te sur la fuce intérieurc du premier article de tous les tarses.

Le nom appliqué à ee genre par M. Latreille vient de deux mots grees qui signifient : pieds velus. Les femelles creusent daus les penles de sable des trous un peu inclinés, profonds de plusieurs pouces oǹ elles pratiquent plusieurs petits terriers qu'elles ont soin de polir intérieurement, et dans chacun desquels elles entassent la pâtée composée de pollen et de miel nécessirire à la nourriture d'une seule de leurs larves; elles prélìrent le pollen des fleur's radiées, telles que les Crepis, les Hieracium et les Leontodon. Elles sont très-vives dans tous leurs mouvemens, piquent très-vîte et très-fortement. Leurs ennemis sont les mêmes que ceux des Halietes (voyez ee mot, à la suite du présent article). On renteontre les Dasypodes des environs de Paris vers la fin de l'été et dans l'automne. Le nombre des espèces n'est pas cousidérable.

\section{Dasypode grecque, $D$. groeca.}

Dasypoda nigra, capite thoraceque segmentis duobus prinis abdominis coterorumque margine infero pilis ferrugineis villosis; ano nigro villoso: alis subfiscis.

Longuen 8 lig. Antennes noires. 'Tête et corselet de même couleur, couverts de poils ferrugiweux. Abdomen noir; ses deux premiers segmens entièrement couverts de poils ferrugineux; les troisième, quatrième, cinquième et sixième nus à leur base, n'y ayant que quelques poils noirs, épars; leur bord inléricur portant une bande de poils ferrugineux un peu interrompue a milieu; anus couvert de poils noirs. Pattes noires chargées de poils ferrugineux. Ailes un peu obscures dans toute leur étenduc. Mále.

De l'île de Naxos. Du Musée royal d'histoire naturelle.

Rapportez en outre à ce genre: $1^{\circ}$. Dasypode hirtipède, Dasyp. Thirtipes. L,ar. Gener. Crust. et Ins. tom: IV. pag. 152. Hâle et femelle. HAв. Syst. Piez. pag. 355. no. 1. Femelle. Dasypoda hirta. $\mathrm{F}_{\mathrm{AB}}$. id. pag. $336 . n^{\circ}$. 2. Mâle. Andrena plumipes. Panz. Faun. Germ. fas. 4. frg. 16. Femelle. Andrena succincta. id. fig. Io. Femelle. Apis farfarisequa. id. fas. 55. fig. 14. Mâle. Melitta Swanmerdanella. Kir в. Monogr. Apum Angl. tom. 2. pag. 174. $n^{\circ}$. I11. Màle et Femelle. Commnne aux environs de Paris. $2^{\circ}$. Dasypode plumipède, Dasypoda plumipes. Lat. Gener. Crast. et Ins. tom. 4. pag. 152. Femelle. Panz. Faun. Gern. fas. 99. fig. 15. Femelle. De lit France méridionale.

COLLE'TE, Colletes. Lat. Sprnor. Klug. Apis. Lrnn. Panz. (Fulln.) Oliv. (Encycl.) Andrena. Fab. Jon. Megilla. Fab. Melitta. Krnb. Evodia. Panz. (Révis.)

Genre d'insectes de l'ordre des Hyménoptères, seetion des Porte-aiguillon, famille des Mellifères, tribu des Andréuètes (division des Récoltantes ).

Parmi les Andrénètes récoltantes les genres suivans ont la division intermédiaire de la lèvre lancéolée ou presque linéaire, ce sont ceux de Dasypode, Scraptèr, Andrène, Halicte et Nomic ; ce caractère important ne se trouve poiut dans les Collètes.

Antennes filiformes, simplement arquées, composées de douze articles daus les femelles, le premier fort long, le second globuleux, le troisième un peu plus long que le précédent, un peu plus mince, ainsi que les stivans, que teux qui viennent ensuite; de treize articles dans les mâles, le premier plus court que dans l'autre sexe. - Labre presque trigone. - MLandibules striées ì leur partie 
extérieure, ayant une forte dent au-dessus de leur pointe qui es! longue et avancée. - Mâchoires ayaut leur lobe terminal entic̀rement coriace, alongé, suns divisions, garni de quelques cils roides. - Palpes articulés, presque sétacés; leurs articles de forme ordinaire, insérés chacun à l'extrémité de celui qui le précède; les maxillaires plus longs que les aulres, composés de six articles, les labiaux de quatre. Articles de tous les palpes allant en diminuaut de longueur vers l'extrémité. - Languette courte, évasée, à trois lobes, l'intermédiane presqu'en forme de cœur. - Téte transversale, étroile, toute sa partie antérienre velue. - Yeux ovales, alongés. - Trois ocelles disposés en triangle sur le vertex. - Corps généralement velu. - Corselet presque globulcux. - Ailes supérieures ayant une cellule radiale un peu appendiculée, presqu'aiguë à sa base et à son extrénité, allaul en se rétrécissaul depuis sou milieu jusqü ì colle-ci, et quatre cellules cubitales, la première plus graude que la seconde, celle-ci et la troisième presqu'égales, un peu rćtrécies vers la radiale, recevant chacune une nervure récurrente : quatrième cubitale à peine commencée. - Abdomen presque conique, de cing segmens outre l'anus dans les femelles, en ayanı un de plus dans les mâles. - Pattes de longueur moyenne; jambes antérieures ayant une seule épiue terminale garnie d'une membrane a sa partie intérieure; jarnbes intermédiaires n'ayant également qu'une seule épine simple, aiguë à l'extrémité; jambes postérieures muuies de deux épines assez courtes, aiguës : crochets des tarses bilides, avec une trìs-petite pelolle dans leur cntre-deux. - Organes de récolte des feurelles consistant daus une palette placée de chaque côlé du mélathorax, et dans une autre sur la partie correspoudante des cuisses postérieures; point de brosse sur le côté extérieur des jambes, ni sur celui du premier article des tarses postérieurs; une brosselte au côté intérieur du premier article de chacuu des larses.

Le nom donné à ce genre par M. Lalreille est liré d'un mol grec qui signifie : colleur; il a rapport à la maniere dont les femelles prépareut leur uid. Elles l'établissent dans des trous qu'elles creusent daus les terrains sablonueux coupés à pic ou dans le mortier qui se trouve entre les pierres des vieux murs; eiles en lissent trés-exaclement les parois au moyen d'une liquenr gluante qu'elles appliquent dessus avec l'extrémité bilide de la division internódiaire de leur languette; celle unême matière leur sert aussi à former de pelites cellules en forme de dé à coudre, dans chacune desquelles elles píacent la pátée de pollen et de unier suffisanle á une de leurs larres. Ces dés sont arrangés de manière que la partie arrondie du second buuche l'orifice du preuier et ainsi de suite; nous eu a vons va quelyutiois une vingtaine placés ainsi a la file les uns des antres. Réunur entre dans le détail des mours de ces Mellifères (ciaquième Mlémoire, sixième volume ). L'espèce qu'il a observée nons paroît être la Collète ceinturée, c. succincta. Ces Hyménoptères sont très-printanniers. On n'en connoît qu'un petit nombred'espèces. MM. Latreille el Kirby n'en citent que deux; nons en counoissons quelques autres, principalement la suivante.

\section{Colnète hérissée, $C$. hirta.}

Colletes nigra, omnind rufo-liirta, pilis aliquot nigris in capite internixtis.

Longueur 5 lig. $\frac{1}{2}$. Noire, couverte de poils liérissés d'un roux-brun noêlés sur la tête de quelques autres de couleur noire. Fewelle.

Le mâle diffère en ce que les poils de la tête sont d'un roux plus clair.

On la trouve dès le commencement d'avril sul les chatons du Saule marceau (Salix caprea), et dans les endroits sablonneux des forêts. Nous l'avons prise plusieurs fois au bois de Boulogne.

Rapportez encore à ce genre : $1^{\circ}$. Audrène mineuse $n^{\circ}$. ro. de ce Dictionnaire (en retranchant le synonyme de Geoffroy qui nous paroît appartenir à une Andrène). Collète ceiniurée, C. succincta. Lat. Gener. C'rust. et Ins. tom. 4. p. 149. Melitta succincta. Kiлв. Monogr. Apun Angl. tom. 2. pag. 32. $n^{\circ}$. 1. Mâle et femelle. Megilla calendarum no. 33. Fis. Syst. Piez. Mále. Andrena succincta $\mathrm{n}^{\circ} .8$. FА id. Femelle. Apis calendarum. Panz. Faun. Germ. fis. ". fig. 19. Mâie. ${ }^{\circ}$. Collète fuuisseuse, Colletes fodiens. Lat. Gener. C'rust. et Ins. tom. 4. pag. 149. Melitta fodiens. Kır в. Monogr. Apum Angl. tom. 2. p. 34. $n^{\circ}$. 2. tab. 15. fig. 1. Hemelle. fig. 2. Male. Ces deux espèces se trouvent aux environs de Paris.

HALICTE, Halictus. LAT. WALKN. (Monogr.) Apis. Linn. Geoff. Scop. Ross. Andrena. Oliv. (Encycl.) Fab. Panz. Jur. Hyloeus. Fab. Illig. Spinul. Klug. Panz. Megilla, Prosopis. Fab. Melitta. Kinв.

Geure d'insectes de l'ordre des Hyménoptères, seciion des Porle-aiguillon, famille des Mellifëres, tribu des Audrénètes (division des Récol(antes).

La troisième subdivision des Andrénètes récoltantes a pour caractère particulier : division intermédiaire de la lèvre courbée inférieurement ou presque druite. Femelles ayant une palette de chaque côté du métathorax et uné autre sur les cuisses postérieures; point de brosses sur le côté extérienr des jambes ui sur celui du premier article des tarses postérieur's : quatre cellules cubitales. (Voyez Parasites.) Celte subdivision renferme les gresres Halicte el Nomie; ce dernier se distingue facilement par la cellule radiale des ailes supérieures d'une largenr presqu'égale dans toute 
son étendue, ayant son extrémité arrondie et parce que la première nervure récurrente aboutit précisément vis-à-vis de la nervure d'intersection des seconde et troisième cubilales. Quant au genre Sphescode que M. Latreille net dans le même groripe (Fam. natur.), nous l'en crnyons suffisauıment séparé par le manque d'organes propres à la récolte dans les femelles, ce qui le place parmi les Parasites.

Antennes filiformes, coudées et de donze artisles dans les femelles, le premier très-long, le second globuleux, les autres courts, cylindriques; droiles, simplement arquées vers leur extrémité, et de treize articles dans les mâles, le premier $\mathfrak{a}$ peine plus long que les deux suivans réunis, ceux-cí courts, le second très-petit, turbiné, le troisième un pcu conique, les autres plus longs que le troisième, ou cylindiques, le dernier quelquefois creusé en dedans et formant un crocliet particulier ou bien renflés inférieurement. $-L a$ bre court, entier, transversal, arrondi latéralement, cilié en devant. - Mandibules cornées, étroites, un peu arquées, terminées en pointe, celle-ci accompagné d'une dent dans les fernellcs, simple dans les mâles. - Mâchoires et Lèyre plus longues que la tĉte; division intermédiaire dc la lèvre courbée inférieurement. - Palpes articulés; leurs articles de forme ordinaire, insérés chacun dans l'échancrure et un peu au-dessous de l'extrémité du précćdent. - Tête avancée, comme prolongée en un museau obıus dans les niâles. - Yeux ovales-alony'́s. - Trois ocelles disposés en ligne courbe sur la partie antérieure du vertex.-Corps alongé, surtout dans les mâles. - Corselet globulenx. - Ailes supérieures ayant une cellule radiale rétrécie depuis son milieu jusqu'à son extrémité, celle-ci ainsi que la base assez pointue, et quatre cellules cubitales, liı première aussi longne que les deux suivantes prises ensemble, li seconde plus courte que la troisième, prcsque carrée, recevant la première nervure récurrente près de la nervure d'intersection qui lui est commune avec la troisième cubitale, cette dernière rétrécie vers la radiale recevant la seconde nervure récurrente au-delà de sa moilié, la quatrième cubitale à peine somucncée. - Abdomen ovale dans les femelles, composé de cinq segmens outre l'anus, le cinquiène ayant au milieu un enfoncement longitudinal et linéaire ressemblant à une fente, servant at développement de l'aiguillon qui se relève à la sortie de l'anus; celui-ci très-court : abdomen des maâles très-long, presque linćaire, de six segmeus outre l'anus qui est plus long que celúi des femelles, - Pattes de longueur moyenne : jambes antérieures munies d'une seule épine terminale gainie d'une meurbrane au côté intérieur; janbes intermédiaires n'ayant également qu'une épine, simple, aiguë à son ex 1 rémité : jambes postérieures en ayant deux, l'intérieure dentée cn scie dans les femelles; crochets des tarses bifides, munis d'une pelnttedins leur entre-deux. - Organes de récolie des femelles consistant daus une palette placée de chaque côlé da métathorax el dans une aulre sin: chacune des cnisses postćricures. Puiul de brosses sur le côté extérieur des jambes ni sur celui du premicr article des tarses postérieurs; une brosselte au côté intérieur du premier article de chacun des tairses.

Tous les Halictes connus, et les espèces sont nombreuses, pourvoient à la nourriture de lcur postérité; chaquc individu est placé à quelques po:1ces cu terre auprès d'une masse de pollen mêlé de miel que la mère récolie elle-même ct y renferme à cette intention. Ces femelles font leurs excavations daus des terrains sablonncux mais assez durs, tels que les sentiers pratiquís dans les champs; elles ne crensent pas Ionjours elles-mêmes le premicr trou perpendiculaire, et dans ce cas un trou lait par un ver de terre leur snflit; elles y descendent et pratiquent à différentes distances de petits terriers d'un demi-pouee à un pouce de longueur, à cliacun desquels elles confient un de leurs $\boldsymbol{x u f f}$. Il arrive sonvent que plusicurs d'entr'elles profitent du mêrne trou perpendiculaire. C'est avec leurs mandibules qu'elles déblayent et transportent la terre qu'elles retirent des petits terriers particuliers doni nous venons de parler. Elles ont pour ennemis les Parasiles de leur tribu, tels que los Sphécodes, et ceux de la tribu des A piaires, notamment les Mlélécles. Les larves de ces genres provenant d'cuuf's déposés dans le nid des Hillictes, dévorent la pâtée qui étoit desiinée aux larves d'Halictes avant que celles-ci soient nées. Des Chrysides et quelques Iclineumonides vont pondre leurs œuts dans ces nids; les linves qui en proviennent font leur proie de cclles des Halictes. Parmi les Ilyménoptères fuuisseurs, le Philante apivore et quelques Cercéris s'emparent sonvent des Halictes, les piqueut de leur aiguillon et les portent dans leur nid pour servir de páture à lcul postérité. Les mâles Halicıes sont très-empressés pour l'accouplement, et lorsqu'on s'est emparć d'une fenelle, il suffit souvent pour en avoir le mîle d'exposer celle-ci, quoique piquáe d'une épingle, bien en vue daris lcs endroils où elle construit son nid; les mâles qui voltigent autour se précipitent sur elle et se laissent prendre facilement. Lcs femelles sont lentes dans leurs mouvemens, si ce n'est lorsqu'elles récolient le pollen, opération dans laquelle elles montrent beaucoup d'activité; elles s'en chargent considérablement, au point d'cn être méconnoissables, et nons avous vu tel Halicte femelle presqu'entièrement noir, devenu d'un bcau jaune-aurore pour avoir fait sa récolte dans les fleurs du Genêt (Spartium scoparium). Elles piquent assez difficilement, étant leutes à tirer leur aiguillon, dont la piquare est fort cuisante. Ces Hyménoptc̀res se nourrissent à l'état parfait, du miel des fleurs.

M. Walcknaër, membre de l'Académie royale 
des inscriptions et belles-lettres de France, connu' à plus d'un titrc dans le monde savant, a donné en 1817 des Mímoires pour servir à l'histuire de cc genre. On y trouve d'intéressans détails que la nature du présent ouvrage ne permet pas d'y insérer.

La plus graude partie des espc̀ces de ce genre appartient à l'Europe. Celles que nous allons inentionner habitent tontes les environs de Paris.

I $^{\mathrm{re}}$. Division. Dernier article des antcnnes un peu creusé et fort crochu extérieurement dans les toâles.

Cette premiche division renferme $: 1^{\circ}$. Halicte zèbrc, Halict. zebrus. W Mâle et femellc. $2^{\circ}$. Halicte à six bandes, Halict. sexcinctus. LAt. Gen. Crust. et Ins. tom. 4. pag. 15.4. Mâle et femelle. Warck. Mém. pağ. 66. Les mâles de ces deux espèces ont ċté regardés comme variélés d'unc seule por Geolfroy (Abeille no. 13.) Ins. Paris. tont. 2. pagr. 4:4. el par fea Olivier, Andrc̀ne alongée no. 25. Encycl.

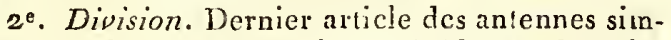
ple, conformć coinme les précédens, dans les deux sexes.

Ire. Subdivision. Abdomen enlièrement noir, ayant des bandes transverses ou des tacbes lar térales formées par des poils conchés.

Placez ici I $^{\circ}$. Malicle qualre bancles, Ilalict. quadristrigutus. LAs. Gen. Crust. ct. Ins. tom. 4. pag. I 54. Mâle et femelle. Haluct. ecaphosus. Wa cok. Mém. pag. 58. Mâle et femelle. 2o. Halictc fouisseur, Halict. fodiens. LAT, id. Femelle. Walck. id. Femelle. (Dans la phrase spécifique changez le mot posticè en celui d'anticè, correction justifice par la description frauçaise.) Lè mâle ne diffère que par son chaperon ayant une petile tache blanclee. $3^{\circ}$. Halicte nidifiant, $\mathrm{Ha}$ lict. niadulans. W.accz. Mlém. pag. 6g. Nuâle et fomelle. $4^{\circ}$. Halicte six taches, Halict. sexnotatus. WV arck. Mémul pag. 72. Feuselle. 50. Halicte perceur, Halict. terebrator. Wa cck. id. Mâle et femelle. 6०. Halicte céladon, Halict. seladonizus. Lat. Gener. Crust. et Ins. tom. 4. pag. 154. Mlelitta seladonia. Kın e. Monogr. Apumı Angl. tom. 2. pag. $57 \cdot n^{\circ}$. 16. N]âle ct femelle.

$2^{\mathrm{e}}$. Subdivision. Abdomen testacé, du moins en partie.

A cette coupe appartiennent 10 . Halicte interrompu, Halict. interruptus. Hyloens interruptus. Panz. Faun. Germ. fas. 55 . Jgr. 4. Mâle. 20. Halicte albipede, Halict. allipes. Hylous albipes. Panz. id. $f 4.5 .7$. fig. 15. Mâle. Prosopis albipes i2 ${ }^{\circ}$. 4. Fab. Syst. F'iez. Mále. Melitta albipes. Kirв. Monogr. Apum Angl. tonl. 2. pag. $71: n^{\circ}$. 29. Mâle. Hylous abdoninalis. Panz, id, fas. 53. fgo. 18. Míle. Melitta abdominalis. Kin в. Monogr. Apum Angl. tomı. 2. pağ.73. no. 3o. Mûle.

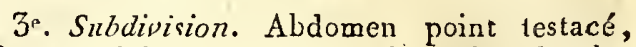
n'ayant ni bandes transversales, ni taches latérales formées par des poils couchés.

On rangera dans cette dernière subdivision Io. Walicte morio, Halict. morio. Hylaeus morio no. 8. Fа в. Syst. Piez. Mâle. Melitta morio. Kan в. Monogr. Apun Angl. tom. 2. pag. 60. no. ' 9 . iiale et femelle. $2^{\circ}$. Halicte bronzé, Halict. ceratus. Melitta arata. Kıв в. Monogr. Apum Angl. tonis. 2. pag. 58. $n^{\circ}$. 17. Mâle et femelle. 3o. Halicte cylindrique, Halict. cylindricus. Hylienes cylindricus $\mathrm{n}^{\circ}$. 1. Fa Faun. Gern. fas. 55. fior. 2. Mấlc.

$$
\text { (S. F. et A. Serv.) }
$$

SCRAPTIE, Scraptia. I AT. Dircoea. Schon. Genre d'insectes de l'ordre des Coléoptères, section des Hétéromères (denxiène division), famille des Trachélides, triba des Mordelloves.

Six genres composent celte tribu; trois d'entr'eux: Rhipiphore, Pélécotome et Myodite se distinguent des aulres par lcurs palpes presque filiformes et par les antennes en ćventail ou trèspectinées dans les mâles. Les Mordelles ont tous les articles des tarses entiers, et leur abdomen qui se iermine en pointe dépasse de beaucoup les ély tres: dans les Anaspes, tous les articles des tarses postérieurs sont entiers. Ancun de ces caractères ne convient anx Scrapties."

Antennes filiformes, insérées dans une écbancrure des yeux, composées de onze articles, la plupart presqu'égaux, courts, presque cylindi-iques; le second le plus court de tous, le troisième et les premiers de ceux qui les suivent, un pea a mircis à leur base, le quatrième un peu plus long que le troisième, le dernier obconique, pointu à l'extrémité. - Labie avancé, mernbiancux, carré, un peu plus large que long, entier.-Mandibules cachées, eornées, arquées; leur côté intérieur largement el fortement échancré, unidenté; lenr extréwité aiguë, refendue $-M M a ̂ t$ choires unembraneuses, à deux lobes; l'extérieur beaucoup plus grand que l'autre, plus large à son extrémitć, obtus et vela; l'intérieur très-petit, aigu. - Palpes avancés, len dernier article trèsgrand, sécuriforme dans les maxillaires, presque triangulaire dans les labiaux. - Lève membraneuse, en carré-long, un peu plus étroite à sa base, arrondie à ses angles, à peine éclancrée dans son milieu. Menton court, demi-coriace; entourant la base de la lèvre en manièré d'anneatr? - Téte peucbée. - Yeux lunulés. - Corps ovaleoblong, assez mou. - Corselet picsque semi-circulaire, arrondi antérieurcment, sa partie postérieure transversale, point rebordée. - Ecusson distinct. - Elytres point rebordées, recouvrant des ailes et l'abdumen. - Abdoment obtus, ne depassint 


\section{S C R}

dépassant pas les élytres. - Jambes presque cylindriques, leurs épines terminales courtcs. Pénultième article de tous les tarses bilobć.

Ce genre, fondé par M. Latreille, n'est composé que d'un petit nombre d'espèces. On les trouve quelquefois sur les fleurs. Leurs mœurs ne sont pas connues. Celle qui a servi de type est la suivante :

\section{Scraptie brune, S. fusca.}

Scraptia, fusca-nigricans, villosula; tibiis tarsisque ferrugineo-fuscis : elytris lavibus.

Scraptia fusca. LAт. Gener. Crast. et Ins. tom. 2. pag. 200. $n^{\circ}$. 1. - Dircaea sericec. G YLLENH. in Scнак. Synon. Ins. append. pag. ig. $n^{\circ} \cdot 26$.

Longueur $2 \mathrm{lig} . \frac{1}{2}$. Antennes, tĉte, corselet et alodomen d'un tesłacé-brun. Parties de la bouche, élyı́res et pattes d'un testacé plus clair. Elytres et coiselet finement poinlillćs, couverts d'un duvet court, couché, de conleur cendrée.

Des environs de Paris.

ANASPE, Anaspis. Groff. Lat. MIordella. Lisi. Fab. Oli.

Genre d'insectes de l'ordre des Coléoptères, section des Hétćromères ( $2^{\mathrm{e}}$. division), famille des Trachélides, tribu dos Mordellones.

Dans cette tribu les Rhipiphores, les Myodites et les Pélécotomes nnl pour caractères distinclifs: palpes presque filiformes. Antcunes des máles eu évenlail ou trc̀s-pectinćes. Des trois autres genres qui complércnt la tribu, celvi de Mordelle se distingue par les articles des tarses qui lous sonl entier's, et par la pointe qui termine l'abdonen, laquelle dépasse beaucoup lcs ćlyłes; lc pénultième article des six tarses est bilobé dans les Scrapties; ainsi ces divers gcurcs ne peuvenl se coufoudie avec celui d'Anaspe.

Antennes insérées au bord extéricnr des yeux, un peu plus longues que le corseler, presque tilifurmes, grossissant insensiblement vers l'extrémité, composées de onze arlicles; les qualre premiers presquc cylindriqucs, les aulres jusqu'au dixicme, turbinés, un peu comprionés, le onzième ovale. - Labre presque seminrbiculiure. Mandibules trigoncs, leur extréajlé un peu arquée, aiguë, bifide on bidentée, leu! côté inférieur presque membraneux. - Máchoires ayant leurs deux lobes petits, presque linćaires, à peu près égaux en longueur, l'intérienr un peu plus étroit.-Palpes maxillaires bèucoup plus grands que les labiaux, leur dcrnier arlicle grand, sécuriforme; les labiaux plus gros à leur extrémité, leur dernier article presque trigone. - Lève presquen coeur; menton assez grand. - Yeux presqu'en croissant. - Corps un peu comprimé latéralement. - Partie supérieure du prothorax ayant sun burd postérieur conpé droit: sternain du méHist. Nat, Ins. Tome $X$. tathorax s'étendant beancoup sur les côtés vers l'insertion des pattes postćrieures. - Eicusson petit, peu distinct. - Abdomen dépassant peu les élytres, ne se terminant point par une poiute aiguë. - Pattes assez longues; cuisses comprinées : épiues lerminales des quał'e dernières jambes graudes, surtont les postćrienes. 'Tarses antérieurs et intermédiaires ayant leur pénulième article bilobé; larses postéricurs composés d'articles tous entiers.

$\Lambda$ près avoir compris le genre Anaspe dans le rableau des genres qu'il devoit publier (voyez Encyclopédie, tome IV, introduction à l'Histoire naturelle, pase 38 ), feu Olivicr jugea à propos de le réunir à celui de Mordelle (voyez $\Lambda$ vaspe à sa lettre); mais ce genre Anaspe ayant été adopté depuis par tons les entomologistes, nous avons cru devoir le rétablir ici, en prévenaut qu'il est mal placé daus le tableau que nous venons de ciler, y élant mis parmi les Tétramères landis qu'il appartient aux Hétéromères. L’exiguilé de leur ćcusson a valu à ces insectes le nom qu'ils portent, tiré de deux mots grecs qui veulent dire : sans écusson. Ces Coléoptc̀res, de trèspetitc laille, fréquentcul les fleurs. Leurs larves ne sout pas connues.

A ce grenre appartiennent les Mordclles suivantes de cc Dictionnaire : ${ }^{\circ}$. frontale no. 17. (Anas. frontalis. L'Anaspe noir no. 1. Geoff. Ins. Par. tom. 1. pag. 316. n'en est qu'une variété, shivant M. Scliculier. ) 20. flave no. I9. (Anasp. flava.) $5^{\circ}$. bicolor no. 25. (Anasp. bicolor.) $4^{\circ}$. humérale no. 16. (Anasp. humeralis; mais il faut retrancher les synonymes de Linué qui appartiennent ì une vraic Mordelle, Mordella humeralis. Linn. Schen.) 5?. thoracique no. i 8. (Anasp. thoracica) el encorc $1^{\circ}$. Anaspe ruficolle (Anaspis ruficollis. - Hordella micollis $\mathrm{n}^{\circ} .27 . \mathrm{F}$ в . Syst. Eleut. ) $2^{\circ}$. Auaspe laché (Anasp. maculata. Mordella obscura. Grument. - Anaspe filuve no. 4. Georf. Ins. Par. tom. 1. pag. 317.)

(S. H. et A. SERv.)

SCUTELLERE, Scutellera. LAM. LAT. PAL.Bauv. Cimex. Linn. Panz. Geoff. De Géer. Pentatoma. OLr. (Encycl. 'Iableau des genrcs.) $T \epsilon \rightarrow$ tyra, Canopus. $\mathrm{F}$ AB.

Genre d'insectes de l'ordre des Hémiplères, section des Héléroptc̀res, famille des Géocorises, tribu des Longilabres.

Le groupe des Longilabres (voy. Pentatome) qui a pour caractères : antennes de cing articles, deux ocellcs apparens, renferme trois genres: Sculellère, Pentalome et Hétéroscèle (celui-ci inédit, indiqué seulement dans les Fam. natur. de M. Latreille et créé par lui ). Les deux derniers sc distingucnt des Scutellèrcs par leur écusson beaucoup plus étroit et plus court que l'abdomen.

La longueur et la largeur de l'écusson couvrat Iff 
tout le dessus de l'al,domen est le seul caractère qui sépare les Scutellères des Pentatemes. Nous renvoyons par conséquent à ce dernier article pour tous les autres caraclères génériques. La multiplicité des espèces et l'évidence du caractère énoncé ci-dessus ont seules autorisé la séparation des deux geures, dont les mœurs sont exactement les mềnes.

Ou peut diviser les Scutellères de celle manière :

I re. Division. Jambes simples.

$1^{\text {re }}$ Subdivision. Une lame abdominale lancéolée. Cuisses antérieures munies d'uae épine.

A. Jambes antérieures dilatées près de leur extrémité.

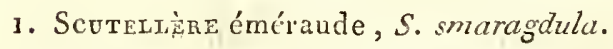

Scutellera suprì̀ viridi-suhanrea, temerè puncfata, corpore suótùs pedibusque viridi-violaceis; untennis nigris : clytrorum membranâ prosertim ad marginem externum fuscâ; laminâ ventrali apice pallidâ.

Longueur 5 lig. D'un vert un pea doré el irrégulièrement ponctuée en clessus. Dessons du coips et pattes de même couleur avec un reflet violet. Auicnnes noires, Jeur troisième article un peu plus court que le second. Nembrane des élvties brune surlout dans sa msitió extériente. Lame abdowinale pále à són extrémité. Bec atteionant la base des hanches postéricures. Femelle.

Du Brésil.

\section{Scurrelere dix laches, $S$. decemguttata.}

Scutellera suprì nutro-fernginea, temerè punctata, thoracis maculis trihns, scutelli tribus, elytri uniuscujusque duatns lnteolis; subtics nigra, thoracis lateribus ferrugineo maculatis, abdominis maculis quinque et laminâ ventrali luteolis: pedibus nigro ferrugineoque mixtis; antennis nigris.

Longneur 3 lig. ' $\frac{x}{2}$. D'un renge ferrugineux en dessus et irrégulièrement porictuée. Corselet ayant postérieurement trois grandes taches juunâlres. Ecusson en ayant un pareil nombre, dont une apicalé; deux taches de mêue couleur sur le bord extéricur de chaque élytre. Membrane de cellesci brune. Dessous du corps noir ; Lcrds extérieurs du corselet ayant un peu de ferrogineux. Abdomen avec cing laches jaunâtres, dont deux sur chaque bord extérieur et une centrale à la base de la lame abciominale, laquelle est aussi jaunâtre. Bec at eignant les hanches intermédiaires. Antennes noires; leur troisième article un peu plus court que le second. Pattes noirúlies mélangées de ferrugineux. Mâle.

Du Brésil.
B. Toutes les jambes sans dilatation.

3. Scutelière têle rouge, $S$. erythrocephala.

Scutellera viridi-aurea, suprà temerè punctata; capite, pedibus maculâque anali binâ et laninâ ventrali mubris: antennis nigris, basi rabris.

Longuenr 3 lig. D'un vert un pen doré changeant en violet, irrégulièrement ponctuée en dessus. Tête, palles, deux taches à l'anus et láme abdominale d'un rouge sanguin. Base des antennes de même couleur, leurs !rois derniers articles, les tarses et l'extrémité des jambes, noirs. Troisième article des antennes un peu plus court que le second. Dec atleignant au plus la base des lianches intermédiaires. Femelle.

Du Brési].

$2^{e}$. Subdivision. Point de lame abdominale.

A. Corps alongć. Abdomen allant en se rétrécissant de sa base à son extrćmité.

a. Corselet armé d'une ćpine latérale.

On placera ici la Scutellère disparate, $S$. dispar. - Tetyra disparn ${ }^{\circ}$. 5. FАв. Syst. Rhyngot. Stoll, Punais. pl. XXXYII. fig. 260. et A. B. l'abricius prétend que l'un des sexes manque d'épines au corselet; nous avons dans notre collecliou la preuve du contraire.

\section{b. Corselet mutique.}

Rapportez à ce groupe $1^{\circ}$. Scutellère ponctuée, S. duodecimpunctata. - Tetyra duodecimpunctata no. 16. FAB. Syst. Rhyngot. D'Afric que. Fabricius s'est trompé en l'inäiguant comme élant de Cayenne. $2^{\circ}$. Scutellère noble, S. nobilis. - Tetyza nobilis $\mathrm{n}^{\circ}$. 6 . $\mathrm{FAB}$. id. $3^{\circ}$. Scutellère marcquée, S. signata. - Tetyra signata no. 7. $\mathrm{F}_{\mathrm{AB}}$. id. $4^{\circ}$. Scutellère Stocker, S. Stockerus. - Tetyra Stockerus $0^{\circ}$. I2. FAB. $i d$.

13. Corps court pour sa largeur.

a. Abdomen ayant au moins la largeur du corselet, ne se rétrécissant pas dans lés deux premiers tiers de sa longueur.

† Ecusson armé d'une dent.

Rapporlez ici-la Srutellère bossue, $S$. gibba. - Tetyra gibba no. 63. FА в. Syst. Rhyngot.

$$
\begin{aligned}
& \text { †t Ecusson mulique. } \\
& \text { * Tons les articles des antennes } \\
& \text { simples. }
\end{aligned}
$$

Beaucoup d'espèces font partie de cetle coupe secondaire, entrautres les suivantes: $1^{\circ}$. Scutellère cyanipède, $S$. cyanipes. - Tetyra cyanipes $n^{\circ}$. 23. FAB, Syst. Rhyngot. Ses cuisses sont quel- 


\section{$\mathrm{S} \mathrm{C} \mathrm{U}$}

quefois presqu'entièrement d'un bleu-noirâtre. $2^{\circ}$. Scutellère de Fabricius, S. Fabricii. - Tetyra Fabricii no. 19. $\mathrm{F}_{\mathrm{Aв}}$ id. 弓० $^{\circ}$. Scutellère annelée, S. annulus. - Tetyra annuliss $\mathrm{n}^{\circ} .20 . \mathrm{F}_{\mathrm{AB}}$ id. $4^{\circ}$. Scutellère maure, $S$. manura. Cette espèce varie beaucoup; la variété la plus ordinaire est le $\mathrm{C} i$ mex maurus. Linv. Syst. nat. 2.716. 5. - Faun. Suec. 9ı̈. - Tetyra maura no. 36. FАв. Syst. Rlyngot. - Faun. franc. Hémipt. pl. 1. fig. 4. C'est la varićté décrite par Geoffroy, Ins. Paris. tom. I pag. $467 \cdot n^{\circ}$. 66. Fabricius rapporte à tort à sa 'Tetyra maura la P'unaise no. 3. de Geoffroy qui nous paroît être la Scutellère scarabéoide. Lat seconde variété est la Tetyra hottentota $n^{\circ} .37$. FAB. Syst. Rhyngot. (en admettaut le synonyme cité de Geuffioy.) - Faun. fratuç. Hémipt. pl. 1. fig. I. On trouve des individus à bords de l'abiomen entièrement bruns, d'autres à bords ferrugiveux entrecoupés ou non de points noirs plus ou woins grands. La couleur du fond est tantôt trèsbrune, lantôt d'un jaune clair; les deux points lattéraux blanchâtles de la base de l'écusson manquent quelquefois. D'autres fois on en voit un grand et ovale placé au milieu du bord postérieur de ce même écusson. $5^{n}$. Scutellère de la Nielle, S. Nigella. - Tetyra Nigella no. 55. 'Аав. Syst. Rhyrgot. - Faun. franc. Hérnipt. pl. 1. fig. II. Dans la description de celle espèce (l'as. Entom. System. tom. 4. pag. 82. $n^{\circ}$. 8.) il exisle une faute typographique qui fait une sorte de contre-sens : au lieu de thorax anticè piceus, posticè nigro punctatus, on doit lire, thorax antice piceus, posticè miger, punctatus. $6^{\circ}$. Scutellère piémontaise, $S$. pedemontana. - Tetyra pedemontuna no. 42. Fав. Syst. Rhyngot. - Faun. franc. Hémipt: pl. 1. fig. 3. $7^{\circ}$. Scutellère semiponciuée, S. sempunctata. - Tetyra semipunctata. $n^{\circ}, 33$.

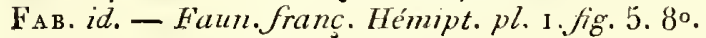
Scutellère siumoise, $\vec{S}$. migrolnneatı. - Tetyra nigrolineatu n ${ }^{\circ}$ 32. $\mathrm{F}_{\mathrm{AB}}$ id. - Faun. frunc. Hémipt. pl. 1. fg. 6. $9^{\circ}$. Sculellère perlée, S'. inuncta. - Tetyra inuncta n ${ }^{\circ}$. 53. $\mathrm{F}_{\mathrm{AB}}$ id. Faun. franc. Hémipt. pl. 4. fig. 3.

\section{** Quatrième et cincuième articles des antenzes dilatés.}

\section{Scuteliène dos bleu, S. ochrocyanea.}

Scutellera ochracea, dorso cyaneo, gibbo: artennis apice nigris; articulis duobus extremis dilatatis, compressis.

La Punaise à dos bleu. Stor., punais. pag. 58. pl. $X I V \cdot$ fig. 92 .

Longueur 5 lig. Testacée; les trois premiers articles des antenues cylindriques, le quatrième ovale, pointu à ses deux extrétnités, très-dilaté; le cinquième comprimé, dilaté, linéaire; ces deux derniers noirs, excepté à leur base. Une très-grande tache d'un bleu-noirâtre occupe le corselel (exceptés ses bords antérieur el latéraux), l'écusson en entier et les élyıres. à l'exception de leur base et de leur hord extérieur. 'Tout le corps est ponclué et très-bombé en dessus. Les angles postérienrs du corselet sont un peu saillans. Bec atteignant les hanches intermédiaires. Second article des anternes an peu plus long que le troisième.

Celte espèce a l'écusson un peu moins grand que la plupart de ses congénères.

Du Brésil.

b. Abdomen presque triangulaire, allant en se rétrécissant depuis le corselet jusqu'à l'extrémité.

\section{Scutemière trimaculée, S. trinaculata.}

Scutellera griseo-pallida, fusco punctatissima; punctis in capite serias sex constituentibus: sctitelli maculs tribus albidis impunctatis, majori ovatâ apicali.

Longneur 4 lig. D'un testacé pầle, un pell grisâtre; entièrement el finement ponctuée de brun, ces points disposés en six séries longitudinales sur la léte. Côtés du corselet épineux. Ecusson portant trois taches blanchûtres non ponctućes, bordées de brun, l'apicale plus grande, ovale. Les quatre derniers articles des antennes alongés, presqu'éganx. Bec dépassant un peu les labches postérienres. Mâle.

De l'île de Java.

On rappórtera encore à ce groupe la Scutellère rayée de blanc, $S$. albolineala. - Tetyca albolineata no. 58. Faв. Syst. Rhyngot. (Cut auteur nous paruît citer Stoll mal-á-propos.) - Faun. franc. Hénipt. pl. 1.jgg. 2.

\section{Corps orbiculaire.}

Cetle coupe comprend $1^{\circ}$. Scutellère globuleuse, $S$. globus. Lat. Gent. Crust. et Ins, tom. $\overline{5}$. pag. $114 . n^{\circ}$. 5. - Tetyca globus $\mathrm{n}^{\circ} \cdot 7^{1}$. FAB. syst. Rtiyngot. - Cimex globus. Coquen. Illustr. iconogri tab. 10. fig. 10. - C'inex scarabceoides. Panz. Faun. Gem. fasc. 56. fig. 25. - Sulcullere scarabéoide. Lat. Dict. d'Hist. nat. 1 pe. édition (en reiranchani les synonymes de Linné et de liaisricius ). - Scutellère scurabéoide. Fatun. f́s sutuc. Hémipt. pl. 1. fig. 8. (1) - La Punaiṣe cuirasse. Geoff. Ins. Paizs. tom. I. jas. $455.72^{\circ} \cdot 2.2^{\circ}$. Scutellère de Vahl, S. Vahliz. - Tetyra Vahlii no. 69. Fав. Syst. Rhyngot. 30. Scutel ère imprimée, $S$. impressa. - '́etyra impressa no. 64. IAB. $\iota d$.

\section{$2^{\mathrm{e}}$. Division: Jambes épineuses.}

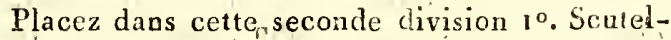
lère fuligineuse, $S$. fuliginosa. L $\mathrm{L}_{\mathrm{AT}}$. Gen. Crust.

(1) La synonymie de cette espèce étoit fort embrouillée. Voyez plus bas Sicutexírie scarabéoïde. 
et Ins. tom. 3. pag. 114. no. 4. - Faun. franc. Hémipt.pl. 1. fg. 7. - Tetyra fuliginosa no. 50 . Faв. Syst. Rhyngot. $2^{\circ}$. Scutellère de Schulz, $S$. Schulzii: - Tetyra Schulzii 11 ${ }^{\circ}$ 74. Faв. id. $3^{\circ}$. Scutellère unicolor, $S$. unicolor. PALIs.-BAuv. Ins. d'Afr. et d'Amér. pag. 32. Hémipt. pl. V. fig. 5. $4^{\circ}$. Scutellère scarabéoide, S. scarabceoides. Cimex scarabcenides. Linv. Syst. nat. 2.716.4. Faun. Suec. 912. (Si l'on eût fait attention que Linné attribue positivement dans sa phrase de la Fauna Suecica des jambes épineuses à cetle espèce, l'on eût évilé de fortes erreurs de :yno-

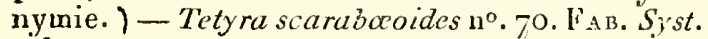
Rhyngot. Retranchez le synonyme de Geollioy qui appartient à la Scutellère globuleuse.

\section{(S. F. et A. Serv.)}

SCUTIGÈRE, Scutigera. Lar. Lat. Scolopendra. Linn. Iulus. Pall. Cemuatia. Illig. LÉACH.

Genre de la classe des Myriapodes, ordre des Chilopodes, famille des Inæquipèdes de Latreille (Fam. nat. du Règn. anim.), établi par M. de Lamarck dans sou Système des animaux sarts vertebies, et placé par cel autenr dans ses Arachnides antennistes. Suivant Latreille, les caractères de ce genre sont : corps alongé, muis point vermiforme ou linéaire, divisé, vn en dessous, en quinze anneaux, porlant chacun une paire de jieds, recouvert en dessus par louit plaques ou demi-segmens, en forme d'écussons, et cachanl les spiracules. Pieds alongés, surtout ceux des deruières paires, avec le tarse long et très-arliculć. Yeux grands, avec une cornée à facettes.

Ces animaux ont les plus yrands rappórls avec les Scolopendres, mais ils en diffèrent par plusieurs caractères, el surlout par les paltes, qui dans ces derniers sont égäles entr'elles; le mềne caractère les éloigne des Jules et des autres gentes voisins. Illiger (Fuune d'Etrurie de Rossi, tom: '2. pag. 259.) a donné le nom de Cermatia à ce genre, long-temps avant que In. de Lamarck l'ait élabli sous celui de Scutigère. Ce nom dé Cemuatia a élé adopté par Léach, mais $\mathrm{M}$. Latreille a conservé dans tous ses ouvrages le nom que $M$. de Lawarck lui a assigné.

Le corps de ces Myriapodes est presque cylindrique, lonø, moins déprimé que celui des Scolopendres, un peu réréci en pointe à son extrémité postćrieure et un peu plus large au bout opposé, le diamère transversal de la têle élant un peu plus grand. Celte têre est prescgue carrée, avec les angles postérieurs obtus et l'extrémité antérieure un peuavancéc ei arrondie. Les yeus sont, suivant Léon-Dufour ( Amn. des sc. nat. tom. 2. pag. 93.), à faceltes, et loỉn' d'être orbiculaires, comme on l'avoit dit avaut lui, ils circonscrivent un triangle dont la base esíantérie ure et arrondie. Wes antennes sont insérées au-devant des yeux, śtacées, presqu'aussi longues que le corps et composées d'une multitude de petits articles, et offrent vers le quart environ de leur longueur, ̀̀ partir du point d'insertion, un article trois ou quatre fois plus long que ceux qui le précèdent et les suivans : à cet endroit les antennes forment un léger conde. Les palpes maxillaires sont saillans, épineux et filiformes. les pieds-mâchoires extérieurs ou pieds-mandibules de Léon-Dufonr s'insèrent, slivant ce naluraliste, sur un demi-anneau fort ćtroit, placé der rière le bord occipital de la têle et caché sous le premier segment dorsal. Ils sont composés de quatre articles, dont le dernier est un crochet brun modérément arqué. Les deax divisions de la fausse lèvre comprise entre ces pieds-mâchoires, ont leur hord supérieur entier el garni d'épines. M. Savigny (Mém. sur les anim. sans vertèbres) a figuré el décrit avec une grande exactitude tous ces organes, et on peut en prendre une idée bien netle ell consultant son ouvrage.

Les huit plaques qui recouvrent le dessus du corps des Scutigères sont assez épaisses et forment autant de pelits boncliers ou écussous presque carrés, un peu carénés dans le milieu de leur longueur, a vec le bord postérieur arrondi aux angles, échancré au milien, et offiast, daus le sinus, une petite fissure élevée sur les bords en manière de lèvre représentant une espèce de stignate. Ces fissures sont en effet destinées au passage de l'air; celle de la dernière plaque ainsi que son échancrure est moins sensible: celte plaque est la plus petite de toutes, la quatrième est presqu'une fois aussi longue que les autres et a été désignée par Linné sous le nom d'élytres. Indépendamment des segmens dorsaux pédigères, Íéon-Dufour a observé (Scut. lineata fern.) deux plaqnes rétractiles arrondies, dépourvues de raies. Au-dessous de ces pliqques, on observe d'abord deux crochels bruns acérés, à peine arqués, biarticulés, puis deux pièees ovalaires hérissćes comme des brosses. Les pattes diffèrent essentiellement de celles des Scolopendres par leur composition, leur longuenr et les coudcs qu'elles forment, et se rapprochent de celles des Faucheurs. Elles tiennent au corps par deux articles correspondans à lis banche, et dont le second est très-court; viennent ensuite deux auties articles plus gros que les suivans, alongés, formant un angle à leur point de réunion qui représente la cuisse. Une quatrième pièce plus alongée que la prćcédente, mais plus mince, forme la jambe, et enfin vientle tarse; ces tarses, à l'exception de ceux de Ia dernière paire de pattes, qui, comme on voit, a bien plus de longriéur que les autres, sont composés de deux ordres d'arlicles qui semblent constituer deux pièces distinctes' l'unéde l'autre par le nombre, la grandeur et la texture des articles, et sans doule aussi par leurs usages. Les huit ou dix premiers articles sont beaucoup plus longs que les suivans, et garuis en dessous d'un duret spongieux et fin. Liautre pièce, qui se termine par un 
seul ongle, et qui est susceptible de se rouler un peu à son extrémité, comme les tarses des Phalangium, est composée d'une multitude innombrable de très-petits articles hérissés en dessons de poils courts et mobiles qui servent très-eflieacement à l'animal pour grimper sur les surfaces les plus verticales et les plus lisses. Les pattes des Scutigères se désarticulent au moindre contaet, et conservent pendant plusieurs minutes après a voir été séparées du corps, une contractilité singulière presque convulsive. Léon-Dufour a remarqué que cette contractilité se conservoit d'autant plus long-temps, que les pattes étoient plus postérieures.

M. Léon-Dufour (Ann. des sc. nat. etc.) a donué une anatomie complète d'une espèce de ce genre, et comme aucun auteuravant lui n'a parlé de l'organisation intérieure des Scutigères, nous allons donner ici un extrait de son travail. Les organes de la digestion se composent $1^{\circ}$. de deux glandes salivaires, moins grandes que celles du Lithobie; elles ont la forme d'une grappe ovale, blanchâtre et granuleuse, composée d'utricules ovales, oblongues, assez serrées eutr'elles et traversées, suivant leur longueur, par une rainure médiane. $2^{\circ}$. Du tube alimentaire, qui a la plus grande analogie avec celui des Lithobies. L'osophage est extrêmement petit, et il est presurue caché dans la tête. Le jabot est-formé par une légère dilatation de l'osoplage, et il se distingne du ventricule chilifique par une différence de texture ; ce dernier est couvert de cryptes glanduleuses rondes ou ovales : cet organe est brusquement séparé de l'intestin par un bourrelet annulaire oì s'insèrent les vaisseaux biliaires. Ce que l'on peut appeler cocum, n'est qu'une dilatation de l'intestin, dans laquelle M. Léon-Dufour n'a trouvé que quelques crottes grisâtres. $3^{\circ}$. Des vaisseaux hépatiques qui sont au nombre de quatre, proportionnellement plus conrts que daus les autres $M_{y-}$ riapodes, et dout l'une des paires est plus grosse que l'autre.

Les organes mâles de la génération sont composés de deux testicules oblongs, amincis à leur bout intérieur, et confluant aussitôt en une anse courte qui reçoit le eonàuit commun des vésicules séminales. Par leur extrémité postérieure, ils dégénèrent chacun en un canal déférent filiforme, qui bientôt offire un renllement aussi considérable que le testicule mème : il se rétréci: enfin en un conduit qui va dans l'appareil copulateur. Les vésicules séminales forment la partie la plus apparente de l'organe générateur'; elles sont forućes de deux utricules ovoides placées vers le milieu de l'abdomen et munies chacune d'un conduit capillaire, qui se réunissent bientôt en un seul canal plus long que tout le corps de linsecte, et qui s'insinue et s'abouche, après bien des circonvolutions, dans l'ause où confluent les extrérnités antérieures des organes sécréteurs du. sperme. Les organes femelles consisteut en un ovaire et deux glandes sé́bacées; de chaque côté de la parlie postérieure de l'ovaire on aperçuit un disque arrondi, semi-diaphane ou opaloide, se teruninant par un gros pédicule. La vulve est armée des deux oôtés d'une pièce mobile qui doit jouer un rúle dans l'acte de la copulaion. En enlevant les plaques dorsales de la Sculigère, ponr. mettre it découvert les viscères, on crève souvent des grlandes ou des sacliets adipeux, d'où s'écoule uue humeur d'un violet-rongeâtre; on trouve aussi au-dessus des viscères, des lobules adipenx blanes, et disposés parfois en mosaïgnue.

Ces animaux se tiennent pendant le jour dans les greniers ou les lieux peu fréquentés des maisous, le plus souvent dans les vieilles planches, les poutres, et quelquefuis sous les pierres; ils ne se montrent que la nuit, et on les voit alors conrir sur les murs avec nne grande vitesse, et y chercher des cloportes et des insectes dont ils funt leur nourriture; ils piquent ces pelis anirnaux avec les crochels de leur bunche, el le vonin qu'ils distilleat dans la plaie avit très-promptement sur eux. C'est principalenent dans les temps pluvieux que les Scutigères paroissent en plus grand nombre; les habitans de la Hongrie les redoutent beaucoup, au rapport d'Illiger.

Le geare Sculigère ne sc compose que d'un nombre borné d'espèces; celle qui est lia phus connue, et qui se trouve à Paris, esı :

\section{La Scutigère rayée, $S$. lineata.}

$S$. pedibus triginta, conpore rufo-favescente; line is longitudinalibus pedumque fasciis curnuleonigris.

Scutigera lineata. LAT. nouv. Diction. d'hist. nat. n. édit. tom. 3o. - Cermatia lineata. Istic. Fanne d'Etrurie de Rossi, ton. 2. pag. 199.Scutigera araneoides. Lat. Gener. Crust. et Ins. tom. 1. pag. 77. et Hist. nat. des Ins. et des Crast. tom. 7. pag. 88. - Sculopendra coleoptrata. Linv. Syst. nat. édit. 13. tom. 1. part. 2. pag. ıo62. FАв. Ent. Syst. tom. 2. pag. 389. Panz. Faun. Ins. Germ. fas. 5 I. fiog. 12. - Scolopendre à ving-huit pattes? Grorr. Hist. des Ins. Com.2. pag. 6,5 .

Quoique MM. Illiger et Latrcille aient jeté.un grand jour sur la détermination de la synonymie de ceite espèce, à laquelle on rapporioit à tort le lulus araneoides de Pallas, on peut encore éleve. des doutes sur l'identité adinise par ces entomologistes entre la Scolopendre à vingt-huit patres de Geofrioy et le Scutigera lineata. L'auteur de l'Histoire abrégée des insectes de Paris donue dans sa phrase spécıfique l'épithète de nigricans à sia Scolopendre, et il répèie dans sa description qu'elle ditēère par sa couleur noirâtre de lit Scolopendre à trente pattes, qui est, suivant lui, d'une couleur fauve. C'est aux entomologistes de Paris 
à fixer les doutes à eet égard, en examinant sur les lieux l'espèce que Geoffroy a décrite.

La Sculigère rayée se trouve en F'rance, dans le Micli et à Paris. Si l'espèce de Geoftroy esı la même, elle est rare. On pent ripporter a ce genre l'Iule aranéö̈de de Pallas, la Scolopendre longicorne de Fabricius; la Cermatia livida de Léach, une espèse (virescenss) de l'Isle-de-firance, et une autre du Voyage aux T'erres Australes de l'éron el Lesueur, dont le corps est brun. (E. G.)

SCYDNENE, Scyamenus. Lat. Anthicus. Fab. Notoxus. Panz. Pselaphus. Park. Illig.

Genre d'insectes de l'ordre des Coléoplères, section des Pentamères, famille des.Clavicornes, nibu des Palpeurs.

Deux genres eomposent celte tribu : Mas'ige et Scydmène. Le premier est bien séparé du secoud par ses antennes presque filifurmes, très-brisées, et encore par les deux derniers arlicles des patípes maxillaires formant une massue ovale.

Antennes presque droites ou peu coudées, sensiblement plus grosses ver's leur extrémité, composées d'articles grenus. - Palpes maxillaires ayant leur troisième arlicle fort grand; le quatrième on dernier aciculaire, peu distinct. Pour les autres caractères poyez Mastice ci-après.

On trouve les Scydmènes sons les pierres, ì terre on dans le sable. Ces Coléoptères sont de très-petite taille; ils ont quelıgue ressemblance avec les L'sélaphes, mais leurs tarses composés de cinq articles et leurs élytres reconvrant tont l'abdomen, les en éloignent beaucoup. Les espèces comues sont toules d'Europe.

A ce genre apparliennent les denx espèces suivantes: 10. Scydiène d'Heliwig, Scydm. Hell"rigii. LaAT. Gener. C'rust. et Ins. tom. 1. pag. 282. $n^{\circ}$. 1. - Anthicus Hellwigii ${ }^{\circ}$. 22 I. Fав. Syst. Eleut. $2^{\circ}$. Scydmène de Godart, Scydml. Godarti. Lat. Gen, Crust. et Ins, tom. 1. pag. 232. $n^{\circ} .2$.

(S. F. et A. SERV.)

MASTige, Mastigus. Iulig. Hofrm. Herdw. Lat. Schen, Ptinus. Fab. Oliv. (Entoni.) Noto.xns. Thunb.

Genre d'inseetes de l'ordre des Coléoptères, section des Pentamères, famille des Clavicornes, tribu des Palpeurs.

Cette tribu ne renferme que les gences Mastige et Scydmène; ce dernier est hien reconnuissable par ses antennes grenues, presque droites et par le deruier antiele de ses palpes maxillatires peu distinct et aciculaire.

Antennes presque filiformes, insérées devant les yeux, forternent eoudées après le premier article, en ayant onze; le premier et le seeond les plu's longs de tou's, coniques, velus; le troisième ef les suivans jusqu'at dixième, cylindro-coniques, presqu'égaux; les derniers augmentant de :rosseur peu à peu : le onzième ovale, alongé.-
Labre coriace, transversal ; son Lord antérienr largement échancré, ses angles aigus. - Mandibules cornées, fortes, presque triangulaires, déprimées, terminées par une dent forte, arquée, très-aiguë, unidentée à sa base interue; elles out au-dessous de leur extrémité un petit appendice inégalement et obliquement tridenté.-Máchoires corlices à leur base; leur lobe terminal presqu'en carré-long, coinme divisé transversalement par une sulure membraneuse en deux articles : leur extréuité membraneuse, finement frangće; leur lobe interne longitudinal, membraneux. - Palpes maxillaires grands, avancés, de qualre articles : celui de la base très-court, le second plus long, conique, aminci a sa base, un peu courbe; le troisième conique, formant aree le quatrième une massue ovale, celni-ei arrondi à son extrémité. Palpes labiaux insérés aux angles antérieurs de la lèvre, courts, de trois articles, le basilaire petit, cylindro-coniqne, le second le plus grand de tous, ćpais, globuleux; le deruier très-petit, eonique, aigu, en forme de dent. - Lèvre membraneuse presque carrée : menton coriace, court, transversal, échancré ì l'insertion de la lèvre, ses côtés arrondis, terıniné en dessus par une petite dent. - Téte ovale. - Corselet presqu'en cour, tronqué postérieuremeut. - Point d'écusson visible.-Elytres réunies, eouvrant enlièremest l'abdomen; celui-ei ovalaire. - Pattes minces; tarses à articles cylindriques, entiers; les quarre premiers égaux; le dernier plus long que les autres, muni de deux petis crochets.

Le nom de ce genre vient d un mot grec, il a rapport à la forme des anteunes, presque semblables à un fouet. Les mœurs sont inconnues et less espèces peu nombreuses. Nous mentionuerons les suivaules :

I $^{\circ}$ 'Mastige palpeur, Mastig. palpalis. I,at. Gener. Cnust. et Ins. tom. 1. pag, 281. $\pi^{\circ}$. 1. tab. 6. fig. 5. - Encycl. pl. 359. fig. 2. De Portugal. $2^{\circ}$. Mastige spinicorne, Mastig. spinicornis. Ptinus spinicomis $\mathrm{n}^{\circ}$. 12. F. $\mathrm{AB}$. Syst. Eleut. Oliv. Entom. t. 2. Ptin. p. 10.n. 10. pl. 1. fig. 5. - Mastigus deustus. Schan. Synon, Ins. tom. 2. pag. 59. $n^{\circ}$. 2. Des îles Sandwieh. $3^{\circ}$. Mastige jaune, Mastig. flavus. Schøs.id.n $n^{\circ} .3$. - Notoxus flavus. Trun a. Nov. Ins. Spec. pag. sог.

$$
\text { (S. F. el A. Sert:) }
$$

SCYLLARE, Scyllarus. FAB. LATR. LAmck. L'́ach. Cancer. Linn. Squilla. Rondel. Ibacus:LÉach.

Genre de Crustacés de l'oridre des Décapodes, famille des Macroures, tribu des Scyllarides, flabli par Fabricius et adopté par tous les entomologistes; ses caractères sont : anlennes latérales ou leurs pédoncules ayant la forme d'une grande crête aplatie et horizoniale.

Le nom de Scyllarus avoit été donné par Aristote au Crustacé que l'on croyoit être le gardien 
de la Pinue marine; Belon voyoit dans une espèee de ce genre l'Aretos d'Aristote; Rondelet en a formé des Sqquilles, en les prenant pour les $\mathrm{Ca}$ rides des Grecs ou le Gammarus des Lalins; il y reeonnoissoit la Cigale marine d'Elien; eutin Scaliger y a cherché le Crangon d'Aristote. Ces animaux portent encore sur les côles de la Méditerranée le nom de Cigales de mer; ils forment un genre bien caraclérisé et bien distingué de tous les autres par la forme de leurs autenmes extérieures. Le corselet de ces Crustacés est presque carré, un peu plus large en devant, a vec deux fossettes arrondies ou ovales, une de chaque côté, le plus souvent situées près des angles antérieur's et destinées à loger les yeux. Les pieds-mâchoires extérieur's ressemblent, abstraetion faite des palpes flagelliformes, aux deux paltes antérieures, sont, comme elles, eourbés en dedans et appliqués l'un contre l'antre dans toute leur étendue. Les antennes latérales sont dépourvues des filets pluriarticulés qui les terminent dans les autres Décapodes; leur pédoncule est inséré en dedans des yeux, sur le devant du corselet, et composé de quatle articles dilatés latéralement, aplatis; le premier est plus petit que le seeond et très-peu dilatésur le côlé extćrieur; le seeond est beaucoup plus grand, dilaté à son côlé extérieur et arrivant jusqu'au niveau du bord extérieur du test; le troisième est très-petit, placé dans une échanerure du second, et le qutrième est très-large, en forme de triangle renversé, avec la base ou le bord terminal arrondi. Les antennes mitoyennes sont placées au milieu de la largeur du corselet, entre les extérieures et se touchant; leur pédoneule est composé de einq articles, presque tous cylindriques et terninés par deux petits appencliees, dont le supérieur un peu plus long, én cône alongé, pluciarliculé, et dont l'inférieur plus conrt, mais plus gros, presqu'ovoïde, très-finement strié transversalement, et finissant brusquement en nne pointe divisée en petits arlicles. Le côté supérieur forme, avant celte pointe, une goultière garnie d'une frange de cils. Ces antennes sont plias longues que les latérales, avancées et faisant un coude à l'extrémilé du second article et à celle du quatrième. Les yeux sont placés dans les fossettes du corselet dont nous avons parlé plus haut; ils sont très-éeartés l'un de l'autre et posés sur un pédicule assez gros, mais très-court. Les paltes sont composées de cinq articles, dont lés deux premiers sont très-courts, le troisième le plus long de tous, le quatriènse court et le einquième plus long que le qualrième, mais beaucoup plus court que le troisième; le tarse ou sixième article est conique, comprimé, et finit en une poiñte très-aiguë et un peu courbée en crochel. Dans fes femelles, le ciuquième articledes pattes postérieures est prolongé à l'angle inférieur de son extrémité eu manière de dent ou de doigt. Ces pattes sont plus eourtes, et leurs points d'insertion forment deux lignes qui divergent a'avant en arrière, de sorte que l'intelvalle pectoral compris entr'elles forme un triangle alongé. Le dessus du test de ces Crustacés est ordinairement raboteux et quelquefois anguleux, ou garni d'une-multitude d'impressions qui représentent une apparence de sculpture. La quene est longue, large, composée de six segrnens, dont le:s côlés forment chacun plus ou unoius un angle : le dessous nollie dans les deax sexes que huit appendices, quatre de chaque côlé. Ils sont petits et eouchés transversalement sur le dessons des anneaux; ils sont composés d'une lame membraneuse presqu'en forne de spatule on elliplique, bordce de cils et porlée sur un court article servant de pédoncule : celle lame est doublée aux deux premiers appendices du mâle, et peul-être aussi aux autres. La fenelle diffère sous ce rapport de l'autre sexe, en ce que ces appendices sont accompagnés d'un filet nembraneux, fonğ, de trois articles, cilié ou velu au bont el servant à retenir les oufs. L'extrémité de la quene est garnie de cinq feuillets à peu près semblables ì ceux des Langousles.

Ces Crustacés sont assez comnuns dans nos mers et se plaisent surtout dans les terrains argileux a demi noyés, où ils se creusent des terriers un perı obliques, d'où iłs sortent quand la mer est calme pour aller chercher leur nourriture. Ils nagent par bonds, et leur nalation est aussi bruyante que celle des Palinures. Pendant la saison de leurs amours, ils s'approehent des endroits tapissés d'herbes et de facus. Les femelles n'abandonnent leurs oufs, qui sont d'un ronge vif, qu'après qu'ils sont développés. On mange ces Crustacés dans les provinces méridionales, et la chair du Scyliare oriental érale par sa bonté celle des meilleuss Crustacés cle nos mers.

Ce genre se compose de sept ì luit espèees, et Léach en a reliré une dont il a fait son genre Ibacus, qui n'a pas été adopté par Latreille. A l'exemple de ce savant, nous divisons ce genre ainsi qu'il suit.

A. Second arlicle des pieds-mâchoires extérieurs sans divisions transverses ni dentelures initant une crête, le long de son côté extérieur; yeux situés près des anglés antérieurs el latéraux du test.

I. Une pièee erustacée et avaneće au milieu du front.

Seyrlare large, $S$. latus.

S. testâ granulatâ; articulo squamiformi antennarum externarum apicis margine integro.

Scyllaris latus. L ${ }_{\Lambda}$ т. Gen. Crust. et Ins. tom. I. pag. 47.- Hist. nat. des Crust. et des Ins. tom. 6. pag. 182. - Seyllare oriental. Bosc. La femelle. - Scyllare orien!al. Risso. - Squille large ou Or- 
chetta. Ronden. Hist. des poiss. liv. 18. chap. 5. GesNer, Hist. anim. tom. 3. pag. 1097.

Cette espèce est une des plus grandes connues, elle alteint jusqu'a un pied de long; sa carapace est tuberculeuse et chagrinée, sans arêtes triangulaires; ses bords latéraux et ceux des articles de Iabdomen sont crénelés. Celte espèce est figurée dans les planches de ce Dictionnaire, $24^{\circ}$. partie, planche 5ı 3 . Elle se trouve dans la Médrceranée, et nous en avons recu un pris dans les mers des Antilles. La planche 314 de ce Dictionuaire repésente le SCrilake oriental, qui appartient à la même division que celui que nous venons de faire connoître; entin la planche 320 représente le Scyllanus sculptus.

II. Point de pièce crustacée et saillante au milieu du front.

\section{Scrleare ours, $S$. arctus.}

$S$, antennis exterionbus cristisve valde dentatis; testầ suprì̀ triforian deniatâ, marginis antico medio appendicabus mullis squamiformihus; segnentun abdominis lateribus edentulis.

Scyllarus arctus. l. Bв. Ent. Syst. tom. 2. pag. 477. - Suppl. Ent. Syst. pag. 398. - Lat. Gen. Ciust. et Ins. tom. I. p. 47. - Scyllare ours. Lat. Hist. nat. des Crust. et des Ins. tom. 6. pag. 180. - Cancer arctus. Linn. Syst. not. édit. 13. tom. 1. pars 2. pas. 1053. - Faun. Suec. édit. 2. $n^{\circ}$. 2040.-Rondel. Hist. des poiss. liv. 11. chap. 6. -Rerm. Gen. Ins. tab. 32. Jig. 3. - Hersst, Canc. tab. 3o. fig. 3.

Celte espèce est converte de séries d'épines et de yranulations sul le corselet. Les antennes extérieures sont profondément dentelées sur les bords. Elle est très-cominune dans la Méditerrusée.

Elle est représentée plazche 287 de ce Dictionnaire.

B. Second article des pieds-mâchoires extérieurs divisé par des lignes inférieures et transverses; son côté extérieur dentelé en manière de crête. Yeux situćs à peu de distance du milieu du fiont et de l'orivine des antennes intermédiaires.

Cette division correspond an genre Ibacus de Léach. Elle ne realerme que le Scyllaras incisus de Péron et Latreille, lbacus Peronii. Léacr, Zool. miscel. tom. 2. tab. 319, figuré dâns ce Dictionnaire, $24^{\mathrm{e}}$. partie, pl. 320. Sa carapace est très-large, crénelée autérieurement, à cinq dents, et pourvue d'une échancrure profunde sur ses côtés. II a été apporté par Péron de la nouvelle Hollande. (E. G, )

SCYLLARIDIS, Scyllarides. Tribu de Crustacés de la famille des Miacroures, ordre des Décapodes, ayant pour caractères : post-abdomen ter- miné par ane nageoire en éventail, presque membraneuse postérieurement. Tous les pieds presque semblables, non en pince; les deux antérieurs seulement un peu plus robustes dans la plupart; les deux derniers des femelles ayant leur avantdernier article armé d'une dent. Dessous du postabdomen n'offiant dans les deux sexes que quatre paires d'appendices, et dont les deux premiers situés sous le premier segment; l'une des deux branches ou divisions de ces appendices, ou du moins de ceux de la seconde paire et des suivantes, très-courte et en forme de dent dans les mâles, linéaire et biarticulée dans les femelles; l'autire division en forme de lame ou de feuillet. Les quatre antennes insérées sur une même ligne; les intermédiaires portées sur un long pédoncule et terminces par deux filess articulés, très-courts; tige des latérales avortée; leur pédoncule composé d'articles fort larges et formaut une crête le plus souvent dentelée. Test déprimé, presque carré, ou trapéziforme et plus large en devant. Animaux lous marins.

Cette tribu, très-voisine de celle des Langoustines (Familles noturelles du Règne animal, pag. 278), embrasse le genre $S_{c y l l o m i s}$ de. Fabricius, et dans la méthode du docleur Léach se partage en trois geures, Scyllarus, Thenus, Ibacus. Mais d'après l'un des carartères dont il fait usage, celui de la présence ou de l'absence de la saillie en forme de dent de l'avant-dernier arlicle des deux pieds postérieurs, l'on peut juger que ce naturaliste, eu établissant ces coupes, n'avoit pas encore observé les différences sexuelles de ces animaux, puisque, suivant lui, l'un des caracteres distiuctits de ses Scyllarus et des Ibacus est d'offirir cette dent, tandis qu'elle n'est propre qu'aux femelles. Celui qu'il tire de la situation des yeux, étant commun alux deux sexes, est sans doute préférable. Mais il faudroit alors établir avec l'espèce que j'avois nommée Latus, ou la Squille large de Rondelet, et qui aujour's'hui me paroît ètre le Scyllarus aquinoctialis de Fabricius, un nouveau genre. Son Scyllare antarctique seroit dans le même cas; car les yeux sont silués à égale distance di milieu du bord antérieur du thorax et de ses angles antérienrs. L'on pcut conclure de ces exemples que la position relative de ces organes se mudifie insensiblement, et que dés-lors ces caractères sont équivoques. Tel est le molif qui nous a déterminé à conserver encore le genre Scyllare dans son intégrité primilive. Quoique le ducteur Léach, en parlant de son Thenus indicus, ne cite aucun synonyme, nous pensons que cette es!ece est le Scyllarus orientalis de Fabricius. Voyez Scyltare. (Latr.)

SCY'TODE, Scytodés. LAT. WaLck.

Genre d'Ar'achnide de l'ordre des Pulmonaires, famille des Aranéides, section des Dipneumones, triba des Inéquitèles, tétali par M. Liblreilie, qui 
lui donne pour caractères : six yeux disposés par paires, une de claque côté, dans une direction oblique, et dont les yeux sont contigus; la troisième intermédiaire, antérieure et dans une direction transverse: la première paire de pieds et ensuite la quatrième plus longues.

Ce genre se distingue du genre Théridion, qui a d'ailleurs beaucoup de caractères communs avec lui, par le nombre des yeux qui est de dix-huit dans celui-ci; le genre Épisine, quoiqu'ay ant encore huit yeux, s'en éloigne parce que ces yeux sont placés sur une élévalion conımune; enlin le genre Pholcus qui teraine la tribu, est séparé par la longueur relative des pattes, dont la première paire et la seconde ensuite sont les plus longues. Ce genre ne se compose encore que d'une seule espèce que M. Latreille a observée à Paris et aux environs de Marseille.

\section{Scrtode thoracique, S. thoracica.}

S. pallido-rufescenti-albida, nigro maculata, thorace magno suborbiculato, posticè rotundatè elevato; abdomine dilutione, subgloboso.

Scytodes thoracica. Lat. Gen. Crust. et Ins, tom. 1. pag. 99. tub. 5. fig. 4. - WALCK. Tabl. des Aranéides, pag. 79.-Araignée thoracique. LAT. Hist. nat. des Crust. et des Ins. tom. 3. p. 56. et tom. 7. pag. 249 .

Longue de trois lignes à peu près. Corps d'un rou geâtre pâle tacheté de noir. Corselet grand el trèsbombé, présentant en dessus deux lignes noires et longitudinales. Crochel des mandibules très-petit; abdowen globuleux avec des points noirs disposés longitudinalement; pattes grêles, avec des anneaux bruns: Cette Araignée se trouve dans les maisons; quelques individus passent l'hiver dans dcs retraites qu'ils se choisissent et paroissent au commencement du printemps : elle se file une toile grande, composée de fills lâches et flottans : elle pond en juillet, et son cocon est formé d'une soie cumpacte. M. Latreille a reçô d'Espagne une Aranéide qui paroitroit appartenir au genre Saytode par le nombre et la disposition des yeux, mais dont la forme du corps la rapproche des Théridions. Elle est d'uu brun-roussâtre ou livide, et sans tacles. (E. G.)

SÉCURIPALPES, Securipalpi. Troisième tribu de la famille des Sténélytres, section des Hétéromères (première division), ordre des Coléoptères. Ses caraciëres sont :

Antennes assez courtes, insérées à nu. - Palpes maxullaires terminés par un article en forme de bache alongée ou cultriforme, quelquefois dentés en scie. - Tète inclinée. - Corps généralement ovale-oblong. - Corselet de la largeur des élytres. - Pénultième artacle des tarses, ou au Hist. Nat. Ins. Tome $X$.

moins celui des quatre antórieurs, coniqque, bilobé.

Celte tribu est susceptible d'être divisée ainsi :

I. Antennes de dix articles. Conopalpe.

II. Antennes de onze articles.

A. Pénultième article de tous les tarses bilobé.

a. Corselet point rebordé. Mélandiye, Dircée, Hypule.

b. Corselet rebordé latéralement. Nothus.

B. Pénultième article des tarses postérieurs entiers.

Serropalpe.

CONOPAlPe, Conopalpus. Gyle. Schen. Lat. (Fim, nat.)

Genre d'iusectes de l'ordre des Coléoplères, section des Ilétéromè̀es (première division), famille des Sténélytres, tribu des Sécuripaipes.

Tous les genres de cette tribu, hors celui de Conopalpe, ont les antennes composées de onze articles.

Antennes longnes, filiformes, insérées dans l'échancrure des yeux, composées de dix ariicles, le second couri, presque globuleux, les suivans un peu aplatis, formant presque des dents de scie juscu'au septième; les trois dernier's presque cylindriques. - Labre avancé, arrondi anlérieurement. - Handibules petites, épaisses à leur base. - Palpes inégaux; les maxillaires alnngés, denlés en scie, de quatre articles, le dernier trèslong, un pen aplati, conique; les lahiaux courts, de trois arlicles, le terminal très-large, sécuriforme. - Téte plus étroite que le corselet. Yeux saillans, fortement échaucrés intérieurement. - Corps presque linéaire, un peu bombé, mou. - Corselet coupé droit en devant, beauconp plus étroit dans cette partie que postérieurement, ses bords latéraux fort arrondis, son bord postérieur s'avançant un peu des deux côtés de l'écusson. - Ecusson moyen, en triangle curviligne. - Elytres bombées, reconvrant l'abdomen el les ailes. - Pattes de longueur mnyenne : premier arricle des tarses au moins aussi long que fors les autres pris ensemble; le pénultième bilobé.

M. Gylleuhall a composé le nom de ce genre de deux mots latins qui expriment la forme dú dernier article des palpos maxillaires. Ses mœurs sont les mêmes que celles des Mélandryes, mais ces insectes ne volent gière qu'à la chute du jour; lorsqu'on veut les saisir ils contractent leurs pattes et se laissent tomber. 
J. Conopalpe flavicolle, C. favicollis.

Conopalpus testaceus, antennis articulis tribus primis exceptis, nigris.

Conopalpus flavicollis. Gru.L. Ins. Sueg. tom. 2. pag. 547. $\pi^{\circ}$. 1. - Schen. Syn. Ins. tom. 1. part. 3. pag. 52, $u^{\circ}$. í.

Longueur 3 lig. $\frac{1}{2}$. Corps entièrement testacé, ponctué, couvert d'uu duvet roussâtre; les sept derniers articles des antenues sont noirs et les ailes noiı îtres.

Nous l'avons pris en été dans la forêt de SaintGermain-en-Laye.

Nota. M. le comle Dejean cite deux antres espèces de ce genre dans son Calalogue, Conopalp. thoracicus de Dalmatie, et Conopalp. collaris de l'ouest de la France. Il est probable que ces deux dernières ne sont que des variétés de l'espèce précédente.

MÉLANDRYE, Melundrya. Faв. Lat. Gyix. Scaen. Chrysomela. Linn. Serropalpus. Bosc. ILhig. Oniv. (Entom.) Dircaia. Fab. Helops. Panz. OL1v. (Encycl.) Lymexylon, Helops. PAYK.

Genre d'insecıes de l'ordre des Coléoplères, section des Hétéromères (première division), famille des Stéuélytres, tribu des Sécuripalpes.

Celte tribu se compose de six genres. (Voyez Sécuriparpes.) Les Conopalpes y torment un groupe particulier, leur's autennes n'étant composées que de dix articles; le genre Dircée est distinct par le dernier article des palpes maxillaires sécuriforme, les antennes un peu plus épaisses vers le boul et le corps convexe. Dans les Hypules le corps est convexe, les antennes presque moniliformes et le dernier article des palpes maxillaires conique; les Serropalpes ont le corps presque cylindrique et tous les articles des tarses postérienrs entiers : enfin les Nothus sout bien reconuoissables par leur corps presque linéaire, le corselet presque carré et rebordé, l'insertion des antennes dans une forte écliancrure des yeux et par les cuisses postérieures renflées daus l'un des sexes, les.mâles probablement.

Antennes filiformes, pubescentes, de longueur moyenne, insérées près, mais hors d'une très-légère échancrure des yeux, composées de onze ariicles; les cinq premiers un peu coniques, le premier plus grand que le second, renflé : les quatre suivaus allant en augmentant un peu de longueur, le sixiè̀me à peu près de la longueur du précédent; les suivans allant en diminuant de longueur, un peu complinés, le dernier pointu à l'extrémité. Labre avarcé, membraneux, transversal, échancré dans son milieu. - Mandibules courtes, trigones, épaisses à leur base, tridenlées intérieurement. - Mâclooires presquentièrement membraneuses. - Palpes inégaux; les maxillaires beaucoup plus longs que les lalịiax, recourbés, de qualie articles, le premier très-petit, les denx suivans un peu coniques, le troisième plus petit que le précédent, le dernier grand, alongé, profondément canaliculé. Palpes labiaux courts, de trois articles, le terminal grand, comprimé, canaliculé. - Lèvre et Menton de consistance membraneuse, presque carrés. - Tête moitié plus étroite que le corselet; chaperon coupé droit antérieurement. - Yeux assez grands, ovales, trc̀sfoiblement échancrés intérieurement. - Corps ovale-elliptique, un peu déprimé en dessus. - Corselet irapézoïdal, coupé carrément à sa parie autérieure qui est plus érroile que la postérieure; ses côtés un peu arrondis, le bord postérieur s'avançant un peu des deux côtés de l'écusson. - Ecusson petil, arrondi postérieurement. - Elytres à peine plus larges que le corselet à leur base, allant un peu en sélargissant jusque vers les trois quarts de leur longueur, couvrant entièremeut l'abdomen et les ailes. - Pattes de longueur moyenne : premicr article des tarses aussi long ou plus long que les suivans réunis, dans les ciuatre larses postérieurs; pénultième arlicle des six tarses bilubé.

Le nom de Mélandrye vient d'un mot grec qui exprime la conleur noire des espèces connues. Cés insectes se trouvent dans le vieux bois carié; ou les rencontre aussi quelquefois dans les chantiers. Ils courent assez vîte el s'envolent facilement. Il est probable que leurs larves vivent dans le bois pourri et qu'elles y subissent leurs métamorphoses. En créanı ce genre dans son Syst. Eleut., Fabricius $\mathrm{y}$ a mis quatre espèces, mais la quatrième (repanda) paroìt à M. Schœenherr être un Hélops.

On placera dans ce genre $1^{\circ}$. Hélops barbu $\mathrm{n}^{\circ}$. 9. rie ce Dictionnaire, Melandrya barbata no. 5. Fa . Syst. Eleut. $2^{\circ}$. Hélops canaliculé no. ı o. Encycl. Melandrya canaliculata $\mathrm{n}^{\circ}$. 2. FAB. id. - G y llen. Ins. Suec. tom. 1. part. 2. pag. 535. $n^{\circ} .2$. Nous avons pris celte espèce ou une trèsvoisiue dans la forêt de Saint-Germain-en-Laye. 30. Mélandrye caraboïde, Encycl. pl. 372. bis. fig. 5. Melandrya caraboïdes. Lat. Gener. Crust. et Ins. tonı. 2. pag. 191. $n^{\circ}$. I. - G YLLEN. Ins. Suec. tom. 1. part. 2. pag. 533. $n^{\circ}$. 1 . Des environs de Paris. $4^{\circ}$. Mélandrye ruficolle, Melandrya ruj $\imath_{-}$ collis. Grlenn. id. pag. 536. no. 3. - Dirccea ruficollis $\mathrm{n}^{\circ}$. 4. F а . Syst. Eleut. - Lymexylon paradoxuln. Р А г F. Faun. Suec. toni. 2. pag. I62. "no. 3. De Finlande.

Nota. L'espèce représentée dans l'Encyclopédie pl. 372 . fig. 4. sons le nom de Melandrya barbata Srurat qui est la Melandrya flavicornis Dufres. Des. Catal. d'Autriche, est-elle différente de la Melandrya barbata de Habricius?

DIRCÉE, Dircaea. Faв. Gru. PANz. (Faun.) Lat. (Fam. nat.) Melandrya. Lat. (Gener.) Xylita. Pay . Serropalpus. HeLLen. Illig. Lymexylon. Paxz. (Ent. Germ.) 
Genre d'insectes de l'ordre des Coléoptères, section des Hétéromères (première division), famille des Sténélytres, tribu des Sécuripalpes.

Six genres sont compris dans cette tribu; celui de Mélandrye a le dernier article des palpes maxil. laires grand et alongé, les antennes filiformes, le corps ovale-elliptique, déprimé en dessus. Dans les Conopalpes les antennes ne sont composées que de dix articles. Les Hypules ont le dernier article des palpes maxillaires étroit, conique, comprimé. Les tarses postérieurs des Serropalpes ont tous lenrs articles entiers; le genre Nothus se distingue par ses antennes notablement plus longrues que le corselet, celü̈-ci très-rebordé latíralement, et par sescuisses postérieures très-renflées dans l'un des sexes.

Antennes filiformes, composées de onze aricles, à peine plus longues que le corselet, allant un peu en grossissant vers l'extrémité. - Mandibules cornées, arquées, unidentées, aiguës ì l'extrémité. - MIâchoires cornées, bifides, leurs lobes arrondis au bout, l'extérieur plus grand que l'autre. - Palpes inégaux; les muxillaires trèsgrands, recourbés, de quatre articles, le premier court, presque cylindrique, les second et troisième obconiques, le termiual plus grand que les autres, en hache triangulaire, plus large à sa base, trouqué ver's son extrérnité, canaliculé en dessous : les deux lames qui composent les bords de ce canal restant ouvertes; palpes labiaux courts, de trois articles, le premier étroit, presque cylindrique, le second dilaté à son extrémité, le irnisième de mêne grosseur, arrondi-obtus à son extrémité. - Lèvre membraneuse, bifide, élargie au bout. - Tête sans cou distinct, inclinée. Corps alongé, presque cylindrique, convexe. Corselet convexe, point rebordé, de la largeur des élytres. - Ecusson petit, arrondi. - Elytres recouvraut l'abdomen et les ailes. - Pattes simples, courtes : tarses ayant leur pénultième article petit, bilobé.

Ces Coléoptères ont les mœurs des genres préć́dens. Toutes les Dircées connues sont d'Europe. Des onze espèces que labricius place dans ce genre, la première (barbata) appartient aux Serropalpes; les troisième (quadrigiettata), cirıquième (bifasciata), sixième (dubia) sont des Hypules. La quatrième (ruficollis) est une Mélandrye. La dixième (humeralis) est un Hallomène. Lai onzième (micans) est le type du gense Orchésie. Les septième (fulsicollis) et neuviè̀me (murina) nows sout inconnues, mais elles doivent se rapporter aux Hypules ou rester parmi les Dircées.

Nous plaçons dans ce grenre: $1^{\circ}$. Dircée discolor. Encycl. pl. $37^{2}$. fig. 33. et pl. 372. bis. fig. 20. Dircal discolor $\mathbf{n}^{\circ}$. 2. Fав. Syst. Elent. Xylita buprestoides no. 1. Payk. Faun. Suec. $2^{\circ}$. Dircée variée, Dirca a variegata ${ }^{\circ}$. 8. FA . id. $3^{\circ}$. Dircée rufipède, Dircaea rufipes no. 3. GYLLEN. Ins. Suec. tom. 1. part. 2. quoique cet au- teur la place dans la division qui répond au genre Hypule.

HYPULE, Hypulus. Payk. Lat. (Fant. nat.) Dircoa. FAb. Gyll. Scticen. Notoxus. PAnz.

Genre d'insectes de l'ordre des Colćoptères, section des Hétéromères (première division), famille des Sténélytres, tribu des Sécuripalpes.

Des genres qui composent cetite tribu avec les Hypules (voyez SÉcuripalpes), celui de Conopalpe a seul les antennes composées de dix articles. Les Mélandryes on le corps ovale-elliptique, un peu déprimé, les autennes filiformes et le dernier article des palpes maxillaires grand, alongé ; ce mêrne artirle des palpes est, dans les Dircées, en haclie triangulaire, canaliculé en dessous et comme formé duns cette partie de deux lumes qui restent ouvertes. Dans les Serropalpes les quatre articles des tarses postérieurs sont tous entiers : enfin le corselet des Nothus est notablement rebordé sur les côlés, en outre dans ce genre ies cuisses postérieures sont très-renflées daus l'un des sexes.

Les caractères génériques des Hypules sont les mêmes que reux des Dircées, à l'exception des suivaus :

Antennes presque moniliformes. - Nấchoires membraneuses. - Palpes maxillaires filiformes, leur dernier article éíroit, conique, comprimé, composé à sa partie inférieure de deux lanes qui se rejoignent et ne laissent point de canal entr'elles. - Lèvere membraneuse, arrondie à l'extrémité, entière.

Les mœurs et les habitudes de ces insectes sont les mêmes que dans les autres genres de leur tribu. Le uom d'Hypule nous paroît tiré d'un mot grec et venir de l'habitude qu'ont ces Coléopières de se cacher sous les écorces d'arbres. Ils sont généralement rares.

Nous mentionnerons les trois espèces suivantes: 10. Hypule quatie taches, Hypulus quadriguttatus. PAY K. Faun. Suec. tom. 1. pag. 251 . no. 1. Dircoa quadriguttata no. 5. FA B. Syst. Eleut. - Gy Lr. Ins. Suec. tom. 1. part. 2. pag. 520. $n^{\circ}$. 3. $2^{\circ}$. Hypule du Chène, Mypulus quercinus. PAYx. id. pag. 252. no. 2. - Dircaea quercina. Gy lx. id. pag. 523. $n^{\circ} \cdot 6$. - Dirccea dubia $n^{\circ} .6$. Fa . Syst. Eleut. - Encycl. pl.372. bis. fig. $21.3^{\circ}$. Hypule bifascié, Hypulas bifusciatus. Des. Catal. - Dircera byfisciata ${ }^{\circ} .5$. $\mathrm{FAB}_{\mathrm{AB}}$. Syst. Eleut. GyLL. id. pag. 522. $u^{\circ} .5 .-$ Notoxus bifasciatus. Panz. Faun. Germ. fas. 6. fgr. 3.

$$
\text { (S. F. et A. SERv.) }
$$

SÉGESTRIE, Segestria. LAt IVA LCK. Aranea. Linn. De Grer. Fab. Oliv. Rossi.

Genre d'Arachnide de l'ordre des Pulmonaires, faraille des Aranéides, section des Dipneumones, tribu des Tubitèles, établi par M. Jalreille aux dépens du grand genre Aranea de Limné, et auquel il donne porr caractcres : clı́licères élar gies $\mathrm{Ggg} 2$ 
an côté extérienr, près de leur base, droites; six yeux dont quatre plus antérieurs for transverse, et les deux autres situés un de claque côté, derrière les latéraux précédens; la première. paire de pattes, et la seconde ensuite, les plus longues de tontes; la troisième la plus conrte.

Les Ségestries se distinguent des Clotho et des Drasses, parce que leur Tangue n'est pas cintréc par les mầchoires, comme dans ces deux derniers genres. Les Clubiones, les Araignées et les Argyronètes qui terminent la tribu des Tubitèles, sont distinguées des Ségesiries par le nombre de leurs yeux, qui est de liuit.

Les mâles des Ségestries ont les paltes beaucoup plus longues que les fenelles; le cinquième article de leurs palpes est alongé, gros à son origine, cylindrique et un peu conclié dans le reste de son ćtendne; il se termine en pointe mousse: un corps de la forme d'une petile bouteille à col long et ciélié est attaché tout près de son origine, en dessous et au côté intérieur; le bout ou l'extrémité de ce corps est alongé, courbé en manière d'S, et ressemble un pen à une queue; il est écailleux, roussâtre, très-lisse, luisiunt, sans poils, placé perpendiculairement au bras et dirigévers la tête. S. longueur égale celle des trois derniers ar!icles des palpes; if les surpasse anssi en grosseur : il pend à un col délić sur lequel il est mobile, mais qui n'cst apparent que lorsqu'on cherche à éloigner le corps du bras. C"est dans l'intériear de ce corps que sont renfermées les parties sexuelles masculines.

Les mœurs de ces Araignées ont été étudiées par De Gécr el par Lister; elles sont nocturnes, et leur habitation est ordinairement quelque fente de vieux mur, le dessous d'une écorce d'arbre ou tout antre lieu couvert. Walckenaer dit qu'elles filent des tubes alongés, très-éroits, cylindiriques, où elles se tiennent en embuscade; leurs six patles sont posées sur aulant de fils qui divergent et vienment se rendre au tube comme à un ceutre commun. Dans celte posture elles altendent que quelque mouche vienne faire remuer lemr filet; aussitôt qưun mallienreux anina l y est embarrassé, les mouvemens qu'il fait pour se dégager sont communiqués par les fils suc lesquels les pattes de l'Araignée sont posées; elle sait par leur moyen de quel côté est sa victime, et elle fond dessus pour la dévorer.

Ce genre ue se compose que de deux espèces; la première est décrite à l'article Aratgnée de ce Dictionnaire sous le $n^{\circ}: 39$. Elle a été décrite et figurée par Walckenaer, Hist. des Aran: fas. 5. tab. 7. fig. I. la femelle, et fig. 2. et 4. le mâle. Lax. Hist. nat. des Crust. et des Ins. tom. 7. pag. 216. $n^{\circ} \cdot 2$. L'autre espèce est :

La Ségrstrie des caves, Segestria cellaria. Segestria perfida. WALck. Faun. Paris. tom. 2. pag. 223. $n^{\circ} \cdot 73 .-$ Aranea florentina. Rossi, Fumu. Etrusc. tom. 2. pag. 133. tab. 19. fig. 3 .
Sa bouche est représentée grossie, p!. 33g, fig. 19, dans les planches de ce Dictionnaire. Celte espèce est lougune de près de 7 lignes; son corps esı velu, d'un noir tirant sur le gris de souris, avec les man. dibules vertes ou blend'acier, et une suite de taches triangulaires noires le long du milieu du dos et de l'abdomen. Elle se trouve dans toute l'Europe dans les caves, dans les lieux humides des maisons. Elle construit son nid dans les coins de mur's, dans les fentes de portes qu'on n'ouvre plus, etc. D'après M. Latreille, l'Araiguée senoculata de Fabricius est une espèce de Théridion; cet auteur nucutionne encore une Araignée à six yeux; il la nomme Scopulorum. Cetle espèce est inconnue à M. Latreille et aux auteur's modernes.

(E. G.)

SÉLANDRIE, Selandria. M. Léacl dans ses Zoologicul miscell. vol. 3. Lond. 1817, a proposé sous ce norn un genre qui a ppartient à la tribu des Tenthrédines, fumille des Porte-scie, section des Térébrans, ordre des Hyménoptères. Son caractère est, d'après l'auteur anglais : ailes antérientes ayant quatre cellules sous-marginales (cubitales) et denx marginales (radiales); anteunes de neuf articles. M. Léach place ce genre dans sa sixième stirps, laquelle a pour caractères : antennes courtes, de neuf à dix articles, plus épaisses dans leur milieu, terminées en pointe; leur troisième article plus long que le quatrième. Corps court, ćpais. Ce genre ne se distingue de celni de Tenthrede que par des caractères trop variables pour devenir génériques. Les Sélandries répondent à nolre quatrième division des Tentlurèdes dans l'onvrage intitulé : Mónographia Tenthredinetarum Symon. extric. Paris, 1823.

\section{(S. F. et A. Serv.)}

SEMBLIDE, Semblis. Fabricits a fondé sous ce nom un genre faisant partie de ses Synistates (Entom, Syst.). Il le caractérise ainsi : mâchoires bifides; labre (labium) corné. Antcnues filiformes. Des espèces qu’il y renferme la Semblis pectinicornis $\mathrm{n}^{\circ} . \mathbf{I}$. (Hémérobe pectinicorne $\mathrm{n}^{\circ} .2$. Encycl.) appartient au geure Chanliode Lax. (uibu des Semblides). La Sentblis lutaria no. 10. (Hémérobc aquatique no ${ }^{\circ}$ 16. Encycl.) est le type du genre Sialis Lat. (mêtne tribu). Les Semblis 10. murginata $n^{\circ} \cdot 7$, bicaudata no. 8. Eelle dernière est la Perle brune no.1. de ce Dictionnaire ) viridis $\mathrm{n}^{\circ}$. $1 \mathrm{l}$. (Perle jaune $\mathrm{n}^{\circ} .3$. Encycl.) sont du genre Perle L.ar. (tribu des Perlides) et la Sembís nebulosa $\mathrm{n}^{\circ}$. 9. est une Némoure (Némoure nébuleuse no. I. Encycl.) Toutes ces espèces sont de la famille des Planipennes, ordre des Núvroptères. (S. F. et A. SERv.)

SEMBLIDES, Semblides. Lat. Fam. nat. (Megaloptera. LAт. Gener. Crust. et Ins. et Encycl.) Seplième tribu de la famille des Planipennes, or- 


\section{S E M}

dre des Névroptères. (Voyez Peanipennes.) Ajoutez aux caractères que les auteunes sont quelquefois pectivées.

M. Latreille dit que ces insectes sont aquatiques dans leur premier âge et que leurs métamorphoses sont incomplètes.

CORYDAle, Corydalis. Lat. Par.-Bauv. Hemerobius. Linn. De Géer. Fab. Oliv. Raphidia. Lins.

Genre d'insectes de l'ordre des Névroptères, section des Filicornes, famille des Planipennes, tribu des Semblides (Méyaloptères Encycl. article' Planipennes ).

'Trois genres composent cette tribu; celui de Chauliode est distinct par ses antenues pectinées. Dans les Sialis, les ailes sont en toit dans le repos, le pénultième artiele de tous les tarses est bilobé et la tête est privée d'ocelles.

Antennes simples, filiformes, composées d'un très-grand nombre d'articles courts, presque cylindriques. - Labre ayant ses côtés arrondis, sa partie antérieure un peul prolongée en pointe obtuse, insérée sous uu avancement de la tête et portant à sa base une carèue transversale. - Mandibules des femelles avancées, à peu près de la lougueur de la tête, aplaties, assez lurges, ter. minées en eroehet et munies de trois denielures au côié interne, celles des mâles très-grandes, de la longuenr de la moitié du eorps, avancées, Etroites, coniqunes-subulées, se croisint l'une sur l'autre, imitant deux cornes, n'ayatut aucunes dentelures. - Mâchoires avancées, visibles; leurs lobes mernbraneux, l'inférieur très-long, le supérieur court, porté sur nne espèce de tige cylindrique. - Palpes nuxillaires insérés sur cette même tige cyliudrique des mâchoires, de six articles; les trois premiers assez grands; les suivans très-petits, le premier de ceux-ci infundibuliforme. Premier article des palpes labiaux trèslong. - Lèvre transversale, membraneuse, s'élirgissant en devant. - Menton étruit postérieurement, très-échancré à sa partie antérieure. Tête très-grande. - Yeux arrondis, très-saillians. - Trois ocelles fort grands, très-oblongs, plucés en triangle sur uue petite éminence du milieu de la tête; l'antérieur posé transversalement, les deux postérieurs obliquement. - Prothorax long, eylindrique, beaueoup plus étroit que la tête; les deux autres parties du thorax plus larges que l'antérieure ou le prothorax. - Ailes grandes, couchées horizontalement sur le corps dans le repos, plus de deux fois aussi longues que l'abdomen. Abdomen terminé par quatre appendices pubescens, savoir : deux supérienrs et deux inférieurs, d'abord un peu divergeus, connivens à leur extrémité ; les inférieurs biarticulés, très-coneaves en dedans. - Pattes de longneur moyenne; tarses de cinq artieles entiers.
On ne connoît pas les mæurs des insectes de ce genre, nou plas que leurs larves. Les espc̀ces conuues sont exotiques.

I. Corydale cornue, C. comula.

Corydulisfusca; alis griseo-fuscis, albido punctatis.

Corydalis comutu. Lat. Gener. Cuzust. et Ins. tom. 5. pag. 199. $n^{\circ}$. 1. Nîle. - Corydalus cornutus. PAL-Bauv. Ins. d'Afiriq. el d'Alnér. p. 18. Névropt. pl. 1. fig. I. Mìle.

Nota. M. de Banvois a trouvé cette espèee ì Philadelphie, sur les bordis de la rivière Skuillkill.

Voyez pour la description et les antres synonymes, Hémérobe cornu n ${ }^{\circ}$. I. pl. 96. fig. '3. de ce Dictionnaire. Mâle. La femelle ne differe que par la fortne de ses mandibules. Voyez De Gérr, Mém. Ins. toun. 5. pag. 562. pl. 27. fig. 2.

\section{Conydale testacíe, $C$. testacea.}

Corydalis palliaè-testacea: mandibulis, antennarunz unedia parle, prothoracis nnaculis quattuor, frontis unicâ, tarsorun apice greniculisque nigris; aìs lutescentè-hyalinis, nevvuris plunibus transversalibus nigris.

Longucur I pouce. D'un testacé-januâtre. Mandibules noires avec mne ligne jaunâtre à leur partie extérieure. Antennes jaunes à leur base et à leur extrémité, noires an milieu. On voit ıne tache de cette coulenr sur le front, portant les ocelles qui sont á demi noirs. Prothorax ayant quatre petites lignes noires disposées carrément. Base des jambes noire ainsi que les quatre derniers articles des tarses et la base du premier. Ailes transparentes, un peu jaunâtres; la plapart de leurs nervures transversales noires, surtuat dans les ailes supérieures. l'emelle.

De l'île de Java.

CHaUltode, Chauliodes. Lat. Pat.-Bauv. Hemerobiuls. Lina. De Géer. Oliv. (Encycl.) Semblis. FAB.

Genre d'insectes de l'ordre des Névroplères, section des Filicornes, famille des Planipenues, tribu des Semblides.

Les genres Corydale, Chauliode et Sialis eomposent cette tribu. Le premicr et le dernier ont leurs antennes simples; les Sialis en outre sont privés d'ocelles; le pénultièmế article de leurs tarses est bilobé et leurs ailes sont en toit dans le repos.

Antennes multiarticulées, sétaeces, pectinées d'nn seul côté a partir du quatrième article, leurs prolongemens latéraux allant en diminuant de longueur, ceux de l'extrémité peu sensibles. Premier artiele presqu'aussi long que les deux suivans réunis, eeux-ei transversaux, très-courts. - Mran- 
d:bules courtes, trigones, déprimées, dentées au cîté intéricur. - Mâchoires presque cornées, leur bord supérieur dilaté en une lane comprimée, arquée, un peu pointue à l'cxtrémité : leur lobe apical presque trigone, déprimé, un peu échancré. - Palpes maxillaires un peu plus longs que les labiaux, de cinq articles, le second le plus long de tous, le dernier beaucoup plus mince que les autres: palpes labiaux de trois articies. Lèvre coriace, presque carrée. - Téte guère plus large que le corselet. - Ieux gros, très-saillans. - Trois ocelles fort grands, très-oblongs, placés en triangle sur une petite éminence du milieu de la tête, l'antérieur posé trausversalement, les deux postérieurs obliquenent. - Prothorax prescue cylindrique. - Ailes très-graudes, près de deux fois aussi Inngues que le corps, couchées horizontalement sur l'abdomell.-Abdomen dépourvn d'appendices. - I'attes de longueur moyenoe; tarses de cinq articles entiers.

M. Latreille en créant ce genre l'a nommé Chauliode d'uu not grec qui signifie : dents avancées; il contient un petit nombre d'espèces d'assez grande taille et propres aux parlies cliaudes ou tempérées de l'Amérique septentrionale. L'une d'elles est l'Hémérole pectiaicorne $n^{\circ}$. 2. de ce Dictionnaire (Chauliodes pectinicornis. Lat. Gen. Crust." et Ins. tom. 3. pag. 198. $\mathbf{h}^{\circ}$. 1.) Les insectes figurés par Drury, Illustr. natur. tom. 1. pl. XLVI. $72^{\circ} .2$ ct 3 . paroissent être de ce genre.

\section{(S. F. et A. Serv.)}

\section{SÉNÉlOPE, Senelops. Dufour, Lat.}

Genre d'Araignée de l'ordre des Pulmonaires, famille des Aranéides, fribu des Latérigrades, établi par Léou-Dufour el ayant pour caractèı : máchoires droites et parallèles, écartées, presque de la même longueur dans toute leur étendue; seconde paire de pattes et la troisième ensuite les pius longraes de toules; la première la plus courte. Lèvre courte, presque carrée, avec l'extrémité supérieure arrondie; huil yeux, dont six de front, et les deux autres silués un de chaque côté, en arrière des deux extrêrnes précédens, les plus gros de tous. Corps très-aplati.

Ce genre se distingue des Micrommates de Latreille par les yeux qui sunt autrement disposés daus ce genre; les Thorrises s'en éloignent par leurs màchoires qui sont inclinées sur la lèvre. On comôî quatre espèces de ce genre; celle qui iui sert de lype a été découverie en Espagne par Ĺon-Dufuur; c'est :

Le Sénézope rayonné, Senelops radiatus. Dơp. Il est long d'environ quatre lignes; son corps esi d'uu brun-jäunâtre livide, pubescent, avec de petives taches noirâtres; le milieu du corselet est plus obscur et a des tignes enfuncées, disposées en rayon. L'abdomen est orbiculaire; les-palles sont longues, avec des bandes ou taches transverses, noirûtres, et une brosse au bout des tarses.

Les autres espèces sont originaires de la Syrie, de l'Ile-de-France et du Sénégal : elles ne sont pas encore décrites. (E. G.)

SËPÉDON, Sepedon. LAT. Scatophaga, Baccha. F а в. Syrphus. Rioss. Musca. P A z.

Genre d'insectes de l'ordre des Diptères, première section, fanille des Athéricères, tribu des Muscides (division des Dolichocères).

Celte division a pour caractères : des ailes; cuillerous petits; balanciers nus; ailes ordinairement couchées sur le corps: antennes de la longueur, au moins, de la face de la tête. Elle renferme les genres Loxocère, Lauxanie, Sépédon et 'Tétanocère.

Les Loxncères se distinguent par le dernier article de leurs antennes plus long que les deux précédens réunis; les Latuxanies par leur tête comprimée transversalemeul et leur corps peu alongé; dans les Tétanocères les antennes ne sunt pas plus longues que la tête, lenrs second et troisième articles sout presqu'éganx en longueur.

Antennes presqu'une fois plus longues que la lête, assez écartées entr'elles à leur base, insérées sur une élévation, droites, avancées, composées de trois articles; le premier très-court, le second le plus long de tous, cylindrique; le troisième une fois plus court que le précédeut, iriangulaire, terniné en pointe, muni d'une soie dorsale, biarticulée à sa base, garnie de poils très-courts. Trompe longue, entièrement ou presqu'entièrement rétractile. - Palpes assez granits, s'élargissant un peu avant leur extrémité. - Tête, vue en dessus, paroissant pyramidale, conique; !riangnlaire vue de face. - Yeux gros, très-saillans, espacés dans les deux sexes. - Trois ocelles rapprochés, placés en triangle sur un tubercule du vertex. - Corps oblong, alongé. - Corselet un peu plas étroil que la tête. - Ailes couchées l'une surl'autre dans le repos. - Balanciers découverts. - Cuillerons petits. - Pattes longues, assez fur!es; cuisses postérieures très-loygues, garnies en dessous de deux rangs de petites épines; leurs. jambes uu peu arquées : premier article des tarses le plus long dé tous, le dervier nuni di deux crocbets et d'une pelotte bifide.

Ces Diptères se tieanent à l'état parfait sur les. plantes qui ont leurs racines dans l'eau, telles que l'Iris pseudacorus el les Scirpus. Nous connoissons deux espèces de ce genre dû à M. Latreille, elles se trouvent aux euvirous de Paris; la plus commune est le Sépédon des marais, Seped. palustris. Lat.-Baccha sphegea no. 1. Faв. Syst. Anthiat. Ce dernier auteur décril une seconde fois cetle mème espèce sous le nom de Scatophaga rufipes $\mathrm{n}^{\circ}$. 18. idem.

LOXOCERE, Loxocera. Mrig. Illig. LAT: 
Fab. Mulsca. Linn. Panz. Schellemb. Syrohus. Róss.

Genre d'insectes de l'ordre des Diptères, première section, famille des Athéricères, tribu des Muscides (division des Dolichocèrcs).

Cette division comprend quatre geures. (Voyez Sépédon.) Celui de Lauxanie a la tête comprimée transversalement et le corps peu alongé; les antennes des 'Tétanocères ne sont pas plus longucs que la tête; ces antennes ont leurs second et troisième articles presqu'égaux en longueur; enfin le geure Sépédon se distingue par le second article des antennes de forme cylindrique et le plus long de tous.

Antennes plus longues que la tête, assez écartées entr'elles à leur base, insérées sur une élévation, avancées, allant en divergeant, composées de trois articles, le premier très-court, turbiné; le second de même forme, un peu plus long quc le précédent; le troisième beau coup plus long que les deux autres pris ensemble, un peu aplati, un peu plus étroit à son extrémité qu'à sa base, celleci portant une soie articulée, garnie de poils très-courts. -Trompe courte, presqu'entièrement létractile. - Palpes courts. - Téte, vue en dessus, paroissant pyramida!e, conique. - Yeux grands. - Trois ocelles rapprochés en triangle sur la partie postérieure du front. - Corps très-long, fort étroit pour sa longueur. - Corselet à peu près de la largeur de la tête. - Ecusson triangulaire, assez grand. - Ailes courtes, couchées l'une sur l'autre dans le repos. - Cuillerons petits. - $B a-$ lanciers découverts. - Abdornen alongé, étroit, prolongé en pointe postérieurement. - Pattes assez grandes; cuisses postéricures muliques, leur's jambes un peu arquées : premier article des tarses le plus long de tous, le dernier wuni de deux crocliets fort pelits et d'une pelotte bifide.

Le nom donné à ce genre vient de deux mots grecs dont le sens est : cornes obliques. On trouve ces Muscides sur les plantes. Leurs mœurs et leurs larves ne sont pas connues. Les auteurs n'en mentionnent qu'une seule espèce. Loxocère Ichneumon, Loxoc. ichneumonea n ${ }^{\circ}$. I. Faв. Syst. Antliat.-Musca aristata. PAnz. Faun. Germ. fas. 73. fig. 24. Des environs de Paris.

\section{LAUXANIE, Lauxania. LAt. Fan.}

Genre d'iusectes de l'ordre des Diptc̀res, première section, famille des Athéricères, tribı des Muscides (division des Dølichocères).

Les geures Lauxanie, Loxocère, Sépédon et 'Tétanocère, composent cetle division. (Voyez SípÉDon.) Dans ce dernier les antennes ne sont pas plus longues que la tête, leur premier article est court. Les Loxocères sont. bien distinctes par leur corps.très-túng et très-étroit ; les Sépédons ont le corps alongé, oblongr, le premier.article des au tenues très-court, et le truisièrme court, triangulaire,
Antennes insérécs vers le miliea de la face antéricure de la tête, très-écarlécs entr'elles à leur base, beaucoup plus longues que la tête, composées de trois articles, le premier plus grand que le second, le troisième lung, presque cylindrique, portant une soie à sa base; celle-ci épatisse, garnie de poils courts à son extrémité. - Palpes dilatés. - Téte couprinće transversalement. - Corps court, arqué. - Ailes couchées sur le corps dans le repos. - Abdomen trignne, dépriné.

Nous donnons ces caracières d'après M. Latreille fondalcur de ce genre. L'espèce qui lui a servi de type est la Lauxanie cylindricorne, Lauxumia cylindricomis n०. I. FAB. Syst. Antliat.-Lauxania mufitarsis. Lat. Gener. Crust. et Ins. tom. 4. pag. 357 . Elle sc trouve dans les bois des environs de Paris. (S. F. et A. Serv.)

\section{SÉPIDIE, Sepidiun. Fab. Lat. OLIV. (Entom.)}

Genre d'insectcs de l'ordre des Coléopières, section des Hétéromères (prcmière division), famille des Mćlasomes, tribu des Piméliaires.

Un groupe de celte tribu a pour caractères: menton ne recouvrant pas la base des mâchoires. (Voyez Pméliatres.) Parmi les genres qui en font partie celui de Scaure se distingue par le onzième ou dernier article de ses antennes sensiblement plus loug que le précédent. Les Moluris ont le corselet convexe, arrondi postérieurement, échancré el devant; les antenmes des Tagénies sont composées d'articles presque perfoliés; celles des Psammodes sont grêles, terminées par uae massue de trois articles. De plus les Moluris, ainsi que les 'Tagénies et les Scaures n'ont pas les côtés du corselec dilatés.

Antennes filiformes, composées de onze articles, le troisième cylindrique, beaucoup plus long que le quatrième; les suivans jusqu'at netvièn.e presqu'obconiques, le dixième presque turbinć, le onzième ovale, point sensiblement plus long que le précédent, pointu à son extrémité.-Labre coriace, avancé, en carré l:ansversal; son bord antérieur entier, cilié. - Mandibules bifides à leur extrémité. - Mâchoires ayant une dent on crocbet corné à leur côté interne.-Palpes maxillaires avancés, de quatre articles, le ciernier un peu plus grand que les autres, prèsqu'uvale, comprimé, tronqué : palpes labiaux de trois articles presqu'égaux. - Lèvre avancée, très-échancrée antéricurement. - Menton court, rétréci: à sa base, ne reconvrant pas l'origine des mâchoires, son bord antérieur presque droit, mais un peu rentrant dans son milieu. - Corps ovale-alongé, souvent très-inégal en dessus. - Corselet déprimé en dessus ou caréné et très-inégal, ses bords latéraux dilatés. - Ecusson nul ou point distinct.Elytres soudées ensemble, embrassant l'abdomen, souvent terminées en pointe. - Point d'uiles. Abdomen ovale. - Jambes cylindriques, ter minées par deux épines très-courtes; tarses courts. 
Les Sépidies se trouvent dans les elimals ehauds de l'ancien contiuent; ainsi que les Pimélies elles parcourent les sables et préférent les lieux secs et incultes. Leurs larves sont incomnes. Nous citerons les espèces suivantes: $1^{\circ}$. Sépidie tricuspidée, S. tricuspidatum no. I. Fав. Syst. Eleut. Ouıv. Entom. tom. 3. Sépid. pl. 1.Jig. 1. $2^{\circ}$. Sépidie variée, $S$. variegatumn no. 2. FA A id.-OLIV. ut supric pl.1.fgo. 2. 3o. Sépidie crêtée, $S$. cristatum $11^{\circ}$. 3. FAB. id.-OLiv. ut suprà pl. 1. fig. 3 . $4^{\circ}$. Sópidie réticulée, $S$. reticulatum n ${ }^{\circ}$. 4. $\mathrm{K}_{\mathrm{AB}}$. id.- Orrv. ut suprá pl. 1 et 2. fig. 4. 5०. Sépidie rugueuse, $S$. rugosum no. 5. Faв. $z d$. - OLiv. ut suprì $p l$. 1. fig.5. $6^{\circ}$. Sépidie rayée, $S$. vittutum ${ }_{10}^{\circ}$.6. Faв. $i d$. -Onrv. ut supri pl. 1. fgo.6. $7^{\circ}$. Sépidie alongée, $S$. elongatum. Unıv. ut suprì pl. 2. fig. 7. (S. F. et A. SERv.)

SÉRICOMYIE, Sericomyia. Iat. Merg. Syrphus. Fab. l'alien. Panz. Mlusca. Linn. De Geer.

Genre d'insecies de l'ordre des Ijiptères, premicre section, famille des Athéricères, tribu des Syrplies.

La seconde division de cette tribr ( voyez Sxrpaies) a ponr caraclice : antennes presque de la luagrueur de la tête ou plus courtes qu'elle. Celle seconde division renferme plusieur's groupes dont l'un est caractérisé ainsi : antennes ayant leurs deux premers arlicles égaux entr'eux, point insérées sur un tubercule frontal. Ailes sans cellule péditorme. Cuisses simples. Soie des antenmes saus arliculation sensible. Dans ce groupe les genres Baccha, Psilote, Pipize, Chrysogastre, Syrphe, Doros (celui-ci doil peul-être êlre réuui avec le précídent) et Parague ont la soie des autenues simple; les Volucelles qui ainsi que les Séricomyies ont celle soie plumeuse se distinguent de ces dernières $I^{\circ}$. par le troisième article des antennes alongé; $2^{\circ}$. par leurs ailes écartées, même dans le repos.

Antennes avancées, un peu penchées, plus courtes que la tête, composées de trois articles, les deux prenier's courts, éganx entr'eux, le troisième le plus grand de tous, formant me palette presqu'orbiculaire portaut à sa base une soie dorsale plumense. - Trompe beaucoup plus courle que la tête et le corselet. - Palpes longs, filiformes, velns. - Téte de la largeur du corselet. - Hypostome perpendiculaile, portant un tubercule; partie inférieure de set hypostome formant une sorte de bec tronqué. - Front élevé en tubercule, ce qui forme uu bourrelet antour de l'insertion des antenues.- - Yeux assez grands, se réunissant un peu au-dessous du vertex dans les málés, espacés dans les femelles. - Trois ocelles disposés en triangle sur le vertex. - Corps ovale, plus ou moins velu. - Corselet un peu convexe. - Ecusśon de grandeur moyenne. - Ailes parallèles, leurs deux bords in térienrs se tonchaur daus lo repos, dépoưrvues de cellule pédifurme.-Cuil- lerons assez grands. - Balanciers longs. - Abdomen convexe en dessus, concave en dessous. Pattes assez grandes; cuisses simples; jambes postérieures arquées; tarses de longueur moyenne, leur premier arlicle au moins aussi long que les trois suivans pris eusemble, le einquième muni à son extrémité de deux forts crochets très-ćearlés, ayant dans leur entre-deux une pelotte forte, bilide.

N1. Meigen décrit quatre espèces de ce genre fondé par M. Latreille. Leurs mours sont ineonnues. Les iusectes parfaits se rencontrent sur les arbres.lLes mâles planent en l'air et se iiennent fort long-temps à la même place, ainsi que eeux des Volucelles, des Eristales et autres genres voisins. Nous allons signaler les espèces connues.

10. Séricomyie bombiforme, Ser. bombuformis no. 1. Neig. Dipt. d'Eur. tom. 3. pag. 343. pl.3r. fig. 8. Femelle. $2^{\circ}$. Séricomyie boréale, Ser. borealis $\mathrm{n}^{\circ} .2$. NE1G. id. fig. 9. Mâle.-Ser. Lappona. LA т. Dict. d'hist. nat. $2^{e}$. édition. Des environs de Paris. $3^{\circ}$. Séricomyie Lippone, Ser. Lappona $n^{\circ}$. 3. Meig. $i d$. pag. 344. (Retranchez les synonymes tirés des ouvrages de M. Latreille.) $4^{\circ}$. Séricomyie bourdonnanle, Ser. mussitans $n^{\circ} .4$. Meig. id. pag. 345. Celle-ci a élé prise sur l'Aubépine dans la forêt de Villers-Coterets.

\section{(S. F. et A. Serv.)}

SÉRIQUE, Serica. Mer. Omaloplia. Még. Des. Calal. Lat. (Fam. nat.) Melolontha. FAв. Oriv. Scarabceus. Linn. De (jeer. Geoff.

Genre d'insectes de l'ordre des Coléoptères, section des Pentamères, famille des Lamellieornes, tribu des Scarabéides (division des Pbyllophages ).

Dans la quatrième subdivision des Phyllophages (voyez Scarabrides) les Hoplies et les Monochèles se distinguent en ce qu'ils n'ont qu'un scul crochel aux tar'ses postérieurs; dans les Céraspis les crochets postérieurs sont iuégaux; les Anisoplies et les Lépisies ont ces mêmes crochets entiers. Le genre Dicranie a le chaperon très-b́chaneré, a vec ses angles antérienrs relevés, caractères que l'on retrouve dans les Diṕhucéphales : lés cuisses postérieures des Dichéles sont grosses et rentléeș, les dernières jambes de ces insectes sont larges et arquées; enfin le corselet beaucoup pliis long que large, notablement rétréci à sa partie postérieure, caractérice les Macrodactyles. Aucun de ces divers caraelères n'existè dans'les Súriques.

Antennes de neuf articies, celui de la base en massue, gonflé antérieurement, velu, le secord globuleux, les troisièmé et quatrième plus longs que le deuxième, cylindriques, les deux snivans cupulaires; les trois derniers format ine massue élroite, linéaire, très-alongée daus lés mâles. Labre 'échancré, velu: - Mandibules très-coustes, ípaisses, triangulaires. - Mâchoires deux fuis plas longues que les maludibules, triangulai- 
res, armées de six dents à leur extrémité - Palpes maxillaires de quatre articles, les trois premiers velus, le dernier presque eylindrique, un peu plus court que les trois autres pris ensemble: palpes labiaux de trois articles, les deux basilaires velus, le terminal très-pointu à l'extrémité, à peine recourbé. - Menton en carré-oblong, son bord antérieur échancré. - C'łaperon rebordé.-Yeux grus, saillans. - Corps assez eourt, ovale, convexe, un peu velouté. - Corselet transversal, son bord antérieur peu sinué, presque droit ainsi que le bord postérieur; bords latéraux arrondis vers les angrles antérieurs. - Ecusson presque triangulaire, un peu plus long que large, presqu'arroudi postérieurement. - Elytres longues, recouvrant des ailes, laissant à un l'extrémité de l'abdomen. - Abdomen épais. - Pattes longues, grêles; jambes antćrieures ununies au côté extérieur d'uue on deux dentelurcs outre la terminale; tarses très-longs, miuces; leurs articles cylindriques; le dernicr muni de deux croeliets égaux, également bilides.

Cè genre avoit été fondé par M. Mégerle de Muhlfeld et adoplé par MM. Lalreille et. Dejean, sous le nom d'Omaloplie; mais aueun de ees auteur's n'en ayant donné les caracic̀res, nous avous dû préférer la dénomination cie Sérique appliquée à ces insectes par M. Macleay, qui en développe les earactèrcs gén riques darns ses Horce entomologico. Cet auteur attribue dix articles aux antenues; nous n'cn royous que neuf; il donne au einquième une forme conique, bien certainement il est cupulaire, ct s'il y eu a trois de cette dernière forme, le dernier est done entièrement caché.

Le nom de ee geure vient d'un mot gree qui signifie : soyeux; il a rapport au duvet court dont le corps est revêtu. Ccs Coléoplères sont d'asscz petite taille; ils vivent à l'état parfait sur les végétaux dont ils rongent les feuilles; leurs larves se nourrissent probablement de raeines ainsi que celles des Hanueion:

$1^{\text {re }}$ Division. Chaperon distinctement échancré.

A eette division appartient le Hanneton brun $n^{\circ} \cdot 73$. pl. 55 . fig. 6. du présent Dictionuaire. Serica brumnea. MicL.

\section{$2^{\mathrm{e}}$. Division. Chaperon entier.}

Nous plaçons ici les Hannetons suivans de ee Dictionnaire. $1^{\circ}$. variable no. 89 . Serica variabilis, $2^{\circ}$. ruricole $\mathrm{n}^{\circ} \cdot 9^{2}$. Serica ruricola. Le Hanneton huméral $n^{\circ} \cdot 9^{3}$. est regardé comme une variété du rurieole par les auteurs modernes.

(S. F. et A. SERv.)

SÉROLE, Serolis. LÉAcr. LAT. Cymothoa. Fab. LAt.

Genre de Crustacé rle l'ordre des Isopodes, see Hist. Net. Ins. Tome X. tion des Aquatiques, famille des Cymothoadés (LAT. Fam. nat. du Règn. anim.), établi par Léach et adopté par Latreillc avec ces caraetères : post-abdomen de quatre segmens; yeux portís sur des tubercules et situés sur le sommet de la tête; trois appendices transverses et terminés en pointe, entre les premiers segmens du dessous de l'abdomen.

Ce genre se distingue parfaitement des Ichtio. philes, Cymothoa, CEga, Synodus, Cirolane, Euridice, Nélocire et Limnorie, par le post-abdomen qui, dans tous ces genres, est de cinq à six segmens, et par les premiers segmens du veutre qui son: déponrvus d'appendiees. Les anlennes supérievres des Séroles sont composées de quatre articles plus grands que les trois premiers des antennes inférieures; le derrier article est eomposé de plusieurs autres plus petits; les antennes inférieures ont cing articles, les deux premiers petits, le troisième et le quatrième, surtout ce dernier, alongés, le einquième composé de plusieurs antres plus petits. La seconde paire de pattes a l'avantdernicr article élargi et l'ongle très-alongé : la sixième paire de derric̀re sert à la marche, est un peu épineuse et a l'ongle légèrement courbé. Les lames branchiales ou appendices antérieturs du ventre sont formées de deux parlies égales, foliacées, arrondies à leur cxtrémité, garnies de poils à lenr base et placées sur uu pédoneule commun; les deux appendices postérienr's et latéraux sont petits et étroils, surlout l'intérieur, qui est à peine saillant; sur les trois premiers arlicles du ventre, entre lcs lames branchiales, il y a trois appendices transverses qui se terminent en pointe en arrière.

La seule espèce qui eompose ce genre est :

La SÉrole de Fabrieius, Serola Fabricii. LÉAcH, Dict. des sc. nat. tom. XII. pag. 340. Cymothoa paradoxa. FAB. LAT.

Ce Crustacé a trois tulsercules disposés en tıiangle entre le derrière des yenx; le dernier anneau d́c sou abdomen est caréné à sa base, et a sa partie silpérieure marquée de chaque côtć de deux lignes ślevćes, l'uue qui s'étend, dans une direcliou oblique, de la parlie supéricure de la base du lubercule de la carène ver's le côté, l'autre se dirigeanı parallèlement à l'auneau antérieur dc l'abdomen, nais u'arrivant pas jusçu’à la carène. Léach ne conuoît que deux individus de ce Crus. tacé; l'un est daus la collection de M. Banks, et vient des mers dc la Terre de Fen, c'est eelui que Fabricius a décril; l'autre vient du Sénécual.

(E.G.)

SERRICAUDES ou UROPRISTES. Nom donné par M. Dumćril ( $Z$ ool. analyt.) à une fumille d'Hyménoptères ayant pour caractères : ventre sessile terminé par une tarière dans les femelles. Ántennes non brisées. Eile est eonposée des genHh h 
res Orysse, Urocère, Sirex, Cymbèce et Tentbrède. (S. F. et A. Serv.)

SERRICORNES ou PRIOCÈRES. C'est sous ce nom que dans la $Z$ oologie analytique, M. Druméril désigne sa cinquième famille de Coléoptères-Pentamères; il lui assigne ces caracic̀res : élytres dures couvrant tout le ventre. Antennes en nasse, feuilletée d'un seul côté et en dedans. Elle est composéc de quatre genres : Lucane, Platycc̀re, Passale et Synodendre. (S. F. et A. SERv.)

SERRICORNES, Serricornes. 'Troisième famille de la section des Penlamères, ordre des Coléoptères. M. Latreille la caractérise ainsi :

Antennes de la plupart filiformes ou sétacées, celles des mâles ordinairement en panache ou en peigne, ou dentées en scie, terminées dans quelques autres en une massue perfoliée ou dentée. Elytres recouviant tout le dessus de l'abdomen, excepté dans le genre Atractocère où les ailes sont nues et étendues. - Pénultième article des tarses souvent bilobé.

L'auteur établit deux grandes divisions dans cette famille.

I. Sternoxes, Sternoxi. (Voyez ce mot.) Cette division renferme deux tribus, Buprestides et Elatérides.

\section{Malacodermes, Malacodermi.}

Corps de la plupart mou, flexible, incliné en devant. - Tête basse ou très-inclinée et entièrement découverte en dessous, c'est-à-dire point cacliée par une saillie antérieure du présternum. - Extrémité postérieure de ce présternum ne se prolongeant pas notablement en manière de pointe ou de corne.

\section{Tribu. Cébrionites, Cebrionites.}

Mandibules terminées en une pointe simple, sans échancrureni dent. - Palpes filiformes ou plus grêles à leur extrémité. - Corps arqué ou bonıbé en dessus, de forme oblongue ou hémisphérique.

A. Mandibules saillantes ou découvertes. Palpes maxillaires filiformes ou en mas. sue, terminés par un article tronqué ou obtus, ne finissant pas en pointe. Corps ovale ou oblong.

a. Articles des tarses entiers. (Antennes simples ou en scie, quelquefois trèscourt es et en massue dans les fcmelles, n'ayant jamais au-delà de onze articles.)

Anélaste, Cébrion, Sandalıs.

b. Pénultième article des tarses bilobé. (Antennes de plusieurs flabellées ou pectinées, composées quelquefois de vingt articles et au-delà.)

† Antennes des mâles flabellées ou pectinées.

Rhipicère, Ptilodactyle.

† † Antennes simples.

Dascille.

B. Mandibules peu ou point apparentes. Palpes maxillaires terminés en pointe. - Corps presque liémispliérique ou en ovoide court, bombé, (sautant dans plusieurs. ) - Antennes simples, de onze articles.

a. Pénultième article des tarses bilobé. Elode, Scirte.

b. Article des tarses entiers. Nyctée, Eubrie.

4. Tribu. Lampyrides, Lampyrides.

Corps droit, mon.-Corselet plat, tantôt deuicirculaire, tantôt carré ou trapézoïde, avancé sur la tête qu'it recouvre totalement ou postérieurement. - Palpes maxillaires au moins, plus gros vers leur extrémité. - Mandibules généralement petites, déprimées, pointues, entières au bout dans la plupart, unidentées an côté interne dans les autres. - Pénultième article des tarses bilobé ; crochets du dernier ni denté, ni appendicé. - Femelles quelquefois aptères ou n'ayant que des élytres très-courtes.

A. Antennes très-rapprochées à leur base. - Bouche petile. - Téte des uns avancée en museau, celle des autres cachée entièremcnt ou en majeure partie par le corselet. - Yeux très-grands dans lcs mâles. - Extrémité postérieure de l'abdornen phosphorescente dans plusicurs.

Iycus, Omalise, Phengode, Amydète, Lampyre.

13. Antennes séparées à leur base par un écart nolable. - Tête point avancée en manière de museau, obtuse ou arrondie en devant, simplement recouverte à sa base. - Bouche et Yeux de grandeur ordinaire.

Drile, Téléplıore, Malthine.

5॰. Tribu. Mélyrides, Melyrides.

Corps généralement ohlong, avec le dos plan ou déprimé. - Mandibules toujours échancrées ou bidentées à leur pointe, étroitcs et alongées. - Palpes du plus grand nombre filiformes, courts. -Téte simplement recouverte à sa base par un 
corselet plat on peu convexe, peu fortement bounbé, généralement en carré plus ou moins long. - Articles des tarses entiers; crochets unidentés ou bordés intérieurement par une membrane formant un appendice semblable à une dent.

\section{A. Palpes filiformes.}

a. Des vésicules intérieures mais exsertiles sur les côtés du corselet et de ta base du ventre.

\section{Malachie:}

b. Point de vésicules exsertiles sur les côtés du corsclet et de la base du ventre.

$$
\text { Zygie, Mćlyre, Dasyte. }
$$

B. Palpes maxillaires terminés par un arlicle plus grand, sécuriforme.-Antennes plus grosses vers leur extrémitć. Premier article des turses fort court.

Pélécophore.

Nota. M. le comte Dejean à qui l'on doit la crćation de ce geure le rapporte dans son Catalogue à la section des Tétramères. N'ayant point ces insectes, nous avons dû en traitant de ce genre à sa lct tre le laisser à la place que son auteur lai avoit assignée. M. Latreille dans ses Familles naturelles le range parmi les Pentamères; mais cet ouvrage n'a paru qu'après l'impression de notre article Pélécophore.

\section{6॰. Tribu. Clairones, Clerii.}

Corps ordinairement cylindracé, plus étroit en devant jusquà l'abdomen. - Tête entoncée postérieuremeut dans le corselet.-Mandibules échancrées ou bifides à leù exırémité. - Antennes tantôt presque filiformes et dentées en scie, tantôt terminées en massue ou grossissant sensiblement. - Pénultiène article des tarses bilobé, le premiei très-court, peu visiblc dans plusicurs.-Les quatre palpes ou deux d'entr'eux avancés, terminés en massue ou plus gros à leur extrémité. Yeux de la plupart ayant une petite échancrure interne près de la base des antennes.

A. Antennes jamais en scie, toujours terminées en massue. - Tarses, vus en dessus, n'offiant que quatre articles, le premier trc̀s-court, caclié en dessus par lat base du second.

$$
\text { Nécrobie, Clairon, Opile. }
$$

B. Antennes soit grossissant sensiblement vers le bout, souvent presqu'entièrement en scie, soit'terminées par sept ou trois articles pius grands et formant une massue dentće. - Cinq articles distincts à tous les tarses.

a. Autcnaes grossissant insensiblement.
Eurype, Axine, Priocère, Thanasime, Tille.

b. Antennes terminées brusquement par sept ou trois articles plus grands que les précédens.

Enoplie, Cylidre.

\section{$7^{e}$. Tribu. Lime-bois, Xylotrogi.}

Corps toujours long, étroit, ordinairement linéaire. - Tête presque orbiculaire ou presque globuleuse, dégagce ou dislincte du corselet par un étranglement brusque en forme de cou. Mandibules courles, épaisses et dentées. - Antennes filiformes ou amincies vers le bont. - Tarses filiformes, leur pénultième article rarement bilobé. - Elytres quelquefois très-courtes.

A. Les quatre tarses postérieurs longs, trèsgrêles. - Antennes un peu élargies ver's leur milieu et amincies vers le bout. - Palpes maxillaires bcaucoup plus grands que les labiaux, pendans, en peigne ou en houppe dans les mâles, terminés dans les femelles par un article grand et ovoide. - Corps trèsalongé, cylindro-linéaire. - Elytres très-courtes dans quelques-uns.

$$
\text { Alractocère, Hylécæete, Iyméxy- }
$$
lon.

B. Antennes de longueur et de grosseur moyenne, de la mćme grosseur partout. - Palpes fort courts, pen ou point saillans, semblables dans les deux sexes et à articles simples.

$$
\text { Cupès, Rhysode. }
$$

8. Tribu. Ptiniores, Ptiniores. (Voyez ce mot.)

$$
\text { (S. F. et A. Serv.) }
$$

SERROPAlPE, Serropalpus. Heluen. Lat. Payx. Gylu. Illla. Dircoea. IAB.

Genre d'insectes de l'ordre des Coléoptères, section des Hétéromères (première division), famille des Sténélytres, tribu des S'curipalpes.

Tous les genres de la tribu des Sécuripalpes, hors celui de Serropalpe, ont le pénultième article de tous les tarses bilobć.

Antennes filiformes, composées de onze arlicles, la plupart alongés, filiforaes, les plus rapprochés de la base plus courts que les autres, un peu obconiques. - Labire avancé, membraneux, presque carré, arrondi antérieurement. - Mandibules petiles, en triangle court, épaisses, presque sans dculs. - Mâchoires nembraneuses, petites, composées de deux lobes, l'extérieur plas grand, obtus. - Palpes inéganx; les maxillaires grands, trois fois plus longs que les labiaur, très-

$$
\text { II h } 2
$$


avancés, comprimés, de quatre articles, le second et le troisième.formant une dent de scie au côté interne (le troisième surtout), le quatrième très-grand, patelliforme : palpes labiaux presque filiformes, de trois articles, le terminal presqne obtrigone. - Lèvre membraneuse, en carré long, plus étroite que le menton, dilarée à son extrémité qui est refendue; menton coriace, presque carré, se rélrécissant un peu ̀̀ son extrémité. Tète inclinée, arrondie. - Corps prescque cylindriqque, alongé, rétréci postérieurement. - Corselet à peine aussi large que long, point rebordé, convexe.-Ecusson petit, distinct. - Elytres de la largeur du corselet, très-alongées, linéaires, rétrécies postérieurement, convexes, recouvrint l'abdomen et les ailes. - Abdomen long. - Pattes longues, grêles; jambes terminées par deux épines fort courtes : tarses minces, le pénultième article des antérieurs et des inter:nédiaires bilobé, ce même article entier dans les tarses postéricurs.

Ta forme de ses palpes maxillaires a valu à ce genre le nom qu'il porte; il est composé de deux mots latins qui expliquent cette conformation. Les larves de ces Coléoptères vivent dans le vieux bois sec, particulièrement dans celıi du sapin; elles le percent presque jusqu'à la moelle et y subissent leurs métamorphoses après s'être rapprochées de l'écorce; ou les y trouve prêtes à paroître sous leur forme parfaite, an mois de juin. On rencontre aussi quelquefois les Serropalpes dans les maisons lorsqu'on y a employé récemment des plauches de sapin. L'espèce la plus connue est le Serropalpe strié, Serropalpus striatus, Lat. Gen. Crust. et Ins. tom. 2. pag. 193. $n^{\circ}$. 1. tab. IX. fig. 12. - Dircca barbata n०. 1. Wа в. Syst. Eleut. Mais son synouyme tiré de l'Entomol. systém. ainsi que celui d'Olivier sont fort donteux. Voyez Lst. Loco citat. et Schоеx. Syzzon. Ins. tom. 3. pag. 48. (S. F. et A. SERV.)

SESARMA. SAY. M. Thomas Say a publié dans le Journal de l'Académie des sciences naturelles de Philadelphie, tom. I, pag. $7^{3}$, sous le nom d'Ocypode reticulatus, la description d'un vrai Grapse, dont il a formé le genre Sesarma; plus tard il a reconou que cet animal devoit être rapjroché des Grapses, quoiqu'il eût les mours des Ccypodes. (E. G.)

SÉSIE, Sesia. Fab. Lat. Ross. Panz. God. Lasp. Sphinix. Linn. Geoff. De Géer. Esper. Hubir. Ernest.

Genre d'insectes de l'ordre des Lépidoptères, famille des Crépusculaires, tribu des Zygénides.

Des dix genres que contieut ce!te tribu, ceux de Procris, Atychie, Glaucopide, Aglaope et Stygie se distinguent par leurs antennes bipectinées, an moins dans les mâles; et ceux d'Figocire, Thyride, $Z_{y}$ gène et $S_{y}$ ntumide ont leurs antennes dépourvues de houppe écailleuse à leur extrémité.

Antennes en fusean, terminées par une petile houppe d'écailles; simples dans les femelles, dentées en.scie dans .les mâles. - Palpes labiaux grêles, écailleux, comprimés à leur base, cylindro-coniques, pointus et relevés à leur sommet, composés de trois articles, le second très-garni d'écailles, le dernier long. - Langue alongée, roulée en spirale. - Ailes horizontales dans le repos, écartées, tonjours vitrées; cellale de la base des inférieures fermée en arrière par deux nervures qui se croisent en X. - Abdomen presque cylindrique, garni à son extrémité d'une brosse d'écailles, quelquefois trilobée. - Jambes postérieures ayant deux paires d'épines, la terminale fort grande.

Les chenilles des Sésies ont seize pattes; elles sont rases, cylindriques, sans corne à l'extrémilé du corps; elles se nourrissent de l'intérieur des végétaux et mêtne du bois du tronc et des racines restées à la superficic de la terre, de quelques arbres forestiers. Lorsque la chenille a pris tout son accroissement, elle se rapproche de l'écorce de l'arbre, y fait nn trou qu'elle boucle avec sa coque, dont la partie extérieure est protégée par de petits morceanx de bois qu'elle $y$ ajuste et qu'elle lie avec de la soie. C'est sous la forme de chrysalide qu'elle passe ordinairement l'hiver; cette chrysalide est cylindrique, ses denx bouts sont atténués, sa tète porte en avant deux pointes saillantes, et chaque segment du corps, à partír du corselel jusqu'à l'anus, est muni de deux rangs d'épines très-fines, un peu inclinées en arrière, dout les postérieures sont plus courtes. Ces épines servent d'appui à la chrysalide lorsque l'insecte parfait est prêt à paroître, pour se porter vivenent sur la partie de sa coque qui répond au trou de l'écorce du végétal dans lequel elle a vếcu. Les poiutes de la tête lui servent à percer la cloison qui fermoit ce trou; à force d'efiorts la clırysalide parvient à faire sortir de l'ouverture à peu près la inoitié antérieu:e de son corps, et après un court repos l'insecte parfait sort de sa peau de chrysalide. C'est ordinairement au printemps que l'on rencontre les Sésies dans lenr dernier état. Elles voleut peu; la plupart des femelles restent toute leur vie sur la lige du végétal qui les a vu naître. Les mâles fréquentent quelguefois les fleurs.

Feu M. Godart dans ses Lépidoptères cé France, ouvrage auquel nous renvoyons le lecteur, a décrit dix-sept espèces de Sésies; nne partie des détails que nous venons de donner sur les mœurs sont mentionnés par lui dans cet ouvragge ainsi que dans quelques-uns de M. Latreille; le reste est dû à nos observations particulières. Fabricius rapporte ving-trois espèces à ce genre, mais plusieur's d'entr'elles appartienuent à celui de Sphinx, telles que les suivantes : Tantalus $n^{\circ}$. I, Hylas $\mathrm{n}^{\circ} .3$, Jadus $\mathrm{n}^{\circ} .4$, Stellatarum 1 $^{\circ} .5$, Pandora 
$\mathrm{n}^{\circ} .6$, fucifornis $\mathrm{n}^{\mathrm{0}} .11$, bombyliformis $\mathrm{n}^{0} .12$, et peut-être aussi brunneus $\mathrm{n}^{\circ} .7$, octonnaculata ${ }_{11}^{\circ}$. 8. et Thysbe $n^{\circ}$. 10. La Sesia marica $n^{\circ} \cdot 9$. pourroit bien appartenir aux Glaucopides. Nous ne savons ì quel genre rapporter la Sesia melas $\mathrm{n}^{\circ}$. 2. Les onze dernières espèees sont bien certainement des Sésies, excepté cependant la dixliuitième (haentorthoidalis. Sphinx Leucaspis. Cв_av.) qui nous paroît être une Glaucopide.

(S. F. et A. SERv.)

SÉTICAUDES ou NÉMATOURES. Nom que donne M. Duméril (Zoolog. analyt.) à une famille d'Aptères dont les earaetères sont : des nî̀choires. Abdomen très-distinct. Des antennes. Six pattes. Ventre terminé par des soies. Elle contient trois genres, Forbieine, Lépisme et Podure. (S. F. et A. SERv.)

SÉTICORNES ou CHÉTOCËRES. C'est le nom que donne M. Duméril (Zool. analyt.) à une famille de Lépidoptères ayant les caractères suivans : antennes en soie, rarement pectinées, et contenant les genres Lithosie, Noetuelle, Crambe, Phalène, Pyrale, Teigne, Alucite et Ptérophore.

(S. W. et A. SERV.)

SIAGONE, Siagona. LAt. Bonell. Dej. (Sp.) Cucujus, Galerita. Fав.

Genre d'insectes de l'ordre des Coléoptères, seetion des Pentamères, famille des Carnassicrs, tribu des Carabiques (seetion des Bipartis).

Dans eette division les genres Eneelade et Siagone forment un groupe partieulier, caraetérisé par le menton inarticulé couvrant tout le dessous de la tête. (Voy. Scaptère.) Les Encelades n'ont pas le côté intéricur de leurs jambes de devant fortement éehancré, ce qui les sépare des Siagunes.

Antennes presque sétacées, un peu moins longues que le corps, composées de onze artieles; ces articles, à l'exeeption du premier, à peu près de même longueur; le premier alongé, eonique; le second et le troisième presque coniques, les autres eylindriques. - Labre transverse, un peu avaneé, presquue coupé earrément, dentelé à sa partie antérieure. - Mandibules fortes, un peu avanećes, arquées, ayant à lem base une assez forte dent. - Palpes peu alongés; dernier article des maxillaires extérieurs allant un" peu en grossissant vers l'extrémité; palpes labiaux ayant ce même article fortement séeuriforme. - Menton inartieulé, sans suture, très-grand, reeouvrant presque tout le dessous de la tête, très-fortement éehancré, ayant dans son milieu une dent bifide. -Tête assez grande, presque carrée, assez plane, anunie d'un sillon transversal à sa partie postérieure. - Corps très-déprimé. - Corselet presque en cœur, éehaneré en devant, un peu prolongré postérieuremen!; séparé des élytres par un étran- glement. - Abdomen ovale. - Pattes de longueur moyenne, euisses assez fortes: jambes antérieures point dentées extérieurement, fortement échancrées an eôté intérieur; artieles des tarses entiers, le dernier le plus grand ${ }^{3}$ tous.

Les espèees connues de ee genre liabitent le nord de l'Afrique et les Indes Orientales; la forme déprimée de leur corps fait présumer qu'elles se tiennent sous les pierres ou sous les éeorces; leurs couleurs ordinaires sont le brun ou le noir. Les auteurs divisent ainsi les Siagones.

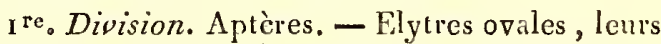
angles huméraux nullement saillans.

On doit rapporter ici : $1^{\circ}$. Siagone rufipède, S. rufipes. Lat. Gener. Crust. et Ins. tom. I. pag. 209. $n^{\mathrm{o}} \cdot \mathrm{x} \cdot \mathrm{pl} \cdot \mathbf{7 \cdot} \cdot \mathrm{fg} \cdot \mathrm{9} \cdot-$ Cucujus rufipes $\mathrm{n}^{\circ} \cdot 7$. Faв. Syst. Eleut. $2^{\circ}$. Siagone fuscipède, $S$. fuscipes. Bonelu. DeJ. Spéc. tom. 1. pag. 359.

$2^{\ominus}$. Division. Ailés. - Elytres moins ovales et leurs angles huméraux mieux prononeés que dans la première divísion.

Là se placent $1^{\circ}$. Siagone déprimée, $S$. depressa. DEJ. Spéc. tom. 1. pag. 36ı. n ${ }^{\circ}$. 5. Galerita depi'essa no. 5. F а в. Syst. Eleut. $2^{\circ}$. Sizgone plane, S. plana. - Galerita plana $\mathrm{n}^{\circ} .6$. Fab. id. 3०. Siagone flésus, S. flesus. De.s. $i d$. pag. 363. $n^{\circ} \cdot 6.2$ Galerita flesus $11^{\circ} .7$. FАв. $1 d$. $4^{\circ}$. Siagone Crapaud, S. Bufo. - Galerita Bufo no. 8. Fab. id. (S. F. et A. SERv.)

SIAGONIE, Siagonium. Nom donné par M. Kirby (Introduct. entoml. 1. 1. 3.) à un genie d'insectes Coléoptères qui répond exactemeat ì celui de Prognathe de M. Latreille. Voyez ProGNATHE à la table alpbabétique.

$$
\text { (S. F. et A. Serv.) }
$$

SIALIS, Sialis. Lat. Hemerobius. Linn. $\mathrm{D}_{\vec{E}}$ Géer. Geoft. Oliv. (Encycl.) Semblis. Mab.

Genre d'insectes de l'ordre des Névroptères, seetion des Filicornes, famille des Planipennes, tribu des Semblides (Mégaloptères Encycl. artiele Planipennes).

Des trois genres qui eomposent cetle tribu, ceux de Corydale et de Chauliode ont trois ocelles très-visibles, Jes ailes eouchées horizontalement sur le corps et tous les articles des turses entiers.

Antennes simples, sétacées, eomposées d'un grand nombre d'articles cylindriques. - Labre avaneé, demi-coriace, transversal, enticr, ses bords latéraux arrondis. - Mandibules petites, cornées, presque trigones, leur extrémité formant brusquement un erochet aigu, sans dent. - Mâchoizes presque crustacées, ayant deux lanières à leur extrémité; celles-ci petiies, presque droites, conniventes, obtuses; l'extérieure coriace, un peu plus épaisse que l'autre : l'interne un pea plus 
longue, presque linćaire. - Palpes filiformes, leurs articles presqu'égaux, cylindriques, les maxillaires plus longs que les labiaux, de quatre articles; les labiaux de trois; le dernier des uns et des antres un pen aminci à sa base, nbtus à l'extrémité. - Lèure carrée. - Tête transverse, déprimée, penchée, de la largen du corselet. Point d'ocelles. - Corps un peu arqué. - Frothorax assez grand, Iransversal, presque cylindrique. - Ailes en toit, rabaissées postérieurement. - Abdomen beaucoup pius court que les ailes. - Pattes de longueur moyenne; tarses de “ing arlicles, le pénuliième bilobé.

Les détails relatifs anx mœu's des Sialis sont mentionués dans cet ouvrage, article Не́uéróse, tome VII, page 52 , seconde colonne, et page 54, seconde colonne jusqu'à la fin de l'article. L'espèce conuue est très-commune aux environs de Paris, c'est le Sialis noir, $S$. niger. Lat. Gener. Crust. et Ins. tonı. 3. pag. 200. $n^{\circ}$. 1. Hémérobe aquarique $\mathrm{n}^{\circ}, 16$. du présent Dictionnaire.

(S. F. et A. SERv.)

SibinIE, Sibinia. Gram. Voyez Trchie.

(S. F. et A. Serv.)

SICAIRES, Sicarii. Seconde tribu de la famille des Tanystomes, première section' de l'ordre des Diptères. Ses caractères sont :

Sucoir de quatre pièces. - Dernier article des antennes toujours déponrvu de stylet ou de soie, offrant des divisions transversales, (au nombre de trois au moins.) - Trompe souvent retirce en grande parlie dans la cavité buccale, terminée jar deux grandes lèvres saillantes.

Cetie tribu renferme les genres Cononyie, Chirouyze et Pachystome.

C(ExOMYIE, Cononryia. Lat. MeIg. Stratromis. Panz. Sicus. Fab. Scheli.

Geure d'insectes de l'ordre des Diptères, prerière section, famille des Tanystones, tribu des Sicuires.

Les Chiromyzes et les Pachysiomes qui composeut cette tribu avec les Conomyies, s'en dislinguent aisément par leur écussou matique.

Antennes ì peine plus longues que la tête, composées de trois articles, le prewier alongé, cylindrique; le second obconique, un peu cyathiforme; le troisième plus long que les premiers, alongé, conique, parnissunt avoir huit anneaux. - Trompe ponvant entrer en grande partie dans la cavité buccale, terminée par deux grandes lèvres saillantes. - Suçoir composé de quatre soies, la supérieure pius forte, canaliculée en dessous. - Palpes presque de la longneur de la trompe, druits, relevés, velus. - Têie plus étroile que le corsclet. - Yeux réunis daus les mâles, espacés dans les femeiles. - Trois ocelies disposés en triangle sur les bords d'upe éminence frontale.
- Corps asscz long. - Corselet ovale, convese, élevé. - Ecusson terminé par deux épines redressées. - Ailes parallèles, couchées l'une sur l'autre dans le repos; cellule discoïdale allant en se rétrécissant ver's son extrémité. - Balanciers assez longs. - Abdomen un peu convexe, tant en dessus qu'en dessous. - Pattes assez grandes, minces : premier article des tarses presqu'aussi long que les quatre autres réunis, le dernier muni de deux forts crochets et de trois pelottes, l'intermédiaire plus relevée que les deux autres.

Nous ne connoissons pas les mœurs de ces Diptères dont le nom vient de deux mots grecs signifiant: mouche de boue. M. Latreitle qui a fondé ce genre en cite deux espèces. $1^{\circ}$. Conomyie ferrugineuse, C. ferruginea. Lat. Gener. Crust. et Ins. tom. IV. pag. 281. - Encycl. pl. 387. fig. 8. Mâle. $2^{\circ}$. Cœnomyie bicolore, $C$. bicolor. id. M. Meigen regarde ces deux espèces comme variét's d'une seule qu'il décrit sous le nom de Conomyia Jerruginea, Dipt. d'Eur. tom. 2. pag. 18. $n^{\circ}$. 1. M. Latreille observe que cet insecte répand une odeur aromatique semblable à celle du mélilot long-temps encnre après sa mort; nouls avons fait la même remarqune. Celle espèce varie beaucoup; suivant M. Meigen, Fabricitis l'a décrite ainsi que ses variétés sous les noms de Sicus ferrugineus, bicolor et errans. M. Wiédemann (Dipt. exotic.) assure que le Sicus crucis du rrêtme auteur est encore la même espèce, qnoique Fabricius lui donne pour patrie les îles de l'Amériqque méridionale.

(S. F. et A. SERV.)

\section{CHIROMYZE, Chiromlyza. WiÉ D. LAT. (Fam.} nat.)

Genre d'insectes de l'ordre des Diptères, première section, famille des Tanystomes, tribu des Sicaires.

- Denx genres composent cette tribu avec celui de Chiromyze, savoir : les Cœnomyies qui ont l'écusson épineux et les Pacliystomes dnnt les antennes de forme cylindrique sont insérées sur une éminence, leur premier article étant le plus long de tous.

ii. Wiédemann créateur de ce genre en donne les caractères dans ses Diptera exotica (Pars I. Kilice. r821.) de la manière suivante : antennes rapprochées, avancées, velues, à peine plus longues que la tête, composées de trois articles, te premier très-court, cylindrique, le second cyathiforme, à peine plus long que le précédent, le troisième subulé, presqu'aussi long que les deux précédens réunis. Bouche petile, point saillante. Yeux des mâles se réunissant sur le front. Trois ocelles. Ailes en recouvrement. Balanciers trèsgrands. Paties assez grandes; les antérieures plas longues que les intermédiaires.

L'auleur a tiré le nom de ce gerre de deux mots grecs don l'un signifie : main et l'autre: mouche; il le rapporte à sa cinquième famille ( $X_{y}$ lotoma') 
dans laquelle le troisième article des antennes n'est pas anvelé. M. Latreille (Fam. nat.) regarde ce troisième article comme annelé, à trois divisions. En l'examinant avec une forte loupe, il nous a paru composé de cinq anneaux, le premier conique, le plus long de tous, glabre à sis base, bordé à sa partie supérieure de cils roides disposés en verticilles; les trois suivans conrts, coniques, velus, allant en diminuant de.grosseur, le cinquième très-petit, terminé par un faisceau de poils.

L'abdomen des femelles observé avec soin sur un individu de la Chiromyze rayée, dans le plus grand développement de l'organe propre à déposer les oufs (style anal. Wiédem.) a quatre segmens; les deux derniers, mais surtout le quatrième, se rétrécissent à leur partic postérieure. Le style anal beaucoup plus étroit que l'abdomen, égalani à peu près les deux tiers de sa longueur, est composé de quatre articulations qui von $\mathrm{en}$ diminuant de longueur de la première à la dernière; les trois premières plus étroites à leur base qu'à leur extrémité qui est évasće, et marquées au-delà du milien d'une carène transversale un peu élevée; la dernière est renflée dans son milien; ces articulations paroissent pouvoir rentrer les unes dans les autres et se loger dans le dernier segment de l'abdomen.

Les Chiromyzes connues sont de l'Amérique méridionale : on n'a point encore de renseignemens sur leurs mœurs. M. Wiédemann en décrit trois espèces. $1^{\circ}$. Chiromyze rayée, Chir. vittata. Longuenr 7 lig. Corps d'un jaune or hracé. Corselet ayant quatre baudes longitudinales brunes; nervures des ailes bordées de brun pour la plupart. Femelle. $2^{\circ}$. Chiromyze brune, Chir. fuscana. Longueur 7 à 8 ligues. D'un bıun ochracé. Corselet avec des bandes longitudinales peu apparentes; les derniers segmens de l'abdomen séparés par une ligne d'une nuance plus claire. Femelle. క̌o. Chiromyze ochracée, Chir ochracea. Longrueur 4 lignes. Enlièrement de couleur d'ochre. Ailes lrunes. Màle. (S. F. el A. Serv.)

SICUS. FAв. Ce geure de Diptères nous paroît répondre à celui de Conomyie Lat. Voyez ce mot page $430^{\circ}$. de ce volume.

$$
\text { (S. F. et A. Serv.) }
$$

SIGALPHE, Sigalphus. LAt. Spinol: Cryptus. Fab. Ichneumon.-De Géer. Olit. (Encycl.) Georf. Bracon. Jun.

Genre d'insectes de l'ordre des Hymélioptères, section des Térébrans, famille des Pupivores, tribu des Ichneumouides (division des Braconides Nов. Voyez tribu des Iclineumonides, pag 43. de ce volume).

M. Latreille dans ses Fam. natur. partage ses Ichneumonites en deux divisions d'après le nombre des articles qui composent les palpes maxil- laires; la seconde de laquelle dépendent les genres : Sigalphe, Chélone, Alysie, Rogas, Cardioclile, Helcon (1) et Euljazus, a pour caractères : palpes maxillaires de six articles (les labiaux de qualre). Dans notre tableau des Ichneumonides la seconde division ane nous nommons les Braco. nides a deux subdirisions d'après les mêmes caractères de palpes; la première se dislinguant par les palpes naxillaires de six arlicles et les labiaux de quatre. Là nous plaçons les genres : Sigalphe, Alysie, Helcon, I'ne et Aulaque : les deux derniers ont l'abdomen implanté à la partie supérieure du métathorax; les Alysies ont les mandibules presqu'en carré, grandes, écartées et leur abdomen n'est point en massue ni concave en dessous ; celui des Helcons est linéaire el composéde sept segmens outre l'anus; la partie antérieure de leur mésothorax s'élève en hosse audessus du prothorax. Quant aux Chélones, la première cellule discoidale supériemre de lenrs premières ailes est confondue avec la jrenière cubitale, ce qui nous les fait slasser parmi les Iclneumonides vrais. Nous ne connoissons pas les genres Rogas, Cardiochile et Eubazus de M. NEes d'Esenbeck, mais cet auteur leur attribue un abdomen plane. Nous pensons donc avoir suffisamment distingué des Sigalphes tous les genres ałmis dans leur groupe tant par M. Latreille que par nous.

Antennes sétacées, multiarticulées, leur premier article le plus grand et le plus gros de tous, ovale-cylindrique, - Mandibules arquées, leur extrémité aiguë, bidentée, la dent inférieure plus petite que la terminale. - pal,ues velus, les vaxillaires sélacés, de six articles, les deux premiers courts, les autres cylindriques, allant en diminuant de longueur et de grosseur jusqu'au sixième; palpes labiaux filiformes, de quatre articles, he second dilaté à sa partie intérieure, le dervjer le plus long de tous. - Téte à peu près de la largeur du corselet. - I cux de grandeur moyenne, saillans. - Trois ocelles grands, placés en lingre courbe sur le vertex, assez rapprochés. - Corps assez. génćralement chagriué. - Corselet ovale-globnleux; prothorax très-court, paroissant ì peine en dessus; mésothorax assez grand, bombé supérieurement, beaucoup plus élevé que les autres parties du thorax : métathorax très-déprimé, un peu plus court que la portion précédente, anguleux, bicaréné en dessus. - Ailes supérieures ajant une

(1) Dans notre tableau des Ichneumonides, page 43 de ce volume, nous avons attribué par crreur aux Helcons, des palpes maxillaires de cinq articles et les labiaux de trois; un nouvel examen nous fait reconnôtre aujourd'hui que les palpes maxillaires ont six articles (les deux premiers fort courts, le troisième aplati et dilaté à sa partie intéricure) et les labiaux quatre. Il s'ensuit de certe rectification que ce genre apparticur à la première subdivision de notre division des Braronides. 
ccliulc radiale assez alongée, allant en se rétrécissant après la seconde cubitale, se terminant cn pointc avant le bout de l'aile et trois cellules cubitales, les deux prcmières presqu'égales, en carré-long, la troisième complète, la plus grande de toutes; une seule nervure récurrente aboulissant dans la promic̀re cellule cubitale près de la nervure d'iutersection de celle-ci et de la seconde; trois cellules discoïdales, l'inférieure descendant jusçu'au boidd postéricur de l'aile. - Abdomen inséré à la partic supérieure du mélathorax, en massue, très-voûté après le premier segment, concave cul dessous, paroissant cn dessus n'être formé que de trois segmens; le premier appliqué au corselet par une base assez large, lc second presqu'aussi long que le premier, le troisic̀me le plus iong de tous; les autres cactrés cn dessous de celui-ci dans la cavité de l'abdomeu : tarière (des femellcs) courte, conique. - Pattes assez fortcs; jambes terminśes par deux fortes épines; premier article des larses presquaussi long quc les quatre autres pris ensemblc; le dernier ayant deux crochets fort courts et une petite pelolte bifide, courle.

La larre du Sigalplic irrorateur vit dans le corps des chenilles de plusieurs Lépidoptc̀res nocturnes. Après y avoir pris tout son accroissement elle en sort ct se file nne coque d'apparence membraneuse, très-mince, ovale-cylindrique et de couleur blanche. De Géer l'a eu de la chrysalide de la Noctuelle Psi.

Rapportez à ce geure le Sigalphe irrorateur, S. irrorutor. Lat. Gen. Crust. et lns. tom. 4. pag. I3.

$V$ oyez pour la description et les anires synonymes, Ichmeumon arroseur $n^{\circ}$. 147 . de ce Dictionnaire. Au synonyme dc Geoffioy, lisez tom. 2. a u lieu de tom. $\mathrm{s}$.

ALYSIE, Alysia. Lat. Cryptus. Faв. Bassus. Paiz. (Révis.) Spinol. Bracon. Jur. Cechenus. InLIg. Ichneumon. Paxz. Faun.

Genre d'insectes dc l'ordre des Hyménoptères, secion des Térébrans, famille des Pupivores, tribu des Ichneumonides (division des Braconides Noв. Voyez Tribu des Ichueumonides, pag. 43. de ce volume.)

Dans les Familles naturelles de M. Latreille, les genres voisins de celui d'Alysie sont : . ${ }^{\circ}$. Sigalphe, qui a l'abdomcn en massue et concave en dessous; $2^{\circ}$. Chélone, dans lequel la première cellule discoïdalc supérieure des premicres ailes est confondue avec la première cubitale : de plus ces deux geures ont les mandibules terminées en poinle; $33^{\circ}$. Helcon, dont les mandibules sont contorinées comme celles des deux genres précédens et dont le mćsolhorax. s'élève en bosse audessus du prothorax. Quaut aux Rogas, aux Cardiochiles el aux Eubuzus de M. Nées' d'Esenbeck, ils ne nous sont pas assez connus pour pouvoil établir leurs différences. Les autres genres dont nous rapprochons les Alysies dans notre tablean des Ichneumonides, pag. 43. de ce volume, sont : 10. Fœne et Aulaque, dont l'abdomen est inséré sur la partie supérieure du métathorax; $2^{\circ}$. Vipion, Bracon et Microgastre, dont les palpes labiaux n'ont que trois articles.

Ce genrc dû à M. Latreille a quelques rapports par ses inandibules tridentées avec les Hyménoptères de la tribu des Gallicoles, et particulièrement a vec le genre Figite (voyez Lat. Fam. nat. pag. 446.); mais les ailes inférieures de ceux-ci n'ont an plus qu'une nervure, et la tarière des femelles est roulée en spirale dans l'intérieur de leur abdomen.

Antennes longues, sétacées, composées d'articles nombreux, presque moniliformes. - Labre pelit, presque trigone. - Mandibules grandes, avancées, alongées, presque carrées, comprimées, appliquées dans le sens de leur largeur aux côtés de la tête, un peu convexes extérieurement, carénées; voûlées cn dessous, ne se rapprochant pas l'une de l'autre, mème dans le repos; leur extrémité nıunie de trois dents, celle du milieu un peu plus grande. - Mâchoures membraneuses. - Palpes maxillaires très-alongés, pendans, filiformes, de six articles; palpes labiaux de quatre articles. - Lèvre mernbraneuse, entière; menton membraneux. - Tếte grande, un peu plus large que le corselet. - Yeux petils. - T'rois ocelles grands, rapprochés en triangle sur la partie sapérieure du front. - Corselet ovale; prothorax étroit, un peu alongé en manière de cou; métathorax un peu anguleux. - Ecusson de grandeur moyenue. - Ailes supérieures ayant une cellule radiale grande, s'approchant du bout de l'aile, se rélrécissant un peu après la seconde cubitale, et trois ccllules cubitales; les deux premières plus petites que la troisième, celle-ci presque complète ou du moins I racée jusqua au bord fostérienr de l'aile : une seule nervure récurrente aboutissant dans la première cellule cabitale, près de la nervure d'intersection de celle-ci et de la seconde cubitale. Triois ccllules discoïdales; la troisième ou l'inférieure s'étendant jusqu'au bord postér eur de l'aile. - Abdomen court, ovalaire, inséré vers la partie inférieure du métathorax par une base large, ridée; simplement déprimé en dessous. Tarière (des femelles) saillante. - Pattes assez grandes, grêles : premier article des tarses le plus long de tous; lc dernier muni de deux crochets très-courts et d'une fort petite pelotte.

Ce genre ne comprend que peu d'espc̀ces; elles sont toutes d'assez petite tälle; la plus commune, Alysie mandibulaire, A. manducator Nов. paroit déposer ses œuts dans le corps des larves qui viveut dans les excrémens humains. Cette espèce est l'Alysia stercoraria. Lat. nouv. Dict. d’hist. nat. $2^{\circ}$. édit. - Cryptus masnducator $\mathrm{n}^{\circ} .73 . \mathrm{F}_{\mathrm{AB}}$. 
Syst. Piez. - Ichneumon manducator. PANz. Faun. Germ. fas. 72. fg. 4. Femelle.

$$
\text { (S. F. et A. Senv.) }
$$

SIGARA, Sigara. FAв. Ce g'enre d'Hémiptères répond en partie à celui de Corise LAT. Voyez ce mot. (S. F. et A. SERV.)

SIGARA, Sigara. LEAch. LAt. (Fam. nat.) Notonecta. Linn.

Genre d'insectes de l'ordre des Hémiptères, section des Hétéroptères, famille des Hydrocorises, tribu des Notonectides.

Quatre genres composent celte tribu, savoir: Nolonecte, Pléa, Sigara et Corise; le dernier se distingue de tons les antres pur le manque d'écusson, et particulièrement des Sigaras par son corps linéaire. Les Notonecles et les Pléas sont reconnoissables en ce qu'elles ont deux articles à tous les larses, même aux antúrieurs.

Ce genre tel qu'il est adopté par M. Latreille dans ses Familles naturelles, a été fondé par le docieur Léach (Trans. Linn. de Londres, vol. iz. pag. 10;). Ces autcurs n'ayant pas donné en détail les caractères génériques, nous ne pouvons que consigner ici les courtes notes extraites de l'ouvräge précité de M. Léach.

Corps ovale, pointu postérieurement, un peu déprimé. - Corselet transversal, linéaire. - Ecusson distinct. - Elytres canaliculées, au moins à la base de leur bord antérieur. - Pattes posiérieures les plus longues de toutes, propres à nager ; tarses antérieurs n'ayant qu'un seul article; les quatre autres en ayani denx.

On ne mentionne qu'une seule espèce.

\section{Sigara naine, S. minutissima.}

Sigarà suprà cinerea; elytriṣ fusco obsoletè maculatis, subtics pedibusque flavis.

Sigara minutissima. İ́AcH ut suprà. - Notonecta minutissinna. Linn. Faun. Suec. 244. goj. Syst. nat. 2. 7 13.3. (en retranchiant le synonyme de Geoffioy qui appartient ì la Flea minutissima. LéACH. LAT.)

Longueur I lig. Cendrée en dessus. Elytres ayant des taches brunes peu distinctes. Dessous du corps ct pattes jaunes. D'Europe.

$$
\text { (S. F. et A. SERv.) }
$$

SLLÈNE. Nom vulgaile donné par Gecfroy (Ins. Paris.) au Salyre Circé no. 110. tom. IX. pag. 5.5. du présent Dictionnaire.

(S. F. et A. Serv.)

SILPHA. Linn. FAB. Nom sous lequel Fabricius comprend daus son Syst. Eleut., des Coléoptères-Pentamères de différens genres. Les Silpha surinamensis $\mathrm{n}^{\circ}, 1$, littoralis $\mathrm{n}^{\circ}, 2$. et livida $\mathrm{n}^{\circ} .3$. sont des Nécrodes. Les espèces de 6 à 21 . inclusivement sont de vritis Silpha (Budiel OLrv,).

Hist. Nat. las. Tome $X$.
La Silpha dentate no. 22. est un Thymalus LAT. et auroit dû par conséquent être placée par l'auteur allemand dans son genre Peltis, lequel correspond à celui de 'Thymale de M. Latreille. Les Silpha limbatu $1^{\circ} .23$ et undata $\mathrm{n}^{\circ} .24$. sont pentêtre aussi des Thymalus. La Silpha minuta $\mathrm{n}^{\circ} .25$. est l'Onalie de la Renoncule no. 20. Encyclop. Quant à la Silpha micans $\mathrm{n}^{\circ} .4$, nous ignorons le genre auquel elle appartient; il en est de même de la Silpha indica no. 5, que Fabricius décrit une seconde fois sous le nom d'Ips grardis $\mathbf{n}^{\circ} .2$, ainsi que l'indique M. Schwnherr, $3 y n$. Ins. tom. 2. pag. 123 .

Ce genre Silpha dans Fabricius se rapporte à peu près à celni de Bouclier du présent Dictionnaire; les Boncliers suivans, $1^{\circ}$ surinamois $n^{\circ} .1$. pl. 164. fig. 20. $2^{\circ}$. littoral $n^{\circ} .2$. pl. id. fig. 21 . $3^{\circ}$. livide $n^{\circ}$. 3. pl. id. fig. 22. appartiennent an genre Nécrode Lat. Fam. natur. Tes espèces depuis le $n^{\circ} .5$. jusqu'au $n^{\circ} .13$. inclusivement, ainsi que les $\mathrm{n}^{\circ s}$. 16. 17. 18.19.20.21. sont des Boucliers. Les espèces suivantes reutrent dans le genre. Thymale. $1^{\circ}$. échancré no. 14. pl. 165. fig. 7. (Thymalus grossus LAt.) $2^{\circ}$. ferruginenx no. 22. pl. id. fig. 13. (Thymalus ferrugineus LAT.) $3^{\circ}$. oblong n ${ }^{0} \cdot 24$. pl. id. fig. 14. (Thymalus oblongus Lit.) $4^{\circ}$. denté $\mathrm{r}^{\circ} .24$. (Thymalus dentatus Lat.) 50. bordé no. 25. pl. id. fig. 17. (Thymalus limbatus Lat.) Voyez 'Inyane. Le Bouclier ondé $n^{\circ} \cdot 26$. est pent-être encore de ce dernier genre. (S. F. et A. SErv.)

SILVIUS. Nom donné par Fubner ì une espèce d'Hespérie voisine du Brontes. (E. G.)

SIlviUS, Silvius. Merg. Lat. (Fam. nat.) Tabanus. FAs.

Genre d'insectes de l'ordre des Diptères, première section, famille des Tanystomes, tribu des Taoniens.

Huit genres composent cette tribu. Les Taons, les Hrematopotes et les Heptatomes se distinguent au premier coup d'wil par le manque d'ocelles: parmi ceux qui en sont pourvus comme les Silvius, le genre Rlinomyze se recomoît an troisième article de ses antenries denté ì la hase; les Acanthomères par la brièveté du premier articlo des antennes et encore par leurs cuisses postérieures unidentées dans les mâles; les Rhaphiorlynques ont leur hypostome terminé par un avancement subulé et le premier article des antennes beaucoup plus court que le second, comme dans le genre Acanthomère. Enfin dans les Curysops, les deux premier's articles des antennes sont éraux en longueur, tous deux cylindriques.

M. Meigen à qui l'on doit ce genre lui donne pour caractères : anlennes avancées, rapprochées, de trois articles; le premier cylindrique, plus lony que le second, celui-ci court, cyathiforme : le troisième subulé, paroissant formó de cing anI i i 
neaux. Trois ocelles. Palpes avancés, biarticulés, velus; leur second article conique dans les femelles, cylindrique dans les mâles. Ailes écartées.

Nous ajouterons que les yeux sont espacés dans les femelles, contigus dans les mâles, et que dans ce dernier sexe les cuisses postérieures ne sont pas unidentées.

Rapportez à ce genre, dont les mœurs doivent être les mêmes que celle des 'Laons, le Silvius du Veau, Silvius Vituli. Ming. Dipt. d'Eur. tom. 2. pag. 27. n०. 1. tab. 13. fg. 13. Fumelle. - Tabanus Vituli. no. 19. Kав. Syst. Antliat.

(S. E. et A. SERv.)

SIMBLÉPHILE, Simblephilızs. M. Jurine (nouv. IMéthod. Hyménopt.) donne ce nom aux Hyménoptères désignés sous celui de Philanthe par M. Latreille. Voyez ze mot. (S. H. et A. SErv.)

SIMPLICICORNES ou APLOCËRES. M. Duméril, dans sa Zuologie analytique, a nommé ainsi une famille de Diptères dont les caractères sont: sucoir nul ou caché. Bouche en trompe, rétractilé dans une cavité du front. Antennes sans poil isolé latéral. Elle est composée des genres suivans: Rhagion, Bibion, Anthrax, Sique, Hypoléon, Stratiome, Cyrte, Némotèle, Cérie et Midas. (S. F. et A. Serv.)

SIMPLICIPÉDES. M. le comte Dejean (Spéciès ) établit sous ce nom une tribu qui correspond à la division des Carabiques nommée les Abdominan $x$ par M. Latreille. Voyez AвромгN.sux à la Table alphabétique.

(S. F. et A. Serv.)

Siyulie, Simulium. Lat. Culex. Linv. Otrv. (Encycl.) Tipula. De Géer. Bibio. Oeiv. (Encycl.) Pald. Scatopse. Fab. Simulia. MeIg. M.ACQ.

Genre d'insectes de l'orcire des Diptères, première section, famille des Némocères, tribu des Tipuluires (division des Florales).

Cette division contient sept genres; cing d'entr'eux se distinguent par la présence de trois ocelles, savoir : Scathopse, Penthétrie, Dilophe, Bibion et Aspiste. Ies Cordyles qui, comme les Simulies, sont privées d'ocelles, en dilfèrent en ce que leurs antennes ont douze articles et que leurs yeux sont entiers dans les deux sexes.

Antennes courtes, épaisses, presque cylindriques, mais grossissant insensiblement de leur base à l'extrémilé, composées de onze articles, les deux premier's distinctement séparés des autres. - Trompe courte, pointue, perpendiculaire, paroissant (d'après la figure donnée par M. Meigen) pourvae d'une soie ou pointe roide. - Palpes alongés, avancés, un peu recourbés, cylindriques, de quatre articles distincts; le premier le plus court de tous, les deux suivans plus longs, un peu renflés, le quasième encore plus long, mais plus menu. - Téte presque globuleuse. Yeux orands, échancrés au côté interne et espacés dans les femelles; se réunissant sur le front et sur le vertex dans les mâles. - Point d'ocelles. - Corps assez court. - Prothorax très-petit, peu visible. - Ailes grandes, larges, parallèles et couchées l'une sur. l'autre dans le repos; les nervures les plus voisines du bord extérieur seules bien distinctes, les autres très-foiblement tracées. -Abdomen cylindrique, composé de sept segmens outre l'anus. - Pattes assez longues; premier article des tarses au moins aussi long que les quatre autres pris ensemble.

Les Simulies, ou au moins l'espèce nommée reptans, sont très-incommodes et piquent assez forlement; elles attaquent les hommes et les animaux, mais il seroit possible que ce fút le fait seul des femelles ainsi qu'on le remarque dans les Cousins et dans les 'Taouiens. M. Meigen décrit douze espèces de ce genre et en mentionne une treizième; aucune d'elles, ne surpasse deux lignes de longueur. Les habitudes des leurs larves et leurs métanorphoses ne nous sont pas connues. L'espèce suivante a été décrite pour la première fois par M. Macquart dans son ouvrage sur les Tipulaires du nord de la France, que nous avons déjà cité.

\section{Simolie printannière, S. vernum.}

\section{Simulium nigrum; tibiis incrassatis.}

Simulia verna. M.1cQ. Ins. Dipt. Tipul. p. 23. $n^{\circ} .2$.

'Longueur une ligne et demie. D'un noil' mat. Corselet chargé d'un léger duvet grisâtre. Abdomen et pattes couverts de poils courts, roussâtres. Balanciers d'un roux clair. Jambes un peu reuflées. Tarses noirs.

On la trouve en mai aux environs de Lille; elle y est rare.

Nota. La Sinulie rampante ( $S$, reptans. LAT. Gen. Crust. et Ins. tom. 4. p. 229. Otez d'a p:ès M. Meigen le syncnyme de l'Atractocera regelationis tiré de la classificalion de ce dernier auteur, qui apparlient à la Simulia ornata $n^{n}$. I. Merg. Dipt. d'Eur. Le mâle de cetle dernière espèce est figuré (dans l'Encyclopédie pl. 386. fig. 9. sous le nom d'Airactocera regelationis.) est décrite dans l'Encyclopédie sous denx noms différens, Consin serpentant $n^{\circ}$. 1r. et Bibion tête rouge no. II. (Le premier nous paroît être la femelle, le second le mâle.) Scatopse reptans no. 2 . FAB. Syst. Antliat. (en retranchant le synonyme du Rhagio colombaschensis. Entom. Syst. qui appartient à la Simulia 'maculata no. 7. Meig. Dipt. d'Eur.)

Le Cousin des chevaux no. 13. du présent Dictionnaire est peut-être aussi une Simulie.

(S. F. et A. Serv.) 
SINODENDRE, Sinodendron. FAB. LAT. Scaraboeus. Linv. De GÉEr. Oliv. (Entom.)

Genre d'insectes de l'ordre des Coléoptères, section des Pentamères, famille des Lamellicornes, tribu des Lucanides.

Dans cette tribu les genres Paxylle et Passale sont distingués par leur labre grand, toujours découvert; la lauguette entière courommant le menton, et les anteunes simplement arquées et velues. Les autres genres où les antennes sont toujours forlement coudées, le labre presque nul ou caché, la languette très-petite et entière, ou grande et bilobée, tantôt saillante et tantôt cachée par le menton, se divisent en trois groupes, dont l'ua a pour caractères : languette cachée par le menton ou déconverle, wais très-petite et entière: il renferme les Sinodendres et les $\mathbb{R}$ sales; mais dans ces deruiers la languette est découverte, le menton grand, transversal, les inaudibules s'avancent au-delà de la tête et diffèrent dans les deux sexes; enfin leur corps est corrt.

Antennes fortement coudées, composées de dix articles; le premier fort long, égalant presque la longueur de la moitié de l'antenne, le second globuleux, un peu turbiné; les cinq suivans globuleux, allant un peu en grossissant du troisième jusqu'au septième inclusivement; les trois derniers formant des feuillets disposés perpendiculairement à l'axe de l'antenne et imitant des dents de scie.Labre peu distinct. - Mandibules cornées, presqu'entièrement cachées. - Mâchoires presque membraneuses, pen avancées, composées de deux lobes, l'intérieur très-petit, en forme de dent. Palpes maxillaires per avancés, filiformes, près de deux fois plus longs que les labiaux, leur second article plus grand que les autres, obconique, le troisième presqu'ovale, le dernier presque cylindrique; le terminal des palpes labiaux plus grós que les précédens, presqn'ovale. - Menton petit, triangulaire, caréné. - Languette cachée par le menton. - Tête petite, cornue ou tuherculée. - Yeux petils. - Corps alongé, cylindrique. - Corselet prescque carré, convexe cu dessus, sa partie antérieure concave surtont dans les mâles, le bord antérieur échancré pour recevoir la tête. - Ecusson petit, arrondi postérieurement. - Elytres recouvrant entièrernent l'abdomen et les ailes. - Abdomen assez épais. Pattes de longueur moyenne; jambes dentées sur deux rangs à leur partic extérieure; dernier article des tarses muni de deux crochets entre lesquels est un appendice portant deux soies.

Les larves des Coléoptè res de ce geure vivent comme celles des Lucanes, dans les troncs d'arbres; c'est ce qu'indique le nom de Sinodendre venant de deux mots grecs signifiant: nuisible aux arbres. L'espèce la plus connue se trouve fréquemment en Normandie dans le tronc creux des vieux pommiers et en Flandre dans les liêtrés cariés; c'est le Sinodendre cylindrique, Sinod. cylindricumn ${ }^{\circ}$. 1. Fa $\mathrm{A}$. Syst. Eleut. - Panz. Faun. Germ. fus. 1. fig. 1. mâle, fas. 2. fig. 1 I femelle. - Scarabceus cylindricus. Oliv. Entom. tom. I. Scarab. pag. $47 \cdot n^{\circ}$. 54. pl. 9. fig. 8o. mâle et femelle. M. Palisot-Bauvois décrit (Ins. d'Afr. et d'Amér.) un Sinodendre des Etats-Unis d'Amérique sous'le nom d'Americanum. Il a les plass grands rapports avec celui d'Europe et n'en est peut-être qu'une variété.

Les huit autres espèces de Sinodendres décrites dans Fabricius n'appartiennent pas à ce genre, ainsi que l’a remarqué M. Latreille. Le Sinodendron cornutum $\mathrm{n}^{\circ} .2$. est une Lamprima LAT., et le Sinodendron muricatum $\mathrm{n}^{\circ} .6$. doit se ranger parmi les Bostriches Lat.

IESALE, Asalus. FAb. LAt. Lucanus. PAnz. Genre d'insectes de l'ordre des Coléoptères, section des Pentamères, famille des Lamellicornes, tribu des Lucanides.

Les Sinodendres et les 㤅ales forment un groupe dans cetle tribu ( voyez Locanides à la Table aiphabétique), mais le genre Sinodendre est reconnoissable par sa languetre caclice par le menton, celui-ci petit, triangulaire, par les mandibules presqu'entierement cachées dans les deux sexes, et enfin par son corps alongé et cylindrique.

Antennes fortement coudées, composées de dix artictes, le premier très-long, courbe, comprimé; le second globuleux; les cinq suivans très-courts, transversaux ; les trois derniers formant des fenillets perpendiculaires a l'axe de l'antenue, imitant presque des dents de scie. -- Labre apparent. Mandibules fortes, s'avancant au-devint de la tête, aiguës à leur extrémité, arquées, émetiant à leur partie supérieure un rameau oblus, imitint ųne corne plas ou moins relevée suivant le sexe. - Mâchoires ayant un appendice très-court, counprimé, arrondi et velu à son extrémité. - Palpes courts; les maxillaires ayant leurs trois premiers articles petits, globuleux, transversanx, le quatriène grand, cylindrique - ovale. - Menton grand, en carré transversal. - Languette trèspelite, distincte, entière. - Tête petite. - Yetix gros, très-saillans en dessous. - Corps couri, convexc en àessus. - Corselet échancré en devant pour recevoir la tête, son bora postérieur un peu lobé dans son nilieu. - Ecusson petit, arrondi postérienrement. -- Elytres recouvrant entièrement labdomen et les ailes. - Abdomen court. - Pattes assez courtcs : jambes larges, aplaties, presque triangulaires, munies d'un seul rang d'épines à leur partie extéricure ; tarses courts, leur dernier article muni de deux crochets entre lesquels est un petit tuluercule portant deux soies divergentes.

Par ses jambes aplaties, son corps conrt et convexe, ce genre a quelques rapports a ver celui de Bolbocère, nais le reste de ses caractères l'en éloigne ainsi que la manière de vivie de la larve 
qui habite les arbres creux et pourris, particulièrement les chênes, suivant le témoignage de MI. Creutzer cilé par Panzer. Les auteurs ne donnent qu'une seule espèce de ce genre. Asale scarabéoïle, Assalus scarabeoides no. 1. FAв. Syst. Eleut. - Lucanus scarabeoides. PANz. Faun. Germ. fas, 26. fig. I 5. Mâle. fig. 16. Femelle.

(S. H. et A. Serv.)

SIPHONAPTÈRES, Siphonaptera. LAT.

Latreille désigue sous ce nom ( Fam. nat. du Rìgn. anim.) le dernier ordre des insectes aplères. Cet ordre est ainsi calactérisé : bouche consistant en un rostelle (ou petit bec) composé d'un tubc extérieur on gaîne (lèvre inférieure) divisée en deux valves articulées, renlermant un suçoir de trois soics (deux unâchoires et la langue) et de deux écailies (palpes) recouvrant la base de ce tube; pattes postérieures servant à sauter; corps très-comprimé sur les côtés; auteunes très-rapprochées de l'extrémité antérieure de là tête, presque filiformes on un peu plus grosses aur bout, de quatre articles : une lame que l'anional élève et abaisse très-souvent, située au-dessous de chaque œil et dans une fossette.

Ces Aptères paroissent intermédiaires entre les Hémiptères et les Diptères; ils subissent des métamorphoses complètes; de même que lcs Parasites, jls vivent sur divers quadrupèdes et sur quelques oiseaux : cette dernière considération les rapproche des dcrniers Diptc̀res ou des Papivores, qui vivent aussi sur les oiseaux.

Cet ordre ne renferme que le genre Poce. Doyez ce mot. (E. G.)

SIPIIONCULĖS, Siphonculata. LAT.

Seconde famille de l'ordre des Parasites établie par Latreille ( Fam. nat. du Règn. anim.) et renfermant les Parasites qui n'ont point de mandibules et dont la bouche consiste en un museau d'où sort à volonté un siphoncule servant.de suçoil. Latreille divise ainsi cettc famille.

I. Thorax très distinct, les six pattes terminées en manière de pince.

Les genres $\mathrm{Pou}, \mathrm{H}$ жmotopine.

II. Thorax très - court, presque nul; corps comme formé simplement d'une tête et d'un abdomen; les deux pattes antérieures monodactyles, les antres didactyles.

Le genie Preire.

Voyez pour plus de détails les mots Parasite et Pou. (E. G.)

SIPHONE, Siphona. MEIG.

Cet auteur dans ses Dipt. d'Europ. nomme ainsi un genre que M. Latreille avoit précédemment appelé Bucente, Bucentes. Voyez ce mot à la Table alpbabétique. (S. F. et A. SERv.)
SIQCE, Sicus. Lat. Tachydromia. Metg. Fab. Fallèy. Calobata. Fab. Musca. Linn.

Genre d'insectes de l'ordre des Diptères, première section, famille des Tanystomes, tribu des Empides.

Däns cette tribu cinq genres, savoir : Empis, Ramphomyie, Hilare, Brachystome et Glome ont leurs antenues de trois articles. D'un antre côté, les Hémérodromies ont les hanches antérieures très-longues; dans les Drapétis le second article des antenues est lenticulaire et les cuisses antérieures sont toujours grêles ainsi que les intermédiaires.

Antennes avancées, rapprochées à la base, insérées sur le haut du front, composées seulement de deux articles; le premier cylindrique, conrt, un peu hérissé de poils; le second ovale ou oblong, muni d'une soie terminale qquelquefois ciliée. Trompe avancée, conrte, perpendiculaire, de la longueur de la tête au plus. - Palpes cylindriques ou en forme d'écailles, couchés sur la trompe. - Ailes obiuses, velues vues à la loupe, couchées l'une sur l'autre dans le repos. - Balanciers découverts. - Tête sphérique. - Ieux ordinairement espacés dans les deux sexes. - Trois ocelles placés en triangle sur le vertex. - Corselet ovale. - Ecusson semi-circulaire, assez élroit. - $A b-$ domen oblong, cylindrique, de sept segmens; pointu dans les femelles. - Pattes assez déliées, les postérieures toujours grêles, plus longues que les autres; cnisses antérieures ou les intermédiaires, renflées. Dans ce second cas, qui est le plus ordinaire, ces secondes cuisses sont toujours finement épineuses en dessous et leurs jambes terminées par nne pointe spiniforme : premier article des tarses aussi long que les quatre autres pris ensemble.

On trouve ces Empides sur les haies et les baissons, et aussi quelquefois sur le tronc des arbres. Ils vivent de proie et courent très-vîle ; leur's métamorphoses sont inconnues. M. Meigen partage ce genve ainsi :

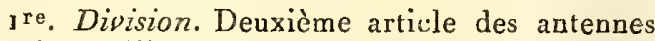
déprimé, elliptique. (Palpes cylindriques; cuisses antérieures renflées.)

A cette division appartient la Mouche arrogante $n^{\circ} .100$. de ce Dictionnaire, ainsi que la Mouche cimicoïde $\mathrm{n}^{\circ}$. 107 . qui est la même espèce, Sicus arrogans. Nов. - Tachydromia arrogans $\mathrm{n}^{\circ} . \mathrm{I}$. Melg. Dipt. d'Eur. tom. 3. pag. 68. Cet auleur rapporte à cette division neuf aulres espèces.

$2^{*}$. Division. Deuxième article des antennes ovale, terminé en pointe. (Palpes en forme d'écaille aplatie. Cuisses intermédiaires renflées, finement épineuses en dessous.)

Placez ici la Mouche coursière no. ro6. de cet ouvrage, Sicus cursitans. Nов. - Tachydromia cursitans no. 3?. MEIG. Dipt. d’Eur. tom. 3. pag. 
83. M. Ncigen décrit quarante-trois espèces de cette division.

HÉMÉRODROMIE, Hemerodromia. HOFFM. Meig. Lat. Tachydromia. Fab. Falièn.

Genre d'insectes de l'ordrc des Diptères, première section, famille des Tanystomes, tribu des Empides.

Cinq genres de cette tribu sc distinguent des antres par leurs antennes composées de trois arti:Ies, ce sont les suivans : Empis, Ramphomyie, Hilare, Brachystome et Glome. Les Siques et les Drapétis qui comme les Hémućrodromies n'ont leurs antennes que de deux articles, sont bien séparés de ces dernières par leur's hanches antérieures de grandeur ordinaire.

Antennes avancées, rapprocliées à leur base, insérées sur le haut du front, composćes seulement de deux articles; le premier court, cylindriqué; le second ovale, un peu poinlu par-devant, muni d'une soie terminale. - Trompe saillante, courte, perpendiculaire. -.. P'alpes subulés ou presque cylindriques, garnis de soies en devant, couchés sur la trompe. --Tête sphérique.-Yeux espacés dans.les deux sexes. - Trois ocelles placés en triangle sur le vertex. - Corselet oblang ou presque cylindrique. - Abdomen cylindrique, de sept segmens: au us obtus dans les mâles, pointu dans les femelles. - Ailes couchćes sur le corps dans le repos, longues, obtuses à l'èxtrémité, velues vues à la loupe, leurs cellules de forme variable. - Balanciers découverts. - Pattes longues, grêles; hanches longues, lcs antérieures principalement; cuisses de devant ordinairement épaisses et épineuses en dessous : premier article de tous les tarses aussi long que les quatre autres pris ensemble.

Ces Diptères sont trc̀s-petits. On les trouve en été sur les haies, les buissons et !es plantes. Ils"se nourrissent de proie, c'est-à-dire d'autres petits Diplères. Leurs métamorphoses ne sont pas encore connues. M. Meigen de qui nous empruntons la plupart des caractères génériques, ainsi que ceux de beaucoup de genres européens de cet ordre, partage ce genre ainsi qu'il suit.

rre. Division. Cuisses antérieures renflées, munies de petites ćpines en dessous. M. Meigen (Dipt. d'Eur.) décrit huit espèces de cette division. La plus connue est le Sicus raptor. IıA t. Gen. Crust. et Ins. tom. 4. pag. 304. tom. 1. tab. 16. fig. I1. et 12. - Hemerodromia mantispa. $\mathrm{n}^{\circ} .5$. MEIG.

\section{2 ${ }^{\mathrm{e}}$ Division. Cuisses simples.}

La seule espèce qui se rapporte à cette seconde division est I'Hémérodromie tachetée, Hemerndromia irrorata $\mathrm{n}^{\circ} \cdot 9$ : Merg. Longueur une lig. $\frac{\mathrm{t}}{4}$. Noire. Pattes ferrugineuses. Ailes brunes ponctuées de blanc.
DRAPEITIS, Drapetis. MeIg. LAт. (Fam.nat.)

Genre d'insectes de l'ordre des Diptères, première section, famille des Tanystomes, tribu des Eapides.

Le groupe des Empides (voyez ce-mot à la Table alphabétique) qui équivaut à la famille des Tachydromies de M. Meigen, et présente pour caractères: intenines de deux articles, contient les genres Hémérodromie, Sique ct Drapétis. Dans les Hémérodromies les hanches antérienres sont très-longues; les Siques ont le second article des antennes ovale-oblong et leurs cuisses antérienres ou les intermćdiaires sont renflées.

Antennes avancées, insérées vers le haut de la tête, rapprochées ì leur base, s'écartant ensuite, plus courtes que la tête, composées seulement de deux articles; le p*emier très-petit, cylindrique, le second lenticulaire, muni d'une suie terminale longuc et nue. -Trompe très-courte, un peu saillante, perpendiculaire, recouverte par les palpes. - Falpes très-peiits. - Tềie presque sphériquc; hypostome très-étroit. - Yeux un peu espacés dans les deux sexes. - Trois ocelles rapprochés en triaugle sur le vertex. - Corps ua peu redressé dans la marche ainsi que dans le repos. - Corselet globaleux; prothorax court, ne paroissant pas en ciessus. - Ailes couchées sur le corps daus le repos, parallèles, velues vues au microscope. -- Abdonten de sept seymens, asse $z$ ovale, avec l'anus terminé en pointe dans les femclles : oblong, presque cylindrique dans les raâles. - Pattes grandes; toutes les cuisses un peu épaisses; leur's hanches de grandeur ordinaire; jainbes sans épines terminales; premier article des tarses un peu plus grand que les autres.

Cestrc̀s-petits Diptères coureut avec une grande agilité et sont par-lä difficiles à saisir. M. Meigen. n'en décrit qu'une seule espèce.

\section{Drapétis menu, D. exilis.}

Drapetis nigra, coxis fenoribusque nigris, tibiis finscis, tarsis luteis, halteribus nigris: abdomine fenince ferngineo, segnentorum apice nigro-fasciato.

Drapetis exilis. Merg. Dipt. d'Eur. tom. 3. pag. 91. no. 1. tab. 23. fig. 27 et 28 .

Longueur $\frac{3}{4}$ lig. Femelle $\frac{x}{2}$ lig. Mâle. Noire. Hanches, crisses et balanciers de cette même couleur. Jambes brunes; tarses jaunes. Abdomen de la femelle à'un jaune-l'ougeâtre ayant en dessus des bandes transverses noires sur le bord postérieur des segmens; celui du mâle en. tièrement noir.

D'Autriche.

2. Drapétrs pieds jaunes, $D$. luteipes:

Drapetis nigrä; pedibus halteribusque pal-o 
lide luteis, femorum posticorum apice tarsisque fuscis.

Longueur une lig. $\frac{x}{4}$. Noire. Pattes et balanciers d'un jaune pâle. Extrémité des cuisses postérieures de couleur brune ainsi que les tarses. Ailes transparentes, irisées. Mâle.

Des envirous de Paris.

\section{(S. F. et A. SERv.)}

SIREX, Sirex. Liñ. Fab. Klug. Jur. Le genre d'Hyménoptères nommé ainsi par Linné, correspond à ceux d'Urocêre, Xiphydrie, Trémex et Céphus, tels quc les admet M. Latreille. Les Sirex de Linné Syst. nat. $1^{\circ}$. gigas $\mathbf{n}^{\circ}$. 1, mariscus n. 6 (mâle du précédent), spectrum $\mathrm{n}^{\circ} .3$, juvencus $n^{\circ} .4$, sont des Urocères. $2^{\circ}$. Columba no. 2 , est un Trémex. $3^{\circ}$. Camelus $n^{\circ}$. 5. appartient aux Xiphydries. $4^{\circ}$. Pygnnceus $n^{\circ}$. 7. est un Céphus.

Fabricius restreignit le genre de Linné en admettant ceux de Xiphydrie et de Céphus. Les Sirex suivans de Fabricius, ${ }^{\circ}$. gigas $n^{\circ}$. I , psyllius $\mathrm{n}^{\circ}$. 2. (tous deux femelles, la scconde u'étant qu'une variété de la première), mariscus $\mathrm{n}^{\circ}$. 14 . (mâle dı gigas), spectrum $\mathrm{n}^{\circ}$. 8. (femelle dont la Xiphydria emarginata $\mathrm{n}^{\circ}$. 2. $\mathrm{F}_{\mathrm{AB}}$. est le mâle), juvencus $\mathrm{n}^{\circ} \cdot \mathrm{g}$. (femelle), noctılio $\mathrm{n}^{\circ}$. 15 . (nuâle dı juvencus), funtoma no. ro. (femelle) sont des Urocères. $2^{\circ}$. Columba $\mathrm{n}^{\circ} .3$, magus $\mathbf{n}^{\circ}$. 4. (femelle), nigrita $\mathrm{n}^{\circ}$. I3. (uâle du magus), flcvicornis $\mathbf{n}^{\circ}$. 6 . et fuscicorris $\mathrm{n}^{\circ} \cdot 7$. (femelle) sont des Tréntex. Quant aux Sirex nigricornis $\mathrm{n}^{\circ} .5$, cyaneus $\mathrm{n}^{\circ}$. I I. et albicornis $n^{\circ}$. 12. nous ignorons it quels genres ils appartiement.

M. Klïg dans sa monographie des Sirex comprend dans ce genre, ceux d'U rocère et de Trémex.

Jurine sous ce mêue nom de Sirex ne comprend que les espèces adnises par M. Latreille daus le genre Urocère. Voyez ce mot.

$$
\text { (S. F. et A. Serv.) }
$$

SISYPHE, Sisyphus. Lat. Scarabaus. Lins. Oriv. (Entom.) Copris. Groff. Oliv. (Encycl.) Ateuchus. Wи́̉. FaB. Jilig.

Genre d'insectes de l'ordre des Coléoplères, section des Pentamères, famille des Lamellicornes, tribu des Scarabéides (division des Coprophages ).

Un groupe de cette division distingué par l'absence de l'écusson (voyez Scarabéides) contient huit genres; ceux d'Onthophage, Phanée, Bousier et Choeridie sont séparés des autres par leurs jambes intermédiaires et postérieures courtes, sensiblement dilatées et plus épaisses à leur extrémité. Parmi les genres dont les quatre dernières 'jambes sont presque cylindriques, les Ateuchus ont neuf articles aux antennes, leuss élytres sont presque carrées, le corps déprimé, au moins en dessuus, et leurs pattes postérieures ne sont pas plizs longues que le corps, ni arquées; enfin les Gymnopleures ainsi que les Hybômes sont reconnoissables par le sinus protiond qu'offie l'angle extérieur de la base des élytres.

Antennes de huit articles; le premier long, presque cylindrique, un peu comprimé; le second globuleux, plus gros que les suivans; ceux-ci peu distincts, les quatrième et cinquième cupulaires, les $t$ rois derniers formant une massue libre, lamellée, plicatile, ovale. - Labre et Mandibules cachés, de consistance membraneuse. - Mấchoires terarinées par un grand lobe membraneux. - Palpes maxillaires de quatre articles, les second et troisième courts, coniques, le quatrième plus long que les deux précédens rénnis, fusiforme, se terminant presçu'en pointe; palpes labianx velas, lenr dernier article peu distinct. - Lève meabraneuse, cachée par le menton. - Téte presque circulaire, un peu prolongée postérieurewent, mutique dans les deux sexes : chaperon muni an bord antérieur de deux à six petites dents. - Ieux paroissant très-peu en dessus. - Corr s court, épais, convexe en dessus et en dessous. Corselet mutique, très-bombé, son bord antérieur échancré pour recevoir la tête; bords latéraux conpés presque droils de leur milieu à l'angle du. bord postérieur, celui-ci arrondi. - Écusson nul. -Elytres presque triangulaires, n'ayant ni échancrure ni sinuositć à lenr partie ex térieure, laissant à découvert l'extrémité de l'abdomen et recouvrant des ailes. - Abdomen court, épais, presque triangulaire. - Pattes assez velues, les postérieures beaucoup plus longues que le corps; hanches interutédiaires très-écartées entr'elles, les autres rapprocbées. Jambes intermédiaires et postérieures très-peu dilatées à leur extrémité, presque cylindriques, arquées; tarses composés d’articles cylindro - coniques; crochets furt grands.

Les Sisyphes ont les mêmes mœurs que les Ateuclus (voyez ce mot.pag. 3jo. de ce volume). Leur noun tiré de la fable leur a été doinné par allusion à l'babitude qu'ils ont de rouler une bonle; celle-ci composée de fiente est destinée à recevoi: leurs uafs. Le pelit nombre d'espèces connues bubite les parties méridionales de l'ancien continent.

On placera dins ce genre $1^{\circ}$. Bousier de Schaffer no. 157. pl. 152. fig. 7. Encycl. (Sisyph. Schafferi L.1T.) $2^{\circ}$. Bousier longipède $\mathrm{n}^{\circ}$. 138. pl. id. fig. 8. Encycl.--Ateuclus minutus $\mathrm{n}^{\circ}, 11$. Faв. Syst. Eleut. - Sisyphus minutus. Des. Catil. Nons croyons devoir aussi rappover aux Sisyphes le Scarabé miriqué, Oriv. Entom. tom. I. Scarab. pag. 188. no. 239. pl. 27. fig. 240. L'aliteur le dit de l'Amérique méridionale; nons prúsumons gue c'est une, erreur.

$$
\text { (S. F. et A. SErv.) }
$$

SITARIS, Sitaris. Lat. Cantharis. Geofr. Or.t. Necydalis. Fab. 


\section{S I T}

Genie d'insectes de lordre des Coléoptères, section des Hétéromères ( $\mathbf{2}^{\mathrm{e}}$. division), famille des Trachélides, tribu des Cantharidies.

Cette tribu contenant un assez grand nombre de genres, nous croyons en faciliter l'étude en présentant le tableau comparatif suivant dont nous prendrous les bases dans les Fam. nat. de M. Latreille.

Cantraridres, Cantharidice. Sixième tribu de la famille des 'Trachélides, section des Hétéromères, ordre des Coléoptc̀res.

Crochets des tarses bifides, le pénultième article de ceux-ci très-rarement bilobé.-Antennes simples ou foiblement en scie. - Tête toujours forte et inclinée. - Palpes filiformes ou simpleınent un peu plus gros du bout, n'étant janıais en massue sécurifornte.

I. Pénultième article de tous les tarses bilobé.

\section{Tétraonyx.}

II. 'Tous les artic'es des tarses entier's.

A. Antennes en massue, ou grossissant inseusiblement vers leur extrémité.

Cérocome, Hyclée, Décatowe, Mylabre, Lydus.

B. Antennes de la même grosseur partont ou plus grêles vers leur extrémité.

a. Point d'ailes. - Elylres plus courtes que la moitié de l'abdomen.

\section{Méloé.}

b. Des ailes. - Elytres de la longueur ou presque de la longueur de l'abdomen.

† Anteunes très-couries, épaisses. Ginas.

† Antennes longrues et grêles.

* Mâclioires de forme ordinaire.

Elytres se rétrécissant fortement - avant lcur milieu, pointues ou spatulitormes ì l'extrémitć.

Silaris.

ฯ Elytres point rétrćcies avant leur milieu.

o. Palpes maxillaires plus gros à leur extrémité. - Antennes ayant leur deuxième article court.

Cantharide.

o o. Palpes maxillaires filiformes. - Antennes ayant liur deuxième article au moins aussi long que lia moitié du suivant.

Apale, Zonite.

* * Mâchoires très-pıolongées, se recourbant sous le corps dans le repos.

Némogrnathe, Gnathie.

Les Sitaris forment seules un groupe dans leur tribu. (Voyez le tableau ci-dessus.)

Antennes longues, filiformes; celles des mâles égalaut presque la longueur dn corps, insérées dans une échancrure intérieure des yeux, composées de onze articles presque cylindriques, le second trois fois plus petit que le suivant; celuici et le quatrième de forme un peu obconique, le dernier pointu, alongé dans les mâles. - Labre avancé, un peu coriace, transversal, entier.Mandibules cornées, fortes, visibles en grande partie, arqućes à l'extrémité, pointues; leur's pointes alongées et croisées l'une sur l'autre. Mâchoires composées de deux lobes, tous deux courts, membraneux, un peu velus à leur extrémité, l'extérieur pas beaucoup plus long que l'áutre, presque trigone, l'intérieur aigu à l'extréurité. - Palpes filiformes, leur dernier article ovale-cylindrique, oblus : plus long que le précédent surtout dans les labiaux, presque conique; les maxillaires un peu plus longs que les autres.Lèvre membraneuse, presque cordiforme, courte, large, surtout à l'extrémilé, profondément échan. crée : mentou membraneux, presqu'en carré trans. versal, un peu rétréci à la naissance de la lèvre. - Tête pencbée. - Yeux échancrés à leur partie intérieure. - Corselet plane, presque carré, ses angles latéraux arrondis. - Ecusson assez grand, tiriangulaire. - Elytres se rétrécissaut fortement avant leur milieu, béautes à leur extrécnité, à peine de la longueur de l'abdomeu, terminées en pointe, re recouvrant pas complétement les ailes clans le repos.-Abdomen coutt.-Pattes fortes; jambes postéricures terminées par deux épines très-courles, assez larges, tronquées à l'extrémité : articles des tarses tous entiers, le dernier terminé par deux crochets bifides à divisions simples, sans dentelures.

Les larves de ces Coléoptères vivent, suivant lcs auteurs, dans le nid de quelques Apiaires récoltantes solitaires et notamment dans ceux des Osmies. On ne sait pas encore si elles dévorent la larve de ces Hyménoptères ou seulemcnt la pâtće destinée par ceux-ci à leur postérité. Ce fait intéressant mériteroit d'être éclairci par les entomologistes du midi de la France où l'on en trouve communément deux espèces. Les Sitaris n'ell confiement qu'un pelil nombre et toutes d'Europc. Nous citerons les suivanles: $1^{\circ}$. Silaris apicale, S. apicalis. LAx. Gener. Crust. et Ins. tom. 2. pag. $222,72^{\circ}, 2,2^{\circ}$. la Cantharide humérale $n^{\circ}$. i 8. 
du présent Dictionnaire, Sitaris humérale, $S$. humeralis. L L ${ }_{\mathrm{T}} i d . n^{\circ} . \mathrm{I}$.

Nous possédons un insecte des Indes orientales voisin des Sitaris et du même gronpe qu'elles, mais dont il diffère $1^{\circ}$. par ses élytres plus courtes que dans ce genre, lesquelles après s'être trèsfortement rétrécies avant leur milieu, s'élargissent subilement en spatule à leur extrémité. $2^{\circ}$. Par les crochets des tarses dont la plus forte division est distinciement dentelée en peigne. $3^{\circ}$. Par les palpes maxillaires plus de deux fois aussi longs que les labiaux. On pourroit en constituer un nouveau genre sous le nom d'Onyctène, Onyctenus, de deux mots grecs qui signifient: ongles en peigne; il se rapprocbe des Némognathes par ce dernier caractère. Onyctène de Sonverat, O. Sonnezatii. Pallide testaceus; oculis, antenzarmn basi elytrormmque et tarsorm apice fusco-nigris. Longueur 4 lig. D'un testacé pầle. Yeux, jase des antennes, extrémité des niandibules, des ćlytres et des tarses d'un brun-noiràtre. Elytres ridées transversalement. Têie et corselet assez fortement pointillés. La plus grancle partie des antemnes el l'abdomen manquent dans notre individu. Rapporté des Indes orientales par feu Sounerat.

(S. F. et A. Serv.)

SITONE, Sitona. MI. Germar daus son ouvrage intitulé : (Insector. spec. nov. aut minùs cognit. vol. I. pag. 4I4.) donne ce nom à un genre de Coléoptères-Tétramères, de la famille des Rhynchophores, tribu des Charansonites, lui assignant pour caractères : rostre court, épais, parallélipipède; ses fossettes le parcourant en entier, cour.bées subitement en dessous. Maudibules cornées, saus dents, pointues à leur extrémité. Maâchoires meurbraneuses, composées de deux lobes, grands, sécuriformes, longuement ciliés. Menton? (glossarium Germ.) corné, presqu'ovale, caréné intériearement. Languetle? (intergerium Gensr.) walle. Quatre palpes presqu'égaux, coniques. Antennes insérées vers le milieu du rostre, courtes, surpassant rarement la moitié du corselet lors. qu'elles sont ployées : leur premier article en massue vers le bout, atteignant le milien de l'cil; leur fouet mince, de sept articles un peu en masse, allant en se raccourcissunt, le dernier appliqué contre la massue; celle-ci étroite, ovale-oblongue. Yeux saillans, hémisphériques. Point de sillon sous le corselet. Ecusson petit, arrondi. Elytres oblongues, un peu plus larges que le corselet, tronquées à leur base, leurs angles huméraux élevés; elles couvrent l'abdomen et des ailes cuurtes. Pattes courtes, presqu'égales. Extrémité des janbes tronquée; un angle à la partie intérieure des jambes de derant. Cuisses en massue, les a térieures principalement. Premier article des tarses oblong, le second trigone. Corselet tronqué à sa base et à son extrémité.

Les espèces indigènes de ce genre se trouvent, suivant M. Germar, dans les épis de seigle, les prés, les chemins et sous les pierres. Il y rapporte les espèces suivantes: $1^{\circ}$. Sitona innulus $n^{\circ} .2$. Germ. Charanson mantelé $n^{\circ} .25 \mathrm{~g}$. Encycl. $2^{\circ}$. Sitona lineata $n^{\circ} .4$. Grв в. Charanson linéé n. 296 . Eucycl. $3^{\circ}$. Sitona gressoria ${ }^{\circ}$. 1. Germ. Chilranson marcheur no. 399. Orrv. Entom. $4^{\circ}$. Sitona regensteinensis no. 8. Germ. Charanson allemaud $n^{\circ} .452$. Oriv. id. $5^{\circ}$. Sitona occator $n^{\circ} \cdot 9$. Germ. Charanson chevelu $n^{\circ} .458$. Oriv. id. et quelques autres, dont une de Buénos-Ayres.

(S. F. et A. SERv.)

SMARIS, Shlaris. Lat. Acarus. Schrant. Tronlbidium. Hermann.

Genre d'Arachnides de l'ordre des Trachéennes, famille dés Tiques, établi par Latreille et ayant ponr caractères suivant ce savant: palpes guère plus longs que le suçoir, droits et sans soies au bont; yenx an nombre de deux; pieds antérieurs plas longs que les autres. Ce genre se distingue lacilement du genre Bdelle, parce que, dirns celui-ci, les palpes sont très-alongés, quils sont coudés et ont des soies au bout. Les Bdelles diffèrent encore des Smaris par le nombre de leurs yeux qui est de quatre.

Les Smaris sout de très-petites acarides vagabondles; leur corps est mou, ovoïde, ronssâtre et parsemé de poils. L'espèce qui sert de iype à ce geure, est :

Le Siraris du Sureau, Smaris Sambuci. Lat. Geñ. Crust. et Ins. tom. 1. pag. : 55. Genre Siral'is, Précis des caract. genèr. des Ins.pag. $180 .-$ Hist. nat. des Crust. et des Ins. tom. 8. pag. 54. - Acaris Sambuci. Schrank, Enum. Ins. Alst. $n^{\circ}$. 1085.- Hекr. Méull. Apt. pl. 2. fig. 8. et $p l$. 9. fig. L. M. N. Il est rouge, parsemé de quelquej poils un peu longs; les antennes et les pattes sont plus longues. Cet insecte se trouve en France sur le surean. Il marche leutemeut. Latreille fense que les 'Trombidions miniatun, papillosum el squammatunz d'Hermann fils (Ménu. Apter.) doivent appartenir à ce genre. (E. G.)

SMERDIS, Stzerdis. LEACH. Voyez le mot Squille. (E. G.)

SWÉRINTHE; Snerinthus. LAT. God. Sphinx. Limn. Grof. Drur. Smith. De Géer. Esper. Cram. Esigraju. Ross. Panz. Hub. Spectnim. Scopol.

Genre d'insectes de l'ordre des Lépidoptères, famille des Crépusculaires, tribu des Splingides.

Quatre genres: Sphinx, Achérontie, Macroglosse el Smérinthe, constituent cette tribu selon il. Latreille. Nous n'en'admeltrons que deux, salvoir Sphinx et Smérintle. Le premier se distingue du second parla massue de ses antènes n'iyant que des stries iransversales et parce qu'il est pourvu 
d'ane langue cornée plus ou moins lovgue, mais tonjours très-distincte.

Quant aux Achéronties et aux Macroglosses, ils formeront des groupes dans le genre Sphinx. Voy. ce mot.

Antennes presque prismatiques, en scic ou pectinées, termiuées en pointe crochue, portant une petite houppe d'écailles. - Langue presque nulle. - Palpes comprimés, couverts d'écuailles très-denses, rapprochés, leur troisième atticle à peine distinct. - Ailes dentelées et fortement sinuées. - Chenilles ayant la tête presque triangrnlaire.

Les Smérinthes ont dans leur premier état les mêmes mœurs et les mêmes ennemis que les Sphinx ( voyez ce mot), mais il nous paroît certain ru'als n'ont pas la même puissance de rol. Les mâles même sont lourds; on ne les rencontre point sur les fleurs, dn moins ceux des especes européennes, et s'iis prenuent quelquefois leur essor, nous croyons que ce n'est que pour aller joindre leurs femelles. Nous rapporterons à ce genre : Io. Smérinthe demi-paon, Snier. ocellatus. LAt. Gener. Crust. et Ins. tom. 4. pag. 2 10. - Sphinx ocellata no. I. Hab. Entom. Syst. - Le Sphiux deni-paon. Georr. Ins. Paris. tom. 2. pag. 79. no. 1.- Exgrabr. Papil d'Europ. $n^{\circ}$. 164. pl. 119.-Esper, Sphinx d'Europ. tab. 1. - Encycl.pl.62. fig. 1-5. - Faun. fianc. Lépidopt. pl. 3o. fig. 5. 2n. Sinérinthe aveugle, Shrer. excacatus. Sphinx excocata. Sмiтн-Аввот, Lepid. Georg. pl. 25. $3^{\prime \prime}$. Smérinthe nayope, Smer. myops. Sphinx myops. Siitr-Aввот, id. $p l$. 26. Ces deux espèces sont très-voisiucs de la première. $4^{\circ}$. Sinérinthe du tilleul, Smer. tilice. LA'r. id. - Sphinx tilio no. 10. F.1s. Entom. Syst. - Le Sphinx du tilleul. Groz. $i d$. $p u g .80 . n^{\circ} .2$. - Encram. Pap. d'Europ. $n^{\circ} .163$. pl. 1 16-118.-Encycl.pl.63. figo. 1-4.5०. Satérinthe du peuplier, Smer. popkli. Lat. id. Sytunx populi no. 9. F'ав. Entom. Syst. - Le Sphinx à ailes dentelées. Geor. id.pag. 81. $n^{\circ} \cdot 3 .-$ Exgram. Papill. d'Eurpp. no.162.pl. 114-116. - Encycl. pl. 62. fig. 7. 60. Sulérinthe du chêene, Smer. quercus. LAT. ¿d. -Sphinx: quercus no. $\overline{3}$. Faв. Entom. Syst: - Evgan. Papill. d'Purop. $n^{n}$. 165. pl. 62.fig. 6. - Encycl. pi. 6z. fig. 6. $7^{n}$. Snérinthe du noyer, Siner. juglandis. Sphinx juótindis. Smiтn-Aввот, id. pl. 29. 8․ Sinérinthe A julus, Smer. Apulus. Sphinx Apulus no. 14. Fas. ia. - Encycl. pl. 66. fig. 2. $9^{\circ}$. Suétinlhe denté,

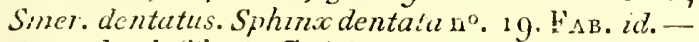
Lincrel. pl. 6ï. fig. 3. (1) $10^{\prime \prime}$. Smérinthe Pholus, Sner. Pholus. Sphinx Pholus $\mathrm{i}^{\circ}$. 24. HaB. id.

(1) Cramer ussure que cette espèce a unc langue longute, rualée en spirale : cependant les dentelures des ailes \& ha conformation des antennes la rapportent ćvidemment au zenre Smérinthe. En seroit-il de ce genre conme de colui da Sphinx où la longueur de la langue est exiremumari varable; l'Atropus en ayant une tris.courte, taids que nous Hisi. Nat. lass. Tonze $X$.
Les espèees suivantes nous paroissent encore appartenir à ce genre; mais nous ne sommes pas certains que toutes soient distinctes de quelquesunes des précédentes.

I $^{\circ}$ Sphinx Achemon. Drury, Ins. tom. I. pl. $X X I X$. fig. I. $2^{\circ}$. Sphinx Gorgon. Cram. $p l$. CXLII.fig E. $3^{\circ}$.Sphinx Phalaris. id.pl.CXLIX. fig. A. $4^{\circ}$. Sphinx Hasdinual. id. pl. CCXLVI. fig. F. 5'. Sphinx Charilus. id. pl. CCXLVII. fig. A. 6॰. Sphinx Myron. id. pl. id. fig. C. $7^{\circ}$. Spluinx Ganascus. Stold, Suppl.-Cram. $p l$. 35. fig. 3. 8․ Spluinx Timesius, id. pl. 40. fig. I. (S. F. el A. Serv.)

SMYNTHURE, Smynthurus. LAT. Podura. Linn. Geoff. De Géer. Fab. Oliv. Lamarck.

Genre de l'ordre des Thysanoures, famille des Podurelles, établi par Laireille aux dépens du genre Podura de Linné et ayaut pour caractères: antenues plus grềles vers leur extrémité, termiuées par une pièce annelće ou eomposée de peti!s aricles; tronc et ahdomen réunis en une masse globuleuse ou ovalaire.

Ces insectes ressemblent beaucoup aux Podures, mais ils en different par les antennes, qui dans ceux-ei sont dela même grosseur dass loute leur longueur et sans anneaux on petils articles a leur extrémitć. Le tronc des Podures est distinetement articulé, et leur abdomen est étroit et oblong. Le genre Smynthure correspond exactement à la seeonde seclion des Pudures de de Gée:. Cet auteur a donné quelques détails sur les babitudes de la plas grande espièce (Sm. brun), qui habite ordinairement les morceaux do bois et les brinches d'arbres qui sont restíes long-temps sur nn territa haunide; on n'en voit jamais dans dos lieux sees, et il parốl que leur nourriture consiste dans les particules bumides du bois à demi-ponrri. Los Sinynthares font de grauds sauts guand on les touche, et on aperçoil aussitôt après le saut, que leur rueue se tronve étendue en arrière et dans une ısême lingre avec le corps; mais peu apries, e!le se remet dans la premiere position, et Parimat aide ce mouvenent en haussant un peu le derière. Outre cotte queie qui ressemble beascoup il celle des Pudures, ces insectes sont pourvus d'un organe tres-extraordinaire et qu'on ne trouve pas atix Poúures: en dessous du corps, justement entre les points des deux dents de lia Guene fonchue, il y ane parlie ćlevée, cylindrique, de laquelle il sort derix longs filets, rembi iseux, transparens, très-flexibles, el gluans ou humides. Ces filets, qui sont arrondis at bout et presque de la longhear de tout l'anial, sout

saisns de M. Lefébure de Cérisy qui a manuscrice une moungraphie des Sphinx, que des esfèces cxoriquics rrès vo -

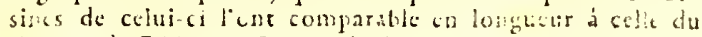

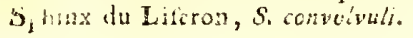

$\mathrm{Kin}$ 
élaneés avec force et vitesse liors de la partie eylindrique dont nous a vons parlé, l'un d'un eôté et l'autre de l'autre, et cela uniquement lorsque l'inseete a besoin de s'en servix; après quoi ils rentrent dans le court tuyau eylindricque comme dans un élui, et en même temps en cux-mêmes, de la mêrne manièrc que les eornes des Limacons rentrent daas leur tête. Voici l'usacre que de Géer a vu que les Snyathures faisoicnt de ces organes remarquables : quand l'insecte, qu'il avoit plaeé dans un vase de tere, márclioit contreles parois, il lui arrivoit souvent de glisser, c'étoit comme si les pieds lui manquoient, de façon griil étoit sur le point de tomber; daus l'instant même les denx tilets paroissoient, étoien'́laneés avee rapidité hor's de leur étui et sattaehoient dans le moment an vase par la matière gluante dont ils eloient enciuits, en sorte que Panimal se troutroit alors comme suspendu à ces deux fi!e!s et qu'il avoit lo temps de se raccrucher de nouvenu avec les pieds. Il est probible, conme le pense de Géer, grue l'insecte se sert de ces filets pour s'attacher atux corps sur lescuels il retombe après avoir fait un saut.

Ce genre se compose de cinq à six espèces; la plus grande et celle gui pout serria de type atu ijcole, est:

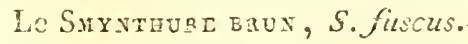

S. fliscus. Lit, Gen. Crust. et Ins. tom. r. pas. 166. Smynthu:e brun. Hist. nat. des Crust. et des Ins. toriz. 3. pag. 82. 7.t.73. fig. 5. 6. - Podura atri. Linx. Syst. nat. edit.15. tom. 1. pars 2. pag. noi3. Fann. Suec. edit. 2. no. 1929. - Ta?ochre brune enfumée. Gror. Hist. des Ins. tom. 2. prig. 608. - Poduie isune ronde. DE GEER, MLén. sur les Ins. tom. 7. pag. 35. pl. 5. fig. 7. 8.-Poaluri atra.FAB. Entom. Syst. tom. 2. pag. 65.

Il est d'une belle eouleur brune luisunte; il se trouve dans toute l'Europe, dans les lieux hulmives.

Les Pouture viriais de Limé et lit Podure noire it aches fures sur le ventre de Geoflroy, apparienent it ce roure. (E. G.)

SOLDTCORNES ou STEREOCERES. Septiène famille des Coléoptères-Pcntanèrés suịvunt R. Duméril (Zool. analytiq.) : en voiciles caraclères. Elytres dures, couvant tout le ventre. Antennes en masse ronde, solide. Wlle contieut les genres Léthre, Escurbot et Anthrèe.

$$
\text { (S. F. et A. SERv.) }
$$

SOUCI. Geoffeny eonfond sous ce nom les Coliades Hyale $n^{\circ}$.53net Eilusa no. 38. Loyezt. IX. pag. 99. et iol. de cet ousrage. Enyrameile a doné aussi le nom de Souci i la Coliade Edusa.

$$
\text { (5. I. et A. Skrv.) }
$$

SOUFFRÉE A QUEUE. Geoffroy applique ee nom à la Phalène du Sureau no. 84. Voyez Encyclopédie, tom. $X \cdot$ pag. $9^{2}$.

$$
\text { (S. F. et A. Serv.) }
$$

\section{SPALANGIE, Spalangia. LAt. Sprivol.}

Genre d"insectes de l'ordre des Hyménoptères, section des Térébrans, fumille des Pupivores, tribu des Clialeidites.

Dans celte tribu les genres Leueosnis, Chalcis, Dirhine et Chirocère ont leurs pattes postérieures à evisses grandes, lenticulaires et à jambes arquées; les Eulophes n'ont que cing à huit articles aux antennes; esfin les genres Eucharis, 'Thoricanthe, Eurytone, Agaon, Périlampe, Eupelme, Misocampe, Ptéromale, Cléonyme et Encyrte ont les antennes insérées prè́s du milieu de la face antériente de laftête et par eonséquent sensiblement ćloignées de la beuche, ee qui distingue totis ces genres de celui de Spalangie.

Antennes composées de dix articles, insérées tout près de la bouehe, sur le rebord antérieur de la lêie, furtement coudéés après le prernier article, celui-ci ussez gros, presque cylindrique, plus long dans les fermelles que dans les mâles, le second bealucoup plus court dans ce dernier sexe que dans l'atre; les huit autres allant en grossissan insensiblement, le dernier deux ou trojs fois plus long que le précédent et le plus gros de tolis. - Mandibules Liclentées. - Palpes unaxillaires et les labiaux n'offrant que deux articles distincts. - Tête triangulaire, forlement creusée postérieurement. - Trois ocelles disposés en ligne contbe sur le haut du front. - Corps alongé. Corselet ayant son premier segment large, s'alongeant et s'amineissant d'une manière sensible en devanl; métathorax loug. - Ailes très-eiliées à lear bord, les supérieures ayant une nerrure qui partant de l'aile sans toueher au bọd extérieur se reeourbe ensuite pour rejoindre ce bord qu'ello suit jusque passú le milieu et émel iutérieurement un peu avant de disparoitre un rameau fort conrt, in peu élargi à son extrćmité qui se recourbe et commence la cellule radialc sans l'achever; une cellule culitale nélant point séparée du disçue et se confondint avec toutes les aulres. - Ahdomen ovale, terminé en pointe, son premier segment formant brusquement un assez long pódicule. pattes de longueur moyenne; hanches assez grosses; cuisses oblongues; jambes droites.

Ce genre fondé par M. Latrcille ne contient qu'me espèce dont les roquirs ne paroissent proint différer de celles des Misocampes. Voyez Cinips.

\section{1: Spalaxgle noire, S. nigra.}

Spalungica nigra, nitida; capite thoraceque punctatis; alis pellacuais, margine pilosis.

Spalangin nigra. LAT. Gen. Crust. et Ins. tom. 


\section{S P A}

4.p. 29. tom. 1. tab. XII. fig. 7. et 8. Ie mâle. Sprvol. Ins. Ligur. fas. 3. pag. 167.

Longueur 3 lig. Noire, luisante, pubescente. Tête et corselet ponctués. 'Tarses testacés. Ailes transparentes, un peu velues surtout à leur bord. Anus pointu.

Des environs de Paris.

Nota. M. Latreille a bien voulu nous communiquer cette espèce et nous permettre de la décrire d'après nature. ( $S$. F. et A. SERv.)

\section{SPARASION, Sparasion. Lat. Ceraphron.} Jur.

Genre d'insectes de l'ordre des Hyménoptìres, section des Térébrans, famille des Pupivores, tribu des Oxyures.

Dans cette tribu les genres Béthyle, Dryine, Autéon, Hélore, Froctotrupe, Cinète ct Bélyte ont des cellules brachiales aux ailes supéricures, et partri les genres qui en sont privés les Diapries ont leurs antennes insérées sur le front et les ailes sans cellules. Tues 'Téléas et lés Scélions n’ont pas les palpes maxillaices silllans et, les Platyrastres cont les antonnes te dix atticles daus les deu $x$ sexcs ei point de col!nle radiale aux ailes supérieures. Quant aux Cómaphous leurs antcnnes sout de onze arlicles, filifurmes daus les deax sexes, et l'abdonien est ovoï in-conique.

Antennes de douze articles dans les deax sexes (I), insérées près de la bouche, liliformes dans les mâtes, en massue et coudíes dans les f́emelles. - Mandibules bidantées.-Palpes maxallaires saillans, filitormes, de cinq arlicles, les labiaux de rrois. - Téte aroudie, front élevé. Alles supérieures n'uyanl qu'une cellule (la d'ildiale, laquelle est incomplète). - Abdomen elliplique, dépriraé, sa base large, point rétrécie en un pédicule étroit. Taricre (des fernelles) peu apparente. - Pattes de longuen moyenne.

L'auteur ne memionne yu'une espèce dc re rretire; elle a trut au pias trois ligncs de lonweur. C'est le Sparasion fromal, Spar. comatus. isт. Gen. Crust. et Ins. tom. 4. p. 35. - Ceraihro⿰氵 comnutus. Jun. Hyménopt. pag. 303. pl. 1 s. Be France et du Piémont.

$$
\text { (S. F. et A. SERv.) }
$$

SPARÉDRE, Sparedrus. MÉc. DeJ. (Culitl.) Culopus. ZiEGL.

Geure d'insectes de l'ordre des Coléoptères, section des Héléromères (1 re. division), fannille des Sténélytres, triba des (is témérites.

Quatre genres composent celle tribu: In $^{n}$. Calope, qui se dislingue des trois atutres par ses an-

(1) Juriue donne treize articles aux axennes de f'indi viaudunt il parke, et qui est tin mấl. tennes dentées en scie et particulièrement des Sparèd'es par le second article de ses tarses postérieur's qui est entier. $2^{\circ}$. Dityle et Edémère séparés du genre Sparèdre par leurs antennes qui sont insérées hors de l'échancrure des yenx et parce qu’ils n'ont que le pénultième article des larses lilobć.

Les caractères de ce genre n'ayant pas encore été publiés, du moins à notre connoissance, nous dirons seulement que les Sparèdres ont les antennes filiformes, insérées dans une profonde échancrure des yeux; l'antépénultième article de tous leurs tarses est bilobé ainsi que le pénuliè̀me. Leur's autres caractères nous semblent êtrc à peu près les mêmes que ceux des Edémères. Nous n'avons aucun renseignement sur les mœurs de ccs inseetes. L'espèce suivante est la seule connue.

I. Spatidide testacé, S. lestaceils.

Sparedrus niger, punctulatus, rufo hirtus; elytris testaceis.

Sparedrus testaceus. Des. Catal. - Calopus testaseus. ZiÉgL. In litter.

Longueur 5 à 6 lignes. Corps noir, finement pointillé, gami de poils roussâtres. Elytres teslaccées.

D’Allemagne et de Polugne.

(S. F. et A. SEnS.)

SPECTRE, Specinum. Nom donné par Scopoli ¿ un genre de lépidontères-Crépuseulaires rưil compose de Splringides. Les espèces qu'il y place appariement au genre Smérintlue ct à quelques divisions de celui de Splinx. Yoyez Spmiz et Sisentate. (S. H. et A. Serg.)

SPEC'TRE, Spectnzin. Ce genre crúé par Stoll répond exactement à la famille des Speetres de M. Latreille (Fann. nat.) Voyez ce mot.

(S. U. el A. SERV.)

SPECTRES, Spectra. Quatrième famille de da sertion des Coureurs, ordre des Orthoptèrcs.

Celle famille a pour caractères :

Ocelles souvent peu distincts on nuls. Anternes insérées sur la partie de la tête antérieure nux yeux. - Elytres t Ailes horizontales, celles$\therefore$ jlissées dans lear longuear, point entièremcnt recouvertes par les élytres. - Pattes uniquement propres à la marche, toutes d'une forme identique; cuisses antćrieures plus on moins complimées, toujours échanerées à leur base. - Prothorax plus court que le inésothorax ou tout au plus de sil longueur. (Insectes se nourrissant de végétaux.)

Nous proposerons de diviser ainsi cette fumille.

I. 'Trois ocelles très-distincts. phasace. 


\section{Point d'ocelles distinets.}

A. Corps ailé ou ayant au moins des élytres.

a. Prothorax égalant presqu'en longueur le mésothorax. Phy!lie.

b. Prothorax plus long que la moitié du mésotliorax.

Prisope.

c. Prothorax court, n'égalant pas en longueur la moitié du mésothorax.

Cladoxère, Cyphocrane.

B. Corps aptère, sans ailes ni élytres.

Bactérie, Bacille.

Les formes des Speetres sont variées et singulièreśs la plupart ressemblent à des branches d'arbres sèches et dénuées de feuilles, lorsque leurs ailes sont reconverles par les élytres et à plus forte raison lorsqu'ils sont privés de ces organes; d'antres, mêrne dans l'état de repos, semblent porter des feuilles; que! quefois aussi le corps, les élytres et le bout des ailes étant verts, cela leur donne l'apparence d'une branche vivante. La tĉte et te corselet de plusieurs espèces sont garnis d'épines ressemblant beaucoup it celles des rosiers ou des ronces. Cette similitude qu'ils ont avec les végétaux semble leur avoir été donnée pour leur sûreté. Les Spectres se trourent pour la plupart entre les Tropiques; un petit nombre seulement a dépassé ces limites. Ces Orthoptc̀res son! en général de grande taille et fort grếles.

PRISOPE, Prisopus. Mlantis, Phasma. Encycl. Spectrum. STouL.

Geare d'insectes de l'ordre des Orthoptères, section des Coureurs, famille des Spectres.

Parmi les Spectres privés d'ocelles et dont le corps est au moins muni d'élytres et souvent ailé, le genre Prisope est distinct par son prothorax plus long que lit moitié du mésothorax.

A l'exemple de H. Latreille (Gener. Crust. et Ins.) nous avions d'abord rangé dans la seconde division des Phasmes les espèces que nous rapportons aujourd'hni au genre Prisope. Les nouvelles coupes génériçues introduites depris pąr M. Latreille (Fam. nat.) sous les noms de Bactérie et de Bacille aux dépens de notre seconde subdivision des $\mathrm{Pbasmes,} \mathrm{qui} \mathrm{étoit} \mathrm{anssi} \mathrm{la} \mathrm{sienne}$ (premier groupe $\Lambda$. Bactérie et second groupe $B$. Bacille), nous ont eahardis à développer ici les caractères de trois nouveaux genres que nons avons micux examinés ou dont nous a vons en connoissance depuis le premier travail que nous venons de mentionner; quoique deux de ces coupes nouvelles (Cladoxère et Cyphoerane) n'aient pas encore été indiqués par te célèbre sutcur dont nous suivons l'exeellente méthode, nous espérons que le développement des caractères propres ì chacune d'elles, engagera les entomologistes à les adopter.

Les Prisopes n'ont point d'ocelles; le premier article de leurs antennes est assez long, déprimé; le second globuleux; le bord postérieur de lenr tête ainsi que les latéraux sont arrondis et le vertex un peu bombé : le corselet va en s'élargissant de la tête à la base des élytres, les bords latéraux du mésothorax sont munis d'un appendice membraneux et denté, le corps est toujours muni d'ailes et d'élytres dans les deux sexes, l'abdomen est convexe en dessus seulement, il s'ellargit un peu vers les avant-derniers segmens dont les bords latéraux ont aussi des appendices membraneux; les cuisses sont larges, aplaties, membraneuses, fortement dentées en scie et entièrement ciliées sur leur bord, les antérieures terminées par deux appendices. ressemblant à de petites feuilles. Les jambes sont dilatées, aplaties, leurs bords membraneux fortement dentés en scie et entièrement ciliés. Dans l'un des sexes au moins les, élytres recouvrent environ les deux tiers de la longneur des ailes. Pour les autres caractères, voyez Prasme.

Le nom de ce genre vient de deux mots grecs dont la signification est: pattes dentées en scic. On y rapporiera les espèces suivautes du présent Diclionnaire : $\mathrm{I}^{\circ}$. Mante Dragon $\mathrm{n}^{\circ} .59$. Prisopus Draco. Noв. 20. Mante sacrée no. 76 . Prisopús sucratus. NoB.

Nota. La création des trois genres Prisope, Cladoxère et Cyphocrane que nous élablissons aux dépens de celui de Phasme, nous force à modifier les caractères de ce dernier de la manière suivante.

Premier anticle des antennes cylindro-conique, le second globulcux. - Tête petite dans les deux sexes, en carré-long; toule sa partie supérienre droile, déprimée; son bord postérieur ainsi que les latéraux, droits; eeux=ci parallèles entr'eux. - Trois ocelles gros, très-distincts, placés en triangle sur le front. - Corps cylindrique, tonjours pourvu d'ailes et d'élytres dans les deux sexes. - Corselet ayant sa partie antérieure jusquà la base des élytres, linéaire; mésothrorax cylindrique, sans appendices membraneux aiusi que l'abdomen. - Elytres très-courtes dans les deux sexcs, recouvrant ì peine le tiers de la longucur totale des ailes. - Abdomen sans ćlargissement notable; anus des femelles ayant sa partie infórieure crcusée en gouttière, celleci ne dépassant pas l'extrémité de l'abdomen. - Cuisses et Jambes grêles, linéaires, sans dentclures nolables. Pour le reste des caractères, vojez $\mathrm{PHasu}$.

Les espèces décrites dans ce Diclionnaire qui resient dans ce genre sont: $1^{\circ}$. Phasule pécyda- 


\section{$S \mathrm{PE}$}

loïde no. I. Espèce différente de la Mante tachetée, voyez Cy phocrane ci-après. $2^{\circ}$. Phasme latéral no. 3. 3०. Phasme rose n०. 4. $4^{\circ}$. Mante phthisique no. 5. Sroul, Spect. fig. 76. Phasma phthisica. Nов. 5०. Mante inflexipède $n^{\circ}$. 14. tom. VII. pag. 641. Phasma inflexipes. Nов.

Ies Spectres de Stoll fig. 27. 85. et 86. nous paroissent être des Phasmes.

\section{CLADOXĖRE, Cladoxerus.}

Genre d'insectes de l'ordre des Orthoptères, section des Coureurs, famille des Spectres.

Le groupe de cette famille ayant pour caractères : point d'ocelles distincts; corps ailé on ayant au moins des élytres; prothorax court, n'égalant pas en longueur la moitié du mésothorax, contient les genres Cladoxère et Cyphocrane. (Voy. SpecTres.) Ce dernier se distingue de l'autre par la forme de sa tête, qui est arrondie et bombée postérieurement ; par son corselet plus large qu'épais, poinț linéaire, ni cylindrique; par ses pattes antérieures moins longues que les postérieures, et encore par le rapprochement qui existe entre celles-ci et les intermédiaires.

Prenier article des antennes cylindro-conique, le second glolmleux. - Tête petite, presque triangulaire, se rétrécissant ver's le corselet; toute sa partie supérieure droite, déprinée, son bord postérieur droit. - Point d'ocelles distincts. - Prothorax extrêmement couct, n'égalant pits en longueur le quart de celle dı mésothorax; celui-ci cylindrique, sans appendices membraneux : métathorax cylindrique, ì peu près de la longueur du mésothorax. - Elytres extrêmement courtes. - Abdomen cylindrique. - Pattes longues, à peu près également espacées; les antérieures beancoup plins grandes que les autres; cuisses et jambes grêles, linéaires, point dentćes. Pour le reste des caractères, roje $z \mathrm{P}_{\text {Hasme. }}$

Cladoxère vient de deux mols grecs qui signifient : branche sèche. Nous ne connoissons qu'une seule espèce de ce genre; ses mœurs, d'après sa conformation, doivent être à peu près semblables à celles des Phasmes.

1. Cuadoxìre grêle, $C$. gracilis.

Cladoxerus, fuscus, lovis; capite pallido lineato, elytris fuscis, exterius viridi-albido marginatis; alis hyalinis.

Longueur 3 pouces. Brun, lisse. 'Tête avec quelques ligaes d'un jaure sale. Elytres ayant leur bord extérieur d'un-blanc-verdâtre. Ailes transparentes. Pattes antérieures de la longneur du coris.

Du Brésil.

CYPFOCRANE, Cyphocrana. Spectmm. Stold. Mantis. Liwn. Plactsma. Lar. Manlis, Phasma. Encyel.
Genre d'insectes de l'ordre des Orthoptères, section des Coureurs, famille des Spectres.

Les genres Cladoxère et Cyplrocrane constituent un grompe particulier dans cette famille. (Voyez Spectres.) Dans les Cladoxères la tête est petite, presque triangulaire, droite et déprimée supérieurement, le colselet cylindrique, toutes les pattes presqu'également espactes, les antérieures beaucoup plins grandes que les autres; le genre Cyphocrane n'a aucun de ces caractères.

Premier et second articles des antennes cylindriques, celui-ci assez court. - Tête fort grosse (au moins daus les femelles), toujours arrondie et boubée postérieurement, ses bords latéraux arrondis.- Point d'ocelles distincts.-Corps assez large, presque plat en dessous, toujours pourv' d'ailes et d'élytres. - Corselet assez large, presque plat en dessons, peu convexe en dessus; prothorax très-conrt, n'égalant pas en longuenr le tiers de celle du mésothorax; métathorax plus petit que celui-ci. - Elytres courtes, égalant it pen près la longueur du tiers des ailes. - $A b d o-$ men plus large qu'épais, presque plane en dessous : anus-des femelles ayant sa partie iuférieure creusée en goutière, celle-ci dépassaut notablement l'extrémité de l'aldomen. - Pattes antérieures point notablement plus longues que les autres; les intermédiaires ayant leur insertion beaucoup plus près des postérieures qae des antérieures: cuisses et jambes linéaires, un peu épiueuses en dessous. Pour les autres caractères, consultez. l'article Prisme.

Ces inscctes sont fort grands; ce sont, après les Phyllies, les moins grếles de tous les Spectres. Leur lête grosse et très-bombée leur a valu leur nom géaćrique tiré de deux mots grecs.

Rapportez aux Cyplocranes, les espèces suivantes de ce Dictionnaire. $1^{\circ}$. Phasme de la Jamäque $\mathrm{n}^{\circ} .2$, CYohocrana Jamaicensis. Nos. $2^{\circ}$. Maute Géant no. 2, Cyphocrana Gigas. Noв. 3о. Mante tachetée no.56. Cyphocrana maculata. Noв. Nous avions à tort regardé cette espèce comme ponvant être la même que le Pliasme nécydaloide. ( Fabricius, Entom. Syst. Suppl. cite inal-à-propos à son Phasma necydaloides les figures de Stoll, spect. pl. IIT. fig. 8. et $p l$. IV. fig..1 r . qui. se ripportent à la Cyphocrana maculata.)

A ce genre appartieunent eneore la Brantis $G_{i-}$ gas. Drun y, Illustr. tom. 2. pl. L. -- Cyphocranct cornuta. Nob. et le Spectue a petites ailes. Stozl, Spect. pag. 61. pl. XXI. fig.77.-Cyphocrana microptera. Noв.

BACTÉRIE, Bacteria. LA'T. (Famn. natur.) plasma. HAB. LAT. (Gen.) Mantis. Lins. Spectrum. StouL. Mantis, Phasma. Encycl.

Genre d'insectes de l'ordre des Orthoptères, section des Coureurs, famille des Spectres.

Les seuls gentes de Sincolves privés dincelles. 
ainsi que d'ailes et a'élytres sont les Bactéries et les Bacilles; les deruiers se distinguent des premières par leurs antennes courtes, subulées-coniques, et par leur tête dont la partie postérieure est déprimée.

Ce genre ront M. Latreille n'a pas cricore publié les caractères se compose des espèces de la première suhdivision (seconde division) des Plias. mes de son Gener. Crust. et Ins. tom. 3. pag. 83. Cette subdivision a pour caractères: corps sans ailes ni élytres; antennes sétacées, alonģées, counposées de nombreux articles; nous y ajoutcrons, tête un peu gonflée postérieurement, ses bords latéraux et postérieur, arrondis : les denx premiers articles des antenues fortement aplatis et comme membraneux. Partie inférieure de l'anus creus.e en gouttièrc dans les fernelles et dépassant considérablement l'extrémité de l'abdomeu.

Bactérie vient d’nn mot grec qui signifie : petit batton. Ce genre correspond exactement an premier groupe de notre seconde subdivision, premiere division des Phusmes. Fojez ce mot.

BACILLE, Bucillus. LAT. (Fitm. nut.) Phasma. FAB. LAT. (Gener.) Mlanäis. Ross. Phasma. Lincycl.

Geure d'insectes de l'ordre des Orthoptères, section des Coureurs, farnille des Spectres.

Parmi les Spectres privés d'ocelles, d'ailes et d'élytres, les Bactéries sont distinguáes par leurs antennes longues, sétacées, multiarticulées et par leu tête arrondie et gonllée postévieurement.

M. Latreille (Gener. Crust. et Ins.) a voit placé les Bacilles ciont le nom vient d'un mot latin qui simnifis : petite baguette, parai les Phasmes. Ils y formeut un groupe particulier dont le carractère est : corps sins ailes ni élytres; antennes trèscourtes, subulées-coniques, grenues, compostes d'un petit nombre d'articles. Dans son nouvel ouvrage intitulé : F'anilles naturelles du Règne animial, ce savant enlomologiste convertit ce groupe en gente : ignorant les caractères de bonche que l'oa peut lui assigner, nous ajouterons it ce qui est mentionné ci-dessus, les signalemens suivans : prenier article des antennes couique, le second giobuleux; lête un peu déprimée postérienrement, ses bords latéraux dröits. Anus des femelles conformó comae dans le genre précédent (Bactérie).

Les Bacilles répondent au second groupe de notre deuxième subdivision, première division des Phasmes. Voyez ce mot.

$$
\text { (S. F. et A. SERt.) }
$$

SPERCHEE, Spercheus. Fas. Panz: Lat. Hydrophilus. ILLIG.

Genre d'insectes de l'orảre des Coléoptères, section des Pcntamêres, farmille des Palpicornes, tribu des Hydropliiliezs.
La division des Hydrophiliens dont les mandibules sont bidcntées à leur extrémité, le corps lrémisphérique on ovoide-convexe et le corselet toujours beaucoup plus large que long, renferwe six geures, dont cinc, savoir: Fydrophile, $\mathrm{Hy}-$ drochare, Globaire, Hydrobie et Limnébie ont les antennes de neuf articles, ce qui les distingue des Spcrchées.

Antennes de la longueur de la tête, insérées sous les côtés du cliapcron, composées de six arlicles, le premier le plus long de tous, cylindroconique; le second plus long que les suivans, cylindrique, le troisicme court, transversal, les deux suivans transrersaux, lenticulaires, le sixième ovale-arrondi; ces cinc derniers firmant une massue cylindrique, perfolice, ảrondie à son extrénuté et pulescente. - Labre caclé, coriace, en carré transversil, denx fois plus large que lonir, ses bords latéranx arrondis en devant. - Mandibules ayant leur côté extéricur très-arqué, aiyn et leur extrémité iridentée; ces dents aiguës, divergentes. - Mâchoires de deux lubes, l'extíreur cn forme de palpe, alongé, grêle, arqué, poin! u el soyeux à s'n extrémice; le lobe intérieur: en carré-long, plat, coriace, ayant son extrénité tronquée oblicuesuent et ciliée : son angle antírienr tornant une dent alongte. - Palpes presque filifirmes, leur dernier article n'ayant guère plus d'épuisseur que les autrès; les tnaxillanes de ax fois plus longs que les labiaux, leur article terninil ovale-alongé, aminci ì sil base, aigu à l'extrémité; dernier article des lahiar ovale. - Levore linéaire, transversale, coriace, velue, son rebord supérieur membranenx ayant deux lobes paroissant divisés en deux parties fort inégales vers le milieu du menton; celui-ci crustacé, en capré transversal, trois fois plus large que long. - Tête forte; chaperon très-échancré en devan!.--Corps ovale-hémisphérique, très-bombé én dessus. Corselet transversal, à peu près de la mềrse largeur partout, plus large que la tête et échancré cn devant pour la recevoir. - Ecusson fort petii. - Elytres beaucoup plus larges que le corseler, arrondies à leur partie bunćrule, reconvrant des ailes et la totalité de l'abdomen. - Pattes propres à la marche; jambes anguleuses, un peu dentévs extérieurement, dépourvues d'épines à leur extrémité; dernier article des tarses assez gros, aussi long que les quatre précédens pris ensemble et terminé par deux forts crochets entre lesquels est un appendice portant deax faisceaux de soies qui sont divergens.

On ne connoît qu'une seule espèce de Sperchée. Elle habite le nord de l'Europe, l'Angleterre, l'Allemagne et même quelquefois les environs de Parıs. Elle se tient à la rácine des plantes aquatiques. C'est le Sperchée échancré, Sp. emarginatus. Lat. Gener. Crust. et Ins. tom. 2. pag. 65. tom. I. tab..IX. fig. 4. - Encycl. pl.35g. fig. 36 et 37 . (S. F. el A. Serv.) 


\section{S P I}

SPERChIUS, Sperchius. Rafinesque. Desh.

Ce genre de Crustacé dont M. Latrcille n'a pas fait mention daus ses ouvragcs, a été établi par N. Rufinesque (Annals of nature, $n^{\circ}$. I). II paroît appartenir à l'ordre des Amphipodes, et semble être voisin du genre Cerapzts de Say. Rufinesque le caractérise ainsi : autennes deux fois plus longues que la têle, à peu près égales entr'elles, avec de longs articles tronqués; celles de la paire supérieure étant néanmoins un peu plus grosses et plus grrandes que les inférieures. Corps comprimé, formé de sept segmens pourvus d'une large écaille de claque côté; le quatrième de ces segrmens étant grand, avec un appendice additionnel en arrière. Partie postérieure du corps (ou abdomen) formée de guatre segmens. Queue avec des appendices courts et recourbés. Pieds au nombre de quitorze, terminśs par un seul orgle ou crochet; ceux de là quatrième paire forts, pourvus d'une main grande, épajsse et arrondie.

Le Sperchius lucidus vit el nage très-bien dans les eaux des sources et des ruisscaux, aux environs de Lexington dans le Kentucky, aúx Etats-Unis. Il a trois quarts de pouce de long ; sa couleur est le brun luisant, ses yeux sont noirs; les appendices de sa quicue sont plus courts que le dernier segment de celle-ci, courbés en dehors et composés de deux articles ct d'un filament terminal.

Comme le Mémoire de M. Rafinesque n’a pas de figures, il est très-dificile de placer ce genre dans une des tribus nouvellement établies par $\mathrm{M}$. Latreille; M. Desinarest (arliclc Madacostracís dit Dict. des sc. nat. et Considérat. etc.) l'a mis dins une note à la suite du genre Cérapus.

$$
\text { (E. G.) }
$$

SPHECCODE, Sphecudes. TAAT. Sphex. IINN. Russ. Apis. Grofr. Proapis. De Géer. Nomada. Fab. Andrena. Oliv. (Encycl.) Panz. Jur. SpiNon. Dichroa. Ilutg. Krog. Melitta. Kirb.

Genre d'insectes de l'ordre des Myménoptères, section des Porte-aiguillon, firmille des Mellifires, tribu des Andrénètes (division des Parrasitcs ).

Une partie des Andrénètes a, suivant M. Iatreille, pour caractères particuliers : division intermédiaire de la languette lancéoléc ou presque linéaire, presque droite, avancée on courbée inférieurement; ce groupe contient les genres Sphécode, Fullete et Nomie. Nais dins ces deux áerniers la division intermédiate de la languette est beancoup plus longue que les latérales.

D'apris notre tablean des Melliferes (poyez Parasires), les senls genres Parasites de la tribu des Aulrérètes sont: Prosope, Sphécode et Rhathyme (I). Les preasières se distinguent en cc

(1) No:s substimons ce nom à celui de Colax, dont M. Vicdenam faisoi l'aplication à ull genre da Biptécs qu'elles n'ont que trois cerlules cubitales aux ailes supéricures et les derniers par leurs trois premières cubitales presqu't́gales entr'elles et dont la troisième reçoit les denx nervures récurreutes.

Antennes filiformes, coudées dans les femelles et composées de douze arlicles cylindriques; simplenent arqquées et de treize articles comme noueux et renflćs au milieu dans les mốles. - Labre trigone, déprimć après sa base, son extrémité o!biuse, joint carénće, échancréc däns les fernelles, cutière cians les nẩles. - Irâachoizes et Lèvre n'égalant pas deux fois la longueur de la tête ; levete courte, presque drovite, sa division intercéédini:e pen courbce inférienrement, les latérales presgu'aussi longues gue l'interácialire, tridentíes ì leur extrímité. - Puatre paizes articulcs, ayat la forme ordinaire. - Téte assez forte, transversale, de lis largeur da corselet. - Ieux de grandeur moyenne. - Trois ocelles placés en triangle sur la partic antérieure du vertex. - Corps poncitué, presque glabre. - Corselet glohuleux; prothorax très-court, rabaissć en devant; métulturax tronqué postéricureurent. - Ecussan peu saillant. - Siles supérieures ayant une cellule radiale un peu appendiculée, rélreeie deptis son milieu et se corminant presqu'en pointc; cette pointe érartée de la côte, et quatre cellules cubitales, la première assez grandc, la scconde la plus petite de touses, recevant la première nervure récurrente, la troisième très-rétrície vers la radiale rerevant la seconde ncrvare récurente, lir quatric̀ne très-grande n'altęgnant pas le beut de l'aile. - Abdomen ovale, un peu trongué à sia base, de cing segmens outre l'anus dans les fimelles, cn ayant un de plus dans les milles. Pattes de longnenr moyenue; jambes antérieures munies a leur extrémité d’une épine bordéc intérienrenent par me nembrane; jambes intermédiares n'ayant qu'nue senle épine terminale, simple, aigué a l'cxirúwité; jambcs postéricures cn ayant deux, bngues, presqu'kgales: dernier a:icle des tares muni de deux crocliets bifides; prenicr artide des tarses antérieurs un peu échitu. cré a sa base: une brossctie sur la face exténieure du preanier arlicle de chacun des tarses; point de palcule, ni de brosse.

Les Hymóngtères de ce geme, dî̀ ì M. Latreille, pondent dans le nid des Melliferes récoltans; leurs larres se nourrissent de la provision destinfe à celle de la propriétaire légitime. Ces Parasites sont fort conarmes pendant toute la helle saison; ils paroissent très-brillans rus au soleil; les fenclles pirguent foriemeat. On lien connốt jưun petit nombre d’espèces.

exotiques à peu pres au même moment ol frous ba lonnions à cortains Millières prasios. 
y. Sphécode giblieux, S. gibbus.

Sphecodes gibbus. LAт. Gen. Crust.et Ins. tom. 4. pag. 155.

Vojez pour la description el les aultes synouymes, Aüdrène ferrugineuse no. 32. de ce Dictionatre. Cetle espèce est très-commune aux environs de Paris; elle varie beaucoup pour le plus ou moius de uoir a l'abdomen et par sal laille, allant depuis deux liynes et demie jusqu'à six lignes. Le mâle ${ }^{c}$ ne diflèe que par lts caractères propres à son sexe.

\section{Srácode dOOlivier, S. Olivieri.}

Sphecodes ferrugineus, albo villosus; capite nigro, alss hyalinis, apice subfuscis.

Jongneur $4 \mathrm{lig}$. $\frac{1}{2}$. Antennes d'un brun-ferrugineux. Tête noire, avec des poils blancs. Labre et bord inférieur du chuperon, ferugineux ainsi gue le milieu des niandibules. Corselel et paltes de conleur ferugineuse avec des poils blancs. Abdomen glabre, ferrugineux. Ailes ransparentes, biunes à l'exlrémité. Màle.

11 a été rapporté d'Arabie par fer M. Olivier, de qui nous le temons.

RHATHYNE, Rhathymus. (Colax. Encych. aricle Parasites.)

Genre d'insectes de l'ordre des Hyménoptires, section des Porte-aiguillon, famille des Melliferes, tribu des Andrénètes (division des Parasites).

Trois genres composent cette division : les $\mathrm{Pro}$ sopes se distingueut par la division internédiaire de leur languette évasée el presqu'en cœur, et par Jeurs ailes supéricures n'offrant que trois cellules cubitales. Les Sphécodes, qui commeles Rhatlyymes cat quatre cellules cubitales et la division intermédiaite de la languette presque droite, diflèrent eisentiellenent de ces derniers par leur écusson nallenent élevé et arrondi postérieurement, et jurce que les nervures récurrentes aboulissent l'une dans lit première, l'autre cuans la seconde cellule cubitale; en outre les crochels des tarses sont bifides dans les Ephécodes.

Antennes filifor:zes, simplement arquuées, insérées chacune dans une petite cavité, de douze asticles dans les femelles, le premier assez grand, ćvasé à sa partje supérieure et recevant en grande partie le second; celui-ci globulenx, les autres cylindriques, le dernier un peu coupé obliqueuent. - Labre presque trigone, mais arrondi postéricuremert. - Téte plus étroite que le corselet, avancée, un peu triangulaire, ayant entre les antemnes un tubercule assez élevé. - Yeux grauds, ovales, saillans. - Trois ocelles placés jresqu'en lignc transversale sur la partie postériciure du vertex. - Métathora.x arrondi postériuvement. - Ecusson trisstelevé, large, aplati en dessus; son bord postérieur s'avançant, un pert échancré dans son milieu. - Ailes supéricures ayant une cellule radiale un peu appendiculée, se rétrécissaut après la troisième cellule cubitale jusqu'à son extrémité qui est arrondie et érartée de la côte, et quatre cellules cubitales, les trois premières presquu'égales, la seconde un peu rétrécie vers la radiale, la troisième l'étant aussi et recerant les deux nervures récurrentes, la quatrième beaucoup plus grande que les autres, atteignant presyue le bout de l'aile. - Jambes anténeures terminces par une épine bifide à son extrémité, garnie intérieurement d'une large membrane : jambes intermédiaires u'ayant qu'une épice teruinale simple, aiguë, crochue à l'extrémité. Jambes postérieures en ayaut cieux, simples, poinlues, fort inégales, l'extérieure longue, un pen courbée au bout; prenier article des tarses plus long que les cuatre suivass réunis; celni des autériturs fortement échancré à sa Lase, pour recevoir la membrane de l'épine: crochets des tarses simples. Pour les autres caractères, voyez SPHÉCODE.

Qunique l'espèce gri nous sert de type soit exolique, nous sommes sûr's qu'elle est parasite, la femelle n'ayant aucun des'organes nécessiires a la récolle. Le nom de Rlathyme vient d'uu mot grec et signifie : paresseux. Nous ignorons les uxours de cet Hyménoplère el quels sont les insectes dans le rid desquels il va déposer ses œufs. Il a des rapports avec les Splécodes, mais il ne nous a pas paru pessible de l'y réunir.

\section{Ruatuy a bicolor, $R$, bicolor.}

Rhathymus niger; capite thoraceque cinereo subvillosis: abdomine pedibusque,ferrugineis; alis violaceo-fuscis, ceneo niteníbus.

Longueur un pouce. Aotennes noires, un peu couleur de poix en dessous. Téte et corselet finement pointillés; on voit quelques poils noirs sur le dos de ce dermier et d'autres blanchâtres vers !e devant; les côtés et la partie postérieure du métathorax ont aussi des poils de cette couleur. Abdomen et palles de couleur ferrugineuse; pattes antérieures un peu plus foncées. Ailes d'un noirviolet avec un reflet bronzé. Femelle.

De Cayenue. (S. F. et A. Serv.)

SPHÉGIDES, Sphegides. Quatrième tribu de la famille des Fouisseurs, section des Porte-aiguillon, ordie des Hyménop!ères. Ses caractères sont:

Prothorax rétreci en devant, formant une sorte de cou. - Base de l'abdomen rélrécie en pédicule ordinairement très-alungé. - Quatre cellules cubitales aux ailes supérieures, dont trois conplètes dans lous.

I. Palpes maxillaires sétacés, notablement plus longs que les labiaux. - Jambes et tarses ayant 
ayant peu ou point d'épines et de cils roides. -Tarses antérieurs des femelles point pectinés, n'ayan't que des cils peu remarquables.

A. Jambes postérieures des femelles n'ayant pas d'épines distincles; leurs tarses antérieurs à articles cylindriques, n’étant propres ni à fouir ni à maçonner. (Insectes probablement parasites.) - Pédicule de l'abdomen très-court.

Dolichure.

B. Jambes postérieures des femelles munies d'un petit nombre d'epines courtes; leurs tarses antérieurs à articles élargis vers l'extrémité et triangulaires, propres à maçonnes. - Pédicule de l'abdomen très-distinct.

Ampulex, Podie, Pélopée.

II. Palpes fliformes, presque d'égale longueur. - Jambes et tarses garnis d'un grand nombre d'épines et de cils roides. - Tarses antérieurs des femelles comme bipectinés de cils roides, propres à fouir; leurs articles élargis vers l'extrémité et triangulaires. Pédicule de l'abdomen très-distinct.

A. Màchoires et lèvre plus conrtes ou guc̀re plus longues que la tête, fléchies au plus vers leur extrémilé. - Presque tous lcs articles des palpes obconiques. - Seconde et troisième cellules cubitales des ailes supérieures recevaut cha. cune une nervure récurrente. (Dans les Chlorious mâles, la première nervure récurrente aboutit à la nervure d'intersection des première et seconde cubitales.)

Chlorion, Sphex.

B. Mâchoires et lèvre beaucoup plus longnes que la tête, formant une promuscide coudée vers le milieu de sa longueur. - Palpes très-grêles, à articles cylindriques. - Seconde cellule cubitale des ailes supérieurcs recevant les deux nervures récurrentes.

\section{Ammophile.}

Nous savons à n'en pas douter que les Ammophiles et les Sphex creusent la terre pour y faire un nid, dans lequel les femelles transportent elles-mêmes différentes proies pour la nourriture de leurs larves, telles qne des chenilles, des insectes parfaits ou des Arachnides; la conformation des pattes des fcmelles telle que nous venons de la décrire est éninemment appropriée à ces deux usages. Retrouvant ces mêmes organes dans les Chlorions, nous devons par analogie leur supposer les mêmes mours.

Hist. Nat. Ins. Tone $X$.
Les Pélor,ées sont connus pour construire leur nid de terre gâchće et maçonnée, les approvisionnant ensuile de différens insectes; aussi voyonsnous aux pattes des femelles les organes propres à ce double travail. La même organisation des pattes daus les Ampulex et les Podies nous persuade que les nids de ces Hyménoptères doivent être maçonnés, de même que celui des Pélopées.

Le manque total d'organes propres à fouir, à maçonner et à transporter une proie, nons indique que les Dolichnres sont parasites, ce que nous avons déjá affirmé des Céropales pag. 183. de ce volume.

DOLICHURE, Dolichurus. LAT. GGener. addit.) Pison. Lat. (Gener.) Pompilus. Sprnol.

Genre d'insectes de l'ordre des Hyménoptères, section des Porte - aiguillon, famille des Fouisseurs, tribu des Sphégides.

Ce genre forme seul une division particulière dans sa tribu. Voyez Sprécrdes.

Antennes filiformes, arquées, insérées près de la bouche aux angles d'un tubercule un peu aplati; de douze articles dans les fcmelles, de treize daus les mûles; le premier article presqu'aussi long que le troisic̀me, à peu près cylindrique; le second très-court, globuleux; le troisième phins long qu'aucun des suivans, de formc cylindrique ainsi qu'eux. - Labre presque coriace, peu apparent. - Mandibules alongées, étroiles, arqnées, aignës à l'extrémité, dentées au côté interne. - Mâchoires droites, leur lobe apical court, membraneux; l'extérienr arrondi, coriace á sa partí externe. - Palpes maxillaires sćtacés, grêles, beaucoup plus longs que les labiaux, de six articles, le premier court; les second et troisième presque coniques; les trois derniers plus longs, plus minces, cyliudriques; palpes labiaux de quatre articles, le premier le plus long de tous, presque cylindrique, les second et troisième obconicues, le dernier ovale. - Lèvre droite, courtc, trifide à son extrémité, ses divisious égales entr'elles, arrondies extérienrement, l'intermédiaire plus large; menton coriace, cylindrique. - Tête forle, assez épaissc; cliaperon un pen avaucé, Ironqué au milieu, échancré sur ses côtés, s'ćlevant tout d'un coup postérieurement et caréné transversalement daus cette partie. Yeux ovales. - Trois ocelles posés en triangrle sur le haut du front. - Corps presque linéaire. Corselet ovale ; prothorax rétréci en devant, formant une sorte de cou; métallorax plus étroit que le mésothorax, anguleux, strié. - Ecusson presqu'aplati. - Ailes supérieures ayant une cellule radiale qui commence à se rétrécir après la seconde cellule cubitale jusqu’à son extrémité; cette extrémité fort éloignée du bout de l'aile, et quatre cellules cubitales, la seconde et la troisième plus petites que les autrcs, fortement rétrécies vers la radiale, recevant claciune une nervure LII 
récurrente; quatrième cubitale atleignant le bout de l'aile. - Abdonzen assez alongé, tenant au corselet par un pédicule très-court, nodiforme, de cinq segmens outre l'anus dans les femelles, en ayant un de plus daus les mâles; ces segmens un pcur étrécis dans leur entre-denx, surtout entre les premier, second et troisième; anus long, trèspointu. - Pattes foibles, grĉles; cuisses un peu aplaties à leur partie intérieure, gonflées à la base de l'extérieure : jambes et tarses nus, nullement propres à fouir; les premières terminées, savoir : les antérieures par une seule épine dentelée intérieurement, surtout dans les mâles; les intermédiaires en ayant deux, assez courtes, presqu'égales; les postéricures en ayant de mĉme deux, assez longues, inégales, l'intérieure plus grande : tarses antérieurs composés d'articles cylindriques, même dans les femelles.

Le nom de ce genre vient de denx mots grecs qui expriment que son abdomen est alongé postérieurement. Il nous paroît évident qu'il est parasite, les femelles n'ayant aucun organe propre à fouic, à maconner ou à transporter une proie. On n'en connoît qu'une espèce; elle est propre aux contrées méridionales de l'Europe, c'est le Dolichure corniculé, Dolichurus corniculatus. Pompilus corniculatus, Spinol. Ins. Ligur. fics. 2. no. XLI. pag. 52. Mlâle. - Dolichumıs ater. LAT. Gener. Crust. et Ins. tom. 4. p. 387. Ce dernier auteur a connu la femelle, mais nous croyons pouvoir répondre par une négation au doute qu'il exprime sur la question de sàvoir si cette feunelle fait son nid elle-même et le construit dansle bois. Voyez Latr. Id. pag. 58.

AMPULEX, Ampulex. Jur. Lat. (Fanı. nat.) Chlorion. Fas. Lat. (Gener.)

Genre d'insectes de l'ordre des Hyménoptères, section des Porte-aiguillon, famille des Fouisseurs, tribu des Sphégides.

Les genres Ampulex, Podie et Pélopée forment un groupe dans cetle tribu. (Voye z SpHÉcides.) Les deux derniers sont distincts du premier par la seconde cellule cubitale de leurs ailes supérieures recevant les deux nervures récurrentes.

Antennes longues, filiformes, insérées chacune sur un tubercule frontal, de douze articles dans les femelles, dc treize dans les mâles; le premier ovale-oblong, court; le second très-petit, les autres cylindriques, le troisième beaucoup plos long que les suivans, qui vont en décroissant de grandeur. - Labre caché par le chaperon. ILañabules sans dents au côté interne dans lés deux sexes, laissant dans les femelles un intervalle entr'elles et les côtés du chaperon. - Palpes maxillaires sétacés, beaucoup plus longs que les labiaux, de six articles, les labiaux de quatre. Languette ayant sa division intermédiaire à pen près de la longueur des latérales, presqu'entic̀re. - Tétc beaucoup plus large que le prothorax; chaperon en toit, fortement caréné longitudinalement dans son nilieu, cette carène beaucoup moius sensible au-dessus du chaperon, mais se prolongeant dans le milieu d'une plaque enfoncée du front jusqu'à l'ocelle inférieur. - Y eux grands, ovales, fort saillans. - Trois ocelles placés en triangle sur la partic antérieure du vertex. Corps assez long. - Corselet fort alongé; prothorax étroit, plus large à sa partie postérieure, rétréci en devant en une espèce de cou; mésothorax fortement ponctué, plus court que le métathorax, celui-ci presqu'en carré longitudinal, sa partie supérieure chargée de lignes élevées, dont plusieurs longitudinales et la plupart trans versales, ses angles postérieurs terminés en épine. - Ecusson étroit, transversal. - Ailes supérieures ayant une cellule radiale appendiculée, allant eu se rétrécissant depuis la seconde cellule cubitale jusqu'ì son extrémité, et quatre cellules cubitales; la première assez grande, recevant la première nervure récurrente; la scconde la plus pelite de toules, presque carrée; la troisième presqu'anssi grande que la prcmière, un peu rétrécie vers la radia!e, recevant la seconde nervure récurrente, la quatriène atteignant presque le bout de l'aile : base des ailes recouverte par deux écailles superposées l'une à l'autre. - Abdomen lisse et de cinq segmens outre l'anus dans les femelles, forlement ponctné et de six segmens outre l'anus dans les mâtes, les derniers étroits et mème peu distincts dans ce sexe. - Pattes longues; cuisses un pela aplaties à leur partie intérieure, gonflées à la base de l'extérieure; les postérieures un peu arquées : jambes ayant pen d'épines et de cils roides, les antérieures terminées par une seule épine un peu membraneuse, unideutée à sa base, bidentée à l'extrémité; jambes intermédiaires en ayant đcux simples, aiguës, presqu'égales ; jambes postérieures en ayant également deux, dont l'une plus forte, dentée en peigne au côté interne; tarses peu garnis de cils roides; leur premier ar ticle aussi long que les quatre autres pris ensemble, le quatrièmc fort court, large, garni en dessous d'unc brossette, creusé en gouttière en dessus pour recevoir une partie du dernier article, lequel est alougé et inséré à la base du quatrième, son extrémité munie de deux forts crochets unidentés dans leur milieu; point de pelottes; tarses antérieurs des femelles ayant la plupart de leurs articles élargis vers l'extrémité et triangulaires, propres à naçonner.

Réaumur nous apprend qu'une espèce d'Ampulex de l'ille de France qu'il nomme Guêpe-IChneumon fait son nid dans les murs et qu'elle l'approvisionne de Kakerlacs. Voyez son huitic̀me Mémoire, tom. $6 . p .280$ et suivantes.

Nous plaçons dans ce genre l'Ampulex comprimée, Ampulex compressa. Jur. Hyménopt. p. 134. Mâle et femellc. - Chlorion compressum no.7. Faв. Syst. Piez. - Encycl. pl.379. fig. I. 
Femelle. Il ne nous paroit pas certain que "'Ampulex fasciata de Jurine, figurée dans ce Dietionnaire, $p l .378$, soit de ce genre.

CHLORION, Chlorion. Lat. liab. Pronceus. Lat. Dryinuls. Fab. Sphex. Jur. Pepsis. Palis.Bauv.

Genre d'inseetes de l'ordie des Hyménoptères, section des Porte-aiguillon, fumille des Fouisseurs, tribu des Sphégides.

Dans la seconde division de celle tribu un gronpe a pour caractères : mấchoires et lèvre plus courtes ou guère plus longues que la tête, néchies au plus vers leur extrémité. Presque tous les articles des palpes obconiques. Seconde et troisième cellules cubitales des ailes supérieures recevant chacune une nervure récurrente. (Toyez Spágides.) Ce groupe se forme des genres Chlorion et Sphex. Le deruier est distinct par ses antennes insérées vers le milieu de la face antérieure de la tête et par la conformation de la seconde cellule cubitale de ses ailes supérieures qui est assea large et presque earrée.

Nous n'allons signaler ici que les earactères génériques différentiels de ceux des Sphex, et nous renvoyons à ce mot pour les autres.

Antennes insérées près de la bouche à la base du chaperou. - Máchoires et Lèyre fléchies seulement vers leur extrémité comme dans les Spliex, mais plus courtes que la tête. - Tête manifestement plus large que le corselet. - Trois ocelles placés en triangle sur le baut du front. - Corps long, glabre. - Prothorax de grandeur moyenne, plus long que dans les Sphex, formant un cou moins pronoucé, moins déprimé. - Ailes supérieures ayant quatre cellules cubitales, la seeoude étroite, un peu rétrécie vers la radiale; la quatrième distinclement commencée. Dans les mâles que nous connoissons, la première nervure récurrente aboutit à la nervure d'intersection, qui sépare la première et la seconde cellules cubitales. Duns les femelles, Jes nervures récurrentes sont comme dans le genre Sphex. - Crochets des tarses unidentếs vers leur milieu.

Ces beaux Hyménoptères exotiques d'une taille au-dessus de la moyenne, doivent leur nom, tiré du grec, à l'éclatante couleur veıte dont quelques espèces sont parées. Pour les mœurs, voyez SpHéGIDES.

$1^{\text {re }}$ Division. Lobe terminal des mâchoires lancéolć. - Division intermédiaire de la lèvre étroite et alougée. - Mandibules très-fortement ciliées intérieurement, ayant une dent médiale, simple et courte. - Cellule radiale appendiculée. (Genre Proncells. LAtr.)

A cette division apnartient le Chlorion maxillaire, Chlorion maxillure. Noв. Proncus muxillaris. La т. Gener. Crust. et Ins. tom. 4. p: 56. -- Pepsis maxillaris. PAL - BAUv. Ins. d'Afr. et
d'Amér. p. 38. Hyménopt. pl. s. fig. I. Femelle. D'Oware.

$2^{e}$. Division. Lobe ierminal des mîchoires court, arrondi à l'extrémité. - Lèvre comme quadrilobée, à divisions courtes. - Mandibules peu eiliées intérieurement, ayant nne dent médiale forte et comme composée de plusienrs pointes. - Cellule radiale sans appendice. (Genre Chlórion. Latr.)

\section{Chronion vert-bleu, C. viridi-ccrulenm.}

Chlorion capite thoraceque viridibus, aureo nitentibus; abdomine pedibusque coeruleis, alurunz lutescentiunn margine infero et cellulcrum caracteristicarum maximâ parte fuscis.

Lnngueur 15 lig. Antennes noires. Tête et corselet d'un beau vert-doré brillant. Abdomen et cuisses bleus; jambes et tarses presque noirs. Ailes jaunâtres avec leur extrémité brune; cette coulenr s'étendant aussi sur la partie earaetéristique jusqu'an bord de la première cellulo cubitale. Femelle.

De Cayenne.

Nota. Dans le Chlorion lobé les ailes sont eolorées de même, mais la partie brune ne s'étend pas sur la cellule radiale ni sur les seconde et troisième cubitales. De plus, celle espèce n'a point de reflet bleu sensible, et elle ne se tronve qu'en Afrique et en Asie.

\section{Chlonion azulé, $C$. azureulit.}

Chlorion viridi-aureum, cceruleo nitens; alarunn lutescentium margine infero fusco.

Longueur i 8 lig. Corps entièrement d'un beau veri-doré à reflet bleu très-prononcé. Ailes jannâtres avec leur bord postérieur brun. Antennes et larses noirs. Femelle.

Patrie inconnue.

Celte espèce differe du Chlorion lobé par sa taille beaucoup plus grande et par le reflet bleu répandu sur tontes les parties de son corps.

A ce genre appartient encore le Chlorion lobé, Chlorion lobatum. LAT. Gener. Crust. et Ins. tollz. 4. p. 57. - I'Ав. no. I. Syst. Piez.

AMMOpHILE, Ammophila. Kirb: Lat. Sphex. Linn. De Géer. Fab. Ross. Panz. Jur. Spinnz. Ichnellinon. Geofr. Pepsis. Fab. Spinol. Pelopecus. Faв. Miscus ( 1 re, fim.). Jun.

Genre d'insectes de l'ordre des Hyménoptères, seetion des Porte-aiguillon, famille des Foursseurs, tribu des Sphégides.

Ce genre forme seul une coupe particulière dans cette tribu. Voyez Sphégides.

Antennes filifurmes, arquées, insérées vers le milieu de la face autérieure de la tête, de douze arlicles dans les femelles, de treize dans les mâles; 
ces articles tors cylindriques à l'exception du second qui est globâleux; le troisième le plus long de tous, les suivans allant en décroissant de grandeur jusqu'au dernier. - Labre peu apparent, presqu'entièrement caché par le chaperon.Mandibules alongées, étroites, arquées, aignës à l'extrémité, dentées au côté interne.-Mâchoires entièrement coriaces, ayant leur lobe apical insensiblement rétréci et acuminé, formant avec la lèvre une promuscide coudée veis le milieu de sa longueur, beaucoup plus longue que la ête. Palpes filiformes, très-grêles, à articles presque cylindriques, les maxillaires de six articles; les labiaux presqu'aussi longs que les maxillaires, de quatre articles. - Tête grosse, plus large que le corselet, surtout dans les femelles; chaperon grand, presque trigone, ordinairement garni de poils courts, couchés. - Yeux ovales. - Trois ocelles placés en triangle sur le vertex. - Corselet ovale; prothorax court, étroit, conique ; mésothorax moins long que le métathorax; celui-ci bombé dans son milieu, arrondi postérieurement. - Ecusson petit. - Ailes supérieures ayant une cellule radiale se rétrécissant peu après la troisième cubitale jusquà son extrémité qui est arrondie, et quatre cellules cubitales, la première au moins aussi longue que les deux suivantes prises ensemble, la seconde recevant les deux nervures récurrentes. - Abdómen sensiblement pédiculé. - Pattes grandes, fortes; jambes et tarses garnis d'un grand nombre d'épines et de cills roides: tarses antérieurs des femelles bipeciinés de cils roides, propres à fouir, leurs arlicles élargis vers l'extrémilé et triangulaires; jambes antérieures terminées par deux épines, l'interne garnie d'une membrane depuis sa base jusque vers les trois quarts de sa longueur où il y a une petite dent. Jambes intermédiaires ayant deux épines assez courtes, simples, aiguès. Jambes postérieures en ayant aussi deux, l'interne plus forte, large, surtout î sa base et dentée en peigne : crochets des tarses aigus, simples.

Les Ammophiles dont le nom vient de deux mots grecs qui signifient : aimant le sable, font leur nid absolument comme les Pompiles (voyez ce mot), mais ils l'établissent seulement dans le sable; ceux de la première division l'approvisionnent d'Arachnides, les autres de larves de Lépidoptèr'es. L'Ammophile sabulosa femelle va chercher assez loin des chenilles, de celles de Noctuelles par préférence et souvent d'une longueur égale à la sienne; elle les pique de son aiguillon vers le milieu du corps, ce qui les engourdit mais ne les tue pas, et les empéche de marcher et de se contracter : ensuile étendant tout son corps sur celui de la chenille, elle l'embrasse avec ses mandibules auprès de la tête, soulève sa partie postérieure au moyen des nombreuses épines dont ses jambes sont armées; ainsi chargée elle ne peut plus voler et ne fait que marcher; si elle apercoit quelqu'obstacle devant elle, tel qu'une pierre ou une touffe de quelques plantes, elle quitte un instant son fardeau et va explorer son chemin en voltigeant au-dessus, puis vient ensuite ressaisir sa proie. Nous avons vu une fois cette femelle ainsi chargée franchir un mur de huit ou dix pieds de haut mais non sans accident, la chenille tomboit quelquefois à terre lorsque l'Ammophile la déposoit sur quelqu'avance de pierre pour reprendre de nouvelles forces. Ce travail étoit des plus rudes et nous a prouvé que ces insectes joignoient une grande persévérance à un vif amour de leur postérité. Ces Hyménoptères à l'état parfait se plaisent dans les lieux sablonneux où ils font leur nid; ils vivent du miel des fleurs. Leur taille est grande ou moyenne, leur corps est habituellement noir ou ferrugineux, le plus souvent de ces deux couleurs.

I $^{\text {re }}$. Division. Pédicule de l'abdomen plus court que celui-ci, formé seulement d'une partie du premier segment. - Point de pelottes entre les crochets des tarses. - Seconde et troisième cellules cubitales rét récies près de la radiale, la quatrièmie à peine commencée.

Nous placerons dans celte première division l'Ammophile arénaire, Ammophila arenaria. LAt. Gener. Crust. et Ins. tom. 4. pag. 54. Pepsis arenaria ${ }^{\circ}$.. 1. FАB. Syst. Piez. Trèscommun aux environs de Paris.

$2^{e}$. Division. Pédicule de l'abdomen noueux dans son milieu garni d'une sorte de membrane látérale après ce nœud, formé du premier segment tout entier (quoique les auteurs le disent formé de deux) et plus long que les antres pris ensemble. - Une pelotte grosse et carrée entre les crochels des tarses.

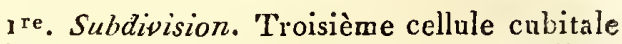
point rétrécie vers la radiale, la quatrième point commencée.

Le type de celte subdivision est l'Ammophile raccourci, Ammophila abbreviata. - Pelupceus abbreviatusno. 8. Fa . Syst. Piez. Mâle. La femelle est plus grande, sa face antérieure est un peu argentée mais non pas dorée, son chaperon est coupé carrément, presqu'échancré dans son milieu; celui du mâle est triangulaire, pointu en devant, cetle pointe alongée, un peu relevée. De l'Amérique méridionale.

$2^{e}$. Subdivision. Troisième cellule cubitale fort rétrécie vers la radiale, la quatrième conımencée.

Nous citerons dans cette subdivision les deux espèces suivantes : $1^{\circ}$. Ammophile du sable, $\mathrm{Am}$ mophila sabulosa. Lat. Gen. Crust. et Ins. tom. 4. p. 54.-Sphex sabulusa no. I. FAB. Syst. Piez. Femelle. Dans le mâle la partie ferrugineuse du 
pédicule et le second segment de l'abdomen ont une petite ligne dorsale noire. Très-commun dans toute la France. M. Latreillc pense que ce mâle est la Pepsis lutaria no. 2. Faв. Syst. Piez. $2^{\circ}$. Ammóphile soyeux, Ammophila sericea.-Sphex holosericea no. 4. FAв. Syst. Piez. Femelle. La moitié postérieure du pédicule, le second et le troisième segmeus de l'abdomen sont ferrugineux; dans le mâle ils portent une ligne dorsale noire. Cette espèce est celle indiquée par Jurine (Hyméa. note pag. 108.) Dn midi de la Fränce.

$3^{\ominus}$. Subdivision. Truisième cellule crbitale pétiolée, la quatrième point commencée (Misque $\mathrm{s}^{\mathrm{re}}$. famille Jurine.)

On rapportera à cette troisième subdivision l'Ammophile champêtre, Ammophila campestris. LAт. Gener. Crust. et Ins. tom. 4. pag. 54. Dans les deux sexes la moitié postérieure du pédicule, le second et le troisième segmens de l'abdomen sont ferrugineux, le quatrième est noir ainsi que le reste de l'abdomen. Des environs de Paris. (S. F. et A. Serv.)

SPHÉGIMES, Sphegino. Ce nom que M. Latreille donnoit dans ses anciens ouvrages à une tribu d'Hyménoptères-Porte-aiguillon fouisseurs, a été changé par lui dans ses Familles naturelles en celui de Sphégides. Voyez ce mot.

\section{(S. F. et A. SERv.)}

SPHÉGINE, Sphegina. MEIG. LAT. ( Fam. nat.) Milesia. $\mathrm{F}_{\mathrm{AB}}$.

Genre d'insectes de l'ordre des Diptères, première section, faunille des Athéricères, tribu des Syrphies.

Un groupe de celte tribu (voyez Sraphies) est ainsi caractérisé : antennes presque de la longueur de la tête ou plus courtes qu'elle, ayant leurs deux premiers articles égaux entr'eux, point insérées sur un tubercule frontal; ailes n'ayant pas de cellule pédiforme : cuisses postérieures renflées. Ce groupe renferme les genres Sphégine, Ascie, Tropidie et Eunère. Dans les deux derniers l'abdomen n'est point aminci à sa base en forme de pédicule; les Ascies ont le troisième article des antennes oblong, l'hypostome presque droit avec sa partie inférieure prolongée presque perpendiculairement.

Antennes avancées, un peu inclinées, de trois articles; les deux premiers très-courts, le troisième presque rond, comprimé, muni d'une soie dorsale nue insérée à sa base. - Bouche ayant son ouverture oblongue, se rétrécissant par-devant. - Palpes recourbés, en unassue, finement cilićs. - Téte hémisphérique. - Hypostome enfoncé, sans bosse; sa partie inférienre prolongée en avant, incisée. - Yeux espacés sur le front dans les denx sexes, celui-ci un peu plus large dans les fenclles. - Trois ocelles placés en triangle sur un tubercule du vertex, l'antćrieur un peu p!us écarté des autres que ceux-ci ne le sont entreux. - Corps long. - Corselet ovale, globuleux. Ecusson saillant, presque triangulaire, prolongé horizontalement sur la base du premier segment de l'abdomen. - Ailes ayant denx cellnles du bord postérieur fermées chacune par'une nervure transversale; celle de ces deux cellules qui avoisine le plus le bout de l'aile ayant cette nervure arrondie; point de cellule pédiforme. - Cuillerons petits. - Balanciers point reconverts. - Abdomen glabre, son premier segment court, le second très-long, aninci en pédicnle; les deux suivans larges, anus court. - Pattes assez grandes; les quatre antérieures minces; les postérieures fortes, leurs cuisses renflées, épineuses en dessous, leurs jambes arquées; premier article de tous les tarses plus long que les autres, celui des postérieurs gros et renflé : dernier article de tons portant deux crochets courts et une pelotte grosse, bifide.

La ressemblance de forme que présente l'abdomen de ces Diptères avec celui de la plupart des Hyménoptères de la tribu des Sphégides, leur a fait donner le nom qu'ils portent. On les trouve sur les fleurs. Leurs mœurs et lenr's métamorphoses sont ignorées : la taille du petit nombre d'espèces connues est au-dessons de la moyenne. M. Meigcn décrit les deux suivantes : $1^{\circ}$. Sphégine grosses cuisses, Spheg. clunipes. ME1G. Dipt. d'Eur. tom. 3. pag. 194. $n^{\circ}$. 1. tab. 28. fig. 5. Mâle. fo. 6 . Femelle. Longueur 3 lig. D'un noir brillant; dernier article des antennes ferrugineux. Troisic̀me serrment de l'abdomen ayant une large bande jaune quelquefois interrompue. Dans la femelle le quatric̀me segment a aussi une bande de même couleur mais plus étroite et toujours interrompue. Balanciers jaunes, ainsi que les quatre premières pattes: les postérienres noires avec l'extrémité des hanches, la base des cuisses et deux anneaux anx jumbes, jaunes. Des environs de Paris. $2^{\circ}$. Sphégine noire, Spheg. nigra. Mrig. id. pag. 195. $n^{\circ}$. 2. Même port et mếme taille que la précédente. Corps entièrement noir. Abdcmen à reflet verdâtre. Pattes à peu près conme dans la première espèce.

$$
\text { (S. F. et A. Serv.) }
$$

SPHÉNISQUE, Spheniscus. KInв, Lat. (Fam。 nat. )

Genre d'insectes de l'ordre des Coléoptères, section des Hétéromères (premic̀re division), famille des Sténélytres, tribu des Hélopiens.

Le troisic̀me groupe de celte tribu a pour caractèrcs : corsclet mesuré au bord postérieur plus large que long, soit trapézoidal, soit presque lunulé. Corps presqu'hémisphérique, quelquefois ovale et arqué ou bien ovale-oblong. Il contient les genres Acanthope, Camarie, Campsie, Sphénisque, Amarygme et Nilion. Voy'ez StéxiLYTRES. 
Les Acanthopes n'ont aucun des articles de leur's antennes conformé en dent de scie, et leur's cuisses antérienres ont une forte épine, au moins duns l'un des sexes. Le genre Camurie n'a que dix arlicles anx antennes, l'avanl-sternum se prolonge en une pointe qui se loge dans une cavité fourchue du mésosternum; les Campsies qui présentent anssi ce dernier caractère, diffèrent en outre des Sphénisques par le chaperon échancxé circulairement, les quatrième et cinquième articles des antennes cylindro-coniques et les côtés exiérieurs du corselet rebordés el tranchans. Dans les Nilions le corselet est lunulé et le corps coirt, velu, absolunent liémisplérique. Quant au genre Amarygme de M. Dalman, qui suivant M. Lalreille est le même que celui de Cnodulon FAB., il ne nous est pas sufinsamment comu pour pouvoir le faire entrer dans cette comparaison.

Ce genre dont le nom vient d'un mot grec qui a rupport ì la forme du corps figuré en coin, a été créé par M. Kirby (Trans. Linn. Centur. of Ins. vol. 12. pag. 5-5) et placé par lui dans sa fumille des Helopia a. Ses caractères sont d'après cet auteur : labre trüusversul, entier; lèvre petite, cunéiforme; mandibules se touchant par leur extrémité. Múchoires ouvertes à leur base. Palpes ayant leur dernier article grand, peu comprimé, presque triangulaire; menton oblong, convexe, un peu échancré à son extrémité; antennes plus épaisses vers le bont, dentées en scie, leur dernier article presque rhomboidal, tronqué obliquement; corps ovale, un peu cunéiforme; élytres élevées en bossi.

Nous joindrons à ces caractères, d'après nos remarques particulières, les notes suivantes : base des antenues recouverte par les rebords avancés de la tête; antennes composées de onze articles, les trois premiers cylindro-coniques, les suivans jusqu'au dixième inclusivement presque triangulaires, élargis intérieurement ef forutant des dents de scie, le onzième presque carré, pas plus long que le précédent (i); extrémité des mandibules lurge, entière, creusée en cniller ; tête très-jnégale en dessus, canaliculée eutre les yeux; chaperon coupé droit en devant, séparé de la têle par une ligne enfoncée, demi-circulaire; yeux très-échancrés; corps glabre; côtés extérieurs du corselet artondis, point rebordés; avantsternum sans pointe; mésosteraum sans cavité; écusson presque triangulaire, souvent un peu atrondi postérieurement; élytres mutiques it leur extrémité, recouvrant des ailes et l'abdomen; pattes longues, tarses antérieurs ayant leurs quatre premier's articies très-courts, le dernier plus long que ceux-là pris ensemble; premier article

(1) En cela notre manière de voir differ: de celle de M. Kirby. des tarses intermćdiaires long, les trois suivans courts, le dernier un peu plus long que le premier; tarses postérieurs ayant leurs premier et dernier articles longs", égaux; les deux intermédiaires courts.

Les Sphénisques ont par la forme du corps ainsi que par leurs conleurs, une singulière ressemblance avec certaines espèces d'Erotyles. On n'a pas de renseignemens sur lenrs mœurs. Nous connoissons trois espèces de ce genre, elles sont propres à l'Ansérique méridionale.

\section{SpaÉnisque Erotyle, $S$, erotyloides.}

Spheniscus niger, elytrorum hasi et parte posteriori albido muculatis, maculis sinuatis, dentatis, quibusdanz subcatenulato-junctis.

Spheniscus erotyloides. K1вв. Trans. Limn. Centur. of Ins. vol. 12. pag. 375. pl. 22. fig. 4.

Ionguear no lig. Corps d'un moir luisant, trèsbombé smpérieurement. 'Tête et corselet tinement pointillés en dessus. Elytres nories, leur base et une grande portion de leur partie postérieure chargées de taches irrégulières d'un blanc jancàtre : ces taches dentel'es, souvent réunies et comme enchaînées les unes aux autres; stries des élytres poiutillées.

1) Brésil.

\section{CAMARIE, Camariz.}

Genre d'insectes de l'ordre des Coléoptcires, section des Hétéromè!es (première division), faurille des Sténélytres, tribu des Hélopiens.

Un groupe de cette tribu caractérisé ainsi : corselet mesuré au bord postérieur plus large que long, trapézoïdal ou p̧resçue luaulé : corps tantôt presqu'hémisphérique, fanlôt ovale et arqué, quelquefors ovale-oblong, se compose de six genres (vayez Sténélytres), dout cinq, Acanthope, Campsic, Sphénisque, Amarygme et Nilion ont les antennes composées de onze articles; il y en a un de woins dans le genre nouveau que nous proposons ici.

Antennes assez courtes, insérées sous les rebords avancés de la tête, composées de dix articles, le premier assez long, conique, le second globuleux, très-petit, le troisic̀me cylindrique, le plus long de tous, les deux suivans cylindro-coniques, le sixième conique mais commençant à s'aplatir un peu et à se dilater au côté intérieur, le septième presque triangulaire, les huitième, neuvième et dixième manifestement comprimés, dilatés à leur partie intérieure, le neuvième beaucoup plus petil que le luuitième et le dixième, celui-ci arrondi à son extrémilé. - Labre grand, cilié et un peu sinué antérieurement, ses angles latéraux arrondis. - Mandibules très.épaisses, se rejoignant dans le repos, larges, entières et Icreusées en cuiller à leur extrémité. -- Palpes 


\section{S P H}

maxillaires probablement conformés comme dans les autres Hélopiens (ils manquen: dans notre individa): palpes labiaux de trois arlicles, les deux premier's courts, coniques, le dernier comprimé, un peu élargi, presque triangalaire. - Menton étroit, carré. - T'éte régulièrement convexe, bord antérieur du chaperon presque droit, celui-ci séparé de la tête par un sillon arqué. - Yeux échancrés. - Corps alongé, glabre, bo mbé en dessus, mais point cunéforme. - Corselet sensiblement rebordé de tous côtés, pas beaucoup plus large postérieurement qu'à sa partie antérieure dont les angles sont arrondis. Avant-sernum prolongé en pointe mousse, un peu creusće en cuiller. - Irésosternum oflrant une cavité fourchne pour recevoir la pointe de l'avantsternum. - Ecusson court, transversal, presque deıni-circulaire. - Elytres graudes, très-couvexes, rebordées, mutiques à l'extrémilé, recouvrant des ailes et la tolalité de l'abdomen, leurs angles huméraux saillans, arrondis. - Pattes assez longues : tarses antérieurs et intermédiaires ayant leurs trois premiers articles courts, le quatrième très-petit, le cinquième au:si long que les quatre premiers pris ensemble; tarses postérieurs ayant leurs trois premiers articles allant en décroissint de longueur, le quatrièmc ou dernier un peu plus long que le premier.

Le nom de ce genre vient d'un mot grec qui signifie : cambré. Nous ignorons ses mœurs.

\section{Camarie brillante, $C$. mitida.}

Camarit viridi-cenea nigra, elytris cupreis parìm profundè sed latè striatis; striis punctatis.

Longuenr I ponce. D'un noir-verdâtre, bronzé. Antennes de même couleur, leurs trois deruiers articles d'un testacé-brun mat. Elytres d'un bruncuivreux très-brillani, ayaut chacune neuf stries peu profondes mais larges, pointillées, et le commencement d'une dixième auprès de l'écusson: les quatre grandes stries qui avoisinent celui-ci se réunissant par paires à leur origine, près de la base des élytres.

Du Brésil.

CAMPSIE, Campsia. Cnodalon. Dalm.

Genre d'insectes de l'ordre des Coléopières, section des IIétéromères (premièı e division), famille des Sténélytres, tribu des Hélopiens.

Dans celte tribu un groupe contenant six genres a pour caractères : corselet mesuré au bord postérieur plus large que long, trapézoïdal ou presque lunulé; corps presqu'hémispliérique, quelquefois ovale ct arqué, ou bien ovale-oblong. (Voyez SténéLtrtres.) Parmi ces genres celui de Camarie est le seul dont les antennes ne soient composées que de dix articles; les antenaes simples, filiformes et les cuisses antéricures armóes d'une épine, au moins dans l'un des sexes, carac:térisent les Acanthopes : le genre Sphénisque a le chaperon coupé droit en devanu, les quatrième et cinquième articles des antennes dilatés en dent de scie, les éfytres et l'avant-sternum mutiques. Dan les Nilions le corps est hćmisphérique, court, velu. Enfin les Amarygmes ont, d'après M. Dalman, le premier article des tarses postérieurs aussi long que les trois derniers pris ensemble.

Antennes assez longues, insćrées sous les rebords avancés de la tête, composées de onze articles, le premier et le seeond coniques, celui-ci très-court, le troisième loug, cylinărique, un peu cambré en arrière, les deux suivaus cylindriques, allint cn décroissant de longueur, les autres jusçu'au dixième inclusivement dilatés à leur partie intérieure et formant des dents de scie, le terminal plus long que le dixièmc, presqu'arrondi au bout. - Labre grand, presque decil-circulaire en devant. - Mandibules très-épaisses, se rejoignant dans le repos, larges, en tières et creusées en cuiller à leur extrémité. - Palpes maxillosires de quatre articles, lc dernier grand, triangulaire; les labiaux de trois articles, les detix prensiers courts, coniques, le dernier un peu ćlargi et comprimé, presque triangulaire. - Menton étroil, presque carré. - Téte régulièrement convexe, hord antérieur da chaperon échancré circulairement d'un augle à l'autre; chaperon séparé de la tête par un sillon très-arqué. - Yeux à peine échaucrés. - Corps alongé', glahre, bombé en dessus mais point cunéitorme. - Côtés extéricurs du corselet presque droits, rcbordés, tranclians; bord antérieur guère plus étroit que le postéricur. - Avant-sternum prolongé en pointe mousse. Mésosternums muni d'une cavité fourchue pour receroir la pointe de l'avant-sternura. - Ecusson en triangle curviligne. - Elytres grandes, trèsconvexes, rebordées, mucronées a leur extréritié, reeouvrant des ailes et l'abdomen. - paties linngues; les mâlés ayant leurs qualre jambes antérieures arquées, rentlées près de la basc du tarse et portautdans celte partie une brosse de poils serrés; tarses antérieurs et intermédiaires ayaut lears trois premiers articles courts, le quatrième très-pelit, le cinquième aussi long que les quatre autres pris ensemble : tarses postérieurs ayant leurs trois premiers articles allant en décroissant de longueur, le quatrième ou deruier presqu'aussi long que tous les précédens réunis.

Le uom que nous dounons à ce genre est tirć du grec, il exprime que'le corps de ces Hélopiens esi bombé en dessus. Nuus ne comnoissons pas leurs niceurs.

I. Campsie testacée, $C$. testaced.

Campsia testacea, antennam apice femoribusque suprì fuscis.

Longuear 1 pouce. Entic̀rement testacée avec 
l'extrémité des antennes et le dessus des cuisses de couleur brune. Elytres ayant chacune veuf stries profondes, pointillées. On voit près de l'écusson le commencement d'nne dixième strie. Mâle.

Du Brésil.

Nous placons encore dans ce genre le Cnodalon irroratum. D̉. An. Analect. entom. p. 62. no. 46 . -Campsie tachetée, $C$. irrorata. Noв. Longueur II à 14 lig. Elle ne diffère de la précédente que par la couleur noire de tout le corps à l'exception đes élytres qui sont testacées, couvertes de nombreuses taches noires dont plusieurs forment des lignes transverses, irrégulières. Mấle et femelle. Du Brésil.

SPHÉRIDIE, Sphœridium. FAB. OLIv. (Entom.) Luat. Dermestes. Linn. Geoff, Hister. De G'́ner.

Genre d'insectes de l'ordre des Coléoptères, section des Pentamères, famille des Palpicornes, tribu des Sphéridiotes.

Ce genre est seul dans sa tribu.

Antennes insérées aux côlés de la tête, en devant des yeux, un peu plus longues qu'elle, coumposées de neuf articles, celui de la base très-long, le second petit, presque globuleux, les troisieme et quatrième très-petits, le cinquième petit, transversal, presqu'infundibuliforme, servant de base à la massue, le sixième formant avec les suivans jusqu'au dernier, une massue ovale, perfoliée, un peu comprimée, le neuvième petit. - Labre caché, coriace, transverso-linéaire, ses bords trèsminces, membraneux, à angles arrondis. $-\mathrm{Man}$ dibules à peine proéminentes, cornées, aiguës à l'extrémité, sans dents, bordées d'rze membrane intérieurement. - Mâchoires composées de deux lobes membraneux, en carré-long, grands, ayant leurs bords velus; lobe supérieur un peu plus grand que l'autre, crustacé à sa base. - Palpes maxilhaires plus longs que les labiaux, un peu plus courts que les antennes, de quatre articles, le second plus long que les autres, épais, obconique, le troisième presque de la longueur du précédent, beaucoup plus grêle, cylindro-conique, le dernier un peu plas petit, presque cylindrique, plus grêle et comme acuminé à son extrémité; palpes labiaux plus courts au moins de moitié que les maxillaires, insérés aux angles apicaux du menton, de trois articles, le second le plus grand de tous, cylindro-conique, portant des soies à son extrémité antérieure, le dernier petit, ovale-conique. - Lèvre membraneuse, transversale, un peu velue, bordant la partie supérieure du menton, concave au milieu, plus large vers ses côtés, composée de deux lobes presque trigones, transversaux, ces deux lobes opposés et réunis dans leur milieu : menton crustacé, en carré transversal, obliquement tronq̨uć à la partie latérale du bord supérieur. - Ieux point saillans. - Corps presqu'hémisphérique. - Corselet transversal ; partie antérieure du sternum prolongée postérieurement en une épine conique. - Ecusson en triangle alongé, étroit à sa base. - Elytres convexes, recouvrant l'abdomen et des ailes. - $A b$ domen plane en dessous. - Pattes ambulatoires, jambes épineuses; tarses à articles entiers, le premier au moins aussi long que le suivant.

Quelques mâles, et notamment celui du Sphéridie scarabéoïde, ont les tarses antérieurs trèsdilatés, munis de deux crochets sensiblement inégaux.

On ne connoit pas les larves des Sphéridies; les insectes parfaits habiteut dans les fientes d'animaux et paroissent préférer les bouses de vache; ils font partie de ce grand nombre de Coléoptères qui semblent destinés. à faire disparoître de la surface de la terre les ordures et les immondices, en se nourrissant des parties humides et gluantes de ces matières et facilitant par ce moyen la dispersion de leurs parties solides.

Ces insectes de taille petite ou moyenne se font remarquer plutôt par le beau poli de leur corps que par leurs couleurs, ordinairement sombres. L'Europe en fournit un assez bon nombre. Nous mentionnerons les suivans: 10 . Sphéridie scarabéoïde, S. scarabeoides $11^{\circ}$. 1. Faв. Syst. Eleut. (Les Spharid. lunatum $\mathrm{n}^{\circ} .2$, marginatum $\mathrm{n}^{\circ} .4$. et bipustulatum no. 3 . du mêne auteur, n'en sont que des variétés suivant MVI. Latreille et Schnënberr.) $2^{\circ}$. cinq taches, $S$. quinquemaculatum $n^{\circ}$. 7. FAB. $i d$. Des Indes orientales. 3o. dy tiscoïde, S. dytiscoides no. 8. Far. id. De l'île Sainte-Hélène. $4^{\circ}$. brillant, $S$. nitidulum no. 16. FAB. $i d$. Amérique méridionale. $5^{\circ}$. jaune, $S$. flavum $\mathrm{n}^{\circ}$. 17. Faв. $i d$. Même patrie. $6^{\circ}$. atomaire, $S$. atomarium $\mathrm{n}^{\circ}$. $18 . \mathrm{F}_{\mathrm{AB}}$. id. $7^{\circ}$. mélanocéphale, $S$. melanocephalumı $\mathrm{n}^{\circ} \cdot 1$. F. $\mathrm{AB} . i d .8^{\circ}$. hémorrboïdal, $S$. hcemorrhoidale $\mathbf{n}^{\circ}$. 22. F AB. $i d .9^{\circ}$. lugubre, $S$. lugubre ${ }^{\circ}$. 20. FAB. id. (en retranchant le synonyme d'Olivier. ) $10^{\circ}$. stercoraire, $S$. stercoreum $\mathrm{n}^{\circ} .21$. FAв. $i d$. $11^{\circ}$. uniponctué, $S$. unipunctutum $\mathrm{n}^{\circ} .24 . \mathrm{F}_{\mathrm{AB}}$. id. $12^{\circ}$. flavipède, S. flavipes $\mathrm{n}^{\circ}$. 23. F ав. $i d$. 13 $^{\circ}$. bordé, S. linblatum $\mathrm{n}^{\circ} .25$. Fab. id. $14^{\circ}$. ruficolle, $S$. ruficolle $\mathrm{n}^{\circ} .26$. FaB. id. $15^{\circ}$. fimétaire, $S$. fimetarium $\mathrm{n}^{\circ} .27 . \mathrm{F}_{\mathrm{AB}} . i d .16^{\circ}$. petit, $S$. minutum no. 3o. FAв. id. $17^{\circ}$. d'Olivier, S. Olivieri. Nов. - Spharid. lugubre. Otiv. Entom. t. 2. Sphérid. p. 7. no. 7. pl. 2. fig. 12. a. b. (en retranchant le synonyme de Fabricius.) $18^{\circ}$. brun, S. fuscum. Oliv. id. pag. 10. $n^{\circ}$. 12. pl. 2. fig. 9. a. b. $19^{\circ}$. testacé, S. testaceum. Oriv. id. pag. I1. $n^{\circ}$. 13. pl. 2. fig. 13. a. b. Ile de France.

Les espèces de Fabricius que nous ne citons pas ici appartiennent à d'autres genres.

Nota. Le docteur Léach fait un genre particulier sous le now de Cercyon des espèces duns lesquelles les deux sexes ont les tarses antérieurs simples. (S. F. et A. Serv.) 


\section{S P H}

SPHÉRIDIOTES, Sphoridiota. Seconde tribu de la famille des Palpicornes, section des Pentamères, ordre des Coléoptères; ses earaetères sont :

Mâchoires terminécs par deux lobes membraneux. - Falpes maxillaires ayant leur seeond article grand et renflé. — Corps presqu'hémisphériqne. - Pattes simplement ambulatoires, point propres à la natation. Jambes épineuses. Tarses ayant leur premier article aussi long an moins que le second.

Elle renferme le genre Sphéridie.

(S. F. et A. SERV.) FAB.

SPHÉRITE, Spharites. Durts. LAT. Hister.

Genre d'insectes de l'ordre des Coléoptères, section des Pentamères, famille des Clavicornes, tribu des Peltoïdes.

M. Latreille dans son nonvcl ouvrage intitulé : Familles naturelles, etc. forme daus cette tribu une division parliculière ainsi caraetérisće : pâlpes maxillaires filiformes ou plus gros a leur extrćmité, point terminés en manière d'alćne. Là vicnnent des subdivisions dont la première se distingue par ses maudibules, dont l'extrémité est entière, c'est-à-dire sans fissure; un groupe de cette subdivision ne renfermant que le genre Sphérite est caraetérisé par ses anteunes en massue solide.

Antennes de onze artieles; le premier assez lon go, gooflé à la partie intérieure de son extrémité, le second globulenx, le troisic̀me conique, les autres transversaux, un pen cupulaires, les trois derniers très-serrés, formant une massue qui paroît solide. - Mandibules fortes, erochues, très-pointues et entières à leur extrémité, ayant deux dèntelures au côté interne. - Palpes ayant leur dernier article un peu plus grand que les précédeus, presqu'ovoïde. - Tête petite; sa partie. antérieure rétrécie et avancée. - Corps presque carré. - Corselet nn peu rebordé, son bord antérieur échaneré pour reeevoir la tête; ses bords latéraux arrondis; bord postérieur se prolongeant un pcu vers l'écusson. - Ecusson cu triaugle curvilinnne. - Elytres tronquées postérieurement, recouvrant des ailes et laissant à nu la moitié inf'rienre de l'anus. - Jambes épineuses; tal"ses filiforınes, lcurs artieles un peu eonigues, le premier plus long que les suivans : le dernier le plus grand de tons, muai de deux croclicts assez forts.

Le nom de ce genre tiré du grec exprime true son corps est sphérique. L'espèee eonnue est le Sphérile glabre, $S$. glabratas. Duexs: Faun. Austri. I. pag. 206. - Sт и м, Deutchs. Faun. vol. I. $X X$. Hister glabratus n०. 9. FAв. Syst. Eleut. De Suede et d'Allemagne.

(S. I. et A. SERv.)

Hist. Nat. Ins. Tonve $\mathcal{X}$. Lin

Genre d'insectes de l'ordre des Diptères, première section, famille des Athérieères, tribu des Muscides (division des Seathophiles).

Dans cette division un groupe formé de cinq genres a pour caraetères partieuliers : toutes les pattes simplement ainbulatoires; antennes insérées entre les yeux. Tćte sans prolongement latéral. (Voyez Scatrophices.) Les Anthomyies et les Scatliophages se distinguent par le troisième artiele de leurs antennes beaucoup plus long que le second et notablement plus long que large; dans les Mosilles les pattes postérieures sout de forme crdinaire et droites; les Thyréophores ont leurs antennes insérées et reçues presqu'cn cntier. dans une cavité frontale profonde : en outre la soie cst distinetement artieulée à sa base et renflée dans ectle partie.

Antennes très-courtes, rapproehées, saillantes, composées de trois articles, le dernier à peine plus grand que le second, plus large que long, semi-orbiculaire, muni à sa base d'une soie simple, sans renficment. - Trompe épaisse, reçue dans le repos sous un avancement arqué qui entoure la partie supérieure de la cavité buecale. - Téte presque sphérique. - Yeux saillans, arrondis. Trois ocelles trc̀s-petits, très-rapprochés en triangle sur le vcrtex. - Corps oblong, déprimé. Ecusson assez grand, arrondi postérieurcment. - Ailes longues, dépassant sensiblement l'abdomen, couchćes l'nne sur l'autre daas le repos. - Cuillerons petits. - Balanciers nns. - Pattes grandes, surtout les postérieures, celles-ci ayant lcurs cuisses renflées et leurs jambes arquées extérieurement.

On doit ce genre à $M$. Latreille; son nom tiré de denx mots grecs a rapport à la forme arrondie du dernicr articlc des antennes. L'espèee la plus connue est peticc, on la trouve communément sur les funiers, et il est probable cue la larve y tronve sa nourritnre. C'est la Sphérocère eurvipc̀de, Spluaroc. curvipes. Lat. nouv. Dict. d'hist. nat. $2^{\mathrm{e}}$ édit. - Musca grossipes. Livn. Syst. nat. 2. 983. 59. (S. H. el A. Serv.)

SPHCRODERE, Spllom derus. DEJ. (Spéc.)

Geurc d'insectes de l'ordre des Coléoptères, scction des Pentauères, famille des Carnassiers, tribu des Carabiques (division des Abdominaux).

Une subtivision des Abdozuinaux a ponr earactère: còté irterne des nandibules entic̀rement ou. presçu'entic̀rement denté dans toute sa longueur. Eile eonlieni les genres Pumbore, Cychre, Scaphinole et Sphérodère. Dans les Pambores les élytres n'embrassent pas l'abdomen et ne sont point carćnées latéralement; lcs Scaphinotes ont les bords latéraux du corselet très-relevés, prolongés postérieureacnt; et dans les Cyclures les $\mathrm{Bl}$ ш ш 
tarses antérieurs son: semblables dans les deux sexes.

Ce genre a été créé par M. le comte Dejean dans son Spéciès. Il lui assigne ces caractères :

Antennes filiformes. - Labıe bifide. - Mandibules étroites, avancées, dentées intérieurement. - Dernier articlé des palpes très-fortement sécuriforme, presqu'en cuiller et plus dilaté dans les máles. - Menton très-fortement échancré. Corselet arrondi et nullement relevé sur les côtés. - Elytres soudées, carénées latéralement et embrassant une partie de l'abdomen. - Tarses antérieurs ayant leurs trois premiers articles dilatés dans les mâles, les deux premiers très-fortement, le troisième beaucoup moins.

C'est de la forme arrondie du corselet qu'est tiré le nom de Spliérodère qui vient de deux mots grrecs. Ces insectes s'éloignent des Cychres, dit P'auteur, par leur faciès qui paroît se rapprocher de quelques petites espèces de Carabes, surtout du convexus. La tête est un peu moins alongée que dans les Cychres, les antennes plus courtes, moins dáliées, le corselet convexe, presqu'arrondi; leurs élytres sont proportionnel'ement moins grandes et un peu moins convexes, enfin les pattes plus courtes et un peu plus fortes. Le pre rnier article des tarses antérieur's des mâles est en triangle'tronqué, le second presqu'en carré transversal et le troisième à peu près cordiforme. M. le comte Dejean y rapporte trois espèces, particulid̀res à l'Aurérique septentrionale.

\section{SphÉrodíre de Leconte, $S:$ Lecontei.}

Spharoderus niger; thorace cyaneo, ovato, posticè trunsversè lineâque utrinquè impressis: elytris oblongo-ovatis, subcupreis, antice striato prunctatis, postice granulatis, inarsine cyaneo.

Sphceroderus Lecontei. DeJ. Spéc. torn, 2. p. 15. $n^{\circ}$. I.

Longueur 6 lig. Noir, corselet ovale, blenâtre, ayant une impression transversale à sa partie postérieure outre deux lignes longitudinales. Elytres ovales-oblongues, un peu cuivreuses, bordées de bleu le long de leur carène, ayanı des stries pointillées à leur partie antérieure : leur extrénité couverte de points élevés, arrondis, un peu oblongs.

Les deux autres espèces sont : $1^{\circ}$. Sphceroderus stenostomus. DEJ. ut suprà no. 2. - Cychrus stenostomus. WÉB. Obs. entom. pag. 43. no. 1. $2^{\circ}$. Sphceroderus bilobus. DEJ. ut suprà $\mathrm{n}^{\circ} .3$.

(S. F. et A. Serv.)

SPHÉROME, Sphoroma. Lat. LAM. LÉach. Oniscus. Linn. PALL. FAB. Cymothoa. FAB. DaLDORF.

Genre de Crustacés de l'ordre des Isopodes, sec. tion des Aquatiqnes, famille des Sphéromides, établi par notre illnstre collaborateur M. Latreille, et formé anx dépens du grand genre Oniscus de Linné. Léach a encore restreint ce genre, et plusieur's espèces de Sphéromes de M. Latreille forment, pour cet auteur, des renres distincts qui ont été adoptés dernièremeut par l'entomologiste français (Fam. nat. du Règn. animt.). Le genre Spherome tel qu'on le conçoit aujourd'hui, peut être ainsi caractérisé : appendices postérieurs de l'abdowen ayant leurs deux lames saillantes, l'extérieure étant plate et de même forme que l'intérieure. Corps susceptible de se rouler en boule.

Ce genre differe des Zuzares (voyez ce mot) par les appendices postérieurs de l'abdomen, dont l'extérieur est plus grand que l'intérieur et convexe en dessus; les autres genres de la même tribu en sont distingués par des caractères organiques qui sont développés au mot SpHÉromides. Toyez ce mot.

Les Spléromes ont heaucoup de ressemblance an premier coup d'œil avec les Amadilles; comme eux ils se roulent en boule au moindre danger et se laissent glisser et rouler entre les pierres et les plantes marines qu'ils habitent; ils restent presque tonjours réunis en grandes troupes; la plupart. se tiennent au fond de l'eau et se portent en fonle sur les différens corps marius dont ils font leur proie : certaines espèces restent toujours cachées sons les pierres ou les plantes amoncelées par les flots sur les rivages de la mer; là elles sont à portée de leur ćlément et peuvent s'y jeter à volonté et à la moindre crainte de danger: d'autres vivent toujours loin des bords; elles se plaisent sur les fucus et les ulves qui tapissent le fond de l'eau. Ces petits Cruslacés marchent et nagent avec une grande dextérité; les Spares et autres poissons en font leur nourriture, suivant Risso. M. Desmarest dit que quelques espèces de Sphéromes sont phospholiques à certaines époques.

Ce genre se compose d'une dixaine d'espèces que Léach a distribuées dans deux conpes.

I. Dernier article de l'abdomen ayant à son extrémité deux légères éclancrures.

Sphérome court, $S$. curtum. Léach, Dict. des sc. nat. toul. 12. pag. 345. - Oniscus curtus. Montagu. Cette espèce est très-rure el habite les côtes d'Angleterre. Le troisième article de son abdomen est légèrement échancré postérienrement, le đènier est pointu à son exfrémité. Les Spherouna prideuxianum et Dumerilii de Léach appartiennent à la mếme division.

2. Dernier article de l'abdomen sans échancrure.

Sphérome denté, Sph. serratum. Léach, Dict. des sc. nat. tom. 12. pag. 346. - Desm. Cons.gén. sur les Crust. etc. pl. 47. fig. 3. - Oniscus serratus. F А . Mant. Ins. tom. 1. pag. 242. - Oniscus glabrator. PALI. Spic. zool. fas. 9. pag. 70. tab. 


\section{S P H}

4. fg. 18. - Sphceroma cinerea. Lat. Risso. Corps lisse; abdomen arrondi à son extrémité; la dernière petite lame venirale arrondie en delior's; yeux noirs; antennes fauves; pattes cendrées, ongles fauves, avec lear extrémité noire; corps cendré uu blanchâtre, marbré de rouge et de gris foncé. C'est cette espèce qui peut être considérée comme le type du genre; elle est fort coumune sur nos côtes et vit en grandes réunions suus les pierres, dans le gravier et sous les tas de fucus.

\section{SPHÉROMIDES, Sphcromides. LAT.}

Famille de Crustacés de l'ordre des Isıpodes, section des Aquatiques, établie par M. Latreille dans ses Familles naturelles du Regne animal, et à laquelle il donne pour caractères : dernier segment abdominal ayant, de cliaque côt's, une tiitgeoire à deux fevillets, ou terminé, lui conipris, par cinç lames foliacées. Pust-abdowen composé de deux segmens; appendices branchiaux repliés transversalement sur eux-mćmes.

Ces petits Crustacés, que Linné avoit placés dans sou genre Oniscns, a cause sans donte de la propriété qu'ils ont de se contracter en boule comme certains Cloportes, different cependant de ces derniers par leur unanicire cle vive et par beaucoup d'autres caractères tirés de leur organisalion intérieure el extérieure. La famille des Asellotes en est bien súparée par la composition du ciernier segment abdominal qui n'a point d'appendices nalatoires latéranx; enfin les Cymothoadés n'ont qu'une nageoire de chaque côté de l'extrémité postíritare du corps. Out:e les caractères généraux des Sphéromides que nons a vons présentés plus bant, nous allons en présenter de plus délaillés, afin de ne plus parler pour chacun des genresque renferme cette farnille, que de ceux propres à les distinguer entr'eux. Les Sphéromides ont quatre antemnes insérćes et rapprochées par paires sur le front, composćes chacune d'un pédoncule et d'une lige sétaccée, multiarticulée; les deux supérieures plus courtes; len: pédoncule composé de trois articles, celui des inférieures de quatre. Les pieds-múchoires sont en forme de palpes sélacés, rapprochés à leur base, divergens, ensuite ciliés au côté interue, et de cincy articles tistinets. Le corps est ovale, convexe en dessus., vonté en dessous et se contractant en bonle enreptiant et rapprochiant, $\in$ n d drssons, ses denx ex. trémités; il est composé d'une tête et de neof' segmens tous Iransversaux, à l'exception an plus du dernier; les sept antérieurs composent te troncet portent clacun une parre de pattes: ces pattes sont terminées par un petit onglet sous lequel est ordinairement une petite dent; il n'y a que le genre Anthure, dont lès pieds antérieurs soient terminés. jarl une main monodactyle. Le prestier segment est furtement échaucré pour receroir la tête; le huilièrne segment est marqué de claque côté de deux lignes enfoncées, incisions ébauchées

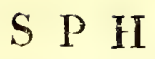

transverses et parallèles, plus ou moins alongées, el que Léach considère comme les traces de segmens ; d'où il suit qu'il considère l'abdomen des Sphéromes comme composé de cinq segmens, dont les quatre premiers sont soudés ensernble et le dernier très-grand; ce dernier segment est fixé aux autres par deux espècés de ginglymes; il est grand, trouqué obliquement de cbaque côté et a la forme d'un triangle arrondi, convexe en dessus, très-voûté en dessons et renfermant dans sa cavité des branchies molles. Le dessous des deux derniers anneaux est recouvert par deux rangées longitadinales d'écailles imbriquées, formées d'un pédicule ou d'un support attaclié transversalenient, et d'une lame ovale ou triangulaire, trèsciliće sur les bords; de chaçue côté et à lia base du dernier segment, se voit un appendice $\mathrm{cn}$ forme de nageoire, composé de irois articlcs; le radical petit, tuberculitorme ; le second dilaté au côté interne en rıanière de lame ou de feuilleı, ovale ou elliptique; le troisième le plasaouvent aussi en forme de fenillet et composant avec le précédent une sorte de nageoire.

Ces Crustacés halitent les bords de la mer; quelques genres aiment mieux les endroits profonds: ils vivent en géuéral sous les pierres, les rochers ou sons les tas de plantes marines. Quand ils sout dans l'eau, ils nagent avec beaucoup de vitesse et sont alors tournés le ventre en haut.

Latreille divise ainsi cette famille.

I. Corps vermiforme. Les quatre antenues à peine de la longueur de la tĉte, coniques, de quatre aricles. Pieds antérieurs terminés par une main monodactyle. Feuille!s du bout de l'abdomen formant par lcur disposition (deux supérieurs, deux latéraux et le ciquième inférieur) et leur rapprochement, une sorte de capsule.

ANTHURE, Anthura. LËach. Oniscus. MovTAGU.

Antmurf. grêle, Anthura gracilis. Léach, Edimb. Encycl. tom. 7. p. 404. Id. Trans. Soc. Lin. tom. 11. pag. 366. - Oniscus gracilis. Mosт $\Delta \mathrm{Gu}$, Trans. Soc. Lin. tom. 9. tab. 5. fig. 6. Le Gammarus heteroclitus, Viviani, phosph. maris, pag. 9. tab. 2. fig. 11 et 12, se rappcrleroit peut-être a c'c genre, mais sa queue est terminće pardeux petils filets sétacés de quatre ou cinq arlicles, re qui l'en ćloigne. Léach pense que l'Oniscus cylindricus de Montagru appartient à ce genre.

II. Corps ovale ou obleng (se mellant en boule); iige res quarc antennes de plusieurs ariicles; les inféricures au moins notablen:ent plus longues que lis rêle. Point le dilatation en furme de main nonrdactyle aux pieds. Chaque appendice latéral de l'extréuité postérienrc du corps formé de deux feuillets portés sur uo article commun, et composant avec le seguent intermćdiaire, une nagevire en éventail.

$\mathrm{Mmm} 2$ 
1. Sutures ou lignes imprimées du premier segment post - abdominal, n'alteignant pus les bords; ces bords entiers. Premier article des antennes supérieures en palette presque triangulaire.

Les genres Zuzare, Sphérome. Voyez ces mots.

2. Sutures du premier segment post-abdominal atteignant ses bords et les coupant. Premier article des antennes supérieures en palette alongée, soit plus ou moins carrée, soit linéaire.

GAMPĖCOPÉE, Campecopea. LÉACH. Óniscus. Montagu. Sphœroma. Lat. Lam. Risso.

Appendices postérieurs du ventre ayant leur petite lame extérieure seule saillante, alongée el courbée. Corps ou thorax ayant l'avaut-dernier. article plus grand que le dernier.

Caitpécopée velue, $C$. hirsuta. Léach, Dict. des scenat. tom. 12. pag. $341 .-$ Desm. Dict. des sc. nat. et Cons. gén. sur la cl. des Crust., etc. pag. 295. pl. 47. fig. 1.-Oniscus hirsutus. MonTAGU, Trans. Soc. Lin. tom. 7.pl.6. fg. 8. Longue d'une ligne et demie; couleur brune; dernier anneau de l'abdomen marqué de quelques points d'un bleu pâle. Il se trouve sur la côte méridionale du Devonshire en Angleterre. M. Latreille pense que le Spheroma spinosa de Risso est la même espèce, quoiqu'il ait cinq lignes de long. Le Campécopée de Cranch forme une autre espèce qui est plus petite que la précédente, peu velue, et ayant le sixième anneau du thorax dépourvu d'épines et simple. Il se trouve à Falmouth en Angleterre.

\section{CILICÉE, Cilicoea. Lréach.}

Appendices postérieurs du véntre ayant, comme ceux des Campécopées et des Nésées, leur petite lame extérieure seule saillante; corps ou thorax ayant les deux derniers segmens d'égale longueur. Abdomen ayant le preaier et le deuxième articles très-courts, soudés au troisième qri est grand; le dernier échancré à son extrémité, avec une petite saillie dans son échancrure. Appendices ventraux postérieurs droits et assez longs.

Cilicée de Latreilie, $C$. Latreillii. Léach, Dict. des sc. nat. tom. I2. pag. 342.-Desm. ibid. et Cons. gén. sur les Crust., elc. pag. 296. pl. 48 . $f g .3$. Longue de quatre lignes environ. Dernier article de l'abdomen ayant deux élévations en bosse; la première (chez le mâle) prolongée et pointue; petite lame caudale extérieure, ayant son extréunité échaucrée postérieurement. Iéach ne connoît pas la localité qu'habite cette espèce.

NÉSÉE, Noesea. LÉach. Oniscus. Adams. SpherOMia. LAT. LAMK.

Ce genre ne diffère des Campécopées qu’en ce que les appendices ventraux postérieurs sont droits et passablement longs, au lieu d'être courbés.

Nésíe hidentée, $N$. bidentata. LÉacH, Dict. des'sc. nat. tom. 12. pag. 342. - Desm. ibid. et Cons. gén. sur les Crust. pag. 295. pl. 47. fg. 2. - Oniscus bidentatus. Adars. Trans. Soc. Lin. tom. 8. tab. 2. fg. 3. Longue de six lignes. Corps lisse; sixième anneau du thorax rugueux, terminé postérieurement par deux piquans ; abdomen rugueux, son dernier anneau ayani deux tubercules ver's son milieu. Couleur cendrée, légèrement striée dé bleu ou de rouge. Celte espèce se trouve sous les pierres et les plantes marines, daus la partie occidentale des côtes de France.

DYNAMÈNE, Dynamene. LÉAcH. Oniscus. Montagu. Sphoroma. Lat. Lamk.

Appendices postérieurs du ventre ayant leurs deux lames extérieure et intérienre saillantes, comprimées, d'égale grosseur et foliacées; abdomen ayant le dernier article marqué d'une simple fente à son extrémité; sixièrne segment du corps prolongé en arrière.

On rencontre ces petits Crinstacés près des rochers des côtes; ils les préfèrent à cause des petites cavités remplies de sä̀le qu'ils présentent et où ces animanx peuvent se loger. Ils fréquentent aussi les plantes marines et les petites flaques d'eau qui restent dans les rochers lorsque la mer est basse. Iis nagent aver beaucoup de vitesse et d'élégance en se toirnant sur le dos comme les Spluéromes, et exécu'ent des évolutions rapides et variées.

Léach les divise en deux putites sections ainsi qu'il suit :

I. Sixième article du corps prolongé en arrière; petite lame extérieure des appendices postérieurs du ventre plus longue que l'intérieure.

Dynamène de Montago, D. Montagui. Léach, Dict. des sc. natur. tom. 12. par. 344. Corps sublinéaire; Je sixième article du thorax avec un prolongement, aplati en dessus; deux tubercules au dertiier article de l'abdomen : la fente presque d'égale largeur. Cette espèce se trouve sur la côte occidentale du Devonshire en Angleterre.

2. 'Tous les' anneaux du corps simples; petire lame extérieure des appendices postérieurs du ventre plus courte que l'intérieure.

Dynamiene rovge, $D$. nubra. Léach, $D_{i}$. $t$. des sc. nat. tom. I2. pag. 344.- Oniscus ruber. MonTAGU (manusc.). Corps sublinéaire; fente du dernier article presqu'égale en largeur dans toute son étendue. Couleur rouge. De la côle occidentale de l'Angleterre; très-commune. Léach décrit une autre espèce de ce genre, qui est verte et qui se trouve dans les mêmes lieux que les précédentes. Le Spharomia Lesueurii de Risso appartient aussi à ce genre. 


\section{$\mathrm{S} \mathrm{P} \mathrm{H}$}

CYMIODOCÉE, Cymodocea. LÉACH. Cymodice. Ihid. Oniscus. Montagu. Sphceroma. Lat.

Appendices postérieurs dı ventrc ayant leurs deux lames extérieure et intérieure saillantes. Corps ne pouvaut pas se rouler en boule; abdomen ou quene ayant le dernier article échancré à son extrémité, avec une petite lame dans l'échiancrure, non foliacée, mais garnie de longs poils de chaque côté.

Cymodocée de lamarck, Cymodocea Lamarckii. LE்ACH, Dict. des sc. nut. tom. 12. pag. 343. - Desn. ibid. et Cons. gén., etc. pl. 48. fg. 4. Lon gुue de ciuq lipnes. Abdoumen lisse, ayant ses troisième et quatrième segmens muniš cliacun de deux épines sur le dos; le dernier ayant son prolongement terminal étroit et sa pointe entière. Cette espèce habite les mers de Sicile.

(E. G.)

SPHÉROTE, Sphoerotus. Genre de Coléoptères. Hétéromères, famille des Sténélytres, tribu des Hélopiens, ćtabli par M. Kirby dans scs Tenebrionida. ( Transact. Linn. Centur. of Ins. vol. 12. pag. 375 .) II lui assigne ces caracteres : labre transversal, arroudi à son extrémité, cilié. Lèvre petite, son extrémité tronquée. Mandibules à peine dentées. Mâchoires onvertes à leur base. Palpes maxillaires grossissant vers l'extrémité, leur dernier article trc̀s-grand, sécuriforme; le même article dans les labiaux un peu plus grand que les autres, presqu'en cloche. Nienton trunqué à l'extrémité, arrondi à sa base, trc̀s-convexe dans son milieu. Antennes allant en grossissant vers leur extrémité, composées de onze articles, le dernier assez gros, tronqué obliquement. Corps ovaleglobuleux, point recourbé.

I'auteur anglais place dans ce genre l'espèce suivante : Sphêrote curvipède, S. curvipes. longueur 5 lig. $\frac{1}{3}$. Corps très-glabre, assez brillant, d'un noir-cuivieux. Elytres presque globuleuses avec des séries de gros points enfoncés; l'intérieur de chaque point ayant une petite ligne enfoncée. Ceite espèce esi dn Brésil et représentée pl. 2 r. fig. 15 . de l'ouvrage précité. C'est l'Helops variolosus. Des. Catal.

\section{(S. F. et A. SERv.)}

SPHEX, Sphex. FAB. Cet auteur compose ce genre de quatre espèces dont trois, $\mathrm{n}^{\text {0s. }}$ I. 2 èl 4 . sont des Ammophiles de MH. Kirby et Latreille. Le Sphex clavus $\mathrm{n}^{\circ}$. 3. nous est inconnu. VoyeAmmophile, article SpaÉgides.

(S. F. et A. Serv.)

SPHEX, Sphex. Linn. De Géer. Scopor. Ross. Jur. LAt. Ichneumon. Georr. Apis. Linn. Proapis. De Géer. Pepsis. Far. Spinoc. Chlorion. FAB.

Genre d'insectes de l'ordre des Hyménoptères, section des Porte-aiguillon, famille des Fouisseurs, tribu des Splégides.

Deux genres, Cllorion et Sphex forment dans la seconde division des Sphégides (noyez ce mol) uu groupe dont le caraclère est : mâchoires et lèvre plus courtes ou guc̀e plus longues que la tête, fléchies an plus vers leur extrémité. Presque tous les articles des palppes obconiques. Seconde et troisième cellules cubitales des a!!es supérieures recevant chacune une nervure récurrcute. Mais les Chlorions se distinguent particulièrement par leurs antennes insérées au-dessous du milieu de la face antérieure de la tćte et par le pen de largeur de leur seconde cellule cubitale.

Antennes sétacées, insérées vers le milieu de $l_{\text {ir }}$ face antérieure'de la tête, de donze articles dans les femelles, de treize dans les inâtes, le preniier plus gros que les autres, ovalc-cylundricque, le second petit, presque glohuleux, lcs suivans cylindriqus s, le dernier conique-alongć. - Mandidibules dentées au côté interne. - Mấchoires et Lèvre guère pluslongnes que la lôte, fléclies seulement vers leur exirémilé. - Palpes filiformes, les maxillaires guère plus longs que les labiaux, de six articles presque tous alongés et obconiques: palpes labiaux de quatre articles, les deux premiers beaucoup plus longs que les strivans, obconiques; les deux dernicrs presqu'ovales. - Téte transversile, de la largeur dn corselet; chaperon boabé. - Yeux grands, ovales. - Trois ocelles placés en triangle sur le devant du vertex. Corps asez long, pubescent. - Corselet long; prothorax court, petit, aminci en devant en un cou un peu déprimé, conique; mésothorax moins long que le métathorax; celui-ei long, convexe, comne tronqué postérieurement. Ecusvon peu relevé. - Ailes superieures ayant une cellule radiale arrondic an bont, ovalealongée, et quatre cellules cubitales, la première aussi grande que les dcux suivantes réunies, la seconde assez large, presque carrée, recevant la première nervure récnrrente près de la nervure d'intersection qui la sépare de la troisième cubitale; celle-ci rétrécie vers la radiale, recevant la seconde nervure récurrente, la quatrième point commencée naais souvent esquissée en pártie. Abdomen globuleux ou elliptique, très-dislinctcment pédiculé, composé cle cinq segrnens outre l'anus dans les femelles, en ayant un de plus dans les mâles, la moitié du premier segment formant le pédicule. - Pattes grandes, fortes; jambes et tarses garnis d'un grand noubre d'épines et de cils roides : tarses intérieurs des fcmelles bipectinés de cils roides, propres à fouir, leurs articles élargis vers l'extrémité et triangulaires; janıbes antérienres terminées par denx épines, l'interne garnie d'ane membrane étroite qui s'élargit dans son milieu, lequel est soutenu par une petite dent; l'extrémité de cette épine interne est bifurquée; celte bifurcation garnie de cils roides; jambes in- 
termédiaires ayant deux épines terninales assex. courtes, simples, aiguës : jambes postérieures en ayant deux, l'interne plus forte, large à sa base et garuie dans cette partie de cils denses; tarses Jongs, leur premier article plus grand que les autres, le dernier terminé par deux crochets aigus, pluridentés à leur base, munis d'une assez forte pelotte dans leur enire-deux.

Les Grecs donnoient le nom de Sphex à des Guêpes de forme grêle, ce qu'indique dans lèir langue la racine de laquelle ce nom est tiré. Les nuceurs de ces Hyménoptères sont les mêmes que celles des Ammophiles (voyez ce mot à l'article SPaÉgIDes); nous ne connoissons pas les proies particulières dont les femelles approvisionnent leurs nids. Ces insectes airuent les climals chauds et l'on ne les trouve en France que dans les parties les plus méridionales. Leur taille est assez grande. Fabricins a placé la plus grande partie des especes qu'il a connues parmi ses Pepsis à abdomon pédiculé. Ses Sphex proprement dits soat les Aunuophiles de MM. Kirby et Latreille.

\section{Sphex languedocien, $S$. occitanica.}

Sphex nigra; capite thoraceque nigro villosis; abdominis segmenti primi parte postıcâ secundique parte anticâ subtùs et lateribus ferrugineis : alis apice lato fuscis.

Longueur io ì $12 \mathrm{lig}$. Noir. Front argente. 'Têle et corselet très-garnis de poils noirs. Dessous e c côtés de la partie élargie du premier segment de l'abdonien, de conleur ferrugineuse ainsi que le dessous et les côtés de la parlie antérieure da second. Ailes presque transparentes, leur extrémité et une parie de leur linbe intérieur ayant une large bordure d'un brun-noiratre. Mâle.

Il a été pris aux euvirons de Montpellier par N. Amédée de Saint-Fargeau, oflicier de la Garde.

\section{SPHEX rayé, $S$. albisecta.}

Sphex atra; abdoninis basi ferrugineâ, petiolo apiceque nigris, segmentis onmibus margine postico paliidis.

Longueur 8 ì 9. lig. Noir. Front argenté. Tète, corselet et pattes très-garnis de poils d'un cendirí-roussâtre. Abdomen ayant son pédicule, ses deux deraieró segmens et l'araus noirs; la partie élargie du premier segment, le second et le troisième fermgineux; le bord postériear de tous, de couleur pále. Fumelle.

Dans le mâle le troisièroe sesrment de l'abdomen est noir. Du Piémonl. Il nons a été envoyé par M. Bonelli sous le nom spévifique que nous iui conservons.

Les espèces suivantes sont aussi de ce genre : I0. Sphex rutipenne, Sphex rufipennis. - Pepsis rufipennis no. 12. Fab. Syst. Piez. 20. Sphex de Pensylvanie, Sphex Pensylpanica. - Pepsis
Pensyluanica no. 15. FAB. id. $3^{\circ}$. Spliex front blanc, Sphex albifrons. - Pepsis albifrons $n^{\circ} .25$. FAB. id. $4^{\circ}$. Sphex argente, Sphex argentatr. - Pepsis argentata no. 9. FAB. id. Ce dernier du midi de la France. $5^{\circ}$. Sphex Iclueumon, Sphex icheumonea. - Chiorion ichneumoneuin n ${ }^{\circ} .6$. FAB. $i d .6^{\circ}$. Sphex flavipenne, Sphex flavipennis. - Pepsis flapiponnis $\mathrm{n}^{\circ}$. 13. F $\mathrm{AB} . i d$.

(S. F. et A. SERv.)

SPHINGIDES, Sphingides. Seconde tribu de la famille des Crépuscularres, ordre des Lépidoptères; ses caractères sont :

Anternes terminées par une petite houppe d'écailles, en massue prismatique; cette massue commençant près du milieu de leur longueur. Palpes inférbeurs larges, très-garnis d'écailles; leur truisième ou dernier article très-petit, généralement peu distinct.

Cette tribu contient les genres Sphinx et Smérinthe.

Les chenilles des Sphingides sont tonjours glabres et munies de seize pattes, leur forme e t cylindrique, quelquefois un peu conique en avant, l'extrémité postérieure du corps a presque toujours une espèce de corue : lorsque celle-ci manque il y a une élévation à sa place. Ces chenilles vivent solitairement el se nourrissent de feuilles de végétaux, elles mangent beauconp à la fois et se tiennent ensuite long-temps en repos. Daiss leur jeune âge leur agilité est grande, el dès qu'on les inquiète elles se suspencient à nn fil à l'aide duquel elies remontent sur la feuille où elles en ont fixé la base; plus àyées on a de la peine à les déteruniner mềme à changer de place, et tantôt avec la tête tantôt avec les derniers segwens du corps elles cherchent à frapper la main qui les touche. Les excrémens de ces chenilles sont de grosses crottes qui ressemblent à de petits barils caunelés. Comme elles passeut toute leur vie sur le même végétal et quelquefois sur une seule brauche on recunnoît aisément l'endroit où elles séjournent en cherchant au dessus de celui que l'ou troure pargerné de leurs croltes. C'est dans la terre ou à sa superficie sous des feuilles qu'ellés construisent lears coques; etles y emploient pen ou point de soie, mais battent les parois qui les entourent de manière a les rendre fort unies. La plupart des Splhingides resient sept it huit mois sous la forme de chrysalides, cependant quelquefois plusieurs indiviáus éclosent au bout d'une quinzaine de jours aprés que la chenille es: entrée en terre; c'est ce qui arrive souvent au Spbiux Atropos, à celui du Tilhymale et probdblement aussi à quelques autres; nais en général, au waius dans nos climats, ces Lépicioptères n'out qu'une seule génération par anuée. Le Sphinx du Caillelait fait seul exception; on le rencontre a l'élat parfait el sous la forme de chenille depuis le printemps jusqu'aux premières gelées. Le plus 
grand nombre des espèces de Sphingidesne sc met en zouvement $\mathrm{g}$ u'at crépuscule et c'est alor's que les máles recherchent leurs femelles, mais ceux de notre troisième subdivision (Macroglosse LAT.) volent et s'accouplent en plein soleil et semblent même rechercher sa présence. Les femelles dispersent leurs œuf's et n'en placent jamais qu'un petit nombre sur la même plante: les mâles meurent aussioôt après l'accouplement. Les Sphingides sont tous de grande taille et ont proportionnellement l'abdomen fort gros.

$$
\text { (S. F. et A. SERv.) }
$$

SPHINX, Sphinx. Linn. Geoff. Fab. De Géer. Lat. Schiff. Esper. Cram. Engr. Rossi. Panz. Prunr. Hub. Spectrum, Macroglossum. Scop. Sesia. FAB. Acherontia, Macroglossum. LAT. (Fam. natur.)

Genre d'insectes de l'ordre des Lépidoptères, famille des Crépusculaires, tribu des Sphingides.

En créant le genre Sphinx Liuné y forma des divisions dont la plupart assez bien tranchées ont servi de base aux travaux des auteurs subséquens; il parcitroit que ce grand naturaliste n'a eu sous les yenx qu'un individn mutilé d'une des espèces qu'il y rapporte ( $S_{p} h i n x$ Nerii) puisqu'il l'a placée dans sa première division qu'il caractérise ainsi : Splinux légitimes à ailes anguleuses. Elle contient cinq espèces; les trois premières entrent aljourd'hni dans le genre Smérinthe, la quatrième nous est inconnue et paroît aussi l'avoir été aux auteurs venus après de naturaliste suédois; la cinquiène qui termine cette division ainsi que les dix-neuf espèces reufermées dans la seconde, celle-ci présentant pour caractère : Sphinx légitimes à ailes entières et anus simple, sont pour nous des Sphinx sauf les nos. Io et 23 . qui nous inconnus. Sa troisième division ainsi désignée : Splinx léçitiunes à ailes entières et auus barbu, forne pour plusieurs auteurs les genres Macroglosse (dont nous faisonis simplement une subdivision des Sohinx) et Sésie que nous admettons. Nous rapportons au premier les espèces 25 . 26.27 et 28 , et an second celles numërotées 29 . 3o. 31 et 32. La quatrième division qu'il appelle, Sphiux illégitimes (adscitce) doit se diviser ainsi : les espèces 34. 36. 37 et 42. sont des Zygènes, la $43^{\mathrm{e}}$. une Aglaope : les n ${ }^{05} .35$ et 38 des Syntomides; les espèces timbrées 40.41 et 46 . appartiennent aux Glaucopides, ce qui est probable anssi des espèces 44 et 45 ; enfin la $47^{\circ}$. espèce est une Procris. La 33e. ainsi que la $3 \mathrm{~g}^{\mathrm{e}}$. ne nous sont pas connues.

Geoffroy qui vint ensuite laissa également dans le genre Splinx toutes les espèces des environs de Paris que linné avoit mentionnées; il y établit trois familles d'après d'antres considérations que celles employées par son devancier. La première qüil no:nma Splainx-bourdons a pour caractères : antenues prismatiques, presqu'égales dans toule leur étendue; point de trompe distincte. 11 . y place quatre espèces; les trois premières sont des Smérinthes, la dẻrnière une Sésie. Sa seconde fanille nornmée Sphinx-éperviers, a les antennes comme dans la précédente famille, une trompe roulce en spirale, les chenilles sont lisses et portent une corue. Sept espèces sont de cette famille. Les nos. 5 et 6 . appartienneut aux Macroglosses Scop. Lat. Les espèces de 7. à I 2 . sont des Splinx. La troisieme famille ou Sphinx-bćliers ayant pour caractères : antennes prismatiques, plus épaisses dans leur unilieu; ane trompe roulée en spirale; chenilles velues, sans corne, ne contient qu'un senle espèce qui est le type du genre Zygène.

Fabricius partagea les Sphinx de Linné en trois genres; Sphinx, Sésie el Zvgène. Le premier contient les Smérinthes, les Thyrides et les véritables Sphinx. Ainsi ses a ${ }^{o s}$. 1. 3.9. 10. 14. 19.24. et peut-être encorele no. 4. sont des Smérinthes. Le no. 8. est la 'Thyride fénestrée, Thyris fentestrina. $\mathrm{L}_{\Lambda \mathrm{T}}$. Les autres espèces doivent rester parmi les Sphinx, sanf peut-être les $n^{o s}$. I 1 et 65 . qui sont douteux entre les Smériuthes et les Sphinx. En faisant le genre Sésie le même anteur y a placé nı certain nombre d'espèces de Sphinx comme nous l'avons dit au not SÉsIE. Voyez ct arlicle.

Fen M. Godart dans ses Lépidoptères de France donue à ce :enre absolument la même étendue que nous.

Enfin M. latreille dans ses Familles naturelles sépare en deux tribus le genre $S_{\text {phinx de Linné : }}$ ce sont les seconde et troisième de sa famille des Crépusculaires; dans la tribu des Sphingides il énonce quatre genres : Smérinthe, Achérontie, Sphinx et Macroglosse; nous ne counoissons. pas suffisamment les caractères da second et du quaI rième pour les admettre comme coupes génériques; le dernier formera parni nos Sphinx la troisième subdivision (prenic̀re division). La tribu des Zygénides de M. Latreille répond à la quatrième division du genre Sphinx de Linné.

Les gen res Smérinthe et Splinx composent seuls, suivant nons, la tribu des Splingides. Le premier a pour caractère qui le distingue du second, les antennes en scie ou pectinées, ef suivant M. Latreille, il en diffère encore par sa langue presque nulle.

Antennes prismatiques, simples ou n'ayant au plus que des stries trausverses, barbues; ces antennes sont terminées en poinle crochue portant une petite houppe d'écailles. - Langue cornée, de longueur variable, mais toujours distincte. Palpes comprimés, très-garnis d'écailles, leur troisième article très-petit, à peine distincl. - Ailes ayaut leurs bords entiers ou médiocrement sinués. Chenilles ayant leur tête de forme ovale-arrondie.

Pour les moeurs, voyez Sphiugides. Les Sphinx sont des Lépidopières géncralement fort gros, 


\section{$46 \%$}

S P H

ornés de couleurs vives et agréablement variées; ils volent avec bcaucoup de légèreté; leur vol, comme celui des Chauve-Suiris, est composé d'un grand nombre de battemens entremêlés de crochets. Ils produisent un bruit très-facile à distingner et qui avertit de leur passage; ils vont ainsi de flenr en fleur, choisissant de préférence les corolles tubulées et y enfonçant leur langue jusqu'au fond pour atteindre les nectaires ou glandes qui sécrc̀tent le miel : pendant qu'ils le recueillent ils restent devant les fleurs inmobiles comme l'Epervier qui guette sa proie, mais ni alors ni dans aucune occasion sls ne planent et leurs ailes sout dans un moupement t'ès-vif et continu, ce que l'on peut observer facilement dans le Sphinx du Caillelait (Sphinx stellatarum). Les chenilles de ces Crépusculaires varient, surtout par la forwe de la partic antérieure ciu corps; quelques-unes ont cefte partie susceptible d'alongement, mouvement qu'elles exécutent lorsqu'elles chercbent leur, nourriture ou qu'elles la prennent; dans ce cas cette partie dn corps samincit et prend la forme d'un cône tronqué dont la face de la tête est la troncature; lorseru'elles sont en repos elles font rentrer cette partic, alors le corps paroit être antérieurement en massue. D'autres u'ont pas cette faculté, quelques-unes de cellcs-ci relèvent leur partie antérieure jusqu'anx premières ou secondes pattes membraneuses et ramenant en devant la face antérieure de leur tête, elles prennent une autiude anilogue à celle que l'ar't du statuaire donne aux Sphinx fabuleux; c'est de cette habitude que le genre a titó son nom. La forme de la corne posée sur l'avani-dernier segment du coros varie également; elle est le plus souvent droile, conique-mince, presque lisse on très-finemeet grentie : daus le Sphinx Atropos elle est contournće et garnie d'asperités remarquables; quelques espèces l'ont linéaire et caduque, car elle n'existe plus après les premiers changemens de peau, et l'on ne voit à sa place વุu'une éminencé peu seusible, c'est ce qui arrive à la chenille du Sphinx Crantor FAz. (Voyez Smith-Aввот, Lépid. de Géorg. pl. 41.) M. Callcel naturaliste furt éclairé a eu occusion d'observer en Dauphiné la chenille du Sphinx de l'Hippophaé. Cette chenille, soit que la lumière lai nussc, suit pour éviler les attaques d'ennemis que. le jour favoriseroit, se cache pendaut que le soleil est sur l'ho:izon, sous les feuilles tornbées au pied de l'arbre et ne sort que la nuit pour prendie sa nourriture. Quclques chrysalides (ce sont eclles des Sphinx dont lä laugne égale ou surpasse la longueur du corps) ont un appendice qui forme un étui particulier à la langue et qui s'étendant au-delà de la tête, reciescénd en dessous et se papproche du ventre.

Le Splinx Alropos offre quelques particularités; le cri qu'il produil et l'apparence siaistre des taches de son corselel gui imiteat assez bien pne tête de mort ont attiré sur lui l'attention, et quelquefois effrayé des cantons entiers. (Voyez REAuMur, Mém. ins. tom. 1. $7^{\mathrm{e}}$. Mém.) Le brnit gu'il fait entendre est un son tremblé qui tient du sifflement; Réatumur l'attribue au frottement de la langue contre les palpes; dans ces derniers temps, M. Lorey donne pour cause à ce cri, l'air qui s'échappe par une trachée placée de chaque côté de l'abdomen et qui dans l'état de repos se trouve fermée par un faisceau de poils très-fins, réunis par un ligament qui prend naissance sur les parois latérales et internes de la partie supérieure de l'abdomen. Ce dernier auteur dit ditns.une note, pag. 19o. du poëme de M. Leroux, inijtulé : Art entomologique, qu'il a coupé non-seulement les palpes et la langue, mais même la tĉte entière du Spbinx Atropos, et que le cri s'est répété après cette amputation tout comme auparavant. Nous rapportons ici ces deux opinions afin de mettre les cntomologistes à mêtwe de faire de nouvelles expériences, suns nous prononcer en fuveur de l'une ou de l'autre. Une accusation pèse aussi sur cette espèce ; François Hüber dans ses Nouvell. observ. sur les Abeilles publiées en 1814 , torn. 2, pag. 291, prétend que ce Sphinx pénètre en automne dans les ruches, occasionne la dispersion des abeilles et pille le miel. Nuus pensons que l'uutorité de M. Hüber est de quelque poids en ce qui concerne l'économie des Mouches à miel, mais nous croyons que ce fait avancé par lui mérite d'être observé de nouveau par les propriétaires de ruches d'aleilles. Il paroít vraiment difficile de croire que les abeilles cèdent si lacilement à l'attaque d'un ennemi sans armes, tandis qu'elles repoussent des assaillans bien plus rcdoutables et jusqu'à l'homme même.

Ce genre est très-norabreux en espèces et répandu sur toute la terre, mais les climats chauds en conticnnent un bien plus grand nombre que les autres.

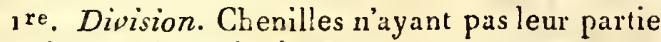
antérieure très-amincie, leur corps portant toujours des raies obliques un longitndinales. - Extrémité des ailcs supérieures presqu'arrondie.

${ }_{1}$ re. Subdisision. Abdomen sans brosse à son extrémité. - Bord postérieur des ailes convexe et entier.

Les uns ont leur chrysalide munie d'un appendice qui sert d'ćtui à la langue; cette langue fort longue. La clienille est toujours pourvae d'un corne conique-mince et droitc. Ce sont les espòces saivanies :

10. Sphinx du Jatrophit, S. Jatropho no. 22. Fав. Entom. Syst. $2^{\circ}$. Splainx de la Caroline, $S$. Carolinas $n^{\circ}$. 25. FАв. id. - Sm de Géorg. $m l .33 .3^{\circ}$. Sphinx rustique, S. risticu

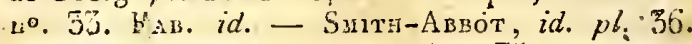
6o. Sphiax du Pin, S. Pinastri n\%. 3.j. Fab. id. - 


\section{S P H}

Encycl. pl. 64. fig. I-3. D'Europe. 5o. Splinx Hyléus, S. Hylceus no. 53. - Encycl. pl. 66. fig. 7. 6०. Spliinx du Liseron, S. Convolvuí no. 54 . Fав. $i d$. - Encycl, pl. 65. fig. I-3. D'Europe. Une variété ou une espèce très-voisine est représentée dans les Lépid. de Géorg. Snita-Aввот, pl. 32. $7^{\circ}$ Sphinx du 'Twëne, S. Ligustri no. 55 . FAn. id. - Encycl. pl. 65. fig. 4-6. D'Enrope. 8^. Spling du Pápayer, S. Caricae no. 67. Faв.id. $9^{\circ}$. S plinx du Micocoulier, S. Drupiferartum. Sицтн-Аввот, id. pl. 36. 10\%. Sphinx du Kalmia, S. Talmiar. Suта-Aввот, id. pl. 57. $11^{\circ}$. Sphinx des Conifères, S. Coniferarum. Sniтн-Aввот, id. $p l .42$.

Nous rapporterons encore à ce mềne groupe, mais avec moins de certitude, les especces suivantes de Cramer.

'ค. S:lhinx Clnentius, S. Cluentiıs, pl. $7^{8}$. fig. B. et $\mu l$. г26. fig. A. $2^{\circ}$. Splinx Annitual, S. Anribal, pl. 216. fig. A. 3o. Sphinx Paplus, S. Paphus. id.fig. B. 4․ Sphinx Anchomélus, S. Anchomelus, pl. 224. fig. C. 5॰. Splinx Gardius, S. Gordices, $p l$. 247. frg. B. 6\%. Splinx Ménéphron, S. Menephron, pl. 235. fig. A. $7^{\circ}$. Sphinx Lucétius, S. Lucetius, $p l$. 301. fig. B. 80. Sphinx Hlorestan, S. Florestan, $p$ \% \$94. fig. B. $9^{\circ}$. S jlinx Pamplite, S. Pamphilus, pl. 594 . fig. E.

Nota. Quelques-unes de ces neuf dernières espèces peuvent être sous d'antres nonıs dans les auteur's cités précédemment.

A ce groupe appartiennent peut-être encore, 10. Sphinx Alopé, S. Alope no. 20. Fas. Entom. Syst. $2^{\circ}$. Splinx Erotus, $S$. Erotus no. 28 . FAв. id. $3^{\circ}$. Splininx Tétrio, S. Tetrio n. 32. F. в. id. $4^{\circ}$. Sphinx payen, S. pagana no. 54 . l' A B. $i d$. $5^{\circ}$. Spltinx plébéien, S. plebeia $n^{\circ} .36$. F Ав. id. $6^{\circ}$. Sphinx de la Tassole, S. Boerhavioe $n^{\circ} .46$. Fав. id. $7^{\circ}$. Sphinx funèbre, S. funebris $\mathbf{n}^{\circ} .47$. Fав. id. 8. Splinx Caricus, $S$. Cä̈cus n. 57. Fab. id. - Encycl. pl. 66. fig. 8. 9 ${ }^{\circ}$. Sphinx agile, $S$. velox $1^{\circ}$. 68. Faв. id. ro ${ }^{\circ}$. Shinx Abadoina, $S$. Abadonna. FAB. Entom. Syst. Suppl.

Les autres ont leur chrysalide mutique à sa partie antérieure; la langüue est courte ou de longoueur moyenne. La corne de la chenille n'est pas toujours droite; nous plaçons ici les $S_{p h i n x}$ suivans:

10. Splinx Alropos, S. Atropos no. 27. FAB. Entom. Syst. - Encycl.pl.6.). fog. 9-11. D'Ë rope. $2^{\circ}$. Splinx Cacus, $S$. Cacus no. $48 . \mathrm{F}_{\mathrm{A}} \mathrm{B}$. id. $5^{\circ}$. Sphinx Ello, S. Ello $1^{\circ}$. $2 \mathrm{~J}$. FA в id. $4^{\circ}$. Sphinx du Tithymale, S. Euphorbioe no. 37. Fав. id. - Encycl. pl. 64. fig. 4-6. D'Europe. 5\%. Splinx Nicéa, S. Nicea. God. Lépid. de Franc. pag. 171. us. 5-6. pl. 17. ter. fig. 1. D'Europe. 6o. Splinx de l'Hippophaé, S. Hiopophaes. God. id.pag. $178 . \mathrm{n}^{\circ \mathrm{s}} .8-9 \cdot \mathrm{pl}$. 17. ter. fig. 2. D'Europe. $7^{\circ}$. Sphinx de la Garance, S. Gallii no. 38. Fав. id. D, Europe. 8. Splinx rayé, S. lineata no. 39 .

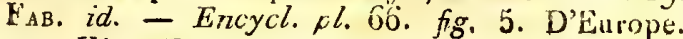
Hist. Nat. Ins. Tome $X$. $9^{\circ}$. Sphinx Chauve-souris, S. Vespertilio $\mathrm{n}^{\circ} .40$. Hав. id. D'Europe. $10^{\circ}$. Sphinx Lachésis, S. Lachesis. FАв. Entom. Syst. Suppl.

Les quatre espèces qui suivent nous paroissent appartenir au même groupe.

Io. Spliux Brontes, S. Brontes. Druny, Ins. tom. 1. $p l$. 29. f.g. 4. 20. Sphbinx Ooheltès, $S$. Opheltes. Cra ar. pl. 285. fig. B. 3०. Sphinx Scyrou, S. Scyron. id. pl. 301. fig. E. $4^{\circ}$. Sphinx accentué, $S$. accentifera. PaL. - Bauv. Ins. d'Afr. et d'Amériq. pag. 263. Lépid. pl. 24. fig. I.

$2^{e}$. Subdivision. Abdomen terminé par une brosse dans les mâles seulènent. - Bord postćrieur des ailes angulenx.

Cette subdivision renferme : $1^{\circ}$. Splivx de l'CEnothère, S. Enotheran ${ }^{\circ}$. 12. Fа в. Entom. Syst.

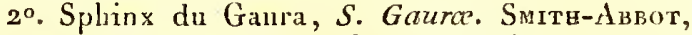
Lépid. de Géorg. pl. 31. 3. Sphinx Múdée, $S . M e$. dea n?. 23. Fа в. id. $4^{\circ}$. Sphinx Nessus, S. Nessus no. 2. FАв. $i d$. 5o. Splinx lugubre, $S$. lugubrus n\%. 5. FАв. $i d$. - SнIтн-Aввот, id. pl. 30. $6^{\circ}$. Sphiux louche, $S$. lusca no.6. FAв. id. $7^{\circ}$. Sphinx asiliforme, $S$. asiliformis no. 7. Fas. id. $8^{\circ}$. Splinx Pénée, S. Penceus ño. I5. Fав. id. $9^{\circ}$, Sphinx $\mathrm{P}_{y}$ las, S. Pylas n. 16. F А . $i d .10^{\circ}$. Sphinx didyue, S. didyma no. 48. F' в. id. I I ${ }^{\circ}$ Splinax 'Thyélia, S. Thyelia no. 7o. FAB. id.

Les espèces suivantes nous semblenł devoir êłre placées ici. 10. Sphinx Hespéra, S. Hespera no. 49. Fав. Entom. Syst. $2^{\circ}$. Sphin x Parque, S. Parce no. 5o. ЕА в. id $3 \%$ Splinx Japix, S. Japix. Ca Ar. pl. 87.fig. C. 4\%. Sphinx Bubasté, S. Bubastus. id. pl. 149 . fig. li. 5\%. Sphinx Oiclus, S. Oiclus. id. pl. 216. jig. (. 6०. Sphinx Pan, S. Pan. id.fig. D). $7^{\circ}$. Sphinx Pluion, S. Pluto. id. fig. E. 8०. Sphinx 'Triptolème, S. Tripsolemus. id. fig. F. $9^{\circ}$. Sphinx Camertus, S. Camertus. id. $p l .225$. fig. A. $10^{\circ}$. Sphinx Danum, S. Danzm. id. fig. B. $11^{\circ}$. Sphins Phégćus, $S$. Phegeus. - S. Fegeus. id. fig. E. $12^{\circ}$. Sphiux Lyctus, S. Lyctus. id. fig. F. I $3^{\circ}$. Splinx Enolrus, S. Enotrus. id. pl. 301. fig. C. $14^{\circ}$. Splinx Ancée, S. Anceus. id. pl. 355. fg. A.

32. Subdivision. Abdomen termilé par une brosse daus les deux sexes. - Bord postérieur des ailes convexe et entier. (Genre Macroglosse, Macroglossum. ScopoL. Lat. Sesia. EAB.)

\section{Ailes opaques.}

Nons rangeons dans ce groupe : $1^{\circ}$. Sphinx Tantale, S. Tantalus. - Sesia Tantalus no. I. FАв. Entom. Syst. $2^{\circ}$. Sphinx Fadus, S. Fadus. - Sesia F'adus " ${ }^{\circ}$. 4. HА в. id. $3^{\circ}$. Sphinx du Caillelait, $S$. Stellatarum. - Sesia Stellatarum no. 5. F A . id. Encycl. pl.67. fig. 3. D'Europe. 40. Sphinx Pandore, S. Pandora. - Sesia Pancoran ${ }^{\circ}$. 6. FA B. id. 5o. Sphinx à zône, S. zonata. Druny, Ins. tom. I. $p l .26$ fig. 5. 6”. Splias Bélis, S. Belis. Carair. 
pl. 94. fig. C. $7^{\circ}$. Sphinx Titan, S. Titan. id. $p l$. 142. fig. F. 8०. Sphinx Cécule, S. Ceculus. id. pl. 146. fig. G. $9^{\circ}$. Sphinx Morphée, S. Morphens. id. $p l$. 149. fig. D. $10^{\circ}$. Sphiux Faro, S. Faro. id. pl. 285. fig. C.

\section{Ailes en partie vitrées.}

Ici uous placerons : $1^{\circ}$. Sphinx Hylas, S. Hylas. - Sesia Hylas 110.3. FA в. Entom. Syst. - Encycl. $p l .67 \cdot$ fg. $8.2^{\circ}$. Splinx fuciforme, $S$. fuciformis. - Sesia fuciformis no. I 1. FAB. id. D'Earope. Le Sphinx fuciformis. Suптн-Аввот, Lépid. de Géorg. $p l$. 43. nous paroît une espèce voisine, mais nou pas la même que la précédente. $3^{\circ}$. Sphinx bornbyliforme, $S$. bombyliformis. - Sesia bombyliformis $\mathrm{n}^{\circ}$. 12. Fав. id. $4^{\circ}$. Sphinx Pélage, S. Pelasgus. CraAr. pl. 248. fig. B.

$2^{\mathrm{e}}$. Division. Chenilles ayant leur partie antérieure amincie en forme de grnin, leur corps portant des taches latérales oculaires. - Extrémité des ailes supérieures aiguë ou presqu'aiguë.

Celte secoude division renferme, ${ }^{\circ}$. Sphinx du Nérion, S. Nerii no. 13. Faв. Entom. Syst. D'Europe. - Encycl. pl. 65. fir. 5-8. 20. Sphinx

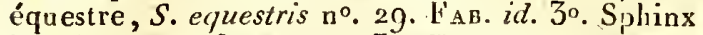
Phorbas, S. Fhorbas no. 5o. Fab. id. $4^{\circ}$. Sphinx du Figuier, S. Ficus n $n^{\circ} .3 \mathrm{r}$. FAB. id. $5^{\circ}$. Sphinx de la Vigne, S. Vitis n ${ }^{\circ}$. 41 . F Lépid. de Géorg. pl. 11. 6”. Sphinx à satellites, S. satellitia $\mathrm{u}^{\circ}$. $42 . \mathrm{F}_{\mathrm{A}}$. id $7^{\circ}$. Splinx Phénix, S. Celerio n ${ }^{n}$ 43. FAB. id. - Encycl. pl. 63. fig. 7-9. D'Europe. $8^{\circ}$. Sphinx de l'Oldenlaude, $S$. Oidenlandiae no. 44. Fав. id. $9^{\circ}$. Sphinx Lycélus, S. Lycetus $\mathrm{n}^{\circ}$. 45. FaB. id. 10 . Sphinx Elpénor, S. Elpenor n ${ }^{\circ} .51$. Faв. id. - Encycl. pl. 64. fig. 7-9. D'Europe. 11\%. Sphinx de l'Epilobe, $S$. Porcellns no. 52. F.а id. - Encycl. pl. 64. fig. 3o-12. D'Europe. 12․ Sphinx Crantor, S. Crantor $n^{\circ}$. 58. FAв. id. - S Мाтн-Аввот, Lépid. de Géorg.pl.4r.-Encycl.pl.66.fig. 9. 13º. Sphinx Alecton, S. Alecto no. 5g. Fab. id. $14^{\circ}$. Sphinx Gnôme, $S$. Gnoina no. 61. F. Ав. id. $15^{\circ}$. Sphinx

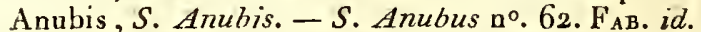
${ }_{3} 6^{\circ}$. Sphinx Néchus, S. Nechus n ${ }^{\circ} .63$. Faв. id. - Encycl. pl. 67. fig. 1. $17^{\circ}$. Sphinx de la Vigne sauvage, $S$. Labruscae no.66. FAB. id. $18^{\circ}$. Sphinx

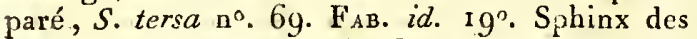
pampres, $S$. pampinatrix. Sитти-Aввот, Lépid. de Géorg. pl. 28.

Nous y joindrons les espèces suivautes, mais a vec quelqu'incertitude. $1^{\circ}$. Sphinx agile, $S$. stri-

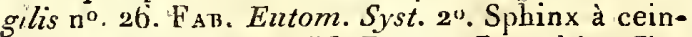
ture, $S$. cingou'ulta no. 56. FAB. id. 3o. Sphinx Clotho, S. Clotho n ${ }^{\circ} \cdot 6$ o. Fab. $7 d \cdot 4^{\circ}$. Sphinx Batus, $S$. Batus $n^{\circ} .64 . \mathrm{F}_{\mathrm{AB}}$. $i d$. 5 ${ }^{\circ}$. 'S hinx Centaure, $S$. Centaurus. - Sphin.x Chiron. Dr UR Y, Ins. tom. I. pl. 26. fig. 3. 6". Sphinx de Drury, S. Dnirai. Sphinx Clotho. DruR ч , id. tom.'2.pl.28. fig. I. $7^{\circ}$. S, hinx lycaon, S. Lycaon. - S. Licaon. Cram. pl.55. fg. A. 8o. Sphinx Drancus, S. Drancus. id. pl. 132. fig. F. $9^{\circ}$. Sphinx Chiron, s. Chiron. id. pl. r37. fig. E. so.. Sphinx Caïus, S. Cajus. id: pl. 146. fig. F. 1: ${ }^{\circ}$. Sphinx Panope, S. Panopus. id. pl. 224. fig. A. 13. 12\%. Sphinx Achéménide, S. Achemenides. id. pl. 225. fig. C. 13\%. Sphinx Acas, S. Acas. id. pl. 226. fig. A. 14 $4^{\circ}$. Sphinx Cécrops, $S$. Cecrcps. id. fig. 13. $15^{\circ}$. Sphinx Ason, S. At'son. - S. Eson. id. fig. C. $16^{\circ}$. Sphinx Actée, S. Actelss. id. pl. 248. fig. A. $17^{\circ}$. Sphinx Hippothoüs, S. Hippothous. id. pl. 285. fo. D. $18^{\circ}$. Sphinx Eaque, S. Eacus. id. fig. E. $19^{\circ}$. Sphinx Néoptolème, $S$. Neoptolennus. id. pl. Zor. fig. F. 20'. Sphinx Pandion, S. Pandion. id. $p l .321$. fig. A. $21^{\circ}$. Sphinx de Cramer, $S$. Crameri. $-S$. Gordius. id. pl. 367 . fig. A. $22^{\circ}$. Sphinx I,ycaste, S. Lycastus. - S. Licastus. id. pl. 38 r. fig. A B. 23․ Sphinx Amadis, S. Amadis. id. pl. 394. fig. C. $24^{\circ} . S_{j}$ hinx Breumus, $S$. Brennus. id. pl. $3 y 8$. fig. B.

Nota. Ces vingt-quatre espèces sont douteuses comme appartenant à cette division; elles ont besoin aussi d'un nouvel examen avant d'être admises comme espèces distincles des précédenles. En outre il est probable que les Sphinx Cisiris et $C r r e-$ sus. Dalm. Analect. Entom. pag. 48. doivent se placer ici. (S. F. el A. SErv.)

SPIIINX-BE்LIERS. Nom donné par Geoffroy à la troisième famille de ses Sphinx. Elie répond au genre Zygène. Voyez ce mol.

$$
\text { (S. F. et A. Serv.) }
$$

SPHINX-BOURDONS. Geoffroy appelle ainsi la première famille de son genre Sphinx. Il y place les Lépidoptères dont nn a formé depuis les genres Smérinthe et Sésie. Voyez ces mols.

$$
\text { (S. F. et A. Serv.) }
$$

SPHINX-ÉPERVIERS. Seconde famille du genre Sphinx dans Geoffroy. Elle coutient les véritables Splinx. Voyez ce mot.

$$
\text { (S. F. et A. SERv.) }
$$

SPHODRE, Sphodrus. Nom donné par M. Bonelli (Obs. entom. Mlém. de l'Acad. de Turin) à un genre de Coléopières de la tribu cues Carabiques. D'après cet auteur ses ra actères sont : langue tronquée. Palpes ayant leur dernier article cylindrique, mais aminci is sa base et plins court que le précédent dans les labiaux. Mandibules alongées; troisième article des antennes alongé, de la longneur des deux premiers pris ensemble. Corselet presque cordiforme, ayant de chaque côté une slrie à sa base; les-angles cie celte base, droits. (Ailes quelquefois courtes.)

M. le comte Dejean rapporte à ce genre dans son calalogue : $1^{\circ}$. Carabus planus $\mathrm{n}^{\circ}$. 47. FAB. 
Syst. Eleul. 2॰. Carabus terricola nº.68. Oniv. Entom. et plusieurs aulres espèces moins connuess.

(S. F. et A. Serv.)

SPONDYLE, Spondylis. FAB. OLIv. LAт. $A t-$ telabus. Linn. Cerambyx. De G'éer.

Genre d'insectes de l'ordve des Coléoplères, section des Pentamères, famille des Longicorues, tribu des Prioniens.

Lorsque nous avons rédigé l'arlicle Proniens, M. Latreille n'admettrit dans cette tribu que les yenres Spondyle et Prione; depuis, dans ses Fam. nat. il cite deux nouveaux genres sous les noms de Thyrsie et d'Anacole; le premier se compose d'espèces qui nous étoient alors inconrues; le second répond absolument à notre première divisior dı genre Prione (voyez ce mot). Les Priones, les 'Thyrsies et les Anacoles se dislingurnt des Spondyles par leurs antennes toujours plus longues que la moilié du corps, composées d'articles alongés; de plus les deux derniers ont les élytres mulles et dans les Priones le corselet est toujours épineux ou denté latéralement.

Antennes hlifuranes, de la longueur du corselet, insérées au devant des yeux, prés de l'échancrure de cenx-ci, composées de onze arlicles aplatis à partir du iroisiène et obconiques excepté le dernier; le premier à peine plus grand que les autres; le second petit, le troisième un peu plus long que les suivans, le dernier ovale, très-aplati. - Labre très-petit, à peine apparent, coriacé, un peu velu antérieurement. - Mandibules cornées, fortes, avancćes, arquées, pointues à l'extrénilé, échancrées à la base de leur côté iulerne, ayant dans cette partie deux petites dents obtuses et une autre vers le milieu. - Mâchoires composées de deux lobes en lanières, l'externe assez coriace, un peu plus grand que l'au!re, conique, aigu à l'extrémité; l'intérieur court, membraneux, presque cylindrique. - $P$ alpes ayant leur dernier article presqu'obconique; les maxillaires un peu plus longs que les autres, de quatre articles, le premier très-petit, cylindrique, les trois autres en cône renver'sé ; le second et le troisième égaux, le terminal un peu plus grand : palpes labiaux de trois artıcles, en cône renversé, allant en augmentant de longueur du premier au dernier. - Lèrre demi-crustácée, cordiforme, concave en dessus, velue, carénće dans sa longueur postérieurement; cette carèue finissant en une dent an milieu de son bord supérieur ; menton crnstacé, transversal, linéaire; son bord supérieur arrondi vers les côtés, sa partie moyenne échancrée à l'endroit de l'insertion de la lèvre. -Tếe courte, presque carrée, un peu plus étroile que le corselet dans lequel sa partie postérieure est reçue. Yeux étroits, alongés, peu saillans, échancrés antérienrement. - Corselet presqu'orbiculaire, tronqué antérieurement et à sa partie postérieure, arrondi sur les côtés, convexe, point rẹordé.
- Ecusson en triangle curviligne.-Eljtres dures, presque linéaires, arondies postérieurement, couvrant des ailes et l'abdomen. - Poitrine graude. - Abdomen court. - Pattes courtes, les intermédiaires très-rapprochées dés antérieures, les postérieures fort élnignées des autres; cuisses assez grosses, ovales, comprimécs; jambes presque conıques, dentelées extérieureneut, muaics à leur extrémilé de denx épines courles; tarses courts, leurs deux premiers arlicles presqu'égaux, triangulaises, le troisième bilobé, le dernier le plus long de tous, conique, muni de deux crochets.

Il paroît que la larve des Spondyles vit dans l'intélieur des vieux arbres, car on trouve l'insecte parfail dans les forêts, particulièrement dans celles de Pins. A ce genre apparlient le $\mathrm{S}$ pondyle buprestoide, Spond. buprestoides. FAB. Syst. Eleut. tom. 2. pag. 376. n'. 1. - Eucycl. pl. 368. fig. r. De France, d'Allemagne, ctc. M. le comle Dejean indique une autre espèce daus son calalogue sous le nom d'Elongatus; clle est d'Allemagne. (S. F. et A. SERV.)

SQUILLE, Squilla. Genre de Crnstacés de l'ordre des Stomapodes.

Celui que Fabricius désigne ainsi, forme maintenant, dans notre méthode, une famille particulière de l'ordre des Stomapodes, celle des Unipeltés, et dont nous exposerons les caractères en traitant ce dernier arlicle. Notre genre Squille se trouve ainsi beaucoup plus restreint que celui de ce célèbre enlomologistc.

La famille des Uuipeltés se partage en denx sections.

1. Segmens du thorax, le premier an plus excepté, découverts en dessus. Bouclier ou test crustacé ou conace; ses côtés point repliés en dessous et n'enveloppant point ceux de la partie du corps qu'il recouvre. Une petite plaque, en forme d'écus. son, obtuse ou simplement acuminée sur l'article antérieur, portant les antennes nitoyennes et les yeux. Cet urticle et les côtés extérieurs au moins de la nagevire posténeure toujours découverts.

Cette section se compose de trois genres, Squille, Gonodactyle et Coronide.

Genre Squjlet, Squilla.

Appendice latéral des six pieds postérieurs linéaire ou filitorme. Doigt des serres (les seconds pieds-mâchoires ou leurs analogues) très-comprimé, en forme de faulx (le plus souvent denté); une rainure très-étroite, denielée sur l'un de ses bords, épineuse sur l'autre, s'étendant daus tou té la longuear da côté interne de l'article précédent.

* Les Grecs, avuns-nous dit à l'article SQuilue de la seconde éaition du nouveau Dictionnaré d'histoire naturelle, distinguoient trois sortes de Nnn 2 
Squilles : les Cyphas ou Squilles bossues, les Crangos s ou Crangines, et les Carides ou petites Squilles. Les premières appartiennent au genre Pénée; les secondes sont nos Squilles proprement dites, et les dernières font partie des Palémons, des Crangons et de quelques autres sous-genres de notre sous-famille des Salicoques : on lcs désigne vulgairement sons le nom de Squilles. Les Crustacés auxguels Fabricius applique cette dénomination, sont appelés sur nos côtes de la lićditerranće, Muntes de mer, Prégodious."

Dans la méthode de Linnæus, ces Crustacés font partie de son genrc Cancer, division des Macroures. Gronovius ( Guzophyl.) les place dans celui d'Astacus ou d'Ecrevisse, et son gen re Squilla est le même que celui d'Aselle d'Olivicr.

Sousla même dénonination générique de Squille, de Géer comprend ces dernicrs Crustacés, divers Amphipodes, et les Squilles proprenent dites de Fabricius. Il a négligé un caractère très-important, que le natnraliste précité a le premier employé, tiré des yeux (pédiculés ou sessiles).

"Les Squilles (article SQuille, nouveau Dict. d'hist. nat. 2e. édit. tom. 52. pag. 93.) ont le corps recouvert d'un test asscz mince, étroit, presque demi-cylindriquc, et divisé en douze segmens. Le premier beaucoup plus long que les autres, recouvert d'une tabletts (le test ou le bouclier) presque carrée, plus ćtroite en devant, on en forme de triangle alongé et tronqué, forme la tête ou la portion autérieurc du tronc. Avec le milieu de son extréunté antérienro est articulée une petitc pièce en forme de triangle renversé, servant de support aax yenx, aux antenneśs intertnédiaires, et offrant en dessus une petite plaque triangulaire, obtuse, qui senıble être un prolongement de la tête, mais dont elle est distinguée par une suture. Les yeux sont situćs transversalemient à l'extrćmité d'un pédicule court, mobile, el formant avec lui un corps qui présente l'aspect d'un warteau. Les antennes mitoyennes sont insćrées immédiatement au-dessous d'eux; lenr longueur t́gale ou surpasse mêtne celle de la tête; elles sont composées d'un grand pédoncule, divisé en trois articles cylindriques, et de trois filets sćtacés, mulliarticulés et insérés à l'extrćmité du pécioncule. Les antennes latérales, plus courtes que les prévédentes, sont iniplantées de chaque côtć dans une échancrure de l'extrénité antéricure de la tĉte, tout prés des antennes mitejennes et dans une même ligne horizontale. l.eur premier article ou le radical est fort grand et occupe l'ścbansture; il forme le support de l'antenne propremeut dite et d'un appendice extérieur qui l'accompagne; cet appendice se compose d'un grand feuillct elliptique, cilié ou velu sur ses bords, et d'un article assez grand, anguleux, lui scrvant de base, sur lequel il se meut, et inséré à l'extrémité du support commun. L'antenne nait de l'extrémité inierne de ce support; elle est formée d'un pédoncule cylindrique, de trois articles, et d'un filet terminal, un peu plus long, sétacé et divisé en un grand nombre de petites articulations. Vue en dessous, la partie supérieure de la têtc présente la figgure d'une pyramide, tronquée au sommet, et fortement comprimée, de chaque côté, dans sa longueur. Imınédiatement au-dessous d'elle sont situés et trèsrapprochés les organes de la manducation et les dix premières pattes. La bouche cst composée d'un labre, de deux mandibules, d'une languette de deux pièces et de deux paires de mâchoires. Le labre forme le milieu de la base antérieure de la pyrumide; il est cintré, entier, et fixé par une pièce plus membraneuse que le reste. Les mandibules sont grandes, presque triangnlaires, comprinnées et de consistance écailleuse on d'émail à leur extrémité, qui s'avance, en se bifurquant, sous lc labre; la branche supérieure forme avec l'antre ou le prolongement terminal de la mandibulc, un angle très-ouvert, et se dirige, en s'élevant, de chaque côté du labre. Son bord interne a deux rangćes de dents; celui de l'autre n'en offie qu'une; lcs deux branches vont en pointe. La portion de la mandibule qui est en deçà est très-épaisse et occnpe les côtés intérieurs de la pyramide. Sa face extérieure est lisse ct plane; à sin extrémité supérieure, près du point où commence la dépression de la mandibule, est inséré un palpe assez long, filiforme, velu, de trois articles, qui remonte de chaque côté du front, en se courbant vers lui. Au-dessous des mandiluules est située la languette; elle est formée de denx pièces comprinées, placées transversalement, une de chaque côté, faisant l'office de michoires, et dont l'extrémité interne est garnie de cils roides et alongés, on de petites épines. Vient ensuite, et dans une direction semblable , la première paire de mâchoires; chacune d'elles est composée de deux articles; le premier a, au côté interne, un avancement cilić; le second fait un coude avec le précŕdent, s'applique sur son hord supśrieur, porte sur sou dos un petit appendice palpiforme, et se termine supérieurement par une épine plus forte ou une sorte d'onglet, accompagné de cils. Les deux mâchoires suivantes, ou celles de la seconde paire, sent foliacées, en forme de triangle alongé, divisé par des lignes 'transverses en quatre articulations, recouvrant la bouche dans un sens longitudinal et lui formant une sorte de lèvre inféricure. Les dix premières pattes, toutes terminées par une pince en grifle et dirigées en avant, sout très-rapprochées et disposées autour de la bouche en manière d'angle, dont le sommet est supérieur. Les deux premières sont insérćes près des bords latéranx de la tête, à la hauteur des denx dernières mâchoires. Les intervalles qui séparent les autres pattes diminuent ensuite graduellement, par l'effet de la convergence de leurs points d'insertion. Celles de la seconde paire ou les 
scrres proprement dites, contrastent, sous plusieurs rapports, avec les autres; clles sont beaucoup plus grandes; leur troisième article, celui qui répond au bras, est, à cet égard, très-remarquilble; il est couclıé, dans le repos, le long des côtés inférieurs de la tête, sous les bords de son test, et sa face interne offre à peu de distance de son extrémité supérieure, une éch ancrure lisse, qui correspoud, dans cet ćtat d'inaclion, aux angles antérieurs du test; la pince est alongrée, ordinairement très-comprimée, avec le bord interne très-finement dentelé dans sa longueur, et armé, vers son origine, d'épines fortes et mobiles; sous ce bord est une rainure, avec une rangée de fosseltes, propres à recevoir les dents de la griffe on de l'onglet mo!sile qui termine la pince. Cet onglet est très-fort, très-acéré, d'une consistance trèssolide et qui approclie souvent de l'émail. Tantôt il a la forme d'un grand crochet, dont le côté interne est plus ou moins denté en manière de peigne (1); tantôt il est ventru (2) ou plus épais à sa base, et finit simplemènt en pointe; le nombre de trous pratiqués dans la rainure de la pince est proportionnel à celui des dents de la griffe. La conformation de ces parties nous indique que l'animal saisit et retient sa proie à la manière des insecles appelís Mantes (voyez ce mot). Les autres pattes onguiculćes sont bien plus petites et beaucoup plus foibles. Leur longneur, it partir des deux supéricures, diminue graducllement; cclles-ci soni un peu plus grêles que lcs antres. La pince est presqu'orbiculaire, cumprimée et repliće en dessous, de manière qu'elle présente sa tranche inférieure el que la pointc règarde la lête. Les six premières pattes sont les analogues des pieds-mấchoires des Crustacés décatpodés; ainsi que dans les Amphipodes, celles de la seconde paire, ou les pieds-mâchoires intermédiaires, représentent maintenant, à raison de leur grandeur et de lcurs usages, les deux sortes de Crustacés précédens. Si Pon en excepte les deux dernières, toutes les pattes onguiculées ont, à lcur origine postérieure, un petit corps membraneux, vésiculaire, plus ou moins susceptible de tuméfaction, en forme de coin ou de sêgment de cercle, et attaché au moyen d'un court pédicule. Desséchés, ces corps ont l'apparence d'une petite écaille. J'avois soupconné qu'ils servoient à la respiration; mais d'après les observations de M. Cuvier, aucun vaisseau n'y aboulit. Le segment qui vient immédiatement après la tête, est plus court que les suivans et sans aucun organe spécial (3); il tient lieu de col. Les trois segmens suivans por-

(I) Les Squilles proprement dites.

(2) Les Gonodactyles.

(3) Les deux dernières patres onguiculées y sont annexées. Cetui qui porte les deux pattes précédentes se montre aussi un peu, mais il est biaucoup plus court. tent chacun une paice de pattes et cui different des précédentes, tant par leurs formes que par leurs propriétés. Elles sont grêles, filifurmes et terminées par un article triangulaire ou conique, comprimé, et dout le côté antéricur est garni de poils ou de cils nonbreux; ils composent une sorte de brosse ct naissent de petils trous alvéolaires, disposés par séries longitudinales. A l'extrémité supérieure du troisième article est inséré un petit appendice ou ramea cylindrique, menu, linéaire, prolongé jusque près du bout de l'article suivant, et oflraut à son extrémité des divisions annulaires, superficielles, et quelgues poils. On voit que ces six pattes sont uniquement propres à la nalation. Plusieurs individus, probablement les mâles, ont près de l'origine de chacune des deux derni rres, un autre appendice crustacé, filiforme, mais arqué el sans articulations. Les cinq segmens suivans, et qui, avec les deux derniers (1), constituent celle partie qu'on désigne improprement sous le nom de queue, ont chacur en dessous unc paire de pieds nageoires; ces organes sont formés de dcux pièces foliacées, en partie membraneuses, vésiculaires, triangulaires ou ovales, bordées de cils nombreux et plumeux, et siluées sur un pédicule commun, avec une branchie composée de filets très-nombreux, articulés, remplis $d^{2} u n e$ matière molle, partant d'un axe comınun et rassemblés en maniere de houppe. L'extrémité antérieure et latérale du premier de ces anneaux branchifères présente une peljle pièce surnuméraire, en forme d'écaille arrondie, et qui semble recouvir la base des deux palles postérieures. Chaque côté de l'arant-dernier segment donne naissance à cet appendice en nageoire qui caractérise plus particulierement les Crustacés décapodes, de la famille des Macroures. Il est composé de trois articlcs; le premier ou le radical se prolonge on se dilate au côté interne, et s'articule, en dessous, avec une autre pièce, en forme de lame ou de fenillet. La saillie interue de cet article se termine ordinairement par des dents très-fortes et très-aiguës; le côté extérieur du sccond offre une rangće d'épines mobiles; le dernier article est en forme de lame ovale on elliptique, et bordé, ainsi que le feuillet interne, d'ine frange de cils nombreux el serrés. Le dernier segnent, ou celui qui est situć enire les appendices natatoires, cst plus grand que les anneaux précédens, presque carré, avec le bord postérieur un peu arqué et arrondi. Le bord offre, dans son contoui, des sinus on des échancrures, avec des dents d'inégale grandeur, et dont les plus fortes ressemblent ì des épines. L'anus est placé sous le dernier segment et près du milien de sa base. Le dessus du corps, ou du moins les deux derniers anneaux, offire des arêtes longitudinales, et dont les extrémités forment au-

(1) Sepr en tour. 


\section{$470 \quad 52 \mathrm{U}$}

tant d'ćpines ou de dents. Aussi est-il nécessaire de ne saisir ces Crustacés, lọrsqu'ils sont vivaus, qu'àvec beaucoup de précautions."

D'après les observations anatomiques de $\mathrm{Ml}$. CHvier, l'intérieur des Squilles, qu'il distingue aussi sous la dénomination de Branchiopodes, présente un petit estomac silué sous le test, armé de dents très-petites et peu nombreusc's, suivi d'un intestin grêle et droit, qui règne dans toute la longueur du post-abdomen ou de la quene, et accompaguć, à droitc et à gauche, d'un certain nombre de lobes glanduleux qui paroissent tenir lieu du foie. Le cour a la forme d'un gros vaisseau alongé el fibreux, s'étendant tout le long du dos, du postabdomen, ct jetant, des deux côtés, des branches, qui se rendent aux branchies et à d'autres partie's.

M. Risso nous apprend que ces Crustacés se tiennent ordinairement dans des profondeurs de trente à cinquante mètres, et qu'ils choirissent les endroits sablonneux ou fangeux, où ils trouvent une nourriture plus abondante et plus assurée. L'accouplement a licu au printcrnps. lies fimelles se cachent sous les rochers, lorsqu'elles veulent se débarrasser de leurs oufs. Au ténoignage de ce naturalisle, ils sont disposés sous les appendices de l'abdomen, comme ceux des Langoustes. Mais sans voulon le démentir à ce sujet, je remarquerai que quoique j'aie vu un très-grand nombre de Squilles, je n'ai jamais trpuvé sur aucun d'eux des aufs. Les appendices ont ici d'ailleurs one aurre destination yue ceux des Langoustes. $\mathrm{La}$ chair des Squilles, ajoute le même auteur, est fort bonue et sert journellement de nourriture. Elles paroissent être fort craintives et fuient au lond de l'eau, lorsqu'on les poursuit. Dans les cnvirons de Villef:anche, on les prend avec un tilet, nommé rustro en langue du pays. Ces Crustacés sont répandus dans toutes les mers des pays chauds.

I. Point d'épines mobiles au bord postérieur. du dernier segineni. Une seule ligne étroite au milieu de ce segment.

Corps peu bombé, point cylindrique.

1. Milleu du burd postérieur du deınier segment tronqué, sans dents ou n'ayant que de très-petites crénelures. Pédicule des deu.x nageoires postérieures plus long que le prentier article de l'appendice extérieur..

Dessus du corps, à l'exception au plus des trois derniers segmens, uni, sans arêtes longitudinales. Quatre épines mobiles vers l'origine du bord antérieur du poing. Milieu du dernier segment ofirant un espace eu forme de triangle renversé, et tracé par deux lignes enfoncées et convergentes postérieurement. Pièce recouvrant le support oculaire et annulaire en forme de cœur renversé, acuminé.

\section{$\mathrm{S} Q \mathrm{U}$}

I. Sqoille queue-rude, Squilla scabricauda.

Pollice decendentato; segmentis duobus posticis suprà spinosulis.

Squilla scabricauda, рE LAм.-Tamane guacu, MA ECgR. Brasil. lib. 4. pag. 186. - LAT. Encycl. méthod. Hist. nat. pl. 325. fig. 1 .

Un peu plus petite que la suivante. Dix dents aux grifies des serres. Dessus des deux derniers seymens dı corps et bord postćrieur de l'antépénultième liérissés de petiles épines; le derricr terminé, de chaque côlé, par trois dents forles, séparées par des échlancrures arrondies; sou bord postérieur échancré au nulieu, avec rrois petices divisions tronquées, de chaque côté; les deux internes plus larges et finement crénelćes; esface triangulaire du milien déprimé on enfoncé, dentelé sur ses bords. Un peu plus petite que la suivante. Cayemne, Brésil. Marcgrave dit qu'on ne la mange point.

\section{SQuille tacletée, Squilla maculata.}

Pollice decendentato; corpore suprà penitùs lovi, fasciis maculisque caruleo-nigris.

Squilla maculata, FAB. DE LAM. - RumpH. Mus. tab. 4. E. - Hев вsт, Krabb. tab. 33. fig. 2. - Lat. Encycl. méthod. Hist. nat. pl. 323.

Corps long de dix pouces, jaunâtre. Dix den!s aux grilles des serres. Tout le dessus du corps uni. 'Trois dents de cliaque côté du dernier segruent, séparées par des angles aigus, et dont la dernière petite; trois bandes transverses sur le bollclier de la tête, bord postérieur des anneaux suivans, des taches sur la dernière et sur les nagoires postérieures, d'un noir-bleuâtre; is [ace triangulaire du milieu de ce segrnunt convexe, sans dentelures.

De l'Océan indien, selon la plupart des auteurs, mais américaine par son analogie avec les espèces de la même division. Recueillie, en effet, à l'ile Saint-Vincent par M. Lesueur, et envoyée par lui au Muséum d'histoire naturele.

3. SQurle glabriuscule, Squilla glabriuscula. Pollice sexdentato; corpore suprà penitìs lavi."

Squilla gabriuscula, DE LAm.

Un peu plus petite que la précédente. Corps entièrement uni. Six dents aux griges des serres. Deux petites dents très-aiguës à chaque bord laiéral du dernier segment; son bord postérieur entier, simplenent échancré au milieu, avec les extrémités latérales arrondies.

\section{Océan indien?}

2. Extrémité postérieure du dernier segment insensiblement arrondie, avec deux fortes dents ou epines au milieu. Pédicule des nageoires pos- 


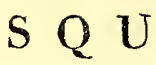

térieures aussi long au moins que le premier article de leurs appendices extérieurs.

A. Poings armés dans toute la longuenr de leúr côté antérieur d'épines; bords latéraux du bouclier de la tête ayant postérieurement une entuille profonde.

\section{SQuilte raphidienne, Squillu raphidea.}

Pollice octodentato; corpore suprà lineis pluribus elevatis, plerisque postice in spinam productis.

Squilla raphidea, FAB.-LAт. Encycl. méthod. Hist. nat. pl. 324 .

Corps long d'environ huit ponces. Petite pièce reenuvrant le support oculaire et antennaire terminé en pointe assez longue. Cing arêtes sur le bouclier de la tête, dont les deux latérales prolongées antérieurement en une pointe aiguë sur les segmens abdominaux, le deruier excepté, et celles des bords latéraux non comprises; plusieurs de ces arêtes terminées postérieurement par une petite épine; deux arêtes de moins sur les segmens thoraeiques déconverts; côtés supérieurs du premier échanerés et unidentés ; le dernier segment abdoninal fortement caréné dans le milieu de sa longueur, avec une petite épine près du bout; ses bords relevés, épais, armés de six Épines, dont les quatre postérieures plus fortes, un pen revourbées; partie du rebord compris entr'elles strié longitudinalement et crénelí. IHuit dents anx griffe's des serres; côlé antérieur de l'article précédent muni, dans toute sa longueur, de dents grêles et alongrées, spinifornes, ahternativement plus grandes et plus petites; trois épines mobiles à sa base.

Indes orientales, Pondichéry. M. Leschenault de ILatour.

Nota. Arêtes dorsales moins prononcées dans de jeunes individus.

B. Côté antérieur des poings simplement épineux (trois épines mobiles) à sa base; bords Latéraux du bouclier de la tête sans entalle remarquable.

Dernier segment ayant dans le milieu de sa longueur une forte earène, avec une petite épine au bout; bord postérieur termine par six dents en forme d'épines, soit relevées on plus épaisses en dessus, soit précédées de petites côtes ou d'un rebord interrompu; les quatre postériemres plus fortes. Bord đes intervalles compris, dentelé. Petite pièce recouviant le support des antenues et des yenx arrondie ou obtuse à son extrémité antérieure.

a. Cing ou trois arêtes longitudinales sur le bouclier de la tête; six sur la plupart des autres segmens (le dernier excepté), dont deux le long du milieu du dos; bord extérieur du dernier avant entre les six pointes, en forme d'épinss, deux dents obtuses, une de chraque côté, à peu de distance de sa base.

Rebord latéral de ee segment divisé par une interruption de deux petiles côtes, dont l'antérieure ou la première terminée par une dent courte et obluse, et dont la seconde finissant par une épine; les denx premières des six du contour de ce segment, plusieurs des lignes élevées des anneaux, ceilles des derniers surtout, terminées par une petite épine.

\section{SQqule Mante, Squilla Míantis.}

Pollice sexdentato; corpore suprà lineis plivimis elevatis; segmento postico bimaculato.

Squilla Mantis, Cancer Mantis, Lin n.-Squilla Mantis, DE GÉER, Mém. insect. tom. 7. pag. 533. pl. 3i. fig. 1-10. - Squilla Mantis, FАв. Rrss. DE LAM. , la variété exeeptée.

On voit, par la synonymie de Linnæus, qu'il y réunit diverses espèees. Colle-ci est longue de six à sept pouces. Elle a des lignes de points enfoncés sur le dernier segment; liuit dentelures environ entre les deux épines du milieu de son bord postérieur, et entre chacune des préeédentes et la latérale la plus voisine; six dents aux griffes; eelle qui termine les angles latéraux et antérieurs da bouclier de la tête très-petite, formée brusquement ; les côtés du premier ( 1 ) seg neut thoraeique sont prolongés en une pointe simple; une autre saillie et terminée par une dent an-desscus, et pectorale; les côtés des segmens thoraciçues suivans sont coupés obliquenent, entiers. On voit deux taches rouges ou d'un bleu-violel, rapprochées ou réunies sur le dernier segment, près da milieu de sa base.

Dans les rochers et sitnf's à une grande profondeur de la Méditerrance (Risso), et même dans les mers du Nord, selon Linnaus.

Les Anciens employoient ses yriffes en manière de cure-dent.

\section{Squilue Nèpe, Squilla Nepa.}

Police sexdentato; corpore suprà lineis plurimis elevatis; thoracis segmentis posticis exlius emarginatis.

Her вst, Krabb.tab. 34. fg. . .

'Très-voisine de la précédente et un peu plus petite. Des lignes de points enfoncés sur le dernier segment; huit dentelures environ entre les deux épines du milieu de son bord postírieur, et entre chacune des précédentes et la labiale la plus voicine; six dents aux griffes; angles latéranx et antérieurs du bouclier de la tête prolongés gra-

(1) Celui qqui se montre le premier à découvert. 
duellement en une dent terminale assez longue; côtés d. premier segmeıt thoracique terminés en un prolongement divisé horizontalemeut en deux dents, dont l'antérieure beaucoup plus forle et arquée en avant; côtés des segmens thoraciques suivans échanerés et bidentés; le dernier de tous ollivant une tache rouge près de sa naissanee.

MI. Miteleaty m'en a donné un inclividu qu'il avoit recu de la Chine. Se tronve aussi à Pondiebéry. Mi. Leschenault de Latour.

\section{Squile Scorpion, Squilla Scorpio.}

Pollice quinquedentato; clypeo lineis tribus elevatis.

Voisine de la Squille Ichneumon de Fabricius, et longue de près de trois pouces. Dernier serment uni entre la earène dorsate et ses borcis; quatre à six dentelures entre les deux épines du milieu de son bord postérieur, et cuatre entre chacune des deux préeédeutes et la labiale la plus voisine; cinc dents aux griffes. Bouelier de la tête n'cffrunt distinctconent que trois lignes élevies; celles de l'avant-dernier segraent plus fortes que eelles des serrnens précédens, en forme de petites eótes. Eyiues du milieu du bord postérieur du der nitr segment plus eourtes ct muius pointues que les analogues des espèees préeédentes. Dentelures comprises entr'elles et les épines voisines moins nombreuses, plus largcs, plus courles et obtuses. Côtés du premier seginent thoracique terminís par un prolongement uu peu arqué et cn forme de dent, arcc une contaille supćrieure el distinguće aussi par une couleur noirutlre; eôtés des au res segmens thoracicges entiers, un peu dilutés en arrière.

Pondıehéry. M. Lesehenault de Latour.

b. Bouclier de la tête et milieu du dos des autres segmens, les deux demiers exceptés, sans lignes élevées; rebords'supérieurs des côtés du dernier prolongés sans internution et sans former de dent jusqu'à l'origine des deux premières épines latérales.

\section{B. Squilla de Desmarest, S. Desmaresti.}

Pollice quinquedentato; clypeo abdominisque dorso, segmentis uitimis exceptis, lavibus.

Squilla Desmaresti, Riss. Hist. nat. des Crust. de Nice, pl. 2. fig. 8.

Espèce rapprochée de la Squille Phalangium de Fabricius. Longne de deux pouccs et demi à trois ponecs. Ciuq denls anx griffes; ligne élcvée de chaque eôté des segmens thoraeiques; deux de plus et extérieures aux préeédentes sur les segmens abdominaux jusqu'au pénulıième exelusivement; six sur celui-ci, dont deux au milieu du dos, et toutes terminées, ainsi que eelles de l'ünneau précédent, par une petite épine. Une carère, finissant aussi en pointe aiguë, le long du dernier segment; six épines fortes et acértes sur son pourtour extéricur; les deux du milieu de l'exlrémité postéricure el quelques-unes des petites dentelures intermédiaires, à ee gu'il u'a paru, terminées par un très-petit article, formaut la pointe; ees dentelures et les latérales de celte exlrémité uonbreuscs ( 9 à 10 par chaque échanerure), fines et pointues. Angles latéranx ct antérieur's du bouclier de la tête sans dents. Côtés da premier sergment thoraciquc un peu dilatés, échauciés en dessus, mais tronqués à lcur extrémité ; ceux des segmeus thoraciques suivans brusquenent déprimés, avee les toords entiers et arrondis.

Javois, autérieurement à la publication de l'ouvrage de M. Rissu sur les Crastacés de Nice, distiugué celle cspèce, dans la collection du Jatdin des Planles, soas le nom d'Acanthura. Cet autenr dit qu'elle fait son séjour dans les zostc̀res de la mer Méditerranée : elle y est très-comm'rne; jen ai reçu plusicurs individus de MM. Bonelli, Lesueur, de Lalimde fils et Roux. M. Geoffioy ie Villeneuve l'a tronvée sur les cóles du Sénéral. $S_{\text {i }}$ conleur varie. Ses oufs sont jaunes. Irur ponte a lieu, suivant M. Risso, en septerobre.

1I. Les deux évines du milieu du bord postérieur du dernier segment mobiles; cinq lignes élevées au milieu de ce segment.

Corps cylindrique.

\section{Squilde stylifère, Squilla stylifera.}

Pollice tridentalo; corpore suprà, segmentis dunbus ultinis exceptis, lavi, spinis duabus mo. bilibus posticè terminato.

$$
\text { Squilla stylifera, DE LAMr. - Squilla ciliatu, }
$$
FAB.?

Corps long d'cnviron deux pouces, jaunâtre ou d'un cendié-verdâtre, luisant, très-uni, à l'execption des deux durniers anneanx. Pièee reeonviant le support des antenncs et des yeux, presque dcuni-cireulaire. Angles antérieurs et latérilux da bouelier de la tête arrondis, sans dents. Premier segment thoraei que apparent, celni qui précède immédiatcment les deux premiers pieds adactyles, peu découvert et presqu'entièrement eaché sous l'extrémité postérieure de ee bouclier; côtés des segmens thoraeiques suivans arrondis, entiers. Six épines, partant ehacune d'une petite élévation, sur le pénulième abdominal; les deux latéralcs iutcrncs plus petitcs et plus hautes. Deux ligncs éle vées et dont l'interne plus foible, de chaque côté de la carène du milieu du dernicr segment; son contour muni de six épines, dont les deux intermédiaires et postérieures en forme de stylets eoniques et mobiles; point de dentelures entr'elles; unc senle dans les autrcs éebanerures ou espaces reufermés entre les autres épines da bord postéricur; un petit tubercule et une ligne 


\section{S Q U}

élevée, formant un pli, de chaque côté, près de la base, au-dessus des deux premières épines latérales. Trois dents aux griffes, dout les deux inférieures beaucoup plus courtes que la supérieure on terminale. Yeux comme dans le genre suivant, dont cette espèce se rapproche par plusieurs calractères.

Ile-de-France. M. Matbieu.

\section{Gente Gonodactyle, Gonodactylus.}

Il s'éloigne du précédent par la forme des doigts des serres. Ils sont ventrus ou en forme de nœud, à leur origine, et se terminent easuite en uue pointe comprimće, droite ou peu courbée. La rainure de l'article précédent est élargie à son extrémilé et simplement striće, ou sans destelures ni épines. Les yeux sont plus gros et plus arrondis, ou moins transversaux que dans les Squilles. Le corps est presque cylindrique, et à l'exception des deux deruicrs segmens, gúnéralement lisse en dessus. Ceux du thorax sont proportionncllement plus courts et plus trensversiux. Les serres présentent aussi quelques auiょes dillérences constantes.

\section{larus.}

1. Gonodactrue seyllare, Gonodactylus scyl-

\section{pollice tridentato.}

Squilla scyllarus, $\mathrm{FAB}_{\mathrm{AB}} \mathrm{DE} \mathrm{L}_{\mathrm{Am}}$ - Cancerscyllarus, Lisn.- Ruspr. Mus. tab. 5. F. - Herest, tab. 34. fig. r. (Figure copiée de Séba et trèsinférieure à la précédente.)

Espèce très-clistiucte de la suivante, que M. de Lamarck lui rénit. Longneur depuis les yeus jusqgu’à l'extrémitć postérieure du dernier seguent, die qquatre pouces et demi à six pouces. Dessus du corps d'un cendrí-verdatte, avec quelques taches blanchâlies en forme de veines ou cle marbrure sur les côlés du bonclier de la tête. Feuillet des antennes latérales, les extrémités et les frangres cles nageoires postérieures d'un rouge foncé; les grifies des serres d'un blanc d'émail en dessus, d'un rouge de sang vif en dessous. Petit bouclier recouvraut le support des antennes presque deruicirculaire, lisse, terininé foiblenent ou très-brièvement en pointe. Ligne élevée du milieu de la partie supérieure du pouce en torace de tranche, avec deux denls aiguë;, spiniformes, écartíes, dirigées en avant; extrémité ce ce doigt conprimée, tranchante, droite, alongée, pointue, formant la troisicme dent. Second segment abdominal et les suivans, jusçu'au pénulièèe exclusivement, ayaut de chaque côté un petit p!i élevé, arqué, graduellement plus étendu à mesure qu'on approche des derniers segmens. Huit petiles côtes longitudinales, terminées par une petite epine, les deux voisines des deux du milieu exceptées; the autre f́lévalion, mais courte, en

Hist. Nat. Ins. Tome X: forme de tuhercule, entre les deux côtes de chacun des côtés. Dernier segmeut profondément divisé tout autour eu six lobes triangulaires, en forme de dents, élevés longitudinalement dans leur milieu, en manière d'arếtes, et terminés par une petite épine; celles des deux lobes du milien du bord postrieur mobiles; bord interne de ces mêmes lobes armé d'une rangée de petites épines et élevé à sa base; milien de ce segrnent fortement élevé en carène longiludinale, arrondi sur le dos, et terminé jar une petite épine; deux lignes élevées, en manière de double rebord, de chaque côté de l'origine de la carc̀ne; uue côte longitudiuale, entre les lignes et l'arête du lobe latéral et supérieur; les deux derniers segmens d'une teinte plus foncée et entrecoupée de jaunâtre pâle.

Ile-de-France. M. Mathien.

2. Gonodactree goutteux, Gonodactylus chiragra.

\section{pollice edentato.}

Squilla chiragra, FAв.-..Cancer falcatus, FonsKat, Henвsт. - Cancer chiragra, Herist, ibid. tab.34. fig. 2. - Lat. Encycl. méthod. Hist. nat. pl. 325. fig. 2 .

Longueur de deux à ruatre pouees, d'un jaunâtre-verdâtre, avec les pouces souveut de couleur rose, et l'extrémité de l'article précédent hlenittre. Extrémilés des nageoires postérieurcs rouggàtres. La pointe terminant le pouce un pen arcquáe. Bouclier du support des antemnes presque carré, terniné antérienrement par trois dents, les cieux latérales formées par les angles; celle du milieu longue, avancée, spiniforme. Dossus du corps jusqua au pénultième segment exclusivement, entièrement uni ; six côles longitudinales uni-épineuses au bout, sur ce segment; le dernier divisé profondément tout antour en quatice lobes triangulaires, en forme de dents, pointus, avec une arête ou côte longitudinale; rebord des deux latéraux une fois interrompu; trois côtes arrondies, dont l'intermédiaire plus forte, sur le milieu du dos de ce segment..

Nota. Les pointes on les épines des lobes et des côtes suuvent détruites ou émoussées dans les individus les plus âués.

Mer-Rouge, Ile-de-France, Indes orientales, et jusquà la nouvelle Hollande. M. Geoffiroy de Ville-Neuve m'en a donné un individu qu'il avoit apporté du Sénégal. Un de ceux du Mnséum d'histoire naturelle offie sur le dernier segment plas d'élévations longiludinales, et se rapproche, à cet égard, de l'espèce précédente. Hais comme il ressemble d'ailleurs, poui toul le reste, à celle-ci, je ue le considère, du moins dans ce moment, que comme une simgle varićté. 


\section{Genre Cononide, Coronis.}

Appendice laféral et postérieur ản troisième article des six derniers pieds (les adactyles et thoraciques) en forme de lame (ou de palette) membraneuse, presqu'orbiculaire et un peu rebordée.

\section{Coronipe Scolopendre, Coronis Scolo- pendra.}

Je n'ai vu qu'un seul individu et en mauvais élat de ce Crustacé. Sa forme est plus étroite et plus déprimée que celle des Squilles. Ses antenues $\mathrm{ct}$ ses pieds sont plus courts. Le corps est d'un brun foncé généralement uni, avec quelques petites lignes élevées, en forme de stries fines et longitudináles, sur une dépression du milieu du dos cle la plupart des segmens. Te bouclier du support anteunaire est presque triangulaire et poinlu au bout. Le dernier segrment est presque carré, un peu tronqué obliquement à chaque extrémité latérale et postérieure, d’aillcurs entier et saus dentelures ni épines distinctes. Les deux serres sont blanchâtres et pointillées de brun. L'avant-dernier atticle ou le poing est ovale, caractère qui dislingue encore ce genre des précédens, très-comprimé, mais un peu plus convexe sur l'une de ses faces, r.vec le bord interne garni de cils très-petits, nombreux, spinuliformes, et armé à sa base de trois à quatre épines mobiles; le ponce, ou la griffe, est semblable à celui des Squilles, comprimé, en faulx ou arqué, et ma olfert à son côté interne une douzaine de dents aiguës; celle qui lernine est la plus forte.

Ce Cirustacé fait partie de la collection dihistoire naturelle forinée au Brésil par M. de Lalande fils. Comme il a de grands rapports avec la Squille pieuse, Syuilla ensebia, de M. Rissa, je soupçonne qu'il a été pris sur'les côtes de lî̀le de Madère, oì ce voyageur s'est arrêté quelques jours, et où il a pris divers animaux, réunis ensuite avec ceux du Brésil.

II. Tégumens supérieurs menbraneux, diaphanes. Bouclier recouvrant la moitié antérieure du conps; les cinq à six derniers segmens seuls décounerts; côtés de ce bouclier se repliant en dessous et enveloppant la portion inférieure du corps, en recouvrement; extrémité antérieure de ce test prolongée en manière d'épée ou d'épine, et s'avancant au-dessus du support des antennes mitoyennes et des yeux : ce support susceptible que se courber en dessous et d'être renfernné dans l'étui formé par le bouclier; nugeoires posterieures recouvertes, dib moins dans le repos, par le dernier seginent du corps.

Animanx très-petis, mous, propres à l'Océan allantique aficain et aux mero des Indes orientales.

Griffes des serres sans dents. Appendices du troisième article des pieds thoraciques et mutiques on des six derniers semblables à ceux des Squilles ou linéaires. Second article des pédicules oculaires beaucoup plus gros que le premier, en forme de cône renversé; yeux proprement dits, gros, presque globuleux.

Genre Ërchthe, Erichthus. Lat. De Laj. (Snerdis, Lвасн.)

Premier article des pédicules oculaires beaucoup plus large que le second. Milieu des bords latéraux du bouclier fortement dilaté en manière d'angle.

Le bonclier et l'abdomen proportionnellemeut plus larges que dans le genre suivant; pointe frontale compriméc, ensiforme. Deux dents à chaque angle latéral et postérieur du bouclier. Dernier segment du corps presque hexagonal, tronqué obliquement et tridenlé de chaque côté, vers son extrémité ; son bord postérieur droit, très - finement dentelé ou cilié, et foiblement échancré au milieu.

1. Érichtne à dents, courtes, Erichthus brevidens.

\section{Clypeo antice inerni.}

Corps roussâtte, longr d'environ dix lignes; point de dent ou d'épine près des extrémités des bords du bouclier. Angles du milieu des bords latéraux du test prolongés et terminés par une forte dent. Les deux dents des angles postérieurs des mêmes bords courtes; la supérieure un perz plus longue. Bord postérieur dı dernier segment un peu plos élroil que les der:x portions adjacentes et tronquées, ou les échancrures de ses côlés.

Pondichíry. M. Leschenanlt de Latour.

\section{2. Ërсснтне vilré, Erichthus vitreus.}

Clypei lateribus antice nediumque versus va. lidè unidentatis.

Erichthus vitreus, Lat. De Lax. - Squilla vitrea, $\mathrm{F}_{\mathrm{AB}}$.

Corps longr d'cnviron un ponce. Une dent, de chaque côté, près de l'extrémité antérieure des bords latéraux alu bouclier. Angles du miliea de ses bords latéraux prolongés et teminés par noe forte dent; la supérienve des deux des angles postéricurs des mêmes bords beauconp plıs longue que l'infórieure, spiniforme; bord postérieur dn dernier segment sensibletnent plus large gne les portions adjacentes et tronquées de ses côtés.

Océan atlautique.

3. Érichtнe commun, Enichthus vuigaris.

Clypei latribas medium versus vix uniden- 
Smerdis vulgaris, LËACH, Notice of the unim. tak. by M.John Chranck.-LAT. Encycl. méthod. Hist. nat. pl. 354. fig. 7 .

Presque semblable à la précédente, et n'en étant peut-être qu'une variélé d'âge. Un peu plus netite. Angles du milieu des bords latéraux du test ne formant qu'une dent très-petite.

Envoyé au Muséum d'histoire naturelle par M. le docteur Léach. Il s'en trouve un individu, mais très-imparfait, dans la collection de Crustacés formée à Pondichéry, pour le même établissement, par M. Leschenault de Latour.

Le Smerdis amuata de M. Léach, ibid. , que j'ai représenté daus l'Encyclopédie méthodiģue, pl. 354 , fig. 6 , d'après un dessin qu'il a eu l'amitié de me prêter, diffère des précédens par le prolongement en forme d'épine du rnilieu du bord postérieur et supérieur du bouclier.

Gerire Alıme, Alima. Ĺ́.

Premier article des pédicules oculaires beaucoup plus long que le second. Bords latéraux du bouclier très-peu arqués ou presque droits.

Corps plus étroit et plus long, surtout postérieurement, que celui des Erichthes. Pointe frontale pareillement plus grêle, spiniforwe. Prenier article des pédicules oculaires lou cylindrique; le suivant très-long; yeux forl gros. Bouclier long, étroit, caréué lougitudinalement dans son milieu, avec une épine aux angles antérieurs et postérieurs des bords latéranx; celle-ci plus forte. Dernicr segrnent figuré comme dans les dernières espèces d'Ericlılies.

\section{Alume hyaline, Alima hyalina.}

Alima hyalma, Léacr, Notace of the anim. tak. by M. John Chranck. - LAт. Encycl. méthod. Hist. nat. pl. 354. fig. 8.

Long de huit à dix lignes; d'un roussâtre clair ef luisant.

Envoyé an BTuséum d'histoire naturelle par M. le doctear Léach.

Le Muséum d'histoire naturelle possède un autre individu, envoyé de Pondichéry pär M. Lesclenanlı de Jatour, qui paroît s'étuiguer du précédent par son abdomen beaucoup plus rourl; mais ce raccourcissement pouvant être un eflet de la dessiccation, je n'ai pas osé établir sur ce curactìre de différence spićcifinue. (LATr.)

STAPHYLIN, Staphylinus. Linn. Georr. DE Géfr. Fab. Oliv. (Entom.) Gat. Grav. Payk. Astrapcens. Lat. (Gener.)

Genre d'iusectes de l'ordie des Culíopteres, section des Pentamères, famille des Brachélytres, tribu bes Fissilainres.

Les caractères de cotte tribu n'ayant pas été encore énoncés dans le présent ouvrage, nous aìons, diartès les principes de M. Ĺatreille, les menticnner ici, d'autant que lit multiplicité des espèces et leur ressemblance nécessitent une connoissance bien précise des caractères.

Fissilabres, Fissilabri. Première tribu de la famille des Brachélyires, section des Peatamères, ordre des Coléoptères; ses caractères sont :

Tête entièrement dégagée et distinguée du corselet par un ét:anglement en forme de cou. Labre profondément échancré.

I. Palpes labiaux, au moins, terminés en massue.

$$
\text { Oxypore, Astrapée. }
$$

\section{Tous les palpes filiformes.}

A. Antennes insérées au-dessus du labre et des mandibules, entre les yeux.

a. 'Tarses antérieurs très-dilatés dans les deux sexes, ou du moins dans les wâles.

$$
\text { Staplyylin. }
$$

b. Tarses antérieuts point dilatés dans aacus sexe.

Xiatholin.

B. Antennes insérées au-devant des yeux, en dehors du labre et près de la base des muudibules.

\section{Lälbrobie.}

Plusieurs des geares établis par linné dans toutes les parties du systène de la nature ont éprouvé depuis la mort de ce grand hornme un tel accroissemeut dans lc nombie des especes, quail a élé facile de reconnoitre dans ces mêmes espèces des caractères sulfisans pour moliver la création d'un graud uombre de coupes génériques. Linné n’a décrii ciue vingt-six espèces dans son genre Staplyylin, parmi iescuelles plusieurs n'appurtiennent pas à la famille des Brachélytres, et même son Stapiry. linus sanguineus n'est pas un Coléoplère Pentämère (poyez Bnyaxis, pag. 22I de ce volume). On peut affirmer qu'aujourd'lua le norubre des espèces connues dans celte famille excède six ce:ts, qui tontes rcistreroient dans le genre Staphylin de Linué. On al donc été forcé de le diviser. Paykull en 1789 se coulenta, dins sa Monographie des Siophylins, contenant cinquante-cinq espèces, de partager ce gonre cn denx groupes (qu'il nomme familles) d'apròs les proporions respectives de largeur de la lêre et du corselet. Fabricius ( Entom. System.) introduisit deux genres noureaux, Oxypore et Pédère. Dans ce même onvrage il décril cinguante-six espèces de Staphylivis, auxquelles il en joignit cinq nouvelles dans le Supplément. Sou geure Oxypore se compose de vingtquatre espècés dont une est décric au Supité. 
ment ; celni de Pédère contient dix espèces. Deux de celles du genre Staphylin n'appartiennent pas à la famille des Brachélytres; le sanguineus est un Bryaxis et le porcatus un Micropèple. Dans Je Systema Eleutheratorum, cet aútenr dócrivit soixante-huit especes de Staphylins parrui lesquelles le porcatus figure encore; il admet le genre Stenus Lat. dont il décrit six espèces, vingl-trois d'Oxypores et dix cle Pćdères. Dans l'intervalle entre la pnblication do l'Entom. Syst. et du System. Eleut., M. Littreille anoit créé les genres Lestève et Stènc. II. Gratvenhorst dans ses Coleoptera microptera proposa ensuite, d'après ses observations et cellcs du professeur Knoch, nent genres nouveanx, savoir : Luthrol ", Cailicère, Aléochare, Oxytèle, Onalic, Trinypore, Tachine, Astrapéce et Pinophile; il reproduisit en outre sous le nom d'Anthophagus celni de Lestève de M. Latreille : dans un ouvragre sulsséquent intitnlé Ronographia Coleopterorum micropteronum, il supprima les renres Callicère, Astrapéc et Pinophile, zaas il en publia trois noureanx sous les nonis d'Evæsthète, Lomćchuse el Piéste.

Dans son Genera Crustaceorum et Insectorum, M. Latreille fit da genre Stapliyliu Lins. nne famille lous le nom de Staphylintens, Staphyliniz, rentermant treizc gemres, Oxypore, Astrappée, Staphylin, Lathrobie, Pédère, Sìne, Oxytèle, Lesieve, Omalie, Proteine, 'Tachinc, Tuchypore ct Aléochare. Cet auteur indiqua quelques divisions dans cctte famille; depuisil l'a partagée en tribns. Nous devons la considérer ici, fians nous arrêter à ses ouvragesinternédisires, senlement telte qu'il ia présente dans ses Familles naturelles sous le nom de Brachélytres, Brachypterk. Elle comprenà dans cet ouvragc quatre tribus, savoir: Fissilubres, Longipalpes, Aplatis et Mícrocéplales; nous venons de domer le tableau de la première tribu an commencement de cct article; celle des Longipalpes contient les genres Pédère, Siliqque, Siènc et Evwstbc̀te : la troisieme est conposće des genres Prograthe, Zirophore, Osorins, Oxycòle, Piésie, Omülie, Lestève, Prolcine et Álévchare; enfin les genres Loméchuse, 'Tachine et Tachypore soni renfermés duns la quatriene. Ainsi ces quate tribus foracent une grande fanille (Brachélytres) q! i représente aujurdhui le gene Staphylin de Linné.

Dans la subdivi ion des Fissilabres qui a pour carazteres: tous les palpes filiformes, antennes iusérćes au-dessus du labre et des nuadibules entre les yeux et qui est compośe des grenres S:apliylin et Xautholin, le dernier se distingue en ce que ses tarses antérieurs ne sout dilzlés daus aucun sexe, que sa lête et son corselet ont une forme alongrée, longinlinale, et que ces deux parties du corps ont leurs bords latérutux parallèles.

Antennes inséı́es an-dessus ẩu labre près de lat base des mandibules, entre los yeux, grossissunt insensiblement vers lenï extrémité, compo- sées de onze articles, le dernier échancré obliquemient. - Labre profondément échancré, presyne bilobé. - Mandibules très-fortes, arquées, se croisant l'une sur l'autrc dans le repos, ayant à lenr côté interne une forte dent. - IIâchoires composées de deux lobes membraneux, l'extérieur presque triangnlaire, s'élargissant à l'extrémité ; l'interne court, large, intérieurement cilié. - Palpes filiformes, presqu'éganx, lenr dernier article n'étant pas beaucoup plus petit que le précédent, les maxillaires de quatre articles, les liabiaux de trois. - Lèvre à trois divisions, les deux latérales en forme d'oreillettes, celle du milieu plus large, un pen échancrée.-Téte grande, prescin'arrondie, entic̀rement dégagée da corselet, ayant an con distinct. - Yeux assez petits, pen saillans. - Corps alongé, étroit, ses côtés parallèles. - Corselet plus large que long, presquc semi-circulaire. - Ecusson triangulaire, court, assez largc à sa buse. - Elytres courtes, presque carrées, convrant des aries (celles-ci longues, plusieurs fois reployćes dans le repos) et laissant a découvert la plus grande partie de l'abdomen. - Abdomer assez long, sourent rebordé, se ré́. trécissant suliteucnt à son cxtréuité, terminé en poinle mousse, composé de sept secrmens, avec la lame inféricnre du dernier arrondie et entière dans les femelles, nons paroissant n'en avoir que six dans les mâles, avec la lane inférieure dn dernier fortement échancrée dans son milien.-Pattes fortes, assez courtes; hanches antérienres yrosses, presqua aussi tongues que les cuisses : janbes un pen coniriues, terminćes par doux épines fortcs; tarses an éricurs très-dilatés dans les deux sexes ou du moins dans les mâles; dernier article de tous les tarses anuni de denx forts crochets.

L,cs larves des Siphylins ainsi que toutes celles des Brachélytres sont d'me forme presqu'entièrement semblable à celle de l'insecte parfait; elles se menvent avec autaut de facilitć, se trouvent dans les mêmes licux et prennent la même nonrriture que lui. On les rencontre dans les endroits où il y a des matières végétales on animales en pnlréfaction, clles attaquent aussi et dévorent d'inutres insecies : ellos se gorgcut queldpuefois tellement de nouriture qu'elles en perdent jus(qu'i la fücuaté de se mouvoir; les seymens de leur abdomen sont alors fortencrit distendus et laissent apercevoir des nembranes hanches entre les plaques ćcuilienses qui le recouvrent. Malgré la ressemblance qui esiste entre la larve et l'iasecte parfait, rous remarquerons que dans la prenière les antennes sont lic̀s-courlcs et ue paroisisent. composécs que de trois articles, les deux preniers alongés, cylindro-coniques, le truisième plus petit, plus grêle, tcrminé par ne soie roide: les palpes sont assez lougs, les waxilinires seuls hien apparens, lens cernitr irlick paroissant gatuni ì son estréristé d'un verlicille de poils roides. Le corselet se compose de truis sermens dis- 
tincts qui répondront chacun aux trois parties ảu thorax de l'insecte parfait : le prothorax est presqu'aussi long que les deux autres segmens pris ensemble, ses quatre angles sont arrondis; le mésothorax et le métathorax ont leurs angles postérieurs seuls arrondis; l'abdomen est composé de huit segmens rétrécis à leur base, ce qui le fait paroître denté latéralement, l'anus est en carré longitudinal; à sa partie inférieure est un assez gros tube. De chacun des angles de sa partie supérieure il part un appendice aussi long que ce tuje, garni de poils longs et roides. Les hanches, les cuisses et les jumbes sont à pen près comme dans l'insecte parfait, elles sont seulenent plus grêles, mais les tarses ne consistent qu'en un crochet assez grand, qui semble inarticulé. L'écusson n'existe pas et l'on n'aperçoit clans la larve aucune partie présentant les ciles et les élytres futures. Telie est la conformation de deux larves de Staphylins que nous avons sous les yeux et qui nous semblent par leur grande taille assez près de passer à leur seconde forme, mais nous ue savons à quelle espèce les rapporter. La nymple ne nous est pas conuue, il est très-probable qu'elle reste daus un parfait repos, et que cet éta! n'est pas de longue durée. Les moeu's de ces insectes ne diffèrent point de celles des autres genres de leur famille. (Voyez Brachélytres à la table alphabétiqque.)

Le genre Stapliylin quoiqu'infiniuncnt restreint aujourd'hui èst encore très-nombreux en espèces et répandu ì ce qu'il paroît dans tous les pays du monde. Lar taille de ces Coléoptères varie beaucoup de la moyente à la plus petite; leur conlen' dominaute est le noir souvent reflété de bleu ou de coulenr métallique; le testacé et le ferrugineux colorent quelcyuefnis certaincs parties du corps. Pour la facilité de l'étude nous diviserons ce geure ainsi qu'il suit, en partie d’après des cousidératioas déjà employées par M. Gyllenhall.

1re. Division. Corsclet entièrement ponctué.

Ire. Subdivision. 'Tête, corselet, Elytres et abdomen velus.

\section{Stapgulin versicolor, $S$. versicolor.}

Staphylinus thorace toto punctato, niger, ferrugineo fuscoque densè pubescens; antennis pedibusque et ano nufis apice fuscis; abdomine

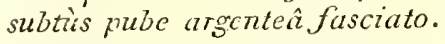

Staphylinus versicolor. Grav. MIonogr. Coleop. micropt. pag. $119 \cdot n^{\circ} \cdot 158$.

Longueur 10 lignes. Noir, ponclué, couvert d'un duvet serré, court, brun nuêlé de ferrngineux et d'un peu de gris; antennes et pattes testacćcs, bruues vers leur extrémité. Dessus de l'abdumen noir, avaut-dernier segment et anus roux, celui-is ayaot à sa base une bande transverse de puils d'us gris arenté, le dernier ter- miné par des poils noirs. En dessous le premier segment est bordé de roux, les trois suivaus nortant une bande transversale de poils courts, couchés, gris à reflet argenté. Femelle.

Da Erésil, province de Para. Il a été trouré dans une forêt buanide près d'un tas de fruits pourris.

Norrs plaçons dans cette subdivision les Statphylins suivans: $1^{\circ}$. bourdon, $S$. hirtus no. 2. EAB. Syst. Eleut. - Encycl.pl. 187.Staphyl.fig. 12.Faun. franç. Coléopt. pl. 12. fig. 5. $2^{\circ}$. nébuleux, S. nebulosus nо. 3. FAв. id. - Encycl. Staphyl. pl. id.fig. 2.-Faun. franc. Coléopt. pl. 12. fg. 7 . 30. souris, S. murinus $1^{\circ}$. 4. FАв. id. - Encycl. pl. 190. fig. 1. 40. chrysocépluale, S. chrysocephalus. Grav. Monogo Coleopt. micropt. $n^{\circ} .146$. pag. 124. - Faum. franç. Coléopt. pl. 12. fig. 6. 5०. pubescent, S. pubescens n ${ }^{\circ}$ 6. FAs.id. - Encycl.pl. 188.fig. 7 .

\section{$2^{\mathrm{e}}$. Subdivision. Corps pubescent.}

2. Staphylin lugubre, S. lugubris.

Staphylinus thorace toto punciato, ater, atro pubescens.

Longneur is 5 lig. Entièrement d'un noir mat ct couvert en dessus d'un duvet court de mêtae couleur. Dessous du corps un peu leisant. Angles postćrienrs de la têle assez prononcés. Feajelie.

\section{De Cayenne.}

Cette espèce surpasse en grandeur touies celles que nous conmoissons.

Cette subdivision contient en outre Io Stap?y ${ }^{\circ}$. Grythroptire, S. ey throptents ${ }^{\circ}$. 16. Hab. Syst. Elcut. - Encycl. pl. s83. fig. 6. - Faum. franc. Coléopt.pl. 12.fig. $5.2^{0}$. stercouaire, S. stercorarius. Oriv. Entom. tom. 3. Siaplyyl. pag. 3 3. $n^{n}$. 18. pl. 3. fio. 23. - Grav. Coleopt. micropt. pag.

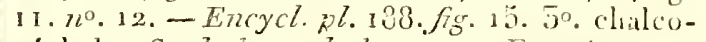
céplate, S. chalcocepialús no. 19. Fin. id.

3c. Subditision. Corps glabre.

Les espèces suivanies sout de celte subäivision. $1^{\circ}$. Staphyl. odorant, S. olenis no 8. FA . Syst. Eleut. - Encycl. pl. 187. Staplyl. fig. 8. I. et 2. $2^{\circ}$. Hleu, S. c aneus no. IT. FAв. id. - Encycl. $p l$. id. fig. 10. $3^{\circ}$. semblable, S. similis $n^{\circ} .9$. FAR. id. - Encycl. pl. 189. fig. х2. $4^{\circ}$. morio, S. morio. Grav. Colcopt. micropt. pag. $6 . n^{\circ} \cdot 4$. $5 \circ$. rufipède, $S$. rufipes. Des. Cattal.-Astrapcous rufipes. Lat. Gener. Chust. et Ins. tom. 1. pag. $285 . n 7^{\circ} \cdot 2.6^{\circ}$. bruuvipède, S. brinnipes no. $=6$. Гав. $i d$.

$2^{\ominus}$. Division. Corselet lisse ou n'ayant qu'un petit nombre de points.

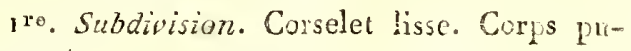
bescent. 
Le Staphylin masillaire, $S$. maxillosus $\mathrm{n}^{\circ}$. 11 . Fав. Syst. Elleut.-Eucycl. pl. 187 . Staphyl. fig. 1.. - Ecuun. franc. Colcopt. pl. 12.fig. 4. appariient à celte coupe.

$2^{\mathrm{e}}$. Subdivision. Corps glabre.

A. Discuue du corselel sans points.

On doit placer ici le Staphylin laminé, $S$. laminatus. Grav. Coleopt. nicropt. $p .16 . n^{\circ} \cdot 17$.

B. Disque du corselet ayant des points rüligés en stries.

Nous mettons dans ce groupe, $1^{\circ}$. Staphyl. dilaté, $S$. dilatatus no. 14. His. Sist. Eleut. 20. inpriné, $S$. impressus. Grav. Coleopt. mieropt. pag. 55. $n^{\circ} .5$ r. 5 . brillant, S. nitidus no. 8. l.AB. id. - Grav. id. pug. 51. $n^{\circ}$. 46. $4^{\circ}$. rouxnoir, $S$. maurorufus. Grav. hionggr. Caleopt. micropt. pag. 56. $n^{\circ}$. 20. 5'. violattre, $S$. molochinus. Grav. Monogr. Coleopt. micropt. p. 46. $n^{\circ}$.6. 6०. brunzé, S. aenens. Grav. Coleopt. micropt. pag. $17 \cdot n^{\circ} \cdot 18.7^{\circ}$. décoré, $S$. decorlas. Grav. id. pag. 19. $n^{\circ}$. 20. $8^{\circ}$. cyanipenne, $S$. cyanipennis n $\mathrm{n}^{\circ} .37$. 1' Ав. Syst. Eleut. $9^{\circ}$. poli, $S$. politus $n^{\circ}$. 22. Fab. id. 10 $0^{\circ}$ frangé, $S$. xantholoma. Grav. Monogr. Coleopt. micropt. pag. $4 \mathrm{I}$. $n^{3} .3$. $1^{\circ}$. agréable, $S$. lepidus. Grav. Coleopt. micropt. pag. 31. $n^{\circ} .45 .12^{\circ}$. noirci, $S$. carbonarius. Grav. id. pag. 25. $n^{\circ} \cdot 31.13^{\circ}$. timétaire, $S$. fincetarius. Grav. id. pag. $175 . n^{\circ} .32 .14^{\circ}$. discoïde, $S$. discoideus. Grav. id. pag. 38. no. 56. $15^{\circ}$. gros yeux, S. boops. Gycr. Ins. Suec. tcm. 2. pag. 3ı2. $n^{\circ} .28 .16 \circ$ préroce, S. proco.x. GrLL. id. pag. 3io. $n^{\circ}$. 26. 17 $7^{\circ}$. céphatote, S. cephalotes. Grul. id. pag. 320. $n^{\circ} .36 .18^{\circ}$. varié, $S$. varius. Grus. id. pag. $321 \cdot n^{\circ} .37 \cdot 19^{\circ}$. albipède, S. albipes. GruL. id. pag. 327. $n^{\circ} \cdot 4 \overline{3} .20^{\circ}$. ordurier, $S$. quisqualiarias. Gy re. $i d . p a g .335 . n^{0} .50$. $21^{\circ}$. pieds jaunes, S. ochropus. Gxul. id. p. 536. $n^{\circ} .51_{1} .22^{\circ}$. ventral, $S$. ventralis. Grul. id. $p .354$. $n^{\circ} \cdot 49$.

Nous placernus encore dans ie genre Staphylin, d’après $\mathrm{H}$. le comtc Dejean, les espèces suivantes: $1^{\circ}$. érythrocéphale, $S$. erythrocephalus $n^{\circ} \cdot 19$. FAB. Syst. Elent. De la nouvelle Hollande. $2^{\circ}$. clilornptère, $S$. chloropterizs $n^{\circ} .5$. FAB. $i d .3^{\circ}$. fémoral, S. fémoratzss no. 24. Faв. id. De Caroline. $4^{\circ}$. fossoyeur, $S$. fossor $n^{\circ}$. 18. Faв. id. $5^{\circ}$. splendide, $S$. splendens $\mathrm{n}^{\circ} .21 \mathrm{HAB} . i d$. $6^{\circ}$. marginé, $S$. marginatus $1^{\circ}$. 58. Fав. id. $7^{\circ}$. mince, $S$. tenuis $n^{\circ} .53$. Fав. $i d$. $8^{\circ}$. castanoptère, $S$. castanopterus. Grav. Coleopt. micropt. $p .10 . n^{\circ} .10$. $9^{\circ}$. jaunâtre, $S$. lutarius. Grav. Mionogr. Coleopt. micropt. pag. $115 . n^{\circ}$. $151.10^{\circ}$. troglodyte, $S$. latebricola. Grav. $i d . p .113 . n^{\circ}$. $129.11^{\circ}$. fouisseur, S. fossator. Grav. Coleopt. niicropt. pag. 164. $n^{\circ}$. 12. Amérique septentrionale. $12^{\circ}$. brunittre, $S$. fuscatus. Grav. id. pag. 164. $n^{\circ}$ 10. $13^{\circ}$. latéral, S. lateratis. Grav. id. pag. 35. $n$. 50.
140. fuligiacux, $S$, fuliginosus. GRAv. id. p. 34. $n^{\circ} .49 .15^{\circ}$. gentil, S. scilus. Grav. Monogg: Colcopt. micropt. pag. 5o. $n^{\circ}$. $13.16^{\circ}$. scintillant, S. scintillens. GRAv. id. pag. 70. $n^{\circ} .53$. I $7^{\circ}$. a.ténuć, $S$. altenuatus. Grav. id. pag. 61. no. 31 . $18^{\circ}$. sale, $S$. conosns. Grav. id. pag. 51 . $n^{\circ}$. 15. $19^{\circ}$. métullique, $S$. metallicus. Grav. Coleopt. micropt. pag. 168. $\pi^{\circ}$. 18. 20\%. âtre, S. atratus. Griv. Monogr. Coleopt. micropt. pag. $84 \cdot n^{\circ} \cdot 74$. $21^{\circ}$. ponctué, $S$. punctus. Grav. Coleopt. micropt. pag. 20. $n^{\circ} \cdot 22.22^{\circ}$. enfumé, $S$. fumarins. Grav. Monogr. Coleopt. micropt. pag. 67, $n^{\circ}$. 43. $233^{\circ}$. sanguinulent, s'. sanguinolenius. Grav. Coleopt. micropt. pag. 36. no. 53. $24^{\circ}$. bipustulé, S. biplustulatus. Grav. id. pag. $37 \cdot \pi^{\circ} .54 \cdot 25^{\circ}$. bimaculé, $S$. bimaculatus. Grav. id. pag. $38 . n^{\circ} .55$. 26". fulvipède, $S$. fulvipes. Grav. id. pag. 24. $n^{\circ} .33 .27^{\circ}$. opaque, S. opacus. Grav. id." p. 26. $n^{\circ}$. 55. 28\%. printannier, S. vernalis. Grav. Monogr. Coleopt. micropt. pag. $7^{5} . n^{\circ} .67 \cdot 29^{\circ}$. lnisant, $S$. micans. Grav. Coleopt. micropt. p. 25. $n^{\circ} .34 .30^{\circ}$ : ceudré, S. cinerascens. Grav. id. $p$. 49. $\pi^{n} \cdot 74$.

ASTRAPEE, Astrapcons. Grav. (Coleopt. miclopt.) Lat. Staplylinus. Grav. (Monogr. Coleopt. niicropt.) Ross. Fas. OLIV.

Genre d'insectes de l'ordre des Coléoptères, section des Pentamères, famille des Brachélytres, tribu des Fissilabres.

La première division des Fissilubres contient deux genres dont le caractère distinctif commun à tous deux est d'avoi: les palpes labiaux terminés en hache, ce sont les Oxypures el les Asirapées, mais les preniers s'isolcnt facilement par leurs palpes masillaires filiformes et par la longueur du dernier article des tarses qui égale celle des quatre précédens pris ensemble.

Le seul caractère indiqué par les auteurs pour séparer le genre Astrapée des Staphylins étant la forme án dernier article des quatre palpes figuré en haclie, nous croyons devnir renvoyer pour les autres caractères au genre Staphylin, pag. $47^{5}$. de ce volume; cependant nous remarquerons $c_{1}$ ue M. Gravenhorst auteur de ce genre, observe en détruisant ce même genre dans sa Monogr. Coleopt. micropt.pag. 36 , que les qnatre palpes sunt termines en hache dans la plupart des individus de la seule espèce qu'il avoit rapportée à ce genre dans ses Coleopt. micropt., ce qui signifie, si nous le compremons bien, que certains individus sont conlormés différemment sous ce rapport. Il ue dit point si ces différences liennent au sexe; nous pensons cependant qu'il en est ainsi, et nous croyons que les entomologistes qui auront occasion d'ubscrver un assez grand nombre d'iadiviclus devront indiquer quelle est la forme des palpes dans ceux ciui ne les ont pas sécuriformes et spécificr leurs sexes, ce qui sera toujours facile, d'après les caractères sexuels que nous avons mer- 


\section{S T A}

tionnés à l'article Staphy nin. Nous ne possédons qu'un seul individu de l'Astrapée de l'Or'me, c'est un mâle, et ses quatre palpes sont distinctement terminés par un article sécuriforme.

Ces insectes se trouvent sous les écorces des arbres. Le type du genre est l'Astrapée de l'Orme, Astrapous Ulmi. GRAv. Coleopt. micropt. p. ، 99 . $n^{\circ}$. 1. - Stapliylinus ulnineus no. 28. F А . Syst. Eleut. Du midi de l'Europe. M. le comte Dejean dans son Catalogue en indique une autre espèce de Styrie sous le nom d'unicolor.

IAATHROBIE, Lathrobium. Grav. Lat. Staphylinus. Linn. Geoff. Paderus. Fab. Oriv. Pinophilus. Grav. (Coleopt. micropt.) Pinophie. LAT. (Fam. nat.)

Genre d'insectes de l'ordre des Coléoptères, section des Pentamères, famille des Brachélyires, tribu des Fissilabres.

Ce genre forme seul un groupe dans la seconde division des Fissilabres, caractérisé ainsi : antennes insérées au-devanı des yeux, en delıors du labre et près de la base des mandibules. Voy. Fissilabres à laarticle SxarHyLin.

Antennes filiformes, insérées au bord antérieur de la tête, au-devant des yeux, en dehors da labre et près de la base des mandibales, composées de onze articles, le premier assez grand, le deuxième court, le troisième plus grand que le second, ceux-cien massue, les suivans presqu'o:biculaires, le dernier ovale, pointu à son extrémité. - Labre profoudément échancré, presque bilobé. - Mandibules cornćes, en triangle alongré, arqnées el üinuës à l'estrénité. - Mâchoires composćes de deux lobes membraneux, l'extérieur presque triangulaire, plus large à son extrémilé, linterne formant une dent aiguë. - Palpes terminés en pointe, les maxillaires an moins deux fois plus lougs que les labiaux, de quatre articles, les second et troisièue pius grands que les autres, couiques, celui-ci alongé, plus épais, le quatrième très-petit, à peine visible, ne formant qu'une pelite porinte : palpes labiaux de trois articles, l'avant-deruier alongé, plus épais, le terminal conformé comme celui des naxillaires. Tête port́ce sur un cou distinct, convexe en dessus, plaue en dess 'us, ayant son bord antérieur brusquement rabattu. - Yeux pelits. - Corps linéaite, alongé. -- Corselet en carré-long, ses angles adoucis, son bord postćrienr droit, transversal, distinctement séparé de la base desélytres. - Elytres presque carrées, un peu déprimées, nn peu plus longues que le corselet, rabaltues sar les côtés, couvrant des ailes, laissant à nu la majeure partie de l'abdomen. - Pattes ripprochées à leur insertion; hanches antérieures deux fois plus courtes et beancoup plus grếles que les cuisses; hanches postérieures très-contes, peu visibles: cuisses épuisses, les antérieures ajant inférieuremeat un ande en forme de denl; jambes ci- liées: tarses à articles courts, ceux-ci égaux en longueur; les antérieurs souvent dilatés.

I.e nom donné à ces Brachélytres vient cie deux mots grecs dont le sens est : qui vit caché; il a rapport aux halitudes de ces insectes dont les mœurs sunt les nièmes que celles des Staphylins.

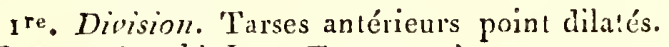
(Genre P'inophie Lat. Fam. nat.)

Cette division renferme les espèces suivantes: ${ }^{\circ}{ }^{\circ}$ Lallirobie marron, L. castaneum. Grav. Coleopt. micropt. pag. 52, $77^{\circ}$. I. $2^{\circ}$. baie, $L$. badium. Grav. id. pag. 55. $n^{\circ}$. 3. $5^{\circ}$. fracticorne, L. fracticorne. GR s . id. pag. 54 . $\pi^{\circ} .5 .4^{\circ}$. bicolore, L. bicolor. Grav. id. pag. 179. $\pi^{\circ}$. I. De l’Amériqge septentrionale. $5^{\circ}$. pallipède, L. pallipes. Grav. id. $n^{\circ}$. 2. Même patrie.

$2^{e}$. Division. Tarses antérieurs dilatés. (Genre Lathrobie LAT. Fam. nat.)

Nous placerons ici 10. Lathrobie multiponcluée, L. multipunctatum. Grav. Coleopt. micropt. p. 52. $n^{\circ} \cdot 2.2^{\circ}$. longuette, L. longulum. Grav. id. pag. $53 . n^{\circ} \cdot 4.3^{\circ}$. linéaire, L. lineare. Grav. id. p. 54. $7^{\circ} .6 .4^{\circ}$. terminée, L. terminatum. Grav. id. pag. 55. $n^{\circ} \cdot 7.5^{\circ}$. alongúe, L. elongatumı. Grav. $i d \cdot n^{\circ} .8 .6^{\circ}$. grèle, $L$. gracile. Grav. $i d$. pag. 182. nn. 5. $7^{\circ}$. velue, $L$. pilosum. Grav. id. pag. $56 . n^{\circ}$. 9. 8\%. brumipede, L. brunnipes. Grav, id. no. !o. $9^{n}$. polie, L. politum. Grav. id. pag. 180. $n^{\circ}$. 3. Amérique sept tentrionale. $10^{\circ}$. longue, L. longiusculum. Grav. id. p. i81, no. 4 . Même patrie. Ino. latipède, $T$. latipes. Grav. Monogr. Cotecipt. micropl. pag. $129 \cdot n^{\circ}$. 1. Pinophilus latipes. Grav. Coleopt. mucropt. p. 202. $n^{\circ} .1$. Mème patrie. $12^{\circ}$. hruue, L. fuscum. (juav. Monogr. Coleopt. nitcropt. pag. $150 . n^{\circ} .5$.

A ce genre apparticunent anssi les lathrobies déprinée, L. dipressum. Grav. Coleopt. micropt. pag. 18ะ. $n^{\circ}$. 6. et fulvipenne, L. fullipenne. GYLLFH. Ins. Sued. (S. If. et A. SERV.)

STATIRE, Statira. LuT. (Fam. nat.)

Genre d'insectes de l'ordre des Coléoptères, section des Hétćromères (deuxic̀ne division), famille des Trachélides, tribu des Iagriaires.

Ceite tribu ne contient que deux genres, Lagrie et Siatire; le prenier se distinglie du second par son corselet carré, peu convexe et presqu'aussi large prós de la tête qu"à son bord postérieur, et par sa tête à pen près aussi large que longre, ne se prolongeant pas au-deli des yeux d'une manière notable. Les caractères des Statires n'étant pas encore publiés, il restrra nécessairement quelques lacuues dans l'énocé́ que nous en allous faire.

Antennes assez longues, filiformes, composées de onze articles, les dix premiers coniques, le sceond fort peril, le onzième cylinảignue, sur- 
passant en longueua les trois précédens réunis (au moins daus les mâles), insérées latéralement sur un tubercule de la tếe, avant le prolongement de celle-ci. - Bouche placée à l'extrémité du prolongement antérieur de la têle. - Labre trèsarancé, llansversil, coupé carré:nent ell devaut. - Dilundibules et Mâchoires fort courtes, peu apparrentes. - Palues maxillaires fort grands, de quatre articles, le premier très-court, le second fort long, cylindro-conique, le troisième très-pelit, obconique, le dernier le plus long de tous, eu couperet alongé : palpes labiaux trèscourts, peu visibles. - Téte rétrécie postérieurement en une sonte de cou, prolongéc en devaut et amincie eu une espèce de museau; chaperon presique carré, un peu convexe. - Keux trèsgrands, assez rapprochés sur le front ainsi qu'en dessous de lat tête, échancrés, recevant dans cette échancrure la buse du lubercnle radical des anteunes. - Corps alongé, rétréci en devant. Corselet rebordé postérieuremenl, convexe, rétréci en deviut. - Ecusson très-pelit, punclifurwe. - Elytres alongées, plus larges que le corselet, très-peu dilatés avant leur extrémité, recouviant des ailes et l'abdomen. - Pattes assez forles; cuisses anférieures un per reaflées : jambes un peu arquées à leur base; tarses très-velus, leur pénultième article bilobé, le premier des postérieurs aussi long que les trois autres pris ensemble.

Il est probable que les mours de ces insèctes s'éloignent per de celles des Lagries.

\section{Statire agrö̈de, $S$. agroides.}

Siativa fusco-testacea, eiytris apice mucronatis, connleo submicantibus, punctulato-striatis, punctisque excavatis quadratis, in series dispositis.

\section{Statira agroides. Drs. Collect.}

Longueur 5 lig. D’un testacé brun; élytres plus funcées, mucronćes à l'extrémité, avec un rellet Jleu-violel qui devoit être plus sensible dans l'insecte vivant. Ces élytres chargées de stries lo:gitudinales formées par de petís points enfoncés, ayant dars les intervalles des stries de larges dépressions carrées, disposées en séries.

Du Brésil.

\section{Statire viridipenne, S. viriäipennis.}

Statira testacea, elytris apice muticis, viridiceneis, punctulato-striatis, functisque excavatis subtrianglularibus, subtemerè positis.

Longueur 7 lig. Testacée. Tèie un peu plus foncée aiusi que le premier article des antenues. Elytres mutiques, d'ua vert mélallique, chargées de stries forinées de petils points enloncés, ayant en outre des dépressions presque triangulaires, placées sans beaucoup d'ordre.

Mème patrie que la précédente.

(S. F. et A. SERV.)

\section{STÉGOPTERES. Voyez Tectipennes.}

\section{(S. F. et A. SERV.)}

STÉlIDE, Stelis. Panz. Lat. Apis. Kirb. Megilla. FAB. Anthophora. Inug. Megachile, Anthidium. LAt. Trachusa. Jur. Gyrodroma. IILUG.

Genre d'insectes de l'ordre des Hyménoptères, section des Porte-aiguillon, famille des Melliféres, tribu des Apiares (division des Parasites).

Parmi les Apiaries Parasiles un groupe a pour caractères : écusson mutique, trois cellules cubiiales aux ailes supérientes. (Yoyez P'AnAsIres.) II reuferme les genres Aliodapé, Pasie, Amnobate e! Stélide. Dans les trois premiers la seconde cellule des ailes supérieures recoit les deux nervures récurrentes, caractère que re présentent pas les Siélides.

Antennes filiformes, brisćes, composées de douze articles dans les fernelles, de treize dans les mâles, le premier long, les autres presciu'égaux enti'enx. - Labre en carré alongé, dépassant les mandibules. - Mandibules assez larges, caunclées en dessus, bidentées au côlé interne. - Palpes maxillaires très-courts, de deıx articles, le premier long, cylindrique, le dernier cylindro-conique. - Trois ocelles disposés en trianzle sur la partie antérienre du vertex. Corps assez alongé.-Corselet court, convexe. - Ecusson mulique. Ailes supérienres ayant une cellule radiale rétrécie depuis son milieu jusqu'à son extrémité, celle-ci assez aiguë, un peu écartée de la côte et trois cellules cubitales, la

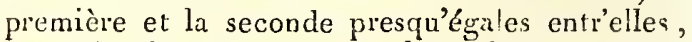
cette deruière rétrécie vers la radiale, recevant la première nervure récurrente; troisième cubitale recevant la seconde nervure récrrrente et n'atteignaut pas le bout de l'aile. - Abdomen cylindrique-ovale, recourbé, convexe en dessus, un peu concave en dessous, dépourvu de poils dans celte partie dans les deux sexes, composé de cinq segmens outre l'anus dans les femelles, en ayant un de plus dans les mâles. - Pattes de longueur moyenne: jambes intermédiaires munies à leur extrémilé d'une épine simple, aiguë; prenier arlicle des tarses très-grand, anssi long que les quatre autres réunis; crochets bifides.

Les Stélides sont parasites des genres $\Lambda$ nthidie, Oswie et Mégachile. On peut voir à l'ariicle PARAsItes les particularités de moenrs el les détails d'organisation communs à tous les Mellifères qui n'ont pis les organes nécessaires pour pourvoir par eux-mêmes leur postérité de la nouriture qui lui convient sous la forme de larve. Ce genre est peu nombreux en espèces. Le nom de Slelis étoit 


\section{S T E}

donné par les Grecs au Gui, qui est une plante parrusite.

\section{StÉLide petile, S. minuta.}

Stelis nigra, segmentis abdominis tribus primis utrinquè lineolâ laterali a!bidâ.

Longueur 3 lig. Antennes noires ; tête et corselet de cette coulen ayant des poils blanchátres. Abdomen noir ; ses premier, second et troisième segmens offraut de chaque côté une tache alongée, blanchâtre; pattes noires, tarses galnis de poils roux. Ailes transparentes, un peu enfumćes vers leur extrémité. Femelle.

Des environs de Paris.

On placera en outre dans ce genre, ${ }^{\circ}{ }^{\circ}$ Stélide rufiventre, $S$. rufiventris. - Anthidium mufiventre. Lat. (Mém. sur les Anthidies, pag. 26.) Du Brésil. $2^{\circ}$. Stélide tête noire, $S$. aterrima. Lat. Gen. Crust. et Ins. tom. 4. pag. 163. 3․ Stélide phéoptère, S. phocoptera. LAT. id. pag. 164. $4^{\circ}$. Stélide nasale, S. nasuta. - Anthidium nasutum. LAт. (Mém. sur les Anthidies, pag. 25.) Ces trois dernières sont des environs de Paris.

Nota. Nous possédons une espèce de l'île de $J a v a$, très-voisine de la Stélide rufiventre.

$$
\text { (S. F. et A. SERv.) }
$$

S'TENCORE, Stenocorus. GeOrF. OLI. (Entom.) Lat. Rhagium. FАв. Ceranbyx. Livn. Leptura. De Grér.

Genre d'insectes de l'ordre des Coléoptères, secrion des Tétramères, fumille des Longicornes, tribu des Lepturètes.

Nota. Nous croyons devoir donner ici, d'après M. Latreille, les caractères de celte tribu avec ses divisions, puisqu'elle n'a été créée que depuis limpression de la lettre $L$ de ce Dictionnaire.

Lepronìtes, Leptureta. Cinquième tribo de la fauille des Longicornes, section des Tétraraères, ordie des Coléoptères.

Antennes insérées hors des yeux, ceux-ci peu Ǵchancrés, assez larges. - Tếte ovoïde ou ovalaire, rétrécie brusquement à sa base en manière de cou. - Corselet conique ou trapézoïdal. Abdomen presque triangulaire. - Corps souvent arqué. - Pattes longues.

d. Tête prolongée derrière les ${ }^{-}$yeux en conservant sa même largeur jusques au cou. - Antennes à articles obconiques, souvent courtes.

A. Corselet mutique, c'est-à-dire sans tubercules pointus sur les côtés.

Desmocère, Vespérus.

B. Un tubercule pointu en forme d'épine Hist. Nat. Ins. Tome $\boldsymbol{X}$.

\section{S T E}

sur le milieu des cótés du corselet.

Siencore.

II. Tête rétrécie en manière de cou immédiatement après les yeux. - Antennes à ar. ticles ordinairement cylindracés.

A. Corselet rétréci postérieurewent. - Antennes velues.

Disténie, Cométès, Sténodère.

B. Corselet élargi postérieurement. - Antennes n'ayiut au plus qu'un duvet conlt, serré.

a. Antenues de onze articles.

Toxote.

b. Antenues de douze articles.

Euryplère.

On voit par ce tableau les caractères différentiels qui séparent les autres genres de cette triba de celti de Stencore.

Antennes tiliformes ou presque filiformes, composées de onze articles, insérées entre les yeux et près de leur bord interne. - Labre saillant, large, arrondi sur les "côtés, cilié, légèrement écliancré. - Mandibules assez fortes, courtes, sans dentelures remarquables, terminées en pointe, un peu arquées. - Mâchoires ayant leur lobe extérieur alongé, aminci à sa base.-Palpes maxillaires de quatre articles, les labiaux de trois; ceux-ci plus courts que les maxilaires; le dernie article des uns et des autres un peu comprimé, presque triangulaire. - Tếte penchée, prolongée derrière les yeux, conservant quelque temps sa même largeur el se rélrécissant subitement en manière de cou. - Yeux plus on moius échancrés mais toujours assez larrges, point lunulés. Corps assez long, plus ou woins rétréci anlérieurement. - Corselet plus étroit que les élytres, rétréci et cylindrique à sa partie antérieure, tesserré et rebordé postérieurement, inégal, muni de chaque côté d'une pointe ou d'un tuijercule. Ecusson assez grand. - Elyties alongées, recouvrant les ailes et l'abdomen. - Pattes fortes; cuisses un peu reuflées; jambes presque coniques, munies à leur extrémité interne de deux épines petites, inégales : tarses garnis de brosses en dessous, leur troisième article bilobé, le dernier alongé, conique, terminé par deüx forts crocliets.

Geoffroy a créé un genre sous le nom de Stencore, Stenocorus, d'un mot grec qui signifie: rétréci, mais il y réunit à tort des espèces de mours fort différentes (les Donacies). Fabricius s'empara de ce nom pour l'appliquer à d'autres Coléoptères Longicornes très-distincts de tous ceux à qui l'auteur français l'avoit donné; du reste il forma trois genres des Stencores de Geoffroy, savoir : Rhagium, Leptura et Donacia, mais le $\mathrm{P} \dot{\mathrm{p}} \mathrm{p}$ 
second avoit d’abord étẻ créé par Linné. M. Latreille jugea avec raison que l'on devoit conserver le nom donné par Geoffroy, et l'appliqua à celle partie dés Rhagium de Fabricius qui avoit été des Stencores pour Geofliroy, ainsi qu'à leurs congenères. C'est de cette manière que nous donnons ici cè genre.

Ces insectes vivent dans le bois pendant leur premier érat et jusqưan moment de leur dernière nuétamorphose; leurs larves, si l'on en croit Fa1) ricius (Entom. syst. tom. I. pars 2. pag. 304), sont héxapodes, nues, blanches, avec la tête et le premier segment du corps écailleux, noirâtres; leur dos est cannelé, ce qu'il rapporte d'après Stroer. Act. Hafn. Les Stencores dans l'état parfait vont peu sur les fleurs; ils restent le plus souvent sur le tronc des arbres, ils s'y promènent en marchant assez vivement pendant la grande chaleur du jour, leur allnre est saccadée et ils tournent souvent la tĉte à droite et à galluhe comme s'ils examinoient ce qui se passe autour d'enx; lorsque le temps est froid its se tiennent à la même place sans bouger, mais daus les deux cas lor'squ'on veut les saisir, ils se cramponnent fortement aux objets sur lesquels ils étoieut posés, ils s'envolent assez difficilervent : on les rencontre souvent accouplćs, ce qui nonterrompt pas la marche de la fcmelle qui trausporte le mále, ordinaireurent plus petit qu'elle et placé alors sur le dos de colle-ci; elle contie ses aufs aux gerçures de l'écorce ou mèrne aux trous déjà existaus dans les arbres forestiers, les Chênes particulièrement. Ces remarques ont été faites sur lcs espèces composant notre seconde division.

I re. Division. Antennes lieaucoup plus longues que la têle et le corselet pris ensenible, un peu distantes à leur base, presque deutées en scie, leur's cinquième, sixic̀me, seplièmc, buitième, ncuvième et dixième articles élant aplatis et presque triangulaires. - Tubercule latéral du corselet, assez obtus. - Ecusson court, presque demi-circulaire. - Elytres pas beancoup plus larges à leur base que le corselet (leurs angles huméraux peu saillaus), rı'allant pas en se rétrécissant de leur base à l'extrémité, de consistance ussez molle. - Year fortement échancrés.

Nous donmerons pour type de cetle division, le Stencore du Saule, $S$. salicis. Otiv. Entom. - Rhagium salicis $\mathrm{n}^{\circ}$. 6. $\mathrm{F}_{\mathrm{AB}}$. Syst. Eleut. Ses élylres sont ou d'un blen-violet cu d'un rougetestacé comme le reste di corps. Il n'est pas rare anx environs de Paris sur le tronc des vieux ormes.

- 2e. Division. Antennes à peu près de la longueur de la tête et du corselet réunis, très-rapprochées à leur base, tous leurs aiticles coniques, íl'exception dı onzième. - Tuberco'elatéral du corselet terminé en épine très-aiguc̈. - Ecusson tsangulirie, à augles aigus. - Elytres beaucoup plus larges à leur base que le corselet (leurs angles humćraux très-saillans), se rél récissant sensiblement de leur base à l'extrémité, de consistance très-dure. - Yeux très-peu échanacés.

Nous plaçons ici les Rhagium mordax no. I, inquisitor $\mathrm{n}^{\circ} .2$, indagator $\mathrm{n}^{\circ} .3$, bifasciatum $\mathrm{n}^{\circ}$. 8. FA B. Syst. Eleut. (Ces quatre espèces sout de France), et de plus le Stencore rayé, Stenocorus lineatus. Oriv. Entom. tom. 4. Stencor. pag. 13. $n^{\circ}$. 6. pl. 3. fig. 22. d'Amérique.

\section{(S. F. et A. SERV.)}

STÈNE, Stenus. Lat. FAв. РАy . Grav. Staphylinus. Linn. Geoff. Poderus. Oliv.

Genre d'iusectes de l'ordre des Coléoptères, section des Pentamères, famille des Brachélytres, tribu de's Longipalpes.

Les caraclères de celle tribu sont: Tête dégagée, étranglée postérienrement. - Labre enlier. - Palpes maxillaires presqua aussi longs que la tête, leur quatrième ou dernier article vaché ou peu apparcnt. Elle comprend les genres Pédćre, Stilique, Stène et Evæstliète.

De ces quatre genres urois, savoir : P'dère, Stilique et Evæstliete ont les aniennes insérées devant les yeux; en outre dans les deux prerniers, res organes vont ell grossiss nt insensiblement, et dans le dernier, leur unassue n'est que de deux arricles, suivani M. Latrcille, caractères suffisans pour séparer ces trois genres de celui de Sièue.

Antennes insérées près du bord interne des yeux, composées de onze articles, le preunier assez long, conique, le second conico-globuleux, le troisieme le plus long de cons, cylindrique; les suivans obconiques, les nenvième, dixiéme et onzième plus gros que les prēcédens, formant une massue; le dernier terminé en poiute. - Labre entier, transversal, son bord antérieur un peu arqué. - Mandibules fourchines, trèsgrêlés, très-arquées. - Palpes maxillaires presqu'aussi longs que la tête, comme terminés en massue, coinposés de quatre articles, le dernier caché ou peu distinct: palpes labiaux trèscourts, très-rapprochís, de trois articles, te second le plus grand de tous, presque globúleux, le dernier peu apparent. - Lèvre membrancuse, très-alongée : meuton presque carré, carénć dans son milieu, cette carène formant une petile dent au bord supérieur. - Tête entièrement dégagée da corselet, étranglée postérieurement. - Yeux globul-ux, très-saillans. - Corps long, trés-étroit, de consislance fort dure. Corselet ovoỉde, tronqué à ses'deux extrémilés. Point d'écusson distinct. - Elytres très-courtes, carrées, recouvrant les ailes el senlemenı la base de l'abdomen. - Abtomen alonøé, comme linéaire, convexe en dessus el en dessous. - Lame inférieure anale entière, arrondic dans les fe- 
melles, fortement échancrée daus les nuâles. Pattes assez longues; hanclies très-courtes; tarses de cinq articles distincts, le premier le plus long de tous, les antres allant en décroissaut de longueur, le pénultième bifide, le deraier terminé par deux croclets simples (1).

La forme du corps de ces inscctes leur a fait donner par M. Latreille le nom de Stène, tiré d'un mot grec qui signifie : sétréci. Ils habitent dans les lieux humides, leur taille est petite et leur couleur ordinairenent d'un noir terne. On en comneit aujourd'hui près d'une trentaine d'espèces, toutes d'Europe. Leur's larves n'ont pas encore élé observées.

Nous citerons $1^{\circ}$. Siène ruguenx, $S$. rugosulus. DEJ. Catal. - Stenus corulescens no. 1. Gru.. In.s. Suec. toin. 2. pag. 463. 20. Siène bimoucheté, S. biguttatus. liar. Hist. nat. des Crust. et Insect. tom . 9. pag. 352. pl. 80.fig. 1. - F $\mathrm{AB}$. n $^{\circ}$ 1. Syst. Eleut. - Encycl. pl. 1go. Prodère. fig. 3. a.ı. 32. Stène oculé, S. oculatus. Gnav. Coleopt. micropt. p. $155 . n^{\circ} .3 .4^{\circ}$. Sic̀ne cicindéloide, $S$. cicindelö̈des. Grav. id. $n^{\circ}$. 4. Pacderus proboscideus. Uliv. Entom. toul. 4. Pédèr. pay. 6. n. 5. pl. 1. fig. 5. a. b. $5^{\circ}$. Stène binoté, $S$. binoiatus. Grav. Monogr. micropt. pag. 229. $n^{\circ} \cdot 8$.

\section{EV ASTHETE, Evorsthetus. Knoce. Grav.} LAT.

Genre d'insectes de l'ordre des Coléoplères, section des Pentamères, fanille des Brachélytres, tribu des Longipalpes.

Cette tribu contient quatre genres outre celui d'Evæsthète, savuir Sı̀̀ne, donı les antenues sont insérées a u bord interue des yeux; Pédère er Stilique dans lesquels ces organes vont en grossissant insensiblement vers leur extréwité.

MM. Latreille et Gravenhorst ne sont pas entièrement d'accord sur los caractères de ce genre. Le premier de ces auteurs n'accordant que deux articles à la massue des antennes tandis que $M$. Gravenhorst lui en donne trois. Ne connoissant pas l'espc̀ce qui constitue ce genre, nous ne pouvons décider cette question. Ŝes caractères génériques. n’ayant été publiés que par M. Gravenhorst, nous allous les donner d'après cet auteur.

Antennes (insérées an-devänt des yeux, suivant M. Latreille) un peu plus longues que la tête, subitement en massue, composées de onze articles; le premier en massue, le second trèscourt, le troisième plus long et plus gros que le précédent; les quatrième, cinquième, sixième,

(1) M. Carcel entomologiste zélé a fait une étude parciculière des partics de la bouche des Stènes; il se propose de publier ua Mémoire sur ce sujet ainsi que la monographie complère des espèces de ce genre. septième et huitième, très-petits; les neuvième et lixième transversaux, fort gros; le onzième le flas gros de tous, ovale, terminé en pointe. Mandibules on faucillc: - Palpes maxullaives de la longrueur de la tête, iriarticulés; leur premier article en massue, le second beaucoup plins court el plns étroit que le premier; le troisic̀ne ovale, plus épais que les autres, finissant ( peutêtre) en pointe. - Téte plus petite que le corselet, ponctuée : chaperon large, entier. - Yeu.x saillans, occupant les côtés de la base de la tête. - Corselet atussi large que long, rétréci vers sa base, de la longueur des élyt tres, mais près de de $u x$ fois plus étroit, ponctus, ayant denx petits enfoncernens ovales-oblongs, sur le disque qui se rétrécissent vers le bout. - Eiytres presque carrées, formant réunies un parallélipipède transversal, ponctuées, ayant quelques enfoucemens autour de l'écusson, couvrant des ailes et beaucoup plus courtes que l'abdomen. - Abdomen épias, rehordć. - Jambes sans épines, articles des tarses petits.

L'auteur ne décrit qu'nue seule espèce. Evasihète scalire, $E$. scaber. Longueur $\frac{2}{3}$ de lirnc. D'un brun brillant. 'Tête rousse; aulennes, palpes et mandibules plus pâles. Patles d'un Lrun-roux. Du nord de l'Allewague.

$$
\text { (S. F. et A. Serv.) }
$$

STÉNÉLYTRES, Stenelytra. Troisième famille de la section des Hétérunières, ordie des Coléoptères. Ses caractères snnt:

Mâchoires inermes. - Mandibules terminées en une pointe simpla dans plusieurs. - Ṕnultiènne article des tarses bilobé dans plusieurs. Antennes ordinairement plus longues que la têle et le corsclet, filiformes cu sélacées, point sensiblement perfo'iées. - Elytres molles dans plusieurs.

Cette famille se compose de cinq tribus.

\section{Devant de là tête n'étant point prolongé sensiblement en forme de museau.}

$$
\text { Ire. Tribu. Hélopiens, Helopii. }
$$

Extrémité des mandibules toujours bidentée (suivant M. Latreille) ou large, entière et creusée en cuiller. - Base des antennes ordinairement recouverle par les bords avancés de la têle. - Palpes maxillares plus longs que les labiaux, terminés par un grand article trianguluire. Tous les ariicles des tarses entiers, leurs crochets simples, sans dentelures.

Nota. Derniers articles des antennes souvent plus courts que les précédens et arrondis, les autres cylindro-coniques. Corps de la plupart ovale ou oblong, arqué el bombé supérieurement; jambes ordinairement sans épines à leur extré-mité.

$$
\text { Pp }=
$$


A. Corselet presqu'en forme de cour tronqué postérieurement.

\section{Hélops.}

B. Corselet presqu'orbiculaire ou presque globuleux.

Pythe, Adélie, Sphérote.

C. Corselet mesuré au bord postérieur plus large que long, soit trapézoidal, soit presque lunulé. - Corps presqu'hémisphérique, ou ovale et arqué, quelquefois ovale-oblong.

Acantbope, Canarie, Campsie, Sphénisque, Amarygme, Nilion.

D. Corselet plus long que large ou presqu'isométrique, soit presque carré, soit cylindracé. - Corps étroit et alongé.

Strongylie, Sténochie, Grammitie, Sténol rachèle.

\section{Tribu: Cistélides, Cistelides.}

Mandibules terminées en une pointe simple. - Antennes insérées à nu. - Pénultième article des tarses quelquefois bilobé; leurs crochets dentelés.

\section{Mycétochare, Allécule, Cistèle,} Listronyque, Prosiène.

3॰. Tribu. Sécuripalpes, Securipalpi. (Voyez ce mat.)

\section{4ं. Tribu. Edénérites, EEdemerites.}

Mandibules bifides. - Pénultième article de tous les tarses bilobé. - Demier article des palpes maxillaires grand, triangulaire. - Antennes insérćes à nu, filiformes ou sétacées, généralement alongées et quelquefois en scie. - Corps érroit, alongée. - Corselet cylindracé, plus étruit postérieurement que la base des álytres. - Elytres souvent molles, flexibles. (Rétrécies dans plusieurs à leur extrémité.)

Nota. Pattes postérieures de plusieurs différentes selon les seses.

$$
\begin{aligned}
& \text { Calope, Sparèdre, Dityle, Edé- } \\
& \text { mòre. }
\end{aligned}
$$

II. Devant de la tête alongé en forme de museau.

5e. Tribu. Rhynchostomes, Rhynchostoma.

Sténostome, Myctère, Rhinosime, Salpingue.

Les mœurs des Stérélytres sont très-variables; aucun d'eux n'habite dans les excrémens ni dans les fumiers. On les trouve sur les végétaux.

$$
\text { (S. F. et A. Serv.) }
$$

STÉNOCHIE, Stenochia. Genre de Coléoptères Hútéromères, famille des Sténélytres, tribu des Hélopiens de M. Latreille, établi par M. Kirby ( Trans. Linn. Centur. of Insect. vol. 12 ) et placé par lui dans sa fauille des Helopidé; ses caractères sont : labre transversal, arrondi à son extrémité; mâchoires ouvertes à leur base; tous les palpes ayant leur dernier article peu comprimé, presque triangulaire; menton presqu'en urapèze, son disque un peu élevé; autennes plus grosses à leur extrémité, le ciervier article oblong; corps linéaire, étroit. L'auteur y rapporte les deux espèces suivantes: $\mathrm{I}^{\circ}$. Sténochie rufipède, $S$. $z$ fipes. Longueur 8 lignes. Verdâtre, bleue en dessus, élytres ayant deux bandes jaunes réunies au bord extérieur; antenues et pattes rousses. Du Brésil. Elle est représentée $p l$. 22. fig. 5. de l'ouvrage précité. $2^{\circ}$. Sténochie cyanipède, $S$. cyanipes. Longueur 6 lignes. Bleue; antennes rousses; corsclet très-court; élytres ayant deux bandes d'un jaune-fauve, réunies au bord extérieur. Du Brésil. (S.F. et A. SERt.)

STÉNOCIONOPS, Stenocionops. Léach. Lat. Maia. Lay k. Cancer. Heasst.

Genre de Crustacés de l'urdre des Décapodes, famille des Brachyures, tribu des Triangulaires, établi par Léach dans ses travaux inédits et adopté par Lutreille (Fam. nat. du Règn. anim.). Les caractères de ce genre nus sont inconnus; M. Desmarest, dazs son article Malacostracís du Dict. des sc. natur., parle de ce genre dans une note; il dit qu'il comprend le Maia taurts de Lamarck, qu'on soupçonne se trouver dans la Méditerranée. ll a la carapace ovale, bordée d'épines sur son contour, inégale et presque mulique en dessus; son front est pourvu de deux fortes épines; les deux pattes anlérieures sont grandes, à troisième article hérissé de tubeícules, à main longue, assez étroite, en partie tuberculeuse, et dont les doigts sont courts et un peu arqués. M. Latíeille lui rapporte le Cancer Conundo d'Herbst. (E. G.)

STENOCORUS. Fab. Cet auteur a donné ce nom générique à plusieurs Coléoptères Longicornes qui appartiennent à des genres fort différeas les uns des autres.

$$
\text { (S. F. et A. Serv.) }
$$

STÉNODÉRE, Stenoderus. DeJ. Catal. LAT. (Fam. nat.) Ceramby x. Faв. Stenocorus. OLIv. (Entom.)

Genre d'insectes de l'ordre des Coléoptères, section des Tétramères, famille des Longicornes, tribu des Leplurètes. 


\section{S T E}

Ce yenre créé par M. le comte Dejean doit, d'après l'insertion extrà-oculaire de ses antennes, être rapporté aux Lepturètes de M. Latreille; il fait partie d'un groupe de cette tribu (voyez Stencore ) qui renferme en outre les genres Disténie et Cumétès, et a pour caractères : tête rétrécie en manière de cou immédiatement après les yeux; arstennes composées d'articles ordinairement cylindracés, velues; corselet rétréci postérieurement. De ces trois genres ceux de Disténie et de Comélès se distinguent par leurs palpes inégaux, les maxillaires étaut trois fois plus longs que les labiaux, et encore par leur corselet épineux latéralement, de plus les antennes des Disténies outre qu'elles sont pubescentes dans toute leur longueur ont en dessous de plusieurs de leurs articles, de longues soies rangées sur une seule ligne, caractère que l'on retrouve aussi dans le genre Cométès.

Les caractères génériques des Stćnodères n'ont pas encore été puibliés.

Antennes pubescentes à leur base, rapprochées l'une de l'aulre à leur insertion, composées de onze articles cylindracés el insérées hors des yelx. - Labre saillant, tronqué carrément en devant. - Mandibules courtes, assez fortes, sans dentelures remarquables, mousses à leur extrémité. - Palpes presqu'égaux, les maxillaires de quatre articles, les trois premiers petits, trèscourts, le deraier un peu plus gros et un peu plus long, ovale, tronqué à son somuet : palpes labiaux de trois articles fort courts, le terninal à peu pròs conformé cornure celui des maxillaires. - Tête rétrécie en manière de cou immédiatement après les yeux : chaperon arrondi antérieurement. - Yeux globuleux, entiers. - Corps rétréci en devanı. - Corselet plus étroil que les élytues, rétréri antérieurement et à sa partie postérieure, inégal en drssıss, un peu renflé sur les côtés, mutique. - Ecusson arrondi postérieurement. - Elytres presque linéilires, arrondics et muliques a leur extrémité, recouvrant des ailes et la lotalité de l'abdomen. - Pattes de longueur moyenne.

Le nom de ce genre vient de deux mois grecs qui expriment le rétrécissement de la partie postérieure de la tête de cus insectes. Il ce conlient à notre connoissavce qu'une seule espèce dont notis ignorons les mœurs. Stćnodère à lignes rac:couacies, S. abbreviatus. Des. Catal. - Ceranabyx abbreviatus $\mathrm{1}^{\circ} .43$. $\mathrm{F}_{\mathrm{A}}$. Syst. Eleut. - Schen. Syn. Ins. tom. 5. pag. 367. no. 14. - Stenocorus suturalis. Gurv. Enton!. Stenc. tom. 4. pag. 29. pl. 3. fig 29. - Schan. Id. pag. 409. $n^{\circ}$. 46 . Des Indes orientales.

Nota. On voit par celte synonymie que $M$. Schornher" a fait un donble emploi de cette espèce, chose bien rare dans cet auteur, toujours si exact.
DISTÉNIE, Distenia.

Genre d'insectes de l'ordre des Coléoptères, section des Tétramères, famille des Longicornes, tribu des Lepturètes.

Des trois genres qui composent le gronpe dans lequel entrent les Disténies (voyez STexcorr), celui de Sténodère a le corselet mutique, les palpes courts, presqu'égaux el les antennes seulement munies d'un duvet serré; ses élytres ainsi que celles des Cométès snnt linéaires, arrondies et mutiques à leur exirémité.

Antennes sétacées, velnes, rapprochées à leur base, be:tucoup plus longues que le corps, insérécs hors des yeux, coraposées de onze articles; le prearier fort long, en nassue alongée, le secoud très-court, crupulaire; les aurres cylindriques, garnis en dessovs d'une langée de longs poils soyeux, à l'exception da dernier. - Labre transversal. - Nandibules ceurles, fortes, obluses à l'extrćmité. - Pulpss grands, inégaux; les maxillaires trois fois plus tnzas que les labiaux, de quatre articies, le promir court, menu; les deux suivans alongés, égaux, coniques; le termimal un pen lus court, plus gurs, peu comprimé, presque triangulaire : palpes labiaux de trois articles, le prenicr menu, le suivant un peu lenfié intéricurcmeat, le dernier gros, ovale, un peu tronqué i sou extrémilé. - Téte rétrície en manière de cou immédiatement arrès les yeux, ayaut dans son milieu antérieur, une ligne longitudinale enfoncée. - Yeurr réniformes. - Corps rétréci en devan! et postérieureesent. - Corselet rétréci antérieurement et à sa partie postérieure, muni d'un tubercule latéral épineux; inézal en dessus, plus étroit que les élytres. - Ecusson arrondi postérienreuient. - Elytres allant en se rétrécissant des angles huméraux à leur extrémité qui est armée d'une épine, reconvrant les ailes el l'abdomen; leurs angles huméraux saillans. - Abdomen étroit, couigne. - Pattes assez longues, fories.

Distétuie vient de deux mots grees qui expriment le double rétrćcissement quofoftre le corselet. Nous érablissons ce genre sur une espèce du Brésil dont les næurs nous sont inconnues.

\section{Disténie changeanle, D. columbina.}

Distenia fusco-testacea, elvtris striato-punctatis, lineâ submarginali longitudinali vindiceneo micante; pedibus subpalladionbus.

Stenecorus columbinus. DEJ. Collect.

Longueur 8 à I 2 lig. IF́un brin testacé. Soies des antennes noires. Elytues a stries pointillies et crónelces, ayanı quelques reflets d'un vert bronzé gorge de pigeon el une ligne de celle inême c uleur prés du bord extérieur, descendant de l'angle humáral jonsqu'ua bout de l'élytre. l'alles dun testacé pâle, les cuisses principalezent.

Du Erésil. 
485

\section{S T E}

COMETES, Cometes.

Genre d'insectes de l'ordre des Coléoptères, section des 'Télraméres, famille des Longicornes, tribudes Lepturètes.

Ce genre avec ceux de Disténie el de Sténodère forme un groupe dans les Lepturites. (Vovez Stencone.) Les Sténodères-sont reconnoissables par leurs palpes courts, prescu'égaux, leur corselet muticjue et leurs ariennes simplement pujescentes. Le genre Disténie differe de celui de Cométès par ses élytres allant en se rétrécissant vers l'extrémité, épintues a bou el par ses antennes plus longues, sétacées; enfin par les paites plas slonyées.

Antennes filiforaes, rapprochées à leur base, veluẹs, un peu plus longues que le corps, insérées hors des yeux, conıposées de ohze articles, le premier très-grand, en massue alongłe ; le second très-court, "cupulaire; les autres cylindro-coniques, assez gros, garnis postériéurewent d'une rangée de longues soies. - Labre court, transversal. - Mandibules forles, conrtes, obtuses à l'extrémilé. - Palpes inégaux; les maxillaires trois fois plus longs que les labiaux, de cuatre articles, le premier petit, grêle, les deux suivans assez longs, coniques, le dernier le plus gros de tous, ovale, peu compriaré : palpes labiaux courts, de trois articles, les deux preaiers presyue cupulaires, le termiual plus gros, ovale. Tête rétrécie postérieurement, mais moins que dans le gemre précédent, portant un bourrelet transversal entre les yeux, immédiatement andessus de l'insertiou des antennes, ayant une petite ligne entoncée qui part de ce bourtelet el atteint presque le bord postérieur ; chaperon transversal. - Ieux rénifur mes. - Corps presque linéaire, pubescent. - Corselet à peu près de la largeur do la tête, plus étroit que les élytres, inégal en dessus, rétréci postérieurement ainsi qu'en devant, muni latéralement d'un tubercu'e épinè̃x. - Ecusson petit. - Elytres linéaires, rebordées, un peu déprimées en dessus; leur extrémité arrondie et mutique, recouvrant des ailes et l'ubdomen. - Pattes courtes, cuisses un pen renflćes; jambes antérieures subitenent dilatées et renflées à leur extrémité, au moins dans l'un des sexes : troisième arlicle des tarses ayant ses deux divisions très-larges, '́gulañt chacune en dinensions, l'article précédent. (Ce dernier caractère n'est peut-ĉtre aussi que sexuel.)

Le nom de ce genre tiré du grec a rapport aux longs poils qui forment une sorte de chevelure à ses anieumes. Nous n'avons aucun renseignement sur ses moul's. L'espèce qui nous sert de type a quelques rapporis de forme avec les Callidies, mais elle seu ćloigne beaucoup par l'insertion des antennes hors des yeux.

т. CouÉrès hirlicorne, $C$. hirticornis.

Cometes nigra, thorace suprà ferruginoo, coxis

\section{S I IS}

et femoram hasi pallidis; elytris punctotis, lineis duabus subelevatis.

\section{Callidiun hirticorne. DEJ. Collect.}

Longueur 5 lig. D'un noir mat en dessus, un peu luisant en dessous; pointillée. Corselet ferrugineux en dessus. Hanches et base des cuisses d'un restacé päle. E'ytres pointillées, ajant chacune deux petites cótes longitudinales peu.prononcées. Mâle.

\section{Du Brésil. (S. F. et A. Serv.)}

STENOPE, STENOPS, Stenopus. Genre de Cristacís de l'ordre des Dícapodes, famille des Brachyures, tribn des Triangulaires. Voyez ce dernier unut. (LATR.)

S'TÉNOPTÉRE, Stenopterts. IfLIG. LAT. (Fam. uat.) Necydalis. Linn. Fab. Oeiv. Lat. (Gener.) Leptura. Geoff. Molorchus. ScBan.

Les entomologisles modernes donnent ce nom venant de deux mots grecs qui signifient : ailes rétrécies, à nue partie des espèces cumposant le genre Nécydale du présent Dictionıaire. Ce sont les numérus de six à dix. Le nom générique de Nécydale est conservé par N. Latieille (Fam. nat.) aux espèces qui ont les ély tres comme tronquées carrément et extrêmement courtes : ce sont les numéros de un à quatre inclusivement. Ces demic̀res constituent le genre Molorchus de Fabricius. M. Schonlerr peuse que le numéro cinq peut appartenir at genre Sitaris. Voyez NEcydale. (S. F. et A. Serv.)

\section{STÉNOPTÈRES ou ANGUSTIPENNES. Dou-} zième faruille des Coléoptères dans la Zoohogie arralytique de M. Dumérıl, section des Hétérumérés, ayant les caractères suivans: Elytres dures, rétrécies. Antenues filifornes, souvent dentées. Elle renferme six genres. Sitaride, (Edénère, Nécydale, Ripiphore, Mordelle et Anaspe.

(S. F. et A. SERv.)

STÉNORHYNQUE, Stenorhynchus. Lamk. LAt. Macropus. LAt. Macropodia. Lèach. Lat. Maia. Bosc. Cancer. Penn. Herbst.

Genre de Crustacés de l'ordre des Décapodes, famille des Buchyores, tribn des Triangulaires, établi par Lamarck et adopté par Latreille (Fam. nat. du Règn. aninu.). Ce genre correspond entièrement au genre Macropodia de Léach on à une partie du genre Macropode de Latreille (Regn. anim. etc.), et ses caractères sont :

Antennes extérieures distanies, ayant la moitié de la longueur du corps, sétacées, insérées en avant des yeux sur les côtés du rostre; leur second arlicle étant trois fois plus long que le premier. Pieds-mâchoires extérieurs ayant leur second article étroit à la base, dilaté à l'extrémité du côté interne, e! le troịsième ovalaire, alongé 
et beaucoup plus étroit. Espace du dessous du rostre, eompris entre la bouche et la naissance des antennes (snrboucbe, Latreille) plus long que large, allart en se rétrécissant vers le haut. Serres égales, grandes, à main alongée et comprimée, avec le carpe de moitié moins long; eelles des mâles deux fois aussi longues que le corps, les autres pattes grundes, grêles et filiformes; celles de la seconde paire ayant trois fois la longueur de l'animal: carapaee triangulaire, avec ses régions branchiales tout-à-fait postérieures et bombées, diıninuant graduellernent de largem on avant jusqu'à l'extréwité d'un rostre assez long qui est fendu dans son milien; yeux écartés, suljréniformes, beaucoup plus gros que leur pédoncule, non susceptibles d'être retirés dans les orbites.

Les Crustacés de ce genre ont beancoup rle ressemblance avec les Inaclus et avec les Leptopodies; M. Latreille les avolt nêne réunis à ce dernier ugente (Règn. anim.). Ils s'en distiogruent par la langueur du rostre, et parce que ce rostre est entier dans les Leptopodies; les Inachus en sont séparés sulfisammınt par un rostre eourt, artondi; par lears antennes plus longues que ee rosire, et surtout par leur surbouche qui est transversale, c'est-à-dire plus longrae que large. Les yeux des Inachus sont rétractiles, ce qui les distincue encore des Sténorhynques; les Camposcies et les Pactoles en sont distingués par la forme de leur corps qui est moins alongé, par leurs pattes et par la composition des feuilets de l'abdomen. Enfin les Maias, les Parthenoyes et auires genres voisins en sonl séparés par la forme de leurs piedsmâcboires extérieurs qui ont le trobicme article presque carré, échancré ou tr.'juqué obliquement à son extrémité interne é suṕrieure, tandis qu'll est en forme de lrisrugle renversé ou d'ovale rétréci inférieuresient dans les genres précédens.

Tue z̧añe Sténorhynque reuferme peu d'espèces. Leur port est remarquable à cause de leurs longues pattes qui les font ressembler ades faucheurs; wous citerons

Le Stŕxoratnque faucheur, S. phalangium. LAT. - Macropodia phalangium. I.E.Ach. L.Aт. Encyl. méth. pag. 298. fig. 6. - DEs art. Malacostracis du Dict. des sc. nat. et Considérat. gén. sur les Crust. pl. 23. fig. 3. Macropus longirnstris. LAт. Gcr. Crust. et Ins. elc. - Maia phalangum. Bose. - Leptopodia phalangium. LÉ A CH, Edimb. Encyl. - C'ancerdodecos. lins. Syst. nat. édit. 13. t. I. pars 2. p. $1046^{\circ}-$ Inachus longirostris. FAB. Suppl. Entom. system. pag. 558. - Vilı. Entom. tom. 4. pag. 145. ¿ab. II. fig. I2. - Ronder. Hist. des poiss. liv. II. ch. 24. - Sе́в A, Mus tom. 3. tab. 20. $n^{\circ}$. I3. Il а uи peu plus d'un pouce de ling depuis la base de la carapase jusqu’à l'extrémité du rostre, qui à à peu près le tiers de la longueul du corps et est bilide a l'extrémité et sillouné dans toute sa longueur en desšus. Antennes dépassant ce rostre des trois quarts de leur longueur. Tubercules de la carapace disposés ainsi qu'il suit : trois en triangle $(2-1)$ șr la région stomacale, un en pointe sur la région cordiale, deax snr les branchiales et hords latéraux du test présentant quelques aspérités? face interne des bras presque scabreuse, velue.

Cette espèce se trouve sur les côtes de l'Océan et dans la Méditerranée. (E. G.)

STÉNOSIS, Stenosis. Nom générique donnẻ par M. Herbst ąux esfèces ou au moins à la plupart des especes dori M. Latreille coumpose son genre Tagénie. Toyez ce mot.

$$
\text { (S. F.et A. SERv.) }
$$

S'TENOSOME, Stenosonna. LEACH. LAT. Idotea. Lat. Oniscus. Prinn. Asellus. Ontv.

Genre de Crustacés de l'ordre des Isipotes, section des Aqualiques, famille des ldutéides, établi jar Léach, et ne diffírat du geure Idotée que par les antennes extérieure qui sont de la longuer: du corps (la têle et le tronc, sans conápreadre la queue), avee le troisiène article un peu plus long que le quatrième. Le corps des Sténosomes est comtae celui des Idotées, alongé, linéaire et étroit.

Les moul's et l'organisation des Sténosomes sont les roêmes que celles des Idotées; e'est pourquoi nous reuvoyons ce mot à la rable qui se trouvera à la fin de eet ouviare. Ce genre est peu nombreux en espèces; cependaat il est divisé en deux sevitions ainsi qu'il suit :

* Côtés du second segrment du eorps et des suivans ayant l'apparence d'une petile articulatiou.

Stérosone unéarre, $S$. lineare. Léaca, Trans. Soc. Linn. tom. 2. pas. 366. - Oniscus linearis. PENa. Brit. zool. tom. 4. pl. 18. fig. 2. (Voye pour la suite de la synonymie le $\mathbf{n}^{\circ} .9$, au mot Asectedece Dictionusire.) Quant à la description de l'es!rèce, elı̀ est incomplète et tout-à-fait mauvaive : nous allons donner celle de Léach et de Desnarest. Base du dernier segment de la queue un peu rótrécie, avec l'extréuité dilatée. tronquée, écbancrée et powrvae d'une dent a chacque angịe latéral ; d'un brun-noirâlre en dessus, blanchâtre sur les côtés : longueur du corps variant depuis nn ponce jusquà deux. Cette espèce se trouve dans la mer, sur les côtes de lo: céan. Olivier, dans l'article Aserwe, dit qu'elle se Irouve dans la mer des Indes. Du reste il seroit bien possible que l'espèce qu'Olivier a déerite ne fût pas la même qute celie de Léach; on ne peut s'assurer de ce fail qu'cu consultant uae collection bien complòie en espèces.

* Pus de traces darticuiations sur le liort en segmens du corpes.

Sténosame нegtique, S. hecticum. Háp.- 
Oniscus hecticus. Parl. Spicil. zool. fas. 9. tab. 4. fig. 10. a. b. c. d. --Idotea viridissima. Risso, Crust. pag. 136. tab. 3.ffg. 8. Longueur un pouce à un pouce et demi. Corps linéaire; dernier segment de la queue échancré prófondément, à angles latéraux saillans. Couleur d"un vert brillant. Cette espèce habite les moyenues profondeurs de la mer de Nice et de toute ia Médilerrauće. Voyez pour une plus longue description le no. 13. "de l'article Aserue de ce Dictionuaice, où celte espèce est appelée Aselle étique. (E. G.)

STÉNOSTOME, Stenostomia. Lat. Leptura. FAB. OLIV. (Encycl.)

Genre d'insectes de l'ordre des Coléoptères, section des Hétéromères ( 1 re. division), famille des Sténélytres, tribu des Rynchostonics.

La cinquième tribu des Sténélytres ( vojez ce mot) contient, ont:e le genre Siénostome, ceux de Hyctère, Rlinosime et Sulpingue : le preunier de ces trois est distinct des Sténostomes par le dernier article des palpes beaucoup plus large, obtrigone; le corps ovale; le corselet trapézoidal et les élytres dures. Les deux derniers genres - nt pour caractere particulier, les antenues plus - rosses à leur extrémité et le devant de la tête formunt un museau dilaté à son extrémité.

Antennes filiformes, insérées au-delà des yeux, sur le museau, composées de onze articles, cylyndro-coniques, le dernier seul ovale-alongé, pointu à l'extrémité. -_ Labre avancé, presque carré, un peu rétréci à sa partie antérieure. Mandibules bificles, alongées. - Mâchoires longrues. - Dernier article des palpes cylindrique : palpes maxillâires fort longs. - Lévre alongée. Téte prolongrée en devant en une sorte de museau aplati, un peu rélséci antérieurement. - Yeux peu saill.ns. - Corps mon, alongé. - Corselet alongé, presque cylindrique, uu pea déprimé. - Elytres molles, recouvrant des ailes et l'abdomen. - Pattes de longueur moyenne; jambes intermédiaires et postérieures un peu arquées; tarses longs, leur pénuitic me article bifide: tarses postérieurs ayant leur preunier article aussi long que les trois autres réunis.

M. Latreille a normú oe genre Sténostome, de deux mots grecs, dont lé seus est: bouche rétrécie. L'espèce qui lui a servi dé type se trouve sur les fleurs, principalersent sur celles de l'Ammi majeur; elle liabite l'Afrique el les parties méridionales de l'Eucope. C'est la Siénostome rostiée, S. rostrata. Lat. ( Nouv. Dict. d'hist. nat. $2^{\mathrm{e}}$. édit. ) - Drs. Catsl, - Leptura rostrata $1^{\circ} .39$. Fав. Syst. Eleut.

Foyez ponr la descriplion et les autres synonymes, Lepture rostrée no. 22. du présent Dictionnaire. (S. F. et A: SERv.)

STENOTRACHELE, Stenotrachelus. LAT.
(Fani. nat.) Dryops. PArK. DeJ. Calul. Calopus. Scher.

Genre d'insectes de l'ordre des Coléoptères. section des Hétéromères ( $\mathrm{y}^{\mathrm{r} e}$. division), famille des Sténélytres, tribu des Hélopiens.

M. Latreille n'a pas encore fait connoître les caractères propres à ce geure, mais comme il est identique avec celui de Dryoj's de Paykull, nous allons les énoncer d'après ce dernier auleur.

Quatre palpes inégaux, les maxillaires sécuriformes, les labiaux filiformes. - Lère membraneuse, largement échancrée. - Antennes filiforrues, moitié plus longues que le corps, insérées au-devant des yeux. - Corselet presque carré. - Ecusson petit, atrondi postérieutement. - Elytres n'étant pas moitié plus larges que le corselet, longnes, cylindriques, recouvrant des ailes et l'abdomen. - Crocliets des tarses accompagnés d'une soie qui les fait paroître bifides.

Ce dernier caraclère indiqué par M. Latreille dans ses Fanr. nat. peut faire soupçonner que la Dryops onea n•. 2. Fав. Syst. Eleut. rapportée à ce qu'il paroît mal-à-propos par Paykull à son Dryops ancuses, el qui est l'CEdémère cuivreuse" $n^{\circ}$. 3. du présent Dictionnaire, appartient aussi à ce genre et $y$ constitue une seconde espèce, originaire de l'Amérique méridionale. Le type du genre dont le nom liré de deux mots grecs signifie : cou rétréci est le Sténotracbèle cuivreux, S. aeneus. - Dryops aneus. Payx. Faun. Suec. tom. 2. pag. 152. $n^{\circ}$. 1. (En retranchant le synonyme de Fabricius.) - Calopus aeneus. Scвor. Syn. Ins. iom. 3. pagr. $411 . n^{\circ}$. 2. Paykull le décrit ainsi : corps alongé, noir en dessous, cuivreux-obscur el trìs-ponctué en dessus. Il habite la Suède el se trouve sons l'écorce des vieux Bouleaux. (S. F. et A. Sanv.)

StTENYO. Rafinesque.

Nom donné par Ralinesque à un genre de Crustacés dont il ne donne pas les caracières.

STÉPHANE, Stephanus. Jur. Illio. Lut. Bracou, Pimpla. lí Bracon. PAnz.

Genre d'insectes de l'ordie des Hyménoptères, section des Térébrans, fanille des Pupivores, tribu des Ichneumonides. (Division des Braconides.) ( 1 )

(1) Le genre Stéphane doit constituer à lai seul une subdivision dans les bracouides, avec ce caracière : palpes maxillaires de ciny articles, les labiaux de quatre. Certe subdivision sera la seconde, celle que nous iudiquons comme reile page $\{3$. da présent voiume, deviendra la crojsième er contiendra tes genres Vipiou, Bracon et Microgastre; le genre Helcon doit être reporté dans la première subdivision. (Voyez tribu des Ichneumonides pagc 43. tone $X$. Un renyoi fautit dans la copie fait que le genre 
Dans ses Familles naturelles, M. Latreille forme un groupe d'Ichneumonides ayant pour caractère : palpes maxillaires de cinq articles trèsinégraux entr'eux; les labiaux de quatre : bouche point avancée en manièrc de bec; antenues filiformes ou sétacées; mandibules entières ou foiblement bidentées à leur extrémité. Ce groupe contient les genres Stéphane et Xoride. Ce dernier diffère de l'autre par ses mandibules rétrécies presqu'immédiatement après la base; par l'article terminal des palpes maxillaires plus long que le précédent et par l'insertion de l'abdomen placée ver's la partie inférieure du métatlorax qui va en pente.

Antennes pelites, très-grêles, sćtacées, insérécs veis le bas de la face, composées de trentedeux articles. - Mandibules courtes, "également épaisses dans toute leur longueur, terminées par une petite dent. - Palpes maxillaires an moins quatre fois plụs grands que les mâchoires, coınposés de cinq articles, le premier assez gros, court, le second manifestement plus long que le premier, aussi"gros que lui, les trois derniers très-longs, très-grêles, cylindriques, presqu'égaux entr'enx : palpes labiaux quatre on cinq fois plus courts que les maxillaires, de quatre articles, le dernier presqu'ovale, plus mince que les précédens. - Téte grosse, globuleuse, couronnée de tubercules, ordinairement au nombre de cinq", portée sur un cou long et mince. Yeux elliptiques, grands. - Trois ocelles disposés en triangle sur la partie antérieure de la tête, très-distans les uns des autres, les latéraux très-rapprochés des yeux à réseau. - Corps long, grêle, comprimé. - Corselet long; prothorax conique , s'avançant en devant en une espèce de lame qui recouvre le cou : mésothorax ovale : métahorax carrć, tronqué droit poslérieurement. - Ecusson peu ou point distinct. Ailes supérieures ayant un cellule radiale longue, pointue à ses de ux extrémités, s'a vançant presque jusqu'au bont de l'aile et deux cellules cubitales, la première presqu'en losange recevant la première nervure récurrente près de la nervurc d'intersection qui la sépare de la deuxième cubitale; celle-ci longue, atteignant presque le bout. de l'aile, et trois cellules discoidales dont la troisième ou inférieure atteint le bout de l'aile, la seconde nervure récurrente manquant. - $A b-$ domen long, en massue un peu comprimée, inséré sur le bord supérieur de la troncature du métathorax, son premier segment très-alongé, presque cylindrique, formant le pćdicule; taric̀re saillante, ordinairement fort longue. - Pattes antérieures et intermédiaires grĉles, les postérieures fortes, leurs hanches longues, à cuisses en

Stéphane $s^{\prime} y$ trouve mal placé, et nous oblige à faire isi cette rectification.)

Hist. Nat. Ins. Tome X. massue; tige de celle-ci courte et grêle : le dessous de ces cuisses armé de fortes épiues; jambes comprimées à la base : premier article de tous les tarses aussi long ou plas long que les quatre autres pris ensemble.

Nota. Tous ces caractères ont été pris sur des individus femelles.

Feu Jurine en ćtablissant ce genre lui a donné le nọ de Stéphane tiré d'un mol grec qui signifie: couronne. L'espèce indigènè, selon le savant auteur génevois, se trouve comme les Pimples, les Xorides et les Helcons le long des arbres et sur les bois abattus; ce qui porte ì croire que sa larve vit aux dépens de celles qui se nourrissent de la substance du bois:

\section{STÉpHaĩe fourchu, S. furcatus.}

Stephanus niger, antennis fuscè testaceis, prothoracis anticâ parte transiersim sulcatâ, emarginato bifurcatấ ; terebroe rufoe vaginâa nigrâ ante apicem albo annulatâ : alis subfuscis.

Lougueur 14 lig. nón compris la taric̀re qni est plus longue que le corps. Noir. Ántennes d'un testacé-brun foncé. Partie antérieure du próthorax sillonnée transversalement, échancrée à son extrémitéqui fail la fourche. Taric̀re rousse, ses fourreaux noirs ayant un large anneau blauc avant leur extrémité. Ailes un pea rembrunies. Femelle.

Du Brésil.

2. Stéphane aigu, S. acutus.

Stephanus niger, antennis fuscè testaceis, prothorace subpunctato, apice acuto; terebroe rufoe vaginâ nigrâa ante apicem albo annulatâ : alis subhyalinis.

Longueur 7 lig. non compris la tarière qui est un peu plus longue que le corps. Noir. Antenines d'un testacé bruuâtre. Prothorax assez pointillé, son extrémité antérieure pointue; tarière rousse, ses fonrreaux noirs ayant un iarge anneau blanc près de leur extrémitć. Femelle.

Même patrie que le précédent.

On placera en outre dans ce genre : $1^{\circ}$. Stéphane couronné., $S$. coronator. - Pimpla coronator no. 28. Fab. Syst. Piez. Ajoulez à la description : longneur 20 lig. non compris la tarière dont la longueur excède celle dı corps. Bord autérieur dn prothorax mutique; cuisses postérieures armées de dents en dessous, comme dans toutis les espèces que nous mentionnons. Tarière rousse, ses fourreaux noirs avec un anneau blanc près de l'extrémité. Antenues d'un testacé noirâtre. Femelle. Notre individu est de Java. $2^{\circ}$. Stéphane cuisses dentées, $S$. serrator. - Bracon serrator no. 29. Fab. Syst. Piez. Femelle. - Stephanus coronatus. Jur. Hyménopt. pag. 93. Mâle el feQqq 
melle. pl. 7. Femelle. - Panz. Faun. Gem. fas. 76 . fig. 13. Femelle. - Encycl. pl. 376. fig. 2. 'lemelle. D'Europe. (S. F. et A. Serv.)

STÉRÉOCÉRES: Voyez Solidiconnes. (S. F. et A. Seriv.)

STERNOXES, Sternoxi. Première dirision de la famille des Serricornes. (Vojez ce mot.) Les Sternoxes contiennent deux tribus et offrent pour caractères :

Corps toujours d'nne consistance ferme et solide, droit. - Tête engagée vericalement dans le corselet jusqu'aux yeux. - Présternum dilaté aux deux extrémités, s'avançant en devant en forme de mentonnière, se protongeant au bout opposé et s'y rétrécissant en forme de corne pointue. - Antennes ordinairemeut guère plus longues que la tête et le corselet, appliquées dans le repos sur les côtés inférieurrs de celui-ci près du sternum.

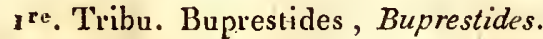

Corps n'étant point propre à sauter. - Saillie postérieure du présternum ne s'enfonçant pas dans une cavité antérieure du mésosternum. - Extrémité des mandibules entière. - Dernier article des palpes presque cylindrique, tantôt presquovoïde ou globuleux.

A. Antennes des mâles simplement pectinées ou en scie : côté interne de leurs articlès dilaté dans toute sa longueur; dents rapprochées ou contiguës.

a. Les quatre premiers articles des tarses courts, larges, aplatis, triangulaires, garnis en dessous d'une pelatte spongiense. Antennes des mâles simplement en scie; dents courtes ne formant pas de peigne ni de panache. (Palpes filiformes ou presque filiformes.)

Bupreste, Trachys, Aphanistique.

b. Tarses grêles. An̉tennes des mâles pectinées ou en panache. (Palpes sonvent terminés par un article plus gros. Pattes généralement comprimées.)

Galba, Mélasis, Phyllocère.

33. Anleunes des mâles branchues au côté interne; base du troisième article et des suivans prolongée inférieurement en un rameau élargi et arrondi au bout : celles des femelles en scie. (Port des.'Taupins. Pattes grêles; pénultième article des tarses bifide.)

Cérophyte.

Nota: Les genres Ptyocère et Ripidius de Thun. berg apparliennent peut-être à l'une des dernicres subdivisions de cette tribu.

$$
\text { 2e. Tribu. Élatérides, Elaterides. }
$$

Corps ayant la faculté de santer lorsque l'insecte est placé sur le dos. - Saillie postérieure dic présternum s'enfonçant à volontẻ dans une fossette antéricure du mésosternum et contribuant spécialement à l'exécution des sants. - Mandibules échancrées ou bifides à leur extrémité. - Palpes maxillaires terminés par un article plús grand, triangulaire ou en forme de bache. (Corps elliptique on linéaire, déprimé ; angles postérieurs du corselet ordinairement prolongés en une forte dent aiguë. Pattes en partie contractiles.)

A. Antennes filiformes ou sétacées. (Point terminées en une massue perfoliée.)

a. Les quatre premiers articles des tarses garnis en dessous de pelotles prolongée. et lobiformes. (Antennes très-rapprochées à leur base.)

Lissode.

b. Articles des tarses point munis en dessons de pelottes prolongées en manière de lobes. (Autemnes ordinairement écartées entr'elles à leur naissance.).

$f$ Labre et mandibules entièrement cachés par l'extrémité antérieure du présternum. Devant de l'épistome ou du chaperon, élargi, transverse et afpliqué sur le présieruum. (Antenues plus rappiochées à leur base que dans les suivans.)

* Point de rainure sur les bords latéraux du corselet.

Cryptosţome, Nématode.

* Une rainure de chaque côté sous les bords laléraux du corselet pour recevoir les antennes.

Eucnémis.

†f Laỉre et mandibules découverts, du moins en dessus. Extrémité antérieure de l'épistome ne dépassant guère al'entre-deux des antennes, tantôt élevée, tantôt de niveau avec la base du labre, soit arrondie, soit allant en pointe et tronquée.

* Extrémité antérieure de l'épistome sensiblement plus élevée que la base du labre, et formant souvent une tranche ou un bord aigu.

Tête dégagée, aussi large ou plus large que le bord antérieur de 
eorselet.' (Yeux trís-saillans. Corps linéaire.)

Exophthalme.

$\Upsilon \Upsilon$ Tête enfoncée jusqu'aux yenx dans le corselet, plus étroite à sa base ell y comprenant les yeux que le bord antérieur du corselet.

Hémirhipe, Taupin.

* * Extrémité antérieure de l'épistome de niveau avec la base du labre.

Ludie.

B. Antennes terminées en massue perfoliée, de trois articles.

\section{'Throsque.}

Nota. Cet arlicle est extrait des Familles naturelles de M. Latreille.

$$
\text { ( S. F. et A. Serv.) }
$$

\section{S'TERNOXES. Voyez ThoractquFs.}

$$
\text { (S. F. et A. SEnv.) }
$$

STÉROṖES, Steropes. StÉv. Schär. Lat. (Fam.nat.)

Genre d'insectes de l'ordre des Coléoptères, section des Hétéromères ( $2^{\mathrm{e}}$. division), famille des Trachélides, tribu des Anthicides.

Celte tribu contient rois geures : Stéropès, Notoxe et Xylophile. On distingue les Notoxes par te dernier article de leur's palpes labiaux formant une petite tête; par les trois deruiers articles des antennes n'tant pas beaucuup plus longs que les autres, le onzième ovale. Les Xylophiles ont les antennes allant en grossissant vers leur extrémité, leurs trois derniers arlicles guère plus grands que les précédeus et Les cuisses postérieures fortes.

Dans le premier volume des Ménoires des uatnralisies de Moscou pag. 167, M. Stéven, donne ainsi les caractères de ce genre. Quatres palpes inégaux, sécurifurmes; mâchoires unıdentées. An tenoes ay ant leurs trois derniers articles filiformes, beaucoup plus longs que.les autres.

Le type est le Stéropès castien, $S$. caspius $n^{0}$, 10. ut suprà. tab. 10. fig. 8. - Scnok. Synon. Ins. tom. 2. pag. 54. $n^{\circ}$. 1 . 'l'ête perpendiculaire, orbiculaire, noire, pubescente. Boushe et antenyes testacées. Palpes waxillaires trois fois plus longs que les labiaux, insérés sur le dos des màchoires, de quatre articles, te premier trèspetit, le second alongé, cunéiforme, le troisième un peu plus courı, obconique, le quatrième sécuriforme, le plus grand de tous. Palpes labiauxx très-courts, insérés sur le nilieu de la lèvre, de trois articles, les deux preniers tiliformes, le troisièmc tronqué obliquement, presque sécuriforme. Maudibules fortes, cornées, ar- quées, sans dentelures, terminées par une deut aiguë, entière. Mâchoires membraneuses, obtuses. Lèvre membraneuse, transparente, plus large à son extrćmité qui est troncquée. Antennes de la longueur des élytres, lemr premier irlicle obconique, les suivans de deux à huit, presqu'égaux, moniliformes, trois fois plus courts que le premier; lcs neuvième, dixièure et onzième trèsalongés, presqu'égaux, filiformes. Corselet de la grandeur de la tête, pubescent, testacé, pressqu'arrondi, un peu plus étroit vers sa base, peu convexe. Ecusson petit, arrondi. Elytres deux fois purus larges que le corselet et ayant plus de trois fois sa longueur, linéaires, pubescentes, testacées avec un point noir soyeux vers leur base; ce caractère ne se retrouve pas dans la femelle, qui du reste est parfaitenent scmblable. Dessous du corsclet ferrugineux, ponctué. Abdomen brun; palles testacées; cuisses postérieures point en milssue. Tarses de quatre articles.

Il se rouve à Kislar et sur les bords de la mer Caspienne, dans les ordures. Celte espèce n'est pas commune, elle vieut quelquefois à la lumière pendant la nuit.

Nota. M. Lalreiile dâns le Règn. anim. ainsi que dans ses Famill. natur. place ce genre parmi ses Aulhicides et conséquemment dans la section des Ilétérumères", ce qui paroit contredire le caractère de tarses donné par M. Stéven qui cep̣endant place aussi son genre Stéropès près des Anthicns. ( S. F. et A. Serv.)

STICTIE, Stictia. Iluig. Voyez Monḱdule, page 496 . de ce volume.

$$
\text { (S. F. el A. Serv.) }
$$

\section{STIGMATES ou SPIRACULES.}

On désignc ainsi les orilices estérienrs de l'appareil de la respiration, chez les arachnides et les insectes; en général ces ouveriures se présentent sous la forme d'une boutonuière plus ou moin; alongée, plus ou moins saillante, entourée d'un anneau cortú, lequel est encilussé dans une pièce à laquelle $\mathrm{M}$. Audonin a donné le nown de péritrc̀me. (Voyez 'Tronax.) Dans les insectes he thorax et surtoat l'abdomen sont les parties oie sont situés les stigmates; M. Léon Dufour ( $A n n$. des sc. nat. tom. 8, pag. 20 ) a désigné les premiers sous le nom de stignates thoraciques, et les derniers sous celui de stignates abdominaux. Dans les arachuides ils sont placés ver's le milieu du corps ou sur le dessus de l'abdomen; leur nom!re varie de deux it huit.

11. Marcel de Serres avoit reconnu deux sortes de stignates, long-temps avaut M. Léon Dufour; les premiers qu'il appelle stigmates siniples, sont les mêmes qui ont éić désignés par Léon Dufour sous le nom de stigmates abdominaux. Les stigmates thoraciques ont reçu de M. Marcel de Serres, le. nom de stigniates composés ou tré- 
maères, 'qui signifie ouverture pour l'air. Les stigmates composćs, ou trémaères, sont tonjonrs propres au thọax; ils sont composés de deux jic̀ces cornées rini, pour chaque inspiration, s'onvrent en dehors, comme les ballaris d'une porte; deux muscles upc̀reut ce unouvement et unc grosse trachée naît de chaque trémaère : on n'en a jamais trouvé que deux, on les voit distinctement daus les Sauterelles et dans les Mantes. Dans les Coléoptères, elles sont situées en arrière de la première paire de pattes, sur la peau fibreuse ct tenace qui joint le corselet ou thorax, au mésothorax; en grénéral ils ont une conformation extérieure différente de celle des stigmales simples ou abdominaux; ils sont bien plus alongés, plus minces et moins saillansque cenx-ci; leurs valves sont légèrement échancrếes sur les côlés, et ordinairement ils sont placés obliciuement à l'axe du corps. Les stigmatcs simples ou abdominaux sont ordinairement placés de chaque côté de la région dorsale de l'abdomen, sur une membrane assez épaisse, mais souple, plus on moins ridée, gui unit les segmens du dos aux plaques du ventre. Il en exisie deux pour chaque anneau, l'uu placé à droite et l'autre à gauche. Ces stigmaies ne sont pas toujour's situés ainsi nous verruns que les diverses circonstances de la vie de l'animal détèrminent leur place.

M. Léon Dufuur a examinéla structure des stigmátes dcs insectes coléoptères; nous allons faire connoitre le résultat de ses observalions : dans le Carabe doré il y a neuf paires de stignates, une au thorax et huit à l'abdomen; ceux-ci se présentent sous forme de petits boutons ellipsoïdés, saillans, bruns, lisses, luisans, durs, cornés el formés de deux valves.ou panneaux dont l'ourerture est creuse uu béante. Ils sont blanchâtres, mais d'une configuration semblable dans les Chlonius; plus ronds et plus ouverts dans les Sphodrus. Ces ostioles pneumatiques, soit du thorax, soit de l'abdomen, offrent entre les deux valves qui les constituent, une scissure des plus étroites, une fente presqu'impcrceplible pour l'inhalation de l'air. Lorsqu'on parvient à fixer convenablement cet organe sous ane forte Ientille du microscope, on découvre que le pourtour de la scisśure est garni d'un duvet excessivement fin, lien plus. marqué dans les stigmates thoraciques. Toutes ces bouches respiraloires sont abritées des influences extérieures par les élytres et par la contiguité du thorax avec la poitrine. Dans le Dy. tique marginal, le Hanneton commun; le Lucaue cerf-volant et le Capricorne héros', et sans doute dans la plupart des genres qui appartiennent aux fumilles dont ces insectes sont les types, les stigmates, au lieu de se présenter sous la forme de boutons bivalves et prolubćrans, offent ordinairement un discue ovale ou oblong entièrement découvert, qnoiqu'entouré d'un mince rebord corné (péritrème) : cc disque observé atteuli- vement à la loupe, pảroît marqué de petites ligoes transversales, à peu près parallc̀les, d'une couleur plus foncée. Le microscope fait reconnoître que ces lignes, disposćes sur deux rangées opposées, prennent naissance des deux bords contraires au bord corné, et que leurs extrémités libres sc regardent en laissant entrelles un intcrvalle linéaire qui parcourt le grand diamètre du stigmale. Chacune de ces lignes est un tronc simple ou bifurqué, dont les côtés et les bouls. émettent des fascicules, des houppes de ramificalions comme les nœuds de certaines Conferves. Ces petils pinceaux sont inégaux en longueur dans le Dytique, et l'intervalle qui sépare les detrx rangćes ve parlage point le disque en denx parties égales. Dáns le Lucane et le Capricorne, cet intervalle est parfailement dans la ligne médiané. Sprengel (Commeritarius de partibus quibus insecta spiritus ducunt. Cum lab.'Lipsia, 1815) a observé nne structure an alogue à celle que M. Léon Dufour a fiit connôitre, dans les stigmales de l'Hydrophile caraboïde. La figure que ce mème auteur donne de ceț orifice trachéal dans le $\mathrm{Dy}$ tique circonflexe, cadre fort bien avec celle que M. Léon Dufour a publiće de ce même organe dans le Dytique marginal.

Les stigmates des Myriapodes nont pas élé observés anatomiquement; ces animaux en ont un grand nombre tuut le long de chaque cĥš́ du curps.

Dans beaucoup de larvés ils ne sont pas placés aux endroils qu'ils occuperont daris l'insecte parfail; ainsi ils occupent la partie postérieure dans les larves de Diptères dont le'corps est enveloppé de coute part par le milieu qu'elles orcupent. Nous avons observé conjointernent avec M. Audouin un fait semblable. dans une larve de $\mathrm{Dn}$ nacie trouvée dans les racines d'un jonc. Tuutes ces larves sont obligées de venir à la surfáce du sol on de l'eau, présenter leurs stigmales à l'air el respirer ainsi. Les insectes parfaits qui vi= vent dans l'eau, tels que les Dytiques, Hydrophiles, etc., sont obligés de monter souvent à la sinface du liquirie pour présenter leur sligmate à l'air ; alors ils soulèvent un peu leurs élytres, et l'on voit que l'air s'attache aux poils et au duvet dont tout le dessus de leur corps est garni, et gue ces insectes l'emportent avec eux au fond de l'eau. Dans les lasves des Libellules, le sligmate postérieur est converti en une valvule tricuspide, située près de l'anus, et qui reçoit seule tout le ligquide qui doit servir à leur respiration. On a remarqué depuis long-temps que le second et le troisieme anneaux des Chenilles sont dépourvas de stigmates et par suile de trachées propres; M. de Blainville a cru voir dans celle absence la prenve que les ailes n'éloient autré chose que des trachées renversées. Celles-ci, rudimentaires dans le corps de la larve, ne se développeroient, suivant lui, que successivement et avec toutes les autres 


\section{S T. I}

parties qui eonstitnent l'insecte parfait. Si les quatre ailes dı thorax représentent les qualı stigmates et par suite les quatre trachées, M. Andouin pense que ces parties doivent s'exclure muluellement, et que le thorax d'un insecte parfait ne devia janıiis offrir à la fois des ailes et des stigmales : or, l'observation prouve qu'indépendamment des"ailes on trouve des stigmates thoraciques.

M. Mauduyt, dans le discours préliminaire de ee Diclionnaire sur les inseetes, a parlé des-stigmates et.a rapporté les exjéricnces qui pronvent que "ce sont les ouvertures de la respiralion chez les insectes. Nous renvoyọs à ee discours, page 3i. (E: G.)

STIGME, Stigmus. Jor. Latr. Panz.

Genre d'insecte de l'ordre des.Hyménoplères, section des Porle-aiguillon, famille des Fouisseurs, tribu des Crabronites.

Un groupe de celle tribu a pour caracières : antenues insérées au-dessous du milieu de la face antérieure de la têle; elaperon cour'c et large; yeux entiers. Il renferme, outre les Stigmes, lcs yenres Melline, Alyson el Goryte doni les ailes supérieures offrent quatre cellibles cubitales; les Pemplrédons, distiagués par la forme de leur troisième eellule discoid alc ou l'infórieure qui est fermée par une nervuse transversale et n'alteint pas le bout de l'aila, d'où il suit qu'il y a deux nervures récurronles; enfin le genre Crabron, dont les prenières ailes n'out seulement que sicux cellules cubitales et ehez lesquels. la cellule radiale est appendiculće.

siitennes filiformes, insérées au-dessous du milieu de la face antérieure de la tête, composées de douze arlicles dans les fentelles, de treize dans les mâles, la plupart de ees articles moniliformes. - Mandibules grantes, trizdentées vers leur extrémilé. - Palpes maxillaires fort longs, filiformes: - Tête grosse, earrée; chaperon eourt et large. - Yeux entiers, grands, elliptiqucs. - Trois ocelles rapprochés"en triangle sur le vertex. - Corps étroit. - Corselet ovale : prothorax étroit, formanl un rebord en avant du mésothorax, prolongé en con à sa partie antérieure; mésothorax bọmbé; métatliorax arrondi postérieurement, un peu eannelé en dessus. - Ecusson grand, point saillant. - Ailes supérienres ayan! un point marginal grand é épais, une eellule radiale assez grande, large à sa base, se rétrćcissant fortement immédialement après la seconde cubitale, terminée en pointe, saus appendiee; trois eellules eubitales, la première assez grande, presque earrée, reeevaut dans son milieu la première nervure réeurrente; seconde cellule cubitale petite, earrée; troisième, ni eommenée, ni tracée; truis cellules discoidales dont la troisième on linférieure atteint le bout de l'aile, la seconde nervure manquant. - Abdomien formé de cinq-seg- mens dans les femelles, en ayant un de plus dans les mîles, marifesteuneat pétiolé, cẻ pétiole composé de la moilié antéricurc du prenicr segment qui s'úvase pnsuite subitenent.- Pattes forles, cuisses renflées dans leur milieu; jambes point épineuses; les postérieures ayant seulement deux ou rrois épines : tarses filifornes.

Il est probable, d'après la conformation "ie leurs pattes, gue les Stigmcs sont inasiles, c'està-dire qu'ils vont pondre dans le rid de quelques Fouisseurs qui approvisionnent eux-mêmes ees nids pour: leur postérité.

Le norn de ce genre est tirć de la grardeur ct de l'f́liasseu: du poist marginal des premièr's ailes qu'on a long-temps appelé inin roprement stigmate. Les anteurs n'en mentionuent que deux espèces, toutes deux fort pelites et que l'on rencontie quelquefois sur les fleurs. La seule que nous counoissions es! le Stigne âtre, $S$. ater. Jur. Hynźnopt. pag. 15g. Mâle et femelle. pl. 9. - LAT. Gener. Crust. ct Ins. tom. IV. pag. 84. - SPINol., Ins. Ligur. fas. 3. pag. 174. m॰. 1. - Stigmus pendulus. Panz. Faum. Germ. fils. i $4 . \mathrm{fg} .7$. Le mâle probablament. Des environs de Paris.

\section{(S. H. et A. Sery.)}

STILBE, Stilbum. Spinor. Lat. Chrysis. Linn. Oriv. (Encycl.) Koss. Jur.

Genre d'insectes de l'ordre des Hyméuoptères, section des.'Térébrans, famille des Pupivores, tribu des Chrysides.

Un'groupe de Chrysides a pour caractère ( vojez pag. 253. dc ce rolume) : corselet poinl rétréci en avant; abdomen voûté en dessous ; máchoires et lèvre courtes, n'ćtant pas prolongéex en trompe; milieu du métalhorax avancé en une pointe scutclliforme. Ce groupe renferme, oure le gcnre Stilbe, ceux d'Liampe el de Pyrie ( Calliste loc. citat.). Mais daus ces deux derniers, l'abdomen ne présenle aucun bourrelet transversal sur l'anus on dernier seganent.

Antennes filiformes, coudées, vibratiles, insérées près de la bouclue, composées de treize articles; le premier fort long, les autres presqu'égaux, courts. - Labre eorné, court, arrondi. - Riandibules triangulaires, aiguës, sans aucunes dentelures ni échancrure à leur côté interne. - Mâchoires s'avinçant eonjointement avec la lèvre et le menton. - Palpes inégaux; les maxillaires de cing articles, les labiaux plus courts que la lèvre, triarticulés. - Lèvre simple, meabraneuse, plus longue que les mâchoires et les palpes, son bord exterue profondément éehareré : menton corné, arrondi à son extrémité. - Téte transversale, un peu plus étroite que le corselet, ayant une dépression frontale large, ovale-arrondie. - Yeux ovales, presqu'angruleux à leu. parlie supćrieure. - Trois ocelles placés en triangle sur le front; l'antérieur dans la dépression frontale, à son bord supérieur, les latéraux hors do 
la dépression, très-près des yeux à réseau. Corps convexe. - Corseliet très-bonbé ell dessus; inétathorax ayant sa partic moyenne séparée de l'antćrieme par un sillon et arancée en une pointe seutelliforme fortement creusée en. dessus. Ailes supérieures ayant une célule radiale trèsincomplète; detx cellules cubitrles; la première recerant la première nervure récurrente, fermée par une nervire transversale seulement tracke: seconde cellule cubitale eonimencée, n'alleignant pas le bout de l'aile, traverséa longiludinalement par une nervure qui part du milieu de la riervure transversale dont nous venons de parler; trois cellules discoirtales; la seconde supérieure n'ćtant pas complétement fernée postérieurement, la troisième ou l'inférieure n'alteigna ot pas lé bout de l'aile et n'étant pas fermée par une nervure transversale, seconde nervure récnrrente manquant. - Abdomen très-houbé en dessus, composé de trois segnmens apparens; le second beauconp plus grand que les autres; le troịsième ou anus ayant un bourrelet transvęrsal très-prononcé et une ligne de points enfoncés au dessous du bourrelet : une tarière (dans les'femelles) longue, rétracti'e, son extrómité restant toujours un pei saillante même daus.le repos: un aiguillon rétractile ayant sá sortie un peu avant l'extrémité de la tarière. - Pattes de longueur moyenne; jambes postérieures lógèrement eonıprimées; tarses alongés, leur prẹmier article le pius griand de tous.

Le nom donné par M. Marimilien Spincla à ces Hyménoptères vient du grec et sionnitie : brillant. Les mœur's des Slilbes sont iés wếmes que eelles des Euchirées. (Foyez ce mot pag. 8. de ce volume.) Les espèces connues habitent les contıćes n:éridivuales de l'ancien continent.

\section{Stilbe splendide, S. splendidum.}

Stilbum splendidum. Sinol. Ins. Ligur. fas. 1. pag. 9. - Chrjsis splendida $1^{\circ}$. 1. Fав. Syst. Piez. - Leper. Mém. surles Porte-tuyaux. Ann. dıs Müs. $n^{\circ} \cdot 9$.

Voyez pour la description et les autres synonymes Clirysis splendide $n^{\circ}$. 1 , de ce Dictionmaire.

\section{STIrse brûlant, S. calens.}

Stilbum calens. Spivor. Ins. Ligur. fas. '1. pag. 9. - Chrysis calens. ${ }^{\circ}$. 4. F Ав. Syst. Piez. - LEece. Mém. sur les Porte-tuyaux. Ann. du MIus. $n^{\circ}$. Io.

Voyez pour la description et les autres synonymes Chrysis brûlant no. 5. de ce Dietionnaire.

Nota. Il est probable que la Chrysis améthystine $n^{\circ}$. 4. Encycl. - Chrysis amethysiina. FAB. LIPEL. est aussi de ce genre.
PYRIE, Pyria (1). Chrysis. Far.

Genre d'insectes de l'ordre des Hyménoptères, section des Térébrans, famille des Pupivores, tribn des Chrysides.

Un groupe de celte tribu (voyez pag. 253. de ee voluine) eontient les genres-Stilbe, Pyrie et Elampe. Le premier se distingue par le bourrelet transversal fort élevé qu'offre l'anus ou troisième segment de l'abdomen, et tes Elampes parce que ce mème segment n'esi point pluridenté dans ces insectes, wais simplement échancré dans son milieu.

La plupart des caractères que prísente ce nouveau genre sont ceux des Stilbes saul les suivans : Tête sans dépression frontale. - Trois ocelles rappróchís en triangle sur "le vertex, les latéraux notablement distans des yeux à réseau. - Corselet un peu convexe : avancement scu:elliforme du métathorax convexe ou plane en dessus. - Ailes supérieures ayant une cellule radiale grando, fort longue, à peu près complète, alleignant presque te bou! de l'aile; une seule cellule cubitale esşuissée presque jusqu'au bord postérieur, reçevao la première nervure récurrente $t$ séparée dans a parlie inovenne par une nervuro longitudinale un peu empiâtće à sa base. - $A b$ domen corivese eu dessus; son second segment guère plus grand que les autres; le troisiène ou anus dépourva de bourretet transversal, ayant seulement une ligne de poinls enfuncés : son bord postérieur pluridenté.

Ce genre coinfondu jusqu'ici avec les Chrysis, s'en éloigne ${ }^{\circ}$. par la forme du inétáthoraa qui dáus les Chrysis est convexe, sans aucun avancement scintelliforme. $2^{\circ}$. Par lés ailes supérieures offiart, dans ce même genre, une cellule radiale moins longue, fermée ou presque fermée bien avant le bout de l'aile et par la cellule cubitale qui est loia d’ètre trácée jusçuau bord postérieur et dans litquelle on ne voit pas cette petite nervure longitudinale qui existe dans les Pyries et les Stilbes.

Le rom générique cst tiré du grec; il exprime la couleur brillante dont le corps de ees Hyménoptères est paré. Les nœur's doivent être les mêmes que celle; des autres genres de leur tribu. (Vojez Euchríe pag. 8. de ce volume.) Le nombre des dentelures qui terminent le dernier segment de l'abdomen est variable; nous en profiterons pour diviser ee genre, en ayant soin de donner un type à chacupe de ces divisions.

${ }_{1}^{\text {re }}$. Division. Anus à six dentelures.

1. Prané émeraude, P. smaragdula.

(1) Nous substituons ce nom à celui de Calliste mentionné dans le cabieau des Chrysides, pag. 253. de ce volume, parce que ce nom de Calliste a été donué par M. Buncili à un genre de Carabiques. 
$P$,ria viridi-riolacea, antennis nigris, ano seirdentato; alis fuscis.

Longueur 4 lig. $\frac{r}{2}$. Corps très-ponclué, d'un vert-dọré changeant en violet. Avancement scutelliforme du métathorax de longueur moyenne. Pattes de la couleur du corps. Antennes noires. Ailes enfunées. Anus muni de six dentelures à son extrémilé. Mâle.

De Cayenue.

Nota. Cetle espèce ne nous paroit pas êtı la Chrysis smaragdule $n^{\circ} .3$. de ce Jictionnaire, Chrysis smaragdula no. 2. Fав. Syst. Piez. vu qué les auteur's comparent cette dernière à la splendida dont notre espèce est bien loin d'avoir la taille, et gu'ils ne parlent pas du prolongement qu'offre le métathorax.

\section{$\mathbf{2}^{*}$. Division. Anus à cinq dentelures.}

Là nons plaçons la Chrysis lusca no 7. F FaB. Syst. Piez. - Pyria lusca. Noв. La dent intermédiaire de l'abdomen est plus courte que les quatre latérales. D'Italie.

3e. Division. Anus quadridenté.

\section{PYRIE armće, P. armata.}

Pyria viridi-aurea, antenmis nigris, ano quadridentato; alis prosertim basi et margine externo fuscis.

Longneụr 6 lig. Córps très-ponctué, d'un vertdoré, Pat'es de celte nềme couleur. Antennes noires. Anus ayant un reflet violet, niuai de quatre dentelures à l'extrémité. Avancement scutelliforme du métathorax très-prolongé , presqu'aigu. Ailes enfumées, brunes à leur base et le long du bord externe. Màle et femelle.

D'Afrique.

$4^{\circ}$. Division. Anus tridenté.

\section{Prnie trident, $P$. tridens.}

Pyria viridi-aurea, antenris nigris; ano tridentato : alis subfuscis.

Longueur 5 lig. Corps Irès-ponclué, d'un vertsombre, doré et nuancé de violet : pattes de la conlëur du corps. Antennes noires. Avancenent scutellilorme du métathorax moins prononcé que dans les autres espèces. Extrémité de l'anus offrant trois dents, l'intermédiaire forte, aiguë, provenant d'une carène élevée qui traverse la ligne de points enfoncés, ceux-ci violets. Aỉes enfumées. Femelle.

Des Etats-Unis. (S. F. et A. SERt.)

STILIQUE, Stilicus. LAt. (Fam. nat.) Parderus. Fab. Oliv. Graten. Gyll. Panz. Payk. (Foun. Suec.) Staphylinus. ParE. (Monogr.)
Genre d'insectes de l'ordre des Colíopieres, section des Pentanières, famille des Brachélytres, tribu des Longipalpes.

Des quatre genres que renferme celle tribu (voyez Longipalpes, pag. 482. de ce volume), celui de Siène esı le seul qui ait les antennes insérées an hord antérieur des yeux. Dans les Evæsthètes tes antenues sont sulitement en massue: celles des Pédères vont en grossissant insersiblement vers leur. extrémité, cn outre res derniers ont le quatriène article des tarses bifide.

Les Stiligues ont beancoúp de caractères com:muns avec les Pédères, ceux qui les en distinguent, sont : antennes filiformes, leurs derniers articles globuleur. Têle ovale, grande. Palpes maxillaires moilié plus courts que la tête, leur dernier article tantôt très-petit, aciculaire, distinct; tantôt peu visible $\epsilon t$ ne formant qu'une petite pointe aiguë à l'extrémité du précéden: Corselet presqu'ovale, rétréci antérieurement et à sa partie postérieure. Quatrième article des tarses entier et de même forme que les précédens.

Ces Brachélytres habitent dans les ordures et sọns les pierres comme les Pédères.

On rapportera à ce genre, $1^{\circ}$. Stilique orbiculaire, $S$. orbiculatus. - Predère orbiculaire n ${ }^{0} .7$. (Encycl.) $2^{\circ}$. Stilique fragile, S. fiastilis. Pædère fragile no. 8. Encycl.

$$
\text { (S. F. et A. SERV.) }
$$

STízE, Stizus. Lat. Jur. Spivol. Bembex. Fab. Oliv. (Encycl.) Crabro. Fab. Ross. Larra, Liris, Scolia. $\mathrm{F}_{\mathrm{AB}}$. Larra. Tllig. Mellinus. P $\mathrm{ANz}$. Sphex. Dки R.

Genre d'insectes de l'ordre des Hyménoptères, section des Porte-aiguillon, farnilic des Fouisseurs ( $2^{\mathrm{e}}$. division), ribu des Bembécides.

Cette seconde division des Fonisseurs a pour caractères : prothorax fort ceurt, en lorme de rebord transversal, linéaire et séparé dans toule son ćtendue par uu intervalie notable de l'origine des ailes supérieures. Elle reuferme les quatre dernières tribus de la famille, savoir : Bembécides, Larrates, Nyssoniens et Crabronites.

Lal tribu des Bembécides présente les caractè̀res suivans : labre entièrement déconvert, trè:saillant; cette tribu contient les genres Bembex, Monédule et Slize. Dans les deux premiers, lé labre forme un triangle alongé; leurs mâchoires et leur lèvre se prolongent en une promuscirle tléchie.

Anterines grossissant insensiblement vers l'txtrémité, amincies vers leur base, insérćes nn peu au-dessous du milieu du fiont, de douze articles dans les femelles, de treize dans les mâles; le premier court, conique, le troisième alongé. Labre entièrement découvert, semicirculaire. Mandibules sans dents ou n'en ayant qu'une trèspetite à leur partie interne. - Mâchoires et Lèvre 
avarcées, mais point prolongées en une promuscide, ni fléchies. - Palpes maxillaires avançant au-delà de l'esırémité des mâchoires, de six articles, le second et le troisieme les plus longrs de tous; tons deux cylindriques; les derniers courts : palpes labiaux de quatre articles. - Lère petite, semicirculaire. - Téte transversale. Yeux grands. - Trois ocelles disposés en "ingle. - Corps gros. - Corselet ovale; prothorax court, ne formant qu'un rebord transversal, très-éloigué de la base des ailes. - Alles supérieures ayant trne cellule radiale dont l'extrémité postérieure s'arrondit un peu en s'appuyant contre le bort extérieur; quatre cellules cubitales, la seconde fortcment rétrécie près de la radiale, recevaut les deux nervures récurrentes; quatrième cubitale ordinairemeut comnencée, et trois cellules discoidales complètes. - Abdomen cońvexe, un pen conique, de cinq segmens outre l'anus daus les femelles, en ayant un de plus dans les mâles; anus de ceux-ci armé de trois pointes spiniformes. - Patles forles, de longueur moyenne; jambes et tarses armés d'épines; dernier-arlicle de ceuxci muni de denx forts crochels simples, ayant une grosse pélotte dans leur entre-deux.

M. Tutreille a nommé ce genre-Stize, d'na verbe grec qui signilic : piquer. Les mœurs de ces Hyménoptères ne sous sont pas comnues, mais leur organisation nous démontre quils creusent dans le säble et approvisionneut eux-mêmes leur nid; ils se plaisent dans des localités trís-chaudes et par conséquent alpartiennent plus aux pays méridionaux qu'aux latitudes froides.

1re. Division. Cellule radiale des ailes supérieures longue, dépassant la iroisième cellule cubitale; première nervure récurdeule droile. Ocelles placés sur le front.

\section{Strize spécieux, $S$. speciosus.}

Stizus niger; capite thoraceque ferruginco villosis : abdonuinis segulentonum primi, secundi,

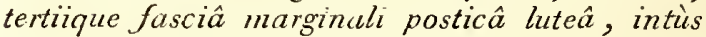
sinuatâ, lateribus auctâ recurvâa; pedibus fermgineis ; alis ferrugineo-hyalinis, apice subviolaceo micantibus.

Sph̆cx speciosus. Dror. Ths. tom. 2. pl. 38. fig. 1. Femelle. - Encycl.pl. 382. fig. 6. Femelle. Le nom de Stizus vespiformis donné à cette figute dans l'explication des planches ne peut laï ềre conservé, et doit rester à l'espèce que Fabricius désigne sous le nom de Larra vespiformis.

Longuêur 15 liğ. Noir; tête et corselet converts d'un duvet ferrugineux. Chaperon et labre jaunes. Abdomen noiratre, ses trois premiers segmens ayant une bande jaune à leur bord postérieur, fortement sinuée à sa partie intćrieure, s'élargissant beaucouṕ sur les côtés et y formant une sorle de crochet. Pattes d'un jaune ferrugineux; ailes transparentes, jaunâtres, ayant un roflet violacé sur l'extrémité et le bord iuternẹ. Màle.

Parrie inconune.

On placera en outre dans cette division le Stize de Hogard, S. Hogardii. Lat. Gener. Crust. et Ins. tom. 4. pag. 100. tom. 1., tab. 13. fig. 12. De Saint-Domingue.

$2^{\mathrm{e}}$. Division. Cellule radiale des ailes supérieures coutte, plus éloignée du bout de l'aile que la troisiène cellule cubitale; preñière nervure récurrente courbe. - Ocelles placés sur le vertex.

\section{Sтize ruficorne, S. ruficornis.}

Stizus ruficornis. LAт. Nouv. Dict. d'hist. nat. ire. édit. - Larra ruficornis n ${ }^{\circ}$. 9. FAB. Syst. Piez. Mâle:

Voyez pour la description et les autres synonymes BEMBEx ruficorne $n^{\circ}$. 4. de ce Dictionnaile.

Celle seconde division contient en oulre: $I^{\circ}$. Slize vespiforme, S. respiformis. - Larra vespifor.'lis no. 1. Faв. Syst. Piez. Des Indes orientales. Nous ajouterons à la description que le prolhorax et le bord pustérieur du premier seguent de l'abdomen sont ferrugineax. $2^{\circ}$. Sire bifiscié, S. bifasciatus. Lat. Noup. Dict. d'hist. nat. ${ }_{1}$ re. édit. - Jur. Hyménopt. pl. 14. Mâle. - Enc ycl. pl. 378.fig. 8. Màle. - Larra bifusciata no. 6. FAB. Syst. I'iez. Femelle. - Scolia tridentata $\mathrm{n}^{\circ}$. 22. FAB. id. Mâle. Du Midi de l'Europe. $3^{a}$. 'Stize sinuc, S. sinuatus. LAt. id. Crabro tridens no. $25 . \mathrm{F}_{\text {i }}$. id. Mâle. Celte espèce se recontre quelitutois aux envitons de Paris. Le Mellinus, rpundus. Paxz. Faun. Gemm. fas. 73 . fig. 19. n'en est peut-être qu'une variélé.

Nota. On doit langer encore parmi les Stizes, mais sans que nous puissions indiquer dans quelle division, $1^{\circ}$. Siize crassicorne, $S$. crassicomis. LAт. Règn. anim. tom. 3. pag. 499. - Larra crassicormis no. 5. Fав. Syst. Plez. C'est probublement la même espèce que le Bembex rufipède no. 12. du présent Didliunnaire. $2^{\circ}$. Stize érythrocéphale, S. erythrocephaliss. LAt. id. Larra erythrocephala $\mathrm{n}^{\circ}$. 2. FAB. id. $-3^{\circ}$. Stize à ceinture, S. cinctus. L.Aт. id. - Iarra cinctu n०. 3. FAB. $i d .4^{\circ}$. Stize anal, S. analis. LAt. id. - Larra analis n०. 8. FAB. id. 5o. Stize à bande, S. cingulatus. LAт. id. - Larra cingulata no. ro. Fab. $2 d .6^{\circ}$. Slize front roux, $S$. rufifrons. LAT. id. - Larra rufifrons $\mathrm{n}^{\circ}$. 11. FАв. id. $7^{\circ}$. Stize bicolor, S. bicolor. LAT. id. - Larra bicolor uo. 12. FAB. id. 8\%. Slize fascié, S. fasciatus. LAт. id. - Larra fasciata no 13. kAB. id.

Monédule, Monedula. Lat. Bembex. Jur. OrIv. (Encycl.) Stictia. Iturg. Vespa. Lirn. DE GÉER. 
Geure d'insectes de l'ordrc des Hymóunptères, section des Porte-aiguillon, famille cies foulisseurs (2e. division), tribu des Bembécides.

Trois genres entrent dans cette tribu (voyez pay. 495 ) : celui de Stize est reconnoissuble par la forme semicirculatire de son labre et par ses mâchoires et sa lèvre qui ne sont point prolongrés en manière de promuscide. Dans les Bembex les palpes maxillaires sont très-courts, composés seulement de quatre articles, selon M. Latreille; tandis que les palpes latiaux n'en ont gue deux, suivant ce nêtue aulcur; la troisic̀ne cellule cnbitale des ailes supérieures n'est point rétrécie rer's la radiate, en sorte qu'il n'exis'e pas d'angle remarrguable cutre les extrémités de cos deux ce!lules.

Antennes coudćes, rapprochécs à leur base, in:ćrées assez près de la base du chaperon, de donze articles dans les femeiles, de treize duns les mâles, le premicr long, assez yros, presque cylinúrique, le second tres-petit, le troisienese forl alonge, ceux de cinç à onze ordinurement dilatés à leur partie postérieure dans les deur sexes, mais plus sensiblement dins les mâles. Labre grand, trigone. - Mandubules iridentées au côté intcrue, se cruisant l'unc sur l'autre audessus du labre duns le repos. - Mâchoires et Lère rròs-longues, linéaires, s'avançant ch une promuscide fléchie. - Palpes tres-grôles, sćtacés; les maxilluires attcignant l'extrémité des mâchoires, composés de six articles; les lakizux de qualre. - Lèrye ayant ses lobes latóraux sé:ifurmes, lintermédiaire linćance - T'ête transtersale, au moins aussi large que le corseler; chaperou transversal, son buráantérieur ćchancré, ayant ses angles latéraux tronqués. - Yeux grands. - Trois ocelles assez distans los uns des autres, placés en triangle sur le vertex. - Corps gros, puliescenl. - Corselet bombé ; prothora: court, ea cóne écrasé, séparé dans toute son étcndue, par un intcrvalle notable, de l'origine des ailes snapérieures; métathorax tronqué droit postérieurement. - Ecusson transversal, peu élevs. Ailes grandes, les supérieures ayant unc ceilule radialc allant un peu cn se rérécissant après la troisième culitale, son extrénité pustérieurc arrondie, s'ćcartunt un pen de la côte; quatre cellules cubitales, la première presqu'aussi longue que les trois autres prises ensemble, en triangle alongré, son sommet ou angle aigu dirigé vers la base de l'aile, la secunde furt rétrúcie vers la radiale, recevant les deux nervures récurrenles; la troisieme rćlrécie vers la radiale; en sorle gu'il exisle un angle renirant très-prononcé entre l'extrémité postérieure de cette troisième cubitalc et la radiale; quatrième cubitale fort courte, atteigrant presque lo bout de l'aile; trois cellules discoidales complètes. - Abdomen conique, de cinq segmens outre l'anus dans les femelles, en ayant un de plus dans les mâles : ce deraier sexe a ordiHist. Nat. Ins. Tome $X$. nairement un tuhercule sur le milicn du second s'gunent de l'abdomen en dessous et l'anus tridenté. - Pattes fortes, assez courtes; jambes et tarses armés d'épices : dernier article de ceux-ci nuni de deux forts crochets simples, ayant une grosie pelotle dans teur entre-deux.

Les Munciules sont d'une taille au-dessus de la moyenne et propres à l'Amérigue; elles oat les mêmes mours que les Bembex; la structure de ces insccles pruuve qu'ils sont ćminemment fouisscurs et qu'ils doivent approvisionner eax-mêtules leur nid. Cumme les muar's des Bernbex étoient mal conmes a l'époque où l'on trita cie ce genre duns ce Dietionnitire, uous allons en donner des lítails caracls d'après nos propres observations. Les lomelles creusent cies luyaux obligues daus les sables mouvars et les approvisionnent de Diplères parvenus à leur étal parfail : le Zembex rostrata s'empare indifírenmout d'Eristales, de Strationndes et des plus grosses espèces du genre Musca, lelles que la vomitoria. Le Bembex tarsata, suivant les observations de M. Läreille, approvisione son nid de Bombyles. Chaque cellule devant rentermer ciuq à six individus de ces différens Diptères : lit nère va souvent à la chasee a l'époqque de sa porite; tontes les fuis qu'elle critte sa cellule pour aller chercher une proie, elle en bourhe l'entrée avec du sable et siit fort bien la retronver à son retour. Quoique faisaut leur nid isoléwent, le même lieu convicul ordinairement à un assez grand nombre de femelles, uous cn avons vu plusienrs fois une irentaine occupées à ce travail dans mu espace sablonneus: d'â pea nròs vingt pieds de dianctre. Lorsque la femelle Bembex a amassé toute la provision nécessaire à chacune de ses larves, elle pond un seul œuf dans chaque cellule et la rebouche soigneusement avec diu sable qu'elle entasse dalls toute la partie da tuyau qui restoit vide. Certaines Chlysides, entr'autres le parropes carnea, dófosent leurs oufs dans ces nids, aussi la natme a-t-e!le accordé a cente deinière espèce des épines anx jambes et aux tarses postérieurs conme elle l'a fait pour les vrais fouissenrs; c'est en l'absence de la mère dont elle a épié les démarches que la femelle Parnopès ronvre le nid du Bembex, on l'y voit entrer à reculons, ce qui annonce sans aucun doute l'intention d'y pondre. Il est probable qu'elle n'y dépose qu'un seul œuf', car on na tronve ordinairement qu'uue senle larve de Parnopès, occupée vers le commencement du priniersps à sncer la larre du Bernbex sur le dos de lacinelle elle se ticnt cramponnée (1). Celle-ci pendant l'automne précédent avoit pris tout son accıoissement en se nourrissant des Diptères déposés dalls sa cellule. Les Bembex out le vol puissant et accompagné d'un bourdonnement fort, coupé et

(1) Obseryations faites nouyellement.

RrE 
aigru, comme l'avoit déjà fort bien remarqué M. Latreille. Ces observalions ont été faites tant à Fontainebleau qu'aux environs de Sézanne et au bois de Boulogne.

\section{Monédule vespiforme, M. signata.}

Monedula signata. Lıт. Gener. Crust. et Ins. tom. 4. pag. 100. - Bembex signata $\mathrm{n}^{\circ}$. 3. FАв. Syst. Piez.

Voyez pour la description et les autres synonymes, Bembex vespiforme no. I. du présent ouvrage.

\section{MonédULE variée, MI. variegata.}

Bembex maculata no. 2. Fab. Syst. Fiez.

Voyez pour la description Bembex bariolé nº. $^{\circ} 1$. de ce Dictionnaire.

On doit comprendre en outre dans ce genre, 10. Monédule de la Caroline, MI. Carolina. Lat. Gener. Crust. et Ins. tom. 4. pug. 100. - Bembex Carolina no. 11. FAв. Syst. Piez. 20. Monédule continue, MI. continua. LAт. id. - Bembex continua $n^{\circ}$. 15. FAB. id., et peut-être aussi les Bembex héros $\mathrm{n}^{\circ} .1$, punctatio $\mathrm{n}^{\circ} .4$, filsciata $\mathrm{n}^{\circ} .6$, americana $\mathrm{n}^{\circ} .13$, spinosa $\mathrm{n}^{\circ} .14$, lineata $\mathrm{n}^{\circ} .16$, striata $\mathrm{n}^{\circ} .17$, et ciliata $\mathrm{n}^{0} .2 \mathrm{I}$. Fab. id. (S. F. et A. Serv.)

STOMAPODES, Stomapoda. Dans l'ouvrage sur le Règne animal de M. le baron Cuvier, jai désigné ainsi un ordre de Crustacés, comprenant le genre Squilla de Fabricius, et duquel j’ai séparé !'espèce qu'il nomme vitrea, pour en former celui d'Erichthe, que le docteur Léach a nommé Sinerdis. J'ai rapporlé depuis (nouveau Diction. d'hist. nat. $2^{\mathrm{e}}$ édit.), au mềne ordre, une aulre conpe générique, établie par ce dernier naturaliste sous le nom de Phyllosonce, mais qui, ̀̀ raison des formes singulières de ces animaux, doit former une famille particulière.

Les Stomapodes ont, ainsi que les Décapodes, les yeux portés sur des pédicules articulés et mobiles, quatre antennes, un grand test ou carapace et des mandibules palpigères. Mais outre que les pieds-mâchoires ont déjà la forme de véritables pieds, le test est divisé en deux parties, dont l'antérieure porte les yeux et les antennes intermédiaires, ou constitue la tête, et les branchies sont annexées aux cinq paires de pattes natatoires du dessous di post-abdomen, ou de cette partie du corps qu'on nomme queue, et qui, de même que dans les Ecrevisses, les Salicocques et autres Décapodes à longue queue, est toujonrs terminé par une nageoire en éventail et formée des mêmes pièces. Plusieurs de leurs pieds (les six derniers dans les Squilles) ont ordinairement à l'extrémité de leur second artiele un appendice filiforme, formant une sorte de rameau, les branchies n'é- tant plus situées, comme dans les Décapodes, sur les côtés dı thorax, mais en arrière des pieds; le cueur a reçu une forme alongée.

Suus le rapport de l'écaille latérale accompagnant dans plusieurs les antennes latérales, de la ténuité du test, de la mollesse dn corps et d'autres caractères, ces Crustacés avoisinent évidemment les Salicoques et les derniers Décapodes macronres. Ils sont tous marins. Leurs différences sexuelles ne sont pas encore bien déterminées; je n'ai point trouvé d'ceut's sur aucun des individus que j'ai examinés.

Dans mon onvrage sur les familles naturelles du Rèyne auimal, $j$ 'ai divisé cet ordre en deux $f a$ milles, les Unipeltés, Unipeltata, et les BipesTÉs, Bipeltata.

PREMIÉRE FA MITLE.

\section{Unipeltés, Unipeltata.}

Corps étroit et alongé. Test long, avec un article antérieur portant fes antennes interacédiaires et les yeux. Les pieds-mâchoires et les quatre pieds autérieurs terminés par nue main monodactyle ou en grifie, et dont le doigt ou le tarse est mobile, en forme de crochet; les seconds piedsmâchoires très-grands, faisant plıs particulièrerement l'office de serres; les six derniers pieds nalatoires terminés par un article en forme de brosse. Antennes latérales ayant à leur base une écaille; les intermédiaires à trois filets. Post-ab)donzen long.

Nota. Pédicules oculaires courts ou pen alongés. Les six pieds natatoires accompagnés dans le plus grand nombre d'un appendice latéral ; extrémité postérieure du corps épineuse on dentée.

Les gemies: SQuille, Gonodactyre, Coronide, Ericuthe, Alime. Voyez SQuilis.

DEUXI ¿̇ ME FAMILLE.

\section{Bipeltés, Bipeltata.}

Corps aplati, membraneux, diaphane. Test divisé en deux boucliers, dont l'antérieur très-grrand, plus ou moius ovale, composant la tête, el dont le second transversal, anguleux dans son contour, portant les pieds-mâchoires et les cinq paires de pieds proprement dits; les pieds, à l'exception des deux derniers, et les deux pieds-mâchoires postérieurs grêles, filiformes, et pour la plupart très-longs ; les quatre pieds-aıâclıoires supérieurs ou antérieurs très-petits ou coniques. Post-abdomen très-petit. Antennes latérales sans écailles à leur base; les intermédiaires à deux filets.

Nota. Pédicule oculaires souvent fort longs.

Le gente PhyLlosome. (Latr.) 
STOMOXE, Stomoxys. Gropt. Far. Ross. Panz. Meig. Conops. Linn. Schranck. Empis. Scopol.

Genre d'insectes de l'ordre des Diplères ( 1 re. section), famille des Athéricères, tribu des Conopsaires de M. Latreille. Voyez Stomoxydes.

La seconde division de cette tribu comprend les genres Bucente, Prosêne et Stomoxe. Le premier diffère des Stomoxes par la soie des antennes aue, la trompe coudée verss son milieu, ayant son extrémité dirigée en arrière dans le repos; le seeond parla soie anténnaire plumeuse des deux côtés et la trompe plus longue que le corps, sans renflement sensible à sa base.

Antennes couchées snr l'hypostome, presquanassi longues que lui, composées de trois articles, les deux preniers courts, le troisième alongé, linéaire, comprimé, un peu arrondi et obtus à son extrémité avee une soie dorsale triartieulée; la seconde articulation grosse, manifestement plus longue que la premiêre; liı troisième demi-plumeuse a'ayant de barbules qu'à sa parlie supérieure. - Trompe courte, dure, eornée, piquante, dépassant la tête, loorizontale, articulée a sa base; la partie qui suit cette artieulation trc̀s-rentlée jusque dans son milieu, dirigée en avaut mêwe dans le repos. - Lèvres très-eourtes. - Palpes pius ou moins longs, presque linéaires, un peu ciliés, insérés sur la base de la trompe. Hypostome perpendieulaire avec deux carènes latérales saillantes; bords de la cavité buecale garnis de cils longs et rides : front large dans les femelles, ayant de chaque eôté une ligne de longrs poils roides. - Yeux elliptiques, presqu'angileux à leurs deux extrémilés, rapproehés ei se touchant dins les máles. - Trois ocelles rapprochés en triangle sur un tuberer.le du vertex qui porte aussi quelques soies longues et roides. Corps eourl, hérissé de poils roides. - Prothorax distingué da mésolboras et séparé de lui par une ligue transviersale enfoncée, très-prononcée. Áles velues vues au microscope, éeartées l'une de l'aurre dans le repos; première eellule du bord postérieur point fermée, atteignant le bont de l'aile, ses deux nervures latérales se rapprochant un peu; seennde cellule assez rapprochée du bord postérieur, fermée par une nervure transversale cinuée : côte des ailes nue ou presque nue. Balanciers recouver's par un euilleron double. Abdomen ovalaire, de qratre segmens. - Pattes de longrueur moyenne.

La forme de leur trompe a valu à ces Diptères le nom de Stomoxe, tiré de deux mots gress qui signifient: bonche aiguë; eet organc est chez enx extrêmement dur et corné, aussi pereent-ils avec facilité non-seulement la peau de l'Homme en s'at. taehant prineipalement aux janles, mais eneore le enir des Bœuf's et des Chevaux. Après la suceion la plaie ne se ferme pas de snite, elle est tellement ouverte que le sang continue à couler quelque temps. L'espèce la plus commune se trouve en France dans les champs, daus les bois et mêne dans l'intérieur des villes depuis le printcmps jusqu'aux premiers froids; elle est extrêmement abondante en automne; sa ressemblance avee la mouche commune ou domesliqne, a fait dire au vulgaire, que les monches d'antomne piquoient. Quelques individus, probablement les femelles qui ne se sont pas aeeouplées, se eaehent pendant l'hiver et s'cngourdissent; nous en avons trouvé dans eet état une vingtaine rémis presqu'en tas dans un trone d'arbre à un endroit où il suintoit ın peu d'luumidité que peut-être ilss sueoient faute d'antre nourrilure, lorsque la tenpérature plus douce les tiroit de leur enguurdissement.

Nous restreignons ce genre aux espèces de Stomoxes dunt Ml. Meigen compose sa troisième division. Cet auteur donne avee doute les fumiers pour habitation à la larve du Stomoxe piquant : nots avons surpris la femelle y pondant, ce qui rend ce fait incontestable. Les Stomoxes se divisent ainsi qu'sl suit :

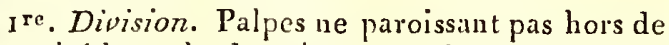
la cavité buccale dans le repos. (Stomoxis propriè dicta.)

Stomoxe piquant, $S$. calcitrans. Mrsg. Dipt. d'Eutop. tom. 4. pag. $160 . n^{\circ}$. 3. - Stonioxis calcitrans n ${ }^{\circ} .5$ et tesselata no. 7. FAB. Syst. Antliat. - Conops calcitrans. Linn. Faun. Suec. n. 1900.- Le Stomoxe. Georr. Ins. Par. tom. 2. pag. 539. $n^{\circ}$ 1. pl. 18. fig. 2. Très-commun en Europe.

2e. Disision. Palpes dépassant la cavité buceale même dans le repos, aussi longs que la trompe. (Homatobia. Roвin. ined.)

$1^{\circ}$. Stomoxe stimulant, S. stimnlans. MeIg. Dipt. d'Eur. tom. 4. pag. 161. no. 4. tab. 38. fig. 8.Stomoxys imitans n ${ }^{\circ}$ 10. FAr. Syst. Antl. D'Allemagne. Nous pensons que M. Mergen se trompe en rapportant à certe espèce le Stomoxys imitans. Lat. Gener. Crust. et Ins. qui nous paroît être le Stomoxys siberita des auteurs (Prosena Noв.), ce qu'a voit aussi soupçonné M. Latrcille. $2^{\circ}$. Stomoxe irrilant, S. irritans. Merg. id.pag. 162. $n^{0} .5$. - Conops irritans. Lixs. Faun. Suec. $n^{\circ} .1901$. - Stomoxis pungens no. 12. Fab. Syst. Antl. Commun dans le nord de l'Europe.

Nota. I.e Stomoxe ventre noir, $S$. melanogaster. Mrig. id.pag. 163. $n^{\circ}$.6. d'Autriche, est probablement aussi de cette division d'après la longueur de ses palpes, mais ses antennes ne son! pas eonnues.

Le Stomoxys muscaria $\mathrm{n}^{\circ}$. I I. FAB. Syst. Antl. est l'Anthomyia muscaria no. 150 . Nleig. Dipt. d'Eur. tom. 5. Le Stomoxys asiliformis $n^{\circ}$. 13. FAB. id. est l'Hybos muscarius no. 6. Mrig. id. tom. 2. Le Stomoxys dorsalis $\mathrm{n}^{\circ}$. 15. 
Fas. id. est la Myopa dorsata no. 20. Merg. id. fom. 4. Le Stomoxys cristata no. 9. FAB. id. est le Bueente 'Tachine ( voyez Bucente à la suite du préseut article), et le Stomoxys minuta $\mathrm{n}^{\circ} .17$. Fab. id. est le Bucente cendré. Voyez id.

PROSENE, Pmonena. Stomoxys. I, At. Meig. FAB. FALL. PANZ.

Genre d'insectes de l'ordre des Diptères ( 1 re. section ), famille des Athéricères, tribu des Conopsaires de M. Latreille. Voyez Stumoxydes.

Des trois genres que contient la seconde division des Conopsaires, celui de Bucente a pour carrelère qui le distingue des P’rosênes, la soiedes intenues nue, lit trompe eoudée vers son milieu, ayant sa partie après le coude raballue dans le repos et dirigée en añière. Les Stonoxes diffèrent des Prosếnes par la trompe plus courte que le corps, fortement renllée à sa hase el par la soie des antemnes plumeuse d'un seul côlć.

Antennes couclıées sur l'hypostome, un peu plus courtes gue lni, eomposées de trois arlicles, les deux premiers très-cotarts, le troisième fort long, linéaire, comprimé, obtus à sou extrémité, unini à sa base d'une soie plumeuse, triarticulée; les deux premières articulations très - courles. Trompe quatre fois plus longue que la tête, foliforme, flexible, arliculée ì sa buse, sa partie après l'articulation presque droite, non coudée. - Lèves longraes, a peine saillantes le long de l'extrémité de la tronpe. - Palpes très-courls, ovales, ciliés, insérés sur la base de la trompe.Hypostome presque plat ; bords de la cavilé buccale garnis de cils longs et roides: front large dans les femelles, ayanı de chaque côté une ligne de longs poils roiłes. - Yeux elliptiques, presqu’anguleux à leurs deux exirémilés, rapprochés et se touchant dans les inâles. - 'rrois ocelles irès-rapprochés en triangle sur le vertex, accoinpagnés de quelques soies longues el roides. - Corps court, hérissé de poils roiles. - Prothorax distingué du mésothorax et séparé de lui par une ligne transversale enfoncée, très-pronnncée. Ailes velues vues au microscope, écartíes l'une de l'autre dans le repos; première cellule du bord postérieur presque fermée par une nervure eoudée, un peu éperonnće à ee coude; la seconde assez rapproclice du bord postérieur, fermée par une nervure trinsversale sinuée: côte des ailes garnie de poils roides, courts, qui la funt paroîlte dentée en scie. - Babanciers recouverls par un cuilleron double. - Abdonen de quatre segmens. - Pattes fort longues, grêles.

Il ne nous a poiut para possible de laisser dans un niême geure des insectes de mours douces, ne nuisant à aucun être, pourvus d'une trompe presque riolle, propre seulement à pomper le miel des fleurs, a vec des insectes s'acharnant sur les animaux afin de sucer leur sang et armés pour cet usage d'une trompe cornée. Celte eonsidération jointe aux earaclères particuliers qu'offient la soie des antennes et les ailes des Prosênes nous paroissent nécessiter la créalion de ce nonveau genre; son nom vient d'un mot gree qui signifie : doux et benin. Le type est la Prusêue de Sibérie, $\boldsymbol{P}$. siberita. Ков.-Stomoxys siberitu ${ }^{\circ} .4 . \mathrm{F}_{\mathrm{AB}}$. Syst. Antliat. et Auctor. - Stomoxys grisea ${ }^{\circ}$. 2. FAB. $i d$. On la trouve aux environs de Paris sur les fleurs composées.

Notı. Ce genre nous paroît appartenir à ha tribu des Muscides ainsi qne eeux qui l'avoisinent.

BUCENTE, Bucentes. Lat. Siphona. Meig. Siomoxys. Fab. Fate. Millsca. De Géer.

Genre d'iusectes de l'ordie des Dijlères ( 1 pé. section), famille des Athéricìres, tribu des Conopisaires de M. Latreille (I).

La seconde division de celte tribu contienl les genres Bucente, Stomoxe et Prosêne; ce dernicr a la soie des autenues plumeuse, sa trompe n'est pas fléehie dans le milieu, et elle a son extrémité dirigée en avant. Ces mêmes caractères se retrouvent dans les Stomoxes, mais la soie de leurs inicunes u'est que demi-plumeuse.

Antennes rabattues sur la face de la tête, aussi longues que l'hypostome, composées de trois arlicles, le premier très-pretit, le second un peu plus lungro, lićrissé de poils roides; le trojsiène trèslong, linéitire, eompriné, obıus à son extrémité, poriant à sa base une soie dorsale nue, triarliculéc, la secoude articulation assez longne. Trompe forl longue, filiforme, flexible, articulie à sa base, coudéc vers son milieu, la portion aprèss le coude se rabatlant daus le repos el dirigeant son extrémité en arrière. - Lèvies courles, pen charnues. - Palpes assez grands, presq̣ue linćaires, un per ciliés, insérés sur la base de la trompe. - Hypostome presque plat; bords de la caviĺ́ buecale garris de eils longs et roides : frout large daus les deux sexes ́cependant uu peu moins dans les mäles), ayant de chaque côlé une ligne de longs poils roides. - Ieux ellipliques, presqu'asguleux à leurs deux extrémités. - Trois ocelles très-rapprochés en triangle sur un lubercule du vertex qui porte en outre des poils roides. - Corps court, conformé comme celui d'une moucbe, hírissé de poils roides. - Prothorcax n'élant point dislingué du mésotlorax par une ligne transversale apparente. - Ailes velues vues au microscope, écartées l'une de l'aulre dans le repos; première. cellule du bord postérieur fermée par une nervure

(1) Nous pensons que ce genre doit être reporté dans la tribu des Muscides. (Voyez Stomoxyoes.) De Géer dit posirivement que la larve de sa Musca geniculata qui appaptient à ce genre et est probablcment le Bucente cendro Lata. vir dans la nymphe d'un Lépidoptère; habisode commune à beaucoup de genres de Muscides. 


\section{$5 \mathrm{TO}$}

arcuće, la seconde courte, fermée par une nervire tränsuersale droite : côte des ailes garnie de poils roides, courts, quil la font paroître dentée en scie. - Balanciers recouverts par un cuilleron double. - Abdomen de quatre segmens. - Pattes de longueur moycnne.

Quoịue le nom gŕnérique de ces Diptères soit tiré d'un not gres qui signifie : pique-bceuf; ils n'inquiètent jumais les hommes ni les animaux et se contentent de sucer le miel des fleurs, particulièrement celui des semi-flosculeuses.

On connoîl cinq espèces de ce genre.

Io. Bucente cendré, B. cincreus. Lat. Gener. Crust. et Ins. tom. 4. pag. 35.5. - Siphona geniculata. Mrig. Dipt. d'Eur. tom. 4. pag. $155 . n^{\circ}$. 1 . - Stomoxys minuta $11^{\circ}$. 17. HА В. Syst. Antliat. $2^{20}$. Bucente de Meigen, B. Meigenii. Nов. - Siphona cinerea. MIEIG. id. pas. 156. $n^{\circ}, 2.3^{\circ}$. Bucente Tachine, B. tachinarius. - Siphona tachinaria.MEIG.id. no.3. tab.37.fig. 25.-Stomoxys cristatu no. 9. FAB. Syst. Anillat. $4^{\circ}$. Bucente ayé, B. nigrovittatus. -- Siphono nigrovittata. MEIg. id. pag. $157 \cdot u^{\circ}$. 4. 50. Bucente inal, $B$. analis.-Siphona analis. Merg. id. $n^{\circ}, 5 \cdot$ tab.37. fig. 24. (S. F. et A. SERv.)

STOMOXYDES, Stomoxy da. M. Meigen (Dipt. d'Europ. tom. 4.) dounc ce nour ì sa vingt-unieme famille qui correspond à la seconde division de la tribu des Conopsaires J.AT. (Fam. nat.) et it laquelle il assigne les caractères suivans: antenntes rabattues, de trois articles, obluses à leur extrénitı́; troisième article ayan une suie; trompe avancéc, coudée; abdomen de quatre sturmens; balauciers recouverts par un donble cuilleron.

liauteur met dans celte famille les gonres Siphoue (Bucente I.ar.) et Stomoxe. Nous reatiquerous ici que tous ses caractères se retrouvent daus la "amille des Muscides. Ceux tires des antennes sont communs it toules les Muscides, celni de la trompe et des balancuers se rencontre dins un assez grand nombre de genres : le curactire d'ubdomen n'est quiue apparence trompense qui vitrie selon le nombre de segmens, souvent rétractiles, employés à protéger iomédiatement les parties de la génération. lie nombre apparent des segmens de l'ibdomen chans les iluscides est ordimairement le môme quo celui indiqué parr Mej. gen pour l'abdowen des Siomoxydes. Noos nensons donc que les genres de celte lamille peusent être sans inconvénient réunis aux Místides, d'atttant que la nourrilure des larves et leurs mítamorphoses sont alssolument les mêues que celles de plusieurs genres de celte derniére tribu. Par les mêmes raisons tirces de l'orgurisution, nous croyons qu'on doit également réunir aux Muscides les genres Myope e: Zodion ciue l'anteur allenarid place dins sa famille des Comupsires, et qui ne nous paroissent avoir que des analogies trompcuses avec les Conops. (S. If. el A. Serv.)
STONPHACE, Stomphax. Nom donné par Mi. Fischer de Waldheiru (Entom. de Russ.tom. 2. pag. $159_{.}$) ì un genre de Coléoptères, que N. Ger. mar avoil nommé Codocera. Voici les caratères que l'antear russe lui assigne : Antennes crudées, le premicr aricle gros, très-velu, les stivans monilifornes, glabres; massue de guatre feuiliets velus. Chaperon transversal, largement échancré. rabre avancé, conique, velı. Mandibules cornées, très-avancées, plus hanles que larges, échaucrécs en dessus à lour partie antćrieure, en sorte cu'clles se crnisent. Náchoires courtes, men. brancuses. Palpes marillaires très-longs, leur avant-dernier arlicle triangulaire, sćcuriforme, le demier alongé, nnince, presque fillforme. Menton transversal, réfléchi, un peu èchancré.

Le type de ce gente est le Stomplace lec crossé, $S$. cracirostris. Fiscr. id. pag. I io. tab. $X X X I T$. Longueur 3 ligg. Entièrement brun, velu. Teux noirs. Elytres striées. De 'Tólis en Géorgie. Celte cepèce est le Lethrus ferrugineus. Escrsch. Mem. de l'Académ. des Scienc. de S. Pétersb. tom. 6. plag. $15 \mathrm{r} \cdot u^{\circ}$. 1. - Codocera ferruginem. Germ. Miagaz. der Entom, tom. IV. ag. Jyg.

Nota. L'autemr rapporte ce genre aux Lucanides; linspection de la figure nous porteroit plutôt à croire quil apparticnt aux Scarabédes.

(S. F. et A. SERv.)

STRATrone, Strationys. Geoff. Fab. Dr Géet. Lat. Waljex. Paxz. Mrig. Ili,ig. Wiédem. Macq. Muluca. Linx. Scop. Hirieg. Scop.

Genre d'insectes de l'ordre des Diptères ( section), farmille des Nolacanthes, Iribu des Strattionydes.

Quatre getres, Ephippie, Stratiome, Odontomyic et Oxycère forment urouve dans cetle tribu. (Yojez Strationyos.) Thes Odontomyies dillerent des Stratiomes par lo second article des antennes prescu'aussi long que le premier, et par

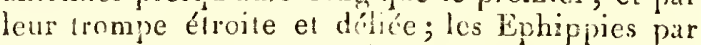
leurs antennes pourvues d'un stylei terminal biar ticulf; le genre Oxycère a le trojsième article de ses antennes divisé en quatre parlies et terminé par un stylcl alongé et hiarticulé.

Antennes longanes, avarcécs, mpprcolices i iem buse, composées de tris arlicles, le prenier. denx on trois fois plus long que le second, celuici cyahifornc, le troisième alongé, presquéen fuscau, ayant cing divisions, tiès-déprimé, faisant un angle avecles antres, dripourvo de sty! tet oc lie soie a son extrénití. - Trompe contro, grosse, charnue, comprimse, rélachale, cachéc daus la cavié buccale lors du repos, ne laissant parcitte alors à l'extériesia que son extrímité forwćc par les deux lc̀ves; colles-ci sillonnées transrorsalement sur les cốs. - Falpes insérés snr les côlés de la lase de la trompe, de trois arti- 
cles, à peu près égaux en longueur, le troisiène plus épais, velu. - Tête hémisphérique. - Yeux grands; espacés dans les femelles, se touchant sur le front dans les mâles. - Trois ocelles dis. posés en triangle sur le vertex. - Corps pubescent. - Corselet ovale, veln ou même cotonneux daus les mâles, l'étant beanconp moins dans les femelles. - Ecusson senuicirculaire, armé postérieurement de deux deuts. - Ailes lancéolées, saus poils, vaes unême au microscope; couchées sur le corps dans le repos, ayant une cellule centrale d'ou partent des rayons se dirigeant vers le bord postérieur. - Cuillerons petits, ne recouvraut point les balauciers. - Abdomen ovale, plane ou peu voúté, composé de cinq segmens. - Pattes issez grêles : tarses ayant leur dernier article muni de deux crochets avec une pelotte trilobće dans leur eutre-deux.

Geoflioy a tiréle nom de ce genre de deux mots grecs qui signifient: Mouche armée. Les mœurs des Strationies, la forme de leurs larves, lear nanière de vivre ainsi que leurs métamorpboses sont les mêmes yue celles des Odontomyies. (Voyez ce mul et de plus Réaum. tom. 4. Mémoir. 7. et 8. , ainsi que Geole. Ins. Paris., tom. 2. généralités du genre Strationys.) M. Meigen (Dipt. d'Europ.) ne fiail du genre Odontomyie qu'il avoit créé dans sa classification, qu'une division du genre Siratiome. Il décrit sept espèces appartenant réellement à ce dernier greure.

Ces espèces sont : $1^{\circ}$. Stratione caméléon, S. chamalcon. Melg. Dipt. d'Europ. tom. "3. pag. 134. $n^{\circ}$. 1. - M.sce. Ins. Dipt. Asiliq. etc. pag. 13o. $n^{\circ}$. 1. $2^{n}$. Stratiome du Mont-Cénis, S. cenisia. Melg. id. pag. 136. $n^{\circ}$. 2. 3o. Straliome des fleuves, S. potamida. Meig. $i d . n^{\circ} .3$. - MAcQ. $i d \cdot p a g \cdot 15 \mathrm{r} \cdot \pi^{\circ} \cdot 2 \cdot 4^{\circ}$. Stratione agréable, S. concmna. Meic. id. pag. 137. no. 4 . tab. 26. fig. 14. Mille. 5o. Stratione tourchue, S. furcata. MIE1G. id. pag. 138. no. 5. tab. 26 . fig. 12. et 13. Femelle. - Mace. id. pag. 131. $n^{\circ}$. 3. A cette espéce doit se rapporter la Stratiomys furcata no. 3. FAs. Syst. Antliat. qui a été donnée mal-i-propos pour synonyme it l'Odontomyie fourchue $n^{\circ}$. 1 . de ce Dictionnaire. Rapportez à cette Odontonyie l'insecte figuré par Réaumu:, tom. 4. pl. 24. fig. 4-7. et les détails qui concernent ces figures duns lés Mémoires 7 . el $8.6^{\circ}$. Siratione des rivages, $S$. riparia. Merg. id. $n^{\circ}$. 6. $7^{\circ}$. Stratiome striée, S. striata. Merg. id. pag. $15 \mathrm{~g}$. ho. 7. - MACQ. id. pag. "כ2. $n^{\circ}$. 4 .

STRATIOMYDES, Strationydes. Seconde tribı de la fanille des Notacanthes, première section de l'ordre des Diptères, ayant pour caractères :

Dernier article des antennes, lorsqu'il est divisé transversalement, offrant au plus cinq à six anneaux, le style ou la soie non compris.

M. Latreille divise ainsi cette tribu.
I. Dernier article des antennes annelé, sourent terminé par un style ou une soie.

A. Antenues flabellées.

Ptilocère.

B. Antennes simples.

a. Dernicr article des antennes soit cylindrique ou en fuseaun, soit en cône alongé, tanlôt sans appendice au bout, tantôt terminé par un style ou par une soie rigide et peu alongée. (Ecusson le plus souvent denté ou épineux.)

f Trompe très-courle, membraneuse, terminée par deux grandes lèvres saillantes devant la tête, point avancée en manière de bec portant les antennes.

Ephippie, Stratiome, Odontomyie, Oxycère.

tf Trompe lougue, grêle, filiforme, retirée dans la cavité inférieure d'une saillie antérieure et en forme de bec de la tête et portant les antennes.

\section{Némotèle.}

b. Dernier article des antennes formant une uasse presque globuleuse ou ovalaire avec une soie longne аи bout. (Ecusson ordinuirement mutique.)

$$
\begin{aligned}
& \text { Chrysochlore, Sargus, Vap- } \\
& \text { pon. }
\end{aligned}
$$

II: Dernier article des antennes inarticulé.

$$
\text { Platyne. }
$$

Nota. $1^{\circ}$. L.e genre Scénopine constitue à lui seul une conpe particulière. (Voyez ce mot et celui de Scénopiniens.) $2^{\circ}$. Le duute élevé par MM. Knoch et Meigen (Dipt. d'Europ. tom. 3 . pag. 133.) sur les véritables larves des Stratiomydes n'a aucun fondemeut. Réaumur a observé la vraie larve de l'Odontomyia ornata, Odontomyie fourchue $\mathbf{n}^{n}$. 1. du présent Dictionnaire, et Genffioy celle de la Stratiome caméléon, et ils en out óltenu les insectes parfaits. Leur exactitude conme ne laisse aucun doute sur la véracité de leurs assertions. Voyez Sthatiome.

EPHIPPIE, Ephippiuin. Lat. Clitellaria. MEтE. Izlig. Vild. Strutionzys. Groff. Fab. Ross. Nomotelus. Fab. Panz. Coqueb. Odontomyia. Olit. (Encycl.)

Genre d'insectes de l'ordre des Diptères ( Ire. section ), famille des Notacanthes, tribu des Stratiomydes.

$\mathrm{U}$ n groupe de cette tribu contient trois geares 


\section{S T R}

(voyez Stratronydes) outre celui d'Ephippie. Les Stratiomes ainsi que les Odontomyies sont distinguées par leurs antennes sans style ni soie, en outre dans les Stratiomes le premier article des an tennes est beaucoup plus longque le second. Dans le genre Oxycère le troisième article des antennes n'a que quatre divisions outre la soie terminale.

Antennes avancées, un peu plus longues que la tête, rapprochées à leur base, s'écartant ensuite, composées de trois articles, les deux premiers courts, presqu'égaux, le troisième assez long, ayant cinq divisions et portant à son extrémité un style biarticulé. - Trompe reutrant dans la cavité buccale dans l'état de repos. - Palpes velus, insérés aux deux côtés de la trompe, de trois articles, le dernier le plus gros de tous. - T'éte transversale, plus étroite que le corselet. - Yeux yrands, espacés dans les femelles, se touchant sur le front dans les mâles. - Trois ocelles disposés en triangle sur un tubercule du vertex. - Corps pubescent.-Corselet hombé.-Ecusson saillant. - Ailes lancéolées, velues rues au microscope, conchées sur le corps dans le repos, ayant une cellule centrale d'où partent des rayous se dirigeant vers le bord postérieur. - $B a$ lanciers découverts. - Abdomen large, ovalearrondi, assez plat, composé de cinq segmens. Pattes assez lungues; tarses ayant leur dernier article muni de deux crochets avec une pelotte dans leur entre-deux.

Le nom d'Eplippie donné à ce geure par M. Latreille est tiré d'un mot grec qui signifie: selle. Les larves vivent, dit M. Meigen, dans le bois pourri, et nous-mêmes avons cru voir l'Ephippie thoracique femelle déposant ses æuts dans de la sciure de bois amassée dans le crenx d'un cerisier sanvage à Saint-Germain-en-Laye. Cette espèce se rencontre dans les bois, sur les feuilles exposées au soleil.

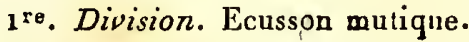

Rapportez à cette division : $1^{\circ}$. Ephippie velue, E. villosum. - Clitellaria villosa. Mrig. Dipt. d'Europe, tom. 3. pag. 120. $n^{\circ}$. 1. tab. 25. fig. 24. Mále. - Odontomyie velue no. 12. Encycl. $2^{\circ}$. Ephippie chauve, E. caloum - Clitellaria calva. Merg. $i d$. pag. $121, n^{\circ} .2 .3^{\circ}$. Ephippie pacitique, $\boldsymbol{E}$. pacificum. - Clitellaria pacifica. Mrgrg. id. no. 3. $4^{\circ}$. Ephippie àtre, E. atratum. - Clitellaria atrata. WrÉDEm. Analect. entom. pag. 14. - Stratiomys atrata no ${ }^{\circ} 23$. FAB. Syst. Antliat. Amérique méridionale.-

$2^{e}$. Division. Ecusson armé de deux épines.

Cette division contient l'Ephippie thoracique, E. thoracieum. Lat. Gener. C'rust. et Ins. tom. 4. pag. 276. - Encycl. pl. 387. fig. 27-3o. Femelle.

Nota. M.M. Meigen et Wiédemann rapportent en outre à cette seconde division la Strationys bilineata no. 5. FAв. Syst. Antliat. - Clitellaria henininopla. Wı́́n. De Sumalra, et vraisemblablement aussi la Strationiys flavipes no. 10. Fab. id. D'Alger. M. Wiédemann (Analect. entoni.) paroît considérer les genres de cette tribu d'une autre manière que les auteurs dont nous suivons habitnellement la méthode, savoir MM. Latreille et Meigen; $1^{\circ}$. l'auteur trancais a tonjonrs attribué un écusson biépineux î ses Ephippies. M. Wiédemann d'accord en cela avec M. Meigen, admet des Eplippies (Clitellaria MeIg. WréDEn.) à écusson mutique; $2^{\circ}$. MM. Latreille et Meigen n'ont point d'Ephippies à écusson quadridenté. M. Wiédemann dans l'ouvrage cité plus haut pagr. 3o. no. 37. a une Clitellaria elongata dout l'écusson porte quatre dents. (Nigro cenea, scutello quadridentato; thoracis lineis, abdoninis maculis argenteis; alis fuscis, fasciâ limpidâ.

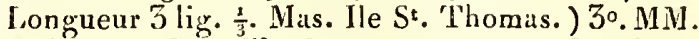
Meigen et Latreille donnent au genre Stratiome comme caractère générique écusson épineux. On voit dans M. Wiédemann, mène ouvrage pag. 29. $\mathrm{n}^{\circ}$. 34. une Strationlys viridana dont l'écusson est mutique. (Nigra, thorace aurato vittato, scurtello mutico et abdominis maculis lateralibns viridibus. Longueur 4 lig. Fenl. Bengale.) $4^{\circ}$. MM. Meigen et Latreille n'admettent dans le genre Sargus que des espèces à écusson mulique; Mr. Wiédemann décrit pay. $3 \mathrm{r} \cdot \mathrm{n}^{\circ}$. 40 . de l'ouvraye précitó un Sargus furcifer (niger, thorace vittis et angulis, abdomine maculis, flavis; scutello appendice lougissimâ apice fürcatâ. Longueur 4. lig. Fem. hrésil.) Auprès de celle espèce il existe dans notre collection un Diptère de cette tribu rapporté de Cayenne par M. Adolple Doumerc, ayunt le troisième article des antennes comprimé, la soie point décidément terminale, l'écusson portant un appendice court et large, bidenté à son extrémité; de plus le Sargus vespertilio no. 14. Faв. Syst. Antliat. a le troisième article des antennes fort long, conique, de six annearx seulement, terminé par uue longne soie et la cellule centrate des ailes érnet quatre rayons. Ces considérations nous paroissent faire un devoir aux naturalistes d'examiner de nouveau les caractères des genres de celle tribu sur lesquels il y a peu d'accord jusqu'ici. M. Wiédemann sonpçonne que l'espèce qu'il appelle Clitcllaria elongata doit faire un nouveau genre.

PlatYNe, Platyma. Whínm. Lat. (Fam. natur.)

Genre d'insectes de l'ordre des Diptères (1 re. section), famille des Notacanthes, tribu des Stratiomydes.

Tous les genres de cette tribu, excepté celui de Platyne, ont le dernier article des antennes unnelć.

Il paroît, suirant M. Wiédetonnn, que ce geme 
a tous les earactéres des Straliones, sauf les suivans :

Premier et second articles des antennes cylindriques, de longueur éyate, le troisième court, comprimé, point annelé, terminé par une petite poivte. - Ecusson ne portant qu'une seule épine qui est relevée.

Le nom de Platyne rient d'un mot gree qui signifie: large. L'espèce que l'anteur donne pour iype est la Platiyne hastée, $P$. hastata. Wrénen. Analect. entonol. pag. 12. fig. 2. Fenelle. -

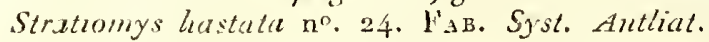
De Guincée. (S. F. et A. Sknv.)

STREBLE, Strelılı. M. Wiédemann (Analect. enton. pag. 19.) noinme ainsi nu geare de Dipticres créé par lui et apparteuant à la seconile section de cet ordie. Voici les caractères qu'il lui assigne: ycux très-pelits, situés aux angles poslérieuri de la lête. Ailes en reeouvrement et parallìles dans le repos, n’allant pas en se rétrécissunt vers leur extrémité, à nervares parallèles.

L'auterr paroit douter que les espèces de ce genre aient cles antennes. Celle qu'il donne pour type esi la Strebice de Le Chave-souris, S. Fespertitionis. Wáden. loc. rit.fgg. 7. - Hippobosca zesperitionis u०. 6. lia s. Syst. Anlliat. De l'Anıérique méridionale. (S. F. el A. Serv.)

STRÉPSIPTERES. Kinв. Foyez Ruipiptéres.

M. Latreille ( $F(m)$. nat.) ayant élevé l'ordre des Myriapodes à la dignité de classe, il en résulte que l'ordre des Rinipipters se trouve aujuurd'bui le dixitme de la classe des insectes.

(S. E. el A. Serv.)

STRIÉE BRUNE DU TERBASCUM. Nom donné par Geolfioy a la Phábena noctua verhasci. Luns. Voyez Noeluelle du Bonillon blanc $n^{\circ}$. 440 . de ce Dictionnatice.

$$
\text { (S. F. et A. SERv.) }
$$

STRONGYLIE, Strongylium. Kin B. LAT. (Fam. nat.) Genre d'insectes del'ordte des Colśoptères, section des Hétéromères ( I $^{\text {re }}$ division), faraille des Sténélytres, rtibu des Hélopiens.

Ce genre fait partie du quatrième groupe de

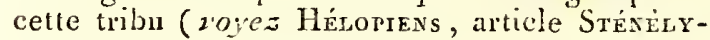
тнEs), lequel a pour caraclès es : corselet plus long que litroe ou presgu'isonétrique, soit piesque carré, soit cylindracé. Corps étroit et alongé. M. Ki:by a ćtabli ce geure (Trans. Linn. Centur. of. Ins. 2ol. 12.) et M. Litireille l'a adopté dius ses $F a m$. natur. L'auleur anglais le carractérise ajnsi ; labre transversal; levre presque cordiforme; mandibules très-eourtes, fortes, terminées par une pointe sans dentelures; machoires écartées, bilolicées à leur extrémité, le lobe extérieur plus grand, arrondi extérieurement, l'intérieur petit, aigu; quatre palpes a yani leñ dernier arlicle grand, sécuriforme; men son presqu'en ceur. Antermes grossissant insensiblement vers leur extrémité, leur dernier article ovale. Corps linéaire, oblong, point rebordé.

Le type est une espèce inédite, de la nonvelle Hollande. Strongylie bronzée, $S$. chalconatum. Kin в. ut suprà. Lahb. 21. fig. 16. Longueur 6 lig. Corps boillant, graltre, d'un noir bronzé. Elytres ayant depetitces fosseltes oblongnes, excavées, caraliculśc's, J'angées presqu'en lignes régulières.

Notu. L'Hclops luceratus. Germ. (Insector. Spec. nov. aut min. $\operatorname{cog} n$.) paroît avuir les caracteres que M. Kirby donme aux Strongylies et ressemble beancoup à l'espéce ci-dessus déerile, mais il est du Brésil. (S. F. et A. Serv.)

S'TYGIDE. Lat. (Fam. nat.) Voyez LoMatie, article ''omomyze. (S. F. et A. Serv.)

S'TYGIE, Stygia. Drap. Latr. God. Bomby: $x$. HubN.

Genre d'insectes de l'ordre des Lépidoptères, farnille des Crépusculaires, tribu des Zygénides.

Le troisième groupe de cetle tribu renferme trois gemres. (J'oycz Zygénides.) Savoir : Glaucopide, qui seul des rois a une langue distincie; Aglaope, qui ainsi que celui de Stygie n'en a point d'apparente mais qui se distingue de ce dernier genre par ses palpes très-petits dont le dernier article est presque nu : ses antennes sans houppe à l'extrénité : les éperons des jambes postérieures très-courts et le dernier seginent de son abdomeu dẹ́pourvu de lrosse au bout.

Antennes courtes, diminuaut insensiblement de grosscur, arguées, bipectinées dans les deux sexes, sans hrupo ì lemr extrémité - Point de langue distincle. - l'alpes épais, cylindriques, en'ièrerneul garnis d'écailles, s'élevant au-dela du cliperon. - Corps ćcaillenx. - Ailes en toit duns le repos; les supérieures oblongues, les inlérieures presqu'arrondies; cellule sous-marginale de eelles-ei fermće par une norvure arçuée d'oà partent deux rameaux paralleles qui aboutissent au bord postérieur. - Abdomen conique, terminé par une brosse de poils. - Jumbes postérieures munies à leur extrémitú d'ćperons de grandeur remarquable.

L'espèce connue de re genre est la Siygie australe, $S$. australis. Drap. - LAт. Gener. Crust, et Ins. tom. 4. pag. 215 . tom. 1. tab. 16. fig. 4 . et 5. - God. Lépid. de Franc. pag. 169. $n^{\circ} .54$. pl. 22. fig. 19. - Bombyx terebellum. Huss. Bomb. tab. 57 . Jig. 24. Longueur 5 lig. Antennes, tête et eorselet àu jaune un peu fauve. Ailes supérieutes mélangées de cette couleur et de brun avec une frange brune à lear bord postériear. Ailes inférieures obscures. Abdomen noirâtre avee une tache jaune et fuuve sur le dessus des premiers segmens.

De midi de la liance.

(S. F, et A. SERF.) SIYGIE, 


\section{S U B}

STYGIE, Stygia. M. Nieigen (Dipt d'Europ. tom. 2. pag. 137.) avoit donné ce nom à un genre de sa septième famille (Bombyliarii). Depuis dansle troisième volume du même ouvrage pag. $v$, il change ce nom en celui de Lomatie, Lomatict, parce que la dénomination de Stygie avoit été donnée préeédemment par M. Draparsaud à un gemre de Lépidopières ct adopté par M. Latreille. Vojez Lomatie, article Tomomyze.

\section{(S. F. et A. Serv.)}

STYLOPS, Stylops. Kinв. Lat.

Genre d'insectes de l'ordre des Rhipiptères.

Cet ordre nc renterme que les genres Stylops et Xénos. Ce dernier difière de l'antre par son abdomen cornć à l'exception de l'anus et par la braucbe supérieure de ses an'enues qui riest pas articulée.

Ce genre a été creéé par M. Kirby ; il lai donne pour caractères : antenncs parlagées en deux branches. (Ajoutez, d'après M. Látreille, branche supérieure partagée en trois petiis articles.) Yeux pédonculés. Elytres (Prébálunciers. LAT. Fam. ncct. ) insérées sur les côtés du prothorax. Ecusson avancé, couvrant l'abdomen. Ailes nayant que de foibles nervures toutes longitudinales, se reployant en éventail. Abdomen prescjue cylindrique, rétractile, entièement charnu.

Le nom de ce genrc vient dc dcux mots grecs qui expriment la position des yeux plaeés sur un pédoncule cylindrique. La larve de la seule espèce connue est molle, presque cylindrique, blanchâtre; sa tête est avancée, cornée, cordiforme, un peu aplatie, roussâtre, avec sa partie postćrieure noire, un peu concave en dessous. Elle vit dans le corps de plusieurs espèces d'Andrènes : pour se transformer en nymplhe elle sort en grande partie de l'intéricur et se fixe sous le recouvremen des lames abdomiuales. Il est à remarquer que sa présence et l'action de prendre sa nourriture anx d́pens de ces Mellilères n'entrainent point leur nort.

I. Struops des Andrenes, S. Melitto.

Stylops aterrima, alis corpore majoribus; pedibus fuscis.

Stylops Melittce. Kinв. Monogr. Apum Angl. tons. 2. pag. 113 .

Longneur 1 ligne $\frac{x}{2}$. Trìs-noire. Ailes plus longues que le eorps. Pattes brunes.

D'Augleterre ei de France.

$$
\text { (S. F. et A. Senv.) }
$$

SUBUIICORNES, Subulicornes. Premic̀re see tion de l'ordre des Névioptères. Ses caractères sont:

Antennes en forme d'alène, guère plus longues que la tête, eomposétes de sept articles, le dernies forné par une soie. - Mandibules et MâElot. Frat. Ins. Tume $X$. choires reeouvertes par la saillie antérieure et supérieure de la tête. - Palpes point saillans. Yeux très-proćminens, ordinairement fort grands. - Ailes étendues horizontalement ou dans une situalion perpendiculaire.

Insectes sujets à des métamorphrses incomplètes, vivant dans l'eau pendant leurs premiers âges. Larves respirant au moyen d'un appareil spécial situé à l'anus ou par des appendices latéraux et extćrieurs en forme de nageoires branehialcs, mais réellement trachéennes.

Cette section comprend les denx premières familles dcs Névroptères; savoir : les Libellulines et les Ephémérines.

FILICORNES, Filicomes. Seconde section de l'orcire des Névroptères, ayant pour raractères: Antennes généralement composées d'un grand nombre d'articles, tantôt plus grosses au bout, tantôt filiformes ou sétacées et plus longues que lia tête. - Mrandibules et an nioins la majeure partie des mîchoircs, découveries. -- Palpes saillans, au moins les maxillaires. - Ailes presque toujours couchées horizontalement sur le corps on en toit, les inférieures plus longues dans ceux cn pelit nombre cù ces organcs sont étendus horizontalement, que dans ceux qui les ont en toit.

Une partie des larves sont terrestres, les autres aquariques; une portion de eelles-ci vivent dans des tuyaux portatifs et construits par elles.

Cetle seconde section comprand la troisiènc et la quatric̀me famille des Névroptères, savoir: les Plinipennes et les Plicipennes.

Nota. Ces deux articles sont extraits des Fam. natur. de MI. Latreille.

$$
\text { (S. F. et A. SERt.) }
$$

SUBULIPALPES, Subulipalpi. Seconde division de la tribu des Carabiques; elle a pour caracteres :

Palpes maxillaires extérieurs et Falpes latbiaux terminćs en manière d'alc̀ne.

Cette division ne contient dans la méthode de M. Latreille, que le genre Bembidion.

$$
\text { (S. F. et A. Serv.) }
$$

SUCEURS, Suctoria. M. Latreille qui aroit donné cette dénomination à son quatričme ordre des insectes dans ses ancicrs ouvrages, l'a ehanré dans ses Fam. natur. cn celui de Siphonaptèrés. Voyez ce mot. (S. F. et A. SERv.)

\section{SUCOIR, Haustellum.}

Ce nom a été donné par divers auteurs d'entomologie à lat bouche d'un grand nombre d'inseetes, et par suite ces insectes ont reçu le nom de suceurs.

Quoiqu'au premier coup d'oeil le suçoir ne présente aucun ragport avee la bouche des insectes $S: s$ 
broyeurs, on de ceux qui ont une bouche composée de mandibules, de mâchoires et de denx lèvres, cependant un examen pliilosophique et comparatif a fait voir à ML. Latreille et Savigny que la bouche des insectes suceurs, ou le suçoir, est compọsée de la même inanière que celle des broyeurs, mais que les diverses pièces qui le composent, revêtent de's formes différentes et approprićes à l'usage que la nature l's a deslinées a remplir. MI. Latreille, dans l'article Bouche du Dictionnaire clizssique d'histoire naturelle, a présenté l'état des connoissances actuelles sur ret orgaue de manducation. Nous ne pouvons micux faire que de reproduire ici la partie de cet article où ce savant sraite du suçoir.

"Nous venons de voir, dil-il, que dans les $\mathrm{Hy}$ ménoptères les mâchoires ct la lèvi'e, réunies longitudinalement en manitre de faiscean, formoient une trompe mohile it son origine, ayant itu centre de cette lase le pharynx. Un rapprochement semblable, et une disposition pareillement tubuleuse des parties de la bouche, ou de quelques-unes d'entr'elles, caractérisent aussi les insectes suceurs. Mais ici les organes de la manducation semblent, au prenier aperçu, n'avoir avec les précéden: que des ritpports très-ćloignés, ou méme en différcr totalement. L.es parties que l'on prend pour les analogues des máchoires, souvent inêrne celles qui représentent les uaandibules, sont fixes et inmobiles, soit entierencut, soit vers leur base (jusquà l'origine des palpes à l'égard des natchoires); et lor'sque l'autre partie ou la rerminale est mobile, celle-ci est longuc, étroite, linéilire, soit en forme de fil ou de soie, soil en forme de lame écailleuse, lancéolće ou subulée, propre à picquer, et imiłant ainsi un dard ou ane lame de lancette. Le pharyax est le point central autour duquel les portions terminales et mobiles de ces organes se rapprochen' eu manière de tube, et où coinmence leur jeu. 'I'antôt la lèvre infćrienre réunie avec li portion inlérieure des mâchoires, et fixe comme elle, lorme la cavité buccale, et les machoires constiluent alurs une sorie de langue roulée en spirale. 'Tantôt elle se prolonge beaucoup et se converlit en un tube articulć ou en une trompe coudée et terminée ordinairement par ceux lèvres susceptibles de se dilater. Jei, dans l'un et l'autre cas, elle scrt de gatue à des pièces tonjours écaillcuses et forantes, en forme de soie on de iancelte, représentant d'autres parties de la bouclie, souvent mềne le labre. Quelquetois celte gaine ( $p u l e x$ ) esı bivalve, mais én général elle est d'une seule pièce, repliće latéralement, pour lormer un tube ouvert en dessus et juscque prìs du bont ; ćest dans ce canal longitudinal on cette groultière, que sont logées les pièces précédentes, connposant par leur ensenble uu suçoic (haustellum). Ici les palpes ont disparu, là on n'en voit que deux; lorsqu'il y en a quatre, deux d'eutr'eux, ou les niaxillaires, sont très-pe- tits et sourent a peine distiacts. Quel guncfois encore, comme dans les Diptères jupipares, la lèvre inférienre n'existe plus on n'est que rudimentaire, et les palpes deviennent la gâne du suçoir. Cette dernièe dénomination, ainsi que celle de suceur's, sont, ainsi que le remarque judicieusenient launarck, très-impropres, puisque res animaux n'aspirent point les sucs fluiles et untritifs en formant un vide, mais quils les font remonter surcessivement it l'entrée de l'oesophage, en rapplochant graduellement les unes des autres, el do manière à laisser entr'clles le moindre vide possible, les pièces dn suçoir, à commencer par son cxlténité inférieure. C'est ainsi, par exemple, qu'une matière contenue dans un vase élastique, conique ou cyliudrique, en seroit expulsće, i l'on comprinoit succcssivement ce vase de bas en haut, ou du fónd à l'outverture."

Concluons de ces observations que le suçoir est nu ou à découvert dans les uns, et caché ou engaiñé dans les autres. l'on exemple du premier de ces deux cas, nous citerons les Lépidoptc̀res; et quant au second, les Héwiptères, les Dipic̀res et nos insectes suceurs proprement dits, ou le genre Pulex. De tous ces insectes, les premiers ou les Lépidoptères sont cenx dont la bouche s’éloigne lc moins din lype de celles des insectes broyeurs, et dans un ordre naturel, ils doivent sous ce rapport venir innédialement après les Hyménoptères. Elle se compose en effet, $1^{\circ}$. d'un labre et de dcux wandibules extrêucne’ul petiles; $2^{\circ}$. d'une trompe roulf́e en spirale, considérće mal-à-propos comme une langue, ofliamt à l'intérieur et dans toute sa longueul trois cinaux, dont celui du milieu sert seul à l'écoulement des matières alimentaires, est formće de deux corps linćaires on fililormes, entourant à lenr origine et imnédiatement au-dessous du labre le plo arynx, représentant, mais sous d'autres formes et d'autres proportions, la portion tercninale des mâclıoires, à partir depuis les palpes, réunis, fistuleux, creusés en gontlière profonde au côlé interne, et pobrtant chacun uı palpe, ordinairement très-petil el tuberculiforme; $3^{\circ}$. d'vue lèvre inférieure, presque triangulaire, immobile, réunie, ainsi que je l'ai dit plus haut, avec la portion inférieure des mâchoires ou dı support des tilets de la trompe, et portant deux palpes triarticulés, très-garmis d'écailles ou de poils, s'élevant de chaque côtć de la trompe, et lui formant ainsi une solte de guine. Le canal in. termédiaire de la trompe est produit par la réu. nion des gouttières de la face interce des filets. Voyez les Mlémoires de Réaumur.

Personne, jusqu'à Savignny, u’avoit lien fait connoître ces détails d'organisa ion, et l'on s'étoit presque horné à l'examen général de la trompe.

Celle des Hémiptères a reçu de Fabricius le nom de rostrum, qu'Olivier a rendu daus notre langue par celui de bcc. Une lame plus ou moins linéaire, coriace, divisée en trois ou quatre arti- 


\section{S U C.}

cles, ronlée sur ses bords pour furmer un corps tubulaire, cylindrique ou conique, toujours dirigrée inférieurement dans l'inaction, ayant le $1 \mathrm{ng}$ cu milieu de sa fuce supérieure ou intérieure un canal formé par le vide que laissent les bords latéraux au point de leur rapprochement; un suçoir, composé de quatre file's très-grêles ou capillatres, corrués, flexibles et élustiques, disposés par paires, mais russemblés en faisceau, et dont les deux inférieurs réunis en un à peu de dislance de leur origine; une pelite piece en forme de languelle triungulaice, ordinairenent dentée au bout, plulót coriace ou presque membraneuse que de cousistance d'écaille, reconvrant, par-derrière ou du côté du corass tubulaire, la base da suçoir, et renfermée avec lui dins la rainate de ce corys engaînant ; une autre pièce de la consistance de la précédente, répondant par son insertion et la place yu'elle occupe, à la lèvie supérieure, couvraal en dessius la base du suçoir, le plus souvent renfermé aussi dans la gaine, en forme de triangle plus ou moins alongé : telles sont les parties qui composent le bec des Ilímiptères. L'impaire supérieure est l'analogne du labre, et nous a paru, du moins par rapport aux cigales, recouvrir la base d'une autre piece plus alongée, terminée aussi en pointe; celle-ci répundroil dès-lor's à l'épilpharynx : l'autre pièce impaire, uais opposée, prolégeanl par-derrière la naissance du suçoir, et siluée immédiatement derrière le pharynx, représente, selon Savigny, la langre de l'hypo-pharyux. Les deux soies supérieures du suçoir, ou les plus extérieures, reaplatent les mancibules, el les deux anlıes les màchoires. Eatin, leur gaine tubulaire s'asijmile à la levre inferieure, mème quatat à ses art:culations. Quelquefois cettc gaine est bitide, comme dans les 'Thrips, et ciueiquefois aême divisée en deux lanes, ansi que dans les Paces. I.es premiers de ces Hécnipleres sont les seuls où nous ayons découvert des palpes. Les partues que ce savant prend pour telles dans l'Hepa neplunea, ne son peui-être que les rudinens d'un article de lia gaine.

Germar adme! quatre palpes dans non nouveaul genre de la firmille des Cicadair es, qun'il notane Co. our ; mais Kirby, qui a pusliédans le mêre temps nue autrecupe géućrique, celled'Oi ocère, offrant des parties semblables, ne considere point ces parlies comme des palpes, mais conne de simples aplendices accompagnant les antemes.

La bouche des Diptères, tels que le Consin, le Tuon, la Munche domestique, a les plus grands rapports avec celle des inseotes précédens. Línsemble de ces pièces forme ce que l'on appelle la trompe (proboscus). Distinguons ég:alement ici le suçair de la gaioe, et quelle grue sult la consistance et la forme du fourreau, conservons-lui la même dénominalion, sans nous eu laisier iurposer par l'autorité de Fabricius, et de quelques autres nutaralistes, qui, lorsqu'elle

\section{$S \cup \mathrm{C}$}

csi plus ferme, plus roide, conique ou cylind:ique, sans empâtement remarquahle au bout, l'appellent suçoir (haustellum), tandis qu'ils désignent exclusivernent ainsi l'ensemble des pièces qu'elle contient, lorsquelle est membraneuse, rétractile et bilibiće. Elle se divise en trois parties principales : $1^{\circ}$. le support, distingué de la suivante par un coude, et souvenl par un petit article géniculaire, mais que nous réunissons avec le support; $2^{\circ}$. la tige; $3^{\circ}$. le sommet ou la tête, formé par deux lèvres, tantôt membrailenses, grandes, vésiculenses, dilatables, striées, ofliant au microscope 111 très-grand nombre de ramitications de trachées; tantôt coriaces, scil pelites et feu dìlinctes de la tige, soit grêles, alongées el formant un article plas dislinct, presqu'anssi long uêeme que la division précédente ( Hyope). Le support est remarquable en ce qu'il est le résuliat du prolongentent de lit inembrane cutance de la partie antérieure et supútieure de la títe ou de l'épis. tome, rénuie avec les parties analognes au labre, aux mandibules, aux mâchoires ê a la portion inférieure de lis lèvre jusqurau menton inclusivement. Ces caractères distinguent particulièrement les insectes de cet ordre de ceux de l'ordre des Hénriptc̀res. (In voil d’ailleurs gue celle giane est construite sur le rlan de celle des derniers. Le milieu de la face supérienre de la lige présente aussi une gouttière recevant le suçoir. Le nombre des pièces de ce suçoir varie selon une progression arithenétique de lrois icr.nes, et dout lia différence est toujours de deux: $2,4,6$; mais dars lous les cas il y en a toujours deux d'impaires, l'une supérienre et représentant le labre, l'autre inférieure placée derière le pharynx, et l'analogue de la langue ou de l'hspopharynx. Ici, dans les Diptcres, ainsi que dans nos sucenrs (pulex), cette soie est toujours écuilleuse, foraste, et contribue, au moins autant que les antres, aux actes de la nutrition; mais il nen est pas aiusi dans les Hémiptères, el voilà une nunvelle considération qui sépare ces iusectes des présédens. Les partica reprósentant les mâchoires existent loujous , et souvent mêtne sont accompagnćes chacnte d'un palpe ; mais ces mâchoires sont soudées avec le support, et ne sont bien distinctes que lorsque leur portion apicale devient mobile, s'alonge et présente la forme d'ane soie ou d'une lancello cornée: c'est ce qui a lieu toules les fois que le suçoir est de quatre on six pières. Dans cette dernière circoastance, deax d'entrelies représentent les mandibalcs; dans l'autre, ou si le sucoir z'est. composé que de quatre soies, les deux soies précédentes manquent nu ve sont au plus que rudimentaires. Quelquefois aussi le labre, prengre touj wris voûté et assez grand, semble offrir les vestiges d'une autre piece : celle-ci deviendroit pour lors l'épipbarynx. Quelquefois encore le support est trés-court, et, dans ce cas, les pièces du suçoit sorleat de la cavitć buccale, et les palpes (raaril. Sss 2 
laires) sont insérés sur les cótés. Les Diptères pupipares ou les Hyppobosques diffèrent de tous les autres par l'absenee de la gaine; les palpes, solis la forme de deux lames alongées, coriaces, s'avançant parallèlement et recouvrant le suçoir, en tienneni lieu.

D'après nos observations et celles de Savigny, de Leclerc de Laval, et du professeu. Nyızsch, relatives aux Ricius, la houche des insectes hexapodes homotènes, ou ne subissant pas de métaunorphoses, seroit assujettie au ruême plan d'organisation que celle des insectes polymorphes. Dans les Poux proprement dits, les seuls suceurs connus de cette division, la trompe (rostellum) consisteroit en un pelit tube inarticulé, renfermant le suçoir et se retirant à volonté dans l'iméerieur d'un avanceruent en forme de museau de la partie antérieure de la tête. Mais en gréuéral l'organisatiou buccale de ces insectes parasites sollicite un nouvel examen et de boanes ligures de détail. Les Ricins, qunique pourvus de mindibules, de mâchoires et d'une lèvre inlérieure, ont ces parlies très-concentrées à l'iustar des insectes suceurs; le labre fait l'office de ventouse, caraetère unique danscette classe d'animxux, et qui semble, de concours avec d'untres, indicuer un 1ype particulier.

Cel examen détaillé de la bouclie des insectes sircens on du sucoir, fait par le plus illusire entomologiste de notre temps, ei résultat de sa longue expérience et de ses nombienx travaux, nous a paru propre à bien faire eoncevoir l'organisation de cct instrument chez les insectes qui en sent pourvus, et nous l'avons reproduit ici dans toute son originalité. (E. G.)

SYBISTROME, Sybistroma. M. Meigren (Dipt. d'Europ.) a établi un geare sous ce nom dans sa famille des Dolichopodes, et lui assigne ces cariactères: anteunes avancćes, de trois articles, le dernier alongé, plat, muni d'une soie dorsale biarticulée, longue; sa prenière articulation alon: gée, deux fois aussi longue que la seconde dans les uáles; yeux toujour's séparés l'un de l'autre; extréniliéde l'abdomen courbe, nuuni à l'anns de deux lames eiliées dans les mâles.

$L^{3}$ iuteur mentionue trois espèces : $1^{\circ}$. Sybistrone discipède, $S$. discipes. Meic. Dipt d’Eur. tom. 4. pag. $71 \cdot n^{\circ}$. I. Longuen: 2 lig. $\frac{t}{3}$. D'un vert-foncé-bronzé. Palpes, front et lyypostome 3) aucs; celui-ci très étroit dans le mâle; antennes noires, leur troisième article pointu, presque triangulaire, muni dans son milieu d'une soie dorsale Pongue, nue, dont la seconde artieulation dans le nâtle est de moitié aussi longue que la première et fait avec lui un angle obtus; elle est plus courte et droite dans la fernelle. Segment anal du mále ferrugineux ; lames de l'anus blanchâtres, bordées de noir, accompagnées de deux filamens jaunes. Balancier's blancs. Pattes jaunes. Tarses antériẹus ayant leurs quatrième et einquième articles d'un noir-foncé, celui-ci large, en forme de disque dans le mâle. Les quatre derniers articles des tarses postérieurs sont bruns. De Hambourg. $2^{\circ}$. Sybistrôme pateliipède, $S$. patellipes. Merg. $i d$. pag. 72. $n^{\circ}$. 2. Longueur 2 lig. $\frac{1}{2}$. Corp's d'un vertbronzé-foncé, lyypostome un peu plus large que dans l'espèce précédente, blanc ainsi que les balanciers. Frout blanchátre avec un reflet métallique. Antemes ayant leurs deux premiers articles noirs, le troisiène ferrugineux, un peu plus longr que dans la discipède. Soie conformée de même. latles jauves, ayant la méme conformation que dans la première espèce. Ailes brunes. On ne connoît que le mâle. Le segment anal manquoit dans l'individu décrit. D'Angleterre. $3^{\circ}$. Sybistrôme nodicorue, $S$. nodicomis. Merg. id. $n^{\circ} .3$. tab. 54. figr. 19. Malle. Longueur 2 lig. Corps d'un vert-foncé-bronzé. Côtés de la poitrine d’un gris d'urdoise. Hypostome et balanciers blancs. Finnt noirûtre. Antennes noires, leur troisième artiele laneéolé, ayant près de son extrémité une trèslongue soie dont la première articulation est longue et finit en rossue, et la seconde a son extrémité blanche, déprimée. Segment anal d'un noirbrillant, muni de deux lames ferrugineuses bordées de noir. Paltes ferrugineuses. Extrémité des tarses noiràtre. Troisième el quatrième articles des intermédiaires d'un noir-foncé, larges, plumeux; le cinquiène blanc. Ailes brunâtres. Mâle. D'Earrope. (S. F. et A. Serv.)

SYLVAIN. Norn donné par Engramelle (Pap. d'Europ.) à diverses espèces de Lépidoplères Diasnes du geure Nympha!e (voyez ce mol tom. IX. pag. 329.) savoir: I $^{\circ}$. Le Sylvain, Nymplale du peuplier mâle ${ }^{\circ} \cdot 17^{5} 2^{\circ}$. Le grand Sylvain, même espèce femelle. $3^{\circ}$. Le perit Sylvain, Nymphale Sybilla $n^{\circ} \cdot 176 \cdot 4^{\circ}$. Le Sylvain azuré, Nymphale Camilla $n^{\circ}$. ${ }^{7} 77.5^{\circ}$. Le Sylvain eénobite, Nymphale Lueille no. 259 . (S. F. et A. Serv.)

SYLVATN, Sylvanus. Lat. Tenebrio. De Géer. Dermestes. Fab. Panz. Colydium. Hab. Payx. Herbs Ip. Ips. Olit.

Genre d'insectes de l'ordre des Coléoptères, section des T'étramères, famille des Xylophayes, iribu des 'Trogossitaires.

Un groupe de 'Trogossitaires (voyez ce mol) se distingue par les earactères suivans: corps ćtroit, alongé; nlassue des antennes de trois articles ou plus; antennes notablewent plus longues que la têtie; maudibules petites ou moyennes, peu ou point saillantes : palpes très-eourts, les maxillaires peu ou point saillans. Il coniprend les genres Latridie et Sylvain. Le previer est séparé dn second en ce que le deuxième article de ses antennes est plus long que le troisième, que la tête porte une ligne transversale enfioncée, et qu'ainsi que le eorsclet elle est p!as étroice que l'abdomen. 
Antennes un peu plus longues que le corselet, point insérées sous un rebord, composées de onze articles courts, le second et les suivans jusqu'au lnitième inclusivement presqu'égaux, les trois derniers formant une massue presque perfoliée. La're petit, avancé, menzbraneux, transversal, entier. - Mandibules déprimées, presque trignnes, à pointe bifide, l'angle externe de leur base avancée en une sorte d'oreillette. - Mâchoires composées de deux lobes, l'extérieur plus grand, presque trigone; l'intérieur petit, dentiforme. Palpes trc̀s-courts, presque filiformes, leur dernier article un peu plus grand, presque cylindrique ; les maxillaires presque denx fois aussi longs que les mâchoires. - Lèvre coriace, en carré transversal, entière : menton denx fois plus grand gue la lèvre, coriace, carré, un peu plus large rue long. - Téte a vancée en derant, sans ligne transversale enfoncée séparant le chaperon. Corps alongé, étroit, presque linéaire, très-déprimé. - Corselet aussi large que la tête et que l'abdomen. - Ebtres recouvrant l'abdomen et des ailes. - Abdomen déprimé, linéaire. - Pattes assez courtes; cuisses un peu en nassue; jamles rninces à leur base, allant en grossissant vers l'extrémité; tarses filiformes.

Ces Coléoptères sont très-petits; on les trouve dans les boutiques des marchands de graines, dans les greniers à blé et aussi, dit-on, sous l'écorce des arbres morls. Leur larve n'a pas encore été observée.

\section{Syivain unidenté, $S$. unidentatus.}

Sylpanus unidentatus. Lat. Gener. Crust. et Ins. tom. 5. pag. 20. no. 1. tom. 1. tab. XI. fig. 2. -Dermestes unidentatus n ${ }^{\circ} .27$. Fab. Syst. Eleut.

Yoyez pour la description et les autres synonymes, Ips unidenté no. 13. de ce Dictionnirire.

\section{Sylvain sixdenté, $S$. sexdentatus.}

Sylvanus sexdentatus. Lat. id. - Dermestes sexdentutus no. 25. Fas. Syst. Eleut. - Colydium fiumentarium $\mathrm{n}^{\circ}$. I2. HAB. id.

Lyoyez pour la description et les autres synouymes, Ips fromentier no. 15. Celte espece qui puroît être originairement exotirgre s'est acclinattée dins nos yreniers à blé et daus les caisses de riz. (S. F. et A. SERv.)

SYLVICOLES on ORNËPHILES. Troisième famille des Coléoptères de M. Dunéril, section des Hétérowérés (Zool. analyt.). Il lui donne pour caractères: Elytres dures, lurges. Antennes fliformes, soupent dentées. Celle fanille renlerme les genres Hélops, Serropalpe, Cistèle, Calope, Pyrocinre et Horie. (S. H. et A. Serv.)

SYMETHIS. FAB.

Genre de Crustacés formé par Fabricius anx dépens de son genre Hippa, et composć de son Hippa variolosa; il caraclérisoit ce genre par la brièveté de ses deux antennes quadriarticnlées, cachées dans une avance du rostre. Ce genre n'a pas été adopté. (E. G.)

\section{SYMETHUS. RAFIN.}

Rafinesque désigne ainsi un genre de CrustacésMacroures qui vit dans les ruisseaux en Sicile, et çu'il caractérise d'une manière si vague, qu'on ne pent savoir ce qu'il a voulu désigner. Voilà sa description : antennes intérieures à denx file:s; palpes tiliformes, alongés. Première paire de pattes chéliforme ou pincifère. (E. G.)

SYNAGRE, Synagris. Lat. Fab. Palis.-Bauv. Vespa. Lixn. Oliv. (Encycl.) Junin. Fab. Dr GÉer.

Genre d'insectes de l'ordie des Hyménoptères, section des l'orte-aiguillon, famillc des Diploptères, tribu des Guêpiaires.

Dans la division de cette tribu qui comprend les Guêpiaires solitaires, les genres Ptérochile, Odynère, Eumène, Discoelie et Céramie se dislinguent dé Synagres par leur languette trilobée, ayant au bout quatre poins glanduleux. De plus les mâles de ces cinq premiers genres n'ont point les mandibules plus longues que celles des femelles.

Antennes insérécs sur le front, au milieu de la face, rapprochées, coudées, surtout dans les femelles, allant en grossissant vers l'extrémité et formant une massue alongée, pointue au bout, composíes de douze arlicles dans les femelles, de Ireice dans los mâles, lo Ireizième crochu; premier article long, cylindrique; le second trèscourt, le troisième plus long que les suivans. Mandibules alongées, trigones, ćtroites, avancées en devant et formant uae espèce de bec, celles des máles trisograndes, offrant l'apparence de colnes, émetlant une longue dent. - Nấchories et Levre longrues, flúchies; les prenières ayant leur. lube teminal alongé, étroit, lancéolé. - Languctte divisíe en quatre filets fort longs, dont deux très-plnmeux, sans points glanduleux au bout. - Palpes maxiluares conrs, de trois articles (de quatre suivant M. Latreille), le dernier imilant un peu un onglet : palpes labiaux près de trois fois plus longs que les maxillaires, de trois arlicles, clacun d'eux portant à son extrémité des soies longues et nn peu roides, le premier presqu'aussi long que les deux autres pris ensermble; le dernier le plus court de tous. - Menton coriace, tronqué ì l'cxtrémité. - Téte corame triangulaire vue en devant, plus étroite que le corselet dans les femelles, tres-grosse et presque carrée à sa partie supérieure dans les mâles. Yeux fortement échancrés. - Trois ocelles disposés en triangle sur le liaut du front:-Corns alongé, pea puhescent. - Corselet ovale, tron- 
qué en devant; prothorax très-étroit à sa parlie antéricure, s'élaryissant sur les côtés et s'étendant jusqu'à la hase des ailes; métathorax étroit, ayant de charque rôté une forte ćpice à sa partie infémeure. - Ecusson bilnberculé. - Ailes ployćes en deux tongitudinaleınent, de la base à leur extrémité; les supérieures ayant une cellule radiale triangulaire, se rétrécissant immédiatement après Lu seconde cellule cubitale jusquàa son extrémité qui est nu peu arrondie, écarlće de la côte el aypendiculce : quatre cellules cubitales, la nremière la plus lonsue de toutes, la seconde tris-rítrécie vers la radiale, recevant les denx nervures récurrenles, lir trisième presqu'en carré transversal, la cquatrieme atteignant presque le bout de l'aile: trois cellules discuidales, la première très-alongée. - Abdomen ovale-conique à pédicule extrêmenent court, de cing segmens oulre l'anus dans les femelles, en ayant un de plus daus les mâles; le premier canpanule, le second plus large que les autres, bombé. - Pattes de longneur moyenoe, articles des tarses ciliés de poils roides, le premier le plus long de tons : crochets bifides, muuis dansleur entre-deux d'une pelotte courte, bilobée.

Ces Hyménoplères d'une taille an-dessus de la moyenne habitent l'Asie et l'A firique. Les espèces connnes sont en petil nombre. V'après la conformation de leurs tarses il est probuble qu'elles ont à peu près les moeurz des Odyuères et qu'elles creusenul les sables durs ou le morlier des murililles, et apportent dalus leurs nids des larves d'insectes pour la nourriture de leur postérité.

\section{Syvagre cornue, $S$. cormutu.}

Synagris cornuta. LAT. Gener. Crust. et Ins. toin. 4. Fag. 135. - FAв. Syst. P'iez. pag. 252. $n^{\circ}$. I Wâle. - Encycl. pl. 332 . fig. so. Măie.

Toyez pour la lescripion des denx sexes et les autres syronymes, Gueppe coruut $\mathbf{n}^{\circ}$. 45 . de ce Dicionllaire.

\section{Srsigre calide, $S$. calida.}

Synagris calida. Pac.-BaUv. Ins. d'Afric. et d'Amér. pag. 26o. Wüle et femellc. Hyménopt. pl. X. fig. 6. Mlâle. - I'espa caliala no. 25. W Ав.

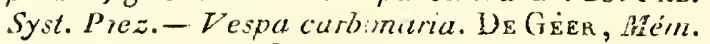
ins. tcm. 7. pug. 6o\%. $n^{\circ} \cdot 7 \cdot p /$. 45. fig. 9. Fiemelle. Cet auteur rapporte a tort a son espece la Iespa capensis nn. z2. de linué. (Syst. nut.)

Nota. Fabricius prétend que le unélahhorax de celte espece puste quatre dents indépelstamment des deux de l'é ussun. (Mvier (Encyel.) ae pade point du tout de dents; cependant il y en a léellement deux petices sur l'écnssun et une de chayne côté de la partie inférieure du métatborax.

fojez pour lu descriplion el les antres syno- nymes, Guêpe calide $n^{\circ}$. 66. de ce Diclionnaire.

\section{Synagre euflammée, $S$, astuans.}

Synagris cestuans. PAL.-Bavv. Ins. d'Afriq. et d'Amér. pag. 2 (6o. Hyménopt. pl. X. fig. 5. Fe-

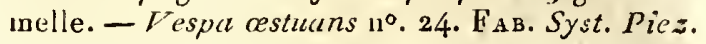

Voyez ponr la description et les autres synonymes, Guêje tnflamméc no. 65 . Femelle.

(S. F. et A. SERT.)

SYNAPIIE, Synapha. Merg. Lat. (Tam. natur.)

Gense d'insectes de l'ordie des Dipières ( ${ }^{\mathrm{r}}$. seclion ), famille des Némocères, tribu des Tipuluires (division des Fungivores).

Un groupe de cetle division a pour caractères : antemus n'étant pas manitestement grenues ni perfoliées, de la lonsueur au plas de la lête el du corselet; seulement deux ocelles visibles. Là se placent les genres Syraphe et Mycétophile. (Voyez Tipularnes.) Celui-ci se distingue du premier par ses jeux oblongs et par ses jambes postéricures épineuses latéralement.

Antennes assez cunrles, avancées, cylindrique, , ayant probablement seize articles, les deux iinlérieurs visıblement séparés, les suivans cylindriques. - Palpes composés de quatre articles, ie precuier très-petit, à peine distinct, les suivaus 'ylindriques, égaux entr'enx. - Téte globuleuse, aplatie par en haut. - Yeux arrondis. - Trois ocelies placés sur le fron!, disposés en ligne presque droile, l'inicrádi.ire à peine visible niêrae vu a la loupe. - Corselet élevé. - Ecusson peii. - Ailes ayant une cellule ovale formée par les deux hranibus de la nerrure longitudinale riu m lien qui se rénnissent avant d'arriver an bord postćrieur. - Abäomen très-comprimé sur les côlés, coruposé de sept segmens : anus des uâles teruiné par une pinc:e de deux ar.icles, le premier grand, ovale, comprimé, velu; le second perit, en buuton. - Pattes de longueur moyenne, janibes éferon ćes à leux extréuité, les postíricures dépourvures d'épines latérales.

B. Heigen ue mentionne qu'une seule espèce de ce gare; on ignore ses mours : il est probable que la larre vil dans les Champignuns.

\section{Synapue fascifie, $S$. fasciata.}

Synapha atru, palpis, femoribus tibiisque ferugneis: alis hyalinis. Mus.

Sinaphafasciatu. Me1g. Dipt. d'Europ. tom. I. p.tg. 22 y. táb. 8. fig. 10-13. Niale.

Longneur 1 lig. $\frac{5}{3}$. Noire avec les cuisses et tes jarnbes de coulcur fermgineuse ainsi que les palpes. Ailes hyalines. Mâle.

D'Allewagre. 'Trouvée en été sur les haiez. (S. F. et A. Sirq.) 
SYNDĖSE, Syndesus. M. Macleay ( Horce Entomol. pag. 104.) élablit un genre d'insectes coléoplères sous ce nom aux dépens des Sinodendron de Fabricius; voici les earacteres qu'il lui doune : seeond arliele des antennes presfine globuleux, le troisième grand, conique, les sept autres (an moins dans les mâles) formant nne mussue lamellée, grande, arrondie, déprimée; mandibules alongées, presque droiles, coniques; palpes maxillaiıes à jeu près de la longueur des mandilunles, leur dernier article cylindrique-ovale, plus long que les autres; eorps cylindrique, à peine plus large que la tête y conıpris la saillie des yeux; écusson petil; corselet convexe, ayant un sillon longitudinal sur le dos; jambes antérieures dentées en scie.

Le type de ce genre est le Syndise cornu, $S$. cornutus. Maes. ut suprà. - Sinodeudron cornutum n ${ }^{\circ}$. 2. Far. Syst. Eleut. - Lamprima. Lat. Règn. anim. tom. 3.pag. 29o. - Lucanus parvas. Donov. Ins. of New. IHolland. tab. 1. 4. 'Terre de Dićmen. (S. F. et A. Serv.)

SYNISTATES, Synistata. Nom dunné par Fabrieius à sa troisième classe des insectes renfermant les genres Ephemera, Phryganea, Semblis, Lepisma, Podura, Hemerobius, Termes, Raphidia, Panorpa et Myrneleon. Le earactère de celte classe est : qualre palpes; mâchoire réunie ea un seul corps avec la lèvre.

$$
\text { (S. F. et A. Serv.) }
$$

SYNODUS, Synodus. Nom que, dars mon ouvrage sur les fanilles naturelles du Rigne animal, j’ai donuć à un genre de Crustacés de lordre dés Isopodes, famihie des Cymorboadés, el distingné des autres gentes dout elie se compose par les earaetères suivans. Post-abdomen de six segmens. Antennes superieures plus constes que les inférieures, insérées an bord antériear de la tête ou paroissant la terminer, lorsqu elle est vne en dessus. Les six pieds antérieurs terminés par un fort crochel; ceux des autres, pelits ou moyens. Corps ovale-oblong. Yeux a facetics. Mlanábules forlics et saillautes.

Ce gemre a élé établi sur une seule espèce ( vorax), de petile taille, et qui habite nos mers. Il avoisine le genre $A E_{g} g$ du ducteur Léach ; mais il s'en éloigne, ainsi que des autres de la même famille, par la saillie des mandibules.

\section{( Latr.)}

SYNTOMIDE, Syntomis. IlLig. LAT. God. Sphinx. Linn. Scopol. Drury. Lisper. Cram. Engram. Prenn. Hubs. $Z$ jogrena. Ross. Fab.

Genre d'iusecte's de 'ordre des Lépidoptères, famille des Crépusculaires, tribu des Zygétides.

Un groupe de eette tribu a pour caractère : antennes sinples dans $I_{t} s$ deux sexes. (Yojez $Z$ YGÉNIDEs.) Avec les $S_{j}$ ntosides ce groupre ren- ferme le genre Sésie qui se distingue par ses antennes terminées par une petite houppe d'écailles et ceux d' Fygocère, Thyride et $Z_{y}$ gène daus lesquels les palpes s'élèvent au-dessus du chaperon; de plus, duns les $\mathbb{E}$ gocères et les Thyrides, les jambes con! terminées par denx épines irès-fortes, et ce dernier genre ainsi que celui de Zygène a l'article terminal des palpes finissant en pointe.

Antennes presqu'tn fuseau, grossissant à peine et insensiblement après le milieu, leur extrémité ne portant point de bouppe écailleuse. - Palpes cylindriques, obtus, très-courts, ne s'élevant pas an-deta du chaperon. - Langue e'n spirale. Ailes grandes, en toit dans le repos; les inférienres ayant leur cellule sons-marginale ćtroite, fcrmée en arrière par l'intersection des deux rameaux nerveux qui se prolongent jusqua bord postéricur. - Abdomen cylindrique, obsus. -. Jambes postérieures n'ayant à leur exirémité que deux épines trés-petiles.

Les Chenilles de ces lépidoptè res sont diurnes, munies de faisccanx de poils; elles se roulent sur elles-mêmes lorsqu'on les iuquiète de même que eelles des Arcties.

Nous nientionnerons les espèces suivantes: $1^{\circ}$. Syntomide Phégée, S. Phegea. God. Lépici. de France, pag. 154. $n^{\circ}$. 49. pl. 22. fig. 14. Syntomis quercus. Lat. Gener. Crust. et Insech. tom. 4. pag. 213. - Sphinx Phogea. Linv. Syst. nat. 2. 805. 35. - Zygoena quenus no. 6. $\mathrm{F}_{\mathrm{AB}}$. Entom. Syst. tom. 3. pag. 388. - Sphinx du Pissenlit. Engram. Faprl. d'Eumop. 20. Syntumide Passalis, S. Passalis. Latr. Id. - Zygreria Passalis $\mathrm{n}^{\mathrm{O}}$. 15. FAв. $1 d$. pag. $39 \mathrm{I}$. Des Indes vilenaales. $3^{\circ}$. Syntomide Cerbere, S. Cerbera. LA T. ia. - Zygona Cerbera no. I6. Fas. id. L'Ehiopie.

(S. F. et A. Serv.)

SYNUCHUS, Synuchus. M. Gyllenball ( ths. Suec.) donne ce nom á un genre d'insectes culéoptères de la tribn des Carabiques de M. Látreille, qui avoil été établi par N. Buvelli sous eelui de 'laphrie. Voyez ce mol.

$$
\text { (S. F. et A. Serv.) }
$$

SYRP'IIE, Syrphus. Fab. (Entom.) Lat. Melg. Ross. Panz. Fallén. Enstulis. Fab. Fallèv. Scopva. Fab. Faldén. Panz. Musca. Linn. Je Géer. Fab. (Entom.) Geofr. Sehraxck.

Genre d'inseetes de l'ordre des Diplères ( ${ }^{\text {re }}$. section ), famille des Athéricères, tribu des $S_{y} x-$ plices.

Des six genres qui composcnt le froupe de celie tribu dans lequel entre le gemre Syrphe ( voyez

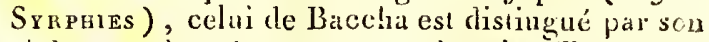
a!ddnneu alorgé en massue; dans les Chuy'sogastres les deux prenières cellules du bord postćrieur des ailes sont éloignées de ce bord. el les nervures transversales qui les ferment infórienrement ne coiserven! pats de para!!élisme avece se bord; 
les genres Pipize, Psilote et Parague ont leur hypostome plane.

Antennes avancces, plus courtes que la tête, rabaltues, insérées sous un rebord du fiont, composées de trois articles; les deux premiers petits, égaux entr'eux, le troisième comprimé, semicirculaire ou oblang, avec une soie dorsale päroissant ordinairement nue à la vue simple. Ouperture de la cavité buccale oblongue, rétrécie par-devant el un peu tronquée daus cetle partie. - Trompe charnue, retirće dans la cavité buccale lors du repos. - Suçoir de quatre suies, snivaut M. Latreille, les inférieures Irès-variab!es sous le rapport de la longueur proporitionnelle. Palpes de forme et de lungueur variables. - T'éte luémisphérique; hypostunse plus ou moins eñfoncé au-dessous des antennes, muni d'un lubercule plus ou noins saillant, situé près de l'ouverture de la cavité buccale. - Yeux tautôl nus , tantôt velus, réunis par en baut daurs les mûles, espacés dars les femelles. -.. Trois ocelles placés eu triangle sur le vertex. - Corps assez long. - Corselet ovale, voûté, velu, surtout dans les mîles. Ecusson semicirculaire. - Ailes grandes, velues vues au microscope, coucliées parallèlement sur le corps dans le repos; leurs deux premières cellules du bord postérieur assez rapprochées de ce bord : les nervures transversales qui les ferment à leur partie iuférieure presque parallèles avec lui. - Cuillerons doubles, petits. - Balanciers découverts. - Abdomen assez longr, assez déprimé, mince, de forme variable, inais toujours linćaire ou elliptique, composé de quatre segmens outre l'anus. - Pattes grêles; tarses ayant leur premier article le plus griad de rous, celui des postérieurs au moins aussi long que les quatre autres pris ensemble, les suivans allant en décroissant de longueur : le dernier muni de deux crochets assez forts, ayant dans leur entre-deux une forte pelotle bitide.

Dans le nouveau Dictionnaire d"Wistoire naturelle, $2^{e}$. édition, M. Latreille avoit proposé de restreindre ce genie aux espèces dont les larves se nourrissent de Pucerons; M. Meigen dans son premier ouvrage sur les Diptères avoit élabli les genies Cheilosia ei Doros qu'jl réunit avec celui de Syrphe dans ses Diptères d'Europe, les caractères des deux premiers lui ayant paru trop peu saillans; il nous paroit certain cependant que les larves des Doros el des Cheilosies ne vivent point sux dépens des Pucerons. Nous avons réuni le premier de ces genres à celui de Baccha. Yoyez ce rout.

Les larves des Syrphes proprement dits ainsi gue leurs habitudes sont assez connues par les travaux de Goedaert et surtout da célebre Réuazour. (Voyez ce deraier auteur tom. III, Mém. $\mathrm{XT}$, ainsi que l'analyse de ce Mémoire, Encycl. zom. IV, pag. CCXXV, CCXXVI et CCXXVII.) Les insectes parfaits vivent du miel des lleurs.
Les mâles ont une grande puissance de vol et se soutiennent long-temps en l'uir à la même place pour guetterle passige des femelles, de la même nanièe que les Eristales; les femelles parconrent très-fiéçuemment en roltigeant les différentes parties des vógétaux où elles espèrent trouver des colonies de Pucerons atin d'y déposer quelques cufs; elles ne metlent jamais dans un même endroit un nombre considérable de ceś œufs, et quoique l'on trouve souvent deux ou trois larves de Syrphes occupres à détruire une même famille de Pucerons, le plus souvent ces larves ne sont pas de la nême espéce; celles din sous-genre Cheilosia vivent probahlement dans le terreau végétal, les insectes parfaits se tiennent ordinairenent dans les bois, sous les futaies claires, près des terrains lin mides. On voil quelcuefois de petils Luissons qui en sont entièrement chargés et autour desquels ils se jouent ensemble en voltigeant, nous ne les avons jamais vn planer en L'ar ni chercher les Pucerons sur les végétaux.

Quoique Fabricius soit le fundateur de ce genre, coin me il en a retiré beancoup d'espèces dans son Systema Andliatorum, le genre Syrphus de cet ouviage be contient aucune espèce que nous puissions rapporter au présent genre; ses Syrphlus mussitans et lapoonum sont des Sćricomyies; le bombyliformis est un Eristale; nous ne conanissons puint les Syrphus tympanitis, yesiculosus, vacuus et obesus; les autres espèces appartiennent aux Volacelles. Le genre Scopsa de Fabricius est celui qui contient le plus grand nombre de nos espèces de $S_{y}$ rphes. (Lion sait que cet auteur a peu de genies purs sous ce rapport.) Les $\operatorname{Srccova} \mathrm{n}^{\mathrm{s}}$. 1 . 2. 3.8.9.11.12.13. 14.17.18.22. 23. sont de vrais Syrphes. Le $n^{\circ}$. 4. est un Parague; l'espèce numérotée 7. est un Xylote et le no. 19. nn Sargus suivant M. Wiédemann. ILes autres nous sont inconnues. On trouve encore quelques Syrphes parmi les Eristalis. Fав. Ce sout les nus. 34 . $36.57 \cdot 46.49 .50 .53 .55 .56$. et 66 .

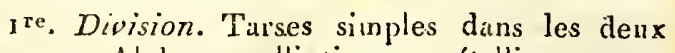
scxes. - Abdomen elliptique, niétallique, sans bandes trausverses. (Genre Cheilosia. Merg. ('lassif:)

Nota. En réunissant, dans ses Diptères äEurope, ce genre aux Syrphes, M. Meigen remarque qu'il y doil former une division particulière distinguée par son corps toujonrs de couleur sombre; sur le front immédiatement au-dessus des antennes on voit une fosselle, et dans les femelles en dehors nne ligne latérale enfoncée : le troisième article des intennes est arrondi. Cet auteur rapporte 34 espèces à cette coupe parmi lesquelles nous citerons comme se trouvant aux environs de Paris : $1^{\circ}$. Syrphe rnficorne, $S$. ruficornis. MeIG. Dipt. d’Eur. tom. 3, pag. 278. no. 1. $2^{\circ}$. Syrplie gros, $S$, grossus. ME1G. id. pag. 281. $n^{\circ}$. 5. $3^{\circ}$. Syrphe fulvicurne, $S$. fulsicomis. Merce. 
id. pag, 288. $n^{\circ} \cdot 18.4^{\circ}$. Syrphe albitarse, S. albitarsis. MEIG. id. pag. 29o. $z^{\circ}$. 22. ว́ ${ }^{\circ}$. Syrphe antique, $S$. antiquus. Merg. id. pag. 291. $n^{\circ} \cdot 24$.

ne. Division. Tarses simples dans les denx sexes. - Abdomen presque d'égale longueur dans les deux sexes, noir ou mélallique, tonjours fascié. - Appareil génital des nâles tonjours caché (genie $S_{j}$ rphus propriè dictus).

${ }^{\mathrm{r}}{ }^{\mathrm{a}}$. Subdivision. Abdomen elliptique dans les deux sexes.

A. Corselet rayé longitudinalement; écusson jaune.

Ce groupe comprend : $1^{\circ}$. Syrphe agréable, S. festivus. Meig. Dipt. d'Eur. tonn. 3. pag. 297. $\pi^{\circ}$. 36. $2^{\circ}$. Syrphe ornó, $S$. ornatus. Merg. id. pag. $298 . n^{\circ} .37$.

B. Corselet d'une seule couleur; écusson de même cuuleur que le corselet on pâle.

a. Une seule bande sur chaque segment de l'abdomen.

Lia viennent: ${ }^{\circ}$. Syrphe dı Poirier, S. pyrastri. Melg. Dipt. a'Europ. tom. 3. pag. 303. $n^{\circ}$. 44. $2^{\circ}$. Syrphe du Rosier, S. rosanum. Merg. id. pag. 338. $n^{\circ}$. 94. 3o. Syrphe transparent, s. hyalinatus. Merg. id. pag. 312. no. $56.4^{\circ}$. Syr. phe du Groseillier, S. ribesii. Merg. id.pag. 306. $n^{\circ}$. 49. $5^{\circ}$. Syrphe noble, $S$. nobitis. MeIG. $i d$. pag. 3r6. $\pi^{\circ} \cdot 6 \% \cdot 6^{\circ}$. Syrphe nitidicolle, $S$. nitidicollis. Meig. id. pag. 3̈o8. $n^{\circ}$. 51. $7^{\circ}$. Syrphe bifiscié, $S$. bifasciatus. Merg. id. pag. Jog. $n^{\circ} .52 .8^{c}$. Syrphe des fleurs, $S$. corolit. HeIs. id. pag. 304. $n^{\circ}$. 46. Tous des environs de Paris.

\section{b. Deux bandes sur la plupart des seg- mens de l'abdornen.}

Le Syrphe à ceinlures, $S$. balteatus. Meic. Dipt. d'Europ. tom. 3. pag. 312. no. 57. appartient à ce petit groupe.

$2^{e}$. Subdivision. Abdomen alongé, presque linéaire.

Celte subdivision renfurme: $1^{\circ}$. Syrphe grêle, S. gracilis. Me1G. Dipt. d'Europ. tonu. 3. pag. 328. $n^{\circ}$. 80. $2^{\circ}$. Syrphe mielleux, S. melithurgus. Marg. id. pag. 329. $n^{\circ} \cdot 82.3^{\circ}$. Syrphe porteéchelle, S. scalaris. Merg. pag. 330. $n^{\circ}$. 83. Ces trois espèces se trouvent aux environs de Paris.

3e. Division. 'Tarses simples dans les deux sexes. - Abdonen linéaire, tuujours fascié, tries. alongé dans les mâles. - Appareil génital de ceux-ci paroissant à l'extérieur sous les derniers segmens de l'abdomen et offrant l'apparence d'une sphère accolée à un globule couvert de poils divariqués. (Sphorrophoria. Nов.)

Nous plaçons ici : $1^{\circ}$. Syrphe de la Meaılue, $S$. Hist. Nat. Ins. Tome $X$.
Menthastri. Merc. Dipt. d'Europ. tom. 3. pag. $325 . n^{\circ} \cdot 75$. D'Allemagne et de Montpellier. $2^{\circ}$. Syrple de la Mélisse, $S$. Melisso. Merg. id. pag. 326. $n^{\circ} \cdot 7^{6} .3^{\circ}$. Syrphe noté, $S$. scriptus. Meig. id. pag. 324. $n^{\circ} \cdot 73.4^{\circ}$. Sylphe rubanné, $S$. tosmiatus. MEIG id. pag. 325. $n^{\circ} \cdot 74$. Ces trois derniers des euvirous de Paris. $5^{\circ}$. Syrphe peint, $S$. pictus. MEIG. id. pag. 326. no. 77. D'Autriche. 6\%. Syrphe hiéroglyphique, $S$. hieroglyphicus. Meis. id. pas. 327. $\iota^{\circ} \cdot 7^{8} \cdot 7^{\circ}$. Syrphe Philinthe, S. Phalanthus. Herg. id. $n^{\circ} \cdot 79$. D'Allemagne.

$4^{\mathrm{e}}$. Divisiou. Tarses antérieurs dilatés dans les mâles. - Abdomen linéaire, presque d'égale longueur daus les deux sexes, noir on mélallique, $\dot{a}$ bandes transverses. (Platycheirus. Noв.)

Nous mentionnerons les espèces suivantes : $1^{\circ}$. Syrphe à palette, S. scutatus. MEIG. Dipt. d'Eur. tom. 3. pag. 333. $n^{\circ}$. 88. $2^{\circ}$. Syrphe ì bouclier, S. peltatus. MEIG. id. pag. 334. $n^{\circ}$. 39 . Des environs de Paris ainsi que le précédeut. $3^{\circ}$. Syrphe albimane, $S$. albinanus. NeIg. id. pag. 333. $n^{\circ}$. 87. D'Allenagrue. $4^{n}$. Syrphe patte élargie, $S$. clypeatus. Meig. id.pag. 335. $n^{\circ} \cdot 9^{0}$. D'Allemagne. 50. Syrphe à manchetles, $S$ manicatus. Mrig. id. pag. 336. $n^{\circ}$. 91. Mêne parie que le précédent. $6^{\circ}$. Syrphe lobé, $S$. lobatus. Herg. id. $n^{\circ} \cdot 9^{2}$. (S. F. et A. Sruv.)

SYRPHIES, Syrphice. Première tribu de la tinmille des Athéricères, première section de l'ordre des Diptères, à laquelle M. Latreille donne pour calactères :

Antennes composées de trois articles, le dernier sans divisions, plus grand que les autres, t: forme de palette ou de massue, souvent muni d'une soie dorsale ou quelquefois d'un style terminal. - Trompe longue, bilabiée, se retirant entièrement dans la cavité buccale, renfermant dans une gouttière supérieure un suçoir de quatre soies et deux palpes linéaires, comprimés, adhérant chacun à l'une de ces soies. - Téte ayan son extrémité antérieure ordinairement avancíc en manière de bec.

Nous diviserous cette nombrense tribu de lit manière suivante, en partie d'après des considérations tirées des derniers ouvrages de M. Latreille.

I. Antennes sensiblement plus longues que lat tête.

A. Troisième article des antennes n'ayant pas de soie dorsale.

Cérie, Callicère.

B. Troisième article des antennes muni d'une soie dorsale.

$$
\begin{aligned}
& \text { Chrysotoxe, Aphrite, C.s } \\
& \text { ratophye. }
\end{aligned}
$$

Nota. Nous ne connoissons pas le genre Spbé- 
comye que M. Latreille range parmi les Syrphies dont les untennes sont plus longues que la tête.

II. Antennes à peine de la longneur de la tête ou plus cuurtes qu'elle.

A. Denxième article des antennes plus longr que le premier. - Antennes insćrées sur un pédicule frontal.

\section{Psare.}

B. Antennes ayant leurs deux premiers articles égaux entr'eux.

a. Antennes portées sur nn tubercule frontal.

† Cuisses postéricures simples.

Milésie, Bracbyope, Rhingie.

† † Cuisses pestérieures renflées.

Xylore.

b. Point de tubercule frontal portant les antenues.

† Ailes n'ayant point de cellule pédiforme.

* Cuisses postérieures renflées.

Sphégine, Ascie, Tropidie, Eumère.

* * Cuisses simples.

ฐ Soie des antennes triartieulée.

Pélécoec̀re.

9 Soiedes anlennes sans artieubations sensibles.

A. Soie des antennes nue ì la vue simple.

n. Abdomen en massue.

Baccla.

o. o: Abdomen linédire ou elliptique.

Syrphe, Clurysogistre, Pipize, Psilote, Parague.

A $\Delta$. Soie des antennes plumeuse. Sériconyie, Volucelle.

$\dagger+$ Ailes ayant leur cellnle sous-marginale pédiforme ( 1 ).

(1) Cetre cellule est pédiforme lorsque la nervure qui la sefare de la première cellule du bord pustéricur forme un profond sinus temeranc dans certe derrière, alors la cellule soas marginale prentla forme de la parric infórieure d'une jambe dons le pied scroit entiòiement étenda.
* Cuisses postérieures simples. Mallote, Eristale.

* Cuisses postérienres renflées.

Hélophile, Mérodon.

Les larves des Syrphies sont apodes, leur corps est membraneux, elliptique ou alongé et aminci en devant, quelquefois terminé par une espèce de quene; leur têle u’a pas de forme constante; ćtant molle et charmue; leur bouche est ordinairement armée de deux croelets écailleux qui servent à déchirer les substances dont se nourrissent ces larves : elles se transforment en nymphes dans len peau même qui devienl une coque en se dnrcissint par la dessiccation; elles y prennent ensuite la forme d'insecte parfiait, lequel sort de la coque en faisant sauter la partic antérieure sons la forme de deux demi-calolles, par l'elforl qu'exerce contre celle raitie une membrane susceptible de se gonller d'uir à la volonté de l'insecte parfait, qu'il a fait sortil de la partie moyenne de la face, immédiatement an-dessons des antenres; cette menıbrane étant rétractile, rentre en totalité après a voir servi it l'nsage que nous venons d'indiquer.

On trouve les Syrplies it l'ćtat parfait sur les fleurs et sur les feuilles des plantes.

Círie, Ceria. Fab. Lat. Scher.e. Melg. Iltig. Musca. Linn. Schnanck. Syrphus. Ross. Panz.

Genre d'insectes de l'ordre des Diptères ( I re. section), faraille des Athéricères, tribu des Syrphies.

Les Céries et les Callicères constiluent un groupe dans ceile tribu. (Loyez Syrpmes.) Lo second de ces genres est distingué du premier par son abdomen conique et parce que liu nervure qui sépare la cellule sous-marginale des ailes de lix première cellule da bord postérieur ne forme pas un angle rentrant dans ceile-ci.

Antenzes plus longues que la tête, insérées sur un lubercule firontal plus uu moius long, quelquefois colonnifurme, composées de triss articles, le premier cylindrique, grossissant à peine antérieurement, plus long que le second; les second el troisième presqu'égraux, formant ensemble une matssue porlant à son extrémité un style pointu, biat'ticulé. - Ouverture de la cavité buccale presquoblongue, tronquée en devant. - Trompe épaisse, charnue, cylindrique, terminće par une double lèvre. - Sucoir de quatre soies, suivant M. Latreille, les inférieures subulées, courbées, plus courtes que les palpes. - Palpes aussi Jongs que la soie supérieure, rylindriques dans la plus grande partie de leur longueur, élurgis et relus à leur sommet. - Tête pluslarge que lecorselet, plane, alongée vers le bas en forme de museau ay ant un tubercule au-dessus de la bouch e. - Yezux espacés el frontlarge dans les femelles, rapprochés el sépa és par ure simple suture dans les mâles. - Truis 
occlles posés sur un tubercule du vertex, rapprochés en triangle. - Corps alongé, presque cylindrique. - Corselet tronqué antérieuremen!, rétréci à sa partie posiéricure. - Ailes à peu près de la longueur de l'abdomen, à moitié ouverles dans le repos, snivant $M$. Latreille, velues vues au inicroscope; la nervure qui sépare la cellale sous-marginale de lit premic̀re cellu!e du bord postérieur formant un angle rentrant dans celle-ci. -Cuillerons très-pretits. - Balanciers découverts. - Abdomen cylindrique, un peu fusiforme dans les femelles, composé de quatre segmens, outre l'anus, celui-ci conique dans les femeles, arrondi dans les mâles. - Pattes de louguenr moyenne, assez forles; jambes amincies a leur base, les postérieures un pen arquées; articles dés tarses bifides; le dernier trongué, terminé pur deux crochets nunis d'une pelutte bilobée dans leur entredeux.

L'bistoire de ces Diptères n'est pas encore eonnue. On les rencontre guelquefuis sur les flents et les trones d'arbre. M. Meigen en mentionue trois espèces.

Ire. Dizision. Antennes insérées sur un tubercule fiontal luag, colonniforme.

\section{Cérie comopsoïle, $C$. conopsoides.}

Ceria nigra, hypostomatis maculà duplici laterali triangulari, frontis lincâ transvers $\hat{x}$ (in fominâ è quatuor punctis, in mari è duabus lineolis angulatin dispositis conizositâ) verticis strigâ, thoracis margine antico, linêt utrinque antè alas puncto ad apices termincetâa alâque scutellari, abdominis primi segnenti maculà utrinquè arcuatô, secundi, tertii quartique margine infero!' teis: pedihus luteis, femorum mediâ parte trbiüsque apice fisco-nigris.

Ceria conopsoides. Mierg. Dipt. d"Europ. tom. 3. pag. i6o. no. 2. - Lat. Gener. Crast. et Ins. tom. 4. pag. 328. - Ceria clavicornis no. 1. Ha в. Syst. Antliat. (Cet auteur lui donne mal-à-propos la Ceria subsessilis pour fenelle.) - Mrusca conopsoides. LinN. Faun. Suec. 1790.-Symphus co. morseus. Panz. Faun. Gem. fis. 44 . fig. 20. Mile.

Longneur 6 lig.; 6 lig. $\frac{1}{2}$. Ankmnes noires, leur préfieule conmun un peu testaeé en dessons. "Tete noire, sa fue antérieure ayant deux grandes taches latérales triangulaires jacnes, quatre points de nêeue couleur placés an lirne tronsverse entre lés yeux, ininédiatenent an-dessus des antennes, ei une ligne transwerse jatme, un peu interronyue daus son milieu, terminant postérienrement le vertex. Corselet noir ayant audevant de chaque aile une ligne jaune aux deux exiréraités de laquelle se trouve un point de wème conleur. I'angrle antérienr est de cette couleur ainsi qu'une ligne transverse sur l'écusson. dbdomeo noir; premier segment ayant de chaque cóte de sa base une tache jaune arquée; hord pustérienr des second, troisième et quatrième segrincns de cette mêtme couleur. Cuisses noires, leur base et leur extrémilé jannes, surtont la première dans les cuisses postérieures; jambes d'un janse un pen tes!acé, brunâtres dans leur milieu, larses tostacés. Burd extérieur des ailes depuis la base jusqu'à son extrénité bran, cetle couleu s'étendant presque jusqu'au milien, le reste de l'aile transparent mais séparé par une ligne brune qui desernd de la bise de l'aile jusqu'á son nilien. Fernelle.

Le snâle differe en ce que, au lien des quatre points an-dessns des antennes, on voil dans celle parlic derz lignes jaunes gui se rejoignent presque en clucron lirisé; la ligne du vertex u'est pas: interrompue; l'extrénité des jambes el des tarses est plus brune.

Des envitons de Paris.

Nota. La description du mâle et de la femelle de cetle essièce ayant élé donnée jusqu'rci d'ine nanicre incorrecte, il nous a semblé utile de décrire les deux sexes avec tous les délails nécessaires.

A celle division appartient en ontre la Cirie vespiforme, C. respifomis. Lat. ut suprì.Merg. Dift. a'Elrop. tom. 3. pag. 161. $\pi^{\circ}$. J. D'Talie et de Barbarie.

$2^{\mathrm{e}}$. Division. Antennes insćrées sur un tubercule frculal lrès-courl. (Encycl. pl. 39 1.fig. 6.)

Le type de celte seconde division est la Céric subsessile, $C$. subsessilis. Illug. Mrig. id. $n^{2} \cdot 1$. - Lat. ui suprà. D’Auvergne.

GALLICERE, Callicera. Meig. Isit. PAN\%. Bibio. FAB. Syrphus. Ross.

Genre d'insectes de Fordre des Dipières ( 1 ". section), famille des Athcricères, tribu des Syrphies.

Les Syrphies dont les atennes sensiblement plus longues que la tête sont dépourvues de soil: dorsale, forment nn groupe qui renterme les genres Córie et Callicère. (Toyez Sxrzurs.) Dans les Céics l'abdomen est cyliadrique ct la nervnre qui sépare la cellule sous-rarginale des ailes de la première cellule du bord postérieur forme un angle rentrant daus celle-ci.

Antennes ärancées, insérées sur un tuberculo frontal, rappiochées à lcur base, composées de Ireis articles, le premier cylindrique, le second a peu près de la même longueur que le précédont, dilaté vers son extrémité, formant avec le Iroisiène une massue longue, un pen déprimée. dilatće dans son milien, terminée par un style assez long, qui ne présente pas d'articalations apparentes. - Ouperture de la cavité buccale. presqu'oblongue. - Irompe épaisse, charuue, cylindrique, terminée par une double lèvre. - Sam coir de quatro soies, suivant M. Latreille, Jes in. 


\section{6}

rérieures subulées, courbées, à peine moitié aussi longues que les palpes. - Palpes ćpais, noneux, velus dins tonte leur longneur, plus courts que la soie supéricure. - Tète plus large que le corselet, hypostome tuberculć. - Yeu.x espacés et front large dans les femelles, rapprochés et n'étaut séparés l'un de l'autre que par une simple sutuice dans les mâles. - Trois ocelles disposés en triangle su: le vertex. - Corps un peu velu, assez court. - Corselet presque giobuleux, tronqué en devant. - Ecusson semi-circulaire. - Ailes un peu plus longues que le corps, velnes vues au microscope, couchées l'une sur l'autıe dans le repos; la nervure qui sépare la cellule sous-inarginale de la première viollule du bord postérieur esı presque droite et ne forme pas d'angle. - Cuillerons petiss. - Balunciers en gruncie partie déconverts. - Abdomen composé de quatre serniens outre l'anns, conique dins les míles, plus ovale dans les femelles. - Pattes de longueur inoyenue, un peu velues: prenier article des tarses long et ronflé (du moins dans les feme!les).

Le nom donné ì ce grenre vient cie denx mols grecs qui signifient: belles comes. On n'en connoit qu'une seule espèce. Callicère bronź́c, C. anea. MeIs. Dipt. a' Europ. tont. 3. pagr. 555. $n^{\circ} .1$. tab. 26. fig. $16-20$. Elle se trouve dans les zontagnes ea Alsace et dans le milili de la lirance.

Nota. Les individns décrits par iJ. Latreille (Gener. Crust. et ins. tom. 4. pug. 329.) et par Rossi (Fuun. Etrusc. 1om. 2. Mug. 208. tab. 10. fig. 4. ) ne sont peut-être que de simples variétés de cette espèce, ainsi que la Callivera cenea. PANZ. Faun. Gem. fas. 104. fig. 17 .

CHRYsotoxe, Chrysotoxum. Nere. Iat. Mulio. Fa B. Fat.r. Scuert. Milesia. Fa b. Syrphus. Ross. Panz. Musca. Linn. Gegfof. De Géer. De Vír..

Genre d'insectes de l'ordre des Diptères ( re. section), famille des Auhricières, tribu des Syrphics.

Trois genres de celle triln, Chrysoloxe, Aplurie el Cératoplyye ont pour caractères consmuns: antennes sersiblement plus longues que la tête, leur troisième article muni dune soie dorsale. Les denx dermiers genres se distimuent faciement des Chrysotoxes par la forme du second article de leurs antennes infininent plus rourl que le premier' et par la première cellule din berd prostérieur des ailes parlagéce en deux par une nervure transversale : en ontre l'ácusson des Aụhrites est bilenté, et dans les Cératopliyes le dernier arijcle des anteunes est manifestement plus long gue les doux premiers pris ensemble.

Antemnes plus longuics quie la tête, insérćes sur un tubercule frontal, enniposkes de irois articles, ordinairemeat presqque d'égale lougnenr entr'eux, le premier cylindrique, le second compriené, garnis tous deux de poils courts, le troisieme quelquefois un peu plus long que le précédent, allant en se rétrécissant rers le bout, comprimé, na, muni d'use soie dorsale nue, inarliculée à sa base. - Ouverture de le cavité buccale ullongue, rétrécie par-devant et un peu sinueuse. - Trompe charnue, cylindrique, cornée dans sa partie inférienre, lerminće par deux lèvres. - Sucoir de quatre soies, suivant H. latreille, les inférieures courles, rnoins longues que les palpes. - Palpes moitié pllus courts que la soie supérieire, presque coniques, un peu relus. - Téte liéraisphérique, plus large que le corsulet; hypostome nu, ayant un luhercule antedessus de la honche. - Yeux espacís dins les fomelies, ceux des uales rapiprochés par-devant et presque contigus. - Trois ocelles placés en triangle sur le vertex. - Corps peu épais, assez convexe, légèremeut pubescen: - Corselet ovale, tronqué en devant. - Ecusson assez grand, transversa!, mulique. - Ailes plus longues que le corps, velues vues an microscope, écartées dans le repos; la nervure qui sépare la cellule sous-marginale do la première cellule du bord postérieur, sinvense, forrant un angle oblus rentrant dans celle-ci gria n’est pas parlagée en deux par cne nervure transversale. - Cuillerons de grandeur moyenne, ciliés. - Balanciers en partie découverts. - Abdoncen elliplique, convexe, pen épais, rebordé, de cinq segrneus outre l'arus. - Pattes assez foibles; cuisses grêles; jamles mn peu en massue; prenier article des talrses ansi long que tous les suivans pris ensemble; crochets couts munis dans leur entre-deux d'une pelolle forte, bilobéc.

Chrysetose est liré du grec; ce nom a rapport aux lignes dorćes es arquées ciue porte l'abdomen de ces Syrphies; leurs llavsf omations ne sont pas connues aon plus rue lenrs larves; Fabricins, sans cn alléguer la raison, pense que ces dernières habient dans les rasines. Schranck, on prétendant qu'clles vivent de Pucerons, paroît avoir pris la hrve d'un Syrphe pour celle d'un Chrysoloxe. Ces insectes perdent après la mort len belle couleur jaune-doré, çni alors se rembrunit beanconp. On en conncît ncul espèces europénnes; on les rencontre sur les fleurs.

$r^{\circ}$. Chrysotoxe double ceinture, C. bicmetum. IIErc. Dijt. d'Europ. tom. 3. pag. 168. $n^{\circ}$. 1. Des cnvirms de Paris. $2^{\circ}$. Chrysotose arrué, C'ar cuarum. Metg. $i d$. no. 2. tab. 27. fig. 7. Wemelle. 3". Chrysotoxe iniermédiaile, $C$. intermedium. MnIG. id. pag. 16g. $n^{n}$. 3. tub. 27. fig. 6. Mâle. $4^{\circ}$. Chrysotosse fusciolé, C. fiesciolatum. MEIG. id. pag. 170. $n^{\circ}$. 4. 50. Chrysoloxe bordé, $C$. marginatum. MeIG. id. pag. $171 \cdot n^{\circ} .5 .6^{\circ}$. Chrysoloxe des forêts, $C$. sylparum. MeIG. id. $n^{\circ}, 6$. $7^{\circ}$. Chrysoloxe costal, C. costale. Mejg. id. pag. 172. $n^{\circ} .7 .8^{\circ}$. Chrysoloxe des jardins, $C$. hom tense. Metg. pag. 173. $n^{\circ}$. 8. $9^{\circ}$. Chrysutoxe linéaire, C. lineare. Musc. id. $72^{\circ}, 9$. 


\section{$S \mathrm{YR}$}

APIRITE, Aphritis. LAт. Microdon. Níne. Fali. Mfulio. Fав. Scheri. Stratiomys, Malio. Panz. Musca. linn. Df. Géen. Sezh.

Genre d'insectes de l'ordre des Diptires (premièse scelion), lamille des Allúricères, tribu des Syrphies.

1)es trois genres qui composent la seconde subdivision de la première division des Syrphies (voyez ce mot), ceux de Chrysoloxe el de Cératophye ont l'écusson mutique, ee qui empíclıe de les contondre avec les Aphrites.

Antenres sensiblement plus longues que la tête, arancées, insćrécs sur un petil tuberculedu front, composées de trois aticles, le premier alongé, cylindrique, aussi long que les dcux suivans réuuls, finement velı, le sccond allant en s'élargissant, le troisième beaucoup plus long que le précédent, conique, pointu à son extrémité, muni a sa base d’une soie dorsale nue. - Owerture de la cavité buccale pelile, ovale. - Trompe charnue, cylindrique, terninée par deux levres. Sucoir de qualre soies, suivant M. Lalreille. pälpes fort petis, a peine visibies. - Tête àssi large que le corselet, un peu lı́misplı́rique, firrtement comprimée en derant; hypostome voúlá, jlane, sans tubercule, grani de poils veloutés.-Yeux espacés dans les denx sexes, mais se rapprochant un peu l'un de l'aulse daus les mâles, en formant cliacun presqu'un apyle dont les sommets aboutissent à nue ligne trausversale eufoncée. - Trois ocelles placés en triangle sur le vertex.-Corps court, un peu velu.-Corsclet contrt, presque globuleux, tronqué en devant. - Dcusson grand, transversal, portant de chaguc cólé de son milien une pelite pointe spiniforme. - Ailes velues vues au mieroscope, coubées presque parallelement sur le corps dans le repos, la uervure qui sépare la cellule sous-mareninale de la première cellule du bord postćrieur un pen siunen:e, formant trois petits angles vers eetle deruicre qui est séparée en deux par nne nervure transversale. - Cuillerons de grandeur moyenne.-Balanciers courts, caebés. - Abdonnen voûté, mince, de qualre segmens ontre l'anıs. - Pattes assez fortes, finement ciliées; premier article des tarses assez long, les autres allant en diminnunt, le dernier fort petil, portant deux crochets ayaul une pelotte bifide dans leur entre-deux.

On trouve les Aphiles sur les lieurs pendant la belle saison, mais ils ne sont pas communs. Leurs larves n’ont pas encore été observées. M. Mieigen en décril quatre espèces.

10. Aphrite apiforme, A. apifornis. - Aphrtis auropubescens. LAт. Gener. Crust. et Tus. Lom. 4. pag. 330.tom. . tab.1. fig. 7. et 8. Fcmelle.Microdon apiformis. MEg. Dipt. d'Europ. tom.3. pag. 163. $n^{\circ}$. 1. $2^{\circ}$. Aphrite variable, $\mathcal{A}$. mutebils. - Microaon mutabilis. Mrug. id. pag. 164. no: 2. 35. Aphrite brillant, A. micans. - Hicrodon micans. Merc. id. pag. 163. $2^{\circ}$. 5. 4․ Aphrite floral, A. anthinus. - Nicrodon anthinus. Nerr. id. $n^{\circ} \cdot 4 \cdot t_{a b} .26 . f i g .54$. Femclle.

CERATOPHYli, Ceratophya. WiEne. (sinal. entom.) LAT. (Fam. nat.)

Genre d'insectes de l'ordre des Diplères (première section), Gamille des Athérićres, tribu des Syrphies.

La seconde subdivision de la premicre division des Syrphies contient les genıes Chrysotoxe, Apluile et Cératoplyye. (Foyez Srrrures.) Duns le premier les deux premiers articles des antennes sollt égaux entr'eux el l'écusson des Aplriles est bidenté; ces caractères éloignent ces deux genres de celui de Céralophye.

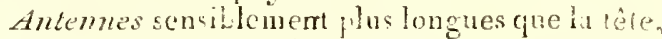
avancées, de trois arlicles, le premier assez rand, cylindrique, le seeond très-cout, cyathiforme, le troisiéme comprimé, lintare, plus long gue les deux autres pris ensenble, muni à sa bise d'une soic nuc. - Téle transversalc, un pen plas large que le corselet. - Corps presque grabre. - Corselet à peu près carté. - Ecusson assez grand, mutique. - Ailes dépasant un pen l'abdomen, la nervare qui sérare la rellale sousmarginale de la premiere cribule du bord posterrieur peu sinueuse; celle demise cellale patslagúce en dous pal une nervure tiansersale.

$\mathrm{Ne}$ connoissant point ce geare, nous en domons les earactères d'aprós lo lexte el la tignte que nous forrnit M. Wiedemann. lee nom de Cípalil'hye vient de denx mols grees qui signifient: porte-come. Les denx especes qu'il décril sou ân lineil.

10. Céralophyc notée, C. notita. WTrén. Arat. entom. pag. I 4.fig. 9, Longucne 3 lig. ․ Nrive. Epaulettes et écusson jumes, ainsi fue deux taclies et une bande rrasrorsale sur l'abdomeu. femelle. $2^{\circ}$. Cratopliye longicome, C. longicompls. Wrenfm. id. Longueur 3 lig. $\frac{3}{2}$. Noire. Abd men aymont it sa base une tache jame terniné postérieurement par deur pointes. l'erelle.

MILESIE, Milesia. Lat. Mab. MeIg. Panz.

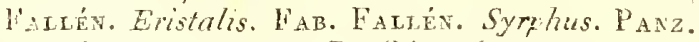

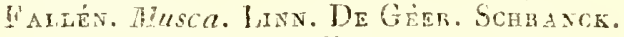

Genre cinsectes de l'ordre des bijlères (prewière section), lamille des Athéricères, tribn des Syptics.

Tu groupe de Syrphies a pour caracteres : ancennes à peine de la longueur de la tése nu plus courtes qu'clle, polćes sur un tubercule frontat; lours deux premicrs arlicles éritux entr'eux; if contitnt les Milésies, les Brachyopes et les Rhingies. (Jovez Srupies.) Ces dernières se dislinguent par l'hypostome fort long, avancé en un bec horizonlal; les Brachyopes on les ailes deux fois anssi longues que l'abdomen, le corps presque glabre et la soie des antennes velue.

dritennes plus contes que la lête, insérées sur 
In avaneement coniuge din front, avancécs, rabattues, composées de trois artiules, les deax premiers fort petils, le troisième lenticulaire, presque rond, quelquefois un peu tronqué, muni a sa base d'une soie dorsale nue. - Ouverture de la cavité buccale oblongue, rétrécie en devant. - Trompe assez épaisse, rentrant dans la cavité buccale lors du repos. - Suçoir de quatre soies, suivant 11. Lalreille, les inlérieures beancoup plus courtes que les palpes. - Palpes plus longs que la soie supérieure, velus, grossissant vers leur esirémité, un peu coulbés dans celle parie. - Téte hémisplérique : hypostome tronqué à l'extrémité, creusé dans son miliea, ou boubé, alongé el luberculé dans cele partie. - Yeux plus ou moins réunis par oi haut dans les mâlles, espacés duns les femelles. -- Trois ocelles placés en triangle sur le vertex. - Corps assez alongé, pubescent gu mème velu. - Corselet boabé, ovile-globulcux, un peu tronqué antérienrement. - Ecusson assez grabd. - Ailes dépascant peu l'uldomen, velues vues an microscope, couchcies parallelement sur le corps dans le repos. La nervare qui ferme frat en haut la remiere cellile du Lord pestérieur, toujours ablique; celle qui sépare relle rellate de la cellate scus-maryinate, tantôl presque dioile, tantôt formant un petit angle obtus lendrint dans lit preniere cellule du bord postérient. - Cuilherous petits, doubles, ciliés a leur bord. - Balanciors en partie couverts. - Abdomeñ lantốt presque cýlindrique, tanlôt elliptique, quelquefois globulicux, composé de qualre segriens outre l'anus, celui-ci ordinairement caclié. - Pattos asse\% lortes, les poslérienres plus lcosares; jambes plus ou moins comprinies: premier article des lirses presqu'aussi long que los quatre autres réunis; le quatriene trcs-coul, le cinguieme muni de deux crochess ayant dans lenr entre-deux une pelotie bilolsée.

La plupart des Milésies se trouvent habiquellement an printerups sur les lleurs, notammeat sur celles du Prunellier, de l'Aubépime et de l'Epinevinatle. Le peu de larves connues vit dans le détritus humide des troncs d'arbres pomris. Ce yenre nombreux est suseeptible de se diriser aiusi ytïi! suit :

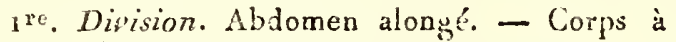
peine pubescent.

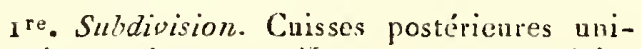
dentées en dessous. - Hypostome ironguć inférieurement, fortemeril creasé dans son milieu, sans tubercule. (Nilesia propriè dicta. Niв.)

Nons placerons ici : 10. Milésie crabroniforme, M. crabroniformis $\mathrm{n}^{\circ}$. I. FАB. Syst. Antlat. Me!g. Dipt. d'Eur. tom. 3. pag. 227. $n^{\circ}$. 1. $2^{n}$. Milésie tulminante, $M$. fulminans. Mírg. id. pag. 228. $n^{\circ}$. 2. tab. 29. fig. 8. Mâle. '3o. Milésie diophthalme, M. diophthalma no. 2. Far. id. - Merg. id. pag. 229. no. 3. Ceз trois espèces appartiennent a la firance uŕvidionale. $4^{\circ}$. Quelques espéces exoiques.

2. Subdivision. Cnisses postérieures maligres. - Hypostome alongé, pelpeudiculaire, ¿ peine tuberculé dans son milieu. (Temnostolna. Noв.)

Celle seconde subdivision contient: $1^{\circ}$. Milésie vespiforme, Mi. vespiformis no. 3. Fав. Syst. Antliat. - Mvig. Dipt. d'Eur. tom. 3. pag. 232. no. 5. Forêts de Villers-Collerels, de Saint-Germain. 20. Milrsie Bourdon, $M$. bombylans no. 8. Ia id. - Merg. id. pag. 253. no. 6. 30. Milésie specicuse, A. speciosa $n^{\circ}$. 6. FАв. id. - Merg. $i d$. pag. $2 \pi^{2} \cdot n^{\circ} \cdot 7$. Au printemps sur les lleurs de l'F." fine Lianclie. Des envirous de Paris. $4^{\circ}$. Milésie irompeuse, M. fullax no. 10. HA s. id. - Eristals semirufus $\mathrm{n}^{\circ}, 5 \mathrm{1}$. FAR. id. - MEIG. id. pag. 235. $n^{\circ} \cdot 9 \cdot$ tab. 29. fig. 10. Mille.

$2^{\mathrm{e}}$. Division. Abdomen plus ou moins globuleux. - Corps laineux. - Cuisses postérieutes uniliques.

$1^{\mathrm{re}}$. Subdivision. Iypostome alongé, yerpendiculaire, tubercué dans son milieu. (C'rorhina. HoFm.)

I.à viennent: 10. Milésie de l'Epine-vinette, M. berterina. MEıg. Dipt. d'Eur. tom. 3. pas. 257. $\iota^{\circ}$. 11. tah. 29. fio. 9. Femelle. $2^{\circ}$. Miléste de l'Epine blanche, M. oxyacanihco. MEsg. id. $n^{\circ}$. 12. $3^{\circ}$. Hilésie colonueuse, M. floccosa. Musc. ia. pag. 238. $n^{\circ} \cdot 13.4^{\circ}$. Milésie asilique, $\boldsymbol{M}$. «1stlica. Merg. id. $2^{\circ}$. 4. 50. Milésie rnticaude, $M$. ruficauda. Vĩg. id. pag. $259 . n^{\circ} \cdot 15.6^{\circ}$. Milésie de la Renoucule, 7 . Rainunculi. Merg. id. $n^{\circ}$. 16. Ces six espèces se trouvent aux environs de Paris dums les bois.

2e. Subdivision. Hypostome tronqué inférieurement, fortement crensé dans son milieu, sans tubercule. (Pocota. Nor.)

Rapprortez à celte coupe la Milésie apicale, $\boldsymbol{M}$. apicata. MeIs. Dipt. d'Enrop. tom. 3. pag. 236. $n^{\circ}$. Io. Des envirous de Paris.

Nota. Schrauck (Faun. Boic.) dil avoir trouvé la nymplue de celle esjèce dans du hois pouri. a Elle est brune, arquée en dessus, aplatie en des"sous, avec deux petils corps en forme de verrues à la têle, ayant une petile quente à l'anus et une * lache blanche, fourchue sur le dos; l'insecie "parlait parut au combencement du mois de " [lai."

DRACHYOPE, Brachyopa. Horf. Meig. Lat. (Fam. nat.) Rhzngla. HALLín. Musca. YAat. Uscinis. Wan.?

Genre d'inaectes de l'ordre des Diptères ( ${ }^{\text {ra. }}$ section), familie des Atbéricères, tribu we Syrphies. 


\section{$S Y R$}

Un fromp de cotte tribu contient les genres Milésie, Brachyope et Rhinģie. ( $V$ oy. SrupHes.) hes Rhingies ont leur hyposlome fort long, a vancé en un bec horizontal. Daus les Milésies les ailes ne :mrpassent guère en longuenr celle de l'abdomen, leur corps est toujour's plus ou moins velu et la soie des antennes saus ancune villosilé.

Antemnes plus courtes que la tête, insćrées sur un avancemen! conique du front, avancées, penchées, composées de trois articles, les deux premiers petits, égaux entr'eux, le iroisième lenticulaire, muni à sa base d'une soie veluc.-Ouperture de la cavité buccale fort longue, comprimce vers le haut. - Trompe assez grosse, rentrant dans la cavité buecale lors du repos. - Sucoir de quatre soies, suivant M. Latreille, les inférieures beaucoup plus courtes que les palpes. Palpes au moins anssi longs que la soie supérieure, presque filiformes, un per comprimés, un peu courbés à leur extrénité, grossissunt peu dans cette partie. - Tête hémisphúrique, plus firnie que le corsclet; hypostome fortemeul creusé dans son wilieu, un peu alongé inférieurement et tronqué dans celle purtie. - Ieux arrondis, nus, se rapprochant plus ou moins dans les mâles, espacés dans les fémelles. - Trois ocelles très-rapprochés, placés en triangie sur un petit tubercule du rertex. - Corps oblong, presque glabre, nayant que de très-pelits poils courts, conchés, squamiformes. -Corselet ovale. - Ecusson grand, semicirculaire. - Ailes très-ggrandes, deux $f$ is aussi longues que l'aldomen, velues vues au microcone, couchées parallèlement sur le corps dims le repes: la nervure qui sépare la cellule sous-marginale de la prenière cellule du bord postérieur, droite; celte dernic̀re cellule dilatée dans la partie qui avoisine le bord. - Cuillerons petits, donbles. Balanciers découverts. - Abdomen ovale, aplati, arqué, composé de quatre segmens outre l'auss. - Pattes assez fortes, les postérieures un peu alougées, à cuisses larges et jambes arquées : premier article des tarses presquaussi long que les quatre autres réunis, gres; les snivans ullant en diminuant de longuenr, le deruier portant derix forts crochets munis d'une pelote bifide dans licir entre-deux.

Les Brachyopes se tronvent sur les lleurs, mais elles sont assez rares. Un ne connoît pas lenrs premiers étals, à moius que l'Oscinis olco de Fabricius ne soil de ce genre; celle-ci, suivant cet auteur et les observations de M. Bose, notse savant compatriote, vit à l'élat de larve dans les vlives.

M. Meigen rapporte à ce gevre: $1^{\circ}$. Brachyope conique, B. conica. Mỉerg. Dipt. d'Eur. tom. 3. pag. $261 . n^{\circ}$. $1.2^{\circ}$. Brachyope bicolore, $B . b i-$ color. Meig. id. pag. 262. $n^{n} \cdot 2$. tab. 3o. fig. 6. Mâle. Des environs de Paris. $3^{\circ}$. Brachyope arquée, B. arcuata. Meig. id $n^{\circ} .3 .4^{\circ}$. Brachyope ferrugineuse, B. feringinea. Mirg. id. pag. 263 . $z^{13} \cdot 4^{4} 5^{\circ}$. Bracliyope scavorde, $B$. scavoüdes.
Merg. id. no. 5. 6॰. Brachyope de lolivier, $B$. Olew. Meig. pug. $264 \cdot n^{\circ} .6$.

Nota. Ces trois dernic̀res especes sout douicuses comme appartenat à ce genre. Tes denx prentières n'rut pas élé vars jar M. Meigen, et duns la derniere la soie des arilennes est nue.

ASCIE, Ascia. Rierg. LAT. (Fam. nat.) Merodon. Fав. Minlesia. Haulén. Syrphus. Paxz. Musca. Geoff. Schranck.

Gena d'insectes de l'ordre des Dinlères (première scction), famille des Athéricères, Hibu des Syrphies.

Le grompe de celle tribu ( voyez Symurs) doat le gence Ascie fart partie, ruterme nu vulte cenx de Splégine, Tropidie ol Eamère. Dan les deux derriers l'abdonen liest pas aminci it $\mathrm{sa}$ base en forme de pédicule. Les Sphégines on le troisième article des antemes prescrue rond, l'hypostome enfoncé et sa partie inflicuse prolongé en avant.

Antennes avancies, plus conries que la lite, composées de trois articles, les dentr prenuiers courts, égaux entreux, le tocisiencoblong, agant une scie dorsale nue, insérée arant le nuiló. Ouverture de la cavité buccale élroite, longue, rétuécie par-devint. - Trompe assez grosse. Sucoir de qualre soirs, suirant M. Latreille, les intérienres beancoup plas conrtes que les palpes. - Pulpes aussi longs que la sute supéricne, cylindriques, terminés en massue, muais the quetques sorics courtes á lenr extrénité - Téte hémisphérique; hypostome presque droit, sa fartie infirence prolongée prescue perpendiculime-

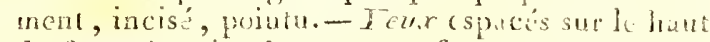
du front dans les dew sexes; front des uiates pins ároil que dons les tomelles. - Prois ocelles disposés en triangle sur le vertex. - Corps assez long, Atroil, à peine pubescerl. - Conselelovaleglobnlux, - Iccusson presgne triangulaire; sum angle posíricur arrondi. - Ales obiuses, dépassan: un peu l'aldomen, velues vnes au nicroscope, couchées paratèlement sar le corpa dans le repros; les deux premieres celluges du brid posterens

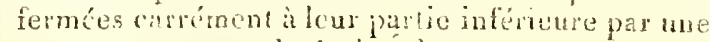
nervure lransversale drofić j la nervure qui sépare la preanierc cellule de la sous-ma rginale, drome. -. Cuillerono presque nuls. - Brelanciers hécunvers. - Abdomen lrés-alongó, nu, en massue, tresrétréci it sa buse, de cuare segmens ontre l'auus, celui-ci très-courl. - Les quare paites anterret:res grếles, les postérieures asscz fortes, lens

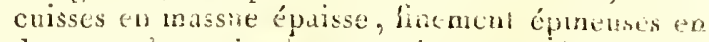
dessous, leurs jambes arçuées : prestier articte des tares grand, épais, le dernier muni de deax crochets ayant une pelotle bifide dans leur entredeux.

On ne connoi perint les premiers élats des Ascies; arrivées a l'état parfin elles fréguentent ke. 
bois et les prairiss, et se tiennent sur les flenrs. M. Meigen en décrit dix espèces, toutes d'assez petite taille.

I․ Ascie goullense, A. podagrica. Meig. Dipt. a'Eur. tom. 3. pag. 186. $n^{\circ}$. 1. -Merodon podagricus $\mathrm{n}^{2}$. го. Fав. Syst. Antliat. Commune pendant prescrue toute l'annce aus environs de Paris. $2^{n}$. Ascie lancéolcee, $A$. lanceolata. Meıg. id. prig. 137. $n^{n}$.2. Des euvirons de Paris. $3^{n}$. Ascie llorale, A. floralis. Mrig, id pag. 188. $n^{\circ}$. 3. Même patrie, inais plus rare. $4^{\circ}$. Ascie dissemblable, A. dispar. Nerg. id. no. 4. tab. 27. fig. 27. Mâle. Jig. 28. Femelle. 5o. Ascie quadriponcmée, $A$.

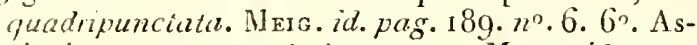
cie interompue, $A$. interntapta. MeIG. id. pag. 19o. $n^{\circ}$. 7. De: environs de Paris. $7^{\circ}$. Ascrie brillante, A. nitidula. Nisig. id. pag. 191. no. 8. 80. Ascie bronzće, $A$. anea. Metg. $i d . n^{\circ}$. 9. Celle espece n'est peut-ètre quine varićté sexuelle de la précédenle. $9^{n}$. Ascie géniculée, A. genicnluta. MeIg. id. pag. 192, no. 10.

Arota. D'apiès un dessin qui lui a été connmnipue, M. Meigen attnet aussi comme éaut de ce yenre une espice de la collection de H. Hoflimanregre, sous le nom d'stscia hastula, pag. 189. $7 \%$. 3 .

EUMÉRE, Eumerus. MEIG. LAT. (Fam. nat.) Eristalis. Fab. Milesia. Lat. (Gener.) Syrphus. Parz. Pipiza. Fallen, Musca. Geofr.

Genre d'in:ectes de l'ordre des Diptères (première section), famille des Albóricètes, tribu des Syrphies.

Un rroupe de la tribu des Syphies (2oyez ce mol) a les caractères suivans : anteunes a peine de la longueur de la tête ou plus courles qu'elle, ayant leur's deux preniers articles égaux entr'eux, point insérées sur un tubereule frontal; ailes dépourvues de cellnle pédiforme; cuisses postérieures renflées. Il comprend les genres Sphégine, Ascie, Tropidie et Eumère. Dans les deux premiers l'abdomen est aminci à sa base en forme de pédicule; les 'Tropidies diffèrent des Eumères par leur hypostome caréné longiludiualenent, leurs cuisses postérieures nuidentées et en ce que la nervure transversale qui ferme la première cellule dn bord nostérieur ne furme pas un angle rentrant avec celle qui sépare la eellule dont nous venons de parler, de la cellule sous-marginale.

Antennes plus courtes que la tête, composées de trois articles, les denx preniers courts, éganx entr'eux; le troisième rond, quelquefois un peu tronqué antérieurement on uin pen pointu, muni d'une soie dorsale nue, triarticulée. - Ouverture de la cavité buccale assez large, un pen pointue par-devant et relevée. - Trompe courte, épaisse. - Sucoir de quatre soies, suivant M. Latreille. - Tếte hémisphérique, un peu déprimée pardevant; hypostome peu arquué, finement vela, sans iuberevle, ni earène. - Yeu.x espacés dans les femelies, se touchant par en hau dans les máles, an moins en un point. - Trois ocelles placís en triangle sur la partie antérieure du verle $\lambda .-$ Corps assez alongé, peu velu, ayant souvent des taclies forwées par de petits poils couchés, presque squamilormes. - Corselet ovale, tronqué autérieuremeıt. - Ecusson grand, semi-circulaire, ses hords finement denticulćs. - Ailes plus longues que le corps, velues vues au microscope, eoucliées parallèlcment sur le corps dans le repos; la nervure transversale qui ferme par en hant la premicre cellule du bord postérieur fortenent oblique; celle qui lin ferme vers le bord postrícur trés-ondulée, formant un angle rentranı en se réunissant à celle qui sépare la celliale dont nous venous de parler, de la cellule sous-marginale. - Cuillerons petits, doubles.Balanciers en partie découverts. - Abdonen oblong, scssile, plas large ou aussi large à sa basi que dans son milieu, presque linéaire dans les mâles, plus pointu ì son extrémité dans les fémelles, composé de quatre segmens outre l'anus, le premier très-ćtroit. - Pattes fortes, les pnstérieures plus grosses et plus longues; leur's cuisses très-épaisses, portant inférieurement une doublc rangée de fines épines; jambes un peu arquées; premier article des tarses assez gros, presqu'aussi long que les quatre autres pris ensemble, ceux-si allant en decroissant de longuenr, le dernier nnui de denx crochets ayant une pelotte bifide daus leur entre-deux.

On reneontre ees Diptères dans les prairieg élevées, sur les fleurs. Leur nom générique vient dc deux mols grees qui ont rapportt à l'épaisseur des cuisses postélieures; on pe connoît pas leur manière de vivre dans leurs premiers états. $M$. Meigen en mentionne douze espèees.

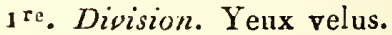

$1^{\circ}$. Eumère grand, $E$. grandis. Merg. Dipt. d'Europ. tom. 5. pag. 203. no. 1. tab. 28. fig. 18. Femelle. $2^{\circ}$. Eumère tricolor, $E$. tricolor. MeIG. id. pag. 204. $n^{n}$. 2. Des environs de Paris. $3^{\circ}$. Eumère varié, E. varius. Meig. id. pag. 205. $n^{\circ}$. 3. $4^{\circ}$. Eumère orné, E. ormatus. Meig. id. $n^{\circ} .4$. Des environs de Paris. 50. Eumère rufieorne, $\boldsymbol{E}$. ruficornis. ME⿺ id. pag. 206. $n^{\circ} .5$.

$2_{2}^{\mathrm{e}}$. Division. Yeux nus ou à peine pubescens.

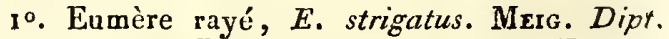
d'Europ. tom. 3. pag. 207. $n^{\circ}$. 7. 20. Eumero grandicorne, E. grandicorris. Merg. id. pag. 208. $n^{\circ} .8$. "3̄. Eumère fuuéraire, E. funeralis. Mrig. id. $n^{\circ} .9 \cdot 4^{\circ}$. Eumère front plane, $E$. planifrons. MEIG. id. pag. 209. $n^{\circ}$. 10. 5 $5^{\circ}$. Eumère lunulé, E. lunulatus. Merg. id. $n^{\circ}$. $11.6^{\circ}$. Eumère à croissans, E. selene. MEIG. id. pag. $210 . n^{\circ} .12$.

Noto. M. Meigen rappoite encore à ce genre, 
sous le nom d'Eumenus micans, l'espèce décrite par Fubricius sous le nom d Eristalis micans $11^{\circ} .45$. Syst. Antliat., qu'il u'a point vae.

BACCHA, Baccha. Meig. (Dipt. d'Eur.) Lat. (Fam. nat.) F. M. Milesia. FAB. Scava. Farlén. Syrohus. Lat. Scaeli. Meig. (Dipt. d'Eur.) Doros. Meig. (Classif.) Lat. (Fam. nat.)

Genre d'insectes de l'ordre des Dipteres ( $y^{\text {re. }}$ section), fauille des Athéricères, tribu des Syrphies.

Un groupe de Syrphies a pour earactères : antenues plus courtes que la tête, ayant leur's deux premiers articles égaux entr'eux, point portées strx un tubercule frontal; ailes dépourvues de collule pédiforme; toutes les cuisses simples: soie des antennes sans articulations sensibles et paroissant nae à la vue simple. (Voyez Srrpanes.) Dans ce groupe se trouvent six genres parmi lesquels ceux de Syrphe, Clirysogastre, Pipize, Psilote et Parague se dislinguent par leur abdomen linéaire ou elliptique. Le genre Baccha de M. Mcigen tel que cet autenr l'úlablit sous paroùt peu dislinct de celui de Syrphe, à moins que l'on ne considère comone un carractère générique sulfisant d'avoir (comne le dit M. Meigen de ses Syrphes ) la soie des anteunes pubescente ou finenient ciliée à sa base lorsqu'on la regarde à un furt microseope : il nous a été impossıble avee de bonnes loupes d'apercevoir ce caractère dans le Syrphus conopseus Mrig. que la forme de son abdomen rapproche tont-ì-fait dn genre Baccha, et dont oous ne croyons pas que la larve soit aphidivore comıne le sout celles des véritables Syrphes. Voyez ce mot.

M. IVleigen dans son premier ouvrage sur les Diptères (Classification, ete.) avoit constitué avee celle espèce un genre particulier sous le nom de Doros, que M. Latreille cite dans ses Familles naturelles. Ne lui trouvant aucun caractère générique suflisaut, nous préférons le réunir au genre bacelia, en prévenant que les trois genres Baccha, Syrplie et Chryspgastre ont besuia d'être travaillés de nouvear, cé que les bornes du présent ouvräge ne nous permettent pas de faire.

Antennes avancéts, un peu rabailues, plus courtes que la tête, eomposées de trois articles, les deux preniers courts, éganx entr'eux, le troisième presque rond, comprimé, ayant à sa base une soie dorsale paroissant nue à la vue simple. - Onverture de la cavitébuccá́e oblongue, érroile, rétrécie par-devant. - Trompe charnue, se retirant dans la cavité buccale pendaut le repos. Suçoir de quatre soies, suivant M. Latreille. Palpes en massue, velus à leur partie antérieure. - Tête hémisphérique; hypostome point alongé au-dessous des yeux, pen eufoncé au-dessous des antennes, ayant un tubercule un peu au-dessous du milieu. - Ycux réunis par en haut dans les mâles, espaeés dans les temelles. - Trois ocelles Hist. Nat. Ins. Tome $X$. disposés en triangle sur la partic antérienre du vertex.-Corps grêle, alongé, glabre.-Corselet ovale, plus ou moins tronqué antérieurement. Ecusson ussez grand, arrondi postérieurectent. Ailes grandes, velues vues au microscope, couchées parallèlement sur le corps dans le repos. Cuillerons pelits. - Balanciers découveäs. Abdomen atongé, en massue, composé de quatre segmens outre l'anus, le premier assez large à sa base, s'amiucissant assez subitement ce pédicule étroil, cylindrique; le second d'abord étruit, cylyndrique, s'ćlargissant un peu vers son dxlrémilé; les troisième et quatrième assez larges, formant la massue avec lauas, celui-ci un peu oblus. - Pattes grêles; jambes (les postérieures surtout) un peu arquées : premier arti te des tarses presqu'aussi long que les quatre autres pris ensemble, ussez épais et très-garni en dessous d'une eourte villosité; dernier arlicle le plus cont de tous, mui de denx crochets ayant une assez forte pelotte bifide dans leur entre-deux.

Les premiers étals de ces Diptères sont inconnus. On les trouve sur les fleurs ì l'état parfuit; on ne voit pas les femelles parcourir les végétaux ponr y chercher des colonies de Pncerons, comme le font celles des véritables Sysphes.

Nons rapporterons ì ce genie : ${ }^{\circ}$. Baccha Conops, B. conopsea. Noв. - Syrphus conopseus. ME1G. Dipt. d'Europ. ton. 3. pag. = $05 . n^{\circ}$. 3... Des environs de Paris. $2^{\circ}$. Baccha alongée, $\bar{B}$. elongata. Merg. id. pag. 197. $n^{\circ}$. 1. tab. 28. fig. 35. Hemelle. Des environs de Paris. 5o. Barcha scutellaire, B. scutellata. MElg. id. plag. 198. $n^{\circ}$. 2. $4^{\circ}$. Baccha Sphégine, B. Sphegina. Meig. Id. $n^{\circ}$. 3. 5o. Baccha obscure, B. obscuripemis. ME1G. $i d$. pag."199. $n^{\circ}$. 4. 6o. Baccha mince, $B$. tabida. Merg. id. $n^{\circ}$.5. $7^{\circ}$. Baccha raccourcie, B. abbreviata. M $\mathrm{E}_{\mathrm{1G}}$. id. pag. 200. $n^{\circ}$.6. $8^{\circ}$. Baccha nigripenne, $B$. nigripennis. Mierg. $i a^{\prime} . n^{\circ} \cdot 7$. $9^{\circ}$. Baccba vitrée, B. vitripennis. Mre1G. id. $n^{\circ} .8$.

CHRYSOGASTRE, Chrysogaster. Meig. Lat. (Fam. nat.) Eristalis. FAB. FALLEN. Syrphus. Panz. Mulusca. Linn.

Genre d'insectes de l'ordre des Diptères (première section ), famille des Athéricères, tribu des Syrphies.

Des six genres dont se compose le groupe de Syrphies (voyez ee mot) où vieanent se ranger les Chrysogastres, eelui de Baeeha se disinguc par son abdomen alongé en massue; dans les Syrphes les deux eellules du bord postérieur des âles sont rapprochées de ce bord et terminées toutes deux par une nervure transversale qui resie presque dans toute sa longueur parallèle ì ce bord; les geures Pipize et Parague ont l'bypostome plane; eelui de Psilote a les yeux velus, et de plus les femelles dans ces eing genres ont le front lisse, e'est-à-dire sans rides ni crénelures. Antennes avancées, un per rabattues, insérées $\mathrm{Yv}$ v 
sous un rebord avancé du front, ordinairement plus courtes que la tête, très-rarement de sa longueur, composées de trois articles, les deux pre. miers petits, ́́gaux entr'eux, le troisième orbiculaire ou un peu ovale plane, ou très-alongé plane, portant î sa base une soie dorsale nue. Ouverture de la cavité buccale oblongue, plus resserrée par-devant, relevée à sa partie supérieure. - Troutpe charnue, épaisse, rentrant à l'état de repos dans la cavité buccale. - Suçoir de quatre soies, suivant M. Latreille. - Palpes longs, courbés, lanellifurmes, un peu en massue ver's leur extrémité qui est légèèrement velue. Tête hénuisphérique; hypostone enfoncé, ordinairement tuber'ulé dans les mâles, uni dans les femelles, son bord inférienr avancé daus ce sexe. - Yeux uus, réunis dans les mâles, très-espacés dans les femelles; front de celles-ci ayant une rangće de rides ou même de créuelures Iransversales, plus ou moins prononcées. - Trois ocelles placés sur le vertex. - Corps presque nu. - Corselet presqu'arrondi, un pen tronqué antérieurement, celui des mâles ayant souvent quelques poils.-Ecusson grand, arrondi postérieurement. - Ailes assez girandes, velues vues au unicroscope, couchées parallèlearent sur le corps dans le repos; les deux premières cellules du bord poslérieur éloignées de ce bord, fermées inférieuremeat chacune par une nervure transversale qui ae conserve pas de parallćlisme avec le bord postérieur. - Abdomen ovale-oblongr, composé de quatre segmens outre l'anus, enlićrement mélallique brillent on ayant au moins ses bords métalliques. - Pattes grêles.

$\mathrm{Oa}$ innore la matuière de vivre des insectes de ce genre pendant les premiers états de leur vie, mais il est probable que leurs larves habilent dins le terreau végélal. Le nom générique vient de deux mots grecs qui expriment la couleur brillante de leur abdomen. Les Chrysogastres à l'état parfait frérquentent les fleurs.

Ces Diptc̀res nouls paroissent avoir nne trèsgrande analnirie avec les espèces dont M. Meigen avoit d'abord formé le gemre Cheilosia, et que dans ses Diptéres d'Enrope il a réunies au genre Syrphe.

ire. Division. Antennes plus courtes que la tête, leur troisieme article orbiculaire ou uu peu ovile.

Cette division renfertre treize espèces que l'on trouvera décrites dans les Diptères d'Europe de M. Meigen : de ce noubre est le Chrysograstre des simetières, C. cometeriorum. MeIg. id.pag. 268 . $n^{\circ} .5 .-$ Eristalis cameteriorum $n^{\circ} .65$. FAB. Syst. Antliat. Le troisième article de ses antennes est orbiculaire. Commun anx environs de Parris.

20. Division. Antennes de la tongueur de la ıète, leur troisième ar̂ticle très-alongé, plane.

Nous plaçons ici le Chrysogastre élégant, $C$. elegans. Mric. id. pag. 272. $n^{\circ}$. 14. Longuenr 2 lig. $\frac{5}{2}$. Corselet cuivreux. Abdomen pourpre. Pattes noirâtres avec les genoux et le premier article des tarses d'un beau jisune. D'Europe.

MALLOTE, Mallota. Meig. LAt. (Fam. nat.) Eristalis. Fab. Syrphus. Fallén.

Genre d'insectes de l'ordre des Diptères (première section), famille des Athéricères, tribu des Syrphies.

Parmi les Syrphies dont les antennes plus courtes que la téte, ayant leurs denx premiers articles égaux entr'eux, ne sont pas portées sur un tubercule frontal, un groupe a pour caractère particulier d'avoir la cellule sons-marginale des ailes pédilorme. (Voyez Sxrpures.) II renfertue outre les Mallotes, les genres Héloplile et Mérodon, qui s'éloignent des premières par leur's cuisse. postérieures renflées, et les Eristäles distingués des Mallotes par la soie des antennes insérée un peu plus près de la base du troisième article, celui-ci oblong ou arrondi; de plus les Eristales mâles ont presque toujours les yeux rémis.

Antennes avancćes, un peu raballnes, plas courles que la tête, inséríes atl-dessous d'un rebord très-prononcé du firont, composées de trois articles, les deux premiers courls, égaux entr'eux, le troisième large, transversal, portant vers son milieu une soie nue. - Ouverture de la cavité buccale oblongue, forlement échancréc par-devant. - Trompe grosse, charnue, retirée dans la cavité buccale lors du repos. - Sucoir de quatre soies, suivant M. Lalreille, les inférieures à peu pròs de la longueur des palnges. - Palpes presque cylindriques, m peu plus éprais vers leur extrémilé, moitié aussi longs que la soie supérieure. - Téte hémisphérique, un peu aplatie en devant; liypostome velu, alongé presque perpendiculairement, tuberculé dans son milieu. - Yeux espacés dans les deux sexes; front un peu plus large dans les femelles. - Trois ocelles placés en triangle sur le vertex. - Corps court, très-velii. - Corselet globulcux. - Ecusson grand, arrondi postérieurement. - Ailes assez grandes, velnes vues au inicroscope, écartées l'une de l'autre dans le repos, leur cellule sous-marginale pédiforme. (Voyez la note pag. 514. de ce volume.) - Cuillerons doubles, ciliés, assez grands.-Balanciers couverts. - Abdomen convexe, globuleux, surtont daus les femelles, composé de quatre segmens outre l'anus. - Pattes forles; cuisses posiérieures simples, grêles, leurs jambes arquées: premiêr arlicle des tarses presqu'aussi long que les qualre suivans pris ensemble, le dernier fort court, muni de deux crochets ayant une forfe pelolle bifide dans leur enire-deux.

Les premiers états de ces Syrphies ne sont pas connus. M. Mieigen soupçonne que les larves viven dans le bois pourri. Le nom du genre vient i'un mot grec qui exprime la villosité de leur corps. 


\section{S I R}

Les espèces connues sont: $1^{\circ}$ Mallote à bandes, R. vittata. Merc. Dipt. d'Eur. tom. 3. pag. 3-8. $n^{\circ}$. 1. D'Antriche. $2^{\circ}$. Mallole Mérille, M. megillifornis. MEIG, id. pag. 579. no. 2. 30. Mallote fuciforme, M. fuciformis. MEIG. id. $72^{\circ}, 5$. tab. 32. fig. 13. Elle se rouve au printemps dans les grands bois des environs de Paris, sur les fleurs de I'Epine blanche et des Pruniers.

ERISTaLE, Eristalis. Lat. MFIG. Far. Syrphus. Faldév. Scopor. Pasz. Fab. Volucella. Schrance. Musca. Linn. De Grer. Geoff. Schranck.

Genre d'insecles de l'ordre des Diptères (preraìre secion), famille des Alléricères, trita dies Syrphies.

Un groupe de cefte tribu eontient les genres Mallote, Eristale, Hélophile et Mérodon. (Voyez Sraphers.) Ces deux derniers ont pour caractère distinctiff : enisses postérieures renflćes. Dans les Mallotes le troisième ar icle des antennes est large, transversal; la soie dorsale est insérće vers le nilieu de eet arlicle; les yeux sont toujour's espacés dans les deux sexes.

Antennes avancées, un peu rabattues, plus conrles que la tête, insérées sons un petit rebord du front, composées de trois articles, les deux premiers petits, éganx entreux, le troisième patelliforme, muni à sa base d'une soie dorsale. Ouverture de liz cavité buccale alongée, étroile, rétrécie en devant, échancrée dans eelte partie. - Trompe assez grosse, rentrant dans la cavité buccale à l'ćtat de repos. - Sucour de quatre soies, suivant M. Larreille, les inférieures un per plas courtes gue les palpes. -- Palpes un peu courbés, cylindriques, assez velus vers leur extrénité, toujours plus courls que la soie supérieure, mais de grandeur variable. - Tête hémisphéruque; hypostome un pen déprirué vers le liaut, ayant un tubercale vers sa partie inférieare. - Yeux des mâles se touchant ordinairement; ceux des femelles esparés, un peu velus dans les deux scies. - Trois ocelles disposés en triangle sur le vertex. - Corps plus on moins velu, ordinairement assez long.-Corselet ovale. - Ecusson semi-circulaire. - Ailes assez grandes, trés-ijrillaates, nues dans la plupart des espèce's, éeartées l'une de l'antre dans le repos; leur cellule sousmarginale pédiforme. ( Voy. La unte pag. 5r4. de ce volune.) - Cuillerons donbles, fiangés sur leur bord. - Balanciers couverts. - Abdomen composé de cuatre segmens oure l'anus, ordinairement cunique, boabé en dessus, quelquefois globuleux dans les femelles. - Pattes assez fortes; cuisses poslérieures simples, lears janbes coniprimées vers l'extrémité; tarses ityant leur premier article presquaussi long que les quatre autres réunis; le dernier petit, runi de deux crochets ayant une pelonte bifide dans lear entredeux.
Les premiers états des Eristales sont connus depuis très-long-temps; ils sont décrits tant par Swanmerdan et Vallisner que par nolre eélèbre Réamur (voyez Mém. 10. tom. 4. et l'analyse de ce Mćwoure, Encycl. tom. IV. pag. CCAtit.) Les larves sont du nombre de celles qui rivent dans la vase des eaux corronpues, et que les anteurs anciens out appnelées vers à queue de Rat. Les iusectes parfaits se pluisent sur les fleüs dont ils sucent le miel, ainsi vue sur les fruils entamés et les ulcères des arbres dont les sucs sont aussi de leur goût. Les femelles font souvent leur pontosans cesser de voler; elles sabaisent pour cela par un mouvement brusque sur les liquides on elles doivent déposer leurs oufs, et les lissent tomber de l'extrémitć de leur abdonen au inoment dù celle-ci tonche la superficie humide; elles se relèrent ensule facilement. Ces Labitudes leur sont cemmunes arec les Libellulines. Au moment où un Eristale se pose sur un corps solide, il ne manque jamais de relever et d'abaisser successivement son abdemen un cerlain nombre de fois, mouvement que l'insecte répète de le tnps en temps. le vol des Eristales est puissant, leurs mouveniens daos eet exereice sont souvent trè-brusques; on les.aperçoit ansi fréquemment en l'air", comrne fixés à une même place pendant quelques minutes : ce sont surtout les males qui se liennent ainsi épiant le passage des femelles et prêts à s'úlaneer sur elles aussilôt qu'ils les aperêivent. La ciurée de l'uceouplement est courte; la plupart des espèces a plusieurs générations par anuée et se reacoutre tiès-communément dans nos climats depuis le commencement du printemps jusfu'a l'ectrée de l'hiver. Quelques individns passent mème cette dernière saison dans une espece d'engourdissement, an moins sous le climai de Paris.

Le genre Eristalis de Fabricins (Syst. Antliat.) est connosé de soixalite-nenf espèces appartenant pour la plupart à divers autres genres; ainsi l'Eristalis apiarius $\mathrm{n}^{\circ}$. 1 . est la fifesembrina mystacea $n^{\circ}$. 2. Meig. Dipt. d'Eur. tom. 5. Les nes. 7. 15. 19. sont des Hélophiles; le ${ }^{0} .31$. est la Mal. lote fuciforme; les $n^{\circ s} .32 .55 .40 .41 .58 .59$. sont des Mérodons; trois Milésies s'y trouvent sous les nos. 35. 39.51. Des Syrpbes, sons les nos. 34 . 36.37 .46 .49 .50 .53 .55 .56 .66 . Les nos. 45 et 52. sont du gerare Eumc̀re; des Pipizes portent les $\mathrm{n}^{\circ} .64$ et 69 . et deux Chrysogastres les a $0^{5} .65$ et 67 . Les nos. 63 et 68 . n’apparliennent pas à lat. famille des Syrphies, et vous n'usons même pas répondre que tous les numéros que nous ne meationuons pas, soient de véritables Éristales.

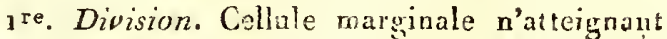
point le bord extérieu: de l'aile. - Aites nues, vues mêtne au microscope.

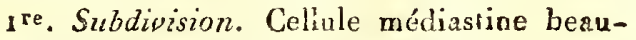
coup plus lougue gue la cellule inarginale. Soie des antennes nue ou presque aue. 
L'Eristale tenace, E. tenax. Meig. Dipt.d'Eur. tom. 3. pag. 385. $n^{\circ}$. 4. appartient à celte subdivision qui coutient en outre probablement: $1^{\circ}$. Eristale cimbiciforme, $E$. cinbiciformis. Merg. id. $n^{\circ}$. 5. $2^{\circ}$. Eristale champêtre, E. campestris. Merg. id. pag. 387. $n 2^{\circ} \cdot 5.3^{\circ}$. Eristale des jardins, E. hortorum. MEIG. id. $n^{\circ}$. 6. $4^{\circ}$. Eristale Renard, E. vulpinus. MeIG. id. pag. $388 . n^{\circ} .7 \cdot 5^{\circ}$. Eristale des forèts, E. syloaticus. Merg. id. $n^{\circ} .8$. $6^{c}$. Eristale des cavernes, $E$. cryptarnm. Merg. id. pag. $389 \cdot 7^{\circ} \cdot 9 \cdot 7^{\circ}$. Eristale apiforme, E. apiformis. Merg. id. plag. $390 . n^{\circ}$. ro. $8^{\circ}$. Eristale Anthophore, E. anthophorinus. Merg. $i d . n^{\circ}$. II.

$2^{e}$. Subdivision. Cellules médiastine et marginale presque d'égale longueur.

A. Soie des antennes nue.

a. Yeux séparrés dans les deux sexes.

Nous plaçons ici l'Eristale sépulcral', E. sepulcralis. Nerg. Dipt. d'Eur. tom. 3. pag. 383. no. I.

b. Yeux des máles réunis.

Ce groupe renferme l'Eristale bronzé, $E$. enens. N'EIG. Dipt. d'Eur. toul. 3. pag. 384. $n^{\circ} .2$.

B. Soie des antennes plumeuse.

a. Abdomen presque globuleux. - Corps très-velu.

Rapportez ici l'Eristale velu, E. intricarius. MEIG. Dipt. d'Eur. tont. 3. pag. 391. no. I2.

b. Abdomen conique. - Corps simplement pubescent.

Les espèces conteaues dans ce groupe sont: эo. Eristale semblable, E. similis. MeIg. Dipt. d'Eur. tom. 3. pag. 392. no. 13. Nons pensons que cette espèce a élé dét rite par Scopoli (Entom. Carniol.) sous le nom de Syrphns pertinax. $2^{\circ}$. Eristale des bois, E. nenonum. Meig. id. pag. 394. $n^{\circ} .16 .3^{\circ}$. Eristale des arbustes. $E$. rerbustorum. MIIs . $i d . p a g .395 . n^{\circ}$. 17. $4^{\circ}$. Eristale jardinier, F. horticola. Mrig. id. pag. 396. $n^{\circ}$. 18. tab. 32. fig. 2r. Màle. 5o. Eristale des rochers, E. mupiuin. MEIG. ill. pag. 397. no. 19. 4ab. 32, fig. 22. Femelle.

Nota. Ces cinq dernières espèces se trouvent all euvirons de Paris.

On y coit joindre: $1^{\circ}$. Eristale des prés, $E$. pratorum. Nert. Dipt. d'Europ. tom. 3. pag. 393. $n^{\circ}$. I $4 \cdot 2^{\circ}$. Eristale des fossés, $\boldsymbol{E}$. fossarum. Neig. $i d . n^{\circ}, 15.3^{\circ}$. Eristale des Alpes, E. alpinus. MeIg. id. pag. "3g8. $n^{\circ} \cdot 20$.

$2^{\mathrm{e}}$. Division. Cellule marginale atteignant le bord extérieur de l'aila. - Ailes velues vues au unicroscope. - Soie des antennes nue.
Ici se place l'Eristale floral, E. floreus. Mrrc. Dipt. d'Eur. tom. 3. pag. 399. $n^{\circ}$. 2 1. Commun aux envirous de Paris.

MÉROdON, Merodon. Metg. Lat. Fab. Syrpllues. PAnz. Eristalis, Milesia. FAв.

Genre d'insectes de l'or'dire des Diplères ( 1 re. section), famille des Athéricères, tribu des Syrphies.

Les Syrphies qui ont la cellnle sous-marginale des ailes pédiforme sont les genres Mallote, Eristale, Hélophile et Mérodon. (Voyez Syrphies.) Dans les deux premiers les cuisses postérieures ne sont point reaflées, mais simples. Les Hélophiles ont l'hypostome tuberculé, leurs dernières cuisses n'unt pas en dessous une forte dent on épine, miris seulement de très-fines dentelures, enfin leurs ailes sont écartées l'une de l'autre dans le repos.

Antennes avancées, rabaltues, plus courtes que la tête, insérées assez bas, sur le devant de la têle, composées de trois articles; les deux premiers courls, éganx entr'enx, le troisième oblong ou elliptique, plane, déprimé avec une soie dorsale nue. - Ouverture de la cavité buccale ovale, un peu rétrécie par-devant. - Trompe charnue, rentrant dans la cavité buccale lor's du repos. - Suçoir de quatre soies, suivant M. Latreille, les inférieures beaucoup plus longues que les palpes. - Palpes courts, un peu en massue, avec de longs poils, ayant à peine le tiers de longueur de la soie supérieure. - Tête hémisphérique; hypostome uni, velu, sans tubercule. Yeux velus, se touchant par en haut dans les wâles, espacés dans les femelles dont le front est flane et un peu ridé. - Trois ocelles disposés en triangle sur le devant du vertex. - Corps assez loug, velu. - Corselet bombé en dessus, gros, gloduleux, un peu troncqué en devant. - Ecussons semicirculaire. - Ailes souvent plus courtes que l'abdomen ou n'étant pas plus longues que lui, velnes vues au microscope, couchées parullèlement sur le corps dans le repos; leur cellule sonsmarginale pédiforme. (Voyez la note pag. 514. de ce volume.) - Cuillerons doubles, assez grands. - Balanciers couverts. - Abdomen alongé, composé de qualre segmens outre l'anus; celui-ci fort petit ainsi que le prenier segment. Pattes assez fortes, surtout les posiérieures; dernières cuisses très-grosses, en massue, souvent courbées, échancrées obliquement au bout, ayant une forte dent au bord de cette échancrure; jambes postérieures courbées, un peu en massue: preaier article des tarses presqu'aussi long que les quatre autres réunis; le dernier muni de deux forts crochets ayant une grosse pelotte bifide dans leur entre-denx.

Le nom donné à ces Syrphies est tiré de deux mots grecs qui signifient : cuisses dentées. Les larves de la plupari des espèces ne sont pas connues; nous avons obtenu les Mérodons équestre 
et transversal des larves décrites par Réaumur, tom. IV. Mém. 12. pag. 499. pl. 34. figr. 1-12. Elles sont grosses, presque cylindriques, apodes, lcurs deux extrémités. un peu pointues le scnt presqu'également, mais la partie antérieure du corps se distingue par la présence de dcux crocliets écailleux susceptibles de se retirer à l'intérieur; ce sont les organes avec lesquels ces Jarves attacuent la subslance de l'oignon de Narcisse dans lequel elles vivent; ils lui servent aussi comme de paltes, et c'est par leur moyen seulement qu'elles peuveut avancer lorsqu'ón les a tirées de l'intérieur de cet oignon. Ces srochets épais à leur basc vont ensuite en diminuant, et se recourbent pour se terminer chacun par une pointe fiae tournée du côté du ventre. Au-dessus de chaque crochet est une corne charnuc dont le bout est refendu; ce bout semble fait de deux manelons qui peuvent s'écarter l'un de l'autre: un peu plus loin et un peu plus bas que les cornes, il y a de chaque côté une petite tache noire, luisante; ces deux taches sont probablement les deux stigmates antérieurs; les stigmates postérieur's sont placés vers l'anus sur une sorte de potit barillet brun ordinairement peu apparenl, mais que la pression fait sortir ; sur le bout de ce barillet on apercoit deux petites cavités, au centre de chacune est un pesit grain noir, semi-globuleux, ce sont là les stigmates postérieurs : audessous du barillet on voit deux appendices charnus entre lesquels est situé l'anus. Ia coulcur de ces larves est d'un blanc-roussâtrc sate, vues à la loupe elles paroisseut grarnies de petits poils; les segmens du corps son tridés et paroissent clagrinés; pour passer à l'átat de nymphe la larve quitte ordinairemeut l'oignon, elle se fail, comme un grand nombre d'aulres Diptères, unc coque de sá propre peau, de la même forne que celle de la Musca yonnitoria, mais beaucoup plus ridée et d'une couleur grise un peu noiratre; sur la partie antérieure el supérieure de celle coquc il y a deux cornes qui aboutissent intérieurentent à deux ressies placées chacune d'un côtć du corselet et qui communiquent avec les stigmales; res cornes sont done l'organe de respiration de la nymple. Pour sorlir de sa corpue l'insecie parlatit soulève une demi-calotte de ta partie antérieure et paroît, dans nos climats, dès lc'mois d'avril.

Il est très-probable que les Mérodons equesiris et transversalis ainsi que lcs suivans, notrilis, constans, Narcissi, ferrugineus el flavicans de N. Meigen et de quelques autres auteurs, ne sont qu'une seule espèce très-variablc que nous dósignerons sous le nom de Mérodon du Narcisse ( $M$. Narcissi), et dont la larve dćcrite ci-dessus vit dans les oignons du Narcisse de Constantinople (Narcissus tazzeta. LivN.) qui culivés en grand a Ollioule sont apportés tous les ans par caisses chez les jardiniers lleuristes de Paris; nous ne croyons pas que l'on ait pris cette espece anx environs de la capitale, nous la eroyons propre anx pays méridionaux. Comme une grande partie des ignons euvoyés d'Ollioule ell sont attaqués, on se procure aisćment de ces larves en prenant chez lcs fleuristes ces oignons gâtés.

Les Mérodons à l'état parfait se trouvent sur les fleurs. Nous mentionnerons les espèces suivantes : $1^{\circ}$. Mérodon clavipède, $M$. clavipes. Mrig. Dipt. d'Eur. tom. 3. pag. 351. no. 1. tab. 3r. fig. 22. Femelle. Des environs dc Paris, on le trouve sur les Euphorbes. La femelle a le plus souvent ses poils d'un gris-blanchâtre, et ccux du mâle ne sont pas toujours d'un rousdoré, comme l'indique la description de M. Meigen, mais seulement d'un roussâtre-pâlc, sans que ces différences proviennent d'une délérioration. $2^{\circ}$. Mérodon du Narcisse, M. Narcissi. Merodon equestris. ME1G. id. pag. 352. $n^{\circ} .2$. tab. 5I. fig. 23. Mâle. (Nous avons deux femelles de cellc variété.) Et Merodon transversalis. MFIG. id. $k a g .354 \cdot n^{\circ}$. 4. (Nous possédons une femelle de cette variété.) Il faut probablement joindre encore à cette synonymie comme simples variétés du Mérodon du Narcisse, lcs espèces de M. Meigen citées plus haut dans les généralités. 3․ Mérodon front hlanc, $M$. albifions. ME1G. id. pag. $359.72^{\circ}$. 15. Du midi de la lirance; pris à Montpellier par M. A. de St. Eargean.

Nota. Le Merodon fernoratus no. 4. FAB. Syst. Antliat. est une Xylote; le Merodon podagricus no. 10. FAB. $i d$. appartient aux Ascies, et M. Witdemann pense quc le MIerodon crassipes $\mathrm{n}^{\circ} .5$. $\mathrm{F}_{\mathrm{AB}}$, id. est un Eristale.

HELOPHILE. NEIG. LAT. (Fam. nat.) Rhingia. Fab. Falién. Panz. Ertistalis. Fab. Syrphuss. Faleén. Panz. Musca. Linn. De Géel. Geoft。 Schranck.

Genre d'insectes de l'ordre les Diptères (première section), famillc des Athéricères, tribu des Syrphies.

Quatrc genres, Mallote, Eristale, Hélophile et Mérodion constituent un groupe duns cettc tribu. (Voyez Syrpmes.) Les tócux preniers sont séparés des autres par leurs cuisses postérieures sinuples el giêles. Dans les Mérodons l'hypostone est sans ubercule, les cuisses postérieures unidentíes cu dessous et les ailes couchées paraliclement sur le corps dirns le repos.

Antennes avancées, plus courtes que la lếle, rabaltues, insérées sous un rebord du front, composées de trois articles, les deux premiers petits, ćganx entr'eux, le troisième plane, presguc rond, ayant à sa base une soie dorsale nue. - Ouverture de la cavité buccale oblongue. - Trompe chainue, retirée dans la cavitć buccale lors du repos. - Suçoir de quatre soies, suivant M. Lalrcillc, les inférieures redressées, aussi longues que les pal [es. - Palpes cylindrigues, redressés, u a po u 
velus vers leur extrémité, à peine moitié aussi longs que la soie supérieure. - Téte hémispluérique; liypostome un peu enfoncé ali-dessuus des antenues, avancé à sa partie inférieure, celle-ci formant une sorte de tubercule. - Yeux nus, espacés dans les deux sexes: front des mâles un peu plus étroit que celui des femelles, leurs yeux un yeu anguleux intérieurement, les deux angles réunis par une ligne transversale du front. - 7 rois ocelles placés en triangle sur le vertex. -- Curps assez lung, presque glabre. - Corselet presque carré. - Ecusson grand, semicirculaire. - ailes assez glandes, velues vues au microscope, écarlées l'une de l'aulre dans le repos, leur celiule sous-ma rginale pédiforme. (Voy. la note pag. 5 :4. de ce volume.) - Cuillerons dubles, grands.Balanciers presque recouverts. - Abdomen assez long, de gquatre segmens outre l'anus, presque conique dans les mâles, elliptique dans les fenelles, presque plat. - Les quatre pattes antérieures assez grêlés; cuisses postérieures grosses, reuflées, en massue alongée, tiès-finement denticulée en dessous, surtout vers leur extrémité; jambes (les deux postérieures principalement) arquées; premier article des tarses presqu'aussi bong que les quatre autres pris enscinble, le dernier muni de deux petits crochets ayant une forte pelotte bifide clans leur entre-deux.

Ce gente dont le nom vient de deux mots grees qui signilient: aimant les marais, be contient qu'un très-p̧etit noubre d'espèces; les larves, au moins rel!e de! Penculus, sont semblables aux Lurves des Erisiales et se trouvent aussi daus les eaux crotpissabtes. Les insectes parfuits n'ont pas l'habilude de furre monoir leur aboumen a la mantire des Eistales, mais ils ont le mérae vol, la mêtue nourriture et sọ rencontrent sur lics fleurs.

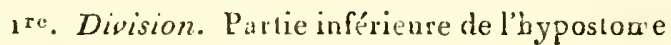
prolongée en bec presqu'horizontal.

A celte division se rapporte l'Hélophile à ligues, H. lineulus. Hetc. Dipt. a'Eur, tom. 3. fug. 369. no. 1. tab. 32. fig. 7. Mâle. Trouvé en Normandie.

$2^{\mathrm{e}}$. Division. Parlic inférieure de l'hypostome simplement taberculée, sans piolongewèt.

1\%. Hélophile lunalé, H. lunulatus. Meig. Dipt. d'Europ. tom. 3. pag. 370. $n^{\circ}$ 2. 2०. Hélophile transfuge, H. trangugas. MeIg. id. pag. 37\%. no. 3. tab. 3z. fig. 8. Hâle. Environs de Paris. 3 . Héloplite des champs, H. camporum. Mete. id.pag. $372 \cdot n^{\circ} \cdot 4 \cdot 4^{\circ}$. Tlélophile à trois bandes, H. Lrisittutus. Meig. id. pag. $373 . \iota^{\circ} .5$. Environs de Paris. 50. Hélophile suspendu, H. pendulus. Mers. id. $2^{\circ}$. 6. Comenur aux environs de Pari . 6०. Hélophile des buissons, H. frutetorm. Merg. id pag. 374. $n^{\circ} \cdot 7 \cdot 7^{\circ}$. Hélophile joli, H. pulchriceps. NEstg. id pag. 375. no. 8. De Porlugal.

(S. E. et A. SEar.)
SYRTSS, Syrtis. Fabricius dans son Systema Rhyngotonum fait un genre sous ce non auquel il donne pour caracière : rostre fléchi, inséré scus le chaperon; chaperon alongé, échancré, convexe en dessons; antennes rapprochées, de quatro articles, insérúes à la base du rostre.

Il place dans ce genre quelques espèces qui figuroient parmi les Acanthia de l'Entom. Syst. les $S_{y}$ rtis crassipes el erosu sont des Phymates. (Voye silis et crassimana appartiennent au genre $\mathrm{Mi}$ crocéphiale. (Voyez ce tnot, page r20. de ce volume.) Nous iguorons à quel genre on doit rapporter les quatre autres espèces.

$$
\text { (S. F. et A. Serv.) }
$$

SYSTROPHE, Systropha. Ilexg. Kuug. LAt. Apis. Ross. Euccra. Scopol. Andrena. Panz. (Faum.) Oriv. (Encycl.) Hylocus. Faв. Anthidium. P'Avz. (Révis.) Ceratina. Jor.

Genre d'insectes de l'orrie des Hyménoptères, serion des Porte-aiguillon, famille des Mellifères, triba des Apiaires (division des Récoltanies).

Dans les Apiaires récollantes solitaires (vojez ParAsitrs) un groupe a pour caractère: point de paletle au métathorax ni aux paltes postérieures; une brosse pour la récolte du pollen des tleura placée sur le côté extérienr des jambes et du premier arlicle des larses des deux pattes postérieures; guatre cubitales; ccclics disposés en ligue transversale. Ce groupe contient quatre autres genres outre celui de $S_{y}$ strophe, $1^{\circ}$. Macrocère. qui s'en dislingue par ses anlennes filiformes dans les deux sexes et très-longres daus les mâles; $2^{\circ}$. Monceque, dans lequel l'épine interne des jambes postérieures est pectinée; $3^{\circ}$. Mélitome. ¿ui a les inâchoires et la lèvre formant une pronuscide dépassant la base des banches postérieu$r \in s ; 4^{\circ}$. Epicharis, donl l'epine des jambes intercoédiaires est pectinée, unidentée avant son exIrénité et les crocliets des tarses dentés. Aucou de ces trois dermiers genes n'a les antennes en massue dans les femelles, ni leurs quatre dernie:s articles contcurnés en spirale dans les mâles.

Antennes brisées et de douze articles dans les femelies, grossissant insensiblement vers l'extrémité, formant une sorte de massue dans ce mềne sexe, simplement arcucées et de treize arlicles dans les mâtes, les quatre derniers plus longs rue les précédens, plus menus, contournés en spirale et formant une espècc de triungle. - Labre pelit, transversal. - Mandibules bidentées.-Mâchoires et Lère formant une promuscide qui ne depasso pas la base des hanches autérieures. - Palpes de forme presqu'ideatique; leurs articles grêles, livéaires; les raxillaires à pen près de la longueur du lobe terminal des mấboires, de sir articles; 
les (rois premiers (mais surlout le troisième) longs: palpes labiaux de quatre articles, le second le plus long de tous. - Lèvre linéaire, peu ou point velue. - Trois ocelles disposés en ligne transversale droite sur le haut du front. - Corps un peu pubescent. - Corselet globuleux. - Ecusson ayant ses eôtés un peu bembés. - Ailes supérieures ayant une cellule radiale rétrécic depuis son milieu jusqu'a son extrémité, celle-ci ne s'écartant pas de la côte : quatre cellules enbitales, la première plus grande que la seconde, la deurième petite, presque carrée, recevant la premic̀re nervure réeurrente très-près de la base de la troisième, celle-ci à peu près aussi grande que la prewière, très-rétrécie vers la radiale, recevant la seconde nervure récurrente; quatrième cubitale à peine commencée : trois cellules diseoïdales, les deux premières ou supérieures assez alongées, la rroisième ou inférieure fermée par une nervure transversale, fort loin du bord postéricur. - Abdomen ovale, convexe, de ciuq segmens outre l'anus dans les femelles, en ayant in de plus et étant recourhé à son extrémité, son second segment portant en dessons deux tuberculcs dans les mâles. - Pattes de longueur moyenne, les deux jambes autérieures munies à leur exırémité d'une épine un peu nembraneuse latéralement, aiguë, mais un pen échancrée obliquement à son extrémité : celle des jaubes intermédiaires simple, aiguë: jambes postérieures ayant cleux épines simples, aiguës, presqu'égales entr'clles; ces jaubes dépourvines de palclle, nais muries d'une brosse sur leur face extérieure ainsi que sur celle du premier artiele des tarses; dernier article de ceux-ci ayant deux croehels bitides munis d'une pelotte dans l'entre-deux.

Les mœurs de ees Apiaires ne sont pas connues. On les trouve daus les parties méridionales de l'Europe.

\section{Systropne spirale, $S$. spiralis.}

Systropha spiralis. Lat. Gener. Crust. et Ins. tom. 4. pag. 157. Mâle et femelle. - Hylarus spiralis. $n^{\circ}$. 6. FAв. Syst. Piez. Mäle. - Anárena spiralis. Panz. Faun. Germ. fas, 35. fg. 22. Màle. - Coqueb. Illustr. Icon. tab. 15. fig. 8. Mille. Apis curvicomis. Ross. Faun. Etrusc. tom. 2. pag. $106 . n^{\sigma} \cdot 9^{21}$. Màle. - Eucera curvicomis. Scopos. An. Hist. nat. 4. pag. 9. Nấle, -- Ceratina spiralis. Juв. Hyménopt. pag. 254. Mâle. Encycl. pl. 383. Jis. 5 et 6 . Màle.

royez pour la description du mâle, Andrène spirale no. 3. de ce Diclionnaire. La lenelle ne diffère que par les caractères indiqués ci-dessus conıme génériques.

Nota. M. Latreille mentionne une autre Systrophe; ces deux espèces ne se distinguent l'une de l'autre, dit-il, que par la différence des tubercules du dessous de l'abdonien dans les mâles.
MACRCCERE, Macrocera. SpINor. (1) LAT. Eucerci. Panz. Fab. Spinol. Centris. Fab. Apis. Ross. Lasius. Jur.

Genre d'insectes de l'ordre des Ityménoptères, section des Porte-iiguillon, famille des Mellifères, tribu des Apiaires (division des Réeoltantes).

Un groupe d'Apiaires récoltantes solitaires comprend los genres Macrocère, Systrophe, Monœẹne, Epicharis et Mélitome. (Voyez PARAsites. ) Les Systrophes ont la première cellule cubitale des ailes stipérieures plus grande que la seconde; les antennes contournées en spirale daus les mâles et en massue dans les femelles. Le genre Monoque a les épines des jambes postérieures pectinées; dans les Mélitomes les inàchoires et la lèvre forment une promuscide qui dépasse la base des hanches postérieures; les Epicharis ont les épires des qualre dernières jambes pectinées.

Antennes filiformes, brisées, composćes de douze articles courts dans les femelles, très-longues, de treize articles dans les míles; ces artiiicles à partir du trojsieme longs, cylindriques et un peu arqués dans ce dertier sexe. - Labre court. - Mandibules étroiles, poinlues, bidentées. - II âchoires et Lèvre formant uue promuscide qui alteint seulement la base des hancises antérieures. - Palpes maxillaires ne paroissant avoir que cinq articles, le dernier étant nul ou très-peu visibie : palpes labiaux de quatre arlicles. - Téte assez forle, basse. - Yeux ovales, cnliers. - Trois ocelles úisposés en ligne droifi" sur le vertex. - Corps assez gros, velu. - Corselet convexe, élevé. - Ailes supérieures ayitrit une cellule radiale comnençant à se réliécir après la troisic̀ me cellule cubitale jusquà son cxtrémité qui est arrondie el écartće de la côte: qualre cellules cubirales, la première un peu plus longue que la seconde, celle-ci en carré longr, recevant la première nervure récurrente près de ia base de la troisiène; troisième cubitale fort rétrécie vers la radiale, recevant la seconde nervure récurrente très-près de la base de la quirrriène, celte dernière à peine commencée : trus cellales discoïdales à peu près égales entr'ell's. - Abdomen convexe, conıposé de ci:lq segmens outre l'anus daus les femelles, eo ayant un de pítis daiss les mâlcs. - Pattes de longueur moyenie, jambes antérieures inunies à leur extrénité d'ine seule épine garnie dans la moilié inférieure de sa longucus d'une large mernbraue latérale : jambes intermédiaires ayant uue seule épine longre, simple, aigü̈; ; jarabes postérieures (des ferrelles) sana paletle, raunies áue brosse sur leur lace

(1) Nous domors cerre indication d'après M. Latreitie, car nous n’avons pas troavé ce genre menrionné lans ies ouvrages tie M. Spinols. 
extérieure ainsi que sur celle du premier article des tarses, ayant daos les deux sexes à leur extrémilé, deux épines longues, aiguës, simples; dernier article des tarses nuni de deux crochets bifides, portant dans leur entre-deux une pelite pelotte.

Les Macrocères dont le nom est tiré de deux mols grecs et a rapport à la grandeur des anlennes des mâles, out ahsolnment les mêmes mœurs que les Eucères. (Voyez ce mot pag. 312. de ce volume.) Les espèces connues au nombre de douze environ habitent les pays ehauds des deux héwisplières.

\section{Macrocìre longicorne. M. longicormis.}

Macrocera nigra; capite rufo villoso, clypeo labroque albidis : thorace et abdominis primo secundoque seginentis rufo willosis; tertis, quarto, quintoque nigro villosis, sexto anique lateribus et pedibus rufo villosis.

Isongnenr 9 lig. Noire. Chaperon et labre blanchâtres. Tête et corselet chargés d'un duvet roussâtre ainsi que les deux premiers seymens de l'abdomen, le sixième, les eôtés de l'anus et les paltes; les autres segmens de l'ałdornen portant un duvet noir. Mâle.

Rapportée de Montpellier par M. de St. Fargeau, officier de la Garde.

\section{Macrocine eafre, Mir. cafra.}

Macrocera nigra, cinereo albidoque villosa; clypei margine inferc testaceo in fomina $\hat{\text {, clypeo }}$ labroque albidis in mare.

Longueur 3 lig. Noire. Tête ayant un duvet cendré, roussâlre sur le labre. Bord iuférieur du chaperon teslacé. Duvet du corselet d'un rouxcendré ; base du premier et du second segmeus de l'abdomen cliargés de poils hérissés cendrés; leurs eôtés les ayaut blanchâtres. Base du troisième segment ayant une bande transverse de poils couchés, blanchâtres. Qualrième segaent en portant une pareille, et de plus une seconde dans son milieu, qui se réunissent sur les côtés; le einquième ainsi que l'anus chargés de poils hérissés roux et noirs. Pattes noires avec des poils roux. Ailes tıansparentes. Fenuelle.

Le mâle diffère par son chaperon et sou labre blanchâtres; le premier segment de l'abdomen entièrement convert de poils roux, hérissés, ainsi que la base du seeond, sur les côtés duquel les poils deviennent blanchâtres; le troisième, le quatrième et le cinquième ont chacun une bande transverse, basilaire, de poils eouchés, blanchâtres. Ie quatrième a'i point de bande dans son milieu; le sixième et l'anus ont des poils hćrissés roux e! noirs.

De Cibfrerie. Du cabizet du Roi.
3. Macrocìre bimaculée, M. bimaculata.

Mracrocera nigra, nigro villosa; pedum posticonum tibiis tarsisque rufo villosis : abdominis segmento quarto fásciâ è pilis stratis albis valde interruptâ; alis subviolaceo fuscis.

Longueur 8 lig. Noire, ehargée de prils bérissés, de cotte couleur; quatriène segment de l'ab. domen ayant nne bande transverse très-iuterrompue, de poils couclás blancs, le cinciuième segment ex trêmement chargé de poils noirs, hérissés. Janbes postérieures ainsi que leurs tarses garnis de poils roux. Ailes brunes, un peu violettes. Femelle.

Envoyée de Pliladelphie au eabinet du Roi par M. Lesueur.

\section{Maerocìne d'Auguste, M. Augusti.}

Macrocera nigra, capite thoraceque rufo villo. sis; abdominis segrnentorum margine infero subdecolori, pilis stratis cinereis villoso: alis hyalimis.

Longneur 4 lig. $\frac{x}{2}$. Noire. Antennes de eelte couleur, leur extrémité antérieurement testacée. Tête et corselet eouverts de poils d'an roux-cendré. Bord des segmens de l'abdomen décoloré et couvert de poils couchés, cendrés. Poils de l'anus cendrés. Pattes noires, leurs poils roux. Ailes transparentes. Femelle.

Le mîle diffère : les poils du corps sont d'un roux plus foncé et le sixième seginent de l'abdomen est culoré comme le précédent; la partie antérieure de la tête est blanchâtre ainsi que la base des mandibules.

Elie a été rapportée du Brésil par M. Auguste de Saiut-Hilaire auquel nous en faisons l'hommage et qui a enrichi le lWnséum de beaucoup d'autres espèces nouvelles d'Hyménoptères.

Rapjortez à ce genre: $1^{\circ}$. Maeroeère antennaire, M. antennata. LAт. noup. Diction. d'hist. nat. $2^{\mathrm{e}}$. édit. - Eucera antémnata no. 8. FАв. Syst. Piez. Mâle. - Panz. Fann. Gem. fas. 99. fig. 18. Mâle. - Apis malvce. Ross. Faun. Etrasc. $n^{\circ}$. 923. Plâle. Des euvirons de Paris. $2^{\circ}$. Macrocère tibiale, $M$ r. tibialis. - Centris tibialis no. 31. Fab. $i d$. Femelle. Des Antilles.

\section{MONEQUE, Monxca.}

Genre d'insectes de l'ordie des Hyménoplères, section des Porte-aiguillon, faurille des Mellifères, tribu des Apiaires (division des Récoltantes).

Les genres d'Apiaires solitaires qui cornposent un groupe dans cette division avec eeux de Monœque et de Mélitome sont : Systropte, Epicharis ct Macrocère : ces trois deruier's se distinguent des deux autres en ce que la cellule radiale de leurs premières ailes est dénuée d'appendiee; 
dans les Mélitomes la qualrière eellnle cubitale n'est que commencúe et les épincs des jambes postérieures sont sans denteluies.

Antennes filiformes, brisées, eomposies de dunze ariicles dans les femelles, de lreize dans les mâles. - Mandibules ćlroites, pointues, bideatées. - Mâchoires recourbées conjointement avec la lèvre. - Tête de grandeur noyenne. Trois ocelles disposés en ligne transversule sur le haut du fiont. - Corps assez gros, velu. - Corselet couvexe. - Ailes supérieures ayant une cellule radiale aiguë à sa base, se rétrécissant depuis son milieu jusçu'i cette base; son extrémité écartée de la côle et portant un appendice; quatre cellules cubitales; lit première plus grande que la seconde, celle-ci un peu rétrécie vérs la radiale, recevant la première nervure récurreute; la troisiéne de la grandeur de la première, rélrécie vers lat radiale, recevant la deuxième nervure récurrente; la quatrième atteignant le bout de l'aile: trois cellules discoïlates. - Abdomen composé de cinq segnens outre l'inus dans les femelles, en ayaut un de plus dans les máles. - Pattes de longueur moyenna; janbes postŕrieures des femelles dépotirvues die palette, initis portant une brosse sur leui face extérieare ansi que sur ectle du premier article des tarses, terminées par deux épines dont l'intérieure est visiblement dentée en scie, l'extérieure l'étant à peine; dernier article des tarses muni de deux crocliets bifides.

Le nom de Monœque vient de deux mols grecs qui indiquent que ces incectes vivent solitaires; les mœurs de l'espèce que nous allons décrité ne sont pas connues, mais sa eonformation indique qu'elles ne peuvent s'éloigner beaucoup de celles aes Macrocères.

\section{Monaque brésilienne, M. brasiliensis.}

Moneca nigra, nigro villosa; tarsis posteriorious punctoque alartum marginali testaceis.

Longuenr 6 lig. Noire, velue; les poils noirs. Jumbes postéricures couleur de poix; lears tarses testacés arec des poils ferrugrineux. Aites enfumées, leurs nervures norres, point marginal des supćriẹures, lestacé. Fernelle.

Du Brésil. Du cábinet du Fioi.

\section{MÉLI'TOME, Melitoma. LAT. (Fam. nat.)}

Genre d'insectes de l'ordre des Ilyménoplèeres, section des l'orte-aiguillon, famille des Metlitères, tribu des Apiaires (division des Récoliantes).

Un groupe d'Apiaires sulitaires de celle divisiou renferme einq genres (voyez Parasites), dont quatre, Systrophe, Monoeque, Epicharis et Macrocère ont leur promuscicle courte (MI. Latreille désignne sous ce nom les mâchoires et la Hist. Nat. Ins. Tomb $X$. lève rénnies), n'atteignant au plus que la base des hanches autérieures, ce qui les distingue des Melicones.

Antennes filiformes, brisées, eourtes dans les deux sexes, de douze articles dans les femelles, de treize dius les nutles, le troisième toujours ämin:i à sal prartie inférieure. - Mâchoires el LèDre réutuies, fromant une promuscide qui dépasse, dans le repos, la base des hanches postérieures. - Téle transversale. - Yeux assez grands. Trois ocelles disposés en ligne transversale sur le hant du fionl. - Corps velu, assez court. - Corselet globuleux. - Ecusson eourt, transversal. Ailes supérieures ayant une cellule radiale, pointue à sa base et à son extrómité qui est écartée de la cóte, el quitre cellules cubitales; la prenière plus grande que la seconde, eelle-ci presque carrée, recevant au-ciessous de son milieu la première nervure récurrente; Ia troisième fortement rétrécie vers la radiale, recevant la seconde nervure récurrente, un peu avan! la nervure d'intersection qui la sépare de la quatrième; cetle dernière cellule un peu eornmeneée ct tracée presque jusqu'äu bout de l'aile : trois cellules discoïdales presqu'égales; l'intérieure fort éloignce du bord postérieur de l'aile. - Abdomen assez convexe, composé de cinq segmens outre l'anus daus les femelles, en ayant un de plus dans les wâles; le prenier assez étroit. - Pattes assez fortes, velues; jambes antérieures munies ì leur extrémité d'une épine garnie d'une nembrane dans toute sa longneur : jambes intermédiaires n'on ayant qu'une, simple, droite et longue; jambes postérieures des femelles, dépourvues de palette, nais portitat une brosse sur leur fice extérieure ainsi que sur celle du premier article des tarses, terminées par deux épines longues, égales, simples, un peu crochnes à leur extrénité; dernier arlicle des tarses muni de deux crochets bifides, ayant une pelolle dans leur entre-deux.

L'espèce qui sert de type à ee genre a été rapportée du Brésil par. M. Auguste de Suint-Hilaire, qui ne nous a conraniqué aucune :emarque sur șes habitudes, nais elles ne peuvent guère s'éloiguer de celles des Euceres.

\section{Mélrtone Euglosse, MI. euglossoides.}

Melitoma nigra; antennis piceis, capite thoraceque rufo viliosis: segmentorum abdominis intermedionm margine infero palis stratis albis yilloso.

Longueur 5 lig. Antennes brunes, un peu testacées à leur face antérieurc. 'Tête et corselet noirs a vec un duvet roux; abdomen noir, son premier seğment avee des poils grisâtres, les second, troisième et quatrième ayan $t$ des poils noir's, et leur bord inférieur chargé d'une bande transverse de poils $\mathrm{X} \times \mathrm{x}$ 
courls, couclés, blancs; le cinquièrne el l'anu; garnis de poils noirs; patles noires, velues; ailes transparentes. liemelle.

Ie mâle diffère en ce que la parlie antériemre de sa tête est plus chargée le poils et que le cinquième segment de l'abdomen a, commc '́es précédeus, la bande transverse de poils couchés, blanes.

De la Capitainerie de Guaratuba au Brésil.

ÉPICHARIS, Epicharis. Krug. Ilitg. Lat. Apis. Olx. (Encycl.) Centris. Fab.

Genre d'insectes de l'ordre des Hymónoptères, section des Porte-aiguillon, famille des Mellifères, tribı des Apiaires (division des Récollantes).

Des cinq genres qui composent le groupe d'Apiaires solitaires de cette division, duquel dépendent les Epicharis (voy. Parasites), le geure Monœque a la quatrième cellule cubitale complète et atteignant le bout de l'aile; les crochets des tarses sont bifides. Les Mélitomes ont une promuscide qui dépasse la base des cuisses posterieures. Dans les Macrocères et les Systrophes les épines terminales des quatre jambes postérieures sont simples, de plus les anteunes des Macrocères mâles sont plus longues que le corps, et dans les Systrophes du mêrne sexe les antennes sont contónunces en spirale et forment une sorte de triangle à leur extrémité.

Antennes filiformes, brisées, de donze articles dans les femelles, de treize dans les máles, et n'étaut pas sensiblement plus longues que dans l'autre sexe. - Labre grand, avancé, arrondi. Mandibules (au moins celles des femelles) grandes, plus larges vers leur extrérnité, qui a trois petites dents peu prononcées. - Mâchoires et Lèvre -fléchies, formant une promuscide qui atteint selllement la base des hanches antérieures. - Palpes maxillaires très-courts, n'ayant qu'un seul article presque globuleux : palpes labiaux sétiformes, aigus, leurs articles droils, peu visibles. - Têle de grandeur moyenne, presque triangulaire vue en devant. - Yeux ovales, alongés. - Trois ocelles disposés presqu'en ligne droite sur le vertex. - Corps assez long, un peu velı. - Corselet elliptique. - Ailes supérieures ayant une cellule radiale, aiguë à sa base, rétrécie depuis le milieu jusqu'à cette partie, son extrémité armondie, éloignée de la côte ; quatre cellules cubitales, la première presque séparée en deux par une fausse nervure qui descend de la rôle, la seconde presque de même grandeur que la précédente, rétrécie vers la radiale, recevant la première nervare récurrente; la troisième rétrécie vers la radiale, recevant la seconde nervure récurrente très - près de la nervure qui la sépare de la qratrième cubitale; celle-ci à peine commencée : trois cellules discoïdales à pen près égales, l'inférieure fort éloignée du bord postćrieur de l'aile. $-A b$. domen alongé, conique, de cinq segmens outre l'anus dans les feme!les, en ayant un de plus dans les mâles. - P'attes assez fortes, très-velues; jamhes autérieures munies d'une épine terminale aiguë, garnie latésalement d'une large membrane échancrée à son extrémilé; jambes iutermédiaires ayant une seule épine terminale dentée en scie, sans dilatation à son extrémité qui est unidentée, cctte dent formant une sorte de crochet; jambes postérieures munies à leur based'une écaille parnissant formée de deux pièces; celles des femelles dépourvuesde palette mais portant une brosse très-garnie de longs poils sur leur face extérieure ainsi que sur celle du premier article des tarses; ces jambes terminées par deux épines, l'intérieure manifestement dentée en scie, l'extéricure l'étant aussi un peu; crocliets des tarses unidenlés, sans pelotte apparente.

I.es Epicharis connues sont an moins d'une taillc égrale à celle de la Xylocope la plins commune en France ( $X$. violacea). Ia forne de leurs mandibules nous paroît iudiquer que ces A piaires travaillent en bois ou en maçonverie. Toutes les espèces habiteut les contrées chaudes de l'A mérique méridionale. Il est difficile dans ce genre, ainsi que dans quelques autres qui en sont voisius, de rapporter les mâles à leurs femelles à cause des diffórences de conleurs, et l'on ne sanroit trop recommander aux voyageurs d'observer les accouplemens et de les rapporter de wanière à ôler toule incertitude.

\section{Epicharis rustique, E. nustica.}

Epicharis dasypus. Klug. Illig. Lat. Gener. Crust. et Ins. toin. 4. pag. 17.8. Femelle. Centris hirtipes $n^{\circ}$. 4. Fab. Syst. Piez. Femelle.

Foyez pon la description Abeille rustique $n^{\circ} .8$ de ce Dictionnaire. Les poils du cor elet sont ferrugineux et deviennent quelquefois cendrés. Femeile.

Nous présumons que l'individu suivant est le mâle. Noir ; tête chargée de poils noirs; labre et chaperon d'un blanc jaunâtre, ainsi qu'une tache au-dessous des antennes. Corselet et abdomen à poils cendrés, les côtés de celui-ci plus velus que le miliea. Pattes à poils noirs, ces poils roux sur les jambes et les tarses postérieurs.

Rapporté du Brésil où se trouve aussi la femelle précédente.

\section{Epicharis fasciée, $E$. fasciata.}

Epicharis nigra, nigro villosa; abdominis segmentorum secundi lateribus, tertii, quarti quintique fusciâ mediâ testaceo pallidis, quinto suprà ani dorso producto; tibiis tarsisque posticis ferrngineo villosis; alis fusco-violaceis. 


\section{S Y S}

Isongueur 10 lig. Noire. Tête et corselet chargés de poils noirs; cốlés du second segment de l'abdomen et bande transversale médiale des troisième, quatrième et cinquième d'un tesıacé pâle ; le cinquième se prolongeant sur le dos de l'anus. Pattes noires avec des poils de même couleur, ces poils Perrugineux sur les jambes et les tarses postérieurs. Ailes d'un brun-violacć. Femelle.

Le mâle présumé est l'individu suivant.' Noir ; tête manie de poils noirs. Labre et chaperon d'un jaune pâle, ainsi qu'une tache sous les antenues.

\section{S Y S}

Corselet à poils cendrés et noirs mêlés; premier, second, troisième et quatrième segmens de l'abdomen garnis de poils blanchâtres sur les côtés : les cinquième, sixième et l'anus ferrugineux avec des poils roux. Pattes et ailes comme dans l'Epicharis fasciée femelle. Quelques individus mâles ont aussi le quatrième segment abdominal ferrugineux.

\section{Brésil ; Rio-Janeiro.}

Nota. Nous connoissons encore plusieurs autres espèces de ce genre. ( $S$. F. et A. SERt.)

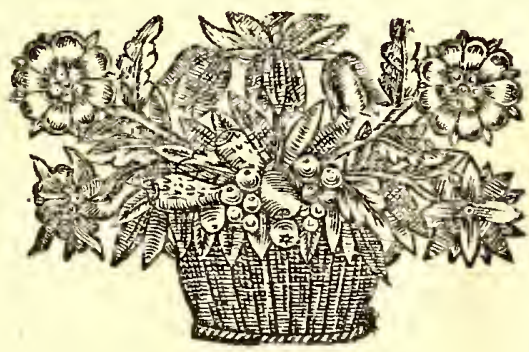




\section{$\mathrm{TAB}$}

$\mathrm{T}$ ABAC D'ESPAGNE. Nom vulgaire donné pay Geoffroy, Ins. Paris. à l'Aroynne Paplia no. 28. tom. IX. pag. 268, de ce Dictionnaire, pl. 57 . fig. 8 - 10. (S. F. et A. Serv.)

TACHINE, Tachino. FAB. Cet autenr a établi sous ce nom dans son Systema Antliatorum un genre d'insectes Diptères; il lui donne poul caractères: palpes minces, filiformes, mus, oblus. Antennes rabattues, de trois articles, le dernier ovale, comprimé. Il en décrit treize espèces, dont cinq sont exociques. Parmi les espèces européennes, celles qui poitent les noms de fera, tesselata, grossa et rotrindata sont des Echinonyies pour M. Latreille, Genera.

\section{(S. F. et A. Serv.)}

TACHINE, Tachina. Meig. M. Meigren daus ses Diptères d'Europe a rćuni sous ce non générique six genres quil avoit fondés dans son premier ouvrage ayant pour titre Classificatron, etc. et nommés alors par lui Melanophora, Lencostoma, Eriothrix, Tachima, Metopia, Exorista. Il lui assigne ces caractères : antennes penchées, ou appliquées contre la têle, de trois articles, le dernier tronqué inférieurement, muni à sa base a'une soie dorsale nue. Bouche accompagnée de moustaches. Ailes écartées, leur extrémité ayant une nervure transversale.

Ce genre dans lequel l'auteur a étahli un grand nombre de divisions, de subdivisions et de gronpes, renferme trois cent quinze espèces, dont plusieurs appartiennent aux genres Mélopie, Múlanophore et Echinomyie de M. Latreille.

$$
\text { (S. F. et A. Serv.) }
$$

TACHINE, Tachinus. Graven. T.at. G YLlen, Staphylinus. Linn. Geoff. Oliv. Park. Fab. Oxypornts. FAB.

Genre d'insectes de l'ordre des Coléoptères, section des Pentamères, famille des Brachélytres, tribu des Microcéphales.

Cette tribu a pour caractères : lête enfoncće postérieurement dans le corselet jusque près des yeux, n'offiant point d'élranglement à sa base. Corselet trapézoidal, s'élargissant de devant en arrière. Ellc comprend les geures Loméchuse, Tachine et Tachypore. Les Loméchuses diffèrent des Tachines par leur corselet dont les côlés sont dilatés et relevés; les 'Tachypores se reconnoissent à leurs palpes subulés; ce seul céractère les sépare des Tachiues, cependant ccs deux genres, vu l'importance attachée aux parties de la bouclie, avcient été adoplés tous deux tels que M. Gravenlıorst les avoit élablis en I802 dans ses Coleopt. micropt.; mais cet anleur en 1806 , dans sa Monographia Coleopterorum micropterorum, détruisit lui-même ces genres, et mêlant les espèces que d'abord il rapportoit à chacun d'cux, il donna les deux geures Tachinus et Tachyporns, fondés seulement sur l'hảbitus extćsieur, en sorte que l'on tronve dans chacun de ces genres des palpes subulés et des palpes filiformes. Nous croyons devoir ici à l'exemple de M. Latreille nous en tenir anx caractères pthliés dans le premier ouvrayge de M. Gravenhorst.

Antennes de la longueur de la tête et du corselet pris ensemble, composées de onze articles, le premier gros, les suivins fort minces, les autres plus gros, presqu'ćraux enlr'eux, le dernier ovale. - Mlandibules presque sans denls au côlé interne. - Palpes filiformes; les maxillaires de quatre articles, les labiaux de trois. - Téte plus étroite que le corselet, rentrée presque jusqu'anx yeux dans l'échancrure antérieure de celui-ci; claperon étroit, rétréci vers son extrémité qui est obtuse. - Corps lisse, brillant, convexe, allant en s'anincissant vers son extrértilé.-Corselet convese, ì hords latéraux rabattus, échancré en devant pour recevoir la parlie postériente de la tête. - Elytres convexes, plus longues que le corsclet, recouvrant des ailes et laissant à nı une parlie de l'abdomen. - Abdomen conique, se terminant presqu'en poinle, portant des poils grands el roides. - Paties de longneur moyenne; jambes cilićes el épiueuses; tarses ordinarement minces, ayaut cing articles distincls.

Les mouvemens de ces Bracliélytres sont rifs et brusques ; e'est à celte luabitude que l'on doit probablement rapporter l'oricrine grecque de lenr now. Ils vivent à l'ćtat parfait dans les malières stercoraires et particulièrement dans les bouzes de vaclie; on trouve aussi cerlaines espèces duns les chanıpignons et les ulcères des arbres. Leur taille est généralement petite. Les larves ne sont pas conmues. Nons diviserons ce genre à la manière de MI. Gyllenhall.

I ${ }^{r \theta}$. Division. Corps large, entièrement ponctué.

On rapportera à celte division : 10. 'Tachine huméral, T. hmeralis. GRav. Coleopt. micropt. pag. $136 . n^{\circ}$ 3. 2०. Tacline brun, T. pullus. Grav. id. pag. I40. no.6. 30. Tachine sordide, $T$. sordidus. GRAv, id. pag. I4r. $72^{\circ} .8$. $4^{\circ}$. 'Tichine bordé, T. marginellus. Grav. id. pag. 143. $n^{\circ}$. 14. 5?. Tachine sutural, T. suturalis. 


\section{TA C}

GRAT. id. pag. 144. $n^{\circ}$. 15. Ces espèces se trouvent aux environs de Paris.

2e. Division. Corps étroit, alongé, aminci aux deux bouls. Corselet et élytres lisses, n'ayant que quelques points disposés par séries.

Elle comprend: $\mathbf{1}^{\circ}$. Tachine tête noire, $T$. atricapillus. Grav. Coleopt. micropt. pag. 148. $n^{\circ}$. $19.2^{\circ}$. Tacline mélanocéphale, $T$. melanocephalus. Grav. id. pag. 144. no 16 . 'Tous deux deFrance.

IOMĖChUSE, Lomechusa. Grav. Lat. Staphylinus. Fав. Paxk. Oniv. (Entom.)

Genre d'insectes de l'ordre des Coléoptères, section des Pentamères, famille des Brachiélytres, tribu des Microcéphales.

Trois genres sont compris dans cette tribu. ( Yoyez Mlicrocéphales, article Tachine.) Les Tachypores et les 'Tachines diffèrent des Lomécluses par leur corselet convexe à bords latéraux rabattus.

Antennes composées de onze articles, le premier épais, cylindrique ou quelquefois en massue, le second en massue courte; le 1roisième de même forme, mais plus long; les suivans cupulaires, le deraier ovale, aigu. - Palpes acuminés. - Tête environ trois fois plus petite que le corselet; front presque plane, souvent un peu rugneux. - Corps épais, rebordé. - Corselet transversal, rebordé, ses bords latéranx larges, élevés ou redressés, son disque un peu convexe, c.łaliculé, ses angles postérieurs aigus. - Elytres presque carrées; P'angle extérieur de leur partie postérieure aign. - Abdomen épais, rebordé, souvent relevé à son extrémité; son demier segment ordinairement aigu. - P'attes grêles, nues.

Ces caractères sont empruntés à la Monographie des Coléoptères microptères de M. Gravenhorst. M. Latreille dans les ouvrages qui ont suivi la publication de celui de l'auteur allemand, a réuni à ce genre les Aléochares bipunctata, lanuginosa, nitida, fumata, nana, Grav. etc. Nons n'avons pas cru devoir l'initer en cela, mais nous pensons que ces espèces ainsi que l'Aleochara fiscipes Grav. pourroient former un genre nouveau dins la tribu des Microcéphales. Entr'autres caractères qui nous paroissent justificr notre opinion, on trouve dans ces espèces, un corselet convexe à bords latéranx rabattus, ce qui les sépare des Loméchnses; ce même corselet échancré en devant pour recevoir la partie postérieure de la tête empêche de les placer dans la tribu des Aplatis; et d'un autre côté ils n'ont point les jambes épineuses comme celles des Tachines et des 'Tachypores.

Les larves des Loméchuses ne sont pas connues; les insectes parfaits se rencontrent quelquefois sous les pierres.
M. Gravenhorst place dans ce genre : 10. Loméchuse bossue, L. strumosa. Grav. Monogr. Coleopt. micropt. pag. 179. $n^{\circ}$. '. De Suede. $2^{\circ}$. Loméch use échancrée, L. emarginata. Grav. $i d$. $n^{\circ}$. 2. De Suède. 30. Loméchuse paradoxale, L. paradoxa. Grav. id. pag. 18o. no. 3. - Staphylinus emarginatus. OL1v. Entom. tom. 3. Staphyl. pag. 3r. no. 44. Staphyl. pl. 2. fig. 12. Des environs de Paris, sous les pierres. Rare. $4^{\circ}$. Loméchuse dentée, $L$. dentata. Grav. id. pag. $181 . n^{\circ}$. 4. De Suède.

Nota. M. le counte Dejean en mentionne dans son Catalogue une cingrnième esjuèce, de Styrie, L. intermedia. DeJ. (S. F. et A. Serv.)

TACHYBULE, Tach, bulus. LAT. (Gener.) Voyez Pison. (S. F. et A. Serv.)

TACHYDROMIE, Tachydromia. FA . Cet auteur ayant adopté dans son Systema Antliatorum ce nom génériųue créé par M. Neigen, y a mêlé des espèces de genres diflérens. Des huit qu'il décrit les nos. 1, 2, 3 et 4 sont de vériables Tachydromies ou Sigues Lat. (Voycz ce mot.) La quatrième est la même espèce que la Calobata arrogans no. 16. du mêne auteur. Les nos. 5 et 6 . sont des Hilares, la seplième ne nous est pas connue, et la luuitième appartient aux Hómérodromies. (S. F. ei $\Lambda$. SERv.)

TAChydrome, Tachydromia. Meig. Dipt. d'Europ. tom. 5. Voyez Sique.

$$
\text { (S. F. et A. Serv.) }
$$

'TACHYDROMLES, Tachydromice. Onzième famille des Diptères d'Europe de M. Meigen, qui lni donne pour caractères: anlennes avanćes, rapprochées it la base, paroissant n’avoir guc deux articles, le dernier portant une soie terminale; trois ocelles; trompe courte, perpendiculaire; palpes couchés sur la trompe; aldomen de sept segmens; crocheis munis de denx pelottes dans leur intervalle.

Nota. M. Meigen olserve que d'après l'an:logie, les antones devroicat être triarticulées, et que dans cette famille, les deax promiers ar ticles des antennes sont probablement tellement rentrés l'un dans l'autre qu'ils sembleut n'en faire qu'un. L'auleur y place les trois gentes Hénórodromie, Taclydromie et Drapétis.

$$
\text { (S. F. et A. Serv.) }
$$

TACHYPE, Tachypus. M. Wéber dans sin ouvrage intilulé Observat. entomol. (Kilia 1801.) a instilué un genre d'iusectes Coléoptères sons ce nom; il correspond ì ceux de Procrusle et de Carabe des auteurs modernes.

$$
\text { (S. F. et A. SinY.) }
$$


TACHYPORE, Tachyporus. Grav. Lat. Gyle. Staphylinus. Linn. Geoft. Oliv. (Entom.) Ross. PAYk. Schranck. Oxyportus. Fab. Tachitus. GRA V.

Genre d'insectes de l'ordre des Coléoptères, section des Pentamc̀res, famille des Brachélytres, tribu des Microcéphales.

Des trois genres compris dans cette tribu ( voy. TAchine) celui de Loméchuse a les côtés du corselet dilatés et relevés; les 'Tachines, extrêmement voisins des Tachypores, s'en distinguent par leurs palpes filiformes.

Les caractères génériques des Tachypores sont les mêmes que ceux des Tachines, si ce n'est que leurs palpes sont acuminés, presque subulés et que leurs antennes à partir du second article vont en grossissant jusqn'au bout, le dernier étint ovale, assez long. Les mœurs de ces insectes ne diffèrent pas de celles des Tachines. Voyez ce mot.

M. Gyllenhall partage ce genre ainsi:

re. Division. Corps court, obtus antérieurement.

$1^{\circ}$. Tachypore Chrysomèle, $T$. chrysomelinus. Grav. Coleopt. micropt. pag. 128. $n^{\circ} \cdot 7 \cdot 2^{\circ}$. 'Tacliypore bordé, T. marginatus. Grav. id. pag. 327. $2^{\circ} \cdot 5$. $3^{\circ}$. Tachypore grenaille, $T^{\top}$. granulum. Grav. Monogr. Coleopt. micropt. pag. 3. $n^{\circ}$. I. T'ous trois des environs de Paris.

2e. Division. Corps alongé, aminci unême en devant.

Le Tachypore agréa!)le, T. lepidus. Gycu. Ins. Suec. tom. 2. pag. 247. no. 12. - Tachinus lepidus. Grav. Monogr. Coleopt. micropt. pag. 26. $n^{\circ}$. 4. des euvirons de Paris, est de cette division. (S. F. et A. Serv.)

TACHYTE, Tachytes. Panz. (Révis.) Ce genre d'insectes Fyménoptères est le même que celui de Lyrops l.at. Voyez ce mot à la table alphabéiique. (S. F. et A. Serv.)

'TAGÉnIE, Tagenia. Lat. Slenosis. Henbst. Akis. FAB.

Geure d'insectes de l'ordre des Coléoptères, section des Ilétéromères (premiere division), famille des Mélasomes, tribu des Piméliaires.

M. Latreille dans ses Familles naturelles ayant adopté six genres nouveaux dans les Piméliaires, et introduit de nouvelles divisions pour leur disiribution, nous croyous devoir les domner ici.

\section{Tribu des Piméliaires.}

I. Dennier article des antennes très-petit comparativeraent an précédent (à peine saillant dans plusieurs; el en forme de cóae très-civurt.
Pimélie, Platyope, Eurychore, Akis, Elénophore, Erodie.

II. Dernier article des antennes très-distinct, soit guère plus petit que le précédent, soit de même longueur ou plus grand, ovoïde ou en cône alongé.

A. Dernier article des antennes point sensiblement plus long que le précédent.

Zophose, Moluris, Psammode, Tentyrie, Tagone, Hénétre , 'Tagénie, Sépidie.

B. Dernier article des antennes sensiblement plus long que le précédent.

Diésie, Scaure, Læna.

Le groupe de cette tribu qui coutient les Tagénies renterwe encore les genres Zophose, Tentyrie, 'Tagone, Hégétre qui sont distincts par leur menton grand, recouvrant l'origine des mâchoires. Dans les Moluris le labre est très-apparent, le corselet presqu'orbiculaire et le corps convexe; les antennes des Psammodes sont grêles et terminées par une massue de trois articles; le genre Sépidie a le troisième article des antennes beaucoup plus long que le suivant et les côtés du corselet dilatés dans leur milieu.

Antennes presque filiformes, grossissant peu et insensiblement jusqu'ì leur extrémité, composées de onze articles, la plupart conrts, presque perfoliés, le dernier très-distinct, guère plus petil que le précédent, presque globuleux. - Labre ì peine visible, son bord antérieur qu'on aperçoir seul, transversal, cilié. - Mandibules aignës à leur extrénité. - Mâchoires onguiculées au côté interue, rétrécies antérieurement à leur base, reçues de chaque côté dans une rainure linéaire. - Palpes maxillaires assez a vancés, du quatre articles, le dernier un peu plis épais que les autres, tronqué : palpes labiaux de trois articles. - Lèvre entière, à peine tébancrée : menton presque carré, son bord supérieur presqu'entier. - Tćte grande, en carré long. - Corps alongé, déprimé ; tête et corselet plus étroits quo l'abdomen. - Corselet presqu'en carré long, naais allant un peu en se rétrécissant vers les élytres. - Ecusson petit, étroit, pointu postérieurement. - Elytres soudées ensemble, laissant ì découvert l'extrémité de l'abdomen, leur's rebords latéraux erubrassant un peu les côtés de l'abdomen. Point d'ailes. - Abdomen ovale-alongé. - Pattes assez forles; cuisses grosses, les antérieuse surtout; jambes s'élargissant insensiblement vers leur extrémité, coinprimées, terminées par deux courtes épiues; dernier aricle des tarses le plus long de tous, inuni de deux crochets assez foris.

Les 'Tagénies se trouvent dans les contrées limitrophes de la Méditerranée, telles que le asidi 
de la France, lltalie, la Barbarie, ete. Tues espèces connues sont en petil nombre, l'urse d'elles est la Tagénie filiforme, T. filiformis. Lat. Gen. Crust. et Ins. tom. 2. pag. $150 . n^{\circ}$. 1. tom. 1. tab. 10. fig. 9. (S. F. et A. SERt.)

'TAGONE, Tagona. Fisch. Lat. (Fam. nat.)

Geure d'insectes de l'ordre des Coléoptères, section des Hétéromc̀res ( $I^{\mathrm{re}}$ - division), famille des Mélasomes, tribu des Piméliaires.

Le groupe de cette tribu, dont le genre Tagone fait parlie, contient en outre ceux de Zophose, Moluris, Psammode, Tentyrie, Hégétre, 'Tagénie et Sépidie; il a pour carractères : dernier artiele des antennes très-distinct, point sensiblement plus long que le précédent. (Voyez Tagḱnie.) Les Moluris, les Psamınodes, les Tagénies et les Sépidics out le menton petit, ne recouvrant pas la base des mâchoires; le corps des Zophoses est suborbiculaire; les Ifégétres ont leur eorselet carré; eutin, dans les'Tentyries, les antennes sont filiformes, leur dernier article n'est pas plus grand que le précédenl; en outre leurs tarses antérieurs ne sont dilatés dians aucun sexe.

Nous allons donner les caractères de ce genre, qui ne nons est pils conuu, d'après M. Fiseher de Waldbeim.

Antennes allant en grossissant vers leur extrémité, composées de onze articles, le premier très-gres, cylindrique; le second obconique; le troisième plus long, cylindrique ; les quatre suivans obconiques; les buitième, neuvième et dixième globuleux-fusiformcs; le dernier grand, très-distiuct, ovoide. - Labre proćrninent, coriace, transverse, renflé au milieu, un pen échancrć et cilié à sa purtie intérieure. - Mandibules triangulaires, fortes, bordées extérieuremont d'une ligne d́levée de cliaque côté qui se termine endent obtuse. - Palpesinaxillaires longs, ayint leur dernier artiele graud, eomprimé, obconique : palpes labiaux plus courts, entièrement velus, leur article terminal grand, ovale. - Lève proéminente, cornée, échancréc : menton carré, arrondi antérieurement. - Co:selet transversal, point orbiculaire. (LAT.) - Corps triangulaire, allant toujours en grossissant jusqu'̀̀ l'endroit où les élytres se courbent subitement. - Elytres soudées ensenıble, leur extrémité fléchie subitement et droit, de manière à terminer l'abdomen par une ligne droite. - Point d'ailes. - Pattes à peu près conformées comme celles des Blaps, mais plus longues dans chacune de leurs parties; cuisses en massue; tarses antérieurs très-dilatés, ciliés.

Le nom de ce genre vient d'un mot grec qui a rapport à l'extension des articles des autennes et des tarses de ces insectes. Les mœurs des Tagones ne doivent pas différer beaucoup de celles des Pimélies. M. Fischer en décrit deux espèees; elles se trouvent sur les bords déserts d'un lac de la Russie méridionale $: 1^{\circ}$. Tagone pointue, T. acu- minata. FIscu. Entom. Russ. tab; 16. fig. 8. Longueur 8 lig. Noire, glabre, brillantc. Corselet rétréci en devant. Elytres lisses, convexes, leur suture formant une lirne enfoncée; $2^{\circ}$. Tagone macrophthalme, T. macrophthalma. Fisce. id. fig. 9. Longueur' 5 lig. Noire, brillante. Corselet presque cylindriçue; élytres lisses, presque planes. (S. F. et A. Serv.)

TALITRE, Talitrus. Lat. Bosc. Léach. Laxx. Cancer. Montzgu. Oniscus. Palias.

Genrc de Cruslacés del'ordre des Amphipodes, famille des Crevettines, ćtabli par MI. Latreille et restreint par Léach, qui a formé, aux dépens du genre primitif de 11. Latreille, deux autres genres adoptés par ce dernier (Familles nat. du genre anim.). Le genre 'Talitre, tel qu'il est conservé par M. Latreille d'après Léach, a pour caractères: corps comprimé; quatorze pattes; quatre antennes composécs d'un pédoneule de quatre articles, dont le premier plus court, et d'un filet terminal subdivisé en plusieurs autres. Antennes supćrieures très-petites, et plus courles que le pédoncule des inférieures. Les deux pattes antérieures plus grandes gue les deux suivantes, allant graduellement en pointe, ou simplement onguiculées (sans pinces). Paltes dela seeonde paire courtes, grêles, terminées par deux articles très-comprimés, et dont le dernier est en forme d'onglet membraneux et obm tus; celles des trois dernières paires assez longues et finissant par un crochet simple. Segmens du corps ponrvus d'écailles latérales; quene composée de cinq articles, dont le dernier est plus petii. Tête non prolongée en forme de bec.

Ce genre et les suivans formés à ses dépens, se digtinguent des Chevrettes de M. Latreille el des autres genres voisins, parce que, dans ceux-ci, les antennes supérieures sont sensiblement plus longues, on au moins aussi longues que les inférieures. Les Phronimes de M. Latieille n'ont que deux autennes distincles ct fort courtes.

On trouve les Talitres sur les rivages de la mer, oì ils se tiennent en sociétés très-noubrenses. Comme les Crevettes, ils nagent de côté; mais le plus sonvent ils sont sur le sable, dans les lieux qui ne sont couverts d'eau qu'à la marée mo: tante : ils se tiennent cachés sous les tas de fitcins rejetés par la mer, ou sous les pierres, et si l'on vient à les déranger en levant mue de ces pierres, on les roit exćculer des sauts très-vifs, et cn uú instant tons sont disparus. Ils exćcutent ces sauts au moyen de leur queue dont ils replieut les appendices sous leur corps, et qu'ils débandent à volonté comme le font les Podures dans la classe des insectes. Risso cite une espèee qui se trouve cn pleine mer, et qui santille toujours à la surface de l'eau pendant les calmes de l'été.

Les corps morts rejetés par la mer, ou d'autres petits Crustacés, forment la nourriture des Taiitres; ils mangent aussi les vers, les petits Mol- 
lusques qu'ils peuvent trouver. Ils changent de peau en été, et ils exécutent cette opération trèspromptement. Suivant M. Bosc, les natites portent leurs femelles, plus petites qu'eux, entre les pattes, et ce fardean ne les empêche pas de sauter. M. Risso dit que les femelies pondeat plusiem's fois dans l'année; mais MI. Latreille pense que ce fait a besoin d'ètre confirmé : ces femelles portent leur's œufs sous les écailles de lia poitrine, et lorsqu'ils sont éclos, les petirs s'altachent aux appendices du dessous de la queue.

On connoit une ou deux espèees de ce genre; nous cilerons :

Le Talitre sauterelle, Talitrus locusta. Lat. Iéach. Desur. Oniscus locusta. Pale. Spicil. Zool. fusc. 9. tab. 4. fig. 7. Astacus locusta. Penn. Cancer ganmarus saltator. HovTagu, Trans. of the Linn. Societ. tom. IX.p. 9f. Long de six à hnit lignes. Tète petite, yeux rapprochés et luisans. Queue terminée par trois appendices bifides et velus, d'un cenciré plus ou moins foncé. Antennes roussâtres, velues ainsi que les trois demières paires de pattes. Il est très-conmun sur toutes les côtes de France.

Orenestie, Orchestia. Léach. Latr. (Fam. nat.) Talitrus. Lat. Bosc. Riss. Lismk. Oniscus. Pallas.

Ce genre a tous les caraetères du précédent, et il n'en diffère que parce que ses pattes antérieures sont terminées par une pince comprimée en grifle; ; celles de la seconde paire sont beaucoup plus fortes, a vec la griffe du bout longue, arciuéc, et s'appliquant sur la tranche aiguëe et antérien:c de la main; cette tratuche est unidentce clans les lemelles. Les mours de ces Crustavés sont les mênes que eelles des Talitres. Nous citerons comme type du genre:

L'Orchestie gamMarelie, Orchestia gamma-

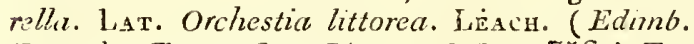
Encycl.; Trans. Soc. Lian. t. X1. p. 3j6.) Talitrus gammarellus. Lat. Riss. Oniscus ganmarellas. Patc. Spicil. fasc. 9. tab. 4. fo. 8. Long de six à sept limnes. Corps d'un vert pâle, nuansé de rougeâtre. 'Tête petite; pinces de la seconde paire très-grosses; quene composée de trois appendiees bifides, dont celui du milieu est fort court. Risso en cite une variété d'un jaune yále. On trouve celte espèce sous les pierres on solss les déjections de lis mer, dans le midi de la Frunce et dans d'autres mers.

Atrxle, Atylus. İ́acir. Gammanzs. E's. Talitrus. LAAT.

Ce genre diffère des précédens, paree que les antennes supérieures sont presquaussi longrnes que les inférieures; leur second article est plus long que le troisième; le même des antennes inférieures est un peu plus court que le troisième. Le devant de la tête est prolongé en forme de bee. Les pieds des denx premières paires sont ronodactyles, teruninés par uu atlicle comprimé. Les pieds des cinq autres paires sont à peu près égaux entr'eux, et linissent par un onylu simple. La queue est terminée par deux filets latéraux et un filet internédiaire, bifides à leur extrémité.

Atrez canew', Atylus carinatus. I'Éach, Zool. Hisc. tom. 2. p. 22. pl. 69. - Trans. Soc. Linn. torn. XI. pag. 357. Gammanus cariuatus. $F_{A B}$. Ent. Syst. tom. 2. p. 5ı5. spec. 3. Long de quatorze lignes; rostre formé par la partie antérieure et supérieure de la tête, un peu iulléchi; les cinq derniers segmens de l'abdomen carenés en dessus et terminc's un peu en pointe postérieurement. On ne connoît pas la patrie de ce Crustacé.

$M$. Risso décrit une espèce de Tálitre ( $T$ '. rubropunctalus) qui ponrroit bien apparlenir au genre Aiyle. M. Latreille pense que le Gammarus nugax de Fabricius, que Phipps a figuré (Voyàge au pôle boréal, pl. 12,fig. 2), appariient aussi à ce genre. (E. G.)

TANIPTERE, Taniptera. Nom donné anciennement par M. Latreille aux insectes Diptères Tipulaires Terricoles qui forment aujon'd'hui le genre Cténophore. Voyez ee mot à l'article Tellicoles. (S. F. et A. Serv: )

TANYPE, Tanypus. Meig. Illig. Panz. Lat. Tipula. Lann. De Géen. Geofr. Chironomus. Fab. WiédeIT.

Geure d'insectes de l'ordre des Diptères, première section, famiile des Némocères, tribu des Tipulares (division des Culiciformes).

Les genres Chironowe et 'Tanype forment un groupe dans la division des 'I'palaires-cnliciformes. (Foyez Trpularres.) Mais les Chironumes se cistiuguent par lears antennes de treize articles dans les míles el de six daus les femelles.

Antenzes insérées au milieu de la lite chacune sur un tubercule épais, avancées, linéaires, de quatorze articles dins les deux sexes, garnis de longs poils dans les inâles, ceux de un à douze spibériques, le treiziènıe long, cylindrique, lo quatorzième pelit, printu, ordinareanent un peu recourbé en dedaus. ( Encycl. pl.385. fig. 13.) ; sphériques et garmis de poils courts daus les femelles, le quatorzième plus épais, formant un bouron un peu oblong. (Encycl. pl. 385. fig. 14.) - Trompe conrte, charnue. - Palpes avancés, recoubés, cylindriques, velus, de quatre articles, le pleinier plus court. - Téte petite. Yeu.c lunulés. - Point d'ocelles. - Corps mon. - Corselet oblong-ovale, eonvexe en dessus, avec trois éminences sur le dos. - Ecussor étroil, un peu élevé postérieurement. - Sternum ayant une plaque élevée entre la première et la seconde paire de pattes. - Ailes étruites, velues, couchées en toii sur l'abdomen dans le repos. 


\section{T A N}

-Pattes déliées; tarses antérieurs ordinairement alongés et avancés lors du repos.

Le nom générique de ces Tipulaires vient du grec; il signifie : qui étend les pieds. Leurs mœurs doivent peu diffćrer de celles des Chironomes. (Voyez ce mot, article Tipulaines.) On les rencontre dans les mêmes endroits; leur taille est fort petite; il y en a vingt-une espèces décrites dans les Dipt. d'Europ. de M. Meigen; nous mentionnerons la suivante : Tanype varié, $T . \nu a$ rius. Merg. Dipt. d'Eur. tom. 1. pag. 56. $n^{0}$. 1 . tab. 2. fig. 12. Mâle. Longueur 2 lig. $\frac{2}{2}$. femelle. 3 lig. 3 lig. $\frac{1}{3}$. mâle. Ailes ayant des nébulosités cendrées et leur bord antérieur marqué de points noirs. (S. F. et A. Serv.)

TANYPĖZE, Tanypeza. Fatrì̀. M. Meigen (Dipt. d'Europ.) en adoptant ce genre d'après M. Fallèn et le piaçant dans sa famille des Muscides, le caractérise ainsi : antennes presque coucbées sur l'hypostome, rapprocbées, de trois articles; les deux premiers très-courts, le dernier oblong, comprimé, son extrémité obtuse, muni à sa base d'une soie dorsale, finement velue vue au mieroscopc. Palpes saillans, oblongs, aplatis, élargis antérieurement. 'Trompe un peu saillante. Hypostome légèrement incliné, aplati, nu; frout plat, soyeux , assea étroit. Yeux oblongs, espacés dans les deax sexes. Trois ocelles placés sur le verlex. Corps assez long. Ailes velues vues au microscope, couchées parallèlement sur le corps dins le repos, leur première nervure longitudinale allant presque jusqu'au milieu du bord antérieur, celte nervure double, mais ses branches étant presque totalement réunies dans la plus grande partie de leur longueur; quatrième nervure longitudinale se courbant à partir de la nervure transversale en se prolongeant vers l'extrémité de l'aile, sans atteindre la troisième nervure longitudinale. Cuillerons très-petits, à peine visibles. Balanciers nus. Abdomen alongé, de cinq segumens outre l'aaus, terminé dans les femelles par une tarière courte, pointue, et dans les mâles par une tenaille qui se dirige en dessous et porte vers son extrémité une longue soie biarticulée. Patles longues, premier article dies tarses aussi long que les quatre suivans pris ensemble.

Le nom de Thaypèze vient de deux mots grees; il signifie : pieds étendus. Le type du genre est la Tanypèze longimane, T. longinana. Mrig. Dipt. $d^{\prime}$ Eur. tom. 5. pag. 374. nov. 1, tab. 52. fo. 13. mầle. fiğ. 14. femelle. Longueur 3 lig. Noire. Sommet de la tête blanc ainsi que les côtés du corselet. Pattes jaunes, tarses bruns. D'Allemagre.

$$
\text { (S. F. et A. SErv.) }
$$

TANYSTOMES, Tanystoma. Seconde famille de la première section de l'ordre des Diptères. M. Laireille lui donne pour caractères :

Trompe sonvent longue, cn totalité ou en maHist. Nat. Ins. Tome $X$. jeure partie saillante. Suçoir composé de quatre à six soies. Larves à têtẻ écailleuse, changeant de peau lorsqu'elles passent à l'état de nymphe.

I. Suçoir de six soies.

$$
\begin{aligned}
& \text { 1re. Tribu. Taoniens, Tabanii. (Voyez } \\
& \text { ce mot.) }
\end{aligned}
$$

II. Suçoir de quatre soies.

A. Dernier article des antennes toujours dépourvu de stylet ou de soie, offrant trois divisions transversales.

\section{2e. Tribu. Sicaires, Sicarï. (Voyez ce mot.)}

B. Dernier article des antennes souvent terminé par un stylet ou une soie, ayant an plus deux divisions.

a. Trompe membraneuse à tige trèscourte, relirée et terminée par deux grandes lèvres saillantes; palpes aussi longs qu'elle lorsqu'ils sont extérieurs. Dernier article des antennes jamais en forme de palette sétifère. Ailes écartées.

\section{3e. Tribu. Mydasiens, Mydasii (1).}

Palpes point extérieurs ou manquant. - Dernier article des antennes terminé par un slylet; eet article tantôt en massue ovoide divisé transversalement en deux avec un ombilic au bout, tantôt en côre alongé, comme en alêne.

$$
\text { Mydas, Thérève. }
$$

Nota. M. Meigen divise cette tribu en deux fumilles: $\mathrm{I}^{\circ}$. Xylotomes, Xylotomoe (voyez ce mot); $2^{\circ}$. Mydasiens, Mydasii. (Voyez ce mot à la table alphabétique.)

$$
\begin{aligned}
& \text { 4e. Tribu. Leptides, Leptides. (Rhagio- } \\
& \text { nides. Lat. Consid. Voyez ce mot.) }
\end{aligned}
$$

b. Trompe tantôt fort courte, terminée par deux grandes lèvres avec les palpes couchés sur elle, tantôt prolongée en forme de petit bec. Dernier article des antennes en palette et portant une soie. Ailes couchées sur le corps, leurs nervures ayant de grands rapports avec celles des Muscides.

(1) Cet article a déjà été traité à sa lettre dans l'Fucyclopédie, mais il ne nous a point paru rédigé conformément aux principes énoncés en dernier lieu par les auteurs, c'est pourguoi nous le reproduisons ici. 
5e. Tribu. Dolichopodes, Dolichopoda.

Nota. M. Meigen dans son quatrième volume des Diptères d'Europe, postérieur aux Familles naturelles de M. Latreille, sépare cette tribu en deux familles dans lesquelles il a établi plusieurs genres nouveaux que nous pensons devoir être adoptés.

f Antennes de deux ou trois articles. Trompe fort courte. (Platypézines, Platypezince. Mrig.)

Cyrtome, Platypèze, Callomyie.

tf Antennes de trois articles. Trompe un peu avancée en bec. (Dolichopodes, Dolichopodo. MEIG.)

Rhaphie, Diaphore, Psilope, Chrysote, Porphyrops, Médétère, Sybistrome, Dolichope, Orthochile.

c. Trompe enlièrement ou presqu'entièrement saillante en forme de siphon ou de bec; cette trompe tantôt cylindrique ou conique, tantôt longue, grêle ou filiforme. Lèvres formant rarement (quelques Anthraciens) une tête terminale. Palpes nuls ou très-petits. Dernier article des antennes n'ayant jamais la forme d'une palette sétig̀̀re.

+ Corps toujours oblong. Ailes couchées sur lui. Corselet rétréci en devant.

* Trompe avancée.

6e. Tribu. Asiliques, Asilici.

Hypostome presque toujours barbn. - Dernier article des antennes alongé, en fusean ou en massine, ordinairement terminé par un stylet ou par une zoie épaisse et roide.

q Hypostome barbu; tête point globuleuse, point entièrement occupée par les yeux, même dans les mâles.

A. Tarses terminés par deux crochets munis d'une pelotte bifide.

o. Dernier article des antennes en massue, sans slylet ni soie.

Laphrie, Cératurǵne.

o o. Dernier article des antennes terminé par un stylet ou une soie.

\section{T A N}

Dioctrie, Dasypogon, Asile, Ancylorhynque.

$\triangle \Lambda$. Tarses terminés par trois crochets sans pelotte.

Gonype. (Leptogaster. MEIG.)

ๆ Hypostome sans barbe. 'Tête globuleuse, entièrement occupée par les yeux.

Edalée.

Nota. Ce dernier genre est placé par M. Meigen dans sa famille des Hybotiniens.

$7^{e}$. Tribu. Hybotins, Hybotini.

Hypostome toujours sans barbe. - Tête globuleuse, entièrement occupée par les yeux dans les mâles. - Dernier article des antennes lenticulaire avec une soie longue en forme de poil.

Hybos, Ocydromie, Damalis?

* * Trompe perpendiculaire.

8e. Tribu. Empides, Empides.

Antennes de trois articles. (Empidiens, Empidice. MeIG.)

A. Dernier arlicle des antennes alongé, conique.

o. Trompe beaucoup plus longue que la tête.

Empis, Ruamphomyie.

○ o. Trompe guère plus longue que la tête.

Hilare, Brachystome.

$\wedge$ A. Dernier article des antennes glubuleux.

Glome.

I Antennes de deux articles, le dernier presque globnleux on ovoide, teijours lerminé par une soie. ('Tachydromiens, Taclisydromice. Merg.)

Hémérodromie, Sique (Tichydromia. Berc.), Drapétis.

$\dagger \dagger$ Corps court et large. Ailes ícartées. 'Tète exacteasent appliqués contre le corselet.

\section{Tribu. Anthraciens, Anthracii.}

Corselet psint relevé en bosse. - Tếta de lä mêne bauteur que lai. 
Trompe longue, avancée.

Corsomyze, Mulion, Némestrine, Fallénie.

ๆ Trompeguère plus longue que la têle.

Hirmoneure, Anthrax, Lomatie (Stygide. Lat. Fam. nat.), Tomomyze.

10. 'Tribu. Bombyliers, Bombyliariz.

Tête basse. - Corselet élevé, comme bossu. Bulcbnciers découverts. - Abdomen triangulaire ou oblong. - Trompe dirigée en avant. - Antennes rapprochées à lenr base, ordinairement terminées par un stylet et sans soie.

9 Abdomen cyliudracé ou ovale.

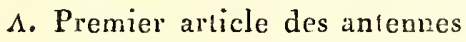
le plus long de tous.

Toxophore, Xestomyze.

$\Lambda \Lambda$. Premier arlicle des antennes de la longueur au plus du dernier et souvent plus court.

Apatomyze, Thlipsomyze, Amycte, Géron, Phihirie, Cyllénie.

f Abdomen court, triangulaire. Ploas, Bombyle, Lisie, Lasie.

Nota. RI. Meigen rómit ces deux dernières tritus en une seule famille sous le nom de Bombyliers, Bombylatriz.

1'. 'lribu. Vésiculeux, Vesiculosa. (Voyez ce mol.)

$$
\text { (S. F. et A. SERv.) }
$$

'TAON, Thanus. Tinn. Geofr. Scop. Sehranex. Fab. De Grer. Panz. Illig. Pato-Bauv. Lat. Meig. HaLLín.

Genre d'insectes de l'ordre des Diptères, première section, farille des Tanystomes, tribu des 'Taonicus.

Un des groupes de cette iribu contient les Taons, les Hrenatopotes et leshéxalomes. ( $V$. Taoniens.) Ces deux derniers genres sont distingués de celni de Taon par le troisieme arlicle de lears antennes sans échaucrure à sa base et divisé sealemeni en quatre articulations.

Antennes avancres, rapprochées à leur base, allant ensuite en s'écartaut, composées de trois articles, le premier court, cylindrique, le second cyathiforme, plus court que le premier, le troisième long, comprimé, dilaté à sa base, échancré en croissant, dont la corne intérieure forme une dent, l'autre se prolongeant en alêne et divisée, passé son miliea, en articulations qui sont an nombre de cinq en comptant celle de la base. - Trompe avancée, presqu'horizontale dans les mâles, plus perpendiculaire dans les femelles, lerminée par deux lèvres assez courtes. - Suçoir de six suies presqu'égales. - Palpes avancés, presqu'aussi longs que le suçoir, de deux articles, le premier assez court, le second conique dans les femelles, plus court et plus gros dans les mâles. - Tête hémisphérique, un peu déprimée, au moins aussi large que le corselet; bypostome régulièrement bombé. - Yeux grands, espacés dans les femelles, réunis sur presque tout le front jusqu'an vertex dans les mâles. - Point d'ocelles. - Corps un peu convexe, assez pubescent. Corselet ovale. - Ecusson de grandeur variable, arrondi postérieurement. - Ailes grandes, lancéolées, velues vues au microscope, liorizontales, écartées l'une de l'autre dans le repos : nervure qui sépare la cellule sous-marginale de la première cellule du bord postérieur bifurquée et formant une espèce d'Y avant d'atteindre ce bord; la branche extérieure émettant rarement en arrière un petit rameau vers sa base. - Cuillerons doubles, grands. - Balanciers cachés en grande parlie. - Abdomen ovale, de six segmens oulre l'arus, légèrement convexe. - Pattes assez grandles, les postéricures un peu plus longues que les autres; tarses courts, leur premier article plus grand que les suirams, le dernier muni de deax forts crochets, ayant dans leur entre-deux une pelotie trifide.

l.es 'Taons porloient, à ce qu'il paroît, chezles Grecs le nom d'CEstres, soit qu'ils fussent confordus avec ces derniels insectes, soit que ce non lear fût propre; la première conjecture paroit la plus vraisemblable. Il est naturel de croire que ces deux genres étant sous différens rapports le fléar des bestiaux, ont été réunis dans ces temps anciens sous un seul nom. Un endroit des Géorgiques de Virgile où il est question de l'CEstre, paroit se rapporter davantage aux véritables CEsires qui cansent aux bestiaux beaucoup plus de terreur que les Taons et font souvent enfuir tout un troupeau de Bœufs du pấturage.
Est lucos Stlari circa ilicibusque virentem
Plurimus Alburnim volitans, cui nomen Asilo
Romanum est, Gęstron Graii vercête vocantes;
Asper, acerba sonans; quo tota exterrita silvis
Difugiunt armenta.

On voit par cette citation gue les Romains. avoient traduit le mot grec OEstre par celui d'Asile. Vallisner pense aussi que l'Cistre des Grees appartient réellement au genre de Diptères dont les piqûres produisent sur le dos des jeunes arimax du genreBœufdes tumeurs durables qui contieunent des larves. Cependant Aristote ainsiqu' Flien ayant positivement dil que la bouclie des (Estres est armée d'un fort aiguillou, on doit croire grue les Anciens en 
général ont confondu sous le même nom les Taons et les CEstres. Cette conformation de bouche $\dot{a}$ aiguillon ne peut s'appliquer à ces derniers qui n'ont point de suçoir piquant, mais bien une tarière anale assez dure pour pouvoir pénétrer la peau des animaux.

De Géer est le seul entomologiste qui ait observé la larve des insectes de ce genre : d'après ce qu'il a vu, celle du Taon des Bœufs (T. bovinus) vit en terre; elle est apode, d'un blanc jaunâtre, ayant près d'un pouce et demi de longueur; son corps est cylindrique, mince antérieurement, divisé en douze segnens; sa lête porte en devant deux grands crochets mobiles de consistance d'écaille, recourbés en dessous, dont elle se sert pour creuser la terre; on ne sait pas bien quelle est sa nonrriture. Parvenue à toute sa grandeur, elle se cliange sans sortir de terre en une nymphe cylindrique; son abdomen est divisé en huit segmens, cliacuu ayant son bord postérieur frangé de longs poils, l'extrémité du dernier est armée de six pointes dures de substance écailleuse, qui aident à la nymphe pour remonter à la surface de la terre lorsqu'après avoir resté à peu près un mois sous cette forme, elle doit devenir insecte parfait; quand les parlies antérieures de la nymphesont hors de terre, sa peau se fend sur la tête et le corselet, et le Diptère sort n'ayant plus que ses ailes à développer.

Les Taons sont généralemenı de grande taille; ils habitent les deux Mondes, se teuant plos particulièrement dans les bois : ils se plaisent dans les endroits les plus chauds, la chaleur donnaut à leur vol une aclivité extraordinaire; au contraire, dans les temps froids ou plavieux, ils se cacheni sous les feuilles et dans les crevasses des écorces, et alors on peut les prendre presqu'à la main. Ils se nourrissent du sang des bestiaux, aucun de ceux-ci n'étant, par la dureté de sa peau, à l'abri des piçûres de leur terrible suçoir, les hommes mêmes ont souvent de la peine à s'en défendre, et. dans les forêts des environs de Paris il nous est arrivé quelquefois de remplir presqu'entièrement en peu d'instans nos filets de gaze de ceux qui venoient nous assaillir en troupes, et d'être obligés de déserter la place faute de pouvoir suffire à les détruire. Les mâles n'ont point les mêmes penchans sanguinaires, ils mangent peu, on les trouve quelquefois sur les fleurs : le plus souvent on les voit voler dans les allées des bois, y faisant en quelque sorte la navelte, restaut quelque temps suspendus à une même place, puis se transportant par un mouvemeat brusque et presque direct à l'autre bout de leur station aérienne pour y reprendre la même immobilité et tournaunt leur tête dans chacun de ces monvemens vers des côtés opposés. En cherchant à nous rendre compte de ces évolutions, nous nous sommes assurés qu'ils guettent alors le passage des femelles et tâchent de les saisir en se précipitant sur elles, puis s'enlèvent, lorsqu'ils ont réussi à s'en emparer, à une hauteur où l'œil ne peut les suivre.

Fabricius (Syst. Antliat.) décrit cinquante espèces deTaons; celle nommée longicomis, $n^{\circ} .45$, n'est probablement pas de ce genre. M. Wiédomann (Dipt. exotic.) dit que c'est une Hæmatopote; le no. I9. est le type du genre Silvius. Mrig. Les espèces appelées par Fabricius antancticus $\mathrm{n}^{\circ} .4$, bicinctus $\mathrm{n}^{\circ} .4^{2}$, itaticus $\mathrm{n}^{\circ} \cdot 24$, hottentota $\mathrm{n}^{\circ} .28$, ne sont point rappelées dans les auteurs modernes que nons connoissons.

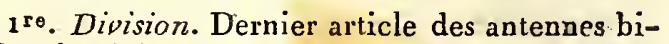
fide; la division qui n'est pas annelée, grande, atteignant plus que la moitié de la longueur de l'autre.

Le type de cette division, dans laquelle d'autres espèces exoliques viennent encore se ranger, est le 'Taon cervicorne, $T$. cervicornis $n^{\circ} .35$. Fab. Syst. Antliat. - Wrédem: Dipt. exotic. pars 1a. De l'Amérique méridionale.

$2^{e}$. Division. Dernier article des antennes en croissant à sa base; la division qui n'est pas annelée, très-courte.

$I^{\circ}$. 'Taon noir, T. niger. Psi.-Bavv. Ins. d'Af. et d'Amér. pag. 54. Dipt. pl. 2. fg. 1. Femelle. De Peusylvanie. $2^{\circ}$. 'Taon bordé, $T$. linibatus. Pas.-Bauv. $i d$. Dipt.pl. 2. fig. 2. Femelle. EtatsUnis. 3॰. Taon albipède, 1: albipes. Merg. Dipt. d'Eur. tom. 2. pag. 45. $72^{\circ}$. 20. Des environs de Paris. $4^{\circ}$. Taon abdominal, T. abdominalis. $\mathrm{F}_{\mathrm{AB}}$. Sy'st. Antliat. $n^{\circ}, 15 .-$ PAL. $_{\text {A v v }} i d . p .101$. Dipt. pl. 2. fg. 4. Femclle. (Cetle figure est trop rousse.) De Caroline. 50. 'Taon des Bœufs, $T$. bovinus. MeIg. id. pag. 43. no. 18 . Environs de Paris. $6^{\circ}$. Taon automnal, T. autumnalis. MEIG. id. pag. 39. $n^{\circ}$. 12. Environs de Paris. $7^{\circ}$. Taon très-noir, T. ater. PAL.-BAUv. $i d . p .101$. Dipt. pl. 2. fg. 5. De Caroline. Un individu femelle de ce même pays que nous avons sous les yeux et qui ressemble parfaitement à la figure et a la description donnée par M. de Bauvois, a de plus vers l'extrémité de liaile une petite place trausparente. 8॰. Taon morio, T. morio. FAB. Syst. Antliat. $n^{\circ}$. 4.-Tubanus ater: Mis.id.pag. 32. no. 1. tab. 13. fig. 24. Feme!le. Environs de $\mathrm{Pa}_{\mathrm{a}}$ ris. $9^{\circ}$. 'Taou solstitial, $T$. solstitialis. Merg. $i d$. pag. 56. $n^{\circ}$. 33. Environs de Paris. 10'. 'Taon luride, T. luridus. ME1G. id. pag. 55. $n^{\circ}$. 32. Environs de Paris. $11^{\circ}$. Taon tropique, $T$. tropicus. Meig. id. pag. 57. $n^{\circ}$. 34. Environs de Paris. $12^{\circ}$. Taon brayant, T. bromius. Merc. id. pag. 52 . $n^{\circ}$. 29. Environs de Paris. $3^{\circ}$. Taon grec, $T$. grocus. MeIG. id. pag. 53. n०. 3o. Environs de Paris. 140.'Tuon fauve, T. fulpus. Meig. id. $p .61$. $n^{\circ}$. 40. Environs de Paris. 15\%. Taon américain, T. americanus. PAL.-BAuv. Ins. d'Afr. et d'Amér. pag. 22. Dipt. pl. 3. fig. 6. Fenelle. De Caroline. 
Nota. M. Palisot-Bauvois dans l'ouvrage ciré ci-dessus décrit treize autres espèces de ce genre, M. Meigen trente-deux. On en trouvera en outre un assez grand nombre dans Fabricius et dans les Dipt. exotic. de M. Wiédemann, ainsi que dans ses Anal. Entom. (S. F. et A. SERv.)

TAONIENS, Tabanii. Première Iribu de la famille des 'Tanystomes (voyez ce mot), première section de l'ordre des Diptères. Elle a pour caractères :

Suçoir de six soies. - Antennes de trois articles, suivant M. Latreille, le dernier sans stylet, ni soie au bout, offirant de quatre à huit divisions transverses. - Trompe très-longue et filiforme dans plusieurs, entièrement extếrieure. - Ailes toujours écartées; nervure qui sépare la cellnle sous - marginale de la première cellule du bord postérieur bifurquée dans tous les genres que nous connoissons, et formant une espèce d'Y avint d'atteindre ce bord.

I. Dernier article des antennes partagé dès sa base en huit divisions.

A. Trompe fort longue, finissant en pointe, ses lèvres ne formant pas au bout de di. latation notable.

Pangonie.

B. Trompe courte, ses lèvres formant au bout une dilatation remarquable.

Aicanthomère.

IT. Dernier article des antennes partagé à commencer vers le milieu de sa longueur en quatre ou cinq divisions. - Trompe de moyenne longueur ou courte, termince par une dilatation furmée par les lèvres.

A. Point d'ocelles.

Taoll, Hrematopote, Héxatome.

B. Des ocelles.

Rhinomyze, Silvius, Chrysops, Rhaphiorliynque.

ACANTHOMËRE, Acanthontera. Wú́dem. Lat. (Fam. nat.)

Gente d'insectes de l'ordre des Diptères, première section, fawille des 'Tanystomes, tribu des Taoniens.

Deux genres de-Taoniens, Pangonie et Acanthomère, ont pour caractère commun : dernier article des antennes partagé dès sa base en huit divisions (voyez TAon1ens); mais dans les Pangonies la trompe est fort longue, finissant en pointe, ses lèvres ne formant pas au bout de dilatation notable.

Antennes rapprochées à leur base, avancées, composées de trois articles, le premier très-court, cylinduique, le second petit, cyathiforme, le troi- sième très-long, conique, un peu comprimé, allant en s'amincissant jusqu'à son extrémilé, partagé dès sa base et ayant huit divisions dont celle de l'extrémité est plus longue que les autres. Trompe courte, entièrement rentrée dans la cavité buccale pendant le repos, son extrémité formée par deux lèvres alongées, assez grosses, paroissant entre la base des palpes. - Palpes filiformes, de quatre articles, les deux premiers velus, le premier très-court, le second assez long, les troisième et quatrième n'ayant point de villosité sensible, le troisième le plus long de tous, le dernier un pen plus grand que le second. - Téte de la largeur dn corsclet, convexe en devant : liypostome ayant de chaque côté un sillon profond et au milieu de sa partie inférieure un tubercule conique, rabcteux. - Yeux grands, espacés dans les femelles. - Trois ocelles disposés en triangle sur les pertes d'un tubercule vertical. - Corps large. - Corselet gros, bombé. - Ecusson presqu'en carré long, transversal, mais un peu arrondi. à sa partie postérieure. - Ailes grandes, dépassant l'abdomen; nervure qui sépare la cellule sousmarginale de la première cellule du bord postérieur bifurquée et form:ınt une espèce d' $Y$, avant d'atteindre ce bord. - Cuillerons petits. - Balanciers découverts, lenr capilule assez évasé en entounoir. - Abdomen large, déprimé, se rétrécissant subitement après ses quatre premiers segmens; le cinquième est de moitié moins large que le précédent, les six autres qui paroissent composer lir tarière sont striés trausversalement, déprimés et vont cn diminuant de largeur. - Pattes grêles; cuisscs postérieures alongées, un peu en massue, velues en dessous, sans ancune dent; jambes intermćdiaires munies ì leur extrćmité de deux courtes épines, les quatre autres jambes en étant dépourvues : premier article des larses aussi long que les qualre suiviuns pris ensemble, le dernier plus long que le précédent, ayant deux crochets avec une pelotte bifide dans leur entre-deux.

Ces caractères génériques sont donnés d'après une femelle; ceux que mentionne M. WViédenann, établis sur uı individu mâle mutilé, diffèreñ en ce qu'il n'a vu que deux articles aux palpes, le premier cylindrique, le second subulé, et que les cuisses postérieures ont une épine en dessous. Ce dernier caractère uous paroît purement masculin.

Le nom de ce genre vient de deux mots grecs qui signifient : cuisses épineuses. Liespèce suivante paroît être la seule connue; elle est de trèsgrande taille.

\section{Acanthomère peinte', $A$. picta.}

Acanthomera capite thoraceque fuscis ; antennis, palpis, pedibus abdomineque suprà fuscè ferruginteis, tarsis basi et apice albido-flavis: alis fuscis, nervuris ferè omnibus flavido limbatis. 
Acanthomera picta. Wrédex. Dipt. exotic. pars 1a. pag. 61. tab. II. fig. 2. Mâle.

Longneur 13 ì 14 ligg. Antennes et palpes d'un brun ferrugincix; tête brtiue; eorselet brun avec quelques auances ferrugineuses aux épaules et sur les côtés; il est couvert d'un duvet eourt d'un gris-roussiatre; on remarque sur le dos trois lignes longitudinales étroites, noires. Ecusson ferragineıx, ses côtés garnis de poils blanchâtlres assez brillans. Abdomen terrugineux en dessus et eomme revêtu d'un velonr's on duvet extrêmement courl; ses troisième et quatrième segmens frangés latéralement de poils ferrugineux; les angles nostérieurs lu second et du troisième portant une tache blanche : segmens composant la tarière, noirs. Dessons de l'abulomeu brun. Palles d'un brun ferragiuenx. Jumbes postéricares ainsi que leurs cuisses, couvertes d'un duvet assez serré, uoir. 'Tous lcs tarses ferragiueux avec !e premier et le dernier articles blanchiltres. Ailes brunes, la plupart de leurs nervures ayant me aurćole d'un ferrugineux pâle. Femelle.

La descriplion de $M$. Wićdcmann fite sur un mâle diffère; le corselet lui a par u couvert de poils gris avec des reflets blanchâlres. Le dessus de Ṕabdomea apparetument détéioré, paroissoil noir; lcs enisses postérieures avoicut en dessuns une épine eonlic, dirigéc en arrière et placke vers leur exlrémilé : les larses enlicrement d'un jaune ferrngineux. l'abdomen ne présentoit que cinq segmens outre l'anus. Telles sont les priucipalcs différences que nous remarquons contre sa description el la nôlre : celle-ei a ćléfide sur un individu femelle très-complet, et p'usienrs de ces différences pourroicut fort bicn n'être que sexuelles. Du brésil.

H ENATOPO'E, Hematopota. Mejc. Lat. Illig. Faleìn. Fab. Tabanus. Linn. Geofr. Scop. Schranck. De Gér. Ross. Paiz.

Genre d'insectes de l'ordre des Diptères, première section, fumille de Tanystomes, tribu des Taoniens.

Les genres Taon, Hrmatopote et Héxatome forment un groupe parmiles Trouiens. (Voyez ce mot.) Les Taons ont le dernier article des antennes épais à sa base, écinatré en croissant dont l'une des cornes forune une dont ct l'autre se prolonge en alène et se partage en cinq divisions. Dans le genre Héxatome le second article des antennes n'est gù̀re plus eourt que le premier; il paroît étranglé daus son milieu et les divisions dn troisième sont tellemeut distinctes qu'elles paroissent même ĉtre des articles.

Antennes avancées, assez rapprochées à leur base, allant en s'écartant à parlir du second article, de longuenr variable, composées de trois articles, le premier velu, an moins trois fois plus long que le seeond, celui-ci très-court, eyathi- forme; le troisième alongé, eonique, partagte ea qratre divisions peu distinetes, dont la première est plus longue qu'aucune des autres. - Trompe saillante, pcrpendiculaire dans les femelles, horizontale dans les mâles, terminée par deux lèvres courles, assez grosses. - Sucoir composé de six soies presqu'égales. -- Palpes saillans, couvrant lit base de la trompe, plus courts dans les mâles que dans les feuclles, velus, de deux articles, le premier cont, cylindrique; le second long, coniçue. - T'ấte luénispluhérique, exeavée postérieurement; hypostome et front velus, avec des plaques nues et brillantes. - Yeux espacés dans les temelles, réunis dans presque toute leur étenche sur le front des usiles. - point d'ocelles. Corps alongé, déprimé.-Corselet ovale, un pú conique antérienrement. - Ecusson étroit, assez long, arrendi pos'érieurement. - siles lancéolées, volues vues an microscope, eouehées en toit sur le corps ct parallèles dans le repos; nervure qui sépare la cellule sous-marginale de la première cellule du bord postérieur bifurquée et formant une espèce d'Y, avant d'atteindre ce bord; la hrauche extérieuré ćmet en arrière un petit rancan vers sa base. - Cuillerons de grandeur inoyenue. - Balanciers découverts. - Abdonen ussez déprimé, mioce, de six segnens oulre l'ann: - Patles gréles; janbes interméliaires tcruinées par une épine, les quatre autres jambes en élant dépourrues; tarses alongés, lear premicr article, surtout celui des pattes postéricures, presqu'anssi long que les quatre suivans pris enscrable, le dernier muni de deux forts crochels atyant une pelolle bilide daus len entre-deux.

Le nom de ces insecies vient de deux mols yrecs et signifie : buvant du sangr; anssi leurs moeurs sont-elles les mêmes que celles des Tuons. Rabricius prétend que leurs larves vivent dars le fumier. M. Mcigen regarde eomme de simples variótés les espèccs oì lc premier article des antenn's est cyliudriçue et celles où il est ovaleglobuleux; nous ne pouvons pas partager eelle upinion puisque les mâles sont en cela conformís de même que leurs femelles, eomme il est facilo de s'en convaincre dans l'H. pluviale si eousmune dans nos environs. Nous établirons deux divisious dans ce genre, d’äprès la forme du prewier article des auteunes.

Ire. Division. Premier article des antennes ovale-gylobuleux.

$1^{\circ}$. Hæmatopote pluviale, H. pluvialis. Me Dipt. d'Eur. tom. 2. pag. 78. $n^{\circ}$. 1. (Nous n'adnettous seulcment que la description et nous retranclions toutes les variétés ainsi que lis fig. 16 . de la planche 14. L'antenne de cetre espère est très - exactement représentée dans la fig. 8.) Très-commune aux environs de Paris. 20. Hæmatopole des Chevaux, H. equorum. MEIG. id. 
pag. 8o. $n^{\circ}$. 2. Des environs de Paris. On la trouve dans les endroits où les chevaux paissent habituellement.

2e. Division. Premier article des antennes alongé, cylindrique.

1․ Hæmalopote alongée, $H$. elongata. Noв. Longueur 5 lig. Oulre le caractère de division, cette espèce diffère de l'Hæm. pluviale en ce que les segmens de son abdomen n'ont de blanc que les poils de la ligne médialc el ceux de leur bord inférieur; que le troisième article des antennes est brun à sa base et que sa taille est un peu plas grande. Femelle. Bois de Bondy.

On rapportera aussi à ee genle : $1^{\circ}$. Hrematopole variée, H. variegata. Mrig. Dipt. d'Ezir. pag. 8ı. $n^{\circ}$. 3. De Barbarie. 20. Hæmalopote lunulée, H. lunata. Meig. id. pag. 82. $n^{\circ}$. 4 . Même patrie. M. Meigen pense que ees deux espèces peuvent se trouver aussi dans l'Europe méridionale. Nous ne croyons pas que les Hama. topota curvipes $\mathrm{n}^{\circ}$. 3. et podagrica $\mathrm{n}^{\circ} .5 . \mathrm{F}_{\mathrm{AB}}$. Syst. Antl. appartiennent à ce genre.

HËXATOME, Hexatoma. MEIG. (Dipt. d'Eur.) Heptatoma. MeIg. (Clussif.) Latr. Fan. Tabanus. SCHRANCK.

Genre d'iusectes de l'ordre des Diptères, piemière section, famille des Tanystomes, tribu des Taoniens.

Le groupe de Taoniens (voyez ce mot) qui renferme les Héxatomes contient aussi le genre Taon qui a le dernier article des antennes épais à sa base avec une échancrure en forbse de croissant dont une des cornes forme une dent et l'autre s'alonge en alêne et se partage en cinq divisions; et le genre Hamatopote qui a le second article des antennes très-court, cupulaire, et les divisions du troisième peu prononcées.

Antennes avancées, plus longues que la têre, composées de trois articles, suivant Mi. Latreille; le premier cylindrique; le second un peu plus court que le premier, divisé dans son unilieu par un étranglenent; le troisiè me presgue cylindrique, plus long que les deux précédens pris ensemble, formé de quatre divisions dont les trois dernières font la moitié apicale de sa longueur. (M. Meigen donne six articles aux antennes des Héxatomes, parce qu'il regarde cos trois dernic̀res divisions comme aulaut d'articles, ct cette manière de voir nous paroît assez bien fondée.) - Trompe de la longueur de la têle, terminée par deux grrosses lìvres. - Sucoir composé de six soies égales. - Palpes très-conrts, insérés sur les côtés et à la base de la trompe, de deux articles, le premier court, cylindrique, le seeond conique dans les ferne!les, ovale dans les måles. - Téte transversale, plus large que le corselet. - Yeux grands, très-espacés dans les femelles, réunis dans les mäics.-Point a’ocelles.
- Corps assez long.-Corselet cylindrique, presque tronqué droit antérieurenient, un peu arrondi à sà partie postérieure. - Ecusson grand, demi-circulaire. - Ailes assez grandes, couehées en toit sur le corps dans le repes, de manic̀re que leurs bords extérienr's sont parallòles : nervure qui sépare la eeliule sous-marginale de la première cellule du bord postérieur, bifurquée et formant une espère d'Y, avant d'atteinàre ce bord. - Cuillerons assez grunds, doubles, ciliés sur leur bord, recouvrant en grande partie les balaneiers. - Balanciers termivés en massue forte, à poine évasée à soll exlrémité. - Abdomen de six segmens outre l'allus, convexe en dessus, aussi litige que le corselel. - Pattes asscz furtes; jarnbes intermédiaires munies de deux épines ì leur extrémité, les quatre autres jambes en étant dépourvues; prenier artiele des tarses le plus long de tous, le deruicr un peu plus grand que le précédent, muni de deux crocliets très-ŕcartés ayant dans leur entre-deus une pelotle courte, trilide.

L.es mœuls des Héxatomes dont le nom vient de deux mots grees qui signifient : divise en six, sont absolument les mênes que celles des 'Taons. (Voyez ce mol.) l.e type de ce genre est l'Héxa. tome binaculée, H. bimaculata. Nug. Dipt. d'Eur. tom. 2. pag. 83. no. 1. tab. 14.jig. 25. Mâle. fig. 24. Fenielle.

Nota. Cette espèce est représentée dans l'Ellcyclopédie pl. 588. fig. 5-9. his, sons le nom d'Heptalome bimacu'će, majs les figntes 8 et 9 . sont faulives en ce qu'clles représentent les antenues comme ayant sept articles.

\section{RIINOMYZE, Rhinonyza. WÉDEM. LAT.} (Fam. nat.)

Genre d'insertes de l'ordre des Diptères, premièı e section, famille des Tanystomes, tribu des 'Taoniens.

Un groupe de celte trilu (voyez 'Thonens) renferme les genres Rhinomyze, Silvius, Cluysops et Raphiorhynque. Dans ces trois demiers lcs palpes sont sculement biarliculés, tandis gue M. Wićdenann atribue trois articles à ceux des Rhinonyzes; en outre ces genres n'ont pas le troisième article des antemnes denté à sa base.

Antennes de trois articles, le premier cy!indrique; le second court, cyalliforme; le troisième alongé, un peu recourbé, uvidenté en dessus ì sa base. - Trompe dirigée en avant, redressée, longup. - Palpes insérés à la buse de la trompe, triarticulés, le premier article trèscourt; le second plus long; le troisième guère plus grand que le second. - I'euxx très-grands, se touchant daus les nâles ef laissant à peine un petit espace sur le vertex. - Trois ocelles. Ailes et port des 'Taons.

Tels sont les caractères que M. Wiédemann 
(Dipt. exotic.) donne à ce genre qui nous est inconnu, et dont le nom vient de deux mots grecs qui signifient: mouche à nez. L'auteur ne mentionne que l'espèce suivante : Rhinomyze brune, R. fusca. W IÉdem, Dipt. exotic. pars I. pag. 5g. Longuenr 6 lig. Brune; base et milieu de l'abdomen ferrugineux. Ailes brunes avec deux taches d'un jaune ferrugineux. De l'île de Java.

ChrYSOPS, Chrysops. Meig. Lat. Fab. Illig. Faltèn. Tabahus. Linn. (Geoff. Scop. Schranck. De Géer. Ross. Panz. Schell.

Geare d'insectes de l'ordre des Diptères, première section, famille des Tanystomes, tribu des Taoniens.

Les genres Rhinomyze, Silvius, Chrysops et Raphiorhynque constituent an groupe dans cette tribu. (Voyez Taoniens.) Le prenier est distingué par les palpes triarticulés ainsi que par le troisième article des antennes unidenté à sa base; l'hy postome avancé à sa partie inférieure en forme de bec, caractérise particulièrement les Rhaphiorhynques; le genre Silvius a les deux premiers articles des antenues inégaux entr'eux, le second plus court que le premier, cyalliforme.

Antennes avancées, rapprochées à leur base, cylindriques, un peu plus longues que la tête, composées de trois articles, les deux preniers égaux entr'enx, formant à peu près la noitié de la longueur de l'antenne, velus, cylindriques; le troisième plus long que le précédent, s'amincissant vers son extrémité, partagé en cinq divisions, la première plus longue que les autres. Trompe saillante, ses lèvres assez grosses. - Suçoir de six soies, - Palpes saillans, velus, beaucoup plus courts que la soie supérieure, de deux articles; le premier conrt, cylindricue, le second conique, alongé. - Téte liémisphérique; luypostome vela, ayant de chaque côté une grande plaque lisse, brillante; sa partie inférieure sans prolongement rostriforme. - Ycux espacés dans les femelles, réunis par en baut dans les mâles. - Trois ocelles placés en triangle sur le vertex. - Corselet ovale, un peu déprimé en dessus, velu sur les côtés. - Ecusson presque triangulaire, ses angles un peu arrondis, - Ailes velues vues au microscope, liorizontales, écartées l'une de l'autre dans le repos, ayant ordinairement des bandes brunes : nervare qui sépare la cellule sons-marginale de la première celluie du bord postérieur, bifurquée et formint une espèce d'Y, avant d'atteindre ce bord. - Cuillerons pelits, ciliés. - Balanciers grands, en majeure partie découverts. - Abdomen assez plat en dessus, finement velu, de six segrmens outre l'anus. Pattes de longueur moyenne, assez grêles; jambes intermédiaires munies de deux épines ì leur extrémité, les quatre autres jambes en étant dépourvues; tarses ayant leur preınier article le plus long de tous, le dernier muni de deux cro- chels, ayant dans leur entre-deux une pelotle trifide.

Le nom de Chrysops vient de denx mots grecs qui expriment la couleur dorée éclatante dont brillent les yeux de linsecte vivant; cet éclat ne subsiste plus après la mort et surtout après l'entière dessiccation. Leurs mours sont celles des 'Taons, nais les Chrysops femelles sont peut-être encore plus acharnées à sucer le sang des hommes et des animaux, se laissant quelquefois plutôt écraser que de lâcher prise; it leur arrive souvent de se gorger tellement de sang qu'elles tombent à terre en voulant s'envoler; les mâles volent et planent dans les cheains, guettant le passage des femelles : on les rencontre aussi quel. quefois sur Jes fleurs dont ils pompent le miel. L'espece la plus commune en France $(C$. cocittiens) s'y tronve depnis le mois de mai jusqu'au connenceinent d'octobre. Fabricins prétend que les larves vivent dans la terre; cet auteur decrit douze espèces comme étant de ce genre, mais M. Wiédemann (Dipt. exotic. pag. $94 . n^{\circ} .56$. ) pense que le Chrysops ferrugatus ${ }^{\circ}$. 2. doit être rapporté an gente Tabanus. M. Meigen mentionne dix espèces européennes.

${ }_{1}$ re. Division. Ailes à bande transversale brune.

$1^{\circ}$. Clrrysops italien, C. italicus. Meig. Dipt. d'Eur. tom. 2. pag. 67. $72^{n}$. 1. tab 14. fig. 7. liemelle. De France et d'Italie. $2^{\circ}$. Chrysops aveugle, C. caecutiens. Merg. id. $n^{\circ}$. 2. tab. 14. fig. 6. ilüle. (Outre le cocutiens nº. 1. Far. Syst. Antl. yui est la femelle, rapporlez comme mâle à cette espèce le Chrysops lugubris no.9. du nême autcur 't comme variété de ce sexe le Chrysops vidacaturs no. 10. idem.) 3o. Chrysops négligé, C. relictus. Merg. id. pag. 69. - Tabanus cacutiens. Panz. Faun. Germ. fas. 13. fig. 24. $4^{\circ}$. Chrysops peint, $C$. pictus. Merg. id. pag. 7o. $n^{\circ} .4 .5^{\circ}$. Chrysops carré, C. quadratus. MeIG. id. pag. jo. $n^{\circ}$ 5. $6^{\circ}$. Chrysops rutipède, C. rufipes. Mrig. id. pag. 7r. $n^{\circ}$. 6. Des environs de Paris. $7^{\circ}$. Chrysops fenestré, $C$. fenestratus. MEIc. id. $n 2^{\circ} \cdot 7$. 8\%. Chrysops marbré, C. mannoratus. NEIG. id. pag. $75 . n^{\circ}$. 8. Des environs de Paris. $9^{\circ}$. Chrysops sépulcral, C. sepulcralis. MEIg. id. pag. 74. $n^{\circ} .10$.

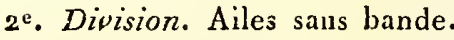

Chrysops vitré, C. vitripennis. MeIg. Dipt. d'Eur. tom. 2. pag. 74. $n^{\circ}$. 11. De l'llalie septentrionale.

RAPHIORHYNQUE, Raphiorhynchus. Wı'DEM, LAT. (Fam. nat.)

Genre d'insectes de l'ordre des Diptères, première section, fänille des Tanystomes, tribu des Taoniens.

Si ce genre n'a que quatre ou cinq divisions au troịsieme article des antennes, ce qui nous 


\section{T A P}

paroît douteux (1), il appartient au dernier groupe des'Taoniens; ce gronpe contient en outre le genre Rhinomyze dout les palpes sont de trois articles et qui a le troisième article des antennes denté à sa base, et les genres Silvius et Chrysops dans Jesquels l'hypostome ne forme point à sa purtie inférieure de prolongement rostriforme ct dont la frompe est saillante, même dans le repos.

Antennes rapprochées à len lase, alvancées, composées de trois articles, le premier très-court, presque cylindrioue; le second aussi très-courr, cyathiforme (le troisièrne n’a pus encore été observé). - Trompe entic̀rement rentrée dans la cavité beccale pendant le repos, son extrénité formée par deux petiles lèvres comprimées, paroissant entre la base des palpes. - Hypostome s'arançant en une espèce de bec subalé, aigu, dont l'extiémité est dirigée obliquement vers le bas. - Tois ocelles. - Ailes écartées daus le repos. - Abaromen aplati. - Fome des Tauns.

Ces caracteres génériques sont empruntés de M. Wiédemann (Dipt. exotic. pars r. pag. 59. et 6o.) qui a tiré le nom de ce genre de denx mols grecs signifiant: bec sibulé. Il ne donne aucun reneignement sur les mours de la seule espèce qu'il décrit et qui ne nous est pas connue. Rhaphiorlynque plantventre, R. planiveniris. WIEDEM. ut suprè. tab. II. fig. 1. Longuenr 15 lig. Corselet ayant des raies d'un lilas obscur. Abdonen lerrugineux bordé de brun; ailes d’un jaune lerrugineax. Femelle. Du Brésil.

(S. F. et A. Serr.)

\section{TAPEINE, Tapeina.}

Genre d'insectes de l'ordre des Coléoptères, section des Tétramères, fauille des Longicornes, tribu des Lamiaires.

Le groupe de Lamiaires (voyez ce mot pag. 334. de ce volume) dont ce genre fait purtie, contient de plus ceux de Colobothée, Hippopsis, Saperde el Gnome, qui ont le corps tiès-itongé proportionnellement it si largen et le corselet presine carré on plus long que large.

Antennes un peu plus longues que le corps daas les femelles, beaucnup plus grandes dans les wíles, séracées, instrétes sur les côtés de lä tête dans une éctrancrure des yeux, sur un rebord latéral du front, qui remplit cotte échancrure dans les fenclles; celles des mâles insérées a la

(1) Nous ferons remarquer que ce genre se rapproche visiblement des Acanthoneres, ayant comme elles les patpes exterieurs et la irompe entiérenent rentrée dans la cavité buccale p-utant le repos, ce qui nou fait présumer que le rr.isiènte articlu des antonns oui manguoit dans l'individu sur lequel M. Wiedemant a éabli ce genre, donc avoir plus de cing divisions. En artendanc holis nous contormons à l'ordie suivi par Bi. Litrulle dans ses Fam. nat.

Hist. Nat. Ins. Tome $X$. partie postérienre d'un long appendice qui naît du rebord latéral du front et s'élend transversaleuent en ligne droile, de manière ì couvrir les yeux : elles sont composées de onze articles dans les deux sexes, le premier plus long que les deux suivans pris ensemble, en massue fort alongée, aminci à sa base (cette base souvent recoubéc el échancrée dans les wâles), garni de quel ques poils longs et épars; le second petit, un peu conique; les suivaus de rrois à dix éganx entreux, cylindro-coniques, ayant des poils courts, épars; cliacun de ces articles pertant à l'exirémité un verticille de poils longs, an nombre de quatre à six : le onzieme ou demier article pas beancoup plus long que le précédent, ayant également des poils couris, épars, et vers son extrémité cuelques poils longs. - Manaibules petites, winies, cachées sous le labre. - Lubre arrondi, transversal. - Palpes assez courls, presqu'ćgaux, lenr dornier article plus long que le précédent, assez gros ì sal base, presqu'en alène ì l'extrémilé. - Téte transversale, un peu moins large que le corselel dans les femelies, plus large que lui dans les nuîles, à cause de la longueur des appendices latéraux chu front; celui-ci aplati en devant, vertical, reburdé, de forme différente selon les especes: chaperon étroit, transversal, séparé de la têta par une ligne enfoncée. - I cux cachés derrière les appendices frontaux, extrêmement rétrécis par ceux-ci, dans leur partic moyenne. - Corps forlement déprimé, large pour sa longrueur, peu épais, hérissé de poils. Corselet transversal, mulique, beaucoup phus large d'un côté a l'autre daus sa partic moyenne, déprincé, brillant, un peu moins large que la base des élytres, rélréci à sa base près de celleci. - Ecusson court, transver'sal, arrondi postérieurement. - Elyties déprimées, aliant en se rétrécissant de leur base à lextrémité, relle-ci arrondie, muliqque; leurs angles luminéraux assez prononcés; elles recourrent des ailes et l'abdomen. - Pattes tories, assez coustes, chargées de ln ngs poils; cuisses en nassue alangée: jaubes intermédiaires porlant à leur partie antériense vers l'exirénilé des coussinets de poils courts, très-serres; les autres janbes en ayant aussi cuelquefois de semblables: tarses counts, leur arlicles prescu'égarax; larses antériears des mâles un peu dilaiés, tres-garnis de poils eu desson"; ces mêmes tarses fort élruils dans les femelles.

Ce gene dont tontes les espèces connues sout din Pirésil, fire son noin d'un wot grec qui exprine que le corps est aplati; cette forme semble indi fuci cue ces insectes viven sous les écorces. Oulie la frle dépression du corps yui les distingue de pesque tons les antres Longicorues, et qui égale a pou prés celle des Cucujes, lá conformation singulière de la tête, surtout dans les mâles, les fail reconnoilte au premier coup d'wil. Lenr taille est assez pctite.

$$
\text { Z z. Z }
$$


1. 'Tapeine couronuée, $T$. coroneta.

Tapeina nigro-picea, punctala; fronte lateribus multuma álatato, in medio suprà enarginato, utringue appendiculuto; appendiculis margine rotundatis.

Longueur 5 lig. Co:ps d'un noir de poix, ve!u, très-ponctıé. Frout et disque du corselet presque lisses et glabres, le premier ayant ses appendices latéraux très-prolongés, leur extrénicé alrondie; sa paric supérieure fortement éclancree, celle échanciare ayant de chaque côté un lobe élevé, arrondi. Antennes et paltes re la couleur du eorps. Premier article des antenues fortement aminei et échancré à sa base. Mâle.

\section{Tapeine brune, $T$ picea.}

Tupeina nigro-picen, punctata; fronte lateribus mediocriter dilulato, in medio suprà cmarginato, utrinquè appendiculito; appendiculis brevibus externè subangulatis.

Longueur 4 lis. Corps d'un noir de poix, velu, très-ponetué. Front et disque du corselet presqie lisses et glabres; eelui-li ayant ses appendices latéraux moyenuement prolongés, leur extrémité arrondie; sa partie supérieurécéchanerée, celte échancrure ayant de chaque côté un lobe déjelé cn angle ve:s les yeux. Autennes et pattes de la couleur du corps: preanier article des antenues point échaneré en dessous. Mảle.

\section{Taperne disparate, T. dispar.}

Tapeina nigro-picea, elytris abdomineque subitis ferruoineis, purictatu; fronte lateribus maximè dilutato, in metlio suprà subangulato et in angulo dapresso.

Acanthocinus dispar. Des. Collect.

Longueur 4 lig. $\frac{1}{2}$. Corps d'an noir de poix, veln, ponctué. Front ayant ses appendices latéraux extrêmement prolongés et suspassant de beaucoup dans leur éleudue transversale toutes les autres parties du eorps; son bord supérieur presque droit, s'élevant un peu en angle dans son miliea qui porce me assez forte dépression. Disque du corselet prescyue lisse et glabre. Elytres el dessous de l'abdomen de couleur ferrugineuse, ponclués. Antennes et pattes de la couleur du corps. Premier article des antennes fortement áchaucré ea dessous. Mùle.

\section{Thpene bicolore, T. bicolor.}

Tapeina ferruginea, elytris nigro-piceis, punc. tata; fronte utrinquè parum dilatato, suprà vix mirginato.

Longceur $5 \mathrm{lig}$. Corps ferrugineux, velu, ponctué. Front n'offiant sur ses côtés qu'un re- bord eourt qui porte les antennes; son bord supérieur peu prononcé; front et disque du eorselet presque lisses et glabres. Elytres d'un noir de poix. Antennes noires, leur premier article ferrugineux, point échaveré à sa base. Pattes lerrugineuses. Femelle.

Nota. L'Acanthocinus planifrons DEJ. Co!lect. appartient eneore ì ce genre.

$$
\text { (S. F. et A. Serv.) }
$$

TAQUE, Tachlzs. Jur. Splvoz. Voyez Mérie, pag. 3g3. de ee volume.

$$
\text { (S. F. et A. SERv.) }
$$

TARENTULES, Tarentuloe. Ce nom a étédonné par M. Latreille (Fam. natur. du rìgne anim.) a une tribu d'Arachnides de l'ordre des Pulmonaires, famille des Pédipalpes, dans laquelle il place le genre Phryue d'Olivier, auquel Fabricius a douné, long-temps après cet anteur, et d'après Brewn, le non de Tarentule. Ce nom a déja été employé pour désigner une araignéc eélèbic eonnue depuis lour-lemps, et appartenant au genre Jycose ( voyez ce mot), très-f́loigné des Tarentules de Fabricius. La tribu que M. Latreille désigne sous le nom de Tarenlules est ainsi earactérisée par ce savant :

Abdomen pédiculé, ayant en dessous, de ehaque côté et près de sa base, deux stigmates ou spiraeules, et se terminant simplement dans quelques-uns par un filet très-articulé sans aiguillon. Palpes en forme de bras el épineux, du ruoins a leur extrémité. Chélicères monodactyles. Les deux pieds autérieurs plus longs, terminés par un tarse long ( sétacé, très-long et antenniforare dans plusieur's ), très-articulé et sans ongles au bout. Langue longue, linéaire, en forme de dard.

Cette tribu renferme les genres Théltphone el Perven. Toyez ees mots.

On a donué le nom de Tanentole, Tarentula, à une araignée célèbre par les fables qu'on a débitées sur son compte, et rentrant dans un geure propie, celıi de Lycose. Nous allons donner les caractères de ee genre, et nous parlerons de la Tarentule quand nous serons arrivés à la description de l'espeee qui porte ce nom.

LYCOSE, Lycosa. Genre d'Araehnides de l'ordre des Pulmonaires, famille des Aranéides, seclion des Dipneumones, triba des Citigrades, établi par M. Latreille et adopté par. M. Walkenaër el par tous les entomologistes. Ses caractères sont : Yeux disposés en quadrilatère anssi long et plus long que large, et dont les deux postérieurs ne sont point portés sur une éminence; première paire de pieds sensiblement plus longue que la secoude.

Ces Araignées ressemblent beaucoup aux Dotomèdes de M. Latreille, mais elles en different par lis manière dont les yeux sont placés sur le thorax 
et par les pattes, dont la seconde paire est aussi longue èt plus longue que la première : elles s'éloignent des Saltiques et autres genres voisins par des caractères de la mêtne valeur. L.es yeux des Lycoses forment un quadrilatère; ils sont disposés sur trois lignes transverses; la première formée de quatre, et les deux autres de deux : les quatre derniers composent un carré dont le côté postérieur est de la longueur de la ligne formée par les antérieurs, on guère plus long ; les deux postérient's ne sont point portés sur des tubercules comme ceux des Dolomèdes. La lèvre des Lycoses est carríe, plus haute que large; la longueur de leurs pattes va dans l'ordre suivant, la quatrième paire la plus longue, la première ensuile, la seconde et la troisième qui est la plus conrte. Lear corps est couvert d'nu duvet serré, et leur abdounen est de foruie ovale.

Les Lycoses courent très-vile; elles habilent presque toutes à terre, et elles se pratiquent des trous qu'elles agrandissent avec l'àye, et dont elles fortifient les parois intérieures avec ıne sorte de soie, afin d'empêcher les éboulemens : d'autres s'éablissent dans les fentes des murs, les cavicés des pierres, etc.; quelques-unes (1.. Allodiome) y font un tuyau composé d'une toile line, long d'environ cinq centimètres, et reconvert is l'extérieur de parcelles de terre; elles ferment ae tuyau au temps de la ponte. 'loutes se lienuent près de Jeur demeure et y gruettent leur proie, sur laquelle elles s'élancent avec nne rapiaité étonnante. Ces Arancides passent l'hiver dars ces trous, et, stiYunt Olivier, la Lycose tarextule a soin d'en botacher exactement l'entrée pendant cette satison. Les Lycoses soricul de leurs tetraites dés les premiers jours dı printemps, et elles cherchent bientôt a remplir le voen de la nature en s'accouplant. Suivant les espèces et suivant la température du printemps, l'accouplement a lieu depuis le mois de mai jusqu'à la mi-jnillet. Suivant Clerck, les deux sexcs de celle qu'il nomme Monticola, préludent par divers petits sauts : la femelle s'étant soumise, le mále, par le moyen d'un de ses palpes, rapproche de son corps, et un peu obliquement, son abdonten; puis, se plaçant par-derrière et un peu de côté, se conche str elle, applífue doncenent et à diverses reprises son organe générateur sur un coips proéminent, que Clerck nomme trompe de la partie sexuelle de la fernelle, en faisant jouer alternativement l'un de ses palpes, jusqu'à ce que les deux individus se séparent par un satullement très-preste. Les Lycoses pondent des oufs ordinarientent sphériques et variant en nombre, suivant les espèces, duepuis vingt à peu près jusqu’à plus de cent qualre-vingt : ces cut's, à leur naissance sont libres, mais la mère les renferme bientôt dans un sac ou cocon circulaire, globuleux ou aplati, el formé de deux calottes réunies par leur bord: ce cocon ou sac à œufs est toujours attaehé au derrière de la femelle par les filières, au moyen d'une petite pelotte ou d'un lien de soie. La femelle porte partout avec elle toute celle postérité future, et court avec célérité nalgr'é celle charre; si on l'en sópare, elle entre en furenr, et ne quille le lisu où elle a fait cette perte qu'après avoir cherché long-lerops et être revenue sonvent sta ses pas. Si elle a le bonheur de retrouver son cocon, elle le saisit avec ses mandibules et prend la fúite avec préeipitation.

Les œufs des Tyycoses éclosent en juil et en juillet. De Géer, qui a berucoup observé les Araignées, présume que la mère aide les petits à soltir de leur ceuf en perçint la coque. Les petits restent encore quelque lemps daus lem coque générale; ce n'est qu'a près leur premier clıangement de peau qu'ils abandoment lenr demente et montent sur le corps de lear mère, ouils se cramponnent; c'est surtont sur l'abdomen e' sur le dos qu'ils s'établissent de préfélence, en s'y arrangeant en gros pelotons qui donuent à la mère use figure hideuse et extritorinaire. ' a r un temps serein et vers la mi-octobre, Listei a observé ine grande quantité de jeunes i.ycoses voltigeant lans l'ail; pour se soutenir ainsi elles faisoient sortir de leurs filières, comme par éjasulution, plusieurs fils simples en forme de rayon de comète, d an éclat extraordinaire et pourpre brillant: ces petites Araignées falisoient urouvvil avec lapidité, et en rond au-dessus de leur tête, lenl's pattes, de manière à rompre leurs fils ou à les assembler en petites peloltes d'un blauc de neige; c'est, sotúenues par ce petit hallon, que les jeanes lycoses sabandonnoient dans l'air et étoient transportées à des hautenrs considérables. Quelquefuis ces longs fils aériens élant réunis en forme de cordes enubrouillées et inégales, devieunent un lilet avec lequel ces Aranéides preanent de petiles monches et d'autres insectes de petite taille.

Le genre Lycose renferme ua asiez grind nombre d'espèces; il en est surtout me qui est trèscommune aux environs de Tirrente, et qui jo zit d'une grande célébrité, parce gue 'e peuple crcit que son venin produit des accidens très-graves. Nous parlerons de ces prétendis accilens en irditant de cette espece. M. Latreille divise ce genre ainsi qu'il suit :

\section{Ligne antélieure des yeux pas plus longra que l'interuédiaire.}

† Yeux de la seconde ligne très-sensiblement plas gros que les duax de la ligue postérieure.

I, y cosetanestule, L. tarentula. Lat. Wasck. Arariea tarentula. Lins. Fab. Ald. (Aran. tab. 39.) Araignée tarentule de ce Dic ionuaire. Elle est longue d'environ un pouce, entièrement noile, avec le dessous de son abdomen rouge el traversé dans son milieu par nue bande noire. Cette Arai- 
gnée ćtant trc̀s-eélèbre, a étć figurée par une foule d'auteurs, mais si mal, qu'il semblc que plusieurs d'entreux se sont plus à cxagrérer lcs formes lideuses de cette araignéc afon d'inspirer plus d'horrcur pour elle, et d'accréditer par ce moyen les absurdités quilis ont débitées sur les propriétés de son venin. Il seroit trop long de mentionner ici les noms des auleur's qui ont parlć de la 'Tarentule et qui l'ont figuréc; nous dirons seulement que, selon les uns, son venin prodıit des symptômes qui approchent de ceux dc la fièvre maligne; selon d'autres, il ne procure que quclques taches érysipélateuses et des crampes légères ou des fourmillemens. La maladie que le vulgaire croit que la Tarentule produit par sa morsure, at reçu le nom de tarentisme, et l'on ne poúl la guérií que par le seeours de la musiquc. Quelques anteur's onl ponssé l'absurctité jusçu’à indiquer les airs qu'ils croient convenir le p? ns aux tarentolati: c'est ainsi qu'ils appelleat les malades. Samuel Itafenrelfer, professeur de Ulm, les a notés dans son Traité des maladies de la peau. Baglivi a anssi écrit sur les Tarentules du nuidi de la France; mais on est bien revenu de la fraycur qu'elle inspiroit de son temps, et aujourd'hui il est bien reconnu que le venin de ccs araignées n'cst dangereux que pour les insectes dont la Tarentule fait sa nourriture. Cette espèce se trouve dans l'fralie méridionale.

Il existe dans le midi de la France une espc̀ce de Lycose qui diflère très-peu de celle que nous venons de décrire, et qu'Olivier a confoudue avcc celle-ci : c'est le Lycosa melanogaster de M. Latrcille ( $L$. tarentula Narbonensis. Walck.). Elle est un pcu plus petite que la précédeute, et en dilfère surtont par son abdomen qui est tout noir en dessous, et dont lcs bords seulement sont rouges. Chabrier (Soc. acad, de Lille, $4^{\circ}$. cahier) a prblić des observations curieuses sur cette espèce.

$\dagger \dagger$ Les qualre yeux postériears presque de même graulcur.

Lycose allodrone. L. allodroma. Lat. WT $\mathrm{W}^{\top}$ LCK. (Hist. des Aranéziles, fasc. 1. tab. 4.) La femelle. Crenek. (Aran. suec. pl. 5. tom.2.) C'est la plus grande des environs de Pari; ; son corselet et son abdomen sont d'un roure mélangé de gris ct de noil. Les paties sont anuelées de rougc et de noir.

II. Lignc antéricure des yeux plus large que l'intermédiaire.

Lycose pirate. $L$. piratica. Walck. Cherct. (Aran. suec. pl.5. tab. 4. lc mâlc, et tab. 5 . la femcllc.) Corselet verdâtre, bordé d'un blanc très-vif. Abdomen noirâtre, entouré de chaque côté d'une ligne blanche avec six puints blancs sur le dos. Elle paroit avoir des rapports avec les
Dolomèdes aquatiques, et court sur la surface de l'eau sans se moniiler. Voy. pour les autres espèces Walckenaek, Latreille, Olivier, Cienck, elci. (E. G.)

TARIERE, Terebra, on Oviscapte. On désigue ainsi un instrument don beaucoup de femellcs d'insectes sont pourvnes, et qui lcur sert à percer et à déposer leurs œufs dans les différens corps où ils doircut se développer. Celte tarièrc est donc une dépendance de l'organe génératenr femelle. Elle cst située à l'anns dans tous les insecics qui cn sont pourvus, et composée de plusieurs pièces, dont lc nombre varie suivant lcs ordres ou les espcces. Dans les Hyménoptère's, clle est composée d'mue base, d'un étui et de deux stylets constituant un dard plus on moins denté en scic í son extrémité, et parcouru daus toute sa longucur par un canal. Le dard de la taric̀re des Cimales est composć lui-mêrne de trois pièces, dont unc au uilieu servant de point d'appui aux deux latérales, qui glissent chacane sur ellc au moyen d'une coulisse. Les deux pièces latérales sont plus grosses à leur extrémité, qui est munic cxlérienrement de fortes dents propres à couper le bois dans lequel les inscctes déposent leurs œufs. Les Orthoptères ont une tarière composée dc dcux lames entre lesquelles passent les œufs. Certains Dipleres, comme les Mouches, los (Estrcs, ete., ont une tarière conformée d'une tonte aulre manière; clle est composée d'une suite d'anocaux rentrant les uns dans les autres coume les tuyaux d'une lorgnettc.

La longueur de la tarière varie suivant les espèces. Dans quel ques Ichneumons, elle est deux fois plus longue que le corps, très-grêle et flexiblc; dans d'autres, elle est beaucoup plus conrlc. Sa forme varie aussi beaucoup; lantốt elle présente la forme de couteaux, de sabres, de scies, dc perçoirs, de sondes, etc. Dans plusieurs insectes elle cst tonjonrs saillaute hor's de l'abdomen, soit altachée seuleacnt par un point, soit adhérente par sa moitié inférieure : dans quelques espéces clle est dirigéc vers la tête et posée sur le dos de l'abuomen, dans l'ination; daus d'antrcs, ellc est placée sous le ventre et se dirige alussi vers la tôte; enfin, dans lc plus grand nombre, elle est dirigée en arrière. D’aulres insectes ont la larièrc cachée dans l'intérieur du corps, alors le demier article de l'abdonen est fendı e $\varepsilon$ la laisse sortir à la volonté de l'auimal.

La tarière n'est pas toujours destinće à pcrcer les corps dims lesqucls les insertes pondent leurs outs; dans un grand nombre d'Ityménoptères elle scrt encorc d'arme offensive et défensive, et porte alors le nom d'aiguillon. Lcs usäges de l'aliguillon des Iy ménoptères sont scmblables ì ceux de la tarière; car, si l'aiguillon, à callse du veuin qui coulc dans son inlérieur, est redoutable pour l'homme et pour plusieurs aumaux, la tarière 


\section{$\mathrm{T} A \mathrm{R}$}

n'a pas une action moindre sur les végétaux dont elle perce l'épiderme. L'aiguillon n'existe que chez les femelles, les mâles n'en ont pas, et c'est pourquoi nous pouvons saisir les mîles des bonrdons, des abeilles, ctc., sans dangcr. Daus les Hynénoptères qui out des individus neutres, comme les abeillcs, les fourmis, elc., ces neutres étant des femelles dont le; organes intéricur's de la génćration sont avortés, sont pourvas cependant de l'aiguillon, qui n'est plus pour cux qu'une arme.

On tronvera de plas grands détails sur la tarière desinsectes, aux arlicles qui trailent des genres qui cn sont pourvus. Nous renvoyons done anx mots Chalcis, Cigale, Cimbex, Cossus, Grillon, Hyánoptines, Icaneumon, Lleucospis, Mouches a scie, Orthoptères, CEstre, laporpe, Prione, Sauterelle, Triche, etc. (E. G.)

TARPE, Tarpa. FAв. PAnz. Li P. Megalodontes. Lut. Spinoz. Cephaleia. Jur.

Genre d'insectes de l'ordre des IIyménoptères, section des Térébrans, famille des Serriferes. (Cette famille répond à la tribu des'Tenthrédines. Lat. Voyez Strrifìres, article Téábraxs.)

Un groupe de celle fanille a pour caracteres: antemnes composées de plus de dix articles; deux cellules radiales et quatre cubitales aux ailes supérieurcs; tarière (dos fenclles) surpassant à peine l'abdomen, celui-ci dóprimé ou comprimé. Il renferme trois genres ontre celni de Tarpe (vojez Tenthride), savoir: Lyda, dont les intennes sout simples et sétacécs; "Céphus et Athalie qui les ont plus grosses vers teur extrímité; en outre dans ce dernier le labre est apparenl.

Antcnnes assez courtes, filiformes, insérées entre les yenx, pecinuées d'un seul côté ou dontóes en scie dues les feuelles, toujours pectinćes d'un senl côté ciins les mâles; de seize arlicics dans les deux sexes, le second fort court, le troisièıne plas long que le précédent et qu'aucun des suivans; les qualorze derniers dentés en scie ou pectinés. - Labre caché par les nıandibules. Mandibules grandes, avancées, étroites, croisées l'une sur l'antre dans le repos, ayant deux forles dents à leur extrémité, l'inférieure prcsciu'échancréc. - Mâchoires et Lève alongées, avancées; les promières coriaces, tormaut avec la lèvre une promnscide cylindrique; languette trifiue. Palpes maxillaires de six articles, le premier très-pelit, le sccond le plus long dc tous, cylindrique, le troisième de niçue formc, le quatricme un peu comprimé, les deux derniers fort petits et plus minces que les précédens : palpes labiaux plus courts que les maxillaires, filiformes, de quatre articles, le deruier un peu ovale-alongé, cilié. - Téte presqu'orbiculaire, de la largeur du corselet. - Yeux ovales, de grandeur moyenne. - Trois ocelles placés sur le milieu du fiont, et disposés en un triangle dont le sommet est trèsoblus. - Corps court, velu. - Corselet transversal; prothorax très - élroit formant un cou assez distinct; mésothorax large, occupant presque toute la partie supérieure du corselel : métalhorax extrêmement court à sa partie supérienre.-Ecusson peu distinct. - Ailes supérieures ay ant denx cellnles radiales, la première presque demi-circulaire, la seconde au moins denx fors plus grande que la première, arrondic à son extrémité, et quatre cellules cubitales, la première petite, les autres presqu'ćgales entr'ellcs, la seconde recevant la premic̀e nervure récurrente, la troisième rélrécie vers la radialo, recovant la donxièue nervure récurente, la quatrièmo n'alleignant pas tout-a-fait le boud cxtérieur de l'aile : trois cellulez discoidales. - Abdomen sesile, un peu dépriuró, assez large, composé de luit segrens ontre l'atnus, le promier échancré à la partie dorsale de son bord inféreur; plaque anale inférieure faite en cuiller, refendue longitudinalement dans les femelies, cone fente format unc coulisse dans laquelle se loge la tarière; cetle même plaque entière dans les mâles : la flarque supérieure entière daus les femelles, très-élroite el tronquée postérieurement dans les mâles, do manière à laisser voir dans ce sexe une partie de l'appareil géuératcur; tarière dépassant pen l'abdiomen. Palles do longueur moyenue; jambes intermédianes et postérieurcs armées dans lenr nilieu de deux grandes épines : promier article des larse presqu'aussi long que les quatre autres rénnis, les trois suivans allant en décroissant de longucur, le dernier assez long, muni de deux crochets ayant une pelotle dans lcar entre-dcux.

Les premiers états des 'Tarpes sont inconnus ainsi que leur manière de viore; clles appartiennent aux climats chauds de l'ancien continent, el particulièrement à ceux qui avoisirent la Méditerranée. Lcars conlcurs sout le noir-brillant et le jaune. Nous meutionuerons les espèces suivantes:

I $^{\circ}$. Tarpe Phónicienne, T. phonicia. SAv. ined. - L.e P. Monogr. Tenthred. $n^{\prime} \cdot 42$. Mlâle. De Syrie. $2^{\circ}$.Tarpe céphalote, T. cephalotes $\mathrm{n}^{\circ}$. I. HAa. Syst. Piez. (en rctranchant le synony ine de Panzer qui appartient à la Turpe de Panzer). Mâle et Femclle. D'Allemagne et du midi de la France. $3^{\circ}$. Tarpe de Klug, T. Klugii. LÉaCa. Zoolog. Miscell. vol. 3. $n^{\circ}$. 2. - Le P. ia. $n^{\circ} \cdot 44$. V'Angleterre. $4^{\circ}$. 'Talpe de Panzcr, T. Panzert. Ĺtach. id. $n^{\circ}$. 3. - Le P. $i d . n^{\circ}$. 45. Mâle el femelle. De France et d'Anvleterre. 5'. Tarpe plagiocéphale, T. plagiocephala nо. 2. FАв. id.L.e P. id. $n^{\circ} .46$. - Tarpa Fabricii. T.éace. id. $n^{0}$. r. Mâle. D’Aurriche. 60. 'Tarpe de Judée. T. judaica. Sav. ined. - Le P. $i d . n^{\circ} .47$. Femelle. De Syrie. $7^{\circ}$. Tarpe Syrienue, T. caesariensis. $S_{A v}$. ined. - Le P. id. $n^{\circ} .48$. De Syrie.

(S. F. et A. Sert.) 
TARSE, Tarsus.

Ce nonı a été donné à la troisième ou dernière partie des pattes des insecles qui répond au pied des autres animanx. Il est coniposé de plusieurs pièees arliculées les unes sur les aurres. Ces pièces, dont le nombre varie d'une it ciug dans les insectes proprement dits, qui vont quelquefois jusqu'ì dix ou douze dans les Aptères, sont nonmées articles du tarse. Le dernier arlicle de ces tarses est toujonrs armé de deux crochets recourbés en dedans; ces erochets sont quelquefois divisés enx-mêtnes en doux parlies, ce qui en fait paroitre qualre au premier coup d'cil. L'article qui dome atlache à ces crochets est toujours nu, raudis que les antres sont plis ou moins couverts de proils eu forme de brosses; quelqnefois on voil des pelotles spongieuses an-dessous de ces articles; ces pelottes sont destinces à coller l'insecte sur les corps les plus polis, et à faciliter sa marche sur les lieux perpendiculaires, et même dans les endroils où il esı obligé de marcher les jambes en hant; d'autres fois ils sont arnés d’un appareil qui paroît destiué à se coller ou à sappiiquer sur le corps de la fenzelle pendant l'accouplement. Daus ceriains mâles de Carabiques, on voit sous les tarses des pièces alongées, cousistant en un axe traveroé par des lames cronquécs plus ou moins parallèles entr'elles : ces lames paroissent composées clles-aiêtaes de petites écailles étroitement imbriquées.

Dans beaucoup d'insectes les tarscs des mâles, surtout les antérieurs, diffèrent de ceux dos femelles et sont plus dilatés et armés d'ornaties propres à maintenir le mâle sur la femelle. Les articles des tarses varient heaucoup pour la forme, ils sont le plus souvent alongés; quelçue fois ils sont carzés ou presque carrés; d'auares lois ils sont arrondis ì leur partie antérieure; on voit des insecles chez lesquels los articles varient de forme dans le mêne tarse; aussi ceux de la base sont simples et entiers, landis que ceux de l'extrémité, excepté le dernier, sont bilobés ou échincrés profondéneut. Dans les Abeille; et dans beaucoup d'autres Hyménoplères, les tarses postérieurs, et mêêne les antérieurs, sont dilatés en lout ou en partie; ils ont pour usage de servir a la récolíe du pollen des fleurs.

lies tarses des insectes ne varient jamais dans les genres; ils sont eonstamment les mêmes dinns tous les insecies qui out quelques rapporls entr'eux. On s'est servi de celte considération pour diviser des Colcoptères en plusieurs grandes coupes. C'est Geolliroy qui a le premier employé ce moyen de division; il l'a aussi appliqué aux Névroptères. Les Coléoptères sont les seuls in ectes que MI. Latreille ait partagés en sections d'après la considération des articles des tarses; il avoit établi une section dans ses ouvrages antérieurs aux Families naturelles du Règne animal, qui renfermoit des insectes auxquels on n'aroit vu que deux artieles aux tarses; e'étoit la section des Dimères de ce savant et de M. Duméril; on a recounu que ces insectes avoient réellement trois articles à tous les tarses, mais que le premier éloit si court qu'on ne l'avoit pas aperçu. En général, les inseries ont le même nombre d'articles à tous les tarses, mais il en existe quelques-uns cbez lesquels cela n'a pas lieu. Ainsi dans quelques Coléoptères, les tarses des pattes de derrière out un article de moins que ceux de devant. D'après ces considérations, les Coléoptères ont été divisés ainsi qu'il suit :

pre. sertion. Cinq articles à tous les tarses. Pentamères.

$2^{\mathrm{e}}$ : section. Cinq articles aux quatre tarses antérieur's et quatre aux postérieurs. - Hétéromères.

$3^{e}$. sectiou. Quatre articles à tous les tarses.Tétramères.

$4^{\mathrm{e}}$. seetion. Trois articles à tous les tarses. Trimères.

5e. section. Un seul article à tous les tarses. Mlonomères.

On pourroit diviser l'ordre des Orthoptères d'apres le nombre des arlicles des tarses, et l'ou anroit encore des Pentamères, des Tétranères et des Trimères. Il en seroit de même ponr les autres ordres, à quelques modifications près. VOYez INSECTES. (E. G.)

TARUS, Tarus. Crairv. Voyez Crminde, article 'Troncatipenes.

(S. F. et A. SERv.)

TAUPE-GRIIJON. Nom vulgaire employé par Geoffroy pour désigner la Courtilière cornmune d'Europe. Voyez Covnsiltíne, article Tradactyle. (S. H. el A. Sert.)

TAUPIN, Elater. Linn. Fab. Geofe. De Géer. Oliv. (Entom.) Lat. Panz. Payk. Herbst.

Genre d'insectes de l'ordre des Coléoptères, section des Pentamères, famile des Serricornes (division des Sternoxes), tribu des Elalérides.

Un groupe de cette tribu a pour caractères: antennes filiformes ou sélacées, écartées à lenr naissance, les quatre premiers articles des farses, ou aul moins quelques-uns d'entr'eux, dépourvus en dessous de pelottes prolongées en manière de lobes (1). Labre et mandibules dé-

(1) On s'apercevra que nous avons changé ici quelques expressions dans l'énoncé du caractère (voyez Elatrinides, pag. $49^{\circ}$. de ce volume), que nous avions rédigé d'après les Fam. natur. de M. Latreille, mais dans plusieurs espèces des gentes Taupin er Ludie le dessous des trois pre- 


\section{$\mathrm{T} A \mathrm{U}$}

couverts, du moins en dessus; extrémité antérieure de l'épistome sensiblement plus llevée que la base du labre et formant souvent une tranche ou un bord aigu; têle enfoncée jusqu'aux yeux dans le corscelet, plus étroite à sa base, en y comprenant les yeux, que le bord antérieur du corselet. Ce groupe contient les genres Hénirlipe et 'Taupin. Le premier a les antennes courtes et pectinées d'un seul côté dans les deux sexes, composćes réellement de donze arlicles, ce qui le distingue des 'Taupins dont aucune espèce n'it en réalité un douzième article, quoique le rétrécissement subit du onzième en présente quelquefois l'apparence.

Antennes sétacées, insérées près des veux, sur les côtés de la partie antérieure de la tête, composées de onze articies de forme variable, mais ordinairement dentés en scie. - Labre découvert en dessus, corné, court, assez large, tronqué ou presqu'écliancré, très-cilié antérieurement. - Mandibules découvertes en dessus, foibles, cornées, arquées, peu échancrées vers l'extrémité. - Mâachoires courtes, presque membraneuses, arrondies, fortement cilićes à leur extrémité. - Palpes maxillaires assez loness, de quatre articles, le preunier petit, les second et troisième égaux, presque coniques, le dernier comprimé, trianguiaire, dilaté, sécuriforae : palpes labiaux plus courts que les autres, de trois articles, les deux premiers petits, le troisième grand, comprimé, triangulaire, sécuriforme. Lèvre avancée, membraneuse, bilide à l'extréwité, ses divisions égales, tronquées : menton corné. - Tête petite, enfoucée jusqu'aux yeux dans le corselet, plus étroite à sa base, en y comprenant les yeux, que le bord antérienr de ce dernier; extrémité antérieure de l'épistone senaiblement píns élevée que la base du labre.Yeu $x$ ovales, peu saillans, posés sur les angles du bord postérieur de la têle. - Corps ovaleoblong, pubescent ou écailleux. - Corselet presqu'en car'ré-long, plus ou zooins rebordé latéralement, assez large pour sa longueur, sa partie postérieure presquaussi large que la base des élytres, il est visiblement rétréci vers la tête, ses bords latéraux s'arrondissant dans cette partie, ses angles pestćrieurs prolongés en pointe plus ou

miers articles des tarses nous a uffert des pelottes lobiformes plus o. moins prólongées : alors te premicr article du tarse est flus long qu'aucun des aurres, et le quatrième, qui n’a jamais d'appendice, est court, cylindrique, de mêne rorme que la base du cinquiène article dont il est peu distinct. Dans les genres Ijissode, Hemirhipe, Exophtalnue, Eucrémis, Tétralobe, Péricalle, ainsi que dans la plupart des espèces de Taupins et de Ludies, le premier article des tarses n'est pas beaucoup plus long que les autres, et le quatrième est conformé comme les précédens. Ce qui nous paroît démontrer la nécessité de quelques réformes dans cctre tribu, qui affecteront particulièrement les genres Tupin et Ludie. moius aiguë. Dessons du corselet ayant de chaque côté une rainure oblique et protonde dians laquelle les antennes se cachent lors du repos; présternum muni postérieurement d'une saillie qui s'enfonce à volonté dans uce fussctte antérieure dı mésosternum. - Ecusson court, presque transversal, arrondi ou échancré à sa parie postérieure. - Éytres longues, dures, assez convexes, allant un peu en s'élargissant jusque passé le milien de leur longuenr, presque toujours arrondies et muliques à leur extrémité, striées, couvrant les ailes et l'abdomen. - Abdomen arrondi au bout: plaçue anale inférieure unie dans les deux sexes. - Pattes a ssez courtes; tarses filiformes; leurs quatre premier's articles n'étaut jamais tous gartis en dessous de pelottes lobiformes; le cinquième aloniré, arrié, un perı renflé à son extrćmité, terminé par deux croctiets.

Les larves vivent dans le bois ou dans le têrreau végétal. De Géer en décrit une ainsi : tête et corps converts d'uce pean écalleuse; les trois premiers segmens de celui-ci portant chacun une paire de pattes écailleuses, articulées, terrinces par un assez long crochet pointu; tête de tigure ovale ayant deux petites antennes coniques, divisées en articulations et insérées sur les côtés; deux mandibules qui ne se cruisent pas, mais qui se rejoignent par leur pointe, stiuées att-devant de la tète; an-dessous des mandibules sont quatre palpes coniques, arliculés. Dernier segment d!n corps ou anus conicet en dessus d'une plagues presque circulaire, asant de chaque côtét trois petiles pointes mousses et vers le derrière denx :i lpendices longs, écuilleux, divisés clacun en denx pointes mousses et arrondies; les deux appendices opposés l'un à l'autre en forme de cioissan!; at.dessous de l'anus on veit ua gros mamelon charnu que la larve retire ou fait sortir du corps à san gré, et qui l'aide dans sa marche en s'appuyant sur le plan de position.

la nymphe ne nous est pas connuc. Les Taupins à l'état parfait volent très-bien, mais ils ont quelque peiuc à s'envoler; la nature leur a donné un autre inoyen de se soustraire au danger; ils exécutent des sauts assez élevés all moyen du prolongement qu'offre leur présternu on qu'eu baissant la tête, ils enfoncent à rolonté dans une cavité du mésosternum; alors en dégageant subitement cette saillie, ils s'élèvent comme pas ressort en frappant le plan de position avec les deux extrémités du corps; pendant qu'ils exécutent ce saut, qui se fait aussi facilement, qu'ils soient posés sur le ventre on sur le dos, ils appliquent toujours les pattes et les antennes sous le corps et les y tiennent fortement serrćes; il paruit qu'en outre ils appuyent dans ce moment les deux yointes latérales du corselet contre les bords des álytres, ce qui augmente la force élastique qui tend à les élever : ils usent surtout de cette faculté de sauter, pour se remettre sur leurs paltes lorsqu'ils 
sont tomliés à terre renversés sur le dos, ce crai arrive ordinairement lorsque la peur leur a fait contrater les pattes.

Le nom d'Ellater clonné à res Coléoplères exprime la faculté quils possedent de sauter comme au moyen d'un ressori. Lia plopart des Tampins volent pendant le jonl', mais un assez grand nombre d'espèces de l'Annćrique méridionaie volent durant la nuil. Brown a observé à Suint-Domingrne le Taupin lnuineux (noctilucus). Le Tampin reluisint (hminosus) de la Guyane et du Brésil vole de roinie daus íobscurité. Ils se font tous denx rerarcuer par des taches lumiuenses placées vers les angles postérieurs da corselot. Uin indirida de cetle demière espece qui avoit été transporté à Pari, dans des bois d'Amérique, y avoit subi sa dernic̀re mélanorphose; il surprit, prar la clatrlé qu'il répandoil, tous ceux qui le virent et fur recunnu par M. Fongeranx. Lécicbre M. de Humbuldr voyageanl sur les lleuves de l'Amérique mériclionale remargua ansoi plusieurs. fois ces insectes.

lus femelles ont une tarière rítractile qui sert à déposer leurs auts; éest une longue piece cylindricre, au bout de laquelle se irouvent deux antres pic̀ces alongées, coniques el pointnes; on en roit entu'elles ume troiciène yur est creuse et sert de conduit ans oufs. Quand on presse l'abdomen des mîles, il en sort trois palies, dont l'intermédiaire est probable:went l'or one sexucl; ces parties sout renlermées boss nu fourrean qui s'ouvre sur les côlés et est soutcnu par deux lianes concaves et écrilleuses.

Les Tunpins se troevent principalement sur les fleur's et sar les végélaux; quolques especus quilfent pen les artures dans lesquel, thes sont nées, telies que le firmgineus, le sumguneus, le ihorucicus, efc. hes nombreuses especes qui conposent ce genre nous ont partu nécessiter d'y établir des divisions.

1re. Division. Detnier arlicle des antennes ré. trési brusinement en une pointe particnlière imilant uis douziène aticle. - Anlennes simples daus les deux sexes.

re. Subdivision. Corselet muri de taches latérales phosplorescentes. (Dans les individus ruorts, ces taches paroissent pâles ou roussâtties.) - Insectes nockuras (I).

Io. Tunpin lumineux, E. noctilucus no. 13. Fав. Syst. E'eut. - Otiv. Entom. tom. 2. T'aup. pag. $15 . n^{\circ}$. ij. fl. 2. fig. 14. a.-Scnas. Synon. Ins. tom. 5 . pag. $267 \cdot n^{\circ}$. I. Amérique méridionale. $2^{\circ}$. Taupin reluisant, Zl. luminosus. Ildig. Berlin. Maga $. f . d$. n. Entd. 1. II. pag. 149. 11.Ins.

(1) Cette coupe est indiquée par M. Scbonhert. Syn.
Scuan. id. pag. $260 . n^{\circ}$. 11. - E. phosphoreus $1^{\circ}$. 14. FAB. $i d$. (en retranchant les synonymes de Lincé et de De Géer). - Oriv. id. pag. 16. $n^{0}$. I4. pl. 2. fig. 14. b. et fig. 20. (retrancliezles synony mes de Linné, de De Géer el de Voët). Diême palrie. $3^{\circ}$. Taupin enflammé, E. ignitus

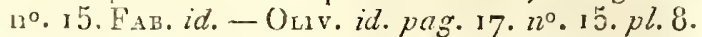
figr. 78. - Scagn, $i d . n^{\circ}$. 14. Même pallie.

1.liger a décrit dans l'auvrage précilé treize autres sspèces des mènes contrées qui sont probablement de ce genre el de celle subdivision; elles sont rapoelées par M. Schœnlıerr Synon. Ins. tom. כ. pag. 267. ei suivantes.

$2^{e}$. Subdipision. Corselet sans laelses latérales phosphoresceutes. - Insectes diurnes.

$1^{\circ}$. Taupin silionné, E. sulcatıs $\mathrm{n}^{\circ} \cdot 27 \cdot \mathrm{FAB}$. Syst. Eleut. - Otiv. Éntom. tom. 2. Thap. pag. 13. $n^{\circ} \cdot 9 \cdot p l$. 2. Jig. Iо. a. b. - SснаN. Synor. Ins. tom. 3. pag. 275. $n^{\circ} .54$. De Cay enne. $2^{\circ}$.

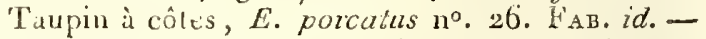
Oliv. id.pag. $14 \cdot n^{\circ} \cdot 10 \cdot p l \cdot 7 \cdot$ fig. $74 \cdot$ - Scaan. id. $\iota^{\circ}$. 53. Amérique méridionale, $3^{\circ}$. Taupin fus-

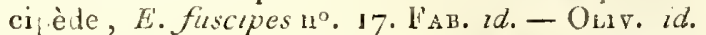
pag. 20. n'. 20. pl.5. fig. 21. - Schan. id. pag. 272. $27^{\circ}$. 55. Des Indes orientales. $4^{\circ}$. Taupun oculé, E. oculatus no. 9. H'AB. id. (en retranchant le synonyme de De Géer). - Oulv. $i a ́$. pag. $11 \cdot n^{\circ} .6 . p l .3 . f_{0} \cdot 54 \cdot a . b$. (en retrauchant le sysonyme de De Géer). - Schæn. $i d$. pag. 27 I. $z 7^{\circ} .28$. Arnérique septeurrionale. $5^{\circ}$. Taupun lonche, E. luscus no. Iо. Fав. id. - Oliv. id. pag. 12. $n^{\circ} \cdot 7 \cdot p l$. 6. fig. 64. a. - S H HeN, $i d . n^{\circ} \cdot 29 \cdot-$ E. oculatus. De Gín, Móm. tom. ID. pag. 159. $n^{\circ}$. 1. pl. 17. fig. 28. Mêne patrie que le précédent. 60. Tайin inyope, E. myops n०. 8. Fав. id. - Schen, id. no. 27.-E. luscus var. Octv. $i d$. pl. 6. fig. 64. b. De Curoline. $7^{\circ}$. Tuupin ferrugiueux, Le ferrugineas $1^{\circ}$. 25 . 1 в. id. - OLrv. $i d$. pag. 21, in. 22. pl.5. fg. 35. - SснаN. id. pag. $274 . n^{\circ}$. 5o. DEurope. Environs de Paris.

$2^{\ominus}$. Division. Dernier article des antennes ovale-oblong, point rétréci brusquement.

Ire. Subdivision. Antennes très-pectinées dans les naâles.

Type : Taupin ramicone, $E$. ramicornis. Pal.-Bauv. Ins. d'aifr. et a'Amér. plag. 10. Colépt. pl. TiL. fig. 5. - Scean. Synon. Ins. tom. 5. pag. $275 \cdot n^{\circ} \cdot 52$. Du Brésil et de la Caroline du Suci. Cette espèce a des peloltes lobiformes trèslongues en dessous des trois preniers articles des larses. (Voyez la note pag. 550 . de ce volume.) Le Taupin ramicorne, $E$. ranicornis du mêne auteur, pagr. 214. Coléopt. pl. IXX. fig. 7. n'en est qu'une siraple variété, quoique l'auteur'ait oublié d'eu avertir; les antenues sont incomplèles, mais paroissent conformées comme dans le premier.

2e. Subdivision. 


\section{T A U}

2e. Subdivision. Antennes simples dans les deux sexes.

A. Troisième article des antennes aussi long ou presqu'aussi long que le quatrième.

a. Troisième article des antennes en dent de scie.

I $^{\circ}$. Taupin velu, E. hirtus. Herbst, Archiv. $V$. pag. $114 . n^{\circ} .31 .-$ Schær. Synon. Ins. tom. 3. pag. $277 \cdot n^{\circ} \cdot 70 .-E$. aterrinus n ${ }^{\circ} .34$. FAв. Syst. Eleut. (en retranchant tous les synonymes.) $-E$. niger. Ourv. Enton. tom. 2. Taup. pag. 28. $n^{\circ} .34$. pl. 6. $f g .65$. (en retranchant tous les synonymes, sauf peut-être celıi de Linné.) Des environs de Paris. $2^{\circ}$. Taupin fascié, E. fasciatus $\mathrm{n}^{\circ} .43$. FAB. id.-Oliv. id. pag. 3r. no. 3g. pl. 5. fig. 46. et pl. 1. fg. 5. - ScH@N. id. pag. 282. no. $n^{\circ}$. D'Europe. $3^{\circ}$. Taupin nigripède, E. nigripes. GrLl, Ins. Suec. I. I. pag. 3g5. no. 23. - Sc日æn. id. $n^{\circ} .89$. Environs de Paris. $4^{\circ}$. Taupin rayé, E. vittatus no. 53. Fав. id. - Schen. id. pag. 288. $\pi^{\circ} .116 .-E$. marginatns. Ourv. id. pag. 34 . $n^{3}$. 43. pl. 3. fig. 29. et pl. 8. fig. 29. b. (en retranchant tous les synonymes hors celui de Geoffroy.) Commun aux environs de Paris. $5^{\circ}$. Taupin thoracique, $E$. thoracicus n?. 77. FAB. $i d$. (en retrinchant le synonyme de Voët.) - Oriv. $i d$. $p a g .44 \cdot n^{\circ}$. 59. pl. 3. fig. 24. (en retranchant le synonyme de Voët.) - Schos. id. pag. 297. $n^{\circ}$. 154. Aux environs de $P_{d}$ ris, sous les écorces. $6^{\circ}$. 'Taupin discicolle, E. discicollis. Hen вst, Coleop.

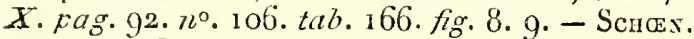
id. pag. 298. $n^{\circ}$. 15̆7. D'Europe. $7^{\circ}$. 'Taupin rufipède, $E$. rufipes $n^{\circ}$. 105. FAB. $i d$. (le synonyme de Geoflioy est douteux.) - Ourv. id. pag. 45. $n^{\circ} .62 . p l .7 \cdot f_{g} \cdot 72 . a \cdot b$. (les synonymes de Geoffioy et de Fourcroy sont douteux.) - Scaen. id. pag. 307. $n^{\circ}$. 198. (le synonyme de Fourcroy devoit paroître douteux à M. Schœnherr, puis(quil regarde comme incertain celui de Geoffroy.) Des environs de Paris, sons les écorces. $8^{\circ}$. 'Taupin bimoncheté, E. biguttatus no. 11 8 . FAB. id. - Orrv. id. pag. 47. $n^{\circ}$. 66. pl. 6. fig. 5g. Sснак. id. pag. 3ı2. no. 227. France méridionale.

\section{b. Troisième article des antennes sim- ple.}

I0. Tanpin montagnard, E. Bricteri no. III. F.в. Syst. Eleut. - PANz. Faun. Germ. fas. 34. fig. 13. - ScHør. Synon. Ins. tom. 3. pag. 3 io. $n^{\circ} .213$. D'Europe. $2^{\circ}$. Taupin croisé, $E$. crucifer. Ouiv. Entom. tom. 2. Tcupp. pag. 52. $n^{\circ} .74$. pl. 5. fig. 44. a. b.-ScHé. id. pag.312. $n^{\circ} .225$. Europe méridionale. $5^{\circ}$. Taupin gentil, $E$. pulchellus $\mathrm{n}^{\circ}$. I14. FAB. $i d$. - OnIV. id. p. 5 r. $n^{\circ} \cdot 73$. pl. 4. fig. 38. a. b. - Schos. id. pag. 3 u . $n^{\circ}$. 2. 9. D'Europe.

$$
\text { Hist. Nat. Ins. Tome } X \text {. }
$$

B. Trojsième article des antennes sensiblement plus court que le quatrième.

a. Troisième article des antennes point globuleux, conique ou en dent de scie.

I . Taupin hémorrhoïdal, E. hemorrhoidalis $n^{\circ}$. 7I. Fав. Syst. Elent. - Scherv. Synon. Ins. tom. 3. pag. 295 . $\mathrm{I}^{\circ}$. I $44 .-E$. ruficaudis. Id. pag. 288. no. I $14 .-$ E. sputator. OlIv. Entont. tom. 2. Taup. pag. 3o. $n^{\circ}$. 38. pl.3. fig. 31. Commun aux environs de Paris. $2^{\circ}$. Taupin cylindrique, E. cylindricus. PАYK. Faun. Suec, tom. 3. pag. 24. $n^{\circ}$. 28. - Scnan. id. pag. $28 \mathrm{I} . n^{\mathrm{n}} .88$. D'Europe. 3․ Taupin sanguin, E. sangzinzenzs nо. 83. FАв. id. ( ôtez le synonyme de Schæfler.) - Oliv. $i d$. p. 40. $n^{\circ}$. 53. pl. 1. fig. 7. et pl. 5. fig. 48. a. (ôtez les synonymes du Syst. Entom. et du Spec. Ins. de Habricius qui appartiennent à l'espèce suivante.) - Schen. id. pag. 299. $n^{\circ}$. 165. Commun en France. $4^{\circ}$. Taupin bout noir, E. prceustus $\mathrm{n}^{\circ}$. 85. Faв. $i d$. - SchæN. $i d$. page. 50I. $n^{\circ}$. 167. Des environs de Paris. 5o. Taupin porte-selle, E. ephippium no. 84. FAB. id. Oliv. id. pag. 4r. no. 54. pl. 5. fig. 48. b. Scacen. id. $n^{\circ}$. I66. D'Europe.

\section{b. Second et troisième arlicles des anten- nes petits et globuleux.}

I . Taupin fulvipède, E. fulvipes. Hensst. Col. X. pag. 46. no. 52. tab. 162. fig. 2. - Sendz. Syn.Ins.tom. 3. pag. 287. no. $112,-$ E. obscurus 11 ${ }^{\circ}$. 63. Fab. Syst. Eleut. (en retranchant lous les synonymes.) D'Europe. $2^{\circ}$. 'Taupin noir, $E$. $n-$ ger. no. 35. FAB. $i d$. (en retranchant les synonymes.) - Scugn. id. pag. 278. $n^{\circ}$. 72. - E. aterrimus. Oliv. id. pag. 28. no. 33. pl. 5. fig. 53. (ôtez tous les synonymes.) Des environs de Paris. $3^{\circ}$. 'Taupin alongé, E. elongutulus ${ }^{\circ}$. gо. ТАв. id. - Onıv. id. pag. 43. $n^{\circ} .57 \cdot p l$. 6.fig. 58. Schox. id. pag. 5or. $h^{\circ}$. 168. Des environs de Paris. 4․ Taupin bimaculé, $E$. bimaculatus no. 121. FAB. id. - OlIv. id. pag. 49. $77^{\circ} .70, p l .5$. fir. 45. a. b. - Sch@N. id. pag. 313. $n^{\circ} .23$ r. Milidi de la Hrance. 5o. 'Taupin bordé, E. limbatus no. I09. F $\mathrm{F}_{\mathrm{AB}}$. (Le synonyme d'Olivier est douteux.) - Scnes. id. pag. 309. no. 207. - E. minutus var. Onlv. $i d$. pag. $53 . n^{\circ} \cdot 76 . p l .6 . f_{g} .62$. a. b. Environs de Paris.

Nota. Nous possédons un des deux individus rapporiés d'Afrique par M. Palisot-Banvois, de l'espèce à laquelle il a dunné le nom d'Elater elegans. Ins. d'Afr. et d'Amériq. pag. 10. Coléopt. pl. 7. fg. 4. qui est sans ancun doute l'Elater cacus no. II. Fab. Syst. Eleut. M. Schenherr admet iui-même comme synonyme de l'Elater

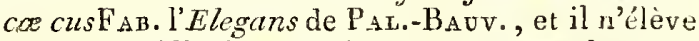
point de difficultés sur le genre; cependant cet insecte n'est pas un Taupin, mais, à ce que nous pensons, il doil être rapporté an genre Triplad.

A a a a 
Aucun de ees auteurs n'a déerit les antennes; l'individu que nous avons en manque ainsi que de pattes; les mandibules, absolument eonformes à la description qu'cn donne M. de Bauvois, sont celles des Triplax et non celles des Taupins, qui n'ont pas de lubereule dentiforme dans le milieu de leur partie internc; du reste le corselet n'a pas même l'apparcnce d'un sillon pour recevoir les antennes duns le repos; le présternum est dénué dc saillie, et le mésosternum de cavité propre à recevoir celte saillie; le bord postérieur du corselet n'a poiut d'angles saillans; il est conformé absolument comme celui des 'Triplax. D'après cela on doit conclure que les antennes dans la fig. 4. citée plus haul, n’ont pas été failes d'après nature, qu'on lui a donné d'imagination des antennes de 'Taupins, el que lorsque l'on pourra voir les tarses de cet insecte on ne les trouvera composés que de quatre articles.

HÉMIRIIJPE, Hemirhipus. T.AT. (Fam. nat.) Elater. FAB. Oliv. (Entom.) Hendst. Schas.

Genre d'insectes de l'ordre des Coléoplères, seetion des Pentamères, famille des Serricornes (division des Stcrnoxes), tribu des Elatérides.

Un groupe de cette tribu conlient les Taupins el les Hémirhipes. (Vojez Taupis.) Dans les premiers les antennes n'ont réellement que onzc articles, quoiqu'il arrive quelquefois que l'échancrure du onzične soil forte et présente alors l'apparence d'un douzième article.

M. Latreillc n'ayant pas encore publié les caractères propres à ce genre, nons nous bornerons a sigualer les plus ipparens de eeux qui l'ćloignent des Taupins.

Antennes ćourles, enmposées de douze arlieles dans les deux sexes; lc premier long, conique; le second très-court, transversal; les dix autres ílabellés, mais d'une manière beaucoup phns prononcée dans les mâles. - Côtés extérieurs du corselet très-rabatius, à peine rebordés.

Lc nom de ce genre cstliré de deux nols grecs et signifie : demi-panache. Mr. Latrcillc indique pour type l'espèce suivante : IIémirhipe linéé, $H$. lineatus. - Elater lineatus no. 12. FAB. Syst. Eleut. - Ourv. Entom. tom. 2. Taup. pag. 10. $n^{\circ}$. 5. pl. 6. fig. 65. (Les anteanes sont décrites et figurćes en dent de scie, cc qui est une faute, car nous avons vérifié qu'elles sont flabellées daus les deux sexcs.) - Scras. Synon. Ins, tom. 3. pug. 272. $n^{\circ}$. 31. Du Brésil.

$$
\text { (S. F. et A. Serv.) }
$$

TAXICORNES, Taxicornes. Seconde famille de la prenicère division de la section des Hétéromères, ordre des Coléoptc̀res. M. Latreille lui attribue les caractìres suivans:

Mandzbules bifides à leur extrémité. - Articles des tarses entiers, les quatre antérieurs au plus exceplés. - Mâchoires dépourvues d'ongllet corné au côté interne. - Corps souvent ailé. - Antennes ordinairement insérées sous les bords latéraux et avancés de la tête, de la longueur au plus de la tête et du corselet, allant en grossissant ou se terminaut en massue, perfoliées en tout ou en partie dins la plupart.

Cette famille eontient trois tribus.

$$
\mathbf{1}^{\text {re }} \text { Tribu. Diapériales, Diaperiales. }
$$

Antennes ordinairement plus ou moins perfoliées, allant en grossissant ou sc terminant par une petitc massue. - Côtés du corselet et des élytres ne débordant point notablement le eorps.

Plıalérie, Chélénode, Diapère, Pentaphylle, Hypophlée, Elédone, Coxèle, Hallomène, Eustrophe.

\section{$2^{\mathrm{e}}$. Tribu. Cossyphènes, Cossyphenes.}

Corps très-aplati, clypéiforme, débordé latéralement par les côtés du corselet el des ély!res (1). - Tête cachéc sous le corselet ou reçue dans une entaillc profonde de son extrémité antérieure.

Hélée, Cossyphe.

\section{3e. Tribu. Crassieornes, Crassicornes.}

Antennes terminćes brusquement en une grande massue, soit entièrement perfoliée, soit eomprimée et plus ou moins en scie an côté interne.

I. Jambes latéralennent épineuses.

Trachyscèle, Léiode.

II. Jarnbes sans épines latérales.

Orchésie, Tét:atome, Cnodalon.

Les Tuxicomes sont ailés; la plupart d'entr'eux habilent dans les champignons, les autres sous les écorces ou à tcrre.

Nota. Cet arlicle est exprail des Fam. nat. de M. Latreille. Le genre Proslène qui dans cet ouvrage fait partie de la tribu des Crassicornes, doil être reporté il la tribu des Cistélides, fanille des Sténélytres. ( S. F. et A. SERV.)

TECTIPENNES ou STEG OPTERES. C'est ainsi que M. Duméril nomme une famille de Névroplères ( $Z$ oolog. analyt.), à laquclle il donue los caractères suivans: Bouche découverte; ses parties très-distinctes. Elle contient neuf genres: Fournilion, Asealaphe, Termite, Psoque. Hémérobe, Panorpe, Raphidie, Semblide et Perle.

(S. F. et A. Serv.)

(1) Ce caractèc particulier distingue cerie tribu de tous les autres liftéromères. 


\section{T E F}

TÉfflus, Tefflus. Léach. Dej. Lat. (Fam. nat.) Carabus. Fa B.

Genre d'insectes de l'ordre des Coléoptères, section des Pentamères, famille des Carnassiers, tribu des Caraliques (division des Abdominaux).

Cette division a pour caractères, d'après M. Latreille : palpes extérieurs point terminés en alêne; côté interne des deux jambes antérienres saus échancrure ou en ayant une en forme de canal oblique, linéaire et ne s'avançant pas ou presque pas sur la face antérieure de la jambe. Cette division se partage ainsi :

I. Côtó interne des mandibules entièrement on presqu'eutièrement denté dans tonte sa longueur.

A. Elytres carénées latéralement et embrassant les côtés de l'abdomen.

Cychre, Sphérodère, Scaphinote.

B. Elytres point carénées, n’embrassant pas l'abdomen.

Pambore.

II. Mandibules sans dents notables ou n'en offrant qu'à leur base.

A. Tous les tarses semblables dans les deux sexes.

Téfllus, Procère.

B. Tarses antérieurs dilatés dans les mâles.

a. Labre bilobé on trilobé.

Procruste, Carabe, Calosome.

b. Labre entier.

† Antennes grêles et alongées.

Pogonophore (Léisías. Lat. Fam. nat.), Nébrie, Omophron.

†† Antennes assez épaisses et courtes.

* Dernier arlicle des palpes alongé, obconirque.

Bléthise, Elaphre.

* Dernier article des palpes court, presque renflé.

Notiophile.

Un gronpe de Carabiques-Abdominaux renferme les genres Té[1] dans le tableau ci-dessus, mais le second de ces genres diffère du premier par son labre bilobé.

Ce grene établi par M. Léach a été carantérisé par M. le comte Dejean (Spcciès tom. 2) de lii manière suivante.

Antennes filifurmes, plus courtes que la moitié di corps. - Labre entier, presque coupé carrément et même un pers avancé dans son milieu. Mandibules légèrement arquées, ai Ђuës, lisses, non dêntées intérieuremen!. - Palpes très-sail- lans, leur dernier article très - forlement sécuriforme, alongé, presqu'ovale et un peu concave en dessus. - Menton très - fortement échancré, ayant une dent simple et peu saillante au milieu de son échancrure. - Corselet presqu'héxagonal. - Elytres très - grandes, convexes, en ovalealongé, soudées ensemble, couvrant l'abdomen. - Pointd'ailes. - Pattes grandes, fortes; échancrure qui termine en dessous les jambes antérieures un peu oblique, remontant un peu sur le côté interne; tarses antérieurs presque semblables dans les deux sexes, les deux premiers articles paroissant cependant très-légèrement dilatés dans les mâles.

Le type de ce genre est le Téfflus de Mégerle, T. Megerlei. Ues. Spec. tom. 2. Carabus Hieyerlei $\mathrm{n}^{\circ}$. 5. Fab. Syst. Eleut. De Guinée.

PROCÉRE, Procerus. NÉg. Des. LAt. ( Fam. nat.) Carabus. Fab. Oli. Bonele.

Genre d'insectes de l'ordre des Coléoptères, section des Pentamères, famille des Carnassiers, tribu des Carabiques (division des Abdominaux).

I.es 'Téftlus et les Procères forment un petit groupe dans celte division. (Voyez le tablea ciconıre.) Les Téfflus diffèrent des Procères par leur labre entier.

M. Múgerle a créé ce grenre, et $\mathbb{B}$. le comte Dejear, clans le tome 2 de son Spéciès, en a posé les caractères ainsi qu'il suit :

Antennes filifurmes. - Labre bilobé. - Mandihules légèrement arquées, trèsaiguës, lisses et "'syant qu'une dent à leur base. - Palpes ayant leur deraier article très-fortement sécuriforme et visiblemeot dilaté dans les mâles. - Menton écliancré, portant dans le milieu de cette échancrure une très-forte dent. - Corselet presque cordifurme. - Elytres en ovale - alongé, soudées ensemble. - Point d'ailes. - Tarses semblables dans les deux sexes. Les autres caractères comme daus le genre Carabe. (Voyez ce not à la table alphabćtique.)

Le nom générique de ces insectes, tiré de la langue latine, exprime qu’ils sont de très-grande taille. Les Procères paroissent cantounés dins lez forêts et les montagnes de la Russie méridionale, de l'Asie mineure et dans celles qui sont au nord de lil Grèce et de l'Italie.

On doil rapporter à ce genre : 10. Procère d'Olivier, P. Clivieri. Des. Spec. tom. 2. - Carahe scabreux no. 6. uta présent Dictionnaire. pl. 17fi. fig. 6. $2^{\circ}$. Procère scalire, $P$. scabrosas. DEJ, it.

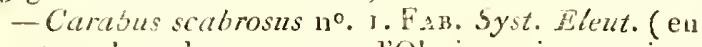
retranclaant le synonyme d'Olivier qui appartient i l'espèce précédente.) De Carniole. 3ॅ. Procère de Tunride, P. Tauricus. Des. id. - Carabus Tauricus. Pale. De Tauride. $4^{\circ}$. Procè̀e du Caucase, P. Caucasicus. Des, $i d$. Du Caracase.

Nota. M. Schonherr (Synon. Insec. tom. I. $A$ ㄴำ 2 
pag. 167.) considc̀re le Carabus scabrosus d'Olivier comme étant la même espèce que le Carabus Tauricus de Pallas, et n'en fait qu'une simple variété du Carabus scabrosus de Fabricius.

\section{(S. F. et A. Serv.)}

'TEIGNE, Tinea. Phalcena. (Tinea.) Linn. De Géer. Tínea. Geoff. Fab. Scop. Ross. Panz. Senranck. Hub. Alucita. Oliv. (Encycl.) phycis, Alucita. Fs

Genre d'insectes de l'ordre des Lépidoptères, famille des Nocturnes, tribu des Tinéites.

Cette tribu renferme sept genres parmi lesquels les Adèles se distinguent des Teignes par leurs antennes presque contiguës ainsi que leurs yeux; les Lithosies, les Yponomeutes et les (Ecophores par leur langue (spiritrompe LAT.) très-distincte et alongée; enfin les Euplocampes et les Phycis par leur's palpes labiaux grands et avancés.

La partie de l'Entomoígie qui traite des Lépidoptères nocturnes et particulièrement des Tinéites nous paroissant être encore très-peu approfondie, et la nalure du présent Dictionnaire ne nous permettant guère d'émettre de nouvelles ilées sur un sujet qui ne sauroit être traité sans de grands développemens, nous nous bornerons à rapporter ici les caractères du genre Teigne tel qu'il est indiqué par M. Latreille dans le Genera Crustaceorum et Insectorum. Nous devous ajouter que ce savant semble avoir restreint ce genre aux espèces que Réaumur appelle fausses Teignes, c'est-à-dire Teignes dont les Chenilles ne transporten prolongrent en forme de galerie à niesure qu'elles étendent leurs ravages.

Quatre palpes distincts; les supérieurs surtout très-petits, courbés, paroissant articulés. - Langue très-courte, composée de deux filamens distincts. - Ailes supérieures très-rétrécies, s'appliquant dans le repos sur les côtés de la partie supérieure du corps et formant un toit arroudi.

Les mœu rs des Teignes sont connues de tout le monde; nous renverrons les lecteurs qui seroient curieux d'en counoître les détails aux Mémoires de Réaumur (vol. 3. Mém. 2 et suivans), qui sont analysés dans le discours préliminaire du présent Dictionnaire pag. CCIX et suivantes, ainsi qu'à l'article Alucite, pour ce qui concerne la 'Teigne granelle.

1. Teigne granelle, $T$. granella.

Alucita granella. F.1в. Entom. Syst. tom. 3. part. 2. pag. 354 . $n^{\text {ग }}$. 15.

Voyez ponr la description et les antres synonymes Alucite granelle $n^{\circ}$. 14. de ce Dictionnaire.

Rapportez ì ce genre: $1^{\circ}$. Teigne des pellete- ries, T. peilionella $\mathrm{n}^{\circ} \cdot 7^{3}$. FAB. id. $2^{\circ}$. Tëigne front jaune, $T$. flavifrontella $\mathbf{n}^{\circ} \cdot 78 . \mathrm{F}_{\mathrm{AB}} . i d$.

(S. F. et A. SERv.)

TÉLÉADE, Teleas. LAT.

Genre d'insectes de l'ordre des Hyménoptères, section des Térébrans, famille des Pupivores, tribu des Oxyures.

Un groupe de cette tribu (vayez Oxyures, pag. 252. de ce volume) contient les genres Platygastre, Téléade, Scélion et Sparasion; il a pour caractères : antennes condées, insérées près de la bouche, celles des femelles plus grosses à leur extrémité; segnent antérieur du corselet (prothorax) court, transversal. Le premier de ces genres se distingue en ce que ses ailes n'ont pas de cellnle radiale et que les antennes sont composées de dix articles, ce dernier caractère se retrouve dans les Scélions. Les Sparasions sont reconnoissables à leurs palpes maxillaires saillans.

Antennes insérées près de la bouche, composées de douze articles dans les deux sexes; alongées et filifiormes dans les mâles; courtes dans les femelles et subitement terminées en massue. - Mandibules bidentées à leur extrémité. - Palpes maxillaires point saillaus, ayant au moins trois articles: palpes labiaux n'en ayant que deux. - Tête transversale, un peu aplatie en devant.Ailes fortement frangées à leur bord, les supérieures ayant une seule nervure, descendant de la base le long du bord de l'aile jusqu'un peu passé le milieu, et là, en s'écartant de ce bord, elle commence une cellule radiale qui reste incomplète. - Abdomen en spatule, peu convexe; son troisième segment beaucoup plus grand qu'ancun des autres : tarière (des femelles) rétractile.-Cuisses en massue.

Les maurs de ces petits Hyménoptères ont échappé jusqu'ici à l'observation. Le type de ce genre est l'espèce suivante.

\section{Téléade clavicorne, $T$. clavicomis.}

Niger, abdominis levis pediculo striato, tibiarum basi et apice piceis : alis opaco-hyalinis.

Toleas clavicornis. Lat. Gener. Crust. et Ins. tom. 4. pag. 33. tom. 1. tab. 12. fig. 9 et 10. Le mâle sous le nom de Scelio longicornis. fig. II et 12. Lil femelle sous celui de Scelio muosulus.

Longuetr a lig. $\frac{5}{4}$. Noir, brillant, pointillé. Abdomen lisse, son pédicule strié ; base el extrémité des jambes de couleur de poix. Premiers articles des tarses de cette dernière couleur. Ailes blanches, mais sans transparence. Pattes postérieures de la fenclle assez fortes; leurs cuisses en massue grosse et dentelées en dessous.

Des environs de Paris.

(S. F. et A. SERT.) 
TÉLÉPHORE, Telephorus. Schaff. De GéER. Oriv. (Entom.) Lat. Cantharis Linn. Fab. Thunb. Payk. Gyll. Falièn. Schen. Illig. Panz. Cicindela. Geoff.

Genre d'inseetes de l'ordre des Coléoptères, seetion des Pentamères, famille des Serricornes (division des Malacodermes), tribu des Lampyrides.

Le second gronpe de celte tribu (voye $z$ LamPYRIDEs, pag. 426 . de ee volume) renferme les genres Drile, Téléphore et Malihine. Dans le premier les antennes des femelles sont courtes, ziatteignant pas la longueur de la tête et du corselet pris ensemble, et les mâles les ont fortement peetinées d'un seul côté. Le dernier article des palpes des Malthines est ovale-pointu, et les élytres de ces insectes sont plus courtes que l'abdomen.

Antennes filiformes, distantes à leur base, presque de la longueur du corps, composées de onze articles, le premier alongé, un peu renflé à l'extrémité; le seeond court, les autres presqu'égaux entr'eux, un peu eoniques. - Labre coriace, arrondi, un peu cilié antérieurement.Mandibules minees, longues, arquées, simples, très-pointues au bout. - Mấchoires membraneuses, arrondies, bifides, leurs divisions égalcs, rapproehées, pen distinctes. - Palpes maxillaires un peu plus longs que les labiaux, de quatre articles, le premier petit, les deux suivans coniques, le quatrième large, comprimé, sécuriforme: palpes labiaux de trois articles, les deux premiers presqu'égaux, couiques; le troisième grand, comprimé, sécuriforme. - Lèvre courte, coriace, tronquuée, légèremcnt écliancrée à sat partie antérieure. - Téte avaneée, un peu aplatie, ordinairement penchée. - Yeux arrondis, très-saillans. - Corps long, souvent presque linéaire, mou, un peu déprimć. - Corselet rebordé, ordinairement de la largenr de la têle, de forme presque carrée, ses angles antérieurs le plus souvent fort arroudis. - Ectusson petit, triangulaire. - Elytres molles, très-flexibles, de la longueur de l'abdomen, linéaires, reconviant des ailes. - Abdomen déprimé. - Pattes de longueur moyenne, leur trochanter saillant; les trois premiers articles des tarses allant en diminuant de grandeur, le qualrième assez large, bilobé; le dernier un peu arqué, terminé par deux crochets.

'Tóléphore, dérivé de deux mols grecs, signifie: porte mort. Le nom de ces Colćoptères vient sans doute de l'habitude qu'ils ont de dévorer des insectes vivans. Les larves ont la tête éeailleuse, plate, munie de deux forles maudibules placées à sa partie antérieure; deux antennes courtes, composées de deux articles un pen velus, le premier plus court que l'autre; quatre palpes articulés, un peu velus, terminés en pointe, insérés sur la lèvre, laquelle est mobile et peul se porter très en avant, et se rctirer ensuite dans sa cavité; c'est par ce uouvement que peadant la marche cette larve porte ses palpes sur les objets qu'elle rencontre : aux trois premiers segmens du corps sont allachées trois paires de pattes assez longues, de consistance écailleuse, divisées en trois articles et terminées par un crochet légèrement courbé; les segmens du corps out quelques rides transversales sur les eôtés, le dernier porte en dessous l'anus qui a une espèce de rebord un peu élevé de manière à former un mamelon; on lui voit un enfoneement au milieu. Quand la larve marche elle applique à chaque pas ce mamelon contre le plan de position et s'cn sert comme d'une septième patte. Ces larves se plaisent dans la terre humide; elles sont carnassières, se nomrrissent de vers et au besoin d'individus de leur propre espèce, suivant les observations de De Géer. Cet anteur a en occasion d'observer que la lárve du Téléphore ardoisé, parvenue vers la fin du mois de mai à toute sa grandeur, a environ un pouce de long et à peine deux lignes de large. Elle se change en nymphe dans la terre sans faire de coque; celte nymphe est longue d'à peu près six lignes; son corps nn peu conrbé en arc est de couleur rouggeâtre pâle; on distingue très-netteinent tontes les parties qu'aura l'insecte parfait. L'abdomen que la nymiphe remue assez facilement se termine par deux petites poinles. Au mois de juin elle quitte sa peau et paroît en insecte parfait. On trouve dans certains auteurs des relalions d'après lesquelles des vers et des insectes se seroient trouvés inêlés avec de la neige el tombés à terre avec elle. De Géer a été en quelque sorte témoin d'un scmblable fait: il apercut une fois daus de la neige une grande quantilé d'insectes et de vers, et parmi enx des larves de Télépliores ; la terre étant alors gelée de plus de trois pieds de profondeur, il étoit impossible de croire que ces insectes en fussent remontés dans cetle neige; il çut avoir remitrqué que ces fait's n'arrivent jamais que lorsque des ouragars en répandant la neige sur lat terre ont déraciné dans les forêts un griand nombre d'arbres, ct ont pu transporter avec eux me wasse de terre et les insectes qu'elle contenoit.

Les 'Céléphores dans leur dernier état se plaisent sur les fleurs; on les y voil ordinairement sucer le miel; mais leur manière d'agir n'est pas toujours aussi innocente; on les surprend sonvent silisissant et mangeant avec avidilé d'aulres insectes. Les femelles mêmes n'épargnent pas toujours les mâles. De Géer a ćtć tćmoin de cet appétit carnassier. Feu Olivier, dans son Entonologie, paroît en donler, mais nous avons eu fréquemment la preuve du fait cité par l'auteur suédois.

$\mathrm{I}^{\mathrm{re}}$. Division. Corps ovale.

Nons plaçons ici : $\mathbf{I}^{\circ}$. Téléphore flavipc̀de, $T$. flasipes. OLir Entom. tom. 2. Téléph. pag. 10. $n^{\circ} \cdot 7 \cdot \mu l .5$. fig. 18. - Cantharis fluvipes $\mathrm{n}^{\circ} .30$. Fub. Syst. Elcui. De la Chine? $2^{\circ}$. 'Téléphore 
trompeur, T. fallax. Germ. Insect. nov. spec. Du Brésil, et en outre quelques autres espèees du même pays.

$2^{e}$. Division. Corps along’é, presque linćaire.

Cetle division renferme: $1^{\circ}$. Téléphore ardoisé, T. füsculs. Onuv. Entom. tom. 2. Téléph. pag. 6. $n^{\circ}$. I. pl. 1. fig. 1. - Cantharis finsca $\mathrm{n}^{\circ}$. I. HAB. Syst. Eleut. 'Tris-commun au printemps aux envirous de Paris. Il a des viriétés que différens aulenrs regardent même comme tes espèces sous le nom de Canch. antica et rustica. $2^{\circ}$. Téléphore disparale, $T$. dispat:-Cantharis dispar $n^{\circ} .3$. FA. $i d$. - Cicindèle à corselet rouge, var. b. Geore. insect. Paris. tom. 1. pag. 17I. no. 2. Cet auteur ayant vu cette espèce acconplée avec te 'Téléphore livide, les at reuardés, probablement avec raison, comme une seule espèce. 3o. 'Téléphore livide, 'l'. lividus. Osıv. id. pag. 7. $n^{\circ} .2$. pl. 2. fig. 8. - Cantharis livida $\mathrm{n}^{\circ}$. 2. FAB. id. irrès-commun anx environs de Paris. $4^{\circ}$. Téléphore noirâtre, T. nigricans. - Contharis rigricans $n^{\circ}$. 9. F'ав. id. Y'Lurope. 5o. 'Téléphore l'uce,

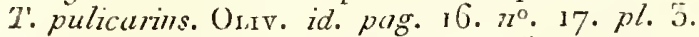
fig. 20. - Cantharis pulicaria $n^{\circ}$. 5o. $\mathrm{F}_{\mathrm{AD}}$. $i d$. Puris. $6^{\circ}$. Téléphore abdominal, T. abdominalıs. - Cantharis abdominalis $\mathrm{n}^{\circ}$. 4. LAB. id. D'Italie et des montagnes de l'Auvergnc. $7^{\circ}$. T'éléphore mélanure, T. nuelanzirns. Oniv. id. pag. 7. $n^{\circ} .4$. pl.5. fig. 21. - Cantharis melanuru ñ ${ }^{\circ}$ 43. FAB. id. Commun aux environs de Paris. $8^{\circ}$. Túléphore fuscicome, T. fuscicornis. Oniv. id.pog. $11.77^{\circ} \cdot 9$. pl. I.fig. 4.-Cantharis fuscicomis. Scnes. Syn.

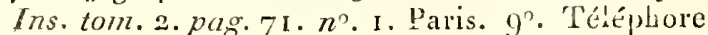
pầie, T. pallidus. Osiv. pag. 14. no, 14. pl. 2. fo. 9. - Cantharis pallida no. 27. Fab. id. M. Schonherr regarde conme une simple variété de cetle espèce le 'I'éléphore pallipède, T. pallipes. Oliv. id. $n^{\circ}$. 13. pl. 1. fig. 5. - Cantharis pallipes no. 24. Far. id. Paris. $10^{\circ}$. Téléphore testaeé, T. testaceus. Or,rv. id. pag. 12. no. 11. pl. 3. fig. 19. - Contharis testacea no. 52. Des eurirons de Paric.

Rapportez en outre à ce genre : $1^{\circ}$. Téléphore anal, T. analis. - Cantharis analis $\mathrm{n}^{\circ} .5$. l' $\mathrm{\text {в.Syst. }}$ Eleut. De Hongrie. $2^{\circ}$. 'Téléphore érnéraude, T'. smaragdulus. OLrv. Entom. tom. 2. Téléph.pag.9. $n^{\circ}$. 6. pl. 2. $f_{S}$. 13. - Cantharis smaragduia $n^{\circ}$. I5. F AB. $i d$. Du Brésil. M. Schøuherr regarde comme même espèce la Cantharis viridescens no. b. Fав. id. 3’. Téléphore obscur, $T$. obscurzes. ... Cantharis obscura n”. 7. Fав. $i d$. Des environs de Paris. $4^{\circ}$. Téléphore de Caroline, $T$. carolinus. - Cantharis carolina no. 8. F $\mathrm{AB}$. id. De Caroline. $5^{\circ}$. Téléphore transparent, $T$. pellucidus. Cantharis pellucida no. 10. FAB. id. D'Allemagne. $6^{\circ}$. T'éléphore ruficorne, T. nuficornis. - Cantharis mficornis no. 11. Fав. id. De Sumatra. $7^{\circ}$. 'Téléphore bordé, T. limbatus. - Cantharis lmbata 120. 12. Fab. id. De la Jamaịque. 80. Téléphore rougeâtre, T. rubens. - Cantharis rubèns no. 13 . Fab. $i d$. D'Allemagne. $9^{\circ}$. 'Téléphore latéral, 7 '. lateralis. - Cantharis lateralis no. 14. $\mathrm{F}_{\mathrm{AB}}$. id. Des environs de Paris. Cette espèce est distinete dı Telephorus lateralis d'Olivier, suivant M. Schoenherr. IO'. 'Téléphore triste, T. tristis. Cantharis tristis no. 16. $\mathrm{FAB}_{\mathrm{AB}} i d$. Des Alpes. $11^{\circ}$. 'Téléphore lugubre, T. lugnbris. - Cantharis lugubbris no. 17. F'AB. id. D'Amboine. 120. 'Téléphore âtre, T. ater. - Cantharis atra no. 18. Fas. $i d$. Da nord de l'Europe. M. le eomte Dejean pense que le Telephorns ater d'Olivier est une espèce différérute de celle-si ; elle est décrite par M. Gyllenhall sous le nom de Cantharis paladosa. i5'. 'T'éléphore marginé, T. marginatus. - Cantharis marginata no. I9. FAB. id. D’Amérique. $14^{\circ}$. 'Téléphore hrmnicolle, T. brunicollis. - Cantharis brunicollis n०. 20. NАВ. id. De Caruline. 15 ". 'Téléphore llavicolle, T. flavicollis. - Cantharis flavicollis no. 2 1 . Fав. id. De Sumatra. $16^{\circ}$. 'T'éléphore diadème, $T$. diadena.Cantharis diadema n $^{\circ} 22$. FАв. id. Amérique seprentrionale. $17^{\circ}$. Téléphore binaculé, T: bimaculatus. Unir. $i d$. pag. I I. $n^{\circ}$. 8. pl. 2. fig. I I.

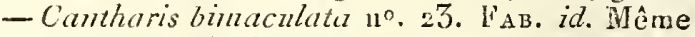
patrie. 18". 'Téléphore bartharesque, T'. barbarns. - Cantharis barbara no. 25. HAв. id. De Barbarie. $19^{n}$. 'T'éléphore hémorriölal, I'. hacenorhoidalis. - Cantharis homorrhoidalis $\mathrm{n}^{\circ} .26$. F $\mathrm{AB}$. id. 1)Allernagne. 200. 'Téléphore rulieolle, T. ruficollis. - Cantharis ruficollis $\mathrm{n}^{\circ} .28$. FАв. id. D'Angleterre. $21^{\circ}$. 'l'b́léphorc nirripenne, T. $n i$ gripemis. -Cantharis nigripennis ॥ $^{\circ}$. 29. FА . 26́. Amérique méridionale. 220. 'Téléphore nélanocéphale, T. melanocephalus. Osiv. id. pag. 9. 12.5. pl. 2. fig. 7. - Cantharis melanocephalo $n^{\circ}$. 31. FAs. id. Coromanùcl. $25^{\circ}$. 'T'éléphore niparti, T. dimidiatus, - Canthatis dimidiata n". 32. If Ar. id. Ile de Ceylan. $24^{\circ}$. 'Téléphorc biponctué, T. bipunctatus. Oniv. id. pag. I5. $n^{\circ}$. 16. pl. 2. fig. 16. - Cantharis bipunctala n". 33. IA A. id. D'Alleragne. 250. Téléphore gai, T. lartus.

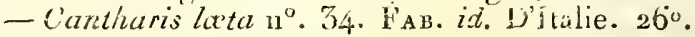
T'éléphore fulvicolle, T. fulvicollis. - Canthuris fulvicollis $\mathrm{D}^{\circ} .35$. FAB. $i d$. (retrinchez d'apres M. Sctoenherr les syonyme d'Olivier.) D'Allemague. $27^{\circ}$. 'l'éléphore linéolé, T'. lineola. - Cantharis lineola no. 56 . FAB. id. Indes orientales. 28\%. T\%léphose double raie, $T$. bivittotas. - Cantharis bivittata $\mathrm{1}^{2}$. 40. WАв. id. Cap de Bonne-Espérance. $29^{\circ}$. 'Téléphore longicorne, $T$ '. longicomis. Cantharis longicomis $\mathrm{n}^{\circ}$. 4I. FАв. zd. Amérique méridionale. 50 ${ }^{\circ}$. Téléphore pectoral, $T$. pectoralis. - Cantharis pectoralis $n^{\circ}$. 44. FАв. id. De Sumatra. 310. 'Téléphore uilidule, $T$. nitidulus. - Cantharis mididula no. 46. FA . id. D'Allemayue, $52^{\circ}$. Téléphore linéé, $T$. lineatus. -

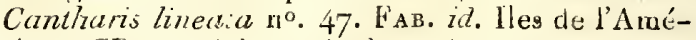
rique. $53^{\circ}$. 'T'éléphore bicolor, 'I'. bicolor. - Cantharts bicolor $\mathrm{n}^{\mathrm{O}}$. 48. Faв. id. De Danemarck. 
Nota. Il nous paroît douteux que les Cantharis abbreviata $\mathrm{n}^{\circ} .37$, brevipennis $\mathrm{n}^{\circ} .38$, et manca no. 3g. FAB. Syst. Eleut. soient de ce genre, leurs ély tres élant raccourcies. Suivant M. Schœnherr, la Cantharis nigripes no. 42. FAB. id. est l'(Edémère notée $n^{\circ}$. 12. du présent Dictionnaire, espèce différente de la Necydalis notata $\mathrm{n}^{\circ}$. I 8. $F_{A B}$. $i d$. qu'Olivier lui donne à tort pour synonyme, tandis que c'est un double emploi du Crioceris adusta no. 56. FAB. Syst. Eleut. La Cantlaris vittata $\mathrm{n}^{\circ}$. 45. $\mathrm{F}_{\mathrm{AB}}$. id est probablement aussi une Edémère. Ia Cantharis nigra no ${ }^{\circ} 49 . \mathrm{F}_{\mathrm{AB}}$. id. appartient au genre Dasyle. Les Cantluaris minima $\mathrm{n}^{\circ} .5 \mathrm{r}$. el biguttata $\mathrm{n}^{\circ}$. 53. sont des Malthines; enfin la Cantharis cardiaca n ${ }^{\circ} .54$. est le mâle du Malachie pédiculaire $\mathrm{n}^{\circ}$. 3. de ce Dictionnaire.

M. Schœnherr cite comme appartenant encore à ce genre : $1^{\circ}$. 'Téléphore conronné, T. coroñatus. - Cantharis coronata. GyLi. Scues. Syn. Ins. tom. 2. pag. 62. $n^{\circ}$. 5. Portugal. $2^{\circ}$. Téléphore à manteau, T. palliatus. - Cantharis palliata. Gyzr. Schen. id. pag. 63. no. 6. D'Espagne. 30. Téléphore roux, T. nufus. - Cuntharis rufa. Itlitg. Gyle. Fale. Schon. id. $n^{\circ} \cdot 8 \cdot 4^{\circ}$. T'éléphore lituré, T. lituratus. - Cantharis litnrata. Fald. Gyll. Schen. id. no. 9. 50. 'Téléplore velu, T. pilosus.-Cantharis piiosa. PAYк. FaLd. Schen, id. $n^{\circ}$. 10. $6^{\circ}$. Téléphore al pin, T. alpinus. - Cantharis alpina. l'Ayк. GyLi. Schan. id. $\pi^{\circ}$. I I. $7^{\circ}$. Téléphore violet, T. violaceus. cantharis violacea. PАyк. Grul. Scuen. id. pag. 64. $n^{\circ}$. 13. 8o. Téléphore flavipenne, $T$. flavipennis. - Cantharis flavipennis. WVЁв. Schen. id. pag. 65. $n^{\circ}$. 20. $9^{\circ}$. 'Téléphore argenté, T. argenteus. - Cantharis argentea. Thunb. Schan. id. pag. 66. $n^{\circ}$. 24. $10^{\circ}$. 'Téléphore ćchancré, T. enarginatus. - Cantharis emarginata. Gru. Schen, id. $n^{\circ} .26$. n $1^{\circ}$. 'T'éléphore alongé, 'T'. elongatus. - C'antharis elongata. Fall. Grul. Schđs. id. no . 29. $12^{\circ}$. 'Télé- phore des marais, $T$. paludosus. - Cantharis paludosa. Fali. Gyle. Schen. id. pag. 67. no 30. 130 . Téléphore flavilabre, 'T' flavilabris.-Can-

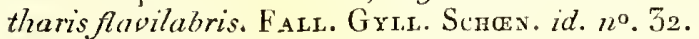
140. 'Téléphore thoracique, T. thoracicus. Otiv. Enton. toni. 2. Téléph. pag. 12. $n^{\circ}$. I 0. $7 \%$ I. fig. 2. - Cantharis thoracica. Grue. Scroen. id. $n^{\circ}$. 34. D’Europe. ${ }^{\circ} 5^{\circ}$. Téléplıore à deux lignes, T. bilineatus. - Cantharis bilineata. Tичмв. Scran. id. pag. 7o. $n^{\circ}$. 55. $16^{\circ}$. Téléptare it trois lignes, T. triluneatus. - Cantharis trilineata. Traunb. Scran. id. $n^{\circ}$. 56. $17^{\circ}$. T'éléphore enfu ı é, T. filmosus.-Cantharis. fumosa. Swartz. Schan. id. $n^{\circ}$. 58. i $8^{\circ}$. Téléplore de Marsbam, T. Marshani. - Cantharis flavicollis. $\mathrm{M}_{\mathrm{A} \mathrm{kH}}$. Schen. id. pag. 71. $n^{\circ}$. 62. 19 ${ }^{\circ}$. 'Téléphore à bouclier, T. clypeatas. - Cantharis clypeata.

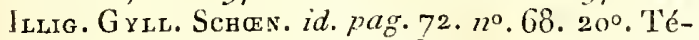
léphore anguleux, T. angulatus. - Cantharis angulata. Grul. Scher. id. $n^{\circ} \cdot 70.21^{\circ}$. Téléphore douteux, T. dubius. - Cantharis dubia. GyLI. Schas. id. $n^{\circ} \cdot 7^{1} \cdot 22^{\circ}$ : 'Téléphore semblable, $T$. assimilis. - Cuntharis assimilis. GYLL. FALL. Schesn. id. pag. $63 . n^{\circ} .8$.

DRILE, Drilus. Oruv. Lat. Désm. Patilinus. Geoff. Fab. Cochleoctonis. Mielz.

Feu Olivier créa ce genre dans son Entomologie et en donna aussi les développemens dans I'Encyclopédie (voyez DriLE) de la manière dont il étoil possible de le faire à une époque où l'on ne connoissoit que l'un des sexes, sans soupçonner gne la femelle de la seule espèce alors connue fút excessivement différente de son inâle. La première connoissance que l'on a eue de celle-ci est due à M. le comte Jgnace Mielzinsky, qui, dans un Mémoire inséré dans les Annales des sciences naturelles de janvier 1824 , décrivit cette femelle ainsi gue sa larve; celle-ci est jaunâtre, de huit à neuf lignes de longueur sur quatre à cinç de largeur. Elle offre les caractères suivans: mandibules très-forles, bifides. Anlennes brunes, de deux articles supportés par une espèce de prolongement membraneux et blanchâtre de la partie supérieure de la tête; qualre palpes, les deux externes légèrement élürgis, très-nobiles; les deux internes plus minces, moins susceptibles de mouvemens. Corps divisé en douze segmens; les trois antérieurs portant chacun une paire de patles bien conformées; les huit suivans ayant chacun une paire de fausses paites; sur le dos de ces segmens on voit deux liouppes de poils de claque côté, posées sur des espèces de namelons; le douzième scgment porte deux honppes de poils terminales plus grosses que toutes les autres, et l'anus qui forme une sorte de pied rétractile; entre les houp. pes de poils du côlé du corps se tronve une rangée de points saillans, glandulenx, ncirâtres. Vers le mois de septembre cette larve, aprc̀s avoir pris tciut son accroissement, reste dans un ćlat d'engourdissement complet; c'cst eu cel éfat que $\lambda$. Desmarest, professeur à l'Ecole vélérinaire d'Alfort, l'a observé; il a rcmarqué que N]. Mielzinsky s'élnit trompé en prenant cet élat d'immobilités qui est précédé d'un cliangement de peau pour l'état de nymphe, tandis ciu'il est tolalement dú an froid, puisçue MI. Desmarest, en réchauffant suffisamment cette larve, lui a donné les moyens de se remeltre en monvenient : ce dernier observaleur a remarqué qu'à celle époque les pattes sont très-courtes, conigues, composées de trois arliculations qui lui ont paru représenter la cuisse, la jambe elle tarse; les antennes dirigées eu avant aiusi que les palpes, étoient excessivement courtes et ne présentuient que deux ou trois divisions à peine distinctes; les yeux n'étoient pas apparens, et les côtés des segrnens du corps avoient des iubercules couronnés de quelques poils; de semblables tubercules formoient sur le dos, de 
chaque côté et en dedans de la ligne des stigmates, une série pareille. Après être resté dans cet état jusqu'au mois de mai, la larve passa à celui de nymphe sans presque changer de longueur ni de largeur; la nymphe a le corps mou, épais, arqué en dessous, composé de douze segrmens, outre la lête, dont les septic̀me, huitième et neuvième sont les plus volumineux; elle est d'un blauc-jaunâtre, lisse, assez luisante sur le dos, totalement dépourvae dc poils et de soies. Sa tête est petite, rabattue, avec deux légères impressions longitudinales sur le front; son chaperon est ar'rondi; au-delà paroissent trois petits corps saillans dont l'internédiairc peut bien êire le labre et les latéraux des mandibules : au-dessous de ceux-ci sont les palpes gros, coniques, envcloppés d'une peau comnune qui laisse néanmoins voir la division de chacun, en quatre articles pour les maxillaires, cn trois pour les labiaux; les antenwes presque du double de longueur de la tête ont leur insertion près du chaperon, leur forme est cylindrique, diminuant peu de grosseur de la base au sommet; clles offrent huit articles dont le premier est le plus grand; elles sont dirigées obliquement et latéralement en arrière. Les yeux sout indiqués par deux petites taches d'un gris-brua, placées derric̀re la base des antennes, d'une forme ovale-transverse. Le preuier segment après la têle est, à l'exception de l'anus, le plus petit de cenx qui composent le corps, il est transverse, sans rebords, à angles arrondis, le bord antérieur échan. cré pour recevoir la tête, le bord postérieur droit; les second et troisième serrmens vont en alugrueutant de longueur et sont légèrement bombés de chaque côté, ces trois segmens portcnt chacun nne paire de paltes; le second seul a un stigmate: les pattes sont plus longues que dans la larve; les segmens suivans augmentent de longueur et de largeur jusques et $\mathrm{y}$ compris le neuvième; chacun d'eux porte un tubercule latéral, lisse, fort saillant, et un léger renflement qui est le vestige des unbercules velus de la larve. Depuis le qualrième jusques et compris le dixième segment on aperçoit des stigmates qui sont comme des points grisîtres, relevés, un peu tubuleux, placés au - dessus des tubercnles latéraux; le onzième seginent plus petil que le dixic̀me, à peu près de la même forme, a ses tubercules latéraux moins saillans et n'a point de stigmates non plus que le douzième ou segment anal qui est le plus pelit de tous et porte cn dessous l'anus et un tubercule bilobé, ou plutôt est termivé par denx pointes mousses. Tonte la surface inféricure du corps est lisse et a tout au plas quelques plis ou rides vers la base des tubercules latéraux.

Cette nymphe reste dans un état parfait d'immobilité, elle jette sealement lorsqu'on la touche une gonttelette de liqueur jaunâtre assez ćpaisse et transparente. Lorsque l'état de la science n'en étoit encore qu'à ce point, M. Mielzinsky plaçoit cet insecte dans un noureau genre, près des Lam. pyres, sous le nom de Cochléoctone, Cochleoctonus. M. Latreille le croyoit voisin des Malachies, et M. Desmarest le rapprochoit des Téléphores; mais ce dernier anteur continuant ses intéressantes observations parvint à obtenir cet insecte à l'état parfait, et le vit accouplé comme femelle avec le Drile jaunâtre éclos aussi cbez lui. Cette expérience renonvelće plusieurs fois a prouvé l'idenlité d'espèce du Drile jaunîtt’e d'Olivier et du Cochleoctonus vorax Mrelz. De plus, M. Desmarest a trouvé dans la coquille vide d'un limaçon dont il avoit une grande quantité en observation, la dépouille de nymphe d'un mâle, très-reconnoissable co ce qu'elle présentoit de larges fourreaux d'antenncs inarqués de stries transversales obliques et courbées, qui étoient évidemınent les indices des filets lintéliaux des antennes pectinées de ce mâle. Dc cette dépouille étoit probablement sorti l'individu mâle qui s'accoupla le premier sous les yeux du savant professeur. Il en ent immédiatement plusieur's auires qui, làchés dans une boîte contenant beaucoup de femelles, s'accouplèrent de suile avec elles.

La larve du Drile se nourrit d'Hélices ou limaçons, particulièrement de l'espèce appelée $N e ́-$ morale. Elle s'introduit dans la coquille, fait périr l'habitant en le déchirast avec ses mandibules. Le mâle du Drilc jaunâtre ćtant déjà décrit à sa lettre daus ce Diclionnaire, nous donnerons ici seulement la description de la femelle.

Drile jaunâtre femelle. Longueur to à i i lig. Corps couvert de petits poils courts d'un jaune orangé, composé de douze segmens portant de chaque côté, depuis le second jusquau dixième inclusivement, une tache irrégulière brune, presque triangulaire; les trois premiers ont chacun uue paire de pattes courtes, un peu plus pâles que lc corps; ils représenient le corselet; les antennes un peu fusiformes, guc̀re plus longues que la tête, unt paru à M. Mielzinsky composées de sept articles et d'un tubercule radical; elles nous paroissent en avoir neuf, et nous ne voyons pas de tubercule radical immohile à la base. Premier articie gros, conique, le second pelit, court, transversal; les suivans un peu triangulaires, formant prescque des dents de scie intérieuremeat; ils sont velus, transversaux et vont en diminuant jusqu'au neuvième. Palpes maxillaires fusiformes, de quatre articles dont le second paroît le plus grand de tous : palpes labiaux très-petits, minces. Mandibules arquées, fortement bidcntćes à l'extrénite, la dent extérieure beaucoup plus longue que l'autre. Point d'ailes ni d'élytres.

Nota. Cette singulière fcinelle est le seul insecte, du moins à notre connoissance, qui à l'ćlat parfait offire le corsclet d'une larve, c'esl-à-dire composé distinctement de trois segmens semblables à ceux du reste du corps. Le mấie a de trois à six lignes de longueur. 
Malthine, Malthinus. Lat. Schone. Cantharis. Linn. Fab. Payk. Grill. Faldìn. Herbst. Marsh. Schranck. Panz. Ross. Thunb. Necydalis. Geoff. Telephorus. De Géer. Orr. (Entom.)

Genre d'insectes de l'ordre des Coléoptères, section des Pentamères, famille des Serricornes (divisiou des Malacodermes), tribu des Lampyrides.

Le groupe de celte tribul d'où dépend les Malthines, contient en outre les genres Drile èt 'Téléphore. (Voyez Lampyrides, pag. 426. de ce volume.) Les Driles sont recunnoissables par leurs antennes fortement pectinées dans les mâles, un peu fusitormes et à peine de la longueur de la lête et du corselet réunis, dans les fernclles. Le genre Téléphore est distingué de celui de Ma!hiue par ses palpes terminés tous quatre par un article sécuriforme et par ses ély'res de la longueur de l'abclomen.

Ce genre a tous les earactères des Téléphores ( voyez ce mot), à l'exceplion de cenx que nous vellons d'annoncer comme diff'ćrentiels, c'est-àdire que les palpes sont terminés par un article ovale-subulé, et que les élytres sont un peu plu. cour'tes que l'abdomen. Le caractère tiré du rétrécissement postérieur de la tête n'est pals général, quoiqu'il soit très-saillant dans les espèces où il existe, et ponroit peut-être servir it diviser ce genre dont l'étymologie du nom est grecque et exprime la mollesse de son corps. Les unœur's sont les niêmes que celles des Téléphores. Toutes les espèces connues ont une petite taille et habiteut l'Europe. M. le eomte Dejean en cile quinze espèces dans son Catalogue, parmi lesquelles cinq se trouvent aux euvirons de Paris; ce sont les suivantes :

$1^{\circ}$. Malthine flave, M. Aapus. Latr. Gener. Crust. et Ins. tom. 1. pag. 262. $n^{\circ}$. 4. - ScHen. Synon. Ins. tom. 2. pag. $73 . n^{\circ}$. 1. $2^{\circ}$. Malthine fascié, M. fasciatus. Scren. id. pag. 74. $n^{\circ} .3 .3^{\circ}$. Malthine bimoucheté, MI. biguttalus. Scrien. id. $n^{\circ}$. 5. - Cuntharis bigutlati $\mathrm{n}^{\circ}$. 53. l'AB. Syst. Eleut. $4^{\circ}$. Malthine marginé, M. marginatus. L L id. pag. 26ı. no. 2. - Scuen. id. pag. $75 . n^{\circ} \cdot 7$. $5^{\circ}$. Mallbiue sanguinico!le, M. sanguinicollis. Scher. id. $n^{\circ} .6$. (S. F. ei A. Serv.)

TELESTO. Genre de Crnstacé établi par Ra finesque (Précis des découvertes somiologiques), et dont nous ne connoissons pas les earactères.

(E.G.)

TELPHUSE, Telpliusa. Genre de Crustacés décapodes, de lil tribu des Quadrilateres, fimille des Brachyures, distingué de ceux de la neême tribu par les caractères suivans : quatrième article des pieds-mâchoires extérieurs inséré au sousmet interne du précédent; celui-ci en forme d'hexagone irrégulier ou de triangle tronqué. Antennes latérules insérées au canthus interne des cavités renfermant les yeux, plus courtes que Hist. Nat. Ins. Tome $X$. ces organes, de per d'articles, leur tige guère plus longue que leur pédoncule. T'est presqu'en forme de eœur, tronqué postérieurement, les tarses à arêtes épineuses ou dentées. Appendices ovifères des fernelles foliacées.

Dans le troisième volume de l'ouvrage sur le Règne animal, de M. le baron Cuvier, javois désigné ce genre sous la dénomination de Potamophile. Ayant su depuis qu'elle avoit été déjia domnée à un nouveau genre de Coléoptères, je lui ai substitué ( Nouveau Dictionnaire d'Histoire naturelle, $2^{\mathrm{e}}$. édit.) celle de Telphuse, empruntée de la Mythologie.

Cetre compe yénérique se compose uniquement de Crustacés d'eau douce, que j'avois, nual-àpropos, réunis aux Ocypodes, mais qui paroissent néanmoins devoir être dis!ingués des Crabes proprement dits, avec lesquels liabricies et Olivier les confondent.

Les halbitudes de ces animaux semblent déjà indiquer une coupe particulière. Leur corps est un peu plus évasé en devant que celai des Crustacés des deux geures précédens, et d'une formo qui se rapprocle un pelı plus de celle d'un cœur. Leurs yeux sont beaucoup plus écartés l'un de l'autre que ceux des Crabes, et peu éloignés extérieurement des angles latéraux. laeurs tarses, comprimés dans le sens des autres articulations des pattes, ont des arêtes dentelées ou épineuses, qu'on n'observe poinl dans ceux-là. Les anlelines latérales présentent encore qquelques différences, mentionnées dans l'exposition des caractères génériques, et se terminent par une tige plus courle que le pédoncile, on en col alongé, et de cinq it huit articles. Entin, les appendices du dessous de l'abdomen des fernelles, celles des dernières surtout, ont leur branche extérieure plus large, en forme d’une lame foliacée, élroile, presque elliplique ou lanećolće, avec des apprences de veines interrompues ou de petitcs nervares d'un violet-bleuâtre. La branche interne est grêle, filiforne, et garnie des deux côtés de faisceaur de poils longs et distans. L'abdomen est d'ailleurs composé, dans l'un et l'autre sexe, de sepi segmeus ou tablettes, dont le demier est triangulaire. Le précédent nofire point à sou extrémité d'échancrure propre à recevoir la base de l'autre. Ainsi que dans les Crislacés précédens, la quatrième paire de paltes et la troisième après sarpassent les autres en longueur. Les tranches des jambes et même la supćrieure des cuisses ont des denlelures.

Le 'lelphuse fluviatile ou le Crabe àe risière d'Olivier, de Belon et de que crues autres naturalistes, a joui, chez les Grecs, d'une grinde célíbricé, témoins les médailles antiques d'Agrigeute en Sicile, sur un côté de la plupart desquelles cet animal est représenté avec une telle expression de vérité el nne telle exactitude de détails, qu'il cst impossible de s'y zóvendre. Il fut 
aussi pour eux le signe de la constellation zodiacale du Cancer. Pline, Dioscoride, Nicandre et d'autres auteurs aneiens en ont fait mention : c'est le Carcinos potamios des Grecs, et le Grancio ou Grutnzo des Italiens. Les cendres de ce Crustacé employées seules, ou mêlées avec de l'encens et de la gentiane, étoient réputées utiles par leurs propriétés dessiccatives, dans le traitement de l'hydrophobie. (Eschirion faisoit brûler vif́s ces animaux dans un plat d'étain, jusqu'à ce qu'ils fussent réduits dầns cet érat. Avicenne les recommande, cuils avec de l'eau d'orge, aux per'sonnes souffirantes des fièvres hectiques. Les Arabes appellent cet animal Saratân, nom qui, à ce qu'on présume, ne lui est point particulier, puisque, snivant Forskbal, il est donné par le même peuple à une espèce d'Oeypode, et qu'en Italie on désigue de la même manière le Crabe de rivière, et un autre Crabe de mer, très-commun, le $M e^{\prime}-$ made. Au rapport d'Elien, les Crabes de rivière prévoient, aiusi que les Tortues et les Crocodiles, le débordement du Nil, et gagnent, environ un inois auparavant, les hauteur's voisines. Ils sont communs aux environs de Rome, et on dit qu'ils se tiennest dans la bourbe, de sorte que les pêeheurs sont obligés, pour les avoir, de creuser un fossé tout à l'entour. Ces animaux s'éloigrnent à une grande distance de l'eau, et peuvent vivre, hors de cet élément, une semaine et quelquefois un mois. On peut aussi conserver ainsi en vie des Crabes, en les tenunt dans des caves ou dans des lieux frais et un peu humides. Jans cette capitale de l'Italie on mange le Telpluse fluviatile dans tous les temps de l'ànnée, et surtoul les jours d'abstinence; inais sa chair est meilleure en été, spéciəlement lorsqu'il mue ou qu'il vient de subir cette épreuve. On sert alors ces Crustacés snr les tables du Pape et des cardinaux. Quelques personnes, afin d'adoucir leur chair, les font périr dans du lait. On les porie au marché, at tachés avec une corde, mais placés à une certaine distance les uns des autres, ponr qu'ils ne puissent pas se ronger mutuellement, et se mutiler ou se dévorer.

M. Méuard de la Groge, correspondant de l'Académie des sciences, éminemment distingıé par son profond savoir en minéralogie, a bien voulu me communiquer des observations qu'il a faites, dans son voyage en Italie, sur ce Crustacé. Quoique je les ai déjà cousiguées dans la seconde éditica du Noupeau Dictionnaire d'Histoire naturelle, article Telphose, je crois devoir néanmoins les reproduire dans un ouvrage qui, comme celui-ci, est spécialement le répertoire de tous les faits relatifs à cette classe d'animaux.

“ Ce fint, dit-il, le 28 juillet 1812 , que j'eus occasion de voir et d'observer ce curieux Crustacé, en visitant le célèhre dégorgeoir ou émissaire du lac d’Albano, auirement lac de Castello.
On sait que le bassin de ce lac est considéré par la plupart des voyageurs, et même des naturalistes, ainsi que celui de Némi, pour le cratère d'un ancien volcan. Il a cinq milles de circuit, et l'on donne jusqu'à quatre cent qualre-vingts pieds de profondeur à l'eau qui en remplit la partic inférieure. Celte eau est limpide, parfailement douce, et nourrit diverses sortes de poissons fluviatiles, des grenouilles communes, elc. Le tropplein s'écoule sans cesse, conıne un gros ruissean, par cet admirable caual sonterrain, long de presque deux milles, et qui se conserve sans aucune délérioration, depuis les preniers temps de Rome. La chaleur qui réguoit dans l'atmospbère, alors que je ine trouvai dans cette contrće, la pureté de l'eau, la solitude, l'ombre et la fraicheur du rivage, le fond qu'ou découvre là juscu'à nne assez grande distance du bord, comme une plage, un'a voient engagé à me baigner, et c'est aiusi que je parvins à saisir lrois ou quatre individus de l'es-pèce de Crabe en question. Je fus très-surpris au premier aspect de ces Crabes, n'étant aucunement préveur. Ils me paroissoient si semblables pour la figure, la grosseur, l'allnre, etc., à celui qu'on trouve coinmunément sur les rivages maritimes, au Cancer Mcnas enfin, que je m'imaginai d'abord que ce pouvoit être des Crabes qu'on avoit apportés de la wer, qui n'est pas, en effet, bien éloignée, pour essuyer de les natu. raliser dans ce lac, et que cela a voit réussi. Cependant je commençai à remarquer qn'ils avoient une couleur blanchâtre ou livide, an lieu que les Crabes marins auxquels je les comparois, sont bruns; ensuite apercevant çà et lì des cärapaces et autres déponilles ou débris fort anciens, voyant que les Crabes étoient répandus snr une assez grande élendue de rivagu, où ils paroissoient tout-i-fait daus leurs babitudes, se plongeant sous l'eau s'ils en étoient dehors, s'y cachant aussi sous les pierres, etc., et montrant beaucoup de vivacité, je ne doutai plus qu'ils ne fussent là dans leur élément, et qu'au contraire ils se seroient trouvés fort inal d'ềre portés dans l'ean salée. Il me parut encore que ces Crabes fluviatiles étoient plus rusés et plus alertes que ceux de mer, qui se laissent prendre asse\% facilement. Je ne pouvois les attraper qu'en les ramenant vers le bord du rivage avec le bout de mou bâton, et cela n'étoit pas facile, tant ils savoient s'esquiver. Ils se défendoient vigoureu-ement aussi quand ils ne pouvoient mieux faire, et je sentois très-bien à la force dont ils étreignoient ce bâton entre leurs serres, cqu'il n'eût pas fait bon les poursuivre avec la main. Un pêcheur, que je trouvai en remontant, me dit aussi qu'ils faisoient venir le sang. Il me confirma que ces Crabes étoient bien naturels dans ce lac, cqu'ils y étoient connus de tous temps, et qu'on les rrouvoit de même, quoiqua'en moindre nombre, dans le lac de Némi ; mais ils se retirent pendant l'hiver dans le fond, dit-il, 


\section{T E L}

et ne reparoissent ainsi sur le rivage qu'en été. Il ajoula qu'ils étoient fort bons à manger, et qu'on les portoit pour cela dans les marchés, conjointement avec les poissons. J'ai appris depuis à Roıne, qu'en effet c'est un inets fort délicat, en les faisant périr dans le lait, où ils se ramollissent d'une manière singulière, et les faisant frite ensuite avec de la farine. On m’a dit eneore que ces Crabes ne sont pas rares dans beaucoup d'eaux douces des environs, pourvu (qu'elles soient pures, à ce qu'il paroît, et qu'ils se trouvent nonseulement dans les lacs, nais aussi dans les ruisseaux et jusque dans les bassius de ees magnifiques fonlaines qui sont une partie des beautés de Rome. Mais on n'en prend point dans le Fluvum Tiberim."

Ces faits m'ont été eonfirmés par M. Antoine de Lamarck, fils du célčbre naturaliste de ce non, et qui, pour perfectionner son talent dans la peinture, a demeuré plusicurs années ì Rome.

Il ne paroit pas que ce Crustaé se reneon tre en Italie, plus au nord. On pourroit cependant l'acclimater dans quclques eantons de nos départemers, situés sur la Méditerranée, puisque, suivant M. Risso, le docteur Audiberti ćtoit parvenu à le naturaliser dans le clımat de Nice. Ce Cirustacé étoit donné en aliraent aux personues attaquécs de la phthisie.

Belon les a trouvés dans des ruissenux du mont Athos. Il raconte que les Caloyers les mangent crus, ces animaux ayant, diseni-ils, plus de goût que lorsquils sont cuits. Leur labitation s'étend jusqu'en Perse, comme on le voit par les vuyages d'Oléarius et d'Olivier. Mais si, en allant toujonrs vers l'est, on gague la côte de Coromandel, on verra qu'une autre espèce de Telphuse, celle que je nomme indiente, et qu'on y appelle en Malabar, Tillé-nandon, y remplace la précédente. Elle fréqueute les lieux où uroît le manglier. Les contrées plus orientales offient-ellcs la même espèce, ou en ont-elles qui leur soient propres, $c^{2} e s t$ ce que j'iguore. Herbst a représenté, d'après un dessin de Plumier, une autre Telpliuse, el qui a pour séjour l'Aınérique méridionale. Il l'a confondue avec la première; mais il n'a connu l'une et l'autre que par des figures. A l'époque où il écrivoit, un grand nombre d'espèı es étureut censées cosmopolites, et on attachoil peu d'importunee à l'iníluence du clirmat sur les raees d'animaux. Cette dernière Telphuse est parfaitement distincte des préeédentes, et forme même un type partieulier.

1. Troisiènue artıcle des pieds-mâchoires extérieurs en forme d'hexagone irrégulier; test plus large d'un quart au phus que long; un enfoncement linéaire et trunsverse dervière les cavités octulaires; son bord postérieur est élevé en manière do pli, et terminé de chaque côté par une dent; chaperon en carré transpersal, rebordé en tout ou en partie; tarses tétragones, et à quatre rangées d'épines.

\section{ESPĖCES DE L'ANEIEN CONTINENT.}

\section{Telphuse fluviatile, T. fluviatilis.}

Maxillipedum externorum articulo tertio subhexagono; testâ vix latiore quàm longiore; clypeo penitis anticè marginoto.

Crabe de rivière, Otrv. Voyag. dans l'Emp. ottom. pl. 3o. Jig. 2. - Gecarcmus fluviatilis, Lam. - Cancer fluviatilis, BEL. RoxdeLET.

Corps plus carré que celui de l'espèce suivante, long de trente-buit millimètres, sur quarante-trois de large, quelquefois plus grand et d'autres fois plus petit, d'un jaunâtre pâle uniforme, ou couleur d'os. Des grains ou des aspérités sur les serres, les côtés antérieurs du test et le dessus du chaperon. Bord inférieur de l'arceau supérieur de la cavilé buccale crénelé, avee une dent triangulaire, allant graduellement en pointe, au milieu, entre les deux lobes de ce bord. Deux éminences carrées, aplalies, séparées par une ligne bifide postérieurement, derrière le chaperon, et beaucoup plus en avant que les enfoncemens linéaires, situés derrière les cavités oeulaires. Rebords latélaux du test en arrière de ces enfoncemens dentelés. Côté interne el supéricur des carpes dilaté en manière de dent ou d'angle, accompagnée de quelques dentelures. Bords internes des doigls et ceux des jambes, le supérieur des cuisses, dentelés; serre droite un peu plus finre.

Rivières de l'Italie méridionale, celles de la Grèee, du Levant, etc.

\section{2. 'Telphose indienne, $T$. indica.}

Maxillipedum articulo tertio subhexagono; testâ transversâ; clypeo ad latera marginato, subtius dilatuto, subbilobo.

Cancer senex, FАв.--Ocypode senex, Bовс. - Heивзт, Krabben, tab. 48.fig. 5.

Corps long de trente-eing millimètres, sur quarante-sept de largeur, d'un brun-roussâlreclair, uni; bord inférieur de l'arceau supérieur de la eavité buceale sans crénelures; une dent large et arrondie, et quelquefois brusquement aiguisée à son extrémité, dans son milieu. Rebords latéraux du test situés derrière la dépression, entiers ou sans dentelures. Cette espèee presque semblable, pour le reste, à la précédente.

Pondichéry. M. Leschenault de Latour.

II. Troisiènue article des pieds-mâchoires extérieurs en forme de triangle tronqué trunsversalcment au sommet, avec le côté exténeur plus grand, arqué; test a"nn tiers plus large que $\mathrm{Bbb} \mathrm{b}$ 
long, sans enfoncentent linéaire et transverse derrière les cavités oculaires; ses bords aigus, finement dentelés en scie; chaperon arqué; tarses striés, à cinq rangées d’épines.

ESPÉE DU NOUVEAU EONTINENT.

\section{Telphuse dentelée, T. dentata.}

Maxillipedum articulo tertio subtrigono, truncato; testâ cordatâ, pone oculos haud impressa; tarsis quinquefariàm spinosis.

\section{Herbst, Krabben, tab. 10. fig. br.}

Corps long de quaranı-hnit millimètres, sur sept centimètres de large, plus aplati et plus en cœur que celui des précédenles, d'un brun-jaunâtre foncé, plane et uni sur le dos, n'ayant qu'un petit sinus, de chaque côté, derrière les angles antérieurs. Cavités oculaires grandes, ovales, laissant un vide remarquable autour des yeux. Bord antérieur du cliaperon entier. Milieu de l'arceau supérieur buccal fortement caréné, avec une pointe triangulaire, avancée, concave en dessus. Pieds-mâclioires extérieurs plus grands et plus larges que dans les eongénères. Flancs presqu'entièrement eachés. Mains ovales-oblongues; les doigts alongés, un peu striés, droits, pointus, a vec des dents, pour la plupart forles et triangulaires ; une pointe forte, an côté interue du carpe; les autres pieds couprimés; tranche supérieure des cuisses et les bords des jambes dentelés. Des poils noirâtres et longs près des côtés de la cavité buccale.

De l. Marlinique et l'Amérique méridionale. Cetie espèce paroît se rapprocher des Cardisomes et des Gécarcius. Elle doit peut-être former un nouveau genre. (Latr.)

TÉNÉBRICOLES ou LYGOPHILES. C'est sous ce nom que M. Duméril dans sa Zoologie analytique, désigne une famille de Coléoptères hétérouzérés ( sa quatorzième) dont les caractères sont: elytres dures, non soudées. Antennes grenues, en masse alongée. Elle est eomposée des genres Upide, Ténébrion, Opâtre, Pédine et Sarrotrie.

(S. F. et A. SERv.)

TÉNÉBRION, Tenebrio. Linn. Geoff. De Géer. Fab. Ojiv. (Entom.) Herbst. Panz. Lat.

Genre d'insectes de l'ordre des Coléoplères, seetion des Hétéronères (première division), famille des Mélasomes, tribu des Ténébrionites.

Des huit genres qui nous sont connus dans cetle tribu, les Cryptiques ont le corps large et ovale; celui des Lijuluges est de cette dernière forme et leur corselet est largement lobé au milieu de sa partie postérieure; le genı'e Opâtre a aussi le corps presqu'ovale, court pour sa largeur; son lalsre est petit, un peu échancré, renfermé dans le sinus médial qu'offre le bord du chaperon : les quatre derniers arlicles des antennes, dans les Toxiques, sont seuls eomprimés, transversaux, formant une massue ovale; les Orthocères ont les six derniers articles des antennes perfoliés, composant par leur réunion une massue fusiforme, grosse et velue; les Chiroscèles ont les jambes antérieures très-èlargies et digitées à leur extrémité; enfin le eorselet des Upis est orale-alrondi, par conséquent beaucoup plus étroit à sa base : tels sont les caractères qui distinguent tous ces genres de eelui de Ténébrion.

Antennes grossissant peu et insensiblement de la base à l'extrémité, insérées aux côtés de la têle et sous ses rebords, composées de onze artieles; les cinq premiers presque coniques, le troisième toujuurs plus long que le second et le quatrième; les cinq suivans un peu aplatis, élargis à leur parlie intérieure, le dernier aplati, ovale-arrondi. - Labre coriace, avancé, presqu'en carré transversal, entier. - Mandibules courles, assez fortes, échancrées à leur extrénité, ayant (au moins quelquefois) une forte dent mousse vers leur milieu. - Mrâchoires ayant un lobe corné à leur côlé interne. - Palpes maxillaires presque filiformes, de quatre articles; le prenier assez pelil, le second conique, le plus grand de tous, le troisiène ovale, le qualrième presqu'obconique, peu comprimé : palpes labiaux filiformes, plus courts que les maxillaires, de trois articles, le dernier presqu'obeonique, peu comprimé. - Lèvre nue, entière. - Tćte beaucoup plus érroile que le corseselel; ehaperon dislinct, séparé de la lête par un sillon transversal, arrondi à sa partic antérienre. - Yeux oblongs, paroissant plus en dessous qu'en dessus. - Corps alongé, linéaire, un peu déprimé. - Corsclet plus large à sa base qu'en devant; celte base presque de la largeur de celle des élytres, bisinuée, rebordée ainsi que les côtés. - Écusson transversal, presqu'arrondi postérieurenent. - Elytres linéaires, arrondies à leur partie postérieure, recouvrant l'abdomen et des ailes. - Abdomen linéaire, alongé. Pattes de longueur moyenne; cuisses antérieures assez grosses: loules les jambes nn peu arquées, surtoul les antérieures dans les mâles (caraetère qui pent servir à distinguer ce sexe); turses cou:ts, le deruier article le plus long de tous.

Ce genre tel qu'il est dans les autenrs dervande à être divisé; plusieurs des espèces que l'on y place n'offrent pas les carantères que nous venons de développer, ainsi donc nous le restreignons au 'Ténébrion de la farine (molitor) qui nous sert de type et à quelques espèces très-voisiues, laissant à d'autres enlomologistes le soin de curactériser les coupes génériques nouvelles pour y niettre les espèces qui s'éloignent nolablement de celles que nous venons de citer.

Les Ténébrions se pluisent dans les lieux obs- 
curs, ainsi que leur nom tiré du latin le fait aisément pressentir; leurs couleurs sont obscures et n'offrent que des nuances du noir au ferrugineux; on les trouve le plus souvent dans les étages inférieurs des maisons, dans des recoins sales et humides, chez les boulangers et dans les moulins sous les huches et aures nueubles où l'on conserve la farine ou le pain qui servent de nourrilure à leurs larves. Les oiseletir's ayant remarqué que les Rossignols, toutes les Fauvettes, les Rouge-gorges el autres oiseaux insectivores analogues à ceux que nous venous de citer sont très-friands des larves du Ténébrion de la farine, les élèvent dans de grands vases fermés dans lesquels ils ajoutent au son et à la farine qu'ils mêlent ensemble des bouchons de liege et des moreeaux d'étofle de laine dont ces larves se nourrissent aussi fort bien, mais il faut avoir soin de fermer ces vases avec un convercle de plomb, car le bois et les étoffes n'opposervient pas aux larves une résistance suffisante. Celle larve, connue vulgairement sous le noin de ver de farine, est longue d'environ un pouce, assez étroite, cylindrique, linéaire, extrêmement lisse, d'un jaune ferrugineux luisant, composée de douze segmens écailleux, outre la tête; celle-ci est un peu aplatie, munie de deux randibules, d'antennes et de palpes très-petits; les trois premiers segmeus du corps ont chacun une paire de patles écailleuses, le dernier est conique, terminé par deux petils crochets écailleux, bruns, immobiles; de la joiniure de ce dernier segment avec l'avant-dernier, la larve fail sorlir lorsqu'elle marche, un mamelon charnu sur lequel est silué l'anus; les côlés de ce mamelon sont garnis à leur extrémité de ehaque côté d'une petite écaille qui paroit servir à aider la locomoion en s'appuyant sur le plan de position. Cette larve change plusieurs fois de peau : elle fuit la lurnière, et lorsquon l'expose au jour, à la surface de la nourriture qu'on lui a destiuće, elle s'y enfonce bien vite; par une dernière mue, elle se transforme en nymphe saus filer de cognue; celte nymphe est plus courte que la larve, un peu plus large, sensiblement dépritnée, jaunitre; elle se tient dans une position arquée et reste irmobile; on aperçoit très-bien toutes les parties de l'insecte parfait détachées du corps de la nymphe et point renfermées sous une seule enveloppe; les pattes ont presque la longueur qu'elles doivent a voir dans Pinsecte parfail ; les élytres et les ailes ont chacune séparément leur fourreau, wais elles sont d'une dimension très-iuférieure à celle qu'elles doivent oblenir. Après être resté près de six semaines dans cet état, linsecte parfitit sort de sa peau de nymple et d'abord il paroit ferrugincux; cette couleur se reubrunit plus ou moins, mais la plupart des individus deviennent noirs, cependaut quelques-uts restent d'un ferrugineux obscur. Ils s'accouplent presqu'immédiatement, et s'écar- tent peu de l'endroit qui les a vu naílte si la nourriture qui s'y trouvoit n'est pas épuisée; lorsqu'ils sortent, ils cherchent toujours les lieux sombres ou ne voyagent que la nuit.

\section{Ténébrion large, $T$. latus.}

Tenebrio niger aut ferrugineo-niger, punctulatus; elytris striatis, striis punctatis vix impressis, aqualiter separatis.

Longueur ro lig. D'un noir mat en dessus, luisant en dessous, finement pointillé ; élytres avec huit stries ponctuées, également espacées; corps plus large que celui du Ténóbrion de la farine, dans lequel les deux avant-dernières stries extérieures son plus rapprochées entr'elles que les autres. Les élytres sont quelquefois ferrugineuses dans res espèces.

Du Sénégal.

Nous plaçons en outre dans ce genre: $1^{\circ}$. 'Ténébrion de la farine, $T$. molitor $\mathrm{n}^{\circ} .8$. Faв. Syst. Eleut. $2^{\circ}$. Ténébrion obscur, T. obscurus no. 9 . $F_{A B}$ id. Très-communs tous deux aux environs de Paris. (S. F. el A. Serv.)

TÉNĖBRIONITES, Tenebrionites. 'Troisième tribu de la famille des Mélasomes, stction des Hétéromères (première division), ordre des Coléoplères. Ses caractères sont:

\section{Des ailes et des élytres libres.}

Cetre tribu contient les genres Cryptique, Evitrage (1), Opâtre, Toxique, Sarrotrie (2), Chiroscèle, Upis et Ténébrion.

11. Latreille ( Fam. nat.) réunit en outre à cette tribu les genres Calcar et Boros, et encore, quoiquavec doule, celui de Cortique, qui pourroit bien, dit-il, être un Tétramère de la tribu des Xylophares. Nous ne commoissons pas ces trois genres.

CRYPTIQUE, Crypticus. I.ata. Blaps. Fab. Helops. OLiv.

Genre d'insectes de l'ordic des Coléoplères, section des Hétéromères (première division), fanuille des Mélasornes, tribu des T'́nébrionites.

Parmi les huit genres de celte tribu qui nous sont connus, les Opâtres ont le labre petit, recu dans une profonde échancrure de la partie anté-

(I) M. Latreille, dans lcs ouvrages qui ont précédé ses Familles naturelles, flaçoit ce genre parmi les Diapérialcs, famille des 'Taxicornes; c'est d'aptès cetre manière de voir que nous en avons traité, page 97 . de ce volume, avant que l'ouvrage précité fût publié.

(2) M. Latreille nommoit, jusqu'à la publication de ses Fam. natur., ce genre Orthocère; c'est suus ce nom qu'il a été rédigé à sa lictre par feu Olivier, dans le presunt Dictionmaire. 
rieure et médiale du chaperon; le genre Epitrage it les antennes grossissant insensiblement de la base à l'extrémité, et la parlie postérieure du corselet plus étroite que la base des élyı•es; enfin, la forme du corps étroite et alongée sépare des Cryptiques les genres 'Toxique, Sarrotrie, Cliroscèle, Upis et 'Ténébrion.

Antennes presque filifornes, un peu moins longues que lia tête et le corselet réunis, insćrées sur les côtés de la tête sous un lobe latéral assez graud, composées de onze arlicles; les six prezuiers presque coniques, les quatle suivans un peu aplatis, presqu'élargis en dent de scie intérieuremeut; le dernier ovoide. - Labre avancé, transversal. - Chaperon arrondi en devänl, sans échancrure. - Palpes maxillaires lerminés par nn article fortement en hache, plus longs que les labiaux, ceux - ci paroissant filiformes. - Tète beaucoup plus étroite cue le corselet. - Corps lurge, ovale. - Corselet lransversal, plus élroit vers la tête, un peu échancré dans celte partie, ses bords latéraux arrondis, surtont les angles antérieurs; sa partie postérieure tronquée, plus large que les élytres. - Elytres convexes, recouvrant des ailes et l'abdomen. - Pattes de longueur inoyenue, jambes courtes; premier article des tirses assez long, les suivilns courts, le dernier le plus long de tous.

L'espèce de ce gen:e qui habite aux environs de Paris, se trouve assez conmunément à terre dans les endroits secs et sablouneux. C"est le Ciryptique glabre, $C$. glaber. Lat. Nouveau Dichonnuire d'histoire naturelle, $2^{\mathrm{e}}$. cidition. - Blaps glabra no. 15. Faв. Syst. Eleut.

Voyez ponr la descriplion et les autres synonyares, Hélops glabre no. 31. du préseut Dictionnaire.

Nota, M. le comte Dejean, dans son Calalogne, mentionne cinq autres espèces de Cryptiques, yratre d'Espagne et une de Cayenne.

ChIROSCÈle, Chiroscelis. Lam. Lat. Schæn. T'enebrio. FAs.

Genre d'insectes de l'ordre des Coléoplères, section des Hétéromères (première division), famillo des Mélasomes, tribu des 'Ténébrionites.

Les genres à nous connus dans cette tribu (voy. 'T'Éx́́Brontess) ont tous les jambes antérieures linéaires, point dilatées ni digitées à leur extrémilé, à l'exception de celui de Chiroscèle.

Les caractères génériques de ce dernier ont été ainsi développés par M. Latreille dans le Gener. Crust. et Ins.

Antennes entièrement moniliformes, composées de onze articles, le dernier formant à lui seul un pelit capitule transversal et un peu globnleux. Labre coriace, entier, avancé, presque carré, arrondi autérieurement. - Palpes maxillaires terminés par un article grand et sécuriforme. -
Menton lunulé, presque cordiforme. - Lèvre pelie, large, échancrée, logée dans un sinus du menton. - Téte avancée. - Corps parallélipipède, déprimé, rebordé. - Corselet presque carré, ses bords latéraux un peu arrondis. Ecusson distinct. - Elytres recouvrant des ailes et l'abdomen. - Abdomen oblong. - Pattes assez fortes; jambes antérieures dilatées et digitćes à leur extrćmilé.

Le type de ce genre, dont le nom vient de deux mois grecs qui expriment la ressemblance des jambes antéricures avec une main, est l'espèce suivante:

Chiroscèle bifenestrée, $C$. bifenestra. Latr. Gener. Crust. et Ins. tom. 2. pag. 144. $n^{\circ}$. 1. Encycl. pl. 36 1. fig. 3-5. - Schan. Synon. Ins. tom. 1. pag. 1 ว̃. $n^{\circ}$. I. De la nouvelle Hollande.

(S. F. et A. SERv.)

TENTHREDE, Tenthredo. M. Jurive comprend sous ce nom (Nouv. méth. Hyménopt.) les genres Cimbex, Abia et Arasis. Voyezces mols, le premier à sa letıre, les autres après l'arlicle suivant.

(S. F. et A. Serv.)

TENTHRÈDE, Tenthredo. I.rnn. Geoff. DE Géer. Fab. Panz. Scop. Spinol. Schranck. Ross. Lat. Líach. Le P. Hylotoma. I'a B. Megalodorites. Spinol. Allantus. Jur. LÉach. Selandria. Líacr.

Genre d'insectes de l'ordre des $\mathrm{H}_{5}$ ménoptères, section des Térébrans, famille des Serrifères. (Cetle famille répond à la tribu des Tenthiédines. Lar. Voyez Serriferes, article Téribrans.)

La fumille des Serrifères se divise ainsi qu'ıl suit :

I. Anlennes de neuf articles. - Tarière (des femelles) dépassant à peine l'abdomen.

A. Denx cellules radiales aux ailes supérieures.

Dolère, Tentbrède.

B. Une cellule radiale aux ailes supérieures. Némate, Pristiphore, Cladie.

II. Antennes de dix articles. - Tarière (des femelles) dépassant à peine l'abdomen. Décamérie.

III. Antennes ayant plus de dix articles.

A. Une cellule radiale aux ailes supérieures. - Tarière (des femelles) dépassant à peine l'abdomen.

a. Cellule radiale sans appendice.

Lopliyre, Schizocère (Cryptus. Le P. AIonogr.)

b. Cellule radiale appendiculée,

Ptérygophore, Ptilie, Hylotome, P'ergne. 
B. Deux cellules radiales aux' ailes supérieures.

a. Trois cellules cubitales aux ailes supérieures. - Tarière (des femelles) dépassant à peine l'abdomen.

Amasis, Abia, Cimbex (I).

b. Quatre cellules cubitales aux ailes supérieures.

† Tarière (des femelles) ne dépassant presque pasl'abdomen. - Abdomeu déprimé ou comprimé.

* Antennes en massue.

Antennes courles, de onze articles. - Abdomen déprimé.

Athalie.

ๆ $\Upsilon$ Antennes longues, à articles nombreax. - Abdomen comprimé.

Céphus.

* * Anıennes filiformes ou sétacées. - Abdumen déprimé.

Tarpe, Lyda. (Pamphilie. LAT. Encycl.)

†† Tarière (des femelles) dépassant l'abdounen. - Abdoinen cylindrique.

Xiphidrie.

C. Trois cellules radiales et trois cubitales aux ailes supérieures. -- Tarière (des femelles ) dépassant beaueoup l'extrémité de l'abdomen.

$\mathrm{X}$ yèle.

Les genres Dolère et Teuthrède forment un groupe dans cette fanille; le premier se distingue du second en ce qu'il u'a que trois cellules cubitales aux ailes supérieures.

Antennes sétacćes, grossissant quelquefuis insensiblement avaut leur extrémité, vibratiles, composées de neuf articles dans les deux sexes. - Laủre avancé, demi - coriace, attaché trans-

(1) Certainement on n'apercevra dans les antennes de ces trois genres, non plus que dans celles des Pergues, qu'un nombre d'articles bien inférieur à dix, mais il n'en est pas moins plus que probabie qu'elles en one effecrivemenc un plus grand nombre, er que les derniers sont amboîtes. Cóest ce que doit persuader l'examen des genres qui précèdent ex qui suivent dans ce rableau. (Foyez en outre Motre Monogr. Tenthred. Paric. 1823. Auct. Le Pel. D. S. F.) Dans les Porte-aiguillon la règle générale coustance est: douze alticles aux anrennes des femelles et treize à celles des mâles; cependane l'emboîtencià des quarre ou cing derniers n'en laisse discinguer que huit dans les gentes Masaris et Célonite qui ont lés antennes terminées en massue. versulement au chaperon, semi-circulaire, enticis ou échaucré. - Mandibules avancées, cornées, forles, bideut'es ou quadridentées, presque triangulaires. - Mấchoires et Lèvre avaneées, furmant réunies une promuscide courte, cylindrique. Languette trifide. -- Palpes maxillaires de six articles, les labianx plus courts, composés de quatre articles. - Téte ordinairement presque carrée, quelquefois un peu globuleuse, égalant ordinairement le corselet en largeur; chapernn assez grand. - Yeux ovales. - Trois ocelles disposés en triangle sur le haut du front. - Corps cylindracé. - Corselet ovale; prothorax trèsétroit, très-abaissé à sa partie supérieure; mésothorax grand, son dessus divisé en quatre portions triangnlaires par deux sillons qui se croisent dans son milieu; nétathorax trc̀s-étroit en dessus, prolongé en dessons de la base de l'abdomen. Ecusson assez grand. - Ailes supérieures ayant dcux cellules radiales égales et quatre cellules cubitales inéyales entr'elles, la première petite, arrondie; deux nervures récurrentes; trois cellnles discoidales. - Abdomen sessile, eomposé de hait segmens outre l'anus; le premier étroit, ćchancré dans le milieu du bord inférieur de sa partie dorsale; plaque anale inférieure faite en cuiller, refendue longitudinalenent daus les femelles, cette fente formant une coulisse où se lnge la tarière; cette même plaque eulière dans les mâles; plaque anale supérienre, entière et un peu pointue au milieu dans les femelles, trèsélroite et tronquée postérieureuent dans les trâles de manière à laisser voir dans ce sexe une partie de l'appareil générateur : tarière (des femelles) dépassant à peine l'abdomen. - Pattes de longueur moyeme; hauclies longues et fortes; toutes les jambes dépourvues d'épines dans leur trilieu; premier article des tarses beaucoup plus long que les intres; les denx premiers articles des tarses postérieurs alongés ct dilatés dans quelqnes mâles.

Les auciens auteurs ont donné aux Tentbrèdes le nom français de Mouches-à-scie; plusieurs l'out étendu à la plupart des Serrifêres. Ce genre tel que nous l'cntendons anjourd'lui ne renferme qu’une partie de celui auquel linné avoit donné ce num tiré d'un moi grec dout la signification est: scie. Il en décrivit cinquante-cinq espèces, et les partagea en six divisions, caractérisées par le nombre ct la forme des articles antennaires dans les difítérentes espèces; la première a pon. earactères : antennes en massue ct renferae dix. espèces dont les six premières appartiennent au genre Cimbijex; les nos. 7,8 , 10, a celui d'Abia, le $n^{\circ}$. 9. probablement anx Hylutomes. La seconde division se distingue par ses antennes que Linné dit n'être pas articulées, et que d'antres auteurs regardent commc composées d'un grand nombre d'ürticles trés-lapprochés et per distincts daus les femelles. Les trois espèces que Linné nuet dans cette divisiou doivent se réduire à deux, la 
ciliaris n'étant que le mitle de l'enodis. Cetle division constitue le genre Hylotome. La troisième division qui a les antennes pectinées, comprend deux espèces : c'est le geure Lophyre des auteurs modernes. La Tent/redo rustica forme à elle seule la quatrième division avec ce caractère: antenues articulées, presqu'en misssue, mais elle le partage avec plusieurs autres Teutbrèdes que Linué mel dans sa cinquième division, dont il caractérise les antennes comme filiformes et com. posées de sept à liuit articles outre la base. (II auroit élé mieux de dire d'une manière absolue huit anlieles ontre la hase.) Les nos. 17, 18, 23, $26,27,28,31,33,37,38,39$, sonl des 'Tenthrèdcs, et peut-être aussi les nos. 22, 25,35 ; les $11^{\circ 5} .21$ et 36 se rapportent au genje Némale, comme les $\mathrm{u}^{\mathrm{os}} .32$ et 34 à celui de 1 olère. Le $\mathrm{n}^{\circ}$. 3o. doit être une Athalie, dont les articles des antennes auront été mal complés; restent les nos. 19,20, 24, 29, guni sont bien des Serriferes, mais que nous ne ponvons rapporter avec certitude à ancun geure : il faut remirquer que plusicurs de ces espèces on les antennes grossissant vers leur extrémité et par conséquent presqu'en massue, landis que d'autres les ont filiformes ou même presque sétacées. La sixième division a pour caractères: antennes sétacces, eomposées d'uu grand nombre d'articles; parrai les espèces qui y sont rangées, les nos. $40,41,43,44,45,46,47,48,49$, sont des Lydas, ce qui est également probatile du $n^{\circ} .42$; le $n^{\circ} .54$. est probablement un Cimbex. Deux Némates sont sous les nos. 50 et 55 . Les $n^{n^{5}} .51,52,5 \overline{5}$, ne samvient, fute de description, être rapportés à aucun geare.

Linné mit en outre dans le geure Sirex deux espèces de Serrifères; son Sirex camelus n 5. est une Xiphidrie, et le Surex pjgmáns $\mathbf{n}^{\circ} .7$, un Cépluss.

Geolfroy vint ensuite e! fit un genre particulier des espèces de la prenière division de Linné, habitant les euvirons de Paris; il l'appela Frélon (Crabro). Il lui donna pour principal earactère: antennes en massue; depuis, Olivier changea le nom de ce genre en celui de Cimbex; les trois espèces décrites pâr Geollioy appartienient réellement à ce dernier genre. Il earactérise ses Tenthrèdes par les antennes filiformes et y fait troisdivisions; la première á antemes de neufarticles, contient trente-trois espèces, parmi lesquelles les nos. 1 $, 7,9,11,13,14,15,22,23,24,25$, $28,29,30$, sunt des 'Tenthrèdes, ce qui est iussi probable pour les $n^{05} .10,17,18$. Les $\mathrm{n}^{03} .3 \mathrm{et}$ 3r. sont des Dolères; le no. 20. min Némale, 53. un Cladie, et 5. une Hylotome, ce qui est également pussille di no. 8. Les espèces $2,4,6,12$, $16,19,21,26,27,32$, ne peuvent pas fácilement se rapporier i un genre déter xiné. La seeonde famille, dout le caraelère est : antennes de onze articles, renferme sous les $n^{0 s}$. 34 et 35 . deux espèces qui paroissent appartenir au geure Athir- lie, si l'auteur a bien compté les articles des antennes. La troisième farnille, à antennes de seize articles, contient sous les $n^{\mathrm{c}^{5}} .36$ et 37 . deux espèces probables de Lydas: le $n^{\circ} .38$. peut fort bien être un Céphus.

M. Latreille regardoit déjà l'ancien genrc Tenthredo Lisv. conme nne fauille, et y avoit établi différentes coupes génériques, lorsque Fabricius, après plusieurs essais particls pour diviser ce genre, finit dans son Syst. Piez. par admellre ceux de Cinbex, Hylotona, T'enthredo, Lyda, Turpa, qui tous avoient fuit jusque-la partie de son genre Tenthredo. Du reste ceux de Cephus et Xiphidria qui appirliennent aux Serrifères a voient élé réunis par lui atu genre Sirex. Nous ue parlerons iei que des espèces qu'il plaee dans son genre Tenthredo, Syst. Piez. où il établit trois divisions. La première a pour caractère : antennes un peu plus épaisses à lcur extréinité, et renferme huit espèces, qui tontes sont de vraies 'Tenthredes. Le $n^{\circ} .7$. est le mâlle de l'espèce $n^{\circ} .6$. La seconde division a les antennes filiformes: quarante-trois espèces la composent; les no5. 9, 10, 11, 13, 14 , $17,19,20,21,22,23,24,27,28,29,32,33$, $34,35,37,38,45,47,49$, sont de vérilables Teuthrèdes; le $n^{\circ} .16$. est le mâle du $n^{\circ} .35$. et le $n^{\circ} 41$. Le mấle du $n^{n}$. 3. Les nce. $26,31,51$, appartiennent probablement aussi au même genre. Les espèces $15,18,25,42,44,50$, sont des Dolères, et les $n^{0^{5}}$. 30 et ' 39 . des Némates. Les $n^{\text {os }} .12,40,43,46,48$, ne sauroient être rapporlés avec cerlitude à aucun genre délerniné de cette familie. Sa troisiòne division renferme les espèces à antennes presque sétacćes, au nombre de douze; les nos. $53,54,59,61$, et probablement ausi 2 , sont des l'enthrèdes; $52,58,63$, appartiennent aux Némates; le no. 60. est une Prisliphore; $55,56,57$, sont douteux. On trouvera aussi plusieurs espèces de véritables Tenthrèdes dans la troisiène division da genre $\mathrm{Hy}_{\text {lo- }}$ toma de col auteur.

M. Jurice dans sa noup. Méthod. Hyménopt. admet neuf genres qui représentent la famille des Serrifères, 10 . Tenthrède, qui a deux divisions; la première renferme les vrais Cimbex et les Abias; la seconde conprend les Amasis. $2^{\circ}$. Crypte, contenant les Hylotowies et les Schizocères. $3^{n}$. Allante, qui répond au geure Tenthrède le P. Monogr. $4^{\circ}$. Dolère, qui a deux divisions. Ce genre est absolument tel que nons l'adinctions. $5^{\circ}$. Némate, qui est dans ce dernier cas. $6^{\circ}$. Plérone, qui a trois divisions; la première renfermant les Lophyres et les Cladies; la seconde et la troisiène des Pristiphores. $7^{\circ}$. C'ćphaléie, qui contient les Lydas et les Tarpes. 80. Trachèle, mêne genre que celui de Céphus Latr. $9^{\circ}$. Uroeère, quii répond à celui de Xipbidric.

M. le docteur Léach a donné dans le Zoolog. Miscell. vol. 3. 1817. un travail sur les Serrifères 
qu'il appelle Tenthredinidea, dcsquellesil écarteles genres Céphus et Xiphidrie à cause, dit-il, de leur oviducte saillant et alongé; raison qui nous paroît peu suffisante, vu que cette partie est un peu saillante dans les Athalies, les'Tarpes, les Lydas; qu'elle s'alonge seulement un peu plus dans les Céphus, qui nous paroissent conduire directement sous ce rapport aux Xiphidries. Cet auleur n'a pas connu les genres Pristiphore et Xyèle. Sa première division (Stirps) contient six genres, savoir : Cimbex, Trichiosioma et Clavellaria, qui rentrent tous trois dans notre genre Cimóex; $Z a r a a$ et Abia, que nous réunissons sous celle dernière dénomination; la seconde division renferme le genre Perga; la troisième cclui de Ptery'gopliorus; la qualrième les Lophyres; la ciuquième est formée des genres Hýloloma et Cryptus; le second comprend les Schizocères et quelques Hylotomes; la sixic̀me contient les genres Meesia (qu'il faut réunir aux Némates), Athalia, Selandria (ce dernier se confond avec les Tentbrèdes), Fenusa (qui appartienl aux Dolères). La septième se compose des genres Allantus et Tenthredo qui forment en parlie notre genre 'Tenthrede; des Dosytheus, Dolerus et Emphytus, que nous réunissons sous le nom de Dolère. Dans la huitième entrent trois genres, Croesus, Nematus (qu'il faut réunir sous ce dernier nom) et Cladius. Lil neuvième et deruière division renferme les 'Tarpes el les Lydas.

Quant au travail de M. Latreille sur cette familie, nous le donnerons en totalité au mot Tentarkédines.

Feu Olivier ayant à l'arlicle Cimbex de ce Dictionnare fort bien traité, d'aprés Ríaumur et De Géer, la partie listorique et descriptive de la majorité des genres qui apparlienneut à la famille des Serritèces, nous nous conienterons de donner ici les détails propres au genre Tenthrède.

Les larves, au moins celles qui sont connues, ont vingt-deux pattes, savoir six écailleuses antérieures et seize niembraneuses, desriuelles deux sont postérieures; ces larves, désignées vulgairemeut sous le nom de fausses chenilles, entrent toutes ou prescue tontes en terre pour subir leur mélamorphose; le plus grand nombre ne forme pas cle coque soyeuse, mais se conlente de battre la terre aulour de leur nouveau domicile où elles sont descendues perpendiculairemeut, ce qu'elles exécutent en donnant à leur corps des mouvemens assez violens; on peut être témoin de ce fait en mellant dans un vase de verre de la terre sur laquelle on élevera ces larves jusqua moment où elles doivent opérer leur transformation, et si le vase est peu protond elles ne se fixeronl que sur sa base; la plupart des larves passent un long temps dans cet élat de diète et de repos sans se changer en nymphe, et comme les 'Tenllirèdes n'ont qu'une génération par an et que leur élat de larve n'a

$$
\text { Hist. Nat. Ins. I'ome } X \text {. }
$$

guc̀re qu'un mois de durée, elles reslert à peu près neuf mois dans leur coque sous la forme de larve; l'état de nymphe ne dure que quinze jours ou trois semaines. Sous celte dernière forme on distingre tontes les parties de l'insecte parfait appliquées contre le corps, mais faciles à reconnoître.

Ce genre est très-nombreux en espèces; parmi les Hyménoplères il est un de ceux qui nuisent le plus aux végétaux. Dans un grand nombre d'espèces lcs femelles fout ioule leur ponte sur une même plante que les larves ont bientôt dépouillée de verdure; plusicurs, principalement dans le repos, contournent et posent de côté les derniers segmens du corps et ne se soutiennent que sur les premières paltes menbraneuses; lorsqu'elles rongent une feuille, la plupart l'attaqnent par le bord qu'elles assujetlissent entre les six pattes écailleuses; elles mangent fort vîte et presque continuellemeot; les plnies nuisent singulièremeut à ces larves, en rendant les feuillcs trop aqueuses, ce qui produit chez elles une espèce de diarrhée et les fait périr.

Les insectes parfails se rencontrent fréquemment sur les végélaux où pondent les fernelles, et sur les fleurs dont la plupart sucent le miel. Plusieus ne se contentent pas d'une nourrilure aussi lécrère el déchirent avidement des insectes à corps mou, ce que font parliculièrement les espèces noires à raies jaunes, telles que la Scropliuluriae, elc., ainsi que la viridis; elles attaquent mêue les Téléphores si redoutables aux anı:es insectes. Il nous a praru remarquable que des insectes puremen! phytbiphages dans leur premier élat pussent devenir, sans qu'il y eût disette pour eux, de véritables eutomophatges; nous avons observé que ccs mênies espèces sucent aussi le miel des fleurs, et que ces mêmes fleurs sont sonvent le théâire de leur voracilé euvers les autres insectes. Les antennes des Tenthrèdes sont vibratiles et paroissent leur servir à toucher les corps qui sont autour d'elles atin de les reconnoître; les petites espèces les contractent ainsi que les pattes, et se laissent tomber pour éviter la main qui veut les saisir. Les Tenthrèdes nous paroissent généralement répandues dans tous les climats.

$1^{\mathrm{re}}$. Division. Antennes grossissant insensiblement avant leur extrémité, assez courtes. (Coryna Noв.)

1re. Subdivision. Abdomen presque deux fois plus long que le corselet. - Seconde et troisième celfutes cubitales des ailes supérieures recevant chacune une nervure récurrente, la quatrième atteignant à peine le bout de l'aile.

1. Гелтнв غ̇de à épaulettes, $T$. scapularis.

Tenthredo lutea; antennarum articulis septem $\mathrm{C} c \mathrm{cc}$ 
ultimis, capite suprà latè, thoracis dorso et pectore nigris; alis hyalinis.

Longueur 3 lig. Antennes noires avec les deux premiers articles jaunes ainsi que la base du troisième. Tête noire. Labre et palpes jaunes, le. premier presqu'aryondi. Mandibules jaunes à leur base. Corselet noir; prothorax, une ligne sous les ailes et partie laitérale du mélathorax, jaunes. Abdomen et pattes de cetre dernière couleur. Ailes ransparentes, leurs nervures d'un brunrougeittre. Femelle.

Des environs de Paris.

Rapportez à cette subdivision: $1^{\circ}$. Tenthrède atripenne, T. atripennis. - Hylotoma atripennis $\mathrm{n}^{\circ} \cdot 26$. Fad. Syst. Piez. (Les jambes et les cuisses anlérieures ont quèlquefors un peu de rougeâtre. Ce synonyne de Fabricius doit être ôté à la Tenthredo cordigera no. 3ı5. Lue P. Monogr. Tenthred.) Màle et fernelle. De Cayenne. $2^{\circ}$. les espèces de 253 ì 296 . Le P. Monogr. Tenthred.

2e. Subdivision. Abdnmen court, n'ayant pas deux fois la longueur du corselet. (Antennes grossissant un peu moins que daus la premic̀re subdivision.)

A. Seconde et troisième cellules cubilales des ailes supérieures recevant cliacune une nervure récurrente, la quatrième atteignant presque le bout de l'aile.

Nous placerons ici les espèces de 297 à 317 . Le P. Monogr. Tenthred.

B. Seconde cellule cubitale des ailes supérieures recevant la premic̀e nervure récurrente; denxième nervure récumente aboutissant à la nervure dintersection qui sépare les seconde et troisième cellıles cubitales; quatrième cubitale atleignant le bout de l'aile.

2. Texthrìde médiocre, T. mediocris.

Tenthredo nigra; palpis pedibusque et abdomine luteo-rufis: hujus segmento primo secundique basi suprà nigris; alıs hyalinis.

Longueur 3 lig. $\frac{1}{3}$. Noire. Labre presqu'arrondi. Palpes, écailles el nervures supérieures des ailes ainsi que l'abdomen et les pattes, d'un jauue roussâtre ; premier segment de l'abdomen et balse du second vis-i-vis t'échancrure du premier, noirs. Ailes transparenıes. Mâle.

Des environs de Paris.

A cette coupe appartient encore la Tenthrède punctigère, T. punctigera n". 3ı 3. Le P. Monogr. Tenthred. - Fuun. frunc. Hyménopt. pl. 7. fgo.6. Femelle. Des environş de Paris.

C. Seconde cellule cubitale des ailes supérieures recevant les deux nervures récurren- tes; quatrième cubitule atteiguant presque le bout de l’aile.

3. Tenthrìde menue, $T$. minuta.

Tenthredo nigra; femorum apice, tibiis tarsisque pallide rufis; alis hyalinis.

Longueur 2 lig. Noire. Jambes et tarses d'un roux pấle ainsi que la base des cuisses. Labre arrondi. Ailes transparentes, nervures brunes; leur point épais de couleur pâle. Femelle.

Envitons de Paris.

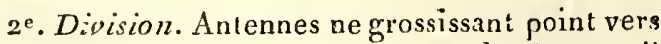
leur extréınité, assez longues. (Tentlıredo propriè dicta. ов.)

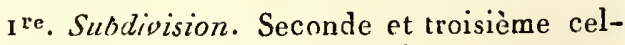
lules cubitales des ailes supérieures recevant chacune une vervure récurrente; quatrième cubitale alleignant presque le bout de l'aile.

A. Antennes ayant des cils placés sur une ligne à leur partie intérieure, depuis le troisième article jusqu'au neuvième inclusivement ( au moins dans les mâles).

Le type de celle coupe est la Tentluède trichocère, $T$. triclzocera no. 240. Le P. Monogr. Tenthred. Mâle. Environs de Paris.

Nota. Nous pensons que la Tenthrède néuresse, T. nigrita $\mathrm{n}^{\circ}$. 47. $\mathrm{F}_{\mathrm{AB}}$. Syst. Piez. - Le P. $\mathrm{n}^{\circ}$. 24 I. id. est la femelle de cette espèce. L'accouplement seul peut prouver ce fait.

B. Antennes simples, sans rangée de cils dans l's deux sexes.

Ce groupe renferme les Tenthrèdes $n^{\circ} .218$ à 239, et de 242 à 252. Le P. Monogr. Tenthred.

$2^{\mathrm{e}}$. Subdivision. Seconde cellule cubitale des ailes supérieures recevant les deux nervures récurrentes; quatrième cubitale atteignant le bont de l'aile.

Le type de cette subdivision est la Tenthrède australe, $T$. australis $\mathrm{n}^{\circ}$. 217 . Le $\mathrm{P}$. Monogr. Tenthred. - Faun. franc. Hyménopt. pl. 3. fig. I. Femelle. Midi de l'Europe.

DOLÈRE, Dolerus. Jur. LAt. Léach. Le P. Tenthredo. Linn. Fab. Panz. Sceranck. Devill. Spliol. Geoff. Ross. Scopol. Pal.-Bauv. - Dosytheus, Fenusa, Emphytus. LÉAch. Hylotoma. FAB.

Genre d'insectes de l'ordre des Hyménoptères, section des 'érébrans, familie des Serrifères. (Celte famille répond aux Tenthrédines Lar. Voyez Serrifíres, article Th́rébrans.)

Les 'Tenlliredes qui composent, dans les Serrifères, un groupe avec les Dolères (voyez'T'ENTHREDE), sédistingruenl de ceux-ci par li présence de quatre cellules cubitales aux ailes supérieures. 


\section{$\mathrm{T} \mathrm{EN}$}

Les Dulères ont les antennes de neuf artieles, toujours sétacées et d'une inanic̀re plus prononcée que dans aucune véritable Tenthrède; les cellules cubilales des ailes supérienres sont seulement au nombre de trois; la tête est presque carrée, à peu près aussi large que le corselet; les articles des larses n'offrent pas de dilatation. Leurs autres caractères ainsi que leurs mœurs sont eenx des Tealhrèdes. Voyez ee mot.

Ire. Division. Mandibules quadridentées. Premic̀re cellule cubitale des ailes supérieures pelite, arrondie; seconde cubitale recevant les deux nervares récurrentes. (Dolerus propriè dictus. Nов.)

Cette division comprend les espèces depuis 356 jusqu'à 373. Le P. Monogr. Tenilhed.

$2^{\mathrm{e}}$. Division. Rrandibules échancrées, légèrement bidentées. - Premiàre cellule cubitale des ailes supérieures alongée, reccvant la première nervare récurcente. (Empria. Nов.)

I $^{\mathrm{re}}$. Subdivision. Deuxième eellule cubitale des ailes supérieures recevant la seconde nervare récurrente.

Les Dolères nos. 341 jusques et compris 355 . Le P. Monogr. Tenthred. apparliement à ette subdivision; l'un d'eux Dolère à taches pàles, $D$. pallimacula no. 344. est représenté Fuun. franc. Hymúnopt. $p l$. 8. fig. 2. Feinclle. Des environs ae Paris.

$2^{\ominus}$. Subdivision. Seconde nervure récurrentc aboutissant à la nervore d'intersection ries première et deuxième cellules cubitales des ailes supérieures.

Nous plaçons ici 1 ${ }^{\circ}$. Dolère à large ccinture, D. Laticinctus $\mathrm{n}^{\circ} .33 \mathrm{~g}$. Le P. Monogr. Tenthred. - Faun. fianc. Hyménopt. pl. 8.fig. 1. Hemelle. Des enviroms de Paris. $2^{\circ}$. Dolère ceinturé, $D$. togatus $\mathrm{n}^{\circ}$. 340. Le P. itt. Femelle. Même palrie.

Cladie, Cladius. Klugg. Lat. Léach. Hylom toma. Fab. T'enthrea'e. Geoff. Ross. P'anz. Pteronus. Juk. Nematus. Léaca.

Genre d'insectes de l'ordre des Hyménoptères, section des Térébrans, "inuille des Serrifères. (Celle famille répond anx Tenthrédines lat. Voyez Serrtféres, arlicle Térébrans.)

Les genres Némate, Pristiphore et Cladie forment ùn groupe dans celle lamilie, ayant pour curacières: antennes de neuf articles; une ecllule radiule aux ailes supérieures. (Voyez İevranède.) Jue premier a quatre cellules cubitales aux ailes supérieures; dausle second les antennes sont nues et leurs articles insérés absolunent au bout les uns dits antres, en outre les mandibules ne présentent qu'une légère éctancrure.

Antcnnes sélacées, de neuf arlicles; les deux de la base posés à l'ordinaire, c'est-à-dirc au bout l'un de l'autre; les suivans tous posés obliquement un peu au-dessous de l'extrémité du précédent; ces articles velus, surtout dans les mâles; quelipees-uus d'entr'eux portant des appendices dans ce sexe. - Mandibules tridentécs. - Ailes supéricures ayant une seule cellule radiale grande et trois cellules cubitales presqu'égales entr'elles; les deux premières l'ecevant chacune une nervure récurrente; troisième eubitale atteignant le bout de l'aile. - Articles des tarses point dilatés. Les autres calractères ainsi que les mours sont ceux des T'enthrèdes. Les larves ne nons sont pas eonnues.

Le non de ce genre exprime la forme des antennes qui paroissent brisées; il est liré d'un verbe grec qui a cette siguification. On n'en connoît encore que peu d'espèces; leur taille est petite.

$1^{\circ}$. Cladie difforme, $C$. difformis. Tat. - Le P. no. 165. Monogr. Tenthred. Mâle. 20. Cladie de Geoffi-oy, $C$. Geoffroy $i$. Le P. no. 166. Monogr. Tenthred. Mâle et femelle. Les auteurs ont cilé mal-i-propos cette espèce de Geoffroy comme synonyme du Lophyrus prini. $3^{\circ}$. Cladie rufipède, C. rufipes. Le P. no. 167. Monogr. Tenthred. Mâle et feinelle. $4^{\circ}$. Cladie noil, $C$. morio. Le P. n. 168. Monogr. Tenthred. Mâle et femelle. 5n. Cladie pallipède, C. pallipes. Le P. no ${ }^{\circ}$ 16g. Monogr. Tenthred. Màle et femelle. Ces cinq espèces se trouvent anx environs de Paris; nous observerons cependaul qu'ancun entomologiste, du moins à notre connoissünce, n’a Irouvé le Cladie.de Geoffroy anx environs de Puris depuis l'anteur auquel nous le dédions. Rossi l'a pris en 'Toscane.

Nota. Le gente Décumérie, Decumeria Nob. dout les prircipaux caractères sont : antennes de dix articles; ailes supérieures ayant une cellule radiale sans appendice, quatre cellules cubitales dont la quatrième alteint le bout de l'aile, ne nons est pas encore suffisanment connu pour en traiter ici, mais ces caractères suffiront pour le distinguer de tous les autres Serrifères. Il en existe deux espèces exoliques dans la collection du Musće d'histoire aaturelle de Puris.

LOPHYRE, Lophyrus. LAT. LÉACH. Le P. Tenthredo. Linn. De Geer, Devill. Panz. Hylotoma. Fab. Panz. Pteroncis. Jur.

Genre d'insectes de l'ordre des Hyménoptères, section des 'Túrébrans, famille des Serrifères. (Cette famille répond aux 'Tenthrédines Lat. Voyez Serrafires, article Térébrans.)

Le genre Schizocère forme avec celui de rophyre une coupe particulière dans cetıe famille, caractérisée par, antennes ayant plus de dix articles; ailes supérieures avec une cellule radiale sans appendice. (Toyez'Tentanide. ) Le premier de ces gentes se distingue de l'autre en ce que ses ailes supérieures offient quatre cellules cubi- 
tales; en outre les antennes des inâles sont dépourvues d'appendices, mais seulement garnies d'une rangée de cils; celles des femelles sont en massue.

Antennes multiarliculées; leurs articles distincts dans les deux sexes; le premier et le second posés à l'ordinaire, c'est-à-dire au bout l'un de l'autre; les suivans tous posés obliquement un peu au-dessous de l'extrémité du précédent; celles des femelles en dent de scie et glabres, celles des mâles penaées, velues. - Mandibules tridentées. - Ailes supérieures ayant une seule cellule radiale grande, saus appendice et trois cellules cubitales presqu'égales entr'elles; la première comme divisée ea deux par un rudiment de nervure qui clescend de la côte, recevant la première nervure récurrente; la seconde cubitale recevant la deuxième nervure récurrente; la troisième alteignaint le bout de l'aile. - Corps court et gros. Jambes intermédiaires et postérieures loujours dépourvues d'épines dans leur milieu. Les autres caractères sont ceux des Hylotomes. Voyez ce mot à la suite du présent article.

Le nom de ce genre vient d'un mot gres qui signifie : omé de panache. Les larves ont vingldeux pattes, dont seize membraneuses; elles vivent presqu'en société, c'est-à-dire que lat plupatt des œufs d'une fenelle ayant été pondus daus le même endroit, les larves qui en éclosent s'écarlent peu les unes des autres. Les Inplyyres habitent presqu'exclusiveneut sur les arbres résineux ou conifères; ils s'y multiplient quelquefois de manière à causer de grands ravages, comme on l'a observé dans une partie de la forĉt de Fontainebleau plantée de Pins. Les larves font leur coque hors de terre, entre les feuilles, ou dans les gerçures des écorces : celtc coque paroît formée de deux couches de soie distinctes, dont l'extérieure est dure et serrée et l'intérjeure molle, ne formant piesque qu'un réseau; elles sont liées l'une à l'autre par des fils peu serrés : une fois renfermée dans sa coque, la larve se change presqu'innédiatement en nymphe et passe peu de temps daus cet état; la coque est eliiptique, l'insecte parfai! délache, pour en sortir, la calottc de l'un des bouts qui reste rejetée sur le côté comme le couvercle d'une boite à charnière. 11 est à croire que les œufs n'éclosent qu'au prinlemps de l'année qui suit leur exclusion. Nous mentionnerons les espèces suivames :

1 ${ }^{\circ}$ Lophyre semblable, $L$. compar. LÉ Zoolog. Miscell, vol. 3. no. 4. - Le P. no. 153. Monogr. T'enthred. Mâle et femelle. D'Lurope. $2^{\circ}$. Lophyı du Pin, L. pini. I. ar. Gener. Crust. et Ins. tonı. 3. pag. 232. - Le P. no. 154 . id. Mâle et fenelle. Aduvirons de Paris. $3^{\circ}$. Lopliyre petit, $L$. minor. l.e P. $\mathrm{n}^{\circ}$. 155. id. Mâle el femelle. Du nord de l'Europe et des environs de Lyon. $4^{\circ}$. Lophyre du Génévrier, L. juniperi. Le P. 1. 156. id. Wale et femelle. Nord de l'Europe. 50. Lo- phyre du Mélèze, $L$. laricis. I،e P. no. 157 . id. - Encycl. $p l$. 375. fig. 6. Femelle. Mâle et femelle. D'Europe. 6\%. Loplyyre américain, L. atnericanus. Léace, Zool. Miscell. vol. 3. $n^{\circ}$. 1. Le P. no. 158. id. Femelle. De Géorgie (Amér. septentr.) $\cdot 7^{\circ}$. Lophyle d'Abbot, L. Abottii. LÉACH, id. no. 2. - Le P. no. 159. id. Femelle. Même pálrie. $8^{\circ}$. Lophyre des conifères, L. picea. I.e P. $n^{\circ}$. 160 . id. Mâle et femelle. Vit sur le Pin sylvestre. Environs de Paris. $9^{\circ}$. Lophyre de Fabricius, L. Fabricii. Ĺ́ach, id. $n^{\circ} .3$. - Le P. no. 161. id. Femelle. De Géoryie (Amér. septentr.). $10^{\circ}$. Lophyre des bois, L. nemorum. Le P. no. 162. $i d$. Femelle. D’Allemagne. $11^{\circ}$. Lophyre des buissons, L. frutetomm. Le P. no. I63. id. Femelle. D'Allemagne.

Peut-être doit-on placer encore dans ce genre l'Hylotoma interrupta no. 4. Faв. Syst. Piez. De l’A nérique méridionale.

SCIIIZOCËE, Schizocerus. InT. (Fam. natur.) Ciyptus. Jun. LÉAch. Le P. Hylotomu. Fab. Tenthredo. Panz. Ross. Devill.

Genre d'insectes dc l'ordre des Hyménoptères, section des T'érébrans, famille des Serrifères. (Cetle famille répond aux 'Tentbrédines LAT. Voyez Serrifínes, article Téríbrans. )

Un groupe de Serrifères offiant pour caractères : antennes ayant plus de dix articles; une cellule radiale saus appendice aux ailes supérieures, se compose des genres Lophyre et Schizocère. (Voyez 'Tentanìde.) Les ailes supćrieures des Lophyres n'ont que trois cellules cubitales, et leurs antennes en scie daus les femelles sont peunées dans les mıâles.

Antennes multiarticulées; celles des mâles toujours divisées en deux après le second article, ayant une rangée de cils; lenrs a!ticles dislincts: celles des femelles en massue alongće, leurs articles après le second peu fuciles à distinguer. Ailes supérieures ay ant une cellule radiale grancie, sans appendicc. - Jambes intermédiaires et postérieures dépourvues d'épines daus leur milieu. Les autres caractères sont les mèmes que ceux de la première subdivision de la seconde division des Hylotomes. Voyez ce mot à la suite.

Schizocère vient de deux mots grecs qui signifient: cornes divisées; il a rapport aux antennes des nut̂les. M. Latreille ayant proposé dans ses Fam. natur. sous ce nom 11 genre dans lequel doivent se placer les espèces que nous avions mises dans celui de Cryptus avec M. I.éach, nons avous cru devoir aujourd'hui abandonner cetle dernièı dénomination que d'untres auleurs ont appliqfuée à un genre d'Icluneunınides. Les larves ne sont pas connues. ${ }^{\circ}$. Schizocère fourchu, $S$. farcatus. - Cryptus furcatus $n^{\circ}$. 149. Is $P$. Monogr. Tenthred. - Hylolome fourchue, Faun. franc. Hyménopt. 'pl. 2. fig. 5. Mâle. Mile et feraelle. Enviruns de Paris. 20. Schizocère de 
Klug, S. Klugii. - Cryptus Klugii. LÉACH, Zool. Miscell. vol. 3. $n^{\circ}$. 2. - Le P. $\mathrm{n}^{\circ}$. 150. $i d$. Mâle et femelle. De Géorgie (Amérique septentrionale ). 3o. Sclizocère pallipède, $S$. pallipes. - Cryptus pallipes. LÉACH, id. $n^{\circ}$. 3. Le P. no. 151. id. Mâle. D'Angleterre. $4^{\circ}$. Schizocère de l'Angélique, $S$. Angelica. - Cryptus Angelica n⿳. 152. Le P. id. Femelle. Du Soissonuois. Le mâle n’est déćrit par aùcun auteur à nous connu, et nous-mêmes ne l'avons pas encore rencontré.

Nota. La Tenthredo geminata. Gmes. $n^{\circ}$. 137 . (Tenthredo. Lesk. Catalog. $n^{\circ} .121$ b.) est le mâle d'une autre espèce que la précédente, et qui appartient probablement à ce genre.

HYlotome, Hylotoma. Lat. Fab. Spinol. Pal.-Baut. Ideacr. Le P. Tenthredo. Linn. Geoff. Schranck. De Géer. Panz. Devill. Ross. Pal.-Bauv. - Cryptus. Jurin. Panz.

Genre d'insectes de l'ordre des Hyménoptères, section des 'Térébrans, famille des Serrifères. (Cetle famille répond aux Tenthrédines LaT. Voyez Serrifìres, article Térébrans.)

Quatre genres forment parmi les Serriferes un groupe qui a les caractères suivans : antcnnes ayant plus de dix articles; une seule cellule radiale appendiculée aux ailes supérieures; ce sont les Pergues, les Hylotomes, les Ptilies et les l'térygophores. L.es deux derniers n'ont que trois celiules cubilales aux ailes supérieures, et dans les Pcrgnes les antennes se termineul brusquement en massuc dans les deux sexes.

Antennes mulìarticulées; celles des mâles filiformes, quelquctois fourchues, ayant leurs articles distincts, portant un rang de cils dans toute leur longucur : celles des femelles grossissant insensiblumeut en inassue, lous leurs articles à commencer du troisiène peu distiucts les uns des autres et paroissant n'en lormer qu'un seul. Labre apparcnı. - Mandibules petites, échancrécs. - Mâchoires et Lèvre avancées, formant réunies une promuscide courte, cylindrique. Languette trifide. - Palpes maxillaiies de six articles; les labiaux plus courls, de quatre articles. - Téte presqu'un carré transversal, égalant presque le corselct en largeur; chaperon court. Yeux ovales. - Trois ocelles disposés en triangle sur le vertex. - Corps cylindracé. - Corselet court, globuleux; prothurax très-étroit, trèsabaissé à sa partie supérieure; mésothorax grand, divisé en dessus en quatre portions triangulaires par deus sillons qui se croisent dans son nulieu; métathorax très-étroit en dessus, prolongé en dessous de la base de l'abdomen. - Ecusson assez grand. - Ailes supérieures ayant une cellule racliale prande, appendiculée e: quatre cellules cubitales presqu'égales entr'elles; la quatrième atteignant le bout de l'aile; deux nervures récurrentes; trois cellules discoïdales. - Abdomen sessile, composé de huit seigmens cutre l’anus, le premier étroit, éch ancré dans le milieu du bord inférieur de sa par: tie dorsale; plaque anale inférieure faitc en cuiller, refenduelougitudinalement dans les femelles; celte Sente formant une coulisse où se loge la tarière; celle mêmc plaque entière dans les mâles; plaque supérieure entière, un peu pointue au milicu dans les femelles; très-étroile et tronquée postérieurement dans les mâlcs, de manière à laisser voir dans cc sexe une parlie de l'appareil générateur : tarière (des femelles) dépassant à peine l'abdomen. Pattes de longueur moyenne; hanches longues; premier article des tarses beaucoup plus long que les autres.

Fabricius (Syst. Piez.) ayant pris le nom de ce gente dans les ouvrages de M. Latreille, $y$ at mêlé un grand nombre d'espèces qu'il est impossible d'y laisser, et dont plusieurs appartiennent a des genres reconnus par lui. Il partage ses $\mathrm{Hy}$ lotoma en trois divisions. La première a pour caractères : antennes pectinées. Elle contient huit espèces. Les nos. 1. 2. 3. 4. 6. 7. sont des Lopliyres. Ise no. 3. n'est que la femelie du Pini $n^{\circ} .7$. Le $n^{\circ} .5$. est probablement une Ptilie; le $n^{\circ}$. 8. appartient aux Schizocères. La seconde division caractérisée par ses antennes inarliculées allant en grossissant vers l'extrémilć se compose de neuf espèces. Les $\mathbf{n}^{\circ s}$. 9. 10. 11.12 .13 .16$. sont des Hylotomes; il seroit possible qu'il en füt de mềne du no. 14. L'espèce $1^{\circ}$. 15 . est une Tenthrède. Le $n^{\circ}$. 17. un Śbizocc̀rc. La troisiène division qu'il distuguc par ses intennes filiformes, de neuf articles renferme douze espèces. Le no. 18 . est un Dolère. Les nos. 25. „6. 28. sont des 'Tenthrèdes; il est probablc aussi que les nos. 19. 20. 22. 24. 27. 29. sont de ce dernier genre. Celui d'Atlialie revendique les nos. 21. et 23 .

Le nom de ces Hyménoptères vient de deux mots grecs qui signifient : coupeur de bois, probablement parce que les femelles fout des incisious dans les planies pour y déposer leurs $\propto$ ufs. Iacs larves ont dix-liuit patles, dont douze membraneuses; cependant De Gćer en a observé deux qui avoient vingt pattes; elles appariennent anx $n^{\circ} .26$. (i) et 27 . de son genre Tcnıhrède. (Mém. tom. 2.) Les larves d'Hylotouses se nourrissent de la même façon que celles des 'Tcuthrèdes, ct vivent presqu'en sociélé comme celles des Lophyres. Elles construisent leurs coques sur les feuilles des plantes, dans les ficntes des écorces ou même sous les feuilles mortes tombées à terre.

(1) Cette espèce est l'Hylotoma ustulata auctor. De Géer s'esr trompé en lui rapporrant cumme synonyme la $T e n-$ thredo nitens Lins. qui est l'Abia nitens. (Voyez ABı, pag. 575 . de ce volume.) Le $n^{\circ} .27$. de De Géer auquel il donue a tort, comme symonyme, la Tenthredo ustulata Lins. ess une aurre espèce d'llyiotome que nous ne connoissons pas. 
Cetie coque est faite comme celle des Lophyres, et linsecte parfait en surt de la même manière ( $\nu o y^{\prime} e z$ page 572 . de ce volume). Les Hylotomes sont très-ardentes pour l'accouplenent, les femelles, de même que celles de beaucoup de Tenthrèdes, pondent tous leurs œufs sur une même plante; ils éclosent de fort bonne heure au printemps. Nous soupçonnons que prescjue toutes les espèces ont deux générations dans l'année. Leur taille est petite ou moyenne.

$1^{\text {re }}$. Division. Toutes les jambes dépourvues d'épines clans leur milien. - Antennes des mâles bilides après le second article. - Seconde et troisième cellnles cubitales des ailes supérieures recevant chacune me nervuré récurrente. ( $D_{i}$ dynia Nов.)

Nous ne connoissons qu'nne espèce de celle division. C'est l'Hylotome de Marion, H. Martini. L.e P. no. 139. BIonogr. Tenthred. Mâle. Du Brésil.

$2^{e}$. Division. Jambes intermédiaires et postérieures munies d'une épine dans leur milieu. Antennes simples dans les deux sexes.

Ire. Subdivision. Seconde et troisième cellnles cubitules des ailes supérieures recevant chacune une nervure récurrente. (Hylotona propnè dicta Аов.)

Aous plaçons ici les espèces de 116 a 138 . Le P. Monogr. Tenthred.

$2^{e}$. Subdivision. Sconde cellale culitale des ailes supérieures recevant la première nervure récurente; demxièate nervurécécurente ahou. tissaal at li nervure d'intersection des seconte et troisième cubilales. ( Scobizu N....)

On doit mettre icj l'Hylotome mélanocéphale, H. melanocephala. L.e P. n'. 140. Rionogr. Tenthred. Femelle. De Cayenne. Nous ne connoissons pas le mäle. Les indivitus femelles que nous avons sous les yenx ont les antennes peu distinctement en massue, très-velues et beaucoup plus longues que dans les auires Hylotomes du mêtne sexe.

Nota. La 'Tenthrède n ${ }^{\circ}$. 8. Grorf. Ins. Paris. tom. 2. appartient peut-ĉtre aux Hyloiones.

AMIASIS, Amasis. LÉAcr. LAT. (Fam. nat.) Cimbex. Fab. Oliv. (Encycl.) Le P. Tenthredo. Devill. Ross. Panz.

Genre d'iusectes de l'ordre des Iyménoptères, section des Térébrans, famille des Serrfères. (Cetie farnille répond aux 'Tenthrédines Lar. Voyez Serriféres, article 'T́źńbrans.)

Les Amasis forment avec les Abias et les Cimbex un groupe parni les Serrifères, offrant les caractères suivans: antennes ayant plus de dix articles, deux cellules radiules et trois ceilules cubitales atix ailes supérieures. (Foyez TEхтниерт.) Dans les Abias la tête est manifestement plus étroite que le corselet; les denx épines terminales des jambes sont tronquées et ne se terminent pas en pointe; de plus les yeux des mâles sont extrêmement rapprochés sur le vertex, et se tonchent presgue. Le genre Cimbex a aussi les ćpines ternuinales des jimbes tronquées, ses mandibules sont tridentées, le premier segmeut abdominal est distincrement échancré en dessus, enfin la premièse cellule cubitale des ailes supérieures reçoit les deux nervares récurrentes; caractères qui ne'se retrouven! pas dims les Amasis.

Antennes terminćes subitement en massue, composées de plus de dix articles, les quatre premier's seuls distincts, les aulies réunis el formant lit massie. - Mandibules bidentćes. - Tête presque de la largeur da corselet. - Corselet court, globulenx; prothorax très-étroit, très-abaissé à sa partie supérieure; mósolhorax grand, divisé endessns en quatre portions triangulaires par deux sillons qui se croisent daus son nilieu; métathorax très-ćtroit en dessus, prolongé eu dessous de la base de l'aljdomen. - Anles supéricures ay ant denx cellules radiales ulongées, presqu'égales entr'elles et trois cellules cubitales, la preniere et la seconde recevant chacune ine nervure récurrente; la troisième atteignant le bout de l'aile. - Premier segnent de l'abdonen saus échancrure. Jambes teruinées par deux épines aiguës; les interméditires et les postérieures dépourvues d'épines dans leur milieu. Les antres caractères comme dans les (imbex (voyez ce mot); mais nous ferons remarquer ici que le caractère antennaire y est mal difini. Le nombre des articles distincts est fort variable dans le genre Cimbex, et il en fant dire autant de ceux qui composent la massue, lesque!s sont peu distincts; c'est ce qui fitit que les dillérens auteurs varient beaucoup dans l'expression du nombre che ces articles. M. Léach a fundé diverses coupes génériques, d'après ce caractère, aux dépens des Cimbex; nous ne les avons pas trouvées assez tranchées, n'ayant pals toujours pu apercevoir le même nombre d'articles que lni. Nous n'adoplons ici que les genres qui se distinguent par d'autres caractères, tels que les Alias et les Amasis. Les espèces indigènes de ce dernier, sont propres aux parties méridionales de l'Europe.

Nola. Retranchez du genre Cimbex (Encycl.) le Cimbex vespiforane no. 16. qui n'appartient pas inêrne anx Térébrans, et est le type du genre Célonite. (Voyez ce mot à la Table alphabétique.)

\section{Ams asis dilatée, $A$. dilatata.}

Amasis viridi-aenea, pedibus luteis, femonum basivïridi-aneâ : antennis nigris; alis violaceis, puncto marginals dilatato, extenso.

Longueur 8 lig. D'un beau vert-brun métallique a rellet bronzć brillant. Hanches et pattes 


\section{T E N}

jaunes arec la base des cuisses de la conlenr du corps. Antennes noires. Ailes d'un brun violet, avec leur point marginal très-dilaté, faisant une forte saillie arrondie au bord extérieur de l'aile. Mâle.

\section{Du Brésil.}

\section{Amasis obscure, A. obscura.}

Anzasis obscura. LеंАcH, Zool. Mriscell. vol. 3. $n^{2}$. 1. - Cimbex obscura no. 1 2. Ha . Syst. Piez. - Le P. no. I05. Monogr. Tenthred. - T'enthredo obscura no. 12. Devilu. D'flalie.

Voyez pour la description et les autres synonymes Cimbex obscur n ${ }^{\circ}$. 15. du préseut Dictionnaire.

On doit rapporter encore aux Amasis : $\mathrm{I}^{\circ}$. Amasis de Jurine, A. Jurince.-Anasis lota. LEA cr, Zool. Miscell. vol. 3. no. 2. - Cimbex Jurince. Le P. ${ }^{\circ}$. 3. Monogr. Tenthred. Mâle. Du midi de la France. $2^{\circ}$. Amasis joyeuse, $A$. lceta. Cimbex lata. Le P. no. 104. id. Mâle et femelle. - Faun. franc. Hynénopt. pl. 1. fig. 6. Femelle. D'Allemagne. $3^{\circ}$. Amasis italienne, $A$. italica. - Cimbex italica. Le P. no. 106. id. Femelle. D'Italie.

ABIA, Abia. Léach. Cimbex. Fab. Oliv. (Encycl.) Latit. I.e P. Tenthredo. Linn. De Géer. Devilu. Jukin. Panz. Zaraea. Léach.

Genre d'insectes de l'ordre des Hyménoptères, section des Térébrans, famille des Serrifères. (Cette famille répond anx 'T'enthrédines Lar. Voyez Sentriféres, article Térébrans.)

$\mathrm{Un}_{\mathrm{n}}$ groupe de celte famille contient les genres Amasis, Abia et Cimbex. (Voyez 'Texthrìde.) Dans le premier et le dernier la tête est presugue de la largeur du corselet et les yeux espacés dáns les deux sexes. Les $A$ masis ont en cuntre les épines terminales des jambes aiguës et les deux nervures récurrentes des ailes supérienres snnt reçues l'une par la première, l'aulre par la seconde cellules cubitales. Dans les Cimbex le premier segment abdoninal est échancré en dessus.

Tête petite, beancoup plus étroite que le corselet. - Yeux rapprochés sur le vertex et presque contigus dans les mâles. - Premier segnzent de l'abdomen sans échanciure. - Janbes ayant leurs deux épines terminales tronquécs. Les autres caractères comme dans les Cimbex. (Voyez ce mot à sa lettre et celui d'Amasis pag. 574 . de ce volume.)

Les larves des Abias ne nous sont pas connues. Ces Hyméuoptèrẻs sont lourds à s'envoler; on les trouve assez souvent sur les fleurs. Leurs mœurs ne different pas du reste de celles des Cimbex; les especes sont de moyenne taille. Nous citerons les suivantes.

\section{Abra fasciée, A. fusciatu.}

Zarcea fasciata. L'́Асн, Zonlog. Miscell. vol. 3. Nâle et femelle. - Cinbex fúsciata $\mathrm{n}^{\circ} \cdot 9$. Fa B. Syst. Diez. - Le P. no. 99. Monogr. Tenthred. Mâle et femelle. - Tenthredo fasciata. Panz. Faun. Gemn. fias. 17. fig. I5. Femelle.

Voyez pour la description et les autres syno-

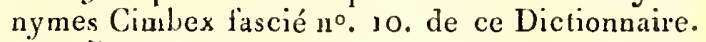
Femelle.

2. Asta nigricorne, A. nigricornis.

Abia nigricornis. LÉACH, id. $n^{\circ}$. т. Femellf. - Cimbex nigricomis. Le P. no. 100. id. Mâle ( femelle. - Cimbex sericea, var. no. 10. ias. Syst. Piez. (Individu euvoyé d'Italie par Allioni.)

Nota. Olivier fait mention de la femelle de eelte espèce à la suite de la description du Cimhex soyeux $n^{\circ}$. 11 . de ce Dictionnaire. L'Abia nigricorne se trouve aux environs de l'aris.

\section{Aвra brillante, A. nitens.}

Abia seincea. LÉACH, id. no. 2. Femelle. Cinbex nitens. Le P. no. 111 . id. Nâle et femelle.-Cinbex sericea no. 10. FA B. Syst. Piez. Les deux sexes. (Cet auteur prend ì tort la T'eztthredo nitens Lins. pour la femelle de celte espèce et la Tenthredo sericea Lins. pour le mâle, c'est tout le contraire.) - Tenthredo sericea. Paxz. Faun. Germ fús. 17. fig. 16. Mâle.

Voyez pour la description et les synonpnes (eu retranchant celui de De Géer et la description de la larve, qui appartiennent à l'Fylotoma ustulata; consultez l'article 11 r sотоме, pag. 573. de ce volune) les Cimbex soyeux no. 11. (en ôtant les individus ì antennes noires qu'il faut rapporter à l'Atria niyricorne) et Cimbex brillant no. 12. de ce Dictionnaire. La áescription du no. I $n^{\circ}$. 12. renferme les deux sexes.

Nota. M. Léach mentionne encore l'Abia brévicorne, A. brevicornis. Zuolog. Miscell. vol. 3. $n^{\circ}$. 3. D'Angleterre?'-Cinbex brevicornis. Le P. no. 102. Monogr. Tentlired.

A'TIIAlie, Athalia. léach. Le P. LAt. (Fant. natur.) Mylotoma. PAB. Tenthredo. Geoff. Schranck. Panz. Devilic. Allantus. Jur. Nematus. Spinol.

Genre d'insectes de l'ordre des Hyménoptères, section des 'lérébraiss, famille des Seruffères. (Celle fanille rópond aux 'T'enthrédines Lat. Voyez Serriféres, article 'Térébrans.)

Les quatre genres Atlialie, Céplius, Lycla et Tarpe composent un groupe dans la famille des Serrifères. (Voyez Tenthrède.) Les trois derniers out les auteanes composées de plus de onze 
articles, le labre eaché ou peu apparent, et les jambes intermédiaires ainsi que les postérieures munies d'épines dans le milieu; de plns les antennes sont sélacées daus les Lydas et pecinérs ou dentćes en scie dans les 'Tarpes. Les Céplus different en outre des Athalics par lenr abdomen comprimé.

Antennes presqu'en massue alongrée dans les deux sexes, composées de onze articles distincts; le troisic̀me plus long que les suivans; ceux de quatre à onze, moniliformes. - Labie apparcnt. - Mandibules bidentées. - Corps mou. - Ailes supérieures ayant deux cellules radiales égates, séparécs par une nervure toujours courte et droile; quatre cellules cubitales inégales, la première petite, arrondie; la seconde et la troisième recevant ehacune une ncrvare récurrente, la quatrieme atteignant le bout de l'aile. - Abdomen sessile, déprimé. - Jambes dépourvues d'épines dans leur inilieu; articles des tarses sans dilatation. Le reste des earactères comme dans les 'Jenthrèdes. (Voyez ce mot.)

MI. Léacl a fondé ce genre, mais il nous parô̂l s'être trompé sur son principal caraclère, du moins les espèces qu'il cite comme types ont réellement onze articles aux antennes au lieu de dix qu'il leur atribue. Il existe des Serrifères à dix articles aux antennes, nous en formons notre grente Décamérie. M. Latreille en adoptant celui ('Alhalie dans ses Fam. nat. lui donne pour caractères: autennes de dix à quatorze articles (loujours simples). Les espèces de Serrifères à intennes sinples el de quatorze articles ne nous sont pas connues, et les Xyèles nous paroissent ctre les seules qui en aieut douze. L'esamen compäratif des caractères des l)écaméries ( voyez pag. 57 . de ce volune) et des Albalies, prouvera sulfisanmeat l'impossibilité de les réunir dans un seul genre.

Nous pensons que les larves des Allitlies, ou au moins quelques-unes, se nourrissent de la moelle des jemnes rameiux, et qu'il faul rapporter à ce gemre la larve dout parle Réaumur, Mém. tom. V, pag. 98. et qu'il représente $p l$. 1o.fig. I-3. Le reste de leur bistone est peu connu. Ies insectes parfaits, d'assez petite taille, liabitent les fleurs et se plaisent aussi sur les jeunes branches des arbres; ils sont lents à s'envoler, et un lieu d'employer ce moyen pour fuir, ils se contraetent en placant leurs antennes réunies entre les pattes, qu'iis couchent le long du corps et se laissent tomber à terre où ils passent un cerlain temps sans donner signe de vie. Plusieurs espèces sont très-communes aux environs de $\mathrm{Pa}$ ris; leurs couleurs dominantes sont le noir et le testacé.

Rapportez à re genre les espèces de 63 à 73 . I. P. Monogr. Tenthred. Paris. 1823.

CÉPHUS, Cephus. Lat. FAB. SPinor. Le P.
Trachelus. Junin. Sirex. Linn. Tenthredo. DEvilu. Astatus. Klug. Panz. (Faun. Germ.) Banchus. Panz. (Faun. Germ.)

Genre d'insectes de l'ordre des Hyménoptères, section des Térébrans, famille des Serrifères. (Cette famille répond aux 'Tenthrédiues LaT. Voyez Serrifìres, article Térébrans.)

Parmi les Serriferes un groupe contient les genres Athalie, Céphus, Lyda et 'Tarpe. (Voyez Tentrakede.) Les antennes de ces dernières sont pectinées ou en scie; celles des Lydas sétacées, et dans les Athalies le labre est apparent, l'abdomen déprimé et les jambes dépourvues d'épines dans leur milieu.

Antennes longues, multiartieulées, lerminées en massue, incérées sur le front, entre les yeux; les deux articles de la base plus courts que les suivans. - Labre presqu'entièrement caché. Mandibules avancées, presque carrées, alongées, tridentćes; leur dent apicale alongée, très-pointue, l'intermédiaire petite, l'inférieure large, tronquée. - Mâchoices el Lèvre avancées, formant par leur réunion une promuscide courte, cylindrique. - Languette trifide, distincteincnt échancrée. - Palpes maxillaives beaueoup plus longs que les labiaux, de six articles très-inégaux; le troisiène assez gros, le quatrième très-long, le cinquième fort court : palpes labiaux de quatre articles, l'avant-dernier très-court, le quatrième long, ovale-conique. - Tête presquc trigone vue en devant; sa partie supérieure en earré transversal. - Yea x petits, assez saillans. - Trois ocelles ảisposćs en triungle sur le haut du front. - Corps étruit, alongé. - Corselet en ovalealongé; prolhorax très-abaissé à sa partie supérieure, alongé en une sorte de cou conique; mésolhorax grand, son dessus divisé en qualte parlies triangulaires par deux sillons qui se croisent dans son milieu : métathorax assez grand en dessus, prolongé en dessous de la base de l'abdomen. - Ecusson assez grand. - Ailes grandes; les supérieures ayant deux cellules radiales, la première petite, presique carríe; la seeonde très-grande et quatre cellules cubitales égales entr'elles; la secondc et la troisième recevant chacune une nervure récurrente; la quatrième atteignant le bout de l'aile : trois cellules discoidales. - Abdomen scssile, long, comprimé latéralement, tronqué obliquement à la partie inférieure de son extrémilé, composé de huit segmens outre l'anus, le premier échancré dans le milier du bord inférieur de sa partie dorsale; plaque anale inférienre faite en cuiller, refendue longitudinalement dans les femelles, eette fente formant une coulisse où se loge la tarière; eette même plaque entière dans les nuâles; plaque analc supérieure entière, poinıne au milieu dans les femelles, très-étroite er tronquée postérieurement dans les mâles, de manière à laisser voir dans ce sexe une partie de l'appareil générateur: tarière 


\section{$\mathrm{T} \mathrm{EN}$}

tarière (des femelles) dépassant l'abdomen. Pattes grêles, assez longues; hanches alongées; jambes intermédiaires avec une épine dans leur milieu; jambes postérieures en ayant deux; tarses fort longs.

M. Latreille (Fam. nat.) dit que les larves sont béxapodes, dépourvues de paltes membraneuses et vivent dans l'intérieur des végétaux. Elles attaquent, dit-on, les boutons à fleurs de quelques arbres fruitiers et l'intérieur de la tige des plantes céréales. C'est sul ces arbres et ces plantes que l'on trouve ordinairement les insectes parfaits. Les espèces connues sont d'assez petite taille; leurs couleurs habituelles sont le noir et le jaune, ou le ferrugineux.

Les six espèces mentionnées par Fabricius (Syst. Piez.) appartiennent toutes à ce genre; consultez en outre Le P. nos. 49 à 62 . Mlonogr. Tenthred. Paris. 1823. (S. F. et A. Serv.)

TENTHRÉDINES, Tenthredinetoe. Première tribu de la famille des Porte-scie, section des Téróbrans, ordre des Hyménoptères, ayant pour caractères :

Patpes maxillaires dans presque tous, de six articles; les labiaux de quatre (1). - Mandibules généralement alongées et conprimées. - Languette trifide. - Tarière composée de deux laroes dentelées en scie, réunies el logées dans une coulisse longitudinale à l'extrémité postérjeure du ventre, très-rarement saillante au-delà de l'änus.

Cette tribu se divise ainsi :

I. Tarière point saillante au-delà de l'anus.

Larves du plus grand nombre munies de pattes membraneusés et vivant à nu.

A. Labre apparent. Côté interne des quatre jambes postérieures offrant au plus et très-rurement une petite épine (genre Perga ).

Larves ayant de douze à seize paltes membraneuses.

a. Antennes n'ayant jamais au-delì de seize articles. (Neuf au noins dans la plüpart.) Toajours simples dans les femelles; celles des mâles soit cilićes ou fourchues, soil pectinées d'un seul côté on r'olliant qu'un petit nombra de rameaux.

t Autennes de trois à huit articles distincts, soit terminćes par un reutlement en forme de bouton, soit par un article fort long et formant une

(1) Les Xyéles, s'il n'y a pas d'erreut, feroient seules exception. Les maxillaires n'auroient que quate articles, et les labiaux n'en offritoient que trois. (Dalman.)

Hist. Nat. Ins. Tome $X$. massue plus ou moins cylindrique, quelquefois ciliées ou fourchues dans les mâles.

* Antennes de cinq à huit articles, ternircées par un renflement en forme de têtle ou de bouton.

Larves ì vingt-deux paltes.

Cimbex, Amasis, Perga.

* * Antennes n'ayant que troi, articles distincts, le dernier en massue alongée ou de la grosseur des précédens, cilié ou fourchu daus les mâles.

Sclizocère (antennes fourchues), $\mathrm{H}_{\mathrm{y}}$ lutome, Ptilie.

t† Antennes de neuf à quatorze articles, mais de neuf seulement dans le plus grand nombre.

* Antennes de neaf articles.

\& Antennes simples dans les deux sexes.

Tentliède, Dolère, Némate, Pristiphore.

$\Upsilon$ ( Antennes rameuses dans les mâles.

Cladie.

* Antenmes de dix ì quatorze articles (toujours simples).

Atualie.

b. Antennes de seize articles au moins, pectinées ou en éventail dans les mâles, en scie dans les femelles.

Ptérygophore, Lophyre.

B. Labre caclıé on peu saillant. Côté interne des quatre jambes postćrieures ayant deux ou trois épines.

Antennes toajours composées d'un grand nozabıe d'articles. Tête grande ou large. Latves connues sans pattes membraneuses.

Mégalodonte (Tarpa FAB.), Pamphilie ( Lyda FAB.).

II. 'Tarière des fenrelles saillante au-delà de l'anus.

Larves saus pattes membraneuses, vivant daus l'intérieur des végétaux.

Xyèle, Cépłus, Xiphidrie.

Les palpes maxillaires des $\mathrm{X}_{\mathrm{y}}$ èles (Mastigocère KLUG.) sont fort longs , repliés et terminés brusquement, en manière de filet.

Nota. Cet article est extrait des Familles naturelles de M. Latreille. (S. F. et A. Senv.)

Dd d d 
TENTYRIE, Tentyria. Lat. Akis. Faв. Pimelia. Oliv. (Entom.)

Genre d'insectes de l'ordie des Coléoptères, section des Hétéromc̀res (première division), famille des Mólasomes, tribu des Pinéliaires.

l.e groupe de cctle tribu d'où dépend ce genre (voyez pagr. 534. de ce volume) contient encore, $1^{\circ}$.Zophose, qui a le corselet transversal. $2^{\circ}$. Molaris, Psamınode, Tagénie et Sépidie, dont le menton est petit, ne recouvrant pasla base des ináchoires. $3^{\circ}$. Tagone, qui a le corps presque triangulaire et le corselet transversal. $4^{\circ}$. Hégètre, dont le corselet u'est peint rétréci à sa base, et les angles postćrieur's presque droits.

Antennes filiformes, insérées sous un rebord latéral dc la tête, composées de onze articles; le premier assez gros, coniquc; ; troisièmc alongé, presque cylindrique; ceux de quatre à huit obconiques; les trois derniers plus courts que les précédens, presque turbinés. - Labre coriace, a vancé, trausversal, entier, arrondi sur les côtés. - Mâachoires rétrécies à leur bitse, ayant un lobe corué au côté interne. - Palpes maxillaires presque filiformes, de quatre articies, le dernier le plus grand de tous, presqu'obconirgue : palpes labiaux filiformes, très-eourts, de trois articles. - Menton grand, recouvrant la bise des miehoires. - Téte ovale-arrondie; clıaperon point distinct de la tête. - Yeux petils, placés sur les côtés du derrière de la tête. - Corps ovale-oblong. - Corselet presqu'orbiculaire, presqu'aussi longr quc large, ses angles postérieurs forlement arrondis, plus large que la tête, un peu plus étroit que la portion noyenae des élytres, laissant entre la base de celles-ci et la sienne, de chaque côté, un large vidc. - Ecusson petit, distinct. - Elytres ovales, soudées enscmble, ayant leurs angles haméraux arronlis; elles collvrent l'abdomen et embrassent un peu ses côtés. - Point d'ailes. -- Abdomen ovale. - Pattes assez longues, jambes droilcs : tarses à articles intermédiaires courts, le dernier et le premier les plus longs de tous; celui-ci presquaussi long que les trois autres, dans les tarses pustéricurs.

Les 'Tentyries habitent le midi de l'Europe, l'Afrique et l'Asie, prélérablement dans les plages sablonneuses et sur les bords de la mer.

$I^{\circ}$. Tentyrie interrompue, T. interrupta. Lat. Gener. Crust. et Ins. tom. 2. pag. I 55 . $n^{\circ}$. I. Commuue sur les côtes méridionales de France, tanı vers l'Océan que près de la Méditerranée.

Nota. M. Latreille place encore diıns ce genre les Pimélies seabriuscule et striatule d'Olivier. Entonb. tom. 3. (S. F. et A. SERv.)

TÉPHRITE, Tephritis. Lıt. Fab. Fald. Panz. Dacus, Dictya, Scatophaga. Faв. Musca. Linn. Di: Géer. Geoff. Panz. Sehranck. Trupanea. Schrance. Tiypeta. Mleig.
Genre d'insectes de l'ordre des Diptères (prenuière section), famille des Athćricères, tribu des Muscides (division des Carponyzes).

Ce genre, lel que uous l'entendons, et tel que M. Latreille le conçoit duns ses Familles naturelles (du moins à c:e que nous présumons), est absolunient le même que celui nommé Trypeta par M. Meigen (Dipt. d'Europ.). Nous n'adopterous pas ce dernier nom parce qu'il nous parcit u'avoir été adonis par aucuu auteur jusquà ce jour, et qu'il piésente dans la langue française une acception ignoble. M. Meirren caractérise ainsi ce genre :

Antennes rapprochées à la base, penchées, plus courtes que l'hypostome, composées de trois articles; les deux premiers courts; le troisiène oblong, linéaire, aplati, obtus à son extrémilé, muni à sa base d'une soie dorsale nue ou à peine pulescente. - Ouperture de la cavité buccale graude, arrondie. - Trompe géniculée, charnue a sa base, rentraut dans la cavité buccale lor's du rcpos. - Palpes insćrés sur la partie supérienre de la trompe, avant son articulation, ovalesoblongs, un peu amincis ì leur base, obtus à leur cxtrémité, planes, un peu cilićs sur les bords. - Tête presqu'hémisphérique; front large dass les deux sexcs, soyeux : liypostome glabre, plane dans son nilieu qui ne présente pas de carène, ayant de chaque côté un léger enfoneement pour recevoir les antemnes. - Y eux presqu'arrondis, espacés dans les deux sexes. - Trois ocelles disposés en triangle sur le vertex. - Corps peu velu. - Prothorax n'étant point distingué du mésothorax par une ligne transversale apparente. - Aile* velues vnes au nicroscope, relevées et vibratiles dans le mouvement, couchées à plat sur le corps dans l'état de repos. - Balanciers découverts. Cuillerons petits. - Abdomen peu bombé, de cing segnens, obıns postérieurement dans les mâles, terminé dans les femelles par une tarière articulée, suillante, plus oa moins longue.

Ces Muscides se trouvent ordinairement sur les planies à lleurs composées, dans les mois les plus chauds de l'aunée; les fémelles déposent presque généralemcnt leurs œufs parmi les semences de ces plantes dont les larves se nourrissent : quelques-unes cependant les introduisent sous l'épiderme dc ces nuêrnes plantes, où la présence des larves orcasiome la formation de galles.

Dans son Systema Antliatorum, Fabricius mentionne quarante-trois espèces de T'éplurites. Les $\mathrm{n}^{\mathrm{o}^{5}}$. I , 5, 13, 15, $16,2 \mathrm{1}, 25,26,28$, 3o, appartiennent réellemeat à ce genre, suivant M. Meigen. Les $\mathrm{n}^{08} .6 \mathrm{et} 7$ sont, pour ce dernier, des Sapromyzes; le no. 12, 1zne Psila; les nos. 17,22, 23, 39, des Ortalis. Le no. 33, unc Piophile; les nos. 34 , 40, 4r, des Sepsis; le no. 35 est la Phore très-noire, $\mathrm{n}^{\circ}$. 1 de ce Dictionnaire; le $\mathbf{n}^{\circ}: 36$, rOchtère Mante no. I. id. Le $\mathrm{n}^{\circ} .37$, une Uhdie Merg. Le no. 38, l'Osciae striée, $n^{\circ} .6$ du présent 
ouvrage. Les ncs. $2,3,4,8,9,10,1$ i , 14, 18, 19 , $20,24,27,29,31,32,42,43$, ne sont pas du genre 'Téplurite, ou du moins sont douteuses.

On trouve des Téphrites dispersées dans d'autres genres de Fabricius (Syst. Antliat.). Sinsi, dans celui de Dacus, les nes. 17, 24, 27, appartiennent aux 'Téphriles. Les Dacus hasiatus no. 15 , et dauci ${ }^{\circ} .22$, sont une même espèce (Trypete solstitialis Merg. ). Le Dacus marmoreus $\mathbf{n}^{\circ}$. 18, est la mème espece que la Tephrtis flavescens

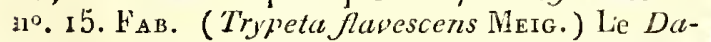
cus scabiosee $\mathrm{n}^{\circ} .26$, est !e même insecte que la Tephritis parietina $\mathrm{n}^{\circ}$. I 5 . (Trypeta Leontodontis Merg.) Les Scatoplaga nos. 28, 29, 31, sont des 'Téphrites ainsi que la Dictya no. 3 .

N. Meigen décrit soixante-lrois espèces de Trypeta daus ses Diptères d'Europe. Il les divise d'une inunière assez peu tranchée d'après les taches que irésentent les ailes. A. Ailes plus ou moins tasciées; espèces de 1 à 3o, parmi lesquelles on trouve aux environs de Paris: Io. 'Téphrite parente, 'T.cognata. - Trypeta cognata $1^{\circ} \cdot 6$. MeIG. Dipt. d'Europ. tom. 5. tab. 43. fio. 19. $2^{\circ}$. 'Téphrite de la Centaurée, T. centaurece. - Trypeta centaurece no. 20. MleIG. id. tab. 49. fig. 3. 30. 'Téphrite à pointe, T. stylata - Trypeta stylata no. 24. MeIg. id. tab. 49. Jig. 12. $4^{\circ}$.'T'ćphrite solstitiale, T. solstitialis - I'rypeta solstitialis $\mathrm{n}^{0} .27$. Meig. id. tab. 49. fig. 10. - Fncycl. pl. 394. fig. 19. 5०. Téphrite quadrifasciée, $T$. quadrifascuaia - Trypeta quadrifasciata $\mathrm{n}^{\circ} .29$. MeIG. id. tab. 49. fio. 3. B. Ailes plus ou mins réticulées; espèces de 31 à 48 . De ce nombre sont: 1․ Téphrite de Westermana, T. Testemanni. - Trypeta Westernanni no. 32. MeIG. id. tab. 5o. fig. 6. Bois de Bondy, le long du canal de l'Ourcq. $2^{\circ}$. Téphri e pariétine, $T$. parietina. Trypeta purictina $\mathrm{n}^{\circ}$. 52. MeIg. id.tab. 5o.fig. 7 . Environs de Pais. C. Ailes entièrement ou presqu'entièrenient sans tachies; espèces de 49 à 54 . Celles de 55 ì 63 . n'étoient pas sullisamment connues de M. Meigen pour qu'il pût assigner les divisions auxquel fes elles appartiennent.

M. Wiédemann dans es Analect. Ent. Kilice. 3824. rapporte aux 'Téphrites les espèces exotiques suivantes : $1^{\circ}$. Téphrite incisće, $T$. incisa $n^{\circ}$. 117. Longueur 2 lig. $\frac{x}{3}$. Jaunâlre; corselet à quatre taches noires. Abdomen à baodes de ceite couleur: ailes bruues, avec quatre baudes et quatie tacbes transparentes. Du Bengale. $2^{\circ}$. Téplrite obsolète, T. obsoleta n ${ }^{\circ}$. 118 . Longueur 2 lig. $\frac{x}{3}$. Couleur de café; abdomen avec des points noirs; ailes brunes ayant des lignes transversales plus pâles et deux taches marginales transparentes. De Java. 30. 'Téphrite armée, T. acrostacta no. 119. Longueur 2 lig. $\frac{x}{2}$. Corselet glauque : abdomen noil'; paltes jaunes : ailes brunes, ayant de chaque còté deux petites bandes marginales, trois taches et l'extrémité transparentes. Mâle et femelle. Indes orientales. $4^{\circ}$. Téphrite pâle, $T$. pallens no. r20. Longneur 2 lig. $\frac{t}{4}$ : Jaune pâle; corselel avec deux brandes noires qui se réunissent en devant : ahdomen ayant des taches à quatre pointes, de même couleur; ailes transparentes. Mâle. De Tanger. 50. Téphrite de Reinhard, $T$. Reinhardi. Longueur I î. ferrugineus : ailes brunes avec une bande à la base, deux lignes vers la côte et trois autres près du bord extérieur, transparentes. Mâle et femelle. Indes orientales. $6^{\circ}$. Téphrite à quatre bandes, T. quadrincisa. Longueur i lig. $\frac{1}{2}$. Noire; frout ferrugineux : ailes brunes, leur base trinsparente ainsi que quatre peites lignes. Fernelle. Indes orientales. $7^{\circ}$. 'Téphrite ponctuée, T. punctata. Longueur 3 lig. Couleur de paille; corselet glauque : écusjon ayant trois bandes brunes; aisdomen et ailes ponctués de brun : celles-ci offrant en outre une bande et des lignes brunes. Nâle. De Guinće. 8’. 'T'éphrite cornue, T' capitata. Longuear 2 ligr. Front portant deux éminences qui soutiennent une soie terminée par une petite lame rhomboidale: ailes ponctuées et fasciées. Mâle. Indes orientales.

Nota. Quelques 'Téphrites se trouvent parmi les espèces du genre Mouche de ce Dictionnaire, mais il est impossible de les spécilier.

$$
\text { (S. F. et A. SERV.) }
$$

TÉRÉBFLLIFÈRES, Terebellifera. Nов. Troisième fumille de la section des 'Térébrans, ordre des Hyménoptères. (Voyez'T'źrímans.) Ses caractères sont :

Antennes soit condées, de douze articles on unvins, seit droites et composécs de treize articles ou plas. - Tarière (des lemelles) cylindrique, cornée, à peine dentée à son extrémité, logée à sa base dans une coulisse abdominale, toujonrs plas ou moins saillante hors de celte coulisse, et droite dans le repos; composée de deux lames latérales, linéaires, converes extérieurement, concaves à l'intérieur, se touchant par leur bord dans toute leur longueur, et reçue au-delà de l'abdomen dans un fourreau composé de deux autres larmes cornées que forme le prolongement latéral de l'extrémité de la conlisse; celte tarière insérée vers le milien de l'abdomen et soutenue $\dot{a}$ sa base par une écaille qui recouvre le point d'insertion, celte écaille de grandeur variable, souvent courte, atteignant rarement à peu près l'extrémité de l'abdomen. - Abdonen point compriné ou comprimé, mais étant alors tronqué postérieurement, ayant habiluellement plus de quatie segmens : anus des mâles complet, sa plaque supérieure recouvrant parfaitement l'inférieure. - Ailes inférieures ayaut toujours plus d'une nervure longitudinale distincte. - Larves se nourrissant de larves d'insectes dans les corps desquelles les femelles introduisent leurs œufs à l'aido de la tarière. 
Celte famille renferme trois tribus : Chalcidites, Iclısenuonides, Trocćrates.

$$
\text { (S. E. et A. SERV.) }
$$

TÉRÉBRANS, Terebrantia. Première section de l'ordie des Hymónoptères; son caracière cst: Abdomen parfuilement sessile dans plusieurs; celui des femelles toujours pourvu d'une tarière. - Antennes ayant ordinairement plus ou moins de doure articles.

La tarière, habituellement composée de deux pièces, conlient un canal longindinal qui donne passage aux reufs; elle a diflérentes conformations, elle est presque plate el deniée en scie dans la fauille des Serrif res (Tenthrédines Lat.). Les deux parties dont elle est composée peuvent agrir séparétnenı; elle est logée dans une coulisse du dessous de l'abclomen vers le milieu duquel elle prend son insertion : lorsque par sa longueur elle dépasse l'abdomen dans le repos, l'extrémité de la coulisse se prolonge de chaque côté en lanies presque plates qui servent de formear is la partic oxtérieure de la larière (1). Dans la tribu des Urouérates la tarière est cylindrique, comprinée, son extrémité pointue a quelques dentclutes trèspetites : il ne paroît point que ses parties paissent agir séparément, toujours une portion de cette tarière dépasse l'ablomen, comme dans les précédens; nous en ôlons le genre Orysse que différens auteurs mettent dans celte tribu, parce que sa tarière est, comme celle des Gallicoles, entièrement rétractile dans l'abdomen; la coulisse extérienre du ventre sert seulement pour la diriger lorsqu'elle en sort : cetle tarière est cylindrique et se roule en spirale dans l'état de repos. Dans Jes diverses tribus que renferme la fumille des Pupivores, cet organe est conformé d'une manière très-différ ente; les Evariales el les Icluneumonides ont leur tarière cylindrique, cornée, à peine dentelée à l'extrémité, plus ou moins saillinte hors de la coulisse abdominale, toujours droite dans le repos. Isa tarière des Gallicoles est couformée comme celle des Orysses. Celle des Chatcidites comme dans les Ichneumonides; seuleanent dans le repos, les Leucospis la relèvent au-dessus de l'abdomen où sont placés, dans ce genre, les fourreaux provenant de l'extrémité de la coulisse veutrale. Les Chrysides ont leur tarière membraneuse, molle, recouverte en partie d'écailles un peu cornées, placées presqu'en toit les unes sur les autres; cette tarière n'est pas pointue, mais cylindrique, accompagnée d'un aiguillon qui n'est

(I) Il n'est point certain que le genre Xiphidrie apparrienne à la famille des Serrifères, il est probable qu'ii doir être reporté dans la tribu des Urocérates, famille des 'Térébellifères; en attendant que l'on connoisse mieux son organisation, il restera avec les Serrifères d'après l'opinion actuelle. point inséré précisément à son extrénité, mais à une distance assez notalile : excepté par son insertion cet aiguilion ne diffère point de celui des Porte-aiguillon. Ia tarière des Oxyures est un iayau solide, non composé, corné, à peine pointu ì son extrémité.

L'abdomen et les antennes des 'Térébrans sont extrêinement variables, et pour la forme et pour le nombre des parties gui les composent. Les larves ont denx manières de vivre fort différenter, se nourrisiant les unes de végétaux et les autres de larves d'insectes.

Nous proposons de diviser cette grande section ainsi cqu'il suil :

I. Une tarière dans les femelles. Point d'aiguillon.

I. Tarière de deux pièces cornées.

A. Tarière (des femelles) comprimée, presque plate. - Larves phyliphages.

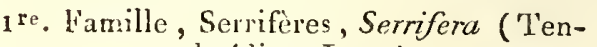
thrédines Lat. ).

B. 'Tarière (des femelles) rétractile dans l'abdomen; cylirsdricue, se roulant en spirale dans le repos. - Larves pbytiphages.

$2^{\mathrm{e}}$. Famille, Spirifères, Spirifera (Gallicoles

Lat. et en outre le genre Orysse).

C. Tarière (des femelles) rylindrique, se logeant en partie dans une coulisse extérieure de l'abdomen dans l'étal de repos, ayant au plus quelques pelites dents vers son extrémité. - Larves zoophages.

3e. Famille, Térébellifères, Terebellifera.

Ire. Tribn. Chalcédites IAat.

$2^{e}$. Tribu. Ichneumonides (Ichneumonides et Evaniales Lat. ).

3e. 'Tribu Urocérates LAT. (à l'exception du genre Orysse).

2. Tarière d'uue seule pièce cornée. - Larves zoophages.

\section{$4^{\mathrm{e}}$. Famille. Canalifères, Canalifera (Oxyures LAt.).}

II. Une tarière membraneuse d'une seule pièce (dans les femelles). Un aiguillon.Larves zoophages.

\section{5้e. Famille. Tubulifères, Tubulifera (Chrysides} LAT.).

(S. F. et A. Serv.) 
TÉRÉdiles. Voyez Perce-bors.

$$
\text { (S. F. et A. S S:R7.) }
$$

TERMES, Termes. Linn. De Géer. Fab. Lat. Hemerobius. Linn. Perla. De Gérer.

Genre d"insectes de l'ordre des Névroptères, section des Filicornes, famille des Planipennes, tribu des Termitines.

Cette tribu, dans les Familles naturelles de M. Latreille, contient deux getnres, suvoir: Terznès et Embie; celui-ci, d’après l'auteur, diffìre du premier par la forme de ses antcnncs.

Antennes filiformes, insérćes devant les yeux, de la longueur du corselet, composíes d'environ dix-hnit articles courts, cylindro-coniques; le premier le plus long de tous, les cinc ou six suivans plus courts que les autres. - Labre membraneux-coriace, avancé, se proloygeant sur les mandibules, presque carré ou un peu trigone, tronqué et obtus en devant, un peu voûté, entier, attaché au cliaperon. - Mandibules cornécs, avancées, dépassint un peeu le labre, triangnlaires ou presque carrées, déprimées, leur côté interne tranchant, muni dc deux ou trois dents courtes, aiguës; celle qui est auprès de l'extrémité plus forte que les autres, cctte extrénité elle-même prolongée en une grandc dent. - IHâchoires ayant leur base crustacéc, comprimée; elles sonl formées dc deux lobes, l'extérieur imitaut la galète des Orthoptères, membraneux, un peu coriace, déprimé, presque trigone, ayant une très-conte articulation à sa base, excavé à sa partie inféricure, reconvrant le lobe interne; celui-ci corné, trigone, comprimé, dilaté intérieurement à sa base, bifide ou unidenté intérieurement. - Quatre palpes filiformes on presque filiformes, les maxillaires plus longs que le's labiaux, de ring articles, les deux basilaires trèscourts; les second, troisième et quatrième presqu'obconiques; le cinquième le plus grand de tous, presque cylindrique: palpes labiaux de trois articles, le premier le plus court de tous. - Lèvre membraneuse, alongúe, divisée à son extrémilé en quatre lanières égales; menton memlsaneuxcoriace, presqu'en carré alongé, un peu plus étroit vers son extrémité. - Téte en ovale court ou presque carrć, un peu plus étroile à sa partie antérieure, arrondie postérieurement; chaperon petit, transversal, déprimé cn devaut, rebordé par une membrane. - Yeux presque semi-globuleux, un peu proéminiens. - Trois ocelles, dont deux plus grands que les autres, placés chacun vers le bord in sième peu visible, posé sủ le milieu de la partie supérieure du fronl. - Corps cylindrique, déprimé, presque linéairc. - Corselet ayant son prothorax nu, recouvert par une lame déprimée, en carré transversal ou semi-circulaire, son bord antérieur droit, le postérienr arrondi. - Ailes presqu'égales, très-longues, étroites, presque linćailes, souvent opaques ou diu moins peu transpareutes, couchées horizontalemcnt sur le corps dans le repos, n'ayant point de nervnres bien distiuctes. Abaomen en carré alongé, plane en clessus, son extrémité arrondie, obtuse, composé de segmens linéaires, transversanx, terminć vers l'anus par deux appendices courts, coniques, biarticulés, placés un de chaque côté. - Fattes courtes; jambes cylindriques, alongées, grêles, munies de deux ou trois petiles épines vers leur extrémité; larses de qualre articles, les prewiers courls, le dernier long, muni de deux crocluets.

Quant anx mours de ces insectes on en trouvera gुnelques détails abrégés à l'article 'TEnmiTINEs. On pour'a aussi en voir d'autres dans l'analyse d'un ouvrage de Smeathman, Encyclop. ton. IV. pilg. ccej; dars celle d"un Mémoire de De Géer, rếue tome, parg. ciij, et tome VI, pag. 404 , diins un alinća où sont rapportées des observalions ảc Lyonet sur de prélendues Fournis des Indes orientalcs, qui ne peuvent être que des Termc̀s. En outre M. Latreille a réuni toutes les notions que l'on a sur les cspèces tant exoliques qu'indigènes de ce genrc à l'article Tranis du noureau Dictionnaire d'Hisioile naturelle, en ayant lui-uréme observé unc espèce daus les cnvirons de Bordeaux avec la sagacité dont il a donué tant d'autres preuves.

Lil larve et la nymphe resscmblent parfaitement à l'insecte parfail; elles n'en diferent que parce que la première est aptére, et que la scconde n'a que des rudimens d'ailes. On rencontre dans les habitations des'Ternès certains individus toujours aptc̀res, dont la tète est autrement conformée que celle des mâles et des femellcs, étant beaucoup plus grande proportionnellement, ainsi que les mandibules : ces individus que M. Latreille croil, avec beaucoup de probabilité, analogues aux femelles stérilcs des l'ourmis, ne paroissent pas se mêler du travail, nais seulement de la défévse de la société dont ils font partie; aussi quelques autcurs leur donnent-ils le nom de soldats.

¡o. 'T'ernès du Cap, T.Capense. De Géen, Mén. Ins. tom. 7. Hémn. 1.pag. 47. no. 2. pl. 38. fig. 1-4.-Lat. Nouv. Dictionn. d'hist. nat. Du Cap de Bunne-Espérancc. $2^{\circ}$. Termès brun, T' fulcumı. Lat.id. De Cayenne. $3^{\circ}$. Termìs morio, T. morio. TAB. Entom. Syst. tom. 2. pag. 9o. no. 5. Des Antilles. $4^{\circ}$. Termès à nez, $T$. nasutum. Isar. id. Jamaique. 50. Termèslucifuge, T. lucifugum. LAT. Gener. Crust. et Ins. tom. 3. pag, 206. $"^{\circ}$. I. Des environs de Bordcanx. 6. Termès voyagear , $T$. viator. LAт. Nouv. Dictionn. d'hist. nat. Du Cap de Bonne-Espérance. $7^{\circ}$. Termès ferrugineux, $T^{\prime}$. ferriginosum. Lat. id. Des Indes orientalcs. $8^{\circ}$. 'Ternès flavicolle, T. flavicolle. Fab. Entom. Syst. tom. 2. pag. 9r. no. 6. D'Esparge et de Montpellier. ( $S$. I'. et A. Senv.) 
TERMITE. Ce nom a été employé par quelques auten's au lien de celui de Termès. Voyez ce mot. (S. F. et A. SERV.)

TERMITINES, Termitince. Cinq̧uième tribu de la famille des Planipennes, section des Filicornes, ordie des Névroptères. Elle offre pour caractères, suivant M. Latreille :

Tous les tarses composés de trois ou qualie articles. - Prothorax en forme de corselel carré ou orhiculaire. - Antennes ordiuairement inoniliformes et courtes. - Ailes généralemént couclıćes horizontalement sur le corps, le dépassant de bcaucoup postérieurement, caduques. - Organes de la manducation se rapprochant bearcoup de ceux des Orthoptères.

Celte tribu renferme les genres Termès et Embie.

Ces insectes vivent en société très-nombreuse: cachés dans l'intérieur de leurs habitations, qui sont souvent coniques et eulièrement composées de terre agglutinée; ils creusent des galeries et les étendent au boin jusqu'à ce qu'ils arrivent aux substances dont ils font leur nourriture dans leurs diflérens états. Ils altacuent ces sulsstances par la partie qui touche le sol, les vident entièrement sans altérer leur forme extérieure. Quoiqu'aimant beaucoup la chaleur, puisqu'ils construisent ordinitiement leurs babitations dans les endroits exposés au soleil des régions équatoriales, ils fuient la lumière et ne s'y cxposent jamais volontairement. Ils sont omnivores el altaquent le bois mort ou vivant, le pain, lesétolfes, elc. Leurs métamorphoses sont incomplètes; leur sociélé se compose principalement de larves, de nymphes et d'une autre sorle d'individus constam. ment apteres, différens des autres par la forme de leurtêt et destinés, ì ce qu'il paruît, uniquement à délendre leur demenre.

$$
\text { (S. F. et A. Serv.) }
$$

TERRESTRES, Terrestres. Puemic̀re division de la famithe des Carnassiers, section des Pentamères, ordre des Colćoplères, ayanl les caractères suivans :

Pattes uniquement propres à la course, point natatoires, les quatre postérieures n'étant point simultanément comprimées ni amincies vers le bout et ciliées. - Mandibules entièrement découvertes. - Mâchoires arquécs ou crochues seulemont à leur extrémité et non dès l'insertion des palpes. - Corps génćraleanent oblong.

Celte division contient deux tribus, savoir, Cicindeletes et Carabiçues. Voyez ces mots à la table alplabétique. (S. F. el A. Serv.)

TERRESTRES, Terrestria. Lat. Seconde section des Crustacés de l'ordre des Isopodes, établie par M. Latreille (Fam. natur. du règne anim.), et rectermant de petils Crustacés dont les deux antennes inlermédiaires sont très-petices, à peine visibles, et de deux articles au plus; elle's a voient échappé à la plnpart des naturalistes. Les preniers feuillets de ceux qui vivent constamonent hors de l'eatu, renferment des pueumo-brauchies, ou des branchies aériennes fuisänt l'office de poumons; l'air y pénc̀tre au moyen de petits trons disposés sur une ligne transverse. Le post-abdomen est couposé de six segmens; le bord postérieur du dernier olfie, daus les uus, deux stylets bifides nuissant du unilieu de ce bord; dans les autres il en présente quatre, un de chaque côté, plus grands, à deux articles, et les deux autres iutérieurs et a un seul arlicle. Les mâles sont distingut's des fémelles par les mênes caractères que les Idotéides.

M. Laireille, dans l'ouvrage que uons avons cité, forme une funille dans celle section; c'est sa famille des Cloportides. Voyez ce mot.

( E. G. )

TERRICOLES, Terricolo. Troisième division de la tribu des 'Tipulaires, famille des Nćnocèrcs, première section de l'ordre des Diptères. M. Latreille hai donse pour caractères:

Point d'ocelles. - Palpes de plusieur's longs, ¿ dernier arlicle alongé. - Extrémité antérieure de la tête rétrécie et prolongée en museau (souvent même avec une saillie poiutue). - Ailes suuvent écartées, à nervures nombreuses réunies trausversalcment, du moins en partic, au-dela da milica de la longueur: deux ou trois cellules discoldales fermées. - Yeux ronds on ovales, sans téchancrure remarquable. - E.xtrémité des jambes épineuse.

Espeeces généralement grandes, vivant pour la pluparl sous la forme de larves el de nymphes dans le terreau ou dans le bois pourri.

1. Antennes te treize articles an moins, $\tan$ tôt soit barbucs ou pectinées, soit en scie; tantôt plus ou moins moniliformes ou noueuses, garnies de poils verticillés.

A. Dernier article des palpes fort long, comme nouenx on articulé. (Antennes souvent barbues, pectinées ou en scie: ailes toujours é artées.)

Cténophore, Pćdicie, Tipule, Néphrotome, Plychoptère.

B. Dernier article des palpes guère plus long que les autres, point noueux. (Ailes le plus souvent couchées sur le corps.)

Rhipidie, Limnobie; Erioptère, Polymère.

11. Antennes de dix articles au plus, grêles ou capillaires, simplement velues ou pubescentes, leurs poils ne forwant pas sensiblememt de verticilles. (Dernier article des palpes 
gù̀re plus long que les antres, point noueux. Ailes le plus souvent couchées sur le corps.)

A. Des ailes.

'Tricliocère, Mækistocère, Dixa, Nématocère Misig. (Hexatoma Latr.), Anisomère Minig.

\section{B. Point d'ailes.}

\section{Chionée.}

Nota. Celle division des Tipulaires, nommće Terricoles, répond à pei près à celle que M. Meigen appelle Rosirato dans sa famille des Tipulaires; mais ce dernier autenr en repousse le genre Dixa et le place parmi les Tipulaircs-fungicoles.

CTÉNOPHORE, Ctenophora. MeIG. ILIIG. Fab. Lat. Wiédem. Macq. Tipula. Linn. Scopol. Geofr. Schranck. De Géer. Ross. Taniptera. Lat.

Genre d'insectes de l'ordre des Diptères, première section, famille des Némocères, tribu des Tipulaires (division des Terricoles).

Les Cténophores font partie d'un groupe qui contient en outre les genres Pédicie, 'Tupule, Néplirotome et Piychoptère. (Voyez TenrteoLEs.) Les Pédicies et les Ptychoptères ont seize articles aux antennes; les Néphrotomes dix-neuf dans les màtes et quinze dans les femelles; le genre Tipule a le second arlicle des antennes cyabiforme et les onze suivans cylindriques : de pius les mâtes dans ces quatre genaes n'unt point les antennes pectinées.

Antennes avancées, composées de treize articles dans les deux sexes; le preuier cylindrique, sillonné transversalement; le second globuleux, presque conique; le troisième de forme variable, les suivans oblongs dans les mâles, presque cylindriques, accompagnés de rameaux latériaux à deux, trois ou quatre brancbes; dans les femelles ces articles sont sans rameaux, ovales-coniques ou oblongs : le treizième ou deruier est petit et dépourvu de rameau dans les deux sexes. - Bouche alongée en un bec court, pointu.-Trompe courte, un peu saillante. - Labre petit. - Palpes conrbés, cylindriques, composés de quatre articles; les trois premiers un peu en nassue, soyeux, d'égale longuenr; le quatrième beancoup plus long, velu, comme noueux ou arliculé. - Tête presque globuleuse.-Yeux ronds. - Pornt d'ocelles.-Corselet ovale; prothorax formant en devant un bourrelet et séparé du resie du corselet par un sillon trans. versal.- Ailes écartées dans le repos, comme vernissées. - Balanciers déconverts. - Abdomen composé de huit segnens; cylindrique, avec l'anus en wassue dans les mâles; fusiforme, avec l'anus terminé par deux lames pointues daus les femelles. - Pattes grèles, de longueur moyenne. Jambes ayant deux épines terminales bien distinctes.

Les belles antennes pectiućes et racoeuses des mâles ont fait donner à ce genre un nom tiré de deux mots grecs qui signifient : porte-peigne. Ises larves sont assez semblables à celles des Tipules; cylindriques, apodes, d'un blanc sale; leur anus porte des appendices disposés en rayons; elles vivent dans le terreau végćtal des arbres qui tombent ell décomposition el s'y tranforment en nymphes dont le corps est garmı d'épines.

$1^{\text {re }}$. Division. Antennes des mâles ayant deux rangs de rameaux, tous deux vers le dedans, placés l'un sur l'autre, les plus courts en dedans.

Cette division compread: $1^{\circ}$. Cténophore bimaculé, C. bimaculata. Heig. Dipt. d'Eusop. tom. 1. pag. I56. no. I. - MAcQ. Ins. Dipt. Tipul. pag. 81. $n^{0}$. 1. De Frauce; environs de l'aris. $2^{\circ}$. Cténophore des marais, C. paludosa. Mera. id.pag. 157• $n^{\circ}$. 2. D'Italie.

$2^{e}$. Division. Antennes des mâles ayant trois rangs de rameaux, un de claque côté et un plus court en dessous.

$1^{\circ}$. Cténophore âtre, C. atra. MEIG. Dipt. d'Eur. tom. I. pag. 158. no. 3. - MAeQ. Ins. Dipt. Tipul. pag. 81. $n^{\circ} .2$. De France; environs de Paris. $2^{\circ}$. Ciénophore nigricorne, C. nigricomis. Mieig. id.pag. I59. $72^{\circ}$. 4. Mûlle. D'Alleinagne. M. Masquart, ia. pag. 82. no. 3. décrit un individu femelle qu'il regarde comme celle de la rigricomis trouvé aux cnvirons de Lille.

3e. Division. Antennes des mâles ayant quatre rangs de rameaux, deux de claque côté, Ies plus courts en dedans des antres.

${ }^{\circ}$. Ctenophore pectinicorne, C. pectinicornis. MeIG. Dipt. d'Eur. tom. 1. pag. I6o. $n^{\circ} .5$. - MAcq. Ins. Dipt. Tipul. pag. 82. n०. 4. De France. $2^{\circ}$. Cténophore à bandes jaunes, C'. fla. veolata. ME1G. id. pag. 16u. no. 6. - M AcQ. id. pag. 83. $n^{2}$.5. Assez commune aux environs de Paris. 50. Cténophore agréable, C. festiva. MEIg. id. pag. $162 . n^{\circ}$. 7. - MAcQ. id. pag. 84. $n^{\circ} .6$. De l'rance; environs de Paris. $4^{\circ}$. Cténophore élégante, C. elegans. Merg. id. pag. 163. $n^{\circ} .8$. tab. 5. Jig. 18. Femelie. Environs de Paris. 50. Cténophore tachetée, C. guttata. ME1G. id. pag. 365. $n^{\circ}$. 9. D'Autriche. 6o. Ciénophore ornée, C. omata. Meig. id.pag. 166. $n^{\circ}$. 10. Même patrie. $7^{\circ}$. Cténophore llavi :orne, C. flavicomis. MFIG. id. $n^{\circ}$. 11. Même patrie.

Nous rapporterons en outre a ce genre deux espèces de Java décrites par M. Wiédemann dans ses Dipt. exotic. donl il ne connoît que des fenelles. 10. Ciénophore ardente, $C$. ardens, pag. 20. $n^{0}$. 2. Longueur 8 lig. Ferrngineuse. Pattes noires; jambes postérieures ayant une bande transverse blanche. Ailes safranées, leur exirémité brune. $2^{\circ}$. Cténophore annelée, $C$. compedita, pag. 21. $n^{\circ}$. 3. Longueur 7 lig. 
Jaune; corselet à bandes noires. Pattes noires; toutes les jambes ayant un anneau blanc; extrémité des ailcs brune.

Nota. La Ctenophora lopta $n^{\circ}$. 8. FAB. Syst. Antliat. des Indes orieulales apparlient aussi à ce geure selon MI. Wiédemann. La Ctenophora quatuormaculata $\mathrm{n}^{\circ}$. 4. FAB. $i d$. est la Linmobia quadrimaculata. Mexg. Dipt.d'Eur. tom. I. pag. 15 . $n^{\circ}$. 64. M. Wiédemann (Dipt. exotic.) rapporte celle même espèce au genre Tipule.

NÉPHROTOME, Nephrotoma. Meig. Lat. IHAcQ. Tipula, EaB.

Genre d'insectes de l'ordre des Diptères, première section, famille des Némocères, tribu des Tipulaires (division des 'Terricoles) (1).

Quatre genres, outre cclui de Néplirolome, composent un groune parmi les 'Tipulaires-Terricoles. (Voyea Terricoless.) Dans ces quatre genres le nombre des articles des antenues est émal dans les deux sexes; les Cićnophores et les Tipules n'ont que treize arlicles aux antennes; celles des Pédicies el des Plychuptères en ont seize.

Antennes avancécs, filiformes; celles des mâles presqu'aussi longues que l'abdomen, arquées, courbes, composées de dix neuf articles; le premier et le troisième cylindricques. le second cyathiforme, le quatrième et les suivans réniformes, échancrés au côté inférieur, un peu plus épais à leur base, du double aussi longues que la tête, et de quivze articles dans les femelles; les irois premiers, comme dans les mâles; tous les autres presque cylindriques, un pcu plus épais à leur Lase. - Palpes avancés, courbés, de quatre articles; les trois premiers d'ćgale grandeur, un peu plus gros vers leur extrécnilé, le quatrieme Leaucoup plus long, cylindrique, comme noueux on arliculé. - Tête prolongée en museru. Yeux arrondis, séparés. - Point d'ocelles. Prothorax séparé du reste du corsclet par une ligne transverse enfoncée, sinceuse. - Ailes lancéolées, écartées. - Abdomen composé de huit segmens. - Jambes à épines terminales courles.

(1) Il existe un arricle Iípárotome à sa lerre dans ce Dicrionnaire; feu $\mathbf{O}$ tivier qui l'a rédigé ne connoissant pas suffisammenr les genres alors nouvellement érablis par M. Meigen a pris, d'après. les ressemblances de couleur, une espèce de Tipulaire (Tipula histio $\mathrm{F}_{\mathrm{A}}$ B. MEı. ) pour une Néphrotome, et il n'a pas connu la vraic Néphruiome dorsale de M. Meigen. Partane de là Olivicr a toralement erré et dans les caractères qu'il donne à son genre Néphrotoms, et dans les ix espèces qu'il $\mathrm{y}$ faic entrer; les cinq premières sont des Tipules, savoir: Nephr. crocata $\Pi^{\circ}$. I, pratensis $n^{\circ} .2$, cornacina $n^{\circ} .3$, dorsalis $n^{\circ} .4$ (celle-ci est la Tipula listro FAB. MEIG.), vittata ${ }^{\circ}$. 5. La replicata $n^{\circ}, 6$ est une Limnobie.

Les 'Tipules q'je nous venons de citer sont de la deaxième division du genre Tipula de M. Meigen, et diffèrent des autes Tipules par les nervures des ailes. Voyez Trpore.

\section{$\mathrm{T} \mathrm{ER}$}

Le nom de ce genre est tiré de deux mots gress qui expriment que la plupart des articles qui composent les antennes des mâles sont réniformes. La seule espèce connue se trouve en France et en Allemagne pendant l'été dans les bois aquatiques et sur les haies; par ses couleurs elle se rapproche singulièrement de plusieurs espèces de la seconde division du genre 'lipule. Olivier a pris pour elle la Tipula histrio. M. Meigren dit que la Néphrotome dorsale ressemble tellement ¿̇ la Tipula scurra, qu'elle n'en est distinguée que par la conformation des antennes et la tache stigmatique des ailes gui est noire, et M. Macquart trouve qu'il y a toujours quelque diffculté à la distinguer de la Tipule cornicine avec laquelle on la trouve. Ise type du genre est la Néphrotome dorsale, $N$. dorsalis. ME1G. Dipt. a'Eur. tom. I. pag. 202. $u^{\circ}$. 1. tab. 5. fg. 22. Femelle.-MAcQ. Ins. Dipt. Tipul. pag. $79 \cdot n^{\circ}$. 1. en retranchant le synonyme d'Olivier énoncé sous le nom de Tipula dorsalis, mais qui ne peut avoir rapport qu'à sa Néphrolome dorsale, Encycl. tom. VIIT. pag. ${ }^{196 .} n^{\nu}$. 4. (Tipula histrio des auteurs.)

LIMNOBIE, Limmobia. MeIg. Lat. (Fam. nut.) Mace. Limonia. Merg. (classif:) Lat. (Gener.) Tipula. Linn. De Géer. Fab. Schranck. Sceicl. Nephrotoma. Oziv. (Encycl.)

Genre d'inscctes de l'ordre des Diptères, première seclion, famille des Némocères, tribu des Tipulaires (division des Terricoles).

Un groupe de cette division contient quatre genres ( voyez Ternicoles); $1^{\circ}$. Rhipidie, qui n'a quc quätorze articles aux antennes dans les denx sexes; celles des mấlcs pectinćes. $2^{\circ}$. Erioptire, dont les nervures des ailes sont velues. $3^{n}$. Polymère, ayant les antennes composíes de vingt. livit article.. $4^{\circ}$. Limnobie, qui ne présente aucun de ces caraclères, mais les suivans.

Antennes filiformes ou presque sétacées, se rejetant sur les côtés, ordinairement composées de seize articles, rarement de quinze ou de dixsept; le premier cylindrique, le second cyathiforme, les suivans plus ou moins oblongs ou globuleux, velus ou soyeux, d'une grossenr décroissante vers l'extrémité : celles des mâles quelquefois plus longues que relles des femelles.-Bouche trc̀s-peu alongće. - Trompe ordinairement trèscourie, un peu saillaule. - Palpes saillans, courlés, babituellement plus longs que la trompe, de quatre articles; les trois premiers allant un peu en grossissant vers leur extrénité, un peu velus; ceux-ci le plus souvent d'égale longueur; le quatrième ordinairement plus grêle, cylindrique, point noueux, ni flexible; le premier plas court dans un petit nombre d'espèces. - Téte petite, ovale, un jeu plate par en haut, rétrécie postérieurement. - Yeux rouds. - Point d’ocelles. - Corps alongé. - Corselet ovale; pro- 
thorax formant un bourrelet par-devant, séparé du reste du corselet par une ligne transversale, enfoncée, sinueuse; métatliorax un peu arqqué. - Ailes couchées parallèlement l'une sur l'autre dans le repos; leurs nervures point velues; bord postérieur des ailes frangé de petits poils. Balanciers découverts. - Abdumen long, effilé, cylindrique à sa base, s'aplatissant vers son extrémité, composé de huit segmens; anus des mâles obtus, celui des femelles torminé par deux lames poiutues, placées l'une contre l'autre. Pattes longues, grêles, fiuement velues; jatnbes terminées par deux pelites épines peu visibles; tarses à peu près de la longueur des jambes.

Les limubies, doill le nom vient de deux mots grecs qui signifien! : vivant dans les marais, habitent les bois bimides et le bord des mares; pendant le grard jour, qu'elles semblent craindre, elles se tiennent à l'ocubre du feuillage; plusieurs espèces, les plus petites surtout, voltigent en troupes vers le coucher du soleil et par un temps calme, s'abaissant et s'élevant alternativement daus l'air, sans s'écarter beaucoup d'un même endroit; les différentes espèces de ce genre paroissent successivement pendant toute la belle saison. M. Macquart, que nous avons eu déjit occasion de ciser quelquefois pour ses ouvrages remarquables sur les Diptères clu nord de la France, observe que le voisinage des eaux, recherché particulièremeut des Limnobies, semble indiquer que la nature y a placé leur berceau; cependant les femelles ont comme les autres 'Tipulaires-'Terricoles, l'abdomen terminé par deux lames cotnées formant une pointe gui servent à celles-ci pour confier leurs ouf́s à la terre; l'auteur cité est donc porté ì croire que les Limnobies déposent les lenr's dans la vase au bord des eaux. Nous adoptons d'antant plus volontiers cette opinion, qu'il nous paroit probable qa'une larve qui pent vive dans une terre entièrement imprégnée d'eau, peut aussi quelquefois pénétrer dans l'eau même, ne fùt-ce que pour aller chercher une autre place lorsque la sécheresse fait baisser l'eau de la mare sur les bords de laquelle elle duit trouver sa subsistance; au reste peut-être par suite d'une senblable circonstance, De Gér a trouvé et observé dans l'eau la lar've de la Linnobie repliée; on trouvera la description et l'instoire de cette larve à l'article Néprrotore de ce Dictionnaire, tome VIll, pag. I $91-19 \overline{3}$.

MM. Nieigen et Macquart divisent ce genre extrêtzement nombreux, d'après la dispostion des nervures des ailes; lous deux y confondent le genre Pédicie Lat. que nous avons cru devoiy conserver; en effel, le dernier article des palpes des Pédicies, malgré l'assertion de M. Macquart, diffère essentiellewent de celui des Limnobies, - quoique les caracteres antemaires du premier de ces genres se retrouvent dans quelques Limnobies, il n'est pas vrai de dire avec M. Meigen, Hist. Nat. Ins. Tome $X$. que le seul caractère distinctif des Pédicies soit l'écartement des ailes dans le repos.

Ne pouvant donner ici des figures d'ailes, il nous est impossible de diviser les Limnobies d'après les principes des deux auteurs dont nous venons de parler ; et en employart d'autres moyens, nous peosions plutôt indiquer des genres à faire que de simples divisions; mais nous devons avouer que ces coupes sont indiquées par M. Meigen dans son caractère géuérique, et qu'elles laissent réunies une grande quantité d'espèces qui ont besoin d'un nouvel examen.

Ire. Division. Trompe plus longue que la tête et même que les antennes. - Articles des palpes presqu'égaus. (Megarhina Noв.)

Ici se place la Limnobic longirostre, L. longirostris. Mejg. Dipt. d'Europ. tom. I. pag. 146. $n^{\circ}$. 53. tab. 5. fig. 3. la têle seulement. tab. 6 . fig. 6. I'aile. - MiscQ. Ins. Dipt. Tipul. pog. 95 . $n n^{\circ}$ 13. De France et d'Alewagne.

2e. Division. 'Trompe plus courte que les antennes et mème que la tête. - Articles des palpes inégaux.

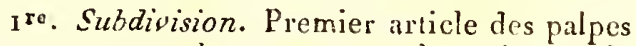
plus court et plus menu que les suivans; le second et le troisième un peu en massue, le dernier oblong, obıus. (Helobia Noв.)

A cette coupe appartient la Limnobie punctipense, L. punctipennis. Meig. Dipt. d'Europ. tom. 1. pag. 147. $72^{\circ}$. 56. tab. 5. flg. 2. la lête du mâle. fig. 3. les galpes. fig. 7. l'aile. - MAce. Ins. Dipt. Tipul. pag. I03. no. 35. D'sllewague et de lirance.

M. Meigen parle encore dans les génćralités dn genre Limnobie pag. 116. d'une Limnobia praticola, qui a la neème conformation que la punctipennis.

$2^{\mathrm{e}}$. Subdivision. I es trois premier's articles des palpes un peu épais antérieurement, égaux en!r'eux en longueur et en grosseur; le quatrième un peu plus long que le précédent, plus grêle et cylindrique. (Limnobia propriè dicta Noв.)

Cette subdivision renferme soixante-deux espéces, c'est-à-dire toutes les Limnobies de M. Meigen, à l'exception des suivantes : $1^{\circ}$. Limnobia rivosa $\mathrm{n}^{\circ}$. 1 . type du genre Pédicie LAT. $2^{\circ}$. Limnobia longirostris $\mathrm{n}^{\circ}$. 53. 3०. Limnobia punctipennis ఎ 50.

Nota. j॰. La limnobie repliée, $L$. replicata. Merg. id. $n^{\circ}$. 48. est décrite dans le présent Dictiounaire sous le nom de Néphrotome repliée no. 6 . $2^{\circ}$. Peut-être devroit-on furmer des sous-genres de la limnobia glabrata no. 47. Me1G. id. qui a dix-sept articles aux autennes, et de la Limn. analis $n^{\circ}$. 45 . qui paroît n'en avoir que quinze; Eee 
tandis que toates les antres Limnobies, ou du moins la très-grande majorité, en ont seize.

M. Maccquart dans l'ouvrage cité plus haut décrit trenle-buit espèces de ce genre. II donne les suivanles comme nouvelles: $1^{\circ}$. Limnobie six taches, L. sexmaculata. Mace. Ins. Dipt. Tipul. pag. 9 r. $n^{\circ}$. 4. Longueur 4 lig. Femelle. Cendrée; ailes avec six taches noirâtres. Lille. $2^{\circ}$. Limnobie nuirâtre, $L$. nigticans. MAcQ. id. pag. 93. $n^{\circ}$. 8. Femelle. D'un cendré-noirâtre. Hanches et base des cuisses ronssâtres. Point marginal des ailes brun. $3^{\circ}$. Limnobie sessile, $L$. sessilis. MAcQ. id. pag. 94. $\pi^{\circ}$. 10. Longueur 3 lig. $\frac{3}{3}$. D'un gris roussâtre. Curselet avec quattre baudes brunes; ailes à point marginal pâle. Lille. $4^{\circ}$. Limnobie platyptère, L. platyptera. MacQ. id. $n^{\circ}$. 12. Longuenr 3 lig. Noire. Ailes larges, sans taches. $5^{\circ}$. Limuobie bordée, $L$. maryinata. MAcQ. id. pag. $9^{5 .} \boldsymbol{n}^{2}$. 14 . Longueur $3 \mathrm{lig}$. $\frac{1}{3}$. FCmelle. Noire; seginens de l'abulomen bordés de fauve; pattes jaunes; ailes à point marginal obscur. 6 $6^{\circ}$. Limnobie âtre, L. atra. MAcQ. id. $n^{\circ} \cdot 15$. longueur 3 lig. Hâle. Noirûtre; patles obscures; ailes sans point matginal. $7^{\circ}$. Limnobie argentée, $L$. argentea. MAc2. id. pag. 97. $n^{\circ}$. 18. Longueu 4 lig. $\frac{1}{2}$. Mâle. Corselet noir, ses côtés d'un blanc argenté; mélathorax gris-cendré. $8^{\circ}$. Limnobie variée, $L$. variegata. NAcQ. id. $n^{\circ}$. 19 . Longueur 5 lig. Noirâtre; ailes marbrées. $9^{\circ}$. Limnobie grise, L. grisea. MAcQ. id. pag. 1oo. $n^{\circ} .26$. Longueur 3 lig. Grise; corselet ayant trois bandes noires; ailes hyalines, leur point marginal trèspâle. $10^{\circ}$. Limnobie unimaculée, L. unimaculata. MacQ. id. pag. roI. $n^{\circ} .28$. Longueur 4 lig. Noirâtre; ailes à point marginal brun. $1^{\circ}$. Limnobie lisse, L. loevigxta. Mace. id. $z l^{\circ}$. 29. Longueur 3 lig. D'un noir lisse; ailes à point uiarginal brun. $12^{\circ}$. Limnobie macroplère, $L$. unácroptera. MAcQ. id. pag. 102. $n^{\circ}$. 32. Lougnenr 3 lig. $\frac{1}{2}$. Rousse; corselet à quatre bandes brunes; ailes fort larges. $13^{\circ}$. Linnobie soyeuse, L. sericea. MacQ. id. pag. 103. $u^{\circ}$. 34. Longueu: 2 lig. $\frac{1}{2}$. Grise, narquée d'une ligne noire; ailes hyalines. De Lille. $14^{\circ}$. Limnobie genoux noirs, $L$. cothurnata. MAce. id. pag. I05. $\pi^{\circ}$. 37. Longueur une lig. $\frac{\frac{3}{3}}{3}$ Jaune genoux noirs.

Parmi les espèces exoliques, M. Wićdemann nous indique: $1^{\circ}$. Limunobie obscure, L. obscura. WiÉd. Dipt. exotic. pag. 14́. $n^{\circ}$. 1. - Tipula obscura no. 18. Fıs. Syst. Anlliat. Amérique méridionale. $2^{\circ}$. Limsobre longimane, $L$. longimana. Wiéd. id. $n^{\circ}$. 2, - Tipula longimana ப $^{\circ}$ I I. FАв, $i d$. Amérique méridion le. 30. Limnobie armillitire, L. armillata. Wrén. id. no. 3 . - Tipula armillaris $\mathrm{u}^{\circ}$ 12. FAB. $i d$. Mème patrie. $4^{\circ}$. Limoobie acrostacte, L. acrostactu. Wiéd. id. $n^{\circ}$. 4. Longuenr 8 lir.r. Bruze; abdomen d'un beau jaune, son extrémité noire; ailes brunes avec deux points et une linule de couleur blanche. De Java. $5^{\circ}$. Limnobie basilaire, L. basi- laris. Wién. id. pag. 15. $n^{\circ}, 5$. Longueur 8 lig. Mále. 7 lig. Femelle. Noire; ailes brunes, leur base d'un beau jaune avec des fascies et des laches blanches. De Java. 60. Limnobie maculée, L. maculata. Wí́. id. - Tipula maculata no. 29. Fab. $i d$. Amérique méridionale. $7^{\circ}$. Limnobie érythrocéphale, L. eiythrocephala. WiÉd. $i d$. Tipula erythrocephala แ०$^{\circ}$ 35. FАв. id. Niême patrie. 8o. Limnobie corselet jaune, L. flavithorax. WIÉD. id. pag. 43. $n^{\circ}$. 3. Longueur 5 lig. Femelle. Noire; corselet d'un jaune de miel; ailes enfumées. Anérique méridionale. $9^{\circ}$. Limnobie à côtes, L. costalis. Wı́́d. Analect. entom. pag. 10. Longnear 3 lig. D'un beau jaune; corselet avec une bande livéaire plus foncée; ailes d'un beau jaune avec une bande large, brune, placée à la côte. Des Iudes orientales.

ÉRIOptère, Erioptera. Meig. Lat. (Fam. nat.) MacQ. Tipula. Livn. FAB. Geopf.

Genre d'insectes de l'ordre des Diptères, première section, familie des Némocères, tribu des Tipulaires (division des Terricoles).

Un groupe de Tipulaires - Terricoles renferme quatre genres, savoir : Rlipidie, Polymère, Erioptère et Limnobie. (Voyez Terricoles.) Lue prenier n'offre que quatorze articles aux antennes dans les deux sexes, celles des unúles pectinées: le second a les siennes composées de vingt-tnit articles, et dans les limnobies les nervures des ailes sont glabres, ce qui sépare ces trois genres de celui d'Erioptère.

Antennes a vancées, sétaccées, finement velues, composées de seize articles; le premier cylindrique, le second cyathiforme, les suivans ovales. Bouche pen alongée. - Trompe charnue, échancrée antérieurement. - Palpes saillans, recourbés, cylindriques, de quatre articles égaux entre eux, cylindriques; le second un pen plus épais, en massue. - Tête conique. - Yeux ronds. Point d'ocelles. - Corps mince. - Prothorax séparé du reste du corselet par une ligne enfoncée , Iransversale, sinuée. - Ailes oblongues, frangées au bord, velnes sur leurs nervures, couchées à plat parallèlement sur le corps dans le repos. - Balanciers découverts. - Abdomen cylindrique ou un peu fusiforme, de huit segmens; anus des femelles terniné par deux la unes cornées qui se réuaissent en une pointe : celui des mâles obtus. -- Pattes longues, grêles; la paire du milieu plas conte que les autres.

Le nom d'Erioptere vient de deux mots grees qui expriment la villosité des ailes. Ces insectes se trouvent dans les prairies marécageuses et sur les broussailles. On ne sait rien de leur premier état.

M. Meigen mentionne seize espèces de ce genre; 11 les divise d'après les nervures des ailes. M. Macrguart en décrit buit espèces du nord de la Fance, qu'il divise ainsi : 
re. Division. Les deux cellules discoïdales supérieures des ailes, d'égale longueur.

I ${ }^{\circ}$. Erioptère noire, E. nigra. MacQ. Ins. Dipt. Tipul. pag. 107. $n^{\circ}$. 3. Louguen 2 lig. Noire; première cellule sous-marginale des ailes à tong pédicule. $2^{\circ}$. Eriopic̀re jaunâtre, $E$. flavescens. MEIG. Dipt. d'Europ. tom. x. pag. IO9. no. 2.MAcQ $i d \cdot p \cdot 106 . n^{\circ} \cdot$ r. $3^{\text {p}}$. Erioptère commune, E. trivialis. ME1G. id. pag. 112. $n^{\circ}$. 8. - MAcQ. id. $n^{\circ} .2 \cdot 4^{\circ}$. Erioptère linée, E. lineata. Mrig. id. pag. 111. $n^{\circ} \cdot 7 \cdot$ - $\mathrm{MACQ}_{\mathrm{BC}}$ id. pag. $107 \cdot n^{\circ} \cdot 4$. 5^. Erioptère noduleuse, E. nodulosa. MAcQ. id. pag. 108. $n^{\circ} .5$. Longucur 2 lig. $\frac{1}{2}$. Corselet gris; abdomen noirâtre; anles légìenenen obscures, lcur point marginal plus brum.

2*. Division. Ailes ayaut leur cellule discoildale supérieure intcrne beancoup plus courte que la cellule discoidale supérieure extene.

$\mathbf{I}^{\circ}$. Erioplère naine, E. pygnacea. Mıcq. Ins. Dipt. Tipul. p. 109. $n^{\circ}$. 8. Longueur $\frac{3}{4}$ lig. D'un gris noirâtre. $2^{\circ}$. Erioptère obscurc, E. obscuna. Meig. Dipt. d'Eur. tom. 1. pag. $115, n^{\circ} .12 .-$ M AcQ. id. pag. 108. $n^{\circ} \cdot 6.5^{\circ}$. Erioptère ochracée, E. ochracea. MEIG. id.pag. 114. $2^{\circ}$. 13. - NACQ. id. $n^{\circ} \cdot 7$.

POLYMĖE, Polymera. WiÉder. Lat. (Fam. natur.)

Genre d'insectes de l'ordre des Diptères, première section, fauille des Némocères, tribu des Tipulaires (divisiou des Terricoles).

Les genres Rhipidie, Eurinptère et Limnobie forment, avec celui de Polynère, un groupe particulier dans les Terricoles (voyez ce mol). Les Rhipidies ont leurs antennes composées de quatorze articles pectinés dans les mâles, les trois premiers exceptés; celles des limnobies ont de quinze à dix-sept articles, et dans le genre Eriop. tère ces organes sont composés de seize articles dans les deux sexes.

$\mathrm{Ne}$ connoissant pas ce genre nous allons eu donncr les caractères d'après $M$. Wiŕdemann. ( Dipt. exotic. pag. 40.) Son nom vient de deux mots grecs qui exprimenl la division de ses antennes en un grand nombre d'articles.

Antennes corposcés de vingt-huit articles, le premier globu!eux, le second cylindrique, alongé; lcs suirans beauconp plus courts, ayant leur base gárnie de poils verticillés. - Pattes très-longues.

M. Latreille (Fam. nat.) ajoute à ces carac,tères : point d'ocelles. Dernier articlc des palp̧es guère plus long que les autres, point noucux; extrémité antérienre de la tête rétrécie et prolongcée en unusean. Yeux sans échancrure. Extrémité des jambes épineuse.

Le 'ype du genre est lit Polymère brune, $P$. fusca. Wiéden. Dipt. exotic. pag. 44. $n^{\circ}$. 5. Femelle. Longuenr 3 lig. Brnne; ailes transparen- tes, jaunâtres; extrémité des tarses blanche. Du brésil.

M IKKISTOCÉRE, Mockistocera. WiÉD. Lat. (Fam. nat.) Tipula. FА .

Genre d'insectes de l'ordre des Diptères, première section, famille des Némocères, tribu des Tipulaircs (division des Terricoles).

Un groupc de cette division comprend les genres Trichocère, Mrkistocère, Dixa, Nématocère et Anisomère. (Voyez Terricoles.) Dans les deux dcrniers les antcines sont composées seulement de six articles; les Dixas et les Trichocères n'ont que les premiers articles de leurs antennes bien distincts, en outre dans les Dixas l'abdomen n'a que sept segmeus, et les antennes n'égalent pas en longucur celle du corps : les palpes des Trichocèrcs sont composés de cing articles. Ces caractères éluignent tous ces Tipulaires des Mækistocc̀res.

Ce genre, qui tire son nom de deux mots grecs exprimant la longueur des antennes, ne nous est connu que par lcs Dipt. exotic. de M. Wiédemann, dont nous allons extraire ses caractères:

Antennes d'une longneur excessive, composées de dix arlicles, le premier cylindrique, épais; le second cyabiforme; les huil derniers cylindriques, filiformes, angmentant de longueur depuis le premier de ces huit jusqu'au dernier. Palpes de quatre articles prosqu'égaux. - Point a'ocelles. - Ailes écartées, lancéolées; leurs nervures come dans les 'Tipules.

L'auteur mentionne deux espèces de ce genre, $1^{\circ}$. Mrekistocc̀re filipède, $M$. fllipes. WIÉDE.M. Dipt. exotic. pag. 4r. - Tipula filipes n०. 8. FAr. Syst. Antliat. De Guinéc. 20. Mrkistocère brune, M. fluscana. Wí́dem. id. pag. 41. Nematocera fuscuna. Wiḱd EM. id. pag. 29. Longueur 6 lig. Femelle. D'un jaune pâle un peu brun. Abdomen taché de bran. Antennes et pattes très-longues; les pretnières ayant deux pouces trois quarts de longueur. De Java.

DIXA, Díxa. Merg. TAt (Fam. nat.) MacQ. Gcure d'insectes de l'ordre des Diptères, première section, famille des Nćmocères, tribu des Tipulaires (division des Terricoles).

Ce genre fait partie d'un groupe de TipulairesTerricoles, qui contient en outre ceux de Trichocc̀re, Nématocère, Anisomère et Mrakistocère. (Voyez Terricoles.) Mais dans les trois premier's le prothorax est séparé du rcsie du corselet par une ligne transversale enfoncée, de plus les Trichocères ont leurs palpes composés de cinq articles; les Mrkistocères se distinguent par l'excessivc longueur dc lcurs antennes.

Antennes assez longues, a vancées, sétacées; leur premier article court, épais, cylindrique, le second un peu plus grand, épais, presque sphérique; les suivans (M. Meigen pense quils sont Eece 2 
an nonbre de donze) très-grểles, finement velus, peu clistincts, surtout celıx de l'extrémité. Palpes avancés, cylindriqques, recourbés, de quatre articles, le premier tiès-petit, les deux suivans d'égale longneur, le dernicr un peu plus long et plus grçle. - Tête petite, assez aplatie en dessus, sans muscau distinc!.- Yeux ronds. - Point d'ocelles. - Corselet assez long, arrondi à ses extrémités; prothorax confondu avec le reste du corselet. - Ailes obtases, couchées parallèlement sur le corps dans le repos. - Balanciers déconvcrts. - Abdomen cylindrique, de sept scgmens. - Pattes dc longucur moyenne; hanches de médiocre longueur; cuisses grêles; jambes nues, terminées par denx petiłes épines.

On trouve lcs Dixas dans les lieux marécageux des forcts ; leur tialle est fort petite, elles évitent le jour et ne volent que ver's le soir; leurs premicrs étals sont encore inconnus. Il seroit cependunt très-desirable que leurs mours fussent observécs, d'autant que les autenis sont partagés sur la question de savoir si elles n'appartiennent pas plutôt aux Tipulaires-Fungivores LAT. (fongicoíc Meig.) qu'aux Terricoles Lat. (rostrutoe Heig.)

M. Meigen décrit quatre espèces de ce genre : 10. Dixil ardive, D. serotina. Merc. Dipt. d'Eur. tom. 1. pag. $217 \cdot n^{\circ}$. I. Longueur I lig. $\frac{\pi}{3}$. Mâle. Corselet d'un bean jaune avec des raies contenr de calté. Abdomen brun avec des bandes blanchàires. Ailes jannîtres. De Prusse. $2^{\circ}$. Dixa estivale, D. cestivalis. Merg. id. pag. 2 I $8 . n^{\circ} .2 .-$ MacQ. Ins. Dipt. Tipul. pag. 57. $n^{\circ}$. 1. Longueur I lig. 3. Mâle. Jannâtre; corselet à trois bandes brunes, l'intermédiaire jumelle; ailcs transparentes. De France et d'Allemagne. $3^{\circ}$. Dixa printannière, D. aprilina. MeIg. id. $n^{\circ}$. 3. tas . 7. fg. 12. Macq. $i d . n^{\circ}$. 2. Long. 2 ligr. Mâle. Corselet pâle à trois bindes noires; abdomen brun; ailes transparentes, sans taches. D'Allewagne et de Frauce. 40. Dixa tachée, D. maculata. MEIG. id.pag. 219 . $n^{\circ}$. 4. Lonsueur 1 lig. $\frac{3}{3}$. Corselet pâle, a trois bandes ncires. Aldomen d'un brun noirâtre; ailes transparentes avec une lache centrala brune. D'Allemagne.

\section{NÉMATOCÉRE, Nematocera. Merg. MAcQ. Hexutomu. Lat.}

Genre d'insectes de l'ordre des Diptères, premic̀re section, famille des Némocères, tribu des Tipulaires (division des Terricoles).

Dans cetle division un groupe renferme cinq genres, y compris celui de Nématocere ( voyez T'RRIC LES ) : $1^{\circ}$. Trichocère, qui a cinq articles aul palpes. $2^{\circ}$. Mrokistocc̀re, ayant les auteunes excessiventent longucs et de dix articlcs. 3n. Dixa, donl le prothorax n'est print séparé du reste du corselet par une ligne transversale. $4^{\circ}$. Anisornc̀re, distingué par le lroisième arlicle des antesnes ayant plus du double de longueur que le suivant. $5^{\circ}$. Nématocère, qui ne présente aucun dc ces caractères.

Antennes presque sétacées, avancées, plıs longues que la tète et le corselet réunis, composées de six articles; les deux inférieurs beaucoup plus épais que les autres, le premicr cylindrique, le second cyathiforme, les quatre suivans grêles, finement vclus, presque d'égale longueur. - Palpes saillans, courbés, de quatre articlcs presque égaux. - Tête ayant son extrémité antérieure prolongée $\mathrm{cn}$ an museau court : front large. Yeurx alongés, ovales. - Point d'ocelles. - Prothorax séparé du reste du corselet par une ligne transversale enfoucée. - Ailes couchécs parallèlcnent sur le corps dans le repos. - Balanciers découverts. - Abdomen déprirné, de huit segmens. - Pattes grĉles; jambes ayant deux épines tcrminales peu distinctes.

Lcs mours de ces Tipulaires ne sone pas connucs. M. Meigen regardant lcurs antennes comme filiformes a tiré le noan générique de deux mots grecs qui ont cette signification. On n'en connoît que denx espèces.

$1^{\circ}$. Nématocère noire, N. nigra. Mera. Dipt. d'Eur. tom. 1. pag. 209. - V AcQ. Ins. Dipt. Tipul. pag. 165. no. 1. - Hexatoma nigru. LA'r. Gen. Crust. et Ins. tom. IV. pag. 260. Des environs de Paris. $2^{\circ}$. Nématocère bicolore, N. bicolor. Me1G. $i d . n^{\circ}$. I. tab. 7. fig. I. Mâle. Longuear 5 ligr. Têtc d'un gris cendré; front plus clair auprès des yeux : corselet d'un glis clair avec trois raies dursales foncées, les latérales courtes; abdomen et pattes d'un brun-noirâtrc; base des cnisses et balanciers jannes : ailes un peu reubrunies, sans point marginal. D'Europe.

ANisoukre, Anisomera. Hofry. Merg.

Genre d'insectes de l'ordre des Diptères, première section, famille des Némocères, tribu des Tipulaires (division des Terricoles).

Un groupe de 'Tipulai:es-'Terricoles contient, outre ce genre, cenx de Trichorère, Mrekistorère, Dixa et Nématocère. (Voyez Terricoles.) Dans les 'Trichocc̀res les antennes composées de plus de six articles ont les demiers indisincts; celles des Mækistocc̀res sont de dix articles et excessivement longues; le prothorax des Dixas n'est poiut séparé dı reste du corselet par une ligne transversale, et leurs antennes ont plus de six articles; eutin, dans les Nématocc̀res, le troisième article des anteunes n'est guère plus long que le suivant. Par celte comparaison aucun de ces genres ne pourrit ètre confondu avec celui d'Anisomère.

Antennes avancées, sétacées, composées de six articles distincts, le premier cylindrique, épais, le second très-petit, cyathiforme, le troisième cylindrique, très-long, faisant à lui seul presque les deux tiers de l'antenne, deux fois an moins plus long que le suivant; les quatrième, cinquième et sirième courts, cylindriques, à peu près 
égaux entr'eux. Ces antennes aussi longres que l'abdonen dans les mâles sont de deux tiers pius courtes dans les femelles, les deux premiers articles étant aussi longs que dans les mîles et semblablement confurmés, Jes quatre a atres très-raccourcis inais yaldant entreux l's ầnes proportions. - Pulpes recourbés. - Tête prolongrée en museau. - Yeux arrondis, súparés. - Point d’oceiles. - Prolhorux séparé du reste du corselet par une ligne rransversale enfoncée. - Abdomen de luuil segmens. - Jambes avec deux épines terminales peu prononcres.

Ces raraclères sont extrails des Dipt. d'Europ. de M. Mejgen. Cet auteur ne mentionne qu'une ceule espéce, c'est l'Anisomère obscure, $A$. obscura. MEIG. Dipt. d'Europ. tom. 1. pag. 210. no. 1. $t a b .7$. fig. 5. Le mâle. Longueur 4 lig.s. Antenues brunes; têle d'un gris-brunâtre. Corselet ayant trois larges raies dorsales foncées, séparées par des lignes jaunâtres; abdomen du mille d'un gris noir avec une ligne dorsale brune; en dessous du premier segment est une large tache, et sur le second une autre tache étroite, toules deux sont de couleur jaune. Palles d'un brun jảunâtre : exirémité des cuisses plus foncée, cuisses antérieures un peu plus épaisses et un peu plus courtes que les autres; nervures transversales des ailes d'on brun jaunâtre. De Portugal.

CTIONEE, Chionea. DAw. LAT. (Fam.nat.) Genrc d'iusectes de l'ordre des Diptères, première section, famille dos Némucères, tribu des Tipulaires (division des Terricoles).

Ce grenre forme seul une coupe particulière dans sa division, et se distingue mère de tons les autres Tipulaires par le manque d'ailes dans les deux sexes.

Antennes filiformes, composées de dix articles, le prewier alongé, cylindrique, le seeond en nassue, aussi long que le premier; le troisième court, globuleux; les autres minces, binéuires, velus a leur extrónité. - Palpes filiformes, de la longueur de la moilié de la têre à peu près, composés de quatre arlicles presqu'éganx, un pen plus gros vers leur extrérvité, velus, le derbier presque cylindrique. - Tête periıe, presque globuleuse, prolongée on un museau épais, nódiocreauent avancé. - Yeux arrondis, un peu saillans, séparés, saus échancrure remarquable. Point d'ocelles. - Corselet petit. - Point d'ailes dans les deux sexes. - Balanciers visibles, en massue. - Abdomen ovale, de huit segmens; zinus des mâles nuni d'vae pince horizontale formée de deux onglers composés chacun de deux articles; le premier épais, charnu, denté à son extrémité; le second corué, linéaire, aigu, recourbé : anus des femelles terwiné par deux valvules posées l'une sur l'autre, l’inférieure plus large, plus courte, ciliée sur ses bords, comprimée vers son extrémité, la supérieure plus longue, plus étroilc, comprimée, redressée, composće de deux lames. - Pattes fortes, alongées, presque linéaires : cuisses épaisses, les posłélieures presque de la longueur du corps; jambes à épines terninales nulles: tarses alongés, de cinq articles distincts, le dernier ayant deux crochets.

On ue connoîl qu'une seule espéce de ce genre; elle se tronve en Suède sur la neigge récernment tombée, circonslance qui a servi à lui donner le nom de Chionée liré du grec. Cost principalement dans les bois quon la rellcontre, même par un froid de 2 à 5 degrés du ỉsermonèlre centigrade, pendant tous les mois de l'hiver. Cet insecte marche très-bien sur la neige et ressemble au premier coup d'ail à une Araignéf par le nanque d'ailes, la coulenr grise et tuut le faciès.

\section{CiIơ ée aranéö̈de, C. arazleoides.} losis.

Chionea corporefusco; pedibus testaceis pi-

Chionea araneoides. Dsum. Analect. Entom. Holm. 1825. pag. 35. no: 1. et Act. Holm. 18,6. pag. $102 . t a b .2$.

Longueur 3 lig. Têle d'un testacé-brun avec quelques poils sur le vertex qui se rabattent en devant; bouche pâle; palpes bruns; corsclet d'un testacé-brun sale, lisse, changeant en cendré; abdomen d'un testacé-lorun obscur arec des poils sur les côtés et des ligrues cendrées qu'on n’aperçoit qu’à un cerłaiu jour ; paltes testacées.

De Suède, en Vestrogollie rewalut lout l'hiver sur la isejge.

Nota. 1․ M. Dalman fait mention d'après l'isis $182 \mathrm{~J}$. 4. Litterarisch. Anzeig. pag. 100. d'uu Dip. líre suns ailes trouvé sur la neige dans le MontJura, el pense que ce pourroit être sa Chionte araúoïle. $2^{\circ}$. De Géer fait aussi mention d'une Tipulaire sans ailes; i] la nomme Tipula atonıbria. tom. VIl. pag. 6o2. no. 8.pl. 44. fg. 27-28. Comune M. Dalman ne cile que le now de cette espèce, nous pensons devoir la rappeler ici aux eniomologistes; elle nous paroit digne de nouvelles observations : elle n'appartient certainement pas au genre Chiouée, puisque De Géer a complé quinze articles aux antennes. Nous sompconnons cependant qu'elle doit entier dans lís Terricoles. L'individu observé étoit une femelle de taille excessivement petite. Corps brun-grisâtre. Artennes très-longues, filiformes, noueuses, de quinze articles, le second tout rond, beauconp plus gros que les antres. Tête ronde. Yeux grands, occupant presque toute la surface de la têle. Abdomen longs, un peu renflé au milieu, conique vers le derrière qui est poinlu, divisé en segrmens, les trois derniers de plus en plus déliés, formant des tuyaux rentrant in peu les uns dans les autres; le bouc du dernier luyau refendu en denx lames pointues comme il l'est dams les Tipnles famelles 
et dans quelques genres voisins, ce qui proure gre cet individu écoil bien du sexe féminin, ainsi gre l'a rearqué be Ǵer. Cet auteur tronva celle espèce dans son appar!rment, courant trèsvice sur sa table à écrire. (S. F. et A. SERv.)

'TERPITLLLS. Nom qne j'ai donné, dans l'ouviage sur le Règne animal de $\mathrm{M}$. le baron $\mathrm{Cu}-$ vier, à une tribu de la famille des Aranéides, correspondante a la section des Aranéides théraphoses de M. le baron Walckenaër. Voyez cet article el celui de Tétrapneurones. (Latr.)

TESSARA'TOHE, Tessartoma. Nов. LAt. (Fam. nat.) Edessa. Fав.

Genre d'insectes de l'ordre des Hámipteres, section des Hétéroplères, famille des Géocorises, tribn des Longilabres.

Ce genre forme senl dans ceite tribu une conpe particulière caractérisée par ses antennes de quatre articles, insérées sous un rebord latéral de lit tếe, et deux ocelles apparens. Voyez LonginaBRES, pag. 5i. de ce volume.

Ancennes filiformes, plus courles que le corps, insérées sous un rebord latéral de la tête, composées de quatre articles un peu comprimés; le premier petit, dépassant pcu lé rebord de la léte; le second plus long que le troisième; le deruier aylindro-corique. - Labre long, très-étroit, presqu'aciculaire, finernent ştrié transversalement, prenant naissance à l'extrémiscé antérieure du chaperon, et recouvrant la base du sucoir. - Suçoir Formé de qiatie soies; les deux iaférieures se rénnissant en nne seule un pera an-delà de icar origine; ce suçoir renfermé dans une giline nomngée $b e c$, lequel est divisé en qualle artic!es distincts, le premier logé ell grande partic dans une coulisse longitudinale : cc bec court, atleignant au plus la base des cuisses intermédiaires, - Téte pelite, reçue postérieurement dans une échancrure placée an bord antérieur du corselet. - Yeux saillans, globuleux. - Deux ocelles saillans, tres-visibles, posés sur la partie postérieure de la tête, assez loin des yeux et au-dessus d'cux. - Corselet grand, large. - Ecusson très-grand, trianguJaire. - Abdomen furmé de segmens transversaux, portant chacun un stignale un peu rebordé; ces segmens au nombre de sept dans les femelles; le septième en dessous, fortement échancré à sa base, quadrangulaire ì son extrémité; anus, dans ce sexe, fendu longitudinalement, occupant le milieu de l'intervalle qui est entre le sixième et le septième segment: de six segmens dans les mâles, le dernier ćch ancré postérieurement et recevant dans cetle échancrure l'anus qui n'est point fendu. - Pattes fortes; cuisses canalisulées en dessous, toutes ou du moins une partie d'entr'elles ayant ordinairement quelques épines; jaubes dépourvues d'épines terduibales; tarses assca courts, de trois articles; le premier dilaté dans les deux sexes, garni de duvet en dessous, le second plus coult que les autres; le dernier terminé par deux crochets ayant use pelolte bilobée dars leur entre-deux.

Les Tessaratomes dont le nom vient de deux mots grecs et exprime que les antennes sont composées de quatre articles, ont été confondues par Fabrieius avee ses $E d e s s a$ qui ont effectivement le bec court comme elles, mais dont les antennes ont distinciement cinq articles assez grêles, ne paroissant point comprimés. Ces Hémiptères en général de grande taille habitent principalement los Indes orientales, et particulièrement lile de Java. Leur's mœurs doivent être à peu près celles des Pentatomes. (Voyez ce mot.)

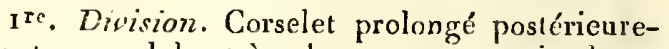
ment en un lobe très-obtus nn peu moins large que lui, s'avançant sur l'écusson et en couvrant presque la moitié. - Sternum élevé dans son milieu, prolongé en àvant en un lobe comprimé et obtus.

I re. Subdivision. Côtés du corselet prolongés en manière de cornes. - Ecusson terminé en pointe aiguë.

\section{Tessaratome canaliculée, T. canaliculata.}

Tessarutoma fusca, thoracis lateribus in cornubus longis, obtusissimis productis, suprà convexis, subtús concavo-canaliculatis : stemi lobo anticè elevato, longo, caput longitudine superante.

Longueur 15 lig. Corps d'un brun luisant. Elytres d'un brun ferrugineux (le corps pouvint aroir des nuanees vertes dans linsecte vivant). Corselet chagriné et pointillé surlont vers ses herds; ses côtés prolongés en un love alongé, troncué a l'extrémité, convexe en dessus, canaliculé inférieurement et formant une espèce de gouttière, 'son bord postérieur un peu échancré : lobe cú sternum, alongé, s'lllevant à sa partie antérienre el dépassant un peu la tête. La partie de l'écusson qui n'est point cachée sous le corselet, canaliculée. Ahdomen dentelé sur ses bords par les angles postérieur's des segmens supérieurs qui dépassent ceux qui les suivent, terminé par six pointes bidentées; les deux extérieures plus longues que les autres, dípendant du sixième segment; les quatre intérieures égóales entr'elles, appartenant au septième. Cuisses mutiques. Femelle.

De Java.

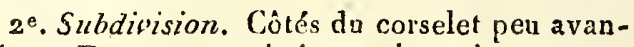
cés. - Ecusson terminé en pointe obluse.

\section{Tessanatome de Sonnerat, T. Sonneratii.}

Tessaratoma testacea; thoracis latcribus sub. rolundis, margine postico subrecto; sterni lobo 


\section{T E S}

subdilatato, anticè parùm producto, horizontali.

Longueur I pouce. Entièrement testacée. Dessous de lia tête et din corselet un peu plus clairs; celui de l'abdomen un peu ferrugineux; bords latéraux du corselet presqu'arrondis, son bord postérieur coupé presque droit : lobe dn sternum d'alsord élargi , s'avançant pell antérieurement dans une direction borizontale, et ne dépassant pas la base des hanches antérieures. Abdomen dentelé sur ses bords par les angles postérieurs des segmens supérieurs qui dépassent cenx qui les suivent. Septième segment ayant quatre petits angles : les deux intérieurs formés par une échancrure. Toutes les cuisses munies en dessous de deux épines courtes, placées à côté l'une de l'autre un peu avant l'extrémité de ces cuisses. Femelle.

Rapportée des Indes orientales par feu Sonnerat.

On doit placer dans cette subdivision l'Edessa papillosa $\mathrm{n}^{\circ}$. 19. FAB. Syst. Rhyngot. Ajoutez ì la synonymie: Srour, Puuais. pl. 38. fig. 271. La Nymphe. De Java. (Tessar. papillosa Noв.) Dans un individu mâle que nous avons sous les yeux nous ne voyons rien d'olivâtre. Le bord postérieur du corselet est jaune comme le reste du corps; le bout de l'écusson seul est brum. Jes autennes ne sont pas noires, mais d'un brun ferrugineux ainsi que les pattes. Cet indiviảu n'a pas l'anus échancré.

$2^{e}$. Division. Corselet ne s'avançant pas sur l'écusson, point lobé.

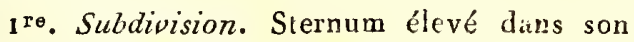
milieu, prolongé en avant en un lobe conıprimé et obtus.

\section{Tessaratome apicale, T. apicalis.}

Tessaratoma fusca; antennarum apice fermgineo, elytrom membranâa aneâ; thoracis lateribus dilatato productis : sterni lobo anticè elevato, longo, coxarum anticarum insertionem superante.

Longneur I $6 \mathrm{lig}$. Corps d'un brun eouleur de poix foncće, luisant. Lernier article des antemnes ferrugineux à base noire. Membrane des élyires bronzée. Côtés du corselet dilatés, arrondis; son bord postérieur Irès-pen avancé sur l'écusson; lit pointe de celui-ri creusée en fossette. Lobe du sternum alongé, s'élevant à sa parite antérieure et dépassant la base des premières hanches. Abdomen un peu deutelé sur ses bords pur les angles postérieurs des segrmens supérieurs qui dépasseut ceux qui les suivent : seplièrme segment ayant quatre petils angles presqu'épineux; les deux inlérieurs formés par une écliancrure. Toutes les cuisses munies en degsous de deux épines placées à côté l'une de l'autre un peu avant l'extré-

mité de ces cuisses, cell - a d a bérienres fo.

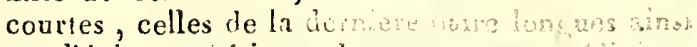
que l'épine postérieure des cursas a. Fenelle.

De Java.

$2^{\circ}$. Subaivision. Sternum sans prolungement.

A. Chaperon à peine échancré. - Côtés du corsele! peu avancés.

\section{Tessaratome robuste, $T$. robusta.}

Tessaratoma fusco-nigra; antennis nigris: thorace scutelloque transversim coriaceo-rugosis ; elytris scutellique apice ferrugineo-fuscis, illonm. membraná subaneâ.

Longueur 22 lig. Corps large, d'un brun noirître. Autennes noires. Corselet el écusson conver!s de rides transversales gui les font ressemble 1 à du cuir ; l'exirémité de celui-ci d'un brun ferrugineux ainsi que les élytres; côtés du corselet un peu dilatés, ses bords latéraux dilatés, arrondis. Abdomen dentelé sur ses bords par les angles postérieurs des segmens supérieurs qui dépassent ceux qui les suivent. Anus échancré. 'Touies les cuisses munies en dessous de deux peliles épines placées à côté l'une de l'autre avant l'extrémité de̋ res cuisses : cuisses postérieures longues, trèsfortes, ayant en outre vers leur base uue grande et forte épine très-poiutue; leurs jambes très-arrguées, surlout à la base. Mále.

De Java.

\section{Tessaratome it damier, $T$. alterratu.}

Tessaratoma fermginea (forsin in wivo rebra); thorace scutelloque transwersim coritceo. rugosis et tenrevè punctatis, scrutelli apice vallido, antennis migm-comeles articuli quarti apice ferrugineo : abdommis margine nigo pallidoque variegato; elylormm nembranâ subaneâ.

La Punaise i hords en damier. Srozs, l'umais. pl. IV. fig. 25 ?

Longueur a ponce. Corps d'ai houx ferrurineax (peut-être rougc daas l'insecte vivant). Corsclet et ócusson converts de rides transversales qui les. font ressembler à du cuir, et ponctués sans ordre. Rxirénilé de l'écusson pâte. Antennes d'un noì. bleuâtre avec l'extrémité du dernier article ferrugineuse. Abdomen bordé en dessus et en dessous de laches carles alternativencnt nciles et pâles, à peine dentelé sur les cốés; lavs la temelle le septième seganent est termicé par quarre angles oblus. Anus du mâle échancré. Toutes les cuisses munies eu dessous de deux épines placés à côté l'une de l'autre avant l'extrémité de res cuisses. Epines exuêmement peites à l'excep- 
tion de la postérieure des cuisses intermédiaires. Mâle et fercelle.

De Java.

Nota. Nous ne citons Stoll qu'avec doute, parce que la figure qu'il donne palloît avoir cinq articles aux antennes, et qu'il indique pour patrie les Indes occidentales. Du ireste la figute convient parfaitement à notre espèce.

\section{Tessaratome obscuie, $T$. obscurca.}

Tessuratoma nigra, rufo-ferrugineo varia; abdominis margine supero nigro mbro maculato, inju izbro nigro maculato: antennis nigris.

Loagrueur 7 ligg. Corps entièrement d'un brun nat mốlé de nuances rougeâtres. Antennes noires. Abdomen à peine dentelé sur ses bords latéraux: bord supérieur noir a vec des taches rouges; l'inférieur rouge arec des taches noires. Septième segmeut terminé par quatre angles obtus. Cuisses munies en dessous de deux petites épines placées à côté l'une de l'antre ver's l'extrémité de ces cuisses, et en outre de quelques autres sur leur longrueur. Femelle.

De Java.

B. Chaperon incisé, fortement hidenté. - Angles antérieurs du corselet prolongés en cornes.

\section{Tessaratome bicorne, T. bicomis.}

Tessaratona testaceo-viriats (forsàn in vivo wividis); thoracis marginati angulis anticis dihatato-subsninosis, longis; scutello brevi thoracecue cortaceo transpersim rugulosis.

Longueur 20 lig. Corps d'un testacé verdâtre môlé de brun ( peut-être tout vert duns l'inscete vivant). Corselet rebordé, s's angres intéricurs dilatćs, prolongís presqueen épine. Ecussoll court, cotivert ainsi que le corselet, te rides transversiales qui les font ressembler à du cuir. Chaperou refendu profondément, ce qui forme deux dents tvancées, presqu'horizontales, assez aiguës. Toutes les cuisses nuuliques. Abdomen peu deutelé sur ses bords latéraux. Septième seginent terminé par quatre angles, les extérieur's fort petits. Femelle.

De Java.

Nota. Les Edessa cumethystina no. 2o et bresicornis $n^{\circ}$. 40. HAB. Syst. Rhyngot. appartiennent encore à ce geure. La preanere est de Sumatra; l'uutie se trouve à la Chine.

\section{(S. F. et A. SERv.)}

'TESSAROPS, Tessarops. Nom donné par M. Rufinesque (Annales générales des sciences physiques, tome Vill, paye 88) ì un nouveau geme de la famille des Araiterdes, et qui s'éloigontroit de tous los nutres du nếme groupe par les yeux, an nombre de quatre seulement, disposés en carré, et dont les denx postérieurs un peu plus gros et un peu plus écartés entreux que les deux antérieurs. Qnoiqu'il n'ait décrit que trèsincomplétement l'espèce unique (maritinla) sur laquelle il a fondé ce nouveau genre, nous permsons qu'il doit venir près de celni d'Erese. Peutêtre même les quatre yeux latéraux, entre lesquels sont situés dans ces dernières Arancíides les quatre autres, cut-ils échappé, à raison de leur extrêare petilesse et de leur écartenent, à l'ubservation de ce naturaliste.

Le Tes arops naritinue habite les rochers on les pierr.s des bords de la mer, an-delà de la hainte-maríe, à la nouvelle Rochelle, près de New-Yorck. Elic est encore commune sur les côtes rocialleuses ei pierreuses de l'île Longue. Sa longuem est de six ligures. L'abdomen est une lois plus voluminenx que le thorax, convexe, arec des points ronds el glabres en dessus, januâtres dans le rấle, grisatres dans la fermelle. I.es palles postérieures sont de la longuent du corps, hispides, d'un gris-brun en dessus, d'un gris-foncé en dessous. Cet aniunal court avec vitesse el sante de très-loin sur sa proie, habitudes qui nous indiquent qu'il appartient à notre division des Ar:tućides saltigrades. Nous desirons que M. Rafivesque supplée par de nouveaux détails aux reuseignemens qu'il nous a donnés sur ce sujet.

(LAtr.)

TÉTANOPS, Tetanops. FAti亡̀r. MI. Meicren tans ses Dipt. a'Europ. donne ainsi les caractères de ce gnenre créé par. M. Fallèn et qu'il place dans sa tamille des Muscides. Antennes petites, écartíes, diriçćes obliquewent en avant, de trois articlcs, les denx premiers petits, le troisiène ovale, compriné, obius à l'extrémité, muni à sa base d'une soie dorsale nue. Trompe retirće dans la cavité buccale pendant le repos. Ouverture de la bouche très-petite. Hypostowe incliné, trc̀s-prolongé à sa partie inférieure, portant deux sillons latéraux, et dans son milieu une élévation carénée. Front large, plat. Yeux arrondis, petits, espacés. Trois ocelles placés sur le vertex. Corselet alongé ; prothorax visiblement séparé d. mésothorax par une ligne transversale. Ailes velues vues au microscope. Balanciers découverts. Abdomen alongé, prescue plane, de cinq segmens, celui des fernelles terminé par une tarière pointue, recourbée, articulée.

M. Meirgen ne mentionne qu'une seule espèce, Thlanops myopiue, $T$. myopina. Merg. Dipt. d'Eur. tom. 5. pag. 353. no. 1. tab. 51. fig. 3. Mále. fig. 4. Fcinelle. Longueur 2 à 3 lig. Blanchâtre. A bdomen ayant des taches latérales noires, de forme carré sur chaque segment. l'attes pâles. Ailes hyalines tachées de brua. De Suècáe.

$$
\text { (S. F. et A. Serr.) }
$$

TETANURE, 


\section{$\mathrm{T} \mathrm{E} T$}

TÉTANURE, Tetanura. Fati.̀̀n. Ce genre d'insectes Diptères établi par M. Fallèn a été adopté par M. Meigen, qui le place dans sa famille des Muscides. Voici les earactères̀ que ce dernier auteur lui assigne : antennes avancées, dirigées obliquement, plus courtes que l'hypostome, de trois articles; les deux premiers petits, le troisième oblong, ovale, obrus, muni dans son milien d'une soie dorsale, velue. Hypostome perpendiculaire, point prolongé an-dessons des yeux , élevé en carène longitudinale dans son milieu avec un sillon de chaque côté. Front plat, large. Yeux grands, ronds, espacés: T:ois ocelles placés sur le vertex. Corselel n'ayant pas de ligne transversale enfoncée séparant le protloriax. Ailes grandes, velues vues an microscope, couchées parallèleunent sur le corps dans le repos; leur première nervure longiludinale simple, s'étendunt jusqu'au milieu du bord antérieur; nervares transversales assez rapprochées l'une de l'autıe. Cuillerons point visibles. Bulanciers daćcouverts. Abdomen alongé, cylindrique, un peu en massue, de cinq segmens. Palles assez longnes, les quatre antérieures un peu éloignées des deux autres.

Le type de ce genre est la Th́lanure ventre pále, T. paillidiventris. Merg. Dipt. d"Eur. tom. 5.' pug. 572. no. 1. tab. 52. fig. 7 et 8. Longueur 2 lig. Noire, brillante. Abdo men presque ferrugineux. Autennes, front et pattes pâles. De Suède.

$$
\text { (S. F. el A. SERv. ) }
$$

TĖ̀TE ARMÉE. Nom vuluaire donné par Geoffroy (Ins. Paris.) à l'Aphodie fossoy eur, tom. X. pirg. 558. du présent Díctionnaire, et décrit sous le nom de Bousier fossoyeur no. . . de ce même ouvrage. (S. F. et A. Serv.)

TÊTE ÉCORCHÉE. Geoffroy (Ins. Paris.) désigne ainsi l'Apodère de l'Aveline, tom. X. pag. 305. du présent Dictionnaire, où il avoit été décrit anciemnement sous le nom d'Attelabe tête écorchée $a^{\circ}$. 2. (S. F. et A. SERv.)

TÉtRAGNATHE, Teiragnatha. Latr. Wasex. Arunea. Linn. Groff. De Gérr. Fab. Oliv. Genre d'Arachnides de l'ortre des Palnonaires, fatnille des Aranérdes, secilin des Dipneumones, tribu des Orbitèles, ćtałli par M. La. treille, çui lai donne" pour caractères : yeux disposés sur deux lignes presque parallé'es et presyu'égales; les deux de chaque extrémité latcírale aussi distans l'un de l'autre que les intermédiaires le sont de leurs correspondans; les deux supérieurs de cenx-ci un peu pius écartés entr'enx que les deux inférieur's. Mandibales étroites, longues, avancées, très-dentées, terminées par un long crochet, rélrécies à leur base, s'écartant veus le bout. Mâchoires étroites, alongées, dilatées seuleisent vers leur extrémité. Ce Hist. Nat. Ins. Tome X.
$\mathrm{TE} \mathrm{T}$

genre se distingue des Lyniphies et des Ulobores par la disposition des yeux et par d'autres caractères tirés des mâchoires et des paltes. Les Epéires ont les yeux différemment disposés, et leurs mâchoires ne sont pas étroites à leur base, mais aussi larges dans toute leur étendue, et formant une pulette arrondie. En général les 'Tétragrathes ont une forme très-aloagée el presque cylindrique, el ce qui les distingue des autres genres de leur tribu, c'est l'attituờe qu'elles prennent dans le repos, et qui consiste ì porter en avant et en ligne droite les guatre pattes antérieures, et à donner la même position, mais en arrière, aux deux pattes postérienres, de solte qu'il n'y a que la troisiene parre de patles qui șoil cirigée sur les côtés et perpendiculairement au corps. Ces Araignées vivent dans les lieux humides, près des ruisseaux; elles se font une toile verticale qu'elles tendent sur les lierbes et sur les buissous. La seule espèce connue en Lurope est:

La Tétragnathe étendue, Tetragnathe extensa. LAtr. Gener. Crust. et Ins. tom. I, pag. 101. - Walck. Hist. des Aian. fas. 5. tab. 6. - Tabl. des Arant. pag. 68. - Araignée étendue. Latr. Hist. nat. des Crust. et des Ins, tom. 7. pag. 249. - Wa w. Faun. Paris. tom, z. pag. 204. - Arunea exténsu. Linv. - Alirgnée à ventre cylindrique et pattes de devant élendues. GEOFF. Hist. des Ins. tom. 2. pag, 642. - Araignée palte-étendue. De Géer. Mlém. sur les Ins. tom. 7. pag. 236. Son corps est roussâtle avec l'abdomen d'inn vert-jaunâtre-doré, et marqué d"une ligne noire el ramiliée le long du dos, et d'une bande de celle conlenr dans la partie opposée du ventre. Ses eôtés ont deux lignes jaunâtres.

Celte Araignée se reneontre dans les premiers jours du printemps, suivant lister, qui l'a vue s'accoupler le 25 nai vers le coucher du soleil. Les deux sexes sont suspendus en l'ain" et parle moyen d'un fil sous la toile: ils applicpuent mutuellemeut leur ventre l'un cnntre l'autre; le mâle est en dessous, et son abdomen s'éten l er ligne droite; celui de la femelle est courbé, et son extrémilé postérieure tonche la base da ventre de l'autre individu; leurs paltes et leurs mandibules sont eutrelacées. Les palpes des mâles sont extrênement composús à leur extrémité. les femelles pondent vers la fin de juin; les cufs sont renfermés dans un cocon de la grandeur d'un grain de poivre assez fort, coruposé de fils assez faches. Li fenelle atlache souvent ces cocons aux joncs ou à des feuilles. I.es cufs éclosent avant l'aulomne, el on voit souvent les pelites Araignées voltiger dans lair soutenues par un paquet de petits fils très-longs et blancs; ee sont ces tils qui ont reça du valgaire le now de fils de la Vierge. Ce ne sout pas seulement le: jeunes 'Tétragnathes qui produisent ee phénoméne, pluIf Iff 
sieurs autres Aranéides sont dans le même cas. On connoît deux ou trois autres espèces de 'Tétragnathes propres à l'Afrique et à l'Amérique.

(E. G.)

TÉTRALOBE, Tetralobus. Elater. Fab. Oliv. (Entom.) Herbst. Scherv. Dru r.

Genre d'insectes de l'ordre des Coléoptères, section des Pentamères, fanille des Serricorues (division des Sternoxes), tribu des Elatérides.

L'introduction des deux unuveaux genres léricalle et Tétralobe dans le groupe a. des Llatérides ( voyez pag. 490 . de ce volume) nous oblige d'eu modifier les caractères ainsi qu'il suit :

a. Les quatre premiers articles des tarses garnis en dessous de pelotles prolongées et lobifurmes.

† Antennes très-rapprochées à leur base. Lissode.

†† Antennes écartées entr'elles ì leur base. Péricalle, Tétralobe.

Le genre Péricalle se distingue des Tétralobes, 10. par ses anteunes simplement dentées en scie dans les deux sexes, leur troisième article en dent de scie, aussi long que le quatrième. $2^{\circ}$. Par le corselel fort long, presque linéaire, dont les angles antérieurs sont à peiue ou point atrondis; le dessons n'offrant point de profond sillon propre it loger les antennes. $5^{\circ}$. Par ses élytres mucronées an bout, allant en diminuant de largeur dès la base jusquuà l'extrémité.

Antennes filiformes, insérées près des yeux, sur les côtés de la pariie antérieure de là tête, composées de onze articles; le premier long, conique, éclianeré postérienrement, les deux suivars éganx entr'eux, très-petits; les huit derniers fortement en scie dans les femelles, flabellís dans les mî́les. - Labre déconvert en dessus, corné, court, assez large, tronqué antérieurement. Mandibules déconvertes en dessus, cornées, arquées, pen échancrées a l'extrémité. - MIàchoires courtes, presque membraneuses, fortenient ciliées à l'extrémité. - Palpes maxillaires assez longs, de quatre articles; le premier petit, les second et troisième égaux, presque cóniques; le dernier un peu comprimé, peu dilaté, presque conique: palpes labianx plus courts que les autres, de trois articles. - Tête petite, enloncée jusqu'aux yeux dans le corselet, plus étroite à sa base en y comprenant les yeux que le bord antérieur de ce dernier; extrémité antérieure de l'épistone sensible. suent plus élevée que la base du labre. - Yeux ovales, peu saillans, placés sur les angles du bord postérieur de la tête. - Corps ovale-oblong; finement pabescent. - Corselet presqu'en carré transversal, très-rebordé latéralement, visiblement rétréci vers la tête, son bord antérieur

\section{$\mathrm{T} \mathrm{E} \mathrm{T}$}

échancré circulairement, les latéraux arrondis à leur extrémité antérieure, ses angles postérieurs prolongés en pointe très-aiguë, s'écartaut en dehors; dessous du corselet ayant de chaque côté une rainure oblique et profonde, dans laquelle les antennes se cachent lor's du repos; préslernum muni postérieurement d'une saillie qui s'enfonce à volonté dans une fosselte antérieure du résosternum. - Ecusson assez grand, en triangle curviligne. - Elytres longues, très-dures, assez convexes, allant un peu en s'élargissant jusque passé le milieu de leur longueur, arrondies à leur: extrémité, terminées chacune par une très-petite pointe suturale, stricies, couvrant les ailes et l'abdomen. - Abdomen arrondi au bout; plaque anale inférieure unie daus les deux sexes. - Pattes assez eourtes; tarses filiformes, leurs quatre premiers articles de même forme, garnis en dessous de pelottes prolongées et lobifurmes, le deruier arqué, conique, terminé par deux crochets.

Le nom de ce genre tiré du grec' a rapport au caractère que présentent les tarses; le iype est le Tétrabue flabellicorne, T. flabellicornis. - Elater flabellicornis $\mathrm{n}^{\circ}$. 2. HAB. Syst. Eleut. (en retran(chint le synonyme de Voët.) Mâle et femelle. Ouiv. Entom. tom. 2. Taup. pag. 8. $\pi^{\circ}$. 1. pl. 3. fig. 23. (Il faut ôter le synonyme de Voët.) Mâle. - Schen. Syzn. Ins. tom. 3. pag. $270 . n^{\circ} .19$. Du Sénégal.

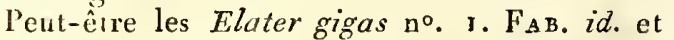
mucronatus Osiv. Journ. d'Hist. nat. 7. pag. 262. $n^{\circ}$. I. pl. 14. fig. 1. le premier de Guinée, le second des Indes orientales, sont-ils de ce genre.

PÉRICALLE, Pericallus. Elater. LINv. Fab. Or.iv. (Entom.) Herrbst.

Genre d'insectes de l'ordie des Coléoptères, section des Pentamères, famille des Serricornes (division des Sternoxes), tribu des Elatérides.

Un groupe de cette tribu coutient les genres Péricalle et Tétralobe. (-Voyez à la colunne ci-contre.) Dans les Tétralobes les antennes des mâles sont flabellées, leur troisième article est simple et aussi court que le second dans les deux sexes; le corselet est presque carré, ayant ses bords latéraux très-arrondis antérieurement, offrant de chaque côté en des ous, un profond sillon pour loger les antennes dans le repos, et les élytres se maintiennent de la même laryeur au moins de la base jusque passé la moitié de leur longueur.

Anternes dentées en scie dans les deux sexes, mais plus fortement dans les mâles; leur second article beaucoup plus court qu'aucun des suivans, le troisième en dent de scie, aussi long que le quatrième. - Episiome ayant ses angles latéraux ordiuairement prolongés, et formant chacun une petite corue dirigée en avant. - Tête fortement déprimée, canaliculée longitudinalement dans son milieu. - Corps long, étroit, poli, très- 


\section{$\mathrm{T} \mathrm{E} \mathrm{T}$}

giabre. - Corselet fort long, presque linéaire, un pen plus étroit que la base des élytres, ses angles antérięurs peu ou point arrondis, à peine creusé en dessous de chaqque côté pour recevoir les antennes dans le repos. - Ecusson très-petit, prèsque rond. - Elytres sans stries prononcées, allant en diminuant sensiblement de largeur dès la base jusqu'à l'extrémité, toujours lerminées par une pointe particulière. - Plaque anale inférieure des femelles portant de chaque côté une fossette oblongue, grande, punctnée et velue. Le reste des caractères sont ceux des Tétralobes. Voyez ce mot.

L'élégance, le bean poli et le brillant des couleurs dans toutes les espèces qui le composent nous font donner ì ce nouvean genre le nom de Périçalle, qui expriaue cette idée dans la langue grecque. Ces insectes, da moins (n) ceux qui nous sont connus, habitent l'Amériqne méridionale, et doivent aroir les mêmes mours que les Tanpins.

I $^{\circ}$. Péricalle bois veiné, $P$. ligneus. - Elater ligneus n ${ }^{\circ} .20$. Fав. Syst. Eleut. - Ou1 . Entom. tom. 2. Taup. pag. 17. no. 16. pl. 2. fig. 15.S'наn. Synon. Ins. tom. 3. pag. 273. no. 39. Femelle. Da Brésil. $2^{\circ}$. l'ériçalle sutural, P. suturalis. - Elater suturalis no ${ }^{\circ}$ 52. FAs. id. OLIV. id. pag. I8. no. 17. pl. I. fig. 3. a. b. c. (en retranchant la fig. 7. de Vuét qui appartient ă $\mathrm{P}$. fourchu.) - Scrøs id. $72^{\circ}$. 43. Mâle. Cayenne et Brésil. $3^{0}$. Péricalle fronticorne, $P$. fronticomis. - Elater fronticomis. DEJ. Caltil. fiemelle. Du Brésit. 4ํ. Péricalle fourclsu, $P$. furcatus. - Eluter furcatus $1^{\circ}$. 51. $\mathrm{NAB}, 2 d_{0}-$ Scuar. $i d . n^{\circ}$. $4 \mathrm{r}$. Brésil et Cayeune.

On trouvera encore plusieurs autres espèces de Taupins dans les auteurs, qui doivent entrer dans le genre Péricalle. (S. F. et A. Serv.)

TÉTRAMĖRES, Totramera. Troisième section de l'ordre des Coléoplères. Son caractère est : Quatre articles à tous les tarses.

$$
\text { (S. F. et A. Senv.) }
$$

TE'TRAONYX, Tetraonyx. Lat. Schors. Apulus. Fab. Schon. Lyttr. KLug.

Genre d'insectes de l'urdre des Coléopteres, section des Hétćromères ( $2^{\mathrm{e}}$. division), fumille des Trachélides, trion des Cautharidies.

Tous les genres de celle tribu, hors celui de Tétraonyx, ont tous les aricles des farses entiers. (Voyez Cantraridies, pag. 43. de ce volume.) Antennes gucre plus longne's que la tète ei le corselet réunis, allant un peu en ģrossissant vers l'extrémité, insérées vers le bas des yeux, trèsprès de leur partie inférieure interne, composées de onze aricles; le prearier grand, cylindro-conique; le second très-pert, transversal; les suivaus jusqu'au dixième inclusivement cylindro-coniques; le dernier plus grand que le précédent,

\section{T E T}

ovale-oblong. - Mandibules un peu crensées en gonttière, sans dents, du moins ì leur extrémité. - Machoires inermes, sans dent ni onglet corné. - Palpes plus gros vers l'extrémité; les maxillaires de quatre articles, les labiaux de trois : article terminal des quatre palpes un pcu ovale; celui des maxillaires aminci, presque pointu à son extrémité, celui des labiaux tronqué. - Téte inclinée, triangulaire, presque cordiforme, à peu près anssi larye derrière les yenx que l'exurémilé antérieure du corselet, resserrée ensuile brusquement en arrière, de sorte que sa base forme une sorte de cou qui se cache presqu'cntièrement dans le corselet. - Yeux un peu ćchancrés à la partie voisine de l'inserion des anleunes. - Corps assez court, de consistance pen ferme. - Corselet petit, presque carré, se rérrécissant sonvent ì sa partie antérieure, dont les angles sont quelquafois arrondis. - Ecusson triangulaire, son angle postérieur arrondi. - Elyties fort grandes, dépassaul et rccouvrant l'abdonen el les ailes. - Pattes assez grandes; toutes les cuisses munies à leur base d'un trochanter gros et saillant; jambes nu pen arquées: pénultiéne article des tarses bifide; le dernier muni de denx crochets bifides.

le noin de Tétraonyx vient de deux mols grees et signifie: quatre ongles. Ces insectes sont propres à l'Amérique; d'après l'observation c'e M. Latreille, ils y remplacent les Mylabres, dont ils doivent avoir à per près les mocurs.

\section{r. TÉtraonyx huil taches, T. octomaculatum.}

Tetraonyx nigrunz; ely tro singulo maculis quatuor rubris.

Tetraonyx octomaculatum. LAт. Gener. Crust. et Ins. tom. IV.pag. 380. - Lat. Voyag. Hezis. et Bonp. Zool. et Anat. comp. pag. 257.pl. XFI. fig. 7. - Encycl. pl. 572. bis. Jig. 24. - SснщеN. Syz. Ins. torn. 5. pag. $43 . n^{\circ}$. I.

Longueur ro lig. Noir. Elylres ajant chacune quatre taches roines.

De la nouvelle Espagne.

Nous n'avons pas va cetle espèce.

2. Tétranyx fixmouchété, T. sexguttatum.

Tetraony:x sericeo-nigrum ; elytro singulo guttis tribus aurev-ferrugineis.

\section{Lytta sexgutata. KLoG. Entom. Brasil.}

longueur 7 à 12 lig. Corps d'un noir soyeux, it rellet bieuátre en dessous. Elytres ayant chacune trois taclies rondes d'un ferrugineux un pendorć, savoir : deux d'ézale grandenr posées à cólél'une de l'uatre vers le liers supérieus de l'ólytse; la troisieme un pea plus grande, placée vers le ticrs inféricur. Antennes et pattes noires.

Du Brésil. 


\section{Tétraonyx bicolor, $T$. bicolor.}

Tetraony.x sericeo-nigrum; ano, coxisfemorumque basi late et thorace ferrugineis, hoc maculâ unagnâa dorsali repandâ nigrâ.

Longneur 7 lig. Corps d'un noir soyeux. Corselet, anus, banches et cuisses, à l'exception de leur extrémitć, de conlenr ferruginense; le premier a en dessus une grande tache dorsale un pen irrégulière d'un noir soyeux. Artennes et palles noires.

Du Brésil.

4. Tétraonyx à collier, T. collare.

Tetroonyx nigro-cœruleun, subnitidum; thorace, abdomine, palpis scutelloque ferrugineis.

Lytta chrysomelina. Klug. Entom. Brasil.?

Longueur 5 lig. $\frac{1}{2}$. Corps d'un noir légc̀rement bleuâtre, assez luisant, très-pointillé. Palpes, corselet ǵécusson et abdomen, ferrugineux; cette couleur borde encore finement la suture et la parlie extérieure des élytres, de la base jusqu’à la moilié. Antennes et paltes noires.

Du Brésil.

\section{Tétraonyx bimaculé, T. bimaculatum.}

Tetraonyx pallidè ferruoineum; antennis, capite, pedibus, femorum basi exceptâa, et elytri singuli maculis duabus magnis, żnâ baseos alterâque apicis, nigris.

Lytta bimiaculata. KLug. Entom. Brasil. Apalus quadrimaculatus $\mathbf{n}^{\circ}$. 2. F.AB. Syst. Eleut.? - Schon. Syn. Ins. tom. 2. pag. 542. $n^{\circ} .2$ ?

Longueur 5 lig. $\frac{r}{2}$. Corps đ’un ferrugineux pâle. Antennes, tĉle, a l'exception des palpes, pattes, les hanches et la base des cuisses exceptées, noires. On voit deux grandes taches de cette couleur sur chaque élytre; l'une tout contre la base, l'autre occupant l'extrémité. Anus brun.

Du Brésil.

Nota. Le synonyme de Fabricius nons paroit appartenir à celle especce, cependant $I^{\circ}$. M. Kliag qui a certainement eu sous les yeux la tuême espèce que nous, ne l'a point reconnue pour l'Apalus quadrinuaculatus de Fabricius, puisqu'il la décrit comme nouvelle. $2^{\circ}$. Si l'espèce de Fiabricius est la même que la uôtre, sa description n'est pas exacte, principalement dans le détail des cuisses et des laches des élytres, et elle n'est pas complète sous d'autres rapports. $3^{\circ}$. Fabricius donne à son $A$. quadrimaculatus, l'A mérique septentrionale pour patrie. Nutre individu et celui de M. Kliig sont du Brésil.

L'incertitnde du synonyme de Fabricius entraine dans le même donte celui de M. Schœnherr. Dans tous les cas, il est certain que l'Apalus quadrimaculatas FAb. Schenn. est un Tétraonyx.

\section{TÉTraonyx biponctué, $T$. bipunctatum.}

Tetraonyx totum sericeo-nigrunt; elytri singuli puncto minuto in parte inferâ, ferrugineo.

Longueur 4 lig. Entic̀rement d'un noir soyèux. Elytres portanl chacune vers leur tiers inférieur, un très-petit point ferruginens.

De Cayenne.

Nota. M. Latreille a vu dans la collection de M. Macleay à Londres, une espèce de Tétraonyx beaucoup plus graude que lcs précédentes et entièrement d'un noir-bleuâtre. M. le comte Dejean dans son Catalogue en mentionne une espèce de Cayenne, qui nous est inconnue, sous le nom de vittatum. (S. F. et A. Serv.)

TÉTRAOPE, Tetraopes. Nom donné par MM. Dalman el Schoenherr à un genre de Colćoptères Tétramères Longicornes, dont le principit caracticre est d'avoir chaque ocil entièrement partagé en deux. Ses autres caraclères nous sont inconnus. Le type est la Lamie tornator $n^{\circ} .64$. de cc Dictionnaire; cette espèce forme une coupe particulière dans le genre Saperde dn mĉme onvrage. Toyez ce mot.

$$
\text { (S. F. et A. Serv.) }
$$

TÉTR APNEUMONES, T'etrapneumones. Première section de notre fitmillc des Aranéides, ayant pour caractères : denx spiracules ou but ches aériennes, et deux cavilés pneumo-bratichiales on pulmonaires de chaque côté du ventre, près de sa base. C'est à M. Léon Dufour, médecin à Saint-Sever, que nous somries red vables de la dćcouverle de ce caractère analomique. Il s'applique aux Aranéides théraphoses ( voyez ce mot) de M. Walckenaër, cu à nos Aranéides terrič̀les, ainsi qu'à celles des genres Filistate et Dysdère. Les caractères assignés par M. Walckenaèr aux Théraploses ne pouvant plus convenir à ces dernières Aranéides, il esi nécessaire de diviser, ainsi que nous $l^{2}$ avons fail klans notre ouvrage intitulé : Familles naturelles dic Règne animal, pag. 3ı̄̃, les Télrapneumiones en deux coupes.

${ }^{\circ}$. Huit yenx dans toutes. Quatre flières, dont denx très-courtes et les deux autres trèssaillintes. Crochet ou doigt mobile des chélicères (mandibules des antennes) replié sur leur côté inférieur ou de celui de leur premier article.

Les genres : Mygate, CTenize (Mygales de M. Walckenaër, ayant un râteau formé par une série d'épines ou de dents cornées à l'cxtrémité supérieure du premier article des chélicères; Araignées minenses d'Olivier), Aтrpe (Olétère, Walck.), EnIodon. 


\section{$\mathrm{T} \mathrm{T} \mathrm{T}$}

$2^{\circ}$. Six yeux dans quelques-unes. Six flières très-courtes. Crochet des chélicères replié transversalement, ou le long de leur face inteme.

Les genres: Finistate, Dysdére.

Dans son travail sur les Aranéides de France, faisant partie de la Faune francaise, M. Walckenaër n’a pas cru devoir profiter des observations importantes de $M$. Léon Dufoulg, relatives au nombre des spiracules et des sacs pneumobranchianx. Il n'a rien changé an signalement rqu'il avoit donné des Théraphoses; mais il leur a adjoint les Filistales, qui, par la généralité de leur's caractères, semblent cependani appartenir à sa seconde section, celle des Araignées.

Les Tétrapueumones ont toujours les yeux, el dont le nombre est le plus souvent dislinct, placés à l'estrémité antérieure dn céphalothorax, et le plus sonvent très-rapprochés. Si l’on en excepte les Filistates, les mandibules sont fortes. Les pieds sont généralement robustes; la quatrième paire et la première ensuite, et dans quclques-uns seulement celle-ci et la précédente, sont les plus longues de toules.

Ces animaux se construisent des hahitations soyeuses, ordinairement tubulaires, tanlôt dans des terriers cylindriques ou sous des picres, tantôt entre des fenilles ou scus des écorces d'arbires. On croit qu’ils en sortent la nuit, pour aller à la chasse de leur proie; mais peut-être attendentils simplement qu'alle se présente d'elie-nême à l'entréc de leur demenre, ou qu'elle y soit arrêtée par la soie. (Latr.)

TÉTRAPTÉRES A AILES FARINEESES Troisièze section de la classe des insectes dans la mélhode de Geofiroy. Elle répond à l'ordre des Lí pidoplères de Linné el de beaucoup d’auien's sulsséquens; c'est la neuvième classe des insectes, dite les Glossales (Glossutu) de Fibricius. Geoffroy rapporte mal-áa-propos ì cette section, l'inseste qu'il nonume phalène culiciforme de l'Eclaire, et qui est le type du gonre Aleyrode LAt. ordre des Hémiptères. Vojez Geofrroy, Ins. Paris. tom. 2. pag. I.

\section{(S. F. et A. SERV.)}

TÉTRAPTÈRES A AlLES NUES. Quatrième section de la classe des insectes dins la mélhode de Geoffroy. Elle répond aux ortres des Névroptères et des Hyménoptères de Linné et des auteurs qui ont écrit aprés lui, sauf Fabricins; le premier de ces ordres reuferme-lı seconde classe de insectes dè cet auteur, dite les Synistale's ( $S_{y}$ nistati), excepté les genres Podura el Lepisma, et la quatrième appelée Odouates (Odonata). Le deuxième ordre (Ilrménoptères) répund à la troisiène classe de Fabricius, uomnce par lui Piézates (Piezata). Voyez Geoff. Ins. Paris. tom. 2. pag. 211. (S. F. et A. SERv.)
TÉTRATOME, Tetratoma. Herbst. Fab. PAYK. LAT. PANZ.

Genre d'insectes de l'ordre des Coléoptères, section des Hétéromères ( première division), fámille des Taxicornes, tribu des Crassicornes.

Un groupe de cette tribu présente pour caractères : jambes sans épines latérules. (Voyez Crassicorres, pag. 554. de ce volume.) Il contient les geares Orchésie, Tétralome et Cnodalon; ce dernier se distingue aisément des Tétratomes par la massue des anleunes composée de six articles en dent de scie. Dans les Orchésies les autennes sunt courtes, terminćes par une massue triarliculée; en outre le quatrieme article des tarses antéricurs et intermédaites est bilobé.

Antennes assez longues, terminées en massne, insérées à nu, composées de onze articles; le premier point recouvert par les bords latéranx de la lête, ceux de deux is sept, jetits; le septième un peu plus grand que le précédent; les quatre autres formant une grande massue ovale, perfoliée. - Bouche étroite, peu avancée. - Difuncïbules ne s'avancant pas au-delit du labre, bifides ì l'extrémité. - Mnâchoires aym leur lobe extérieur grand, obtrigone; l'interne petit, dentiforme. - Palpes inévaux; les maxillaires beaucoup plus longs que les labiaux, a liant en grossissant de la base à l'extrérnicé, composés de ruatre articles, le dernier le plus gros de tous, presqu'oltrigone, obliquement tronqué à sa parlie antérieure : les labiaux filiforines, près de trois for plus courts que les maxillares, triarliculés. lèvre nue, presque carrée, un peu plus large i l'extrémité; son bord supćrieur entier; inenton presque carré. - Téte plus étroite gue le corse el.- Keux ronds, proéminene.-Corps ov:laire, un pea déprimé. - Corselet un pen plus ¿troit que les élylres, transversal, à peine rebordé; ses côtés un peu raballus, arrondis aimsi que les angles. - Ecusson distinct. - Ely tres longues, linéaires, arrondies à leur extrémilé, a peine rebordées, recouvrant l'abdomen et les ailcs. - Pattes de longuear moyenne; jambrs conservant à peu prés la même large ur dans coute leur éleudue, point épiueuses lalćralement; tarses à arlicles entiers.

Les espèces de ce genre ảont le nonı liré du grec a rapport au nombie d'articles dout la nassue des anteunes est composée, vivent daus les cliampignons; leurs larves nout pas encore été décrites; on trouve les iusectes parfaits vers la fin de l'antumne. Nous cilerons, 10. Tétratoue des champignons, ' $l$ '. fungorum, in a s. Syst. Eleut. n⿳. 1. - LAT. Gener. C'rust. et Ins. tom. 2. pag. 180. $n^{\circ}$. 1. Lom. I. lab, 9. fig. 10. - Encyel. pl. 372. bis. fig. 7. 8. Des environs de Paris. $2^{\circ}$. 'Tétratome de Vesmarest, T. Desinarestio. Lat. id. $n^{\circ}$. 2. - Encycl. pl. $36 \mathrm{i}$. fig. 16. "Trouvée en décembre atu bois de Boulogre dians le bolet du Chêne. 
Fabricins rapporte quatre espèces à ce genre. M. Latreille (Dictionnaire d'Histoire naturelle, $2^{\mathrm{e}}$. édit.) peuse que la Tetratoma ancora $n^{\circ}$. 4 . n'est pas du genre, et il regarde comme possible qu'il en soit de mêne pour la seconde et la troisième.

LËIODE, Leiodes. LAt. Anisotoma. Illyg. FAB. Sphoridium. Oliv. (Entom.) T'etratoma. Herbst. P'anz.

Geure d'insectes de l'ordre des Coléoptc̀res, section des Hétéromères (première division), famille des laxicornes, tribu des Crassicornes.

Ia seconde division de celle iribu a pour caractère : jaubes épiocuses latéralement; elle conticnt les genres Trachyscele et Lćiode. (Vojez Chassiconnes, pay. 554. de ce volume.) Dans le premier, suivant Ni. Latreille, la massue des anteunes est de six articles, et de plus ces articles sont-presqu'égaux entr'eux, le second de la massue n'élant pas plus petit que ceux quil'avoisineml.

Antennes en massue, insérées à nu, composées de onze arlicles, les truis premiers presque cylindriqnes, le rroisième un per plus long que les précédeus, les trois suivans plus cuurts, obconiques, les cinq derniers formant une massue oblungue, perloliée; les septiène, huitic̀ne, neuvième et dixièue presque globuleux; le lunitiène beaucoup plus peth que lesseptième et neuvième; lc onzième presqu'ovale. - Mandibules avancées au-delà du labre, bifides à leur extrémité. Machoires composées de deux lobcs membrauenx, l’extérieur étront, presque linéaire, ressemblant ¿ un palpe, l’intérieur de la même longueul mais beaucoup plus lurge. - I'alpes courts; les maxillaires plus longs que les labiau, leur dervier article presque eylindrique, lo termial des labiaus presqu'ovale. -- Lepre nue, membraneuse, formant un angle aigu, profondénent échancrée, ses angles laréraur avancés; menton corné, lransversal, eu lriangle wonqué, allaut en s'élargissantl de la base a l'extrúmitć, son bord supérieur droil. - Téte ovale. -- Corps en ovale court, un per convexe en dessus, lisse, wabre. - Corselet transversal, ćchincré anterieurcuient, ses côtés arrondis, revordés. - Ecusson assez grand. - Elytres robordées, recouvrant des alies et l'abdomen. - Pattes de longueur moyenne; jaabes épincuses à leur parlie extérieure : tarses composés d'articles cutiers.

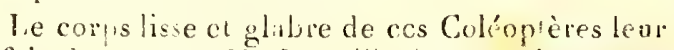
a fait donact par R. Larreille le nom de Lérade firc du gree. ?anzer dit que la bésode canelle vit daspla 'lrulle, el laykull donate le hois pourri pour deueure à l'humeràlis. Nous citerons les ospèces suivantes:

10. Lériode canelle, L. cinnamomea. - Tetratoma cinnamomea. Paxz. Faun. Germ. fies. 12.fig. 15. - Encycl. pl. 372. ois. fig. 17-19.
De France et d’Allemagne. $2^{\circ}$. Lébode brune, $L$. picea. Lat. Gener. Crust. et Ins. tum. 2. pag. $18 \mathrm{I}$. $n^{\circ}$. 1. Des environs de Paris. 3o. léinde terrugineuse, L. ferruginea. LAT. id. D'Allemagne. $4^{\circ}$. Léiode hnmérale, L. humernlis. L_t T. id.pag. 82. - Anisotomir humeralis no. 2. FAB. Sj st. Eleut. D’Allemagne. (S. F. et A. SERv.)

TÉTRIX, Tetrix. Lıт. Gryllus (Builla). Lixn. Acrydium. Geofr. De Géer. l'ab. Oliv. (Encycl.) Panz.

Genre d'insectes de la troisième section de l'ordre des Orthoplc̀res, division des Sauteurs, furille des Acrydiens.

Les Tétrix constituent parmi les Acrydiens une coupe pariiculière ayant pour caractère : extrémilé antélieure du prósternum concave en forme de mentonnière et recevant unc partie de la bouche; point de pelottes entre lcs crochets des tarses. (Voyez Acryolens, page 344. de ce volunie.)

Ces Orthoplères ont en outre les antennes composćes seuleuncnt de treize à quatorze arlicles; la languette quadrifidc et l'extrémité postérieure du corselel fortement prolongéc en arrière el finis. sant en printe; cellt-ci altent ou dépasse àême le bout de l'abdomen; les élytres sont extrêmement courles et prennent la lorme d'une écaille ovale qui ne recouve pas laile, mais se rejctte sur le cólé; chaque écaille ayant à peu prc̀s deux lignes de longueur. Les parlies sexuelles extérieures des 'Tŕlix dulferent de celles de Criquets proprement dits : duns les lemelies les quatre pièces alongées, ćcaillerses gui servent a déposer les aufs sorit dertelées en scie sur leur lıord et ont extérieurétuent des aspérnlés cone une râpe, landis que cos mêres parties ont leurs bords aigus dans les Crigucls feruellcs; les,individ as mâles de ce dernier genre portent ordinairement de chaque côté de l'anus un appendice plus ou moins long, paroissant inarliculé, dont les máles 'Tétrix sunt toujours dćponrvus. (Voyez pour les caractères géneriques autres que ceux que nous venous de nentionuer, l'artic̀le Carquet du présent Dic!lonnaire.)

Les mours des Tétrix sont absulument lés mêraes que celles des Criquets, avec lcsquels la plupart des auteuis les ont confondues; elles paroisent ainer encore plus la chialear qu'eux, car elles se lienuent habituel!ement sur les sables, lcs aures et les troncs d’arbre les plus $\in \mathrm{x}-$ posés à l'urdeur du solcil. Lcur nom vient d'un verbe grec qui exprime celle striblation que prodnisent leaucoup d'Acrydiens, mais cette f́dculté est-elle communc aux 'Tónix? C'est ce dont l'exiguité de lenrs élylres pent faire douter. Dans l'aricle que nors venons de citer, Olivier atribue en grineral anx Criquets, et avec juste raisos, le goût et la faculté de voyager, aiusi 


\section{T E T}

que celle de pouvoir soutenir de longs vols, mais nous ne pensons pas que ces habitudes soient celles des Tétlix.

re. Division. Pointe postérieure du enrselet dépassant l'alidomen. - Ailes f́yalant an moins la longueur do celte pointe. (Carène uuédiale du corsclet peu élevée.)

1. Térrix subulće, T'. subulata.

Tetrix fusca, punctis nigris temerè spara; antennis albidis, apice fuscis: alis subpelluciars, violaceo micantibus.

Tetrix subulata. Lat. Gener. Crust, et Ins. tom. 3. pag. 107. $n^{\circ}$. 1. Exceptis varietatihns.

Longuenr 7 lig. Brune, chargíe de pelites taches irrégulières et de points noirâtres; base des antennes blanchâtre ainsi que celle de la partie rabaltue latérale du prolongement thoracique; pattes à bandes transverses irrégulières moins foncées que la couleur du ford'; ces bandes mieux prononcées sur les paltes anlérieures. Ailes transparentes à nervures brunes et reflet violet. Femelle.

Commune aux environs de Paris.

Nota. Cetle espèce ayant élé décrite d'une manière imparfaite sons le nom de Criquet subulé $\mathrm{n}^{\circ} .75$. daus ce Dictionnaice, nous avons jügé ulite d'en douner les caractères plus exactement; d'ailieurs nous observerwins que lis phlnpart des synonymes quon lui rapporte sont inipplicables, car les auteurs anciens ont confondn sons le nom de Gryllus subulatus, différen'es espèces fort dislincles. Fabricius (Entom. Syst.) va jusqi’à dire que son Acrydium subulatum peut n’être qu'une simple variélé de l'Acrjolimm bipunctatum ('Tétrix biponctuée no. 6 ).

Nous connoissons un mâle voisin de la Tétrix subulće, dans lequel le corsclet ainsi que son prolongemeut porlent sur leur parlie supérieure des lignes longitudinales alternativement hrunes et grisâtres. Eist-ce le måle de cette espècé, oı de quelqu'autre de cette division?

\section{Tétrnix de Panzer, T. Panzeri.}

Tetrix subfusca; antenuis albidis, apice. fuscis: capitis thoracisque dorso et pedibus posterioribus pallidis, processu thoracico ad basin utrinque fusco semilunato; alis fuscis, margine extero hyalino violaceo micant thus.

Tetrix subulata var. B. LA'T. Gener. Crust. et Ins. tom. 3. pag. 108. - Acrydium bipunctatum. Panz. Faun. Germ. fas. 5. fig. 18. Demptis omnibus synonymis.

Longueur 6 lig. $\frac{1}{2}$. Elle est d'un bren moins foncé que la précédente. Antennes blanchâtres, leur extrémité brune; dessus de la tête et du cor- selet ainsi que le prolongement de ce dernier d'un blanc-grisâtre; on voil à la base de celui-ci, de chaque côté, une lache presque demi-circulaire d'un brun fucé : palies poslérieures d’un grisjainâtre; extrénité des cuisses brune; les quatre aulres paltes annelées de brnn el de grris-jaunâtre; ailes fort bruues, lenr bord antérieur transparent, ayant sur leur totalité un reflet violâtre. Femelle.

Forêt de Bondy.

Nola. I $^{\circ}$. La figure de Panzer que nous cilons appartient cerlainenent à notre espèce et à la division dans laquelle nous la pluçons; il est difficile de conceroir comment cet an'eur a pu considérer, d'après les synonymes qu'il rapporte, le corselel comme ne surpassaul pas la Inngucur de l'ablomen, tandis que sa figure offire positivement le contraice; du reste il ue décrit pas l'insecte qu’il représente. $2^{\circ}$. Ia variété $A$. de lar Tetrix subulata citée par N1. Ialreille ut suprú, ayant le corselet blauc a la hase du prolongement rinoracique (Schrarf. Icon. Ins. Ratis. tab. 161. fig. 2 et 3 .), est probablement ure espèce particulière.

\section{Tétrox bimacnlée, T. bimaculata.}

Mále et femelle. Forêt de Bondy.

Voyez pour la description Criquet bimaculé $r^{\circ}{ }^{\circ}$ 11. des especes moins connues, de ee Diclionnaire.

\section{Tétrrx marginée, T. marginata.}

Tetrix fusca, punctis lineolisque nigris sparsa; antennis albudis, apice fuscis: thoracis cupitisque dorso albido marginato, femorum posticorum carinâ externâ tibiarumque ejusdem paris facie posticâ albidis; alıs fuscis, margine extero hyalino violaceo micantibus.

Longneur 5 à 6 lig. Brune, clargće de points et de petites ligues éparses, noirâtres. Antennes blanchâtres, brunes à leur extrémité : côtés extérieurs du vertex et du dessus du corselet bordés par une ligne blanchâtre ; carène externe des cuisses postérieures d'un blanc-juntâtre ainsi que la face postérieure de leurs jambes. Ailes brunes, leur bord extérieur transparcnt : elles ont sur leur totalité un reflet violâtre. Mále et femelle.

Furêt de Bondy.

A celle division appartiennent encore, $I^{\circ}$. Tétrix thoracique, T. thoracica. - Criquet thoracique $n^{\circ} .77$. de ce Dictionnaire. Celle espèce est peut-être la vartété A. de la Tetrix subulata Lat. Gener. quenous avons mentionnće plus haut. $2^{n}$. Tétrix crochue, T. hamata. - Ciqquet crochu $\mathrm{n}^{\circ} \cdot 78$. cie ce Diclionnaire. $3^{\circ}$. Tétrix indienne, T. inda. - Crique! indien $n^{0}$. 79. id. $4^{\circ}$. Téllix purpurine, T. purpurascens. - Criquet purpurin no. 80. id. 


\section{$\mathrm{T} \mathrm{IT}$}

$2^{\circ}$. Division. Pointe postérieure du corselet ne dépassant pas l'abdomen. - Ailes plus courtes que eelle pointe. (Carène médiale du corselet plus élevée que dans la première division.)

\section{5. 'Tétrix mueronée, T. mncronata.}

Tetrix fusco-nigra, thoracis carinâ multiun ele'atâa, anticè suprà caput acuminato productâ, subincirva $\hat{a}$; antennis nigris, basi apiceque et capitis parte anteriori albidis.

Longueur 6 lig. D'un brun presque noir, chargée d'un grand nombre de petils tubercules gris; curène da corselet fort ćlevée, prolongée en devant en une pointe aiguë qui s'avanee sur la tête, celte pointe un pen recourbée; pointe posiérieure du prolongement thoracique un peublanchâtre, ainsi que la partie antérueure de la tête, la base el l'extrémité des antennes. Femelle.

Du Brésil.

Nota. Elle ressemble par le prolongement antérieur de sa carène à la Tétrix crochue citée dans l'autre division, mais la Tétrix mueronće appartient certainement à eelle-ri.

\section{Tétrix biponcluée, T. bipunctata.}

Acrydium bipmnctutum. FAB. Ent. Syst. tom. 2. pag. 26. $n 2^{\circ} \cdot 2$.

Toyez ponr la description et les autres synonymes Criquet biponetué $n^{\circ}$. 74. du présent currage. Nous pensons que l'on a eontondu plusieurs espèces sous ce nom.

7. T’́́tax point d'exclamation, T. exclumationis.

Teirix fusca, rufo varia; antennis albidis, apice nigris; thorace albido, lmeis duabus tate. ralibus longitudinalibus nigris : supericie majort, extius profundè emarginatâ; pedibus posticis corpore dilutioribus.

Longuemr 5 lig. Corps brun, mélangé de roussuitre; antennes blanchûtres avee l'extrémité noire. Corselet d'un blanc sale, ayant de chaque côlé àe sa carène dorsale deux lignes très-noires, la stpérieure plus grande, profondróment ćchancrée an nilieu de sa partie extérieure; cuisses postérienres plus claires que le reste du corps, ayant principalement sur leuts carènes des points noirs. Temelle.

Environs de Puris.

On doil placer ici, ${ }^{\circ}$. Télrix malade, T. morbillosa. - Acy dium morbillosum. HAB. Ent. Syst. tom. 2. pag. 25, $n^{\circ}$. 1. - Criquet africain $n^{\circ} \cdot 73$. de ce Dictiomaire. $2^{\circ}$. Tétrix bossue, T. gihba. - Criquet bossn $n^{\circ} \cdot 76 . i d .3^{\circ}$. Térrix bifasciée, T. bifasciata. - Criquet bifasrié $n^{\circ}$ : 10. des espèces moins counues de ee Dictionnaire.

(S. F. et A. SERV.)
TETTIGOWÉTRE, Tettigometra. Lat. Genm. Fnlgora. Panz.

MM. Latreille et Germar désignent sous ce nom un genre d'insectes de la tribu des Fulgcrelles, famile des Cicadaires, section des Flomoptères, ordre des Hémiptères; ils lui donnent ponr caractères : antennes épaisses, cyliridruques, insérćes sous les yeux, mais point dans leur sinus inférieur, susceplibles de se cacher transversalement lors du repos entre les angles postérieurs de la tête et le corselet; eomposées de trois artieles; le second presquovale-cylindrique, denx fois plus long que le premier, portant une soie insérée dans une cavilé oblique de son extrémité; tête horizontale, aplatie en dessus et en dessous, triangulaire, point rebordce; yeux latéraux, trigones, point saillans, placés aux angles postérieur's de l'occiput; deux ocelles; élytres ayant à leur base une petite éeaille transversale trèsapparente; corps ovale, déprimé; jambes muliques; leur extrémité portant une courome de fines épines.

Les 'lettigomètres sont petiles et se tronvent sur diff́crentes plantes; elles s'échappent en santant lorsqu'on veut les saisir; on n'en connoît eneore "fuc peu d'espèces. 1". Teltiyomètre verdàtre, T. virescens. Lat. Gener. Crust. et Ins. tom 3. pag. 164. $n^{\circ}$. 1. Des enrirons de Paris. $2^{\circ}$. Telligronètre dorsale, T. dorsalis. Lat. Hist. nat. des Crust. et des Ins. Longueur 2 lig. Elle ressemble à la précédente; d'un vert un peu jauvâ!re; pattes rouges; une tache eommune, à la Lrase des deux élytres, d'un rouge sanguin et $\in \mathbf{n}$ forme de cour. Mâle. Trouvée en Anjou par M. Carreel à qui nous la devons, et à Paris, suivant MI. Latreille. $\overline{3}^{\circ}$. 'Teltigomètre oblique, T. obliqua. LAт. id. Longueur a lig. Têle et eorselet conleni de chair ainsi que l'écusson; élytres Iransparentes, un pfu couleur de charr, avec Irovis batndes obliques rousses; eorps noir eu dessous ; côtćs de l'ábdomen blancs; pélles eouleur de chair, poncluées ?e noir. D'Auliche. $4^{\text {n }}$. Tetttigomètre ombrée, T. umbrosa. Genm. Magaz. entom. Halle. 1821 . pag. 7. Ferrugineuse, brune en dessous; élytres ayant ieur base et lcur extrémilé blanchầ res avec le bord extérieur ponctué de noir. De 'T'auride? (S. F. el A. Serv.)

TETTIGONE, Tettigonia. FAв. Cet auteur a appliqué ee nom aux insectes Hémiplères générallement connus sous celui de Cigale. Vo,ez ee mol. (S. F. et A. Serv.)

TE'TTIGONE, Tettigonia. Geoff. Lat. Cicuda. Linn. Geoff. De Geen. Fab. Scuranee. Iassus. FAB.

Genre d'insectes de l'ordre des Hémiptères, section des Honoplères, fanille des Cicadaires, tribu des Cicadelles (division des Teltigonides).

'Trois genres eomposent avec celui-ci un groupe 
dans les Tettigonides. (Voyez ce mot.) $1^{\circ}$. Les Scaris, dont le corps est triangulaire et l'écusson prolongé en une pointe très-longue et fort aiguë. $2^{\circ}$. Les Penthimies, qui ont les élytres rabattues, croisées vers l'extrémité et le corps elliptique. $3^{\circ}$. Les Proconies, distinguées par le renflement du premier article des anleunes, leur tête manifestement plus longue que large et leur corselet rhomboidal.

Antennes insérées dans une cåvité près des yeux et entr'eux, composées de trois articles, les deux premiers petits, égaux, presque cylindriques, le troisième en cône alongé, terminé par une soie fort longue. - Bec biarticulé, assez long, atteignant la base des hanches intermédiaires. - Téte transversale, un peu moins longue que le corselet, aussi large que lui; son bord antérieur arrondi, épais; elle est échancrée circulairement dans toule l'étendue de sa partie postérieure : côtés de sa partie inférieure un peu creusés. - Yeux peu saillans, placés snr les côtés de la tête, contre le corselet. - Deux ocelles apparens, placés sur le verlex, près de son bord postérieur, assez écarlés l'un de l'antre. - Corps linéaire. - Corselet point dilaté latéralement, transversal, arrondi en devant et sur les côtés, coupé presque droit postérieurement. - Ecusson triangulaire, un peu plus large que long, conpé droit à sa base. - Elytres recouvrant des ailes et l'abdomen, embrassant les côtés de ce dernier, plus dilatées vers le tiers de leur longueur, allant en diminuant insensiblement ver's lur's extrémités; celles-ci arrondies, se tenant droites et ne se croisant point. - Abdomen composé de cinq segmens outre l'anus ; plaque anale refendue dans toute sa longueur, recevant dans les femelles, la tarière et ses fourreaux; les bords de celte plaque un peu écartés vers l'insertion de la tarière et laissant apercevoir la base de celle-ci ; les máles ayant ces bords bien clos et absolument rapprochés dans toute leur élendue. - Pultes antérieures et internédiaires issez longues, munies d'épines futes el nonbreuses; cuisses postérieures grêles, fort longnes; leurs jambes longues, droites, gannies d'épines très-fortes, trèsnombreuses el ierminées en dessous par une demi. couronne d'ípines qui débordent l'extrémi é de la jambe et atteignent le plan de position : tarses de trois articles, le premier au moins aussi long que les deux autres réuais, prolongé ainsi que le second, chacun sous la base de celui qui le suit, en un rang d'épines; ces épines et celles de l'extrémité des jambes sont courtes, serrées, presqu'égales entr'elles : dernier article des tarses munı de denx crochets gros, courts, épais.

Les Tettigones dont le nom vient d'un mot grec qui signifie: Cigale, sont généralement petìes, mais presque toujonrs orn es de couleurs agréables et variées. On est encore loin d’avoir décrit toutes les espèces connues. Malgré les travaux de Hist. Nat. Ins. Tome $X$.
M. Germar dont nous avons beaucoup profité, et le peu que nous y avons ajouté en proposant quelques nouveaux genres (voyez Tetriconides), nous pensons qu'il faudra nécessairement en créer un plus grand nombre dans cette tribu. Les mours des Tettigones sout celles des autres Cicadelles. (Voyez Tetrigonides.) Nous allons citer les espèces qui appartiennent à ce genre, tel que nous venons d'en présenter les caractères.

\section{Tetrigone vernissée, $T$. vernicoşa.}

Tettigonia nitida, subtis lutea, ano nigm; capitis lutei vertice lineolisque nigris; thorace suprà nigro viltâ mediâ lateâ : ely tris nigris, fassciis duabus longitudinalibus luteis, post medium desinentibus, vittâque transversâ latâ ante upicem luteis.

Longueur 5 lig. Corps brillant et comme vernissé, jaune en dessous; extrémité de l'abdomer, noire: tête jaune avec le vertex et trois potites lignes, de couleur noire; une de chaqque côté sous la base des antennes, l'autre an milieu de la partie la plıs avancée de la têle. Corselet noir en dessus avec une large bande trausverse dans son milieu, de couleur jaune. Elytres noires, ayant chacune deux bandes longitudinales james qui partent de la base el s'élendent presque jusqu'aux deux tiers de l'élytre, l'extérieure plus large à son extrémitć et l'intérieure à sa base : sur le reste de chaque élytre est une large bande transverse jaune. Pattes et base des antennes jaunes. La soie de cellesci trés-longue. Femelle.

\section{Du Brésil.}

\section{Tettigone quadrirayée, T. quadrivitíata.}

Tettigonia rubro-sanguinea, capitis vertice, thoracis anticâ parte elytrorumque fasciis tratusversis tribus nigris; pedibus dilutioribus.

Longneur 4 lig. D'un rouge sanguin; vertex et partie antérieure du corselel, de couleur noire; trois bandes noires, transverses, communes aux denx élytres; l'une près de la base, lit scconde au-delà du milieu; la dernière vers le bout de l'élytre, dont l'extrémité est pâle. Pattes et dessous du corps plus páles que le dessus. Femelle.

D'Amériqque.

Nota. La disposition des bandes noires dans cette Tettigone est absolument la même que cians

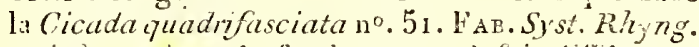
mais la couleur du fond est tout-à-fait difléente.

Parmi les espèces décriles nous mentionterons les suivantes: ${ }^{\circ}$. Teltigone farineuse, T. forinosa.-Cicada farmosa $\mathrm{n}^{\circ} \cdot 4 \mathrm{H}$. RAB. Sy st. Phyng. Femeile. De Java. $2^{\circ}$. Telligone à docize poists, T. duodecimpunctata. Genм. Magaz. entom. Ifalie. 1818. pag. 66. $n^{\circ}$. 14. Femelle. Du Brésil. 50. Teltigone sanglante, T' cruenta. -.. Cicada $\mathrm{G} g \mathrm{grg}$ 
cruenta $\mathrm{n}^{0}$. 28. F $\Lambda$ в. id. Femelle. Amérique méridionale. $4^{\circ}$. Tetligone frontale, $T$. frontalis. Grrm. id. pag. 64. no. 1 . Femelle. Du Brésil. $5^{\circ}$. Tettigone splendide, T. splendida. - Cicada splendida no. 29. FAB. id. Amérique mćridionale. $6^{\circ}$. Tettigone verte, T. viridis. Germ. id. pag. $7^{2}$.

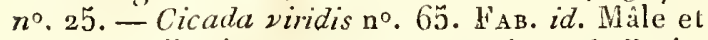
Femelle. Elle n'est pas rare aux environs de Paris.

(S. F. et A. Seru.)

TETIIGONIDES, Tettigonides. Troisièrne division de la tribu des Cicadelles, famille des Cicadaires, section des Homoptc̀ces, ordre des Hé. miptères.

Les travaux de M. Germar ayant multiplié les gemres dans la tribu des Cicadelles, et desirant nous-mêmes cn proposer ici quelques-uns de nouveaux, nous avons | ensé qu'il étoit utile d'y introduire des divisions caractérisées. Voici celles que nous $y$ formons.

Cicaderies, Cicadellae. Quatrième tribu de la famille des Cicadaires; ses caractères sont :

Ocelles au nombre de deux ou nuls. - Antennes insérées en dessous de la tète, entre les yeux, composées de trois articles. - Corselet lout au plus dilaté littéralement.

I. Jambes postérieures simples. (Ulopides, Ulopides.)

\section{Ulope, Ethalion.}

II. Jambes postérieures munies d'une seule épine ou de plusieurs toujours rangées sur une même ligne. (Cercopides, Cercopides.)

A. Point d'ocalles apparens.

Euryıèle.

B. Oceiles apparens.

Cercopis, Aphrophore. Ptyèle, Lìdre.

III. Jambes postérieures triangulaires; leurs angles garnis dans toute leur longueur d'épines tines, ordiraircment fort nombrenses. ('Teltigonides, Tettigonides.)

A. Ocelles placćs sur le uilieu de la partie supérieure de la tète.

a. Bord antéricur de la tête arrondi, épais.

Scaris, Penthinie, Tettigone, Proconie.

b. Bord antérienr de la tête mince, presque tranchant.

Eupélix.

B. Ocelles placés sur la ligne qui sépare la partie supérieure de la lête, de l'inférieure.

Evacanthe.

C. Ocelles placés sur le milieu de la partie antérieure de la tête.

Iassus.

Nota. Nons ne connoissons pas suffisamment les genres Coclidia et Gypona de M. Germar, ce qui nous empếche de les comprendre dans le préseut tableau.

I.es Cicadelles virent toutes, pendant leur vie entière, de la sève des végélaux; elles savent la pomper au moyen de leur bec qu'elles tiennent enfoucé à travers l'écorce tendre des jeunes bianches. La larve est presque semblable à l'insecle partait, et a les mêmes organes de locomotion, à l'exceplion de ceux du vol dont elle est entièrement dépourvue. Taa nymphe est également douée de ces facultés et ne se distingue de la larve que par la présence de quatre étuis séparés les uns des autres rcnfermant les élytres et les ailes; plusieurs dc ces larves et de ces nymphes se tiennent cachées dans une goutte de liqueur mousseuse qui ressemble exactement à de la salive; cette eau est le produit dcs excrétions de linsecte : elle est quelquefois tellement abondante, que dans les années où l'Aphrophore spuniaire. s'est multipliée en grand nombre, on éprouve une espèce d'ondée en passant sous les Saules blancs ( Salix alba) qui en sont chargés. Toules les Cicadelles ont plus ou moins la taculié de sauter pour éviter leurs ennenuis; afin d'exécuter ce mouvement, la nature leur a donné des orgares particuliers; nous disons particuliers, parce gue tout en reconnoissant à beaucoup d'uutres insectes celte mêue faculté de s'élever en l'air par un mouvement brusque, nous avons ici l'oc:casion d'admirer. la variété des moyens que l'allteur de la nature emploie pour remplir le mêne but.

La plupart des insectes sauteurs ont les cuisses postérieures fort grosses; parmi ceux-ci les Coléoplères qui sautent ont ordinairement les jantbes postérieures arquées et de plus, ceux qui jouissent éminemment de la faculté de sauter, tels que les Altises, les Orchestes, etc., ont tout le long de la partie inférieure de la cuisse une rainure où se loge la jambe avec effort au moment où le saut va être exécuté; à cet instant elle en sort vivement, ce qui produit l'effet d'une détente et élève l'insecte au-dessus du sol : les bords de cette rainure sont le plus souvent garnis d'une ou de plusieurs épines; ceux des Coléoptères dans lesquels la rainure n'est pas complète, mais ne s'étend que sur la partie la plus voisine du genon, possèdent aussi, quoique dans un moindre degré, la faculié de sauter, et nous ne croyons pas qu'aucun de ceux qui en sont totalement privés et dont les jambes postérieures ne sont point ar- 


\section{T E T}

quées de manière à s'appliquer sar la convexité inférieure de la cuisse, puissent exécuter ce mouvement.

Les Orthoptères sauteurs ont comme les Coléoptères dont nous venons de parler, les cuisses postérieures renflées et la rainure placée de même, leurs jambes ne sont pas arquées et leur mouvement pour s'élever est encore favorisé par la longueur des cuisses et des jambes, l'extrémité de celles-ci peut s'appuyer fortement sur le sol et s'y faire un point d'appui par le moyen de deux ou quatre épines qui dépassent le bout de la jambe.

Parmi les Hyménoptères il se tronve aussi des insectes sauteurs tels que quelques Misocampes et les Chalcis; leurs cuisses postérieures sont grosses et leurs jambes arquées; cenx qui sautent le mieux ont en outre les banches d'une grandeur remarquable.

Les Puces qui conslituent l'ordre des Siphonaptères; les Acanthies et les Psylles parmi les Hémiptères; les Psoques qui font partie des Névroptères, jonissent tous de la faculté de sauter, et n'ont pas les cuisses postérieures renflées : la pelitesse des espèces de ces deux dernięrs genres ne nous a pas permis d'observer chez eux les organes du saut. Dans les Puces l'extrémité des jambes postérieures et tous les articles des tarses à l'exception du dernier, sont garnis d'épines dispersées, inégales, hérissées, très-pointues, au moyen desquelles elles peuvent se fixer pour prendre lenr élan; en ou!ré les paltes postériemes qui exécutent le saut sont plus longues que les autres.

Dans les Hémiptères-Homoptères des qualre tribus qui composent la fanille des Cicadaires, l'organe qui favorise le saut diffèı e de tons cenx que nous venons de désigner; il consiste en une couronne d'épines courtes, serrées, presqu'éyales entr'elles, que porte l'extrémité des jambes postérieures et qui forme l'emboîtement dn premier article des tarses. Dans tous les genres de ces tribus, ces couronnes d'épines existent, mais plu. sieurs d'entr'eux ont en outre de semblables épines rangćes en couronne à l'extcémité inférienre des deux premiers articles des tarses, el cenx-là sautent plus haut et plns vivement que les autres. Les cuisses postérieures des Cicadaires ne sont pas renllées. La totalité de celle organisation nous paroît propre à elles seules.

Quoique nous ayons altribué à la phripart des insectes sauteurs des cuisses postérieures rentlées, et à beancoup d'entr'eux des cuisses canaliculées en dessous, nous ne prétendons pas que ces altribints, surtout lorsqu'ils sont sépürés l'un de l'autre, indiqent daus les espèces ou dans les sexes qui en sont pourvus la faculié de sauter. Nous ne pensons pas non plus avoir mentionné tous les genres d'insectes sauteur's, et décrit leurs orga- nes; ce travail sernit beaucoup trop long pour le cadre anciuel nous sommes restreints.

Les Cicadelles femelles sont pourvues d'une tarière avec laquelie elles font des entailles dans l'écorce des végétaux, pour y déposer leurs aul's.

\section{EURYMĖE, Eurymela. Hoffmans. (1).}

Genre d'insectes de l'ordre des Hémiplères, section des Homoplères, famille des Cicadaires, tribu des Cicadelles (division des Cercopides).

Excepté les Eurymèles, tous les genres de Cercopides offrent des occlles apparens. Voyez pag. 602 . de ce volume.

Antennes très-courtes, insérées dans une cavité prc̀s des yeux et entr'eux, sous le bord avancé de la tête, composées de trois articles égraux, globuleux; le dernier terminé par une soie courle. - Bec très-court, biarliculé, dépassant à peine la base des hanches antérieures. - Téte extrêmement courte vue en dessus, trinsversale, de la largeur du corseles, formant un triangle curviligne tronqué inférieurement, quand elle est vue en face. - Yeux proéminens, placés sur les côtés de la tête, contre le corselet. - Point d'ocelles apparens. - Corps court, triangulaire. - Corselet point dilaté latéralement, transversal, court; ses bords latéraux très-étroits; bord antérieur arrondi, le postérieur s'avançant un pen entre la base des élytres, tronqué presque droit vis-à-vis de l'écusson. - Ecusson triangulaire. Elytres recouvrant des ailes et l'abdonen, enveloppant les côtés de celui-ci, leur extrémité et leur bord extérieur, arrondis. - Abdomen com. posé de cinq seginens oulre l'anus daris les femelles; plaque ande refendue dans tonte sa longueur, recevint dans ce sese, la tarière et ses fourreanx, les bords de cette plaqque nn peu écartés vers l'insertion de la tariere, et laissant apercevoir la base de celle-ci. - Pattes de longueur moyenne; cuisses postérieures courles, légè rement canaliculées en dessous, à banches courles; leurs jambes assez longues, anguleuses, ayant sur leur angle antérieur urie forie épine, terminćes en dessous par une demi-courorne d'épines qui débordent l'extrémité de la jamle et atteignent le plan de position; tarses de trojs articles; le premier plus long que le second; ces deux articles prolongés chacun sous la base de celni qui les suit, en nne rangée d'épines; ces épines, ainsi que celles de l'extrémité des jambes, conrtes, serrées, presqu'égales entr'elles; dernier article des tarses longr, muni de deux cruchiets.

La lête des Eurymèles vue en dessus ne paroit qu'un simple rebord, ce qui les rapproche des

(1) L'espèce qui constitue ce genre nous a éré envoyéé par M. de Brébisson, sous le nom d'Eurymela fenesiraia Hurfa, que nous lui cunseryous. 
Fillalions, dernier genre du groupe des Ulopides. Ce groupe a les jambes postérieures eutièrement dépourvues d'épines, el nos quatre premiers genres de Cercopides, Eurymèle, Cercopis, Aphrophose et P'tyèle n'en ont qu'une ou deux. Les dernières jambes des Lèdres offrent quatre épines, ce qui nous mène naturellement aux Teltigonides qui ont les jambes postérieures ciliées de nombreuses épines dans toute leur longueur. Du reste la forme de la tête et la structure des autennes jointes au peu de longueur du corselet, nons paroîtroient toujours devoir nécessiler l'établissement de ce genre, quaud bien même on découvriroit par la suite que ics Eurymièles ont des ocelles, ce que nous n'avons pu apercevoir malgré toutes nos recherches.

\section{Eurymite fenestrée, E. fenestrata.}

Eurymela tota punctato-coriacea, atro-violacea; capitis lateribus thoraceque subtis et fomorum basi palludis; abdomine rubido, elytri cujusque maculis duabus parvis pellucıdis, unâa marginali; alis azureis.

Longueur $3 \mathrm{lig}$. $\frac{x}{2}$. Entièrement chagrinée et ponctuée; d'un noir-violacé un peu métallique; côlés de la lête, dessous du corselet, hanches et base des cuisses, d'un jauue. pâle. Dessous de l'abdomen rougeâtre ainsi que la base exlérieure des élytres; celles-ci ayant chacuue deux taches blanchâtres, transparentes; l'une très-petite placée vers le milieu de l'élytre, l'autre posée près de l'extrémité et sur le bord extérieur : ailes azurées ainsi que le dessous des élytres. Femelle.

Du Brésil.

Cerroopis, Cercopis. Fab. Schranck. Panz. Jat. Germ. Cicada (Ranatice). Linn. Cicada. GEofr. De GÉer.

Genre d'insectes de l'ordre des Hémiptères, section des Homoptères, fimmille des Cicadaires, tribu des Cicadelles (division des Cercopides).

Quatre genres, Cercopis, Aphrophore, Ptyèle et Lèdre, réunis par leurs occiles apparens, forment un groupe dans celle division. (Voyez CIcadelles, pay. 602. de ce volume.) Les trois derniers out la tête aussi large que le corselet, ce qui les éloigne des Cercopis.

Antennes insérées entre les yeux, sous le bord avancé de la tête, composées de trois articles; le premier court, cylindrique; le second de même forme mais deux fois plus long que le premier; le troisième très-petit, glohnleux, terminé par une soie plus longue que les trois articles qui la précèdent pris ensemble. - Bec extérieurement biarticulé, articles presqu'égaux; ce bec atteignant tout au plus la base des hanches intermédiaires. - Tête peu penchée, presqu'horizontale, obiuse, beaucoup plis étroite que le corselet, uuicarénée en dessus dans le milieu du verlex; son bord antérieur avancé, presque tranchant; la partie inférieure sous ce bord, sourent carénće et marquée de stries transversales. - Yeux peu proéminens, placés sur les côtés de la tête, contre le corselet. - Deux ocelles apparens, placés sur le verlex, rapprochés, posés sur les deux pentes de la carène de la tête. - Corps ovale, convexe en dessus. - Corselet court, point dilaté latéralement, héxagonal ; son bord antérieur coupé droit. - Ecusson triangulaire, son angle postérieur aigu. - Elytres opaques, colorées, réticulées vers le bout, convrant les ailes et l'abdomen, plus longues que celui-ci ainsi que les ailes, leurs bords latéraux et leur extrémité, arrondis. Abdomen court; plaque anale inférieure refendue dans toute sa longueur, recevant daus les femelles la tarière et ses fourreaux; ses bords, dans ce sexe, un peu écartés vers l'insertion de la turière et laissant apercevoir la base de celle-ci; les mâles ayant ces bords bien clos et absolument rapprochés dans toule leur étendue. - Pattes de longueur moyenue ; cuisses postérieures légeremen canaliculées en dessous, courtes, à hanches fortes, assez longnes; leurs jambes assez longues, auguleuses, ayant sur l'angle extérieur une ou deux fortes épines posées sur une même ligne longitudinale, termiuées en dessous par une demi-couronne d'épines qui débordent l'extrémité de la jambe et atteignent le plan de position: tarses de trois articles; le premier plus long que le second; ces deux articles prolongés chacun sous la base de celui qui les suit en un rang d'épines; ces épines, aiusi que celles de l'extrémité des jambes, courtes, serrées, presqu'égales entr'elles : dernier article des tarses assez long, portant deux crochets.

Les mœurs des Cercopis ne diffèrent pas de celles des autres Cicadelles. (Voyez ce mot pay. 602. de ce volume.) Les nombreuses espèces de cette tribu sont généraleınent petites, mais c'est parmi les Cercopis que l'ou trouve les plus grandes et les plus larges; ces Hémiptères sont en outre remarquables par le brillant et la vivacité de leurs conleurs. La plupart des espèces babitent dans les climals chauds.

Ire. Division. Portion antérieure de la partie inférieure de la tête convese, arrondie.

\section{Cencopis tricolore, C. tricolor.}

Cercopis capite, thorace suprà, tibiis tarsisque et abdominis suprà subtùsque lineis transversalibus, nubro-sanguineis; thorace subtus elytrisque nigris, horum maculis quatuor oblongis, albidis ad basım.

Longueur I pouce. Antennes, tête, dessus du corselet et ses bords en dessous, d'un rouge sanguin. Corselet chagriné, son dessous, ainsi que les élytres, de couleur noire; la base de ces der- 
nières un peu sanguine; vers la base de chaque élytre on voit quatre taches ovales-alongées, d'un blanc-jaunátre, rangées sur une mêtme ligne; la seconde en partant du bord extérieur, presque cordiforme, écliancrée du côté postérieur. Patles rougeâtres; les cuisses, surtout les quatre dernières, sont en grande partie noires, principalement vers la base. Abdomen portant alteruativement des raies transverses rouges et noires, tant en dessus qu'en dessous. Femelle.

De l'île de Java.

\section{Cercopis à collier, $C$. collaris.}

Cercopis nigra, capitis subtùs et anticè thoracisque suprà rubrorum maculâ communi nigrâ, elytris basi et ad apicem rubris, nigro maculatis, in medio testaceis: pedibus nigris.

Longueur I l lin. Corps noir en dessous; têle d'un rouge sanguin avec le vertex noir. Corselet d'ın rouge sanguın en dessus ainsi que les bords latéraux en dessous; le milieu de sa partie antérieure portant une tache noire, en carré-long transversal qui se réunit à la tache de la tête. Base des élytres d'uu rouge sanguin, leur milieu testacé; leur hord postérieur d'un rouge sanguia bordé de noir; celle couleur s'élargissant de chaque côté, en remontant vers le milieu de chaque élytre; vers la base de chacune d'elles on voit deux lignes noires se réunissaut un peu par leur bont supérienr : écusson et palles, noirs, les quatre cuisses antérieures plus ou moins rouges en dessous. Femelle.

Du Brésil.

\section{Cercopis de d'Urville, $C$. Utvillei.}

Cercopis nigra, nitidu; facie, tibiis tarsisque et elytri singuli maculis tribus ad basin rufo aurantiacis: elytrorum maculà intermediâ triangulari nigro unipunctatâ.

Longneur 10 lig. Noire, brillante. Partie antérieure de la tête d'un roux pâle; élytres ayant chacune vers leur base trois taches d'un rouxorangé; la plus voisine de l'écusson lougue, ovale; l'intermédiaire triangulaire, portant un point noir; celle du bord extérienr petite, ovale. Patles rousses avec les qualre cuisses postéricures noires ainsi que l'écusson. Femelle.

Cette espèce nouvelle a été rapportée par M. d'Urville, capitaine de la corvette la Coqualle.

\section{Cercoprs à deux raies, $C$. bivittata.}

Cercopis nigra, nitida; ely tris fuscis, ceneo nitentibus, albido bivittatis.

Longueur 9 lig. Noire, brillante. Corselet finement poiutillé ; élytres d'un brun foncé à reflet cuivreux - verdàtre, agant chacune deux bandes blanchâtres communes qui les partage presque régulièrement par tiers. Femelle.

De l'ile de Java.

\section{Cеr coprs apicale, C. apicalis.}

Cercopis subtùs nigra, suprà sanguinea, elytronum puncto ad nedium apicibusque latis, nigris.

Longueur 7 lig. Tête d'un rouge sanguin avec le bec et la partie qui l'avoisine, noirs. Abdomen, pattes et dessous du corselet, noirs. Le dessus de celui-ci et ses bords latéraux en dessous, d'un rouge sanguin. Ecusson de cette couleur, ainsi que les deux tiers antérieurs des élytres; sur le milieu de cette partie ronge est un point noir, assez gros; le tiers postérienr des élytres est également noir, et la ligne qui sépare les deux coulenrs rouge et noire, est un peu ondulée. Femelle.

De Cayenne.

\section{Cercoprs fuscipenne, C. fuscipennis.}

Cercopis fusca; capite, thorace pedibusque dilutè rubro-sanguineis.

Longueur 6 à 7 lig. 'Tête, corselet et pattes d'un rouge sangrin un peu pấle. Ecusson, élytres et dessous du corps d'un brun rougeâtre : le bord des élytres est d'une nuance un peu plus claire. Corsclet fortement rebordé postérieurement et sur les côtés. Mâle et fenoelle.

De l'île de Java.

\section{Cercopis moucheiée, C. guttata.}

Cercopis mbra; capite fusco, thorace elytrorunque apice et punctis nigris.

Longueur 5 lig. D'un rouge sanguin; tête un peu brune; dessous du corselet noir, ainsi que la pirtie postérieure des élytres et leur bord extérieur; les deux tiers antérieurs de celles-ci, d'un rouge sanguin avec des points noirs formant presque deux lignes obliques : alsdomen testacé, portaut en dessous, de chaque côté, une ligne noire. Paltes entièrement d'un touge sanguin. Femelle.

Le mâle (ou du moins la Cercopis que nous regardons comme telle et dont nous avons plusieurs individus) diffère en ce que le bout des ćlytres n'est point noir et que leurs points sont bien moins distincts.

De l'île de Java.

8. Cercopis quadrifasciée, C. quedrifasciata.

Cercopis subtùs testacea; suprà nigra fasciils quatuor pallide luteis, duobus posticis salde interruptis.

Longueur 4 lig. $\frac{1}{2}$. Abdomen, dessous da corsclet et de la tête, partie antérieure de celle-ci 


\section{0}

d'un jaune rougeảtre, peut - être sanguin dans linsecte vivant; vertex et sternum noirs. Corselet noir en dessus, ayant à sa base une bande transverse jaune. Ecusson et élytres de conleur noire, lear base cormmone avec une bande jaune qui n'atteint pas les angles huméraux; deux antres bandes de même couleur sur les élytres, fort iulerrompues dans la partie dorsale, l'une vers le milieu de l'ćlytre, l'autre un peu avant son extrémité. Paltes testacées, genoux et tarses noirs. Mâle.

Du Brésil.

$2^{\circ}$. Division. Portion antérieure de la partie inférieure de la tête convexe, tricarénée.

Cette division compreud : $1^{\circ}$. Cercopis blessée, C. vulneruta. Germ. Magaz. entom. Halle. 1818. pag. $45 . n^{\circ}$. 15. - Cercopis sanguinolenta. Lat. Gener. Crust. et Ins. tout. 3. pag. I 57. $n^{\circ}$. I. (en retranchant les synonymes de Linné et de Fabricius.) - Panz. Faun. Germ. fus. 33. fig. I2. (en retranchant les symony ues de Liuné, de Fabricius et de Scopoli; rous n'avons pu vérifier ceux de l'ouvrage intilulé : Naturforsch, ni celui de Fuesly.) - La Cigale à taches rouges. Geofr. Ins. Paris. tom. 1. pag. 4r8. no.6. pl. 8. fig. 5. - StoLI, Cigal. pl. 5. fig. 27. Assez commune aux environs de Parrs, daus la forêt de Saint-Germainen-Laye priacipalement. $2^{\circ}$. Cercopis sanguiuolente, C. sunguinolenta. Germ. id. pag. 44. $n^{\circ}$. 13. - L'AB. Syst. Rlyyng. pag. 92. $n^{\circ}$. 20. (en retranchant les synonymes de Geulfiroy, de Panzer et de Scopoli ; les autres sont douleux, a l'exception de celui de Linné.)-Cicada sanglainolenta. Lixx. Syst. nut. 2. 708. 22. (en relranchant les synonymes de Scopoli et de Geoffiroy.) Du midi de la France. On ne la trouve pas aus enviroris de Paris.

$3^{\ominus}$. Division. Portion antérieure de la partie inférieure de lis têre peu comprintée latéralemenl, unicarénée au milieu.

\section{Cencopis liturée, $C$. liturata.}

Cercopis atia; elytrorum lineolis longitudinalibus irregulanbus, thoracis subtis maculis coxaramque et femorum apice sangumeis: capitis parte inferroi cuneiformi.

Longuenr 5 lig. $\frac{r}{2}$. D'un noir mat. Dessous du corselet ayant des taches d'un rouge sanguin; extrémité des hanches et des jambes de celte même conleur, ainsi que plusieurs lignes longitudinales irrégulières placées sur les élytres; partie inférieure de la tête amincie en coin. (L'abdomen minque.)

Du Brésil.

10. Cencopis ceinturée, $C$. cingulata.

Cercopis flava; fasciâ angustatâ, elytris et scutelli apice communi nigrâ.
Longnear 4 lig. $\div$. D'un assez beau jaune. Elyıres portant une bande étroite noire au tiers de leur longueur, dans laquelle se trouve prise l'extrémité de l'écusson qui est anssi noire. Pattes jaunes; jambes antérieures et leurs tarses, noirs ; les quatre postérieures ayant leur extrémité noire ainsi que celle des tarses. Cuisses intermédiaires de cette même couleur à l'extrémité. Mâle.

De l'Amérique méridionale.

\section{Cracoprs bumérale, $C$. humeralis.}

Cercopis atra; thorace subtùs pedibusque sanguineis. fusco mixtis : elytrorum lineolâ humerali fusciâque submaculari ante apicem sanguineis.

Longueur 3 lig. :. D'un noir mal. Dessous da corselel et pattes d'un rouge sanguin mêlé de noir. Elytres ayant une petite ligne humćrale et une bande au-dessons des deux tiers de leur longueur, d'un ronge sangrin; cette bande composée de taches, dont plusieurs se réuuissent. Femelle.

\section{Du Brésil.}

12. Cercoprs boucher, $C$. lanio.

Cercopis nigra; elytrorum basi et fisciâ irregulari ad marginem et ad suturam dilatatâ sanguineis: rostro et capitis parte inferâ luteo-lividis.

Longneur 3 lig. Noire. Bec et partie inférieure de la tête d'un jaune livide; côtés du corselet en dessous et anus d'un jaune rongeâtre; base des élytres d'un rouge sanguin ainsi qu'une baude transversale irrégulière placée à peu près aux demx tiers de-élytres, s'élargissant au bord extérieur et vers la suture. Paltes tuntes noires. Mầle.

\section{Du Brésil.}

Nota. Ces denx dernières Cercopis sont voisines des espèces européennes par les couleurs.

A celte division apparlient encore la Cercopis cruentata $\mathrm{n}^{\circ}$. 14. FA . Syst. Rhyng. Commune à Cayenne et à Surinain. La Cercopis rubra, Gern. Magaz. entom. Halle. 1818. pag. 41. $n^{\circ} .5$, de B.hia, est peut-être la même espèce.

$4^{\mathrm{e}}$. Division. Portion antérieure de la partie inféricure de la tête, extrêmement couprimée latéralement, formant comme une lame tranchante.

13. Cercopis face comprimée, $C$. compressa.

Cercopis rubro-sanguinea; rostro, elytrorum nuargine postico pediousque quatuor anticis et posticonum apice nigris: capitis parte inferiori cultrato-compressâ. 
ra Cigale pourprée. Stour, Cigal. pl. $X X I$. fig. 112 .

Longueur $6 \mathrm{lig}$. D'un ronge sanguin; bord postérieur des élytres et bec de coulenr noire ainsi que Ics quatre pattes antérieures, l'extrémité des jambes postćrieures et leurs tarses. Le corselet est un peu plus foncé que le reste du corps et peut guelquefois paroitre noir. Mále.

De Cayenne.

Les espèces suivantes sont encore de ce genre: ro. Cercopis sanguine, C. sanguinea ${ }^{\circ} .4 . \mathrm{FAB}$. Syst. Rhyns. Amérique méridionale. $2^{\circ}$. Cercopis de Panzer. - Cercopis Panzeri. Nob. - Cercopis atra. Panz. Faun. Germ. fus. 33. fig. 13. (Cette figure porte le nom de Membracis atra. Oiez le synonyme de Fabricius qui, selon nous, se rapporte à la Penthimie âtre. Voyez Penthime parmi les gcnres rattachés au mot 'TETTrgovides.) D'Europe. $\overline{3}^{\prime \prime}$. Cercopis linéolée, $C$. lineola $\mathrm{n}^{\circ}$. 53. F $\triangle A$. id. Amérique méridionale. $4^{\circ}$. Ccrcopis hématile, C. homatina. Germ. Mhagaz. entom. Halle. 1818. pag. 3g. $n^{\circ}$. 1. Brésil. 50. Cercopis fourchue, $C$. furcata. Germ. id. $n^{\circ}$. 2. Brésil. 6॰. Cercopis parée, C. festa. Germ. id. pag. 40. $n^{\circ}$. 3. Brésil. $7^{\circ}$. Cercopis sœur, $C$. somria. Genm. id. pag. 41. $n^{\circ}$. 4. Brésil. Capitainerie de Saint-Paul. $8^{\circ}$. Cercopis ponctuée, $C$. punctigera. Germ. id. pag. 42. $n^{\circ}$. 8. Bipsil. $9^{\circ}$. Cercopis colon, $C$. colon. Germ. $i d$. $n^{\circ}$. 9. Brésil. $10^{\circ}$. Cer copis mélanoptère, $C$. melanoptera. Germ. id. pag. 45. n’. 10. Brésil. 110. Cercopis dorsale, C. dorsata. Germ. id. $n^{\circ}$. I I. De Montpellier. $12^{\circ}$. Cercopis cinq tacbes, $C$. quinquemaculala. Germ. id. $z^{\circ} \cdot 12$. De Portngral. 130. (Cerropis sanglante, $C$. mactata. Gers. id. pag. 44. $22^{n}$. I4. C̈est peul-être la Cicada sangumolenta. Scop. Entom. Carniol. $n^{\circ}$. 330. De Carniole, d'Is ric et de Styrie. 1 $^{\circ}$. Cercopis pélrilife, $C$. petrificata. GERM. id. pag. 45. $n^{\circ} \cdot 16$. Brísil. 15\%. Cercopis terreuse, C. terrea. Gersi. $2 d . p a g .46 . n^{\circ} .17$. brésil.

APHROPHORE, Aphophora. Gens. LAт. (Fam. nat.) Cercopis. FAB. 'Pasz. C'rcada. hiNx. Geoff. De GÉr. Panz.

Genre d'insectes de l'ordre des II'miptères, section des Homoptères, famille des Cicadaircs, tribu des Cicadelles (division des Cercopides).

Le second groupe des Cercupides contient quatre genres (voyez pag. 602, de ce volume). Celui de Cercopis est distinct par sa tête beaucoup plus étroite que le corselet; dans les Pijèlcs la tête et le corselet ne sont point carénés en dessus ot leurs octlles sont notablement espacés l'un de l'autre. Les Lèdres ont le corselet muni a'appendices élevés et le dessous des tarses dépourvu d'épines.

Antennes instrées entre les yeux, dins une caviié, sous le bord avancé de ia tête, compo- sćes de trois articles: le premier court, cylindrique; le second de mêne forme, mais deux fois plus long que le premier; le troisiène trèspetit, glubuleux, terminé par une soie plus longuc que les trois articles qui la prćcc̀dent, réunis. - Bec extérieurement biarticulé, à articles presqu'égaux; ce bec alteignant au moins la base des hanches postérieures. - Téte transversale, presqu'horizontale, un peu anguleuse en devant, de la même largeur que le corselet, un peu carćnée en dessus dans le milieu du vertex : bord antérieur de la têtc avancé, presque tranchant; la partie inférieure sous ce bord, point carénée, marquée de stries transvcrsiles. - Yeux assez proéminens, placés sur lcs côtés de la tête, contre le corselel. - Deux ocelles apparens, placés sur le vertex, assez rapprochés, posés sur les deux pcntes de la carène de la tête. - Conpis ovale-alongé. - Corselet point dilaté latéralement, ayant une carène lougitudinalc dans son milieu; son bord autérieur s'avancant en un angle très-pronoucé sur lit têtc; bord postérieur se prolongeant entrc la base dcs álytres, tronqué vis-à-vis de l'écusson et formant un angle réntrant dans cette partie. - Ecusson triangulaire, son angle postérieur aign. - Elytres colorées, demi-opaques, couvrant les ailes et l'abdomen, plus longues que lui ainsi que les ailes; leurs bords latéraux très-arrondis, atllant en sc dilatant jusquc vers le tailieu, et en se rétrécissant assez firrcuent vers l'extréurité qui finit prescqu'en pointe. - Abdonen court; plaque auale refendue dans toute sa longuenr, recevant dans les femelles la tarière et ses fourreaux; ses bords dans ce sexe un pell écartés vers linsertion de la tariere et laissant apercevoir la base de celie-ci : les nầles ayant ces bords bien clos et absolument rapprochés dans toute leur étendue. - Patles de longueur moyenne, cuisses postérieures légèrement canaliculées en dessous près de la base des jambes, courtes; leurs hanches fortes, leurs jambes assez. !ongues, angulenses, ayant sur lenr angle extérieur deux épines post́cs sur une même ligne longitudinale, terminées en dessons par une demicouronne d'épines qui déloordent l'extréınité de la janibe et atreignent le plan de position; tarses de trois articles; le premier plus long que le second ; ces deux article prolongés chacun sous $l_{a}$ base de celui qui les suit en un rangr d'épines; ces épines ainsi que celles de l'extrémitć des jambes, courtes, serrées, presqu'ézales entr'clles; dernier arlicle des tarses assez long, portant deux crochets.

A fhrophorc, composé de deux mots gres's, signifie : porte-écume. Pour les mœnrs de ces iusectes, voyez Cicadeldes, pag. 6oz. de ce volume. Les espèces sont d'asez petite taille et de couleurs olscures. $1^{\circ}$. Apbrophore écumcuse, $A$. spumaria. Grrm. Mlagaz. entom. Halle. Iö́ö. pag. 5o. no. 1. 'Très-commune aux eaçirons de 
Paris. 20. Aphrophore rustique, A. rustica. Cercopis rustica no. 51. FАB. Syst. Rhyng. M. Germar rapporte avee doute eelte espèee de Fabrieius à son Aphrophora anotheree pag. 53. $n^{\circ} .5$. Nous avons sous les yeux une $A_{p}$ prophore des environs de Paris assez eonforme à la description que Fabricius donne de sa Cercopis rustica, et peut-être la même. Longueur 4 lig. : D'un gris roussâtre, chargée de points bruvs enfoncés; partie postérieure de la têle ayant, ainsi que la parlie antérieure du corselet, quelçues petites places irrégulières exemptes de ces points; élytres avec une ligne eommune, un peu brune, peu distincte, faite en chevron brisé doni la pointe est dirigée en avant, et plus bas vers le unilieu de l'élytre une très-petite fache blanche sur une des nervares. Dessous du eorps et surtout l'abdomen un pell rougeâtres. Ailes eutièremeut transparentes à nervures noires. Mâle.

PTYĖle, Ptyelus. Aphrophora. Germ. Cerm copis. Fa B. Cicada. Panz.

Geure d'insectes de l'ordre des Hémiptères, seclion des Homoptc̀res, famille des Cicadaives, tribu des Cicadelles (division des Cercopides).

Quatre genres eonstituent un groupe parmi les Cercopides ( voyez pay. 6oz. de ce volume). La tête des Cercopis est notablenent plus étroile que le eorselet; les Aphrophores se distingueut par la tête et le corselet unicarénés en dessus et les ocelles rapprochés l'un de l'autre; dans le genre Lèdre le eorselet préseute deux appendiees élevés et les tarses n'ont point d'épines eu dessous.

Tête arrondie en devant, point carćnée en dessus. - Ienx proéminens. - Denx ocelles apparens, notablement éeartés l'un de l'ảutre. - Corsclet ayant son bord antérieur arrondi, point caréné dans son milieu. Les autres caractires sont les mênes que ceux des Aphrophores, avee lesquelles M. Gerniar a confondu la plupart des especes que nous plaçons dans ee nouveau genre; nous le nornmons Ptyèle, du mot grec qui signifie : salive. Les moeurs sont eelles des autres Cicadelles.

1. Pтrìle fer à cheval, P. ferruni-equinum.

Ptyelus mubro-testaceus, capitis margine antico triangulo nigro notato, thoracis disci maculâa arcuatâ nigrâ ferrum-equinum imitante, scutello elytrisque et pedibus nigro macnlatis.

Longueur 9 lig. D'nn testacé rougeâtre avee des taches nurres, savoir: une sur le bord antésieur de la tête, une de ehaque eôté du vertex près des ocelles; plusieurs sur le corselet, tantôt réunies, tantôt séparées, formant une ligne arquée en fer à clieval : un assez grand nombre sur l'éeusson et sur les élytres, dont plusieurs se réunissent. Cuisses antérieures ainsi que leurs jam- bes, tachées de noir; leurs tarses de cette dernière couleur. Ailes transparentes. Mâle et femelle.

De la côte d'Angole.

\section{Pryèce de l'Gillet, P. Dianthi.}

Ptyelus luridus, capitis,antice punctis duobus, thoracis maculâ dorsali magnâ fuscis; ely trorum maculis marginalibus duabus albido subpellucidis; abdomine fusco, luteo marginato.

La Cigale brune des CEillets. Stoss, Cigal. pag. 77. pl. XIX. fig. 105. et B.

Longueur 2 lig. D'un jaune sale mêlé de brun. Tête et corselet jaunâtres; on voit deux points bruns sur la partie la plus avaueée de la tête à sou bord antérieur et une grande tache dorsale de même couleur sur le eorselet; eelle-ci peu sensible dans le mâle : élytres ayant à leur bord extérieur deux taches triangulaires d'un blanc presgue transparent. Dessous de l'abdomen brun, bordé de jaune; pattes pâles; crochets des tarses bruns. Mâle et femelle.

Cette espèce, commune aux environs de Paris, vit dans ses différens états sur les Eillets (Dianzthus), suivant Stoll.

Nous mentionnerons en outre, $1^{\circ}$. Ptyèle bordé, P. marginellus. - Aphrophora marginella. Germ. Magaz. entom. Halle. 18ı8. pag. 54. $n^{\circ}$. 8. Cicada lateralis. Panz. Faun. Germ. fas. I. fig. 24. - Cercopis marginella no. 37. Fав. Syst. Phyng. $2^{\circ}$. Ptyèle angnleux, P. angulatus. Cercopis angulata n०. 49. FАв. id. 3o. Ptyèle rayé, $P$. lineatus. -- Cercopis lineata $\mathrm{n}^{\circ}$. 42 . $\mathrm{F}_{\mathrm{AB}}$. id. Ces trois espèces sont communes aux ellviruns de Paris.

LEDRE, Ledra. FA b. LAt. Germ. Cicada. Lin. Geoff. Membracis. Schranck. Ociv. (Encycl.)

Geure d'insectes de l'ordre des Hémiptères, section des Homoptères, famille des Cieadaires, ribu des Cicadelles (division des Cercopides).

Les genres Cercopis, Aphrophore et Plyèle eomposent avee celni de Ledre le seeond groupe des Cercopides (voyez pag. 602. de ce volume). Les trois preiniers genres unt le premier et le second articles des tanses garnis eu dessous d'une rangée d'épines eourtes el serrées, et lcur corselet ne présente point d'appendices dursaux.

Antcunes insérées entre les yeux, près d'une cavité, sous le bord antérieur de la tête, composées de trois articles; les deux premiers-épais, presqu'égaux; le second arrondi à soll extrémité; le troisièrae en cône alongé, minee, prenant insensiblement la forme d'uue suie longue. - Bec assez court, de deux articles, ne dépassant pas la base des hanches intermédiaires. - Téte transversale, grande, plane en dessuus, très-pjeu eonvese en dessus, portant dans son wilieu une ca- 


\section{$\mathrm{T} \mathrm{ET}$}

rène longitudinale plus pronoucée dans les femelles que dans les mâles; bord antérienr de la tête demi-circulaire, tranchant; son bord postérieur échancré circulairement dans toule sa largeur qui est égale à celle du corseler. - Yeux petits, assez saillans. - Deux ocelles apparus, placés au has des pentes de la carène. - Corps longo, presque linćaire, peu épais, un peu convexe en dessus, tout-a-fuit plat en dessous. Corselet point dilaté litéralement, portant de chaque côté de son disque, mu appenơice aplati, élevé en espèce de crête, ct un yeu denticulé : bord antérieur du corselet un peu arrondi; bord postérieut se prolongeant entre la base des élytrus, tronqué vis-à-vis de l'écusson et formant un angle rentrant dars cette partie. - Ecusson large, triangulaire, sa base arroudic; il est teruiné postérieurement en pointe aiguë. - Elyires grandes, réticulécs dans une. grande portion de leur partie postérieure, couvrant des ailes et dépassint de beaucoup l'abdomen, de fortne presque linéaire, s'arrondissant vers leur extrénité. - Abdoinen court, de six segrnens outre l'anus daus les femelles, en ayant un de plus duns les mâ!es; plaque anale refendue dians toute sa longueur, recevant dans les femelles la tarière et ses fonnreanx; ses bords, dans ce sexe, un peu écartés vers linsertion de la tarière el laiss.unt apercevoir la bise de cellc-ci : les mâles ayaut ees bords bien clos et aissolument rapprochés dans toule leur étendue. - Pattes de longueur moyenne; les postérieures ayant leurs hanches conrtes et leur's jambes longues avec l'angle extérieur dilité de la hase à l'exirérnité, portaut trois ou quatre deuls à leur parlie inférietire; ces jambes terminées en dessous pat une double couronne d'épines yui débordent l'extrémité de la jaube et atteignenı le plan de position; tarses de trois articles; le premier guc̀re plus long que le second; le dernier muni de deux erochets; ces trois articles velus en clessous, n’ayant aucune épine.

I.es Lìdres privées des appeudices eouronnés d'épinesque l'on trouve sous les tarses de quanticé de Cicadelles, sautent moins fícilement que celles-ci, mais leurs grandes ailes doivent leur donner le moyen d'éviter, en s'euvolaut, le dauger quiles menace. Lcurs larves ne sont pas commues particulièrement.

\section{J.Ène oreillarde, L. aurita.}

Ledra aurita. LAт. Gener. Crust. et Ins. tom. 3. pag. 158. no. 1. - Fа в. Syst. Rhyng. pag. 24 . no. 1.-Genм. Magaz. entom. Halle. 1318. pag. 54. $n^{\circ}, 1$. Des euvirons de Paris.

Voyez pour la description et les autres synonymes, Mernbracis oreillarde no. 26. de ee Dictionuaire. A la citation de Stoll, lisez (au lieu de pl. 22. 23. ) pl. IV. fig. 23.

Fabricius place encose parmi ses Ledra trois Hist. Nat. Ins. Tome $X$. autres espèees des Indes orientales; mais il est douteux qu'elles appartiennent à ce genre, surtout les deux deruières.

\section{SCARIS, Scaris. Iassus. FAB.?}

Genre d'insectes de l'ordre des Hémiptères, scction des Homoptères, famille des Cicadaires, tribu des Cicadetles (division dies Tellignonides)'

Qualre gentes composeut un groupe dalus les Tettigonides ( poyez ce mot), savoir : Scaris, Penthimie, Teltigone el Proconie. Le corps est linéaire dans ces deus derniers, et leur écusson ainsi que celui des Peuthiuies, a'ollive pas de pointe pirticulière; en outre la tête des Proconies est prolongée cn angle antérieurement: quant au genre Pentlimie, son eorps elliplique et l'exirénité de chacune de ses élyires rabatlues el se croisant sur l'dutre, l'éloignent des Scaris.

Antennes insérées dans une cavité près des yeux 11 entr'eux, sons le bord avancé de la têle, composées de trois arlicles, les denx premiers cylindrignes; le promier plus comri que le second, le troisième conique, se terminant en une soie assez longrae. - Bec très-court, atteignant seulement la base des hanclies anléieures, biarticulé; son premier articte paroissant à peine à l'extérieur de la cavité buccale. - Téte conte vue en dessus, transversale, beaucoup plas ćtroile que le corselet, mais ccpendant de la neêne largenr que sa parlie antérieure, arrondie à son bord intérieur qui est épais : elle est creusée circulairement à sa partie postérienre. - Teux point proérnineus, placés sur les côtés de la lête, contre le corselet. - Deux ocelles apparens, ćcarlés l'un de l'autre, posés sur le dessus de la tète. Corps prescque triangulaire. - Corselet pount dilaté latéralement, trassversal, assez tong, se rélrécissant autérieurement el aussi un peu ì sa partie postérieure pour pénétrer eutre la base des élyires, tronqué droit vis-à-vis de l'écusson. Ecusson triangulaire, prolongé pustérienrement en une pointe longue et aiguë. - Elytres recouvrant des ailes et l'abdomen, enveloppant les côlés de celui-ci; leur bord extérieur arrondi, ainsi que leurs extrémités; celles..ci droites et ne se croisant pas. - Abdomen composé de cinq semens outre l'anus dans les femelles; plaque anale refendue dans toute sa longueur, recevant dans ce sexe lia tarière et ses fuurreanx; les bords de celte plaque un peu écarlés vers l'insertion de la tarière et laissant apercevoir la base de celle-ci. - Pattes antérieures et intermédiaires de longueur moyenne; lenrs jambes munies d'épins lines et nombreuses; jambes postérieures ayant leur's cuisses fort longues, un peu canaliculées en dessous dans toute lear longuenr; jambes également fort longues, garnies d'épines très-fines, très-norubreuses et terminées en dessous par une demi-eouronne d'épines qui débordent l'extréruité H. h h h 
de la jambe et atteignent le plan de position; tarses de trois articles, à peu près égaux; les deux premiers prolongés chacun sous la base de celui qui le suit en une rangée d'épines: ces épines ainsi que celles de l'extrémité des janbes, courtes, serrées, presqu'égales entr'elles; deruier article des tarses muni de deux crochets.

Le nom de ces Cicadelles vient d'un mot grec gui signifie: sauteur. La conformation de leurs pattes prouve qu'elles out une grande facilité d'éviter le danger par des sauts très-élevés et trèsélendus, commeles autres'Teltigoniảes, dont elles doivent avoir les aœurs.

\section{Scarrs ferrugrineuse, S. ferruginea.}

Scaris ferruginea, elytris fuscioribus.

Iassus ferrugineus $\mathrm{n}^{\circ} .2, \mathrm{Fав.} \mathrm{Syst.} \mathrm{Rhyng.?}$

Longueur 6 ligg. Entièrement ferrugineuse; tête et corselet striés transversalement. Dessous du corps un peu pále; élylres fortement réticulćes, plus foncées que le reste du corps, wiêlées de nuances brunes, leurs nervures très-saillantes. Pattes brunes: hase des cuisses postéritures plus pâle. Femelle.

Cette espèce est probablement de l'Amérique méridionale.

PENTHIMIE, Penthimia. Germ. Cercopis. Fab. Cicada. Panz.

Genre d'insectes de l'ordre des Hémiptères, section des Homoptères, famille des Cicadaires, tribu des Cicadelles (division des Tettigonides).

Un groupe de Tettigonides a pour caractères: ocelles placés sur le milieu de la partie supérieure de la tête, celle-ci ayant son bord antérieur arrondi, épais. (Voyez 'lemtrgonides.) Les genres Scaris, Proconie et Teltigone qui entrent dans ce groupe avec les Penthimies, en diffèrent par leurs élytres non croisées, dont l'extrémité est droite et point rabattue; de plus les Tettigones et les Proconies ont le corps tinéaire. Dans les Scaris les élytres vont en se rétrécissant du milieu à l'extrémité, et le corps est iriangulaire.

Antenıes iusérées duns une cavité, près des yeux et entr'eux, sous le bord un peu proéminent de la têle, composées de trois articles, les deux premiers fort petils; le troisième extrêmement court, muni d'une scie très-courte. - Bec trèscourt, biarticulé, alteignant au plus la base des hanches antérieures. - Téte courte, transversale, presqu'uussi large que le corselet, obtuse et arrondie à son bord antérieur qui es! '́pais, échancrée circulairement dans loute l'étendue de sa partie postérieure: côtés de sa partie inférieure un peu creusés. - Yeux grands, peu saillans, placés sur les cótŕs die la tête, contre le corselet. -Deux ocelles apparens, écarlés l'un de l'antre, pasés sur le milieu de la partie supérieure de la tête. - Corps elliptique, un peu bombé. - Corselet point dilaté latéralement, transversal, de forme trapézoidale. - Ecusson triangulaire, sa base curviligne. - Elytres recouvrant des ailes et l'abdomen, allant en s'élargissant presque jusqu'a leur exirémité, rabaltues et croiscées l'une sur l'autre dans cette partie. - Ahdomen conposé de cinq segrmens outre l'anus; plaque anale refendue dans toule sa longueur, recevant dars les fenelles la tariore et ses fourreaux; les bords de celle plarque un peu écartés vers l'insertion de la tarière et laissant apercevoir la base de celleci ; les mâles ayant ces bords bien clos et absoluneut rapprochés dans toule leur ćtendue. Pattes antérieures et intemédiaires de longuenr moyenne; lenrs jambes munies de quelques fines épines : paltes postérieures ayant leurs cuisses fort longues, un peu canalicnlées en dessous daus presque toute leur longueur; jambes également fort longues, très-arquées, garnies d'épines trèsnoubreuses, fortes, surtout celles du rang extirieur, et terminées en dessous par une demi-couronne d'ćpines qui débordent l'extrémité de la jambe el alteignent le plan de position : tarses de trois articles; le premier plus long que les denx suivans réunis, prolongé ainsi que le second, chacun sous la base de celui qui le suit, en une rangée d'épines; ces épines ainsi que celles de l'extrémilé de la jambe, courtes, serrées, presqu'égales entr'elles : dernier article des tarses muni de deux crochets.

Les coulenrs sombres de ces Hémiptères lenr ont fait douner un nom tiré du grec qui exprime: liidée de deul. M. Latreille avoit forné avec la Cercopis hoemorrhoa F $\mathrm{F}_{\mathrm{AB}}$ et la Cicada cethiop's Panz. La seconde suhdivision de la première division de ses Tettignnes (Gener. Crust. et Ins. tom. 3. pag. 16r.) ('est cette subdivision don: M. (Germar a fait le genre Penthimie. Quant aux nıœus elles ne different point de celles des autres Ciradelles. Les Peuthinies, éminemment sau cuses, sont de petite taille.

$1^{\circ}$. Penthimie âtre, P. atra. Germ. Magaz. entom. Halle. 1818 . pag. 48. $n^{\circ}$. I. - Cercopis atra ${ }^{\circ} .27$. Far. Syst. Rhyng. (en retranchaut le synonyme de Panzer, qui appartient à la Cercopis de Panzer, voyez Cercopis à la suite de l'ar. ticle Teltigonides.) - Cicada athiops. l'axz. Faun. Germ. fas. I1.fig. 17. De France et d'Allemagne. $2^{\circ}$. Penthimie thoracique, $P$. thoracica. - Cicada thoracica. Panz. Faun. Germ. fas. 61. fig. 18 . Màle. - Cercopis sanguinicollis $\mathrm{n}^{\circ} .2 \mathrm{~g}$. FAB. id. Mûte. - Cicada hamorrhoa. P̀A fig. 16. Femelle. - Cercopis hemorrhoa $\mathrm{n}^{\circ} .28$. iA a. id. Femelle. Environs de Paris.

PROCONIE, Proconia. Cicada. Fab. Tettigonica. Gerar.

Genre d'insectes de l'ordre des Héniptères, seclion des Homoptères, famille des Cicadaires, 
tribu des Cicadelles (division des Tcttigonides ).

Les Proconies composent avec les genres Scaris, Penthimie et Tettigone un groupe dans celte division. (Voyez Tetrigonides.) Les Scullis ont le corps triangnlaire el l'écusson fiuissant en une très-longue pointe; on reconnoît les Penthimies à leur corps elliptique, lenrs élytres rahattues à l'extrémité et croisées l'une sur l'autre daus cette partic. Dans le grenre Telligone les deux premiers articles des ant'unes sont pelits, égaux entr'eux, et la tête est transversale ainsi que le corselet.

Antennes ayant leur premier article plus gros que le second, un peu di!até extériemrement, le second cylindrique, le troisième peu épais ì sit base, terminé pur une soie fort longue. - Tête plus longue que larare, triangulaire, aussi longue que le corselet. - Yeux grands, saillans, débordant de beaucoup le derrière de la tête. Corselet point dilaté lat téraleraent, rhombordal; son bord postérieur échancré vis-à-vis de l'écusson, les latéraux forant chacun un angle. Ecusson triangulaire, sa base sinneuse. - Elytres presque linéaires. - Jumbes postérieures légèrement arquées: prenuier article des tarses presqu'aussı long que les deux aulıes rénnis. Les antres caracteres sont coux des Tettigoues, Voyez ce mot.

Le nom de ces Cicadelles vient de deux mols grees qui signifient : conique en devant; il exprime la forme de lenr tête. Ces insectes, tous étrangers à l'Europe e' habitant les climats chauds, sont éminemment satuteurs. Leurs mœurs ne doivent pas différer de celles des Teitigones.

re. Division. Corselet portant dans son milieu un appendice relevé en forme de crête.

La Proconie crêtće, P. cristata. - Cicada cristata $n^{\circ}$. 4. Faв. Syst. Rhyng. Hemelle. De Ciayenne, est le type de cette division.

\section{a $^{\mathrm{e}}$ Division. Corselet sans appendice.}

\section{Proconte excavée, P. excavata.}

Proconiu nitida, subtùs pallidè lutea, maculâ ad terebrce insertionen nigrâ; capite suprà valdè canuliculato nigro, lateribus apicisque maculâ luteis, subtùs luteo, lineis arcuatis duabus nigris; thoracis suprà nigri lineoles duabus lateralıbus luteis; elylris nigris, fiesciis duabus punctoque baseos luteis: pedibus posterioribas apire fuscis.

Longueur $8 \mathrm{lig}$. Corps luisant, son dessous $d^{\prime} u n$ jaune pâle avec une tache triangulaice noire an-dessus de l'insertion de la tarière ; têle profondément canaliculće en dessus dans le sens longiludinal; elle esı noire avec les côtés jaunes; on voil en outre une tache de cette couleur près de l'angle antérieur; son dessons est jaune avec deux lignes transverses, ar'puées, noires. Co:selet poir en cessus, ayant une ligne latérale juune: flytres noires avec deux bandes transverses, ondées, jaunes; la supérieure n'alleignant pas le borá extérieur el linférieure ne s'avançant point jusqu'à la sulare: base des élytres portant un point jaune. l'attes jaunes, les postérieures biunes à l'extrćmité. Femelle.

Du Brésil.

Nous plaçons de plus dars cetle division, $1^{\circ}$. Proconic tuchetée, P. adspersa. - Cicada adspersa no. 2. Fав. Syst. Rhyng. Femelle. Du Brésil. $2^{\circ}$. Proconie albipenne, P. albipennis. $-C i-$ cada albipennis n॰. 3. FAs. id. Fenelle. Du Brésil. $3^{\circ}$. Proconie quadriponstuce, $P$. quadripunc. tata. - Tettigonia quadripunctata. Germ. Magaz. entom. Halle. 1818. pag. 58. no.3. bis. Fenielle. Brésil. $4^{\circ}$. Proconie obluse, P. obtusa. - Tettigonia obtusa. Genм. id. pag. 62. $n^{\circ}: 7 \cdot-$ Cicada obtusa no. 7. I A в. id. Femelle. Brésil et Cay enne.

EUPEIIX, Eupelix. Germ. Tettigonia. Lat. Cicada. Fab.

Genre d'iusectes de l'ordre des Hémiptères, section des Homoptères, famille des Cicadaires, tribn des Cicadelles (division des Tettignonides).

Parmi les Tettigonides dont les ocelles sont placés sur le milien de la partie supérienre de la tête, les Scaris, les Penthimies, les Tettigones et les Proconies se distinguent des Eupélix par le bord antérieur de leur tête arrondi et épais.

Antennes insérces cbacune sur le bord d'une fossetie profonde, entre les yeux, vers le milieu de la partie inférienre de la tête, composées de trois articles, les deux premiers moniliformes, égaux; le troisième un peu rentlé à sa base, portaut une soie courte.-- Bec de longueur moyeune, dépassant un peu la base des hanches a utérieures. - Tête horizontale, triangulaire, prolongée en devant, beancoup plus longue et plus large que le corselet, carcénée à ses faces supérieure et inférieure; tout son bord antérieur mince, presque tranchant; sa partie postérieure échancrée circulairement dans toute son étendue. - Yeux petits, presque divisés en denx par le bord de la tête qui savance fortement de chaque côté. Deux ocelles apparens, placés sur les bords latéraux de la tête, vers leur milieu.-Corps un peu ovale. - Corselet point dilaté latéralement, presqu'en carré transversal; son bord antérieur un peu arrondi, le bord postérienr sinué. - Ecusson triingulaire, un peu arrondi à sa base. - Elytres recouvrant les ailes et l'abdomen, un peu élargies vers leur base, embrassant les côtés de l'ahdomen. lies autres caractères sont ceux des 'Tettigrones. Voyez ce mot.

Le nom d'Eupćlix est tiré de deux mots̀ grecs. qui expriment l'étendue et la forme singulière de la tête de ces insectes, dont les mœul's doivent être les mêmes que celles des autres genres de leur division. Les Eupélix forment la cinquiène 
division du genre Tettigone. Lat. Gener. Crust. et Ins. tom. 5. pag. 16:.

\section{ฯ. Eupźlux fuligineuse, $E$. fuliginosa.}

Enpelix nigro-fuliginosa, subsquamosa; squa mis nigris albidisque; elytris apice el margine extemo subhyalinis: tibiis albidis.

Longueur $2 \mathrm{lig} \cdot \frac{3}{2}$. D'un noir mat el fuligineux; corps presque couvert de petites papilles, la plupar: noires; quelques-anes de celles de la tête et des élytres, de couleur blanche; partie postériente des élytres, et surtout leur loord extérieur, presque transparens, peu chargés de papilles; pattes noires; jambes et larses en grande partie pâles et presque transparens.

De France.

A ce genre apparlient encore l'Eupélix cuspidée, $E$. cuspidata. Gern. Magaz. entom. Hitlle. 1818. pag. 94. $n^{\circ}$. 1. - Cícada cuspidata n ${ }^{\circ} 86$. FAB. Syst. Rhyng. De France et d'Angrleterre.

ÉVACANTHE, Evacanthus. Tettigonia. Lat. Germ. Cicada. Linn. Geoff. De Gier. Fab. PANz.

Genre d'insectes de l'ordre des Hérniplères, section des Iomoptères, famille des Cicadiaires, tribu des Cicadelles (division des Telligonides).

Dans celte division cinq genres, savoir: Scaris, Penthimie, 'Telligone, Proconie et Eupélix ont les ocelles plucés sur le milieu de la parlie supérieure de la tête, et les Jassus sur le milieu de sa partie antérieure : caractères qui éloignent tous ces genres de celui d'Evacanthe.

Soie des antennes assez courte. - Bec alleignant la base des hauches intermédiaires. - Téte aussi longue que le corselet, presque triangulaire, un peu arrondie à sa partie antérieure... Y peu proéminens. - Deux ocelles apparens, placés sur la ligne qui sépare la partie supérieure de la tête, de l'inféricure. - Corps linéaire. Bord postérieur du corselet arrondi ainsi que les laiéraux. - Eljtres linéaires, ảroites; leurs extrémilés ne se rapprocliant pas l'une de l'autre. - Abdomen des femelles dépassant de beaucoup les élytres; celui des inâles notablement plus court qu'elles : anus de ceux-ci portant à sa base dcux grands appendices en fuucille qui l'égalent en longueur. Les autres caräclères, ainsi que la manicre de vivre, sont comme dans les Tettigones. Troyez re mot.

M. Latreille (Genera) avoit ćtabli une division particulicre dans ses Tetligones (lit troisième du getire) pour y pliacer la Ćicada interrupta des auteurs. Ayant tronvé à réunir quelques autres caractères génćriçues assez saillins pour les joindre à ceux que ce savant auteur avoit développés, nous avons cru devoir faire de cette conpe un genre propre sous le nora d'Evacantle, tiré de deux mots grecs qui exprimont que les palles sont munies de nombreuses épines d'une longueur remarquable. Ie type est l'Evacanthe interrompue, $\boldsymbol{E}$. interniplus. - Tettigonia interrupta. Lat. ut suprà. - Germ. Magaz. enloni. Halle. 1818. pag. 72. $n^{\circ} \cdot 26$. - Cicade interiupta $n^{\circ}$. 67. FAв. Syst. Rhyng. Mâle et femelle. Trèscommun en ćlé aux environs de Paris smr l'Ortie dioïque (Uitica dioica).

IASSUS, Iassus. Fab. Germ. Tettigonia. Lat. Cicada. Linn. Panz.

Genre d’insecles de l'ordre des Hémiptères, section des Homoplèrcs, famille des Cicadaires, tribu des Cicadelles (division des lelligonides).

Des sept genres qui composent cette division, ceux de Scaris, Penthimie, 'Tetligone, Eupélix et Proconie ont les ocelles placés sur le milieu de la partie supérieure de la tête : dans les Evacanllics ils sonl posés sur la ligne qui sépare la partie supériene de la tête, de la face inférieure; ce qui disingue ces genres de celui d'lassus.

Soie des antermes courte. - Bec atteignant seulement la base des luanches antérieures.-Téte Iransversale, ne formant qu'un rebord au-devant du corselel. - Deux ocellés apparens, placés sır le nilieu de la partie antérieure de la tête. Corps court, rétléci postérieurement, en triangle alongé. - Corselet transversal, bearicoup plus long que la tête. - Ecusson un peu prolongé en pointe. - Extrénités des élytres conniventes. Le resle des caracteres, ainsi que les mœurs, sont les mêmes que dans les Tetligones. Voyez ce inot.

M. Latreille en plaçant l'Iassus lanio FAB. dans la première division de ses Tettigones (Gener. Crust. et Ins.), l'a cependant isolé, en le donuant comme type d'une subdivision. Nous avons pensé que différens caractères quoffie, non-seulenient celle espèce, mais beaucoup d'autres, nons peimeltoient, à l'exemple de Fabricius et de M. Germar, d'en fuire un genre. On a décrit un certain nombre d'lassus, mais mallheureusement les auteurs n'ont pas pris asscz de soins dans leur's descriptions, pour les rendre reconnoissables; en sorle que nons nous tronvous également empêchés, ou de citer les espèces quils mentionnent suns pouvoir les vérifier par nous-mêmes, on de les décrire comme nouvelles. Nous allons donner ici les trois suivantes, mais sans garantir quelles ne soient pas déjà publiées dans des ouvrages que nous n'avons pas sous les yeux.

\section{I Assus nacré, I. margarita.}

Iassus pallidus, scutello fusco, bimaculato; elytris margaritaceis, fasciâ mediâ transversî fuscâ aureo miçante.

Longueur 2 lig. D'un jaunâtre pâle; écusson ayant ì sa base deux petites taclies d'un bruan roussâtre; élytres couleur de macre de perle; 


\section{T H A}

leur milieu traversé par une bande d'un brun roussâtre à reflet doré. Femelle.

Euvirons de Paris.

\section{IAssus linéolé, I. lineolatus.}

Iassus griseo-rufus, capite thoraceqne nigro maculatis; scutello maculis quinque triangularibus nigris: clytris subpellucidis, nervuris fusco sublineatis; abdomine migro, incisuris citreis.

Longueur 2 ligg. D'un gris roussâtre ; tête ayant eu dessus quelques points noirs; corselet offiant dans son milieu une ligne longitudinale pâle; sur chaque côté, près de la lêle, on aperçoit cinq ou six points noirs, irréguliers. Ecusson portant cinq laches triangulaires, noires, dont trois supérieures et denx inférieures : álytres presque trausparentes, leurs nervures brunes dans certaines portions de leur étendue, ce qui fait paroître les élytres conme ayaut de petiles lignes irrégulières, brunes. Abdomen noir avec le bord des segmens d'uı jaune citron: paltes pâtes, rayées de noirâtre. Feınelle.

Environs de Puris.

\section{Inssus dorsigère, $I$. dorsiger.}

Iassus pallidus, rufo irroratus; elvtrorum basi latè fầ, maculà communi dorsali pallidî́; apice subhyalino, nervuris rufis, basi albis: abdomine fuscè-rufo, incisuris albidis; pedrbus nifis.

Longueur 2 lig. $\frac{1}{2}$. Têle et corselei d'un jaune pâle, tres-lachệ́s de roux. Base des ćlylues jusque passé le milieu, d'un roux assez foncé avec quelques pelits points blanchâlres et une tache de même couleur commune aux deux élytles; extrémité de celles-ci plus pâle, presque transparenle avec ies nervures brunes, mais blanches dans la partie qui avoisine le brun des élytres. Pattes roussâtres: abdomen d'un roux-bruu en dessus avec le bord des segrmens blanchâtre, jaune en dessous. Fernelle.

Environs de Paris.

R̂apportez encolc à ce genre l'Iassns boucher, I. lanio no. 4. FA B. Syst. Rhyng. - Germ. Magaz. entom. Halle. $18 ̈$ เ8. pag. 81. no. 1. Mâle et iremelle. Des environs de Paris.

$$
\text { (S. F. el A. Serv.) }
$$

'IE'TYRE, Tetyra. Nom générique donné par Fabricius aux Héuziptères norumés Scurllères par MM. Lamarck el Latreille. Voyez Scutentier.

$$
\text { (S. H.el A. Senv.) }
$$

THÄ̈S, Thais. Genve d'insectes Lépidoptères. Foyez Papillon, tom. 1X. pay. 8I. 804 et 3 I 2. (S. F. et A. SERV.)

THALASSINE, Thalassina. LATK. Líach.
Lank. Dessr. Astachs. Fab.? Cancer. Herbst. Ce genre de Crustacés, établi par H. Latreille, a été placé par cet entomologiste dans l'ordre des Décapodes, famille des Macroures, tribu des Astacines; il le caractérise ainsi : pédoncnle des antennes latérales dépourvu de saillie en forme d'écaille on d'épine; lame extćrieure des appendices natatoires du bout de la queue d'une seule pièce; les quatre pieds antérieurs terminés par une serre dont le doigt inféricur, ou celui cua est imınobile, n'est qu'ébauché ou en forme de dent. Lalreille avoit rénni à ce genre (Règn. anim.) les genres Gébie, Culianasse et Axie de Léach; mais il les en a séparćs depuis. Les Gébies diftèrent des'Thalassines par lir forme presque triangulaire et non linéaire des feuillets du bout de la queue. Dans les Culianasses, les deux premières paires de pieds ont une serre à deux doig's très-distincte, et ceux de la troisième paire sont terminés par un onglet gui aunque aux qualre demiers. Enfin les Axies different de notre genre parce que, ayant, conme les Caliunasses, les deus première? paires de pieds eu pince didaclyle, tous les suiVans finissent par un onglet.

Les guatre antenues des 'Thalassines sont insérées sur une ầue ligne horizonlale; les extérieures sont médiocrement- longues (un conquiène de la grandeur du corps), sétacées, winces, ayant leur pédoncule simple et mutique ; les intermédiaires sont plas courtes, elles ont lemr pédoncule médiocrement long, et elles sont divisées en deux files dont l'intérieur est le plus court. La tige externe des pieds-mâchoires extérieurs est formée de six articles velus, dont le premier est le plus long et épineux, et les autres inermes. Lees pieds de la premicre paire sont plus grands, plus épais que les suirans, et en forme de serres à deux doigts, dont l'immobile est le plus court. Los pieds de la seconde paire sont plus petits et de même lorne, wais avec le doigt inférieur ou imunobile encore plus court. Les pieds des trois der. nières paires sont monodactyles et vont en décroissant de longueur. La carapace est alongće, un peu renflée et plus liarge postérieurement: elle est iermince par un rostre et marrucéc d'un sillow transversal arqué. L'ał domen est très-long, étrou, linéaire, lorné de six segmens dont le dernier est pourvu d'une large écaille natatoire intermédiaire, et de quatre lames latćrales très-ćtroites et linéaires; les yeux sont petits. On ne connoit qu'une seule espèce de ce genre. Elle est propre aux mers de l'lnde, et est trés-rare dans les collections.

'Thalassine scorpionoine, Thaluesina scorpionoides. Latr. Gener. Crust. et Ins. tom. I. pag. 52. - Léacu. Desir. Cons. génér., elc. pag. 203. pl. 35. fig. I. - Cancer anomalus. Hen Bst, Cancer. tab. 62.-Astacus scaber:" Fa . Suppl. entom. Syst. pag. 407. - Líaca, Zool. Miscell. 
tom. 3. pag. 28. tab. ı3o. Long de 6 à 7 pouces; rosire rebordé, avec son bord antérieur granulé; cuisses pourvues sur leur Iranche inférieure de deux séries de petites épines; dessus de la main et du doigt mobile des serres présentant deux carènes longitudiuales dentées en scie.

$$
\text { (E. G.) }
$$

THANA SI V E, Thanasimus. Lat. Clerus. Geoff. De Geer. Fab. Oliv. Payk. Panz. Sincen. Altelabus. Lins.

Genre d'insectes de l'ordre des Coléoptères, seclion des Pentamères, famille des Serricornes (division des Malacodermes), tribu des Cluirones.

Un grompe de celle tribu renferme les grenres Eurype, Axire, Priocère, Tille et Thanasime. (Voyez Clatrones, pag. 427. de ce volume.) Les quatre preniers diffèrent des 'llamasines en ce que la plupar des anticles de leurs antemes sont dentés en scie; en cuutre le corselet est cyliudrique on presque cylindrique dans les Axines, les Priocères et les 'Tilles: celui des Eurypes a une forme prescrue carrée. Lescrenres Axine t: Eurype se distingnent encore des Thamasintes con ce ciuils ont l'arlicle terminal des palpes maxillaires, sécuriforme.

Antemes grossissant insensiblement vers le bout, leur extrémité point en scie, composéed de onze arlicles, le premier le plus long de tous, en massue; le secon!l petit, presque globnleux; les quatre suivans cylindro-coniques; les septième, huitième, nenviène el dixième turbinćs; le onzième plus grand qu'aucun dés précédens, ovale. - Mandibules bilides à leur extrémité. Machoires bifides. - Pápes maxhlaires filiformes, de quatre arlicles; les labiaux de trois, le dernier sécurifurme. - Lèvre alongée, son extrémité écharcrée. - Feux échanctés intérieurement. - Corps un peu convexe, relu. - Corse'et vu en dersus, parnissant cordiforme, rétréci posterieurement. - Ecusson petit, ponctiforme. - Elytres plus larges que le corselet, recouvrant $\mathrm{d}$ es ailes et l'abdomen. - Pattes assez forles, velues; tarses ayant leurs cinq arlicles distincis, bilobés (le pénulième surtout); le demier lerminé par deux cruchets fort écartés l'un de l'autue.

Les 'Thanasimes dont le nom tiré dı grec signifie : qui porie lu mort, se trouvent ì l'état parfait le plus sourent sur le bois et les arbres mors, a u moirs en partie; mats leurs larves ne se nourrissent pas de celle substance ligneuse, quoique vivant dans son intérieur; elles y dévorent les larves des iusectes xylophages. M. Litreille présume (Règne anlinal) que la larve du 'Thanasine mutilkaile attaque particulièrement celles des Vrillettes. Il est probable que ces larves jouissent de la faculté de percer le bois pour y chercter les larves et les nymphes dont elles font leur nourriture, de même que les Clairons qui habitent les nids de l'Osmia muraria percent les cloisons de terre qui séparent les larves de cet Hyinénoptère. Il nous paroît également cerlain que les plus petires espéces peuver:t vivre en assez grand nombre dans le corpis d'une seule larre, quand elle est d'une certaine grosseur; ce que semble prouver un lait qui u'est pis rare, c'est de voir sortir da isuis huit ou dix 'Thanasines à la file les uns des autres; ce que nous avous vu du Thanasine formitaire. Les $e_{-}$ péces contaues appartienuent à l'Europe ou à l'Amérique.

\section{1. 'Thaxastre mutillaire, T. mutillurius.}

Thanasimus mutillarius. Lat. Gener. Crust. el Ins. tom. 1. pag. 27 1. - Clerus mutillarius $1{ }^{\circ}$. 1 . FAB. Syst. Eleut. - Oliv. Entom. tom. 4. Clair. pag. I 1.nn. 12.pl. 1. fig. 12.-- Paxz. Faun. Gem. fas. 31. fig. 12. - Schar. Synon. Ins. tom. 2. pag. $42 . n h^{\circ} .1$.

Voyez pour la descriplion et les autres synonymes (celui de Schranck est duuleux suivant M. Schoenherr), Clairon imutillaire no ${ }^{\circ}$ I. du présent ouvrage.

2. 'Tuanasime ichneumonaire, T. ichneumonelks.

Thanasimus ichneumonous. Lat. Gen. Crust. et Ins. tom. 1. pag. 271. - Clerus ichneumoneus no. 3. Ha . Syst. Eleut. - Oniv. Entom. tom. 4. Clair. pag. 13. no. 15. pl. 1. fig. 15. - ScHex. Synon. Ins. tom. 2. pag. $43 . n^{\circ} .3$.

Toyez pour la description et les antrès synonymes, Clairon ichneumonaire n. 3. de ce Dictionndire.

\section{Thavasime formicaire, T. formicarius.}

Thanasimus fornicarius. LA T. Gener. Crust. et Ins. tom. 1. pag. 270. $2^{\circ}$. 1.-Clerus fomnicarms $\pi_{1}^{\circ}$. 5. $\mathrm{H}_{\mathrm{AB}}$ Syst. Eleut. - OLrv. Entom. tom. 4. Clair. pag. 12. $n^{\circ}$. 13. pl. 1. fig. 13. - Panz. Faun. Germ. fis. 4. fig. 8.-Scuar. Synon. Ins. tom. 2. pugt 43. $n^{n} .5$.

Voyez pour la description et les autres synonymes, Clairon furuicaire $n^{\circ} .6$. de ce Dicionvaire.

4. 'Tharasime quadinaculé, T. quadrimueulutus.

Thanasimus quadrimaculatus. LAт. Gener. Crust. et lns. tom. 1. pus. 271. - Cle rus quadrimaculutus $11^{\circ}$. 8. Haz. Sy st. Eleut.-Parz. Faun. Germ. fus. 43. fig. 15. - Scran. Syn. Ins. tom. 3. pag. $44 . n n^{\circ} .11$.

Voyez pour la description et les autres syno- 
nymes, Clairon quadrimaculé no. ro. de ce Dictionnaire.

EURYPE, Eurypus. Kirb. Lat. (Fam. nat.)

Genre d'inscctes de l'ordre des Coléoplères, section des Pentamères, famille des Serricornes (division des Malacodermes), tribu des Clairones.

Cinc genres composent le groupe de Clairones duquel font partie les Eurypes (2'oyez Clasiores, pag. 427. de ce volume), suvoir : Thanasime, ayant le corselel presque cordiforme et le dernier article des palpes maxillaires presque filiforme; Axine, qui sc distingue, ainsi quc les Priocères, par le labre ćchancré et le corselet cylindrique; dans ces derniers l'article terminal des palpes maxillaires est oblong, el 'Tille, qui avec le corselet cylindrique a la lève entière et le corps convexe; le dernier article de ses palpes maxillaires n'cst point sécuriforme.

B1. Kirby a fondé ce genre dans les Transactions Linnéennes (Century of insect. pag. 389 ). Sun nom est tiré de dells mots grecs qui siguitient : pieds larges. Voici les caractères qu'on lui assigne.

Labre transversal, entier. - Lèvre bifide. Palpes terminés par un article sécuriforme; les maxillitires de quatre articles; les labiaux de deux. - Antennes dentées en scie. - Corselet presque carré. - Corps dépriné.

Nous ne connoissons pas l'espèce qui a servi de type à ce grenre, mais nous doutuns fort que les palpes labiumx ne soient comproés que de deux articles clans les Eurypes, les 'Tilles ei les Axincs, comme le dit M. Kirby. Nuús suxumes plutôl disposés à penser que l'article hasilaire de ces palpes est fort petit, mais non pas uul; de plus tons les anteurs accordent trons articles aux palpes labianx des Tilles, et M. Kirby lui-niême donue re nontbre d'arlicles à ceux des Priocères; les Thinasimes, dont il ue parle point, sont égalenicnt ainsi conformés, ce qui nous porte à croire que le fait avancé par l'auteur anglais doit ćrre soumis à an nouvel examen. L'espèce décrite tsi :

\section{EurtPe rougeâtre, $E$. rubons.}

Eurypus rubens, punctulatissimus; antennis apice, elytrorum basis latere exteriori et lineolâ apicis propè suturam, nigris.

Eurypus rubens. Krrs. ut suprà. pl. XXI. fig. 5.

Longuemr 6 lig. Corps linéaire, oblong, un pea brillant: très - ponctué, velu, rongeâtre. Tète orbiculaire; bouche avancée; mandibules cachées. Palpes maxillaires assez longs; lenr prenier article très-court, presque cylindrique, les denx suivans courts, obconiques; le dernier grand, presque triangulaire : palpes labiaux très- conrts; le premier article filiforme, le second un peu plus grand, mais point triangulaire. Menton presque transversal, carré. Antennes dentées en scie, au moins dans une partie de leur longueur (les quatre derniers articles manquoient dans l'individn observé), ronsses, noires vers l'extrćmilé. Yeux proéminens, presque hémisplériques. Corselet uu peu aplati en dessus avec deux impressions sur le dos; élytres presque planes, leur base extérieure et une ligne presque sulurale vers l'exIrémité, dc conleur noire; patles courtes, épines terminales des jambes irès-petites. Avant-dersier article des tarses très-large, bilobé.

Du Brésil.

AXINE, Axina. Krab. Lat. (Fam, nat.)

Gente d'insectes de l'ordre des Coléoptères, section des Pentamères, famille des Serricornes (divioion des Malacodermes), tribu des Clairones.

Les genres Eurype, Axine, Priocère, Thanasime et Tille composeni un groupe dans celle tribu. (Voy. Clairones, pag. 427 . de ce volune.) Linns les trois derniers l'article rerminal des palpres maxillaires n'est pas sécuriforme; en outre les Tilles et les Priocères ont le corps convexe; le corselet des Thanasimes est cordiforme. Le gente Eurype est distingné de celui d'Axine par son corselet presque carré el par son labre enlier.

Le nom d'Axine, tiré de la forme du dernier article des quatre palpes de ces insccles, vient d'un mot gres qui siguifie : hache. M. Kirly e:l le fondateur de ce genre (Transact. Linnéer. Century of insect. pag. 38g.) Il lui altribue pour caractères :

Labre echancré. - Lèsre bifitc? - Palpes terminés par un article grand, sécuriforwe; lis maxillaires de trois articles, les labiaux de den:. - Antennes dentées en scie. - Corselet cylitdrique. - Corps un pen dépriné.

Nous somues loin de garantir que le nounble d’articles assigné anx palpes par M. Kirby serit exact ; on peut voir nolre observation sur ce sujet à l'article Eurye qui précède; eile doil sappliquer anx quatre palpes du genre Axine. H. Kir: y ne mentionue qu'uue senle espèce de ce gonte.

\section{Axune anale, A. anclis.}

Axina sublìs fusca, suprà pallidè nefescens; élytrorum latenbus fuscisque duabus et pedbus fuscis.

Axina analis. Kвв ut suprà. pag. 5y! pl. AXl. fig. 6.

Longuear 6 lig. Corps linéaire, velu, bran en dessous, pále en dessus; lête penchéc, orbicnlaire, poncluće, rousse; labre transversal ; mandibules sans dents; palpes roux; preanier article 
des maxillaires alongé en massue, le seeonu? obconique; prenier arliele des labiaux conformé con:me celui des maxillaires; yeux grands, réniformes, velus, distinctement réticulés; antennes plus courtes tue le corselet, rousses; corselet islongé, ponctué, roux, avec des impressions d $\mathrm{r}$ sales, ses côtés un peu bruns; élystes un peu aplaties supérieurement, poncluées, avec les côtés et deux bandes trausverses de conleur hrune; la première de ces bandes placée avant le nilieu, étroite, anguleuse, raccoureie intérieuremen!; la seconde p!us litrge, moins foncée, placée vers l'extrémité; il y a en outre quelipues points hrons épars str les élytres, mais lcur extrémité cost sins taches; partes brunes; épines leminales des jambes tres-petites; larses garnis en dessous d'un long duvel; abdousen ayant en dessous ses deux derniers seguneus d'un jaune püle.

Da Brésil. (S. F. ei A. Serv.)

'THELXIOPE, Thelxiopa. Rafixesque.

L'anteur donne ce nour à un grenre de Crustacés que M. Latreille avoit déjà nommé Homole. Voyez ce mol is la table alphabélique.

\section{(E. G.)}

TIIELYPHONE, Thelyphonus. LAT. Phalangium. Imsn. Palias. Heabst. Scurpio. Gronov. Tarentula. Fab. Ce gene d'Arachnides de l'ordre des Pulmonaires, fumille des Pédipalpes, tribu cles 'Tarentules, a ćté ćtahli pur H. Latreille aux dépeus du grand gente Phalangium de Linné. Ses caractères sont: palpes gros, courts et terminés par une pince de deux doigrts; corps oblung aver le corselet ovale et le bord de l'abdomen muni d'une soie articulée formant une queue; les deux tarses antérieurs courts, d'une même venue et à articulalions peu nombreuses. Ce genre se distingue des Phrynes par ses palpes, ses tairses antérieurs et sun corps alongé, tandis qu'il est court el arroudi duns la plupart, et surtout par l'abdonien muni d'une queue articulće et en forme de soie. On trouve ces Arachnides dans les pays chauds de l'Amérique et des Indes orientales: on en eonnoit trois espèces.

Le Théryphove a queve, Thelyphonus caludatus. Iua . Hist. nat. des Crust. et des Ins. tom.7. pag. $132 . p l$. 6o. fig. 4.-.Thelyphonus proscorpio. Ibik. Gener. Crust. ct Ins. tom. 1. pag. 130. Phalangum caudatum. Linn. - Paldas, Spicil. zool. fás. 9. pag. 30. tab.5.fig. 12. - Tarenlula culiduta. Hab. Ent. Syst. tom. 2. pag. 435. Hensst, Nalurg. placl. tab. 5. fig. 2.-SÉsa, ikus. tom. r. tab. 70. fig. 7. 8. - karir. Gen. Ins. tab. 2g. fig. 11. Celte espece est longue d'un peu plus d'un pouce, d'un brun foncé. On la trouve aux Indes orientales. L'espèce que l'on trouve à la Martinique y. a reẹu le now de vinaigrier, parce qu'elle exhale une odeur aeide quand on l'inquiète. (E. G.)

\section{THĖE, Thenus. LéAch.}

M. Léach a élahli ce genre de Crustaeés aux dépens du genre Scyllure de M. Latreille; mais ce dermier auleur n'ayant pas trouvé ses caraclères sufisamment tranclićs, l'a réuni à son gente Scyllare. Toyez ce mot. (E. G.)

'THÉRAPHOSES, Theraphosa. C'est ainsi que, dans son lableau des Aranérdes, M. Walckenaer désigne la premiere section des animaux de cette famille, et quil caractérise ainsi : nấchoires horizontales; palp̄es insérćs à l'extérieur ou sur les côlés exlérieurs des mâchoires; mandıbules articulces liorizontalement, proéminentes, munies d'un onglet mobile qui se replie en dessous.

Les 'Théraphoses comprennent les Araignées mineuses d'Olivier et quelques-unes de scs Araignées tapissières, comine l'Aviculaire et autres inalogues. Elles composeut, dans l'onvrage sur le Règne animal de M. Clivier, notre tribu des Aratnéides territèles. Leurs mandibules, ou plutòt leur's chélicères, sont a väncées, arquées en dessus, et leur crochet se replie presque perpendiculairement sur lcur côté inférieur. La lévre ou la languette n'est presque point saillanie entue les mâchoires dans la plupart, et dans les autres, ou ceux où elle s'avance entre les mâchoires, elle a une torme presque linéaire. Un autre caraetère gínéralement propre a ces Aranćides, c'est que leul abdomen n'offie bien distinctement que quatre filières, dont deux souvent beaucuup plus longues, et divisées en trois artieles au moins. Les organes crpulatenrs des mâles, ou cenx que l'un avort considérés comme tels, et qui sont siluís atudernier article des palpes, sont liès-sinples, ne consistent quien une piece écuilleuse, en furme de boulon, et terminée en une pointe arqúe et très-aiguë, ou bien en manière do cure-oreille.

Cette seclion on tribu se eornose des genres Mygane, C'tenize. (Araignées mineuses ou maçounes), Atypes (Olétére TValck.), Eriodon.

Ces animatux, d'apres les observations de $M$. Léun Dufour, nous présentent un carractère d'une valeur bien supérieure à celle des précédens. Il est tiré du nounlir: des cavités pueumo-branchiales, qui est de quattre au lien de deux (voyez Tetrapneumones ). Mais comme il s'applique ellcore aux Filistates et aux Dysdères, qui, d'après les principes de M. W Valckenaer, appartiennent à sa seconde section générale, celle des Araignées proprement dites, les caractères précédens ne seront plus absulus. Vojez 'T́trapacumones.

(LATH.)

'THËRATE, Therates. LAT. Des. (Speciès.) Cicendela. Fab. Wéb. Schen. Eurychiles. Bonela. 
Genre d'insectes de l'ordre des Coléoptères, section des Pentamères, famille des Carnassiers (division des Terrestres), tribu des Cicindélètes.

Les travaux de MM. Latreille et Dejean dans l'ouvrage intitulé: Histoire nat. et iconogr. des insect. Colécpt. a'Europ. et ceux du dernier dans son Spéciès génér. des Coléopt. nous mettent à même de dorner ici un tableau de la tribu des Cicindélètes.

Cicindélètes, Cincideleto. Première tribu de la famille des Carnassiers (division des Terrestres), section des Pentamères, ordre des Culéoptères. Ses caractères sont :

Mandibules fortes, très-dentées intérienrement. - Languette très-petite, cachće par le menton. ralpes labiaux composés de quatre articles distincts; le premier étant libre et dégagé du support. - Mâchoires ouguiculées, c'est-ä-dire terminées par une pointe articulée avec leur extrémité supérieure. - Yeux $x$ très-saillans. - Tarses longs et grêles.

I. Une dent au milieu de l'échancrure dı menton.

A. Tarses non dilatés dans aucun sexe. Manticore.

B. Les trois premiers articles des tarses antérieurs dilatés dans les nuâles.

a. Troisième article des tarses antérieurs des mâles nou prolongé.

† Pénulitième article des palpes labiaux $n o n$ renflé.

Mégacépbale, Oxycheile, Cicindéle.

†† Pénultiòme article des palpes labiaux renllé, plus gros que le dernier.

Dromique, Euprosope.

b. 'Troisième article des tarses antérieurs des milles prolongé obliquement en dedans.

Citénostome.

II. Point de dent au milieu de l'échancrure du menton.

A. Troisic̀me et quatrième articles des tarses beaucoup plus courts que les premiers.

'Thérate.

B. 'Tous les articles des tarses presqu'égaux. Tricoudyle, Colliure.

Le genre Thérate forme à lui seul une coupe particuliêre dans cette tribu. Ses caractères essentrels sont:

Hist. Nat. Ins. Tome $\boldsymbol{X}$.
Labre très-grand, en forme de demi-ovale, légèrement convexe, très-avancé, recouvrant presqu'entièrement les mandibules. - Polpes maxillaines internes très-petits, peu distincts et d'un seul article. - Point de dent au milieu de l'échancrue du menton. - Yeu.x encore lus saillans que ceux des Cicindèles. - Corselet arroudi et presque globuleux dans son milieu, avec deux sillons transversalux très-profonds, placés, l'un antérieurement, l'autre ì sa partie postérieure. - Elytres ayant à leur base une petie élévation assez warrquée; leur extrémité échancrée ou terminée en une pointe assez aiguë. - Avant-demier seginent de l'abdomen assez forlement échancré dans les wâles. (Ce caractère existe aussi dans les Cicindèles quoiqu'il ne soit pas mentionné.) - Tarses presquc semblables dans les denx sexes (les Cicindeles mâtes ont les trois premiers articles des tarses antérieurs dilatés, alongés, ciliés foriement, surtont en dedans), le troisiène article plus court que chacun des deux premiers et légèrement échancré à son extrémité pour recevoir le quatrième : celui-ci très-court et corciforme. Le reste des caractères comme dans les Cicindeles. Voyez ce mot.

Le nom de ces Coléoptères vient d'un mot grec qui signifie : chasseur, et exprime qu'ils doivent vivre de proie conme toutes les antres Cicindélètes. Le petit nombre d'espèces connues habitent exclusivenent les iles au nord de la nouvelle Hollande et celles de la Sonde.

Rapportez à ce genre, $1^{\circ}$. Thérate labiée, $T$. labiata. Lat. Hist. nat. et iconogr. des ins. Coléopt. - DEJ. Spec. tom. 1. pag. 158. no. 1. Cicindela laliata ${ }^{\circ}$. 3. Fав. Syst. Elent. -

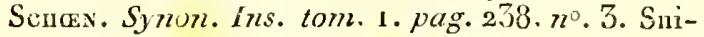
vant les observations de M. de la Billardière, qui l'a trouvée daus les îles au nord de la nouvelie Hollande, c'est au temps des orages qu'elle paroît le plus commusément; elle se tient ordinairement sur les feuilies des arbres et vole avec rapidité. $2^{\circ}$. Thérate Havilabre, T. flavilabris. Lat. Noay. Dict. d'hist. nat. $2^{\mathrm{e}}$. édit. - Ciciridela favilabris $\mathrm{n}^{0} .62 . \mathrm{FAB}, i a^{2}-\mathrm{Schen}, i d . p a g .246, \pi 7^{\circ} .65$. 3․ Thérate fusciće, T. fasciata. LAT. id. - C cindela fasciata $n^{\circ} .63 . \mathrm{F}_{\mathrm{AB}} . i d .-\mathrm{ScH}$. $n^{\circ}$. 66. $4^{0}$. 'Thérate bleue, T. cyanea. LAT. Hist. nat. et iconogr. des ins. Coléopt. pag. 64. $n^{\circ} .1$. pl. 1. fig. 2. 50. 'Thérate spiniponne, T. spinipennis. LAT. id. $n^{\circ}$. 2. pl. 1. fig. 3. 6०. Thérale mipartie, T. dimidiata. Des. Spec. torn. 1. pag. 159. $n^{\circ}$. 2. et tom. 2. Suppl. pag. $437 \cdot n^{\circ} \cdot 2$. Lol1gueur 5 lig. D'un bleu céleste brillant; base des élytres, labre, pattes et abdomen jaunes. De Java. $7^{\circ}$. Thérate basilaire, $T$. basalis. DeJ. id tom. 2. Suppl. pag. 437. $n^{\circ}$. 3. Longueur 5 lig. $\frac{x}{2}$. D'un bleu céleste brillant; élytres violettes, un peu tronquées a leur extrémité ; leur base, le labre, les pattes et l'abdomen, testacés. Ile de Waigion, à Ii ii 
l'ouest de lit nouvelle Guinée, sur les feuilles des arbres; son vol cst rapide.

MÉGACÉPHALE, Megacephala. LAT. DeJ. (Speciès.) Cicindela. Linn. De Géer. Fab. Oliv. Sch N.

Genre d'insecles de l'ordre des Coléoplères, section des Pentamères, famille des Carnassiers (division des 'Terrestres), tribu des Cicindélètes.

Les trois genres Mézracéphale, Oxycheile et Cicindèle constiluent un groupe parmil les Cicindélètes (voyez ce mol, pay. 6r7. de ce volume); le dernier a les palpes labianx peu alongés, ne dépassunt pas les maxillaires externes, lenr ariscle terminal point sécuriforme. Dans les Oxysheiles, le labre est triangulaire et recouvre les mandibules, ce qui distingue ces deux gemres de celui de Mézacéphale.

Labre trilnsversal, per avancé, laissant les mandibules à découvert. - Mandibules larges, forlement dentées, peu saillantes. - Palpes maxillaires ayant leur dernier article légèrement sécuriforme : palpes labiaux alongés, plus grands que les maxillaires externes; leur premier article alongé, très-saillant au-delà de l'extrémité supériense de l'échancrure du menton, le second trèscont, le troisième très-long, cylindrique, le dernier sécuriforme. - T'êto plus grosse que dans les autres Cicindólètes (à l'exception des Manticores). Front large, plane ou très-légèrement couvexe. - Yeux grands, assez peu saillaus. Dos des élytres un peu convexe. (Celui des Cicindèles est presque plan.) - Tarses antérieurs des mâles ayaut leurs ırois premiers articles dilatés, courts, presqu'en triangle renversé, ciliés fortement, surtout en dedans; le troisième non prolongé (les Cicindèles mâles offrent ce même caractère). Le reste des caractères comme cen des Cicindèles. Voyez ce mot.

Le non donné à ces insectes vient de deux mots grecs et signifie : grande tête. Il avoit été applicqué comme nom spécifique à l'une des espèces primitivenent connue. Les mœurs des Méracéphules doivent être les mêmes que celles des Cicindèles. 'Toutes les espèces sont exotiques.

1re. Division. Corps aptère. Insectes de l'ancien continent. (Apiema Nов.)

1. Mégacéphale du Sénégal, M. senegalensis.

Megacephala senegalensis. Lat. Gener. Crust. et Ins. tom. 1. pog. 175. $2^{\circ}$. 1.-Cicindela me-

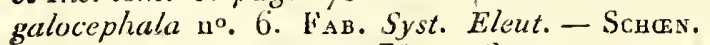
Synon. L.es. tom. 1. pag. $238 . n^{\circ} .6$.

Voyez pour la description et les autres synonymes, Cicindèle mégacéphale $\mathbf{n}^{\circ} .2$. de ce Dictionnaite.

On doit placer en ontre dans cette division la
Mégacéphale de l'Euphrate, MI. Euphratica. I.AT. Hist. nat. et iconogr. des insect. Coléopt. pag. 37 . tab. 1. fg. 4. Mấle. -- DEJ. Spec. tom. 1. pag. 7 . $n^{\circ}$. 19. Longueur 8 lig. $\frac{x}{3}$. D'un vert cuivrenx brillant; bonche, antennes, pattes et extrémité de l'abdomen, juunes. Elytres un peu rngueuses avec une grande taclie commune cordiforme jaune à leur exirérnité. Trouvce sur les bords de l'Euphrate par feu Olivier. Cette espèce, qui se rapproche par les couleurs de la Mégacépliale carolinrise, a le premier article des palpes labiaux proportiunnellement plus long.

$2^{\mathbf{e}}$. Division. Corps ailé. Insectes du nouveau continent. (Aźgacephala propriè dicta Noв.)

\section{Mégacéphale carolinoise, $\boldsymbol{M}$. carolina.}

Mregacephala carolinensis. L.Aт. Gener. Crust. et lis. tom. 1. pag. 175. no.2. tab. 6. fig. 9. Megacephala carolina. DEJ. Spec. tom. 1. pog. 8. $n^{\circ}$. 2. - Cicindala carolina $\mathrm{n}^{\circ}$. 8. FAв. Sysi. Eleut. - OL1v. Entom. tom. 2. Cicind. pag. 39 . u०. 31. pl. 2. fig. 21. - Schas. Synon. Ins. tomi. 1. pog. $238 . u^{\circ} .8$.

Voyez pour la description et les autres synonymes, Cicindèle carolinoise $n^{\circ}$. 34. du présent ouvrage.

\section{MÉg acÉPBale vilginienne, M. virginica.}

Megacephala virginica. DEJ. Spec. tom. 1. pag. 10. $u^{\circ} .3 .-$ Cicindela virginica $\mathrm{n}^{\circ} \cdot 7 \cdot \mathbf{F}_{\mathrm{AB}}$. Syst. Eleut. - Schषn. Synon. Ins. tom. 1. pag. 238. $n^{\circ} \cdot 7$.

Voyez pour la description et les autres synonymes, Cicindèle virginienne $n^{\circ} .35$. de cet ouviage.

4. Mégacéphale équinoxiale, M. aquinoctialis.

Megacephala requinoctialis. DEJ. Spec. tom. r. pag. 14. $n^{\circ}$. 8. - Cicindela a quinoctinlis $n^{\circ}$. бо. FАв. Syst. Eleut.-Scн®N. Synon. Ins. tom. 2. $p a g .246 . n^{\text {n. }} 63$.

Voyez pour la description et les autres synonymes, Cicindèle équinoxiale $n^{\circ} .38$. du prośsent Diclionnaire.

Celle division comprend encore, $I^{\circ}$. Mégracéphale voisine, 211. affinis. Dus. Spec. tom. I. pag. 12. $n^{0}$. 5. Longueur 6 lig. $\frac{7}{8}, 7$ lig. W'un vert obscur; bouche, antennes, patles et anus testacés; extrémité des élytres portant une tache commune cordiforme, tres-échancrée, de cet!e nuêtne couleur : genoux bruns. De Cayenie. $2^{\circ}$. Mégácéphale brćsilienne, M. brasiliensis. Des. Spec. id. pag. 11. $n^{\circ}$. 4. Du Brésil. 3o. Mégacéphale aculipenne, M. acutipennis. Des. id. pag. 13. $n^{\circ}$. 6. (en ôlant le synonyme d'Olivier quu nurus paroît appartenir à la virginica.) Longueur 5 lig. 
$\frac{3}{4}, 6$ 'ig. $\frac{1}{4}$. D'un cuivreux obseur; bouche, antennes, anus et pattes testacés; élytres ponetnées, terminées chacune par une épine, et ayant sur son extrémité une taclie oblique testacée. We SinintDomingue. $4^{\circ}$. Mégacéphate variolúe, M. variolosa. Des. id. pag. 14. $n^{\circ}$. 7. Longneur 5 lig. $\frac{1}{2}$, 6 lig. D'un noir onscur en dessus; élytres chargées de points excavés. De Cayenne. 11 est possible que celte espèce, suiraul l'observation de M. le comte Dejean, doive se rapporter à la Cicindela sepulcralis no. 9. Fав. Syst. Eleut.; mais cet auteur ne parie pas de l'inégalité des élytres.

\section{OXYCHEILE, Oxycheila. Des. (Speciès.)} Cicundela. Fab. Oliv. Scnen.

Genre d'insectes de l'ordre des Coléoplères, section des Pentauières, famille des Carnassiers (division des Terrestres), tribu des Cicindéletes.

Les genres Mégacéphale et Cicindèle font partie du même groupe de Cicindélètes que les Oxycheiles. (Voyez Gax; volune.) Le premier se distingue de ces dernières pur son labre transversal, peu avancé, Iaissant les nandibules à déconvert, et par ses palpes labiaux plus longs que les maxillaires externes; les Cieindéles ont le dernier article des palpes labiaux presque cylindrique, à peine un peu plus gros a son extrémité.

Antennes minces, déliées.-Labre très-giand, avancé en pointe, triangulaire, recouviant les mandibules et dépassant l'endroit où elles se cruisent dans le repos. - P'alpes labiaux alongés, aussi longs que les maxillaires externes; leur premier article assez long, saillant au-dela de l'extrémité supérieure de l'échancrure du menton; le second très-court; le troisième très-long, cylindruque, légèrement cuurbé, le demier sécuriforme. - Tête point très-grosse, un peu alongće, presque plane. - Yeux assez saillans latéraleinent, mais point en dessus. - Corselet à peu près de la largeur de la tête, son bord postérienr sinué, presque trilobé; le lole internédiaire recouvrant en très-grande partie l'écusson, donı la pointe paroît à peine entre la base des ćlyties. Elytres clu double pius larges que le corselet, assez alongees, peu convexes, sélargassint un peu pustérieurement. - Abdomen ayant son avant-kiernier segrnent assez forterrent échaneré en dessous dans les mâles. - Pattes graudes, alongées; Ia:- $^{-}$ ses antérienrs des mâles ayant leurs trois premitrs articles dilatés, ciliés également des denx còtés: les deux premiers grossissant vers l'extrémité, le troisieme non prolongé, presque cordiforme. Voyez pour les autres caracières, ceux des Cicindè̀es.

Le nom de ce genre vient de deux mots grecs qui signifient : lègre pointue. Ses babitudes et ses mour's n'ont 'pas encore été observées, mais elles ne doivent gucère, d'après l’analogie, différer de celles des Cicindèles.

\section{Oxy'hente triste, O. tristis.}

Oxycheila tristis. Dev. Spec, tom. I. pag. 16. $n^{\circ}$. 1. - Cicindela tristis no. 13. $\mathrm{v}_{\mathrm{AB}}$. Syst. Eleut. - Schax. Syzon. Ins. tom, 1. pleg. $24 i \cdot 76^{\circ} \cdot 19$.

Yoyez pour la description el les autres sym.nymes, Cicindèle triste no $15 . p / .174$. fig. 12 . de ce Din!limaire.

Nota. Olirizr donne pour patrie à celle espéce l'Auérique septentrionaic er entriautres la Ciaroline; nos individus et ceux de M. le ccir.:e Dejean sont du Brósil. Ce dernier atuteur (Spreciès) dit que la Cicindelo bipustulata Lat, no $13 . t a b .16$. fig. I et 2. du Voyage de M. de Humboldt, parcit apparienir aux Oxycheiles.

DROMIQUE, Dromica. DeJ. (Speciès.) Cicindela. L,aт. (Hist. natur. et iconogr. des ins. Coléopt.)

Genre d'insectes de l'ordre des Culeoptères, tribu des l'entamères, famille des Carnassier's (division des 'J'errestres), tribu des Cicinatélètes.

Ce genre forme avec celui d'Euprosoge un groupe dans eelle tribu. (Voyes Cicrndécétes, pag. 617 . de ce volume.) Ce deınier lilliere des Droniques en ce que la dent 'jui se trouve al nilieu de l'échancrure du menton est très-pronuncée; que le troisième article des palpes labiaux esi moinś renijé, et que tous les palferes sont proportionacllement un peu plus longs; en ontre les Euprosopes sont ailés.

Labre un peu avancé, et recouvrant presçu'entiérement les mandibules. - Palpes proportionnellement assez courts; les labiaux ne dépassant pas les inaxillaires externes, ayant leurs deux premiers articles trio-rourts; le prenier ne dépassant pas l'exlrénité de l'échancrure ảu menton; le troisième assez grand, rentlé, prosçu'ovalare: le dernie! Jeaucoup plns mince, court, grossissant très-lég rement vers l'extrénité. -- IIEnton ayant une dent peu prononcée au wilien de son échancrure. (Cete dent existe aussi dano les Ciceradèles.) - Corselet un peu alongé el réuéci postérieurement. - Elytres en ovale très-alougé, très-rétrécies anlérieurement, terminces ęi pointe vers l'extrémué, soudées, recouvrani l'abdonea. - Point d'uiles. - Abdomen ayant en dessuus son avant-dernicr segment assez forteneat échancré dansıles inâles. - Tarses anténeurs des mâles ayant leurs trois premiers arlicies presque cylindriques, léfrèrement dilatés (ils le sont plus fortenent dans les Cicindèles mâtes), alongés, ciliés plus fortersent en dedans qu'en délors; leur troisième artucle non prolon ractères, yovez Cicindít.

Un mot grec qui signitie : coureur a été appliqué par.M. le comte Dejean, conme nom géliii 2 
nérique à ces Cicindélètes, dont les lıabitudes, à l'exception de la faculté de voler, doivent être à peu près les mêmes que celles des Cicindèles. Le type du genre est: la Dromique resserrée, $D$. coarctata. DEs. Spec. toni. 2. Suppl. pag. 435. $u^{\circ}$. I. - Cicindela courctata. Lat. Hist. nat. et iconogr. des ills. Coléopt. pag. 37. pl. I. $f_{S g} .5$. Femelle. Longueur 5 à 6 lig. D'un cuivreux obscur; élytres très-ponctnées, ayant sur les côtés une bande raccourcie et sur l'exirénité une petite liunne, blanchâtres. Du Cap de Bonne-Espérince.

EUPROSOPE, Euprosupus. Lat. (inéd.) DeJ. (Speciès.) Cicindela. Lat T. (Hist. nat. et iconogr. des ins. Coléopt.)

Genre d'insectes de l'ordre des Coléoptères, section des Pentanères, famille des Carnassiers (division des 'Terrestres), tribu des Cicindélètes.

Un groupe de Cicindélètes contient les Dromi-

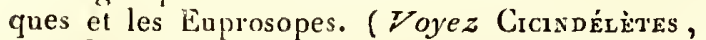
pag. 617 . de ce volume.) Les premières ont la dent du milieu de l'échancrure du menton peu saillante; leurs palpes labiaux sont proportionnellement un peu plus courts que ceux des Eupro. sopes, avec leur troisième aricle assez grand et renflé; les Dromicques diffèrent encore du genre Luprosope en ce qu'elles sont aplères.

Antennes furl minces et déliées (plus que dans les (icindèles) jusque vers l'extrémité où elles paroissent $u n$ peu plus grosses. - Labre avancé, bombé, crénelé à sa partie antérieure. - Palpes labiaux ne dépassant pas les maxillaires externes; leurs deux premiers articles très-courts; le premier ne dépassant pas l'extrémité de l'échancrure du meuton; le troisième presque cylindrique, un pea renflé, plus gros que le dernier; celui-ci très-mince, conrt, girossissant très-légèrement vers l'extrénité. - Yeux très-gros, très-saillans (plus que cenx des Cicindèles).-Ecusson placé haut, sa pointe à peine engagée entre la base des ślytres. - Elytres plus alongées et plus parallèles entr'elles que celles des Cicindèles, recouvrant des ailes et l'abdomen. - Abdomen ayant en dessous son avant-dernier segment assez fortement éclancré dans les mâles. - Pattes très-longues, assez cléliées; titrses antérienrs des mâles ayant leurs trois premiers arlicles dilatés, aplatis, peu alnngés, carénés longitudinalement en dessus, ciliés également des deux côtés; les deux premiers s'éla rogissint un pen vers l'extrémilé et légèrement échancrés; le troisième non prolongé, presqu'en cour. Les autres caractères sont ceux des Cicindèles. Toyez ce not.

Les espèces de ce genre doivent à peu près vivre conıme les Cicindèles. Le type est l'Euprosope quadrinoté, $E$. quadrinotatus. DEJ. Spéc. tom. 1. pag. $151, n^{\circ}, 1 .-$ Cicindela qreadrinotata. LAT. Hist. nat, et iconogl, des ins. Coléopt. pag.
38. pl. 1. fig. 6. Iongneur 7 à 8 lig. D’un vert brillant; élytres variées de cuivreux, avec deux taches blanches sur chacune. Du Brésil.

Nota. M. Latreille pense que l'on doit peut-être róunir à ce genre la Cicindela viridula. Scнбеx. $S_{y} n$. Ins. toin. 1. $n^{\circ} .3$ r. De l'lle-de-France, où elle vit, d'après l'assertion de M. Catoire, sur les froncs d'arbre; et deux autres espèces inédiles, l'une du même pays, et l'autre envoyée de Java par MM. Diard el Duvaucel.

C'TÉNOSTOME, Ctenostoma. Krug. Lat. (Fam. nat.) DeJ. (Speciès.) Caris. Fisch. Collyris. Fat. Schoen.

Genre d'insectes de l'ordre des Coléoptères, section des Pentamères, famille des Carnassiers (division des Terrestres), tribu des Cicindélètes.

Ce genre forme à lui seul une coupe dans sa tribu. ( Voyez Cicindécetres, pag. 617. de ce volume.)

Antennes sélacées, longues, menues, composées de onze articles; le second très-petit, le quatrième plus cour' que le précédent et que le suivant. -- Labre avancé, assez grand, bombé, crénelé à sa partie antérieure. - Mandıbules n'ayant pas de deutelures dans leur moitié inférieure. - Mâchoires munies d'un onglet terminal très-petit, se confondant avec les cils internes. - Les six palpes très-saillans; les quatre extérieurs fort alongés; les maxillaires externes de qualre articles; le premier beaucoup plus conrt que le second, celui-ci fort long, un peu courbé, presque cylindrique; le troisième assez cour!, cylindro-conique; le dernier pas beaucoup plus long que le précédent, gros, sécuriforme : les maxillaires internes tilifurmes, de deux articles fort longs ; palpes labiaux un peu plus longs que les maxillaires externes, de quatre articles; ies deux premiers très-courts; le troisième très-long, cylindrique : le dernier court, sécuriforme. Menton éclıancré, muni d'une dent au milieu de son échancrure. - Tête grande, plane, presqu’en losauge. - Yeux petils, assez saillans sur les côtés, mais nullement en dessus. - Corps étroit, alongé. - Corselet en forme de nœud globuleux; ses bords antérieur et postérieur relevés en forme de bourrelet. - Ecusson presqu'entièrement caché par le corselet, sa pointe n'atteignant pas la base des élytres. - Elytres alongées, rétrécies antérieuremert, s'élargissant ensuite vers l'extrémité postérieure, recouvrant l'abdomen, paroissant soudées. - Point d'ailes propres au vol. - Abdonen ovoïde, alongé, rétréci en devant, ayant son avant-dernier segment légèrement échancré dans les mâles. - Pattes longues, déliées; tarses antérieurs des mâles ayant leurs trois premiers articles dilatés, le troisième prolongé obliquernent en dedaus.

Clénostome a pour étymologie deux mols grecs 
qui signifient : bouche en peigne. Les trois espèces connues de ce genre appartienneul aux contrées les plus chaudes de l'Amérique méridionale.

$1^{\circ}$. Clénostome formicaire, $C$. formicarium. DeJ. Spec. tom. 1. pag. 154. $n^{\circ}$. 1. - Collyris formicaria no. 3. FAB. Syst. Eleut. - Scuan. Syn. Ins. tonz. 1. pag. 236. no. 3. De Cayenne et du Brésil. $2^{\circ}$. Cténostome trinoté, C. trinotatum. Des. Spec. id. pag. 155. $n^{\circ}$. 2.-Ctenostoma formicaria. LAr. Hist. nat. et iconogr. des ins. Coléopt. pag. 36. pl. 2. fig. I et 2. Mâle. Du Brésil. 3․ Cténostome rugueux, C. rugosum. Kevg. Enton. Brasil. Spec, pag. 7. $n^{\circ}$. 3. tab. 3. fig. 3. - DEJ. id. pag. 156. no. 3. Du Brésil. $4^{\circ}$. Cténostome Ichneumon, C. ichneumoneum. DeJ. id. tom. 2. Suppl. pag. 436. $n^{\circ}$. 4. Longueur 5 lig. $\frac{7}{4}$. D'un noir bronzé; élytres ponctuées, avec une bande transverse sur le milieu et la partie postérieure, jannes. De Rio-Janeiro. Elle se tient sur les branches d'arbre, et court avec beavicoup de célérité. (S. F. et A. Serv.)

THÉRÉVE, Thereva. FAB. (Syst. Antïat.) Cet auteur place dans ce genre quatorze espèces de Diptères qui appartiennent aux genres Pliasie. Lat. Meig.; Xyste Merg.; Trichopode Lat. el Xylote Mesc. I A At. Ainsi les Th. subcoleoptrata $\mathrm{n}^{\circ} .1$, hemiptera $\mathrm{n}^{0} .2$, crassipennis $\mathrm{n}^{\mathrm{n}} .3$, obesa $\mathrm{n}^{\circ} .6$, analis $\mathrm{n}^{\circ} .7$, cinerea $\mathrm{n}^{\circ} .13$, sont des $\mathrm{Ph}$ asies da mêue nom spécifique. Dans les Dipt. d'Europ. de M. Meigen, la Th. affinis no. 4. est la femelle de la Phasia hemiptera Meig.; la Th. holosericea $\mathrm{n}^{\circ}$. 5. est la Xysta holosericea Me1G.; les Th. pennipes no. 8 , hirtines $n^{\circ} .9$, lanipes $\mathrm{n}^{\circ}$. 10 , plumipes $11^{\circ} .11$ et pilipes $\mathrm{n}^{\circ} .12$, sout des 'Trichopodes Lat. Fam. nat.; enfin la Th. dubia no. 14, est la Xylota lateralis Merg.

(S. F, et A. Serv.)

THÉRÈve, Thereva. LAt. Me1g. Bibio. Faв. Falicen. Panz. Ross. Schranck. Leptis. Fab. Nemoletus. De Géer. Ouv. (Encycl. caract. des genr. d'ins.) Tabanus. Georr. Musca. Linn.

Genre d'insectes de l'ordre des Diptères (premiere section), famille des Tanystomes, tribu des Mydasiens.

Cette tribu renferme deux familles dans la méthode de M. Meigen, salvoir : les Xylotomes et les Mydasiens. Elle ne contient que deux genres fort différens l'un de l'autre, Mydas et Thérève. (Voy. Mydasiens, pag. 537 . de ce volune.) Le prenier se distingue du second pai la trompe saillante dans le repos, par le troisième article des antennes infiniment plus long que les deux premiers pris ensemble, confrormé en inassue échinancrée à son extrémité, enfin par les nervures des ailes dont aucune n'atteint le bord postérieur de l'aile.

Antennes avancées, rapprochées, composées de trois articles; le premier cylindrique, assez long, le second cyathiforme; les deux premiers velus; le troisième conique, alongé, nu, à peu près de la longueur du prenier, portant au bout uue petite pointe conique qui sert de base à un style court, droit. - Trompe entièrement cacliée dans la cavité baccale lors du repos. - Palpes un peu plus longs que la soie supérieure, cylindriques, formant un bouton à l'extrémité, velus extérieurement. - Téte des fernelles spbérique; celle des mûles presque hémisphórique. - Yeux espacés dans les femelles, rapprochés et séparés par une simple suture dans les mâles. - Trois ocelles placés sur le vertex. - Corps assez long, très-velu. - Corselet ovale, sans ligne enfoncée transversale. - Ecusson hémispliérique. - Ailes laucéolćes, velues vues au microscope, à moitié ouvertes dans le repos; plusieurs de leurs nervures aboulissant au bord postérieur de l'aile. - Carllerons simples, très-petits. - Balanciers décorverts. - Abdomen conique, de sept segmens. Pattes assez grandes, grêles; jambes ayant deux fortes épines à leur extréaité : tarses longs, grêles; leur dermier article terniné par deux crochets muais d'une pelotle bifide dans leur entredeux.

Les Thćrèves se rencontrent babituellement isolées sur les fleurs et quelquefois réunies sur des buissons où elles semblent se jouer en voltigeant, ce.qui est probablement le prélude de l'accouplement. M. Meigen a trouvé plusieurs larves de la 'Ihérève enuoblie ( $T$. nobilitata) daus un vieux tronc d'arbre pourri. Lorsqu'elles ont atteint toute leur grandeur, celle-ci est de quatorze lignes; ces larves sont susceptibles de mouvemens torlueux; le corps est d'un blanc sale avec des taches jaunâtres et trausparenies: sur le premier segment est une ligne dorsale noire et sur l'avant-dernier, on le din-neuvième, il y a quelques soies; l'anus ou dernier segment á deux tuyaux respiratoires; la tête est petite, noire, cornće : ces larves se transformèrent er nymphes oblongues au mois de mai, et les insecles parfails parurent en juin.

Le genre Bibio $\mathrm{F}_{\mathrm{A} \text { в. (Sy'st. Antliat.) contient }}$ treize espèces. Les $n^{o s} .1,3,4,6,7,8,10,11$, 12,13 , sont des Thérèves, mais le $\mathrm{n}^{\circ}$. 11 est la femelle du $n^{\circ} .13$, et le $n^{\circ} .8$ le mâle du no. 3. Le $n^{\circ} .2$ est la Callicera onea Merg., le no. 9 la Phora florea MeIg., et le no. 5 l'Athorix marginata MeIg.

Dans ses Dipt. d'Europ. M. Meigen décrit vingt-une espèces de ce geure, parmi lesgualles on tronve le plus communément:

$1^{\circ}$. Thérève ennoblie; T. nohilitata. Meis. Dipt. d'Eur. tom. 2. pag. 116. n०. 1. $2^{\circ}$. Thérève plébéienne, T' plebeia. ME1G. id. pag. 117 . $n$. 3. (Le synonyme de Geoffroy rapporté avec doute à celte espèce par MI. Meigen, appartient $\dot{a}$ la Thérève vuisine, $T$. confinis Malg.) Frisck trouva dans la terre liumide (probablement détri- 
tus végétal) les larres de celte espèce. $3^{n}$. Thlérève vieille, 7 . anilis. MEIG. id.pag. $125 . n^{\circ}$. 16 . $4^{\circ}$. Thérève annelée, T. annulata. Mrig. id. pag. 126. $n^{\circ}$. 17. Des environs de Parlis. $5^{\circ}$. 'Thérève voisine, T. confinis. MeIg. id. pag. $127 n^{\circ}$. 19 . Cownune aux environs de Paris. Le Taon no 6 . de Geoffroy (Ins. Paris. tom. 2. pag. 462.) est la femelle de cette espèce : la variété ıneutionnée même page nous paroît êlre le mâle.

\section{(S. F. et A. SשRv.)}

'THERIDION, Theridion. WValck. Latr. Aranea. Jinn. Fab. Geoff. Ouiz. Scylodes. Lata. Latiodectus. W Valck. Genre dialuignées de la famille des Aranéldes, section des Dipneumones, tribu des Inéquitèles, établi par M. Walckesaer et adopté par M. Latreille, àvec ces caracteres : yeux au nombre de huit el disposés ainsi : qualıe ál nuiliell en carré, et dont les deux antérieur's placés sur une petite érainence, et deux de clüque côtć, situćs aussi sur une élévation commune. Corselel en forme de cour renversé ou presgue triaugulaire : la prewiére paire de pattes et ensuite la quatrièuse les plus longues de toutes. Mâchoires inclinćes sur la lève.

Les Théridions sont très-voisius des Scytodes, mais its s'eu dislingueut facilentent par le nombre des yeux qui n'est que de six dans ces dernicrs. Dans les Eipisines, les ycux sont au nosabre de huit, mais il, sont rapprochés sur une élévation commune; le corselet des Lpisines est étroit et presque cylindrique, et non en torrue de cour renversé. Enfin tes Ploolcus qui ont encore buit yeux, se distingueut des Théridions parce que les premières et secondes paires de pieds sont les plus longues.

Le genre Théridion est un des plas curieux par la var:été de ses mours el de son industrie; aussi voit-on varier en même ritison les organes principanx, et particulièrenent la forme de la lèvre. Celle des unathoires et le placement des jeux n'éprouvent que de légc̀res modifications; et comme de toutes les Aranéíles celles-ci sont les plus pelites, elles sont d'aulant plus difficiles à ob̉ server. Ce gremre est nombreux en espèces : en gésnéral elles se rapprocihent un peu des Episines par la mollesse de leur abdomen et la variété des couleurs dont il est orné. Leurs paltes sont longues et délicées. Leurs habiludes oat été observées par plusieurs nitnralistes, et surtout par MIM. Walckenaer et Rossi, qui ont donné des délails for curleux sur l'accou lemeut et la manière de chasser de deux espèces très-remarcqubles de ce genre. On trouve les Théridions sous les pierres ou'les anas de découbres; qualques espèces Labiteut les endroits peu fréquentés de nos maisons, et c'est ordıairenent entre les méubles, au coin des altmoires ou aux anglés des mur's

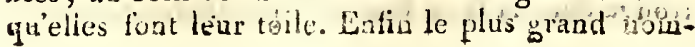

bre des espèces se troure sur les anbres ou sur les fleurs.

M. Walckenaer aroit établi un gerre sons le non de Latrodecte, mais M. Latreille l'a réuni à ses Théridions, après s'être convaincu par"lobservation, que les caractères que $\mathrm{H}$. Wallkenacr lisi avoit assignés n'étóient pas suflisans pour cons. titner une coupc génćricque. Les Théridions de M. Walkenaer, ou le même geare de M. Latreille, moins les espèces qui forment le genre Latrodecie da premier de ces natturalistes, avoient été partagés (Tableau des Aranéides, etc.) en lauil petites tamilles basées sur la disposition des yeux, el sur d'autres caractères pris dans les mál. choires, la lèvre et l'abdomen. M. Latrille a pro. pösé un au!re arrangement dans le Nouveau Dictionnaire d'histoire naturelle, édilion de 1819. Nous allous suivre ses divisions.

I. Les deux yeux latéraux postérieur's séparés, ainsi que les deux intermédiaires, des yeux antérieurs correspondans, par un écart très-sensible; les huit yenx disposés sur deax lignes transverses, prescu'égales et presque parallèles. Lèvie triangulaire.

A. Lèvre plus courte de moitié au moins que les mâchoires, dilatée extérieurement à sa base, avec le sommet obtus oa arrondi.

Théhidion malhignatte, Th. 13-guttatus. Latr. - Latrodecle nalmignatte. Walck. Tabl. des Aran. pag. 81. pl. 9.fig. 83. 84. -- sranea 13gutetata. Russ. Faun. Etrusc. tom. 2. pagr. 136. tah. 9. fig. 13. - FAB. Entom. Syst. toin. 2. pag. 409. Corps noir, long de près d'un centimère; a)domen globnleux, avec treize peties taches, d'un rouge de sang. C'est cctte espèce qui est connue a l'ile de Corse sous le nom de Marmignatto ou II Irmagnatto, et dont, suirant Rossi, la morsurc est nortelle pour l'hornne même. lues sudorifiques et les scarifications suffisent à peine pour faire disparoitre les graves symptônes produits par sa morsure. Ponr saisir sa proie, qui se coxpose surtout de Criquets, elle tend sur les sillons des champs différens fils, afin d'urrêter ou de gêner lenr marche: le corps ı enversé, et snspendue par les frattes de levant, elle tiro, à l'aide des postólieares, de nonveaux fils qu'elle lance très-vi!e, et par un mourement ondulutoice, sur les palles du Crirguet gqui s'est engayé daus son jriége, jusciu'à ce qu'elle l'ait garotté pour s'en approcher sans crainle. Elle le pique près du cou, ce qui le fait périr dans des convulsions violentes, ct le suce ensuite à son aisc. Si on renferme danls un vase un Criquet et une de ces Araignćes, elle re cherche pas à le mordre; inais clie s'épuise en chcrchant a l'envelopper avec les fils qu'elle lii lance, jusqu’à ce qu'elle périsse de fatigue. Ellc nx a taque point les Scorpions et les Araignées çui partagent sa captivité ; mais si l'u 'uet aves 
elle un individu de son espèce, elle l'altaque et le combat jusqu'à la uort de l'un des deux. Le cocon de cetle Aranéide est de la grandeur d'une noiselte. Quand ce Théridion est commun, un Hyménoptère du même pays cn détruil un grand nombre; cet Hyménoptère est connu dans le pays sous le nom trivial de Mouche de Saint-Jean. M. Latreille pense que c'est une espèce de $S_{p h}$ ex ou de Pompile.

B. Lèvre un peu plus courte seulement que les mâchoires, en forme de triangle presquisocèle, of pointu au somnet.

Théridion porte-triangle, Th. triangulifer: Walck. Hist. des Aran. fas. 3. pl. 5. Corps de la femelle long de sept millimètres; anus d'un brun jaunâtre; abromen globulenx; son dessus, avant la ponte, blanc ou jaune, avec deux bandes rougeâtres, longitudinales, très - anguleuses ou dentées sur leurs bords ; dessous et palles jannâtres. On trouve celle espèce à Parris, dans lcs armoires abandonnées ou rarement visitćes. Sa ponte a lieu vers le commencement de septembre, et lés œufs sont renfermés dans un cocon composé d'une soie blanche et molle, de la grossenr d'un pois el atlaché au liant de la toile par des fils d'un tissu très-clair et flasque.

II. Ycux latéraux rapprochés, mais non contigus. Les yeux des especes de celle division forment un quadrilatère Irès-alongé; ils sont porlés sur une álévation commune. Leurs mâchoires sonl cylindriques et courtes; la lèvre est large, surtour à sa base, et très-arrondie au soinu et. D'après M. Walckenaer, elles se cachent sous les picres, les champignons, etc., et formen!, pour envelopper leurs outs, un cocon sphérique, composé ciune bourre dense, compacte, uaie, midis ne formant point de lissu.

Théridion marqué, $T /$. signatum. WALck. Faun. Paris. tom. 2. pas. 209. $n^{2} \cdot 45$. Abdomen brun, avec quatre traits jaunes placés dans son contour. On le trouve aux environs de Paris. A cette division apparticut encore le Theridion abscurum du mêcue auteur.

JII. Yeux latéraux se touchant, ou géminés.

Toutes les espèces de cette division recouvrent leurs oufs d'une bourre lâche et peu serrée.

A. Lèvre presque carríe on cu forme de trian. gle élarogi à sa base et largement trunqué au bout.

* Abdomen globuleux, ou plus sphérique qu'ovalaire. Les espèces de celle subdivision habitent les licux sombres, tels que l'intérieur des maisons, des caves, ou le dessous des pierres.

t Lìve en forme de carré large.
ThérIDION CRYPTICOLE, Th. crypticolens. WaLck. Faun. 2yurs. tom. 2. pag. 207. $n^{\circ}$. 35.Tabl. des Aran. pl. 8. fig. 75. 76. Audomen d'un rouge pâle, avec des lignes noirâtres. On le trouve aus environs de Paris.

† † Lèvie en forme de triangle élargi à sa base el largement trouqué à son sommet.

ThÉRIDION A QUATRE POINTS, Th. quadripunctatum. Walck. Tabl. des Aran. pag. 73 . pl. 7 . fig. 6g. 7o. (Voyez la suite de la synonymie et la descriplion de cette espèce, au mot Araicń́z de

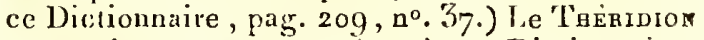
tacaeté, Aranea muculata de ce Dictionnaire, pag. $209, \mathbf{1}^{\circ} .38$, appartient aussi à celle division.

\section{* * Abdomen ovalaire.}

Ces espèces habitent les plantes, et en rapprochent les feuilles pour s'y renfermer an lenups de la ponte.

Théridion covronné, Th. redimittum. Watcr. Tabl. des Aran. pag. 73. pl. 7. fig. 67. 68. Aranea redimitta. LA T. Hist. nat. des Crust. et des Ins. tom. 7. pag 238. (Voyez la suite de la synonymie et la descriplion, article Araignée, p. 207, $\mathrm{n}^{\circ} .33$ de ce Dicionnaire.) Les Araig nées ovale el raÝ̇e du mêne Dictionnaire, pag. ₹̂ 10 et $211, n^{05} .46$ et 47 , appartiennent à cette division. La première est l'Alarignée à bande rouš de Geoffroy. D’après M. Latreille, l'Araignée se-noculée de Fabricius servit voisine de la dernière? espèce ; elle est décrite pag. $209, \mathrm{n}^{\circ} .59$ de ce: Dictionnaire.

TuÉridion bienfaisant, Th. henignum. Walck. Tabl. des Aran. pag. 77.-Hist. des Aran. fas. 5. tab. 8.-Faun. Paris. tom. 2. pag. 209. no.43.-Lister, pag. 55. tit. 15. 'Trc̀s-pelit. Curselet brun avec des poils gris a sa partie antérieure : abdouien ovale, nais élevé; fauve avec une série de taches noiles le long du milieu du dos, dont ba premic̀re grande, carrée, bordée antérieurement de poils gris, et les autres ou les postérieures transverses. (Femelle.)

Mále assez semblable à la femelle dans son premier âge, mais tıès-différent lorsquil est atlulte. Corps noir, avec les palles fauves; abdomen ovalion alongé, à poils ferrugineux et à taches peu maxquécs. Cette petite espèce est très-commune aux environs de Paris. C'est sur elle que M. Walclenace it fait les observations les plus intéressantes relativement à soll accouplement. Nous allons en donner ici l'extrait tel que M. Latreille l'a consigné daus le Nouveau Dictionnaire d'histoire naturelle, 1819 .

"Nos jartins, nos potagers, offrent très-communément, surtout en automne, celte espèce. Sa 
toile irrégulière, malgré son extrême ténuité, garantit souvent les raisins de la morsure des insectes. Il est mêwe rare que l'on serve ce fruit saus que l'animal ne s'y trouve. Il se plaît aussi à tendie des fils sur la surface des feuil!es, entre les fleurs à corymbes et à l'extrémitè do rifférens végétaux. La femelle fait trois pontes différentes en été. Son cocon est lenticularre, aplati, d'un tissu serré et d'un blanc très-éclatint.

"Les jouissances de l'amour absorbent icllement les deux sexes, que l'on peut, lorsque l'aecouplement a conmencé, détacher la feullie yai en est le théătre, observer, avec une forte loupe, celte union, sans que le couple en paroisse un instant troublé.

"L'accouplement s'effeciue le plus ordinairement sur des arbustes de nos jardins, tels que des lilas, des rosiers, etc., vers la ui-mui, et plus particulièrement dans la matinéc des jours où le temps est disposé à l'orage. Les deux sexes se recouvrent d'un tissu riare ct délié qu'ils consiruisent en commun. Le mâle, après avoir tendu quelques fils sur celle partie de la leute, oi sa femelle est placée, s'avance vers elle, lui chatouil!e, une minute ou deux, taulôt avec l'organe généraleur, tantôt avec ses denx premic̀res paltes, le dos, et la détermine enliu a sortir de l'étal imnobile et contracté où elle se tient. Elle soulève un peu son ventre; les pattes du mitle se portent aussiôt sur sa partie sexuelle et provoquent au plaisir par leur's titillitions vives te précipitées. Cédant à ces instances, la femelle se tourne sulatement vers le mâle, pose ses paltes sur son corselet, se voil soutenue par les sienues, et lui donne la facilité d'appliviuer l'extrécatté antérieure d'un de ses palpes contre l'organe sexuel propre a la femelle. Celle-ci ayant sa lête opposée à relle du mále, soutenue par quel ques fils et s'aidant d'une de ses pattes postér'seures, fät passer toutes les autres par-dessus sa tête, et les rejelle du côté opposé au palpe fécondateur qui est mis en action. Le mâle, appryé fortemeat contre la feuille, par le bout de l'abdomen, a son corselet et ses palpes relevés en l'air; les trois prenières paltes, du côté opposé à celur du palpe agissant, soutienuent la femelle, landis que la dernière, du mêtne rang, est ployée sous l'abciomen qui s'incline de ce còté; l'autre patte postérieure et le palpe mis en jeu, sont alongés et tendus; les trois autres paltes, de ce côté, s'auitent ou caressent doucewent l'abdomen de la femelle. Gependunt, lorsque le mâle a perdu son ardeur par $h_{\downarrow}$ jouissance, il arrive asse $\angle$ souvent que les deux sexes ne sout plus face á face, mais que leur's corprs sont placés parallèlement l'un à l'autre.

"Ils restent accouplés pendant deux on trois minutes, et quelquefois plus long-temps. Ia femelle se sépare la première, et alongeant ses patles sur le corselet du wâle, saute parr-dessus lii, fait quelques pas et se refourne. Celni-ci la poursuit, s'arrête à quelque distance d'elle, sa face opposée à la sienue, el cluerche encore à la retenir en tendant quelques nouveaux fils autour d'eile, qui, quelquefois, lui tourne le dos. Souvent elle se fait un rempart avec les trois prenières paires de pattes qu'elle ramasse par-dessus la tête. Le mâle en fail autant, mais de leusps à autre il étend une patte pour cliatouiller l'abdomen de sa compagne, qui se prête enfin à de nuuveanx platisirs. Cers scènes, lorsque le temps est favorable, se renouvellent jusqu'i sept ou huit fois dans l'espace de deux heures. Les anom's terminés, les deux sexes vivent tranquillement ensemble, et celle bonne union paroît être génćrale partai les Théridions, et faire une exception particulière.

• Les organes générateurs du mâle, ainsi que dans les autres Aranéides, ne se développent et ne se monlrent sous le dernier article des palpes, formant an-dessus d'eux une espèce de calotte, terminée en pointe, que dans l'état adulte et vers le temps de l'accouplement. Ils présentent un appareil de pièces compliquées, de différentes formes, rougeâtres, et çui contribuent plus on moins directement à la génération. Celles dont l'action est plus immédiale, sont : $3^{\circ}$. le pénis, qui a la forme d'un petit corps cylindrique, alongé, d'une substance rougcâtre, et termiué par une pelite pièce d'un noir très-luisant; $2^{\circ}$. un atutre corps, sanguinolent, transparent, globulaire, et qui, a a moment de l'intromission du pénis, devient trèsrouge, se gonfle à un tel point, glie son volume est cinq ou six fois plus considérable qu'il n’étoit primitivement. Les deux pénis étant insérés $1 n$ peu sur le côté intérieur des palpes et un peu terminés en dedans, représentent deux petites cornes rentrantes et inclinces l'une vers l'autre; on remarque, en untre, la convexité et le gonflement du dernier article des palpes, dont la base forme une espèce de calcile ou de ciapsule anx corps globuleux qui accorapagnent le pénis; l'action des pattes antérieures du mâle qui le serrent conre sa femelle, augmentent la pression de ces pièces, el fait que le pénis s'enfonce de plus en plus dans la partie féminine destinée à le recevoir. Un relàcliement gónéral et respectif dans les organes annonce que l'acte de la copulation est termuiné; mais il se renouvelle bientôt et jusqu'à donze fois, dans le conrt espace de trois minutes. A l'oil ura, les deax individus paroissent être, pendint tout ce temps, daus uue parfaite inmobilité, et ce n'est qu'avec une forte lompe que l'on découvre ces exercices amonreux. L'accouplement fini, les pieces dont nous avons vu le jeu, rentrent dans lu cavité qui leur est propre. "

B. Lèvre deni-circulaire.

Les espèces de cette division renferment lenrs œufs dans une enceloppe de soie d'un tissu serré, 


\section{T II I}

formant un cocon globuleux. Elles habitent les plantes et l'intérieur des_bâtimeus. Leur abdomen est globuleux et renflé à sa partie supérieure.

A cetie division appartiennent les Araigvées A NERTURES, LUNULEE et FORMOSE, pag. 210 , nos. 41,42 et 45 de ce Dictionnaire. On rapportera oncore à cette division le Théridion apHane de Walckenaer, et l'Arajgnée des morts de Rossi, qui fait son séjour dans les collections d'insectes.

(E. G. )

THIE, Thia. Léach, Latr. Cancer. Herbst. Geure de l'ordie des Décapodes, famille des Brachyures, tribu des Arqués, établi par Léach, et adopté par M. Latreille dans le Règne animal et dans les Familles naturelles du Règne animal. Ce genre peut être ainsi caractérisé : carapace tronquée postérieurement, globuleuse : antenne; latérales longues et velues : tous les pieds, à l'exception des serres, terminés en nageoires. Les Coristes sont les crustacés les plus voisins des Thies; ils s'en distinguent cependant par la forme alongrée de leur test, et surtout par le troisième article de leurs pieds-mâchoires, qui est plus long que le second, tandis que dans les Thies il e) t plus court. Les Atélécycles out les antenues exterues plus courtes que le curps, enfin les Portumnes ont les antennes simples courtes et le corps aplati. La carapace des Thies est presqu'orbiculaire avec le front avancé. Les yeux sont très-petits, à peine saillans, et conteuus dans des urbites dout le bord postérieur est sans aucune fiffure. Les antennes extérieures sout plus longues que le corps, ciliées des deux côtés, a vec le troisième article de leur pédoncule alongé et cylindrique; le troisième article des piedsmâchoires extérieurs est beaucoup plus court que Ie second, tronqué et presqu’échancré du côté interne et près de son extrénité. Les pieds de la première paire sont un peu plus longs que le corps daus les nuâles, avec les mains comprimées; ceux des autres paires ayant les tarses deux fois plus courts que les jambes, et terminés par un article aigu, sillonné et flexueux. L'abdomen du mâle a son premier arlicle trausversal, arqué et linéaice; le second un peu plus long, avec la partie antérieure un peu plus avancée en arc; le troisième beaucoup plus grrand, le quatrième presque carré et échancré au bout, et le cinquième triangulaire.

Ce genre ne comprend encore que les deux espèces suivautes :

Trie polie, Thia polita. Léace, Misc. Zool. tom. 2. pl. 103. - Cancer residuus. Herвst, tom. 3. pag. 53. tab. 48. fg. 1 ? Carapace convexe, lisse, printillée dans quel ques places, ayant sa partie antérieure, ou le tront, entière et arHist. Nat. Ins. Tome $X$.
T' $\mathrm{H} \mathrm{O}$

quée, et quatre plis peu marqués de chaque côté. On ne connoît pas sa patrie.

The de Brainville, Thia Blainvillii. Risso, Journ. de Phyf. oct. 1822. pag. 25t. Carapace globuleuse, très-glabre, luisante, d'un vert feuillemorte, finement ponctuée; firont avancé, foiblement sinueux au milieu; yeux petits, d'un rouge hyacinthe; antennes latérales longues; pinces courtes, renflées, terminées par des dents blanchâtres, les autres pattes minces, aplaties, crochues. On la trouve dans les mers de Nice.

(E. G.)

THLIPSOMYZE, Thlipsomyza. WIÉDEM. LAT. (Fam. nat.) Geure de Diplères créé par M. Wiédemann dans ses Diptera exotica, et placé par M. Latreille dans la tribu des Bombyliers, famille des Tanystomes, première section de l'ordre des Diptères. L'anteur suédois lui donne pour caractères : antennes de trois articles; le premier alongé, cylindrique; le second presque cyathiforme; le troisième pas plus long que le prewier, subulé, un peu courbe, terminé par un petit style pointu. 'Trompe avancée, alongée; cinquième nervore longitndinale des ailes n'atteignant pas le bord de l'aile; la fourche apicale réunie par une nervure de jonction avec la troisième nervure longitudinale.

Le type du genre, dont le nom vient de deux mots grees qui signifient: Mouche comprimée, est la 'Thlipsomyze comprimée, T. compressa. WIÉDE.r. Dipt. exotic. pars I. pag. 178, tab、1. fig. 4 (Bombylius compressus n ${ }^{\circ}$. 3o. Fab. Syst. Antliat.) D'Alger. Cette espèce diffère beaucoup des Bombyles; la tête est plus large que le corselet; les pattes plus grandes que celles des Bombyles; le corselet est glabre, nullement laineux et n'a que quelques poils. L'abdomen n'est pas globuleux, mais étroit et comprimé.

(S. F. et A. Serv.)

THOMISE, Thomisus. W ALck. Lat. Aranea. Linn. De Géer. Oliv. Fab. Heteropoda misumena. Lat. Genre d'Arachnides de l'ordre des Pulmonaires, famille des Arauéides, section des Dipneumones, tribu des Latérigrades, établi par M. Walckenaer et adopté par M. Latreille, qui lui assigne pour caractères essentiels : yeux au nombre de huit, formant le plus souvent, par leur réunion, un segment de cercle, ou un croissant; les deux latéraux postérieurs plus reculés en arrière, on plus rapprochés des bords latéraux du corselet que les autres. Mâchoires inclinées sur la lèvre; corps da plus grand numbre aplati, à forme de crabe, avec l'abdomen grand, arrondi ou triangulaire. Animaux pouvant marcher en tous sens, étendant leur's pattes dans toute leur longueur, lorsqu'ils sont en repos, et dont les quatre antérieures, ordinairement plus lon$\mathrm{K} \mathrm{k} \mathrm{k} \mathrm{k}$ 
gues, tantôt presqu'égales et tantôt de différentes longneurs, la seconde paire surpassant la première.

Ce genrc se distingue facilement des deux autres genres de la même tribu, les Microinmates et les Sénélopes, parce que, dans ceux-ci, les mâchoires sont droites et parallèles; d'autres caractères tirés de la position des yeux et de la longueur respective des pattes, servent aussi à les en séparer. En général, et comme l'a observé M. Walckenaer, il n'est point de genre qui soit plns facile à rcconnoîlre au premier conp d'œil, et qui soit plus difficile à caractériser d'une manière précise.

Le corps des Thomises est court, aplati, et ouvent brun ou roussâtre ; l'abdomen, dans plusieurs, s'élarģit postérieurenent et a une forme friangulaire. Les yeux sont placés sur le devant du tronc; les denx latéraux postérieurs sont souvent plus reculés en arrière que les deux intermédiaires de la même ligne, et ils forment plus ou moins un croissant ou un segment de cercle dont la courbure est tonrnée en avant; les yeux latéraux sont souvent portés sur des tubercules et plus gros; mais en général ils sont proportionnellement plus petits que dans les autres Aranéides. Les mandibules ne sont pas très-fortes; leur première pièce, dans plusicurs, n'a presque pas de dentelures et se rapproshe de la forme d'un coin; le crochct est fort pelit. Les mâchoires sont longitudinales, presque de la même largenr, mais inclinées sur la lèvre et ne laissant au-dessus d'elles qu'un vide très-petit, on le fermant entièrement. La levve est tantôt presque carrée, tantôt en ovale plus ou moins alongé, soit arrondie, soit pointue au sommet. Les palpes sont filiformes dans les fcmelles, terminés en massue ovoïde dans les mâles. Le corselet est ordinairement en forme de cœur, large, aplati ; cependant dans quelques espèces, il est élevé et tombe brusquement à sa partie antérieure. L'abdomen varie quant à ses proportions relatives; il est en général arrondi ou pyramidal; sa base s'avance sur le dos du tronc et reconvre ainsi son extrémité postérieure. Les pattes varient pour la longueur relative; dans an grand nombre, la seconde paire, et ensuite la première, sont les plus lougues; dans d'autres, la première surpasse un peu la seconde; mais alors elle est naturellement plus grosse que les autres, et que les postérieures surtout. Les Tho. mises étalent toujours leurs pattes quand elles sont en repos, et marchent ell avant, de côté ou à reculons, coinme le fout les Crabes.

Ces Arachnides ont en général le corps glabre ou très-peu velu; elles courent à terre, sur les buissons, et on les voit souvent grimper sur les arbres les plus élevés, d'où elles sc laisscnt tomber en filant une corde qui leur seit a remonter au besoin. Quand elles sont suspendues à leur fil, elles peuvent se balancer et imprimer à ce fil un mouvement en le dirigeant à volonté. Quelques petites espèces se tiennent dans les corolles des fleurs, où elles semblent être à l'affût, attendant que quelque petite monche vienne s'y poser, pour en faire leur proie. En général les Thomises ne construisent pas de toiles pour prendre leur proie; ils s'ćlancent dessus ou les poursuivent à la course. M. Walckenaer a observé que quelques espèces s'emparent de la toile abandonnée par d'autres Aranéides, et qu'elles profitent du fruit de lemrs Iravaux.

De Géer a observé que les Thomises d'Europe s'entre-dévoroient quand elles étoient réduites en captivité. Ayant mis dans un même poudrier plusieurs individus du Thomise citron, il vit bientôt leur nombre diminuer; les plus forts avoient dévoré les plus foibles, et il fut obligé de séparer cenx qui :estoient: parmi ces derniers, il se trouvoit un mâle tont différent des femelles, et Dé Géer fut témoin de l'accouplement de ces Arachnides, qui a lieu sans danger pour le mâle.

Les œufs des Thomises sont plus ou moins jaunes, quelquefuis d'une couleur de chair pâle; its sont ronds et ne sont point rénnis entr'eux par nue matière visqueuse. La mère les place dans une coque composée d'une soie blanche, très-serrée, et formant un tissu papyracé ou soyeux : ce cocon est ordinairement orbiculaire et fort aplati. La femelle ne se sépare jamais de son cocon quand elle craint pour lui ; elle le tient sous sa poitrine, et si on parvient à s'en emparer, elle ne quitte price qu'après a voir été grièvement blessée. C'est dans les fentes de murs ou du bois, sur des arbrisseaux ou entre des feuilles, que les 'Thomises placent leur cocon; elles le fixent au moyen de quelques fils. Les œuf́s éclosent vers la fin de juin ou an commencement de juillet; les petits passent l'hiver cachés sous des tas de feuilles sèches ou sous d'autres corps capables de les préserver du froid.

Le genre Tlomise se compose d'un assez grand nombre d'espèces. M. Walckenaer, dans son $T a$ bleau des Aranéides, en inentionne trente-trois, qu'il place dans clix familles, dans lesquelles if forme des coupes et des races. M. Latreille a établi dans le Nouvera Dictionnaire d'histoire naturelle, des coupes plus simples et en moins grand nombre : ce sont ces divisions que nous allons suivre ici.

I. Yeux disposés sur denx ligues parallèles, droites, très - rapproclı́es (la postérieure plus longue), l'antérieure placée toujours près du bord antérieur du tronc, ou lui étant presque. contiguë.

Les espèces de cette division sont toutes exotiques, grandes; leur's unandibules sont très-fortes, liérissées de poils et même dentées au côté interne; la lèvre se rapprocbe de la forme carríe, elle est courte dans plusieurs; les yenx sont inégaux; les intermédiaires antérieurs sont rappro- 


\section{$\mathrm{THO}$}

chés sur une petite saillie ou éminence; le corps est presque tonjours aplati, recouvert d'un duvet ; l'extrémité antérieure du tronc u'est point élevée et ne tombe pas brusquement; l'abdomen est ovale; les pattes sont longues, grêles; la seconde paire, et ensuite la première, sont ordinairenıent les plus longues.

\section{Thomise cancénide, Thomisus cancerides.}

$T$. oculis quatur anterioribus, propioribus; corpore cinereo-nigro, thorace cinereo-pallido circumdato; pedibus, ingentibus annulis ejusdem coloris.

$$
\text { . } \mathrm{s}, \mathrm{g} \text {. }
$$

WaLck. Tabl. des Aran. "pag. 29. pl. 4. fig. 29 e! 3o (les yeur et la bouche).-LAT. Nouv. Dict. d'hist. nat.

Cette espèce, dont nous avons un individu sous les yeux, est longue de près d'un pouce; son corselet est en forme de cœur renversé et tronqué aux denx extrémités; il est très-plat et tout couvert d'un duvet brun; il n'y a que le duvet des bords qui soit blanc. Les mandibules sont saillantes, assez fortes; les palpes sont de la lon nneur dn corselet, velus et terminés par un bouton ovoille. Les pattes sont brunes, annelées de griscendré ; elles sont convertes de duvet et de longs poils; leur article basilaire est couvert d'un duvet plus long et plus soyeux, d'un gris plus blanchâtre, comne celui qui borde le corselet. Jjabdomen de notre individu est à peu près de la grandeur du corselet, arrondi et aplati; on voit qu'il étoit couvert d'un duvet brun et qu'il avoit des taches ceudrées et tränverses comme les pattcs. Les pariies de cette Araiguée où les poils ne sunt pas enlevés, paroissent d'une couleur fauve-marron, qui doit étre la couleur de tout le corps.

Cette espèce a été rapportće de la nouvelle. Ilollande par Péron.

\section{Thomise de Lamarce, Thomisus Lamarcki.}

T. oculis linea antice majoribus, subcequalibus; ejusdem mediis dnobus subapproximatis, proeminentice parvo impositis; corpore cinereogriseo ; mandibulis nigricantibus; pectore, abdominis subtùs needio maculâque transversâ dorsali ad basin, fasciis pedum inferis, atris.

I.a т. Gen.Crust. et Ins. tom. 1.pag. 1 13.-Aranecs nobilis? FAB. Suppl. Entom. Syst.pag. $29 \mathrm{r}$.

Cette espèce est nn peu moins grande que la précédente; son tronc est un peu plus convexe, recouvert, ainsi que les palles, d'un duvet griscendré; celui qui garnit l'abdounen est brun. On remarque à sa base supérieure une petite bande noire en forme d'arc; le milieu du ventre est de la unême couleur, et il a antour une teinte roussàtre. Les pattes sont alongées, avec des piquans noir's et assez nombreux; la seconde paire, et en. suite la première, sont les plas longues. Le dessous des cuisses est noir à sa base, et cette couleur se divise, du côté de la jambe, en deux rangées de points; les jambes ont une bande noire près de leur origine inférieure; le duvet des tarses est obscur ; la poitriue est roussâtre. On trouve cette Araignée à l'Ile-de-France.

A cette division appartient le Thomise Plaguse de M. Walckenaer, et les Thoınises Marron, Leucosie el Chasseur, de M. Latreille.

II. Yeux placés sur une ou deux lignes courbes, foruant un segment de cercle ou un croissant.

A. La troisième paire de pattes plus longue que là quatrième.

'I'Honise Tigré, T. tigrinus. Walck. Tabl. des Aran.pag. 34. - L.A т. Gener. Crust. et Ins. tom. 1. pag. 114. - Araignée tigrée, IAs . Hist. nat. des Crust. et des Ins. tom. 7. pag. 281. pl. 62. fig. 2.-Araignée tigrée. Wácк. Faun. Paris.tom. 2. pag. 230. - Frisch, Ins. tom. 10. tab. 14. Rom. Gener. Ins. tab. 3o.fig. 5. - Panz. Faun. Germ. fas. 33. $n^{\circ} .21$ ? Voyez pour les antres synonymes el la description, l'article Araignée de (e) Dictionnaire, $n^{\circ}$. 101 .

Le Thomise flamboyant de M. Walckenaer, ou l'Araignée flamboyante de ce Dictionnaire, $n^{\circ}$. I08, appartient à cette division.

B. La troisième paire de pattes plus conrte que la quatrième (et généralement que toutes les autres).

* Seconde paire de paltes plus longue seulement que la première.

† Toutes les pattes presque de la même grosseur (alongées); yeux formant un croissant profondément échancré postérieurement, le dernier des latćraux étant très-reculé en arrière, et l'antérieur très-rapproché de l'intermédiaire correspondant de la première ligne; troncature antérieure du corselet égalant au plus la moitié de son dianètre; mandibules cylirdriques.

\section{'Thomise oblong, Thomisus oblongus.}

T. pallido-flavescens, suprà albido-yillosus, abdomine subcylindrico, lineis tribus longitudinalibus, obscuris.

Thomise oblong. Wa cck. Hist. des Aran. fors. 4. tab. 5. Tabl. des Aran. pag. 38. - L.s. Gener. Crust. et Ins. tom. 1. pag. I 12.--Araignée oblongue. Fann. Paris. tom. 2. pag. 228. - Lat. Hist. nat. des Crust. et des Ins. tom. 7. pag. 230. Muller, Zool. Danic. prodr. $n^{\circ} .2306$.

Cette espèce est longue de quatre lignes environ; son corps est étroit, alongé, d'un jaunâtre trèspâle ; ses yeux sont noirs. Le corselet est rayé longitudinalement de brun; les deux lignes du milieu $\mathrm{Kk} \mathrm{kj} 2$ 
sont larges et convergentes postérieurement. L’ab. domen est fort alongé, cylindracé, avec trois raies brunes longitudinales, dont celle du milieu plus forte, et dcs points de la même couleur, dont deux plus marqués, à sa pointe postérieure. Les pattes sont sans taches. Le mâle ressemble à la femelle. Celte Araignée est commune aux environs de Paris.

A cette division appartiennent les Thomises disparate, argenté, rhombifère, cespiticole, de M. Walckenaer, et le Thomise arlequin dc $M$. Latrei!le.

$\dagger+$ Les deux paires de paltes postérieures sensiblement ou brusquement plus grêles que les anlérieures; yeux formant un simple segment de cercle point ou peu concave postérieureunent; les quatre derniers disposés sur une ligne transverse, presque droite, ou peu arquée en arrière à ses extrémités; les latéraux peu éloignés l'un de l'autre; troncature antérieure du corselet large, plus grande quc la moilié de son plus grand diamètre transversal; mandibules en forme de coin ou rétrécies au bout, et formant, réunies, un triangle.

\section{Thomise arrondi, Thomisus rotundatus.}

T. ater, lateribus lineâ favâ introrsìm simuatâ, abdomine subtus obliquè striato, pedibus annulatis.

Thomisus rotundatus. WALck. Hist. des Aran. fas. 2. tab. 7. Faun. Paris. pag. 231. no. 89.-

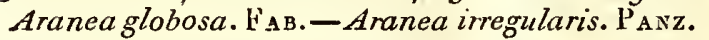
Faun. Ins. Genn. fas. 74. tab. 10.-Arunea plantigera. Rossr.

Cette eipèce est longue d'environ trois lignes; elle cst noire et luisante. Le corselet est plus élevé au milieu du dos, un peu incliné, et mêne déprimé triangulairement, à sa partie antérieure. Les yeux forment un segrment de cercle court et large, les quatre de la ligne antérieure étant presqu'en ligne droile; les latéraux sont un peu plus gros, et posés sur une légère éminence; le bandeau (I) et une partie des mandibulcs sont d'un jaunâtre brun. Dans d'autres individus, ces parties sont toutes noires, ainsi que le corps. L'abdomeu est globulaire, son dos est rouge ou jaunâtre tout autour, et son milieu offie une grande tache noire, très-découpée et divisée angulaiłement sur ses côtés; le ventre est noir, avec des lignes trausversales inclinées et rougeâlres. Les paltes sont un pcu velues; les quatre antérieures noires, avec les jambes et les tarses entrecoupés de brun et de blanc jaunâtre; les quatre dernières d'un blanc jaunâtre, avec des taches d'un brun

(1) M. Walckenaer donne ce nom à l'espace sous-oculaire, ou à l'intervalle du céphalothorax qui est entre la première ligne d'yeux er la base des mandibules. noirâtre. On trơve celte Araignée en France, en Allemagne et en Italie.

Le Thomise Diane de M. Walckenaer et l'Araignée rurale no. 100 de ce Dictionnaire, apparlienuent à cette division.

* Seconde paire de pattes de la longueur de la première, ou même un peu plus courte.

† Yeux dispersés ou point groupés sur une éminence parliculière du tronc, et formant un lar segment de cercle.

Thomise crêté, Thomisus cristatus. WVALK. Tabl. des Aran. pag. 732.-Araignée crêtée. Ibid. Faun. Paris. tom. 2, pag. 232, - LA T: Hist. nat. des Crust. et des Ins. toni. 7. pag. 286.-Araignéc jardinière. Ibid. pag. 288.

Cette espèce a été décrite dans ce Dictionnaite sous les noms d'Araignée jurdinière, no. 105 et d'Araignée huppée $1^{\circ}$. 1 10. Nous renvoyons à ces descriptions, où l'on trouvera la suile de la synonymie.

Les Thomises floricole, lynx, chargé, coupé ef rugueux de M. Walckenaer, et les Araignées hideuse ( $\left.n^{\circ} \cdot 103\right)$, cilron $\left(n^{\circ} \cdot 99\right)$, calcyne $\left(n^{\circ}\right.$. $102)$, arlequine $\left(\mathrm{n}^{\circ} .106\right)$ de ce Dictionnaire, appartienncnt aussi à cette division.

$\dagger \dagger$ Yeux groupés sur une éuninence particulière dn tronc, et formant un croissant triangrulaire. Cette division ne renferme qu'une espèce peu connue, le Thomisus malacostraceus de M. Walckenaer, Tabl. des Äran. pag. 33. pl. 4. fg. $3_{1}$ et 32 . Celte espèce est pelile et brune; ses yeux sont placés sur une éminence en forme de tubercule, et représentent un segment de cercle presque triangulaire et dont la poiute est tronquée. Péron et Lesueur l'ont rapportée de la nouvelle Hollande. (E. G.)

THORACIQUES ou STERNOXES. C'est sons ce nom que M. Duméril (Zool. analytiq.) dásigne la huitième famille de ses Coléoptères Pentamérés. Il lui donne pour caractères: élytres dures, couvrant tout le ventre; corps alongé, aplati. Antennes filiformes, souvent dentées. Corselet en pointe, ou sternum saillant. Elle se compose des genres Cébrion, Atope, 'Trosque, Taupin, Bupreste et Trachys.

$$
\text { (S. F.' et A. SERv.) }
$$

THORACIQUES, Thoracici. Troisième division de la tribu des Carabiques; celle division offre pour caraclères:

Palpes extérieurs point terminés en alène. Côté interne des jambes autérieures fortement échancré. - Extrémité postérieure des elytres entière ou simplement sinuée. - Premiers articles des deux ou des quatre tarses antérieurs des mâles, sensibiement plus larges que les suivans, 


\section{$\mathrm{THO}$}

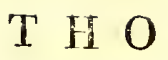

garnis en dessous de papilles ou de poils, forInant tanlôt des lignes, tanlôt une brosse serrće et continue.

Nous partagerons cette grande division, ainsi que l'a fuit M. le comte Dejean (Spéciès, tom. I.), de la manière suivante.

I. Tàrses des mâles dilatés aux pattes antérieures seulement.

A. Articles dilatés des tarses antérieurs des mâles, de forme carrée ou arrondie.Crochets des tarses point dentelés intérieurement. (Patellmanes, Patellimanus.)

a. Une dent au milien de l'échancrure du menton.

† Les deux premiers arlicles des tarses antérieurs dilatés dans les mâles.

Panagée.

$\dagger+$ Les trois premiers articles des tarses antérieurs dilatés dans les mâles.

* Dent du wilieu de l'échancrure du menton, simple.

Loricère, Calliste, Oode.

* Dent du milieu de l'échancrure du inenton, bifide.

Chlænie, Epomis, Dinode.

b. Point de dent an milieu de l'échancrure du menton.

† Mandibules pointues.

Rembe, Dicole.

t Mandibules obtuses.

Licine, Badister.

B. Articles dilatés des tarses antérieurs des unâles, en cœur ou triangulaires. ( $\mathrm{F} \dot{\mathrm{E}}-$ ronrens, Feronii. Voyez ce mot à la table alphabétique.)

II. Tarses des mâles dilatés aux pattes antérieures el intermédiaires. (Harpaliens, Harpalii. Voyez ce mot à la table alphabétique.)

LORICÉRE, Loricera. IAAt. Bonell. Dej. (Spéciès.) Carabuis. Linn. Fab. Ontr. PAтK. Panz. Schorn. Buprestis. Geofr.

Genre d'insectes de l'ordre des Coléoptc̀res, section des Pentamères, famille des Carnassiers (Terrestres), tribu des Carabiques (division des Thoraciques, subdivision des Patellimanes ).

Un groupe de cette subdivision contient les Loricères, les Callistes et les Oodes. (Voyez Patellimanes, dans cette colonne.) Les deux derniers genres se distinguent du premier par leurs autennes simples, c'est-à-dire point garnies de poils disposés presqu'en verticilles.

Antennes filiformes, plus courtes que la moitié du corps, composées de onze articles; le premier aussi grand que les trois suivans, légèrement arqué, un peu renflé, presqu'en fuseau; le second court, presqu'arrondi ; le troisiène un peu plus long, presque cylindrique; le quatrième à peu près de même forme que le second; les cinquième et sixiène un peu plus longs, grossissant un peu vers l'extrémité; les suivans presque cylindriques; le dernier légèrement ovalaire; les six premiers gar. uis de poils longs, roides, comne verticillés. Labre court, arrondi.--Mandibules très-courtes, arquées, aiguës, un peu dilatées à leur basc. Mâchoires écluancrées sur le dos, qui est unidenté. - Palpes peu saillans; leur dernier article assez alongé, presqu'ovalaire, tronqué à l'extrémité. - Mrenton assez court, légèrement concave, fortement échancré, ayant une dent simple au milieu de son échancrure. - Tếte arrondie, presque triangulaire, très-rétrécie derric̀re les yeux, tenant au corselet par une espèce de cou tic̀s-court, cylindrique, dont elle esı séparée par une impression très-marquée. - Yeux saillaus.-Corselet arrondi. - Elytres assez alongées, presque parallèles, arrondies à l'extrénité, recouvrant des ailes et l'abdomen. - Pattes assez longues; jambes antérieures ayant une échancrure assez forte à leur côté interne : tarses composés d'articles alongés, presque cylindriques; les antérienrs ayant leurs trois premiers articles très-fortement. dilatés duns les mâles; le premier presqu'en triangle; les denx suivans en carré moins long que large, dont les angles sont un peu arrondis; le quatrième bifide, beaucoup plus petit que les trois premiers. Dans les femelles, les quatre premiers urlicles des tarses anlérieurs sont presque triangulaires, un peu écbancrés à leur extrémité.

La seule espèce connue de ce genre habite en Europe dans les lienx humides et principalement sur les bords des rivières, sous les pierres et sous les herbes aquatiques rejetées par les flots; elle court très-vîte et vole très-bien dans les temps couverts et sombres.

\section{Lonicère pilicorne, L. pilicornis.}

Loricera pilicornis. DEu. Spéc. tonı. 2. pag. 293. $n^{\circ}$. 1. - Loricera cenea. Lat. Gener. Crust. et Iris. tom. 1. pag. 224. $n^{\circ}$. 1. tab. 7. fig. 5. Carabus pilicornis $\mathrm{n}^{\circ}$ 128. Ha Orrv. Entom. tom. 5. Carab. pag. 67. no. $35 . \mathrm{pl}$. I I. fig. 119.-Scern. Syn. Ins. tom. 1. pag. $19^{9 .}$ $n^{\circ} .178$. - Faun. franç. Coléopt. pl. 6. fig. 7.

Voyez pour la description et les autres synonymes, Carabe pilicorne no. 9o. de ce Dictionnaire. 
CALLISTe, Callistus. Boxer. Dej. (Spéciès.) Lat. (Fam. nat.) Carabus. Fab. Olit. Paxz. Ross. Schranck. Buprestis. Founc.

Genre d'unsecles de l'ordie des Culéoptères, section des Pentamères, fumille des Carnassiers ('lerrestres), tribu des Carabiques (division des Thoraciques, subdivision des Patel!imanes).

Dans le groupe où est placé le genre Calliste, se trouvent encore ceux de Loricicre et d'Oode. (Voyez Patellimanes, pag. 629. de ce volune.) Les Loricères se distinguent par leurs autennes hérissées de poils conme verlicillés; les Oodes par le dernier article des palpes alongé, tronqué à l'extréuité, ainsi que par la forme de leur corselet rétréci autérieurement et aussi large que les élytrơs à sa base.

Antennes filiformes, presque de la longueur de la moitié du corps, composées de onze articles, presque de nême longueur, à l'exception du second qui est moitié plus court que les autres; le premier un peu plus gros, piesqu'ovalaire; les second et troisième presque cyilindriques : tons les autres légèrement comprimés. Labre conrt, presque transversal, très-légèrement échancré. - Mandibules peu avancées, foiHlement arquées, un peu étroites, très-airuës. Palpes peu sailians; leur dernier article assez alongé, ovalaire, presque terminé en pointe. Menton assez grand, un peu concave, presque divisé en trois lobes, ayant une dent simple au milieu de son écbancrure. - Tête presque triaugulaire, un peu rétrécie postérieurement.- Yeux peu sailians. - Corselet arrondi, un peu en cœur. - Elytres en ovale assez alongé, recouvrant des ailes et l'abdomen, leur estrémité entière. Patíes de longueur moyenne; jambes antérieures assez fortement échancrées au cóté interne; tarses composés d’articles alongés, presque cylindriques : tarses antérieurs des mâles ayant leurs trois premiers arlicles très-forternent dilatés, en forme de carré dont les angles sont un peu arrondis, gurnis en desšous de poils longs et serrés, formant une espèce de brosse; le quatrième triangulaire, fortement échancré, beaucoup plus petit que les trois prewiers.

L'agréable distribntion des couleurs de la seule espece conıue a valu à ce genre la dénomination de Calliste, tirée d'un mot grec qui sigrritie : trèsbeatu. On la rencoutre ordinairement dans les bois; elle..se trouve dans toute l'Europe, mais n'est pas très-commune aux cnvirons de Paris.

\section{Caldiste lunulé, $C$. lunatus.}

Callistus lunatus, Des. Spéc. tom. 2. pag. 296. $\pi^{\circ}$. 1. - Carabus lunatus ${ }^{\circ}$. 194. FAB. Syst. Eleut. - Schur. Syn. Ins. tom. I. pag. $214 . n^{\circ}$. 263. - Faŭh. franç. Coléopt. pl. 4. fig. 2. Nlâle.
Voyez pour la description et les autres synonynes, Carabe lunulé no. 145. du présen Dictiounaire.

OODE, Oodes. Boneli. DrJ. (Spéciès.) Liat. (Fam. nat.) Harpalus. Grulen. Carabus. Fab. PAYk. PANz. SchœN.

Genre d'insectes de l'ordre des Coléoptères, section des Pentanères, famille des Carnassiers ('Terrestres), tribu des Carabiques (division des Thoraciques, subdivision des Patellimanes).

Un groupe de Patellimanes se compose des genres Loricère, Calliste et Oode. (Voyez PATElimanes, pag. 629. de ce volume.) Le premier a les antenues hérissées de poils disposés presqu'en verticilles; dans les Callistes le dernier article des palpes est ovalaire, presque pointu, el le corselet rétréci postérieurement, plus étroil que les élytres à sa base.

Antennes filiformes, un peu plus courtes que la moitié du corps, composćes de onze articles. - Labre court, presque transversal, coupé carrément ou un peu échancré à sa partie antérieure. - Mandibules peu avancées, légèrement arquées, assez aiguës. - Pulpes peu avancés, leurs articles ussez alongés, presqu'égaux; le dernier ovalealongé, tronqué à son extréuité. - Menton assez grand, un peu concave, presque trilobé, fortement écliancré, ayant une assez forte dent simple, plus on moins arrondie et obtuse, au milieu de son échancrure. - Téte presque triangulaire, un peu rétrécie postérieurement. - Corps elliptiqu. - Corselet presuju'en Irapèze, légèremeit convexe, rétréci antérieurement, et aussi large que les élytres à sa base. - Elytres assez alongées, presque parallèles, arrondies postérieurement, recouvrant des ailes et l'abdomen. - Pattes de longueur moyenne; jambes antérieures assez fortement échancrées au côté interne : tarses composés d'articles presque cylindriques et bifides à l'extrémité : tarses antérieurs des mâlex ayant leurs trois preuiers articles assez fortement dilatés; le premier trapézoïdal; les deux autres en carré dont les angles sont un peu arrondis, garnis tous trois en dessous de poils très-serrés qui forment une espèce de brosse.

Le nom de ces Carabiques est tiré d'un mot grec qui a rapport à la forme de leur corps. Un en connoît six espèces.

Io. Oode beau, O. pulcher. Des. Spéc. tom. 2. pag. $375 . n^{\circ}$. r. Indes orientales. $2^{\circ}$. Oode grand, O. grandis. DEs. id. pag. 376. $n^{\circ}$. 2. Longueut 7 lig. $\frac{3}{2}$. Noir ; élytres profondément striées, presque sillonnées; les stries très-légèrement pointillées. Indes orientales. $3^{\circ}$. Oode américain, 0 . rméricanus. $\mathrm{D}_{\bar{x}}$. id. pag. $377 \cdot n^{\circ} .3$. Longuen 6 lig. Ovale, noil brillant; élytres à stries trèsfinement pointillées; leurs intervalles très-plans. Amérique septentrionale. $4^{\circ}$. Oode liélopioids, 


\section{T $\mathrm{H} \mathrm{O}$}

O. helopinides. Des. id. pag. 378. n०. 4. - Cara-

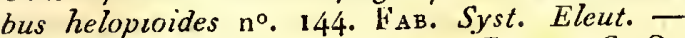
Scnas. Syn. Ins. tom. 1. pag. 203. $n^{\circ} \cdot 196$. On le trouve en France, en Suede, en Allemagne sous les pierres et sous les débris des végćtaux, dans les endroits humides. 50. Oode espagnol, O. hispanicus. Des. id. pag. 379. $n^{\circ}$. 5. Longneur 3 lig. $\frac{3}{4}$. Ovale, noir ; élyties finement striées : tarses roux. D'Espagne et peut-être des Indes orientales. $6^{\circ}$. Oude mélallique, 0 . metallicus. DEJ. $i d . n^{\circ} .6$. Longueur 3 lig. $\frac{1}{3}, 3$. lig. $\frac{3}{4}$. Corps bronzé cn dessus ; élytres fine:nent striées : paltes d'un brun noirâtre. Cayenne et Brésil.

CHL ENIE, Chlonius. Bonela. Dej. (Spéciès.) Lat. (Fam. nat.) Harpalus. GxLl. Carabus. Linn. Fab. Oliv. P'Anz. Payk. Ross.

Genre d'insectes de l'ordie des Coléoplères, section des Pentamères, famille des Carnassiers ('Terrestres), tribu des Carabiques (division des Thoraciques, subdivision des Palellimanes).

Les Chlænies font partie d'un groupe de cette subdivisión qui contient aussi les genres Epomis et Dinode. (Voyez Pateldimanes, pag. 629. de ce volume.) Les Lipomis se distinguent par le dernier article des palpes fortement sécuriforme, et les Dinodes par ce inême article des palpes court, légèrement sécuriforme.

Antennes filiformes, ordinairement à peu près de la longueur de la moitié du corps, coniposées de onze articles. - Labre assez court, presque transversal. - Palpes assez alongés; leurs articles presqu'éganx; le dernier alongé , légèrement ovalaire, tronqué à son extrćmité. - Menton assez grand, légèrement coucave, fortement échancré, ayant une dent bifide plus ou moins saillante placée au milieu de son ćchancrure. T'éte assez avancée, presque triangulaire, plus ou noins rétrécie postérieurement. - Yeux plus ou moius saillans. - Corselet ordinaireınent plus ou moins cordiforme, plus étroit que les élytres ( s'élargissant postérieurement dans quelques espères, lelles que le sulcicollis et le tomentosus). - Elytres en ovale plus ou moins alongé, recouvrant les ailes et l'abdomen, leur extrémité entière. - Pattes plus ou moins alongées; jambes antérieures assez forlemeut échancrées au côté interne; articles des tarses plus ou moins alongés, très-légètement triangulaires et bifides à l'exírémité : tarses antérieur's des mâles ayant leurs trois premier's articles très-fortement clilatés, en forme de carré dont les angles sont un peu arrondis et garnis en clessous de poils très-serrés qui forinent une espèce de brossc.

Les Chlæuies sont ordinaircment d'une couleur verte ou métallique assez brillante; ils sont fiuement ponctués et revêtus d'un léger duvet court et serré, ce qui leur a fait donner leur nom, venant d'un mot grec qui a cette signification; quelques espèces, en petit nombre, ont le corps lisse et glabre. Ils paroissent répandus sur presque toule la surface de la terre, cependant on n'en a pas encore tronvé à la nouvelle Hollande. Ces $\mathrm{Ca}$ rabigues exhalent une odeur alcaline très-forte et très-désagréable. M. le comte Dejean, de qui nous empruntons ces dćtails, eu décrit soixantesix espèces.

Nous diviserons ce genre en partie d'après les considérations employées par ce savant entomologiste.

Ire. Division. Labre coupé carrément, ou légèrement éehaneré à sa partie antérieure. Mandibules peu avancées, assez arquées. (Chlcenius propriè dictus. ов.)

jre. Subdivision. Elytres ornées de taches jannâtres.

M. le comte Dejean place dans celte subdivision les cinq espèces suivantes : $1^{\circ}$. Chlænie quadrinoté, C. quadrinotatus. De.s. Spéc. tom. 2. pag. 299. $n^{\circ}$. I. Longueur to lig. 'Tête et corselet d'un vert cuivreux brillant; corselet ponctué; élytres d'uu vert brun, pubescentes, striées; intervalles fdes stries converts de très-petits grains. Antcnnes, pattes, deux taches sur chaque élytre et leurs bords, d'un jaune pâle. Sćnégal. $2^{\circ}$. Chilænie macule, $C$. maculatus. Des. id. pag. 3oo. $n^{\circ}$. 2. Longueur 6 lig. $\frac{3}{4}$. Tèle et corselet d'un vert cuivreux, ce dernier protondément ponctué; élytres d'ua cuivreux obseur, striées : intervalles des stries très-ponclués; leurs bords de conleur jaune ainsi que deux taches placées sur chacune d'elles : pattes de celle dernière couleur. Indes orientales. $3^{\circ}$. Chlænie bimaculé, $C$. bimaculatus. DEJ. id. pag. 30I. $x^{\circ}$. 3. Longueur 5 lig. $\frac{1}{2}, 6$ lig. Tète et corselet d'un vert cuivreux; celui-ci alongé, peu ponctué ; élytres d'un brun noirâtre, ayant cbacune une tache jaune à sa partie postérieure; cuisses de celte dernière couleur. De Java. $4^{\circ}$. Chlænie binoté, C. binotatus. DEJ. id. pag. 302. $\pi^{\circ}$. 4. Longueur 5 lig. $\frac{1}{2}$. D'un brun noir ; tête verdâtre; corselet un pen arrondi, très-ponclué; élytres ayant chacune une tache fanve à sa partic postérieure; cuisses de cette même couleur. De Java. $5^{\circ}$. Chlienie bilunulé, $c^{\prime}$. bisignatus. DEJ. id. pag. 3o3. $n^{\circ}$. 5. Longueur 5 lig. 'I'cte et corselet d'un vert cuivreux, celui-ci prescqu'arrondi, ponctué; ély tres d'un brun noir un peu cuivreux, chatune ayant une lnnule janne à sa partie postérieure; paltes de cetle dernière conleur. Ilc-de-France.

$2^{e}$. Subdivision. Elytres sans taches, ilyant seuleınent une bordure janne ou une tache de celte couleur à lemr extrémilé.

Cette subdivision dans le Spéciès de M. le comte Dcjean contient vingt-deux espèces; nous cilerons les suivautes : 
I. Chlжnie velouté, C. velutinus.

Chloenius velutinus. Des. Spéc. tom. 2. pag. 308. $n^{\circ}$. 11.-Carabus murginatus. Ross. Faun. Itrusc, tom. 1. pag. 212. $n^{\circ}$. 524. (Ce synonyme est appliqué à tort par MI. Schoenlıcrr, selon Mi. le com!e Dejcan, au Carabus festivus n$^{\circ} .74$. $\mathrm{F}_{\text {Ав. }}$ Syst. Eleut. qui est aussi un (hlonius.)

Voyez pour la description, Carabe ceint n ${ }^{\circ}$. I 18 . de ce Dictionnaire. (Eu ôtant les synonymes de Fabricius, de Linné el peut-être aussi celui de Fuesly.) Cette espèce ne se trouve pas aux Indes orientales; commune dans le inidi de la France, ellc est tres-rare aux environs de Paris.

Rapportez à cette subdivision : $1^{\circ}$. Clılænie marginé, C. marginatus. DEJ. Spéc. tom. 2. pag. 3o5. $n^{\circ} .7$. Longuear 6 lig. $\frac{3}{2}$. 'Tête et corselet d'un vert cuivreux brillant; celui-ci ayant des points enfoucés, épars : élytres d'un brun verdâtrc tirant sur le cuivreux, striées; les stries finement ponctućes; leurs intervalles lisses; bords des élytres, antenues el pattes testacés. Des Indes orientales. $2^{\circ}$. Chllenie bordé, $C$. limbatus. DEJ. $i d$. pag. 306. $n^{\text {o }}$. 8. Longneur 5 lig. $\frac{1}{2}, 6$ lig. 'Tête et corselet d'un bronzé cuivreux brillant; celui-ci ayaut des puints enfoncés, épars : élytres d'un cuivrenx noirâtre, à stries profondes : leurs intervalles lisses. Antennes, paittes et bords des élytres, jaunes. Des Indes orientales. $3^{\circ}$. Cblænie sulcipenne, $C$. sulcipennis. DEJ. id. pag. 307. $n^{\circ}$. 9. Longueur 5 lig. $\frac{7}{2}, 6$ lig. $\frac{1}{2}$. Tête et corselet d'un vert bronzé brillant; celui-ci ayant des puints enfoncés, épars : élytres noirâtres, sillonnées; les intervalles des sillons, lisses. Aniennes, pattes ct bords des élytres, d'un jaune pâle. De

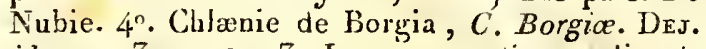
id.pag. $311, n^{\circ} .13$. Longueur 7 lig., 7 lig. $\frac{1}{3}$. 'Tête et corselet d'un vert bronzé brillant; celnici ayant des points enfoncés, épars : élytres d'un vert bronzé, pulescentes, à stries; les intervalles 'de cellies-ci irès-finement granulés; ćlýtries avec une bordure d'un jaune ferrugineux obscur : cuisses d'un brun noirâtre. Anteunes, jambes et tarses, testacés. De Sicile. $5^{\circ}$. Chlæme vitidicolle, $C$. nitidicollis. Des. id. pag. 314. $n^{0}$. 16. Longueur 5 lig. Tête et corselet d'un bronzé cuivreux brillant, celui-ci ayant des points enfoncés, peu mil'qués, épars : élytres d'un vert brun, cuivreux, à stries garnies de points peu marqués; leurs intervalles lisses; clles ont une bordure sinuée, testacée. Antennes et pattes de cetle dcrnic̀re couleur. Indes orientalcs. $6^{\circ}$. Chlanie poncticolle, $C$. puncticollis. DEJ. id. pag. 315. $n^{\circ} .17$. Longueur $4 \mathrm{lig} \cdot \frac{1}{2}$ Dessus du corps pubescent, d'un vert brun cuivreux; corselet cordiforme, chargé de points très-enfoucés : élytres ayant de fiues stries ponctuées; leurs intervalles très-finement granulés : leurs bords jaunes. Autennes et pattes de cette dernière couleur. Des Indes orientales. $7^{\circ}$. Chlærnie voisin, C. sobrinus. DEJ. id. pag. 3 it $n^{\circ}$. I 8 .

\section{T II O}

Longueur $3 \mathrm{lig} . \frac{3}{4}$. Tête d'un vert bronzé; corselet et élytres bronzés, obscurs, pubescens; celui-la cliargé de points enfoncés, profonds : élytres à stries tines et poncluées; leurs intervalles finement grauulés; leur bordure qui s'élargit postérieurement, de couleur jauné, ainsi que les an- $^{-}$ tennes et les pattes. Des Indes orientales. $8^{\circ}$. Chlæ. nie terminal, C. terminatus. Des. id. pag. 318. $n^{\circ}$. 20. Longueur 4 lig. $\frac{1}{2}, 5$ lig. Dessus du corps d'un vert obscur bronzé, pubescent. Corselet presque carré, trc̀s-ponctué ; élytres à stries un peu ponctnées; leurs intervalles finement granulés; elles ont une bordure très-nince en gćnéral, mais plus large postérieurewent, de couleur testacée. Base des antennes et pattes testacées. Du Caucase. $9^{\circ}$. Chlænie sinné, C. sinuatus. DEJ. id. pag. 32 1. $n^{\circ}$. 23. Longuenr 4 lig. $\frac{1}{2}$. Corps un peu pubescent, tête et corselet d'un vert bronzé, celui-ci presque carré, chargé de points : élytres d'un vert brun bronzé à stries un peu ponctuées; leurs intervalles très-finement ponctués, à bordure jaunâtre; celle-ci plus large postérieurement. Antennes et paltes jaunes. Des Indes orientales. $10^{\circ}$. Chlænie lunulé, $C$. lunatus. DEJ. id. pag. 325. $n^{\circ}$. 27. Longueur 5 lig. Tète et corselet d'un vert obscur bronzé, celurci ayaut des points enfoncés, épars; ély tres obscures, un peu pubescentes, $\dot{a}$ stries nn peu ponctuées : leurs intervalles chargés de points, avec une ligne arquée, placće vers l'extrémité et d'uı jaune ferrugineux. Antennes et pattes de cet:e même couleur. lle de Bourbon.

Nota. Les Carabes rural nº. 116. et marginé $\mathrm{n}^{\circ}$. 117. de ce Dictionnaire sont probablement de ce genre et de celle subdivision, à laquelle appartiennent encore les Carabus spoliatus n ${ }^{\circ} .7^{2}$. (Chlonnius spoliatus $\mathrm{n}^{\circ} .14$. DEs. Spéc.) féstivus ño. 74. (C'hlonius festivus $\mathrm{n}^{\circ}$. 12. DEJ. id.) tenuicollis $\mathrm{n}^{\circ}$. 79. (Chloenius tenuicollis $\mathrm{n}^{\mathbf{0}}$. 38 .

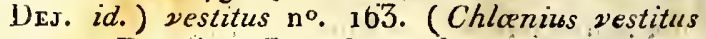
no. 22. DeJ. id.; F F . Syst. Eleut.

3e. Subdivision Elytres n'ayant ni taclies, ni bordure.

Cette subdivision renferme dans le Spéciès DEJ. trente-cinq espèces.

2. Chlanis quadricolor, C. quadricolor.

Chloenius quadricolor. Des. Spéc. tom. 2.pag. $337 . n^{\circ}$. 39. - Carabus quadricolor $\mathrm{n}^{\circ} .52$. $\mathrm{FAB}$. Syst. Eleut. - Osiv. Entom. tom. 3. Carab. pag. 77. $n^{\circ}$. 102. pl. 10. fig. 111. a. b. - Scraces. Syn.17is. iom. 1. pag. 181. no. 68.

Voyez pour la description, Carabe quadricolor $n^{\circ}$. 104. de ce Dictionnaire.

3. Chl一an soyeux, $C$. sericeus.

Chlonizus sericeus. DIs. Spéc. tom. 2. pag. 347: $n^{\circ} .47$. 


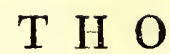

Voyez pour la description et les antres synonymes, Carabe soyeux no. 89 . du présent ouvrage.

Les espèces suivantes sont décrites comme nouvelles par M. le comte Dejean. $1^{\circ}$. Chlænie nègre, C. nigrita. DEJ. Spéc. tom. 2. pag. 327. $n^{\circ}$. 28. Longueur I 4 lig. $\frac{1}{2}$. Noir, élytres sillonuées. Du Sénégal. $2^{\circ}$. Chlæuie fémoral, C. femoratus. DEJ. id. pag. 328. $n^{\circ}$. 29. Longueur 10 lig. '. 'Tête et corselet d'un vert cuivreux; élytres noirâtres, sillonnées; chaque sillon contenant une ligne de points. Pattes nuires; cuisses ayant une large tache rousse. De Java. $3^{\circ}$. Chlınie rufipède, C. rufipes. Des. id. pag. 33 r. $n^{\circ} .32$. Longueur 6 lig. $\frac{3}{4}, 7$ lig. $\frac{1}{4}$. Corps pubescent, d'un bleu violet en dessus. 'Tête étroite, ponctuée; corselet rétréci antérieurement, chargé de points; élytres à stries fines, ponctuées : leurs intervalles tinement granulés. Antennes et pattes d'un roux ferrugineux. Amérique septentrionale. $4^{\circ}$. Chlænie coballin, C. cobaltinuls. DEJ. id. pag. 33 r. $n^{\circ} .33$. Longueur 7 lig. $\frac{1}{2}, 7$ lig. $\frac{3}{4}$. Corps pubescent. Tête ponctuée, d'un vert bronzé. Corselet de même couleur, un peu rétréci, chargé de points enfoncés. Elytres d'un bleu noirâtre à stries fines, ponctućes: leurs intervalles très-finement granulés. Antennes et pattes d'un roux ferrugmeux. Amérique septentrionale. $5^{\circ}$. Chlanie triculore, C. tricolor. Des. id. pag. 334. no. 35. Longueur 5 lig. $\frac{1}{3}, 6$ lig. Corps pubescent. Tête lisse, d'un vert bronzé un peu cuivreux. Corselet de cette même couleur, ovale, tronqué en devant et en arrière, très-ponctué; élytres d'un blcu violet, à stries ponctuées: leurs intervalles très-fiuement granulés. Antennes et pattes d'un roux ferrugineux. Amérique septentrionale, Géorgie. $0^{\circ}$. Chlænie de Cayenne, C. cayennensis. DEJ. $i d$. pag. 334. $n^{\circ}$. 36. Longueur 7 lig. $\frac{3}{4}$. Corps bleu céleste en dessus. Tête presque lisse. Corselet un peu rétréci, carré, ponctué. Elytres un peu pubescentes, à stries ponctuées : leur's intervalles ponctués. Antennes et pattes testacées. De Cayenne. $7^{\circ}$. Chlænie brillant, C. nitidulus. Des. Spec. tom. 2. pag. 341. $n^{\circ}$. 42. Longueur 5 lig. $\frac{5}{n}$. Dessus du corps d'un brun bronzé. Bords du corselet et des élytres verts : celles-ci à stries finement ponctuées : leurs intervalles ayant quelques points trèspetits, enfoncés, épars. Antennes et paltes d'un roux ferrugineux. Des Indes orientales. $8^{\circ}$. Chlænie tête brillante, $C$. nitidiceps. Des. id. pag. 342. $n^{\circ}$. 43. Longueur 5 lig. $\frac{1}{2}$. Tête d'un vert cuivreux brillant. Corselet d'un vert bronzé obscur, très-ponctué. Elytres d'un noir violâtre, à stries profondes: leurs intervalles très-linement granulés. Antennes et pattes d'un roux ferrugineux. Cap de Bonne-Espérance. $9^{\circ}$. Chlænie oblong, C. oblongus. DEs. id. pag. 344. $n^{\circ} .45$. Longueur $4 \mathrm{lig} . \frac{1}{2}$. Corps alongé, oblong, d'un vert cuivreux en dessus, pubescent; tête presque lisse; corselet alongé, peu distinctement ponc-

Hist. Nat. Ins. Tome $X$. tué ; élytres à stries : leurs intervalles pen visiblement ponctués. Antennes et pattes d'un jaune ferrugineux. De Buénos-Ayres. 10. Chlænie vertpré , C. prasinus. Dés. id. pag. 345. $n^{\circ}$. 46. Longueur $8 \mathrm{lig}$. Corps pubescent; tête d'un vert un peu bronzé; corselet de cette mêue couleur, cordiforme, un peu rétréci, ponctuć; élytres un peu alongées, vertes, à stries ponctuées : leurs intervalles finement granulés. Anus ferrugineux. Antennes el pattes jaunes. Amérique septentrionale. $11^{\circ}$. Chl renie tibial, C. tibialis. 1)EJ. id. pag. 352. $n^{\circ} .52$. Longrueur 4 lig. $\frac{3}{2}, 5$ lig. Corps pubescent; lête li se, d'un ver l bronzé ; corselet très-ponctué, d'un vert bronzé un peu cuivreux; élytres vertes, à stries un peu ponctuées : leurs intervalles très-finement granulés. Antennes ayant leurs trois preniers articles d'un ronx ferrugineux; cuisses noires, jambes d'uu testacé pẩle. D'Espagne et du midi de la France. $12^{\circ}$. Chlænie nigripède, $C$. nigripes. Des. id. pag. 353. $n^{\text {} . ~} 53$. Longueur 4 lig. $\frac{1}{2}, 5$ lig. $\frac{1}{2}$. Corps pulsescenl; Tête et corselet très-ponctués, d'un bronzé cuivreux; élytres vertes à stries fines et ponctuécs : leurs intervalles très-finement ponclués. Antennes avec leurs deux premiers articles d'un roux feror ruginenx. Paltes noires. Pyrénées orientales et Navarre. Cette espèce varie. 150. Chlænie riche, C. dives. Des. id.pag. 354. $n^{\circ}$. 54. Longuenr 5 lig. Corps pubescent; tête très-ponctuée, d'un rouge cuivreux; corselet de usême couleur, rugneux, très-ponctué; élytres vertes à stries fines et ponctuées : leurs intervalles très-finement ponctués. Antennes et paltes noires. Espague, Salamanque. I $4^{\circ}$. Chlienie tête bronzée, C. ceneocephalus. DEJ. id. pag. $362 n^{\circ} .6$ r. Longueur 4 lig. $\frac{1}{2}$. Corps pubescent; tête d'un cuivreux doré; corselet blen-de-ciel, étroit, un peu cordiforme, trèsponctué ; élytres de même couleur, striées : intervalles des stries chargés de très-petits points. Antennes et paltes d'un roux ferrugineux. Russic méridionale.

Nota. On doit placer dans cette subdivision les Carabus holosericeus no. I25. (Chlanius holosericeus no. 55. DEJ. Spéc.) et nigricornis $\mathbf{n}^{0}$. 156. (Chloenius nigricornis no. 51. DEJ. id.) Fa Syst. Eleut.

2e. Division. Labre fortement échancré. Mandibules avancées, étroites, assez droites. (Agrenter. Nов.)

Cette division renferme trois espèces dans le Spéciès de M. le comte Dejean. Les deux suivantes sont nouvelles.

$1^{\circ}$. Chlænie verdâtre, $C$. chlorvdius. Des. Spéc. tom. 2. pag. 365. $n^{0}$. 64. Longueur 5 lig. $\frac{1}{2}, 6$ lig. T'ête et corselet d'un bronzé cuivreux, poncınés; élytresun peu pubescentes, d'un noir bronzé, à stries profondes et un peu poncluées, ayant une bordure verdâtre. Antennes et pattes d'un rollx ferrugi-
Llll 
nenx. Indes orientales. $2^{\circ}$. Chlænie élégant, $C$. elegantulus. DEJ. id. pag. 367. $n^{\circ} .66$. Longueur $3 \mathrm{lig}$. $\frac{1}{2}$. Corps pubescent; tête d'un vert bronzé, ponctuée; corselet de mêrne couleur, cordiforme, ponctué ; élytres d'un noir violet, striées : intervalles des stries chargés de points. Antenues et palles d'un janne ferrugineux. Amérique septentrionale.

ÉPOMIS, Epomis. Bonelr. DeJ. (Spéciès.) Chlanius. Lat. (Fam. natur.) Carabus. Faв. SCHCEN.

Genre d'insectes de l'ordre des Coléoptères, section des Pentamères, famille des Carnassiers (Terrestres), tribu des Carabiques (division des Thoraciques, subdivision des Patellimanes).

Dans cette subdivision trois genres composent un groupe particulier, ce sont ceux de Chlænie, d'Epomis et de Dinode. (Voyez Patelinmanes, pag. 629. de ce volume.) Les (hlenies sont séparés des Epomis par le dernier article de leurs palpes un peu ovalaire, tronqué à son extrémité; et les Dinodes par ce même article des palpes court, légèrement sécuriforme.

Le genre Chlænie étant très-surchargé d'espèces, nous avons pensé que l'on pouvoit adopter celui d'Epomis, quoiqu'il n'offie qu'un seul caractère qui le différencie des Chlæuies, celui de la forme du dernier article des palpes qui est alongé et fortement sécuriforme, plus dilaté dans les mâles. Les autres caractères sont absolument les mêmes que ceux des Chlæuies (première division). Voyez ce mot, pag. 63r. de ce volume.

Les trois espèces placées dans ce genre par M. le comte Dejean sont de l'ancien continent.

$1^{\circ}$. Epomis Crosus, E. Croesus. - Carabus Crasus $\mathrm{n}^{\circ} .7 \mathrm{I}$. Fa в. Syst. Eleut. - Scgєn. Synon. Ins. tom. 1. pag. 187. $n^{\circ} \cdot 96$. De Guinée. $2^{\circ}$. Epomis circonscrit, E. circumscriptus. Des. Spéc. tom. 2. pag. 36g. $n^{\circ}$. 1. D'Italie et de Erance. Il y est rare. On le trouve anssi en Nubie. 3०. Epoinis noirâtre, E. nigricans. DEJ. id. pag. $37 \mathrm{I}$. $n^{\circ}$. 2. Des Indes orientales.

DINODE, Dinodes. Bovelu. Des. (Spéciès.) Chlonius. Lat. (Fam. nat.)

Genre d'insectes de l'ordre des Coléoptères, section des Pentamères, famille des Carnassiers ('Terrestres), tribu des Carabiques (division des "Thoraciques, subdivision des Patellimanes).

Les genres Chlænie, Epomis et Dinode sont réunis en un groupe dans la subdivision des $\mathrm{Pa}$ tellimanes. (Voyez ce mot, pag. 629. de ce volume.) Les Chlænies ont le dernier article des palpes alongé; ce même article est alongé et forlement sécuriforme dans les Epomis.

Ce geure se rapproche infiniment des deux précédens, et n'en diffère que par les caractères suivans.
Palpes moins longs; leurs articles plus courts, plus gros; le dernier légèrement sécuriforme dans les denx sexes. - Antennes un peu plus courtes; leurs huit derniers articles un peu plus gros et légèrement comprimés. - Corselet plus arrondi.

il. le comte Dejean ne mentionne que deux espèces de ce genre, $1^{\circ}$. Dinode rufipède, $D$. rufipes. DeJ. Spéc. tom. 2. pag. 372. $n^{\circ}$. 1. Midi de la France, Italie, Dalmatie, Hongrie, Russie méridionale, Cap de Bonne-Espérance. $2^{\circ}$. Dinode rotondicolle, $D$. rotundicollis. DEJ. id. pag. 373. $n^{\circ}$. 2. Longneur 5 lig. Dessus du corps d'un vert bronzé; tête ponctuće ainsi que le corselet; celui-ci presque rond; élytres à stries un peu ponctuées : leurs intervalles ponctués. Base des antennes et pattes rousses. Amérique septentrionale.

REMBE, Rembus. Lat. Dej. (Spéciès.) Carabus. НАв. Herbstr. Schan.

Genre d'insectes de l'ordie des Coléoptères, section des P'entamères, famille des Carnassiers (Terrestres), tribu des Carabiques (division des Thoraciques, subdivision des l'atellimanes).

Les Rembes et les Dicœles forment un petit groupe parmi les Patellimanes. (Voyez ce mot, pag. 629. de ce volume.) Ces deruiers diffèrent des Rembes en ce qu'ils ont le dernier article des palpes assez fortement sécuriforıne; en outre leur corselet est presqu'aussi large à sa base, que les élytres.

Antennes filiformes, plus courtes que la moitié dı corps, composées de onze articles. - Labre ccurt, assez étroit, très-fortement échancré en deni-cercle. - Mandiöules courtes, peu saillantes, très-légèrement arquées, assez larges à leur base, un peu pointues à leur extrémité. - Palpes maxillaires assez alongés; les labiaux plins courts et ayant leurs articles un peu plus gros; le dernier des uns et des antres, presqu'ovalaire, tronqué à l'extrémité. - Menton un peu concave, fortement échancré, sans dent apparente au milieu de son échancrure. - Tête presque triangnlaire, un peu rétrécie postérienremenı.-Corselet presque carré, très-légèrement en cœur, un peu plus étroit que les élytres. - Elytres assez alongées, presque parallèles, arrondies à l'exxtrémilé, recouvrant des ailes et l'abdomen. - Pattes de longueur moyenne; jambes antérieures assez fortement échancrées au côté interne; tarses conıposés d'articles alongés, presqu'en triangle, bilides à leur extrémité; tarses antérieurs des mâles ayant leurs trois premiers articles assez fortement dilatés: le premier presqu'en trapèze, les deux autres en carré dont les angles sont un pen arrondis; tous ces articles garnis en dessous de poils assez longs, formaut une espèce de brosse peu serrée.

Les Rembes connus sont des Indes orienlales. Nuus citerons, ${ }^{\circ}$. Rembe poli, $R$. politus. DEx. 


\section{$\mathrm{T} \mathrm{H} \mathrm{O}$}

Spéc. tom. 2. pag. 381. no.1. - Carabus politus no. 106. Fав. Syst. Eleut.-Scræn. Synon. Ins. tom. 1. pag. 193. $n^{\circ}$. 147. Indes orientales. Java. $2^{\circ}$. Rembe imprimé, $R$. impressus. DEJ. id. pag. 383. $n^{\circ}$. 2. - Carabus impressus $\mathbf{n}^{\circ}$. Joo. $\mathrm{F}_{\mathrm{AB}}$. Syst. Eleut. - Schen. id. no. 140.

Nota. Cet article a déjà été traité à sa lettre dans ce Dictionnaire, mais sans tous les détails nécessaires; c'est pourquoi nous le reproduisons ici.

DICCELE, Dicclus. Bonell. Dej. (Spéciès.) LAT. (Fam. nat.)

Genre d'insectes de l'ordre des Coléoptères, section des Pentamères, famille des Carn ssiers (Terrestres), tribu des Carabiques (division des 'Thoraciques, subdivision des Patellimanes).

Un groupe de Patellimanes contient les genres Rembe et Dicœle. (Voyez Patellimanes, pag. 629. de ce volume.) Les Rembes sont séparés des Dicoles par la forme du dernier article des palpes qui est presqu'ovalaire et tronqué à l'extrémité, ainsi que par la hase deleur corselet, sensiblement plus étroite que les élytres.

Antennes filiformes, tout au plus de la longuecir de la moitié du corps, composées de onze ariicles. - Labre très-étroit, peu avancé, presque carré, échincré antérieurement, ayant dans son milieu une inpression longitudinale qui le fait paroitre composé de deux parties. - Mandibules peu avancées, assez fortes, légèrement arcquées, non dentées intérieurement, pointues à l'extrémilé. - Palpes assez alonyés, leur dernier article assez fortement sécurifurme dans les deux sexes. - Menton un peu concave, forternent échancré, sans dent apparente au milien de son échancrure. - Téte ovale ou arrondie, un peu déprimée, légèrement échancrée en arc de cercle, ayant en outre à sa partie antérieure deux impressions assez fortement marquées. - Yeux ordinairement très-peu saillans. - Corselet assez grand, carré ou trapézoïdal, très-fortement échancré antérieurement pour recevoir la tête, presqu'aussi large que les élytres à sa base; cellê-ci plus ou moins échancrée. - Elytres ordinairemenı peu alongées, se rétrécissunt vers l'extrémité qui est plus ou moins arrondie, recouvrant les arles et l'abdomen. - Pattes assez fortes; jambes antérieures distinctemeut échancrées au côté inlerne; tarses composés d'articles plus ou moins alongés, presque triangulaires et bifides à l'extrémité : tarses an!érieurs des mâles ayant leur's trois premiers articles assez fortement dilatés; le premier presqu'en trapèze; les deux autres en carré dont les angles sont un pen arrondis; ces trois articles garnis en dessous de poils assez longs, formant une espèce de brosse peu serrée.

Le nom de ce geure est tiré de deux mots grecs; il désigne les deux impressions que l'on remarque sur la partie antérieure de la tête. Les espèces connues appartiennent à l'Amérique septentrionale et affectent des couleurs foncées, telles que le noir et le violet. M. le comte Dejean en décrit six espèces.

${ }^{\circ}$. Dicele clialybé, D. chalybeus. Des. Spéc. tom. 2. pag. 385. $n^{\circ}$. I. Amérique septeutrionale, Louisiane. $2^{\circ}$. Dicœle alternant, $D$. alternans. DEJ. id. pagr. 387. $n^{\circ}$. 2. Longueur 9 ling. Ovale, large, d'un noir opaque. Curselet presque carré, rétréci en devant; élytres sillonnées, avec une ligne latérale élevée; les côtes alıernativement très-finement granulées, allernativement lisses, avec quelques points enfoncés, épars. Amérique septentrionale. $3^{2}$. Dicole opaque, $D$. furvus. DEJ. id.pag. 388. $n^{\circ}$.3. Amérique septentrionale. $4^{\circ}$. Dicole simple, D. simplex. DEJ. id. pag. 389. $n^{\circ}$. 4. Longueur 7 lig. $\frac{3}{4}$. Ovale-oblong, d'un noir presqu'opaque; corselet en carré un peu alongé, un peu rétréci à sa partie antérienre; élytres striées, avec une ligne latérale élevée. Ainérique septentrionale. $5^{\circ}$. Dicœle alongé, $D$. elongatus. DEs. id. pag. 3go. $77^{\circ}$. 5. Amérique septentrionale. $6^{\circ}$. Dicœle poli, $D$. politus. DEJ. id. pag. 39 !. $n^{\circ}$. 6. Longueur 6 lig. Alongé, oblong, noir-brillant; corselet en carré alongé ; élytres à stries profondes. Amérique septentrionale.

LICINE, Licinus. Lat. Des. (Spéciés.) Carabus. Fab. Oliv. Ross. Panz. Schen. Calosoma. Scress.

Genre d'insectes de l'ordre des Coléoptères, section des Pentamères, fumille des Carnassiers (Terrestres), tribu des Carabiques (division des Thoraciques, subdivision des Patellimanes).

Ce genre avec celui de Badister forme le dernier groupe de celle subdivision. (Voyez Patellimanes, pag. 629. de ce volume.) Celui-ci diffète des Licines par le dernier arlicle de ses quatre palpes extérieurs, ovalaire, terminé presqu’en pointe, et parce que les Baditters mâles ont trois articles dilatés aux tarses antérieurs.

Antennes filifornes, à peu près de la longueur de la moitié du corps, composées de onze articles. - Labre très-court, étroit, écliaucré. Mandibules courtes, très-peu saillanles, arrondies, très-obluses, armées d'une dent asiez forte placée près de lenr extrémité. - Palpes peu alongés; les labiaux plus courts que les maxillaires externes: dernier article des quatre palpes extérieurs assez fortement sécuriforme, plus dilaté dans les mâles. - Menton assez étroit, légèrcment concave, très-fortement écliancré, sans dent au milieu de son échancrure. - Tête arrondie, presque plane, déprimée, écliancrée antérieurement en arc de cercle. - Yeux peu saillans. - Corselet ordinairement plus ou moins arrondi, quelquefois presque carré ou cordiforme, toujours fortement échancré à sa partie antérieuré pour recevoir la têle. - Elytres assez grandes, Llll 2 
assez planes, ordinairement en ovale plus ou moins alongé, recouviant l'abdomen; lcur extrémité entičre ou légèrement sinuée. - Pattes assez grandcs; jambes antérieures assez fortement échancrées au côlé interne : tarses composés d'articles presque cylindriques ou en triangle trèsalongés, bifides à leur extrémilé; tarses antérieurs des mîles ayant leurs deux premiers articles très-fortement dilatés; le premier presqu'en forme de trapèze; le second presqu'en ovale, moins long que large; ces deux articles garnis en dessous de poils longs et serrés, qui forment une espèce de brosse, et plus forternent ciliés en dedans qu'cn deliors.

Les espèces connues sont d'Europe et du nord de l'Afrique. On les tronve sous les pierres et dans les bois; elles préfèrent les terrains secs et arides. 'Tous les Licines connus sont de couleur noire.

\section{Licine agricole, L. agricola.}

Licinus agricola. LA'r. Gener. Crust. et Ins. tom. 1. pag. 200. $n^{\circ}$. 2. - DEJ. Spéc. tom. 2. pag. 394. $n^{\circ}$. 1.-Carabus agricola. OLıv. Entom. tom. 3. Carab. pag. 55. no. $64 . p l .5$. Jig. 53.

Voyez pour la descriprion, Carabe agricole no. 65 . de ce Dictionnaire.

A ce genre appartiennent eacore: $1^{\circ}$. Licine silphoide, L. silphoides. Lat. Gen. Crust. et Ins. tom. I. pag. 200. n०. 3. - DEJ, Spéc. tom. 2. pag. $394 . n^{\circ} \cdot 2 .-$ Carabus silphoides no. 109 . ГА А. Syst Eleut. - Panz. Fann. Germ. fas. 92.fig. 2. - Schoes. Syn. Ins. tom. 1. pag. $194 . n^{\circ} .154$. (Ce deruier auteur rapporte à tort à cette espece le Carabe agricole d'Olivier.) En Espagne et dans toute la France. $2^{\circ}$. Licine granulé, $L$. granulatus. DEJ. id. pag. 3g6. n०. 3. Longueur 6 lig. $\frac{3}{2}$, 7 lig. Noir; corselet arrondi, ponctuć, presque lisse dans son milieu; élytres ovales, ayant trois ligraes élevées et des stries ponctuées : leurs intervalles un peu élevés, un peu ruģueux, profondément ponctués. D’Espagne et de Portugal. 3o. licine sicilien, L. siculus. DEs. id. pag. 396. $n^{\circ}$. 4. Longuear 6 lig. $\frac{x}{2}, 7$ lig. $\frac{x}{2}$. Noir ; corselet large, court, arrondı, presque iransversal, ponctué, presque lisse dans sa partie moyenne; élytres ovales, à stries ponctuées: leurs intervalles un peu élevés, profondément ponctués. De Sicile. $4^{\circ}$. Licine brévicolle, L. brevicollis. Des. id.pag. $397 . n^{\circ}$. 5. Longueur 5 lig. $\frac{3}{4}$. Noir ; corselet court, arrondi, presque transversal, ponctué, sa partie moyeune presque lisse; élytres ovales, avec trois lignes un peu élevées, chargées de stries ponctuées: leurs intervalles un peu élevés, profondément ponctués. De Barbarie. 50. Licine égyptien, L. cegyptiacus. DEз . id.pag. 398. $n^{\circ} .6$. D'Egypte. $6^{\circ}$. Licine pelioide, $L$. peltordes. DEs. id. $n^{\circ}$. 7. De Portugal. $7^{\circ}$. Licine égal, L. aquatus. DEs. id. pag. 5̆g9. $n^{\circ} .8$. Longueur 5 lig. $\frac{1}{2}$,
6 lig. $\frac{1}{2}$. Noir ; corselet presqu'arrondi, très-ponctué; élytres ovales-oblongues, à stries ponctuées: leurs intervalles plans, très-ponctués. Des Pyrénées. Montagnes du département des Basses-Alpes. $8^{\circ}$. Licine Casside, L. cassideus. DEJ. id. pag. 400. $n^{\circ}$. 9. - Licinus eniarginatus. LAT. Gen. Crust. et Ins. tonı. 1. pag. 199. no. 1. tab. 7. fig. 8. - Carabus cassideus no. 108 . Fа в. Syst. Elcut. - Schas. Syn. Ins. toni. 1. pag. u 94. no. 152. - Carabus enlarginatıs. Ouıv. Entom. tonı. 3. Carab. pag. 55. $n^{\circ}$. 65. pl. 13. fig. $150 .-$ Scras, id. pag. 225. no. 316. - Faun. franc. Coléopt. $p l$, 4. fig. 5. Femelle. France, Allemagne, Russie nućridionale. $9^{\circ}$. Licine déprimé, L. depressus. DEJ. id. pag. 40r. no. 10.Carabus depressus. Scвєеn. id. pag. 194. $n^{\circ}$. 153. France, Allemagne, Suède, dans les bois et les montagnes, $10^{\circ}$. Licine de Holfmansegg, $I$. Hofmanseggii. DEJ. id. pag. 402. $n^{\circ}$. II. Carabus Hofmanseggii. Panz. Faun. Germ. fas. 89. fig. 5. - Calosoma Huffnianseggii. Sck๔x. id. pag. 228. $n^{\circ}$. I1. Il varie beaucoup. Dans presque toute l'Erope méridionale. $11^{\circ}$. Licine oblong, L. oblongus. DEJ. id. pag. 404. $n^{\circ}$. I 2 . Longuenr 5 lig. $\frac{\pi}{2}$. Noir ; corselet presque cordiforme, peu distinctement ponctué; élytres oblongues, à stries finement ponctuées : leurs intervalles plans, à peine ponctués. Des Basses-Alpes.

BADISTER, Badister. Clairv. Lat. (Consid. et Fam. nat.) DEJ. (Spéciès.) Amblycluzs. Gxul. Carabus. Fab. Oliv. Panz. Payk. Ross. Scaranck. Schon.

Genre d'insectes de l'ordre des Coléoptères, section des Pentamères, famille des Carnassiers (Terrestres), tribu des Carabiques (division des Thoraciques, subdivision des Patellimanes.)

Le dernier groupe de celle subdivision ne contient que deux genres, Licine et Badister. (Voyez Patellimanes, pag. 629. de ce volume.) Les palpes extérieurs des Licines sont terminés par un article distinclement sécuriforme, et dans ce genr'e les mâles ont le troisième article des tarses antérieurs simple et sans dilatation.

Antennes filiturmes, à peu près de la longneur de la moitié du corps, composées de onze articles. - Labre très-courí, étroit, ćchancré. - Mandibules courtes, très-peu saillantes, arrondies, trèsobtuses, presqu'écbancrées à l'extrémité, sans dent à la partie intérieure de cette extrémité. Palpes maxillaires externes assez alongés: leur dernier article alongé, ovalaire, terminé presqu'en pointe; les labiaux presque moilié plus courts : leur article terminal ovalaire, plins court et plus reuflé que celui des maxillaires externes, finissant presqu'cn pointe.-Menton assez étroit, légèrement concave, fortement échancré, saus denı au milieu de son échancrure. - Tête presque comme dans les Licines, arrondie, presque plane, déprimée, échancrée autérieurement en arc de 
cerele. - Ieux peu saillans. - Corselet plus ou moins cordilorme, très-échaneré anlérieurement pour recevoir la tête. - Elytres en ovale plus ou moins alongé, recouvrant des ailes et l'abdomen, leur extrémilé arrondie. - pattes de longueur moyenne; jambes antérieures échancrées au côté interne; tarses composés d'articles alongés, presque cylindriques, bifides à l'extrémitć ; tarses antérieurs des inâles ayant leurs trois premiers articles fortement dilatés; le premier presqu'ea forme de trapèze; les deux autres en carré moins long que large, leurs angles (surtout les antérieurs), très-arrondis : ces trois articles garnis en ảessous de poils issez serrés, formant une espèce de brosse et plus fortement ciliés en dedans qu'en deliors.

Le petit nombre de Badisters connus liabite en Europe. Le nom générique vient d’un mot grec et signifie : coureur. Leur corps est ordinairement varié de couleurs tranchées.

\section{Badister bipustulé, B. bipustulatus.}

Badister bipustulatus. DeJ. Spéc. tom. 2. pag. 406. $n^{\circ}$. 2. - Licinus bipustulatus. Lат. Gener. Crust. et Ins. tom. I. pag. 200. $n^{\circ}$. 4.-Canabus bipustulatus nº. 184. Faв. Syst. Eleut.. - Panz. Faun. Germ. fas. 16. fig. 3. - Sсвє . Syn. Ins. tom. ז. pag. 21 1. no. 248. - Carabus crux minor. Oriv. Entom. tom. 3. Carab. pag. 99. $n^{\circ}$. 137 . pl. 8. fig. 96. a. b.

Voyez pour la description et les autres synonymes, Carabe petite croix, $n^{\circ} .137$. du présent Dictionnaire. (En retranchant ceux de l'Entomologie d'Olivier, de linné, de Schafler et cle Devillers qui appartienuent à la Lebia crux minor L.at. et celui de Schranck qui se rapporte au Dromius quadrimaculatus BONELL.)

Rapportez en outre à ce genre, $1^{\circ}$. Badister céphalote, B. cephalotes. DEJ. Spéc. tom. 2. pag. 406. $n^{\circ}$. 1. Longueur $3 \mathrm{lig} . \frac{1}{2}, 3 \mathrm{lig} . \frac{3}{4}$. Noir; corselet de la largeur de la tête ; écusson et pattes de couleur rousse; élytres de cetıe mème couleur à leur partie antérieure : la postérieure noire avec la sulure et une tache transversale, semilunaire, commune aux deux élytres, de couleur rousse. De France. $2^{\circ}$. Badister de Knoch, B. lacertosus. Drs. id. pag. 408. $n^{\circ}$. 3. Nord de l'Allemagne. 3o, Badister bonclier, B. peltatus. DeJ. id. $z^{\circ} .4$. - Carabus peltatus. PAnz. Faun. Gem. fas. 37. fig. 20. - Scnen. Syn. Ins. tom. 1. pag. $214 . n^{\circ}$. 259. Dans presque toute l'Europe. $4^{\circ}$. Badister humćral, B. humeralis. DEJ. id.pag. 4 IO. $n^{\circ} .5$. Allemagne, France, Suisse, Italie.

$$
\text { (S. I. et A. Serv. ) }
$$

THORAX, Thorax. Le thorax, dans les animaux articulés, est cette partie de l'enveloppe extérieure ou da squelette siluće entre la tête et l'abdomen. Lor'squ'on l'examine avec quelqu'attention, on voit qu'il est formé par la réunion de plusieur's anneaux qui supportent ehacun une paire de patles. Le nombre des segmens qu'on observe au thorax varie toujours suivant les différentes classes, et quelqucfois entre chacun des ordres qu'elles renfermenl. On en compte généralement cinq dans les Crustacés, quatre dans les Arachnides et trois dans les Insecles. Nous ne connoilfous aucun animal articulé qui ait un ou dcux anneaux an thorax. Ne pouvant ici nous étendre sur l'analomie de celte partie du corps, nous renverrons au travail ex profésso sur ce sujet (1), et nous nous bornerons à l'étude générale du thorax des Inseetes.

On nomme Рrothorax (2) le premier segment, celui qui se voil en arricre de la tête; nous lui conservons en français les noms de corselct et de collier, dont M. Latreille s'est toujours servi pour le désignner.

Le deixième segment s'appelleMÉsothorax (5).

Le troisiène segment a reçu le nom de DÉт. THorax (4), mot employé à peu près dans le même sens par MM. Kirby et Latreille.

Le prothorax, le mésolhorax et le métathorax réunis constituent le thorax; la connoissance de ce dermier ne sera donc complète que lorsque nous aurons éludié séparéncnt les parties de son ensemble. 11 est toujours formé dans la série des iusectes bexapodes par ces trois segmens, bien que ceux-ci aient des proportions relatives ordinairemcnt opposées : ici c’est le mésothorax qui s'est le plus accru, là c'est le métathorax, ailleurs c'est le prothorax. Chacun d'eux, cependant, est composé des nièmes ćlćmens de parlies, et eli connoître un, c'est connoître lcs deux autres : aussi pouvons-nous énumérer tous ces élémens, et indiqucr leurs connesions, sins craindre do rencoutrer des cas parliculiers yui détruiroicnt ce que notis allons poser en principe général. En nous énonçant de cette manière, nous ne voulons cependant pas dire que les mêmes pièces se retrouvent toutes et constamment dans chaque segment; car dans ceux qui sont rudimentaires, plusieurs d'entr'elles ont une existence douteuse ou ont même disparu entièrenent; dans d'autres cas, elles sont intimement soudées el ne constiluent elu apparence qu'une senle pièce; mais nous prétendons, qu'abstraclion faite des modifications qu'entraine l'état rudimentaire ou de soudure intime,

(1) Audouin, Recherches anatomiques sur le thorax des animaux articulés: ouvrage préscncé à l'Acadrmie royale des sciences, dans la séance du 15 mai 1820 , et imprimé par décision de l'Institut dans te Recueil des mémoires des savans étrangers, et dans le Journal ayant pour titre : Annales des sciences naturelles, par MIM. Audouin, Bronguiart \& Dumas.

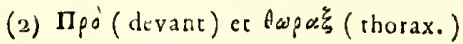

(j) Meros (milieu) et $\theta$ ap $\alpha \xi$ (thorax.)

(4) MEtá (après) es Dopaz (thorax.) 
l'anneau thoracique est composé des mêmes parties, c'est-à-dire, que s'il étoit plus développé et les pièces divisées, celles-ci seroient en même nombre et dans les rapports qu'on leur observe, lorsqu'elles se rencoutrent tontes et qu'elles sont distinctes. Nous admettons daus chaque segment une partic inférieure, deux parties latérales et une partie supélieure.

\$. Ier. Une pièce unique constitue la parlie inférieure, c'est le sternum (1). Il n'est pas pour nous une simple éminence accidentelle, ne se rencontrant que dans quelques espèces; il se retrouve dans tous les insectes et forme nne pièce à part plus ou moins développée, souvent distincte, souvent aussi intimement soudée aux pièces voisines, avec lesquelles il se confond.

Notre pièce sternale comprend donc le sternum de tous les auteurs; mais ses limites nous sont connues, et son existence démontrée dans toutes les espèces et dans chaque segment.

§. II. Les parties orủinairement latérales sont furmées de chaque côté par deux pièces principales: l'une antérieure, appuie sur le slernum et va gagner la partie supérieure, nous la nommons Episternu (2); la deuxième, que nous avons appelée Epimira (3), se soude avec la précédente et lui est postérieure; elle remonte aussi jusçu'a sa partie supérieure et repose dans certains cas suc le sternum; mais elle a en outre des rapports constans avec les hanches du segment auquel elle appartient, concourt quelquefois à former la circouférence de leur trou, et s'articule avec elles, au moyen d'une petite pièce (Trochantin) que nous croyons également inconnue, et sur laquelle nous reviendrons tout à l'heure.

Eufin il exisle une troisième pièce, en général très-peu développée, et qu'on aperçoit rarement; elle a des rapports avec l'épisternum et avec l'aile; toujours elle s'appuie sur l'épisternum, se prolonge quelquefois in térieurement le long de son bord anlérieur, ou bien, devenant libre, passe au-devant de l'aile, et se place même accidentellement au-dessus. Nous l'avions d'abord désignée sous le nom d'Hypoptère, mais son changement de posilion relativement à l'aile, nous a filit préférer celui de Paraptére (4).

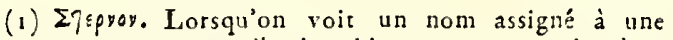
partie, on pense que celle ci est bien connue au moins daas ses limites; il n'en est pas ainsi du sternum, mot si souvent employć par tous les entomologistes. Fabricius, dans sa Philosophia entomologica, nomme S Ternem la ligne moyenne de la poitrine, très-saillante dans la Dytique, l'Hydrophile, le Taupin. C'est roujours d'une manière tresvague que les auteurs en ont parlé; ausun, a ma connois. sance, n'en a rigoureusement fixé les contours ct les rapports.

(2) $\mathrm{E} \pi i$ (sur) et б7ipyer (sternum.)

(3) Exi (sur) et pupos (cuisses.)

64) De zapo'(près de), et de $\pi \tau$ rypar (aile.)
La réunion de l'épisternum, du paraptère et de l'épimère, constitue les Flancs (pleurce) (1).

L'ensemble de la partie inférieure ei des parties latérales, c'est-à-dire la réunion du sternum et des flancs, constitue la Poirrine (pectus) (2).

A celles-ci peuvent se rattacher trois autres pièces assez imporlantes.

La première se voit au-dessus du sternum, et à sa face interne, c'est-ì-dire àl'intérieur du corps de l'insecte; elle est remarquable par l'importance de ses usages, et quelquefois par son volume. Elle est située sur la ligne médiane, et naît ordinairement de l'extrémilé postérieure du slernum; elle affecte des formes secondaires assez variées et paroît généralement divisée en deux branches. M. Cuvier l'appelle la piece en forme d'y grec, parce qu'il l'a observée daus un cas où elle tiguroit cette lettre. Nous lui appliquons le nom D'Entotrorax (3), parce qu'elle est toujours située au-dedans du thorax.

L'entothorax se rencontre conslamment dans chaque segment du thorax, et semble être, en quelque sorte, une dépendance du sternum.

Si c'étoit ici le lieu d'entretenir de ses usages, nous ferions connoitre comment il se comporte pour proléger le système nerveux, et pour l'isoler dans plusieurs cas de l'appareil digestif et du vaisseau dorsal; mais nous réservons pour un aulre travail ce sujet important, qui sera traité d'ailleurs incessamment sous un point de vue très-

(1) Kirby a employé la même dénomination, mais, selon nous, d'une manière moins précise. Il défnir les flancs : les côtés perpendiculaires du tronc. Or, il est à remarquer que ces. côtés peuvent être formés, tantốt par l'épisternum et l'épi-" mère réunis, tantôt en grande partie par le sternum, qui se prolonge laréralement; d'autres fois par la partie supèrieure qui descend jusqu'auprès de la ligne moyenne inférieure. On conçoit que dans relle ou telle de ces circonftances, les fancs comprendroient des pièces fort différentes.

La dénomination de flancs a pour nous une acception précise : chacun d'eur résulte toujours de la réunion de l'épisternum, du paraptère et de l'éfiumère, quelque positioa d'ailleurs que ces trois pièces affectent.

(3) On a appliqué le nom de poitrine à la partie inférieure des deux segmens pustéricurs du thorax réunis, er on s'est privé ainsi de l'avantage de fouvoir désigner par un nom l'ensemble du sternum et des flancs des trois anneaux du thorax, c'est-à dire l'espace compris inférieurement entre la tête et l'abdomen. J'ai pensé qu'en définissant la poirrine : l'ensemble des parties inférieurts et latérales du thorax, je déterminois rigoureusement la valeur de mon txpression, et que l'on pourroit eacore nommer poitrine la partic inférieure et latérale de chaque segment en particulier, en ayanr soin de dire la poitrine du prothorax, la poitrine du mésothorax, la poitrine du mérathorax, suivant qu'on voudroit désigner l'un ou l'aucre de ces anneaux. Je propose enfuite de donner le nom d'Araicie-poitrine à l'ensemble des parties inférieures et latérales du mésuchorax et du métathorax réunis, lorsqu'on voudra les désigner cullectivement.

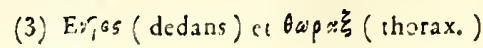


élevé par un anatomiste distingné, M. Serres, médecin de l'liospice de la Pitié (1).

L'entothorax n'existe pas senlement dans le thorax; on le retroure dans la tête, et il devient un moyen assez certain pour démontrer que celleci est composée de plusieurs segmens, comme nous l'ćtablirons plus tard. Il portera dans ce cas le nom Entocéphale; on l'observe enfin dans le premier anneau de l'abdomen (segment mé́diaire, l,atr.) de la cigale, et la pièce nommóe par Réaumur Triangle écailleux, est sans aucun doute son aualogue. Nous l'appellerons alors ENTUGASTRE.

La seconde pièce s'observe le long du bord an. térieur de l'épisternum, quelquefois du sternuzn, et mêrne à la partie supérieure du corps; elle consiste en une ouverture sligmatique, entourée d'une petite pièce souvent cornée; nous avons nommé cette pièce enveloppante Рёнттй̀e (2).

On ne rencontre pas toujours le péritréme, parce que l'ouverture stignatique est clle-même oblitérée, ou bien parce qu'il est soudé intimement aux pièces voisines; mais lorsqu'il est visible, il est bieı nécessaire de le distinguer. Sa position est importante, et devient un guide assez sûr dans la comparaison des pièces et daus la recherche des analogues.

Quant à la troisième pic̀ce, nous en avons déjà parlé en faisant connoître l'épimère; en effet, nous avons dit qu'il s'articuloit avec la rotule, au moyen d'une petite pièce inconnue jusqu'ici; cetle pièce, qui n'est pas une partie essentielle du tholax, mérite cependant que nous lui appliquions un nom, parce qu'clle accompagne l'épimère, et parce quelle se trouve associée aux parties de la patte, qui toutes ont reçu des dénominations; nous l'appellerons Troсн a rrin (3), par opposition avec Trochanter, qui désirne, comme on sait,

(r) Les observations dont il s'agit ont été faites pendant le courane de l'annce 1819 . Le résulcar le plus im. portant auquel M. Serres el moi arrivâmes alors, fut a comparaison immédiate de l'entochorax avec la verrèbre des animaux pourvus d'un squelette intérieur.

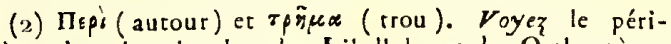
trème dans les planches des Libellules et des Orthoptères. (Mémoire des savans étrangers de l'Institut.)

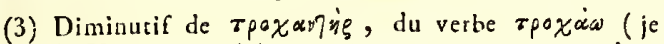
tourne). Nous avons ćté en quelque sorte contrants dans cette circonstance de nous conformer à l'usage, en appliquant à une pièce de l'enveloppe extérieure des insectes, un nom employé dans le squelette de l'homme. Le mot trochanter, si généralement adopié en entomologie, réclamoit celui de trochantin, pour désigner une pièce ordinairement plus petite, et qui est à la rotule ce que le trochanter est daus bien des cas a la cuisse. Nous ajouterons d'ailleurs que nous accordons au mot trochantin le sens vulgaire, c'est-adire celui qu'il avoit avaut qu'on ne l'appliquât à une partic apophysaire du squelette de l'homme, arec laquelle nous ne prétendons pas le comparer. une petite pièce jointe à la rotule d'une part et la cuisse de l'autre.

Le trochanlin est tanıôt caché à l'intérieur du thorax, tantôt il se montre à l'extérieul', suivant que la rolule est ou n'est point prolongée à la partie interne. Dans certains cas, il peul devenir immobile et se souder avec elle.

Ici se termine l'énumération des pièces qui concourent à former la poitrinc de chaque segment. On a pu remarquer que jusqu'ici elles n'avoient été ainsi mentionnées par aucun entomologiste.

Si donc on veut éludier anatomiquement un insecte, on doit, après aroir divisé son thorax en trois segnens, rechercher à la partie inférieure de chacuu d'enx un Sternum, et de chaque côté les flancs, composés d'un Episternum, d'uit Paraptère et d'un Eoimère. On recherchera aussi un Entolhorax, un Péritrème, un 'Trochanlin. Je dis qu'on aura à rechercher, et uon pas qu'on devra tronver toutes ces pièces dans chaque insecte. Très-souvent, en effet, leur réunion est si intime, qu'on ne peut dénontrer leur existence en isolant chacune d'elles; mais quand on a vu ailleurs la poitrine formée par un certain nombre d'élémens, il est plus rationnel de croire que dans tous les cas les mêmes matériaux sont euployés à sa formation, que de supposer sans ccsse des créations nouvelles.

On ne sauroit nier d'ailleurs que pour l'élude, il devient indispensable de grouper ainsi les phénomènes, à moins de faire cousister la science dans l'accumulation de faits épars et n'ayant entr'enx aucune liaison.

\$. III. La partie supérieure est aussi peu connue que l'inférieure. La seule pic̀ce qu'on lui ait distinguée, c'est l'écusson (1). ll est très-développé dans le mésothorax des Scutellères, rudimentaire dans celui de la plupart des Hyménoptc̀res, des Diptères, des Lépidoptères, etc. Sa position entre les deux ailes l'a fait regarder trop exclusivement comme un point d'appui dans le vol.

On a retrouvé l'écusson dans plusieurs Coléopltères et quelques autres insectes, mais on l'a méconuu ailleurs, ou bien on a indiqué comme tel des parties bien différentes; de plus, on a cru cct écusson proprc à uil seul segment du tronc, le mésothorax, tandis que nous l'avons rencontré

(t) L'emploi que l'on a fait du mot écusson est très. varié; comme on s'est atruché spécialementà la forme, on a nommé indistinctement du même nom plusieurs pièces bien différentes. Nous ne nous occuperons pas d'énumérer ici les discordances nombreuses qu'on rencontre dans la phipart des auteurs. Fabricius, dans sa Philosophie entomologique, définic l'écusson d'une manière bien vague. Il dit : Scutellum Thoraci posticè adharens, inter alas porrcctum. etc. etc. Les détinitions des auteurs plus récens ne sont guère plus exactes ni plus précises. 
quelquefois plus développé dans le métathorax, et qu'on le retrouve jusqu'à certain point dans le prothorax.

Les recherches nombreuses que nous avons faites nous ont prouvé que l'écusson ne forme pas à lui seul la partie supérieure, mais que celle-ci est composée de qualre pièces principales suuvent isolées, d'autres fois intimement soudées, ordinairement dislinctes. Nous leur avous donné des noms de rapports, c'est-à-dire basés sur leur position respective qui ae sauroit changer.

Nous conservons le nom de Scutellum (Ecusson) à la pièce qui l'a déjà reçu dans les Hémiptères, et nous rappelous l'idée d'écusson dans les nouvelles dénominations.

Ainsi nous avons nommé Prascutur (Ecu antérieur) la pièce la plus antérieure ; elle est quelquefois tres-graude et cachée ordinairement en tout ou en partie dans l'intérieur du thorax.

La seconde pièce est notre Scotum (Ecu); elle est fort importaule, souvent très-développée, et s'articule toujours avec les ailes ( 1 , lorsque celles-ci existent.

La pièce qui suit est le Scutrllum (Ecusson); elle comprend la saillie accidentelle nommée Ecusson par les entomologistes.

La quatrième pic̀ce a élé appelée PostscotelLum (Ecusson postérieur); elle est presque toujours cachée entièrement dans l'intérieur du thorax; tuntôt elle se soude à la face interne du scutellum et se confond avec lui; tuutôt elle est libre, et n'adbère aux autres pièces que par ses extrémités latérales.

'Telles sont les pièces que nous avons distinguées à la partie supérieure.

Nous avons déjà reconnu qu’il éloit nécessaire d'embrasser par un seul nom des pièces qui, ayant des rapports inlimes de développement, semblent constituer par leur réunion un même système, et se grouper pour des fonclions communes. Nous serons constaus dans cette manière de voir, uiile dans la méthode et indispensable, je crois, en anatomie.

Ainsi, nous nommerons tergum, dans chaque segment, la partie supérieure, c'est-à-dire la réunion des quatre pièces qui la composent, et nous dirons le tergum du prolhorax, le tergum du mésothorax, le tergum du métathorax, suivant que nous voudrons désigner celte partie dans tel ou tel segment du thorax; mais toutes les fois que nous emploierons seul le nom de tergum, nous prétendrons désigner tous les tergum réunis,

(1) Les petites pièces articulaires de l'aile paroissent en effer se joindre spécialement avec le scutum. Le scutellum et le postscutellum se prolongent bien aussi jusques à l'aile; mais ils n'aboutissent pas tant aux nervures principales qu'à l'expansion membraneuse qui est postérieure à ces nervures.

\section{$\mathrm{T} \mathrm{H} \mathrm{O}$}

c'est-à-dire l'espace compris entre la tête et le premier anneau de l'abdomen.

On se rappelle que nous avons appliqué le nom de Thorax à l'ensemble des trois anneaux qui suivent la tête; mais les deux derniers, c'est-àdire le mésothorax et le métathorax, paroissent plus dépendans l'un de l'autre, et tandis que le prothorax, comme on l'observe dans les Coléoptères, est très-souvent libre, il n'en est pas de même du segment moyen et du segment postérieur, qui sont toujours joints d une manière plus ou moins intime. Cette association constante a fait appliquer, comme nous l'avous dit, le nom de poitrine à leur partie inférieure. De Géer et Olivier ont proposé le mot dorsum (dos) pour leur ensemble supérieur. Nous ne croyous pas devoir adopter cette dénomination, qui nous servira dans une autre occasion ( 1 ); et de même que nous avons employé le nom d'arrière-poitrine, lorsqu'il s'est agi de dèsigner la partie inférieure, nous nommerous AnRiÉre-tergum le tergum da mésothorax et celui du métathorax considéré collectivement.

C'est une chose si importante et en même temps si diflicile de s'entendre sur de semblables matières, et ou s'est occupé si peu, jusqu’à présent, d'une notnenclature anatomique, que j'ai pensé qu'il m'étoit permis d'insister tant soit peu sur ce sujet.

Ce que j’ai déjà dit a pu faire naître le desir de voir refondre la nomenclature actuelle, pour en édifier uue sur un nouveau plan. On a sans doute senti qu'aux dénomiluations impropres de sternum, de hanche, de cuisse, de lèvres, de mâchoires, il seroit important de substituer des nonıs ou tout-à-fait insignifians, ou qui fussent fondés sur la position respective des pièces. Personne ne conçoit mieux que moi combien de tels changemens seroient profitables à la science et en activeroient les progrès; mais, quoique peu disposé à faire la moindre concession à une routine aveugle, je crois qu'll faut accorder quelque chose à l'usage, et que pour opérer une réforme dans la nomenclature d'une science, il faut attendre qu'on y soit en quelque sorte forcé par une masse d'idées acquises bien coordonnées. Or, dans l'état actuel de l'Entomologie, je ne saurois me dissimuler la témérité d'une semblable entreprise.

Pour compléter ce que nous avons à dire sur tes divisions générales du thorax, nous ajouterons quelques autres dénominations nouvelles.

(1) Nous réservons le nom de dorsum, en français dos, pour désigner toute la partie supérieure de l'animal articulé, et nous appelons ventre, venter, sa parrie inférieure. Ces dénominations seront surtout utiles dans la description zoologique des espèces : on dit vulgairemens d'un insecte qu'il est posé sur le ventre, pour indiquer la situation naturelle de tout son corps, ou qu'il est placé sur le dos, lorsque sa partie supérieure tout entière est renversée. 


\section{$\mathrm{T} \mathrm{H} \mathrm{O}$}

Nous avons parlé de l'entothorax, et nous l'avous considéré comme une pièce distincle en rapport intime avec le sternum, qui lui donne constamment naissance. Il existe en effet d'antres pièces qui lui ressemblent à certains égards, mais qui en diffèrent parce qu'elles sont accidentelles; ce sont des prolongemens, sorte de lames cornées que l'on remarque aussi à l'intérjeur du thorax, mais qui résultent toujours de la soudure de deux pièces entr'elles, ou des deux portions paires de la même pièce réunies sur la ligne moyenne. Leur présence n'est pas constante, mais lorsqu'elles existent, elles deviennent un moyen excellent pour distinguer la limite de certaines parties, qui à l'extérieur offient à peine une légère traee de soudure. Nous leur appliquons le nom général d'Apodèmes, et nous appelons apodèmes d'insertion (I), celles qui donnent ordinairenent at taclie à des muscles.

Les autres apodèmes, qui résultent aussi de la soudure de deux pièces, mais qui s'observent à leur sommet, ne servent plus à l'iusertion des museles, mais ordinairement à l'artieulation des ailes: nous les nommons apodemes articulaires ou d'ariculation.

Un caractère important des apodèmes est de naître de quelques pièces cornées, et de leur adhérer si intimement, qu'elles ne joui sent d'aucune mobilité propre et ne peuvent pas en être sépatées.

Nous avons démontré dans nos Reeherehes que ees apodèmes d'insertion se retrouvent dans les mêmes circonstances chez les Crustacés, et qu'ils constituent les lames saillantes, sorte de cloisons que l'on remarque à l'intérieur de leur thorax et qui naissent toutes des lignes de soudure des différentes pièces qui le composent.

Nous distinguons dans lintérieur du thorax de l'insecte d'autres pièces très-importantes et qui ont quelqu'analogie avec les apodèmes d'insertion, mais qui en diffèrent parce qu'elles ne naissent pas du point de réunion de deux pièces, qu'elles sont d'ailleurs plus ou moins mobiles, et constituent autant de perites parties distincles et indépendantes. Tantôt elles sont évasées à une de leurs extrémités, pédiculées à l'autre, et ressemblent assez bien an chapeau de certains champignons. De cette nature, par exemple, sont les deux pièees que Réaumur a reeonnues dans le premier segnient de l'abdomen de la Cigale, et quil nomme ou plutôt qu'il définit les plaques cartilagineuses. Plusicurs observatenrs les ont reeonnues à l'intérieur du thorax : nous leur appliquons la

(I) Azó (de) et jefece (lien), c’est-à-dire qui doir sa naissance à la soudure, ou au lien qui unit deux ou plusieurs pièces.

Hist. Nat. Ins. Tome $X$. dénomination générale d'épidème (1). Tantôt elles ont la forme de petites lamelles donnant aussi attaeke ì des muscles et jouissant d'une très-grande mobilité. Plusieurs auteurs en ont également fait mention.

Quelque forme que ces pièces affectent, nous leur appliquons alors le nom d'épidème d'insertion.

Nous nommons au contraire épidènes d'articulation, toutes ces petites pièees mobiles, sorte d'osselets articulaires que l'on reneontre à la base des ailes, nous réservant d'appliquer à elaeune d'elles un nom partieulier. Elles ne servent plus à l'atlaehe des muscles, mais à celle des appendiees supérieurs, et le nom d'épidèmes peut leur convenir eneore à quelques égards.

Lorsqne nous traiterons ailleurs de la formation de chaque pièce du squelelte, nous appuierons davantage sur ces parties très-curicuses.

Il esi une autre distinction que nous croyons utile d'établir.

Lorsqu'on a séparé le thorax de la tête et de l'abdomen, et divisé le premier en trois seginens, il en résulie des trous limités par la cireonférence de ehaque arceau.

La tête offre antérieurement nn orifice, on pourroit le nommer orifice buccal; celui qu'on remarque postérieurement s'appelleroit onfice occipital.

Le prothorax préseute un trou, on le nommeroit trou pharyngien, on appelleroit celui du mésolhorax trou cesophagien, et celui du mélathorax trou stomacal. Suivant ensuite que l'on voudra désigner le diamètre antérieur ou postćrienr de chacun de ees trous, on emploierit le mot orifice, et l'on dira l'orifice pharyngien antérieur ou postéricur, l'orifice cesophagien antéricur. ou postérieur, elc.

Ces dénominations sont-elles futiles et de peu d'importanee? je ne le pense pas. Elles nous seront d'un grand seeours, lorsqu'étudiant dans un Mémoire ad hoc les trous et les cavités, nous démontrerons que certaines lois qui président it la formation du squelette des animaux vertébrés (2), s'observent aussi dans les inseetes; que, par exemple, les trous, les cavités, résultent constamment de la réunion de plusieurs parties; que chaque pièee est divisée sur la ligne moyenne du corps en deux portions égales; qu'il n'existe aucune pièce impaire, en un not que la loi de symétrie, de conjugaison, celle relative aux eavités, se retrouvent tout aussi constamment dans les animaux articulés que dans les vertébrés; tant il est vrai que, dans des cireonstances que l'on considere comme éloignées (le squelette des

(1) Ezi (sur) et dipu (lien), c'est-à-dire qui s'apquie sur le point de soudure d'une ou de plusicurs pièces, ou qui est adhérent à un muscle, à une pièce cornée, er érablit ainsi un lien entr'eux.

(2) Voyez l'ouvrage de M. Serres sur l'ostéologie.

$\mathrm{M} \mathrm{m} \mathrm{m} \mathrm{m}$ 
vertébrés et celui des invertébrés), la nature, pour arriver à un but aualogue, sait employer les mêrnes moycns.

Ce que j’ai dit jusqu'ici a dû être saisi facilement de tout le monde, et sans observer très-minutieusenent la nature, on a pu prendre une idée satisfaisante de la composition du squelette, et du thorax en particulier. Qaiconque ne s'en tient qu'aux résultats principaux d'un trävail et se contente de notions générales, peut se borner à l'énoncé que je viens de présenter ; il lui suffit de se rappeler que, dans tous les insectes, le thorax est divisé en trois segmens; que cliacun d'eux est composé inférieurement d'un sternum et d'un entothorax, latéraleinent d'un péritrème, d'un parap. tère, d'un épisternum et d'un épimère ; supérieurement d'un præscutum, d'un sculum, d'un scutellum et d'un postscutellum; il lui suffit, dis-je, de se rappeler toutes ces choscs pour se firurcr exactement le coffire pcctoral cliez les insccics. Le thorax des Arachnides ct celui des Crustacés sont beaucoup plus simples. Les rechcrches de M. Audouin étant encore inédites, nous n'auticiperons pas sur leurs résultats; elles seront présentées incessamment à l'Académie des sciences.

(AUDOUIN.)

\section{LAT.}

THRIPS, Thrips. Linn. Geoff. De Géer. Fab.

Genre d'infectes de l'ordre des IIémiptères, section des Homoptères, famille des Hyménélytres, tribu des 'Thripsides.

Ce genre forme seul la tribu des Thripsides. Voyez ce mot.

Antennes insérées au-devant des yeux, rapprochées, presque sétacées, à peu près de la longneur de la tête et du corselet pris énsemble, composées de huit articles; le premier court, le second et les suivans jusques et compris le septième, obconiques; les deraiers de ccux-ci plus petits que les précédens; le liuitième le plus petit de tous, aigu. - Bec partant de la base inférieure de la tête, très-petit, déprimé, conique, horizontal, composé d'une gaine à deux valves triarticulées, entre lesquelles est placé le suçoir. - Labre alongé, linéaire, un peu conique, recouvrant presqu'entièrement la gaine du bec. Palpes très-courts, filiformes, de trois articles; les deux premiers très-courts; le troisième alongé, cylindrique. - Tête déprimée, en carré long. Corps linéaire, étroit, déprimé, terminé postérieurement en pointe, formant une sorte de queue. - Corselet ayant son segment antérieur apparent, très-yrand, composant presqu'à lui senl tout le corselet, déprimé, presque trapézoïdal : second segment apparent, très-court, tränsversal, linćaire. - Ecuffon triangulaire. - Elytres et ailes presque nuembraneuses, à pell près semblables entr'elles, linéaires, cilićes sur leurs bords, étendues horizontalement sur l'abdomen. - Abdo- men en triangle alongé, conique postérieurement. - Pattes courtes; cuisses antérieures beaucoup plus grande; que les autres; tar'ses très-courts, composés de deux articles; le dernier vésiculeux, sans crochets.

Le nom de Thrips éloit appliqué par les Grees à une larve vermiforme qui habitoit dans le bois. Les 'Tlurips, dans l'acception des modernes, vivent $\mathrm{fnr}$ les fleurs, les plantes, \& sons l'écorce des arbres, dans leurs premiers états ainsi que sous leur forme parfaite. Les espèces les plus grandes n'out guère plus d'une ligne de longueur; elies sont d'une agilité extrêrne et semblent plutôt sauter que voler; lorsqu'on les inquiète, elles relèvent et courbent en arc l'extrémité de leur corps à la manière des Brachélytres. (Staphylinus. Lins.)

$1^{\circ}$. Thrips noir, T. physapus LAт. Gener. Cruft. et Inf. tom. 5. pag. 172. $n^{\circ}$. 1. $2^{\circ}$. 'Thrifs du Génévricr, T. juniperina. $n^{\circ}$. 4. FАв. Syjt. Rhyng. II vit dans les galles \& les boutons en fleurs du Génévrier. $3^{\circ}$. Thirips fascié, T. fascia$t a, n^{\ominus} \cdot 7 \cdot \mathrm{F}_{\mathrm{AB}} . i d$. sur les fleurs composées. Ces trois espèces sont fort communes aux euvirons de Paris.

Fabricius cite encore dans son $S y f$. Rhyng. cinq autres espèces, qui peuveut être effectivewent de ce gente. (S. F. et A. SERv.)

'THRIPSIDES, Physapi. Seconde uibu de la famille des Hynénélytres, section des Homoptćres, ordre des Hlémiptères. Elle a pour caractères : Antennes composées de huit articles. - Elytres et ciiles linéaires, frangées, conchées parallèleunent sur le corps. - Second article des tarses remplacé par une vésicule, sans cruchets. - Métamorphoses iucomplìtes. - Bec accompagné de petits palpes. - Prothorax grand.

Cette tribu ue renferme que le genre Thrips.

(S. F. et A. Serv.)

THROSQUE, Throscus. Lat. Elater. Linv. Geoff. Oliv. (Entom.) Dermefles Fab. Payk. Panz. Trixagus. Kug. Grluen. Schen.

Genre d'insectes de l'ordre des Coléoptères, section des Pentamères, famille des Serricornes (division des Sternoxes), tribu des Elatérides.

Ce genre forme a lni seul une coupe particulière dans sa tribu; tous les autres Elatérides ayant leurs antennes filiformes ou sétacées, point teruinées en unc massue perfoliée.

Antennes composées de onze articles; les deux premiers un peu plus lougs que les suivans, le premier plus long que le second, presque cylindrique; le second globuleux; le troisième tet les suivans, jusqu'au huitième inclusivement, trèspetits, égaux, graniformes; les trois derniers grauds, dilatés à leur côté iuterne et formant une inassue ovale, deulée en scie, qui se loge, lor's dı repos, dans une cavité du dessous des any les pos- 


\section{T II Y}

térieurs du corselet; le dernier article aigu à son extrémité, le dixième plus court que les autres de la massue. - Mandibules cornées, fortes, presque trigones, angulenfes, leur dos arqué, leur pointe en croct.et aigu, entier. - Mâchoi. res composées de deux lobes membraneux, l'externe plus grand, obtus; l'interne petit, en dent aiguë. - Palpes lrès-courts, terminés en nuassue; leur dernier article sécuriforme; les maxillaires un peu plus longs que les labiaux. - Lèvre membraneufe, presqu'échancrée; menton coriace, assez grand, trausverfal; fon bord supérienr se prolongeant dans son milien en une dent ai nuë. - Tćte enfoncée jusqu'aux yeux dans le corselet. - Corps elliptique, déprimé, étroit. - Corselet presque trapézordal, s'élargissant insensiblement depuis là tête jusqu'ì la base des élytres, sans rebords, lobé postérieurement et terminé dans cette partie par des angles aigus. - Sternum terminé antérienrement par une carène presque demi-cylindrique, obtuse à sa partie postérieure qui entre dans lat cavité pectorale. - Ecusson pelit, transversal. - Elyties alongées, étroites, rebordées, recouvrant des ailes el l'abdomen. Abdomem alongé, linéaire. - Pattes courtcs, comprinées, contractiles; jambes presque cylindriques, un peu comprimées, plus étroites a leur lase; lenrs épines terminales très-petites; tarses grêles.

La seule espèce connue de ce genre est petite et se trouve sur diverses plantes. Suivant MI. Latreille, elle saule à la manière des 'Taupins. C'est le 'Throl'que dermestoïde, T' dermestoides Lat. Gener. Crust. et Irts. tom. 2. pag. 37. $7^{\circ}$. 1. Elater dernestoides Livn. Syst. nat. 2. 636. 38. - Trixagus adstrictor Schen. Syn. Ins. tom. 2. pag. $96 . n^{\circ}$. 1. Il habite les lieàx ombragés, plantés de chênes. Suivant l'obsêrvation de M. Hellwiy, il subit ses métamorphoses dans le bois de cet arbre. M. le Comle Dejean l'a trouvé en Espagure. Il n'est pas très-commun aux environs de Paris. (S. F. et A. Serv.)

THYMALE, Thymalus. LAt. Des. (Catal.) Peltis. Kug. Payk. liab. Dej. (Catal.) Schen. Caflida. Oriv. (Encycl.) Panz. Ross. Silpha Linn. Fab. Oli.

Geare d'insectes de l'ordre des Coléoptères, seciion des Pentamères, famille des Clavicormes, tribu des Peltordes.

M. Latreille ayant travaillé récemment cette tribu dans ses Famulles naturelles pour y introduire de nouvelles coupes géuériques, uous allons eu présenter ici le tableau. (L'article Peltoìdes a déjà été traité à sa lettre daus ce Dictionnaire, d'après les anciens ouvrages de cel auteur.)

PELTOÏDES, Peltoides. Seconde tribu de la fa nille des Clavicornes, section des Pentameres, ordie des Coléoptères : ses caractères sont :
Pattes point contractiles, séparées à leur insertion par des intervalles à pen près égaux; jambes antérieures sans dents, n'offiant au plus que des cils ou de petites épines. - Mandibules comprimées, alongées, terminées en pointe fortc, entière ou bifide. - Corps soit oblong, soit ovale et déprimé, quelquefois hémisphérique, généralement peu garni de poils, quelquefois recouvert d'un duvet plas aboodant: dessous des premiers articles des tarses garni de brosses dans ce dernier cas. - Tête rarement dégagée du corseiet \& alors plus large que lui, le plus souvent enfoncée dans une échancrure de cetlc partie du corps, ou inclinée sous elle. - Palpes maxillaires plus courts que la tête, ne faisant point de saillie remarquable. - Abdomen n'étant pas de formc ovalaire, ni embrassé iotérieurement par lcs élytres.

I. Palpes maxillaires filiformes ou plus gros à leur extrémité, point terminés en manière d'alène.

A. Extrémilé des mandibules entière, c'està-dire sans fissure.

a. Autennes en massue solide. Sphérite.

b. Antennes en massue composée d'articles distincts les uns des autres.

† Elytres toujours tronquées. - Tête mesurée postérieurement ou dans sa plus grande largeur, guère plus érroite que l'estrémité antérieure du corselet \& séparée de lui par ua étranglcment bien prononcé, forurant une espèce de cou.

Nécrophore, Nécrode.

$\dagger †$ Elytres point tronquées dans la plapart.-Tèie beaucoup plus étroite que le corselet, point ou foiblement resserrée postérieurement.

Bouclier, Agyrte.

B. Extrémité des mandibules fendue ou bidentée.

a. Corps n'ayant point simultanément une forme naviculaire ou elliptique avec les deux extrémités rérrécies en poin. te. (Antennes point terminées pirr cinq articles plus gros \& globuleux.Elytres point tronquées. - Pattes ni lougunes ai grêles.)

$\dagger$ Missue des anlennes fornéc an moins de deux articles et point logrée dıns des cavités de corselet.

* Massue des antennes toujours for. $\mathrm{M}$ เ $\mathrm{mm} 2$ 


\section{T H Y}

mée brusquement, ovale ou arrondie, peu alongée, de deux ou trois articles. - Elytres recouvrant entic̀rement ou presçu'entièrement l'abdomen. Corpssoit presqu'hémisphérique, soit en ovale court, clypéiforme. - Corselet presque demi-circulaire, fortement échancré en devant pour recevoir la tête.

Thymale, Colobique, Strongyle, Nitidule.

* * Massue des antennes alongée dans plusieur's qui out les élytres courtes et tronquées. - Corps oblong ou ovale. - Corselet presque carré ou en trapèze; droit ou un peu concave en devant, guère plus large que la tête.

I Elytres de plusieurs courtes et tronquées. - Tarses ne paroissant avoir que quatre articles, le pénultième étant court et enchâssé dans les lobes du troisième : celui-ci et les deux premiers très-garnis de brosses en dessous, courts et larges. - Nassue des antennes généralement brusque et grande.

$\Lambda$. Elytres tronquées. Extrémité postérieure de l'abdomen, nue.

Ips, Cerque.

$\Lambda \Lambda$. Elytres arrondies postérieurement, recouvrant entièrement l'abdomen.

Dacné, Byture.

\ Elytres toujours arrondies postćrieurement, recouvrant elltièrement l'abdomen. - Tarses grêles, filiformes, à cinq articles distincts, également découverts, sans brosses en dessous. - Antenues généralement presque grenues; leurs trois derniers articles plus grands, formant une massue alongée.

Antlıérophage, Cryptophage.

$\dagger \dagger$ Massue des antennes d'un senl article, logée dans des cavités particulières du corselet.

Micropèple.

b. Corps naviculaire, rétréci et pointu aux

\section{$\mathrm{T} \mathrm{H} \mathrm{Y}$}

deux bouts. - Antennes terminées par cinq articles globuleux, formant la massue. - Elytres tronquées. Scaphidie.

II. Palpes maxillaires alongćs, terminés brusquement en alc̀ne. (Corps ovalearqué. - Tête basse. - Massıe des antennes alongée, de cinq articles.)

Cholève, Mylœque.

Nota. Ce tableau est extrait des Familles naturelles. LAT.

Un groupe de cette tribu renferme avec le genre Thymale, ceux de Colobique, Strongyle et Nitidule. (Voyez le tableau ci-dessus.) Les deux derniers ont les trois premiers articles des tarses antéricurs courts, larges, dilatés; les mandibules des Colobiques sont recouvertes et cachées par un avancement de l'extrénitć antérieure de la tête.

Antennes composées de onze articles, le troisic̀me aussi long que le suivant; les trois derniers dislincts, formant une massue compriméc, presqu'ovale, évidemment perfoliée; les deux premiers articles de cette massue transversaux, arrondis; le dernier plus grand, ovale-orbiculaire.-Bouche découverte,-MIandibules avancées, proéminentes, bifides à l'extrémité. -Mâchoires composées de deux lobes; l'extérieur court, presque trigone, courbé en dedans, cilié à son extrémité; l'intérieur formant un onglet corné et arqué. - Palpes ayant leur dernier article plus épais que les précédens, presquovale. - Lèvre coriace, presque carrée, plus étroite que le menton, entière; son bord supérieur cilié : menton en carré transversal. - Téte beaucoup plus étroite que le corselet, enfoncée dans cette partie du corps. - Corps elliptique, ses extrémités arrondies. - Corselet presque demi-circulaire, fortement échancré en devant pour recevoir le tête. - Ecusson transversal, presque triangulaire. Elytres point tronquées, recouvrant entièrement l'abdomen et les ailes. - Pattes de longueur moyenne, assez fortes; tarses ayant leurs trois premiers articles sans dilatation, point bifides, le quatrième quelquefois très-petit, peu visibIe; le dernier plus grand que les quatre autres pris ensemble, terminé par deux crochets.

Les Thymales vivent dans le bois, sous la forme de larves. On les trouve à l'état parfait sur les arbres morts ou sous les écorces.

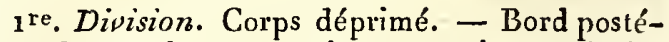
rieur du corselet un peu sinueux, point demi-circulaire. (Pelíidion Noв. Peltis Des. Catal.)

1. Thymale gros, $T$. grossus.

Thymalus lunatus. Lat. Nouv. Dict. d'Hist. nat. $2^{\mathrm{e}}$. édit. - Peltis grossa. no. I. FAB. Syst. 


\section{$\mathrm{T} \mathrm{H} \mathrm{Y}$}

Eleut. - Scnळx. Syn. Ins, tom. 2. pag. 182. $n^{\text {o. }} \mathbf{I}$.

Voyez pour la description et les autres synonymes, Bouclier écliancré, $n^{\circ}$. I 4. $p l$. 165. fig. 7 . de ce Dictionnaire.

2. Thy male ferrugineux, $T$. ferrugineus.

Thymalus ferrugineus. LAt. Gener. Crust, et Ins. tom. 2. pag. 9. $n^{\circ}$. I. - Peltis ferruginea, $n^{\circ}$. 2. F $\mathrm{AB}$. id. - Scute. tom. 2. pag. 132. $n^{\circ} .2$.

Voyez pour la description et les autres synonymes, Bouclier ferrugineux, $n^{\circ}$. 22. pl. 165. fig. 13. et pl. 35g. fg. 22. de ce Dictionnaire.

\section{Thymare denté, $T$. dentatus.}

Thymalus dentatus. LAт. Nouv. Dict. d'hist. nat, $2^{\mathrm{e}}$. édit. - Silpha dentata $\mathrm{n}^{\circ} .22$. HА а. Syst. Eleut. - Peltis dentata. Scнеn. Syn. Ins. tom. 2. pag. 131. $n^{\circ} .5$.

Voyez pour la description et les autres synonymes, Bouclier denté no. 24. de ce Dictionnaire.

\section{Thymale oblong, T. oblongus.}

Peltis oblonga no. 3. Fав. id. - Schen. id. pag. 133. $n^{\circ} .3$.

Toyez pour la description et les antres synonymes, Bouclier oblong no. 23. pl. 165. fig. 14. et $p l .359 . f g .23$. de ce Dictionnaire.

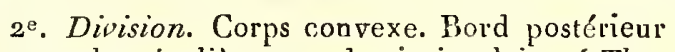
du corselet régulièrement demi-circulaire. ( Thymalus propriè dictus. Nов.)

\section{Thymale bordé, T. limbbatus.}

Thymalus limbatus. Lıт. Nouv. Dict. d'list. nat. $2^{\ominus}$. édit. - Pelitis limbata no. 4. Fав. Syst. Eleut. - Sceøn. Syn. Ins. tom. 2. pag. 134. $71^{\circ} .6$. - Cassida. Oriv. Entom. tom. 6. pl. 1. fig. 15.

Voyez pour la decription et les autres synonymes, deux espèces qu'il fant réunil en une seule, savoir : Casside brune $n^{\circ}$. I I. et Casside bordée $n^{\circ}$. 12. du présent Dictionnaire.

Nota. M. Schœuherr décrit ainsi une nouvelle espéce de ce genre, qu'il nomme Pellis rugosa, Syn. Ins. tom. 2. pag. 133. $n^{\circ}$. 4. Longueur 3 lig. Corps oblong, rugneux, convexe en dessus; entièrement brun. Bords de la tête et dı corselet roussâtıes; élytres striées, réticulćes. De SierraLéon. Cette espèce nous paroît apparteuir à cette division. (S. F. et A. SERV.)

THYNNE, Thynnils. FAB. LAT. JUR.

Genre d'insectes de l'ordre des Hyménoptères, section des Porte-aiguillon, famille des Fouisseur's, tribu des Sapygites.

Les genies Scotæne et Polochre forment un groupe dans cetle tribu avec les Thynnes. Le prenier differe de ceux-ci par le corps liuéaire et par l'abdomen ovale, plus érroit à sat base que dans son miliea; et les Polochres par leurs yeux échancrés el réniformes.

Antennes presque sétacées, grêles, composées de douze articles dans les femelles, de treize dans les mâles; elles sont droites et de la longueur de la tête et du corselet réunis, dans ce dernier sexe; premier article un peu plus long que les antres, obconique, le second très-contrt, le troisième presque cylindrique, un peu rétréci ì sa base, de la lougnear des suivans; ceux-ci cylindriques, les deruiers un peu plus menus que les précédens; le treizième aigu à son extrémité. - Labro petil, coriace, un peu avancé, arrondi, cilié. - Mandibules longues, croisées l'une sur l'autre daus le repos, terminées par une dent forte, aiguë; len. côté interne relendu an-dessons de l'extrémité et formant une dent obtuse. - Mâchoires entiêrement coriaces, courles, terminées par un lobe obtrigone, très-voûté. - Palpes fililormes; les maxillaires plus longs que les labiaux et dépassant un peu les mâclioires, composés de six articles, les cinq premiers obconiques; le premier un peu plus court que les suivans: le second et le troisiène un peu plus épais; les quatrième, cinquième et sixième assez menns, celui ci presque cylindrique : palpes labiaux de quatre articles, les trois premiers obconiques, le quatrième un peu plus long que les intermédiaires, assez menu, presque cylindrique. - Lève en cocur tronqué, trilobée; les lobes latéraux se prolongeant en angle, l'internédiaire supporté à sa base par une écaille coriace, triangulaire; menton coriace, alongé. - T'ête un peu plus étroite que le corselet, transversale. - Yeux entiers. - Trois ocelles saillans, rapprochés, placés en triangle sur le vertex. - Corps oblong, pubescent. - Corselet convexe, élevé dans son milieu; prothorax transversal, bordé à sa partic antérieure; métathorax fortemeut eu pente. - Ailes supérieures ayant une celInle radiale étroite, très-alongée et quatre cellnles cubitales presqu'égales et carrées; la seconde et la troisième recevant chacune une nervure récurrente; la quatrième alteignant le bout de l'aile. - Pattes conrtes; jambes antérieures terminées par une épine munie incéricurement d’une membrane; jambes intermédiaires et postérieures terminées par deux épines aiguës, presqu'égales.

Nota. Ces caractères ont été pris d'après des individus mâles.

Les mceurs des Thynnes ne sont pas connues. Le type du genre est le 'Tluynne denté, $T$. dentatus ño. 1. Fab. Syst. Piez. De la nouvelle Hollande. Mâle. - Lat. Gener. Crust. et Ins. tom. 4. pag. I1 1. tom. I. tab. XIII, fg. 2. 3. et 4. Mâle. - Encycl. pl. 382. fig. 8. Mâle.

Des quatre espèces que Fabricius place dans ce 
genre, celle que nous venons de citer est la seule qui lui appartienne. Le $T$. emarginatus $n^{\circ}$. 2. est une Stélide ; l'abdominalis $\mathrm{n}^{\circ}$. 3. et l'integer $\mathrm{n}^{\circ} .4$. sont probablement des Cælioxydes.

$$
\text { (S. H. et A. SERV.) }
$$

THYRÉOCORISE, Thyreocoris. Nom donné par Schranck aux Scutellères. Voyez ce mot.

(S. F. et A. Serv.)

THYRÉOPIIORE, Thyreophora. MEIG. IlLIG. Lat. Musca. Fab. Paxz. Coqueb. Scatophaga. MEIG.

Genre d'insectes de l'ordre des Diptères, première section, fanille des Athéricères, tribu des Muscides.

Ce genre est placé par M. Latreille (Fam. nat.) däns un groupe de Mluscides de la division des Scathophiles ( voyez ce mot), où il met en outre los genres Anthonyie, Mosille, Scathophage, Sphérocère, et avec doute, ceux de Ropalonère et de Timie. Les Anthomyies et les Scatophages se distinguent des 'Thyréophores par le dernier' article des antennes en carré long; la tête des Mosilles est compriı́ée transversalcment, et par conséquent plus large qu'elle n'est longue dans le sens de la longueur du corps; les Sphérocères ont les antennes presqu'eutièrement découvertes avec le dernier article semiorbiculaire, plus large quc long. Dans les Ropalomères l'hypostome est luberculé, suivant M. Wićdenanu, et le dernier article des antennes est ovale; les Timies ont le troisième article des antennes ovale-comprimé, et leur hypostome offie un enfoncement dans son inilieu.

Antennes très-petites, enfoncées chacune dans une fossette de l'hypostone, vraisemblublement de trois articles; le prenier petit, point distiuct, le demier lenticulaire, plane, muni à sa base d'une soie dorsale nue. - Ouverture de la cavité buccale petite; liypostome fortement iucliné, a vec deux impressions oblongues, séparées dans le milieu par une carène longiludinale. - Tête ovale, bombée en dessus; front large, bombé. - Yeux petits, arrondis.-Trois ocelles disposés en triangle sur un tubercule antérieur du front. - Corselet n'ayant pas de ligne enfoncée transverse, séparant le prothorax. - Ecusson petit, presque triangulaire dans les femelles; celui des mấles presqu'aussi long que la moitié de l'abdomen, aplati, coupé droit postérienrewent, terminé par deux soies roides. - Ailes velues vues au microscope, couchées parallèlement sur le corps dans le repos et dépassant beaucoup son extrémité; première nervure longitudinale simple. - Cuillerons petits, frangés. - Balanciers petits, découverts. - Abdomen elliptique dans les femelles; linéaire et plane dans les mấles; de six segmens, le dernier ou anus terminé dans les feuciles par nne tarière courte. - Cuisses postérieures épaisses; leur's jambes un peu courbées, avec deux petits tubercules vers leur milieu.

Le nom de ce genre vient de deux mots grecs qui signilient : porte-bouclier; ce qui a rapport à la forme ainsi qu'à la grandeur de l'écusson des mâles. On ne connoît pas encore les larves. Les individus de la Thyrćophore cynophile trouvés en. France ont étć pris sur des Chiens morts; ce n'est donc pas, comme le soupçonne M. Meigen, par un sinule luasard que l'individu figuré par Panzer avoit été trouvé en Allemagne sur le cadavre d'un Chien : cette espèce ne paroît guère avant le mois de novembre; elle est rare aux environs de Paris. Une personne digne de foi, mais qui n'est pas entomologistc, a remarqué que pendant la nuit la têtc de lit Thyréophore cynophile femelle, répandoit une lunière phosphorique assez vive; cette lueur attira son attention et lui fit porter la main sur cet insecte qui étcit entré dans sa chambıe, et s'y tenoit en repos. Nous citerons les deux espèces suivantes.

Io. 'Thyréophore cynophile, T. cynophila. Meig. Dipt. d'Europ. tom. 5. pag. 401. $n^{\circ}$. 1. tab. 54. fg. 14. Mâle. fig. 15. Femelle. Il est étonnant que cette espèce, Ggurée par Panzer, et mentionnée depuis long-temps dans le premier ouvrage de M. Meigen, ainsi que dans ceux de M. Latreille, ne se trouve point dans Fabricius. $2^{\circ}$. Thyréophore fourchue:, T. furcata. Lat. Gen. Crust. et Ins. tom. 4. pag. 359. - Musca furcatu. Coque b. Illust Icon. tab: 24. fig. 9. Mâle.-Scatophaga furcatu. MeIG. id. pag. 252. $n^{\circ}$. 12. Commune aux environs de Paris sur les charoynes. (S. F. et A. Serv.)

THYREUS. Nom donné par Panzer dans la Révision de sa Faunc germanique au genre Crocise, Crocisa Lat. C'est la première division du gente Mélecte du présenı Dictionnaire, pag. 107. de ce volume. (S. F. et A. Serv.)

THYRIDE, Thyris. Hoffm. Lat. God. Sphinx. Fab. Esp. Hobn. Engram. Ross. Phunn.

Genre d'insectes de l'ordre des Lépidoptères, fanille des Crépusculaires, tribu des Zygénides.

Cing genres composent un groupe dans celte tribu; il a pour caractères : antennes simples dans les deux sexes. (Voyez Zrónidies.) Les Sésies ont une petile houppe d'écailles à l'extrémité des antennes; les palpes des Syntomides sont très-courts, obtus, et ne s'élèvent pas au-delà du cliaperon, en outre les épines des jambes postérieures de ces dernières sont très-petites. Dans les Egocères le second article des palpes est garni de puils formant un faisceau avancé en bec et its ailes sont disposées en toit dans le repos. Le geure Zygène se distingue de celui de 'Thyride par ses antennes ea massue forte et brusque, et par les épines terminales des jambes postérieures, qui sont très-pelites. 


\section{T H Y}

Antennes légèrement en fuseau, presque sétacées, simples et sans houppe d'écailles à leur extrémité. - Palpes cylindro-coniques, s’élevant notablement au-delà du chaperon, leur dernier article presque nu, terminé en pointe. - Langue en spirale. - Ailes horizontales, dentelées, anguleuses, éeartées; les infériemres ayant leur cellule sous-marginale fermée, ou paroissant fermée eu arrière par une nervurc arquée. - Abdomen conique. - Jambes postérieures munies à leur extrémité de dcux épines très-fortes.

Le nom de ces Lépidoptères est pris de la partie vitrée des ailes de la seule espèce connue jusqu'aujourd'lui : ses premiers états n'ont pas encore été observés. L’insecte parfait se tient dans les haies herbeuses; il est rare anx environs de Paris: nous l'avons pris à Mendon, sur la lisière des bois. C'est la Thyride fénestrine, T. fenestrina. l.a т. Gener. Crust. et Ins. tom. 4. pag. 212. (iod. Lépidopt. de France, pag. 12.3. $n^{\circ} .36$. pl. 22. fig. 1. - Sphinx fenestrina n ${ }^{\circ}$. 8. Fab. Entom. Syst. (S. F. et A. Serv.)

THYRSIE, Thyrsia. Dalm. Lat. (Fam. nat.)

Genre d'insectes de l'ordre des Coléoptères, section des Tétramières, famille des Longicornes, tribu des Prioniens.

Cette tribu, qui ne contenoit que les gentes Spondyle et Piione lorsque nous avons rédigé l'article Phionrevs, s'est augmentée de deux autres dans les Familles naturelles de M. Latreille, savoir : Tbyrsie et Anacole. Les denx preniers se distinguent par leurs antennes dépourvues de fascicules de poils et leurs élytres fermes et coriaces; quant aux Anacoles, outre que leurs antennes sont glabres, leurs élytres ont une forme presque triangulaire et se rétrécissent en pointe à l'extrémité qui est béante.

Nous ne connoissons ce genre que par les Analecta entomologica du célèbre professeur M. Dalman, qui le place avee doute parmi les Céranbycins, près des Cténodes, et auquel nous emprun. tons ses caractères.

Antennes fusiformes, grossissant vers le milieu, très-velues, leurs poils disposés presqu'en faisceanx. - Palpes filiformes, un peu obtus à leur axtrémité. - Mandibules cornćes, arquées, bidentées au côté interne, nues. - Corps oblong, assez mon. - Corselet court, mutique. - Elytres recouviant entièrement les ailes et l'abdomen. Pattes courtes, comprimées.

Le type de ce genre, dont le nom vient d'un mot grec qui exprime la forme des antennes, est la Thyrsie latérale, T'. lateralis. DALm. Analect. entom. pag. $17 \cdot n^{\circ} \cdot 1$, tab. 3. Longueur 7 à 8 lig. Noire, soyeuse ; corselet d un rouge sanguin pâle, taché de jaune : frout et une baude latérale sur chaque élytre, d'un beau jaune. Du Brésil.
ANACOLE, Anacolus. Lat. (Fam. natur.) Prionuls $1^{\mathrm{re}}$. division (Encycl.)

Gemre d'insectes de l'ordre des Coléoptères, section des Tétramères, famille des Longicornes, tribu des Prioniens.

Les genres Spondyle, Prione et Thyrsie composent avec celui d'Anacole la tribu des Prioniens, dans les Familles naturelles de M. Latreille; les trois premiers se distinguent du quatrième par leur's élytres recouvrant entièrement les ailes et l'abdomen, et point béantes à l'extrémité.

Antennes longues, composées de onze articles, fortement dentées en scie à partil du troisième dans les mâles, l'étant moins fortement et seulement à partir du sixième dans les femelles. Mandibules assez étroites, crochues au bout, dentelées intérieurement. - Palpes de longueur moyenne, leurs articles cylindracés. - Tête uı peu excavée entre les yeux. - Corps court, presque carré.-Corselet presque carré, sans crénelures, muni d'épines latśra!es. - Ecusson large, presqu'en triangle eurviligne, obtus à son extrémité.-Elytres plus courtes que l'abdomen, surtont dans les mâles, laissant une partie des ailes à découvert, trèsbéantes à leur suture, allant en se rétrécissant vers lenr extrénité, terninées en pointe arrondie et mutique; leurs angles huméraux peu prononcés, arrondis. - Abdomen court, son dernier segment sans échancrure dans les deux sexes. Pattes assez courtes; jambes muliques; tarses ayant leurs quatre premiers articles tort élargis, surtout dans les mâles. Les autres caractères comme dans les Priones. Voyez ce mot.

Les Anacoles, dont le nom vient de deux mots grecs qui indiquent la brièveté des élytres, équivalent à notre première division du genre Prione. Les caraclères génériques de ces insectes n'ayant pas encore été publiés, nous venons d'exposer ceux qu'un examen attentif nous a fait apercevoir. Pour les espèces, voyez Prione, première division. (S. F. et A. Serv.)

\section{TIHYSANOURES, Thysanoura. LATR.}

L'ordre auquel N. Latreille donne ce nom, est le premier de la classe des insectes; dans ses ouvragres antérieurs aux Familles naturelles da Règne animal, cet ordre étoit le second, parec que la classe des Myriapodes faisoit encore partie des insectes, ce qui n'a plas lien dans l'ouvrage que nous venons citer. Quoi quil en soit, l'ordre des Thysanoures n'a pas clangé, et il a toujours pour caractères : des maudibules et des nı choires; des yeux à facettes, ou composés de plusicurs occlles. Antennes notablèment plus Iongues que la tête. Abdomen teruiné par des filets ou par une quene fourchue servaut à sauter. Anirnanx le plus souvent couverts de petites écailles ou liérissés de poils.

Cet ordre comprend deux familles, ce sont 
les Lépismènes et les Podurelies. Voyez ces mots. (E. G. )

TILle, Tillus. Otrv. (Entom.) Lat. Panz. Kirb. Chrysomela. Linv. Clerus. F' Ав. Otiv. Lagria. PANz.

Genre d'insectes de l'ordre des Coléoptc̀res, section des Pentamères, famille des Serricornes (division des Malacodermes), tribu des Clairones.

Un groupe de Clairones a ponr caractères : antennes grossissant insensiblement; cing articles distincis à tous les tarses; il renferme, outre les Tilles, les genres Eurype et Axine dont les palpes maxillaires sont terminés par un article sécuriforme; Priocère, qui a le labre échancré et la lèvre bifide; Thanasime, dont les antennes n'ont pas leurs derniers articles dentés en scie et dont le corsclet est presque cordiforme.

Antennes grossissant insensiblement vers le bout, composées de onze articles, formant des dents de scie à partir du quatrième jusquáau dixième inclusivement. - Labre transversal, entier. - Palpes maxillaires filiformes, de quatre articles (de trois seulement, suivant MI. Kirby, ce qui indique que le premier est très-court et ne lui a pas paru mobile): palpes labiaux de trois articles (de deux, selon M. Kirlyy), le dernier très-grand, sécuriforme. - Lè̀re petite, entière. - Corselet cylindrique. - Corps convexe. Le reste des caractères comme dans les Thanasines. Voyez ce mot.

Les Tilles dans leur prenier état vivent dans le bois et probablement anx dépens des larves xylophages. Dans l'état parfait ils se tiennent le plus souvent sur le bois; lorsqu'on les saisit, ils mordent les doigts avec une si grande opiniâtreté que si l'on cherche à les en détacher, la tête se sépare du corps plulôt que de lâcher prise; c'est de cette parlicularité qu'est tiré le nom de Tille, venant d'un verbe grec qui signifie: mordre. Cette habitnde leur est commune avec les Thanasimes. Ces Coléoptères ne sont pas communs aux environs de Paris.

Fabricius ( Syst. Eleut.) décrit cinq espèces de Tilles. Ses nos. 2. 3. et 5. sonı des Enoplies: plusieurs auteurs regardent le Tillus ambulans $\mathrm{n}^{\circ} .4$. comme une simple variélé de l'elongatus $n^{\circ}$. I. Le Tille unifascié est placé par cet autenr dans son genre Clerus.

\section{ThLLe unifascié, T' unifasciatus.}

Tillus nnifusciatus. Lat. Gener. Crust. et Ins. tom. 1. pag. 269. no, 2. - Scraen, Syn. Ins. tom. 2. pag. $46 . n^{\circ} .2 .-$ Clerus unifasciatus $\mathrm{n}^{\circ} \cdot 9$. Faв. Syst. Eleut. - Otiv. Entom. tom. 4. Clairon. pag. 17. $n^{\circ} .21$. pl. 2. fig. 21.

Voyaz pour la description et les autres syno- nymes, Clairon unifascié no. I1. pl. 360. fig. Ir. de ce Diclionnaire.

Ce genre comprend en outre le Tille alongé, T. elongatus. Lat. Gener. Cmst. et Ins. tom. I. pag. 269. $n^{\circ}$. 1. - FАB. $n^{\circ}$. 1. Syst. Eleut. Scren. Syn. Ins. tom. 2. pag. 48. $n^{\circ}$. I. Le Tillus ambulans $\mathrm{n}^{\circ} .4 . \mathrm{F}_{\mathrm{AB}}$. id. n'est probalement qu'une variété de celte espèce; il n'en diffère que par son corselet entièrement noir.

$$
\text { (S. F. et A. Serv.) }
$$

TIMIE, Timia. Wiédem. Lat. (Fam. nat.) Merg. Ce genre d'insectes Diptères, de la tribu des Muscides, a été fondé par M. Wiédemann (Anal. entom.) et adoplé par MM. Latreille et Meigen. Ses caractères sont: antennes petites, écartées l'une de l'autre, insérées dans une petite fossette sous le rebord du front qui est relevé en croissant, composées de trois articles, les deux premiers trc̀s-courts, le troisième en palette oblongne, muni à sa base d'une soie dorsale nue. Lèvres de la trompe et palpes saillans, ceux-ci comprimés, assez larges, obtus à leur extrémité. Hypostome prolongé au-dcssous des yeux, échancré inférieurement, rebordé. Front large. Yeux oblongs, écarlés. 'Trois ocelles placés en triangle sur le vertex. Corps glabre. Ailes couchées paral. lèlement sur le corps dans le repos; leur première nervure longitudinale simple, atteignant le milieu du bord antérieur ; la quatrième nervure longitudinale se courbant à partir de la nervure transversale et se prolongeant vers l'exırénité de l'aile pour rejoindre le bout de la troisième nervure longitudinale. Cuillerons et balanciers petits. Abdomen ovale, aplati, de cinq segmens outre l'anus, muni d'une tarière biariculée dans les femelles. Pattes de longueur moyenne.

Timia vieut d'un mot grec qui signifie: précieux. M. Wiédemann soupçonne que l'espèce qu'il décrit habite dans les galles ou dans les racines des Salicornes, c'est la Timie érythrocéphale, T. erythrocephala. WiÉDEMr. Anal. entom. pag. IJ. fig. 6. Longueur 3 lig. Noire; tête, écusson et pattes d'un jaune rougeâtle; ; jambes noires à leur extrémité. Elle se trouve sur les bords du Jaik et du Wolga, sur les fleurs de la Nitraire et des Tamarisques.

II. Meigen décrit une seconde espèce sous le nom de Timie apicale, T. apicalis, Dipt. $d^{\prime}$ Eur. tom. 5. pag. 388. $n^{\circ}$. 1. tab. 53. fig. 16. Femelle. Longueur 5 lig. Noire. Tarses roux. Ailes ayant une tache apicale brune. De Portugal.

(S. F. el A. SERT.)

TINÉïTES, 'Tineites. Troisième tribu de la famille des Noclurnes, ordre des Lépidoptères, ayant pour caractèrcs:

Chenilles à seize pattes (quelques minenses paroissent én avoir dix-huit, toules membraneuses, selon De Géer. ), vivant ordiuairement dans 


\section{T I N}

des tuyaux fixes ou portatifs, fabriqués des substances qu'elles rongent ou de pure soie lorsqu'elles habitent le parenchyme des feuilles, les fruits ou les semences; un petit nombre vivant à découvert. - Ailes supérieures longues et étroites; les inférieures larges, plissćes dans le repos, ayant un frein; toutes quatre entières et sans fissules, $\tan$ tôt couchées sur le corps, tantôt moulées autour de lui ou pendantes et serrées sur les côtés, avec leur extrémité postérieure relevée en crête de coq. - Antennes sétacées. - Palpes maxillaires visibles, en forme de filets nus et membraneux, ou a peine perceptibles, tuberculiformes, de deux articles au plus; les labiaux très-appirens, courts et presque cylindriques, on rejetés en arrière de la tĉte en forme de cornes allant en pointe. - Corps linéaire ou triangulaire, long et étroit.

Cette tribu se divise de la manière suivante:

I. Antennes et yeux écartés.

A. Une langue en spirale très-distincte et alongée.

a. Ailes couchées horizontalement sur le corps ou en toit arrondi. - Palpes labiaux de la longuenr au plus de la tête.

\section{Lithosie, Yponomeule.}

b. Ailes pendantes. - Palpes labiaux beancoup plus longs que la tête et rejetés en arrière jusçuau-dessus du corselet.

\section{Oecopliore.}

B. Langue trc̀s-courte ou presque nulle. ( $U_{n}$ toupet de poils ou d'écailles sur la tête.)

a. Palpes labiaux grands, avancés. Euplocampe, $\mathrm{Phycide}$

b. Palpes labiaux très-petits, point saiilans.

Teigne.

II. Antennes (très-longues) et yeux presçue contigus.

Adèle.

Nota. Ces caractères sont extraits des Familles naturelles de M. Latreille.

Les Tinéiles sont ordinairement pelites, mais souvent ornées de couleurs très-brillintes. Plusieurs de leurs chenilles vivent dans des tryanx nou portatifs qu'elles ont filés, et les prolongent à mesure qu'ellcs changent de place pour avancer; quelques autres chenilles ne se forment pas de tuyaux, mais se pratiquent des galeries dans l'intérieur des feuilles. Elles subissent leurs métamorphoses dans ces différentes habitations.

LITHOSIE, Lithosia. FAB. LAt. God. OcEHist. Nat. Ins. Tome $\boldsymbol{X}$. sern. Phaloena (Bombyx et Noctua). Linn. Phalena. Geofr. Cram. Engram. Bomby x. Fab. Oniv. (Encycl.) Rioss. Hunn. Noctua. Scop. Esp. Panz. Tinea. Geofr. Ross. Setina. Schranck. Euprepia. Ochsein.

Gcnre d'insectes de l'ordre des Isćpidoptères, fanille des Nocturnes, tribu des Tinéites.

Un groupe de Tinéites (voyez ce mot) contient avec le genre Lilhosie celui d Y ponomente qui cn dilfère par ses palpes labiaux de la longneur de la tête, le dernier aricle de la longueur du précédent ou plus long, obconique.

Antennes sétacées, simples dans la plupart, 'quelquefois pectinćes dans les mâles. - Langue distincte, alongcée, roulée co spiralc dans lc repos. - Palpes maxillaires cachés; palpes labiaux plus courts que la têie, cylindıriques, recourtés, composés de trois articles, le dernier sensib]cment plus court que le second, eylindrique. Ailes supérieures longues et élroites, couchées horizontalement sur le corps, ainsi que les inférieures, ou se moulant autour de lui ; cellu! discoïdalc des ailcs inférieures formée par une nervure en chevron plas ou moins prononcée el toninant sa convexité du côté du corps. - Chenilles à seize pattes, vivant à nu.

On ne connoît qu'un petit nombre de ces dernières; leur manic̀re de vivre varie beauconp suivant les espèces. Celle de la $L$. quadra habiie sur le Chène; elle se muliplie quelquefois dans certaines parties de forêts, de manierc a les déponill' de leur verdure, ce que nous avons vu plusieurs fuis dans la forêt de Saint-Germain, du côté du pavillon de la Muette. Cetle chenille est brune avce des lignes jaunes ou rougeâtres, garnie de toulfes de poils qui ne sont pas assez serrés pour empêclier de distinguer la couleur du fond. Dans sa jeuncsse elle réunil légc̀rement quclques feuilles enscmble pour s'abriter ; elle vit ensuitc, dès qu'elle a pris à pcu près la moitié de sa croissance, entièrement à nu : elle marchc beauconp, et lorsque l'arbre sur lequel elle habitoil est dépouillé de ses feuilles, clle court vitc s'établir sur nu autre. La chenille de la $L$. pulchella vit sur l'Héliotrope d'Europe (Heliotropium europceum ). D'uutres se nourrissent des lichens qui se trouven! sur les pierres; ce sont.ces dernières dont les mœurs ont servi à dénommer ce genre, Lithosie, tiré de deux mols grecs dont le sens est : qui vit sur les pierres. Puur passer à l'état de chrysalides, les ehenilles se filent des coques de soie qu'elles recouvrent en partie des végétaux dont elles se nourrisent; quelques-unes restent tout l'hiver en chrysalides. Les insectes parfaits volent peu pendant le jour et se tiennent souvent durant des hcures entières posés à la mêmc place; cependant les mâles recherchent leur's femelles pour l'accouplement, vers lhcure de midi.

Plusieurs espèces de Lithosies flat 'ent l'œil trèsagréablement par des couleurs teudres et fraiches,

$\mathrm{N} \mathbf{n} \mathbf{n}$ 
telles que le rose et le blanc de neige; aussi ontelles reçu des noms analogues.

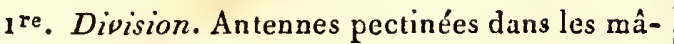
les. (Ctenia Noв.)

\section{Lithosie Chouetle, L. grammica.}

Lithosia grammica. LAt. Gener. Crust. et Ins. tom. 4. pag. 221. - God. Lépidopt. de France, tom. 4.- Bombyx grammica. no ${ }^{\circ} 182$. Fав. Entom. Syst.

Voyez pour la descriptiou et les autres synonymes, Bombyx Chouette $n^{\circ} .2$ I5. pl. 82. fig. I. Femelle. de ce Dictionnaire.

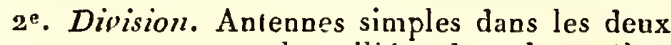
sexes, ou tout au plus ciliées dans les mâles. (Lithosia proprie dicta Nов.)

\section{Lithosie belle, L. pulchra.}

Lithosia alis anticis nigris, suprà rioulis ad basim et maculâa repandâa mediâ albis, suprc̀ subtùsque maculis rubris albo marginatis; inferioribus albis, margine lato nigro, subtis albo bimaculato; thorace capiteque albo, nigro rubroque variis; abdonine albo, utringuè fasciâ maculari nigrâ.

Envergure 16 lig. Ailes supérieures noires, leur base ayant des lignes ondées blauches; leur milieu offrant une tache de cette mềne couleur, sinuéc et irrégulière : elles sont chargćes en oulre de taches rouges entourées de blanc; ces deruières taches, ainsi que celle de couleur blanche du milieu de l'aile, visibles en dessous; ailes inférieures blanches avec une large bordure noire ondée, plus large vers la partie qui rejoint les supérieures, et portant dans cet endroit deux taches blanches. 'Tête et corselet variés de blanc, de noir et de rouge. Abdomen blanc avec une ligne de points noirs de chaque côté.

De l'Ile-de-France. Elle nous a été donnée par M. Catoire, qui en avoit élevé la chenille.

\section{Lithosir gentille, L. pulchella.}

Lithosia pulchella. Lat. Gener. Crust. et Ins. tom. 4. pag. 221. - Gov. Lépidopt. de firance, tom. 4. - Bombyx pulchella no. 224. FАв. Entom. Syst.

Voyez pour la description et les autres syuonymes, Bombix gentil $n^{\circ} .257 \cdot p l$. 83. fig. 8. de ce Dictionnaire.

4. Litrosie jolie, L. bella.

Lithosia bella. LAr. Gener. Crust. et Ins. tom. 4. pag. 221. - Bomby $x$ bella n'. 223. FAB. Entom. Syst.

Voyez pour la description et les autres syno- nymes, Bombix joli $n^{\circ}$. 256.pl. $7^{2}$. fg. 10. de ce Dictionnaire.

\section{Lithosie ornée, L. ornatrix.}

Bomby $x$ ornatrix no. 125. FAB. Entom. Syst.

Voyez pour la description et les autres synonymes, Bombix orné ${ }^{\circ}$. 258. de ce Dictionnaire.

\section{Liтнолте collier ronge, L. rubricollis.}

Lithosia mubicollis. Lat. Gener. Crust. et Ins. tom. 4. pag. $22 \mathrm{I}$. - God. Lépidopt. de France, tom. 4. - Bomby $x$ rubricollis. no. 245. FА . Entom. $S_{\mathrm{j}}$ st.

Voyez pour la description et les autres synonymes, Bombix collier rouge $n^{\circ} \cdot 269 . p l$. 83 . fig. 10. de ce Dictionnaire.

\section{Litiosie crible, L. cribnum.}

Lithosia cribrum. Lat. Gener. Crust. et Ins. tom. 4. pag. 221 . - God. Lépidopl. de France, tom. 4. - Bombyx cribrum. no. 248. FАв. Entom. Syst.

Voyez pour la description et les autres synonymes, Bombix crible $n^{0}$. 271. fig. 2. de ce Dictionnaire

On doit meltre encore dans celte division, $1^{\circ}$. Lithosie quadrille, L. quadra no. I. FAB. Entom. Syst. Sup. -- L.t t. Gen. Crust. et Ins. tom. 4. pag. 221. - God. Lépidopt. de France, tom. 4. - Encycl. pl. 85. fig. 8. Femelle. Commune aux environs de Paris. $2^{\circ}$. Lithosie aplatie, $L$. complana $\mathrm{n}^{\circ}$. 3. FA B. id. - LAT. id. - God. id. 'Trèscommune aux environs de Paris. 30. Lithosie roulóe, $L$. convoluta. no. 4. FAB. id. - Lat. id. De France.

Ce genre renferme en outre, $1^{\circ}$. Lithosie priverne, $L$. priverna. - Bombyx priverna $\mathrm{n}^{\circ} .250$. Encycl. - Bomby priverna no. 227. Faв. Eintom. Syst. $2^{\circ}$. Lithosie mésomelle, L. mesomella. God. Lépidopt. de France. tom. 4. 30. Lillısie candide, $L$. candida. God. $i d .4^{\circ}$. Lithosie tamis, L. cribella. God. id. $5^{\circ}$. Lithosie muscerde, $\boldsymbol{L}$. muscerda. - Bombyx muscerda. Hoвs.

OECOPHORE, Oecophora. LAT. Phalorna (Tinea). Linn. De Géer. Tinea. Geotrr. I Aa. Schiff. Scop. Ross. Schranck. Hubs. Nemapogon. Schranck. Alucita. Ort. (Encycl.)

Genre d'insectes de l'ordre des Lépidoptères, famille des Nocturnes, tribu des Tinéites.

Les Oecophores contituent à elles seales une coupe daus cetle tribu. Vojez Tinéites.

Antennes simples, écartées à leur base. Langue distincte, alongée, roulée en spirale dans le repos. - Palpes maxillaires cachés; palpes labiaux beaucoup plus longs que lin tête \& rejetés 


\section{T I N}

en arrière jusqu'au-dessus du corselet, composés de trois articles, le second plus long que la tête, ordinairement écailleux, le troisième l'étant peu ou même nu, obconique, se recourbant en manière de corne au-dessus de la tête. - Ailes longues, étroites, très-inclinées de cibaque côté du corps, bordées d'une large frange. - Chenilles ayant ordinairement seize palles, rarement quatorze; tantôt pénétrant dans le parenchyme des végétaux \& y pratiquant des galeries, tantôt vivant dans l'intérieur des semences.

Ces Lépidoptères sont très-petits; leurs ailes ont babituellemeut des couleur's métalliques \& brillantes.

1. Oecophore flavelle, O. favella.

Oecophora flavella. Lat. Gener. Crust. et Ins. tom. 4. pag. 223. - Tine flavella. $\mathrm{n}^{\circ}$. 15. F. Entom. Syst. Suppl.

Voyez pour la description et les atitres synonymes, Alucite flavelle $n^{\circ}$. 8 . de ce Dictionnaire.

Rapportez à ce genre, $\mathbf{I}^{\circ}$. Oecophore soufrée, o. sulphurella, Jax. Noup. Dict. d'Hist. nat. $2^{\mathrm{e}}$. édit. - Tinea sulphurella. $n^{\mathrm{0}}$. 27. LA B. Ent. S st. Suppl. $2^{\circ}$. Oecophore de Linuć, O. Linneella. J.A t. Gener. Crust. et Ins, tom. 4. pag. 223. - Tinea Linneclla. $n^{\circ}$. 77. Fав. id. $3^{\circ}$. Oecophore de Roesel, $O$. Roesella. Lat $i d$. Tine 2 Roessella. $n^{\circ} \cdot 75$. Fав. id. $4^{\circ}$. Oecophose de Leuwenhcek, $O$. Leutsenthoekella. LAT. id. -Tinea Leuwenhoekella. $n^{\circ} \cdot 76$. FA.$i d .5^{0}$. Uecophore à bractées, $O$. bracteella. LA'T. $\iota d .-$ T'inea bracteella. $n^{\circ} \cdot 28.1 \mathrm{l}^{\mathrm{A}} \mathrm{B} \cdot \mathrm{id} \cdot 6^{\circ}$. Oecophore d'O. livier, O. Oliviella. Latr. ıd. - Tinea Oliviella. $z^{\circ}$. 5g. FAв. $i d .7^{\circ}$. Oecophore de Brongniard, $O$. Brongniardella. Lat. id. - Tinea Brongniardella. $n^{\circ}$. 85. Faв. $1 d .88^{\circ}$. Oecopliore de Geofrioy, $O$. Genffroyella. Lax. id. - Tinea Genffroyella. $n^{2}$. 62. Fав. id.

EUPLOCAMPE, Euplocampus. Lat. (Fam. nat.) Euplocamus. Lat. (Gener.) I'trea. Lab. Pyralis. Scop. Hubs.

Genre d'iusectes de l'ordre des Lópidoptères, famille des Nocturnes, tribu des 'Tincítes.

Un groupe de Tinéitcs a ponr caractères : antenues et yeux écartés ; langue très-courte ou presque nulle; tête munie d'un loupte de poils ou d'écailles; palpes labiaux grauds et avancés. II contient les gerntes Euplocanpe \& Phycide. Ces dernières se distinguent des Euplocamper par leurs anienues simplement ciliées ou burbues dans les mâles.

M, Latreille (Genera) donne à ce genre les caractères fuivans :

Antennes trés-pectinées. - Palpos labiaux. ayant leur second ariche très-chargé d'écailles lingnes el formant un faisceau pruloagé; le trozsième $u$, retressé.
Le type est l'Euplocampe tacheté, $\boldsymbol{E}$. gutteblus. - Euplocamus guttellus. Lat. Hist. Nat. des Crust. et des Ins. - Tinea gultella. FAB. Entom. Syst. tom. 3. part. 2. pag. 293. $n^{\circ}$. 26. D'Europe.

ADÉLE, Adela. I،Aт. Phalona. (Tinea) Linn. De Géer. Alucita. Fab. Oliv. (Encycl.) Ross. Tinea. Scop. Geoff. Hubn. Nemapogon. Schranck.

Genre d'insectes de l'ordre des Lépidoptères, famille des Nocturnes, rribu des Tinéites.

'Tous les genres de cette tribu (voyez Tinëitrs), hors celui d'Adèle, ont les antennes et les yeux écartés.

Antennes tiès-longues, rapprochées à leur base. - Langue alongée, dislincte. - Palpes labiaux cyliudriques, grêles, guère plus longs que la tête, très-velus, redressés. - Tête petite, presque pyra. miclale, liès-velue.- - Yeux se touchant presque à leur partie postéricure. - Anles pendantes, alongrées, plus larges à lenr bord postérieur. - Chenilles habitanı un petil tuyau composé de portions détachées des végétaux dont elles se nourrissent, et l'emportant partout avec elles.

Ces petits Lépidoptères sont remarquables par les belics couleurs métalliques dont leurs ailes sont ornćes et par l'extrêtue longueur de leurs antenues.

1. Adíle de Swammerdam, L. Swammerdamella.

Alucita Swammerdamella. Faв. Entom: Syst. Suppl. pag. 5.3. $n^{n}$. 3. (La Fuun. suecic. y ext nal citée, lisez: 159ı. au lieu de 138r.)

Toyez pour la description et les autres synonymes, Alucile Swammerdamelle $\mathbf{n}^{\circ}$. 26 . de ce Dictionnaire.

2. Adìne à poils, $A$. pilella.

Alucita pilella. IAB, id. $n^{\circ} .6$.

Voyes pour la description et les antres synonymes, Adèle pilelle $\mathrm{n}^{\mathrm{O}} .27$. de ce Dictionnaire.

3. Adèze de Robert, A. Robertella.

Alucita Robertella. Fав. id. $n^{\circ} .7$.

Voyez pour la description et les autres synonymes, Alucite Robertelle $n^{\circ} .28$. de ce Dicitionnaile.

4. Adìle de Frisch, A. Frischella. Alucila Frischella. Faв. id. pag. 504. no. 10.

foyez pour la description et les autres synonyraes, Alucie Frischelle no. 29. de ce Dictionnaire.

5. Adìne de Réaunnr, A. Reaumurella. Adela Reaumurella. Lat. Gener. Ciust. ct Ins. Nnna 2 
tom. 4. pag. 224. - Alucita Reaumurella. FAB. id. pag. 502. $n^{\circ}$. I. (à la citation de Geoffroy, lisez : 193 . an lieu de $19^{2 .}$ )

Voyez pour la description et les autres synonymes, Alucite Réaumurclle no. Zo. de ce Dietionnaire.

\section{AdÈle de De Gćer, A. De Geerella.}

Adela De Geerella. LAт. id. - Alucita De Geerella. $\mathrm{F}_{\mathrm{AB}}$ id. pag. 504. no. 8. (à la citation de TVienn. Verz. au lieu de no. 21. lisez: $n^{\circ}$. 25.)

Voyez pour la deseription et les antres synonymes (en ijoutant ì eelıi de Geoffroy, $p l$. I 2. fig. 5.), Alucite De Géerelle no. 34. de ee Dictionnaire.

\section{A dìle de Sulzer, A. Sulzella.}

Adela Sulzella. LAт. id. - Alucita Sulzella. FAв. $i d$. $n^{\circ} \cdot$ 9. (⿳亠丷厂犬 la citation de Wienn. Venz. lisez: 1 43 , au lieu de 123 .)

Voyez pour la description et les autres synonyues, Alueite Sulzelle no. 35. de ce Dictionnaire.

\section{ADÈLE verte, A. viridella.}

Alucita vindella. FAB. id. pag. 503, $77^{\circ} \cdot 4 \cdot$ (ì la citation de IVienn. Verz. lisez : viridella au de vindella.)

Voyez pour la deseription el les autres synonymes, Alueite viridelle no. 36 . de ce Dictionnaire.

\section{Adìle cuivreuse, $A$. cuprella.}

Alucita cuprella. FAв. id. pag. 505. $77^{\circ}$. 14.

Doyez pour la description et les autres synonymes, Alueite cuprelle $n^{\circ} .37$. de ee Dictionnaire.

\section{AdÈLE fasciée, A. fusciella.}

Aiucita fasciella. F $\mathrm{AB}$. $i d$. $n^{\circ}$. I 5 .

Voyez pour la description et les autres synonymes, Alucite faseielle ${ }^{\circ}$. 88. de ee Dietionnaire.

Nota. Les Alucita Latreillella $\mathbf{\Sigma}^{\circ}$. 2. et $\boldsymbol{P a n -}$ zerella no. 5. Fав. id. sont certainement aussi du genre Adèle. (S. F. el A. SErv.)

TINGIS, Tingis. Fab. Panz. Lat. Cimex. Linv. Geoff. De Gere. Fourc. Devill. Acanthia. Sehraxck. Sehell. Wolf. Panz.

Genre d'insectes de l'ordre des Hćmiptères, section des Hétéroptères, famille des Géocorises, tribu des Membraneuses.

Dans ses Faniilles naturclles MI. Latreille earactérise ainsi eette tribu :
Membraneuses, Membranaceo. Seconde tribu de la famille des Géoeorises.

Gaîne du suçoir n'offiant à découvert que deux ou trois artic!es. - Labre court, sans stries. Toutes les pattes insérées près de la ligne médiane du dessous du corselet, terminées par deux crochets distincts, naissant du milieu de l'extrémité du dernier artiele, et ne servant point à courir ni à ramer sur l'eau. - Bec droit, cngaîné à sa base ou dans toute sa longueur. - Tête point rétrécic postérieurement en manière de cou. - Yeux de grandeur ordinaire.

Cette tribu se divise ainsi qu'il suit :

I. Pattes antérieures ravisseuses ou terminées en pince. - Antennes en massue.

Macroeéphale, Pliymate.

II. Toutes les pattes semblables et simplement ambulatoires.

A. Autennes filiformes ou plus grosses à leur extrémiié.

$$
\text { Tingris, Arade. }
$$

B. Antennes sétacées.

Punaise.

Les Tingis et les Arades eomposent l'avantdernier groupc de leur tribu. Le dernier de ces genres differe du premier par ses antennes filiformes, dont tous les articles et principalement le dernier sont eylindriques, et par son eorps opaque dans toutes ses parlies.

Antennes insérćes très-près l'une de l'autre, dans la plupart à la base supérieure du bec, composées de quatre articles; le troisième beaucoup plus long qu'aucun des autres; le quatrième ovale, souvent épais. - Bec logé lors du repos dans un canal dont les bords sont élevés et membraneux, alleignant la base des hanches postérieures. Tête trinsversale, point avaneée. - Corps déprimć, mewbraneux; ses membranes réticulées et en grande parlie transparentes.-Corselet souvent prolongé postérieurement en plaee d'écusson. - Elytres beaucoup plus larges qnel'abdomen, voútées en dessons, leurs côtés extérieurs dilatés, formant en dessousune expansion qui embrasse les côtés de l'abdomen : elles reeouvrent desailes et l'abdomen. - Abdomen composé de sept segmens outre l'anus; anus des femelles sillonné longitudiualement dans son milieu; eelui des mâles entier, sans sillon longitudinal. - Toutes les pattes semblables, simplement ambulatoires; tarses de trois articles, le dernier terminé par deux croehets distinets.

Les Tingis, toutes de petite taille, vivent dans leurs différens élats sur les végétaux; celle du Poirier ( $T$. pyri.) se multiplie tellement dans de eertaines années sur eet arbre, qu'elle enlève tout le parenchyme des feuilles, lesquelles do- 
viennent transparentes dès le mois d'aon̂t et tombent de suite, ce qui empĉche lcs fruits de parvenir à maturité et les arbres d'en produire les années suivantes. Les jardiniers désignent ordinairement cet insecte sous le nom de Tigre. D'autres espèces excitent quelquefois par leurs piqûres des monstruosités qui prennent souvent la forme de galles; ainsi la Tingis clavicorne, qui habite en état de larve dans la fleur de la Germandrée petit chêne (Tencrium chamaedrys), fait gonfler cette fleur dont le pétale devient alors fort épais et dont le limbe ne peut se développer. Les métamorphoses de ces insectes sont les mêmes que celles des Pentatomes. Voyez ce mot.

ire. Division. Corselet se prolongeant postérieurement en manic̀re d'écusson.

Ire. Sabdivision. Côtés du cotselet fortement dilatés et unembraneux. (Tingis propriè dicta. Мов.)

$1^{\circ}$. Tingis crêlée, T. cristala. Lat. Gen. Crust. et Ins. tom. 3. pag. 140. - Panz. Faun. Germ. fas. 99. fig. 19. I'Europe. $2^{\circ}$. 'Tingis à appendices, T. appendicea. - Cimex appendiceus. Fочнс. Entom. Paris. tom. 1. pag. $212 . n^{\circ} .57$. -Devile. Entom. Linn. tom. I. pag. 488. $n^{\circ} .28$. pl. 3. fig. 19. (lisez tab. 3. au lieu de $t a b, 2$. et retranchez le synonyme de Fabricius.)-Tingis punaice à fiaise antique. Let. Gen. Crust. et Ins. tom. 3. pag. 140. - La Punaise à fraise antique. GeOfF. Ins. Paris. tom. 1. pag. 461. $n^{\circ} .57$. 3o. 'Tingis? carénée, T. carinala. LAT. id. PAnz. Faun. Germ. fas. 99. fig. 20. Cette espèce a les antennes insérées sur les côtés de la tête el distantes; aussi nous paroît-elle ue devoir être rapportée à ce genre qu'avec doute. $4^{\circ}$. Tingis du Poirier, T. pyri no. 9. FAв. Syst. Rhyng. (retranchez le synonyme de Geoffiroy qui apparilient à la Tingis à appendices.) - LAT. $i d$. 5 $5^{\circ}$. Tingis $\mathrm{du}$ Cotonnier, $T$. gossypii no. Io. FAB. id.-LAT. $i d$. Des Antilles. 6०. Tinuis du Chardon, T. cardui no. 3. Faв. Syst. Rhyng. - Lat. id. - Paxz. Faun. Germ. fas, 5. fig. 24. $7^{\circ}$. 'Tingis bordée, T. marginata. LAT. id. - Acanthia marginata. Wolf. Icon. cimic. fas. 4. pag. 132. tab. 13. fig. 126.

$2^{\mathrm{e}}$. Subdivision. Côtés du corselet simplemeut rebordés, à peine dilatés. (Monanthia. Nов.)

1ค. Tingis clavicorne, T. clavicornis $\mathrm{n}^{\circ}$. I. Fав. Syst. Rhyng. - Lat. Hist. nat. des Crust. et des Ins. - La Punaise ligre. Geof f. Ins. Paris. tom. 1. pag. 461. $n^{\circ}$. 56. $2^{\circ}$. Tingis de la Vipéline, T. echii n ${ }^{\circ}$. 8. Fав. id. - Lat. Gen. Crust. et Ins. tom. 3. pag. 140. - Acanthia echii. Wouf. Icon. cimic. fas. 4. pag. 13o. tab. 13. fig. 124. $3^{\circ}$. 'Tingis mélanocéphale, T. melano- cephala. Lat. id. - PANz. Faun. Germ. fas. 100. fig. 21 .

$2^{e}$. Division. Ecusscn distinct du corselet. (Piesma Noв.)

I $^{\circ}$ Tingis grosse lête, T. capitata. Lat. Gen. Crust. et Ins. tom. 3. pag. 140.- Acanthia capitata. Wolf. Icon. cimic. fas. 3. peg. J31. tab. 13. fig. 125. $2^{\circ}$. Tingis quadricorne, T. quadricornis. Léon Durour. "Cetle espèce, qui a pour caractère singulier quatre épines à la têle, placées sur deux rangs et dirigécs en avant, a été trouvée en Espagie par M. Léon Dufour.

ARADE, Aradus. Fab. PANz. I.am. Cimex. Linn. Geofr. De Gérr. Acanthia. Schranck. Wolf. Coreus. Schell.

Genre d'issectes de l'ordre des Hémiptc̀res, section des Hétéroptc̀res, famille des Géocorises, tribu des Membraneuses.

L'avant-dernier groupe de cette tribu contient les genres Tingis et Arade. (Voyez MembraneuSEs, pag. 652. de ce volume.) Le premier est distingué des Arades par ses antennes, dont le dernier articlc toujours ovalc est souvent épais, et par son corps membraneux, en grande partie diaphane.

Antennes cylindricues, insérées ì la base du bec, sur les côtés de la parlie autérieure et avancée de la têtc, composées de quatre articles cylin. driques; le seconá aussi long ou même plus loug quie le troisième. - Bec de trois articles apparens, renfermé à sa base dans un canal rebordé, scs bords ćlevés.-Tête avancée, en triangle alongé, son angle antérieur assez arrondi. - Corps trc̀smince, trìs-déprimé, opaque.-Corselet ayant ses bords latéranx dentclés ou finement sinueux. - Ecusson disinct. - Elytres moins larges que l'abdomen, recouvrant des ailes. - Abdomen trc̀s-plat; ses bords latéraux relevés, en forme de nacelle; anus des femelles sillonné longitudinalement dans son milieu; celui des mâles sans sillon longitudinal. - Toutes les pattes semblables, simplement ambulatoires, insérées sur la ligne médiane du corselet; tarses de trois articles, les deux premiers Irès-courts, le dernier terminé par deux crochets distincts.

Les Arades dans tous leurs états vivent sous les écorces des arbres, aux dépens des larves qui se nourrissent de bois et se tiennent it sa superficie, en quoi ils sont très-favorisćs par la formc extrêmement aplatie de leur corps. Ces Hémiptères sortent quelquefois de leur retraite, nuais en général ils paroissent craindre le grand jour; leur démarclie est assez vive et saccadée. 'Toutes les espices connues sont de taille moyenne, uniformément fuligineuses. Leurs métamorphoses sont lcs mêmes que celles des Pentatomes. Vojez ce mot. 


\section{$0)_{4}^{\prime}$}

${ }_{1}$ re. Division. Angles antérieurs dn corselet prolongés ehaeun en un appendiee aplati qui s'avanee de chaque côté de la tête sans la toueher. - Côtés postérieur's de la tête derrière les yeux, plus ou moins dilatés eu un appendice dentelé. Insectes du nouveau continent. (Dysodius. Noв.)

Le type de cette division est l'Airade lunulé , A. lunulutus n $^{\circ}$. 2. Faв. Syst. Rhyng. - Laт. Gener. Coust. et Ins. tom. 3. pag. 141. Amérique méridionale.

$2^{\ominus}$. Division. Angles antérieurs du corselet arrondis. - 'T'ète simple, sans dilatation derrière les yeux. - Insectes de l'ancien eontinent. (Aradus propriè dictus. Nов.)

Nous mentionnerons, $1^{\circ}$. Arade du Bouleau, A. betulae no. 1 1. FA . Syst. Rhyng. - LAт. Gen. Crust. et Ins. tom. 3. pag. 141. 20. Arade déprimé, $A$. depressus $n^{\circ}$. 10. Faв. id. Ces deux (spèces sont d'Europe. (S.'F. et A. Serv.)

'IIPHIE, Tiphia. Fab. Ross. Lat. Panz. Jun. Sprnol. Sphex. Scop. Schranek. Bethylus. Panz.

Genre d'inseetes de l'ordre des Hyménoptères, seetion des Porte-itiguillon, fumille de's Fouisseurs, tribu des Scoliètes.

Les deux genres 'Tengyre el Tiphlie forment le promier groupe de edte tribu (voyez Sconières), lerpel offie pour caraelères : palpes maxillaires longs, leur's alticles sensiblement inégaux. Promier article des antennes obconique. Les 'Tengyres se disinguent par leurs manlibules biclentées; en outre lin cellule radiale de lenrs ailes supérieures est fermće et pointue à l'extrémité, celle-ci rapprochéc du bnut de l'aile, la troisième cellule eubitale est complcte ; nous ajouterons que dans les 'Tengyres malles, les antennes sont plus longues que la tête et le eorsclet réunis.

Antennes filiformes, plis courtes, dans les deux sexes, que la tête el le eorselet pris ensemb e, composées de donze aricles dans lés fernel'es, de treize dans les mâles; le premier le plus longr de lous, le seeond guère plus court que le troisième, les suivans un peu renflés et ároúés dans les mâles. - Labre eaché, petit, coriace, en earré transversal, rilić.- Iifandibules f : tes, a vancées, étroites, arquées, croisćes l'une sur l'antre dins le repos, strices longitudina!ement, point dentées.--Mâchoires coriaces, très-comprimée's, en carré alongé , leur lobe trrminal presque nembranenx. - Palpes maxillaires raballns, moitié plus longs que les mâchoires, deux fois plus grands que les labiäux, composés de six artiv!es presciue cylindriques, le premier et le dernier plus longs que les antres, le premier un peu aninei à sat base, le sixième cylindrique; palpes labianx de quaire articles à pen près égaux, les trois premiers ubconiques, le terminal ovalaire.-Livre courte, rélléehie, vôn!ée, arrondie à l'extréuité, n'ayant pus de lobes latcranx distiucts: menton coriace,

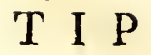

obconique, tronqué droit transversalement à son extrémité. - Tête de la largeur da corselet, déprimée sous les antennes, arrondie et convexe postérieurement. - Yeux ovales, rejelés sur les côtés de la tête, écartés et entiers dans les deux sexes. - Trois ocelles rapprochés, plaeés en triangle sur le vertex. - Corps oblong, velu, point linéaire. - Corselet assez alongé; prothorax en earré transversal, prolongé latéralement jusqu’a la naissunce des ailes supérieures : mésolloorax étroil ; métathorax eoupé brusquement à sa parlie postćrieure, ayant une cavité profonde de ehaque côté. - Ecusson petit, transversal. Alles supérieures ayant une cellule radiale ineomplète daus les femelles, fermée et coupée carrćment à sa partie posiérieure par une nervure transversale, l'extrémité de èelte cellule éloignée du bout de l'aile dans les mâles; trois eellules cubitales, la première recevant la première nervure récurrente, plus longue que la seeonde, celle-ci recevant la seconde nervure réeurrente; la troisième í peine eommeneće, mais tracée dans toute sa longueur jusqu'au bout de l'aile. - Abdomen ovale, consposé de ciuq segmens dans les femelles, en ayant un de plus duns les mâles; plaque anale inférieure de eeux-ei se rétrécissant pour furmer une espèee de croehet creusé intérieurement en gouttière, ce croehet ne dépassant pas l'extrémité de la plaque anale supérieure. - Pattes courles, épaisses; cuisses élargies, conprimées, surtout dans les feuelles: janbes antérieures éehancrées avant leur extrénité el portant une épine nembranemse latéralement; les internédiaires et les postérieures terminées par deux épiues aiguës; ces jambes épaisses, deutelées, très-garnies d'épines; larses alongés, munis d'épines disposćes en verticilles, leur dernier article ayant deux crochets Lifides avec une pelote dans leur entredeux.

I.es mours de ces Hyrnénoplìres sont celles de lous les Fouisseurs qui approvisionnent eux-aiêmes leur nid. On les trouve dans les endroits sablonneux où ils ereusent des trous perpendiculaires, principalement dans les sentiers où la superficie da sable a clé consolidée par la marclie. On les rencontre aussi sur les flenrs, du mitl desquelles ils se nourrissent. Leur vol est asscez lourd, et ils ne prennent leur essrn qu'avee une certaine difficulié, excepté dans le lemps de la plus grande chaleur du jour. Les femelles piquent très-fortement et très-promptement; la douleur que cause celte piqûre est très-cuisante. La proie donl les larves se uourrissent est inconnue.

Eubricius (Sy:t. Piez.) mentionue ving!-trois espéces de ce gense, mais lä plupart ne lui apparliement pas; ainsi les Tiphies, maculata $n^{\circ} .5$, obscura $n^{\circ} .8$, namea $\mathrm{n}^{\circ} .9$, el serena $n^{\circ} .10$. sont des Myzines, et la Tiphia pedestris $\mathrm{a}^{\circ} .23$. est le type du genre Myrunéeode.

Nons eiterons, 10. Tiphie fémorale, T. femo= 


\section{T I P}

rata no. 1. Faв. Syst. Piez. - Jur. Hyménopt. pl. 9. Femelle. - Encycl. pl. 377. fig. I 1. Femelle. - Panz. Faun. Germ. fas. n. fig. 3. Femelle. Très-commune aux environs de Paris. Les cuisses intermédiaires el postérieures ainsi que leurs jambes sont rousses; ces parlies sont dine nuance plus claire dans le mâle. $2^{\circ}$. Tiphie morio, T. morio n०. 2I. FAв. id. $3^{\circ}$. 'Tiphie velue, T. villosa $\mathrm{n}^{\circ}$. 22. FAB. id. Les mâles dans ces deux espèces sont absolument semblables à leurs femelles par les couleurs. On les trouve aux environs de Paris.

TENGYRE, Tengyra. LAT.

Genre d'insectes de l'ordre des IIyménoptères, section des Porte-aiguillon, fausilie des Fouisseurs, tribu des Scoliètes.

Ce genre forme avec celui de Tiphie une coupe parmi les Scoliètes. (Voyez ce mol.) Les Tiphies diffèrent des'Tengyres par leurs mandibules simples, sans dentelures; par leur cellule radiale terminée dans les mâles par une nervure transversale qui rend son extrémité carrée ; celte extrómitć ćloignée du bout de l'aile. Les antennes des Tiphies, tant niàles que lemelles, sont plus courtes que la têle et le corselet pris ensemble.

On ne connoîl pas encore les femelles de ce genre, ainsi les caractères génćriques que nous allons développer sont pris d'après des individus mâles.

Antennes filiformes, beancoup plus longues que la tête et le corselet pris ensemble. - Mándibules bidentées. - Lèvre tronquée à son cxtrénité, un peu échancrée; menton ayant à son extrémilć une petite pointe placée dans le milieu. -Corps très-long. - Ailes supérieures ayaut une cellule radiale fort longue, pointue à son extrémité qui est rapprochée du bout de l'aile; trois cellules cubitales complètes; les deux premières recevant chacune une nervure récurrente. - Pla que anale inférieure se rétrécissan beaucoup pour former un crochet creusé intérieurement en gouttière, qui dépasse un peu la plaque anale supérieure. - Pattes assez longues ; leurs cuisses et leurs jambes grêles; celles-ci presque déponrvues d'épines ainsi que leurs tarses. Le reste des caraclères sont ceux des Tiphies. Voyez ce mot.

Le type de ce genre dont on ignore les mours, est la Tengyre de Sanvitale, T. Sanvitali. Lat. Gen. Crust.et Ins. tom. 4. pag. 116. Mâle. D'Iralie et de Piémont. Nous l'avons prise dans la forêt de Muntmorency, près l'étang de la chasse.

$$
\text { (S. F. et A. SERv.) }
$$

TIPULAIRES, Tipularia. IaAt. Seconde tribu de la famille des Némocères, première section de l'ordre des Diptères.

Plusieurs auten's confondent ensemble les trikus des Culicides et des Tipulaires de M. Latreille sous celle dernière dénomination, ce qui nous

\section{T I P}

engage à donner ici les caractères de la famille des Némocères el des deux tribus qu'elle renferme, exlraits des Familles naturelles.

N'́mocères, Nemocera. Première famille de l'ordre des Diptères, première section; ses caracitères sont:

Antennes composées au moins de six articles et le plus souvent de cuatorze à seize. - Larves ayant tonjours la tête écailltuse et changeant de peau pour passer à l'état de nymphe.

$$
\text { Ire. Tribu. Culicides, Culicides. }
$$

Trompe cylindrique, longue, avancée, renflée au bout. - Sucoir de six pièces. - Palpes dirigés en avant et très-velus, du moins dans les mâles. - Antennes filiformes, de la longueur de la tĉle cl du corselel réunis, conposées de quatorze articles, plumeuses dans les mâles, poilues daus les femelles. - Yeux lunulés. - Point d'ocelles. - Ailes couchées sur le corps, ayant des nervures longiludinales garnies de cils ou d'écailles. - Pattes longues. - Larves aquatiques, conservant la faculté de se mouvoir el de nager sous la forme de nymple.

I. Point d'appendice détaché aux côtés du prothorax.

A. Palpes des mâles ou même des deux sexes, au moins de longueur de la trompe.

Cousin, Anophèle.

B. Palpes plus couris que la trompe dans les deux scxes.

a. Trompe droite. Æedès, Sabéthès.

b. 'Trompe courbée vers son extrémité. Mégarline ( 1 ).

II. Prothorax portant de chaque côté un appendice détaché.

Psorophore.

2e. Tribu. Tipulaires, Tipularai.

Trompe tantôt très-courle et terminée par deax grandes lèvres, tantôt en forme de siphon ou bec soit très-court, soit fort long, mais dirigé le long du dessous du corps. - Sucoir de deux pièces. Palpes peu velus, ordinairement conrbés, quelquefois élevés et alors très-courts.

(1) Nous avons donné ce nom à notre première division du genre Limpobie (pag. 585. de ce volume) qui nous paroît c'evoir former un sous-genre. L'ouvrage de M. Rubineau où ce nêne nom de Mégarhine est appliqué à un mouveau genre de Culicides, comme on le voit daus le rableau ci-dessus, ayant été livré au public avant le nôtre, nous changerons notre nom de Megarhina eh celui d'Hclias. 
I. Antennes grêles, filiformes ou sétacées, sensiblement plus longues que la tête, du moins dans les mâles, ayant plus de douze articles dans le plus grand nombre. Pattes longues et grêles.

A. Point d'ocelles.

a. Palpes toujours courts. - Extrémité antérieure de la tête, point prolongée en museau. - Ailes toujours on couchées ou cn toit à nervures généralement peu nombreuses, les parcourant en divergeant dans un sens longiludinal, point réunies transversalement au limbe postérieur. - Yeux lunulés. - Jambes sans épines. (Espèces petites, vivant en élat de larve et de nymphe daus l'eau ou dans des galles végétales.)

† Antennes des mâles plumeuses ou ayant au moins un faisceau de poils; celles des femelles poilues. Culiciformes, Culiciformes.

* Antennes des máles plumeuses des deux côlés et jusqu'au bout.

- Antenres entièrement composées dans les deax sexes d'articles ovales-cylindriques.

Corèthre.

99 Antennes des deux sexes moniliformes inférieurement, terminćes après leur partie moniliforme soit par un article fort long et liné:iire, soit par deux articles dont le dernier est renflé et ovalaire.

Chironome, Tanype.

* A Antennes des deux sexes presqu'entièrement moniliformes, avec les cinq derniers articles plus alongés; celles des mâles n'ayant qu'un faisceau de poils situé à leur base.

Cératopogon, Macropèze?

† $\dagger$ Antennes des deux sexes moniliformes, garnies de soies verticillées ou simplement pubescentes.

Gallicolles, Gallicoloe.

Psychode, Cécidomyie, Lestrémie, Lasioptère.

b. Palpes de plusieurs, longs et à dernier article alongé. - Tểle ayant son extrémité antérieure rétrécie, prolongée en musean (souvent même avancée en saillie pointue). - Ailes souvent écartées, à nervures nombreuses, réunies transversalement, du moins en partie, au-delà du milieu de leur longueur; deux ou trois cellules discoïdales fermées. Yeux ronds ou ovales, sans échancrure remarquable. - Jambes terminées par deux épines. (Espèces généralement grandes, vivant pour la plupart sous la forme de larve et de nymple dans le terreau ou le bois pourri.)

Terricoles, Terricolce. (Voyez ce mol.)

B. Deux ou trois ocelles. (Yeux ordinairement ronds.-Ocelle impair plus petit. -Antennes simples. - Dernier article des palpes jamais très-long, ni noueux. -Ailes couchées sur le corps. - Deux épiues terminales aux jambes.)

Fongivores, Fungivorce.

a. Antennes point manifestement grenues ni perfoliées.

† Antennes plus longues que la tête et le corselet réunis. (Capillaires.)

Macrocère, Bolitophile.

†† Antennes de la longueur au plus de la têle et du corselet réunis.

* Deux ocelles.

- Synaphe, Mycétophile.

* * Trois ocelles.

Léia.

b. Antennes soit grenues, noueuses, soit perfoliées.

† Antennes de la même grosseur ou plus menues vers le bout.

* Museau prolongé en manière de bec.

Rhyphe, Gnoriste, Asindule.

* * Museau point rostriforme.

$\uparrow$ Yeux entiers.

Platyure, Sciophile, Campylomyze.

ฯ ণ Yeux échancrés. Mycétobie, Molobre. (Sciara Merc.)

$\dagger \dagger$ Antennes en massue perfoliée, presqu'en forme de râpe.

Céroplate.

II. Antennes de douze articles au plus, plus courtes que la tête et le corselet pris ensemble, 
ensemble, épaisses, cylindraeées, moniliformes ou perfoliées. - Pattes ordinairement eourtcs. - Ailes larges. - T'rois ocelles égaux dans la plupart.

$$
\text { Florales, Florales. }
$$

A. Point d'oeelles.

$$
\text { Curdyle, Simulie. }
$$

B. Des ocelles.

a. Antenues de onze articles.

Seathopse, Penthétrie, Dilople.

b. Antennes de huit à neuf artieles.

Bibion, Aspiste.

ANOPIiEle, Anopheles. Mrig. Lat. (Fam. nal.) Rob. Desv. Macq. Culex. Linn. Hab. Olrv. (Encycl.) Schranek.

Genre d'inseetes de l'ordre des Diptères, première seetion, famille des Némocères, tribu des Culieides.

Le premier groupe de eette tribu contient les Cousins et les Anophèles. (Voyez Culterdes, pag. 655. de ce volume.) On dislingue les premiers par lenrs palpes inégatux dans les deux sexes, plus longs que la trompe dans les mâles, plus courts qu'elle dans les femelles.

Antennes avancées, filiformes, composées de quatorze articles, plumeuses daus les mâles, poilnes dans les femelles. - Palpes avaneés, de la longueur de la trompe dans les deux sexes, conposés de cinq articles; le premier très-court, les deux suivans longs, cylindriques; les deux derniers dans les mâles, fortement eomprimés, se rejetant sur le côté, velus extérieurement, de la longueur du troisieme pris ensemble: palpes des femelles droits, filiformes, presque nus; leurs artieles d'inégale longueur. - Trompe en massue à son extrémité, plus longue que la tête et le corselet réutis. - Ailes eouchées horizontalement sur le corps dans le repos : leurs nervures. ebargées d'écalles.

Il est probable que les mœurs de ces Diptères, dont le nom vient du gree et signifie : importun, sont les mêmes que celles des Cousins. Linné dit que leurs larves habilent dans l'eau; il ajoule que l'insecte parfait ne pique pas. Les Anophèles se tienneat dans les endroits marécagreux.

\section{Anophèle bifurqué, $A$. bifurcatus.}

Anopheles bifurcatus. Mrig. Dipt. d'Europ. tom. 1. pag. 11. no. 1. - MAcQ. Tipul. du nord de la France, pag. 163. $n^{\circ}$. 1. - Rов. Desv. Mém. de la Soc. d'hist. nat. de Paris, tom 3. 1827. pag. 410. $n^{\circ}$. 1. - Culex trifurcalus n०. 5. F_13. Syst. Antliat. (en retrunebant le synonyme Hist. Nat. Ins. Tome $\boldsymbol{X}$. de Meigen qui appartient à l'A. maculipenue.) et Culex claviger ${ }^{\circ} .6$. $\mathrm{F}_{\mathrm{AB}}$. id.

Voyez pour la deseription et les autres syucnymes, Cousin bifurqué no. 5. de ee Dictionnaire.

Ce genre renferme en outre, $1^{\circ}$. Anophèle maeulipenne, $A$. maculipennis. Merg. Dipt. d'Eur. tom. 1. pag. 11. $n^{\circ}$. 2. tab. 1. fg. 17. Femelle. - Ros. Desy. id. pag. 4lı. no. 5. D'Allemagne et des environs de Paris. M. Macquart ut suprà décrit une espèee sous le même nom et qui est peut-être la même; nais il n'a pu y reeonnoítre les deux lignes obseures dn dessus du eorselet dont parle M. Meigen. $2^{\circ}$. Anophèle albimane, $A$. albimanus. Wieden. Dipt. exotic. pag. 10. $n^{\circ}$. I. - Roв. Desv. id. pag. $411, n^{\circ} .5$. Longueur 2 lig. $\frac{2}{3}$. Brun. Alsdomen ayant de grandes taches triangalaires grises. Ailes taehéts de brun. Extrémité des tarses d'un blanc de neige. Femelle. De Saint-Domingue. $5^{\circ}$. Anophèle velu, A. villosus. Rов. Desv. id. pag. $411 . n^{\circ} .2$. Longuemr $3 \mathrm{lig}$. Il ressemble exaetement à l'A. bifurqué, mass celui-ei a l'abdomen presque glabre, tandis gुue dans cette nouvelle espèce if est velu. Des euvirons de Paris. $4^{\circ}$. Anophèle argenté, A. argyritarsis. Rов. Desv. id. $n^{2} .4$. Inngueur 2 lig. $\frac{1}{2}$. Trompe noire; eorps noirütre; abdornen sans raehes; pattes grêles, d'un brun pâle; extrémité des tarses postérieurs, blanche, avec un reflet argonté. Femelle. Du Brésil.

IEDÉS, Edes. Hoff. MeIg. Lat. (Fam. nat.) Roв. Desv.

Genre d'inseetes de l'ordre des Diptères, première section, fanille des Némoeères, tribu des Culicides.

Un groupe de eette tribu renferme les genres Edès et Salléthès. (Voyez pag. 655. de ce vislinme.) Ce dernier se distiugue par ses jambes intermédiaires qui sont dilutées et fortement ciliées, ainsi que leurs tarses.

Antennes avaneées, filiformes, composées de quatorze artieles, plumeuses dans les mâles, poilues dans les fenelles. - Trompe droite, avaneée, au moins de la lougueur du eorselet. Palpes très-eourts dans les deux sexes. - Ailes couchées sur le eorps dans le repos, leurs nervares ehargées d'éeailles. - Jumbes intermédiaires, ainsi que leur's tarses, siusples, ni dilatés, ni eiliés.

Elès vient d'un mot grec qui signifie : déplaisant, incommode. Le type du genre est l'Æidès eendré, ZE. cinereus. Merg. Dipt. d'Eur. tom. I. pag. 13. no. 1. - Roв. Desv. Mém. de la Soc. d'hist. nat. de Paris, tom. 3. 1827 . pag. 411 . $n^{\circ}$. I. Longueur 2 lig., 2 lig. $\frac{1}{2}$. Plutôt brun que gris ; prothorax garni de poils rougeattres. Ailes sans taehes; cuisses plus pâles que le reste des paties. D'Europe. Il cst rare anx envirous de Paris. 
SABÉTHÉ, Sabethes. Rов. Desv.

Genre d'insectes de l'ordre des Diplères, première section, famille des Némocères, tribu des Culicides.

Ce gente avec celui d'Adès forme un groupe dans cette iribu, caractérisé par le manque d'appendice aux côtés du prothorax, les palpes des deux sexes plus courts que la trompe qui est droite. (Voyez pag. 655. de ce volume.) Les Edès sont distingués par leurs jambes et leurs tarses simples, c'est-à-dire ni dilatés, ni ciliés.

Ne connoissant pas ce nouveau genre, nous en donnerons les caractères d'après l'auteur, tels que nous les trouvons dans son Essai sur la tribu des Cubicides, inséré dans les Mém. de la Soc. d'hist. nat. de Paris, tom. 3. 1 827. pag. 38o.

Trompe droite. - Palpes labiaux fort courts. - Jambes et tarses intermédiaires dilatés, fortezent ciliés.

Le type du genre est le Sabéthès riche, $S$. locuples. Rов. DEsv. id.pag. $412 . n^{\circ}$. I. Longueur une ligne. D'un bleu violeı métallique; abdoınen avec des taches latérales triangulaires argentées. Du Brésil.

M. Robineau Desvoidy pense que cette espèce ne pique pas.

MÉGARHINE, Megarhinus. Roв. Desv. Culex. Fab. OLIV. (Encycl.) Wiédem.

Genre d'insectes de l'ordre des Diptères, première section, famille des Némocères, tribu des Culicides.

Ce nouveau gente forme seul dans sa tribu une coupe particuliere dont le caractère est : point d'appendice détaché aux côtés du prothorax; palpes plus courts que la trompe; celle-ci reconrbée vers son extrémité.

M. Robineau Desvoisy (Essai sur la tribu des Culicides, Mém. de la Soc. d'hist. nat. de Pais, tom. 3. 1827. pag. 38o.) donne ainsi les caractères de ce genre qui nous est inconnu et dont le nom vient de deux mots grecs qui signifient: grand nez.

Trompe alongée, ayant son extrémité recourbée. - Palpes labiaux plus courts que la trompe, composés de cinq articles; le premier plus épais que les autres, le second plus court que les suivans, les trois derniers cylindriques. - Ailes couchées parallèlement sur le corps dans le repos.

x. MÉgarhine hémorrhoïdal, MI. hamorrhoidalis.

Megarhinus haemorrhoidalis. Roв. Desv. Mém. de la Soc. d'hist. nat. de Paris. tom. 3. 1827. pag. $412 . n^{\circ}$. 1. - Culex hamorrhoidalis $\mathrm{n}^{\circ} .8$. FaB. Syst. Antliat.

Voyez pour la description et les autres synonyymes, Cousin hémorrhoïđal no. 8.' du présent Dictionnaire.
PSOROPHORE, Psorophora. Rob. Dest. Cullex. FAB. WiÉDEM.

Genre d'iusectes de l'ordre des Diptères, première section, famille des Némocères, tribu des Culicides.

Tous les autres genres de cette tribu se distinguent de celui-ci par l'absence d'un appendice détaché aux côtés du prothorax. Voyez pag. 655. de ce volume.

Les caractères assignés à ce nouveau genre par M. Robineau Desvoidy dans son Essai sur la tribu des Cnlicides, Mém. de la Soc. d'hist. nat. de Paris, tom. 3. 1827. pag. 380. sont les suivans :

Ocelles très-distincts. - Prothorax muni de chaque côté d'un appendice détaché. - Mésothorax renflć, ses côtés ayant chacun une fossette triangulaire distincte. - Antennes coutes dans les deux sexes; leur quatrième article alongé, le cinquième petit, styliforme.-Pattes les femelles ciliées.

Nous ne connoissons pas ce genre; nous mentionnerons les deux espèces suivantes: $1^{\circ}$. Psorophore ciliée, $P$. ciliata. Rов. Dest. Mém. de la Soc. d'hist. nat. de Paris, tom. 3. 1827. pag. 413. $n^{\circ}$. !. Mâle et fenelle. - Culex ciliatus no. 10. Fa в. Syst. Antliat. De Caroline. $2^{\circ}$. Psorophore de Bosc, P. Boscii. Roв. Desv, id. $n^{\circ}$. 3. Longueur 2 lig. $\frac{1}{3}$. D'un jaune pâle; pattes d'un jaune brun : nervares des ailes velues. De Caroline.

Ces deux espèces sont de celles qui tourmentent les habitans'du pays, et quils nomment Mosquites.

CORÉThRE, Corethra. Meig. Lat. Mace. Tipula. De Géer. Chironomus. Fab.

Geure d'insectes de l'ordre des Diptères, première section, famille des Némocères, tribu des Tipulaires (division des Culiciformes).

Ce genre constitue seul une coupe particulière dans cette division, caractérisé ainsi : antennes des mâles plumeuses des deux côtés et jusqu'au bout, entièrement composées, dans les deux sexes, d'articles ovales-cylindriques. (Voyez ' $\Gamma_{1}$ pULAMRES, pag. 656.)

Antennes avancées, filiformes, composées de quatorze articles oblongs, un peu renflés à leur base, les deux derniers un peu plus longs, surtout dans les mâles; tous garnis dans ce sexe de longs. poils verticillés qui diminuent de longueur progressivement, ces mêmes poils courts dans les femelles. - Trompe cliarnue. - Palpes avancés, recourbés, cylindriques, velus, composés de quatre atticles, le premier très-court, les autres d'égale lon rueur. - Téte petite. - Yeux lunulés. - Point d’ocelles. - Corps mince, alongé. Corselet ovale.-Ecusson ovale. - Ailes étroite., couchées parallèlement sur le corps dans le repos, leurs nervures longitudinales nombreuses, velues, leur bord postérieur garni d'écailles lancéolées, pointues; point de nerrures transversales $-B a-$ 


\section{T I P}

lanciers découverts. - Abdomen cylindrique, un peu aplati à sa partie postérieure dans les máles, composé de huit segmens, le dernier ou l'anus armé de denx crochets dans les mâles. Pattes grêles, de longueur moyenne, insérées très-prčs les unes des autres.

Le nom de ce genre vient d'un mot grec qui siguifie : plumet. Réaumur Irouva en juillet et août la larve de la Corètlire plumicorne dans l'eau ; son corps est transparent, presque cylindrique, plus gros à sa partie antérieure; la tête porte en devint un double crochet; on aperçoit antérieurement deux corpuscules réniformes et deux autres semblables, mais plus petits vers l'anus; le dernier segment du corps porte en desious une nageoire ovale en forme de feuille et l'anus est muni de deux cornes charnues. Ia nymple est oblongue, avec deux petites cornes sur la tête et deux nageoires elliptiques à l'anus. L'insecle ne reste en état de nymphe que pendanı dix à douze jours. De Géer trouva la larve de la Corèthre culiciforme au mois de mai dans des marisis; elle est d'un brun clair, oblongue, son corselet est très-épais; on voit à l'intérieur deux corpuscules oblongs d'un brun foncé; au bout du huitième segment ou anus, qui porte en dessous une touffe de poils rayonnés, est un tuyau conique, relevé. La nyınphe est brune, ordinairement arquée; sa partie antérieure porte deux cornes et l'auus deux nageoires en forme de feuilles. Linsecte ne reste dans cet état que huit jours environ.

Les Corèthres sont de petite trille. On les trouve dans les endroits bumides et au bord des eaux. Les espèces connues sont en petit nombre. $1^{\circ}$. Corèthre plumicorne, $C$. plumicornis. Meng. Dipt.d'Eur. tom. 1. pag. 15. $n^{\circ}$. 1. tab. 1. fig. 22. Màle. - Mace. Tipul. du nord de la France, pag. ${ }^{152 .} n^{\circ} .1$. - Corethra lateralis. Encycl. pl. 385. $n^{\text {o. }}$ I. Femelle. $2^{\circ}$. Corèthre pâle, $C$. pallida. Me1G. id. pag. 16. $n^{\circ}$. 2. - MAcQ. id. pag. $153 . n^{\circ} .3$. Suivant cet auteur, elle volige en troupes nombreuses au bord des eaux. 30. Corèthre culiciforme, C. culiciformis. MEIG. id. $n^{\circ}$. 3. - M M Gener. Crust. et Ins. tom. 4. pag. 247. Ces trois espèces se trouvent en France et en Allemagne.

Chironome, Chironomas. Meig. Lat. Fab. Wiéd. Tipula Lin. Geof. Sch affF. Scop. Schranck. De Géer. Ross.

Genre d'insectes de l'ordre des Diplères, première section, famille des Némocères, tribu des 'ípulaires (division des Culiciformes).

Un groupe de cette division a pour caractères: antennes des mâles plumenses des deux còtés et jusqu'au bout, moniliformes inférieurement dans les deux sexes, terminées après la partie moniliforme soit par un article fort long et linéaire, soit par deux articles dont le deruier est renflé et ova-

\section{T' I P}

laire. (Voyez pag. 656.) Il renferme les Chironomes et les Tanypes; ceux-si sont reconnoissables par leurs antennes composées de quatorze arlicles dans les deux sexes, dont la partie supérieure non moniliforme est composée de deux articles, le dernier court et ovalaire.

Antennes filiforınes, avancies, insérées presquau milieu de la tête, placée sur une élévation disciforme; celles des mâles garnies de longs poils coniques, épais, composées de treize articles; le premier court, cylindrique, les onze suivans lenticulaires on sphériques, le dernier très-long, cylindrique. Autennes des femelles de six articles; le premier court, cylindrique, les quatre suivans turbinés ou ovales, garnis de poils verticillés, le dernier très-long, cyliudrique, un peu velu. - Trompe courte, charnue. - Palpes saillans, recourbés, cylindriques, un peu velus, de quatre articles; le premier pe!it, les deux suivans d'égale longueur, le dernier le plus long de tous. - Téte petite, presque plane antérieurement, portant une carèce longitudinale dans son milieu. - Yeu.x luuulés, plus larges à leur partie inférieure. - Point d'ocelles - Corps grêle, alongé. - Corselet ovale, son dos bombé, ayant trois bandes oblongues, légèrement élevées, l'intermédiaire partant d'auprès de la têle et s'avançant jusque vers le noilieu. du corselet; les deux autres siluées près de l'insertion de cliaque aile : sternum présentant un espace légèrement convexe qui sépare l'itisertion des pattes antérieures de celle des intermédiaires; métalhorax en forme de croissant, ayant une ligne longitudinale enfoncée. - Ecusson étroit. Ailes lancéolées, couchées parallèle inent sur le corps dans le repos, finement frangrées au bord postérieur, leurs nervures en nonbre moyeo, toutes longitudinales. - Balanciers décuuveris. - Abdomen loag, mince, finement velu, coniposé de huit segmens; celui des unáles linéaire, ayant l'anus fortement tronqué, muni de deux petits crochets. Abdomen des femelles cyliudrique, obtus postérieurement. - Pattes longues, grêles; tarses antérieurs très-alungés dans la plupart des espèces.

Quelques larves de Chironomes ont élé observées. Linné, dans la Fauna suecica, décrit ainsi la larve de sa Tipula plumosa. (Chironomius plamosus. Merg.) Corps rougeâtre, filiforme, conposé de douze segmens; queue fendue. Avantdernier segment du corps portant quatre filets; elle a deux paties dutérieures et deux postérieures, et vit dans l'eau. Une autre larve de Chironone $a$ été connue de Réaumur (Mém. Ins. tom. V. pag. 29-39.pl. 5. fog. 1 - o. ) Le corps est fort long, vermiforme, ordinairement d'un rouge-sanguin, composé de onze segmens, le premier un peu plus grand que les autres; la lête est fort petite. M. Macquart, qui a aussi observé celtelarve, a remarqué que sa tête porte deux points noirs qu'il regrarde commé de yeux : il a également distingué deux antennes O००० 2 
( probablement des palpes) courtes, cylindriques, composées de deux articles, le second fort menu. I a bouche est peu distincte; sous le premier segment sınt deux tentacules pédiformes, bordés de très-petites pointes en crochets; deux lones filets charnus très-flexibles sont insérés au milien des côtés de l'avant-dernier segment; la base du dernier en présente deux semblables; il est terminé par deux tubes ovales-alongés dont l'ouverture est ciliée, et par quatre mamelons plus petits. Celte larve habite en société dans des deneures qu'elle se construit au lond des eaux ou sur les rives; les matériaux que ces larves emploient sont des débris de terreau et de feuilles, que Réaumur a cru leur voir réunir au moyen de fils de soie, les mouvemens qu'elles faisoient daus ce moment étant les mêmes qne ceux des insectes auxquels la anture a accorclé la faculté de filer. Clıaque larve se fait un lourreau plus ou moins tortuenx (la réunion de ceux-ci forme des masses irrégulières), dont la surface offie l'ouverture de chaque tnyau. Lewr corps sort souvent en partie de ces habilations, alors sa partie postérieure paroît cramponnée dans l'intérieur du tuyau à l'aide des quatre filets charnus dont nous avons parlé; les deux tubes ovales qu'on voit à cette même partie sont probablement l'organe extérieur respiratoire. La larve abandonne quelquefois son tuyau et va en construire un autre; elle se meut dans l'eau en se contournant vivement; aucun de ses organes ne remplit les fonctions de nageoires. C'est dans sa celIule qu'clle snbit sa métamorphose en nymplse; celle-ci ne differe des autres nymphes de Tipulaires que par les éligans panaches qui ornent le corselel et la parlie postérieure du corps, et qui sont probablement placés à l'extrémité des trachées aériennes qui servent à la respiration; le panache du corselet est surtout renarquable en ce qu'il esi composé de cinq tiges plumeuses qui s'écartent en rayonnant; les jarnbes antérieures, trop longues pour être appliquées contre le corps comme les antres, sont contournées d'une manière particulière. Lés étuis qui renferment les ailes sont grands. Pour opérer satransformation, la nymphe quitte son fourreau et vient à la surlace de l'eau. Nous avozs observé qu'en sortant de sa pean de nymphe, l'iusecte parfait tient ses pattes posées sur l'eau sans s'y enfoncer, jusqu'à ce que le développement et le dessèchement de ses ailes lui permeltent de prendre sa volée.

Plusieurs auteurs ont attribué cette larve au Chironome pluraeux. Il paroit qu'ils se sont trompés, telle est au moins l'opinion de M. Meigcn, qui remarque que l'insecte parfait, fguré par Réanmur, porte sur cliaque aile trois taches noires qu'on ae retrouve point dans le Chironome plumeux.

D. Géer a vu la larve du Chironome stercoraire (Mém. Ins. tom. YI. pag. 388, $n^{\circ} .22$. pl.22. fg. 14-20. et pl. 23. fig. 1.) qui vit dans les fumiers. Elle est vermiforme; sa tête est mu- nie de deux antennes (probablement des palpes), courtes et coniques, et de deux crochets placés de manière ì faire l'office de pioches pour se frayer un chemin dans le fumier en le fouillant.

Les Chironomes, surtout les mâles, volent en troupes nombreuses dans les temps orageux et humides, an-dessus des marais et au bord des eaux, dans lesquelles ont vécu les larves. Lorsqu'ils sont posés, leur's quatre paltes postérieures seules les sontiennent d'ordiuaire sur le plan de position; les antérieures sont alors relevées et dirigćes en avant; elles ont un mouvement continuel et alterratif de haut en bas et de bas en haut, habilude qui leur a valu l'application d'un mot grec qui signifie : gesticuler en cadence. Les espèces de ce genre sont nombreuses et presque toutes fort petites. Le corps de plusieurs est vert ou presque transparent; quelques autres sont d'un noir foncé. Les individus de chaque espèce sont ordinairement fort nombrerx et se tiennent cantonnés.

MM. Meigen et Macquart divisent ainsi ce genie :

\section{Ire. Division. Ailes nues vues au microscope.}

$\mathrm{I}^{\mathrm{re}}$. Subdivision. Balanciers blanchâtres.

Cette subdivision renferme dans les Diptères d'Europ. de M. Meigen cinquante-six espèces, parmi lesquelles nous citerons $: 1^{\circ}$. Chironome plumeux, C. plumosus. Mrig. Dipt. d'Europ. tom. 1. pag. 20. no. 1. - Mace. Tipul. du nord de la Frunce, pag. $137 . n^{\circ} .1 .-$ Encycl. pl. 385. fig. 6. Femelle. (M. Meigen regarde comme donlteux le synonyme de Geoffroy en raison de la taille moilié plus petite que cet auteur donne à l'espèce qu'il décrit.) 'Très-commun aux environs de Paris. ${ }^{\circ}{ }^{\circ}$. Chironome gesticulatemr, C. motitator. Merg. id. pag. 45. $n^{\circ}$. 55. - M AcQ. id. pag. 147. $n^{\circ} .32$. De France et d'Allemagne. $3^{\circ}$. Chironome menn, C. tenuis. MAcQ. id. pag. 139. $n^{\circ} .6$. Longueur une lig. $\frac{3}{4}$. Corselet verdâtre, à trois bandes lougitudinales noires. Abdomen et pattes noirâtres. Ailes transparentes. Assez commun. $4^{\circ}$. Chironome noir, C. niger. MAcQ. id. pag. 142. $n^{\circ}$. 13. Longueur une ligne $\frac{1}{2}$. Norr. Pattes d'un binn-noirâtre. Assez commun. 5०. Chironome grêle, $C$. gracilis. M McQ. id. $n^{\circ}$. 14. Longueur une ligne. Corselet jaune à bandes longitudinales noires. A bdomen d'un brun-noir; pattes jaunâtres. Mâle. $6^{\circ}$. Chironome pallipède, $C$. pallipes. Mace. $i d . n^{\circ}$. 15. Longueur 2 lig. Brun. Antennes et pattes pâles. $7^{\circ}$. Chironorne testacé, $C$. testaceus. MAcQ. $i d . n^{\circ}$. 16 . Longueur une lig. Testacé; corselet à bandes longiludinales brunes; palles pâles. Commun. $8^{\circ}$. Chironome tacheté, C. maculatus. MacQ. id. pag. 144. $n^{\circ}$. 22. Longuenr uue ligne. Noirầre; pattes roussâtres; ailes tachelées. Femelle. $9^{\circ}$. Chironome anneló, $C$. annulatus $\mathrm{N}_{\mathrm{AcQ}}$. id. pag. $146 . n^{\circ}$. 27. Longne ur une ligne $\div$. Noir. Janbes et tarses à baude blanche. Commun. $10^{\circ}$. Chironome trois anneaux, C. triannulatus. MACg. 
$i d . n^{\circ}$. 3o. Longueur une ligne $\frac{t}{4}$. Corselet jaune à bandes longitudiuales noires. Premier, quatrième et cinquième segmens de l'abdomen jaunes; jambes antérieures ayaut une bande blanche. Assez rare. $11^{\circ}$. Chironome bordć, $C$. murginatus. MAcQ. $i d . p a g .148 \cdot n^{\circ} .33$. Longueur une lig. $\frac{1}{4}$. Corselet jaune à bandes longitudinates noires; aldomen noir, ses segmens hordés de jaune; pattes noires, jambcs à anneaux blancs. iz ${ }^{\circ}$. Chironome unifascié, C. unifasciatus. Mace. $i d . n^{\circ}$. 34. Longueur une ligne. Corselet jaune à bandes longitudinales noires; abdomen noir avec le prenier segment jaune; jambes antérieures ayant une baude blanche.

\section{$2^{\mathrm{e}}$. Subdivision. Balanciers noirs ou bruns.}

M. Meigen placc dans cette subdivision six espèces. Nous cilerons : $1^{\circ}$. Chironome stercoraire, C. stercorarius. MEIG. Dipt. d'Europ. tom. I. pag: 46. $n^{\circ}$. 57. - M.AcQ. Tipul. du nord de la France, pag. 148. $2^{\circ}$. 35. De France et d'Allemagne. Fort counmun. $2^{\circ}$. Chironome humćral, C. humeralis. M McQ. id. pag. 149. $n^{\circ}$. 38. Longneur une ligue $\frac{1}{2}$. Noir. Corselet marquć d'une taclie jaune de chaque côté; pattes obscures; ailes blanches avec une ligne noire à leur base. Nûle. Assez rare.

\section{2e. Division. Ailes velues vaes au microscope.}

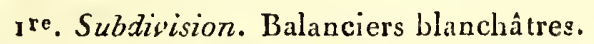

Dans les Diptères a'Europe, cette subdivision comprend onze espèces. Nous mentionnerons : 10. Chironome fuscipède, $C$. fuscipes. Mel g. Dipt. d'Europ. tom. 1. pag. 49. $n^{\circ}$. 65. - MacQ. Tipul. du nord de la France, pag. 150. $n^{\circ} .40$. De France et d'Allemagne. $2^{\circ}$. Chironome flavipède, C. flavipes. MEIG. id. pag. 5o. $n^{\circ}$. 67. - MAcQ. $i d$. $77^{\circ}$. 39. De France et d'Allemagne.

\section{$2^{\mathrm{e}}$ Subaivision. Balanciers noirs ou bruns.}

Cette subdivision ne contient que les deux espèces suivantes : $1^{\circ}$. Chironomc picipède, $C$. picipes. Meic. Dipt. d'Europ. tom. 1.pag. 52. $n^{\circ}$. 74. D'Atlemagne. $2^{\circ}$. Chironome brun, C. fuscus. Meig. id. $n^{\circ} \cdot 7^{5}$. Même patrie.

Nous citerons encore counme élant de ce genre, le Chironome agréable, $C$. festivus. Wiédem. Analect. Entom. pag. 10. Longneur 3 lign. $\frac{3}{3}$. Vert. Corselet à bandes longitudinales ferrugineuses. Bords des segmens de l'abdomen, noirs. Míle. Amérique septentrionale.

On doit recirer du genre Chironomus Fав. Syst. Antliat. les espèces européennes $\mathrm{n}^{\mathrm{cs}} 7,14,16$, $27,29,30,44$. qui appartiennent au genre ' $\mathrm{Ta}$ nype, ainsi que le $n^{\circ} \cdot 23$. Ce dernier de l'Amérique méridionale. Les nc ig. et 22. sont des Corèthres. i.e genre Cératopogon revendique les espèces suivantes : nos $20,31,35$. Les nos 37 et 42 sont des Molobres. (Sciara MerG.) Le no. 39 est du genre Polymera Wiéden. el le no. 40. du genre Dorthesia du inême auteur. Le no. 45 est une Cécidonyie, ce qui est également probable des $n^{c s} .41$ et 49 . Le $n^{\circ} .47$ appartient au gevie Simulie. Les nus. $24,39,43$ et 43 sont douteux.

CÉRATOPOGON, Ceratapogon. MEtg. MacQ. Lat. Panz. Wiédem. Tipula. Linn. Sceranck. Schell. Chironomus. Fab. Culex. Oliv. (Encycl.) F.A?

Genre d'insectes de l'ordre des Diptères, prenière section, famille des Némocèrcs, tribu des Tipulaires (division des Culiciformes).

Un groupe de Tipulaires-Culiciformes contenant les genrcs Cératopogon et Macropèze offie pour caracic̀res : antennes des deux sexes presqu'euiièrement moniliformes, avcc les cinq derniers articles plus alongés; ceties des mâles n'ayant qu'un faisceau de poils silués à leur base. (Voyez pag. 656.) Les Miacropèzes sont disinctes des Cératopogons par leurs antennes ayant quatorze articles cylindriques, et encore par la longucur disproportionnée des pattes postérieures.

Antennes avancées, filifornes, plus lougues que la lĉte, insérécs sur un disque épais, composćes de treize aricles dans les deux sexes; les huit inférieurs globuleux ou ovales, garnis de longs poils dans les mâles, lesquels forment un bouquet ou pinc eau dirigé obliquement en dehors; les cing derniers articles cylindriques-ovales: dans les femelles tous les articles sont semblabics pour la forme à ceux des mâles, mais seutement garnis de poils courts. - Trompe un peu saillante. - Palpes insérés des deux côlés de la base de la lèvre inféricure, saillans, courbés, cyliudriques, velus, composés de quatre articles; le premier court, le second trois fois aussi long que lc premier, les deux derniers assez courts. - Téte déprimée en avant. - Yeux lunulés. - Point d'ocelles. - Corps mince, alongé. - Corselet ovale ou presque globuleux, sans bandes élevées, mais ay ant une impression sur sa partie postérienre dorsale : métalhorax très-court, caclié sous l'écusson. - Ecusson élroit. - Ailes lancéolées ou fortement arrondies à l'extrémité, velues vucs au microscope, couchées parallèlement sur le corps dans le repos; leurs nervures, en nombre moyen, toutes longitudinales. - Balanciers découverts. - Abdomen cylindrique, de huit segmens, quelquefois un peu déprimć dans les mâtes. - Paltes presque d'égrale longueur, rapprochées à leur insertion, sans intervalles ćlevés.

On trouve les Cératopogons, dont le nom vient de deux mots grecs qui signifient: cormes barbues, sur les broussailles, les haies, les fleurs, surlout dans les pays boisés, bas et hunides. Cc séjour, ainsi que l'analogie, ne permettent guère de douter qu'ils ne se développent dans les eaux; cependant on ne connoît encore ni leurs larves, ni leurs métamorphoses. Ce genre est nombreux en es- 
pèces; elles sont fort petites et se multiplient beaucoup. Celles de la première division, suivaut M. Meigen, piquent plus vivement que l'exiguité de leur taille ne pourroit le faire croire.

$1^{\text {re }}$. Division. Cuisses grêles, simples, sans épine. (Culicoides.)

Nota. Le genre Cinlicoïde Lat a été établi, à ce que nons croyons, sur l'inspection d'individus femelles de l'espèce que MM. Meigen et Macquart regardent comme étant le Culex pulicaris Livv. La fenelle a les muêmes antennes que les Cératopogons de ce sexe, et le nuâle a les sienues exactement conformées comme dans les mâles Cératopogons. On pourroil faire un genre sous ee nom de Culicoide, de la présente division; nous pensons qu'out:e le caractère tiré des cuisses, mentionné ci-dessus, on doit admettre que lá trompe est plus longue que la tête et conique (au moins dans les femelles); par conséquent sa forme et ses dimensions proportionuelles sont différentes de celles des véritables Céralopogons. Ces derniers sont des insectes tout-à-fait innocens, qui ne piquent point et ne vivent pas de proie, tandis que MM. Meigen et Macquart s'accordent à dire que les Cératopogons de leur première division piquent la peau humaine rue. Ce dernier auteur a été à même d'ubserver qu'ils vivent aussi de proic.

Cette division renferme vingt-neuf espèces dans les Dipt. d'Europ. de M. Meigen, parmi lesquelles nous citerons : $1^{\circ}$. Cératopogon fascié, $C$. fásciatus. MeIg. Dipt. d'Eur. tom. 1. pag. 79. $n^{\circ} \cdot 27$. - Mace. Tipul. du nord de la France, pag. 121. $n^{\circ}$. 1. De France et d'Allemagne. $2^{\circ}$. Cératopogon ailes de neige, $C$. niveipennis. Mrig. id. pag. 73 . $n^{\circ}$. 12. - MAcQ. id. pag. 124. $n^{\circ}$. 10. Longueur une ligne. Noir; ailes d'un blanc de neige; balanciers et tarses blancs. On le trouve au printemps. M. Macquart l'a surpris suçant une espèce de $\mathrm{Chi}$. ronome plus grand que lui, dont il s'étoit emparé.

$2^{\mathrm{e}}$. Division. Quelques-unes des cuisses épineuses en dessous. (Ceratopogon proprie dictus.)

${ }_{1}$ re. Subdivision. Cuisses antérieures épineuses en dessous.

M. Meigen range sept espèces dans cette subdivision; nous citerons le Cératopogon spinipède, C. spinipes. MEI G. Dipt. d'Eur. tom. I. pag. 81. $n^{\circ}$. 33. Mâle.-PAnz. Faun. Germ. fas. 103. /ig. 14. Mâle. D'Allemagne.

$2^{\mathrm{e}}$. Subdivision. Cuisses postérieures renflées, épineuses en dessous.

Cette subdivision contient cinq espèces dans les Dipt. d'Eur. de M. Meigen.

I. Cératopogon molio, C. nuorio.

Ceratopogon morio. Meic. Dipt. d'Eur. tom. 1. pag. 84. $n^{\circ}$. 40. - Mace. Tipul. du nord de la

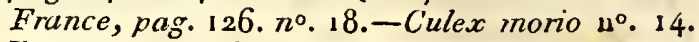
Fав. Syst. Antliat. 1

Voyez pour la description et les autres synonymes, Cousin morio no. 12. de ce Dictionnair(.

Nous mentionnerons encore le Cératopogcu fémoral, C. femoratus. Mrig. Dipt.d'Eur. tom. 1. pag. 83. $n^{\circ}$. 37. - M McQ. Tipul. du nord de lis Frunce, pag. 124. no. 12. - Encycl. pl. 385. fig. 16. Mitle. De France et d'Allemagne.

M. Meigen cile en outre quatre espèces de la collection de M. le comte Hoffinansegg, savuir : deux de Portugal et deux de Berlin, décrites par M. Wićdemann. Ces espèces sont peut-être de la première Division.

M. Nacqual: signale comme nouvelles les espèces suivantes: $1^{\circ}$. Céralopogon cendré, $C$. cinereus. MacQ. id. no. 2. Longuenr 2 lignes. Corselet cendré ; abdomen noir; paltes fauves; genoux noirs; cuisses grêles, muliques. $2^{\circ}$. Cératopogon brillant, $C$. nitidus. M AcQ. id. pag. 122. $n^{\circ}$. 3. Longueur 2 lig. Noir; pattes fauves; ailes sans taches. Conmun. Il ressemble beaucoup au $C$. tibialis Merg., inais ses cuisıes antérieures n'ont pas d'épiues. $3^{\circ}$. Cératopogon unimaculé, C. unimaculatus. MAcQ. id. $n^{\circ}$. 4. Longuenr 1 lig. $\frac{x}{2}$. Noir; pattes fauves; ailes marquées d"une tache obscure sur la première cellule unarginale; cuisses grêles, mutiques. Assez rare. $4^{\circ}$. Cératopogon ruficorne, C. ruficornis. MacQ. id. $n^{\circ} .5$. Longueur une ligne. Antennes et pattes roussâtres; colps d'un nuir luisant ; cuisses grêles, muliques. Rare. 5०. Céralopogon brévipenne, $C$. brevipennis. MAcQ. id. pag. 123. $n^{\circ}$. 7. Longueur une ligne $\frac{1}{4}$. Nuir; pattes velues; les deux premierg articles des tarses roussâtres; ailes courtes; cuisses grêles, muliques. Rare. $6^{\circ}$. Cératopogon fauve, C. fulous. $\mathrm{M}_{\mathrm{ACQ}}$. id. pag. 125. $n^{\circ}$. 13. Fauve; abdomen ayant une tache noirâtre; pattes avec lenrs irticulations noires; cuisses antérieures épineuses. Femelle.

\section{MACROPĖZE, Macropeza. MeIg. LAt. (Fam.} nat. )

Genre d'insectes de l'ordre des Diptères, première section, famılle des Némocères, tribu des Tipulaires (division des Culicifornes).

Un petit groupe de cette division se compose des genres Céralopogon et Macropèze. (Voyez Tipulaires, pag. 656.) On séparera aisément les Cératopogons des Macropèzes par leurs antennes n'ayant que treize articles, et par leurs pattes presqu'égales en longueur.

Antennes iusérées sur un petit tubercule rond, avancées, aussi longues que la tête et le corselet pris ensemble, filiformes, velues, composées de quatorze articles; le premier cyathiforme, nu; le second da donble aussi long que le premier; les sept suivans devenant peu à peu plus courts, tous un peu amincis à leur base; les quatre suipaws 
plus longs, absolument cylindriques : le dernier un peu plus court que les précédens. - Point d'ocelles. - Ailes lancéolées, alongées. - Abdomen cýlindrique, terminé en pointe, composé de huit segmens. - Pattes antéricures de longueur ordinaire; les intermédiaires plus longnes d'un tiers que les antérieures; les postérieures extrêmement longues.

Tels sont les caractères donnés par M. Meigen à ce genre dont on ne connoît que le sexe fémiuin. La longueur des paltes postérieures lui a fait donner son nom tiré de deux mots grecs. Le type est la Macropèze albitarse, $M$. albitarsis. Meıc. Dipt. d'Eur. tom. I. pag. 87. no. 1. tab. 3. fig. I. Femelle. Longueır 1 lig. $\frac{1}{3}$. Tête noire; corselet gris-cendré, avec trois raies noires, étroites; abdomen noir; balanriers blancs; ailes hyalines, leurs nervures d'un brun pâle; pattes noires; tarses blancs. D'Europe.

CÉCIDOHYIE, Cecidomyia. Lat. Mrig. MacQ. Tipula. Linn. De GéEr. Chironomus. Fab.

Genre d'insectes de l'ordre des Diptères, première section, famille des Némocères, tribu des 'Tipulaires (division des Gallicoles).

Les quatre genres Psychode, Cécidomyie, Lestrénie et Lasioptère composent cette division. (Voyez 'Trpularres, pag. 656.) Les Psychodes se distinguent par leurs ailes en toit, $\grave{a}$ nervures nombreuses, et par leurs antennes courtes : ce dernier caractère appartient aussi aux Lasioptères, qui en outre n'ont que denx nervures à leurs ailes et dont les articles des autennes sont rapprochés les uns des autres. Dans les Lestrémies, les antennes sont de quiuze articles dans les deux sexes, et l'une des nervures de leurs ailes se bifurque vers son milieu.

M. Meigen (Dipt. d'Eur.) n'a point connu le genre Lestrémie fondé par M. Macquart sur une Tipulaure du noid de la France. L'auteur allemand fait une division particulière du genre Psychode sons le nom de Tipulaires - Noctuéformes. Il compose sa division des 'Tipulaires-Gallicoles des genres Lasioptère, Cécidomyie et Campylomyze : ce dernier se distingue des Cécidomyies, ainsi que des Lasioptères, par la présence des ocelles. M. Latreille place les Campylomyzes parmi ses Tipulaires-Fongivores.

Antennes moniliformes, insérées chacune sur un petit tubercule, rapprochées à leur insertion, aussi longues que le corps dans les mâles, un peu plus courtes dans les femelles; composées d'articles pédicellés, distans, velus, ordinairement au nombre de vingt-quatre dans les mâles (n'en ayant que donze dans la Cécid. du Groseiller ), toujours de douze dans les femelles. - Bouche peu avancée. - Palpes recourbés. - Tête petite. - Yeux lunulés. - Point d'ocelles. - Corps assez long. - Corselet ovale. - Ailes obtuses, leur surface velue, frangées de longs poils, surtout au bord postérieur, couchées paralièlement sur le corps dans le repos, ayant trois nervures longitudiuales, toutes simples et point fourchues. Balanciers découverts, leur pédicule assez long. - Abdomen de huit segmens, cylindrique dans les mâles, pointu dans les femelles, portant à son extrérnité, dans ce sexe, une tarière plus ou moins longue, composée de plusieurs tuyaux susceptibles de rentrer les uns dans les autres. Pattes longues proportionnellement au corps, grêles, velues; jambes sans épines terminales; premier article des tarses très-court.

Le nom de ces insectes vient de deux mots grecs dost la signification a rapport à la nourriture des larves, lesquelles vivent dans les galles des véǵtanx. Ce sont de fort petits Diptères, très-délicats, qui perdent ordinairement leurs couleurs áprès la mort. De Géer a donné l'histoire de la Cécidomyie du Saule. (C. salicina.) II trouva sur une espèce de Saule, dont il n'indique pas le nom spécifique, le vingt-sept avril, des galles d'une llature singulière, ressemblant à des roses doubles, de couleur verte, occupant l'extrémité des jeunes branches. Au milieu de ces feuilles, au centre de la rose, est une petite cellule conique, en forme de bouton, composée de feuilles plus petiles. Là , babite seule une larve d'un jaune rougeâtre, suns pattes; son corps de douze segmens est un peu aminci à la partie anlérieure; la têle est arrondie. Le onze mai suivant, dans ces unêmes galles, De Géer trouva une coque blanche très - mince, qui enveloppoit, sans la cacher entièrement, une nynuphe rouge à pattes blauclies, dont l'abdomen d'un rouge un peu plus clair portoit une ligne dorsale d'un rouge obscur. Ayaut renfermé dans une boite quelques-unes de ces galles, il en sortit de petiles Tipulaires, que plusicurs auteurs, et nolamment M. Macquart, paroissent a voir observées depuis De Géer, et qu'ils rapportent à la Cécidomyie du Saule.

De Géer décrit en outre les mœurs de trois espèces de 'Tipulaires, voisines de la première, savoir: la Tipula juniperi Lrnn., que M. Meigen place avec doute dans le genre Lasioptère, et les Tipula pini et loti, qui ont paru à MM. Latreille et Meigen ètre des Cécidomyies.

M. Macquart dit avoir obtenu la Cécidornyie du Saule de galles à peu près semblables à celles décrites par De Géer et trouvées sur le Saule vulgaire (Salix alba). Il a anssi observé sur l'Armoise aurone (Artemisia abrotanum ) une larve de Cécidomyie qui vit sur les jeunes feuilles de cette plante sans y produire d'altération et sans se renfermer dans une cellule; elle se forme une coque très-alongée pour s'y changer en nymphe.

M. Meigen décrit dix-sept espèces de ce genre et en mentionne cinq autres d'après les auteurs; nous in liquerons, $1^{\circ}$. Cécidomyie noire, $C$. nigra. MEIG. Dipt. d'Eur. tom. '. pag. 95. $n^{\circ}$. 4. tab. 3. fig. 11. Femelle - Mace. Tipul. du nord de la 
France, pag. II6. $n$. 4. De France et d'Allemagne. $2^{\circ}$. Cécidomyie des marais, $C$. palustris.

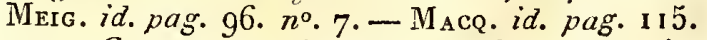
$\pi{ }^{\circ}$. 2. Commune en France. M. Maequart a observé au mois de mai beaneoup de fernelles posées sur les épis eu fleur du Vulpin des prés (Alopecurus pratensis); elles introduisoient leır tarière entre les valves des glumes, sans doute pour y déposer leurs aufs. $\overline{3}^{\circ}$. Cécidonyie jaune, $C$. lutea. Mrtg. id. pag. 99. no. 16. -- Encycl. $p l$. 385. fig. 22. Miile. fig. 23. Femelle. IM. N! acquart donne comme nouvelles les espèces suivanfes: $1^{\circ}$. Cécidomyie variće $C$. variegata. MAcQ. id. pag. I $15 . n^{\circ}$. 3. Longuear une ligne $\frac{1}{z}$. Alles légèrement taehelées; paltes variées de noir et de blanc. Rare. $2^{\circ}$. Cécidonyie orangŕe, $C$. auranticrca. $\mathrm{M}_{\mathrm{Ac}}$. id.pag. I16. $n^{\circ}$. 5. Longueur une ligne. Corps et ailes d'un jaune orangé. Rare. 50. Cécidomyie pygmée, $C$. pygmana. Mace. id. pag. $117 \cdot n^{\circ} \cdot 7$. Longrueur $\frac{1}{4}$. de ligne. 'Têle el corselet obscurs; abdônen rougeâtre. Hâle.

\section{TESTRÉMIE, Lestremia. Maco.}

Genre d'inseetes de l'ordre des Diptères, première section, famille des Némocères, tribu des 'Tipulaires (division des Gallicoles).

Des trois genres qui composent cette division avec les Lestrémies (voyez Trpulaines, pag. 656.), celui de Psychode se distingue par ses ailes ayant des vervures nombreuses; les Céeidomyies se reconnoissent à leurs antennes eomposées de vingtquatre ou de douze articles, aux nervures des ailes seulement au nombre de trois, et à lit brièvelé du premier article des tarses. Dans les Lasioplères, les autennes sont composées de plus de quinze articles et leuts ailes n'offient que deux nervures longitudinales. En outre, dans ces trois genres, ancune nervare des ailes a'est bifurquée, ee qui les sépare des Lestrémies.

MI. Maequart a créé ce genre, et lui attribue ees caraeteres.

Antennes velues, courbées en avant, un peu moins longues que le eorps, compośes de quinze urticles globuleux, pédicellés dans les inâles. Ailes larges, ayant einq nervures, dont la troisième, à partir de la eôte, est bifurqnée darss son milieu. - Balanciers à long pédicule. - Pattes grrêles, assez longues; premicr article des tarses long.

L'auteur ne décrit qu'une seule espèee, Lestrémie eendrée, $L$. cinerea. MAcQ. Tipul. du nord de la France, pag. i $17 \cdot n^{\circ}$. 1. Longueur une ligne. D'un gris roussâtre. Au mois de mai, dans les prairies.

LASIOPTÈRE, Lasioptera. MeIg. MacQ. LAT. (Fam. nat.) Tipula. linvi. Schranck. De Géer.

Genre d'insectes de l'ordre des Diptères, première section, famille des Némocères, tribu des 'Ṭipulaiies (divișion des Gallicoles).
Les Gallicoles se eomposent des genres Psychode, Céeidomyie, Lestrémie et Lasioptère. On reeonnoît les Psychodes à leurs ailes en toit dans le repos et ehargées de beancoup de nervures. Le genre Lestrémie n'a que quinze artieles anx autennes, et ses ailes offrent eiuq nervures longitudinales, dont l'une est bifurquée au milieu. Les Céeidomyies ont les articles des autennes pédicellés et distans les uns des autres; les nexvures des ailes sont au nombre de irois.

Antennes avancées, filiformes, velues, composées de plus de quinze articles, ees articles globuleux. - Trompe petite. - Palpes saillans, recourbés, composés de quatre articles; les deux inférieurs épais, en mas uə; les deux autres grêles, eylindriques. - Tête petile, sphérique. Feux lumulés. - Point d'ocelles. - Corps assez gros daris les feinelles. - Corselet globuieux. Ailes velues, leurs bords frangés, couchées l'une sur l'autre dans le repos, n'ayant que deux nervures dont aucune n'est bifurquée. - Abdomen de hnit segmens, eylindrique dans les mâles, terminé en pointe dans les feraelles. - Pattes longues, grếles.

Le noin de ces Tipulaires vient de deux mots grecs qui expriment que leurs ailes sont frangées. Elles vivent probablement dass les galles des végétaux.

I Te. Division. Premier article des tarses trèscourt.

1I. Meigen place quatre espèces dans cette division; nons eiterons, $I^{\circ}$. Lasioptère peinte, L. picta. Merg. Dipt. d'Eur. tom. I. pag. 89. $n^{\circ}$. 1. $t a b$. 3. fig. 3. Femelle. $2^{\circ}$. Lasioptère albipenne, $L$. albipennis. MeIg, id. $n^{\circ} .3 .-\mathrm{M}_{\mathrm{Ac}}$. Tipul. du nord de la France, pag. 165. $n^{\circ}$. I. De Franee et d'Allemagne.

$2^{\mathrm{e}}$. Division. Premier arliele des tarses plus grand qu'aucuu des autres.

Trois espèees sont placées dans cette division par M. Mejyen, mais l'une d'elles n'y est qu'avec doute; nous mentiounerons la Lasioplère brune, L. obfuscata. Meig. ut suprà. pag. 9o. $n^{\circ} .5$.

MACROCERE, Macrocera. Meig. Panz. Lat. (Fam. nat.) MacQ.

Genre d'insectes de l'ordre des Diptères, première section, faınille des Némoeères, tribu des Tipulaires (division des Fongivores).

Le premier gronpe de eette division, caractérisé par les antennes point manifestement grenues ni perfoliées, plus longues que la tête et le corselet réunis, contient deux genres, Macroeère et Bolitophile (voyez pag. 656.) : ce dernier diffère du premier par ses ocelles disposés transversalement sur une ligne droile, et paree que l'une des eellules qui avoisinent la côte des ailes est fermée postérieurement par une nervure transversale. 
M. Meigen joint à ce groupe le genre Dixa, qui se distingue des deux préeédemment nommés, par le manque absolu d'ocelles, et qui fait partie des Tipulaires-Terricoles Lat. Voyez Dixa, pag. 587 . de ce volume.

Antennes avancées, courbées, arquées, sétacées, aussi longnes ou plus longnes que le corps; les deux articles de la base, épais, sphériques, lisses; les suivans cylindriques, finemenı velus, point distinctement séparés, et par conséquent difficiles à compler. - Palpes recourbés, de quatre articles. - Tête un peu plıs étroite que le eorselet, aplatie par devant; front large. - Yeux ronds. - Trois ocelles disposés en iriangle, les deux postérieurs plus grands, lantérieur fort petit. Corps alungé, menu. - Corselet ovalaire, sans ligne enfoncée transversale sur le dos.-Ecusson petit. - Ailes grandes, obtuses à l'extrémité, conchées parallêlement sur le corps dans le repos; cellules qui avoisinent leur côte point férmées postérieurement par une nervure transversale. Balanciers découverts. - Abdomen cylindique, un peu élargi an milieu dans les femelles, de sept segmens. - Pattes grêles, de longueur inégale, les postérieures plus grandes que les autres; banches ulongées; jawbes munies de deux épines terminales.

On trouve ces Tipulaires, dont le nom vient de deux mots gress qui ont rapport à la longueur de leurs antennes, dans les bois humides et sur le bord des eaux. On ignore leurs premiers élats.

Ce geure est composé de six espèces dans les Dipt. d'Eur. de M. Meigen. Nous citerons, $1^{\circ}$. Macrocère jaune, M. Lutea. Meig. Dipt. d'Europ. tom. 1. pag. 225. $n^{\circ}$. 1. - M. Ace. Tipul. du nord de la France, pag. 54. no. 5. - Encycl. pl. 385. fig. 38. $2^{\circ}$. Macrocère ailes tachetées, M. maculipennis. Maeq. id. $n^{\circ}$. 4. Longueur 2 lig. $\frac{1}{3}$. Ferrugineuse. Ailes marquées d'une tache stigmatique, en ayant une autre et l'extrémité, noires; sénmens de l'abdomen bordés de noirâtre. Fort comenuue au mois de juillet dans les bois. $3^{\circ}$. Maerocère naine, M. nana. MAcQ. $i d . n^{\circ}$. 6. Longueur une ligne $\frac{1}{2}$. Jannâtre. Corselet ayant trois bundes liaéaures. Abdomen fuscié de noir. Rare.

BOLITOPHILE, Bolitophila. Me:c. Mace. Iat. (Fam. natur:)

Genre d'insectes de l'ordre des Diptères, première section, fauille des Némocères, tribu des Tipulaires (division des liongivores).

Ceux des Tipulaires-liongivores dont les antennes point nantestement grenues, ni perfoliées, surpassent en longueur la tête et le corselet réunis, sont les genres Macrocère et Bolitophile. Le preınier est dislingué du second par ses ocelles disposés en triangle et par les cellutes des ailes, dont aucune de celles qui avoisinent la còte n'est fermće postérieurement par une nervure trausversale.

Hist. Nat. Ins. Tome $\boldsymbol{X}$.
Antennes sétaeées, avancées, plus longues que la tête et le corselet pris ensemble; leurs deux articles basiliares épais; les autres indistincts. Trompe pen saillante. - Palpes recourbés, cylindriques, saillans, de quatre arlicies, he premie: très-court. - Téte pelite, légèrenent aplatie en dessus. - Yeux ronds. - Trois ocelles placés sur le front, disposés en ligne transversale presque droite, lintermédiaire glus pelil que les autros. - Corps rnince, alon ré. - Corselet a rrondi ovale. - Ailes obtuses, cunchées parallelement sur ic corps dans le repos; lears nervures assez nombreuses; l'unè des cellules voisines de la côle lermée par une nervure transversale. - Balanciers découverts. - Abdomen très-long, grêle, presque cylindrique dans les mâles, un peu fusiforme daus les femelles. - Pattes alongées; lanches assez longues; cuisses un peu épüisses ainsi que les jamibes; celles - ci terminées par deux courtes épines.

Le nom donné à ce genre par M. de Hoffinansegg, semble indiquer que les larves vivent dans les bolets, mais aucun entomologiste, à notre connoissance, ne les a encore décrites. Les espèces connues sont les suivantes :

${ }^{\circ}$. Bolitophile cendrée, B. cinera. ME1G. Dipt. d'Eur. tom. 1. pag. 221. no. 1. tab. 8. fig. 1. M Ace. Tipul. du nord de la France, pag. 55. $n^{\circ}$. 1. Dans les bois. $2^{\circ}$. Bolitophile brune, $B$. físca. Mero. id. $n^{\circ}$. 2. D'Allemagne.

LEIA, Leia. ME1G. LAT. (Fam. nat.) Mycetophila. MAcQ. Oriv. (Encycl.)

Genre d'insecles de l'ordre des Diptères, première section, famille des Némocères, tribu des Tipulaires (division des Fongivores).

Ce genre constitue seul une coupe particulière

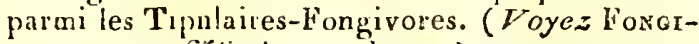
vores, pag. 656. de ce volume.)

Antennes filifornes, courbées, avaneées, anssi longues que la lête et le corselet réunis, eomposćes de seize aricles; les deux premiers distinctement séparés l'un de l'autre, soyeux; les suivans finement velus. - Trompe à peine saillante. Palpes saillans, recourbés, assez longs, de quatre articles, le premier très-petit. - Téte robde, ayunt une légère impression à la partie an'érieure, un peu eufoncée postérieuremeni dans le corselet. - Yeux arrondis-ovales. - Trois ocelles distincts. - Corps de longueur uroyenne. - Corselet fortement boubé, sans ligne trausversale enfoncée. - Ecusson petit. - Ailes ubtuses, conchées parallclement sur le corps dans le repos, n'ayant qu'un nombre médiocre de nervares. - Balunciers découverts. - Abdomen ordinair sment cylindrique, conposé de sept segmens. - Pattes assez cuntes; cuisses fortes, comprincées; jambes terwiuées par deux épines; ja mbes intermédiaires

P p p p 
et postérieures finement épineuses à leur partie extérieure.

Les mœurs et les premiers états des Léias ne sont pas connus. Leur nom vieut d'un mot grec qui exprime que le corps est lisse et poli.

r re. Division. Ocelles rapprochés en triangle sur le vertex.

\section{T. Léïa mi-partie, L. dimidiata.}

Leia dimidiata Merg. Dipt. d'Europ. tom. I. pag. 254. $n^{\circ}$. I.

Voyez pour la description et les autres synonymes, Mycétophile mi-partie, $n^{\circ} .3$. de ce Dictionmaire.

M. Meigen décrit en outre deux autres espèces de cette division.

$\mathbf{2}^{\mathrm{e}}$. Division. Ocelles disposés en ligne courbe sur le front.

\section{LeïA bimaculée, L. bimaculata.}

Leia bimaculata MeIc. Dipt. d'Eut. tom. I . pag. $256 . n^{\circ} \cdot 7$.

$V o y^{\prime} z$ pour la description et les autres synonymes, Mycétophile bimaculée $\mathbf{n}^{\circ}$. 7 . de ce Dictionnaire.

\section{LËïA anale, L. analis.}

Leia analis Nerg. id. pag. $257 \cdot 7 u^{\circ} \cdot 9$.

Voyez pour la description et les autres synonymes, Mycétophile douleuse de ce Dictionnaire.

On trouve encore cinq autres espèces te cette division dans les Dipt. d'Europ. de B. Meigen.

\section{GNORISTE, Gnoriste. MeIG.}

Ganre d'insectes de l'ordie des Diptères, première section, famille des Némocères, tribu des Tipulaires (division des Fongivores).

Un grunpe de Fongivores contenant les genres Rhyphe, Gnoriste et Asindule, a pour caracteres : antennes grenues, noucuses on perfuliées, de même grosseur, ou plus menues vers le bont; museau prolongé en manière de bec. (Voy. Fongrvones, pag. 656 . de ce volume). Ou distingue les Rhyphes des Gnoristes par ce que la trompe des premiers est plus courte que la tête; en outre leurs autennes vont en diminuant de grosseur vers le bout, ainsi que celles des Asindules, qui ont leurs palpes iusćrés vers la base de la trourpe, celle-ci refendue ir son extrémité, et les yenx échancrés Lentrs ailes ont toutes les cellules du bord postérieur, sessiles.

Antennes avancées, cylindriques, filitormes, arquées, aussi longues que la tête ct le corselet pris ensembie, composées de seize articles, les denx de la base plus épais, courts, presque cyathiformes; les suivans grenus, finenent velus. Trompe saillante, un peu raballue, deux fois aussi longue que la tête, ne paroissant point refendue à son extrémité. - Palpes petits, insérés vers et a vant l'extrémilé de la trompe, leurs articles peu distincts, paroissant au moins au nombre de trois; celui de la base le plus épais de tous. - Tête plus étroite que le corselet, légèrement comprimée en devant. - Yeux entiers, arrondis, oblongs. Troisocelles placés en triangle sur le front, les deux supérieurs plus distincts. - Corps alongé, mince. - Corselet ovale, bombé en dessus. - Ailes couchées horizontalement sur le corps dans le repos, n'ayant point de cellule discoïdale inférieure fermée ; deux de celles du bord postérieur, pétiolées. - Balanciers déconverts. - Abdomen conposé de sept segmens, fortement comprimé dans les femelles, en massue postérienrement et terminé par deux crochets velus dans les mâles. $P$ attes assez grandes; cuisses miuces; jambes terminées par deux épines, finewent épineuses sur les côtés; tarses assez grands.

Le type de ce genre est le Gnoriste apical, $G$. apicalis. MEIG. Dipt. d'Eur. tonı. 1. pag. 243. $t^{\mathrm{D}} \cdot$ 1. tab. 9. fig. 1. Mále.

\section{ASINDULE, Asindulum. LuAT.}

Genre d'insectes de l'ordre des Diptères, première section, famille des Némocères; tribu des Tipulaires (division des Fongivores ).

Trois genres, Rhyphe, Guoriste et Asindule, forment par leur réunion un petit groupe parni les 'Tipulaires-Fongivores. (Voyez pag. 656. de ce volume). Les Rhyphes sont bien séparís des deux derniers genres par leur trompe plus courie que la tête, et par leurs ailes offrant distincletnenl une cellule discoidale. On distinguera les Gnoristes des Asindules, à leurs palpes insérés ver's l'extrémité de la trompe, celle-ci paroissant entière à son exIrémité : ils ont en outie les yeux saus échancrure, les antennes filiformes, et deux cellules du bord postérieur de l'aile, pétiolées.

Antennes simples, sétacées, composées de seize articles, la plupart cylindriques et peu distiucts les uns des autres. - Trompe beaucoup plus longue que la tête, dirigŕe en arrière le long de la poitrine, terminée par deux lèvres alongées qui la font paroître bifide. - Palpes insérés assez près de la base de la trompe, composés de trois articles; le premier assez long, plus gros que les antres, le second à peu près de la même longuentr que le précédent, mince vers sa base, allant ea rrossissant insensiblement vers son extrémité; le troisième grêle, filiforme, plus long que le prócédent. - Téte petite, prolongée à sa parlie antérieure en un museau doù sort la trompe. - Yeux. alongés, échancrés à la parlie supérieure de leur côté inlerne. - Trois ocelles distincts, espicés, disposés en triangle sur le vertex. - Corps de longresur moyennc. - Corselet gros, bombé, un peu ovale. - Ailes couchées parallodenenu sur le corps dass le repos, dépourvues de cellule discoi- 
dale inférieure ; toutes les cellules du bord poslérieur, sessiles. - Balanciers grands, découverts. - Abdomen des mâtes, déprimé, mince à sa base, allant en s'élargissant jusqu'à l'avant-dernier seyment, composé de huit segrmens outre l'anus, celui-ci muni de deux pinces courtes et grosses. (Nous ne connoissons pas les femelles.) - Pattes alongrées, hanches furtes, particulièrcment les antérieures; jambes terminées par deux épines.

Le nom de ces 'Tipulailes vient d'un verbe grec qui signitie : réunur, et de la particule privalıve; il ex priune la séparation des deux parties qui terminent la trompe. Ce genre est voisin des Guoris!es par la longueur de la trompe, et des Platyures par les nervures des ailcs. On n'en connoil qu'une seule espèce, ses mœurs sontignorées; c’estl'Asindule noir, $A$. nigrum. Lat. Hist. nat. des C'ritst. et des Ins. tom. I4. par. 290. - Gen. Crust. et Ins. tom. 1. tab. 14. fig. 1. Uu le trouve en France dans les lieux aqualiques, mais assez rarement.

PI. ATYURE, Platyura. Meig. Mace. Lat. (Fam. nat.) Ceroplatus, Sciara. l'aв.

Geare d'insectes de l'urdre de: Diptères, première section, famille des Némocères, tribu des 'Tipuläires (division des l'ongivores).

Un groupe de Fongivores a pour caractère : yeux entiers; museau point rostrifurme; antenues de la mêue grosseur ou plus menues vers le bout, zrenues, noueuses ou perfoliées. (Voyez pag. 656$.$) Il comprend, outre les Platyures, les Cias-$ pylomyzes, qui s'en distinguent par leurs antennes composées seulement de quatorze articles, et les Sciophiles dout les jambes sont épineuses latéralement, et qui ont une petile cellule carcée sur le disque des ailes.

Antennes de même grosseur partout, ou plus menues vers le bout, de la longueur du corselet, avancées, comprimées, composées de seize artieles; les deux de la base distuncts l'un de l'autre, le pieanier cylindrique, le second sphérque; les suivaus plus ou moins comprinés, finemeut velus, moins distinctement séparés les uns des autres que les deux premiers. - Trompe un peu saillante. - Palpes saillans, cylindriques, courbés, counposés de quatre articles; les trois premiers d'éçale longuenr, le qualrième un peu plus long. - Tete un per plus étroite que le corselet, assez aplatre par devant. - Yeuzi un peu oblongs, entiers. Trois ocelles rapproctés en triangle sur le front, inégaux; le plus petit placé en devant. - Corps assez alongé. - Corselet presque sphérique, boubé. - Ecusson petil, rond. - Ailes arrondies a leur extréruité, couchées paralléleusut sur le corps dans le repos, leur disque n'olliaut aucune cellule fermée. - Balanciers découverts. - Abdomen menu, composé de sept segmens, un peu cylindrique à sa base, allant orduairement eu se diłatant vers la partie postériemre, légèrement déprimé.-Pattes longues, grèles; lanches très-alon- gées; cuisses assez forles; jambes point épiueuses sur liss côtés, terainées par deux fortes épines.

Le non de ces Diplères exprime la dépression de leur abduain. On les trouve à l'état parfait dans les hois et sur les haies. Ce genre cst assez nombreux en espèces.

I $^{\mathrm{re}}$. Division. Première cellule marginale fermáe part une nervure transversale oblique avant d'atteindre le Lord extćrieur de l'aile.

Nous mentionnerons: $1{ }^{\circ}$. Platyure noire, $P$. atrata. Mlerg. Dipt. d'Europ. tom. 1. pag. 233. $n^{\circ}$.2. - Plaiyura nigra. Mace. 'Tipal. alu nord de la France, pagr. $47 \cdot n^{\circ} \cdot 1$. 1) Francc. $2^{\circ}$. Pla tyure margiuée, $P$. malginata. HEIG. id. pag. 232 . $n^{\circ}$. 1. tab. 8. figr. 14. D Allemagne. Rate.

$2^{\mathrm{e}}$. Division. Preuiere rellule marginale alteignantle Lord extćrieur de l'aile.

$1^{\circ}$. Dlatyure fasciée, P. fasciata. Me1g. id. pag. 240. $n^{\circ} \cdot 15 .-\mathrm{N}_{\mathrm{AcQ}}$. id. pag. 48. no. 2. Rare dans le nord de la France. $2^{\circ}$. Platyure pallipède, $P$. pallipes. MAcQ. id. $n^{n}$. 3 . Lougueur'S lig. $\frac{x}{2}$. D'un roussâtre päle; alidomen à bandes obscures; pattes d'un jaune-blanchâtre. Ritre. $3^{n}$. Platyure

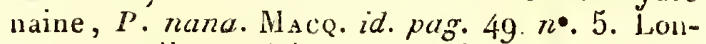
guenr une lig. $\frac{3}{4}$. Noire; pattes fauves; ailes terminées par une bande noirâtre. Rare. $4^{\circ}$. Platyure jaune, $P$. $R a v a$. Mace. $i d \cdot n^{\circ}$. 6. Longueur une ligne . Jaune; ailes jaunâtres. Rare. $5^{\circ}$. Platyure biculuie, $P$. óicolor. $\mathrm{N}_{\mathrm{acc}}$ id. $n^{\circ}$. 7 . Longueur nne ligue $\frac{3}{4}$. Dessus du corps noir, dessous tauve. Rare.

\section{CAMPYLOMYZE, Campylomyza. W IÉdem.} MEIG. MACQ. Lat. (Fam. nat.)

Genre d'insectes de l'ordre des Diptères, première section, faumille des Némoceres, tribu des 'Tipulaires (division des Fongivores).

Un groupe de cette division a pour caractères: yeux entiers; museau point rostriforme; anlennes de la ınême grosseur ou plus menues vers le boul, grenues, noueuses ou perfohées. (Voyez pag. 656.) Il se compose des gemres Platyure, Sciophile et Campylonyze; mais les deux premiers out les antennes composées de seize articles, ce ; qui les sépare des Canpylomyzes. Les jambes'des Sciophiles oblatdeux forles épiues terminales, ainsi que celles dịs Platyures; en outre les quatre dexnières jambes soul ex lérieurement garuies d'épines dans les Platyures.

Antennes liliformes, avancées, aussi longues que la lête et le corselet réunis, composées de quatorze articles, les deux premiers un peu plus épais, les suivans courts, cylindriques, fiuement velus. - Trompe courbée. - Palpes avancés, recourbés, anguleux; leurs articles coniques. Trois ocelles distiucts, placés en triangle sur le vericx. - Corps assez gros. - Corselet elliptique. -Ailes velues, couchées parallèlement sur le corps PPPP 2 
dansle repos, planes, obtuses, n'ayaut que trois nervures longitudinales et une transversale près du milieu, vers la côte. - Abdomen paroissant composé de huit segınens, cylindrique daus les mâles, plus épais au milieu dans les femelles; anus muni de deux pelites pointes. - Pattes de longueur moyenne; jambes sans épines terminales distinctes, mutiques extérieurement; premicr article des tarses plus long que le second.

Ces caractères, empruntés de M. Meigen, ont été établis d'après des individus femelles, le seul mâle que cet auteur ait eu en sa possession étant en partie mutilé. Il place ce genre parmi les 'Tipulaires-Gallicoles; cette division renferme en outre chez lui les genres Lasioptère et Cécidomyie, qui diffèrenl des Campylomyzes par l'absence des ocelles. Au reste, il ne paroit pas convaincu que la place qu’il lui assigne soit la véritable.

Le nom générique tiré de deux mots grecs, siguifie : mouche courbée, et indique la courbure de la trompe.

M. Meigen décrit quatre espèces de Campylomyzes; l'une d'elles est la Campylonyze bicolore, C. bicolor. Meig. Dipt. d'Eur. tom. 1. pagr. 102. no. 2. - MAcQ. Tipul. du nord de la France, pag. 166. $n^{n}$. 1. De France et d'Allemagne. Rare.

MYCÉTOBIE, Mycetobia. MEIG. MAce. LAT. (Fant. nat.)

Genre d'insectes de l'ordre des Diptères, première section, famille des Némocères, tribu des Tipulaires (division des Fongivores).

Un groupe des 'Tipulaires-Fongivores a pour caracteres : antennes grenues, noueuses ou perfoliées, de même grosseur ou plus menues vers le bout; museau point rostriforme; yeux échancrés. Les Mycétobies et les Molobres composent ce groupe. (Voyez longivores, pag. 656. de ce volume.) (ce dernier genre se distingne du premier par ses palpes composés sealeurent de trois articles, selon M. Meigen; par ses yeux profondément échancrés, très-rapprochés l'un de l'autre à leur partie supérieure; enfin, par ses ocelles placés au dessus des yeux, sur la partie inférieure $\mathrm{d}$ is vertex.

Antennes filiformes, avancées, rabattues, composées de seize arlicles, les deux inférieurs visiblement séparés l'un de l'autre. -iTirompe peu saillante. - Palpes de quatre articles, suivant M. Meigen. - Téte ronde, aplatie en dessus. Ycux réniformes, assez écartés l'un de l'autre à leur partie supérieure. - Trois ocelles dislincts, placés en trianule sur le front, entre la partie supérieure des yeux ; l'inférieur plus petit. - Corps mince. - Corselet presque sphérique, bombé, sans ligne transversale enfoncée sur le dos. Ecusson petit. - Ailes larges, couchées parallèlement sur le corps dans le repos. - Abdomen presque cylindrique, un peu élargi au milieu dans les fernelles, composé de sept segmons. - Jambes terminées par deux épines, n’en ayant point de latérales.

Le nom de Mycétobie est formé de deux mots grecs qui expriment que ces insectes viveut dans les champignons. M. Meigen a effectivement trouvé le mâle de la Mycétobie fasciée ( $M$. firsciata. Meig. Dipt. d'Europ. tonı. 1. pag. 230. $\left.n^{\circ} .2.\right)$ dans une espece de bolet assez commune, Boletus versicolor.

On trouve en France l'espèce suivante : Mycétobie pallipède, $M$. pallipes. MeIG. ut suprà $n^{\circ} .1$. tab. 3. fir. 10. - MAcQ. Tipul. du nord de la France, pag. $5 \mathrm{1}, n^{\circ}$. I.

MOLOBRE, Molobrus. IAat. Sciara. Fas. Meig. Mace. P'anz. Wiéd. Tipula. Linn. Geopf. Panz. Hirtea, Chirononeus. FAB. Bibio. Olrv. (Encycl.)

Genre d'insectes de l'ordre des Diptères, première section, famille des Némocères, tribu des 'lipulaires (division des Fongivores).

Un groupe de cette division conlient deux genres, Mycétobie et Molobre. (Voyez Fonglvorrs, pag. 656 . de ce volume). Le premier diffève dư second par ses palpes quadriarticulés, ses yeux simplemnent r'éniformes, assez écartés et laissant entr'eux un espace sur lequel sont placés les occlles.

Antennes filiformes, avancées, arquées, courbées, finement velues, un peu plus longues que la tête, composées de seize articles, les deux de la base plus épais, distinctement séparés l'un de l'autre. - Trompe un peu saillante, mais point alongéc. - Palpes saillans, courbés, velus, composés de trois articles, suivant M. Meigen, égaux entr'eux, en massue. - Tête petite, sphérique. - Yeux profoudément échancrés, se touchaut presque sur le front. - Trois ocelles placés audessus des yeux, disposés en triangle, l'inférieur plus petit. - Corps assez gros. - Corselet ovale, bombé, sans ligne transversale enfoncée, mais en ayant trois longitudinales. - Ecusson étroit. - Ailes grandes, obluses, velues vines au microscope, couchées parallèlement sur le corps dans le repos. - Balanciers découverts. - $A b$ domen inince, velu, de sept seymens, cylindrique dans les mâles avec deux crochets à l'anus; celui-ci épais et en massue, terminé en pointe dans les femelles.-Pattes longues, grêles, finement velues; hanches alongées; cuisses sillonnées au côté interue; jambes terminées par deux épines.

M. Meigen isole ce genre (qu'il nomme Sciara) dans une section pariculice appelée par lui les Lugubres. (Lugubres.) Voyez Tipularres Meig. ci-après. Cet auteur est le seul qui ait observé des circonstances ayant rapport à la manière de vivre de ces insectes. Il vit sortir au mois de 
mars, de la terre contenue dans un pot de fleurs, un grand nombre d'individus du Nolobre byalipenne, M. hyaïpennis. (Sciara hyalipennis. Merg. Dipt. d'Europ. tom. 1. pag. 285. $t^{\circ} .21$.) I a peau des nymplies, restée à demi dans la terre, énnil dépourvie de pointes, de couleur blanchâtre, a vec le corselel jaune, du moins en parlie; peu d'lieures après leur apparition, ces Tipulaires sacconplèrent, et il en parut une nouvelle génération au mois de juin, ce qui sembleroil prouver que leur entier dévéloppement s'effectue en deux mois, au moins dans la belle saison. On trouve les Molobres depuis le printeaps jusqu'en zutoune, sur les buissons, les fleurs el les gazons; leur taille ne dépasse pas quatre lignes, et est souvent beancoup au-dessous : ils affectent en ğénêral des couleurs sombres.

\section{1re. Division. Balanciers bruns.} MeIg.

Elle contient seize espèces dans les Dipt. d'Eur.

\section{J. Molobre floral, M. Thoma.}

Molobrus Thoma. Lat. Gener. Crust. et Ins. tom. 4. pag. 263. - Sciara Thomze. Me1g. Dipt. d'Eur. ton. 1. pag. 278. $n^{\circ}$. 1. tab. 4. /g. 3. MAcQ. Tipul. du nord de la France, pag. 167.Encycl. pl. 386. fig. 15. Mâle. fig. 16. Femelle.

Voyez pour la description et les autres synonymes, Bibion floral $\mathbf{u}^{\circ}$. 6 . de ce Dictionuaire. Il est comnun aux environs de Paris.

Nous cilerons cncore le Molobre pieds verdâtres, M. viridipes. - Sciara viridipes. MAce. Tipul. du nord de la France, pag. 3o. $n^{\circ}$. 2. Longueur une lig. $\frac{1}{3}$. Noir ; palles d'un gris verdâtre ; ailes obscures. Rare.

\section{2*. Division. Balanciers jaunes ou pâles.}

Celle division renferme douze espèces dans louvrage précité de M. Meigen; !'une d'elles est le Molobre flavipède, M. Alavipes. - Sciara flavipes. Merc. Dipt. d'Europ. tom. 1. pag. 283. no. 17. - M $\mathrm{M}_{\mathrm{AcQ}}$. Tipul. du nord de la France, pag. 31. $n^{\circ}$. 6 . Il se trouve au mois d'août dans les bois, en Frante et en Allemagne.

M. Wiédemann (Dipt. exotic.) cite trois espèces nouvelles, d'Amérique : $1^{\circ}$. Molobre américain, M. americanus. - Sciara americana. Wí́dem. Dipt. exotic. pag. 33. Longueur 3 lig. Noir; ailes brunes; base de l'abdomen ayant une bande transversale rousse. Du Brésil. $2^{\circ}$. Mololre fulviventre, $M$. fulviventris. - Sciara fulviventris. WIÉDEM. id. pag. 44. $n^{\circ}$. 6 . Longneur 3 lig. $\frac{7}{-}$. Noir; base de l'abdomen portant des poils fauves. 30. Molobre noir, M. niger. - Sciara nigra. WIÉDEM. $i d \cdot n^{\circ} \cdot 7$. Longueur 2 lig. $\frac{1}{3}$. Entièrement noir; antennes paroissant blanches vues à certain jour. De Savannal.
CÉroplate, Cemplatus. Bosc. Lat. Hab. Dalm. Platyure. Melg. MAcQ.

Genre d'insectes de l'ordre des Diptères, première section, famille des Némocèrcs, tribu des Tipulaires (division des Fongivores).

Parmi les grenres de celle division, celui de Céroplate forme à lui seul une coupe parliculière caractérisée par les antennes en massue perfolife, presqu'en forme de râpe. Voyez Fonglvores, pag. 656. de ce volume.

Antennes très-comprimces, plus larges dins leur milieu, presqu'en forme de râpe, atteiguant au moins la longueur de la moitié du corselet, composées de seize arlicilcs; les deux premiers distincts l'un de l'autre, très-courts. - T'rmp. très-courte, terminée par deux lèvres assez distincles. - Palpes très-courts, ovoïdo-coniques, n'offianı distinctement qu'un seul article. - Tete petile, penchée, presqu'orbiculaire. - Yeu.* glands, occupant presque la partie antérieure de la léte, in peu échancrés intérieurement. Trois ocelies disposés presqu'en ligne droite sur le vertex. - Corps de longueur moyenne. - Corselct bombé. - Ailes conchées parallèlement sut le corps clans le repos. - Abdomen linéaire, plus large que le corselet. - Pattes très - grêles; hanches postérieures grandes.

Le nom de ces 'Tipulaires est tiré de deux mois grecs, et signifie: cornes aplaties. La prenicre espèce fiut décrite par le savant M. Bosc (Act. de la Soc. d'hist. nat. de Paris, tom. 1. pl. 7. fig. 3.) sous le nom de Céroplate lipuloide; il en avoî́ trouvé la larve sur les bolets du Chêne, où Réaumur l'avoil éalement observée. Suivant ce dernier auleur, elle csl molle, tıès-longue pour sa grosseur, presque cylindrique, vermiforme : elle vit de la partic pureuse inférieure de ces charrapignons, et enduit à niesure qu'elle s'avance, celle parlie d'une luameur visqucuse qu'elle st́crète, et qui l'empêclse de s'en délacher. Pour se métamorphoser, elle se forme une petite coque alongée, presque cylindrique, comme dentée d̀ sa partie postérieure, et composée de la liqueur visçueuse dont nous venons de parler. Réaunıur remarque que lcs antennes dans la nymphe sont appliquées an-dessus du corselet, tandis que dans la plupart des nymphes, et parlicu!ièrement dans toutes les autres 'Tipulaires qu'il a observées, elles sont placées sous le corselet. La partie thoraciqure de cettc nymphe est relevée en bossé.

Nous citerons trois espèces de Céroplates.

\section{Céropiate lipnloïde, $C$. tipuloides.}

Ceroplatus favescens, thoracis lineis longitudinalibus abdominisque segmentorum margine transversali nigris.

Ceroplatus tipuloides. Bosc. Act. de la Soc. d'hist. nat. de Paris, tom. 1. pag. 42. pl. 7 . fig. 3. - L L T. Nouv. Dict. d'hist. nat. tom. IV. 
pag. 542. - FAB. Syst. Antliat. no. 1. - Platyura tipuloides. Merg. Dipt. d'Eur. tom. I. pag. 233. $n^{\circ} .3$.

Longueur 4 à 5 lig. Jaunàtre. Corselet ayant des lignes longitudinales noires; on voit des bandes transverses de cette même couleur sur l'abdomen.

Des environs de Paris. Rare.

\section{Céroplate testacé, $C$. testaceus.}

Ceroplatus testaceus, thoracis lineis longitudinalibus tribus abdominisque maculis lateiralibus fuscis.

Ceroplatus testaceus. DAim. Analect. entom. pag. 98. $n^{\nu} \cdot 15 .-$ Platyura tipuloides. Bl AcQ. Tipul. du nord de la France, pag. 49. $n^{\circ}$. 8. (en retriuchant tous les synonymes, qui atppartienuent à lespèce précédente).

Longueur 5 lign. 'Tesłacé, a vec trois lignes longitudinales brunes sur le corselet, et des taches de cette même couleur sur les côtés de l'abdomen.

De Suède et du nord de la France.

\section{Céropiate charbonné, $C$. carbonarius.}

Ceroplatus ater, abdominis segmentis margine laterali albidis.

Ceroplatus carbonarius n॰.2. Fa . Syst. Antliat. - Lat. Nouv. Dict. d'hist. nat. tom. IV. pap. 543 .

Longueur ". Noir. Bords latéraux des segrmens de l'abdomen, blanchatres.

De la Caroline, d'où il a été rapporté par H. Bosc.

Nota. Le Ceroplatus atralus $n^{\circ}, 3$. FAB. Syst. Antluat. n'est pas de ce geure; il appartient à celui de Platyuie Latr.

CORDYle, Cordyla. Meig. Late.

Geure d'insectes de l'ordı des Diptères, première section, famille des Nénocères, tribu des 'Tipulaires (division des Florales).

Le premier groupe de celle division caractérisé par l'absence des ocelles, contitnt les Curdyles et les Sumulies. (Voyez pag. 657.) Ces derrieres n'ont que onze arlicles aux antenues, et leurs yeux, échancrés au côté incrue, se réunissent sur le veriex dans les mâles.

M. Meigen place ce genre parmi ses TipulairesFongicules, daus le second groupe qui a pour caractères : antennes de seize articles, coniprimées. Cependant il n'accorde que douze articles a a antennes des Cordyles, et de plus, parmi les genres qui figurent duus ce gruupe, celui-ci est le seul qui manque d'ocelles.

Antennes avancées, plus épaisses ver's leur extrémité, composées de douze artieles; les deux premiers distans l'un de l'autre, le terminal semiglobuleux. - Yeux arrondis, entiers, espacés dans les deux sexes. - Point d'ocelles.-Jumbes nuuuies de denx épines à leur extrémité, mais n'elı ayant pas de latérales.

Le nom de ce genre, dont on ignore les mours, vient d'un mot grec qui signifie: massue. Il est tiré de la forme des antennes, qui grossissent vers l'extrémité.

M. Meigen (Dipt. d'Eur.) cite deux espèces de Cordyles : $1^{\circ}$. Cordyle brune, C. fusca. Mrig. Dipt. d'Eur. tom. 1. pag. 274. $n^{\circ}$. I. Fe melle. Lat. Gener. Crust. et Ins. toin. IV. pag. 268. - Encycl. pl. 386. fig. 6. Femelle. Trouvce en octobre pres d'Aix-la-Chapelle, dans un bois. $2^{\circ}$. Cord yle crassicorne, C. crussicornis. Mroro. id. pag. 275. i $i^{\circ}$. 2. tab.10. fig. 1. D'Autriche.

ASPISTE, Aspistes. Hofru. Migig. Lat. (Fant. nat. )

Genre d'insectes de l'ordre des Diptères, première section, launille des Némocères, tribu des Tipulaires (division des Florales).

Le deruier groupe des T'Tipulaires-Florales ayaut poui caractères : des ocelles; antennes de huit a neuf articles, se connose des genres Bibion et Aspiste ( voyez pag. 657. de ce volume.) Dans le premier les antennes ont neut articles, ct qui le distingue du second.

Antennes avancées, un peu plus longues que le corsclet, conıosées de huit articles; les deux preniers un peu épaiz vers leur extrémité, les cius suivans courts, s'élargissant peu à peu; le dernier plus large, ovale, et paroissant avoir un enfoncement dans sou milien. - Trois ocelles. Corselet cont't:- Abdonien composé de huit segmens. - Jambes antérieures ayant une épine terminale.

On ne connoit pas les habitudes des Aspistes. Les caractères de ce genre ont été rédigés par M. Meigen d'après un dessin communiqué par M. Schiippel, représentant une femelle. Le type est l'Aspiste de Berlin, A. berolinensis. Mero. Dipt. d'Eur. tonı. 1. pag. 319. no. I. tab. 11. fig. 16. Femelle. Longuear une ligne. Entièrement d'un brun-noiràtre. Ailes hyalines. Des eavirons de Berlin. (S. F. et A. Serv.)

TIPUlaires, Tipularice. Mace. Section de l'ordre des Diptères.

Dins son ouvrage intitule : Insectes Dipteres du nord de la France, M. Macquart caractérise ainsi cette grande section:

Corps ordinairement ètroit. 'Tête petite, inclinée. Trompe le plus souvent courte et épaisse. Lèvre supérieure petite et coniqne. Soies (mandibules, mâcboirts et lungue ) ordinairement nulles. Palpes alongés, subsétacés, de quatre à cinq articles. Antennes filiformes ou sétacées, plas longues que la tête, composées de six articles औu 


\section{T I P}

moins. Yeux grands, ovales ou réniformes. Yeux lisses, tantôt au nombre de trois, tantôt nuls. Thorax grand, élevé. Abdomen ordinairement menu. Pieds grêles et alongés. Ailes couchées ou écartées, lon rues et assez étroites, leurs nervures formant ordinairement une cellule médiastine, rat'ement une stigmatique; une ou deux marginales, une ou deux sous-marginales; une, deux o: trois discoïdales; trois, quatre ou cinq postéricures; une anale, une axillaire et une fausse.

l'auteur range ainsi les genres qu'il admet dans celle section :

I. Antennes non piumeuses.

A. Antennes à peine aussi longues que la tête.

a. Des yeux lisses. (Tipulaires - Musciformes.)

Scathupse, Bibion, Dilophe. Campylomyze?

b. Point d'yeux lisses. (Tipulaires-Rampantes. )

Simulie.

B. Antennes plus longues que la tête.

a. Des yeux lisses.

† Hanches peu alongées. (TipulairesXylophagiformes. )

\section{Rliyphe.}

†† Hanclies alongées. ('Tipulaires-Fongicoles.)

Sciare, Mycétophile, Scioplile, Platyure, My célobie, Macrocère, Bulitoplile, Dixa.

b. Point d'yeux lisscs.

+ Yeux entiers. (Tipulaires.Terricoles.)

Trichocère, Ptychoptère, Tipule, Néphrotome, Cténophore, Rhipidie, Limnobie, Erioptère, Nématorì̀re.

†† Yeux échancrés.

* Antennes courtes. ('Tipulaires-Phalénoìdes. )

Psychode.

* A Antennes alongées. ('TipulairesGallicoles.)

Cécidomyie, Lestrémie, Lasioptère.

H. Antennes plumeuses. (Tipulaires-Aquatiques. )

Cératopogon, Tanype, Chironome, Corèthre, Cousin, Anophèle.

$$
\text { (S. F. et A. Serr. ) }
$$

TIPUlatres, Tipulatio. MeIg. Premiè famille de la première division de l'ordre des Diptères.

Cette famille dans M. Meigen répond, pour les genres européens, à celle des Némocères de M. Latreille. L'auteur allemand lui donne pour caractères :

Antennes composées d'un grand nombre d'articles (au moins six), dirigées en avant. Palpes alongés, articulés. Balanciers découverts. Abdomen composé de sept à huit segmens.

I. Les Culiciformes, Culiciformes. Yeux lnnnlés. Point d'ocelles. Antennes des mâles en panache, simples ou un pell velues dans les femelles. Bouche point proémincnte. Palpes de cinq articles. Corselet sans ligne transversale enfoncée. Abdomen de huit segmens.

A. Trompe avancée, plus longue que les antennes. Pulpes droils. Nervures des ailes chargées de petites écailies.

Cousin, Anophèle, Aedès.

Nota. Celte division répond à la tribu des $\mathrm{Cu}$ licides. Lat.

B. Trompe plus courte que les antennes. l'alpes recourbés.

Corèthre, Chironome, Tanype, Cératopogon, Macropèze.

Nota. Celle division correspond aux TipulairesCuliciformes. LAT.

iI. Les Gallicoles, Gallicolae. Yeux lunulés. Antennes velues, verlicillées. Palpes recourbés. Ailes obtuses, velues, ayant deux ou trois nervures longitudinales. Jambes sars épines terminales.

Iasioptère, Cécidomyie, Campylomyze.

Nota. M. Latreille place les deux premiers genres, ainsi que celui de Psychode, parmi ses Tipulaires.Gallicoles; les Campylomyzes sont renvoyées par lui à ses'Tipulaires-Fongivores.

III. Les Nocluéformes, Noctuaformes. Yenx lunulés. Point d'ocelles. Antennes eu fuseau, velues, moniliformes. Ailes larges, velues, sans nervures transversales. Jumbes sans épines terminales.

\section{Psychode.}

Nota. Voyez la remarque sur la division précédente.

IV. Les Porte-hees, Rostrato. Yeux ronds, espacés. Point d'ocelles. 'Tête prolongrée en inuseau. Palpes recourbés. Corselet ayant une ligne transirersale enfoncéc et arquée. Abdomen de huit segniens. spines terminales des jambes, petites. 
Erioptère, Limnobie, Rhipidie, Cténophore, Tipule, Néphrotome, Plyehoptère, Nématocère, Trichocère.

Nota. 'Tous ses genres appartiennent aux Tipulaires-'Terricoles. $L_{A} \mathrm{x}$.

V. Les Fongieoles, Fungicolce. Yeux arrondis ou alongés, espacés. Ocelles peu distinets ou nuls. Palpes recuurbés, de quatre articles. Corselet sans ligne transversale enfoncée. Aldomen de sept segmens. Hanches alongres. Jambes munies de denx épines terminales.

A. Antennes velues; la plupart de leurs articles peu distinets; les deux premiers renflés.

Dixa, Bolitophile, Macrocère.

B. Anteunes de seize articles, comprimées. Synaphe, Mycétolie, Platynre, Gnoriste, Seiophile, Léia, Myećlophile, Cordyle.

Nota. Tons ces genres appartienneut aux Tipulaires-Fongivores Lat., sanf celui de Dixa qui liat partie des Terricoles, et de Cordyle qui se range parmi les Florales.

VI. L.es Lugubres, Lugabres. Yenx profondémeni éehancrés et réunis vers le vertex. Oeelles de grandeur inégale. Antennes cylindriques. Palpes de trois articles. Corselet sans ligne transversale enfoncée. Abdomeu de sept segmens.

Sciare.

Nota. Ce genre est plaeé par M. Latreille daus ses 'Tipulaires-Fongivorcs.

VII. Les Latipennes, Latipennes. Yeux rouges, rapprochés dans les mâles, espacés et réniformes dans les femelles. Point d'oceiles. Antennes cylindriques. Palpes de quatre arlicles. Trompe perpen. dieulaire. Abdomen de huit segarens. Ailes très-larges.

\section{Simulie.}

Noka. Ce genre appartient aux Tipuiaires.Florales. LAT.

VIII. Les Musciformes, Musciformes. Yeux noirs, rapproeliés dans les nâles, arrondis et espacés dans les femelles. 'Trois ocelles ŕgaux en grandeur. Antennes eylindriques. Corselet sans ligne transversale enloncée.

Seathopse, Penthétrie, Dilophe, Bibion, Aspiste, Rhyphe.

Nota. Les Museiformes Mnis. répondent aux Tipulaires-florales LAT.; mais ce dennier auteur renvoie parmi ses Tipulaires-Fongivores le genre Rhyphe, et il admet dans ses lilorales ceux de Cordyle et de Simulie.

(S. F. et A. SERt.)

T I P U L E, Tipula. Linn. Geofr. Scop. Schranek. Fab. De Gíer. Devill. Maig. Wiédem. Lat. Nephrotonia. Oziv. (Encycl.) Ptychoptera. FAB.

Geure d'iusectes de l'ordre des Diplères, première seetion, fanille des Némocères, tribu des Tipulaires (division des Terricoles).

Linné réunit dans ce genre la plupart des Tipulaires qu'il a eonnues, in nombre de soixanteune espèces. Geoffroy en retranch a plusieurs dont il compofa ses genres Bibion \& Scarbopse. M. Bosc déeouvril dins les environs de Paris une espèee inédute dont i! forma le genre Céroplate. M. Latreille fonda ceux de Pfychoda, Cecidomyia, Pedicia, Afindulum, Rhyphus, Molobrus (Sciara. Fab.) et Simulium. M. Meignen, dans ses deux ouvrages sur les Diptères et notamment dans le dernier, adinet tiente-huit genres (2oy. 'Tipulaires. Meig.), dont toules les espèees eussent été probablemeut mises par Linné daus son genre Tipula. Les espèees que le é́lèbre auterir sućdois décrit daus le $S_{y}$ fema Naturoe doivent être rapportées, savoir: les Tipules $1108.1,14,15$, au genre Cténophrore; $n^{\circ}$. 2. à celui de Pédicie; les $n^{\text {os. }} 3,4,5,6,9$, so, 13 . sont des 'Tipules, ee qui qui eft probable aufli du $n^{0}$. 12. L'espèe tínbrée 8. est une Ptyehoptère; les nos. 17,18 , 22, appartiennent aux Limnobies; le ${ }^{\circ}$. 19. au grnre Erioptère; 21. est une Trichoeère; 35. ot 52. sont des Tanypes et peut-âtre aussi le $n^{\circ} .24$. Les Chironomes revendiquent les nos. $26,29,3$ r, 32, 35, 37. Le nº.38. est la femelle du Bibio Marci, dont le $n^{\circ} .4^{2}$. est le nầle. A ce genre appartiennent eneore les nos. $40,4 \mathrm{I}, 46$. Le no. 3g. est un Molobre; le $n^{0} .44$. un Dilophe; le $\mathbf{4}^{\circ} .47$. une Psyehode; le no. 48. le rapporte probablement aussi à ce genre; 50. est un Scatbopse; $5 \mathrm{I}$. une Lasioptère ; 54, 55, 6r. trois Céeidomyies; enfin le $n^{\circ}$. 57. est un Cératopogon. M. Meigen pense que le $n^{\circ}$. 58. est le mâle du Simulium reptans. Les dix-liuit autres especes de Tipules décrites par Linné ne sont point raprelées dans lés auteurs récens. On trouve encore trois véritables Tipulaires dans le genre Calex Liss. Ainsi lo Culex pulicaris paroît être un Cératopogon. Les Culex reptans et equinus sont du genre Simulie. Parmi les Diplères que l'on doit ranger dans les Tipulaires, Fabricius (Syst. antliat.) admet, outre le genre Tipula, eenx de C'eroplatus, C'tonophora, Ptychoplera, Chironomus, Psychoda, Hirtea, Scathopse et Sciara. Ces genres sont bien loin pour la plupart d'être purs; ainsi, dans celue de Tipula, dont nous nous oecuperons seul ici, et qui eontient quarante-six espèces, il ne faut regarder comme véritables Tipules que les $\mathrm{n}^{\circ} .9,2$, $3,4,5,6,7,9,10,13,15,16,17,19,21$, $2 \overline{3}$, 


\section{T I P}

23 et 25. Le no. 8. est une Makistocère Wré.D. Les nos. $11,12,18,24,27,28,29,30,31,32$, $33,34,55,36,38,59,41,42,43$. sont des Limnobies. Le $n^{\circ}$. 14. appartient au genre Pédicie LAT., et le n०. 20. aux Néphrotomes : 37 . et 45 . sont des Erioplères; le no. 40 . une Trichocère, le $n^{\circ}$. 46. une Sciopliile; entin les nos. $22,26,44$. ue sont pas rappelés par les auteurs inodernes. Nous dexons ajouter que la Ptychoptera $\mathrm{n}^{\circ} .2$. est une Tipule.

MI. Macquart, dans ses Diptères du nord de lu France (Tipulaires), propose un gente nouveau sous le nom de Lestrémie pour une espèce qu'il il découverte dans les environs de Lille. M. Wićdemann (Dipt. exotic. pars 1a.) créa ceux de Mrakistocère et de Polymère, qui comprennent quelques espèces exotiques, et M. Dalman a donné les caractères génériques du nouveau genre Chionée, établi daus ses Analecta entomologica, sur une espèce aptère qui se trouve en Suède.

Ciny genres composent nu groupe dans la division des 'Tipulaires-Terricoles ( Voy. pag. 582. de ce volume). 'Trois d'entr'eux, Pédicie, Néplirotome et Ptycloptère, ont quinze articles ou plus aux antennes, et les Cténophores qui, comme les Tipules n'en ont que treize, diffèrent de cellesei parce que le second est globulen: $x$, ei que le ciuquième et les suivans, à l'exception du dernier, ont des rameaux latéraux dans les mâles : ils sont ovales-coniques dans les femelles.

Antennes presque sétacées, cylindriques, rapprochées à leur insertion, composées de treize articles: le premier cylindrique, velı, ridé transversalement; le second petil, cyathiforme, finement velu; les dix derniers cylindriques, garnis de soies; le terminal petit: ces articles ordinarement un peu arqués. - Trompe courle, charuue, à lèvres terminales assez grancies, arrondies, séparées, chacune d'elles élargie et velue antérienrement, marquée d'une bande transversale. - Palpes saillaus, courbés, insérés latéralement, à l'origrine de la trompe, composés de quatre articles, les trois premiers égaux en longueur, velus, en massue, le dernier alongé, cylindrique, finement velu, flexible, comme noueux. - Téte presque sphérique, un pea alongée par derrière en forme de cou, prolongée en devant en wae sorte de muscau cylindrique yui se termine en pointe. - Yeux saillans, un pea oblongs, sans écluancrure.-Point d’ocelles. - Corps alongé. - Corselet ovale, relevé en bosse à sa partie antérienre, marqué dans son milieu d'une ligne trausversale enfoncée; métathorax voûté. - Ecusson petit. - Ailes lancéolées, à moitié ouvertes dans le repos. - Balanciers découverts. - Abdomen alonģé, cylindrique, composé de huit segmens, terwiné en pointe dans lés femelles; cette pointe formée de deux écailles conniventes, dures: anus obtus, souvent en massue dans les mâles. - Pattes très-longues, grêles; épines terminales des jambes, petites; dernier

Hist. Nit. Ins. Tome $X$. arlicle des tarses terminé par deux crochets mnnis dans leur entre-deux d'une pelote charnue, en massue.

Réaumur a décrit la larve de la Tipula oleracea; espèce très-commune aux environs de Paris. Elle a le corps en forme de cylindre alongé, un peu aminci aux deux bonts, grisâtre et sans pattes. Sa tête est écailleuse et porte deux petites antennes; les organes de la manducation consistent en deux petits crochets cornés qui ne semllent pas faits pour agir mutuellement l'un contre l'autre, quoique se touchant par leur pointe, mais bien contre deux pièces placées en dessous qui sont fixes, écailleuses, convexes extérieurement et concaves à la partie inlérieure, le bord supérieur cle ces dernières pièces est denté, et cliaque crochet semble fait pour presser contre ces dents les matières qui doivent être broyres; il y a en onlre me partic triangulaire, charnue qui sépare les précédentes et semble tenir lieu de langue ou de lèvre supérieure. Réanmur ne put déconvric de stigmates sur les segmens du corps de ces larves, si ce n'est au postérieur, où l'on aperçoit six rayons ou angles charnus, dont deux plus courts que les autres : entre ceux-ci on voit d'abord deux grands stigmates rélracliles sous lesquels quatre aulres beaucoup plus pelits sont rangés. Réaumur croit que les premiers servent'seuls à l'aspiration de l'air, qui, après avoir circulé dans les trachées intéricures, ressort par les quatre pe!ils. Ces larves se tienneni sous terre, mais près de sa surface, à la hauteur des racines des plantes; elles paroissent se nourrir de terreau, et comme elles sont exlrêmement multipliées dans certains cantons et dans cerlaines années, le mouvement continuel qu'elles fon! autour des racines, exposent celles-ci à êlre desséchées par la chaleur du soleil en soulevant la terre qui les protégeoit.

Lia nymphe est alongée, cylindriq̧ue, a vec deux pectites cornes à la tête propres à la respiration, et de pelits tubercules épineux sur les seguens de l'abdomen, qui l'aident à faire sortir de terre nne partie du corps, lorsqu'elle doit paroîlre en insecte parfait. La femelle de cette espece lorsqu'elle veut pondre, se lient presque perpendiculairement en s'accrochant par les patles antérieures à quelque brin de plante; elle fait pénétrer dans Ja terre les lames anales ćciilleuses qui lermineat l'abdomen, et c'est en passant dans les intervalles que les oufs, de forme oblonque, sont déposés : ils ne sont point tous placés dans un même endroit, mais dispersés. La fécondité de ces femelles est considérable. Pour voir les parties génilales du mâle, Réaunur pressa entre ses doigls le dernier segment de l'abdomen, ce qui procura l'écartement des parties suivanies. On en remarque quatre de chaque côté de l'extrémité de ce segrment; l'une qui est extérieure semble nembraneuse, elle est concave et fail la morité d'une espèce de boîte qui renferme le reste; des trois

Qqฯ q 
autres l'une est un crochet long, écailleux, dílié et terunine par une pointe : les troisième et quatrième pièces sont écailleuses ; la première de ces deux s'élargit à meśure qu'élle s'śloigne de son origine, et se termine par uue tête plate; trèssiallante; la quatrième et deruière est une lane faite en croissint. T'out cet appareil met le mâle ra élat, lors de l'accouplement, de maintenir l'extrémité anale de sa femelle. Du milieu de l'espace que laissent entr'elles les pièces que nous venons de décrire, s'élève un petit corps à peu près cylindrique que l'on doit regarder comme ftant la partie caractéristique du sexe masculiu. i'accouplement dure long-lemps et les deux saxes volent ensemble peudant sa durée, sans se désunir.

Ce genre, quoigiue restreint, est encore nombreux eu espèces.M. Meigen (Dipt. d'Eur.) en mentionne cinarante-quatre. Les 'Tipules sont généralement grandes; lenr taille, qui atteint quelquefois quinze cul seize lignes, descend rarement jusqu’à quatre lignes.

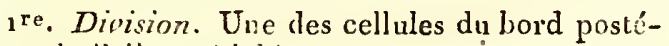
rieur de l'aile, pétiolée.

M. Meigen plice dans cetle division trentequatre espèces. Uue des plus communes on France est la 'Tipule des cnltures, $T$ ' oleracea. MeIG. Dipt. d'Eur. tom. 1. pag. $189 \cdot 72^{\circ}$. 30. Mace. T'ipul. du nord de la France, pag. 68. $7^{\circ}$. 2. Ce dernier auteur, dans l'ouvrage cité, décrit les trois espèces suivantes comme nouvelles. $1^{\circ}$. Tipule nigricome, T. nigricomis. MiACQ. id. pag. $73 . n^{\circ}$. I 1 . Longueur 6 lig. $\frac{1}{2}$. Cendrée; anteunes entièrement norres; corsclet à quatre bandes obscures; ailes tacletées. Nord de lis France. $2^{\circ}$.'lipule arrosce, T. irrorata. MAcQ. id. pag. 74. $n^{\circ}$. 14. Longueur 6 lig. Corselet cendré, à quatre bandes oliscures; abdomen d'un gris-roussâtue; ailes cendrées, nuarbrćes de blanc, à stigmate noirâtre. Nord de la France. $3^{\circ}$. 'Tipule tariere courte, ' $T$ '. breviterebrata. $\mathrm{M}_{\mathrm{AcQ}}$. $i d$. pag. $75 . n^{\circ}$. 16. Longueur 7 lig. Corselet cendré; base de l'abdomen roussâtre; tarière (de la femelle) courte; ailes lègérement obscures, à stignate pî̉le. Trouvée à IIazebrouck.

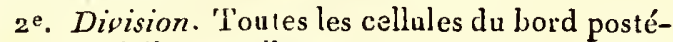
rieur de l'aile, sessiles.

Le nombre des especes de cette seconde division est de dix dans les Dipt. d'Eur. de M. Meiyen. Nous citerons :

\section{Tirule saframée, T. crocata.}

Tipula crocata. Merg. Dipt. d'Eur. tom. 1. pug. 192. $n^{\circ}, 35 .-$ Wace. Tipul. du nord de la France, pag. $77 \cdot n^{\circ} \cdot 20$.

Voyez pour la description et les autres synonymes, N'éfurolome saftanée no. 1. de te Dictionnaire.

\section{Tipule des prés, T'. pratensis.}

Tipula pratensis. Meig. id. pag. ig4. no. 37 .

Voyez pour la description et les antres synonymes (en relranchanl comme donteux ceux de De Gécr et de Scopoli), Néphrotome des prés $n^{\circ} .2$. de ce Dictionnaire.

\section{Tipule cornicine, $T$. cornicina.}

Tipula cornicina. MEIG. id. pag. 200. $n^{\circ} .44 .-$ Msce. id. pag. $76 . n^{\circ} \cdot 17$.

Voyez pour la description et les autres synonymes (en relranchant celui de De Géer qui appartient à la Tipule histrion), Néphrotowe cornicine de ce Dictionnaire.

\section{Tipule histrion, T. histrio.}

Tipula histrio. Meig. id. pag. 198. $n^{\circ} .42 .-$ MAce. id. pag. $176 . n^{\circ}$. 18. - Tipula flavomaculuta. De Ġer. Mém. Ins. tom. 6. pag. 347. $n^{\circ}$. 9. tab. 19. fig. 2-9.

Vojez pour la description et les autres synonymes (en retranchant ceux de Meigen et de Mi. Latreille, qui appartiennent à la Néphrotome dorsale pag. 584. de ce volume), Néplirolome dorsale, tom. VIII. pag. 196. de ce Dictionnaire.

On doit en outre rapporter à ce genre lesespèces exoliques suivantes données par M. Wiédemann (Dipt. exotic. pars $1^{\text {a }}$. Kilioe. 1821.) comme nouvelles : $1^{\circ}$. Tipule tarses blancs, T. pedata. WIÉDEUr. ut suprà pag. 23. $n^{\circ}$. 2. Longueur 10 ligg. Coulenr d'ocre; extrémité des ailes, brune; jambes antérieures ayant une bande transverse blanche; les postérieures en ayant deux : extrémité des tarses, blanche. Fenélle. De Java. $2^{\circ}$. Tipule sœur, T. soror. Wiéd. $i d$. pag. 24. $n^{\circ} .3$. Longueur 8 lig. $\frac{1}{3}$. D'un brua pâle; corselet et abdomen à bandes brunes; ailes d'un brun trèspále, leur bord extérieur brun. Femelle. Cap de Bonne-Espérance. 3º. 'Tipule de Java, T. Jusana. WIÉDEM. id. pag. 27. no. 7. Longueur 6. lig. D'un beau jaune; corselet et abdomen à trois bandes noires; côtés du premier à peine tachés de brun; pattes couleur d'ocre. Mâle. De Java. $4^{\circ}$. Tipule antennaire, T. antennata. WIÉdEM. id. pag. 28. $n^{\circ}$. 8. Longueur 5 . lig. D'un beau jaune; corselet à trois bandes noires, ses côtés tachlés de noir; pattes noires. Mâle. Cap de Bonne-Espérance. $5^{\circ}$. 'lipule courte, $T$. brevipentris. WIÉdem. id. pag. 43. $n^{\circ}$. 4. Longnenr 7 lig. De couleur d'ocre; corselet jaune à trois bandes de couleur d'ocre; faltes bruncs, très-alongées; base des jambes, blanclie. Femelle. Amérique.

Dans le même ouvrage le savant professeur de Kiel décrit nne espèce à anlennes peclinées qui nous paroît, d'après ce caractère, ne pouvoir être admise dans le genre Tipule Maig. Lat. : c'est sa 
Tipule peclinée, T. pectinata. Wúdem. id. pagr. 24. $n^{n}$. 4. Longueur environ 8 lig. De couleur d'ocre; corselet à trois bandes janne; antenues pectinécs; ailes jaunâtres. Mâle. Amérique méridionale.

Le même auteur dans l'ouvrage intitulé : Anctlecta entomologica Kilice, 1824 , décrit l'espèce nonvelle suivante: 'lipule triple raie, T'. trina. WiÉder. ut. snprà pag. 11. Longueur 1 pouce. 1)e couleur d'ocre; abciomen à trois bandes brunitres; ailes décette mêne couleur arec une t.ache brune a la base et une autre au wilieu, de ınême couleur. Kemelle. Du Brésil.

\section{(S. F. et A. Serv.)}

TYQUES , Ricinior. LAT.

M. Latreille (Fam. nat. du Règne aninu.) désigne ainsi une famille d'Arachnides de l'ordre des 'Trachéennes, démembrée du grand genre Aearus de Limné, et qu'il caractérise de la manière suivante : pieds au nombre de huit, n'ćlant pas propres à la natlation; animan $x$ vivant hors de l'eau, vagabonds ou parasites; bouclie en forme de siphon ; chélicères, qui en font partie, inarticulćes et converties en lumes de sucoir, et point terminées par un crochet ou doigt mobile.

Cetle famille se distingue de celles des Phalangiens et des Acarides parce que ces Arachuides ont une bouche composée de chélicères avec un duigt mobile, tandis que les 'Tiques n'ont qu'un siphon. La famille des Hydrachnelles, ayaul la bonche enume lestiques, s'en distingue parce que ses espèces vivent duns les eaux; enfin la familles des Mlicrophthires s'en éloigne parce que les Arachnides qui la composent n'ont que six pieds. M. Latrei le partage ainsi les genres de sa famille des 'liques:

I. Des yeux. Corps tonjours plus ou moins épais, ovale ou oblong. Animaux vagabends.

Le's genres BdolleE, SMaris. (Vojez ces mols à la table alphabétique.)

II. P'oint d'yeux. Corps très-piat, lorsque l'anirwal ne s'est point repu. Animaux habituellement fixés sur d'autres de la division des vertíbrés.

Les genres Ixode, Angas. (Voyez ces mots à la table alphabélique.) (E. G.)

TIRCIS. Nom vulgaire appliqué par Geoffroy (Ins. Par.) au Sutyre Egérie $n^{\circ}$. 39 . tom. IX́. pag. 504. pl 58. fig. 1. et 2. du présent Dietionnaule. (S. F. et A. Serv.)

'TOMIQUE, Tomicus. Lat. Demestes. Iins. Ips. De GEYr. Bostrichzes. Panz. Fab. Herbst. Parx. Oliv. Sculjtns Ouiv. (Entom.) Apate, Hylesinus. F $\mathrm{AB}$.

Genre d'insectes de l'ordre des Coléoptères, seetion des Tétramères, famille des Iyluphitges, tribu des Scolytaires.

Un groupe de la tribu des Scolytaires (zoyez ce mol) a pour caracteres : tous les arlicles cies tarses entiers; il renferme les genres 'Jumique et Platype : celui-ei se distingue de l'autre par ses antemes noffiant distinctement que six articles dout le dernier forme nue massue solide, c'eft-àcire qui ne paroit point articulée.

Antennes en massue, inscirécs aux côlís de la têle, ayant sept articles avant leur massue, celle-eci comprimée, ovale-orbiculaire, composéc de trois ou gualre arlicles transversaux dont le premier est filus grand que les antres, et coriace. - Mandibules coniques, presque triangulaires, se touchant à leur partie intérieure, sans dentelne's dis inctes. - Mâchoines coriaces, comprintées, consisiant en un lobe triangalaire plus latge inles risurement, rétrćci à sa partie supérieure et cilić intérieurement. - Palpes presqu'égaaux, trcis-courts, mais distincts, un peu ćpais à leus base : les maxillaires de quatre articles, les labiaux de trois, le dernier très-petit. - Lèvre petite, ne paroissant que comme nn tubereule entre les palpes; menton presqu'obconique. ićte de la largeur du corselet à sa partie postérieure, obtuse en devant. - I échancrés à leur partie intérieure. - Corps cylindrique. - Corselet cylindrique, firisant à lui senl le tiers de fa longueur du corps, tronriué droit postérieurement. - Elytres recouvrant l'abdomen et les ailes, quelquefois enfuncées à leur partie postérieure; celte cavité bordée d'épines ou de poils roidcs. - Pattes eourtes; jambes triangnlaires, dentées; tarses courts, tous leurs articles entiers.

Les larves des Tomiques vivent dans le bois et le percent en divers sens; c'est d'après cette habiiude que leur nom a été tré d'un verbe grec qui signitie : conper, percer. Les insectes parfails se trouveul sur le bois.

\section{Tomique bordé, T. limbatus.}

Apate linubata $n^{\circ}$. 20. F $\mathrm{F}_{\mathrm{AB}}$. Syst. Eleut. Bostrichus limbatus. Ou1v. Entom. tonu. 4. Bostrich. pag. $37 . n^{\circ} \cdot 22 . p l$. 3. fig. 22.

Voyez pour la description et les autres synonymes, Bostriehe bordé no. I8. de ce Dictionnaire.

Nous eiterons en outre les espèces suivantes : 10. 'lomique typographe, T. typographus. Lat. Gener. Crust. et lns. tom. 2. pag. $276 . n^{\circ}$. r. Scolytus typogiaphus. Otr. Entom. tom. 4. Scolyt. pag. $7 \cdot 2^{\circ} \cdot 7 \cdot$ pl. 1. fig. 7. a. b. - Encycl. pl. 367. fig. 7. Des environs de Paris. $2^{\circ}$. To nonique du Mélése, 'T'. laticis. - Bostrichns laricis no. 10. Fab. Syst. Eleut. $3^{\circ}$. Touxiquue bidenté. T. bidens. - Bostrichus bidens $n^{\circ} .22$. FAB. $i d$. $-S c o l v t n s$ bidens. On.rv. id. pag. 10. $n^{\circ}$. 13. pl. 2. fig. 15. Encycl. pl. 367. fig. 13. $4^{\circ}$. Tomique chaleo- 
graphe, T. chalcographus. - Bostrichus chalcographus $n^{\circ}$. 11. FAB. id. - Orrv. id. pag. 7 .

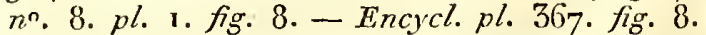
5o. 'Tomique monographe, T. monographus. Bostrichus monographus $77^{\circ}$. 13, F rons de Paris. 60. Tomique micrographe, T' nicrographus. - Bostrichus micrographus nn. 15. Fas. $i d$. - Otiv. id. pag. 9. $n^{\circ}$. 12. pl. 2. fig. 12. - Encycl. pl.367. fig. 12. Environs de Paris. $7^{\circ}$. 'I'omique velu, T. villosus. - Hylesinus villosus $n^{\circ}$. 7. FA B. id 8०. Tomique du Dattier, T. dactyliperda. - Bostrichus dactyliperda no. 14. F. Ав. id. $9^{\circ}$. Tomique disparale, T. dispar. - Apate dispar $n^{\circ} .21$. FАr. id. De France. Iо ${ }^{\circ}$. Tomique marqué, T. signatus. - Apate signata $n^{\circ} .22$. FАв. id. $11^{\circ}$. 'Tomique polygraphe, $T$. polygraphuss. - Bostrichus polygraphus no. 12. Fав. id. De Suède.

Nota. M. Ie comle Dejean mentionne encore douze antres espèces de ce genre dans sou Catalogue. (S. F. et A. SERT.)

TOMOMYZE, Tonımyza Wí́deM. LAtr. (Fain. nat.)

Genre d'inseetes de l'ordre des Diptères, première section, famille des 'Tanystomes, tribu des Anthraciens.

Un groupe d'Anthraciens a pour caractère : trompe guère plus longue que la tête. Il comprend les genres Hirmoneure, Anthrax, Lomatie et 'Tomomyze (Voyez pag. 538. de ce volume). Les trois premiers ont des oeelles distinets, et leurs antennes sont munies d'un style terminal ; en outre les Hirmoneures et les Antbrax les ont distantes à leur base.

M. Wiédemann a élabli ce genre sur une espèce qui habile en Afrique; il lui donne les earactères suivans:

Antennes peu éeartées à leur base, composées de trois articles, le premier court, presque cylindrique; le second très - court, presque globulenx; le troisieme plus long que les deux autres pris ensemble, subulé, s'éeartant sur le côté (nous paroissant, d'après la figure gravée, n'avoir pas de style terminal). - Hypostome court, dirigé en avant, en toit. - Trompe courte, à peine proémiuente. - Ocelles nuls, ou du moins point distincts. - Ailes éearlées. - Pattes courles. Abdomen eomposé de six segmeus.

Le type du genre est la Tomomyze anthracoïde, T. anthracoides. Wiédem. Dipt. exotic. pars $\mathrm{1}^{\mathrm{a}}$. pag. 152. Longueur 4 lig. Noire, brillante. Abdomen taché de blanc; ailes enfumées. Femelle. Du cap de Bonne-Espérance.

hiRMONEURE, Himoneuta. MeIg. Wiédear. LAT. (Fam. nat.)

Genre d'insectes de l'ordre des Diptères, pre mière section, famille des Tanystomes, tribu des Authraciens.
Le second groupe re cette trilsu a pour caractère : trompe guère plus longue que la tête (Vo): pagr. 538. de ce volume). Des quatre-gentes qu'il renferme, ceux de Lomalie et de Tomonyze ant les antennes rapprochées à leur base; ce dernier n'al pas d'ocelles distinets. Les Anthrax qui, comme les Hirmoneures, ont lenrs antennes distantes, en diffèrent par le second arliele cyathiforme et pac leurs ocelles visiblement disposés en triangle équi latéral. Ce dernier caractère se retrouve dans les Lomaties.

Nous donnous les caractères génériques suivans d'après M. Meigen.

Antennes petiles, avaneées, écartées l'une de l'autre à leur base, dirigées de côté, composées de lrois arlieles sphériques, presqu'égaux; les deux premiers un peu velus, le troisième nu, muni d'un assez long style terminal. - Tromipe cachée, retirée dans la cavité buecale lors da repos. - Tête hémisplérique; front étroit. - Trois ocelles distinets; les deux poslérieurs posés sur le vertex, l'antérieur écarté des autres, placé sur k haut du front. - Tarses munis de trois pelotes.

On ignore les mœurs de ces Diptères. Nous citerons deux espèces, les seules connues jusqu'à présent. ${ }^{\circ}$. Hirmoneure obscure, $H$. obscura. MEIG. Dipt. d'Eur. toin. 2. pag. I32. tab. s6. fig. 7 . Longueur 7 lig. $\frac{1}{2}$. Têle grise; hypostome jaune; eorselet noirâtre avec des poils jaunes sur les côtés et d'autres un peu gris sur la poitline; abdomen jaunâtre avec des poils gris; ailes d'un grisbrunâtre, surtout all bord extérieur; balanciers noirâtres; cuisses jaunes; jambes et tarses un peu plus foncés. De Dalmatie. $2^{\circ}$. Hirmoneure exotique, H. exotica. Wréd. Analect. Entom. pag: 2o. $n^{\circ}$. 5. Longueur 9 lig. Cendrée ; antennes et palles rougeâtres; abdomen à bandes transverses noirâtres; bord extérieur des ailes brun. Femelle. De Montévideo.

LOMATIE, Lomatia. MeIG. (Dipt: d"Europ. tom. 3. pag. $V_{\text {. }}$ ) Stygia. MeIG. (Dipt. d'Europ. tom. 2. pag. 137.) MAeQ. Stygide. LAT. (Full. nat.) Anthrax. F $\mathrm{AB} . \mathrm{P}_{\mathrm{ANZ}}$.

Genre d'inseetes de l'ordre des Diptères, premičre section, fumille des Tanystomes, tribu des Anthraeiens.

Les genres Hirmoneure, Anthrax, Lomatie et Tomomyze composent le second groupe de cette tribu, lequel a pour caractère: trompe guère plus longue que la tête. (Voyez pag. 538. de ce volume.) Les deux prezuiers ont les antennes distantes, le second article de celles-ci est posé droit sur l'extrémité du premier. Daus les 'Tomomyzes le troisième article des antennes est dépourvu de style terminal, et lears ocelles sont nuls ou point distinets.

Antennes avaneées, rapprochées à leur base, s'écartant ensuite l'une de l'autre, courtes, composées de trois artieles; le premier court, épais, 
$s^{n} y e n x$, un peuplus gros et arrondi au sommet qui est échaneré latéralement; le second inséré sur cette échanernre, encore plus court que le premier, cyalliforme; le troisième long, conique, nu, muni d'un style mince et petit. - Tronlpe retirée dans la cavité buccale que son extrémité dépasse à peine et terminée par deux lèvres clarnues, réunies en forme de goullière. -- Palpes courls, presque cylindriques. - Téte sphérique, creusée postérieurement. - Yellx réniformes, réunis sur le front dans les mâles, espacés dans les femelles. - Trois ocelles dislincıs, disposés en triangle équilatéral sur le vertex. - Corps assez déprimé. - Corselet ovale, sans ligne transversale enfoncée. - Ailes laneéolées, velues vues au microseope, à moitié ouvertes dans le repos. - Cuillerons très-petits, leurs bords frangés. Balanciers découverıs. - Abdomen longr, elliptique, très - peu convexe. - Pattes grêles, les postérieures alongées; tarses munis de deux pelotes.

Le nom de Lomatie vient d'un mot gree qui signifie : frange, ce qui nous paroît avoir rapport à la conformation des cuillerons. Ces Diplères, qui ont de l'analogie avec les Anthrax, se trouvent le plus souvent sur les fleurs et non pas sur les sables où celles-ci se plaisent. M. Meigen mentionne trcis espèces : une d'elles est commune aux environs de Paris, c'est la Lomatie latérale, L. lateralis. - Stygia lateralis. MEIG. Dipt.d'Eurr. tonl. 2. pag. 140. $n^{\circ}$. 3. - M AcQ. Insect. Dipt. du nord de la France, Asiliques, etc. pag. 62. $n^{\ominus} .1$.

ANThrax, Anthrax. Scorol. Fab. Panz. Meig. Seheli. Lat. Macq. Wiédem. Falek̀n. Musca. Linn. Geoff. Schranck. Devill. Herbst. Nemotelus. De Géer. Oriv. (Encycl. Tableau des genres, toin. IV. pag. 39.) Bibio. Ross. Scunanck. Asilus. Linn.

Genre d'insecles de l'ordre des Diptères, première seclion, famille des Tanystomes, tribu des Anthraciens.

La trompe guère plus longue que la tête est le caractère du seeond groupe des Anthraciens. (Voyez ce mot pag. 538. de ee volume.) Il contient les genres Hirmoneure, Anthrax, Lomatie et Tomomyze. Ces deux derniers ont les antennes rapprochées à leur base; dans les Hirmoneures le second article des antenmes est splıérique et leur ocelle antérieur est placé beaucoup plus bas sur le front que les deux autres.

Antennes avancées, distantes à leur base, se rejetant sur les côtés, courles, composées de trois articles; le premier cylindrique, assez long; le second court, cyathiforme; le troisième de conformation variable, tanlôt bulbiforme avec un style alongé, lequel est ou terminé par quelques soies, ou muni d'une pelite pointe particulière; tantôt conique avec un style biarticulé.-Trompe entièrement cachée dans la cavité buccale, ou à peu près de la longueur de la lête, terminće par deux lèvres longrues, aplaties en forme de gouttière. - Palpes courts, cylindriques, velus. Têle sphérique, un peu excavée à sa parlie postérieure. - Yeux rćniformes, toujonrs séparés même sur le front, celui-ci étroit dans les mâles. - Trois ocelles disposés en triangle équilatéral sur le vertex. - Corps ordinairement dépriuné.Corselet ovale, velu. - Ailes laneéolćes, velues vues a microscope, grandes, forl écarlćes, même dans le repos; leurs nervures de fortue variable. - Cuillerons petits, simples. - Balanciers découverts, mais souvent caelıés sons les poils du cor'selet. - Abdonzen oblong, veln, très-légèrement hombé, le plus souveut plat, composé de sept segrweus. - Pattes grêles, menues, les postérieures ordinarement plus longues proportionnellement; dernier article des tarses mumi quelquefois de deux pelotes sous leurs crochets, en wanquant dans quelques espèces.

Les Authrax ne sont point eneore connues dans leurs deux premiers états; leur nom vient d'un mot grec qui signifie : charbon, dont la couleur d'un noir mat se trouve sur le corps et sur les ailes de la plupart des espèces. Leur vol est d'une grande légèreté et la longueur de leurs ailes leu. permet de l'aecélérer ou de le modére: à volonté; elles aiment particulièrement les localités trc̀schaudes et s'y posent souvent à terre pour recevoir avee plus de force l'influence des rayons du soleil. Dans les 'temps sombres et froids, elles restent presqu'engourdies et se laissent saisir à la main sans songer même à s'éelıapper. C'est sur les fleurs qu'elles vont chercher leur nourriture, qui ne consiste qu'en une pelite quantilé de miel.

Fabrieius ( Jyst. Antliat.) décrit quarante-cinq espèees d'Anthrax, mais il faut observer que la dix-septième est du genre Mrulio; la vingl-buitième et la trente-sixième sont des Lomalies, et la trente-septième, la femelle de l'Athérix Ibis $F$.s. Metg. Les nos. $6,1 \overline{5}, 42$. sont douteux et n'ont pas été rappelés par les auteurs subséquens.

M. Meigen mentionne cinquante-huit espèces européennes. Nous aurions désiré pouvoir adopter les divisions établies dans ee genre par cet auteur et fundées sur la conformité des nervures des ailes aux figures données par lui dans ses planches; mais comme nous $\mathbf{n}^{2}$ avons pas iei la même faeulté d'offrir des figures, et qu'il seroit impossible d'exprimer par des phrases ces différences peu saillantes, quoique visibles, nous érablirons des groupes basés sur les couleurs des ailes et sur la manière donl ces couleurs sont distribuées.

$1^{\text {re }}$ Division. Ailes entièrement hyalines, c'est-à-dire sans mélange de couleur charbonnée.

Le type de cette division est l'Authrax holtentote, A. hottentota n ${ }^{\circ}$. 3. F. Ar. Syst. Antliat. Anthrax circundata. Meic. Dipt. d'Eur. tom. 2. pag. 143. no. 2. - MAcQ. Insect. Dipt. du nord de 
la France, Asiliques, ete. pag. 58. $n^{\circ}$. 2. Coumunc eil lirance.

$2^{\mathrm{e}}$. Division. Ailes en partie liyalines, en partie de couleur charbonnée.

Ire. Subdivision. Ailes hyalines à base noire; ces couleurs point mélangées.

Nous indiquerons: : ${ }^{\circ}$. Anthrax demi-cieuil, $A$. semiatra. Nerg. Dipt. d'Eur. tons. 2. pag. 157. $n^{\circ}$. 25. - M AcQ. Insect. Dipt. du nord de la France, Asiliques, etc. pag. 58. $n^{\circ} .3$. 'Très-commune en France. $2^{n}$. Anthrux à poils fauves, $A$. fulvoTirta. WiÉden. Dipt. cxotic. pars I a. pag. 149. $n^{\circ}$. 46. Irongueur 3 !ig. $\frac{1}{3}$. Noire, chargée de poils fauves, bérissés; côlés de l'abdomen ferruginenx; ailes hyalines, noires à leur base sans urélange, celle couleur allant jusqu'à la moilié. Feuelle. Anérique septentrionale, Géorgie.

$2^{\mathrm{e}}$. Subdivision. Ailes hyalines el clarbonnées; ces conleurs mélangées.

$1^{\circ}$. Antlirax Pandore, A. Pandora. Meic. Dipt. d'Eur. tom. 2. pag. 170. $n^{\circ} .44$. tab. 17. fig. 12. - MAeq. Insect. Dipt. du nord de la France, Asiliques, etc. pag. 61. $n^{n}$. 8. -Wı́́derir. Dipt. exotic. pars 1 a. pagr. $135 . n^{\circ}$. 253. Des parties méridionales de l'Europe, particulièrement dans le midi de la France et en Russie; elle se rouve aussi cn Barburie, suivant Fabricius et M. Wiédemann. $2^{\circ}$. Anthrax ventre blanc, $A$. leucogas. ter. MeIG. id. pag. 163. $n^{\circ}$. 34. tab. 17. fig. 21. L'aile. D'Autriche.

3e. Division. Ailes entièrenent noires ou charbonnées.

Nous indiquerons comme type l'Anthrax Tantale, $A$. Tantalus no. 29. Fав. Syst. Antliat. Sa description est peu exacte. - Wiédem. Dipt. exotic. pars $1^{a}$. pag. 120. $n^{\circ}$. 2. De 'lranquebar.

Ce dernier décrit comme nouvelles et appartenant à ce genre les espèces suivantes: $1{ }^{\circ}$. Anthrax herroine, A. heros. Wrédem. Dipt. exotic. pars ia. pag. 126. $n^{\circ}$. 1 o. Longueur 9 lig. Corps Lérissé de poils roux; abdomen ayanı quatre bandes blanches transverses; la première à la base du premier segment, la seconde à celle du troisième, les deux dernières sur les sixième et septième segmens; les côtés des quatrième et cinquième de cette même eouleur ; ailes hyalines, brunes à la base, qui porte un point transparent. Male. Du cap de Bonne-Espérauce. $2^{\circ}$. Anthrax apicale, $A$. apicalis. WIÉD. $i d . n^{\circ}$. 11 . Longueur 9 lig. Noire; abdomen bronzé; ailes noircs, leur extrúmité et nre tache en lunule sur le disque, byalines; jambes laineuses. Du cap de BonneEsspérance. $3^{\circ}$. Anthrax penuipede, $A$. pennipes. WiÉDEM. id. pag. I29. $n^{\circ}$. 14. Longueur 6 lig. $\frac{3}{3}$. Noire; abdonen un peu mélallique; ailes nonres, leur extrémité byaline; janbes postérieures en- peunées. De Java. $4^{\circ}$. Anthrax mélanoptère, $A$. me:lanoptera. WIÉdem. id. pag. 130. $n^{\circ}$. 15. Lengueur 6 lig. Corselct avec un duvet jaune; abdcmen à bandes juunes transverses; ailes brunes. De la Tartarie díserte. $5^{\circ}$. Anthrax demi-blanche, A. semialba. Wi ́́dem. $i d$. $n^{\circ}$. 16 . Longueur 5 lig. $\frac{3}{2}, 6$ lig. Corselet couvert de poils jaunes; abdousen revêta d'un duvet d'un blanc éclatant; bort extérieur des ailes brun. Dans les contrées méridionales désertes, près de la mer Caspienne. 6०. Authrax calfie, A. caffra. Wrédem. id. pag. 131. $n^{\circ}$. 17. Longueur 6 lig. Brune; abdomen liuscié de blanc; ailes bruncs a leur basc, avec deux bandcs obliyues de même coulenr. Femelle. Da cap de Bonne-Espérance. $7^{\circ}$. Anthrax brillante, A. rutila. WIÉdem. id. pag. $132 . n^{\circ} .18$. Longnear $5 \mathrm{lig}$. $\frac{1}{4}$. Noire; corselet à poils fauves; abdomen tachić de blanc; bord extérieur cles ailes lauve. Díserts de la Tartarie méritionale. 8०. Anthrax de Pallas, A. Pallasii. Wí́der. id. $u^{\circ}$. I 9 . Lougueur 5 ligr. $\frac{1}{2}$. Noire, avec des poils de mêae couleur; ailes ayant leur base noire ainsi que deux bandes qui se réunissent au bord extérieur. Bords de la mer Caspienne. $9^{\circ}$. Anthrax du Cap, A. capensis. WiÉdeM. id. pag. 133. $n^{\circ}$. 20. Longueur 5 lig. Corps couvert de poils el de duvet jaunes; abdomen fascié de blanc; ailes brunes, leur extrémité hyaline avec des points bruns. Cap de Bunne-Espérance. IO$^{\circ}$. Authrax veinée, $A$. venosa. WIÉDEM. $i d$. pag. 134. $n^{\circ} .21$. Longueur 5 lig. Noire, couverte de duvel jaune; abdounen fascié de blanc; toutes les nervures des ailes bordées de brun. Cap de Bonne-Espérance. 11\%. Anthrax longirostre, $A$. longirostris. Wrédem. $i d$. $n^{\circ}$. 22. Longueur 4 lig. Corps muni d'un duvct jaune; abdomen laché de blanc; bord extérieur des ailes brun jusqu'à moitié, avec des laclies carrées, hyalines. Cap de Bonne-Espérance. $12^{\circ}$. Authrax lachetée, $A$. maculosa. Wiédes. $i d$. pag. 136. $n^{\circ}$. 24. Longueur 3 lig. $\frac{1}{3}$. Noire, revêtue d'un duvel jaune; abdomen fascié de blaue; base des ailes brune : on voil des taches de même couleur sur le bord. Du eap de Bonne-Espérance. 13․ Anthrax chalcoïde, $A$. chualcoides. WiÉd em. id. $n^{\circ}$. 25. Longucur 3 lig. $\frac{x}{2}$. Corps muni d'un duvet un peu métallique; abdomen ayant une bande transverse blauche, interrompue; anus blanc; ailcs liyalines. Déserts méridionaux, vers la mer Caspientre. $14^{\circ}$. Anthrax Polyphême, $A$. Polyphenuus. Wiédem. id. pag. 138. $n^{\circ} .27$. Longueur 9 lig. D'un brun jaunàlre ; abdomen ayant trois bandes blanches lransverses; ailes brunes, avec des laches hyalines, dont une triangulaire placće vers le bout de l'aile. Du Brésil. 1 $5^{\circ}$. Anthrax de Hessius, $A$. Hessii. Wienem. id. pag. I39. $n^{\circ}$. 29. Longueur $6 \mathrm{lig}$. Noire; abdomen fascié de blanc; ailes hyalines, avec la base et quatre - points bruns. Du cap de Bonne-Espérance. $16^{\circ}$. Anthrax rousse, A. rufa, Wiédem. id. pag. 140. $n^{\circ}$. 31. Longueur 6 lig. Noire, à poils roux; 


\section{T O M}

ailes brunes, leur extrémité plus claire. Du cap de Boune-Espérance. 17 $7^{\circ}$ Anthrax ponctipenue, 1. punctipennis. WríDEM. $i d . n^{\circ}$. 32. Longueur 5 lig. $\frac{1}{2}$. Brune.; corselet rayé de blanc; abdomen fascié de blanc; ailes à points bruns. Müle. Cap de Bonne-Espérauce. $18^{\circ}$. Anthrax transparente, A. hyalina. WiÉdeM. id. pag. 141. $n^{\circ}$. 54. Lonyueur 5 lig. Noire; abdomen fascié de jaune; ailes très-hyalines, avec un peu de brun à la base. Femelle. De Java. $19^{\circ}$. Anthrax six bandes, A. sexfasciata. Wi亡̀d EM. id. pag. 142. $n^{\circ} .35$. Longueur 5 lig. Noire, à poils jaunes; abdomen a vec six bandes transverses grises; ailes entièrement byalines. Femelle. Du cap de Bonne-Espérauce. $20^{\circ}$. Antlirax brune, $A$. fusca. Wiśdem. id. pag. 1 $45 . n^{\circ} .39$. Longueur 4 lig. Brune, à poils ferrugineux; base des ailes brune, le reste trunsparent avec trois points, dout deux bruns et l'autre noir. De l'A mérique méridionale. $2 \mathrm{I}^{\circ}$. An. thrax simple, $A$. simplex. Wíndem. id. pag. 146. $n^{\circ}$. 40. Longueur 4 lig. Corps couleur de charbon, tout hérissé de poils jaunes à l'exception du front; ailes transparentes, leur base d'un brun clair. Cap de Bonne-Espérance. 220. Antbrax face blanche, A. leucostoma. WiÉdent. id. $n^{\circ}$. 41. Longueur 4 lig. $\frac{x}{2}$. Noire; hypostome d'un blanc brillant; abdomen ayant des bandes transverses de cette couleur, qui est aussi celle de l'anus; bord extérieur des ailes noir. Femelle. Cap de BonneEs pérance. $23^{\circ}$. Anthrax mi-partie, A. dimidiata. IVí́Dem. id. pag. 148. $n^{\circ}$. 44. Longueur 3 lig. $\frac{1}{2}$. Noire; abdomen couvert d'un duvet blanc brillant; ailes brunes depuis la base jusqu'à moitié, cette partie portant quatre points plus noirs. Du Brésil. 24. ${ }^{\circ}$. Anthrax fauvette, $A$. fulvula. WIÉdens. id. $n^{\circ}$. 46. Longueur 4 lig. Noire, à pcils fauves; ailes d'un jaune transparent, leur bord extérienr brun. Mâle. De Java. 250. Anthrax naine, A. pusilla. Wréden. id. pag. ı 50. $n^{\circ}$. 48. Longueur 2 lig. $\frac{x}{2}$. Noire; abdomen à bandes tiansverses d'un blanc brillant; ailes noires de la base jusqu'à la moitié, le reste transpareut, portant deux points noirs. Mále. Du cap de BonneEsperiance.

Le même auteur, dans ses Analect. entomol., donne cinq autres espèces comme nouvclles: $\mathrm{I}^{\circ}$. Antbrax Mérope, $A$. Merope. Wrédem. Analect. entom. pag. 22. $n^{\circ}$. 11. Longueur 7 lig. Noiràtre, à poils jaunes; écusson rougeâtre; abdomen ayant de chaque côté de grandes taches de celle niême couleur; ailes hyalines, leur bord extérieur brun. Mâle. De Guincée. $2^{\circ}$. Authrax Déesse, A. Dia. Wréd. id. pag. 23. $n^{\circ}$. 12. Longueur 5 lig. $\frac{3}{2}$. Noirâtre, à poils gris; abdomen ferrugineux fascié de blanchâtre; ailes byalines, leur bord extćrieur brun. Mâle. De Tranquebar. 3․ An lirax hérissée, A. lasia. Wix́ners. $1 d . n n^{\circ} .13$. Longueur 5 lig. Noire, à poils jaunâtres; ailes hyalines, la cellnîe qui borde la côte, brune : pattes rougeâtres. Màie. Cap de Bonne-Espérance. $4^{\circ}$. Anthirux diffuse,
A. diffusa. Wréd. id. $n^{\circ}$. 14 . Tongueur 4 lig. $\frac{2}{3}$. Couleur de suie; abdomen fuscié de blanc bri:laut; ailes à base noire, le reste transparent, avec trois points noirs. Cap de Bonne-Espérance. $5^{\circ}$. Anthrax Absalon, $A$. Absalon. Wréd. id. pag. 24. $n^{\circ}$. I5. Longueur 2 lig. $\frac{1}{2}$. Noire, à duvet jaune; bords latéraux dn corselet blancs; abdonien ayant deux bandes transverses de même coulenr; ailes avec leur bord extérieur étroit, noir, dentelć. Des Indes orientales. (S.F. e! A.SERv.)

TORDEUSES, Tortrices. Cinquième tribu de la famille des Nocturnes, ordre des Lépidoptères.

M. Latreille lui assigne ces caractères :

Chenilles ayant ortinairement seize pattes, quelquelois quatorze seulemeut, les anales ne manquant jamais, roulant des feuilles ou liant des fleurs qui leur serverit d'habitalion; quelques autres vivant dans l'intérieur des fruits. - Ailes entières, c'est-à-dire point divisées en lanières, étant, dans le repos, disposées en toit très-écrasé ou presqu'horizontal, formant le plus souvent a vec le corps un triangle court, large, arqué en dehors vers la partie antérieure : cet élargissement produit par la dilatation extérieure de la côte des premic̀res ailes, les inférieures ayant un frein. Palpes maxillaires à peine perceptibles, tube:culiformes, de deux articles au plus; les labiaux très-apparens, tantôt courts, cylindracés, tantôt recourbés au-dessus de la tête en forme de cornes.

I. Ailes supérieures élargies à leur base ct arrondies dans cette partie.

A. Palpes labiaux plus conrts que la tête, leurs articles peu distincts, presque glabres. - Hanches antérieures trèsconprinées, aussi longues au woins que les cuisses.

Natronule Noв.

B. Palpes labiaux plus longs que la têie, leurs arlicles fort distincts. - Hancbes antérieures point aplaties, plus courtes que les cuisscs.

a. Dernier article des palpes labiatix droit ou presque droit, point conique ni cn furme de corne.

$$
\text { Pyrale, Xylopode, Frocérale. }
$$

b. Dernie: article des palpes labiaux recourbé sur lit lềte, en cône alongróé, imitant une corne.

Volucre.

II. Ailes formant avec le corps un triongle alongé, presqu'horizontal, le bord extéricur des supérieures élant droil ct point arqué à sa base.

IIerminic. 
Nota. A l'article Pyrale de ce Dictionnaire, nous avons annoncé que ce genre nous paroissoit susceptible d'être divisć en plusieurs autres, sous le rapport des palpes labiaux et de la conformation dcs chenillcs; c'est ce que M. Latreille a exécuté dcpuis dans ses Fam. nat. Nous ajoutons nous-mêmes ici un genre nouveau à cenx qu'il a indiqués dans cet ouvrage : ainsi, actuellenient on doil restrcindre le genre $P_{y}$ rale aux espèces qui, comme les nos. I , 2, 3, 4,6, 7, 9, 10 et I 9 . ont le second article des palpes labiaux maniticstement plus long que le troisième et plus chargé d'écailles, ce troisic̀me court, tronqué oul obtus, nc sc recourbant pas sur la tête. 11 est probable que les cspèces nos. $8,11,12,13,14,15,16$, 17 et 18 . que nous n'avons point vues en nature, sont aussi des Pyrales. I. $\mathrm{n}^{\circ}$. 5. est le type de notre geure Matronule; les nos. 20. et 21 . appartiennent aux Volucres.

MATRONULE, Matronula. Noв. Pyralis (Enc.)

Genre d'insectes de l'ordre des Lépidoptères, famille des Nocturnes, tribu des Tordeuses.

Dans celte tribu les Herminies se distinguent par leurs ailes formant avec le corps un triangle alongé, presqu'liorizontal, le bord extérieur des supérieures ćlant droil et point arqué à sa base. hies autres genres ont, comme les Matronules, les ailes supérieures élargies ct arrondies à leur base; mais ccux de Pyrale, Xylopode, Procérate et Volicre sont bien séparés des Matronules par leurs palpes labiaux plus longs que la tête, à articles fort distincts, ainsi que par les hanches antérieures plus courtes que les cuisscs, ct point comprimées.

Palpes labiaux cylindriques, beaucoup plus courts que la tête, composés d'articles peu distincts, aucun d'eux n'ćtant plus velu, ni plus mince que lés autres. - Hanches antérieures très-comprimécs, au inoins aussi longues que les cuisses. - Ailes supérieures trc̀s-élargies à la base de leur bord extérieur. Les autres caractères comme dans les Pyralcs. (Voyez ce mot.)

Le type de ce genre est la Matronule de Godart, III. Godarti Noв. Voyez pour la description $\mathrm{Py}-$ rate de Godart n ${ }^{\circ}$. 5 . de ce Dictionnaire.

PROCÉRATE, Procerata. Lat. (Fam. nat.) Pyralis. FAB.

Gcnre d'insectes de l'orare aes Lépidoptc̀res, famille des Nocturnes, tribu des Tordeuses.

Trois genres composent un groupe dans cette tribu, savoir: Pyrale, qui a le second article des palpes notablement plus long que le troisic̀me, et Xylopode, dont les palpes sont courts et le corps peu alonģ́; ; en outre les pattes membrancuscs des chcnilles de cc genre ont la forme de jambes de bois. Ces caractercs séparent ces genres de celui de Procérate, le troisième du groupe. (Voyez pag. 679.)

Palpes labiaux avancés, peu recourbés, point prolongés au-dessus de la tête et ne prenant pas la forme de cornes, composés de trois articles; le second et le troisieme presqu'également longs et écailleux. - Corps alongé, d'une forme intermédiaire entre la triangulaire et la demi-cylindrique. Les autres caractères sont ceưx des $\mathrm{Py}_{\mathrm{y}}$ rales. (Voyez ce mot.)

MI. Latreilie indique pour type la Procérate de Saldoncr, P. Saldonana. LAT. (Fam. nat.) Pyralis Saldonana no. 3g. FAB. Entom. Syst. tom. 3. part. 2. Des environs de Paris.

HERMINIE, Herminia. IAT. Phalona. ( Pyralis.) Linn. Fhalcena. Geoff. De Géer, Detili. Ross. Cram. Crambus, Hyblaca. Fab. Pyralis. Schifr. Scop. Hubn.

Geure d'insectes de l'ordre des Lépidoptèrcs, famille des Nocturnes, tribu des Tordeuses.

Les Herminies forment à elles seules la seconde division de la tribu des Tordeuses. (Voyez pag. 679. de ce volume.)

Antennes souvent cilićes ou presque pectinées, dilatées au milieu dans les mâles ou rentlées vers la partie inférienre. - Palpes labiaux recourbés, comprimés, très-griands. - Ailes trigones, prcsqu'horizontalcs, formant avec le corps, dans le repos, un triangle alongé; leur bord extérieur étant droit. - Chenilles à quatorze pattes; la première paire de membraneuses, manquant.

Les Hcrminies sont peu brillantes, de couleur généralement grise, et ne variant entr'clles que par des nuances plus ou moins foncées. On croit que leurs chenilles viveut dạns des fenille qu'elles roulent. Quelques mâles se font remarquer par les touffes de poils dout leurs cuisses antérieures sont intéricurement garnies; ils peuvent les développer ou les replier à volonté. Nous citerons les espèces suivantes :

$1^{\circ}$. Herminie barbue, H. barbalis. LAt. Nouv. Dictionn. d'hist. natur., 2e. édit. - Crambus barbatus no. 2. Fав. Entom. Syst. Suppl. Mâle. - Crambus tentacularis no. 6. Fab. id. Femelle. Des environs de Paris; dans les prés. Sa chenille vit sur le trèlle (Trifolizum pratense), suivant M. Latreille, et aussi sur lc pissenlit (Taraxacum vulgare), d'après Fabricius. $2^{\circ}$. Herminie éventail, H. ventilabris. LAT. id. - Crambus ventilabris no. 4. FAв. id. - Encycl. pl. go. fig. 11. Mâle. Commune en France dans les bruyères. Les mâles de ces deux espèccs ont leur's cuisses antérieures garnies de toufles de poils. 30. Herminie à trompe, II. proboscidalis. LAT. id. - Crambus proboscideus. $\mathrm{n}^{\circ} .7$. , et Crambus ensatus $\mathrm{n}^{\circ} .8$. FaB. id. $4^{\circ}$. Herminie à bec, $H$. rostralis. LA'T. id. Crambus rostratus no. 1 I. FA.B. $i d$. - Le Toupet à pointes. Geofr. Ins. Paris. tom. 2. pag. 168. no. 1 1.6. On la trouve en France dans les bois, an milieu de l'été. La chenille est verte et vit sur' le Charme, suivant M. Latreille. 5\%. Herminie goupillon, H. aspergillus. LaT. Gener. Crust. et 


\section{$\mathrm{T} O \mathrm{U}$}

Ins. tom. 4. pag. 229. - Crambus aspergillus. Coqueb. Iconogr. tab. XVII. Jig. 10. - Encycl. pl. 397. Lépidopt. nº 7. De Caroline. 6. Herminie flèche, $H$. sagitta, LAT. $i d$. Hyblcea sagitta $n^{\circ}$. 5. FАв. Entom. Syst. tom. 3. pars $2^{\mathrm{a}}$. Des Indes. ( S.F. et A. Serv. )

TORTUE. Geoffroy (Ins. Paris.) a donné ee nom à deux Lépidoptères diurnes de son genre Papillon. L'un est la grande Tortue (voyez VANeSSE POLYehlore, tom. IX. pag. 304. $n^{\text {D. }} 2 \mathrm{I}$ de ce Dictionnaire); l'autre qu'il nomme petite Tortue. Voyez VANeSSE de L'OrTIE, tom. IX. pag. 3o6. $n^{\circ} .23 \mathrm{du}$ présent ouvrage.

$$
\text { ( S. F. et A. SERv. ) }
$$

TOUPET A POINTES. Nom vnlgaire donné par Geoffroy (Ins. Paris. tom.' 2. paag. 168. $n^{\circ}$. 116 ) à un Lépidoptère nocturne de son genre Phalène; c'est l'Herminie à bee, H. rostralis LAт. (S. F. et A. SErq. )

TOUPET TANNE. Nom trivial appliqué par Geoffroy (Ins. Paris. tom. 2. pag, 131. $n^{\circ} .43$.) à un Lépidoptère nocturne. Il appartient probablement au genre Crambus LAT., ou à celui d'Herninia du même anteur.

$$
\text { (S. F. et A. SERv.) }
$$

TOURLOUROUX. Nom donné par des voyageurs et nos eolons amérieains à des Crustacés décapodes, de notre tribu des Quadrilatères, famille des Braehyures, très-remarquables par leurs habitudes, appelés aussi collectivement Crabes de terre, et dont diverses espèces ou variétés ont reçu aussi les dénominations de Crabes violets, Crabes peints, Crabes blancs, etc. A l'artiele Crabe de ce Dietionnaire, il a déjà été fait mention de ces animaux; mais outre que leurs caractères distinctifs n'y ont pas été assez développés, que ces Crustaeés forment dans la méthode aetuelle des groupes génériques bien cireonscrits leur histoire présente anssi des lacnnes qu'il est important de remplir, et c'est ce qui nous a déterminés à leur consacrer un article spécial et supplémentaire.

Les 'Tourlouroux eomposent dans notre tribu des Quadrilatères une petite section particulière, et que nous signalerons ainsi : quatrième article des pieds-mâchoires extéricurs inséré près du milieu du sommet du précédent ou plus en debors. Antennes intermédiaires très-distinctes, très-sensiblement bifides à leur extrćmité : leur premier article plus transversal que longritudinal. Corps, le post-abdomen non eompris, élevé, épais, en furme de ecur tronqué postérieurement; chaperon toujours plus étroit que le test, mesuré dans son plus grand diamètre trausversal. $Y$ eux $x$ insérés de chaque côlé du chaperon, dans de grandes cavités, qui se terminent avant la dilatation latérale du

Hist. Nat. Ins. Tome $X$.

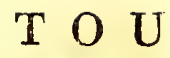

test et beaucoup plus courtes que son diamètre transversal, abstraction faite de l'espace oceupé par le chaperon. Serres robustes.

La dénomination de Tourlouroux a élé empruntée de la langue des Caraibes, qui par le mot d'Itourourou désignent un petit Crabe de jardin (Dict. de la langzze caraïbe du père Raymond Breton). Dans la narration de ses voyages a:ıx îles de l'A mérique, le père Labat a rẻuni diver'ses observations sur ces animaux. Il en disingue quatre espèces; les Tourlouroux, les Crabes violets, les Crabes blancs et les Cériques ou Ciriques (1). Les deux premières sont du genre Gécarcin; la troisième rentre dans celui que nous établissons ieì sous le nom de Candisome, et il paroît même, d'a près l'Essai sur l'histoire naturelle de la France. équiinoxiale de Barrère, que l'on confond aussi sous le nom de Crabe blanc, un Crustacé d'uu antre genre, l'Uca-una de Marcgrave (poy. Uc $\Lambda$ ). Quant aux Cériques, il y en a, selon Chanvelon (Voyag. à la Martinique, pag. Io8), de deux sortes; l'une qui se trouve dans les rivières et se nomme simplement $C$ érique, me paroît appartenir a u genre Grapse, ou pent-être à celui de Telphuse ( voyes ce mot); l'autre, appelée Ciri-apoa par les Brésiliens, et Xirika par les naturels de la Guiane, r'habile point l'eau douce. Le Ciri-apoa et le Ciri-obi de Mlarcgrave doivent être rapportés au genre Lupa du docteur Léach. Les dénominations de Ciri, de Xirika, de Cérique ou Cirique, ont, à ee que je erois, une origine commune. Mais les Grapses ou les Crustaeés d'ean douce, qu'on appelle Cériques à la Martinique, sont désignés an Brésil sous les noms d'Aratu, Caranauna, et à Cayenne par celui de Ragabemba ou de Soldat en notre langue. Si Barrère ne s'est point trompé dans sa synonymie, son Crabe de vase ou des palétuviers, que l'on pourroit d'abord, à raison de l'identité d'habilation, regarder comme voisin des Crabes blancs, est la Guaia apara de Marcgrave : or ce dernier Crustacé est évidemment du genre Calappa, très-éloigné cie ceux de la tribu des Quadrilatères. La dénomination de Guaia paroît a voir été donnée eollectivement, par les habitans du Brésil, à divers Crustacés déeapodes brachyures, tels que des Crabes proprement dits, des Leucosies, et, eomme nous venons de le voir, à une espèce de Calappe.

Cette dislinction de Crabes de terre a voit été faite, avant le père Labat, par Rochefort, auteur d'une Histoire naturelle das Antilles. Celui - ci seulement ne fait point mention des Cériques, et nomme Crabes peints, eeux que le père Labat appelle violets. 'Tout ee que dit Fermin des différentes espèces de Crabes de Surinam est exirait de ces historiens, et de eelui-ci surtout.

Les Tourlouroux sont les plus petits de tous les

(1) C'est le genre gecarcinus de M. Léach. R.r. 
Crabes de terre; le plus grand diamètre des individus de la plus forte taille ne s'élève guère audelà de trois pouces, tandis qu'on en trouve parmi les Crabes blancs qui ont plus de sept pouces de large, et que l'on pent passer le poing dans l'intervalle compris entre leurs doigts ou les branches de leurs tenailles. Selon ces auteurs, les 'Tourlouroux ont l'ecaille (le test) dur, quoique fort mince, naturellemeat rouge, avec le milieu du dos plus foncé ou comme marqué d'une tache noire. La couleur s'éclaircit peu à peu sur les côtés, et le dessous du corps est ll'un rouge clair. La serre gauche est tonjours plins petite que la droite. Ces Crustacés pincent vigourensement et ne lâchent point prise. Ils frappent leurs mordans l'un contre l'autre, comme s'ils vouloient épouvanter à leur tour les objets qui les ont effrayés. Leur cliair est agréable au goût; mais attendu, selon Rochefort, qu'il y a beancoup à éplucher, et qu'on estime qu' elle provoque à la dyssenterie, on ne la recherche que dans la nécessité. Le père Labat dit néanmoins que des trois espèces de Crabes de terre, elle est la plus délicate, et, avec celui qu'on désigne sons le nom de violet, une vraie manne pour le pays. Les Carribes et les Nègres en mangent habituellement, et les blancs inême en servent sur leurs tables, accommodés de diverses manières. Ce voyageur est toutefois d'avis qu'il faut s'être accoutumé dès l'enfance à ce genre d'alimens, qu'autrement on a de la peine à le digérer, qu'il produit des humeurs froides et hypocondriaques, et qu'en un mot, cette nourriture n'est pas bonne aux Européeus, dont la constitution n'est pas aussi robuste que celle des naturels du pays et des personnes chez lesquelles l'habitude du travail augmente ou facilite les facultés digestives. Au témorgnage des mêmes auteurs, les Crabes de terre vivent de feuilles, de racines et de frnits tombés à terre qu'ils saisissent avec leurs mordans, et qu'ils coupent et déchirent eusuife avec leurs dents ou mandibules. Mais comme parmi ces fruits, il y en a qui, tels que le rnanceniller (hippomane mancinella, LrN.), sont des poisons, ou du moins d'un usage dangereux, on ne mange guère que les Crabes violets et les Tourlouroux, parce qu'ils habitent ordinairement les montagnes ou les plantations de cannes, où l'on ne trouve pöint de ces fruits vénéneux. Le Crabe blanc établissant sa demeure sur les bords de la mer, où le manceniller est commun, et pouvant en manger le fruit, est dès-lors moins recherché. On seroit d'antant plus exposé à s'empoisonner, que l'animal, selon le père Labat, n'en paroît pas éprouver d'accident fấcheux. Aussi s'abstient-on de manger les Crabes que l'on renconlre sous cet arbre, sans en excepter même les violets et les Tourlouroux, à l'époque de l'année où, pour un motif que nous ferons bientôt connoître, ils ont gagné les rivages maritimes. Ils sont alors dans la situation des Crabes blancs, et par con- séquent d'un nsage suspect ou dangcreux. On prétend que les feuilles des sensitives ou mimosa communiquent anssi à la chair de ces animaux, lorsqu'ils s'en nourrissent, une qualité vénéneuse, et l'on ne mange point, pour la miême raison, ceux qui se tiennent dans les localités propres à ces végétaux. On peut, dit-on, recounoître s'ils sont sains ou non, par la couleur du taumalin on taumalis, gne Rochefort dit être une substance huileuse de l'intérieur de leur corps, et qui, selon le père Labat, est une matière verdàtre, proprè aux mâles. Si cetle substance est noire, l'animal est empoisonné. Mais Jacquin et d'autres auteurs nient qu'il attaque les fruits du manceniller. Lion dit même que l'on ne s'est jamais aperçu, dans dans l'île de la Grenade, que quelqu'un ait été incommodé pour avoir mangé de ces Cruslactes, quoiqu'on les y prenne souvent sous cet arbre. Des personnes dignes de confiance, et parmi lesquelles je citerai M. Moreau de Jonnès, correspondant de l'Académie des sciences, qui a fait un long séjour à la Martinique, où il a étudié avec nn zèle au-dessus de nos éloges les productions natnrelles, ainsi que la géographie physique, M. Royer, l'un des secrétaires du Muséum d'histoire naturelle, et feu Maugé, qui avoit encore voyagé aux Antilles, m'ont assuré que les 'Tourlouroux se nourrissoient habiluellement de matières animales, et qu'ou en tronvoit même beaucoup dans les cimetières. M. Moreau de Jonnès les a vis, dans un temps où la fièvre jaune exerçoit de cruels ravages à la Martinique, emporter des lambeaux de cadavres humains. L'analogie, al surplus, confirme ces faits.

Mais si les'Tourlouroux ne sont point fiugivores, d'où provient cetre qualité délélère qu'ils ont dans certains cas? On a imagriné qu'elle leur étoit conmuniquée par des filons de cuivre sous-maring. Mais celte opinion et quelques autres relatives à l'explication du même phénomène sont dénuées de preuves, pour ne pas dire invraisemblables. Il seroit plus naturel de soupçonner avec M. Moreau de Jonnès, que ces animaux, ainsi que plusienrs poissons, sunt sujets à certaines maladies ou d quelques affections qui rendent alors l'usage inté rieur de leur chair dangereux pour nous. Peut-êtré encore faut-il l'attribuer à ce qu'ils se sont nourris de cadavres trop corrompus. Ne seroil-il pas encore possible que, privés de leurs matières animales ou de leur's alimens habituels, les Tourlorroux et autres Crustacés analogues fussent contraints de se nourrir de fruits, et même de ceuz du manceniller? N'avous-nous point des exemples que plusieurs animaux, natu rellement carnassiers, devieunent herbivores par circonstance? N'en connoissons-nons point qui sont omnitores ? Est-il bien constaté que les Crabes ne sont point duns l'un ou l'autre de ces cas? et les dégâts qu'ils font dans les jardins, lorsqu'ils y pénèirent, ne seroient-ils que l'elfet d'us simple instinct des- 


\section{$\mathrm{TO} \mathrm{U}$}

tructeur, et dont ils ne tireroient aueun avanlage pour leur subsistance? Habitant des lieux déserts où l'on trouve peu d'animaux, comment pourroient-ils y vivre? Voilà, ce me semble, des questions qu'il seroit utile de résoudre, non par des raisonnemens, mais par des expériences positives ou l'observation. Rien ne seroit plus facile à vérifier, prisqu'il suffiroit de renfermer un certain nombre de ces Crustacćs dans un terrain clos, et de leur donner successivement pour nourriture diverses sortes de substances, au nombre desquelles il faudroit cumprendre les fruits du manceniller et les feuilles de mimosa.

Les Crabes peints ou violets sont d'une taille moyenne entre les Tourlouroux et les Crabes blancs, et remarquables par la beauté, ainsi que par l'agréable mélange de leurs couleurs. Les uns sont d'un violet panaché de blanc; les autres sont d'un beau jaune, chamarré de lignes grisâtres ou purpurines. On en trouve dont le fond est tanné, et rayé de rouge, de jaune el de vert. J'indique à l'ar. ticle GÉGARCIN-TOUR LOUR oUx les principales varićtés de nuances que j'ai observées dans les individus de la collection du Muséum d'histoire naturelle et dans ceux que je possède. Les. 'Tourlouroux des autcurs ne me paroissent pas former, comme ils l'avancent, une espèce propre, mais une variété du premier âge des Crabes peints ou violets. Les plus jeunes ont le dessus du test d'un rouge foncé ou violet, tandis que dans les plus âgés ou les plus grands, il est entièrement jaune. Les individus rutermédiaires ou de moyen âge, participent plus ou moins de ces deux teintes.

Les Caraibes (1), ainsi qu'il le paroit, d'après leur langue, ont bien remarcqué, à l'égard de ces a nimaux, tant cette variété de couleurs que certaines particularités d'habiludes, de localités et de formes.

Les Crabes peints rôdent, en plein jour, sous les arbres, y cherchant leur nourriture. C'est surtout le matin et le soir, après les pluies, qu'on les y trouve plus spécialement, et ils y sont souvent en troupes nombreuses. Si on feint de vouloir les arrêter avec nne bagnette ou quelqu'autre corps, car il y auroit du danger à se servir de la main, ils fuient atssilôt, en marchant de côté, et en employant les 1 uses et les moyens de défense dont nous avons parlé plus haut. Ils gagnent le plus vite possible leurs clapiers, ou l'asile que

(1) Crabe violet qui devient rouge, Tiboukou; fem., Oulalcibe.

Crabe blanc, Oyema; fem, , Heulle.

Crabe jaune, Cüaiboullele.

Crabe qui a du poil, Cociha.

Crabe buurfier, Oüabiia.

Crabe machinotre, Acaca Heuton.

Crabe de natie galauds, Onala'bouga.

Crabe de mer, Mata'youman."

Esterisse, Ichorilou. leur présente le tronc de quelqu'arbre pourri, les cavités qui sont sous ses racines, on les fentes de quelque roclier. S'ils jugent que le danger est passé, ils sortent, mais avec précaution, du fond de leur retraite, et ils y rentrent au moindre bruit. Maugé m’a raconté qu'ils grimpoient quelquefois sur les arbres, afin d'y surprendre de jeunes oiseaux dans lenrs nids.

Le besoin de se reproduire les oblige d'abann. donner pour quelque temps, chaque année, vers le mois de mai ou de juin, dans la saison des pluies, les montagnes où ils font leur séjour habituel, et de venir au bord de la mer. Ils descendent en si grand uombre, que les chemins et les bois en sont tout couverts. Guidés par lenr instinct, ils se dirigent vers les points dont la pente naturelle facilite leur voyage et lear permet d'aborder plus commodément à la plage maritime, terme de leur course. C'est une sorte d'ar'mée qui marche en ordre de bataille, suivant toujours et sans rompre ses rangs, nue ligne droite. Ils escaladent les habitations, franchissent les rochers et autres obstacles qu'ils rencontrent, mais non sans danger; plusieurs y perdent la vie par suite de leurs ckutes et d'aulres accidens. Malheur aux possesseurs des jardins et des plantations qui se trouvent sous leur passage! Ils coupent arec leurs mordans les jeunes plantes que l'on cultive. Ils pénètrent même dans les maisons qui leur présen. tent des issues favorables, et y font un tel vacarme, qu'il est impossible de dormir; car c'est ordinairement lia nuit qu'ils voyagent, ou que du moins ils cheminent davantage. Lorsqu'ils marchent pendaut la présence du soleil sur l'horizon, ils font, dit-on, deux haltes le jour, soit pour se repaitre, soit pour se reposer. Lorsqu'ils sont dans l'intérieur des habitations et qu'on les poursuit, ils se défendent avec courage et une surte d'opiniâtreté; se redressant sur leurs pattes, ils présentent leurs pinces et s'en servent comme d'une sorte de bouclier. La pointe d'une épée nue ne les épouvante mêure pas, ainsi que l'a éprouvé M. Moreau de Jonnès, qui m’a d'ailleurs confirmé, comme témoin oculaire, une partie de ces faits.

Les mâles étant alors bien nourris et les femelles étant cliargées d'œufs, leur chair dédornmaye ın peu les colons des visites importunes de ces animaux et des dégáts qu'ils font. Rochefort se borne à faire émigrer les Crabes peints; mais le père Labat avoue que cette habilude est commune à tous les Crabes, à ceux qu'il appelle soldats ou les haguas, aux écrevisses, et même aux lézards et aux serpens.

Parvenns au rivage de la mer, les Crabes peints ou violets s'y baignent, dit-on encore, à trois ou quatre reprises; pnis se retirant dans la plaine ou les bois voisins, ils s'y reposent quelque temps. Les femelles reviennent ensuile à l'eau, et, s'étant un peu lavées, elles ouvrent leur queue, font tomber les cufs qui y sont attachés et prennent

Rrr 2 
un nouveau bain. Cette opération achevée, elles cherchent à gagner, dans le même ordre et par la même route, leurs domiciles; mais les individus les plus vigoureux peuvent seuls y åriver. La plupart sont, à leur retour, dans un tel état de maigreur et de foiblesse, qu'ils sont contraints'de s'arrêter dans les premières campagnes qu'ils rencontrent, afin de recouvrer les forces nécessaires pour continuer leur voyage, plus pénible que le premier.

Rejetés par les flots sur le sablon de la grève, et après y avoir été échauffés pendant quelque temps par l'ardeur du soleil, les œufs éclosent. Les petits ne tardent pas à s'établir dans les lieux voisins propres à leur fournir les alimens convenables, et lorsqu'ils ont acquis assez de vigueur, ils se rendent dans les montagnes pour y former de nouvelles farnilles. Ceux qui leur ont donné le jour, et qui ont eu le bonheur de rejoindre leur habitation primitive, ont une nouvelle épreuve à essuyer; c'est le temps de la mue. Le père Lebat le place avant leur voyage; mais il est postérieur, suivant Rochefort, ce qui me semble plus vraisemblable.

Une crise aussi violente pour eux exige qu'ils soient à l'abri de tout danger extérieur. Ils s'emprisonnent volontairement dans leurs terriers et en ferment l'issue; on prétend même qu'ils s'y enveloppent de feuilles d'arbres. Quelques auteurs ont avancé, mais sans fondement, et probablement sans avoir au préalable cunstaté l'exactitude et la généralité du fait, que c'étoit dans le but de pourvoir, pendant cette vie inactive, à leur subsistance. Il est aisé de voir qu'on a voulu douner à ces animaux la prévoyance de la fourmi. On lit dans Rochefort une observation de Dnmontel relative à leur mue, et qui confirme les présomptions fondées sur l'analogie ou l'uniformité générale de cette sorte de mutation. La chair de ceux qui viennent de se dépouiller de leur ancienne robe est très-estimée, ì raison de la mollesse et du rajeunissement des parties. Ces Crustacés out reçu, dans cet état, le nom de Crabes boursiers. Leurs tégumens ne forment qu'une pellicule rouge, tendue, et semblable à du vélin mouille. On conçoit qu'ils sont plus délicais ou qu'il y a moins de déchet.

Les œufs passent aussi pour un mets friand ou de très-bon gcût. Ils sont petits et réunis, sous la queue de la femelle, en deux pelotons séparés l'un de l'antle par une membrane accompagnée d'une matière épaisse de la couleur de ces cufs, mais qui devient blanche par l'action du feu; au lieu que ces œufs, soumis à la même épreuve, deviennent rouges. J'ai parlé plus baut d'une substance qu'on retire de lintérieur du corps de ces animaux, et qu'on appelle le taumalin ( 1 ). Elle entre

(1) C'est peut-être le foie, désigné par les Anciens sous les noms de mecon, de papaver et de mutis, dans la composition de la sauce avec laquelle on les mange.

Les Crabes blancs se tiennent au pied des ar bres, des palétuviers surtout, qui sont situés dans les lieux bas et marécageux, ou près des rivages maritimes. Ils font des trous en terre et s'y retirent comme les lapins dans leurs clapiers. Rarement se montrent-ils le jour, et lorsqu'on fouille dans le sable afin de les découvirir, on les y trouve presque toujours ayant la moitié du corps dans l'eau. La nuit est le temps de leurs courses; c'est aussi alors qu'à l'aide de flambeaux de bayac, ou de bois de chandelle, on leur fait la chasse. On les prend par dessus le dos, et on les met dans un sac ou dans un panier dont le couvercle s'emboîte; mais il faut nne certaine adresse ou de l'habilude pour les surprendre et les saisir, car ils s'éloignent pen de leurs demeures, marchent très-vite, et s'emparent au besoin du premier gîte qu'ils rencontrent, sans distinction de propriétés. Snuvent ils se renversent sur le dos et présententleur's mordans; on les saisit alors par les pattes de derrière et on les rétablit dans leur promière position.

Cette chasse se fait encore le jour, en fouillant a vec une serpe dans les terriers où ils sont cachés, et particulièrement à l'époque de la mue, puisqua'ils n'en sortent pis alors l'espace de cinq à six semaines. Les nègres ont l'habitude de faire un trou au côté intérieur de chacune de leurs pinces atin d'y introduire et d'y fixer, par lıne opposition réciproque, l'extrémité d'un des doigts de chacune d'elles et de former ainsi un cercle; ils les enfilent ensuite dans un bâtou et les portent, en cet état, au narché. J'ai appris ce fait de $M$. Royer, et le trou que j'ai observé aux ferres de plusieurs gros Crustacés venus des Antilles ou de Cayenne, en est une confirmation.

Chauvalon dit que les Crabes violets ont élé détruits en grande 'partie à la Martinique, et que les Cillaïbes les y importent des îles voisines; mais cela n'est point général pour tous les cantons, puisque M. Moreau de Jonnès m’a dit a voir vu dars cette colonie une grande quantité de ces animaux. Chauvalon, au surples, en nous renvoyant, pour la figure du Crabe violet, à l'histoire naturelle de la Jamaïqne de Sloane, nous a mis à portée de hien distinguer l'espèce de Crustacés nommée ainsi par les voyageurs français.

Le Clabe bourreau, cancer camifex, d'Herbst, espèce de mon genre Cardifome, est le seul Crustacé de cette subdivision que l'on ait encore observé dans l'ancien continent. Il habite les lieux marécageux des environs de Pondichéri, et porte, dans la langue malabare, le nom de vellé-nandou. Le dernier mot nandou, qui signifie en général un Crabe ou un Cancre, est remarquable eu ce qu'il est presque littéralement ićentique avee celai de nhamdu ou nhamdiu, désignant, chez 
les Brésiliens, les grosses araignées (mygales), que nos colons appellent araignées crabes.

Dans un travail original et plein d'intérêt sur les Crustacés fossiles, M. Desmarest, professeur à l'Ecole vétérinaire d'Alfort, a décrit un Gécarcin (trispinosus) et plusieurs espèces de Gonéplaces, genre voisin du précédent et de la même famille. Ces Crustacés fossiles, et presque tous des Indes orientales, ont cela de propre que leur encroûtement est de nature argilleuse et non calcaire, comme celle de la plupart des autres Crustacés fossiles. Ce que nous venons de dire au sujet de l'habitation des Crabes de terre, semblables en cela à presque tous les autres Crustacés de la même famille, celle des Quadrilatères, nous donne la raison d'une telle disparité dans les matières qui enveloppent ces animaux.

Les Tourlouroux composent trois genres, Gécarcin, Cardisome et Uca. Nous allons en présenter les caractères essentiels et indiquer les espèces qui s'y rapportent et qui ont été décrites, pour la jlupart, à l'article CraBE de ce Dictionnaire.

\section{Gente I. Gécarcin, Gecancinus. Léach.}

Second et troisième articles des pieds-nấchoires extérieurs, grands, très-aplatis, comme foliacés, arqués au bord extérieur, courbes; le troisième un peu plus grand que le précédent, en forme de trangle curviligne, dont le sommet obtus, atteignant le chaperon; le quatrième article inséré derrière le précédent et recouvert par lui, aiusi que les deux derniers ou suivans; un angle rentrant et interne très-prononcé vers la jonction des second et troisième articles; flagres entièrement cachés. Les quatre antennes recouvertes par le chaperon; les latérales très-petites; les intermédiaircs séparées l'une de l'autre par une simple arête. - Pattes de la troisième et quatrième paires les plus longues de toutes après les serres. - Yeux proportionnellement plos cour's que dans les genres suivans, reçus dans une cavité presqu'en forme de triangle renversé, et n'offiant sous le canthus interne qu'une petite échancrure. - Tarses à six arêtes, dont les deux supérieures et les deux inférieures an moins dentelées on épineuses.

Gécarcin tourlouron, G. ruricola.

Cancer ruricola. Linn. - Herbst. Kiabben. tab. 3. fig. 26. Jeune âge; ibid. tab. 4.; tab. 49. fig. 1. - Tourlouroux, Crabes violets, Crabes peints. Rochefort. LABAT.

\section{Genre II. Cardisome, Cardisoma. Lat.}

Les six articles des pieds-mâchoires extérieurs découverts, droits; le troisième plus court que le précédent, presqu'en forme de cour, avec le milieu du bord supérienr échancré; flagres en partie découverts. Les quatre antennes insérées en dehors du chaperon; le premier article des latérales grand, large, presqu'en forme de cour. - Pattes de la tróisième et quatrième paire les plus longues de toutes après les serres; tarses à quatre arêtes dentées ou épineuses. - Chaperon sensiblement transversal (celui des Gécarcins presqu'aussi long que large ).

Ces Crustacés sont désignés sous le nom de Crabes blancs.

Rapportez à ce genre, $1^{\circ}$. l'Ocypode cordata. Lat. Gener. Crust. et Insect.; ejusd. Gecarcinus carnifex. Nouv. Dict. d'hist. nat. $2^{\mathrm{e}}$. édit. $2^{\circ}$. Comme variété à serres d'inégales grandeurs, le Cancer guanhumi de Marcgrave. $3^{\circ}$. l'Ocypode carnifex de M. Bosc, figuré par Herbst. Krabben. tab. 4I. fg. I. Ici le prcmier segment du postabdomen de la femelle est plus large que le suivant, tandis que duns le nême individu de l'espèce précédenle, il est plus étroit. Le post-abdomen des mâles des deux espèces offre aussi quelques autres dilférences.

Genre III. UcA, Uca. LAt.

Les six articles des picds-mâchoires extérieurs découverts, droits; le troisic̀me un peu plus étroit que le précédent et point échancré à son sommet; le pédoncule du flagre à découvert. Les quatre antennes pareillement à nu. Les secondes pattes les plus longues de toutes; longueur des suivantes diminuant ensuite progressivement; toutes les pattes très-velues, à tarses sillonnés, sans épines ni fortes dentelures aux arêtes.

Le test plus dilaté ct pius bombć latéralement que celui des précédens; cavités oculaires plus oblongues, sans tubercule ou élévation au canthus interne. Chaperon demi-circulaire; sommet de la cavité buccale plus étroit et plus cintré que dans les genres précédens, et divisé en deux par une petite cloison. Premier article des antennes latćrales guère plus large que le second, trèscourt, semi-annulaire.

\section{$\mathrm{U}_{\mathrm{CA}_{A}}$ una, U. una.}

Uca una. LAT. Nouv. Dict. d'hist. nat. $2^{\mathrm{e}}$. édit. ; ejusd. Ocypode fossor. Hist. nat. des Crust. et des Ins. - Cancer uca. Linn. ejusd. C. cordatus. - HeRbst. Krabben. tab. 6. fig. 38.

\section{( LAT. )}

TOURNIQUET. Geoffroy (Ins. Paris.) donne ce nom au Gyrin nageur ${ }^{\circ}{ }^{\circ}$ 1. du présent Dictionnaire. (S. F. et A. SERv.)

'TOURTEAU, nom du Crabe pagure, Cancer pagurus de Linné. H. Latreille (Fam. natur. du Règ. anim.) a établi un genre sous ce nom; il est voisin des Crabes proprement dits, mais ses caractères ne sont pas encore publiés.

(E.G.)

TOXIQUE, Toxicum. LAT.

Genre d'insectes de l'ordre des Coléoptères, 
section des Hétéromères (première division), famille des Mélasomes, tribu des Ténébrionites.

Des huit genres qui nous sont connus dans cette tribu, ceux de Cryptique, Epitrage et Opâtre, se distinguent des Toxiques par leur corps large et ovale; les six derniers articles des antennes plus larges que les précédens, en séparent les Sarrotries (Orthocère, Encycl.), les Ténébrions et les Upis; enfin les Chiroscèles sont les seuls Ténébrionites qui aient lẹs jambes antérieures très-dilatées et diuitées.

Antennes composćes de onze articles; celui de la base le plus long de tous, obconique; le second très-pelitt; les troisième, quatrième, cinquième, sixième et septième cylindriques, un peu obconiques, conrts; le troisième cependant un peu plus long que les suivans; les huitième, neuvième, dixième, transversaux, un peu dilatés au côté interne, formant une massue ovale-comprimte avec le onzième, celui-ci presqu'orbicalaire. - Labre coriace, avancé, presque carré. - Palpes maxillaires ayant leur dernier article un peu plus gros que les antres, cylindro-conique, comprimé. - Corps alongé, presque linéaire, un peu déprimé. - Corselet presque carré, un peu plus long que large, un pen rétréci antérieuremênt. - Ecusson distinct. - Elytres alongées, linéaires, n'embrassant point l'abdomen sul les côtés et recouvrant des ailes. - Pattes courtes, surtout les antérieures; cuisses en ovale-alongé, étroites; jambes presque cylindriques, légèrement comprimées, les antérieures foiblement élargies au bout; leurs épines terminales presque nulles.

On ne connoîl pas les mœurs de la seule espèce de ce genre. C'esi le Toxique de Riche, T. $R i$ chesianum. LAт. Gener. Crust. et Ins. tom. 2. pag. 168. $n^{\circ}$. 1. tom. 1. pl. IX. fig. 9. Longueur 5 à 6 lig. D'un noir mat velouté, obscur. Elytres ayant chacune huit stries formées par des points alignés. Des Indes orientales.

$$
\text { (S. F. et A. SERV.) }
$$

TOXOPHORE, Toxophora. MEIG. WIÉDEM. Lat. (Fam. natur.) Bonbylius: Fab. Oliv. (Encycl.)

Genre d'insectes de l'ordre des Diptères, première section, famille des Tanystomes, tribu des Boubyliers.

Un groupe de cette tribu a pour caractères: abdomen cylindracé ou ovale; premier article des antennes le plus long de tous. Il renferme les genres Toxophore et Xestomyze. (Voy. pag. 539. de ce volume.) Le dernier se distingue par ses antennes peu rapprochées, dont le second article est cyathiforme et le troisième presqu'en fusenu.

Antennes avancées, plus longues que la tête, rapprochees à leur base, composées de trois articles, les deux inférieurs cylindriques, le premier la plus long de tous, le troisième conique. -
Trompe avancée, arquée, deux fois plus longue que la tête. - Palpes minces, cylindriques, aigus, arqués. - Tête hémisphérique. - Yeux réunis dans les mâles (les femelles ne sont pas connues). - Trois ocelles disposés en triangle sur le vertex. - Corps assez alongé, velu. - Corselet trèsbombé. - Ailes velues vues au microscope.Balanciers découverts. - Abdomen conique, obtus, courbé en dessous, de sept segmens. Dernier article des tarses muni de deux pelotes.

On ne connoît pas les mœurs de ces Bombyliers, dont le nom vient de deux mots grecs quai expriment la forme arquée de leur abdomen. Les espèces que l'on y place paroissent assez anomales, ainsi qu'on le verra par leurs caractèrcs.

\section{Toxophone cuivreuse, $T$. cuprea.}

Toxophora cuprea. WiÉDEM. Dipt. exotic. pars $1^{\mathrm{a}}$. pag. 178. $n^{\circ}$. 1. - MeIG. Dipt. d’Eur. tom. 2. tab. 19. fig. 16. L'aile. - Bombylius cupreus n. $^{\circ}$ I. Faв. Syst. Antliat.

Voyez pour la description et les antres synonymes, Bombille cuivreux $n^{\circ}$. 10. de ce Dictionnaire.

Les auteurs mettent encore dans ce genre : $1^{\circ}$. Toxophore maculée, T. maculata. Merg. Dipt. d'Eur. tom. 2. pag. 237 . $n^{0}$. 1. tab. 19. fig. 13-15. Mâle. Longueur 4 lig. Pattes et hypostome blancs; corselel et abdomen converts de poils serrés couleur de soufre; ce dernier offrant diverses lignes détachées noires, qui sont peutêtre produites par l'enlèvement fortuit des poils. Ailes jaunâtres au bord antérieur et à la base, ayant quatre cellules ạu bord postérieur; la première pédiculée, presqu'en forme d'Y; la seconde divisée en deux par une nervure transversale, audessous de la bifurcation de la précédente: troisième article des antennes coudé, comme brisé, aussi long que le second. Du midi de la France. Rare. $2^{\circ}$. Toxophore de Java, T: Javana. W IÉdEM. id. pag. 179. $n^{\circ}$. 2. - Me1G. Dipt. d’Eur. id. tab. 19. fig. 12. L'antenne. Longueur 3 lig, $\frac{t}{2}$. Noire; abdomen cuivreux, a yant sur son milieu une ligne longitudinale blanchătre et une autre de chaque côté, plus large et dentée en scie extérieurement; dernier article des antennes plus court que le second, muvi d'une petite pointe particulière. De Java. (S. F. et A. SERV.)

TOXOTE, Toxotus. MEg. Des. Catal. Lat. (Fam. nat.) Pachyta. Meg. Des. Catal. Rhagium, Leptura. Faв. Scron. Leptura. Oriv. (Encycl.) Leptura, Stenocurus. OLIv. (Entom.) Genre d'insectes de l'ordre des Coléoptères, section des Tétramères, famille des Longicornes, tribu des Lepturètes.

Un groupe de cette tribu contient deux genres, 
Toxote et Leptnre. (Voyez pag. $48 \mathrm{r}$. de ce volume. Dans le tableau que nous citons, le genre Lepture a été omis par errenr typographique.) Les Leptures se distinguent dès Toxoles par leur labre court, transversal, coupé carrément ou un peu arrondi antérieuremént, et encore par leurs palpes maxillaires dont le premier article est plus court que le second; le terminal presque cylindrique, très-peu comprimé. En outre les Leptures ont le corselet mutique.

Labre anssi long que large, presque carré, un peu échancré au milieu de sa partie antérieure. - Palpes maxillaires assez longs, composés de quatre articles; !es deux premiers presqu'égaux entr'enx, chacun d'eux plus long que le troisième; le terminal grand, élargi, surtout vers son extrémité, wn peu creusé longitudinalement dans son wilieu, comme tronqué à son extrémité. - Corselet muni latéralement d'un tubercule. Les autres caractères sont ceux des Leptures. Voyez ce mot.

Nota. Lorsque le genre Lepture a été fait dans ce Dictionnaire, on renfermoit alors dans celte coupe générique des espèces qui ont servi depuis à la formation de différens genres. Nous n'admettuns aujourd'hni comme Leptures, que les espèces qui out le labre court, transversal, coupé carrément ou un peu arrondi antérieurement; les palpes assez courts, avec le premier article plas court que le second, celıi-ci plus long que le précédent et que le suivant, pris isolément; le quatrième ovale-alongé, assez arrondi à son extrémité, presque cylindrique, très-peu comprime. Le corselet dans ces espèces n'a point de tubercule latéral.

Les mœur's de ces insectes sont les mêmes que celles des autres Longicornes. Voyez Stencone.

${ }^{\mathrm{re}}$. Division. Tubercules du corselet, épineux. (Toxotus proprie dictus.)

\section{Toxote méridional, T. moridianus.}

Toxotus meridianus. DEs. Catal. - Leptura meridiana no. 13. FАв. Syst. Eleut. - Sc日心. Synon. Ins. tom. 3. pag. 478. $n^{\circ} \cdot 17$.

Voyez pour la description et les antres synonymes, Lepture méridienne $n^{\circ}$. 3r. de ce Dictionnaire. (A la citation de De Géer, an lieu de pag. 5o5. lisez : pag. 13o. $n^{\circ} .5$. )

\section{Toxote huméral, $T$. humeralis.}

Toxotus humenalis. Des. Catal. - Leptura bumeralis no. 25. FАB. Syst. Eleut. - Stnas. id. pag. 484. $n^{\circ} \cdot 28$.

Voyez pour la description et les autres synonymes, Lepture hamérale no. 45. de ce Dictionnaire.

A cette division appartiennent anssi, $x^{\circ}$. Toxote coureur, T. cursor. DEJ. Catal. - Rhagium cursor no. 4. Fав. Syst. Eleut. - Sc日usi. Syn. Ins. tom.
3. pag. 415. $n^{\circ}$. 8. Femelle, - Rhagium noctis no. 7. FAв. $i d$. Mâle. D'Autriche. $2^{\circ}$. 'Toxote disparate, T. dispar. DeJ. Catal. - Rhagium dispar. Scваn. id. pag. 416. $n^{\circ}$. 9. D’Allemagne. 3०. Toxote à ceinture, T. cinctus. Des. Catal. Rhagium cinctum no. 5. $\mathrm{F}_{\mathrm{AB}}$ id. - ScнषN. id. $n^{\circ}$. ı. Même patrie.

$2^{e}$ Division. Tubercules du corselet, obtus. (Pachyta. MEg. DeJ. Catal.)

\section{Toxore quadrimaculé, T. quadrimacu-} latus.

Pachyta quadrimaculata. Des. Catal. - Leptura quadrimaculata no. 4I. FAв. Syst. Eleut. Schone Synon. Ins. tom. 3. pag. 488. no. 45. Encycl. pl. 220. fg. 17.

Voyez pour la description et les autres synonymes, Lepture quadrimaculée $n^{\circ}$. 23. de ce Dictionnaire (en retranchant celui de Leptura octomactulata FAB. Nov. Syst. qui appartient à la Leptura decempunctata no. 34. Ourv. Entom.)

\section{Tохоте interrogation, $T$. interrogationis.}

Rachyta interrogationis. DEJ. Catal. - Leptura interrogationis n०. 45. FAB. id. - Sc日en. id. pag. $490 . n^{\circ} .52$.

Voyez pour la description et les autres synonymes, Lepture interrogation $n^{\circ} .26$. du présent Dictionnaire. La Lepture marginelle $n^{\circ} .27$. n'ea est qu'une variélé.

Nous plaçons encore dans cette division le Toxote grillé, $T$. clathratus. - Rhagium clathratum no. 9. Нав. Syst. Eleut. - Sc日єn. Syn. Ins. tom. 3. pag. $417 \cdot n^{\circ}$. 13. La Leptura reticulata no. 63. Fab. $i d$. en est une simple variété. D’Autriche.

EURYPTÈRE, Euryptera.

Genre d'insectes de l'ordre des Coléoptères, section des 'Tétramères, famille des Longicornes, tribu des Lepturètes.

Tous les genres de cette tribu n'ont que onze articles aux antennes, à l'exception de celui que nous proposons ici. Voyez pag. 481. de ce volume.

Antennes presque filiformes, nn peu velnes, composées de douze articles; le premier long, conique; le second très-court, cupulaire; le troisième assez long; le quatrième plus court que le précédent; les articles de quatre à dix, un peu dilatés intérieurement, presqu'en dent de scie; le onzième cylindrique; le douzième court, conique. - Labre court, coupé droit antérieuremnnt, un peu échancré dans son milien. - Mandibules minces, fortement bidentées à lear partie intérieure. - Palpes maxillaires composés de quatre articles; le premier très-court; les deux suivans égaux, coniques; le quatrième cylindrique, pas 
beaucoup plus gros que les précédens, égalant presqu'en longueur le second et le troisième pris ensemble, arrondi à son extrémité. - Tête prolongée et amincie à sa partie antérieure; cette partie faisant à peu près la moitié de la longueur totale de la tête. - Yeux échancrés antérieurement. - Corps assez court. - Corselet élargi postérieurement, presque triangulaire, allant en se rétrécissant forte:nent de sa base jusque vers la tête, ses angles postérieurs prolongés en une forte épine, ayaut $m$ lobe tronqué dans le milieu de cette base, lequel s'avance vers l'écusson. Ecusson petit, triangulaire. - Elytres allant en s'élargissant de la base à l'extrémité, celle-ci un peu large, un pea déprimée, tronquée et sinuée : ces élytres recouvrant les ailes et l'abdomen, un peu béantes à leur extrémité. - Pattes de longueur moyenne, plus courtes que dans les geures voisins; cuisses simples, point en massue; arlicles des tarses courts et larges.

Euryptère vient de deux mots grecs qui expriment la forme des élytres. Ce genre nouveau nous paroît suffisamment justifié par les caractères que nous venons de développer. Nous ne connoissons que l'esp̄èce suivante :

\section{Euntptére latipenne, E. latipennis.}

Euryptera pubescens, nifo-ferruginea, antennis longitudine dimidii corporis, nigris; thoracis lineis duabus in dorso nigris; elytronum apice et maculâ superiori supernè et infernè bifidâ, nigris.

\section{Leptura latipennis. DEJ. Collect.}

Longueur 7 lig. Corps pubescent, son duvet presque généralement roussâtre ; antennes noires, pubescentes, de la longueur de la moitié du corps. Tête noire en dessus, ayant un peu de roux audessous des antennes; d'un roux pâle en dessous. Corselet d'un roux ferrugineux, avec deux bandes dorsales, longitudinales, noires, qui n'atteignen! pas le bord postérieur; le dessous du corselet offie deux semblables lignes. Elytres rebordées, a vec une carène élevée le long de la suture dans sa moitié inférienre seulement; angles postérieurs de leur échancrure prolongés en une épine distincte: base des élytres, jusqu'aux deux tiers, d'un ferrugineux-testacé; cetle base portant dans son milieu une tacke noire assez grande, bificle par en haut et par en bas; tier's inférieur de l'élytre de cette même couleur. Abdomen, écusson et pattes de couleur noire. Hanches et base des quatre cuisses antérieures testacées, surtout en dessous.

Du Brésil. (S. F. et A. Sert.)

\section{TRACHÉENNES, Trachearice.}

On donne ce nom au second ordre de la classe des Arachnides, parce que leurs organes de la respiration consistent en trachées rayonnées ou ramifiées. Le cœur qui existe dans les Arachnides pulmonaires, est remplacé ici par un simple vaisseau dorsal ; la respiration s'opere par des trachées qui reçoivent ordinairement l'air par deux spiracules abdominaux ou thoraciques. Les organes sexuels sont uniques. Le nombre des yeux ne va pas au-delà de quatre; le plns souvent il n'y en a que deux; quelques-uns même en manquent. La bouche d'un grand nombre est en forme de siphon.

M. Latreille (Fam. natur. du Règn. anim.) divise cet ordre en sopt familles, savoir : les Pycnogonides, Fadx-Scorpioys, Phalangiens, Acarides, Típdrachnelies, Tiques et Mrcropnthires. Foyez ces mots, tant à leur lettre qu’à la table alphabétique. (E. G.)

'TRACHÉES. Dans quelques Arachnides et dans les Insectes, l'acte de la respiration ne s'exécule pas, comme dans les animaux à sang rouge, par une diges!ion de l'air daus un organe circonscrit et isolé; et quoique le but de cet acte soit, chez tous les animaux, d'apporter une modificaiion dans les divers organes du corps en faisant servir à leur mutrition l'un des élémens de l'air, l'oxygène, il peut arriver des circonstances favorables où l'air se rend directement aux organes pour agir immédiatement sur eux : c'est le cas des Arachnides tracliéennes et des Insectes. Dans les animaux à poumons, c'est le fluide dela nutrition qui vient chercher l'air dans les poumons, tandis que dans les Insectes c'est l'air qui se rend directement aux fluides nutritifs pour compléter leur élabolation. Les organes destinés à transporter ainsi l'air daus toutes les parties du corps ont reçu le nom de trachées.

Les trachées sont des canaux ordinairement élastiques, qui partent des ouverlures nounmées stigmates on spiracules, se ramifient à l'infini, et vont se répandre dans toutes les parties du corps en figurant des arbuscules très-élégans et en entourant d'une infinité de ramifications tous les organes intérieurs. M. Cuvier et M. Marcel de Serres ont reconnu deux sorles de trachées trèsdifférentes entr'elles par leur composition; ce sont les trachées tubulaires et les trachées vésiculaires.

Les trachées lubulaires sont composées de trois membranes, une externe, une interne et une autre intermédiaire. Les deux premières sont formées par une membrane cellulaire assez épaisse et très-extensible, tandis que l'intermédiaire l'est, au contraire, par un filet cartilagineux roulé en spirale, et qu'on déroule avec facilité. Sprengel n'admet que deux membranes à ces trachées; mais d'après sa description, il est évident qu'il en signale trois. Réaumur soupçonnoit l'existence de la membrane interne qui a été admise par. Swammerdam. Cette me mbrane est adhérente à l'intermódiaire, et il est très-difficile, sinon impossible, 
de l'en isoler. Les circonvolutions du fil élastique qui forme la membrane intermédiaire sont brillantes et comme argentées : c'est à ce fil cartilagineux que les trachées doiveut la propriété qu'elles possèdent d'être toujour's ouverles, élastiques, et de pouvoir, après avoir étć compriusées par quelqu'organe, reprendre de suite leur forme tubulaire. Ces trachées sont les seules qui présentent de nombreuses ramifications allant se distribuer dans les plus petites parties du corps des insectes, dans les antennes, les pattes et jusqu'au bout des tarses.

Les trachées tubulaires peuvent être distinguées elles - mêmes en trachées artérielles et trachées pulmonaires : ces deux ordies de trachées tubulaires, quoiqu'ayant la même organisation, n'ont pas les mêmes usages et méritoient d'êıre distinguées. Plusieurs anatomistes avoient reconnu depuis long-temps qu'il exisloit chez les insectes deux sortes de trachées; les unes destinées à faire arriver l'air dans le corps, et les antres à le répandre dans toutes ses parties. Réaumur pensoit que les insectes inspiroient l'air par les stigmates, mais qu'ils l'expiroient par tout le corps. Les trachées que M. Marcel de Serres a nommées artériẹlles, se rendent directement aux stigmates, y pirennent l'air imnédiatement, et le distribuent ensuite aux différentes parties dı corps. Les trachées pulmonaires ne reçoivent pas l'air d'une manière immédiate; elles ne communiquent même avec l'air extérieur qu'au moyen des premières, et servent pour ainsi dire de réservoir à l'air que les premicres y ont versé : elles sont beaucoup moins ramifiées, plus grosses, et leur marche est ordinairement plus régulière.

La seconte espèce de trachées, les trachées vésiculaires ou utriculaires, offrent une organisatiou essentiellement différente de celle des tracliées tubulaires; elles présentent des poches plus ou moins étendues, qui communiquent les unes avec les autres au moyen de ramifications toujours uniques et jamais arbusculées comme celles qui partent des urachées spirales. Ces trachées sont composées seulement de deux membranes celluleuses très-blanches, fort souples et très-extensibles : elles ne communiquent jamais immédiatement avec l'air; elles envoient tuujours un rameau aux trachées tubulaires qui leur fournissent ce fluide. Ces trachées étant dépourvizes du filet élasrique qui tient toujours ouvertes les trachées tubulaires, sont afluissées sur elles-mêmes toutes les fois qu'elles ne son! pas pleines d'air : aussi, dans les insectes qui out les trachées vésiculaires trèsétendnes, et qui ont besoin d'une graude quantité d'air, on observe un appareil destiné par la nature à soulever leurs parois lors de l'inspiration; ce sont des espèces de côtes qui, suivant M. Marcel de Scrres, ont leur attache aux parois de ces vésicules. Ces côtes sont cartilagineuses, demisphériques et mues par des muscles particuliers. Un examen comparatif a démontré à M. Audouin que ces espèces de côtes ne sont autre chose que de petites apophyses du bord de cbaque anneau du ventre; ces cốtes ne sont donc pas des appendices distincts ct articulés", ne pouvant lrouver leur analogue ailleurs, mais simplement un prolongement insolite du bord antérieur des segmens abdominaux. Du reste, ces côtes n'existent gure dans les espèces qui ont des trachées vésiculaires d'une certainc étendue. On n'observe point de ces côtes dans les Lépidoptères, les Coléoptères amellicornes et les Diplères, où les trachées véc. siculaires ont à peinc un demi-millimètre. Dans certains Orthoptères, au contraire, comme les Gryllons, les 'Truxales et les Criquets, ces trachées offient un grand développement, et les côtes ou cerceaux cartilagineux existent toujours. - M. Léon Dufour a consigné dans les Annales des sciences naturelles (tom. 8. pag. 23. pl. 21 bis. fig. I. ) la découverte qu'il vient de faire d'un nouvel organe inspiratoire trachéen, ou du moins une disposition toute spéciale de ces vaisseaux aériens. Il l'a observé dans la poitrine des Priones, et il pense que cclie disposition doit se tronver dans les autres Longicornes. L’intérieur de cette cavité (la poitrine), dit cet habile anaiomiste, est tapissé par une couche assez épaisse d'un tissu blanc, d'un aspect moelleux, mais d'une texture cohérente. On peut, en le saisissant avec une pince et en le tirant à soi avec précaution, l'enlever tout d'une pièce, car il ne paroît avoir de connection essentielie qu'avec les deux stigmates qui forment son origine et sa terminaison. Examiné de plus près, cet organe pulmonaire se trouvc composé, $1^{\circ}$. de deux troncs trachćens considérables, connivens entr'eux, d'une part, au stigmate thoracique, de l'autre, au prenuer stigmale abdominal ou pectoro-abdominal; $2^{\circ}$. d'un lacis inextricable de ramuscules aérifères nés des deux troncs précités, et de lobules adipeux qui leur sont adhéıens; en un mot, d'une sorte de parenchyme. M. Léon Dufour a aussi observé ce rudiment d'organe pulmonaire pectoral dans les P'unaises d'eau. Sprengel avoit bien observé quelque chose de semblable dans les Splinx; mais le siége de ces agglomérations, qu'il désigne sous la dénomination de organa vesiculoso - cellalaria, n'est pas restreint dans la poitrine, comme cela á lieu dans les Punaises d'eau et dans les Priones.

Les insectes peuvent être partagés, d'après M. Marcel de Serres, en trois classes bien distinctes, d'après le mode de respi ration. La premic̀re division se compose de ceux qui vivent dans l'air et qui le respirent immédiatenent; de ceux qui, vivant dans l'eau, sont obligés de monler à sa surface pour venir recevoir l'impression de l'air ; et enfin de ceux qui décomposent l'eau pour s'empare. de son oxygène. Nous présenterons ici le tableau de M. Marcel de Serres pour faire apprécier d'nn seul coup d'ceil les différens modes de respiration des insectes. 


\section{RESPIRATION DANS L'AIR.}

10. Avec des trachées $\left\{1^{\text {re }}\right.$. Division..... Des trachées artérielles.

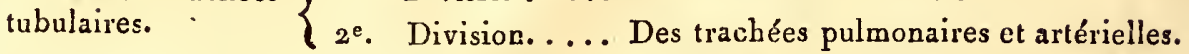

$2^{\circ}$. Avec des trachées
vésiculaires. $\left\{\begin{array}{c}\text { Toujours deux or- } \\ \text { dres de trachées... }\end{array}\right\}\left\{\begin{array}{l}\text { avec des cerceaux cartilagineux, } \\ \text { sans cerceaux cartilagineux. }\end{array}\right.$

\section{II. respiration DaNs L'zau.}

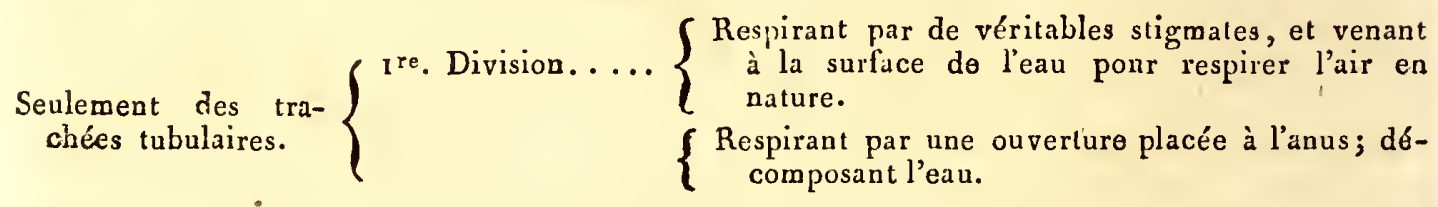

Les trachées artérielles existent dans tous les insectes; elles forment autour des stigmates des paquets extrêmement multipliés. Mais pour que la communication s'établisse entre toutes ces traclıées, il existe un tronc commun qui s'étend d'un stigmate à l'autre, et qui s'ouvre dans cette partie; c'est de ce tronc commun que partent ces nombreux paquets qui vont distribuer l'air dans toutes les parties du corps. La direction des trachées est alors presque toujours trausversale. Dans la plupart des Coléoptères des genres Cérambyx, Blaps, et dans presque tous les 'Ténébrionites, on n'observe que les trachées artérielles; elles osunt extrêmement multipliées dans la poitrine, et même à un tel point qu'elles recouvreut presque on entier les muscles de cette partie. On les voit toutes présenter une direction transversale, et comme elles sont for' rapprochées, elles forment sur les muscles des stries parallèles tellement pressées, qu'à peine distingue-t-on entr'elles quelques légers intervalles. Les trachées artérielles existent seules dans les Phalangiums, chez lesquels M. Latreille les a le premier observées, et dans quelques autres genres analogues d'Arachnides. Leur système respiratoire est formé de troncs communs qui, situés dans le corselet, sont le centre d'où partent toutes les autres ramifications; ces troncs communs se trouvent près des stigmates, où ils envoient une branche. Les chenilles, ou les larves des Lépidoptères, noffrent aussi que des trachées artérielles.

Les trachées artérielles et les trachées pulmonaires réunies se rencontrent dans la plupart des Coléoptères. Un certain nombre d'Ortuoptères offient à la fois des trachées artérielles et pulmonaires; de cè nombre sont les Forficules, les Blattes, Pliasmes, Mantes, Achètes, Locustes et 'Tanpes-gryllons. Les organes respiratoires des Forficules et des Blaties présentent peu de différence.

Comme on l'a vu dans le tablean précédent, les insectes qui respirent dans l'air aveo les deux or- dres de trachées tubulaires et avec les trachées vésiculaires, sont partagés en deux sections; ceux qui ont des cồes ou cerceaux dans les trachées vésiculaires, et ceux où ces organes en sont dépourrus : le premier de ces modes de respiration est le plus compliqué, et on ne le voit janais que dans les espèces qui ont besoin d'une grande quantité d'air ; dans ceux qui, destinés à parcouril de grands espaces dans l'air, ont eu besoin d'une plus grande puissance de vol, et par cela même d'une plus grande légèreté dans tont leur corps. Les trachées pulmonaires ont, dans l'ordre qui présente ce mode de respiration, nn trèsgrand développemeut; car l'on peut considérer toutes les tracliées vésiculaires comme appartenant au système des trablées pulmonaires.

L'ordre des Orthoptères présente les espèces oì les traclsées vésicularires sont les plus étendues; c'est dans les genres Gryllon et Truxale qu'on observe les côtes les plus alongées et les plus mobiles; dans ces trachées ces côtes sont disposées de roanière à être parfaitement libres par leur parrie supérieure : ayant une forme demi-circurlaire, elles représentent des cerceaux dont l'étendue diminue toujours à mesure qu'elles s'approchent de l'abdomen. Ces côtes sont au nombre de sept dans les genres que nous avons cités plus haut; elles sont mues par des muscles particuliers, et res muscles, au nombre de deux pour chaque côte, sont composés de faisceaux muscur leux, charnus, épais et fort courts. Ces trachées vésiculaires sont distribuées dans tout le corps avec une profusion élonnante; elles communiquent entr'elles par les trachées pulmonaires.

I.es trachées vésiculaires sont à peu près générales chez les Hyménoptères; lorsqu'on leur voit prendre un grand développement, il existe en nêne temps un appareil de cerceanx cartilagineux qui est propre à les mouvoir dans les noouvemens d'expiration.

Les insectes dont les trachées vésiculaires n'ont 
jarnais de cótes sont en assez grand nombre; la plupart des Lamellicornes, les Buprestides. M. Léon Dufour a observé des trachées vésiculaires dans la poitrine des Dytiques. En géuéral ces trachées ne sont pas arrangées dans un ordre régulier; leur diamètre n'est jamais considérable, et leur nombre est infini, surtout daus l'abdomen qu'elles occupent en grande parie. Ces trachées pénèrrent dans les plus petites parties, et sont surtont trèsmultipliées dans la bouche et daus ses diverses pièces; elles forment autour des yeux composés comme une série circilaire de petites poclies dont la communication a lieu au moyen des trachées tubulaires. Les muscles du corselet et de la poitrine sont également couverts d'une grande quantité de ces poches, surtout ceux des ailes, où elles sont raugées les unes à côté des autres dans un ordre assez régulier. Daus l'abdomen, les trachées vésiculaires se multiplient encore davantage, et entourent le tube intestinal el les organes générateurs d'un tissu inextricable. Chez les

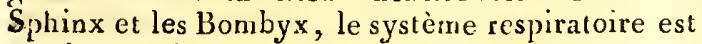
aussi compliqué, mais il est composé commc celui des insectes que nous avons cités plut haut. Dans les Scutigères, les trachées vésiculaires reçoivent directement l'action de l'air ; cette disposition est remarquable, et nous pensons qu'on ne l'a encore observée que dans le Myria pode. M. Marcel de Serres dit que ces trachées se distribuent ou s'unissent aux troncs pulmonaires qui sonl ici placés sur les côtes inférieures du corps, tandis qu'ordinairement on les rencontre sur le dos et qu'elles entourent le plus souvent le vaisseau dorsal. C'est à la base des sept pièces écailleuses du dos des Scutigères que l'on voit lcs stigmates, qui sont au nombre de sept, et auxque!s vienuent aboulır les poches pneurnatiques an nombre de deux par anneau. Ces poches sont ovalaires, accolées base à base, et communiquent avec le tronc commun des traclićes pulmonaires. La plupart des Diptères offient des tracbées vésicuiaires sans côtes; ces trachées sont très-nombreuses et communiquent entr'elles par des tracliées tubulaires.

Les insectes qui vivent dans l'eau ont deux modes de respiration: les uns viennent à la surface chercher l'air nćcessaire à leur consommation; les autres décomposent l'eau pour s'emparer de son oxygène.

Les preııers respirent par de véritables stigmates, et n'ont que des trachees tubulaires; il n'y a que les Dytiques dans lesquels Léon Dufour ait observé une ou deux trachées vésiculaires, ce qui avoit échappé à M. Marcel de Serres. Ce savant a tenté beaucoup d'expériences pour savoir si les Hydrophiles, Dytiques, etc., qui vivent dans l'eau, décomposent l'air; mais il n'est pas arrivé à des résultals satisfaisans. Si ou observe des Dytiques et d'aulres insectes aquatiques, on verra qu'ils ne peuvent rester long-temps sous l'eur, et qu'ils vienueat souvent à la surface pour introduire, par des procédés qui varient suivant les espèces, une certaine quantilé d'air dans leurs stigmales. Tous ces insectes respirent par des trachées artérielles ct pulmonaires; cette disposition se voit aussi dans les Népes, les Notonectes, les Gerris, les Naucores, etc.

Le second mode de respiration dans l'eau, celui où les insectes décomposen extraire l'oxygène, est cxtrênemert remarquable. Ce mode de respiration a lieu dans les larves des Libellules, et l'on observe dans ces larves nir appareil respiratoire particulier conformé de manière à pouvoir attcindre le but auquel il est destiné. Réaumur, et après lui M. Cuvier, ont fait connoitre dans cette larve une valvule tricuspide qui aboutit à une vaste ouverture dans laquelle on distingue un organe particulier garni de fines trachées disposées sur dix rangs et pourvu en outre de corps vésiculaires qui aboutissent à des vaisseaux aériens situés plus profondément, et que l'un reconnoit être des trachées. Il est démontré que cette larve ne vient pas respirer l'air en nature à la surface du liquide; il faut donc qu'elle exhale celui contenu dans l'eau, ou qu'elle décompose celle - ci. L'observation n'a pas cncore répondu d'une manière bien satisfaisante à l'une ou l'autre de ces deux questions; mais les expériences tentées par MI. Marcel de Serres tendroient à faire pencher pour la dernière opinion, si la singularité de ce mode de respiration", si différent de ce qu'on remarque dans tous les animaux aquatiques, ne comımandoit à cet égard la plus graude réserve. Les larves et nymphes des Libellules emploient ce mode de respiralion pour faciliter leur mouvement dans l'eau; pour cela elles emplissent d'eau leur cavité aldominale, et la faisani sortir a vec violence, le jet qui en résulte, s'appiyant sur la masse du liquide environuant, force le corps de l'insecte à avancer. Nous avons ru souvent ces larves se lancer dans une ligne droite comme des flèches, et atleindre les petits insectes dont elles font leur nourriture. D'après M. Dumćril, les larves des Ephéruères, des Phryganes, des Cousins et des Toumiquets, sembleroient avoir de véritables branchies toujours en mouvement quand l'insecte respire. C'est, dit-il, une sorte d'anomalie dans les insectes, qui mérite une atteniion toute particulière, surtout dans les Ephémcres, si, comme Swammerdam l'a persé, ces insectes ont en outre la faculté de féconder les oeufs après qu'ils sont séparćs du corps de leur mère; ce qui est une analogie marquée avec les poissonș et avec quel ciues repliles batraciens.

En terminant cel article, nous ne pourons omettre de parler d'une découverte récente que M. Léon Dufour vient de faire, d'un mode de respiration bien singulier, quoique rentrant dins ceux que nuus avons fait connoirire. Cet anatomiste a découvert dans les viscères des cassida viridis et pentatoma grisea, des larves qui Ssss 2 
lui ont donné deux espèces d'Ocyptères (voyez ce mot). Il a observé que ces larves, hermétiquement enfermées dans le corps de ces insectes, sont obligées d'usurper un de leurs stigmates pour $\mathrm{y}$ appliquer l'extrémité d'une longue queue où sont situées les trachées et où elles viennent aboutir dans une ouverture conique. On n'avoit pas jusqu'à présent d'exemple d'un mode de respiration aussi merveilleux. Nous renvoyons pour plns de détails au Mémoire même publié dans les Annales des sciences naturelles, tom. Io, pl. II.

TRACHĖLE, Trachelus. Jor. Genre d'Hyménoptères qui répond à celui de Céphus. Voyez ce mo i, pag. 576. de ce volume.

$$
\text { (S. F. et A. SERv.) }
$$

TRACHÉLIDES, Trachelides. Quatrième famille de la section des Hétéromères, dont elle compose seule la seconde division, ordre des Coléoptères.

Les caractères de cette famille, et par conséquent de cette divisiou, sont les suivans :

Tête presqu'en forme de cœur, aussi large on plus large derrière les yeux que l'extrémité antérieure du corselet, resserrée ensuite brusquement en arrière, de manière à former une sorte de cou, qui entre seul dans cette dernière partie. Corps souvent mou et flexible. - Mâchoires iner'mes, sans onglet corné. - Articles des tarses du plus grand nombre entiers; crochets bifides daus la plupart. (Insectes vivant sur les végétaux, contractant leưr corps lorsqu'on les saisit. Quelques larves sont parasites.)

Nota. Quelques-uns de ces insectes sont employés en médecine comme vésicans.

I. Antennes tantôt simples, tantôt flabellées, pectinées ou en scie. - Crochets des tarses entiers dans la plupart (le seul genre Rhipiphore excepté); pénultième article des tarses bilobé dans le plus grand nombie.

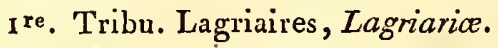

Pénultième article des tarses bilobé. - Corps alongé, plus étroit en devant. - Corselet cylindracé ou carré. - Palpes maxillaires terminés par un article plus grand, triangulaire. - Antennes simples, filiformes ou grossissant insensiblement vers le bout, le plus souvent grenues au moins en partie, et terminées (au moins dans les mâles) par un article plus long qu'aucun des précédens

\section{Lagrie, Statire.}

2ø. Tribu. Pyrochroïdes, Pyrochroides. Voyez ce mot. 3e. Triba. Mordellones, Mordellona.

Tarses variant sous le rapport de la forme de leurs articles et des crochets du dernier. - Corps élevé, a rqué. - Téte basse. - Corselet trapézoïdal, ou demi-circulaire. - Elytres soit très-courtes, soit de longueur ordinaire, mais alors rétrécies et finissant en pointe ainsi que l'abdomen. - Antennes le plus souvent en scie; celles de plusieurs mâles en panache ou pectinces. - Palpes de forme variable.

A. Antennes des mâles en éventail ou trèspectinćes. - Palpes presque filiformes.

a. Crochets des tarses, bifides. Rhipiphore.

b. Crochets des tarses, entiers, finiples. Pélécotome, Myodite.

B. Antennes (même celles des mâles) tout au plus dentées en scie. - Palpes maxillaires terminés par un article plus grand, triangulaire ou sécuriforme. Mordelle, Anaspe, Scraptie.

\section{$4^{e}$. Tribu. Anthicides, Anthicides.}

Pénultième article des tarses bilobé. - Corps oblong. - Corselet en forme de cœur ou divisé en deux nœuds. - Dernier article des palpes maxillaires plus grand que les précédens, en forme de hache. - Antennes simples ou un peu en scie, filiformes ou grossissant insensiblewent vers le bout.

$$
\text { Stéropès, Notoxe, Xylophile. }
$$

\section{5e. Tribu. Horiales, Horiales.}

Tous les articles des tarses entiers; le dernier terminé par deux crochets dentelés et accompagnés chacun d'un appendice en forme de soie. Corps oblong. - Corselet carré, aussi long que la dimension transversale de la base de l'abdomen. - Téte souvent très-forte. - Mandibules saillantes. - Palpes presque filiformes.

$$
\text { Horie, Cissite. }
$$

Nota. Les larves de plusieurs espèces de oes trois dernières tribus sont parasites.

II. Antennes simples ou foiblement en scie. Crochets des tarses, bifides. - Pénultième article des tarses, très-rarement bilobé. - Tête toujours forte et inclinée. - Palpes filiformes ou simplement un peu plus gros au bout, mais point en massue sécuriforme.

6. Tribu. Cantharidies, Cantharidice.

Voyez ce mot pag. 439 . de ce volume. 
Cet article est extrait des Fam. nat. de M. Latreille. (S. F. et A. SErv. )

TRACHONITE, Trackonites. Ce nom, cilé par M. Desmarets dans ses Observations générales sur les Crustacés, extraites dn Diclionnaire des sciences naturelles, a été donné par M. Latreille à un genre cie Crnslacés auquel M. Léach donne le nom de Mrrnrax, adopté par M. Latreille luimême et par tons les entomolngistes. $V$. Mrtarax à la table alphabétique. (E. G.)

'TRACHUSE, Trachusa. Jor. Ce genre d'Hyménoptères, daus Jurine, renferme cenx qui sont aujourd'hni connus sous les noms de Dasypode (voyez ce mot pare 404. de ce volume), Cœlioxyde (id. pag. 108.), Dioxyde ( $i d$. pag. Iog.), Stélide (voyez ce mot à sa lettre), Anthidie (id. pay. 3ı3.), Osmie (voyez ce mot à sa lettre), Anthocope (id. pag. 314.), Mégachile (voyez ce mot à la table alphabétique), Hériade ( voyez pag. 3ı4. de ce volume), Eucère (id. pag. 3ı2.), el Panurge ( voyez ce mot à sa lettre).

(S. F. et A. Serv.)

TRACHYDÉRE, Trachyderes. DaLm. Schen. Grel. Cerambyx. Linn. Fab. Olit. De Géer. LAт. (Gener.)

Genre d'insectes de l'ordre des Coléoptères, section des Tétramères, famille des Longicornes, tribu des Cérambycins.

Nous allons donner les caractères propres à cette tribu.

Cérambrcins, Cerambycini. Seconde tribu de la famille des Longicornes. Lat. (Fam.nat.)

Antennes insérées daus une échancrure des yeux. - Tête avancée ou penchée, mais point perpendiculaire, s'enfonçant dans le corselet jusqu'aux yeux; sa partie postérienre sans rétrécissement brusque. - Dernier article des palpes presqu'en forme de cône ou de triangle renversé, ou bien cylindrique et tronqué à son extrémité. - Ailes repliées sons les élytres : celles - ci ni très-courtes, ni subulées. - Labre très-distinct.

Nota. M. Latreille (Fam. nat.) n'ayant pas établi de divisions dans cette grande tribu, nous pensons rendre l'étude des genres plus facile en $\boldsymbol{y}$ introduisant les suivantes :

I. Tête ayant sa partie antérieure notablement avancée, rétrécie en devant depuis les yeux, et formant une sorte de petit museau. Rhinotrage.

II. Tête ayant sa partie antérieure assez courte et à peu près de même largeur que la postérieure.

A. Corselet cylindrique; ni déprimé en des- sus, ni élurgi sur les côtés, ni globu-. leux; aussi large que long.

Callichrome, Purpuricène, Capricorne, Phónicocère.

13. Corselet élargi sur les côlés, souvent déprimé en dessus; ui globuleux, ni cylindrique.

a. Corselet biuberculé de chaque côté. Pattes antérienres n'étant pas éloignées l'une de l'autre à leur insertion, non plus que les intermédiaires.

Dorcacère, Lophonocère, Ctćnode, "irachydère.

b. Corselet unutique latéralencnt. - Pa:tes antérieures éloignées l'une de l'autre à leur insertion ainsi que lcs intermédiaircs.

Mégadère, Lissonote, Distichocère.

C. Corselet arrondi latéralement, mais point dilaté, toujours déprimé en dessus.

\section{Callidie.}

D. Corselet parfaitement globulenx, point déprimé en dessis.

$$
\mathrm{Cl}_{\mathrm{y}} \text { tus. }
$$

E. Corselet étroit, alongé, cylindracé, beau. coup plus long que large; sa partie antérieure plus éiroite que la tête.

Obrion, Cartalle, Leplocère.

Dans le tableau ci-dessus, un groupe contient les genres Dorcacère, Lophonocčre, Clénode et Trachydère. Les trois premiers sont distingnés du dernier par leur écusson petit, arrondi postérieurement.

Antennes glabres, plus longues que le corps, peu ou point dentées en scie, composées de onze articles, le dernier, dans les mâles, on échancré ou allant en diminuant un pen avant son extrémité : dans ce même sexe les derniers articles seulement, plus ou moins comprimés. -Mandibules coudées, presque tuberculées extérieurement. Palpes maxillaires guère plus longs que les labiaux, leur dernier article un pen obconique, presque cylindrique, ainsi que celui des labiaux. - Yeux échancrés pour recevoir l'insertion des antennes. - Corps se rćtrécissant à partir des angles huméraux des ćlytres. - Corselet élargi latéralement, bituberculé de cliaque côté, trèsinégal et tuberculé en dessus, ses angles postérieurs fortement échancrés; présternum ayant deux tubercules, dont l'antérieur presque pointu; sa pointe se recourbant en arrière, le posterieur simplement élevé, mais toujours assez avancé, séparé du premier tubercule par un sillon transversal : on voit en outre deux autres tubercules près de chaque bord latéral de ce présternum. - 
Ecusson fort long, triangulaire. - Elytres souvent tronquées postérieurement; angles extérieur's de cette troncature étant alors tuberculés on épineux : angles buméraux des élytres prolongés, munis d'un enfoncement assez profond; elles recouvrent des ailes et l'abdomen. - Pattes courtes, fortes; les antérieures n'étant pas très - éloignées l'une de l'autre à leur insertion, non plus que les intermédiaires.

Le nom donné à ces Longicornes vient de deux mots grecs qui font allusion aux rugosités remarquables que présente leur corselet. Les espèces connues, dont les mœurs doivent être les mêmes que celles des autres Cérambycins, habitent les parties chaudes de l'Amériquue méridionale.

\section{I. 'Т'васатdére thoracique, T. thoracicus.}

Voyez pour la descriptiou, Capricorne thoracique $n^{\circ} .44 . p l .210 . f i g .4$. de ce Dictionnaire.

\section{2. 'I'RAch DÈnE rufipède, T. rufipes.}

Trachyderes rufipes. Scaøn. Syn. Ins. tom. 3. pag. $365 . n^{\circ}$. 2. - Ceranby $x$ rufipes $n^{\circ} .44$. FАB. Syst. Eleut.

Voyez pour la description et les autres synonymes, Capricorne rufipede $n^{0} .46 . p l .210 . f i g .5$. de ce Dictionnaire.

\section{5. 'Trachydire cordonné, T. succinctus.}

Trachyderes succinctus. Scaqn. id. pag. 364. $n^{\circ}$. I. - Cerambly succinctus $n^{\circ}$. 20. Fа в. Syst. Eleut.

Ioyez pour la descriplion et les artres synonymes, Capricorne cordouné $n^{\circ}$. 47. pl. 210. fig. 6. du présent onvrage.

\section{Trachydire mi-parti, T. dimidiatus.}

Trachyderes dimidiatus. Schск. id. pag. 366. $n^{\circ}$. 8. - Cerambyx dimidiatus no. 45. F AB. Syst. Eleut.

Voyez pour la description et les autres synonymes, Capricorne mi-parti $n^{\circ} .43 . p l .210$. fig. 7 . de ce Dictionnaire.

\section{Tracaycére bicolore, T. bicolor.}

Traclyderes bicolor. SсHск. id. no. 9. - Cerimby.x licolor $n^{\circ}$. 49. pl. 2 ro. fig. 8. de ce Dictionnaire.

\section{6. 'Trachy dère strié, $T$. striatus.}

Trachyderes striatus. ScнєN. id. pag. $365 n^{\circ} .4$. - Ceramby $x$ striatus $n^{\circ}$. 42. FAB. id.

Loyez pour la description et les autres synonymes, Capricorne sırié no. 50. pl. 2 Io. fłgr. 9. de ce Dictionnaire.

\section{Trachydere note, $T$. signatus.}

Trachyderes signatus. Scн®м. Syn. Ins. tom. 3. Append. pag. $177 \cdot n^{\circ} .247$.

Nota. Plusieur's Trachydères de M. Schœuherr ne nous semblent pas appartenir à ce genre, tel qu'il vient d'être caractérisé.

$$
\text { (S. F. et A. SERV.) }
$$

TRACHYS, Trachys. FAB. Cet auteur place dans ce genre les espèces de Buprestes à corps très-court et triangulaire, dont $M$. Latreille fait la troisième division de ce dernier genre.

(S. F. et A. SERT.)

\section{TRACIIYSCÈLE, Trachyscelis. LAT.}

Genre d'insectes de l'ordre des Coléoptères, section des Hétéromères (première division), famille des Taxicornes, tribu des Crassicornes.

La première division de celle tribu a poar caractère : jambes latéralement épineuses. (Voyez Crassiconnes, pag. 554. de ce volume.) Le genre Léiode qui la courpose a vec celui de Trachyscèle, se distingue de ce dernier par la massue des antennes formée de cinq articles seulement, le secoñd beaucoup plus pelit que ceux qui l'arcisineut.

Antennes en massue, à peine plus longues que la lêle, composćes de onze articles; le premier alongé; les troisième, quatrième et cinquième pelits, transversaux ; les six dérniers formant, seIon M. Latreille, une massue brusque, en forme d'ovale court ; le huitiène (le second de la massue) pas plus petit que les septième et neuvième pris isolément. - Labre transversal, avancé. Mandibules assez avancées, lenr extrémité entière. - Máchoires composées de deux lobes, l'extérieur un peu plus grand que l'intérieur, velu à son extrémité. - Palpes allant en grossissant vers leur extrémité; le dernier article plus grand que les autres, presqu'en forme de triangle renversé. - Téte plus étroite que le corselet; chaperon linéaire, transversal, formant une sorte de bourrelet, séparé de la tête par un sillon transversal, profond. - Corps bombé, élevé. - Corselet un peu plus étroit que les élytres, bombé, rebordé. - Ecufon petit. - Elytres très-convexes, recouvrant des ailes et l'abdomen. - Pattes très-fortes, propres à fouir; janbes dilatées, épineuses : les antérieures allant en s'élargissant vers leur extrémité, très-dilatées dans celle partie qui est prolongée au-delà de l'insertion du tarse, garnies extérieurement de cils rombreux et roides; premier article de tous les tarses plus grand quatacun des suivans.

Le nom générique de ces petits Coléoptère vient de deux mots gress qui signifient : jambes hérissées. Les 'Trachyscèles habitent les rivages de la Mléditerranée. M. le comte Dejean en mentionne trois espèces dans son Catalogue; la plas 
commone est le Traebyscèle aphodiö̉de, $T$. aphodioides. LAT. Gener. Crust. et Ins. tom. IV. pag. 379. (S. F. et A. SERV. )

TRAGOSITE, Tragosita. PAYK. Ce genre contient dans la Faun. Suec. (tom. r. pag. 91.) de cet auteur, trois espèces : la première est le Trngosite caraboïde, T. Caraboides auctor. Les deux suivantes sont du genre Boros Herbst. Voy. Dejean Catal. et Herbst. Coléop. tom. VII. pas. 3ig. (S. F. et A. SERV.)

TRAPEZIE, Trapezia. Genre de Crustacés décapodes, de la famille des Braehyures, tribu des Quadrilatères, distingué des autres genres de cette tribu par les caractères suivans : quatrième article des pieds - tuâchoires extérieurs insérć à l'extrémité supérieure interne de l'article précédent ; test presque carré, déprimé, un peu rétréci postérieurement; pédicules oculaires insérés ì ses angles antérieurs; antennes latérales insérées hors des cavités oculaires, entre leurs extrémités intérieures et leurs antennes intermédiaires; tarses point deutelés.

Ce genre, que j'ai établi (Fanilles naturelles du Règne annmal) sur quelques Crustacés des mers orientales, et dont les habitudes me sont inconnues, se rapproehe de eeux de Grapse, de Rhombille et de Crabe. Les serres sont grandes, avec le bord interne des bras tranchanr, armé de six dentelures, et la portion des pinces ou des mains qui précède les doigts fort grande, comprimée, en forme de carré long; les doigts sont courts et pointus, ou crochus a bout. Les autres pattes sont petites, de forme presqu'identique, a vec les tarses très-eourts, eoniques, un peu velus, saus stries ni deuts; il m’a paru que celles de la seconde paire surpassoient un peu les autres en longuenr. La fausse queue ou le post-abdomen est composée de sept segmens; celle des mâles forare un triangle étrait et alongé; celle des femelles est grande, presqu'ovale, avec le dernier segment demi-eirculaire, et de la largeur du précédent ì sa jorrction avec lui.

1. Bords latéraux du test ayant chacun deux dents, celle formée par l'angle extérieur comprise.

\section{Traptizie fiont denté, $T$. dentifrons.}

Testa utrinque bidentata, flavescenti-rufa, clypeo quadridentato.

Très-petite; d'un roussâtre jaunâtre et luisant, unie; milieu de eharque bord latéral du test offiant une dent ires-aiguë, en forme d'épine; angles aniérieurs prolongés aussi en une pointe acérée; une éehancrure de clraque côté, près du canthus interne des cavités oculaires; chaperon terminé par quatre dents, dont deux au milieu, courtes, assez pointues, séparées par un angle, et les deux autres sur les côtés, eomme eoupées carrément, a vee un sinus et quelques dentelures. Serres trèsgrandes, larges, eomprimées, unies; doigls courts, ponctués et striés extérienrement, appliqués exactement l'un contre l'autre, pointus, croehus et noirâtres au bout; serre gauebe un peu plus forle, avec des dentelures très-courtes au bord interne des doigis; ceux de la pinee opposée n'en ont presque pas.

Australasie, Péron et le Sueur.

Cette espèee, dont je ne connois que lindividu mâle, n'est peut-être qu'une variété du Cancer cymodoce d'Herbst, Krabben, tab. 5 I. fg. 5.

\section{TrapézIe ferrugineuse, $T$. ferruginea.}

Testa utzinque bidentata, fulva, nigra, varia, clypeo suberoso.

Un peu plus grande que la précédente, fanve, avec le dessus du test mélangé de noir, et Irèslisse; ses bords latéraux bidentés; une échanerure de chaque côté, près du canthus interne oeulaire; bord antérieur du chaperon droit, un peu et inégalement dentelé, comme rongé. Serres très-grandes, unies; la droile un peu plus forte. Dents supérieures du bord interne des bras un peu dentelées; les denx plus lautes paroissant formées ¿'une seule, largement échancrée et bidentée; tranche supúrieure des mains aiguë; doigts forts; un peu courbes, connivens, striés extérieurement; bord interne de ceux de la main droite dentelé dans toute sa longueur vers la face externe; quelques dents, par intervalles, un peu plus fortes; doigts die l'autre main beaneoup moins dentelés; le milieu de leur bord interne droit et tranchant : de pe'its poils jaunâtrcs sur les autres pattes.

Celle espèce a été recucillie daus la mer Rouge, et y avoit été trouvce dans les interstices des Madiépores. M. Roux, conservatenr du Musée de Marseille, m'en a douné un individu femelle.

\section{Trapézte points-fauves, T. tufo-punciaics.}

Testa utrinque bidentata, favida, mfo-puntata, clypeo sexdentato.

Cancer nufo-punctatus, HERBst, Krabben, tab. 47.fg. 6. - Ocypode rufo-punctata. Bose.

Des plas grandes du genre; jaunâtre, tontc ponctuće de fauve. Six dents au chaperon, dont les deux latérales formées par les angles iutemes des cavités oeulaires. Doigls des serres, à l'exception du bout, dentelés.

Patrie inconnue. Je n'ai point va celle espèee.

II. Bords latéraux du test n'ayant qu'une dent', celle qui est formée par l'anglo antérieur. 


\section{TrapézIr digitaire, T. digitalis.}

Testa utrinque unidentata, fusca; clypei modio bidentato; chelis cequalibus.

'Très-petite; d'un brun noirâtre luisant, avec quelques espaces du test plus foncés; les pattes d'un brun clair tirant sur lc jaunâtre, et le côté interne des pinces, ainsi que les doigts, d'une couleur livide; un légrer sinus de clraque côté, près de l'cxtrémitć interne des cavités oculaires; deux pelites dents pointues au milieu du bord antérieur du chaperon ; côlés de ce bord finement et légèrement dentelés. Dent intérieure de la tranche interne des bras moins prononcée que dans les espèces précédentes; angle interne du carpe lérgèrement avancé en pointe et obtus; portion des pinces précédant les doigts en carré long, comprimée vers les tranches, surtout vers l'inférieure, qui est très-aigü̈; doigts courts, un peu dirigés intérieurement, pointus, sans stries distinctes, avec des points enfoncés; ceux de lit main gauehc contigus an bord interne, et, le bout excepté, finersent dentelés; ceux de l'autrc main plus étroits, dentelés seuleant à leur base, écartés l'un de l'autrc au sommet; une saillie forte et dentelée ì la base de l'index; quatre ì cinq petites dents à la parlie opposée du bord interne du pouce.

Mî́le; de la mer Ronge. Envoyé par M. Ie Fébure de Cérisy, officier de la marine.

\section{Trapézie entière, $T$. integra.}

Testa utrinque unidentata; clypeo subtiliter serruto; digitis hiantibus.

Cancer glaberrimus, Hznвsт, Krabben, tab. 20. fig. 11 b.

Pelite; d'un brun roussâtre; chaperon finercent dẹntelé en scie, sans échancrures ni dents plus avancées les unes que les autres. Doig's des serres écartés entr'eux; la gauche un peu plus forte.

Patrie ignorée. (Latr.)

TREMLX, Tremex. Jur. Lat. (Considér.) Sirex. Linn. De Géen. Fab. Klug.

Genre d'insectes de l'ordre des Ilymćnoptères, secion des Térébrans, fumille des Térébelliferes, tribu des Urocérates.

Cctle ribu (voyez pag. 580. de ce volume et le mot Urocḱates) contient les genres Urocère et 'Trémex. Le premier diffère dc l'autre par ses antennes longues, composées de dix-neuf articles ou plus; par la présence de quatre cellules cubitales aux ailes supérieures, dont la seconde et la troisième reçoivent chacune une nervure récurrente.

Antennes courtes, filiformes, légèrement comprimées, composées de çuatorze articles dans les femelles, de treize dans lcs máles ( 1$)$ - Mandibules dentelées au côté interne. - Palpes maxillaires très-pelits, de deax articles; les labiaux de trois; le dernier de ceux-ci très-gros, garni de poils hérissés. - Téte couvexe en devant, tronquée et même crcusée postéricurement. - Yeux petits, ovales-alongés. - Trois ocelles placés en ligne courbc sur le front entre les yeux. - Corps longr, linéairc. - Corselet cylindrique, coupé droit is sa partie antérieure, un peu échancré dans cette partie. - Ecusson triangulaire, le côté entrc les deux angles supérieurs forlement éch ancré. - Ailes supérieures ayant deux cellules radiales; la première pelite, érroite; la seconde incomplète : trois cellules cubitales; la première linéaire, serrée contre le bord extćrienr; la dcuxic̀me fort longue, recevant les deux nervures rćcurrentes; la troisième incomplète; trois cellules discoidules complètes, longiiudinales. - Abdomen sessile, liaćaire, grossissant un peu et insensiblemeut vers son extrémité, qui se rétrécit subitement et se terwine cn pointe, composé de huit scgmens outre l'anus; le premier foiblement échancré à son bord postérieur, le dernicr fort grand, surtoue dans les femelles; dans cc sexe, ee segmont offie une forte déprcssion circulaire dorsile vers son cxtrénité, et la plaque anale supérieure est poin. tue : taric̀re (des fecuelles) prenant son insertion après le sixième segment, placće ensuite, lors dı repos, dans une coulisse bivalve surpassant de bcaucoup l'abdomen ct composée de deux lames concaves, canaliculées; dernier segment de l'abdomen des mâles en dessous, divisé en deux plaques, laissant entr'elles une échancrure; leur anus ayant la plaque supérieure presque nulle et l'inférieure entière, en forme de cuiller; cet anus est pointu à l'extrémiţé. - Pattes antérieztres et intermédiaires courtes; leurs tarses aussi longs quc les cuisses et les jambes prises eusemble; paltes postérieures fort longues, leurs tarses dans la mĉmc proportion que pour les autres; jambes et tarses de cetle paire fortement comprimés; premier article de tous les tarses ordinuirement aussi long que les autres pris ensemble et même un peu plus loug dans les postérieurs. (Ce dernier caractére n'a été pris que sur les femelles.) Dernier article des tarses terminé par deux crochets munis d'une petite pelote dans leur intervalle.

Les espèces de ce genre sont grandes; elles habitent les forêts de haute futaie. Les auteurs disent, qu'ainsi que celles des Urocères, leurs larves vivent aux dépens des végétaux; nous avor:s des ruisons de croire cette opinion mal fondée; il est bien vrai que les larves de ces deux genres

(1) Une faute, probablement typographique, fait dire à N. Jurine, treize articles dans les femeiles et quatorze dans les mâles. Cer auteur paroî́ s'être trompé sur le nombre des cellules cubicales des ailes. 


\section{T R I}

habitent dans le bois, mais elles s'y nourrissent de larves de gros Coléoptères, et particulièrement de ceux de la famille des Longicornes; c'est ce que nous ont paru démontrer les débris trouvés auprès d'une coque d'Urocère, dans la forêt de Villers-Coterets. Le nom appliqué à ces Hyménoptères par feu Jurine, se rapporte à la nécessité où est la femelle de percer le bois avec sa tarière pour la faire pénétrer jusquà l'endroit habité par. la larve qui doit servir de proie à sa postértté. Les espèces connues sont en petit nombre.

- 10. Trémex mage, T. magus. Ju r. Hyménopt. pag. 8r. Mâle et feinelle. - Sirex magus $n^{\circ}$. 4 . $F_{\triangle B}$. Syst. Piez. Femelle. - Encycl. pl. 332. fig. 3. Femelle. - Sirex nigrita n ${ }^{\circ}$. 13. FAв. $i d$. Mále (selon M. Klüg). D'Europe. $2^{\circ}$. Tréarex fuscicorne, T. fuscicornis. Jur. $i d$. Mâle et femelle.Sirex fuscicornis $\mathbf{4}^{\circ} .7 . \mathrm{F}_{\mathrm{\alpha}}$. id. - Encycl.pl. 382. fig. 2. Femelle. D'Europe. $3^{\circ}$. 'Trémex Colombe, T. Columba. - Sirex Columba no. 3. Fав. id. E'ncycl. pl. 382. fig. I. Femeile. Amérique septentrionale. (S. F. et A. SrRp, )

TRIANGULAIRES, Trigona. Nom que j'ai donné à une tribu de Crustacés, de la famille cles Brachyures, ordre des Décatpodes, et dont les cillactères sont : tous les preds insérús sur le même plın, toujour's à découvert, aucun d’eux terminé en nayeoire. Epistone ou surbouche carré, aussi long ou presquaussi long que large. Thoracide généralement triangulaire ou subovoïde, raboteuse ou inégale, rétrécie et avancée en manière de pointe, de bec, ou plus ou moins cornue à son extrémité antérieure. Serres des mâles souvent plus grandes que celles ds l'antre sexe.

Les Crustacés qui composent celte tribu, forment, dans la mélhode de Linné, les deux divisions ${ }^{\star} \mathrm{c}^{\star},{ }^{\star} \mathrm{d}{ }^{\star}$, de ses Crabes brachyures ou à courte queue, et quil signale ainsi : thorace suprà hirto aut spinoso, thorace suprâ spinoso; ce sont ce qu'on appeile vulgairement sur nos côtes, les Araignées de mer (famille des Mrajides, LíACH), et auxquelles il faut associer les espèces analognes. Ces animaux comprenueut les genres Parthenope et Inachus de liabricius. iiM. de Lamarck et Bose les avoient d'abord rénnis en un, sous le nom de Maja, donné par les Grecs à une espèce très-coumune dans nos mers, la Méditerranée particnlièrement, el la plus grande des indigènes ( $20 y e z$ plus bas, maia squinado). Ea adoptant, dans mes prenters ouviages celle réunion, je crus cependant devoir en délacher génériquenent les espèces à longues palles ou les putites Araignées de mer, ainsi qu'une autre, bieu distinguée de tonies les Maias ou Maja., selon l'orthographe de ces deux naturalistes, par l'extrêtne peulesse et la forme des deux pieds postérienrs. Celle-ci constitue te genre Lithode, et les précédenies celui de Mlacrope, déncinnation que le docteur Léach a resplacée par celle Hist. Nat. Ins. Tome $X$. de Macropodie, la première ayant déjà été employée par Thunberg pour désigner un genre de Coléoplères. Les différences que présentent les Miaris daus le nombre apparent des tablettes ou segmens de lear post-abdomen ou quene, dans leurs pieds, leurs anteunes, ele., on donné au meêtase naturaliste anglais le moyen d'établir plasieurs autres coupes génériques que nous avons fait connoitre, d'apprés des communications manuscriles, dans lia seconde édilion du Nouveau Dictionnaire d'histoire naturelle, article $M_{\mathrm{A} 1 \mathrm{~A}}$. Ce trävail, litit sur la collection de Crustacés da Jardir du hoi, est postérieur à la publication du second volume de ses Mélanges de zoologie, ouvrage oǹ il avoit déja élajli quelques antres gemes, dérivant tontjours de celui de Maïi, el que nous alvons exposís dans le truisième tome de l'ouvrage sur le Règne animal de M. le baron Cuvier. Le genre Inacius de Fabricius étant très-étendu, le docteur Léach a beaucoup contribué à l'éclaircir par la découverte de plusieuts caraclères négligés ou inaperçus jusqu'alors, et dont il a profité pour l'établissement d'un grand nombre de nouveatux groupes génériques. M. Anselme Gaëtan Desmarest, fits du célèbre minéralogiste de ce nom, professeur de zoologie à l'kcole royale vélérinaire d'Alfort, etc., a, dauns un excelleut livre intitulé: Considérations générales sur la classe des Crustacés, fait tous ses efforts pour faciliter l'étude de cette partie de la science, en présentant, arec autaut de méthode que de clarté possibles, cette multitude de coupes génériques proposées parle le naturaliste angluis, et en indiquant leur correspondance, soil avec les miennes, soit avec celles que M. de Lamarck a exposées, en dernier lieu, dans son Histoire naturelle des animaux $x$ ans vertèbres. Avant que d'essayer nous-mêtmes de répandre quel ques lumieres sur ce sujel, nous devons prévenir nos lecteurs à légard d'une dissidence que l'on pourroit remarquer daus nutre suppatition des articles clu pédoucule des antennes latéralcs el celle de M. Léach. Le premier de ces articles se confond souvent par sa fixité el ses soudures avec le test, de nuanière qu'il semble plutôt en faire partie gun'être une dépendance de l'antenue. Ce năturaliste considère alors l'article. suivant comme le preuier, tandis que selon mid manière de voir, il est réellement ie second.

I. Les deux pieäs postérieurs propres, ainsi que les autres, à la marche, terminés par un tarse allant en poinle et jumais beaucoup plus petits que les préccédens. Tablettes du post-abdamen s'étendant dans toute sa largeur, de consistance unforme.

1. Les deu.x pieds antérienrs terminés comme à l'ordinatre par une main didactyle; les autres simples.

A. Troisiène article des pieds-mâchoires extéTett 
rieurs presque carré, peu ou point rétréci inférieurement au côté interne; ce côté tronqué obliquement ou échancré ì son sonunet; l'article suivant inséré dans cette troncature ou dans cette echancrure. (Post-abdonzen de la plupart des femelles composé de sept tablettes; celui des autres individus du même sexe de cinq; trois à celni de leurs mâles.)

Nota. Le calractc̀re tiré de la forme du troisième article des pieds-mâchoires extérieurs et du mode d'insertion de l'arlicle suivant, etc., relativement à quelques yonres, tels que ceux de Camposcic et d'Hyménosome, un peu ambigu. Voyez la division $\mathrm{B}$.

n. Serres des deux sexes ou des máles au moins très-grandes, s'étendant latéraleme'nt et perpendiculairement it l'axe du corpss, depuis leur origine jusqu'au carpe, repliées ensuite sur ellesmêmes; doigts bnusquement inclinés; les autres pieds propoitionnellement fort courts. (Yeu.x toujours renfermés dans lcurs cavités.)

Gentre I. Lambrus, Lambrus (Léach). Antennes latćrales très-courtes, dc la longueur au plus des yeux; le premier article totalement situé au-dessous des cavités oculitires. P’ost-abdomen du mâle composé de cinq tabletles.

Foyezl'articles Parthésope de ce Dictionnaire.

Genre 2. Parthénope, Parthenope. Antenues latérales très-courtes, de li longueur au plus des yeux; le premier article titalement situé au-dessous des cavitćs oculaires. Post-abdomen des deux sexes de sept tablettes.

Voyez le même article.

Genre 3. Eur ynome, Eurynone (Léach). Antennes latérales notablemcnt plus longues que les yeux; İe premier article p:olongé jusqu'à l'extrémité supérieure inlerne des cavités oculaires (paroissant se confondre aveo le test).

Post-abdomen dc sept tablettes dans les denx sexes; serres des femelles beaucoup plus courles que celles des mâles.

On n'en connoit qu'une espice, l'Eury nome raboteuse, Eurynome aspera (Lغ̇Aca, Melacost. Podopht. Brit., tab. 17.), et (que Pennänt avoit décrite et figrurée dans sa Zoologie britannique (tom. 4. pl. 9. A. 20) sous le nom de Cancer asper. Voyez planclie 3or. fig. I-5. de l'Altas d'histoire natur. de ce Dictionnaire.

b. Serres des mâles, dans ceux mêne où elles sont les plus grandes, tout au plus une fois plus longues que le corps, toujours avancées; leuns doigts point inclinés brusquement. (Premier article des antennes latérales toujours prolongé jusqu'à l'extrémité supérieure interne des cavités oculaires, fort grand, el pa."oissant se confondre avec le test.)

\section{T R I}

* Post-abdomen des fenuelles toujours composé de sept tablettes; le nềme nonzbre à celui de la plupart des mâles, six dans les autres. Dessous des turses soit dentelé ou éfineux, soit garnid'une frange de petits appendices ou cils en massue. Longueur des pieds les plus longs (les seconds) n'excédant pas celle du test, nesurée depuis l'enttre-deux des yeux jusqu'à l'origine du post-abdonen.

† Pédoncules oculaires très-courts ou de longueur mo,enne, pouvant se retirer totalenient ou en majeure partie dans les cavités qui leur sont propres.

- Serres des nấles au moins notablenent plus épaisses que les pieds suivans.

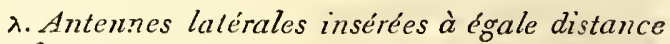
des fossetles recevant les antennes intemédiaires et de celles où sont le's yeux, ou plus rapprochées des dernieres.

\section{B. Post-abdomen des nuâles de six tableties.}

Genre 4. Acantmonyx, Acanthonyx. Latr. Maja lunulata. Risso.

Nota. Corps déprimé, plan et presquı'uni en dessus. Serres fortes. Jambes ayant au côté inférieur un avancemennt en forme de dent ou d'épine. Tarses arqués, très-dentelés et velus en dessous.

La sutnre postérieure du troisième segment du post-abciounen n'étant pas toujours bien prononcée, je u'avois d'abord ( Nouv. Dictionn. d"hist. natur., $2^{\mathrm{e}}$. édit. tont. 18. pag. 3\$7) complé à celle partie du corps que cinq (mâle) et six (femelle) tablettes.

B3. Post-abdomen des mâles, ainsi que celui desfenelles, de sept tablettes.

Genre 5. Mitnkax, Mithrax (LÉAcr). Serres des deux sexes très-robustes, comme presque celles de nos Crabes; doigts creusés à leur extrémité en manière de cuiller. 'Tige des antenues latérales petite, sensiblement plus courte que leur pédoncule. (Yeux très-conts, point ou peu saillans.)

Cancer aculeatus. Hersst. - ejusd. Cancer 7ispidus. - ejusd. Cancer dama.

Genre 6: Pise, Pisa. Serres des femelles petites ou moyennes; celles des inâles plus grandes, mais poiut tic̀s-robustes; doigts terminés en pointe, point croisés au bout en cuiller. Tige des antennes latérales plus longuc que leur pédoncule.

Je rapporte à ı genre les suivans du docteur Léach.

I. Dessous des zarses égaux, deux rangées de dentelures ( jambes et tarses de la mêne longueur).

Lie G. Naxia. 
II. Dessous des tarses n'ayant qu'une rangée de dentelurcs ou sans dents.

A. Les troisiemes pieds beaucoxp plus courts dans les mâies que les seconds.

Le G. Choninus.

B. Longueur des pieds, à commencer aux seconds, diminuant progressivemeni ou ne changcant poini brusquement.

a. Tarses dentelés.

Le G. Pisa.

b. Tarses inermes, mais garnis inférieurement d'une frange de gros cils ; en massue.

Le G. Lissa.

Voyez l'arricle Pise de ce Dictionnaire.

$\lambda \lambda$. Antcnnes latérales insérées sous le musean, plus pres des fossettes recovant les antennes intermédiaires que des cavités oculaires.

Gente 7. Péricère, Pericera. (Lat.)

Cancerfuscatus. Or.rvier.

_- Serres, même des mâles, à peine plus épaisses que les pieds suivans (muains presque cylindriques).

Genre 3. MÄ̈, Maja (LÉACH). Second article des antennes latéralcs paroissant naître du canthus jnterne des cavilés oculaires. Carpe presqu'aussi long que le poing (la main jusqu'à l'origine des doigls ). Thoracide ovoide.

Maja squitiado. Bose. Lat. Léaer.

Genve 9. Mrcippe, Ricippe (Lي́ach). Premier article des antennes latérales un pen courbe ou replié anyulairemeut; son extrénité supérieure fortement dilatée, furmant les cavités oculaires en manı̀̀e de lame transverse et oblique; l'article suivant inséré au-dessous de son bord supérietr. Carpe plus long que le poing. Thoraeide presque carrée.

Cancercristatus. Lis.-Cancerphilyra. IIEnвs'т.

t† Pédoncules oculaires fort longs, grêles, tonjours saillans.

Genie io. Sténocionops, Stenocionops (Léaen).

\section{Cancer cervicornis. Herbst.}

* * Post-abdomen do quelques fomelles ayant moins de sept articles. Dessous des tarses sans dentelures, ni épines, ni cils en massue. Longucur des pieds les plus longs surpassant d'une demi-fois au moins, et le plus souvent beaucoup plus, celle du test, mesurée depuis l'entre-denx des yeux jusqu'd̀ l'origine du post-abdomen. ( Corps proportionnellement plus court que dans les genres précédens, en forme d'ovoïde court ou subglobuleux.)
† Post-abdomen des deux sexes de sept tıblettes.

- Antennes latérales à tige très-courte, en formo de siylet alongé; second article du pédoncule plus grand que le suivant. Ireux pourant se retiver dans lours fossettes lorsque l'animal les rejette en arrière. Bords latérux du test formant dorrière cos cavités une saillie en forme de dent ou d'angle, garnissant ces organes.

Gonre I1. Irys, Mras (Líacn). Pédien'es oculaires presqu'entierenent découverts lorse qu'ils sont redressés; leurs cavités ovales et as éz grandes. Côté extélieur du second article des antennes latérales compriné, en manière de carrène.

Corps subovoilde; bords latéraux du test dilarés par derrière les catrités oculaires, en forme d'ureilietle forte, déprinće et pointue.

Cancer aranens. Lix. - C. pipa. Herbst.

Genru 12. Phalangipe, Phalangipus. Lat. Pédicules oculaires trc̀s-courts, fort peu exsertiles; leurs fossettes très-petites, presçuorbiculaire. Second article des anlenues latérales cylindrique, pell ou point comprimé. Corps presque globuleux on triangulaire.

Sous la dénomination générique de phalangipo (pieds de faucheur, ou phalangium), je counprends les Libinia , les Doclaca et les Focria du docteur Léacl. Les caractèrcs de ces genres n'étaut généralenent fondés que sur les proportions relatives des pieds, me paroissent très-incertains. J'observerai seulement, $1^{\circ}$. yue dans les Libivies les serres des mâles, toujours plus éparisses que les deux pieds suivaus, sont aussi longues ou presque aussi longues qu'eux (voyez Libinia canaliculata, $S_{A}$, Journ. acad. scienc. natur. de Phalud. tom. 1. pag. 27. tab. 4. fig. 1.), et que la longueur de ces deruiers est un peu moindre que le double de celle dia eorps; $2^{\circ}$. que dans les DoCLÉEs, les serres des mâles sont notablement plus courtes que les mêmes pieds, et que la longuen: de ceux - ci ne surpasse guère que d'une fois ou d'une fois el demie celle du corps, dout la forme est globuleuse, et qui cst tonjours recouvert d'un duvet noirâtre; $3^{\circ}$. que dans les Egéries, les seconds pieds sout cine ou six fois plus longs quo le corps, dont la forue est celle d'un triangle court. Les serres sont filiformes, avec les poings forl alongés, presque linéaires. Aux Dorlées se rapportent les Inachus opis et Hybridus de Fabricius. Les espères qu'il nomme Longipes et Lar sont probablement des Egéries.

- - Tige des antennes latérales longue, sétacée; troisicine article de leur pédoncuie, aussi long ou même plus grand que le précédent. Pćdicules oculaires toujours saillans. 
Gente 13. Hamie, Halinus. Iatr.

Ce genre a été établi sur deux espèces de la collection du Jardin da Roi, et dont l'une paroît être très-voisine du Cancer superciocisus de Linné. ( Herbst. Krabbez. tab. 14. /ig. 87.)

†† Post-abdomen des mâles de trois tablettes; celui des fenuelles de cinq.

Geure 14. Stŕxope, Stenopus ( LÉs cu).

J'avois d'abord désigné l'espèce scrvant de type à cette coupe sous le nom de Maja longipes; MM. Léach et de Lamarck en ont cnsuite formé un genre propre que le premier a nommé Stenopus, et le second Leptopus. II se rapprocbe beaucoup de celui d'Egéric de celui-là.

13. Troisiène article des pieds-mâchoires exténieurs, soit en forme de triangle renversé ou presque ovale, rétréci inférieureinent, soit presqu'en. forme de cour, apec l'extrénuité supérieure tronquée ou échanucrée, l'article suivant inséré à cette extrémité, vers son angle externe. (Postabdonzen du plus grand noinbre des individas femelles de six tablettes.

Nota. Pédicules oculaires le plus sonvent entièrement découverts, du moins lorsqu'ils son! relevés. Corps plus ou moins triangulaire, terminé autéricurement dans la plupart par un prolongement long et pointu. l'ieds longrs et grêles; serres ordinairement plus courles que les deux pieds suivans. Crustacés généralement petits, et faisant leur séjour habituei parmi les Algrues.

a. Post-abdomen des deux sexes de sept tablettes. Seconds pieds et suivans presqu'égaux.

\section{Gente i5. Camposcie, Camposcia (Léach).}

Corps ovoïde, très-obtis ou émoussé en devant. pédicules oculaires alongés, très-courbes, insérés ì ses angles antérieurs, se logeant en arrière dans des fossettes situées sous les bords latćraux da test. Longueur des pieds paroissant augmenter un peu progressivement de devant en arriêre, à commencer anx seconds.

b. Post-abdomen desfenelles de six tablettes au plus. Pieds de grandeurs inégales; les quatre derniers sensiblement plus petits.

* Epistome presque isométrique ou transversal. Base des antennes inteınédiaires peu éloignée du bord supérieur de la cavité buccale.

† Corps très-aplati. Premier article des antennes latérales se tenninant plus bas que l'extrémité supérieure des yeux.

Gente 16. Нтме́nosome, Hyzzenosonza (Lе́ach). Corps triangulaire on suborbiculaire. M. Desmarest a représenté (Consid. génér. sur la classe des Crust. pl. 26. fig. I.) une espèce de cetie dernière division, rapportée par feu de Lalande du cap de Bonne-Espérance; c'est l'H. orbiculaire. Le post-abdomen des deux sexes est composé de six tablettes. On en comple moins dans d'autres espèces; mais, eu égard encore àla forme du corps, à celle du premier article des antennes latérales, qui est tantôt libre, tantôt engagé, ainsi qu'à la sailie et la position des yeux, il sera convenable de séparer génériqucment quelques-unes de ces espèces. Dans l'orbiculaire, les antennes Ialérales sont insérćes dansles cavités oculaires, près de l'angle ex térieur, et libres ou dégragées jusqu'à la base. Les launbrus, les Parlhénopes elles Hyménosomes sont distingués de tous les autres Triangulaires, en cc que le premier article de ces organes ne śélève jamais à la hauteur du bord supérieur de ces fussettes, et qu'il cst inséré au-dessous d'elles on vers lenr canthus extéricur, conne dans l'espèce d'Hyménosone précitée : aussi avois-je d'abord pensé à placer ce genre près des précédeus.

†† Corps plas ou moins convexe. Premer article des antennes latérales (toujours fixe) formant une apparence de carène oul d'arête entre les fossettes des antennes intermédiaires et celles des yeux, et se tenninant au-delà de l'extrémité supérieure de celles-ci.

Nota. Post-abdomen de six tabletles dans les deux sexes.

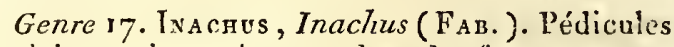
oculaires nnis, se logeant dans des fosselles; une dent ou une épine, dans les mâles, à l'exirémité postérieure de ces cavilés. 'Tous les tarses presque droils ou foiblement arquées.

Rapportez ì c.e genre lcs Inachus suivans de Fabricius, Phalangium, Scorpio.

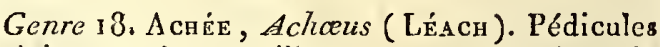
ocnlaìres toujours saillans, avec un tubercule antérienr. Les quatre tarses postérieurs très-arqués, en faucille.

Achous cranchii. LÉACu.

On pourroit réunir ce genre au précédent, qui nc comprend d'ailleurs qu'un petit nombre d'espèces (1).

* * Epistonne plus long que large, en fornue de triangle alongé et tronqué au" somnet. Un grand espace entre l'origine des antennes intermédiaires et le bord supérieur de là cavité buccale.

Pédicules oculaires toujours saillans. Test triangulaire, terminć triangulairement en une pointe styliforme, entière ou bifide. Pieds généralement très-longs et filiformes.

(1) Ici vient se placer le genre EunXpode (Eurypodius), que nous avons établi avec une espèce des îles Malouines, dont les partes ambulatoires ont le métatarse dilaté en mageoire. (E. G.) 


\section{T R I}

Gente 19. Sténony voue, Stenorynclizls. (Lam.; Macropodia, Léach.) Post-abdomen des deux sexes de six tablettes.

Inachus plualangiam, $\mathrm{F}_{\mathrm{AB}}$ - - Ejusd. I. longirostris. Voyez l'article STÉnORYNQUE de cet ouvrage.

Gente 20. Leptoponis, Leptopodia (LÉACH).

Yost-abdomen des mâles de six articles, celui des lemelles de cinc.

Inachus sagittarius, $\mathrm{F}_{\mathrm{AB}}$.

Nota. 'Troisième article des pieds-mâchoires extérieurs en forme de triangle renversé, échancré au bord supérieur. Mains fort longues, presque cylindriques et très-étroites. Museau formé d'une pointe fort longue, armée de petites épines.

2. Les quatre ou six premiers pieds antérieurs simples; extrémité interne de l'avant-dernier article des quatre postérieurs prolongée en une dent formant avec le dernier une pince ou main didactyle. (Post-abdomen comme dans le genre précédent.)

Gente 21. PActore, Pactolus (LÉAch.) Paetolus boscii. LÉach.

II. Les deux pieds postérieurs excessivement petits, comparativement aux autres, repliés, peu apparens, et comme inutiles. Post-cebdomen membraneux, avec des espaces crustacés sur les côtés et au bout, représentant les segmens.

Gente 22, Lithode, Lithodes (LAtr.).

Lithodes arctica, LATr.; Cancer maja, Linv.; Parthenope maja, Fав.; ejusd. Inachus nıaja.

(LATR.)

TRIBOLIE, Tribolium. M. Macleay, dans ses Annulosa javainca (Number 1. London, 1825.), a établi sous ce nom un genre de Coléoptères, démembré de celui de Colydium Herest. Il lui assigne pour caractères: antennes insérées sous le chaperon, auprès de la base des mandibules, composées de onze articles; les huit premiers globuleux, presqu'égaux, allanł très-peu en grossissant; les trois derniers peu serrés, formant une massue; les neuvième et dixième presque cyathiformes; le dernier ovale-transversal. Bouche cachée sous le chaperon, celui-ci plan, trans. versal, ayant ses bords latéraux arrondis. Yeux presqu'entourés par le chaperon. Corselet en carré transversal, un peu rebordé. Corps assez déprimé, presque linéaire. Tarses de cinq articles.

L'auteur indique pour type le Colydium castaneum. Hersst. Coleopt. tom. VII. pag. 282. no. 3. tab. 112. fig. 3. E. qui paroît être la Trogosita ferruginea $\mathrm{n}^{\circ} .23$. $\mathrm{F}_{\mathrm{AB}}$. Syst Eleut.

(S. E. et A. SERv.)
TRICHIE, Trichius. Fab. Lat. Schenn. Payk. Panz. Gyle. Pal.-Bauv. Schranck. Scaraboeus. Linn. Geoff. De Géer. Res. Melolontha. Oitv. Cetonia. Oliv. Fab.

Genre d'insectes de l'ordre des Coléoptères, section des Pentamères, famille des Lamellicornes, iribu des Scarabéides (division des Mélitopbiles).

Ce genre forme avec ceux d'lnca et de Lépitrix, le second groupe des Mélitophiles, qui a pour caractères: pièce triangulaire ne saillant point en dessus, et ne s'avançant pas dans l'intervalle compris entre les angles postérieurs du corselet t ceux de la base des élyties. (Voyez Mécrtophiles, pag. 35o. de ce volume.) Les Lépitrix ne présentent qu'un seul crochet aux tarses postérieurs, et leurs antennes n'ont que neuf articles. Dans le genre Inca le menton est large, grand, très-échancré en devant; le chaperon profondément bifide dans les mâles et notablement relevé à son bord antérieur dans les femelles: les jambes antérieures de ces insectes sont très-échancrées à leur base interne dans les deux sexes. Les Trichies n'offrent aucun des caractères que nous venons de signaler.

Antennes à peu près de la longueur de la tête, composées de dix articles; le premier le plus long de tous, hérissé de poils roides, surtout à sa partie postérieure; les trois derniers formant une massue lamelléc, ovale-alongée, un peu velue, un peu plus longue dans les mâles que dans les femeiles. - Labre presque membranenx, caché sous le chaperon. -- Mandibules le plus souvent aplaties en forme de lames, ordinairement nembrancuses dans presque toute leur étendue, fortement ćchan. crées à letur extrémité, l'échancrure extérieure plus sulide, presque cornée, un peu ciliée. Mấchoires alongées, étroites, terminées par un lobe garni de poils en forme de pinceau. - Palpes maxillaires composés de quatre artıcles; les labiaux de trois. - MIenton pelit, à peine échancré. - Tête petite; chaperon ui relevé, ni fourchu. - Yeux peu saillans. - Corps épais, un peu déprimé en dessus. - Corselet souvent presqu'orbiculaire, un peu transversal. - pièce tríıngulaire nullement saillante. - Ecusson ordinairement en triangle curviligne. - Elytres déprimées, recouvrant des ailes et laissant à nu une partie assez notable de l'extrémité de l'abdomen. - Abdonien assez épais. - Pattes fortes; jambes antérieures sans échancrure à leur base; les quatre autres raboteuses, ayant uue ou deux épines à leur angle externe : dernier article des tarses muni de deux grands crochets égaux, enticrs.

Ce genre renferme jusqu'à présent des espèces qui diffèrent notablement les unes des autres par diverses parties de leur organisation, et dont les mœurs ne sont pas tout-à-fail identiques; quelquesunes vivent dans le terreau végétal en état de larves, telles que le $T$. nobilis, le fasciatus, etc. , mais les larves de plusieurs autres attaquent le 


$$
7,2
$$$$
\text { T R I }
$$

bois; de ce nombre sont celles de l'eremita et de l'hemip!erus. Les insectes parfuits, en conséquence de cette différence d'habitudes, n'ont pas exactement les mêmes allures; les denx sexes, dansles espèces dont les larves habitent le terreau, se tiennent habiluellement sur les fleurs, tandis que l'eremita et l'hemiptents lemelle s'éloignent peu de l'arbre où ils sont nès. I.es espèces qui fréquentent les fleurs, se contentent d'en sucer le miel at moyen de la houppe de poils dont chaque mâchoirc est munie; elles n'altaquent point les pélales. Le 'T'. ermite sc tient quelquefois sur les ulcères des irbres pour sucer la liqueur qui en découle. Les 'Trichies femelles de la seconde division ont l'abdomen terminé par une longue pointe cornée, non rétractile, dentelée sur les bords, qui leur sert de tariere pour introduire leurs oeufs dans le bois.

Ire. Division. Anternes au moins de la longueur de la tête, la plupart des articles intermédiaires, coniques. - Ecusson triangulaire ou transversal, - Janbes antérieures bidentées ou tridentées extérieurement. - Tous les tarses ayanı leur premier article à peu près de mềne longueur que le sccond, on guère plus long que lui.-Anus simple dans les deux sexes.

Ire. Subdivision. Nandibules entièrement cornées. - Ecusson en triangle rectiligne, plus long que large, sillonné longitudinalemeut dans son milien. - Tous les tarses plus courts que les jambes. - Jambes antérieures tridentées au côté externe. - Menton nu. - Derniel article des palpes un peu dilaté extérieurement. (Osmoderma_Noв.)

\section{Truche ermite, $T$. eremita.}

Trichius eremita no. I. Faв. Syst. Eleut. Lat. Gen. Crust. et Ins. tom. 2. pug. 123. $n^{\circ} .1$. -Srhen. Synon. Ins. tom. 3. pag. 99. $n^{n} \cdot 2$.

Voyez pour la description et les autres synonymes, Cétoine hermite $n^{\circ} .89$. du présent ouvrag' .

Nota. Le corselet de la femelle a ses bords extérieurs arrondis; le sillon longitudinal du milieu peu profond; les deux dépressions latérales plus étentues que dans le mâle; près de l'écusson on remarque deux dépressions parallèes, transversales, beancoup plus prononcées dans ce sexe que dans le mâle; celui-ci a les bords latéraux du corselet presque droits. M. Gyllenhall (Ins. Suec. toin. 1. pag. 56. $7^{\circ}$. 5, ) fiait de ce mâle, à l'exemple de $M$. Knoch, une espèce particulière sous le nom de Trichius eremiticus. Les caractères differenciels qu'il lui assigne, sont : le sillon longitudinal du corselet et les côtes qui l'avoisinent moins prononcés, ainsi que les tubercules qui terminent celles-ci ver's la tête; les points enfoncés da corselet plus nombreux que dans l'eremita, et conlluens ì la partie antérieure: caractères que
T R I

nous retrouvons dans notre mále, outre ceux que nous venons d'indiquer uous-aêmes. M. Schoenherr nous paroît avoir pris le mâle pour la fenelle, et vice versâ, ptisqu'il cite l'eremiticus GrLı. comme synonyme de celle-ci; et dans son quatrième volume, pag. 256 . no. 5. ce deruier auteur cite l'opinion de M. Schoenterr en paróissant l'adopler. Cet insecte pris vivant exliale une odeur musquée assez sembluble à celle du cuir de Russie.

Nous plaçons encore dans celte subdivision le Trichie scabre, $T$. scaber. Par.-BAuv. Ins. $d^{\prime} A$ friq. et d'Amér. pag. 58. Colćopt. pl. 4. fig. 2. Je Pensylvanie.

2e. Subdivision. Mandilunles membraneuses.

A. Ecusson en triangle curviligne, à peine plas long que large. - Tarscs pustérieurs aussi longs que les jambes ou guère plus longs qu'elles. - Jumbes antérieures tridentées au côté externe. - Menton nu. - Dernier article des palpes un peu dilaté extérieurement. (Agerius №в.)

\section{Triceie bordé, T. limbatus.}

Trichius limbatus. Sceqn. Syn. Ins. tom. 3. pag. 206. $n^{\circ} \cdot 19$.

Voyez pour la description et les autres synonymes, Hauneton bordé $\mathrm{n}^{\circ}$. 106 . de ce Dictionnaire. Sa patrie est l'Afrique.

B. Ecusson transversal, court, arrondi postérieurement. - Menion velu. - Jarnbes autérieures bidentées au côté externe.

a. Dernier article des palpes un peu dilaté extérieurement. - 'Tarses postérieris aussi longs que les jambes ou guère plus longs qu'elles; ceux des mâles plurs alongrés que ceux des femelles. - Pygidion portant vers son extrémité un enfoncement beaucoup plus notable dans les femelles que dans les unâles. (Gnorinuıs Nов.)

\section{Thrcere noble, $T$. nobilis.}

Trichius nobilis no. 2. FAB. Syst. Eleut. Lat. Gener. Crust. et Ins. tom. 2. pag. 123. $n^{\circ}$. 2. - Scres. Syn. Ins. tom. 3. pag. 10o. no. 7 . (en retranchant le synonyme de Schranck Enumi. austr. qui appartient à la Cetonia aurata F'AB., et y substituant le synonyme suivant: $S c a r a b$. nobilis Schranck Enum. pag. 10. $n^{\circ}$. 15. appliqué mal à propos par M. Schœenherr à la Cetonia arsrata.)

Voyez pour la description et les antres synonymes (en lisant $f g$. ı. au lieu de $f g$. 1. ̀̀ la citation de l'entomologie), Cétoine noble n‥90. du présent Dictionnaire. 


\section{T R I}

Nota. Le mâle a les jambes intermédiaires trèsfortement arquées, ce qui doit lui servir dans l'aecouplensent. Ce caractère sexuel n'est mentionné par aucun auteur, du moins à notre connoissance.

\section{4. 'Trлсене variable, T. variabilis.}

Trichius octopunctatus no. 3. Fав. Syst. Elent. - Schау. Syzr. Ins. tom. 3. pag. I02. $n^{\circ} .8 .-$ Encycl. pl. 161. fig. 16. Femelle.

Voyez pour la description et les autres syno. nymes, Cétoine variable $n^{\circ} .91$. de ee Dietionnaire.

Nota. A l'exemple d'Olivier, nons restituons à celte espèce le nom que lui a voit donné Linné. Le trâle a les jambes intermédiaires très-arquúes.

b. Dernier article des palpes cylindrique. - Tarses postérieur's notablement plus longs que les jambes. - Pygidion sans enfoneement. (Trichius propriè dictus. Nов.)

\section{Trichie rayé, T. vittatus.}

Trichius vittatus. Sенळа, Synon. Ins. tom. 3. pag. $104 . n^{\circ}$ 11. - Cetonia vittata n०. 76 . Fав. Syst. Elleut.

Voyez pour la description et les ant:es synonymes, Hanneton zèbre ${ }^{\circ}$. 94. de ce Dictionnaire.

Nota. Le mâle a les jambes fort velnes, les intermédiaires très-arquées, garnies extérieurement d'uu grand nombre d'épines courtes et roides, surtout vers l'extrémité, qui se prolonge nolablement au-dela de l'insertion du tarse; dans ce sexe le corselet est beaucoup plus velu que celui de la femelle. Ce mâle esı le Scarab. tomentosus. De GéEr. Mém. Ins. tom. 7. pag. 644. $n^{\circ}$. 46. $p l$. 48. fog. 8. Nous en avons une variété dans laquelle les lignes longitudinales des élytres manquent tout-à-fait. Du cap de Bonne-Espérance. Nous doutons que celle espèce se tronve dans l'Amériquc méridionale, comme le dit Olivier et quelques autres auteurs.

\section{Threnie faseié, T. fasciatus.}

Trichius fusciatus $n^{\circ}$. 4. FAB. $i d$. Senæn. id. pag. 103. $2^{\circ}$. го. - SeнœN. Append. pag. 39. $n^{\circ} .60$.

Voyez ponr la description et les autres synonymes, Cétoine fasciée $n^{\circ} .9^{2}$. de ce Dietionnaire.

Nota. Le mâle a l'avant-dernier segment de l'abdomen en dessous, indépendamment des poils qui se trouvent dans les deux sexes, chargé à sa base de deux sections de cercle garnies d'écailles serrées, jaunâtres; le reste du même segment est entièrement muni de stries transversales, serrées. La femelle n'a pas les placjues d'écailles jaunes; les stries sont rates, écartées et inégales. Cette espèce varie beaucoup par le plus ou moins de noir sur les ćlytres; l'une des variétés assèz commune en France est le Trichus succinctus $n^{\circ} .5$. F A B. Syst. Elent. (Cétoine cordonnée nº 93 . du présent Dictionnaire). Il paroit que le nord de l'Europe en renferme plusieurs autres. Voyez Schonerr. Syn. Ins. Append. pag. 39. et 40.

\section{Trienie lunule, $T$. lunulatus.}

Trichius lunulatus $n^{\circ}$. 11. F $\mathrm{F}_{\mathrm{AB}} . i d .-\mathrm{ScH}$ œN. $i d$. pag. 105. (Cet auteur ne le considère que comme une variété du $T$. piger.)

Voyez pour la description et les autres synonymes, Cétoine lunulće no. $9^{6}$. de ce Dietionnaire.

Nota. Dans l'individu que nous possédons, l'avant-dernier segment de l'abdomen a de chaque côté, en dessous, une ligne d'écailles jaunes : lout le dessous de l'abdomen porte des stries transversales, irrégulières, écartées.

\section{Tricute paresseux, $T$. piger.}

Trichius piger no. 13. КАв. id. - SенळN. id. $n^{\circ} .14$.

Voyez pour la descriplion et les autres synonymes, Céroine paresseuse $n^{\circ}$. 97. de cet ouvrage. (A la citation du Mantissa. FAB. ajoutez $\mathrm{x}$. apicis le mot tome. )

Nota. L'avant-dernier segrnent de l'abdomen dans l'individu que nous avons sous les yeux, at en dessous, comme l'individu précédent, une ligne d'écailles jaunes de chaque côté; ces lignes sont un peu plus longues ici, et le dessous de l'abdomen est ponctué.

9. Trichie buveur, $T$. bibens.

Trichius bibens $n^{\circ} .8 . \mathrm{FAB}_{\mathrm{AB}} i d$. - Schas. $i d$. pag. $105 . n^{\circ} \cdot 13$.

Voyez pour la description et les autres synonymes, Cétoine bident n ${ }^{\circ} .94$. de ce Dictionnaire. (Au synonyme de Fibricius lisez bibens au lieu de bidens.)

Nota. L'avant-dernier segment de l'abdomen dans notre individu porte en dessous une ligre lacérale d'écailies jannes, comıne dans les individus précédens, el le dessous de l'abdomen a un assez grand nombre de stries fines, ondulées, écartées les unes des autres.

10. Trienie delta, T. delta.

Thichius delta no. 14. FАв. id. - Sencen. id. pag. $106 . n^{\circ} \cdot 15$.

Voyez pour la deseription el les autres syno- 
nymes, Cétoine delía no. $9^{8}$. de ce Dictionnaire. (A la citation de Drury lisez 1. et 2, au lieu de 12.)

Nota. Il paroît que la description à laquelle nous renvoyons a été faile d'après un inclividu défectueux. Dans ceux que nous cxaminons, loute la partie antérieure de la tête est testacée et porte deux taches rondes, réunies, formćes d'écailles d'un jaune vif. Diturs l'un des sexes, que nous présumons être le màle, presque tout le dessous du corps est garni d'écailles de cette même couleur, à l'exception d'une plaque presque rhornboïdale eutre la base des cuisses postérieures, et d'une autre beaucoup plus pelite placée sur l'antépénuliième segmeut de l’abdomen. L’anus est nu, testacé, avec denx pelites taclies ovales, écailleuses, jaunes, sur son discque. Dans l'antre sexe, la femelle suivant nous, la base de l'abdomen est latćralement garnie d'écailles jaunes; la base du pénultième segrnent en porte uue large bande contiuue, et les trois précédeus en ont une étroite de chaque côté qui finit en pointe avant d'atteindre le milieu de ces segurens. 'Tuute la prartie supérieure de l'abdomen laissée à découvert par les ćlytres, est chargée d'écaillcs jaunes, a l'exception de l'exrrémité qui est nue et reutre en échancrure dans la partie écailleuse. Le corselet est presqn'entièrement bordé de sembiables écailles; d'autres forment sur sun disque le contour d'un delta grec.

$2^{\ominus}$. Division. Antennes beaucoup plus courtes que la tête; la plupart des articles intermédiaites, transversaux. - Ecusson étroit, linéaire. - Jambes antérieures munies extérieurement de cing dents. - Tarses postérieurs ayant leur premier article beauconp plus long que le second. - Anus des femelles muni d'une tarière saillante, non rétraciile. - Dernier article des palpes cyindrique. - Menton nu. (Valglis Scrib..)

\section{Tarchis hémiptère, T. henipteras.}

Trichius hemipterus no. 9. FaB. Syst. Eleut. Schav. Syn. Ins. tom. 3. pag. 107. $\pi^{\circ}$. 23. (A la citation de fourcroy, au lieu de p. 81.2. lisez pag. 8. 12. A celle de Scopoli, lisez variegatus au lieu d'homipterus.)

Voyez pour la description et les autres synonymes, Cétoine hémiptere ${ }^{\circ}$. 99. de ce Dictionnaire.

\section{Trucare canalicnlé, T. canaliculatus.}

Trichius canaliculatus $n^{\circ}$. 10. FAB. $i d$. Mâle et femelle. - Scres. $\imath d$. pag. 108. $n^{\prime} .27$. Ficuelle.

Voyez pour la description et la synnymie, Cétoine cannelée $n^{\circ} \cdot 10 \overline{3}$. de ce Diclionmaire. Mâle.

Dans son Syst, Eleut. Fabricius compose ce genre

\section{T R I}

de vingt-une espèces, mais douze seulement lui appartiennent avec certitude; ce sont les no $: 1$, $2,3,4,5,8,9,10,11,12,13,14$. Le no. 6 . est une Cétoine; 7. une Popillie; 15 . et 17. deux Lépitrix Encycl., I6. nous paroît être une Macraspis, 18. une Pachycnème Encycl. Les n ${ }^{09}$. 19, 20, 21. sunt douteux. M. Schonherr place les deux premiers parıni les Anisonyx, et le dernier dans ses 'Trichies. La Cetonia vittata $n^{\circ} \cdot 76$. FAB. Syst. Eleut. est le Trichie rayé $n^{\circ}$. 5 . du présent article.

Différens auteurs, dans l'appendice de l'ourrage cité de M. Schunherr, ont décrit plusieurs espèces sous le nom générique de Trichius, qui ue nous paroissent pas, pour la plupart, appartenir à ce geure. Ainsi le Trichins Bonplandi. pag. $196.11^{\circ}$. 276. est la femelle de notre lnca serricole. Voy. pitg. 38 i. de ce volume. (S. F. et A. SЕнт.)

'TRICHIOSOME, Trichiosoma. LÉAc日. Gente d'Hyménoptères proposé par cet autcur dans le Zool. Miscell. vol. 3. 1817 , dépendant de la tribu des Teuthrédiuètes. Lat. (Tenthredinidea.LÉcr.) Il lui donne pour caractères : cinq articles aux antennes avant la massue; celle-ci presque solide, composée de trois articles. Corps velu. Premier segment de l'abdomen, surtout dans les mâles, peu échancré ; les qualre cuisses postérieures dentées; celles des mâles épaisses.

Les principaux caractères de ce genre sont tirés du nombre et de la conformation des articles antennaires; il est très - diflicile de distinguer lo nombre de ceux qui composent la massue, ce qui esı cause que ce genre supporte peu l'examen. Son nom vient de deux mots grecs qui signifient: corps velu. Il n'a pas été adopté par M. Latreille, et rentre aussi pour nous dans celui de Cimbex.

(S. F. et A. Serv.)

TRICHOCÉRE, Trichocera. MEIG. MAcQ. LAT. (Fam. natur.) Tipula. Linn. De GÉER. Fab. Schranck. Geofe.

Genre d'insectes de l'ordre des Diptères, première section, famılle des Némocères, tribu des Tipulaires (division des Terricoles).

Un groupe de cette division a ponr caractères: antennes de dix articles au plus, grĉles ou capillaires, sinuplement velues ou pubescentes; leurs poils ne formant pas sensiblement de verticilles. Dernier article des palpes guère plus long que les autres, point noueux; corps ailé; ailes le plus souvent couchées sur le corps. Ce groupe coutient cinq genres : Mrkistocère, Dixa, Némalocère, Anisomère et 'Trichocère. Les trois premiers sont distincts de ce dernier par leurs palpes n'ayant que quatre articles; de plus, dans les Mrkistocères, les articles des palpes sout presqu'égaux; les antennes ont tous leurs articles distincts, leurs ailes sont écartées, mêtne dans le repos. Le prothorax des Dixas n'est pas visiblement séparé du 
reste du corselet. Enfin les Nématocćres ainsi que les Anisomères n'ont que six articles aux antennes.

Antennes avancées, sátacées, aussi longues que la tête et le corselet pris ensemble, composées de plus de huit articles, les derniers indistincts; les deux premiers plus épais que les autres; le basilaire cylindrique, le second cyathiforme, lessuivans oblongs; les derniers pubescers, devenant de plus en plus grêles et ne pouvant plus se distinguer. Trompe un peu saillante. - Palpes saillans, courbés, cylindriques, velus, composés de cinq articles; les premier, quatrième et cinquième un peu plus courts que les autres.-Téte petite, conique, alongée autérieurement en un bec court, obtus en dessus; front tuberculé. - Corps grểle. - Corselet ovale, ayant une ligne transversale enfoncée qui sépare le prothorax du reste du corselet. Ailos proportionnellernent grandes, arrondies à l'extrémité, couchées parallèlemeni sur le corps dans le repos. - Balanciers découverts. - Abdomen délié, composé de buit segmens, un peu dépriué ; anus obtus dans les màles, pointu dans les femelles. - Pattes longues, grêles.

Le nom de ces Diptères vient de deux mots grecs qui expriment la villosité des antennes. Leur séjour et leurs habitudes pendant les premiers états de leur vie ne sont pas connus. Les espèces sont peu nombrenses, mais les individus de chacune d'elles, de petite taille en général, se rencontrent ordinairement en grande quantité à la fois; ils volent par nuées en automne et au printemps, et nêtme dans l'biver, lorsque la température est douce. C'est dans les endroits humides qu'on les rencontre, et il est assez probable que lears larves vivent dans le terreau végétal un peı détrempé. Nous citerons les espèces suivantes :

${ }^{\circ}{ }^{\circ}$ ' ''richosère brune, T. fiscata. Mrig. Dipt. $d^{\circ}$ Eur. tom. 1. pag. 212. no. 1. $2^{\circ}$. 'Trichocère d'biver, T' hiemalis. Merg. id. pag. $253 . n^{\circ} .2$. - MAcQ. Tipul. du nord de la France, pag. 62. $n^{\circ} .1 .5^{\circ}$. Trichocère petite, T. parva. MEIG. $i d$. $n^{\circ}$. 3. - M AcQ. id. $n^{\circ}$.2. $4^{\circ}$. 'Trichocère précoce, T. regelationis. MeIG. id. pag. 214 . $n^{\circ}$. 4. tab. 7 . fig. 9. Femelle. - MAcQ. id. no. 5. 50. Trichocere tachetée, $T$. naculipennis. Meig. $n^{\circ} .5$. D'Autriche. 6. Trichocère annelée, T. annulata. MEIG. id. pag. 215. $n^{\circ}$. 6. Mêne patrie que la précédente. (S. F. et A. Serv.)

TRICHODACTYLE, Trichodexctylus. Genre de Crustacés décapodes, de la tribu des Quadrilatères, famille des Brachyures, et qui se distingue des autres genres de la même tribu par les caractères suivans: quatrième article des pieds - mâchoires extérieurs inséré an sommet interne du précédent; celui-ci en forme de triangle alongé, arqué extérieurement et comme terminé en maDière de crochet à son extrémité supérieure in-

Hist. Nat. Ins. Tome $X$. terne. Test carré. Yeux silués d̀ ses angles antérieurs. Antennes latérales insérées au canthus inlerue de lenrs cavités. Tarses, le bord excepté, couverts d'un duvet serré.

J'ai forı́é ce genre sur une seule espèce (fuviatilis) apportée du Brésil, où elle fréquente les eaux douces, par feu de Lalande, et que j'avois d'abord rangée (Galeries du Musém d'histoire natnrelle), mais avec doute, parmi les Telphuses. Test long long de vingt-trois millimètres sur vingt-cing de large, presque carré, presque plane, rebordé, pointillé, égal, lavé d'un rouge purpurin, particulièrement en devant, avec quelques petites taches blanchâtres; chaperon un peu incliné, avec le bord antérieur arrondi, foiblement échàncré au milieu; deux pelites pinces de charque.côté, à quelque distance des yeux, avec deux dents trc̀spetites ct peu saillantes. Yeux petits, très-écartés. Serres unies, avec une deni pointue au côté interue du corps; pinces ovalaires, avec les doigts ou mordans pointus, armés intérieurement d'environ six dents obtuses el blanchâtres; serre droite un peu plus forte, avec les dents plus grandes; son pouce rougeâtre; doigts de l'antre main noirâtres en dêhor's; les autres pattes unies, un peu comprimées, sans dentelures ni épines; tarses coniques, assez longs, entièrement garnis, à l'exception de la pointe, d'un feutre ou duvet serré noirâtre; pattes de la quatrième paire et de la troisième un peu plus longues. Post-abdomen de sept segmens ; celui du mâle triangulaire; celui de la fernelle en forme d'un yrand ovale, tronqué à sa naissance, avec les denx premiers segmens plus étroits.

Près de ce genre vient se placer celui de Múniz, Melia, indiqué dans mon ouvrage sur les Familles naturelles du Règne animal, et que j’ai établi sur une espèce représentée planche 305 , fig. 2 , de l'Atlas d'histoire naturelle de l'E:ıcyclopédie mélliodique, sons le nom de Grapsus tesselatus.

Les Mélies on t pareillement un test presque carré, et dont les angles antérieurs sont occupés par les y'eux. Le qualrième article des pieds-máchoires extérieurs est aussi inséré au sommel interne du précédent; inais celui-ci est presque carré. Les tarses sont garnis de franges de poils, et sans épines ni dentelures. Les antennes latérales sont d'ailleurs insérées, ainsi que dans les Trichodactyles, au canthus intorne des cavités oculaires.

\section{Méur damier, M. tesselata.}

Grapsus tesselatus. L.AT. Encycl. méthod. hist. natur. pl. 3o5. fig. 2. - Telphusa? Tesselata. ejud. Galeries du Musém d'hist. natur.

Corps presque carré, long d'un centimètre, généralement uni, déprimé, d'un jaunâtre pâle, avec des lignes d'nn rouge vif sur le dessus da test et sur celui des pattes; celles du test formant 


\section{6}

T R I

des polygones ou une sorte de damier; quelquesunes des aréoles lavées de rougeâtre; les lignes des pattes transverses; une autre de celte couleur à la base des pédicules oculaires. Cavités de ces pédicules ovales, assez grandes ; leur bord supérieur entier ou sans feutre. Yeux un peu réniformes. Chaperon avancé, un peu transversal, distingué de clraque côté de l'angle interne des fossettes oculaires par une échancrure formant un angle divisé en deux lobes égaux; coupés carrément. Test un peu plus élevé et présentant l'apparence d'une carc̀ne transverse derrière le chaperon; deux petites dents aiguës à ses bords latéraux, l'nne formée par l'angle antérieur, et l'autre postérieure; un petit pli transverse se rendant à celleci ; un autre pli, pareillement transverse, un peu arqué, à cốlé de celui-ci; quelques-uns seulement à la partie postérieure du test; zailieu du dos sans impressions distinctes. Les trois premiers articles des antennes latćrales cylindriques; le second et le troisième petits, égaux. Le troisième des piedsmâchoires extérieurs presque carré, un peu anguleux à sa base, avec l'angle supérieur du cóté externe obtus ou arrondi; le dernier article long et cilié. Les serres, dans les deux sexes, plus courtes et plus menues que les autres pattes, égales, presque cylindriques, de la même grosseur, unies; quelques dentelures sur le dessons des bras; carpe presqu'aussi long que la pince, obconique; le poing cylindrique, comprimé; doigts un pen plus longs que lui, coniques, comprimés, pointus, sans dents apparenles, et garnis de poils; les autres pattes un peu moins grêles, de la même forme, un peu velnes, assez longues, et généralement anies, avec les tarses courts, coniques, comprimés, sans stries distinctes, terminés brusquement en une pointe écailleuse un peu arquée; une fiange de poils sur leurs tranches, particulic̀rement sur l'inférieure; la quatrième paire de paltes, la troisième et la cinquiène ensuite, les plus longues de toutes; les devix dernières paires presqu'égales. Abdomen de fa femelle en forme d'ovale alongé, tronqué à sa base, velu sur ses bords, de sept segmens; les deux premiers plus courts que les trois suivans, mais de la inême largeur et pareillement transversaux; le sixième un peu plus large et un peu plus long; le dernier presque triangulaire. Abdomen du mâle en triangle alongé, à en juger par les premiers segmens, les seuls quirestent dans l'individu que j’ai observé; les deux premiers plus courts et transversaux; le premier échancré ou concave au bord postérieur; le troisième beaucoup plus grand, en forme de triangle alongé, tronqué an bout, avec quatre soies ou crins disposées en carré.

Ce joli Crustacé a été observé par M. Mathieu sur les côtes de l'Ile-de-France. L'extrémité des pinces m'a offert, dans tous les individus que j'ai vus, une matière visqueuse et formant une petite palette, dont j'ignore l'origine et l'usage.

\section{T R I}

Je rapporterai au même genre et sous le nom spécifique de QuadaIDENTEE, quadridentata, un autre Crustacé faisant partie de la collection du Jardin du Roi, où il est placé dubitativement a vec les 'Telphuses, et dont la patrie m'est inconnue. Pédicules oculaires petits, teiminés en manière de tête. Test long de vingt-trois millimètres sur trente de largear, d'un jaune pâle, sans taches, finement chagriné, avec une ligne enfoncée et fourchue derrière le chaperon; impressions dorsales ordinaires, très-superficielles, très - arquées, commençant à peu de distance des cavités oculaires, et beaucoup plus écartées l'une de l'autre en ce point qu'à l'antre bout ; chaperon transversal, a vecle bord an térieur droit, un peu rebordé, échancré angulairement dans son milieu, et divisé ainsi en deux lobes presque carrés et lransversaux; extrémités latérales du bord antérieur du test comme tronquées obliquement; leur angle postérieur ou latéral formant une dent déprimée et un peu obtuse; nne autre dent, pareilletmeut obtuse, mais plus étroite et conique, au bord latéral, derrière la précédente et à peu de distance d'elle. Premier article des antennes latérale plus grand, en carré long, avec les angles supérieurs un peu dilatés; grandeur des articles suivans diminuant progressivement; les derniers manquent. Serres grandes, épaisses, avec les bras, le dessus du carpe et la face extérieure des pinces cliagrinés; une dent élevée et conique près de l'extrémité de la tranche supérieure des bras; une autre forte et obtuse au côté interne du carpe; pinces en forme de triangle alongé; deux rides courles, convergentes et formées par des aspérités à sa naissance, en devant et inférieures; un sillon longitudinal un peu au-dessous de sa tranche supérienre; doigls de la longueur environ du poing, droits, coniques, comprimés, pointus; bord inférieur de l'iudex rebordé extérieurement; des points enfoncés. et dont plusienrs disposés en séries longitudivales sur le côté extérieur du ponce de celui de la serre gauche particulièrement; cette serre plus petite; bord interne de ses doigts offrant cinq dents yui s'engrainent; les deux du bont petites et aiguës, les autres larges, plus hautes, transversales et obtuses; d'autres dents, mais plus obtuses, lobiformes ou molaires, au unême bord des doigts de la serre droite; son pouce offrant à sa base une dent plus forte, presque cylindrique, obluse, tournée en arrière ou du côté dn corps. Les autres pattes grêles, assez longues, comprimées, généralement unies, sans dentelures, a vec les tarses grêles, striés, droits, comprimés, allant insensiblement en pointe, bordés de poils sur leur face postérieure; stries garnies de duvet; la quatrième paire de pattes et la troisième a près les plus longues de toutes. Abdomen de la femelle en triangle alongé, de sept segmens transversaux : les piemiers linéaires, le second plus court que les adjacens. (LAT.) 
TRICHODE, Trichodes. Her bst. Fab. Ce genre répond éxactement à celui de Clairon, Clenus Lat. Ce dernier auteur lui a conservé le nom imposé par Geolfroy.

Le genre Clairon de ee Dictionnaire doit être rétormé ainsi qu'il suit : les espèces nos. 12.-19. appartiennent senles à ce senre dansson état actuel. Les n'•. 8, 9, 20. sont des Opiles. (Voyez ce mot.) Les nos. 24, 25, 26. des Nécrobies. (Voyez ce mot.) Le no. I1. est un Tille. (Voy. ce mot.) Les nos. $1,2,3,4,5,6,7$, ro. appartiennent au genre Thanasime. (Voy. ce mot.) Celui de Dasyte revendique le $n^{\circ} .23$. Nous soupçonnous que les nos. 21. et 22. sont des Orsodacnes. (S. F. et A. SERV.)

TRICHOPTÈRE, Trichoptera. M. Meigen, dans son premier ouvrage intitulé : Classific. des Dipt. avoit donné ce nom au genre Psychode Lat. Dans ses Dipt. d'Eur. il adopte ce dernier nom. Voyez Psremode. (S. F. et A. Serv.)

TRICONDYLE, Tricondyla. LAт. (Iconogr. et Fam. natur.) DEs. (Spéc.) Cicindela. Ourv. Collyris. Scroen.

Genre d'insectes de l'ordre des Coléoptères, section des Pentamères, famille des Carnassiers (Terrestres), tribu des Cicindélètes.

Dans le groupe de Cicindélètes qui a pour caractères : point de dent au milieu de l'échancrure da menton, les Thérates se distinguent des Tricondyles par leur corps ailé, ni étroit ni alongé; par le corselet court, presqu'en forme de cairr, et encore par les troisième et quatrième articles des tarses beaucoup plus courts que les premiers. Les Colliures qui, avec les 'Tricondyles complètent ce groupe, diffèrent de celles-ci par leur corselet conico-cylindrique, aminci vers la partie antérieure.

Antennes de longneur moyenne, filiformes, composées de onze arlicles. - Mrandibules fortes, dentées. - Mâchoires terminées par une poinle articulée a vec leur 'extrémité supérieure. - Palpes peu saillans; les labiaux composés de quatre articles distincts, le premier libre, l'avant-dernier dilaté. - Languette très-petite, cachée par lo menton. - Menton dépourva de dent au milieu de son échancrure. - Téte longue. - Yeux grands, globuleux, très-proéminens, un peu recouverts en dessus par un avancement demi-circulaire. - Corps long, étroit, bombé. - Corselet en sphéroïde oblong, terminé en avant et ell arrière par une partie évasée qui est séparée du milieu du corselet par un étranglement - Elytres longues, bombées, rétrécies à leur base, allant, jusque passé leur nilieu, en s'élargissant insensiblement, enveloppant les côtés de l'abdomeu. - Point d'ailes. - Abdomen long, son avantdernier segment assez fortement échancré en dessous dans les mâles. - Paties très-longues, jambes minces; tarses à articles presqu'égaux; les antérieurs ayant leurs trois premiers articles dilatés dans les uiâles, le troisième (dans les deux sexes) prolongé obliquement en dedans, le quatrième un peu échancré; sa partie antérieure peu prolongée.

On ne connoît que deux espèces de ce genre : elles habitent les Indes orientales et l'Australasie.

\section{Tricondye aptère, T. aptera.}

Tricondyla aptera. LAт. Hist. nat. et Iconogr. des Ins. Coléopt. d'Eur. pag. 65. pl. 11. fig. 6. - DeJ. Spéc. tom. 2. pag. $458.77^{\circ} .2 .-$ Collyris aptera. Schen. Syn. Ins. tom, 1. pag. 236. $n^{\circ} \cdot 4$.

Voyez pour la description et la synonymie, Cicindèle aptère $n^{\circ} .1$. dn présent Didiounaire. Elle habite la Nouvelle-Guinée et la NouvelleHollande, et se tient sur les troncs d'arbre où, suivant M. le comle Dejean, elle marche trèslentement.

\section{Tricondye blene, T. cyanea.}

Tricondyla cyanea. DEs. Spéc. tom. 1. pag. 161 .

Longueur 8 lig. $\frac{1}{2}$. Bleue; élytres profondément ponctuées, un peu rugueuses à leur partie antérieure, relevées en bosse vers le milicu; cuisses ferrugineuses. De Java.

Colliure, Colliuris. Lat. Dej. (Spéc.) Coblyris. Fab. Schen. Cicindela. Oliv.

Genre d'insectes de l'ordre des Coléoptères, section des Pentamères, famille des Carnassiers ('Terrestres), tribu des Cicindélètes.

La seconde division de cetle tribn est ainsi caractérisée : point de dent au milien de l'échancrure du menton. Les genres Thérate, Tricondyle et Colliure la composent. (Voyez CicindéIÉxes, pag. 6i7. de ce volume.) Les 'Thérates ont les troisième et quatrième arlicles des tarses beancoup plus courts que les premiers; le corselet court, presqu'en forme de cœur, et les antennes longues. Ies Tricondyles sont aptères, lenr corselet est en sphéroide oblong; les antennes sont proportionuellement plus longnes que celles des Colliures.

Antennes courtes, grossissant quelquefois un peu vers le bout, composées de onze articles, le troisième long, comprimé, courbé. - Labre arrondi, convexe, dentelé antérieurement. - Mandibules dentEes. - Mâchoires terminées par nne pointe articulée avec leur extrémité supérieure. Palpes peu saillans; les labiaux composés de quatre articles; le premier dilaté presqu'en triangle avec une dent à son extrémité intérieure; le second très-court , à peine visible; le troisième plus ou moins dilaté et aplati, on tout au moins courbé; le deruier sécuriforme, surtout dans les mâles. - 
Menton déponrvu de dent au milien de son échancrure. - Tête assez grosse, arrondie, très-rétrécie postérieurement, tenant au corselet pal un col conrt et beaucoup plus étroit qu'elle. - Yeux saillans.-Corps étroit, alongé.-Corselet conicocylindrique, aminci vers sa partie antérieure, tèrminé à ses deux extrémités par un bourrelet séparé du milieu du corselet par un érranglement. Ecusson presqu'entièrement caché par le corselet, sa pointe n'atteignant pas la base des élytres. Elytres alongées, s'élaryissant presqu'insensiblement jusque près de l'extrémité, paroissant recouvrir des ailes et couvrant l'abdomen. - Avantdernier segment de l'abdonnen des mâles très-légèrement échancré en dessous. - Pattes longues, déliées; tarses à articles presqu'égaux; quatrième article de tous les tarses, dans les deux sexes, prolongé obliquement en dedans.

On ignore les mœurs de ces Coléoptères. Ils habitent les parties les plus méridionales do l'Asie et les íles au nord de la Nouvelle-Hollande.

\section{Colliure échancrée, C. emarginata.}

Colliuris emarginata. Lat. Hist. nat. et iconogr. des Ins. Coléopt. d'Eur. pag. 66. - DeJ. Spéc. tom. I. pag. $165 . n^{\circ}$. 2. - Colliuris longicollis Lat. Gener. Crust. et Ins. tom. I. pag. 174. $n^{\circ}$. I. tab. VT. fig. 8. (en retrancliant le synonyme de Fabricius qui appartient à la Longicolle.)

Voyez pour la description et le synonyme de l'Entomologie d'Olivier, Cicindèle longicolle $n^{\circ}$. 2. $p l$. 356. fgo. 6. de ce Diclionnaire (en ôtant le synonyme de Fabricius qui appartient à la Longicolle.)

Nota. Fabricius (Syst. Eleut.) paroît mentionner cette espèce comme variété de sa Longicollis.

Ce genre contient en outre, $1^{\circ}$. Colliure longicolle, C. longicollis. LAT. Hist. nat. et iconogr. des Ins. Coléopt. d'Eur. pag, 67. no. 2. pl. II. fg. 3. - Des. Spéc. tom. 1. pag. 163. no.1. Colly ris longicollis $n^{\circ}$. I. FAB. Sy'st. Elent. (en retranchant les synonymes d'Olivier et de Latreille qui appartiennent à la Colliure échancrée). Longueur 8 à 9 lig. Nolablement plus grande que la C. écliancrée; pénultième article des palpes labiaux triangulaire (ce même article est assez étroit et presque lunulé dans la C. échancrée). Des Indes orientales. $2^{\circ}$. Colliure de Diard, $C$. Diandi. LAt. Hist. nat. et iconogr. des Ins. Coléopt. d'Eur. pag. 67. Elle diffère de la C. échancrée par les caractères suivans : tête et corselet d'un cuivreux foncé; élytres bronzées, leur extrémité postérieure presque lisse, simplement tronquée. De lî́le de Java, d'où elle a été rapportée par MM. Diard et Duvaucel. 3०. Colliure grande, $C$. major. LAT. id. pag. 66. $n^{\circ}$. I. pl. i1.fig. 4 . Longueur I I à 12 lig. - Collyris aptera no. 2. I AB. Syst. Eleut. - Scran. Syn. Ins. tom. 3. pag. $236 . n^{\circ} .2$. Des Indes orientales. $4^{\circ}$. Colliure crassicorne, C. crassicornis. Dej. Spéc. tom. I. pag. 166. $n^{\circ}$. 3. - Colliuris longicollis. DEs. Catal. Longueur 6 . lig. $\frac{1}{2}$ à 7 lig. Bleue; élytres profondément ponctuées, arrondies à leur extrémité qui eft uı peu échancrée; cuisses ferrugineuses; antennes de la longueur de la tête, allant un peu en grossissant vers l'extrémité. Des Indes orientales.

Nota. Le genre Colliure de ce Diclionnaire n'est pas celui-ci; il répond exactement au genre Casnonie Lat. Voyez ce dernier mot à la suile de l'article 'Troncatipennes. Fabricius (Syst. Eleut.) compose son genre Collyris de trois espèces; nous venons de citer les deux premières. La troisième est un Cténostome. Voyez ce mot pag. 620. de ce volume. (S. F. et A. SERV.)

TRIDACTYIE, Tridactylus. Our. (Encycl. Tabl. des genr.) Lat. Xya Inlig. Acheta Coqué.

Genre d'insectes de l'ordre des Orthoptères, seconde section, famille des Grilloniens.

Cette famille contient quatre genres, Courtillière, 'Tridactyle, Grillon, Myrmécophile. (Voy. pag. 343. de ce volume.) Ce dernier nous es! inconau, et par cette raison nous ne pouvons le faire entrer dans la comparaison suivante. Les. Courtillières \& les Grillons diffèrent des Tridactyles en ce qu'ils ont tous les tarses organisés de la manière ordinaire, c'est-à-dire composés d'articles implantés à la suite les uns des autres.

Antennes assez courtes, composées de dix à douze articles distincts, presque moniliformes. Mrâchoires terminées par une pièce cornée, dentée; celle-ci recouverte par une autre pièce voûtée, de consistance membraneuse. - Lèvir quadrifide. - Tiois ocelles peu apparens. Corps un peu cylindrique. - Corselet aussi large que long. - Elytres et ailes horizontales. - $A b$ domen terminé par quatre appendices. - Point de tarière (dans les femelles.) - Pattes antériezures propres à fouir; leurs jambes munies d'épines à leur extrémité seulement; leurs tarses de trois articles insérés à l'exirémité de la jambe et susceptibles d'êlre reçus dans un sillon qui se trouve à la partie postérieure de la jambe; jambes intermédiaires comprimées, presqu'ovales, se rétrécissant vers l'extrémité; leurs tarses conformés comme les antérieurs : cuisses postérieures forles, propres à sauter, leurs jambes alongées, grêles, quadrangulaires; leur côté supérieur un peil échancré, dentelé, dilaté vers l'extrémité qui est couverte de quelques lames écaillenses très-serrées contre la jambe, leur extrémité portant au lieu de tarses, deux ou cinq appendices mobiles.

Les espèces connues de ce genre se trouvent sur le sable du bord des rivières; elles y creusent des trous au moyen de leurs pattes antérieures, de même que les Grillons et les Courtillières; elles 
sautent beaucoup mieux que ceux-ci \& même très-haut, du moins l'espèce indigène, qui a été observée par M. L. Dufour.

Ire. Division. Jambes postérieures terminées, à défaut de tarses, par cinq appendices; deux plus courts, extérieurs, les trois inlermédiaires plus longs, comprimés, un pen ciliés et dentelés en mauière de peigne à leul partie supérieure. (Tridactylus propriè dictus.)

Le Tridactyle paradoxal, T. paradoxus. LAT. Gener. Crust. et Ins. tom. 3. pag. 97. $n^{\circ}$. т. Acheta digitata. Coqu вв. Illustr. iconogr. Decad. 3. pag. 98. tab. XXI. fig. I. - Encycl. pl. 397. Orthopt. fig. 1-4. De Guinée, est le type de certe division.

$2^{\circ}$. Division. Jambes postérieures terminées, à défaut de tarses, par deux appendices. (Xya. ILLIG.)

\section{Tridactrle varié, T. variegatus.}

Tridactylus fufco-grifeus, thoracis ely'troruinque margine externo et scutello lineâ dorsali longztudinali albidis; pedibus albido variis; tarsis posticis didactylis.

Xya variegata. ILLIG. LAт. Règn. animal. tom. 3. pag. 378 .

Longueur a lig. D'un gris-brun. Bords extérieurs du corselet et des élytres blanchâtres; écusson ayant une ligne longitudinale dorsale de cette couleur; pattes panachées \& annelées de blanc. Du midi de la France.

COURTILLIĖRE, Gryllotalpa. LAт. Gryllus (Acheta) Linn. De Géer. Panz. Gryllus. Geoff. Oniv. (Encycl.) Acheta. FAB.

Genre d'insectes de l'ordre des Orthoptères, seconde section, famille des Grilloniens.

Dans celte famille, les Tridactyles se dislinguent par leurs tarses postérieurs remplacés par des appendices digitiformes; dans les Grillons proprement dits, les jambes antérieures n'ont pas de dilatation, les antennes sont plus longues que le corps et la tarière des femeiles est très-saillante.

Antennes sétacées, pas plus longues que la tête et le corselet pris ensemble, coinposées d'un grand nombre d'articles. - Labre arrondi à son extrémité, entier. - Mandibules multidentées. - Mâchoires ayant à leur extrémité une forte dent. - Dernier article des palpes obconique, pas plus long que le précédent. - Lèvre quadrifide. Tête ovale, prolongée en avant. - Deux ocelles très-distincts, le troisième point apparent. Corps'alongé, cylindrique, linéaire. - Corselet plus long que large, presqu'ovale, tronqué antérieurement, arrondi à sa partie postérieure. Elytres courtes, s'appliquant sur le dos et s'y modelant; ailes plus longues que le corps, formant dans le repos, une espèce de lanière prolongée au-delà des élytres; la partie supérieure de cette lanière dure, presque cornée. - Abdomen terminé par deux appendices; anus des femelles dépourvu de tarière. - Pattes antérieures ayant leurs cuisses munies en dessons vers la base, d'un appendice dentiforme; ces cuisses canaliculées pour recevoir le côté interne des jambes; celles-ci palmées, courtes, obtrigones, garnies à leur extrémité de dents verticales furtes, striées; tarses de ces pattes, insérés extérieurement et appliqués contre la jambe; leurs deux premiers articles dilatés en dessous chacun en une très-forte dent; jambes postérieures courtes, épineuses à l'extrémité; leurs tarses de forme ordinaire; dernier article muni de deux crochets.

Les mœurs de ces insectessont décrites à l'article Grixion (voyez ce mot), genre avec lequel on confoudoit autrefois celui-ci.

\section{Courtillière vulgaire, G. vulgaris.}

Gryllotalpa vulgaris. Lat. Gener. Crust. et Ins. tom. 3. pag. 95. no. I. - Acheta gryllotalpa. Fab. Fint. Syst. tom. 2. pag. 28. - PANZ. Faun. gem. fas. 88. fig. 5.

Voyez pour la description et les autres synonymes, Grillon Taupe no. 1. pl. 128. fig. $3-15$. de ce Dictionnaire.

Nota. A la fin de la description que nons venons de citer, il est question d'une espèce de Cayenne, beancoup plus petite que celle d'Europe et n'ayant que deux dents aux jambes antérieures; c'est la Courtillière didactyle, $G$. didactyla. Lat. id. $n^{\circ}$. 2. Ce dernier auteur mentionne quelques autres espèces des Indes et d'Afrique, qui diffèrent principalement de la Courtillière vulgaire par la réticulation des élytres.

$$
\text { (S. F. et A. Serv.) }
$$

TRIDACTYLES ou TRIMÉRES. Vingtdeuxième famille des Coléoptères selon M. IOuméril ( Zool. analytique). Ses caractères sont : tarses composés de trois articles. Elle contient les genres Dasycère, Eumorphe, Endomyque, Scy inne et Coccinelle. (S F. et A. Serv.)

TRIGONE, Trigona. JUR. LAT. Melipona. LAT. Truig. Krug. Apis Ohiv. (Encycl.) Faв. Centris? FAB.

Genre d'insectes de l'ordre des Hyménoptères, section des Porte-aiguillon, fanil!e des Mellifères, tribu des Apiaires (division des Récoltantes).

Une coupe particulière de cette division a pour caractères : femelles pourvues d'une palette à la dernière paire de jambes; pattes posterieures sans épines à leur extrémité; cellule radiale des ailes supérieures ouverte; cellules cubitales mal tracées. 
Elle ne comprend que le genre Trigone. (Voyez pag. 5. de ce volume.)

Antennes filiformes, coudées, composées de douze articles dans les femelles, de treize dans les mâles. - Labre transversal. - Mandibules lisses à leur partie extérieure, excavées en dessous, comme tronquées à leur extrćmité, sans dentelures au côté interne on n'cn ayant que de trèsfines. - Mlâchoires et lèvre très.alongées, formant une sorte de trompe coudée et repliée en dessous dans le repos, appliqnée contre sa gaine. Palpes maxillaires filiformes, composés de six articles; palpes labianx de quatre articles, les deux premiers ressemblant à des soics écailleuses et embrassant les côtés de la languette; les deux autres très-petits; le troisic̀me inséré un peu audessous de l'extrémité du second qui se termine en pointe. - Tête assez grosse, transversale. - Yeu. $x$ assez grands. - Trois ocelies disposés presqu'cn ligne transversale. - Corps pubescent. - Corselet convexe, presquc sphérique. - Ailes supérieures ay ant une cellule radiale grande, inconplète, c'està-dire ouverte à son extrémité; trois cellules $\mathrm{cu-}$ bitalcs mal tracées, souvent difliciles à distinguer; La première petite; la scconde trìs-resserrée vers la radiale, presque triangulairc; la troisième trčsgrande, n'atteiguant pas' le bout de l'aile; une seule nervure récurrente, aboutissant dans la seconde cellule cubitale : cellules discoildales peu distinctes, la troisième ou inféricure, paroissant manquer en totalité. - Abdomen le plus souvent triangulaire, sa section transversalc représentant un triangle curviligne dont la partie supérieure forme le côté le plus grand, ou quadrangulaire; cette même partie formant les deux côtés les plus pelits du carré dans la scction transversale, composé de cinq segmens ou tre l'anus dans lcs femelles, ea ayant un de plus dans les mailes. - Pattes assez fortes; jambes intermédiaires terminées par une épine simple., courte, aiguë : jambes posstérieures sans épines à lcur extrémité; partie intćrieure du premier article de lcurs tarses garnie de brosse, sa partie externe ainsi que celle des jambes portant unc palette; dernier article de tous les tarses muni de deux crochets simples.

Les 'Trigones doivent à la forme la plus ordinaire, de leur abdomen leur nom tiré de deux mots grecs signifiant, triangle. Elles habilent les climats les plus chauds et presqu'exclusivement l'Amérique. D'après les relations de différens voyageurs, il est certain qu'elles vivent en société et fabriquent de la circ et du miel; ceiui-ci est mangeable et les habitans le réroltent pour leur usage. On assure que ces sociétés durent plusieurs années, comme celles des Abeillcs; inais les espc̀ces de Trigones ne sont pas suffisamment connues, et il est probable que jusqu'ici il n'existe dans les collections d'Europe aucune femelle féconde. Dans près de quaranle espèces que nous ayons décrites dans une Monographie des Apiaires encore inédite, nous n'avons trouvé qu'un seul mâle sans pouvoir le rapporter à aucune ouvrière connue; cela prouve qu'il faudroit aux Trigon:'s des historiens, tels que Réaumur ou Hüber de Genève, pour les étudier de près, et aujourd'lıui qu'il se trouve en Amérique beaucoup d'entomologistes distingués, on ne sauroit trop les engager d observer avee soin ces Hyménoptères intércssans; l'analogie d'organisation démontrée dans notre tableau des Mellifères cité ci-dessus, nous porte à croire que ces Apiaires sociales pourroient devenir domestiques à la manière des Abeilles, et que leur miel et leur cire seroient susceptibles d'entrer dans le commerce airsi que dans les usages privés. Voyez AbridLe amalihée $n^{\circ}$. 102. de ce Diclionnaire.

I re. Division. Abdomen convexe en dessus, peu sensiblement caréné en dessous. (Melipona Lat.)

Nous citerons, $1^{\circ}$. Trigone commune, T. fuvosa. Jur. Hyménopt. pag. 246. l'uuvričre. - Mélipona favosa. Lat. Gener. Crust. et Irs. tom. 4. pag. 182. l'ouvrière. - LAT. Mém. sur les Abeilles, pag. 3o. $n^{\circ}$. 1. - Apis favosa $n^{\circ} .11$. Fab. Syst. Piez. l'ouvrière. De Cayenne.

$2^{n}$, Division. Abdomen court, triangulaire, fortement caréné en dessỏus. (Trigona LAT.)

\section{Trigorn Amalibée, $T$. Anralthea.}

Trigona Amalthea. Jor. Hyménopt. pag. 246. l'ouvrière. - Lat. Gener. Crust. et Ins. tom. 4. pag. 183. l'ouvrière. - Apis Amalthea $n^{\circ} .8$. FAB. Syst. Piez. l'ouvrière.

Voyez pour la description (de l'ouvrière), Abeille Amalıtée $n^{\circ}$. 102. de ce Dictionnaire.

A cette division se rapporte encore la Trigone à jarobes rousses, T.ruficrus. Jur. id. l'ouvrière. Lat. id. l'ouvrière. Du Brésil.

3e. Division. Abdomen alongé, presque carré, le dessus formant un angle obtus (Tetragona Nов.)

Le type est la Trigone alongée, T. elongata. Le P. inéd. Antennes noires, leur partie antérieure d'un jaune testacé; tête noire; chaperon jaune ainsi que l'orbite intérieur des yeux et une tache sous les antennes; corselet noir à poils roux; abdomen alongé, brun, le bord inférieur de chaque segment est jaune; anus testacé, à poils roux; pattcs antérieures et intermédiaires testacées, leurs tarses noirs; pattes postérieures noires, à jambes alongées, testacées à la base; ailcs transparentes, nervures pâles. Ouvrière. Du Brésil.

Nota. La Trigone fluette, T. angrustata. Lat. Mém. sur les Abeilles, pag. 36. doit aussi appartenir à cette division d'après la forme de son abdomen. 
Plusieurs autres espèces de ce genre sont décrites dans le Mćmoire de M. Latreille que nous venons de ciler. ( $S$. F. et A. SERv.)

TRILOBFTES, Trilobites. Nom donné à un groupe d'animanx que l'on ne trouve plus qu'en élat fossile (1), dont le corps, de figure ovalaire, présente inmédiatement, à la suite d'une partie antérieure en forme de grande têle ou de bouclier serni-lunaire, un nombre plus ou moins considérable d'anueaux transverses, et qui, à raison de deux sillons partageant longitudinalement chacun d'eux en trois espaces, le dos et les flancs, le font paroître comme divisé en trois séries de lobes. Linné a distingué ces animaux par la dénomination commune d'entomolithus paradoxus. Ilnmenback, Knorr et Guettard en ont décril et figuré diverses espéces. Les travaux de MM. Cuvier et Brongniarl, ceux de plusieurs naluralistes anglais, ayant imprimé à l'étude de la géologie une forte impulsion et $y$ ne direction nonvelle, les Trilobites ont particulièrement fixé l'attention de plusieurs savans, et parmi les ouvrages ou les mémoires qui ont paru sur cet objet, on doil metire au premier rang la Monographie de l'un des géologues que je viens de citer, M. Alexandre Biongniart, membre de l'Académie royale des sciences, professeur de minéralogie au Jardin du Roi, et dirccleur de la manufacture royale de porcelaine de Sèvres (2). Nul doute que les Trilobites soient des animaux arliculés; mais, à quelle classe appartieunent-ils? c'est snr quoi il $y$ a eu partage d'opinions. D'après la plus commune cependant, et qui est celle de Linné, de Fabricins (3), les Trilobites seroient des Cruslacés. Dans le troisiènıe volume de l'ouvrage sur le Règne animal, par M. le baron Cuvier, $j$ 'avois dit que quelquesuns de ces corps paroissoient avoisiner les Limules, et que les autres sembloient se rapprocher des Gloméris, premier genre de l'ordre (aujourd'hni classe) des Myriapodes; j'ai rejeté depuis ( $M e ́-$ noires du Muséum d'histoire naturelle) ce sentiment, et jai avancé que ces animaux avoient plus de rapports avec les Oscabrions ou les Chitons de Linné, et qu'ils formoient auprès d'eux une famille particutière, mais dont nous ne possédons plus d'analogues vivans. L'un des caractères essentiels des Crustacés, ainsi que des autres

(1) Les premiers que l'on observa furent trouvés, il y a plus de cent ans, à Dudley, en Angleterre, et dans des couches calcaires profondes er considérables. Voyę̧ LuxD, Philos. trans., année 1698 .

(2) Nous citerons encore, d'après lui , M. Schlotheim, qui a le premier étudié ces animaux sous des points de vue nouveaux, et M. Wahlenberg, qui nous a tait connoîtrè ceux de la Suède. Depuis la publication de l'ouvrage de M. Brongniart, il en a paru encore d'autres, sant chez l'étranger qu'en France, sur les mêmes objets.

(3) Voyez le Cymothea paradoxa de son Entomologie sysćmatique, tom. 2 , pag. 503. animaux compris par Linné dans la classe des Insectes, est d'avoir des pieds articulés. Or, c'est un fait avéré que, quoique l'on ait recueilli en France, en Suède, dans l'Amérique septentrionale, etc., une quantité considérable de Trilobites, aucun de ces fossiles n'a offert de vestiges de pieds ni d'antenues. M. Bronguiart le déclare posilivement. * Enfin ni moi, ni aucun des observateurs qui ont étudié ces animaux, n'y ont jamais rien vu qui ait pu être comparé à des antennes ou à des pattes. n Hist. natur. des Trilobites. pag. 4. Persuadé, d'après cela et d'après quelquesautres considérations tirées de l'état où on les trouve, qu'ils étoient privés de ces organes, et qu'on ne pouvoil dès-lors ranger ces animaux avec les Crustacés, les Oscabrions me paroissoien têtre les seuls articulés avec lesquels on pût comparer les Trilobites, el déjà quelques naturalistes avoient eu la même idée. M. Victor Audouin, dans un Mémoire ad hoc, et faisant partie des Annales générales des sciences physiques, par MM. Bory de Saint-Vincent, Drapiez et Van Mons, combattit mon opinion, à laquelle, au reste, je n'ai donné aucune suite. D'autres zoologistes, $M$. de Blainville notamment, ont considéré comme des pattes branchiales, analogues à celles des Apus, des Branchipes, etc., leslobes latéraux; mais ces parties ne présentent pas la moindre articulation, et il est aisé de voir, surtout d'après la manière dont elles se terminent ( voyez l'/iist. nat. des Trilob. de M. Brongniart, $p l$. 1. fig. 2. D.; pl. 2. fig. 1. A., fig. 2. C. , fig. 4. C.; pl. 3. fig. 5, 6, 9.; et pl. 4. fig. 1. et fig. 10.), que ce sout de véritaLles divisions segmentaires du corps, analogues à celles que l'on observe sur les côlés du corps de divers Cymolloas, à celles que nous offiriroit le second bouclier des Limules, si les sillons étoient plus profonds et partageoient distinctement sa surface supérieure en trois séries de pièces, et comparables encore à ces petites plaques que l'on voit, au nombre de nenf, do chaque côté, sur.le dessous du corps des Gloméris. Les paltes des Bopyres sont extrêmemenl perites; et dans la supposition probable que les Tribobites fussent habituellement fixées sur divers corps, les organes de loco-motion pouvoient n'être que rudimentaires, et n'auront laissé aucune empreinte bien visible.

Les substances où on a trouvé des Limules fossiles ne présentent pas non plus de débris des mêmes parties. Malgré ce caractère négatif, tout porte à croire que les Trilobites sont de véritables Crustacés, ayant un bouclier antérieur essentiellement semblable à l'antérieur des Limules, dont le corps, par le nombre (I) des segmens, se rapproche de celui des Myriapodes et des Gloméris surtout, mais avec celte différence que les segmens

(r) De onze à vingt deux dans la plupart. 


\section{2}

sont divisés en trois lobes, dout les latéraux plus larges ou plus étendus transversalement, et dont le post-abdomen est formé, soit par un grand segment demi - circulaire (voyez Groméris) ou triangulaire, soit de plusieurs dont la grandeur dininue graduellement, el qui, par la réunion, composent, de même que dans plusieurs Crustacés amphipodes et isopodes, uue sorte de queue plus ou moins alongée et triangulaire. Quelguesunes de ces 'Trilobiles pouvoient se concentrer' en boule, à la manière de quelịues Crustacés précédens et des Gloméris, faculté dont aucun Branchiopode connu ne nous offie d'exemple. Il existe un grand vide entre les derniers Crustacés et les Myriapodes; peut - être, dans l'origine, ćtoit-il rempli par les Trilobites, qui, sous quelques rapports, auroient pu se rattacher aux Oscabrions.

Parmi les genres que M. Brongniart a établis dans ce groupe d'animaux, il en est un, celui d'Agnoste, dont les caractères, si l'on étoit sûr que les sujets qui les ont fournis ne sont pas mutilés, nécessiteroient une modification dans le signalement général. Le corps est demi-circulaire ou réniforme; quelques espèces d'Oscabrions seunblent offrir une exception pareille.

N'ayant poiut trailé ici des Crustacés fossiles, et ayant renvoyé nos lecteurs au bel ouvragc que M. Anselme Desmarest a publié sur cette matière, et accompagnant celui de MI. Brongniart sur les Trilobites, nous nous bornerons à un tableau synoptique des genres que celui-ci a proposés.

Ces aniouaux, en admettant par analogie une ou deux paires de pieds pour chaque segment thoracique, se rangent naturellement dans notre division des Crustacés rnullipèdes (Fam. nat. du Règne anim.), c'est-à-dire près des Brauchiopodes phyllopodes, qui sont immédiatement suivis des limules, conaposant nofre orüre des $\mathrm{Xy}-$ phosnres. Les caractères présentés plus haut les distinguent suffisamment des uns et des autres.

I. Corps ovale ou elliptique.

A. Corps de plusiegurs se contractant en boule; doux éminences oculiformes ou triangulaires et peu alongées sur le bouclier de la plupart. Segmens ne débordant point les côtés du corps et réunis jusqu'au boust.

Gente 1. CaLYMÈn, Calymene.

Corps se contractant en boule ( 1 , oblong et rétréci postérieurement en manière de quene triangulaire et alongée. (Bouclier aussi large ou plus large que long.)

Genre 2. Asapae, Asaphus. Colps ne se con-

(1) En employant ce caractère en première ligne, les Trilobites se diviseroicat en deux familles, les Contractiles et les Etendus. tractant point en boule, presqu'ovale, terminé postérieurement en manière de queue semi-circulaire. Bouclier aussi large ou plus large que long. Des tubercules oculiformes à paupières ou granuleux.

Genre 3. Ogrgie, Ogygia. Corps ne se contrnctaut point en boule, elliplique. Bouclier plus longr que large; ses ongles postérieurs prolongés en manière d'épines : deux caroncules oculiformes simples, on suns paupières ni grauulation.

B. Corps ne se contractant jamais en boule, sans éminences oculfformes sur le bouclier. Segmens, ou du moins ceux du thorax, débordant le corps, et libres ou séparés à leur extrémité lutérale.

\section{Gente 4. Paradoxtde, Paradoxides.}

\section{Corps demi-circulaire ou réniforme.}

\section{Genre 5. Agrostr, Agnostus. •}

Voyez, quant aux espèces, l'ouvrage précité de M. Brongniart et les nouvelles recherclies de MM. de Bazoches, Deslongchamps, membres de la Société Linnéeune du Calvados, et qui, de mếne que celles de plusieurs collègues, rendeut les services les plus importans à la géologie de ce département. (LATR.)

TRIMERES, Trimera. Qualrième section de l'ordie des Coléoplères. Son caractère est :

Tous les tarses n'offiant que trois arlicles. (S. F. et A. SERV.)

\section{'TRIMÉRÉS. Duméris. Voyez Tridactrezs.} (S. F. et A. SErv.)

TRINEURE, Trineura. Nom donné par M. Meigen dans son ouvrage intitulé : Classification des Dipt. a'Europ. au genre fondé par M. Latreille sous le now de Phore. Fabricius, dans son $S_{3}$ st. Antliat., adopte le genre Trineure, rnais le reduit à une seule espèce, celle que M. Meigen nomme Rufipes, et 11 . Latreille Phora pallipes. Voyez Yhore. (S. E. et A. Serv.)

TRIONGULIN, Triungulinus. Léỡ Dörorr. Pediculus. Linn. M. Léon Dufour vient d'établir ce grenre dans le treizième volune des Annales des sciences naturelles. Il appartient à l'ordre des Parasites de M. Latreille, et son auteur lui assigne les caractères suivans : corps alongé, déprimé, d'une même venue. Tête distinctc, portant des yenx et des palpes. Tronc formé de trois pièces égales, où s'articulent les pattes. Abdomen de la largeur du tronc, divisé en dix-segmens égaux. Antennes insérées en devant des yeux, composées de trois articles distincts, dont le dernier se termine par une soie simple, aussi longue qu'elles 


\section{T R I}

qu'elles. Deux palpes saillans, d'un seul article oblong et droit. Bouche inférieure, peu apparente. Yeux latéraux, arrondis. Six pattes à peu près égales entr'elles. Tarses formés par un seul article fort court, en quelque sorte rudimentaire, oi s'implante une griffe plus ou moins replicée ver's l'axe du corps, et composée de trois ongles ou crochets distincts, cornés, pointus, mobiles. Dernier segment de l'abdomeu terminé par deux longues soies simples, inarticulćes. Insectes vivans sur les Hyménoptères, velus, ayant une démarche assez agile.

Ce genre se distingue des autres genres du même ordre par plusieurs caractères très-faciles à saisir, et principalement par les trois crochets des tarses, par le filet inarticulé des antennes, et par ceux qui terminent le dernier serment de l'alidomen.

Le Pou de l'Abeille, décrit par Linné sous le nom de Pediculus apis, pourroit bien être la même chose que le Triongnlin. Ce l'ou a été figuré par Frisch, dans sa description des Iusectes d'Allemagne, \& sa figrure paroit avoir été copiée dans la planclie 253. de ce Dietionnaire; mais elle est si mauvaise qu'on ne peut savoir si elle a rapport au parasite qui fait le sujet de cet article, ou a une autre espèce; cepeudunt comme il est probable que c'est lui qu'elle représente, M. Léon Dufour lit ritpporte avec doute à sorl Triongulin des Andrenetes. Ce genre ne se compose encore que d'une seule espèce; M. Léon Dufour l'a trouvée ea juillet 1827 , sur l'Andrencb carbonaria de Fabricins. Il est probable que ce parasite se trouve sur d'autres Hyménoptčres et dans d'autres localités, \& cue l'ou pourra l'observer à laris si ou le cherche sur les Hyménoptères apiaires.

Triongun des andravètes. Triungulinus andienetarum. Léon Durour. Ann. des sc. natur. tom. 13. pag. 64. pl. 9. fig. 13. An Pediculus apis? Lins. Syft. nat. 2. 1020-40.

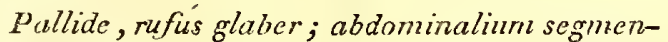
torum angulis posticis spinula terminatis; penultimo segmento spinula longiori setiformi werrusqque munito.

Cet insecte n'a pas tout à-fait une ligne de longneur; il est grêle, uniforménent étruit dans torte son étendue : ce qui justifie l'ćpilhète de fillformis donnée par linuæus a son pediculus apis. Tète arrondie, avec les yeux noirâtres bien maarqués. Antennes au moins aussi longrues que la tóte; le premier article fort court, le second oblong, légère ment renflć en dehors, le troisième r.ylindroide, aussi long que le prćcédent, mais plus grềle, et se terminant par une soie dont l'insertion est brusqne. Palpes insćrós, un de chaque côté, en dessons des tégumeus supóricurs de la

Hist. Nat. Ins, Tome $X$. tête, formés d'un seul article oblong, cylindroïde, pâle, glabre. Les trois pièces qui constituent le tronc sont à peu près earrées avec les angles obtus; chacune d'elles donne insertion à une paire de pattes: celles-ci sont de moyenne longueur, très-propres à la marche, égales ou presqu'égales entr'elles; les antérieures sont cependant un peu plus courtes. Hanche composée de deux articles courts, où le microscope découvre quelques poils. Cuisse plus grosse que la jambe, et légèrement cambrée. Tibia de la longueur de lá cuisse. Ongle intermédiaire de la griffe, plus long que les latéraux, et tcrminé ell pointe de lancelle. Ces ongles, susceptibles de divers mouvemens de délucliun et d'inflexion, servent au 'Triongulin pour s'accrocher avec force aux poils des Hyménoptères, dont il est parasite; il est moềne difficile de lui faire lâcher prise. Segmens de l'abdomen ayant la forme d'un carré longr Iransversal. Chäcun d'eux a ses angles postérieurs terminés par une très-petite pointe ou poil corné subulé, que le microscope met en évidence. Le pénultième de ces seymens a de chaque côté une véritable soie plus longue que le poil subulé des précédens, nais bien plus courte que celles qui s'observent au dernier segment : ces dernières égalent au moins l'abdomen en longueur.

Nota. Nous venons d'apprendre en corrigeant l'épreuve de cet article, que M. Carcel, entonılogiste instruit de la capitale, vient de déconvrir (juin 1828) le Triongulin aux environs de Paris. i. Lalreille nous assure en même temps, que cet insecte n'est pas nouveau, et qu'il est parfaitement dócrit et figuré par Kirhy et par d'autres auteurs. (E. G.)

triplax, Triplax. Hernst. Payx. Fab. Oliv. (Entom.) LaT. Tritoma. Lat. Fab. Oliv. (Encycl. 'Tableau des genres.) Silpha. Lins. Anthribus. 1)e GéER. Erotylus. Odiv. (Encycl.) Elater? l'Ab. PAL. BaUv.

Geure d'insectes de l'ordre des Coléoptères, section des 'létramères, famille des Clavipalpes.

Cetle farille a pour caractères:

Les trois premiers articles des tarses garnis de brosses en dessous; les deux intermédiaires larges, triangulaires, le troisième profondément divisé en deux lobes. - Mâchoires armées intérieurement d'une deut coruée. - Antennles terminées en tue massne plus ou moins ovalaire et perfoliée. - Corps le plus souvent orbiculaire ou ovale.

I. Dernier article des palpes maxillaires grand, transversal, en forme de croissant ou de hache.

$$
\text { Erotyle, 'Triplax. }
$$

Nota. Cette division répond à la tribu des Erotylènes. Lar. Nonw'au Dictionn. d'hist. natur. $2^{3}$. édition.

$\mathrm{X} \times \mathrm{x} \times$ 
II. Dernier article des palpes maxillaires à peine plus gros que le précédeut.

\section{Langurie, Phalacre.}

Nota. Cette seconde division répond à la tribu des Globulites. Lat. Nouv. Dictionu. d'/hist. nat. $2^{\mathrm{e}}$. édıt. Depuis, dans ses Fatn. natur., l'auteur a supprimé les deux tribus nommées Erotylènes et Globulites.

La première division de cette famille est composée des genres Erotyle et Triplax. L.e premier diffère du second par la massue des antennes ordinairement plus oblongue, par le lobe interne des mâtchoires corné, en forme d'onglet dont l'extrémité porte deux dents distinctes, inégales; le disque du corselet des Erotyles est très-souvent moins convexe que celui des Triplax, et les articles intermédiaires des antenıes sont habitucllement plus alongés que dans le genre dont nous traitons ici.

Antennes ayant leurs articles intermédiaires courts, presque moniliformes; les trois derniers formant une massue ovale, perfoliée, aplatie. Mâchoires coinposées de deux lobes, l'interne pelit, membraneux, portant une seule dent à son extrémilé; celle dent à peine visible. - Disque du corselet convexe. - Janbes s'élargissant vers leur extrémité et formant un triangle alongré. Pour les autres caraclères, voyez Erotrue.

Les espèces europćennes de ce genre vivent dans les bolets. On ne connoît point encore suffisamment leurs premiers états.

Ire. Division. Corps ovale-oblong. (Triplax propriè dicta.)

1. Triprax violelle, T. violacea.

Triplax nigro-violacea, capite thoraceque et elytris punctatis; punctss in duobus printis inordinatis, in tertiis seriatis : seriebus longitudinalibus.

\section{Triplax violacea. DEs. Catal.}

Longueur 3 lig. D'un violet noilâtre; corselet à peine rebordé sur les cćtés, ponclué sans ordre ainsi que la tête; élytres finement pointillées; ces points rangés en stries longitudinales.

Des Alpes de Croatie.

2. Triplax russe, $T$. russica.

Triplax russica. Oniv. Entom. tom. 5. Tripl. pag. 491. Erotyl. pl. I. fig. 1. - Triplax nigripennis $1 l^{\circ} . \mathrm{I}$. FАВ. Syst. Eleut. - LАт. Gener. Crust. et Ins. ton. 3. pag. 70. $2^{\circ} .2$.

Voyez pour la description et les autres synonymes, Erotyle russe no. 38. de ce Dicliounaire.

\section{Trrplax rulipède, T. Rufipes.}

Triplax unfipes no. 2. Faв. Syst. Eleut. - Oniv. id. pag. 492. Tripl. $p l$. 1. flg. 4 .
Voyez pour la description et les autres synnnynıs, Erotyle rufipède $n^{\circ} .37$. de ce Diciionnaire. Des environs de Paris.

On placera encore dans cette division la Triplax bronzée, T. cenea no. 3. FAB. Syst. Eleut. - Oriv. Entolll. torlu. 5. Tripl. pag. 49ı. $n^{\circ} .6$. pl. 1. fig. 3. D'Allemagne.

$2^{\circ}$. Division. Corps presqu'hémispbérique. (Tritonua DEJ.)

Le type est la Triplax bipustulée, $T$. bipustulata. Otrv. Entom. tom. 5. Tripl. pag. 49\%. $n^{\circ}$. 3. pl. I. fig. 5. - Tritona bipustulata $n^{\circ} .3$. FAB. Syst. Eleut. (en ôtault le syuonyme de Geoffiroy qui appartient au Mycétophage quadrimaculé de ce Dictionnaire.) - LAt. Gener. Crust. et Ins. toin. 3. pag. 69. $n^{\circ}$. 1. Des environs de Paris, dans les bolets.

Nota. I'Elater cacus no. 1 I. Fав. Syst. Eleut. (Elater elegans. PAL.-BAuv. Insectes d'Afr. et d'Amér. pag. 10. Coléopt. pl. VII. fig. 4.) est probablement du genre Triplax. Ces auteurs ont omis de parler d'un tubercule presque bidenté qui est placé un peu au-dessous de l'insertion des paltesinlermédiaires. Cousultez le Nota pag. 553. de ce volume. (S. F. et A. Serv.)

TRISTAN. Nom vulgaire donné par Geoffiroy (Ins. Paris. tom. 2. pag. 47. $n^{\circ}$. 14.) au Salyre hypéranthus no. 162. tom. 9. pag. 533. de ce Dictionuaire. (S. F. et A. SERv.)

TRITOME, Tritoma. Geofr. Cet auteur ayant cru que l'insecte nommé depuis Mycétophage quadrimaculé n'avoit que trois articles aux tarses, en constitua un genre particnlier sous le nom de Tritome. Ce Coléoptè!e est Tétramère. Voyez Mrcétophage. (S. F. et A. Serv.)

TRITOME, Tritoma. LAT. (Gen.) Ce genre est le nuêrne que celui de Triplax du présent ouvrage. M. Latreille en réunissant les deux genres Tritome et Triplax dans le Nouveau Dictionnaire d'histoire naturelle, $2^{\mathrm{e}}$. édition, conseille de s'en tenir it cette dernière dénomination. Le genre Tritonzce Fab. PAYK. et Oliv. (Encycl. Tabl. des genres) paroît se rapporter en partie à notre seconde division du genre Triplax. Voyez ce mot.

$$
\text { (S. F. et A. Serv.) }
$$

TRIXA, Trixa. Genre de Diplères créé par M. Meigen (Dipt. d'Eut.) dans sa famille des Muscides. Il lui donne pour caractères : antemes courtes, insérées chacune dans une petite cavilé du front, rabattues, de trois articles courts; le premier très-court, les secoud et troisième Égaux entr'eux : celui-ci ovale, portant une soie dursaie nue, courte, biarticulée. Ouverture de la cavitć buccale trc̀s-petite, ovale. Trompe ca- 
chée lors du repos dans la cavité buccale, géniculée, sa base très-courte. Palpes insérés à la base de la lèvre, épais, cylindriques, obtus, très-garnis de soies, un peu saillans. Tête ovale; hypostome velu des deux côlés, muni de quelques soies, mais sans moustaches proprement dites: front velu, ayant un sillon longitudinal peu enfoncé. Yeux fort espacés dans les femelles, beaucoup plus rapprochés et plus grands dans les mâles. Trois ocelles placés en triangle sur le vertex. Corps bérissé de poils. Corselet Lombé, garni de poils, séparé vers son milieu par une ligne transversale enfoncée. Ailes lancéolées, velues vues au microscope, à moitić ouvertes dans le repos; deux cellules du bord postérieur fermées chacune par une nervure 1 ransversale avant d'atteindre ce bord. Cuillerons grands. Balanciers cachés. Abdomen ovale, garni de poils hérissés, composé de quatre segmens. Pattes assez longues; pelotes des tarses fort longues dans les inâles.

M. Meigen dit que l'on trouve ces Muscides dans les pays boisés et marécageux; elles planent presque toujours en l'air, et l'auteur pense qu'elles vivent de proie. On ne sait rien de leur premier état. M. Meigen en décrit six esp̣èces européennes, qu'aucun auteur n'avoit connues avant lui.

$1^{\circ}$. Trixa des Alpes, T. alpina. MeIg. Dipt. d'Eur. tom. 4. pag. 223. $n^{\circ}$. I. Longueur 6 lig. Abdomen noir; bord antérieur des trois derniers * gemens ayant de chaque côté une ligne trans. verse d'un blanc jaunâtre; pattes ferrugineuses. Corselet gris cendré. 'Tête d'un blanc grisâtre; ligne longitudinale du front noire. Nuâle. $2^{\circ}$. Trixa bleue, T. carulescens. Meig. id. pag. 224. $n^{\circ}, 2$. I.ongueur 5 ligg. 'I'êtc d'un jaune rougeâtre; trout ayant une large raie noire dans la femelle. Corselet d'un blanc brunâtre, reflété de brun sur le dos. Aldomen noir avec des bandes transversales bleuâtres; ventre d'un juune blanchâtre. Pattes fauves. Femelle. 3o. Trixa grise, T. grisea. Meig. id. $n^{\circ}$. 3. Longueur 5 lig. Abdomen gris, portant it sa base deux bandes transverses noirâtres ; pattes ferrugineuses. Mále et femelle. $4^{\circ}$. Trixa ferrurineuse, T. ferruginea. Merg. id. $n^{\circ}$. 4. Longueur 5 lig. Ferrugineuse; abdomen portant des bandes transverses noires, brillantes. Pattes de la couleur du corps. Femelle. $5^{\circ}$. 'Trixa dorsule, T. dorsalis. Mr.ig. id. pag. 225. $n^{\circ}$. 5. Longuenr 5 li.r. Abdomen roux avec une large bande dorsale noire; ailes ayant un point brun sur la nervure transversale du milieu. $6^{\circ}$. Trixa variće. T. variegala. Mrig. id. $n^{\circ}$. 6. Abdomen blanc, varié de noir; ailes ayant la nervure trausversale du milieu noire, bordće de brun.

Nota. M. Neigen rapporte à ce genre parmi les espèces exotiques déjà décrites, la Trixa à crocbet, $T$. uncana, qui est la Dictya uncana nº. 19. Far. Syst. Antlat. De l'Amérique méridionale. (S. F. et A. Serv.)
TRIXAGE, Trixagus. Kugell. GrLx. Ilatg. Schan. Voyez Throsque.

\section{(S. F. et A. SERv.)}

TROgOSITE, Trogosita. FAB. Schœr. Fabricius adopta ce genre iondé par Olivier, en modifiant son nom sans raison. Il y mit beaucoup d'espèces qui ne lui appartiennent pas. Celles portant les nos. 14, 15, 16, 23, 24, 25. sont des Phaléries Lat. (Gener.); le genre Langurie prend le no. 10.; 26. est le type du genre Prostomis; 13. appartient aux Calcars; 7 . est un Boros. Les espèces que nous pouvons ciler avee certitude comule étant du genre Trogossite sont les nos. 3.6.8. et 9. Les numéros que nous ne mentionnons pas, nous sont inconuus. (S. F. et A. SERv.)

TROGOSSITAIRES, Trogossitarii. Quatrième tribu de la famille des Xylophages, section des Tétramères, ordre des Coléoptères.

Cette tribu a pour caractères, antennes de onze articles.

I. Corps presque globuleux on ovale. - Antennes perfoliées, au moins à leur extrémité.

Mycétophage, Triphylle, Diplyylle, Lithophage, Agathidie (1).

II. Corps étroit et alongé.

A. Massue des antennes de deux articles.

Ditome, Lycte, Diodesme.

Nota. M. Latreille rapporte à ce groupe, mais avec doute, le genre Corticus DEs. Catal.

B. Massue des antennes de trois articles ou plus.

a. Antennes guère plus longues que la tête. Colydie.

b. Antennes notablement plus longues que la téte.

f Mandibules petites ou moyennes, peu ou point saillantes.

* Palpes très-courıs; les maxillaires peu ou poinl saillans.

Latridie, Sylvain.

* * Palpes maxillaires saillans. Méryx.

$\uparrow †$ Mandibules fortes et avancées. 'Trogossite, Prostomis.

Nota. Les caractères des genres Triphylle, Diphylle, Lithophage, Diodesme et Corticus, n'ont pas encore été publiés.

(1) M. Latreille plaçoir aurrefois 'ce genre dans la famille des Clavipalpes, et c'est ainsi que nous en avons trajté pag. $; \mathrm{I}$. de ce volumie.

$\mathrm{X} \times \times \times 2$ 
DITOME, Ditoma. LAr. (Addend. Gener. et Fam. nat.) Bitoma. Henist. Lat. (Gener.) Lyctus. FAB. PAYK. Ips. Oliv.

Genre d'insectes de l'ordre des Coléoptères, section des Tétramères, famille des Xylophages, tribu des Trogossitaires.

Trois genres composent un groupe dans cette tribu, savuir : Ditome, Lycte et Diodesme. (Voy. Trogossitaires.) Le dernier ne nous est pas connu, et les Lyctes diffèrent des Ditomes par leurs antennes beaucoup plus longues que la tête et par leur's mandibules a vancées.

Antennes à peine plus longues que la tête, composées de onze articles, séparés et distincts; les deux derniers formant une massue perfoliée. Mandibules cachées. - Tête rentrant jusqu'aux yeux dans le corselet. - Yeux peu saillans. Corps un peu déprimé, alongé, étroit. - Corselet carré. - Tarses ayant leurs trois premiers articles presqu'égaux, le premier n'élant pas notablement plus long que le suivant.

Ces Coléoptères sont de petite taille et vivent sous les écorces d'arbres. Le nom générique est tiré de deux mots grecs qui font allusion à la massue des antennes.

\section{Ditome crénelée, $D$. crenata.}

Ditoma crenata. LAт. Gener. Crust. et Ins. tom. 3. pag. 16. $n^{\circ}$. $\mathrm{I}$.

Voyez Lyctus à sa lettre, et pour la description et les synonymes, Ips crénelé no. 7. de ce Dictionnaire.

LYCTE, Lyctus FAB. PAYK. LAt. Ips, Iyctus Oliv. (Encycl.) Bitoma Herbst.

Genre d'insectes de l'ordre des Coléoptères, section des Tétranieres, famille des Xylophages, tribu des Trogossitaires.

Un groupe de cette tribu caractérisé ainsi : corps étroit, alongé; massue des antennes de deux articles, renferme les genres Ditome, Lycle et Diodesme. (Voyez Trogossitaires.) Ce dernier ne nous est pas connu. Les Ditomes sont séparées des Lyctes par leurs antennes à peine plus longues que la tête et par leurs mandibules cachées.

Antennes visiblement plus longues que la tête, composées de onze articles séparés et distincts; les deux derniers formant une massue perfoliée. Mandibules avancées. - Tête saillante. - Yeux un peu élevés. - Corps presque linéaire. - Cor selet presque carré, un peu plus étroit que les élytres, surtout à sa partie postérieure. - Tarses ayant leurs trois premiers articles presqu'égaux, le premier n'étunt pas beaucoup plus long que le suivant.

Feu Olivier dans ce Dictionnaire n'a donné le caractère du genire Lycte que d'après Fabricius. La plupart des espèces qu'il cite, toujours d'après ce dernier anteur, n'apparliennent pas d ce genre, ou du moins sont fort douteuses. Ainsi l'I ps picipède $\mathrm{n}^{\circ}$. 8. (Lyctus tom. VII. pag. 589.) et le Lyctus bipustulatus (même page) sont des Rhizophages. Le genre Cérylon comprend l'Jps tarière ${ }^{\circ}$. 5. (Lyctuls zit suprà) et le Lyctus histéroìde (même tome, pag. 5 go.) Lilps crénelé $n^{\circ} .7$. (Lyclus même tome, pag. 589.) est le type du genre Ditome. Le Lyctus denté (même page), nous paroit être nn Sylvain. Le Lyctuss juglandis (id. pag. 5go.) est, d’après le Catalogue de M. le comte Dejean, du genre Synchita. Le Lyctus brun et le Lyctus brillant tous deux pag. 5go. sont donteax.

Ces Coléoptères sont petits et se trouvent sur les vieux bois.

\section{Lусте canaliculé, L. canaliculatus.}

Lyctus canaliculatus $n^{\circ}$. 13. FAB. Syst. Eleut.Iyctus oblongus. La T. Gener. Crust.et Ins. tom. 3. pag. $16 . n^{\circ} .1$.

Voyez Lyctus à sa leltre, et pour la description et le synonyme de l'entomologie, Ips oblong no $n^{\circ} 9$. de ce Dictionnaire. (Les synonymes de Geoffioy et de Fourcroy doivent être rctranchés, suivant M. Latreille. Nouv. Dict. d'hist. nat. $2^{\mathrm{e}}$. édit. Ils appartiennent à une autre espèce de Lycte.)

\section{Lycte resserré, $L$. contractus.}

Lyctus contractus $n^{\circ}$. 16. FAB. Syst. Eleut. (en lisant à la citation de Geoffroy, $n^{\circ}$. 8. au lieu de no. 10.)

Vоуеz Lyctus à sa lettre, et pour la description et les autres synonymes, Ips resserré no. 6 . da prèsent ouvrage.

Quant aux espèccs de Lyctus décrits par Fabricius (Syst. Eleut.) les nos. 1. 2. 4. sont des Rhizophages; 5 . est probablement un Sylvain; 17. un Cérylon, ainsi que le $n^{\circ} .9 ; 8$. appartient au genre Synchita DeJ. Catal.; 10. est le type du genre Ditome; 13. et 16 . sont de vrais Lycles; $3,6,11,12,14,15$. sont douteux.

COL.YDIE, Colydium. Fab. Herbst. Pare. Oriv. (Encycl.) Ips Ourv. Trogosita Fab.

Genre d'insectes de l'ordre des Coléoptères, section des Tétramères, famille des Xylophages, tribu des Trogossilaires.

Dans les Trogossitaires à corps étroit, alongé et qui ont la massue des antenues composée au moins de trois articles, tous les genres, à l'exception de celui de Colydie, ont les antennes notablement plus longues que la tête.

Antennes à peine plus longues que la tếte, insérées sous ses bords latéraux, composées de onze articles séparés et distincts; le premier et le second plus longs que les suivans, ceux de trois a huit inclusivement, très-courts, transversaux, tec- 
minées subitement par une massue perfoliée, de trois articles. - Labre très-petit, avancé, linéaire, transversal, entier. - Mandibules déprimées, presque trigones, bifides à leur extrémité, l'ang!e externe de la base, prolongé en oreillette. - Mâchoires formées de deux lobes, l'extérieur plus grand, obtrigone; l'interne petit, dentiforme. - Palpes très-courts, presque filiforwes; lenr dernier article plus gros, formant une sorte de massue distinetement tronquée. Lèvre coriace, en carré transversal, entière : menton plus grand de moitié que la lèvre; eoriace, carré, un peu plus large que long. - Tête trèsobtuse à sa partie antérieure, presque tronquée transversalemen1. - Corpslinéaire. - Tarses ayant leurs trois premiers articles presqu'égaux; le premier n'étant pas notablement plus long que le suivant.

Les Colydies habitent le vieux bois dans leurs différens états. Toutes les espèces connues sont d'assez petite taille. Ce genre a été traité dans cet ouvrage par feu Olivier d'après Fabricius, ainsi que le précédent. Voyez Lyctus à sa lettre. Il cite quatre espèees desquelles il faut retrancher I'Tps tromentier no. 15. (Colydium, tom. PII. pag. 588.) qui est le Sylvain sixdenté no. 2. de ce Dictionnaire.

\section{Corrdie alongé, $C$. elongatum.}

Colydium elongatum $n^{\circ}$. 5. F A $_{\text {B }}$ Syst. Eleut. L. T. Gener. Crust. et Ins. ton. 3. pag. $2 \mathrm{I} . \varkappa^{\circ}$. I.

Voyez pour la description et les autres synonymes, Colydium, tom. VII. pag. 588. et I $\mathrm{ps}$ linéaire $n^{\circ} .4$. de ce Dictionnaire.

On le trouve anx environs de Paris.

Nota. Le Colydie filiforme, $C$. filiforme no. 7 . FAв. Syst. Eleut. Colydium filifomie, tom. VII. pag. 588. Oniv. Encycl. n'est probablement qu'une variété de celle espèce.

\section{Coltrie sillonné, C. sulcatum.}

Colydium sulcatum $n^{\circ}$. I. FАв. Syst. Eleut. T'rogosita sulcata $n^{\circ} .22$. FAB. id. Colydium sulcatum. LAT. id.

Voyez pour la description et les antres synonymes, Colydium, tom. VII. pag. 588. et Ips sillonné no. 2. de ce Dictionnaire.

Fabricius (Syst. Eleut.) comprend treize espèces Aans ce genre. Les nos. 1.5.7. sont certainement des Colydies. Le no. 12. est probablement un Sylvain. Les autres ne nous sont pas connus.

LATRIDIE, Latridius. Herbst. Kugrll. Lat. Tenebrio. Linn.? De Géer. Dermestes. Fab. PAYK. Anthicus. Fab. Ips. OLiv.

Genre d'iusectes de l'ordre des Coléoptères, section des Tétramères, famille des Xylophages, tribu des Trogossitaires.
Un groupe de cette tribu présente pour caractères : corps étroit, alongé; antennes notablement plus longues que la tête, leur massue composée de trois articles ou plus; mandibules petites ou moyennes, peu ou point saillantes; palpes trèscourts, les maxillaires peu ou point saillans. Le geare Sylvain qui compose ce groupe avec les Latridies, se distingue de ceux-ei, en ce que le second article des antennes et les suivans sont presqu'égaux entr'eux; que la tête n'a point de ligne transversale enfoneée qui en sépare distinctement le chaperon, et qu'ainsi que le corselet, elle est aussi large que l'abdomen.

Antcnnes notablement plus longues que la téte, composées de onze artieles séparés et distincts; le premier épais, le seeond pas plus long que le troisième; celui-ci presque cylindrique, trèsgrêle ainsi que eeux qui le suivent immédiatement; ces antennes sont terminées brusquement en une massue perfolicée, de trois articles. - Mandibules petites, caehćes. - Falpes très-courts. - Tête beaucoup plus étroite que le eorselet, sa partie antérieure courte, obtuse, un peu avanecée, portant une ligne transversale enfoncée qui prend naissance de chaque eôté, à l'insertion des antennes. - Corps oblong, déprimé. - Corselet plus étroit que les élytres. - Tarses ayant leurs trois premiers articles presqu'égaux, le premier n'étant pas notablement plus long que le snivant.

Ces petits Coléoplères se rencontrent dans l'intérieur des maisons sur le vieux bois : quelquesuns se plaisent dans les caves, principalement sur les planches bumides et autour au bondon des tonneaux.

\section{Latnide nain, L. minutus.}

Latridius minutus. Lat. Gener. Crust. et Ins. tom. 3. pag. 19. - Latridium transversum. Lat. id. tom. 1. tab. XI. fig. 3. (la citation de Linné est douteuse.)

Voyez pour la description et la synonymie, Ips nain $n^{\circ}$. 23. de ce Dietionnaire.

On rapportera à ce genre, $1^{\circ}$. Ips enfoncé $\mathrm{n}^{\circ} .22$. $2^{\circ}$. Ips transversal $n^{\circ} .21$. de ce Dictionnaire.

\section{MÉRYX, Meryx. LAT.}

Genre d'insectes de l'ordre des Coléoptères, section des Tétramères, famille des Xylophages, tribu des Trogossitaires.

Ce genre constitue seul dans sa tribu une conpe particulière ainsi caraetérisée : corps étroit, alongé; antennes notablement plus longues que la tête, leur massue de trois articles ou plus; mandibules petites ou moyennes, peu ou point saillantes; palpes maxillaires saillans.

Outre ces caractères, nous indiquerons les suivans :

Antennes composées de onze articles, la plupart presqu'obconiques, les trois derniers un peu 
plus épais que les autres; les neuvième et dixième presque turbinés, le dernierovale. - Labre eoriaee, presque carré, échan eré en eœur. - Mandibules eaehées, bifides à leur extrémité.-Mâchoires composées de deux lobes, l'extérieur presque triangulaire, l'intérieur dentiforme.-Palpes en marsue, leur dernier artiele presqu'oltrigone, plus grand que les autres. - Menton plus large que la levre, deux fois plus large que long, en calré transversal. - Yeux assez proéaiuens. - Corselet un peu plus ćtroit que les ély tres, presque earré, échaneré en eœur, ses angles antérieurs dilatés el arrondis. - Abdomen en earrć long:

Le type de ce genre dont on ignore les mœurs est la Mléryx rugueuse, $\boldsymbol{M}$. rugosa. Lat. Gener. Crist. et Ins. tom. 3. pag. 17. $n^{\circ}$. 1. tom. 1 . tab. XI. fig. 1. Des Indes orieutalcs, d'où elle a élé rapportée par feu Riche.

$$
\text { (S. F. et A. Serv.) }
$$

Trogossr'TE, Trogossita. Oliv. Lat. Tiogositu. l'a b. Illig. SchđN. Tragosita. PAYK. P.xz. platycerus. Geoff. Tenebrio. Linn. Devill. Tenebrio, Lucanus. Ross.

Genre d'insectes de l'ordre des Coléoplères, seetion des Tétrauières, famille des Xylophages, tribu des Trogossitilires.

Un petit groupe de eelle tribu est caraetérisé ainsi : corps étroit, alongé; massue des antennes de trois artieles ou p!us; antennes notablement p'us longues que la lête; mandibules fortes et avaneées. (Vayez 'Inogossitanes.) Il contient outre le genre 'Trogossite, eelui de Prostonis, qui s'en distingue par ses mindibules beaucoup plus longues el dentelies daos toute l'étendue de leur partie interne.

Antennes notablement plus longues que la téte, enais n'ígalant point celle-ei et le eorselet pris ensemble, nonilitormes, allant en grossissant vers leur extrémité, ou en massue brusque : elles sont eomposćes de onze artieles; le prewier gros, le seeond petit, globuleux, les quatre suivans un peu plus gros, mais de neeme forne que le seeond; les einq derniers eomprimés, allant en grossissant et s'élargissant à leur partie interue dans l'un des sexes; dans l'autre les sixième el septième semblables aux quatre préeédens (aucun de ees six articles n'étant plus gros l'un que l'autre); les trois derniers seulement sont subitement élargis il leur partie interne, plus grands que les autresei très-comprimés (1).-Labre petit, eoriaee, avaneé, cn earré transversal, velu antérieurement. -Man-

(1) Cetre difference dans les antennes, dont nous attribuons la cause a la distinction des sexes, n'a été observée que dans le Trogossice mauritanique. Toutes les autres espèces, de chacune desquelles nous n'avons vu que peu d'individus, n'one la massue des anrenmes que de trois articles. dibules fortes, avancées, triangulaires, un peu concaves en dessous, bidenlées vers leur exirémité, leur bord extérieur épais. - Mâchoiros n'ayant qu'un seul lobe visible, eoriace, comprimé, alongé, étroit, un peu arqué; sa partie antérieure et son extrémité ciliées : le lobe basilaire très-petit, point apparent extérieurement. - Palpes eonrts, les maxillaires un peu plus longs que les labianx, presque filiformes, de quatre arlicles, le dernier plus long que le préeédent; eylindrique-ovale; palpes labiaux de trois articles, le dernier épais, ovale-obtus - Lère eoriaee, presque carrée, sc rétrécissant uu peu et insensiblement à sa partie inférieure, son bord supérieur un peu velu, entier : pienton cruslacé, très-eourt, formant une ligne transversale dont les deux bouts sont recourbés. - Téte assez forte, un peu plus étroite que le corselet, sa partie postérieure reçue entre les deux angles antérieurs de eelui-ei.-Yeux oblongs, point saillans. - Corps glabre, alongé, presque linéaire, déprimé.-Corselet légèrement rebordé, plus large en devant qu’à sa parlie postérieure; ses angles antérieurs souvent prolongés en avaitt; bords latéraux un peu sirondis : angles postérieurs peu saillans. Il est séparé des elytres par un étranglement. Ecusson presque nul. - Elytres presque linéaires, arrondies postérieurement, assez déprimées, røeouvrant des ailes et l'abdonien.-Abdomen long. - Pattes courtes, fortes; les postérieures insérées assez loiu des inlermédiuires; eelles-ci rapprochées des antérieures; tarses filiformes; leur's trois premiers articles égaux entr'eux, velus en dessous; le dernier long, arqué, un peu renflé vers son extrémité el muni de deux eroehets assez courts.

Olivier et Fabricius clonnent à ce geure einq articles aux tarses, et il est eertain que dans un assez grand nombre d'espèces, vous avons aperęu, en regardanı les tarses en dessous avec une forto loupe, nn premier article très-petit, forl pea distinet et point du tout visible en dessus; il exista aux tarses postérieurs ainsi qu'aux autıes; eependant Paykull (Faun. Suec. tom. 1. pag. 91.) affirme que les tarses antérieurs el interwédiaires ont cinq attieles, tandis que les postérieurs n'en offrent que quatre.

La maniere de vivre du Trogossite mauritanique en état de larve est déerite daus ee Dictionnaire à l'article CADELLe ( voyez ce mot), nom que l'on donne à cette larve dans le midi de la France. Parvenue à toute sa grosseur, elle a environ huit lignes de long et une ligne de large; son corps est blanchátre, eomposé de douze segmens assez dislinets, bérissés de poils épars, courts, roides; la tête est dure, éeailleuse, noire, munie de deux mandibules arquées, tranebantes, cornćes, trèsdures. Les trois premiers segmens du corps portent chaeun une paire de pattes eourtes, éeailleuses; ils ont quelques taclies obscures; le dernier est terminé par deux crochets corvés, très-durs. Cette 


\section{$\mathrm{T} R \mathrm{O}$}

larve est très-communc dans l'Europe méridionale et fait un trc̀s-grand tort au froment renfermé dans les greniers; elle altaque aussi les arbres morts, et mêtue le pain et les noix.

Le nom appliqué par Olivier à ce genre vient de deux mots grecs qui signifient : rongearde blé ou de pain, l'un de ces mots ayant cetle duuble acception. Les espèces que nous connoissons habitent l'Europc, l'Afrique et l'Amérique.

Ire. Division. Tête ayant uu sillon longritudinal dans son milieu.

I. Trogossite colosse, T. colossus.

Trogossita nigra-subcarulea; thorace antice pilis rufis ciliato, cum capite tenussiniè punctulato; elytris cujusque striis decem crenato-punctutis, intervallis seriatim punctatis.

Longueur 2 pouces $\frac{3}{4}$. Noire, tirant un peu sur le bleu-violâtre, surtout en dessous; tĉte trèsfinement pointillée, son sillon raccourci postérieurement; corselct fiueruent pointillé, garni antérieurement de poils courts et roux, visiblement reLordé sur les côtés et postérieurement, ses angles autérieurs fort prononcés, prolongés en avant; on voit une petite dent placée un peu su-dessous de la moitié du bord latéral ; élyties ayant chacune dix stries crénclées, leurs intervalles portaut de pctits points enfoncés rangés sur une liguc; pattes de la couleur du corps; jambes antérieures ayant quelques petites dentelures peu prononcées, les autres eutièrement mutiques; antennes et palpcs noirs.

De Cayenne.

\section{Trogossrte brillante, T. festiva.}

Trogossita viridi-aureo nitens; elytris auratocupreis, singuli maculis duabus carulescentibus; antennis nigris.

\section{Trogossita festiva. DEJ. Collect.}

Longueur 9 lig. D'un vert doré brillant; tẻte et corselet ponctués; sillon de la têtc très-raccourci, accompagné de chaque côté d'un point enfoncé; corselet coupé presquc carrément en devant ct bordé de poils roux, dans cette partic, prescfue sans rebords latéraux; ćlytres d'un cuivreux doré très-brillant, ayant chacune deux tachcs bleues presque carrées, l'une un peu au-dessous de la base, l'autre vers le milieu; suture et bord extérieur verdâtres; paltes d'un noir-verdâtre; antennes, mandibules et palpes noirs.

Du Brésil.

\section{Trogossite de Doumerc, $T$. Doumerci.}

Trogossita capite, thorace elytrisque viridiaureis; antennis, palpis, pedibus abdomineque testaceis.
Longueur $4 \mathrm{lig}$. Tète, corselet et élytres d'un vert doré, fivement pointillés; ces dernières à stries pcu distinctes, mais pointillées ; l'intervalle de ces stries portant des points moins enfoncés, presque rangés en ligne. Abdomen, palpes, antennes et pattes d'un testacé-biun.

Rapportce de Cayenne par M. Adolphe Doumerc, de qui nous la tenons.

Nous rangerons en outre dans celte division, $I^{\circ}$. 'Trogossite bronzée, T. anea. Oriv. Entom. tom. 2. Trogoss. pag. 7. $n^{\circ}$. 3. pl. 1. fg. 3. Trogosita aenea $\mathrm{n}^{\circ}$. 18. Fав. Syst. Eleut.-Scнen. Syn. Ins. tom. 1. pag. 157. $n^{\circ}$. 13. Du Brésil. $2^{\circ}$. Trogossite verdître, $T$. virescens. Ohiv. id. pag. 8. $n^{\circ} .5 . \mathrm{pl}$. 1. fig. 5. -Trogosita virescens no. 9. FAB. id. - Schen. id. pag. 156. $n^{\circ} .8$. Amćrique septentrionale, Caroline. $3^{\circ}$. Trogossitc bleue, T. ccerulea. Onıv. id. pag. 6. $n^{\circ}$. 1.pl. s. fig. I. - Trogosita carulea no. 3. FАв. id. (à la citation de Panzer, lisez : tab. 14. au lieu de $t a b$. 19.) Midi de la F́runce ct Autriche.

$2^{\mathrm{e}}$. Division. Tête sans sillon, ayant à sa partic antćrieure une large dépression peu prononcée.

\section{Trogossite grande, $T$. grandis.}

Trogossita nigra, punctata, seriebus punctonum in elytris per paria dispositis à basi ultrà unedium; punctis cateris inordınatis; el,tris cujusque disco lineis quatuor tenuibus longiludinalibus abbreviatis.

Trogossita grandis. Des. Collect.

Longucur 16 à 24 lig. Noirc, ponctuée; élytres ayant leurs points depuis la buse juscu'au-delà du milieu, disposés eu lignes longitudinales, ces lignes un peu rapprocliées par paires; disquc des élytres portant quatre lignes longitudiuales enfoncées, très-fines : chacune de ces lignes placéc cntre les couples de lignnes de points; extrémité des élytres cliargée de points sans ordre. Dessous du corps et paltes d'un teslacé noirâtre, ainsi que les palpes. Toutcs les jambes sont armées de fortes denis à leur côté extćrieur.

Du Sénégal.

\section{Trogossute cylindrique, $T$. cylindica.}

Trogossita subconvexa, fusca, punctata; elytris profundè striato-puuctatis.

Longueur 4 à 6 lig. Corps un peu convexc, d'un testacé-moirâtrce, ponctué; élytres ayant des stries assez prolondes et ponctuées.

Amérique boréale.

Dans cclle division se place la Trogossite mau. ritanique, T. manrilanica. OLrv. Entom. tom. 2. T'rogoss. pag. 6. $n^{\circ}$. 2. pl. 1. fig. 2. - Trogosita caraboides $\mathrm{n}^{\circ}$. 6. FAB. Syst. Eleut. (en retranchan£ 
le synonyme de Linné, qui appartient au Cychrus rostratus, suivant M. Schœnherr.) - Scncx. Syn. Ins. torn. 1. pag. 155. $n^{\circ}$. 5. Commune en France, surtout dans la partie méridionale.

Nota. La Trogosita bipustulata no. 8. FAв. id. appartient encore à ce genre.

$$
\text { (S. F. et A. S zRr.) }
$$

TROGULE, Trogalus. Genıe d'Aruchuides de l'ordre des 'Trachéennes, fanille des Phalangiens, élabli par. M. Latreille aux dépers des Platangiums de Linné, et ayaut pour caractères : corps ovale, déprimé, dur, ayant l'extrémité antérieure avancée en forme de chlasperon qui reçoit, dins une cavilé inférieure, les mandibules el les autres parties de la bouche. Yeux au nombre de deux, séparés et pen sensibles; mandibules terminćes pal deux pinces; abdomell ovalaite, à divisions apparentes; palpes simples et filiformes; huit pattes. Le geare 'l'rogule, aliusi caractérisé, se distingue de tous ceux de la famille des Phalangiens par l'extrémité antérieure de son corps rui recouvre toutes les parties de la bouclie, taudis que daus les autres geures ces parties sont saillantes et à découvert. La seule espece connue juscia'a préseut dans ce gente est :

Le Trooule vépiforae, Trogulus nepcefornis.

T. obscuro-cinereus, coloreve terreo; abdominis dorsi medio lateribusque obsolete, subcarinatis; tarsorum articuli primi apice externo producto.

Trogzulus nepaformis. Lat. Gener. Crust. et Ins. tom. 1. pag. 142 . pl. b. fig. 1. - Ibid. Hist. nat. des Crust. et des Ins. toms. 7. pag. 327. Faucheur a bec. Lat. Hist. nat. des Foumis et recueil de Mém. pag. 374 . - Phalangium tricarinatum. Lins. Syst. nat. ed. 13. tom. 1. pars 2. pag. 1029. - Acarus nepaformis. Scop. Ent. sarn. no. 1070. - Phulangum carinatum. HАв. Ent. Syst. tom. 2. pag. $4 \overline{3} 1 .-$ Wal. . Faun. Paris. tom. 2. pag. 252. - Røis. Gener. Ins. tab. 29. fig. 8.

Celle Arachnide a le corps long de quatre lignes, ellipsoide, chagriné el d'un cendré terreux. L'avancement antérieur recouvrant la bouche est triangṇlaire; les côtés du corselet ont le bord en saillie. Le milieu de l'abdomen a, dans sa longueur, une ligne ou carène élevée; les pattes antérieures sont plus grosses que les antres; l'articulation qui répond à la cuisse est rentlée, et sa partie supérieure offre quelques petiles élévations on aspérités formant une toible apparence de crète. Les tarses sont composés de quatre articles, dont le premier est un peu renflé à son extrémité, avec l'angle extérieur prolongé en forme d'épine.

On trouve cet insecte en Firunce, en Alletnagne et en Espagne, sous les pierres. (E. G.)

\section{T $\mathrm{R} \mathrm{O}$}

TROGUS, Trogus. Panzer, dans sa Révision de la Faun. Germ. (Nuremb. 1805, 1806.) a établi sous ce nom un genre d'Hyménoptères-Ichneumonides, auquel il donne pour caractères : quatre palpes inégaux, les maxillaires de cinq articles; le second très-grand, dilaté, en forme de coutre de charrue, le troisième cylindrique; les autres plus étroits, linéaires, insérés sur le dos des unâchoires; palpes labiaux insérés à l'extrémité de la lèvre, composés de quatre articles, presqu'ćgaux; les trois premiers plus épais, le deruier "orêle, liuéaire. Lèvre membraneuse, bilide à l'extréruité, ses lobes triangulaires, aigus. Midchoires courtes, cornées, droites, obtuses. Mandibules épaisses, courtes, aignës, bificles au bout, à lobes inégaux. Antennes sétacées.

L'auteur donne pour type le 'l'rogus bleu, $T$. caruleator. Paxz. Faun. Germ. fas. "f. fig. 13. Ichneumon caruleator $n^{\circ} .79$. Fab. Syst. Piez.

$$
\text { (S. F. et A. Serv.) }
$$

TROMBIDION, Trombidium. Genre d'Arachnides de l'ordre des 'Trachéenues, fumille des Acarides, établi par Fabricius aux dépens du graud gente $A c$ curus de Linné, et ayant pour caractères: corpls presque carré, ordinairement rouge, déprimé, mou, marqué de plusieurs entoncemens, chvisé en deux parties, dont la première on l'antérieure très-petite, portaut les yeux, la bouclıe et la première paire de paltes; huit pieds uniquement aubulatoires; yeux au nombre de deux, écartés et porlés sur des pédicules; deux palpes saillaus, pointus au bout, avec un appendice mo. bile; une sorte de doigl sous cette extrémité; maudibules en grilfes.

Ce genre se distingue des Erytbrées parce que ceux-ci nout pas les yeux portés sur un pédicule saillant et immobile; les genres Ganase, Chejlite, Uropode et Oribale en sont suflisarnment distingués par leurs palpes qui n’ont point d'appendice mobile is leur extrémité.

On connoit un a sez grand nombre de 'Trombidions, et c'est à Muller el surtout à Frédétick Ilerunan que l'on est redevable de celte connoissance. Cet au'eur a publié un ouvrage sur les Acarus et autres geutes d'Apteres, intilulé $M \dot{e}$ moires aptérologiques, accoupagné de très-belles planches coloriées. Les Trombidions vivent dans les campagnes, suc les pluntes, les arbres et sous les pierres. On les rencontre plus particulièrement au printemps. Presque loutes les espèces décrites sont européennes; on n'en connoit ciu'une qui soit exolique, mais il est prubable que, si l'atention des voyageurs se porte sur les Arachnides de perite taile, on en découvrira nu grand nombie daus les contrées équaloriales.

Le Trombidion conorart, Trombidium tiactorium.

T. subatsadratum, coccinoum, immaculalum, tomentosa-hirsitissimum; 
tomentoso hirsulissimun; pilis selaceis, alonsatis, barbatis.

Trombidium tinctorium. LAT. Gener. Crust. et Ins. tom. I. pag. 145. - Ibid. Hist. nat. des Crust. et des Ins. tom. 7. pag. 397. pl. 61. jig. 1. - Ibid. Descript. d'Ins. d'Afr. recueillis par M. Caillaud, Voyag. à Mléroé, vol. II. pl. LVIII., fig. 1. - Hen м. Mém. aptér. pag. 20. pl. 1. fig. 1. - Acarus tinctorius. Liкn. Syst. nat. edit. ı3. tomi. 1. pars 2. pag. 1025. - P PLLAS, Spicil. zool. fas. 9. pag. 42. tab. 3. fig. 1 I. - $S_{\mathrm{LABB}}$. Hicrosc. tab. 2 .

Il est long de quatre à einc lignes; son corps a la forme cl'un triangle renversé dont la base est en devant, avec les angles arrondis ou très-obtus. Il est très-soyeux, d'un beau rouge-verixilon, árec les pieds plus pâles; le dos ollie plusieurs courtes impressions transverses. La première et la dernière paire de pieds sont les plus longnes de toules. On trouve ce Trombidion daus l'Tade, en Afrique et à Cayenne. Il est probable que les individus de ces divers pays forment autant d'espèces distinetes, 'rnais jusqu'à présent aucune obsèvation n'a été faite à ee sıjet.

Le 'Trombidion sativé, Trombidium holosericeum.

T. subquadratum, coccineum, immaculatum, tomentosum; tomento brevi, e pilis papillivisque cylindricis, apice rotundatis, aut obtusis, efformato.

Trombidium holosericeum, Lat. Gen, Crust. et Ins. tom. 1. pag. 146. - Le Trombiclion satiné, ibid. Hist. nat. des Crust. et des Ins. tom. 7. pag. 396. - Herm. Mém. apter. pag. 20. pl. I. fig. 2. et $p l .2$. fig. 1. - Acarts holosericeus. LiNn. Syst. nat. edit. 13. tom. 1. pars 2. p. 1025. - Ibid. Faun. Suec. edit, 2. $n^{\circ}$. 1979. - La Tique rouge satinée, terrestre, Geofr. Hist. des Ins. tom. 2. pag.624. - Mitte satinée, terrestre, DE GÉer, Mém. sur les Ins. tom. 7. pag. 136. pl. 8. fig. 12-15. List. de Aran. pag. 100. tit. 38. fg. 38.

Il n'a pas une ligne de longneur. Son corps forme une sorte d'ovale coupé ou très-obtus aux deux extrécnités; il est large, aplati'en dessus, eouvert de poils d'un rouge d'écarlate, très-courts et fort sęrés; sa pear a des rides et des enfoncemens qui la rendent très-inégale. Ce petit animal est très-commun en France et aux environs de Paris; on le trouve au printenps, conrant sur les herbes dans les chainps, et dans les bois. Quelques personnes croient qu'il seroit un poison mortel si l'on venoit i l'avaler. (L. G.)

TROMBIDITES, Trombidites. M. Léach défynes ainsi une petite famille d'Arachnides rentermant les genres Trombidion et E⿱一土㇒ththré; il. Lui

Hist. Nat. Ins. Tome $X$. assigne pour caractères : bouche munie de mandibules; palpes avancés, avec un appendice mnbile au bout. Dans la méthode de M. Latreille (Fum. nat. du Règn. anim.), celle pelite division fait partie de sa famille des Acarides. Voyez ce mot à la table alpliabétique. (E. G.)

TROMPE ol PROBOSCIDE, Proboscis. On donne en général ce nom aux pièces qui composent la bouche des Insectes et de quelquea Arachnides, quand elles sont prolongées en avant pour former un tube membraneux et rétractile, corné, recourbé sous la poitrine; ou quand cette bouche est seulement portée par un avancement anlérieur de la tête. Ce mot a été appliçné d'une manière trop générale pour qu'on n'ait pas senti le besoin d'arrêter l'abus qui en a tété fait, et qui donnoit lieu à une grande confusion dans la description des organes de la manducation des Arachnicies et Insectes : anssi H. Latreille a.t-il cherché, dans ces derniers temps, à distinguer les diverses modilications de la trompe et à restreindre l'acception trop étendue de celle dénomination, qui désiogrooit indifféremment la bouche d'un insecte broyeur, tel qu'un Colénptère (Charancon), et celle d'un Diptere, qui vit d'alimens liquides et les iniroduit dans son estomac par un tube souvent membraneux et rétructile, qui seul doit être appelé trompe. Ce savant, dans son article Boucrz du Dictionnaire classique d'histoire naturelle, el dans une note dépendante des généralités sur le Condylopes de son ouvrage sir les familles naturelles du Règne animal, a montré les différences qui existent dans la forme de la bouche des Crustacés, Araclunides et Inseetes; il a appliqué ì ehaque modification importante dans lia forme de eet organe, des détominations distinctes, et a conservé le nom de trompe ou proboscide (proboscis) à l'ensemble des pièces qui composent las bouclue des insectes Diptères : c'est celte nowenclature qu'il a employée dans le demier ouvrage que nons arons cité, et elle a été adoptée pa: tous les entomologistes. Nons allons donc commencer par faire connoitre la trumpe daus l'acception restreinte de ce mot; nons passerons ensuite en revare les diverses modificalions de li bouche des Crustacés, Arachnides et Insectes qua: portoient le no:n de trompe avant quil leur ers ait assigné un-plus convenable, et nous fercas connoît:e successiveneut ces diverses dénominations.

La trompe des Diptères, ou leur bouche, dans son maximum de composition, est formée de six pièces comme celle de tous les insectes broyeurs. Deux de ees pièces remplacent la lèvre supérieure et l'inférieure, les quatre autres sont les analogues des mandibules et des mâclioires; ees parties son? plus ou moins alongées et ne sont pas distinetes dans tous, puisque les Diptères, dont la honche est arrivée au minimux de compositiou, n'oas.

$$
\mathrm{Y} Y \mathrm{JY}
$$


plus que deax de ces pièces distinctes. Il y a des espèces qui offrent une composition intermédiaire, c'est-à-dire que leur trompe a quatre pièces séparóes et apparentes; dans celles-ci ce sont les mandibules, on les parties qui les représentent, qui ont disparu en se soudant avec la lèvre snpérieure, ou en restant à l'état rudimentaire. Les mâchoires se sont réunies à la lèvre inférieure dans ceux qui n'ont plus que deux pièces à la trompe.

La lèvre inférieure, ou la partie qui la représente, a reçu le nom de tige ou gaîne du suçoir; cette partie se divise en trois antres qui ont reçu les noms de support, tige et sommet. Le support est dislingué de la tige par un conde, et souvent par un petit article géniculaire que M. Latreille lui réunit. La tige est plus on moins alongée; enfin, le sommel ou la tête est formé par denx lèvres, tantôt membraneuses, grandes, vésiculeuses, dilalables et striées; taniót coriaces, fort petites et peu distinctes de la tige, fort grêles, alongées et formant nn article plus distinct, presqn'aussi long mêzne que la division précédente, comme on le roit dans les myopes. Le support est remarqnable en ce qu'il est le résultat du prolongement de la membrane cutanée de la partie antérieure et supérieure de la tête on de l'épistome, réunie avec les parties analogues au labre, aux mandibules, anx mâchoires et à la portion inférieure de la lìvre jusqnau menton inclusivement. Cette tige, composée comme on vient de le voir, sert à maintenir les lancettes, qui ne sont antre chose qque les extrénités des mấchoires et des mandibules. Ces lancettes servent à percer les tissus dans lesquels l'insecte cherche les sucs qu'il doit pomper, et la gaine ne concourt nullement à l'entrée de ces sucs dans l'estomac; ces liquides y sont introduits par le canal que laissent entr'elles les lancettes; elles les font remonter successivement jusqu'à l'entrée de l'csophaye, en se rapprochant graduellement de bas en haut, et de manière à Paisser le moins de vide possible entr'elles. On peut comparer l'effet qu'elles produisent à celni qu'on obtiendroit si l'on comprimoit successivement de bas en haut un tube élastique rempli d'une matière liquide.

Les parties ou lancettes qui représentent les mâchoires existent toujours, et sourent même sont accompannées chacune d'un palpe; mais ces mâchoires sont soudées avec le support, et ne sont bien distinctes que lorsque leur portion apicale devient mobile, salonge, et présente la forme d'une soie ou d'une lancette cornée; c'est ce qui a lieu toutes les fois que le suçoir est de quatre ou de six pièces.

La trompe d'nn grand nombre de Diptères peut se retirer en entier dans la cavité buccale; dans ce cas elle se termine par un empátement; dans d'antres cas elle est toujours saillante et plus ou moins cylindrique ou conique. Dans le premier cas sa gaine est membraneuse; dans le second elle est plus ou moins solide on cornée. Qnand la trompe est membraneuse ét très-courte, les deux palpes sont insérés sur les bords de la cavité bnccale; hors de cette circonstance ils sont situes sur le support de la trompe près de son premier coude : c'est surtout dans les Syrphes que l'on peut se convaincre qu'ils indiquent l'existence des mâchoires; dans ces Diptères, on les voit adhérer à deux des pièces dn suçoir. Nous a vons aussi reconnn ce fait clez un genre de Tipulaire. (Mémoire sur un insecte Dipt. du genre Bolitophile: Annal. des scienc. nat. tom. 10. pl. 18. fig. 5.) Nous avons observé que ses palpes étoient accompagnés de deux petites pièces pointues, filiformes, qui sont à nos yeux les mâchoires de l'insecte.

La manière dont les Diptères se servent de lenr trompe a été observée par Réanmul'; il l'a décrite avec détail dansle tome 4 de ses Mémoires pour servir à l'histoire des Insectes. Tout le monde a été à même d'observer un Cousin quand il cherche à nous piquer, et il est facile de voir qu'il fait sortir du bout de sa trompe une pointe très-fine qu'il ne tarde pas à inlroduire dans notre peau. Cette pointe est contenue dans la gaîne du suçoir; elle est composée des mâchoires, des mandibules et de la lèvie supérieure, et c'est elle senle qui pénètre et qui pompe le sang. Le bout de l'étui ou de la gainne reste sar le bord de la plaie, il sert à maintenir la lancette, et la gaíne se replie snr elle-même à mesure que la lancette entre dans la cliair. Les Mouches agissent de même, seulement leur lancette est plus courte et n'a pas besoin de pénétrer si avant que celle des Cousius. Cettc. lancette sort entre les lèvres membraneuses qui terminent la gaîne, et comme cette dernière est très-molle, elle doit se comprimer snr elle-même au lieu de se plier comme celle des Cousins, pour laisser agir la pointe.

Le mot trompe a été employé pour désigner la bouche des Hyménoptères, qui ayant nne lèvre supérieure et deux mandibules cornées et courtes comme les insectes broyeurs, ont déjà la lèvre inférieure et les mâchoires prolongées en snçoir. Dans ces insectes, les màchoires engainent longitndinalement les côlés de la lèvre; ces parties sont réunies en faisceau et composent ainsi un corps tubulaire servant de suçoir, puisque les snbstances alimentaires, ordinairement molles ou liquides, pénètrent entre les mâthoires et la lèvre, et arrivent au pharynx par la pression qn'exerçent successivement sur cetle dernière pièce les deux autres. M. Latreille a donné à celle espèce de trompe le nom de promuscide (promuscis).

Daus les Lépidoptères, qui sont les insectes suceurs dont la bouche s'éloigne le moins de celle des broyeurs, elle est composcé d'un labre et de deux mandiluales extrêmement petiles, d'une trompe roulće en spirale, offirant à l'intérieur et dans toute sa longueur trois canaux, mais dont celui da milieu sert seul à l'écoulement des ma- 


\section{T R O}

tières alimentaires. Cette trompe est formée de trois pièces linéaires ou filiformes, entourant à leur origine, et immédiatement au-dessons du labre, le pbarynx, représentant, mais sons d'autres formes et d'autres proportions, la portion termiuale des mâchoires à partir des palpes et la lèvre inférieure; les deux pièces qui représenlent les mâchoires portent chacune un palpe ordinairement très-petit et tuberculiforme; la pièce intermédiaire ou lèvre inférieure, est presque triangulaire, réunie, comıe on l'a dit pins haut, à la partie inférieure des mâchoires, immobile et portant deux palpes triarticulés, très-garnis d'écailles ou de poils, s'élevant de cliaque côté de la trompe, et lui formant ainsi une sorte de gaine. Cette trompe a reçu de $\mathrm{H}$. Latreille le nom de spiritrompe (spirirostrum).

Dans les Héuiptères, la trompe ou le bec est composée d'une lame plus on moins linéaire, coriace, divisée en trois ou quatre aricles, roulée sur ses bords ponr former un corps tubulaire, cyliudrique ou conique, toujours dirigće iuféjieurement daus l'inaction, et ayant le long du uilieu de sa face supérieure, un canal formé par le vide que laissent les bords latéraux au poinı de leur rapprochement. Cette gaîne est ici la lève inférieure; elle renferme un suçoir composé de quatre filets très-grêles ou capillaires, cornés, flexibles et élastiques, disposés par paires, mais rassemblés en faisceau, et dont les deux inférieurs sont réunis en un à peu de distance de leur origiue. Une pelite pièce recouvre par derrière, ou du côté du corps tubulaire, la base du sucoir ; elle est triangulaire, ordinairement dentée au bout, plutôt coriace ou presque membranense que de consistance d'écaille; enfin une autre pièce de la consistance de la précédente, répondant par son insertion et la place qu'elle occupe à la lìvre supérieure, couvre en dessus la base du suçoir, ou est le plus souvent renfermée avec lui daus la gaîne. Telles sont, dit M. Latreille, les parties qui composent le bec des Hémipières. L'impaire supérieure est l'analogue du labre, et nous a paru, du moins par rapport aux Cigales, recouvrir la base d'une autre pièce plus alongée, terminée aussi en pointe; celle-ci répondroit dèslors à l'épipharynx : l'autre pièce impaire, mais opposée, protégeant par derrière la naissance du suçoir, et siluée immédiatement derière le pharynx, représente, selon Savigny, la langue ou l'hypopharynx. Les deux soies supérieures du suçoir ou les plus extérieures, remplacen! les mandibules, et les deux autres les mâchoires. Cette modification de la bouche a reçu de M. Latreille le nom de rostre (rostrum).

$\mathrm{La}$ bouslie des Puces est analogue à celle que nous venons de faire connoître; sa gaine est bivalve; elle renferme un suçoir de trois soies, dont deux représentent les mấchoires, et la troisième la langue; deux petites écailles ou palpes reconrrent la base de ce tabe. Celte bouche, ainsi composée, est ce que M. Lats eille appelle rostelle (rostellum).

Dans les Poux, la trompe semble consister eu un petit tube inarticulé, renfermant un suçoir, et se retirant à volonté dans l'intérieur d'un avancement, en forme de museau, de la partie antérieure de la tête. Cette espèce de trompe porte le nom de siphoncule ( siphonculus). Quelques Crustacés, tels que les Caliges, les Pandares, etc., et quelques animaux formant les limites entre les Arachnides et les Crustacés, les Pycnognnides, ont un bec indivis, tubulaire, quelquefois accompagné de chélicères et de palpes, tantôt privé de ces deux sortes d'organes. Celle espèce de trompe est désignée par M. Latreille sous le norn de siphon (siphon). Quelques Mites ont aussi une bouche prolongée en suçoir, formée de lames ou lancettes réunies; c'est encore un siphon pour M. Latreille. Du reste, il est probable que re nom changera quand de nouvelles observatious auront mieux fait connoitre la bouche de ces animaux.

Enfin le nom de tronipe a été appliqué, comme nous l'avons dit plus haut, au prolongement antérieur de la lête des Rbyochophores, des Parnopates et de quelques autres Cléoptères; ce prolongement porte cependant une bouche propre à broyer les alimens, et composée des mêmes pièces que celle des autres insectes broyeurs. M. Latreille a désigné celle saillie sous le nom de proboscirostro (proboscirostrum). (E. G.)

\section{TRONC, Truncus.}

Le nom génćral de tronc a étédonné à cette partie du corps des Crustacés, Arachinides el Insectes, qui donne atlache aux oryanes du mouvement, et qui renferme presque toujours les principaux organes de la vie. Dans les Hexapodes ou les linsectes, ce tronc est distinct de la tête; il est formé de trois anneaux portant chacun une paire de pattes, et if a reçu le nom de thorax (yoyez ce mol). Dans les Crustacés et les Arachnides, le tronc est confondu avec la têle; entin dans les Myriupodes, il n'est pas distinct de l'abilomen de telle manière, qu'on ne sauroil à quel anneau s'arrêler pour con? noitre la partie du corps de ces animaux qui correspond au thorax des Hexapodes, et au tronc des Cruntacés et des Arachnicies, si les oryanes de la manducation et ceux du mouvement, ne venoient aider dans cette recherche.

On voit donc qu'un examen philosoplicge de ces parlies doit précéder la comparaison du tronc d'un Insecle avec celui des arliculés plus élevés dans l'échelle; $c^{7} e s t$ cet examen que nous allons entreprendre d'une manière abrégée, et ell présentant sur celle matière les principes du plus célèbre entornologiste de notre époque, M. Latreille, publiés dans ses derniers ouvrages, et qu'il a bien voúlu nous développer dans des con- 
versations que nous regardons comme les meilleures leçons de philosophie entomologique que nons ayous reçues de lui.

Les organes inférieurs des Crustacés, Arachnides et Insecles, sont tous des espèces de pieds; les uns sont propres à la manducation, ils ont reçn le nom de mandibules, mâchoires, etc.; les autres, destinés à l'ambulation, sont les pieds proprement dits. Ces organes se modifient tant pour la forme que pour le nombre et les propriétés; ainsi l'on voit, dans les Crustacés les plus composés, que le tronc donne attache à onze paires d'appendices, non compris le labre et la langue ou lévre inférieure. Six de ces appendices concourent à former la bouche, et les cinq autres forment les organes locomoteurs. Dans les Cruslacés moins élevés, les derniers appendices de la bouche commenceut à prendie lú forme de pattes, comne on le voil dans les Stommapodes, dans les I. onodipodes, eic.; mais c'est surtout chez les Amphipodes que les quatre derviers pieds-mâchoires de la bouche des Crustacés supérieurs sont convertis en véritables organes locomoteurs. Il en est de mấme pour les Crustacés plus inférieurs, leur bouche se simplifie de plus eu' plus, et la nuture, duus ces animaux semble ne retrancher que par le bas et laisser toujours exister les orgaves principaux de la manducation. Chez les Atachnides, ce principe est eucore manifesté d'une manière plus posilive; car, dans ces animaux, les organes que l'on'avoit pris jusqu'à présent pour des mandibules, ne sont autre chose que lcs analogues des antennes intermédiaires des Crustacés, modifiées pour servir d'organes de prélıension ef concourant à la manducaíon. Dèslors, si l'on suil la corrélaticn des parties, on verra que ce qu'on a appelé palpe avec des mâchoires dans les Arachnides, reprúsente des mandibules azalogrues à celles des Crustacés décapodes. Les deux autres mâclioires et les pieds-mâchoires de ces derniers sont convertis ici en de véritables pieds. Enlin nous amivons anx Myriapodes, qui ont deux mandibules comme les Crustacés maxillaires. Dans ces animaux, dit M. Latreille ( $F a$ milles naturelies du Rìgne animal), la siluation des organes sexuels ou l'intcruption dans l'ordre des stignates détcrinine les limiles dı thorax. comparé à celui des Insectes ou des Condylopes hexapodes; celie proposition exige quelques éclaircissemens. II. Savigny suppose que les Myriapodes a'ont point de languette; la pièce qui se trouve immédiatement an-dessous des mandibules et qu'il assimile à une sorte de lèvre inféreure, est formée, suivant lui, de deux paires de mâclioires réunies sur le même plan. Mais si on la compare avec la languette des Apus, des Cyames et de divers Garnmarus dont il a donué des figures, ou verra qu'clle a les plus grauds rapports avec cette lèvre iıféricure des Myriapodes, et qu'on peut la considérer comme idenlique. Dès-lors, les quatre appendices articulés sous la forme de palpes ou de pieds qui viennent immédiatement après cette languette, ou les pièces qu'il nomme lèvres auxiliaires, représenteront les mâchoires, et les pieds qui succèdent, les pieds-mâchoires et des pieds ordinaires; les unes et les autres doubles. Dans divers Chilopodes mâles, les organes sexuels élant précédés de sept paires de pattes, si de ce nombre l'on retranche les deux premières ou les maxillaires, ces organes sexuels seront placés à la jonction des derniers piedsmâclıoires et des pieds proprement dits. Dans plusieurs Scolopendres, lordre des stigmates change du septième au huilième segment. Les six paires de pattes antérieures à celles de ces anneaux, sont les analogues des pieds-mâchoires, toujours estimés doulsles. I,es six pieds ordiuaires des Insectes représentant, d'après ce que nous avous dit, les mêmes pieds-mâchoires, on voit que, là comme ici, ou dans ces Myria podes comme daris les Insectes, la dernière paire de ces organes sert de limites au thorax et à l'abdomen. Les quatre premiers appendices articulés et supćrieurs, en forme de palpes ou de pieds, des Limules et des Arachnides, répondant aux quatre mâchoires des Crustacés maxillaires, ces animaux sont snscepiibles des mêmes applications. Ainsi les organes sexuels, ou du moins ceux des femelles, sont inmédialement situés après ceux de ces appendices qui représentent les pieds-mâchoires, et à la jonction du thorax et de l'abdomen. Sous le rapport numérique des pieds, les Insectes sont, relativement aux Condylopes hyperhexapes, dans un état foctal.

Pour comparer le tronc ou thorax d'un insecte avec celui des animaux articulés supérieurs, il faut prendre pour terme de comparaison, l'animal le plus élcvé relativement à lai, ná Crabc, nne Lcrevisse, par exemple : on trouve dans ces animaux un tronc qui donne attache aux organes suivans : un labre, une paire de mandiJules, une langue, denx paires de mâchoires, trois paires de pieds-mâchoires, et enfin cinq paires de pattes ambulatoires. Nous ne parlons pas ici des pattes natatoires qui appartiennent à l'abdomen.

En partant de ces principes, on voit dans un Colćoptère, par exemple, que par l'ordre de succession des parties, ce quion appelle mandibules est irc̀s-bien l'analogue des mandibules des Crustacćs; ce qu'on appelle mâchoire avec les palpes représente la prenière paire de mâchoires des Crustacés; les palpes labiaux et la languelte représentent la deuxic̀me paire de mâclioires des Crustacés; et gun'entin les trois paires de pattes ambulatoires représentent les pieds -mâchoires de ces derniers. Dès-lors il manque aux Insectes les pieds ambulatoires des Crustacés, qui, s'iis existoient, viendroient se placer aux cinq premiezs anneanx de leur abdomen. On voit 


\section{$\mathrm{T} \cap \mathrm{O}$}

par celle comparaison, que les trois anneaux du thorax des Insectes ne sont plus les analogues du thorax des Crustacés supérieurs; et que le tronc ou thorax de eeux-ci est reprósenté chez les Insectes, par les einq premiers anneaux de l'abdomen, ou, en d'autres termes, que le thorax de ces derniers répond à la partie du tronc des Crustaeés qui porte les trois paires de pieds-mâehoires.

Le tronc des Crustaeés et des Arachnides afFeete des formes très-variées; ses divers anneaux sont plus ou moins sensibles inférieurement, en dessusils sont soudés ensemble, et forment ainsi une seule pièce qui embrasse les flancs de l'animal et sert à le protéger. Voyez Trorax. (E. G.)

TRONCATIPENNES, Truncatipennes. Première division de la tribu des Carabiques, famille des Carnassiers (terrestres), section des Pentamères, ordre des Coléoptères. Ses caractères sont :

Palpes extérieurs point terminés en alène. Caté interne des deux jambes antérieures forlement échaneré. - Extrémité postérieure des élytres le plus souvent tronquée.

I. Crochets des tarses sans dentelures.

A. Dernier artiele des palpes de forme ovalaire et terminé presqu'en pointe.

s. Premier article des antennes plus eourt que la tête.

Mormolyee, Casnonie, Odaeanthe.

b. Premier artiele des antennes presque aussi long que la tête.

Cordiste.

B. Dernier artiele des palpes alongé et plus ou moins sécuriforme.

a. Mandibules avaneées, presque droiles. Drypte.

b. Mandibules courtes, peu avaneées. Galérite, Zuphie, Polistique.

C. Dernier article des palpes peu alongé, cylindrique, ou grossissant insensiblement vers l'extrémité.

a. Antennes moniliformes on grossissant vers l'extrémité.

Helluo.

b. Antennes filiformes.

† Labre court, transversal, laissant les mandibules à découvert.

Aptine, Braehine, Corsyre.

t† Labre avancé, recouvrant plus ou moins les mandibules.

Catascope, Graphiptère, Anthie.
II. Crochets des tarses dentelés en dedans.

A. Corps plus ou moins alongé. - Elytres ordinairement alongées.

a. Dernier article des palpes labiaux fortement sécuriforme, au moins dads les mâles.

Agre, Cyıninde, Calléide.

b. Demier article des palpes labiaux non séeuriforme.

Cténodactyle, Démétrias, Dromie.

B. Corps plus ou moins large et aplati: Elytres presque earrées.

a. Dernier artiele des palpes labiaux fortement sécuriforme.

Plochione.

b. Dernier article des palpes labiaux point sécuriforme.

Lébie, Coptodère, Orthogonie.

MORMOLYCE, Mormolyce. HAGENB.

Genre d'insectes de l'ordre des Coléoplères, section des Pentamères, famille des Carnassiers (terrestres), tribu des Carabiques (division des 'Troneatipennes ).

Trois genres, Mormolyce, Casnonie et Odacanthe composent un groupe parmi les'Troncalipennes. (Yoyez ce mot.) Les deux derniers se distinguent des Mormolyces par leur corselet sans dilatation latérale et sans dentelures; par les élytres qui recouvrent seulement l'abdomen sans le déborder latéralement; de plus, les antennes dans ces deux genres, ne sont guère plus longues que la tête et le eorselet pris ensemble et sont eomposées d'articles presqu'égalix.

Antennes iusérées au-devant des yeux, filiformes, de la lougueur du eorps, composées de onze articles; le premier épais, un peu en massue, arqué, plus court que la tête; le second très-petit; le troisième très-long, cylindrique, un peu plus épais vers son extrén:ilé; le quatrième assez long, mais moins que le préeédent; les suivans jusqu'au disième inclusivement presqu'égaux; le onzic̀me un peu plus long que les précédens, légèrement recourbé en crochet à son extrémité. Labre corné, découvert, earré; son bord antérieur à peine échaneré. - Mandibules fortes, cornées, aiguës, ayant tune dent au milieu de leur partie interne. - Mâchoires cornées, leur extrémilé en forme de lobe étroit se terminant en pointe courbe, fortement ciliées. - Palpes maxillaires internes de deux artieles égaux, grêles; les extérieurs de quatre artieles; le premier très-court; le seeond long, épais, un peu comprimé; le troisième de moitié plus court que le précédent; le quatrième un peu plus long que le troisième, arrondi, obtus palpes labiaux de trois 
articles; le premier très-court; les deux autres égaux, arrondis; le troisième obtus. - Lèvie cornée, courte, tridentée; la dent da milieu trèscourte, les latérales larges, obtuses; languette spongieuse, presque cordiforme aulérieurement et no peu fendue; menton corné, très-court, son bord antérieur f́chancré. - Téte très-longue, déprimée, point rebordée, allant en diminuant insensiblement vers sa partie postérieure, un pen convexe entre les yeux; cette partie portant une impreftion longitudinale. - Yeux proéminens, bémisphériques. - Corps ailé, déprimé, de consistance presque meinbraneuse. - Corselet assez long; ses bords latéranx un peu élevés, dilatés et dentelés : sá partie antérieure tronquée ainsi que la postérieure. - Ecusson en partie caché sous le boıd postérieur du corselet, plus long que large, pointu. - Elytres presque membraneuses, très-dilatées à leurs bords latéraux, point rebordées, fortement échancrées postérieurement et laissant l'extrémité de l'abdomen à découvert, très-prolongées an-delà du corps : en dessous les élytres avant leur dilatation latérale, forment un rebord qui enveloppe les côtés de l'abdomen. - Abdomen ovale - cylindrique, déprimé. Cuisses comprimées, presque linéaires; les antérieures un peu grêles; leur's trochanters petits, élevés ainsi que ceux des cuisses intermédiaires : trochanters postérieurs grands; jambes comprimées, presque droites; les antérieures fortement échancrées avant leur extrémité qui est dilatée et un peu gonflée; tarses linéaires, plas courts que les jambes, leur premier article plas grand qu'aucnn des suivans; ceux-ci éganx entr'enx; crochets simples, très-menus, recourbés, divergens.

On doit la connoissance de l'espèce singulière qui constilue ce genre à M. Hagenbach (Mormolyce novum Coleopt. genus descript. Norimberg. ap. J. A. C. Stum. 1825.), duquel nous arons empranté les caractères énoncés ci-dessus.

\section{Monsource feuille, M. phylloides.}

IHormolyce tota picea, nitida; elytrorum margine dilutiori. a. b.

Mormolyce phylloides. HAGXB. ut suprd. fig.

Longnenr 2 ponces 4 lig. Entièrement de coulenr de puix et luisante. Bords des élytres moins foncés ; la partie des élytres qui recouvre le corps offre neuf lignes longitudinales enfoncées; la cinquième porte deux on trois tubercules; partie dilatée des élytres réticulée; ailes blarches à servures ferrugineuses.

De la partie occidentale de l'ille de Java.

CASNONIE, Casnonia. LAs. ( Hist. nat. et Icon. etc. et Fam. nat.) Der. (Spéc.) Ophionea. KLvG. Odacuntha. FA9. Screx. OuIT. (Enfygl.)
Altelabus. Lrnx. Colliuris. Di Gírr. Oriv. ( $\mathbb{R}_{n-}$ cyclop.) Agra. Lat. (Gener.) Macrotrachelus. LAT. (Encych, Planch.)

Genre d'iusectes de l'ordre des Coléoptères, section des Pentamères, famille des Curnassiers (terrestres), tribu des Carabiques (divísion des Troncalipennes ).

Les $\mathbf{M}$ rrmolyces, les Casnonies et les Odacanthe formentus groupe dans les Troncatipennes, lequel a pour caractère particulier : premier article des antennes plus court que la tête. (Voyez'TroncatzPENNEs.) Le genre Odacanthe dilfère des Casnonies par son corselet de forme ovale-alongée, presque cylindrique, et par la tête peu prolongée posiérienrement, arrondie dans cetle partie. Le geure Mormolyce se distingue par son corselet dilaté et dentelé latéralement, et par les côtés de ses élytres qui débordent de beaucoup l'abdomen.

Antennes beaucoup plus courtes que le corps, composées de onze articles presqu'égaux entr'eux; le premier plus court que la tête. - Dernier article des palpes ovalaire, terminé presqu'en pointe. - Tête presqu'en forme de losange, prolongée et très-rétrécie postérieurement, taisant un angle dans cette partie; celle-ci terminée par un col court, mais distinct. - Corselet alongé en forme de cou, très-rétréci antérieuremenl. Elytres légèrement tronquées à leur partie postérieure. - Jambes antérieures très-échancrées au côté interne; tarses filiformes; leur pénuliène article au plus bilide; crochets simples.

Ce genre exotique répond exactement à celui de Colliure De GeEr, mentionné à sa lettre dans ce Dictionnaire. On ignore ses mœurs.

\section{Casronir de Surinam, C. Surinamensis.}

Agra Surinamensis. Lat. Gener. Crust. et Ins. tom. 1. pag. 195. no. 2.

Voyez pour la description et les antres synonymes, Colliure surinamoise $n^{\circ}$. I. de ce Dicitionnaire.

\section{Casnorre cyanocéphale, C. cyanocephalu.}

Casnonia cyanocephala. LAT. Hist. nat. et icon. elc. pag. 130. tab. VII. fig. 6. - Des. Spéc. tom. 1. pag. 173. $n^{\circ}$. 4. - Odacantho cyanocephala. Scadn. Ins. Syn. tom. 1. pug. 237. $n^{\circ} .3$.

Voyez pour la description et les antres synonymes, Odacanthe cyanocéphale $n^{\circ}$. 4 . de ce Dictionnaire.

Nota. Le pénultième article des tarses est presque bilobé, selon M. le comte Dejean.

\section{Casnoriz du Sénégal, C, Senegalensis.}

Casnonia rufa, capite elytrorumque fascis unicâ nigris : tarsorun articulo penultimo haud bilota. 
Longuear 4 lig. Testacée. Tête noire à l'exception du cou; élytres striées, ayant dans leur partie moyenne inférieure, nne bande large, commune et transversale, noire; on voit au-dessous de cette bande, sur chaque élytre, une tache plus claire, presque transparente; chaque strie est marquée d'une ligne de points enfoncés fort distincte; extrémité des cuisses, noire; pénultième arlicle des társes paroissant entier.

\section{Du Sénégal.}

Nota. Elle diffère de la précédente par la forme du pénultième article des tarses; par l'absence de la bande transverse à la base des élytres, et encore par les stries de celles-ci, qui ont des points plus prononcés, ainsi que nous pouvons le conclure d'après les descriptions de la Casnonie cyanocéplale, que nous ne connoissons pas, et que l'on dit être des Iudes orientales.

Ce genre contient encore, $1^{\circ}$. Casnonie de Pensylvanie, C. pensylvanica. Des. Spéc. tom. x. pag. $171 . n^{\circ}$. 1. - Agra pensylvanica. LAT. Gener. Crust et Ins. tom. 1.pag. $196 . n^{\circ} .3 . t a b .7 \cdot$ fig. 1. - Macrotrachelus pensylvanicus. LaT. Encycl. pl. 356 . fig. 3. Amérique septentrionale. 20. Casnonie rufipède, $C$. nufipes DEJ. id. pag. '72.' $n^{\circ}$. 2. Long. 4 lig. Noire, un peu cuivreuse; pattes ronsses. Amérique septentrionale. $3^{\circ}$. Casnonie rngicolle, $C$. rugicollis DEs. id. pag. 173. $n^{\circ}$. 3. Long. 3. lig. $\frac{3}{4}$. D'nn noir cuivreux; corselet portant des rides transversales; élytres striées, ayant une tache pâle à leur partie postérieure; antennes et paltes rousses, mêlées de pâle. Cayenne?

Nota. Le genre Odacanthe du présent Dictionnaire contient sept espèces. Les nos. 1. 3. 6. appartiennent aux Cordistes; le $n^{\circ} .4$. est la Casnonie cyanocéphale; 5 . un Notoxe, suivant M. Latreille; 2 . et 7 . sont senls du genre Odacanthe.

Les espèces d'Odacanthes de Fabricius (Syst. Eleut.) sont au nombre desix; mais la première et la dernière appartiennent seules à ce genre. Les nos. 2. et 5. sont des Cordistes; 3. une Casnonie; 4 ., snivant M. Latreille, se rapporte au genre Notoxe.

CORDISTE, Cordistes. LAT. (Hist. nat. et icon. etc. et Fam. nat.) DEJ. (Spéc.) Calophaena. Krug. Odacantha. FАв. Oxiv. (Encycl.) Scrax. Carabus. OlIv.

Genre d'insectes de l'ordre des Coléoptères, section des Pentamères, famille des Carnassiers (terrestres), tribu des Carabiques (division des Troncatipeunes).

Ce genre, par le premier article des antennes presqu'aussi long que la tête, forme une coupe particulière dans sa division. Voyez Troncatipennes.

Antennes filiformes, presqu'aussi longues que le corps, composées de onze articles, le premier presquáaussi long que la tête; le second très-court.
- Demier article des palpes ovalaire, terminé presqu'en pointe. - Tête arrondie, rétrécie postérieurement. - Yeux très-saillans. - Corselet presque plane, un peu plus long qne large, presque cordiforme. - Elytres plus larges que la tête, presque planes, parallèles, en forme de carré très-alongé, fortement tronquées au bout, ayant ordinairement les deux angles prolongés en forme de dent on d'épine. - Jambes antérieures trèséchancrées an côté interne; tarses ayant leurs quatre premiers articles larges, plus on moins en forme de cœur ou de triangle reuversé, garnis de duvet en dessous; le pénultième presqu'en demicercle, le dernier ne formant qu'une courte saillio an-delà du précédent; crochets simples.

Le nom de Cordiste est tiré d'un mot latin et fait allusion à la forme des articles des tarses de ces insectes et anssi à celle de lenr corselet. Tous les Cordistes sont exotiques; on ignore leur manière de vivre.

\section{Corbiste acuminé, $C$. acuminatus.}

Cordistes acuminatus. LAt. Hist. nat. et Icon. etc.pag. 127. tab.VII. fg. 4. -Des. Spéc. tom. 1 . pag. $179 \cdot n^{\circ}$. 1. - Odacantha acuminata. SCHсs.. Syn. Ins. tom. 1. pag. $237 \cdot n^{\circ} \cdot 7$.

Voyez pour la description et les antres synonymes, Carabe acuminé no. 86. et Odacanthe acuminée $n^{\circ}$. 1. du présent ouvrage.

\section{Condrste bifascié, $C$. bifasciatus.}

Cordistes bifasciatus. Des. id. $n^{\circ} .3 .-O d a c a n-$ tha bifasciata. Scaces. id. $n^{\circ} .2$.

Voyez ponr la description et les antres synonytres, Carabe bifascié no. 119. et Odacanthe bifasciée $n^{\circ} .3$. de ce Dictionnaire.

\section{Cordrstz alongé, $C$. elongatus.}

Cordistes elongatus. LAT. id. pag. 128. - Odacantha elongata. Scucs. id. $n^{\circ}$. 5 .

Voyez pour la description et les antres synonymes, Odacanthe alongée no.6. de ce Dictionnaire.

Dans ce genre on placera encore le Cordiste maculé, C. maculatus. Lat. Hist. nat. et icon. etc. pag. 127. tab. VII. fig. 5. - DEJ. Spéc. tom. 1. pag. $180 . n^{\circ} .2$. Long. 5 lig. Pâle; élytres noires avec nne large bande transversale inlerrompue et l'exırémité pâles. De Cayenne.

DRYPTE, Drypta. Lat. Fab. Scegn. Des. (Spéc.) Carabus. Ross. Cicindela. Oniv.

Genre d'insectes de l'ordre des Coléoptères, seclion des Pentamères, famille des Caruassiers (terrestres), tribu des Carabiques (division des Troncatipennes).

Ce genre a des caractères qui lui sont particuliers et qui l'isolent de tous les autres Carabiques Troncalipennes. Voyez ce dernier mot. 
Antennes Gliformes, plus courtes gue le corps, coinposćes de onze articles; le premier a moins aussi loug que la tête, allant en grossissant vers l'extrémité;-le secould très-court. - Labre coriace, Iransverse, presque linéaire. - Mandibules cornées, avancées, presque droites, fort longnes, courbèes à leur extrémité. - IIâchoires coruées, avancées, alongées, cachées sous les mandibules; fort ciliées ì leur partie antérieure, terminées ì angle droit par un crochet fort long. Palpes maxillaires interues alougés, très-grêles, tilifornes, de deux articles égaux; les maxillaires extérieurs, ainsi que les labiaux, termninés par un article plus gros que les autres, obliquement tronqué et sécuriforme dans les deux sexes, plus couri que le précéden!. - Lèvre cornće, avancée au-delí de l'iusertion des palpes, petite, linérire, ayant de chaque côté ì sa base, une dent memJiraneuse et portant à son extrémité quelques poils d:cits. - Menton très-grand, corné, presqu'orbiculaire. - Tête alongée, triangulaire. - Yeux proéminens. - Corselet long , étroit, presque cylindrique, un peu plus large antérieurement. Elytres beaucoup plus larges que le corselet, tronquées postérieurement, recouvrant l'abdomen et les ailes. - Extrémité de l'abdomen un peu découverte. - Pattes de longueur moyenue; jambes antérieures très-échancrées an côté interne; pénultième article de tous les tarses fortement bilobé dans les deux sexes; tarses antérieurs ayant leurs trois premiers articles légèrement dilatés et ciliés plus fortement en dedans qu'en dehor's, dans les mûles : crochets simples.

Le nom de Drypte tiré d'un verbe grec a été donné à ce genre en raison de ses mandibules propres à déchirer. Ces Carabigues ont les parties de la bouche fort avancées, de manière qu'ils peurent atteindre les.insectes don: ils se nourrisseat, jusque dans les trous où ceux-ci se réfugient. Les espèces conuues sont en petit nombre.

\section{Dequpe échancrée, $D$. emarginata.}

Drypta emarginata. Lar. Gener. Crust. et Ins. tom. 1. pag. 197. no. 1. tab. VII. fig. 3. - LAT. Wist. nat. et icon. etc. pag. I18. no. I. tab. $X$. fig. 1. - FАв. Syst. Eleut. pag. 230. $n^{\circ}$. 1. Scran. Syn. Ins. tom. 1. pag. $237 \cdot n^{\circ}$. 1. - DEJ. Soéc. tom. 1. pag. $183 . \pi^{\circ} .1$.

Ce genre contieat en outre, $1^{\circ}$. Drypie cylindricolle, D. cylindricollis n ${ }^{\circ}$. 2. FАв. Syst. Eleut. - Lar. Hist. nat. et icon. etc. pag. $119 . n^{\circ} .2$. sab. I. fig. 2. - Des. Spéc. tom. 2. pag. 441 . $r^{0}$. 5. D'talie et du midi de la France. Rare. $2^{\circ}$. Diypte linéole, D. lineola. DEJ. Spéc. tom. I. pag. $184 . n^{\circ}$. 2. Long. 4 lig. D'un bleu obscur; tête, corselet, une bande longitudinale sur les élytres, de couleur ferrugineuse; antennes et pátes de cette même couleur. Des Indes orientales. 3०. Dirypte australe, D. arsstralis. Des. id.

\section{T R O}

pag. $183 . n^{\circ}$. 5. Long. 4 lig. D'un Hea obscur; tête, corsclet tet une Lande longitudinale sur les élytres, de couleur ferrugineuse. Nouvelle-Hol!úde. $4^{\circ}$. Drypie lon yicolle, D. longicollis. DEJ. id. $n^{\circ}$. 4 . Long. 5 lig. $\frac{1}{4}$. Alongée; d'un bleu noiràtre; corselet cylindrique; cuisses d'un jaune brillant. Des Indes orientales. 5०. Drypte flavipède, D. flavipes. DEJ, id. tom. 2. pag. $442 . n^{\circ}$. 6 . Wiedear. Zool. magaz. 11. 1. pag. 6o. $n^{\circ} .90$. Des Indes orientales.

Nota. M. le docteur Léach a formé un genre nouveau avec la Drypte longicolle $n^{\circ}$. 4. sous le nom de Desera; il lui donne pour dénomination spécilique celle de Bonelliana.

GALERITE, Galerita, Fab. Lat. Schon. Des. (Spéc.) Carabus. Linné. De Géer. Oziv.

Genre d'insectes de l'ordre des Coléoplères, section des l'entamieres, famille des Carnassier's (terrestres), tribu des Carabiques (division des 'Troncalipennes).

Les genres Galérite, Zuphie et Polistique forment un groupe dans les Troncatipennes. (Voyez ce mot.) Les deux derniers se distinguent de l'autre, par leur corps très-peu épars; et encore parce que les tarses antérieurs des male n'ont pas de dilatation bien sensible.

Antennes filiformes, presqu'aussi longues ywo le corps, composées de onze articles; le prewne. it peu près de la longueur de la tête, rétréci vers sa base; le second un peu plus court que les suivans. - IIandibules courtes, peu avancées. Palpes très-saillans; les maxillaires externe; $\in t$ les labiaux ayant leur dernier article grand, courprimé, fortement sécuriforme dans les deux sests. - Lère coriace dans sa partie moyenne; son bord supérieur portant une deut tronquéc asunie de deux poils; les côtés membraneux, prolongés à leur extrémité en une dent : mentur écliancré, portant dans son milieu une dent échalıcrée. - Tête oroïde, plus étroite que le corsulet, rétrécie postérịeurement et portée sar un cou avancé, très-court, cylindrique, dont elle est sḉarée par un étranglement. - Corps assez épais, un peu coutexe en dessous, déprimé en dessus. - Corselet plane, plus ua moins alongé, tronqué transversalconeut a sa partie postérieure. - Elytres presque planes, en ovale plus ou moins alongé, tronquées à l'extrémilé, recouvrant des ailes et l'abdomen. - Abdomen ayant sa partie postérieure un peu découverte. - $p$ attes très-longnes, jambes antérieures très-échancrées au côlé interne; articles des tarses presque cylindriques; leur nénultième article bifide, mais non bilobé : les trois premiers articles des tarses antérieurs des uâles fortement dilatés en dedans : croclets simples.

Les mœurs et les habitudes des Galérites sout encore ignorées. Toutes les espècés connues sont d'assez grande taille.

I. GaLÉRTR 
1. GALÉRIte américaine, G. americana.

Galerita americana no. I. FAв. Syst. Elent.I.A т. Gener. Crust. et Ins. tom. 1. pag. I 97. n०. ז . tab. VII. fig. 2. - Scucen Syn. Ins. tom. 1. pag. 229. no. 1. - DEJ. Spéc. tom. 1. pag. 187. n०. 1. Z Encycl. pl. $356 . \mathrm{fig} .4$.

Voyez pour la description et les antres synonymes (en lisant $n^{n}$. 42. au lieu de 4r. au synonyme du $S p e c$, de Fabricius), Carabe américain n०.77. du présent ouvrage.

2. Galérite occidentale, G. occidentulis.

Galerita occidentalis. Scucr. id. n०. 5. - DEJ. id. $p a g$. $188 . n^{\circ} .2$.

Voyez pour la description et le synouyme de l'Entomol. d'Oriv., Carabe occidental no. 79. de ce Diclionnaire.

M. le comte Dejean décrit les six autres espèces suivantes : ${ }^{\circ}$. Galérite du Brésil, G. braviliensis. DEJ. Soéc. tom. 2. pag. 4ł2. no. 6. Longueur 9 lig. $\frac{1}{2}$. D'un blen noirâtre; dessıs de la têle et du corselet roux. Elytres ovales, profondément sillonnées; intervalles des sillous portant des stries transversales très-fines. Du Brésil. 20. Gulérite unicolore, G. unicolor: LAт. Hist. nat. et Icon. etc. pag. $117 \cdot$ tab. YI.fig. 6. - DEJ.Spér. tom. I. pag. $189 \cdot n^{\circ} .3$. Longueur $6 \mathrm{lig} \cdot \frac{1}{2}$. D'un bleu noirâlre; élytres sillonnées; intervalles des sillons marqués cliacun de deux lignes. De Cayenne. $3^{\circ}$. Galérile africaine, G. africana. DeJ. id. pag. jgo. $n^{\circ}$. 4. Longueur so lig. $\frac{1}{2}$. D'un bleu noiritre; élytres sillonnées; leurs intervalles velus. Séuégal, cốle de Guinée. $4^{\circ}$. Gillérite de Lacordaire, $G$. Lacordairei. DEJ. Spéc. tom. 2. pag. 443. no. 7 . Longueur $7 \mathrm{lig} . \frac{1}{4}$ D'un brun noirấtre; élytres d'un bleu noirâtre, un peu sillonnées; intervalles des sillons contenant chacun deux lignes. De Buénos-Ayres. On la trouve pendant l'hiver. 5\%. Galérite ì collier, G. collaris. DzJ. id. pag. 444. $n^{2}$. 8. Lonourueur 8 lig. Noire, corselet roux; élytres d'un bleu noirâtre, un peu sillonnées; intervalles des sillons chargés chacun de deux lignes. De Buénos-Ayres. 6. Galérite ruficolle, G. ruficollis. DEJ. id. pag. 191. n०. 5. Longueur 8 lig. $\frac{1}{3}$. Noire; corselet roux. Ile de Cuba.

Fabricius, à quil'on doit la création de ce rrenre exotique (Syst. Eleut.), y comprend neuf espèces, dont la première seule lui appartient. Le $n^{\circ}$. 3. est un Helluo, et peut-être aussi le n. 2.; 4. est une Zuphie; 5, 6, 7, 8. des Sirgones; 9 . est le type du genre Polistique.

HeLluUO, Helluo. Bonet.r. Lat. DeJ. (Spéc.) Galerita. FAB. Schan. Brachinus? FAB.

Genre d'insectes de l'ordre des Coléoptères, section des Pentamères, famille des Carnassicrs (terrestres), tribu des Carabiques (divisiou des Troncatipennes).

Hist. Nat. Ins. Tome X.
Ce genre est distinct des autres de sa division par l'ensemble des caractères suivans : crochels des tarses sans dentelures; dernier arlicle des palpes pen alongé, cy'indrique ou grossissant insensiblement vers l'extrémité; antennes moniliformes ou grossissant vers le bout. ( Vo, ez TroxcaTIPENNES.) Il oflie en outre ces caractères:

Antennes de onze articles, toujours beaucoup plus courtes quie le corps. - Labre tantôt court et transverse, tantĉt avancé et arrondi. - Mandibules courtes, peu saillantes. - Languette entièrement cornée. - Menton unidenté au milieu de son échancrure. - Tête ovale, plus ou moins rét récie postérieurement.-Corselet presque plane et cordiforme, au noins aussi large que la tête. - Elytres tronquées à leur extrémité, en: ovale ou en carré très-alongé, recouvrant l'abdomen.Point d'ailes. - Abdonncn ayant sun extrénité un peu découverte. - Pattes assez forles, peu alnngées; jambes antélieures très-échancrées au côté interne : articles des tarses assez courts, plus ou moins bifides ou cordiformes; le pénulième bilobé dans quelques éspèces; crochets simples.

On peut remarquer par l'examen de ces caractères, empruntés à M. le comie Dejean, que los espèces d'Helluos different assez essentiellemert entr'elles, ce qui doit anener jar la suile l'établissement de que!ques genres nouveaux. I.es espèces mentionuées par les auleurs sont toutes exctiques. Teur histoire n'est pas encore connue.

${ }^{\circ}{ }^{\circ}$ Helluo velu, H. hirtus. Lat. Hist. nat. et iconogr. des Ins. Coléop. d'Eur. pag. 95. tab. I'II. fig. 1. - DEJ. Spéc. tonn. 1. pag. 284. no, 1. Galerita hirta $n^{\circ}$. 3. Fав. Syst. Eleut. - Scnan.

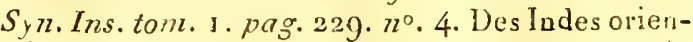
tales. $2^{\circ}$. Helluo de Cayenne, $H$. cayennensis. DEJ. Spéc. tom. 2, pag. 459. n.o. 6. Longueur 6 lig. $\frac{r}{2}$. Noir, pubescent, très-ponclué; labre transversal; élytres ovales - oblongues, à stries ponctuées. De Cayenue. 30. Hellino à côtes, $H$. costatus. LAт. id. tab. V1. fg. 5. Du port Jackson. $4^{\circ}$. Hellno tripustulé, H. tripustulatus. DEJ. id. pag. $286 . n^{\circ} .3$. Longueur 5 lig. $\frac{1}{3}$. Brun, très-ponetué; labre arrondi, lisse : blylres ayant deux taches testacées; cuisses de même couleu:. Boucha, antennes, jambes et tarses de couleur ferrugincuse. Ile de Java. On doit peut-être rapporter, suivant M. le comte Dejean, le Brachinus tripustulatus $n^{\circ}$. 6. FAB. Syst. Eleut. à celle espèce. $5^{\circ}$. Helluo salls taches, H. impictus. Drs. id. pag. 287. $n^{\circ} \cdot 3$. Longueur 6 lig. Brun, très-ponclué; labre arrondi, lisse, ferrugineux. Bouche, antennes, abdomen et paltes de conlenr ferrugineuse. Tle de Java. 60. Hellno du Brésil, H. brusiliensis. DEJ. id. pag. 288. no. 4. Longueul 7 lig. $\frac{3}{4}$. Noir, nubescent; labre transversal, unitenté; élytres alongées, parallèles, profondément strićes. Bouche, anteunes et jambes ferrugineuses. Du Biésil. 7". Helluo bout brûlé, H. praeustus. DEJ. id. pag. $28 \mathrm{~g}$. no. 5. Longueur 7 lig. Ferrugineux;

$$
\text { Z } 22 z
$$


corps très-ponclué; labre presqu'arrondi ; élytres ayant de légères côtes, leur partie postérieure brune ainsi que l'abdomen. Amérique septentriouale. 8`. Hellun pygrmée, $H$. pygineus. DEJ. Spéc. zom. 2. pag. $460 . n^{\circ} \cdot 7$. Longueur 2 lig. Ferrugineux, très-ponctué; labre transversal; corselet alongé, cordiforme; élytres alongées, ayant des lignes élevées; antennes et pattes testacées. Amérique septentrionale. L'auteur pense que cette espèce doit former probablement un geure nouveau.

APTINE, Aptinus. Bonele. Lat. (Iconogr. et Fam. nat.) Des. Carabus. Linv. Ontv. Brachinus. Wér. Fав. Schan.

Genre d'insectes de l'ordre des Colćoptères, section des Pentamères, famille des Carnassiers (terrestres), tribu des Carabiques (division des 'Troncatipenues).

Un groupe de ce!te division a pour caractères : crochets des tarses sans dentelures; dernier article des palpes peu alongé, cylindrique ou grossissant insensiblement vers lextrénité; antennes fliformes; labre court, transversal, laissant les mandibules à découvert. Il çornprend les Aplines, les Brachines et les Corsyres. (Voyez TroncatipenNes. ) Les deux derniers diffèrent des Aptines en ce quiils sont pourvus d'ailes et que les mâles, dans ces deax genres, n'ont pas de dilatatiou bien prononcée aux trois premiers arlicles des tarses antérieurs; en outre, dans les Brachines, les élytres sont tronquées carrément à leur extrémité : quant aux Corsyres, leurs élytres forment un ovale fort cjurt et presqn'orbiculaire, le dernier article des palpes est cylindrique, et le corps est beaucoup moins épais que celui des Aptines.

Antennes fliformes, composées de onze articles. - Labre court, laissaut les mandibules à découvert. - Dernier article des palpes maxillaires externes, aiısi que celui des labiaux, légèrement plus gros que les précédens, allant un peu en grossissant vers son extréaité. - Menton n'ayant qu'une très-petite dent, ou même point de dent, au milieu de son échancrure. - Corps assez épizs. - Corselet cordiforme. - Elytres ovales, assez alongées, allant en s'élargissant vers le bout, tronquées obliquement à l'extrémité de manière à former un angle rentrant dont le sommet répond à la suture; ces élytres recouvrent presque tout l'abdomen. - Point d'ailes. - Abdomen ovale, point aplati, un peu découvert à sa partie postérieure, renfermant des organes sécrétant une liqueur caustique, sortant de l'anus a vec explosion, s'exhalant aussitôt en vapeur d'une odeur pénétrante. - Pattes de longueur moyenne; jambes antérieures très - échancrées au côté interne; les trois premiers articles des tarses antérieurs toujours sensiblement dilatés dans les mâles : crochets simples.

Le nom donné à ces insectes par $\mathbf{M}$. Bonelli vient d'un mot grec exprianant qu'ils n'ont point d'ailes. Les inœurs sont les mêmes que celles des Brachines (voyez l'article suivant), mais on les trouve plus particulièrement dans les montagnes. Ils habitent les climats chauds, tels que l'Europe méridionale et le cap de Bonne-Espérance.

\section{Aptrne nigripenne, $A$. nigripennis.}

Aptinus nigripennis. De. Spéc. tom. I. pag. 291. $n^{\circ} \cdot 1 .-B$ Bachinus migripennis $n^{\circ}$. 5. FAs. Syst. Eleut. - Schon. Syn. Ins. tomi. 1. pag. $230.70^{\circ} .5$.

Voyez pour la description et les autres synonymes, Carabe fastigié $n^{\circ}$. 78. de ce Dictionuatre.

Ce genre contient encore : $1^{\circ}$. Aptine balisie, A. balista. DEJ. Hist. nat. et iconogr. des Ins. Coléopt. d'Eur. pag. 1oo. $n^{\circ}$. 1. tab. VIII. fig. 1. - Des. Spéc. tom. 1. pag. 292. no. 2. Espagne, Portugal, midi de la France. $2^{\circ}$. Aptine mutilé, $A$. mutilatus. DEJ. Hist. nat. et Icon. etc. pag. IOI. no. 2. tab. VIII. fg. 2. - DEJ. Spéc. id. pag. 293. $n^{\circ}$. 3. - Brachinus mutilatus $n^{\circ}$. 7. FAs. Syst. Eleut. - Sс нек. Syn. Ins. tom. 1. p. 230. $n^{\circ}$. 7. D'Antriche. $4^{\circ}$. Aptine des Pyrénées, $A$. pyreneus. DEJ. Hist. nat. et icon. etc. pag. 102. $n^{\circ}$. 3. tab. LIII. fig. 3. - DEJ. Spéc. id. pag. 295. $n^{\circ} .5$. Longueur 3,4 lig. Noir; élytres sillonnée: ; antennes ferrugineuses; pattes testacées. Des $P_{y}$ rénées orientales. $5^{\circ}$. Aptine lancier, $A$. jaculator. DE.J. Hist. nat. et Icon. etc. pag. 103. tab. VIII. fig. 4. - DEJ. Spéc. id. $n^{\circ}$. 6. Longueur 4 lig. , 4 liy. $\frac{1}{3}$. Brun; élytrès à peine sillonnées, pubescentes; lête et corselet roux; pat tes testacées. De l'Europe méridionale. $6^{\circ}$. Aptine noirci, $A$. atratus. DEJ. Spéc. id. pag. 294. $n^{\circ}$. 4 . Longueur 4 lig. $\frac{1}{2}$. , 5 lig. $\frac{1}{2}$. Noir; élytres à côtes; antennes et pattes d'un brun-ncir ; corselet ayant à sa partie postérieure une impression transversale. D'Autriche. $7^{\circ}$. Aptine brun, $A$. infuscatus. DEs. id. pag. 296. $n^{\circ} \cdot 7$. Longneur 2 lig. $\frac{x}{2}$. Jaunâtre; élytres ayant une grande tache obscure à leur partie postérieure; abdomen de cetle dernière couleur. Cap de Bonne-Espérance. $8^{\circ}$. Aptine pygmée, $A$. pygineus. Des. Spéc. tom. 2. pag. 46r. no. 8. Longueur 2 lig. $\frac{x}{4}$. Tête et corselet alongés, très fineinent pointillés, de couleu: rousse; ély tres brunes, presque striées : antennes et pattes testacées. De Barbarie, Tanger.

BRACHINE, Brachinus. WÉB. Fab. Bonell. Lat. Schan. Dej. Stèv. Sturu. Carabus. Linn. Onv. Buprestis. Georf.

Genre d'insectes de l'ordre des Coléoptères, section des Pentamères, famille des Carnassier's (terrestres), tribu des Carabiques (division des Troncatipenues).

Ce genre forme un groupe dans cette division avec ceux d'Aptine et de Corsyre. (Voyez Trox- 
CATIPENnes.) Les Aptines diffèrent des Brachines par le manque d'ailes, et en outre par les élytres dont l'extrémité est obliquement tronquée, de inasière à former un angle rentrant doni le somaiet répond à la suture; les Aptines males ont les truis premier's articles des tarses antérieur's sensiblement dilatés : les élytres des Corsyres forment un ovale court, presqu'orbiculaire, et le deruier article de leur's palpes est cylindrique.

Menton dépourvu de dent au milieu de son ćch ancrure.-Corps ailé. - Corselet assez alongé, un peu plus large que la tête antérieurement. Elytres du donble plus larges que le corselet, assez alongées, coupées carrément à leur extrćmité. Turses ayant leurs articles presque cylindriqnes: farses antérieurs point sensible nent dilatés dans les mâles. Les autres caractères sont ceux dcs Aptines. Voyez ce mot, article précéden:.

Les Brachines, nommés ainsi d'un verbe grec (ini signifie : fáire du bruit, ont, comme les Aptines, la proprićté remarquable de lancer avec détonation par leur anus une liqueur caustique et vaporisable. Ce fut Rolander qui obscrra le premier cette particularité. (Mém. de l'Académ. de Stockholm, 1750. pag. 292.tab. 7. fig 2.) l'insecte ne produit cette explosion que lorscinil se croit menacé de quelque danger, et la nature paroît lui en avoir douné la faculıś comme un moyen de défense. Rolander prétend que le Bracline pétard peut répéter cette manouvre jusçu’à vingt fois presque de snite, et qu'il éloigne par ce moyen les grosses espèces de Carabiques qui cherchent à le dévorer. M. Léon Dufour a particulièrement observé cette proprićté dans l'Aptine baliste, et il a donnó (Annal. du Musée d'hist. nat. tom. 18. pag. 7o. et Bulletin des sciences de la Société philom. juillet $8_{12}$ ) une description détaillée des organes qui sécrètent cette substance; cile paroît se rapprocher de la nature des acides caustiques. Dans les grandes espèces comme celle dont nous venons de parler en dernier, elle occasionne à la peau sur laquelle elle est lancée une couleur vive et durable, et la brûle assez sensiblement : au moment de l'explosion que l'insecte produit ordinairement dès l'instant qu'il est inquiété, un voit sortir cette matière sous l'apparence d'une fumée blanchâtre dont l'odeur est furte et piquante; il répète cette explosion dix à douze fois; mais lorsqu'il est fatigué elle se fait sans bruit, et au lieu de fumée on ne voit plus qu'une liqueur jaune ou brunâtre qui se tige à l'instant et fornie une légère croûte ; observée à l'état liquide, elle laisse échapper quelques bul!es d'air et présente une apparence de fermentation. Ces propriétés sont communes à toutes les espèces de Brachines et d'Aptines et aux deux sexes de chaque espèce : toutes aussi se cacbent sous les pierres; il n'est pas rare de trouver plusieurs espèces sous le même abri et d'y rencontrer un grapd nombre d'individus de chacune d'elles.
Leurs premiers élats sont encore inconnus. Ces Carabiques paroissent généralement répandus dans tous les climats.

Ire. Division. Elytres sillonnées, ayant des côtes élevées et fort saillantes.

Nota. Cette division comprend en général lez plus grandes espèces du genre; elles sont presque toutes de l'ancier continent.

\section{Brachine bimaculé, B. bimaculatus.}

Brachinus biniaculatus $n^{\circ}$. 1. FАв. Syst. Eleut. (Au synonyme de Voët lisez I. au lieu de 2.) - Scres. Syn. Ins. tom. I. pag. 229. $n^{\circ}$. I. (Au synony̆me de Voët lisez 1. au lieu de 2, et 34 . au lieu de 74.) - Dej. Spéc. tom. 1. pag. 299. $n^{\circ} .2$.

Voyez pour la description et les autres synonymes, Carabe bimaculć no. 83 . de ce Dictionnaire.

Nota. Il est probable que la varićté mentionnće est une espèce particulière.

\section{Brachine uni, B. complanatus.}

Brachinus complanatus $n^{\circ}$. 2. FAB. id. ( En retranchant le synonyme de Linnć.) - Schers. id. pag. $230 . n^{\circ}$. 2. - DEJ. Spéc. tom. 1. pag. 3 เा. $n^{\circ} .19$.

Voyez pour la description et les autres synonymes, Carabe uni no. 76. de ce Dictionnaire.

Dans cette division entrent encore les espèces suivantes : $1^{\circ}$. Brachine espagnol, B. hispanicus. DEJ. Hist. nat. et Icon. etc. pag. 104. $\pi^{\circ}$. 1. tab. VIII. fg. 5.- DeJ Spéc. tom. 1. pag. 305. $n^{\circ} .8$. Longueur 7. lig. 'Tête et corselet roux, sans taclies; élytres noires avec une taclie humérale, une large bande dcntelée placée sur le milieu et n'atteignant pas la su!ure, de couleur testacée ainsi que les pattes. Espagne; baie d'Algésiras. $2^{\circ}$. Brachine de Jurine, B. Jurinei. DEs. id. pag. $298 . n^{\circ}$. 1. Longueur 9 lig. $\frac{1}{2}$. Testacé; élytres noires avec le bord latéral, une grande tache carrée placće sur le milieu et leur extrémité, de couleur testacée. Du Sénégal. 3º. Brachine discicolle, B. discicollis. De.s. id. pag. 3oo. $n^{\circ} .3$. Longueur 7 lig. $\frac{1}{4}$. Tète jaune à sa partie antérieure, ferrugineuse postćrieurement; corselet brun portant de cliaque côté une grande tache rousse; élytres noires avec un point huméral, une large bande dentelée située sur le milieı, n'atteignant pas la suture, de couleur jaune; l'extrémisé des élytres est aussi de cette couleur, ainsi que les anteunes et les pattes. Indes orientales. $4^{\circ}$. Brachine de Catoire, B. Catoirei. DEJ. id. pag. $30 !$. $n^{\circ} .4$. Longueur 7 licr. $\frac{1}{2}$. Tête et corselet ferrugineux, sans taches; élytres alongées, noires, avec un point buinéral, une bande sinuée, placée dans le milieu, a'atteignant pas la suture, testacés. 
Antennes, paltes et extrémité des élytres de celle dernière couleur. Du Bengale. 50. Prachine semblable, B. affinis. DE. $i d . n^{\circ}$. 5. Lnngueur 7 lig. $\frac{x}{2}$. 'Têle et corselet testacés; les bords de ce dernier' un pell obscurs; élylres noires avec un point huméral, une large bande sinuée, placée snr le milieu, n'alleignant pas la suture, testacés. Antennes, pattes el extrémité des élyltes de cetle dernière couleur. Indes orientales. $6^{\circ}$. Brachine vertical, B. verticalis. DEJ. id. pag. 302. $n^{2} .6$. Longueur' 7 lig. 'T'ête teslacée, verlex obscur'; corselet obscur, avec deux laches testacées peu apparentes; élyıres noires, leur bord latćlal, une bande sinuće placće suc le milieu, n'atteiguanl pas la suture, de couleur lestacée. Antennes et pattes testacées ainsi que l'extrémité des ćlytres. Nouvelle-Hollande. $7^{\circ}$. Brachine africain, $B$. africanus. DEJ, id. pag. 303. $77^{\circ} \cdot 7$. Longueur 6 lig., 6 lig. $\frac{x}{2}$. Têle et corselct roux, sans taches; élytres noires avec une bande siuuée placée dars le milieu, n'attcignant pas la suture, de coulenr rousse ainsi que leur extrémilé; antennes et pattes de celle dernière couleur. De Barlsarie. 8०. Brachine ambigu, B. ambiguls. DEJ. id. pag. 3o4. $n^{\circ}$. 9. bongucur 7 lig. $\frac{3}{4}$. Tète jaune, vertex obscur; corselel obscur avec deux taches jaunes peu apparentes; élytres noires avec une tache liumérale, une bandẹ sinuée, située dans le milieu, n’alteignant pas la suture, jaunes. Extrćmité des élytres légèrement bordée de jaune; antennes et palles de celle couleur. Des îles Phi. lippines. $9^{\circ}$. Brachine de Java, B. javanus. DEJ. id. pag. 305. $n^{\circ}$. 10. Longueur 8 lig., 8 lig. $\frac{1}{2}$. "Tête teslacée, vertex obscur; corselet obscur avec deux taclies oblongues testacées : élytres obscures ayant un point liunéral, une bande étroite, dentelće, placée au milieu, n’alteignant pas la sulure, testacés; antennes el paltes de celte dernière couleur. De Java. $10^{\circ}$. Brachine fuscicolle, B. fuscicollis. DEJ. id. pag. 306. $n^{\circ}$. 11 . Longueur $7 \mathrm{lig}$. $\frac{1}{4}$. 'Tête testacée, vertex obscur; corselet obscur, sans taches; élytres obscures avec un point huméral, une bande érroite, dentelée, placée au milieu, n'atteignant pas la suture, testacés; anlennes et pattes de celte même couleur. De Java. $1^{\circ}{ }^{\circ}$. Brachine interrompu, $B$. interruptus. DEJ. id. $n^{\circ}$. 12. Longueur 8 lig. $\frac{x}{4}$. 'Têle testacée, verlex obscur; corselet obscur avec deux grandes tachès testacées; élytres olsscures ayant un point huméral, le bord latéral vers la partie antérieure, une bande linéaire, dentelée, interrompue, placée dans le milieu, n'atteignant pas la sulure, testacés; antennes et paltes de cette même couleur. De Java. I $2^{\circ}$. Brachine enfumé, B. fumigatus. Des. id. pag. 307. $7{ }^{\circ}$. 13. Longueur 7 lig. $\frac{3}{2}$. Têle jaune, vertex obscur ; corselet abscur avec deux taches jaunes; élytres obscures, jaunes à l'extrémité; antennes et pattes de celte même couleur. Iles Philippines. 13․ Brachine du Sénégal, B. senegalensis. DEJ. id. pag. 308. no. 14. Longueur 6 lig. $\frac{7}{4}$. Testacé ; élytres noirès, s'élargissant vers leur extrémité, ayant un point humséral, les bords latéraux, une bande dentelée placée au milieu, n'atteignant pas la suture, de couleur lestacée, ainsi que leur extrémité. Da Sénégal. 140. Brachine parent, $B$. sobrinus. DF. Spéc. tom. 2. pag. 462. $n^{0} .41$. Longueur 6 lig. $\frac{1}{4}$ à 7 ligg. Tête et corselet teslacés, sans taches; élytres noires avec un point hurnéral très-petit, le bord latéral, une large bande au milieu sinuée el racconrcie, et l'extrémilé testacés; antennes el pattes de celte nuêne conleur. Des Indes orientales. $15^{\circ}$. Brachine parallèle, B. parallelus. DE.J. Spéc. tom. 1. pag. 308. $n^{\circ}$. 15. Longueur 6,7 lig. 'Testacé; élytre's noires, presque parallèles, ayant un point huméral, les bords la télaux, une bande dentelée, siluée au milicu, n'alleignant pas la sulute, et l'extrémité de coulcur testácée. Du Sénégal. 16". Brachise hordé, B. marginatus. Des. id. pag. 3og. $n^{\circ}$. 16. Longueur 7 lig. Tête teslacée avec un point noir sur le vertex; corselet testacé arec le bord poslérieur ainsi que l'antérieur, noirs; élytres presque parallèles, unires, avec un point huméral, les bords laléraux, une bande dentelée, situce au milieu, n’alleignant pas la suture, testacés; anlenues, extrémilé des élyties el pattes de celte dernière conleur. Côte de Guinée. 17º. Brachine marginal, B. marginalis. DEJ. id. pag. 310. $n^{\circ}$. 17. Longueur 6 lig. Tête testacée, vertex noir; corselet noir, ayant de chaque côté une tache testacée; élytres noires, prescyue parallèles, a vec un point huméral, les bords latéraux, use bande dentelée, siluée au milieu, n'alleignant pas la siture, et l'extrémilé, testacés, ainsi que les antennes et les pattes. Des Indes orientales. I $8^{\circ}$. Brachine de Bauvois, B. Bauvoisi. DEJ. $i d$. $n^{\circ}$. 18. Longueur 5 lig. Testacé ; élytres noires, presque parallèles; un point huméral, les bords latéraux, une bande sinuée, raccourcie, placée ver's le milieu, leur extrémité, une tache sur l'écusson et de peitis points peu visibles vers la suture, de couleur testacée. Côte de Guinée.

$2^{\mathrm{e}}$. Division. Elytres à côtes peu élevées, quelquefois même presqu'insensibles.

\section{Brachine fumant, B. fumans.}

Brachinus fumans $\mathbf{n}^{\circ}$. I I. F AB. Syst. Eleut. Lat. Gen. Crust. et Ins. tom. 1. pag. 188. $\pi^{\circ}$. I. - ScHen. Syn. Ins. tom. 1. pag. $230 . n^{\circ} .11 .-$ DEJ. Spéc. tom. 1. pag. 317. $n^{\circ} \cdot 27 \cdot$

Voyez pour la description et les autres synonymes, Carabe fumant $n^{\circ} .81$. de ce Dictionnaire.

\section{Brachine pétard, B. crepitans.}

Brachinus crepitans no. I 2. FaB. Syst. Eleut. (à la citation de la Faun. Suec. lisez 792. au lieu 


\section{T R O}

de 272.) - Ls r. Gen. Crust. et Ins. tom. 1.p. I89. no. 2. (A la cilalion de De Géer lisez tom. 4. an lieu de tom. 7.) - Scuæn. Syn. Ins. tom. 1. pag. 2.00. $n^{\circ}$. I 2. - Des. Hist. nat, et Icon. etc. $p a g$. 105. $n^{\circ}:$ 2. tab. VIII. fig. 6. - DEJ. Spéc. tom. I . pag. 318. $n^{\circ}$. 30. - Faun. franc. Coléopt. pl. 1 . fig. $\cdot 4$.

Voyez pour la description et les antres synonymes, Carabe pétard $\mathbf{n}^{\circ}$. 82 . de ce Dictionnaire.

Nota. Les individus indiqués comme n'ayant pas l'abdomen obscur, ne peuvent appartenir à cette espèce.

On placera en outre dans celte division : $\mathbf{I}^{\circ}$. Bracline pistolet, B. sclopeta no. 13. FAB. Syst. Eleut. -Sencis. Syn. Ins. tom. I. pag. 231 . no. 13. - Des. Hist. nat. et Icon. ete. pog. Iog. $n^{\circ} .7$. tıb. IX. fig. 3. - DeJ. Spéc. tom. I. pag. 322. $n^{\circ}$. 36. Très-commun anx environs de Paris. $2^{\circ}$. B.ruchine tète rousse, B. ruficeps $\mathrm{n}^{\circ}$. 10. FAB. $i d$. - Scher. id pag. 23o. $n^{\circ}$. Io. - Dr. Spéc. tom. 1. pag. $314.72^{\circ}$. 23. Du cap de Bonne-Espérance. $3^{\circ}$. Bracbine caustique, $B$. causticus. Des. Hist. nat. et Icon. etc. pag. I 14. $n^{\text {. }}$ I 2. tab. IX. fig. 8. - DEJ. Spéc. tom. I. pag. 313. $\pi 0^{\circ}, 21$. $L$ ingueur 5 lig. D'un jaune ferrugineux; élytres ayant une large baude longitudinale sur la suture et une graude tache un peu au-delà du milieu sur chacune, se joignant à là bande suturale et n'atteignant pas tont-à-fait le bord extérieur, de couleur noirâtre. Midi de la France; environs de Montpellier. Rare. $4^{\circ}$. Brachine longipalpe, $B$. longipalpis. Des. id. pag. 314. no. 22. Longueur 3 lig. $\frac{1}{4}$. Tête el corselet ferrugineux à leur partie supérieure; élytres obscures avec le bord latéral, une bande transverse sur le milieu, raccourcie et inırrompue, de couleur pâle, ainsi que les antennes, les pattes et l'extrémité des élytres. Des Indes orientales (1).5०. Brachine buruyant, B. explodens. DEJ. Hist. nat. et Icon. ete. pag. 107.

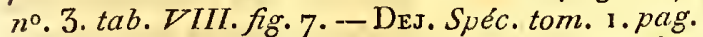
320. n०. 3ı. Longueur 2 lig. $\frac{1}{2}$. Ferrugineux; élytres bleues; troisième et quatrième arlicles des antennes obseurs ainsi que l'abdomen. Très-commun aux environs de Paris. $6^{\circ}$. Brachine glabre, B. glabratus. Des. Hist. nat. et Icon. ete.pag. $108.7{ }^{\circ} .4$. tab. VIIT. fig. 8. - DEJ. Spéc. tom. I. pag. 320. $n^{\circ} .32$. Longueur 2 lig. $\frac{x}{3}, 3$ lig. Ferrugineux; élyt res bleues; abdomen obscur. Midi de l'Europe; Franee méridionale. $7^{\circ}$. Bracline détonnant, B. psophia. Des. Hist. nat. etIcon. etc. pag. 108. no.5. tab.IX. fig. 1. - DEJ. Spéc. tom. 1. pag. 321 . no. 34. Longueur 2 lig. $\frac{1}{2}, 3$ lig. $\frac{1}{2}$. Ferrugineux ; élytres d'un bleu verdấtre. Même patrie que le précédent. 80.

(I) Par la conformation de ses palpes certe espèce, suivant M. Le comte Dejead, poitroit peut-être constituer un genre nouveau.
Braenine bombarde, B. bombarda. DEJ. Hist. nat. et Icon. ete. pag. $\log \cdot 2^{\circ}$. 6. tab. IX. fig. 2 , - DEJ. Spec. tom. 1. pag. 3z2. no. 35. Portugal et midi de la France. $9^{\circ}$. Brachine bipustulé, $B$. bipustulatus. Scran. Syn. Ins. tom. 1. pag. 231. $n^{\circ} .15$. tab. III. $/ \mathrm{g} \cdot 7 \cdot$ - D D. Hist. nat et Icon. etc. pag. I 10. $n^{\circ}$. 8. tab. IX.fig. 4. - DEJ. Spéc. tom. I. $p a g .323 . n^{\circ} .37$. Longueur 3 lig. Ferrugineux; élytres verdattres, ayant chaeune uue taehe tes:acée à leur partie postérieure; abdomen obseur. De Kislar. $10^{\circ}$. Braehine exbalant, B. exhalans. Senas. $i d . n^{\circ} .14 .-$ DEJ. Hist. nat. et Icon. etc. pag. 1 1 1. no. 9. tob. IX.fig. 5. - DE. Spéc, torn. I. pag. 324. $n^{\circ}$. 58. Longueur 2 lig. à 2 lig. $\frac{1}{2}$. Ferrugineux; élytres d'un bleu obscur, avee deux taches jaunes sur cliacune; ablomen obsenr. Italie e midi de la France. $I^{\circ}$. Braclime eroisé, $B$. craciatus. Schen. id. no. I6. tab. III. fig. 8.-DEJ, Hist. nat, et Icon. ete. pag. 1]2. $n^{\circ}$. Io. tab. $I X$. fig. 6. - Des. Spéc. tom. 1. pag. 324. no. 3g. De Kislar. I $2^{\circ}$. Brachine des lhermes, B. thermamm. Stév. Mrém. de la Soc. imp. des nat. de Mosc. t. I 66. tab. X. fig. 7. - DE. Hist. nat. et Icon. etc. pag. $113 . n^{\circ}$. I 1 . tab. 1 K. fig. 7. - DEJ. Spéc. tom. 1. pag. 525. $n^{\circ}$. 40. Montagnes du Caucase, près des bains de Constantin (1). 130. Braehine six taches, B. sexmaculatus. Des. id. pag. 3 ı. $n^{\circ}$. 20. Longueur 4 lig. $\frac{1}{2}$. Ferrugineux; élytres brunes, leur bord extérieur testacé; trois taches sur chacuue de même couleur, ainsi que les pattes. Des Indes orientales $14^{\circ}$. Brachine petites côtes, B. subcostalis. DEJ. id. pag. 3r 5. $n^{\circ} \cdot 24$. Longuen 3 lig. $\frac{3}{4}$. Ferrugineux; angles postérieurs du corseleê saillans, aigus; élytres bleues; abdomen obscur. Du cap de Bonne-Espérance. 150. Brachine liséré, $B$. marginellıs. Des. Spéc. tom. 2. pag. 463. $n^{\circ} .42$. Lougueur $6 \mathrm{lig}$. Tête et eorselet d'un roux ferrugiueux; élytres brunes; leurs bords, la base des antennes el les palles d'un jaune ferrugineux. Environs de Buénos-Ayres, pendant l'hiver. $16^{\circ}$. Brachine alternant, $B$. atternans. DEJ. Spéc. tom. I. pag. 316. no. 25. Longueur 7 lig. $\frac{1}{3}$. Ferrugineux; angles postérieurs du corselet saillans, aigus; élytres d'un bleu obscur; leurs deuxième et troisième côtes élevées; abdomen obscur. Amérique septentlionale; Géorgie. $17^{\circ}$. Brachine fuscicorne, B. fuscicornis. DeJ. Spéc. tom. 2. pag. 463. no. 43. Longueur 5 lig. D'un roux ferrugineux; angles postérieurs du corselet prolongés, aigus; élyures d'un bleu violet; abdomen, antenres, jambes et tarses obscurs. Très-commun pendant l'hiver aux environs de Buénos-Ayres. 180. Brachine pallipède, B. pallipes. Des. id. pag. 464. no. 44. Longueur 3. lig. $\frac{1}{4}, 4$ lig. $\frac{1}{2}$. Tête et corselet d'un roux ferru-

(1) M. le comte Dejean observe que, par la conformation de ses palpes, certe espèce pourroir être le type d'un genre particulier. 
gineux; angles postérieurs du corselet prolungés, aigus; élytres brunes; abdomen obscur; base des antennes et pattes d'un jaune ferrugineux. Avec le précédent. $19^{\circ}$. Brachine voisin, B. vicinus. DEJ. id. pag. 465 . $n^{\circ}$. 45 . Longueur 4 lig. $\frac{1}{2}$. Tête et curseler ferrugineux; angles postérieurs de celui-ci peu prolongés, presqu'aigus; élytres brunes; abdomen obscur; base des antennes et pattes d'un jaune ferrugineux. Avec les précédens. $20^{\circ}$. Brachine quadripenne, B. quadripennis. DEJ. Spéc. tom. 1, pag. 3,5, $n^{\circ}$. 26. Longueur 5 lig. Ferrugineux; angles postérieurs du corselet saillans, aigus; élyıres larges, presque carrées, d’un bleu noirâlre; abdomen obscur. Amérique septentrionale. $21^{\circ}$. Brachine porte-cœur, B. cordicollis. Des. Spéc. tom. 2. pag. $466^{\circ} . n^{\circ} .46$. Longueur 4 lig. Ferruginenx; angles postérieurs du corselet prolongés, aigus; élytres bleues; antennes ayaut leurs troisième et quatrième articles obscurs; abdomen de cette dernière conleur. Amérique sep. tentrionale. $2^{\circ}$. Brachine céphalore, B. cephalotes. Des. Spéc. tom. 1. pag. 317. $n^{\circ}$. 28. Longrear 4 lig. Ferrugineux; angles postérieurs du corselet saillans, aigus; élytres bleues. Amérique suptentrionale. $23^{\circ}$. Brachine fuscipenne, $B$. fus: cipennis. Des. id. pag. 318. $n^{\circ}$. 29. Longueur 2 ligr. $\frac{7}{2}, 3$ lig. Ferrugineux; angles postérieurs du corselet saillans, aigus; élytres et abdomen bruns. Cap de Bonne-Espérance. $24^{\circ}$. Brachine imwaC.licorne, B. immaculicornis. DEJ. Spéc. tom. 2. pag. 466. $n^{\circ} .47$. Longueur $4 \mathrm{lig}$. $\frac{1}{2}$. Ferrugineax; élytres verdâtres; abdomen obscur. Il est plus grand que le Brachine péla rô. Espagne, I alie, midi de la France. $25^{\circ}$. Brachine oblong, $B$. oblongus. UEs. Spéc. tom. 1. pag. 321: no. 33. Longueur 5 lig. $\frac{1}{3}$. Ferrugineux ; élytres brunes. D’Egypte.

fabricius en adoptant ce gen'e dans son Systema Eleutheratorum y rappurle treize espèces; mais il fatit rendre au genre Aptiae les nos. 5. et 7 . Le ${ }^{a}$. 6. appartient aux Helluos. Les $n^{\circ}$. 3, 4, 8, 9. sont douteux. Les six autres espèces sont certainement du genre B achine.

CORSYFE, Corsyra. Stíq. Dej. (Spéc.) Cymindis. Fisc E.

Genre d'insectes de l'ordre des Coléoptères, section des Pentamères, famille des Carnassiers (lerrestres), tribu des Carabiques (division des 'lloncatipennes).

Les trois genres Aptine, Brachine et Corsyre constituent un groupe dans celle division, (Voyez Troncatipennes.) On séparera aisément les deux premiers genres de celui de Corsyre par lears pilpes externes, dont le dernier article est plus gros que le précédent, renflé vers son extrémité; et par leurs èlyires de forme ovale assez alongée; en outre les Aptines sont dépourvis d'aités et les mâles ont les trois premiers articles des tarses antérieurs sensiblement dilatés.

Antennes filiformes, plus courtẹs que le corps, composées de onze articles. - Labre court, transverse, légèrement échancré, laissant les mandibules à découvert. - Mandibules courles, peu saillantes. - Dernier article des palpes, cylndrique. - Menton ayant une denl peu avancée, au milieu de son échancrure. - Tête presque triangulaire, point réltécie postérieurement. Corps court, large, aplati. - Corselet plus large que la têle, convexe, arrondi. - Elytres larges, en ovale peu alongé, presqu'orbiculaire, recouviant des ailes el l'ábuomen. - Jambes antérieures écliancrées au côté interne. - Tarses composés d'articles presque cylindriques; tarses antérieurs des mâles n'ćtant que très-légèrement dilatés; crochets simples.

II. Siéven a établi ce genre sur une seule espèce qui halite en Sibérie. On ne sait rien de ses nuars, ni de ses premiers élats; c'est la Corsyre fuseau, C. fusula. DEs. Spćc. tom. I. pag. 327. $n^{\circ}$. 1.-Cymindis fusula. Fiscr. Entom. de Russ. 1. pag. 123. $n^{\circ}$. 4. tal. 12. fig. 3. Long. 3 lig. $\frac{1}{2}$. Brune, très-poncture ; élytres tormant pres. qu'un cercle; leurs bords, une tache bumérale, une bande Iransverse placée presçu’à l'extrémité, d'un roux testacé; ces tachés ct ia bande se joignent les unes aux autres. Antennes et pattes forrugineuses. De Sibérie.

CATASCOPE, Catascopus. Kirb. Lat. (Hist. nat. et icon. el Fam. nat.) DEJ. (Spec.) Carabus. WIÉDEM.

Genre d'insectes de l'ordre des Coléoptères, section des Pentanières, famille des Carnassiers (lerrestres), tribu des Carabiques (division des 'Troncatipeunes).

Le dernier groupe de Troncalipennes à crochets des tarses sans dentelures, présente pour caractères: Labre avancé, recouvrant plus ou moins les mandibules. Il contient trois genres, Catascope, Graphiptère et Anthie. (Voyez'Taoncatrpennes). Ces deux derniers diffèrent des Catascopes par leur labre arrondi, leur menton sans denl au milieu de son échancrure, le manque d'ailes, et pa. leurs élytres arrondies à learrs angles humeraux.

Antennes filiformes, beacoup plus courtes que le corps, composées de onze articles. Labre avancć, échancré antérieurearent, recouvrant presqu'entièrement les mandibules. - Pal. pesexterieurs filiformes, ayant leur dernier article cylindrique. - Menton ayant au milieu de soin échancrure une dent arroudie, peu avancée. Tête assez grosse, presque triangulaire, peu rétrécie postérieurement. - Yeux gros , ' assez saillans. - Corps assez aplati. - Corselet un pe $\mathrm{a}$ plus large que la tête autérieurement, rétréci à sa partie postérienre. - Elytres du double plus lárges que le corselet, presque planes, en carré plus ou moins alongé, fortement échancréeșà l'ex trémité, recouvrant des ailes et l'abdomen. Jambes antérieures échancrées ă côté interne. - 


\section{T $\mathrm{NO}$}

Turses composés d'articles presque cylindriques; crochets simples.

On doit l'établissement de ce genre à M. Kirby qui en a donné les caractères dans les Transactions Linnéennes, tom. 14. pag. 94. Son nom est tiré d'un verbe grec dont le sens est : regarder autour de soi; l'auteur n'en mentionne qu'une espèce.

Les habitudes de cesinsectes ne sont pas connues. Ils babitent les Indes orientales.

$1^{\circ}$. Catascope grosse tête, C. fucialis. Des. Spéc. tom. 1. pag. $329 \cdot n^{\circ}$.1. - Catascopus Hardvickii. Кгв B. Trans. Linn. tom. 14. pag. 98. tah. 3. fig. 1. - Lat. Hist. nat. et Icon. etc. pag. 116. tub. VII. fig. 8. - Carabus facialis. Wiéden. Zool. magaz. tom. 1. part. 3. pag. $165 . n^{\circ}$. 12. loong. 6 lig. $\frac{7}{4}$. Dessus de la tête et corselet verts; Alytres d'un bleu-verdâtre à stries ponctuées; dessous du corps d'un bleu obscur ainsi que les pattes. Des Indes orientales. ${ }^{\circ}$. Catascope émeraude, C. smaragdulus. DEs. id. pag. 33 i. $n^{\circ} .2$. Long. $3 \mathrm{lig} \cdot \frac{1}{4}$. Vert en dessus; élytres stuiées, les stries latérales seules poncluées; burd extérieur doré : dessous du corselet, abdomen et pattes de couleur brune. De Java.

GRAPIIPTÈRE, Graphipterus. Lat. DeJ. Anthia. Eab. Carabus. Ouvv. Cicindela. De Géer. firss.

Genre d'insectes de l'ordre des Coléoptères, section des Pentamères, famille des Carnassiers (terrestres), tribu des Carabiques (division des Troncatipennes).

Les genres Graphiptère, Anthie et Calascope composent un groupe parmi les Troncatipennes. (Voyez ce mot.) Les Catascopes ont le labre échaucré en devant; le menton offre dans son milieu une petite dent ; les ćlytres sont carrées et recouvrent des ailes. Dans les Anthies les élytres sont convexes, en ovale assez alongé, peu ou point tronquées à leur extrémité; l'abdomen est épais et convexe en dessous. Les Graphiptères n'ont aucuns de ces caractères.

Antennes filiformes, bien plus contes que le corps, comprimées, composées de onze articles; le troisième beaucoup plus loug que les autres. Labre avancé, arroudi, presque plane, recouvrant presçu'entièrement les mandibules. - Palpes ex. térieurs filiformes, terminés par un article cylindrique. - Languette cornée longitudinalement dans son milieu, membraneuse sur les côtés. Tête point très-grosse, ni rétrécie postérieurement. - Yeux assez grands, peu saillans. - Corps court, large, déprimé, peu épais. - Corselet cordiforme, beancoup plus large que la tête antérieurement, fort rétréci à sa partie postérienre. - Elytres planes, larges, à peine en ovale, presqu'orbiculaires; leur' extrémité visiblement tronquée; le urs angles huméraux arrondis. - Point $d^{3} a i l e s$. - Abdomen déprimé en dessous. - Pat-

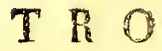

$m 3: 3$

tes de longnenr moyenne; jambes an:érieures trìso échancrées au côlé interne; tarses antéricurs aे peine dilatés dans les mâtles; crochets simplus.

Ces Carabiques paroissent habiter exclusivenent l'Afrique, depuis la Barbarie jusqu'au cap de Bonne-Espérance, l'Arabie et les parties de l'Asie qui en sunt voisines. Les espèces connues ont le corps noir, tacheté ou rayé de blanc ou de. cendré; ces taches formées par an duvet conrt; c'est it quoi leur nom, tiré de deux mots grecs, fait allusion.

On a remarqué que !es espèces tachetées sont plus particulières à l'Eyypte. Toutes se plaisent dans les sables brúlans. On ignore leurs premier's états.

\section{Graphiptère varié, G. variegatus.}

Graphipterus variegatus. DEJ. Spéc. tom. I. pag. 333. $n^{\circ}$. 1. - Anthia variegata $n^{\circ}$. 13. $\mathrm{F}_{\mathrm{AB}}$. Syst. Eleut. - Scuøn. Syn. Ins. tomt. 1. pag. 235. $n^{\circ} .18$.

Voyez pour la description et les antres synonymes, Carabe bigarré $\mathbf{n}^{\circ}$. 21 . de ce Dictionnaire:

\section{Graphirtère moucheté, $G$. multiguttutus.}

Graphipterus luctuosus. DEJ. id. p. 335. $n^{\circ} .3$ ? - Anthia multiguttata. Sсног. id. $n^{\circ} .19$.

Voyez pour la description et le synonyme de l'Entomol. d'Oliv., Carabe moucheté $\mathbf{n}^{0} .57 \cdot \mathrm{r} \%$ 178. fg. 9. de ce Dictionnaire.

\section{Grapatptére trilinéé, G. trilineatus.}

Graphipterus trilineatus. LAT, Gen. Crust. et Ins. tom. 1. pag. 187. $n^{\circ}$. 2. - Lat. Hist. nat. et Icon. etc. pag. 96. tab. VI. fig. 3. - DEs. Spéc. tom. I. pag. 337. $n^{\circ}$. 5. - Anthia trilineata $n^{\circ}$. 1 5. F. A . Syst. Eleut. - Sc日erv. id. $n^{\circ} .21$.

Voyez poư la description et les autres synonymes, Carabe trilinéé no. 58. pl. 178. fig. 10. de ce Dictionnaire.

Ce genre comprend encore : $1^{\circ}$. Graphiptère de Latreille, G. Latreillei. Nов. - Graphipterus multiguttatus. Lat. Gener. Crust. et Ins. tom. I. pag. 186. $n^{\circ}$. 1. tab. VI. fig. I 1. (En retranchant tous les synonymes sauf celui de l'hist. nat. des Crust. et des Ins.) - Des. Spéc. tom. I. p. 334. $n^{\circ}$. 2. D'Egypte. $2^{\circ}$. Graphiptère point d'exclamation, G. exclamationis. LAT. id. $p .187 \cdot n^{\circ} .3$. - LaT. Dict. d'hist. nat. tont. X. pag. 88. fig. 7 . - Anthia exclamationis $n^{\circ}$. 14 . FАв. syst. Eleut. - Scres. Syn. Ins. tom. I. pag. 235. $n^{\circ}$. 20. De Barbarie. $3^{\circ}$. Graphiptère petit, G. minutus. Lat. Hist. nat. et Icon. etc. pag. 96. tab. VI. fig. 4. - Des. Spéc. id. pag. 336. no. 4. Longuenr 5 à 6 lig. Noir; bord du corselet et des élytres blanc; celles-ci portant un grand nombre de points de cette même couleur. D'Egypte. 
Nota. Les Carahes cicindéloides $n^{\circ} .56$. el effacé $n^{\circ} .6 \hat{6}$. de ce Dictionnaire appartiennent probablement à ce genre.

ANTHIE, Antlicia. Wéb. Fab. Lat. Dej. Thunb. Bonelz. Carabus. Linn. Oliv. Thunb. De Géer.

Genre d'insectes de l'ordre des Coléoptères, section des Pentamères, fämille des Carnassiers (terrestres), tribu des Carabiques (division des Troncatipennes).

Nota. Les Anthies ont les élytres très-peu tronquées postéricurement; dans quelqques espèces, elles ne le sont pas visiblement.

Le dernier groupe des 'lroncatipennes à crochets des tarses sans dentelures, caractérisé par le labre avancé, recouvrant plus ou moins les mandibules, est formé des geures (autuscope, Graphiptère et Anthie. (Vojez Troncatipennes.) Dans les Catascopes le labre est échancré antérieurement; leur menton a une petite dent au wilieu de son échaucrure; leurs élytres recouvrent des ailes et ont leu:s angles huméraux assez saillans. Le genre Graphiptère s'éloigne des Anthies par ses élytres planes, presqu'orbiculaires, sensiblement tronquées au buut, et encore par l'alsdomen qui est déprimé en dessous.

Aiztennes filiformes, plus courtes que le corps, composées de onze articles, ne paroissant point comprimés; le troisième beaucoup plus longr que les autres. - Labre grand, un peu convexe, arrondi, avancé, recouvrant presqu'entièrement les mandibules. - Mandioules trè-grandes et avancées, surtout dans les mâles. - Palpes extérieurs ayant leur dernier article presque cylindrique ou grossissant un peu vers l'extrénité. - Languetie grunde, ovals, avancée entre les palpes labiaux, entièrement cormée. - Menton déponrvu de dent au milieu de son échancrure. - Tête grande, assez alongée, sonvent un peu rếtrécie derrière les yeux. - Yeux assez grands, plus ou moins saillans. - Corps épais, plus ou moins alongé. - Corselet presque cordiforme, plus large que la tête à sa partie antérieure, prolongé postérieurement dans quelques mâles. - Elytres convexes, en ovale alongé, simplement sinuées ou même presqu'arrondies à. l'extrémité, recouvrant l'abdomen. - Point d'ailes. - Abdomen épais, convexe en dessous. - Pattes grandes, fortes; jambes antérieures très - échancrées au côté interne; tarses autéricurs légèrement dilatés dans les mâles : crochels simples.

Ces Coléoptères sont de grande taille; leur corps est noir, il a habituellement des taches blanches formées par un duvet court qui garnit des enfonce. mens. Leur patrie est l'Afrique et l'Asie, depuis la mer Rouge jusqu'au Bengale : ils se plaisent dans les sables les plus chauds; leurs premiers états n'ont pas encore été observés.

\section{Anthie maxillaire, A. maxillosa.}

Anthia maxillosa $n^{\circ}$. I. Faв. Syst. Eleut. (En lisant à la citation d'Olivier : tab. 1. fig. 10. au lien de $t a b$. 4. fig. 39. le synonyme de Voët est douteux, suivant M. Schœnberr.) - SchøN. Syn. Ins. tom. 1. pag. 232. $n^{\circ}$. 1. - DEs. Spéc. toin. 1. pag. $339 . n^{\circ}$. 1 .

Voyez pour la description et la synonymie (en. ajoutant ì celle de l'Entomologie d'Olivier : nâlé et $p l$. 1 . fg. 10. Femelle.) Carabe maxillaire $\mathrm{n}^{\circ} . \mathbf{}$. pl. 176. fig. 3. Màle. De ce Dictionnaire.

Notu. Le Carabus agilis. Tuuns. (Noy. Ins. Spec. III. pag. 70. - Carabe immaculé $n^{\circ} .4$. Encycl.) est peul-être la femelle de cetie espèce, suivant M. Gyllenhall cité par M. Schoenluerr; ce dernier auteur cloute de la vérité de cette assertion.

\section{Antme thoracique, $A$. thoracica.}

Anthia thoracica $n^{\circ}$. 2. FAB. $i d$. ( A la citalion d'Olivier lisez : 5. b. au lieu de 5. 6., et à celle d'Herbst : 2. au lieu de 12.) Mâle et femelle. Anthia thoracica. Schø. id. pag. 232. no. 3. Mâle. - Anthia fimbriata. Schœs. $i d$. $n^{\circ}$. 4. Femelle. - Anthia thoracica. Des. id. pag. 340. $n^{\circ}$. 2. Mâle et femelle. - Carabus thoracicus. Or.iv. Entom. tom. 3. Carab. pag. 14. $n^{\circ}$. 2. pl. 10. fig. 5. b. Mâle.

Voyez pour la description et les synonymes du mâle, Carabe thoracique no. 2. de ce Dictionnaire, et pour cenx de la femelle, Carabe frangé $n^{\circ} .3$. pl. 176 . fig. 4 .

\section{Antrie six taches, $A$. sexguttata.}

Anthia sexguttata $n^{\circ}$. 4. FAB. id. - LAт. Gen. Crust. et Ins. tom. 1. pag. 185. $n^{\circ}$. 1. - Scher. id. pag. 233. 17०. 8. - DEJ. id. pag. $341 . n^{\circ} .3$.

Voyez pour la description et les autres synonymes, Carabe six taches no. 5. pl. 176. fig. 5 . de ce Dictionnaire.

\section{Antrie dix taches, $A$. decemgnttata.}

Anthia decemgrttata $n^{\circ}$. 3. F' Аз. id. (Lisez tom. 7. au lieu de 47. à la cilation de De Géer.) - LAt. $i d$. pag. 186. $n^{\circ}$. 2. (En lisant éd. 12. au lieu de 13 . à la citation de Linné.) - Scras. id. pag. 232. $n^{\circ}$.5. - DEJ. id. pag. 349. $n^{\circ}$. 10.

Voyez pour la descriplion et les antres synonymes, Carabe dix taches no. 16. pl. 177; fig. 2. de ce Dictionnaire.

Nota. Le Carabe alongé no. 19.pl. 177. fg. 3. de ce même ouvrage. - Anthic quadriguttatc $n^{\circ}$. Iо. FAв. Syst. Eleut. n'est 'qu'uue variété de cette espèce. A la citation du Spec. de Fabricius lisez 300. au lieu de 3. 


\section{$\mathrm{T} \mathrm{R} \mathrm{O}$}

5. Axtrie sixmaculée, A. sexmaculata.

Anthia sexmaculata $n^{\circ} \cdot 7 \cdot$ FAn, id. - Schar. id. pag. 234. $n^{\circ}$. $11 .-D_{\text {EJ. }}$ id. pag. 346. $n^{\circ} \cdot 7 \cdot$

Voyez pour la description et la synonymie, Carabe sixmaeulé no. 17. de ce Dícliomaire.

6. Antrie sillonnée, $A$. sulcata.

Anthia sulcata $\pi^{\circ}$. 6. FАв. id. - Scgers. id. pag. 234. $n^{\circ}$. $10 .-$ DEu. id. pag. 345. $n^{\circ} .6$.

Voyez pour la deseriplion et les autres synonynnes, Carabe sillonné 1 $^{\circ}$. 18. pl. 177. fig. 18. de eet ourrage.

\section{Avture languissanle, A. tabida.}

Anthic tabida $n^{\circ}$. 1 1. FAB. id. - Scmen. id. pag. 234. $n^{\circ}$. 15. (En lisant 44. au lieu de 41. au synonyıne de Voët. ). - Des. id. pag. 354. $n^{\circ} .13$.

Voyez pour la description et les autres syno-

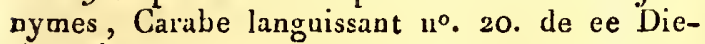
tionnaire.

On doit placer en outre dans ee genre, $1^{\circ}$. Anthie chasseresse, $A$. venator $n^{\circ} .5$. FАв. Syst. Elent. - Scran. Syn. Ins.tom. 1. pag. $234 . n^{\circ} \cdot 9$. - Des. Spéc. tom. 1. pag. 342. no. 4. Du Sénégal. $2^{\circ}$. Anthie Nimrod, $A$. Ninnrod. $n^{\circ} \cdot 9 \cdot$ Fав. $i d$. - Sencen. id. no. 13. - DeJ. id. pag. $343 . n^{\circ} .5$. Du Sénégal. $3^{\circ}$. Anthie six notes, $A$. sexnotata.

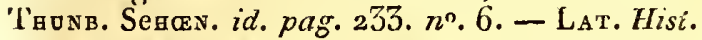
nat. et icon. elc. pag. 94. tab. VI. fig. 2. - DEJ. $i d$. pag. 352. $n^{\circ}$. 12. Longneur I pouce. Noire; élytres ayant eliacune huit sillons cotonneux et trois points blancs. Du eap de Bonne-Espérance. $4^{\circ}$. Antlie douze taches, $A$. ditodecim punctata. Bonell. Mémoires de l'Acad. dessciences de Turin, Observ. entom. 2. p. 19. ${ }^{\circ}$. 1. - LAT. id. p. 94. tab. VI. fig. I. - Des. id. pag. 348. $n^{\circ} .9$. Rapportée d'Arabie par feu Olivier. $5{ }^{\circ}$. Anthe bordée, $A$. marginata. DEs. id. pag. $347 \cdot n^{\circ} .8$. Longueur I ponee. Noire; bords du corselet et des élytres, blanes; eelles-ci striées, portant huit taches blanehes. De Nubie. $6^{\circ}$. Anthie binonchetée, A. biguttata. Bonell. id. pag. 20. no. 2. Des. id. pag. 351. $n^{\circ}$. 11. Du eap-de Bonne-Espérance.

Fabricius (Syst. Eleut.) met seize espèees dans ce genre. Les nos. 8. et 12. nous sont iueonnus; ceux de I3. à i5. appartiennent aux Graphiptères; le $n^{\circ}$. 16 . est peut-être aussi de ee genre. A la citation d'Olivier, pour ee dernier, lisez: obsoletus au lieu de villosus.

AGRE, Agra. Fab. Lat. Schan. Klug. Dex. Carabus. Oliv. Drypta. Schan.

Genre d'inseetes de l'ordre des Coléoptères, section des Pentainères, famille des Carnassiet's (terreștres), tribu des Carabiques (division des T'on caipenues ).

Hist. Nat. Ins. Tome $X$.
Un groupe de Troncatipennes à eroehets des tarses clentelés en dedans, offire pour earactères : eorps plus ou moins alongé; élytres ordinairement alongées : dernier artiele des palpes labiaux fortewent sécuriforme, ał moins dans les mâles. Il eontient les genres Agre, Cyminde et Calléide. (Voyez Troncatipenres.) Dans les deux dernier's la tếle est peu rétrécie postéricurement ; elle n’a pas d'étranglement sensible qui la sépare du eorselet; celui-ci est cordiforme; le eorps est trèsaplati. En outre les Cymindes ont tous les artieles des tarses entiers.

Antennes filiformes, beaucoup plus eourtes que le corps, eomposées de onze articles. - Palpes maxillaires externes filiformes; dernier article des libbiaux très-dilaté, fortement sécuriforme.Tête ovale, très-rétrćeie postérieurement et tenant au eorselet par un eol court dont elle est séparée par un étranglement très-prononcé.-Corps long, étroit, assez épais. - Corselet alongé, étroit, rériéci en devant. - Elytres à peu près du double plus larges que le eorselet, assez alongées, un peu eonvexes, allant en s'élargissant ver's l'exirémité qui est tronquée; les angles de cette tronealure portant le plus souvent une épine.-Pattes assez grandes; jambes antérieures échanerées au côté interne; tar'ses (surtout les quatre antérieurs) ay ant leurs trois premiers articles plus ou moins larges, triangulaires ou corditormes; le pénultière fortement bilobé ; eroebels dentelés en dedans.

Les Agres sont propres à l'Amérique méridionale, quoique Fibricius et M. Klüg donnent pour pairie à lenr Agra attclaboides, les Indes orientoles; ce qui paroît une erreur à $\mathrm{M}$. le comte Dejean ainsi qu'ì nous. Les mours de ees insectes ne sont pas connues; mais il y a lieu de eroire qu'ils viveat de proie, ce quandique leur nona générique, tiré du grec. Les espèces sont encore si peu eommunes daus les collections, qu'il n'a guère élé possible jusqu'aujourd'bui de les spécitier parfaitement et d'après une comparaison faite entr'elles sur la nature; e'est pourquoi il se pourruit, qu'en rapportant iei les espèees mentionnées par dillérens auteurs, nous tissions quelque double emploi, ce dont on comprendra la possibilité, en observant que M. le eomte Dejean, dans son Spéciès, ne cite qu'avee doule la plupart des synonyajes qu'il tire de la Monograplie du docteur K lüg, où vingt cspèees sont décriles.

$1^{\circ}$. Agre de Cayenne, A. cayennensis. Lat. Gen. Crust. et Ins. tom. 1. pag. 195. no. : Agra anea no. 1. FAB. Syst. Eleut. - KLug. Entom. monogr. pag. I2 $n^{0}$. 1. tab. 1. fg. I. - DE.J. Spéc. tom. 1. pag. 198. $n^{\circ}$. 1. - Scnow. Syn. Ins. tom. I. pag. 236 . $n^{\circ}$. 1. - Carabus cayennensis. OLrv. Entom. tom. 3. Carab. pag. 53. no.6o. pl. 12. fig. 133. De Cayenne. $2^{\circ}$. Agre rousse, $A$. rufescens. KLuc. id. pag. 14. $n^{\circ}$. 2. tab. I. fig. 2 . Longueur 10 lig. D'un brull-cuivreux; antennes et pattes d'un brun roussâtre; tête ovale, lisse;

Aa a a a 
corselet alongé, ponctué, raboteux ; ciytres cliargées de poinis enfoncés, leur extrémité obliquement tronquée, bidentéc. De Bahia, au Brésil. Cette espèce ést peut-êtrc la même que l'Agra rufescens. DeJ. Spéc. tom. 1. pag. $445 . n^{\circ}$. 5. que cet autenr décrit ainsi : longueur 9 lig. $\frac{1}{2}$. D'un roux-cuivreux; tĉle ovale, étroite, lisse, arec des poin!s épars sur sa partie postérieure; corselet profondément ponctué; élytres ayant des lignes de points profondément enfoncés, leur cxtrémité obliquement tronquée, échancrée et bidentée; anlennes et pattes rousses. Elle se trouve à RioJaneiro, dans les bois touffus, sur les branches d'arbre. $3^{\circ}$. Agre brunâtre, $A$. infuscata. Kuvg. id. pag. 15. no. 3. tab. 1. fig. 3. Longueur 9 lig. D'un cuivreux-noirâtre; tête étrottc, lisse; corselet alongé, ponctué; élytres anec des points cuivreux, leur extrémité bidentée. Du Para au Brésil. Une espèce également du brésil, trèsvoisine de celle-ci, ou u'eu étaut pent-être même qu'une variété, a été ligurée par M. Latreillc (IIist. nat. et Iconogr. clc. tab. VII. fig. 2.) sous le nom d'Agra brentoides. $4^{\circ}$. Agre trèsnoire, $A$. aterima. Klug. id. pag. $17 \cdot n^{n}$. 4. tab. 3. fig. 4. Longueur 7 lig. Très-noire; tête fort étroite, lisse ; corselet très-étroit, ponctué ; élytres à stries pointillées, leur extrémité munie de deux dents aiguës. De Bahia au Brésil. $5^{\circ}$. Agre variolée, A. variolosa. Kuvg. id. pag. 18. no. 5.tab. 1. fg. 5. Longueur 5 lig. D'un cuirreux-brunâtre, velue; tête ovale, portant une excavation à sa base; corselet alongé, ponctué ; élytres à stries ponctuées, comme ridées et plissées, leur extrémité tronquée et bidentée. De Bahia au Brésil. $6^{\circ}$. Agre excavée, $A$. excavata. Kuvg. id. pag. so. $n^{\circ}$. 6. tab. I. fig. 6. Longueur 5 lig. D'un cuipreux-noirâtre; tĉte ovale, avec une excavation à sa base; corselet alongć, ponctué; élytres ì stries ponctuées, leur extrémité tronquée, bidentée. Du Para. $7^{\circ}$. Agre enfoncée, $A$. immersa. KuvG. $i d$. pag. 21. $n^{\circ}: 7 \cdot$ tab. I. fig. 7. I jongueur 4 lig. D'un cuivreux-noirâtre, un peu velne; tête excavée, lisse ; corselet alongé, ponctué ; élytres cuivreuses, à stries ponctuées, leur extrémité tronquée, bidentée. Du Para. 8०. Agre chalcoptère, $A$. chalcoptera. Kuvg. $i d$. pag. $23 . n^{\circ}$. 8. tab. 1. fig. 8. Longucur 5 lig. $\frac{x}{2}$. 'Tête noire, excavée à sa base; corselet d'un noir-cuivreux, alongé, ponctué, un peu velu; élytres d'un cuivreux-verdâtre avec des stries ponctuées et des excavations éparses, leur extrémité tronquée, presque bidentée. Du Para. $9^{\circ}$. Agre brévicolle, A. brevicollis. KLUG $i d$. pag. $25 . n^{\circ}$. 9. tab. 1 . fig. 9. Longueur 5 lig. $\frac{x}{2}$. D'un noir-cuivreux; tềte étroite, excavée à sa ba.e; corselet alongé, ponctué ; ćlytres à stries ponctnées, leur extrémité cuivreuse et bidentée. Du Para. 10 ${ }^{\circ}$ Agre amincie, A. attenuata. Klog. id. pag. 26. no. 10 . tab. 2. fig. I. Longueur 6 lig. Tête ponctuée à sa partie postérieure, noire ainsi que le corselet; élytres cuivreuses, à stries ponctuées, leur extrémilé bidentće. Du Brésil. M. le comte Dejean, Spéc. tom. 1. png. 201. $n^{\circ}$. 4. décrit ainsi, sons le nom d'Agra puncticollis, une espèce ì laquelle il apporte avec doute l'atcenuata do docteur Klige. longueur 5 lig. $\frac{1}{2}$. D'un roux - cuivreux; têle étroite, lisse, ponciuće à sa partie postélieure; corselet très-ponctué; ćlylres brillantes, à stries poncluées, leur extrémité tronquée, bidentée; antennes et pattes rousses. Du Brésil. I1 ${ }^{\circ}$. Agre à points brillans, $A$. gemmata. Krug. id. pag. 28. $n^{\circ} .11$. tab. 2. fig. 2. Longueur 7 ligg. $\frac{x}{2}$. Têle étroite, lisse; corselet excavé, ponctué, tous denx de couleur rousse, ainsi que les paltes; élytres d'un testacé - roussâtre avec des points cuivreux et quelques taches noires, leur extrémité bidentée. Da Brésil. M. le comle Dejean regarde comıne pouvant être la même espèce celle qu'il décrit sous le nom d'Agra brentoides. Spéc. tom. 1. pag. 200. $n^{\circ}$. 3. Longueur $7 \cdot$ lig. $\frac{1}{4}$. Corps cylindrique, d'un rouge-cuivreux; tête étroite, lisse; corselet portant des lignes de points enfoncés; élytres profondément ponctuées, leur extrémitć trunquée avec une dent à la partie extérieure de la troncature; antennes et pattes rousses. Celte espèce n'est point l'Agra brentoides LAT. Hist. nat. et Iconogr. etc. pag. 131. tab. VII. fig. 2. (Voyez plus haut, Agre brunâtre no.3.) $12^{\circ}$. Agre enchaînée, $A$. catenulata. Kuvg. id. pag. 29. $n^{\circ}$. 12. tab. 2. fig. 3. Longueur 5 lig. Rousse, avec un reflet cuivreux brillant; iête lisse; corselet ponctué, raboteux; élytres ayant des points enfoncés, leur extrémité unidentée. Du Brésil. 130. Agre géniculée, $A$. geniculata. Krug. id. pag. 3o. $n^{\circ}$. 13. tab. 2. fg. 4. Longueur 6 lịg. $\frac{1}{2}$. D'un brun-noirâtre; tête étroite, lisse; corselet alcngé, ponctué; élytres à points enfoncés, leur extrémité presque tridentée; pattes jaunes avec l'extrémité des cuisses brune. Du Para. 140. Agre pieds rouges, $A$. erythropus. Des. Spéc. tom. 1. pag. 199. $n^{\circ}$. 2. D'un cuivreuxnoirâtré ; tête ovale, lisse; corselet peu ponctué; élytres ayant des lignes de points enfoncés, leur extrémité un peu tronquée, l'angle extérieur de cette troncature unidenté; antennes et pattes rousses. De Cayenne. M. Dejean rapporte à cette espèce l'Agra rufipes KuUG. Entomb. monogr. pag. $31.70^{\circ}$ 14. tab.2. fg. 5. Longueur 6 lig. $\frac{1}{2}$. Brune; corselet avec des points enfoncés; élytres à stries ponctuées, leur extrémité tridentée ; antennes et pattes rousses. Amérique méridionale. Celte espèce ne nous paroît pas être l'Agra rufipes FAB. dont nous parlerons plus bas. $15^{\circ}$. Agre ruficorre, A. ruficornis. Kuvg. id. pag. 33. $n^{\circ} .15$. tab. 2. fig. 6 . Longueur 6 lig. $\frac{x}{z}$. D'un noir-cuivreux; tête étroite, lisse ; corselet alongé, ponctué, raboteux; élytres à stries ponctuées, lenr extrénité tronquée, presque tridentée; bouclie, antennes et paltes d'un brun-roussâtı e. Du Para. 16\%. Agre attelaboide, $A$. attelaboides。n ${ }^{\circ}$. 3. Faв. Syst. 
Eleut.-Scaten. Syn. Ins. tom. 1. pag. $236 u z^{\circ} .3$. - Krvc. id.pag. 34. $n^{\circ}$. 16. tab. 2. fig. 7. Fabricius et M. Klïg donnent pour patrie à cette espèce les Indes orienlales, ce qui puroît douteux. $17^{\circ}$. Agre fémorale, A. femorata. Krvg. id. pag. 36 . $n^{\circ}$. 17. tab. 2. fig. 8. Longneur 7 lig. D'un cuivieux-noirâtre ; tête ovale, lisse; corselet alongé, raboleux, ponctué; élytres à stries ponctućes, leur extrémité tronquée, tridentée; cuisses épaisses. Du Para. 180. Agre gravée, $A$. exarata. KLUG. id.pag. 38. $n^{\circ}$. 18. tab. 2.fig. 9. Longueur $8 \mathrm{lig.} \mathrm{D'un} \mathrm{cuivreux-noirâtre;} \mathrm{tête} \mathrm{ovale} \mathrm{arec} \mathrm{une}$ légère impression à sa parlie postérieure; corselet alongé, rabotenx, ponclué; élytres à stries ponctuées, leur extrémité tronquée, tridentée. Dir Para. 19. Agre mulipliée, $A$. multiplicata. KLUG. id. pag. 3g. no. 19. tab. 3. fig. 1. Longueur $6 \mathrm{lig} \cdot \frac{3}{4}$. D'un noir-cuivieux; derrière de la tête ayant une foible impression; corselet assez alongé, ponctué ; élytres à stries ponctuées, leur extrémité pourprée, tridentée. Du Para. 20 . Agre cuivreuse, $A$. cuprea. KLuc. $i d$. pag. 41. $n^{\circ} .20$. tab. 3. fig. 2. Longueur 7 lig. D'un noir foncé, tirant un peu sur le violet; têle ayant une petite fossette à sa partie postérieure; corselet alongé, ponctué; élytres à stries ponctuées, leur extrémité cuivreuse, tridentée. Du Para. 210. Agre rulipède, $A$. rufipes no. 2. FАв. Syst. Eleut. Schar. Syn. Ins. tom. 1. pag. 236. ñ. 2. Anérique méridionale. 22 ${ }^{\circ}$. Agre petite, $A$. parvula. l.AT. Hist. nat. et Iconogr. elc. tab. VII. fog. 3. (L'auteur ne l'a point décrite.) Du Brésil.

CYMINDE, Cyznindis. Lat. Grulenh. Dej. Fisch. Tarus. Cenirv. Carabus. Fab. Oliv. Payk. Sa Y. Anomaeus. Fiscr.

Geure d'insectes de l'ordre des Coléoptères, section des Penlamères, famille des Carnassier's (terrestres), tribu des Carabiques (division des 'Troncatipennes ).

Dans cette division un groupe contenant les Agres, les Cymindes et les Calléides, offre les caractères suivans : crochels des tarses dentelés en dedans; corps plıs ou moins alongé ; élytres ordinairement alongées; dernier article des palpes labiaux fortement sécuriforne, au moins dans les mâles. (Voyez Troncatipennes.) Les Agres sont reconnoissables par leur tête très-rétrécie postćrieurement, ayant un cou appareut dont elle est séparée par un étranglemeut; leur corselet est alongé, étroit, rétrécu en devant, et le pénultième article des tarses bilobé; ce deruier caractère se retrouve dans le genre Cálléide, gui a eu oulre les trois premiers articles des tarses presque triangulaires, ce qui le sépare des Cyınindes.

Antennes filiformes, plus cour'es que le corps, composées de onze articles. - Dernier article des palpes labiaux plus ou moins sécuriforme, plus dilaté dans les mâles. - Tête ovale, pera rétrécie postérieurement. - Corps alongé, aplati. - Cor- selet cordiforme, légèrement convexe, rétréci postérieurement ; sa parlie antérieure plus large " que la iête. - Elytres planes, en ovale-alongé, tronquées à l'extrémité. - Articles des turses presque cylindriques, les quatre derniers des antéricurs légèrement dilatés dans les mâles; crochets des tarses dentelés en dedans.

Ces Carabiques se cacheut sous les pierres et paroissen 1 cratndre le jonr, d'où $M$. Latreille leur a appliqué le nom de Cymindis, que les Gress donnoient à nu certain oiseau de uuit; ils se trou. vent dans presque toute l'Europe, notamment sur les montagaes, et dans le nord de l'Afiique et de l'Amérique. Les types sur lesquels $M$. Fis ber a établi le geure Anomcous (Entom. de Russ.) sont des mâles de Cywundes. M. le comte Dejean mentionne vingt-six espèces de ce genre, tant dans son Spéciès que dans l'Iconographie des Culéoptères.

I $^{\circ}$. Cyminde croisée, $C$. cruciata. Des. Hist. natur. et iconogr. etc. pag. 133. $n^{\circ}$. 1, tab. $X$. fig. 7. .... DEJ. Spéc. tom. 1. pag. 205̄. $n^{\circ}$. 1. Anomcens cruciatus. F1sci. Entom. de Russ. tont. 1. pag. 128. $n^{\circ}$. 2. tab. 12. fig. 2. Russie méridionale. $2^{\circ}$. Cyminde latérale, C. lateralis. DEJ. Spéc. tom. т. pag. 204. $n^{\circ}$. 2. - - Fiscr. $i d . p a g$. 1 ¿o. $n^{\circ}$. 1. tab. 12. fg. 1 . Russie méridiouale. $3^{\circ}$ 。 Cyruinde bunérule, $C$. humeralis. Lıт. Gener. Crast. et Ins. tom. 1. pag. Igo. $n^{\circ}$. 1. (Il paroît que $M$. le comte Dejean regarde comme douleux les symonymes de Paykull, de Panzer et de Rossi.) - Des. id. no. 3. - Carabus humeralis no. 63. FAB. Syst Eleut. (Le sjuonyme de Paykull est douleux, suivant M. Dejean.) - Oriv. Entom. tom. 3. Carab. pag. 95 . no. 13 r. pl. 13. fig. 154. ( Selon M. Dejean le synunyme de Paykull est douteux ). - Carabus humerosus. Scron. Syn. Ins. tom. 1. pag. 184. $n^{n}$. 84. Nord de l'Europe. $4^{\circ}$. Cyminde sulurale, $C$. suturalis. DEJ. id. pag. 206. $n^{\circ} .4$. Longueur 4 lig. $\frac{\pi}{4}$. Pâle ; tête et corselet ferrugineux; élytres à stries ponctuées, leurs intervalles pouctués : la suture et une ligne sur la partie postérieme dés élytres, de couleur brune peu foncée. Egypte. 5०. Cyminde dorsale, $C$. dor salts. DEs. id. pag. 206. n०. 5. - Anomaus dor. salss. liscr. id. pag. 127. $n^{\circ}$. 1. tab. 12. fig. 1. Russie míridionale. $6^{\circ}$. Cyminde linéée, $C$. lineata. DEJ. id. pag. 207. no. 6. - Carabus lineatus. Schon. id. pag. 179: $n^{\circ}$. 61. Russie méridionale. $7^{\circ}$. Cyminde humagrique, C. homagrica. Des. id. pag. 203. no. 7. - Lebia homogrica. Faun. fianc. Coléopt. pag. 10. no. 1. pl. d. fig. 5. France et Allemagne. $3^{\circ}$. Cyminde ceinturée, $C$. cingulala. Des. id.pag. $209 \cdot 22^{\circ}$. 8. Longueur $3 \mathrm{lig} \cdot \frac{3}{4}$. Nuire, poncluée, base des élytres profondément ponctuée; leur bord extérieur de couleur ferruginense ainsi qu'une tache humérale qui se réunit à ce bord. Bouclie, antennes et patles de cette dernière couleur. Alpes de S yrie. $9^{\circ}$. Cyuninde réunie, C. coadunata. DEJ. id. pag. 2 ro. $n^{\circ} \cdot 9$. Longueur $3 \mathrm{lig.}{ }_{3}^{+}, 4$ lig. Noire, pouctuée; curselet roux; Aara 2 


\section{0}

hase des ílftues profondément ponctuée; leur bord extćrienr de couleur ferrugineuse ainsi quaue taabe luunérale qui se rétuist à ce bord. Bouche et antennes de celle dernicie couleur; pattes un peu plus pîles. Midi de la France. $10^{\circ}$. Cyminde zaélanocéphale, C. melanocephala. Des. id. pag. $210 . n^{0}$. 10. Longueur 3 lig. $\frac{1}{2} ., 4$ lig. Noire, un yeu pubescente, couverte de points très-seriés; corselet roux; élytres ayant leur bord latéral et une tache humćrale souvent peu distincte, de couleur ferrugineuse ainsi que la bouche et les antennes; pattes plus pâles. Pyrénées orientales. $11^{\circ}$. Cy uninde axillaire, C. axillaris. DEJ. id.pag. 211. 76". 11. - Carabus axillaris no. 66. FaB. Syst. Elent. - Scres. id.pag. 185. $n^{\circ}$. 86. D'Autriche. $12^{\circ}$. Cy soinde angulaire, C. angularis. Dus. id. pag. 212. $n^{\circ}$. 12. - Gŕ LL. Ins. Suec. tom. 2. pag. 173. $n^{\circ}$. 2. Suède, Russie. 13. Cynuinde maculée, C. maculata. Des. id. $n^{n}$. 13. Longueur 3 lig. $\frac{1}{2}$, 4 lig. Brune, un peu pubescente, couverte de points très-serrés; f́lytres ayant leur bord extérieul", une tache humérale réunie à ce bord, et un point à l'extrémité souvent peu visible, de couleur ferruginense ainsi que la bouche et les antenues; pattes plus pâles. Suède, Russie, Prusse. $14^{\circ}$. Cy minde binotée, C. binotata. Des. id. pag. 213. $n^{\circ}$. 14. - Frscr. id. pag. 121. $n^{\circ}$. 2. tab. 12. fig. 2. Sibéric, Russie méridionale. $15^{\circ}$. Cyminde ponctuée, $C$. punctata. Des. id. pag. 214. no. $15 .-$ Cymindis basalis. GruL. id. pag. 174. $n^{\circ}$. 3. - Carabus hameralis. Schon. id. pag. 185. $n^{\circ}$. 85. (Er excluaut tous les synonymes, selon M. le comte Dejean; ceux de Fabricius et d'Olivier se rapportent à la Cyminde humérale $n^{\circ}$. 3.) Hautes monlagnes de l'Europe'; en Suède dans les plaiues. $16^{\circ}$. Cyminde américaine, $C$. americana. DEJ. id. tom. :. pag. 446. $n^{\circ}$. 22. Longueur 5 lig. $\frac{i}{2}$. Brune, un peu pubescente; tĉte et corselet profondément ponctués; élytres couvertes de points très-serrés; leur bord latéral et une taclse humérale qui s'y rattache, de couleur testacée ainsi que les pattes; bouche et antennes ferrugineuses. Amérique sepientrionale. $17^{\circ}$. Cyminde pubescente, C. pubescens. Des. id. tom. 1. pag. 215 . no. I6. - Carajus pilosus. SAY. Trans. americ. Soc. pag. 10. $n^{\circ} .5$. A mérique septentrionale. $18^{\circ}$. Cyminde miliaire, $C$. miliaris. n० ${ }^{\circ}$ 65. Faв. id.Schon. id. pag. 185. $n^{\circ}$. 87. France et Aatriche. $\mathrm{x} 9^{\circ}$. Cyminde onychine, $C$. onychina. DEJ. id. pag. $217 \cdot n^{\circ}$. 18. Longueur 3 lig. $\frac{1}{4}$. Brune, un peu pubescente, profondément ponı:luée ; corselet rétréci postérieuremeut; ćlytres rembrunies, à stries ponctuées profondément, les intervalles. ayant aussi des points; bouche, antennes et pattes ferrugineuses. Sous les pierres, dans les endroits secs et arides. Espagne, Portugal, 20\%. $\mathrm{Cy}-$ minde de Famin, C. Faminii. Des. id. tom. 2. pag. $447 \cdot n^{\circ} \cdot 23$. Lougueur 3 lig. $\frac{1}{2}$. D'un ferrugineux obscur; tête un peu striée ; corselet aplati, très-finement granulé avec une ligne longitudi-

\section{T R O}

nale enfoncée; élytres plus olsscures, un peu sillonnées, très-fincment granuleuses; anteunes et palles rousscs. De Sicile. $21^{\circ}$. Cyuninde varicé, C. variegata. DEJ. id. tom. 1. pag. $217 \cdot n^{\circ}$. 19 . Longueur 4 lig. Brune, ylabre, sans points ; élytres à stries ponctuées; leur bord. latéral et plasicurs taches éparses peu apparentes, de coulenr ferrugineuse ainsi gue les autennes et les paltes. Des Autilles. $22^{\circ}$. Cyminde parallèle, $C$. parallela. DEJ. id. pag. $218 . n^{\circ}$. 20. Longuear 4 lig. $\frac{3}{4}$. Brune, glabre; corselet presque carré; élytres presque parallèles, à stries ponctuées, portant chacune deux points enfoncés; elles ont une ligne humérale et nu point peu apparent vers leur extrémité, de couleur ferrugineuse ainsi que les an tennes et les pattes. Ile de Cuba. 230. Cyminde norio, C. morio. DEJ. id. pag. 219. no. 2 I. Lon. gueur $5 \mathrm{lig}$. Noire, glabirc; élytres presque parallèles, a stries ponctiées; elles ont chacune deux points enfoncés; bouche, antennes et tarses de cou!eur brune. Atnérique septentrionale. $24^{\circ} \cdot \mathrm{Cy}-$ minde aplatie, $C$. complanata. Des. id. tom. 2. pag. $448.77^{\circ}$. 24 . Longueur 5 lig. Glabre; têle d'un roux-obscur; corsclet roux, presque carré; élytres fort larges, noirâtres, avec des stries pointillées, peu profondes, et trois points enfoncés; lear bord extérieur de couleur ferrugineuse ainsi que les antennes : pattes plus pâles. Aınérique septentrionale. $25^{\circ}$. Cyminde australe, $C$. australis. DEJ. id. pag. 449. $n^{\circ} \cdot 25$. Longueur 4,5 lig. Ferrugineuse; corselet cordiforme, presque transversal; élytres fort larges, noirâtres a vec des sillons peu marqués, couvertes de points peu profonds, et ayant chacune trois points enfoncés; leur bord extéricur et une bande longitudinale un peu oblique, de couleur testacée. Port Jackson, Nouvelle-Hollande. Suas les écorces. $26^{\circ}$. Cyminde discoidale, C. discoidea. DEJ. Hist. nat. et iconogr. elc. pag. 134. no. 2. tab. X. fig. 8. Longueur 4 lig. $\frac{x}{2}$. Ferrugineuse; élytres testacées; s!rices; ces stries un peu ponctuées, leurs inter-? valles ayant des points peu visibles et portant denx taches commuues de couleur noire, la première vers la base, la seconde plus grande placée vers le niliea; ces taclies réunies sur la suture; pattes testacées. De Cátalogne.

CALLÉIDE, Calleida. Des. LAT. (Fam. nat.) Carabus. Fab. Oliv. (Entom.) Schen. Cymindis. SAY.

Genre d'insectes de l'ordre des Coléoptères, section des Pentamères, famille des Carnassiers (terrestres), tribu des Carabiques (division des Troncalipenues ).

Trois genres, Agre, Cyminde et Calléide formeut un groupe dans cette division; il a pour caractères: crochets des tarses dentelés en dedans; corps plus on moins alongć; élytres ordinairement alongées; dernier ariicle des palpes hlabiaux fortement sécuriforme, au moins dans les 


\section{T R O}

mâles. (Voyez Troncatipennes.) La tête des Agres es! fort rétrécie postérienrement ; elle a un con distinct dont elle est séparée par un étrauglement, lenr corselet très-alongé est rétréci en devant; leur corps est assez épais. Dans les Cymindes les articles des tarses sont cylindriques, le pénulième entier. Tous ces caractères sont opposés à ceux des Calléides.

Antennes filiformes, beaucoup plus courtes que le corps, composées de oure articles. - Dernier article des palpes labiaux fortement sécuriforme. - Tête ovale, peu rétrécie postérieurement. - Corps alongé, aplati. - Corselet presque cordiforme, alongé, arrondi antérieurement, plus ou moins rétréci à sa partie postérieure. - Elytres alongées, peu convexes, parallèlement tronquées à l'extrémité, plus ou moins en carrć loug. Tarses ayant leurs trois premiers articles assez larges, presque triangulaires, le pénulième fortement bilobé ; le dernier terminé pir deux crochets dentelés en dedans.

l,e nom de ces insectes est tiré de deux mots grecs qui expriment lenr brillanie couleur e! leur forıne élégante. D'après l'opiniou de M. le comte Dejean, les espèces qui $s^{2} y$ rapportent seroient fort dispersées sur la terre, et se trouveroient principalement en Amérique, à la Nouvelle.Hollande et au cap de Bonne-Espérauce.

1. Calléide décorée, $C$. decora.

Calleida decora. Lat. Hist. nat. et icon. etc. pag. 132. tab. VII. fig. 7. - DEJ. Spéc. tom. I. pag. 224. $n^{\circ} .5$ - Carabus decorus no. 6o. FAB. Syst. Eleut. - Sснек. Syn. Ins. tom. I. pag. 183. $n^{\circ} .77$.

Voyez pour la description et les autres synonymes, Carabe ruficolle $\mathrm{n}^{\circ}$. 128. de ce Dictionnaire. (M. Scbœnherr atroit dû, suivant nous, rapporter à celle espéce le Carabus mficollis. F.a в. Mantiss.)

Les autres espèces de Calléides sont, I․ Calléide mélallique, $C$. metallica. Dex. Spéc. tom. I. pag. $221 . n^{\circ}$. I. Longueur 5 lig. $\frac{1}{4}$. D'un cuivrenx noirâtre; corselet cuivreux ; élytres un peu verdâtres, à stries profondémeni ponctuées, et portant deux impressious. Du Brésil. $\because$. Calléide bordée, C. marginata. Der. id. pag. 222. $n^{\circ}$. 2.-Cymindis viridipennis. SAY. Trans. americ. Soc. pag. 9. $n^{\circ}$. 3. Géorrie, Amérique septentrionale. Zo. Calléide verdâtre, $C$. arugizosa. DEJ. $i d . n^{0}$. 3. Longueur 3 lig. $\frac{1}{\text {. }}$. Tête et corselet d'un cuivreux ferrugineux; élytres de couleur cuivreuse à stries poncluées et portant deux iupressions; abdomen, antenues et paties de conJeur ferrugineuse. Da Brésil. $4^{\circ}$. Calleide viridipenne, C. viridipennis. Des. id. pag, 223. $n^{\prime \prime} .4$. Longueur 3 lign. $\frac{3}{4}$. Rousse; corselet à stries irans. versiles, sa partie postérieure carrée; élytres veltes à stries profondes et ponctuées, leur bord ex- térieur et la sulure de couleur ronsse. Brésil. 50. Calléide rubricolle, $C$. rubricollis. Des. id. pag. 225. $n^{\circ}$. 6. - Dromius deconus. Des. Calal. Longueur 3 lig. $\frac{1}{4}$. D'un vert brillant; corselet, artennes, jambes et tursez de conleur ronsse. Amérique septentrionale. $6^{\circ}$. Callóide émerade, $C$. smaragdina. Des. id. $n^{\circ} \cdot 7 \cdot-$ Dromitus festinans. Des. Catal. Longneur 3 lig. $\frac{3}{4}$. D'un vert brillani; corselet oblong, ses angles postérieurs arrondis : base des antennes rousse; palles d'un blen-noir. Géorgie, Amérique septentrionale.

Nota. M. Latreille regarde aussi comme pouvant appartenir à ce geurc le Carabus festinans no. 93. Faв. Syst. Eileut. - Scнnze. Syn. Ins, tom. 1. pag. 190. $n^{\circ}$. 118. De Cayenne.

\section{CTÉNODACTYLE, Ctenodactyla. DEs.}

Genre d'insectes de l'ordre des Coléoptères, section des Pentamères, farnille des Cirnassiers (terrestres), tribu des Carabiques (division cies Troncatipennes ).

Parmi les 'Troncatipennes à crochets des tarses dentelés en dedans, un yroupe a pour caractères: corps plns ou moins alongé; dernier article des palpes labiaux point sécuriforme. (Voyez Troncatipennes.) Il renferme avec le genre Clínodactyle, cenx de Dromie et de Démétıias qui s'en distinguent par leur tête peu sensiblement rétrécic à sa partie postérieure, et par le dernier article des palpes cylindrique.

Antennes filiforues, beau coup plas courtes que le corps. - Palpes pea alongés, leur dernier article ovalaire, presque terminé en pointe.-Téte arrondie, assez grande, rétrécie brusquement à sa partie postérieure qui forme une espèce de cou cylindrique dont elle est séparée par un étranglement. - Corselet à peu près de la largetr de li tête, presque plane, plus long que large. - Ely. tres alongées, du double plus larges que le corse. let, un peu convexes, atlant en s'élargissant vers l'extrémité qui est arrondie. - Tareses ayant lenrs trois premiers articles larges; le premier un peu alongé, triangulaire; les deus stiivans courts, très-larges, trianrulaires ou cordiformes, le quatrième très-fortement bilobé, le dernier terwiné par denx crochets dentelés ea dedans.

Le nom de ce genre vient de lieux mots grecs qui expriment ce dervier caractère. On n'en connoît qu'une espèce dont les mceurs sont ignorées; c'est la Ctérodactyle de Cheviolat, C. Cheurolutir. DEJ. Spéc. tone. Y. pas. 227. $72^{\circ}$. \&. Longueus 5 liy. Dessus du corps d'un bleu-boirâtre, le dessous bruu; corselet roux; antennes et pattes testacées; élytres ayant des suries ponctúées biel marqáées. De Cayenne.

DÉMÉTRIAS, Dcmetrias. Boner. Drs. (Spéc.) Luat. (Fum. nat.) Dromius. Genm. Les. (Catal.) Lebia. Gremern. Dorrs. Carubus. Hag. Otrt. Sczer. Lisr.? Buprestis. Grozr. 
Genre d'insectes de l'ordre des Coléoptères, section des Pentamères, famille des Carnassiers (errestres), tribu des Carabiques (division des Tronealipennes).

Un groupe de Tronealipennes à croehets des tarses dentelés en dedins, est ainsi caractérisé : corps plus ou moins alongé; deruier article des palpes labiuax point séculiforme, et contient les genres Ciénodactyle, Démétrias et Dromie. (Voy. 'L'honcatipennes.) Le premier est distinct par la firme de la tète, dont la partie postérieure est brusquement rétrécie, portée par un eou distinct ct séparée de celni-ci par un étranglemen!; le dernier article des palpes est ovalaire. On distinguera les Dromies des Démétrias par les artieles des tarses tous entiers, les quatre premiers élant presque eylindriques.

Dernier article des palpes eylindrique. -Tête ovale, peu rétrécie posı́rienrement. - Corps alongé. - Corselet presujue cordiforme. - Elytres 1 ronquées au bout. - Tarses aynnt leurs trois premiers articles presque triangulaires, le quatriètne fortement hilobé, le dernier muni de deux crocliets dentelés en dedans.

Ces Carabiques sont de petite taille; les espèces connues habitent l'Earope : on les trouve au printemps sur les taies et les broussailles, ou volant à l'approche de la nuit.

\section{Démétrasas alongé, D. elongatulus.}

Demetrias elongatulus. Des. Spéc. tom. I. pa.. 232. $n^{\circ}$. 4. - Dromius elongatulus. DEs. Catal. - Lebia elongatula. Dufts. Faun. austr. pag. 257. $n^{\circ}$. 26. - Carabus atricapillus. On1v. Entont. tom. 3. Caiab. pag. I11. $n^{\circ}$. 155. pl. 9 . fig. so6. a. b. (En excluant les synonymes de Fabrieius et de Linné.) - Lébie tête noire. Faun. fianç. Coléopt. pl. 1. fig. 8.

Longueur 2 lig. $\frac{x}{2}, 3$ lig. Pâle; tête noire; corselet roux, un peu rétréci a sa parie postérieure, dont les anules sont relevés et uu peu sailians; élytres à stries peu visibles, leurs intervalles ponctués; poitrine et base de l'abdowen d'un brun-noirâtre.

Voyez pour le reste de la deseription, Carabe tête uoire $n^{\circ}$. 156 . de ce Dietionnaire, en retranchant les synonymes de Fabrieias, de Linné et de De Villers. A ce!uı de Geoffroy, qu'il faut conserver, lisez : le Bupreste fauve à tête noire, au lieu de Bupreste noir sans stries.

Ce genre eontient en outre: $1^{\circ}$. Démétrias impérial, D. imperialis. DEJ. Spéc. tom. 1. pag. 229. $n^{2}$. 1.-Dromius imperialıs. Germ. Coléopt. Spec. nop. pagr. 1. $n^{\circ}$. I. - Des. Catal. - Lebra atricapilla var. c. Gyelene. Ins. Suec. tom. 2. pag. 183. n॰. 9. - Carabus atricapillus var. e. Scher. Syzr. Ins. tom . 1. pag. 2 I9. $n^{\circ} .277$. A peu près de lis taills du Démétrias alongé. Pâle; tête et dessous du corselet d'un brun noirâtte; corselet roux en dessns, rútréci à sa partie postérieure ; élytres à stries ponctuées, peu marquées, portant quatre points enfoncés; suiure d'un brun-noirâtre, eetle eouleur élargie dans le miliea; une tache au bord postérieur de mêne couleur, érnet tant souvent un rameau qui la réunit à la bande sulurale. Autriche, Dalmaile, Suède. $2^{\circ}$. Démétrias uni punctué, D. unipunctatus. DEJ, id pag. 23o. $n^{\circ}$. 2.--Dromllus unipunctatıs. Gerм. id. no. 2. - Lebia atricapılla var. d. Schan. id. Même taille que les précédens. Pâle ; tête noire ; corselet ronx , un peu rélréei à sa partie postérieure; élytres à stries pouctuces, peu distinctes, ayant en ontre quatre impressions; suture d'un bruu-noirûtre; cette eouleur dilatée avant l'extrémité en une taehe ronde. Autriche, France, envirous de Paris. 3०. Démétrias tête noire, $D$. atricapillus. DEs. id. pag. $231, n^{\circ} \cdot 3 .-$ Dromius atricapillus. DEs, Catal. - Lebia atricapilla. Dufrs. id. GrLleng. id. - Carabus atircapillus? Lins. Syst. nat. 2. 673. 42. - Scres. 2d. (En exeluunt tous les synonymes, excepté celıi de Linné, qui cependant est douteux.) Mềne taille que les préeédens. Pâle; tête noire; corselet roux, un peu rétréci à sa partie postérieure; élytres à stries peu visibles, leurs intervalles ponctués; dessous du corselet et base de l'abdomen d'un brun-noirâtre. France, Allemagne, Suède?

DROMIE, Dromius. Bonell. Dej. Stét. Lat. (Fam. nat.) Lebia. Dufour. Gyllenh. Duets. Carabus. Fab. Oliv. Schen. Panz. Ross. ?

Genre d'inseetes de l'ordre des Coléoptères, seetion des Pentamères, famille des Carnassiers (terrestres), tribu des Carabiques (division des Troneatipennes).

Ce genre compose avee ceux de Cténodactyle et de Démétrias, une eoupe particulière dans les Troncatipenues; tlle a pour caraetères : erochets des tarses dentelés en dedaus; corps plas on moins alongé; dernier artiele des palpes labiaux point sécuriforme. (Voyez Troncatipennes.) Les Cténodatyles ont la tête rétrécie brusqueuènt à sa partie postérienre, pourvue d'un eou distinct, dont elle est séparée par un étranglement; de plus le dernier article de leurs palpes est ovalaire. Les tarses des Démétrias ont leurs trois premiers articles presque triangulaires et le quatrième fortement bilobó, ce qui sépare ces deux genres de celui de Dromie.

Antennes filiformes, plus eonrtes que le corps. - Dernier article des palpes cylindrique. - Téte ovale, peu rétrécie postérieurement.-Corps plus ou moins alongé, un pen aplati. - Corselet plus ou moins cordiforme, plus ou moins alongé. Elytres planes, plus ou moins alongées, tronquées ì Leur extrénité. - Tarses ayant tous les articles prescque cylindriques, le pécultième presqu'en- 


\section{$\mathrm{T} \mathrm{R} \mathrm{O}$}

tier; le dernier muni de deux crocbets dentelés en dedans.

Ces Coléoptères, dont le nom, tiace d'un verbe - vece, exprime l'agilité avec laquelle ils courent, sont de petite taille; une grande partie des espèces appartient à l'Europe, les antres à l'Amćrique du uord. On les trouve sous les éeorces et sous les pierres. Les uns, d'une couleur junnître on brinne, se rapprochent des Démétrias; ceux'dont le corps est uoir, un peu métallique, ont une forme un peu plus raccourcie.

\section{DROMIE quadrimaculé, D. quadrinaci- latus.}

Dromius quadrimaculatus. DEJ. Spéc. torn. I. pag. $239 . n^{\circ} .8$. - Carabus quadrimaculatus $\mathrm{n}^{\circ}$. 203. HAB. Syst. Eleut. - Ouiv. Entom. tom. 3. Carab. pag. 107. $n^{\circ}$. เ 5o. pl. 8. fig. 8g. a. b. c: d. - Screx. Syn. Ins. tom. 1. pag. $217 . n^{\circ} .275$. (En excluant les varuélés.) - Lebia quadrinaculutı. Faun. franç. Coléopt. pl. 1. fig. 7 .

Voyez pour la description et les autres synonyıts, Carabe quadriuaculé $n^{\circ}$. 151 . de ce Dictionnaire.

\section{Dromie agile, D. agilis.}

Dromius agilis. DEJ. id. pag. 240. $n^{0} \cdot 9 \cdot-C a-$ rabus agilis $\mathrm{n}^{\circ}$. 83. $\mathrm{F}_{\mathrm{AB}}$. Syst. Eleut. - Carabus fenestratus $\mathrm{n}^{\circ} .210$. FAB. id.-Carabus quadrinaculatus var. c. et d. Scran, id. pag. 217. et 218. $u^{\circ} .275 .-$ Carabus alcticus?" Oulv. id. pag. 97. $n^{c}$. 153. pl. 12. fig. 145.-Dronius bimaculatus. $\mathrm{D}_{\mathrm{LJ}}$. Catal.

Voyez pour la description et le synonyme, Carube agile $\mathbf{n}^{\circ}$. 136 . de cet ouvrage.

\section{Drome tronqné, D. truncatellus.}

Drontius truncatellus. DEs. id.pag. 248. $n^{\circ}, 18$. - Carabus truncatellus $\mathrm{n}^{\circ}$. 222. $\mathrm{F}_{\mathrm{AB}}$. id. - OLiv. id. $p a g .113 . n^{\circ}$. 160. pl. 13. fig. 159 a. b. Schen. id. pag. 196. $n^{\circ}$. 161. (A la citation du Syst. nat. de Linné, lisez 673. au lieu de $67^{2}$.)

Foye $z$ pour la description el les autres synonymes, Carabe tronqué $n^{\circ}$. 163 . de ce Dictionnaire.

Ce genre renferase encore : $1^{\circ}$. Dromie longue tête, D. longiceps. Des. Spéc. tom, 2. pag. 450 . $n^{0} .21$. Longueur 2 lig. : - Alongé; tête alongće, oblongue, d'un noir un peu ferrugineux; corselel presqu'en carréa alongé, roux ; élytres pâles à strie; peu marquées; leur suture brune; antennes et pat'es pâles. De Volhynie. 20. Dromie linéaire, D. linearis. DEJ. id. tom. 1. pag. 233. $n^{\text {o. }}$ 1. Carabus linearis. Ouv. Entonn. tom, 3. Carab. pag. 111. $n^{n}$. 156. pl. 14. fig. i67. a. b.-Scras. Syn. Ins. tonu. 1, pag. 218, no . 276. Environs de Paris. $3^{\circ}$. Dromie mélanocéphale, $D$. melanocephalus. Des. id. pag. 234. $2^{\circ}$. 2. Longueur nue
T R O

lig. : Tête noire; corsclet carré, roux ; élytres légèrement striées; antennes et paltes pûles; dessous du corps ferrugineux. Allemagne, Angleterie, Lyon. Comnun aux environs de Paris. $4^{\circ}$. 1)roune sigua, D. sigma. Des. id. pag. 235. $n^{\circ}$. 3. - Dronnius fúsciatus. Des. Catal. - Lebice fasciata. Durrs. Faun. austr, 2. pag. 255. $n^{\circ}$. 24. - Carabus signat? Ross. Faun. Etrusc. tom. 1. pag. 226. $n n^{\circ} .664$ - - Scuck. id.pag. 226. $n^{\circ}$. 338. Autriche, Finlande, laalie ( si le synonyme de Rossi lui apparicint ). 50. Dromie guadrimoucheté, D. quadrisignatus. Dev. id. pag. 256. $\mathrm{n}^{\circ}$. 4. Longueur I lig. $\frac{3}{6}$, Tête noire; corselet carré, roux; élytres légèrement striées, brunes, ayaut chacuue deux grandes taches de couleur páte, l'une à l'angle bunnéral, l'autre à l'extrímité; antennes et pattes pấles; dicssucis diu corps d'un brinn de poix. Midi de la lirance, environs de Pa. ris, sous les écorces. 6 ${ }^{\circ}$. Drouic bifiascié, $D$. bifusclatus. DEJ. id. pag. 237. $n^{\circ}$. 5. Longueur une lig. $\frac{1}{2}$. Tête noire; cor'selet carré, roux; ćlytres légèrement striées, brunes, avec deux grandes taches pâles, l'une à l'angle buméral, l'autre de forme seni-lunaire à l'extrémité; antenues et patIes pâles; dessous du corps couleur de poix. Miême locialiıé que les précédeus. $7^{\circ}$. Dromie fäscié, $D$. fasciatus. DEJ. id. pag. 238. $70^{\circ}$. 6. - Carabus

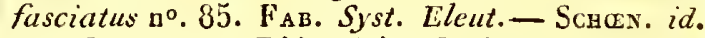
pag. 89. $n^{\circ}$. 112 . D'Autriche. $8^{\circ}$. Dromie quadrinoté, D. quadrinotatus. DEs. id. $n^{\circ}$. 7. Carabus quadrinotatus. PAnz. Faun. Germ. fas. 75 ffg. 5. - Schan. id. pag 221. $n^{0}$. 292. Des enviruns de Paris. $9^{\circ}$. Dromie méridional, $D$. meridionalis. DEs. id. pag. $242 . n^{\circ}$. 10. Longueur 2 lig. $\frac{T}{2}$. Oblong; tête et corselet ferrugineux, celui-ci presque carré, ses angles postéricur's, arrondis ; élytres brunes, striées, portant une ligne de pelits poiuts enfoncés; autenues et paltes pâles. France méridionale. $\mathrm{o}^{\circ}$. Dromie bordé, D. marginel lus. Des. id. pag. 243. $n^{\circ}$. II. - Carabus marginellus no. 37. FAB. id. -Carabus quadrimaculutus var. z. Schase. $z d$. pag. $218 . n^{\circ}, 275$. Autriche. $11^{\circ}$. Dromie double-plaie, D. Liplagiatus. DEs. id. $n^{0}$. 12. Longueur I lig. $\frac{1}{2}$. Assez alongé, d'ura noir obscur; élytres ayant une grande taclie humérale pîle; antennes et pattes de cette dernière couleur. Amérique septentrionale. 120. Dromie glabre, D. glabratus. Des. id. pag. $244 . \pi 0^{\circ}$. 15. - Lebia glabrata. Durts. id. pag. $240 . n 2^{\circ} .16$. Allemagne, Dalmatie, France, Espagne, Petussic móridionale. $3^{\prime \prime}$. Dronie cortical, D. corticalis. DEJ. id. pag. 245. $n^{0}$. 14. - Lebia corticalis. Düоuк, Annal. gén. des scienc. phys. tom. 6. -18 e. calnier, pag. 222. $n^{n}$. 10. Longueur \& lig. $\frac{?}{8}$. Alongé, d'un cuivreux noirâtre; élytres presuue lisses, ayant dans leur milicu une tache püle. Natvarre, unidi de la France, et peut-ôtre de la Russie méridionate et d'Autriche. $14^{\circ}$. Dromic pallipède, $D$. pallipes. Des. id. pag. $246 . r^{\circ}, 35$. Longucur une lig. $\frac{1}{2}$. Oblong, d'un cuivienx abs. 
cur; élytres légèrement striées; pattes pâles. D'Antriche. 15\%. Dromie tacheté, D. spitolus. Drs. $i d . n^{\circ} .16$. Longtieur une lig. $\frac{1}{4}$, une lig. $\frac{1}{2}$. Oblong, dun noir un peu cuivreux; ćlytres obscures, légèrement striées, ayant chacure denx points enfoncés, souvent peu apparens, et denx taches pấles, yeu distinctes, l'une liumérale, l'autre placre à l'exirémité; la sulure a une ligne pâle; jumbes d'un pâle obscur. Midi de l'Ërope, Allemagnte. Nota. Les Dromius obsoletus, imapressus, atratus, Drs. Calal. n'en sont que des variétés. $16^{\circ}$. Dromie sillonné, D. subsulcatus. Dgs. id. tom. 2. pag. 451. $n^{n} \cdot 22$. Longueur une lig. $\frac{1}{2}$. Noir ; élytres cuivreuses, légèrement sillonnérs, ayant cluacune denx points enfoncés. Amérigue septentrionale. $17^{\circ}$. Dromie ì petits points, D. punctatellus. DEJ. id. tom. 1. pag. $247 . n^{\circ} \cdot 17 .-$ Lebia vunctatella. DuFrs. id. pag. 248. $2^{\circ} .15 .-$ Lebia fuveola. Gy n. Ins. Saec. 2. pog. $185 . n^{\circ} .5$. Environs ae Paris, Suede, Anmele. 18 . Dromie juadrille, D. quadrillum. Dk. id. pag. 249. no. 19. - Lebia quadrillum. Duprs. id. pag. $246 . n^{\circ}$. 12. Environs de Paris, Autriche, Espagne, Jaalie, Dalmatie. $19^{\circ}$. Droinie taches hlanches, D. albonotalus. DEs. id. $30^{\circ}$. 20. Longueur i lig. $\frac{1}{a}$. D'un noir un peu cuivreux; ćlytres striées, leurs intervalles ponctués: sur chacune d'clles on voit une baude sinuce, raccontrie, quelquefois interrumpue, de cunleur: blanelse. De Portugal.

LËBIE, Lebia. Lat. Bonell. Gy hien. Dufts. Des. Lampria. Bonell. LAt. (Fan. nut.) Camabus. Linn. Fab. Oliv. Schoex. Russ. Buprestis. GEกTE.

Genre d'insectes de l'ordre des Coléoplèıes, section des Pentamères, famille des Carnassiers (terrestres), tribu des Carabigues (division des 'Troncalipennes).

Un groupe de Troncatipennes à crochels des tarses dentelés eu dedans, offie pour caracteres: rorps plus ou moins large et aplati ; élytres presque carrées; dernier irticle des palpes laliaux point sécuriforme. (Voyez 'Toncampennes.) Ontre les Lébies, il renterme les genres Coptodère et Orthogonie, qui se distinguent des preniières par le bord poslérieur du corselet coupé carrément, et par leurs élytres plus alongées que celles des Lébies.

Antennes filiformes. - Dernier article des palpes filiforme ou presqu'ovalaire, tronqué à l'extrémité, jamais sécuriforme. - Tête ovale, peu rétrécie postérieurement. - Corps court, aplati. - Corselet court, transversal, plus large que la. tête, prolongé postéricurement dans son milieu". - Elytres larges, presqu'en carré régulier, tronquées à l'exirémité. - Articles des tarses piesque triuugulaires ou cordiformes, le pénultième bifide ou bilubé; le dernicr ununi de deux croche!s dentelés en dedans.
Les Lébies, dont le nom vient d'un verbe grec qui signifie: prendre, vivent probablement de proie comme les autres Carabiques. On les trouve en Europe et en Amérique sous les écorces des arbres et sous les pierres. Leur taille est générilement au-dessous de la moyenne; leurs couleurs sont agréables et varićes.

Nota. Les caractères du genre Lanıpria BoNeLl. uous paroissant pen trauchés, nous le réanissons avec les Lébies, à l'exemple de M. le comle Dejean.

\section{LÉsie cyanocéplale, $L$. cyanocephald.}

Lebia cyanocephala. I,Aт. Gen. Crist. et Ins. tom. 1. pag. 191. $n^{\circ}$. 1. tab. 6. fig. 12. (A la cilation du Syst. nat. de Linné, lisez 671 . an lien de 7I.) - Des. Spéc. tom. 1. pag. $256 . n^{\circ}$. 3. Faun. franc. Coléopt. pl. 1. fig. 6.-Carabus cyanocephalus no. 167. FAв. Syst. Eleut. - SeнEN. Syn. Ins. tom. I. pag. 208. $u^{\circ} \cdot 227$.

Voyez pour la description et les autres synonymes, Carabe tête bleue no. 127. de ce Dictionnaire.

\section{LËвIE petite croix, L. crux minor.}

Lebia crux ninor. LAт. $i d$. plag. 192. $n^{\circ}, 2$. - Des. id. pag. 26 3. $u^{\circ} \cdot 9 .--$ Carabus crux minor $11^{\circ} .377$. l' ав. $i d .-$ Schan. $i d$. pag. $210 n^{\circ}$. $23 \mathrm{~g}$.

Voyez pour la description et les autres synonymes, Curabe grand-croix $n^{\circ}$. 13I. de ce Dictionnaire. (En retranchant les synunymes de Linué qui appartiennent au Panagće grand-croix nº. 5).

\section{3. Ĺ́ñ lurque, L. turcica.}

Lebia tucica. DEJ. id. pag. 262. $n^{\circ}$. I . Carabus turcicus no. I 8 r. FAB. id. (A la citation d'Olivier lisez fg. 68. au lieu de 6o. ) - Schas. id. pag. $211 . n^{n} \cdot 244$.

Voyez pour la description et les autres synonymes, Carabe turcique $n^{0} .133$. de ce Dictionnaire.

On la trouve en France, aux environs de Paris.

\section{LÉB1E hémorrhoïdale, L. haenıorrhoidalis.}

Lebia hemorrhoidalis. DeJ. id. pag. 266. $n^{\circ} .15$. - Carabus hemorrhoidalis. no. 182. FaB. id. Sсве́, id. pag. $211, n^{\circ} \cdot 245$.

Loyez pour la descriplion et le synonyme, $\mathrm{Ca}$ rabe hémorrboital no. 134 . de ce Dicticiunaire.

On la trouve en France, aux environs de paris.

\section{L̇́bie rayée, $L$. vittata.}

Lebia vittata. Des. id. pag. 267. $n^{\circ} \cdot 17 .-$ Carabus vittatus $\mathbf{1}^{\circ}$. 178 . FAB. id. - Schen. id. pag. $210 . n^{\circ} .241$. 
Voyez pour la description et les autres synonymes, Carabe rayé na. 132. pl. 179. fig. 16. du présent ouvrage.

Les espèces suivantes entrent aussi dans ce genre: $1^{\circ}$. Lébie peinte, $L$. picta. Des. Spéc. tom. 1. pag. $254 . n^{\circ}$. 1. Longueur 5 lig. $\frac{x}{2}$. Rousse, ponctuée; corselet portant deux taches noires; élytres testacées, avec deux taches et la suture nuires. Du Sénégal. $2^{\circ}$. Lébie fulvicolle, $L$. fulvicollis. DEJ. id. pag. 255 . $n^{\circ} .2 .-$ Carabus ful vicollis $\mathrm{n}^{\circ}$. I 27. F.1в. Syst. Eleut. - Sснак. Syn. Ins. pag. 198. $n^{\circ}$. 177. De Barbarie. 3o. Lébie chlorocéphale, L. chlorocephala. Des, id. pag. 257. $n^{\circ}$. 4. - Grulent. Ins. Suec. tom. 2. pag. 180. $n^{\circ}$. 2.- Carabus chlorocephalus. Sснек. id. pag. 209. $n^{\circ}$. 223. D'Autriche. $4^{\circ}$. Lébie rufipède, L. rufipes. DEJ. id. pag. 258. $n^{\circ}$. 5. Longueur 2 lig. $\frac{x}{a}$. D'un bleu-noirâtre; corselet, poilrine et pattes de couleur rousse; élytres bleues à stries ponctuées ainsi que leurs intervalles; ces points peu apparens. Midi ce la France. 50. Lébie viridipenne, L. viridipennis. Des. id. tom. 2. pag. 452. $n^{\circ}$. 24. Longueur 2 lig. $\frac{1}{-}$. Têle verte; corselet roux ; élytres d'uu vert d'émeraude brillant, à stries finement pointillées ainsi que leurs intervalles; dessous du corps roux; patles pâles; cuisses, extrémité des jambes et tarses, noirs. Amérique septeutrionale. $6^{\circ}$. Lébie tricolore, $L$. tricolor. DEJ. id. pag. 453. $n^{\circ}$. 25. - S. Y . Trans. americ. Plit. soc. pag. I1. $n^{\circ}$. 1. Amérique septentrionale. $7^{\circ}$. Lébie ventre noir, $L$. atriventris. DEJ. id. pag. 454. $z^{\circ}$. 26. - S $\mathrm{S}_{\mathrm{AY}}$. id. pag. 13. $n^{\circ}$. 3. Annérique septentrionale. $8^{\circ}$. Lébie cyanoptère, L. cyanoptera. DEJ. id. tom. I. pag. 258. $n^{\circ}$. 6. Longueur 3 ligries. D'un beau jaune; élytres bleues; antennes, jambes el tarses, noirs. Du Brésil. 9․ Lébie sellée, L. sellata. DEJ. id. pag. 259. $n^{\circ}$. 7. Longueur 5 lig. Rousse; élytres d'un roux testacé avec deux taches noires dorsales communes aux deux élytres, l'une vers la base, l'autre plus grande placée à la partie postérieure; elles on i en outre une ligue humérale noire ; jambes et tarses de cette dernière couleur. De Cayenne et du Brésil. $10^{\circ}$. Lébie dorsale, $L$. dorsalis. DEJ. id. tom, 2. pag. 455. $n^{\circ}$. 27. Longueur 5 lig. D'un testacé roussâtre; élytres pấles avec deux taclies dorsäles communes, l'une à la base, l'autre plus grande placée à la partie postérieure, de couleur noire ainsi que les antennes, les jambes et les tarses. Du Brésil. I $1^{\circ}$. Lébie cyathigère, L. cyathigera. DEJ. id.tom. 1. pag. 260. $n^{\circ}$. 8. - Carabus cyathiger. Ross. Falun. etrusc. tom. 1. pag. 222. no. 52g. tab. 7. fgo. 3. - Scacen. id. pag. 210. $n^{\circ}$. 240. France méridionale, Italie. $12^{\circ}$. Lébie nigripède, $L$. nigripes. Des. id. pag, $26 \%$. $n^{\circ}$. 10. Longweur 2 lig. $\frac{3}{4}$. Noire; corselet et élytres de couleur rousse ; celles - ci portant wue croix noire; pattes de cette dernière couleur. Dillyrie et du midi de la France. $13^{\circ}$. Lébie quadrinıaculée, $L$. quadrinuculata. DEJ. Hist. Nat. Ins. Tome $\boldsymbol{X}$. id. pag. $264 . n^{\circ}$. 12. Longneur 2 lig. Noire ; eorselet roux; élytres striées, noires avec une grande tache humérale et une petite à l'extrémité de couJeur testacée ainsi que les pattes. Espagne, midi de la France, sous les écorces. $14^{\circ}$. Lébie humérale, L. humeralis. Des. id. $n^{\circ}$. 13. - Lebia tarcica. DuFrs. Faun. aust. 11. pag. 245. $n^{\circ}$. 1 1. De Dalmatie. $15^{\circ}$. Lébie anale, $L$. analis. DEJ. id. pag. 265. $n^{\circ}$. 14. - Lehia ornata. SAY. id. pag. 13. $n^{\circ}$. 4. Amérique septentrionale. 16 $6^{\circ}$. Lébie à collier, L. collaris. DEJ. id. tom. 2. pag. 456. $n^{\circ}$. 28. Longueur 2 lig. $\frac{x}{2}$. Rousse; tête et élytres noires. Anérique seplentrionale. $17^{\circ}$. Lébie gentille, $L$. pulchella. Des. id. pag. $457 \cdot n^{\circ}$ : 29. Longueur 2 lig. $\frac{1}{4}$. 'Testacće; lête bleue ainsi que deux bandes transverses sinuées, placées sur les élytres, l'une à la base, l'autre vers le milieu. Amerique septentrionale. i $8^{\circ}$. Lébie bifasciée, $L$. bifasciata. DEJ. id. tom. 1. pag. 266. $n^{\circ}$. 16 . Longueur 2 lig. $\frac{1}{2}$. Rousse; tête, anus et pattes de couleur verte; élytres de cette même couleur avec deux bandes rousses, l'une avant le milieu, l'autre ì l'extrémité. De Cayenne. $19^{\circ}$. Lébie quadrirayće, L. quadrivittata. DEJ. id. pag. 268. $n^{\circ}$. 18. Longuenr 2 lig. $\frac{x}{2}$. Tête et dessous du corselet noirs; corselet et abdomen roux ; élytres noires avec deux bandes raccourcies, pâles. Amérique septen!rionale. $20^{\circ}$. Lébie sillonnée, $L$. sulcata. DEs. id. pag. 269. $n^{\circ}$. 19. Longueur 3 lig. Ferrugineuse; élytres sillonnées, ayant deux bandes ondulées et obliques, brunes. De Cayenne. $21^{\circ}$. Lébie brune, L. fuscata. DEJ. id. pag. $270 . n^{\circ}$. 20. Longueur $3 \mathrm{lig}$. $\frac{1}{2}$. Brune; bord du corselet, antennes et paltes de couleur testacée; élytres testacćes avec la partie moyenne de leur sulure brune, celle couleur s'élargissant aux deux extrémités. Il y a une tache ovale brune de chaque eôlé de la bande suturale. Amérique septentrionale. $22^{\circ}$. Lúbie bordée, L. marginicollis. DFJ. id. pag. 271. $n^{\circ} \cdot 21$. Longueur 2 lig. D'un cuivieux-noirâtre; bord latéral du corselet, pâle; élytres d'un verl-cuivreux. Amérique septentrionale, Géoryie. $23^{\circ}$. Lébie verte, L. viridis. DEJ. id. $n^{\circ}$. 22. Longueur 2 lig., 2 lig. $\frac{z}{2}$. D'un bleu verdâtre; antennes, jambes et tarses, noirs. Amérique septentrionale. $24^{\circ}$. Lébie tuberculée, $t$. tuberculata. DEJ. id. pag. 272. $n^{\circ}$. 23. Longueur 2 lig. $\frac{1}{3}$. Brune; bord latéral du corselet, pâle; élyires tuberculées. De Cayenne.

COPTODÈRE, Coptodera. DeJ.

Genre d'insecles de l'ordre des Coléoptères, section des Pentamères, famille des Carasssiers (terrestres), tribu des Carabiques (division des Troncatipennes ).

Le demier groupe des Troncatipennes à crochets des tarses dentelés en dedans, a pour caractc̀res : corps plus ou moins large et aplati; élytres presque carrées; dernier article des palpes labiaux uon sécuriforme. Il est composé des gen$\mathrm{B} b \mathrm{bb} \mathrm{b}$ 
res Tébie, Coptodère et Orthogonie. (Voy. Trovcatipennes.) Les Lébies ont le bord postérieur du corselet prolongé daris sou milieu, et les élytres presqu'en carré régulier. Dans les Orthogonies le péuultième article de tous les tarses est bilobé, et leurs antennes sont filiformes.

Antennes plus courtes que le corps, de onze articles plas on moins monilitormes. - Dernier article des palpes cylindriq̣ue. -- Tête ovale, peu zétrécie postérieurement. - Corps court, aplati. - Corselet court, transversal, sa partie postézieure coupée carrément. - Elytres planes, en carré alougé, trouquées au boul. - Tarses antéricurs ayant leurs trois premiers articles presque triangulaires ou cordiforme; ces mêmes articles presque cylindriques dans les quatre tarses postérieurs: le pénaliième de tous, en cœur on bifide, mais nou bilobé; crochets des larses dentelés en dedans.

Le nom de ces Carabiques vient de deux mots grecs et fait allusion à la troncature postérieure de leur corselet. On en connoît six espèces, remarquables par le brillant des couleurs; elles balitent l'Amérique.

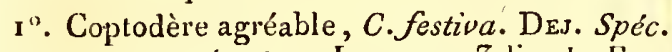
tom. 1. pag. $274 \cdot 72^{\circ}$. 1. Longueur 3 lig. $\frac{1}{4}$. Ferrugineuse; corselet portant deux taches d'un vertcuivreux; élytres d'un vert-cuivreux a vec deux bandes trausversales, ondulées, interrompues, d'un beau jaune. Ile de Cuba. $2^{\circ}$. Coptodère notée, C. notata. DEs. id. pag. $275 . n^{\circ}$. 2. Longueur 2 lig. $\frac{1}{4}$. Tête noire; corselet roux taché de noir ; élytres d'un cuivreux-norrâtre avec une bande interrompue, placée avanl le milieu, d'un beau jaune aiusi que le bord et l'extrémité, cette couleur s'élargissant daus cette dernière partie. Amérique septentrionale. $3^{\circ}$. Coptodère échancrée, $C$. emarginata. DeJ. id. pas. 276. $n^{\circ}$. 3. Longueur $4 \mathrm{lig} . \frac{1}{4}$. Dessus du corps cuivreux; élytres échancrées à l'extrémité et portant chacuu e trois points enfoncés; dessous du corps ferrugineux : bouche, antennes et pattes de couleur pâle. $4^{\circ}$. Coptodère cuivreuse, C. cerata. DEs. $i d . p a g .277 \cdot n^{\circ}$. 4. Lebia arata. Kroca. Lougueur 2 lig. $\frac{1}{4}$. Dessus du corps d'un vert-cuivreux, son dessous obscur; antennes et pattes brunes. Amérique septentrionalc. $5^{\circ}$. Coptodère brune, $C$. picea. DEJ. $i d$. tonı. 2. pag. 458. $n^{3}$. 6. Longueur 2 lig. $\frac{\pi}{4}$. D'un brun-noirâtre; dessous du corps brun; élytres foiblement sillonuées; antennes et pattes d'un beau jaune. Du Brésil. $6^{\circ}$. Coptodère quadripustulée, C. quadripustulata. DEJ. $\imath$ d. tom. 1. pag. 278. $n^{\circ}$. 5. - Dentetrias quadripustulatus. KuvG. Longueur 2 lig. $\frac{x}{2}$. Ferrugineuse; Elytres brunes avec deux taches testacées sur chacune. Du Brésil.

ORTHOGONIE, Orthogonius. Des. Plochio-

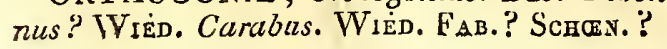

Genre d'insectes de l'ordré des Coléoptères, section des Pentamères; famille des Carnassiers (terrestres), tribu des Carabiques. (division des Troncatipennes).

Le dernier groupe de cette division, contenant les geures Lébie, Coptodère et Orthogonie, a pour caractères : crochets des tarses dentelés eu dedans; corps plus ou moins large et aplati ; élytres presque carrées; dernier article des palpes labiaux non sécuriforme. (Voy. ThonCatipenNes.) Daus ce groupe les Lébies sont recounoissables par lear corselet ayant le milieu de son bord postérieur prolongé et les élyıtres en carré régulier. Le genre Coptodère diffère de celui d'Ortirogronie par ses antennes à articles plus ou moins moniliformes et par le pénultième article des tarses seulearent bifide ou en cueur, mais point bilobé.

Antennes filiformes, plns courtes que le corps. - Dernier article des palpes cylindrique. - Téte ovale, peu rétrécie postérieurement. - Corpss large, un peu aplati. - Corselet plus large que la tête, assez court, transversal, coupé carrément à sa partie postérieure et antérieure, arrondi sur les côtés. - Elytres un peu plus larges que le corselet, convexes, en carré assez alongé. - Articles des tarses triangulaires ou en cœur, le pénultième fortement bilobé; crocbets des tarses dentelés en dedans.

La forme en carré long da corps de ces insectes justifie leur nom tiré de deux mots grecs. Ils sont d'assez grande taille, de couleur noire ou brune, et ressemblent un peu par la forme aux Harpales ; mais un examen plus atteutif démontre qu'ils avoisinent les Lébies. Des quatre espèces connues, trois sont des Indes orientales et la quatrième d'Afrique.

Io. Orthogonie doublé, O. duplicatus. DEJ. Spéc. tom. 1. pag. 279. $n^{\circ}$. I. - Carabus duplicatus. Wiéd. Zool. Magaz. torn. 1. part. 3. pag. I66. $n^{\circ}$. 14. De Java. $2^{\circ}$. Orthogonie alternaut, O. alternans. Des. id. pag. 280. $n^{\circ} \cdot 2 .-$ Plochionus alternans? WrÉD. id. tom.2. part. 1. pag. 52. $n^{\circ} \cdot 75$. Longueur 6 à 8 lig. Dessus du corps noir ; élytres à stries profondes et ponctuées, leurs iutervalles alternativement plus larges et portant uue ligne de points enfoncés. Dessous du corps ct pattes de couleur brune. De Java. $3^{\circ}$. Orthogonie fémoral, O. fermoratus. Dss. $i d$. pag. 281. $n^{\circ}$. 3. Longueur 5 à 7 lig. Brun; élytres à stries profondes et ponctuées, leurs intervalles presque lisses; cuisses ferrugineuses. De Java. $4^{\circ}$. Orthogonie raccourci, O. brevithorax. DEJ. id. pag. $282 . n^{\circ} \cdot 4$. - Carabus abdominalis? $n^{\circ}$. 142 . FAB. Syst. Eleut. - ScHळN. ? Syn. Ins. tom. 1. pag. 203. $n^{\circ}$. 194. Longueur 5 lig. $\frac{1}{2}$. D'un brun noirâtre; élytres profondément striées, leurs intervalles ponctués; antennes et pattes ferrugineuses. De Sierra-Léon. ( S. F. et A. Senv.) 


\section{$\mathrm{T} R \mathrm{O}$}

TROPIDIE, Tropidia. MeIg. Lat. (Fam. nat.) Eristalis. FaLxév.

Genre d'insectes de l'ordre des Diptères (première section ), famille des Athćricères, tribu des Syrphies.

Parmi les Syrphies dont les antennes sont à peine de la longueur de la tête ou plus courtes qu'elle, un groupe a pour caractères : antennes ayant leurs deux premiers articles égaux entr'eux, point portées sur un tubercule froutal; point de cetlule pédiforme aux ailes; cuisses postérieures

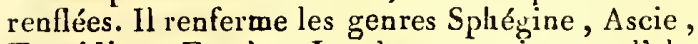
Tropidie et Eumère. Les deux premiers ont l'abdomen aminci à sa base en forme de pédicnle, et leurs cuisses postćrieures ainsi que celles des Eumères sunt garnies en dessous, dans lis plus gyrande partie de leur longueur, d'épines petites et nombreuses; ces caractères ne se retrouveat pas dans les 'Tropidies.

Antennes plus courtes que la tête, point insérées sur un tubercule frontal, composées de trois articles; les deux premiers éganx entr'eux, le troisième patelliforme, portant une soie dorsale nue. - Hypostome caréné, lisse. - Ailes velues vues au microscope, couchées paralle lement sur le corps dans le repos, mais un pcu en toit, sans cellule pédiforme. - Cuisses postérieures rentlćes, portant en dessous, vers leur extrémité, uue torte deni.

Le nom de ce genre vient d'un mot grec qui exprime la forme de l'hypostome. Ces Diptères se trcnvent à l'étal parfait sur les fleurs, mais on ignore leurs premiers étals, quoiqu'ils doivent se rapprocher beancoup de ceux des Mérodons. il. Meigen en décril deux espèces.

$1^{\circ}$. Tropidie fascióe, T. fásciata. MeIg. Dipt. d'Eur. tom. 3. pag. 346. no. 1. tab. 31. fig. 13. Mâle. Longueur $4 \mathrm{lig}$. Noire; antennes rousses; abdomen ayant des bandes transverses interrompues, de cette mônc couleur. Mâle et femelle. Autriche, France, environs de Paris. ${ }^{\circ}$. TropiHie milésiforme, T. milesiformis. Merg. id. pag. 3.7. no. 2. tab. 3I. fig. 14. L'Aile. Longueur 4 lig. Noire, brillante; antennes trupes; abdomen ayant denx bandes transverses, intcrrompues, jäunes. Mâle. De Suède. (S. E. et A. Szrv.)

TROX, Trox. FAB. Lat. Ouiv. (Ent.) Schan. Scarabaus. Linn. De Geer. Geoff. Silpha. Linn.

Genre d'insectes de l'ordre des Colćoptères, secrion des Pentameres, famille des Lamcllicornes, rribu des Scarabéides (divisịon des Arénicoles ).

Le groupe de celte division dont fait partie ce genre, contient en outre, d'après M. Latreille, cenx de Phobëre, d'Hybosore, et peut-être aussi celni d'Orphré. M. Nacleay (Hore Entomol.) met dans sa famille des Trogida le genre Acanthocère que $M$. Latreille paroît en éloigner; l'auteur anglais nadmet point dans cette famille le
T R O

genre Orphné, il le classe parmi ses Geotrupidce. Les genres Phobère el Acanthocère ont été faits aux dépens de cului de Trox, et le départ des espèces qui eutrcnt dans ces deux nouveaux genres doit donner lieu à des modifications dans le caractère générique des 'Trox; mais MM. Latreille et Macleay n'indiquant pas les espèces qui doivent aujourd'hui rester parmi les Trox, nous nous contenterons ici de donner les caractères de ce dernier genre tels qu'ils étoient avant la création des genres Phobère et Acantbocère, et d'après le Genera de M. Latreille.

Les Orplinés diffèrent des Trox par leur abdomen convexe en dessous el dont les flytres laissent l'extrémité dícouverte en dessus : dans les Hylosores, le tuitième ariicle des antennes reçoit les deux derniers et forme avec eux une massine arroudie, presque conique, ces trois articles n'étant point divergens; en outre, dans ces deux genres le corps n'est pourvu ni de tubercules ni de papilles, ce qui les éloigne encore des Trox.

Anterincs à peine plus longues que la tête, susceptibles de contraction, et alors se cacliant sous les côtés du corselet et sous les hanches antérienres, composées de dix articles; le premier grand, presque couique, arqué ct convexe antérieurement, couvert de poils roides; le second beaucoup plus petit que le premier, mais plus gros que les suivans; ceux-ci grenus, arrondis; les trois derniers libres, formant rénnis nne massue ovale, feuilletée.-Labre presque crustacé, épais, un peu rabattu, demi-circulaire, velu. - Mandibules presque trigones, leur partie extérieure Epaisse, large, relne; leur bord interne aminci, droit, tranchant, ayant une sinuosité à sa base. - Mtâchoires ayant un appendice interne, coriace, étroit, nsuui à son extrémité d'une dent cornée , arquée. - Palpes maxillaires plus longs que les mîcboires, un peu plus grands que lcs palpes labiaux, assez épais, de quatre articles; palpes labianx de trois; premier article des cquaire palpes très-petit, le dernicr presqu'ovale. Menton crustacé, trćs-velu, transverse, ses côtés arrondis, son bord antćrieur bidenté. - Tête courte, en triangle transversal, rentrant entièrement dans une échancrure du corselet; chaperon très- court. - Corps ovale, très-raboteux.-Corselet ayant son bord antérieur fortement ćchancré pour recevoir la tête, ses bords latéraux souvent déprimés, ciliés ou tuherculés. - Ecusson petit, mais distinct. - Elytres convexes, en ovale tronqué antérieurement, arrondies et très-convexes à la partie postérieure, recouvrant entièrement l'abdomen et rarement des ailes, le plus sompent réunies. - Abdonuen aplati en dessous. - Pattes insérées à égale distance les unes des au tres, ordinairement ciliées, les antérieures se contractant contre la poitrine et la partie inférieure de la tête ; leurs cuisses grandes, ayant à leur partic extérieure, qui est généralement lisse, une tache velue : leurs

$\mathrm{Bbb} b \mathrm{~b}_{2}$ 
jambes portant extérieurement trois ou quatre dents, dont les inférieures plus petites, munies en outre à leur extrémité d'une ąutre plus grande, large, souvent obluse et échancrée; les quatre janıbes postérieures munies de deux épines à leur exllémilé; erochets des tarses très-forts.

Les 'Trox, dont le nom vient d'un verbe grec qui signifie : ronger, se plaisent dans les champs sablonneux et sees. Ils courent assez vite sur. la terre; on les trouve souvent sous les substanees animales desséehées, dont ils rongent les parties tendineuses; ils se montrent prineipalement au printemps et au eommeneement de l'été. Lorsqu'ils sont menaeés, ils se eontractent en appliquant les pattes et les antennes eontre le corps, el font quelquefois entendre un petit bruit aigu oecasiontlé par le frollement de quelques parties extérieures. Tontes les espèces conuues sont naturellement noires, tuberculées ou garnics de faisceaux de papilles qui se ehargent facilencut de poussière et les rendent en apparence de conleur grise. On ne connoît pas leurs larves, mais il est probable qu'elles vivent de charognes et autres substances animales en décom position. Nons a vons remarqué que les bords latérarux du corselet des espc̀ces étrangères sont fortement dilatés, tandis qu'jls ne le sont point ou à peine dans celles d'Europe.

$1^{\circ}$. 'T'rox sabulenx, T. sabulosus $n^{\circ}$. 3. Fав. Syst. Eleut. (En retranchant le syuonyme d'O!ivier, les autres sont douteux.) - Sches. $S_{y} n$. ins. tom. I. pag. I I $7 \cdot n^{\circ}$. 4. (En exeluant le synonyme d'Olivier, les autres sont douteux, sauf ceux de Fabricius.) - Trox hispidus. Oriv. Ent. tom. I. Trox. pag. 9. no. 8. pl. 2. fig. 9. a. b. (Les synonymes sont douteux.) Commun aux environs de Paris. Les élytres sont habituellement séparćes, recouvrant des ailes repliées qui, dans leur développement, dépasseut les élytres el sont très-propres au vol. $2^{\circ}$. Trox perlé, 7 . perlatus. DEJ. Catal. - Trox sabulosus. OLIv. id. pas. 8. $n^{\circ}$. 6. pl. г. fig. I. (En retranehant les syonymes tirés de Fabricius, les autres sont douteux à l'exception de eelui de Geoffroy.) - Le Scarabé perlé. Geofr. Ins. Paris. tom. I. pag. 78 . $n^{\circ}$. I I. Des euvirons de Paris. (Ce dernier synonyme est rapporté à tort par M. Schœnherr au Trox hispidus.) Celte espèce a les élylres réunies. 3․ 'Trox hispide, T. hispidus $n^{\circ}$. 4. FAB. id. (En retranchant le synonyme d'Olivier qui appartien: au 'Trox sabuleux; celui de Laicharting est douteux.) - Schen. id. pag. 118. $n^{\circ} .5$. (En retranchant le synonyme d'Olivier qui se rapporte au Trox sabuleux, et celui de Geoffroy qui appartient au Trox perlé, les autres sont douteux à l'exception de celui de Fabricius.) Des envirous de Paris. Ses élytres sont réunies. $4^{\circ}$. 'Trox arénaire, T. arenarius $n^{\circ}$. 5. FAB. $i d$. ( A la citation de Laicharting lisez 3 r. a lieu de 3o.) - Onrv. $i d . p a g$. 10. $n^{\circ}$.9.pl. I. fig. 7. a. b. - Schas. id. pag.
118. $n^{\circ}$. 6. Commun aux environs de Paris. Ses élytres sont réunies.

Fabricius mentionne dix espèces de Trox. Le $n^{\circ} .9$. est une Elédone Lat. Le no. 7. le type du genre Phobère Macleay. Le no. 10. celui du そ̌eure Acanthocerus du même auteur.

\section{(S. F. et A. SERv.)}

TRUXALE, Truxalis. FAB. LAT. Gryllus. (Acrida) Llin. Acrdium. De Géer.

Genre d'insectes de l'ordre des Orthoptères, troisième section, fumille des Acrydiens.

Un gronpe de cette famille conlient les genres Proseopie, 'Truxale et Xiphicère. (Voyez SAvTEURs. ) Le premier se distingue par le prolongement de sa têie fort élevé, supportant les yeux au-dessus de sa parlie moyenne, et par ses antennes plus eourtes que la tête. Les Xiplieères n'ont point les antennes prismatirues; leurs euis. ses postérieures n'alteignent pas l'extrémité de l'addomen; leur's yeux sont gros et saillans, et en général leur corps est plas gros à proportion que eelui des Truxaies : la têle est moins longue relalivement au corselet que dans ees derniers.

Antennes ensifornes, triangulaires, prismatiques, aussi longues que la tête el le corselet pris ensemble, multiarienlées, insérées entre les yeux et l'extrémité de la tête, sur les côtés de celles-ei et sous ses bords latéraux. - Mandibules multidentées. - Mâchoires tridentées à l'extrémité. Dernier article des palpes presque conique. Tête conique, relevée, plins longue que le corselet. - Yeux ovales, peu proéminens. - Trois ocelles; savoir, deux placés sous les rebords de la tête, entre l'insertion des anteunes et les yeux; le troisième posé en dessous de la têle, fort éloigné des deux autres, entre la base des yeux. Corps comprimé, étrcil, alongé. - Corselet plus court que la tête, son bord postérieur. prolongé en un angle qui reconvre la base des élytres dans le repos. - Elytres longues, étroites, pointues au bout, un peu plus longues que les ailes. - Ailes assez grandes, pointues à leur extrémité, assez amples vers la base; leur partie postérieure fort arrondie. - Abdomen ćtroit, un peu comprimé. - Pattes grêles, à peı près égalemeıt espacées entr'elles; les quatre an!érieures petites, leur's jambes ayaut quelques pelites épines; palles postérieures très-longues, à cuisses grêles, mutiques, plus longues que l'abdomen; jambes fort longues, leur extrémité mnuie de qualre fortes épines et armées extérieurement de deux rangs d'épines; tarses composés de cinq artieles (considérés en dessous), les qualre premiers égaux dans les antérieurs et les intermédiaires; le cinquième beaneoup plus long qu'aueun des autres, niuni de d€ux erochets et d'une forte pelote dans leur entredeux : tarses postérieurs ayant leur premier article très-court; le second fort long; le troisième à peu près moitié plus court que le précéden:; le 


\section{T R Y}

quatrième encore plus court; le cinquième presque de la longueur des deux précédens réunis, terminé par deux forts crochets ayant une grosse pelote dans leur entre-deux.

On ignore les mœurs de ses Orthoptères, qui sont propres aux climats chands. Fabricius en décrit six espèces, mais les deux dernières au moins sont fort douteuses. Nous citeruns ici seulement la suivaute en p:évenant, d’après M. Latreille, qu'il est probable que plusieurs espèces de l'ancien continent sont confondues avec elles; pour les bien distinguer les unes des autres, il seroit nécessaire de les examiner sur le vivant. Truxale grand nez, T. nasutus. FАв. Ent. Syst. tom. 2. pag. 26. $n^{\circ}$. I. D'Afrique, et peut-être aussi du midi de la France.

$$
\text { (S. F. et A. Serv.) }
$$

TRYPĖTE, Trypeta. M. Meigen désigne sous ce nom le gente 'Téphrite. Voyez ce mot.

(S. F. et A. SERv.)

TRYPOXYLON, Tiypoxylon. LAT. FAB. PANz. Spinol. Apius. Jur. Sphex. Linns.? Schranck. Ross.

Genre d'insectes de l'ordre des Hyménoptères, section des Porte-aiguillon, famille desFouisseurs, tribu des Crabronites.

Une coupe particulière de cette tribu a pour caractères : antennes insérées au-dessous du milien de la face antérieure do la tête; chaperon court, large; yeux échancrés. Elle ne contient que le genre Trypoxylon.

Antennes filiformes ou grossissant insensible. ment vers l'extrémitć presqu'en massue, beitucoup plus longues que la tête, point coudćes ni roulées en spirale, insérées au-dessous du milieu de lit face antérieure de la tćte, composées de duaze articles dans les femelles, de treize dans les máles, le sccond beaticonp plus court que le troisième dans les deux sexes. - Labre point apparent. - Mandibules étroites, sans deuts, n'ayant qu'uue seule petite crénelure interne. Palpes maxillaires courts, composés de six articles, les labiaux de ciuatre. - Lèvre dilatée à l'extrémité, enlière ou pen échancrée, saus appendices latéraux ou les ayant très-petits. - Téte assez forte, plus large que le corselet, trausversale; chaperon large, court. - Y cux $x$ fortement échancrés. - Tiois ocelles placés en triaugle sur le vertex. - Corps long et grêle. - Corselet alongé, ovale; protborax fort court, en forme de rebord transversal, linéaire et séparé dans toute sou étendue par un intervalle notable, de l'origine des ailes supérieures : métatlorax presciue conique. - Ecusson fort grand. — Ailes courtes; les supérieures ayant nne cellule radiale fort longne qui se rétrécit après la première cellule cubitale; trois cellules cubitales, la première très - longue, recevant la première nervure récurrente; seconde culitale fort petite, rétrćcie de moitié vers la radiale, revevant la deuxième nervure récurrente; troisième cubitale presque complète : trois cellules discoidiles, la troisième, ainsi que les seconde et troisieme cubitales, souvent peu distincte. - $A \dot{b}$ domen fort alongé, en massue vers l'extréminé, s'anincissitut insensiblement en pédicule vcrs sa base, composé de cinq segmens outre l'anus dans les femelles, en ayant un de plus dans les mâles. - Pattes assez courtes; jambes sans épines latérales, les antérieures $\approx t$ les intermćdiaires terminécs par une épiue simple; jambes postérientes en ayant deux presqu'égales; premier article des tarses plus long que les suivans, lcs autres allant en décroissant de longucur jusqgu'au cinquième, celui-ci un peu plus long que le quatrième, ayant a suu extrémité deux crochets gros et conrts, munis dans leur entre-deux d'une pelote grosse ct courte.

Le nom de Trypoxylon vient de denx mots grees qui signifient : perce bois, ce qui suppose aux espèces une industrie qu'elles n'ont point; il est vrai que les femclles déposent leurs oenfs dans des trous, mais gu'elles trouvent déjà faits dans le bois. Les 'Trypoxylons n'oit aucun organe propre à transporter une proic; ils nous parvissent donc ĉtre parasites des Fuuisseurs; nous les avons viss souvent entier successivement dans divers trous où des Pompıles, véritables Fy'nénoptères Fouisseurs, avoient commencé leur nid; il est probable d'après cela que les entomologistes qui ont dit que le Trypoxylon poticr (figzzlus) revêt d'une couche de terre délayée les trous uì il fait son nid, y apporte une Aracbnide, y dépose un œâf et iriaçonue l'ouverture, lui ont accordé des facultés quili n'a pas, mais qui sont celles de plusieurs Pompiles que nous avons souvent eu occasion d'ubserver. On peut voir sortir un $\mathrm{Hy}$ ménoplère d'un nid d'insecte, sans en conclure que ce nid a été construit par lui, car tons les Parasites (ct dans les Fouissturs plusieurs genres sont parasites) naissent dans des nids arlistement formés, mais auxquels'ils n'ont pas travaillé; il sufit pour s'assurer qu'ils ne sont pas prédatenrs, et que par une cause nécessaire ils ne construisent pas eux-mêtnes de nid, de voir quie la nature leur a refusé les organes qui servent it transporter une proie, c'cst-ì-dire des épiues latérales aux jambes intermédiaires et postćrieures. Il y a donc lieu de conclure, d'après ce que nous venons d'exposer, que le nom de potier donné it l'espèce la plus commune de Trypoxylon anx environs de Paris, ne lui convient pas, et si nous le maintenons ici, c'est parce que nous pcrisons que s'il fallait changer les noms spécifiques qui sout dans le noćme cas que celui-ci, la nomenclature seroit bien souvent bouleversée.

Linné eu décrivant son Sphex figulus (Syst. nat. pag. 942. $n^{\circ}$. 11.) est le premier auteur qui, d'après Bergman, lui attribue la faculté de ma- 
conner et de transporter des Araignées dans son nid; mais il nous paroît fort douteux que cet cette espèce dont l'abdomen, dit Liuné, est à peine pétiolé, soit le Trypoxylon figulus, qui a l'abdomen très-notablement pétiolé; de plus les segmens de l'abdomen de celui-ci sont d'une teinte uniforme et non pas luisans sur leur bord. Nous connoissons un Pompile (Pompilus petiolatus VAnderlinden) auquel la description du Sphex figzulus de Linné convient parfaitement, mêze celle des mœurs.

Fabricius (Syst. Piez.) place six espèces dans ce genre; les deux dernic̀res appartienuent à celui de Psen; les nos. 3. et 4. ne nous sont point connus et pourroient bien n'être pas des Trypoxylons. Les $\mathrm{n}^{\mathrm{o}}$. I. et 2. vont être mentionnés ici.

\section{Trupozyron clavicorne, $T$. clavicerum.}

Trypo.xylon nigrum ; antennis clavatis; tarsis pedumique anticorum parte anticâ pallidè testaceis.

Long. 2. lig. $\frac{1}{2} ., 4$. lig. Noir; antennes en massue, conrles; paltcs antéricures d'un testacé pâle en devanl; tous les tarses de ccllc dernière couleur; ailes trausparentes, ì peine bordées de brun vers l'extrémité. Mâle et femelle. Des environs de Paris, dans les bois.

Ce genre contient eccore, $1^{\circ}$. Tispoxylon albitarse, T. albitarse $n^{\circ}$. 1. FAB. Syst. Picz. D'Amérique. $2^{\circ}$. Trypoxylon polier, T'figulus $n^{\circ} .2$. Fab.id. (S. F. et A. Serv.)

TUBITÉLES, Tubitela. Tribu d'Arachnides de l'ordre des Pulmonaires, fumille des Aranéides, section des Dipneurones, établie par M. Latreille (Fam. nat. du Règne anim.), el correspontant à la seconde ser lion de ses Aruignćes fileuses. (Règno animal.) Les caractères généraux de cette tribu sont : filières extéricures saillantes, cylintriques, rapprochées en un faisceau dirigé en arrière; crochets des mandibules repliés en travers le long de leur côté interne; pieds robustes, les deux premiers et les deux derniers, ou vice versî́, les plus longs. Abdomen de grandeur moyenne et ne contrastant point par son volume avec celui du Thorax, comme cela a lieu dans les Inéquitc̀les et Orbitèles. Ces Arachnides filent des toiles blanches, d'un tissu serró, qu'clles placent dans des fentes, des trous de tnurs, sous des pierres, entre les branches et les feuilles des végétaux et jusque dans l'eau Ces toiles sont ordinairement plicées dans une situation horizantale; quelquefois elles ont la forme de luyan ou de nasse; d'autres fois elles sont contournées en trémie, dans lesquelles res Araignées se tiennent renfermćes et à l'alfût de leur proie. Aussitòt qu'un malheureux insecte s'est engagć dans leur filet, elles en sont averlies par lcs mouremens qu'il fait pour s'échapper, acconrent, se précipileut sur luị et l'entraị- nent au fond de leur trou où elles le dévorent tranquillement; leurs cocons ou paquets d'wufs sont placés au fond de ce tron; elles en ont le plus grand soin, et le défendent a vec acharnement si on cherche à l'enlever.

Cette tribu a été partagée par M. latreille en deux grandes divisions ou sections, dont la seconde est elle-mème divisée en deux sous-divisions; elle comprend six genres dont nous donnerons les caractères en renvoyant à l'article AnaIg n'é de ce Dictionnaire, pour la conuoissance des épèces de chacun de ces genres qui y sont décrites.

I. Langue (lèvre WaLck.) cintrée par les mâchoires.

Clotilo, Clotho. Walckenaer. Lat. UrocTEA. LÉON DUF.

Huit yeux, placés sur deux lignes transversales; lcs deux filières supéreures beauconp plus longues que les autres; pieds presqu'égaux; mâchoires inclinées sur lä lèvre dont la furme est triangulaire; corps déprimé ou à poine convexe, à peu près orjiculaire; palpes presque de uème grosseur que les paltes, ne sinsérant point dans un sinus du bord interne de la mâchoire, mais bien au-dessus de ce bord et en quelque sorte sur la surface supérieure de l'organe maxillaire.

La senle espèce connue de ce genre se trouve en Catalogne, dans diverses antres parties de l'Espagne et dans le midi de la France. On doit à M. Léon Dufour que!ques observations trc̀s-intéressantes sur cette espèce, nous allons reproduire ici ce qu'ellcs offseut dc plus important. Cette Araignée établit, à la surface infériéure des grosses pierres, ou dans les fentes des rochers, une coque en forme de calotte ou de patelle, d'un bon pouce de diamètre. Son contour préseute sept à huit échancrures dont les angles seuls sont fixés sur la pierre, au moyen de faisceaux de fi's, tandis que les bords sont libres. Cette singulière tente est d'une admirable texture; l'extérienr ressemble à un taftetas des plus fius, formé, suivant l'ikge de l'ouvrière, d'un plus ou moins grand nombre de doublures. Ainsi, lorsque l'Araiguée, encore jeune, commence à établir sa retraite, elle ne fabrique que denx toiles entre lesquelles elle se tient à l'abri. Par la suite, et à chaciue mue, selon M. Léon Dufour, elle ajoute un certain nombre de doublures; enfin, lorsque l'époque marquée pour la reproduction arrive, elle tisse un appartement tout exprès, plus duveté, plus moelleux, où doivent être renfermés et les sacs des œufs et les petits réccmment éclos. Quoique la calotte extérieure ou le pavillon soit, à dessein sans doule, plus ou moins sali par des corps étrangers qui servent à en masquer la présence, l'appartement de l'industrieuse fabricante est toujour's d'une propreté recherchée. Lcs poches ou sachels qui renferment les ceufs sont an nombre 
de quatre, de einq ou même de six, pour elıaque habitation qui n'a cependant qu'uue seule habitante.

Ces poches ont une forme lenticulaire et plus de quatre lignes de diamétre. Elles sont d'un talfetas blanc comme la neige, et fournics intérieurement d'un édredon des plus fins Ce n'est que dans les derniers jours de décembre ou au mors de janvier, que la ponte des oul's a lieu. Il talloit prémunir la progéniture contre la rigneur de lu saison et les incursions ennemies; tout a été prévu. Le réceptable de ce précieux dépôt est séparé de la toile inımédiatement appiiquée sur la pierre, par un duvet moelleux, et de la calotte extérieure par les divers étages dont il a été parlé. Parmi les échancrures qui bordent te pavillon, les unes sont tout-à-fait closes par la continuité de l'étoffe; les autres out leurs bords simplement superposés, de manière que l'animal soulevant ceux-ci, peut à son gré sortir de sa tente et y reatrer. Lorsqu'elle quitte son domicile pour aller à la chasse, eile a peu à redouter sa violation, var elle seule a le secret des échancrures impénétrables, et la clef de celles où l'on peut s'introcluire. Lorsciue les petits sont en état de se passer des soins naternels, ils prenuent leur essort et vont établir ailleurs leurs logemens particuliers, tandis que la mère vient mourir dans son pavillon. liespièee qui a été le sujet de ces observations a étú dícrite pour la première fuis par MM. Latreille et Walckenaer; e'est

\section{Le Cloteo de Durand, Clotho Durandii.}

C. thorace fusco-brunneo, pallido favo marginato; abdomine nigro, maculis quinque rufis, $2,2,1$; pedibus castaneo-brunneis.

Chotho Durandii. Lat. Gener. Crust. et Ins. tonl. 4. pag. 370. - Uroctea quinque maculata. I.Éon DUF. Ann. générales des scienc. phys. I. 5, pag. Ig8.pl. 76. fig. 1. a. f. Cette Araignée est longue de quatre à cing lignes, son corselet est brun, bordé de jaune; déprimé, ou peu convexe; on y remarque, entre les yeux et l'origine des mandibules, une porlion remarquable dn front tombant vertiealement. Les yeux sont arrondis et cristallins dans l'animal vivant. L'abdomen est noir, a vee cinq taches rouges arrondies. Les pattes sont d'un brun-marron, de longueur moyenne, et terminées par des ongles pectinés. L'individu que nous avons sous les yeux a été pris aux environs de Montpellier.

DDRASSE, Drassus. W ALCK. Lat. Aranea. Livn. Gnaphosa. LAt.

Huit yeux placés très-près du bord antérieur du thorax; mâchoires arquées au côté extérienr, formant une ceinture autour de la lèvre qui est alongée et presqu'ovale; les quatre filières presque égales; la quatrième paire de pieds, et ensuite la prenière plus longues. Ce genre a été d'abord indiqué par M. Latreille dans la première édition du nouveau Dictionnaire d'histoire naturelle, sous le nom de Graphose, mais c'est M. Walckenaer qui l'a caractérisé d'une manière positive, daris son tableau des Aranéides (page 45.). Il dillère des Cluthos par plusieurs caraelères faciles à saisir, et surtont parce que ses filières supéricures ne sont pas plus longues que les inférieures; il est bien séparé des Filstates parce que dans ees dernières Araignées, les yeux sunt portés sur une élévation. Les Drasses surpreunent leur proie, et se tiennent à l'uffût pour allendre le moment favorable de s'en saisir. Leur demenre consiste en une cellule de soie très-blanche, placée dans l'intérieur des trous des murs, des arbres, sous les pierres et dans les feuilles qu'elles roulent fort adroitement pour cet effet. C'est au fond de ces trous qu'clles eatraineut la proie qu'elles ont saisie, pour la dévorer tranquillement.

On connoît sept ou huit espéces de ce genre; six habitent les environs de Paris, la septième est originaire de la Caroline; M. Walckenaer les range dans trois divisions ainsi qu'il suit :

1. Yeux sur deux courbes opposées par leur côté convexe; mâchoires très-dilatées dans leur milieu. Arünéides se tenant derrière les pierres et les cavités des murs. - Les Lithopailes, Litho. philoe. Walck.

Drasse lucifuge, Dirussus lacifugus.

D. mandibulis nigricantibus; thorace pedistsque obscure bunnneis; femoribus dilutioribus, rufescente bnunneis; abdomine murino-nisis, sericeo.

Drassus lucifugus. WValer. Tabl. des Arar. pag. 45. - Araignée lucifuge, ibid. Faun. Paris. tom. 2. pag. 22 I. - Graphose. Lat. Nowv. Dict. d'hist. nat. tab. tont. 24. pag. $134 .-$ Drassus melanogaster, ibid. Gener. Crust. et Ins. tom. I. pag. 87. - Araignée melanogasire, ibid. Hist. nat. des Crust. et des Ins. tom. 7. pag. 222. - Araignée lucifuge, ibid. loc. cit. pag. 225. Scrafr. Icon. Ins. tab. 10I. fg. 7. Cette espèce est d'un brun foncé, avec les mandibules noirâtres et l'abdomen d'un noir soy eux. On la trouve sous les pierres anx environs de Paris. M. Latreille l'a prise dans le département de la Corrèze.

2. Yeux sur deux lignes eourbes, parallèles; mâchoires peu dilatées dans leur milieu. Arai gnées se renfermant dans les feuilles des plantes qu'elles plient et rapprochent. Les Phytophiles eachées, Phytophila abscondito. W $_{\text {ALCK }}$.

Drasse nocturne, Drassus nocturnus.

Abdomine nigro-punctis duobus albis; basi lunula alba. 
Aranea noctuma. Livv. Faun. Suec. édit. 2. no. 2010. - Act. Ups. 1736. pag. 33. no. 11. Drassus nocturnus. - W ALck. Tabl. des Aran. pag. 46. ibid. Faun. Paris. tom. 2. pag. $22 \mathrm{I}$. $77^{\circ}$. 68. Cette espèce est noire; son abdomen est ovale, alongé, marqué de deux taches blanches sur le milieu du dos, ayant la base entourée d'une lunule blanche anguleuse. On la trouve dans les bois des environs de Paris. Linné observe qu'elle ne sort ciue la nuit. Elle forme son nid dans les feuilles des arbres.

Une espèce très-voisine, le Drassus ater de Latreille (Gen. Crust. etc. tom. I. pag. 87), se rapproche baaucoup de celle que nous venons de décrire, mais elle en diffère parce qu'elle est toute noire et qu'elle construit un cocon rougeâtre, orbiculaire, se divisant en denx valves panyracćes. Ce nid est placé sous les pierres. On la trouve aussi aux environs de Paris où elle est commune.

3. Yeux sur deux lignes courtes, parallèles; les latéraux rapprochés entr'eux; mâchoires peu dilatées dans leur milieu. Aranéides coustruisant sur la surface des feuilles une toile fine et blanche, transparente, à tissu serré, sous laquelle elles se tiennent. Les Phytophiles apparentzs, Phytophile conspicuce. WALCK.

Drasse vert, Drassus viridissinuls. Walck. Faun. Paris. tom. 2. pag. 2:2. $17^{\circ}$. 52, Elle est toute verte. On la trouve communément aux environs de Paris.

\section{Langue non cintrée.}

A. Six yeux.

SÉGESTRIE, Segestria. Voy. ce mot.

B. Huit yeux.

ClUBIONE, Clubiona. Lat. W A tck. Aranea. Inix. DE GÉer. Yeux presqu'égaux, placés sur le devant du corselet et sur deux lignes. Màchoires droites, alongées, écartées, subitement dilatées à leur extrémité et élargies à leur base extéricure pour l'insertion des palpes. Lèvre alongée, coupée en ligne droite à son extrémité ; filières extérieures, presqu'égà'ement longues. Pattes propres à la course et variaut respectivement de longueur; la premic̀re paire el ensuite la quatrième, sont généralement les plus longues; mais dans certaines espèces cette deruière, et ensuite la première ou la seconde, dépassent les autres. Ce genre diffère des Araignées proprement dites par les filières qui, dans ces dernières, ne sont pas d'égale longueur. Les Argyronètes s'en éloignent par la forme de l'extrémité des mâchoires et par celle de la lèvre. Ces Araignées sont voraces; elles épient lenr proie et courent arrès; on les voit tendre autour des chambres des fils de soie fine et blanche destinés à embar- rasser les insectes dont elles font leur proie : d'autres tendent leurs filets dans les cavités des murs, contre les pierres; entin, quelques-unes s'enveloppent dans les feuilles.

On connoît une douzaine d'espèces de Clubiones, presque toutes se trouvent aux environs de Paris. M.W alckenaer les a distribuées dans cinq scctions que nous allons faire connoître.

I. La quatrième paire de pattes plus longue que les autres; la seconde sensibiement plus longue que la première; la troisiène la plus courte. Yenx sur deux ligues parallèles, droites; maudibules dirigées en avant. Ces Arachnides se renferment dans les feuilles ou sous l'écorce des arbres. Leur cocon est aplati. Les Dryades, Dryades. WALCK.

Clubione soyeuse, Clubiona holosericea. Lat. Gener. Crust. et Ins. tom. 1. pag. 92. -W ALCE. Faun. Paris. tom. 2. pag. 219. $n^{\circ} .66$. -Ibid. Tabl. des Aran. pag. 42. - Aranea holosericea. Lat. Hist. natur. des Crust. et des Ins. tom. 7. pag. 218.

Voyez pour la description et la suite de la synonymie, l'article Araignés de ce Dictionnaire, pag. $212 . \mathrm{n}^{\circ} .51$.

2. Première paire de pattes plus longue, la quatrième ensuite; la troisième la plus courte. Yeux ramassés en derni-cercle; corselet poin tu à sa partie antérieure; mâchoires courtes, peu dilatées à leur extrémité; lèvre légèrement échancrée à son extrénité; mandibules verticales. Ces Anaréides se tiennent dans les feuillos sèches. Les HamadRTADES, Hamadryas. WaLcK.

Clebrone accentuée, Clubiona accentuata. WALCK. Foun. Paris. tom. 2. pag. 226. no. 75 . Son abdomen est ovale, d'un jaune pâle, marqué de deux accens circonllexes sur le milieu du dos. Elle est commuue dans les feuilles sèches.

3. Première paire de pattes la plus longue, la quatrième ensuite, celle-ci surpassant un peu la seconde; la troisième la plus courte. Lèvre légèrement échancrée à son extrémité ; yeux latéraux rapprochés; mandibules verticales. Les espèces de ce groupe se renferment entre des feuilles quelles rapprochent. Les Nruphes, Nymptice. Wasck.

\section{Clubrone nouraice, Clubiona nutrix.}

C. ungulis nigris; thorace mandibulisque dilute rufescentibus; pedibus dilutioribus; abdomine fluvo-viridi, fascia longitudinali obscuriore.

Clubiona nutrix. WALck. Tabl. des Aran. pag. 43.-LAт. Gen. Crust. et Ins. tom. 1. pag. 93.Araignée nourrice. Wa cck. Faun. Paris, tomb. 2. pag. 220. - Lat. Hist. nat. des Crisst. et des Ins. tom. 7. pag. 221. Son corselet, ses pattes et ses mandibules 


\section{T U B}

mandibules sont ruuges, l'extrémité seule de ces dernières est noire. L'abdomen est alongé, verdàtre. Celte espèce se trouve aux envirous de Paris; on la rencontre vers la fin de l'été sur le panicaut des champs ou chardon Roland. Sa coque est assez ronde, d'une soie blanchâtre; elle la place eutre des feuilles plićes. Celte division renferme encore les Clubiones maxillosa $\mathrm{F}_{\mathrm{AB}}$. Amarantha, Aloma, Erratica, Epinelas de Walckenaer.

4. Première paire de pattes plus longùe que les autres, la quatrième ensuite, la troisième la plus courte; yeux laléraux, rapprocliés; corselet trèsbombé à sa parlie antérienre; lève coupée en ligne droite et légèrement écluancríe à son extrémité. Ces Aranéides se renferment dans une toile fine pratiquée dians les cavités et les lieux obscurs. Les Parques, Parcce. Walck.

\section{Clumione atroce, Clubiona atrox.}

C. brunnea; pedibus dilutioribus, tibiis maculis obscurioribus; abdominis dorso macula antica subquadrata, nigra fuvoque murginata.

Clubiona atrox. W ALCK. Tabl. des Aran. pag. 44. - Lat, Gen. Crust. et Inls. toml. i. pag. 93. - Alaignée atroce. Lat. Hist. nat. des Crust. et des Ins. tom. 7. pag. 222. - DE GÉER. MIém. sur les Ins. tomi. 7. pag. 253. pl. 14. fig. 24. 25. LIster. Aran. pag. 68. tit. 2 I. fig. 21. - AI.BIN. pl. 2. fig. 9. 10. Elle esl loute brune avec le corselet très-bombé en devant; l'abdomen a une grande tache quadrangulaire noire, bordée de jaune-paille. Elle passe l'hiver dans les fentes des mulailles; on la voit souvent errer dans les maisons de Paris. On doit rapporter à cette division la Clubione cruelle ( $C$. sceva.) de Walckenaer. Elle vient de l'île des Kauguroo, à la NouvelleHollaude.

5. La quatrième paire de pattes plus longue que les précédentes, la première ensuite, la troisième la plus courte; màchoires bumbées à leur base et vers leur extrémité; yeux sur deux lignes courbées, parallèles; les latéraux disjoints et écartés. Les Aranéides de cette compe funt leur demeure sous des pierres; leur cocon est globuleux. On n'en connoît qu'une espèce. Les F'uries, $f_{a}$ rice. WALCK.

\section{Clubione lapidicole, Clubiona lapidicolens.}

C. thoracemandibulisque pallide rufescentibus, pedibus dilutioribus; abdomine cinerascente.

Clubiona lapidicolens. W ALck. Tabl. des Aran. pag. 44. - Clubiona lupidicola. Lat. Gen. Crust. et Ins. tom. I. pag. 9r. - Araignée lapidicole. Waxck. Faun. Paris. tom. 2.pag. 222.-Aranea lapidaria. LA T. Hist. nat. des Crust. et des Ins. tom. 3. pag. 53. - Ibid. tom. 7. pag. 221, 225. Hist. Nat. Ins. Tonie $X$.
Son abdomen est ovale, les pattes sont rongeâtres. On la trouve sous les pierres, aux environs de Paris.

Araignée, Aranea. Linn. Gromf. De Géer. Fab. Ollv. Lam. Lat. Tugencuriu. Lat. Walck. Argelena, nyssa. WaLcK.

Linné, Geolfroy et tous les auteurs jusqu'd Latreille, accordoient à ce mot Araignée un sens très-étendu; on l'emploie encore .vulgairetnent pour désigner toutes sortes d'Arachnides. Actuellement les Arachnides qui portoieut ce nom forment une fumille que l'on désigne sous le nom d'Aranéides, partagée en plusieurs genres. Par une singularité assez remarquable, M. Walckenaer, dans sa méthode, en divisaut celle fauille eu genres, avoil omis de conserver le nom d'Arairnée à l'un d'eux. M. Latreille a pensé qu'il ne falloit pas rayer ce mot des catalogues, et que le genre Aranea des anciens auteurs devoit être conservé; il a donc formé son genre Araignée proprement dit des genres 'Tagéulaire, Agélène et Nysse de M. Walckeuaer. Il a réuni ces trois genres, qui ae présentoieut pas des différeuces très-saillantes, et son genre Araignée, tel que nous l'adoptons ici, a pour caractères : liuit yeux à la partie antérieure du corselet, placés quatre par quatre sur deux lignes transversales, arquées (les latéraux plus rapprocliés du bord antérieru du corcelet et les quatre du milieu formant ua carré plus reculé ); mandibules presque droites, ayant sur leur côté interne un sillon dentelé sur les deux bords, lequel reçoit le crochet; mầchoires droiles, presque terminées en forme de palette; lèvre carrée, tantôt plus hautes que large, les deux filières supérieures très-saillantes; paltes alongées, la prewière ct la dernière paire plus longues.

Les espèces qui composent ce genre habitent, pour la plupart, nos demeures; elles y fabriquent ces toiles que l'on voit suspeudues dans les embrasures des fenêtres, les encoignures des murailles, etc. Homberg ( Mémoires de l'Académie des sciences, annće 1707. pag. 339.) a donné une description fort curieuse de la manière dont les araiguées font leurs toiles; l'étendue de cet ouvrage ne nous permet pas de le présenter ici. Suivant M. Lepelletier (Bulletin de la Société plizlomatique, avril 18 13.), l'époque des amours a lien, pour plusieurs araignées, vers les mois de novembre, décembre el janvier. La copulatiou s'opère après les nêmes préliminaires que dans les autres genres de la famille des Aranéides, et la poute se fait deux mois après. Les espèces qui servent de type a ce geare se trouvent clans nos maisons。

Araignée domestique, Aranea domestica. Lat. Gen. Crust. et Ins. tom. I, pag. 96. - Tagenaria domestica. Walck. Tabl. des Aran. pag. 49.-

$\mathrm{Cccsc}$ 
Araign ́́ domeslique. Wa LCx. Falun.Paris. tom.2. pag. 216. - Lat. Hist. nat. des Crust. et Ins. tom. 7. pug. 227. - Lister. Aran. pag. 59. tit. 17. fig. 17.

Voyez les autres synonymes el la description de celle espèce à l'article Arraignée no. 5o. de ce Dictionnaire.

Araignée cabrintrioze, Aranea labyrinthica. I.AT. Gener. Crist. et Ins. tom. I. pag. 95. 'Tugénaire. LAT. Nouveau Diction. d'hist. nat. tom. 24. tabl. pag. I34. - Araiguée labyrinthique. Lat. Hist. nat. des Crust. et des Ins. tom. 7. pag. 226. - Agelena labyrinthica. W ALck. Tabl. des Aran. pag. 51. - Araignée labyrinthique, ibid. Faun. Paris. tom. 2. pag. 217.

Voyez pour les autres synonymes et la description de cette espèce, l'article ARAIGNÉ, no ${ }^{\circ}, 52$. de ce Dictionnaire.

On doit encore rapporter à ce genre la Tagenaria civilis de Walckenaer (Faun. Paris. et hist. des Aran. tab. 5. fascicule 5.); la Tagenaria agrestis du même, et sa Tagenaria murina. Son Agelena novvia, rupportée de la Caroline par MI. Bosc, est aussi une araignée. Ii en est de mème du Nyssus coloripes de cet auteur, qui vient de la Nouvelle-Hollande. Enfin, la Tagenaria medicinalis de Henz, décrile et figurée d.us le Journal de l'Acad. des scienc. natur. de Philadelphie, vol. 11. février 1821. pag. 53. et pl. 5. fig. I., doit aussi faire partie du genre A raignée. Sa toile peut être comparée, sous plusieur's rapports, avec celle de l'Araignée domestique; on l'emploie fréquemment en médeciue dans l'Amérique du nord.

ARgyronète, Argyroneta. Lat. Walck. - Aranea. Linn. Geoff. De Géer. Fab.

Co genre, ćtabli par M. Latreille aux dépens du grand genre Aranea de Linné, a été adopté par M. Walckenaer ( Tabl. des Aran. pag. 84.), qui le place dans sa division des Nayades. MI. de Lainarck (Anim. sans vert. toin. 5. pag. 98.) ne le distingue pas des Araignées. Les caractères di genre Argyronète sont : huit yeux, ceux du milieu formaut un carré, les autres situés de chaque côlé et géminés; mùchoires presque droites, cylindriques, coupées obliquement à leur sommet du côté interne, élargies à leur base; lèvre triangulaire, arrondie à son extrétnité, dilatée à sa base; pattes d'uue étendue médiocre; la première paire étant la plus longue, la quatrième ensuite, et la troisième plus courte que toutes les autres; filières extérieures presqu'également longues. Ce genre ressemble entièrement aux Clubiones par le nombre des yeux, les filières et la direction des mâchoires; il n'en est distingué que parce que ces deruières parties sont coupées à leur sommet dans presque toute leur largeur, et que leur lèvre est triangnlaire. Il dillère des Araignées propres, par les filières et par la longueur relative des pattes. On ne connoit encore qu'une espèce d'Argyronète; son histoire est des plus curieuses, et plusieurs auteurs que nous allons citer ont contribué à la rendre plus complète.

Argtronète AQuatique, Argyroneta aquatica. LA T. Nouv. Dict. d'hist. natur. tom. 24. Tabl. pag. 134. - Gen. Crust. et Ins. tom. 1. pag. 94. - Walck. Tabl. des Aran. pag. 94. - Araignée aquatique, ibid. Faun. Paris. tom. 2. pag. 234. - Lalanda de Lignac, Mémoire pour servirà conmencer l'histoire des Aruignées aquatiques, in-80. Paris, 1799. - Schar F. Icon. Ins. tab. 158. fig. 6. Mas.

Voyez pour les antres synonymes, la description de l'espèce et ses mours, l'article AraignéE de ce Dictionnaile, tom. 4. pag. 226. n०. 112.

$$
\text { (E. G.) }
$$

TUBULIFE'RES, Tubulifera. Cinquième Fanille de notre première section de l'ordre des $\mathrm{H}_{\mathrm{y}}$ ménopières. (Voyez TÉRÉBRANs, pag. 58o. de ce volume. ) Elle répond à la tribu des Chrysides. Lat. Voyez Puplvores, pag. 253. de ce volume.

(S. F. et A. SERv.)

TURQUOISE. Ce nom a été appliqué par Geoffroy (Ins. Paris. tom. 2. pag. $129 \cdot n^{\circ}$. 40.) à un Lépidoptère Crépusculaire qui depuis a servi à l'établissement du genre Procris. Voyez $\mathrm{P}_{\mathrm{R}}$ och de la Statice. (S. F. et A. Serv.)

TYLOCÈRE, Tylocerus. M. Dalman, dans ses Analecta entomologica (Holmice, 1825.) pag. 57, a séparé des Téléphores, sous le now de Tylucère, un sous-genre ayant les caractères survans : antennes de la Tongueur du corps, assez épaisses; leur premier article grand, ovale; les suivans obconiques, allant en augmentant; le deruier grand, presque linéaire, de la longueur du premier, terminé en cône. 'Tête déprimée. Yeux petits, arrondis, saillans. Corselet plus court que la tête, presque carré, ses bords très - réfléchis; angles antérieurs arrondis, les postérieurs droits, un peu proéminens; deux callosités sur le disque du corselet. Ecusson semi-ovalaire. Elytres à peine plus larges qu: le corselet, linéaires, déprinées, leur extrémité arrondie. Pattes grêles. Le type de ce sous - genre est le Téléphore (Tylocère) crassicorne, Telephorus (Tylocerus) crassicornis. Daliz. ut suprà. Longueur 5 lig. Brun; tête et corselet d'un testacé jaunâtre; an tennes en massue, brunes, avec le premier article jaune, De la Jamaïque.

$$
\text { (S. F. et A. Serv.) }
$$

TYLOS, Tylos. Latr.

Genre de l'ordre des Isopodes, section des Ter- 
restres, famille des Cloportides, établi par M. Latreille (Fant. nat. du Regn. anim.), et dout les caractères ne sont pas encore publiés.

$$
\text { (E. G.) }
$$

TYPHIS, Typhis. Rrsso, Lat. IАam.

Ce genre ful d'abord placé par son auteur dans la famille des Crevettines, qui contenoit les genres Phronine; Typhis, Euphée, Talitre, Crevette, Chevrolle et Cyame. M. Latreille, dans le troisième volume du Règne animal de M. Cuvier, le plaça dans l'ordre des Isopodes, et dans une section de cet ordre, à laquelle il donnoit le nom de Phytibranches. Enfin dans ses Familles naturelles, ce savant a reporté le genre qui nous occupe dans l'ordre des Anphipodes, où l'avoit mis son auleur primitif. Dans ce dernier ouvrage, le genre ' $\mathrm{T} y$ phis et les genres Ancée et Pranize composent une famille qu'il désigne sous le nom de Décempèdes, et dont nous allons faire connoître les caractères.

\section{DÉCEMPÈDES, Decempedes. Latr.}

Celle famille reuferme des Crustacés qui u'ont que dix pieds onguiculés et propres à la marche. Ce caractère seul la distingue des autres familles du même ordre, dont tous les individus ont quatorze pieds.

\section{TYPHJS, Typhis.}

Corps arrondi; tê!e grros*e, portant deux antennes très-petites; yeux petits; les quatre premières pattes terminées par une pince à deux doigts; tronc formé de sept segmens, et ayant de chique côté une lame pouvant s'ouvirir et se fermer comme les battans d'une porte. M. Latreille, qui a vu ce genre, en conne nne description détaillée dans le Nouveau Dictionnaire d'histoire naturelle: nous allons la reproduire ici. "Ces Crustacés, d'après l'examen que j'en ai fait, doivent être placés immédiatement à la suite des Phronines, et représentent, dans cet ordre, les Sphéromes, genre de l'ordie des Isopcdes; la tête est grande, forme un ovale transverse, bombé, et olfre en devant une sorte de chaperon, figuré en losange, diltingué à sa base par une ligne enfoncée et arquée, et avancé en ang'e tronqué, au milieu du bord antérieur; au-dessous est, de chaque côté, un enfoncement, sous lequel est une petite pièce transverse qui se prolonge jusqu'à la bouche, et portant à son extrémité antérieure une petite antenne sélacée, de trois à quatre articles, dirigée aussi vers la bouclie. On voit aussi, audessous du chaperon, un petit corps, qui est peut-être le rudiment d'une autre antenne. La bouche est protubérante, et l'on y distingue une sorte de lèvre, surmontée de deux palpes, et quelques antres parties; les yeux ne sont point saillaus, et on ne les distingue que par la lucidité des espaces qu'ils occupent ; le tronc est formé de six lames ou demi-anneans transverses, et aug- mentés, à chacun de leurs bouts, d'une petite pièce carrée ; avec celles du cinquième demi-anneau s'articule une lame presqu'elliptique, alongée, qui s'applique en remontant le long des autres petites pièces accessoires; une autre lame, parlant de chaque côté du sixième demi-anneau, se réunit avec la précédente par sonbord inférienr ou le plus éloigné du corps, de sorte que ces denx pièces, ainsi joinles, lui forment, de chaque côté du tronc, une valve mobile, ou comme un battant de porte. M. Risso les prend pour des parties des deux dernières pattes. La quene, en forme de triaugle alongé ou conique, est composée de cinq segmens, dont le dernier allant en pointe et sans appendice au bout, du moins, je n'en ai pas apereu; le dessous de cette queue est garni d'appendices, disposés sur deux rangs, semblables à ceux que la même partie nous offre dans les Salicoques, et consistant en deux petits feuillets, portés sur ua pédicule; les pattes sont au nowbre de dix, dont six monodactyles ou terminées simplement en pointe, et quatre avec une main didactyle au bout, nonobstant que M. Risso ne donne ce caraclère qu'à la première paire. L'aniunal, en baissant la tête, et contractant ses pattes, en repliant sa queue le long de la poitrine, et en rapprochaut les deux valvules latérales, peut ainsi se mettre facilement en boule, et garantir ses organes essentiels $»$.

Typhs ovoïde, Typhis ovoides. Risso. Crust. de Nice. pag. 122. pl. 2. fig. 9.-Lamk. Hist. nat. des anim. sans vert. tom. 5. pag. 166. - D EsM. Consid. sur les Crust. anticle Malacostracés du Dict. des sc. nat. pag. 282. pl. 5. fi guré dans l'allas de ce Dict. pl. 336 . fig. 36 . D'a près Risso, le corps de ce Crustacé est long de vingt quatre millimètres; il est ovoïde, lisse, d'un beau janne clair et luisant, parsemé de petits points rougeâtries. Cet auteur dit qu'il quitte rarement les fonds sablonneux, et que, lorsqu'il vient nager ì la surface de la mer, si on veut le saisir, il replie sa qreue sous son corps, el au moyen des deux lames foliacées des côtés du trone, il cache tous ses organes, forme une boule et se laisse tomber au fond. On ne le reneontre aux environs de Nice que pendant l'été et dans les momens où la mer est calme. Suivant M. Latreille, le voyageur Leschenault a trouvé dans les mers des Indes orientales une espèce de Typhis, qui paroìt semblable à celui đe Risso.

ANCÉE, Anceus. Risso. Latr. Lamk. Gnathia. LÉACE.

Quatre antennes médiocrement longues; les extérieures l'étant plus que les intérieures, et terminées pardes articles déliés et en soies, les intérieures grosses et poflues. Deux yeux composés; mâles ayant au-devant de leur tête deux grandes saillies, eu forme de mandibules avancées. Corps oblong, 
déprimé, formé de cinq segmens, dont les deux premiers sont très-larges, sillonnés et soudés ensemble. Dix pieds monodactyles, dont les six premiers courts et dirigés en avant, et les quatre derniers plus longs et portés en arrière. Queue de qualre segmens, terminće par une lame natatoire intermédiaire aignë, et deux lames plus larges placées une de chaque côté.

Ce genre se distingue aisément du précédent par l'absence de pince aux quatres premières pattes, et pard'autres caractères aussi tranchés; l'espèce qui lui sert de type a été placée par M. Risso dans le voisinage des Pagures, mais fort à tort, car ce Crustacé n'a aucun rapport avec ceux-là. Il ne se compose encore que de deux espèces, dont l'une a des caractères qui la feront entrer plus tard dans un genre distinct.

Ancée forficulatre, Anceus forficularis. Risso. Crust. de Nice, pag. 52. pl. 2.fig. 10. - Lavk. Hist. nat. des anim. sans vert. tom. 5. pag. 167.
- Figuré dans l'atlas de ce Dictionnaire, $p l .336$. fig. 24. Celle espèce est longue de six millimètres. Son corps est alongé, déprimé et blanchâtre. On le trouve dans la mer des environs de Nice, dans les régions des coraux; il se tient caché dans les interstices des coraux.

Le Cancer maxillaris de montagne. (Transact. Soc. linn. de Londres, tom. VII. pag. 66. pl. 6. fig. 2. Il a les plus grands rapports avec l'Ancée forficuiaire, dont il diffère par la longueur relalive des antennes, par la position de ses yeux et par le dernier segment de sa queue qui est arrondi. Il se trouve sur les côtes d'Angleterré.

PRANISE, Praniza. (Voyez ce mot.)

(E. G.)

TYRONIE; Tyronia. Rafinesque doune ce nom à un nouveau genre d'Isopodes dont les caractères. nous sont inconnus. (E. G.) 


\section{U C A}

$\mathrm{U}$ CA, Uca. LAт. Genre de Crustacés de l'ordre des Décapodes établi par M. Latreille, et dont les caractères sont exposés à l'article 'Touncounoux pag. 685. de ce Dictionnaire. (E. G.)

ULÉÏO'TE, Uleiota. LAT. Brontes. FAB. Grilen. Schan. Cucujus Herbst. Oriv. Cerambyx. Linn.

Genre d'insectes de l'ordre des Coléoptères, section des Tétramères, famille des Platysomes.

Cette famille qui n'est point divisée en tribus, contient six genres dans les Famt. nat. Lat. savoir : Parandre, Passandre, Cucuje, Uléiote, Dcndrophage, Hémipèple. Les deux derniers n'ćtoient point adoptés par M. Latreille lors de la rédaction de l'article Pratysomes du présent Dictionnaire. Celui d'Hémipèple nous étanı en tièrement inconnu, nous ne pouvons le faice entrer dans la comparaison suivante. I.es Parandres et les Passandres ont les bords latéraux du corselet saus crénelures ainsi que les Cucnjes et les Dendrophages, ce qui éloigne tous ces genres des Uléiotes; en outre dans les Cucujes les antenues sont momiliformes; celles des Parandres le sont aussi et beaucoup plus courtes que le corps; le genre Passandre a les siennes composées d'arlicles comprimés, obconiques, presqu'en scie, et le dernier article des palpes maxillaires arrondi à l'extrémité.

Antennes filiformes, au moins de la longueur du corps, composées de onze arlicles, le premier très-long, allant en grosissant vers son extrémité, un peu arqué, les autres assez longs, presque cylindriques. - Liabre prolongé entre les mandibules, membraneux, sa partie antérieure arrondie, entière. - Mandibules fortes, cornées, avancées, déprimées, trigones; leur bord extérieur arqué. - Mâchoires ayant leui lobe intérieur muni d'un onglet corné; l'extérieur grand, presque carré. - Dernier article c'es palpes presque conique allant en pointe. - Lèvre Jargement échancrée, courte, coriace; menton crustacé, très-court ${ }_{2}$ transverso-linéaire, obliquement tronqué à sa partie intérieure de cliaque côté, plus étroit ì la base qu'à l'extrémité. - Tête déprimée. - Yeux globuleux. - Corps déprimé. - Corselet presque carré, ses bords latéraux crénelés, déprimé en dessus. - Ecusson assez grand, triangulaile, presque transversal. - Elytres un peu plus larges que le corselet, très-déprimées, presqu'en carré long, arrondies postérieurement, recouvrant l'abdomen et les ailes. Abdomen.déprimé. - Pattes assez courtes; les intermédiaires insérées assez près des antérieures; les postérieures plus éloignées, cuisses assez grosses, un peu en massue; tarses fort courts, tous leurs articles entiers.

Le nom de ces insectes est tirć du grec et indique leur séjonr habituel dans les forêts. Jeurs mœurs sont celles des Cucujes. Toyez ce mot.

Le genre Brontes Fав. (Syst. Eleut.) contient nominativement cinq espèces; le $n^{\circ} .2$. est le type du genre, le no. 3. n'en est qu'une variété; le no. 4. appartient aux Cucnjes; les nos. 1. et 5 . sont douleux.

\section{UrËiotote flavipède, $U$. flavipes.}

Uleiota flavipes. LAт. Gener. Crust. et Ins. tom. 3. pag. 26. $n^{\circ}$. 1. - Brontes flavipes $n^{\circ} .2$. FAB. Syst. Eleut. (Au synonyme de linné lisez 624. 17. au lieu de 625. 15.) - Sснек. Syn. Ins. tomt. 3. pag. 57. n०. 2. (A la citation du Syst. nat. de Linné lisez 624. au lien de 625. ) - Cucujus flavipes, Oliv. Entom. tom. 4. Cucuj. pag. $7 \cdot n^{\circ} .6$. pl. s. fig. 6. a. b. - Encycl. pl. 364. I. fig. 5.

Toyez pour la description et les autres synonymes, Cucuje flaripède $n^{\circ}$. 8. de ce Dictionnaire, en ajoutant que les mandibules du mâle ont chacune à leur partie extérieure un prolongement en forme de corne, assez long, avancé, arqué, terminé en pointe aiguë.

$$
\text { (S. F. et A. Sravo) }
$$

ULIDIE, Ulidia. Genre de Diptères créé par M. Meigen (Dipt. d'Eur.) dans -sa famille des Muscides; il lui doune pour calactères : antennes inclinćes, petites, plus courtes que l'hypostome, assez éloignées l'une de l'autre, composées de trois articles; les deux premiers petits, le troisième oblong, elliptique, comprimé, muni à sa base d'une soie dorsale nue. 'Trompe presqu'entièrement rentrée dans la cavité buccale, géniculée. Palpes aplatis, élargis à leur extrémité, un peu velus sur leurs bords. Hypostome descendant andessous des yeux, rugueux, rétréci au milieu, le bord de la bouche nu et relevé; front très-large, plàt, rugueux. Yeux ronds. Trois ocelles placés en triangle sur le vertex. Corps presque nu, ayant seulement quelques poils courts, épars. Prothorax séparé du mésotborax par une suture transversale. Ailes couchées parallèlement sur le corps dans le repos, velues vues au microscope. Abdomen ovale, légèrement déprimé, composé de quatre segmens autre l'anus; celui-ci obtas dans les máles et terminé dans les femelles par une tarière articulée. Pattes de longueur moyenne.

Ulidie vient d'un mot grec qui signifie : couture, cicatrice, , ces Diptères ayant leur front 
comme couturé. $\mathbb{M}$. Meigen soupçonne que ce genre est le mĉme que celui de Mosillus Lat. Nous ne partageons pas cette opinion. On ne dit rien de ses mœurs. L'auteur en cite trois espèces: I0. Ulidie florale, $U$. demandata. MeIg. Dipt. d'Eur. tom. 5. pag. 386. no. 1. tab. 53. fig. I 2. Femelle. - Tephritis demandata $n^{\circ} .37$. Fав. Syst. Antliat. Des cnvirons de Paris. $2^{\circ}$. Ulidie érytlrophithalme, $\tau^{\top}$. erythrophthalma. IVErg. id. pag. 387. $n^{\circ}$. 2. Long. 2. lig. Noire, brillante; yeux d'un beau rouge; ailes peu enfumées; cuillerons et balanciers blancs; pattes noires; tarses postérieurs d'un testacé pâle. D’Autricle. $3^{\circ}$. Ulidie brillante, $U$. nitida. MIEIg. id. $n^{\circ}$. 3. Long. 2. lig. Noire, brillante; pattes entièrement de la coultur du corps. (S. F. et A. SERv.)

\section{ULOBORE, Uloborus. LAT.}

Genres d'Arachnides de l'ordie des Pulmonaires, famille des Aranćides, section des Dipneumones, tribu des Orbitèles, établi par M. Latreille, et que nous ferons connoître après avoir élabli les caractères de la tribu à laquelle il appartient.

\section{ORBITĖLES, Orbitela.}

Crochets des mandibules repliés en travers le long de leur côté interne; mâchoires droiles et sensiblement plus larges à leur extrémité; filières extérieures presque coniques, peu saillantes, convergentes, disposées en rosettes; pieds grêles, la première paire et la seconde ensuile toujours les plus longues; yeux au nombre de buit disposés quatre au milieu, formant un quadrilatère et deux de chaque côté. Ces Aranéides font des toiles en réseau régulier, composé de cercles concentriques croisés par des rayons droits, se rendant du centre, où elles se tiennent presque toujours, à la circonférence. Quelques-unes se cachent dans une cavité ou dans une loge qu'elles se sont construites près des bords de la toile, qui est tantốl horizontale, tantôt perpendiculaire. Leurs œufs sont très-nombreux, agglutinés et renfermés dans un cocon assez grand. Cette tribu renferme les quatre genres suivaus :

LINYPHIE, Liniphia. Lat. Wasct. Aranea. LunN. De Géer.

Mâchoires, carrées, droites, presque de la même largeul'; yeux disposés de la manière suivante : quatre au milieu, formant un trapèze dont le côté postérieur, plus large, est occupé par deux yeux beaucoup plus gros et plus écartés; les quatre autres groupés par paires, une de chaque côté et dans une direction oblique. Ce genre se dislingue des Ulobores par les quatre yeux de devant qui sont placés à intervalles égaux dans ces dernic̀res. Il s'éloigne des Tétragnathes par les mâchoires qui dans ces dersières sont très-étroites. Les Épéires entin ont les deux yeux de chaque cóté rapprochés et presque contigus, ce qui los en éloigne suftisamment.

Les Linyphies vivent sur les buissons, les pins, les geniévriers, ou dans les coins des murailles et des fenêtres des maisons. Ellcs y construisent une toile horizontale, suspendue entre les branches, si c'est un arbre, mince, et dont l'étendue varie en raison des distances des points d'attache. Pour la maintenir parfaitement horizontale, elles tendent par dessus des fils perpendiculaires et obliques qu'el!es fixent aux lieux environnans. L'animal se tient ordinairement au milieu de sa toile, dans une position renversée, ayant le ventre en haut. Un insecte a-t-il le malheur de se laisser engager dans ce filet, la propriétaire accuurt, le per.e a vec ses mandibules à travers la toile, et ensuite y fait une décbirure afin de le faire passer et de le sucer; ce qu'elle fait sans l'envelopper de soie., car l'insecte est affoibli par le venin et presque mort. Les mâles ressemblent si peu à leurs femelles, qu'on ne les croiroit pas de la mêrne espèce; ils se trouvent toujours placés dans la même toile, pendánt le nois de septembre. Leurs pa!tes sont beaucoup plus grêles et plus alongées; leur abdomen est aussi beaucoup plus long. Leurs palpes sont terminés par un gros bouton qui se sépare en deux quand on le presse, et présente deux pièces écailleuses en forme de valves de coquille, da milieu desquelles on voit sortir d'autres pièces; on en remarque surtout deux en forme de crochets, et un luyeau court et annelé. D'après De Géer, ces mâles n'ont rien à craindre de leurs femelles, qui les reçoivent sans chercher à attenter à leur vie, comme cela à lieu cliez plusieurs autres Aranéides. Les deux sexes, au moment de l'accouplement, sont dans une position renversée, le ventre de l'un vis-à-vis le tronc de l'autre; ils entrelacent leurs pattes, et le mâle introduit le bouton de l'extrémité de ses palpes dans l'ouverture sexuelle de la femelle, et l'y laisse une ou deux minutes : il recommence le même jeu plusieurs fois de suite avec ses deux palpes aliernativement; pendant tout ee temps son venire a un mouvement continuel de vibration. A l'époque de la ponte le ventre des femelles grossit beaucoup. Le cocon dans lequel elles déposent leurs œufs est composé d'uné soie lâche; elles le placent auprìs de leur toile. Les cufs sont d'un rougeâtre tirant sur le jaune; ils ne sont point agglutinés entr'eux.

Ce genre se compose jusqu'à présent de deux espèces que nous allons faire connoître.

Liny PIIE Traang olatre. Linyphia triangularis. Lat. Gen. Crust. et Ins tom. 1. pag. 100.WaLck. Tabl. des Aran. pag. 70. - Araignée triangulaire. Lat. Hist. nat. des Crust. et Ins. tom. 7. pag. 242. - Walck. Faun. Paris.tom. 2. pag. 214.-Aranea Albini. Scop. Entom. Camiol. pag. 3g6. - Lister. tom. ig. fig. 19. pl. 64. - 


\section{$\mathrm{U} \mathrm{L} \mathrm{O}$}

Albiv. pl.30.f. 148. Voyez pour la description et les autres synonymes, le $n^{\circ}$. 34. pag. 208 . article Araigne de ce Dictionnaire.

Linyphie montagnarne, Linyphia montana. Wa ccr. Tabl. des Aran. pag. 71. Voyez pour la description et les autres synonymes, le $\mathbf{n}^{\circ} .35$. article Araignée de ce Dictionnaire.

ULOBORE, Uloborus. Lat.

Les quatre yeux postérieurs placés à intervalles égaux, sur une ligne droite; les deux latéraux de la première ligne plus rapprochés du bord antérieur du corselet que les deux compris entr'eux, de sorte que cetie ligne est arquée eu arrière. Mâchoires s'élargissant et s'arrondissant de la base à l'extrémitć, premier article des tarrses postérieur's ayant une rangée de crins exırêmeuient déliés; crochets de leur extrémité, ainsi que de celle des autres tarses, extrĉmement petits. Corps alongé et presque cylindrique.

Ces Aranéides se tienment au centre de leur toile; elles portent en avant, et en ligne droite, les quatre pieds antérieurs, et dirigent les denx derniers en arrière; ceux de la troisième paire sont étendus latéralement. Les toilcs de ces Arachnides sont semblables à celles des autres Orbitèles, mais plus lâches et horizontales. Dès qu'un iusecte s'est engagé dans leur filet, elles l'emmaillotent en un instant et le succut après. Leur cocon est élroit, alongé, ānguleux sur ses bords, et suspendu verticalement par un de ses bouts à un réseau; l'antre extrémilé est comme fourchue, ou terminée par deux angles prolongés, dont l'un plus court et obtus; cliaque côté a deux angles aigus. La seule espèce connue de ce genre est :

L'Únobore de Walckenaer, Uloborts IValckenaerius. Lat. Gen. Crust. et Ins. tom. 1. pag. 110. - Regn. anim. tom. 3. pag. 88. Cette espèce a près de cinq lignes de long; elle est d'un jauneroussâtre, couverted'un duvet soyeux formant, sur le dessus de l'abdomen, deux séries de pelits faisceaux. Les pattes sont de la même couleur avec des anneaux plus pâles. On la trouve dans les bois des environs de Bordeaux et dans d'autres départemens méridionaux.

\section{TÉTRAGNATE, Tetragnatha. Voyez ce mot.}

ÉPEÏRE, Epeira. Walck. Lat. Aranea. Linn. Geoff. De Géer. Fab. Ohiv. Lat. Lamk. Huit yeux dont quatre intermédiaires formant un carré et les autres rapprochés par paires, une de chaque côté. Mâchoires droites, dilatées dès leur base, en forme de palette ovale ou arrondie; lèvre presque demi-circulaire ou triangulaire. Cäochets des mandibules repliés le long de leur côté interne, filic̀res cxtérieures presque coniques, peu saillanles, disposées en roseltes; la première paire de pieds et ensuite la seconde les plus longrues de toutes.

Les Epéires vivent solitaires et séparées; chaque individu forme une toile à réseaux réguliers, composée de spirales ou de cercles concentriques croisés par des rayons droits qui partent d'un centre où l'Araiguée se tient ordinairement immobile, le corps renversé ou la tête en bas. Les toiles de quelques espèces exotiques sont composées de fils si forts qu'elles arrêtent de pelits oiseaux; celles de notre pays n'arrêtent que les insectes légers et petits : à cet eflet, elles sont suspendues verticalement entre les branches d'arbres, ou dans les eucoignures des murailles; plusieur's ont une position oblique, il en 'est wême qui sont horizontales. Quelques espèces construisent auprès de leur toile une demeure cintrée de toute part ou en forme de tuyeau soyeux, ou bien ouverte par le haut et figurant un nid d'oiseaux. Des feuilles réunies eutr'elles par des fils constituent les parois de ces habilations. Elles filent un cocon le plus souveut globuleux et rempli d'une bourre de soie plus épaisse, et qui contient un très-gränd nombrc d'œufs agglutinés entr'cux. La ponte a lieu vers la fin de l'été ou at commencement de l'automne.

Le grenre Epéile est très-nombrenx en espèces, et l'on peut y rapporter à peu près toutes celles qui sont dćcriles dans la famille des Araignées tendeuses de ce Dictionnaire pag. 198 à 206 . Nous citerons cependant celles que nous rapportons au genre Epéire d’un maniére plus certaine. M. Walckenaer, pour faciliter la distinction des espèces, les a distribuées dans plusieurs familles que nous allons faire connoître.

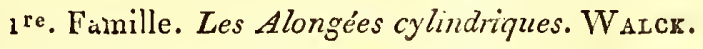

Mâchoires courtes, arrondies; lèvre aussi large que haute; corselet bombć à sa partie autérieure, pourvu de deux petits tuberculcs dans son milieu. Abdomen alongé, cylindrique. Pattes trèsalongées.

Epéïre chrysogastre, Epeira chrysogaster. Walck. Tabl. des Aran. pag. 53. - Aranea pilipes. Lat. Hist. nat. des Crust. et des Ins. tom. 7 . pag. 274. no. 85. - Fав. Entom. Syst. pag. 425. $n^{\circ} .67$.

Cette Epéire est longue de près d'un pouce ; son corselet est noir avec un duvet soyeux doré en dessus, et deux tubercules apparens et rapprochés derrière les yeux. L'abdomen est long, brun, avec dewx bandes et uue raie dans l'entre-deux, longitudinales, parallèles et blanchâtres le long du dos; les côtés offient des raies ou des traits, et le dessous des points de la même couleul: Les pattes sont très-noires, excepté les articulations 
des cuisses; elles n'ont pas de brosses, mais elles sont hérissées dans leur longueur de petits piquans. les parties de la bouche sont noires. On trouve cette espèce au Bengale et dans d'autres contrées des Indes orientales. M. Latreille pense que l'espèce que Fabricius nomme Longipes n'en est qu'une variété.

Epëïre plumipède, Epeira plumipes. Walcr. Tabl. des Aran. pag. 54. Aranea plumipes. LAT. Hist. nat. des Crust. et des Ins. tom. 7. pag. 275. - Aranea edulis? Le Brllard. Relat. du voy. à la rechcerhe de La Peyrouse, tom. 2. pag. $\mathbf{2} 39 \mathrm{el}$ 240. Atlas. pl. 12. fig. 4. $n^{\circ}{ }^{2}$ 2. C'est cette espèce que M. Latreille pense être l'Edulis que les habitans de la Nouvelle-Hollande et de quelques îles de la mer du Sud maugent au défaut d'autres alimens; elle est très-voisine de l'Aranea esuriens de Fabricius. Elle est noire, avec des taches ou des poiuts soyeux et argentés sur le corselet. L'abdomen est d'un jaunâtre-brun, avec des poiuts enfoncés. Ses pattes sont brunes avec des taches noires. L'extrémité des quatre jambes antérieures et celle des postérieures a une plus grande abondance de poils, uue sorte de brosśe. Cette espèce a été rapportée au Muséum par Riche.

L'Araignée à brosses (Epeira clavipes. WALCK. Lat.), article Araignée no. I3. de ce Dictionnaire; l'A raignée longimãne $11^{\circ}$. I 29. , et l'Araignée longues pattes n ${ }^{\circ}$. 145 ., sont aussi des Epéires. iI. Walckenaer pense que la Longirnane pourroit bien être la mêtre espèce que celle que Linné a nommée Clavipes. Il croit aussi que celle nonımée Longues pattes se rapproche beaucoup de la plumipède de $M$. Latreille. Du reste, on ne sera bien certain que ces rapprochemens sont exacts que lorsque de nouvelles observations auront éclairci suffisamment la question. - L'Araignée figurée par Séba, et que M. Walckenaer nomme Epeirc sebce, lui paroît cependant se rapprocher beaucoup de lEp. chrysogaster. Elle est représentée dans la nouvelle édition que nous donuons de l'ouvrage de Séba, tom. 4. pl. 99. fig. 9. Séba l'avoit reçue des Indes.

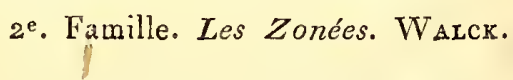

Mâchoires courtes, arrondies, aussi larges que bautes. Corselet très-plat, revêtu de poils argentés. Ablomen ovale, traversé par des bandes de différentes couleurs. Ces Aranéides forment un cocon qui a la forme d'un ovoïde tronqué.

Epéïre fasciée, Epeira fascienta. W ALcK.Tabl. des Aran. p. 55. La t. Gen. Crust. et Ins. tom. I. pag. 106. Aranea fasciata. F. 4 . Ent. Syst. pag. 414. $n^{\circ}$. 28. - LA T. Hist. nat. dss Crust. et des Ins. tom. $7 \cdot p \cdot 269 \cdot n^{\circ} \cdot 79 .-$ Aranea formosa. Virler. Ent. tom. 4. pag. 130. pl. 11. fig. 10. - Aranea phragnitis. Ross. Faun. etrusc. tom. 2. p. 128. tab. 5. fig. 13. et tab. 9. fig. 5. - Aranea zebra. Razoumowskx. Hist. nat. du Jorat. tom. 1. pag. 244. $n^{\circ}$. 233. - Aranea speciosa. Pallas (trad. de la Peyronie) vol. 2. pag. 543. - Aranea trifasciata. Frael. Descr. anim. pag. 86. $n^{\circ} .30$. tab. 24. fig. E. - Sulzer. pl. 254. fig. I 5. -Aldr. de Ins. lib. 3. pag. 607. fig. 9. Voyez pour les autres synonymes et la description le mot AralGNÉE de ce Dictionnaire no. 1 . Cette belle espèce a été trouvée aux environs de Paris.

L'Araignée fastueuse d'Olivier, décrite sous le no. 15., article Araignée de ce Dictionnaire, appartient aussi à cette division. M. Walckenaer y rapporte deux espèces nouvelles qu'il nomme Epeira latreillana et mauriciana. L'une vient du Bengale et l'autre de l'lle-de-France.

\section{3e. Famille. Les Oculées. WALcK.}

Mâclıoires très-courtes, aussi larges que lıautes; corcelet très-plat, revêtu de poils argentés. Huit yeux, dont les six antérieurs sont portés suir des tubercules avancés.

Epeïre voleuse, Epeila latro. Walck. Tabl. des Aran. paro. 56. - Aranea latro. Fab. Ent. Syst. tom. 2. pag. 4!2. $n^{\circ}$. 19. OLIV. Encycl. Voyez la description de cette espèce au no. 156. de l'article Araignée de ce Dictionnaire.

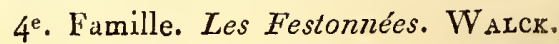

Mâchoires courtes, arrondies, aussi larges que hautes. Corselet très - plat, cusuert de poils argentés. Abdomen découpé, festonué ou mamelonné: - Ces Aranéides font un cocon qui a la figure d'un ovoïde tronqué.

Epéíre mamelonnée, Epeira mammata. Wasck. Tabl. des Aran. pag. 56. Aranea manw mata. Olrv.

Voyez pour les autres synonymes et la description de cette espèce le $n^{\circ}$. 14 . de l'article Ar.aIGNÉE de ce Dictionnaire.

EłËire soyeuse, Epeira sericea. WaLck. Tabl. des Aran. pag. 56. Voyez la description de cette espèce à l'article Arargnée no. 2 . de ce Dictionnaire. L'Epeira australis de M. Walckenaer appartient à cette famille. Elle habite l'lle-de-France et le cap de Bonne-Espérance.

\section{5e. Famille. Les Triangulaires. Waxck.}

Mâchoires très-courtes, arrondies à leur extrémité. Lèvre arrondie, aussi large que haute. Yeux intermédiaires postérieurs plus rapprochés et plus pelits que les antérieurs. Corselet convexe. $\mathrm{Ab}-$ 


\section{U L O}

domen ovale, triangulaire, revêtu en dessus, ̀̀ sa partie antérieure, de deux tubercules charnus, coniques, ayant en dessous deux courbes blanclies on jaunes opposées. - Ces Aranéïdes forment une toile verticale.

Epéíne anguleuse, Epeira angulata. Waycr. Tabl. des Aran. pag. 57. - Ibid. Hist. des Aran. fasc. 4. tab. 6. Femelle. Aranea angulata. IAst. Hist. nat. des Crust. et des Arach. tom. 7. pag. 25o. - W ALck. Faun. Paris. tom. 2. pag. 189. - Lrnv. Iter Gothl. $n^{\circ}$. 206. - Sulzer. Insect. pag. 254. pl. 39. fig. 13. Voyez pour la description et les autres synonymes le $n^{\circ}$. 5. article Araignée de ce Dictionnaire. On doit rapporter à cette famille les espèces suivantes : Epeira cornuta. WALce. Tabl. des Aran. p. 57. - L'Epeira bicornis. W ALCK. Faun. Paris. tom. 2. pag. 190. $n^{\circ}$. 2. - Epeira gibbosa. W AlcK. Faun. Paris. tom. 2.p. $190 . n^{\circ} .5 .-$ Epeina cruciata. W ALck. Faun. Parls. tom. 2. pag. 19o. $n^{\circ}$. 4. - Epeira bituberculata. W ALck. Faun. Paris. tom. 2. pag. 191. $n^{\circ}$.5. - Epeira dromaderia. Walck. Falun. Paris. tom. 2. pag. 19I. $n^{\circ}$. 6. - Epeira anaglypha. W ацск. Tabl. des Aran.pag. 58. Aranea humata. Bosc. Inédite. Cette dernière vient de la Caroline.

6e. Famille. Les Ovalaires à mâchoires courtes, arrondies. WALCK.

Mâchoires courtes, arrondies à leur extrémilé. Lèvre aussi large que hante. Yeux intermédiaires postérieurs plus rapprochés que les intermédiaires autérieurs. Corselet concare. Abdomen ovale, sans tubercules, découpures ni épines; deux courbes jaunes ou blanches, opposées en dessous. - Aranéides formant une toile verticale; cocon globuleux.

\section{$\mathrm{I}^{\mathrm{re}}$. Race. Les Ovalaires triangzulaires. $\mathrm{W}_{\mathrm{ALCK}}$.}

Abdomen ovale, triangulaire. - Aranéides ne construisant pas de demeure près de leur toile.

Eptíne diadême, Epeira diaderna. Walcr. Tabl. des Aran. pag. 58. - Lat. Gen. Crust. et Ins. tom. I pag. 106. - Aranea diadema. LAT. Hist. nat. des C'rust. et des Ins. tom. 7. pag. 255. pl. LXIV. fig. 1. a 5. - Walck. Faum. Paris. tom. 2. pag. 192. Aranea Linnei. Scop. Entom. C'arn. pag. 39z. $n^{\circ}$. 1077. - Voyez pour la description et les autres symonyrnes de cette espece le $\mathbf{n}^{\circ}$. 3. article Araig née de ce Diciomnaire.

Celte division comprend encore l'Epeira mellitagria. WA Wck. Faun. Paris. tom. 2. pag. 19I. $n^{n}$. 7. - L'Épeina myagria. Ibid . $n^{\circ}$. 8. - Li Epera alsine. Isid. pag. 183. $n^{\circ}$. 10. Et l'Epeira diypta. Iivid, pag. 198. $n^{\circ}$. 19 .

Hist. Nat. Ins. Tome $X$. 2e. Race. Les Ovalaires triangulaires, larges. W ALCK.

Abdomen triangulaire, très-large, deux courbes jaunes, opposées en dessons. - Aranéides se formant près de leur toile une demeure non recouverte par en haut, qui imite une coupe on un nid d'oiseav.

Epéïre cratène, Epeira cratera. Walck. Tabl. des Aran. pag. 59. Aranea cratera. Ibid. Faun. paris. tom. 2. pag. 197. n⿳. 15. - Scirers. Icon Ins. Ratish. pl. 49. fig. 5. 6. Son abdomen est globuleux, large, pubescent, rougeâtre, avec des bandes longitudinales plus foncées, bordées de jaune. Cette espèce varie peu; elle se construit un nid recouvert seulement en dessus de quelques fils, et imitant une coupe ou un nid d'oiseau. Elle se trouve aux environs de Paris.

EPÉïn AgalĖne, Epeira agalena. Watck. Tabl. des Aran. pag. 59. Aranea agalena. Ibid. Faun. Paris. tom. 2. pag. 197. - LAт. Hist. natur. des Crust. et des Ins. tom. 7. p. 260. - Ar. notatus. Alrin. pag. 49. pl. 10. fig. 49. Voyez pour les autres synonymes et la description de cetle espèce, l'Araignée alphabétique no. 3o. article Aratgné de ce Dictionnaire. A cette division appartiennent encore les Epeira nuyabora. WALck. Faun. Paris. tom. 2. pag. 198. $n^{\circ}$. 17. - Epeira triguttata. WaLck. loc. cit. pag. 198. no. 18.-FAB. Ent. Syst. tom. 2. pag. 419. no. 46.; et l'Epeira solers de Walckenaer, inédile et venant de Lyon.

\section{3e. Race. Les Opalaires opiformes. WALcK.}

Abdomen ovale, globuleux, oviforme. - Aranéides formant, dans la partie supérieure de leur toile, une demeure cintrée de toules parts par ua tube de soie ou par des feuilles qu'elles rapprochent.

a. Aranéides formant leur demeure en rapprochant des feuilles et en les liaut par des fils.

Epéíne scalatre, Epeira scalaris. Walck. Tobl. des Aran.pag. 6o. Aranea scalaris. - LA t. Hist. natur. des Crust. et des Ins. tom. 7. pag. 257. -WaLck. Faun. Paris. tom. 2. pl. 6. Jig. 3. Martyn. english. speders. pl. 13. fig. 10. - Ibid. pl. I4. Fg. 10. Lavaten's, Essai on Physconomy. in- $4^{\circ}$. Loond. i 790 . vol. 3. pag. I29. Il y a uue très-bonne figure dans la viguette qui est all bas de la page. - PANz. Faun. Gemm. 4.-24. Arranea Betulce. - Sulzer. pag. 254. tab. 29. fig. 14. Voyez pour la description et les autres syuonymes, l'Araignée pyramide no. 29. article Araignée de ce Dictionauire.

L'Léïne pâle, Epeira pallida. W'Alcr. Arai$D d d d d$ 
gruée pâle $n^{\circ}$. 6. de ce Dictionnaire, appartient à celte division.

M. Walckenaer rapporte avec incertitude à cette division les Epéires acalyphe, Céropége, Adiante et Diodie, qu'il a décrites dans la Faune parisienne, tom. 2. pag. 199. nos. 20, 2 I , 22 et 23.

b. Aranéides formant une demeure entièrement composée de leur soie.

On doit rapporter à cette division les espèces décrites dans ce Dictionnaire arlicle Aratgnée, ${ }^{005} .4,8,9$, ro, 12. Les nos. 9. et so. ont été réunis par M. Walckenaer, et ne sont que la même espèce décrile sous des noms différens par les auteurs. M. Walckenaer leur a conservé le nom d'Epeira umbratica. Le no. 12. est l'Epeira apoclissa de Walckenaer.

\section{$7^{\mathrm{e}}$. Famille. Les Ovalaires à mâchoires alongées. WALCK.}

Mâchoires alongées, droiles à leur extrémité. Lèvre plus baule que large. Yeux intermédiaires d'en bas plus rapprochés que les yeux intermédiaires d'en liaut. Corselet convexe. Abdomen ovale sans découpures, tubercules ni épines, ayant sous le ventre deux lignes droites parallìles d'une couleur pluss pâle.

\section{1re. Race. Les Verticales. WaLcx.}

Abdomen cylindrique on globuleux. - Aranéides formant à la partie supérieure de leur toile un tube de soie où elles se tiennent. Toile verticale.

Epéín e calophylle, Epeira calophylla. WaIck. Tabl. des Aran. p.62. - Lat. Gen. Crust. et Ins. tom. 1. p. 108.-Aranea calophylla. ibid. Faun. Paris. tom. 2. pag. 200. $n^{\circ} .25$. - LA T. Hist. nat. des Crust. et des Ins. tom. 7. pag. 73. - Scнег F. pl. 42. fig. 174. - Voyez pour la description et les autres synonymes de cette espèce, l'Araignée portefenille de ce Dictionnaire, article Araignée no. 11. M. Walckenaer rapporte à celte division șon Epéïre tubuleuse, Epeira tubulosa. Faun. Paris. tom. 2. pag. 200. $n^{\circ} .24$. - Lister. p. 40. tit. 7. fig. 7. -Araneus hamatus. CLERcK. p. 51. no. 2. pl. 3. tab. 4. - Axbin. pl. 35. fig. 174 .

\section{$2^{\mathrm{e}}$. Race. Les Inçlinées. W atck.}

Abdomen ovale, triangulaire. - Aranéïdes ne formant point de demeure à la partie supérieure de leur toile. Toile inclinee.

Epéine inclinée, Epeira inclinata. Walck. Tabl. des Aran. pag. 62. Aranea inclinata. ibid. Eaun. Paris, tom. 2. pag. 201. $n^{\circ}$. 26. - LAT.
Hist. nat. des Crust. et des Ins. tom. 7. p. 264 . - Lister. p. 24. tit. 1. - Araneus segmentatus. Clerck. pag. 45. $n^{\circ}$. 13. pl. 2. tab. 6 fig. 1. ol 2. - Albin. pl. ViIL. fig. 36. - Scmerf. Icon. pl. 158. fg. 7.- Voyez pour la description et les autres syuonymes de cetle espèce l'A raignée réticulée no. 117., article AraignéE de ce Dictionnaire.

M. Walckenaer rapporte à cette division l'Epéile antriade, Epeira antriada. W. ALcK. Faun. Paris. tom. 2. pag. 201. $n^{\circ}$. 27. L'Épéire arabesque (Epeira arabesca) de son Tableau des Araneëdes, pag. 63., rapportée par M. Bosc de l'Amérique du nord; et son Epéire brune (Epeira fusca) du même ouvrage, décrile par M. Latreille sous le nom d'Epeira Menardii. - Voyez pour sa description le no. 20. , article Aratg née de ce Dictionnaire.

\section{3e. Race. Les Horizontales. WALcK.}

Yeux postérieurs plus gros, mais non plus écartés. Abdonen oviforme. - Aranéiles formant une toile Lorizontale.

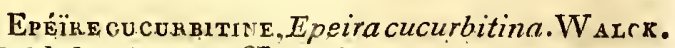
Tabl. des Aran. p. 63. - Lat t. Gen. Crnst. et Ins. tom. 1. pag. 107.; et Règne arum. tom. 3. pag. 9I. - A raignée cucuthiline. Walck. Fusun. Paris. tom. 2. p. 202. Hist. des Aran. 2-111. - LAT. Hist. nat. des Crust. et des Ins. tom. 7. pag. 265. - Lister. Aran. Suec. pag. 34. tit. 5. fg. 5. Voyez pour les autres symonymes et la descrit-tion de cette espèce les nus. 19. (pag. 203.) et 10. (pag. 236.) de ce Dictionoaire, à l'arlicle Araigné. Au no. ro. est la description de l'Aranea Frischii de Scopoli, queM. Walckenaer rapporte à la Cucurbitine. L'Epéire circulce, Epeira circulata de M. Walckenaer, Tabl. des Aran. pag. 63., appartient à cette division. Elle vient de Surinars.

\section{8e. Famille. Les Irrégulières. W ALck.}

Abdomen de forme irrégulière, et terminé en tous sens par des tubercules charnus.

\section{Ire. Race. Les Triconiques. WALCK.}

Abdomen triconiques. - Aranéides suspendant à un fill'insecte qu'elles ont sucé. Toile verticale.

Epéïre conlque, Epeire conica. Walck. Tabl. des Aran. p. 64. Lat. Gen. Crust. et Ins. tom. 1. pag. rog.; et Règne anim. tom. 3. pag. 9г. Aranea conica. WALCK. Faun. Paris. tom. 2. pag. 202.; et hist. des Aran. 2. $111 .-$ Sulzer. Geschichte. pag. 254. tit. 3. fig. 2. - Voyez pour les autres syuonymes et la description, l'article Araignée no. 18. de ce Dictionnaile. 


\section{U L O}

2e. Race. Les Mamelonnées. W ALck.

Abdomen irrégulier, revêtú de plus de trois tubercules charnus. Yeux intermédiaires portés sur des tubercules proéminens.

Epéïre oculée, Epeira oculata. Walck. Tabl. des Aran. pag. 64. Aranea oculata. WALCK. Faun. Paris. tom. 2. pag. 428. Higurée dans l'Atlas de ce Dictionnaire, pl. 340. fig. 5. à II.

\section{Famille. Les Epineuses. WaLck.}

Abdomen irrégulier, revêtu de tabercules cornés, poinlus, semblables à des épines. Mandibules rrès-courtes et renflées à leur insertion. Curselet relevé à sa partie antérienre.

\section{$1^{\mathrm{re}}$. Race. Les Epineuses alongées.}

Corselet et abdomen alongés. Pattes alongées.

Epéïe grête, Epeira gracilzs. Walck. Tab?. des Arun. p. 65. - Ibid. Hust. des Aran. fasc. 3. tab. 5. Figurée dans l'Allas de ce Diclionnaire, pl. 33g. for. 3o. et 40. La toile de cette espèce est très-gluanle. lille setrouve dans la Caroline.

M. Walckenaer rapporte à cette division l'Epéire militaire, Epeira militaris. Walcr. Tabl. des Aran. p. 65. - Aranea miltaris. La'r. Hist. nat. des Ciust. et des Ins. tom. 7. pag. 275. Voyez sa description à l'arlicle ARAIGnÉE no. 22. de ce Dictionnaire. - L'Eprire pomlue, Epeira aculeatu. W A Lcr. Tabl. des Aran. p. 65.-Epéiie armée. L.A T. Gen. Crust. et Inss. tom. 1. pag. 103. Spec, 2. - Voyez pür les autres syuonymes et la descriplion le $n^{\circ}$. 26 . arlicle AraigneE de ce Dictionnaire. - L'Ep'́re épineuse, Epeira spinosa. Walck. Tabl. elc. p. 6j.--Araignée épineuse. Lıs. Hist. natur. des Crust. et des Ins. tom. 7. pag. 276. - Voyez pour les autres synonymes el la description le $\mu^{\circ}$. 23. article AraIGNEE de ce Liclionnaire. - L'Épíire éloilée. WaLCK. Tabl. pag. 65. Aranea calcitrapa. Bosc. Juéd. De la Caruline. L'Epéire armée, Epeira armata. WaLck. Tabl. pag. 65. Lat. Cen. Crust. et. Ins. tom. 1. pag. 103. Epére fourchue, Araiguée fourchue. Lat. Hist. nat. des Crast. et des Ins. tum. 7. pag. 176. Spec. 89. - Voyez pour la description ef ses synunymes le $n^{0} .24$. urlicie Aratgne de ce Dictionnaire. - L'Araneus cancrifomms mujor, Sloane Tamaica. tom. 2. pag. 197. $n^{\circ}$. 1 4. pl. 225. fig. 3.

Nous croyons devoir aussi rapporier à cette divisiun l'Eućcire à queue courbe, Epeira curvicanda. Vadtrier. Ann. des scienc natur., mars 1824. tom. 1. pag. 261. pl. 18. Celle espece est très-:easurquable en ce qu'elle a de chargue côté da ventre use lonoue épine couthée él dedans, et trois fois plas longue que l'abdomen. Sa couleur générale est le jaune fauve; son corselet et la base des mandiluules seules sont d'un noirblenâtre. Cette espèce se trouve dans l'île de Java.

\section{2e. Race. Les Courtes. WALCK.}

Corselet et abdomen trc̀s-larges et très-courts. Patles courtes.

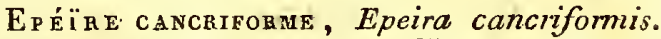
W a Lck. Tabl. des Aran. pag. 65. -LA т. Gener. Crust. et Ins. tom. 1. pag. 103. - Aranea cancrifornis. Lat. Hist. nat. des Crust. et des Ins. tom. 7. pag. 276. - StabB. Microsc. tom. I. Voyez pour les autres synonymes et la descriplion de cette espèce, l'article ArAig NÉE no. 25. de ce Dictionuaire. Il faut supprimer la citation de l'Aranea hexacantha de Fabricius, qui forme une espèce distincte à laquelle M. Walckenaer a donoé le nom d'Epéïre hexacanthe. 'Tabl. des Aran. pag. 66. - L'Épéire cancriforme est frgurée dans l'A tlas de ce Dictionnaire, pl. 353. fig. 4 . à 7 .

\section{Epéïre de Serville, Epeira Servillei. Nob.}

Elle est longue de trois lignes et large de quatre; son corselet et ses mandibules sont noirs, luisans et couverts d'un léger duvel grisâlıe sur les côtés. Les pattes sont d'un brun rougeâtre très-obscur; leurs deux derniers articles ont quelques taches annelées, jaunes. L’abdomen esı très-large, aplati, d'un jause clair; il a de chaque côté deux épines. courtes, coniques, noires à la base, fauves à la poinle et couvertes de poils; on roil deux épines semblables et un peu plus longues au milieu de son bord posté ieur. lee dessus de l'abdomen porte vingt-cinq laches arrondies assez grandes, en forme de cicaltices, d'uu fauve noir, disposées ainsi : douze près du bord antérieur, dont les deax plus extérienres sont plus grandes, composées de deux cicatricules accolées, et placées chacune en face el un pea au-dessus de la première épine latérale; neul suivent également le contour postérieur, dunt les deux extérieures plus grandes, simples, el placées vis-a-vis les secondes épines latérales; et enfin quatre au milieu, formant un trapèze donz le graud côté est à la parlie postéricure. Outre ces taches on voit sur les côcés de l'abdomen une quantité de petils points noirs, luisans, élevés en tubercules, et qui ne sont bien apparens qu’a la loupe. Le dessous est de la couleur du dessus, mais très-rayé par des rides plus brunes. Celte espèce se trouve au Brésil; nous l'avons dédiée à notre collaborateur M. Audinet Serville, comme un téaıignage de haute estime et d'awitié.

Epsirz de Leperteter, Epeira Lepelctieri. Ddddd 2 
Nos. Zoologie du Voyage autour du Monde, du capilaine Duperrey.

Elle est longue de denx lignes et demie et à peu près aussilarge; son corselet est d'un noirviolet foncé, presque carré, un peu plus loug gue large; ses palpes et ses pattes sont d'un rouge brique, a vec l'extrémité un peu brune. L'alddomen est beaucoup plus large que long, hexagone, d'un jaune doré, avec six pointes aiguës et cornées disposées ainsi : denx de chaque côté dirigées latéralement, l'antérieure beancoup plus petide, et deux au bord postérieur, divergentes. Ces Epéires sont d'un blett-violet très-foncé. Le dessus de l'abdomen présente vingt-trois taches d'un noir-violet, disposées de la manière suivante: dix sur le bord antérieur, neuf sur le postérieur, et quatre au milieu. Le dessons de l'abdomen est de la couleur du dessus, a vec des rides plus on moins enfoncées; l'anus est très-saillant, d'un beau bleu-violet foncé. Cette espece a été prise par MMI. d'Urville et Lesson dans les îles de 'Taüti , Bourou, Amboine, et dans d'áutres îles de la mer du Sud. Nous la dédions à notre savaut collaborateur M. Lepeletier de Saiut-Fargeau, qui a rendu de grands services à la science qu'il cullive.

M. Walckenaer rapporte encore à cette division l'Epéire tétracanthe, Epeira tetracantha. Tabl. des Aran. pag. 66. - Aranea tetracantha. LAT. Hist. nat. des Crust. et des Ins. tom. 7. pag. 277. - Voyez pour les autres synonymes et la descriplion de cette espèce l'article ArAIg NÉE no. 27. de ce Dictionnaire; elle est figurće dans l'Atlas, $p l$. 258. fig. a. b. - L'Epéïre transversale, Epeira transversalis. Tabl. pag. 66. De Timor. - L'Epéire large, Epeira lata.pag. 66. Espèce inédite de la collection de M. Dufresne.-L'Aranea fornicata. FAB. Lat. Hist. nat. des Crust. et des Ins. tom. 7. pag. 277., décrite sous le $\mathrm{n}^{\circ} .28$. article Araignée de ce Dictionnaire. - L'Araneus luzon bovinus. Pertv. Gaz. tab. 26. fig. 5., voisine de l'Epeira transpersalis WAICK. - Ara. neus luzon testaceus trilineatus. Perrv. loc. cit. fig. 6. - Araneus luzon crastaceus connu lunato. PErrv. ibid. fig. 7. - Araneus luzon testaceus angustatus trilineatus. ibid. fig. 8. Ces quatre espèces sont des Philippines. Suivant M. Walckenaer l'Araneus tribulus de Fabricius, Ent. Syst. tom. 2. pag. $428 . n^{\circ}$. 78 ., formeroit une division dans cette famille ou une famille distincte.

\section{3e. Race. Les Aplaties. WALcK.}

Abdomen ovale, très-plat, couvert én dessus d'un corps dur et comme chagriné, entouré d'épines très-petites.

a. Abdomen ovale, échancré.

\section{U L O}

Epéïr souclitr, Epeircclypeala. WaIcx.Tabl. des Aran. pag. 67. Espèce inédite.

b. Abdomen arrondi, entier.

EPÉ̈̈re scurironme, Epeira scutiformis. W ALck. Tabl. pag. 67. Espèce inédite rapportée de l'ile de Tinior par M. Péron.

\section{joe. Famille. Les Conronnées. Watcr.}

Corselet large, relevé à sa partie antérieure et revêtu au-dessus, de tubercules coniqués, imitant les pointes d'un diadême. Yeux portés sur des tubercules. Mandibules très-courtes, fortes, renflécs à leur insertion. Mâchoires alongées, droites à leur extrémité. Abdomen sans épines. Pattes et palpes aplatis.

Eptéïe impértale, Epeir a sexcuspidata. Watck. Tabl. des Aran. pag. 67. - Lat. Gen. Crust. et Ins. tom. 1.p. 105. - Aranea sexcuspidata. F AB. Entom. Syst. tom. 2. pag. 427. $n^{\circ} \cdot 76$. Elle est brune; son corselet porte six tubercules disposés en deux lignes transverses, les trois antérieuŕs portent les yeux. Palpes, jambes et tarses comprimés. Ceite espèce a été rapportée du cap de Bonne-Espérance par MM. Péron et Lesueur.

On tronve des figures d'Epéiires dans l'Encyclopédie japonnaise. Le savant M. Abel Rémusat a bien voulu nous permettre de parcourir cet ouvrage, qu'il possède seul, et nons avons reconnu deux especces de ce genre fort bien représentées. (E. G.)

ULOME, Uloma. Mígrrle. Dej. Calal.

Ce genre équivaut à la première division du genre P̂halérie (voyez ce mot), et doit conserver ce dernier nom générique selon M. Latreille Fans. nat. La seconde division reçoit de lui, dans le même ouvrage, le nom de Chélénode ; elle répond au genre Phaleria. Des. Catal.

(S. F. et A. Serv.)

ULONATES, Ulonata. Nom donné par Fabricius à sa seconde classe des insectes; elle a pour caractères : quatre palpes; mâchoire recouverte par une pièce particulière. (Galea $\mathrm{F}_{\mathrm{AB}}$. Galet!e Or,Iv. (asquette Lat.) qui est de forme obtuse. L'auteur la divise de la manière suivante : $1^{\circ}$. Antennes filiformes. Genres Acrydium et Gryllus. $2^{\circ}$. Antennes ensiformes. Genre Truxalis. $3^{\circ}$. Antennes sélacées. Genres Forficula, Blatta, Mantis, Acheta et Locusta. Cette classe répond à celle des Dermaptères $D_{E}$ GÉER, ou à l'ordre, des Orthoptères Oniv. LA'T. (S. F. et A. SERv.)

ULOPE, Ulopa. Germ. Tettigonia. LAt. (Fam. nat. )

Genre d'insectes de l'ordre des Hémiptères, 
seclion des Homoptères, famille des Cicadaires, tribu des Ciradelles (division des Ulopides).

La division des Ulopides se compose des genres Ulope et Athalion ( voyez par. 6oz. de ce volume ); ce deruier se distingue par sa tête n'étant pas plus large que le corselet et dont les bords ne sont pas tranchans, et encore par ses ocelles trèsapparens.

Antennes courtes, très-ćcartées l'une de l'autre, insérícs entre les yeux, chacune dans une cavilé, composées de trois articles; les deux premiers fort courts, épais; le troisième presque cylindrique, terminé par une soie assez longue qui se dirige vers le plan de position.-Bec court, cylindrique, un peu déprimé, s'étendant dans le repos sous la poilrine; son extrémité dirigée vers la partie postérieure du corps, soutenu par une grande lame qui cache la base et le chaperon en entier. - Tête plus large que le corselet, déprimée en dessus, ses rebords tranclians. - I enx grands, saillans, oblongs, placés aux angles postérieurs de la tête. - Deux ocelles peu distincts el placés tellement près du bord posiérieur de la tête quỉls peuvent être souveut recouverts par la partie antérieure du corselet. - Corselet court, en carré transversal. - Ecusson triangulaire. Elyties longues, un peu en forme de coquille, convexes dans leur milicu, un peu réticulées. Foint d'ailes. - Abdornen convexe en dessus, ventre ayant un rebord latéral très-marqué; anus des femelles grand, ayant une fente longitudinale; celui des mâles muni de crochets. - Pattes de longueur moyenne, les postérieures ne paroissant point propres à sauter; leurs jambes et leurs tarses entièrement dépourvus d'épiues, et saus dilatation; celles-là presque cylindriques; tarses de trois articles, le dernier muni de deux crochets épais.

la seule espèce que nous rapportons à ce genre créé par M. Germar, nous paroit différer essentiellement des autres Cicadelles par la masse de ses caractères, mais ses mœurs doivent être à peu près les mêmes.

\section{UrOPE des bruyères, U. ericetorum.}

Ulopa testacea, thoracis margine elytronumque fasciis duabus pallidis, hòrum lneis irregularibus fuscis.

Ulopa obtecta. Germ. ? Magaz. entom. Halle. 1818. pag. 54. $n^{\circ}$. 1 .

Longueur 2 lig. Corps d'un testacé-roussâtre, assez fortement ponctué en dessins, bords du corseleı pâles; élytres très-fortement ponctuées, de la couleur da corps, avec deux bandes irrégulières blanchâtres et de petites lignes brunes placées sans ordre : la fente de l'anus est bordée de brun dans la femelle; le dessous du ventre est de cette dernière couleur dans le mâle; pattes testacées.

Nous l'avons trourće dans la forêt de Fontaine- bleau. M. Carcel l'a prise dans l'Anjon, et M. de Bazoche nous l'a ellvoyée de Normandie.

ATHALION, Aethalion. Lat. (Considér.) Lystra, Tettigonia. FАв. Aethalia. Gв м.

Genre d'insectes de l'ordre des Hémiptères, section des Homoptères, famille des Cicadaires, tribu des Cicadelles (division des Ulopides).

Celte division renferme les genres $\mathbb{F}$ thalion et Ulope. (Voyez Ulopides, pag. 6o2. de ce volume.) Ce dernier se distingue par ses antennes insérées entre les yeux et sur le même plan de la tĉte qu'eux, ainsi que par les ocelles placés sur la parlie supérieure de la lête.

Antennes courles, très-écartées l'une de l'autre, insćrées à la parlie inférieure de la tête, beaucoup au-dessous des yeux dont elies sont fort ćloignées, composées de trois articles dont le dernier est terminé par une soie de longueur moyenne. - Bec assez long, a!teignant la base des cuisses intermédiaircs; son premier article presqu'entic̀rement caché par une lame assez grande. - Téte ne paroissant (vue en dessus) que comme un rebord très étroit en avant du corselet, aplatie à sa partie antérienre.-Yeux assez saillans, placés aux deux extrémilés de la tête. - Deux ocelles distincts, posés sur le bord inférieur de l'ap̧latissement de la tête-Corselet ì peu près aussi loug que large, prolongé posiérieurement entre la base des élylres. - Ecusson de grandeur moyenne, triangulaire, un peu conrexe, prolongé en une poiale horizontale. $-E l y-$ tres grandes, assez plates, disposées en toit dans le repos, couvrant les ailes et dépassant l'abdomen. - Abdonten court, un peu concave en dessous; anus des femelles fendu longitudinalement.-Les quatre pattes antérieures de longueur ınoyenne; jambes postérieures longues, arquées, presque cylindriques, un peu canaliculées latéralement, sans dentelures ni épines, paroissant peu propres à sauter; tarses con posćs de trois articles, le dernier terminé par deux crochets fort épais.

Nous ne connoissons qu'une espèce de ce genre, élabli par M. Latreille; nous n'avons point de notions sur sa manière de vivre.

\section{Eтнадion réticulé, Ae. reticulatum.}

Aethalion luteo-testaceum, oculis elytrisque rubris, his viridi-pallido reticulatis, tibiis posticis nigro triannulatis.

Cicada reticulata. Linn. Syst. nat. 2. 707. I8. - Stront. Cigal. pl. XIV.fig. 74. et A. - Lystri reticulata. FAB. Syst. Rhyingot. pag. 6o. no. I 6. - Tettigonia reticulata. F Aв. ejusd. pag. 41 . $\pi^{\circ}$. 42.-Tettigonia minuta. FAB. Entoni. Syst. tomi. 4. pag. $26 . n^{\circ} .37$.

Nota. L'individu femelle que nous possédons est plus grand que celui décrit par De Géer, il est plus frais quaucun de ceux yus par les auteary 
cités. Les yeux et les élytres sont rougeâtres, les réticulations de celles-ci ainsi que les bords du corselet et la raie longitudinale un peu élevée quil porte sur son milieu, sont de couleur vert pomuse. On sait que ces couleurs passent lacilement au blanc, lorsqu'elles sont exposées à la lumière.

Voyez pour la description et les antres synonymes, Cigale réticulée no. 38. de ce Dictionnaire. Stoll dit que cotte espéce se trouve sur les citronniers. (S.F. et A. SERv.)

ULOPIDES, Vlopides. Première division de la tribu des Cicadelles. (Voyez 'Tetrigonides.)

\section{(S. F. et A. Senv.)}

UNIPELTES, Unipeltata. LAT.

B. Latreille donne ce nom à une famille de l'ordre des Stommapotes, renfermant des Crustacés dont le corpus cat étroit et alongé; le thoracide alongé, avec une articulation antérienre portant les antemes intermédiaires et les yeux. Les pieds-mâchoires et les quatre pieds antérieurs sont terminés par une main monodactyle on en grifle, dont le duigt mobile ou le crocliel est formé par le tarse; les dix autres pweds sont ealatoiles, avec le dernier article ev forme de brosse. Les antennes latćrales ont une écaille à leur base; les intermćdiaires sunt termináes par trors filets. Le post-abdumen est long. Celle famlle renterme les genres Squilae, Goxodactyle, Coronide, Ehichte et Alime. Tuus ces genres ont été trattés au mot SQuilhe de ce Diclionarire, auguel nous renvoyons.

$$
\text { (E. G.) }
$$

UNIVALVES, Univalvia. Lat.

3I. Latreilie donue ce noan à la première famille de l'ordie des Lophiropodes; il la caraclérise ainsi (Faml. nat. du Regnze aninal) : test d'une senie pucre ec laissant à décuuvert la unjeure partie du vilps.

Cette familie ne renferme que le genre $\mathrm{C}_{y}$ clope. (Voyez ce mot.) (L.G.)

UNOGATES, Unogata. Fabricius désigne sous ce non sa sepitèute classe des insectes. Il lui dunne pour caractères.: deux palpes avancés; màchoire corncé, onguiculée, el y place l's genres Trombidium, Arunea, Phalangrium., Tarantula et Scorpio. Cette classe forme en partie celle dés Arachnides Lat. Faḅicicius a rejeté dans sa ciasse des Antliales les geures Pycnoganon, $N_{3} m$ phon et Acarus, que M. Latreille niet aussi dans ses Arachnides. (S. F. et A. Serv.)

UPIS, Upis. FАв. LAT, (Fam, nat.) $\mathbf{P}_{\text {Ачк. }}$ Grilen. Attelabus. Linn. Tenebrio. De Geer. (iliv. (Entón.)

Genre d'insectes de l'ordre des Colćoptères, section des Héléromères (première division), famille des Mélasomes, tribu des Ténébrionites.

Celle rribu contient les genres Cryptique, Epitrage, Opâtre, Toxique, Sarrotrie (Orthocète Encycl.), Chiroscèle, Upis el Ténébrion. (Voyez Ténébionites.) Daus les Ténébrions, les Cryptiques et les Opâtres, la partie posiérieure du corselet est de la même largeur que la base des élytres; le corps des Ejitrages est de furme naviculaire, sa partie la plus large est un peu avant le nilieu, près de la base desélytres; le genre 'Iuxique a les huiliènıe, neuvième, dixième articles des antennes traurersaux, comprimés, formant avec le onzième, une espèce de mássue; les jaunbes ancéricures dilatées et digitées à leur extrémité, caractérisent les Chiroscèles; enfin les Sarrotries ont les antennes courtes, très-velues et composées de dix articles seulement. Les Upis n'ont aucun de ces caracieres.

M. Latreille place en outre dans cette tribu les genres Calcar, Boros, et avec dunte celui de Cortique, qui nous sont inconsus.

Antennes insensiblement renflées vers l'extrémilé, composées de onze articles; les seprième, buitième, neuviéme et dixième presque semi-globuleux, arrondis; le onzième obliquement counique, ovale, pointu à sun extıéaité. - Labre apparent. - Palpes inégaux, les maxillaires de. quatre articles, les labianx de truis; derner article des quatre palpes un peu plas gros que les. autres, cyludru-conique, coinprimé. - Menton ovale, presiguecarré, son bord supérleur arrondi. - Téte assez liorte, plus longue que large. - Yeux oblongs, placís aux bords láciraux de la tête. Corps alongé, point déprimé. - Corselet plus étroit que les élytres, surtout à sa jonction avec elles. - Ecusson triangulatire. - Elytres au moins trois hois plus longues que le corselel, leur partie la plus large étan! au-deli du milieu, recouvrant des ailes et l'abdomeu. - Abdomen aplaii en dessous. - Pattes alungées, minces; cuisses en massue alongée; jambes droiles, presque dépourvue's d'épines terminales; tar'ses velus en dessous, leur dernier article muni de deux crochets.

L'espèce qui a servi de type à ce geare habite en Suède dans les bolets ligneux. C'est. l'Upis céramboïde, U. ceramboides $\mathrm{n}^{\circ} .1$. F $\mathrm{F}_{\text {AB }}$. Syst. Eleut. - PAYk. Faun. suec. tom. 3. pag. 356. na. 1. G YLLEN. Ins. suec. tom. I. pag. 594 . $n^{\circ}$. I.

\section{(S. F. et A. Sert.)}

UPOGÉBIE, Upogebia. LíaCh. Gebia. LÉacr. Latr. Desm. Gebios. Risso. Thulussina. Latu. Herlistium. Léach. Cancer (Astacus). MonTAGU.

M. Léach donnoil le nom d'Upogebia an\%.Crustacés quu'il dósignne actuellement sous celui de Gebiir. Ce genre á été adopté par M: Latreille (Fam. nat. du Règn. anim.); il le range dans sa famille 
des Macroures, tribu des Astacines. Comme celte tribu n'a pu être traitée à sa lettre, nous allons la présenter iei, en laisant eonnoître les genres qui la composent.

\section{AS'PACINES, Astacinor. LATr.}

Antennes intermf́diaires avancées, terminées par denx filets anssi longs ou plas longs que leur pédoncule; relui des latérales (qui sont toujours sélacées) oflrant des saillies en forme de dents ou d'écailles. Appendices inférieurs du post-abdomen gúnéralement grands et contigus à leur extrérbité. J.es denx pieds antérieurs, au moins, en forme de serres à deux mordans, dont celui qui représente l'inciex, ou l'imaobile, quelqueíois plus crurt, en forme de dent.

I. Les quatre pieds antérieurs au plns didactyles, ayant le doigt inferieur plus conrt que le pouce ou le doigt mobile. Feuillet extérieur des appendices latéraux de la nageoire terminant l'abdonen sans suture transverse. Les six derniers pieds, et même dans plusieur's les précédens, garnis de cils nataroires. 'Test ordinairenent peu crusłacé ; premier auticle des autennes laiérales peu ou point épineux.

'THALASSINE, Thalassina. (Voyez ee mot.)

\section{GÉBIE, Gebia. LËach.}

Les quatre antennes insérées sur la même ligne, avancées; les latérales à pédoncule nu, les intermédiaires terninées pardeux filets alongés; pieds antérieurs en forme de serres, avec l'index notablement plus court que le pouce; les autres pieds simples, velus à leur extrémité, ayant de pelites franges de poils sur leurs bords extérietirs. Carafrace peu épaisse, nembraneuse, assez semblable pour la forme à celle de l'Ecrevisse, porlue ou plutôt garnie de très-petils piquans, et lerminíe en avant par une poiute ou rostre peu avancé : elle se prolonge en dessous jusifu'it la base des paltes, de manière à la reeouvrir en partie. Abdomen assez long, avec les lames natatoires qui le terminent entières, fort larges et surmontées de côtes longitudinales; ces feuillets presque triangulaires. Ce dernier caractère distingue parfaitement les Gélbies des 'Tbalassines.

On connoit quatre espèces de ce genre, toutes propres aux mers de l'Europe : ce sont des Crustacés assez rares, que l'on rencontıe dans les endroits où la mer est habituellement calme, et où il y a des plages sablonneuses; elles se ereusent dans le sable ou dans la yase, de petits trous dont elles ne sortent que la nuit; c'est alors qu'elles vont chercher leur nourriture, qui consiste en Annelides et petits Mollusugues vivant dans le sable. Elles nagent avee leur queue, en la repliant et l'étendant avee furce.
Gél IE DE DArrs, Gebia Dasicana. Rrsso. Joys?. de Pliys. et d'Hist. nat. tom. 95. pag. 2433. (Gebios. ) - Dess. Consid. sur les Crust. pag. 204. Nous allons reproduire la description de M. Risso. Son corps est alongé, mince, d’un blare nacré. luisanl; son corselet est uni, renflé, termiué pá un petit rostre subconique, glabre; les yeux sont petits, noirs, situés sur de gros pédicules; lts antenties extérieures sont beaucoup plus longues que les internes; les palpes (pieds-mâchoires) sont longs et ciliés; la première paire de pattes conrte, la seconde plus grande, toutes les deux tarminées par de longues pinces eourbées, dont une à peine ébauclíé ; la droite de la seconde paire beaucoup plos Inngue et plus grnsse; toutes les auires paires do pattes sont petites, aplaties, garnies de poils a leur sommet; l'aldoonen est long, romposć de six segmens glabres; les éeuilles caudales sons arrondies et ciliées : la longueur du corps est de dix-huit milliaères, et sat largeur de quatre. Celte espèce se trouve an mois de juin snl le litroral de Nice; elte se tient daus les régions madréporiques.

Gébif ÉTotrée, Gebia stellata. Léach. Mal. Brit. tab. 3ı. fig. I à 9. - Cancer (Astacus) stellatus. - Moxtago. Trans. Linn. Soc. tom. g. tab. 3. fig. 5. - Desm. Consid. gén. sir les Crust. pag. 204. $p l .35$. fig. 2. Lonque de près de deux pouces. Abdomen totalement crustacé, terminé par des lames foliacées; l'extérieure arroudie. l'intérieure coupée obliquement et ayant une forme triangulaire; celle du milieu en forme de trapèze, plus longue que large et très-peu arrondie à son bord postérieur. Serres grosses, ayant le doiggt imnobile un peu moins grand que l'autre, mais pas de moitié plus petit. Des côtes de France et d'Angleterre. Celle que nous avons sous les yeux nous a été donnée par M. d’Orbigny.

Gébie riveraine, Gebia littoratis. Desa. Cons。 gér. sur les Crust. pag. 204. - I'halassina littoralis. Risso. Hist. des Crust. de Nice, pug. 76 . $p l$. 3. fig. 2. L'individu que nous avons sous les yeux est long de près d'un pouce et denii; il ressemble entièrement à l'espèce précédente, et a'en differe que par les pinces qui sont plus petites, et dont le doigt inférieur ou pouce n'atteint pas le qualt des la longuenr de l'autre. Nous avons reçu ce Crustacé de Gènes; il nous a été donné par M. Pu. retto, géologue instruit de ee pays. Nons posstédons un individa tout-à-fait semblable, pus ara Antilles.

Gébie derture, Gebia deltura. Céach. Mala. Brit. tab. 31. fig. 9. 10.; et Transac. Lin. Soc. tom. XI. pag 342. Longue de deux pouces et demi. Abdomen ayant sa partie supérieure membraneuse, terminée par des lanes extérieures arrondies et presque dilatées au bout, et par unts 
lame intermédiaire deltoïde, tronquée, mais couvertes de quelques lignes de poils. Des côtes d'Angleterre.

AXIE, Axius. Líach. Lat. Desm. Thalassina. Lat. Cancer. Herbst.

lieds de la première paire à peine inégaux, terminés par une pince bien formée; pieds de la seconde paire égaux, plus gros que les suivans, aplatis ct terminés par une pince très-plate et à doigts égaux ; les autres pieds plus miuces, aplalis et pourvus d'un ongle comprimé. Pédoncule des nntennes intermćdiaires formé de trois arlicles, dont le premier est le plus long; pieds-mâchoires extérieurs ayant leurs deux premiers articles assez longs, ćgaux. Autcnnes placées sur la même ligne. On ne connoît qu'une seule espèce de ce genre, c'est :

I'AXIe stir Trans. Soc. Lin. tom. XI. p.343.; et Malac. Brit. tab. 33. Desn. Cons. sur les Crust. p. 207. pl. 36. fig. I. Long de trois ponces et deni. Carapace formant en avant un rostre court, caréné dans son milien, et dont les bords sout rclevés et terminés en arrière par deux lignes saillantes, peu prolongées. Ecailles lalérales de la quene arrondies, l'intermćdiaire triangulaire, alongée, pointue. Des có̀es d'Angleterre; rare. M. d'Orbigny nous cn a envoyé un individu pris sur les côtes de La Rochelle.

CAlianasse, Calianassa. Léach. Desm. Thalassina. Lat. LAmк. Cancer (Astacus). Montagu. Mlontagua. LÉach.

Pieds de la prcmiere parre très-inégaux, terminćs par une pince bieu formée et comprimée; pieds de la seconde paire égalenscut didaciyles, cenx de la troísième monodactyles, ceux de la quatrième simples, et les dcruiers presque didactyles par le prolongement en dessous de l'avantdernier article, sur lequel le dernier peut s'appuyer comme sur un doigt mobile. Second article des pieds-mâchoires extćrieurs le plus long de tous. Carapace peu alongće, lisse, terminée brusquement par un petil rostre. Abdomen grand, assez large, presque membraneux, pourvu à son extrémilế de lames foliacées, dont les latérales sont très - larges, arrondies, et l'intermédiuire presque triangulaire et obluse au bout. Ce genre n'est composé que d'une seule espc̀ce; elle vit dans les sables de nos plages et se creuse un trou comme les Gćbies.

Calianasse souterraine, Calianassa subterranea. Léacr. Edimb. Encycl, -Malac. Brit. tab. 32.-Desm. Consid. sur les Crust. pag. 205. pl. 36. fig. 2. Elle est longue de deux pouces. Le rostre est un per en carene en dessous et arrondi à sa pointe. On la trouve sur les côtes de France et d'Anglelerre.
II. Les six pieds antérieurs didactyles; feuillet externe des appendices latéraux de la nageoire terminant l'abdomen, divisé par une suture trangverse.

NÉPHROPS, Nephrops. LÉach. Lat. Desh. Astacus. Uliv, Fab. Lat. Penn. Cancer. Linn.

Filet supérienr des antenucs inter'médiaires plus gros que l'inférieur. Premier article du pédoncule des autennes extérieures pourvu d'une écaille qui s'étcnd jusqu'à l'extrémilé de ce pédoncule; second arlicle des pieds-mâchoires extérieurs denté en dessus et crénelé en dessous. Pieds de la première paire très-jrands, inégaux, à mains alongćes, prismatiques et dont les angles sont épineux; les deux paires suivantes de grandeur ordinaire, terminées en pinces; les deux dernières paires simples. Côtés des segmens de l'abdomen anguleux; ycux trèsgros, réniformes, portés sur de courts pédoncules beaucoup moins épais qu'eux. Ce genre diffère des Ecrevisses propres, par les yeux et par l'écaille des antenues extérieures : il ne se compose, jusqu'à présent, que d'une seule espèce.

Népurops de Norwége, Nephrops norwegicus. LEA ACH. Mlalac. Brit. tab. 36.- Desm. Consid. sur les Crust. pag. $213 . p l .37 \cdot$ fg. 1.-Astacus norwegicus. Lat. Hist. nat. des Crust. et des Ins. tom. 6. pag. 241. pl.53. fig. 1.-PENNant. Zool. Brit. - Ascan. Icon. rev. nat. tab.39.- Herbst. tab. 26 . fig. 3. (Voyez pour les autres synonymes et la descripution de cette espèce, le ${ }^{\circ} .25$, article Ecrevisse de ce Diclionnaire.)

\section{HOMARD, Hoinarus. LAT. (Fam. natur.)}

Ce genre ne diffčre des Ecrevisses que par le sixième article de l'abdomen qui est formé de pièces soudées, tandis que ce dernier article est eutier dans celles-ci. Les Homards sont tous narins, tandis que les Ecrevisses sont fluvialiles. M. Laireille $n^{3}$ a pas encore publié les caractères qu'il assigne à ce genre; l'espèce qui lui sert de type est l'Ecrevisse homard de ce Dictionnaire, article Ecrevisse no. 1.

ÉCREVISSE, Astacus. (Voyez ce mot), qui renferme la description, sous ce nom, de plusiemrs Cruslacés appartenant à d'autres genres; l'Ecrevisse de rivière $n^{2} .2$. de cet árticle est la seule qui appartienne évidemment à ce genre.

(E. G.)

URA. On donne ce nom au Brésil à un Cruslacć qui paroît appartenir, suivant M. Bosc, au genre des Ecrevisses, \& dont on mange beaucoup. (E. G.)

URANIE, Urania. Genre de Lépidoptères- 
Diurnes de la tribu des Hespérides. (Vojez tom. IX. pag. 708.) (S. F. et A. SERV.)

UROCERATES, Urocerata. Nов. Troisième tribu de la famille des 'Térébellifères ( $20 y$. ce mol), section des Térébrans (voyez ce mol), ordre des Hyménoptères.

Cette tribu a pour caractèrés :

Palpes maxillaires de deux articles, le premier ordinairement peu visible; palpes labiaux de trois articles. - Mandibules larges, courtes, tridentées. - Languette entière. - Antennes vibraliles, composées de treize à trente articles. - Téte presque globuleuse. - Ailes supérieures ayant deux cellules radiales, la dernière incomplète. Plaque supéricure du premier segment de l'abdomen divisée en deux au milieu et échancrée à sa parlie inférieure; plaque anale supérieure prolongée en une pointe particulière dans les femelles; cette plaque nulle dans les mâles; l'inférieure entière dans les femelles et sans coulisse dans son milieu, prolongée dans les mâles en uıe pointe particulière. - Turière (des femelles) droite, demi-comprimée.

Les larves des Urocérates vivent aux dépens des larves des Coléoptères xylophages, et principalement de celles des Longicornes.

Les genres Urocère et Trémex composent cette tribu. (Voyez ces mots.)

$$
\text { (S. F. et A. SERV.) }
$$

UROCÈRE, Uiocerus. Geoff. Lat. Sirex. Linn. De GÉer. Fab. Jur. Panz. Ku ug. Ichneumon. De GÉER. Scopor. Xiphydria. FAB.

Geare d'insectes de l'ordre des Hyménoptères, section des Térébrans, famille des Térébellifères, tribu des Urocérates.

Les Urocères et les Trémex composent cette tribu. ( Voyez URocÉrates.) Les derniers sont distingués des Urocères par leur's antennes courtes, composées seulement de treize à quatorze articles, aiasi que par leurs ailes supérieures n'offrant que trois cellules: cubitales, dont la seconde reçoit les deux nervures récurrentes.

Antennes longues, sétacées ou filiformes, insérées sur le front et entre les yeux, composées de dix-neuf arlicles ou plus, les inférieurs plus longs que les autres. - Labre point apparent, coriace, linéaire, un peu rétréci dans son milieu, son extrémité ciliée. -Mandibules cornées, avancées, presque triangulaires, assez grosses à leur base, ayant au côté interne deux ou trois petites dents courtes, leur extrémité prolongée en une deat assez longue et un peu aiguë. - Mâchoires ayant leur lobe externe coriace, en forme de languette. - Palpes maxillaires très-courts, l'étant deux fois plus que le lobe externe des mâ-

Hist. Nat. Ins. Tome $X$. choiles, n'étant pas insérés sur lui, cylindriques, en forme de petites cornes, composés de deux articles; le premier à peinc visible : palpes labiaux avancés, de la longueur de la lèvre, composés de trois arlicles sans compter le tubercule radical; les deux premiers presque cylindriques, le premier très-court et à peine visible dans plusieurs, le dernier plus grand, beaucoup plus épais que les autres, obcouique, chargé tele lnngs poils, tronqué obliquement à son extrémité. - Lèvre longuludinale, en cône déprimé, alougré ; sa par'tie antérieure divisée en trois lobes. - Têté semiglobuleuse, de la largenr du corselet ou plus étroite que lui. - Teux petits, oblongs. - Trois ocelles rapprochés sur le baut dn front, placés eir ligne courbe, celui du milieu étant un peu plus bas que les autres. -.. Corps cylindrique. - Corselet cylindrique; prothorax coupé droit antérienrement, ses bords latéraux un peu avancés au-dessous des épaules; métathorax très - c ourt. - Ecusson transversal, en losauge dont un des angles auroit été tronqué; on remarque deax petits tubercules de chaque côté en dessous. Ailes supérieures ayant deux cellules radiales; la première petite, la seconde fort longue, incomplète; quatre cellules cubitales, la première fort petite, la seconde la plus grande de toutes, recevant la première nervure récurrenle; la troisièrue moyenne, recevant la seconde ucrvure récurrente; la quatrième incomplèle; trois cellules discoidales complètes. - Abdomen cylindrique, sessile, conıposé de huit segmens outre l'anus, ces segrmens transversaux, le huitième un peu plus long que les précédens dans sa partie supérieure; anus dts femelles triangulaire; son extrémité prolongée eu une pointe parliculière assez longue; tarière droite, composée de denx pièces formant presqu'un cylindre creux servant de conduit atrx œuts, eatièrement saillante, même dans le repos, insérée sous le ventre à la base de la plaque inférieure du huitième segment de l'abdounen, laquelle plaque est fendue dans toute sa longueur, ses boris formant une coulisse qui reçoil la base de la tarière; celle-ci dépassant l'abjomen et protégée à sa sortie par deux valves demi-aplaties qui sont la continuation des côtés de la coulisse : anus dis mâles n'ayant point de plaque anale supérieure distincte, et laissant les parties génitales à décollvert; la plaque inférieure prolongée en une pointe triangulaire tronquée. - Pattes cintérieures et intermédiaires assez courles; jambes antérieures ayant vers leur extrémité une épine f́largie au boul, et terminées par une poin e latérale; jarmbes inter mé diaires munies à leur extrémité d'une épine sinple; jambes et tarses postérieurs alongés dans les femelles, plus gros daus les mâles, souvent comprimés, surtout dans ce dernier sexe; premier. article des tarses le plus long de tous, égalant souvent en grandeur les quatre deruiers; le

\footnotetext{
lise ee
} 
terminal ayant deux crochets fortement unidentés, munis d'une petite pelote dans leur entre-deux.

I.e nom d'Urocère est composé de deux mots grecs, et a rapport à la partie cornée et pointue qui termine l'abdomen de ces insectes. Quoique plusieurs auteur's aient pensé que la larve des Urocères vit de bois, et que nous soyons bien certains nous, foêmes que l'insecte parfait y dépose ses œufs, nous avons des raisons de croire que celle larve est carnassière d'après les débris que nous avons trouvés auprès de sa coque, tels qu'nne tête écailleuse qui nous a paru très-distinclement être celle d'une larve de Colćoptère; nous pensons donc que comme ceux des Pimples, des Xorides et de quelques autres Ichreumonides, ces ceufs, quoique déposés dans le bois, ne donnent point naissance à des larves plytiphages, mais bien à des larves carnassières.

Les Urocères ont ponr demeure les grandes forêts, cependant on les renconlre quelquefois dans les villes, même dans Paris, auprès des chantiers et des bâtimens nouvellement construits, parce (qu'ils y ont óté amenés dans le bois de constructious. Ils habitent de préférence les pays du Nordd et les montagnes froides, péuplés de Pins et de Sapins; leur taille est ordinairement au-dessus de la moyenne dans lenr ordre, mais elle est trèsvariable pour les individus d'une même espèce : il est ordinaire que les mâles ne portent pas la même livrée que les femelles. Roësel, qui a vu la larve et les œufs de l'Urocère géant, dit que I เ première est alongée, rayée, jaunâtre , cylindrique, avec une tête écailleuse et six pattes très-courtes; l'extrémité du corps est reuflée : les œnfs sont fort alongés et pointus aux deux extrémités. Nous mentionnerons les espèces suivantes.

10. Urocère géant, U. gigas. L.at. Gen. Crust. et Ins. tom. 3. pag. 243. $n^{n}$. 1. Mâle et femelle. -- Sirex gigas n०. 1. Faв. Syst. Piez. Femelle. - Sirex mariscus n॰. 6. FAB. id. Mâle. Nord de l'Europe, France, environs de Paris. Le Sirex psyllius $n^{\circ}$. 2. Fab. idt. est regardé comme uue variété flus petice de la femelle de l'Urocère géant. $2^{\circ}$. Urocère Taureau, $U$. juvencus. LAT. $i d$. pag. $244 . n^{\circ}$. 3. - Sirex juvencus no. 9. Fab. id. Femelle. - Sirex noctilio n ${ }^{\circ}$. 15 . F $\mathrm{AB}$. id. Mâle. Sirex juvencus. Jun. Hyménopt. pag. 79. Mâle et femelle. pl. 7. Genre 11. La femelle. France, Allemagne. $3^{\circ}$. Urocère spectre, U. spectrum. Lat. id. pag. 243. $n^{\circ} .2$. - Sirex spectrum no. 8. FАв. id. Femelle. - Xiphydria emarginata no. 2. FAB. id. Mâle. France, Allemagne.

$$
\text { (S. F. et A. SERv.) }
$$

UROCÉRE, Urocerus. Jur. Voy. XIPAIDrie.

$$
\text { (S. F. et A. Senv.) }
$$

\section{U. R O}

UROPODE, Uropoda. Lat. Acarus. De Géer.

Genre d'Arachnides de l'ordre des 'Trachéens, 1 famille des Acarides, établi par M. Latreille, et auquel il donne pour caractères : organes de la manducation cacliés; corps recouvert d'une peau écailleuse; pattes très-courtes; un filet à l'anus, au moyen duquel l'animal est attaché an corps de divers insectes coléoptères, et seınble être suspendu en l'air. Ce genre ne se compose jusqu'à présent que d'une seule espèce que l'on trouve en Europe.

Uropode végétante, Uropoda vegetans. LAT. Gen. Crust. et Ins. tom. 1. pag. 158 . Milc végélative. Lat. Hist. nat. des Crust. et des Ins. tom. 7. pag. $38 \mathrm{I}$; et tom. 8. pl.67. fig. 8. - DE GÉER, Mémn. surles Ins. tom. 7. pag. 123. pl. 7 . fig. 15. - Voyez la description et les autres synonymes de cette espèce à l'arlicle Mrre de ce Dictionnaire, pag. $698.11^{\circ} .26$. (E. G.)

\section{UROPRISTES. Voyez Serricaudes.}

(S. F. et A. SERv.)

\section{UROPTERE, Uroplera. LAT.}

M. Latreille désigne ainsi (Fam. nat. du Règn. anim., 1 825.) la seconde famille de l'ordre des Amplipodes, comprenant des Crustacés qui ont quatorze paltes, y compris les quatre derniers pieds-mâchoires représentés par les quatre pieds antérieurs; le corps arqué ; les appendices latéraux de l'extrémité postérieure de leur corps en forme de feuillets et servant de nageoires. Ces Crustacés ont les plus grands rapports avec les Phronimes; comme eux, ils vivent dans l'intérieur des Zoophites, mais ils en sont cependant distingnés par plusieurs caractères très-saillans. Cette famille est composée de deux genres dans l'ouvl'age que nous avons cité plus haut; nous allous les faire connoître, et vous présenterons ensuite deux nouveaux genres, l'un décrit par M. Milne Edwąrds, et l'antre découvert par nous.

HYPÉRIE, Hyperia. Lat. Dem.

M. Latreille a proposé ce genre, pour la première fois daus ses Fam. natur. du Règne anim. Il avoit communiqué ses caractères essentiels à M. Desmarest, qui les a présentés dans l'ouviage intilulé : Considérations génér. sur la classe des Crustacés, extrait du Dictionn. des scienc. nat. Ces caraclères sont : quatre antennes sétacées; les dix pieds proprement dits médiocrement longs et tous terminés par un article simple et pointur, 'I'ête assez petite, ronde, plane en devant, point prolongée en rostre. Corps conique, terminé par deux lames triangulaires, alongées, horizontales. M. Desmarest, d'après M. Latreille, rapporte à ce genre la figure de l'Encyclopédie à laquelle M. Latreille a donné avec doute le nom de Phronime, 


\section{$\mathrm{URO}$}

et qu'il nomme actuellement Hypérie deLEsueur, Hyperia Suerii. Elle est représentée pl. 328 . fig. 17. et 18.

Nous possédons un petit Crustacé que nous rapporterons avee doute à cette espèee; il a été tronvé par notre ami d'Orbigny fils sur les côtes de La Rochelle et dans l'intérieur du eorps d'un gros Rliysostome.

Suivant M. Latreille, il est probable que le Cancer gammarus Galba de Montagu, décrit et figuré daus les Transactions linéennes de Londres, vol. XI. pag. 4. pl. 2. fig. 2. appartient à ce genre ou en forme un très-voisill. Nous reproduisons ici la description de l'auteur anglais: eorps ovalaire, un peu alongé vers la queue, lisse, luisant, et d'une couleur veri-olive, finement piqueté de brun, mais devenant, par la dessiccation, d'une teinte brun-rougeâtre. Antenues du mâle extrêmement courtes, celles de la femelle au contraire, au nombre de quatre, très-longues, minces, presque de la longueur du eorps. Arliculation du eorps, indépendamment de la tête et de celles qui portent les nageoires caudales, au nombre de onze. Tête large et ressemblant beaucoup à eelle d'un Mite. Chez le mâle, on n'aperçoit aucune trace de division entre les yeux, et une continuation de la même membrane transparente recouvre le tout; chez la femelle les yeux sont grands et marqués distinetement par une division. Les deux paires de pattes antérieures (eomme eelles du $C$. spinosus) sont petites et pas subchéliferes, mais occupent la place des bras et diffèrent à peine des ciuq paires de pattes suivantes, lesquelles sont toutes pourvues d'un onglet. Nageoires abdominales, trois paires; nageoires caudales, plates, bifides, et au nombre de cinq; celle du milieu très-large et reeouvrant les autres qui peurent s'étaler latéralement.

Longueur I pouee au plus. La femelle est un peu plus minee, et son corps ne dimiuue pas si brusquement vers la queue. Les yeux sont distinets, et pendantla vie d'une teinte rouge-vif, réticulés et marqués de eluaque eôté d'une ligne noire qui est probablement produite par une pupille.

Le Cancer monoculö̈des. Mantagu, loc. cit. vol. XI. pag. 5. pl. 2. fig. 3., est eneore trèsvoisin des Hypéries. Montagu le décrit ainsi : corps minee, eomprimé, ayant dix artieulations lisses et d'une eoulenr pâle; les sept premières jointes de chaque côté à une large plaque de forine ovalaire; ces plaques paroissent suseeptibles de se fermer et de reeouvir tous les membres externes, tels que les pattes, les antennes et probablement les nageoires eaudales. Il n'y a point de bras visibles, mais il y a plusieurs paires de pattes armées de griffes eroehues et légèrement subulées. Quatre antennes, les supérieures un peu plus longues qư les inférieures, et éga-
Jant la moitié du eorps environ. Yeux très-petits; trois paires de nageoires candales, subulées.

Longueur $\frac{1}{8}$. de pouce. l'eu commune. Cette espèce paroît rattacher le Cancer au Nonocle, mais il se rapproche davantage du premier à cause de la disposition de ses membres.

\section{PHROSINE, Phrosina. Risso.}

Deux antennes à peine apparentes; yeux sessiles; tête prolongée sur le devant en forme de nuuseau; inandibules palpigères; corps oblong, un pen arqué, sub-arrondi sur les côtés, à segrinens crustacés transverses : dix pattes monodactyles, dissemblables; le dernier artiele falciforme, aigu au sommet.

Phrosine en crotssant, Phrosina semilunata. Riss.

Journal de phy's. et d'hist. natur. (Mémoire sur quelques Crustacés observés dans la mer de Nice. Octob. 1822. pag. 244. à 246.) - Hist. natur. de l'Europ. mérid. tom. 5. pag. 91. pl. 3. fig. 10. à 12. - Desn. Consid. gén. sur les Crustacés, pag. 258.

Corpore oblongo, lutescente, mberrimo; capite cornuto; oculis minimis.

Cette Plurosine a le corps oblong, renflé antérieurement, teinté de jaune, plus mince postérieurement et eoloré de rouge pourpre; la tête est grosse, arrondie en dessus, armée de deux pointes coniques qui forment au milieu comme une espèce de eroissant; le front est tronqué, sinué; le museau pointu, perpendiculaire, gharni à snn extrémité de mandibules palpigères, avee de pttits palpes sétacés qui entonrent l'onverture de la bouche; l'œil est peiit, sphérique, noir, orné en dessus de deux taches oblongues plaećes obliquement de chaque côté. Le corselet est divisé en cinq anneaux arrondis, glabres, luisans, à peine séparés par des lignes transversales dont l'antérieure et la postérieure sont arquées; les paltes sont monodactyles, à cinq artieles aplatis; la première paire eourte, mince, crochue, et la seconde nn peu moins longue que la troisiènie, ont leur avant-dernier article armé d'aiguillons; toutes les trois sont implantées et correspondent chaeme à la base des trois preniers anneanx; la quatrième paire de pattes est fort grande, à articulation inférieure, large, longue, ovalaire: les deux qui viennent ensuite sont triangulaires, gatnies sur leurs angles latéranx d'une pointe; la quatrième artienlation est ovale, hérissée sur une de ses faces de quatre aiguillons disposés en forıne de dents de peigne; la dernière disposée en longue pointe subtile, aiguë, courbée, semblable à une faux; la cinquième paire de pattes un peu plus courte et égale à la préeédente. La queue, peu convexe, est composée de cinq segmens sulEeee 2 


\section{2}

quadrangulaires, aigus en dessous, le dernier terminé au milieu par une petite pointe. Les écailles caudales son 1 oblongues, ciliées; la plaque intermédiaire courte, aplatie, au sonımet arrondi.

La femelle est garnie de cinq rangs d'appendices alongés, ciliés, plus longs que cetix du mâle. Ses œufs sont iransparens.

Longueur 0,020, larg. 0,007. Séjour, profondeurs sablonneuses. Apparition, avril.

Phrosine gros ail. Phrosina macrophtalina. Riss. loc. cit. Dera, ibid.

\section{P. corpore oblongo, rubro-violaceo, capite} hyalino; oculis maximis.

Elle diffère de la prćećdenle par son corps oblong, d'un rouge-violet, renflé antérieurement, aminci vers la queue. Sa lête est transparente, lisse, unie. Le front est arrondi ; le museau aigu, perpendiculaire, avec les mandibules palpigères, rt de très-petits palpes situés autour de la bouche. l'œil est très.gros, ovalaire; noir; le corselet est divisé en cinq anneaux à peine séparés par de légers sinus transverses, droits. Les patles sont monodactyles, à cinq arlicles sub-arrondis, le dernier aigu; chaçue paire de patles est insércé a la hase de chaque anneau. La queue, peu convexe, est composte de cinq segmens sub.quadrangulaires, aigus à leur extrénité inférienre, le dernier arrondi. Les écailles caudales sont oblongues, la plaque intermédiaire sub-arrondie.

La femelle est pleine de très-petits cuf's globuleux en juillet. Longuenr 0,010, larg. 0,003. Séjour sur le Pyrosome élégant. Apparition, férrier, juillet.

N. Risso se livre ensuite ̀̀ quelques réflexions sur la place que ces Crustacés doivent occurer. 11 pense quills doivent être placés près des l'bronimes, tant par leur conformation que par leurs habiludes : ils présenteni une tête prolongée en bec comme les Atyles de M. Léach, mais ils en diffèrent par beaucoup de caracières; leur lête se courbe perpendiculairement sur la poitrine en long museau, ce qui lui donne un peu l'aspect de celle d'un quadrupède plantigrade; ils avancent en rejetant leur queue en arricre quand elle est courbée sous le corselet, et ils nagent assez vile. L'espèce à qui j’ai imposé le nom de Pbrosine en eroissant, dit Risso; c'est par rapport à sonfront qui est orné de deux prolongemens solides qui présentent cette forme. Les Phrosines sont peu communes sur les côtes de Nice.

THËIISTO, Themisto. Nов. (1)

Le Crustacé qui fait le sujet de eet article ap-

(1) Thémisto , nymphe, fille de Neprune er de Doris.

\section{U R O}

partient évidemment à la famille des Uroptères, tant par le nombre de ses pieds que par la forme des appendices de la queue. Nous lui assiguons pour caraetères essen(iels : corps oblong, composé de douze segmens non eompris la lête. Tronc en ayant sept. 'Tête entièrement oecupée par les yeux, arrondie, point prolongée inférieurement en rostre ; portant quatre antenues dont les supérieures plus courtes que la tête, cuurbées au bout, et les inférieures plus longues. Quatorze pieds; les deux premières paires courtes, dirigées en avant, couchées sur la bouche et représentant les deux dernières paires de pieds-mâchoires des Crustaeés supérieurs; les deux suivantes beaucoup plus grandes, terminées par uı erochet dirigé vers la queue; la troisième paire on la cinquième, en y comprenant les jueds.mâchoires, plus longue que le corps, ayant l'avantdernier article très - long, garni en dedans d'un rang d'épines droites qui forment uue esjèce de peigne, et termiué par un croehet conrbé inlérieurement; celle palle dirigée vers la bouche, ainsi que les deux dernières paires qui sont de moitié plus courtes, conformées de même, mais sans peigne à l'avaut-dernier arliele. Queue terminće par six appendices natatoires, longs, aplalis, bifides à l'extrémité, dont qualıe s'insèrent sous le dernier segnent, et deux sur l'avant-dernier. Trois paires d'appendices bifides sous les trois autres segmens de la quene.

Ce genre diffère des Hypéries par ses palles, qui sont de grandeur inégale, et par la forme et la longueur relative de ses antennes; il est bien séparé des Phrosines de M. Risso, dont les anıennes sont pen apparentes, et la tête prolongée inférieurement en un rostre porlant les parties de la bouche. Du reste, ñous n'ćtablissons ces différences que sur la description que cet auteur a donncé de ce genre, et sur la figure incomplète de son. Histoire naturelle du midi de l'Europe.

La tête de notre Crustacé est aưsi longue que large, arrondie, ayant en avant et vers la partie inférieure une espèce d'enfoncement dans lequel sont iusérées les antennes. Les supérieures sont presque de la longueur de la tête, plus épaisses à leur base que les inférieures, composées de quatre arlicles distincts; le premier article forwe a peu près le tier's de la longueur tolale de l'antenne, les deux suivans son t rès-eour's; entia le dernie: est le plus long de tous, il se rétrécit en poinle courbće en dedans, et l'on aperçoit de très-légères apparences d'anneaux dans sa lungueur. Ies antennes inféricures ont le double de la longueur. des précédentes; elles sont également composées de quatre articles, donl le prenier très-court, le second plins long, le roisieme aussi long que les deux prenier's pris ensemble, et le quatrieme plus long que les trois précédens; ce dernier article semble composé, comme dans les auteunes supé- 


\section{U R O}

rieures, d'un grand nombre de pelites articulations. La bourche est composée, $1^{\circ}$. d'une lèvre supérieure globuleuse, trilobée inférieurement, mèmbraneuse; $2^{\circ}$. d'une paire de mandibules trèsrecourbées en dedans, terminées par deux divisions dentelécs et ciliées à leur extrémité, et portant sur leur dos un palpe de quatre articles, beancoup plus long qu'elles et conché, dans le repos, en dessus et contre la lèvre supérieure dont il embrasse lá base et le contour; $3^{\circ}$. d'une lèvre inférieure large, profondément échancrée au milieu, ayant ses côtés dilatés, et armée de cils au côté interne de ses deux lubes; $4^{\circ}$. et de trois paires de mâchoires proprement dites, dont les premières ou celles qui viennent après la lèvre inférieure, sont bifides, ayant la division supérieure beaucoup plus étroite qne l'inférieure, courbée, ciliée et terminée par deux épines aiguës; la division inférieure triangulaire, armée de longués épines et de cils très-nombreux. Les mầchoires suivantes sont également bifides; la division supérieure ou extérieure est la plus large, elle est coriace, courbée en dedans, aplatie, arrondie et élargie à son sommet, qui présente inférieurement une épine forte et aiguë, suivie extérieurement de plusieurs petites denls : celte pièce recouvre presqu'entièrement la division inférieure qui est coriace, et divisée à son extrémité en quatre fortes denis cornées, aceompagnées en dedans d'un rang de longs cils. Enfin, la troisic̀me paire de mâchoires représente une lèvre; les deux mâchoires se sont réunies à leur base, et la pièce qu'elles composent est divisée supérieurement en trois lobes dont l'intermédiaire, le plus court, est Lifile à son extrémité et bordé de cils. Les deux lubes extérieurs sont également bordés de cils, surtout intérieurement : nous n'avous pas apercu d'arliculation; ces lobes sont membraneux, trèsmous et transparens, ils s'appliquent sur les antres pièces de la bouche et conconrent à lá fermer. Toules les pièces que nous venons de décrire prennent atlache à la partie infúrieure de la tête; celles que nous allons faire connoitre, et qui représentent les quatre pieds-mâchoires des Cirustacés décapodes, premnent leur inserion au-dessous des deux preniiers seginens du trone; ces segmens sunt un peu plus étruits que les suivans; le premier donne allache ì une paire de petits pieds tic̀s-courts dirigés en avant, appliqués sur la bouche, et composés de cinq atliculations, dont la première est aussi grande que les quatre dernières ensemble; la seconde très - courte, plus étroite; la troisièrne au moins denx fuis plus longue que la seconde, plus large et dilatée vers son uiliea; la quatrième de la longucur de la précédente, beaucoup plus étroite, cylindriqne, et la cinquième très-petite et en forme d'épine ou de crochet. La seconde paire, ou les pieds-mâchoires extéricurs, ressemble ḋ la précćcienle, elle u'en diffère que parce que le troisième arlicle a son extrémilé interne prolongée en une pointe courbée en dedans et venant s'opposer au quatrième article pour former une sorte de piuce ou de main : ces deux petites pinces sont également couchées vers la bouche.

Les cinq paires de pieds proprement dits sont insérées sur les cinq segmens qui, avec les deux premiers dont nous avons parlé, fornent le tronc de notre Crustacé ; ces segmens n'ont point d'appendices extérieurs. Les quatre premiers pieds sont presque trois fois plas longs que les pieds-mâchoires extérieurs; ils sont également composés de cinq articles, dont le premier très-long, large ver's sa partie supérieure qui se rétrécit tout-î-coup et donne attache au second article, le plus court de tous, celui-ci est étroit à sa hase et large à son extrémité; le troisième est deux fois plus long que le précédent, très-élargi à sa base et au côté intérieur, qui est armé d'épines et contre lequel peut s'appliquer le quatriène article; celui-ci est aussi long que celui qui précède, un peu courbé en dedans, beaueoup plus étroit, cylindrique, et terminé par le cinquième article ou le tarse qui forme un crochet aighun. Ces deux paires de paltes ont leur crochet tourné vers la parlie postérieure de l'animal. La troisième paire es! la plus extraor. dinaire, elle est an moins trois fois plus longue que les précédentes; son premier article est aussi long que les trois premiers des paltes antérieures; il a à peu près la même forme. Le second esi trèscourt, plus large à son extrémité ; il donne insertion au troisième, qui est de la longueur des deux prewier's réunis, presqu'aussi large dans toute sa longucur. Le quitrième est beaucoup plus étroit, presqu'aussi longr que les précédens réunis, aplati, de la même grosseur dans toute sa longueur; il est armé en ảedans, ou du côté qui regarde la tête, d'un range d'épines d'égale longueur, perpendiculaires, et qui lui donoent l'aspect d'un loug peignc. Le dernier article, ou le tarse, est trés-petit et en forme d'ongle ou de crochet; ce crochet, ainsi que celui des deux pattes postérieures que nous a!lons décrire, est tourné vor's la tête cu opposé à celui des deux paires de pattes antérientes. I.es deux paires de pattes postérieures onl encore la mêrne direction; elles sont de moitié plus conrles que la paire prícédente, composées d'articulations semblables, mais n’ayant pas de pcigne au côté interne dư quatrième article. L'abidumen est composé de cinc segmens; les trois premiers sont grands, dilatés sur les côtés, replićs en dessous et terminćs postérieurement, et de chaque côté, par une petite épine : le quatrième est beaucoup moins long el bien moins large; enfia, le cincruième est encore plus petit, terininé postérieurement par un petit lobe trianguline qui a une apparence d'articulation. Les trois premicrs anneax don= 
nent chacun attache à une paire d'appendices ratatoires, dont le premier article est court, presque quadrangulaire; cet article supporte deux filets multiarticulés ayant presque le double de sa longueur, et garnis entièrement de lnogs poils qui sont eux-mêmes ciliés. Le quatrième article donne insertion postérieurement à deux appendices aplatis, composés d'un article basilaire ayant le double de sa longueur, et portant à son extrémité deux lames aiguës, ciliées, appliquées l'une sur l'autre dans le repos, et qui s'étendent quand l'animal veut s'en servir pour nager. Enfin, le dernier article donne attache à quatre appendices semblables aux deux précédens; ces six laınes concourent à former une queue en éventail qui doit servir à l'animal ponr exécuter des sauts et des bonds dans l'eau.

La seule espèce avec laquelle nous avons établi ce singulier genre a été trouvée sur les côtes des îles Malouines par M. Gaudichaud, pharmacien et naturaliste de la corvelte l'Uranie. Nous proposons de la consacrer à ce naturaliste, aussi savant que modeste, et nous saisissons cette occasion de lui exprimer publiquement notre amitié, ainsi que notre reconnoissance pour la générosité avec laquelle il nous a fait don de plusieurs Crustacés précieux recueillis par lui dans son voyage sutour du Monde.

Théursto de Gaudicuaud, Themisto Gaudichaudii. Nов.

Long de neuf à dix lignes depuis la tête jusquàà l'extrémité des filets de la queue. Tête grosse, globuleuse, entièrement occupće par les yeux et d'un jaune brunâtre. Corps et paltes d'un jaune pâle; pattes de la troisième paire à partir de la queue, plus longues que le corps. Le seul individu que nous ayons eu à notre disposition est conservé dans l'alcool,

A la suite des Uroptères, nous devons faire mention d'un nouveau genre que vient d'établir M. Milne Edwards dans les Annales des sciences naturelles. Ce naturaliste pense qu'il forme le passage entre les Amphipodes et les Euphées de M. Risso, que M. Latreille réunit à son genre Apseude. M. Edwards croit qu'en modifiant un peu les caractères de la famille des Ưroptères, son genre s'y placera aisément et d'une manière naturelle.

\section{RHOÉ, Rhœea. Mrrne Edw.}

Quat re antennes dont les supérieures sont grosses, bifides et plus longues que les inférieures; quatorze pattes, dont les deux premières terminées par une pince, et les autres par un ongle crochu. Le deruier article de l'abdomen alongé et supportant deux appendices terminés par de longs filamens. Tels sont les caractères essentiels de ce genre, que M. Edwards a représentés. Il le décrit de la manière suivante : ce petit Crustacé est alongé, un peu comprimé et presque linéaire; la tête n'est pas séparée du premier segment thoracique d'une manière aussi distincte que dans la plupart des animaux de cette classe, et son extrémité antérieure se prolonge sous lá forme d'un rostre pointu et légèrement recourbé. Les yetrx, au nombre de deux, sont circulaires, très-petits, et insérés sur les cốtés de la tête près de son bord antérieur et inférieur. Ies deux paires d'antennes sont insérées l'une au-dessus de l'autre ; les supérienres ou moyennes dont la longueur est moindre que celles du corps sont trèsgrosses surtout près de leur base; elles sont terminées par deux filamens inégaux multiarticulés, pourvus de quelques poils assez courts, l'inférieur a environ deux fois la longueur du supérieur, et ne dépasse guère celle de leur pédoncule commun qui est formé de trois articles dont le premier (c'est-à-dire l'article basilaire) est le plus gros et surpasse en longueur les denx autres réunis. Les antennes inférieures (ou externes), moins longues que les supérieures, sont formées d'un article basilaire très-court, et d'uu second article alongé et presquae cylindrique, auq̣uel succède un flament multiarticulé qui s'amincit très-rapidement, et qui porte une rangée longitudinale de poils roides et assez longs.

La bouche est garnie comme à l'ordinaire de pattes-mâchoires, dont les postérieures sont soudées entr'elles près de leur base, et ont la forme de palpes garnis d'un grand nombre de poils; on distingue à chacune trois article dont le dernier est arrondi. Le corps de ces Crustacés est formé de denx portions assez distiuctes; l'une thoracique, l'autre abdominale. Des sept anneaux qui furment la première, le plus antérieur, comme nous l'avons déjì dit, est presque confondu avec la tête; le second, un peu moins large que le premier, se prolonge de chaque côté en bas et en avant, de mauière à former une pointe un peu recourbée qui cache l'articulation de la patte correspondante; les autres segmens ne présentent point cette disposition, et ne sont point pourvus, comme dans la plupart des Crustacés du même ordre, de pièces latérales distinctes de celle qui en forme la portion dorsale. Chacun de ces arceaux est pourva d'une paire de pattes ambulatoire, en sorte que le nombre de ces appendices est de quatorze. La première paire se termine par uue pince dont le doigt immobile est fort large; la main est très-courte, les deux articles suivans sont plus étroits; enfin le bras est remarquable par sa forme presqu'ovalaire. Les pattes de la deuxième paire plus longues, mais moins larges que les premières, n'ont point de pinces; la main n'est ni renflée ni aplatie, elle présente sur' son bord une série de quatre épines assez fortes et 


\section{U S I}

une à son angle supérieur et antérieur; enfin, elle s'articule avec un ongle assez large à sa base, un peu croclsu et dentelé sur son bord intérieur. La lnngueur des autres pattes diminue graduellement d'avant en arrière; elles sont toutes assez minces, et terminées par un grand ongle crochu sans dentelure, l'avant-dernier article n'est pas épineux, mais supporte un grand nombre de poils; enfin, les cuisses ne sont pas élargies comme dans la plupart des Cruslacés de la famille des Créveltines. L'abdomen est formé de six anneaux, dont les cinc premiers sont très-courts, et le dernier, an contraire, renıarquable par sa longueur. Les premiers portent chacun une paire de fausses paltes dont le pédoncule eśt assez court, et supporte deux lames ovalaires et ciliées. Ces appendices sont assez gros relalivement au peu de développement des segmens de l'abdomen auxquels ils appartiennent, aussi sont-ils pour ainsi dire presque les uns contre les autres. Enfin, l'article terminal de l'abdomen, dont la forme est alongće et un peu aplatie, présente de chaque côté ver's l'angle postérieur une petite éclancrure où s'articule un pédoncule cylindrique, et un peu recourbé en dedans, gui supporle à son tour deux filamens garnis de quelques poils, l'un assez court, l'autre au contraire presqu'aussi long que le reste de l'animal.

Rhó de Latreille, Rhoa Latreillii. Edw. Ann. des scienc. nat. tom. 13. pag. 292. pl. 13. $\mathrm{A}$, fig. 1 à 8 .

Il est long d'environ trois lignes; sa couleur est blanchâtre. Cé Crustacé paroît vivre à des profundeurs considérables dans la mer; car c'est en dragiant sur un banc d'lıuitıes près Port-Louis, anx euvirons de la Rochelle, qu'il a été pris.

( E. G.)

USIE, Usia. Lat. Mrig. Voluccella. Fab. Coqueb. Bombylius. Ross.

Genre d'insectes de l'ordre des Diptères, prenière section, famille des Tanystomes, tribu des Bombyliers.

La seconde division de cette tribu a pour caractères : abdomen court, triangulaire ; elle contient quatre genres, savoir: Ploas, Bumbyle, Usie et Lasie. (Voyez Bombyliers, pag. 539. de ce volume.) Le premier se distingue par ses antennes très-velues à la base, dont le premier article est beaucoup plus gros que les autres; par la brièveté de sa trompe à peine plus longue que la tête; par ses palpes apoarens et son corps très-velu. La longueur du premier article des antennes, le troisième terminé en pointe et la totalité dir corps couverte de poils longs et touffus, sont les caractères distinetifs des Bombyles. Quant au genre Lasie de M. Wiédemann, nous ue le connoissons que par les caractères qu'en donne ce savant auteur ; il nous paroit différel principalement des Usies par la grandeur de sa trompe, presque deux fois aussi longue que le corps, celuici paroissant très-velu.

Antennes avancées, moitié aussi longues que la tête, rapprochées à leur base, divergentes ensuite, composées de trois articles, le prenier pas plus long que le second, presque cylindrique, un peu plus épais en devant, presque nu; le second court, cyathifurme, presque nu; le troisième alongé, fusiforme, point comprimé, son extrémité obluse. - Trompe saillante, du double aussi longue que la tête. - Palpes point apparens. Tête sphérique. - Yenx hémisphériques, séparés l'un de l'autre (au moins dans les femelles). - Trois ocelles disposés en iriangle sur le vertex. - Corps simplement pubescent ou presque glabre. - Abdomen court, assez large, ovale, légèrement bombé, composé de six segmens outre l'anus. - Ailles étroites, obluses, velues vues au microscope, ì moitié ouvertes dans le repos. Cuillerons simples, petits. - Balanciers découverts. - Pattes de longueur moyenne; dernier article des tar'ses muni à son extrémité de deux. crochets ayant deux pelotes dans leur entredeux.

Le nom de ce genre vient d'un mot grec qui exprime la longueur et la flexibilité de sa trompe. Les Usies n'ont été tronvées jusqu'à présent que dans les parties les plus chandes de l'Europe et de l'Afrique. Les insectes parfails fréquenten! les fleurs; leurs premiers élats sont incounus.

Io. Usie bronzée, U. cenea. Lat. Gen. Crnst. et Ins. tom. 4. pag. 315. tom. 1. tab. 15. fg. 2. - Merg. Dipt. d'Eur. tom. 2. pag. 226. no. 1. tab. 18. fgr. 21. Femelle. Du Languedoc. $2^{\text {n. Usie }}$ des fleurs, U. florea. LAt id. - MeIG. id. pag. 227. $n^{\circ}$. 2. - Voluccella florea no. 1. Fas. Syst. Antliat. De Barbarie. Suivant M. Latreille, on en trouve aux environs de Bordeaux une variété moitié plus petite. $5^{\circ}$. Usie petite, $U$. pusilla. MeIg. $i d$. pag. 229. no. 6. tab. 18. fig. 22. Femelle. Elle a élé prise à Carpentras sur le îhy vulgaire. (Thymus vulgaris.)

\section{LASiE, Lasia. Wí́deir. Lat. (Fam. nat.)}

Genre d'insecles de l'ordre des Diptères, première section, famille des T'anystomes, tribu dos Bombyliers.

Les genres Ploas, Bombyle, Usie et Lasie con:lituent la seconde division de celle triba; celte division a pour caractère : abdomen court, triangulaire. (Voyez Bonbrumers, pag. 53 g. de ce volume.) Dans les trois premiers geures la trompe n'est pas à beaucoup près proportionnel!ement aussi longne que dans les Lasies, et les écailles 
qui reconvrent la base des ailes sont beaucoup plus petites que celles de ce dernier genre.

Nous allons donner les caractères des Lasies d'après M. Wiédemann, ces insectes nous étant inconnus.

Antennes avancées, rapprochées, étroites, lancéolées, comprimées, composées de trois articles; le premier cylindrique, le second discoïdal, le troisième lancéolé. - Trompe beaucoup plus longue que le corps, dirigće horizontalement en avant. - Point äocelles ( selon l'auteur suédois, qui a décrit un mâle dians lequel le rapprochement des yeux pouvoit rendre l'observation des ocelles difficile); trois ocelles dislincts dans les femelles, suivant M. Latreille. (Fam. nat. pag. 492.) Ailes ouvertes, l'écaille qui recouvre leur base, très-graude. - Corps hérissé de poils.

Le nom de ce genre vient d'un mot grec qui fait allusion à ce dernier caractère. Le type est la Lasie brillante, L. splendens. WríD. Analect. Entom. pag. $11 \cdot f g$. 3. Longueur 3 lig. $\frac{3}{4}$. Mâle. Corselet cuivreux; écusson et abdowen d'un violet d'acier. Du Brésil. (S. F. et A. SERV.)

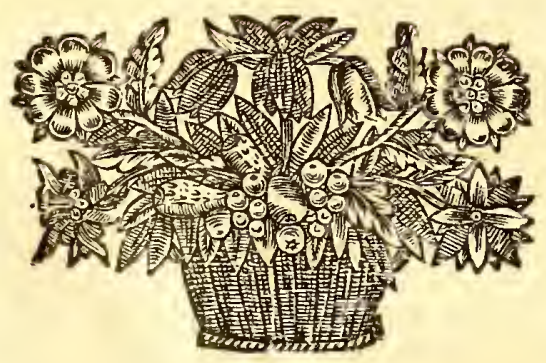




\section{A G}

$\mathrm{V}$

A G A BON DES, Erraticce. LAT.

M. Latreille comprend sous cette dénomination les Aranéides de la section des Dipneumones qui, ne faisant pas de toiles, et ne tendant pas même cie fils pour surprendre leur proie, sont obligées, pour se nourrir, de conrir après elle ou de sauter dessus. Leurs yeux sont toujours au nombre de huit, s'étendent sur tout le front, on presqu'autant dans le sens de sa hauteur que dans celui de sa largeur, et forment, par leur rémion, soit un un triangle curviligne ou un cercle tronqué, soit un quadrilatère ou un trapèze. Celte division comprend deux tribus, les Citigrades et les Saltigrades.

\section{CITIGRADES, Citigradoe. Lat.}

Les pieds ne sont pas générulement propres à la course, et l'animal ne saute pas sur sa proie. Ise groupe oculaire forme, soit un triangle curviligne ou un ovale tronqué, soit un quadrilatère ou un trapèze. Les yeux les plus extérieurs sont tonjour's rapprochés du milieu du front et éloigués des angles latéraux de l'extrémité antérieure du céphalothorax.

I. Groupe oculuire formant un triangle curviligne tronqué.

\section{OXYOPE, Oxyope. Lat. Voyez ce mot.}

CTĖNE, Clenus. WaLcK. LAT.

Huit yenx inégaux entr'eux, occupant le devant et les côtés du cor'selet, placés sur trois lignes trins. versales, s'alongeant de plus en plus, et disposés de manière à former un groupe de quatre an centre, et de deux de chaque côté et en avant; lèvie carrée, plus haute que large, rétrécie à sa base; tnâclioires droites, écartées, plus hautes que larges, coupées obliquement et légèrement échancrées à leur côté interne; pattes alongres, éteudues latéralement; cuisses renflées; la première paire plus longue que la seconde, et la seconde plus quue la troisiène.

Les caractères de ce genre ont élć pris sur une Araignée assez grosse envoyée de Cayenne à la Société d'histoire naturelle de Paris, et que M. Walckenaer nomme Ctène pouteux, Ctenus dubius, dans son Tableau des Aranéïdes, pag. 18. Il en figure la bouche et les yeux $p l$. 3. fg. 21 . et 22. du mêne onvrage, mais il n'en donne pas de description. Cette Araignée étoit en très-mauvais état, car son abdomen et la quatrième paire de pattes mariquoient. M. Walckenaer pense qu'nne A raignée dont il possède un dessin inédit d'Oudi- not, et que l'on trouve aux environs de Paris, appartient à ce genre, ainsi que celle qu'Albin it figurée $p l$. 34. f.g. 167. Mais il n'a jamais vu ces espèces.

II. Groupe oculaire formant un quadrilatère prefqu'aussi long au moins que large.

LYCOSE, Lycosa. Voyez ce mot à la suite de l'àrticle Tarentules.

DOLOMĖDE, Dolomedes. Lat. Waxck. Aranea. Linn. De Géer. Fab.

Yeux représentant par leur ensemble un quitdrilatère un peu plus large que long, disposés súr trois lignes transverses dont l’antériecte formée de quatre et les deux autres de deux chacune; les deux postérieurs situés chacua sur une petite élévation; la seconde paire de pieds aussi longue que la première. M. Walckenaer, dans son $T_{a-}$ bleau des Aranéides, pag. 15, ajoute à ces carac. tères que les màchoires sont droites, écartées, plus bautes que larges, et que la lèvre est courte, carrée, aussi haute que large : ces caractères sont figurés dans le même ouvrage, $p l$. 2. fig. 17. à 20 .

Ce genre se distingue facilement des Lycoses, parce que ces derniêres Aranéides n'ont pas les yeux postérieurs portés sur des pédicules, et que le groupe des huit yeux forme un carré aussi long. que larye; leur première paire de pieds est plus longue ou aussi longue que la seconde. Les Dolomedes chassent et courent après leur proie; elles construisent, seuleraent it l'époque de la ponte, alentour des plantes, une toile dans laquelle elles déposent leur cocon, qu'elles gardent assiduement, ainsi que leurs petits, long-temps aprés quils sont éclos : elles emportent leur cocon fixé sous leur corselet, quand elles sont menacées. M. Larreille a partagé ce genre en deux sections, que $M$. Walckenaer nomme familles.

A. Corselet alongé; abdomen ovale, arrondi à son extrémité; yeux de la ligne antérieure égaux; mûchoires à côté interne convexe. Les espèces de cette division habitent le bord des eaux; elles courent à leur surface sans se mouiller. Les femelles fabriquent une toile irrégulière qu'elles placent entre les branches des végétaux, prìs du lien qu'elles habitent, et dans laquelle elles déposent leur cocon. Ce sont les Dolomèdes riveraines, riparice, de M. Walckenaer.

\section{DOLOMÈDE BORDÉ, Dolonedes marginatus.}

\section{Fffff}


Walck. Tabl. des Aran. pag. 16. - LAт. Gen. Crust. et Ins. tom. 1. pag. 118. - Ariignée bordée, WAlck. Faun. Paris. tom. 2. pag. 256.LAt. Hist. nat. des Crust. et des In. tom. 7. pag. 297. - PAnz. Faun. Germ. fasc. 71. tab. 22. TYoyez pour les autres synonymes ct la ciescription, le $11^{\circ}$. 62. article Arargné de ce Dictionnaire.

Dolonède entouré, Dolomedes finibriatus. W' alck. Tabl. des Aran. pag. 16. Foyez pour les autres synonymes et la description, l'Araignée fiangée $n^{\circ} .60$. de ce Dictionnaire.

Dolonìde roux, Dolomedes rufus. W Alck. Tabl, des Aran. pag. 16. - Aranea rufa De Géer, tom. 7. pag. 319. no. 4. pl. 3g. fg. 6. et 7 . Elle appartient aussi à cette division. Elle se trouve dans l'Amérique du nord.

B. Corselet court, en cour ; abdomen ovale, alongé et terminé en pointe à son extréaité; yeux latéraux de la ligne antérieure plus gros que les autres; mâchoires à côté interne presque droit. Ces Aranéides habitent les bois et les forêts. Ce sont les Sylvines, Sylvina', de M. Walckender.

Dolomède admirabee, Dolomedes mirabilis. WV ALCK. Tabl. 'des Arun. pag. 16.-LAt. Gen. Crust. et Ins. tom. I. pag. I17. - Araignée admirable, W ALck. Faun. Paris. tom. 2. pag. 236. - Lat. Hist. nat. des Crust. et des Ins. tom. 7 . pag. 296. - Aranea obscura. FА . Ent. Syst. tom. 2. pag. 4l9.-Aranea Listeri. Scopol. Ent. Cam. no. IOg8.-Oniv. Encycl. pag. 227. n०. 17. - Lrster. Aran. pag. 8o. tit. 27. 28. - Schærf. Ins. Ratish. pl. I87. fg. 5. 6. - Friscr. tom. I4. Voyez pour'les autres synonymes et la description, l'Áraignée agraike d'Olivicr, article AraiGNÉE no. 5g. de ce Dictionnaire, ainsi que l'Araignée de Lister, placée dans les espèees moins connues, $p a g \cdot 237 \cdot n^{\circ}$. 17. qui est la wême.

On ne connoît jusqu'à présent que ces quatre espèces de Dolomèles.

III. Groupe oculaire formant un trapèze court et large.

\section{MYRMÉCIE, Mymecium. Lat.}

M. Latreille a établi ce genre dans les Annales des sciences naturelles, tom. 3. pag. 27. Il Lui assigne pour caracières: groupe oculaire, composé de huit yeux petits, six rapprocbés au milieu du front, quatre au milieu formaut un carré; Jes deux latéraux antérieur's un peu plus jetits et disposés, avec les deux antérieurs des précédens, sur une ligne transverse; les deux derniers placés sur les côtés supérieurs du céphalothorax, trèsécartés l'un de l'autre, en arrière des précédens, un peu plus gros, insérés à l'extrémité d'une pelite élévation oblique, et formant avec les deux intertuédiaires et postérieurs des précédens une ligne transverse, arquée en devant. Chélicères (mandibules ) fortes, leur premier articlc épais, convexe en dessus, dentelé en dessous. Màchoires droites, un peu élargies, arrondies el très-velues à leur'extrénité supérieure; palpes du rvâle terminés par un article renflé à sa hase, allast ensuite en poinic ou presque pyriforme; le dernier de ceux de la femelle cylindrique et long. Lèvre (langue) presque carrée, un peu plus longue que large, arrondie latéralement au bord supérieur, a vec une ligne imprimée et transverse près de sa base. Pieds longs, presque filiformes, ceux de la quatrième parre et de la première les plus longs; ceux de la seconde ensuite.

Les Orypodes, les Ciènes; les Iyycoses et les Dolomèdes, se distingueut du genre $\mathrm{M}_{\mathrm{y}}=$ rimécie, parce que, dans les deux premiers, les yeux forment un triangle curviligne, et que, dans les seconds, ils sont disposés en quadrilatère presquaussi long au rooins que large. Les Myrimécies en diffèrent encure par la forme de leur corps, qui est bien différente et tout-à-fait remarquable; il est étroit, alongé; le thorax est comme articulé cu apparence, et n'otfie d'ailleurs aucune incision transverse; plusieurs étranglemens le partagent en trois. La division antérieure, beaucoup plus grande en tous sens, est carrée, porte les organes de la manducation, les quatre pieds antérieurs et les y'eux; les deux autres divisions superficielles du thorax ont la forme de nœuds ou de bosses, et servent chacune d'attache à une paire de pattes, ou aux quatre postérieures. Le thorax est resserré entre ces deux nœuds, et à la suite du second, il se rétrécit brusquement d'une manière cylindrique. La division antérieure représente la tête des insectes hexapodes réunie au prothorax, la seconde le mésothorax, et la troisieme le métalhorax; à celle-ci est suspendu, an moyen d'un pédicule court et cylindrique, l'abdomen, qui est beaucoup plus court que le thorax, recouvert depuis sa naissance jusqu'auprès du milieu d'un épiderme solide ou coriace, divisé en deux lames ou plaques, l'une supérieure et l'autre inférieure; il est mou, et presque membraneux ensuite.

Ce genre se compose de trois espèces, dont deux sont figurées dans un très-beau manuscrit de dessins d'Aranéides de la Géorgie amćricaine, peintes par Abbot, et que 11 . Walckenaer possćde; la troisième, et celle qui a servi de tylje au genre, est:

Le Mrrmécie faupe, Myrnecium nefum. Lat. loc. cit.pl.2. Long d'environ 6 lignes, fauve, luisant, presque glabre, avec l'extrémité des palpes, des cuisses, du premier article des pieds postérieurs et le bout de l'aldomen, noirâtres. Il se trouve aux environs de Rio-Janeiro.

SALTIGRADES, Saltigrada. Voyez ce mot. (E. G.) 
VANESSE, Vanessa. Genre de LépidoptèresDiurnes de la tribu des Papillonides. (Voy. tom. IX. pag. 291.807. et 818.)

$$
\text { (S. F. et A. Serv.) }
$$

VAPPON, Fappo. LAT. FAB. Pachygaster. Meig. Macq. Nemotelus. Panz. Sargus. Faldèn. Genre d'insectes de l'ordie des Diptères, première section, famille des Notacanthes, tribu des Stratiomycles.

Un groupe de cette tribu a pour caractères : antennes simples; leur dernier article anuelé, formant une masse presque globuleuse ou ovalaire, muni à l'extrémité d'une soie longue; écusson ordinairement muique. (Voyez Stratiomydes.) Il est formé de trois genres, $1^{\circ}$. Chrysochlore, distinct par son écusson épineux. $2^{\circ}$. Sargns, ayant l'abdomen déprimé en dessus et le premier article des antennes plus long que le second. $3^{\circ}$. Vappon, qui fait le sujet de cet article.

Antennes insérées daus un enfoncement antérieur de la tête, non loin du bord supérieur de la bouche, rapprochées à lenr base, dirigées en avant, composées de trois articles; le premier très-court, presque cyliudrique; le second aussi court, mais plus large que le premier, orbiculaire; le troisième presque sphérique, un peu comprimé, beancoup plus grand que les précéclens, paroissant divisé en quatre anneaux, muni d'une soie terminale, un peu velue à sa base. - Trompe cachée dans la cavité buccale, lors du repos. Palpes insérés vers la base de la trompe, un peu velus, divergens, coniques. - Tête hémisphérique-alongée. - Yeux espacés dans les femelles, convergens sur le front dans les mâles. - Trois ocelles disposés en triangle sur le haut du front. - Corps presque triangulaire, glabre. - Corselet un peu oblong, plus large à sí partie postérieure qu'í l'antérieure. - Ecusson mutiqne. - Ailes assez grandes, lancéolées, velues vues au microscope, couchées horizontalernent et parallèlement sur le corps dins le repos, ayant une cellule discoidale émettant trois nervures qui atteignent le bord postérieur de l'aile. - Balanciers découverts. - Abdomen plus large que la partie postérieure dı corselet, très-convexe en dessus, concave en dessous, ses segmens peu distincts. $\boldsymbol{P}$ attes de longueur moyenne.

Des larves du Vappon noir ont été trouvées par MI. Carcel dans le terreau d'Orme; elles s'y tientnent dans les paries les plus bumides et ont besoin de plus d'une année pour leur entier développement. M. Macquait les ayant reçues de M. Carcel, les a décrites d'après nature; il'dit qu'elles ont à peu près deux lignes et demie de longueur, arrivées près de l'époque de leur transformation. Leur corps est alongé, un peu ovale, très-déprimé, luisant, d'un gris roussâtre et marqué de trois bandes longitudinales obscures; il est coro- posé de onze segmens distincts, arrondis sur les côtés: cltaque segment a quelques poils sur le dos, et de chaque côté une scie alongée et deux courtes; le onzième seyment ou anus est graind, semi-circulaire, noir bordé de roussâtre, avec une petite ligne transversale enfoncée vers l'extrémité, et en dessous une ligne longitudinale légèrement rebordée; les bords de cet anus sont munis de liuit soies. La tête e:t cornée, alongée, beauconp plus étroite que le corps, conique, obtuse, un pell courbée en dessous, d'un roux clair avec les côtés obscnrs; les yeux sont petits, noirs, luisans, accompagnés de deux petites soies; la boucbe est très-petite, entourée d'nn rebord; son ouverture'est peu distincte ainsi que ses parties : cette bouche semble occupée tout entière par un petit corps blanc. Pour se transformer, la larve s'élc̀ve vers la surface du terreau, y reste inmobile sans changer de peau, et passe intérieu. rement à l'état de nymplie; la déponille de la larve sert de coque à celle-ci, sans changer de figure. En ouvrant cette coque on voit que la nymphe a toutes ses parties enveloppées d'une pellicule mince, mais très-distinctes, et qu'elle n'occupe qu'une partie de son domicile.

Lcs Vappons à l'état parfait fréquentent les fleurs, les haies et les buissons. La seule espèce connue est le Vappon noir, $V$. ater. Lat. Gener. Crust. et Ins. tom. 4. pag. 279. - FАв. Syst. Antliat. pag. 254. no. 1. - Pachygaster ater. Meig. Dipt. d'Eur. tom. 3. pag. 102. $n^{\circ}$. 1. tab. 24. fig. 17. Mâle. - M $\mathrm{M}_{\mathrm{AcQ}}$. Ins. Dipt. Asiliq. etc. pag. 112. - Vappo ater. Encycl. pl. 387. fg. 49-53. Celle de la femelle est fautive, la tête étant représentée beaucoup trop large. Cette espèce se trouve aux environs de Paris.

(S. F. et A. SERv.)

VÉlie, Velia. Lat. Hydrometra. Fab. Cimex. Ross.

Genre d'insectes de l'ordre des Hémiptères, section des Hétéroptères, famille des Géocorises, tribu des Rameurs.

'Trois genres entrent dans cette tribu, Hydromètre, Gerris et Vélie. (Voyez Rameurs.) Celui d'Hydromètre diffère des Vélies par le troisième article de ses antennes plus long quaucun des autres, et par le corps délié et linéaire. Les Gerris ont le bec divisé en quatre articles distincts et les quatre dernières pattes fort éloignées des antérieures, rappruchées à leur insertion, trèslongues et menues.

Antennes filifurmes, composées de quatre articles, le premier le plus long de tous, le dernier cylindrique, un peu ovale, - Bec ne paroissant extérieurement composé que de deux articles, les deux premiers étant très-courts, point visibles. - Labre caché, très-court. - Tête presque verticale, sa partie antérieure qui porte le bec, dirigée vers le bas. - Yeux très-saillans, globa: 
lẹx. - Corps assez court, en ovale-alongé, le corselet élant la partie la plus large. - Corselet presque triangulaire, tronqué en devant, plus large à sa base qu'á sa partie antérieure. - Elytres et ailes couchées sur l'abdomen, étroites. Abdomen allant un peu en diminuant de largeur vers son extrémité; ses bords latéraux relevés, formant uue espèce de canal recevant les ailes et les élytres; plaque anale inférieure sillonnée longitudinalenent dans son milieu dans les femelles, celle des mâles entic̀re, sans sillon longitudinal. Pattes assez distanles les unes des autres à leur insertion; les antéricures épaisses, assez courtes, ravisseuses; les intermédiaires les plus graandes de toutes, grêles, n'étanı pas deux fois plus longues que le corps, insérées à égale distance des deux autres paires; pattes postérieures assez grosses, leurs cuisses surtout; celles-ci armées en dessous de deux fortes épines duns les mâles, muliques dans les femelles; tarses ne paroissant composés gue de deux articles.

Les mœurs des Vélies sont peu connues; elles se trouvent communément dans la France méridionale. M. Latreilie dit qu'elles courent simplement sur l'eau avec une grande vitesse, sans paroître ramer et nager par saccades comme les Gerris.

${ }^{\circ}$. Vélie des ruisseaux, $V$. rivulorum. Lat. Gener. Crust. et Ins. tom. 3. pag. $132 . n^{\circ}$. 1. -

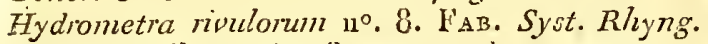
Elle a des ailes et des élytres; on la trouve conmuuément dans les fontaines de nos départemens méridionaux. Mâle et femellc. $2^{\circ}$. Vélie des mares, D. fossulanum. Lat. Nouv. Dict.d'hist.nat. $2^{\circ}$.édit. - Hydrometra fossularum no. 9. F.ав. id. D’Italie. Rossi assure ne lui avoir jamais va que des fourreaux d'élytres et d'ailes, quoiqu'il ait été témoin de l'accouplement. $3^{\circ}$. Vélie vagabonde, $V$. cirrrens. LAт. id. pag. $133 . n^{\circ}$. 2.-Hy drometra currens no. 12. FАв. id. Femelle. - Hydrometra aptera $n^{\circ}$. I1. FAB. $i d$. Mâle. D'Jtulie et de France. On ne connoît que des individus aptères, et il esı probable qu'elle s'accouple dans cet état.

(S. F. el A. Serv.)

VELOURS JAUNE. Geoffioy (Ins. Par. tom. 1. pag. ro2. $n^{\circ}$. 8.) désigne par ce nom vulgaire in Coléoptère du genre Byture, décrit daus le présenl Dictionnaire, sous la dénomination de Dermeste velu n'. 15.' (Toyez ce dernicr mot et celui de Byture, pag. 45 . de ce volume.)

(S. F. et A. Serv.)

VELOURS NOIR. C'est sons ce nom que Geoffroy, dans son Hist. abrég. des Inus. Par. tom. I. pag. $84: n^{\circ} \cdot 23$. désigne un Coléoplère-Pentamère qui appartient au genre. Sérique (Omaloplia. Des. Cutal.) Voyez ce mot, et pour la description, Hanneton hụméral no. 953, de ce Dictionnaire. (S. F. et A. SERv.).
VELOURS VERT. Nom trivial appliqué par Geoffroy (Ins. Par. tom. 1. pag. 233. ) au Cryptocephailus sericeus des auteurs. Voyez Gribous $i$ soyeux $n^{\circ} .3$. du présent ouvrage.

(S. F. et A. Serv.)

\section{VELOURS VERT A DOUZE POIN'TS} BLANCS. La Cicindèle champêtre, $C$. campestris. Auctor. a été désignée suus celte dénomination vul. gaire pa: Geoffroy (Ins. Par. tom. 1.pag. 153. $n^{\circ}$. 27.) Voyez Cicindèle champêtre $n^{\circ} \cdot 9$. du présent Dictionnaire. (S. F. et A. SERV.)

VENIN, Venenum. Beaucoup d'insectes, et un bien plins grand nombre d'Arachnides, sont pourvis, pour leur défense et pour donner la mort aux Insectes dont ils font leur proie, d'une liqueur ácre, caustique, ayant la propriété de produire une vive inflammation aux tissus qui en sont imprégnés, el que l'on a nommée venin. Cette liqueur est préparée dans des vaisseanx de deux espèces; les uns, placés à la partie antérieure da corps, fournissent le venin que les Arachnides et les Scolopendres introduisent par leurs morsures; ils ont reçu le nom de vaisseaux salivaires: Ies. autres, silués ordinairentent près de l'anıs, sont destiués à sécréter le venin que les Hyménoptères. et les Scorpions répandent par leur aignillon; ces vaisseaux forment un systène particulier qui a reçu le nom d'appareil des sécrétions excrémentitielles. Les vaisseaux sécréleurs du venin affectent des formes très-variées dans les différens lnsectes et dans les Arachuides; en général ils sout composés d'un organe préparateur, d'un réservoir ou vessie, et d'un conduit excréteur : c'est ce conduit qui vient aboutir à l'aiguillon ou aux mandibules, percées dans ces cas, el qui répand une goutlelette de venin dans la plaie eu même temps que la pointe est introduite. Les mêmes nuscles qui font pénétrer l'aiguillon compriment en même temps la vésicule ou réservoir du venia, et font ainsi couler le poison dans la plaie.

Le venin des Insectes n'est mortel pour les animaux supérieurs que dans le cas où ils seroient piqués en même temps par un grand nombre de ces Insectes; hors ce cas, l'homme n'a pas à craindre pour sa vie; il peut lui arriver une enflure de la partie piquée, une inflammation douloureuse et quelques autres accidens du même genre, mais ils se dissipent au bout de deux ou trois jours an plus. Il n'en est pas de même à l'égard des Insectes, contre lesquels ce venin est destiné à agir; aussitôt qu'ils sont piqués, ils entrent dans des convulsions d'une dirée plus on moins grande, et finissent par mourir. La. piqû́re du Scorpion d'Europe a bicn fait périr des pigeons et des chiens, mais on n'a pas d'exemple qu'elle ait occasionué la mort d'animaux plus grunds. En Afrique, ils sont plus dangereux et d'une taille 


\section{E R}

plus grande, et l'action de leur venin est bien plus intense.

Ce seroit ici le cas de faire connoître les Arachnides et les Insectes qui sont pourvus d'une appareil venimeux, mais l'étendue de cet ouvrage ne nous le permet pas, et en outre il en a été question à l'article Insectes de ce Dictionnaire, et dans le Discours préliminaire. Du reste, un trouvera des détails assez étendus sur le venin des différens genres d'Arachnides et Insectes aux articles qui leur sont propres, el auxquels nous renvoyons. Voyez surtuut les mots Abeille, Araignée, Cuusin, Scolopendre et Scorpionides.

(E. G.)

VER A QUEUE DE RAT. Les anciens auteurs ont donné ce nom aux larves des Eristales. Elles vivent dans les eaux slagnantes et corrompues. Voyez Eristale, pag. 523. de ce volume.

(S. F. et A. Serv.)

VER A SOIE. Sous ce nom vulgaire, généralement reçu en France, Geoffroy (Ins. Par. tom. 2. pag. $116 . n^{\circ}$. 18.) désigne le Bombix à soie $\mathrm{n}^{\circ} .9^{8}$. de ce Dictionnaire.

$$
\text { (S. F. et A. SERv.) }
$$

VER BLANC. Les jardiniers français appellent de ce nom la larve da Hanneton vulgaire, et l'appliquent quelquefois aussi it celie de l'Oryctes masicorne. Voyez ces mols.

(S. F. et A. Serv.)

VER DE FARINE. Nom vulgaire par lequel on désigne la larve du Ténébrion de la tarne. Voyez 'T́É́terion. (S. F. et A. Serv.)

VER DE FROMAGE. On désigne vulgairement par celte expression des larves ayant ordinairement la faculté de sauler, et qui vivent aux dépens de différens fromages. Elles appartiennent ì diverses espèces de Mluscides.

(S. F. et A. Serv.)

VER DU VTNAIGRE. Nom trivial que l'on donne à la larve d'une petite espèce de Muscides décrite daus ce Dicionnaire sous le nom de Mouche des celliers no. 77. M. Latreille. (Gen. Crust. et Ins. tom. IV. pag. 357.) met cette espèce dans le grenre Mosillus. A sa citation de Linné et de Fibrivius lisez: Cellaris au lieu de Cellaria.

( S. F. et A. Serv.)

VER-LION. Nom donnć pas quelques anciens auteurs à la larve de la Leptis ver-lion. $V$. Leptis, pay. 28I. de ce volume. (S. F. et A. Serv.) -

VER LUISANT, Lampyris. Nom appliqué par Geolfroy (Ins. Par. tom. 1. pag. 165.) au geure Lampyre. Yoyca ce mot. (S. li. et A. Serv.)

VERDET. Par celte délromination triviale Geoffroy (Ins. Paris. tom. I. pag. 73. $n^{\circ} .5$. ) signale un Coléoptère. Pentamère du genre 'Trichie ( $T$. nobilis.) Voyez ce mot. Cet insecte est décrit dans le présent ouvrage sous le nom de

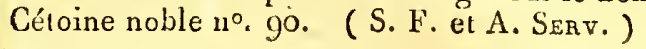

VERT DORE.. Geofiroy donue ce nom (Insec. Par. tom. 2. pag. 149. $2^{\circ}$. 81.) à la Noctuelle chrysite $n^{\circ} .276$ de ce Diclionnaire. Cette espèce doit entrer dans le genre Chrysoptère. I.ax. Fam. natur. (S. F. et A. SERv.)

\section{VERTEX, Veitex.}

On doune ce nom à la partie tout-à-fait supérieure ou verticale de la tête des Insectes; c'est sur le verlex que se trouvent ordinairemeut les pelits yeux lisses. (E. G.)

VERTUBLEU. Geoffroy appelle de ce nom deux espèces de Chrysomèles: l'une (grand Vertubleu. Ins. Par. tom. 1. pag. 260. no. 10.) est la Chrysomèle du Gramen no. 3o. de ce Dicionnaire; l'autre ( petit Vertublen Geoffroy, id. pag. 261. $77^{\circ} \cdot 12$.) doit être rapportée à la Chrysomèle fastueuse $n^{\circ} \cdot 71$. du présent ouvrage.

( S. F. ct $\Lambda$. SERv.)

VÉSICANS on EPISPASTIQUES. C'est le nonz. de la onzième famille des Coléoplères de $\mathrm{H}$. Duméril. ( Zool. analyt.) Elle apparlient aux Hétéromères et présente les caracières suivans : élytres molles, flexibles. Antennes très - variables. Elle se compose des genres Dasyte, Lagrie, Noloxe, Anthice, Meloé, Cautharide, Cérocome, Mylabre, Apale et Zonite.

$$
\text { (S. F. et A. Serv.) }
$$

VÉSTCULEUX, Vesiculosa. Onzième tribu de la famille des Tanystomes, première section de l'ordre des Diplères.

M. Latreille caractérise ainsi cette tribu :

Tête inclinée. - Corselet élevé. - Caillerons grands, recouvrant les balanciers. - Trompe nulle on dirigée postérieurement sous le corps dans le repos. - Antennes tantôt très-petites, de deux articles avec une soie terminale, tantôt de trois articles, le dernier sans soie ni style, alongé et cylindracé, on renflé en forme de bouton. Abdomen grand, renflé, vésiculeux.

I. Une trumpe très-apparente dirigée le long de la poitrine.

$$
\text { Panops, Cyrle. }
$$

II. Point de trompe apparen!e.

$$
\text { Astomelle, Acrocère, Ogcode. }
$$

CYRTE, Cyrtus. Lat. Mejg. Acrocerl. Mä. Empis. 1)EVILL. 
Genre d'insectes de l'ordre des Diptères, première section, famille des 'lanystomes, rribu des Vésiculeux.

Les Vésiculeux munis d'une troinpe apparente sont les Panops el les Cyrtes. Les premiers ont les antennes plus longues que la têle, de trois articles, le dernier alongé, cylindrique, sans soie.

Antennes très-petites, presque verticales, insérées sur le haut du front, presque sur le vertex, composées de deux articles; le premier cyliadrique, le second ovale avec une longue soie terminale. - Trompe avancée horizontalement dans l'action, dirigée le long de la poitrine lors du repos, plus longue que la tête. - Palpes subulés, insérés à la base de la trompe. - Téte pencliée, très-pelite, globuleuse. - Yeux grands, occupant presque tonte la tête, réunis l'un à l'autre dans toute la partie antérieure. - Trois ocelles disposés en triangle sur le vertex. - Corps gros, court, glabre. - Corselet court, gros, très-élevé. - Ailes lancéolées, sans poils, vues même au microscope. - Cuillerons yrands, convexes. - Balanciers petits, cachés. - Abdomen très-grand, très-distendu, vésiculeux, composé de quatre segmens outre l'anus. - Pattes minces, assez longues; premier article des tarses presqu'aussi long que les quatre autres pris ensemble, le dernier ayant ì son extrémité deux crochets très-divergens, munis dans leur entre-deux de trois petites pelotes.

Le nom de Cyrte vient d'un mot grec qui signifie : bossu. L'espèce qui sert de type à ce genre est le Cyrte bossu, C. gibbus. Meig. Dipt. d’ Eur. tom. 3. pag. 92. no. 1. tab. 24. fig. 3. et 4. Cyrtus acephalus. Lis. Gener. Crust. et linsect. tom. 4. pag. 317. - Acrocera gibba no. 1. FAB. Syst. Antliat. - Encycl. pl. 3g2. fig. 3g. et 40. Il habite en Barbarie, dans les environs de Lyou, dans l'Angoumois et en Anjou, où il a été pris par M. Carcel dans la Forêt de Fontevrault.

ASTOMELLE, Astomella. Dur. Lat.

Genre d'insectes de l'ordie des Diptères, première section, famille des Tanystomes, tribu des Vésiculeux.

La seconde division de cette tribu renferme les genies qui n'ont point de trompe appareute, c'est-à-dire Astomelle, Acrocère et Ogcode; les deux derniers diffèrent des Asiowelles par leurs antennes courtes, n'ayant que deux articles dont le deruier est muni d'un style on d'une soie.

Ne connoissant ce genre que par une remarque qui se trouve dans le Gener. Crust. et Insect. de M. Latreille, tom. 4. pag. 5rg., et par le peu qu'il en a publié dans ses Consid. génér. sur les Crust., les Arachn. et les Ins. pag. 3g3., nous ne pouvons iudiquer que le caractère tiré des antennes et de la trompe.

Antennes de la longueur de la tête au moins, composées de trois articles; le dernier presqu'en boulon alongé, couprimé, saus soic. - Point de trompe apparente.

Le nom d'Astomelle est formé d'un mot grec qui signifie bouche, et de la particule privative. Le type du genre dont nous ne connoissons pas la description est l'Astomelle bordée, $A$. marginata. L. Dufour. Elle a été trouvée en Espagne.

ACR OCÈ E, Acrocera. Meig. MAcQ. LAt. Henops. Fab. Fallèn. Syrphus. Panz.

Genre d'insectes de l'ordı'e des Diptères, piemière section, famille des Tanystomes, tribu des Vésiculeux.

Les genres Astomelle, Acrocère et Orcode composent la seconde division de cette tribu; celle division a pour caractère : point de trompe apparente. Les Astomelles sont distinguées par leurs antennes de la longueur de la tête au moins, de trois articles, le dernier saus soie; celles des Ogcodes sont insérées au-devaut de la tête, un peu au-dessus de la bouche.

Antennes très-petites, insérées sur le vertex, composées de deux arlicles, le premier orbiculaire, le second fusiforme avec une longase soie terminale, nue. - Point de trompe distincte. Téte petite, ovale, pencliée. - $Y$ eux grands, occupant presque toute la tête, à peine séparés l'un de l'autre en devant par une suture. - Trois ocelles placćs sur le vertex. - Corps gros et court. Corselet beaucoup plus large que la lête, gros, élevé. - Ailes lancéolées, couchées en toit sur le corps dans le repos, sans poils vues même au microscope. - Cuillerons grands, convexes. Balanciers petits, point apparens. - Abdomen gros, sphérique, vésiculeux, composé de quatre segmens outre l'anus. - Pattes de longuetr moyenne, grêles; premier article des tarses aussi long que les quatre autres pris ensemble; le dernier muni de denx crochets ayant trois pelotes dans lenr entre-deux.

Le nom d'Acrocère formé de deux mots grecs qui signitient : antennes et vertex, est tiré de la position des premières sur la partie supérieure-de la tête. On trouve ces Diptères sur les tleurs, mais leurs larves ne sont pas connues. M. Meigen en décrit cinq espèces dans ses Diptères d'Europe.

Le genre Acrocera Fа. (Syst. Antliat.) n'est point celui dont nous traitons ici, il équivaut a celui de Cyrte Lat. Celui d'Henops, du mêne auteur, contient deux espèces dont la première est du genre Ogcode. Encycl. (Henops. MEIG.) La seconde est une Acrocère Mrig.

${ }^{\circ}$. Acrocère sanguine, $A$. sanguinea. Lat. Gener. Crust. et Ins. tom. 4. pag. 3 I8. - MeIg. Dipt. d'Europ. tom. 3. pag. 94. n०. 1. tab. 24. fg. 9. ( Par une erreur typographique on lit tig. 10. a la citation de la plancie.) - Encycl. pl. 387. fg. 55-58. 20. Acrocère cuisses noires, $A$. 
nigro femorata. MEIG; id. pag. $9^{5} \cdot n^{0} \cdot 2 . t a b .24$. fog. 10. Longueur 2 lig. Noire; abdomen testacé ayant sur le dos des points noirs triangulaires placés un sur chaque segment en ligne longitudinale; patles rousses, cuisses noires. D'Anjou. 3०. Acrocère globule, $A$. globulus. Meig. id. $n^{\circ} .3$. - Lat. id. $4^{\circ}$. Acrocère albipède, $A$. albipes. ME1G. $i d$. pag. $96 . n^{\circ}$. 4. De France. 5०. Acrocère sphérique, $A$. orbiculus. Meig. id. pag. 97. $n^{\circ}$. 5. - M.ce. Ins. Dipt. Asiliq. etc. pag. gi. $n^{\circ}$. 1. - Henops orbiculus ${ }^{\circ}$. 2. l'Ав. Syst. Antl. De France. (S. F. et A. SEnv.)

VÉSI'TARSES ou PHYSAPODES. M. Duméril donne ce nom, daus la Zoologie analytique, à une famille d'Héniptères présentant pour caractères : élytres planes, étroites, couchées sur le dos. Paltes courtes. 'Tarses termivés par une petite vessie. Elle ue contient que le genre Thrips.

$$
\text { (S. F. et A. SERV.) }
$$

VIPION , Vipio. LAT. ( Hist. nat. des Crust. at des Ins. et Fuוn. nat.) Bracon. Lat. (Gen.) JuR. FAB.

Geure d'insectes de l'ordre des Hyménoptères, section des'Térébrans, famille des'Térébellifères, tribu des luhnenmónides (division des Braconides ).

Les Bracons et les Microgastres composent, avec les Vipions, la troisième suludivision de nos Bracorides. (Vojez Ichneumonides, pag. 43. de ce volune, ainsi que la note en bas de la page 488.) Celle troisième subdivision ayant pour caractères : palpes maxillaires au moins trois fois plus longrs que les labiaux, de six apticles, les labiaux de trois: première cellule discoïdale supérieure des premières ailes, distincte de la première cellule cubitale. Les deux premiers genres se distinguent de celui de Vipion, en ce que leurs autclioires et leur lèvre sout courles, cachées, point prolongées en museau; en outre les Microgastres ont le second article cies an ieuncs entièrement retiré dans le prenier.

Mâchoires et lèvre avancées en tune sorte de musein. - Ailes supérieures ayant une cellule radiale assez yrande, pointue à ses deux extrémités; trois cellules cubitales, la première petite, recevaul la première nervure récurrente; la seconde collule cubitale deux tois plus longue que lâ prúcédente, termiucée curróment; troisième cubitale atteignant le bout de l'aile : trois cellules discoödales, la première distincte de la prenic̀re cubitale; la troisième on inférieure atteigruant le bord postérienr de l'aile; point de seconde nervure récurente. Yoyez pour les autres caracrères ceux du genre Bracon, pag. 39. de ce volume.

Les mœurs des Vipions sont aussi les mêmes que celles des Bracons. Les insectes parfaits fréquentent les fleurs et y prenneut leur nonrituxe;. on les trouve plus particulièrement sur celles des chardons. Nous citerons les deux espèces suivantes :

10. Vipion nominaleur, $V$. nominator. - Bra= con nominator. no. 8. Far. Syst. Piez. La femelle. - Jur. Hyménopt. pag. 110. La femelle. Sa tarière est deux fois aussi longue que le corps. Le mâle ne diffère pas pour les couleurs. Des environs de Paris. ${ }^{\circ}$. Vipion minateur, $V$. urinator. - Bracon urinator. no ${ }^{\circ}$ 34. FAB. id. Mlâle. Jun. id. Mâle et femelle. Celle - ci est semblable a u mâle; sa tarière est à peu près de la longuenz du corps. Des environs de Paris.

$$
\text { (S. F. ct A. SERV.) }
$$

VOLANT DORÉ. La Phalène $n^{\circ} \cdot 97$. GEOFF, (Ins. Paris. tom. 2. pag. 159.) porte ce nom valgaire. C'est la Noctuelle de l'Arroche $1^{\circ} .347$. du présent ouvrage. ( S. F. et A. SERv.)

VOIUCCELLE, Voluccella. FaB. Geofhroy avoit étalsli un genre sous le nom de Volucelle: Fabricius appliqua ce nom générique à d'autres espèces de Diptères que celles indiquées par l'auteur francais, et le dénaturant de manière à lni ôter son étymologie, réunit sous celni de Tohnccella six espèces, dont les nos. 1, 2, 3, 4. appartiennenı aux Usies, et les nos. 5. 6. aux Pthiries. (S. F. et A. SERV.)

VOLUCELLE, Volucella. Geoff. Scraff. LAt Meig. Schranck. (Faun. Boica) Musca. Lins. Geoff. Sceranck. (Enum. Austr.) Devild. DE Géer. Ross. Uliv. (Encycl.) Conops. Scopol. Syrphus. Fab. Ross. l'anz. Schell, Fazzìn. Herbst.

Genre d"insectes de Fordre des Diplères, première section, famille des. Athéricères, tribu des Syrphies.

Le caractère de la seconde division de celle tribu est : antennes presque de la longueur de la tête ou plus courtes qu'elle. (Voj'ez SYrphies.) Dans celte division le groupe où nous plaçons les gcrires Séricomyie et Volucelle est caractérisé ainsi : antennes ayant leurs deux premiers articles égaux entr'eux, point insérées sur un tubercule frontal; ailes sans cellule pédiforme ; cuisses simples; soie des antennes sans articulations sensibles, celte soie plumense. Jes Séricomyies sont dislinguées des Volucelles par le troisième article de leurs antennes formant une palette presqu'orbiculaire et par leurs ailes parallèles dans le repos. Nous ajouterons à ce groupe le genre Temnocère, qui nons ćtoil inconnu lors de la rédaction. de notre article Syrphies; il diffère des Séricomyies et des Volucelles par l'ćcusson armé d'épines et par le troisième article des amennes beancoup plus long et fortement écliancré latésalement. 
Antennes avancées, penchées, point insérées sur ua tubercule frontal, plus courtes que la tête, composées de trois articles; les deux premiers petits, égaux entr'eux; le troisième oblong, patelliforme, comprimé, portant à sa base une soie pendante, fortement bipennée, plus grande dans les femelles que dans les mâles. - Ouverture de la cavité buccale oblongue, étroite. - Trompe beaucoup plus courte que la tête et le corselet pris ensemble, carhée dans la cavité buccale pendant le repos. - Palpes cylindrique, finement ciliés. - Hypostome un peu enfoncé à sa partie supérieur'e, s'alongeant en forme de cône à l'inférieure; fiont élevé et formant un bourrelet autour de l'insêtion des antennes. - Téte hémisphérique, au moins de la largeur du corselet, un peu comprimée par devant. - Yeux grands, réunis sur le haut du fiont dans les mâles, espacés dans les femelles. - Trois ocelles disposés en triangle sur Je vertex. - Corps de forme variable. - Corselet plus ou moins bombé.-Ecusson grand, oblong, arrondi postérieurement, comme crénelé le long du bord postérieur qui porte de très-petits tubercrles et des poils assez roides. - Abdomen de forme variable, composé de quatre segmens outre l'anus, celui-ci petit, presque caché dans les individus desséchés. - Ailes lancéolées, velues vues au microscope, écartées dans le repos, sans cellule pédiforme. - Cuillerons donbles, grancis, frangés sur leurs bords. - Balanciers cachés. Pattes assez fortes; cuisses simples; jambes postérieures arquées; tarses de longueur moyenne, leur premier article au moins aussi long que les trois suivans pris ensemble, le cinquième nuai à son extrémité de deux forts crochets très-écartés, ayant une forte pelote bifide dans leur entredeux.

Le nom de Volucelle créé par Geoffroy est tiré d'un mot latin, et il exprime très - bien l'agilité de ces Diptères. Les larves des Volucelles proprement dites, ou européennes, habiient dans le nid des Bourdons et des Guêpes. Réaumur eut occasion d'observer, près de passer à l'élaî de nymphes, celles qui vivent aux dépens des premiers; elles sont apodes, presqu'en forme de cône dont la tête fait le sommet, celle-ci paroît armée extérieurement de deux cornes cliarnues assez courtes qui se toucheut à leur origine et s'écartent ensuite. A cetle même partie on observe une fente d'où sortent deux crochets écailleux qu'on pourroit appeler des mandibules, et dont le bout est large et refendu; le second segment du corps porte de chaque côté, près de sa jonction avec le troisième, un stigmate pen distinct; l'extrémilé postérieure da corps, qui est la plus grosse et comme arrondie, est munie d'une espéce de plaque en demi-cercle dont la circonférence émet six rayons charnus, coniques, divergens; an centre de ce demi-cercle sont placés deux tuyaux adossés l'un contre l'antre, qui sunt des stignates et servent à la respiration; la partie inférieure da corps de cette larve, celle sur laquelle elle exirute les mouvemens de locomation, est séparie de la supérieure par deux rangs de petiles épines: il est probable que ces larves, ainsi que beaucoup d'autres des genres voisins, se font une coque de leur propre peau sans subir de mélamorphose exlérienre pour se cbanger en nymphes. Réaumul ne put parvenir à les avoir dans ce dernier état, mais cet observateur eut une femelle de la Volucelle à zones, qui pondit des wufs blancs et oblongs, desquels sortirent des larves absolument semblables at celles que nous venons de décrire d'après lui; il crut même à leur identité d'espèces, opinion que nous ne partageons pas. D'après nos observations, les larves des Volucelles à zones et vide vivent dans le nid et aux dépeus des larves et des nymplies de la Gaêpe Frélon. Les Volucelles Buardon et plumeuse déposent leurs œufs daus les nids de Bonrdons où Réaumur a vu exercer à leurs larves de très-grands ravages. Lit mavière de-vivre deslarves des Vulucelles trun:parente et enflée n'est pas connue.

L'un de nous communiqua l'aunée dernière, à l'Acadénie des sciences, une notice renfermant quelques iemarques sur les espèces de ce genre; il fit observer l'affuité binare qui se trouve entre elles, allinité qui est justifiée non-senlement par la forme et le plus ou le moius de villosité du corps, mais aussi par la manière de vivre des larves que nous venons de citer : il remarqua que de légères différences de coulenrs autorisoient seulement la formation de trois espèces au lieu des six reconnues par les auteurs, et notamnent par M. Meigen; il mit sous les yeux de l'Académie des accouplemens entre les Volucelles Bourdou et pluneuse, où les deux sexes de ces espéces jonoieut un rôle inverse dans cette action. Una individu ressemblant pour les couleurs de la parlie anlérieure du corps à la Volucelle plumeuse, et pour les derniers segmens de l'abdomen à lá Volucelle Bourdon, paroissoit prouver la fécondité de ces accouplemens; il citoit diverses figures de Schælïer (Icon.) qui a représenté quelques autres variétés : il communiqua ausssi plusieurs individus intermédiaires par leur's couleurs entre la Volucelle transparente et la Volucelle enfíée, et entre les Volucelles à zones et vide.

Cependant il est beaucoup plus ordinaire de rencontrer fréquemment des accouplemens formés par des individus semblables. Au moment de la copulation qui suit de près celui de l'apparition de l'insecte parfait, les Volucelles se rassemblent en grand nombre, ou pour mienx dire il paroît que le même lieu eu a va éclcre une très-grande quantité à la fois. On peut observer des Eylantiers en fleur chargés de Volucelles, et autour desquels en même lemps beaucoup d'ind ${ }_{-}$vidus voltigent et planent; un peu d'attention fera remarque:des accouplemens, et ordinairement ils 


\section{$\mathrm{VOL}$}

seront formés entre individus de même couleur mais on $\mathrm{y}$ verra toujour's un nombre à peu près égal de Volucelles Bourdon et plumeuse, et quelquefois ces deux espèces s'accoupleront l'une avec l'autre. L'époqne de la floraison de l'Errlantier indique celle de ces unions. Les Volucelles à zones et vide s'accouplent en automne et paroissent en même temps; c'cst à la fin d'avril que se montrent ensemble les Volucelles transparente et enflée. Ces renseignemens pourront mettre les entomologistes à même d'observer de nouveau ces faits; en attendant, nous nous conformerons à la manière de voir des auteur's qui nous ont précédés, quoique la nôtre y soit tout-àfait opposée par rapport à la distinction des espèces.

Nous allous diviser ce genre d'après des considérations tirées de la seconde cellule marginale des ailes, ainsi que de la forme et de la couleur dn corps. On remarquera que les Volucelles étrangères à l'Europe diffèrenı des indigènes d'une manière très-prononcée.

re. Division. Seconde cellule marginale des ailes saus dilatation sensible à sun extréraité. Yeux velus dans les mâles seulement. (Corps point métallique; espèces européennes; Volucella propriè dicta. Nов.)

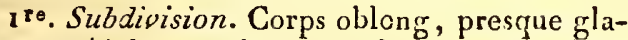
bre. - Abdomen àlongé-ovale, peu convexe. (Larvcs vivant aux dépens de celles de la Guêpe i'r'ćlon.)

A cet te subdivision appartiennent, $\mathrm{I}^{\circ}$. Volucelle à zones, $V$. zonaria. MeIG. Dipt. d'Eutr. tom. 3. p. 416. $n^{\circ}$. 5. tab. 32. fig. 27. Mầle. - Syrphus inanis $\mathrm{n}^{\circ}$. I. FAB. Syst. Antliat. (En retrauchant tuus les synonymes, sauf celui du Syst. nat. Lirn n., celui de Geoffiroy appartient au Nemotelus pantherinus. Mâle. MEIG. $i d$. pag. I 15. $n^{\circ} .2$; celui de la Faun. Suec. Linn., aınsi que ceux de la Mantiss. LA A. en lisant Ins. I. au lieu de Ins. 2., de De Géer, de Scheffér et de Panzer, se rapportent à la Volucelle vide.) - La Mouche à zones. Georr. Ins. Par. tom. 2. pag. 504. $n^{\circ} .23$. Longueur 8 lig. 'Tête et corseiet d'un jaune-testacé brillant ; abdomen d'un beau jaune, le bord inférieur des deux premiers segmens noir et formant deux bande transverses assez larges. Mâle et femelle. Commune aux eavirons de Paris ver's la fin d'août dans les endroits voisins du nid de la Guêpe Frélon. (V.Crabro.) $2^{\circ}$. Volucelle vide, $V$. inanis. MeIG. id. pag. 407. $n^{\circ}$. 6. $-S_{\text {r rpplius }}$ micans no. 2. Fав. id. Longueur 6 lig. T'ête et corselet d'un jaune terne, celui-ci portant sur son disque supérieur quatre lignes longitudinales noires dont les intérieures se tonchent presque; abdomen jaune terne; bord inférieur du premier, du second et du troisième segmens, noir et formant trois bandes transverses moins larges que Hist. Nat. Ins. Tome $X$. dans la précédente. Mâle et femelle. On la trouve dans les mêres lieux et à la même ćpoque que lia Volucelle à zones.

Nota. Dans la description du Syrphe vide da Nouv. Dictionn. d'hist. nat. $1^{\mathrm{re}}$. édit. MI. Latreille a certainement eu en vue les deux Volucelles cidessus. L'insecte décrit dans l'Eucyclopédie sous le nom de Mouche vide $\mathrm{n}^{\circ}$. 1. est le Nemotelus pantherinus. Mâle. Merg. Dipt. d’Eur. pağ. 115. $n^{\circ}$. 2. La variété b. indiquée à la suite de la description, est la Volucelle vide que nous venons de mentionner. Les synony mes rapportés dans ce mêne article s'appliquent à différentes espèces : ceux de Fab. Spec. Fab. Mantiss. Linn. Fauns. Suec.Gamel. Syst, nat. De Géer. Sch erfr.Schrancer. $n^{\circ} .919$. Scopol. $n^{\circ} .933$. ( lisez 953 .) appartiennent à la Volucelle vide. Ceux de Linn. Syst. nat. Scopor. $n^{0}$. 954. (lisez 952.) SchaAnck $n^{0} .921$. RÉaum. Harris. fig. 2. (lisez fig. 4.) se rapportent à la Volucelle à zones. Le synonyme de Geoffroy s'applique au Nemotelus pantherinus. Mâle. Meig. Celui de Poda est doutenx.

Nous avons un individu intermédiaire entre les Volucelles à zones et vide; nous le décrirons ainsi : tête et corselet d'un jaune-testacé brillanı; celui-ci ayant sur son disque supérieur quatre lignes longitudinates noires dont les intérieures se touchent en yrande parlie; abdomen d'un bean janne, le bord inférieur des deux premiers segmens noir et formant deux bandes transverses. Femelle. Des environs de Paris.

$2^{\mathrm{e}}$. Subdivision. Corps court. - Abdomen presque globuleux, très-bombé.

\section{A. Corps presque glabre.}

Nous plaçons ici : $\mathrm{x}^{\circ}$. Volucelle transparente, $V$. pellucens. La t. Gen. Crust. et Ins. tom.IV.pag. 322. - Merg. Dipt. d'Eur. tom. 3. p. 404. $n^{\circ}$.3. Syrphus pellucens n$^{\circ}$. 3. FAB. Syst. Antliat. (A la citalion d'Harris lisez : fig. 2. au lieu de fig. 4.) - Mouche transparente no. 3. Encycl. (A la citation de Fab. Mantiss. lisez: Ins. I. al lieu d'Ins. 2.; à celle de Graéliin lisez : 2833. au lieu de 2865.; à celle d'Harris lisez: tab. 10. fig. 2. an lieu de tab. 20. fig. 4.; à celle de Sulzer liscz: 133. au lieu de 33.) Longneur 6 ligr. Noire; tête, écusson et côtés du corselet d'un jaune-testacé ; premier segment de l'abdomen blanc, transparent, coupé au milieu par une ligne noire longitndiaale dans le mâle. Mâle et femelle. Commune anx environs de Paris, surtout en avril et mai. $2^{\circ}$. Volucelle entlée, $\nu$. inflata. Meig. id. pag. 405. $n^{0}$. 4.tab. 32. fig. 28. Femelle. - Syrphus influtus no. $^{\circ}$. $F_{A B}$. $i d$. Longueur 4 lig. $\frac{1}{2}$. Tềle, corselet et premier segment de l'abdomen d'un jaune - testacé; disque du corselet portant une grande tache carrée noire. On voit une ligne noire longitudinale sur le milieu du premier segment de l'abdornen plus prononcće dans le mâle ; le reste de l'abdomen 
est noir. On la trouve dans les mêmes endroits et ¿ la même époque que la précédente.

Il existe dans la collection de M. Carcel une Volucelle qui a beaucoup de rapports avec les deux précédentes : elle a la tête et le corselet plus bruns que dans la Volucelle enflée, le disque supérieur du deruier très-noir; le premier segment de l'abdomen est lurun, les derniers ont quelques poils courts, roux. Ces dermiers caractères paroissent la rapprocher de la Volucelle Bourdon; il y a un jeu cie transparence sur les côtés du premier segment de l'abdomen comme dans la Voluce!le enflée. Trouvée en Anjou.

\section{B. Corps velu. (Larves vivant aux dépens de celles des Bourdons. )}

Ce groupe contient: $1^{\circ}$. Volucelle Bourdon, I. bombylans. Lar. Gen. Crust. et Ins. tom. IV. pag. 322. - Syrphus bombylans. Lat. Nouveau Diction. d'hist. nat. r $^{\text {ro }}$ édit. (En citant Linné, le célèbre auteur français auroit dû désigner l'ouvrage dont il vouloit par'er, la Volucelle décrite dans la Faun. Suec. sous le nom de Musca bombylans. 1792., étant différente de celle dont la phrase se trouve dans le Syst, nat. p. 983. $n^{\circ} .25$. Nous aurions aussi désiré savoir si en citant la IMusca mystacea Linn. comme mâle de la Volucelle Boul'don. Nouv. Dict. d'hist. nat. $2^{\mathrm{e}}$. édit., il entend parler de la Musca mystacea. Livn. Syst. nat. et Faun. Suec. $n^{\circ} \cdot 1795$., qui est la Mesembrina mistacea Mrig.; ou bien de la variété mentionnée dans la Faun. Suec., 1793. b., comme fernelle de la précédente, et qui est une variété de la Volucelle plumeuse. A ce même article de la Volucelle Bourdon, Dict. d'hist. nat. $2^{\mathrm{e}}$ édit., on ne précise point non plus l'ouvrage de Linné duquel on cite la Musca bombylans, et l'on attribue le sexe masculin exclusivement à la Mrtsca mystacea Linv., et le féminin à la Musca bombylans sans aucune espèce de motifs, car on trouve autant de mâles que de femelles auxquels conviennent les descriptions de ces deux espèces prétendues.)-Volucella bombyluns. Meic. Dipt. d'Eur. tom. 3. pag. 402. no. 1. (En retranchant le synonyme de la Faun. Suec. Linn. qui appartient à la première variété mentionnée à la fin du présent article.) Longueur 6 lig. Noire; tête jaune; moitié postérieure de l'abdomen couverte de poils roux. Mâle et femelle. Très-commune anx environs de Paris dans les mois de mai et de juin. $2^{\circ}$. Volucelle plumeuse, $V$. plumata. Meig. $i d$. pag. $403 . n^{\circ}$. 2. -Volucella mystacea. LA T. Gen. Crust. et Ins. tom. 4. pag. 322. - Syrphus mystaceus $11^{\circ}$. 5. FAB. $i d$. (En retranchant les synonymes de De Géer, du Syst. nat. Lins. qui appartiennent à la Mesembrina mystacea MeIG., ainsi que celui de la Faun. Suec. Lins. $n^{\circ}$. 1793., sauf la variété b. qui est une variété de la Volucelle plumeuse.) Longuear $6 \mathrm{lig}$. Noire ; tête jaune; dessas du corselet à l'exceplion de son dis- que, écusson et côtés du premier segment de l'abdomen ayant des poils jaunes; moitié prostérieure de l'abdomen chargée de poils blancs. Mâle et femelle. Mêrnes localités et même saison que la précédente.

Divers individus se rapprochent plus ou moins d'une de ces Volucelles, ou mêue des deux. Dans ce dernier cas est la Musca bombylans, Linn. Faun. Suei. 1792., décrite ainsi : noire, corselet velu, jaune ainsi que la base de l'abdomen, l'extrémité en dessus chargée de poils fauves. Mâle et femelle. Elle est assez rare aux environs de Paris; on l'a prise dernièrement en Normandie mêlée avec les deux Volucelles précédentes.

D'autres individus tels que ceux décrits par Fabricius (Entom. Syst.) sous le nom de Syrphus mystaceus ont seulement les poils du corselet jaunes ainsi que ceux de l'extrénité de l'abdomen; les poils de la base de ce dernier, sont noirs. Quelques individus, fort rapproclés de ces derniers, ont en ontre des poils jaunes à la base de l'abdomen. On pourra voir une partie de ces variétés dans Schæffer, Icon. $t a b . X$.

2e. Division. Seconde cellule marginale deз ailes très-dilatée à son extrénnité. - Yeux velus; cette villosité plus apparente dans les mâles. (Corp? métallique; espèces exoliques; Ornidia Noв.)

Nous prenons pour type de cette division la Volncelle gonflée, $V$. obesa. - Syrphus obesus no. 14. FA B. Syst. Antliat. Femelle. Cette espèce, que Fabricius indique comme étant des îles de l'Amérique, nous paroît s'ćtendre, d'après les individus que nous avons sons les yeux, à tous les climats chauds de l'Amérique et de l'Asie, et même se trouver à l'Ile-de-France. Le mâle que nous lui rapportons a tout le disque du premier segment abdominal en dessus, voirâtre et comme velouté. Nous croyons encore pouvoir rapporter à cetie division le Syrphus vesiculosus $\mathbf{n}^{\circ} .11$. Fab. id. De l'Amérique méridionale.

Le genre Syrphus FAB. Syst. Antliat. équivant à peu près à celui-ci et renferme quatorze espèces. Nous avons cité plus haut celles qui lui appartiennent réellement. Les nos. 6 . et 7 . sont des Séricomyies (voyez ce mot); le no. 12. un Eristale; les nos. 9. 10.13. ne nous sont pas conuus.

\section{TEMNOCERE, Temnocera.}

Genre d'insectes de l'ordre des Diptères, première section, familie des Alhéricères, tribu des Syrplies.

Ce nouveau gen re, que nons connoissons seulement depuis peu, entre dans un groupe de la tribu des Syrphies où nous n'avions placé précédemment que les Séricomyies et les Volucelles. (Voyez Syrphins.) Ces deux derniers genres diffćrent des Temnocères par le troisieme article des antennes beaucoup moins long, entier, et en onire par leur écusson dépourvu d'épines. 


\section{R I}

Antennes ayant leur troisième article très-long, un peu comprimé, échancré avant son milieu et fort rétréci dans cette partie, un pea plus épais et presqu'en massue à son extrénité, mumi d'une soie droite, un peu bipennée vers la base, nue à l'extrémité. - Hypostome droit, à peiue creusé. - Ecusson armé d'épines au bord postérieur. Les autres caractères sont ceux des Volucelles. ( $V o y$. ce mot.) Les nervures des ailes sont exactement conformées comme celles de la première division de ce genre.

Il nous paroît que les caractères énoncés justifient suffisamment l'introduction de ce genre nouveau dont nous tirons le nom de deux mots grecs qui signifient : antennes entaillées. T'espèce qui nous sert de type est probablement nouvelle.

\section{Tempocire violâtre, T. violacea.}

Temnocera nigro-fusca; hypostornate antennisque pallidè luteo-rufis; scutello fusco-testaceo, spinis utrinquè tribus; abdomine fusco-violacente; alis hyalinis, costầ à basi ad medium et fasciâa mediâ, trunsversâa , repandâ, abbreviatâ, fuscis.

Longueur 5 lignes. Noire, luisante. Hypostome d'un jaune pâle. Yeux velus. Antennes testacées. Écusson d'un brun-testacé, armé de six épines, trois de chaque côté. Abdomen d'un brun-noirître à reflet violet; pattes noirûtres; corps muni de poils truns. Ailes transparentes, leur côle et quelques nervures de leur partie supérieure assez forlement rembrunies. On voit une bande Iransversale, ondulée, partant du milieu de la côte, et qui s'avance vers le centre de l'aile en s'aumincissant. Mâle. De la Chiue.

$$
\text { (S. F. et A. SERt. ) }
$$

VRILLETTE, Anobium. Fab. Oliv. (Entom.) Panz. Payk. Gyllen. Schen. Lat. Ptinus. Linn. De Géer. Byrrhus. Geoff.

Genre d'insectes de l'ordre des Coléoptères, section des Pentamères, famille des Serricornes (division des Malacodermes), tribu des P'tiniores.

Les Dorcatomes forment avec les Vrillettes dans cetle tribu un groupe caractérisé par les antennes terminées bruscjnement pir irois aricles plus grands que les ilutres (poyez Priniores), et ils se distinguent de ces dernieres par leur corps hémisphérique-orlsiculaire et leurs antennes composées de neuf articles seulement.

Antennes assez longues, filiformes, insérées près des yeux, écartées l'une de l'aulre à leur base, composées de onze articles; les trois derniers très-alongés, écartés, épais ; les neuvième et dixième obconiques, le onzième ovale. - Labre corné, assez large, un peu avancé, arrondi ou légèrement éclancré antérieu:ement. - Mandibudes couries, cornées, très-dures, terminées par

\section{R I}

trois dents aiguës. - Mâchoires courtes, presque cylindriques, membraneuses et bifides à leur extrémité, leurs lobes égaux, arrondis. - Palpes maxillaires filiformes, un peu plus longs que les labiaux, composés de quatre articles; les deux premiers petits, les autres un peu plus gros, presqu'éganx entr'eux : palpes labiaux courts, de trois arlicles, le dernier un peu plus gros que les autres. - Languette inembraneuse, presque bifide, ses divisions arrondies, égales. - Téte enfoncée dans le corselet. - Yeux arrondis, saillans. - Corps alongé, presque cylindrique, arrondi antérieurement et à sa partie postérieure.-Corselet court, bombé, rebordé latéralenient. - Ecusson petit, arrondi postérieurement. - Elytres convexes, un peu rebordées, ordinarrement de la longueur de l'abdomen, le recouvrant ainsi que les ailes. Pattes de longueur moyenne; jambes et cuisses simples; tarses filiformes, leur prenier article long, les autres courts, un peu aplatis, presqu'en cœur, le dernier un peu renflé au bout, muni de deux crochets.

Geoffroy fonda ce genre et lui donna en latin le uom de Byrrhus, que Limné appliqua depuis à un autre genre de Coléoptères. L'auteur suédois donna aux Vrilletles et aux Ptines, qu'il confondoit dans un neême genre, le nom de Ptinus. Fabricius sépara ensuite les Ptines des Vrillettes, mais au lieu de rendre à celles-ci le nom que leur avoit assigné Geoffroy, il leur donna celui d'Anobium, qui paroît tiré du grec et signifier ressuscité. Il a rapport à la faculté qu'ont ces Coléoptères de paroitre morts en se contractant dans le danger, et de reprendre ensuite la vie et le mouvement. Leur nom français de Vrillette vient de ce que les larves en rongeant le bois y forment de petits trous cylindriques; ce bois leur sert de nourriture, et quelque sec qu'il soit, il suffit à ces larves pour leur accroissement. Les vieux meubles finissent par tomber totalement en poussière lorsqne ces larves y sont en grand nombre. L'insecte parfait paroît ordinairement vers le printemps et cherche à s'accoupler; on croit que c'est pour amener la réunion des sexes quil a reçu la faculté de produire un petit bruit que l'on entend tròs-sonvent lorsque l'on est couché dans des alcoves formées de cloisous de planches, mais on n'est pas entièrement d'accord sur les moyens employés par l'insecte pour produire ce bruit; les uns prétendent que c'est en rungeant le bois, d'autres assurent que c'est en le frappant avec les mandibules. Après l'accouplement la femelle pond ses oufs dans les fentes du bois. La larve est petite, blanche, nolle, alongée; elle a six pattes courles; la tête écailleuse, est munie de deux mandibules en forme de pinces fortes et tranchantes; elle ronge le bois, et après en avoir tiré la substance, elle le rend en petits grains très-fins; lorsqu'elle est prête à subir sa mélamorphose, elle se rapproche de la superficie du

$$
\mathrm{G}_{\mathrm{g}} \mathrm{ggg} 2
$$




\section{8}

bois, de sorte que l'insecte parfait, ponr sortir, n'a qu'une cloison mince, facile à percer. Une espèce se nourrit de substances moins dures, elle attaque le pain, la farine et la colle. Ces insectes sont d'assez petite taille et affectent des couleurs sombres.

Dans le Syst. Eleut. de Fabricius, le genre Anobium contient quinze espèces. Les nos. 3. 7 . 14. appartiennent au genre Cis Lat.; ce qui est probable aussi du n ${ }^{\circ}$. I 5 . suivant M. Schœnherr. Les $\mathbf{a}^{\mathrm{c}}$. I 2. et 13. sont fort douteux. Les autres numéros sont rapportés par !es auteur's au genre Vrillette.

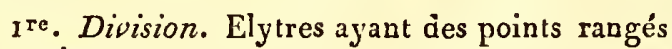
en stries.

Io. Vrillette striée, A. striatunı. Lat. Gener. Crust. et Ins. tom. 3. pag. 276. $n^{\circ}$.3. - GriL. Ins. Suec. tom. 1.p. $291.77^{\circ}$. 4.-Anobium pertinax no.6. FAB. Syst. Eleut. (En retranchant les synonymes de Linné et de De Géer, qui appartieunent à l'espèce suivante.) - ScrøN. Syn. Ins. tom. 2. pag. I 13. $n^{\circ} .7$. Commune aux environs de Paris. $2^{\circ}$. Vrillette opiniâtre, $A$. pertinax. Orıv. Entom. tom. 2. Vrillet. pag. 6. $n^{\circ}$. 2. pl. 1. fig. 4 . -GyLr. id.pag. 288. $n^{\circ}$. 1.-Anobium striatum no. 2. Fab. id. (A la citation d'Olivier, lisez 6 .

\section{U L}

au lieu de 9.) - Scrøs. id. pag. 101. no. 3. Ptinus pertinax. Linv. Syst. nat. 2. 565. 2. D'Allemagne et de Suède. $3^{\circ}$. Vrillette rufipède, $A$. rufipes $n^{\circ}$. 4. FaB. id. -Schon. id. pag. 102. no. 5 . Allemagne et Suède. $4^{\circ}$. Vrillette fauve, $A$. castaneum no. 5. FA . id. - Schas. id. pag. 103. $n^{0}$. 6. Des environs de Paris. $5^{\circ}$. Virillette de la farine, $A$. paniceum no. 9. Fab. $i d$. - Schon. $i d$. pag. 105. $n^{0}$. 15. Des environs de Paris.

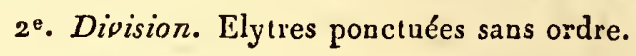

${ }^{\circ}$. Vrillette marquetée, $A$. tesselatum $\mathrm{n}^{\circ}$. $\mathrm{I}$. FA B. Syst. Eleut. (A la citation d'Illiger, lisez: 325. au lieu de 225.) - Scran Syn. Ins. tom. 2. pag. 101. $n^{\circ}$. 1. Très-commune aux environs de Paris sur le vieux bois et non dans les cadavres comme le dit Fabricius. $2^{\circ}$. Vrillette molle, $A$. molle $\mathrm{n}^{\circ}$. 8. FAв. $i d$. Assez rare aux environs de Paris. 3०. Vrillette du Sapin, A. abietis no. 10. Fab. $i d$. -Schon. id. pag. I04. $n^{\circ}$. I1. De Suède. (S. F. et A. SERv.)

VULCAIN. Nom donné à un Lépidoptère Diurne par Geoffroy. (Ins. Paris. tom. 2. pag. 40. $n^{\circ}$. 6.) C'est la Vanesse Atalante n'. 54. tom. IX. pag. 3ig. de ce Dictionnaire.

(S. F. et A. SErv.) 


\section{$\mathrm{X} A \mathrm{~N}$}

X Montago. Lat.

Ce genre, que M. Latreille a rapporté à son genre Cancer, a été établi par Léach, et ne diffère des Crabes proprement dits, que parceque ses antennes extérieures, extrêmement courtes, sont insérées dans le canthus interne des yeux, au lieu de l'être entre ce cantlus et le front. Sa carapace est bosselée, avec les bords moins nettement dentelés ou plissés. M. Léach fait connoître deux espèces de ce genre; elles sont propres aux mers de l'Europe.

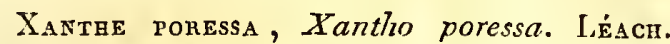
Risso, Hist. nat. du midi de l'Europe, tom. 5. pag. 9.-Cancer poressa. OLIv. Zool. Adr. pag. 48. pl. 2. fig. 3. - Risso. Crust. de Nice, pag. 11. $n^{\circ}$. r. Long de vingt millimètres, large de vingthuit. Carapace bosselée, présentant quatre points coniques sur chacun de ses bords latéraux; front quadrilobé; pinces grosses, un peu comprimées, striées en dessus, pustuleuses et à dents noirâtres. De la mer Méditerranée, Adriatique et de l'Océan.

Xaxthe floride, Xantho flovida. Léactr. Cancerfloridus. Montagu.-Cancerincisus, Xantho incisa el florida. Léacr. Mal. Brit. tab. I1. Plus grand que le précédent; carapace bosselée, pourvue de quatre dents obtuses de cliaque côté. Front droit, avec une fissure dans son milieu; doigts noirs. On le trouve sur les côtes d'Angleterre et de France.

Le Cancer floridus de Fabricius n'est pas la même espèce que celle de Léach. Si on n'adopte pas le genre Xanthe, il faudra changer le nom du Xantho florida, pour qu'il n'y ait pas deux espèces de Crabes sous le même nom.

M. Risso, dans son Histoire naturelle du midi de l'Europe, décrit une troisième espèce de Xanthe sous le nom de rivulosus, c'est le Cancer rivu. losus de son Hist. des Crust. de Nice. Il est long de vingt-quatre millimètres et large de vingt-huit. Son test est lisse, luisant, d’un vert pâle tacheté de pourpre brun ou violâtre, avec deux impressions longitudinales bien marquées; les bords latéraux sont munis de quatre tubercules, les intermédiaires fort grands; le front est coupé en ligne droite; les pinces sont grosses, épaisses, glabres, munies d'un tubercule en dessus; les pattes sont aplaties, garnies de quelques poils. On le trouve dans la mer de Nice. Il varie beaucoup pour la couleur. (E. G.)

XÉNOS, Xenos. Ross. King. LAT. (Règn. anint.)
Genre d'insectes de l'ordre des Rhipiptères,

Cet ordre ne renferme que les genres Stylops et Xénos. (Voyez Rurpiptèrrs.) Le premier diffère du second par son abdomen entièrement charnu, et par la branche supérieure des antennes divisée en trois articulations.

Antennes partagées en deux branches; ces deux branches entières. - Yeux pédonculés. Elytres (prébalanciers Lat. Fam. nat.) insérées sur les côtés du prothorax. - Ecusson avancé, couvrant l'abdomen. - Ailes n'ayant que de foibles nervures, toutes longitudinales; se repliant en éventail. - Abdonten presque cylindrique, corné, à l'exception de l'anus.

Le nom de Xénos vient d'un mot grec dont le sens est : qui reçoit l'hospitalité. Ces insectes, comme on le sait, proviennent de larves qui habitent dans le corps des Polistes. On ne connuit encore que deux espèces de ce genre.

\section{X'́nos des Guêpiaires, $X$. vesparum.}

Xenos ater; abdomine pedibusque subfuscis; alis albidis.

Xenos vesparum. Ross. Append. Mantiss. tom. 2. pag. 114. no. 97. tab. 7. fig. 13. b.

Longueur une lig. D'un noir foncé; abdomen et pattes d'un brun très-pâle, demi-transparent; ailes blanches avec un reflet opaque.

On le trouve en France et en Italie. Sa larve vit aux dépens de la Poliste française, $P$. gallice $n^{\circ}$.6. de ce Dictionnaire, sans lá faire périr.

\section{Xínos de Peck, X. Peckii.}

Xenos fuscus; pedibus lividis, tarsis nigricantibus; untennarum ramulis albo punctatis.

Xenos Peckii. Kirb. Mém. tom. XI. Trans. Linn. Societ. London. - Encycl. pl. 396. fig. $10-14$.

Longueur I lig. D'un brun noirître; pattes livides, tarses noirâtres; branches des antennes pointillées de blanc.

De l'Amérique septentrionale. Sa larve vit aux dépens de la Poliste brune, P. fuscata $n^{\circ}$. 4. FAB. Syst. Piez. (S. F. et A. Senv.)

XESTOMYZE, Xestomyza. Wréd. Lat. (Fim. nat.) Hirtea. FAb.

Genre d'insectes de l'ordre des Diptères, premic̀re section, famille des Tanystomes, tribu des Bombyliers. 
Le premier groupe des Bombyliers se caractérise par l'abdonen cylindracé ou ovale et le premier article des antennes le plus long de tous. Il renferme les genres 'Toxophore et Xestomyze. (Voyez pag. 53g. de ce volume.) Le premier a ses antennes rapprochées à leur base, leurs deux premiers articles étant cylindriques; ce quile distingue des Xestomyzes.

Ne connoissant pas ce genre, nons en donnerons les caractères d'après M. Wiéllemann.

Antennes assez écartées l'une de l'autre, avancées, alongées, composées de trois articles; le premier le plus long de tous, cylindrique, un peu gonflé dans son milieu; le second très-court, cyathiforme, le troisième de longueur moyenne par rapport aux deux précédens, fusiforme, pointu à son extrémité. - Tiompe a vancée, de la longueur du corselet. - Trois ocelles placés sur le vertex. - Ailes ouvertes dans le repos. - Pattes lougues.

Deux mols grecs qui signifient: mouche rase, ont servi d'ćtymologie au nom de ces Diplères. Leurs mours sont inconnnes. M. Wiédemaun en décrit deux espèces: $1^{\circ}$. Xestomyze lugubre, $X$. lugabris. Wréd. Dipt. exotic. pars 1a. pag. 153. tab. fg. 2. Longueur 3 lig. $\frac{3}{3}$. Noire, brillante; balanciers rougeâtres; aile'senfumées, avec la côte et deux taches jaunes. Du cap de Bonne-Espérance. $2^{\circ}$. Xestornyze costale, $X$. costalis. WiÉD. Anal. entom. pag. 24. $n^{\circ}$. 16. Longueur 3 lig. Noire; corselet ayant des lignes longitudinales blanchâtres, peu marquées; abdomen avec les incisions du second et du lorisième segment blanchâtres; côte et extrémilé des ailes, brunâtrıs. Mâle. De Megador.

Nota. M. Wiédemann place eu outre dans ce genre l'Hirtea Chrysanthemi n०. I I. FAB. Syst. Antliat. D'Espague. (S. F. et A. SER .)

XIPHIDRIE, Tiphidria. Lat. Fab. Spinoz. Le P. Sirex. Linn. Panz. Ross. Urocenus. Jur. Panz. Hybonotus. Klug. Astatus. Panz.

Genre d'insectes de l'ordie des Hymcinoptères, section des 'Térébrans, famille des Serrifères. Voyez ce mot pag. 566 . de ce volume.

Parmi les Serrifères à antennes de plus de dix articles et dont les ailes supérieures ont deux cellules radiales et quatie cubitales, tous les genres, exceplé celui de Xiphidrie, ont l'abdomen déprimé ou comprimé, et la tarière des femelles ne dépasse pas l'abdomen d'une mauière bien notable.

Antennes sélacées, vibraliles ; insérées près de la bouche, multiarliculées; premier et troisieme articles les plus longs de tous; les derniers très-petits, peu distincts. - Labre caché ou pen apparent. - Mandibules courtes, nuais visibles, épaisses, ayant intérieuremeut trois ou quatre petites dentelures, l'apicale plus forte. - Palpes maxillaires à peine plus longs que les labiaux, plus grêles, composés de six arlicles; le troisième le plus long de tous, cylindrique : les lahianx de qualre; le premier le plus long de tous; le dernier comprimé, presque triangulaire, plus large à son extrémité et trunqué, - Lèvre renfermće dans un pelit tube obconique qui lui sert de gaîne. - Téte clemi-globuleuse, arrondie et conrexe à sa partie supérieure, ayant un cou alongé fort distinct. - Yeux assez pelits, saillans, arrondis. - Trois ocelles placés presqu'en triangle au bas du front. - Corps assez long, linéaire, cylindrique. - Corselet ovale, un peu bonıé. - Ecusson grand.-- Ailes supérieures ayant deux cellulus radiales presqu'égales, la prewière demi-circulaire; quatre cellules cubilates presqu'égales; les seconde el troisième recevant chacune une nervure récurrente; quatrième cubitale alleignant le bout de l'aile; trois cellules discoïdales: la troisième ou inférieure fermée, fort éloiguée du bord postérieur de l'aile. - Abdomen cylindrique, presque linéaire, composé de huit segmens outre l'anus; plaque anale inférieure des femelles refendue dans toule sa longueur pour recevoir la larière : celle-ci dépassant de beaucoup l'extrénité de l'abdomen; plaque anale supérieure manquaut presqu'entièrewent dans les mâles et laissant à découvert la plus grande parlie des organes générateurs. - Pattes courtes; jambes antérieures terminées par une seule épide un peu écbancrée à son extrémité; jambes inicrı́diaires et postérieures en ayant deux presyu'égales, de forme ordinaire; premier .ricle des larses le plus long de tous; le qualrième fort petit, le cinquième beaucoup plus long que le précédeut, maui de deux crochets courts et forls, ayant une pelote dans leur entre-deux.

Le noın de Xiphidrie, tịré du grec, a rapport à la larière des femelles. Il est probable que les larves de ce genre qui, à ce que naus pensons, nont pas encore été observées, vivent dans le bois. On trouve quelquefois les insectes parfaits sur les bûches rangées en chantier dans les forêts, pendant le printemps qui en suit l'abat tage ; ils cou. rent vivenuent sur ce ioois et comme par saccades, ou bien voligent à l'entour. Le peiit, nombre d'espèces connues est d'Europe.

10. Xiphidrie Chameau, $X$. Camelus no. 1. Faв. Syst. Piez. Le mâle. (En relranchant la description de la femelle qui appartient à la X. fasciée, et le synonyme de Rosși, qui pourroit bien se rapporter à la X. annelke.)-LE P. Mronogr. Tenthred, pag. 2. $n^{\circ}$. 3. Mâle et femelle. Des environs de Paris. $2^{\circ}$. Xiplidrie fasciée, $X$. fasciata. LE P. id. pag. 3. no. 4. Mâle et temelle. - Xiphydria Camelus no. 1. Fав. id. Femelle. Des environs de Paris. 30. Xiphidrie Dromadaire, X. Dromedarius no. 3. Fав. id. Femelle. - Le P. $i d . n^{\circ}$. 5. D'Allemagne et du midi de la France. $4^{\circ}$. Xiphidrie annelée, $X$. annulata. Lat. Nous. 
Dict. d'hist. nat. $2^{\mathrm{e}}$. édit. - LE P. id. $\mathrm{n}^{\circ}$. 6. Mâle et femelle. - Urocerus annulatus. Jor. Hyménopt.pag. 75 . pl. 7. Femelle. - Encycl. pl. 375. fig. 9. Femelle. Des environs de Paris.

Le genre Yiphydria Fas. Syst. Piez. contient trois espèces. Nous en avons cilé deux. Le $n^{\circ} .2$. (emarginata) est le mâle de l'Urocère spectre. Voyez Urocíre. (S. F. et A. Serv.)

XORIDE, Xorides. Lat. Cryptus. Fab.

Genre d'insectes de l'ordre des Hyménoptères, section des 'Térébrans, famille des 'íérébellifères, tribu des Ichneumonides (division des Ichneumonides vrais ).

M. Latreille (Fam. nat.) fait un gronpe particulier dans ses Ichneumonides pour les genres Stéphane et Xoride; le prenier se distingue éminemment du second par la présence aux ailes supérieures des deux premières cellules discoidales et de la première nervure récurrente. Dans notre tableat des Ichneumonides, pag. 43. de ce volume, nons groupons les Xorides avec les Pimples, les Ichneumons, les Peltastes, les Ophions et les Acœnites; ces cinq derniers genres se distinguent des Xorides par leur tête transversale et lenrs mandibules fortement échancrées au bout; quant au genre Stéphane, qu'vue erreur typograplique fail figurer dans ce inême groupe (voyez pag. 43. de ce volume), il appartient à notre division des Braconides, où il constitue une coupe particulière. Voyez la note en bas de la pag. 488. de ce volume.

Antennes sétacées, vibratiles, multiarticulées; le premier article presque cylindrique, le second entièrement visible.-Mandibules presqu'entières ou à peine échancrées à leur extrémité.-Palpes maxillaires plus longs que les labiaux, composés de cinq articles; le premier pas plus court que le second; le cinquième grêle à son extrémité, plus long que le précédent: palpes labiaux de quatre articles, le dernier presque triangulaire, plus grand que le troisième. - Tête presque convexe, comme globuleuse, surtout à sa partie antérieure, pas plus large que longue. - Yeux peu saillans, de grandeur moyenne. - Trois ocelles placés en triangle sur le vertex. - Corps long, étroit. Corselet alongé, cylindrique; métathorax convexe en dessus et s'arrondissant postérieurement. Ailes supérieurés ayant une cellule radiale et deux cubitales, la première confondue avec la première cellule discoidale supérieure; point de première nervure récurrente; seconde cubitale recevant la deuxième nervure récurrente et atteignant le bout de l'aile : deux cellules discoidales, savoir: la seconde supérieure et la troisième ou inférienre ; celle-ci complète et fermée bien avant le bord postérieur de l'aile. - Abdomen alongé, subova. aire dans les femelles et muni d'une tarière assez longue; linéaire dans les mâles. - Pattes de longueur moyenne; les postérieures (surtout les jambes et les tarses) plus longues proportionnellement que les autres : jambes antérieures terminées par une seule épine, les intermédiaires et les postérieures en ayant deux; premier article des tarses presquaussi long que les trois suivans pris ensemble, le quatrième très-court; le cinquième terminé par denx crochets munis d'une pelote dans leur entre-deux.

Les espèces placées par $M$. Latreille et par noûs dans ce genre, se rapportent à celui d'Anomalon Jur. Elles sont peu connues quoique nombreuses. Fabricius a donné les descriptions de plusieurs, quil a dispersées dans différens genres, mais elles sont beaucoup trop succinctes pour permettre de les reconnoître avec cerlitude.

M. Gravenhorst fait annoncer en ce moment un ouvrage complet sur cette tribu; nous pensous que ce sera un bien grand service rendu à la science, car il est peu d'ourrages d'entomologie plus indispensable que celui-là.

10. Xoride indicateur, $X$. indicatorius. LAT. Gener. Crust. et Ins. tom. IV. pag. 5. et tom. I. tab. 12. fig. 3. Femelle. De Frince. $2^{\circ}$. Xoride prieur, $X$. procatorius. LA T. id. - Cryptus preecatorius no.11. FАв. Syst. Piez.

$$
\text { (S. F. et A. Serr.) }
$$

\section{XYA, Xya. Illig. Voyez Tridactrie.}

$$
\text { (S. F. et A. SERV.) }
$$

XYÉLE, Xyela. DaLm. LAt. (Fam. nat.) $p_{i-}$ nicola. Bréb. Lat. (Nouv. Dict. d'Hist. nat. $2^{e}$. édit.) Mastigocerus. Klvg.

Geure d'insectes de l'ordre des IIyménoptères, section des 'Térébrans, famille des Serrifères. Voyez ce mot pag. 566.

La troisième division des Serrifères ayant ponr caractère: anteunes composées de plus de dix articles, contient quinze genres, dont quatorze n'offrent qu'une ou deux cellules radiales aux ailes supérieures; de plus les antennes dans ces geures sont presque droites et leur troisième article n'est pas notablement plus long que les autres, ce qui les sépare des Xyèles.

Antennes longues, filiformes, coudées après le troisième article, composées de douze articles; le premier long, épais; le second épais, presgne globuleux; le troisième le plus long de tons; les autres fort petits, courts, formant par leur réunion un filet très-grêle. - Labre peu saillant. - Mandibules furtes, ayant trois ou quatre dents au côté interne. - Palpes maxillaires fort longs, repliés sous les côtés de la tête, de qualre articles, selon M. Dalman; le premier très-court, le second oblong, le troisième plus long que les deux premiers pris ensemble, conique, finissant presqu'en pointe, le quatrième filiforme, grêle, de inême longueur que le précédent. (Suivant nous, cet article est divisé en (rois.) Palpes labiaux très-g grêles, de trois articles 
selon M. Dalman, (nous les croyons de quatre : le premier étant fort petit.) - Téte transversale, portée sur une espèce de cou. - Yeux de grandeur moyenne, pëu saillans. - Trois ocelles placés en ligne courbe sur le vertex; les deux extérieurs beaucoup plus gros que l'interinédiaire qui est placé un peu au-dessous d'eux. - Corps court, un peu déprimé. - Corselet transversal. - Ecusson fort petit. - Ailes supérieures ayant trois cellules radiales, la première la plus petite des trois; trois cellules cubitales; la première et la seconde recevant chacune une nervire récurrente; troisième cubitale petite, atteignant à peine le bout de l'aile; trois cellules discoidales complètes; la seconde supérieure petite. - Abdomen sessile, composé de huit segmens outre l'anus; le premier échancré en dessus, sa plaque supérieure refundue dans son milieu; plaque anule supérienre entière dans les femelles, "l'inférieure refendue longitudinalement dans ce sexe pour former une coulisse dans laquelle la tarière est reçue; cet!e tärière dépassant l'abdomen, égalant en longueur plus que la moitié de celui-ci : anus des mâles ayant sa plaque supérieure presque nulle et laissant à découvert les organes générateurs; plaque intérieure fort longue, enticre, arrondie en cuiller. $p$ attes de longueur moyenne, jaubes intermédiaires et postérieures portant une épine dans leur milieu.

Ce genre avoit été proposé presqu’à la fois sous trois nouns différens par trois naturalistes; l'un d'eux, M. Dalman, l'appela Xyela, d'un mot grec qui signitie petite épée; il fiut allusion à la tarière des femelles, et ce nom a prévalu. M. Brébisson l'ayant trouvé sur des arbres verts lui avoit donné le nom de Pinicala, et M. Klïg celni de Mastigocerus, de deux mots grecs qui expriment la forme des antennes ressemblant $\dot{a}$ un fouet. On ne sait rien des mœurs de ces insectes, si ce n'est qu'ils se rencontrent sur les Pins et les Genćrriers. Les deux espèces connues sont fort petites.

${ }^{\circ}{ }^{\circ}$. Xyèle petite, $X$. pusilla. Dara. Analect. entom. pag. 28. $n^{\circ}$. 1. Mâle el femeile. tab. III fig. 1. Mâle. fg. 2. Femelle. - LE P. Monogr. '́enthred. pag. I. $n^{\circ}$. 1. Mâle et femelle. - Pinicola julii. BRÉв. Lat. Noup. Dict. a'hist. nat. $2^{e}$. édit. Mâle et femelle. De France et de Suède. $2^{\circ}$. Xyèle longuette, $X$. longula. Da Fernelle. - LE P. $i d . n^{\circ}$. 2. Femelle. De Suède.

(S. F. et A. Serv.)

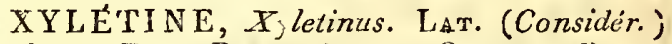
ptilinus. Fab. Panz. Schen. Gyllen. Payk. Herist. Anobium. Inlig. Herestr. Serrocerus. KUGEL.

Genre d'insectes de l'ordre des Coléoptères, section des Pentamères, famille des Serricornes, tribu des Ptiniores.

Une division de cette tribu a pour caractères : antennes filiformes, flabellées ou pectinées. (Toyez
Ptiniones.) Elle renferme outre le genre Xyléline celui de Prilin qui se distingue du premier par le corps alongé, cylindrique, et par les antennes qui sont en panache ou flabelliformes dans les wâles.

Antennes deutées en scie dans les deux sexes. Corps en ovale court. Pour les autres caractères. voyez Prilin.

Ces insectes, ordinairement de couleur sombre e! de petite taille, ont les mœurs des Piilins et des Vrillettes. Nous citerons les deux espèces suivantes.

10. Xylétine pectiné, $X$. pectinatus. - Ptilinus pectinatus $n^{\circ}$. 4. $\mathrm{FAB}$. Syst. Eleut. - ScHGe. Syn. Ins. tom. 2. pag. 112. $n^{\circ}$. 5. D'Allemagne. $2^{\circ}$. Xylétinc noir, $X$. ater. - Ptilinus ater. Panz. Faun. gern. fas. 35. fig. 9. - Ptilinus serratus $n^{\circ}$. 5. अав. $i d$. - Ptalinus pectinatus var. b. Scras. id. pag. 113 . D'Aulriche et des environs de Paris. Il n'est peut-être qu'une variété du X. pectiné suivant lopinion de M. Schouberr.

Le genre Ptilinus Faв. (Syst. Eleut.) contient cinq espèces dout deux, comuse on vient de le voir, appartiemnent aux Xylétines. Le no. 1 . est un Rbipicère, le no. 3 . est le Drile jaunâtre mâle de ce Dictionnaire. Le $n^{\circ}$. 2. seul est un véritable Ptilin. (S. F. et A. Serv.)

XYLITE, Xylita. $\mathrm{P}_{\Delta \mathrm{rx}}$. Les deux espèces que cet auteur place dans ce genre sont rapportées par les entomulogistes modernes au genre Dircée. Voyez ce mol pag. 418. de ce volume.

(S. F. et A. SeBV.)

XYLOCOPE, Xylocopa. Lat. Fab. PANz. JUR. Spinol. Klug. Apis. Linn. Geoff. Scherfr. De Géer. Cnrist. Ross. Kirb. Oliv. (Encycle) Centris, Bombus. FAB.

Genre d'insectes de l'ordre des Hyménoptères, section des Porte-aiguillon, famille des Mellifères, tribu des Apiaires (division des Récoltantes).

Parmi les Apiaires Récoltantes solitaires, c'està-dire dont les femelles ont les jambes postérieures privées de palette, et qui ne vivent pas en société, un groupe a pour caractères : point de paletle au métathorax ni aux cuisses postérieures; une brosse pour la récolte du pollen des fleurs placée sur le côté extérieur des jambes et du premier article des tarses des pattes postérieures dans les femelles; quatre cellules cubitales aux ailes supérieures; ocelles disposés en triangle. Ce groupe contient, outre les Xylocopes, six autres genres (yoy. Parasites), savoir : Centris, qui a la seconde cellule cubitale parallélipipède et la cellule radiale longuement appendiculée; Lagripode, dont la cellule radiale n'a point d'appendice et la troisième cubitale est un peu rétrécie vers la radiale; Anthophore, dont la seconde cellule cubitale reçoil dans son milieu la première nervare récurrẹnte, 
ren'e, tandis que la deuxième ncrvure abontit vis-à-vis de celle qui sépare les troisième et quatrième cubitales; Mélilurge, qui présente uue gaatrième cellule cubitale presque eornplète et dont les mâles ont les antennes grossissant à partir du troisième article et terninées en une sorte de massue; Leslis, ayant pour caractère distinctif une radiale extrêmement étroite. Quant au genre Acanthope, après l'avoir mieux examiné, nous pensons devoir le réunir aux Apiaires-Parasites. les einq genres dont nous avons d'äbord parlé, qualle different encore des Xylocopcs, outre les caractères énoncés, par leur palpes labiaux, dont les deux premier articles sont en forrue de soies écailleuses, tıès-cooprimés, nıembraneux sur leurs bords. Nous n'a yons vu que deux individus du genre Lagripode, et il nous a été impossible d'anaiyser leur promuscide.

Antennes filiformes dans les deux sexes, eoudées, eomposées de douze arlicles dans les femelles, de treize dans les nuáles. - Mnâchoires et lèvre très-alongées, formant une promuscide coudée et repliée en dessous dans le repos, appliquée contre sa gaîne. - Labre sillouné, denicireulaire, son bord antérieur très-cilié, échancré. - Mandibules sillonnées en dessus. - Irâchoires eiliées, comme peclinées, échancrées ạu-dessous de l'iusertion des palpes; leur prolungement terminal en triangle alongé, coriace. Palpes maxillaires beaucoup plus courts que le prolongement terminal des mâchoires, sétacés, composés de six articles qui vont en diminuant de longueur, le basilaire le plus grand de tous : palpes labiaux composés de quatre arlicles grêles, linéaires, presque semblables pour la forne el la consistauce à ceux des palpes maxillaires, les deux premiers fort longs (surtout celui de la base), le second recevant à son exlrémilé l'jusertion du troisiene; les deux derniers fort petits. - Lèvie velue. - Téte assez forte daus les femelles, plus petite dans les mâles. - Yeux plus grand's dans ceux-ei que dans l'autre sexe. -- T'rois ocelles disposés en triangle. - Corps un neu velu, quel quefois presqu'écailleux dans les mâles. - Corselet presque sphérique. - Ailes supérieures ayant une cellule radiale assez alougée, avec un petit appeudice ì son extrémité, celle-ci s'écartant du bord exterieur; quatre cellules cubitalcs, la première pelite, souvent coupée en deux dars presque tonte sa longueur, par une nervure surabondaute qui part du bord extéricur; la seconde plus grande que la première, presque triangulaire; première nervure récurrcnte aboulissant à la ne:vure d'intersection qui sépare les seconde et troisième eutitales : cette dernière presqunen carré long (son eôlé le plus large étant celui qui fouche à la radiale), reeevant la seeonde nervure séeurrente; quatrième cellule cubitale seulement commencée; trois eellules discoildales complètes. - Abdomen en ovale tronqué à sa base, un peu

Hist. Nat. Ins. Tome $X$. bombé, bordé latéralernent d'une frange de pcils touffis, composé de cinq seynens outre l'anus dans les femelles, en ayant un de plus dans les mâles. - Pattes fortes; jambes antérieures munies à l'extrémité d'une épine aiguë ayant à sa base une large membrane latérale; jambes intermédiaires ayant une épine simple, aigue à l'extrémité; jambes postérieures terminées par deux ćpines sioples; ces jambes, dans les femelles, munies au eôté extérieur d'une lırosse pour la récolte du pollen; premier article des tarses de celte paire de palles, dans le même sexe, éla:gi et portant à sa face extérieure une brosse servant aussi à la récolte; crochets des tarses bifides.

On a tiré le nor de ces Apiaires de denx mots grecs qui signilient : coupeuse de bois, dénomination justilice par leurs unœurs, dont on verra les détails à l'article Abeille perce-bois $\mathrm{n}^{\circ}$. 2. de ce Dietionnaire. Ce genre est fort nombrenx en espèces, en exoliques surtout; leur taille est au. dussus de la moyenne dans cet ordre; les femelles affectent généralement la couleur noire, les mûles portent souvent une livrée difiérente. On trouve ces 1 y mónoptères dans toules les parties du monde; ils affeetionnent particulièrement les plus châlndes. Les mandibeles des femelles, qui s'occupent seules de la construction des nids, sont beaucoup plus fortes et plus dentelées que eelles des nuâles.

Fabricius (Syst. Piez.) décrit dix-sept espèees comme étant de ce genre, mais le $n^{\circ} .5$. est le type de celui d'Acanthope Kuvg. et le $1^{\circ}: 17$. est une Oswie. Du reste Fabricius a lait plusieurs dcubles emplois, comase on pourra le voir dans la synonymie des uspèees que nous allons mentionner.

$\mathrm{I}^{\mathrm{re}}$. Division. Yeux trc̀s-espaeés dans les deux sexes.

${ }_{1}$ re. Subdivision. Ocelles posés sur lés pentes d'une ligne frontale élevée. - Labre (au moins dans les lemelles) portant trois lignes inégales, élevćes.

\section{Xylocope frontile, $\boldsymbol{X}$. frontalis.}

Iylocopa frontalis no. 8. Fав. Syst. Piez. Femelle.

Toyez pour la deseription de la femelle, Abeille frontale no. 6. du présent Dietionnaire. Le mâle ne nous est pas connu.

Nous placerons aussi dans eetle subdivision la Xylocope frangée, $X$. fimbriata $n^{\circ} .7$. FAB. $i d$. Femelle. De Cayenne. Mấ!e ineonnu.

$2^{\mathrm{e}}$. Subdivision. Point de ligne frontale élevée; une fossette près de chaeun des deux ocelles supérieurs. - Labre (dans les femelles) sans lignés élevées, portant seulement un tubercule au milieu de sa base.

Hhhh h 
2. Xýọcope violette, $X$. violacea.

Xylocopa violacea. Lat. Gener. Crust. et Ins. tom. IV. pag. 159. Mâle et femelle. - Xylocopa violacea $\mathrm{n}^{\circ}$. 3. FAв. Syst. Piez. Femelle. (Eu retranchant le synonyme de De Géer qui appartient à la X. large patte femelle.) - Xylocopa fentorata $\mathrm{n}^{\circ}$. 4. FAB. id. Mâle.

Voyez pour la description de la femelle et les autres synonymes (en rotranchant celui de De Géer qui se rapporte à la X. large patte femelle), Abeille perce-bois $n^{c}$. 2. du présent ouvrage. Le mâle se distingue de la femelle en ce que l'avantdernier article de ses antennes, ou mêrne quelquefois les deux avant-deruiers, sont d'un jaunetestacé, et que les hanches postérieures ont leur dernière articulation grosse et tuberculée. Cette espèce, très-commune dès le commencement du printemps aux environs de Paris, est purement européenne, et feu Olivier n'auroit pas dû, dans l'article auquel nous renvoyons, lui associer des espèces exoliques qui en sont réellement distinctes.

\section{XrLocope caffre, $X$. caffra.}

Xylocopa caffra. LAт. id. Mâle et femelle. Bonbus caffrus no. 17. FAB. id. Femelle. - Bomebus olivaceus $\mathrm{n}^{\circ} .20 . \mathrm{F}_{\mathrm{AB}}$. id. Mâle.

Voyez pour la description et les autres synonymes de la femelle, Abeille caffre no. 11.; et pour ceux du mâle, Abeille olivâtre no $^{\circ}$. 3o. de ce Dictionnaire.

4. Xylocope corselet jaune, $X$. astuans.

Xylocopa aestuans. Lat. id. - Bombus astuans $\mathrm{n}^{\circ} .44 . \mathrm{F}_{\mathrm{AB}}$. Femelle. - Apis leucothorax. Cerist. Hyménopt. tab. $V$. fig. 5. Femelle.

Voyez pour la description de la femelle et les autres synonymes, Abeille corselet jaune no. 26 . de ce Dictionnaire, en ajoutant que tous les poils de la tête sont noir's ainsi que ceux qui garnissent les côtés du corselet, et que les ailes n'ont pas de Ieflet cuivreux.

Nota. Les individus nombreux que nous avons vus étoient tous des Indes orientales ou d'Egypte.

\section{Xyцocope brésilienne, $X$. brasilianorum .}

Xylocopa brasilianorum. LAT. id. Mâle. Xylocopa brasilianorum no. 11. FAB. id. Mâle. - Apis brasilianorum. Cenrst. id. tab. $V$. fig. 刃. et 2. Mầle.

Voyez pour la description du mâle et les autres synonymes, Abeille brésilienne no. $7 \cdot$ du présent ouvrare. La femelle diflère par les caractères suivans: antennes brunes, un peu testacées_en dessous. Têtle noire, couverte de poils roux ainsi que le corselet. Abdomen d'un brun-noirûtre, ses bords extérieurs garuis de poils roux ainsi que le dessus du cinquieme segment et celui de l'anus; pattes antérieures testacées, les intermédiaires brunes à cuisses testacées; les postérieures totalement brunes; toutes les six sont chargées de poils roux. Ailes presque transparentes avec un reflet cuivreux. Le mâle est très-commun dans les collections, la femelle y est rare.

\section{XrLocope nègre, $X$. nigrita.}

Xylocopa nigrita no. 9. FAB. $i d$. Femelle.

Voyez pour la description de la femelle et les autres synonymes, Abeille nègre $n^{\circ} .4$. de ce Dictionnaire; ses ailes ont un reflet violet. Le mâle nous est inconnu.

Cette seconde subdivision comprend encore, $1^{\circ}$. Xylocope tête blanche, $X$. albiceps $\mathrm{n}^{\circ}$. 13 . Faв. Syst. Piez. Femelle. D'Afrique. $2^{\circ}$. Xylocope barbue, $X$. barbata $n^{\circ}$. 14. F $_{\text {AB. }}$ id. Femelle. De Cayenne. 3०. Xylocope dorée, $X$. aurulenta. - Bombus aurulentus $\mathrm{n}^{\circ} .42, \mathrm{~F}_{\mathrm{AB}}$. id. Femelle. De Cayenne. $4^{\circ}$. Xylocope vitrée, $X$. fenestrata $\mathbf{n}^{\circ}$. 6. FAB. id. Femelle. Du Bengale. $5^{\circ}$. Xylocope timide, $X$. trepida $\mathrm{n}^{\circ}$. 10. $\mathrm{F}_{\mathrm{AB}}$. id. Femelle. Cap de Bonne-Espérance. $6^{\circ}$. Xycolope d'Antigna, $X$. antiguensis ${ }^{\circ}$. I5. FА в. id. Femelle. De l'Amérique méridionale. On ne doit pas rapporter à cette espèce l'A beille d'Antigoa $\mathrm{n}^{\circ} .24$. de ce Dictionnaire.

$2^{\mathrm{e}}$. Division. Yeux manifestement rapprochés dans les wâles.

\section{XxLOCope large patte, $X$. latipes.}

Xylocopa latipes no. 1. FAB. Syst. Piez. Mâle. - Apis gigas. De GÉer. Mém. Ins. tom. 3. pag. 576. $p l$. 28. fig. 15. Femelle. - Christ. Hymén. tab. IV. fig. 1. et 2. Femelle.fig. 3. Mâle.

Voyez pour la description du mâle et les autres synonymes, Abeille large patte ${ }^{\circ}$. 1. $p l .107$. fig. 6. et pl. 382. fig. 9. de ce Dictionnaire. les ailes ont un reflet cuivreux. La femelle diffère par ces caractères : antennes noires, un peu testacées en dessous à leur extrémité; tête entièrement noire ainsi que le corselet et l'abdomen; pattes de cette même couleur; tarses antérieur's simples; hanches postérieures ayant une forte épine. Doit-on regarder comme étant la mêtrue espèce une Xylocope mâle et feraelle du même pays, dont les ailes n'ont pas de reflet cuivreux, et doı, le mâle a les côtés du chaperon blancs, et un point de même couleur au milieu de ce chaperon?

Cette division comprend aussi la Xylocope de Caroline, X.Carolina.-Centris Carolina $\mathrm{n}^{\circ} .14$. Fa B. Syst. Piez. Femelle. Amérique septentrionale. Le unâle diffère de la femelle par le labre, le chaperon, l'orbite des yeux et une petite ligne sous les antennes, d'un jaune pâle; les pattes ont 


\section{Y L}

un reflet violet, les antérieures sont garnies de poils cendrés.

CENTRIS, Centris. Fab. Lat. Apis. Lins. De Gíer. Oriv. (Encycl.) Christ. Lasius. Jur. Trachusa, Hemisia. Klug. Bonıbus. Fав.

Genre d'insectes de l'ordre des Hymćnoptères, section des Porte-aiguillon, famille des Mellifères, tribu des Apiaires (division des Récoltantes).

Sept genres composent un groupe distinct parmi les Apiaires-Récoltantes solitaires. (Toyez PARAsites.) Nous en ôtons aujourd'hui le genre Acanthope et le reportons aux Apiaires-Parasites. Les Xylocopes, les Anthophores et les Méliturges n'ont qu'un appendice fort court à l'extrémité de leur cellule radiale; les genres Lestis et Lagripode en sont totalement privés; de plus, les Lestis ont leur radiale extrêmement étroite. Dans les quatre premiers genres cités, les épines des jambes postérieures sont simples, point pectinées; enfin, la seconde cellule cubitale des Lagripodes est plus petite que la troisième. Tous ces caractères séparent ces diverses Apiaires des Centris.

Antennes filiformes dans les denx sexes, coudées, composées de douze articles dans les femelles, de treize dans les mâles, le troisième, dans les deux sexes, mince dans la plus grande partie de sa longueur, s'élargissant subitement à son extrémité. - Mâchoires et lèvre très-alongées, formant une promuscide coudée et repliée en dessous dans le repos, appliquée contre sa gaine. IITandibules quadridentées au côté interne. - $P$ alpes maxillaires très-grêles, de quatre articles : pulpes labiaux égaleuient composés de quatre articles, les deux inférieurs aplatis, membraneux, fort grands comparativement aux deux derniers; le troisième et le quatriène courts, rejetés sur le côté du second. - Téte de grandeur moyenne. $Y$ eu $x$ assez grands, ovales, espacés dans les deux sexes, mais un peu plus rapprochés sur le vertex dans les mâles. - Trois ocelles disposés presqu'en triangle sur le vertex. - Corps de longueur moyenne, plus ou moius velu. - Corselet presque carlé, un peu bombé. - Ailes supérieures ayant une cellule radiale assez large duns son milieu, son extrénité écartée dn bord extérieur munie d'un long appendice qui s'avance assez près du bout de I'aile; quatre cellules cubitales, la première presque séparée en deux parties par une nervure qui descend perpendiculairement du bord extérienr, plus petite que la seconde; la seconde à pen près parallélipipède, plus grande que la troisième, recevant la première nervure récurrente; la deuxième uervure récurrente aboutissant à la nervure d'intersection des troisième et quatrième cellules cubitales; troisième cubitale fort rétrécie vers la radiale; quatrième cubitale commencée ; trois cellules discoïdales complètes. - Abdomen an peu bombé, composé de cinq segmens outre l'anus dans les femelles, en ayant an de plas dans les mâles. - Pattes assez furtes; jambes antérieures munies à l'extrémi:é d'une épine garnic à sa partie inférieure d'une large membrane, fortement pectinée dans le reste de son étendue : jambes intermédiaires en ayant une simple, aiguë à l'extrémité; jambes postérieures protégées a leux insertion par une écaille particulière, terminées par deux épines; l’intérieure fortement pectinée, l'extérieure l'étaut aussi, mais moins distinctement; ces jambes, dans les femelles, munies a côté extérieur d'une brosse pour la récolte du pollen; premier article des tarses postérieurs, dans ce mêrne sexe, élargi, portant à sa face extérienre une brosse pour la même récolte; ce premier article prolongré a sa partie inférieure au-delì de l'insertion cu second article et du côté opposé à cette insertion, ce prolongement garni de poils serrés et droits; crochets des tarses bifides.

Les Centris forment un genre assez nombreax en espèces et propre aux climats chauds de l'Amérique; leur taille est habituellement au-dessus de la moyenne; les mœurs n'ont pas encore été étadiées, mais l'analogie porte à croire qu'elles sont les mềmes que celles des Anthophores. Voyez ce mot à la suite de cet article.

Fabricius en créant le genre Centris dans son Syst. Piez. y rapporte trente-six espèces. Les nos. I. et 3. sont des Euglosses; 4. une Epicharis; 13. est le type du genre Lithurge. LAT. (Fam. nat.); 14. est une $\mathrm{X}_{y}$ locope; 16. une Antbophore; 19. et 20. sont les deux sexes d'une même espèce, type de notre genre Lestis; 3o. appartient anx Méléctes, et 31. aux Macrocères. Les nos. 6. 23. et 29. sont cerțainement des Centris. Les autres $n^{\circ s}$. ne nous sont pas assez connus pour que nous puissions décider à quels genres ils doivent être rapportés.

Ire. Division. Jambes postérieures munies à leur base d'une écaille paroissant double.

\section{Centris hémorrhoidale, $C$. hemorrhoidalis.}

Centris hemorrhoidalis no. 23. Faв. Sy'st. Piez.

Voyez pour la description et les autres synonymes, Abeille hémorrhoidale $n^{\circ}$. 8g. de ce Dictionnaire.

Cette division comprend encore : I $^{\circ}$. Centris américaine, $C$. ameticanorum - Bombus americanonum $n^{\circ}$. 16. FAB. Syst. Piez. (En retranchant le synonyme de l'Entoni. syst. qui appartient pour la phrase à une espèce qui ne nous est pas connue, et quant à la description au Bonbus antericanorum .) $2^{\circ}$. Centris fourchue, $C$. furcata. - Bombus furcatus $n^{\circ} \cdot 41$. FА . id.

$2^{\mathrm{e}}$. Division. Jambes postérieures munies à leur base, d'une écaille simple. 


\section{Centris cotonneuse, $C$. lanipes:}

Centris lanipes $n^{\circ}$. 29. FА в. Syst. Piez.

Voyez pour la description et les antres synonymes, Abeille cotonneuse $n^{\circ}$. 95. de ce Dictionnaire. Ajoutez que les poils des pattes sont ro'ix, et que les ai!es presque transparentes, ont un rellet, violet et doré.

On placera en outre ici la Centris longimane, c. longimana ${ }^{\circ}$. 6. FAв. id. Femelle. Le mâle diffère par son labre brun avec une petite taclie blanchâtre au milieu; ses pattes sunt d'un brun noirâtre.

ANTHOPHORE, Anthophora. Lat. Spixol. Megilla. Fab. Panz. Krvg. Lasius. Jur. Apis. Linn. Geoff. Panz. Sentefr. Scop. De Géer. Devilil. Ross. Christ. Oliv. (Encycl.) Kirb. Centris. Fab. Panz. Anthidium. Fab. Saropoda. LAt. Heliophila. Krog. Andrena. Oriv. (Encycl.)

Genre d'insectes de l'ordre des Hyménoptères, section des Porte-aiguillon fumille des Mellifères, tribu des Apiaires (division des Récoltantes).

Un groupe d'Apiaires-Récoltantes solitaires covtient sept genres dans le tablean de cette tribu. (Voyez pag. 5. de ce volume.) Nous en ôtons cclui d'Acan thope que nous reportons maintenant parmi les A piaires-Parasites. Les antres sont $: 1^{\circ}$. Centris, dont la cellule radiale a un loner appendice; la première cellule cubilale paroît séparée en deux par une nervure qui descend perpendiculairement du bord extérieur; de plusles épines des dernières jambes, l'intérieure surtout, sont pectinées. $2^{\circ}$. Lestis, ayant la celluie radiale extrêmement étroite et les croclsets des tarses seulement dentés. 3․ Xylocope, dont la première nervure récursente aboutit à la nervure d'intersection des seconde et troisième cnbitales, tandis que la deuxiène nervure récurrente est reçue par lä troisième cubitale. $4^{\circ}$. Lagripode, ayant la cellule radiale sans appendice et les jambes postérienres terminées par une épine fortement pectinée. 5๊. Nićiturge, dislingué par la seconde nervure récurrente des ailes supériéures qui est reçe par la troisième cellule cubitale; par la quatrième cellule cubitale atteignant presque le bout de l'aile, et par les antennes des mâles qui grossissen! insensiblement en massue à partir du troisieme ariicle. $6^{\circ}$. Anthopluore, dont les caraclères gŕnériques dilfèrent de tous ceux que nous vezous d'énoncer.

Antennes filiformes dans les deux sexes, coudées, composées dc douze articles dans les femelles, de treize dans les mâles; le troisième dans les deux sexes, mince duns la plus grande partic de sa longuenr, s'élargissant subitement a son extrémité. - Labre long, rahatiu et rentrant, lors du repos. - Mandibules presque fourchues à leur extrécoité ( au raoins dıns les femelles.) La dent qui est au côté interne étant fort près de l'extrémité. - Mấchoires et lèvre très-alongées, formant une promuscide condée et repliée en dessous dans le repos, appliquée contre sa gaîne. - Palpes maxillaires ordinairement de six articles, quelquefois de cinq, le dernier à peine visible dans ce dernier cas : palpes labiaux de quatre articles, les deux inférieurs aplatis, membraneux, fort grands (le basilaire surtout), comparativement aux deux derniers; ceux-ci courts. - Tête transversale, plus basse que le corselet, presquaussi large que la partie antérieure de ce dernier, sa face bombée, surtout dans les mâles. - Y eux de grandeur moyenne, espacés dans les deux sexes. - Trois ocelles disposés en triangle sur le vertex. - Corselet sphérique, bombé. - Ailes supérieures ayant une cellule radiale assez large, terminée par un petit appendice; quatre cellules cnbitales, la première point divisée, la seconde un peu rétrécie vers la radiale, recevant dans son milieu la première nervure récurrente : deuxième nervure récurrente aboutissant à la nervure d'intersection des troisième et quatrième cubitales; troisième cellule cubitale rétrécie vers la radiale, la quatrième point commencée, mais tracée jusquau bord postérieur de l'aile; trois cellules discoidales complètes. - Abdomen court, gros, conique et composé de cinq segmens outre l'anus dans les feinelles, obtus à son ext rémité et ayant un segment de plus dians les mâles que dans l'autre sexe. $-P$ atles assez fortes; jambes antérieures munies à l'extrémité, d'une épine garnie à sa base d'une membrane, simple et aiguë à son extrémité; jambes intermédiaires en ayant une longue et aiguë; jambes postérieures protégées à leur insertion par une écaille particulière, terminées par deux épines longues, simples et aiguës; ces jambes dans les femelles munies au côté extérieur d'une brosse pour la récolte du pollen; premier article des tarses postérieurs, dans ce même sexe, élargi et porlant à sa tace extérieure une brosse pour la mêure récolte : ce premier article prolongé à sa parlie inférieure au-telà de l'insertion du second article et du côté opposé à celte insertion, ce prolongemeut garni de poils serrés, droits; crochets des tarses, bifides.

Comme les autres Apiaires-Récoltantes, les Anthophores, dont le nom a pour étymologie deux mols grees qui signifient : porle fleur, approvisionnent !eur nid de pollen de fleurs et de uniel, donl elles composent une pûte qui sert de nourriture à leurs larves. C'est dans les terrains un peu salylonneux, coupés à pic ou en pente rapide, ou dans le morlier des vieux murs, qu'elles creusent des cylindres recourbés dont les deux extrémités sunt ouvertes à la superficie; elles y construisent alors des cellules mises bont à bont l'une de l'autre dont l'intérieur est lort poli et comme lissé, probablement par une liqueur 
qu'elles dégorgent; chaque cellule est séparée de la suivante par une cloison faite de mortier, et ne contient qu'un œuf et la provision nécessaire à une larve. Les mâles sont très-ardens pour l'accouplement : à cette époque on les voit parcourir la façade des terrains sur lesquels les femelles qui viennent d'éclore se tiennent à leur sortie du nid pour sécher leurs ailes encore moites; ils se jetlent dessus avec violence. Dans ce cas le vol du mâle a cela de particulier qu'au lieu de tenir le corps dans une position horizontale, il est perpendiculaire; ce vol est lent, quoique le mouvement des ailes soit plus actif que dans le vol ordiuaire, sa lenteur cermet d'observer que les parties génitales sont alors sorties et développées : l'accouplement s'effectue en l'air, mais non pas loors de la portée de la vue. Nous avons quelquefois suivi des yeux des couples d'Anthophores, ils ne s'éloignent pas beaueoup du point de départ, la jonction dure quelques minutes, le mâle est ensuite rejeté violemment par l'effort des pattes postérieures de la femelle, du moins à ce qu'il nous a paru; il tombe à terre, s'y débat quelques instans et meurt. L'alyant ramassé, nous avons pu nous assurer que l'abdomen ne contenoit plus alors aucune des parties de la génération, et quuelques débris de parties jutérieures que l'on apercevoit au bout de l'abdomen, nous convainquirent qu'elles avoient été brisécs à leur base comısune au moment de la sćparalion des deux sexes. Les mâles éclosent les premiers, et les oufs qui les produisent ont été aussi pondus les premiers; il sont placés près de la sorlie du tuya cylindrique dont nous avons parlé, ce qui donne l'explication de la manic̀e dont ce tuyau est construit; ses deux ouvertures étoient nécessaires pour que l'individn le premier éclos de l'œuf pondu le premier, pât sortir, saus nuire aux antres, qui remplissent derrière lui le reste du cylindre.

Les Anthophores ont pour ennemis partieuliers parmi les Apiaires-Parasites (voyez PanAsires), les Mélectes, les Epéoles, les Philérèmes, les Pasites ei les Anmobates, dont les larves, ćlo. sent avant les leurs, dévorent les provisions amassées avant la naissance de la larve de l'Anthophore : plusieurs Chalcidites et entrautres les Leucospis déposent aussi leurs eufs dans lenrs cellules; les larves qui en éclosent lorsque l'labitant naturel a déjà pris à peu pròs lonte sa grosseur, le dévorent lui-mêne : quelques Ichneumonides, dans leur premier état, vivent aussi aux dépens des larves d'Anthoplicies. Les premicri déposcnt leurs œulis dans les cellules lorsgu'elles ne sont pas encore aclievées, ni fermćes par une cloison; les femelles de ces dcux dernicres tribus percent avec leur tarière les enveloppes cxtérieures du nid el parviennent à y faire pénétrer le bout de cet ins'rument qui sert de cunduit à l'œuf qu'elles y déposeut.
Les Anthophores en presque totalité sont propres à l'ancien continent, une seule espèee a été trouvée dans l'Amérique scptentrionale; nous n'en connoissons pas de l'Amérique méridionale, où il semble que ce genre soit remplacé par celui de Centris. Leur taille, sans atteindre les plus grandes dimensions, est ordinairement un peu au-dessus de la moyenue, et ne descend jamais jusqu'à la plus petile. Le bourdonnement commun à toutes les espèces et la villosité du corps les ont souvent fait confondre avec les Bourdons, mis ici il n'y a ni société ni ouvrières.

Le genre Megilla. FAв. (Syst. Piez.) conlient trente-quatre espèces; huit seulement appartiennent avec cerlitude au genre Anthophore, savoir : les $n^{08}$. $1,2,3,6,7,12,13,14$. Le $n^{\circ}$. 5. est un Bourdon; 8., une Nomie; II., une Stélide; les Halictes revendiquent les $n^{\circ s} .22,28,32$; le genre Cératine le no. 3 r., et les Collètes le no. 34 . Les aulres $n^{o s}$, sont douleux.

Le genre Anthophora FAB. ( $i d$.) répond, au moins en partie, à ceux de Mégachile et d'Osmic, et nullement à nos Anthophores.

I re. Division. Tous les poils de l'abdomen liérissés. (Anthophora propriè dicta.)

$1^{\mathrm{re}}$. Subdivision. Tarses intermédiaires des mâles ayant des faiseeaux de poils.

\section{Antuopmon e pilipède, A. pilipes.}

Anthophora pilipes. I.Aт. Gen. Crust. et Ins. tom. IV. pag. 175. Hale et femelle. - Megilla pilipes no. 6. Кав. Syst. Piez. Nâle et femclle.

Voyez pour la description de la femelle et le:s autres synonymes, Andrène velue $n^{\circ}$. 19. de ce Dictionnaire. Le mâle dithere par les curractères suivans : partie antérienre du premier article des antemnes, jaunâtre; clatperon de celte mêrne couleur ayaut de cluaque côté une tache unidentée et son bord inféricur, nuirs. Labre jausâtre nuni d'un poiut noir de chaque côté; base des mandibules pol'ant une lache jaunatue. Tous les articles des tarses intermédiaires garnis du cêté des paties postérieures de longs cils; le preurier et le dornier porlant eliacun une touffe de poils serrés, du côté qui rcgarde les paites antćrieures: lous ces poils et ces cils sont noirs. L'anus porte aussi quelques poils de eetie couleus.

Celte cspèce est extrêmement commune au printemps sur les fleurs aux environs de Paris.

Nota. L'Abeille patte velne no. 53. du présent ouvrage est peut-être le mâle que nous venons de décrirc; la deseription est fort imnarfaite, mais elle appartient cestaineisent à nn nuâle de celle subdivision. Le synonyme de Geoflioy ne peut que difficilcment s'appliquer au mâle de zolre Anthophore pilipède. 
2. Asthophore rétuse, $A$. retusa.

Mlegilla acervorum no. 2. FAB. id. (En retranclianı les synonymes de Linné.) Femelle.

Voyez pour la description de la femelle et les autres synonymes, Abeille rétuse no. 63 . de ce Diclionnaire; mais on lui attribue à tort des ailes d'un noir-violet, elles sont incolores et transparentes. Le mâle diffère par ces caractères : premier arlicle des antennes blanchâtre à sa partie an. térieure; cliaperon de même couleur, avec sa base et son bord inférieur noirs. Orbite antérieur des yeax, blanchâtre ainsi que le labre qui a de cbaque côlé un point noir. Tête, corselet et côtés des deux premiers segmens de l'abdomen, chargés de poils roux : pattes ayant des poils mêlés roux et noirs; premier article des tarses intermédiaires garni de cils noirs, du côté des pattes postérieures.

Des environs de Paris.

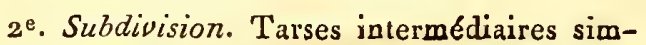
ples dans les deux sexes.

\section{A. Pattes postérieures simples.}

Ce groupe contient : $1^{\circ}$. Anthophore pariétine, A. parietina. Laт. Noùv. Dict. d'hist. $\mathbf{2}^{\mathrm{e}}$ édit. Mâle et fernelle. - Megilla parietina n०. 3. FАв. Syst. Piez. Femelle. Des environs de Paris. $2^{\circ}$. Antbophore quadrimaculée, $A$. quadrimaculata. - Megilla quadrimaculata no. I4. Faв. id. Mâle. Ia femelle n'est pas connue. Des environs de 'aris. $3^{\circ}$. Anthophore tricolore, A. tricolor. Megilla tricolor no. 7. FАв. id. Mâle. Cet auteur indique pour patrie les îles de l'Amérique; nous pensons que c'est une erreur.

B. Cuisses postérieures renflées ainsi que leurs jambes; premier article des tarses postérieurs épineux (au moins dans les mâles.)

\section{Axтнорнове fémorale, A. femorata.}

Voyez pour la description du mâle, Abeille grosse cuisse $n^{\circ}$. 78 . de ce Dictionnaire. La femelle n'est point connue.

$2^{\mathrm{e}}$. Division. Abdomen ayant des bandes transversales formées par des poils couchés. (Saropoda? LAT. )

\section{Anthophore de l'Iris, $A$. ireos.}

\section{Mâle.}

Anthidium ireos n. 4. ГАB. Syst. Piez.

Voyez pour la description du mâle et les autres synonymes, Abeille Iris no.68. de ce Dictionnaire, en ajoutant : premier article des anteunes et les neuf derniers blanchâtres en dessus; les trois intermédiaires et le dessous des autres, noirs. La femelle n'est pas connue.

De Russie.
5. Anthopene bimaculée, $A$. bimaculata.

Saropoda bimaculata. Lat. Gen. Crust. et Ins. tonı. IV. pag. 177. Mâle et femelle.

Voyez pour la description du mâle et la synonymie, Abeille arrondie $n^{\circ} \cdot 73$. de ce Dictionnaire. La femelle diffère en ce que le chaperon porte de chaque côté une grande tache carrée, noire; que le qualriène segment abdominal est eutièrement couvert de poils couchés, cendrés; que le cinquième, avec ces mêmes poils, a le bord postérieur noir.

On la trouve communément aux environs de Paı sur les fleurs à la fin de l'été et en automne.

\section{Aктнophore à zones, A. zonata.}

Megilla zonata n $^{\circ}$. 13. Far. id. Femelle.

Voyez pour la description de la femelle et les autres synonymes, Andrène à zones no. 17. de ce Dictionnaire. Le mâle diffère par les caractères suivans : un peu plus petit; claperon entièrement blanchâtre; bord inférieur du cinquième segment de l'abdomen ayant une bande semblable à celle des précédens; le sixième et l'anus chargés de poils nuirs.

Dans cette division nous rangerons encore : $1^{\circ}$. Antlophore fasciée, A. fusciata. - Megilla fasciata no. 12. Faв. Syst. Piez. Femelle. Le mâle diffère par le cinquième segment de l'abdomen ayant une bande seoblable à celle des précédens; le sixième et l'anus sont couverts de poils noirs. Des Indes orientales. $2^{\circ}$. Anthophore double ceinture, $A$. bicincta. - Centris bicincta n $^{\circ}$ 16. F $\mathrm{AB}$. $i d$. Femelle. Le mâle n'est pas counu.

Du Bengale.

MÉLITURGE, Meliturga. LAt.

Genre d'insectes de l'ordre des Hyménoptères, section des Purte-aiguillon, famille des Mellifères, tribu des Apiaires (division des Récoltantes).

Dans l'avant-dernier groupe des Apiaires - Récoltantes solitaires, nous avons fait entrer sept genres. (Voyez Parasites.) Celui d'Acanlbope ne doit pas y rester, mais rentrer dans les Apiaires-Parasiles. Le genre Centris a la cellule radiale des ailes supérieures longuement appendiculée; l'épine terminale des jambes antérieures est fortement pectinée vers son extrémité, celle des intermédiaires est simple. Dans les Lagripodes, la cellule radiale est sans appendice et leurs jambes postérieures n'ont qu'une seule épine qui est trèsfortement pectinée. La seconde nervare récurrente des Anthophores aboutit à la nervure d'intersection des troisième et quatrième cubitales, et cette dernière cellule n'est pas même commencée, mais seulement tracée : les deux épines qui terminent les jambes postérieures sont simples. Les Xylocopes ont leurs palpes labiaux composés d'articles presque semblables pour la forme et la con- 
sistance; leur seconde cellnle cubitale est presque triangulaire, et la quatrième est $\grave{a}$ peine commencée; la cellule radiale extrênement étroite, et les crochets des tarses dentés distinguent les Lestis. Nous observons encore que dans ces cinq genres les antenues des mâles ne vont pas en grossissant sensiblement jusqu'à l'extrémité pour former une espèce de massue.

Antennes grossissant insensiblement à partir du troisième article et formant une massue un peu comprimée, surtout dans les mâles. - Labre court, avancé. - Mandibules sans dent au côté interne. - Palpes maxillaires de six articles distincts. $Y$ eux grands, surtout dans les mâles où ils sont rapprochés sur le vertex, mais sans se toucher. Trois ocelles placés vers le bas du vertex. - Corselet peu bombé. - Ailes supérieures ayant leur première nervure aboutissant dans la seconde cellule cubitale près de la nervure d'intersection des seconde et troisième cubitales; seconde nervure récurrente reçue par la troisième cubitale trèsprès de la base de la quatrième; cette dernière atteignant presque le bout de l'aile. - Abdomen ovale-oblong dans les femelles, gros et assez court dans les mâles. - Jambes antérieures munies à l'extrémité d'une épine garnie dans presque toute son étendue d'une membrane; celle-ci se termin?nt par une dent vers l'extrérnité de l'épine : jambes intermédiaires ayant une seule épine à leur extrémité, finement dentelée, longue, surtout dans les femelles; les trois articles intermédiaires des tarses de ces deux paires de pattes dilatés latéralement, des deux côtés dans ces dernières, seulement du côté extérieur dans les mâles; jambes postérieures terminées par deux épines finement dentelées; premier article de leurs tarses sans prolongement. Les autres caractères sont ceux des Anthophores. (Vo, ez pag. 796. de ce volume. )

Le type de ce genre, dont les mœurs doivent peu différer de celles des Anthophores, est l'espèce suivante :

\section{MÉltturge clavicorne, $M$. clavicornis.}

Meliturga nigra, rufo villosa; clypeo albido.

Meliturga clavicomis. LAT. Gen. Crust. et Ins. tom. IV. pag. 176. Mâle., et tom. I. tab. XIV. fig. 9. (On a indiqué par erreur fig. 14. Mâle. Représenté sous le nom d'Eucera clavicornis.)

Longueur 6 lig. Noire, chaggrinée; tête, bords latéraux de l'abdomen et bord inférieur de son dernier segment, garnis de poils d'un roux pâle, les côtés de l'anus garnis de poils couchés d'un roux brillant : disque du chaperon d'un blancjaunâtre; tarses, épines terminales des jaunbes et poils des pattes, roux. Ailes transparentes, leurs nervures testacées. Femelle.

Le mâle diffère en ce qu'il est beaucoup plus velu el que l'abdomen l'est tout entier; le dessous du premier article des antennes, une petite ligne au-dessus du chaperon, celni-ci tout entier, d'un blanc-jaunâtre, ainsi que deux taches sur le labre; premier article des tarses, brun.

On la trouve dans le midi de la France, à Lyon, à Montpellier.

LESTIS, Lestis. Centris. Fab. Apis. OsIv. (Encycl.)

Genre d'insectes de l'ordre des Hyménoptères, section des Porte-aiguillon, famille des Mellifères, tribu des Apiaires (division des Récoltanles).

Parmi les Apiaires-Récoltantes solitaires, $n n$ groupe contient sept genres ( voyez PArasites); nous en retranchons les Acanthopes, que nous reportons aux Apiaires-Parasites. Des six genres qui constituent aujourd'hui ce groupe, celui de Centris a la cellule radiale des ailes supérieures suivie d'un long appendice. Les Lagripodes ont leur première nervure récurrente reçue par la seconde cellule cubitale; la quatrième cellule cubitale du genre Anthophore est seulement tracée, mais point commencée. Dans les Méliturges mâles les antennes sont presqu'en massue compriinée. Les Xylocopes ont leur seconde cellule cubitale presque triangulaire. Enfin dans ces cinq genres les crochets des tarses sont bifides et la cellule radiale n'ést pas sensiblement étroite.

L'espèce qui nous sert de type ne nous est connue que par deux individus, l'un mâle et l'autre femelle, faisant partie de la collection entomologique du cabinet du Roi ; nous n'avons pas pu analyser leur bouche, ni examiner assez en détai! plusieurs de leurs caractères; nous nous contenterons de mentionner les suivans, ils se rapprocbent un peu de ceux des Xylocopes.

Antennes filiformes dans les deux sexes, coudées, composées de douze articles dans les femelles, de treize dans les mâles. - MIâchoires et lèvre très-alongées, formant une promuscide coudée et repliée en dessous dans le repos, appliqunée contre sa gaîne. - Trois ocelles disposés en triangle sur le vertex. - Ailes supérieures ayant une cellule radiale extrêmement étroite, munie à son extrémité d'un appendice court; quatre cellules cubitales; la première plus longne que la seconde, celle-ci presque parallélipipède, plus large que longue, la troisième plus grande qu'aucune des précédentes; première nervure récurrente aboutissant à la nervure d'intersection des seconde et troisième cubilales; cette troisième cubitale recevant la seconde nervure récurrente; quatrièz:e cubitale commencée et s'étendant jusqu'au milieu de l'espace qui est entre sa base et le bout de l'aile. - Pattes comme dans les Xylocopes; cro. chets des tarses simplement dentés. 


\section{Lestrs Mouche, L. muscaria.}

Centris muscaria no. 20. FaB. Sjst. Piez. Femelle. - Centris boinbylans no. 19. FAB. id. Míle.

Voyez pour la description et les autres syno. nymes, Abeille Mouche no. 88. (feme!le.) et Abeille Bombille no. 87. (mûle.) du présent ouvrage. (S. F. et A. Serv.)

XYlOPHAGE, Xyliphagus. Merg. Fa. Lat. Mar:Q. Nenhotelus. De Géer. Asilus. Schedr.

Genre d'insectes de l'ordre des Diptères, première section, famille des Notacantlics, tribu des Xylophagiens.

Des quatre genres qui cntrent dans cette tribu (yojez Xrsopangrens), celui d'Hermélie diffère des Xylophages par les antennes, dont le troisiène arlicle est en massue, très-comprimé, rétréci dans son milieu, son dernier anneau aussi long que les sept autres pris ensemble; les Béris onı leur écusson épineux ainsi que les Cyphomyies, dont en outre l'abdomen est orbiculaire.

Anternes avancées, rupprochćes, presque cyliadriques, dirigées droit rers le côté, composées de trois articles; le premier cylindrique, le second cyathiforme, court; le troisième alongé, un peu conique, divisé en liuit anneaux, le dernis pas beaucoup plus long que le précédent. Trompe rentrée dans la cavité buccale lors du repos. - Palpes avancés, redressés, composés de deux articles, le second grand, ovale, velu. - Téte aplatie, déprimée. - Yeux espacés daus les deux sexes, ceux des mâles cepeudant un peu rapprocbés. - Trois ocelles rapprochés, placés els triangle sur le vertex. - Corps assez alongé, presque linéaire. - Corselet coupé droit en deviłul, rélréci à sa partie postérieure. - Ecusson grand, semi-circulare, mulique. - Ailes velues rues au microscope, couchées parallèlement sur le corps dans le repos. - Cuillerons simples, très. pelits. - Balunciers déconverts. - Abdonnen alın'gé, composé de six seçmens outre l'anus, cylindrique daus les mâles, conique et terminé par une tarière, dans les femelles.-- Pattes assez longues; janbes terminées par une épine; tarses assez longs, leur premier article plus grand que les qualre autres pris ensemble, le dernier terminé par deux crochels courts, munis de trois pelotes dans leur entre-deux.

Les Xylophages ont tiré leur nom de deux mots grees qui signifient: mangeur de bois. En effet des larves du $X$. noir ont été trouvées dans des tronces d'arbre pourris, par M. Baumahauer; el M. Latreille a observé une femelle qui cherchoit à pondre dans la carie d'un vieux Orme. M. Meigen partage ce genre en deux divisions, d'après la longueur proportionnelle des deux premiers articles antennaires; il en décrit six espèces eu- ropéennes, et M. Wiédemann une de l'Amérique du Nord. Leur taille varie de trois a six lignes.

${ }_{1}^{\mathrm{re}}$. Dirision. I'remier article des antennes plus long que le second. - Toutes les cellules du bord postérieur de l'aile, ouvertes. ( Xylophagus proprie dictus.)

$1^{\circ}$. Xyloplage noir, $X$. ater. Merg. Dipt. d’Eur. tom. 2. pag. 11. $n^{\circ}$. 1. Mâle et femelle; tab. 12. fig. 14. Femclle. - Lat. Gen. Crust. et Ins. tom. IV. pag. 272. - M AcQ. Ins. Dipt. du nord de lus France, Asiliq. elc. pag. 141. $n^{\circ}$. 1. Mâle et femelle. De France et d'Allemagne. 11 nous paroît que le Pacbystome subulé no. 2. du présent ouvrage n'est que le mâle do $X$. noir ; teile est égulement l'opinion de M. Meigen, puisqu'il rapporte avec certiude à ce mâle, l'Eimpis subulata de Panzer, d'après laquelle la description de ce $\mathrm{Pa}-$ chystone a été laile dans l'Encyclopédie. $2^{\circ}$. Xylophage à ceinure, $X$. cinctus. Meig. $i d$. pag. 12. $n^{\circ}$. 2. (Il est probable que cet auteur se trompe en rapportant à celte espèce le $R$ hagio syrphoides PAxz. Faun. Germ. fas. 77. fig. 19. qui nous paroît appartenir at l'achystome syrphoïde no. I. de ce Diclionnaire.) - Xy lophagus cinctuls. LA T. id. - M AcQ. $_{i d .} n^{\circ}$. 2. Femelle. (En retranchant, parl les mêmes motifs que nous venons d'exposer", le synonyme de Panzer.) De France et de Danemarck. $3^{\circ}$. Xylophage garotlé, $X$. compeditus. NeIg, $i d$. pag. 13. $n^{\circ}$, 3. D'Autriche.

2e. Division. Premier et second articles des antennes écaux en longueur. - Troisième cellule du bord postérienr de l'aile fermée. (Subula MlÉGERLE.)

10. Xylophage tacheté, $X$. maculatus. Meig. Dipt. d'Eur.tom. 2. pag. 13. $n^{\circ}$. 4. Mâle et femelle; tab. 12. fig. 15. Müle. (En retranchant le synonyme de M. Lalreille qui appartient au X. varié.) - Mace. Ins. Dipt. du nord de la France, Asiliq. etc. pag. 142. $n^{\circ} \cdot 3$. (En retranchant le même synonyme.) De France et d'Autriche. $2^{\circ}$. Xyloplage varié, $X$. varius. Meig. $i d$.pag. 14. $n^{\circ}$. 5. Mäle et fernelle. - Xylophagus maculatus. L.A r. Gener. Crust. et Ins. tom. IV. pag. 272. (En ôtant les synonymes de $F$ 'ab. et de M. Neigén, quị appartiennent à l'espèce précédente.) - $X_{3}$ lophagus ater. Lat. Gener. C'mst. et Ins. tab. XVI. $f_{\text {gig. }} 9$. el 10. Mále. - N $\mathrm{AcQ}_{\text {. }} i d$. $n^{\circ}$. 4. Des environs de Paris ẹt d'Autriche. 3०. Xylophage bordé, X. marginatus. MEIG. id. pag. i5. $n^{\circ}$. 6. Mâle. Du midi de la France el d'Autriche.

A ce genre appartient en outre le Xylophage américaiu, $X$. anericanus. WIÉDEM. Dipt. exotic. pars $1^{\mathrm{a}}$. pag. 5ı. Longueur 5 lig. Corselet jaune, laché de noir; abdomen roux avec les incisions des segmens, jaunes. Mâle. Amérique sèp. tentrionale. (S. F. et A. Sery.) 


\section{Y L}

XYLOPHAGES ou LIGNIVORES. Nom donné par M. Duméril, dans sa Zoologie analytique, à une famille de Coléoptères Tétramères (la vinglième de cet ordre), offriant pour caraclères : antennes en soie, non portées sur un bec, et renfermant les genres Rhagie, Lepture, Molorque, Callidie, Saperde, Capricorne, Lamie et Prione. (S. F. et A. Serv.)

XYLOPHAGES, Xylophagi. Seconde famille dc la section des Tétramères, ordre des Coléoptères. Ses caractères sont :

Tous les articlesdes tarses ordinairement entiers; quelçuefois le pérultième est bilobé, et, dans ce dernier cas, les palpes sont très-petits et coniques. - Antennes ayant souvent moins de onze articles, plus grosses a leur extrémitẻ ou en massue.

I. Antennes ayant moins de onze articles.

A. Corps tantôt subovoïde ou cylindrique, tantôt linéaire, quelquefois clypéíforme. - Corselet de la largeur de l'abdomen, da moins ì son bord postérieur. - Palpes petits. - Antennes terminées en massue, offirant au moins cinq articles a vant cette massuc.

n.re. Tribu. Scolytaires, Scolytarii. Voyez ce mot.

2e. Tribu. Bostrichins, Bostrichini.

Palpes (au moins les maxillaires) itès-appa rens, filiformes on plus gros au bout.

Bostriche, Psoa, Cis, Némozome, Cérylon, Rhizophage, Clypéastre.

B. Corps oblong, très-aplati, rétréci en devant. - Abdomen plus large que le corselet. - Palpes grands (coniques). - Antennes composées de deux articleš , le dernier très-grand; ou de dix et perfoliées dès la base. - Lèvre grande, cornée. - Elytres tronqućes.

ろe. Tribu. Paussiles, Paussili. Voyez ce mot.

II. Antennes'de onze articles.

4e. Tribu. Trogossitaires, Trogossitarii. Voyez ce mot.

Nota. Cet article est tiré des Fanillles naturelles de M. Latreille. (S. F. et A. Sirnv.)

XYLOPHAGES, Xylophagi. Seconde famille des Diptères de M. Mcigen, la première de sa seconde division. L'auteur lui donne pour caractères :

Antennes avancées, rapprochées à la base, triarticulées; dernier article divisé en huit anHist. Nat. Ins. Tome $X$. neaux; trompe cachée, à lèvres saillantes; trois ocelles; abdumen composé de huil segmens; balauciers découverts; ailes couchées parallèlement sur le corps; trois pelotes entre les crochets des tarses.

Cette famille contient les genres Béris, Xylophage et Coenomyie. Elle répond à la tribu des Xylophagiens, famille des Notacanthes LAT.; mais ce dernier auteur place le genre Cœnomyie dans sa tribu des Sicaires, famille des Tanystomes. (S. F. et A. Serv.)

XYL OPHAG IENS, Xylophagii. Première tribu de la famille des Notacauthes, première section de l'ordre des Diptères.

Les caractères de cette famille n'ayant pas été donnés dans le prćsent ouvrage, nous allons les consigner ici.

Notacanthis, Notacantha. Troisième famille de la première section de l'ordre des Diptères.

Suçoir de deux pièces. - Trompe du plus grand nombre, membraneuse, très-courte, retirée dans la cavité buccale pendant le repos, ses deux lèvres paroissant seules à l'extérieur; celle des autres longue, grêlc, cachée par le prolongement de l'hypostome. - Antennes ayant leur dernier articte divisé en plusieurs anneaux. Ailes couchées sur le corps dans le repos, ayant une cellule discoïdale qui émet quelques nervures divergentes vcrs le bord postérienr. - Ecusson souvent armé de dents ou d'épines. - Larves (au moins celles qui sont décriles) aquatiques; leur corps terminé par une espèce de tabe formé par les derniers segmens du corps et propre it la respiration; la peau servant de coque à la nymphe en se durcissant, mais sans cbanger de forme.

jre. Tribu. Xylophagiens, Xylophagii.

Dernier article des antennes divisé en huit anneaux.

$$
\begin{aligned}
& \text { Hermétie, Xylophage, Béris, Cy- } \\
& \text { phomyie. }
\end{aligned}
$$

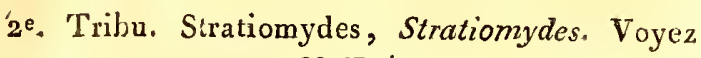
ce mot.

La plupart des Notacanthes habitent les lieux marécageux et se tiennent sur les fleurs ou sur les feuilles'des végélaux; quelques autres, particulièrement les Xylophagiens, fréquentent lcs bois, et paroissent faire leur ponte dans la carie des arbres.

hermétie, Hermetic. Lat. Fab. Wiédem. Musca. Linn. Nemotelus. De Géer.

Genre d'insectes de l'ordre des Diptères, préI i i i i 
mière section, famille des Notacanthes, tribu des Xylophagiens.

Quatre genres composent cettc tribu, savoir : Hermétie, Xylophage, Béris et Cyphomyie. (Voyez Xylophagiens.) Les trois derniers se distinguent par l'article terminal des antennes linéaire, sans rétrécisscment dans aucune portion de son étendue, et par le dernier anneau de cet article qui n'est pas plus long que chacun des autres pris séparément.

Antennes beaucoup plus longues que la tête, composées de trois articles; le premier assez long, allant en grossissant de sa base à l'extrémité ; le second court, nn peu conique; lc troisième en Inassue, trc̀s-comprimć, rétréci dans son milieu, sa base ou moitié inférieure jusqu'à l'étranglement, alongée, presque conique, divisée en scpt anncaux; le huitième anneau allant en s'élargissant vers son extrémite, indivis, presqn'elliptiquc, un peu concave en dessons, aussi loug que les sept autres pris ensemble. - Tête transversale, un peu bo:nbée en devant. - Yeux grands. - Truis ocelles disposés en triangle sur un tubẹcule du vertcx. - Corps alongé. - Corseleten carré loug, un peu plusétroit autérieurement; prothorax séparé du méso! horax par une ligne transversale entoncée, arquée. - Ecusson assez grand, muticque. (X. Latreille, Gener. Crust. et Ins. tom. IV. pag. 2 II. dit qu'il a quelquefois deux épines.) - Ailes couctuées pariallèlement sur le corps dans le repos, ayant une cellule discoidale qui émet deux paires de aervures divergentes ver's le bord postérieur. -Cuillerons point distincts. - Balanciers longs, découverts. - Abdomen ovale, un peu bombé en dessns, composé de six segmens outre l'anus. Pattes de longueur moyenne, grêles; tarses longs, leur premier article aussi grand que les quatre autres réunis; l'avant-dernier fort petit; le terminal un per plus long, muni dc denx crochets trèsécartés, ayant dans leur entre-deux une pelote grosse, profondément bifide.

Les mœurs de ces Diptères exotiques ne sont pas connues. Les espc̀ces quc nous possédons sont assez grandes, et au moins de taille mogenue parmi les Diptc̀res.

${ }_{1}^{\circ}$. Hermétic transparente, H. illucens. TAT. Gen. Crust. et Ins. tom. IV. pag. 271.-Nemotelus illucens. DE GÉ̇a. Mém. Ins. tom. 6. pag. 205. $n^{\circ}$. 3. pl. 29. fig. 8-10. Amérique méridionale. (L'Hermetia illucens no . I. FAB. Syst. Antliat. est une autre espèce, et peut-être l'Hermetia leucopa LAт.) - Musca leucopa. Linv. id. Syst. nat. 2.983.23. (La Muscaillucens Liss. id. 2. 979. 2. est incomplélement décrite, mais d'a près la citation de la collc tion de De Géer, il paroît certain que c'est l'Hermetia illucens LAт.) $2^{\circ}$. Hcrmétie pectorale, H. pectoralis. WiÉd Ex. Analect. Entonz. pag. 19. $n^{\circ} .2$. Longueur 4 lig. Noire; sternum et pattes de couleur rousse; tarses noirs à base blanche. De Guinée.
BERIS, Beris. Lat. Meig. Mace. Stratiomys. Geoft. Fab. Panz. Falièn. Ilusca. Linn. Schaarck. Deville.

Genre d'insectes de l'ordre des Diptères, première section, faunille des Notacanthes, tribu des Xylophagiens.

Lcs Béris composent avec les Hermćties, les Xylophages et les Cyphomyies, la tribu des $\mathrm{Xy}$ lophagiens. Le genre Hermétie est distinct par ses antennes, dont le troisième article est en magsue, très-comprimé, rétréci dans son milieu; te dernier anneau de celui-ci presqu'aussi long à lui seul que les sept autres pris ensemble. Les Xylophages ont l'écusson mutique; dans les $\mathrm{Cy}^{-}$ phomyies l'abdomen est orbiculaire, aussi large que long, et l'écusson n'olfre que deux épines.

Antennes avancées, compusées de trois articles; les deux premicrs courts, un peu velus; le premier assez aminci à sa base, le second cyathiforme, le troisic̀me long, nu, divisé en huit anneaux égaux entr'eux, le dernier seulement un peu plus petit que les autres, conique. - Trompe ayant son extrémité peu saillante. - Palpes petits, de trois articles, un peu plus épais ver's !eur extrémité-Tête hćmisphérique, très-comprimée dars les femelles. - Yeux assez yrands, se touchant sur le front dans les mâles, fort espacés dans les femelles. - Trois ocelles placés en triangle sur un tubercule du vertex. - Corps assez court, étroit. - Corselet ovale ; prothorax séparé du mésothorax par une ligne transversale enfoncée. Ecusson assez grand, armé de quatre à huit épines an bord postéricur. - Ailes velues vaes au microscope, couchées parallèlement sur le corps dans le repos, ayant une cellule discoïdale qui émet quatre nervures divergentes vers le bord postérieur, la troisième très-courte, à peine com. mencée. - Cuillerons simples, petits. - Balanciers découverts. - Abdomen assez long, elliptique, plane, de six segmens outre lanus. Pattes grêles, assez longues; tarses ayant leur premier article à peu près aussi long que les quatre autres réunis, ceux-ci presqu'égaux entr'eux, le dernier muni de deux crocliets ayant dans leur entre-deux une pelote divisée en trois; premier article des tarses postérieurs gros, velu en dessous ( surtout dans les mâles).

On ignore les premiers états des Béris, mais il est probable que les femelles déposent leurs æafs dans le terreau humide des vieux arbres. Leur taille est petite. M. Meigen place onze espèces dans ce genre, et le divise ainsi :

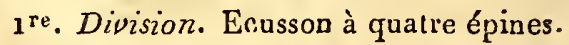

I $^{\circ}$ Beris luisante, B. nitens. Lat. Noúveau Dict. d'hist. nat. $2^{\mathrm{e}}$. édit. - MEIG. Dipt. d'Eur. tom. 2. pag. 2. $n^{0}$. 1. Femelle. - MAcQ. Insect. Dipt. du nord de la France, Asiliq. etc. p. 136. $n^{\circ}$. 1. Femelle. Des environs de Paris. $2^{\circ}$. Béris ibiale, B. tivialis. Merg.id. pag.3. $n^{\circ}$. 2. Mále et 


\section{Y L}

ferrelle.tab. 12. fig. 8. Femelle.-Mace. id. $n^{\circ} \cdot 2$. Mâle et femelle. Des environs de Paris; en mai. 5०. Béris obscure, B. obscura. MIE1G. id. pag. 4. $n^{\circ}$. 3. Femelle. D'Europe. Cette espèce pourruit peut-être appartenir à la division suivante, MI. Meigen n'ayant pas pu s'assurer du nombre des épines de l'écusson.

$2^{\mathrm{e}}$. Divzsion. Ecusson à six épines.

10. Béris métallique, B. chalybeata. ME1G. Dipt. d'Europ. tom. 2. pag. 4. $n^{\circ}$. 4. Mâle. Mace. Ins. Dipt. du nord de la France, Asiliq. etc. pag. 137. no. 3. Mâle. De France et d'Angleterre. $2^{\circ}$. Béris clavipède, $B$. clavipes. ME1G. $i d$. pag. 5. $n^{\circ}$. 5. - MAcQ. id. $n^{\circ}$. 4. Mâle et femelle. Assez commune en France. 3o. Béris armée, $B$. vallara. ME1G. $i d . n^{\circ}$. 6. Mâle et femelle..-MAcQ. id. pag. 138. no. 5. Mâle et femelle. - Beris nigritarsis. Lat. Gen. Crust. et Ins. tom. IV. pag. 273. (En retranchant le synonyme de Panzer qui appartient à la Béris clavipède.) Des environs de Paris. $4^{\circ}$. Béris féruorale, $B$. femorulis. Meic. id. pag. 6. no. 7. Femelle. D’Autriche. 50. Béris noire, B. nigra. $\mathrm{M}_{\text {EI . }} i d$. pag. 7. $n^{\circ}$. 8. Femelle. - MAcQ. id. $n^{\circ}$. 6. De France et d'Angleterre. 6०. Béris nigripède, B. nigripes. MEIG. id. $n^{\circ} \cdot 9$. Femëlle. D'Autriche.

3. Division. Ecusson à huit épines.

1०. Béris cuisses jaunes, $B$. flavofenzorata. MeIa. Dipt. d'Eur. toin. 2. pag. 8. no. 10. Femelle. D’Autriche. $2^{\circ}$. Béris fuscipède, B. fusci. pes. MEIG. id. no. 11. Mâle. - MAcQ. Ins. Dipt. du nord de la France, Asiliq. etc. png. $139 . n^{\circ} \cdot 7$. Mâle. De France et d'Angleterı. $3^{\circ}$. Béris flavipède, $B$. flavipes. Mace. $i d . n^{\circ}$. 8. Longueur 2 lig. $\frac{1}{2}$. Corselet du mâle d'un noir cuivreıx, d'uı vert brillant dans la femelle; abdomen noir; pattes fauves, tarses noirâtres; ailes brunes dans le mâle, presqu'byalines dans la femelle. Des environs de Lille.

$A$ ce genre appartiennent encure, $1^{\circ}$. Béris six dents, B. sexdentata.-Strationiys sexdentatu no. 36. FAв. Syst. Antliat. Selon M. Meigen elle pouroit être identique avec la Béris fuscipède, ou bien n'être que la femelle de la Béris métallique. $2^{\circ}$. Béris quadrilinéée, $B$. quadrilineata. Strationys quadrilineatu no. 34. $\mathrm{AAB}$. id. De Sierra-Léon.

Le genre Stratiomys FAB. Syst. Antliat. renferme trente-six espèces qui appartiennent à différens genres. Les nos. $1,3,9$, sont de véritables Strationes. 2, 6, 7,8,17,18, 19, 25, 27. des Odontomyies. Les espèces 4 . et 23 . constituent le gente Ephippie. On placera daus les Cyphomyies les nos. 1:, I2, 3o. Le no. 24. est une Platyne. Le genre Oxycère revendique les nos. $28,29,31$, el les Béris les nos. $34,35,36$. Ceux que nous ne citons pas appartiennent à des espèces qui nous sont inconnues.
CYPHOMYIE, Cyphomyia. Wiédem. Lat. (Fam. nat.) Stratiomys. FАв. Cофиев. Odontomyia. Un1v. (Encycl.)

Genre d'insectes de l'ordre des Diptères, première section, famille des Notacanthes, tribu des Xylophagiens.

Les trois genres Hermétie, Xylophage et Béris composent cette tribu avec celui de Cyptomyie. Les Herméties ont le troisième article des antennes en massue, très-comprimé, rétréci dans le milieu; son dernier anneau presqu'aussi long à lui seul que les sept autres pris ensemble. L'écusson mutique et l'abdomen alongé, cylindrique ou conique, éloignent les Xylophages des Cyphomyies; entin, les Béris ont toujours plus de deux épines à l'écusson, et leur abdomen est de forme alongée, elliptique.

Antennes avancées, rapprocliées à leur base, allant en s'écartant après le premier article, beaucoup plus longues que la tête, composées de trois articles; le premier cylindrique, le second cyathiforme, le troisième alongé, linéaire, légèerement comprimé, divisé en huit anneaux, le huitième pas plus grand qu'aucun autre des précédens, conique. - Trompe cachée dans la cavité buccale lors du repos, laissant à peine voir les lèvres à l'extérieur. - Tête plus étroite que le corselet; celle des femelles un peu carrée, creusée à sa partie postérieure, avec le front el le vertex trèsbombés; celte tête petite et liétnisphérique duns les mîles. - Yeux petits et très-espacés dans les femelies, grands et rapprochés sur toute l'étendue du front dans les mâles. - Trois ocelles très-rapprochés, disposés, en triangle sur un tubercule dı vertex. - Corps court. - Corselet ovale; prothurax assez grand, séparé du mésotborax par uae ligne transversale enfoncée, distincte. - Ecusson grand, son bord postérieur muni de deux épines. - Ailes velues vues au microscope, conchées parallèlement sur le corps dans le repos, ayant une cellule discoïdale qui émet trois nervures divergentes atteignant le bord postérieur. - Cuillerons simples, petits. - Balanciers découverts. - Aỏdomen presqu'orbiculaire, un peu plus large que long, un pea bombé, composé de cinq segmens outre l'anus. - Pattes grêles, assez longues; tarses ay ant leur premier article presqu'aussi long que les quatre autres réunis; les trois suivans allant en décroissant de grandenr; le cinquième deux fois plus long que le précédent, muni de deux crocliets très-divergens, ayant dans leur entre-deux trois pelotes dont lintermédiaire est la plus furte et paroît tronquée carrément.

On ne conboit encore que quatre espèces de ce genre; elles sont propres à l'Amérique mérilionale. M. Wiédemann a tiré son nom de deux mots grecs qui siguifient : Mouche bossue, peut-être à cause de la légère convexité de l'abdomen. Les mours ne sont pas connues. 
1. Cyphomye bleue, $C$. cyanea.

Cyphomyia cyanea. WiÉder. Analect. Ent. pag. 13. - Stratiomys cyanea. CoqueB. Illustr. icon. pag. 100. tab. 23. fig. 4. Fiemelle.

Voyez pour la description de la femelle et les autres synonymes, Odontomyie bleue n ${ }^{\circ} .8$. de ce Dictionnaire. Nous ferons observer que le brun de l'abdomen change en bleuâtre dans l'insecte frais, et que le premier article des tarses est blanc depuis sa base jusqqu'à l'extrémité. Nous regardons c smme mâle de cetle espèce un individu du même pays; il ne diffère de la femelle que par sa tête, extièrement d'un noir-bleıâlı’e.

$A$ ce genre appartiennent en outre, $1^{\circ}$. Cyphomyie tachée, C. maculata. Wrénem. id. - Stratiomys maculata n ${ }^{\circ}$ 3. F н. . Syst. Antliat. Amérique méridionale. $2^{\circ}$. Cyphomyie albitarse, $C$. albitarsis. Wréd. id. Mâle et femelle. - Stratiomys albitarsis n०. I 2. FAB. id. Du Brésil. 30. Cyphomyie llamme, $C$. auriflamma. WiÉD. id. fig. 4. Mâle et femelle. Du Brésil.

$$
\text { ( S. F. et A. SERV. ) }
$$

XYLOPHILES, Xylophili. Troisième division de la tribu des Scarabéides, famille des Lamellicornes, section des Pentamères, ordie des Coléoptères.

Les caractères propres à celte division ont été mentionnés à l'urticle Scarabéides. (Voyez ce m.st.) Nous la partagerons ainsi :

๑. Mandibules saillantes, découvertes.

A. Labre entièrement caché. (Corpss de couleur sombre.)

o. Côté extérieur des mandibules simple, sans crénelures ni dents.

Phileure, Oryctès.

oo. Côté extérieur des mandibules sinué, crénelé ou dentelé.

Scarabé.

$\Lambda \Delta$. Bord antérieur du labre apparent, séparant distinctement le chaperon des mandibules. (Corps ordinairement brillant, ou offiant des couleurs variées.)

o. Ecusson grand, triangulaire.

Chasmodie, Macraspis.

oo. Ecusson petit, ordinairement semi-circulaire.

Rutèle, Hexodon, Pélidnote, Chrysophore, Oplognathe.

T. Mandibules déprimées, presqu'entièrement recouvertes en dessus par le chaperon. - Labre tolalement caché.

Cyclocéphale.
ORYCTES, Oryctes. IrLIg. Lat. Scarabous. Linn. Payk. Panz. De Géer. Geoff. Oliv. (Entom.) Geotrupes. Fab. Schon.

Geure d'insectes de l'ordre des Coléoptères, section des Peutamères, famille des Lacnellicornes, tribu des Scarabéides (division des Xylophiles ).

Les genres Plileure et Oryctès forment dans celte divisiou un groupe caractérisé par les mandibules saillantes et découvertes, dont le côté extérieur est simple, sans crénelures ni dents, et par le labre entièrement caché. (Voyez XysoPances.) Les Phileures se distinguent des Oryctès par leur corps déprimé et par les côtés du corselet manifestement dilatés.

Les Oryctès out le corselet sans dilatatiou latérale; leurs caractères génériques sont presqu'entièrement les mêmes que cerax des Scarabés. (Voy. ce mol.) Ils ne different de ces derniers que par leurs mấchoires coriaces à l'extrémité, dépourvues de denis, simplement velues, et par le côté extérieur des maudibules qụi n'est ni. sinué ni denté.

Les femelles de ce genre déposent leurs oufs dans les terreaux, les furniers, les terres grasses. Les larves sout molles, ordinairement courbées en arc, surtout à leur partie postérienre, en sorte qu'elles ne peuvent s'étendre en ligne droite et qu'elles marchent mal sur un plan uri. La'tête est dure, écailleuse, munie de denx antennes courtes, filiformes, et de quatre palpes; le corps est cumposé de douze segunens, et porte six palles écailleuses. Quant à ses parties inlérieures, elles offient, dit le savant auteuy du Regne animal, un estomac cylindrique, entouré de trois rangées de petits cæcums, un inteslin grêle, trèscourt, un colon énormément gros, boursoufflé et un rectum médiocre. Dans linsecle parfait ces inégahilés disparoissent, et il n'y a qu'un long intestia presque d'égale venue. Ces larves subissent lerrs métamorphoses dans l'endroit où elles ont vécu, et s'y forment, avecles débris des matières qu'elles ont rongées, uue coque ovoïde dont les parties sout liées avec une substance glutineuse qu'elles tirent de leur corps. La peau qui recouvre la nymphe laisse voir assez bien les parties que l'insecte parfait doit avoir.

Ce genre n'ayyant été que meutionné à sa lettre dans ce Dictionnaire, nous avons dû lui donnev ici plus de développemens, aujourd'hui qu'il est généralement adopté. Son nom vient d'un verbe grec qui signifie : fouiller. Les espèces connues sont loutes de taille grande ou moyenne, d'uue couleur noirâtre, brune ou marron clair. Nous citerons :

$1^{\circ}$. Oryclès nasicorne, O. nasicornis. LAт. Gen. Crust. et Ins. tom. 2. pag. IO2. no. I. - Gcotrupes nasicomis $\mathrm{n}^{\circ}$. 11. FAB. Syst. Eleut. (A l1 citalion du $S_{\jmath}$ st. nat. de Linné, lisez 15 . au lieu de 14. ) - Schics. Syn. Ins. tom, 1. p. $33 . n^{\circ} .53$. 


\section{Y L}

-Le Moine. Georf. Ins. Paris. tom. I. pag. 68. no. 1. - Encycl. pl. 142. fig. 8. Il habile dans les couclies des jardins potagers on vit sa larve. (Voyez les généralités.) Il en sort le soir à la brune et prend alors son vol.. Celte espece, fort cornmune dans toute l'Europe, est très-connue des jardiniers des environs de Paris et de beauconp d'autres personnes, sous les noms de Licorne ou de Rhinocéros. $2^{\circ}$. Oryctès Boas, O. Boas. Geotrupes Boas n ${ }^{\circ}$ 23. FАв. id. (En relranchant le synonyme du Scarab. Augras de l'Entom. Syst., et celui d'Olivier, qui ont rapport à l'espèce suivaute.)--Scecen. id. pag. 8. $n^{\circ}$. 32. ( lin retranchant la variélé, qui est l'espèce suivaute. ) Encycl. pl. 142. fig. 5. Du cap de Bonue-Espérance. 3o. Oryctès Aucrias, O. Augias. - Scarabaeus Augias n०. 47. Fав. Ent. Syst.-OLiv. Ent. tom. i. Scarab. pag. 37. no. 39: pl. 24.fig. 212. - Geotrupes Boas, var. b. Schon. id. pag. 9. $n^{\circ} .32$. - Encycl. pl. 1 42. fig. 6. De Ceylan. Nous i.rnorons pourquoi liabricins l'a réuni à sou Geotrupes Boas dans le Syst. Eleut. M. SchœnLerr n'en fait qu'une variélé de celle espèce, ce qui nous semble une faute. $4^{\circ}$. Oryclès Rhinocéros. O. Rhinoceros. LAт. id. pag. I 33. - Geotrupes Rhinoceros no. 46. FАв. Syst. Eleut. - Sсном. id. pag. $16 . n^{\circ}$. 68. Des Indes orientales. 5\%. Oryctès Silene, O. Silenus. -Geotrupes Silenus n०. 51 . Fав. id. - Schasn. id. pag. 17. $n^{\circ} .7^{5}$. Du midi de la France. 6०. Oryctès Orion, O. Orion. - Geotrupes Orion n ${ }^{\circ}$ 26. FAв. id. - Schon. id. pag. 9. $n^{\circ}$. 35. Du Sénégal.

CHASMODIE, Chasmodia. MAcr. (Horoentom.) Lat. (Fam. nat.) Rutela. (Encycl.)

Genre d'insectes de l'ordre des Coléptères, section des Peutamères, famille des Lamellicorres, tribu des Scarabéides (division des Xylophiles).

Les deux genres Chasmodic et Macraspis se distinguent de tous les autres Xylophiles par li grandeur de leur écusson. (Voyez XYLophines.) Les Macraspis diffèrent des Chasmodies pár le labre et. le chaperon entiers.

M. Macleay a earactérisé ee genre dans ses Horce entomologica, de la manière suivante:

Antennes de dix articles, le premier grand, presqu'arqué, conigue; le second un peu globuleux, le troisième assez long, presque cylindrique; les quatrième, cinquième et sixième courts; le septième très-court, cyathiforme; leur massne *vale-alongée. - Labre avancé, cilié, bifide, aes divisions arrondies. - Mandibules fortes, corzées, alongées, canaliculées en dessous, leur bord extérieur profondément échancré, dépassant latéralement le claperon; leur bord interne membraneux, cilié : point de dent à leur extrémité interne. - Mấchoires cornées, bidentées, membraneuses à leur partie supérieure, ciliées; ces cils formant des pinceaux avancés. - Palpes maxillaires ayant leur troisième article presque globuleux, le quatrième ovale, obtus à son extrémité : palpes laliaux grêles, insérés sur les angles du menton, leur dernier article presqu'aigu. Menton alongé, concave, ses bords latéraux sinués on profondément excavés à l'endroit de l'insertion des palpes, son extrémité tronquée, fortement ciliée. - Tête presque carrée.-Chaperon profondément Echancré, son bord réfléclii. Corps ellipsoide, déprimé. - Corselet deux fois plus large que loug. - Ecusson grand, triangnlaire. - Sternum s'étendant jusqu'à l'insertion de la première paire de paltes, émoussé. - Pattes assez fortes; jambes antéricures tridentées, les postérienres un pen comprimées; tarses de longueur moyenne, leurs crochets divisés. (Nous pensons que M. Macleay s'est trompé sur ce dernier caractère, l'un des crochets nous paroissant entier dans les quatre tarses postérieurs.)

Le nom de ce genre fait allnsion à l'échancrure remarquable que présentent le labre et le chaperou, échaucrure tellement forte qu'elle fait paroître ces ders parties bifides. Ce genre répond à la prewière subdivision de la première division da genre Rutèle de ce Diclionnaire.

Outre la Cliasmodie brune (Rutela bninnea no. 2. Encycl.), nous avons rapporté à la mème section la Macraspis emarginata Des. Catal., qui nous paruît être la même espèce que la Chasmodia viridis $\mathbf{n}^{\circ}$. 1 . de M. Macleay, qui la décrit ainsi ut suprà pag. 155. D'un vert noir brillant, trèsglabre en dessus; corselet rebordé; élytres point sensiblement striées; anus et côtés du dessous du corps ayant des rides; cuisses et dessous du colselet très-velus. Du Brésil.

Nota. La Rutèle Cétoine no. 1. du présent Dictionnaire, devra probablement former un nonveau genre lorsque l'on connoîtra les crochets de ses tarses, et il est forl doutenx que M. Macleay l'eût placée dans ses Chasmodies; elle a bien le chaperon et le labre bifides comme ces dernières, mais elle ressemble aux Cétoines par la présence de la pièce triangulaire entre les angles latéraux du corselet et les angles supérieurs des élytres, et diffère encore des Chasmodies par le bord extérieur des élytres entier, tandis qu'il est denté dans ce dernier genre.

MACRASPIS, Macraspis. MAcL. (Hore entom.) Lat. (Fam. nat.) Rutela, Cetonia. (Encycl.) Cetonia. Fab. Rutela. Schoen. Scarabceus. Linn. De Géer.

Genre d'insectes de l'ordre des Coléoptères, section des Pentamères, famille des Lamellicornes, tribn des Scarabéides (division des Xylophiles ).

Un groupe de cetle division a pour caractères: écusson grand, triangulaire; les genres Chasmodie et Macraspis le composent. (Voyez XYLogu- 
zEs.) Les Chasmodies sont reconnoissables par lenr labre et leur chaperon bifides.

Voici les caractères assignés à ce genre par son auteur.

Antennes ayant leur premier article conique, peu alongé, et leur massue oblongue, grande, urais n'égalant pas la moilié de la longueur totale de l'antenne. - Labre transversal, son bord antérieur presque demi-circulaire, avancé, coriace, entier, velu, son extrémité presquaiguë. - Mandibules presque triangulaires, comprimées, concaves en dessus, leur cồté extérieur proéminent, échancré, à peiae bidenté, leur pointe un peu échancrée à la partie intérieure. - Mâchoires ayant leur bord intérieur membraneux et portant à leur extrémité deux lobes tridentés, de substance cornée. - Palpes maxillaires ayant leur dernier article grand, presque globuleux-ovale, ce même article dans les labiaux, ovale-alongé. - Irienton alongé, presque carré, concave, ses côtés sinnés, son extrémité tronquée, à peine échancrée, point ciliée. - Téte presque carrée. - Chaperon arrondi, son bord réflécli. - Corps ellipsoïde, déprimé. - Corselet deux fois plus large que long, son bord postérieur écbancré. - Licusson fort grand, en triangle alongé. - Sternum poiuta, prolongé jusquà l'origive de la tête. - Pattes assez fortes; jambes antérieures tridentées, les postérieures presque comprimées; tarses ayant uu de lcurs crochets entier et l'autre bifide.

Macraspis est tiré de deux muts grecs qui signifient grand écusson. Ce genre est propre à l'A mérique méridionale, ainsi que le précédent. On doit y placer les espèces comprises dans la seconde subdivision de la première division du genre Rutèle Encycl. La Macraspis quadrivittata Macr. Horce entom. $p .157 \cdot n^{\circ} .1$. est not:e Rulèle quadrirayée. Cet auteur mentionne une espèce nouvelle qu'il nomme Macraspis birayée, M. bivittata. Dessus du corps testacé brilliunt, le dessous noir ; tête fuuve avec une ligne transversale noire; corselet ayant deux taches noires; écusson fauve bordé de noir : on voit une bande longitudiuale sur les élytres, de couleur noire ainsi que leur suture; pattes testacées. Amérique méridionale.

PÉlidNote, Pelidnota. MAct. (Horce entom.) LAT. (Fam. nat.) Rutela, Melolontha. (Encycl.) Melolontha. FAв. Rutela. Schen. Scarabceus. Lixs.

Genre d'insectes de l'ordre des Coléoptères, seclion des Pentameres, famille des Lamellicornes, tribu des Scarabéides (division des Xylophiles ).

Parmi les Xylophiles dont le bord antérieur du labre est apparent, \& sépare distinctement le chaperon des mandibules, un groupe a pour caractères : écussun petit, ordinairement semi-circulaire. Il contient cinq genres. ( oy. Xy Lophirss.) Celui d'Oplognathe nous est inconnu. Le gen:e Rutèle a son écusson triangnlaire; le corps des Hexodons est presqu'orbiculaire, plat en dessous; leur tête est carrée et rentre, lors du repos, dans une profonde échancrure du corselet. Les Chrysophores ont leurs pattes postérieures fort longues, a cuisses rentlées et jambes alongées et arquées; ce qui distingue ces trois genres de celui de Pélidnote.

M. Macleay, en établissant ce genre dans ses Horce entomologica, pag. 157 ., lui donne pour caractères :

Antennes de dix articles, celui de la base grand, un peu arqué, conique; le second presque globuleux; le troisième plus long, presque cylindrique; les quatrième, cinquième et sixième courts; ie septième très-court, cyathiforme; leur massue ovale. - Labre avancé, trausversal, presque demi-circulaire, velu on cilié, son bord antérieur échancré. - Mandibules un peu comprimées, triangulaires, aplaties en dessus, leur bord extérieur arqué, échancré, leur extrémité bidentéc à la partie interne. - MIâchoires courtes, épaisses, velues, courbes, ayant six forles dents aiguës à leur extrćmité intérieure. - Palpes maxillaires ayant leur premier article court, presque cylindrique, le second plus long, le troisième plus court, plus épais à son extrémicé, le dernier ovale, un pen caualiculé : palpes labiaux courts , lear arlicle terminal ovale. - Menton court, carré, convexe à sa partie postérieure ou obtus, ses côtés sinués, son bord antérieur échancré, avec les angles arrondis. - T'ête presque triangulaire, sans suture transversale. - Chaperon arrondi, obtus, rebordé. - Corps ovale, convexe, point recouver't postérieurement par les élytres. - Sternum très-court, un peu obtus. - Ecusson de grandeur ordinaire, demi-circulaire.-Pattes assez fortes; jambes antérieures tridentées extérieurement; crochets des tarses inécuaux.

Les Pélidnutes correspondent à la première subdivision de la seconde division da genre Rutèle de ce Dictionnaire. La seconde subdivision constitue à elle seule ce deraier genre dans son état actuel.

\section{CHRYSOPHORE, Chrysophora. Des. (C.Catal.)} LAT. (Fam. nat.)

Genre d'insectes de l'ordre des Coléoptères, section des Pentamères, famille des Lamellicornes, tribu des Scarabéides (division des Xylophiles ).

Un groupe de cette division conlient les genres Rutèle, Hexodon, Pélistnote, Chrysoplore et Oplognathe. (Vojez Xyzophizes.) Ce dernier ne nous est pas connu. Les Rutèles ont l'écusson triangulaire; dans les Hexodons le corps est orbiculaire, plat en dessous, et la tête rentre, lors da repos, dans une profonde échancrure du corselet; le genre Pélidnote a les cuisses postérieures et leurs jambes simples, ni longues, ni arquées, 


\section{Y L}

nii renflées : caractère qui lui est commua avec les deux premiers genres précités.

Antennes de dix articles, le premier gros, couique, cilié postérieurement; le second globuleux; les trous suivans coniques, allant en dimininuant de longueur; les sixième et septième cyatbifirmes; les trois derniers formant une massue alongée, ovale, velue. - Mandibules déconvertes._- Falpes ayant leur dernier article grand, ovale-cylindrique. - Lèvne grande, échancrée è devant. - Chaperon point séparé de la tête par une ligne transverse, un peu rebordé, arrondi en devant, un peu tronqué antérieurement. Corps gros, épais. - Corselet transversal, ses angles antérieurs très-saillans, ses côtés arrondis, légèrement sinués, un peu rebordé et sinué postérieurement. - Eccusson assez grand, demi-circulaire. - Elytres un peu rebordées, se rétiécissant du milieu à l'extrémité, recouvrant des ailes, laissant à nu l'extrémité de l'abdomen, leur angle sutural presque prolongé en pointe spiniforme. - Pattes fortes; les deux jambes antérieures à peine tridentées extérieûrement; les deux postérieures très-longues, très - arquées, terminées intérieurement par une grande épine inarticulée, un peu croclue; cuisses postérientes resflées; tarses ayant leur cinquième article aussi grand que les quatre autres pris ensemble; les Jeux tarses postérieurs très-longs; crochets antérieurs presqu'sgaux, l'un bifide, l'autre entier; les quatre crochets postérieurs presqu'égaux aussi, mais simples.

Les noms, tant générique que spécifique, donnés à la senle espèce conuue de ce genre, sont tirćs du grec; ils indiquent l'éclat extraordinaire dont eile brille. Les caractères que nous venons d'énoncer ont été pris sur un individu mâle faisant partie de l'immense collection de M. le comte Dejean, qui a bien voulu nous le communiquer avec une lienveillance qu'il a eue envers nous dans toute occasion, et dont nous le remercions ici bien sincèremeut.

1. Cerryophore chrysochlore, $C$. chrysochlom.

Chrysophora suprà viridi-aurea, subtìs viridicuprea: antenizis testaceis; elytris excavato purctatis.

\section{Chrysophora chrysochlora. Des. Catal.}

Longueur $18 \mathrm{lig}$. D'un beau vert doré en dessus, d'un vert cuivreux en dessous; antennes testacées, leur premier article ayant en dessus une tache cuivreuse; tête et corselet fiuement pointillés; élytres couvertes d'une multitude de gros points enfoucćs, qui les font paroître guillochées; pattes d'un vert cuivreux ainsi que l'auus; tarses d'un vooir-bleuâtre. Nẩle.

MI. le com!c Dejean nense que la femelle a les jambes postérieures moins longues et moins arquées.

Rapportée du Pérou par MM. de Humboldt et Bonpland. Nous croyons que M. Latreille a décrit cetie espèce sous le nom de Melolontha chrysochlora dans le Voyage de M. de Humboldt, mais nous n'avons pas eu communication de cet ouviage.

CYCLOCÉPHALE, Oyclocephala. LAT. (F cm. nat.) Chalepus. $\mathrm{H}_{\mathrm{AcL}}$. (Hora entom.) Melolontha. FAb. Oliv. Schqn. Geotrupes. Schæn. Scarabceus. Voet.

Genre d'insectes de l'ordre des Culćoptères, section des Pentamères, famille des Lamellicornes, tribu des Scarabéides (division des Xylopliiles ).

Les Cyclocéphales forment une coupe particulière dans leur division. (Voyez Xruornles.)

M. Macleay, dans ses Horce entonologicer, a désigné ce genre sous le nom de Chalepus; Mi. Latreille en l'adoptant a changé cette dénomination, qui avoit déjà été employée génériquement. Les caractères donnés par l'auleur anglais sont les suivans:

Antennes presque coudées, composées de dix articles; le premier presque couique, ou plutôt grossi à sa partie antérieure; le second presque globuleax, petit; les sixième et septième plus grands que les autres, cyathiformes; massue de trois articles, presque comprimée, alongée, ovale. - Labre caché sous le chaperon, son bord antérieur demi-circulaire, à peinc visible, un per échancré à sa partie iuférieure. - Mandibules épaisses à leur base (peu découverics et déprimées, suivant M. Latreille), triangrulaires, arquées à leur partie extérieure, point dentées, leur pointe aiguë. - Mâchoires crustacées, fortes, alongées, un peu comprimées, à peine sinuées, leur extrémité armée de six dents courres, fortes et cornées. - Palpes maxillaires ayant leur premier article à peine distinct; le second presque conique, le troisième plus court, conique; le dernier alongé, cylindrique-ovale, plus grêle à sa base et à son extréinité : palpes labiaux courts, insérés sur le dos des lobes du menton; premier article grêle, conique; le second plus court, plus épais, conique; le deruier cylindrique-ovale. Mcnton presque carré, un peu rétréci de chaque côté à son exırémité, son bord snpérieur profondément échancré, ses lobes presquu'arrondis, convexe en dessus, son bord postérieur échancré ou plutôt excavé. - Tête presque carrée ou trapézondale, ayant une suture transversale. - Chaperon tron qué à sa partie antérieure, à peine échancié. -Corps presque convexe. - Corselet iransversal, ses bords latéraux convexes, le postérieur tronqué. - Sternum simple, sans prolongement. - Elytres ne recouvrant pas entièrement l'abdomen. - Jum. 
bes antérieures portant trois dents à leur cóté externe.

Le nom de Cyclocéphale venant de deux mots grecs, a rapport à la forme de la tête de ces insectes. M. Latreille dit avec raison, que ce genre semble faire le passage de la division des Scarabéides-Xylophiles à celle des ScarabéidesPbyllophages, et il ne seroit pas étonnant qu'il eût les moeurs de ceux-ci. Nous indiquerons pour type l'espèce suivante :

\section{Cyclocépeale géminée, $C$. geminata.}

Chalepus geminatus. MAcL. Hore entomol. pag. $149 \cdot n^{\circ}$. 3. - Melolontha geminata $11^{\circ} .33$. Fab. Syst. Eleut. - Schen. Syn. Ins. tom. 3. pag. 187. $n^{\circ}$. 115. - Geotrupes lugubris. Scnen. id. tom. 1. pag. 21. no. g6. tab. 2. fig. 1.

Voyez pour la description et la synonymie, Hanneton douteux no. 51 . de ce Dictionnaire.

$$
\text { (S.'F. et A. Serv.) }
$$

XYLOTE, Xylota. Meig. Lat. (Fam. nat.) Milesia. Fab. Falè̃n. Musca. Linn. De Géer. Geoff. Scheli. Schranck. Syrphus. Panz. FalLìx. IIerodon, Scova, Thereva. FAв.

Geure d'insectes de l'ordre des Diplères, première section, famille des Arhéricères, tribu des Syrphies.

Un groupe de Syrphies a pour caractères : antennes ayanı leurs deux premiers articles égaux entr'eux, portées sur un tubercule frontal. Il renferune les genres Milésie, Brachyope, Rhingie et Xylole. (Voyez Syrphies.) Les trois premiers se distinguent du dernier par leurs cuisses postérieures simples.

Antennes insérées sur un tubercule élevé, situé sur le front, avancées, un peu penchées, composées de trois articles; les deux premiers petits, velus; le troisième orbiculaire, comprimé, ayant à sa base une soie simple. - Ouverture de la cavité buccale ovale, rétrécie en devanı. - Irompe cachée dins la cavité buccale lors du repos, terwinée par deux lèvres qui restent un peu saillantes. - Palpes ou coniques ou cylindriques, de longueur variable. - Tête hémisphérique, déprimée eu devani; bypostome creusé, uni ou n'ayant qu'un très-petit lubercule. - Yeux nus, réunis duns les mâles, espacés dans len femelles. - Trois ucelles placés en triangle sur le vertex.-Corselet :morrue carré, un peu bombé à sa partie antérieure. - Ecusso. úemi-splérique. - Ailes lancéolées, velues vues au microscope, couchées parallèlement sur le corps dans le repos. - Cuilleronis petits. - Balanciers découverts. - Pattes antérieures courtes, menues; les postérieures fortes, beaucoup plus longues que les antres, leurs cuisses en massue, garnies en dessous de fines épines, leurs jambes arquées.

Dix-neuf espèces de Xylotes sont mentionnées dans les Dipt. d'Europ. de M. Meigeu; il forme deux divisions dans ce genre; la première ne renferme qu'une seule espèce, qui diffère beaucoup des autres par divers caractères et par la nourriture de la larve : c'est la Xylota pipiens, dont De Géer a trouvé la larve dans du fumier de cheval. Celle larve est brune, plus grosse vers la lête que par derrière, celle-ci est ternuinée par une petite pointe fine; au lieu de paltes, chaque segment du corps a ell dessous de pelits mamelons charnus au moyen desquels la larve marche, ou plutôt se traiue lentement. Elle se fait de sa propre peau une coque ovale d'un brun obscrir, pointue a son extrémité. M. Meigen dit avoir reçu la dépouille d'une nympbe de la $X$. pigra. Elle étoit brane, dure, oblongue, assez arrondie en dessus, aplatie en dessuus; sa partie antérieure portoit deux petites cornes, et l'anus avoit une queue courte. Les femelles des espèces de la seconde division se rencontreut fréquemment sur les arbres pourris $\mathrm{t} t$ dont les parties intérieures sont réduites en terreau, ce qui fait présumer qu'elles y fonı lev.r ponte. On trouve aussi ces Diptères sur les fleurs. Xylote vient d'un mot grec et signifie : habitant le bois.

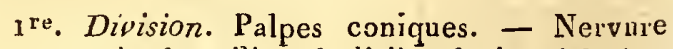
transversale du milieu de l'aile, droite. (Syritta Noв.)

Nous ne connoissons qu'une seule espèce de cette division, c'est la Xylote chanteuse, $X . p i-$ piens. Meig. Dipt. d'Eur. tom. 3. p. 2 I3. $n^{\circ}$. I. Mâle et femelle. Cette espèce, extrêmement commuve en France et en Allemagne, varie beaucoup.

2e. Division. Palpes presque cylindriques, grossissant un peu vers l'extrémité. - Nerviure transversale du milieu de l'aile, plus ou moins oblique. ( $X_{3}$ lota propriè dicta. Nов.)

$\mathrm{y}^{\mathrm{re}}$. Subdivision. Hanches postérieures des mâles armées d'une épine longue el grête.

$1^{\circ}$. Xylote indolente, $X$. segnis. Meig. Dipt. d'Eur. tom. 3. pag. 220. no. 12. Commune aux environs de Paris. $2^{\circ}$. Xylote nonchalaute, $X$. ignava. Meic. id. pag. 221. $n^{\circ}$. 13. Des environs de Paris. $3^{\circ}$. Xylote paresseuse, X. pigra. Meıc. $i d . n^{\circ} .14$. Même patrie que les précédentes.

$\mathbf{2}^{\mathrm{e}}$. Subdivision. Hanclies postérieures des mâles armées d'un tubercule un peu aigu.

${ }^{\circ}$. Xylote des bois, $X$. sylparzm. Merg. Dipt. d'Eur. tom. 3. pag. 223. $n^{\circ}$. 17. Aux envirous de Paris, dans les forêts. $2^{\circ}$. Xylote des fleurs, $X$. florum. MEIG. id. pag. 217. $n^{\circ}$. 8. Des envirous de Paris.

3e. Subdivision. Hanches postérieures entiérement simples dans les deux sexes.

10. Xylote lente, X. lenta. Merg. Dipt. d'Eur. 
tom. 5. pag. 222. $n^{\circ}, 15$. Des environs de Paris. $2^{n}$. Xylote latérale, $X$. lateralis. Merg. id. pag. 224. $n^{\circ}$. 18. De France, d'Autriche et de Suede.

$$
\text { (S. F. et A. SER. ) }
$$

XYLOTOMES, Xylotomce. Cinquiòne famille des Diptères de M. Meigen. (La quatrièrne de sa seconde division.) Il la caractérise ainsi :

Anteanes avancées, rapprochées à leur base, triarticulées, dernier article sans divisions. Trompe cachée. 'Trois ocelles. Abdomen cylindı ique, conıposé de six segrmens outre l'anus. Balanciers découverts. Ailes écartécs. Deux pelotes entre les crochets des tarses.

Cette fauille ne contient que le genre Thereva, qui rentre dans la tribu des Mydasiens, fanille des 'Tanystomes de M. Latreille.

$$
\text { (S. F. et A. SERV.) }
$$

XYPHOSURES, Xyphosura. LAT.

M. Latreille donne ce nom à un ordre de Crustacés de la section des Edentés, auquel il assigne les caractères suivans : point de siphon; base des pieds (ceux du céphalothorax ou de la division autérieure du corps qui, les deux derniers exceptés, servent uniquement à lil locomotion et à la préhension ) liérissée de petites épines et filisaut l'office de mâclıoires; test dur, divisé en deux boucliers, offiant en dessus deux sillons longitudinaux et recouvrant tout le corps, qui se termine en dessus par uie pièce très-dure, ensiforme et mobile. Ces animaux sont collstamnent vagabonds. Cet ordre ne contient qu'un genre que nous allons faire connoître.

LiMULe, Limulus. Mulc. Fab. Lat. Léach. Monoculus. Lins. Xyploosura et Xyphotheca. Grovor. Polyphemus. Lamk. Cancer clusius.

Le corps des Limules est divisé en deux parties; la première ou l'antérienre, que M. Latreille nomme céphalothorax, est recouverte par un bollclier lunulé, débordant et portant deux yeux trèsécartés l'un de l'autre, entre lesquels M. Cuvier a observé trois petits yeux lisses rapprochés; au-des. sous de la carapace dont nous venons de parler, sont insérés, sur une saillie conique, en forme de bec ou de labre, deux corps semblables à deux petites serres de Crabes, didactyles on monodactyles, selon les sexes, composés de deūx articles que M. Latreille considère comme les antennes, et que Savigny assimile à la seconde paire de pieds-mâchoires des Crustacés, ainsi qu'aux mandibules des Arachnides, et auxquels il donne le nom de mandibules succédanées ou fausses mandibules; à la suite de ces antennes se trouvent six paires de pieds, dont les deux derniers réunis forment un grand feuillet portant les organes sexuels, et dont Hist. Nat. Ins. Tome $X$. les dix autres libres, et tous, à l'exception des deux premiers, didactyles. Ces pieds sont composés de six arlicles, le radical ou la hanche est hérissé de piquans ou épines dont le nombre est très-considérable aux deux ou trois premières paires de pieds: ces articles tiemnent lieu de mâchoires; l'article suivant, ou le premier de la cuisse, offie aussi quelques épines. La dixième paire de pieds diffère des autres par divers caractères, et surtout par les hanches, qui ne sont point maxillaires, et par l'extrémité intérieure du dernier arlicle de la jambe, qui se termine par quatre petites lames mobiles, droites, alongées, pointues, égales et rapprochées en un faisceau longitudinal; la partie extérieure de cette même extrémité de la jambe donne attache au dernier article, qui est terniné comme les autres par deux doigts mobiles qui diffèrent un peu des prćcédens. Le pharynx débouche entre les hanches de loules ces palles; l'œsophage se dirige en avant, l'estomac des limules étant situé, comme dans les Crustacés décapodes, vers le bord antírieur du test. La seconde partie du corps des Limules, ou la postérieure, est recouverte par un bouclier qui a en dessus la lorme d'un trapézoíde échancré postérieurement, a vec les bords latéraux almés d'épines mobiles el altermantes; en dessons, et clans un creux en forne de boîle presque carróe, sont cinq paires de feuillets ou de larges pieds natatoires dont la face postérieure est garaie de brauchies. I’anus est placé à la racine de la pointe qui termine le corps; cette pointe est cornée, trìs-dure, droile, trigone, très-pointue et souvent arinée sur le dos de petites dentelures; elle s'insère dans une cavité au milieu de l'échancrure postérieure de la seconde pièce du test, et elle est articulée a vec elle par le moyen d'une lête dont les deux côtés sont dilatćs et appuyés sur deux saillies de celle pièce; le cœur, comme dans les Stommapodes, est un gros vaisseau garni en dedans de colonnes charnues régnant le long du dos et donnant des branclies des deux côtés; un œsophage ridé, remontant en avant, conduit dans un gosier très charnu, garni intérienrement d'une veloutée cartilagineuse toute hérissée de tubercules et suivi d'un intestin large et droit. Le foie verse la bile dans l'intestin par deux canaux de chaque côté. Une grande partie du test est remplie par l'ovaire dans les femelles, et par les testicules dans les mâles.

Clusius ou Lécluse et Boutius sont les premiers naturalistes qui aient mentionné et figuré des Limules. Muller les confond avec les Apus ; Fabricius les en a distinguées, mais il les a placées dans son ordie des Kleistagnathes ou Décapodes Brachiures de M. Latreille. Enfin, Lamarck ayant conservé le nom de Limule au genre Apus, appelle Poly phème le genre dont nous traitons. Ces animaux vivent dans les mers des pays chauds, $\mathrm{Kkkkk}$ 
et viennent le soir, presque toujours par conples, dans l'été, sur les plages sablonneuses ou marécageuses; la femelle, qui est plus grosse, porte sur son dos le mâle, sans que celui-ci y soit en état d'accouplement ni violemment attaché : leur's mouvemens sont fort lents et très-circonscrits, et lorsqu'ils marclient on ne voit ancune des paltes. Dès qu'on les touclie, ils s'arrêtent et relèvent leur queue pour se défendre. Ils restent toute la nuit à moitié hor's de l'ealı, et ne cherchent à se sauver que quand ils sentent que le danger commence à être émincnt. Leur queue est très-redoutée dans l'fnde et en Caroline, parce qu'on est dans l'opinion que sa piçûre est venimeuse. Les sauvages se servent de cette pointe en guise de fer de tlèche. I a chair des Limules est bonne à manger, et leurs œufs sont très-délicats. On sert sur les tables, à la Chine et au Japon, l'espèce qui lui est propre, et qui arrive, aver, l'âge, à une longrueur de deux pieds. Ces animaux se trouven! dans les ners des deux Irdes, depuis l'équateur jusqu'an quaranlième degré de latitude. Ils sont communs dans le golfe du Mexique, sur les côtes de Caroline, aux Moluques et dans les mers dı Japon et de la Chine. Les Aróricains appellent ces Crustarés King - Krab. Les nìgres des bords de la mer se servent du test vide pour puiser de l'eau ou pour d'autres usages domestiques. On connoit quatre ou cinq espèces de ce genre,

Limule Porypaène, Limulus Polyphemus. Lat. Gen. Crust. et Ins. tom. 1, pag. 11. - Hist. nat. des Crust. et des Ins. tom. 4. pag. 96. - Limulus Cyclops. FAB. Suppl. Ent. Syst. p. J 7 1. (Jenne.) Monoculus Polyphemus. I.1vN. Syst. nat. id. 13. tom. I. purs 2 p. 1057 .- Limulus Sowarbi.LÉAcH. (Zool. Hiscel pl. 84.) Sќr.a. Mus. noup. édit. ( 1828$) p a g .4$. pl. XYIT. $n^{\circ}$. 1. a. b. Il varie selon l'áge pour la laille et la conleur. Lues vieux sont d'un brun-noirûtre, et les jeunes d'un jannitre qui tire sur le brun. L'arêle du milieu dn dos a, sur chaque pièce du test, trois épines : le siylet formant la queue est à perr près de la longueur du corps. Celte espèce se trouve sur une griande partie des côles sallonneuses de l'Inde et de l'Amérique.

Limole des Molvques, Limulus moluccanus. LAт. Gen. Crust. et Ins. tom. I. pag. 1 1. - Hist. nat. des Crist. ei des Ins. tom. 4. pag. 92. pl. 16. 17. - Cancer moluccanus. Cinus. exot. lib. 6. cap. 14. pag. 128. - Bovт. Jav. lib. 5. cap. 3r.

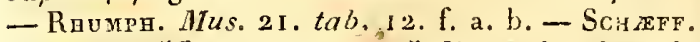
Monog. I $756 \cdot t a b \cdot 7 \cdot$ fig. 4. 5 . 11 actuiert jusqu'à deux pieds de longueur, et diftère du précédent parce qu'il n'a point d'ćpines sur l'arête du milieu de la première pièce du test, laquelle se termine eu avaut par une petite élévation fourchne. Il est très-commun dans les Indes orientales, aux Moluques. Les Japonais l'appellent Kabutogani ou Unkia. M. Léach, dans le Dict. des scienc. nat., décrit une espèce sous le nom de Limulus tridentatus, et qui paroit être la même que la précédente. Sa patrie est inconnue.

On connoît encore quatre autres espèces de Limules; deux ont été décrites par M. Latreille dans le Noup. Dict. d'hifloire natur. sous les noms de Rotundicauda et Virescens. Les deux autres sont publices par Léach dans le Dictionnaire des sciences natur. sous les noms de $M a$ cleii et Latreillii.

Enfin, une septième espèce a servi à Léach pour instituer un nouveau genre gue $M$. Latreille n'adopte pas. Léach clonne le nom de TAcHYPLÉE, Tachypleus à ce genre. II a les caractères généraux des limules; le dernier article des appendices des première et deurième paires de pattes ambulatoires est étroit à la base, renflé intérieurement vers son nilieu, et se terminant tout-àcoup en pointe. Deux doigts égaux terminent ceux de la qualrième et de la cinquième paire. M. Desmarets (Considér. sur les Crust., article extrait du Dict. des scienc. natur.) rapporle à ce genre le LrMule hétérodaciyle, Limulus heterodactylus. I.AT. Gen. Crust. et Ins. tom. 1. pag. 12. - Hist. natur. des Crust. et des Ins. tom. 4. pag. 89. C'est son Tachypleus heterodactylus, loc. cit. pag. 356. On le trouve dans les mers de la Chine.

On a trouvé une espèce de limule à l'état fossile; elle est rare et n'a été observée que dans des conches d'une antiquité moyenne. M. Desmarets lni a donné le nom do LiMuLE DE WALCH, Limulus IV alchii, dans son Hist.. nat. des Crust. fossilcs, pag. 139. tab. XI. fig. 6. et 7., c'est le Cancer perversus de Knorr et Walch. (Monum. dus déluge, tom. 1. pag. 136. pl. 14.) Elle ne diffère des espèces vivantes que par le rebord de la prenière pièce de la carapace, qui est arrondi au lieu de former un angle aigu devant la bouche, et par d'autres caractères tirés de la forme et des épines du test.

\section{XYPHOTHEQUE, Xyphotheca. Voyez XY-} PHOSURES.

\section{XYSTE, Xysta. Meic.}

Genre d'insectes de l'ordre des Diptères, famille des Muscides de cet auteur ; il lứ assigne pour caractères : antennes noilié aussi longues quue l'hypostome, couchées, composées de trois articles; le premier petit, les deux suivans presque d'égale longueur, comprimés, le dernier oblus à l'extrémité, muni à sa base d'une soie dorsale nue, biarticulée. Trompe cachée dans la 
cavité buccale. Palpes assez longs, cylindriques, un peu velus." 'Tête hémisphérique; hypostome ayant un sillon longitudinal des deux côtés, arqué dans le milien; auprès du sillon est une ligne de poils roides assez longs. Yeux presque réunis sur le front. Trois ocelles placés en triangle sur le vertex. Corps assez court. Corselet bombé, garni de poils roides. Abdomen bombé, muni de petits poils très-courts, ou presque nu, composé de quatre à cinq segmens outre l'anus. Ailes lancéolées, velues vues au microscope, à moitié ouver- tes dans le repos. Balanciers recouverts par un grand cuilleron double.

Les mœurs de ces Muscides ne sont pas connucs. L'auteur place deux espèces dans ce genre : $1^{\circ}$. Xyste cilipède, $X$. cilipes. Merg. Dipt. d'Eur. tom. 4. pag. 182. $n^{\circ}$. 1. tab. 3g. fig. 5. Longueur $3 \mathrm{lig} . \frac{1}{2}$. Noire; corselet et extrémité de l'abdomen cendrés; jambes postérieures ciliées. Du midi de la France. $2^{\circ}$. Xyste soyeuse, $X$. holosericea. MEIG. $i d . n^{\circ}$. 2. Antriche et midi de la France.

(S. F. et A. Serv.) 


\section{Y E U}

$\mathbf{Y}_{\text {EUX }}$, oculi.

Comme ce sujet n'a pas été traité au mot CEIL, nous sommes obligés de faire connoître ici les organes de la vue des Crustacés, Araclinides et Insectes. Ces organes ont une composition bien différente de celle que l'on a reconnue depuis long-temps dans les animanx vertćbrés; ils sont de deux sortes, les uns connus sous le nom d'yeux. composés ou de facettes, et les autres sous celui d'yeux simples ou lisses.

Les yeux composés on chagrinés sout ordinairement placés sur les parties latérales de la tĉte; leur forme est très-variable et leur surface extérieure est plus ou moins convexe. Leur composition a été observée dans plusieurs insectes par I.eurwenhoek, Swamnerdan, Cuvier et Marcel de Serres; il résulte des observations de ces anatomistes, que l'œil des insectes est composé : $1^{\circ}$. d'une cornée d'autant plus convexe que l'animal est plus carnassier, transparente, dure, épaisse, ordinairement enchâssfé daus une sorte de rainure de la tĉte, et offrant plusieurs milliers de facettes hexugonales, disposíes regnlièrement; chaque facelte pent être étudiée isolćment, c'est-à-dire gue chacune d'elles constitue un oeil distinct pourvu de toutes ses parties. $2^{\circ}$. Un enduit opaque peu liquide, très-adhértent à la face internc de la cornée, diversement coloré, le plus sonvent

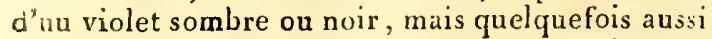
de couleur verte ou ronge, ce qui rend l'enduit très-distinct d'une sorte de vernis très-boir propre à la choroide. 11 n'est pas rare de voir plusieurs conleurs réunies sur un seul œil ; celni-ci paroit alors bariolé de brun ei de vert, dc vert et de rouge; plusieurs Orthoptères, Névroptères et Diptères, offrent cette disposition curicuse. Dans tous les cas c'est à l'enduit de la cornće qu'est due la couleur, souvent très-vive et brillante, des yeux des Insectes; malhcureasement il s'altère promplement, ce qui fait que les yeux des Insectes morts perdent tout leur éclat; cet enduit est trâversé par des nerfs, ainsi que nous le verrons plus loin. $3^{\circ}$. Une véritalle choroide ou membrane celluleuse, quelquefois striće, qui existe assez constamment et qui est recouverte d'un vernis noir, sorte de pigmentum nigrum 'qu'elle sćcrè̀te peut-être. Swammerdan ne paroît pas avoir đissingué cet enduit de celui de la cornée; mais suivant l'opinion de Marcel c'e Serres, il est fort différent. La choroide et son veruis n'es istent pas toujours, ils manquent dans les Blattes; toutes les espèces qui fuient la lumière, telles que les Ténés rions, les Blaps, les Pédines, etc., semhleat également en être privécs; alors l'enduit de la connée est beauccuǵ plus foncé que de coutume.
La membrane choroïdienne est fixée par sa circonférence à tout le bord de la cornée, elle en suit les contours, et a des rapports intimes avec les trachées qui y sont trc̀s-abondantes. $4^{\circ}$. Des vais. seaux aériens qui jouent un rôle fort important. Ils naissent d'assez gros troncs situés duns la tête, et fornent autour de l'œil une trachée circulaire qui envoie une infinité de rameaux, lesquels, en se bifurgnant, donuent lieu à de nombreux triangles isoscèles. Ces triangles, dont la base regarde en dehurs et quii sont placés au pourtour du cône optique, recoivent, dans chayue intervalle angulaire qui sépare leur sommet, un filet nerveux qui traverse la choroïde et va gagner la surface externe de l'enduit de la cornée. L'assemblage des trachées et des filets nerveux furme à la crrconférence de l'œil une sorte de réseau dont l'aspect est très-gracieux. Les trachćes sont tellement abondantes sur la choroide, que cette menibrane paroît en être formće, el que, daus tons les cas, il est cerlain que les genres qui manquent de choroïde sont également privés de trachée circulaire. $5^{\circ}$. Des nerfs qui naissent d'ún gros tronc; lequel, après être parti imméliatement du cerveau, est entouré quelquefois par une petite trachée circulaire, ou bien traverse les fibres du muscle adductear de la mandihale. Ce gros tronc augmente bientôt de volume; il s'épanouit et forme une sorte de cône plus ou moins élargi, dont la base regarde la cornće transparente. De nombreux netfs partent de cette base, ils s'engagent entre les trachées de la choroide, traversent cette membrane et son vernis, pénétrent dans l'enduit de la cornće, et chacun d'eux aboutit enfin à une des facettcs de la cornée transparente; de sorte que les filets nerveux sont ainsi immédiatement en contact aves lc fluide lumineux qui leur arrive après avoir traversé seulement la connće transparente. Cette dispnsition des files nerveux qui constituent ainsi autant de petites rétines qu'il y a de facettes à la cornée de l'ouil, est assez facile a voir dans les Libellules, les Truxales et les Criquets; mais il faut avoir la précaution, ainsi que l'indique M1. Marcel de Serres, d'ouvrir la cornée de dehurs en dedans, et de l'enlever seule et saus l'enduit qui la tapisse; alors on aperçoit une infinitć de petits points blancs qui ne sont antre chose que les extrémités de chaque filet nerveux, ce dont on peut encore se convaincre en les suivant à travers l'enduit de ta cornéc, et à travers la choroilde jusqu'au trour cominun. Swamnerdam avoit désigné ces pctites rétines sous le nom de fibres pryramidales. L'œil de l'insecte ne renferme donc aucune humeur proprement dite, il n'y a ni cristallin, ni humeur vitrée, et la vision est chez 
eux bien plus simple que dans les animaux vertébrés, dont les nerfs situés au fond de l'œil ne reçoivent la lumière qu'après qu'elle a traversé diver's milieux de densités diffét entes. Les yeux composés des Insectes, tels que nous venons de les décrire, différeroient encure de ceux des Crustacés, auxquels Blainvilie at reconnu, derrière la cornće transparente, une choroïde percée d'une infinité de trous, puis un vériable cristallin qui appuie sur un ganglion nerveux, divisé en une multitude de pelites facettes.

Les yeux composés des Crustacés sont souvent mobiles et portés sut des pédoncules plus ou moins lougs, ordinairement d'une seule pièce cylindrique et rarement de deux. Une fosselle, quelquefois très-profonde, placée plus ou moins en avant du test, est destinée à loger ce pédoncule, qui est tantôt eourt et plus gros que l'œil qu'il supporte, tántôt long et plus petit que le clianètre de ce niche ail. Dans quelques genres (Gélalimes, Gonopsace, Podophthalme), ces pédoncules s'inśerent sur les côtés d'une avanc e du bord a térieur du test; dans quelques autres (Ocypodes), ils dépassent les yeux, qui semblent alors altachés à l'une de leurs faces : quelquefois celte partie dépassant les yeux est garnie d'une touffe de poils. Ils existent seuls dans les Crustacés Brachyures et Macroures, dans les Stomnapodes, dans la plupart des Crustacés sessilioeles et des Entomostracés ; chez les Cyames, ils sınt accompagnés de denx yeux lisses; chez les Limules, ils existent aussi et sont suivis de trois yeux lisses. Les yeux composés n'existen: pas chez les Araignnées; chez les Insectes, ils existent presque toujours, soit seuls, soit accompagnés de trois yeux lisses. Ils sont le plus souvent sessiles, arrondis, globuleux ou réniformes, souvent ils sont échancrés pour recevoir l'insertion des antennes (Longicornes, etc.). Chez quelques Coléoplères, ils sont réunis sur le front, el ces insectes sembleut n'avoir qu'un seul œil ( $Z$ igobs, Schaenh.); ils sont portés sur uu pédoncule chez quelques Diplères (Achias, Diopsis); mais ces pédoncu!cs ne sont pas articulés comme on le voit chus les Crustaeés, ce ne sont que des prolongemens des côtés de la tête portan! les yeux et les antennes. Les yeux composés offrent souven!, guant à leurs dimensions, des différences nolables duan les deux sexes. Beaucoup de mâles de Diptères sonı distingués des femelles, parce que les yeux occupent toute la tête, tandis qu'ils ont un bien moindre volume chez celles-là.

Les yeux siniples ou lisses ont une organisation différente de celle des précédens; on y distingne: $1^{\circ}$. une coruće transparente formée par une membrane externe, dure, convexe eu dehors, concave en dedans, lisse, c'est-à-dire ne préseutant aucune apparence de facette; $z^{\circ}$. un enduit de conleur variée tapissant la face interne de la cornée, mais qui n'est peut-être pas distinct du verris de la ehoroide; $3^{\circ}$. une sorte de choroide asse $z$ épaisse, plus étendue en surface que la cornée elle-même, colorée en noir dans quelques cas seulement, assez souvent rouge ou bien d'un blanc mat tout particulier ; $4^{\circ}$. des irachées qui ne naissent pas d'un vaisseau aérien eireulaire et ne constituent pas la choroide, mais semblent se distribuer à sa surface; $5^{\circ}$. des nerfs partant directement du cerveau ou d'un nerf plus considérable qui $\mathrm{y}$ prend son origine, suivant que les yeux lisses sont écartés les uns des autres, comme cela a lieu dans tous les Iusectes parfaits, ou qu'ils sont très-rapprochés, comme on le voit dans les Chewilles. Les filets nerveux, après avoir traversé la choroide et l'enduit de la cornće, ront se terminer immédiatement au-dessous de celle-ci, de sorte que le méeanisme de la vision est analogue à celui des yeux composés, à cette senle exception près, que chaque cil lisse est nn seul organe, tandis que l'œil composé est formé par la réunion d'un yrand nombre d'yeux.

Les yeux lisses existent ehez plusieurs Crustaeés sessiocles et dans un grand nombre d'Entomostraeés; dans plusieurs, ils sont associés à des yeux composés, comme on l'a vu plus haut; d'autres fois (Apus) ils existent senls, et on n'en compte que deux gros el un pelit. Enfin, chez qnelques Entomostrácés (Branchipes), les deux yeux lisses u'existent que dans la jeunesse de l'animal, et ils sont remplaeés plus tard par des yeux composés.

Les yeux lisses existent seuls chez les Aracl:nides; ils varient en nombre depuis deux jusqu'a huit. Ces yeux sont disposés en groupe au-devant du céphalothorax, et leur position a servi de base et forme un des caractères dont on se sert pour classer ces a nimaux. Ces sortes d'yeux existent encore seuls dans les Myriapodes; ils sont réunis en groupes plus ou moins nombreux et plaeés de chaque côté de la tête, où ils forment des amas subglanduleux qui ont l'aspect d'yeux à faceltes.

Dans les Insectes, ils sont toujours associés aux yeux composés; on en trouve aux Orthoptèces, Hémiptères, Névroplères, Hyménoptères, Lépidoptères et Diptères. Ils sont en géuéral uu nombre de trois, disposés en triangle et situés sur celle pactie de la lête qu'on a nommée vertex. (Vojez ce mot.) Les Coléoptères et quelques espèces des ordres que nous avons énumérés plus haut en sont privés à l'état parfait. Certaines larves n'ont que des yeux lisses. (E. G.)

YPONOMEUTE, Yponomeuta. LAt. God. Phulana. (Tinea.) Linn. De Géer. Cram. Devill. Tinea. Fab. Geoff. Schiff, Scop. Ross. Schranek. Hubn. Alucita. Oliv. (Encycl.) Lithosia. FAB.

Genre d'insectes de l'ordre des Lépidoptères, farnille des Noeturnes, tribu des Tinéites.

Les deux genres Lithosie et Y Yonomeute constituent le second groupe de cetle tribu. (Voyez Tinciites.) Le premier gen re diffère du second par 
ses palpes labiaux plus courts que la tête, ayant leur dernier article sensiblement plus court que le second et cylindrique.

Antennes simples, sélacées, écartées. - Spiritrompe distincte. - Palpes labiaux de la longueur de la tête, relevés, le dernier article de la longueur du précédent ou plus long, obconique. - Ailes se moulant autour du corps en forme de demi-cylindre; les supérieures très-étroites, leur largeur à l'extrémité égalant au plus le tier's de celle du bord postérieur des ailes inférieures; celles-ci ayant leur cellule discuïdale fermée en arrière par une nervare arquée dont la convexité regarde le bord postérieur.-Chenilles à seize pattes, vivant en société sous une toile commune.

L'babitude que ces chenilles ont d'envelopper avant de les manger, les feuilles dans des toiles où elles vivent en société, a fait donner à ce genre un nom qui signifie en grec : manger caché.C'est aussi dans ces toiles qu'elles font leur coque, les plaçant le plus près possible les unes des autres; en outre lorsqu'elles marchent, elles tapissent de soie l'étendue du terrain qu'elles parcoureut. (Voy. l'article Cernille, tom. $V$. p. 598 . seconde colonne, de ce Dictionnaire.) On a essayé en Allemagne de tirer partide cette dernière habitude, en les obligeant de construire sur un sol donné, qu'on les force de parcourir en entier, un tissu coutinu que l'on détache ensuile de ce sol ; c'est en couvrant successivement ses parties des feuilles dont elles se nourrissent que l'on y parvient. Ce fail a été consigné dans la Bibliothèque universelle de Genève, cahier de févilier 1825 . Il paroît même que ces tissus ont été employés à la parure. Les espèces qui onl servi à ces essais, sout les chenilles des Yponomeutes du Fusain et du Cerisier. Ces Lépidoptères sout assez pelits el de couleurs peu brillautes. Nous citerons les espèces suivantes.

I. Yponomede de la Vipérine, $Y$. echiella.

Yponomeuta echiella. LAт. Nouv. Dict. d'hist. nat. $2^{\mathrm{e}}$. édit.-God. Lépidopt. de France, tom. 4 .
-Tinea bipunctella. FAB. Entom. Syst. Suppl. pag. $48 \mathrm{r} \cdot \pi^{\circ} .3$.

Voyez pour la description et les autres synonymes, Alucite biponctuelle no. ${ }^{\circ} 3$. de ce Dictionnaire.

De France.

A ce genre apparliennent encore, $1^{\circ}$. Yponomeute du Fusain; $\boldsymbol{Y}$. evonymella. Lat. Gener. Crust. et Ins. tom. IV. pag. 222.-God. Lépidopt. de France, tom. 4. - Tinea evonymella. FAB. Entom. Syst. Suppl. pag. 48r. no. 5. Commune aux environs de Paris. 20. Yponomeule du Cerisier, $Y$. padella. LAT. id. -God. id. - Tinea padella. FAв. id. pag. 482. $n^{\circ}$.6. Commune aux environs de Paris. $3^{\circ}$. Y ponomeute aspergée, $Y$. irrorella. God. id. - Lithosia irrorata. FАв. id. pag. 46I. $n^{\circ}$. 12. De France. $4^{\circ}$. Y ponomeute plombée, $Y$. plumbella. God. id. -Tinea plumbella. FAB. id. pag. 482. $n^{\circ}$. 7. De France. $5^{\circ}$. Yponomeule de l'Alisie:, $Y$. cratcegella. God. id. - Tinea cratorgella. FAB. Entom. Syst. tom. 3. part. 2. pag. 3oz. $n^{\circ}$. 66. De France. 6०. Yponomeute de l'Epine, $Y$. acanthella. God. id. De Prance. $7^{\circ}$. Yponomeute petit deuil, $Y$ : funerella. God. id. - Tinea fiune rella. FA . Fint. Syst. Suppl. pag. 483. $n^{\circ}$. 10. De France. 8०. Yponomeute suivaute, $Y$. sequella. God. id. - Tinea sequella. FAB. Ent. Syst. tom. 3. part. 2. pag. 29o. $n^{\circ} .15$. De France. $9^{\circ}$. Yponomeute nuignonelte, $Y \cdot p u-$ siella. God. id. - Tinea pusiella. FАв. id. pag. 30 1. $n^{\circ}$. 64. - Tinea lithospermella. Huв . Beytr. (S. H. el A. SEar.)

YPSOLOPHE, Ypsolophus. Nom donné par FaJricius (Ent. Sy'st. Suppl.) à un genre démembré de celui de T'inea de sou Lintomologica systemaltica. Il répond à peu près à celui d'Alucile LAT' Les espèces que nous pouvons citer comme appartenant véritablement à ce dernier genre, sont : Ypsol. nemorum $n^{\circ}$. 12., unguiculatus $7 l^{\circ} . \mathbf{2}$.,

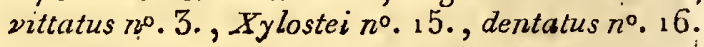
(S. F. et A. Senr.) 


\section{Z A R}

ZaREE, Zaraa. Genre btabli par M. le Dr. Léach dans le Zool. Miscell. (vol.3. 1817.) pour y placer un Cimbex des auteurs. (C. fasciata.) Les caractères qu’il donue à ses Zarées sont : antenmes ayant cunc articles avant leur massue; celle - ci composée de deux articles distincts. Ce genre lui a paru différer des Abias avec lesquelles nous l'avons réuni ( voyez pag. 575 . de ce volume), parce que la massue des antennes n'auroit que deux articles, tandis qu'elle en a trois, selon lui, dans les Abias. Ces caractères ne sont pas assez distincts, et nous paroissent même en contradiction a vec l'analogie, qui doil faire regarder les Cimbex et autres genres voisins comme ay ant plus de dix articles aux antennes, les derniers étant renfermés dans ce que l'on appelle $l a$ massue. (S. F. et A. Serv.)

ZÉLIME, Zélinaa. Genre de Lépidoptères Diurnes de la tribu des Papillonides, fondé par Fabricius dans son Syst. glossat. En voici les caractères publiés par Illiger, Magaz. I 807 : palpes courts, de deux articles; le second ayant son extréaité arrondie. Antennes longues, terminées en bouton. Toutes les pattes semblables. Le type est le Papillon Pylade, $P$. Pylades no. 54. de ce Dictionnaire. Illiger dit que l'auteur y place en outre deux autres espèces, mais il ne les spécifie pas. (S. F. et A. SERv.)

ZÉLUS, Zelus. Ce genre d'Hémiptères a été instilué par Fabricius dans son Syst. Rhyngot. Il lui donne pur caraclères : rostre court, arqué; antenne sétacées, insérées au bout de la tête, vers la hase du rostre. Il y place trente-neuf espèces. M. Latreille, en adoptant ce genre dans son $G e-$ nera, le signale ainsi : corps linéaire; premier arlicle des antennes plus long que la tête et le corselet pris ensemble; pattes antérieures point ravisseuses, à hanches courtes; les quatre pattes postérieures très-longıes, capillaires. Ce dernier auteur y fait entrer les Zelus lorigipes no. 6. , coronatus $\mathrm{n}^{\circ} . \mathrm{Z}_{\mathrm{r}}$, el octospinosus $\mathrm{n}^{\circ}$. 30. F. Syst. Rhyng.

Les caractìres de ce genre nous paroissent peu distincls de ceux des Réduves, parce qu'un grand noubre d'espèces participent du caractère des Zólus et des Réduves.

Nota. Le genre Pétalochère, Petalocheirus Pat.-Bauv. (Ins. d'Afriq. et d'Amér.), réceminent adopté par M. Latreille dans ses Fam. nat., répond à un groupe particulier du genre Réduve. Voyez pag. 274. de ce volume.

(S. F. et A. Sент.)

\section{ZÉNOBIE, Zenobia. Risso.}

Nouveau genre de Crustacés de l'ordre des Isopodes, voisin des Idolées, établi par M. Risso dans le cinquième volume de son Hist. natur. de l'Eur. méridionale, et anquel il assigne les caractères suivans : corps étroit, linéaire; abdomen à cinq segmens, les quatre premiers fort courts, le dernier alongé, très-convexe, tronqué; antennes extérieures conrtes, à cinq articles; les intérieures plus courıes en ont quatre; pieds trèsinégaux, la première paire médiocre, monodactyle, la secoude et la troisième très-longues, les autres courtes.

ZÉnobte pRIsmatrque, Zienobia prismatica. Rrsso, Hist. natur. du midi de l'Europ. tom. 5. pag. 110.

$Z$. thorace glaherrimo, nitidissimo, pellucido, olivaceo-virescente, linea una centrali, duabus lateralibus nigrescentibus longitudinalibus picto; segmentis omnibus punctatis impressis, sparsis, sculptis; abdomine griseo opaco, segmento ultimo integro; pedibus testaceis.

Son corps est très-lisse, luisant, translucide, d'un vert-olivâtre, peint d'une ligne lcngitudinale et de deux latérales, noirâties et sculptées de pelits points espacés : les antennes extérieures sont anıelées de blanc et de brun; l'abdomen est d'nn gris opaque, à dernier segment entier; les pattes sont jaunâtres; la première paire est courte, les deux suivantes longues, les quatre dernières fort petites. Longueur 0,009 , larg. 0,002 . Séjour dans dans les interstices des Polypiers corticaux. App. Avril, mai.

Zénobie de la Méditerranée, Zenobia mediterranea. Russo, loc. cit. pag. 111 .

$Z$. thorace glaberimo, nitidissimo, olivaceoviridi, lineis quinque olivaceo brunneis longitudinalibus picto; segmentis omnibus punctatis, impressis, sparsis, sculptis; abdomine segmento ultimo postice suprà tenuiter emarginato; antennis pedibusque griseis.

Elle diffère de la précédente par son corps plus lisse, plus luisant, d'un vert-olive peint par cinq lignes longitudinales de brun-olivâtre et sculptées par des points largement éparpillés; les antennes et les pieds sont d'un gris clair, et le dernier segment de l'abdomen est foiblement émarginé. Longueur 0,012, larg. 0,002. Séjour, régions des Algues. App. Février, mars.

A côté de ce genre, M. Risso en place deux 
autres également nouveaux, et dont nous allons reproduire la description.

\section{ARMIDE, Amida. Risso.}

Corps linéaire; abdomen à quatre segmens, les trois premiers très-courts, le dernier alongé, sinué; antennes extérieures moins longues que le corps; pattes à ongles simples.

Anmide verte, A. viridissima. Risso, Hist. nat. du midi de l'Eur. tom. 5. pag. 109.

A. corpore viridissimo, glaberrimo, nitido; segmentis omnibus punctulis numerosissimis inpressis, sculptis; oculi plumbei; antennis, $a b-$ domine pedibusque pallidioribus.

PaLl., 9, 4, 10? Riss. Hist. nat. des Crust. 336, $2,111,8$.

Son corps est très - lisse, luisant, d'un beau vert, à segmens sculptés par un nombre infini de très-petits points; la tête est échancrée sur le devaut; l'oil bleuâtre, les antenues, l'abdomen et les pieds d'un vert pâle.

La femelle est beaucoup plus grande. Long. o,05o, lirg. o,oog. Séjour, moyennes prolondeurs. App. Hiver et printemps.

Armide bimarginée, $A$. bimarginata. Risso, loc. cit.

A. corpore griseo, cinereo, fusco; segmentis rugosis; oculi nigri; abdomine articulo ultimo bimarginato.

Son corps est d'un gris cendré obscur, composó de segmens rugueux, le dernier terminé par deux échancrures profondes; la tête est arrondie, un peu échancrée sur le devant; l'œil noir, réticulé; les deux premiers articles des'antennes extérieurs, courts, renflés, les deux suivans trèslongs; les pattes postérieures beaucoup plus longıes que les antérieures. Long. 0,014, larg. 0,005. Séjour, parmi les zostères. App. Avril, mai.

Armide pustulée, A. pustulata. Risso, loc. cit.pag. 110.

A. corpore griseo, intense corruleo; capite pustulato; segmentis omnibus lateralibus acutis; oculi nigri; abdomine articulo ultimo subtruncato.

Son corps est d'un cendré bleuâtre foncé, à segmens terminés en pointe de chaque côté; la tête est pustulée; l'œil noir; les quatre premiers articles des antennes extérieures alongés, le cinquième plus long, les autres fort courts; les quatre articles des intermédiaires de la longueur des deux premiers des antennes extérieures; les palpes pectinés; les pattes comme rabougries; les segmens de l'abdomen étroits, le dernier caréné, presque tronqué au sommet. Long. 0,025 , larg. o,007. Séjour, régions des algues. App. Prin-
temps.

\section{HÉBE, Hebe. Risso.}

Corps alongé, un peu convexe; corselet à dix articles, les trois postérieur's très-pelits; l'abdomen à un seul seginent, coult; tête petile, arrondie; antennes souvent égales, à cinq arlicles; yeux grauds, convexes; appendices nâtaloires
subulés.

HÉBÉ PonCtuée, Hebe punctata. Risso, loc. cit. pag. 108.

H. coipore griseo-fulvo, nigro punctato; antennoe albescentes, nigro annulato; oculi nigri; cauda rotunduta.

Son corps est alongé, bombé, d'un gris funve, confusément pointillé de noir ; la têle est petite; arrondie; les antennes fort courtes, presqu'égat les, blanchâtres, annelées de noir; l'oil fort gros, d'un noir d'ébène; la troisième paire de pattes trois fois plus longue que les autres, tontes armées de crochets aigus. La queue est arrondie; les ânpendices extérieurs subulés, les iutérienrs dilatés eu nageoires. Long. 0,012, larg. 0,003. Séjour, régions des fucus. App. Avril, mail.

(E. G.)

ZĖTHE, Zethus. Genre d'Hyménoplères ins tilué par. Fabricius dans.son Syst. Piez. aux dépens de celui de Vespa de son Entom. Syst. Il lui donne pour caractères : bouche composée d'une langue avancée, trifide; mâchoire avancée, fléchie dans son milieu, sétacée, enveloppée; lèvre plus longue que la mâchoire, largement écbancrée, soulenue de chaque côté par une soie; antennes coudées, filiformes. Il y place six espèces
exotiques.

Ce genre n'est pas mentionné dans les Familles naturelles de M. Latreille. Il nous paroît se riapporter à la première division du genre Poliste de ce Dictionnaire. Voyez ce mol.

$$
\text { (S. F. et A. SER. ) }
$$

ZEUXIE, Zeuxia. MEIg. Genre d'insectes de l'ordre des Diplères, famille des Muscides de cet auleur. Il lui donne les caractères suivans :

Antennes rabaltues, couchées contre la tête, composées de trois articles; le premier court; les second et troisième linéaires, égaux entr'eux, le dernier comprimé, obtus, portant à sa base une soie plumeuse, biarticulée; ouverture de la cavité buccale accompagnée de moustaches; palpes avancés, en massue, nus, horizontaux, plus longs que la trompe dans l'état de repos; ailes velues vues au microscope, écartées dans le repos, ayant deux cellules du bord postérieur, fermées chacune par une nervure transversale : une épine vers le milieu du bord extérieur; balanciers cachés ; cuillerons 
grands ; front large ; yeux nus ; trois ocelles placés en triangle sur le vertex; prothorax séparé du mésothorax par une ligne transversale enfoncée ; abdomen conique, composé de trois segmens outre l'anus, le premier court.

M. Meigen ne décrit qu'une seule espèce, Zeuxie cendrée, $Z$. cinerea. MEIG. Dipt. d'Eur. tom. 5. pag. 8. $n^{\circ}$. 1. tab. 42. fig. 13. Femelle. Longueur $3 \mathrm{lig}$. Noire; hypostome et front blancs; celni-ci avec une raie noire étroite; palpes couleur de rouille; corselet d'un gris clair a vec quatre raies noires à sa partie antérieure, et trois postérieurement; abdomen d'un gris cendré changeant en brun; ailes presqu'hyalines. Femelle. Europe.

$$
\text { (S. F. et A. SERV.) }
$$

ZEUZĖRE, Zeuzera. LAt. God. Cossus. Fab. Panz. Bombyx. Schiff. Scop. Esp. Huba. Engr. Oriv. (Encycl.) Hepialus. Schan ancis. Phabcena. (Noctua.) Linn. Sch жFF.

Genre d'insectes de l'ordre des Lépidoptères, famille des Nocturnes, tribu des fuux Bombyx.

La première division de cette tribu a les caractères suivans: chenilles toujour's rases, à seize paltes, vivant dans l'intérieur des végétaux, le plus souventligneux; bords des segmens abdominaux de la chrysalide dentés ou épineux; insectes parfaits à spiritrompe très-courte ou presque nulle; antennes de quelques mâles garnies inférieurement d'un double rang de barbes; celles de leur's femelles et des deux sexes des autres, offirant dans toute leur longueur une série de petites dents courtes, arrondies et serrées. Cette première division se compose des genres Cossus et Zeuzère; le premier se distingue du second par ses antennes ayant un seul rang de deuts dans les deux sexes,

Antennes sétacées, simples, colonneuses à ia base dans les femelles; celles des mâles pectiB'́es dans toute leur moitié inférieure, la supérieure nue. - Spiritrompe très-courte. - Ailes en toit dans le repos; cellule discoidale des inférieures fermée transversalement en arrière par une gervure ondée, et divisée longitudinalement par un rameau fourchu qui descend de la base au bord yostérieur; un crin. - Anus des femelles laissant sortir une tarière longue, cornée, tubulaire, servant de conduit aux ceut's pour les introduire dans le bois.

Quant aux mœurs de ces insectes (voyez l'article Bomsix, pag. 2. première colonne.) On n'en connoît que peu d'espèces; nous citerons les suivantes :

\section{Zeuzìne du Maronnier, $Z$. Asculi.}

Zeuzera Asculi. Lat. Gen. Crust. et Ins, tom. IV. pag. 217 . Mâle et femelle. - God. Lépid. de France, tom. 4. pag. 54. $n^{\circ}$. 6. $p l$. 3. fig. 2. et 3 . Mâle et femelle. - Cossus Asculi. Fab. Entom. Syst. tom. 3. part. 2. pag. 4. $n^{\circ}$. 4. Mûle. (A la

Histoire Nat. Ins, Tome $X$. citation de Schæffer, lisez $: t a b .31$, au lieu de tab. 38.)

Voyez pour les mours, la description et les autres synonymes, Bombix du Marronnier no. 125 . pl. 78. fig. 1. femelle; et $p l$. 84. fig. 3. du présent Dictionnaire.

A ce geure appartiennent en outre: $\mathbf{I}^{\circ}$. Zeuzère porte-échelle, $Z$. scalcris. - Cossus scalaris. FAB. Entom. Syst. tom. 3. part. 2. pag. 5. $n^{\circ}$. 5. De la Chine. $2^{\circ}$. Zeuzère du Poirier , $Z$. pyrina. - Cossus pyrinus. Faв. id. $n^{\circ}$. 6. De l'Amérique septentrionale.

COSSUS, Cossus. Fab. Lat. God. Hepialus. Schranck. Bomzbyx. Fab. Schiff. Scop. Esp. Ross. Panz. Hubn. Oliv. (Encycl.) Phalcena (Bombyx.) Linn. Geoff. Scherff. Engr. Cray.

Genre d'insectes de l'ordre dcs Lépidoptères, famille des Nocturnes, tribu des faux Bombyx.

Cette tribu se compose de deux divisions; les caractères de la première sont énoncés dans l'article précédent. (Voyez ZEuż̀r. E.) Les genres Cossus et Zeuzère en dépendent; les dernières sont distinctes par leurs antennes qui sont simples et cotonneuses à la base dans les femelles, pectinées seulement à leur partie inférieure dans les mâles.

Antennes sétacées, de la longueur du corselet, n'ayant dans les deux sexes qưue seule rangée de dents courtes, transversales et obtuses. Palpes très-distincts, cylindriques, assez épais, couverts d'ćcailles. - Spiritron pe très-courte. Ailes comme dans les Zeuzères.

On trouvera des détails sur les habitudes de la chenille de l'espèce la plus commune de Cossus article Bombix, pag. 2. premièrc colonne et pag 57 . de ce Dictionnaire. Pierre Lyonet a publié en 1762 un travail particulier sur cette chenille, intitulé : Traité anatomique de la chenille qui ronge le bois du Saule, avec dix-huit planches où sont figurées toutes les parties intérieures de cette chenille, représentées avcc une rare perfection.

Fabricius, à qui l'on doit ce genre, y met six espèces; les trois premières lui appartiennent certainement; le $n^{\circ}$. 3. (Bombix tarière $n^{\circ} .21, p l$. 77. fig. 7. de ce Dictionnaire) n'est peut-être qu'une variélé du no. I. M. Godart le pense ainsi, et croit même que ce pourroit être simplement un Cossus ligniperde tourné au gras. Les nos. 4. 5. et 6 . sont des Zeuzères.

Nous mentionnerons les espèces suivantes :

I. Cossus ligniperde, C. ligniperda.

Cossus ligniperda. Fав. Entom. Syst. tom. 3. part. 2. pag. 1. $n^{\circ}$. 1. - LAT. Gener. Crust. et Ins. tom. IV. pag. 2J7.-God. Lépid. de France, tom. 4 .

Voyez pour les mœurs, la description et les LIIII 
autres synonymes, Bombix Cossus no. $121, p l .73$. fig. I. de ce Dictionnaire. (A la citation du Syst. nat. de Linné, lisez : 827. au lieu de 837.)

\section{Cossus strix, C. strix.}

Voyez pour la description et les autres synonymes, Bombix strix no. 120. $p l .7^{2}$. fig. 2. de ce Dicliounaire.

Rapportez encore à ce genre le Cossus onguiculé, C. ungtuiculatus. FAB. Ent. Syst. tom. 3. part. 2. pag. 4. $n^{\circ}$. 2. D'Italie.

\section{( S. F. et A. SERv. )}

ZIGZAG. Geoflioy (Ins. Paris. tom. 2. pag. II3. $n^{\circ}$. 14.) applique celle dénomination à un Lépidoptère Nocturue; c'est le Bombyx dispar no. 126 . du présent Dictionnaire.

\section{(S. F. et A. Serv.)}

ZIROPIIORE, Zirophorus. M. Dalman, professen à Stockholm, a créé ce genre, et y fait entrer deux espèces nouvelles; il le place dans sa fawille des Staphyliniens (Brachélytres LAT.) M. Latreille, dans ses Familles naturelles, le fait dépendre de la tribu des Aplatis, et le donne comme répondant à celui de Leptochire de $M$. Germar. Il nous paroit avoir beaucoup d'aflinilés avec le genre Pies!e Grav. (voyez ce mol) que M. Latreille place aussi dans celte tribu. Nous ne connoissons ni l'un ni l'autre. L'auteur suédois, dans ses Analect. entomol. (Holmice, 1823), lui attribue les caractères suivans :

Antennes filiformes, composées de onze arlicles; le premier en massue, ceux de quatre ì onze cylindriques, velus; mandibules arquées, dentées à l'extrémité; palpes courts, filiformes; les maxil. laires de quatre articles, les labiaux de trois; corps alongé, déprirné, presque linéaire; corselet carré, canaliculé en dessus, ses angles postérieur's échancrés; pattes courtes; jambes antérienres crénelées.

Le nom générique est tiré de deux mots grecs; il exprime la brièveté des élytres, çui ne revêtent que la base de l'abdomen. Les espèces sont : $1^{\circ}$. Zirophore fronticorne, $Z$. fronticomis. DALM. ut suprà, pag. 24. $n^{\circ}$. 1. tab. IV. fig. I. Longueur 5 lig. Noir ; anus el tarses d'un roux-brun; antennes velues, ferrugineuses; tête armée de deux épines aiguës, dirigées en avant; élytres ayant chacune cinq stries. Patrie inconnue. $2^{\circ}$. Zirophore à pincean, $Z$.penicillatus. DALM. $i d . n^{\circ} .2 . t a b . I V$. fg. 2. Longueur 3 lig. $\frac{1}{2}$. Noir; base des antennes, anus et paltes d'un roux-brun; tête raboteuse, mulique ; antennes de la longueur du corps, leur premier arlicle ayant dans son milieu un tubercule d'où sort un faisceau de poils droits, ferrugineux; élytres ayant chacune cinq stries et le commencement d'une sixième. De la Guadeloupe.

L'auteur soupçonne que le Cucujus spinosus no. 9. Fав. Syst. Eleut. de l'Amérique méridionale, est encore du genre Zirophore.

(S. F. et A. SERV.)

\section{ZOADELGES. Voyez SAnguisuges.}

(S. F. et A. SERV.)

ZODION, Zodion. LAt. Meig. Myopa. FAB. Falièn. Olit. (Encycl.)

Genre d'insectes de l'ordre des Diptères, première section, famille des Atbéricères, tribu des Conopsaires de M. Lalleille.

Plusieurs genres compris dans cette tribu nous paroissent avoir peu d'analogie entr'eux; nous nous contenterons en ce moment de la diviser davantage que ne l'ont fait nos prédécesseurs, et seulement autant que nous le permet le caractère que lui a donné M. Latreille.

Conopsarres, Conopsarice. Seconde tribu 'de la famille des Athéricères, prenière seciion de l'ordre des Diptères.

Sucoir composé de deux pièces. - Palpes extérieurs à la trompe. - Tronpe saillante en forme de siption, soit cylindrique ou conique, soit sélacé.

J. Anlennes avancées, leur troisième article r'ayant au plus qu'un style. - Corps long, étroit.

1. Antennes an moins de la longneur de la tête et du corsclet pris ensemble; leur troisième article pointu à l'extrémité, ayant au plus un style terminal. ( $\mathrm{Co}$ nopsariae propriè dicta.)

Cépliène, Conops.

B. Antennes pas plus longues, on même quelquefois plus courtes que la tête; leur troisième arlicle obtus à son extrémité, muni d'un style dorsal. (Myoparice Nов.)

Zodion, Myope.

1I. Antennes rabattues; leur troisième article arrondi à l'extrémité, muni d'une soie dorsale plus ou moins plumeuse. - Corps court. (Stomoxydoe Meig. (1).)

Bucente, Prosène, Stomoxe.

(i) Comme nous avons donuć au mor Stomoxy des les caractères que M. Meigen atrribue à cette famille, nous allons présenter ici ceux qu'il assigne à celle des Conopsaires, qui est la vingrième dans sa méthode. Aittennes avancées, de trois articles, terminées en poince; trompe avanć́e, coudée ; corseler sans cou; abdomen de quatre ou cinq segmens outre l'anus; balanciers découverts; ailes couchées. M. Meigen place dans cette famille les genres Conops, $Z \circ$ dion et Myopa. 


\section{$\mathrm{Z} O \mathrm{O}$}

Les mœurs des Conopsaires et leur organisation sont excessivement différentes suivant les genres: pour démontrer la seconde assertion, il nous suffira d'indiquer les caractères énoncés dans le précédent tableau. Pour prouver la première, nous allons entrer dans quelques détails qui ne concerneront qu'une partie des genres, les autres ne nous étant pas suffisanment connus. Les larves des Conops vivent en parlie dans la cavité abdominale des Bourdons (Bombus), ainsi que le dit M. Latreille, Genera, tont. IV. pag. 336., fait qui a été aussi observé par M. Carcel; et nousmèmes avons vu des Conops s'introduire dans le nid de certaines espèces du geare Guêpe (Lespa), et nous pensons que les larves de ces Conops peuvent vivie aux dépens de celles de ces Hyménoptères. Les Conops à l'état parfait frúquentent les fleurs ainsi que les Zodions et les Myopes. M. Robineau-Desvoidy nous a assuré qu'une larve qui avoit vécu dans l'intérieur du corps d'une chenille lui avoit donaé une Myope. Une larve du genre Bucente, observée par De Géer, avoil vécu dans la chrysalide d'un Lépidoptère ; l'insecte parfait vit sur les fleurs ainsi que les Prosènes. Nous avons été témoins que le Stomoxe piquant dépose ses cufs sur le fumier dont il est probable que se nourrit sa larve. Ce Diptère a pour nourriture le sang de l'homme et des animaux. Voy. Stomoxe et STomoxydes.

Les genres Zodion et Myope forment un groupe dans leur tribu. (Voyez le tableau ci-dessus.) Le second se distingue du premier par sa trompe deux fois coudée.

Antennes avancées, plus courtes que la tête, composées de trois articles; le premier petit, trèscourt, cylindrique; le second ubconique, formant avec le troisième, qui est presque triangulaire et obtus, une massne ovale-alongée et comprimée, ce dernier muni d'un style dorsal distinctement biarticulé - Trompe filiforme, pen cornée, longue, avancée, articulée et coudée seulement à sa base, terminée par deux lèvres courtes. - Palpes insérés à la base de la trompe, très-potits, cylindriques, garmis de snies obtuses. - Tête assez forte; hypostome gonflé eu forme de vessie, un peu excavé au-dessous des antennes; front large. - Yeux ronds, espacés dans les deux sexes. - Trois ocelles disposés en triangle sur le vertex. - Corps étroit, alongé. Corselet presque sphérique, ses angles antérieurs formant cbacun une bosse fort prononcée; prothorax peu distinct du mésothorax dans sa partie dorsale moyenue; métathorax fort court. - Ecusson très-petit. - Ailes velues vues au aicroscope, couchées parallèlement sur le corps dans le repos. -Cuillerons très-petits. - Balanciers découverts. - Abdomen cylindrique, composé de quatre segmens outre l'anus, hérissé de quelques soies roides, son extrémité recourbée en dessous. - Pattes de longueur moyenne; jambes un peu en massue, al- lant en grossissant de la base à l'extrémité, un peu arquées : tarses longs, leur premier article le plus grand de tons, gros, cylindrique; les trois suivans triangulaires, le dernier fort conrt, mani de deux forts crochets ayant dans leur intervalle deux pelotes fort longues dans les deux sexes.

On ne connoîl que deux espèces de ce genre; elles sont d'Europe et de petite taille, ce à quoì leur nom tiré du grec fait allusion. On les rencontre sur les fleurs, du miel desquelles elles se nourrissent.

Fabricius (Syst.Antliat.) a connu ces espèces et les met daus son genre $M_{y}$ opa, auquel il rapporte seize espèces, dont dix seulement appartiennent avec cerilude à ce dernier genre; savoir, les nos. $1,2,3,4,5,6,8,9,13,14$. Les nos. 7. et 11 . ne forment qu'une espèce qui est du geure Zodion; les $n^{\circ s}$. 12. et 16. sont absolument dans le même cas. Les $\mathbf{n}^{\circ s}$. 10. et 15 . ne nous sont pas connus.

Le genre Myope du présent Diclionnaire renferme dix-sepi espèces. Les nos. 1. 12. I6. nous sont inconnus; ceux de 2 à 11 . ainsi que 14 . et 15. sont bien du genre; les $n^{o s}$. 13 . et 17 . appartiennent aux Zodions.

\section{Zodios cendré, $Z$, cinereum .}

Zodion cinereum. NeIG. Dipt. d'Eur. tom. 4. pag. 138. no. 1. tab. 37. fig. 6. et 7. - Myopa cinerea no. 12. F ${ }^{\circ}$. Syst. Antliat. - Myopa tibialis $n^{\circ}$. 6 . FAB. $i d$.

Voyez pour la description, Myope tibial n ${ }^{\circ}{ }_{17} 7$. de ce Diclionnaire.

Commun aux environs de Paris.

\section{Zodron noté, $Z$. notatum.}

Zodion notatum. MeIG. id. pag. $139 \cdot n^{\circ} \cdot 2 .-$ Myopa irrorata $\mathrm{n}^{\circ} \cdot 7$. FAB. id. Myopa tesselata no. I1. Faв. id.

Voyez pour la description, Myope marqueté $n^{\circ}$. i3. de ce Diclionnaire.

Nota. Ces deux espèces ne sont peut-être que les deux sexes de la même. Si cela est ainsi, Fabricius auroit fait quatre espèces d'une seule.

$$
\text { (S. F. ei A. Serv.) }
$$

ZOE, Zoea. Bosc. Lat. Lam. LÉach. Monoculus. Sta $\mathrm{Z}_{\mathrm{AB}}$.

Ce genre, que M. Latreille plaçoit (Règne anim. ) à la suite des Branchiopodes et prc̀s des Cyclopes et des Polyphèmes, fait actuellement partie de l'ordre des Décapodes (Fam. nat.). Il appartient à la famille des Macroures, tribu des Schizopodes; ses caractères sont : corps ayant un test presqu'ovale, avec lequel la tête se trouve confondue, terminé en avant par un très-long rostre infléclii. Quatre antennes presqu'égales, dont les extérieures sont bifides et coudées; deux yeux presque sessiles, extrêmement gros et sail- 
lazs, placés à la base du rostre et au-dessus des antennes. Une grande pointe relevée et dirigée en arrière, placée à la partie postérieure du corselet ou de la carapace. Abdomen long, replié en dessous, formé de quatre segmens aplatis, presqu'égaux, étroits, et d'un cinquième terminal, plus grand et fourchu. Pattes très-courtes, cachées sous le corps, à peine visibles, à l'exception des deux dernières qui sont très-longues et en nageoires.

Ce genre a été établi pour la première fois par M. Bosc; il se compose de deux ou trois espèces très-petites et très-rares dans les collections.

Żoé pélagique, Zoea pelagica. Bosc. Crust. tom. 2. pl. 15. fig. 3. et 4. Long diun quart de ligne, transparent comme du verre, ayant les yeux et une tache à la base de l'épine dorsale, d'uo beau bleu. Il a été trơuvé dans l'océan Atlantique.

Zó a Masse, Zoea clayata. LÉAcH. Journal de physiq. avril 18:8. pag. 304. fig. 4. - Figuré dans l'Atlas de ce Diclionnaire, pl. 354. fig. 5. Il est un peu plus grand que le précédent, son rostre est droit et non infléchii ; le test est globuleux avec deux longs prolongemens en massue de chaque côté. On l'a trouvé sur' la côte occidentale de l'Afrique.

M. Latreille pense que le Monoculus taurus de Slabtuer, Microscop. tab. 5., pourroit appartenir à ce genre. Il est figuré dans l'Atlas de ce Dictionnaire, pl. 333. fig. 1.; et M. Latreille, dans l'explication de celte planche, lui donne le nom de Zoea Slabberi. (E. G.)

ZONE. Nom donné par Geoffroy à sa Phalène no. 36. (Ins. Paris. tom. 2. pag. 127.) Ce Lépidoptère est la Phalève zône no. g. de ce Dictionnaire; il y est décrit sous le nom de Bombyx zône no. 252. (S. F. et A. SErv. )

ZONI'TE, Zonitis. Faв. Lat. Schœn. Apalus. Oriv. Mylabris. Fab. Schen. Meloe. Pazi.

Genre d'insectes de l'ordre des Coléoptères, section des Hétéromères ( $2^{\mathrm{e}}$ division), famille des Trachélides, tribu des Cantharidies.

Un groupe de celte tribu contient les genres Apale el Zonite. (Voyez Cartraridies, pag. 439. de ce volume. ) Le premier est séparé du second par ses quatre palpes égaux en longueur et par son corselet arrondi.

Antennes filiformes, plus longues que le corselet, insérées dans un sinus intérieur des yeux, composées de onze articles alongés, grêles, presque cylindriques; le premier aussi long que le troisième; le second obconique, de moitié plus court que celui-ci; le onzième en fuseau, terminé brusquement en une pointe courte. - Labre avancé, re squue coriace, presque carré, entier. -
Mandibules cornées, triangulaires, un peu arquée à leur extrémité qui est aiguë.-Mâchoires composées de deux lobes membraneux, l'interne à peine apparent, garni d'une frange de poils, le lobe apical alongé, pointu à l'extrémité, ayant. uue frange de poils inégaux. - Palpes filiformes, un peu inégaux ; leur dernier article presque cylindrique, un peu aminci vers sa base, tronqué à son extrémité; les maxillaires un peu plus longs que les labiaux; ceux-ci ayant leur second article alongé. - Lèvre membraneuse, presque carrée, profondément bifide; menton presque coriace, à peu près en carré long, allant un peu en se rétrécissant vers l'ex trémité. - Tête inclinée, triangulaire, presque cordiforine. - Yeux alongés, un peu échancrés à. leur partie intérieure. - Corps presque cylindrique, assez mou. - Corselet petit, presque carré, à peu près aussi large que les élytres. - Ecusson, distinct. - Elytres molles, alongées, linéaires, recouvrant entièrement l'abdomen et des ailes, un peu rabattues par les côtés، - Pattes alongées; jambes postérieures terminées pạ une forte épine. dont l'exirémité est dilatée, excavée et tronquée obliquement; tous les articles des tarses entiers; crochets bifides.

Le nom de Zonite vient du grec et a rapport. aux bandes transversales que plusieurs espèces* portent sur les élytres. Ces Coléoptères se tiennent sur les fleurs; ils habitent l'Europe méridionale, en Afrique, dans l'Asie-Mineure, en Syrie et en Perse. Il paruit, selon les renseignemens. donnés par M. Latreille, que leurs larves vivent, aux dépens de celles de quelques Apiaires.

\section{Zonite tachelée, Z . sexmaculata.}

Zonitis sexmaculata. Lat. Gen. Crust. et Iirs. tom. II. pag. 224. no. 2: - Scнon. Syn. Ins. tom. 2. pag. 340. $n^{\circ}$. 8. - Apalus sexmaculatus. Oriv. Entom. tom. 3. Apal. pag. 5. $n^{\circ}$. 2. pl. 1. fig. 3.

Voyez pour la description, Apale tacheté n’.2. de ce Dictionnaire.

\section{Zonite bout brûlé, $Z$. prousta.}

Zonitis prousta no. 2. FАB. Syst: Eleut. Scren. id. pag. 33g. $n^{\circ} \cdot 2$.

Voyez pour la description, Apale briqueté no. 3 . de ce Dictionnaire.

Nota. M. Schœnherr donne comme variété du mâle de cette espèce la $Z$ onitis nigripennis $\mathrm{n}^{\circ} .3$. Fab. $i d$.

A ce gence appartiennent encore : $1^{\circ}$. Zonite pâle, $Z$ - pallida no. 1. F Ав. Syst. Eleut. - ScвœN. Syn. Ins. tom. 2. pag. 33g. $n^{\circ}$. 1. Iles de l'Amérique? $2^{\circ}$. Zonite mutique, $Z$. nutica $\mathrm{n}^{\circ} .5$. FAB. id. - Sugen. id.pag. 340. $n^{\circ}$. 4. France méridionale. Cette espèce est peut-être la même que l'A pale immaculé $n^{\circ}$. 4. de ce Dictionnaire. $3 \circ$. 
Zonite fulvipenne, Z. fulvipennis $\mathrm{n}^{\circ} .6$. F. $\mathrm{A}$. $i d$. - Schen. id. $n^{\circ}$. 5. De Hongrie. $4^{\circ}$. Zonite quadriponctuée, $Z$. quadripunctata. Des. Calal. Mylabris quadripunctata no. 15. FА в. id.-ScнеN. id. tom. 3. pag. 43. D'Espagne. 5०. Zonite bifasciée, $Z$. bifasciata. Swartz. Schen. id. tom. 2. pag. 340. $n^{\circ}$. 13. Noire; élytres d'un roux-testacé avec deux bandes noires ondulées. De Hongrie. $6^{\circ}$. Zonite noire, $Z$. atra. Swartz. Schen. $i d$. $n^{\circ}$. 12. Totalement noire. De Hongrie. $7^{\circ}$. Zonite du Caucase, $Z$. caucasica. Drs. Catal. - Meloe caucasica. PALL. Icon. p. 94. 24. tom. 6. fig. 24. - Mylab̄ris sexmaculata no. 16. FA B. id.-ScнеN. id. tom. 5. pag. 43. Russie méridionale.

Nota. Le genre Apale de ce Diclionnaire comprend trois espèces de Zonites sous les nos. 2. 3 . et 4. Le $n^{\circ}$. 1 . est seul du genre Apale. Ajoutez aux caractères génériques : palpes égaux en longueur; corselet arrondi ; élytres deux fois plus larges que le corselet. Ces caractères nous paroissent être les seuls qui distinguent les Apales des Zonites.

Il n'est pas certain que l'Apalusquadrimaculatus no. 2. F Ав. Syst. Eleut. - Scнœ N. Syn.Ins. tom. 2. pag. $342 . n^{\circ}$. 2. appartienne au genre Apale.

Dans le Systema Eleutheratorum de Fabricius il $\mathrm{y}$ a onze espèces de Zonitis de décrites. Les ${ }^{106}$. 7. 10. 11 . sont des Némognathes; les nos. 4 . et 9 . sont douteux; les autres appartiennent vraiment aux Zonites.

GNATHIE, Gnathium. Kinв. Lat. (Fam. natur.)

Genre d'insectes de l'ordre des Coléoptères, section des Hétéromères ( $2{ }^{\mathrm{e}}$. division), famille des Trachélides, tribu des Cantharidies.

Nous donnons ici ce genre parce qu'il paroît adopté par M. Latreille dans ses Fam. nat. Il compose, avec celui de Némognathe Lar. , un groupe dans les Cantharidies, ce groupe est distinct des autres par les mâchoires très-prolongées, se recourbant sous le corps dans le repos. (Voyez Cantharidies, pag. 43g. de ce volume.) Les Némognathes nous paroissent différer des Gnathies par leurs antenues filiformes.

Voici les caractères que $M$. Kirby assigne à ce genre (Transact. Linn. vol. 12. Century of. Ins. pag. 425.)

Antennes allant un peu en grossissant vers leur extrémité, composées de onze articles; le second à peu près aussilong que le quatrième; le troisième plus long quaucun des suivans, ceux - ci presqu'obconiques, les buitième, neuvième et dixième presque cylindriques, le dernier alongé, conique. - Labre transversal. - Mandibules avancées, alongées, leur extrémité recourbée, très-aiguë, sans dents. - Mâchoires ouvertes, portant un appendice très-long et très-grèle. Palpes filiformes, leurs articles cylindriques. Lèvre très-petite, à peine visible. - Menton tra- pézoïdal ? - Tête inclinée, alongée, poriée par un col court et étroit. - Corps presqu'en coin, presque linéaire. - Corselet bombé. - Jambes lerminées par deux épines; dernier article des tarses muni de crochets bifides.

Le nom générique est tiré d'un mot grec qui exprime la longueur des mâchoires. L'auteur ne mentionne qu'une seule espèce, elle paroît nonvelle; c'est la Gnathie de Francillon, G. Francilloni. Long. 2 lig. $\frac{2}{3}$. Corps un peu velu, noir en dessus, brinn en dessous; cou brun en dessus; mandibules rousses; corselet glabre, ronx en dessus; élytres un peu rugueuses. De Géorgie.

(S. F. et A. SERV.)

ZOPHOSE, Zophosis. LAT. Erodius. FaB. Oliv. Schin.

Genre d'insectes de l'ordre des Coléoptères, section des Hétéromères (première division), famille des Mélasomes, tribu des Piméliaires.

Un groupe de la tribu des Piméliaires a pour caractères: dernier article des antennes très-distinct, point sensiblement plus long que le précédent: il contient les genres Zophose, Moluris, Psammode, 'Tentyrie, Tagone, Hégètre, 'Tagénie et Sépidie. (Voyez Prála alres, pag. 534. de ce volume.) Ceux de Moluris, Psammode, Sépidie et 'Tagénie se distinguent par leur menton assez petit, laissant à découvert la base des mâchoires. Dans les Tentyries le corselet est presqu'orbiculaire, à peu près aussi long que large; le corps des Tagones est presque triangulaire; le genre Hégètre a le corselet carré, plus étroit que les élytres : caractères qui séparent ces divers genres des Zophoses.

Antennes composées de onze articles; les sept premiers presque cylindriques, un peu plus gros à leur exirémité; les quatre autres un peu élargis, plus courts que les précédens, comprimés; les huitième, neuvième et dixième prescque triangulaires, le dernier un pea plus grand que le précédent, écbancré de côté à son extréunité, celle-ci aiguë. - Labre avancé, en carré transversal, entier, coriace. - Palpes maxillaires ayant lenr dernier article le plus grand de tous, linéaire, comprimé.-Menton grand, plas large que longr, ses côtés arrondis, cachant la base des mấchoires; son bord supérieur échancré. - Téte presque carrée, beancoup plus étroile que le corselet.-Corps suborbiculaire on en ovale cont, convexe en dessus. - Corselet trois fois plus large que long; sa partie postérieure de la largeur de la base des élytres; il est fort rétréci antérieurement et échancré pour recevoir la partie postérieure de la tête; angles latéraux antérieurs aigus. - Ecusson nul. - Elytres réunies, recouvrant l'abdomen et embrassant ses côtés en dessous. - Point d'ailes Pattes grêles; jambes dentelées et épineuses, terminées par deux longues épines; tarses antérieurs courts, leurs quatre premiers articles triangulai- 
res; le premier un peu plus long que les autres : tar'ses intermédiaires et postérieurs longs, ayant leur premier article à peu près aussi long que les quatre autres pris ensemble; dernier article de tous les tarses plus long que le précédent, munide deux crochets.

La couleur noire de ces Colćoptères leur a fait donner le nom de Zuphose, tiré du grec; leurs mœurs doivent être à peu près les urêmes que celles des Pimélies et des lirodies. Ils habitent les cliunals chauds de l'ancien continent. Ou n'en connoît qu'un petit nombre d'espèces.

\section{Zophose Tortue, $Z$. testudinaria.}

Zophosis testudinaria. Lat. Gener. Crust. et Ins. tom. 2. pag, 146. n , 1. tab. X. fig. 6.-Erodius testudinanus $n^{\circ}$. 1. FaB. Syst. Eleut. - Schen. Syn. Ins. tomi. I. pag. $124 . n^{\circ} .1$.

Voyez pour la description et les autres synonymes, Erodie Torlue no. I. de ce Dictionnaire.

Nota. M. Latreille place dans ce genre les espéces suivantes :

\section{Zopnose trilinéée, $Z$. trilineata.}

Zophosis trilineata. LAт. id. - Erodius trilineatus. Schщn. id. pag. $125, n^{\circ} .4$.

Vojez pour la description et les autres synonymes, Erodie trilinéé ${ }^{\circ}$. 8. de ce Dictionnaire.

\section{Zophose quadrilinéce, $Z$. quadrilineuta.}

Zophosis quadrilineata. LAт. id. - Erodius quadrilineatus. Schan. id $n^{\circ}$. 11 .

Voyez pour la clescription, Erodie quadrilinéé $n^{\circ} \cdot 7$. de ce Dictionnai,e.

\section{Zopgose naine, Z. minutu.}

Zophosis minuta. Lat. id.-Erodius minutus no. 5. FAB. $i d$. - SCEEN. $i d . n^{\circ} \cdot 9$.

Voyez pour la description et les autres synonymes, Erodie nain $\mathbf{n}^{\circ} .9$. de ce Dictionnaire.

Ce genre comprend eucore, selon son auteur, la Zophose pointillée, Z. punctulata. - Erodius punctulatus. Otiv. Entom. tom. 3. Erod, pag. 7 . $n^{\circ} \cdot 7 \cdot p l$. 1. fig. 7. - Schan. Syn. Ins. tom. 1. pag. $125 . n^{\circ}$. 12. Palrie incounue.

$$
\text { (S. F. et A. Serv.) }
$$

ZOZIME, Zozimus. LÉAcH.

M. Léach a donné ce nous à un genre élabli aux dépens des Crabes proprement dits, avec le Cancer aneus et quelques autres espèces dont les pieds sont un peu aplatis; ce gerre n'a pas été adopté.

(E. G.)

ZUPHÉE, Zuphrea. Risso.

M. Risso, dans le 5e. volusse de son Hiṣtoire naturelle de l'Europe méridionale, établit sous ce nom un genre de Lœmodipodes, voisin des Nymphons, et auquel il donne pour caractères : corps oblong, convexe; têle subtriangulaire; yeux grands, convexes; corselet à cinq articles entiers, r.pprochés; queue de six anneaux, le dernier alongé, triangulaire; six paires de pieds égaux.

ZuPHÉE dU spare, Zuphcea sparicola. Risso, loc. cit. tom. 5. pag. 104.

Z. corpore dorso lutescente, fascia una transversa, nigro in medio picto; cauda articulo ultimo acuto.

Son corps est jaunâtre, peint au milieu d'une bande transversale noire; l'œil est saillant, noir; la lête forme une espèce de triangle; les segmens du corselet sont très-rapprochés; la queue est fort longue, d'un jaune pâle, subtransparente, terminée par un long anneau aigu. Long. 0,008 , largeur o,oor. Ś́jour, sur les spares. Apparoit en été; il $\mathrm{g}$ a plusieurs espèces. Telle est la description de $M$. Risso, que nous avons transcrite en entier. A côté de genre, il en place un autre qui est nouvean, et quil nomme Hexone.

\section{HEXGNE, Hexona. Risso.}

Corps ovale, terminé en arrière brusquement en pointe; corselet à six segmens; queue subtrigone, à cinq anneaux; six paires de pieds égaux, armés d'ongles courbes, aigns.

Hexone parasitr, Hexona parasitica. Risso, loc. cit. pag. 104.

H. corpore dorso mebro, fascia una longitudinali alba, lineis tribus angustioribus transversis picto; cauda albida.

Son corps est d'un rouge laque, traversé au, milieu par une petite baude longitudinale blanche, et de trois lignes étroites transversales; la têle est triangulaire; les segmens du corselet sont égaux, arrondis, séparés, et terminés en pointe obluse sur leurs bords latéraux; les pieds sont renflés à leur base, pointus au sommet; la queue est courte, blanchâtre. Longueur 0,002 , largeur $000 \frac{6}{2}$. Séjour, sur le bopyre. Apparoît en été.

(E. G.)

ZUPHIE, Zuphium. IaAt, Des. Galerita. Fab. Sснсе. Carabus. On1v. (Entom.) Ross.

Genre d'insectes de l'ordre des Coléoptères, section des Penlamères, famille des Carnassiers (terrestres), tribn des Carabiques (division des Troncatipennes).

Un groupe de 'Troncatipennes à crochiets des tarses sans dentelures, a pour caraclères : dernier article des palpes alongé, plus ou moins sécuriforme; mandibules courtes, peu avancées. ( $V o y$. Troncatipennes.) On y place, outre les Zuphies, 


\section{Z U P}

10. Galérite, qui se distingue par son corps assez épais et par les tarses antérieurs, dont les trois premiers articles sont fortement dilatés dans les mâles. $2^{\circ}$. Polistique, ayant le premier article des antennes plus court que la tête.

Antennes filiformes, presque sétacées, leur premier article au moins aussi long que la tête, le second très-court. - Dernierarticle despalpes alongé, assez fortement sécuriforme dans les deux sexes. -Tête presque triangulaire, très-rétrécie postírieurement, et tenant au corselet par un col court et très-étroit. - Corps déprimé. - Corselet plane, cordiforme. - Elytres planes, en ovale-alongé, recouvrant des ailes et l'abdomen. - Abdomen déprimé. - Pattes de longueur moyenne, assez fortes; articles des tarses presque cylindriques; ceux des antérieurs très-lérèrement dilatés dans les mâles et ciliés également des deux côtés.

On ne connoît qu'une seule espèce de ce genre, elle habite sous les pierres et les écorces; $\mathrm{Zu}$ phie odorante, $Z$. olens. LAт. Gener. Crust. et Ins. tom. 1, pag. 198. $n^{\circ}$. 1. (A la citation d'Olivieı, lisez : $p l$. 13. fig. 156. au lieu de $p l$. I . fig. 126.) - Dru. Spéc. tom. 1. pag. 192. -- DE. Hist. nat. et icon. etc. pag. $121 . n^{\circ}$. 1. pl. $X . f g .3$. - Galerita olens no. 4. Н'ав. Syst. Eleul. - Carabus olens. Oniv. Entom. tom. 3. Carab. pag. 94. $\pi^{\circ}$. 129. (Au lieu de $p l$. 11. fig. 126., lisez: pl. 13. fig. 156.)

Midi de la France, Italie, Russie méridionale, Espagne.

Nota. La Zuphie fasciolée LAm. appartient au genre suivant.

POLISTIQUe, Polistichus. Bonela. Des. Lat.

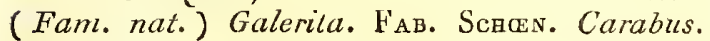
FAB. ScheEN.

Genre d'insectes de l'ordre des Coléoptères, section des Pentamères, famille des Carnassiers (terrestres), tribu des Carabiques (division des Tironcatipennes ).

Un groupe de cette tribu est formé des trois genres Galérite, Zuphie et Polistique. (Voyez Troncatipennes.) Le corps assez épais et les trois premiers articles des tarses antérieurs fortement dilatés dans les mâles sont des caractères propres aux Galérites. Dans les Zuphies le premier aricicle des antennes est au moins aussi long que la tête.

Antennes à articles ovales-coniques; le premier plus court que la tête; le second presqu'aussi long que le troisième. - Palpes ayant leur dernier article assez fortement sécuriforme dans les deux sexes. - Tête beaucoup moins rétrécie postérieurement que dans les Zuphies, ayant un cou assez large, peu distinct du reste de la tête. Pattes comme dans le genre précédent, mais les articles des tarses sont courts, presque bifides; les autres caractères sont ceux des Zuphies.

Ce genre, quoique peu différent du précédent, étant aujourd'hui admis par M. Latreille dans ses Fam. nat., nous avons cru utile de le reproduire ici qnoique nons en ayons déjà parlé succintement pay. 173 de ce volume. M. le cumte Dejean en décrit deux espèces, qui se trouvent sous les picrres dans les endroits humides.

1․ Polistique fisciolé, P. fasciolatus. Des. Spéc. tom. 1. pag. 194. $\pi^{\circ}$. 1. - DEJ. Hist. nat. et icon. etc. pag. 123. no. 1. pl. X. fig. 4. Zuphium fasciolatum. Lat. Gen. Crust. et Ins. tom. 1. pag. I 98. $n^{\circ}$. 2. - Galerita fasciolata ${ }^{\circ}$. 9. FАв. Syst. Eleut.-Scнøn. Syn. Ins. tom 3. pag. 229. $n^{\circ}$. 9. Ces trois derniers auteurs rapportent à cette espèce le Carabus fasciolatus Ross. Ce synonyme appartient, d'après M. le comte Dejean, au P. discoidal. Midi de la France, Espague, Italie, Russie méridionale. Rare aux environs de Paris. $2^{\circ}$. Polistique discoidal, P. discoideus. Des. Spéc. tom . 1 . pag. 196. $n^{\circ}$. 2. - DE. Hist. nat. et icon. etc. pag. I 25. $n^{\circ}$. 2. $p l . X$. fg. 5. Des environs de Kislar et peut-être aussi d'Italie. (S. F. et A. SERv.)

\section{ZUZARE, Zuzara. LÉACH. LAT.}

Genre de l'ordre des lsopodes, famille des Sphéromides, établi par Léach dans le Diction. des scienc. naturelles, et auquel il donne pour caractères: appcndices postérieurs de l'abdomen ayant leurs deux lames saillantes, l'extérieure élant plus grande que l'intérieure, convexe en dessus. Corps susceptible de se rouler en boule; abdomen ayant son dernier article échancré à l'extrémité avec une légère saillie sortant du fond de l'échancrure. Ce genre est très-voisin des Sphéromes, qui n'en sont distinguées que parce que les appendices extérieurs de la queue sont planes, et de même forme que les intérieurs; il se distingue des autres genres de la famille par des caractères qui sont exposés à l'article SPHÉromides de ce Dictionnaire. M. Desmarest décrit, d'après Léach, deux espè̀ces de ce genre.

ZuZARE DEMT-PonctoÉE, Zuzara semi-punciata. LEACH, Dict. des scienc. natur. tom. XII. pag. 344. Corps lisse, à segmens ponctués postérientenient; le septième prolongé en arrière, ce prolongement dirigé en bas, ponctué en dessus, granulé de cliaque côté à sa base; lame extérieure des appendices du ventre terminée brusquement en pointe. Patrie inconnue.

ZuZare diadème, Zzzara diadenla. LÉAch, loc. cit. Corps lisse, septic̀me segmeut du corps prolongé en arrière, ce prolongement dilaté en forme de diadême; lame extérieure des appendices du ventre finissant graduellement en pointe arrondie au bout. Mers de la Nouvelle-Hollande.

(E. G. )

ZYGÈNE, Zygcena. Fab. God. Lat. Ross. 
Panz. Schranck. Sphinx. (Adscita.) Linn. De Géer. Sphinx. Groff. Sch zff. Schif. Esp. Cham. Engr. Devill. Phuns. Hubn. Anthrocera Scopoz.

Genre d'insectes de l'ordre des Lépidoptères, famille Aes Crépusculaires, tribu des Zygénides.

Les deux genres Zygène el Syntomide forment un groupe dans la première division de leur tribu. ( Voyez Zygénides.) Les Syntomides se distinguent des Zygènes par leurs palpes labiaux courts, obtus à l'extrémité, ne s'élevant pas au-delà du chaperon.

Antennes longues; celles des mâles, au moins, fortement et subitement en massue contournée. - Spiritrompe dislincte. - Palpes cylindro-coniques, pointus à leur extrémité, s'élevant audessus du chaperon. - Ailes alongées, en toit dans le repos; cellule sous-marginale des inférieures, large, partagée longitudinalement par un pli, feróée en arrière par une nervure ondée d'où partent quatre rayons qui aboutissent au bord postérieur. - Abdomen presque cylindrique, obtus; anus des mâles ayant une ouverture trèsprononcée. - Jambes couvertes d'écailles courtes, couchées; les postérieures ayant leurs épines, tant latérales que terminales, trc̀s-courtes. Chenilles à seize pattes, courtes, renflées au milieu, amincies à chaque bout, peu velues; coque solide, coriace, placée contre la tige de la plante o ù a vécu la chenille, de forme ovoide ou en bateau; chrysalide conique; Penveloppe des ailes terminée dans plusieurs en une pointe saillante.

Les iusectes parfaits de ce genre paroissent peu de temps après le changement de la chenille en clirysalide; ils sont lourds, paresseux et volent peu; ils ne le font même que lorsque le temps est très-chaud, et se tiennent ordinairement sur les plantes; c'est là que l'accouplement a lieu, et là que les femelles déposent leurs œufs : les deux sexes ne vivent guère que le temps nécessaire pour s'accoupler et pondre. On en connoît un assez grand nombre d'espèces qui nous paroissent appartenil à l'ancieu continent, et notamment au midi de l'Europe. En général, la couleur du fond de leurs ailes (au moins des supérieures) est d'un vert foucé, glacé, changeant souvent en bleu, avec des taches rouges quelquefois entourées de noir ou de blanc.

$1^{\circ}$. Zygène de la Filipendule, Z. Filipendulae. FAB. Ent. Syst. tom. 3. part. 1. pag. 386. no. 1. (En retranchant la variété et les synonymes qui lui appartiemnent, ils se rapportent à la $Z$ ygène du Peucédan.) - LAт. Gen. Crust. et Ins. tom. IV. pag. 213. - God. Lépidopt. de France, tom. 3. pag. 1 27. no. 37. pl. 22. fig. 2. - Encycl. pl. 68. fig. I. Très-commune aux environs de Paris. $2^{\circ}$. Zygène du Peucédan, Z. Peucedani. God. idem, pag. 131. no. 38. pl. 22. fig. 3.-Zygcena Filipendulce var. FAB. $i d$. Des environs de Paris. $3^{\circ}$. Zygène du Chc̀vrefeuil'e, Z. Loti. FAв. id.pag. 387. no. 3. L $\mathrm{L}_{\mathrm{AT},}$ id. - God. id. pag. 134. $77^{\circ} .39$. pl. 22. fig. 4. De France. 40. Zygène de l'Hippocrépis, $Z$. Hippocrepidis. God. id. p. 136 no. 40. pl. 22. fig. 5. De France. 5०. Zygène du Cylise, Z. Cytisi. God. id. p. 138. no. 41.pl. 22. fig. 6 . De France. $7^{\circ}$. Zyg gène de l'Artichaut, $Z$. Cynara. God. id. pag. 139. $n^{\circ}$. 42. pl. 22. fig. 7. Des C'́vennes. 80. Zygène Sarpédon, $Z$. Sarpedon. God. id. pag. 141. no. 43. pl. 22. fig. 8. Midi de la France. $9^{\circ} . Z y g e ̀ n e$ Rhadamanthe, $Z$. Rhadamanthus. God. id. pag. 143. no. 44. pl. 22. fg. 9. Du midi de la France. $10^{\circ}$. Zygène du Sainfoin, $Z$. Onobrychis. FAB. id.p. 39o. no. 1 2.-LAт. id. God. id. pag. 146. $n^{\circ}$. 46. pl. 22. fig. I 1. - Encycl. pl. 68. fig. 3. Des environs de Paris. $11^{\circ}$ Zygène de la Lavande, $Z$. Lavandula. FAB. id. pag. 387. no. 4. God. id. pag. 144. $n^{\circ}$. 45. pl. 22. $n^{\circ}$. 10. Du midi de la France. $12^{\circ}$. Zygène languedocienne, $Z$. occitanica. God. id. pag. 149. $n^{\circ}$. 47. pl. 22. fig. 12. Du midi de la France. 130. Zygène de la Bruyère, $Z$. fausta. FAB. id. pag. 397. no. 37. - LAT. id. - God. id. p. I5o. $n^{\circ}$. 48. pl. 22. fig. 13. - Encycl. pl. 68. fig. 5. Midi de la France. $14^{\circ} .7 y g$ gene calfie, $Z$. caffra. $\mathrm{F}_{\mathrm{AB}}$. $i d$. pag. $390 . n^{\circ}$. 13. Du cap de Bonne-Espérance.

Outre les espèces de Zygcena de Fabricius que nous venons de citer, cet auteur en mentionne un grand nombre d'autres qui sont douteuses ou appartiennent à des genres différens. Les $n^{0 . s}$. 8 . et 9. sont des Zyyènes, mais il n'est pas certain qu'elles soient distinctes de quelques-unes de celles que nous venons d'énumérer. Le gạre Syntomide prend les nos. $6,15,16$; celui de Glancopide les nos. $22,23,24,26,27,29,34,35$, 50,53 , et peut-être aussi les nos. 17, 21, 49, 52. Le $n^{\circ} .38$. est une Aglaope; le $n^{\circ}$. 62. une Sésie. On placera dans les Procris les $n^{\circ 5}$. 68. et 69. Ceux que nous ne citons pas sont au moins fort douteux. (S. F. et A. SErv.)

ZYGÉNIDES, Zyganides. Troisième tribu de la famille des Crépusculaires, ordre des Lépidoptères.

\section{Elle a pour caractères :}

Antennes du plus grand nombre n'offrant pas de houppe à leur extrémité; en forme de fuseau ou de cornes de Bélier. - Palpes labiaux grêles, comprimés, cylindracés ou coniques, leur troisième article très-distinct._- Chenilles sans corne à l'extrémité postérieure du corps, et se renfermant dans une coque bien formée pour passer à l'état de chrysalide : les unes vivant dans l'intérieur des végétaux; les autres à nu, celles - ci velues et semblable aux chenilles des Nocturnes.

I. Antennes simples, point pectinées dans les deux sexes.

A. Antennes terminées par une petite houppe soyeuse. (Antennes toujours en fuseau ; ailes 


\section{Z Y G}

ailes horizontales, écartées, plus ou moins transparentes; anus barbu.)

Sésie.

B. Antennes sans houppe à leur extrémité.

a. Jambes postérieures ayant chacune à leur extrémité deux épines très-fortes. Egocère, Thyride.

b. Jambes postérieures n'ayant chacune à leur extrémité que deux très-petites épines. (Abdomen cylindrique, obtus; ailes grandes, très en toit.)

Zygène, Syntornide.

II. Antennes bipectinées dans les mâles, simples dans les femelles.

Procris, Atychie.

III. Antennes bipectinées dans les deux sexes.

A. Une spiritrompe distincte.

$$
\text { Glaucopide. }
$$

B. Point de spiritrompe distincte.

$$
\text { Agrlaope, Stygie. }
$$

AEGOCÈRE, AEgocera. LAт. Bombyx. FAB. phaloena. Cram.

Genre d'insectes de l'ordre des Lépidoptères, famille des Crépusculaires, tribu des Zygénides.

Les cinq genres Sésie, Agocère, Thyride, Zygène et Syntomide forment la première division de cette triba. (Voyez Zrgénides.) Celui de Sésie se distingue par ses antennes terminées en une petite houppe soyeuse; Zygène et Syntomide par leurs jambes postérieures n'ayant à leur extrémité que deux épines très-peites. Dans les Thyrides les palpes sout dépourvus de faisceau de poils, les ailes sont horizontales, écartées, anguleuses, en partie transparentes. De plus, dans ces quatre genres, le bout de l'antenne ne devient pas subitement plus grêle et ne se courbe point d'une manière qui n'appartieut qu'aux Ngocères et à plusieurs genres de la tribu des HespériesSphinx Lat. à laquclle il paroîl que M. Bois-Duval se propose de réunir les $E$ gocères dans une monographie de la tribu des Zygénides qui doit paroître incessamment.

Antennes bien fusiformes, sans houppe d'écailles à leur extrémité qui s'amincit subitemeut en une pointe assez longue, un peu courbée. Palpes labiaux ayant leur second article garni de poils formant un faisceau qui s'avance en manière de bec. - Spiritrompe distincte. - Ailes en toit dans le repos, totalement couvertes d'écailles, entières ì leur bord postérieur. - $A b d o-$ men conique. - Jambes postérieures munies à leur extrémité de deux épines très-fortes.

Le nom de ces Lépidoptères vient de deux Hist. Nat. Ins. Tome $X$. mots grecs et signifie : comes de bouc. On n'en cite qu'une seule espèce, ses premiers états sont inconnus ainsi que ses habitudes; c'est l'Egocère Vénulia, FE. Venulia. LAт. Gener. Crust. et Ins. tom. IV pag. 212. - Bombyx Venulia. Faз. Entom. Syst. Suppl. pag. 438. Du Bengale.

ATYChIE, Atychia. Hofrman. Lat. Ineig. Sphinx. Esp. Huвn. Noctua. Huвn.

Genre d'insectes de l'ordre des Lépidoptères, ramille des Crépusculaires, tribu cles Zygénides.

La seconde division de cette triba comprend les Zygénides dont les antennes sont bipectinées dans les mâles, simples dans les femelles. Elle contient les genres Procris et Atychie; dans celles-là les palpes ne s'élèvent pas au-delà du chaperon et sont nus; les ailes sont longues et les jambcs postérieures n'ont à leur extrémité que deux épines très-courles.

Antennes bipecinées dans les mâles, simples dans les femelles. - Spiritrompe distinctc. Paipes labianx s'élevant notablement au-delà du chaperon, très-velus. - Ailes courtes. - Jambes postérieures terminées par deux épines trèsfortes.

Le type de ce genre, dont les premiers états n'ont pas encore élé observés, non plus que les inæurs, est l'Atychie Chimère, $A$. Chimara. LAT. Gen. Crust et Ins. tom. IV. pag. 214. D'Europe.

GLAUCOPIDE, Glaucopis. FAB. (Syst. Gloss.) LAT. Zygoena. FAв. (Ent. Syst.) Sphinx. (Adscita.) Linn. Sphinx. Crax. Drur.

Genre d'insectes de l'ordre des Lépidoptères, famille des Crépusculaires, tribu des '̌ygénides.

Ce geare forme à lui seul une coupe particnlière dans la troisième division des Zygénides. Voyez ce mot.

Antennes bipectinées dans les deux sexes. Spiritrompe distiucte. -.. Palpes labiaux presque cylindriques, s'ćlevint notablement au-dessus du chaperon, leur dernier arlicle un peu grĉle, point écailleux. - Jambes postérieures garnıes d’épines latérales et de deux terminales longues.

Ce genre, dont toutes les espèces sont étrangères ì l'Europe, paroit être confiné entre les tropiques : il tire son nom de mots grecs qui ont rapport aux laches d'un bean vert dont beaucoup d'espćces sont oruées; on ne connoît point leurs métamorphoses, ni lcurs habitudes. Nousindiquerons les espéces suivantes :

I $^{\circ}$ Glaucopide Polymène, G. Polymena. Latr. Gen. Cnust. et Ins. toml. IV. pag. 214. -Zygarnu Polymena. HAB. Entom. Syst. tom. 3. part. I. pag. $396 . n^{\circ}$. 34. De la Cbine. $2^{\circ}$. Glaucopide Léthé, G. Lethe. - Zygrenza Lethe. Fав. id. n॰. $\mathrm{Mm} \mathrm{m} \mathrm{mm}$ 


\section{6}

35. D'Afrique. 3․ Glancopide Auuré, G. Auge. IAAт. id. - Zygcence Auge. FAB. id. pag. $401 . n^{\circ}$. 53. Du Brésil. $4^{\circ}$. Glaucopide Androwaque, G. Andromacha. - Zygena Andromacha. FАв. id. pag. 3g3. no. 26. Da Brésil. C'est peut-être le mâle de la Glaucopide Augé. 50. Glancopide Argynne, G. Algynnis. LAt. id.-Zygana Argynnis. FAB. $i d . n^{\circ} .24 .6^{\circ}$. Glancopide Cassandre, G. Cassandra. - Zjgence Cassandra. FAB. id. pag. $392 . n^{3}$ 22. (A la citation de Cramer, lisez 394. au lieu de 494.) Da Brésil. $7^{\circ}$. Glaucopide Hyparque, G. Hyparchus. - Z grena Hyparchus. FAB. id. pag. 3g3. $n^{\circ}$. 23. De Sierra-Léon. $8^{\circ}$. Glancopide fllavicorne, G. fluvicornis. - Zygona flavicornis. FAB. $i d . p .594 . n^{\circ} .27$. De Cayennne et du Brésil. Dans nos individus la plus grande partie des antennes, la tête et les pattes sont noires. $9^{\circ}$. Glaucopide Eryx , G. Eryx. - Zygcena Eryx. FAB. id. no. 29. Amériçue océridionale.

On doit pent-être encore rapporter à ce genre les Zygana nos. 17, 2 I, 49 et 5\%. FАв. Entom. Syst.

A G [.A OPE, Aglaope. Lat. Gód. Sphinx. (Adscita) Linn. Sphinx. Esp. Exgr. Hubn. ZZygoenu. FAв. (Ent. Syst.) Glaucopis. FAB. (Syst. Gloss.)

Genre d'insectes de l'ordre des Lépidoptères, famille des Crépusculaires, tribu des Zygézides.

Le dernier groupe des Zygénides se compose des Aglaopes et des Stygies; celles-ci sont séparées des Aglaopes par les caractères suivans: palpes labiaux épais, cylindriques, entièrement recouverts d'écailles et s'élevant au - dessus du chaperon; épines des jambes postérieures, tant les latérales que les terminales, très-fortes; anus barbu.

Antennes bipectinées dans les deux sexes. Palpes labiaux petits, presque nus, à peu près cylindriques, leur dernier article un per plus grêle que les précédens. - Point de spiritrompe distincte. - Ailes oblongues; ceilule sous-marginale des inférieures fermée et divisée longitudinalement par deux rameaux nerveux qui s'entrecroisent sur la ligne de clôture. - Anus dépourvu de brosse. - Epines des jarabes postérieures, tant les latérales que les terminales, très-courtes, peu visibles. - Chenilles courtes, ramassées, peu garnies de poils.

Le type de ce geure, dont les mœurs ne nous sont pas connues, est l'Aglaope malbeurease, $\alpha$. infuusta. Lat. Gen. Crust. et Ins. tom. 4. pag. 215. God. Lépidopt. de France, tom. 3. p. 175. $n^{\circ}$. 53. pl. 22. fig. 18. - Zygana infausta. $\mathrm{F}_{\mathrm{AB}}$. Ent. Syst. tom. 3. part. 1. pag. 397. $n^{\circ} .38$. Du midi de la France; très-rare aux eavirons de Paris. (S. F. et A. SEgr.)

\section{Z Y Gr}

\section{ZYGIE, Zygia. Fab. LAt. Scean. Illig.}

Geure d'insectes de l'ordre des Coléoptères, section des Pentamères, fawille des Serriconnes (division des Malacodermes), triba des Mélyrides.

Les trois genres Zygie, Mélyre et Dasyte composent, dans cette lribu, un groupe caractérisé ainsi qu'il suit : palpes filiformes; point de vésicules exsertiles sur les côtés du corselet et de la base du ventre. (Voyez Mélyrides, pag. 426 de ce volurae.) Les Mélyres sont distinc ts par le quatrième article des antennes turbiné ou conique ainsi que les suivans, et par le disque de leur corselet qui est plane. Le genre Dasyte a le corps étroit, alongé, très-souvent presque linéaire, la tête à peu près transversale; les crocbets des tarses sont bordés à leur base intérieure par une membrane qui forme un appendice dentiforme; presque tous les articles des antennes sont turbinés.

Antennes filiformes, composées de onze articles; les second et troisième presque cylindriques, fort menus, celui-ci alongé, le quatrième et surtout les suivans dentés en scie, comprimés, presque transversaux. - Corps ovale. - Corselet presqu'en trapèze, rétréci à sa partie antérieure, son disque élevé. - Elytres flexibles, recouvrant les ailes et l'abdomen. - Pattes filiformes; crochets des tarses entièrement cornés, n'ayant qu'une petile dent peu visible vers l'extrénité.

La seule espèce connne est la Zygie oblongue, Z. oblonga n०. 1. F Ав. Syst. Eleut. - La'. Gen. Crust. et Ins. tom. 1. pag. 264. no. 1. tab. VIII. fig. 3. - Schan. Syn. Ins. tom. 2. p. 33g. no. 1. I) Espagne et d'Orient. Feu Olivier l'a trouvée à Bagdad, dans l'intérieur des maisons.

DASYTE, Dasytes. Payx. Fab. Lat. GyLe. Schon. Panz. Dermestes. Linn. Schrancr. Cicmdela. Geofr. Melyris. Oriv. Telephorus. DE GEer. Lagria. Panz. Ross. Fab.? T'illizs. Marsh. PAnz. Clerus. De Géer. Cantharis. Sehranck. Scopul. Anobium. 'Гпunb. Hispa. FAв.

Genre d'insectes de l'ordre des Coléoptères, section des Pentamères, famille des Serricornes (division des Malacodermes), tribu des Mélyrides.

Un groupe de Mélyrides se distingue par ses palpes filiformes et par l'absence de vésicules exsertiles sur les côtés du corselet et de la base du ventre; il conlient les $Z_{y}$ gies, les Mélyres \& les Dasytes. (Voyez MÉLY rIDEs, pag. 426. de ce volume.) Les deux premiers genres s'éloignent des Dasytes par leur corps ovoide et par les crochets des tarses entièrement cornés.

Antennes filiformes, composées de onze articles, la plupart de forme turbinée, courts, à peu près aussi larges que longs. - Labré corné, ar- 


\section{Z Y G}

rondi, cilié. - Mandibules cornées, arquées, aiguës à l'extrémité, celle-ci refendue.-Mâchoires membraneuses, courtes, bifides; leur lobe extérieur grand, arrondi au bout, l'intérieur rétréci vers l'extrémité qui porte une pointe particulière.-Palpes iuégaux, les maxillaires composés de quatre articles; le premier court, le secoud plus long, obconique, le troisième épais, court; le quatrième épais, de la longueur du second, tronqué obliquement à son extrémité : palpes labiaux plus courts, de trois articles; le preuier court, le second plus long, plus épais, ubconique, le troisième encore un peu plus épais, alongé obliquement, tronqué à l'extrérnité. Lève profondément échancrée à l'extrémité, presque bifide. - Tête presque transversale, iuclinée, rentrant dans le corselet jusqu'aux yeux lors du repos. - Corps étroit, alongé, presque linéaire, plus ou moins hérissé de poils. - Corselet assez grand, un peu convexe, légèrement rebordé. - Ecusson petit, arrondi postérieurement. - Ely. tres alongées, presque linéaires, flexibles, un peu rebordées, recouvrant des ailes et l'abdomen. $P$ attes de longueur moyenne; dervier article des tarses muni de deux crochets bordés à leur base intérieure par une membrane qui s'élargit en un appendice dentiforme.

Le nom de ce genre vient du guec et a rapport aux poils dont les espèces ont généralemeat le corps hérissé. Il répond en grande partie à celui de Mélyre de cet ouvrage; mais l'auleur y réunit l'espèce qui constitue le genre Mélyre (MI. viridis $F_{A B}$ ) Les Dasytes ne sont connus qu'à l'étut parfait; on les trouve sur les graminées, sur les fleurs syngénèses et ombellifères. Les espèces sont nombreuses; la taille des indigènes est pelite ou sooyenue.

\section{d. Dasyte rayé, D. lineatus.}

Dasytes lineatus 口 $^{\circ}$. 5. FAв. Syst. Eleut. Scren. Syn. Ins. tom. 3. pag. 13. no. II.

Voyez pour la description et les autres synonymes, Mélyre rayé $n^{\circ} .7$. du préseut Dicionnuire.

\section{Dasyte nohle, D. nobilis.}

Dasytes nobilis. Scnen. id. pag. I4 no. 17 . -Melyris nobilis. Iluig. Col. Borluss. 1. pag. 3og.

Vovez pour la description, Mlélyre bleuâire $n^{\circ}$. 8. de ce Dictionnaire. (Ea retranchant tous les synonymes de Fabricius qui apparliennent au Dasyte bleu.)

3. Distre âtre, D. ater.

Dasytes atern ${ }^{\circ}$. I. FAB. id. - LAT. Gen. Crust. et Ins. tom. I. pag. 264. $n^{\circ}$. 1. - ScBgs. id. pag. II. $n^{\circ} .2$.

Voyez pour la description et les antres synonywes, Mélytre âtre no. 9. de ce Dictionnaire. (La planche indiquéc après la description appartient à l'Entomologie d'Olivier.)

\section{Daste noir, $D$. niger.}

Dasytes niger no. 4. FAB. id. - Scuq.N $i d$. pag. 12. $n^{\circ} \cdot 9$.

Voyez pour la description et les autres synonymes, Mélyre velu no. 10 , de ce Dictionnaire.

5. DAsyte quadripustulé, D. quadripustulatus.

Das, tes quadripustulatus. Schers, id. $n^{\circ}$. 8. Hispa quadínipustulata $n^{\circ} .6 . \mathrm{F}_{\mathrm{AB}}$. id.

Voyez pour la description, Mélyre quadri-

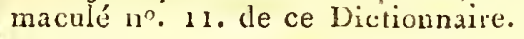

\section{D.asxte plombé, D. plumbeus.}

Dasytes plumbeus. Des. Catäl.

Voyez pour la description et la synonymie, Mélyre plombé no. 12. de ce Dictionnaire.

Nota. M. Schcenherr donne cette espèce comme synonyme de son Dasytes flavipes no. 13.

\section{Dasyte floral, D. floralis.}

Dasytes floralis. Gy L.. Ins. Suec. tom. 1. pag. 326. no. 3. - Schen. id. pag. 13. $n^{\circ}$. 10.

Voyez pour la description, Mélyre floral $n^{\circ}$. 15. de ce Dictionnaire.

\section{Dastтe brillant, D. subarzeus.}

Dasytes subceneus. Sснег id. pag. 15. $n^{\circ}, 20$.

Voyez pour la description, Rílyre bronzé $n^{\circ}{ }_{4}$ 14. de ce Dictionnare.

\section{Dasyte testacé, D. testaceus.}

Dasytes testaceus. Scren. id. pag. 16. $n^{\circ}, 29$ 。

Voyez pour la description, Mélyre testacé $\mathrm{n}^{\circ}$. 15. de ce Diclionnaire.

Nota. M. le comte Dejean (Calal.) ne le regarde que comme une variété du $D$. pallipes.

ro. Dasyte flavipède, D. flavipes.

Dasytes flavipes $n^{\circ}$. 6. Fвв. id.-Sсвєк. id. pag. 13. $n^{\circ} .13$.

Voyez pour la description, Mélyre flapipède $n^{\circ} .16$. de ce Dictionaaire.

$\mathrm{Mmmm} 2$ 
I I. Dastite douteux, D. dubius.

Dasytes dubius. Scнаn. id. pag. 16, no. 3o.

Voyez pour la description, Mélyre douteux no. 5. de ce Dictionnaire.

Nota. M. le comte Dejean dans son Catalogue n'en fait qu'une variété du $D$. pallipes.

On placera en outre dans ce genre : $1^{\circ}$. Dasyte rubripenne, $D$. rubripennis. LAT. Voyag. Humb. et Bonpl. II. IV. pag. 258. $2^{\circ}$. 26. tab. 17. fig. 3. à 4. a. - Scricen. Syn. Ins. tom. 3. pag. II. $n^{\circ}$. 1 . Noir, velı ; élytres rouges, tachées de noir. Aøérique équinoxiale. $2^{\circ}$. Dasyte scutellaire, $D$. scutellaris no. 2. Fab. Syst. Eleut. - Scics. id. pag. 12. $n^{\circ}$. 5. D'Espagne. 3․ Dasyte bipustulé, $D$. bipustulatus. Scherv. id. no.7. - Hispa bipustulata $\mathrm{n}^{\circ} \cdot 6$. F $\mathrm{AB}$. id. D'Italie et d'Allemagne. $4^{\circ}$. Dasyte hémorrhoïdal, $D$. homorrhoidalis $\mathrm{n}^{\circ} .3$. Fab. $i d$. - Schorv. $i d$. no. 6. D'Espagne et de Barbarie. $5^{\circ}$. Dasyte nigricorne, D. nigricornis $n^{\circ}$. 10. FAB. $i d_{\text {. }}$-SCugn id.pag. 15. $n^{\circ}$. 22. De Suède et des environs de Paris. 6०. Dasyle bleu, D. coe ruleus $\mathrm{n}^{\circ}$. 7. F $\mathrm{FB}$. id. (En retranchant le synonyme d'Olivier, lisez : cyaneus an lieu de carulea, et celui de Geoffiroy. Ces synonymes appartiennent an Dasyte noble no. 2.) - Schar. id. pag. 14. $n^{\circ}$. 16. $7^{\circ}$. Dasyte obscur, D. obscurtus. Grul. Ins. Suec. I. III. Add. p. 685. I-2. - Schon. id. $n^{\circ}$. 14. De Suède. $8^{\circ}$. Dasyte linéaire, $D$. linearis no. I 1. FAB. $i d$. (A la citation de Crentz, lisez: Tillus, an lieu de Tixtus. - Sсвєе id. pag. 16. $n^{\circ}$. 25. Des environs de Paris. $9^{\circ}$. Dasyte pallipède, D. pallipes.-SсnжN. id. pag. $13 . n^{0}$. 12. Environs de Paris. $10^{\circ}$. Dasyte morio, $D$. morio. Grid. Schesn. id. Append. p. 11. no. 14. Oblong, noir, velu; corselet court, égal; élytres un peu rugueuses, finement pointillées. De Barbarie. $11^{\circ}$. Dasyte rougeâtre, D. rubidus. Grus. Schøn. id. pag. 12. $n^{\circ}$. 16. Oblong, d'un violet-noirâtre, hérissé de poils longs; élytres d'un châtain clair, profondément ponctuées, l'extrémité plus claire; antennes ferrugineuses ainsi que les paltes. De Hongrie. (S. F. et A. SEnv.) 


\title{
TABLE ALPHABETIQUE
}

\section{DES ARTICLES TRAITES DANS CE DICTIONNAIRE,}

\author{
AILLEURS QU'A LEUR LETTRE.
}

A bomlnaux. Soustraib.T. $\mathrm{X}, P .555$

Ábia.

Acanthocère.

Acanthomère.

Acanthoscèle.

Achias.

Aconite.

Acrée. Tome IX.

Acrocère. Tome $X$.

Acrydiens. Fam.

Adèle.

AEdès.

AEgialie.

AEgocère.

AEsale.

AEschrotès.

AEthalion.

Agacéphale.

Agariste. Tome IX.

Agachidie. 'Tome X.

Agathis.

* Agénie (1).

Agláé.

Aglaope.

Agre.

* Agreuter.

Agyre.

Akis,

Alcine.

Alćochare.

Aleyrode.

Allodapé.

Alphée.

Alyde.

Alysie.

Alyson.

Amasis.

Amblytère.

Ammobate.

Ammophile.

Amnaothée.

Amphicome.

A muphinalle.

Ampulex.

Anacole.

Anaspe.

Ancée.

Andrénètes. TR1B.

Anisomère.

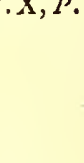

575

363

541

38.2

99

227,806

782 Anthobies. Sous-trib.

344

651

657

350

825

435

357

$-65$

370

802

38

38
202

105

826

737

633

44

$\begin{array}{r}42 \\ \hline\end{array}$

475

$2: 6$

$24 !$

IS

387
60

432

49

584

365

17
451

$45 \mathrm{I}$
$\times 51$

354
$3-6$

368

450

647

409

755

4
588

(1) L'astérique indique les sousgenres.
Anisonyx. Tome X.

Anisoplie.

Anophèle.

Anoplognathe.

Antéon.

Anchicides. Tйb.

Anthidie.

Anthie.

Anthocope.

Anchomyie.

Anchophore.

Anthraciens. TR1B.

Anthrax.

Anchure.

Aphodie.

Aphrite.

Aphrophore.

A piaires. TRLB.

Apion.

Apodère.

Apogonie.

Apore.

Apotome.

* Aprême.

Aptine.

Arade.

Araignée.

A rénicoles. Sous-tras.

Aréode.

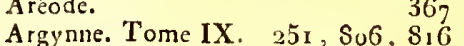

Argyronètre. Tome X.

Armadille.

Ariste.

Armide.

Asaphe.

Ascie.

Aside.

Asiliques. TniB.

A sindule.

Aspiste.

Astacines.

Astate.

Astemme.

Ascomelle.

Astrapée.

A teuchus.

Achalie.

Athanas.

A thérix.

A thyrée.

Arractocère.

Atychic.

Atye.

150

350

283
Page 376 Atyle. Tome X.

3-4 Aulaque.

65̃ Auconomée.

364 Axine.

Page 536

30

328

615

(69) BacCHA.

52 I

313 Bacille.

736 Bactérie.

350 Badister.

314 Barbicorne. Tome IX.

137 Bélostome. 'Tome X.

$79^{6}$ Bélyte.

Bembécides. Trib.

Bembex (1).

Béris.

Biblis. Tome IX. $\quad 325, \mathrm{SO}_{7}, 8_{2}$

512

607

305

304

365

I 83

386

618

230

653

753

348

254

235

385

$8: 6$

712

5 I 9

27
538

$63 \mathrm{~s}$

606

267

$1 \% \frac{14}{3}$

323

782

478

350

595

329

361

$3 \circ 9$
$8 \cdot 25$

Bipartis. Sous-тrab. 'Tome X. 345

Bolbocère.

Bolitophile.

Bombyliers. TntB.

Bopyre.

Bords des ailes. Détall.

446

445

705

$27 \mathrm{I}$

210

495

497

802

265

Bostrichins. TnIB. $80 \mathrm{I}$

Bousier (2). $\quad 355$

Brachiale (cellule). Détaid. $\quad 264$

Brachine.

Brachyope.

Bracon.

Braconides. Sous-trib.

Brassolide. 'Tome $\mathbf{1 X}$.

Bruchèles. Trib. 'Tuıne X. 306

Bryaxis. 221

Bucente. 500

Buprestides. Trie. 490

Buthus. $\quad 398$.

Byture.

45

Calavore. 30 Tor

Calianasse. $\quad 768$

Calläide. $\quad 740$

Callicère. $\quad 515$

Calliste. 630

Calliste (voyez Pyrie). $\quad 253$

Calobate. $\quad 159$

Calosome. 170

Calymène. $\quad 212$

Camarie. $\quad 454$

Campécopée. $\quad 460$

(I) Voyez, pour les détails des mours, tome X, pag. 497 , et pous. le genre, le mot Bembex à sa lettre.

329 (2) Er de plus à sa lettre. 
TABLE ALPHABE்TIQUE.

Campsie. Tome X.

Camptodonte.

Campylomyze.

Canalifères. FA $\mathrm{M}$.

Cantharidies. Trub.

Capse.

Cardisome.

Casnonie.

Castnie. Tome IX.

Catascope. Tome X.

Cébrion.

Cébrionites. Tris.

Cécidomyie.

Centris.

Céphus.

Cérambycins. $T_{\mathrm{R} 1 \mathrm{~B}}$.

Círaphron.

Céraspis.

Cératine.

Cérarophye.

Cératopogon.

Cercéris.

Cercupides. Sous-taib.

Cercopis.

Cérie.

Céropale.

Céroplate.

Cerque.

Cérylon.

Céthosie. Tome IX. 242, SoG, $8 x$

Chalcidites. 'Tran. 'Tome $X$.

Charausonites. Trab.

Chasmatoptère.

Chasmé.

Chasmodie.

Chauliode.

* Cheilosie.

Chélone.

* Chélostome.

Chemnie.

Chevralle.

Chionáce.

Chiromyze

Chiron.

Chironome.

Chiroscèle.

Chlænie.

Chlamyde.

Chlorion.

Choridie.

Cholève.

Chrysides. Tars.

Chrysogastre.

Chrysophore.

Chrysops.

Chrysoroxe.

Cicadelles. Trib.

Cicindélètes. T'лів.

Cilicée.

Cinète.

Cione.

Cis.

Cistélides. $T_{\text {GLB. }}$.

Cirigrades.

Cladie.

Cladoxère.

Clairones. $T_{R 1 B}$.

Clavigère.

Clavipalpes. FAM.

Cléonyme.
Page 455 | Clepre. Tome $\mathbf{X}$.

384

667

439

Clotho.

325 Clubione.

685 Clypéastre.

726 Cnodalon.

794 Calioxyde.

734 Conomyie.

289 Colaspe.

426 Colar (voyez Rhathyme.)

663 Coliade. Tome IX. 85, 804, 8

$79^{5}$ Collète. Tome $X$.

5-6 Colliure.

$6 y^{3}$ Colobique.

150 Colobothée.

3 go Colytic. 'T'ume VII. 588 , r. X.

18 Comérc̀s. Tome X.

5 I 7 Conocéphale.

66. Conopalpe.

103 Conopsaires. Fam.

602 Conopsaires. 'I'r1B.

6o4 Coprophages. Soos-тniв.

5 I 4 Coprodère.

18.2 Cordiste.

66y Cordyle.

45 Coré

224 Curèrhre.

Coronide.

252 Corsyre.

3 (6) Corydale.

377 * Corync.

378 Cosson.

805 Cossus.

421 Cossyphènes. Tratb.

512 Courtillière.

42 Crangnon.

315 Crassicornes. TRlB.

220 Crémastocheile.

217 Crćpusculaires. Faм. Tome IX.

589 * Criorhine. Tome X.

430 * Crocise.

$3{ }^{2} 9$ Cryptique.

659 Cryprocère.

566 Cryptode.

631 Cryptorhynque.

13 Crytope.

$4 \tilde{s}_{\text {I }}$ Crène.

356 * Crénic.

46 Crérisce.

253 Cténodactyle.

521 Cténophore.

806 Cténostome.

544 Cubitale (cellule). Déra1z.

5 I6 Culicides. Trin.

6o2 Culiciformes. Sous-t bib.

6 I 7 Culicoïde.

400 Cupès.

210 Cyane.

299 Cychre.

224 Cyclocéphale.

484 Cylas.

775 Cyllénie.

57 I Cyminde.

445 Cymodocée.

427 Cymothoé.

222 Cyphocrane.

713 Cyphomyic.

67 Cyrte.

445

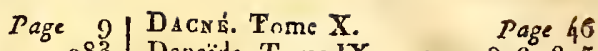
283 Danä́de. Tome IX. 1;2, 806, 8:5 384 Dasypode. Tome X. 404

325 Dasyre. 826

$75 \mathrm{x}$ Dasyus. 36y

752 Décamérie. $57 \mathrm{~g}$

71 Decempèdes.

96 Démétrias.

108 Dendroïde. $26 \mathrm{c}$

430 Diapériales. Trab. $\quad-554$

12 Diaprie. $21 x$

4 Dichèle. 373

13 Dicale. 635

405 Dicranie. 3\%1

707 * Didymic. 574

45 Dilophe. 388

336 Dinode. 634

716 Dionyx. 22x

486 Dioxyde.

34 I Diphucéphale. 37\%

417 Dircée. 4 IS

S18 Discoidale (cellule). Détalz. 26́t

818 Disténie, 485

348 Ditome." 75

745 Dixa.

727 Dolère. 570

jo Dolichopodes. Trib. 538

58 Dolichure. 449

658 Dolomède. 757

474 Dorcadion. 337

34 Doscatome. 24́o

421 Doryphore. Ia

$55_{9}$ Drapétis. 437

302 Drasse.

817 Drile (1). $\quad 55$. 55

54.

709 Dromique. 6ry

554 Dyuamène. 527

379 * Dysodie. 654

59 Echinomyis.

107 Ecrevisse.

* Ectrichodie.

177 Egéon. 329

301 Elatérides. Tвів. 490, $5 y^{7}$

394 Elédone.

727 Eléphastome. 360

650 Elode. 392

$22^{\circ}$ Em ides. $T_{\mathrm{R} 1 \mathrm{~B}} . \quad 538$

$74^{1}$ Empidiens. Fas. 538

583 * Emprie. $57 \varepsilon$

$62^{\circ}$ Encyrre. 66

264 Epéire. $\quad 759$

655 Epéole. 104

656 Ephippie. $\quad 502$

662 Epicharis. 530

308 Epitzage. 97

217 Eponis. 63?

$17^{\circ}$ Eproboscidés. SeCt. 351

807 Erèses. $33 \mathbf{2}$

304 Erioptère. 586

I6I Eristale. 523

739 Erotylènes. Trub.

461 Erycine. Tome IX. 553, So8, 827

233

$8 \mathrm{n} 3$

782

(1) Et de plus à sa lettre. 
Eucère. Tome X.

Eachlore.

Euchrée.

Euménie. Tome IX.

Eumère. Tome X.

Eumolpe.

Euparie.

Eupélix.

Euplocampe.

Euprosope.

Eurybie. Tome IX.

Eurychore. Tome X.

Eurymèle.

Eurype.

Euryptère.

Eurytome.

Evacanthe.

Fvaesthète.

Evaniales. Tris.

Féroniens. Sous-trib.

Filicornes. SECT.

Fissilabres. Trib.

Florales. Sous-tnib.

Fane.

Fongivores. Sous-trib.

Fourmilions. T'вав.

Fracticornes. Soes-ratb.

Galérite.

Galgule.

Galiicoles. Sous-trib.

Gallicoles. Taib.

Gébie.

Gécarcin.

Géniate.

Géophile.

Géorisse.

Géotrupe.

Gerris.

Gibbie.

Glaphyre.

Glaucopide.

Globiceps.

Globulites. Tris.

Gnathic.

Guatophylle.

Gnome.

* Gnorime.

Gnoriste.

Gonodacryle.

Graphiptère.

Grilloniens. FА м.

Gymnétis.

Gymnopleure.

* Henatorie.

Hæmanopote.

Halicte.

Hallomène.

Manneton (1).

Harpaliens. Sous-tRIB.

Hẻbé.

Hédychre.

Hégètre.

(1) Et de pitus à sa lettre.
Page $3 \mathbf{r}_{2}$ Helcon. Tome $\mathrm{X}$. Page 40 368 Héliconie. Tom. IX. , ,6, So6, 816

8

$\mathrm{S}_{2} 6$

520

. 3

357

611

65

620

458

${ }_{12} 6$

603

6.5

$65_{7}$

67

612

483

252

629

$5+5$

$47^{5}$

657
30

656

148

306

270

656

252

76

685

365

$39^{5}$

194

361

265

240

377

825

326

213

82 I

328

337

70

666

$4 \div 3$

735

343

380

352

499
542

542
400

301

366

629

8,6

8

126

* Héliocanthare. Tome X.

* Hélius (I).

Helluo.

* Hólobie.

Hélophile.

Hélopiens. $T_{\mathrm{R}}$ B.

Hélore.

Hémérobins. Taıs.

Hémérodromie.

Hémirhipe.

Hériade.

Hermérie.

Herminie.

Hesperides. Taib. Tom.

Trib. Tom. IX.

Hesperie.

Hespéries-Sphinx. Thrb.

Hétérocère. Tom. X.

Hétérotome.

Hexatome.

Hexone.

Hippolyte.

Hippopsis.

Hismoneure.

Hollayménie.

Holoprile.

Homard.

Hoplie (2).

Horiales. $\Gamma_{R 1 B}$.

Hybôme.

Hybusore.

Hyborins: TRlB.

Hydromètre.

Hylécate.

Hylésine.

Hylotome.

Hyménocère.

Hyspérie.

$35 \mathrm{I}$
585

729

5.55

483

148

148

437

554

Hypophlée. Tom. VII, 588, X. 96

Hypule. Tone X.

Inssus.

I 'éa. Tom. IX. Trin.

Idoréc. Tom. X.

Inca.

Lagria1res. Thab.

Lamiaires. TRLB.

Lampyrides. Trif.

Languric.

Lasie.

Lasioprère.

Lachrobie,

Lamidie.

Lauxanic.

420

Lèdre.

Léia.

Léïode.

Lépisie.

Leprides. TRд.

Page $38 \mathrm{r}$

Leptis.

28 I

ibid.

Leptomèrc. 217

Lepture (1). 687

Jeprurères. Trib. $4 \mathrm{SI}$

Lestève. $\quad 215$

Lestis. 799

Leucothyrée. $36 f$

Libychée. 'Tom. IX, 169, $806, \mathrm{~S}_{13}$

Licine. 'Tom. X. 635

Ligie. $\quad 235$

Limacode. $\quad 227$

Lime-bois. Tris.

ro6 Limule. 809

Limnobic.

Lipare. 300

Lispe.

Lichobie. $\quad 306$

Lithosie. 649

Livie. $\quad 229$

Lixe. 300

Locustaires. FaM. $\quad 344,3$.

Lomatie. 676

Loméchuse.

Longilabres. Trus.

Longipalpes. 'Trib.

Lophyse.

Loricère.

Loxocère.

Lycose.

Lycre (3).

Lygée.

Lyniphie.

Lytmate.

333

58

482

57

629

422

547

716

322

758

328

Macraspis.

805

* Macraspis. 316

Macrocéphale.

Macrocère. $\quad 527$

Macrocère. $66 i_{4}$

Macrodactyle. $\quad 372$

Ichreumonides. Triв. $43,252,488$ * Macroglosse.

Macronote.

Macronyque.

Macrope.

Macropèze.

Makistocère.

Malacodermes. Divis

465

196

337

662

$58=$

426

334 Mallote.

Malthine.

$56 r$

260

Mastige.

Matronule. 680

$\begin{array}{ll}\text { Méchidie. } & 36.2 \\ \text { Mégacépbale. } & 618\end{array}$

Migalope (3). 3 so

Mégalopières. Гraв.

Mégarhine. 658

(1) Et de plus à sa letrre.

(2) $I d e m$.

(3) Notre Mégalope linéé no. 6. est

(I) Il faut substituer ce nom à celui la même espèce que celle désignée par de Mégarhine.

(a) Consultez en outre la page 3,5 ., seconde colonne, tome $X$, pour une rectification de caractère.

M. de Mannerhcim (Mém. de l'Acad. imp. de Saint-Pétersbourg, tom. 10, pag. 302.), sous le nom de $M$ eg. Henningii. 
* Mégarhine (1). Tome X. Page 585 Mlélandrye.

Mélanophore.

Mélecte.

* Mélipone.

Mélitome.

Mélitophiles. Sous-trib.

Méliturge.

Melline.

Mélyrides. TriB.

Membraneuses. Trib.

Mérie.

Mérodon.

Méryx.

Mésochère.

Mésonychie.

Méropie.

Microcéphales. Tnis.

Microgastre.

Micropèple.

Micropèze.

Milésie.

Miris.

Misolampe.

* Misque. I Ie. Fam. Jur.

Molobre.

Moluris.

* Monanthie.

Monédule.

Monochèle.

Monceque.

Mordellones. Tвı.

Morion.

Mormolyce.

Morpho. Tome IX.

Mosilie. Tome X.

Nycétobie.

Mydasiens. Trib.

Myodite.

Myopaires. Sous-Tan.

Myrine. Tome IX.

Myrmécie. Tome X.

Nématocère.

Némocères. FaM.

Néphrops.

Néphrotome.

Nísée.

Nika.

Notacanthes. FaM.

Nymphale. Tome IX.

Nymphow. Tome X.

OCHODÉE.

CEcodome.

CEcophore.

CElémérices. Trib.

Ogygie.

Oniticelle.

Onthophage.

* Onyctène.

Oode.

Orbitèles.

(t) Changez senomencelui d'Helius.

$39^{3}$

524

717

I 06

107

99

41

41
46

159

517

3.3

27

453

665

127

653

$49^{6}$

375

528

692

355

725

435, So

$\mathrm{r} 38$

668

537

$2 y^{1}$

818

$59^{2}, 829$

778

$5 S S$

655

653

568

584

328

SoI

329,825

254

360

I 27

484

712

356

353

$44^{\circ}$

630

758
* Ornidie.

Orphné.

107 Orthogonie.

710 Oryctès (1).

529 * Osmoderme.

350 Oviscapte.

793 Oxycheile.

45 Oxygnathe.

426 Oxystome.

$6 \tilde{5}_{2}$ Oxyures. TRiB.

Cachronime.

Pachylide.

Pachymère.

Pachype.

* Pachysome.

Pachyce.

Palémon.

Pandale.

Panorpates. Trib.

Papillon (2). T'ome IX.

Parasites. Tome X.

Parnassien (3). Tome IX.

Pasiphée. Tome X.

Patellimanes. Sous-t nib.

Pavonie (4). Tome IX.

Pélidnote. Tome X.

* Pélidnote.

* Peltidion.

Peltoödes. Trв в. (5)

Pennicorne (6).

Penthimie.

Péricalle.

* Péralochère.

Phanée.

Phasme (7).

Phobère.

Phyllophages. Sous-trib.

* Piesme. Tonse X. 653

Piméliaires. Trab. (8).

* Pinorhie.

Planiceps.

* Platychère.

Platygénie.

Platyue.

Platypézines. FAM.

Platyure.

Plectris.

* Pocote.

Polistique (9).

Polymère.

786

363
-46

746
804

;02

548

619

383

383

$2{ }_{2}$

$-5$

62

322

$3: 6$

352

687
325

330

148

sol, $\operatorname{sog}$.

So 4

So 4
330

$6: 29$

807

800

317

644

643

59 í

$2-4$

354

414

53

534
479

330

5,3

$3 \div 8$

503

538

$36 \%$

369
5.8

823
537

Polymerces

537

(1) Et de plus à sa lettre.

(2) Idem.

(3) Idem.

(4) Idem.

(5) Idem.

(6) Voyez en outre l'arricle Sca-
Piéride. Tome IX. 105 So5 340

Page 536

349

Tachydromiens. Fam. (6).

Temnocère.

* 'Temnostome.

Tengyre.

* Tétragone.

* Térraupe (7).

'Thais. 'Tome IX.

* Tricome. TomeX.

Uranie. Tome IX.

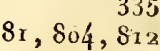

Polyommate. Tome IX. Page 595

Prisope.

Procère.

Proconie. Tome $\mathrm{X}$.

Prosêne.

Psorophore.

Pryìle.

Recticoryes. Sous-trib.

306

634

544

448

367

484

Sa B́́Thìs.

658

293

46o, 808, 826

tere.

Serriferres. Fam.

* Sphérophorie.

506,580

SuUs-TRIB. (5). $\delta$ IS

800

808

RE à sa letrte.

(7) Et de plus à sa letrre.

(8) $I$ dem.

(9) Idem.

* Valgeg.

Vanesse. Tome IX. 291, Sog, 704

* XxA.

709

(I) Et de plus à sa le tre.

(2) Idem.

(3) $I d \mathrm{~cm}$.

(4) Idem.

(5) Idem.

(6) Iden.

(7) Idem.

FIN DE LA TABLE ALPHABETIQUE. 


\section{ERRATA.}

Page 13, 1re. colonne, ligne $1^{\text {ree }}, 33$, lisez : 32 .

Page 3o, 2e. colonne, ligne $3 \mathrm{~S}, 15 \mathrm{I}$, lisez: 150.

Page 40, 1re. colome, ligne 43, ces, lisez: les.

Page 53, 1 re. colonne, ligne $28, P$. Stollii, lisez: $P$. liturata, et ajoutcz à la synonymie : Cimew lituratus. Fав. Syjt. Rtyng. pag. 1 jo. no. 84. - Panz. Faun. Germ. fasc. 40. fig. 19 .

Page 58, $2^{\mathrm{e}}$ colonne, ligne 28 , ajontez, après la citation de Linné, Fa 13. Syst. Rhyng. pag. $176 . n^{\circ}$. Iog.

Page $68,2^{e}$. colonne, ligne 16 , ajoutez, après le mot Lat, Semblis. Fab.

Page $9^{\circ}, 1^{\mathrm{re}}$. colonne, après la ligne 40 , ajoutez : des environs de Paris.

Page $9^{1}, 1^{\text {re }}$ colonne, après la ligric 17 , ajouzez : dos environs de Paris.

Idem. $2^{\mathrm{e}}$. colonie, après la ligne 4 , ajoutç : des environs de Paris.

Page 95, $2^{\mathrm{e}}$. colonne, ligne $48,1^{\circ} \cdot 1 /$, lisez : $1^{\circ} \cdot 2$ 4.

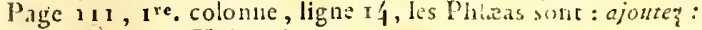
avec les Holoptiles.

Page 12S, 1re. colonne, ligne 33 , effacez: $:$ S. F. ex $A$. Ser.y.)

Page $158,2^{\mathrm{c}}$. colonne, ligne $\mathrm{S}$, à la grandeur des parties de la bouche, lisez : à la largeur du corps proportionnellement à son épaisseur.

Page $162, \mathbf{1}^{\text {re }}$ colonne, ligne 4 'j, cinq, lisez : quatre.

Page $163,1^{\text {re }}$ colonne, ligne $25,1^{\circ} .14^{3}$, lisez $: 10^{\circ}$. 153.

Page 173, z $^{\mathrm{re}}$. cololine, ligne 6 , syononymes, lisez: synonymes.

Page $18 ;, 2^{\mathrm{e}}$. colonne, ligne 3 , patics, lisez : pattes.

Page 205,2e. colonne, ligne $4^{6}$, adopé, lisez : adopré.

Page $212, \mathrm{x}^{\mathrm{e}}$ colonne, ligne 20 , figure, lisez : figuré.

Page $238,2^{\mathbf{2}}$. colonne, ligne 43 , llétéromères, lisez : Pentamères.

Page $240,2^{\mathrm{e}}$. colonne, ligne 36 , lisse, lisez : giabre.

Page $26_{2}, 2^{\circ}$. colonne, ligne 23 , écussontes racé, lisez: ćcusson restacé.

Page 266, 1re. colonne, ligne 3, de, lisez: des.

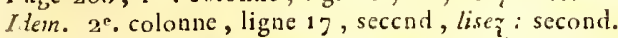

Page 269 , I'e. colonne, ligne 2 , cylindriq., lisez: cylindriques.

Idem. $2^{\mathrm{c}}$. colonne, ligne $\mathrm{S}, \mathrm{e}$, lisez : dc.

Page $27 \mathrm{I}, \mathbf{1}^{\mathrm{re}}$. colonne, ligne 37 , manque, lisez : manque.

rdem. Idem, ligne 43 , d'un, liscz: d'une.

Page $283,2^{e}$. colonne, ligne 12 , la fumelle, après ce mot ajoutez : -

Page 289 , ${ }^{\text {re }}$. colonne, ligne $\mathbf{6} 6$, par le nombre des, lisez: par le nombre des articles des.

Page $291,2^{\circ}$. colonne, ligne $26, n^{\circ} .7$, mettez une demiparenchèse aprìs le chiffre $7:$ (.

Page 300, $2^{\mathrm{e}}$. colonne, ligne 11, 258, lisez: 268 .

Page 3o3,2e. colonne, ligne 3 , Rynchites, lisez: Rhynchites, ainsi que dans le reste de cette colonne et dans la suivanre.

Page $306,1^{\text {re }}$ colonne, ligne 6,2 , lisez: 21 .

Page $315,2^{e}$. colonne, avant-dernière ligne, R. tèle, lisez: Rutèle.

Page $316,2^{c}$. colonne, ligne 2, subdivison, lisez : subdivision.

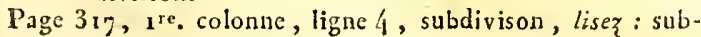
division.

Idem. Idem, ligne ro, après quadrirayée ajoutez $\mathrm{r}^{\circ} .11 \mathrm{I}$.

Idem. $2^{6}$ colonne, ligne 24,12 , lisez : 22.
Page 32f, $2^{e}$. colonne, ligne 40, subdivison, lisez : subdivision.

Page 338 , tre. colonne, ligne is, mennière, lisez : meunic̀re.

Idem. Idem, ligne 20 , la Lamia, lisez: les Lamia.

Page $344,2^{\text {e }}$. colonne, ligne S, ajoutez au hout: (S.F. et A. SERv.).

Page $347, \mathbf{1}^{\mathrm{re}}$. colonne, ligne 28, Rhyncophores, lisez: Rhynchophores.

Page $359,2^{\mathrm{e}}$. colonne, ligne 10 , orientale, lisez : orientales.

Page 366, Ire. colonne, ligne 2o, sans bosses, liseza : sans brosses.

Page 368, are. colonne, ligne 3i, pl. 16 , fig. 1 (i) , liser: pl. $162, f i g .16$.

Page $394,2^{\circ}$. colonne, ligne 12 , preque . lisez : presque.

Page 429 , Ire.colonne, ligne 20, section, liscz : division.

Page $432, \mathbf{I}^{\mathrm{ro}}$. colonne, ligne 11 , supérieure, lisez : inféricure.

Page $4.18,2^{\mathrm{e}}$. colonne, ligne 50 , après le mot prothorax, ajoutez : prolongé latéralement jusqu'à la naissance des ailes supérieures.

Page 463 , 1'e. colonne, ligne 37 , qui nous inconnus, lisiz: qui nous sont inconuus.

Page 465, ${ }^{2}$. colonne, ligne 17, Entom. Syst., ajoutez: d'Europe.

Page 4S1, 1". colonnc, ligne 17 , tête noire, liscz: très noire.

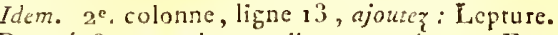

Page $49^{3}, 2^{\mathrm{e}}$. colonne, licic 27 , ajoute? $: \mathrm{FAB}_{\mathrm{AB}}$

Page $459,2^{e}$, colonne, ligne 24 , stomoxis, lisez: stomoxys,

rdem. Idem, ligne 26 , idem, zdem.

Idem. Iden, ligne 45, idem, idem.

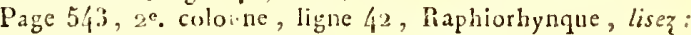
lihaphiorhynque.

Page 544, 1re. colonne, ligne ifs, idem, idem.

Idcon. $2^{\circ}$. colonne, ligne $5 t$, liaphiorhynque, Raphiorhynchus, lisez : Rhachiorhynque, Rhaphiorhynchus.

Page 550, $2^{\mathrm{e}}$, colonne, ligne 6 , Patilinus, lisez Ptilinus.

Page 5 5 , I ${ }^{\circ}$. colonne, ligne 13 , peint, lisez : point.

Ition. Iitem, idem, et les, lisez : et a les.

Page 5So, $2^{\circ}$. colonne, ligne 35 , Chalcédites, lisez: Chalcidices.

Puge 583, $2^{\mathrm{c}}$ colonne, ligne 21 , atra, lisez: atrata.

Page $598, \mathbf{r}^{\text {re }}$ colonne. ligne $\mathbf{3} 3$, seconde, lisez : première.

Idem. $2^{\mathrm{e}}$. colonne, ligne 31 , de celles de, lisez : de celles des.

Page 6o3 . 1 $1^{\text {re. }}$ colonne, ligne 56, indiqent, lisez: indiquent.

Psge $616,2^{\mathrm{e}}$. colonne, ligne 6, Cicendela, lisez: Cicindela.

Page 655, I $^{\text {e. }}$ colonne, ligne 37, Desvoisy, lisez : Desvoidy.

Page 695, $1^{\text {re }}$ colonne, ligne 7 , Trogosite, lisez : Trogossite.

Page jo1, $1^{\text {re }}$, colonne, ligne 35 , javainca, lisez: javanica.

Page $72 \mathrm{~S}$, tre. colonne, a près la ligne 47 , ajoutcz en alinća: Voyez pour la description er le synonyme de l'Entomologie d'Olivier, Cicindèle échancrée no. 39 . de ce Dicrionnaire.

Page 736 , $\mathbf{1}^{\text {re. }}$ colonne, ligne $\mathbf{I}$, cicindćloïdes, lisez : cicindéloìde.

Page 758 , ${ }^{\text {re }}$ colonne, ligne 11 , d'un beau rouge, liser d'un brun rolige. 


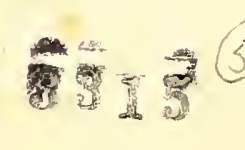






